

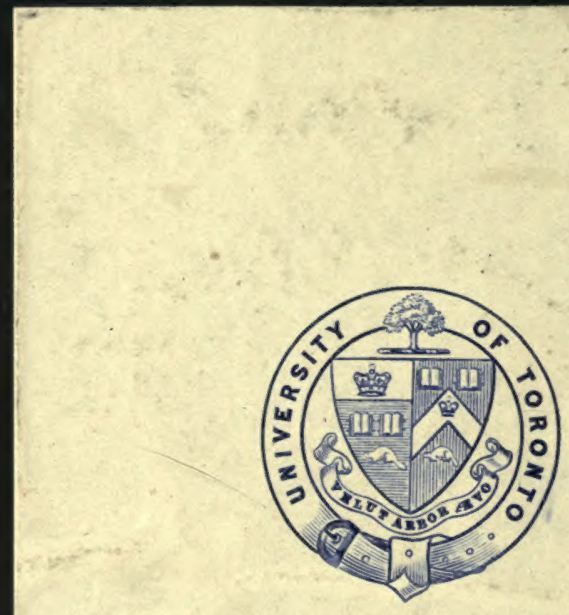

Dresented to

The Iibrare of tbe

University of Toronto

thime Blate Sig.
from the books of
The late Hon. Ed wand Blate 
Digitized by the Internet Archive in 2007 with funding from Microsoft Corporation

http://www.archive.org/details/britannicayearbo00chisuoft 


\section{THE \\ BRITANNICA YEAR-BOOK 1913}




\section{TO THE OWNER OF THIS YEAR-BOOK}

7 HE Britannica Year-Book has for its province the temporary aspects of the world's life. It affords information that holds

1 for the current phases of things. The Encyclopadia Britannica (Eleventh Edition) deals with the vastly wider realm of knowledge and information that has withstood the test of time. It supplies the basis on which the new information, the new developments, the substantial progress of the present year must rest, that great account to which the new acquisitions are but small additions in the sum total of the things men know and by which their actions in the present are inevitably guided.

\section{A description of the new Encyclopredia Britannica is printed as an advertisement at the back of the Year-Book}

What the Britannica Year-Book does for the limited section of knowledge affected by a year's changes the Encyclopadia Britannica does for the whole vast range of human thought and achievement throughout all history. The 29 volumes of the Encyclopædia are indispensable as an interpretation and survey of the vast masses of facts lying behind the events of the day to which the new information contained in the Year-Book must necessarily continually refer, because all history, all development, is continuous, and a fact that comes into prominence to-day, a new step in the evolution of knowledge, cannot be isolated from the facts that went before and are a part of the heritage from the preceding age.

These two books, products of the modern spirit of efficiency, the Britannica Year-Book and the Encyclopedia Britannica, spring from a common impulse and are part of a single plan, executed by the same international organization of authorities. They attain their greatest usefulness when serving together, each ${ }_{1}$ as the complement, or companion, to the other, and it is especially the YearBook reader who by his tastes and requirements will best appreciate the invaluable services which the Encyclopadia Britannica can render and whose need for this work is most pressing.

\section{SEND FOR THE 160-PAGE PROSPECTUS}

No advertisement and no mere pamphlet are adequate to describe this wonderful new work. We have therefore had to prepare a book about it of 250,000 words, with many illustrations and specimen pages on India paper. It costs us more than fifty cents a copy to print and mail. You should examine this prospectus describing the most notable literary undertaking of the age. It will be sent you, by mail, without any obligation to you, together with full particulars of prices, payments, bindings, bookcases, etc.

\section{The Encyclopaedia Britannica}

120 WEST 32nd STREET, NEW YORK 


\section{BRITANNICA YEAR-BOOK}

\section{3}

A SURVEY OF THE WORLD'S PROGRESS SINCE THE COMPLETION IN 1910 OF THE ENCYCLOP\&DIA BRITANNICA, ELEVENTH EDITION

\section{COMPRISING}

A REGISTER AND REVIEW OF CURRENT EVENTS AND ADDITIONS TO KNOWLEDGE IN POLITICS, ECONOMICS, ENGINEERING, INDUSTRY, SPORT, LAW, SCIENCE, ART, LITERATURE, AND OTHER FORMS OF HUMAN ACTIVITY, NATIONAL AND INTERNATIONAL,

UP TO THE END OF 1912

EDITED BY

HUGH CHISHOLM, M.A., OXON.

Editor of the Encyclopedia Britannica

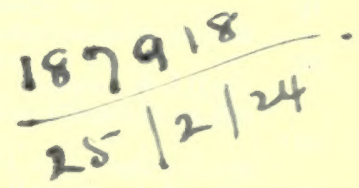

The Encyclopedia Britannica Company, Limited

LONDON

The Encyclop edia Britannica Company

NEW YORK 
Copyright, in the United States of America, 1913, by

The Encyclopædia Britannica Company

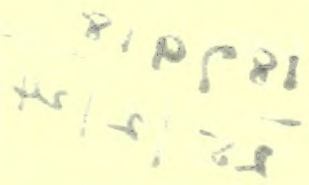




\section{Contents}

Preface : by The Editor

Diary of Events in 1911 and 1912

PART I. INTERNATIONAL AND GENERAL:-

Section I. Politics ANd Economics:-

"Special International Affairs and Events" (The Morocco Crisis of IgII; Italy and Tripoli; The Balkan Crisis of Igi2; China, 'Mongolia, \& Tibet; The Panama Canal Controversy; England's withdrawal from the Sugar Convention; The Titanic Disaster; General Booth; The Rise of Syndicalism): by THE EDITOR

"The Turco-Italian War": by MAJOR H. H. WADE, R.A., editor of the English official Army Review and Journal of the Royal United Service Institute: .

"The Balkan War": by MAJOR H. H. WADE, R.A. (ut supra)

"The World's Armies": by E. JoHN SolAno, inventor of the Solano Battlepractice Target and Section Fire Target, used by the British War Office for musketry training; editor of the Imperial Army Series of Military Training Manuals

"The World's Navies": by Gerard FienNes, Member of Executive Committee of the English Navy League, naval critic to the Pall Mall Gazette and Observer, author of The Ocean Empire, its dangers \& defences

"International Law \& Peace": by Sir Thomas Barclay, Ph.D., LL.B., Member of the Institute of International Law, Vice-President of the International Law Association, author of Problems of International Practice and Diplomacy

"International Finance": by SIR GEORGE PAISH, editor of The Statist, author of Railways of Great Britain, Railroads of the United States, Investments in other lands, etc.

"The Extension of Telegraphic Communication": by ChARLES BRIGHT, F.R.S.E., M.Inst.C.E., M.I.E.E., consulting engineer to the Commonwealth of Australia, author of Submarine Telegraphs, Underground Cables, Imperial Telegraphic Communication, etc.

"Woman's Suffrage": by Mrs. W. L. CoukTNEy (Janet E. Hogarth), formerly Superintendent of Women Clerks in the Bank of England, 1894-I906; and Librarian of the Times Book Club, 1906-10

SeCtion II. SCIENCE:-

"Astronomy": by Professor Herbert Hall Turner, D.Sc., F.R.S., Savilian Professor of Astronomy; Oxford, President of Royal Astronomical Society, I903-04, author of Modern Astronomy, Astronomical Discovery, etc.

"Geography and Exploration": by O. J. R. HowARTH, M.A., assistant-secretary of the British Association, Geographical Scholar, Oxford, I90I

"Geology": by Frederick William Rudler, I.S.O., F.G.S., Curator \& Librarian of the Museum of Practical Geology, London, I879-1902, President of the Geologists' Association, I $887-89$

"Meteorology": by Professor Cleveland ABbe, A.M., LL.D., Professor of Meteorology, United States Weather Bureau, editor of Bulletin of Mount Weather Observatory, author of Meteorological Apparatus, Methods, etc.

"Physics": by EDMund EDWARd Fournier D'AlBE, B.Sc., A.R.C.Sc., member of the Royal Irish Academy, asșistant lecturer on Physics at Birmingham University, inventor of the Optophone and improved Phonoscope, author of The Electron Theory, Wonders of Physical Science, etc.

"Chemistry": by James C. Philip, M.A., Ph.D., D.Sc., assistant professor of Chemistry in the Imperial College of Science, South Kensington, author of Romance of Modern Chemistry, Physical Chemistry, etc.

"Biology and Zoology": by Peter Chalmers Mitchell, D.Sc., F.R.S., F.Ż.S., secretary to the Zoological Society of London, examiner in Biology to the Royal College of Physicians, $1892-96,1901-03$, examiner in Zoology to the University of London, 1903, author of Outlines of Biology, etc.

"Botany": by J. B. FArmer, M.A., D.Sc., F.R.S., Professor of Botany, Royal College of Science, London, formerly Demonstrator of Botany and Assistant 


\section{CONTENTS}

Professor of Biology in Oxford University, joint-editor of The Annals of Botany and of Science Progress

"Physical Anthropology": by W. L. H. Duckworth, M.A., M.D., D.Sc., Lecturer in Physical Anthropology and Senior Demonstrator in Human Anatomy, Cambridge University, author of Morphology and Anthropology, etc.

"Cultural Anthropology": by Robert RANulf MARET, M.A., Reader in Social Anthropology, Oxford University, organising secretary of the International Congress of Anthropological Societies, author of The Threshold of Religion, etc.

"Philology":-

"The Austric Family of Languages": by Charles Otto Blagden, M.A., M.R.A.S., F.R.A.I., member of Council of Royal Asiatic Society, I910, Examiner in Malay to University of London, I9II, joint author (with Prof. W. W. Skeat) of Pagan Races of the Malay Peninsula, etc.

"Medicine": by Stephen PAget, F.R.C.S., Hon. Secretary of the Research Defence Society, London, Surgeon to the Throat \& Ear Department, Middlesex Hospital, author of Experiments on Animals, Chronicles of the Royal Medical and Chirurgical Society, etc.

"Dentistry": by EDWARD CAMERoN Kirk, D.Sc., Professor of Dental Pathology and Therapeutics, University of Pennsylvania, editor of The Dental Cosmos.

"Osteopathy": by G. W. Riley, Ph.B., D.O., member American Osteopathic Association, Ex-President New York State and City Osteopathic Societies, Chairman of Council of A. T. Still Research Institute, Chicago

Section III, Art and Literature:-

"English Literature": by Тномаs Secсомве, M.A., Professor of English, R.M.C., Sandhurst, Lecturer in History, East London College, 1907-12, assistant editor Dictionary of National Biography, 1891-I901, author of The Age of Johnson, Bookman History of English Literature, etc.

"Shakespeare and the Elizabethan Drama": by Edmund Kerchever Chambers, C.B., Principal Assistant secretary, Board of Education, London, author of The Medieval Stage, editor of the Red Letter Shakespeare, etc.

"Australian Literature": by FRANK FOx, formerly editor of the Sydney Bulletin

"English Canadian Literature": by LAWRENCE JOHNSTON BURPEE, F.R.G.S., F.R.S.C., formerly Librarian of the Ottawa Public Library, author of Bibliography of Canadian Fiction, Dictionary of Canadian History, Canadian Essays, Canadian Life in Town and Country, etc.

"French-Canadian Literature": by Lieut. Col. William Wood, D.C.L., F.R.S.C., formerly President of English Section of Royal Society of Canada and of Historic Landmarks Association, author of The Fight for Canada, The Logs of the Conquest of Canada, etc.

"American Literature": by HENRY WALcotT Boynton, author of Life of Was $\dot{h}$ ington Irving, Bret Harte, A Reader's History of American Literature (with T. W. Higginson), etc.

"French Literature": by MADAME Dúclaux (Agnes Mary Frances Robinson), author of Grands Ecrivains d'Outre-Manche, La Reine de Navarre, etc,

"German Literature": by Professor John George Robertson, M.A., Ph.D., Professor of German in University of London, author of History of German Literature, etc.

"Italian Literature": by LUIGI VILLARI, author of Italian Life in Town and Country, etc., Italian vice-consul in New Orleans, 1906, and Philadelphia, 1907

"Dutch Literature": by HENRI ZONDERVAN, editor-in-chief of Winkler Prins' Encyclopaedia, author of Nederland buiten Europa, Insulinde in Woord en Beeld, etc.

"Belgian Literature": by MADAme LAlla VANDERvelde, secretary of the Institut des Hautes Études of the Université Nouvelle, Brussels

"Danish Literature": by William RENTON PrIOR, B.A., Member of the Danish Historical Society, Corresponding Member of the Royal Danish Geographical Society, London correspondent of the Berlirske Tidende, Copenhagen

"Norwegian Literature": by Simon Christian HAMmer, M.A., author of Boerkrigens Historie, Georg Stang, etc., Christiania correspondent of La Gazette de Hollande

"Spanish Literature": by Baldomero Sanin Cano, Graduate Professor of Colombia, under-secretary of finance in Colombia, 1905-08, editor of the Revista Contemporanea (Bogotá)

"Portuguese Literature": by EDGAR PREstage, Lecturer in Portuguese literature in Manchester University, Corresponding member of Lisbon Royal Academy of 


\section{CONTENTS}

Sciences, etc., editor of Letters of a Portuguese Nun, Azurara's Chronicles of Guinea, etc.

"Russian Literature": by GEorge E. DoBson, British Vice-consul, St. Petersburg, formerly Times correspondent in Russia

"Classical Literature": by M. O. B. CASPARI, lecturer in Ancient History at London University, formerly lecturer in Greek at Birmingham University

"Palaeography": by Sir Edward Maunde Thompson, G.C.B., D.C.L., LL.D., F.B.A., formerly Director and Principal Librarian of the British Museum, author of Handbook of Greek and Latin Palaeography, joint editor of Publications of the Palaeographical Society...

"The Drama": by William Leonard Courtney, M.A., LL.D., Professor of Dramatic Literature, Royal Society of Literature, editor of The Fortnighlly Review, author of The Idea of Tragedy, The Development of Maeterlinck, K it Marlowe, etc.

"Progress of the Cinema Theatre": by J. P. Middleton

"Music": by FILsON Young, author of Mastersingers, More Mastersingers, Wagner Stories, Christopher Columbus, The Sands of Pleasure, "The Things That Matter" (Pall Mall Gazette), etc., formerly editor of The Oullook

"Painting, Sculpture and Architecture": by PAUL GEORGE KONODY, art critic to the Daily Mail and Observer, formerly editor of The Artist, author of Velasquez, etc.

"American Painting and Sculpture": by Royal Cortissoz, art editor of the New York Tribune, author of St. Gaudens, La Farge, etc.

"American Architecture": by MONTGOMERY SCHUYLER, corresponding member American Institute of Architects, author of Studies in American Archifecture, etc., contributing editor to The Architectural Record

"American Arts and Crafts": by MIRA BURR EDSON, editor of The Arts and Crafts Magazine

"Illustrative Process-work": by EDwin BALE, R.I., Art Director to Cassell and Co., I 882-I907, secretary to Artists' Copyright Committee

\section{Section IV. Archaeology and Excavation:-}

"Babylonia and Assyria": by Leonard William King, M.A., F.S.A., Assistant keeper of Assyrian Antiquities, British Museum, Lecturer in Assyrian at King's College, London, author of Annals of the Kings of Assyria, ete.

"Egypt": by Professor W. M. Flinders Petrie, F.R.S., L.L.D., D.C.I., Edwards Professor of Egyptology, University College, London, author of History of Egypt, etc.

"Palestine and the Semitic Area": by Arthur Ernest Cowley, D.Litt., sublibrarian of the Bodleian, Oxford, joint-editor of Catalogue of Hebrew MSS. in the Bodleian, etc.

"Hittites": by David GEorge HoGarth, M.A., F.S.A., F.B.A., Keeper of the Ashmolean Museum, Oxford, Director of British School at Athens, 1897-1900, and Cretan Exploration Fund, I 899, author of The Nearer East, etc.

"Crete": by Ronald Montague Burrows, D.Litt., Principal of King's College, London, formerly Professor of Greek in Manchester University, chairman of the Aegean Islands Committee, author of The Discoveries in Crete, etc.

"Aegean Civilization":

"Sites of Middle and Nearer East": $\}$ F.S.A., F.B.A. (ut supra)

"Sites of Greece Proper": by Alan John Bayard Wace, M.A., Fellow of Pembroke College, Cambridge, Lecturer in Ancient History and Archaeology in St. Andrews University, Corresponding Member of the Imperial German Archaeological Institute, author of Prehistoric Thessaly, Catalogue of the Sparta Museum, etc.

"Cyprus": by Professor John Linton Myres, M.A., F.S.A., Wykeham, Professor of Ancient History in Oxford University, joint-author of $A$ Catalogue of the Cyprus Museum, etc.

"New Light on Greek Art": by Professor Percy GArdner, Litt.D., LL.D., Professor of Classical Archaeology in Oxford University, member of the Archaeological Institutes of Germany, Austria, America, and Greece, joint author of Manual of Greek Antiquities, etc.

"The Protection of Ancient Monuments": by "X"

Section V. Philosophy, Education and Religion:- -

"Philosophy": by Professor Alfred Edward Taylor, M.A., D.Litt., F.B.A., Professor of Moral Philosophy in St. Andrews University, examiner in philosophy to Manchester University, I9II, author of The Problem of Conduct, Elements of Metaphysics, etc. 


\section{CONTENTS}

Education:-

"The Montessori System":

"The Problem of Mental Defectives": $\}$ by THE EDITOR

"The Blind": by Sir Francis J. Campbell, LL.D., F.S.A., F.i..G.S., Principal of Royal Normal College for the Blind, Upper Norwood, London

"The Deaf and Dumb": by F. G. Barnes, Hon. Secretary of the National Association of Teachers of the Deaf, Homerton College, London

Religion:-..-

"The Church of England, and Anglican Communion": by J. G. PenderelBRODHuRST, editor of The Guardian, London, part author of Abbeys and Churches of England and Wales.

"The Roman Catholic Church": by John SNEAD-Cox, editor of The Tablet, London, author of Life of Cardinal Vaughan, Jubilee-tide in Rome, etc.

"The Free Churches": by Rev. Professor A. J. Grieve, M.A., B.D., Professor of New Testament and Church History at the United Independent College, Bradford

Section VI.

"Law and Justice": by Edward Manson, Master of the Supreme Court, London, joint editor (with Master Sir John Macdonell) of The Journal of Comparative Legislation

"The British Law of Artistic Copyright": by Edwiv BALE, R.I. (ut supra)

\section{Section VII. Engineering and Industry:-}

"Aeronautics": by John HENRY LeDEBoer, editor of Aeronautics, London, hon. editor of Aeronautical Journal, Associate Fellow of the Aeronautical Society, joint author of Mechanics of the Aeroplane, The Aeroplane, etc.

"Ships and Shipbuilding": by John Harper Narbeth, M.V.O., Chief Constructor, British Admiralty

"Internal Combustion Engines": by Archibald Sharp, B.Sc., A.M.I.C.E., author of Balancing of Engines, etc.

"Steam Boilers": by JAMES TAYLOR Milton, M.I.C.E., Chief Engineer surveyor to Lloyd's Registry of Shipping, vice-president Institute of Naval Architects, member of Council of Institute of Marine Engineers

Electrical Engineering (I. Electric measurements; 2. Electro-chemistry and Electro-metallurgy; 3. Railway electrification and power-transmission; 4. Electric lighting; 5. Electric heating; 6. Telephony; 7. Wireless Telegraphy and Wireless Telephony): by Professor John Ambrose Fleming, D.Sc., F.R.S., Pender Professor of Electric Engineering in London University, author of The Principles of Electric Wave Telegraphy and Telephony, etc.

Military Engineering:-

"Heavy Field Ordnance": by CAPT. Frank MARTYN Rickard, R.A., Inspection Department, Royal Arsenal, Woolwich

"Field Artillery": by Liect.-Col. Henry Arthur Bethell, Associate Member R.A. Committee, Lefroy Medallist for contributions to Artillery Science, author of Modern Guns and Gunnery, etc.

"Small Arms": by MAJOR G. H. S. Browne, Experimental Officer, Hythe School of Musketry

"Naval Ordnance": by CoL. A. G. Hadcock, R.A., Manager of Gun Department, Elswick Works, Newcastle-on-Tyne, part author of Modern Artillery, etc.

"Armour Plate": by MAJOR WV. E. EDWARDS, R A., Inspection Department, Woolwich Arsenal, Lecturer on Armour and Explosives at Royal Naval Whar College, Greenwich, 1904-09

"Mining": by ALEEN GREENwEl, F.C.S., A.M.Inst.C.E., editor of The Colliery Gutrdian, London, author of Analysis of British Coals and Coke, etc., assisted by Herbert Greenwell

"Metallurgy": by IV. Roseshaix, D.S.C., Superintendent of The Metallurgical Department, National Physical Laboratory (England), Member of Council, Institute of Motals, ('arnegie Medallist of Mron and Steel Institute

"Solid, Liquid and Gaseous Fuels": by Professor V'ivian Bram L.ewes, F.I.C., F.'.'.., Professor of ('hemistry, Royal Naval College, (ireenwich, Chief Superintending ( Bas Examiner to Corporation of City of London

"Gas Manufacture":

"Coal Tar":

"Gas Lighting":

"Oil Lighting":

"Acetylene":

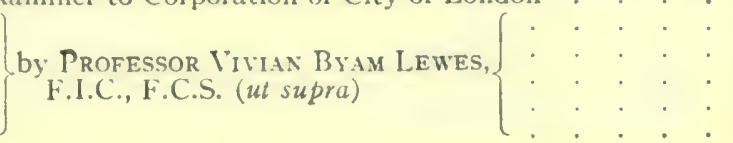




\section{CONTENTS}

"Petroleum": by Sir Boverton Redwood, Bart., D.Sc., F.R.S.E., Adviser on Petroleum to the British Admiralty, Home Office, and India Office, and to the Port of London Authority, author of Petroleum, its Production and Use; Treatise on Petroleum, etc.

"Agriculture" (Progress of Scientific Research: British Agriculturai Organisation), by Alfred Daniel Hall, M.A., F.R.S., Commissioner under British Development Act, late Director of the Rothamsted Experimental Station, formerly Principal of Wye Agricultural College, author of The Soil, Fertilisers and Manures, etc.

"Dry-farming in America": by ELLERY C. CHILCOTT, in charge dry land agricultural investigations, Bureau of Plant Industry, U.S. Department of Agriculture

"American Dairy-farming": by Hubert EVERetT Van Norman, Professor of dairy husbandry, Pennsylvania State College.

"Poultry-farming": by JOHN HENRY ROBINSON, editor of Farm Poultry, and author of Principles and Practice of Poultry Farming . .

"Horticulture": by JOHN WeAthers, F.R.H.S., lecturer on Horticulture to the Middlesex County Council, author of Practical Guide to Garden P.lants, etc.

"Bee-keeping": by Thos. William Cowan, author of British Bee-keepers' Guide-book, The Honey Bee, etc., inventor of Cowan's Rapid Extractor, etc.

"The Fur Industry": by Siegmund Politzer, of Phillips, Politzer \& Co., fur merchants, London

"The Cotton Industry and Trade": by Professor Sydney John CHAPMAN, Professor of Political Economy and Dean of the Faculty of Commerce in Manchester University, author of The Cotton Industry, The Lancashire Cotton Industry, etc.

"The Linen Industry": by Thomas Woophouse, Head of the Weaving and Textile Designing Department, Technical, College, Dundee . . . . . 437

"The Jute Industry": . . \} by Thomas Woodhouse \{ . . . . 438

"The Rope-Making Industry": . $\}$ (ut supra) $\{.0440$

"The Wool Industry": by Professor Aldred FARrer Barker, M.Sc., Professor of Textile Industries at Bradford Technical College, editor of Journal of Bradford Textile Society, author of Wool Carding and Combing, The Wool YearBook, etc.

"New Fibres": by C. F. CRoss, B.S.C., F.I.C., joint author of Researches in Cellulose

\section{Section VIII.}

"Sports and Games": by Arthur William Browne, M.A., sub-editor of The Field, London

"American Sports": by Walter CaMp, author of Book of College Sports, American Football, etc.

\section{PART II. NATIONAL AND LOCAL: -}

\section{Section I. The British Empire:-}

"English History": (1. The Crown; 2. The Empire; 3. Domestic Politics in the United Kingdom; 4. Labour Questions, by THE EDITOR. 5. English Finance, by W. M. J. Williams, author of The King's Revenue. 6. British Obituary, by THE EDITOR)

"The United Kingdom" (with England and Wales): by O. J. R. Howarth (ut supra), Harold Macfarlane, F, Roy. Stat. Soc., and others

"Scotland": by DONALD MUIR, of the Glasgow Herald

"Ireland": by W. R. Wells, assistant-editor of the Irish Times

"India": by James Sutherland Cotton, M.A., editor of The Imperial Gazetteer of India, etc.

"Ceylon": by W. MARTIN LEake, secretary to the Ceylon Association, London

"British Malaya": by the Malay States Information Agency, London

"Hong Kong": by Herman Spooner, Technical Superintendent, Indian section, Imperial Institute

"Wei-hai-wei": by Herman SPooner (ut supra)

"Fiji, and Dependencies": by ALBERT BruCE JACkson, Technical Superintendent, Australian Section, Imperial Institute

\section{"Gibraltar":}

"Cyprus":

"Malta":

\}y Albert Bruce Jackson (ut supra)

"British East Africa": by Frank R. CANA, F.R.G.S., author of South Africa from the Great Trek to the Union 


\section{CONTENTS}

"Liberia": by Sir Harry HaMilton Johnston, G.C.M.G., K.C.B., D.Sc., R.G.S. Gold Medallist, formerly H.M.'s Yice-Counsul in Cameroon, 1885 , Consul in Niger Coast Protectorate, 1887, Consul-general for Uganda, I899-1901, author of British Central Africa, Lganda, Liberia, The Negro in the New World, etc. IID2

"Monaco": by the Consul-General in London . . . . . . . . . . II04

"Morocco": by F. R. CANA (ut supra) . . . . . . . . . . . 1105

"Norway": by Simox Christian HAMmer, M.A. (ut supra) : $: \because 108$

"Persia": by George A. Llovd, M.P., Special British Commissioner in 1908 to report on trade in Turkey, Mesopotamia and the Persian Gulf, formerly hon. attaché to H.M. Embassy at Constantinople . . . . .

"Portugal" (and dependencies): by Kixgsley G. Jayne, Fellow of the Portuguese Society of Historical Studies, author of Vasco da Gama and his Successors. III9

"Russia" (and dependencies): by GEORGE E. DoBson, British Vice-Consul in St. Petersburg, formerly correspondent of The Times in Russia . . . : . I125

"Siam": by W. H. MUNDIE, editor of The Bangkok Times . . . . . . II 34

"Spain": by KiNGSLEY G. JAYNe (ut supra) . II35

"Sweden": by Louis ZetTERSTEN, secretary of the Swedish Chamber of Commerce, London correspondent of Stockholms Dagblad, and FrEDrIK FrITHIOF IIERxer SoderberG, Ph.D., foreign editor of Stockholms Daghlad

"Switzerland": by REv. W. A. B. COOLIDGE, author of Guide to Switzerland, formerly editor of the Alpine Journal . . . . : . . . . . I143

"Turkey": by O. BrilliaNT (ut supra), and Count Léon Ostrorog, recently Foreign Adviser to the Ministry of Justice at Constantinople. . . . . . II49

General Statistics: by Harold Macfarlane, F.Roy.Stat.Soc. • . . . II64

List of Members, 63rd United States Congress. . . . . . . . . . II75

Votes, United States Presidential Election, r908 . . . . . . . . . . II79

Votes, United States Presidential Election, I9r2 . . . . . . . . . I180

Index $.+\cdots+\cdots$ 


\section{PREFACE}

This volume is designed to fill a somewhat conspicuous gap in the critical literature hitherto available to the general public concerning contemporary affairs. In a more systematic way than has been attempted before, and for a larger area and range of subjects than are covered by ordinary Year-Books, it puts into convenient shape, as a Review for continuous reading and a Register for occasional reference, what may be described as an international stock-taking, by carefully selected authorities, of the progress of events all over the world and the substantial advances in all branches of knowledge from about 1909-10 up to the beginning of 1913 .

It differs in several notable respects from the familiar type of Year-Book.

In the first place, it is a " double number." Instead of dealing with the past year only, it shows the status quo at the beginning of 1913 , by means of a historical record and review which includes I9I I as well as the whole of I9I2, and goes back even earlier so as to make the genesis of the contemporary situation, and the essential facts bearing on it, fully comprehensible,

Secondly, while omitting, as sufficiently accessible already in various widely used Almanacs and Annuals of guide-book character, a good deal of purely formal detail unconnected with the real march of progress, it brings together, on the other hand, by means of a narrative survey, a mass of information and research on subjects of great practical interest, ignored or quite inadequately dealt with by the ordinary type of Year-Book, but here carefully digested and critically presented:

Thirdly, it is planned throughout, with the co-operation of contributors specially qualified for the purpose, not only to deal with the salient facts of national progress in different countries, but to approach them, as well as those subjects $(e . g$. the sciences, arts and industries) which represent a world-movement independently of national or racial divisions, as far as possible from an international standpoint, and not, as in other Year-Books intended for English-speaking readers, from one that is more or less narrowly and disproportionately English or American.

Fourthly, the Britannica Year-Book, while complete in itself as a record and survey of the new material of contemporary interest and importance during the period it covers, is deliberately conceived at the same time as having behind it, for all questions on which earlier and more general information is desired,--together with subjects on which no substantial addition has been made to the knowledge available in rgro,- the Encyclopaedia Britannica itself, the IIth edition of which may be regarded as a digest of innumerable Year-Books up to the time of its publication. Each is thus a complement of the other. The YEAR-BOoK not only provides, independently, an encyclopaedic review of purely contemporary additions to. history and knowledge, focussing attention on the new data accruing from 1910 to 1913 , but also acts organically as a companion - and pro tanto a corrective - to what is admittedly the most comprehensive and most authoritative of all general works of reference, for which, when published in I9IO-II, all this later material was non-existent. In the latter respect it comes in direct series, though in a different form, with the IIth edition of the Encyclopaedia Britannica, and carries on, under the same auspices, with the same ideals, and with the same corpus of contributors-selected and enlarged for adaptation to the circumstances-the same attempt to give accurate and disinterested expression to the best judgment of the civilised world.

The progress of today is indeed organically related to that of yesterday. The recent additions to history and knowledge which the BRITANNICA YEAR-BOoK reviews for a limited period have naturally an independent importance, simply as constituting the active movements of prime contemporary interest in 1913 , a knowledge of which is essential to any rational understanding of current affairs and opportunities. But 
these, after all, are but the passing scene: the great drama is of the ages, and can only be appreciated with all its acts on record.

A "Year-Book" must, of course, include many details which are beyond the scope of an encyclopaedia, and vice versa. A general encyclopaedia cannot reasonably be expected to deal with certain aspects of practical life determined by purely contemporary conditions, the facts in regard to which are bound to alter as each new year comes round. It is the function of shorter lived periodical publications, arranged on different lines, to provide the public with the material necessary for acquaintance with what is strictly contemporary; they are not wanted for the purpose of covering the whole history of any subject, or the whole accumulation of knowledge about it, in so far as time has sifted its value,-this is the function of the encyclopaedia,-but only to record the additions and alterations that have been made within a limited period, or the slatus quo for a new start in regard to matters which, by their nature, are periodically changing. Thus, by contrast with the Encyclopaedia Britannica, it is the object of the BRITANNICA YEAR-BOoK, while serving substantially to bring up-to-date the information there given, and to guide the reader where desirable to such information in it as is specially valuable concerning matters in which lapse of time has made no difference, to provide, in its turn, adequate material for reading or reference on such contemporary questions as can be dealt with from an annual standpoint more practically and in relatively greater detail than is possible or suitable in an encyclopaedia. It is planned accordingly on lines which are primarily appropriate to an annual survey. The treatment of different sorts of information is grouped, according to subject-matter, in Parts and Sections, and not under a succession of dictionary headings in alphabetical order; but it is indexed so as to provide not only for convenient internal reference but also for the use of those who wish to supplement the information given in the Encyclopaedia Britannica by the later information given in the YEAR-BOoK.

The fundamental idea which dominates the plan of the volume is that the world's progress may be regarded from two points of view, as concerned either (I) with matters of general-i.e. non-national and non-local-interest, or (2) with directly national and local developments. The progress of Science, for instance, is really an international question; from a scientific point of view it does not essentially matter in what country a new discovery may be made. Science has its own world, and so have Philosophy, Religion, Education, Law, Literature, Art, Industry and Sport. For this reason the YEAR-BOOK is divided into two main parts, Part I dealing in a series of sections, subdivided where necessary, with general subjects which have an independent interest irrespective of nationality, and with political and economic questions which are primarily of common international concern, while Part II deals with political, social, and economic progress in each of the different countries of the world, taken as sovereign national units playing a distinctive part in the organisation of human effort and achievement. It is only natural that a work which, being in the English language, will circulate mainly among English-speaking readers, should deal more fully in this latter respect with conditions in the British Empire and the United States than with those of foreign countries; but the increasing importance of international relations is so widely felt among the English-speaking people in all its branches that the attempt of the BRITANNICA YEAR-BOOK to provide a more complete annual register of progress in all parts of the world, inspired by the desire to eliminate national prejudice and to enable its readers to know what is going on in the other countries besides their own, is calculated to promote both national and international interests.

'The character and scope of the BRITANnICA YEAR-BOok may be best understood from its list of Contents; but both are the direct result of its origin, which may be given a few words of explanation.

The name itself indicates that the YEAR-Book issues from the same mint as the Encyclopaedia Britannica. When the isth edition of that work-by common consent in a class by itself among encyclopaedias for scholarly international authority and comprehensiveness of treatment-was completed in 1910, its publication brought to a 
formal conclusion a unique combination of the world's ripest judgment on every sort of subject, in the shape of a vast body of individual contributors and advisers, linked up and concentrated as they had been, for several years, for the purpose of co-operating with one another and with the editorial staff in recording the sum of human knowledge and activity according to the latest sources and materials. But the relations created by long and close association still subsisted. The great "engine of co-operative effort, dedicated to the service of the public," was finished; the engineers remained, no longer in that workshop, but forming still an aggregate of "consulting opinion" such as had never before been ranged under one organisation. Although no question of a later edition of the Encyclopaedia Britannica was likely to arise for a considerable period, the opportunity for utilising again so widespread an alliance of expert knowledge, and maintaining it for public use, was the direct outcome of a new feature in the IIth edition itself, by which it differs radically both from previous editions and also from other works of similar magnitude.

The simultaneous publication of all its volumes in I9Io-r I had made it possible from the first to plan it in all its parts as a single organism, so that the whole work embodies an ordered system, representing uniformly a survey taken at the same date; its separate articles, though distributed for convenience of reference under alphabetically-arranged headings throughout the volumes, are closely interrelated by a consistent scheme, with a common point of view and a common terminus; they are thus peculiarly adapted for systematic study or reference as compared with any number of disconnected books or treatises produced independently by individual authors at varying dates. Its last complete predecessor, the th $^{\text {th }}$ edition, had been brought out in successive volumes at intervals during fifteen years, a method of publication and therefore of preparation which made it impossible in that case - and similarly makes it impossible in so many other contemporary works of correspondingly ambitious aims - to obtain any homogeneity or consistency of treatment or to secure the advantage of real co-operation as distinct from a mere collection of individual contributions. The result is that, for the first time in the history of publications of this calibre, the IIth edition of the Encyclopaedia Britannica stands comprehensively, within the lines reasonably possible for a general encyclopaedia at all, for a complete survey taken at a single date, namely I9Io, according to the materials then available for judgment.

This fact by itself, taken in connection with the inevitable fate attending all publications, in the continuous progress of events and accumulation of new materials after they once appear, brought to light a further desideratum in regard to the later progress. What the organisation which had been brought into being for surveying the sum of knowledge up to I9ro had done, it might also do, with peculiar advantage to the public, for surveying and recording what was new and of special interest for strictly contemporary purposes. The present volume is the result. For the period since the date of the survey in the IIth edition of the Encyclopaecia Britannica,--short indeed in time, but exceptionally fertile in the emergence of new issues and in the record both of international and of national progress, especially as regards the sort of information which is of interest and importance for immediate current use as distinct from the place it may eventually take in the perspective of history,--the BRITANNICA YEAR-Book, so to speak, takes up the running where the Encyclopaedia Britannica stopped.

For the selection of the subjects dealt with, particularly those in the various sections of Part I, the Editor has not only utilised the willing and valuable services of some of the most eminent of his former contributors, and others of equivalent distinction who are recognised authorities on the new questions here treated, but has had the advantage of suggestions and advice from many others among what may well be considered the most representative body of "consulting opinion" in the world. In numerous cases, it need hardly be said, the contributors of important articles in the Encyclopaedia Britannica have advised that, in so short a time, nothing of sufficient moment had occurrcd to make any addition to the account given there desirable. Naturally this applies especially to technical subjects of a general kind, the accounts of which in the En- 
cyclopaedia Britannica are by specialists whose knowledge is at the stage which it takes some years of general practice to keep up with. The names of the contributors of the various articles might speak for themselves as regards the authority of the writers. It may be added however that it sometimes happens that, the higher the authority, the more incumbent it is, for official or national reasons, to preserve anonymity; and this has been necessary in at least one instance in the present volume. It was not the object of the Editor, in the case of the Britannica YEAR-Book any more than in that of the Encyclopaedia Britannica, merely to parade a number of eminent or fashionable authors, but to provide the public with the best available knowledge from the most competent sources, where a disinterested care for real enlightenment and candid criticism were the abiding motives for publicity.

In the preparation of the BRITANNICA YEAR-BOoK, the Editor desires to acknowledge in particular, among the services of his staff, those of Mr. O. J. R. Howarth, especially in the organisation of sections $\mathrm{i}$ and iii in Part II, Mr. C. C. Whinery, head of the New York editorial staff, in the organisation of section ii of Part II, and Mrs. W. L. Courtney (Janet E. Hogarth) in general editorial work and the compiling of the index.

Hugr CHISholm.

February, 1913. 


\section{DIARY OF EVENTS}

January:-

1911

1. Pauper disqualification for old age pensions in the United Kingdom ceases to be operative-Gen. Juan Estrada inaugurated President of Nicaragua.-U. S. Dept. of State renews diplomatic relations, broken of Dec. I I 000 with Nicaragua - A French Jew, Léon Beron, found stabbed to death on Clapham Common, London.-Druses defeated by Turks east of Kerak, in the Hauran and driven into the desert.-New star discovered in the Milky Way by T. H. Espin of Walsingham Observatory, Durham.

2. Statue of General Wolfe unveiled by Lord Roberts at Westerham, Kent.

London Police surround a house in Sidney Street, Mile End, to effect the capture of the murderers of three policemen at Houndsditch on Dec. 16, 1010. Soldiers and Maxim guns brought to their aid. The house and inmates destroyed by fire.-Govt. of India putlish order prohibiting from July I emigration of indentured Indians to Natal-Railway accident at Gaika's Loop, near Cathcart, Cape Colony; I8 killed, 50 injured.-M. Regnard, French actor, shot dead in a restaurant at Paris. - Sweden agrees to lend officers for the Persian gendarmerie.-First Postal Savings Banks opened in U. S. post offices.-U. S Government's Panama Canal libel suit instigated in roos by Pres. Roosevelt against New York $W$ orld dismissed by U. S. Supreme Court.

4. Earthquake at Vyernyi in Russian Turkestan; 40 people killed.-Peru agrees to submit her dispute with Ecuador to Hague Tribunal.-Australia wins test match against South African cricketers at Melbourne by 80 runs.Death of Syed Abdul Ahad, Emir of Bokhara.- Institute of France declares against admission of women to membership. -U. S: Govt. files in New York City petition in equity under Sherman law against Hamburg American Packet Co. and 12 other trans-Atlantic lines.

5. King of Spain and Señor Canalejas, Prime Minister, leave Madrid on a visit to Melilla, Morocco.

6. $£_{9 \circ, 000}$ contributed for the relief of sufferers by the colliery disaster at Bo!ton, Lancashire, on December $2 \mathrm{I}$.David Davies, "the old shepherd of Dartmoor," released from prison by order of the British Home Secretary.- Resig nation of Tang Shao-yi, Pres. of Chinese Ministry of Communications; he is succeeded by Sheng Kan-pao.

7. The Commission of Senators in Italy report that the Second Chamber should be more representative.-Prince Albert of Monaco grants constitutional govt.-Carnegie Trust Company of New York closed by state superintendent of banks.

8. Rioting in Lisbon; newspaper offices wrecked.

o. Mr. Lloyd George confers with Parliamentary Committee of Trade Union Congress on British Govt. scheme for insurance against sickness and invalidity. - Treaty between France and Liberia signed in London.- Stinie Morrison arrested in London for murder of Léon Beron on Clapham Common.- Board of Trade inquiry into loss of the "Waratah" resumed in London.-First South American Postal Congress meets in Montevideo.-Elliott Northcott (b. I 860) of W. Va. appointed U.S. minister to Nicaragua.

Io. Pres. Taft instructs Secretary of American Navy to reprimand Commander Sims for saying at the Guildhall, London, that bis country would come to the aid of Great Britain in the event of a foreign war.-French Chamber reopens; M. Brisson re-elected Pres.-Prussian Landtag reopens.-Debate on Lorimer case begins in U. S. Senate.-Royal Commission on Canals and Waterways in Great Britain issues tenth Report.-Manuel E. Oranjo elected Pres. of Salvador-Secretary of State Knox and Juan Parades, special envoy for Honduras, sign treaty by which U. S. guarantees loan from American bankers to Honduras without assuming financial protectorate.-Cincinnati (Ohio) Chamber of Commerce and other buildings burned, with a loss of about $\$$ I, 000000 .

II. German Emperor's Society for the Promotion of Scientific Research formally constituted in Berlin. Chinese National Assembly dissolved.-Emilio Estrada elected Pres. of Ecuador-New Palace of Justice, Rome, spened by King Victor Emmanuel--Resignation of Rumanian Liberal Cabinet; $M$. Carp forms Conservative Ministry.-General strike declared on Portuguese railways, followed by strike of shop assistants in Lisbon.-Fighting between Mexican Govt. troops and insurgents near Comstock, Texas.
12. Rioting at Bombay between Shiah and Sunni Mahommedans, - Señor de Almeida, Portuguese Minister of the Interior, threatens resignation.-New Ministry formed in Chile by Señor Rafael Orrego,-Pres. Taft in special message to Congress asks $\$ 5,000,000$ for fortifying Panama Canal.

13. Portuguese Cabinet crisis averted.-Another earthquake in Russian Turkestan; over 200 killed - Settlement of Atlantic Fisheries Regulations announced from Washington. - South Africa wins third test match against Australian cricketers at Adelaide by 38 runs. - Rembrandt's "Night Watch" in Ryks Museum, Amsterdam, damaged with knife by discharged naval cook.-Robert Caldwell principal witness in Druce case (see $E, B$. xxii, IIod) dies in New York City in insane asylum.

I4. Judgment of High Court of Bombay in Nasik conspiracy case published in London; sentence of transportation for life with forfeiture of property on Savarkar, Indian student, confirmed.-Portuguese railway strike settled; gas-workers on strike in Lisbon ejected by govt. troops.French force ambushed in Morocco; 5 killed, 6 wounded.U. S. battleship "Arkansas," 26,000 tons displacement, aunched at Camden, N. J.

I5. Railway accident at Vire, France; 3 killed.-Three negroes lynched at Shelbyville, Kentucky,-King Alfonso returris to Spain from Melilla.

r6. M. Pichon, in French Chamber, defends the AngloRussian agreement.-Remains of German balloon, "Hilderbrandt " containing bodies of two aeronauts, found under ice in lake in Pomerania.-Keels laid at Pottsmouth and Devonport of two new British battleships, "King George V" and "Centurion."

17. M. Briand, French Premizr, shot at by Jizoline, a madman, in Chamber of Deputies-German submarine $\mathrm{U} 3$ sinks in Kiel harbour; 3 lives lost.-Redistribution of Seats Bill occasions violent scenes in Parliament of Western Australia.-Explosion on U.S battleship "Delaware" causes 8 deaths.-Death of Sir Francis Galton, aged 88

18. The Mutjihids of Nedjif issue manifesto exhorting Sunnis and Shiahis to sink all differences and combine to protect Turkey and Persia from foreign aggression. French Senate pass bill for regulating liquor traffic in France-Dr. Kotoku and 23 others sentenced to death at Tokio for conspiracy against life of Mikado.-Mrs. Horace West wins libel action in the High Court, London, against her father-in-law, Sir Algernon West; damages $£_{\mathrm{I}, 250}$ Colombian troops invade Peruvian territory.-H. Clay Howard (b. I860) of Kentucky appointed U. S. minister to Peru, as successor of Leslie Combs.-Powder explosion at Keating gold'mine, Radersburg, Montana; six lives lost. 19. Ways and Means Committee of the U. S. House of Repregentatives given power to appoint committees.American Institute of Architects closes its 44th annual convention at San Francisco.-Reciprocity Conferences take place between Canadian ministers and U. S'. State Dept.-Chinese Assembly's Constitutional programme published with the 'Throne's modification.-Mr. Percy Simmons, defeated Unionist candidate for St. George's in the East. London, wins $£_{5,000}$ damages for libel from Liberal Opinion-Champagne riots at Epernay, France.Resignation of Pres. Gondra of Paraguay; succeeded by Col. Jara

20, M. Briand, French Premier, speaks in Chamber on the government's relations to the General Confederation of Labour.-Dr. Talbot, Bishop of Southwark, translated to Bishopric of Winchester.-Rioting at Hankau quelled by British and German bluejackets; I2 Chinese killed, I3 wounded.--Ecuador refuses to submit her dispute with Peru to the Hague Tribunal. - Andrew Carnegie adds $\$ 10,000$, $\infty 00$ to endowment of Carnegie Institution of Washington, D. 'C -Dr. H. C. Bumpus (b. I862), director of American Museum of Natural History since I902; resigns.

21. Pres. Taft speaks in New York on the duty of the U. S. to fortify the Panama Canal-Mexican Govt. troops ambushed at Galanea by insurgents, losing 80 dead and 50 wounded.-U.S. War Dept. sends cavalry to Mexican frontier to preserve neutrality of American territory.Rifaat Pasha speaks in Turkish Chamber on RussoGerman Agreement and Bagdad railway.-Wales beats England in Rugby football at Swansea by I5 points to II 22. Honduran gunboat "Horner" seized by U. S. 
cruiser "Tacoma" for violating neutrality.-U. S. Govt. agrees to act as arbitrator in Haiti and Santo Domingo boundary dispute.

23. Accident on Taff Vale Railway, S. Wales; Ir killed, injured.-British Minister at Teheran presents fresh note to Persia, since the three months given her to restore order have expired.- Prof. Edouard Branly elected to the French Academy by 30 votes as against 28 for Mme. Curie.-Mr. D. G. Phillips, American author, shot dead in New York. - Vinoyak Savarkar put on trial at Bombay for abetment of murder of Mr. Jacksom, Indian official at Nasik in December I900-Mahomed Farid, Egyptian Nationalist leader sentenced to six months' imprisonment at Cairo for seditious writings. - Inauguration at Paris of the Oceanographic Institute built by Prince Albert of Monaco.--National Republican Progressive League (of U. S.) organised at Washington.

24. Twelve Japanese anarchists executed at Tokio for conspiracy against life of Mikado.-Lord Gladstone arouses indignation in Rhodesia by commuting death sentence passed on Umtali native for assaulting a white woman.

25. Four troops of American cavalry sent from Fort Sam Houston, Texas, to preserve neutrality on Rio Grande in Mexican revolution.-Lord Curzon installed Lord Rector of Glasgow Uniyersity.

26. Summary of proposed Reciprocity Agreement between Canada and U. S. published at Washington and Ottawa, Pres. Taft urges U. S. Congress to adopt it.Bill providing for adoption of Greenwich time in France read a first time in French Senate--Death of Sir Charles Dilke in London, aged 60.--Monsignor Duchesne elected to French Academy in place of Cardinal Mathieu.-Pres. Taft sends to U. S. Senate special message recommending ratification of treaty of January Io with Honduras for loan from American bankers.

27. Lord Methuen, at King William's Town, South Africa, advises formation of a S. African army.-Port o London Authority publishes improvement scheme, es-

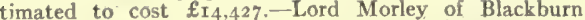
delivers Presidential address to the English Association on "Science and Letters."

28. Duke of Connaught announced to succeed Earl Grey as Governor of Canada.-Constitution and Franchise bills of Alsace-Lorraine read a first time in German Reichstag.-Internat. Rugby football match between England and France at Twickenham won by England, 37 points to nil. - Wales beats Ireland in Association football at Belfast by 2 goals to $x$--Diamond Match Company (U.S.A.) surrenders for general ase patent for harmless friction match.

29. Mexicala captured by Mexican insurgents.-Pres. Alfaro of Ecuador forced to abandon plan to lease Galapagos Islands to U. S. for 99 years.

3o. Duke of Connaught entertained at Guildhall, London, on return from S. Africa.-Eruption of Taal volcano in Lake Bourbon, Luzon, Philippine Is.; 1,300 killed.Bill creating permanent tariff board passed by U. S. House of Representatives 186 to 93-- United Mine Workers of America amend their constitution by requiring call for general strike to be referred to members.

3I. British Parliament meets; Mr. J. W. Lowther elected Speaker for the fourth time.-Sir Wilfrid Laurier speaks in Dominion House of Commons in favour of reforming rather than abolishing the Senate.-German Foreign Secretary and British Ambassador in Berlin sign treaty extending extradition to various British colonies and protectorates.River and Harbour appropriation bill $(\$ 36,000,000)$ passed by U. S. Senate.-Canadian Board of Trade declares (6o-44) against reciprocity.

February:-

I. Dynamite explosion at Jerșey City, U.S.A.; 30 persons killed, 200 wounded, much damage to buildings and shipping.- Trial and conviction in King's Bench Division. London, before Lord Chief Justice, of Edward Frederick Mylius for libelling King George V, by stating that prior to his marriage with Queen Mary he had been morganatically married; sentence I2 months' imprisonment. - "Thun derer," British super-Dreadnought, launched from 'Thames Ironworks.-Annual Conference of British Labour Party at Leicester; Pres. urges reversal of Osborme judgment. Board of Trade enquiry into loss of "Waratą " concluded General lock-out declared by Mastcr Printers' Association in London.

National Convention of Welsh Nonconformists at Cardiff pass resolution demanding disestablishment and disendowment of Church in Wales.-M. Pichon replies in French Senate to criticisms of Anglo-French Treaty of 1004.-Rt. Rev. J. B. Crozier, Bishop of Down, elected Archbishop of Armagh and Primate of all Ireland.-
Revolution in Northern Haïti-Persian parliament au thorises employment of five Americans as financial advisers. -Honduras Congress refuses to approve negotiations for American loan.-Alfred Stedman Hartwell, Chief Justice of Supreme Court of Hawaii, resigns.

3. German Crown Prince arrives in Calcutta.-Sir John Fuller appointed Governor of Madras. - Sir $T$. $G$ Carmichael appointed Governor of Victoria-Mr. Charles Aitken appointed Keeper of Tate Gallery, London, vice Mr. D.S. MacColl, appointed Keeper of Wallace Collection. - Fishing village on ice outside Björkö, Finland, carried out to sea: most of the inhabitants saved. - Sir Joseph Ward, New Zealand Premier, speaks at Wellington, N. Z., on Imperial Defence.-Pres. Taft tenders services of U. S. to assist in restoring peace in Honduras $-20,000$ Chicago garment workers on strike decide to return to work on whatever terms they can make individually.

4. Russian Govt: demand strict precautions in Manchuria to prevent plague spreading into Siberia.-Poisoning case at Dalkeith, Scotland. Mr. Charles Hutchinson and his guests at a supper party seized with illness; two deaths result, and his son Mr. John Hutchinson, disappears (see Feb. Ig).-Wales beats Scotland in Rugby football at Edinburgh by 32 points to ro.

Singer.

6. State opening of British Parliament by King George $\mathrm{V}$, the four self-governing dominions being represented by their High Commissioners.-British Labour Party elect Mr. Ramsay Macdonald as Chairman,-French Chamber pass Govt. Bill for protecting champagne-Archbishop of Canterbury presides at meeting in London to promote friendly relations between England and Germany.Dynamite explosion at Piute Powder Co., Ishpeming. Mich. U.S.A killing I5 men--Sani-ed-Dowleh, Persian Minister of Finance, assassinated.-Sublime Porte, Constantinople, partially destroyed by fire.

7. Ways and Means Committee, U.S. House of Representatives, approves Reciprocity Agreement with Canada. -Mr. Justice Grantham at- Liverpool Assizes defends himself against charges made in House of Commons of partisanship in trying election petitions.-Plague in Manchuria reported to be spreading. - South African cricketers beat Victoria at Melbourne by 8 wickets.-Execution of Gen. Millionard, leader of Haitian revolutionists.

8. Pres. Taft sent to U.S. Senate for ratification a draft treaty with Great Britain for protection of seals in Bering Sea.-Mr. Asquith in House of Commons strongly condemns Mr. Justice Grantham's speech at LiverpoolMexican Govt. troops defeated by insurgents near Mulata. - Pres. Davilla of Honduras and General Bonilla, revolutionary leader, agree to an armistice.

9. Mr. Asquith receives Trade Union deputation on Electoral reform.- Turkey indicates desire to open up pourparlers with British Govt, concerning Mesopotamia and Persian Gulf.-Lord Charles Beresford retires under age rule (65) from Active List of British Navy.-Debate on Reciprocity Agreement with U. S. opened in Canadian Parliament - $£_{20,000}$ contributed by Aga Khan and Nawab of Rampur towards foundation of Mahommedan University at Aligarh.

Io. Royal Commission on Land Transfer Acts publishes final report in London.-Persia's appointment of W Morgan Shuster to reorganise her, finances announced at Washington, D. C

II. Pres, Taft and Mr. Roosevelt speak in defence of Reciprocity Agreement with Canada.-Russia begins to withdraw from Kazvin troops sent there two years before -U. S. Senate follows House (Jan, 3I) in choosing San Francisco as site for Panama Canal. Exposition in I9r 5 Ireland beats England in Rugby football at Dublin by 3 points to nil-England beats Ireland in Association football at Derby by 2 goals to 1 . - Oxford beats Cambridge at Association football in London by 3 goals to 2 .

12. Visit to London of Belgian Minister of Commerce and members of Belgian Executive Committee of Brussels Exhibition.

13. Debate on second reading of German Navy Es timates begins in Reichstag.-Nicaragur placed under martial law after an explosion in govt. barracks, Managua.

14. Arbitration between France and Great Britain concerning escape of Savarkar from Marseilles begun at the Hague-Statue to 8th Duke of Devonshire unveiled in London by Lord Lansdowne. - Railway accident at Courville, France; three trains collide and catch fire, ro killed. - McCall Canadian Reciprocity bill passed by the U. S. House of Representatives 221 to 92 .-Twenty-two men indicted for selling vofes at election held in Menard county, Illinois, in Nov. 19ro. 
15. Sir Edward Grey, Sir Alired Lyall and Sir William Anson elected trustees of British Museum.-U, S. Com merce Court holds its first public session.-Announced at Washington that contracts have been signed by the Honduran envoy and American bankers for a $\$ 7,500,000$ loan to Honduras.

16. Mr. Fielding makes statement in Canadian Parliament on Reciprocity Agreement.-By-election for Cambridge University results in return of Sir J. Larmor (Unionist) - Dr. T. H. Warren, Pres. of Magdalen College, Oxford, elected Professor of Poetry, Oxford.-Juarez, Mexico, placed under martial law.-Russia decides to make military demonstrations against China because of alleged violations of St. Petersburg treaty of $\mathbf{r} 88 \mathrm{I}$.

17. Horncastle division of Lincolnshire by-election results in return of Capt. A. G. Weigall (Unionist), majority 107-Convocation in London passes resolutions deprecating marriage in church of divorced persons and any extensions of facilities for divorce,

18. Chinese Govt. reply to Russian note of protest on disregard of treaty obligations in Chinese Turkestan.Pres. Taft signs bill opening lands to homesteaders in Red Lake Indian reservation, Minn.-Manuel Bonilla with three other Honduran revolutionists, indicted in $U$. $S$. District Court at New Orleans for violation of neutrality laws (see April 22).-Mark Twain Library dedicated at Redding, Conn.-Hoe Art Sale begins in New York.

19. John Hutchinson, charged with poisoning his father and another at Dalkeith, Scotland, arrested in Guernsey, but immediately commits suicide (see Feb. 4).-Japan denounces existing commercial treaty with Canada.

20. Dr. Gregory, Dean of St. Paul's, aged 92, resigns.

21. Train catches fire near Perm, Russia; 7 killed, 32 injured.-Australians beat South African cricketers at Melbourne by 530 runs, and win the rubber-King George $V$ holds his first Levée at St. James's Palace. - China's reply to Russian ultimatum received and approved in St. Petersburg.-Meeting held in Sydney in support of active defence policy and compulsory military training.-Police constable murdered in Calcutta. - Treaty of Commerce and Navigation, operative July 17, I0II for twelve years, signed at Washington by representatives of U.S. and Japan.

22. Parliament Bill read first time in British House of Commons by $35 x$ to 227 - Court of. Inquiry in London decides that "Waratah" capsized on July 28 , ro09, between Port Natal and Cape Town-Canadian Parliament carry unanimously resolution affirming Canada's decision to preserve intact bond of union with Empire and full liberty to control her own fiscal policy.-Wiltshire (Westbury) by-election results in return of Hon. Geoffrey Howard (Liberal), majority 58I.

23. Debate in German Reichstag on second reading of Army Bill.-Lord Minto, ex-Viceroy of India, presented with freedom of City at Guildhall, London.-North Louth election petition, Mr. H. Hazelton (Ind. Nationalist) unseated.-Death of Gen. Lebrun, French Minister of War.-French Chamber of Deputies pass bill for construction of twc battleships.

24. Hague Tribunal finds in favour of Great Britain in the Savarkar case (see Jan. 14). - German Reichstag pass Army Bill.-French Government's majority falls to 16 in debate about clerical legislation. - U. S. Senate ratifies new commercial treaty with Japan.-Lord Rosebery speaks on Dickens at Mansion House, London,-Gloucestershire (Forest of Dean) by-election results in return of $\mathrm{Mr} . \mathrm{H}$. Webb (Lỉseral), majority 3,068 .

25 Court of Appeal gives judgment in favour of plaintiff in case of Osborne v. Amalgamated Society of Railway Servants-Five Bulgarian Ministers charged with systematic violation of the law to their own advantage. Ireland beats Scotland in Rugby football at Edinburgh, $x 6$ points to I0.-In Manila about 300 native dwelling are destroyed by fire.

27. Resignation of French Cabinet under M. Briand - Second reading of Parliament Bill moved in House of Commons by Mr. Asquith; Opposition amendment moved by Mr. A. Chamberlain. - Death of Lord Wolverhampton, aged $8 \mathrm{I}$.

28. Mr. Fisher, Prime Minister of Australian Common wealth, announces that his govt. intends to nationalise monopolies, - British War Office announce organisation of Air Pattalion.

March:-

x. New French Cabinet formed under M. Monis. General Smuts outlines Government proposals for South African defence in Union Parliament.-Pres. Taft approves Appalachian Forest Reserve Act of U. S. Congress. - John Mitchell, former head of United Mine Workers of America, resigns from National Civic Federation.-José Batele y Ordonez elected Pres. of Uruguay.
2. Second reading of Parliament Bill passes British House of Commons by majority of 125 .-British Departmental Committee on Accidents in Factories and Workshops issue report - Conference at Leeds draws up agreement as to working hours for provincial and Irish printing trade-Lord Denman appointed Governor General of Australian Commonwealth.-Gainsborough's "Portrait of the Linleys" and Titian's "Man in a Red Cap" sold in London for $£_{40,000}$ and $£_{30,000}$ respectively.-Henry S Boutell (b. 1856) of Illinois appointed minister to Portugal as successor of Henry T. Gage, resigned.

3. Countess Trigona, recently Lady in Waiting to Queen of Italy, murdered in Rome by Baron Vincenzo di Paterno, who commits suicide.-Sir Edward 'Tennant raised to British peerage as Lord Glenconner and appointed Lord High Commissioner of General Assembly of Church of Scotland.-Pres. Taft signs bill abolishing Federal Circuit Courts, to take effect Jan. I, Ior2.-The Panama Canal fortification bill passed by U. S. Senate.-Suit begun in Cleveland, Ohio, in Federal Court, for dissolution of "Electrical Trust." (See Oct. I 2.)

4. U. S. Congress ends without voting on Reciprocity Bill; Pres. Taft at once calls extraordinary session to meet on April 4 for that purpose.-U.S. Senate passes permanent tariff board bill with amendment, but it is killed by filibustering in the House (see Jan. 30).-Chinese Government notify Russian Government that they no longer desire revision of Treaty of 1881 . - Jubilee of emancipation of Russian serfs celebrated in St. Petersburg.-Honduran Congress appoints Francisco Beltian provisional President.

5. Fire at cinematograph exhibition in wooden building at Bologoe, between St. Petersburg and Moscow; over 90 killed, 40 injured.-Block of buildings at. Minneapolis, Minn., destroyed by fire, with a loss of about $\$ \mathbf{I}, 000,000$.

6. At Detroit, Mich., seven persons are indicted for conspiracy to defraud of 48,000 acres of coal lands in Alaska.-Mexican insurgents repulsed at Asas Grandes.The Association football match between Wales and Scotland results in a draw.

7. Mr. Asquith informs Welsh deputation that after the Parliament Bill is passed Welsh Disestablishment will take front place in Liberal programme.-Australia wins fifth test match against South African cricketers by 7 wickets.R. A. Ballinger, U. S. Secretary of the Interior, resigns from cabinet; Walter L. Fisher (b. 1862) of Chicago is appointed his successor.-About $20,000 \mathrm{U}$. S. troops ordered to San Antonio and other points on Mexican border and four cruisers hurried to Galveston.

8. Debate on Declaration of London in British House of Lords.-Debate on Bagdad railway and on Canadian Reciprocity agreement opened by Mr. Balfour in British House of Commons. - Free Church Council at Portsmouth pass unanimous vote in favour of Welsh Disestablishment. 9. By-election in Bootle division of Lancashire results in return of Mr. Bonar Law (Unionist), majority 2, I94.By-election in N. E. Lanarkshire results in return of $\mathrm{Mr}$. $J_{6}$ D. Millar (Liberal), majority $\mathbf{I}, 200$ - - Mr. Borden's amendment to refer Reciprocity agreement to electorate defeated in Canadian parliament by. III votes to 70 .Lord Howard de Walden wins law suit in King's Bench Division, London, against Mr. John Lewis, draper, for affixing defamatory placards on houses on the Howard de Walden estate; damages one farthing.- Seillière art sale begins in Paris and results in total of over $£_{52}, 000$. Pres. Taft assures Pres. Diaz that no action by the United States against Mexico is indicated by the mobilisation of 30,000 American troops on Mexican frontier.

ro. Greenwich time adopted in France and Algeria.Russian police confiscate 30,000 copies of Tolstoy's collected works.-Martial law declared in Paraguay.

II. Trial of 30 Neapolitan Camorrists, charged with murder of Gennaro Cuocolo and his wife on June 5, I006, begins at Viterbo--Rioting in Athens over attempt to insert amendment in Constitution requiring exclusive use in public offices and churches of a "purified literary language."-Turkish Foreign Minister makes proposals to Great Britain with regard to Persian Gulf and Bagdad railway, - Sir Joseph Ward, New Zealand Prime Minister. speaking at Sydney, advocates an Imperial Council and graduated contributions to an Imperial fleet.-Shipbuilding strike at Edinburgh terminated after 7 months. - Wales beats Ireland in Rugby football at Cardiff by 16 points to nil.-Fourteen men killed by landslide on property adjoining Norman open pit iron mine at Virginia, Minn.

12. Mexican insurgents defeated at Agua Prieta by Government troops.

13. Further Russian troops withdrawn from Kazvin, Persia - - Sir R. Henderson reports on naval defences of Australia.-Lord Rosebery speaks on Scottish industries at 
Mansion House, London.-Sir Edward Grey speaks in British House of Commons in favour of Peace Treaty with America.-England beats Wales in Association football at New Cross by 3 goals to none.-Constitutionality of Federal corporation tax affirmed by U. S. Supreme Court.

34. London Associated Chamber of Commerce resolve that Declaration of London ought not to be ratified.-Russian minister in Peking presents ultimatum to Chinese Government complaining of unfriendly attitude of China to Russian trade.-First aerial post arranged at United Provinces Exhibition, Allahabad, India.-Mr. Edward White elected chairman of London County Councit.Stinie Morrison, baker, sentenced to death at Central Criminal Court, London, for murder of Leon Beron on Clapham Common on January Ist.-Dixon sate of silver plate begins at Christie's.-The Chicago Art Institute receives from Edward B. Butler $\mathbf{8} 8$ paintings by Inness. - In Vermilion county, 111. grand jury retarns 38 indictments, 14 of them dealing with electoral corruption (see April r9)

I5. North Louth (Ireland) by-election results in return unopposed of Mr. Augustus Roche, Nationalist, in place of Mr. R. Hazleton (N.), unseated on petition.

16. Delimitation of Franco-Turkish frontier between French Sudan and Tripoli and between Tunis and Tripoli arranged.-Federal grand jury in Chicago indicts promoters of Alaska Central Railway for conspiracy to get title to 10,000 acres in Matanuska coal-field.

17. First appearance of a woman, Anna Rogstad, as Deputy in Norwegian Storthing.-Cunard company acquire Thomson line of steamships from London to Canada.

18. Resignation of Signor Luzzatti and Italian ministry. -Death of race-horse "Flying Fox," former winner of the Derby, in France-Roosevelt storage dam in Arizona (capacity I, 284,000 acre-feet) formally opened.-Scotland bent Ireland in Association football by 2 goals to 0 , and England beat Scotland in Rugby football by 13 to 8 .

19. China returns conciliatory reply to Russian demands. 20. Seditious Meetings Bill made permanent by Legislative Council at Calcutta--Monarch Refrigerating Co. warehouse, Chicago, III., destroyed by fire, with loss of about \$ I, , , , ,

21. King George receives deputation of representatives of Protestant Churches on occasion of Tercentenary of the Authorised Version of the Scriptures.-Sir Evelyn Wood appointed Chief Constable of the Tower of London.Turkish loan of $£ 6 ; 000,000$ over-subscribed in Berlin.Debate in British House of Commons on circular issued by $\mathrm{Mr}$. Holmes, late Chief Inspector of Elementary Schools, advising appointment of University men as Inspectors.

22. Pres. Taft explains that presence of American troops near Mexican frontier is only precautionary.-Rioting in $\mathrm{S}$. Wales in connection with miners' strike.-Mr. Alfred Parsons elected full member of the Royal Academy, London. 23. Centenary of National Society, London; Mr. Balfour speaks at Mansion House-Brentiord by-election results in return of Mr. W. Joynson Hicks, Unionist, unopposed.

24. German Emperor and Empress visit Austrian Emperor at Viehna.-Mexican Cabinet resigns.-Mr. Haldane, British Secretary for War, raised to the peerage as Viscount Haldane.-Departmental Committee on Law of Pilotage issue report in London:- Mr. Lewis Harcourt and Lord Esher appointed trustees of new London MuseumMukerji, Indian youth, sentenced at Calcutta to ' 4 years' imprisonment for bomb-throwing.-Race for Grand National at Liverpool won by Mr. F. Bibby's "Glenside." Judge Speer of U. S, Circuit Court, Savannah, Ga., fines Merchants' and Miners' Transportation Company $\$ 20,000$ for discrimination.

25. Sittings of Duma and Russian Council suspended for three days with view of passing Zemstvo Bill.-Dr. Armitage Robinson, formerly dean of Westminster, installed as dean of Wells.-Señor de la Barra becomes Minister for Forejon Affairs in Pres. Diaz' new Mexican cabinet.-Fire in factory of Triangle Waist Company, New York; r47 girls killed (see Dec. 7)-Cambridge wins Oxford and Cambridge Athletic Sports in London by 6 events to

27. Italian Jubilee celebrations begin in Rome.-Russia presents ultimatum to China.-M. Guchkoff, President of Russian Duma, resigns. - General Committee of King Edward Memorial adopt scheme for statue and alterations in St. James's Park, which rouses much opposition and is finally postponed. - Fire in picture palace at Middles. brough, Yorks.; 2 children killed, 15 injured.-Señot Madero, leader of Mexican rehels. refuses to lay down arms until Pres. Diaz is displaced.- Louis Duveen and Joseph I. Duveen. Loniton art dealers, fined $£_{2}, 000$ each in New York for evading American customs duties on objects of are.
28. Loss of Australian coastal steamer "Yongala" with all on board on Barrier Reef, of Queensland; crew 70 , passengers 68.-Russian Duma and Council resume sittings, and attack action of $\mathbf{M}$. Stolypin in advising the Trar to enact Zemstvo Bill.-Russo-Chinese difficulty settled by Chinese concessions.

20. Tercentenary of Authorised Version of Bible celebrated in Albert Hall, London; speeches by Archbishop of Canterbury, Mr. Asquith and Mr. Whitelaw Reid.Fire in Capitol, Albany, N. Y.; damage $\$ 5,000,000$

30. New Italian Ministry formed under Signor Giolitti. " "The Monarch," British battleship, launched at Elswick on Tyne-German Imperial : Chancellor, :spealsing in Reichstag, states that schemes of disammament or limita tion of armaments are impracticable, but that England and Germany have agreed to exchange information as to shipbuilding programmes:- Rioting in wine districts of Aube, France; military called out.

3I. Lötschberg tunnel between Kandersteg and Rhone Valley completed.-Mr. R. Mathias; Liberal M.P. for Cheltenham, unseated because his agent had made a false return of expenses.--Modak, Indian youth, bentenced at Bombay to 7 years' transportation for bomb-throwing at Kolhapur.-Murder of Mr. Noel Williamson and Dr. Gregorson by Abors, Indian frontier tribe.

April:- -

I. Spanish ministerial crisis; resignation of Canalejas Cabinet averted - Fez, Morocco, besieged by rebel tribes Albanian rising spreads along Turco-Montenegrin border. -Mexican Congress reassembles; Pres. Diaz promises reforms-Oxford and Cambridge boat-race at Putney results in victory of Oxford by $23 / 4$ lengths. - England and Scotland play drawn match in Association football at Liverpool.-Sir Hamilton Goold-Adams appointed High Commissioner for Cyprus.

2. Decennial census taken in United Kingdom; women suffragists attempt to evade enumeration.-Berber attacks on Fez repulsed.

3. General revolt of Moorish tribes from Taza to the Atlantic.-Dublin Corporation reject motion in favour of presenting address to King George when he visits Dublin. - Railway accident near Westbourne Park, London; killed, several injured.-Lord Roberts brings: forward motion in House of Lords respecting military defence of British Empire; carried next day by on votes to 40.Progress of Parliament Bill in British House of Commions accelerated by use of new "Kangaroo". closure, enabling chairman of Committee to make a selection among amendments to be discussed. - United States and Great Britain agree to arbitrate Webster claim.-Great Britain and Japan sign new commercial treaty.-Albanian insurgents defeated by Turkish troops at Scutari.-David Davies the "Dartmoor Shepherd " arrested at Llan-y-mynech for housebreaking.-U. S. Supreme Court holds that commodities clause of Hepburn Act prohibits railroads from operating coal mines.-Benjamin F. Bush, Pres. of Western Maryland Ry., chosen Pres. of Missouri Pacific Ry., as successor of Geo. J. Gould.

4. U. S. Congress meets in extraordinary session to deal with Reciprocity Agreement with Canada; Champ Clark (Dem.) chosen Speaker of House of Representatives.-Mr. Fielding, Canadian Minister of Finance, delivers Budget speech in Dominion House of Commons, and estimates record surplus of $£ 6,100,000$. - Prince Arthur of Connaught invests Prince Regent of Bavaria with Order of the Garter. - British House of Commons enters on Committee stage of Parliament Bill,-Japanese-American commercial treaty ratified in Tokio.-Charles D. Hilles becomes Sectietary to U. S. President,-Carter H. Harrison elected mayor of Chicago.

5. German Crown Prince and Princess arrive in Rome. - Centenary of death of Robert Raikes, founder of Sunday Schools, celebrated in London and Gloucester.-Death of Mr. Moberly Bell, managing director of the Times, London, aged 64.-Treaty of Commerce and Navigation between U. S. and Japan proclaimed (see Feb. 2I).

6. Council of Russian Empire adopt interpellation regarding enactment of Zemstvo Bill by ukaz. - Signor Giolitti, in Italian Chamber, outlines ministerial policy including electoral reform, payment of deputies, and workmen's pensions - Bill to incorporate Imperial Steam ship (ompany, which aims at an All-Red Route, passed by Canadian Senate-Explosion in Banner Mines, Littleton, Ala., causes death of 128 miners, mostly convicts. 7. M. Jean Cruppi, French Foreign Minister, speaks in Senate on foreign relations of France. - Free Trade Union conference in London: Mr. Winston Churchill speaks. Sale of old r 7 th century silver at Christie's; two porringers fetch $£_{1,000}$ and $£_{2,000}$ - Copyright Bill read secorid 
time in British House of Commons.-Turkish troops near Scutari defeated by Albsnian insurgents. -73 men and boys lose lives in fire at Price Pancoast Colliery, Throop, Lackawanna $\mathrm{Ca}$., $\mathrm{Pa}$.

8. Opening of Archaeological Exhibition in Rome.Fire in a wooden building at Poona during Ramuavi festival; 200 persons reported burnt-Mr. Winston Churchill wins action for slander against Mr. T. B. Spencer, who had charged him in an election speech in Devonshire with having broken parole in escaping from Pretoria during Boer. War. - Portrait by Hoppner sold at Christie's for 6,200 guineas. - Fez attacked by Berber force, 7,000 strong. -Judgment of Circait Court, Connecticut, in case of Danbury; Conn., hatters and Union of United Hatters of North America, awarding about $\$ 232,000$ for damages sustained by alleged boycott, is set aside by Circuit Court of Appeals, on a-writ of error:- 5 oth ansiversary of founding of Massachusetts Institute of Technology celebrated in Boston by congress of Technology,-Right of U. S. to arrange reciprocal tariff with Canada affirmed by new Court of Customs Appeal.

10. Despatch of Indian force to Assam frontier to punish murder of Mr. Noel Williamson and his companions by Abor tribe.-M. Monis, French Premier, announces that Government intend to proceed with delimitation of champagne area, but French Senate condemn this policy by a large majority.-Shah of Persia gives $£ \mathrm{r}, 000$ towards erection of Mahommedan mosque in London.

II. M. Jaurès produces scheme for Socialist organisation of France in Chamber of Deputies--Exeter election rẹcount results in seating of Mr. Duke, Unionist, by one vote, in place of Liberal.

12. Champagne riots renewed at Epernay, France; military called out.-British Home Secretary commutes death sentence on Stinje Morrison, convicted of murder of Léon Béron, to penal servitude for life.-Rebel tribes defeated by Moroccan troops outside Fez.-Democratic majority in U. S. House of Representatives decide to pass Canadian Reciprocity Bill as soon as possible.-M. Hamon, Director of Accounts at French Foreign Office, dismissed and arrested-M. Pierre Prier, French airman, flies from London to Paris without a stop.-British House of Commons rises for Easter recess.--Towns of Big Heart, Okla. and Whiting, Kan., nearly destroyed by heavy windstorms.

13. Fighting between Mexican troops and insurgents; insurgents capture Agua Prieta.-U. S. House of Representatives votes 296 to 16 in favour of the direct election of U. S. senators.

14. Lord Haldane appointed to Judicial Committee of Privy Council vice Lord James of Hereford, resigned.Religious procession through streets of London to St. Paul's, headed by Bishop of London.-British Social Democratic Party's conference opens at Coventry.Resignation of Dr. D. Jayne Hill American ambassador in Berlin,-Bill providing for publicity of campaign contributions before and after national elections, and limiting expenses of candidates, passed by $U$. S. House of Representatives.-Dr. D. K. Pearsons, American philanthropist, on his grst birthday, gives to colleges $\$ 300,000$

15. French Chamber adjourns after passing Finance Bill.-British warship ordered to Delagoa Bay owing to political disturbances there.-Pres. Taft orders American cavalry to Arizona to protect property on Mexican border. - Loan of $£_{10,000,000}$ to China arranged by American, British. French and German bankers.

17. Report of Select Committee on Educational System of South Africa issued at Cape Town.-Annual Shakespeare festival begins at Stratford-on-Avon.-Independerit Labour Party's conference opens at Birmingham-Residents of Douglas, Arizona, wounded by bullets from engagement between Mexican troops and insurgents; United States troops cross frontier and stop conflict.-Daughters of the American Revolution convene at Washington in 20 th continental congress.

18. Protocol signed by Bolivia and Peru agreeing to submit any difference arising among Mixed Delimitation Committee to Royal Geographical Society, London.-Mexícan Government promises Pres. Taft to restrain fighting near American border-Monument, by J. Maxwell Miller, unveiled in grounds of St. John's College, Annapolis, Md. in memory of French soldiers and sailors "in the struggle for American independence.

ro. Portuguese Govt. decree complete separation between Church and State--Portuguese mail steamer, "Lusitania," wrecked off Cape Point", passerigers and crew rescued by H.M.S. "Forte"; 3 lives lost.-Mexican insurgents capture Santiago Pupasguinvos and propose an armistice.-M. Chedanne, French Foreign Office architect arrested.-Six persons sentenced at Howrah, India, to terms of imprisonment for conspiring against the King Emperor.-French Govt. instruct Gen. Moinier at Shawia, Morocco to comply with Sultan of Morocco's request to send native troops to Gharb district-By-election at Had dington results in return of $\mathbf{M r}$. J. D. Hope (Liberal), majority 468-Colonial Secretary announces in British House of Commons that Colonial Premiers will be invited to sttend meeting of Imperial Defence Committee.Amundsen Polar expedition's ship "Fram" arrives at Buenos Aires.-City and Suburban Handicap at Epsom won by Mr. T. Baring's "Mushroom." - Vermilion county Ill., grand jury return nine corrected indictments against persons indicted on March I4 - Completed choir of Cathedral of St. John the Divine at New York consecrated by Bishop Greer.

20. Report of Adm. Sir R. Henderson on Australian Commonwealth fleet published in London.-First railo phone for wireless telegraphy to and from moving trains established at Stratford-on-Avon.-French Govt. informs Spanish ambassador at Paris of its intention to send an armed force to $\mathrm{Fez}$.

2I. Pres. Fallières arrives at Sfax, Tunis.-U. S. House of Rep. pass Reciprocity Bill by 264 votes to 80 . - Mr. John Redmond, speaking at Holyhead, declares that the Irish Party will support Wélsh Church Disestablishment.

22. Railway accident at Blaauwkrantz Bridge, South Africa: 30 killed or fatally injured $-D r . W . R$. Inge appointed Dean of 'St. Paul's, London-British team win Anglo-American chess match played by cable.-Final tie for Football Assoc. Cup at Crystal Palace, London, results in draw between Bradford City and Newcastle United Pacific Mail steamer, "Asia," attacked by Chinese pirates after being wrecked on Finga Rocks in China Sea.-Indictments of February r 8 against Bonilla and other Honduran revolutionists dismissed.

23. Four days armistice concluded between Mexican Govt. and insurgents to discuss terms of peace.-First constitutional election held in Monaco.

24. British House of Commons reassembles and resumes Committee stage of Parliament Bill-Dr. H. M. Burge, Headmaster of Winchester College, appointed Bishop of Southwark.-Edict issued in Peking notifying cessation of plague after a death-roll of 60,000 .- Curt is Guild (b. 1860), governor of Massachusetts roo6-on; appointed U. S. ambassador to Russia.-William Woodville Rockhill (b. 1854) appointed $\mathbf{U}$. S. ambassador to Turkey as successor of Oscar S. Straus.-Henry S. Boutell of III appointed U.S. minister to Switzerland-By an explosion in mine No, 20 of Davis Coal and Coke Company at Elk Garden, W. Va., 23 miners lose their lives.

25. Imperial Education Conference opened in London: speech by Mr. Runciman. - Letters from King George $V$ and Pres. Taft read at Tercentenary Bible celebration at New York - In Hoe Library sale in New York, Gutenburg Bible sold for $f$ ro,, 00 . - Australia reduces rate of postage to all parts of the British Empire to $I d$. the half-ounce. Day census taken of City of London gives a total of 362,742 , being 61,358 more than in 1001 .

26. Amendment to Parliament Bill providing for Referendum rejected in British House of Commons by 286 votes to 164,-Canadian Copyright amendment bill introduced in Dominion Parliament.-Miners Federation of Great Britain decide to submit dispute in South Wales coalfield to árbitration.-Final tie for Football Assoc. Cup (England) won by Bradford City against Newcastle United, one goal to nothing.-Race for the Two Thousand Guincas at Newmarket won by M. J. B. Joel's "Sunstar."-Floods at Buenos Aires; much damage and some loss of life.-French relieving force under Major Brémond teaches Fez.-First Blind Workers' Exhibition in the world opened in New York by Pres. Taft.

27. French Govt. inform Powers signatory to Act of Algeciras of measures adopted for relief of Fez.-Persian Govt. defeated on British Loan Bill.-Mr. Asquith informs deputation from House of Commons that he will bring their memorial urging creation of an Advisory Imperial Council before Imperial Conference.-Australian Referendum returns show majorities of about 200,000 against Constitutional Amendment and Monopolies questions.-Laurits S. Swenson (b. 1865) of Minnesota appointed U. S. minister to Norway, as successor of Herbert H. D. Peirce.-U. S. Senator Frye of Maine resigns as president pro tempore of Senate; and Reapportionment bill, increasing membership to 433 , is passed by House. -15 th annual art exhibition opens at Carnegie Institute, Pittobutg. Pa.; John White Alexander's painting "Sunlight" awarded medal of first class.

28. Mr. Asquith and Mr. Balfour speak at Lord Mayor's Meeting, Guildhall, London, in support of Anglo-American 
Arbitration Treaty.-Pres. Tait, speaking in New York, states that Reciprocity with Canada will never again have such a favourable opportunity.-By-election at Cheltenham results in Unionist victory for Mr. Agg-Gardner; majority 4--Railway accident at Martin's Creek, Pa.; II killed, 35 injured. - Chinese riots at Canton; govt. offices burnt.

20. Turia International Exhibition of Industries opened by King and Queen of Italy,-Dr. Ryle, late Bishop of Winchester, installed as Dean of Westminster.-British battleship, "Princess Royal," launched at Barrow-inFurness by Duchess of Fife.-British expedition against Tong tribes on Gold Coast reported successfully concluded. 30. Fire at Bangor, Maine; 3 lives lost and damage estimated at $\$ 3,500,000$.

May:

r. British warship "Conqueror," largest Clyde-built vessel, launched at Dalmuir.-Meeting at Mansion House, London, to inaugurate Anglo-German Friendship Society.E. Barry wins Sculling Championship of England.-Five small towns near Canton taken by Chinese insurgents.-U. S. Supreme Court decides that Federal government, not states, control forest reserves.

2. Prize of $\$ 10,000$ for American opera offered by Metropolitan Opera Company, of New York, awarded to Horatio W. Parker and Brian Hooker for "Mona."

3. South Birmingham by-election results in return of Mr. L. S. Amery (Unionist) unopposed.-Autograph sale at Leipzig; Mr. J. Pierpont Morgan gives $£_{5,000}$ for a letter of Martin Luther to Charles V and presents it to the German Emperor.-Mr. J. Lowther, Speaker of British House of Commons, celebrates silver wedding.

4. Mr. Lloyd George introduces National Health Insurance Bill in British House of Commons.-Peace negotiations begun between Pres. Diaz and Mexican insurgents. -Protest made in Anglican House of Convocation against Bishop of Hereford's invitation to Nonconformists to be present at Holy Communion in Hereford Cathedral on June 28.-Congress of Internat. Law, Madrid, confirms right to use aerial craft in war--British army airship wrecked on Farnborough Common, Surrey.-Sir Edward Grey speaks in British House of Commons on AngloAmerican Agreement. - Capt. John Henry Gibbons, U.S.N. assigned to duty as superintendent of Naval Academy at Annapolis, Md.

5. Sir G. Kemp's Womens' Enfranchisement Bill passes second reading in British House of Commons by 255 votes to 88 - Conservative protest in Dominion House of Com mons against U. S. proposed changes in Fishery Regula tions.- Scarcity of food and fear of popular rising reported from Fez.-Anglo-Japanese commercial treaty ratified at Tokyo. - Third National Peace Congress, at Baltimore, Md. endorses James Speyer's plan for financial neutrality during war.

6. Mr, Borden, Canadian Opposition leader, speaking at dinner to Premiers of British Columbia and New Brunswick, attacks Reciprocity Agreement with AmericaPeace negotiations in Mexico suspended.-Mr. Asquith speaks at Manchester on Parliament Bill-Barnstaple by-election results in return of Sir George Baring (Liberal) majority 488. - M. Vallon, French airman, killed at Shanghai.-Mr. G. Hamel wins aeroplane race, Brooklands to Brighton, in $57 \mathrm{~min}$. $10 \mathrm{sec}$.

8. British and Chinese Govts, sign agreement in Peking to decrease Chinese production of opium and its import from India in equal proportions for seven years. - Chinese Grand Council abolished and Cabinet of ten created by edict, with Prince Ching as Premier.-Congregational Union's Annual Assembly opens in London.-Internat. Cotton Congress opens in Barcelona.-Lord Lansdowne's Reconstitution of House of Lords Bill introduced.--Germany warns France of possible serious consequences of an occupation of Fez.-After debate of two weeks, Farmers Free List bill, without amendment, passed by U. S. House of Representatives, 236 to 109.-Dr. Frederic A. Lucas appointed director of Museum of Natural History, New York City.-Fairbanks, Alaska, flooded by breaking of ice dam.

9. M. Berteaux, French War Minister, speaks in Chamber on delay in relieving Fez.-High Court London, decides that Form VIII, issued under Budget Act (1900-10) is invalid.- Fire at Empire Theatre, Edinburgh, causes loss of ten lives, including Lafayette, music-hall illusionist

10. Juarez captured by Mexican insurgents; garrison made prisoners.- $M$. Stolypin in Russian Duma defends Government use of Emergency Clause in Constitution.

II. German Reichstag rejects Alsace-Lorraine Constitution Bill by $\mathbf{1} 3$ votes to $\mathbf{1 2}$. $-\mathrm{Mr}$. Balfour, speaking at Primrose League demonstration in Albert Hall, London, defends Lord Lansdowne's Bill for Reconstitution of House of Lords.

12. Rioting at Zürich in connection with builders strike.-Festival of Empire inaugurated at Crystal Palace, London, by King George and Queen Mary.-Demonstra. tion of military aerial flying at Hendon, Middlesex. Dubof, Peters and Rosen, accused of being concerned in burglary and murder of policemen at Houndsditch (Dec. 16, 1910), acquitted at Central Criminal Court, London; Nina Vassilieva, convicted of being accessory after the fact, sentenced to two years' imprisonment.

13. Pres. Taft, speaking in New York, contrasts American administration of criminal law unfavourably with that of England.-Demonstration against Holmes circular organised at Albert Hall, London, by National Union of Teachers (see March 21). -American Geographical Society removes to new building in New York City, gift of Collis $\mathbf{P}$. Huntington.

14. Dedication of memorial at Addington, Surrey, to five Archbishops of Canterbury.-Internat. Institute of Agriculture holds general assembly at Rome.

15. German Emperor and Empress and their daughter arrive in London.--Motion for rejection of Parliament Bil in British House of Commons negatived by 363 votes to 242 ; third reading carried by 362 votes to 241 . - U. S . Supreme Court orders dissolution of Standard Oil Company within six months. - Supreme Court sets aside sentences of imprisonment passed in 1009 on Federation of Labour leaders-Prince Lidj Jeassu proclaimed Emperor of Abyssinia.-Peace negotiations resumed between Gen. Madero and Mexican Government party in Mexico

16. Queen Victoria Memorial in London unveiled by King George in presence of German Emperor and Empress. -Mr. Lloyd George introduces Budget in British House of Commons-Celebration at Dublin and Aldershot of centenary of battle of Albuera.-German airship "Deutschland "wrecked at Düsseldorf.-U. S. House of Representatives appoint a Committee under Augustus $O$. Stanley, Kentucky, to investigate affairs of Steel Trust.-Nomination of Henry L. Stimson (Rep.), of New York, as Secretary of War to succeed Jacob M. Dickinson (resigned May. 12), confirmed by U. S. Senate.-Sale of the $\$ 50,000,000$ Panama Canal bond issue is opened to the U. S. public.

17. U. S. Secretary of State Knox submits to British and French ambassadors draft of general arbitration treaty. - Arrangement in regard to prices and taxes on potash at Hamburg momentarily settles dispute between $\mathrm{U}$. S. and Germany.

18. Prince Arthur of Connaught opens Coronation Exhibition at White City, Shepherd's Bush, London. MM. Pierre Marie and Paul Dupuy, French airmen, killed at Bethény, near Rheims, France--Ring given by Queen Elizabeth to Lord Essex sold at Christie's for 3,250 guineas. -Debate in British House of Lords on Canadian Reciprocity Agreement.-Mr. Roosevelt declares in the Out look that U. S. ought not to bind itself to arbitrate questions of national honour, independence, and integrity.

8. Temporary tariff agreem int with Japan passed by Canadian House of Commons.-Portrait by Raeburn sold at Christie's for 22,300 guineas. - Nottingham election petition against return of Capt. J.A. Morrison (Unionist) dismissed.-U. S. Grovt. begins suit at New York against so-called Lumber Trust.

20, American, British, French and German bankers sign a $\mathcal{f}_{\mathrm{I}}, 000,000$ loan in Peking to be applied to construction of Chinese railways.-German Emperor and Empress leave London.

2x. M. Berteaux, French War Minister, killed, and $M$ Monis, Premier, injured by fall of an aeroplane at Issyles-Moulineaux near Paris.French relief column under General Moinier enters Fez; Mulai Hafid's Moorish troops commit wholesale outrages on neighbouring villages. Peace signed at Juarez between Mexican Govt. and insurgents.

22. East Cork election petition results in unseating of Captain Donelan (Nationalist) for illegal payments.German Reichstag passes second reading of Workmen's Insurance Consolidation and Amendment Bill.-Lord Lansdowne's Reconstitution of House of Lords Bill read a second time in House of Lords without a division.British naval airship launched at Barrow-in-Furness.

23. Imperial Conference opened in London under presidency of Mr. Asquith.-Meeting at Albert Hall, London in support of Imperial Preference--New York Public Library on Fifth Avenue opened.-General strike at Montevideo, Uruguay.-At dinner to Colonial Premiers, London, Sir Edward Grey proposes toast of Anglo-American Arbitration.-Russia warns Turkey that concentration of troops on Montenegrin frontier is a menace to peace. 
24. Cunard liner "Ivernia" strikes on Daunt's Rock, near Queenstown, Ireland; mails and passengers saved.-? Henry J. Duveen, London art dealer, fned $£_{3,000}$ in New York for evasion of American customs duties on objects of art.-Pres. Taft refuses to pardon Charles W. Morse, of New York, and John R. Walsh, of Chicago, convicted bankers,-Edwin V. Morgan (b. I865) of New York appointed U. S. minister to Portugal as successor of Henry S. Boutell.

25. Resignation of Porfirio Diaz, Pres. of Mexico; Francisco Léon de la Barra chosen provisional president. - Provisional census returns published for England and Wales, showing increase of population of ro.9r per cent.Walter Benson, British airman, killed at Hendon.-U. S. battleship "Wyoming," 26,000 tons displacement, launched at Philadelphia.

26. German Reichstag passes Alsace-Lorraine Constitution and Franchise Bills.-Provisional census returns published for Ireland, showing decrease of population of 1.7 per cent.--Collision between British cruiser "Inflexible" and British battleship "Bellerophon" in Solent; both vessels damaged.-M. Védrines, French airman, wins $\mathbf{P}$ aris to Madrid race, 727 miles in 12 hrs. $18 \mathrm{~min}$.

27. I0,000 boys and girls take part in pageant of Empire held in Hyde Park, London.-Dominion Premiers entertained by Eighty Club, London; Mr. Lloyd George speaks-Cardiff conference of South Wales miners rejects terms of settlement in Cambrian Coal Trust dispute.French Govt. express sympathy with Russian note to Turkey on Montenegrin question (see May 23). - Investigation of U. S. Steel Corporation begun by Stanley committee, (see May 16).-Rt. Rev. Edmond F. Prendergast appointed Roman Catholic Archbishop of Philadelphia.- "Dreamland," Coney Island, N. Y., amusement resort, destroyed by fire.

29. National Insurance Bill passes second reading in British House of Commons.-Parliament Bill passes second reading in House of Lords without a division--U. S. Supreme Court decides that Tobacco Trust is a combination in restraint of trade and directs its dissolution within six months.-Pope issues Encyclical condemning anti-religious attitude of Portuguese Republic.-Portuguese elections result in Govt. victory.-Japan and Russia express desire to share in Four Powers $£$ ro, 000,000 loan to China (see May 20).-Death of Sir W. S. Gilbert, British dramatist, aged 74 .

30. King George sends message of congratulation to South Africa on anniversary of establishment of Union.Internat. Musical Congress opens in London: Mr. Balfour speaks.-General Assemblies of Church of Scotland and United Free Church discuss question of union.-Workmen's Insurance Bill passed by German Reichstag by 232 votes to 58 .

3I. White Stat liner "Titanic" launched at Belfast (see April 15, ror 2).-Explosion at Laloma, Nicaragua; I 50 persons killed.-M. Beaumont, French airman, wins Paris to Rome aeroplane race.--Mr. J. B. Joel's "Sunstar" wins the Derby at Epsom.

June:-

x. Turkish forces resume operations against Albanians. -Imperial Conference begins two days' discussion of Declaration of London, which is finally approved.- $\mathrm{Mr}$. Lloyd George attends special meeting of British Medical Association, London, to discuss National Insurance Bill.-Hull (Central) election petition results in unseating of Sir H. S. King (Unionist) - - Pres. Taft speaks at Chicago in favour of Canadian Reciprocity.-Underwood bill, providing for a $50 \%$ reduction in tariff on wool, endorsed by Democratic caucus in U.S. House of Representatives.

1. British Govt. refuse to receive Moorish Embassy at Coronation of King George owing to cruelties of Shereefian troops near Fez.-Mr. W. Broderick-Cloete's "Cherimoya" wins "The Oaks" at Epsom.

3. Mirdites, Albanian tribe, revolt against Turks and proclaim autonomy of Albania.-Lt. C. A. Cameron and his wife sentenced at Edinburgh to three years' penal servitude for fraudulent insurance of a necklace, afterwards alleged to have been stolen.

4. King of Italy unveils equestrian statue of Victor Emmanuel II in Rome--Portuguese Govt announce readiness to waive some part of Separation Law (Church and State).

5. Sultan of Turkey visits Salonika.-Keel laid at Glas gow of Cunard liner "Aquitania," largest British mercantile vessel_-Lt. Bagne, French military airman, lost in Mediterranean while flying to Tunis - - Eugene A. Noble (b. 1865), president of Goucher College, Baltimore, Md., 1008-1x, elected president of Dickinson College, Carlisle, $\mathrm{Pa}$.
6. King Ferdinand of Bulgaria visits Emperor of Austria at Schönbrunn.-Tazzia, Moorish pretender, defeated neas Alcazar.-Death of M. Rouvier, former "renier of France.

7. Earthquake at Mexico City; 63 killed, 75 injured.Reorganisation of Portuguese Foreign Office decreed. Germany warns France that Moroccan sovereignty must be respected.-Further rioting in champagne districts of France.

8. Resignation of Belgian Cabinet under M. Schollaert owing to failure of Education Bill. -Finance Committee of U.S. Senate report Reciprocity Bill, with Senator Root's amendment appended.- Spanish troops land at Larache, Morocco, and march to Alcazar; Moorish Govt. protes against violation of their territory - Birkbeck Bank London, suspends payment.-Pageant of London opened at Crystal Palace by Prince Arthur of Connaught. Federal investigation of so-called "Coke Trust" begun at Pittsburg, Pa.-Pres. Taft sends to U. S. Senate message recommending loan contract with Nicaragua.

9. At Meadow Brook, Long Island, N. Y.. America beat England in second polo test match, thus retaining the Cup. - Herr Schendel, German airman, and passenger killed at Berlin.-U. S. Senate committee on Foreign Relations approves loan of $\$ 10,000,000$ by American bankers to Nicaragua.

ro. Prince of Wales invested with Order of Garter.Grrman battleship "Friedrich der Grosse" launched at Hamburg.-Honorary degrees conferred at Oxford on premiers of New Zealand, South Africa and Newfoundland. -Mr. Lloyd George speaks at Orford on National In surance Bill.

Ix. American squadron of four battleships welcomed at Kronstadt by Russians.

12. France announces that she will deal with Spain as regards Morocco without consulting ether Powers.-Birk beck Bank, London, reopened to pay so/- in the $f$ :Internat. Horse Show opens at Olympia, London.-U.S House of Rep. resolution in favour of direct election of United States senators, with an amendment providing for Federal control, passed by Senate, 64 to 24 .

13. General election in Austria results in reverse for Christian Socialists.-Turkey offers terms of peace to Albanians.-Underground railway system recommended for New York to cost $\$ 257,480,000$.-Miners' Federation of Great Britain resolve not to be further responsible for continuance of dispute in South Wales--Presbyterians General Assembly, Toronto, pass resolution in favour of Anglo-American Arbitration Treaty.-Mr. W. Morgan Shuster, American financier, placed in complete control of Persian finances.

14. Seamen's strike begins at Liverpool, Southampton, Bristol and other ports.-Ross and Cromarty by-election results in return of Mr. Ian Macpherson (Liberal), majority 2,464 . - New Belgian Ministry formed under M. de Broqueville-Merging of twenty-one concerns in seventeen cities into General Baking Company announced at New York.

15. British Embassy in Constantinople informed that Mr. Wavill, British explorer, has been arrested by Turkish authorities and imprisoned at Hodeidah-Mrs. Proudlock an Englishwoman, sentenced to death at Singapore for murder of a mine manager; subsequently pardoned (July 8)- - Great wave at Trieste does extensive damage to shipping and causes loss of about roo lives - Ascot Gold Cup won by Mr. C. E. Howard's "Willonyx."-Internat Boundary Commission gives to Mexico part of disputed Chamizal tract near El Paso, Texas.

16. Persian Premier suddenly leaves Teheran--M Cruppi, French Foreign Minister, obtains vote of confidence in Chamber by large ma jority - Mr. Lloyd George receives deputation of women with regard to position of their sex under Insurance Bill

x7. Mr. R. D. Ashe, English Collector at Tinnevelly, India, murdered by a native, who then commits suicide.Procession of 40,000 women suffragists from Thames Embankment to Albert Hall, London.-Internat. Women's Suffrage Congress closes at Stockholm.--London County and Westminster Bank, London, take over business of Birkbeck Bank.-Lord Curzon speaks at banquet of Empire Press Union, London-Sir Wilfrid Laurier speaks at luncheon to Colonial Premiers at Constitutional Club, London.-Panama Canal bond issue in America (\$50. $\infty 00,000$ at $3 \%$ ) largely oversubscribed, at an average price of 102.2I (see May I6)-Detective William J. Burns and James Hasseck, of Los Angeles, indicted at Indianapolis on charge of kidnapping J. J. McNamara.

18. Lemartin, Princeteau and Landon, airmen, killed at Vincennes. France, at start of European Aviation Circuit race-Rioting at Cardiff in connection with seamen's strike. 
19. Constituent Assembly opens in Lisbon and sanctions decree exiling Royal Family.-Lond Rosebery speaks at lunch given in Westminster Hall to representatives of Dominion parliaments.-Meeting of British admirals at Westminster Palace Hotel, London, condernns Declaration of London--United States grants official recognition to new Portuguese Republic.

20. Coronation Honours List published in London, in cluding nine peerages, ro Privy Councillorships, 20 baronetcies, 56 knighthoods, and over 120 promotions to orders, including the O.M. for Sir George Trevelyan and Sir E. Elgar, - Final meeting of Imperial Conference, London.-Shakespeare Costume Ball at Albert Hall, London. West Ham election petition results in unseating of $\mathbf{M r}$. Masterman (Liberal). - In second ballots of Austrian General Election Christian Socialists lose 17 seats out of 20.-Democratic wool-revision bill passed by U. S. House of Representatives, $22 \mathrm{I}$ to 100 .

21. King, George and Queen Mary receive Dominion Premiers and oversea representatives at Buckingham Palace, London--Duez, former liquidator of Erench religious orders, sentenced in Paris to 12 years, penal servitude for embezzling public funds. - White Star liner "Olympic" completes maiden voyage to New York in 5 days, I6 hours, 42 min.-German Emperor visits American battleships at Kiel.-U.S. Senate's amendment of bill for direct election of U. S. senators rejected by House of Rep.-U.S. Circuit Court at Wilmington, Del., orders dissolution of the E. I Du Pont de Nemours. Powder Co--McAneny-Willcox subway report accepted by New York City Board of Estimate and Apportionment.

22. Coronation of King
Westminster Abbey, London.

23. King George and Queen Mary drive in state through London.-French Govt. defeated and ministry resign.Turkish force surprised and routed by rebel Arabs in Yemen; $\mathbf{x}, 000$ killed; 500 wounded. - Federal grand jury in Chicago indicts fourteen officials of "Lumber Trust" for violation of the Sherman anti-trust law.

24. King George reviews British fleet at Spithead.Germany and Japan sign new commercial treaty.-Austrian battleship "Viribus Unitis" launched at Trieste.Seamen's strike at Southampton settled.-U. S. Circuit Court at St. Louis, Mo., decides that the Union Pacific Railroad's ownership of Southern Pacific Railroad stock is not illegal.

25. Monument to John Stuart Mill inaugurated at Avignon.-Race for the Grand Prix de Paris won by Marquis de Ganay's "As d'Atout."

26. King George and Queen Mary attend State Opera períormance at Covent Garden Theatre, London.Brighton by-election results in return of Mr. John Gordon (Unionist) unopposed.-Coast Erosion Commission issues final report in London.-Resignation of Baron Bienerth, Austrian Premier; he is succeeded by Baron Gautsch.

27. Mr. Balfour moves resolution of protest against Declaration of London at meeting in City.-Seamen's strike spreads at British ports; trade of Hull, Yorks. blocked.-Strike of dockers and carmen at Liverpool and Manchester aggravates difficulties of settling seamen's strike.-New French Ministry formed under M. Caillaux. - King George and Queen Mary attend gala performance at His Majesty's Theatre, London.-Mr. Lloyd George receives deputations from County Councils Associations and Municipal Corporations with reference to National Insurance Bill.

28. King George and Queen Mary visit Royal Agricultural Show at Norwich. - Shipowners' Association of United Kingdom pass resolutions in favour of increased rate of seamen's wages, but refuse to recognise men's associations. 29. King George and Queen Mary attend Service at St. Paut's Cathedral and are entertained to lunch at Guildhall--Mr. Lloyd George meets representatives of Friendly Societies with regard to National Insurance Bill. Four aeroplanes presented to British Govt. by Mr. H. performed for first time in England at Covent Garden Theatre. London.-Federal grand jury in New York City indicts 83 officers of 36 companies manufacturing steel wire, charged with conspiracy.

Ko. King George and Queen Mary entertain 100,000 school children at Crystal Palace, London.-M. Caillaux, French Premier, declares policy in Chamber.-Thackeray Centenary celebrated in London; Lord Rosebery speaks. Mr. H. Bottomley. M.P., condemned in $£_{50,000}$ damages in London trial of case of Master 0 . Bottomley for alleged fraudulent misrepresentation,-Nicolay A. Grevstad (b. I85r) of III. appointed U. S. minister to Paraguay and Uruguay.-At Baltimore, Md., Cardinal Gibbons celebrates fiftieth anniversary of his ordination and twenty-fifth of his cardinalate.

July:-

x. German Govt. announces despatch of gunboat to Agadir to protect German interests in S. Morocco. British cruiser "New Zealand" launched on Clyde--Devid Davies, "Dartmoor Shepherd," released from prison by order of Home. Secretary (see Jan. 6), re-committed at Shrewsbury Assizes for house-breaking, - Gordon-Bennett cup for speed in aviation won back for America by Mr. C. T. Weyman,-Compulsory service for military and naval forces inaugurated in Australia.-U. S. Consulate-general at Bogota, Colombia, permanently closed,-U. S. Interstate Commerce Commission orders investigation of express companies.-Earthquake shocks in central California felt as far north as Redding and south to Los Angeles.

3. Seamen's strike settled at Liverpool, Hull and other ports.-British House of Commons rejects Mr. 'Buteher's amendment to Naval Prize Bill; referring Declaration of London to an expert Commission, by 30 r votes to $23 \mathrm{I}$. Bill passes second reading.-Severe heat wave in United States and Ontario; many deaths. - Two competitors in European Aviation Cincuit race arrive at Hendon, Middlesex, Védrines leading.

4. Pres. Fallières pays a visit to Amsterdam and is met by Queen Wilhelmina.-German Govt. : send cruiser "Berlin" to Agadir to replace gunboat-Rioting in Manchester in connection with carters' strike--King George reviews 20,000 Boy Scouts in Windsor Great Park.

5. Lord Lansdowne's amendment to Parliament Bill accepted by 253 votes to 46 in House of Lords - HuH by-election results in return of Mr. Mark Sykes (Unionist), majority 278.- Sir John Edge and Syed Ameer Ali madé members of Judicial Committee of the Privy Council-T Oxford wins cricket match at Lords against Cambridge by 74 runs.-Death of Maria Pia, Queen Dowager of Portugal.-United States, Great Britain and Italy submit Note to Haiti demanding settlement of their clpims. King George makes award on Alsop case, Chile being ordered to pay $\$ 935 ; 000$ to United States.-Martial law proclaimed in Paraguay.-Resolution providing for direct election of $\mathrm{U}$. S. senators referred by House of Rep. to a conference committee of senators and representatives.

6. Treaty signed for arbitration of claims between U.S. Einstein (b. 1877) of New York appointed U. S. minister to Cesta Rica as successor of William L. Merry; resigned June 28, 1911.-Evan E. Young (b. 1878) of South Dakota appointed U. S. minister, to Ecuador, as successor of Williams-C. Fox, resigned July $x_{0}$-Charles Dunning White (b. 1868) of New. Jersey appointed U. S. m nister to Honduras as successor of Fenton R. McCreery tesigned July r.-William W. Russell (b. 1859), of D. C appointed $\mathbf{U}$. S minister to Dominican Republic. $-\mathbf{H}$ Percival Dodge (b. I870) of Massachusetts appointed U.S minister to Panama, as successor of Thomas C. DawsonU. S. Attorney-General begins suit against Lehigh Valley Railroad under commodities clause of Hepburn Act to separate coal-mining from railroading.-International Christian Endeavor convention begins at Atlantic City with attendance of 10,000 delegates. -Glasgow (Tradeston) by-election results in return of Mr. Dundas White (Liberal) majority 1,086 - Lord Kitchener and Premiers of Australia, New Zealand and Newfoundland, visit Glasgow and are presented with freedom of city,- Nine competitors in European Aviation Circuit race arrive at Calais, Vedrines leading.--Resignation of Sir Eldon Gorst, British Agent and Consul-General in Egypt.

Convention between Great Britain. United States, Russia and Japan, to suspend pelagic sealing for fifteen years, signed in Washington.-European Aviation Circuit race won by "Beaumont" (Lt. Conneau), French airman. Kent (St. Augustine's) by-election results in return of Mr. Ronald McNeill (Unionist) unopposed.

8. King George and Queen Mary arrive in Dublin and receive loyal welcome. - West $\mathrm{Ham}$ by-election results in return of Baron de Forest (Liberal), majority $\mathbf{T} .03 \mathrm{~T}$ Manchester dock strike settled.-Tercentenary of Charterhouse School celebrated et Godalming. Surrey,-Eton beats Harrow at cricket at Lords by 3 wickets.-Henley Regatta closes: Eton wins Ladies' Challenge Plate: Magdalen College, Oxford, Grand Challenge Cup; Thames Rowing Club, Stewards' Cup and Silver Goblets; and W. D Kinnear Diamond Sculls.

9. King George and Queen Mary attend service in St. Patrick's Cathedral, Dublin, and visit Maynooth College-French Ambassador has an interview wit German Foreign Secretary in Berlin concerning Agadir incident. 
ro. Russia informs Germany of her support for France on Morocco question--Russian battleship "Poltaver" launched on the Neva.-Mr. Balfour speaks at dinner to celebrate Mr. Chamberlain's 75th birthday in London. - Forest fires in Northern Ontario; 400 lives lost.

11. King George reviews I 6,000 troops in Phoenjx Park Dublin:-French Chamber decides by 476 votes to 77 to postpone discussion of French policy on Morocco question. -Zeki Bey, Turkish official and fournalist, shot dead in Coristantinople.-Major J. R. Chancellor appointed Governor of Mauritius.-Railway accident at Bridgeport, Conn.; I 2 killed, 44 injured.-Royal Commission on Tuberculosis issues Final Report in London.

I2. King George and Queen Mary leave Dublin.Death of Sir Eldon Gorst:-U. S. Attorney-Genera Wickersham recommends dismissal of Dr. Harvey. W Wiley, chief of Bureau of Chemistry in Dept: of Agriculture, for violation of the law. - James Whitcomib. Riley gives a $\$ 75,000$ plot of land to Indianapolis Ind:, U:S.A., for a public library.-Au Sable City, Mich., destroyed by forest fires.

13. Investiture of Prince of Wales at Carnarvon Castle. -Anglo-Japanese alliance renewed for ten years. $\rightarrow$ Wick low (East) by-election results in return of Capt. Donelan (see May 22) unopposed.-Glasgow seamen's strike settled.

14. King George and Queen Mary open new building of University College of North Wales at Bangor.-French national Fete celebrated.

I5. King George and Queen Mary visit Aberystwith and lay foundation stone of National Library of. Wales.Lord Kitchener! appointed British Agent and ConsulGeneral in Egypt. Turk ish column under Edhem Pasha ambushed by Albanians near Ipek; 200 killed and wounded. -New treaty of commerce and customs agreement between Germany and Japan ratified at Tokyo-Cork (East and North-East) by-elections regult in return of $\mathrm{Mr}$. J. Muldoon and Mr. T. M. Healy (Nationalists) unopposed.

17. King George and Queen Mary arrive in Edinburgh and stay at Holyrood.-It is announced that Germany demands concession of territory in French Congo as compensation for forgoing her rights in Morocco--Railway accident at Mülheim, Baden; 12 killed, ro injureit. Development Commission issue first annual report in London.-Northumberland miners vote in favour of strike to end three-shift system - - Sir Robert Chalmers, K.C.B. appointed Permanent Secretary of the Treasury. Treaty of Commerce and Navigation between U. S: and Japan becomes effective (see February $2 x$ and April 5.)-House publicity bill, passed by U. S. Senate with amendments (see Aprili 14 and Aug, ro).-U. S. Government brings suit against Philadelphia \& Reading Railway to force it to give up control of coal companies.

I8. American gunboat sent to Haiti to protect American interests.-Mohammed Ali, ex-Shah of Persia, begins an attempt to recover his throne.

I9. King George and Queen Mary attend dedication of Chapel of Order of Thistle at. St. Giles's Cathedral, Edinburgh.-Mr. John Burns speaks at Conference of Nationa Association for Prevention of Consumption.-Spain apologises to France for affront offered to $M$. Boisset French Corisular Agent at Alcazar.-United States Govern ment-ratifies treaty with Great Britain providing for arbitration of certain pecuniary claims.

20. Parliament Bill, as amended, read third time in British House of Lords.-Bedfordshire (Luton) by-election results in return of $\mathrm{Mr}$. C. B. Harmsworth (Liberal) majority 6r3.-King Nicholas of Montenegro lays before representatives of England, France, Russia, AustriaHungary, and Italy a proposed arrangement between Turks and Albanians. - Prince Henry Motor Competition through Germany and England between German and Royal British Automobile Clubs concludes in London with victory of British.

2I. King George and Oueen Mary leave Edinburgh and return to London.- Letter published from Mr. Asquith to Mr.-Balfour, stating that the Government will advise the $\mathrm{K}$ ing to exercise his prerogative by creating a sufficient number of peers to secure passing of Parliament Bill as introduced,- Mr. Lloyd George speaks on Morocco Crisis at Mansion House, London-Lord Selborne speaks at Constitutional Club, London; on Government's attitude towards Constitution-Explosion on board British destroyer "Kangaroo"; 2 killed, 5 injured--Somerset (West) by-election results in return of Col. Boles (Unionist. majority 604

22. Mr. Asquith has an audience with King George as to action of Govt. on Parliament Bill.-Great fire at Stam boul during celebration of third anniversary of Turkish Constitution; nearly 5,000 houses burnt.-Aeroplane race over $\mathrm{I}$,oro miles circuit in Great Britain begins at Brooklands, Surrey.-King's Prize shooting competitions at Bisley, Hants., result in Bronze Medal going to Corporal J. Trainer, Canada, Silver Medal to Private A. G. Garrod, Gold Medal to private W. I. Clifford, Canada.-Canadian Reciprocity bill passes U. S. Senate, 53 to 27

24. Mr. Balfour, Lord Lansdowne and Mr. Asquith have audiences of King George - British House of Commons assemble to consider Lords' amendments to Parliament Bill. Mr. Asquith endeavours to make statement but is shouted down, and the Speaker adjourns the House. -British cruiser "Fox" captures two dhows in Persian Gulf with rifles and ammunition on board.-Reciprocity Bill strenuously opposed in Canadian Parliament and appeal to the country demanded.-Fur seal treaty ratified by U. S.: Senate (see July 7)-CU. S. Interstate Commerce Commission orders lower freight rates from eastern points to points between Missouri river and Pacific Coast.-In Texas state-wide prohibition defeated by majority of over 6,000 .

35. Lord Lansdowne and Mr. Balfour appeal to Peers to pass Parliament Bill rather than force the Crown to use prerogative.-Mr. Asquith's interrupted speech in House of Commons published; Lord Hugh Cecil shouted down in House of Commons by Ministerialists.-Dam at Fernbank. on Ohin river near Cincinnati, is opened for use.-In New York, 37 of 83 men indicted in connection with alleged "Wire Trust," plead guilty and pay: fines of $\delta_{1,000}$ to $\$ \mathbf{r}, 700$.

26. Dinner to Lord Halsbury given in London by "Die Hard" opponents of Parliament Bill, Lord Selborne presiding -First Universal. Races Congress opens in London.-British Medical Assocíation meet at Birmingham and consider attitude of profession towards National Insurance Bill.-Aeroplane race over $\mathbf{x}$,oro circuit of Great Britain won by "Beaumont" (Lt. Conneau), Védrines second.-Queen of Holland and Prince Consort visit King and Queen of the Belgians at Brussels.- Maharaja of Gwalior gives $£ 8,000$ for charitable institutions to commemorate the Coronation.-Pres. Taft signs the Canadian Reciprocity bill passed by U. S. Congress.-Pres. Taft sends to the U. S. Congress message on Controller Bay (Alaska) controversy and-opens to private entry 12,800 acres near Bering coal field of Alaska.

27. Cunard liner "Laconia" launched at Wallsend.Race for Goodwood Cup won by Lord: St. Davids' "Kil. broney." - Senator La Follette's compromise wool-tariff bill passes U. S. Senate, 48 to 32 .

28. Violent thunderstorm in London accompanied by wind velocity of 54 miles per $h r$. and $I . I$ inch rainfall in I5 minutes. - Sir Wilfrid Laurier lays Imperial naval defence scheme as passed by Imperial Conference before Canadian House of Commons.-At farewell banquet in New Zealand to Irish envoys, Acting Premier makes speech in favour of Home Rule.-Railway accident at Crewe; 30 injurad.-Portuguese Republic protests to Spain against permitting monarchical plotters to meet on Spanish territory.-Haitian revolutionists defeated at Les Cayes; fifth American warship sent to Halti.

20. Sir. Wilfrid Laurier advises dissolution of Canadian Parliament_-Bethnal Green by-election results in return of Mr. C. F. Masterman (Liberal), majority 184--World's Sculling Championship won at Parramatta river, N.S.W. by Richard Arnst, in record time of 19 min. 46 sec. for 3 miles, 330 yds.

3I. Naval agreement with British over-sea Dominions issued in London as Parliamentary paper. Court of Appeal in London dismisses Mr. H. Bottomley's appeal against judgment condemning him in $f_{50,000}$ damages (see June 3o).-Prince of Wales gazetted a midshipman to H.M.S. "Hindustan,"-British Govt. protests to Moorish Govt. against expulsion of two British subjects from. Agadir.Persian Mejliss place price of $£_{33}, 000$ on head of Mohammed Ali, ex-Shah-Russian Minister to Persia moves to force resignation of Mr. Morgan Shuster, Financial Adviser. -Increases in commutation rates of railroads serving New York City, except those of Pennsylvania Railroad, approved by U. S. Interstate Commerce Commission.

August:-

r. Strike begins in London Docks. $\rightarrow$ U. S. Senate passes Farmers' Free List Bill.-Fire at lunatic asylum, Hamilton. Ont.; many lives lost.-Haitian revolution successful.King's Cup at Cowes won by Sir M. Fitzgerald's yacht 'Julian."

2. Anglo-American and Franco-American arbitration treaties signed at Washington.-S. W. Lancashire byelection results in re-election of Sir Ryland Adkins (Liberal), majority $4 \mathrm{II}$ - Two newspaper correspondents expelled from Agadir.-German Emperor's Cup at Cowes won by 
Ilerr Krupp von Bohlen's yacht "Germania."-Suit is brought against Chesapeake \& Ohio, Hocking Valley, and other American railways and coal companies for violation of the Sherman anti-trust law.

3. Lord Haldane delivers address at Oxford on "Great Britain and Germany: a Study in Ethnology." - Malissori tribes at Podgoritza, Montenegro, on advice of King Nicholas, accept Turkish concessions and return to Albania. - Landon Docks Improvement scheme announced.National Congress of French railwaymen pass resolution against sabotage.-Internat. Peace Conference at Bern, Switzerland, proposes to form permanent bureau of peace. - In U. S. Congress Reapportionment bill with several amendments passed by Senate; Underwood Cotton Revision bill passed by House.

4. London dock strike spreads to Surrey Commercial Docks.-Note circulated in Berlin stating that conversations between Herr Kiderlen-Waechter and M. Cambon tend to agreement on the Morocco question.-Pres. Simon of Haiti leaves the island. - Suit begun by U. S. Govt. in Circuit Court at Columbus, Ohio, against "Soft-Coal Trust.

5. Arbitration Treaties referred by U.S. Senate to Committee on Foreign Relations.-roo lives lost by sinking of a boat carrying Egyptian passengers on Nile.-New YorkPhiladelphia aviation race won by Lincoln Beachey in 2 hours 22 ? minutes.

6. Demonstration of dock labourers in Trafalgar Square, London; Sir A. Rollit's award announced, giving $\mathbf{I d}$. an hour increase of wages, making. $8 \mathrm{~d}$ an hour, with rs, an hour overtime--Meeting of French and Spanish working men in Madrid protests against military operations in Morocco.

7. Mr. Balfour's Vote of Censure on the Government negatived in British House of Commons by 365 votes to 246 . - London dockers refuse to return to work until other transport workers aresatisfied; complete cessation of work in port of London. - Strike of railway porters at Liverpool. At Dacca, India, three conspirators sentenced to transportation for life, and 32 others to terms of from three to ten years' imprisonment by Sessions Judge.-At Calcutta judgment given in High Court on Midnapur conspiracy case; Mr. Weston, magistrate, and two police officers condemned in damages (see Aug. 17, 1912).-Mr. Bertrand Stewart, English subject, arrested at Bremen, Germany, for espionage.-International Cup for Schooners at Cowes won by German Emperor's yacht "Meteor," and Royal Thames Yacht Club's Cup won by King of Spain's yacht "Hispania"

8. British House of Commons reject Lords' amendments to Parliament Bill.-Lord Curzon's Vote of Censure on the Govt. passed in House of Lords by 282 votes to 68 .- Strike of London carmen.- South Australian Legislative Assembly pass Govt. Bill for restricting power of Upper House. Pres. Taft signs Reapportionment Bill passed by $U$. Congress, increasing number of representatives in House to 433

o. House of Lords finally debate question of accepting Parliament Bill,-Fire at Carlton Hotel, Pall Mall, London; Mr. J. Finney, American actor, burnt.-Australian steamer "Fifeshire" wrecked off Cape Guardafui; 25 persons (in one boat) drowned-French steamer "Emir" collides with British steamer "Silverton" in Straits of Gibraltar; 86 lives lost.-General Sir John French appointed Chief of British Imperial Staff.-Tenth Zionist Congress opens at Basel, Switzerland.

ro. House of Lords pass Parliament Bill, deciding by 131 votes to $I_{4}$ not to insist on their amendments. Resolution in favour of payment of members carried in British House of Commons by 256 votes to 158 - Provisional agreement arrived at in London between jightermen and carmen and their employers.-Rioting at Liverpool in connection with dock strike.-Turk ish Government express readiness to make same terms with Mirdites and other Albanian clans as with Malissori.

I1. Lonclon dock strike committee issue manifesto declaring strike at an end.

12. Foreign Relations Committee of U.S. Senate amend arbitration treaties.-Mr. H. P. James, British Assistant Commissioner, murdered by natives on Brass boundary, Nigeria.-A Aproint ments announced of John (i. A. Ieishman (b. 1857 ), of Pennsylvania, U. S. a mbassador to Germany as successor of David Jayne Hill (resigned April 14); Thomas J. O'Brien (b. 18.12), of Michigan, U. S ambassador to Italy; Charles Page Bryan (b. 1856), of Illinois, U. S. ambassador to Japan; Larz Anderson (b. 1866), of D. C. U. S. minister to Belgium; Arthur M. Beaupre (b. 1853), of Illinois, U. S. minister to Cubs: Lloyd Bryce (b. 1851), of New York, U. S. mini,ter to Netherlands and Lusemburg; and John B. Jackson (b. 1862), of New Jersey, U. S. minister to Rumania, Servia and Bulgaria.

13. Serious heath fires in Surrey, England.

r4. British House of Commons vote supplementary estimate of $£ 252,000$ for payment of members by $24 I$ vote to 128 . - South Wales Miners' Federation decide at Cardif that ten months' strike of Cambrian coal miners shall cease. - Liverpool shipowners declare lock-out of all men engager on cargo work; labour leaders in reply declare genera strike of all transport workers in Liverpool district. Radium Institute, established and equipped by Lord Iveag and Sir E. Cassel, opened in London.-General Cincinnatus Leconte elected president of Haiti.-Wool bill prepared by conference committee of U. S. Senate and House passed by U. S. House of Representatives.

15. Further rioting in Liverpool; 2 men killed.-Railway Strike threatened in England- - Mr. Asquith and Mr. John Burns confer in Downing Street with representatives of both employers and men.- Pres. Taft vetoes resolution of U.S Congress admitting Arizona and New Mexico to statehood. -U. S. Senate committee on Foreign Afiairs reports unfavourably on arbitration treaties with France and Great Britain.-Conference Wool Bill passed by U. S. Senate, 38 to 28.-Retrial of Mr. Lewis, charged with murdering a native, at Salisbury, Rhodesia, results in his acquittal.Canadian election campaign opened in Ontario.

16. Mr. Lloyd George makes, a statement in British House of Commons as to treatment of railway strike.Mr. John Burns confers in London with railwaymen and representatives of railway companies. - The companies arrange for patrolling and defence of their lines by troops. Food famine threatened in Liverpool--Bulgarian guerrilla leader, Apostol Petkoff, killed in encounter with Turkish troops.

I7. British Railway Strike negotiations fail, and proposal by Mr. Asquith to appoint Royal Commission to investigate grievances is refused by railwaymen's leaders.-Strike declared, but negotiations re-opened at night.-Wool bill and Farmers' Free List bill vetoed by Pres. Taft

18. British Railway Strike spreads; extensive interrup tion of traffic.-Mr. Winston Churchill makes statement in House of Commons as to proposed Govt, action in main taining order and protecting food supply.-Agreement between London transport workers and their employers signed at Home Office--Memorial tablets to Edward VII unveiled at Marienbad, Austria,-Lieut. Leslie Ridge, British military airman, killed.-Max Schultz, German subject, arrested at Plymouth for espionage, and on Aug. 28 committed for trial.-Resolution admitting Arizona and New Mexico to statehood under certain conditions adopted by U. S. Senate.

19. Late at night British railway strike declared at an end.-The Govt. agree to appoint special commission to investigate questions in dispute.-Strike riots at Llanelly killed, I 2 wounded.-Russo-German Agreement concerning Persian tailways signed. - Young French airman shoots secretary of Hendon Aerodrome, Middlesex, and then shoots himself.-British army manoeuvres abandoned owing to drought.-Anti-Jewish rioting at Tredegar, Monmouth.Emilio Estrada elected Pres. of Ecuador.-Campaign Publicity bill signed by Pres. Taft (see April 84 and July 17).-Amended measure granting statehood to Arizona and New Mexico passed by U. S. House of Rep-U.S. House of Rep. fails to override President's veto of Farmers' Free List Bill.

20. British railwaymen's demonstration in Hyde Park decides to accept strike settlement; but it is rejected in Manchester.

21. Majority of British railwaymen resume work.Agreement reached at Liverpool between shipowners and dockers. - Socialist meeting in Berlin passes resolution protesting against Germany's policy in Morocco, and against any policy which threatens to bring on a European war.-Pres. Taft signs statehood bill admitting Arizona and New Mexico to the Union under certain conditions. - James T. Du Bois (b. I85x), of Pennsylvania, appointed U. S. minister to Colombia.

22. Strike riots continue at Darlington, Hull and other places in the North of England.-Debate in House of Commons on the Government's conduct in using military force during railway strike.-Parliament adjourns unti Oct. 24. - Leonardo da Vinci's "La Gioconda" found to have vanished from the Louvre. Paris.-Ex-Shah of Persia's army reported to have been routed at Savadkuh; loss 300 men.-Pres. Taft vetoes Cotton Bill; special session of American Congress closes.

23. Delhi Durbar preliminary manoeuvres cancelled owing to drought in India.

24. Dr. Manuel Arriaga elected Pres. of Portuguese 
Republic--Liverpool transport workers' strike settled.British steamer "Foam Queen" seized in London, owing to suspicion of carrying men and war material to a foreign revolutionary govt.

25. French Govt. formally recognise Portuguese Republic -British steamer "Arizona", seized at Barrow-in-Furness on suspicion of carrying men and war material to a foreign revolutionary govt.-Lehigh Valley train wrecked near Manchester, N. Y, 37 lives lost-Harry N. Atwood reaches New York in his aeroplane flight from St. Loui (begun Aug. 14); establishing new world's record for distance.

26. Panic at cinematograph show, Canonsburg, Pa.; 25 killed, many injured.-Motor char a banc accident nea Medomsley, Durham; ro killed, 20 injured.-Argentine battleship "Rivadavia," largest in the world, launched at Quincy, Mass-U. S. Postmaster-General announces that after Sept. 1, magazines will be transported in carloads as fast freight.-In a test of guns designed for use against aeroplanes, made at Indian Head, Md.4 a projectile from a one-pounder reached a calculated height of 10,800 feet.

27. German Emperor speaks at Hamburg on the "place in the sun" which should be secured for Germany by an increase in her navy.-Pope receives Cardinal Archbishop of Rio de Janeiro in Rome and bestows blessing on churche of South America.-Violent wind-storm at Charleston S. C., destroys fifteen lives and a million dollars' worth of property.

28. Mr. Redmond Barry, Attorney-General of Ireland, appointed Lord Chancellor of Ireland-Dr. Gore, Bishop of Birmingham, made Bishop of Oxford-Emperors of Russia and Japan exchange felicitations on final settlemen of all claims arising from Russo-Japanese War.-United States acquire four small islands at western end of Panama Canat.

29. Australian Commonwealth Government apply to British Admiralty for 1,683 naval officers and men--Mr. Lloyd George speaks in Wales on the duty of churches towards economic unrest.--Warwickshire wins English County Cricket Championship for first time.

30. British Association meeting opens in Portsmouth; Sir William Ramsay delivers presidential address on "The Sources of Energy," and the probable exhaustion in 175 years of British coal supply. $-\mathrm{M}$. Cambon returns to Berlin with the French proposals for an agreement with Germany which are stated to include cession of territory in French Congo.

31. Inquest on two men shot by soldiers at Liverpool on Aug. I5 results in verdict of "justifiable homicide." Threatened strike on Great Eastern Railway, England, averted by Board of Trade-_ "Adoration of the Magi" by Mabuse sold by Dowager Countess of Carlisle to National

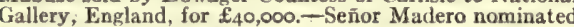
for presidency of Mexico.

Sepiember:-

1. Rioting in northern France because of high food prices - Mr. J. J. Frisbie, American airman, killed at Norton, Kansas

2. New. Portuguese Cabinet formed under Senhor Chagas, with Dr. Vasconcellos as Foreign Minister.Further food riots in France-Cholera outbreak at Constantinople; 36 cases, 16 deaths.-Tramcar accident at New Cross, London; $x$ killed, $I 7$ injured.-Capt. Camine and Lieut. de Grailly, French military airmen, killed flying to manoeuvres.-M. Marron, French airman, killed at Chartres.-Lord Gladstone speaks at Salisbury, Rhodesia, on black peril.-Banquet given by the Tsar at St. PetersAurg to King Peter of Servia.-Violent volcanic eruption in the Bogoslof Islands, Alaska, throws up several new islands. 3. Great fire at Scottish Co-operative Wholesale Society, Glasgow - German Emperor speaks at Potsdam on German-American friendship at unveiling of statue to General von Steuben, given by Americans,-Marriage of Princess Helena of Servia to Duke Ivan Constantinovitch at Peterhof:

4. Trade Union Congress of Great Britain opens at Newcastle-on-Tyne.-Further fire in Glasgow destroys Town Hall and Tolbooth.-President Fallières reviews French Navy at Toulon,-French Government's Morocco proposals communicated to Herr von Kiderlen-Waechter in Berlin.-M. Garros, French airman, reaches record height of $x_{3}, 800 \mathrm{ft}$. at St. Miło.

5. Trade Union Congress pass resolutions condemning use of military in recent strikes, and requiring Government to bring in measure reversing Osborne judgment. $-\mathrm{Dr}$. H. Russell Wakefield appointed Bishop of Birmingham M. Leforestier, French airman, killed at Huelva, Spain.Lord Denman opens Federal parliament at Melbourne. German Emperor bolds naval review at Kiel $-\mathrm{T}$. W.
Burgess, English athlete, swims across English Channel from S. Foreland to Cape Grisnez.- "Macbeth" produced by Sir Herbert Tree at His Majesty's. Theatre, London.Floods in Yangtse Kiang valley, China; many deaths.

6. Ex-Shah of Persia's army defeated.-Canada with. draws from Fisheries Treaty of 1008 with United States. Further food riots in France--Mr. Deakin, speaking in Australian Parliament, denounces suggestion that Australia might remain neutral in time of war-Canadian Government seizes American fishing schooner at Louisburg, Cape Breton Is., for violating treaty of $18 \times 8$.

7. Strike riots at Wexford, Ireland.-Dr, F, E, Ridgway appointed Bishop of Salisbury.-Report of Government commission on high food prices issued in France.-Pres. Taft speaks in Connecticut, deprecating Senate Com. mittee's attitude to arbitration treaties. - British shipping companies engaged in Atlantic trade announce 10 per cent ncrease in freight rates.

8. Rice famine riots reported in China-Fighting between Peruvians and Bolivians at Manuripe,-Capt. Postnikoff, Russian General Staff, sentenced to 8 years' penal servitude for high treason.-Collapse of annex to El Dorado Theatre at Nice kills 60 workmen.-Lieut.-Col. Sir H. L. Gallwey appointed Governor of Gambia.Strikes of schoolboys in Liverpool, Hull, Grimsby, Sheffield and other English towns.

9. First aerial post in United Kingdom inaugurated between Hendon and Windsor.-Lord Mayor of London arrives in Vienna on a Municipal visit-Cunard liner "Lusitania" completes round trip to New York and back in just over 12 days. - Motor boat accident on Lake Trasimene causes loss of 14 lives.-Raimund Eyring, German airman, killed at Weil-Mr. Galbraith Cole ordered by Governor of Mombasa to be deported for killing a native and exciting racial enmity-Run on German savings banks owing to fear of war with France-Corporation of $\$ 100,000,000$, affiliated with Southern Pacific rail road, formed to take over trolley lines in California, U.S.A. xo. German Socialist conference opens at Jena with speech by Herr Bebel on Morocco question.

xx. German army manoeuvres begin.-Attempt to repeal Prohibition laws of 1884 in Maine defeated on popular vote by narrow majority, $-\mathrm{Mr}$. Ure speaks at Glasgow on Taxation of Land Values,-Protest meetings in Paris against high food prices.-Mr. Hubert, British airman, injured in aerial post at Hendon.-Chinese cruiser "Hai Chi" visits New York.-Eruption of Mount Etna causes much damage.

12. Germany's counter proposals on Morocco question considered by French Cabinet. French army manoeuvres begin at Belfort.-Rev. S. Swann rows across English Channel from Dover to Sangatte, in 3 hours $50 \mathrm{~min} .+-$ Lieut. Chotard, French military airman, killed near Versailles - Mr. R. Fowler, American airman, starts ftight across America - Eleven men of I7th Uhlan regiment drowned whilst swimming horses across the Elbe near Pirna.-Serious unrest reported from Szechuan, China.Port Arthur opened by Japan to merchant shipping.Fourth conference of governors of states of U. S. begins at Spring Lake, N. J

13. Veto Bill restricting power of Upper House rejected by legislative Council of South Australia,-German Emperor at close of German army manoeuvres expresses thanks to aviators.-Food riots at Criel, France-Strike of tailors and dressmakers in New York - Ouincentenary celebration at St. Andrew's University, Scotland.-St. Leger race at Doncaster won by "Prince Palatine."

I4. M. Stolypin, Russian Premier, mortally wounded by Bogroff, an Anarchist, at gala performance, Kieff.-Nomination of candidates for Canadian parliament. - Food riots at Charleville, France; troops called out

r5. Mr. John Redmond speaks at Dublin on Home Rule during Irish tour of Eighty Club.-Pres. Taft begins cam paigning tour of $x 5,000$ miles.-Lord Rosebery speaks at University College, Dundee, on universities of the future. -M. Nieuport, French airman, fatally injured at Charny, France.

16. Strike of goods porters declared on Irish railways.Jubilee of British Post Office savings banks.-Herr Harder speaks at Berlin on German policy in Morocco:- Pres. Taft speaks at Erie, $\mathrm{Pa}$., on Arbitration Treaties.-Motor accident during race at Syracuse, N. Y.; 9 persons killed and 14 injured.

r7. Lieut. R. A. Cammell, British military airman, killed at Hendon--Food riots at Vienna; martial law declared.

18. Death of M. Stolypin, Russian Premier--Reported that Salia-ed-Dowleh has become Pretender to Persian throne,- Revolutionary plot discovered at Barcelona, and general strike reported at Valencia, Spain.-German reply 
to French Morocco proposals handed to M. Cambon at Berlin.

10. Martial law proclaimed in Spain.-M. Kokovtsoff appointed Prime Minister in Russia. - British Home Office issues circular concerning constitution of a force of special constabtes for use during strikes.-French airship " Adjutant Reau" flies from Issy-les-Moulineaux to Belfort and back in $2 x$ hours. - Sir Wilfrid Laurier speaks at Ottawa on Reciprocity.-Federal grand jury in Boston U.S.A indicts six officers of United Shoe Machinery Company under Sherman law (see Mar. 2, rore).

20. Collisio. in Solent between British cruiser "Hawke" and White Star liner "Olympic;" both much damaged.Two English officers arrested at Emden, Germany, on charge of espionage.-Irish railway companies refuse to reply to ultimatum . of Amalgamated Society of Railway Servants. - Gun explosion on French cruiser "Gloire" off Toulon; 5 killed. - Rioting at Leeds in connection with colJiery strike.-Death of Sir Robert Hart, former InspectorGeneral of C ninese Customs.

21. General strike declared on Irish railways-General election in Canada results in Conservative majority of 48 and rejection of Reciprocity Agreement with United States.-Death of Arabi Pasha.-Chinese troops relieve besieged city of Cheng-tu in Szechuan province.-Severe earthquake at Valdez, Alaska, breaks military cable.

22. Irish railway strike spreads to Belfast.-Funeral of M. Stolypin at Kieff-Castellane, airman, killed at Elmira, N. Y.-Cloudburst in Italy, causing burst of lava from Mt. Vesuvius and engulfing town of Resina in mud.-French battleship "Jean Bart" launched at Brest.-Mr. Edward Mannering rows from Dover to France and back in 12 hours, $40 \mathrm{~min}$.

23. Demonstration against. Home Rule at Craigavon; near Belfast: Sir E. Carson speaks.--Reported that Italian troops have landed on coast of Tripoli.-Argentine battleship "Moreno," sister ship of "Rivadavia," launched at Camden, N. J. (see Aug, 26).-Strike of railway carmen begins on Missouri, Kansas \& Texas Railroad, affecting about 1,500 employes.

24. New comet discovered independently by M. Quénisset in France and Mr. Brown in England.

25. Unionist conference at Belfast pledges itself to establish provisional Government in Ulster if Irish Home Rule becomes law.-Explosion on French battleship "Liberte" at Toulon: 226 killed, r36 injured.-French draft of Morocco Agreement handed to Herr von KiderlenWaechter in Berlin.-Bank of Egypt, London, suspends payment.-British naval airship wrecked at Barrow on first launching-Execution of Bogroff, murderer of M. Stolypin.-Sir A. H. Hardinge appointed British Minister in Lisbon, and Sir F. H. Villiers British Minister in Brussels.-General Botha at Losberg denounces suggestion that South Africa might remain neutral in case of Great Britain being engaged in war.-Strike of clerks, demanding recog. nition of Federation of Railway Employes, called on Illinois Central Railroad.

26. Kilmarnock Burghs by-election results in return of Mr. W. G. C. Gladstone (Liberal), majority 2,286.

27. Irish railway strike collapses. - Injunction granted in High Court, London, restraining Ear's Court Co. from allowing proposed Johnson-Wells boxing contest. - Motor omnibus accident in Paris; I r killed, 9 injured-Farewell banquet at Ottawa to Earl Grey.-U. S. Government brings suit against so-called Lumber Trust at Denver (see May Ig).

28. Italy presents ultimatum to Turkey.-General strike threatened of British postal employes; speech by Mr. Herbert Samuel. - New building of (Oriel ('ollege. Oxford, built by bequest of Mr. Cecil Rhodes, opened-Germany formulates fresh demands in reply to French draft agreement with regard to Morocco.-Mr. Carnegie offers Italian Government $\AA_{50,000}$ for a Hero Fund.

20. Italy declares war on Turkey - - Hakki Bey's Turkish Ministry resign.-New comet discovered in Russia.-First General Election in Sweden under proportional representation results in defeat of Conservative Government - Capt. Engelhardt, German military airman, killed at Johannisthal.

30. Turkey appeals to the Powers.-Preveza bombarded by Italian fleet, and Tripoli coast blockaded-France's reply to latest German proposais regarding Morocco approved by French Cabinet.-Austen and Costello, $\mathrm{Pa}$., destroyed by bursting of dam; gas explosion and fire follow; I 50 lives lost - Anti-Republican rising at Oporto and Villa Nova. Portugal. - Resignation of Swedish Cabinet under Herr Lindman.-Strike begins in Amerca on Harriman railways and Illinois Central, called by federated shop crafts. x. Parnell monument by Saint-Gaudens unveiled n Dublin by Mr. John Redmond.-Collision in North Sea between steamers "Glasgow" and "Hatfield"; I8 lives ost -German Emperor informs Sultan of Turkey that he is placing intervention proposals before the Powers.-General Madero elected President of Mexico.

2. British vessel conveys $I, 300$ refugees from Tripoli to Malta.-Triple murder at Kidsgrove, Staffs, by Karl Kramer; a German, afterwards proved insane.

3. Italy makes official announcement to Powers of blockade of Tripoli.-British troops ordered to be ready to proceed to Persia from India.-Anglican Church Congress opens at Stoke-on-Trent.

4 : Italian squadron bombards Tripoli forts. - Said Pasha forms new Tarkish Ministry. -Railway strike terminated in Ireland.-Sale of Bennet collection of Oriental China in London to Sir W. Lever for $£_{300, \infty}$. U. S. AttomeyGeneral files brief in the Supreme Court, under Sherman law, against anthracite coal-carrying railroads.

5. Italian flag hoisted at Tripoli.-Fresh Royalist plots in Portugal. - Shots fired at Minister of Justice in Austrian Reichsrath.-Triple murder of wife and two children at Newcastle-on $T$ yne by husband who afterwards commits suicide in prison--Four wall paper manufacturers and several dealers indicted by Federal grand jury in Cleveland, Ohio, under Sherman law.

6. Royalist invasion of Portugal repulsed-Temporary Governor of Tripoli appointed by Italians; force of marines landed.-Duke and Duchess of Connaught leave London for Canada.-Miners' Federation of Great Britain resolve to demand minimum wage for all workers in coal mines. Tyrone (North) by-election results in return of Mr. $\mathbf{T}$. W. Russell (Liberal), majority 18.-Mr. Bepin Chandra Pal sentenced in Bombay to one month's imprisonment for sedition - Mr. R. Borden becomes Canadian Premier and forms ministry.-By the breaking of two dams on Black river, Wisconsin, near Black River. Falls, five persons are drowned and $\$ 2,500,000$ damage is done.

7. Signor Giolitti, speaking in Turin, defends Italy's action in Tripoli. - New Swedish ministry formed under M. Staaf-Gordon-Bennett Balloon race won in America by German balloon "Berlin II." - Mr. Balfour speaks at Haddington on his action as regards Parliament Bill.General Luis Mena elected President of Nicaragua. Firemen on Georgia \& Florida railroad return to work after ten days' strike, receiving their demand of $50 \%$ of engineers' pay.

8. Anarchist attempt to wreck Darjiling mail near Saidpur, India.

9. Turkey addresses circular note to Powers with regard to possible mediation.-British battleship " $\mathrm{K}$ ing George V" launched at Portsmouth.--International Maritime Conference meets in Paris.-International Committee of Cotton-growing Associations meets in Berlin.-Lord Haldane speaks at Aberdeen in reply to Mr. Balfour on Parliament Bill.-Mr. J. Redmond speaks at Swindon on Irish Home Rule-Mr. Lloyd George holds conference with British Medical Association and Friendly Society. representatives.

ro. British Minister at Teheran informs Persian Government that he intends to increase Consular Guards. - Sir E. Carson speaks in Dublin against any measure of Home Rule.-Mr. $J$. Redmond speaks in London in favour of Home Rule - British Government appoint Industrial Council, chairman Sir G. Askwith, for conciliation in trade disputes.-Woman's Suffrage carried in California by small majority. - Mersa Tobruk, Tripoli, captured by Italians.

I. Revolutionary outbreak at Wu-chang, Central China. - Italian Expeditionary force lands first battalion in Tripoli.-Cesarewitch stakes at Newmarket won by." Willonyx."

I? National Conference of Friendly Societies opens in Edinburgh to discuss Insurance Bill.-Chinese revolution spreads. - Portuguese Government sends troops to Oporto to prevent Royalist attack.-U.S. Circuit Court at Toledo Ohio, forbids General Electric Company to manufacture or sell electric lamps except under its own name; and orders dissolution of National Electric Lamp Company (see Mar. 3)

13. Duke and Duchess of Connaught welcomed at Quebec,-Mlle. Thirion, French subject, sentenced to six months' imprisonment at Leipzig for espionage.-U. S Circuit Court at Baltimore, Md., orders dissolution of Bathtub Trust."

14. Yuan-Shih-kai recalled from banishment and appointed Viceroy of Hunan and Hupeh, China.-Fighting in Morocco between Spanish forces at Melilla and Riff tribes. -Duke and Duchess of Connaught welcomed at Ottawa 
55. Collision between Missouri Pacific passenger train and fast freight near Fort Crook kills seven persons and injures many others.

16. Fighting in Mexico; 200 Zapatistas killed.-Cholera riots in Italy near Rome.-Centenary of National Society celebrated at Church House, Westminster.-Methodist Conference at Toronto pass resolution protesting against any Church having power to overrule civil authorities as regards marriage.-Lord Rosebery speaks at Glasgow on libraries as "cemeteries of dead books."-Pres. Taft's special train narrowly escapes being dynamited near Santa Barbara, California--Senator La Follette endorsed for Pres. of the U. S. by 200 Progressive Republicans at Chicago.

17. Turkey promises Bulgaria to demobilise and withdraw her troops from Bulgarian frontier. - Chinese Imperial troops despatched to quell revolt in Central China.

18. Indecisive battle at Hankau between Chinese troops and revolutionaries.-Turkish Government imposes tax of $100 \%$ on Italian imports.-German Emperor unveils statue of Emperor Frederick at Aix-la-Chapelle-Dr. George Edgar Vincent inaugurated president of University of Minnesota.

rg. Persian Government appeals to British Government not to despatch Indian troops to reinforce Teheran Consular Guards.-Turkish Chamber passes vote of confidence in Said Pasha's Government.-Portuguese Chamber passes Bill giving ministry extraordinary powers in dealing with Royalist conspirators.-Mr. Birrell, at Ilfracombe, outlines British Government's proposed Home Rule Bill.-Mr. Lloyd George comes to an understanding with the Friendly Societies on amendment of Insurance Bill-Italians bombard| Bengazi, Derna and Homs in Tripoli,--U. S. Interstate Commerce Commission orders all express companies to furnish details of their operation by December 1 - Chairman Nelson A. Aldrich presents to U. S. National Monetary Commission a revision of his plan for banking and currency reform.

20. Report of British Railway Commission on recent strike issued in London.- Tramway accident at Moseley near Manchester; 5 killed.-National American Woman Suffrage Association convenes at Louisville, Ky - Twelve miners drowned in the iron mines at Hibernia, N. J., by inrush of water, due to accident in blasting.

2x. Chinese revolutionaries capture towns on Yangtse.Portuguese cruiser "Sao Rafael" wrecked near Vella de Conde; I man lost, 12 injured.-Austrian archduke Charles. second in succession to the throne, marries Princess Zita of Parma.

22. Mr. J: Redmond, speaking at Baltinglass, Wicklow, states that Government Home Rale Bill, as foreshadowed, will be satisfactory to Ireland

23. German Imperial Chancellor, speaking in Reichstag, defends German protective system in spite of high prices. Mr. Winston Churchill becomes First Lord of the Admiralty, and Mr. M'Kenna Home Secretary, in British government- - Meeting at Mansion House, London, to consider purchase of Crystal Palace.

24. British House of Commons re-assembles.-Chinese revolutionaries capture Sianfu and Kiukiang.-Lord Grey speaks in London on Canada's loyalty to the Empire.

25. Legation Guards at Peking strengthened.-France and Germany arrive at an agreement on all points concern ing Morocco.-British battleship "Australia" launched on Clyde--Mr. F. A. Aglen succeeds Sir R. Hart as Inspector General of Chinese Customs.-Sheng Hsuan-Huai, Chinese Minister of Communications, impeached by Chinese National Assembly.

26. Chinese Emperor, under threats from Senate dismisses Sheng Hsuan-Huai, Minister of Communications. - Chinese Republic proclaimed under Li-Huan-Hung. Turco-Arab attack on Italian forces in Tripoli repulsed.Italian. Govt. notifies Powers officially of cessation of Ottoman rule in North Africa.-First meeting of new Industrial Council, London.-Proceedings begun in United States Circuit Court at Trenton, N. J., for dissolution of Steel Trust.-Philadelphia Athletics (American League) for second successive year retains the world's baseball championship, having defeated New York Giants (National League) in four out of six games.

27. Yuan Shib-kai made military dictator of rebellious provinces of China.-Keighley, Yorks., by-election results in return of Mr. S, O. Buckmaster (Liberal), majority 825 .

28. Accident to American boat express at Colwic, Staffs. 3 . persons injured.-Chinese Imperial troops successful in skirmish near Hankau.

29. Monument to Bossuet unveiled at Meaux, France.Two new Roman Catholic provinces of Liverpool and Birmingham formed in England; Archbishop Bourne of
Westminster created Cardinal--Persian Government troops defeated by Turcoman rebels near Bender-Gez.

30. Chinese Emperor issues edict apologising for past errors and granting a Constitution.-Italian troops reported to have slaughtered Arabs indiscriminately in and near Tripoli.-U. S. Supreme Court decides that on inter-state railways, even in cars used only in intra-state runs, equipment must comply with requirements of Federal Safety Appliances Act.

3r. Hankau re-captured by Chinese revolutionaries.Strike of 6,000 London taxi-cab drivers. - Building accident at Le Meriot, France, causes so deaths.-Australian Commonwealth cabinet resigns. November:-

I. Fighting between Turkish troops and Italian warships at Ain Zara, Tripoli.-Italian Prime Minister telegraphs to London denial of report of indiscriminate slaughter by Italians in Tripoli-Yuan Shih-kai appointed Prime Minister of Chins, but later refuses to accept appointment. -Amalgamation of London General Omnibus Co. with Metropolitan District Railway Co. \& Underground Electric Railways Co of London-Mr. Whitelaw Reid American ambassador to Great Britain, delivers address at Edinburgh on "The Scot in America."

2. Mr. J. Redmond speaks on Home Rule at City Liberal Club, London. - France and Germany initiate treaty concerning exchange of territory in Africa.-French Govt. formulates proposals to start municipal bakers' and butchers' shops:-Turkish Embassy in London replies to Italian Prime Minister's protest.-U. S. navy reviewed by Pres. Taft in Hudson River.

3. Conference at Downing Street, London, between ministers and representatives of British railway companies. - Max Schultz, German subject, sentenced at Exeter to $2 \mathrm{r}$ months' imprisonment in second division for espionage.Mr. Borden, Canadian premier, and Mr. White, Finance Minister, speak at Halifax and Leeds (Canada) respectively on Canada's future policy as regards tariff and reciprocity. - Russian Govt. demand apology for insult to two Russian consular officers offered by Persian gendarmerie at Teheran.

4. Railwaymen's Unions of Great Britain decide to take ballot as to acceptance of Special Commission's Report. Franco-German treaties signed in Berlin - South Wales coalowners refuse principle of minimum wage--Ulster Unionists issue manifesto declaring that they will not accept an Irish Legislature - Imperial Cancer Research Fund issue Fourth Report.-Fighting between Turks and Italians near Shara Shat, Tripoli.

5. Italy annexes Tripoli and Cyrenaica by Royal decree. -M. Caillaux, French Premier, speaking at St. Calais, insists that France must have entire freedom of action in Morocco.

6. Mr. Balfour speaks to Nonconformist Unionist Association, London, on Government's Home Rule proposals. Mr. Asquith receives deputation urging British mediation between Italy and. Turkey.-Lord Curzon purchases Tattershall Castle, Lincolnshire, a is th century fortress mansion, in order to preserve it as a national monument.General Botha announces that the Union Govt. will raise $£ 5,000,000$ for the development of South Africa.

7. Mr. Asquith announces to a deputation in London that the govt. next session will bring in a bill for Manhoor Suffrage-British Home Secretary appoints committee to deal with storage of explosives - Russian Foreign Ministe states that both Russia and Great Britain will remain neutral in Persian affairs.-General Wu Lu-chew, Governor-designate of Shansi, assassinated by Manchu soldiers.Sir Edward Grey, in British House of Commons, denies interview reported in an Austrian newspaper with British Ambassador at Vienna.-Elections are held in eighteen American states.

8. Mr. Balfour, at a meeting in the City of London, announces his resignation of the leadership of the Unionist Party.-Resignation of the Portuguese Cabinet - Chinese province of Chihli joins revolutionaries.-Mr. Shuster, financial adviser in Teheran, makes charges against British and Russian govts.-Mr. Lionel Smythe, A.R.A., elected a full member of the Royal Academy, London.-Rioting occurs in Tunis over demarcation of an Arab cemetery. Tariff Reform league dinner at "White City," London speeches by Mr. Austen Chamberlain, Mr. Bonar Law, Mr. F. E. Smith and Mr. Chaplin (chairman). - £ro,ooo given to Oxford University by Miss Mary Shillito to endow a Readership in Assyriology.-American Tobacco Company's reorganisation plan is approved by $\mathbf{U}$. S, Supreme Court.-Telegraphers on the Southern and on the Baltimore and Ohio railways, U.S.A., go back to work after a strike begun in the summer, winning an $8-\mathrm{hr}$. day and increased pay. 
9. King George unveils memorial to Edward VII in Guards'. 'Chapel, London.-At Guildhall banquet Mr. Asquith speaks on home affairs and foreign relations, and Mr. Churchill on the supremacy of the British Navy.London taxi-cab strike partially settled.-Debate in Germah Reichstag on Franco-German treaties opened by Imperial Chancellor; Conservative attack on England reported to have been applauded by the Crown Prince.-Chinese Republic proclaimed at Canton; viceroy seeks British protection at Hong-Kong. - National Union of Women's Suffrage of Great Britain issues protest against exclusion of women from proposed Manhood Suffrage Bill. - Mr. E. T. Hooley examined in London Court of Bankruptcy - Nobel prize for literature awarded to Maurice Maeterlinck.-U. S. municipal elections marked by Socialist suocesses.-Sultan Mulai Hafid of Morocco consents to conditions of Franco-German treaty of November 4.-U. S. Commerce Court grants temporary injunction, staying Interstate Commerce Commission's order affecting reductions in rates from points East to points between Missouri river and Pacific. Coast.-Dedication of granite temple over the cabin near Hodgenville, in which Abrahan Lincoln was born.

10. Prince Arthur of Connaught, the Archbishop of Canterbury', the Lord Chancellor and Lord Morley, appointed by King George as a Commission to transact business for him during his absence in India.-Massacre by Manchus at Nanking. - The Throne in China accepts the principles of the Constitution as formulated by the National Assembly.-Dockyard Arsenal at Shanghaj captured by rebels. Hankau reported to be in flames. - Italian positions in Tripoli attacked by Turks and Arabs.-Persian . Govt. refuse to offer apology to Russia for insult alleged to have been offered to two consular agents by gendarmerieRev. A. Donglas, British Missionary, shot owing to a misapprehension by a Portuguese official in Nyasaland II. King George and Queen Mary leave England for India - Russia sends ultimatum to Persia, and Teheran Cabinet resigns. - It is stated that the German Emperor's displeasure with the Crown Prince is shown by his being sent to Dantzig. - Conclusion of Reichstag debate on Franco-German treaties.-German battleship "Kaiserin" launched at Kiel.-Señor Vasconcelles forms new Ministry in Portugal.

12. Pres. Taft returns to Washington after 15,000 miles political tour.-Spanish municipal elections show majority for Monarchists.

13. Mr. Bonar Law chosen Unionist leader in British House of Commons.-Oldham by-election; victory of $\mathbf{M r}$ Bartley Denniss (Unionist), majonty 1, 632.- Yuan Shih-kai arrives in Peking. - New London Opera House under Mr. Hammerstein opens with "Quo Vadis."-Birmingham stipendiary magistrate prohibits boxing contest for World's Featherweight Championship as illegal in England.Resignation of Sultan of Zanzibar.-American Federation of Labour begins its 31st Annual Convention at Atlanta Ga.-Monument erected by United Mine Workers of America, is unveiled at Cherry, 111. to memory of miners who lost their lives in Cherry mine disaster, Nov, 13, 1000 14. Imperial Edict is issued in China commanding Yuan Shih-kai to accept Premiership.-Special commission appointed to reorganise French Foreign Office.-Bavarian Diet dissolved owing to conflict between govt. and Centre Party - Dr. Waldstein resigns Slade Professorship of Fine Art at Cambridge University (Eng.), and offers $\sum_{1,000}$ to promote study of architecture-MM. Bienaimé and Rumpelmayer, two French airmen, fly from Compiègne to Courtland, $\mathbf{T}, 056$ miles, in $161 / 2$ hours.-U. S. Commerce Court holds that action of Interstate Commence Commission in dividing country into rate zones (July 26) was invalid.

Miners' Federation of Great Britain decide to make further efforts to secure settlement of minimum wage question without resorting to strike.-Huth library sale begins in London-Commander F. G. Brine washed overboard from H.M.S. "St. Vincent" and drowned.

16. Centenary of John Bright's birth celebrated at Rochdale, Lancashire,-King of Servia visits Paris. Yuan Shih-kai forms Cabinet in China.-Mr. Bonar Law, as Leader of Unionist Party, addresses National Union Conference in Leeds on Unionist policy, - Duke and Duchess of Connaught open Canadian Parliament. White Star Company's action in the Admiralty Division of the High Court against H.M.S. "Hawke" for damaging "Otympic" in collision begins in London.-Portuguese parliament reopens with sieech on Government's policy by Senhor Vasconcellos, the new Premier,- - Russian Govt. receiving no reply to ultimatum to Persia, despatched troops to Kazvin. - Notification of pulmonary tuberculosis made compulsory in Great Britain.-Mr. Roosevelt attacks Pres. Taft's attitude to the Trusts in The Oullook (New York).-Federal grand jury at New York indicts thirteen officials of Baltimore and Ohio and Louisville and Nashville Railroads for rebating.

17. Yuan Shih-kai orders troops to Hankau to suppress Chinese rebels.-Herr von Kiderlen-Waechter, German Foreign Secretary, makes statement before Budget Committee of Reichstag with regard to new treaties.-Mr. Asquith and Mr. Lloyd George receive a deputation at Downing Street, on Woman's Suffrage-Crystal Palace London, sold to Lord Plymouth for $£_{210}, 000$.-Court of Appeal in London declares Forms 4 and 8 for valuation returns under Finance Act invalid (see May 9).--Earthquake in Southern and Central Germany. - Strike in French Govt. dockyard at Lorient; settled next day.

18. Night mail train from Paris to Marseilles robbed by thieves, who escape.-Elections in Victoria, Australia, reveal decline in power of Labour Party,-British Legation at Teheran requests $\mathrm{K}$ ing George to mediate between Persia and Russia.-Russia breaks off diplomatic relations with Persia.-H.M.S. "Centurion" launched at Devonport by Mrs. Winston Churchill.-Liepmannssohn's sale of musical autographs and M.S.S. begins in Berlin.In a mine of Bottom Creek Coal and Coke Co., Vivian, W. Va., about 30 miners are killed by coal-dusi explosion. - Bernardo Reyes and others indicted by U. S. District Court in Texas for violating neutrality laws by fitting out an expedition against Mexico.

19. British railwaymen meet in London to discuss report of Govt. Inquiry Commission; conflicting decisions.Pres. Caceres of San Domingo assassinated. - In India Major Bower's punitive expedition captures an Abor entrenched position

20. King George axd Queen Mary meet Khedive and Lord Kitchener at Port Said.-Meeting at Memorial Hall Farringdon Street, London, at which Mr. McCullagh, a war correspondent, describes alleged Italian atrocities in Tripoli. -Yuan Shih-kai has interview with Peking correspondent of the Times on condition of China.-Dr. . Mawson's Antarctic expedition starts from Adelaide, and a Japanese expedition starts from Sydney.-Fra Angelico's "Madonna della Stella" stolen from San Marco Museum, Florence. Mazarine Bible (Huth collection) sold in London for $£_{5}, 800$.

21. Suffragist raid in Whitehall, London; over 200 arrests.-General Botha speaks in Bloemfontein on need of national union of the two white races in S. Africa. S. Somerset by-election results in Unionist gain by returm

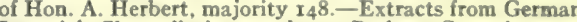
Imperial Chancellor's speech to Budget Committee of Reichstag published in Berlin.-British Consular report on Belgian Congo issued.-Another Abor entrenchment captured; Major Bower slightly wounded.

22. 148 cases, arising out of London Suffragist raid come before magistrate at Bow Street-M. Caillaux announces to Foreign Affairs Committee of French Senate that the secret clauses of the Anglo-French Declaration of $\mathbf{1} 904$ will be published.

23. Persian Foreign Minister replies to Russia, conceding Russian demands.-Herts (Hitchin) by-election results in return of Lord Robert Cecil, majority $\mathbf{r}, 633$.-Mrs. Pethick Lawrence sentenced to one month in Second Division for participation in London Suffragist raidRailway bridge collapses near Montreuil-Bellay, France. throwing train into river; 30 killed.-Crown Prince of Sweden undergoes operation for appendicitis.-Debate in French Chamber of Deputies on Government's alleged employment of agents provocateurs. - Italy notifies Powers of her intention to blockade Dardanelles.

24. Anglo-French Declaration of zoos concerning Ezypt and Morocco, with five secret Articles, published in London and Paris.-Explosion at Bibby's oil-cake mills, Liverpool: 27 killed, over 100 injured.- Sharp fighting at Tripoli and Derna; heavy Arab losses.-Mr. Lloyd George speaks at Bath on Woman's Suff rage.-British Medical Association decide to oppose working of Insurance Bill unless they get satisfactory terms from County Committees, -Death of M arquess Komura, Japanese statesman.-"Madonna della Stella" of Fra Angelico, stolen on November 20, is recovered.

25. Mr. Charles Brookfield sppointed Joint Examiner of Plays in Great Britain from January $\mathbf{x}$ next.-Miss Felicia Lyne, American prima donna, makes her debut in grand opera at the London Opera House in "Rigoletto."-Lieut. von Loringhoven, German aeronaut, killed at Döberitz. Lieut. C. F. Dugdale, British cavalry officer, killed in riding chool at Rome - Nanking bombarded by Chinese revolutionaries.-Rioting in Brazil over election of State Governor. 
26. Fighting in Tripoli results in decisive victory for the Italians. - Rioting in Lisbon.-Decroce, Italian airman, killed at Turin.

27. King George and Queen Mary arrive at Aden.President of the German Navy Leagt e speaks at Frankfurt on necessity of strengthening German Navy.--Spanish commanders agree to terms with 65 Riff chiers.-Chinese Imperialist troops recapture Han-Yang, but revolutionaries capture positions-commanding Nanking.-Sir Edward Grey makes statement in British House of Commons on Morocco negotiations.-Mr. Lloyd George holds conference in London with representatives of Friendly Societies. - Sale of Abdul Hamid's jewels in Paris; pearl necklace fetches $£_{36,804}$ - - Irving B. Dudley (b. 1861), of California, resigns post of U. S. minister to Brazil.

28. Mr. Lloyd George receives British deputation in London representing domestic servants, and reassures them with regard to Insurance Bill,-In the British Parliament the names of the Commissioners who will administer the Insurance Act are announced, viz., Sir R. Morant (Chairman), Mr. John Bradbury, Mr. D. J. Shackleton, Mr. J. Lister Stead, and Miss Mona Wilson.-The Archbishops of Canterbury and York issue manifesto against Welsh disestablishment.-Murder of Lord George Sanger, circus proprietor, at East Finchley,-Wu-chang capitulates to Chinese Govt. Troops. - Strike of Paris taxi-cab drivers. - Convocation at Oxford University rejects a statute making Greek optional for science and mathematical students. - Sharp fighting between Arabs and Italians near Bengazi, Tripoli-Committee of U. S. House of Representatives receive report from Louis D. Brandeis exonerating President from charges made in connection with Controller Bay.

29. Domestic Servants Protest Meeting in Albert Hall, Loudon, against Insurance Bill.-Sufiragist disturbance at City Temple, London, prevents $\mathrm{Mr}$. Asquith from speaking-M. Mosca, Austrian airman, killed at Trieste.Russian Govt. demands from Persia dismissal of Mr. Shuster and Mr. Lecoffre, financial advisers.-M. Salmet at Hendon reaches record height of 9,000 feet with Blériot monoplane,-Chinese revolutionaries enter Nanking.

30. Sir E. Grey makes statement in British House of Commons on situation in Persia.-Murderer of Lord George Sanger found decapitated on railway near Highgate, London.-South African Defence Bill published in Cape Town. - Debate in French Chamber of Deputies on reorganisation of French Foreign Office--Pope Pius X creates three American cardinals, Archbishop Farley (b. I842) of New York, Archbishop O'Connell (b. 1850) of Boston, and Monsignor Falconio (b. 1842), apostolic delegate to Washington, D. C. -The shares of the subsidiary companies of the Standard Oil Company of New Jersey are distributed among its stockholders pro rata.

December:-

1. Internat. Opium Conference opened at the Hague.Persia refuses to dismiss Mr. Shuster; Russian troops ordered to advance. - Council of Railway Companies Assaciation in London agree to meet representatives of Railwaymen's associations.-Explosion at Armitage dye-works, Bradford, Yorks.; x killed, 20 injured.-Chinese revolutionaries capture Purple Mountain, near Nanking.-Lord Lansdowne speaks at Derby on Parliament Act and need for restoring the Constitution.-Ala-ed-Dowleh, ex-Governor of Fars, assassinated at Teheran.

2. Coronation of King Vajiravudh of Siam at Bangkok. -King George and Queen Mary arrive at Bombay.-Three days' armistice at Wu-chang signed at Hankaw--Russians advance towards Teheran-Public opinion in America excited by confession of J. J and J. B. MacNamara of responsibility for dynamite explosion in office of Los Angeles Times on Oct. I, rgro.-Eladio Victoria elected provisional Pres. of Santo Domingo.

Herr Reeb, German airman, killed at Breitenfurt.M. Prévost reaches 9,800 feet with a passenger at Courcy near Rheims, in a Deperdussin monoplane--Mr. Tod Schriver, American airman, killed at San Juan.-Rioting at Ishtib follows on an explosion in a Mosque; much loss of life.

King George V drives in state to Exhibition grounds, Bombay. - Chinese armistice extended to Is days.-New comet discovered by $M$. Schaumasse at Nice.-Fires in Jersey City do damage amounting to $£_{200,000}$. - Mr, B. J Duveen, London art-dealer, fined $£_{3}, 000$ in New York for evasion of American customs duties on objects of art.Italians capture oasis of Ain Zara in Tripoli--Rupture between King Alfonso of. Spain and his aunt, the Infanta Eulatia, owing to publication of her autobiography.Persian Mejliss appeals to U. S. for aid against Russia. U. S.-Supreme Court decides that a person or association is limited to one coal land entry in Alaska. - The 62nd Con- gress of the U.S. meets in its first regular session.- Suit is filed in U. S. Circuit Court against National Cash Register Company of Dayton, Ohio, charging conspiracy in restraint of trade.-John D. Rockefeller resigns presidency of Stand ard-Oil Company of New Jersey; John D. Archbold is chosen to succeed him.

5. German Imperial Chancellor replies in Reichstag to Sir E. Grey's speech in House of Commons. - Two outbreaks of fire in Delhi--J. B. McNamara sentenced at Los Angeles to life imprisonment and his brother John to Is years for having blown up office of Los Angeles $T$ imes on Oct. I, I010.-Arbor stronghold at Kekar Monn Ying captured by Gen. Bower--British Postmaster General announces extension of wireless telegraphy, and cheapening of cable rates between Great Britain and both the colonies and the U. S.-Pres, Taft in a special message to U. S Congress recommerids amendments to Sherman Act, federal incorporation for interstate commerce companies and a new commission to approve plans for reorganisation of trusts.-Bill to abolish U. S. Commerce Court introduced in U. S. Senate by Miles Poindexter.

6. Chimese Regent resigns and guardians are appointed for infant Emperor-British Home Secretary appoints Committee to enquire into selection and summoning o juries,-Mr. H. Oxley, English airman, and a pupil, killed at Filey, Yorkshire.-Insurance Bill passes its third reading in British House of Commons after Mr. H. W. Forster's amendment to postpone its coming into operation had been rejected by 320 votes to 223 - -Mr. A. C. Gow, R.A., made Keeper of Royal Academy, London,-American Rivers and Harbours Congress begins its eighth annual session at Washington, D.C.

7. King George and Queen Mary enter Delhi.-General election in New Zealand; govt. majority reduced.-Chinese edicts issued abolishing pigtail and ordering means to be devised for adopting Western calendar.-Naval Price Bill passes British House of Commons by a majority of 47 . Mr. Bonar Law speaks at Bootle (Lancashire), on Home Rule.-Mr. H. Bottomley, M.P., applies for receiving order at London Bankruptcy Court.-Lord Morley, in reply to Lord Curzon, makes statement in House of Lords on Persian affairs.-M. Kistemaecker's play, La Flambée, dealing with espionage, produced at the Porte St. Martin theatre, Paris.-Franco-Spanish negotiations with regard to Morocco begin in Madrid.-American jury finds the two owners of the Triangle Waist Co., of New York City, not guilty of manslaughter (see Mar. 25). - Death in London of Sir George Lewis, solicitor, aged 78.-It is announced in British Parliament that the Irish Commissioners under the National Health Insurance Act will be Mr. J. A. Glynn (chairman), Mr. W. S. Kinnear, Dr. W. J. Maguire, and Mrs. Dickie.

8. King George places in position at Delhi the All-India memorial of King Edward. - Shops Bill passed by British House of Commons.-Pres. Taft indicates that he will press U. S. Senate to ratify British and French Arbitration Treaties.-American Peace Society convenes at Washington, D. C.-After examining wreck of "Maine" in Havana harbour naval experts report that ship's destruction was due primarily to an external explosion.

9. Armistice in China continued until December 24Explosion in coal-mine near Briceville, Tennessee; over roo men entombed.-Trial of Cullera strikers concluded at Sueca, Spain.-Report of L. D. Brandeis on the Controller Bay controversy accepted by committee on expenditures of U. S. House of Representatives.

ro. Nobel Prizes distributed at Stockholm.-Death of Sir Joseph Hooker, O.M., at Sunningdale, aged 94.Tramcar accident at Oporto; I 4 killed, 30 injured.-Onecent letter postage and parcel post recommended by Postmaster-General, U. S.

Ix. At Board of Trade Conference in London, settlement arranged between railway companies and leaders of the railwaymen's unions, whereby strike averted.-U.S. Railway Securities Commission reports against Federal regulation of issue of new securities until federal incorporation act is passed.

12. King George holds Coronation Durbar at Delhi and announces transfer of the Indian capital from Calcutta to that city which will be largely rebuilt for the purpose House of Lords reject second reading of Naval Prize Bill. Mass meeting in New York in favour of Arbitration treaties broken up in disorder; Mr. Carnegie refused a hearing. Queen of Spain gives birth to a daughter--Explosion on board H.M.S. "Orion"; 8 injured.-Cabinat crisis in Persia; Mejliss refuse to accept Ministry willing to submit to Russia - Sherwood Service "dollar-a-day" Pension bill giving a pension of $\$ 15$ to $\$ 30$ a month to every soldier and adding $\$ 75,000,000$ a year to the country's expenditure, 
passed by U. S. House of Representatives 229 to $92,-$ Oxford beats Cambridge in Rugby football match at Queens Club by to points to nil.

13. P. \& O. liner "Delhi," with Princess Royal and Duke of Fife on board, wrecked on Morocco coast.-Sir John French's Report on British Territorial Force published in London.-Cape Appeal Court decides that if any of a man's near ancestors was coloured, he must be regarded as of non-European descent_- "Les Sauterelles," play attacking French colonial system, by Emile Fabre, produced at Vaudeville theatre, Paris.-Five persons accused of espionage in interests of England sentenced at Leipzig to terms of penal servitude varying from 12 to 2 years.- Sulzer Resolution asking for abrogation of U.S. treaty with Russia of 1832 on account of Russia's refusal to admit American citizens who are Jews passes House of Representatives by 300 to I (see Dec. Io')

14. King George reviews 50,000 troops in DelhiDebate on Franco-German Agreement begins in French Chamber.-Mr. Asquith in House of Commons promises to appoint Standing Committee on Estimates.-British War Office offers money prizes for military aeroplanes. Mr. Asquith receives sympathetically deputation from Anti-Suffrage League - Miss EleanorDavies-Colley, M.D., admitted Fellow of Royal College of Surgeons; first woman so honoured.-British Prime Minister expresses in House of Commons his sense of gallantry of crew of French cruiser "Firant" who saved passengers on "Delhi."-AntiBritish boycott begun in Persia.-John W. Garrett (b. 1872 ) of Maryland, appointed U. S. minister to Argentina. - Bill prescribing eight-hour day for all contract labour for U. S. Govt. passed by U. S. House of Representatives-At Indianapolis, Ind., Federal grand jury begins investigation into alleged dynamiting conspiracy.-Andrew Carnegie gives $£_{2}, 000,000$ for endowment of internat. peace founda tion.

15. King George lays first stone of new imperial capital at Delhi.-M. Millerand speaks in French Chamber on Franco-German Agreement.- Treaty between U, S, and Great Britain, Japan and Russia abolishing pelagic sealing
becomes effective (see July 7).-Lord Roberts in England publishes letter alleging unpreparedness of British Army for war.-Seamen's strike at Funchal, Madeira; martial law prevails.-Cretan Deputies prevented from sailing for Greece by French cruiser which escorts steamer intended for them to Suda Bay.-Austrian Premier, Count Sturgkh, makes statement on foreign policy,-Insurance Bill passes third reading in House of Lords, without a division.

16. King George leaves Delhi for shooting trip in Nepal. - Gaekwar of Baroda apologises in a letter to the Viceroy of India for failure to observe correct etiquette in doing homage to King George at Delhi Durbar.-Sir Edward Grey and Mr. Lloyd George speak at Horticultural Hall London, in favour of Woman Suffrage; the latter is attacked when returning from the meeting.-Lord Haldane at Bradford speaks in reply to Lord Roberts' criticism of Territorial Force.-British Parliament prorogued.-AustriaHungary announces assent in principle to Franco-German Agreement. - Fighting between Arabs and Italian sailors at Suara, and Derna in Tripoli.-Public meeting held at Boston. Mass., to devise a "progressive" organisation in Republican party, - Urgency Deficiency bill $\left(\$_{2}, 270,000\right)$ passed by U. S. House of Representatives without amendment.

King George telegraphs to Pres. Falliêres his thanks for services rendered by French seamen to "Delhi" and his grief at loss of brave lives.-Russia and Turkey come to an agreement on the independence of Persia.

18. M. Caillaux speaks in French Chamber on FrancoGerman Agreement.-American Ambassador at St. Petersburg is instructed by Pres. Taft to denounce Russian commercial treaty, which would therefore come to an end on January $x$, ror 3.- Persian Cabinet try again unsuccessfully to get assent of Mejliss to Russian demands. - Sale of Mathys art collection in Brussels. - It is announced in British Parliament that the Welsh Commissioners under the National Health Insurance Act will be Alderman T. J Hughes (Chairman), Dr. Meredith Richards, J. Rowland, $M$ iss Violet Douglas-Pennant.-Receivers for Wabash Railroad Company, U. S., appointed on bill of complaint filed by Westinghouse Air Brake Co.

ro. Pres. Taft speaks in New York in favour of proposed Arbitration Treaties.-Pres. Taft's announcement of termination of Russian treaty unanimously ratified by Senate, and (Dec. 20) by House.-Turkey recognises right of Egypt to occupy Sollum Bay during continuance of Turco-Italian war. - Rioting at Dundee by carters on strike: 300 soldiers sent from Edinburzh.-Meeting of 2,000 floctors in Queen's Hall, London, to protest against serving under Insurance Act.-Fighting between Turco-Arab force and Italians at Bir Tobras, near Ain Zara in Tripoli; six Italians killed, 78 wounded. -In the "Hawke"."Olympic" case (see Nov. I6) the Court finds the faulty navigation of the "Olympic's": pilot responsible, but holds the owner free from liability owing to pilotage being compulsory; an appeal is entered.

20. N. Ayrshire by-election results in defeat of $\mathbf{M r}$. Anderson (Liberal), new Solicitor-General for Scotland, by Capt. Campbell (Unionist) majority $271-$ New Zealand elections leave Govt. of Sir J. Ward in a minority:-French Chamber agrees to Franco-German Agreement by 393 votes to 36 . - Cotton operatives at Accrington strike owing to refusal of two to join Union, and general lock-out follows in N. E. Lancashire-Mr. Asquith announces - Royal Commission to enquire into question of appointments in Civil Service-Final Report of Royal Commission on Tuberculosis published in London-Cornerstone laid of first settlement house for the blind in New York City. Appointment of Scottish Commissioners under National Insurance Act announced; J. Leishman (Chairman) Dr. J. C. McVail (Deputy Chairman), J. McNicol and Miss M. M. Paterson.

21. Miners' Federation of Great Britain decide to take ballot on question of striking for minimum wage--Mr. G. A. Redford resigns office of Examiner of Plays in England. French Court Martial appointed to enquire into causes of explosion on battleship "Liberte" acourts senior officers.In first test match in Australia the Australian cricketers beat M.C.C. by 146 runs.-Bank messenger robbed in Montmartre, Paris, by thieves who escape in a motor-carTurkish hospital ship. "Kaiserieh" captured by Italian cruiser "Puglia," on suspicion of being really a transport.Mr. Justice Bargrave Deane, in Divoree Division of High Court, London, decides that Gaekwar of Baroda; being a ruling savereign, cannot be cited as co-respondent in the case of Statham iv. Statham. - Elliott Northcott (6. 1860), of W. V. appointed U. S minister to Veriezuela - George T. Weitzel (b. I873), of Missouri, appointed U. S. minister to Nicaragua.-Pres. Taft, in a message to Congress, asks for two battleships a year until Panama Canal is finished; urges extension of merit system, establishment of rural parcel post, and legislation to lessen court expense and delay; and commends report of National Monetary Commission.

22. Military mutiny in Braga, Portugal--Persia accepts Russian demands, which include dismissal of Mr. Shuster.Spanish reply to French proposals concerning Morocco received by France:-Govan by-election in Scotland results in return of Mr. Holmes (Liberal) by reduced majority of 086.-Mr. R. Cory, S. Wales coal-owner and Liberal, leaves Liberal Party on Home Rule issue-British steamer "Menzaleh" seized by Italian warship "Puglia." - Death of Señor Emil o Estrada, Pres. of Ecuador.-Fighting at Tobruk, Tripoli; heavy Turkish losses; Italians 7 killed, 16 wounded-Rules of U. S. Supreme Court revised to reduce cost of litigation.

23. French Committee appointed to consider FrancoGerman treaty meet, and are addressed by MM. Fallières and Pichon. - "The Miracle." a wordless mystery spectacle, produced in London at Olympia by Prof. Max Reinhardt. Anti-Trust prosecution of Australian Coal Vend results in imposition of penalties exceeding $\sum_{50,000}$-Fighting between Russians and Persians at Tabriz; Russian reinforcements sent from Erivan.-Fighting between Spaniards and Moorish tribesmen at Melilla.

24. Dundee carters' strike settied through mediation of Sir G. Askwith.-Persian Mejliss dissolved by coup d'état; Mr. Shuster dismissed; martial law proclaimed at Teheran. -Record long distance flight without landing (462 I/ miles) made at Pau by French airman, Gobe.

26. Surrender of General Reyes, leader of counterrevolutionary movement in Mexico, to Pres. Madero:Committee of French Senate sits to hear Prime Minister and Foreign Minister on points of difference in interpreting Congo part of Franco-German Agreement.-Fighting near Derna, Tripoli, between Arabs and Italians; Italians lose 3 killed and 77 wounded.

27. Great cottion lock-out begins in Manchester-Mr. Smart. Acting British Consul in Persia, attacked and wounded near Kazerun.-Russian repressive measures taken against Persian rioters. - Epidemic of poisoning in municipal sheiters. Berlin. causes 71 deaths and is finally traced to adulterated spirits. - Six Bosnian immigrants murdered near Kotchana in Macedonia, the motive being sacial hatred.-Fighting between Spaniards and Moors in Melilla district: heavy Moorish losses.

28. Count Aerenthal speaks on Foreign Policy to Hungarian Delegations. - Coal strike at Troerky, S. Wales. 
-Yuan Shih-kai causes issue of an edict in which the Throne expresses itself willing to abide by decision of National Convention. - Field Museum of Natural History, Chicago, receives gift of $\$ 250,000$ from $N$. W. Harris.

29. Mr. Lloyd George speaks at Cardiff on the Churches and poverty.-Chinese provisional Convention sitting at Nanking is reported to have elected Dr. Sun Yat Sen as Pres. of Chinese Republic.-Patriarch of Lisbon and other Church dignitaries expelled from their dioceses by $\mathbf{F}$ )rtuguese Govt.-Disclosure of secret negotiations between individual French ministers and Germany made before Senate Committee on Franco-German treaty.

30. King George and Queen Mary arrive at Calcutta and are received with great enthusiasm.-Resignation of Turkish Cabinet.-Peace banquet in New York addressed by Pres. Taft, who replies to Mr. Roosevelt"s criticisms of Arbitration Treaties.-Metropolitan Street Railway system in New York absorbed by New York Railways Company with Theodore P. Shonts as Pres.-Extension of S. Wales mining strike.

3r. The business of the National Telephone Company in England passes to H.M.'s Govt., and telephone service comés completely under Post Office.

\section{Jowiary-_ 1912}

1. Fighting between Chinese Revolutionists and Imperialists resumed at Hankow.-New Swiss Civil Code comes into operation (see Times, Feb. 23).-England beats France in Assoc. football at Tufnell Park by 7 goals to 1 . 2. Tang Shao-yi, the Government delegate at the Chinese Peace Conference, resigns.

3. Capt. Scott's Antarctic Expedition reaches a point 150 miles from the South Pole (see Apr, x),-Ulster Unionist Council at annaal meeting at Belfast resolve to repudiate the authority of an Irish Parliament if set up under the Home Rule Bill- - Strike of Belgian miners begins at Mons. -M.C.C. cricket eleven win second Test Match at Melbourne by 8 wickets.

4. Paris motor-car bandits murder an old man and his housekeeper at Thiasis.-Earthquake shocks in California and Nevada.

5. Chinese Republican manifesto, signed by Sun Yat Sen, issued at Shanghai.-Unionist demonstration with procession of 20,000 men at Omagh; Sir E. Carson speaks.

6. Paris railway accident, 9 killed, 18 injured.-Pres. Taft signs proclamation admitting New Mexico as the 47 th state of the U. S.

7. Italian warships sink seven Turkish gunboats off Kunfida.-Collision between British battleships". Revenge" and "Orion," in Portsmouth harbour.

8. Formation of British Naval War Staff announced by Mr. Winston Churchill.-Evictions of small holders carried ouit by the Salvation Army at Boxted, Essex-Democratic National Committee meets at Washington, and decides to hold presidentíl convention at Baltimore, Md., on June 25. W. J. Bryan's supporters are defeated on two roll-calls.National U. S. Monetary Commission, created roo8, presents to Congress a plan for reorganisation of banking system, including establishment of a national reserve association

9. French Parliamentary Session opens; M. Brisson re-elected President of Chamber of Deputies.-French Senate Committee discusses Moroccan agreement; M. de Selves, Foreign Minister, resigns owing to disclosure of intrigue against him by $M$. Caillaux, the Premier,-Equitable Life Assurance building in New York destroyed by fire; 6 lives lost.-British Miners' ballot on the question of a strike begins.-Death of "Gallinule" a famous studhorse, at the Curragh, Ireland.-U. S. Supreme Court decides that Federal Hours of Service law of roo7 takes precedence over state laws for trainmen and applies to trains carrying interstate shipments; also that Interstate Commerce Commission had a right to allow higher freight rates for shorter route under practically identical conditions

10. French Cabinet crisis; Caillaux ministry resigns.- King George and Queen Mary leave Bombay for England. 11. M. Antoine Dubost re-elected President of the French Senate - The Russian steamer "Russ" sinks in the Black Sea with 172 persons on board-Rioting at Bahia Brazil; Government building bombarded.--Spanish Council of War and Marine sentences seven of the Cullera rioters (see Sept. I8 IoIr) to death-England beats Wales in Assoc. football at Tufnell Park by ro goals to 0 .

12. In the first ballots of the German elections for the Reichstag, the Socialists win 26 seats.-Coal rises 35. and 3s. $6 \mathrm{~d}$. a ton in London, according to quality:-The Lord Chamberlain issues a notice that music-halls may apply to be ficensed for the production of stage plays $-\mathrm{M}$. Ruchon- net, French airman, killed at Vidame.-The King of Spain signs a decree pardoning 6 of the 7 condemned Cullera rioters.-The Manchu princes resolve to request the Chinese Throne to retire to Jehol.

13. M. Poincaré, as Premier and Foreign Secretary, forms new French ministry; $\mathbf{M}$. Bourgeois Labour Minister, M. Briand Minister of Justice, M. Millerand War Minister, M. Delcassé Minister of Marine.-Védrines, French airman, attains a speed record of 80 miles an hour near Pau.

I4. Spanish Cabinet resign against reprieve of Cullera rioters.-Anti-clerical demonstration in Lisbon.

15. Señor Canalejas, Spanish Premier, resumes office."Oedipus Rex" in English produced under Herr Reinhardt's direction at Covent Garden, London-Fighting in Asunción, Paraguay, results after three days in the reinstatement of President Rojas.-U.S. Senate, by 58 votes to 8 , decides to discuss arbitration treaties in public sessions-U. $\mathrm{S}$. Supreme Court holds Employers' Liability Law of 1008 tc be constitutional.-U. S. cruiser "Maryland" ordered to Ecuador to protect American interests.

16. Bomb attempt on Yuan shih-Kai, Chinese Premier, at Peking.-Swedish Riksdag opens; woman's suff rage bill announced.-U. S. Govt. warns Cuba that if the military continue to interfere in politics intervention may again be necessary.- Death of Henry Labouchère, English politician and journalist, at Florence, aged 80

r\%. Fighting between Italians and Turks at Derna, Tripoli.-Italian warship seizes French mailboat "Carthage" in the Mediterranean.-M.C.C. cricket eleven win Third Test Match at Adelajde by 7 wickets.-Pres. Taft in a special message to $\mathrm{U}$. S. Congress recommends changes in administration estimated to save $\$ 11,000,000$.-Dr. Harvey W. Wiley's conduct of pure food investigation approved by a committee of the U,S. House of Representatives.-United Mine Workers' convention at Indianapolis, Ind., favours government ownership of all industries and votes to demand higher wages for all coal miners.-Terminal Storage Company Warehouse in New York City burnt; damage about $\$ 1,000, \infty 00$

r8. Turkish parliament dissolved-British Miners ballot on a strike results in a vote of 445.80 I for and II 5.72 against.-Wreck of "Wistow Hall" off Aberdeenshire; 5 drowned.-Baron von Winogradoff, Russian naval officer, and Wilhelm von Cerno, engineer, sentenced at Leipzig to 3. years' imprisonment for espionage-Fighting nea Tripoli between Arabs and Italians.-M. Henri de Regnier received as a member of the French $\Lambda$ cademy. - Fighting at Guayaquil in Ecuador between the troops of the Quito Govt. and the Provisional Govt.; over 1,000 killed. Edwin V. Morgan (b. 1865) of New York appointed U. S. ambassador to Brazil as successor of minister Irving B. Dudley.-Pres. Taft pardons Charles W. Morse, sentenced January 3, 1910 to I5 years' imprisonment for violation of U. S. banking laws.-John. P. White re-elected pres. of United Mine Workers of America.

10. Lancashire cotton lock-out ends.-Italian warship off Sardinia seizes French mailboat "Manouba," carrying Red Crescent officers and men to Tunis.-Lieut. Boerner. French airman, seriously injured at Senlis.

20. Second ballots for German Reichstag begin.-Sir Edward Grey speaks at Sunderland on foreign affairs.

2x. Cardinal Bourne's reception at Westminster Cathedral, London.- Street rioting in Bukarest, as a demonstration against the Carp Ministry

22. Campaign against Home Rule opened in Lancashire and Cheshire by Mr. Austen Chamberlain, Sir E. Carson, Mr. F. E. Smith, and Mr. Walter Long.-M. Poincaré, French Premier, makes statement in Chamber as to gunboats seized by Italians-Railway accident in IHlinois; Mr. J. T. Harahan, President of the Railroad Co., and others killed.-U.S. Supreme Court decides that railways may not refuse to carry into prohibition territory intoxicat ing liquor shipped from another state.

23. Frederick the Great bi-centenary celebrated in Berlin.-A party of British visitors, selected from both Houses of Parliament, leave London for Russia, to return the visit of the Russian Duma to London in Sept. rorr."Rue de la Paix," play by MM. Abel Hermaut and Marc de Toledo, produced at the Vaudeville theatre. Paris. Federal Court at Buffalo, N. Y., fines Standard Oil Compa ny of New York $\$ 55,000$ for accepting railroad rebates,U.S. Supreme Court upholds order of Interstate Commerce Commission (enjoined by Circuit Court in Minnesota). forbidding increase in rates on lumber from Pacific Coast to mid-western points.

24. King George and Queen Mary arrive at Malta on their return voyage to England-Carmaerthen Borough by-election results in the return of Mr. Llewelyn Williams (Liberal) by I,28I, showing a reduction of 951.-Resigna- 
tion of Mr. Percival Hughes, Chief Conservative Agent, London.-Measure requiring U. S. Pres. to publish indorsements of candidates for federal judiciary is passed by the U. S. House of Representatives $r_{4} 8$ to 82 .

25. French Senate Committee adopt the Morocco agreement.-British visitors arrive in St. Petersburg.Cyrus E. Wood (b. 186I), of Pa., appointed U.S. minister to Portugal.

26. Mr. Bonar Law addresses London Unionists in the Albert Hall. "Manouba" incident settled (see Jan, 19) - Khartum Cathedral consecrated by Bishop of London.

27. Announcement in the Press that Mr. Pierpont Morgan's loan collection will be withdrawn from the Victoria \& Albert Museum, London, so as to avoid death duties."The Coronation," a play by Laurence Housman, refused a licence by the Lord Chamberlain.

28. Turkish attack on Aiu-Zaca (Tripoli) repulsed-U. S. Secretary of War recommends concentration of troops at eight strategic points, and closing of many army posts 29. Duke of Fife dies in Egypt, aged 62.-Mr. Morgan Shuster, ex-financial adviser in Persia, is entertained at a banquet in London.-German National Defence League const ituted in Berlin.-General strike at Lisbon.-Glasgow and Greenock dock strike.-U.S. House of Representatives pass $\geqslant$ ( 210 to 100 ) bill reducing duties on steel and iron.

30. Charity Commissioners' Enquiry opened at Colchester into the Salvation Army's evictions of tenants from small holdings at Boxted, Essex.-Mr. Roosevelt interviewed by the Chicago Evening Post; he stated that he did not want, and would not seek, but would accept the Presidency. - The Bishop of Winchester makes a speech on Anglo-German relations at his diocesan Conference. Winchester.-King George and Queen Mary arrive at Gibraltar on their return voyage to England.-Copyright treaty signed at Budapest between the United States and Hungary.

31. British doctors decline to attend conference convened in London by the Insurance Commissioners and the Joint Committee-Trial of Mr. Bertrand Stewart for espionaze before German Supreme Court at Leipzig--Lisbon strike ended by the action of the Portuguese Government.Mr. F. E. Smith speaks at New Cross on the Unionist programme.-Fighting in Mexico between Zapatistas and Federal troops.-Fight between gendarmes and motor-car bandits at Les Autrais goods station near Ftampes, France; one gendarme and one bandit killed:-Bill creating Children's Bureau in U. S. Department of Commerce and Labour passes U. S. Senate-Violent earthquake shock felt at Valdez, Alaska.-Rev. Austin Dowling of Providence. R. I. is named bishop of new Roman Catholic diocese of Des Moines, Iowa.

Fehruary:-

I. Miners' strike notices issued in South Wales to leave work on February 29, unless minimum wage demand is conceded.-Presbyterian Convention in Beltast protests against Home Rule.-Paris taxi-cab strike riot.-Board of Trade Report issued on first two years' work of Labour Exchanges in Great Britain.-.-French War Minister abolishes the system of secret reports.-Mrs. Caroline W. Neustadter's will bequeathes $\$ 1, \infty \infty 0, \infty 00$ for establishing model homes near New York City.

. British submarine A 3 , with 4 officers and 10 men, sunk during manoeuvres of the Isle of Wight.-East Edinburgh by-election results in the return of $\mathbf{M}-\mathbf{J} . \mathbf{M}$ Hogge (Liberal). - Senator La Follette in jures his prospects as presidential candidate by an attack on newspapers in a speech at Philadelphia.-Strike at Tilbury Docks, London.

"L'Assaut," a play by Bernstein, produced at the Gymnase Theatre, Paris. - Sofia fettes in honour of the coming of age of Prince Boris, Crown Prince of Bulgaria, begin.-Pres. Taft in special message to $U$. S. Congress recommends international commission on high cost of living and a federal commiss on on industrial relations.-Pension appropriation bill, carrying \$152,000,000, passed by U. S. House of Representatives. - Second Philippine legislature ends, with important measures pending: Governor-General Forbes calls extra session.-Convention of United Mine Workers at Indianapolis. Ind., adjourns after being in session since January 16.

Mr. Bertrand Stewart sentenced at Leipzig to $3 \frac{2}{2}$ years' detention in a fortress for espionage - Mr. Lloyd (ieorge speaks on finance at the City Liberal Club.Telegram published from the Princes and People of India to the British nation expressing gratitude for the Royal visit. - Wales beats Scotland in Rugby football at Swansea by 21 points to 6 .

4. King George and Queen Mary arrive at Spithead.Three factories burnt in Philadelphia, Pa.; loss about $81,000,000$.
5. King George and Queen Mary arrive in London.Announcement of donation of $£_{100,000}$ for endowment of home science at'King's College, London.- Servian Cabinet resign.-Bavarian Cabinet resign.

6. Nanking Assembly accepts Yuan Shih-kai's proposals for Chinese Constitutional reform.-King George and Queen Mary attend a Thanksgiving Service for their safe return at St. Paul's Cathedral, London-French naval programme, involving expenditure of $f 60,000,000$ in 8 years, disclosed in debate in Chamber of Deputies.

7. Coal coníerence of employers' and miners' representatives meets in London and fails to agree.-German Reichstag opens.-Dickens centenary celebration beld-Lord Haldane goes on a political mission to Germany ${ }_{1}-£_{100,000}$ raised for Bedford College for Women, London.-U.S. Dept. of State reaffirms policy for the "open door" in China.-U. S. marines landed at Puerto Cortes, Honduras, to protect American interests.-Extra session of the Philippine legislature, called on Feb, .2, ends without passing appropriation bills. Belfast.

9. Mr. Winston Churchill speaks on the Navy at Glasgow.-Heinrich Grosse, a German, sentenced at Winchester to 3 years' penal servitude for espionage.-Lord Spencer resigns the office of Lord Chamberlain.-M. Ribot speaks in the French Senate on the Franco-German Morocco treaty.-Glasgow dock strike riot-Death of Père Hyacinthe (Charles Loyson), in Paris, aged 84.-Amendment to Army appropriation bill, by which cavalry force is reduced from 15 regiments to 10 , adopted by U.S. House of Representatives.

10. French Senate ratifies Morocco Agreement bill.E. T. Hooley sentenced in London to a year's imprisonment for false pretences.-Glasgow dock strike ends. - Death of Lord Lister at Walmer, aged 84 - Fighting at Derna in Tripoli.-England beats Ireland in Association football at Dublin by 6 goals to $I$

12. Sir Edward Grey created K.G.-The Manchy dynasty abdicates in China and a Provisional Republic is established.-Mr. Lloyd George speaks on the Insurance Act in the London Opera House.-In a speech at Chicago, III., Mr. Woodrow Wilson begins campaign for Democratic Presidential nomination.

13. Yuan Shih-kai empowered as organiser of the Chinese Republic.-M.C.C cricket eleven win the Fourth Test Match at Melbourne.-Pres. Tait's Lincoln Day speech at New York outlines his future policy.-Trial of Miss Malecka on a charge of conspiracy begins at Warsaw.

I4. British Parliament opens-Arizona admitted to American state-hood.-Lord Sandhurst appointed Lord Chamberlain.-Lord Carrington resigns the office of Lord Privy Seal and is created Marquess of Lincolnshire.- Lord Crewe succeeds Lord Carrington as Lord Privy Seal while retaining the India Secretaryship.-Lord Pentland resigns the office of Secretary for Scotland and is succeeded by Mr. T. McKinnon Wood. - Sale of old silver, including Edward VI apostle spoons, at Christie's.-Parasite of Dum-dum or black fever discovered by Captain W. S Patton, I.M.S., asst. Director of the King Institute of Preventive Medicine, Madras.-Sir Walter Egerton appointed Governor of British Guiana.

15. Labour Amendment to the Address in British parliament in favour of a minimum wage rejected-London and North Western Railway appoint an official as "Grievance hearer."-German Chancellor speaks in the Reichsta on Lord Haldane's visit. - Myron T. Herrick (b, 1854) of Ohio appointed U. S. ambassador to France as successor of Robert Bacon, resigned January 2,- Two bank messengers are held up in a taxicab at noon in financial district. New York City, and robbed of \$ 2,000,-Railroad officials and steel-rail makers confer at New York City as to safer rails.-Comer-stone laid of National "Maine" Monument in Central Park, N. Y. to commemorate the U.S.S. Maine" destroyed in Havana harbour before outbreak of Spanish-American War in 1808 .

16. German Chancellor speaks in the Reichstag on the results of the General Election.-Norwegian Cabinet re. signs.-Mr. Hobhouse speaks against Woman Sufirage at Bristol. - Sir Bingham Sweet-Escott appointed Goyernor of the Fiji Islands.- U. S. House of Representatives passes Army appropriation bill, with term of enlistment increased from 3 to 5 years and reduction of number of cavalry regiments from 15 to 10--Major-General Frederick C. Ainsworth. Adjutant-General (b. 1852) of the U. S. army, is retired from active service upon his own application.

17. Death of Count Aehrenthal, Austro-Hungarian Foreign Minister, aged 57.--Plot against Count Terauchi the Japanese Governor-General, discovered in Korea.- 
"The Mind the Paint Girl," play by Sir A. Pinero, produced at the Duke of York's Theatre, London.-Mr. D. Graham Gilmour, British airman, killed at Richmond.

18. Anglo-Russian Note on future policy presented to the Persian Govt.--Riot at Serajevo, Croatia, during a Croatian demonstration against Hungary.

19. Mr. Ellis J. Griffith, chairman of the Welsh Liberal members, becomes. Under-Secretary to the Home Dept. in British Govt.- Sir Starr Jameson's motion of censure on the South African Govt. for their treatment of the Civil Service rejected by 72 to 34 .-The Kaiser speaks on German Unity at Kiel after the launching of a dreadnought.-Fifty persons drowned through the foundering of a launch near Rangoon.-U. S. Supreme Court decides that it belongs to. Congress, and not the Court to determine whether a state by its adoption of the initiative and referendum has ceased to be republican in form within the guaranty of the Federal Constitution.

20. Mr. Asquith invites coal-owners and miners to meet him and discuss means for averting a strike.-Count Berchtold succeeds Count Aehrenthal as Austro-Hungarian Foreign Minister, and Dr. de Billinski becomes joint Minister of Finance.-In British Parliament the official opposition amendment to the Address is rejected by 324 to 231 votes.-Coal rises $2 \mathrm{~s}$. a ton in London.-Houston, Texas, largely destroyed by fire.-Pres. Taft transmits to U. S. Congress report of Employers' Liability Commission. - Sale of Weber collection of pictures in Berlin; $\boldsymbol{f}_{29,500}$ paid for a Mantegna - British Medical Association meet in London to consider the attitude of the profession towards the National Insurance Act.-Tuberculosis Prevention Committee appointed by the British Chancellor of the Exchequer, with Mr. Waldorf Astor as Chairman.

2x. Mr. Roosevelt, speaking before the Ohio Constitutional Convention at Columbus, outlines a "Charter of Democracy." - Sir Edward Grey speaks in British Parliament on the Persian Question.-U. S. House of Representatives passes bill revising chemical schedule of tariff so as to increase revenue.-U. S. grand jury in Albany, $\mathrm{N}$. Y., indicts Delaware \& Hudson Company under commodities clause of Hepburn Act.

22. British coalowners and miners meet at the Foreign Office:--"The Secret Woman," a play by Eden Phillpotts, produced in London in spite of the Censorship.-Mr. Knox, U. S. Secretary of State, starts on Central American tour Tariff Reform Amendment to Address in British House of : Commons negatived by 258 to 193.-Lord Morley speaks in the House of Lords in defence of the change of the capital of India from Calcutta to Delhi.-Hébert case, involving validity of $\mathrm{Ne}$ Temere decree, decided in Canada on the grounds that the decree has no civil effect.-Pres. Taft sends to the U. S. Congress message recommending report of commission on second class post matter for increased rate on newspapers and magazines.-U. S. grand jury at Cincinnati, Ohio, indicts the officials of National Cash Register Company and Adams Express Company.

23. Mr. Lloyd George speaks at the Albert Hall, London, on Woman Suffrage.-Italian Parliament adopts bill rati fying the annexation of Tripoli. - Death of the Grand-duke of Luxemburg, - Lord Kitchener welcomed at Khartum.Charity Commissioners' report on Boxted small holdings evictions issued.-The British Medical Association appoint a State Sickness Insurance Committee to deal on their behalf with the Govt.

24. Mansion House meeting in London on threatened coal-strike.-Italians sink two Turkish war-ships in Beirut harbour.-Mr. Roosevelt declares himself willing to accept Republican nomination as a candidate for the American Presidency.-New speed records in flying made at Pau by Tabuteau, French airman,-Mr. Winston Churchill declares against the Conciliation Bill (Women's Suffrage) in a letter to the secretary of the Dundee branch of Women's Freedom League.-Glasgow (St. Rollox) by-election results in return of N.S. McKinnon Wood (Liberal) by 460 , a reduction of $\mathbf{x}, 448$. - - Ireland beats Scotland in Rugby football at Dublin by ro points to 8

25. Jamaica tramway riots, suppressed on the 26 th

26. Coal miners start strike at Alfreton, Derbyshire.Massachusetts strike riots. - South African Commission on Trades and Industries issue their Report.-Anti-Hungarian disturbances at Agram, Mostar and Spalato-U. S. Supreme Court decides in favour of Southern Pacific Railroad in the "main-line grant" cases involving claim to California land valued at more than $\$ 1,000,000$.

27. 'Miners' national conference meets in London. Further negotiationsat Downing Street.-Fighting between Arabs and Italians at Margheb in Tripoli; heavy Arab loss. -Revolution in Paraguay; Pres. Rojas compelled to resign and Pres. Peña appointed.-Paris motor-car bandits steal a. car and shoot a policernan dead - Anthracite coal miners in Pennsylvania demand a. $20 \%$ increase in wages and an eight hour day (see April I and May 18).

28. Lord Loreburn, Lord Curzon and others address an Anti-Suffrage meeting in the Albert Hall, London.

29. Military mutiny in Peking; looting of city.-Fighting in the Zemmer district of Morocco between French soldiers and natives.-Mr. Neil Kennedy appointed Chairman of the Scottish Land Court, and Sir Robert Patrick Wright Chairman of the Board of Agriculture for Scotland. -Capt. Maurice Hankey appointed Secretary to the British Committee of Imperial Defence-Senator Joseph M Dixon of Montana selected as manager of Roosevelt campaign to secure Republicas presidential nomination.

March:-

x. Coal strike becomes general in Great Britain.-M.C.C. cricket eleven win the Fifth Test Match at Sydney by 70 runs.-Window smashing by suffragettes in London: arrest of Mrs. Pankhurst and others,-Death of George Grossmith at Folkestone, aged 65.-The Registration (Plural Voting) Bill read a second time in the British House of Commons by 223 votes to 142 .

2. Pres. Taft warns Americans in Mexico to observe neutrality laws; the American ambassador there advises Americans to leave danger zones.-All indictments against officers of United Shoe Machinery Company-except that chrarging monopoly by leasing patented machinery-dismissed in U.S. District Court in Boston (see Sept. I0, I0II) -M. Venezelos, Greek. Premier, begins a political tour through; Greece.-Deathof Edward Blake, Canadian statesman, at Toronto, aged 79.--Dollfus picture sale begins in Paris.-Mrs. Pankhurst sentenced in London to two months' imprisonment for window smashing.-Peking placed under martial law.-The "four nations" banks (England, France, Germany and the U. S.) agree, with the approval of Russia and Japan, to make a loan to China.Scotland beats Wales in Association football at Edinburgh by I goal to 0 .

4. Fighting at Derna in Tripoli.-Over 200 suffragettes arrested for window-breaking in London.-Retirement of Admiral Sir Arthur Wilson from active list of British Navy - Trial of Frederick Henry Seddon and his wife for murder by poisoning begins in London - - German miners' strike in Dortmund district, - Death of Admiral Aubry, commander in chief of Italian naval forces, on his flagship at Toronto, aged 63.-Murder of Mr. Frederick Day, British missionary, at Chichau, near Peking.-Bill passed by U. S. House of Representatives declares all citizens of Porto Rico to be citizens of United States.

5. South Manchester by-election results in loss of seat to the Government by defeat of Sir A. Haworth on acceptance of office; majority for Mr. Gla zebrook (Unionist) 579.Mr. and Mrs. Pethick Lawrence and other suffragists arrested in London on charge of conspiracy in connection with wholesale window-breaking.-Revolutionary conspiracy discovered in Bangkok, Siam.-Milestones, a play by Arnold Bennett and Edward Knoblauch, produced at Royalty Theatre, London.

6. Nicaragua newspaper staffs arrested for suggesting use of dynamite against American Secretary of State.

7. Capt. Amundsen reports having reached South Pole on December 14, r9I1.-U. S. Senate-adopts AngloAmerican and Franco-American Arbitration treaties by 76 votes to 3 after striking out (by 42 votes to 40 ) article 3 constituting Joint High Commission, and excluding certain questions as not arbitrable.-Khuen-Hedervary Cabinet in Hungary resigns.-Non-stop flight, London to Paris, made by $M$. Salmet, French airman, in 3 hours 12 minutes.Standard Oil Company of Indiana increases its capital stock from $\$ 1 ; 000,000$ to $\$ 30,000,000$.

8. British Government holds a conference with coalowners and miners on the means of settling the coal strikeMr. Asquith entertained at a lunch given at Covent Garden Theatre to celebrate the passing of the Parliament Act.Admiral Sir Arthur Wilson appointed to the Order of Merit.-By-election at Hereford results in the return of Mr. W. A. S. Hewins (Unionist) unopposed-Pres. Taft speaks at Toledo (Ohio) against the "recall" of judges.M. Jaures speaks in the Chamber of. Deputies against French Government's policy in Morocco.

0. The Ambassadors of the Great Powers ask ltaly to state the terms on which she would accept arbitration in the war with Turkey.-King George lays the foundation stone of the new County Hall in London-Sir H. Hesketh Bell appointed Governor of the Leeward Islands.-General increase of $5 \%$ to $7 \%$ announced in wages of textile workers in New England affecting more than 125,000 persons.Ireland beats. Wales in Rugby football at Belfast by 12 points to 5 . 
ro. Yuan Shih-kai takes the oath of office as President of the Chinese Republic, - Suzanne Bernard, French aeronaut, killed at Etampes.

11. Miners'Federation of Great Britain agree to meet the coal-owners and to discuss the coal strike with the Prime Minister, provided the minimum wage principle is not discussed. - Westphalian and French miners strike in sympathy with English miners.- Submarine "A" raised and taken to Portsmouth.--Spanish Ministers of Finance, Public Works, Public Instruction and Marine resign"Crown of India," masque by Sir E. Elgar, produced at the Coliseum Theatre, London.--U. S. Supreme Court permits holder of a patent to sell patented article with restrictive licence requiring use therewith of certain unpatented articles. - Suit against "Sugar Trust" begun by U. S. Govt. at Nev York (see March 3r).-England beats Wales in Association football at Wrexham by 2 goals to 0 .

12. Joint conference of coal-owners and miners begins in London.-Report of Vivisection Commission published in London. $-£_{2} 0,000$ given to endow a Balfour Chair of Genetics at Cambridge University - Explosion of dynamite at Bombay.- Attorney-General Wickersham files brief in U. S. Supreme Court to dissolve merger of Union Pacific and Southern Pacific R.R. systems (see Dec, 2), - Of the labour union officials at Indianapolis, Ind., indicted (Feb 14) for dynamite conspiracy 46 plead "not guilty" (see Oct. I).

13. Royal Commission appointed in England to enquire into the methods of appointment and promotion in the Civil Service-Lieut. Seville, French airman, killed at Pau.-The Italians attack Turco-Arabs near Bengazi, Tripoli, and inflict heavy losses.-American anthracite operators, in conference at New York, refuse miners demands.

14. Unsuccessful attempt on the life of the King of Italy by an anarchist. Alba.-Frederick Henry Seddon found guilty of murder at the Old Bailey; his wife acquitted. - Banquet in honour of the new Chinese Republic given in Paris.-Pres. Taft forbids shipment of arms from $U$. into Mexico, acting under special authority from Congress. -Lawrence, Mass., strikers in 6 mills return to work (see January $\mathrm{II}$ ).

15. Joint Conference of British coal-owners and miners breaks up without agreement. - Sir J. Thomson given the Order of Merit.-Oklahoma decides to support Mr. Roosevelt as Republican candidate for the Presidency.-Protest from the "four-nations" banks (Great Britain, France, Germany and U. S.) against a loan to China by an AngloBelgian syndicate as an infringement of their agreement with the Chinese Govt.-New star in Gemini first observed at Greenwich.-Mona, opera by Prof. H. W. Parker, first performed at the Opera House, New York.-Dr. Harvey W. Wiley (b. 1844), chief of Bureau of Chemistry of United States Dept. of Agriculture, resigns his position.-By a vote of 108 to 103 , the U. S. House of Representatives passes bill placing sugar on free list.

16. P. \& O. liner "Oceana" sunk after a collision with the German barque "Pisagua" of Beachy Head; fourteen lives lost by the swamping of a boat.-Resignation of the German Finance Minister, Herr Wermuth.-U. S, battleship "Maine," after being raised from Havana harbour, towed out to sea and sunk.-Lord Kitchener inaugurates new drainage works at Ibshaw in Egypt.-Scotland beats England in Rugby football at Inverleith by 8 points to 3 Scotland beats Ireland in Association football at Belfast by 4 goals to 1.-England beats Holland in Association football at Hull by 4 goals to 0 .

I8. Strike of London taxi-cabs for one day; settled on the roth.-Mr. Winston Churchill introduces the Navy Estimates in the British House of Commons.- Rutherford E Son a play by Miss K. G. Sowerby, produced at the Little Theatre, London-Coal rises $4 \mathrm{~s}$. a ton in London. Mahlon Pitney takes oath as an Associate Justice of U.S. Supreme Court, his nomination (Feb. 19) baving been confirmed by Senate (March r3) - General wage increases made in cotton mills of Maine, Massachusetts and Rhode Island - A locomotive boiler explosion in the yards of the Southern Pacific R.R. at San Antonio, Texas, kîls as strikebreakers and injures many more.

19. Mr. Asquith introduces Minimum Wage Bill in the British House of Commons to settle the cosl strike.-Mr Tom Mann, syndicalist leader, arrested on a charge of inciting soldiers to mutiny.-Asunción, Paraguay, besieger by revolutionaries. - In U. S. House of Representatives Excise Tax bill passed, by 252 (including 80 Republicans) to 40 taxing net income from business sources I per cent and designed to restore loss of revenue from abolition o sugar duties (March 15); River and Harbour appropriation bill also $(\$ 26,000,000)$ passed.-Delaware, Lackawanna and Western R.R., U.S.A., fined $\$ 2,000$ for violation of Hepburn law.

20. Mr. Roosevelt defeated by Mr. La Follette in the Presidential primaries of Nortb Dakota.-Conference at Cleveland, Ohio, between American bituminous coal miners and coal-owners-By a coal-mine explosion at McCurtain, Okla., 52 men were killed.

2I. Mr. Balfour moves the rejection of the Minimum Wage Bill in the British House of Commons; second reading passes by 348 to 225--Asunción, Paraguay, taken by revolutionaries; Provisional government establishod under Navero, with Gondra as Minister of War and MarinemAmerican bituminous coal operators at Cleveland (Ohio) refuse miners?' demands.

22. Guy Bowman, journalist, and B. E. \& C. E. Buck printers, sentenced in London to 0 and 6 months' hard labour respectively for publishing and printing an article in the Syndicalist tending to incite soldiers to mutiny.German Armaments Bill provides for increased expenditure on the Army and Navy up to 19r6.-French Chamber passes a Vote of Confidence in the Government's Morocco policy.-Chinese National Assembly at Nanking raided by women-Mr. Thomas McKenzie elected leader of the Liberal-Labour Party, in office in New Zealand.-Fighting between Spaniards and Moors in the Riff, County Morocco. -American bituminous coal-miners refuse to work under existing scale.

23. British coal-owners and miners confer separately at the Foreign Office on the minimum wage figures.German and Austrian Emperors meet at SchönbrunnOxford and Cambridge Athletic Sports end in a tie.-Sale of Sir W. Farrer's collection of pictures at Christie's, London.-Pres. Taft signs an Act passed by the U. S. Senate, March 16, giving local citizenship to all residents of the Philjppines who were Spanish subjects in 1899 and to their children.-Four railway companies and four ore-dock companies fined by Federal U. S. Court in Cleveland, Ohio, $\$ 123,000$ for rebating.-Association football match between Scotland and England at Glasgow results in draw.

24. U. S. Interstate Commerce commission rules that there must be no difference between interstate and intratate rates for traffic moving under the same conditions.

25. Motor-car robbery and murder near Paris by high waymen, who escape-Greek elections result in majority for M. Venezelos-Price of coal advanced in London by 5s. to 45 s. a ton.-British, French, German and American Ministers hand Yuan Shih-kai a protest against the Anglo-Belgian loan to China-Martial law proclaimed at Meshed by the Russian consul-general,-Sale of Roussel art collection begins in Paris. - U. S. battleship "Florida" attains a speed of 22.54 knots, best speed so far attained at any trial in $U$. S. Navy.-Mississippi river overflows levees at Cairo, Ill. - Wales beats France in Rugby footbal at Newport by 14 points to 8 .

26. Minimum Wage Bill passes the British House of Commons by 213 to 48 .-Coal-owners and miners' joint conference fails to agree; negotiations broken off.-The mill-owners of Lowell, Mass, declare a general lock-out on account of labour trouble in the state.-Pres. Tait in message to U. S. Congress sends Tarifi Board's cotton schedule, recommending reduction of duties - Officers of "Beef Trust" (U.S.A.) are acquitted in a case under pena provision of Sherman Law.

27. National Congress of Miners' Federation of Great Britain decides to take a ballot on the question of resumption of work. - Natural history collection of Canon Norman presented to the Natural History Museum, London.Chou Tzu-chi made Governor of Shantung.-Fighting in the Sudan between British Camel Corps and followers of a Moslem fanatic, who is killed with $I x$ of his followers.

28. Women's Enfranchisement (Conciliation) Bill rejected in British House of Commons by 222 to $208 . \rightarrow \mathrm{Mr}$. and Mrs. Pethick Lawrence and Mrs. Pankhurst (suffra gists) committed for trial on charge of conspiracy.Minimum Wage Bill passes House of Lords - In Kings Bench, London, in case of $R$. versus Walker, it was decided that the custody of a child might be given to foster-parents as against natural parents if this were most to the interest of the child in the judgment of the Court-Italians issue a proclamation to the Arabs of Tripoli.-Democratic party in the U.S. House of Representatives re-affirm their decision not to authorize construction of Dreadñoughts.

20. Chinese Ministry formed, with Tang Shao-yi as Premier. - German Govt. defeated in Reichstag on Post Office Estintates by combination of Centre Party, Poles and Socialists - P \& O. liner "Syria" collides with French steamship "Circle" off Algiers. - $-1,000$ rifles and $1,000,000$ rounds of ammunition sent to American residents in Mexico City with consent of Mexican Govt.-U. S. Senate passe 
Smoot pension bill providing a double standard of pension for age and service and involving an addition to the pension roll of $\$ 20,000,000$ a year for the coming five years.Compromise between American coal operators and bituminous coal miners increases rate on screened lump coal 5 cents a ton.

30. Home Rule demonstration in Dublin attended by 100,000 people.- Oxford and Cambridge boat-race results in both boats sinking and is declared by the umpire "no race."--Sultan of:Morocco signs a treaty making Morocco a French Protectorate.-Emperor of Austria threatens to abdicate unless situation between Ausiria and Hungary improves.- Three men arrested in connection with French motor-car murders. $\rightarrow$ French navy law passed providing for two new fleets.-Federal U. S. jury in New York City fails to agree in Govt. suit of American Sugar Refining Company (see March $1 x$ ).

A pril:-

x. Oxford and Cambridge boat-race re-rowed, resulting in a victory for Oxford. - The Prince of Wales arrives in Paris for a stay of some months:-News received that Capt. Scott, on Antarctic expedition had on Jan. 3 reached a point I 50 miles from the South Pole and is remaining in the Antarctic for another winter.-Partial eclipse of the moon.Sun-Yat Sen and the Provisional Govt in China lay down office--Carpenters' strike in Chicago.-Fortnight's suspension of American coal-mining industry begins.-Wool bill passed by U. S. Houșe of Reps. by I89 (20 Republicans) to 92 (I Demacrat) puts duty of 20 per cent on raw wool and 30 to 45 per cent on woolen manufactures' (see July 25):-U. 'S.' Supreme Court, reversing Commerce Court, holds that Interstate Commerce Commission can ask from water lines reports on intra-state business as well as on inter-state.

2. Mr. Lloyd George introduces the Budget in the British House of Commons.-Lord Cheylesmore elected Chairman of the London County Council.-Mr. Hamel crosses the English Channel in an aeroplane with a lady passenger--British punitive expedition in the Sudan resisted by the Annaks; 2 British and 3 . Egyptian officers killed.-Dacca conspiracy case in India results on appeal in acquittal of 21 prisoners and reduction of sentence for 14. - The Russian Senate at St. Petersburg decide that of I46 Americanis charged with attempted revolution 94 should be acquitted and 52 sentenced to penal servitude or imprisonment.

3. British House of Commons rises for Easter recess.Croatian autonomy suspended.-Serious floods reported in Mississippi basin:-Arrest of Carouy, one of the Fronch motor-car highwaymen.-New York Public Service Commission rejects application of New York Central system to acquire New York, Ontario \& Western Railway.

4. Ballot of British coal-miners results in majority of 42,998 against resuming work.-Memorandum issued by the joint Committee of the Church of Scotland and the United Free Church concerning Church re-union in Scotland.-Another motor-car robbery committed in France near Choisy-le-Roi.-Chinese Republic proclaimed in Tibet. -Pres. Taft in a special message to U. S. Congress asks an appropriation for the Commission on Economy and Efficiency

6. National Conference of Miners' Federation of Great Britain meets in London and endorses the decision of it executive that the men should resume work.-Russia decides to join the "Four Powers" banking syndicate for the issue of a loan to China.-French warship's launch swamped in Tangier harbour, 5 persons drowned.

7. Argentine elections take place under compulsory and secret ballot, and result in weakening the influence of the Union Nacional.-Paris police make three arrests in connection with the motor-car crimes.-Celebration of the 75th anniversary of the founding of the University of Atheris.

8. Mr. Bonar Law arrives in Belfast and is enthusiastically received.-Celebration of the anniversary of the declaration of Greek Independence at Athens, - Socialist distarbances at San Diego, California.-Excursion steamer sunk on the Nile after a collision; heavy loss of life--England beats France in Rugby football at Auteuil by 18 points to 8 . 9. Anti-Home Rule demonstration in Belfast addressed by Mr. Bonar Law.-Preferential agreement between Canada and West Indies signed at Ottawa-Sir Herbert Tree produces "Othello" at His Majesty's Theatre, London.-Pres. Taft signs bill creating a Children's Bureau (see April r 7).-Esch match bill putting tax of $2 c$ a hundred on matches made of poisonous white phosphorus, passed by U.S. Congress.

io. Rioting among coal-miners in South Lancashire.White Star liner "Titanic" leaves Southancashire. maiden yoyage to New York. - Sir Starr Jameson resigns leadership of Unionist Party in South Africa and is succeeded by Sir Thomas Smartt.-Ituly lands a fresh body of troops in Tripoli.-Illinois presidential primaries resul in favour of Mr. Roosevelt.-Advisory Committee to the British National Health Insurance Commissioners appointed consisting of 150 members; Chairman the Chancel lor of the Exchequer; Vice-chairman Mr. C. F. G. Masterman.

Ii. Rioting of coal-miners in S. Lancashire collapses.Irish Home Rule Bill introduced into British House of Commons by Mr. Asquith.-Mr. Knox, United States Secretary of State, visits Cuba.-Mme. Sarah Bernhardt appears as Queen Elizabeth in M. Emile Moreau's play of that name in Paris - Lord Balfour and Mr. Austen Chamberlain entertained at $\$$ t. Petersburg by the Russian and English Bank.-Maine delegation declares for Mr. Roosevelt.

12. Memorial to Queen Victoria unveiled at Cimiez.Kiangsi and Hunanese troops mutiny at Nanking--Price of coal in London reduced by ros. a ton-Mediation proposals made in Constantinople by the Powers with regard to the war in Tripoli.-Italians occupy Fort Bu-Kemmesh, Tripoli, and cut caravan routes to Tunisia.-Lord Hardinge, Viceroy of India, opens Upper Chenab section of the Punjab irrigation scheme.-Bomb explosion in a Paris taxi-cab.Ideal Home Exhibition opened at Olympia, London.Maritime Court at Hamburg decides that in the collision between $P$. and $O$. liner "Oceana" and German barque "Pisague," the "Oceana" was at fault.-Federal U. S. grand jury at Buffalo, N. Y., indicts Adams Express Company and American Express Company for exceeding schedule rates.-Large dike at Greenville, Miss., broken by flood

13. Memorial to King Edward VII at Cannes urveiled. - Scottish Medical Council meet at Edinburgh and reaffirm the six "cardinal points" to be insisted on if doctors are to work the National Insurance Act.-An "Amend the (Insurance) Act" league inaugurated in London.-The presidential "primaries"' of Pennsylvania show a majority for Mr. Roosevelt.-Busoni's opera, "Die -Brautwahl." produced at Hamburg,-Railroad Commission of California, forces Wells, Fargo \& Co. to file a complete schedule of express rates:

I4. Death of M. Henri Brisson, President of the French Chamber of Deputies, aged 76. - General Huang Hsing appointed Generalissimo of the Southern Forces of China.

5. Mr. Balfour speaks against the Home Rule Bill in

British House of Commons. -The White Star liner "Titanic," after striking on an iceberg, sinks in the Atlantic; I.513 of the passengers and crew drowned, $7 \mathrm{rr}$ saved.New Defence Bills introduced in German Reichstag.-M Poincarê, French Premier; speaks at Council General of Meuse Department on the political situation in France.Sir Joseph Saba Pasha, Egyptian Finance Minister, resigns. r6. Turkish Govt. approached by the Powers on the question of terminating the war with Italy.-References to "Titanic" disaster in British House of Commons, American House of Representatives, and German Reichstag.-First cross-channel flight by a woman; Miss Harriet Quimby (see July 2) - Strike riots attended by loss of life occur in Peru:- Turks attack Fort Lombardia at Derna Tripoli, and are repulsed

r7. Investigation into causes of "Titanic" wreck ordered by U.S. Senate (see May 28); Marine:House retief fund opened in London for sufferers:- Resignation of Count Khuen Hedervary, Hungarian Premier--Russian Premier, M. Kokovtsoff, speaks at Moscow on popular representation-Eclipse of the sun.-Price of coal falls 5. a ton in London.-Mutiny of native troops at Fez.-Russia and Japan join with the "four nations" (Great Britain. France, Germany and the United States) to guarantee the $f 60,000$, ooo Chinese Reorganisation Loan.-Mexico refuses to recognise $U$. S, government's right to interfere in her affairs.-Miss Julia C. Lathrop appointed head of the Children's. Burreau (see April 9),-M. John Verrept, French airman, killed at Versailles.

i8: Dardanelles closed to shipping by the Turkish Government; Italian warships bombard forts at entrance.Cunard liner "Carpathia," with survivors of the "Titanic," arrives at New York.-Rioting at Lena goldfields, Siberia; shooting of strikers by police.

19. French reinforcements enter Fez.-E. Nottingham by-election results in return of Sir $J$. D. Rees (Unionist) by x, 324,-Lieut. de Ville d'Avray, French airman; killed at Verdun-Price of coal in London falls from Is. to $2 \mathrm{~s}$. ton according to quality.-Memorial service at St. Paul's Cathedral, London, for those who perished in the "Titanic. -Opening in New York of Senatorial Committee's inquiry 
into the causes of disaster. Dithngham Immigration bill, making ability to read and write a condition of entrance into U. S., passed by U. S. Senate.

20. French liner "La France," of the Compagnie Générale Transatlantique, sails from Havre on her maiden voyage.-Dr. de Lukacs, Hungarian Minister of Finance, becomes Prime Minister.-U. S. Senate urges treaties with maritime powers providing for safety at sea.-U. S. House of Representatives passes measure requiring report of contributions and expenditures for candidates for Pres. and Vice-Pres.-Cyclones in Alabama, Georgia, Illinois and Indiana cause death of nearly a hundred persons.-Final tie for Football Association Cup played at Crystal Palace results in draw.

22. German Reichstag begins debate upon Defence Bills.-The Archbishop of Canterbury speaks at Carnaryon against Welsh Church Disestablishment.-Mr. A. J. Balfour appointed Clifiord Westbury at Glasgow.-Further French reinforcements enter Fez; order restored.-U. S. Senate passes bill granting independent tobacco companies an appeal from decree of Federal Circuit Court approving dissolution of Tobacco Trust.--Eastern U.S.A. railroad locomotive engineers who voted (April z2) to strike, their demands for wage increase and better working conditions having been refused Mar. 25, accept offer of mediation made by U. S. Commissioner Neill and Judge Knapp. (See April 23, 30, Nov. 24.)

23. Turkish Government replies to Powers' enquiry as to whether they would terminate the war with Italy, that they could only accept mediation if the sovereign rights of Turkey were maintained and Italy. evacuated Tripoli.The Home Rule Bill is accepted by the Irish Nationalist Convention at Dublin. - Bill for the Disestablishment and Disendowment of the Church in Wales introduced into the British House of Commons by Mr. McKenna.-Insurance Act Amendment League holds first meeting in London- Russian Ambassador at Constantinople hands to the Porte written protest against the closing of the Dardanelles.Italians take possession of the island of Stampalia, near Crete,-Arabs attack the Italian force landing at BuKemmesh, Tripoli, and are repulsed with much loss.--Offer of mediation made by U.S. Commissioner Neill and Judge Knapp accepted by the railroads (see April 30 ).

24. The firemen on the White Star lines "Olympic" refuse to sail owing to dissatisfaction with the provision of boats; the vessel is detained at Southampton.-The ministers of the Four Powers demand that the AngloBelgian loan to China shall be cancelled.-Ratification by the United States Senate of the Declaration of London 1909. - Lord Methuen speaks at Cape Town on Imperia Defence on the eve of his departure from South Africa.M. Jouin, assistant Chief of the Paris Detective Service, is shot dead whilst endeavouring to arrest motor-car bandits. 25. Inauguration of the new Campanile of St. Mark's, Venice.-The Education in Single-School Areas Bill withdrawn from the Standing Committee of the House of Commons.-Major General E. C. Bethune becomes DirectorGeneral of the British Territorial. Force.-Pres. Taft speaks in Mass. against Mr. Roosevelt.-Debate on the German Defence Bills in the Reichstag concluded.-Debate in the Russian Duma on the shonting of strikers on the Lena goldfields. Siberia.-Death at Folkestone of Mr. Justin McCarthy, aged 8r. - Sixteenth annual art exhibition opens at Carnegie Institute, Pittsburg, $\mathbf{P a}$.; Charles Sims's painting "Pastorella" awarded medal of the first class.

26. Memorial service at St. Margaret's, Westminster, for the American victims of the "Titanic" disaster. Voyage of the "Olympic" abandoned owing to refusal of the firemen and sailors to sail.--Field-Marshal Sir William Nicholson appointed a member of the Committee of Imperial Defence, London.-Draft ordinance issued at Salisbury, Rhodesia, abolishing trial by jury in the case of serious crimes involving race differences.-M. Sazonofi, Russian Foreign Minister, speaks in the Duma on foreign affairs.

27. General Lyautey appointed first French ResidentGeneral in Morocco-Mr. Roosevelt speaks in Mass. against Pres. Taft.- The Persian Govt. makes a series of arrests on suspicion of members of the late Mejliss.Committee on Banking and Currency of U. S. House of Representatives begins enquiry into "money trust," it powers having been expressly enlarged, April 25. - Owing to protests from U. S., Great Britain. France and Germany, China cancels contract for a Belgian loan of $£ 10,000,000$ German battleship. "König Albert," launched at Danzig. 28. The Cretan Deputies to Athens are arrested on board the "Peloponnesus" by the British cruiser "Minerra" and taken to Suda Bay - Arrival at Plymouth of the survivors of the crew of the "Titanic."-Bonnot, chief of the motor- car bandits in Paris, and Dubois killed after a siege with dynamite at Choisy-le-Roi, near Paris, -U. S. Army transport "Buford" leaves San Francisco for Mexican Pacific ports to remove American citizens, - The 5oth anniversary of founding of Vassar College celebrated in Poughkeepsie, N. Y.

29. Yuan Shih-kai opens the Advisory Council in Peking.-M. Vedrines, French airman, seriously injured near Epinay-sur-Seine,-Enquiry ordered by U.S. Senate into contributions and disbursements in Presidential campaigns of 1904 and 1908 .

30. The second reading of the Home Rule Bill is moved by Mr. Winston Churchill in the British House of Commons.-Liverpool shipping strike settled,-Ship-building strike breaking out at Hamburg.- "Acesng." enquiry begun in London before Mr. Dickinson and Assessors.- The steamer "Texas" strikes a mine in the Gulf of Smyrna and sinks with a loss of 68 lives.-Count Berchtold speaks on foreign relations in the Hungarian Delegation Committee.Royalist raid into Portugal occurs at Moncao.-Suit brought in St. Paul, Minn., for dissolution of Internat. Harvester $\mathrm{Co}$-Arbitration agreement signed in $\mathbf{N}, \mathbf{Y}$ City between employers and railway engineers (see April 22, 23 and Nov. 24).

May:-

I. Porte decides to re-open the Dardanelles to shipping. -British Admiralty's scheme for reorganising the Fleet into six battle squadrons announced,-Committee for enquiring into the hours and conditions of labour for van and warehouse boys appointed by British Home Secretary. - Tailors of the West End, London, strike for an increase of wages and better workshops.-Race for Two Thousand Guineas won at Newmarket by Sweeper II.-Massachusetts presidential primaries result in a tie between Taft and Roosevelt.-First of the two French fleets provided by the Navy Law of March 30 , fully commissioned.-U. S. Secretary of State Knox issues report which shows that Japan is not attempting to control Magdalena Bay, Lower California.-Mississippi levee at Torras, La., breaks.

2. "Titanic" enquiry opened in London under presidency of Lord Mersey. - Afghan tribal rising at Khost; Mangals and Jadraus rebel against the local Governor, and besiege him in Matun-Post Office appropriation bill $(\$ 260,000, \infty)$ passed by U. S. House of Representatives, including authorisation for establishment of parcel post.Strike begins on Chicago newspaper owned by William $\mathrm{R}$. Hearst.

3. State Sickness Insurance Committee of British Medical Association issue pledge to members to resign all contract work unless Association's demands are met by the Government. - A Rembrandt belonging fo Lord Feversham sold to Mr. Frick, of the U. S., for $£_{50,000}$-Italians capture Lebda, near Tripoli-Bengal Chamber of Commerce protests against change of the Indian capital to Delhi.-Action for damages, brought in the High Court. I-ondon, by the "Pisagua" against the "Oceana," decided against the latter.-Railways entering Chicago grant freight-handlers half wage increase demanded.

4- Italians occupy Rhodes.-Trial of the "Olympic" seamen at Portsmouth for mutiny results in verdict of "guilty," but no penalty is imposed.-French column attacked near Mekinez by Moroccan tribesmen.-Rioting in Lisbon in connection with textile workers' strike.

6. Mr. Asquith addresses a Scottish deputation on "Home Rule all round."-German Emperor calls conference in Berlin to consider the safety of sea-going passengers.- $\mathrm{Mr}$ Bryce's conduct as British Ambassador at Washington is defended in the British House of Commons by Sir E. Grey. -Royal Academy exhibition opens at Burlington House, London.-Duke and Duchess of Connaught start on \& tour through Canada.-Employers' Liability and Workmen's Compensation bill passed by U. S. Senate.

7. King George leaves London fer inspection of the Fleet.-Browning centenary celebrations in London.P. \& O. shipping strike threatened in London.Maryland presidential primaries show small majority for Mr. Roosevelt. - New anti-typhoid serum submitted to French Academy of Sciences by Metchnikof and Broughton Alcock.-Mr. A. Chamberlain speaks against Home Rule bill in British parliament.

8. P \& O shipping strike in London averted. - Sale of Wertheimer collection at Christie's in London,-Mr. W. Llewellyn elected.A.R.A.-Rioting among miners in anthracite coal district of Pennsylvania.-New medicinal treatment of cancer is submitted by Dr. Grezda of Agram to the Paris Academy of Medicine-Break-down of the Minimum Wage Act in South Wales owing to refusal of miners to accept award. - Fighting in Albania results in loss of 9 to Turkish troops and 15 to rebels. 
9. Home Rule Bill (Ireland) passes second reading in British House of Commons by 372 votes to 271 . - Count von Wolff-Metternich resigns his post as German Ambassador to London, and is succeeded by Baron Marschall von Bieberstein.-Fusion of National Conservative Union and Liberal Unionist Council under title of "National Unionist Association of Conservative and Liberal Unionist Organisations" announced in London. - Trial of Tom Mann at Manchester for inciting soldiers to mutiny ends in sentence of six months' imprisonment in second division.-King George takes a trip in a"submarine.-Committee to enquire into sale of patent medicines meets in London.-Socialist disturbance in Prussian diet ends in expulsion of Herr Borchardt.-River and Harbor appropriation bill passed by the U. S. Senate with amendments $(\$ 34,000,000)$.

IO. British Board of Trade regulations for unemployment insurance issued.- South Wales Miners' Council call a general conference to consider decisions of the District Wages Board.-Miss Malecka, a British subject, condemned at Warsaw to four years' penal servitude for belonging to the Polish Socialist Party, a revolutionary organisation.-Böllart, a coppersmith, sentenced at Leipzig to 4 years' penal servitude for betrayal of naval secrets.-Mr. Bonar Law speaks at Primrose League annual demonstration in Albert Hall, London, on Unionist prospects.-Amalgamation announeed of two London Liberal papers, the Daily News and Morning Leader.-Legislative, Executive and Judicial appropriation bill, abolishing Commerce Court and making other changes, passed by U. S. House of Representatives.

II. South Wales miners decide to boycott District Wages Board.-Battle between Mexican Federal troops and rebels at Torreon.-Pres. Taft signs general pension bill (passed by $\mathrm{U}$. S. Congress) increasing the roll nearly $\$ 26,00,000$ annually.

13. Mr. F, E. Smith speaks against second reading of Welsh Church Disestablishment Bill in British House of Commons.-E. V. B. Fisher, English airman, and $\mathrm{Mr}$. V. L. Mason. American passenger, killed at Brooklands, Surrey,-Italian warships seize islands of Piskopi, Nisero, Kalismo, Lero and Patmos.-Pres. Taft appeals to the women of California to vote for him in the presidential primaries.-U. S. Serrate's amendments to measure providing for direct election of U. S. senators accepted by House-Anti-Russian riot at Lemberg.-Budget Com mittee of German Reichstag adopt Navy Law Amendment Bill-German Emperor ' in private conversation with Burgomaster of Strassburg threatens to suppress consti tution of Alsace-Lorraine and incorporate those provinces with Prussia.-Fighting at Djakova in Albania.-Strike of workers in gold mines at Waihi, New Zealand, begins, owing to a dispute between two rival labour organisations.

14. King George goes to Aldershot to spend a few days with his Army.-Mr. Balfour speaks in British House of Commons against Welsh Church Bill.-Garnier and Vallet, French motor-car highwaymen, are shot after being besieged by the police with dynamite.-Clayton blll, prohibiting issuing of injunctions without notice, passed by U. S. House of Representatives, 244 to $3 \mathrm{I}$.

15. Death of King Frederick VIII of Denmark in Hamburg. Mr. Asquith speaks in British House of Commons on Welsh Church Bill.-Mr. Winston Churchill announces Supplementary Naval Estimate, and, speaking at a public dinner, states that there will be an increase in naval personnet:-Trial of Mr. and Mrs. Pethick Lawrence and Mrs. Pankhurst on charges of conspiracy begins at Central Criminal Court, London--California presidential primaries result in a large majority for Mr. Roosevelt.-Loan negotiations between the "Six Nations" banks and China concluded.-Austrian Premier, Count Sturgkh, threatened with blindness and temporarily superseded by Minister of the Interior, Baron von Heinold.-Foreign policy debate in British House of Lords.-Fighting at Lhasa between Chinese and Tibetans.-Death of General Jara, Dictator of Paraguay from January to July Iox $x$

16. Welsh Church Bill passes second reading in British House of Commons by 348 votes to $26 \%$ - Mr. Horatio Bottomley (Liberal M.P. for Hackney), resigns his seat in Parliament.-United States submarine "Geo" wrecked off Long Port, N. J.-New Zealand Arbitration Court fines Builders \& Contractors' Union at Auckland £6o for ordering a strike.-Provincial general election in Quebec results in large Liberal majority.-Resignation of $\mathrm{Mr}$. John Murray, Premier of Victoria; he is succeeded by Mr. W. A: Watt.-Agricultural appropriation bill, with $\$ 2, \infty 00,000$ added to House estimates, passed by U. $\mathbf{S}$. Senate.

r7. Bills introduced in British House of Commons for control of the feeble-minded.-Debate in Reichstag on the
German Emperor's threat to Alsace-Lorraine-Retirement of M. Georges Louis, French Ambassador to St. Petersburg. - Massenet's opera, "Don Quichotte," . produced in London.-Turkish garrison in Rhodes surrender.-Eugene W. Debs of Indiana nominated candidate for the American Presidency by Socialist National Convention with Mr. Emil Seidel as vice-president.

18. Resignation of South African Union Finance Minister, Mr. Hull.-Sid Mohammed Hiba, son of Mal Ainin, becomes Pretender to Sultanate of Morocco.-Railway accident in Paris; 13 killed, 43 injured:-Japanese cruise Kongo, " and U. S. battleship "Texas," the two heaviest and most powerful cruisers yet built, are launched at Barrow-in-Furness, Lancashire and Newport News, Va. respectively.-U. S. House of Representatives enlarges powers of committee investigating "Money Trust." Petition filed by U. S. District Attorney at New York against Herman Sielcken and others to break up alleged Coffee Trust." - At Wilkesbarre, anthracite mine worker ratify wage agreement in convention and decide to return to work (see May 20)

I0. Aeroplane accident at Amesbury, Wilts., results in death of one spectator-Town of Melville, La., inundated by breaking of levee on Atchafalaya river; 500 persons rendered homeless.

2o. Yeprim; Persian Chief of Police, killed in action after gaining a victory over Mujallal-es-Sultan near Hainadan.-Prince George of Cumberland killed in motor accident at Friesack in Germany.-Enrico Malatesta, an anarchist, sentenced in London to three months' imprisonment for publishing a libel, and recommended for expulsion. - Sentence on Tom Mann, syndicalist leader, reduced by Home Secretary from 6 months to 2 months.- Sale of the Dollfus collection of drawings in Paris.-Report of the Lorimer Committee made to U. S. Senate.-Turkish Council of Ministers decide to expel all Italians from Turkey, except artisans, widows and orphans and members of religious orders.-Anthracite miners and operators sign new agreement at Philadelphia.

21. Debate in British House of Commons on Board of Trade's regulations for life-saving at sea.-King George opens new building of the Royal Society of Medicine in London.-Mr. Bonar Law speaks at Glasgow on Tariff Reform.-London lightermen strike; British Govt. appoints Court of Inquiry under Sir Edward Clarke.-Miners Federation National Conference meets in London to receive reports on fixing of minimum wage in different districts Name of the Society of Knights Bachelor is by King George's command changed to Imperial Society of Knights. -M. Crombes, Belgian airman, flies across the Channel and back without alighting in England.-German Defence Bills are passed by the Reichstag. - Italians occupy island of $\operatorname{Cos}$

22. Presidential primaries in Obio show decisive majority for Mr. Roosevelt.-Trial of Mrs. Pankhurst and Mr. and Mrs. Pethick Lawrence for conspiracy in con nection with the London suff ragist raids results in sentences of 9 months' imprisonment in the second division.Count Tisza elected President of the Hungarian Chamber after a violent scene.-Australian cricket eleven at Lord's beat M.C.C. and Ground by 5 wickets. - German Reichstag adjourns till November after violent debate provoked by Socialist attacks on the Emperor-Death at Monte Carlo of Count Osten-Sacken, for 17 years Russian Ambassador in Berlin.- Two Calcutta constables convicted of torturing prisoners to extract confessions. - International Flowe Show opens in London.-Provision in Army appropriation bill adopted by conference committee of U. S. Senate and House, which would make Major-General Wood, U. S Army, ineligible as Chief of Staff.-Measure placing socalled Friar Lands under jurisdiction of Philippine Government passed by U. S. House of Representatives.-A murderer in Utah executed by shooting.

23. Count Berchtold, Austrian Premier, arrives in Berlin or a visit.-General strike of freight-handlers in the United States begins. - London lightermen's strike spreads to al transport workers connected with the docks. - Hungarian General Strike in support of universal suffrage begins with rioting involving much loss of life.-M. Paul Deschanel elected President of French Chamber of Deputies in place of M. Brisson.-Two battalions of American Marine despatched to Cuba to protect American interests. - The "Imperator," of the Hamburg-America line, the largest liner yet built, launched at Hamburg by the German Emperer-News received of the Chinese revolutionar party's successes in Kashgaria.-Ven. W. O. Burrows, Archdeacon of Birmingham, appointed Bishop of Truro.Panama Canal bill, admitting American-owned ships free and excluding vessels owned by railroads, passed by the 
U. S. House of Representatives (see July IX).-Presbyterian General Assembly, at Louisville, refuses to admit women to pulpit. - Twelfth International Congress of Navigation opens at Philadelphia.

24. London Transport Workers' strike enquiry under Sir Edward Clarke opens.- South Hackney by-election results in return of Mr. H. Morison (Liberal) by majority of 503 , being a reduction of over 3,000 .- Further rioting in Budapest in connection with general strike.-General Lyautey arrives at Fez and is met by the Sultan's representative, El Mokri-Funeral of King Frederick of Denmark.- Research Hospital opened at Cambridge, England.-Canada and Australia win large gold medals for fruit at International Flower Show, London.-Partial settlement of London tailors' strike--Empire Day celeMr: and Mrs. Pethick Lawrence, suffragists convicted of conspiracy, granted special prison privileges.-U. S. Government proceedings against Coffee Trust begun in Federal District Court, New York.-Demachy art sale opens in Paris.-At general Methodist conference in Minneapolis, Minn., the last of the eight new American bishops are elected-Board of Estimate approves the new Subway system in New York City.-Edson J. Chamberlin appointed president of Grand Trunk Railway Company of Canada.

25. Count Berchtold, Austrian Premier, received by the German Emperor at Potsdam.-Fez attacked by Moorish tribesmen.-Rioting occurs at Lisbon in connection with trial of Portuguese political prisoners.-Anglo-Iatin Exhibition opened in London.-Eight hundred English school children visit Paris as guests of the Paris Municipality, to take part in musical competition.-Lieut. von Schlichting, German airman, killed at Johannistbal.- $£_{1}, 000,000$ given by Mrs. Walter Russell Hall for relief of poverty in Australia.-Nine United States war vessels ordered to assemble at Key West for possible service in Cuban waters. - Americans warned by revolutionary leader Zapata to leave Mexico City.

26. Demonstration of London transport workers on strike held in Trafalgar Square, London.

27. British Govt. afford police protection for unloading and transport of food to Central markets of London.Turkey obtains assent of British Govt. to appointment of five British officers as members of the directorate of ber European gendarmerie.-Rioting occurs in Cyprus betreen Greeks and Turks.-Mr. John Boraston appointed principal agent of United Conservative and Liberal Unionist parties of Great Britain - Cuba informed by Pres. Taft that mobilising of American fleet at Key West does not mean intervention.-Amendment to Naval appropriation bill, applying eight-hour law to mining of coal used by navy adopted by U.S. House of Representatives.

28. Sir Edward Clarke reports to the Local Government Board on the strike of London transport workers; the Govt. invites both parties to a conference.-Committee of Inquiry of the U.S. Senate issue report on the sinking of the "Titanic."-Conference between committees of the Church of Scotland and the United Free Church with regard to Scottish Church Reunion agreed upon.-Fire in a cinematograph theatre at Villa Real, Spain; 8o killed.Australian cricket eleven beat South Africa at Manchester by an inning and 88 runs. - Fez again attacked by Moroccan tribesmen, who obtain an entrance into the city but are repulsed. $\rightarrow \infty 0$ U. S. marines landed at Guantanamo, Cuba. -Naval appropriation bill (\$II0,000,000), without provision for new battleships, passed by the U. S. House of Representatives.

29. London shipowners refuse Govt.'s invitation to meet the transport workers in conference.-New Jersey presidential primaries give a large majority for Mr. Roosevelt. - Lord Kitchener visits Malta from Egypt to confer with Mr. Asquith and Mr. Winston Churchill on defence problems.

30. Turkish patrol attacked at Kalodere in Albania; 3 killed, 4 missing. - Italians bombard Scalanova, near Smyrna, owing to killing of two Italian sailors by Turks.-Port of London Authority refuse Govt.'s invitation to meet the transport workers in cosference, $-\mathrm{N}$. W. Norfolk by-election results in return of Mr. Hemmerde (Liberal) by reduced majority of 645 . - Fighting at Sefru, ncar Fez; rebels repulsed.-Lord Kitchener's first report on Egypt. issued.-Death of Mr. Wilbur Wright, airman, aged 45 . German Emperor unveils a monument at Brandenburg to the Elector Frederick I, and speaks on German Unity.Sir Wilfrid Laurier speaks on Reciprocity at a banquet at Montreal.-Wolf-Ferrari's opera, "The Jewels of the Madonna," performed at Covent Garden Theatre, London. -University of London appoint a Committee to consider the question of a suitable site.-Carcano art sale begins in
Paris.-Steel bill, passed by the House Jan. 29, is passed by $U$. S. Senate, with an amendment repealing Canadian reciprocity act.

31. London transport workers and employers confer with Ministers at Home Office, but decline to meet each otherWelsh National Library building fund-Greek Minister of Finance, M. Dimitrakopoulos, resigns, owing to the forcible exclusion from the Chamber at Athens of the Cretan deputies.-Steengracht gallery at the Hague closed to the public.-Strike of waiters in New York becomes general.Turkish patrol attacked in Albania; four killed.-House bill for an eight-hour day on all government contract work passed by U.S. Senate; conference report upon Agricultural appropriation bill rejected. June:-

I. King Ferdinand of Bulgaria visits Emperor of Austria at Vienna.-Queen and Prince Consort of Holland visit Paris and are welcomed by French Pres.-British Admiralty announce that Malta will be maintained as a naval baseItalian subjects ordered to leave Chios.-Mr. Redman, British instructor to the Shereefian army, killed in fighting at Fez.-Mr. Falconer Madan appointed Bodley's Librarian at Oxford.-Rioting at N. Y. in connection with waiters' strike_-Cunard liner "Carmania" seriously damaged by fire at Liverpool. - Cretan deputies endeavour to force an entrance into the Chamber at Athens and are repulsed. Chamber prorogued till October 1.-Persian Govt. troops enter Kernanshah, and the pretender Salar-ed-Dowleh takes flight.-Lieut. Stille and Herr Buchstatter, German airman, killed at Bremen.-Ruby, a mechanic, killed while flying with Collardeau (French airman) at Juvisy.-Philip Parmelee, American airman, killed at North Yakima, Washington - Scotland wins internat, golf match at West ward Ho, Devon--Legislative, Executive and Judicial appropriation bill eliminating radical provisions of Housé is reported in U.S. Senate.U.S. transport "Buford" arrives at San Francisco, having brought 364 American refugees from Mexican to Californian ports.

2. Belgian elections, turning on school question, result in Clerical victory.

3. Albanians attack Turkish troops in Ipek and are repulsed--Hungarian Premier, Dr. de Lukacs, refuses to alter Army Bill.-Widener library bequeathed to Harvard University.-Great fire at Stamboul destroys four mosques, seven schools, and over 1,000 houses, - Visiting German warships received by Pres. Taft in Hampton Roads, U.S.A. 4. Transport Workers'. Federation of Great Britain resolve on a national strike unless the London demands are granted.-Mr. Bruce Ismay gives evidence before the "Titanic" Inquiry Commission in London.-London tailors' strike ends-Canada resolves to join in the celebration of a hundred years of Anglo-American peace. - Strike riots at Oviedo, Spain; one person killed.-Hungarian Chamber, after scene of disorder, accepts Army Bill.-U.S. battleship "Arkansas" damaged of coast of Maine.-Rioting in Belgium over result of elections.

5. Mr. Lloyd George makes a statement in British House of 'Commons with regard to Transport Workers' strike. American marines landed in $\mathrm{Cuba}$, and a division of the American fleet sent to Cuban waters. - South Dakota Presidential primaries show a majority for Mr. Roosevelt.-Suit filed in U.S. District Court in N. Y. City against Prince Line, Lamport \& Holt Line, Hamburg American Line and Hamburg-South American Line as a combination contrary to Sherman Act.-Scene in Hungarian Chamber; Opposition expelled by police, and in their absence Count Tisza's majority pass Army Bill.-Sale of Jacques-Doucet Collection in Paris-Huth Library Sale at Sotheby's, London.-Race for the Derby at Epsom won by Mr. Raphael's "Tagalie."-Fighting between Turkish patrol and Bulgarian troops near Egri Palanka on Bulgarian irontier.-Parcel post convention between U.S.A. and Re. public of Panama signed at $W$ ashington, D.C.

6. Sultan Mulai Hafid of Morocco leaves Fez unuer French protection (see Aug. 13).-Cobalt, Ontario, Canada, destroyed by fire- "Hundred Years Ago" costume ball at the Albert Hall, London. -U.S. Repuhlican National Committee meets in Chicago, elects Victor Rosewater chairman, and votes to open hearings of contested delegations to representatives of the press.

7. M. Kovacs, Hungarian Deputy, fires at Count Tisza in the Hungarian Parliament, and then shoots himself.French Govt.'s Electoral Reform Bill submitted to a Committee of Chamber of Deputies.-King Ferdinand of Bulyaria arrives in Potsdam on a visit to German Emperor. - Mr. John Ball at Westward Ho, Devon, wins British Amateur Golf Championship for the 8th time.-Bagdad Railway Report for ror I published.- Strike of Bostod 
(Mass.) car-workers results in rioting.-Explosion of powder magazine at Wellersdorf, near Wiener-Neustadt, kills I4 and injures Io persons.--Mr. A. Lee's "White Slave Traffic"? Bill in British House of Commons adopted by the Govt.-U.S. Supreme Court holds that railways cannot carry railway supplies (coal especially) at rates cheaper than those charged to public.-U.S. Republican National Committee in Chicago decides the first 24 contests that come before it in favour of the delegates for Taft. The "Ohio" and "Minnesota," U.S. battleships, arrive at Guantanamo, Cuba.-Race for "The Oaks" at Epsom won by Mr. J. Pratt's" Mirska."

8. French submarine "Vendémiaire" sunk near Cherbourg by battleship "St. Louis;" 25 drowned.-Ban of Croatia, $\mathbf{M}$. de Cuvaj, shot at by $\mathbf{L}$. Jakitch, a law student at Agram; M. de Hervoitch, his companion, and a gendarme mortally hurt (see Aug, 12). - Italians attack Zanzur, Tripoli, and inflict heavy losses on Turks.-King Nicholas of Montenegro visits the Emperor of Austria at Vienna.King George reviews the National Reserve Troops in Hyde Park, London.-Aerial "Derby" at Hendon, England, won by $\mathbf{F}$. Hamel.-Visseur, Belgian airman, killed whilst flying as a passenger at Rheims.-Forty-eight Taft delegates are seated by Republican National Convention.-Memorial to Christopher Columbus unveiled at Washington, D.C.

9. Hospital Sunday in London; King George and Queen Mary attend St. Paul's Cathedral.-Kimmerling, French airman, with a passenger, Tounet, killed at Mourmelon-leGrand.-Aerial race, Berlin to Vienna, begins.-Visiting German battleship squadron anchors in Hudson river, $N$. Y 10. Lord Loreburn resigns Lord Chancellorship of Great Britain and is succeeded by Lord Haldane:-British House of Commons passes the second reading of the White Slave Traffic Bill--London Transport Workers' negotiations with employers break down, and a national strike is declared -Miss Malecka is pardoned by the Tsar, but prohibited from visiting Russia for life.-German Navy League holds I th annual meeting and is addressed by Admiral von Koester on need for increased activity and inadequacy of Navy Law.--Renewed disorder in Hungarian parliament - Berlin-Vienna aerial race won by $\mathrm{H}$. Hirth, German air man-General strike of seamen at Havre delays, sailing of liner "La France." - Russian troops enter Kashgar to maintain order amongst revolutionary Chinese.-Conference report on Army appropriation bill, legislating General Wood out of office as Chief of Staff, is adopted by U.S. Senate.-U.S. Supreme Court adjourns.

Ix. Transport Workers' order for national strike obeyed at Manchester, Bristol, Plymouth, Southampton, and Swansea_-Sir Rufus Isaacs, K. C. Attorney General, be comes a member of the British Cabinet-Mr. Horatio Bottomley is adjudicated a bankrupt. - Hythe by-election results in return of Sir P. Sassoon (Unionist). by majority of 17 18. - Congress of Chambers of Commerce of the British Empire opened in London by Mr. Asquith.-The Regen of Persia leaves Teheran for Europe-Committee of Hungarian House of Magnates adopt Army Bill by 20 votes to 14 - - Havre Seamen's strike spreads to Calais and Brest.-U.S. Senate votes against an appropriation fo Commerce Court.-U.S. District Court at Toledo fines Hocking Valley Ry. Co. $\$ 42,000$ and Sunday Creek Coa Co. $\$ 20,000$ for rebating. - Nearly 90 miles of levees in Louisiana break. - Lieut. L. W. Hazelhurst, Jr. US. A and $\mathrm{Al}$ Welsh, a professional aviator, killed at army aviation field, College Park, Md.

12. Col. J. E. B. Seely becomes Secretary of State for War in the British Govt.-Mr. Austin Chamberlain move a vote of censure in British House of Commons on the Home Secretary (Mr. McKenna) for refusing police protec tion to a party of free labourers at Purfleet. It is rejected by 337 votes to $260,--$ Demonstration of $13,000 \mathrm{men}$ in the Albert Hall and Hyde Park against Welsh Church Bill speeches by Mr. Bonar Law and the Archbishops of York and Canterbury.-Bunyan's copy of Foxe's "Book o Martyrs" sold to Mr. Pierpont Morgan for $£_{2}, \infty 00$-U'S Senate adopts an amendment to Legislative, Executive and Judicial appropriation bill, repealing law creating Commerce Court. - Republican National Committee de cides contests from Arizona, California, Louisiana, Michi gan and Mississippi in favour of Taft delegates. Roosevelt announces that his platform will favour woman's suffrage. - Count Tisza has special audience with the Emperor Francis Joseph, who praises his conduct as Pres. of the Chamber.-England defeats S. Africa in cricket at Lord's, London, by an innings and 62 runs.-Lord Heneage's motion in House of Lords to postpone operation of the Insurance Act until I9r3 negatived without divisions.

I3. Arab attack on Lehda, Tripoli, repulsed with heavy loss.-Mr. Balfour speaks on Home Rule at Preston.
Eight Suffragist women arrested in Dublin on a charge of window breaking.-Committee of Inquiry at Cherbourg in to loss of submarine "Vendémiaire" acquits capt. of battleship "St. Louis."-Khost valley rebellion in Afghanistan reported to be subsiding. - Kieff newspapers publish result of an inquiry disproving charge of ritual murder against Jews.-Miss Malecka arrives in London after her release from Russian prison.-U.S. House of Representatives votes $\$ 25,000$ appropriation for President's travelling expenses. Mounts Katmai, Redoubt and Iliamna, Alaska, in eruption. -Strike riots in Perth Amboy, N. J at American Smelting and Refining Co.'s works.-Decree filed in U.S. Circuit Court, at Wilmington, Del., ordering dissolution of E.I. DuPont de Nemours Powder Co. before December. - Conference report on Army appropriation bill accepted by U.S House of Representatives. - Visiting German battleship squadron leaves N. Y. - 13 contests decided in favour of Roosevelt delegates by Republican National Committee.

r4. King George's birthday celebrated officially throughout British Empire.-Birthday honours include 4 peerages, batonetcies, and $25 \mathrm{knighthoods.-Mr}$. Waiter Long and Sir Edward Carson address national Home Rule protest meeting at the Albert HIall, London.-Memorial presented to Home Secretary signed by over roo members of British House of Commons asking for Ist division treatment for suffragist prisoners. - French force leaves Fez for Sefru. Chinese troops mutiny at Tsinanfu.-Dr. Robert Bell awarded $f_{2,000}$ damages in London for libel by Dr. Bashford in the course of criticisms on his cancer treatment published in British Medical Journal.-Republican National Committee decides contests in Okalahoma and Tennessee in favour of Taft delegates.

15. Theodore Roosevelt arrives in Chicago, to take personal leadership of his adherents who are trying to nominate him for the Presidency in Republican National Convention.-Republican National Committee seats 26 Taft delegates and 4 Roosevelt delegates from Texas, but decides all Virginia and Washington contests for Taft delegates,Sloane Laboratory (physics) of Yale University is dedicated. -Hungarian House of Magriates adopts Army Bill by 174 to 33. - New Portuguese Ministry formed under Dr. Duarte Leite.-Fighting at Bu Sceifa, near Misurata, Tripoli, over disembarcation of an Italian Expeditionary Corps; 50 Arabs killed; 2 Italians killed, 9 wounded.

16. French Aerial "Derby" begins.-Railway accident at Malmstatt, Sweden; 20 killed (I Englishman), 14 injured. 17. Franchise and Registration Bill introduced into British House of Commons by Mr. J. A. Pease-Mr. McKenna, British Home Secretary, announces that the Anarchist Malatesta will not be expelled after imprisonment.-Tang-Shao-yi, Chinese Premier, announces his intention to resign.-New Cretan Govt. formed.-Pres. Taft vetoes Army appropriation bill, passed by U.S. Congress.-American Beef Trust, National Packing Company, notifies U.S. Dept. of Justice that it will endeavour to dissolve by August I (see July 20)--Supreme Court of Canada declare Federal Parliament incompetent to pass a general marriage law for the Dominion; and decide that mixed marriages solemnised by a Protestant clergyman are valıd. -French Aerial "Derby" won by French airman. Garros. 18. Republican National Convention for selection of Presidential candidate opens at Chicago.-U.S. Interstate Commerce Commission begins an inquiry into transportation of anthracite coal.-Baron Marschall von Bieberstein, the new German Ambassador, arrives in London.-French airship "Conte" with crew of six rose to record height of $0,022 \mathrm{ft}$. in Paris.-Mrs. Julia Clark, American aviator, killed at Springfield, Ill - Retirement of Sir Sidney Colvin, keeper of Prints and Drawings, British Museum, London.Judgment delivered by the Privy Council in London in the case of L. O. Clarke, Pres. Magistrate of Mymensingh, India, who appealed against decree of the High Court of Bengal (Jan. I2, I909), and judgment of Mr. Justice Fletcher in the lower court (June 19, I008), condemning him in damages for exceeding his powers of search at Jamalpar'April 1907. The appeal was allowed and the plaintiff given the costs of both the previous trials.

r9. Pennsylvania (Roosevelt) delegation bolts Republican National Convention and Roosevelt members leave Credential Committee. Gov. Hadley's motion to bar from voting on contests 72 contesting delegates is defeated 569 to 477 - Two French military airmen. Capt. Dubois and Lieut. Peignan, killed near Doua! by collision of their aeroplanes - Montenegrin Cabinet resign and a new Ministry is formed under Gen. Martinovitch.-British House of Commons, voting in Committee on Mr. Agar Robartes Amendment to Clause $\mathbf{r}$ of the Home Rule Bill, decides by majority of 60 against excluding four counties in the province of Ulster from the operation of the Bill.-Rebel 
raid at Vuchitru in Albania.-Pres. Talt signs eight hour Liw for contract work for C.S. Govt.

20. On final appeal, in the Thompson-Banister case, House of Lords decides that a clergyman is not entitled to refuse the Sacrament to persons who have married under the Colonial Marriages (Deceased Wife's Sister) Act, I906. Holmfirth (Yorks.) by-election results in return of Mr. S. Arnold (Liberal) by a majority of $\mathrm{x}, 370$. - Race for the Ascot Gold Cup won by Mr. Pilkington's "Prince Palatine". Russian Duma votes five years naval programme, including $£_{50,000,000}$ for construction.-French seamen's strike spreads to Marseilles. - Chinese troops mutiny at Mukden. - Debate on Language clause in Civil Service Bill begins in South African Parliament.- "Six Powers" Loan to China negotiations concluded in Paris.-London Transport strike leaders confer with Chief Liberal Whip.-Poyer, French motor-car bandit, arrested in Paris.

21. British troops sent from Hongkong to Canton.Port of London authority proposes to remove restrictions limiting men competent to act as lightermen on Thames. Dr. G. F. McCleary, editor of Public Heallh, appointed Principal Medical Officer to the National Insuranc? Commissioners.-Railway accident near Halifax, Yorks.; 4 killed, over 20 injured.- Mr. Campbell Dodgson appointed to succeed Sir S. Colvin as Keeper of the Dept. of Prints and Drawings, British Museum. - Lisbon tramway strike leaders arrested; trams run under military protection.Lt. Felix von Falkenhayn, German military airman -illed at Döberitz. - Fighting near Fez between French and Moorish tribesmen.-Sundry Civil appropriation bil $(\$ 109,577,414)$ passed by U.S. House of Representatives. U.S. Interstate Commerce Commission orders Delaware, Lackawanna \& Western Railroad to lower coal rates.W. J. Bryan announces his opposition to Alton B. Parker for temporary chairman of Democratic National Convention. Credentials Committee of Republican National Convention settle most contests for Taft delegates.

22. Mr. Taft nominated as regular Republican candidate for the U.S. Presidency by $56 \bar{I}$ votes, against Roosevelt ro7, LaFollette 4I, Cummins I 7, 344 not voting; Mr. Roosevelt "bolts" and makes proposals for new Progressive party. - Mr. Tom Mann, syndicalist leader, released from prison after serving six weeks of his sentence.-Draft Agreement on Morocco handed by Spanish Government to French Ambassador at Madrid.-Both seamen and employers at Marseilles refuse French Govt.'s offer of arbitration in seamen's strike,-Further rioting in Lisbon; bomb explosions and conflicts between troops and tramway strikers.-New building of Royal Academy of Music, London, opened by Prince Arthur of Connaught - Coaching Marathon race a Olympia, London, won by Mr. W. H. Moore of New York. -G. H. Patching (S. Africa) wins Ioo yards race at Stamford Bridge, England, in of seconds.-Balloon race of Royal Aero Club won by Mrs. John Dunville.

M. Ehrmann, French airman, injured at Vienna.Prince of Wales comes of age.

24. Industrial Council open public enquiry in London on agreements, in relation to labour unrest.-Mrs. Pankhurst and Mrs. Pethick Lawrence, Suffragist leaders, re leased from prison.-Death of Field Marshal Sir George White, V.C. aged 76. - On Budget Debate in British House of Commons Government majority on an amendment altering tea duty falls to 22; Chancellor of the Exchequer announces that five millions out of last year's surplus will go to reducing National Debt and a million to extra naval expenditure,-Dalai Lama of Tibet leaves Kalimpong for Lhasa.-Mutiny of Albanian troops at Monastir-Govt. of India Bill passed by House of Lords after speeches from Lord Curzon and Lord Crewe.-Alton B. Parker of New York chosen by Democratic National Committee to be emporary chairman of Democratic National Convention. - Samuel Gompers, President of American Federation of Labor, sentenced by Supreme Court of Washington, D.C. to a year's imprisonment for contempt.

Democratic Convention for selection of Presidential candidate opens at Baltimore- - Violent protest made in Iritish House of Commons by $\mathbf{M}_{r}$. George Lansbury, Labour Member, against forcible feeding of Women Suffragist prisoners.-Mr. Asquith receives deputation urging adoption of proportional representation in Ireland as a means of safeguarding rights of minorities under Home Rule.-British'Board of Trade Inquiry into loss of "Oceana" decides that its captain was responsible.-British Colonial Secretary appoints Committee under Sir Kenelm Digby to consider Land Question in British West Africa.-Death of Sir Lawrence Alma-Tadema at Wiesbaden, aged 76 .

26. King George and Queen Mary open Welsh National Museum at Cardiff.-Debate in House of Lords on question of undue baste in bringing the Insurance Act into opera tion July 15.-Encaenia celebration at Oxford; hozrary degrees conferred on Lord Crewe, Admiral Sir A. K. Wilson Sir G. Askwith, Mr. Henry James, Mr. Robert Bridges, and Prof. Cumont of Brussels.-Sotheby sale of mezzotints in London realises $£_{25,165}$. Test match between. England and Australia cricketers at Lord's left drawn.- South African ministerial crisis averted by re-arrangement. Austrian Chamber adopts Army Bill on second and third readings by a two-thirds majority - Lt. Etienne, French military airman (injured June ro), dies in Versailles hospital. -In Democratic National Convention W. J. Bryan refuses chairmanship of Credentials committee; by $5551 / 2$ to 495 the rule for unit voting of state delegations is abrogated.

27. Debate on Colonial Vote in British House of Commons; Mr. Harcourt reviews work and progress of last six years-Protest meeting of domestic servants against Insurance Act in Albert Hall, London.-Italians attack and take Sidi Said in Tripoli, carrying intrenchments after severe fighting.-Estenoz, lea. s: of Cuban rebels, reported killed. - Mutiny of Turkish troops extending in Turkey.-Francis Bacon memorial unveiled by Mr. Balfour at Gray's Inn, London.-Capt. Bayo, Sp=nish military airman, fatally injured at Madrid.-Baron Vincenzo Paterno sentenced to penal servitude for life for murder of Countess Giulia Tringona on Murch 2.-Mr. Pethick Lawrence British suffragist leader, released after serving 5 weeks of his sentence--Ehlers, German sailor, sentenced at Leipzig to siz years' penal servitude for betraying naval secrets.

28. Debate in British House of Commons on treatment of suffragist prisoners, opened by Lord Robert CecilWindow breaking by sufragists in London and provincial towns as a protest against forcible feeding.-Ilkeston byelection results in return of Col. Seely (re-elected on appointment as War Minister) by a majority of $12 \mathrm{Ir}$, a reduction of 2,800 . - Yuan-Shih-kai accepts resignation of Chinese Premier, Tang-Shao-Yi-Free State education controversy in South Africa settled.-Funeral procession of Field Marshal Sir George White across London.- $\boldsymbol{U}$.S. Int-ratate Commerce Commission suspends new restrictions of baggage carried free by railways and stea mships In Democratic National Convention at Baltimore on the first ballot for Presidential nomination Champ Clark receives $440 \mathrm{y} / \mathrm{v}$ votes, Wuodrow Wilson 324 , Judson Harmon r48. Oscar Underwood $1171 / 2$ and Thomas R. Marshall 31 ; eleven more unsuccessful ballots are taken.-Death of $\mathrm{Mr}$. Enoch Edwards, President of the Miners' Federation of Great Britain, aged 60.-Lord Morley delivers an address on Democracy at Mancheste:.- - Celebration of bi-centenary of birth of Jean Jacques Rousseau at Geneva.-Zeppelin airship "Schwaben" wrecked at Düsseldorf.

20. Mr. Lloyd George speaks at Woodford on the "free the land" policy.-Demonstration against Welsh Church Eill at Cardiff.-French Congress at Quebec; Mr. Bourassa protests against Americanism.--Thirty-five Arabs sentenced to death in Tunis for participation in November riots (see Nov. 8), - Lu Cheng-Nsieng, Chinese Foreign Minister, appointed Premier.-Schadt, German airman, killed at Mülhausen.-Lt. Blaschke, Austrian officer, flies up to

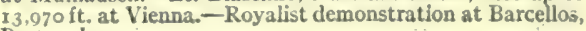
Portugal.

30. Rousseau bicentenary celebrated in Paris.-Benno König, German airman, fatally injured at Hamburg."Sokol" (physical culture) Slav festival begins at Prague. July:-

I. Pres. Taft names William Marshall Bullitt, of Louisville, to be U.S. Solicitor-General as successor to F. W Lehmann, resigned June 26.-Resolution passed in both branches of U.S. Congress extending appropriations of last fiscal year through July - Miss Harriet Quimby, American aviator, and her pilot, killed at Dorchester Bay, U.S.A.-
Hibernians attack Protestant Sunday school excursion party near Maghera, Ireland.-Ude district of Belgian Congo opened to freedom of trade. - Cyclone sweeps over Western Canada, destroying Regina and causing great loss of life-French Chamber ratify the treaty establishing protectorate over Morocco by 460 votes to 79.- Sir Francis Champneys elected President of Royal Society of Medicine, London.- Taylor Art Sale begins at Christie's, London.Death of Dr. Milovanovich, Servian Premier, at Belgrade, aged 50.- Serious outbreak of foot and mouth disease stops showing of cattle, sheep and pigs in Royal Show at Doncas ter-Command performance at Palace Music Hall, London, attended by King George and Queen Mary.

2. Opening of Congress of Universities of the Empire in London by Lord Rosebery.-Dr. Woodrow Wilson nominated as Democrat ic candidate for the American Presidency on the 46 th ballot at Baltimore, receiving 990 votes, against 84 for Champ Clark and 12 for Harmon. Thomas Riley Marshall nominated for Vice President.-Debate in House 
of Lords on naval position in the Mediterranean.--Labour Party threaten to absent themselves from British House of Commons if Liberals contest vacant seat at Hanley.Colliery strike and riot at Cwymtillery, Monmouthshire.Mr. George Foster, Canadian Minister for Trade and Commerce, : speaks at the Constitutional Club, London."Titanic" relief fund reaches $\$ 307,500$; the Public Trustee and others deputed to draw up a scheme for dealing with the crew.- Portuguese Royalists reported to be concentrated near Tuy.-Army appropriation bill without clause affecting Major-General Wood again passed by U.S. House of Representatives.-Three Nationalists arrested in Cairo for conspiring against Govt.-Mr. Vaniman's transatlantic airship "Akron" with crew of five explodes in mid-air at Atlantic City and falls into the sea; all kilied.

3. First clause of Home Rule Bill carried in British House of Commons by majority of 92 - Board of Trade enquir in London into loss of "Titanic" concluded.-Mr. Lloyd George gives breakfast at II Downing St., to inaugurate Radical land policy.-Mine explosion near Oberhausen Germany; 16 miners killed and 6 injured,-A. Piatt Andrew, Assistant Secretary of U.S. Treasurv, attacking efficiency of Secretary MacVeagh, resigns--House Bill revising chemical schedule of tariff rejected by U.S. Senate - After adopting a platform Democratic National Convention at Baltimore, Md., adjourns.

4. Mr. Borden, Canadian Premier, and other Canadian ministers arrive in London-Labour Party in British House of Commons pass a resolution that each individual member is at the disposal of the party to go to Hanley and Crewe for election purposes.-Bicentenary of Trinity College Medical School celebrated in Dublin.-German Emperor and Tsar of Russia meet at Port Baltic.-French shippin strike spreads from seamen to dockers.-Emperor Francis Joseph's reign reaches 63 years 7 months 2 days, and equals Queen Victoria's - Railway accident near Corning (N. Y.) 40 killed, 50 injured. - Reply of National Health Insurance Commissioners to British Medical Association published. Accident on Delaware, Lackawanna \& Western R.R., New Gibson, N. Y.; 39 killed, 86 injured.-Sir Francis May Governor of Hongkong, shot at by a Chinaman.-Genera Huerta reported to have captured rebel positions in Morocco-Hadji Adil Bey, Minister of the Interior, returns to Constantinople after tour through Ottoman Dominions.Leonardo da Vinci celebration at the Sorbonne, Paris

5. Rhodes Memorial erected on Table Mountain, dedicated by Lord Grey.-Dock Strike Committee in London decide that strike shall continue-Rioting takes place among dockers on strike at Havre--Capt. E. B. Loraine and Staff Sergeant R: Wilson, British military airmen, killed on Salisbury Plain.-Funeral of Sir L. Alma Tadema in St. Paul's Cathedral, London.-Eilers, an American subject, sentenced at Leipzig to 4 years ${ }^{2}$ penal servitude for espionage - M. Mounet-Sully celebrates 4 oth anniversary of début at the Comédie Française--Holland admitted to Berne Copyright Convention.-General Gourand in Morocco defeats Pretender and his Sebala force.-Dedication of Champlain Memorial Lighthouse, at Crown Point, N. Y. given by New York State and Vermont to U.S.-Nava appropriation bill, with amendment providing for building two battleships, passed by U.S. Senate-Railway accident at Ligonier, Pennsylvania; 17 killed, 30 injured

6. King George's proposed visit to Royal Albert Dock extension on July $x 7$ cancelled owing to strike.-King George and Queen Mary attend Henley Regatta in the State barge:-Official communiqué issued from Port Baltic concerning the meeting of the German Emperor and the Tsar.-Govt. of Moroccodecide to open the port of Mehedia to foreign trade on January I, I013.-Mr. Imre Schwaiger of Delhi presents sacred peacock in steel to British Museum - "Olympic" runs aground in New York harbour.Prince Katsura starts from Tokyo for a European political tour--Opening of the Stadium for the Olympic Games at Stock holm by the King of Sweden.-At Henley, the Rowing Club de Paris win the Thames Challenge Cup; the Sydney Rowing Club the Grand Challenge Cup; Eton the Ladies Challenge Plate; New College, Oxford, the Stewards'. Challenge Cup; Queens College Cambridge, the Wyfold Challenge Cup; E. W. Powell (Vikings' Club) the Diamond Sculls; Christ Church I, Oxford, the Visitor' Challenge Cup, and Logan and Rought. (Thames Rowing Club) the Silver Goblets.

7. German Imperial Chancellor visits St. Petersburg.Dynamite explosion at Rancagua, Chile; 38 killed.Portuguese Royalist attack on Valenca repulsed; Capt. Couçeiro threatens Montalegre but retires.-Call issued in New York signed by sixty-three men from forty states, summoning delegates to a national Progressive Convention at Chicago, on August 6.
8. London Dock. Strike Committee issue a statement that they regret the cancellation of the King's visit but express "both indebtedness and respect to his Majesty" Second reading of Franchise Bill moved by Mr. Harcourt in British House of Commons - Capt. Couceiro bombards Chaves, but is repulsed by troops sent by Portuguese Govt. to oppose Royalist insurgents. - International Miners Congress opens at Amsterdam.-Camorra trial at Viterbo begun March torr, ends in 8 of the accused being sentenced to 30 years' imprisonment, and the rest to terms of from 4 to 20 years.- Mr. Chamberlain celebrates his $76 \mathrm{th}$ birthday; shilling fund opened.-In the New York seamen's strike one striker killed and two policemen shot.-King George and Queen Mary begin an "industrial" tour in Yorkshire--Turkish Govt. declare a state of siege in the Kruja district of Albania.-Misurata, Tripoli, occupied by Italian troops.-Resignation of Mahmud Shevket Pasha, Turkish War Minister.

9. Memabers of both Houses of British Parliament inspect the Fleet at Spithead.-Explosion at the Cadeby coal mine near. Sheffield causes loss of 80 lives including three Govt. inspectors of mines. King George and Queen Mary visit the pit after the accident.-Portuguese Govt. call out reserves; Royalist troops under Capt. Couceiro retire into Spanish territory - Second Lt. Soares, a naval officer, shot in the street at Lisbon.-French Chamber of Deputies accept the principle of Govt. Electoral Reform Bill, involving proportional representation.-M. Badel, French airman, killed at Châlons.-Schatz, a German factory official, sentenced to 9 months' imprisonment at Saargemünden for lese-majeste. - Havre dockers on strike resume work.Hsiung Hsi-ling, Chinese minister of finance, presents note to the bankers of the Six Powers-Mackenzie Ministry New Zealand, resign; Mr. Massey summoned.-Djavid Pasha appointed acting commandant of the Monastir Army Corps, Albania.-Charles D. Hilles, Secretary of Pres. Taft. chosen chairman of Republican National Committee and manager of Taft campaign for U.S. Presidency.

10. Sir Edward Grey speaks in British House of Commons on the Anglo-Russian Agreement and Foreign Affairs. and is followed by Mr. Bonar Law.-Mr. Borden speaks at Royal Colonial Institute, London, on Canada's position in world politics.-Rioting in London by dockers on strike; Io injured.-Mr. Asquith receives deputation from Belfast Chamber of Commerce on Home Rule.-Cambridge cricket eleven beats Oxford at Lords by 3 wickets.-A. N. S. Jackson, British athlete, wins the 1,500 metres race at the Olympic games, Stock holm, in 3 mins. $56 \frac{4}{5} \mathrm{sec}$, a world's record. - Another Egyptian arrested in Cairo for conspiracy against the Khedive and Lord Kitchener._-Massey Ministry formed in New Zealand.-German punitive expedition sent to Kaiser Withelm's Land, New: Guinea, in consequence of murder of Herr Petersen, the ornithologist-French Chamber of Deputies pass Electoral Reform Bill by 330 to 2I7; violent demonstration by Opposition.-U.S. War Department sends rifles and ammunition to protect Americans at Hermosillo, Mexico.

Ix. The Port of London employers pass resolution expressing confidence in Lord Devonport as chairman and affirming their decision to agree to no conditions till the men return to work. - Further rioting at London docks.-Great Britain protests before U.S. Senate against provision in Panama Canal bill which permits American ships free use of canal (see May 23 and July I3).-U.S. House of Representatives, acting on report of Judiciary Committee, votes by 222 to I to impeach Judge Archbald of U.S. Commerce Court.-Sir W. Plender's Report on the renumeration of doctors in certain selected areas issued in London.- Rioting at Dunkirk in connection with French dockers' strike.Celebration of millenary of Oxford City at Oxford.-Arrest of Governor of Valença in connection with Royalist rising. - Greek and Armenian patriarchs and Bulgarian Exarch combine to protest against enrollment of Christian subjects up to the age of 45 in Turkish army.-P. \& O. liner "Persia" runs aground near Marseilles.

12. Franchise Bill read a second time in British House of Commons by 200 to 218 , after speeches by Mr. Balfour, Mr. Asquith and Mr. Bonar Law.-Mr. F. E. Smith speaks at Belfast in the Boyne celebrations, and Capt. Craig, M.P. announces that an Ulster Day will be inaugurated.- Mr. Lloyd George and the Governor of the Bank of England speak at the Mansion House on national finance and the fall in consols.- Conference between the Govt. and Lord Devonport on the London dock strike.-Sale of Raeburns at Christie's for prices of from 3,900 to 6,800 guineas, and of a Rembrandt for 5,800 guineas. - England wins Elcho Shield at Bisley.-Saskatchewan provincial elections result in an increased majority for the Liberals. - Seizure of arms and ammunition at Belas by Portuguese Republican troops. 
-General strike at Zurich caused by importation of German workmen.-Point Tupper (N.S.) destroyed by fire--New York shipping strike spreads to Pennsylvania Railroad freight dockers.-At Atlantic City, N.J., National Prohibition Convention nominates Eugene W. Chafin and Aaron S. Watkins for President and Vice-President of U.S.

13. Hanley by-election results in return of Mr. Outhwaite (Liberal) by majority of 654 . - Report by Sir Roger Casement on treatment of Indians in Putumayo rubber industry, Peru, issued in London.-Mr. Lloyd George speaks at meeting in Kennington to celebrate Insurance Act.--Two women suffragists arrested for attempt to burn Nuneham House, near Oxford.-Five Chinese Ministers, including Finance minister, resign, and a committee of three is appointed to deal with foreign loans.-Mr. Knox, U.S. Secretary of State, formally notifies Senate of British protest against preferential treatment of American shipping in Panama Canal. - Senator Lorimer unseated by U.S. Senate on the ground that his election as Senator from Illinois was secured by corruption.

14. Hyde Park dock strike demonstration; some disorder.-Portuguese Govt. issues note denying that Spanish Govt. have assisted them by discouraging Royalist plots Railway accident near Chicago; 15 killed, 30 injured.

5. National Health Insurance Act comes into operation in the United Kingdom.-U.S. Senate begin formal consideration of Panama Canal Bill.- "Hindle Wakes," play by Stanley Houghton, produced at Playhouse Theatre, London.-Meeting between Lord Bevonport and represenIatives of London Transport Workers-Lord Curzon opens debate in House of Lords on the Trans-Persian Railway replies by Lord Morley and Lord Crewe.-Prince Henry of Prussia speaks at Frankfurt-am-Main on German Unity at the golden jubilee of the League of German Marksmen. -Turkish Chamber pass vote of confidence in the Govt. by 194 votes to 4 -M. Olivères, French airman, killed at Bourg-en-Bresse-Mr. Asquith receives deputation of miners in regard to Minimum Wage Act.-It is announced that William F. McCombs will direct campaign of Woodrow Wilson for U.S. presidency.-U.S. Interstate Commerce Commission promulgates order relating to express rates, practices, accounts and revenues (see Oct. 9) 16. Hurshid Pasha, Turkish Acting Minister of War, resigns owing to disaffection of the army in Albania.Albanians present a remonstrance setting forth their grievances to the Grand Vizier.-Mr. Borden, Canadian Premier and members of Canadian and S. African parliaments, dine at British House of Commons; speech by Mr. Borden on Imperia! Union.-Italians accused by Turkish Commander in Tripoli of poisoning the wells.-Sir Percy Girouard resigns post of Governor of East African Protectorate, and is succeeded by Mr. H. C. Belfield.--Taylor art sale closes, having reslised nearly $£ 359,000$.-Beaufoy first four-folio Shakespeare sold in London for $\mathfrak{f}_{3,500}$. - Lord Devonport and Transport Workers strike leaders confer with $\mathrm{Mr}$. Asquith.-Royalist conspirators at Torres Vedras arrested by Portuguese Govt.-General Mahmud Mukhtar becomes Minister of War in Turkey. - Stadium events in Olympic Games at Stockholm result: America r28, Sweden rro, England 68 (British Empire I ro), Finland 46, Germany 37 France 21, S. Africa 16, Canada, I3. Australia 13.- Herman Rosenthal, a gambler, about to testify against New York Police Department, shot dead in New York (see Aug. 20). 17. The Turk ish Ministry of Said Pasha resigns owing to dissensions in the Cabinet-Negotiations for set tlement of Loadon dock strike end in failure.-Australia beats S Africa at Cricket at Lord's, by ro wickets. - Fighting in Northern Persia between Shahsevens and Russian troops.

-U.S. House of Representatives pass Bill for creating Dept. of Labor.

Debate in British House of Commons on Finance Bill: Mr. Lloyd George and Mr. Bonar I saw speak on fall in price of Consols.- Mr. Asquith arrives in Dublin and has a cordial reception.-Both parties to London dock strike reject compromise suggested by the London members of the House of Commons,- Sultan of Turkey appoints Tewfik Pasha Grand Vizier. - Supplementary Naval Estimate for $\mathcal{L}_{000,000}$ is issued by British Admiralty.-Campaign arainst Electoral Reform Bill begins in France.-Li-HonHung. who attempted to assassinate Sir F. May at Canton. sentenced to imprisonment with hand labour for life.Suffragist attempt to set fire to Theatre Royal, Dublin.Sergt. H. Ohmundsen (Royal Scots) wins Bronze Medal in King's Prize at Bisley.-Monument unveiled at Acote's hill in Chepachet, R. I., to Thomas Wilson Dorr, of "Dorr's Rehellion.

10. Mr. Asquith speaks in Dublin on the future of the Home Rule Bill-- Hatchet thrown by suffragist at Mr. Asquith's carriage wounds Mr. Redmond-Mental
Deficiency Bill read a second time in British House of Commons. - Attempt by Italian torpedo boats to enter Dardanelles results in narrowing of the channel left open to neutral shipping.-Tewfik Pasha decides to form new Turkish ministry.-Albanians agree to truce pending despatch of Parliamentary Commission to investigate their grievances. - Failure of attempts to form non-party Cabinet in China-U.S. Govt. 's special agent arrives at Iquitos to proceed to Putumayo district to see that Peruvian Govt. punish those guilty of cruelty to native Indians.- Sergt. G. H. Harvey (S. Africa) wins Silver Medal in King's Prize at Bisley:-England wins 2 events in Rowing.competitions of Olympic Games.-Rose arrested for murder of Herman Rosenthal in New York.

20. Committee of British Medical Association resolve to break off negotiations with the Govt. on the National Insurance Act unless their minimum demands are met.Emperor of Japan announced to be seriously ill of uraemia. - M. Poincaré, French Premier, speaks on home and foreign politics in the Vosges dept. and declares the Government's intention to carry proportional representation.-Ghazi Mukhtar Pasha appointed Turkish Grand Vizier; forms a Cabinet containing Kiamil, Nazim, Hilmi and Ferid Pashas, Zia Bey and Djemal-ed-Din.-M. Klotz, French Finance Minister speaks at St. Gratien on the fall in the French Rente.-King's Prize at Bisley (Gold medal) won by Private A. G. Fulton (Queen's Westminsters).-Prishtina taken by Albanian rebels, who propose a conference. Dissolution of National Packing Company ("Meat Trust") of U.S. announced (see June I7).

21. Pan-American students' congress opens at Lima, Peru.-Prince Katsura arrives in St. Petersburg on : political mission.--Rebels blow up a train near Mexico City-Mr. E. H. Watts, a Bucks county gentleman, mutdered by gamekeeper W. Farrow, who commits suicide,

22. Mr. Borden speaks at banquet given by London Chamber of Commerce on results of his mission and on responsibilities of the Empire.-Mr. Wimston Churchill makes statement in British House of Commons on need for increased provision of ships and men in North Sea fleet and on proposed naval force to be kept in Mediterranean. King George opens new railway dock at Immingham near Great Grimsby.-It is announced that Mr. Lloyd George, with the support of Mr. Asquith, will embark upon a land policy campaign in the autumn - Mr. Austen Chamberlain speaks on future policy of Unionist Party.-Committee of British Medical Association pass resolutions in favour of working with the Govt. with regard to the Sanatorium benefit of the National Insurance Act.-Dock strike in Liverpool as protest against new clearing house system Attack on sanatorium near Lucan, Co. Dublin, by mal-content residents. - Two German naval officers drowned by capsizing of pinnace belonging to battleship "Thüringen," near Nidden.-U.S. District Judge Cornelius H. Hanford of Washington resigns, and investigation of his case is dropped by the House of Representatives.

23. British Medical Association in full meeting confism Committee's decision to insist on minimum demands of the profession before agreeing to work National Insurance Art.-Debate in House of Lords on British naval policy initiated by Lord Selborne-_Eight girls lose their lives in fire in Moor Lane, City of London; a ninth dies sulsequently in hospital. - Foundation at Oxford of Gladstone Professorship of Political Theory and Institutions.-Armgard Karl Graves sentenced at Edinburch to 18 . months' imprisonment for espionage-Dr. Ethel Smyth, musical composer and suff ragist, arrested for conspiracy in suff ragist attempt to set fire to Nuneham House, Oxford, on July $x_{3}$ U.S. Senate votes to continue annual appropriation for Tariff Board, against which House voted.

24. British Medical Association in full meeting decide to work sanatorium part of National Insurance Act on terms to be agreed upon with the Govt.-Rioting at London docks after march of dockers through the streets of the City to Tower Hill where meeting is addressed by the strike leaders. Mr. Ben. Tillett asks the men to join him in a prayer "that God would strike Lord Devonport dead." . Two bread vans are overturned and plundered. two carts set on fire, and fyghting occurs with men at work. The police charge with batons and about 20 of the strikers are injured. Twenty arrests made--Lord Lansdowne, speaking at annual meet ing of Rural League, out lines future land policy of Unionist Party - Mr. Winston Churchill makes further statement in British House of Commons on Govt.'s naval programme. -First International Congress on Eugenics opened in London by a banquet at which Mr. Balíour speaks.-It is reported that potato disease has appeared in Ireland.M. Clémenceau in an open letter defnes his grounds for opposing M. Poincaré's Government's scheme for electoral 
reform by proportional representation--Meeting of Tsar of Russia and King of Sweden at Pitkapaasi Bay, Finland. - Sundry Civil appropriation bill and measure creating single-chambered legislature of 16 members for Alaska passed by U.S. Senate,-Prof. Herschell Parker and Belmore Browne announce from Tolvina, Alaska; that they ascended to within 300 feet of summit of Mt. McKinley.

25. Debate in British House of Commons on Imperial Defence Committec.-M. Poincaré replies to $M$. Clémenceau's attack on the Government proposal for proportional representation. - Serious floods in Pennsylvania, Ohio and West Virginia. - General Ameglio, commanding Italian troops at Rhodes, reported to have visited $\mathrm{K}$ alymnos and to have stated that the Aegean islands occupied by Italy would never be restored to Turkey.-Greek Govt. order an armoured cruiser and 8 torpedo boats to be built at the Vulkan works, Germany.-Senator LaFollette's wool tariff bill passed by U.S. Senate (see April r and August 9).-U.S. marines ordered home from Guantanamo, Cuba.

26. By-election at Crewe results in Unionist victory for Mr. E. Craig by majority of 966.-Meeting at Calcutta to express discontent with Privy Council's judgment in Mymensingh Case (see June r8). - Officers of the Turkish Army, claiming to represent Adrianople Army Corps, demand resignation of new Cabinet and subsfitution of a Young Liberal Ministry.-Fire at a champagne factory at Epernay, France; 5 persons missing.-Lowther Lodge, Knightsbridge, London, sold to the Royal Geographical Society for \&Ioo,opo.- Naval wing of the British Royal Flying Corps sanctioned by an Order in Council.- Liverpool meeting resolves to form a Society to advocate a State medical service in Great Britain.-Chinese Advisory Council approve names of 5 new ministers.-Govt. majority in British House of Commons falls to 3 on a motion respecting business.-Dr. Ethel Smyth, charged with conspiracy, discharged owing to insufficient evidence (see July 23). -Duc de Lorge killed in lift accident in London. - Strike of 2,000 workmen on Grand Trunk railway, near Fort George, B.C. -Excise Tax bill passed by U.S. Senate, 37 to 18 , with amendments creating permanent tariff commission and repealing Canadian reciprocity act.

27. London Transport Workers' Strike Committee recommend port workers to resume work at once.-Mr. Bonar Law, speaking at Blenheim, says it is the duty of the Unionist party to support Ulster in resisting the Home Rule Bill:-Messrs. Harland \& Wolf, Belfast, ship-builders, announce gradual shutting down of their works owing to trouble and intimidation amongst their employees.-Last section of Bagdad rallway, from El Helif to Bagdad, begun.--Extension of Tube railway from the Barik of Liverpool st., London, opened.-Visit of Mr. Borden and Canadian ministers to Paris.-Three miniatures by Mrs. Frank Eastman stolen from Royal Academy, London. Turkish Cabinet issue manifesto to population of Northern Albania stating that armed force will not be used against them, and that a Parliamentary Commission will enquire into their grievances- -Joseph Fischer, German airmañ; with a passenger (Kugler) killed near Munich.-Capt. Dom Joao de'Almeida, Portuguese royalist, sentenced at Lisbon to 6 years' imprisonment followed by ro years' deportation to a Portuguese Colony:-Substitute for House Free-Sugar bill, proposed by Senator Henry Cabot Lodge, fixing duty at 1.6 cents a pound, passed by U.S. Senate.

28 . Mass meeting of London port workers resolves to continue strike in defiance of leaders.-Turkish Parliamentary Commission of Enquiry arrives in Prishtina, Albania. -Shuja-ed-Dowleh, Acting Governor of Tabriz, agitates against Persian Govt., who propose to supersede him.

20. London Transport 'Workers' Strike Committee decide to adhere to their recommendation that the men should return to work.-Death of Mutsuhito, Emperor of Japan, aged 50.- Mr. Borden and Canadian Ministers received by President of French Republic-Royal Commission appointed under presidency of Lord Fisher to consider storage and supply of liquid fuel to British Navy. -Spanish Govt. refuse to expel Portuguese royalists from Spain-Attempted assassination of Hassam Bey, leader of Albanian insurgents, at Uskub, Albania:-Judgment delivered by Privy Council in the Canadian mixed marriares ( $\mathrm{Ne}$ Temere) case. Supreme Court of Canada's decision that the provincial legislatures have jurisdiction in such matters is upheld:-Collapse of landing stage at Binz, in Rủgen, Baltic Sea; ró persons drowned--Mr. E. H. Tennyson d'Eyncourt appointed Director of Naval Construction to British Admiralty in place of Sir Philip Watts, who is retained as adviser.- Judge Archbald makes formal answer in U.S. Senate to charges against him (see July II). - Govt. suits discontinued on payment of $\$ 250,000$ by sugar companies into U.S. treasury for customs frauds in
Philadelphia-First National Conference of American newspaper and magazine writers assembles at Madison, Wisc--Balloon "Uncle Sam," under Capt. H. E. Honeywell, wins international elimination trial, sailing from Kan sas City, Mo., to Manassas, Va., 915 miles.Lieut. Charles Becker of the New York police arrested on charge of having instigated murder of Herman Rosenthal (see July I6).

30. Yoshihito Harunomiya, Crown Prince of Japan. proclaimed Emperor.-London Court of Inquiry on the loss of the "Titanic" present their Report through Lord Mersey. - Turkish Chamber carry vote of confidence in the Cabinet by $1 \times 3$ votes to 95 - Royal Commission appointed to examine into Public Services in India: Lord Ishington (Chairman), Earl of Ronaldshay, Sir Murray Hammick, Sir Theodore Morison, Sir Valentine Chirol, Frank George Sly, James Ramsay Macdonald, Herbert A. L. Fisher Gopal Krishna Gokhale, Walter Culley Madge, Abdur Rahim.-Many London transport workers resume workRioting in Toronto in strike of freight handlers at Port Arthur docks:- Canadian Federal Govt order enquiry into "Empress of Britain's" collision with "Helvetia"

3I. Serious rioting, with use of revolvers, at London docks; over 20 injured.- Prince of Wales terminates his stay in France.-Mr. Thomas Mackenzie, late Prime Minister of New Zealand, appointed High Commissioner. - British Prime Minister and First Lord of the Admiralty invited to visit Canada.-Turkish Government lay before Chamber their proposed modifications of the Constitution. - Mr. Asquith in House of Commons criticises Mr. Bonar Law's speech at Blenheim (see July 27 ) on Utster's right to resist Home Rule-Epidemic of typhoid fever reported from Ottawa.-Albanian delegates at Prishtina demand dissolution of Turkish Chamber.

A ugust:-

1. British Govt. announce decision to withdraw from Brussels Sugar Convention on September $r$, roi 3 - End of Belfast shipyard trouble at Messrs. Harland \& Wolff's. -Dr. G. E. Morrison, formerly Times correspondent at Peking, appointed Political Adviser to President of Chinese Republic -Mr. Taft accepts Republican nomination for Presidency.-Sale of Queen Maria Pia's jewels, pledged with Bank of Portugal.-Railway accident at Rio de Janeiro; ro killed, 50 injured.-Goodwood Cup won by $\mathrm{Mr}$. Buchanan's "Tullibardine." - Throwing of a: bomb in Kotchana, Bulgaria is followed by a riot in which nearly 200 Bulgarians are killed or wounded by Turkish soldiers. 2. Fighting at Lhasa; Tibetans repulsed by Chinese. The inhabitants of Nikaria, Aegean Sea, depose the Turkish authorities and declare independence.-Three miniatures stolen from Royal Academy, London, returned by post anonymously.-End of F rench seamen's strike at Havre.U.S. Senate, by vote of $\mathbf{5 4}$ to 4 , passes Lodge resolution extending Monroe Doctrine to foreign corporations holding territory on American continents. - Stanley committee for investigating: U.S. Steel Corporation report's to Congress suggesting legislation to control combinations.

3. Montenegrins attack Turkish blockhouse on TurcoMontenegrin frontier; 50. Turks killed, I2 Montenegrins killed and i 5 wounded.-Mr. Lindsay Campbell: Australian airman, killed at Byfleet, England.-U.S. Senate withdraws Canadian reciprocity "rider" of Steel bill.

4. Turkish Senate accept Govt.'s modification of Constitution, empowering Sultan to dissolve Parliament. Five Englishmen arrested near Kiel, Germany, fot espionage.-Eruptión of . Mt. Etna, Sicily.-Nine boy scoats drowned off Kent coast by capsizing of boat.-U.S. marines landed in Nicaragua, to protect American interests

5. M. Poincaré, French Premier, leaves Dunkirk for Russia on political mission.-Mr. Roosevelt's Third Party (Progressive) Convention opens at Chicago.-Turkish Parliament dissolved by Iradeh; Chamber meets and passes vote of no confidence in Government.-British Home Office Enquiry into Cadeby Colliery explosion -opens at Doncaster.-British War Office appoint committee under the chairmanship of Sir Henry Norman to enquire into wireless telegraphy developments. - Italians occupy Zuara, Tripoli. - British Admiralty issue regulations as to commissions to be offered to men in the navy who have qualified as warrant officers.-Further frontier fighting between Turks and Montenegrins.

6. Mr. Roosevelt declares his programme of social reform (including general minimum wage) at Chicago Convention.-Pres. Taft sends message to Congress asking for immediate legislation to establish authority in Panama Canal zone, and to fix maximum tolls.-Rolla Wells (b. 1856), formerly mayor of St. Louis, made treasurer of $\mathrm{U}$.S Democratic National Committee-Talaat Bey and Diavid Bey, leaders of Committee of Union and Progress, leave Constantinople for Salonika.-Earl of Liverpool appointed 
Governor of New Zealand in succession to Lord Islington, - Mr. MacCallum Scott, Member of British House of Commons, suspended for disregarding Speaker's authority; he makes an apology next day.-Trial of women suffragists at Dublin for attempt to set fire to Theatre Royal (see July I 8); Miss G. Evans and Wm. Measey Leigh sentenced to 5 years $^{3}$ penal servitude. - King's Cup won at Cowes by Lord Dunraven's yacht "Cariad." - Arab attack on Zaagar, Tripoli, repulsed. - Railway accidents at Lozanne, France ( 5 killed, 15 injured), and at Labotant, France (2 killed, 20 injured).

Turkish Minister at Cettigne announces intention to leave Montenegro owing to dissatisfaction with Montenegrin reply to his remonstrances.-Debate on British withdrawal from Sugar Convention in House of Commons; speeches by Mr. Austen Chamberlain and Mr. Asquith. Motor-boat, $36 \mathrm{ft}$. long, arrives at Queenstown, Ireland, having crossed the Atlantic in 24 days.-Master of Elibank, Chief Government Whip in British House of Commons, resigns appointment and seat in parliament; he is succeeded as Chief Whip by Mr. Percy H. Illingworth, M.P.-Arrest of Kaid Trihahi at Mazagan, Morocco, after a siege of the house of a Spanish subject, in which he had received Spanish consular protection.-Russo-Japanese Agreement reported, determining spheres of influence in Mongolia and Manchuria.-Woodrow Wilson accepts Democratic nomination for U.S. Presidency,-Progressive party nominates Theodore Roosevelt and Gov. Hiram Johnson, of California, as candidates for U.S. President and Vice-President.

8. Manchester (N.West) by-election results in unionist victory for Sir J. Randles, majority $\mathbf{x}, 202$. - Turkish Minister leaves Cettigne.- Earthquakes in Turkey in the region of the Dardanelles; casualties 6,000.-German Emperor speaks at Krupp centenary celebrations.--Lord Robson resigns office of Lord of Appeal and is succeeded by Lord Justice Fletcher Moulton; J. A. Hamilton appointed Lord Justice and Mr. S. Howlatt a Judge,-Martial Law proclaimed at Salonika.-Five Englishmen arrested as spies near Kicl are released.-The Pope issues an Encyclical on the Putumayo cruelties. - Mine explosion at Lothringen Mine, near Bochum, Westphalia IO3 men killed.-Gen. Cincinnatus Leconte, President of Haiti, perishes in a fire at his palace.-Dam No. 26, on the Ohio river, near Cham bersburg, ro miles below Gallipolis, Ohio washed away.

9. U.S. Senate passes Panama Canal Bill by 47 votes to 15.-M. Poincaré arrives at Kronstadt, after receiving salute of 21 guns from the German fleet as he entered the Baltic-German Emperor visits Lothringen mine to condole with sufferers.--Porte reply to Bulgarian remonstrances on the Kotchana massacres, promising strict inquiry and punishment for the guilty. - M. Beaumont, French airman, begins Paris to London flight on a hydroplane-Gen. Tancrede Auguste chosen President of Haiti. - Pres. Taft vetoes wool bill adopted by House on August 3 and Senate August 5.-Luther Conant Jr. (b. I872) appointed U.S. Commissioner of Corporations.

во. Mr. Winston Churchill in letter to Sir George Ritchie, attacks Mr. Bonar Law's and Sir Edward Carson's speeches on Ulster as incitements to Lawless violence.Albanian leaders formulate plan of reform and submit it to Ibraham Pasha; ten clauses accepted by Turk ish Government on the IIth.-U.S. House of Representatives passes measure requiring all ocean-going vessels to be equipped with life-boats enough for every person on board.

11. Train attacked near Mexico City by Zapatistas; 20 passengers and 35 soldiers killed.-M. Poincaré received by the Tsar at Peterhof.-Trial of Egyptians charged with conspiracy against the Khedive begins in Cairo (see July 2 and 10).-Bomb explosions at Salonika, Turkey.

12: Mr. Bonar Law replies to Mr. Winston Churchill's letter-Abdication of Mulai Hafid, Sultan of Morocco, announced; pension $£_{14,000}$ a year. - Further earthquakes at Gallipoli, Turkey.-L. Jukitch, Croatian law-student, sentenced to death at Agram for attempted assassination of Ban of Croatia (June 8) and murder of M. de Hervoitch. - Collection of modern British pictures presented to Luxem. bourg Gallery, Paris, by modern British artists - Strike of miners in Ebbw Vale. Monmouthshire.

13. Trial of Egyptians charged with conspiracy at Cairo results in sentences of 15 years hard labour for one and 15 years imprisonment for two.-Protest meeting at Sofia against Turkish régime in Macedonian and Kotchana massacre,-Mr. R. C. Fenwick, British airman, killed on Salisbury Plain.-England wins last Test Match against South African cricket eleven at the Oval, London, by Io wickets.-Prince Katsura appointed Grand Chamberlain and Keeper of the Great Seal, Japan.-Ixtapa, Mexico, captured by Zapatistas; 200 killed of garrison and inhabitants. - Resignation of Zia Pasha, Turkish Minister of the
Interior - Further fighting on Turco-Montenegrin frontier. - Mulai Y usef proclaimed Sultan of Morocco.-Post-Office appropriation bill is passed by U.S. Senate.

I4. General Botha appointed an honorary general of the British Army. - Khost rebellion in Afghanistan terminated by concessions to the tribes.-National Memorial at Halifax; N, S. to Nova Scotian Assembly, first opened $175^{8}$, dedicated by Duke of Connaught. - Fourteen medical members of National Health Insurance Advisory Committee decline to withdraw though requesíed to do so by British Medical Association; thirty other medical members withdraw.-Massacre of Christians at Berane on the Montenegrin frontier; 12 villages burnt.-Steel and Iron tariff. revision bill, passed by U.S. Congress, vetoed by President Taft, but passed by House of Representatives over his veto. - Bill re iucing cotton duties about $21 \%$, passed by House August 2, passed in U.S. Senate; Army appropriation bill again passed with provisions objectionable to Pres. Taft eliminated.

I . Report of Merchant Shipping Advisory Committee on life-saving at sea published in London.-Celebration of 25th year of reign of King Ferdinand of Bulgaria at Tirnovo.-Mr. Montagu, British subject, committed for trial at Constantinople for having shot Mr. Dayan on August 8.- Arabs defeated by Italians at Zuara (Tripoli); Italians, 6 killed, 98 wounded - Pres. Taft vetoes Legislative, Cxecutive and Judicial appropriation bill, passed by U.S. Congress (Aug. 7), because of "riders" providing for restriction of civil service and abolition of the commerce court (see Aug. 22), - Bill providing for commission on Industrial Relations passes U.S. Senate,

16. Austrian Foreign Minister, Count Berchtold, invites Great Powers to engage in "conversations" upon the situation in the Balkans, with a view to "co-ordinating their several efforts in the interest of Balkan peace."-M. Poincaré terminates his official visit to Russia.-U.S. Senate agrees to Panama Canal Bill as modified by Joint Conference of the two Houses.-Notification of poliomyelitis (infantile paralysis) and cerebro-spinal fever made compulsory in England and Wales.-Capt. Lord, master of the Californian" issues explanatory statement as to failure of that ship to come to the rescue of the "Titanic."-Mr. G. B. Haddon-Smith appointed Governor of the Bahamas. - Fighting in Shawia district of Morocco, French lose 3 killed, 20 wounded:-Jacob Gould Schurman (b. 1854) of York appointed U.S. minister to Greece and Montenegro as successor of George $H$. Moses, resigned July I 2.-Wool and Steel tariff-revision bills fail to pass U.S. Senate over President's veto-Mr. Roosevelt opens at Providence, R. I., campaign for U..S. presidency.

I7. Albanian insurgents march towards Salonika, reac; ing Kuprili in force--U.S. House of Representatives adopts report of Joint Conference of the two Houses on Panama Canal Bill; British Chargé d'Affaires at Washington makes representations to the President against infraction of Hay. Pauncefote Treaty.-Mr. Justice Woodroffe in High Court of Bengal allows the appeal of Mr. Weston and two police officers of Midnapur against their condemnation in damages by Mr. Justice Fletcher, and dismisses them from the suit, with costs,-Germany approves Count Berchtold 's proposal with regard to the Balkan "conversations." -Generals Hwang-hui and Chang Chin-wu arrested and summarily executed for revolutionary conspiracy at Peking.-Montenegrias attack Turkish blockhouse near Berane on the frontier; 4 Turks killed. - Garrison of Managua, Nicaragua, massacred by insurgents. - Emperor of Austria celebrates 8 and birthday. - The British Government present memorandum to China requiring China to refrain from despatching a military expedition to Tibet.

19. British Govt. accepts Count Berchtold's Balkan "conversations" proposal.-Prince Katsura included among the Genro (Elder Statesmen) of Japan.-Peking Advisory Assembly resolves by 52 votes to II to petition Yuan-Shih-kai for an explanation within three days of execution of two generals. - Pres. Taft sends message to Congress urging an amendment to the Panama Canal Bill allowing foreign nations to test validity of free tolls provision, and stating that the Bill is not intended to repeal any part of the Hay-Pauncefote treaty.-Conference report on Naval appropriation bill, authorising construction of one battleship, accepted by U.S. Senate.-Fighting at Tilbury Docks, London, between union men and free labourers: revolver shots fired.-Ibrahim Pasha grants Albanians at Uskub 24 hours in which to submit.-Five persons found shot at Eastbourne, Sussex, in a burning house.-Guillermo E. Billinghurst elected President of Peru.

20. Peking Advisory Assembly demand attendance of Premier and Minister of War.-Forty Chinese pirates raid British island of Cheungchan, near Hong-Kong. - Confer- 
ence at Salonika between Albanians, under Isa Boletinatz, ind Ibrahim Pasha: Ibrahim Pasha announces that Albanian chiefs at Prishtina have accepted Turk ish Government's terms, and that the insurgents are returning to their homes.- Indictment of murder in first degree returned by grand jury in New York against Police-Lieut. Becker and "gangsters" for killing Herman Rosenthal.-Lt. Kaskoff, Russian military airman, drowned off Sevastopol. -El Hiba, Moroccan Pretender, enters Marakesh,Death of General Booth, founder of the Salvation Army, in London, aged 83.-W. Hurlock, Walworth draper prosecisted for non-compliance with British National Health Insurance Act, and fined $\mathrm{fr}_{5}$ and $£_{5} .5 \mathrm{~s}$. costs, this being first prosecution under the Act.-Conference report on Naval bill providing for one battleship accepted by U.S. House of Representatives,-George R. Sheldon (b. r857) chosen treasurer of U.S. Republican National Committee.

2x. American marines landed at Bluefields, Nicaragua, by request of Nicaraguan. Government.-Hilmi Pasha, Turkish Minister of Justice, resigns.-Yuan-Shih-kai declines to attend Peking Advisory Assembly.-Reported that peace has been concluded at Lhasa between China and Tibet.-French Govt. agree to join in Count Berchtold's Balkan "conversations."-Macedonia "liberation" speeches defivered at mass meeting of Bulgarians at Phillipopolis. - Herr von Vollmar speaks in Bavarian Diet on social democratic patriotism.- - Further fighting near Berane on Montenegrin frontier; Christian villages burnt.-Resignation of Montenegrin Cabinet announced.

22. East Carmarthen by-election results in return of Rev $\boldsymbol{T}$. Jones (Liberal) by reduced majority of 2,728 . England wins final Test Match against Australian cricket eleven at the Oval, by 244 runs, thereby winning Triangular Tournament (England, Australia, South Africa).-Col. Mangin's French force defeats Moroccan pretender. El Hiba, near Marakesh.-U.S. Appropriation Bill (see Aug. r5) finally passed without objectionable "riders:"-Conference reports on Indian and Sundry Civil appropriation bills agreed to by U.S. Senate.

23. Bahaloo tribesmen attack Bander Abbas, Persia.Sir Hugh Clifford appointed Governor of Gold Coast. 24. Sun Yat Sen visits Yuan Shih-kai in Peking and receives popular welcome.-Pres. Taft signs Panama Canal bill, Labour Commission bill, Civil appropriation bill (with no provision for - a Tariff Board) and several others. $\rightarrow$ Massacre of Servians by Turks at Sienitza, on Servian frontier.-Montenegrins make surprise attack on Berane. -Fighting in Timor, Malay Archipelago; native rebels defeated by Portuguese troops.-Miss Julia Curran, Englishwoman, found dead in a New York hotel.-Fire at General Post Office, London, causes suspension of all telegraphic communication.-French Govt. decide to dissolve Teachers' Unions by Sept. Io, owing to anti-patriotic resolutions passed at. August Congress at Chambéry.

25. Ali Danish Bey becomes Turkish Minister of the Interior, and Halim Bey Minister of Justice--Lieut. Manzini, Italian military airman, killed in Tripoli--Trial of Korean conspirators resumed at Seoul, Korea.-Mass meetings at Sofia to advocate autonomy of Macedonia.Fighting at Suk-el-Arba, near Marakesh; Moors repulsed by French.

26. Toronto Industrial Fair opened by Duke of Connaught. -300 Russian sailors sent on shore at Sevastopol to be tried for revolutionary propagandism.-U.S. Senate pass resolution for investigation by Campaign Funds Committee into alleged contributions by Standard Oil Co, to Mr. Roosevelt's x 904 election.-Prince Arthur of Connaught leaves England for Tokio to convey to the Emperor of Japan the order of the Garter.-Hydro-aeroplane race from St. Male to Jersey won by Weymann.-Exceptional rainfall (over 6 in. at Norwich) causes extensive floods in eastern counties of England, with interruption of railway and telegraph service; two lives lost.-Egyntian nationalists arrested at Cairo for posting seditious placards.-General Deficiency appropriation bill passed by U.S. Senate-First session of 62 nd Congress of U.S. adjourns at 4.30 P.M. Governor Marshall, Democratic nominee for U.S. Vice Presidency, opens campaign in Portland, Me.

27. British Chargé d'Affaires at Washington renews protest with regard to the Panama Canal rates.-Posthumous title of Emperor of Meiji conferred on Mutsuhito late Emperor of Japan.-Strike of miners in Rhondda district, Wales.-Corner-stone of cathedral of St. Albans, Toronto; laid by Duke of Connaught.

28. Mr. Borden in answer to deputation from Women's Social and Political Union in London states that he has no intention of introducing a bill into the Canadian parliament to give women votes on the same terms as men.-U.S. troops ordered to proceed to Nicaragua. - Germany asks that Spanish and French portions of Moroccan customs should be fixed in forthcoming Franco-Spanish treaty. - Lieut. Chandenier, French military airman, burnt to death near Crecy-sur-Serre,-General Botha speaks at Frederikstad, Transvaal, or. South African Nationalism and its compatibility with Imperial co-operation.-Duke of Connaught leaves Montreal for a tour in western Canada.

29. Fighting at Suk-el-Arba, Morocco; El Hiba's forces repulsed by French under Col. Mangin,-Funeral of General Booth; procession through London.-Railway accident at Vauxhafl, London; r killed, 20 injured. - Cruiser "Sydney," built for Australian Govt., launched at Glasgow.Great floods in Wen-chan river district of China destroy 30,000 inhabitants. - Cunningham claims to Alaska coa lands finally cancelled by U.S. Dept. of the Interior, and lands become part of public domain.

30. Mr. Borden leaves London for Canada. - Centenary of "Comet," first steamship, celebrated at Glasgow, Mr. Cody wins British Army Council's prize for best military aeroplane.-Political rioting in Para, Brazil; newspaper office burnt.Chinese Finance Minister signs contract with London firm of Birch Crisp \& Co. for loan of $£_{10}$, $\infty, 0, \infty$, secured on free surplus of salt gabelle:-Senate of the island of Samos presents note to Commanders of French and British warships at Valley and to Russian consul at Smyrna demanding evacuation of the island by the Turkish troops.

3I. US Interstate Commerce Commission suspends proposed increases in ireight rates between East and Pacific Coast till Dec. 31:-Col, C. P. Townsley becomes superintendent of U.S. Military Academy at West Point, N. Y., as successor to Gen. Thos. H. Barry.

September:-

Mr. Roosevelt denies soliciting or accepting Standard Oil money in presidential campaign of 1004 .

2. 45th Trade Union Congress of Great Britain opens at Newport, Mon.-Fighting in Mexico; Zapatistas routed with 60 casualties.-British cavalry manoeuvres begin.

British Trade Union Congress by large majority pass resolution to oppose Government's Trade Union Bill, unless amended to meet their wishes.-German Emperor attends Swiss Army Manoeuvres at Zurich-Sheik Shawish arrested at Cairo on charge of participation in conspiracy against Khedive and Lord Kitchener-- Mr. Montagu acquitted of having shot Mr. Dayah at Constantinople on August 8 (see Aug. I's)._- "Drake," historical drama by Louis Parker, produced at His Majesty's Theatre, London.-Railway accident at Riola, Italy; 3 killed. I5 injured.-Ohio vote ratifies proposed constitutional amendments, except eight (including that for woman suffrage).-Vermont elections result in no majority vote or governor, and the election is thrown into the legislature (see Oct. 2). -6th triennial congress of International Association for Testing Materials meets in New York City. - Break in Erie canal at Bushnell's Basin, near Rochester, N. Y., does much damage.

4. British Association meeting opens at Dundee, with Presidential address from Prof. Schäfer on Nature and Origin of Life-New regulations for life-saving at sea issued by British Board of Trade.-Sir Edward Grey writes to Newcastle Chamber of Commerce stating that Panama Canal Act undoubtedly violates Hay-Pauncefote treaty.Explosion at Clarence coal-mine, Pas de Calais, France; 24 lives lost,-Marseilles shipping strike ends.-Great Britain wins International Trophy for marine motoring at Hunting. ton, N. Y - Collision on Piccadilly underground electric railway, London; Is persons injured.-Chinese Minister notifies British Foreign Office, and Yuan-Shih-kai notifies British Minister, that loan of $£$ ro, 000,000 to China has been arranged with British firm.-Evan E. Young resigns as U.S. minister to Ecuador.-Eighth International Congress of Applied Chemistry meets at Washington, D.C.

5. Interview at St. Petersburg between Russian and French Ambassadors with regard to Count Berchtold 's Balkan proposals. - News received in Paris that ship conveying French Borodino commemoration monument has sunk in the Baltic with all on board, including the sculptor, M. Paul Besanval.-Colonel Mangin's French force leaves Suk-el-Arba to march on Marakesh.-Fifteen Christians massacred by Turks at Heimeli, near Skutari, Turkey.Twenty-foot hydroplane "Tech Jr." on Huntington Bay, New York, makes I mile at record rate of 58.3 statute miles an hour-Federal (U.S.) District Court hold Armour \& Co. responsible for damages for infected meat product.

6. British Trade Union Congress votes against Syndicalism, by passing resolution re-affirming support of independent working-class political action-Capt. P. Hamilton and 2 nd-L.t. Wyness-Stuart. British military airmen, kulled near Hitchin, Herts.-Mr. Borden welcomed at Quebec on 
his return from England-German Emperor entertained at Bern by Swiss President.-M. Garros, French airman, reaches record height of $16,405 \mathrm{ft}$. at Houlgate, near Trouville, France-Russian Govt. presents note to China continuing Treaty of St. Petersburg for ten years, except with regard to the free exchange of products in the so verst zone on each side of the frontier of $\mathrm{fli}$, which is to expire in 1913 - South African mall contract with Great Britain signed at Cape Town,

7. Interview at Buchlau between Herr von BethmannHoslweg and Count Berchtold concerning Austrian Balkan proposais.-Centenary of Battle of Borodino celebrated at Moscow in presence of Tsar.-British Admiralty issue fresh regulations for the control and discipline of the Navy.U.S. golf championship won by Mr. Jerome Travers. Col. Mangin's French force enters Marakesh and rescues 9 French prisoners; El Hiba escapes.

8. M. Klemm appointed to succeed M. PoklewskiKoziell as Russian Minister in Persia.-Four spectators killed by aeroplane at Gray, Haute Saône, France--Mass meeting in Athens to protect against condition of Greek population in Turkey.-Fighting between Turks and Bulgarians on Rumelian frontier, near Karatepe.

9. Resignation of M. Trifkovitch and Servian Cabinet. - German Army Manoeuvres begin in Saxony.-Motor tacing accident in New York, 6 persons killeó, 20 injured. -New comet discovered by Mr. W. F. Gale, Australian astronomer.-Italian force ambushed near Zanzur, Tripoli. - Prof. Vilhjalmar Stefansson returns to Seattle, after four years' explaration in Arctic.-Democrats elect Jos. T. Robinson governor of Arkansas, U.S.-William T. Haines (Rep.) elected governor of Maine, U.S.-International aviation cup won by Jules Védrines at Chicago, flying 125 m. at rate of $105 \mathrm{~s} / 2 \mathrm{~m}$. an hour.

10. International Congress of Association for Labour Legislation opens in Zurich-Mid-Lothian by-election results in unionist victory for Major Hope, majority $32 .-$ French Army Manoeuvres begin in Tours district of western France-Lt. Hotchkiss and Lt. C. Bettington, British military airmen, killed near Oxford.-Continuation Committee of Presbyterian Convention in Belfast issue manifesto protesting against Home Rule Bill.-The Times, London, issues its 40,000 th number with special supple. ment on History of the Press.-Mr. Borden speaks at Ottawa on Imperial Defence.-Papal Legate arrives in Vienna to attend Eucharistic Congress.-Bomb explosion at Doiran fair, near Salonika, 30 killed, 60 injured. - French Govt. announce that in future practically the whole French navy will be concentrated in the Mediterranean.-Railway accident near Erie, Pennsylvania; 6 killed, so injured.Robert G. Valentine of Massachusetts, U.S. Commissioner of Indian Affairs, resigns to work for election of Roosevelt.

Ix. Mr. Winston Churchill speaks at Dundee on Insurance Act and Home Rule.-M. Fournay, French airman, makes continuous flight of 13 hours, covering $63 \mathrm{I} 1 / 4$ miles. - Turkish Committee of Union and Progress at Salonika elect Prince Said Halim Secretary General.-Lt. Moizo, Italian military airman, taken prisoner by Arabs in Tripoli. -Fighting between Turks and Malissori at Ischafkisch on Montenegrin frontier; heavy Turkish losses. - "Everywoman," modern morality play, produced at Drury Lane Theatre, London-Mr. A. Belmont's "Tracery" wins the St. Leger at Doncaster, Yorks.- - Southern Pacific Railway asks U.S. Government for protection in Mexico.-Paul Peck, holder of American duration flight record, fatally hurt at Chicago.

12. Mr. Churchill speaks at Dundee on a federal system for the United Kingdom.-New Servian Cabinet formed under M. Pashitch-Mr. Buxton W. Gibson, American lawyer, arrested in New York for the murder of a client. Mrs. Rosa Szabo--Dr. Niceta Budka appointed first Ruthenian Bishop in Canada.-Russian Duma dissolved. -British battle cruiser "Princess Royal" completes contract trials and achieves record speed.-Fred W. Carpenter (b. 1873) of California appcinted U.S. minister to Siam as successor to Hamilton King, d. Sept. 2, 1912.

13. Funeral of Mutsuhito, Emperor of Japan, at Tokio General Count Nogi and his wife commit suicide as the funeral procession leaves the palace.-Peruvian Chamber of Deputies pass resolution protesting against attitude of Gt. Britain and United States regarding Putumayo atrocities, but demanding punishment of those guilty of cruelty to Indians.-Revolution in Santo Domingo; United States decides to intervene, - Salar-ed-Dowleh, Persian pretender, reported captured

14. Interment of Mutsuhito, Emperor of Japan, neat Kyoto.-Rioting at Belfast during a football match; over soo persons injured.-Lord Denman, Governor General of Australia, turns first sod of Trans-Australian railway.-
Launch of British battleship "Audacious" at Birkenhead. Mr. Howard Gill, American airman, killed at Chicago. Murder of a ticket-collector at Aubrais station, near Orleans, by motor-bandits.-German torpedo boat, G $17 x$, sunk by battleship "Zähringen"; 6 men drowned.-Report: ed that Chinese forces in Tibet under General Tseng-Tingling have captured Litang and Hsiangcheng.-Inspector Cornelius G. Hayes dismissed from New York force for making "false official statement" that he had been ordered not to raid Tenderloin resorts; two "gunmen" implicated in murder of Herman Rosenthal (July 16) arrested.

15. Railway accident at Blainville, near Nancy, France; 20 persons injured.-Fighting between Moorish tribesmen and French column at Sidi Kacem, Morocco; French loss 9 killed, 30 wounded.-By capsizing of sailing launch on Lake Michigan ten recruits and a gunner's mate of U.S. naval training school, Chicago, are drowned.

16. British Army Manoeuvres begin.-Sir Edward Carson arrives in Belfast and is welcomed by the Orangemen of Ulster. - Terms on which Turkey is reported to be prepared to make peace with Italy are announced by a correspondent of the Temps.-Liung Men-ting becomes Chinese Foreign Minister-Chinese Finance Minister announces difficulties with regard to London loan owing to opposition of foreign governments.-Carden Hall, Cheshire, a I6th century half-timbered house, destroyed by fire.-Chinese Council holds secret session to consider British and Russian protest against Chinese military expeditions to Tibet and Mongolia; Tibetan expeditions recalled. -Gun explosion on British battleship "King Edward VII": I killed, 3 injured.-Renewed fighting between Turks and Malissori, lasting three days, near Tuzi on Montenegrin frontier.-New York Press purchased by Frank A. Munsey, and begins to support Progressive ticket.

17. Railway accident at Ditton Junction, Lancs.; train catches fire; 15 killed, 40 injured. - Irish mail train set on fire in Wales; 8 injured.-British steamship "Barrowmore" injured by mine off Salonika.-King George arrives at Cambridge to attend British Army Manoeuvres.-Opening of Dutch States General at the Hague; Socialist street disturbances.-Disturbance in Hungarian Chamber at Budapest; Opposition deputies removed by police. M. Legagneux, French airman, rises to record height of $18,767 \mathrm{ft}$. at Houlgate, Trouville, France.-Scott expedition to Baffin Land in search of gold returns unsuccessful to St. John's, Newfoundland, bringing survivors of Munn expedition.-Italians defeat Turco-Arabs at Derna in Tripoli; Italian loss 6r killed, II3 wounded; Arab loss over I, 000 British Consular service made available for Canadians.

18. Ulster demonstrations against Home Rule begin at Enniskillen; speeches by Sir E. Carson, Lord Hugh Cecil and others - Funeral of Count Nogi and his wife at Tokio. Emperor of Japan invested with Order of Garter by Prince Arthur of Connaught. - Street rioting at Budapest; many injured, 80 arrests.-Chinese Council announces acceptance of Russian conditions concerning Outer Mongolia, but will resist any aggression on Inner Mongolia.

19. Martial law proclaimed at Scutari, Albania, owing to continued fighting between Malissori and TurksTerms of Solemn Covenant against Home Rule, to be signed by Unionists of Ulster on Ulster Day (Sept. 28), published in Belfast.- Demonstration against Home Rule at Lisburn, Ulster; Sir E. Carson speaks.-Copyright treaty between U.S. and Hungary ratified by representatives of the two countries at Washington (see Jan. 30 and Oct. I6).

20. M. Sazonoff, Russian Foreign Minister, arrives in London on political mission.-Demonstration against Home Rule at Londonderry, Sir E. Carson and Mr. F. E. Smith speak.-Mrs. Leigh, sufiragist, released from Mount joy prison, Dublin, after 44 days' hunger strike (see Aug. 6) - British Army airship "Gamma" wrecked near Devizes.Kermanshah, Persia, evacuated by Salar-ed-Dowleh, Persian pretender.-Italians occupy Zanzur, Tripoli, after ten hours fighting; 200 Italians killed and wounded; heavy Arab loss.

2I. Demonstration against Home Rule at Coleraine; Sir E. Carson, Mr. F. E. Smith, and Mr. Hugh Barrie speak.Turkish troops despatched to Adrianople owing to rumoured critical situation in Bulgaria.-Mr. H. J. D. Astley, British airman, killed at Belfast.-Lt. Berger and Lt. Zunghanns, German airmen, killed near Chemnitz, and Bittner. German parachutist, killed at Berlin.-Mr. Lloyd George opens Institute at Llanystumdwy; suffragist interrupters roughly handled by crowd. - Three hundred armed Cretans and revolutionary leader, Soloulis (banished since 1008). land in Samos and are joined by many natives; fight. ing with Turkish troops.

Turkish garrison in Samos reinforced-Chinese Government inform syndicate of bankers supported by the 
Six Powers that, unless an immediate advance is granted, they must proceed with the Crisp loan.-Typhoon in Japan causes immense damage and loss of life.-Turkish Govt. issue scheme for reform in Turkish provinces both in Europe and Asia by decentralisation.

23. M. Sazonoff arrives at Balmoral Castle, Scotland, and is received by King George.-Bolivian cabinet reconstituted with Señot Saracho as Foreign Minister and Sefor Ascarruiz as Minister of Finance.-Chinese Government express regret that they cannot accept the Six Powers loan on the terms offered.-Death of the Infanta Maria Teresa, sister of King Alfonso XIII of Spain.-Railway accident at Merville, near Caen, France; 2 killed, several injured. - Isth International Congress of Hygiene and Demography meets at Washington, U.S.A.

24. Mr. Borden speaks at Toronto on Imperial unity.Emperor of Austria and Count Berchtold address AustroHungarian Delegations on foreign policy.-Death of Baron Marschall von Bieberstein, at Badenweiler, aged 7o.Demonstration against Home Rule at Dromore.-Malissori attack Turkish ammunition escort near Lake Skutari, Albania.-Lt. Thomas, French military airman, killed at Givronval.-Lt. Szekeresy, Austro-Hungarian army, and six soldiers arrested on Servian territory.-Turkish Govt. decide to hold general army manoeuvres in the Adrianople district and in Macedonia.-U.S. Govt. decides to send to Santo Domingo two commissioners and 750 marines.

25. British Minister in Peking protests to Yuan Shih-kai against the Crisp loan to China.-Demonstration against Home Rule at Portadown; Sir E. Carson and Mr. F. E. Smith speak.-Lt. Ragazzoni, Italian military airman, killed at Rome.-Explosion on board British cruiser "Southampton"; $\mathbf{I}$ killed, $\mathbf{I}$ injured.-Fighting in Samos; Turkish troops kill women and children; British and French cruisers land marines to protect foreign subjects at Vathy.-Señor Mena and 700 revolutionaries in Nicaragua surrender to Rear-Admiral Southerland, U.S. Navy.

26. Prospectus of Chinese Government $5 \%$ Gold Loan issued by Birch Crisp \& Co. in London.-Demonstrations against Home Rule at Ballyroney (Lord C. Beresford speaks) and at Newtonards (Lord Londonderry speaks); pledge for Irish peers and first signatures published.Exhibition of night flying in illuminated aeroplanes at Hendon, Middlesex.-M. Charles Voisin, French airman, killed in motor accident at Belleville-sur-Saône-Capt. C. L. Bumbaugh, American airman, killed at North Manchester, Ind.-Fighting on Montenegrim frontier; 3 Turks killed, 7 mortally wounded; Montenegrins 15 killed and wounded. - Turkish Govt., persuaded by French Ambassador, abandon proposed grand manoeuvres; decide to hold divisional manoeuvres in eleven different divisions.

27. Demonstration against Home Rule in Ulster Hall, Belfast; Sir E. Cárson speaks.-General strike threatened on all Spanish railways, and put to the vote--Turkish Govt. stop Servian war-material at Salonika and refuse to allow it to be conveyed through the Turkish lines.

28. Signing of Solemn Covenant against Home Rule by people of Ulster.-Majority of doctors of the United Kingdom resign contract practice with medical clubs as a protest against the terms offered under National Insurance Act.-Land taxation conference opens in Glasgow.-Lord Rosebery speaks at Postwick near Norwich on land taxation-French battleship "Paris" launched at Toulon.Io6 Koreans sentenced at Seoul to from 5 to ro years' imprisonment for conspiracy against the life of Count Terauchi.-J. L. Longstaff, British airman, killed at Hempstead, N. Y.- Lt. L. Rockwell and Corporal Frank Scott, American airmen, killed at College Park, Md.

29. Hostilities in Samos suspended; British and French flags hoisted in Vathy, and town patrolled by British and French marines.

30. Decree for general mobilisation of the Bulgarian army signed at Sofia, and martial law declared in districts of Philippopolis and Bourgas.-Decree for general mobilisation of Servian army signed at Belgrade.-Montenegrin Government apologise to Turkey for attack on Turkish ammunition escort on Sept. 24--Demonstration against Home Rule at Liverpool; Sir E. Carson and Mr. F. E. Smith speak.- Royal Commission on Public Records issues first report in London.-Stated that M. Sazonoff and Sir E. Grey are agreed that neither Russia nor England desire the partition of Persia and are considering the best way of strengthening her government.-Announced that $£_{2}, 000$, ,oo of the Crisp Chinese loan has been subscribed by the public.-Rioting at Lawrence, Mass., in protest against imprisonment of strike leaders.-U.S. Senate committee investigating campaign contributions renews its sessions at Washington.-Pulitzer school of journalism at Columbia University formally opened.
1. Imperial enclave formed to inelude Delhi, India; to be known as Chief Commissionership of Delhi; Mr. W. M. Hailey appointed Chief Commissioner.-Turkish imperial irade issued ordering generat mobilisation of Turkish army: Servian demand for release of ammunition, seized by Turks, rejected-Decree for general mobilisation of Montenegrin army signed at Cettigne.-Decree for general mobilisation of Greek army and navy signed at Athens.-Anglican Church Congress opens at Middlesborough, Yoris.Strike of Cotton-workers at Oldham, Lancs.-Demonstration against Home Rule in Glasgow; Sir E. Carson speaks. Explosion on board U.S. destroyer "Walke"; one officer killed, several seamen injured.-Spanish Central Union of Railwaymen decide on general strike to begin Oct. 8."The Turning Point," English version of H. Kistemaeckers" "La Flambée," produced at St. James's Theatre, London.-Trial of labour union officials, indicted Feb. I4, for conspiracy to transport dynamite, begun at Indianapolis, U.S.A. (see Dec. 28).

2. Mr. Lloyd George confers with medical members of Insurance Advisory Committee on scale of medical remuneration under Insurance Act.-Demonstration at Cettigne in favour of war with Turkey.-Bulgarian troops seize Turkish blockhouses in Djuma-i-Bala district. - Mark Wilks, imprisoned for refusal to pay his wife's income tax, released from Brixton prison, London.-M. Sazonoff leaves London for Paris.-Vermont (U.S.A.) legislature elects Allen M. Fletcher, Rep., as Governor (see Sept. 3).

3. Demonstration at Constantinople in favour of war with Bulgaria; Nazim Pasha, minister of wax, appointed Commander-in-Chief of Turkish forces; Turkish frontier guards attack Montenegrins near Berane.-Reported that Belgian capitalists have lent $\ell_{10,000,000}$ to China in $\mathrm{CON}$ nection with railway contract between Honan and Shansi. - British Insurance Commissioners issue provisional regulations as to administration of medical benefit.-Royalist conspirators in Portugal sentenced at Lisbon to six years' imprisonment followed by ten years' deportation. Mr. J. P. Morgan informs Committee of U.S. Senate that his firm contributed to Republican funds in 1904 and 1908 but without motive of securing benefits.-Miss G. Evans, Suffragist, serving sentence of penal servitude for attempted burning of Theatre Royal, Dublin, released on grounds of health.-Railway accident near Westport, Conn ; 7 persons killed, 40 injured.-Celebration of centenary of Cortes of Cadiz at Cadiz.-r8 persons arrested for rioting in Cyprus on May 27 sentenced at Limasol to terms of imprisonment varying from 9 months to 15 years.

4. British submarine $\mathrm{B}_{2}$ sunk in English Channel by liner "Amerika"; 15 lives lost.--Services held in London to celebrate 250 th anniversary of Great Ejectment of Presbyterian clergy in 1662 . - Turkish government withdraw troops from Samos.-Demonstration of sympathy with Bulgaria at St. Petersburg railway station.-Demonstration before Sultan's palace at Constantinople in favour of war.-M. Poincaré confers with M. Sazonoff in Paris.American marines capture Coyotepe, Nicaragua, with loss of 4 killed and 5 wounded, and Nicaraguan Government troops recapture Masaya with loss of roo dead and 200 wounded-Harry Vardon wins News of the World profes. sional golf championship at Sunnyside-Special U.S. Senate committee investigating campaign contributions hears testimony from Ex-Pres. Roosevelt.

5. M. Poincaré communicates to British Foreign Office French proposals for averting war in the Balkans, which involve joint action of Austria-Hungary and Russia in Balkan capitals and joint action of all the Powers in Constantinople-Bulgarian and Servian parliaments meet at Sofia and Belgrade in extraordinary session.-Jack Zelig, a witness in forthcoming trial of Police Lt. Becker for murder of Rosenthal, shot dead in New York.-Spanish general railway strike averted.-Mr. Asquith, at Ladybank. Fifeshire, says that the Government will not bow to the threats of Ulster but adhere to their intention to place the Home Rule Bill on the Statute Book.

6. Death of M. Beernaert, Belgian Minister at Lucerne, aged 83 . - British and other Governments signify adhesion in principle to French proposals for avcrting war in the Balkans.-Court martial at Constantinople condemns one Moslem to death and one to penal servitude for lile for complicity in Kotchana massacre.-American forces take the town of Leon, Nicaragua.

7. Proposed peace agreement between Italy and Turkey presented to Italian Cabinet at Rome by Signor Giolitti.British House of Commons re-assembles; Sir Edward Grey makes statement on Balkan crisis.-Debate on report of Court of Inquiry into loss of the "Titanic" in British House of Commons.-Mr. Lloyd George authorises state- 
ment that he is not in favour of a "single tax."-Opening of Danish Parliament.-Turkish Govt, announce willing ness to apply Law of the Vilayets of Turkey in Europe (1880), drawn up in agreement with the International Commission for Eastern Rumelia, for reform of abuses.-Essad Pasha and nine battalions of Turkish troops sent to Tuzi. Trial of Police Lt. Becker for murder of Rosenthal begins in New York.--St. Paul's Protestant Episcopal church, Boston, Mass., U.S.A., proclaimed a cathedral.

8. Montenegro declares war on Turkey, and attacks Turkish fortress of Detchitch opposite Podgoritza; fighting also reported near Berane.-Austro-Hungarian and Russian Governments present Note, in name of Powers, to Balkan States--Archbishop of Canterbury speaks at Cardiff against Welsh Church Disestablishment-At Lexington, $\mathbf{K} \mathbf{y}$., new world's trotting record of a mile in $\mathrm{I} .5^{8}$ is established by "Uhlan."

- King Nicholas of Montenegro issues proclamation calling upon all Montenegrins to join in "holy war" against Turkey; Montenegrins capture Detchitch.-Rumania assures Bulgarian Govt. that she will maintain neutrality. - The Anarchist, Alba, sentenced in Rome to 30 years' imprisonment ( 7 in solitary confinement) for attempt on life of King Victor Emmanuel III (see March 14).-Mr. Balfour speaks at Haddington on Home Rule Bill.-International Congress on Archaeology opens in Rome.-Fighting near Derna, Tripoli, results in repulse of Turks and Italian occupation of Sidi Abdallah district.-Express carriers ordered by U.S. Interstate Commerce Commission to show cause why proposed rates should not be made effective (see July r5). -75th anniversary of founding of Mount Holyoke College U.S.A.; $\$ 500,000$ endowment fund announced as over-subscribed.

zo. Powers, through Austro-Hungarian Embassy, present joint Note to Turkish Government, pressing scheme of reforms.-Mr. Bonar Law's amendment to guillotine resolutions for Home Rule Bill in British House of Commons negatived by 323 votes to 232 . - Mr. George Wyndham speaks at Limerick on Unionist policy for Ireland. Centenary of Drury Lane Theatre, London, celebrated. Kagelmann, formerly, of German navy, sentenced at Leipzig to six years' penal servitude for espionage.Anniversary of revolution celebrated in China,-German army airship $\mathbf{M}_{3}$ destroyed by fire, and airships $\mathbf{M r}_{\mathbf{r}}$ and $\mathrm{M}_{2}$ damaged.-Fighting near Derna in Tripoli; Turks repulsed. Italians lose 12 killed and $8_{3}$ wounded. - Termination of general strike on Spanish railways. - Nobel prize for medicine awarded to Dr. Alexis Carrel, Rockefeller Institute, New York.-Rice Institute, Houston, Texas, dedicated.-Federal court, Tacoma. Washington, U.S.A. finds C. E. Houston and John H. Bullock guilty of conspiracy to defraud government on Alaska coal contracts. II. Montenegrins take Skiptchanik, near Tuzi, Albania. - Malissori revolt against Turkey, and attack Turkish army in rear. - Reported that peace negotiations between Italy and Turkey are broken off; Italian feet ordered to Aegean Sea.-Rumanian Cabinet crisis.-Debate in British House of Commons on Government motion for appointing Select Committee to enquire into agreement between Marconi Wireless Telegraph Co and British PostmasterGeneral-Prince of Wales begins residence in Oxford as commoner of Magdalen College.-Mr. Bonar Law speaks on recent by-elections at dinner of Constitutional Club, London-Resignation of Herr Kaempf, President of German Reichstag.- United States pays Canada $\boldsymbol{£}_{40,000}$ as compensation under Fur Seal Convention of xori.-New Zealand Defence Bill passes second reading in House of Representatives.

12. Heavy fall on London, Paris, Berlin, Vienna and other stock exchanges in consequence of prospective war in the Balkans--Sultan of Turkey issues proclamation ordering general mobilisation.-British battleship "Iron Duke" launched at Portsmouth by Duchess of Westminster.-New Chinese province formed in West Szechuan and Eastern Tibet, named Hsikangseng, with capital Baanfu (Batang).

13. Bulgaria, Servia and Greece present identic notes to the Turkish Chargés d'Affires in Sofia, Belgrade and Athens, demanding that Turkey shall within six months grant autonomy to Macedonia. In reply to the AustroRussian note they regret that they cannot accept the safeguards which it proposes for Macedonian reform.

14. Cretan Deputies admitted to Greek Chamber.Turkish force enters Servia; engagement near Ristovatz. - Tuzi surrenders to Montenegrins under Crown Prince Danilo.-Small Turkish force enters Bulgaria, south of Philippopolis. - Turkish Government, in reply to Note of the Powers, deny that Treaty of berlin is apolicible to present situation and repudiate foreign intervention.-
Mr. Roosevelt shot at and wounded at Milwaukee, Wisc. by fanatic named John Schrank.-Lord Chancellor admits in House of Lords in reply to Lord Russell that liability of husband to imprisonment for non-payal of wife's in come tax, as instanced in case of Mark Wilks, is indefensible, and promises amendment of law.-Centenary of death of Sir Isaac Brock, Canadian hero, celebrated in St. Paul's Cathedral, London.-Robbery at jewelier's shop in Edgware Road, London, by armed thieves who escape in a taxi-cab. - U.S. Interstate Commerce. Commission decides that freight rates from Boston on imported goods must not be lower than from New York City.-Pres. Taft reviews 123 U.S. warships in the Hudson river.

15. Preliminary peace agreement signed by Italian and Turkish delegates at Ouchy, Switzerland.-Turkish Govt. decide to make no reply to Note from Balkan states, and to recall Turkish Ministers from Sofia, Belgrade and Athens.-Montenegrins capture positions on the Rogame Heights. - Turkish troops bombard and burn Kriva, near Bulgarian frontier. - British Legation at Peking refuses to receive notification of London (Crisp) loan of $£$ ro,000$\infty$ to China.--International Conference on time-reckon. ing opens in Paris.-Mr. Lloyd George severely heckled in British House of Commons with regard to Land Inquiry Committee- Order placing all U.S. fourth-class postmasters in civil service signed by Pres. Taft.

16. Montenegrins capture Berane.-Turkish Ministers leave Sofia and Belgrade.-Prince Lichnowsky appointed German Ambassador to Great Britain.-New Zealand Defence Bill passes Committee stage in House of RepreSentatives.-Imperial Preference dinner at Grosvenor ham speak. - Typhoon kills nearly $\mathbf{I}, 000$ persons in Cebú, Philippine Is.- Vera Cruz, Mexico, occupied by rebel force under General Felix Diaz.-International Art Congress opens in Rome.-Race for Cesarewitch at Newmarket won by Mr. R. Sievier's "Warlingham."-Copyright treaty between U.S. and Hungary becomes effective (see Jan. 30 and Sept. 19).-Deciding game for world's baseball championship won by Boston American League team over New York Nationals at Boston.

17. Turkish Minister leaves Athens.-Turkey declares war on Bulgaria and Servia.-Bulgarian army advances towards Mustafa Pasha pass.-Secession of Mr. and Mrs. Pethick Lawrence, Suffragist leaders, from Women's Social and Political Union, London.-Lord Haldane, installed as Chancellor of Bristol University, delivers address on Civic Universities.

18. King Ferdinand of Bulgaria issues manifesto proclaiming holy war.-Bulgarian army occupies Mustafa Pasha and advances towards Adrianople.-Servia and Greece also declare war against Turkey.-Turkish Government addresses firman to Tripoli and Cyrenaica granting them autonomy - Peace Treaty between Turkey and Italy signed at Ouchy, Switzerland.-Mr. Monk, minister of Public Works, resigns his seat in Canadian Cabinet owing to difference of opinion on Naval Defence policy. Main storehouse of U.S. arsenal at Benicia, Cal., destroyed by fire, with estimated loss of $\$ 3,000,000$. - The Saratoga battle monument at Schuylerville, N. Y. (erected 1882) is dedicated.

19. Montenegrins capture Gusinji.-Turkish warships bombard Varna and Baltchik, Bulgaria, but retire.Greeks invade Macedonia and occupy Elassona.-Three German subjects, Bauchelin, Thibaut and Berger, sentenced at Leipzig to 8 and 6 years' penal servitude for espionage at Metz,-Helen Craggs, English suffragist. sentenced at Oxford to nine months' hand labour for attempt to set fire to Nuneham House (see July 13).Lt. Beissijarth and Lt. Lang, German airmen, killed near Giengen, Germany.-M. Schaumasse, Nice Observatory, discerns comet afterwards recognised as Tuttle's comet. 20. Recognition of Italian sovereignty in Tripoli and Cyrenaica by British Govt. officially announced in Rome. - Servian army occupies Poduyevo near PrepolatzAmédée Lacour, French airman, killed near Mussidan, France. - U.S. Govt. urges upon Mexico necessity of keeping open port of Tampico and of maintaining communication between it and Mexico City.

21. Greeks take Diskata, Thessaly, and land on Island of Lemnos.-Bulgarians capture Fort Chermen on road to Adrianople.-Servians occupy Sultan Tepé in Osogoviya Mts. - Turks attempt landing at Euxinograd, north of Varna, and bombard unfortified town of Kavarna.French Government recognise officially Italian sovereignty in Tripoli.-Trafalgar Day celebrations in London and elsewhere.-Mrs. Pankhurst, English Suffragist leader, speaks at London Pavilion in favour of militancy.International Conference on White Slave Traffic opens at 
Brussels.-Lt. Gericke, German airman, with a paissenger, Stieler, killed near Spansberg-German navy airship $\mathrm{Lr}$ injured at Johannisthal.

22. Kirdjali captured by Bulgarians; Prishtena captured by Servians; and Kotchana occupied by Servians and Bulgarians.-Sir William Conyngham Greene appointed British Ambassador to Japan--Lord Roberts and Lord Curzon speak on National Defence at Manchester.British Government appoint Select Committee of House of Commons to enquire into alleged Putumayo atrocities and responsibility of British directors.--Serious illness of Tsarevich of Russia announced.

23. Greek army occupies Selfidje; Servian army occupies Novi Bazar.-Meat riots in Berlin owing to butchers refusal to sell Russian meat.-Danish Premier introduces Constitutional Reform Bill, including Woman Suftrage:Vera Cruz, Mexico, captured by Federal ttoops; Gen. F. Diaz taken prisoner.-Mr. Lloyd George announces in British House of Commons Government's decision to increase fees payable to doctors under Insurance Act to 9s. per head, including drugs, at increased cost of $£ \mathrm{r}, 650$, 00 - National tribute offered to Mme. Sarah Bernhardt on her 6oth birthday at Savoy Hotel, London.

24. Bulgarian army takes Kirk Kilisse, with over 30 guns; 2 aeroplanes and 1,200 prisoners.-Servian army takes Kumanovo and advances on Uskub. - The Six Powers protest against Chinese Govt.'s assignment of Tientsin salt gabelle as security for London (Crisp) loan. - French Govt, refuse to allow Belgian loan to be floated in Paris.-British Govt. announce Royal Commission to enquire into congestion of legal business.-British battleship "Marlborough" launched at Devonport by Mrs. W. Churchill - First Congress of Men's International Alliance for Women's Suffrage opens in London.-Rear-Admiral Tchagin, Commander of Russian Imperial Yacht, commits suicide.-Sir Gerald Strickland appointed to succeed Lord Chelrisford as Governor of N.S. Wales,-Mr. H. Hawker, British airman, achieves record at Brooklands by remaining 8 hours $23 \mathrm{~min}$. in the air. - Death of Viscount Peel, ex-Speaker of British House of Commons.--Outbreak of plague reported from Mauritius; 19 deaths.-Dr. Ezra Squier Tipple (b. I86e) inaugurated president of Drew Theological Seminary, Madison, N. J.-Police Lieutenant Charles Becker found guilty in New York of murder in first degree for killing of Herman Rosenthal (see July 16, Aug. 20, Nov. 20).

25. Bulgarians advance on Adrianople.-Greeks occupy Kozhani. - Trial of Portuguese Royalists, arrested in May, resumed at Oporto; 34 acquitted, 4 sentenced to imprisonment.-France and Spain come to an agreement concerning all difficulties in Morocco.-Brazil police defeated by brigands in Parana. - "Ariadne auf Naxos," opera by Strauss, produced at Stuttgart.

26. Servians occupy Uskub, which the Turks have abandoned, and capture 123 guns.-M. Poincaré speaks at Nantes on possibility of European intervention in Balkan war--M. Mairoesco, Rumanian Premier, reconstitutes his Cabinet.-Saad-ed-Dowleh becomes candidate for Premiership of Persia.-M. Charpentier elected member of French Academy. - International Convention for regulation of exhibitions signed in Berlin.-General Diaz and two Mexican officers sentenced to death by court martial. 27. Bulgarians occupy Ishtip.

28. Servians occupy Kuprulu.-Bulgarians occupy Drama and cut Turkish line of communication with Constantinople at Baba Eski.-Servian and Montenegrin troops combine at Sienitza.-Tsar of Russia sends message of congratulation to King Peter on success of Serviari army: -Eleven Powers signatory to Peace Protocol of $190 x$ protest to Chinese Govt. against application of salt gabelle to London (Crisp) loan.-Mr. Louis Coderre becomes Canadian Secretary of State.-Strike of coopers at OportoFranco-Italian declaration of mutual friendship in Africa simned in Paris -Irish steamship "Tenet" sinks in Bristol Channel, 6 lives lost.

29. Greeks occupy Veria.-Battle between main Turkish force under Nazim Pasha and Bulgarians begins near Lule Burgas in Thrace.-Servians establish civil government in conquered cities of Macedonia.-Ghazi Mukhtar Pasha, Grand Vizier of Turkey, resigns and is succeeded by Kiamil Pasha.-In British House of Commons Mr. Goldsmith's amendment to Home Rule Bill, obliging Lord Lieutenant to refer every Bill passed by Irish Parliament to Imperial Executive, defeated by 114 votes.-Canon Hensley Henson appointed Dean of Durham.-Railway accident at Streetville, Ont.; 2 killed, 28 injured.

30. Bulgarians take Lule Burgas.-Death of Mr. Sherman, Vice-President of United States.-Anglo-German friendship Congress meets in London.-American battle- ship "New 'York" launched at Brooklyn, N. Y.-Lt Hamburger, Bavarian military airman, killed at Oberweisenfeld.-Rumanian Parliament dissolved.-Helen Craggs, suff ragist (see Oct. Io), discharged from Holloway prison after serving 12 days of her sentence.-Race for Cambridgeshire at Newmarket won by Mr. L. Winans's "Adam Bede.

3I. Main Turkish army under Nazim Pasha routed by Bulgarians, who capture Tchorlu, and force Turks to retreat towards Chatalja lines. Servians occupy Prisrend. Greeks occupy Grevena, and Islands of Imbros and Thasos. Montenegrins take Ipek.-French Government propose that Powers should jointly proclaim "disinterested. ness" and offer to mediate between Turkey and Balkan allies.-Moslem riot in Bulak district of Cairo.-General Lyautey arid M. Emile Boutroux elected members of French Academy - In British House of Commons Government amendment of Clause 8 of House Rule Bill, providing for first Senate to be nominated by the Crown, and subsequent Senate by proportional representation, carried by 298 votes to 200 .-Death of Isa Boletinatz, Albanian guerrilla leader--Motor car accident at Alicante, 9 persons drowned-- Lt. Poultrain. French airman, dies of injuries received Oct. 18. - "L'Idée de Françoise," by $M$. Paul Gavault, produced at Renaissance Theatre, Paris. November:-

r. Bulgarians occupy Demotika.-Govt. amendments to White Slave Traffic Bill, authorising arrest on suspicion without warrant and making flogging possible penalty for second offence, passed by British House of Commons. Lord Curzon speaks at Glasgow against woman suffrage. - Borough Council elections in London result in large majority for Municipal Reformers.-The Pope sends a letter to Portuguese clergy condemning Law of Separation and censuring clergy who have accepted stipends under it: - Gordon Bennett race, Stuttgart to Moscow, won by two Frenchmen, M. Bienaimé first and M. Leblanc secondLieut. Dahm, German officer, sentenced at Warsaw to 5 years' hard labour for espionage.-In Omaha, Neb., Federal grand jury indicts 5 railroads for rebating - Gen. Mario G. Menocal, Conservative, is elected president of Cuba.

2. King Peter of Servia enters Uskub in triumph.Montenegrin powder magazine explodes at Antivari; 5 soldiers killed. - Ex-Sultan Abdul Hamid taken to Constantinople from Salonika.-Turkish troops rally at Tcherkesskeui.-British battleships and destroyers ordered to Turkish waters.-Explosion on U.S. battleship "Vermont" near Norfolk, Va.; two men killed, four seriously injured. -Adolfo Diaz, Conservative, is elected president of Nicaragua, without opposition.

3. Turkish Govt. begs Powers to intervene and bring about suspension of hostilities, and consents to allow each Power to send a warship to Constantinople. -Greeks capture Prevesa.-Five lives lost in fire at John Barker \& Co., drapers, Kensington, London.

4. Greeks take Yenidje and capture 18 guns.-French Government reject Turkish appeal for intervention.Treaty between Russia and Mongolia concluded at Urga, Siberia.-Mr. Justice Parker decides, in Chancery Court, London, that the Bank of England is not entitled to deduct income tax from dividends before Finance Act for year has passed.-British House of Commons reject amendment to Home Rule Bill, providing that the First Chamber should be elected by proportional representation, by 265 votes to I62.-Crown solicitor excludes certain Belfast magistrates from hearing charges of riot against persons re-arrested after Recorder's court had entered nolle prosequi.- "A Venetian Night," by Max Reinhardt, refused licence at Palace Theatre, London, by Lord Chamberlain.-M. Borrelly, French astronomer, discovers new comet at Marseilles.-U.S. Supreme Court promulgates simplified rules of equity procedure in Federal courts.

5. Bulgarians defeat Turkish retreating force, driving it back on Chatalja lines; Turks lose 25,000 killed and wounded, 2,000 prisoners and 37 field guns.-General election in U.S. results in sweeping Democratic victories and election of Wilson and Marshall as President and VicePresident. Arizona, Kansas and Oregon adopt woman's suffrage; West Virginia, state-wide prohibition of sale of intoricants. - Sir E. Grey states in British House of Commons that Balkan States have right to formulate terms of peace and that Powers can scarcely intervene unless requested by both Parties.-Count Berchtold assures Foreign Affairs Committee of Austrian Delegations that Austria is in accord with other Powers on question of intervention in Balkan war.-Mr. Philip Snowden's amendment to Home Rule Bill, substituting local register for parliament ary register and thus giving votes to women rate-payers, rejected in British House of Commons by 314 votes to 
14x. Window-breaking follows in West End of London. - Select Committee of House of Commons appointed to inquire into fatal accidents caused by motor omnibuses in London.-Sir H. Barron, Governor of Tasmania, appointed Governor of West Australia.-French parliamentary commission appointed to inquíre into depopulation in France--Lieut. Petrovics, Austrian military airman, killed at Gorice. Carniola.-Sub-Lieut. Maréchal, French military airman, killed at Chartres-American aviation altitude record broken by H. B. Brown, Staten Island, $5,300 \mathrm{ft}$, with passenger.

6. Greeks seize island of Tenedos.-Turkish force at Tcherkesskeui retreats towards Chatalja lines.-Emperor Francis Joseph speaks to Hungarian Delegations on need of speedy settlement in Balkan War.-Kiamil Pasha summons Council of Ministers and Generals at Constantinople to discuss military situation; they decide to continue the war-Select Committee to inquire into Putumayo atrocities holds first meeting in London.-Native attacks on German factories reported from Liberia.-" "Royal George," Canadian Northern liner, runs on rocks at Point St. Laurent, Quebec.-Lieut. Altrichter, German military airman, with his engineer, killed at Halberstatt.

Bulgarians occupy Tchorlu and Muradli; and capture fort of Delijunus at north end of Chatalja lines.Montenegrins occupy Djakova.-Rioting occurs at Valle de Torno and Candos, Portugal. - French battleship "France" launched at St. Nazaire-Mr. Lloyd Geonge addresses letter to British Medical Association giving information as to regulations under Insurance Act for inspecting doctors' work, fixing remuneration, etc.-Lord Kitchener approves scheme for redistribution of reclaimed land among jellahin.-King's Bench, Dublin, inhibit Belfast magistrates from hearing riot charges (Noy, 4), - ViceChancellor of Oxford prohibits production there of "Hindle Wakes," play by Stanley Houghton.

8. Salonika surrenders to Crown Prince of Greece.Sheikh-ul-Islam at Constantinople calls upon Ulema to preach a holy war-It is reported that Austria-Hungary objects to Servia obtajning a port on the Adriatic-Mr. Bonar Law speaks in Liverpool on need for military preparedness as illustrated by Balkan war, and announces scheme for redistribution if Unionists come into power. Lord Chamberlain consents to license "A Venetian Night. - "King Harlequin," opera by G. H. Clutsam, produced in Berlin.-Brazilian Government sends troops against insurgents (see Oct. 25). -Two American cruisers ordered to Mediterranean to protect American citizens. 9. Bulgarians begin attack on Chatalja lines.- $M$. Pashitch, Servian Premier, states that Servia must have a port on the Adriatic.-Greeks capture Pentepigadid.Cyril, enters Salonika.-Mr. Asquith, at Guildball, London, deprecates "raising and pressing of isolated questions", arising out of the war, prior to a general settlement.-Mr. Bryce resigns post as British ambassador at Washington.Paris police arrest persons suspected in connection with rolbery on Nov, 8 of post-office at Bezons by armed men who shot postmaster dead.- Mass meeting of northern doctors at Manchester condemn proposed conditions of service under Insurance Act.-Mr. Michaelis buys from Sir H. I ane collection of Dutch Masters for presentation to South Airica.-Woman-suffrage victories in elections of Nov. 5 celebrated in New York City by an evening parade of 15,000 women.

I0. Socialist demonstration against war in Vienna.Rodosto evacuated by civil population.

11. Govt. defent in British House of Commons by $2 x$ votes on Sir F. Banbury's amendment to Hom? Rule Bill, limiting financial contribution of Imperial Exchequer to $£_{2,500,000}$ in any one year. - Taunton by-election results in return of Sir Gilhert Wills (Unionist), majority 285.-Royal Commission on Divorce and Matrimonial Causes issues Report in London; minority report signed by Archbishop of York, Sir W. Anson and Sir L. Dibdin opposes extension of grounds for divorce. - Unionist camjaign in Ionklon opened by speeches from Lord R. Cecil, Sir R. Finlay and others.-M. Daneff, President of Bulgarian Parliament, received in audience by Austrian Emperor-Diplomatic relations between Chile and Peru resumed after $21 / 2$ years' suspension. - Resignation of General Michel, Belgian Minister of War.-Railway accident at Yazœo, I-a.: I 8 killed, 90 injured.-U.S. Secretary of War refuses to allow transatlanti: steamship companies to increase leagth of piers in Hudson river opposite New York City to $x, \infty \circ \circ \mathrm{ft}-32 \mathrm{nd}$ annual convention of American Federation of Labor meets at Rochester, N. Y.

I2. King Ceorge of Greece arrives in Salonika -

Bu'garians occupy Rodosto-Austro-Hungarian Minister at Belgrade has interview with Servian Premier and sug. gests preference for Austrian trade, autonomy for Albania, and a Servian port on the Aegean.-Sortie from Adrianople repulsed.-Señor Canalejas, Spanish Premier, assassinated in Madrid by Serrato, an anarchist, who commits suicide. -Federated Malay States offer Ist class armoured ship to British Navy, - Opening of Portuguese Parliament; speech by Premier on failure of Royadist insurrections.- Nobel prize for Physics awarded to M. Gustaf Dalen (Switzerland), and for Chemistry divided between Prof. Grignard (France) and Prof. Sabatier (France)-Stafford House, London, sold to Sir William Lever.-Steamer "Zelia" lost off Dublin; 7 lives lost.-Debate on White Slave Trafic Bill in British House of Commons; clause carried making flogging penalty for male offenders; Bill read third time,

13. Turkish Government instruct Nazim Pasha to open negotiations for armistice. with Bulgarian generals.-Mr. Asquith moves in British House of Commons to rescind vote on financial clauses of Home Rule Bill given on sith; disorderly scene follows; Speaker first suspends and then adjourns debate. - Chinese Minister for Foreign Affairs resigns on Mongolian question.-Pres.Taft issues proclamation fixing Panama Canal tolls at \$1.20 per. net ton.-M Poincaré speaks in Paris on European Concert and policy of France, - Sir Cecil Spring Rice appointed British ambassador to U.S. - Resignation announced of President. James McCrea of the Pennsylvania Railroad Co., vice-president Samuel Rea chosen in his place.-Railway accident near Indianapolis, Ind; 15 killed, 20 injured.

14. At suggestion of Speaker, British House of Commons adjourns till 18th. - Lord Lansdowne and Mr. Bonar Law speak at meeting of National Unionist Association, Albert Hall, London.-Count Romanones sworn in as Spanish Premier.-Powers enquire at Sofia whether Bulgaria wil accept their mediation.-Franco-Spanish treaty initialled in Madrid.-Larz Anderson, minister to Belgium, appointed U.S. ambassador:to Japan as successor to Charles P. Bryan, resigned Nov. II.

15: Outbreak of cholera reported among Turks at Chatalja lines.-Kiamil Pasha proposes to King Ferdinand cessation of hostilities with a view to direct discussion of preliminaries for peace,-Greek marines occupy peninsula of Mt. Athos.-Servians attack Monastir-Capt. Kostevitsch, Russian officer, sentenced at Berlin to two years detention for espionage-Mr. William O'Brien, speaking at Cork, condemns financial clauses of Home Rule Bill Mr. Austen Chamberlain, speaking in Queen's Hall, London, defines Unionist land policy.-Gun explodes at Shoeburyness; 4 men seriously injured-Capt, Amundsen lectures before Royal Geographical Society, London, on South Pole discovery. - Nobel prize for literature iwarded to Gerhart Hauptmann. - President-elect Woodrow Wilson promises to call U.S. Congress in extraordinary session not later than April 15, 1913 to revise tariff.-Agreement supplementing Newfoundland fisheries award ratified at Washington.-Clinical Congress. of Surgeons of North America in New York City closes after session of 3 days.

16. Arrest at Constantinople of Talaat Bey and other members of Committee of Union and 'rogress on charge of conspiracy.- Montenegrins occupy San Giovanni di Medua.-Law promulgated in France amending Corle Napolépn and permitting establishment of paternity of an illegitimate child-Mukhtar, Ezyntian nationalist, sentenced to ro years' imprisonment for sedition-German Emperor inaugurates Bober Valley dam, Silesia.-Wonga Shoal lighthouse, Adelaide, destroyed by collision with sailing ship - 28th annual exhibition National Horse Show Association opens in New York City.

17. Bulgarians begin general attack on Chatalja lines. - Servians capture Monastir.

18. Servians and Montenegrins capture AlessioNaval guards landed from foreign warships in Constantinople.-British House of Commons decides how tc proceed with Home Rule Bill-Chinese Govt, decides to make military demonstration in Mongolia.-Railway accident to Simplon-Calais express at Longpre, France; driver killed.-Great storm in Jamaica causes loss of over 100 lives-Imperial Education Advisory Committee holds first meeting in London.--U.S. Supreme Court upholds decree of dissolution, handed down by the Federal Court of Maryland, against the Standard Sanitary Manufacturing Co. ("Bath-Tub Trust").

10. Balkan allies telegraph to Porte terms on which they will grant peace-British Medical Association decide no to accent service under Insurance Act on terms proposed. but by majority of $\mathrm{x}_{0}$ to 84 resolve to confer further with Mr. Lloyd George. and select five representatives.British Govt decide to drop Mental Deficiency Bill for the session.-Prison mutiny at Rochefort, France; 3 persons 
killed.-Railway accident near Gull Lake, Canada; I8 killed-Gladstone Professorship of Political Theory and Institutions founded at Oxford.-Duke of Northumberland appointed Chancellor of Durham University.Four "gunmen," arrested for share in murder of Herman Rosenthal, found guilty in first degree 'see Aug. 20).

20. Hostilities at Chatalja suspended while conditions of peace are discussed.-Greeks occupy Florina and cut off 'Turkish retreat from Monastir. - Servia permits AustroHungarian Foreign Office to communicate with Consul Prochaska at Prisrend; whose recall' Servia had demanded. - South African Party Congress opens at Pretoria, and South African Unionist Congress opens at Johannesburg. - Russian Cossack troons leave Urga for Soutbern Mongolia - Archbishop of Canterbury, speaking in Convocation, commends Minority Report of Divorce Commission. -Britisb House of Commons pass. new Financial Resolution for Home Rule Bill by. 3 I 7 votes to 195,-Theft of fro, $\infty$ in gold, whilst in transit from London to Alexandria, reported from Port Said.-Suit brought by U.S. Govt. against Federal Sugar Refining Co. of Yonkers, N. Y., for \$rig,080 alleged under-valuation. - Carmi Thompson (b. I87o), sec. to Pres. Taft, appointed U.S. Treasurer as successor to Lee McClung, resigned Nov I4: 2I. Porte declares terms of Allies unacceptable and orders resumption of war.-Bulgarian torpedo boats attack Turkish cruiser "Hamidiyeh" in Black Sea.-Greeks occupy: Mytilene.-Opening: of Canadian Parliament.Capt. Paiva Couceiro, Portuguese Royalist leader, sentenced to 6 years' imprisonment with exile:--Signor Bertoliniappoiated first Italian Colonial Minister.-Mr. Carnegie offers to provide pensions of $£_{5}, 000$ for future U.S. expresidents or their widows.-National Woman Suffrage Association holds convention in Philadelphia.

22. Archduke Francis Ferdinand visits German Emperor in Berlin.-Bulgarian delegates leave Kirk Kilisse for Chatalja to resume discussion of armistice; Nazim Pasha meets Gen. Savoff outside Chatalja lines,-Bulgarians occupy Dedeagatch, Malgara, Rodosto and Gumuljina.Mr. Ásquith speaks at Nottingham on Home Rule Bill and the disorder in House of Commons-British House of Commons appoint Select Committee to inquire whether Sir Stuart Samuel has vacated his seat, through his firm making a profit from Govt. contract for purchasjng silver for India.-Cambridge University abolishes restriction limiting divinity degrees to members of Church of England by majority of roo.-Violent cyclonic storm over Bombay and Western India.-Native chiefs arrested in Sierra Leone for "Human Leopard" cannibal practices. - John Schrank, who shot ex-president Roosevelt pronounced insane by board of alienists, at Milwaukee, Wisc. - O'Gara Coal Co. and 3 subsidiaries of New York Central System indicted by a Federal (U.S.) grand jury at Chicago for rebating.-Theodore Marburg named U.S. minister to Belgium, succeeding Larz Anderson-Frey, French airman, killed at Batteny, and Laurent, French military airman, killed at Villesauvage, near Etampes.

23. Servians occupy Ochrida.-King Peter of Servia returns to Belgrade.-Bolton by-election results in return of Mr. T. Taylor (Liberal), majority 1, I75.- Sir George Ross apnointed leader of Liberal majority in Canadian Senate- National Commission on Depopulation opens in Paris. - El Hiba, Moorish Pretender, defeated by El Glawi, who enters Tarudant and receives submission of Sus tribes.-Mine explosion near Alais, France; 24 lives lost.-Mr. Galsworthy's play "The Eldest Son" produced at Kingsway Theatre, London.-American Federation of Labour closes 32 nd annual convention at Rochester, N. Y. Samuel Gompers re-elected president.-Retirement of Manuel Calero, Mexican Ambassador to U.S. announced. -Official announcement that Gordon Bennett international ba!loon cup was won by French balloon Picardie, piloted hy $M$. Bienaime, making, $1,35^{8}$ miles, the world's record. - Harvard and Yale football match won by Harvard at New Haven, 20 to 0.

24. Rioting at Budapest in conpection with Socialist anti-war meetings.-Panic at cinematograph show, Bilbao, Spain; 14 killed, 60 injured.-Greeks occupy Chios.Samos proclaims its union with Greece.-Locomotive engineers of Eastern railroad U.S. awarded an increase of wages by arbitration board ' see April 22, 23,30).-Eugene V Debs, Socialist candidate for U.S. Presidency, indicted for bribery by Federal grand jury in Kansas.

25. Balkan and Turk ish peace delegates meet at Baghtchetsh outside Chatalja lines.-Heavy fall of stocks in Vienna and Berlin owing to rumour of trouble between Austria and Russia over Servian question.-Austrian warships recalled from Levant.-Conference between $\mathrm{Mr}$. Lloyd George and Mr. Masterman, and a committee of
British Medical Association.-Conference in New York City on workmen's compensation legislation. - Fire at Union Sulphur Works, Brooklyn.-Explosion in Starch Works at Waukegan, 1ll., kills 23 persons and injures 100. - Tacloba, in Philippines, almost destroyed by typhoon.First Trade union (goldsmiths) formed in China.

26. Austrian Consul at Prisrend, Herr Prochaska, de tained for some days by Servians, arrives at Uskub.Tsar of Russia receives. Austro-Hungarian Ambassador at Tsarskoe Selo.-Bow and Bromley by-election results in defeat of Mr. G. Lansbury. (Suffragist and Socialist), who had resigned to test feeling on Woman Suffrage; majority against, 851.-Nineteen Syndicalists, belonging to society of "Sou du Soldat," sentenced in Paris to 3 months' imprisonment and a fine for insulting the Army Eleven Russian sailors shot at Sevastopol for mutioy.Death of the Countess of Flanders, mother ot the King of the Belgians.-M. Bataille's play "Les Flambeaux" produced at Porte St. Martin Theatre, Paris-Leaders of Lawrence (Mass.) strike acquitted on murder charge. - The Indiana constitutional amendment case is carried to the Federal Supreme Court.

27. Run on Austrian and. German savings banks in Galicia, Northern Hungary and East Prussia.-FrancoSpanish Treaty, signed at Madrid.-Sir Edward Henry Commissioner of Metropolitan Police, London, shot at and wounded by motor-car driver-Albert ' $T$. Patrick, convicted of murder (I 1902 ) of W. M. Rice, pardoned by Gov, Dix of New York, -Wreck on Pennsylvania R.R near Glen Loch, $\mathrm{Pa}_{2}$, kills 2 and injures 30.

28. 9,000 Turks under Yaver Pasha surrender to Bulgarians near Dedeagatch.-Servians occupy Dibra.Austrian Premier announces jntroduction of three Army Bitls.-Albanian delegates at Valona issue proclamation of independence and elect. Ismail Kemal Bey as bead of Provisional Government.-German Imperial Chancellor orders Governor of East Prussia to issue re-assuring statement to stop run on savings banks. - Fourth Russian Duma opens with patriotic speech on Balkan crisis by M. Rodzianko, President.-White Slave Traffic Bill read a second time in British House of Lords.- Organised attempt to destroy letters in pillar-baxes made by. women suffragists in London and provincial towns.-Railway accident to Russian train near Harbin; is killed, 52 injured

29. Lord Haldane and Mr. W. Churchill speak at Eighty Club dinner, London, and Lord Curzon at Plymouth on European situation and British military necessities, Charles H. Hyde, ex-chamberlain of New York City, convicted of accepting a bribe as a public officer.

30. Servians occupy Elbasau. - Waihi miners' strike, New Zeaiand, declared at an end.

December:-

2. German Imperial Chancellor speaks in Reichstag on Balkan crisis.-King Ferdinand and his Finance Minister leave Sofia for Chatalja.-Greek delegates delay negotiations for armistice, and Greek gunboat bombards Valona - Cabinet crisis at. Tokyo; resignation of General Uyhara Minister of War.-Archbishop Nonel installed provisional President of Republic of Santo Domingo, succeeding Victoria, resigned November 28.-Lord Rosebery speaks at Bathgate on Lord Roberts's warnings as to efficiency of Territorial force-U.S. Congress assembles.-U.S. Supreme Court (reversing circuit court) orders dissolution of Union Pacific-Southern Pacific railway mergerSeveral American bishops named at papal consistory. 3. Armistice signed at Chatalja between Turkey, Pres. Taft's message on Foreign Affairs read in Congress. - Impeachment of Judge Archbaid begins in U.S. Senate. - Mr. Balfour speaks in City of London on Govt.'s parliamentary policy.-Mr. Lloyd George, speaking to deputation of Women's Liberal Federations of Wales, condemns militancy, whilst expressing sympathy with woman suffrage.- Oxford University abolishes restriction of Divinity degrees to priests of the Church of England by $15 \mathrm{I}$. votes. - Sth annual conference of governors meets at Richmond Va., adjourning Dec. 7.-In rear collision on Cincinnati \& Muskingum Valley R.R. near Dresden, Ohio, 7 are killed and 8 fatally injured.-Federal grand jury investigates agreement between New York, New Haven \& Hartford and Grand Trunk railways.

4. Catholic Centre Party in German Reichstag condemn policy of Imperial Chancellor and Federal Council as regards Jesuit law of 1877 .- Mr. Winston Churchill announces to British House of Commons proposed increases of pay in British Navy.-Resignation of Marquis Saionji, Japanese premier.-National Rivers and Harbors Congress meets in Washington, D. C.

5. Canadian Premier announces offer of three Dread- 
noughts to British Navy, to cost $£_{7,000,000}$ - Turkey, Bulgaria, Servia and Montenegro appoint delegates to attend Peace Conference in London.-M. Poincaré speaks in Chamber of Deputies on Balkan crisis.-British Insurance Commissioners issue final Memorandum as to medical benefit under Netional Insurance Act.-Col. Seely, sjeaking in London, denies charges of inefficiency made ajainst Territorials.-Mr. J. Scott Mason, Governor of British North Borneo, killed by fall from his horse; Mr. Aylmer C. Pearson appointed to succeed him.-U.S. House of Representatives passes Adamson bill for physical valuation of railroads and regulation of stock and bond issues by Interstate Commerce Commission, - Indictment of July I, 1009 against American Sugar Refining Co. for violating Sherman anti-trust law by acquiring Pennsylvania Sugar Refining Co. is withdrawn (see Mar. 3I).

6. Austro-Hungarian Government assents to British proposal of meeting of Ambassadors in London to discuss Balkan settlement.-Austria and Italy protest at Athens against Greek bombardment of Valona,-Admiral Prince Louis of Battenberg and Vice-Admiral Sir J. Jellicoe appointed First and Second Sea Lords of British Admiralty - Mgr. Vladimir, Metropolitan of Moscow, 'appointed Metropolitan of St. Petersburg and President of Most Holy Synod.-British Medical Association issue Report on Government's final terms for medical service under Insurance Act.-Pres. Taft's message on domestic and insular affairs, read in Congress, recommends Aldrich currency reform, opposes Philippine independence, etc

7. It is announced from Vienna that the Triple Alliance has been renewed without change.-Hassan Riaz Pasha, Governor of Skutari, refuses to accept the armistice and continues hostilities.-A French and a German airship ordered for British Navy.--Strike on North Eastern Railway, Gateshead, owing to reduction of Knox, an enginedriver, after conviction for drunkenness when off duty.Portuguese corporal sentenced to I year's imprisonment for ahooting Rev. A. J. Douglas at Kango, East Africa, in November I9I I. - In report on the Westport wreck (Oct. 3 ) the U.S. Interstate Commerce Commission severely censures the N. Y., N. H. \& H. R.R. for failure to instal safety devices.-Republican governors of 12 states confer in Washington, D. C., on party reorganisation. - In a head collision on the Western Maryland R. R. near Pen Mar, Md. 5 are killed and 2 injured.

8. Turkish cavalry and artillery withdrawn from Tripoli.-Agreement announced between the United States and Great Britain on composition of arbitration tribunal for certain long-standing pecuniary claims.

9. Resignation of General von Auffenberg, Austrian War Minister, and of General von Schemua, Chief of General Staff.-King Charles of Rumania opens Rumanian Chamber with pacific speech on Balkan crisis.-Protest against violation of Hay-Pauncefote Treaty by Panama Canal Act presented to U.S. Secretary of State by British Ambassador at Washington.-Resignation of Mr. Beeby, New South Wales Minister of Lands. - Massacre of Belgian customs inspector and staff by Kurds at Lohinjan on Turco-Persian frontier.-Henri Rouart art sale begins in Paris; $£ 8,400$ paid for a Corot, and $£ ₹ 7,400$ for a Degas. U.S. Supreme Court holds Chicago Stock Yards Co. is within the interstate commerce law, thereby reversing decision of Commerce Court - A $\mathbf{4}^{\text {-inch }}$ gun explodes during a test at Sandy Hook, U.S.A., but with no loss of life.-The U.S. House of Representatives passes legislative, executive and judicial appropriation bill, with no provision for the Commerce Court.- "Money Trust" hearings resumed before U.S. Congressional Committee.

ro. General Krobatkin becomes Austrian War Minister and General Konrad von Hötzendorf Chief of General Staff,-Turkish infantry leave Tripoli.-Grand Duke Nicholas visits King Charles of Rumania at Bucharest.Collision off Portland Bill between British battleship "Centurion" and steamer "Derna." - Sir E. Grey states in letter to Miss Haldane that Cabinet will accept decision of House of Commons on a woman suff rage amendment to Franchise Bill. - False alarms of fire given in London by wmen suffragists - In Inter-University Rugby foothall match Cambridge beats Oxford by ro points to 3 .- Mem bers of Progressive party confer in Chicago. - New National Association of Port Authorities ends a two-days conference at New York City.

1I. Sir E. Grey announces in British House of Commons that Ambassadors of Great Powers will meet in London for "informal and non-committal consultation" on Balkan Question. - Capt. A. B. Eckford killed by tribesmen near Shiraz, Persia.-M. Garros, French airman, reaches record height of $18,670 \mathrm{ft}$. at Tunis.

13. Death of Prince Luit old, Prince Regent of Bavaria aged 91.-Fighting between Greeks and Turks near Yanina.-White Slave Traffic Bill passes British House of Lords. - British House of Commons conclude Committee Stage of Home Rule Bill.-Russia warns China that a rupture of negotiations is imminent if settlement of Mongolian question is further delayed -M. Edouard Müller elected President of the Swiss Confederation.-United States battleship sent to San Domingo.-Debate on Franco-Spanish treaty opened in Spanish Chamber by Count Mortera.-The medal of honour of the National Institute of Arts and Letters, U.S.A., awarded to William Rutherford Mead for architecture (see E. B. xvii, 945).Keeper of disorderly house in New York City accuses police of corruption.

13. British Minister at Teheran addresses note to Persian Foreign Minister demanding punishment of murderers of Capt. Eckford.-Mr. Choate, in New York, denounces any refusal to submit Panama Canal question to arbitration.-Danish House passes Bill to amend Constitution, by 95 votes to $\mathrm{x} 2,-$ In Philadelphia suit is filed by U.S. istrict attorney against "candy trust."

14. Resignation of General Botha, Premier of South Africa.-Strike on North Eastern Railway settled; enginedriver Knox to be given a free pardon and re-installed, and strikers to forfeit six days' pay.-South Africa beats Wales at Rugby football at Cardifi by 3 points to nil. U.S. Senate approves erection of a Lincoln memorial temple in Potomac Park, Washington, D. C to cost $\$ 2, \infty 00,000$. - Interstate Commerce Commission orders all interstate express companies to submit before February I, I9I3 complete statements of their business on designated days.-In Chicago suit filed for dissolution of the Elgin Board of Trade and the American Association of Creamery Butter Manufacturers for conspiracy to fix price of butter. -William Henry Fox (b. I 858 ), director the John Herron Art Institute, Indianapolis, Ind., U.S.A., since 1005 , is elected curator in chief of the Museums of the Brooklyn Institute of Arts and Sciences, to take charge Jan. I, I9I3. in place of Frederic $A$. Lucas, recently retired.

15. Death in London of Mr. Whitelaw Reid, American Ambassador.-Lieut. Wilfrid Parke, R.N., naval airman, and Mr. A. Hardwicke, killed at Wembley,-Attempt to lynch Peruvian Government Commissioners sent to Putu. mayo rubber district.-Reported shooting of several persons at Holda on British territory by Portuguese force from Goa, India.

16. Peace Conference of Balkan, Greek and Turkish delegates opened at St. James's Palace, London, by Sir Edward Grey.-British Minister at Peking protests to Chinese Government against violation of Opium agreement.-Mr. Bonar Law speaks at Ashton-under-Lyne on Tariff Reform policy of Unionist party, and advocates Colonial Conference to consider question of food taxes. Confédération du Travail declares 24 hours' strike in France as protest against war-Naval engagement between Greek and Turkish fleets outside Dardanelles.-Turkish sortie from Skutari repulsed by Montenegrins. - Carl Louis Alsberg is named chief of the bureau of chemistry, U.S. department of agriculture, successor to Dr. Harvey Wiley. U.S. Supreme Court in the Reading coal case holds there is no general combination for restraint of trade. 4th biennial exhibition of contemporary oil painting opens at the Corcoran Art Gallery, Washington, D.C.; rst prize to Childe Hassam for "The New York Window."-U.S. Senate chooses as alternating presidents A. O. Bacon (Georgia) and J. M. Gallinger (New Hampshire)

x7. Peace Conference adjourns until Turkish delegates receive instructions as to whether they may deal-with Greeks before Greece signs the Chatalja armistice.-iMeeting of Ambassadors of the Great Powers at the Foreign Office, London, Sir E. Grey presiding- - Herr Edl's report on Prochaska incident published in Vienna.-Prince Katsura directed by Emperor of Japan to form a Cabinet. Peruvian Government order arrest of Julio Arana, director of Putumayo rubber industry.-Spanish Chamber of Deputies adopt Franco-Spanish Treaty by 216 votes to 22 . -Death of "Common," famous English racehorse.-Pres. appoints 9 members of commission on Industrial Relations provided for by act of Congress approved Aug. 24.Montgomery Schuyler, Jr. (b. I877) of New York, first Secretary of the American Embassy at Mexico City, named U.S. minister to Ecuador-Wm. J. Flynn (formerly deputy commissioner of police in New York City) appointed chief of the U.S. Secret Service as successor to John E. Wilkie.-Federal Grand Jury at Chicago indicts John Carstensen, vice-president of the New Yorl Central Railroad, for alleged rebating (see Nov. 22)

18. Marquis di San Giuliano speaks in Italian Chamber on beneficial economic efiect of Triple Alliance, and sug. 
gests neutralisation of Albania.-Lord Grey speaks at Mansion House, London, on British-American peaceM. Kokovtsoff speaks in Russian Duma on Balkan crisis. - Mine explosion at Mengede, near Dortmund, Germany; 25 killed, 15 injured. - M. Garros, French airman flies from Tunis to Sicily, 143-miles.-Burnetz immigration - bill, excluding immigrants over 16 years old unable to read, passed by the U.S. House of Representatives, 178 to 52 . - Illinois Republicans confer on party reorganisation.

19. Prince Katsura forms a cabinet in Japan, with Baron Kato as Foreign Minister.-Green Park site for London memorial statue of Edward VII abandoned in favour of site at bottom of Waterloo Place-Bodies of Mr. $\mathrm{H}$. Kearney and Mr. Chester Lawrence, American airmen, found in sea near Redondo Beach, Cal.-U.S. warns rebel leaders in San Domingo not to disturb provisional government on penalty of American intervention.-Pres. Taft sends a message to Congress on departmental affairs and urging that Cabinet members have seats, but not votes, in both houses.-Pres. Taft leaves Washington for Panama. - U.S. Congress adjourns for Christmas recess. - J. Pierpont Morgan testifies before "Pujo committee."

20. Conference of Ambassadors in London announce Great Powers' acceptance of principle of Albanian autonomy together with a provision guaranteeing Servia commercial access to Adriatic.-Delegates to London Peace Conference entertained at Mansion House of Lord Mayor. - General Botha forms new South African Cabinet, excluding Gen. Hertzog and Col. Leuchars.-Mr. F, E. Smith, at Dudley, states that main object of Unionist party is Imperial Preference, and that a Colonial Conference is only a means to that end.-Select Committee of House of Commons recommend reference of Sir Stuart Samuel's case (see Nov. 22) to Judicial Committee of Privy Council. -Florence," British steamer, wrecked off : Cape Race, Nfd.; 22 drowned.-Memorial service held in Westminster Abbey for Mr. Whitelatw Reid, the coffin being conveyed next day to Victoria station on a gun carriage with a military escort, for transport to United States on British warship.-Fire at Blöhm \& Voss' shipbuilding yard, Hamburg. -U.S. government files suit at Los Angeles, Cal.; to recover from Southern Pacific Railroad Co. mineral lands in Fresno county.

21. Peace Conference again adjourned because revictualling of Adrianople is demanded by Turkish delegates. - British Medical Association rejects Govt.'s - proposals under Insurance Act by $x 8_{2}$ votes to 21 . - Fighting between Greeks and Turks near Yanina; Djavid Pasha killed. - M. Poincaré speaks in French Chamber of. Deputies on Powers' attitude to-Balkan question.-Duke of Connaught elected chancellor of Cape University.-Section of Bagdad railway through Taurus opened to traffic:Strike in Kiel dockyard. - French force Col. Massoutier besieged at Dar-el-Kadi near Mogador, Morocco.-Aeroplane collision near Paris; Jacques Delcassé injured.

22. M. Chemet, French airman, flies from Venice to Trieste and back in a hydro-aeroplane.

23. Lord Hardinge, Viceroy of India, wounded and his attendant killed by bomb thrown from a house in Delhi during State entry into the capital.-Territorial claims of Balkan League presented to Turkish delegates at. Peace Conference - Greeks repulse Turkish attack at Dodona and occupy Koritza,-Oliannes Bey Kouyoumjian, Armenian Catholic, appointed Governor of the Lebanon.-
British Govt. refuse British Medical Association's proposal for administering medical benefit independently of Insurance Committees. - Completion of Assuan dam celebrated in presence of Khedive and Lord Kitchener.-Two Kritish steamers wrecked in Gulf of Mexico; 22 lives lost.-Dr. Weiskirchner.-Christian-Socialist, elected Burgomaster of Vienna.-Decision dismissing all indictments but one against the United Shoe Machinery Co. for violation of the Sherman law appealed to Supreme Court. - Patrolman and two collectors from disorderly houses for New York City police indicted.-Federal Grand Jury indicts officials of the New Haven and the Grand Trunk railways for conspiracy to restrain trade.

24. Attempt to assassinate Prince Yamagata in Japan. -Quebec Legislature pass Bill dqubling tand subsidy for Montreal-Hudson's Bay railway,-Hostile demonstration in Teheran against M. Mornard, Treasurer-General of Persia.-French force besieged at Darsel-Kadi near Mogador, Morocco, relieved by Gen. Brulard - Kiel dockyard strike settled.-Mr. E. Petre, British airman, killed at Marske-on-Sea, Yorks.-U.S. Steel Corporation announces increased wages for its 200,000 employees.

26. M. Poincaré accepts candidature for French Presidency.-Chinese Govt. replies to British note on Tibet that it regards any agreement to maintain status quo as unnecessary - P. \& $O$. liner "Narrung," conveying emigrants to Australia, disabled by storm off Ushant, France, and puts back to London,-U.S. government sues the Kellogg Toasted Corn Flake Co. for fixing a uniform jobbers' and retailers' price.

27. M. Ribot accepts candidature for French Presidency.-American liner "Austrian Prince" sinks after collision with "Amasis" in Montevideo harbour.

28. - Turkish proposals, presented to Peace Conference, unanimously repudiated by Balkan Allies.-Principals of International Association of Bridge \& Structural Ironworkers convicted at Indianapolis, Ind. of complicity in dynamite outrages. - Irish Unionist Members of Parliament propose to move amendment to Home Rule Bill excluding Ulster.-Demonstration in Pretoria in favour of Gen. Hertzog, addrissed by Gen. De Wet.

29. Resignation of M. Makaroff, Russian Minister of Interior, and appointment of M. N. A. Maklakofi as acting minister.

30. Death of Herr von Kiderlen-Waechter, German Foreign Secretary.-Gen. . Sukhomlinoff, Russian War Minister, received by German Emperor in Berlin.-New York City and Newark garment workers strike.-Samuel M. Felton is elected president of the Pere Marquette Railroad, successor to Wm. Cotter, resigned Dec. I4 Sentence of penal servitude passed on 33 labour leaders convicted in dynamite conspiracy trial (see Dec, 28).

31. China defaults on payment of Boxer Indemnity instalment through failure to obtain foreign loan.Panels of British doctors willing to serve under Insurance Act close, but are subsequently kept open in certain cases tonllow of more coming in.-Spanish Cabinet re-constituted by Count Romanones, the Premier.-Ex-Pres. Castro of Venezuela detained at Ellis Island, New York, pending decision as to whether he is an undesirable alien.London taxi-cab drivers decide to strike on Jan. IThree New York, New Haven and Hartford railway officials are arrested for manslaughter for the Westport wreck (see Oct. s). 


\begin{tabular}{|c|c|c|}
\hline \multicolumn{3}{|c|}{ CALENDAR FOR 1913.} \\
\hline JANUARY. & FEBRUARY. & MARCH. \\
\hline 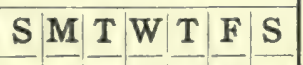 & 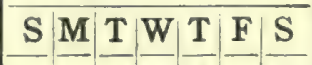 & $\mathbf{S} \mathbf{M} \mathbf{T} \mathrm{W}$ T $\mathbf{F}$ \\
\hline \begin{tabular}{lll|l|l}
$\ldots \ldots \ldots$ & 2 & 3 &
\end{tabular} & 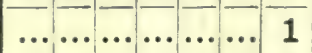 & $\begin{array}{llll}\ldots & \end{array}$ \\
\hline \begin{tabular}{lll|l|l|l|l|}
5 & 6 & 7 & 8 & 9 & 10 & 11
\end{tabular} & \begin{tabular}{lllllll|l}
2 & 3 & 4 & 5 & 6 & 7 & 8
\end{tabular} & $\begin{array}{llllllll}2 & 3 & 4 & 5 & 6 & 7 & 8\end{array}$ \\
\hline 12131415161718 & 9101112131415 & 9101112131415 \\
\hline 19202122232425 & 16171819202122 & 16171819202122 \\
\hline $262728293031 \ldots$ & $2324 \quad 25262728 \ldots$ & 23242526272829 \\
\hline ................... & & $3031 \ldots \ldots \ldots \ldots$ \\
\hline APRIL. & MAY. & JUNE. \\
\hline \begin{tabular}{|l|l|l|l|l|l|l|}
$\mathbf{S}$ & $\mathbf{M}$ & $\mathbf{W}$ & $\mathbf{T}$ & $\mathbf{F}$ & \\
\end{tabular} & 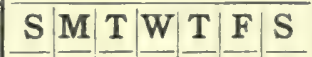 & 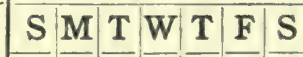 \\
\hline $\begin{array}{lllll}\ldots \ldots & 2 & 3 & 4\end{array}$ & \begin{tabular}{|l|l|l} 
& \\
$\ldots$
\end{tabular} & $\begin{array}{llllllll}1 & 2 & 3 & 4 & 6 & 7\end{array}$ \\
\hline 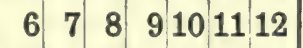 & 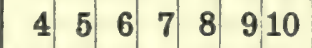 & \begin{tabular}{l|l|l|l|l|l}
8 & 9 & 10 & 11 & 13 & 14
\end{tabular} \\
\hline 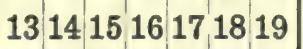 & \begin{tabular}{|l|l|l|l|l|l|l|l|l|l|l|l|}
11 & 14 & 16 & 1
\end{tabular} & \begin{tabular}{|l|l|l|l|l|l|}
5 & 16 & 18 & 20 &
\end{tabular} \\
\hline 20212223242526 & 18192021222324 & 22232425262728 \\
\hline $27282930 \ldots$ & 25262728293031 & $2930 \ldots \ldots \ldots \ldots$ \\
\hline$\ldots$ & $\ldots \ldots \ldots$ & $\ldots$ \\
\hline JULY. & AUGUST. & SEPTEMBER. \\
\hline 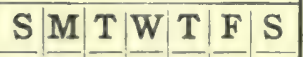 & 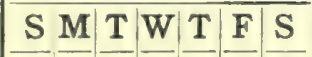 & $\mathbf{S}: \mathbf{M}: \mathbf{T}|\mathbf{W}| \mathbf{F}: \mathbf{S}$ \\
\hline \begin{tabular}{ll|lllll}
$\ldots \ldots$ & 2 & 3 & 4 & 5
\end{tabular} & 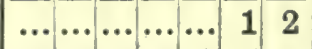 & \begin{tabular}{|lllllll}
$\ldots$ & 1 & 2 & 3 & 4 & 5
\end{tabular} \\
\hline $\begin{array}{lllllll}6 & 7 & 8 & 9 & 10 & 11 & 12\end{array}$ & 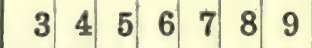 & \begin{tabular}{l|l|l|l|l}
7 & 8 & 9 & 1011 & 12
\end{tabular} \\
\hline 13141516171819 & 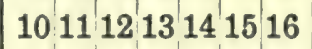 & 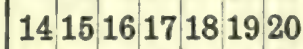 \\
\hline 20212223242526 & 17181920212223 & $21: 222324: 252627$ \\
\hline $2728293031 \ldots$ & 24252627282930 & $282930 \ldots$ \\
\hline 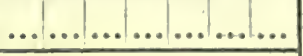 & $31 \ldots \ldots \ldots \ldots \ldots$ & \begin{tabular}{ll|l}
$\ldots \ldots \ldots \ldots$ \\
\end{tabular} \\
\hline OCTOBER. & NOVEMBER. & DECEMBER. \\
\hline 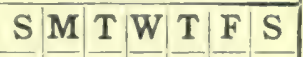 & \begin{tabular}{l|l|l|l|l|l}
$\mathbf{S}$ & $\mathbf{M}$ & $\mathbf{W}$ & $\mathbf{T}$ & $\mathbf{F}$ & $\mathbf{S}$ \\
\end{tabular} & 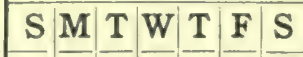 \\
\hline $\begin{array}{lllll}\ldots \ldots & & 2 & \\
\end{array}$ & $\begin{array}{lll} & & \\
\end{array}$ & $\begin{array}{llllll}\ldots & 1 & 2 & 3 & 4\end{array}$ \\
\hline 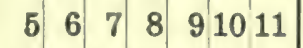 & \begin{tabular}{ll|llllll}
2 & 3 & 4 & 5 & 6 & 7 & 8
\end{tabular} & \begin{tabular}{l|l|l|l|l|l}
7 & 8 & 910 & 112 & 13
\end{tabular} \\
\hline 12131415161718 & $91011 \quad 121314 \quad 15$ & $\begin{array}{lllllll}14 & 15 & 16 & 17 & 18 & 1920\end{array}$ \\
\hline 19202122232425 & 16171819202122 & 21222324252627 \\
\hline $262728293031 .$. & 23242526272829 & $28293031 \ldots \ldots$ \\
\hline & $30 \ldots \ldots|\ldots|$ & $|\ldots \ldots| \ldots \ldots$ \\
\hline
\end{tabular}




\title{
The Britannica Year-Book
}

\author{
Part I. General
}

\section{SECTION I. POLITICS AND ECONOMICS.}

The political history of the world since Igog-Io is dealt with, so far as individual countries are concerned, in Part II of the YEAR-BOOK. From what may be described as the international point of view-that of an observer of the world's general progress rather than of the recorder of purely national domestic events-the salient aspects of national history and $W$ elt-politik ultimately form a single unit; but for practical purposes it is convenient in such a volume as this to deal under each country with its own political history, and to isolate certain special aspects of events of international importance, in which more than one nation is primarily involved or interested, for treatment apart. This is therefore done in the present section of Part I of the YEAR-BooK, the other sections of which are devoted to the progress made in those general subjects which have a life and interest of their own, irrespective of the nationality of those who are agents in their continuous development for the benefit of humanity at large.

\section{SPECIAL INTERNATIONAL AFFAIRS AND EVENTS}

More and more, as the world in all its parts is brought into closer touch, is an adequate knowledge of international relations vital to the nations by themselves and their individual citizens. The individual exertions of nations and their citizens are dominated by international conditions in the world's organisation, not only for war and peace as positive ends, but also for purposes of political, social, financial, and commercial progress, which are directly affected by events, movements, and influences, originating beyond the control of any one of them.

During the period from I910 to the end of 1912, it so happens, there have been, in all the continents of the world, Europe, Asia, America, and Africa, exceptionally momentous political and territorial developments, and even outside these continents the boundaries of the sphere of knowledge have been enlarged in the untracked spaces of the Antarctic by Amundsen's and Scott's achievements in reaching the South Pole. Since IgI I China has started on a new career as a Republic, and there is no telling what germinating consequences may follow from the change. In the middle East the state of Persia has developed to a point at which the interests of the rest of the world peremptorily demand some better system of orderly government. The Turkish Empire, as the result of the Balkan War, is in convulsions; and in the Balkan Peninsula itself new Powers have arisen, whose future relations with the international grouping in Europe have still to be settled. That grouping-with the Triple Alliance on one side and the Triple Entente on the other-has become more firmly established as the result of prolonged tension, mainly due to a continued assertion by Germany of her military strength, and her naval ambitions. While the domestic politics of the United Kingdom are passing through a stage of perplexing uncertainty and bitter conflict, great advances have been made towards the organisation of the British Empire as a 
unit of political strength. In the United States the presidential campaign of IOI 2 and its result have brought a new political party into existence; and the defeat of the Reciprocity Agreement in Canada has checked a notable movement towards cooperation with the neighbouring Dominion. Meanwhile a period of bounding commerce and good financial credit has synchronised with a widespread movement of industrial unrest, largely stimulated by the increased cost of living, in all the countries of Western civilisation. Most of these movements, and the details concerning them, are treated elsewhere in the YEAR-BOok; in what follows a few specially interesting questions are dealt with, which are of direct international importance and fall naturally for discussion under no one country in particular.

\section{The Morocco Crisis of rgi I}

The main disturbance in European politics during 19 II was due to the action of Germany in claiming compensation from France on account of the new situation in North Africa which was being brought about by the extension of French influence in Morocco. It had been hoped that the Act of Algeciras ${ }^{1}$ in 1906, followed by the FrancoGerman Convention of I9o9, had finally settled the lines on which France enjoyed a privileged position, as the mandatory of Europe, in the " peaceful penetration " of that country; but the progress of affairs (see Morocco, in Part II, sect. iii of the YEARBook) compelled an extension of the French military occupation, which, in the view of the German Government, went altogether beyond what was warranted, and in June an intimation to this effect was given in Paris by the German Ambassador, who suggested that the German objection to French control of Morocco might be removed by concessions of territory elsewhere. The French Government, apparently not taking this diplomatic move seriously, and fortified by the Anglo-French cntcnte, was not disposed to offer any such "compensation," or to admit that its action in Morocco went beyond what had been provided for by existing agreements; and the world was startled soon afterwards (July Ist) by the announcement that the German gunboat "Panther" (joined shortly after by the cruiser "Berlin ") had been sent to the closed port of Agadir. near the mouth of the Sus river, for the protection of German trading firms in that part of Morocco. At the same time the German Press became very active, and the suggestion was made that Germany meant to occupy the port of Mogador and assert herself in the southern part of the country. The impression was distinctly given that Germany intended to reopen the whole Morocco question, and to proceed de noso by way of partition between herself, France, and Spain; and though such a policy was afterwards repudiated by the German Chancellor (Nov. gth). this was the interpretation which both the British and the French Governments and public opinion generally first gave to the German coup.

On July 3rd, Sir Edward Grey plainly told the German Ambassador in London that the Cabinet must discuss the situation as an entirely new one; the British attitude could not be " disinterested " and Great Britain would decline to recognise any new arrancements made without her being consulted; and on July 6th Mr. Asquith stated catcgor cally in the House of Commons that Great Britain would act in concert with France. The speeches delivered later in the year by the German Chancellor (Nov. oth and Dec. 5 th), and Sir Edward Grey (Nov. $27^{t h}$ ), after the crisis had passed away, were the first public explanations of the actual course of events; and for a protracted period, while "conversations" were passing between France and Germany, and the French and Finglish (iovernments were acting in loyal fulfilment of the understanding between them. peace and war hung in the balance. As Sir Edward Grey subsequently made clear, the real aims and objects of (iermany were at first very imperfectly disclosed, a 2 d the apparent inspiration given to the German Press seemed to indicate that they world be incompatible with either French or British interests.

The first concrete proposal (July i 5 th) from Germany by way of territorial compcnsation for the alleged damage to her rights in Morocco was that France should cede the

1 See E. B. xviii, 858 . 
whole of French Congo from the coast to the river Sanga, and also her right of preemption to the Belgian Congo; but up to July 2 Ist, the requests made by the British Government for definite information as to German intentions were passed by in a way which suggested that Great Britain was being treated as of no particular account in the matter. The result was that, after consultation with Mr. Asquith and Sir Edward Grey, Mr. Lloyd George made a speech that day at the Mansion-house which caused considerable sensation, particularly as it was delivered by a British statesman who had been generally regarded as sympathetic towards Germany and an opponent of militarism. He declared pointedly that if a situation were to be forced on Great Britain in which peace could only be preserved by the surrender of her position in Europe, and she was to be treated as of no account in the Cabinet of Nations, peace at that price would be an intolerable humiliation. So far as the actual language used by Mr. Lloyd George was concerned, it might have been a rhetorical flourish in the mouth of any statesman in any country; indeed the German Chancellor afterwards (Nov. gth) accepted his words as a patriotic declaration which might equally well have come from a German minister. But it was meant as a warning to Germany, and was universally interpreted, and welcomed both in England and in France, in that sense, while in Germany it created a furious uproar and a situation of unprecedented bitterness. In the result, and in opening diplomatic communications, in an ostensibly amicable spirit, between the German and British Governments, its effect was a good one, but not by any means in the immediate relations between the two peoples. Anti-English feeling in Germany boiled over, and for a time it looked as though a rupture was inevitable.

This state of tension between England and Germany, though relieved by the peaceful issue of the Franco-German conversations, was in fact independent of the Morocco difficulties themselves. Mr. Lloyd George's speech simply put the match to an highly inflammable situation, brought about by mutual suspicion and jealousy; and the determination of Great Britain, without distinction of party, not to allow France to be brow-beaten by Germany over the Morocco question, brought all the elements of national antagonism into play. On the part of the Governments on both sides however cooler heads were displayed. On July 2 th the German Ambassador told Sir Edward Grey that Germany did not propose to establish herself in Morocco, and was prepared to make concessions to France; and on July 2;th the German Government sent a dispatch, repudiating any intention to injure British interests, and expressing the hope that the arrangement contemplated with France would diminish further opportunities for friction. From this point the negotiations concerning Morocco and the compensation to be made to Germany proceeded more smoothly, though at times they caused considerable anxiety. At length however, on November 4 th, two Franco-German treaties were signed, one recognising a French protectorate over Morocco, and the second providing for the cession by France of about 100,000 square miles of territory in the Congo basin.

It was perhaps inevitable that, in the circumstances, no particular national satisfaction should exist in either country over the result. In Germany the public had been led to expect much more, and the Colonial Minister, Herr Lindequist, resigned in protest against the insufficiency of the compensation obtained. The discussions in France over the ratification of the treaties disclosed some intriguing on the part of the Premier, M. Caillaux, behind the back of the Foreign Minister, M. de Selves, during the negotiations, which resulted in the resignation of $\mathbf{M}$. de Selves, and then to the fall of the Ministry: But peace had been preserved, with honour, under highly unpropitious conditions. Germany had asserted herself, in a decidedly provocative way, and with the result of securing a large addition of Colonial territory. France had obtained a free hand in Morocco, at a price well worth paying. And Great Britain had shown her determination to uphold the Anglo-French entente at all costs. It should be added that, on the merits, and irrespectively of the methods adopted, the French action in Morocco, though practically forced upon France by the conditions in that country, undoubtedly provided justification for the German view that the arrangements contemplated in I 906 and I 909 had been altered to Germany's detriment. The Anglo-French agreement of 1904, by 
which Great Britain obtained a free hand in Egypt in return for giving France one in Morocco, had no real parallel in the shape of French concessions to Germany; and it could hardly be expected that Germany would be contented without compensation of some sort. This was secured, and Germany's reiterated claim for a larger place " in the Sun " was aggressively vindicated.

The achievement left the international situation in Europe where it was. Germany could count, of course, on her allies, when she threw the sword into the scales. Any idea however that may have been entertained that France could be coerced, and that the Anglo-French entente would not stand the test, must have been dissipated. It was clear that French confidence, by no means conspicuous in the crisis of 1905 , had been completely restored. The entente with Great Britain was decidedly strengthened; and as between Germany and Englan' an object-lesson was given to the British Empire, which all parts of it were quick to grasp, of the dangers of the naval situation, with AngloGerman relations as they existed, and Germany forcing the pace in competition with Great Britain on the sea. The naval rivalry between the two countries remained one of the permanent dangers in international politics, and German susceptibilities were once more touched on the raw a little later when on February 9, I9I 2 Mr. Winston Churchill at Glasgow described the British fleet as a "necessity" and the German only a "luxury," but the British Government sent Lord Haldane to Berlin on a mission to smooth matters over, with apparently good results, and relations gradually became normal again. As between the Triple Alliance (Germany, Austria, Italy) and the Triple Entente (France, Russia, England) the crisis served even to clear the air; and this was shown in the most public way at the beginning of July 1912, when the German and Russian Emperors had a meeting, accompanied by their foreign ministers, at Port Baltic. Emphatic recognition was then given to the relations existing between the Powers by an official communique saying that "there could be no question of producing alterations in the grouping of the European Powers, the value of which for the maintenance of equilibrium and of peace has already been proved."

\section{ITALY AND TRIPOLI}

The case is somewhat different with the ensuing annexation of Tripoli and Cyrenaica by Italy, to which, after a one-sided war (see below) had gone on from November IgI I till October I9I2, Turkey was compelled to submit by the pressure of the Balkan crisis. The contemporary historian cannot satisfactorily pronounce, for want of exact information, on either the moral or the legal aspects of this piece of territorial self-aggrandisement. The reasons given in Italy's sudden ultimatum to Turkey (Sept. 26, I9I I), prefaced by no warning to any of the Powers, but announcing her intention to proceed to establish a military occupation in Tripoli and Cyrenaica, followed as it was by a declaration of war (Sept. 20th) which gave no proper opportunity for peaceful negotiations, were by themselves quite insufficient-however adequate to justify the taking of strong measures-to satisfy impartial international jurists that a simple redress of the undoubted grievances of which Italy had a right to complain was the real motive foi such peremptory action. If consideration is given only to the normal procedure expecied between nations in such circumstances, it can only be said that in this case once more "might" asserted itself, irrespectively of public law or international rights. But the real circumstances are still not definitely known. There is good reason for believing that Italy's action was really forced on her as an alternative to other eventualities, which, without in any way safe-guarding Turkish rights in Tripoli, would have demolisher the whole claim of Italy herself--long an integral part of her national policy--to fall heir to those rights whenever Turkey should become unable to ex:rcise them.

If, as has been hinted, the Italian government had information that the FrancoGerman negotiations were proceeding in such a way that Germany was being driver to look for compensation for the French annexation of Morocco by extending her influence elsewhere along the North African coast,-and it is suggested that, with Turkey's consent, Germany had an eye on a Tripolitan harbour for a Mediterranean point d'appui,- 
no other course was open than some immediate action, which would once for all secure for Italy what had long been understood to be her special preserve, without offering any formal opportunity for a split within the Triple Alliance itself. If the moment had come in any case, for some other Power than Turkey to become master of Tripoli, the whole case against Italy, from the point of view of the public law of Europe, as presented by the contemporary critics who accused her of wantonly breaking the peace without adequate cause, would fall to the ground. The situation in September rgr I was in that case one of deep concern for Italy, her relations with the Triple Alliance being complicated by the necessities of her own Mediterranean policy; she acted swiftly and finally, and as matters turned out with entire success.

To what extent the actual possession of Tripoli and Cyrenaica, with a somewhat undefined hinterland of uncertain value, may prove a remunerative addition to Italian territory, has yet to be discovered; the substitution of Italian for Turkish sovereignty however can only be regarded, on the merits, with satisfaction from the point of view of the world's progress. The course of the military operations is dealt with elsewhere in the YEAR-BOok, but one particular aspect of the war may be emphasized here. It put Italy in a position of considerably increased strength as a factor in international politics. One-sided as the war was, it provided an opportunity for testing the Italian military and naval resources and giving both army and navy practice and experience under service conditions, the importance of which can hardly be exaggerated. Instead of being the weak member of the Triple Alliance, Italy at the end of I9I 2 was full of a new consciousness of national vigour and efficiency, the effect of which on the balance of power in Europe was not likely to be to her disadvantage.

\section{The Balkan States and Turkey}

After a protracted period of tension over the Macedonian question (see $E$. B. xvii, 22I, 222), the long expected crisis between the Balkan States and Turkey reached an acute stage at the opening of October I9r2. In the early summer Bulgaria, Servia, Montenegro and Greece had come to a definite agreement for co-operating as a league in a common policy, not merely for securing from Turkey the long promised "reforms" in Macedonia and enforcing the old stipulations of the Berlin Treaty, but for obtaining a real autonomy for Turkey's European provinces with their Christian inhabitants. The insurrection in Albania had for some time been creating trouble; and in August fresh exasperation was caused by Turkish massacres of Bulgarians at Kotchana and of Serbs at Berane, so that throughout the Balkan States public opinion became hot for action. The governments of Bulgaria, Servia, Montenegro and Greece now prepared to deliver an ultimatum insisting on their demands, and for this purpose started mobilising their forces on September 3oth. Turkey replied with similar measures, and for some days it was uncertain whether war could be averted, while the Great Powers, and especially Russia and Austria, strove for peace by diplomatic pressure on Turkey.

On behalf of Austria-Hungary Count Berchtold had only recently been trying to set the Powers in motion once more for a common policy in Macedonia, and now they hastily entered into communication, under the lead of France, to devise some formula which would satisfy the Balkan League without either creating differences between themselves or making concessions too difficult for Turkey. The Porte, tardily recognising the necessity of doing something, made it known that it was prepared to give effect to the abortive "Law of the Vilayets " drawn up in I880; and it was arranged by the Powers that a Joint Note should be presented to Turkey, inviting the immediate discussion of reforms, coupled with the intimation that no breach of the territorial integrity of the Ottoman Empire was proposed. At the same time it was left to Austria and Russia jointly, on behalf of Europe, to urge patience on the Balkan League by assurances that reforms would be instituted. The Balkan Allies, however, wanted more than that. They stipulated, not only that the Powers should guarantee Macedonian autonomy, but that they themselves should be included with the Powers as its administrators; and though on October Ioth the Collective Note was duly presented to Turkey, the situation 
had then passed beyond the power of diplomacy to control the march of events. On October Sth Montenegro declared war and invaded Albania; on the $13^{\text {th Greece, Bulga- }}$ ria and Servia presented their ultimatum; and by the 17 th a formal state of war existed between the Allies and Turkey. (For the events of the war, see below).

At the outset it was the declared object of the Powers to co-operate in localising the war, themselves remaining neutral, and to keep its results, whatever they might be, from embroiling the rest of Europe. With this end in view they agreed to notify the belligerents that the territorial status quo would not be allowed to be altered. But the unexpectedly rapid and overwhelming success of the Allies, and the complete collapse of the Turkish arms, upset all the preliminary formulas. By the end of October it was clear that the old maps of Eastern Europe might be rolled up, and that "Turkey in Europe" had ceased to exist. It was no longer a question of maintaining the status quo. That was gone for ever so far as Turkey was concerned. The "Eastern Question" (see E. B. viii, 83 I et seq.) had entered an entirely new phase, with the proof that Bulgaria and the allies were in a position, by their own strong hand, to make "the Balkan States for the Balkan peoples "the principle of a territorial readjustment. The problem now was hew the old ambitions and rival sympathies of Austria and Russia in that part of the world should be reconciled with the new situation. Speaking at the Guildhall, London, on November gth, Mr. Asquith gave public expression to the necessity of recognising the logic of the stricken field, when he said that " on one thing I believe the general opinion of Europe to be unanimous - that the victors are not to be robbed of the fruits which have cost them so dear;" and in reference to alarming reports of growing tension bet ween Austria-Hungary and Servia concerning the latter's declared policy of extending her territory to the Adriatic, he emphatically deprecated the raising and pressing at this stage of isolated questions which would probably assume a more tractable aspect when the time came for a general settlement in which Europe as a whole must have a voice.

Mr. Asquith's speech was made at an opportune moment. Just previously (Oct. 3oth) a proposal by the French Premier, M. Poincaré, that all the Powers should make a declaration of "disinterestedness," in the territorial readjustment resulting from the war, had done harm rather than good. Austria was not prepared to be other than very much "interested" in the matter, and was irritated at the suggestion that she should subscribe to such a declaration. But Mr. Asquith's "wait and see" formula-putting into other words for the policy of Europe his favourite advice on difficult points of English domestic politics-had a soothing influence and was generally approved.

Everything now depended however on a speedy conclusion to the actual fighting. The Bulgarians had driven Nazim Pasha's main army back to the Chatalja lines and were threatening to march on Constantinople itself. An appeal was made by Turkey to the Powers to mediate, but to no purpose; and on November I 2 th the Porte applied directly to the Allies for an armistice, as the Powers advised. On the I gth the terms of the Allies were notified, plenipotentiaries being nominated by them and invited from Turkey in order to discuss conditions of peace. The Allies demanded the surrender of all Turkish positions still holding out in Europe, including the Chatalja lines, as well as Adrianople, Scutari and Yanina, only Constantinople and a strip of adjacent territory being left to Turkey. On the 2 ist the Porte rejected these terms, bitterly complaining that Europe, which had stepped in to save Greece in 1897 when Turkey was the victor, would do nothing now for Turkey when the position was reversed. Nazim Pasha was ordered to continue fighting till "reasonable and moderate conditions" were proposad. At the same time, however, he and Izzet Pasha, Osman Nizami Pasha and Shadan Bzy, were appointed Turkish plenipotentiaries to carry on furt her negotiations for an armistice, Dr. Daneff, General Savoff and General Fitcheff being nominated as Bulgarian delegates.

The possibility of European complications at this juncture acted as an encouragement to Turkey to hold out. Servia, whose arms had been so conspicuously successful in the west-central area, was straining the patience of Austria almost to breaking-point by aggressively announcing her determination to incorporate the whole of northern Albania, including a good deal more of the Adriatic coast than the Dual Monarchy was 
prepared to see in her hands. On November 23 rd M. Pashitch, the Servian Premier, issued a statement to the Press, of which the crucial portion was as follows:

"Servian arms have conquered far more territory than Servia intends to retain, but Servian policy has established a minimum of territorial expansion which does no more than cover her conationals and her national necessities. For this minimum Servia is prepared to make every sacrifice, since not to do so would be to be false to her national duty. No Servian statesman or Government dare betray the future welfare of the country by considering for a moment even the abandonment of this minimum. Servia's minimum requisite to her national development is economic independence, save, possibly, in so far as regards a Customs union with her allies and a free and adequate passage to the Adriatic Sea on the Adriatic coast. It is essential that Servia should possess about 50 kilometres from Alessio to Durazzo. This coastline would be joined to what was formerly Old Servia approximately by the territory between a line from Durazzo to Ochrida Lake in the south and one from Alessio to Djakova in the north."

So flagrant a defiance of Austria's susceptibilities made European diplomacy in the interests of non-intervention and peace a matter of the greatest difficulty. Moreover Austrian public opinion was stirred up during November by reports of Servian ill-treatment of the Austrian consul at Prisrend, Herr Prochaska; for some time his whereabouts was not known, and it was even suggested that he had been killed. Eventually he was found to be unharmed, and the truth appears to be that he had himself acted with great indiscretion. By the middle of December the Prochaska affair had ceased to trouble, but so long as the worst of the tension lasted between Austria and Servia over the Albanian question it was used by the Austrian Press Bureau as a method of exciting antiServian feeling. The consequence was that at the end of November Austria made open preparations for emergencies by establishing a military censorship and taking other preliminary steps for mobilisation; and Russia was forced, for this reason, to strengthen her forces at the same time, since the Austrian mobilisation was clearly directed against the possibility of Russia feeling bound to give effect to her sympathies with Servia.

The Albanian question was in any case certain to be, for some time to come, the least "tractable" of all the problems in the new territorial settlement; but the advance of such extreme Servian pretensions at this stage was discountenanced even by those Powers who were prepared to see a considerable extension of Servian territory, including a sufficient access, for commercial purposes, to the Adriatic. In view of inevitable later developments it should be noticed that, apart altogether from considerations of political expediency, the full Servian demand as put forward by M. Pashitch, and justified by him on ethnological and historical grounds, might well appear an exaggerated one to an impartial student of the international question. According to M. Pashitch " about Io per cent of the I 50,000 inhabitants " of the territory claimed were Servian; "more than half the Albanians are Christians; observers such as Hahn and Baldacci admit that the Albanians in the district" (i.e. the northern half) "are of ancient Servian origin," and so forth. This is not borne out by the article on Albania in the Encyclopaedia Britannica (i, 48 I et seq.), which is perhaps the most authoritative independent account available, from first-hand knowledge, of the country and its inhabitants. Moreover it is in direct conflict with the careful analysis of the ethnological position in Albania given in the London Times of November 25 th; writing from Constantinople on November I 2 th (before M. Pashitch published his manifesto), the Times correspondent gave the following facts with regard to the territory in question.

"In the Vilayet of Skutari there is one Slav village-that of Vraka, near Skutari. Gusinje is inhabited by a majority of Albanians. The halance of its population is composed of Mahommedan Slavs. In the Novi Bazar region, though the Kazas (counties) of Akova (Bielopolyé) and Kolashin are mainly Albanian, the majority of the population is Christian Slav with a fair proportion of "Bosniaks" (Moslem Serbs). Leaving this important tongue of land, we come to Ipek. In the entire Kaza (county) of Ipek there are, according to the best ethnological map of the district-the work of neither Serb nor Albanian, Austrian, or Turk -42 villages inhabited exclusively by Serbs, 123 villages inhabited by Albanians, Moslem and Catholic, 44 "mixed" villages inhabited by Moslem Albanians, Catholic Albanians, and Serbs, and the "mixed" town of Ipek. Allowing for the proportion of Serbs and Albanians in the "mixed" villages and in Ipek as being equal, and assuming, as do Turkish census reports, that a house represents five souls, one finds that the inhabitants of 
the 13,5I I houses of Ipek Kaza at the beginning of the 20th century were 46,or5 Moslem and Catholic Albanians, 21,390 Serbs, and 150 Gipsies. These results hardly justify Slav ethnological claims to Ipek, the more so as the balance has swung further against the Serbs in the last ten years. In Djakova there are not 5 per cent of Serbs. In Rozhaj Kaza, north of Ipek, the Albanians have a four to one majority. Prisrend was once the seat of Servian kings. But to-day, according to the best available information, four-fifths of the population of Prisrend Kaza are Albanians. Even further east the Albanians are in a majority. There are less than 150 Serb houses in the Kaza of Katchanik; if Mitrovitza is mainly Servia Vuchitrn is Arnaut, and Albanians form the majority of the population of the Prishtina and Ghilan districts. In all Kossovo north of the Shar range, omitting the Kaza of Katchanik but including the Sanjak of Novi Bazar, there were in the first years of the 2oth century at least 300,000 Moslem and Catholic Albanians, against 120,000 Christian and perhaps 30;000 Moslem Serbs. These figures scarcely support the contention of Goptchevitch and other writers, ever ready to create "facts". in support of their propaganda that Old Servia is predominantly Slav. Historical claims founded on temporary occupation or on episodes such as the conquests of Stephan Dushan are not too strong. If the Serbs once overran all Albania, the Turks overran Servia and Hungary. As for the theory that the majority of the Moslems of Old Servia are in reality "Albanized and Islamized Serbs," the fact that this present majority of the population of Old Servia differs in language and religion from the Servian minority is surely a sufficient answer.":

Albanian " nationalism," in fact, is a question which really provides difficulties of its own for the future government of this part of the Balkan area. On November 28th a further complication was introduced by a movement started by the Albanian leader, Ismail Kemal Bey, under whom as "president of the provisional government " the independence of Albania was proclaimed by a "national assembly" at Valona. This step, combined with the determination of the Powers not to allow the extreme Servian demand to act as an apple of discord, resulted in relaxing the tension as regards Austria during December; and meanwhile events were proceeding more satisfactorily in the direction of peace negotiations between the Balkan Allies and Turkey.

On November 20th discussion began at Chatalja over the terms of an armistice, and on December $3 \mathrm{rd}$ an agreement was signed for a suspension of hostilities and for peace negotiations to begin in London on December I 3 th, the belligerents meanwhile simply remaining in the positions already occupied. The armistice was signed by Bulgaria, Servia, and Montenegro, but not by Greece, though Greece proposed to take part in the peace negotiations; so that war still went on between Greece and Turkey. At the same time there was a marked improvement in the relations of the Great Porers, owing largely to a proposal made by Sir Edward Grey on November 27 th that their representatives in one of the capitals should hold informal and non-committal consultations for the purpose of mutual agreement on the points on which Europe must make her voice heard in the final settlement. On December IIth Sir E. Grey was able to announce that all the P'owers had agreed, and that their ambassadors in London would act.

In spite of the danger to European peace which still existed in the fact that Austria, and therefore Russia, kept her military preparations on a war footing, the situation during December was cleared a good deal by explicit declarations of policy in Germany, France and Russia. On December and the German. Chancellor, speaking in the Reichstag, said that the exchange of views between the Powers was having "favourable results, promising a satisfactory settlement." If, as he hoped would not be the case, insoluble dificulties appeared, it would, of course, be for the Powers directly concerned to give effect to their claims. "This applies to our allies. If, contrary to all expectations, they are attacked and find their existence menaced, we, in lovalty to our duty, should have to take our stand firm and determined at their side." This declaration of solidarity as between the Powers of the Triple Alliance was coupled with a notalle statement by the German Foreign Minister, Herr von Kiderlen-Waechter (his last important utterance before his sudden death within a month), as to German relations with England and therefore with the Triple Entente. During the recent crisis, he sa.d, German relations with England had been those of peculiar confidence, "and have rot only provided a happy intimacy but have done good service to the promotion of agreement;" and he expressed his "conficlent expectation that this will continue." On

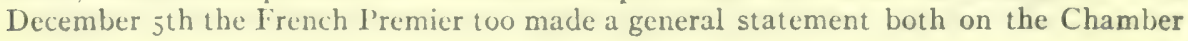


and on the Senate. The aims of France, he said, would be "(I) continuity of her foreign policy, and consequently attentive and persistent exercise of her alliances and friendship, $(z)$ sincere and constant endeavours to secure the agreement of Europe and peace, (3) a firm and calm resolve to make French rights respected and to maintain the national dignity." Finally on December 18 th the Russian Premier, M. Kokovtsoff, in the Duma, said that while Russia could not remain indifferent to the efforts of the Slav peoples to obtain better conditions, she had no selfish designs; " faithful to our alliances and understandings; and sure of the support of our friends, we can see no use in setting up groups of Powers one against the other." . These declarations showed that, while the grouping of the Powers remained firm, it was modified by a recognition that there were common European interests above the group interests. The announcement on December 8th that the Triple Alliance, which would nominally expire in May I914, had been renewed for another seven years, was obviously made in the interests of Austria. But having made her demonstration, Austria was now taking the situation more calmly, and relying on her power to assert herself, with her allies, only if necessity should arise. Count Berchtold's own policy was a peaceful one, but his task was complicated by the existence of a domestic party more inclined to wave the sword; and it was rather a matter of domestic interest than as bearing on European diplomacy that on December gth the Austro-Hungarian War Minister (Gen. von Auffenburg) and Chief of the Staff (Gen. von Schemua) resigned, and were succeeded: by Gen: Krobatkin and Gen. Konrad von Hötzendorf. What was of more importance, for international reasons, was the heavy military expenditure in Austria, which was straining her finances and upsetting the money markets:

London was now the scene both of the meeting of the Peace Delegates, and of the conferences between the ambassadors of the Powers. By December 13 th the plenipotentiaries had arrived, and their first meeting was held on December I6th. Bulgaria was represented by Dr. Daneff, M. Majaroff, and Gen. Paprikoff, Greece by M. Venezelos; M. Skoulidis, M, Gennadius, and Dr. Streit; Servia by M. Novakovich, M. Nikolich, and Dr. Vesnich; Montenegro by M. Mioutchkovich, M. Popovich, and Count Voinovich; Turkey by Mustafa Reshid Pasha, Gen. Salih Pasha, and Osman Nizami Pasha. Little progress was made at the meetings held on December 17 th, Igth and 2 Ist, owing first to the objection of Turkey to the Greeks being included, which was eventually waived, and then to Turkey asking for the revictualling of Adrianople, which was flatly refused. Meanwhile the ambassadors had begun to meet on December $I_{7}$ th, and at their third meeting on December 2oth they came to an important agreement as regards Albania, which was promptly announced as follows: "The ambassadors have recommended to their governments, and the latter have accepted, the principle of Albanian autonomy, together with a provision guaranteeing to Servia commercial access to the Adriatic. The six governments have agreed in principle on these two points."

On the 23 d the Balkan allies presented their demands to the Turkish delegates, and on the 28 th Turkey made her first counter-proposals, which were promptly rejected, and followed these on January ist (after an abortive session on Dec. 30 th) by others. The Allies demanded the surrender by Turkey of all territory west of a line extending from Rodosto to Cape Malatra, $5 \mathrm{~m}$. S. of Midia, and of all the islands of the Aegean, including Crete, with the exception of certain islands near the mouth of the Dardanelles to be specified by the Powers, but so as to leave the peninsula of Gallipoli to Turkey; they were content to leave the Powers to decide as to the administration of Albania. The Turkish proposals, as defined on January rst, conceded the surrender of all occupied territory west of the vilayet of Adrianople, but insisted on the retention of the vilayet of Adrianople subject to a rectification of frontier with Bulgaria, and of the Aegean Islands, while leaving the protecting powers to decide as to Crete. In answer to these counterproposals the Allies "took note" of Turkey's agreement to cede the territories west of Adrianople, with the proviso that this must include territory whether occupied or not yet completely occupied; the rest they described as " unacceptable." On January 3 rd Reshid Pasha went a little further, and was prepared to cede even the south-western 
district of the vilayet of Adrianople; but the patience of the Allies was now nearly exhausted. They gave the Turkish delegates till Monday, January 6 th, to decide whether Turkey would (I) relinquish her sovereignty over Crete, (2) cede the Aegean Islands, and (3) agree to a frontier leaving the town of Adrianople to the Allies; otherwise, they declared, the negotiations would be broken off. Reshid Pasha's reply was at first promised for the following day, and was then postponed till the 6th, but it was believed that he had received instructions from Constantinople to refuse to give way on the question of Adrianople. This proved to be the case. On the 6th Reshid Pasha read out a statement, which, though conciliatory in tone, insisted that Turkey could not add Adrianople to her other concessions. The Balkan delegates then declared the negotiations "suspended."

Consultations followed between the Great Powers, and on Jan. I 7 a collective note was presented to Turkey advising the Porte to give way as regards Adrianople and to leave the Powers to arrange as to the Aegean Islands. The Turkish Cabinet on Jar. 22 obtained the approval of the National Council for this course, but next day the Young Turks again asserted themselves in Constantinople and upset the government. A crowd collected in the streets, and Enver Bey at their head demanded the resignation of the Grand Vizier, which immediately took place. Kiamil Pasha was succeeded by Mahmud Shevket Pasha, and once more the demands of the Balkan Allies were refused. At the end of January the armistice was formally declared to be at an end.

\section{The Independence of Mongolia}

The setting up of a Republic in China introduces a new international problem in that part of the world; and it remains to be seen how far the balance of power in Asia may be affected by results under the new régime. The Chinese revolution provided an opportunity for a formal assertion of independence on the part of the northern or Outer section of Mongolia, inhabited by the Kalka tribes, whose capital is Urga, and whose native ruler is the Hutukhta Lama, known as Bogdo Gegen (Living God). It was to Urga that in 1904, when the British expedition went into Tibet, the Dalai Lama went for refuge for about two years; one of the chief centres of Lamaistic Buddhism, it is the object of yearly pilgrimages, especially by the Russian Buriats; and Russian commercial interests are also strongly represented, in view of its proximity to the frontier town of Kiackta. Under Mancbu rule, Outer Mongolia was subject to the authority of a resident Chinese $A m b a n$, but the immediate result of the fall of Manchu power in China and the setting up of a Chinese Republic was a revolution at Urga, and the repudiation of Chinese suzerainty. The four Khans of Tushetu, Setzen, Sairnoyan and Jassaktu (see E. B. xv, 642d)-Mongol Princes reputed to be descendants of Jenghiz Khan-combined under the Hutukhta Lama to set up an independent government; and the safety of the Chinese officials in Urga, and the protection of the Chinese bank, were only secured by the presence of the Russian Cossack troops who formed a permanent garrison in connection with the Russian consulate.

It is obvious that this breaking-away of Mongolia from China simply means an accretion to the Asiatic territory subject to Russian influence. In effect it is a distinct step in the partition of the Chinese Empire, and marks a natural development in the slow opening of the unknown East to modern ways. It is worth noting that the Times correspondent (Aug. 8, I 1 12), who gave some details of the state of affairs at Urga, says that "while expressing the most friendly sentiments towards Russia, the Mongols appear to view with suspicion all advances from America. This suspicion is based on the alleged preference shown in the past by Americans to Chinese and Manchus in the matter of favours which were refused to Mongolian Princes, such as the facilitating of the education of their children in America. The Americans are considered to be too friendly with the Chinese to be real friends of the Mongols." In fact Russia, like Japan, has a civilising mission in this part of Asia, in which, both for geographical and for racial reasons, neither Britain nor America can play anything like so effective a part; and it is important to recognise that the closer accord between Russia and Japan, who in 1912 
agreed in defining their respective spheres of interest in Manchuria and Mongolia, makes any recovery of Chinese authority improbable. The Chinese Government was warned in September r9r 2 that Russia would support the Mongols if an expedition were sent against them.

\section{The Situation in Tibet.}

Similarly, in Tibet, the attempt made after the British expedition to Lhassa in I904 to maintain a recognition of Chinese authority has broken down, in direct consequence of the new situation in China itself. British intervention in I906 was prompted by apprehensions of Russian intrigue, in the person of the Buriat Dorjieff, whose ascendancy in Lhassa at that time was inimical to British interests and to the relations between Tibet and India. The result of the expedition, and of the Anglo-Russian Convention in I907, was to remove the difficulties so far as England and Russia were concerned, but the internal situation in Tibet developed on lines which had not been foreseen, in consequence of the reestablishment of a Chinese suzerainty which previously had become merely nominal. ${ }^{1}$ Chinese troops were sent to Lhassa, the Dalai Lama fled to India and was formally deposed by the Chinese Government, and a direct exercise of Chinese suzerainty was instituted; but when the Chinese revolution occurred, the garrison at Lhassa mutinied and committed gross excesses, and retaliation by the Tibetans resulted in a state of turmoil, in which Chinese authority was destroyed. The Dalai Lama returned to Lhassa and reasserted himself in practical independence.

A new situation was thus created in the autumn of I9I 2 , in which the recognition of Chinese suzerainty, contained in the Anglo-Chinese Convention of 1890 , the AngloChinese Convention of 1906, and the Anglo-Russian Convention of 1907, ceased to be operative; and it became clear that the arrangements made on behalf of the Indian Government for the protection of British interests in Tibet would require reconsideration. It was known moreover that Dorjieff had once more made his appearance in Lhassa. The immediate prospect was thus unsatisfactory in various ways. What is certain is that the conditions are entirely adverse to another restoration of Chinese authority. Tibet has become independent of the new Chinese régime, and, in so far as British relations depended on the recognition of Chinese control, this aspect of its international status disappears. The Anglo-Russian Convention of 1907 definitely admitted " the fact that Great Britain, by reason of her geographical position, has a special interest in the maintenance of the status quo in the external relations of Tibet;" and the Treaty of Lhassa, besides dealing with British commercial rights, provided that, without British consent, Tibet might not cede or lease any territory, admit representatives or agents of any foreign power, give mining or other concessions to foreigners, or pledge her revenues. It may be expected that British relations with Tibet will in future be readjusted so as to assert British influence there irrespectively of the obsolete international theory that it is part of the Chinese Empire. British policy in this matter was defined in a Memorandum presented on August I 7, I9 2 to the Chinese Government, in which it was intimated that Great Britain would make it a condition of her recognition of the Republic that China should leave the Tibetan situation to develop on its own lines and should cease to regard Tibet as a Chinese province.

\section{The Panama Canal Act Controversy}

On August 24, I9 2 President Taft signed the Panama Canal Act, which had been passed by the American Congress, and it became law in spite of a protest from Great Britain which has led to a controversy of considerable international interest.

The Act provided in detail for the general operation of the Canal and the regulation of commerce passing through it, but the point in question was concerned with the tolls. The President was empowered, within his discretion, to impose tolls not exceeding $\$$ I.25 per registered ton on all vessels using the canal except vessels engaged in the American coastwise trade (restricted by law already to American vessels) on which no tolls at all were to be levied. The British contention, more or less informally con-

${ }^{1}$ See E. B. xxvi, 928. 
veyed to the American Government, while the Act was still under discussion, by way of a warning that a formal protest would follow, ${ }^{1}$ was that this was a violation of Article III of the Hay-Pauncefote Treaty of Igor, which said that "the canal shall be free and open to all vessels. . . . so that there shall be no discrimination against any nation in respect of the conditions and charges of traffic." It was also intimated on behalf of Great Britain that if the Act was passed, in spite of the protest, she would appeal for arbitration as to its legality to the Hague Tribunal under the Treaty of IgII. The result of this protest was a special message to Congress by President Taft on August Ioth, before the bill was finally passed, in which he argued that the exemption of American "coastwise vessels" from tolls was not a violation of the treaty. (It may be noted that on December 2I, I9I I, he had sent an earlier message, dealing with the importance of leaving it to the President, within certain limits, to fix the tolls, and had said, without referring to the Hay-Pauncefote Treaty, that he was "confident that the United States has the power to relieve from the payment of tolls any part of our shipping that Congress deems wise.") As, however, "distinguished lawyers of the House and Senate" and also Great Britain differed from this construction, he recommended Congress to pass a resolution, or add a clause to the bill, distinctly saying that nothing in it should be " deemed to repeal any provision of the Hay-Pauncefote Treaty or to affect the judicial construction thereof," and giving a right of action against the United States in the District Courts, with appeal to the Supreme Court, to any foreigner who considered the provisions of the Treaty to be violated to his detriment. This suggestion, however, was not acted on, and, so far as Great Britain was concerned, was regarded as obviously unsatisfactory. A domestic court of law was not the place for arguing the violation of a treaty right. According to President Taft's contention, and the purport of the new Panama Canal Act, the HayPauncefote Treaty was not being violated at all, and the proper place for having that question decided, according to the Arbitration Treaty of ror r, was the Hague Tribunal.

In the Press of both countries during August and September President Taft's attitude in this matter was sharply criticized, more hotly indeed in the United States than in England owing to the approaching Presidential Election. A considerable body of American opinion regarded the passing of the Act, without further consideration for the British protest, as a reproach to the national honour, and President Taft was bitterly accused of making the Lnited States appear guilty of a breach of faith. This was rather unjust, because President Taft made it quite clear that he did not consider the exemption of coastwise shipping from tolls to be a violation of the Hay-Pauncefote Treaty; on the other hand it was difficult to understand how, on the wording of the Treaty and the Act, he could arrive at such a conclusion, or how, if a difference of opinion existed, he could resist the British contention that a decision should be given by the Hague Tribunal, as provided in the Arbitration Treaty of which President Taft. himself had been a notable champion. In England this naturally was the view gener.ally taken. In the United States, on the other hand, there had always been among; the public at large a tendency to regard both the Clayton-Bulwer Treaty and its suc. cessor the Hay-l'auncefote Treaty as really inapplicable to the conditions under which the Ianama Canal was actually being constructed; the United States was paying the whole cost, and the rest of the world was contributing nothing. - what right could Great. Britain have to interfere? The fact was that, while the legal right was disputed by so eminent a lawyer as President Taft, the moral right in other respects was clearly on the American side, and it seemed absurd to Americans, on general principles, tha: they should be prevented from giving a preference to American shipping if they wanted to

So far as concerns American and British shipping, the substantial facts of the economic and commercial situation might well seem to an impartial critic to make the point at issue comparatively unimportant, while affording a very natural explanation

1 The formaI protest was contained in Sir E. Grey's despatch of Nov. I4, delivered at Washington on Dec. 9. 
of American anxiety to obtain some advantage from the canal in return for the enormous cost of constructing it single-handed. For American shipping, in fact, carries only a small proportion of American trade, and there is no immediate prospect of serious competition with British shipping in this respect. According to a report issued by the U.S. Commissioners of Navigation, ${ }^{1}$ the percentage of United States exports and imports carried in American vessels fell from $75.2 \%$ in I 850 (in $1870,35.6 \%$ ) to $8.7 \%$ in 1910; of the total American sea-borne trade in 1910 , valued at 5,700 million dollars, more than nine-tenths was carried in foreign vessels.

Apart altogether from the effect of the Civil War, the character of American shipping has changed in later years, the shipping engaged in the foreign trade having steadily diminished from 1,518 thousand tons in 1865 to 782 thousand tons in 1910 ; the shipping engaged in the coasting trade has indeed greatly increased, especially since 1895 ,from 3,38 $\mathrm{I}$ thousand tons in $\mathrm{I} 865$ (3,728 thousand tons in 1895$)$ to 6,668 thousand tons in roro,- - but this, of course, is due to the coasting trade being restricted to American vessels. The prime factor in the decline of American merchant shipping and shipbuilding, so far as general foreign trade is concerned,-and this has been shown conclusively by the American Merchant Marine Commission,-is the fact that wages in the shipbuilding industry are about twice as much in the United States as in Great Britain, and freights cannot be earned to compensate for the higher cost of American ships. The advocacy of protection and subsidies for American shipping, which is common to all political parties in the United States, is due to a natural and patriotic revolt against what nevertheless is the fact, namely that the carriage of American seaborne trade (other than the coasting trade) is, to the extent of nine-tenths, in the hands of Great Britain and Germany in the Atlantic together with Japan in the Pacific, simply because wages in those countries are so much lower. How this can be altered so as to recover American trade for American shipping is a very large question, which will not be solved to-day or to-morrow. Undoubtedly there has been a sanguine expectation that, particularly as regards the trade between North and South America, the making of the Panama Canal would enable some advantage to be gained for American shipping at the expense of foreign shipping, and this is at the root of the controversy as to the rights of the American Government under the Hay-Pauncefote Treaty. But whatever may be the rights of that matter, it is well to bear in mind that, on the general question of the comparative extent of national shipping in international trade, it is really not of much importance. For the American Government to subsidise American vessels engaged in the coasting trade by giving them an advantage in the passage of the Panama Canal-whether this can or cannot be done justly and honourably under the terms of the Treaty - is of very minor consequence to non-American shipping because in any case it is excluded by American law from the coasting trade altogether; and no subsidy of this kind, consistently with what is economically possible for the working of the finances of the Canal at all, can be enough by itself to enable American shipping to compete in neutral markets with non-American. So far as British shipping is concerned the conditions under which it does so much of the American carrying trade cannot be appreciably affected, at any rate for some time; and any new conditions arising in the distant future must be treated according to circumstances.

Whether it is wise of the United States to raise such questions at all, which challenge international friction and also foreign action in defence of other national economic interests, is, of course, another matter altogether. The making of the Panama Canal was for the United States primarily a strategic undertaking, impelled by the importance of being able to join up the Atlantic and Pacific Oceans more readily than by sending ships round the Horn as was necessary in the Spanish-American War. As a factor in international commerce the economic value of the Canal cannot yet be safely estimated. Geographically, as compared with land transport across Central America, it has not the same trade advantage as the Suez Canal, and it has been far more costly to make. Owing to its effect on shortening the routes for sea-borne commerce, as between certain

${ }^{1}$ See an article by J. Ellis Barker in the Nineteenth Century and After, for October I9I2. 
countries, it is, no doubt, destined to play a considerable part in local industrial development; and in this direction Great Britain appears to stand to lose in comparison with the Eastern American States and also with Japan. But the resulting increase in the carrying trade itself will go where the shipping can be most economically produced and freights most economically earned.

\section{EngLand's Withdrawal from the Sugar Convention}

Some surprise was expressed in the British Parliament at the suddenness with which, at the beginning of August I912, Mr. Asquith's Government appeared to have arrived at the decision to give notice (as had to be done, if at all, before Sept. rst) that Great Britain would withdraw from the Brussels Sugar Convention. But Mr. Asquith was quite entitled to reply that anybody who had followed the course of events since the Convention of 1902 was renewed in 1907 for a further five years had no valid reason for surprise at notice of withdrawal being given. The declaration in Parliament that Great Britain would withdraw was indeed somewhat mysteriously abrupt, coming as it did at the fag-end of the summer just when Parliament was about to adjourn; and it was natural for the Opposition to suspect that the Free-Trade party in power had an eye on influencing the impending by-election in South-west Manchester, though, if this was so, the result was a signal failure. But otherwise the action of the Government was in accord, rightly or wrongly, with their avowed policy since Igo8 (see E. B. xxvi, 45-47). In the autumn of I9I I Sir Edward Grey had explicitly declared (Dec. 7th) that unless Russia was allowed to export in the ensuing year at least 500,000 tons of sugar instead of the 200,000 to which she was restricted by the arrangement of 1907 , Great Britain would no longer be a party to the Convention; and owing to the opposition to this proposal, mainly from Germany, this threat only had the effect of getting the signatory Powers to agree to increasing the limit of the Russian export by 50,000 tons a year. In such circumstances the British decision was inevitable, apart altogether from the fact that the Liberal party and its leaders had always been opposed in principle to the Convention and had for several years been seeking an excuse to denounce it.

What is of more importance is to note the incontrovertible success which had followed the adoption of the Brussels Convention in 1902 , and which had made it possible for the British Government to denounce it in 1912 without much fear of a renewal of the conditions which had originally brought it into being. The object of the Convention had been to abolish the bounty-system by which the production of beet-sugar in Continental Europe was bolstered up, and for practical purposes the bounties had now been abolished and were not likely to be renewed, because France, Germany, Austria-Hungary, Belgium and Holland had decided to maintain the Convention, in spite of Great Britain's withdrawal (which was followed by that of Italy), for another five years. The security against unfair competition provided by the machinery of the Convention, which had already given new life to cane-sugar manufacture in the West Indies and elsewhere, was therefore in a fair way to be maintained without the necessity of British adhesion. It was to save the West Indies that Mr. Chamberlain had taken the matter up in 1806 . with the result that the Brussels ('onference of 1898 was convened, leading eventually to the agreement of 1002 ; and during these years, owing mainly to its operation, the cconomic situation had entirely altered. In the discussion in the House of Commons on August 8 th it was remarkable that the official representatives of a Liberal Government gave no countenance to the more extreme Free Trade view, still asserted by a few Radical members of Parliament, that the Convention had done no good and had even been detrimental to British interests. On the contrary, Mr. Acland, the Under-Secretary for Foreign Affairs, explicitly denied that the operation of the Continental bounty. system, by which the British consumer for a time obtained sugar at an artificially chear price, while the continental consumer paid an artificially dear ene, was economically sound or advantageous, even from the British point of view. He justified the action o: the Government on the ground that the object sought had been attained, and that there would be no going back, but that failure to realise expectations in this respect would not 
prejudice any further measures. And on the point that injury would be done to the nascent industry of beet-cultivation in England both he and the Prime Minister insisted that the return to "economic freedom " would untie the hands of the Government and enable the Treasury to give it financial assistance.

So far as the production of cane-sugar in India is concerned, it will be remembered that in 1899 countervailing duties on bounty-fed imports were actually imposed by the Indian Government; and, if necessary, the same course would presumably be adopted again. In the West Indies, apart altogether from the improbability of the renewal of the Continental bounty-system, the whole situation had materially altered since the Brussels Convention had come into existence. Though the efforts successfully directed towards establishing the cultivation of other agricultural products-cotton, cocoa, fruit, etc.-in the West Indies could never do away with the fact that the growing of canesugar is their staple industry, yet they had done much to add to the resources of the islands. But, what was of more importance, the market for West Indian sugar had been extended and seemed likely to become more profitable in the United States, and, under the new system of Canadian preference, exports to Canada were being stimulated. The possibility therefore that the British withdrawal from the Convention might injure West Indian prospects in the British home market had no longer the same terrors for West Indian sugar-producers. They had come to look to the American and Canadian market, and West Indian imports to Great Britain had consequently diminished even while the Brussels Convention protected them there,-a point which English opponents of the Convention entirely misinterpreted as involving its failure to benefit the West Indies at all. What the Convention did to promote British home interests, so far as the West Indies were concerned, consisted primarily in restoring confidence and a sense of security to the cane-sugar industry, so that British capital again flowed into it, and orders were regularly given, to a considerable amount, for machinery from British manufacturers. The principal danger to be anticipated from Great.Britain's withdrawal would be the renewal of that want of confidence in the security of the industry which had done so much harm in the years preceding 1.902 , and a corresponding loss to home traders and manufacturers; but on the whole such a result is now improbable. At the same time, from a British Imperial point of view, it was not a comfortable reffection that the economic prosperity of the British West Indies was being secured by reliance on Canada and the United States, with the mother-country standing aloof and introducing what; on the face of it, was an element of insecurity.

\section{The Titanic Disaster}

No single event in IgI 2 could compare, in the intensity of its universal appeal to human emotion, with the awful disaster to the "Titanic." At 2.20 A.M. on April I 5th, that great White Star liner, the largest afloat, on her maiden voyage, went to the bottom of the Atlantic in lat. $4 \mathrm{I}^{\circ} 46^{\prime \prime} \mathrm{N}$., long. $50^{\circ} \mathrm{I}^{\prime \prime} \mathrm{W}$.; about $2 \frac{3}{4}$ hours after striking at full speed on an iceberg, with a loss of 1,513 souls out of 2,224 on board. ${ }^{1}$ It had been supposed that such a vessel was unsinkable, and the tragedy has raised numerous questions as to methods of ship construction, and additional provision of life-saving equipment, reference to which is made elsewhere in the YEAR-BOok (under "Ships and Shipbuilding "). Whether much good however can be expected in this direction simply from increased provision of boats appears highly doubtful. The "Titanic" had nominally boat accommodation for double the number saved, and the 20 boats launched were meant to hold $\mathrm{r}, \mathrm{I}_{7} 8$ persons instead of the $65_{2}$ they actually contained when they left the ship; moreover the disaster occurred under exceptional conditions for getting people safely off, in the way of smooth water and fine weather. The most salutary lessons would seem to lie in the following directions: first, improved design and construction so as to provide a really unsinkable ship; secondly, greater precautions in navigation and lookout,- - for the "Titanic" was going at I 8 knots (according to Lord Mersey an " excessive speed"), though it was known that icebergs were exceptionally numerous on the

' The exact figures are doubtful, but those given are from Lord Mersey's report. 
course; thirdly, better and more regular organisation on ship-board, by boat-drill (there had been none on the "Titanic") and otherwise, for the emergency of having to abandon ship; and fourthly, a compulsory service of "wireless" on all liners, working day and night, - for it was one of the most lamentable incidents in the whole terrible story that the "Titanic's" "wireless" call for help, picked up all over the ocean and nobly responded to by the "Carpathia" (Capt. Rostron) seventy miles off, fell on deaf ears on the "Californian" only 8 or 10 miles away. "The full record of the disaster is contained in the reports of the inquiries held at once in America by a committee of Congress under Senator Smith, and later in London by a special commission presided over by Lord Mersey (report issued July 3oth). Painful and difficult though it may be to distribute blame in such a case, there can be little doubt that the loss of life- -8 I 7 passengers out of 1316 , and 696 out of a crew of 908 -was much greater than ought to have been possible. Captain E. J. Smith (b. I853), a highly experienced seaman who had been for 38 years in the service of the White Star Company and who now went down with his ship, seems to have been averse from taking steps at first which might cause a panic on board; otherwise there should have been time, if adequate means of organisation and of commanding discipline had existed, not only to get more people into the boats but to improvise rafts. In naval circles it is known that the opinion is strongly held that this should have been done, since the injuries received by the ship made it certain that she would sink in a given time. If this be so, it points to a weakness in the higher command, or the means provided for exercising it in the organisation of the crew on the "Titanic," for which no merely material equipment could compensate. It may be admitted that a natural expectation of security had been engendered, alike among the owners, officers and passengers of these magnificently appointed liners, which, until a crisis actually came, had made it almost unthinkable that it could come in that way; but the fact remains that the responsibility for the lives of passengers rests with those who control the ship. In this case it was not the inadequacy of the physical means of escape that accounts for the large proportion of the lost who remained on board; it was the inadequate organisation for purposes of using them, and inadequate information as to the necessity. Apart from that, both Great Britain and America could mingle sorrow and pride over many fine incidents of the tragedy, with its long death-roll of prominent people from both sides of the Atlantic. When it came to the sending away of the boats, the order was "women and children first." The figures of the 7 I I saved by the "Carpathia" (including about 60 who were picked up in the boats after the ship went down) speak for themselves:Women: Ist ciass, I 40 out of 144 ; 2nd class, 80 out of 93 ; 3 rd class, 76 out of 165 ; crew, 20 out of 23. Children: Ist class, 6 out of $6 ;$ 2nd class, 24 out of $24 ; 3$ rd class, 27 out of 79 : Men: 1 st class, 57 out of $175 ;$ 2nd class, 14 out of $168 ; 3$ rd class, 75 out of 462 ; crew, 192 out of 885 . Altogether the percentage of women saved was 74.35 , of children 52.29 , of men 20.27. The comparatively small proportion of 3 rd class passengers saved was shown to be purely accidental and not due to any preference being deliberately given to others; they were handicapped however by their quarters being remote from the boat-deck, and by so many of them being foreigners.

\section{General Booth}

The death of "General" Booth on August 20, I9 2, at the age of eighty-three; has removed a remarkable personality from the world. The founder of the Salvation Army had lived to see it grow from small revivalist beginnings in the 'sixties - the name itself being adopted and a definite system established in I 880 -and to pass through a period of contempt and hostility, till for some years before he died it had become a recognised institution, of widespread religious power and social efficiency. The "General "was

1 Apart from the "Californian's" "wireless" operator having gone to bed, however, Lorc Mersey was satisfied that if her captain had realised the situation properly she could have saved "many, if not all, of the lives that were lost;" for evidence showed that distress rocket: sent up on the "Titanic" were actually seen from the "Californian," though noaction wastaken in respense to them. The incredibility of such a disaster appears, in that case, to have paralysed the capacity for inference.

${ }^{2}$ See E. B. iv, 239, and xxiv, 100. 
a. leader whose strong will and personal magnetism were allied with an intense belief in his:mission to "save souls," of a type rare at any period in history, and unique-at any rate in its practical results - in these latter days. The fundamental fact in human nature that man is a religious animal, and that religion; hot and strong, appeals to factors in human life which are open to no other influences; has been illustrated once more by the success which attended the initiation of his missionary zeal and fervour. Superior people might scoff at what Huxley called a "corybantic " type of revivalist Christianity, but it caught hold of thousands from whose lives the very foundations of social refinement and intellectual culture were absent. In this respect indeed the Salvation Army was not original: what was original was the way in which "General "Booth gave organic form, under a quasi-military system, to revivalist methods which have always been emotionally effective, and the extent to which he brought its influence to bear on the most intractable of social problems, the moral and economic wreckage of the underworld of the modern community. Intense faith; profound and tireless sympathy; and a disinterested devotion superior to all criticism on the score of crudity of ideas and methads, could alone have won for "General "Booth the place he came to occupy in the social and religious: world towards the end of his life. In the early 'nineties he might have passed away simply as the fanatical hot-gospeller of an insignificant sect of streetcorner psalm-singers; it would have been inconceivable then that he should end his life as one for whom a place in Westminster Abbey. was thought appropriate, one of the autocrats of the religious world. Whatever may be the future of the vast organisation created under his leadership, such a history is sufficient testimony to the strength of character of the man who brought it into being, and the immensity of the opportunity for social service which he had the genius to grasp and set in motion. "General " Booth was primarily an evangelist, and the immense extension of the administrative work of the Salvation Army, involved in the sacial and economic enterprises connected with various aspects of the "Darkest England" scheme since I890, was only made possible, no doubt, by the devoted co-operation of others, within the Army and outside; but all of this depended on the disciplined obedience and passionate religious solidarity which issued from the evangelical fervour of which he was the fount and origin. In his successor, his son Mr. Bramwell Booth (b. 1856 ), nominated for that position in sealed orders by the founder as long ago as I880, a new "General " steps into his place, whose long executive experience as " Chief of the Staff." should augur well for the maintenance of the social activities of the Salvation Army throughout the world; and its characteristics simply as a religious organisation have long become fixed on lines which will naturally follow the inspiration given by their creators.

\section{LABOUR UNREST AND "SYNDICALISM"}

During $x 9 r o-12$, as may be seen from the historical accounts for individual countries in Part II of the YEAR-BOOK, the "Labour Unrest" has been a very conspicuous social feature in all the countries of Western civilisation, both in Europe and America. Generally speaking, the new symptom which has riveted public attention in the unrest of the wage-earning classes has been the rise of what is known as "Syndicalism," under the influence of which has become manifest a further stage of the evolution of ideas, and the evolution of organised action, in the assertion of the claims of Labour as opposed to Capital. In the readjustment of social-economic relations between operatives and employers, notably in Great Britain, America, France and Germany, Syndicalism is a new development, superimposed upon the older ideals and aims represented both in the general theory of Socialism and in the practical work of trade-unionism, whether of the earlier and more restricted industrial and friendly-society type or of the newer militant political type which is actively represented in the parliamentary Labour parties. For "Syndicalism" - which, as a term, is derived simply from the French word for tradeunion (syndicat) - comprises in itself both an extreme application of. Socialist theory and an extended application of the methods of militant trade-unionism. ${ }^{1}$

1 For detailed accounts of the rise and progress of the modern Labour movement and its ideas and organisation, see especially the articles in the $E$. $B$. on "Labour Legisla- 
The connection between Syndicalism and both Socialism and Trade-unionism may be seen at once from a summary of its three leading ideas: (I) Labour is the source of all wealth and therefore the only proper title to its enjoyment; (2) the workers in any great branch of industry ought to own the materials and machinery with which they work, and to control the administration; (3) the method of achieving this result is for trade-unions to take " direct action " by strikes, and particularly by "general " strikes.

But the distinguishing feature of Syndicalism, as a form of socialistic trade-unionism, is really in its interpretation and application of these three principles, each of which, no doubt, is part of the general theory either of orthodox Socialism or of ordinary tradeunionism; for the rise of Syndicalism is directly due to disappointment among the convinced Socialists of the operative class at the economic results hitherto attained either by trade-unionism, by the Co-operative movement, or by parliamentary action on the lines of state-socialism.

Starting with the proposition that labour is the only source of wealth, the syndicalist is in passionate revolt against society as organised. He regards it as essentially unjust that those who do what (in his view) is the hardest, most disagreeable, and most necessary work should receive individually a comparatively small proportion of the value of the product, while others, contributing either nothing in work, or doing what is comparatively pleasant and (as he thinks) easy, receive large salaries or amass enormous fortunes. And, in his view, the only remedy for this is for the operative class to insist on owning and controlling the materials and machinery of industry, and distributing the profits according to their own more enlightened estimate of the relative values of the various sorts of labour which have made the industry a remunerative one. He is thinking of his own particular sort of Labour, and not of the community as a whole, and this is the point at which he parts company with the ordinary Collectivist who advocates state or municipal ownership. The usual idea of modern democracy is not at all satisfactory from the syndicalist point of view, because the public as a whole includes not only "Labour" (i.e. manual labour) but the upper and middle classes as well,- -a host of people, in fact, who are regarded by him as only unproductive consumers, fattening on the real workers. The State, as such, he sees organising itself, even on democratic lines, in such a way as to keep Labour still in subjection to the propertied classes; and parliamentary action in consequence proceeds in a manner which makes things substantially no better for Labour than before. Having come to the conclusion that, on existing lines, the increased political representation of Labour in Parliament is to a large extent a sham and a humbug, the syndicalist falls back on the necessity of working directly for the rights of the operative class by means of the weapon to their hand in the trade-union organisation. This is the meaning of "direct action." It includes anything that will drive Capitalism out of the industrial organisation, and compel it to hand over the control to the workmen themselves. For this purpose anything is legitimate, from malingering and shirking to destruction of machinery and wrecking of trains; but the strike is the effective weapon, and particularly the "general strike," a simultaneous strike of all workers - either in one industry, allied industries, or all industries-which will put Property at Labour's mercy and consummate the social revolution.

In the case of an inchoate movement of class-opinion like this, what is of most immediate importance to society at large is to realise its existence, and to know what are the ideas behind so many of the contemporary manifestations of "Labour unrest." They have been admirably analysed, and no less admirably criticised, by Mr. and Mrs. Sidney Webb, - who are not likely to be accused of want of sympathy with either the socialist or the trade-unionist movements, -in a special supplement of The Crusade for August 1912 (the organ of the National Committee for the Prevention of Destitution, tion", (xvi, 7 et seq.), "Socialism" (xxv, 301 et seq.), "Communism", (vi, 791 et seq.), "Anarchism" (i, 9I 4 et seq.), "Cooperation" (vii, 82 et seq.), "Trade Unions" (xxvii, I 40 et seq.), "Strikes and I.ock-outs" (xxv, I024 et seq.), "Arbitration and Conciliation" (ii, 33I et seq.); and other articles indicated under "Economics and Social Science" in Index Volume, p. 893. On the whole question, historically, no single hooks are so informing as Mr. and Mrs. Sidney Webb's Industrial Democracy and History of Trade Unionism. 
37, Norfolk Street, Strand, London). As they point out, the documentary materials for a detailed study of syndicalism are not easily accessible, but it may be useful to give (with some corrections) their note on the literature of the movement, under the influence of which its ideas have recently spread so widely:

"The series of pamphlets by Mr. Tom Mann, under the general title of The Industria Syndicalist (Bowman, 4, Maude Terrace, Walthamstow), from June, Igro, onwards, are perhaps the most important English source; together with The Miners' Next Step (Robert Davies \& Co., Tonypandy, 1912). Of easily purchaseable books in English there are not many. Far and away the best is The Labour Movement in France, a Study in Revolutionary Syndicalism, by Dr. Louis Levine (Columbia University Series, 1912). A corrective on the other side is Syndicalism and the General Strike, by Mr. Arthur Lewis (Fisher Unwin: I9I2). A volume by Mr. J. Ramsay MacDonald, M.P., on Syndicalism (Independent Labour Party Office, I912), should be consulted. But for the best exposition the student must turn to France, and must there go through the files, especially of Le Mouvement Socialiste, and, further, of La Voix du Peuple, L'Action Directe, La Vie Ouvrière, La Bataille Syndicaliste, and other weekly and monthly journals. No less characteristic are the numerous pamphlets by Edouard Berth, Paul Delesalle, Victor Griffuelhes, A. Labriola, Hubert Lagardelle, L. Niel and Êmile Pouget (mostly published by Marcel Rivière, Paris). The most considerable "intellectual" on the Syndicalist side is Georges Sorel ${ }^{1}$ (Reflexions sur la Violence, I908 and 1910; La Decomposition du Marxisme, $2 \mathrm{~d}$ edition, 1910; and various other works). Other Syndicalist books are: La Grève Générale et le Socialisme: enquête internationale, opinions et documents, by Hubert Lagardelle (Cornély, Paris, 1905); and the very explicit Comment vous ferons la révolution, by E. Pataud and Émile Pouget (Tallandier, Paris) a lengthy "Utopia" describing both the process of revolution and the way the new society organises itself. Of expository and critical books, the reader will find most useful Syndicalisme Révolutionnaire et Syndicalisme Réformiste, by Felicien Challaye (Alcan, Paris, Igog); Syndicalisme et Démocratie, by C. Bouglè (Paris); Le Syndicalisme contre le Socialisme: origine et développement de la Confédération Générale du Travail, by Mermeix. Les Transformations de la Puissance Publique: les Syndicats des fonctionnaires, by Maxime Leroy, 1907 , will be found suggestive. For modern Trade Union history in France, see Histoire des Bourses du Travail, by Fernand Pelloutier, 1902; L'Evolution du Syndicalisme en France, by Mlle. Kritsky, 1908; and Histoire du Mouvement Syndical en France, 1789-1906, by Paul Louis (Paris, 1907.)'

The account given by Mr. and Mrs. Webb, as the result of their careful study of Syndicalist literature, should be studied in full, but a few extracts may be made here in summarised form. As to the class-feeling behind the movement, they say:

"The manual working wage-earner sees himself and all his fellow wage-earners toiling day by day in the production of services and commodities. This toil is continued without cessation year in and year out, under the orders of persons of another social class who do not share his physical exertion. He sees the service and commodities that he feels he is producing sold at prices far exceeding the amount which he receives in wages. He has, of course, been told that this price has to pay large salaries to managers and other officials, and has to cover payment of rent and interest to the owners of the land and the capital. But this does not satisfy him of the reasonableness of the enormous and constant inequality between the wage he receives and the income enjoyed either by the owners of the instruments of production or by their managers and agents who rule his life. This inequality of income results in a society in which one-tenth of the population own nine-tenths of the accumulated wealth; in which one-fifth of the adults take to themselves two-thirds of the annual product, and allow only one-third to be shared among the four-fifths who are manual working wageearners; in which, in spite of a wealth-production greater than the world has ever known, one-third of all these manual working wage-earners have scarcely a bare subsistence, whilst most of the other two-thirds are so little removed from this low level that the slightest interruption or dislocation of industry reduces many of them to destitution. In dramatic contrast with this penury and destitution he sees hundreds of thousands of wealthy families wasting in idleness and senseless extravagance hundreds of millions of pounds annually out of the wealth that is produced. Something is radically wrong with a socicty that produces this inequality. To the wage-earners who are 'class-conscious ' the explanation seems simple. Whilst they and their fellows are contributing the whole of the physical toil involved in the production, distribution, and exchange of commodities, they are excluded from the ownership both of the instruments of production and of the products of their labour. The ownership of the land and the other instruments of production carries with it the power of giving orders as to how they shall be used. The manual working wage-earner finds himself spending his whole life in subjection to the arbitrary orders, even the irresponsible caprices, of the employers and their agents.

${ }^{1} \mathrm{M}$. Sorel however has recently abandoned Syndicalism and become the editor of a French Legitimist journal. 
"To the growing intelligence of the manual workers in the great industries it seems that trade-unionism, however much it benefits particular sections, has in no way diminished inequality. The trade-union of the orthodox type assumes and accepts as permanent the very organisation of industry against which the 'class-conscious' wage-earner is revolting. If the workers in an industry can form a trade-union, and elect their own officials to lead them in a strike, or to negotiate with the employer, why should not the same body of manual workers, who form in every business organisation the immense majority, elect the general manager and the foreman, the buyer and the salesman, who are now appointed by the capitalist private owner of the enterprise to administer it for his own profit? All that stands in the way seems to be the private ownership of the instruments of production, entailing as it does the ownership of the whole product."

Neither Co-operation nor State-Socialism of the ordinary political type appears to offer any real remedy for the social inequality of which our revolting wage-earner is so bitterly conscious. Successful as the Co-operative movement has been, so far as the working-class members are concerned who are consumers, he feels that it has done very little for the producers whom the co-operative societies employ:

"Thus in England, though the fifty million pounds of capital of this most profitable business is owned by the two and a half million working-class members, and all the managing committees are most democratically elected, yet the 120,000 men and women who work in the stores and their factories are, as producers, paid weekly wages, and work under the orders of managers and foremen over whom they exercise no more influence and control than in the enterprises of private capitalism."

It is the same with " nationalisation" or " municipalisation," which have become the ideal of the Fabianite State-socialists, and also with the results, so far as our wageearner sees, of getting Labour members into Parliament, where conventional ideas of property and the necessity of the support of a miscellaneous electorate block the way:

"When Socialism was worked out to mean the transfer of industry from private to public ownership, it became plain that it by no means meant handing industry over to the manual workers. The ownership and control passed to the whole body of citizens, among whom the wage-earners in any particular industry found themselves in an insignificant minority, receiving wages and obeying orders just as before. Nor do the Syndicalists see that the progress of this sort of Socialism has in itself any tendency to lead to any other state of things. Its tendency is to induce the manual workers to put their reliance on the promises of the politicians, who are for the most part not of the manual working-class, while such workingclass members as are elected quickly fall away, with the great change in the circumstances of their lives, from that full 'class-consciousness' which is bred of the wage-earner's insecurity, impecuniosity, and subjection to the orders of others."

The Syndicalist, in fact, objects to one of the fundamental doctrines of democracy. Unlike the ordinary Socialist, who relies for progress on the conversion of a majority of the community, the Syndicalist has no satisfaction in the subjection of the "conscious minority" of intensely feeling workmen to the "incompetent vote" of an inert and apathetic mass, and is not prepared to wait for their conversion. "French Syndicalism," writes Hubert Lagardelle, one of its leaders, " was born of the reaction of the proletariat against democracy." "The minority," writes Emile Pouget, the most representative of French syndicalists, "is not disposed to give up its claims and aspirations before the inertia of a mob not yet animated and stirred by the spirit of revolt." Instead of looking to the " public," or the whole community, the Syndicalist considers that the manual wage-earners must rely exclusively on themselves. "The working-class movement," says M. Victor Griffuelhes in L'Aclion Syndicaliste, " having arisen from the miseries of the wage-earners, ought to include only wage-earners, and ought to be conducted only by wage-earners, exclusively for the specific interests of the wage-earners." Instead of being " guided by abstract ideas expounded by intellectuals," it is the business of the manual workers simply to "fight against the employers, in order to extract from them, and to their hurt, even greater ameliorations of the worker's lot, on the way to complete suppression of exploitation."

In the organised warfare which the manual workers are to wage on employers, without any foolish consideration for anybody but themselves, the two principal weapons used by the Syndicalists are the "irritation strike" and the "general strike,"-strikes being advocated not so much as a means of insisting, as with the older trade unionism, on 
collective bargaining, but directly for the purpose of hurting Capital and making the control of industry by anyone but the workers impossible. The "irritation strike," as may be read in the Miners' Next Step, " depends for its successful adoption on these men holding clearly the point of view that their interests and the employer's are necessarily hostile. If the men wish to bring effective pressure to bear, they must use methods which tend to reduce profits. One way of doing this is to decrease production while continuing at work." The French form of "irritation" is what is known as sabotage, concerning which M. Pouget blandly writes as follows:

\begin{abstract}
"If you are a mechanic, it isvery easy for you, with a pennyworth of some sort of powder, or even with sand, to score lines on your rollers, to cause loss of time, or even costly repairs. If you are a carpenter or cabinet-maker, what is easier than to injure a piece of furniture, so that the employer will not notice it, nor at first the customer, but so that customers will presently be lost? A tailor can quite easily ruin a garment or a piece of stuff; a shopman with some stains will make it necessary to sell off damaged goods at a low price; a grocer's assistant causes breakages by faulty packing. No matter who may be to blame, the master loses his customers. . . As the employer is an enemy, it is no more disloyal for the workman to entrap him into ambuscades than to fight him face to face."
\end{abstract}

But the fullest form of "direct action" is the general or national strike, by which the continuance of industry is to be paralysed altogether, and by which the syndicalist aims at consummating the transfer of all industries from control by the capitalist class to control by the operatives:

"The general body of wage-earners, by deliberately suspending all labour on a given day, by tearing themselves away from the exploitation to which they are subjected and by which the existing social order is maintained, cut away that social order at its very base. If they cease to work for the employing class, and for the great joint stock companies, they destroy at one blow the economic dominion exercised upon them. And as this economic dominion is translated in the region of politics by the authority of the State government, the State government itself will crumple to pieces simultaneously with what is but its other side, the system by which millions of men are used for the profit of a minority. From this paralysis of the machinery of the State, and of all its services, public and private, to the socialisation of the means of production is but a step." (P. Louis.)

The complete "general strike" is, of course, the final Revolution, but, as M. Griffuelhes says, "the industrial or localised general strikes which precede it really constitute a necessary gymnastics, just as the army manoeuvres are the gymnastics of war."

And what next? On that point Syndicalism is decidedly vague. "Directly we think of definite aims," says M. Griffuelhes, "endless disputes arise. Some will say that their aims will be realised in a society without government, others that they will be realised in a society elaborately governed and directed. Which is right? I do not take the responsibility of deciding. I wait to decide whither I am going until I shall have returned from the journey which will itself have revealed whither I am actually going." "No more dogmas or formulas," writes Hubert Lagardelle, " no more futile discussions as to the future of society; but a feeling of the fight, quickened by practice, a philosophy of action which accords preeminence to intuition, and which declares that the simplest workman in the heat of combat knows more about the matter than the most abstract doctrinaires of all the schools."

These then are the general ideas behind the Syndicalist movement, and their connection with much that has recently happened and is happening in Europe and America is not far to seek. From a different point of view, and a different point of feeling, from that of the wage-earner, with his limited outlook, it is not difficult to criticise them. Mr. and Mrs. Webb do so, alike on ethical and on practical grounds; the methods advocated are, they say, wrong in themselves, and would not result in achieving their object. But meanwhile society has to realise the sort of passionate feeling that animates the movement, and to consider on what lines, of education on the one hand and of wise social reform and industrial regulation on the other, its militant propaganda can best be met. The problem is most acute in Great Britain and the United States. In France syndicalism is already on the wane, and one of its French originators recently described it as now only an "article d'exportation."

(Hugh Chisholm.) 


\section{THE TURCO-ITALIAN WAR, 1911-12}

On September 28, I9I I, the Italian ultimatum demanding that Turkey should permit the military occupation of Tripoli was presented to the Porte, and on the 2 th the Italian Government declared war. Italy, having taken the initiative in the dispute, was in advance of Turkey with her preparations. In order to give the Italian expedition a national character, a special force was formed of contingents from different army corps, and was assembled at Naples, Genoa and Palermo. The Italian fleet had been practically ready since September Ist, and needed only to summon its reservists. Lieut.-General Caneva was appointed Supreme Commander of the naval and military forces, composed as follows:

Nary.-Commander in-Chief, Vice-Admiral Aubry. First and Second Squadrons (Ist, 2nd, 3rd and 4th Divisions). First Squadron: 4 battleships, 4 cruisers, 8 destrovers; Second Squadron: 4 battleships, 5 cruisers, 8 destroyers; Training Division: 4 battleships, I cruiser; Independent Division: I battleship, 3 cruisers, and a torpedo flotilla; Red Sea Division: 5 cruisers, 6 torpedo craft.

Expeditionary Army Corps. Ist Division, (Ist and 2nd Brigades); 2nd Division, (3rd and 4 th Brigades); Army Troops, 7 battalions infantry, 6 mountain batteries, besides technical troops, 2 dirigibles and 6 aeroplanes. Total: 3 I battalions, 6 squadrons, I 8 batteries, about 40,000 men. Steps were taken to mobilise a 3 rd, and subsequently a $4^{\text {th }}$ Division.

The Turkish Navy consisted of 4 battleships, 2 protected cruisers and 27 torpedo craft, besides some old gun boats in the Red Sea. The inefficiency of the personnel rendered this fleet a negligible factor. The 'Turkish force in the vilayet of Tripoli consisted of the $42 \mathrm{~d}$ Independent Division, (I4 battalions, Io squadrons, 6 batteries) with an actual strength of about 5000 , to which must be added some 3000 Redifs. The coast defences of Tripoli town were old fashioned masonry forts armed with obsolete guns. Munir Pasha was in command of the troops. Three Turkish divisions were stationed in Yemen, whence a raid might seem possible against Eritrea.

The Libyan coastline is rocky, and difficult of access. Marsa Tobruk is the best harbour. Tripoli itself is exposed in northerly winds; Benghazi and Derna are open roadsteads. The country consists of an arid plateau divided into two portions, corresponding to Tripolitana and Cyrenaica, by the deep indentation of Sydra Bay. Caravan roads enter the province on the east from Sollum and Siwa; on the west along the coast by Zuara, and further inland by Nalut to Gharian. Important oases in the interior are Azizie and Gharian, in the west, and Aujila in the east. The population of the interior consisted of Berbers and nomad Arabs. The chief influence among the latter was that of the Senussi sect.

Viall Operations.--During the first week of the war, the Duke of the Abruzzi's Independent Division sank or blockaded in their ports, all the Turkish torpedo craft in the Idriatic. In deference to Austrian sentiment, these operations were then suspended. ()n the $4^{\text {th }}$ of October part of the Ist Squadron seized Marsa Tobruk, which was re(juired as a base. The Turkish fleet had left Beyrout on September 28 th and had only learned of the outbreak of war when off Rhodes next day. No attempt was, apparently, marle by the Italians to intercept it, and it reached the Dardanelles on October ist. On () ctober $3 d$, when the exodus of Italian subjects was complete, the 2d Squadron and Training I ivision bombarded the coast forts of Tripoli; the garrison, except for a few gunners, had withdrawn inland towards Gharian. On the 4 th, the forts were finally silenced and on the 5 th the town was occupied by a naval brigade. A blockade of the Libyan coast was declared on the $3 \mathrm{~d}$ of October.

Transport of the Italiun Expeditionury Force. - Some to transports had been chartered for the expedition; tonnage was allowed at the rate of I 300 tons per battalion; 900 per squallon and i ioo per battery. About rooo infantry and artillery of the 2 d Division sailed on October $5_{\text {th }}$ to garrison Marsa Tobruk. But for the rest of the force a pause of some days ensued. Meanwhile the sit uat ion at Tripoli was critical, as the enemy were showing signs of activity; five infantry battalions were therefore hurried on in advance, reaching Tripoli on the ith of October. The transport of the bulk of the ist Division commenced on the eth and was concluded on the Isth. by which time about 20,000 
troops had landed. The remaining 5 battalions of this division were landed at Homs on October 2 ist.

The transports conveying 10,000 men of the $2 \mathrm{~d}$ Division arrived off Benghazi on Oc. tober I 8 th escorted by part of the First Squadron. On the morning of the Igth, fire was opened by the ships and a landing was effected on Giuliana Point, west of the harbour, in the face of opposition by some 300 Turkish regulars and 2000 Arabs. In the afternoon the troops, under General Ameglio, advanced on Berca, which was captured by nightfall. After a nocturnal bombardment by the fleet Benghazi was occupied by the Italians on the 2oth. The rest of the $2 d$ Division occupied Derna on the 18 th, an attempt made on the IIth having failed, owing to bad weather. During the passage of these convoys from Italy to Africa, the Independent Naval Division patrolled the entrances to the Aegean Sea.

Land Operations. - The Italian operations were limited, at the outset, to the occupation of the coast towns. The defeat of Adowa ( 1896 ) had not been forgotten and public opinion favoured a cautious policy. It was hoped that the Arabs would accept the situation, and that the Turkish troops, cut off from the coast, would surrender or retreat across the frontier. The Italian entrenchments round Tripoli had a front of Io miles; on the right, west of Bu Mellian wells, the field of fire was good; in the centre, near "Fort" Mesri-an old earthwork-it was indifferent; for two miles on the left, in the oasis, it was limited to a few yards.

The Turks had now established an advanced base at Ain Zara. Early on October 23d, Neschat Bey, who had succeeded Munir Pasha; directed a strong attack through the oasis, against the left of the Italian line. At the crisis of the fight, when most of the reserves had been drawn in, the Arabs in the suburbs behind the entrenchments treacherously rose in arms, and assailed the Italians in rear. The situation was for a time most critical, and it was only after eight hours fighting that the attack was driven off by the remaining reserves. After this incident, drastic measures were taken to disarm the natives and to clear the zone in rear of the outpost line. On October 26 th the Turks again attacked the centre and left of the line, and were only repulsed when most of the Italian reserves had been employed.

General Caneva now withdrew his left to Mesri and Dahra, abandoning Fort Hamidieh and "Fort" Mesri. The attacks on the $23 \mathrm{~d}$ and 26 th had cost the Italians 374 killed and only ${ }_{5} 8$ wounded, the small proportion of the latter being remarkable.

It was now evident that the Arab population must be considered hostile and that more troops wolild be needed. General Caneva was, therefore, reinforced by the $3 \mathrm{~d}$ Division from Italy; the Ist and $3 \mathrm{~d}$ Divisions at Tripoli were organised as an Army Corps under General Frugoni.

On November 5th the annexation of Tripoli and Cyrenaica by Italy was decreed, possibly as an indication that no compromise would be accepted.

Thus reinforced, General Caneva resumed the offensive. On the 7 th of November Fort Hamidieh was retaken by a brigade of the $3 \mathrm{~d}$ Division, and on the $26 \mathrm{th}$, after an attack by three brigades, the old outpost line and "Fort "Mesri were reoccupied. This success was followed up on December 4 th by an attack on the Turkish base at Ain Zara. The advance was carried out in three columns, of a brigade each, which converged on the Turkish position. The Turks, finding their flanks threatened, abandoned their camp and eight guns, and retreated towards Gharian, leaving detachments at Tarhuna and Azizie. Ain Zara was now strongly fortified by the Italians; Tajura was occupied, and the whole oasis was cleared of the enemy.

On the night of December I8th and igth, a force of three battalions, one squadron, and one battery under Colonel Fara, set out from Ain Zara to surprise a hostile force reported at. Bir Tobras. Misled by incorrect maps the column lost its way; at daybreak the enemy was encountered in superior force; after maintaining its ground with difficulty during the day, the column withdrew by night to Ain Zara. That a disaster was averted was due to the skill and gallantry of Colonel Fara, who was rewarded by promotion to Major-General. 
Heavy rain fell from November 13 th onward, adding greatly to the discomfort of the troops and increasing the difficulty of operations.

During this period the aeroplanes had done good service, in spite of violent winds; the dirigibles had, however, been reshipped to Italy for repairs owing to damage suffered in a storm in December r $91 \mathrm{I}$.

Meanwhile in Cyrenaica the Turks had attacked Benghazi on the night of December Ioth and IIth and Derna on December I6th and 26th. On the latter occasion the Italians lost 4 killed and 77 wounded. In January Enver Bey, who had now assumed command of the Turks in this quarter, took up a central position near Benghazi, and tried to entice the Italians beyond the range of the ships' guns. Additional reinforcements (including one brigade 4 th Division and a combined Brigade) reached Cyrenaica in November and December IgII.

The total number of Italian troops in Africa at the end of I9I I had risen to 100,000 distributed approximately as follows:

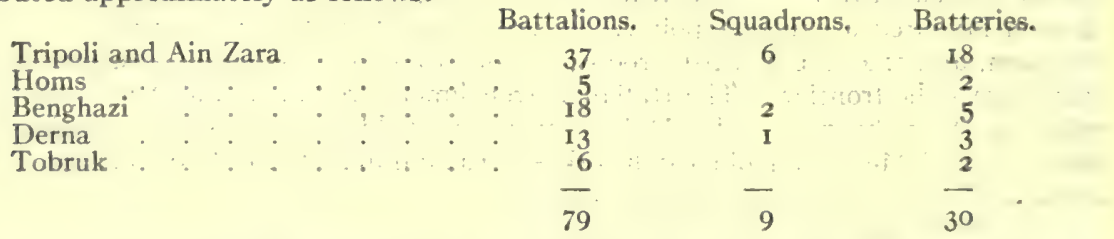

In addition 4 battalions, 2 squadrons and ro batteries were awaiting embarkation at Naples. A battalion of Askaris from Eritrea reached Tripoli early in February I9r2.

The Turks and Arabs combined were estimated at I 2,000 round Tripoli and I0,000 to 20,000 in Cyrenaica.

The Winter of IOII-12.-After the action of Bir Tobras the war entered on a new phase, which lasted till April I9I2. Except for local enterprises the Italians remained on the defensive on land, allowing the enemy to waste his strength in attacking their entrenchments. These attacks were pressed with great vigour and sometimes succeeded against outlying works, but were always repulsed in the end with heavy loss to the assailants. The only exception to this policy was an attempt to occupy Zuara with troops of the roth Brigade from Italy. The town was bembarded on the 17 th of January, but no landing could be effected owing to the rough weather and to the opposition of the Turks entrenched on the beach.

The seizure of the French vessels "Manouba" and "Carthage" by Italian warships January I6th and I8th, on suspicion of carrying contraband and combatants, evoked a protest from France; Italy finally gave way and released the vessels.

On January I 8 th and Igth the defensive perimeter of Tripoli was extended by the occupation of Gargaresch; on February 27 th the heights of Merkeb, two miles south-east of Homs, were captured by the Italians and held in spite of efforts by the Turks to retake them on February 28th and March 5th and 6th. On February I th and again on March $3 \mathrm{~d}$ vigorous attacks were made on the Italian lines at Derna; on the latter occasion Enver Bey is said to have been wounded. Marsa Tobruk was attacked on February 23d and again on March IIth.

On March I 2 th a brilliant success was gained by General Ameglio over a strong force of the enemy assembled near the Fojat oasis within range of the defences of Benghazi. The attack was carried out by two columns supported by heavy artillery; the enemy were completely defeated, losing 400 killed. The Italians lost 29 killed and 62 wounded. This victory earned General Ameglio a step in rank.

Meanwhile, on February 23d, Italian cruisers had appeared off Beirut and had sunk two small Turkish warships which were in the port. This step was, perhaps, intended as a warning that Italy would extend her sphere of operations if peace were not concluded.

Operations in the Red Sea. - The Italian operations in the Red Sea were directed to neutralising the Turkish gun boats in this sea, and, indirectly, to putting pressure on 
Turkey by hampering her operations in Yemen. On January 7, I91 2, owing to reports of an intended raid on Eritrea, some Italian destroyers searched the channels among the Farsan Islands and put seven Turkish gun boats out of action, while two cruisers bombarded Jebel Tahr and Loheia. A blockade was then declared of the coast between $14^{\circ} 30^{\prime} \mathrm{N}$. and $15^{\circ} \mathrm{II}^{\prime} \mathrm{N}$. This limit was afterwards extended to I 5.I $5 \mathrm{~N}$. so as to include Kamaran Island. On various occasions Turkish camps and forts at Akaba, Hodeidah, Mocha, Djebana, and Sheikh Said were shelled by Italian warships.

Operations in the Spring of I9I2.-An attempt at mediation having failed early in March, steps were taken by Italy for more active operations. The next phase of the war consisted in the strengthening of the Italian hold on the Mediterranean littoral, and the extension of naval operations to the Aegean:

The town of Zuara, near the Tunisian frontier, served the Turks as a collecting centre for contraband of war, smuggled in over the Tunisian frontier On April roth a force of about 10,000 men from Italy, Tripoli and Homs, were landed on the Macabez Peninsula, under cover of a demonstration by the fleet against Zuara. Forwa, on the mainland, which is accessible by a ford from Macabez, was occupied next day. The enemy still retained Sidi Said at the neck of the peninsula and could use the caravan route through Regdalin, so miles further inland.

The dirigibles " $\mathrm{P}_{2}$ " and " $\mathrm{P}_{3}$," which had now returned from Italy, flew over from Tripoli during these operations, and subsequently carried out reconnaissances, and dropped bombs into hostile camps and entrenchments.

On May 2d the garrison of Homs captured Lebda, two miles further east along the coast, and retained it in spite of determined attacks on May $30 t h$, and June 8th and I 2 th. On the latter occasion the Turco-Arabs captured two forts, but were finally repulsed with a loss of 400 killed.

Admiral Aubry died on March 4th and was succeeded by Admiral Viale. On.April I 5 th, the First Squadron left Taranto and a concentration with part of the Second Squadron and the Duke of Abruzzi's flotilla took place in the southern Aegean: : On the 18 th, after cutting the cables between Lemmos and Imbros; the fleet (less the $3 \mathrm{~d}$ Division) under Admiral Viale approached the Dardanelles, preceded by two cruisers which tried to lure the Turkish ships out of the channel. Failing in this object the fleet bombarded the outer forts. Meanwhile the $3 \mathrm{~d}$ Naval Division destroyed: some wireless telegraph stations in the Southern Aegean, and sank a Turkish gunboat at Vathy (Samos): Under cover of these operations the Italians occupied the island of Stampalia, where they established a naval station; the Turks replied by closing the Dardanelles to all traffic, an action which involved them, as was perhaps foreseen by the Italians, in difficulties with neutrals. The straits were reopened for traffic on May Ioth.

Early on May 4th a force consisting of about ro,ooo troops from Benghazi, Tripoli and Tobruk, in 7 transports, arrived off the island of Rhodes. A disembarkation was effected in Kalithea Bay on the south coast of the island, while a portion of the fleet demonstrated against the town; 8000 troops were disembarked in two hours and the whole force within eight hours. The town of Rhodes was occupied next morning, but the majority of the garrison withdrew to Psithos, twelve miles inland. On May r5th, by a skillfully combined movement with two columns, which landed by night on opposite sides of the island, and a third which moved inland from the town of Rhodes; the Turkish force, about Iooo strong, was forced to surrender. By the end of May the Italians had occupied the islands of Stampalia, Neros, Piscopos, Kharki, Rhodes, Scarpanto, Casos, Karpathos, Patmos, Kalminos, Lipsos, Kos and Simi.

Meanwhile, at Tripoli, it had been decided to crush a Turco-Arab force which was entrenched at the oasis of Zanzur. The total force employed was 13,000 men. At daybreak on June 8th, the attacking force (2 brigades Ist Division) advanced eastwards from Gargaresch, keeping touch with the fleet on its right. The remaining troops were held in reserve in two bodies, at Gargaresch and Bu Mellian, to protect the left flank and rear of the attack. After severe fighting the Ist Division captured the position, but other bodies of Arabs hurried up from the south and intervened between the Ist 
Division and Gargaresch, till the advance of the second group of reserves compelled them to retire. The Italians then fortified a point on the coast north of Zanzur but the oasis itself was not yet occupied.

Occupation of Misrata.-The victory of Zanzur enabled General Caneva to spare troops for the occupation of the important oasis of Misrata. On June I 5 th a composite division about 10,000 strong, drawn from Italy, Tripoli, Derna and Benghazi, under General Camerana, landed at Bu Sceifa, five miles from Misrata, under cover of a demonstration by the fleet at Ziliten. After repelling an attack by 5000 Turco-Arabs on July $2 \mathrm{~d}$, Camerana moved against Misrata on the 9 th. The advance was made in three columns, the right column keeping touch with the fleet. The centre column took Zuruk after severe fighting while the right column routed the enemy's left. The force then occupied Misrata. The Italian casualties were 9 killed and I 2 I wounded. An attack on Gherem by General Fara (southwest of Misrata) on July 2oth brought on a rear guard action which cost the Italians I 9 killed and 87 wounded.

Meanwhile, on the western frontier, on June 26th, Garioni had attacked the enemy's position at Sidi Said with two columns, one advancing along the Peninsula and one moving parallel to it from Fort Forwa. After three days' fighting, the enemy were driven from successive positions and fell back to Sidi Ali. The Arabs could, however, still use the road through Regdalin and Zuara and the occupation of these places was therefore decided on. Garioni's force was first increased to 20,000 men. On August

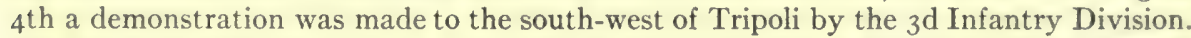
On the same night a force of 5000 men ( 6 battalions and 2 batteries) under General Tassoni, landed just east of Zuara which was captured next morning. Simultaneously Garioni's force moved east along the coast from Macabez and joined hands with Tassoni. The enemy withdrew to Regdalin. On August I 5 th the combined forces under Garioni captured the Samad hills, between Regdalin and Mensua, thus definitely closing the coastal roads to contraband traffic.

General Caneva's policy of allowing the enemy to wear themselves out by attrition had caused some discontent in Italy. It was urged that for 100,000 regular troops to remain on the defensive against some 6000 Turks and 20,000 Arabs was injurious to Italian prestige. On September 5 th, it was announced that, the first phase of the campaign having been concluded by the occupation of all the points of the coast, General Caneva's task was accomplished. He was then recalled, and two independent commands were formed under Generals Briccola and Ragni in Tripolitana and Cyrenaica respectively. It was understood that an expedition to Gharian would take place in the autumn of IgI 2.

The last naval operation took place on the night of July I 2 th and $I_{3}$ th, I9I2. About midnight five Italian torpedo boats, under Commander Millo, entered the Dardanelles to attack the Turkish fleet anchored above the narrows. After reaching Kilid Bahr under a heavy fire, the leading boats were stopped by steel cables and the flotilla retired. Four of the boats were hit but none seriously damaged. The fear of an Italian landing compelled the Turks to keep 30,000 troops within reach of the Dardanelles forts.

We now reach the closing phase of the war. Early on September $22 \mathrm{~d}$ a force of three brigades from Tripoli attacked the Turco-Arab position south of Zanzur. The defenders, who were estimated at 8000 , were driven off by 8 A.M. Two impetuous counter-attacks by Turco-Arab reinforcements, which hurried up from Suani Beni Adam, were defeated by the evening after fierce fighting at close quarters. The Italians lost 208 killed and 256 wounded.

The last serious fighting took place in Cyrenaica. On September i 5 th the Italian garrison of Derna had advanced their line to Kasr el Lebn and Casa Aronne three miles south-east of the town. On the 17 th these positions, which were held by three brigades, were attacked by Enver Bey with a strong force supported by guns. After severe fighting the Turco-Arabs were repulsed with a loss of I roo killed. On October 7 th the Italians captured the important position of Sidi Abdullah, three miles south-west of Derna; under cover of this operation a battalion and two batteries landed at Bombah, 
which was occupied without fighting. On October IIth, the Italian line was still further advanced on the Sidi Abdullah plateau, the enemy being driven back with heavy losses.

The Italian troops now present in Libya numbered about I I0,000, viz. Tripoli and neighbourhood 45,000; Zuara and Sidi Said 15,000; Homs 6000; Misrata ro,000; Benghazi I 2,000; Derna 20,000; Tobruk 6000. The Turco-Arab forces were estimated at about 40,000 , with a few guns.

Meanwhile, the Balkan crisis had arisen, and the Turkish mobilisation was being hampered by inability to transport troops across the Aegean Sea.

Peace with Italy was indispensable, but the negotiations came to a deadlock on October 12 th. Preparations were being made in Italy for active naval operations when on October I 5 th the Porte accepted the Italian terms, and peace was signed. Turkey agreed to withdraw her troops from Libya, without formally recognising Italian sovereignty. Italy consented to restore the captured islands and to guarantee a portion of the Ottoman debt corresponding to the revenues of Libya.

The war had cost Italy about sixteen millions sterling, up to the end of August 19 1 2, or $£ 47,250$ a day.

(H. H.WADE. Major.)

\section{THE BALKAN WAR: October-December I9I2.}

Military conventions for joint action against Turkey had been signed during the summer of I9I 2 between Bulgaria, Servia, Greece and Montenegro. Some preparatory naval and military measures were taken by the Allies during September, at first secretly, and more openly on the announcement in the latter part of September that grand manoeuvres of 200,000 Turkish troops were to be held near Adrianople. The manoeuvres in question were cancelled on the advice of the Powers, and the Turkish reservists were dismissed; nevertheless, on September zoth, the four States of the Balkan League issued orders for mobilisation, a step to which the Porte replied by a similar order on October Ist, and by impounding some 150 Greek vessels lying in Ottoman ports. Mobilisation and concentration appear to have been completed in Bulgaria, Servia, and Greece about October I 2th to I6th; and in Montenegro, where distances are shorter, by the 7 th. In Turkey serious delay was caused by the inability to transport troops over the Aegean because of the war with Italy, and by the absence of many units from their peace stations owing to recent political disturbances.

Montenegro, having finished her concentration first, declared war on October 8th. This step was probably taken to anticipate intervention by the Powers; it may also have been desired to capture Scutari before its defences could be further strengthened, and to detain as many Turkish troops as possible in the west. On October I 3 th the other States of the Balkan League presented an identic note to Turkey demanding reforms in Macedonia, and the demobilisation of the Turkish Army. On the I 7 th the Porte, declining further negotiations, declared war on Bulgaria and Servia. Some attempt was made to detach Greece from the League, but on the evening of the 17 th that Power declared war upon Turkey.

The Turkish territory in Europe was divided geographically into three principal regions, forming distinct theatres of war:-an eastern region of open country in Thrace; a western mountainous region between the Vardar Valley and the Adriatic; and a central belt of rugged country between the Aegean Sea and the Rhodope Mountains; the latter range was crossed by passes on the Uskub-Sofia and Serres-Struma Valley-Sofia roads, but was otherwise impassable for large bodies. Strategically, the eastern theatre of war, on the direct road to Constantinople, was of greatest importance, and it was in this direction that Bulgaria deployed her largest masses. But the geographical conditions and the territorial ambitions of the other allied States favoured a development of their chief strength in the western theatre of war.

The Bulgarian forces destined to invade Thrace consisted of 8 regular divisions. various reserve brigades (afterwards formed into 2 additional divisions), and I cavalry division, with a total strength of about 200,000 . These troops were organised in three 
armies:- the Ist Army (General Kutincheff), comprising the Ist and 8th Divisions (50,000 men with 100 guns), which was originally assembled near Sofia and then secretly transported by rail through Philippopolis to Yamboli; the 2nd Army (General Ivanoff), composed of the 3 rd and 8th Divisions and the Cavalry division (50,000 men with 260 guns), which was concentrated about Tirnova; and the 3 rd Army (General Dimitrieff) with the $4^{\text {th }}$, 5th, 9th Divisions ( 72,000 with 250 guns), which was concentrated east of Yamboli. A secondary force composed of the 7 th Division (General Todoroff), about 24.000 strong, was assembled near Dubnitza; the object of this force was to invade Macedonia by the Struma and Mesta Valleys and preserve communication between the allied forces in the eastern and western theatres of war. Finally the 2 nd Division $(24, \infty 00)$ under General Kovacheff was to cross the frontier south of Haskovo and safeguard the right of the and army. A Bulgarian detachment, said to be formed from the Ist Army Inspection, accompanied the 2nd Servian Army along the Kustendil-Uskub road. The total force under arms at the outset was 340,000 . General Savoff was in chief command, with headquarters at Stora Zagora.

The Servian forces were concentrated in 4 groups or armies:-the Ist Army, consisting of three Ist line, or two 2nd line divisions, and I cavalry division (about 97,00 with 232 guns), under the Crown Prince and General Putnik, on the Nish-Vranya road; the so-called 2nd Army (General Stephanovich), composed of one Ist line division (21,000 with 36 guns), strengthened by a Bulgarian detachment, on the Kustendil-Uskub road; the 3 rd Army (General Yankovich), composed of one Ist line and two 2nd line divisions, (50,000 with I 20 guns), near Kursumlje; and a 4th or Ibar Army (General Zikhovitch), consisting of one 2 nd line division (15,000) at Raska, with detachments of 7,000 and 3,000 3 rd line troops at Ivanjica and Vzice respectively. The total force under arms was 200,000 men with 430 guns.

The Greek forces .were assembled in two principal masses. On the east the main army of 4 divisions $(44, \infty \circ)$, afterwards increased by 3 reserve divisions, under the Crown Prince and General Danglis, was concentrated near Larissa and Trikala with a view to operations in Thessaly against the Turkish Southern Army; on the west a secondary group (originally about I 2,000) under General Sapuntsakis, based on Missolonghi, was to neutralise the Turkish forces in Epirus, and capture Prevesa.

The Montenegrin forces formed 3 armies:-a Central Army, under Prince Danilo, of 5 brigades ( 1 t, 000 men), with 20 guns; a Southern Army of 3 brigades (8,000 men), with heavy artillery; and a Northern Army of 3 brigades ( 0,000 men), with I 2 guns. The first two armies were destined to advance north and south of Lake Scutari against the town of Scutari and Mount Tarabosch. The Northern Army was to invade the Sanjak of Novi Bazar, and join the Servians. Headquarters were at Podgoritza.

The Turkish forces were organised in 3 principal armies and several minor groups, as follows: (I) A Main or Eastern Army in Thrace, consisting of the Ist, 2nd, 3rd, 4th, I 7 th and I 8 th Army Corps and a cavalry corps, besides various Redif divisions, making, it is said, about I 6,000 rifles, 3,000 sabres and 3 I 2 guns in all at the outbreak of war. This force, which was commanded by Abdullah Pasha, was based on Constantinople, Eregli, and Rodosto, and was being concentrated in the area Dimotika, Eski Baba, Kirk Kilisse, Adrianople. The latter place was surrounded by a girdle of strong modern forts with a perimeter of at least 22 miles, and garrisoned by about 32,000 men under Shukri Pasha. Kirk Kilisse had only 3 permanent forts, but these had been supplemented by numerous scmi-permanent works, converting it with an entrenched camp. (2) A Western Army destined to oppose the Servians, consisting of the 5 th, 6 th and 7 th Corps and six Redif divisions (04,000 with 260 guns), under Zekki Pasha; the greater part of this army was in the Plain of L'skub, with advanced posts pushed up towards Vranya and Kustendil; three dlivisions, with numerous Arnaut auxiliaries, making about 40,000 in all, were in the Sanjak of Novi Bazar and in the Lab Valley. (3) A Southern Army, including 2 independent and I Asiatic Redif divisions, about 30,000 in all, under Hassan Tahsin P'asha, concentrated at Kozhani and Diskata, and intended to oppose the Greek main army. In addition there was a force of 24,000 , known as the Struma Army (24,- 


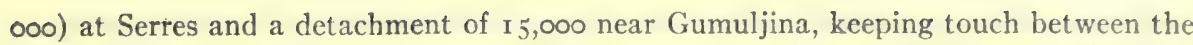
Turkish Eastern and Western armies. There were also independent groups of 18,000 under Essad Pasha in Epirus, between Janina and the Greek frontier; and of 20,000 chiefly Albanian Redifs, at Scutari and Tuzi under Hassan Riza Pacha. The above figures are necessarily only estimates, representing the best information available at Christmas I9I2. The numbers in Thrace were being constantly augmented by the arrival of troops from Asia. Ali Riza Pasha was in chief command in Macedonia. The supreme command of the whole Ottoman forces was given to Nazim Pasha.

As regards the maritime forces, the Greek Navy (I modern cruiser, 2 I torpedo craft and I submarine) was assembled off Salamis; 4 destroyers purchased in England and 3 obtained from Germany were still on their way out. The Bulgarian flotilla ( 6 coastdefence torpedo boats) was at Varna, which port, like that of Burgas, was fortified and defended by mine fields. The Turkish Fleet ( 3 battleships, 2 cruisers and 20 torpedo craft) was in the Bosporus and the Dardanelles; both these Straits were defended by powerful coast defences; while the Dardanelles channel was mined at Chanak.

\section{Eastern Theatre of War.}

Operations of the Bulgarian Armies. - The Turks hoped to complete their concentration on the railway while the Bulgarians wasted their strength against Kirk Kilisse and Adrianople. They apparently believed that the latter fortress, which lies on the natural line of invasion from Eastern Rumelia, would be the first objective of the invaders. General Savoff's initial dispositions were designed to confirm this impression, though his main attack was really to be directed against Kirk Kilisse.

On October Igth the and Army (Ivanoff), which had advanced from about SimenliTirnova, moving on both banks of the Maritza, occupied the frontier post of Mustapha Pasha; on the two following days it closed on Adrianople from the north and west; meanwhile, the 3 rd Army (Dimitrieff) was advancing on Kirk Kilisse from the north in four columns, on a front of 30 miles (Petra to Samakov); the Ist Army (Kutinchefi) advanced on the right (west) of the 3 rd army.

From October 22 nd to the 24 th the Ist and 3 rd Bulgarian Armies were engaged north and north-west of Kirk Kilisse. It appears that the Turks, who had brought jo,000 men up to this flank, attempted a night attack, which was repulsed by the Bulgarians, and that a panic then ensued among certain Redif divisions. Kirk Kilisse was captured on the $24^{\text {th }}$ with large quantities of supplies, and the Turkish army, much disorganised, fell back to the railway and to Bunarhissar. Dimitrieff's centre was moved forward to Kavakli, where a Turkish rearguard was driven back after an obstinate fight.

Meanwhile, the 2 nd Army had attacked Adrianople ( 22 nd-23rd), but had failed to capture any of the main defences; a Turkish sortie had been repulsed with the loss of 12 guns. On October 23rd the Ist Bulgarian Army pushed its right wing to the Tunja Valley, north of Adrianople; it next advanced its left wing to the Maritza Valley, south of that fortress, thus completing the investment (Oct. 29th). The Bulgarian cavalry occupied Eski Baba (Oct. 27th), capturing 4 locomotives and 243 trucks.

While these operations were in progress, the 2 nd Bulgarian Division had crossed the Rhodope range from the north, and defeated a Turkish force at Kirjali (Oct. 2oth); part of this division then descended the Arda valley to join the 2 nd Army before Adrianople. Further east, the main body of General Todoroff's force in the Struma Valley had captured the important Kresna defile and was approaching Demirhissar, while a force detached to the Mesta Valley had occupied Buk on the Salonica-Dedeagach railway, thus severing communication between the Turkish Eastern and Western Armies; other portions of the 7 th Division had advanced south-west, to Kochana and Strumnitza.

The Bulgarian ist and 3 rd Armies made no further advance till October 28th; the pause, which was perhaps due to the failure of the attack on Adrianople, enabled Abdullah Pasha ${ }^{1}$ to effect a change of front to the line Lule Burgas-Viza; this position, 20 miles in extent, was held by the 4 th, rst and 2 nd Corps (in order from left to

${ }^{1}$ Accounts differ as to whether Nazim Pasha or Abdullah Pasha was in command. 
right), while the 3 rd Corps was in reserve in rear of the right. Abdullah Pasha's plan was to remain on the defensive on the left at Lule Burgas, while his right wing, supported it is said, by some troops landed at Midia, took the offensive towards Kirk Kilisse.

The Bulgarians attacked on the 29th with the rst Army, reinforced by 3 brigades from the troops investing Adrianople, against Lule Burgas, and with the 3 rd Army against Viza. The Turkish positions in the open country on the left were poorly entrenched; their troops had been for days without food, and ammunition was scarce. From the first their artillery was overwhelmed by the better served guns of the Bulgarians. On the 3 Ist their left centre (Ist Corps) gave way, and on November ist the whole left wing fell back in some disorder to Chorlu, abandoning a great part of its artillery. The 3 rd Corps in the hilly and wooded ground, on the right flank gained some success on October 3 Ist, but on November 2 nd it too was driven back. The Bulgarians only pursued for a short distance, and the Turks retreated slowly towards the Chatalja lines, covered by a cavalry division. This battle ended the first stage of the war in Thrace, which had cost the Turks about 30,000 killed and wounded and at least 20,000 missing.

For reasons which remained obscure the Bulgarian Army - or at any rate its right wing-halted on the battlefield till November 7 th; this delay was concealed at the time, and reports were disseminated in the Press of a vigorous pursuit, and of a second victory near Cherkesskeui. Actually the Turkish rearguard did not leave Chorlu till November 6 th; on the following day the Bulgarians advanced on both sides of the railway; on the Ioth/I I th their right wing drove the Turks out of Rodosto in spite of the fire of a Turkish warship; by the I 3 th they had pressed the Turks back across the Kara Su.

The Chatalja lines, in which the Turkish Army was now assembled, were a position of great natural strength extending along a chain of heights across the peninsula from sea to sea, protected on either flank by lakes, and in front by a swampy river valley. The defences consisted of about $\mathrm{r}$ Io works of various dates, armed with heavy guns and providing several tiers of fire. Owing to the absence of pursuit, the Turkish army had largely recovered from its disorganisation, and the arrival of Asiatic reinforcements had to some extent replaced the losses suffered at Lule Burgas. But cholera had broken out and was making ravages among the troops and refugees in rear of the lines.

On November I 7 th the Bulgarians unmasked their batteries and commenced an attack with the Ist Army (3 divisions) on the Hamidieh forts west of Hademkeui, and with the 3 rd Army (4 divisions) against the Turkish lines south of Lake Derkos. The Bulgarian artillery, consisting chiefly of field batteries, was unable to silence the enemy's fortress guns on the higher ground. The Turkish warships rendered effective assistance on the southern flank. After gaining ground on the night of the 1 th/ $/ \mathrm{sth}$, the attacking troops were either withdrawn or driven back across the Kara Su, and the action was broken off by the Bulgarians under cover of an artillery cannonade on the roth. The bulk of the Bulgarian forces was withdrawn west of Chatalja village, and billeted in villages along the railway, covered towards the east by ent renchments about Chilskeui and Kalissakeui.

Meanwhile, negotiations for an armistice had been commenced at the instance of Turkey. The Allies demanded as guarantees the surrender of the besieged fortresses and the evacuation of the Chatalja position, conditions which the Turks, elated by their success, refused even to consider. Hostilities were resumed on November 2 Ist, but discussions were again commenced on the $24^{\mathrm{th}}$, and no serious land fighting took place in this quarter till the signature of the armistice (Dec. $3 \mathrm{rd}$ ).

The reports of an intended attack on the Dardanelles led the Turks to assemble 30,ooo troops in the Gallipoli P'eninsula, where Torgut Shefket Pasha was appointed to command. Some Kurdish and Hamidieh cavalry were shipped across the Sea of Marmora to operate in the Kuru Dagh and Tefkur Dagh hills, north of the Peninsula.

Meanwhile, in the central theat re of war, General Todoroff with the main body of the 7th Division had advanced from Demirhissar on Salonica, reaching that town just after its capitulation to the Grecks. Portions of this army then occupied Kavalla (Nov. I 5 th) and Serres (Nov. 2oth). 
The end of November was marked by a Bulgarian victory near the Aegean coast. As already mentioned, a force of I $_{5}, 000$ Turks had been defeated at Kirjali on October zoth and had retired towards Gumuljina, where their presence constituted a threat on the rear of the troops investing Adrianople. During November, operations against this force were undertaken by'various Bulgarian detachments; one column of the 2 nd Division, advancing from Kirjali, drove the Turks southwards to Gumuljina; while other columns, consisting largely of cavalry, pushed down the Maritza valley to cut the Turks off from Dedeagach. Gumuljina was captured on November 2 2nd; the Turks then retired along the railway to Fere station, and finally took up a position north of Merhanli village. There the Bulgarian columns closed round them, and after an artillery combat on the 26 th, the whole force surrendered on the 27 th. The prisoners numbered 12,000 , including Yawer Pasha and his two divisional commanders. While these operations were in progress, a portion of one of the Bulgarian columns, which had descended the Maritza valley, had entered Dedeagach (Nov. 26th), capturing large quantities of rolling stock; another detachment had moved farther east to Malgara, midway between Dedeagach and Rodosto. The occupation of Dedeagach rendered possible the transfer of part of General Todoroff's army to Thrace. This force, numbering about $12, \infty 00$, was embarked at Salonica in Greek transports between November 23 rd and 27 th, and landed at Dedeagach about the 28 th-3oth. Railway communication from Dedeagach to Dimotika was opened about November 2 2nd.

Of the siege of Adrianople meanwhile few details became known; the garrison under Shukri Pasha maintained an active defence, and, in spite of prolonged bombardment and numerous costly attacks, no important success was gained by the besiegers, except the capture of the Kara Tepe and Papas Tepe forts on November Ioth. It does not appear that the Bulgarian ordnance was of sufficient power for the task imposed on it. After the capture of Kirk Kilisse (Oct. 24th) a portion of the investing force was withdrawn to reinforce the field army, and their places were taken by 3 rd line troops. At the begin ning of November 45,000 troops of the Ist and 2 nd Servian Armies are said to have joined the besieging force. Attempts by the garrison to break out towards the south and east were repulsed on November I8th and 24th. A final unsuccessful assault was made on the west front just before the conclusion of the armistice.

The Bulgarian recruits of the $I_{91} 3$ and I 914 contingents were called out to replace losses, and left for the front after a short training on November 25 th.

\section{Western Theatre of War.}

Operations of the Servian Armies.--The Servian plan of campaign was apparently for the rst and and Armies to converge on the plain of Uskub while the 3rd Army safeguarded the right flank of the movement, captured Prishtina, and moved on Uskub via the

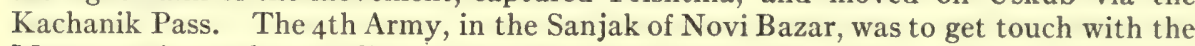
Montenegrins and neutralize the Moslem elements in this region. On the other hand Zekki Pasha's intention was, it is stated, to keep his army concentrated near Uskub, and act on interior lines against the Servian Ist and 2nd Armies; while the troops in the Sanjak were to prevent a junction of the Servians and Montenegrins, and to raid the Servian communications.

On October Igth the Ist Servian Army crossed the frontier, and on the 22nd-after delaying, to allow the advance of the 2 nd and 3 rd Armies to make itself felt - it came in touch with the Turkish 6 th and 7 th Corps near Kumanovo. The Turks attacked on the 23rd, but were repulsed; early on the 24th the Servian Ist Army took the offensive, assisted by a detachment of the 2nd Army, and gained a complete victory. Meanwhile the Servian 2 nd Army had occupied Strazin on November 2 2nd, and had reached Kratovo, where part of the Turkish 5th Corps was defeated on the 26 th. The Turkish Army, demoralised by its defeat at Kumanovo and finding its retreat threatened, evacuated Uskub without further fighting, abandoning most of its artillery ( $I I_{5}^{-I} 20$ guns) and immense quantities of stores. The Servians entered Uskub on the 26 th.

The greater part of Zekki Pasha's Army retired from Uskub to Kaprulu; but one 
detachment, too late to follow this road, escaped westwards to Kalkandele. After a vain attempt to reorganise the troops, Kuprulu was abandoned on November Ist, and the Turkish army continued its retreat in two portions, a detachment following the Vardar valley, while the main body retired through Perlepe towards Monastir.

Meanwhile, the Servian 3 rd Army had taken Mitrowitza and Prishtina (October 22nd) -the latter after severe fighting-and was advancing by Ferisovich towards Prisrend. In the Sanjak of Novi Bazar the 4th Army had captured Sjenica on October 24th, gaining touch with the Montenegrins, and Novi Bazar after 3 days fighting on October 27 th. Plevlje was taken on the $28 \mathrm{th}$, the Turkish garrison escaping over the Austrian frontier; Nova Varosh surrendered on November 5th. By the middle of November the region north of Kachanik Pass was practically in the hands of the Allies. The main body of the 4th Servian Army reinforced by two newly formed reserve divisions then moved towards Ipek, and continued the pacification of the country.

After the capture of Uskub the Servian armies were partly reconstituted. One and line division of the Ist Army and the one division of the and Army, under General Stephanovitch, were dispatched by rail, via Sofia, to assist the Bulgarians in Thrace. A portion of the Ist Army, consisting chiefly of cavalry, pushed down the Vardar Valley, defeater some Turkish detachments at Demir Kapu, and Doiran (Nov. 5th), and eventually entered Salonica after its surrender to the Greeks on November 8th.

The bulk of the Ist Army (4 divisions) pursued the main body of Zekki Pasha's Army along the Kuprulu-Monastir road. The Turkish rearguard was defeated in a two days battle (Nov. 4th/5th), near Perlepe, which town was occupied on the 6th. Here the advance of the Servians appears to have been suspended for a week, owing perhaps to difficulties of supply and to a heavy snowfall which commenced on November 7 th.

The 3 rd Servian Army moved from Ferisovich against the Turkish detachment which had retired westwards from Uskub; this army occupied Kalkandele on October 3 Ist. From this point the pursuit was continued by the Morava and line division, which now came under the orders of the Ist Army, to Gostivar (Nov.3rd), and thence to Kirchevo; here the Turks were reinforced, but were again defeated after heavy fighting on November 6th. The Morava Division now suspended its pursuit and prepared to co-operate with the Ist Army's advance from Perlepe on Monastir.

Though a decisive battle was still to be fought, political reasons inducea the Servians to send the remainder of Yankovich's army (2 divisions) on a difficult march across the snow-covered mountains to the Adriatic coast. The route taken was by Prisrend, and across the Mirdite country, where the troops were well received. The Servians captured Alessio on November 17 th/I 8 th after slight opposition, with the aid of 5 Montenegrin battalions. After a short rest at Alessio a portion of the 3 rd Army, accompanied by several hundred Malissores, marched southwards along the Adriatic coast to Durazzo, which they reached on November 28 th.

The main body of the Ist Servian Army (4 divisions and I cavalry division) appears to have resumed its advance about November I 4 th, by which time the Morava and line Division from Kirchevo had come up in line with it on the right. The Turkish Army, consisting of the remains of the 5 th, 6 th and 7 th Corps, occupied a front of 20 miles from Novak to Gopes; 2 independent divisions were in reserve at Monastir. Their total strength is variously put at 35,000 men with 50 guns and 90,000 men with 100 guns. On the 17 th, without waiting for the arrival of the Greek Main Army from Salonica, the Servian troops forced the passage of the swift running Cerna, wading breast deep through the icy water. On the $\mathrm{I} 8 \mathrm{th}$ and Ioth the Morava Division, on the right flank, enveloped the Turkish left, while the approach of the Greek Army from Ostrovo threatened their line of retreat. After four days fighting, in which the Servian gunnery again asserted its superiority, the Turks gave way (Nov. Igth/2oth). Some fragments of their army broke through towards Florina and Gonitza, and reached the Grammos mountains; but the greater part were dispersed or fell into the hands of the Greek columns near Banitza. The Servians captured 5,000 prisoners and the greater part of the Turkish artillery. Their cavalry pursued as far as Florina, where they joined hands 


\section{BALKAN WAR}

with the Greeks. The Morava Division captured Resna on November 2 ist, and a force was then despatched via Elbassan (Dec. Ist) to Tirana, where touch was gained with the Servian troops at Durazzo. Dibra surrendered on November 29th. On the same day, at Valona, Ismail Kemal Bey proclaimed the independence of Albania.

Operations of the Montenegrin Armies.-Montenegro had started the war, and on October gth all three Montenegrin armies were set in motion. The Northern Army (Vukovich) occupied Bjelopolje on the I3th, and then turned off towards Berane, where the Turks ( 5 battalions, and 3,000 Arnauts) were defeated on the I 5 th with the loss of 700 prisoners and.12 guns. Berane was occupied on the I6th. Vukovich next occupied Plava (Oct. Ioth), and Ipek, after an obstinate defence, on October 3ist. Meanwhile, a portion of his army had advanced to Sjenica, where it got touch with the Servians on October 24th. Farther north an irregular brigade crossed the Tara and attacked Plevlje on October 28 th in conjunction with the Servians.

The Central Army fired the first shot in the war on October gth. On the roth it stormed the fortifications of Dechich; on the I4th it obtained the surrender of Tuzi with six Nizam battalions and three guns. Meanwhile General Martinovich's army was advancing south of Lake Scutari; a right wing detachment of this army was thrown across the Boyana River. Both armies were, however, brought to a standstill in the second week of October, before the defences of Scutari and Mt. Tarabosh; siege operations were then commenced and were carried on chiefly by artillery fire, but the fortifications proved too strong for the Montenegrin guns; the defence was active, and repeated sorties were made against the investing troops.

In November one brigade of Martinovich's army was detached southwards along the Adriatic coast and occupied San Giovanni de Medua on the 16 th, afterwards assisting the Servians to capture Alessio on the 17 th/18th. On November 23 rd this brigade was recalled to the siege of Scutari, where the situation had became critical owing to the attitude of the Mirdites. On the 28 th all the Montenegrin forces-except some detachments in the Sanjak of Novi Bazar-were ordered to concentrate round Scutari; the King then took over the supreme command, with General Vukovich as Chief of the Staff. Operations round Scutari were continued during the peace conference, as the armistice was not recognised by the Turkish commander.

Operations of the Greek Armies.-On October I8th the Greek Main Army crossed the frontier at the Meluna Pass; on the I 9 th the Turkish advanced troops were driven from Elassona; a Greek detachment was sent from the latter place to Caterina (on the coast) which was occupied on the 28th. Meanwhile the Main Army advanced northwards and completely defeated the Turkish Southern Army at the Sarantoporos Defile, capturing 22 guns. The Greeks pursued through Serfije (Oct. 23rd) to Kozhani, whence the 5 th Division was detached as a left flank guard, towards Banitza. The rest of the Greek Army advanced to Verria, which was reached, after some fighting at the Tripotamos defile, on October 29th. The Turkish Struma Army made a final attempt to save Salonica by taking up a position with its main body $(25,000$ men) at Yenidje Vardar on the left flank of the Crown Prince's line of advance, while a detachment at Plati Bridge barred the direct route to Salonica. The Greek Army defeated both these forces on November 2nd, capturing I4 guns, and, after a difficult march across the swampy Kampania plain, received the surrender of Hassan Tahsin Pasha and 29,000 Turkish troops at Salonica on November 8th. An attempt by part of the garrison to break out towards the east was frustrated by Tocloroff's Bulgarian force on the gth.

The 5th Greek Division, 4,500 strong, which had diverged to the north-west from Kozhani, engaged a Turkish rearguard at Nalbandkeui on October 29th; on November 2nd it was attacked near Banitza by I 5,000 Turks and fell back on Sorovech; here it suffered a further reverse on November 5 th and retreated towards Kozani, losing -it is said-I 2 guns, which were retaken by the Servians at Monastir.

On November $15^{\text {th }} 5$ divisions of the Greek Main Army left Salonica, to co-operate with the Servian Ist Army, marching in two columns, one via Kailar, which picked up the $5^{\text {th }}$ Division on its way, and one by the direct Salonica-Vodena road, on Monastir. 
The 2 columns united near Banitza, encountering little opposition, though their approach no doubt influenced the result of the battle of Monastir. As it was, they captured large numbers of prisoners and several guns in the defiles of Pisoderi and dispersed some bodies of Turkish troops retreating via Florina. On November $25^{\text {th }}$, the Greek cavalry, supported by an infantry division, attacked Kastoria (south-west of Sorovech), capturing more prisoners and guns. In December the Main Army, advancing by Goritza, defeated the Turks at the Sangoni Pass, and then pushed on towards Janina.

The Western Greek Army under General Sapuntsakis crossed the frontier near Arta on the outbreak of war, and detached a force with some heavy guns to besiege Prevesa; that fortress surrendered on November 4 th, after bombardment by sea and land, with 500-600 prisoners. The main column continued its advance towards Pentipigadia, but met with a slight reverse on October 23 rd. On November I4th General Sapuntzakis had again advanced and had captured Mount Metsovo. On November 28th his troops appeared before Janina. Meanwhile the Turkish force in Epirus had been reinforced by the remnants of the Western Army from Monastir.

Hostilities were continued during the Peace Conference, as the Greeks were not parties to the armistice. About December Ioth an attack was made on the Turkish position near Janina, while a force of 2 Greek battalions and some irregulars was landed at Santa Quaranta to effect a diversion on this flank. This detachment was re-embarked after an encounter with 8 Turkish battalions west of Janina. On December I 2th/I 3 th the Greeks attacked Janina and made some progress towards the Bizani fort; on the $20 t h / 2$ nd the Turks took the offensive against the Greek forces south of Janina but were repulsed with heavy losses.

\section{Naval Operations.}

Except in the inland seas the Greek fleet had held undisputed maritime command throughout the war. About October I 7 th some destroyers were detached to the Ionian Sea to assist in the siege of Prevesa and blockade the Epirus coast; about December 4 th Greek warships are said to have bombarded Valona and occupied the island of Sasseno, evoking a protest from the Albanian provisional government. The remainder of the fleet, under Admiral Conduriotis, acting in the Aegean, occupied Mudras Bay (Lemnos) as a base, on October $2 \mathbf{I s t}$, and blockaded the Dardanelles. Subsequently the islands of Thasos, Imbros, Samothrace, Tenedos, Ikara, Psara, and Strati were captured by the fleet, and troops were landed on Chios and Mitylene, where fighting continued for some weeks. On October 3 rst a Greek torpedo boat sank the old Turkish cruiser Feth-iBulend in Salonica harbour.

The Turkish fleet was occupied during October in convoying transports from Trebizond and Sinope to Constantinople, and in blockading the coast of Bulgaria. In November it assisted in the defence of the Chatalja lines, enfilading the Bulgarian attacks on the southern flank. On November 2 Ist the cruiser Hamidieh was badly damaged by a Bulgarian torpedo attack about I 5 miles off Varna. On December i6th the Turkish fleet issued from the Dardanelles and exchanged shots with the Greek squadron, afterwards retiring within the straits.

After negotiations commencing on November $25^{\text {th }}$ between the plenipotentiaries of the Turks and Allies at Bagchekeui, in front of the Chatalja lines, an armistice was signed on December 3 rd between Turkey on the one hand, and Bulgaria, Servia, and Montenegro on the other. The chief conditions were that the belligerent armies should retain the positions they then occupied; that the besieged fortresses should not be revictualled, and that the Bulgarian army should receive supplies by way of the Black Sea and of Adrianople, but not for Io days after the signing of the armistice. It was also stipulated that negotiations should begin in London on December I 3 th. Greece declined to sign the armistice, being unwilling to relax the blockade of the Epirus coast. The interrup. tion of the Turkish maritime communications was therefore maintained during the peace conference.

(H. H. WADE.) 


\section{THE WORLD'S ARMIES AND THEIR DEVELOPMENT}

\section{Tendencies of Military Progress:}

During the years I9IO-I 2 no very large increase in numbers has been made in any army. On the other hand certain European armies have suffered more or less serious losses in men and war material as the result of recent campaigns. No important change in organisation is recorded except in the case of the Russian army which is now being reorganised. In some armies organisation has been modified with a view to perfecting arrangements for rapid and secure mobilisation and for increasing the numbers available on the outbreak of war. The most important as well as general change in military armaments has been the employment of aircraft, the influence of which upon land warfare is an interesting problem, while in some cases improvements and increase in artillery and machine guns are also recorded. Both the intercommunication and rearward services of armies generally have been improved through the development of wireless telegraphy and mechanical transport.

The tendency of military progress undoubtedly continues to lie in the direction of constant readiness for war based upon very complete and thorough previous preparations. The Great Powers have been concentrating their energies and resources during peace in developing the power to strike with their whole strength and with the fullest effect immediately hostilities commence. It is considered in military circles that wars between neighbouring civilised states in adjacent territories will not under 'existing conditions be long or protracted. They will tend to be comparatively short, but extremely severe struggles. Under these conditions the power to strike quickly and with overwhelming force at decisive points is essential for success. Modern strategy accordingly aims at securing the initial advantage by surprise if necessary, and pressing it by a sustained offensive until resistance is crushed without affording either time or opportunity for the enemy to recover his morale and strength. The whole object of good strategy is to gain the initiative and strike the first effective blow, and then follow it as quickly as possible with a decisive blow:

It is possible, of course, that conflicts between civilised peoples may still be protracted as in the case of the South African and Manchurian campaigns, if armies have to be despatched great distances over land or sea to operate in vast theatres of war thinly populated with civilised men or inhabited by savage races and lacking in adequate supplies, roads, railways and other facilities for communication. But in wars between neighbouring states such as the first phase of the Balkan campaign of 1912 , or in conflicts between Great Powers, when opposing armies will come quickly into touch and operate in thickly populated theatres of war well supplied with roads and railways, which make it possible for troops, with the help of efficient rearward services and mechanical transport, to move rapidly over considerable distances, the final crisis cannot under ordinary circumstances be delayed very long. It is highly improbable that such struggles will be protracted, more especially in the case of great industrial communities.

Apart altogether from the loss of life and expenditure involved in actual fighting, which in conflicts between Great Powers must be stupendous, the interruption of the normal activities of national existence and particularly the paralysis of trade and industry consequent upon warlike operations on a vast scale, coupled with the probable shortage and increased cost of the necessities of life, will all seriously drain the resources and sap the strength of the combatant peoples if continued for any length of time. There is moreover the possibility that such conflicts, owing to factors that are considered below in relation to the Balance of Power, may become almost universal, involving many allied peoples whose territories comprise whole continents with calamitous effects which must be felt throughout the world. Although these considerations are not likely to deter nations from engaging in wars upon sufficient provocation in the present temper of humanity, they will certainly tend to make them more onerous and costly and therefore less protracted,

In view of these tendencies success in war to-day depends primarily upon readiness 
for war during peace. Nations will stand or fall according to their strength at the hour of trial and the rapidity with which they are able to develop it to strike an effective blow. It must be remembered that while the duration of war tends to become shorter, the time required for making necessary preparation for it tends to become longer. An army is now too complicated a piece of mechanism to improvise or create hastily. It is no longer possible to make men in a short time into efficient soldiers, much less into efficient officers, upon whom devolves the whole work of training armies in peace and leading them in war. Even weapons have been transformed by science into instruments which are only effective in expert hands. For all these reasons the tendencies of military progress strongly militate against the possibility of making untrained or half trained men into efficient soldiers after war breaks out with any prospect of success or utility. On the other hand to oppose efficient soldiers with partly trained or ill-equipped troops, however courageous and strong in numbers, is utterly futile. That they will be doomed to useless slaughter and certain defeat under such circumstances is the clearest of military truths. To-day nothing but complete readiness justifies the experiment of war.

\section{Numbers, Organisation, Armament.}

The following figures are approximate throughout and include all ranks.

Austria-Hungary.-Establishments: Peace 425,000; War, 2,300,000. The effect of the Army Bill of I 1912 will be to add about $45, \infty 00$ men during it the next five years. There has been no important change in organisation. The chief development in armaments, apart from aircraft, has been a large increase in machine guns.

France.-Establishments: Peace, 610,000; War, 3,900,000. The normal organisation of the army consists of 23 Army Corps and 4I Cavalry Brigades. The chief development in organisation and armament, apart from aircraft, has been the reorganisation of the field artillery, as the result of which 656 field and mountain guns, I 2 heavy guns and about 6,000 men have been added to the peace establishment.

Germany.-Establishments: Peace, 623,000, War, 4,150,000. By the recent Defence Law (Military) two new Army Corps have been organised out of the extra divisions and brigades of the former 23 Army Corps-thus making in peace 25 Army Corps, each of two divisions and six extra brigades. To complete the two new Army Corps, field and foot artillery batteries, 2 Pioneer Battalions and 2 Train Battalions were to be raised in I9r2. In addition, the number of machine gun companies is being doubled-at present one regiment in each infantry brigade is provided with a machine gun company. These changes will result in an increase of numbers.

British Empire.-United Kingdom:-Regular Army (Peace establishment) 137,500.

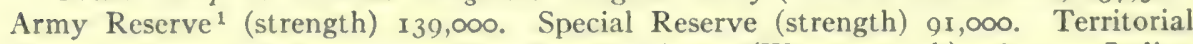
Force $^{2}$ (strength) 260,000. India:-Regular Army (War strength) 76,700. Indian Army, Native troops (regimental establishments) I 59,000. Reserve 36,000. Colonies and Egypt:-Regular Army (Peace establishment) 45,000. Self-Governing Dominions: ${ }^{3}$ Canada:-Dominion Troops, Permanent Force 3,000; Militia 42,000. Australia:Commonwealth Troops, Permanent Force 2,400; Citizen Forces 35,000. New Zealand:Dominion Troops, Permanent Force 500; Territorial Force 34,000. South Africa:the Union Defence Force has not yet come into existence. Changes in the armament of the Regular Army in the United Kingdom, apart from aircraft, include the issue of an improved cartridge and the adoption of a new Howitzer gun. There has been no important change in the organisation or armament of the Regular Army abroad, the Indian Army or the Territorial Force. The Canadian Militia has been reorganised and the Australian and South African Forces established on the basis of a moderate

${ }^{1}$ A National Reserve has been formed, but enlistment carries no obligation of training or service and the force is at present without organisation, equipment, arms or uniform.

2 This force is not fit to take the field against continental troops. Its training and equipment are to be completed after the outbreak of war and it is expected that some months must elapse before it is ready for service.

The troops of the Self-foverning Dominions as a whole are not yet organised, equipped, staffed, trained or armed to fulfil the requirements of modern war. 


\section{THE WORLD'S ARMIES}

amount of more or less general compulsory training for youths and adults between certain ages. It will be some years before these forces can reach their full strength.

Italy.-Establishment: Peace 250,000; War $1,215,000$. The period of service in the army has been altered from three to two years without affecting its numbers. There has been no important development in organis: ttion or armaments apart from aircraft. The campaign in Tripoli has not appreciably weakened the army through losses of men or war material.

Japan.-Establishment: Peace, 226,000; War 1,001,000. No important development in organisation or armament, apart from aircraft, is recorded.

Russia.-Establishment: Peace I,200,000; War 5,530,000. The army is at present in the process of reorganisation. When completed this work will simplify military organisation and render it more homogeneous without, however, increasing the army in numbers. The former active army organisation of field and reserve troops has been modified by abolishing reserve units and substituting a number of new field units which add 6 new Army Corps and a Cavalry Division to the peace establishment. The troops have also been redistributed, 7 Army Corps and 2 Cavalry Divisions being centrally massed about Moscow and Kazan ensuring greater security for mobilisation. The most important development of armaments, apart from aircraft, has been a large increase of artillery.

Other Countries.-No important change in numbers, organisation and armament, apart in some cases from the provision of aircraft, is recorded in the case of other armies throughout the world with the following exceptions. The reorganisation of the United States and Belgian armies has been decided. In the latter case an increase in numbers and efficiency will result in the course of time. The Turkish army sustained severe losses in men and war material as the result of the campaigns in Tripoli and the Balkans. The Greek, Servian and Bulgarian armies sustained losses which are to some extent counterbalanced by the capture of .Turkish war material, including artillery.

\section{The Influence of Aircraft.}

The influence of aircraft on military operations, despite peace tests, must to a large extent remain a theoretical and speculative question until decided by actual experience in war. Consequently the subject can only be dealt with tentatively and very generally. Both dirigible airships and aeroplanes of different types, the latter carrying observers as well as pilots, will be employed. Their activities will be affected according to the season of the year and by conditions of weather, wind, cloud, mist and darkness. Airships will have the advantage of longer flight, greater stability and larger radius of action, while aeroplanes will be swifter, present less vulnerable targets and be less costly to provide. At present the main tendencies in the employment of aircraft are: (I) in the case of dirigible airships, their development for (a) strategical reconnaissance over a large area, (b) night reconnaissance; (2) in the case of aeroplanes, their development for (a) tactical reconnaissance by day, (b) observation of artillery fire. Both types of aircraft will be used for aerial wireless telegraph signals and intercommunication services generally, especially over a wide front when other communications are blocked or difficult. Both will further be employed for aerial photography, making aviation maps and in varying degrees for offensive action with light guns and explosives.

Thus the principal use of aircraft will be to obtain and transmit information. Their radius of action in strategical or tactical reconnaissance will be far greater and swifter than that of cavalry. Within a few hours the results of an aeroplane reconnaissance along seventy miles of country should be in the hands of a commander-a task which cavalry would probably require some days to perform. The information obtained by aircraft reconnaissance will probably be more accurate and complete than that which would usually be supplied by cavalry. For example, mountains, rivers and covering troops cannot screen the movements of an army from aircraft, and though small numbers of troops may be hidden from them in broken or wooded country, it will be extremely difficult for large numbers or marching columns to escape observation. 
Aircraft, then, will mainly influence operations through increased facilities for information. They will enable commanders to base plans upon certainties where formerly they were forced to act upon conjecture or in ignorance of material factors. They will render it more difficult to mislead or mystify an opponent. They will probably tend to concentrate power in commanders-in-chief and curtail the freedom of subordinate leaders. They will save cavalry much distant reconnaissance and accordingly increase the value of that arm in its other duties, which consist of affording protection to troops and action on the battlefield. Aircraft will not replace cavalry nor revolutionise its action. They will supplement but not wholly usurp one of its functions, namely, reconnaissance.

In regard to offence, a certain amount of the moral effect will be produced by dropping bombs on troops, arsenals and cities; and this effect will undoubtedly be great on a civilian population even if the explosives do little damage." It is certain that attempts will be made to limit the activities of aircraft and to destroy them, for which purpose special weapons will be perfected for use on airships, aeroplanes and on land. It is also certain that opposing forces will attempt to gain superiority in aircraft which will result in an overwhelming advantage against an enemy. Hostilities in future may possibly commence with a preliminary phase of aerial combat between opposing aircraft with the object of obtaining the "command of the air." The results that an unopposed aircraft may be able to achieve will obviously be reduced to a great extent by the pressure of efficient hostile aircraft.

\section{The Balance of Power.}

In considering the effect of recent military changes and developments upon the balance of international power, it is necessary to remember that the military factor of this problem cannot be considered wholly independently of its other main factors, policy, sea power and wealth. The naval and military energies of war-power are closely interrelated, and both are influenced by considerations of policy on the one hand and wealth on the other. It must also be remembered that the more equally the scales of power are balanced the more sensitive they become to the play of the various forces which disturb their equipoise and react upon nations in unrest and at times in acute tension. Under these conditions which prevail at the present day even relatively unimportant military developments must appreciably affect the balance of power, while those of a far-reaching nature may completely alter the whole international situation.

Three formal alliances and one unwritten accord still in the main preserve the balance of power between the great nations of the world. These are the Triple Alliance between Germany, Austria and Italy, the Dual Alliance between France and Russia, an unwritten accord known as the Triple Entente between Britain, France and Russia, and an alliance between Britain and Japan. The Triple and the Anglo-Japanese Alliances have both recently been confirmed and extended for a further term of years while the grouping of the Powers during political crises in the present and more immediate past tend to confirm the strength, reality and continuance of the Triple Entente. For practical purposes the operation of the Triple and Dual Alliances and the Triple Fintente is confined to the continent of Europe, while the scope of the Anglo-Japanesc Alliance is definitely limited to the territories of the allies in Asia.

Among the various peoples of European descent who inhabit and dominate the continents of North and South America, Africa and Australasia, there is at present ne "balance of power" in the sense of the international policy in force in Europe and Asia. They are not yet divided by dangerous rivalries and sharp racial antagonism. or grouped accordingly like older nations into opposing armed camps nor do they ap. preciably affect the balance of power in Europe and Asia. They are happily to a grea: extent domiciled upon different continents according to their principal national and racial origin as Spanish and Portuguese Latins and Anglo-Saxons, and many of then are separated from the others by natural barriers and vast distances of land or sea. The British Self-(ioverning Dominions, owing to the peculiar constitution of the British 
Empire, are under no definite obligation to furnish troops to assist the mother country beyond their borders in the event of war in any part of the world, but the trend of Imperial policy inclines towards combined action by the naval and military forces of the whole British Empire in a supreme emergency.

Practically the whole military power of the world is thus confined, for international purposes, between the shores of Britain and Japan, within the contiguous continents of Europe and Asia. Its strongest and most numerous armies are massed in the smallest of its continents. Europe is the pivot of world power and the great danger zone of political cyclones. The armies of Europe are the huge counterweights which turn or balance the scales of international power. To-day these armies control the destiny of Europe; to-morrow they may control the destiny of the world. For the rapid development of sea-power by the great military nations-which is the most important development in armaments since the substitution of nations-in-arms for standing armies of limited size-may extend their power of offence to territories surrounded by ocean frontiers. The significance of this possibility can be realised by remembering that the limits of military power at present are racial as well as geographical. The Slavs, Teutons and Latins of Europe possess it. With a single exception the independent Asiatic races, the Latins of America and the Anglo-Saxons throughout the world, in a comparative sense lack military power.

Factors of Change.- It is clear from this general survey that the effect of recent military developments upon the balance of power must be considered separately in relation firstly to Europe, secondly to Asia, and lastly to the international situation as a whole. With regard to Europe the question is no longer limited to changes in the relative strength and advantages of the Triple Entente and the Triple Alliance respectively. With the probable continuance of the Balkan League as constituted in r9r2, apart from the possible ultimate inclusion of Rumania and Turkey, a new military power may have come into existence, destined to exercise a profound influence upon the balance of power not only in Europe but also in Asia and perhaps beyond the confines of these continents. Even in the somewhat improbable event of the disruption of the League, the principal results of the Balkan war-the practical disappearance of Turkey from Europe, a Mediterranean seaboard for Bulgaria, the economic independence of Servia with an outlet to the Adriatic, and the political independence of Albaniamust in time affect the balance of power in Europe through economic considerations and changes in policy and sea power as well as through military developments.

Apart from the Balkan War perhaps the most important recent military changes in Europe are those which affect the balance of power through the completion of railways, redistribution of troops and mobilisation. These changes aim at gaining the initiative and strategic advantage on the outbreak of war by a rapid mobilisation and concentration of troops at the desired points. The German strategic railways running both to the Eastern frontier and the Belgian frontier have been completed and the German railway system is now linked up with that of Belgium. The conversion of the Russian railways running to the Western frontier from a single to a double track is practically complete. While rearrangements in the German army ensure more rapid mobilisation and an increase of numbers in the first line on the outbreak of war, the redistribution of the Russian army makes mobilisation more secure as well as more rapid.

In the event of war these changes affect the relative position of France and Germany on the one hand and Germany and Russia on the other. Through an alliance or understanding with the Belgians or by violating their neutrality and overwhelming their resistance, the Germans may attempt the rapid concentration of a large force in Belgian territory with the object of turning the line of the French northern frontier defences by advancing into France through Belgium. Although Russia formerly possessed on her Western frontier a force superior to that with which the Germans could oppose it, the latter could be mobilised more quickly. Under the present scheme of reorganisation Russia should be secure from the danger of German attack before her mobilisation is complete, but on the other hand, notwithstanding the improvement of her western 
railway, some time must elapse before the Russian army can take the offensive against Germany and her allies.

The Triple and Dual Alliances. - In the absence of exact information regarding the war plans of different nations it is difficult to estimate the precise effect of these changes in advantage to one or other of the great groups of European Powers in the event of hostilities in which actual fighting at any time must be confined to a comparatively few uncertain points in an immense theatre of war. While France and Russia possess the advantage in numbers the Triple Alliance undoubtedly possesses great advantages as regards situation in the theatre of war. The French and Russian armies together number on war establishment alone about 9,500,000 men as against the total war establishment of about 7,500,000 German, Austrian and Italian troops. ${ }^{1}$ The armies of the Dual Alliance, however, are widely and completely separated by the territories of their possible enemies, while those of the Triple Alliance are better situated for combined action because for the purpose of war their territories become a single country cutting Europe in two from North to South, with coasts upon the Baltic, North Sea and Mediterranean. The land communications of their territories until invaded are secure, enabling the three armies to concentrate and reinforce one another, while the French and Russian armies must depend for these facilities upon sea communications threatened by hostile fleets.

On the whole therefore the changes under consideration seem to favour German strategy, with its principle of a strong offensive, upon which the war plans of the Triple Alliance are probably based. They will undoubtedly facilitate these plans, the object of which may be to launch swift, overwhelming attacks from one or more points simultaneously against France and Russia, or alternatively to hold back the Russian forces while every effort is concentrated upon crushing their apparently more accessible and vulnerable French ally as quickly as possible-a task which should not be easy, as the French army is one of the most formidable and efficient in the world. If the latter plan proves successful Russia will be faced with the necessity of making peace or continuing the war single-handed. Thus the Powers of the Triple Alliance, owing to advantages of situation, may succeed in concentrating their combined strength upon the armies of the Dual Alliance in turn-a manoeuvre which is practically impossible for the latter to employ against the former. ${ }^{2}$ It is clear, however, that the military situation as it stands may be altered by two important factors. These are the intervention of Great Britain as a member of the Triple Entente and possible developments of recent events in the Balkans.

The Triple Entente.-The military potentialities of Great Britain either as a kingdom or as an empire cannot be considered apart from sea power. Her power of military offence depends entirely upon the maintenance of her sea communications by the force of predominant naval strength. Without command of her sea communications as a whole her troops in any part of the world may become immobile beyond her frontiers and incapable of combined action with the rest. Thus situated the British Empire is without unity for the purpose of military offence. Its scattered armies may be isolated from one another and the power of each limited to the defence of a portion of its enormous territories. Even with the command of their sea communications as a whole assured to the British it is uncertain to what extent in a supreme emergency the combined military strength of their Empire could be concentrated in any part of the world and whether it could be so concentrated in time to be effective. The military forces of the Dominions are all organised for local defence in separate places, not for combined offence in any one place. In no case are these troops yet ready to meet the best Euro-

${ }^{1}$ Despite the dispersion of the Russian army for the defence of a vast Asiatic Empire the Dual Allitnce should be sure of superior numbers in Europe, though not necessarily at decisive points at the decisive moment.

" The forces of the Dual Alliance, however, may be able to exert effective simultaneous pressure against (iermany, as it is claimed that combinat ion ly separated armies, though still difficult, has been made easier by the use of telegraphy. Cierman opinion is said to hold that the telegraph has made operations on exterior lines effective. 


\section{THE WORLD'S : ARMIES}

pean armies in the field, and in view of the exigencies of warfare it is not certain whether, or to what extent, or when, any of them would be available for service abroad. Nor is it certain whether or how far, the Regular Army in India, Egypt and the Colonies together with the native Indian Army would be available as reinforcements for Britain or her allies at decisive points either at the decisive moment or at all.

The British Empire is not one in a military sense. Its navies do not command the seas as a whole against those of the Triple Alliance. Even with the help of the French and Russian fleets it is improbable that its shortest and most direct line of sea communications with Egypt, India and Australasia through the Mediterranean would be sufficiently secure for the transport of troops at the outbreak of war and while the Austrian and Italian fleets were in being. These facts, considered in connection with the tendency of any wars between great European Powers to be comparatively short in duration, make it probable that the effective military intervention of Britain in such a war would be confined to troops from the United Kingdom. Unless the struggle became prolonged or the combined fleets of the Triple Entente in its early stage gained complete command of the sea and more especially of the Mediterranean, it is improbable that reinforcements from India, the Colonies and the Dominions would arrive in time to intervene effectively in Europe as part of a British force. It might, moreover, be impossible either in time for effective action or at all for the British to withdraw troops from certain parts of the Empire without imperilling their safety or disturbing the tranquillity of territories inhabited by vast alien and subject populations.

Thus British military intervention in Europe, in the early stage of war at any rate, would probably be limited to troops from the United Kingdom, namely the Expeditionary Force, which includes practically the whole of the Regular Army in home stations, brought up with reserves to six divisions, numbering with cavalry about $x 68, \infty 00$. These troops; would probably be despatched to co-operate with the French army. At first. sight the intervention of 168,000 men in a struggle between armies together numbering over I7,000,000 men on war establishments may seem unimportant, especially as it would still leave the French troops numerically inferior to the German. This small force, however, might prove of the utmost value to its allies, especially if the Germans attempted to advance through Belgium, for the British command of the sea would enable it, with or without French or Belgian reinforcements, to threaten the enemy's flank and lines of communication from the coast-an operation the risks and difficulties of which are clearly great but not insuperable. If utilised with judgment, skill and daring, and provided it could be despatched in time and maintained in the field, the British Expeditionary Force might help materially to turn the scales of advantage in favour of the Triple Entente, and enable the French and Russian armies to gain the initiative and press a vigorous attack against the Germans and their allies.

It is, however, doubtful, whether the Expeditionary Force could be despatched to the Continent in time or at all. The position of Britain in the event of war between the Triple Alliance and the Triple Entente will disclose the reason for this doubt. If the fleets of the Triple Entente gain command of the sea Britain is practically secure from military offence by the Triple Alliance. If Britain loses command of the sea her power of offence is paralysed and her existence is at stake on the fortune of war upon the continent and perhaps in any event: With her fleet "in being," Britain is considered secure from military offence by the Triple Alliance, except for possible raids. In theory it is considered that the results of these raids would be limited to their moral effect upon the nation, which might be very great, and to the loss and confusion occasioned by the possible destruction of naval bases, of communications such as bridges and railways, and of property in harbours, industrial centres and generally. The invasion of the United Kingdom, despite British fleets in being, by a hostile raiding force of at least 70,-oo men has authoritatively been declared to be a practical possibility, and there can be no certainty that its strength will never exceed this number. ${ }^{1}$. It is both asserted and

${ }^{1}$ It may, however, be that the enemy would not be able to detach largely from his force for the invasion of Britain, at any rate in the early stages of the struggle under consideration. 
admitted on the highest authority that the Territorial Force, which is intended for the defence of Great Britain - and presumably Ireland-in the absence of the Regular Army abroad, is unfit to meet good Continental troops in the field, and that this weakness cannot be remedied until some months after the outbreak of war. ${ }^{1}$

This then is the position of Great Britain. Her obligations to the Triple Entente, as well as her own vital interests and ultimate security, might and most probably would demand the despatch of the Expeditionary Force to the help of her allies on the continent immediately war broke out or very soon afterwards. Sound strategy in any event would also demand this step, in order to develop the greatest possible strength at the decisive point, which in this case is the Continent. But under the circumstances Britain could not fulfil her obligations to her allies nor act in her own interest to the best advantage and in accordance with the principles of sound strategy, without leaving herself to a serious extent defenceless in the event of invasion for some months after hostilities commenced owing to the unreadiness of the Territorial Force. Theoretically she might be well advised to despatch the Expeditionary Force to the continent and take what strategists would term the " minor" war risks of invasion by raiding forces. Actually this is what she might do if the principles of strategy were the sole consideration and statesmen and soldiers were perfectly free to act upon them. Once war broke out, however, many other factors would be certain to influence and determine the national councils. It is possible that the instinct of self-preservation might impel a frightened people to forbid the despatch of the Expeditionary Force until too late or perhaps altogether, because rightly or wrongly they would feel that its absence would leave them insufficiently protected against the dreaded risk of invasion. In this case neither the demands of national honour and interests nor those of sound strategy might be able to make head against the clamour of popular fear whether it were justified or not. It must be remembered that panic clouds the vision and dominates the acts of nations as well as men, and that statesmen without distinction of party have never been more subservient to the force of public opinion than at present.

For these reasons it is not sufficiently certain that Britain would be able to render military aid to the Triple Entente in the event of war with the Triple Alliance. ${ }^{2}$ The counterstroke of invasion would probably be threatened or made by Germany with the object of frightening the British people into retaining the Regular Army at home and depriving their allies of its assistance. If the military offence of Britain were paralysed the balance of advantage from the recent changes under discussion would seem to lie in favour of the Triple Alliance as against the Triple Entente. But this conclusion, together with estimates based upon it regarding the value of Great Britain to the Triple Entente, must be modified when other essential factors of the problem, such as wealth and sea-power, are taken into account. The nations of the Triple Entente, whose resources include the immense wealth of Britain, are better able to sustain the financial strain of war, especially if it becomes prolonged, than those of the Triple Alliance whose individual and combined economic strength is not so great. The supe-

It is questionable whether it would be sound strategy for him to do so before the power of the formidable armies arrayed against him were broken, or finally defeated.

${ }^{1}$ It is argued that the defects of the Territorial Force under existing conditions are to some degree irremediable, as its armament in artillery and rifles is inferior, as it is without adequate and efficient rearward services and other necessary equipment such as aircraft, which cannot well be improvised hastily, while its officers, upon whom will devolve the duty of training and leading it, are themselves to a large extent untrained.

2 Certainty as to the power of Britain in this and perhaps in any event to intervene effectively in hostilities on the continent by despatching a military force appears to depend upon three essential conditions. The first is the readiness and fit ness of an adequate force to undertake the military defence of the British Isles against Continental troops immediately war breaks out. The second is public confidence in the military arrangements for dealing with any hostile forces which may succeed in invading the British Isles during the absence of the Regular Army. The third is power to despatch the reinforcements and material necessary to make good the wastage of war, and maintain the Expeditionary Force in the field, while providing amply for the reruuirements in men and material of garrisons in naval bases, forts, etc., and of field forces in the United Kingdom. 


\section{THE WORLD'S ARMIES}

rior naval power of the Triple Entente, which is largely due to British fleets, if maintained, together with their peculiar advantages of situation, should enable Great Britain and France to keep their oversea channels of trade and food supplies open to the world during war, while they closed up those of their more or less land-locked enemies of the Triple Alliance, with the gravest economic consequences, especially in the case of Germany. Finally, if their superior naval strength gained them complete command of the sea, both France and Britain might be able to draw reinforcements from their armies abroad, and perhaps if necessary, from Russia.

The Balkan League.-If the Balkan League, with or without addition to its component states, becomes a permanent factor of European policy, a new great military Power may be added to those which constitute the Triple Alliance and the Triple Entente. In this case the results of the Balkan war may completely transform the conditions which have so far governed the balance of power. At the opening of I913 it was impossible either to anticipate exactly the land and sea frontiers and the ultimate component states of the League, or to say whether its policy would be one of isolation from the two rival groups of great Powers or an alliance or other understanding with one of them with regard to common action in the event of war. It has become clear, however, that the balance of power in Europe may henceforth depend to a great extent upon the policy of the League. The general situation of its territories places its armies on the flank of Austria and may possibly place them on the flank of Russia, while its future fleets can be based on the Black Sea and the Mediterranean. The intervention of the League, therefore, in favour of either group of Powers would be of the utmost consequence and might prove the determining factor of victory in a war between them. The very possibility of such intervention must lead to careful reconsideration, and in some cases perhaps to modifications, of the strategic principles upon which the respective war plans of the Powers have been based.

The Balance of Power in Asia.-No recent development of naval, military or political activities tends at the present time to disturb the balance of power in Asia as adjusted by the Anglo-Japanese Alliance. On the contrary the good relations existing between the three great Asiatic Powers, Russia, Britain and Japan, have enabled them to deal with difficult and even dangerous problems in a spirit of amity and mutual consideration which makes for the maintenance of peace. Possible rivalries in the south-west and north-east of Asia have been averted by the division of Persia into Russian and British spheres of influence, while the Chinese provinces of Mongolia and Manchuria have been divided into Russian and Japanese spheres of influence. As a result the recent Persian and Chinese revolutionary movements have not reacted unfavourably upon the international situation in Asia or elsewhere. It is impossible to forecast exactly the consequences of what may prove to be the practical expulsion of the Turks from Europe and their concentration in Asia Minor, but there is no reason to suppose that these changes will disturb the balance of power in Asia in the immediate future.

The International Situation.-The international situation is never free from elements of uncertainty and danger. It is also subject to continual change because its political activities are generally measures of temporary expediency adapted to the play of forces which unite or divide nations according to the agreement or conflict of their interests at any time. So long as the balance of power between the various groups of allies in any part of the world is maintained, the danger to peace from issues between them is minimised. The moment the balance of power between these groups is seriously disturbed, the danger to peace from such issues becomes acute, for the very, foundation upon which the international structure rests is weakened or fails to support it. Thus the gravest perils of the political situation at all times are not concrete issues between rival groups of allies, which as a rule tend to unite the nations of each group more closely together in defence of their common interests and, as it were, automatically lock the scales of power at an even balance. They are usually forces which disturb the balance of power itself by weakening or disintegrating one of the groups essential for its maintenance or by altering the grouping of nations so as to make any one combination 
predominant. At the end of 1912 the possible results of the unfinished Balkan War, and the problem of British military weakness for offensive purposes, constituted the most important uncertain factors in the equilibrum of international power and therefore of international peace.

(E. John Solano.)

\section{THE WORLD'S NAVIES ${ }^{1}$}

Since I 10 progress in the navies of the world has taken two directions: (I) the number of countries claiming a measure of sea-power has been enlarged; (2) the power of existing navies has shown a progressive increase, less in numbers than in size, power, vision, hearing and reach of warships.

Spain, Holland, Argentina, Chile and Australia have joined the number of those States which aspire to own "Dreadnought" ships. Brazil was already included in the list, and, despite recent events, it may be necessary to include Turkey also. Negotiations were proceeding at the end of 19I2 for the construction of two "Dreadnoughts" to the order of Portugal. With the opening of the Panama Canal, sea-power will be found to be established in all the oceans of the world.

In regard to the second point, we may deal first with size and power. Table I compares the latest ships building in $x_{9} \mathrm{I}_{2}$ for the naval Powers with the original Dreadnought. The increase in the displacement of battleships is from about 18,000 tons to over 30,000 .

Table I. Batleships.

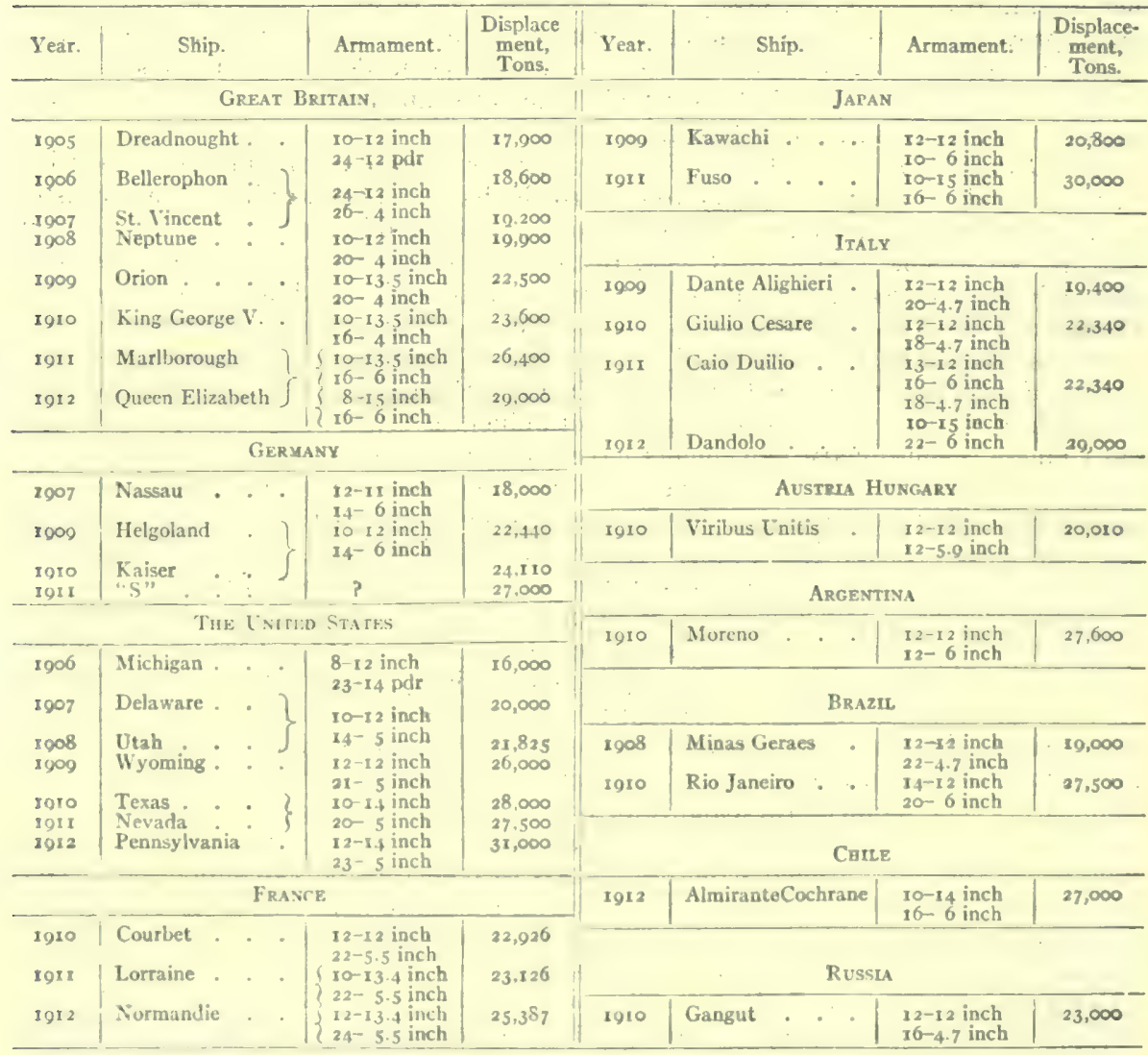

' See E. B. xix, 308 et seq. 
We turn next to battle cruisers, a new class of ship of great significance in the naval progress of the world. Of these there are three types in existence, although two of the three do not bear the name. The first type is represented by the Italian "San Giorgio" class, the Russian "Rurik," and the Greek "Giorgios Averoff." They range from 10,000 tons to $x_{5}, 000$, and are armed with weapons of about ro-inch calibre. The second type are the Japanese "Tsukuba" and "Kurama " classes, ranging from I 2,000 to I4,000 tons, and carrying as their primary armament 12 inch weapons. The third type are the vessels, only built by Great Britain, Germany and Japan, which are fast "Dreadnoughts." Table II gives particulars of this latter class.

Table II. Battle Cruisers.

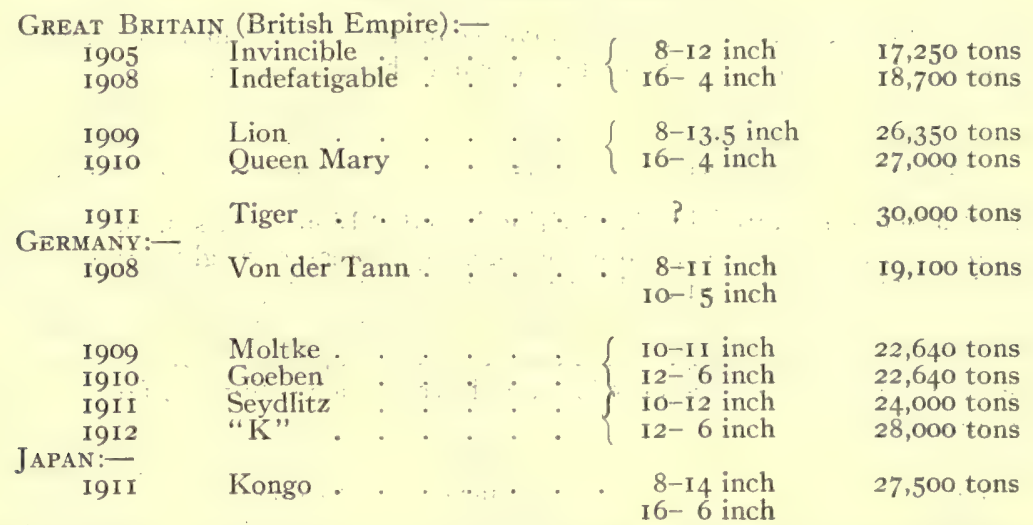

The "Australia" (a sister ship of the "Indefatigable") and the "New Zealand " are contributions of the British Dominions to the world's naval progress.

The worth of the battle cruiser is shown by the fact that the British Admiralty have determined to compose the Mediterranean Fleet entirely of this class of ship. It will probably also in the future constitute the whole of the British fleets on distant service.

Increase of "vision," in the case of ships, does not primarily belong to the ships themselves, but is owing to the immense advance made in aviation. The hydroplane is now a recognised arm of the naval service, and it cannot fail to have far-reaching results in the early obtaining of information about an enemy's fleet. It is too early to say that the aeroplane has been properly co-ordinated with the naval service. But the establishment of a naval section of the Royal Flying Corps in connection with the British Navy gives promise of an efficient service. While Great Britain, France and the United States have adopted the aeroplane, Germany seems rather to rely on the dirigible.

"Hearing" is, of course, wireless telegraphy. A British warship off the coast of Spain communicated in ror 2 direct with Bombay. A British Imperial chain of stations is being established which will need only one relay from England to Australia. During the Balkan crisis in the autumn of I9I 2, the "Weymouth," a British cruiser, was in continuous communication from Constantinople with Whitehall.

"Reach" may be either strategical or tactical. The former is expressed in the term " enduring mobility," and is bound up in the question of oil fuel, which is estimated not only to give three knots extra speed, but also to increase the fuel endurance of ships by 25 per cent. Added to which, they can take in fuel wherever they happen to be without returning to port for it. The latest battleships of the British Navy are designed to carry oil fuel only. A Royal Commission, with Lord Fisher as Chairman, has sat to consider the question of the supply of oil fuel to the Navy, and the feasibility of adopting the internal combustion type of engine as the propulsive power. The Commission were confronted in I9I 2 with the difficulty that internal combustion engines were all of the reciprocating type. They were looking for one on the turbine principle. The only internal combustion engine based on the turbine principle was the Gnome, generally used 
for aeroplanes; and so far it had proved beyond the power of mechanics and metallurgists to produce this type outside France.

Tactical reach is involved in the increased range of guns and torpedoes. In Ino 8 and onwards, the Germans, abandoning their principle of arming their ships with the lightest heavy gun which would be effective against armour, adopted a weapon corresponding to the I 2-inch which was for years the standard heavy weapon in other navies. The details of this weapon are as follows:-

$\begin{array}{ccccc}\text { Calibre. } & \text { Weight. } & \begin{array}{c}\text { Length in } \\ \text { calibres. }\end{array} & \begin{array}{c}\text { Weight of } \\ \text { projectile. }\end{array} & \begin{array}{c}\text { Muzzle } \\ \text { velocity. }\end{array} \\ \mathbf{1 2 . 0} \text { in. } & 51 \frac{1}{2} \text { tons } & 50 & 98 \mathrm{I} \text { lbs. } & 2,838 \mathrm{f} \text { s. }\end{array}$

But the following year saw a general advance in the size of primary artillery. Great Britain led the way with a 13.5 inch gun, of which the following are the particulars:-
Calibre.
Weight.
Length in calibres
Weight of
projectile.
Muzzle
I3.5 in. $\quad 76$ tons.
45
$1,25^{\circ}$
velocity.
2,82I f.s.

This weapon is mounted in the "Orion " and "Lion" classes, but it has been followed by another of identical calibre but slightly increased weight, firing a projectile of $\mathbf{r}, 400$ lbs. This is mounted in the "King George V," "Queen Mary" and subsequent classes. It is likely that the new ships will mount a weapon of $\mathrm{I}_{5}$, or some probably of 16.25 , inch calibre, weighing 122 tons, and firing a projectile of $2,200 \mathrm{lbs}$.

Other nations which have adopted a gun above 12 inch calibre, so far as is known, are the following:-

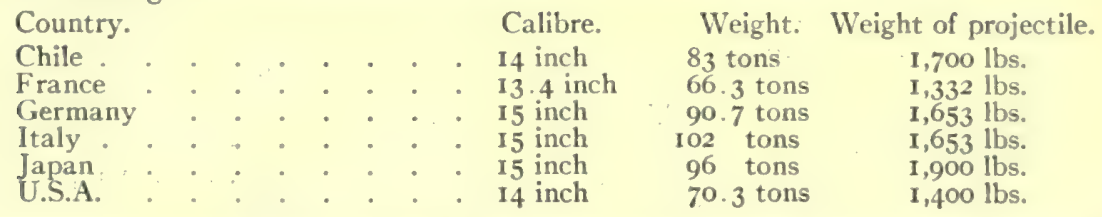

In regard to some of these countries, the information must be accepted with reserve. The guns have certainly been built and tested; but there is no official information that they have been adopted for naval use. Notably is this the case with Germany.

As regards the torpedo, all the naval nations have now adopted a $2 \mathrm{I}$-inch weapon, which, with hot air, has an extreme range of 10,000 yards and an initial speed of 33 knots.

Armour.-Krupp cemented continues to be the standard armour of the world, at any rate for heavy plates. The American Bethlehem plate is a modification thereof. The Richardson armour, which is an alloy of molybdenum, has given excellent results on the testing ground, but has not at present been adopted, owing to the reluctance of the great manufacturing firms to incur the expenditure involved in laying down the necessary plant. For lighter plates, a vanadium compound has been adopted by the British Admiralty, which proposes to employ it for the light-armoured cruisers ordered under the programme of $1912-13$.

There is a distinct tendency noticeable towards an increase both in the prolongation and in the thickness of the armour belt. The II inches of the "Ireadnought "have become 13 inches in later vessels, while, in the American "Oklahoma " class, the belt is to extend over 400 feet of the 575 which is the total length of the ship.

In British battleships the main armour-belt, which was II inches thick in the "Dreadnought" and the "Bcllerophon " classes, was reduced to $9 \frac{1}{2}$ inches in the "St. Vincent " class, rose to I 2 inches in the "Neptune" and "Orion " classes, and has been further increased to $13 \frac{1}{2}$ inches in the "King George V" and subsequent classes. For battle cruisers, it has risen steadily from 7 inches in the "Invincible " to 9 inches in the "Lion." The latest classes are to have special armoured gratings over the funnels as a protection against attack by aeroplane, and also an armoured upper deck.

in German battleships, the main belt has progressed from $9 \frac{3}{4}$ inches in the "Nassau " 
class to $\mathrm{I} 2$ inches in the "Kaiser" class, the latest completed, while in the " $\mathrm{S}$ " now building it is alleged that a $I_{5}$ inch belt is contemplated. Battle cruisers vary from 7 inches in the "Von der Tann " to $9 \frac{1}{4}$ inches in the "Seydlitz."

American practice has varied considerably. The "Michigan" class have a long, narrow belt of II inches tapering to 9 inches covering two-thirds of their length. In the "Delaware" the belt is also of II inch armour, long and narrow, but continued upwards about the turret bases. In the "Utah" and "Florida" this extension is again abandoned; in the "Texas" class the thickness of the plate is increased to I 2 inches, but the belt remains narrow, whereas in the "Nevada " there is a long and wide belt of no less than $\mathrm{r}_{4}$ inches in thickness, and this armour is carried up to the base of the funnels and to the top of the barbettes and conning-tower. These ships will be the most heavily armoured in existence; but American practice has been curiously inconsistent in the matter of armour protection.

The Japanese do not pin their faith to armour. Their "Dreadnought " battleships have a 12 inch belt amidships which covers less than one-third of the ship. It is, however, very wide. The battle cruisers are to have a ro inch belt amidships.

The French navy has apparently abandoned its faith in heavy plating, for the new "Dreadnought " battleships of the " Courbet " and "Lorraine " classes only have very short and narrow belts of $10 \frac{3}{4}$ inch armour, the rest of the hull being covered with 7 inch plates. The turrets, however, are protected by 12 inch armour in the former class, and by no less than $\mathrm{I} 7$ inch in the latter.

The Italians, true to their tradition, are armouring their new ships of the "Dante Alighieri " and "Conte Cavour " classes very lightly. A short but wide belt $9 \frac{1}{4}$ inches in thickness is their main defence, and the turrets are equipped in the same manner.

The Austrian "Viribus Unitis" class has a short and narrow belt of I I inches, and the turrets have the same protection. The belt is reduced to 4 inches near the ends, and the extreme bow and stern are unprotected.

Naval opinion, which tends to uniformity all over the world in the matter of armament and speed, is thus seen to be curiously divided as to the value of armour protection and the best way of applying it.

The Battle Cruiser. - In the British Navy the fast armoured cruiser of the "Dreadnought" type has now been definitely distinguished from other classes by the name " battle cruiser." The Germans, on the other hand, retain the name "Panzer-kreuzer" for all armoured cruisers alike. But the functions of the battle cruiser, as understood in Great Britain, are specific. She is neither a heavily armed cruiser nor a lightly armoured and speedy battleship. She is sometimes traced to Italian influence; but she embodies the very antithesis of the Italian conception of including battleships and armoured cruisers alike under the title of "nave di battaglia."

The term "cruiser" to denote a separate class of ship belongs to the day of the ironclad. In the sailing era, warships were divided into ships-of-the-line and frigates. The former, up to the 74 's, and in some cases including them, were used frequently for cruising duties. They were detached to act independently if required; they were flung first into battle in a general chase; they were occasionally used, as Nelson proposed to use them at Trafalgar, as a separate light squadron. Battle cruisers are intended to perform similar duties; they have nothing whatever in common with the frigate, which is to-day represented by the smaller armoured cruiser, the protected cruiser and the scout. In the British Navy, the battle cruiser, with her high' strategical mobility-the sum of speed and fuel endurance - is particularly marked out for oceanic service, where distances are long, and where rapid reinforcement of a threatened area may be required. If the past is any guide to the future, the Imperial Fleet will be composed, so far as its fighting units go, of battle cruisers.

So far, only three Powers have adopted the battle cruiser:- - Great Britain, Germany and Japan. The type has developed into the biggest ship afloat, and is extremely costly, the price of construction running up to $£ 2,500,000$ in the case of the German ships. Table III shows the evolution of the type. 


\section{THE WORLD'S NAVIES}

Table III. Battle Cruisers.

\begin{tabular}{|c|c|c|c|c|c|}
\hline Year. & Ship.: & $\therefore$ & Armament & Speed. & Fuel Capacity \\
\hline $\begin{array}{l}\text { AT BRITA } \\
\text { I905. }\end{array}$ & Invincible & & $8-12$ inch & 28.6 & 2,500 tons \\
\hline 1908 & Indefatigable & ${ }^{\prime}$ & $8-12$ inch & 29.12 & 2,500 tons \\
\hline 1909 & Lion & : & $8-13.5$ inch & $\begin{array}{c}31 \cdot 78 \\
\text { designed } 28\end{array}$ & 3,500 tons \\
\hline 1910 & Queen Mary & 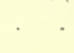 & $8-13.5$ inch & designed $2 \mathrm{I}$ & 3,500 tons \\
\hline I91I & Tiger & . & $8-?$ & & 4,000 tons \\
\hline $\begin{array}{l}\text { RMANY:- } \\
1907\end{array}$ & Von der Tann & . & 8-1I.inch: & 28.12 & 2,800 tons \\
\hline 1908. & Moltke & & 10-I I inch & 28.57 & 3,100 tons \\
\hline 1910 & Seydlitz & & $10-12$ inch & designed 27 & 3,100 tons \\
\hline 191I & ¿X, & : & Io-I2 inch & designed 3o & 3,100 tons \\
\hline AN:- & & & & & \\
\hline 1910 & Kongo & 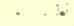 & $8-14$ inch & designed 27 & tons \\
\hline
\end{tabular}

Cruisers and Scouts.- The needs of different nations in the matter of commerce protection and in the distances over which their fleets may have to operate are so various that it is hopeless to look for any common rule in the construction of light cruisers and scouts. Moreover, the perfecting of wireless telegraphy and the arrival of the aeroplane have fundamentally altered the conditions of the question, in the opinion of many naval officers. Within the last four years, Great Britain, Germany, Japan, Italy, Austria-Hungary and Brazil have alone built light cruisers.

The only striking variation in type has been made by Great Britain, a new class of " light-armoured cruiser," designed for a special tactical reason, having been projected in the current programme. Of these ships, eight are being laid down. They will be of 3,700 tons displacement, will carry 6-6 inch guns (or ten 4 inch); will be protected with four inches of special vanadium steel armour; speed 3 I knots. Their special function is to repel attacks by torpedo craft on the battle fleet during a fleet action.

Apart from these ships, the cruiser construction of Great Britain has been under two heads:- ( I) Protected cruisers designed for fleet and general service, (2) unprotected cruisers designed for service with the torpedo flotillas.

The details of British and foreign building are given in Table IV.

\section{Table IV. Cruisers.}

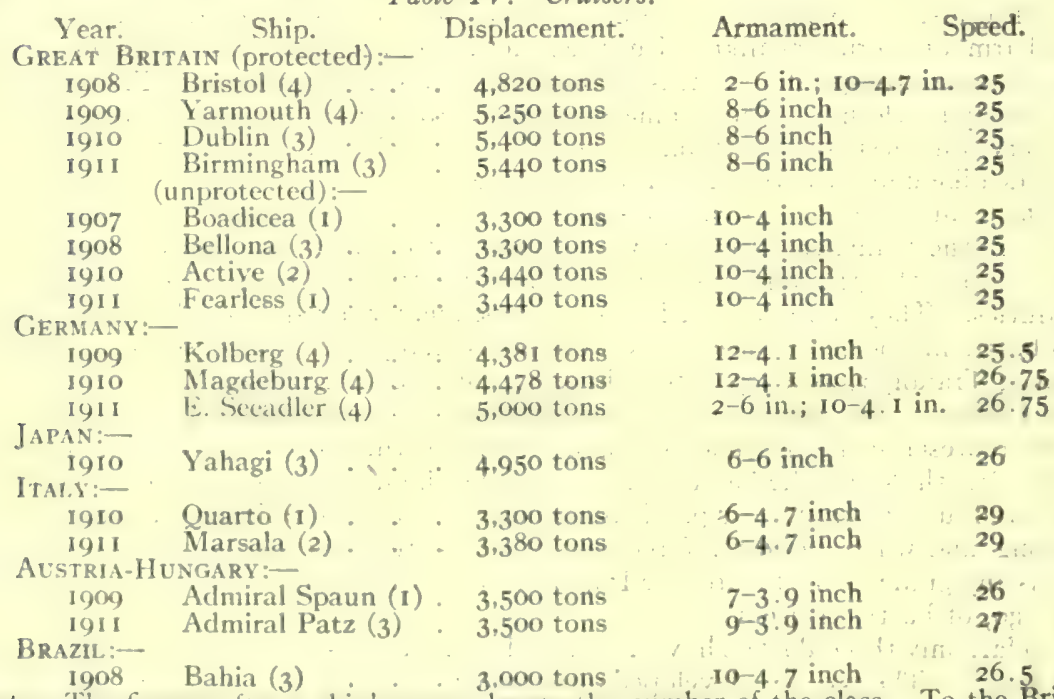

Note. - The figures after a ship's name denote the number of the class. To the Britlsh total there should be added three ships identical with the "Birmingham " cla'ss building for the Australian Government. 
Torpedo Craft (Above Water). - There has been continuous activity in the construction of torpedo craft among all naval nations since r909, but the type presents few new features, except in the engineering department. The British Admiralty are experimenting with a boat fitted with geared turbines, and with one with internal combustion engines for cruising purposes. The details concerning this type of ship are given in Table V.

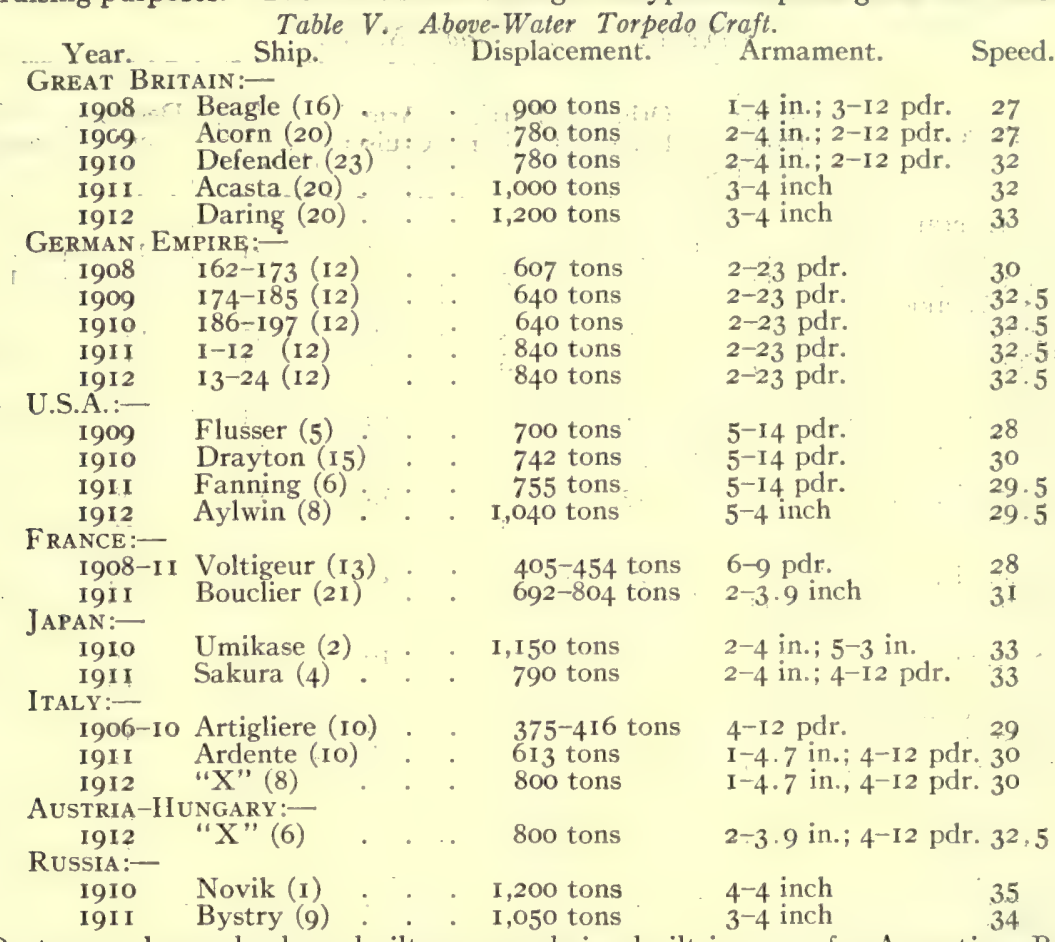

Destroyers have also been built, or were being built in I9r 2, for Argentina, Brazil, Chile, China, Denmark, Sweden, Norway, Holland, Spain, Portugal and Rumania, while Greece has recently purchased four from Argentina. The increased size, which is a common feature, has been devoted, in the majority of cases, to increased fuel supply, and to the fitting of enlarged torpedo-tubes to carry the $2 \mathrm{I}$ inch torpedo. The primary rôle of the destroyer, namely, as an antidote to the torpedo-boat, is being more and more lost sight of. The ships are used for cruiser duties and for service with battlefleets. But the above-water torpedo-boat is practically obsolete. All modern destroyers are fitted with wireless telegraphy.

Submarines. - The submarine has taken the place of the above-water torpedo-boat as a weapon of offence. The latest designed type are of 940-1,200 tons displacement, have a radius of action of 2,000 miles or over, a surface speed of 20 knots, mount two 4 inch guns, are fitted for wireless telegraphy, and have ample living accommodation for officers and men. In Table VI an interesting comparison is given between the latest type ( $F$ class) of British submarine, an earlier type (A class), a torpedo-boat of the "coastal " type, and a destroyer of the 27 knot class, now passing out of sérvice.

\section{Table VI.}

$\begin{array}{lc}\text { Vessel. } & \text { Displacement. } \\ \text { "F" class } & \mathbf{1 , 2 0 0} \\ \text { "A (submarine) } & 204 \\ \text { Torpedo boat i } 33 & 308 \\ \text { Destroyer "Boxer" } & 260\end{array}$

Armament.
$\begin{aligned} & 2-12 \text { pdrs. } \\ & 6 \text { tubes } \\ & 2 \text { tubes }\end{aligned}$
$\begin{aligned} & \text { 2-12 pdr.; } 3 \text { tubes } \\ & \text { I-12 pdr.; } 5-6 \text { pdr. } \\ & \text { I tube }\end{aligned}$$\quad \begin{gathered}\text { Speed (On surface) } \\ 26 \mathrm{kts} .\end{gathered}$


The table shows that the submarine has taken her place among the offensive forces of sea-power, and that we are approaching a time.when there will be one type of torpedo-craft only - that which is able to operate above or below the surface at will.

Table VII shows the comparative strength in $1912-13$ of the naval Powers in effective ships of all the various classes.

Table VII. The World's Navies.

\begin{tabular}{|c|c|c|c|c|c|c|c|c|c|}
\hline Power. & & & $\begin{array}{l}\text { Battle- } \\
\text { ships. } \\
\text { Dread- } \\
\text { noughts. }\end{array}$ & $\begin{array}{l}\text { Other } \\
\text { Types. }\end{array}$ & $\begin{array}{l}\text { Battle } \\
\text { Cruisers. }\end{array}$ & $\begin{array}{l}\text { Arm'd } \\
\text { Cruisers. }\end{array}$ & $\begin{array}{c}\text { Pro- } \\
\text { tected } \\
\text { Cruisers. }\end{array}$ & $\begin{array}{l}\text { Destroy- } \\
\text { ers. }\end{array}$ & $\begin{array}{c}\text { Sub- } \\
\text { marines. }\end{array}$ \\
\hline $\begin{array}{l}\text { BRITISH EMPI } \\
\text { Completed }\end{array}$ & :- & . & 15 & 40 & 8 & 34 & 84 & 212 & \\
\hline $\begin{array}{l}\text { Building } \\
\text { GERMAN EMPI }\end{array}$ & $\therefore$ & & II & $\therefore$ & 2 & 34 & 13 & 20 & $\begin{array}{l}15 \\
14\end{array}$ \\
\hline Completed & . & . & 10 & 20 & 3 & 9 & 38 & 121 & 24 \\
\hline $\begin{array}{l}\text { Building } \\
\text { U.S.A.:- }\end{array}$ & . & . & 7 & $\cdots$ & 3 & $\ldots$ & 4 & 12 & 12 \\
\hline $\begin{array}{l}\text { Completed } \\
\text { Building }\end{array}$ & . & . & $\begin{array}{l}8 \\
.5\end{array}$ & 22 & $\begin{array}{l}\cdots \\
\cdots\end{array}$ & $\begin{array}{l}15 \\
\cdots\end{array}$ & $\begin{array}{l}14 \\
\cdots\end{array}$ & $\begin{array}{l}42 \\
8\end{array}$ & $\begin{array}{l}3 \mathrm{I} \\
8\end{array}$ \\
\hline $\begin{array}{l}\text { JAPAN :- } \\
\text { Completed . } \\
\text { Building }\end{array}$ & : & · & 2 & 13 & $\because$ & 13 & I6 & $5^{8}$ & 12 \\
\hline FRANCE:- & ${ }^{\circ}$ & & I & $\cdots$ & 4 & $\cdots$ & $\ldots$ & & 3 \\
\hline $\begin{array}{l}\text { Completed } \\
\text { Building }\end{array}$ & . & : & iI & 20 & $\because$ & 19 & 7 & $\begin{array}{r}74 \\
9\end{array}$ & $\begin{array}{l}69 \\
20\end{array}$ \\
\hline ITALY:- & & & & & $\cdots$ & $\cdots$ & $\cdots$ & & \\
\hline $\begin{array}{l}\text { Completed } \\
\text { Building }\end{array}$ & . & - & I & 8 & .. & Io & 4 & 28 & 16 \\
\hline AUSTRIA-HUN & $\dot{R Y}$ : & & 7 & $\cdots$ & $\cdots$ & $\cdots$ & 3 & 18 & 4 \\
\hline $\begin{array}{l}\text { Completed } \\
\text { Building }\end{array}$ & . & . & $\begin{array}{l}1 \\
6\end{array}$ & 6 & $\because$ & 3 & 6 & 12 & 6 \\
\hline RUSSIA:- & & & 0 & & $\because$ & $\cdots$ & 3 & 6 & 12 \\
\hline $\begin{array}{l}\text { Completed } \\
\text { Building }\end{array}$ & . & . & $\cdots$ & 8 & . & 6 & 8 & $94^{\circ}$ & 29 \\
\hline $\begin{array}{l}\text { Building } \\
\text { ARGENTINA :- }\end{array}$ & . & . & 7 & $\cdots$ & 4 & $\ldots$ & $\ldots$ & Io & 8 \\
\hline $\begin{array}{l}\text { Completed } \\
\text { Building }\end{array}$ & . & · & . & $\cdots$ & $\cdots$ & 4 & 3 & ..' & I \\
\hline $\begin{array}{l}\text { Building } \\
\text { BRAZIL:- }\end{array}$ & - & . & 2 & $\ldots$ & $\ldots$ & . & $\cdots$ & . & . \\
\hline $\begin{array}{l}\text { Completed } \\
\text { Building }\end{array}$ & - & • & 2 & $\cdots$ & $\cdots$ & $\therefore$ & 4 & 10 & $\because$ \\
\hline $\begin{array}{l}\text { Building } \\
\text { CHILE:- }\end{array}$ & • & & 1 & $\cdots$ & $\cdots$ & $\cdots$ & I & $\therefore$ & 3 \\
\hline $\begin{array}{l}\text { Completed } \\
\text { Building }\end{array}$ & . & . & $\because$ & $\cdots$ & $\cdots$ & 2 & 4 & 12 & $\because$ \\
\hline SPAIN:- & & & & & . & $\cdots$ & $\cdots$ & $\ldots$ & 2 \\
\hline $\begin{array}{l}\text { Completed } \\
\text { Building }\end{array}$ & . & . & $\ddot{3}$ & I & - & 3 & 5. & 7 & . \\
\hline $\begin{array}{l}\text { Building } \\
\text { TURKEY:- }\end{array}$ & ${ }^{\circ}$ & & 3 & $\cdots$ & $\cdots$ & $\cdots$ & $\cdots$ & . & \\
\hline $\begin{array}{l}\text { Completed } \\
\text { Building }\end{array}$ & : & . & i & $\begin{array}{l}3 \\
\ldots\end{array}$ & $\begin{array}{l}\ldots \\
\ldots\end{array}$ & $\begin{array}{l}\therefore \\
\cdots\end{array}$ & 3 & 9 & $\begin{array}{l}\cdots \\
\ldots\end{array}$ \\
\hline
\end{tabular}

Expenditure.-Owing to the differing budgetary methods of the various States, it is difficult to compare naval expenditure satisfactorily. The difference of cost of the voluntary personnel of Great Britain and the United States on the one hand, and the conscript navies of all the other Powers on the other, vitiates the comparison. For instance, in the German Budget, the charges for non-effective services and naval works are borne on other estimates. The following are the charges (1912) of the chief naval Powers:-Great Britain, $£ 44,085,400$ (plus $£ 990,000$ supplementary); German Empire $£ 22, \infty 88,746$ (plus $\{734, \infty 00$ under new Navy Act); United States, $£ 25,944,798$; France,

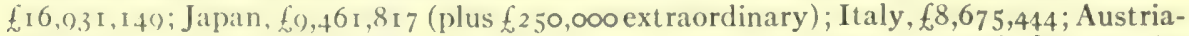
Hungary, $f_{5}, 823,200$; Russia, $f_{2} 18,669,825$. It must be borne in mind that, in the newer navies, those of (iermany, Austria-Hungary and Japan, for instance, the sum devoted to new construction is proportionately more and that devoted to maintenance 
proportionately less. All things being taken into consideration, there is probably little difference between the naval expenditure of Italy and Austria-Hungary, or even between that of the United States and Japan, regarding what each gets for its money.

Personnel.- The number of active service ratings voted by the several Powers is as follows:-Great Britain, 137,000 with 58,000 reserves; German Empire, 54,69 I with I I0,000 reserves; United States, 60,217; France 62,000 with I 20,000 reserves; Japan, 48,000 with 15,000 reserves; Italy, 33,500; Austria-Hungary, I8,500; Russia, 50,3 I3, with 30,000 reserves. The reserve figures are only approximate.

German Navy Law.-The most important feature of the naval year I9I2 was the passing of the new German Navy Law. By this, three additional first-class armoured ships were to be added to the German navy, the first to be laid down in 19I3, another in 1916 , and the third at some date unspecified; a third battle-squadron is to be kept in commission with full crews and the personnel to be increased by I4,3 io men. The effect of German expansion on international relations is shown in the British Admiralty Memorandum set out below.

The British Dominions.-The entry of the British Dominions oversea into the area of naval affairs may be said to date from 1909, when New Zealand voted a battle cruiser for the service of the Royal Navy, and Australia began to create a Fleet Unit, to consist at the outset of one battle cruiser, three protected cruisers, three destroyers, and some submarines. All the ships of the three former classes are now in the water, and two of the destroyers in commission. The Australian Fleet Unit will eventually be manned by Australian crews, and will be administered by a Navy Board in the Commonwealth itself. The officers will be trained in an Australian Naval College. A larger scheme, worked out by Admiral Sir Reginald Henderson, has been adopted by the Australian Government, by which, in 22 years, the Commonwealth will be provided with a fleet of four battle cruisers, twelve protected cruisers, and twenty-four destroyers, with submarines. The whole will pass under the British Admiralty in the event of war.

Canada, in the meantime, under the government of Sir Wilfrid Laurier, took the preliminary steps towards creating a small navy, to consist of five small cruisers of the Bristol class and one Boadicea, with 6 destroyers and submarines. Arrangements were made for training officers and men, and the cruisers "Niobe" and "Rainbow" were purchased from the British Government as a nucleus. When Mr. Borden succeeded Sir Wilfrid Laurier, however, these dispositions were altered, and, as a result of conferences held between Canadian ministers and the Home Government in I91 2, it was proposed that the Dominion should contribute three ships to the mother navy as an emergency measure pending future arrangements by which an Imperial Admiralty might be established to control the naval defence of the whole Empire. (See CaNADA in Part II.)

The Union of South Africa has been in consultation with the Admiralty as to the best way in which it may join in the movement for naval defence; New Zealand has been contemplating a further offer; the Council of the Federated Malay States, on the motion of the Sultan of Perak, offered in November I 9 I 2 a first-class armoured ship to the Home Government, which accepted the offer; and a movement was even said to be in progress among the native princes of India for co-operating in the same direction.

The Panama Canal.-The approaching opening of the Panama Canal is likely to have an important bearing on the naval situation in the near future. Theoretically, the power of the Navy of the United States is almost doubled thereby, since the journey of about 9,000 miles round Cape Horn necessary to shift the Atlantic flect to the Pacific area is thereby avoided; but it has yet to be seen whether, in point of fact, public opinion in America will permit of the transfer. The opening of the Canal indubitably gives importance to the fleets of the South American Republics, which will shortly have seven "Dreadnought" ships in their hands. The existence of an "A.B.C. Alliance" (Argentina, Brazil, and Chile), however, rests only on rumour. The United States harbour of Guantanamo, with Jamaica in friendly hands, controls the Atlantic entrance to the Canal, while, if the efforts to obtain the Galapagos Islands are successful, the Pacific entrance will be equally secure.

(Gerard Fiennes.) 


\section{The British View of the Balance of Power.}

Under " Canada " in Part II of the YEAR-BOoK, the proposed addition to the British Navy of three Canadian "Dreadnoughts " is fully dealt with, but it will be useful to give here the important Admiralty Memorandum of December 5, I0 I2, which explains why, in the opinion of the British Government, the international naval position has become a menace to the Empire:-

I. The Prime Minister of the Dominion of Canada has invited His Majesty's Government through the Board of Admiralty to prepare a statement of the present and immediately prospective requirements of the naval defence of the Empire for presentation to the Canadian Parliament if the Dominion Cabinet deem it necessary.

The Lords Commissioners of the Admiralty are prepared to comply and to supplement, in a form which can be made public, the confidential communications and conversations which have passed between the Admiralty and Ministers of the Dominion Parliament during the recent visit to the United Kingdom.

The Admiralty set the greatest store by the important material, and still more important moral, assistance which it is within the power of Canada to give to maintaining British naval supremacy upon the high seas, but they think it necessary to disclaim any intention, however indirect, of putting pressure upon Canadian public opinion, or of seeking to influence the Dominion Parliament in a decision which clearly belongs solely to Canada.

The Admiralty therefore confine themselves in this statement exclusively to facts, and it is for the Domizion Government and Parliament to draw their own conclusions therefrom.

2. The power of the British Empire to maintain the superiority on the sea, which is essential to its security, must obviously be measured from time to time by reference to the other naval forces of the world, and such a comparison does not imply anything unfriendly in intention or in spirit to any other Power or group of Powers. From this point of view the development of the German Fleet during the last fifteen years is the most striking feature of the naval situation to-day. That development has been authorised by five successive legislative enactments, viz., the Fleet Laws of 1898, 1900, 1906, I908 and 1912. These laws cover the period up to 1920 .

Whereas in 1898 the German Fleet consisted of 9 battleships (excluding coast 'defence vessels), 3 large cruisers, 28 small cruisers, I 13 torpedo-boats and 25,000 men, maintained at an annual cost of $f 6,000,000$, the full Fleet of 1920 will consist of 4 I battleships, 20 large cruisers, 40 small cruisers, I 44 torpedo-boats, 72 submarines and IoI,500 men, estimated to be maintained at an annual cost of $£ 23,000,000$. These figures, however, give no real idea of the advance, for the size and cost of ships have risen continually during the period, and, apart from increasing their total numbers, Germany has systematically replaced old and small ships, which counted as units in her earlier Fleet, by the most powerful and costly modern vessels. Neither does the money provided by the Estimates for the completed law represent the increase in cost properly attributable to the German Navy, for many charges borne on British naval funds are otherwise defrayed in Germany; and the German Navy comprises such a large proportion of new ships that the cost of maintenance and repair is considerably less than in navies which have been longer established.

3. The naval expansion of Germany has not been provoked by British naval increases. The German (iovernment have repeatedly declared that their naval policy has not been influenced by British action, and the following figures speak for themselves:-In 1905 Great Britain was building 4 capital ships, and Germany 2. In Igo6 Great Britain reduced to 3 capital ships, and Germany increased to 3. In 1907 (ircat Britain built 3 capital ships, and Germany built 3. In 1908 Great Britain further reduced to 2 capital ships, and Germany further increased to 4.

It was not until the efforts of Great Britain to procure the abatement or retardation of naval rivalry had failed for 3 successive years that the Admiralty were forced in I909, upon a general review of the naval situation, to ask Parliament to take exceptional measures to sccure against all possible hazards the safety of the Empire. In that year, 8 capital ships were laid down in Great Britain, and 2 others were provided by the Commonwealth of Australia and the Dominion of New Zealand respectively-a total of 10 .

4. In the spring of the present year the fifth German Navy Law was assented by to the Reichstag. The main feature of that law is not the increase in the new construction of capital ships, though that is important, but rather the increase in the striking force of ships of all classes which will be immediatcly available at all seasons of the year.

A third squadron of 8 battleships will be created and maintained in full commission as part of the active battle fleet. Whereas, according to the unamended law, the active battle fleet consisted of 17 battleships, 4 battle or large armoured cruisers, and 12 small cruisers, it will in the near future consist of 25 hattleships, 8 battle or large cruisers, and 18 small cruisers; and whereas at present, owing to the system of recruitment which prevails in Germany, the German Fleet is less fully mobile during the winter than during the summer months, it will, through the operation of his law, not only be increased in strength, but rendered much more readily available. Ninety-nine torpedo-boat destroyers, instead of 
66 , will be maintained in full commission out of a total of $144 ; 72$ new submarines will be built within the currency of the new law, and of these it is apparently proposed to maintain 54 with full permanent crews. Taking a general view, the effect of the law will be that nearly four-fifths of the entire German Navy will be maintained in full permanent commission; that is to say, instantly and constantly ready for war.

So great a change and development in the German Fleet involves of course, important additions to their personnel. In I 898 the officers and men of the German Navy amounted to 25,000 . To-day that figure has reached 66,000 . The new law adds 15,000 officers and men, and makes a total in 1920 of ror,500.

The new construction under the law prescribes the building of 3 additional battleshipsI to be begun next year, 1 in I916-and 2 small cruisers, of which the date has not yet been fixed. The date of the third battleship has not been fixed. It has been presumed to be later than the six years which are in view. The cost of these increases in men and in material during the next six years is estimated as $£_{10}, 500,000$ spread over that period above the previous estimates.

The facts set forth above were laid before the House of Commons on: July 22, 1912, by the First Lord of the Admiralty.

5. The effect of the new German Navy Law is to produce a remarkable expansion of strength and readiness. The number of battleships and large armoured cruisers which will be kept constantly ready and in full commission will be raised by the law from $2 \mathrm{I}$, the present figure, to $33^{-}$an addition of 12 , or an increase of about 57 per cent.

The new fleet will, in the beginning, include about 20 battleships and large cruisers of the older type, but gradually as new vessels are built the fighting power of the fleet will rise until in the end it will consist completely of modern vessels.

The complete organization of the German Fleet, as described by the latest law, will be 5 battle squadrons and a fleet flagship, comprising 4I battleships in all, each attended by a battle or armoured cruiser squadron, complete with small cruisers and auxiliaries of all kinds and accompanied by numerous flotillas of destroyers and submarines.

This full development will only be realised step by step; but already in I9I4 2 squadrons will, according to Admiralty information, be entirely composed of what are called Dreadnoughts, and the third will be made up of good ships like the "Deutschlands" and the "Braunschweigs,". together with 5 . Dreadnought battle cruisers.

This great fleet is not dispersed all over the world for duties of commerce protection or in discharge of Colonial responsibilities; nor are its composition and character adapted to those purposes. It is concentrated and kept concentrated in close proximity to the German and British coasts.

Attention must be drawn to the explicit declaration of the tactical objects for which the German Fleet exists as set forth in the preamble to the Naval Law of 1900 as follows:-

"In order to protect German trade and commerce under existing conditions, only one thing will suffice namely, Germany must possess a battle fleet of such a strength that even for the most powerful naval adversary a war would involve such risks as to make that Power's own supremacy doubtful. For this purpose it is absolutely necessary that the German Fleet should be as strong as that of the greatest Naval Power, for, as a rule, a great Naval Power will not be in a position to concentrate all its forces against us."

6. It is now necessary to look forward to the situation in I915.

In Home Waters. - In the spring of the year I9I5 Great Britain will have 25 "Dreadnought" battleships and 2 "Lord Nelsons." Germany will have I " "Dreadnought" battleships. Great Britain will have 6 battle cruisers. Germany will have 6 battle cruisers. These margins in new ships are sober and moderate. They do not err on the side of excess. The reason they suffice for the present is that Great Britain possesses a good superiority in battleships, and especially armoured cruisers, of the pre-Dreadnought era. The reserve of strength will steadily diminish every year, actually because the ships of which it is composed grow old, and relatively because the new ships are more powerful. It will diminish more rapidly if new construction in Germany is increased or accelerated. As this process continues greater exertions will be required by the British Empire.

Mediterranean Station.-Four battle cruisers and four armoured cruisers will be required to support British interests in the Mediterranean during the years I9I3 and I9I4. During those years the navies of Austria and Italy will gradually increase in strength, until in 19I5 they will each possess a formidable fleet of 4 and 6 Dreadnought battleships'respectively, together with strong battleships of the pre-Dreadnought types and other units, such as cruisers, torpedo-craft, \&c. It is evident, therefore, that in the year I9I5 our squadron of 4 battle cruisers and 4 armoured cruisers will not suffice to fulfill our requirements, and its whole composition must be reconsidered.

Overseas.- It has been necessary within the past decade to concentrate the fleet mainly in Home waters. In 1902 there were 160 British vessels on the overseas stations against 76 to-day:

7. Naval supremacy is of two kinds, general and local. General naval supremacy consists in the power to defeat in battle and drive from the seas the strongest hostile navy or 
combination of hostile navies wherever they may be found. Local superiority consists in the power to send in good time to, or maintain permanently in, some distant theatre forces adequate to defeat the enemy or hold him in check until the main decision has been obtained in the decisive theatre. It is the general naval supremacy of Great Britain which is the primary safeguard of the security and interests of the great Dominions of the Crown, and which for all these years has been the deterrent upon any possible designs prejudicial to or inconsiderate of their policy and safety.

The rapid expansion of Canadian sea-borne trade, and the immense value of Canadian cargoes always aftoat in British and Canadian bottoms, here require consideration. On the basis of the figures supplied by the Board of Trade to the Imperial Conference of I9II, the annual value of the overseas trade of the Dominion of Canada in 1909-10 was not less than $f_{72}, 000,000$; and the tonnage of Canadian vessels was 718,000 tons, and these proportions have already increased and are still increasing. For the whole of this trade wherever it may be about the distant waters of the world, as well as for the maintenance of her communications, both with Europe and Asia, Canada is dependent, and has always depended upon the Imperial Navy, without corresponding contribution or cost.

Further, at the present time and in the immediate future, Great Britain still has the power, by making special arrangements and mobilising a portion of the reserves, to send, without courting disaster at home, an effective fleet of battleships and cruisers to unite with the Royal Australian Navy and the British squadrons in China and the Pacific for the defence of British Columbia, Australia and New Zealand. And these communities are also protected and their interest safeguarded by the power and authority of Great Britain so long as her naval strength is unbroken.

8 . This power, both specific and general, will be diminished with the growth not only of the German Navy, but by the simultaneous building by many Powers of great modern ships of war.

Whereas, in the present year, Great Britain possesses 18 battleships and battle cruisers of the Dreadnought class against I9 of that class possessed by the other Powers of Europe, and will possess in 191324 to 21 , the figures in 1914 will be 31 to 33 ; and in the year 1915, 35 to 5 I.

The existence of a number of navies all comprising ships of high quality must be considered in so far as it affects the possibilities of adverse combinations being suddenly formed. Larger margins of superiority at home would, among other things, restore a greater freedom to the movements of the British squadrons in every sea, and directly promote the security of the Dominions. Anything which increases our margin in the newest ships diminishes the strain, and augments our security and our chances of being left unmolested.

9. Whatever may be the decision of Canada at the present juncture, Great Britain will not in any circumstances fail in her duty to the oversea Dominions of the Crown.

She has before now successfully made head alone and unaided against the most formidable combinations and she has not lost her capacity by a wise policy and strenuous exertions to watch over and preserve the vital interests of the Empire.

The Admiralty are assured that His Majesty's Government will not hesitate to ask the House of Commons for whatever provision the circumstances of each year may require. But the aid which Canada could give at the present time is not to be measured only in ships or money. Any action on the part of Canada to increase the power and mobility of the Imperial Navy, and thus widen the margin of our common safety, would be recognised everywhere as a most significant witness to the united strength of the Empire, and to the renewed resolve of the overseas Dominions to take their part in maintaining its integrity.

10. The Prime Minister of the Dominion having enquired in what form any immediate aid that Canala might give would be most effective, we have no hesitation in answering, after a prolonged consideration of all the circumstances, that it is desirable that such aid should include the provision of a certain number of the largest and strongest ships of war which science can build or money supply.

\section{INTERNATIONAL LAW, ARBITRATION AND PEACE}

Since roro events have been testing the value of some of the principles and institutions with which jurists and statesmen had endeavoured to create a distinctive character for the new century. Whether these new principles and institutions are standing the test satisfactorily is still more or less a matter of conjecture. The object of this survey is to examine different international manifestations in reference to the law and practice of nations which it has been the object of the Hague Conferences of 1899 and 1907 to make precise and binding, the progress made by arbitration as a method for arranging difficulties between States, its displacement of coercive methods, and the prospects of peace as a positive object of the many agencies at work for its preservation. 


\section{The Development of "International Law."}

When the various articles on questions of "International Law " in the I Ith edition of the Encyclopaedia Britannica were written, the Hague Conventions of r907 were still fresh and the controversy on the Declaration of London had not yet become a serious obstacle to its ratification. Since then there has been time for the rules therein laid down and codified to undergo careful examination. Leaving the Convention (No. I 2) relating to the establishment of an international Prize Court (which has been ratified by none of the parties) out of consideration, the result as regards the Hague Conventions ${ }^{1}$ has been that Great Britain has ratified all but the ist, relating to the pacific settlement of disputes, the 5 th, referring to the rights and duties of neutral states and persons in war on land, the roth, adapting the principles of the Geneva Convention to naval war, and the $13^{\text {th }}$, relating to the rights and duties of neutral Powers in maritime war. The United States, on the other hand, has ratified the rst, the 5 th, the roth and the r 3 th, but not the 6 th affecting the status of merchant ships at the outbreak of hostilities or the 7 th relating to the conversion of merchant intc war ships. The states which have ratified none of the Conventions include Italy, Turkey, Bulgaria, Servia, Greece and Montenegro. ${ }^{2}$ France, Germany and Austria-Hungary have ratified all but the 14 th, and Russia all but the I Ith and 14 th. Of the great Powers, only Great Britain and the United States have ratified the $\mathrm{I}$ th, prohibiting projectiles from air ships.

It is an interesting, though no doubt quite a fortuitous fact, that none of the belligerents in contemporary wars (I9IO-I2) have thus far bound themselves to observe any of the Conventions of 1907. Italy, Turkey, Greece, Servia and Montenegro, however, ratified the Conventions of $1899,{ }^{3}$ and, although there is no specific provision in the Convention for the pacific settlement of international disputes, as there is in the I907 conventions, ensuring the observance of the earlier convention pending ratification of the revised versions of 1907 , Art. 9 of that of 1907 states that " the present convention, on being duly ratified, shall take the place in the relations between the contracting Powers of the convention for the pacific settlement of international disputes of July 29, 1899." In the case of the other renewed conventions the clause runs: "The convention of 1899 remains in force as between the Powers which signed it, which do not ratify also the present convention." Captious critics might ask what force attaches to this clause in an unratified agreement, but it has, at any rate, the value of an uncontested acknowledgment by the parties to the conventions of I 899 that the mere signing of modified conventions on the same subject is not a denunciation of the existing conventions.

In spite of the non-ratification of the 1907 conventions by the Parties engaged in the Italo-Turkish and Balkan-Turkish wars, there could be little doubt that they would

1 The following is a list of the conventions adopted in 1907:-

I. For the pacific settlement of international disputes. 2. Respecting the limitation of the employment of force for the recovery of contract debts. 3. Relative to the commencement of hostilities. 4. Concerning the laws and customs of war on land. 5. Respecting the rights and duties of neutral Powers and persons in war on land. 6. Relative to the status of enemy merchant ships at the outbreak of hostilities. 7 . Relating to the conversion of merchant ships into war ships. 8. Relative to the laying of automatic submarine contact mines. 9. Respecting bombardment by naval forces in time of war. IO. For the adaptation of the principles of the Geneva Convention to maritime war. II. Relative to certain restrictions on the exercise of the right of capture in maritime war. 12. Relative to the establishment of an International Prize Court. I3. Respecting the rights and duties of neutral Powers in maritime war. I4. Prohibiting discharge of projectiles, etc., from balloons.

2 The others are Argentina, Brazil, Chile, Colombia, Cuba, the Dominican Republic, Ecuador, Spain, Luxemburg, Paraguay, Peru, Persia, Uruguay and Venezuelá. These and the 5 mentioned make 19 out of the 44 states represented at the Hague in 1907.

3 The Hague Conventions adopted in 1899 were as follows:-

1. For the pacific settlement of international disputes. 2. Relating to the laws and customs of war by land. 3. For the adaptation to maritime warfare of the Geneva convention of 1864. Three declarations on the following matters were also adopted:(a) Prohibition of the launching of projectiles and explosives from balloons. (b) Prohibition of the use of projectiles, the only object of which is the diffusion of asphyxiating or deleterious gases.

(c) Prohibition of the use of expanding bullets. 
endeavour to carry out their provisions in so far as applicable to the military operations involved. The rules laid down at the Hague have more than the nature of "pious wishes." They were the deliberate enunciation of international law based on universally acknowledged principles, as understood by specialists on the subject from every quarter of the world. They have been, in turn, incorporated by specialists and teachers in the common law of civilised states, and, ratified or not ratified, where principles and deductions therefrom are involved the Hague Conventions are now law as international law has never before quite been law.' It will be seen below that something similar has happened as regards the Declaration of London, and it is well-known that though neither Spain nor the United States were parties to the Declaration of Paris, they both observed its provisions during the war of 1898,2 simply because the provisions of that Declaration had become a part of the public law of Europe, and not to have observed them, irrespectively of the Declaration, would have been illegal.

The future of the Declaration of London seems, in this respect, likely to be similar to that of the Declaration of Paris. The Declaration consisted of a series of articles relating to blockade, contraband of war, destruction of neutral prizes, transfer to the neutral flag; convoy, resistance to search etc., which had been drawn up for the guidance of the International Prize Court, provision for the establishment of which had been made under No. I 2 of the Hague Conventions: ${ }^{3}$

The Convention for the establishment of the Court had provided under Art. 7 that in the absence of a treaty between the parties, governing the case, the Court should apply "the rules of international law," and that if " no generally recognised rule " exister, the Court should give judgment in accordance with "the general principles of justice and equity." The London Conference was called for the purpose of "laying down the generally recognised principles of international law in accordance with Art. 7 of the Convention" in question. On December 8, I9I I the Naval Prize Bill, providing for the accession of Great Britain to the Convention and consequentially to the Declaration of London, was adopted in the House of Commons by a majority of 172 to 125 votes. On the I $3^{\text {th }}$ of the same month it was rejected by a majority of 145 to 53 votes in the House of Lords. Under the Parliament Act it might still become law in two years with other bills thrown out by the House of Lords, but this would require three successive adoptions by the Commons and rejections by the Lords, and public feeling in Great Britain has not seemed sufficiently friendly to the measure to warrant any certainty that the Government would be able to count on ultimate success for the Bill even in the Commons. The objections formulated against the Bill referred both to the composition of the International Prize Court and to provisions of the Declaration itself.

The two subjects are really distinct, though the British Government has seemed to regard them as inseparable. The fact that the preamble is worded in such a way as to assume ratification of the Convention for the establishment of an International Prize Court, has not prevented the Italian and Russian governments from treating the Declaration as a statement of the international law of prize. By a Royal Decree, dated October I 3, I 9 I, the Italian government issued instructions " in conformity with " the Declaration of Paris and with the principles laid down in the Hague Conventions " as well as in the Declaration of London of February 26, I909, which the Royal Government desires should be equally observed in so far as the dispositions of the laws of the Kingdom

${ }^{1}$ See E. B. xiv, 694, "International Law."

"See E. B. vii, 914, "Declaration of Paris."

${ }^{3}$ That Convention had provided that "jurisdiction, in matters of prize, is exercised in the first instance by the Prize Courts of the belligerent captor" and that "the judgments of the national Prize courts" might be "brought before the International Prize Court-(1) when the judgment of the national Prize Courts affects the property of a Neutral Power or individuad, (2) when the judgment affects enemy property and relates to (a) cargo on board a neutral ship, (b) an enemy ship captured in the territorial waters of a neutral Power, when that Power has not made the capture the subject of a diplomatic claim, (c) a claim based upon the allegation that the seizure has been effected in violation, either of the provisions of a convention in force between the belligerent Powers, or of an enactment issued by the belligerent captor. (Arts. 2 and 3). See E. B. xxii, 374, "Prize." 
allow, although they have not yet been ratified by Italy," for the conduct of naval commanders in relation to capture and prize. ${ }^{1}$

The terms of this Italian Decree, which are specially interesting as being based substantially on the provisions of the (unratified) Declaration of London, may be taken as the latest embodiment of international practice on the subject. They were communicated to other Powers, including Great Britain, and no objection was taken to them.

\section{"Exercise of the Right of Capture and of Prize in Time of War.}

"By a Royal Decree, dated October I3th, there were approved the following instructions in conformity with the Declaration of Paris of April I6, I856, which belligerent states are under the obligation to observe, and with the principles laid down in the Hague Convention of October 18, 1907, as well as in the Declaration of London of February 26, 1909, which the Royal Government desires should be equally obșerved in so far as the dispositions of the laws of the Kingdom allow, although they have not yet been ratified by Italy, and which are to regulate the conduct of naval commanders in operations relating to capture and prize during the war.

"I. Turkey having taken no action to show that she intends to abstain from the capture and making prize of Italian merchant ships, but having been the first to make prize of Italian ships, the capture and making prize of Turkish merchant vessels and of their cargoes being enemy's property, is hereby authorised, with the exception of fishing boats and small coasting vessels.

"II. National or neutral merchant ships under any flag will be captured, according to the dispositions of the following paragraphs, if they: (a) Try to violate the blockade. (b) Carry contraband of war. (c) Give assistance to the enemy. (d) Forcibly resist visit.

"III. The blockade must be effective, that is, maintained by a force sufficient to prevent access to the blockaded ports and coast. Violation of the blockade consists in an attempt to penetrate within the blockaded zone or to leave it during the period established by the declaration of blockade. The capture of ships attempting to violate the blockade cannot take place outside the sphere of action of the ships charged with maintaining it.

"IV. If the vessel making for a blockaded place is in ignorance of the existence of the blockade, which has been declared after her departure from the last port of call, notification of the blockade shall be given her and an entry to that effect made in the ship's log by an officer of one of the blockading vessels. ${ }^{2}$

"V. Vessels that under stress of necessity are obliged to touch at a blockaded port will be allowed to enter, after giving proof that they are compelled by force majeure, and to leave again, provided that they do not take in or discharge cargo there. ${ }^{3}$ If, however, the vessel is carrying articles of contraband of war it shall be arranged that these shall be deposited on board one of the blockading ships. Neutral warships shall always be allowed to pass freely through the blockading line. ${ }^{4}$

"VI. Contraband of war are: cannons, guns, carbines, revolvers, pistols, sabres and all sorts of portable firearms; munitions of war, military implements of all kinds, and in general everything which, without manipulation, can serve directly for land or sea armament.

"Such articles are subject to capture or confiscation if it is proved that their destination is the enemy's territory or naval forces, whether transported directly or by means of transhipment or of transit overland. ${ }^{5}$

"VII. If the articles of contraband constituce a small part of the cargo, the naval commanders can, if they think good, receive such articles in deposit, making an entry to this effect in the ship's log or, failing this, issuing a declaration to that effect, and then permit the vessel freely to continue her voyage.

"VIII. Ships are liable to capture for assisting the enemy which (a) directly take part in the operation of war in the enemy's favour, (b) are chartered by the Government of the enemy State, or placed under the orders or inspection of one of his agents or employed to carry troops or news in the enemy's interest. ${ }^{6}$

"IX. Ships or goods captured or taken as prize will be conducted to the nearest port of the Kingdom, or, when that is not feasible, to a neutral port to be put at the disposition of the naval authorities or of the consular authorities, as the case may be, together with a detailed report of the capture or prize accompanied by the relative documents.

"If the observance of this prescription might compromise the safety of the capturing vessel or the success of the warlike operations in which she is engaged, the commander shall have the faculty of destroying the prize, after having provided for the safety of the persons, papers and documents on board and of everything else which may be material to arriving at a decision as to the legality of the prize. ${ }^{7}$

"X. Members of the enemy's armed forces found on board a neutral vessel may be made

I See Sir T. Barclay, Turco-Italian war and its problems (I9I2), p. I23.

2 See Decl. of London, Art. 16.

${ }^{3}$ See Decl. of London, Art. 7.

4 See Decl. of London, Art. 6.

5 See Decl. of London, Art. 30.

${ }^{6}$ See Decl. of London, Art. 46.

${ }^{7}$ See Decl. of London, Art. 49. 
prisoners of war, even if the vessel-either in the absence of the conditions laid down in paragraph 8 , or in circumstances where the captain's good faith is manifest-be not liable to capture. ${ }^{1}$

"XI. To fulfill the above conditions, the visiting of merchant vessels shall take place (with the exception of the cases treated in the following articles) every time there is sufficient motive for believing that the exercise of this right may result in the confiscation of the ship or cargo in accordance with the practice authorized in such cases by the regulations in force, and by international maritime usages.

"XII. Ships escorted by a neutral war vessel are exempt from visit; naval commanders will limit themselves in such cases to demanding, when they think fit, from the commander of the conveying ship a written declaration regarding the nature and cargo of the convoys.

"If there is reason to believe that the confidence of the commander of the convoying vessel has been abused, these suspicions shall be communicated to him in order that he may proceed alone to make the necessary verifications, issuing a written report on the subject. ${ }^{2}$

"XIII. Naval commanders must abstain from the right of visit, capture, and prize, and from any act of hostility in the ports or territorial waters of neutrals.

\section{"The Prize Commission.}

"By another Royal Decree of the same date, a Prize Commission, presided over by a magistrate with the rank of President of the Court of Appeal, or of President of Section of the Court of Cassation, has been composed as follows:- Ordinary members: (a) An admiral, member of the Superior Naval Council. (b) A legal adviser of the Foreign Office. (c) A Councillor of State. (d) The Director-General of the Mercantile-Marine. (e) The Inspector of the body of Harbour Authorities. (f) A Councillor of the Court of Appeal. There shall be four assessors, of whom two shall be chosen from among the admirals and two from categories (c) and (f). A magistrate of the Public Prosecutor's Office, of not lower rank than a Public Prosecutor ("procuratore del Re"), shall act as Royal Commissioner. He has no deliberative voice, and is charged with stating the case in the Government's name, and with giving his conclusions. He shall not be present at the voting. The Commission shall be assisted by a secretary, who has no vote. Five members of the Commission form a quorum; in the case of an equality of votes, the President, or whoever is fulfilling his functions, shall have the casting vote. The parties shall have the right to present written memoranda, which are to be given to the President of the Commission. The representatives of foreign Powers accredited to the Royal Government can address to the Royal Commissioner such observations as they shall think advisable in the interests of their nationals. The sentences of the Prize Court shall be supported by a statement of the grounds on which they are based. The only appeal from these sentences, which are otherwise not subject to appeal, challenge or revocation, is to the Supreme Court of Cassation according to the letter and practice established by Article 3 of the law of March 3I, I877. The decisions of the Prize Commission shall be communicated to the Ministers of Foreign Affairs and Marine within eight days of their pronouncement.

A rumour that the Ottoman Government had declared grain contraband of war (Oct. I9I I) led the Russian Government, in order to prevent any misunderstanding, to issue a note in which it stated that " basing itself on the Declaration of Paris of 1856 and on Articles 24 and 33 of the Declaration of London," it considered that cargoes of corn were subject neither to arrest nor to confiscation when addressed from Russian ports on the Black Sea to Italian or other ports so long as such cargoes are not destined for Italian field forces or for Italian official consignees. "Any attempt to arrest or confiscate the above-mentioned cargoes," the note went on, "the Russian Government will regard as a violation of the rights of Russia, and the Government gives warning of the heavy responsibility which the Turkish Government would incur in such circumstances."

The Turkish Government immediately replied by issuing a list of articles declared to be contraband of war, comprising grain, but it was coupled with a declaration stating that, although Turkey had not adhered to the Declaration of London she intended conforming thereto. Thus contraband, visit and search, and questions of neutral shipping generally, would be dealt with in accordance with the provisions of the Declaration. Under Article 24 of the Declaration of London food-stuffs are expressly stated to be conditional contraband, but another Article (Art. 35) provides that conditional contraband is not liable to capture except when found on board a vessel bound for territory belonging to or occupied by the enemy or for the armed forces of the enemy and when it is not to be discharged in an intervening neutral port. Another Article provides that even when conditional contraband (except bullion, coin and paper money) is destined

1 See Decl. of London, Art. 47.

${ }^{2}$ See Decl. of London, Art. 62. 
to a government department of the enemy state, if the circumstances show that the goods cannot in fact be used for the purposes of the war, it is not liable to capture. ${ }^{1}$

Thus Russia and Turkey have adopted the rules of the Declaration of London relating to contraband; and Italy has applied it practically in full, although it has not yet been ratified by any Power, ${ }^{2}$ and this has been done without any: question whatsoever of the existence or non-existence of an International Prize Court. The obvious conclusion is that its provisions are becoming an authoritative statement of international law adjusted to the needs of civilised mankind, and, whether ratified or not, and whether an International Prize Court ever comes into being or not, they seem destined to become, like the Declaration of Paris, part of the public law of Europe and the world.

\section{II.: Disregard of Treaties.}

The value of international treaties has been much discussed in connection with Russia's action in Persia and Italy's attack on Turkey. As regards Persia, under the Anglo-Russian agreement of August 3I, I007, the parties, having " mutually engaged to respect the integrity and independence of Persia," entered into purely negative covenants not to seek or promote concessions of a political or commercial character in zones neighbouring each others? territories north and south of certain lines of demarcation, with an intermediate zone open to both. The occupation of Tabriz and other Persian towns by Russian troops, the hanging by Russian military authorities of the leaders of the progressive party under martial law, ${ }^{3}$ the imposing of the resignation of an American Treasurer-General (Mr. Shuster) ernployed by the Persian Government,-all were cases of intervention in apparent violation of the agreement of 1907 .

The Italian aggression against Turkey, of whose "independence and territorial integrity" she was one of the guarantors; and the annexation of Tripolitana and Cyrenaica, were similarly violations of her treaty engagements which may some day be explained, but, nevertheless for the present remain ill-omened precedents. The breaches were not confined to a violation of Turkey's territorial integrity. When Russia in $187 \mathrm{I}$ proposed that, circumstances having changed since 1856 , a modification in certain of the provisions of the Treaty of Paris was necessary, the subject was submitted to a fresh conference of the Powers, who thought the occasion a suitable one for recording a solemn contractual pledge as to the sanctity of treaties. The protocol, which forms part of the existing public law of Europe, runs as follows:

It is an essential principle of the law of nations that no Power can liberate itself from the engagements of a treaty, nor modify the stipulations thereof, unless with the consent of the contracting Powers, by means of an amicable arrangement.

This was undoubtedly intended to prevent any party to the Treaty of Paris from setting up the rule rebus sic stantibus, which is supposed to be a tacit condition attaching to all treaties, enabling parties to them to escape from their provisions when the circumstances under which they were entered into have so changed as to render them obsolete or incapable of application. Italy was a party to this protocol. Moreover, the Treaty of Paris (Art. 8) provides that:

If any difference arise between the Sublime Porte and one or more signatories threatening the maintenance of their good relations, the Sublime Porte and any or each of these Powers, before resorting to force, will place the other contracting parties in a position to prevent recourse to such an extremity by their mediating influence.

An official denial was given to the statement ${ }^{5}$ that Italy had given an opportunity to

1 Barclay, Turco-Italian war (1912), p. 99:

2 See Barclay, op. cit. p. 99.

${ }^{3}$ See Prof. E. G. Browne, The Reign of Terror at Tabriz (Oct. 1912).

${ }_{4}^{4}$ Art. 7 of the Treaty of Paris of 1856 provides that: Their majesties undertake, each for himself, to respect the independence and territorial integrity of the Ottoman Empire, to guarantee in common the strict observance of this undertaking, and consequently they will consider any act of a nature which might infringe it as a question of general interest.

${ }^{5}$ On November $3 \mathrm{~d}$, in reply to a question, Sir. E. Grey said: "The first communication of any intention to seize Tripoli which H.M. Covernment received was the notification of the declaration of war on September 30th." See Barclay, op. cil: p. 37. 
the British Government, before proceeding to extremities, to exercise this "mediating influence." It is obvious that the very object of the clause was to prevent the creation of faits accomplis by such actions as Italy's aggression.

These violations of treaties can only be considered by themselves as tending to set back the progress of law and order in the civilised world. The sanctity of treaties is the very foundation of international morals, and any violation of them is a shock to that fabric of mutual trust and consideration which has been built up in the course of a century, and which forms at present the public law of the civilised world-a law governing not only the relations of states. with one another, but safeguarding security in the international dealings and intercourse of their respective citizens.

The case of the Panama Canal, again, is one of particular interest between Great Britain and the United States. Under the Hay-Pauncefote Treaty of November r8, $190 \mathrm{I}$ it is provided that "the canal shall be free and open to the vessels of commerce and of war of all nations . . . on terms of entire equality, so that there shall be no discrimination against any such nation, or its citizens or subjects, in respect of the conditions or charges of traffic or otherwise." By the Panama Canal Act of I912, passed by the United States Congress, such a discrimination however was distinctly made. Sec. 5 provided that " no tolls shall be levied upon vessels engaged in the coastwise trade of the United States," and the American coastwise trade is restricted to American vessels. This departure from the terms of the treaty was supported in the United States on the alleged ground that the circumstances under which the treaty was concluded had undergone an essential change,-in other words, though not specifically stated, that the rule of rebus sic stantibus applied. President Taft's Memorandum, in reply to the British diplomatic note protesting against the Panama Canal Act, set out not only that "the canal is being constructed by the United States wholly at its own cost, upon territory ceded to it by the Republic of Panama for that purpose," but that, as " the treaty leaves all nations desiring to use the canal with full right to deal with their own vessels as they see fit, the United States would only be discriminating against itself if it were to recognise the soundness of the British contention." It is unnecessary here to discuss a situation which at the time of writing was open to more than one mode of friendly settlement; all that need be said is that, in the ordinary course, such a case would be an entirely proper one to be submitted to arbitration.

\section{Open-door Policy.}

The "open-door" policy which tends to prevail wherever it is possible to safeguard the general interest of mankind against the encroachments of individual states, was re-enunciated in the Franco-German agreement of November 4, I9ri. In Article 4 of that agreement " the French Government" declared that, "firmly attached to the principle of free trade in Morocco," it would not lend itself " to any inequality either in the establishment of customs duties, dues or other taxes or in the establishment of transport tariffs by railway, river and any other way and in general in any matter affecting transit." The treaty contains further restrictions to prevent preferences being given under colour of weights and measures, rebates or any other method by which French or any other subjects might obtain an advantage over those of any other state.

Another interesting and significant application of the same principle is provided by the agreement of August II, IgIo between Sweden, Norway and Russia with reference to the status of Spitzbergen. On February 25, 1909, at the instance of the Norwegian Government, a conference met at Christiania to discuss the position which had arisen out of the discovery of mining resources on the island. The states invited to the conference were Sweden, Russia, Great Britain, Germany, France and the United States. The capital invested in Spitzbergen coal-mining was of Norwegian, British and American origin, but Norway claimed prior rights owing to the preponderating share of Norwegians in the Spitzbergen fisheries. Sweden claimed a prior right on account of her scientific expeditions to the country, which had practically made industrial exploitation there possible. In I87 I the Swedo-Norwegian Government proposed to annex the island, 
but, owing to objections on the part of Russia, this idea was abandoned. Since then, Germany has come upon the scene, and, true to her policy of keeping as much of the world open to free competition as possible, she had objected to control over the island being granted to any single Power. A project for the Government of Spitzbergen and the adjacent islands by a commission of the three contiguous Powers, Sweden, Norway and Russia, drawn up and submitted to the other Powers, was amended to meet certain observations. The three Powers met at Christiania from January 15 to 26 , I9I2, and the agreement then finally adopted has now been ratified.

This document guarantees equality of rights to subjects and citizens of all Powers alike while declaring that the islands continue to retain their character of terra nullius. The rather ambiguous sense of terra nullius is explained in a chapter of the Convention itself. The term is used more especially in respect of sovereignty, inasmuch as the island belongs to no Power, is not annexable and is permanently neutral. However, as regards property, all the soil is public property (Art. 4I) and only rights of occupation are grantable. It will be interesting to see how this condominium, which resembles to some extent the Anglo-French régime: in the New Hebrides, will develop as a practical method of dealing with hitherto unoccupied territory.

\section{Territorial Waters.}

The problems connected with territorial waters continue to perplex Foreign Offices in Northern Europe. The contention between the English trawlers and the Scottish line fishermen in Moray Firth, the one for freedom to fish outside the three-mile limit without reference to ultimate consequences detrimental to the fish supply itself, and the other for protection of the spawning beds and against the destruction of immature fish in the trawl-nets, continue to be a source of trouble, especially owing to the fact that the trawling interest can elude the operation of the Scottish Acts by registering their vessels in a foreign port and carrying a foreign flag.

The difficulty in the way of a solution of the problem is the existence of a rule-ofthumb practice which embraces in one formula fishery questions and those which are involved in the law of neutrality. The experience of the last few years has only accentuated the need of separating the two subjects. The investigations of the International Council for the exploration of the North Sea may "bring the exercise of sea-fishing more into accord with the natural conditions regulating the growth and increase of fish in neighbouring seas and thus permanently increase the supply in the North Sea markets." The recent accession of the United States to the Council and the expected accession of France show that the objects for which the Council was founded by the North Sea States commend themselves to others not immediately interested in the present scope of the Council's investigations.

The common interest of mankind in the preservation of the fish supply, and in the consequent protection of spawning areas, and prevention of the destruction of young fish, may ultimately entail a different and more complicated treatment for fishery rights than the very simple formula of the three-mile limit. In fact, it may involve a change of principle under which a common interest in the prosperity of high sea fishing may outweigh the local interest attaching to the inshore industry.

In I9I I considerable emotion was caused among the British trawling interests by a claim put forward by Russia to extend the width of her territorial waters to 12 miles. The subject arose in connection with the so-called White Sea, or, to speak more precisely, the Barents Sea Fisheries. The trawling banks extend, it seems, some 120 miles to the north and west of the Kanin peninsula which borders the east side of the entrance to the White Sea. The Russians, therefore, argue that the proposed I 2 mile limit would only very slightly reduce the available fishing area. Russia claims the sea south of a

${ }^{1}$ Meanwhile an interdepartmental committee has been appointed by the British Government "to consider if it is practicable or desirable to extend for fishery purposes the limits of territorial waters, and whether prohibition or further regulation as to the methods or times of sea fishing are desirable, more particularly in relation to trawling for herring and to report accordingly," Times, June $28,1912$. 
line from Cape Sviatoi to Cape Kanin as a closed sea, a claim in which it is contended both Norway and Great Britain have tacitly acquiesced. ${ }^{\mathfrak{1}}$

Involving analogous considerations is the still controverted question of Hudson Bay, which is entirely surrounded by Canadian territory. Its entrance like that of the White Sea exceeds any width suggested for the closing of bays. In principle there is no difference between Hudson Bay and the Gulf of St. Lawrence. Yet it is held by certain authorities that Hudson Bay like the White Sea is a closed sea. No such claim has ever been made for the Gulf of St. Lawrence, which is in a similar position. ${ }^{2}$

The question of bays in connection with the existing territorial waters practice was dealt with in the North Atlantic Fisheries case by the Hague Court in its award of October 25 , rgro. The three-mile limit was confirmed and bays were the subject of a recommendation to adopt in principle the ten-mile width of the Norih Sea Fisheries convention. ${ }^{3} \quad$ The award is dealt with more fully below in connection with arbitration.

\section{$V$. The Law of the Air.}

The law of the air of late has from time to time occupied the attention of Governments. Under a British Act (Aerial Navigation Act, June 2, I gII) " for the purpose of protecting the public against danger," the Government is empowered to forbid aerial navigation over certain areas according to circumstances or limit it to certain kinds of air-craft. These very wide powers are obviously capable of application on such a scale as practically to amount to the assertion of absolute sovereignty over the superincumbent air of the whole of British territory.

Questions affecting international law may arise out of any far-reaching exercise of this claim. Have foreign air-vessels a right of innocent passage through the air, as they have through the territorial waters, of any state? It has been suggested that, following the analogy of the sea, no state is entitled to claim sovereignty over a greater height than cannon-range can command, that to assert a claim over the air ad coelum over any country is as exaggerated as the now obsolete claims over whole seas, which were eventually whittled down to a margin of sea following the trend of the adjacent coast. The Institute of International Law, ${ }^{4}$ at its Ghent meeting in I006, declared the air free, subject only to such rights as the necessities of self-preservation required. This view seems to follow the analogy of the relation of the high sea to territorial waters.

Mr. H. Brougham Leech ("The Jurisprudence of the Air," Fortnightly Review, August 1912) has made the following apt observations on the subject:

"There is, from one important point of view, a marked difference between the open sea and supraterritorial air. An ordinary vessel on the open sea cannot damage persons or property on land; a war-vessel cannot do any such damage save of deliberate intention. Furthermore, collision at sea cannot be productive of any injury to those on land. But any vessel traversing the supra-territorial air can do much mischief to those on the earth beneath; any accident to such vessels may result in serious injury; and accidents, arising either from collision, storm, or the failure of the machinery, are not only more liable to happen, but they may involve injuries to third partics, from the risk of inflicting which, sea-going vessels are entirely free. Therefore the analogy between the open sea and the supra-territorial atmosphere breaks down and the state is entitled to protection against these unusual dangers."

Prof. Sir Erle Richards, in a lecture delivered at Oxford (Oct. 26) ${ }^{5}$ on the sovereignty of the air, has expressed the opinion that the theory of the air being free had in fact never been accepted as a principle of International Law. It found no support in any analogy which could be drawn from the Laws of Nations. "States," he said, "must be the judges of the necessary safeguard they imposed for their protection." "The principle of state sovereignty over the air was the only basis on which International Law could safely rest."

1 Times, March 11, 1911.

${ }^{2}$ See, on the contention that Hudson Bay is by immemorial usage an open sea, T. W. Balch, "la I3aie de Iludson," Revue de droit international, I9II.

3 See E. B. xix, 787; "North Sea Fisheries." Also xxviii, 409; "Territorial Waters."

"See E. B. xxi, I5; "Peace."

- See Times, October 28, I912. 
A suggestion has been made, and seems to have obtained considerable support among French jurists, that there is a distinction between freedom of the air and freedom of passage through the air, that all the progress and development of aviation requires is freedom of passage and that there is no need to lay down any principle as to freedom of the air in connection with aviation. This, however, is a mere theoretical distinction, and facts are settling the matter for themselves. As it is only when comparatively near to earth that the flight of aviators can be controlled by any police, no effort seems as yet to have been made to impose regulations exceeding what it is practically within their power to enforce. Very serious matters will, nevertheless, some day arise out of aviation in time of peace. The more important have been summed up by Mr. Leech as follows:

(a) Provision for the collection of customs dues, and for the prevention of smuggling;

(b). Prevention of the landing of persons suffering from infectious diseases;

(c) Prevention of the importation of undesirable aliens;

(d) Prevention of the inspection from airships, and of the sketching and photographing of forts, arsenals and Government stores and buildings.

(e) Special precautions against the operations of anarchists, bomb-throwers, and other such persons, and prevention of the importation of dynamite and other dangerous explosives.

The questions arising out of the use of air-vessels in time of war are still more serious. At the Hague Conference of 1899 the following declaration was adopted:

"The Contracting Powers agree to prohibit, for five years, the discharge of projectiles and explosives from balloons, or by other new methods of a similar nature. The present Declaration is only binding on the Contracting Powers in case of war between two or more of them. It shall cease to be binding from the time when in a war between the Contracting Powers, one of the belligerents is joined by a non-Contracting Power."

Only Great Britain did not ratify it, but on expiry of five years it ceased to be operative. At the Conference of 1907 , however, it was renewed till the close of the next Conference. This time only Great Britain and the United States, among the Great Powers, ratified it, and in fact ample use was made of aeroplanes for bomb-dropping during the Turco-Italian war. At present, therefore, aviation in wartime is subject only to the general provisions of warfare as laid down by the Hague Military Conventions and such general principles of International Law as states choose to respect.

\section{Arbitration.}

Those who regarded the new Arbitration treaties as heralding the ever wider adoption of judicial methods in the settlement of serious differences between states must have been disappointed by the course of recent events. In February I904 the RussoJapanese war broke out; in I905 came the Franco-German crisis over the Morocco question; in 1907 began the Russian intervention in Persia; in I9Io came the French intervention in Morocco; in I9I I a fresh Franco-German crisis coupled with serious Anglo-German friction; in the same year began a war between Italy and Turkey, and in I9I 2 the Balkan war. In none of these cases of violence, potential or actual, was any attempt at a solution of the difficulties by arbitration even suggested by any Power.

This is not, however, imputable to ill-will towards arbitration on the part of European Foreign Offices alone. It would have been difficult to submit any of the cases in question to adjudication by a tribunal for the application of "justice," and no rules but those of justice have yet been devised for the decision of cases between states. Really dangerous difficulties with few exceptions have thus far involved considerations which have no reference to the moral principles governing the private life of civilised mankind. Thus, it is difficult to see how a court of arbitration could deal with a claim based on a preponderating interest, with the invasion of a neighbouring state on the ground that it was not properly governed, or with a claim to colonial territory by a state which had too little against another which had more than it could employ.

On the other hand, the cases which have been tried by the Hague Court have pro tanto removed causes of friction past and possible, as well as causes which might have been fanned into greater importance by difficulties of direct settlement. 
Eleven cases ${ }^{1}$ have now been tried by the Hague Court since its creation in 1899:

1. U. S. A. v. Mexico (Pious Funds of the Californias). Award: October 14, I902.

2. Germany, Britain, Italy v. Venezuela (Claims). Award: Feb. 22, 1904.

3. Germany, France, Britain v. Japan (Jap. House Tax). Award: May 22, I905.

4. France $v$. Great Britain (Muscat Dhows). Award: August 8, I905.

5. France and Germany (Deserters at Casablanca). Award: May 22, 1909.

6. Norway and Sweden (Maritime Frontier). Award: October 23, 1909.

7. Great Britain v. U.S. A. (Atlantic Fisheries). Award: Sept. 7, 19ro.

8. U.S. A. ข. Venezuela (Orinoco S. S. Co.'s Claim). Award: October 25, I9Io.

9. France ข. Great Britain (Arrest of Savarkar). Award: February 24, I9I I.

I0. Italy $v$. Peru (Canevaro Claim). Award: May 3, I9I2.

II. Russia v. Turkey (Claim for Unpaid Interest). Award: November II, I912.

The case of the deserters of Casablanca was one which, had the relations between Germany and France been good, would probably never have arisen at all. In the French army there is a "foreign legion" used for colonial service. Six privates belonging to it deserted and obtained passports from the German Consulate at Casablanca. All six were supposed to be German subjects, but it turned out eventually that only two were Germans. The deserters were arrested, in spite of some resistance on the part of persons in the service of the Consulate. Hot words passed in the newspapers, but the two Governments agreed to refer the matter to the Hague, which gave its decision in favour of France on grounds too obvious to require examination.

The case between Sweden and Norway turned on a frontier question which arose out of the separation of these two states. It was decided in favour of Sweden without a murmur on the part of the Norwegians.

The case of the North Atlantic Coast Fisheries ${ }^{2}$ was the most important of the matters which have as yet been dealt with by the Hague Court, not only on account of the gravity of the issue generally, but also on account of the different delicate questions dealt with in the award. The case related to the respective British and American rights in Newfoundland waters under Art. I of the Anglo-American Convention of October 20, I8I8. This article provided that the inhabitants of the United States should for ever, in common with British subjects, have liberty to take fish of every kind on certain specified coasts of Newfoundland, and that they should also for ever have liberty to dry and cure fish in any of the unsettled bays, harbours and creeks, on the specified parts of the southern shores of Newfoundland and of the coast of Labrador, but that, so soon as any portion thereof became settled, it would not be lawful for these American fishermen to dry or cure fish thereat without previous agreement for such purpose with the inhabitants, proprietors or possessors of the ground. The United States, on the other hand, renounced liberty to take, dry or cure fish on or within three marine miles of any of the British American coasts, bays, creeks or harbours not included within the specified limits. American fishermen, however, had the right to enter such bays and harbours for the purpose of shelter or repairs, the purchase of wood, and the obtaining of water, but they were to be under restrictions to prevent any abuse of their privileges.

Differences arose as to the scope and meaning of these provisions. The United States authorities protested against the British claim to deal in their regulations with the hours, days and seasons when fish may be taken, with the methods, means and implements used in fishing operations etc. There was also a difference of opinion as to the mode of measuring the three marine miles off any of the coasts, bays, creeks, or harbours referred to in this article. There were also a number of subsidiary points.

The award confirmed the British claim to make such regulations as were appropriate or necessary for the protection and preservation of the fisheries or desirable or necessary on grounds of public order and morals, provided they did not unnecessarily interfere with the fishery itself and were not so framed as to give an advantage to local over American fishermen; any question as to the reasonableness of any regulation was to be referred

1 The first four of these cases are dealt with in E. B. ii, 328, 329.

2 The arbitrators were Prof. I ammasch of Vienna (President), Dr. Savornin Lohman, Dutch Minister of State, Judge George Gray, Sir Ch. Fitzpatrick and Dr. Drago, ex-Minister of Foreign Affairs of the Argentine Republic. 
to a commission of three expert specialists, one to be designated by each of the Parties and the third not to be a national of either Party and to be appointed by the Court. ${ }^{1}$

To enable the Governments to deal with any difference of views between them before resorting to the Commission, the Court recommended official publication of any regulations as to hours, days and seasons for taking fish, as to methods, means and implements, etc. two months before their coming into operation, to enable the United States Government to raise any question as to their inconsistency with the treaty of 1818 , in which case the Commission would decide on the difference. On the question of the mode of measuring the three marine miles, the Court decided that in case of bays, the three marine miles should be measured from a straight line drawn across the body of water at the place where it ceases to have the configuration and characteristics of a bay. At all other places the three miles were to be measured following the sinuosities of the coast. It recommended, however, adoption of the method followed in the North Sea Fisheries Convention (May 8, I882) of fixing the line at the part of the bay nearest the entrance when the width does not exceed ten miles. From the opcration of this general proposition, the award excepted a certain number of bays " where the configuration of the coast and the local climatic conditions are such that foreign fishermen, when within the geographic headlands, might reasonably and bonâ fide believe themselves on the high seas," and fixed for these certain points between which the line should be drawn.

The long and detailed award is full of interesting points connected with fishery methods, territorial waters and bays, and will certainly have considerable influence in the treatment of similar matters in the future.

The Orinoco S.S.Co. claim between the U.S.A. and Venezuela raised the question whether, if an umpire exceeds his powers and bases his decision on errors of law and fact essential to the issue, the award is liable to revision. The Court decided that it was, and proceeded to revise it accordingly,--a precedent of the greatest moment.

The Savarkar case turned on the delicate question of whether a fugitive under a criminal charge, who had escaped from the ship on which he was being conveyed to his place of trial (India) and had been arrested by the police of the country (France) to which he escaped and immediately handed over (in error) by that police to those in charge of him, should not have been delivered back to the Government of the state to which he had escaped and been dealt with under the Extradition treaty existing between the two states concerned. The Arbitrators decided that as there had been in the circumstances no "atteinte a la souveraineté " of the country to which the prisoner had escaped and all parties had acted in good faith and no disavowal of the surrender had been made known till two days later, after the departure of the vessel, the action of the local police though taken in error closed the incident. This decision, based on considerations outside the strictly legal question involved, marks the difference between arbitrators, who as such can disregard technical questions, and a justiciary court, which has little latitude when confronted with an unquestioned legal principle such as the universal one that a fugitive who sets foot on foreign soil is beyond the jurisdiction of the police of his country except by operation of a treaty of extradition. The fact that the French Government made a claim shows that it had not waived its right. Though it is evident that, if France had declined to grant extradition (as she very possibly might), the liberation of Savarkar by the British authorities might have involved difficulties, the precedent should be regarded as a compromise rather than a judicial decision.

The Canevaro affair between the U.S.A. and Peru arose out of a loan made to the Dictator Pierola in 1880 by semi-Italian bankers. The question turved on 'an assessment involving no principle of law of any general interest.

The Turco-Russian case related to interest on an indemnity payable by Turkey to Russian claimants or their nominees, which had been satisfied by instalments after long intervening delays. The arbitrators while admitting the justice of the claim in

1 The Court appointed Dr. P. P. C. Hoek, scientific adviser to the Netherland Fisheries. The other members who have since been appointed are Dr. Hugh Smith, on behalf of the U.S.A., and the Hon. Donald Morison, Newfoundland Minister of Justice. 
principle, decided against Russia on the ground that the Russian Government when accepting instalment, never made any reserve as to interest.

As regards standing Arbitration Treaties the efforts made to meet the difficulty of embracing in any formulae all differences which may arise between the contracting states have rather tended to show where that difficulty really lies than to solve it. A number of treaties, certainly, have been concluded in which all differences without distinction of character are made arbitrable. The latest of these, the Treaty of November 20, 1909 between Italy and the Netherlands, provides that:

"The high Contracting Parties engage to submit to the Permanent Court of Arbitration established at the Hague by the Convention of July 29, 1899 all differences of whatever character which may arise between them which they have not been able to solve by diplomatic methods, and this shall apply also to differences arising out of facts prior to the conclusion of the present convention." 1

Nearly all the standing treaties hitherto concluded, however, except " national honour" and "vital interests" from their operation. It would appear as if few Governments were ready to take the responsibility of binding themselves to arbitrate without a means of escape from the obligation. The new treaties between Great Britain and the United States, and the United States and France, are no real exception in this respect. Though they provide for investigation by a preliminary joint commission of inquiry for all cases whatsoever, they confine arbitration to "claims of right made by one against another under treaty or otherwise, and justiciable in their nature by reason of being susceptible of decision by the application of the principles of law or equity " (Art. I). This obviously excepts from arbitration all questions based on policy and not on grounds of legal right, which amounts for practical purposes to the adoption under another formula of the "vital interests" clause. Under the ordinary formula, it is in the discretion of either party to a dispute to describe the difference as involving a "vital interest," and it is then removed from the operation of the treaty. An aggressor who has no equitable basis for an application to the Hague Court or any other tribunal of independent judges, is obviously not likely to accept the jurisdiction of a court which would practically have no alternative but to find against him. Thus, in his ultimatum to Turkey (Sept. 26, I () I ) the Marquis di San Giuliano took care to state that the issue between his country and Turkey constituted "so far as Italy is concerned a vital interest of the very first order." This was evidently intended to enable his Government to meet any suggestions as to arbitration with the reply that no great Powers had yet agreed as between them to have recourse to arbitration where vital inferests were concerned.

The Anglo-American Treaty of Arbitration of August 3, rgrr, is, nevertheless, a most interesting new departure in the effort to deal with " vital interests" by pacific means though not by arbitration. The treaty sets out by defining the scope of arbitration. It does not, however, provide that arbitration, even when applicable, shall forthwith come into operation, but prescribes a certain number of preliminary stages:

I. Request by either party to submit any differences to a Joint Commission of Inquiry.

2. Power to either party to postpone the reference to the Commission for one year from the date of the request "to afford an opportunity for diplomatic discussion and adjustment of the questions in controversy, if either party desires such postponement."

3. The appointment by each party of three of their nationals to the Commission.

4. Holling of the inquiry followed by a report upon the "particular questions or matters referred to it, for the purpose of facilitating the solution of disputes by elucidating the facts and to define the issues presented by such questions, and also such recommendations and conclusions as may be appropriate."

5. If the difference persists, the case becomes the subject of an agreement of reference to arbitiation, which is to provide for the organisation of the tribunal, define the scope of the powers of the arbitrators and determine the question or questions at issue.

The obvious object of the treaty is to create a series of steps calculated to divert attention from the issue to the method of settlement, and thus enable diplomacy to gain

1 Italy entererl into a similarly all-embracing treaty with the Argentine Republic during the last Hague (onference (Sept. 18, 1907). Other unlimited treaties are in force between the Argentine Republic and (hile (I9O2), Denmark and the Netherlands (1904), Denmark and Italy (1905), Denmark and Portugal (1907). 
time for a calm examination of the points involved. The merit of the treaty lics chiefly in the ingenuity with which the procedure of conciliation and settlement is prolonged. When the two Governments are equally desirous of a peaceful adjustment, the treaty will be a means for the removal of any question, whether arbitrable or not, from being complicated by controversy on the part of an over-zealous public opinion.

A less ambitious, but much improved edition of the existing "common form " of standing arbitration treaty is that which has been adopted by France and Denmark (Aug. 9, roII). This treaty provides as usual (Art. I) that:

"Differences of a judicial character and more particularly those relating to the interpretation of treaties existing between the two contracting parties, which may arise between them and which it has not been possible to settle by diplomacy, shall be submitted to arbitration, in the terms of the convention for the pacific settlement of international differences" (Hague, Oct. 18, 1907), "provided they do not affect the vital interests, independence or honour of either of the contracting parties nor the interests of third Powers."

Art. 2, however, provides the exception that "Differences relating to the following matters shall be submitted to arbitration without the reservations mentioned in Art. I:

"I. Pecuniary claims for damages when the principle of an indemnity has been admitted;

"2. Contractual debts claimed from the Government of one of the parties by the Government of the other as due to its nationals;

"3. Interpretation and application of conventional stipulations relating to commerce and navigation.

"4. Interpretation and application of conventional stipulations relative to:-Industrial property, copyright, . . posts and telegraphs .... submarine cables . . \& \&c.

"In respect of class 4 , the contracting parties have the right to defer submitting such cases to arbitration until after the national courts have decided finally on them.".

This treaty also contains a clause providing that the arbitral court shall decide, in case of difference, what category a case belongs to.

Thus three new forms of arbitration treaties have been devised in the course of the last three or four years in the place of the old common form of treaty (i.e. the AngloFrench form of October I4, I903). The old form applies to " differences of a juridical order or relating to the interpretation of treaties " and excepts from its operation matters involving "vital interests" or "national honour." That between France and Denmark of August I9I I makes "vital interests " and " national honour " a part of the principle, and, excepting them from its operation, makes arbitration obligatory without qualification in certain defined matters. The Anglo-French and Anglo-American 'Treaties of August Igr I go further, and provide a pacific method, though not arbitration, for dealing with cases even involving vital interests and national honour; and that between Italy and the Netherlands of November 1909 throws out the exception altogether.

The progress of experience has not confirmed the expectation current at the beginning of the present century that arbitration might become a substitute for war. Only states between which no casus belli seems possible have, thus far, ventured to place all cases without exception within the scope of compulsory arbitration, and in the Turco-Italian and Balkan wars no reference to a court of arbitration could have dealt with the issues involved except on principles of treaty obligation and justice which would have necessarily condemned the aggressors. Nevertheless, arbitration removes from controversy all the smaller issues, and, under the influence of public opinion, its scope is being gradually enlarged, and the number of possible cases of conflict correspondingly reduced.

The following later treaties of arbitration (renewals starred) have been added to the list given in the article on "Peace" in Ency. Brit., Vol. xxi:

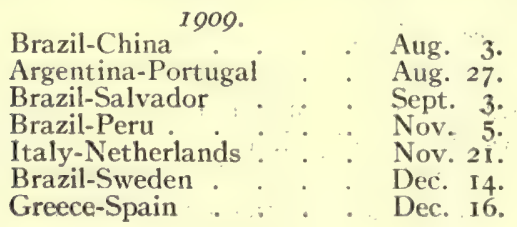

IOTO.

Costa Rica-Italy
Costa Rica-Panama

Brazil-Haiti

Brazil-Dominican Republic Apr. 29.

Belgium-Honduras . Apr. 29.

Brazil-Colombia : July 7.

*Austria Hungary-Great Britain

Russia-Spain

Brazil-Russia

Brazil-Greece

Greece-Italy
July 16.

Aug. 15.

Aug. 26.

Aug. 28.

Sept. 2. 
Italy-Spain

Sept. 2

Austria Hungary-Brazil : Oct. I9.

Italy-Russia $\quad \therefore \quad \therefore \ldots$. Oct. 27.

Belgium-Italy ..... Nov, I8.

Italy-Norway ... .... Dec. 4.

Brazil-Uruguay

Brazil-Paraguay
IOII

Jan. 12 .

Feb. 24 .
*Bolivia-Peru

Italy-Sweden

Argentina-Ecuador

Argentina-Venezuela

*United States-France.

United States-Great Britain Aug. 3.

*Denmark-France .... Aug. 9 .

Brazil-Denmark

Argentina-Colombia
Mar. 3 I.

Apr. 30.

July 16.

July 24 .

Jan. 20.

\section{Restrictions on War.}

The next best condition of things to avoiding war is to restrict its area and effects when it unfortunately break out to the minimum consistent with its object. Such a restriction was one of the features of the Turco-Italian war. Thus simultaneously with the despatch of the ultimatum to Constantinople t $_{3}$ the Marquis di San Giuliano despatched a note to the Italian Legations and Consulates in the Balkan States--of which the following passage is significant:

The Italian Government is determined to settle the Tripoli question in conformity with the interests and dignity of Italy; but, whatever the means she may have to employ in order to secure this end, the basis of her policy will continue to be the maintenance of the territorial status quo in the Balkan Peninsula and the consolidation of European Turkey. Not only, therefore, does the Royal Government not wish to encourage any movement against Turkey in the Balkan Peninsula, but it is firmly resolved to redouble its efforts to prevent, particularly at this moment, anything of the kind happening, and if any hopes or illusions have been formed or are likely to be formed in that sense they must be dispelled immediately, and you will suit your conduct and language to these ends directly the opportunity presents itself to do so.

At the beginning of the war, Italy also declared her intention not to land any troops in any part of the Ottoman Empire except Tripoli and Cyrenaica. The extinction of the lights along the Adriatic, Mediterranean and Red Sea coasts of Turkey, nevertheless, became a very serious matter. Italy's undertaking not to carry operations of war beyond the coast of the territory in question did not overcome the difficulty, inasmuch as it was to be presumed that she would only so bind herself provided Turkey entered into an engagement not to invade her Red Sea possessions. Nor did she restrict herself absolutely in accordance with her engagements, but, later on, landed troops on Greek islands, and threatened, and, in certain cases fired upon, different cities on the coast of Asia Minor, though she explained that this was solely for the purpose of destroying Turkish war vessels, which might otherwise have attacked Italian merchant ships.

The neutralization of the Red Sea was also mooted in the course of the war, and indeed the reason which led to the neutralization of the Suez Canal seems to be almost as strongly in favour of the Red Sea, as a more or less narrow highway of navigation, being assimilated to it. The inconvenience of the extinction of lights on the Turkish coast brought the need of such neutralization home to the shipping interests using the canal.

Incidentally it may be mentioned that, neutralized as the canal is, it is still legally on Turkish soil, as was admitted in the "Kaissari" incident at the beginning of the war. The vessel in question was conveying troops to replace others in the Yemen whose terms of service had expired. It was considered as not affected by the twenty-four hours rule imposed by Art. 4 of the Suez Canal Convention, and allowed to remain at Port Said under cover of the canal being a part of Turkey as well as neutralized.

\section{The Malecka Case.}

Of isolated international incidents, the only truly interesting one of late years has been that of the arrest in Poland of Miss Malecka, which once more raised the vexed question of mixed nationalities. This lady was Russian by descent under Russian law and British by reason of her birth in England under British law. She was arrested early in IOI I on a charge of abetting a political conspiracy, and seemed exposed to being detained in prison without trial for an indefinite time. But owing to pressure from the British government she was at last put on trial at Warsaw, and on May ro, Ior 2 was 
found guilty and sentenced to four years penal servitude to be followed by exile to Siberia for life. So far as the law was concerned, the Russian Government was acting within its international rights; but distrust of the Russian law and procedure, and especially of the Russian punishments to which this Englishwoman was exposed, excited British public feeling. The Russian Government wisely found a means of letting the lady return to England. On June Ioth, as the result of a petition to the Tsar, she was released on the terms that she should not again set foot in Russia. The case showed indeed the desirability of assimilating the laws of different states on nationalities. Assimilation, however, would mean, in the case of English law, the surrender of time-honoured principles in favour of foreign principles which, if more logical, are less elastic and might not be suited to the varied conditions of a wide-spread empire.

Among recent literature, bearing on the subject of this article, the following books may be mentioned:- Higgins, Hague Peace Conference (London, 1909), and War and the Private Citizen (London, I9I2); James B. Scott, Hague Peace Conferences (2 vols., Baltimore, 1909); Oppenheim, International Law (2 vols. 2nd edition, London I9I2); George G. Wilson, International Law (St. Paul, Minn., I910); F. E. Smith and J. Wylie, International Law (London, 19II); Alvarez, Le droit international Américain (Paris, I9Io), and Codification du droit international (Paris, I912); Bray, British Rights at Sea under the Declaration of London (London, I9I I); T. G. Bowles, Sea Law and Sea Power (London, 1910); Cohen, Declaration of London (London, I9I I); Bentwich, Declaration of London (London, I9II); Lemonon, Conférence navale de Londres (Paris, I909); Reventlow Grossbritannien, Deutschland und die Londoner Conferenz, (Berlin, I9II); Niemeyer, Seekriegsrecht nach der Londoner Declaration (Berlin, 1910); Catellani, La dichiarazione di Londra (Padova, I912); Wehberg, Capture in War on Land and Sea (trans. London, I9II); Civis, Cargoes and Cruisers, Britain's rights at sea (London, I9I I); Baty, Britain and Sea Law (London, I9II); P. Müller-Heymer, Der Panamakanal (Berlin, I909); Lord Ch. Beresford, The Betrayal (London, 1912); Norman Angell, The Great Illusion (London, I910); Barclay, Turco-Italian War and its Problems (London, I9I2); Hazeltine, Law of The Air (London, I9I I).

(Thomas BARClay.)

\section{INTERNATIONAL FINANCE AND ECONOMICS ${ }^{1}$}

The four years I909-I 2 constituted a period of rapidly increasing prosperity throughout the world from a financial point of view, and in every respect were the antithesis period of of the years from 1893 to 1896 . Fully to appreciate the conditions it is good credit. essential to recollect those of the former period. In the nineties the world suffered from a general breakdown of credit which brought bankruptcy and disaster to many countries. The four years since I 909 have been a period of unbounded confidence and good credit, bringing expansion and progress to almost every nation. In the nineties prices of commodities fell to figures not previously recorded in modern times; in recent years they have risen to a level not witnessed for nearly 30 years. In the nineties employment was scarce, more especially in the young and food-producing countries; in recent years employment has become plentiful both in the young and in the old countries, and wages have advanced in most countries to rates not previously reached. In the nineties the fall in prices of commodities had a specially detrimental effect upon the welfare. of the food-producing countries; while the industrial or manufacturing countries and districts derived much benefit from the low cost of food and material. In recent years the rise in prices of commodities has brought renewed prosperity to persons engaged in agriculture throughout the world; and while the advance in the cost of living has in some degree diminished the consuming power of those engaged in the manufacturing industries, the conditions have been beneficent for the world in general and much more equitable for all sections, the creditor and manufacturing countries having enjoyed a high degree of prosperity, in company with, and not at the expense of, the debtor and mainly agricultural lands.

The period has been marked by a great deal of labour unrest. This unrest occurred in the mining, manufacturing and distributing industries, in which the cost of living had risen much more rapidly than the rate of wages in comparison with the previous abnormal period of low cost of living. The re-adjustment of wages, and the advances in prices of manufactured goods and of minerals that have now taken place, have again

${ }^{1}$ See E. B. x, 347 et seq. ("Finance"), and articles enumerated in Index Vol., p. 893. 
given the manufacturing countries a fair participation in the general prosperity. It is apparent, however, that the prosperity of the last four years has been felt mainly by the agricultural countries and districts, which have gained advantage from Prices and the recovery in prices of foodstuffs and of raw material, and which suffered
wages.

so seriously in the nineties from the low prices which then prevailed. The influence exercised upon the economic welfare of the wage earners of Great Britain by the movements in prices and in wages and by the variations in the volume of employment is apparent from a contrast of the Board of Trade index-numbers of prices, wages and employment respectively, first, in the four years of good credit throughout the world which culminated in I891, next, in the four years of bad credit from 1893 to 1896 , and finally, in the past four years. This is shown in Table I.

Table I, British Board of Trade Index Numbers.

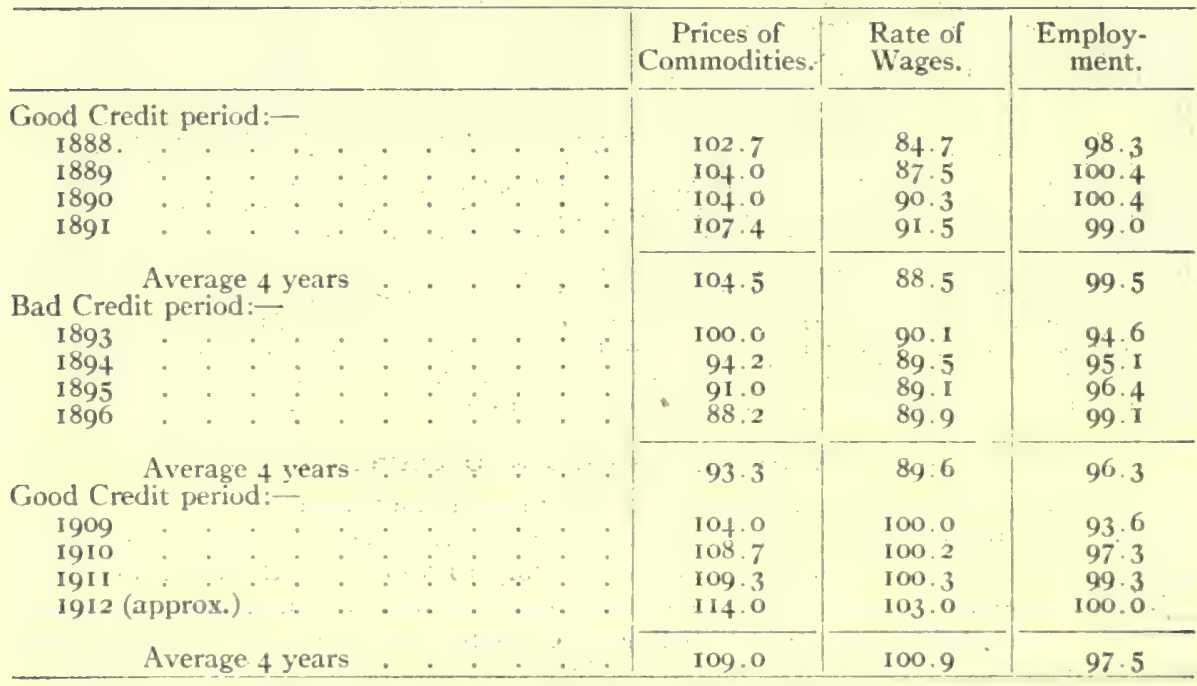

It would take us too far here to describe in any detail the various causes of the greatly increased activity of trade, the relatively high cost of living, the labour unrest, The influence and the advances in wages throughout the world in the last four years. The capital.
of But in the main these things, as well as the great volume of emigration from Europe to the New World, result from a single cause, viz., the high condition of credit in the young and food-producing countries, and the great sums of capital which the lending countries have consequently supplied to them. This high condition of credit has partly arisen from the world's great output of gold, from the accumulation of gold, and from the encouragement which large stocks of gold have given to the free investment of capital wherever it could be profitably employed.

To realise the importance of these things it is again necessary to recollect the adverse conditions in the nineties, when the credit of the young countries was at a low ebb, and Stocks of the borrowing states could not secure the capital needed for their developgrocks of ment. At that time, with bad credit and very low prices of foodstuffs
gents and raw material, gold accumulated in the Banks of England, France and Crermany notwithstanding the world's small production of gold; in the past four years of good credit gold has accumulated in the young or borrowing countries, and not in the old of lending states. and this has materially assisted the movement of capital from the old to the young countries. This will be apparent from a contrast, first, of the stocks of gold in the Banks of England, of France and of Germany in 1896 in comparison with 1892 , and second, of the stocks of gold in these three institutions in I9I 2 in comparison with r 908 . This is shown in Table II. 
Table II. Stocks of Gold in Lending Countries.

a. Bad Credit Period, $1892-06$.

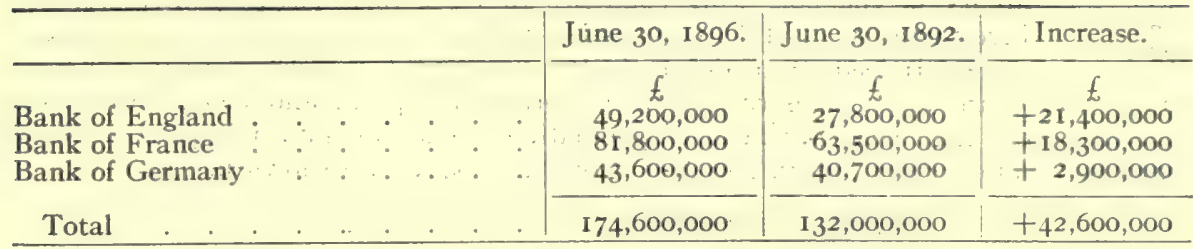

b. Good Credit Period, Igo8-12.

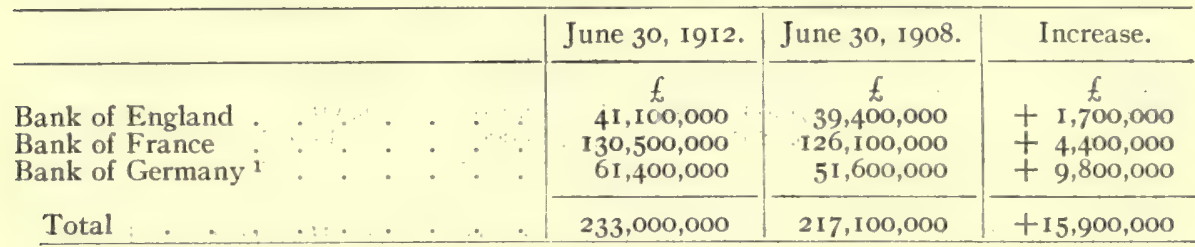

1 Includes about $\ell_{17}, 000,000$ of silver.

The comparison becomes the more striking when supplemented by a statement (Table III) of the world's gold productions in $1893^{-96}$ and in $1909^{-1} 2$ respectively.

Table III. World's Gold Productions in 1893-06 and 1909-12. Bad Credit Period.

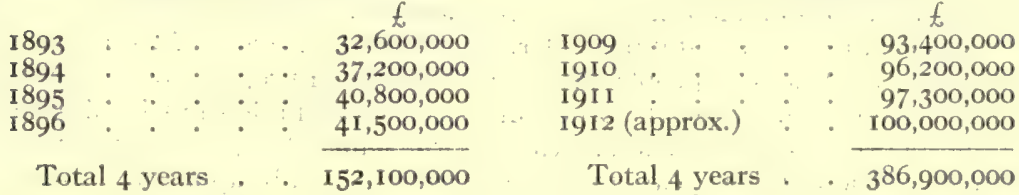

It will be noticed that, whereas in $1893^{-96}$ the world's production of gold was only $f_{152,000,000}$, and the accumulation of gold in the three principal lending countries was $f 42,000,000$, in the past four years, in which the world's production of gold has been $f_{3} 87,000,000$, the accumulation of gold in these countries came to less than $f_{\mathrm{I}} 6$,$\infty, \infty \infty$. It is unnecessary to make similar comparisons as to the chief borrowing countries in the two periods; it suffices to state that whereas in the period of bad credit they held little or no gold, at the end of r9 2 they possessed enormous stocks.

Some notion of the immense sums of gold accumulated by the chief borrowing countries, in comparison with the amounts held in 1896 , may be obtained from Table IV.

Table IV. Gold Held by Debtor Countries in I896 and 1912.

Argentina (Conversion Office)

Austria-Hungary (Bank of)

Brazil (Conversion Office)

Canada

India

Japan

Russia (Imperial Bank of)

U. S. of America (Treasury)

Italy (Bank of)

\begin{tabular}{|c|c|}
\hline June 1912. & June I896. \\
\hline$f$ & $f$ \\
$42,767,000$ & Nil \\
$51,586,000$ & $22,880,000$ \\
$22,950,000$ & Nil \\
$28,012,000$ & $3,415,000$ \\
$22,253,000$ & Nil \\
$23,128,000$ & $9,093,000$ \\
$151,782,000$ & $80,400,000,00 e^{\prime} 96$ \\
$247,652,000$ & $29,573,000$ \\
$40,976,000$ & $12,116,000$ \\
\hline $631,106,000$ & $157,477,000$ \\
\hline
\end{tabular}

Expansion. E $+42,767,000$ $+\quad 28,706,000$ $+22,950,000$ $+24,597,000$ $+22,253,000$ $+14,035,000$ $+71,382,000$ $+218,079,000$ $\begin{array}{r}28,860,000 \\ \hline\end{array}$ 
With such large stocks of gold in the borrowing countries and with the activity of trade which the good credit has created, there is no nervousness concerning the ability of the borrowing countries to meet their engagements, and the New capital investment of capital by the older in the younger countries is on a great
issues.

scale. Indeed, from one end of the world to the other, great works of public utility are under construction with borrowed capital, and consumption has reached a very high level per head of population. The amounts of capital publicly raised in London, Paris, Berlin and New York in 1909-12 are shown in Table V.

Table V. Public Issues of Capital, 1900-12.

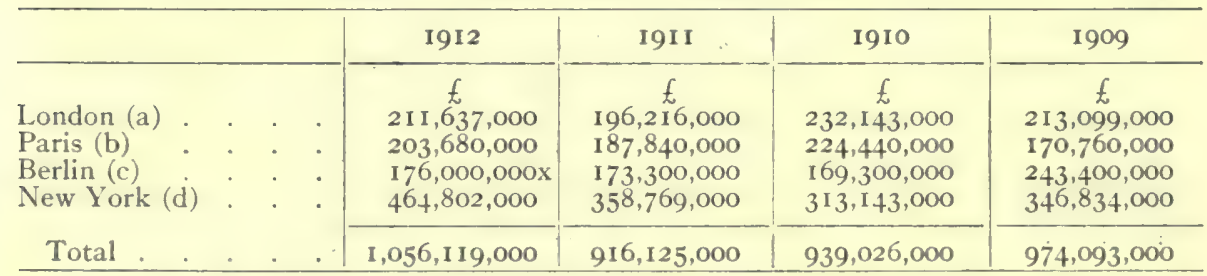

(a) From The Statist: (b) From the Moniteur des Interêts Matériels: (c) From the Frankfurter Zeitung: (d) Railroad \& Industrial Corporations from the New York Journal of Commerce. $\mathrm{x}$ Approximate.

The aggregate sum, $£_{1}, 056,000,000$, of new capital raised by public issues in the four leading money markets of the world in I9I 2 , is by far the largest ever publicly subscribed in one year, and indicates the feeling of confidence and the spirit of enterprise which animate investors everywhere. Indeed, at no time has capital shown greater mobility. From all quarters of the world demands for capital have been readily responded to by the capitalists of England, of France and of Germany. Moreover, although the American people have borrowed from Europe a good deal of capital on the one hand, they have, on the other, invested considerable sums in Mexico and in Central and South America. The greatness of the sums of capital supplied by Great Britain alone in the last four years to various countries will be apparent from Table VI, taken from the Statist.

Table. VI. Great Britain's Capilal Subscriptions, 1900-12.

United Kingdom

Canada

Australasia

Africa

India and Ceyton

Other British Colonies and Possessions

\section{Total British (oolonies}

United States .

Argentina

Brazil

Chile

Mexico

Russia

China

Japan

Other Foreign Countries

\begin{tabular}{|r|r|r|r}
\hline 1912 & 1911 & 1910 & \multicolumn{1}{c}{1909} \\
\hline $52,122,000$ & $32,244,000$ & $43,089,000$ & $30,691,000$ \\
\hline $37,469,000$ & $36,793,000$ & $33,040,000$ & $37,687,000$ \\
$13,414,000$ & $3,6+2,000$ & $10,180,000$ & $12,015,000$ \\
$6,553,000$ & $12,409,000$ & $12,950,000$ & $14,340,000$ \\
$3,896,000$ & $5,278,000$ & $14,676,000$ & $15,885,000$ \\
& & & \\
$2,618,000$ & $2,810,000$ & $12,562,000$ & $5,069,000$ \\
\hline $63,980,(000$ & $60,932,000$ & $83,403,000$ & $84,996,000$ \\
\hline $23,005,000$ & $20,782,000$ & $31,545,000$ & $21,778,000$ \\
$15,665,000$ & $15,452,000$ & $16,595,000$ & $23,987,000$ \\
$13,343,000$ & $19,314,000$ & $10,989,000$ & $7,498,000$ \\
$3,912,000$ & $8,271,000$ & $4,685,000$ & $4,159,000$ \\
$2,819,000$ & $3,304,000$ & $4,946,000$ & $9,110,000$ \\
$12,681,000$ & $6,082,000$ & $3,937,000$ & $9,672,000$ \\
$8,845,000$ & $1,555,000$ & $6,329,000$ & $1,196,000$ \\
$3,231,000$ & $5,880,000$ & 32,000 & $4,231,000$ \\
$12,134,000$ & $22,400,000$ & $26,588,000$ & $15,781,000$ \\
\hline $211,737,000$ & $196,216,000$ & $232,143,000$ & $213,099,000$ \\
\hline
\end{tabular}


A large part of the capital subscribed in recent years has been for new railway construction in Canada, Argentina, Brazil and Russia, and the completed mileage of new railways in the decade ended in I9I5 will reach a greater total than Iafluence on has been attained since the eighties and will be nearly twice as great as production. completed in the nineties. This railway construction is opening up to settlement vast areas of virgin land, and, in conjunction with the renewed profitableness of the farming industry throughout the world, is the main cause of the great volume of emigration from the old to the new countries. The number of immigrants into the United States, Canada, Argentina and Brazil in the last four years has been unprecedented, and all the preliminary preparations have been made for bringing into cultivation the additional land upon which to produce the food and raw material needed by a population growing in numbers, in wealth and in consuming power. Among the great reproductive and costly works now almost completed are the Panama Canal and the Canadian Transcontinental Railway. The prosperity of Australia in consequence of good seasons and the high prices of wool and of mutton has caused immigration to be resumed on a large scale after practical suspension for over 15 years, and is causing preparations for opening up the whole of the continent from north to south and east to west by great transcontinental systems of railways.

Indeed, from one end af the world to the other there has been movement, progress and prosperity, and production and consumption have been unprecedented both opening of actually and in proportion to population. In this movement the East China. has participated in common with the West. Probably the greatest single event of the period has been the revolution in China in I9I I, which caused the overthrow of the Manchu dynasty and the conversion of the country to a modern system of Government and to Western ideas of education and of progress. This event is as yet too recent for its real influence to be appreciated or felt. But the re-awakening of China, following upon that of Japan, is expected to modify profoundly the course of history both politically and economically. One of its first effects has been the willingness of foreign nations in general and of Great Britain in particular to supply China with the capital needed for her development. Throughout I9I 2 negotiations were in progress for a loan of $£ 60,000, \infty 00$ to China by the Six Powers especially interested in the country politically or commercially; and at the close of the year arrangements were practically concluded for a loan of $f_{25}, 000,000$. During the negotiations a loan of $f_{10,000,000}$ was placed in London with the firm of Birch Crisp \& Co., by China, against the wish of the British Government, which was only partially carried out.

The prosperity of India, in consequence of good crops, favourable prices of commodities, and a high state of credit, also calls for notice, especially as this prosperity has Expansion in brought about a great expansion both in the export and import trade Expansion in of the country and caused the import of no less than $f 27,000,000$ of gold
India. in the I2 months to March 3I, I9I2. The amount of gold absorbed by India since I 909 is, indeed, so remarkable and of such wide economic importance that the annual figures (years ending March 3 Ist) are worth setting out in detail, together with those for the total world's gold production. In I909-IO, the world's goldproduction being $£ 93,000, \infty 00$, the net value of gold imported and produced in India was $f_{17, \infty 00,000}$; in I910-II the corresponding figures were, world $£_{06}, \infty 00,000$, India

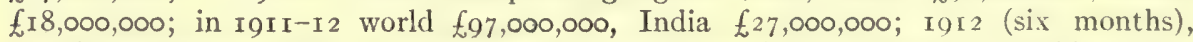

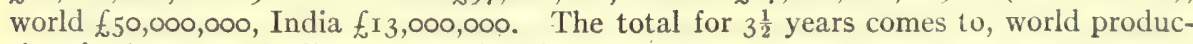
tion $£ 336,000,000$, India consumption $£ 75,000,000$.

But for this great absorption of gold by India, representing 27 per cent of the world's gold production in the 18 months up to September 1912, trade would probably have become even more active and prices of commodities would have risen to still higher levels. The prosperity of India has brought about a great demand for silver rupees, and after an interval of five years the India Government has again had to purchase a large quantity of silver for coinage. ${ }^{1}$ Up to middle of December I 9 I 2 these

${ }^{1}$ The secrecy with which this operation had to be conducted, to avoid a rise in the price 
purchases of silver had reached $f_{7}, 000,000$, and for the whole of the fiscal year ending March 31, I9I3, they were expected to reach $£ 10,000, \infty 00$. These purchases of silver were operating already to reduce the amount of gold imported into the country, and if as anticipated India were to buy foreign goods in I9I3 as freely as was indicated by the orders in existence at the end of 1912 the quantity of gold that would be sent to that country in I9I3 might well fall to more moderate proportions, a factor which would tend to prevent monetary stringency in the world's money markets.

The activity of trade throughout the world in recent years did not extend to the United States in any marked degree until ror2. This was due to consumption inconditions creasing and trade improving after the 1907 banking crisis faster than In America. the economic conditions warranted; to an excessive speculation in Western farm lands in 1909-10 which caused a temporary lock-up of banking resources; and to relatively poor crops. In I9I2, however, the American crops of every kind and description proved superabundant, and far more than sufficient to meet the needs of the American people; and as the world's consumption is on a great scale no difficulty has been experienced in disposing of the surplus production to other lands. At the close of 1912 conditions in the United States appeared to be unusually sound. Indeed confidence regarding the continuance of international prosperity was in some measure due to the excellent position on the American side of the Atlantic. The consequences of the lock-up of American banking funds in farm mortgages in roro would have been much more serious than they were but for the activity of international trade and the ability of the American people to sell manufactured goods freely in the world's markets. The course of trade in recent years in the United States has been, extreme depression in 1908 following upon the banking crisis of 1907 , a great recovery in 1909 , a halting tendency in I9ro and I9II, and another great expansion in I9I 2 after it became evident that the crops would be unusually abundant. In brief, the United States had not up to I9x 2 played any great part in bringing about the activity in international trade (apart from an increased demand for foodstuffs in consequence of short crops), but it was expected to be a factor of real importance in the crop season of $191_{2}-13$, both in supplying other countries with food and raw material and in purchasing manufactured goods in return.

The great flow of capital in recent years to the borrowing states has stimulated production and consumption from one end of the world to the other. All countries Effects of produce commodities needed directly or indirectly by all other states; credit on and when credit is good everyone can produce the things required in whatcommerce. ever part of the world they are produced. Hence in the period of good credit under consideration the volume of international trade has grown by leaps and bounds. To deal with the foreign trade of the whole world would be beyond the limits possible to the present survey. But the figures for Great Britain will indicate the remarkable expansion in international trade in recent years, the immense effect which periods of good and bad credit have upon international commerce, and the influence of the period of good credit upon foreign trade so far as that country is concerned. The values of British trade in typical years in which the credit of the younger or borrowing nations was good or bad are set out in Table VII.

In considering the growth of British imports and of the trade balance, account has to be taken of the rapidly increasing income of Great Britain from interest on capital Foreign trade placed abroad, from shipping, and from services rendered to other nations, of Cireat by British bankers, brokers, insurance offices and others. It is computed Britain. that the income from these sources is now upwards of $f 300,000,000$ per annum. An excess of imports over exports of $f_{14} 6,000,000$ for 1912 confirms the of silver, led to the contract being placed by the Indian Council with Messrs. Samuel Montagu \& (o., and one result was a curious parliamentary incident. Sir Stuart Samuel, the Liberal M.P., was a partner in the firm, and it was contended that he had vacated his seat by making a profit out of a government contract. The question was investigated by a select committee, which was unable to decide it and recommended its reference to the Privy Council; and no conclusion had been arrived at when 1912 ended. 
Table VII. Trade of Grea! Britain (in Millions of $f^{\prime} s$ ).

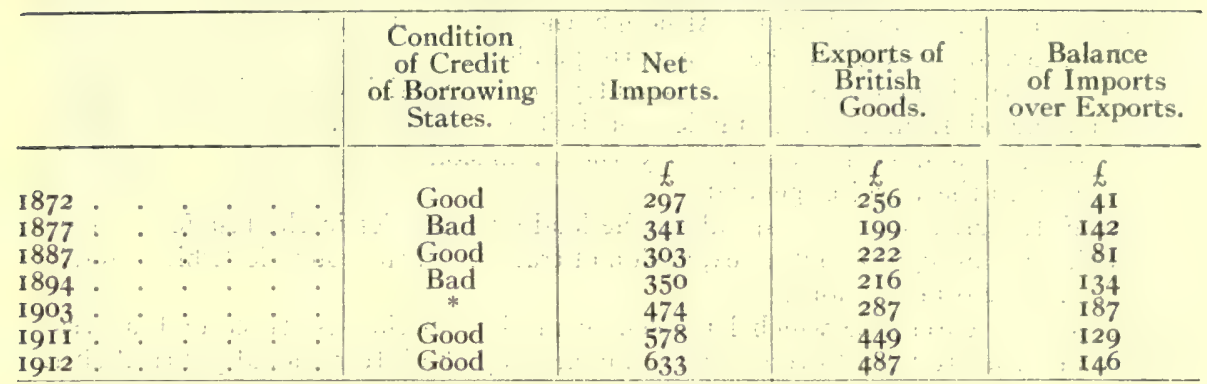

*Great Britain's ability to lend was interfered with by South African War.

evidence that about $f_{\mathrm{N}} \mathrm{r} 60,000,000$ of British capital was supplied to Indian, Colonial and foreign countries during that year. In the last ro years Great Britain has supplied other lands with about $£ \mathrm{I}, 200,000,000$ of new capital, and the large growth of $\ell_{\mathrm{I}} 59_{2}-$ $000, \infty 00$ in British imports since 1903 arises as to about two-thirds from the growth in the income of the country from interest and services, and as to only one-third from the expansion in exports. On the other hand the expansion of $£ 200,000,000$ in the exports of British goods in I9I 2 compared with 1893 was mainly brought about by the large additional sums of capital supplied by Great Britain to other lands. In brief, by lending capital freely abroad Great Britain has given the outside world about $£$ r6o,$\infty, 0 \infty 0$ a year additional spending power, a sum which has passed from hand to hand and from country to country, expanding consumption and production wherever the influence of the credits was felt, until finally the credits were settled by exports of goods to those persons and to those countries which desired to purchase British goods.

A typical instance may be given of the effect of these great investments of capital. In the last five years Great Britain has supplied Canada publicly with $£$ I $76, \infty 00, \infty 00$ The trade of capital and privately with a considerable sum in addition. The total of Canada. amounts are calculated to average about $f_{40,000,000}$ a year. A growth of between four and five per cent per annum in the population of the country, a probable expansion of nearly roo per cent in the country's railway mileage in the decade to $19{ }_{5}$, and a several-fold expansion in the agricultural output in the last ten years, show clearly the effect of these great loans of capital upon the internal trade of Canada. The effect upon her foreign trade has been equally remarkable (see Table VIII). In the year ending August I903, when Great Britain supplied Canada with but a small quantity of capital, the imports into the country were worth only $f_{0} 48, \infty 00,000$; but in the year ending August 1912 they were valued at no less than $f_{1} 2 \mathrm{I}, \infty 00, \infty 00$. In this period ( $\left.1903^{-12}\right)$ the exports from Canada only grew from $£ 46, \infty 00, \infty 00$ to $£ 66,000,000$. Thus an expansion of $£ 73,000,000$ in imports was attended by a growth of only $£ 20,000,000$ in exports, the balance of $£ 53,000,000$ being paid for by capital borrowed from abroad and wealth taken into the country by immigrants. The greater portion of this sum was met by the large investment of about $f_{40,000,000}$ of British capital in Canada in I9I 2 in comparison with a relatively small sum in 1903 .

Table VIII. Trade of Canada - I2 months to August 3 Ist. (In Millions of $f^{\prime} s$ ).

Imports for consumption

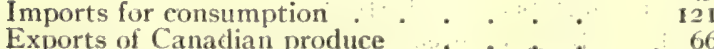
1911-12 1902-3. Inc.

Excess of imports .

Gold; net imports . . . . . . $\quad$ I

Excess of imports

$f$
21
66
$\frac{55}{1}$
$\frac{1}{56}$

\begin{tabular}{cc}
$f$ & $f$ \\
48 & +73 \\
46 & +20 \\
\hline 2 & +53 \\
2 & -1 \\
\hline 4 & +52
\end{tabular}


The experience of Canada is the same as that of other countries supplied with large amounts of capital from abroad. Although the expansion in the exports of goods from Great Britain to Canada has not corresponded to the great amounts of capital supplied by British investors to that country, the capital invested has brought an increased demand from other countries for British goods, and the generous credits granted to Canada have been settled by the expansion in the exports of goods by Great Britain to the world in general.

In brief, the great loans of capital by the lending countries in the last few years of good credit have brought about an expansion of trade in all the countries which produce things needed by other nations.

The spirit of enterprise which has been so marked in the last three or four years has in some measure been fostered and stimulated by the international political situacredit tion in Europe, and by the fear that the building of a great navy by Ger-

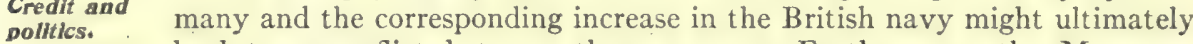
lead to a conflict between these powers. Furthermore, the Moroccan difficulty between France and Germany, which became acute in IgIr, the seizure of Tripoli by Italy, and later the attack upon Turkey by all the Balkan States with the exception of Rumania, created intermittent feelings of anxiety lest a European conflict should become inevitable. It is true that these difficulties were settled one after the other; that Germany withdrew all claims upon Morocco on receipt of compensation in the French Congo; that Italy and Turkey arranged peace; that the relations between Germany and England steadily improved throughout I9r2; and that the rapid success of the Balkan Allies simplified one part at all events of the problem in the east of Europe; nevertheless, these events caused investors to place capital outside of Europe to an unprecedented extent. At the end of I9I 2 additional anxiety was caused by Servia's claim not only to all the territory forming part of Old Servia, but also to Albania, a claim which caused preparations for war and the mobilisation of a great army by Austria. There was, indeed, for a time in November and December serious uneasiness lest a peaceful solution of the situation, as between the Great Powers themselves, should not be found. Much was done to dispel these fears at the end of the year by the prospect of a general agreement to create an open port on the coast of Albania, to construct a railway from Servia to the sea under the guarantee of the Powers, and to set up an autonomous Albania. The immediate consequence, even while the conclusion of peace between Turkey and the allies was still uncertain, was a renewred feeling of confidence in the stability of the European situation and in the strength of European securities; but on balance the prices of European securities showed a serious decline, owing to the desire of investors to purchase stocks not likely to be affected by the political complications in Europe.

Another influence affecting the security market has been the desire to dispose of low-interest stocks and to transfer the capital to securities giving a higher return. In fact, the fashion in securities in the last few years of good credit has been,

Effect of high or low yield on securities. as one would expect, the exact opposite of that in a period of bad credit. In the nineties, when the credit of the young countries was at a low ebb and capital accumulated in the older countries, the de nand was almost exclusively for safe stocks, and no thought was paid to the rate of interest so long as the stocks were considered secure. In the recent period of good credit stocks possessing "chances" have been much sought for, and little or no attention has been paid to the security of the stocks provided there was the prospect of increased dividends and the possibility of a substantial increase in the market value of the security. The result of this fashion has been that speculative securities upon which the dividends were increasing have been in great demand, while stocks and bonds upon which the dividends were stationary - whether shares of public companies, or the obligations of governments - have been out of favour. A comparison of the prices of securities in various countries shows that the change of fashion has been universal, the securities sought after being those upon which dividends were increasing 
or were likely to increase, while the securities paying fixed rates of interest or steady rates of dividends have been ignored. This condition of mind caused a boom in rubber securities in I910, when over $f_{2} 1,000,000$ of capital was raised in the London market for new rubber companies, and when prices: of rubber shares rose to high figures in consequence of actual or anticipated dividends. It also created a great demand for securities of oil, shipping and other companies' shares, where the profits have expanded rapidly in consequence of the trade activity. In Table IX the prices of a number of securities quoted on the London Stock Exchange at the end of ror 2 are contrasted with those at the end of 1908. The changes show clearly the demand for securities giving relatively high rates of interest or increased rates of dividend in comparison with securities where the rates of interest and dividend have been low or stationary. The prices of securities at the end of September 1912 are added to show the fall in stocks in the last three months of $\mathrm{I}_{9} \mathrm{I}_{2}$ in consequence of the Balkan crisis.

Table IX. Courses of Prices on the London Stock Exchange.

\begin{tabular}{|c|c|c|c|c|}
\hline & $\begin{array}{c}1908 \\
\text { Dec. 3I }\end{array}$ & $\begin{array}{c}\text { 1912 } \\
\text { Sept. } 30\end{array}$ & $\begin{array}{c}1912 \\
\text { Dec. } 28\end{array}$ & $\begin{array}{c}\text { Rise } \\
\text { or fall } \\
\text { (4 years). }\end{array}$ \\
\hline 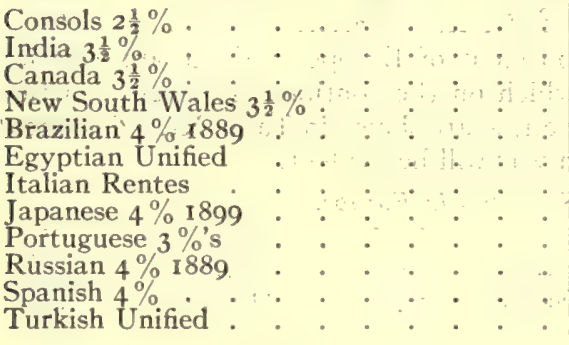 & $\begin{array}{c}84 \frac{1}{1^{6}} \\
98 \frac{7}{8} \\
99 \\
100 \\
80 \\
102 \\
103 \frac{1}{2} \\
84 \frac{3}{8} \\
60^{\frac{3}{4}} \\
84^{\frac{3}{4}} \\
96 \\
92 \frac{3}{4}\end{array}$ & $\begin{array}{l}74 \\
91 \frac{1}{4} \\
96 \\
95 \\
86 \frac{1}{4} \\
100 \frac{1}{2} \\
96 \\
83 \frac{1}{2} \\
65 \\
93 \\
92 \\
89\end{array}$ & $\begin{array}{l}75 \\
91 \\
96 \\
96 \\
83 \\
99 \\
97 \\
84 \\
65 \\
91 \\
90 \\
86\end{array}$ & $\begin{array}{l}-9 \frac{1}{16} \\
-\quad 7^{\frac{1}{8}} \\
-4 \\
+3 \frac{1}{2} \\
-3 \\
=6 \frac{1}{2} \\
=\frac{3}{8} \\
+4 \frac{1}{4} \\
-6 \frac{1}{4} \\
-6 \frac{3}{4}\end{array}$ \\
\hline $\begin{array}{l}\text { Great Western Ry. Ord. } \\
\text { L. \& North Western Ord. } \\
\text { L. Brighton \& S. Coast Defd. } \\
\text { Midland Deferred } \\
\text { North Eastern "Consols" } \\
\text { Bengal \& N. Western Ord. } \\
\text { Canadian Pacific Ord. } \\
\text { Grand Trunk Ordinary } \\
\text { B. Ayres Great Southn. Ord. } \\
\text { Buenos Ayres Western Ord. } \\
\text { Bank of England Stock } \\
\text { Lloyd's Bank } \text { f }^{8} \\
\text { London City \& Mid. Bank } \\
\text { London County \& Westminster Bank } \\
\qquad 5\end{array}$ & $\begin{array}{l}124 \\
133 \\
86 \frac{1}{2} \\
56 \frac{3}{4} \\
128 \\
148 \\
181 \frac{7}{8} \\
20 \frac{3}{11^{6}} \\
125^{\frac{1}{2}} \\
125^{\frac{1}{2}} \\
266^{\frac{3}{4}} \\
32 \frac{3}{4} \\
50 \\
23^{\frac{3}{8}}\end{array}$ & $\begin{array}{r}116 \frac{1}{4} \\
133 \frac{1}{4} \\
93 \frac{1}{1} \\
70 \frac{1}{4} \\
122 \frac{1}{2} \\
156 \frac{1}{2} \\
288 \frac{1}{4} \\
28 \frac{1}{2} \\
129 \\
131 \\
239 \frac{1}{2} \\
27 \frac{1}{4} \\
45 \\
20 \frac{3}{8}\end{array}$ & $\begin{array}{l}117 \frac{3}{4} \\
133 \\
94 \\
70 \frac{3}{4} \\
121 \frac{1}{15} \\
156 \\
268 \frac{1}{2} \\
29 \frac{1}{2} \\
124 \frac{1}{2} \\
124 \\
242 \frac{1}{2} \\
28 \frac{1}{4} \\
46 \frac{1}{4} \\
21 \frac{1}{8}\end{array}$ & $\begin{array}{l}-6 \frac{1}{4} \\
+\quad 7 \frac{1}{2} \\
+14 \\
-6 \frac{1}{2} \\
+\quad 8 \\
+86 \frac{5}{8} \\
+\quad 9 \frac{5}{16} \\
-1 \\
-11 \\
-23 \frac{1}{2} \\
-\quad 4 \frac{1}{2} \\
-3 \frac{3}{4} \\
-\quad 2 \frac{1}{4}\end{array}$ \\
\hline 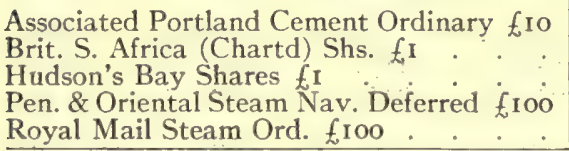 & $\begin{array}{l}0 \frac{15}{16} \\
\text { I6s. } 3 \mathrm{~d} . \\
7 \frac{11}{11}^{\frac{1}{6}} \\
206 \frac{1}{2}^{6} \\
53\end{array}$ & $\begin{array}{l}7 \frac{3}{4} \\
29 \mathrm{~s} \\
13 \frac{1}{16} \\
330 \\
148 \frac{1}{2}\end{array}$ & $\begin{array}{l}7 \frac{3}{16} \\
26 s .6 d . \\
12 \frac{11}{16} \\
320 \\
137\end{array}$ & $\begin{array}{l}+6 \frac{1}{4} \\
+\operatorname{Ios} 3 \mathrm{~d} \\
+5 \\
+\quad 513 \frac{1}{2} \\
+\quad 84\end{array}$ \\
\hline
\end{tabular}

It is noteworthy that gold-mining shares have also suffered neglect in common with high-class securities in the recent good-credit period. In the nineties the demand Gold-mining for gold-mining shares arose from the recognition that the supply of gold shares.

was inadequate to the world's needs. At the present time it is generally admitted that the world's production of gold is sufficient, and inasmuch as large incomes can be gained from the investment in securities. which have benefited and are benefiting from the activity of the world's trade arising in part from the great production of gold, the inducement to purchase gold-mining shares has largely disappeared. Of course, diamond, silver and other mining shares are not in the same 
category as gold-mines, for the prices of diamonds, of silver, of copper and of other metals have risen, whereas the price of gold is stationary; indeed, measured by other commodities it has fallen heavily. In other words, gold has depreciated, while the prices of all other commodities have appreciated; and whereas the profit from goldmining has declined and is declining, the profit from producing other commodities has greatly risen and is still rising. The rise in silver and diamond-mining shares and the decline in gold-mining shares will be apparent from Table $\mathbf{X}$. The price of Rio Tintos in December 1912, it may be noted, shows a decline brought about by recent liquidation in Paris in consequence of the Austrian mobilisation.

Table X. Prices of Mining Shares.

\begin{tabular}{|c|c|c|c|c|c|}
\hline & & $\begin{array}{c}1908 \\
\text { Dec. 3I }\end{array}$ & $\begin{array}{l}1912 \\
\text { Sept. } 30\end{array}$ & $\begin{array}{c}\text { I9I } 2 \\
\text { Dec. } 28\end{array}$ & $\begin{array}{l}\text { Rise or fall } \\
\text { (4 years). }\end{array}$ \\
\hline 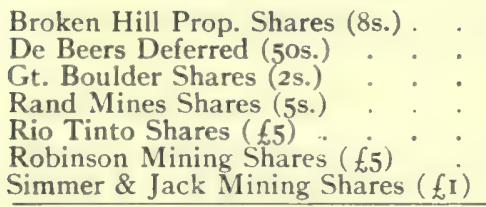 & 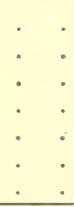 & $\begin{array}{l}1 \frac{15}{16} \\
11 \frac{1}{8} \\
28 \%- \\
7 \frac{29}{32} \\
75 \frac{1}{2} \\
10 \frac{1}{4} \\
2 \frac{3}{32}\end{array}$ & $\begin{array}{l}2 \frac{11}{16} \\
22 \frac{1}{4} \\
10 / 3 \\
6 \frac{29}{32} \\
84 \frac{5}{8} \\
3 \frac{5}{8} \\
1 \frac{1}{16} \\
\end{array}$ & $\begin{array}{l}2 \frac{21}{32} \\
21 \\
12 / 6 \\
6 \frac{17}{32} \\
73 \frac{1}{8} \\
33^{\frac{1}{2}} \\
1\end{array}$ & $\begin{array}{l}+\frac{23}{32} \\
+9 \frac{7}{8} \\
-15 / 6 \\
-1 \frac{3}{8} \\
-2 \frac{3}{8} \\
-6 \frac{3}{4} \\
-1 \frac{3}{32} \\
\end{array}$ \\
\hline
\end{tabular}

The fall in high-class securities on the continent of Europe, and the appreciation in industrial stocks and in banking shares, which on the continent so largely participate in the increased profits of industrial companies, are shown in Table XI. The great decline in prices in consequence of the Balkan war will be evident.

Table XI. Prices of Securities in Europe.

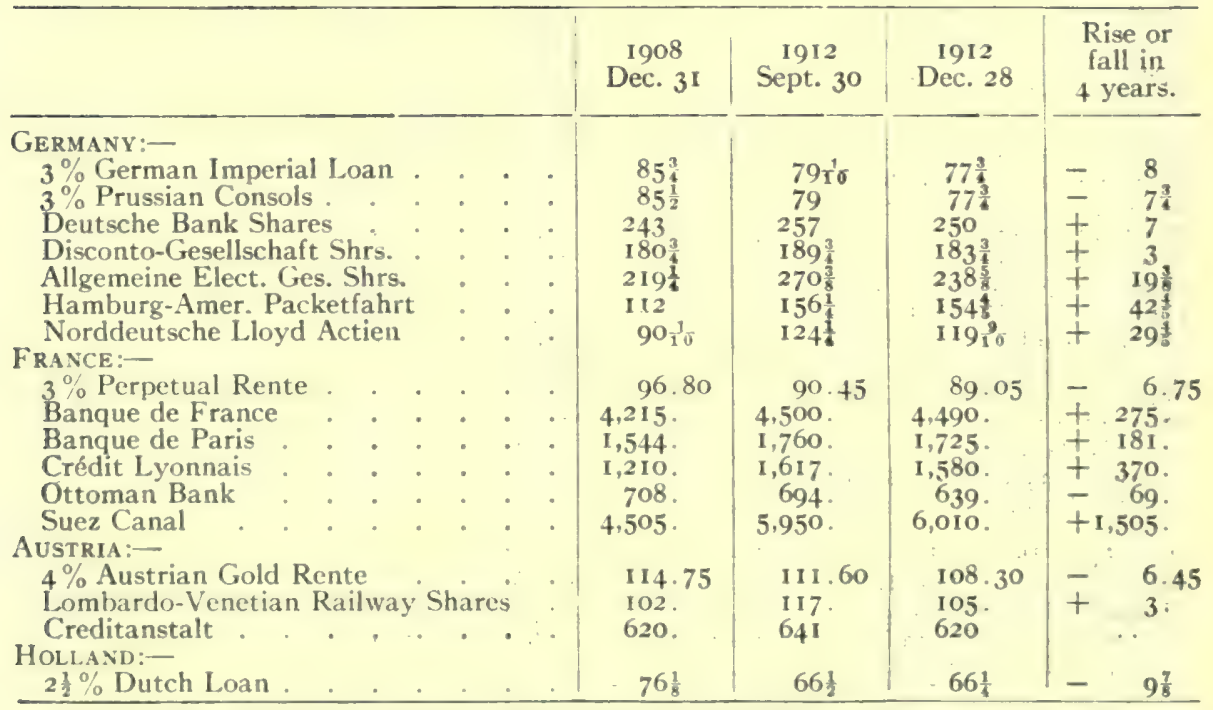

In the United States similar conditions have prevailed (see Table XII), and prices of bonds and shares have generally fallen except where the profits are expanding and the dividends are increasing.

The immense production of gold has prevented any great rise in the rate of interest for "banking money." Of course, "banking money" is an entirely different comBanking modity to "investment money" or capital. Money that is placed permoney. manently in securities is the savings of the public and is mainly under the control of the general investor; whereas banking money consists for the great part of the unused cash balances of companies, business houses, and individuals, 
Table XII. Prices in the United States.

\begin{tabular}{|c|c|c|c|c|c|}
\hline & & $\begin{array}{c}1908 \\
\text { Dec. 3I }\end{array}$ & $\begin{array}{l}\text { I9I2 } \\
\text { Sept. } 30\end{array}$ & $\begin{array}{c}1912 \\
\text { Dec. } 28\end{array}$ & $\begin{array}{l}\text { Rise or } \\
\text { fall in } \\
4 \text { years. }\end{array}$ \\
\hline $\begin{array}{l}\text { New York City } 4 \frac{1}{2} \% \\
\text { Atchison, Topeka \& Santa Fé Common } \\
\text { Erie Common } \\
\text { Louisville \& Nashville Common } \\
\text { New York Central Common } \\
\text { Pennsylvania R. R. Shares } \\
\text { Reading Common } \\
\text { Union Pacific Common } \\
\text { American Sugar Refining } \\
\text { American Telephone \& Telegraph } \\
\text { Anaconda Mining Shares } \\
\text { General Electric Common } \\
\text { People's Gas } \\
\text { United States Steel Common }\end{array}$ & ? & $\begin{array}{r}112 \frac{1}{8} \\
100 \frac{3}{8} \\
34 \frac{1}{2} \\
125 \frac{5}{8} \\
125 \frac{1}{3} \\
131 \frac{7}{8} \\
142 \frac{5}{8} \\
183 \frac{5}{8} \\
131 \\
127 \frac{1}{4} \\
49 \frac{7}{8} \\
157 \frac{1}{2} \\
77 \frac{1}{2} \\
104 \frac{5}{8} \\
53 \frac{3}{4}\end{array}$ & $\begin{array}{r}98 \frac{1}{2} \\
109 \frac{3}{4} \\
37 \frac{5}{3} \\
163 \frac{1}{1} \\
117 \frac{1}{2} \\
124 \frac{3}{3} \\
173 \frac{3}{1} \\
175 \\
127 \frac{1}{2} \\
144 \\
46 \frac{7}{8} \\
183 \frac{1}{2} \\
64 \frac{1}{2} \\
116 \frac{3}{4} \\
79^{\frac{3}{4}}\end{array}$ & $\begin{array}{l}96 \frac{1}{2} \\
105 \\
31 \frac{5}{8} \\
140 \\
107 \frac{1}{2} \\
121 \frac{5}{8} \\
166 \frac{3}{8} \\
159 \frac{1}{8} \\
116 \frac{1}{2} \\
140 \\
39 \frac{3}{4} \\
184 \frac{3}{4} \\
55^{\frac{5}{8}} \\
114 \\
66 \frac{7}{8}\end{array}$ & $\begin{array}{r}-15 \frac{5}{5} \\
+\quad 4 \frac{5}{8} \\
-12 \frac{7}{8} \\
+148 \\
-18 \\
-10^{\frac{1}{4}} \\
+23^{\frac{3}{4}} \\
-24 \frac{1}{2} \\
-14 \frac{1}{2} \\
+13 \frac{1}{1} \\
-10^{\frac{5}{8}} \\
+27 \frac{1}{8} \\
-21 \frac{7}{8} \\
+19 \frac{3}{8} \\
+13 \frac{1}{8}\end{array}$ \\
\hline
\end{tabular}

and is under the control of bankers. In Great Britain banking money is increasing at the rate of about $£ 30,000,000$ a year; whereas the total savings of the country available for investment in securities or in other forms of property or for the acquisition of other wealth are now about $£ 350,000,000$ per annum. In other countries the amount of money under the control of bankers also represents but a small part of the savings available for investment. Although the general public changes its policy in the matter of investments from time to time, at one period demanding high-class stocks with low rates of interest, and at another low-class stocks with high rates of interest, bankers pursue practically the same policy in periods of good and of bad credit. Banking money in Great Britain is mainly engaged in financing international commerce and national trade from the producer to the consumer, and the nature of the securities upon which banking funds are advanced is practically the same from period to period. The fluctuations in the rate of interest are brought about by the changing volume and values of the goods to be financed in proportion to the funds which bankers have at their disposal. The great production of gold in recent years has enabled payment to be made to the backward countries, whose systems of banking and of currency are not highly developed, with unusual facility, and has kept down the demand that otherwise would have been made upon banking credits in proportion to the values of the goods to be financed. Nevertheless, the volume of international trade has become so great that relatively high rates of interest have been current notwithstanding the great production of gold.

High rates of interest for banking money are sometimes brought about by a sudden feeling of anxiety and consequent contraction of credit, a condition of things that Baak
rates. subsequently creates a redundant supply of money and brings low rates of interest. Owing to the banking crisis in the United States in 1907, the breakdown of the banking system of that country at that time, and the exceptional demand upon the stock of gold in Great Britain, the Bank of England rate in that year averaged $£ 4 . x 8$ s. 6 d. per cent. In the following year, when trade, both in the United States and in other countries, seriously suffered from the after affects of the crisis, and when the demand for banking accommodation was exceptionally small, the average Bank of England rate was only $£ 3$. os. 3 d. per cent. In I909, when trade was still affected in some measure by the previous crisis in the United States, the average rate was still as low as $£ 3$. Is. $8 \mathrm{~d}$., although the Bank rate rose to 5 per cent in October in consequence of a great rise in the price of cotton and an unusual drain of gold to Egypt. In I9ro, however, the money market felt the effect of the rapid recovery in trade in America, of the rise in the prices of commodities, and of the exceptional lock-up of bankers' resources in financing a real-estate speculation in the Western states of the American Union, and the average Bank of England rate rose 
to f3. I4s. 6d. per cent on the average for the year. In IgI there were no abnormal demands for money; indeed, the uncertainties with regard to the Moroccan situation caused investment money to accumulate in the banks, and the average Bank of England rate for the year was no higher than $f_{3}$. 9s. $4 \mathrm{~d}$. In I9I2 the average Bank of England rate rose to $£ 3.15 \mathrm{~s}$. 6d., in consequence mainly of the disturbance to credit arising from the wars between Italy and Turkey, and the Balkan States and Turkey. These wars, with the anxiety they created as to a conflict between the Great Powers, caused large withdrawals of cash from the State Banks of France, Germany and Austria. The withdrawals of cash were increased by the mobilisation of troops in Austria and the payment for supplies by loans obtained from bankers. The political situation thus caused an expansion in the coin and note circulation of the three banks mentioned of nearly $£ 80,000, \infty 0$ in a period of four months instead of a normal sum of about $£ 30,000, \infty 00$. The result of this great drain upon the resources of the State Banks of France, Germany and Austria was an advance in the value of bankers' money throughout the world. During the closing months of I9I 2 the Bank of England rate was 5 per cent, the Bank of France rate 4 per cent, - an unusually high rate in France,while the German and Austrian bank rates were 6 per cent. The conclusion of peace between the Allies and Turkey was looked forward to with the expectation that it would result in a great reflux of cash into the continental banks and renewed ease in the money markets. Whether or not an improvement in the general political situation would induce French bankers to replace the money they had withdrawn from Germany and from Austria had yet to be determined. If not, the value of bankers' money in both of these countries would remain relatively high for some time to come. Having regard, however, to the probable activity of the world's trade and the great volume and value of the merchandise to be financed, it was evident that banking money would remain in good demand at profitable rates of interest notwithstanding a gold production at the rate of about $\left.f_{1}, \infty, 0 \infty 0, \infty\right) 0$ per annum.

The average rates for banking money in England, France, Germany, Holland and Belgium since I902 are shown in Table XIII.

Table XIII. Average Bank Rates in Europe, Igoz-12.

\begin{tabular}{|c|c|c|c|c|c|c|c|c|c|c|c|c|c|c|c|}
\hline & \multicolumn{3}{|c|}{$\begin{array}{c}\text { Bank of } \\
\text { England Rate } \\
\text { Per Cent. } \\
f \text { s. d. }\end{array}$} & \multicolumn{3}{|c|}{$\begin{array}{l}\text { Bank of } \\
\text { France Rate } \\
\text { Per Cent. } \\
f \text { s. d. }\end{array}$} & \multicolumn{3}{|c|}{$\begin{array}{l}\text { Imperial Bank } \\
\text { of Germany } \\
\text { Rate Per Cent. } \\
£ \text { s. d. }\end{array}$} & \multicolumn{3}{|c|}{$\begin{array}{l}\text { Bank of } \\
\text { Holland Rate } \\
\text { Per Cent. } \\
\& \text { s. d. }\end{array}$} & \multicolumn{3}{|c|}{$\begin{array}{l}\text { Bank of } \\
\text { Belgium Rate } \\
\text { Per Cent. } \\
£ \quad \text { s. d. }\end{array}$} \\
\hline 1902 & 3 & 6 & 7 & 3. & 0 & 0 & 3 & 6 & 6 & 3 & o. & 0 & 3 & o & o \\
\hline 1903 & 3 & 15 & o & 3 & 0 & 0 & 3 & I6 & 9 & 3 & 7. & II & 3 & 3 & 5 \\
\hline 1904 & 3 & 5 & 10 & 3 & 0 & 0 & 4 & 4 & 7 & 3 & 4 & 10 & 3 & o & 0 \\
\hline 1905 & 3 & o & 2 & 3 & 0 & 0 & 3 & 16 & 3 & 2 & 13 & 6 & 3 & 3 & 5 \\
\hline 1906 & 4 & 5 & 4 & 3 & 0 & 0 & 5 & 2 & II & 4 & 2 & 2 & 3 & 16 & 9 \\
\hline 1907 & 4 & 18 & 6 & 3 & 9 & 3 & 6 & 0 & 7 & 5 & 2 & o & 4 & 18 & 10 \\
\hline 1908 & 3 & o & 3 & 3 & I & 0 & 4 & I5 & 6 & 3 & 7 & 10 & 3 & II & 6 \\
\hline 1909 & 3 & I & 8 & 3 & 0 & $o$ & 3 & 18 & 5 & 2 & 17 & 7 & 3 & 2 & 2. \\
\hline 1910 & 3 & I 4 & 6 & 3 & 0 & 0 & 4 & 6 & I I & 4 & 4 & 7 & 4 & 2 & 3 \\
\hline I9II & 3 & 9 & 4 & 3 & 2 & 9 & 4 & 7 & 10 & 3 & 8 & Ia & 4 & 3 & 0 \\
\hline 1912 & 3 & 15 & 6 & 3 & 7 & 6 & 4 & 19 & 5 & 4 & o & 0 & 4 & 8 & 10 \\
\hline
\end{tabular}

(George Paish.)

\section{THE EXTENSION OF INTERNATIONAL TELEGRAPHY}

Submarine Cables.-The approximate length of submarine cable in active work at the end of $\left.\mathrm{I}^{\prime}\right) \mathrm{I} 2$ was 277,000 miles, of which but a sixth was under any government control, the remainder being administered by private enterprise, the capital invested representing some 35 million pounds sterling. Whilst it has generally been recognised that the cables afford a highly efticient method of telegraphy, and that the parties administering them provide, as a whole, an eminently satisfactory service, it has for a long time been felt by governments and by the public at large that the service is of a very costly nature; and that having regard to the increasing demand for speedy com- 
munication with a country's outlying possessions-as well as with other nations-it requires considerable development on a basis of substantial reductions in the tariff.

From a national standpoint, the actual control of a cable is a matter of first importance. It means that a country can gather together its distant resources at short notice when desired without fear of interruption, and by this means is provided with an extra insurance against attack. Thus cable control under normal peace conditions is of even greater value than the achievement of such control in times of war.

Partly on strategic accounts and partly with an eye to improving on the facilities for rapid communication with distant dependencies, a general feeling has of late sprung up amongst the principal European powers for establishing their own national cable links. Hence, within comparatively recent years, Italy, France and Germany have each in turn produced their own factories for the construction of submarine telegraphs, and these countries have now their own separate cables to most of their respective outlying dominions and tributaries. Thus, an agreement was recently entered into between the French and German governments, the object of which is to render these countries independent of British cables-more especially for communication with Africa. But, immediately, perhaps, the most striking feature of this agreement is the laying of a Franco-German state cable between Brest and Emden, with German extension to Monrovia (West Coast of Africa) and Pernambuco (South America).

Another highly important event occurred when, at the beginning of $x 9 \mathrm{x} 2$, the Western Union Telegraph Company of America took over on a 99 years lease all the five cables of the Anglo-American Telegraph Company, together with the single line of the Direct United States Cable Company. By this practical absorption all the trans-Atlantic Cables between the United Kingdom and Canada (or the United States) have come under American control, the Commercial Cable Company of New York being the "Western Union's" only competitor. It seems quite likely that this absorption may make for an improved service in certain respects as well as lead the way to further developments. It is also obviously beneficial from a general American standpoint. But from a national British point of view the change has led to serious misgivings.

If telegraphic communication between a Great Power and its over-sea dominions were only needed for private individual purposes, there would be no sufficient justification for a government embarking on the expenditure of public money for state-owned cables. But such communication has important national aspects, (I) strategically, (2) politically, and (3) for developing inter-imperial trade. Whatever may be thought about state trading in general, there are more sound reasons in favour of governmentowned strategic cables to distant possessions than would apply in the instance of state railways or the government land telegraph system of a country, both of which may be said to serve individual interests rather than national or imperial.

For Great Britain the most striking case for a state cable is between the mother country and Canada. Indeed, whilst in order to effect a satisfactory connection with the Imperial Pacific cable, there has always been the need for an All-British Atlantic cable and land line across Canada, this need-in the opinion of constructive British Imperialists-became a positive and urgent necessity so soon as all the existing Atlantic cables came directly under the control of a United States Company. Other gaps in an AllBritish system are between Gibraltar and Bathurst, and between Bathurst and Barbados, and the suggestion has been made that in the latter case an extension to Bermuda would meet and connect up with the proposed Imperial Atlantic cable via Halifax. ${ }^{1}$

1 Telegraphic communication to and between the West India Islands is in a highly unsatisfactory position. 'The Royal Commission appointed in 1909 to enquire into the trading relations between Canada and the West Indies strongly urged that the rival cable systems should be taken over by the state. Though having the benefit of evidence from "wireless." experts, they recommended further cables rather than "wireless," except in a few minor instances. The Imperial government have not acted on this report, proposing that any necessary developments should be effected by "wireless." On the other hand, Canada and the West Indies adhere to the findings of the Canada-West Indies Commission, and at the Ottawa Conference in April 1912 adopted (unanimously) resolutions to that effect. 
Far the greater amount of the existing cable systems is in the hands of private enterprise. But it is obvious in such a case that national interests and those of the public are liable to run counter to those of the companies concerned. Thus the feeling in favour of the communicating links with the rest of the British Empire being administered by the state has, of late, gained considerable force. There are some, indeed, who would like the entire cable system as at present controlled by British cable companies taken over by the government. That, however, will be clearly inadvisable for high diplomatic reasons. Moreover, it would in all probability be quite impracticable.

The cable companies-almost entirely the outcome of British private enterprisehave certainly effected very substantial reductions in the telegraph tariff to different parts of the world. These rebatements appear at their best when a comparison is made with the earliest days, when the desire for communication at such distances was far less, and when the commercial pioneers had a greater right to exact high rates.

Whilst increased overhead charges and the cost of additional cables constitute a genuine commercial objection to tariff reductions, this difficulty has of late been, to a great extent, met by the invention of the cable relay. This permits of a cheaper type of cable for a given volume of traffic; and, correspondingly, by its adoption at intervening points, the same type of cable has a greater earning capacity.

It is now over ten years since a proposal was made for a universal 6d., 9d., or Is., rate throughout the British Empire, the suggestion being that the traffic revenue of the various lines to different parts of the Empire should be " pooled together." Since then, there have been a number of irresponsible proposals of a sort that moves public fancy and sensation-about enormous cable rates reduced to even as low a figure as $\mathrm{Id}$. a word on a universal footing throughout the world. A reform of this character would involve numerous international difficulties. Moreover, it is more natural that each nation should limit its energies for reform to the reduction of rates within its own sphere of action.

It was on the first day of IgI 2 that reduced rates for deferred messages by cable became an accomplished fact. An innovation of this character satisfies, in a great measure, prevailing needs in supplying an alternative service intermediate between the sometimes unnecessarily speedy yet costly cablegram and the despatch of a letter by mail occupying several weeks in transit. The reform is mainly effective for developing private messages, for increasing the bulk of press news between the different parts of the world - thereby tending towards greater accuracy and better understanding. It also obviates the necessity of coding and decoding in the case of many business cablegrams of a non-urgent character. For the eventual realisation of deferred " ordinary " rates between the mother country and the greater part of the British empire, English people are largely indebted to the persistence of the British Postmaster-General (Mr. Herbert Samuel). In the case of long distances such as that between the United Kingdom and Australia, this innovation is especially appreciated-owing to the length of time occupied by the mail on the one hand, the cost of "cabling" on the other; and the All-British Pacific cable may, therefore, be cited as a good example of the way in which deferred rates turn the line to better account during the more or less idle hours of the night, as well as during non-mutual business hours. On this line alone up to the end of September as many as 228,437 words had been sent at deferred rates during 1912." When this system of deferred rates comes to be more widely known and understood, it will undoubtedly be even more utilised-for social as well as business purposes. With the opening of 1913 a system of cheap week-end cable letters (not less than 30 words) came into opcration between the United Kingdom and nearly every other part of the British Empire. The system was inaugurated as far as Canada was concerned by the Western Union Telegraph Company in the carly part of I9 I 2, and was some months later adopted by the Eastern Telegraph Company and the Pacific Cable Board between the mother country, South Africa and Australia. The messages can be handed in on any day

1 The All-British Pacific cable is, as a matter of fact, an excellent example in every way of expansion. Laid in 1002 , it only carried about 200,000 words in all during its first year whilst its present volume of traffic exceeds ten times that amount. 
during the week to be transmitted on a Saturday night or during Sunday for delivery on Monday or Tuesday.

The "deferred" rate system has also been applied to Press cablegrams, and this should prove an enormous impetus to the circulation of news of a not too urgent character. A reduction in press rates between any two countries invariably means that the newspapers of each print a greater volume of matter about the other, which, again, means an increase of business between them-in addition to a better understanding and more friendly relations being developed. In fact, a lowering of price in anything invariably leads to increased demand-and in proportion to the degree of rebate. Where some sort of guarantee of traffic is given, further reductions should reasonably be looked for in many directions. The cable companies at present demur to extending the deferred rate plan to coded messages, fearing apparently that too large a proportion of their traffic would become " deferred."

If the effect of distance is to be satisfactorily overcome we must commune a great deal more than we do through wires that bring us into speedy touch. The facilities at present available do not permit of this, partly owing to cost, but also on account of an actual insufficiency of cables to bear any considerable increase of traffic during mutually busy hours. Many more cables are required in a variety of directions, for accommodating an increase of traffic such as would undoubtedly result from any considerable reduction of tariff. It may be said that, meanwhile, the network goes on increasing steadily from year to year-as much as ever. The preponderance of cable worked by private enterprise as against that by governments is gradually becoming greatly modified, partly because it is seen that public interests are bound to differ from shareholders' interests in such a case. It will, no doubt, in time be recognised that a nation's oversea communicating links should be put on the same footing with general defence-the Navy, Army, etc. - to which it serves as so important an auxiliary. A great war may, at any moment, make this abundantly clear, but in that case the lesson will be dearly bought.

Radiotelegraphy. - A few years ago there would have been but little to record in regard to radiotelegraphy or "wireless," except in the matter of experimental work. But things have moved rapidly of late years, following on steady progress in the practical realisation of this branch of applied science.

It suffices here to say that-like most other branches of applied science-radiotelegraphy, even in its present form alone, is the work of many hands of different nationalities. The different systems at present available, in so far as they differ fundamentally, do so mainly in regard to the form of oscillations, or waves, emitted and the method of producing them. These may be classed under the following heads, in the order in which they were brought to public notice:-(a) the spark, or intermittent wave, of Marconi and others, (b) the quenched spark-Telefunken, Lepel, etc., (c) the continuous (undamped) wave of Poulsen and others.

By far the most of the practical, and long distance continuous commercial work has, as yet, been effected by the Marconi and Telefunken systems, ${ }^{1}$ though, on the other hand, in the opinion of some, other systems possess several advantages. For instance, the Galletti system has certain favourable characteristics. This method has recently been taken up by the Indo-European Telegraph Company with a view to serving as an auxiliary to their cable and land line service between England and India. With this idea, it is being put on trial for working between France and the United States.

A recent invention that is likely to prove of great value is the high-frequency alternator of Prof. Rudolph Goldschmidt. The Goldschmidt patents are worked by the Compagnie Universelle de Télégraphie et de Téléphonie sans Fil (ro million francs capital) of Paris. This company has just established a high-power trans-Atlantic station near Hanover (Germany) with two Goldschmidt alternators (I 50 K.W. high frequency out-

${ }^{1}$ At the end of 1912 , of coast stations-European and non-European-there were 107 Marconi stations and I6I others, of which 85 were Telefunken stations. Of ship stations, there were 726 Marconi (including the Italian Navy) and 583 others, of which the Telefunken Company had 289 ; or, adding the 245 Telefunken stations of the German Navy, we get Marconi 726 , others 828 , of which 534 were Telefunken. 
put), which will shortly have its counterpart in a corresponding station at Atlantic City New Jersey, U.S.A. As soon as this is completed a trans-Atlantic service will be established between Germany and the United States, which is to be supplemented by another station equipped by the same French company on the west coast of France.

The quenched musical spark system of Baron von Lepel was bought up within the last 2 years by the Compagnie Générale Radiotélégraphique of Paris, which now effects the greater part of French radiotelegraphy. This company has lately disposed of its English and colonial patent rights to the Anglo-French Wireless Company of London, which also works the Goldschmidt patents in England on behalf of the Compagnie de Télégraphie et de Téléphonie sans Fil.

The French Government have determined to establish wireless communication between France and her colonies. It is proposed to establish as many as five separate chains of stations. One of these will have stations in the south of France, in Tunis, Jibutil, Pondicherry, and Cochin China, with a branch to Madagascar. The South American and African chain, starting from the same station in the south of France, will connect with stations in Morocco, Colomb-Bechar, Senegal, Timbuctoo, Bangui, and Martinique. These two systems will be followed up by a connection across the Pacific, with stations at Noumea and Tahiti. One is also to be erected in the west of France to establish communication with North America. The total cost of the complete system will be about $£ 807,800$.

The Poulsen system was first put into practice in Denmark some six years ago, and a little later a station was established at Cullercoats on the eastern coast of England-this station having since been taken over by the British Post-office, along with all the other commercial stations previously owned by wireless companies. For some years, the system was turned to very little practical use, though the reasons for this are in no way associated with its technical merits as a system. Within the last two years the Poulsen system has been greatly developed by means of (automatic working) improvements due to Professor Pedersen. In this form the system has been lately taken up by an American organisation, the Federal Telegraph Company of San Francisco, formed, in the first place, for establishing wireless communications between San Francisco and Honolulu, the range being over 2,000 miles-or somewhat in excess of that dividing the North Atlantic Ocean. Wireless stations on the Poulsen-Pedersen system have also been established by this Company at I4 different cities-some covering land ranges of over I,, 00 miles-in different parts of the United States. In the case of San Francisco and Los Angeles additional apparatus has had to be installed to meet the increased traffic since the original installation was effected in $191 \mathbf{I}$. The Canadian government also contemplate the adoption of the Poulsen-Pedersen system for effecting wireless communication with the mother country-between Halifax and a station in the British Isles, subject to satisfactory demonstrations of its capacities.

Like the Australian Commonwealth, the United States government recently decided not to pledge themselves to any particular system. They propose to buy what is wanted in the open market and establish their own system of radiotelegraphy. On this basis the following were at the end of 1912 the projected radiotelegraphic stations of the United States government-some of which had actually been installed:-Arlington (Washington), Panama, San Francisco, Honolulu, Guam, Manila, Porto Rico, San Antonio (Texas), Fort Leavenworth (Kansas), Fort Omaha and Fort Riley. Several of these are intended to serve strategic ends. It may be added that the amended Radiotelegraph Act of the United States came into operation on December 13, 19r2. It establishes a system of complete Federal control over wireless communication, and requires all operators to be licensed, amateurs being placed under very severe restrictions and forbidden to transmit messages over more than 750 feet, with the object of preventing them from interfering with the operations of the State and commercial systems.

France, Germany, and Japan have each been maturing large schemes of wireless communication in the Pacific. Three years ago a secret conference at which the British Government were represented was held at Melbourne to consider the same ques- 
tion. The conference agreed that wireless stations in the Pacific which could be put in protected places would prove exceedingly useful for communication with the fleet and in the event of the existing cables being cut. It was therefore determined to erect the stations without delay. This, however, was not done, and the causes seem to be that the Admiralty adopted the theory that such a means of communication in the Pacific would be of small strategic value, and that the Postmaster-General held that its commercial value would be negligible. The Australian and New Zealand Governments think the exact reverse; and they have repeatedly told the Home Government that in their efforts to maintain the supremacy of British trade in the Pacific they would be seriously handicapped if any interested foreign Power established radiotelegraphic communication ahead of them. The French Government apparently agree as to the importance of wireless telegraphy in the Pacific, and it will probably be found that the Governments of Germany and Japan are of the same opinion.

From a British standpoint, the most important wireless project is undoubtedly the Imperial wireless scheme, which towards the end of I9 2 was under close discussion by a select committee of the House of Commons. As proposed by the government the scheme embraced stations on the Marconi system in England, Egypt, the East African Protectorate, South Africa, India and Singapore. Apart from its strategic purpose, such a scheme could not fail to be of immense advantage for the rapid and simultaneous dissemination of important Imperial news to the various corners of the British Empire. Neither the Dominion of Canada, the Commonwealth of Australia, nor the Dominion of New Zealand, however, became parties to the scheme, preferring, in each case, to make their own arrangements for a system of radiotelegraphy with the same objects in view.

It is evident that the Atlantic Ocean will soon be the scene of much radiotelegraphy; for in addition to the various projected stations already referred to, the Marconi Company are establishing a second trans-Atlantic service between Norway and the United States for the Norwegian government.

Since the realisation of the International Convention of 1906 , wireless telegraphy has proved invaluable on several occasions to ships under distress as well as in connection with the saving of life in the case of actual wrecks. The most notable instance of this was the "Titanic" disaster, since it was to radiotelegraphy more than anything else that the survivors owed their lives. Not the least amongst the lessons inculcated by that tragedy were those associated with maritime radiotelegraphy, the most important being the absolute necessity of a continuous watch by night as well as day. Another is obligatory inter-communication between all ships installed with the apparatusirrespective of the system used:

The second conference under the International Radiotelegraphic Convention was held in London from June 4 to July 6, r9 2 . Perhaps the most important new regulation passed at this conference was that relating to compulsory inter-communication. The principle had already been accepted by the majority of the administrations adhering to the Convention, but on this occasion those which had previously stood out from its practice--the United Kingdom and the British possessions, Italy, Japan and Portugalannounced their future adherence. Thus the principle is now embodied in the Convention. A proposal for the obligatory installation of an emergency source of power met with unanimous approval. The conference passed a resolution in favour of compulsory equipment of ships. Provision was further made for improved watch on ships. Ships in distress are now to control the working of the station in the neighbourhood, whilst the ship operator is placed under the captain's control.

Developments in radiotelegraphy have occurred at such a pace that we may be any day brought face to face with a complete change in the art, and even now there are several inventors closely working at the problem of effective wireless signalling without any vertical aerial. This in itself would be a very important revolution, if only on account of the large proportion of the cost in long range work that is attributable to the extremely high steel masts at present involved. ${ }^{1}$ It is generally recognised that radio-

1 Under the proposed Imperial wireless contract these were to be 300 feet high, and the 
telegraphy is still more or less in its infancy. This being so, every incentive should be given towards encouraging ingenuity. At one time the construction and laying of cables was closely confined. Since those days, however, the public and the taxpayer-if not the shareholders-have benefited by the healthy competition that is now the rule.

Cables and "Wireless": Relative Value.-As there appears to be an impression that radiotelegraphy is likely to be more effective than cables from a strategic point of view, let us especially consider the two methods from this standpoint. To begin with, the wireless method has an obvious and highly important advantage here, in that communication can be directly effected with a fleet itself instead of merely with the nearest cable station. We have, however, to remember that, by cable, a message-besides being more sure to reach the other end-is far more strictly confined to the quarter for which it is intended. It is sometimes suggested that the use of a secret code meets all objections under this head. On the other hand it may be questioned whether radiotelegraphy as yet adapts itself sufficiently to codes to render it suitable for codework on anything like a large scale, and certainly no reliance should be placed on the secrecy of codes. Again from a strategic standpoint, one great objection to placing reliance on radiotelegraphy in its present stage is that messages can be transmitted without their source being detected by the receiver. This may be an advantage to the belligerent; but, on the other hand, it is equally likely to be the reverse. Similarly, it is impossible for the sender of a wireless message to tell who may-or who may not-be at the other end, or how many ends there are. In short, radiotelegraphy is likely to prove a double edged weapon in warfare. Indeed, a cable - the location of both ends of which is known-is really the only satisfactory and sure source of communication in a strategic sense. "Wireless" is so new as to be still something marvellous; but if the order of the two inventions had happened to be reversed the cable would now be regarded as an obvious improvement, coming as a boon for confining the paths of our messages direct to the individuals for whom they are alone intended. And apart from being, as we already know, a ready prey to gales, etc., radiotelegraphic stations, even though placed well inshore, must always form a fairly easy target for shooting down from a distance. ${ }^{1}$ Shallow water cables are, of course, always liable to be cut in time of war; but probably the safest means of communication in such emergencies is the really deep sea line in the open ocean-such as the All-British Pacific cable. From the strategic point of view, too, it should be remembered that interruption to a cable is more speedily remedied than the destruction of a wireless station. The station at Nauen was actually estimated to take as much as 6 months to reinstate, and in November 1912 had still not been made good though that period has already elapsed. Again, the cable can even be worked from a small row boat in emergencies. That, however, is of course impossible with radiotelegraphy. In the matter of working speed, the advantage hitherto associated with the cable is now in some doubt; for at least one " wireless " system is capable of working at an equal if not greater speed, though not yet demonstrated on extreme ranges. Where, however, the cable has still the advantage here is in the effective working speed maintained, say, throughout a day, owing to the far less amount of repetition work involved. This is largely due to certain external and unavoidable interruptions of one sort or another, seriously influencing the regular progress of "wireless" work where they do not affect cable telegraphy. The cable is also still at a distinct advantage as regards regular uninterrupted -indeed invariable-day and night service, independent of atmospheric and climatic conditions. With radiotelegraphy this state of things cannot, in reality, be said to prevail to-day, though certainly very great advances have, of late, been made in this direction. For instance, when the Marconi Company first established their trans-Atlantic service messages could scarcely be sent by day at all; now, however, a more or less continuous service has been provided. "Atmospherics" (electricity in

thirty at each station were to cost $£ 32,500-3$ fairly large proportion of the proposed $f 60,000$ per station for the proposed initial 6 stations in this considerable scheme.

${ }^{1}$ Experiments have been directed towards obviating che use of high masts or towers, but do not appear to have been turned to practical account so far. 
thunderstorms, etc.) are still, however, a constant source of trouble in all "wireless," the atmosphere causing discharges - of an especially powerful character in the case of work, whereas cables are practically immune to such disturbances-forming, indeed, what may be termed a "closed circuit." It is notorious that most of the messages from Tripoli during the recent Turco-Italian war came by cable rather than by " wireless;" moreover the Italian government has since established further cable communication. Germany, France and Italy, though with far fewer important distant possessions than Great Britain, are developing their cables particularly as methods of communication. The German government subscribes annually to two Atlantic cables no less than $f_{0} 85^{-}$ $\infty 0^{\infty}$, and a further $£ 75, \infty 0$ towards the German-Dutch cables to the East.

Dealing with facts as they are to-day the mean view of the relative merits of telegraphy by cable and "wireless" leads to the conclusion that each has its independent sphere. Whereas the cable has still the advantage in the matter of sureness, accuracy and secrecy, a wireless system can be established at less cost. Thus, the tariff of the latter should be on these two accounts lower than that which prevails with the former. We have an example of this in the case of the Marconi trans-Atlantic service, where the rates are now half those charged by the cables serving between the same points. ${ }^{1}$ It only remains to be said that if cables were to be supplemented in each case by radiotelegraphy (instead of by another cable) an eminently practical comparison of the service in every respect would be thereby afforded. The two rival methods should be worked together. Radiotelegraphy is bound to be extremely useful to a cable system-as feeders to a trunk line, for auxiliary and breakdown purposes, etc. Similarly, the cable is evidently extremely useful to wireless organisations-trans-Atlantic and otherwise-in meeting prevailing difficulties.

(ChARLES BRIGHT.)

\section{THE WOMAN SUFFRAGE MOVEMENT ${ }^{2}$}

In England the movement for securing the parliamentary franchise for women entered afresh upon a "militant" stage in the autumn of I0IO. Its supporters had been encouraged by the grant of two days of Government time in July to the

Government attitude in England. debate on Mr. Shackleton's Bill, known as the "Conciliation" Bill, and by the majority of IIO on the second reading; and they were proportionately discouraged when, in November I9I0, Mr. Asquith announced in a letter to Lord Lytton that he could give no further facilities before the dissolution of parliament. The immediate result of his refusal was a raid on the House of Commons, organised (Nov. I8th) by the Women's Social and Political Union. Many arrests were made, but when the prisoners were brought up the next day at Bow Street, the magistrate, acting on instructions from the Home Office, took the unusual course of discharging them all. This leniency, far from propitiating the militants, led to further troubles, and 153 women were arrested on November 2 2nd for a raid on Downing Street. They received sentences either of a fine, or imprisonment for I or 2 months. On the other hand the more cautious suffragists, after Mr. Asquith had said in reply to a question in the House of Commons on November 22nd, that if his government were still in power, he would in the next parliament give "facilities for effectively proceeding with a Bill," framed to admit of free amendment, claimed that this made woman suffrage an issue at the general election of December, and awaited the verdict of the country. Comparatively little attention however was given to the subject by the electorate, and in a few places where woman suffrage was directly put forward by candidates it was a pronounced failure. A suffragist candidate in East St. Pancras obtained only 22 votes; the Liberal candidate for South Salford, whom they strongly supported, lost the seat; and Sir Victor Horsley, a pronounced suffragist, was defeated for the University of

1 At one time there was in reality very little difference between the two charges, but since the Post Office have more completely recognised the Marconi trans-Atlantic system, andas with cables-service instructions no longer have to be paid for, the apparent difference has become an actual difference.

${ }^{2}$ See E. B. xxviii, 786 et seq. 
London. Nevertheless, a modified "Conciliation" Bill, introduced the following session into the new House of Commons by Sir George Kemp, was read a second time by a majority of 167 on May 5, ror r, and a promise was given by the Government that as time was not available that year, the Bill would be given special facilities during I9I 2 .

Meantime, by way of calling attention to their grievance, many suffragist women determined to evade the Census enumeration on April 2, I9I I, on the ground that if the Government denied them citizenship, it could not reasonably enrol them as Extra-par: citizens. They, therefore, arranged to spend the night in the houses of tactics. sympathising friends or in public places, and their project was in a measure successful. On June $\mathrm{I} 7$ th the largest procession of women ever marshalled, said to exceed 40,000 persons and over 4 miles in length, marched from the Thames Embankment to the Albert Hall. Over 5,000 meetings were held in favour of the "Conciliation Bill," a demonstration attended by 500,000 people took place in Hyde Park, and another, attended by 10,000 people, in Trafalgar Square.

It was understood that militancy was to be abandoned until the fate of the new Bill should be known, but when in November r9I I Mr. Asquith announced to a deputation

Militancy his intention of bringing in an Electoral Reform Bill for something akin to resumed. adult manhood suffrage, violent agitation broke out afresh, the contention being that this was being done in order to make the extension of the franchise to women a political impossibility. A deputation of the suffragist leaders was assured by Mr. Asquith on November I 7 th that though he personally was opposed to their movement the Government would bow to the decision of the House of Commons should an amendment to the new Reform Bill admitting women to the franchise be introduced and carried. But the Women's Social and Political Union refused to be pacified, and on the night of November 2 nd window-breaking occurred at the Government offices and in many parts of London. Amongst others arrested was Mrs. Pethick Lawrence, who was sentenced to one month's imprisonment. On December I 2 th and I3th the majority of the window-breakers were sentenced to two months' imprisonment. On December I 7 th Mr. Lloyd George was assaulted on his way back from a meeting at the Horticultural Hall, London, where he and Sir Edward Grey had spoken in favour of Woman Suffrage. Nevertheless on February 23, I9 2 Mr. Lloyd George again appeared upon a Suffrage platform at the Albert Hall and spoke in favour of the cause. Sir Edward Grey had expressed his sympathy with the movement in letters to Lord Lytton published in November and December rg 1. On the other hand Mr. Winston Churchill declared his opposition in a letter to a Dundee correspondent on February 24, I9I2, and on February 28 th Lord Chancellor Loreburn and Mr. Lewis Harcourt took the same side at a large meeting in the Albert Hall organised by the National League for Opposing woman suffrage. It was clear that the Government were hopelessly divided; but the fate of the Conciliation Bill, which might have profited by cabinet disagreement, was adversely affected by a violent outburst of window-breaking and disorder which occurred between March ist and 4th, I9I2. By a pre-concerted plan a number of women, armed with hammers, went out and broke the plate glass windows of the principal Rejection of London shops. When brought before the magistrates many of the window Concillation breakers received sentences of hard labour. The wantonness of the damage and the loss caused to innocent people produced a reaction in public and parliamentary opinion, and on March 28 th the Conciliation Bill was rejected on second reading by a majority of 14 . Seeing the need of some change of tactics, the non-militant National Union of Women's Suffrage Societies formed an alliance with the Labour party, and decided on May $14^{\text {th }}$ to support Labour candidates in opposition to Liberal candidates, where the latter were unsatisfactory on the woman suffrage question. The Women's Freedom League adopted the same policy. The Labour party responded by largely supporting Mr. I'hilip Snowden's suffrage amendment to the Home Rule Bill.

On March 5, I9I2 the headquarters of the Women's Social and Political Union, at Clement's Inn, London, were entered by the police, who arrested Mr. and Mrs. Pethick Lawrence on a charge of conspiracy in connection with the window-breaking raid. 
Warrants' had also been issued against Mrs. Pankhurst and her daughter Christabel; the former was already in custody for window-breaking, but the latter fled the country.

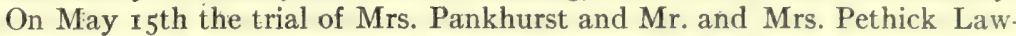

Conspiracy

trials, and

others.

rence for unlawful conspiracy to incite members of the Women's Social and Political Union to commit damage began before Mr. Justice Coleridge at the Central Criminal Court, London. It resulted in a conviction and sentences of nine months' imprisonment in the Second Division. On June 3 rd the three prisoners were transferred to the First Division upon undertaking not to repeat their offence while in prison. Miss Christabel Pankhurst remained out of the country.

On July I3, I9r2 Miss Helen Craggs was arrested near Nuneham House, Oxford, the residence of Mr. Lewis Harcourt, with house-breaking tools and petroleum in her possession, and on July 23rd Dr. Ethel Smyth was arrested in connection with the attempt on Nuneham, but was discharged on the 26th. Miss Craggs was convicted at the Oxford assizes on October Igth and sentenced to nine months' hard labour.

In the same way Mrs. Mary Leigh and Miss Gladys Evans were arrested in Dublin, in connection with Mr. Asquith's visit there, for attempting to set on fire the Theatre Royal on July t8th. Mrs. Leigh was also charged with throwing a hatchet at Mr. Asquith's carriage on July Igth. The two were convicted at Dublin on August 6th and sentenced to five year's' penal servitude.

None of these sentences was áctually served. Mrs. Pankhurst and Mrs. Pethick Lawrence were released on June 24 th and Mr. Pethick Lawrence on June 27th. Mrs. Prison Leigh and Miss Evans were released on September 2oth and October 3rd treatment. respectively, and Miss Craggs on October 3 oth (after only a week's imprisonment). In each case the release was on grounds of health, the prisoner having usually resorted to the tactics of refusing food and resisting forcible feeding, known as the "hunger strike," which had already been pursued by a number of suffragist prisoners since I9o8. The persistence in these tactics had continued to cause serious embarrassment to the Government, and the practice of forcible feeding greatly exercised the public conscience, violent protests being made by many people against such methods of "torture." On April r8th the Home Secretary had stated in the House of Commons that forcible feeding was only administered if the prisoner's health could stand it; if not, she was discharged, or let out on ticket of leave. On June I4th an influential petition for First Division treatment for all suffragist prisoners was presented to the Home Secretary. On June 25th Mr. George Lansbury, a Labour member, spoke very hotly in the House of Commons against forcible feeding, and on June 28th Lord Robert Cecil brought about a debate on the subject by moving to reduce the salary of the Home Secretary. The Home Secretary then explained that after First Division privileges had been granted to the leaders convicted for conspiracy, the other suffragists then in prison for window-breaking had claimed the same treatment and had adopted the hunger strike as a protest against its refusal, so that the Government were faced with the dilemma of treating acts of wilful damage or calculated to endanger life as political offences, or else of setting the prisoners free, with or without a short preliminary period of forcible feeding, which, when resisted, was undoubtedly capable of being injurious to health. From this dilemma no escape was found, Mr. Bernard Shaw's cynical suggestion that, if the women insisted on trying to starve themselves to death, they should be allowed to, being rather too logical for official minds.

The dissensions amongst the different sections of suffragists on the vexed question of militant tactics came to a head in October I9I 2, when Mr. and Mrs. Pethick Lawrence Secession of who had contributed largely to the funds of the militant societies, announced Mr. and Mrs. their withdrawal from the Women's Social and Political Union, which Pethick Lawrence.

under the guidance of Mrs. Pankhurst and her daughter was preparing for a further campaign. A difference as to the proposed plans was the reason given for this Pethick Lawrence secession. Protests against militancy and violence had meanwhile been made by the National Union of Women's Suffrage Societies and by the Men's League for Women's Suffrage at intervals during the two years, especially 
in March 1912, after the window-breaking raid, and in July I9I2, after the Dublin outrages. But the appeals were unheeded. On September 2 ist women suffragists interrupted a speech by Mr. Lloyd George at Llanystumdwy, and were very roughly handled by the crowd; while in Dublin, after the attack on Mr. Asquith on July Igth, the suffragisis barely escaped being thrown into the Liffey. New forms of irritation were now introduced. On the night of November 28 th an organised attempt was made to destroy by corrosive liquid the contents of a large number of pillar post boxes in London and certain provincial towns; and other similar occurrences continued during the year.

Meanwhile, on November 5, I9I2, Mr. Philip Snowden moved as an amendment to the Home Rule Bill for Ireland that the local government register should be substituted for the parliamentary register, a measure which would have enfranchised Irish women ratepayers; but the amendment was lost by 3 I 4 votes to I4I. It was supported by fivesixths of the Labour members present. On November 26th Mr. George Lansbury, who had resigned his seat in the House of Commons as member for. Bow \& Bromley in order to test the feeling of his constituency on the suffrage question failed to secure re-election, when he stood as a Suffragist and Socialist candidate.

The final blow to hopes of early legislation was dealt when in February I9I 3 the government dropped its Franchise Bill, and the proposed amendment to include women went with it. The Speaker unexpectedly ruled that if Sir E. Grey's amendWithdrawai ment were carried, to that effect, it would become a different Bill from the of the one introduced and must begin de novo: and no other course was possible Franchise but to withdraw it. This disappointment added fresh fuel to the flames
Bill of "militancy," and its activity was shown in a further series of outbreaks, including the destruction of letters in pillar-boxes and a bomb explosion at Mr. Lloyd George's country-house, which was in process of building.

Outside Great Britain the chief advance of the movement has been in California, where woman suffrage was adopted on October IO, I9I I by a small majority. Mr. Roosevelt during his election campaign of I9I 2 appealed to the women Woman of California, and it was claimed that his success at the "primaries" was

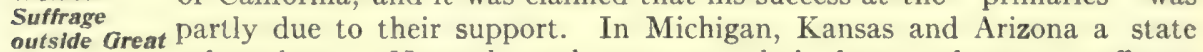
outside Great
Britain. referendum on November 5 th gave a result in favour of woman suffrage. On the other hand, in the state of Ohio, woman suffirage was rejected on September 4, I9I2, and a state referendum in Wisconsin on November 5 th also resulted adversely. In Norway a woman, Anna Rogstad, who had been elected as a vice-deputy to the Storthing in 1009, actually took her seat there in March I0I I for a fortnight; but in the elections of October Igr 2 no woman candidate was successful even as vice-deputy. Iceland during I9I I adopted woman suffrage, but as the measure had to be passed by two successive parliaments, it could not become operative until I9r3. A woman suffrage bill was recommended in Sweden in the speech from the Throne at the opening of Parliament, January I6, I9I2. 'The bill introduced by the Social Democrats passed the Second Chamber in May I9I2, by 66 votes; but was rejected in the First Chamber by 28 votes. In Denmark a Government bill to amend the constitution, which included the extension of the franchise to all women over 25 , was introduced in October I9I2, and passed the Lower House by a large majority on December 13 th.

A deputation from the Women's Social and Political Union was received in London, but not encouraged, by Mr. Borden, the Canadian Premier, on August 28, 1912, and a threat was made of sending over members of the Union to inaugurate a militant campaign in Canada. Miss I. Wylie left London for that purpose on September 29th.

In June Ig I I an International Woman Suffrage Alliance Congress met in Stockholm, at which 24 countries were represented. In October rot 2 this Congress met again in London; and the Men's International Alliance for Woman Suffrage, formed during the Stockholm Congress, also held its first Congress.

(Janet E. Courtney.) 


\section{SECTION II. SCIENCE}

\section{ASTRONOMY ${ }^{\text {: }}$}

The Sun.-There were considerable total eclipses of the sun on May 8, rgro (visible in Tasmania), on April 28, I9I I (visible in the South Pacific), and on October Io, IgI 2 (visible in Brazil): but on all three occasions bad weather rendered the expeditions for observation almost fruitless. On the other hand an eclipse on April I7, I9I2 (which barely reached totality in Portugal, and was annular in France, Germany and Russia), was favoured with particularly fine weather and produced results which open up new possibilities for the utilisation of eclipses, whether total or only nearly so. A. Fowler at South Kensington (magnitude of eclipse 0.92 only) observed a multitude of lines in the spectrum of the reversing layer for over half-an-hour; showing that large partial eclipses are available for important work of this kind. H. F. Newall at Cambridge obtained photographs of 30 or 40 lines within five minutes of the greatest phase (0.90), using a powerful spectrograph: he concludes that " exccedingly valuable work could be carried out with an instrument of high power by an observer who, at a total eclipse, stationed himself definitely outside the belt of totality, so as to obtain a large partial eclipse (say 0.99). At such a station his programme could be much more leisurely and complete than on the central line."

A recent outcome of earlier cclipse work is the discussion of the polarization of the corona, as observed by expeditions from the Lick Observatory. Precision has thereby been given to previously vague knowledge, the maximum of 37 per cent of polarization being put at 5 minutes from the sun's limb. This result accords well with the view that the corona consists largely of finely divided matter ejected from the sun.

Our knowledge of the physical and chemical constitution of the sun has however been extended in recent years far more by observations made without an eclipse at all, particularly by work with the spectroheliograph $(E . B . x x v, 618)$ an instrument for photographing the sun in light of one wave length only. With the high dispersion obtainable with modern instruments, it is possible to limit the light used not merely to a particular "line" but to a special part of it. In the case of calcium for instance the dark $\mathrm{K}$ line of the solar spectrum is very wide, and over many parts of the disc it is doubly reversed, that is to say, a bright line is superposed centrally on the wider dark one, while the bright line has in turn a narrow dark one down the middle. This central dark line is denoted by $\mathrm{K}_{3}$; its bright wings by $\mathrm{K}_{2}$, and the outer dark wings by $\mathrm{K}_{\mathrm{I}}$. The letters $v$ and $r$ are often added to the suffixes to distinguish the violet wing from the red. It is provisionally assumed that $\mathrm{K}_{1}, \mathrm{~K}_{2}, \mathrm{~K}_{3}$ correspond to low, mean, and high levels in the calcium envelope, with successively lowered pressure and temperature. Spectroheliographs of only moderate dispersion give pictures of $\mathrm{K}_{2}$ and $\mathrm{K}_{3}$ together: but recent advances have been made by separating the components, so that for instance the $\mathrm{K}_{3}$ photographs taken by $\mathrm{H}$. Deslandres at Meudon have revealed interesting features of which only the most prominent are represented in the $\mathrm{K}_{2-3}$ pictures. At the high $\left(\mathrm{K}_{3}\right)$ level the sunspots disappear, the bright flocculi are less extended, and linear dark markings-filaments as Deslandres calls them-are pronounced. These filaments are even better shown when the light selected for use is the central part of the red line of hydrogen. Besides the filaments, Deslandres has described a network of fine streaks which he calls alignments, most of which are faintly dark, and a few feebly bright. One view of their nature is that they are the higher and cooler parts of prominences seen projected on the sun's disc, and appearing dark because of their absorption: in support of which is cited the fact that where the filaments reach the limb of the sun a prominence is almost invariably present. According to J. Evershed, however, many large prominences do not show absorption markings when the sun's rotation brings them onto the disc. Against this again may be set the conclusions of A. Ricco, who has ingeniously projected the prominences observed at the sun's limb onto his disc seven days later and finds a

${ }^{1}$ See E. B., articles enumerated in Index Volume, p. 888. 
close resemblance to the filaments, or possibly (as Deslandres suggested later) to the alignments.

We may confidently expect more light on these important points from the magnificent "tower telescope" which G. E. Hale has set up on Mount Wilson, in California. The tower itself ( 176 feet from ground to top of dome) was already erected in September Igro when the International Union for Solar Research assembled on Mount Wilson; but there has been some delay in obtaining a suitable object-glass for the telescope (of I 2 inches aperture and 150 feet focal length). Success was not attained till the third attempt, but a very satisfactory lens was delivered by J. Brashear in May I9r 2: and the latest reports indicate that the chief difficulties of this immense undertaking have been overcome. It was feared by various critics that so high a tower would shake, but Hale's ingenious plan of encasing an inner tower of rods in an outer tower of tubes (to each rod a tube surrounding it) has proved perfectly successful, so that " the delicate operation of photographing the flash spectrum has been carried out when the wind was blowing twenty miles an hour, and there has never yet been an occasion when it was necessary to stop work because of trembling of the image."

The sun's rays are reflected down this huge fixed telescope by moving mirrors at the top of the tower, and an unexpected difficulty declared itself in the unequal heating of these mirrors, with consequent changes in focal length of several feet. It was met and defeated by keeping water steadily circulating in water jackets covering the edges and backs of the mirrors.

At the foot of the tower the rays are received into a well 75 feet deep, containing a combined spectrograph and spectroheliograph. A revolving table makes it possible to change the apparatus in the well with ease and rapidity, so as to obtain within a few minutes half-a-dozen spectroheliograms in different colours, and then a number of spectrograms.

Many solar phenomena centre round the solar spots, as to the origin and nature of which we are still but ill informed. The most striking feature of their appearance is the cycle of about ir.I25 years; but A. Schuster showed recently that this is not the only cycle concerned, periods of $4.8,8.3$ etc. years being also traccable in the records. His work suggests a major period of 33.375 years of which others are submultiples: thus dividing by 7 we get 4.77 years, a period found by Schuster in his analysis, and confirmed by a special small rise in the last cycle. The period of 33.375 years is close to that of the November meteors, and it is possible that the revolution of the swarm may exercise control over the occurrence of sunspots. Schuster has also examined the influence of the planets, obtaining positive evidence which satisfies him, though it has been challenged by F. J. M. Stratton working on somewhat different lines. Schuster remarks that though the tidal attraction due to a planet would be very small compared with the sun's gravitational attraction the latter may be effectively diminished by light repulsion for very small particles near the surface; in which case the tidal action of the planet might easily assert itself.

A summary of much recent work on the sun (especially by Hale who detected the magnetic phenomena through the Zeeman effect, and by Evershed who detected the radial movements in sunspots) is provided by the hypothesis as to the nature of a sunspot recently formulated by Hale, as follows:-

"As the result of an eruption or some other cause tending to produce rapid convection, a gaseous column moves upwards from within the sun toward the surface of the photosphere. Vortex motion is initiated by the difference in rotational velocity of adjoining zones, or by irregularities of structure, and is maintained by convection. The circulation in the vortex is vertically upward and then outward along the photosphere, as in a terrestrial tornado. Expansion produces cooling of the centre of the vortex, and a comparatively dark cloud (the umbra) results. As in Harker's electric furnace experiments, ${ }^{1}$ a rapid flow of negative ions sets in towards the cooler gases at the centre from the hotter gases without. The ions, whirled in the vortex, produce a magnetic field. The descending gases (specially hydrogen) in the higher atmosphere of the sun are drawn in toward the pole of the magnet along the lines of force, as in Birkeland and Störmer's theory of the aurora. This accounts for the configuration of the hydrogen $(\mathrm{Ha})$ flocculi, as shown by the spectroheliograph. 
"Hitherto we have assumed the spot to be single. The typical spot-group originates through the development of a second spot to the east (following) the primary spot, the line joining the two making only a small angle with the equator. The polarities of the two principal spots (smaller companions are usually present) are opposite, and the hydrogen $(\mathrm{Ha}$ ) flocculi surrounding a bipolar group resemble the lines of force about a bar magnet. Two alternative hypotheses may be offered to account for these phenomena. According to the first, the lower extremity of the vortex of the primary spot, lagging behind the upper extremity turns up to meet the photosphere thus producing a horse-shoe vortex. As in the case of single (unipolar) spots, the hydrogen and other high-level gases flow toward the two members of the group along the lines of force. According to the second view, the two vortices are independent with nearly radial axes. The necessary criteria of selection can probably be found by a comparative study of the principal members of a bipolar group, special attention being directed to the inclination of the axes of the vortices to the line of sight (as given by the Zeeman effect), the direction of flow (inward or outward) of the vapours at different levels, and the relative temperature and pressure of the two spots."

The details of work at the Mount Wilson Observatory by W. S. Adams on the sun's rotation have been published in an important memoir. The observations are all satisfied by a law in which the velocity of rotation increases outwards from the surface, and the equatorial acceleration decreases.

The Moon. - The prediction of the precise place of the moon in the heavens at any given moment has been a problem of increasing interest from the earliest times till now. It attracted the attention of the ancients from their desire to predict eclipses: of astronomers before Newton from their desire to help sailors to find their longitude: of astronomers since Newton from their desire to test the accuracy of the law of gravitation with the utmost refinement. Recent work has shown that the law of gravitation alone is insufficient to explain the moon's movements. The situation was thus summed up shortly before his death (in July I909) by Simon Newcomb, who had spent much of his life on the problem:-

"I regard these (outstanding) fluctuations (of the moon) as 'the most enigmatical phenomenon presented by the celestial motions, being so difficult to account for by the action of any known causes that we cannot but suspect them to arise from some action in nature hitherto unknown.".

This crisp statement was only rendered possible by an enormous amount of devoted work on the part of many people; centuries of observation at the observatories of Greenwich and Paris; careful scrutiny of these records by Newcomb and more recently by Cowell; great labour in working out the theory of the moon's movements by various eminent mathematicians, and the formation of tables, especially those of Hansen; and a recent reconstruction of the theory by $\mathrm{E}$. W. Brown, following the methods of $\mathrm{G}$. W. Hill. Brown is proceeding, with financial help from Yale University, to the construction of new tables of the moon, which may be confidently expected to isolate these puzzling anomalies from various defects in the older tables. Meanwhile new tables have been published in France (in IgII) which represent the completion of a project begun by Delaunay half a century earlier. Delaunay was drowned by the upsetting of a pleasure boat at Cherbourg in I872, but his work was carried on by Tisserand, Schulhof, Andoyer, Radau and others. In completing the tables full use has been made of the opportunities afforded by recent work. They will be used in the French predictions, which will give a valuable check on predictions made by Brown's tables when ready. It now remains to supplement this considerable improvement in the means of prediction by corresponding improvements in the observation of the moon's place. The way has already been shown by the successful photographic observations taken at Harvard and reduced by H. N. Russell of Princeton. By an ingenious device the moon is photographed along with the stars surrounding it. The difficulty is of course to avoid fogging the plate with the bright moonlight; and so blotting out the tiny star images. The device used by E. S. King of Harvard is to cut off the moonlight during the greater part of the exposure by a screen placed at some distance outside the lens, past which the rays from surrounding stars càn edge to reach the lens.

Planets and Satellites.-H. Struve has published the discussion of measures on Mars

1 At the British National Physical Laboratory. 
and his satellites cxtending over 32 years, from which he deduces the mass and compression of the planet, and the rates of revolution of the planes of the orbits of his satellites. The results are perhaps not of general interest, but represent a notable advance in our accurate knowledge of the solar system.

Among discoveries of minor planets, now made by hundreds per year, one stands out as of great interest. An object designated MT was discovered by Palisa of Vienna on October 3, I9II, which was apparently very close to the earth: but after observations had been secured on October 4, moonlight and cloud interrupted them so that the tiny object could not be recovered, and was thought to be lost. However some determined computers at the Observatory of the University of California made the very most of the scanty observational material, with the happy result that images were identified on plates taken on October II and October I7. It now appears that the approach to the Earth is not such as to offer all the advantages at first expected, but the successful prosecution of the search is in itself matter for congratulation. Other minor planets of special interest are Eros, and the Jupiter groups. Eros was photographed at a number of observatories in $1900-1$ with the object of finding the sun's distance, and the successful completion of the campaign was marked by the award of the gold medal of the Royal Astronomical Society to A. R. Hinks in February Igr 2 for his patient and exhaustive collation of the observations. The best measures of the sun's distance, including the wholly independent measures with the spectroscope at the Cape Observatory, are now in satisfactory accord at about 92,900,000 miles. The Jupiter groups represent in actuality a type of motion long thought to be of merely theoretical interest. If three bodies attract one another, it is impossible to predict their movements in general formulae: but if they happen to be placed at the corners of an equilateral triangle it can be proved that they will so remain. If the configuration be slightly disturbed, it will tend to recover itself. On the line joining Jupiter to the sun as base we can erect two equilateral triangles in the plane of Jupiter's orbit. The vertex of one is occupied by one known minor planet (Patroclus) and the other vertex by no less than three (Hector, Achilles and Nestor). The occupation is never exact; these little bodies describe complicated paths in the neighbourhood of the theoretical point: and their recent discevery has naturally led to the study of such motions, especially by E. W. Brown and G. H. Darwin. They have shown that departures from the equilateral triangle may be quite large, and in commenting on his results Darwin remarks:-

"These orbits throw some light on cosmogony, for we see how small planets with the same mean motion as Jove (his generalised planet) in the course of their vicissitudes tend to pass close to Jove, ultimately to be absorbed into its mass. We thus see something of the machinery whereby a large planet generates for itself a clear space in which to circulate about the sun."

New tables of Jupiter's satellites were published by R. A. Sampson in August rgro, as the outcome of twelve years' devoted work in discussing the accumulated observations of the past, especially those made by modern photometric methods at Harvard Observatory. To expedite their use in prediction Sampson issued the tables before publishing the theory on which they are based, and they have accordingly been used for the predictions of the Nautical Almanac for ror4. "In the place of antiquated tables of no value except as directing an observer when to go to his telescope, astronomers now have precise formulae with which the observations of the future will naturally be compared" (R. A. S. Council Report for rgri).

The rotation period of the planet Uranus was determined for the first time in August IOI I at the Lowell Observatory. No markings on his disc have been detected which would enable an observer to watch the rotation directly: the only hope was to measure with the spectroscope the velocities of approach and recession of the limbs. But since spectroscopes have been available the axis of Uranus has been too unfavourably placed. Slipher and Lowell took the earliest opportunity afforded by the slow revolution round the sun to better perspective, and detected a rotation in the retrograde direction in $10_{4}^{3}$ hours. The near accordance with the so hour rotations of Jupiter and Saturn is noteworthy. 


\section{ASTRONOMY}

Comets.-Numerous comets have been recently discovered or recovered, but they have generally been too small for special notice. Halley's Comet was followed up to the beginning of June I9II. Its photographic magnitude as determined at Helwan (Egypt) was the same 394 days after perihelion as 238 days before, showing the long persistence of the exciting effect of the sun. The return of roro will be remembered for the accurate prediction by Cowell and Crommelin, and for the transit of the comet across the sun. The calculations of prediction were carried out with such care that the discrepancy with fact was minute: and yet the calculators were able to declare with confidence that even this minute discrepancy must be referred to "some cause whose character is not yet recognised." At the transit no trace of the comet appeared on the sun's disc, but the tail appeared unexpectedly on both sides of the earth simultaneously.

Another comet of special interest, Encke's, which has a short period of $3 \frac{1}{3}$ years only, was re-discovered on July 3 I at Algiers only three degrees above the horizon-striking testimony to the climate of Algiers. The subsequent observations led firstly to the detection of a clerical error in the computations, and further to a reassurance as to the correctness of the assumed mass of Mercury, on which the rgo8 observations seemed to throw doubt. The anomalies in 1908 are probably due to a further change in the acceleration of the Comet's mean motion, but the return of 1914 will probably settle the point.

It has recently been asserted by E. Strömgren that all the cases of supposed hyperbolic orbits of comets disappear on rigid examination. If this be so, we may regard all comets as permanent members of the solar system, none being alien intruders. But Strömgren's conclusions have not yet won general acceptance, several computers having quite recently published hyperbolic elements of comets.

Comet IgII c discovered by W. R. Brooks on July 20, I9 I became visible to the naked eye and had a tail $25^{\circ}$ in length. Some fine photographs were secured, notably by : E. E. Barnard.

A more exact knowledge of the spectra of the tails of comets dates from I907. The spectrum consists generally of a series of double bands, which were identified by Fowler in I 909 with bands obtained from carbon monoxide at a pressure of about $0.0 \mathrm{Im}$. In one or two cases negative bands of nitrogen have also appeared. The chief bands in the head of a comet are those of cyanogen and the Swan bands of carbon, the latter being possibly derived from carbon monoxide; and it is only necessary to suppose that this gas is expelled from the head in order to explain the spectrum of the tail. The decomposition of cyanogen in the head might account for the nitrogen in the tail.

New and Variable Stars.-A new star of the 4th magnitude was discovered by the Norwegian astronomer Enebo in Gemini on March I 2, I9 I 2, and was attentively watched and photographed. Considerable interest was excited by a reported discovery of the lines of radium in its spectrum, by Giebeler of Bonn: but the evidence is questioned.

A feature of recent work has been the extension of the scrutiny of variability to a higher grade of accuracy. Thus E. Hertzsprung, guided by the spectroscopic observations of the pole star which showed its velocity to be variable in a period of close on 4 days, detected a minute variation in the light in the same period. So little was this previously suspected that the pole star was used as a standard of (constant) brightness in more than one long investigation. The range found by Hertzsprung from his study of 418 photographs is less than a fifth of a magnitude-about I 7 per cent of the light: and even this small range was reduced to one-third-less than 6 per cent-by J. Stebbins using a selenium photometer. Now C. G. Abbot has found variations in the radiation of our own sun at least comparable with these, so that we may regard the gáp between our sun and the variables as bridged. Indeed it becomes a question whether every star is not variable within limits of this kind. The beautiful work of Stebbins with his selenium photometer opens up definite prospects of settling this great question. As an instance of the delicacy of this instrument the case of the variable Algol may be quoted. It had already been shown that the variation was due to the eclipsing of a bright body by a dark one, but former observations showed no variation in the light between the 
end of one eclipse and the beginning of the next. Stebbins detected minute changes in this interval which are fairly interpreted to mean that the "dark" body has a feeble light of its own, and is moreover illuminated by the "bright " body so as to exhibit phases. Other similar cases have since been found by R. S. Dugan of Princeton.

Another addition to the facilities for accurate observation of stellar brightness is due to Schwarzschild, who passes a photographic plate to and fro in its plane so as to obtain from each star over a wide area a patch of uniform density, and has already measured in this way the brightnesses of 3522 stars ranging nearly to the gth magnitude.

Double Stars.--Most of the doubles are revolving so slowly round each other as to suggest that we must wait many decades before we can profitably determine their orbits, or deduce other conclusions from the observations. But Hertzsprung has recently made an ingenious suggestion for reaping some of the fruits by anticipation. Assuming average values for the particulars as yet unknown to us, he deduces from the observed arc of motion, however short, the distance of the double star. Now in a number of cases this distance has been directly determined and can be compared with the above deduction: and the comparison shows that the relation of determination to deduction is nearly constant. Deductions can therefore be used to supply approximate determinations in cases where they have not been made; individual instances may be in error, but the average will not be far wrong. The new method has indicated more than one conclusion of considerable interest.

At Ottawa it has been found that $\gamma$ Geminorum is a spectroscopic binary of the exceptionally long period 6 years, which bridges the gap between spectroscopic and visual doubles, since at least one of the latter has a shorter period. Betelgeux is probably also a long period spectroscopic binary.

Nebulae.-A complete descriptive list of nebulae photographed at the Lick Observatory was published in October I9I 2: the Reynolds reflector at Helwan in Egypt is being successfully devoted to the systematic exploration of more southern nebulae: and the five foot mirror on Mount Wilson has already produced many striking pictures. A general conclusion from all such work is that drawings (made before the days of photography) are quite untrustworthy. From his photographs of the spectra of spiral nebulae E. A. Fath concluded that they are probably unresolved star clusters with gaseous envelopes; and there is some evidence of a progressive change of spectrum with the form.

J. II. Nicholson has formulated a hypothetical constitution of certain elements with the simplest possible type of atom, one of them being provisionally called nebulium. He can thus account theoretically for all the observed lines in the spectra of nebulae, and was successful in predicting the existence of one line which had not been previously noticed, but which was found, on searching, by W. H. Wright.

The Stars in General. - A recent discovery of fundamental importance is the relation of the spectral type of a star, and therefore of its probable age, to the rate at which it moves. Briefly expressed, the law is that the older a star is, the quicker it moves. The facts supporting this statement emerged from the mass of observations with the spectroscope made at the Lick Observatory under W. W. Campbell's direction, and he made the first announcement in his Silliman lectures in January r 10 : the detailed information followed later, and confirmation was forthcoming from the quite independent study of proper motions by Lewis Boss. It may be that astronomers are not justified in deducing the relative ages of the stars from their spectra, but in any case they had arranged the stars in a certain order from the appearance of their spectra, which afterwards turned out to be also the order of rapidity of their movements. (It may also be mentioned that it has recently been found possible to make estimates of the temperature of various stars, which at first were rough, but are beginning to show better accordance. These also indicate the same order as the spectra and the motions.) Campbell's remarkable table illustrating this fact may be given here:- 


\begin{tabular}{|c|c|c|c|c|}
\hline $\begin{array}{l}\text { Type of } \\
\text { Spectrum. }\end{array}$ & $\begin{array}{l}\text { Number } \\
\text { of Stars. }\end{array}$ & $\begin{array}{c}\text { Average } \\
\text { Radial } \\
\text { Velocity. }\end{array}$ & $\begin{array}{l}\text { Deduced } \\
\text { Motion } \\
\text { of Sun. }\end{array}$ & $\therefore \quad$ Correction \\
\hline B & 225 & 6.5 & -20.2 & +4.1 \\
\hline A & 177 & II.O & -16.8 & +1.0 \\
\hline F & 185 & 14.4 & -15.8 & to. 1 \\
\hline G & 128 & 15.0 & -16.0 & -0.2 \\
\hline $\mathrm{K}$ & 382 & 16.8 & -21.2 & +2.8 \\
\hline $\mathrm{Mr}$ & 73 & 17.1 & -22.6 & +3.9 \\
\hline
\end{tabular}

The first and third columns chiefly concern us. The first shows the type of spectrum on the Harvard classification, and in the order assigned for age or physical development of the star: the third gives the average velocity in $\mathrm{km}$. per sec. The fourth column shows the velocity of our own sun deduced from the different groups, and the fifth a curious general correction which seems to be required by the means of the groups. (If real it would mean that the B stars for instance are moving generally outwards from the sun at $4 \mathrm{~km}$. sec.: but Campbell is inclined to interpret the column $\mathrm{K}$ as systematic error in the measurement of the various types of spectrum.)

The meaning of this striking association of movement with age, or at least with spectral type, is not yet clear. In the astonishment immediately following the discovery some rather wild suggestions were made, as for instance that a star was at birth not subject to gravity, but only gradually came under its influence. It seems probable however that some simpler explanation than this can be found, and one such is indicated below: but the chief requirement at present is further investigation. If the B stars alone are considered, especially those with large velocities, $H$. Ludendorff has shown that their velocities follow. J. N. Lockyer's classification of probable life-history in a striking manner, those on the ascending branch of Lockyer's curve having positive velocities (outwards from our sun) and those on the descending branch negative (inwards). There may be other facts of this kind still to come.

It is a further outcome of the Lick observations that the stars of types A and B tend to move parallel to the plane of the Galaxy. Assuming that this is exactly true, H. C. Plummer has shown that the distances of the stars and their complete movements can be deduced from a combination of telescopic and spectroscopic observations. The deductions will be exactly correct only if the assumption is exact, but if it is roughly true the deductions will also be roughly true. Plummer has accordingly deduced the complete motions of more than I 50 stars with the result of finding them fall into several groups of stars with similar motions, the association being in some cases strikingly defined. It had already been suggested by J. Halm, in discussing Kapteyn's hypothesis of two star streams (for which see article "Star" in the $E$. B.), that there must be a third stream present moving towards a vertex nearly coinciding with that of one of the former two: Plummer's results suggested a still greater number of streams towards that vertex, though they fail to indicate the opposite vertex. Evidence of the complexity of stellar movements has also come from other quarters. L. Boss's discovery of a special cluster in Taurus, and Ludendorff's confirmation of the Ursa Major clusters, were followed by the detection, by three investigations simultaneously, of two groups of stars of the helium type, having nearly equal and parallel motions. One of these is spread over a large area in Scorpio and Centaurus: the other consists of about seventeen stars in and near Perseus. Finally it has been noticed that the helium stars generally do not conform to the two star-streams.

Amid this increasing complexity there is one suggestion of a unifying principle. It has been pointed out by $\mathrm{H}$. H. Turner that if the stars around us form a limited system (as has been suggested by others) isolated by distances large compared with its own dimensions from other such systems, then the gravitational attraction of the system as a whole will result in a central attraction on the individual members. Further, that if the system started from rest, the movements of individual stars would approximate to oscillations backwards and forwards through the centre. Putting aside for a moment the obvious difficulties of congestion at the centre, then there would at any given mo- 
ment be some stars on their way to the centre and others on their way from it, and the perspective appearance of these two classes would be precisely the same as that which has given rise to the hypothesis of two star-streams. Parallel lines and lines converging to a point have the same perspective appearance: we can only differentiate them by a knowledge of the distances. Now it is just in respect of distance that our knowledge of the stars is most deficient. Direct measures take us only a little way from our sun, and to probe further into space we must trust hypotheses such as those of Hertzsprung and Plummer above mentioned. Using Plummer's figures, Turner finds indications of an actual acceleration towards a system-centre which he fixes provisionally in direction RA $94^{\circ} \mathrm{Dec}+12^{\circ}$ at a distance of go light years. Confirmation of these figures is also forthcoming from an entirely independent argument from the distribution of double stars in various directions, put forward by T. Lewis in 1906: and again from the general distribution of all stars:

- The congestion at the centre can be avoided if there is a sufficient departure from accurately radial motion, which would be quite consistent with observed facts. Were the radial motions undiluted, the phenomenon would have earlier attracted general attention, and would not have been at first denied by so acute an observer as L. Boss. (His objection has been since withdrawn.) As it is they are largely diluted by cross motions, so that they only emerge as averages from the discussion of numbers of stars. These cross motions suffice to carry the stars wide enough of the centre to avoid collision and may even suffice in certain cases (for instance in the case of the helium stars) to destroy the "two-stream" appearance altogether. But it is quite possible that they have developed in the course of ages of interaction between the individual stars, and that if the system were originally formed from a vast nebula condensing under gravitation, the condensation may have been very nearly along radial lines, resulting ultimately in a sudden congestion at the centre which would appear to distant systems as a " new star." Such a rapid congestion would be followed by an explosive expansion, the fragments being dispersed to something short of their original distance: gravitational attraction would ultimately draw them together again, and so on. There would be a sequence of explosions of decreasing violence, seeing that on each occasion energy would be dissipated. If the fragments became stars, the earliest-formed stars would have the largest velocities, as Campbell has found. The speculation is worthy of note if only for the reason that it shows the possibility of explaining Campbell's remarkable result without having recourse to any hypothesis not already familiar.

It is mentioned above that our direct knowledge of the distances of the stars is very limited; but progress is being made, and the last year or two have seen some notable additions to the published material, especially in the work of A. R. Hinks and H. N. Russell at Cambridge and Princeton, and of Frank Schlesinger at the Yerkes Observatory. An interesting confirmation of Boss's parallax ( $\left.0^{\prime \prime} .0253\right)$ for his Taurus cluster, found by combining spectroscopic velocities with proper motions, was obtained by the direct determination ( $\left.0^{\prime \prime} .023\right)$ of Kapteyn.

The great 5 -foot reflector of the Mount Wilson Observatory has already been effectively employed on the spectra of the stars, chiefly for types A and B, which are of special importance in the study of " star-streaming." In the course of this work more than 50 stars with variable velocities have been found; and attention is drawn to 7 stars moving with exceptional speed, including the "runaway star" Groombridge 1830 , for which a velocity of $343 \mathrm{~km}$. per sec. is found.

General.-Among losses by death must be specially mentioned that of Henri Poincaré (July I 7, 1012), a mathematician who illuminated a wide range of sciences; and that of Lewis Boss (Oct. 5, I I 2), whose patient work has put our knowledge of the positions and motions of the stars on a new basis.

The scientific papers of Sir W. Herschel (I $738-1822)$ have been collected and published in two large quarto volumes by the Royal Society and the Royal Astronomical Society.

The meeting of the Int ernational Lnion for Co-operat ion in Solar Research on Mount 
Wilson, Cal., in September I910 was attended by 83 astronomers of 12 different nations. It was decided to extend the scope of the Union to include Astrophysics generally; and this decision following on the extension of programme of the International Committee for the Astrographic Chart in 1909 practically arranges for a friendly partition of astronomy between these two organisations.

The Directors of National Ephemerides met in conference at Paris in October I 1 I and adopted various unifying principles, as well as a general scheme of co-operation.

Signals sent by wireless telegraphy from the Eiffel Tower have recently been observed at Greenwich and at observatories on the Continent; and a general scheme of longitude determinations by this method is now being arranged.

(H. H. TURNER.)

\section{GEOGRAPHY, EXPLORATION AND TRAVEL}

Antarctic. ${ }^{1}$ - The final conquest of the North Pole by Peary and the successes of British and other expeditions in the South have shifted general interest in polar exploration from the Arctic to the Antarctic. On February i I, I9I0 the French explorer Dr. Jean Charcot arrived at Punta Arenas on his ship the "Pourquoi Pas?", having carried on from his former expedition a coast survey as far as Adelaide Island. He discovered a great gulf to the south, and saw the inaccessible coast of Alexander I Land. He had wintered at Petermann Island, and made excursions thence in the South Shetlands; afterwards, again turning south, he reached $126^{\circ} \mathrm{W}$, sailing between $69^{\circ}$ and $7 \mathrm{I}^{\circ} \mathrm{S}$., and discovering new lands to the west and south of Alexander I Land. His party suffered from scurvy; the ship was damaged in collisions with ice, and food and coal ran short. He reached Rouen in June, and results of his journey appeared later in the year in Rapports preliminaires and Pourquoi Pas? dans l'Antarctique (Paris).

On June I, I9 Io Capt. Robert Falcon Scott (b. I868) despatched the "Terra Nova" from London for his second Antarctic journey. She went by Cape Town (Sept. 2) and Australia to New Zealand, and in these countries additions were received to the funds or equipment of the expedition, towards which $£ 20,000$ had been granted by the Treasury. The expedition left New Zealand for the south on November 29, I9Io, with a larger scientific staff than had ever previously been taken. It included Dr. E. A. Wilson (zoologist) as chief, surgeons G. M. Levick (zoologist) and E. L. Atkinson (bacteriologist and parasitologist), Lieut. H. L. L. Pennell for magnetic and meteorological observations, Messrs. T. Griffith Taylor and R. E. Priestley (geologists), E. W. Wilson and D. G. Lillie (biologists), A. C. Garrard (zoologist), C. S. Wright (chemist), Dr. G. C. Simpson (physicist) and Mr. H. G. Ponting (photographer). Lieut. (afterwards Commander) E. R. G. Evans was second in command, and Lieut. V. L. A. Campbell was to lead the "eastern party" which was intended to land in King Edward VII land.

The ship, after encountering heavy weather, entered the pack ice on December 9. McMurdo Sound was safely reached and the main party was landed, to establish winter quarters at Cape Evans. A western party was landed on the western side of the Sound. The eastern party was prevented by ice-cliffs from landing on King Edward VII land as was intended, but did so on February I8, I9I I at Cape Adare. From the "Terra Nova " investigations were subsequently carried on in the neighbourhood of the Balleny Islands, and new mountainous land was twice observed to the west of Cape North, about $69^{\circ} 50^{\prime}-68^{\circ} 30^{\prime} \mathrm{S}$. and $163^{\circ} 20^{\prime}-\mathrm{I} 58^{\circ}$ I $5^{\prime} \mathrm{E}$. Stewart Island was reached on the homeward journey on March 27, I9II. The ship returned south in the following summer, and brought back news of the year's work. Campbell's party at Cape Adare had experienced heavy weather, and had not apparently been able to proceed far afield, but meteorological and magnetic observations had been made. The "Terra Nova " embarked them on January 4, I9I 2, and landed them again in Terra Nova Bay, Victoria Land, on the 8 th; it was intended that they should re-embark in February, after exploration overland, but this was impossible, and they would have to find their own way back to McMurdo Sound. The western party had made important geological and other investigations; they were taken off by the ship on February 15.

Tee E. B. xxi, 960 et seq. 
The main party was occupied in scientific work in various directions, besides laying depots for the advance towards the Pole. Dr. E. A. Wilson, writing from McMurdo Sound on October 3I, I9II, reported that regular observations had been made of atmospheric pressure, temperature, and velocity and direction of wind, and that the upper atmosphere had been studied by means of small balloons for the first time in the Antarctic. Magnetic observations, gravity observations by pendulum, and tidal observations had been kept up; marine biology, parasitology, and ice study had received attention. Wilson led a remarkable expedition in June-August (winter), IgII, across the barrier to Cape Crozier, to study the winter breeding of the Emperor penguins. Petrological investigations revealed various mineral quartz veins.

The work of depot-laying being completed, Scott with the main polar party started on November 2, I II I, and proceeded at first by easy stages. He reached the continental plateau by way of Beardmore glacier on December 10, and was left by the last supporting party on January 4,1912 in $87^{\circ} 36^{\prime}$ S., within 150 miles of the Pole. Lieut. Evans, who led this party, was overtaken by scurvy, and returned to New Zealand (April I. 1912) on the "Terra Nova," but otherwise the health of all had been generally good. The latest news then brought from Scott was that he was about to move forward, with Dr. Wilson, Capt. Oates, Lieut. Bowers and petty-officer Evans as his companions. It was only on Feb. Io, I9I3, that their tragic fate became known. The "Terra Nova" returned that day to New Zealand, having learnt on Jan. I8 at Cape Evans that, after successfully reaching the Pole on Jan. 18, I912, and there finding Amundsen's tent and records (see below), they had perished on their return journey. Pettyofficer Evans had died on Feb. I7 after an accident; the others were then caught in a prolonged blizzard, in miles south of One Ton Camp, and succumbed to exhaustion, Oates on March I 7 , the others (whose bodies were found by a search party under Surgeon Atkinson on Nov. I2) about March 29. A diary kent by Scott up to, March 25 was found, in which he left a characteristically brave last message, explaining the misfortunes to which their end was due, and appealing to his countrymen to provide for their dependents.

It became known towards the end of rgro that Capt. Roald Amundsen, the Norwegian explorer, before making a crossing of the Arctic region, for which plans had been announced, was to visit the Antarctic, and make an attempt to reach the South Pole. On February 4, I9II the "Terra Nova" found the Norwegian expedition established in the Bay of Whales, but Scott, who had heard of Amundsen's intentions in New Zealand, did not allow them to affect his own plans. News was received later that Amundsen had been successful, having reached the Pole on December $14^{-17}$, 191 I. His expedition was favoured with good weather conditions not only for the polar march but during practically the whole year of its sojourn in the Antarctic, while the march itself, thanks to a careful system of depots and efficient teams of sledge-dogs, was carried out without any of the deprivation and suffering characteristic of previous polar journeys. The journey southward from the base--about 870 miles-occupied 56 days, the greatest elevation reached on the plateau being $10,750 \mathrm{ft}$.; the return march was made in 39 days. Three days were spent at or in the vicinity of the Pole, complete observations being taken. The polar plateau was named King Haakon VII Plateau, and the name of Queen Maud was given to a range of lofty mountains (10,000-15,000 ft.) which were observed between about $85^{\circ}$ and $88^{\circ} \mathrm{S}$., being a continuation of the mountains of South Victoria Land. Other investigations were carried out near and east of the Bay of Whales by a party under Lieut. Prestrud left behind at the base, while Nansen's famous old ship, the "Fram" (Capt. Nilsen), after landing the expedition, was employed in oceanographical research over a wide area.

An expedition left Germany in May rqri. It was led by Lieut. Filchner, who previously made a journey to Spitsbergen for the sake of experience. His plans were to proceed by way of South America to Coats Land, the coast of which was to be traced south or south-west, and a base station was to be established. An attempt was contemplated to cross the lower part of the Antarctic continent to Ross Sea. The ship (the 
"Deutschland") was commanded by Capt. R. Vahsel, who had accompanied the "Gauss" expedition, and there was a scientific staff of eleven, including Dr. Heim as geologist, Dr. W. Brunnecke (oceanographer) and Dr. Barkow (meteorologist).

An Australasian expedition is also in the field, under the leadership of Dr. D. Mawson. Its chief support was obtained in Australia and New Zealand, the commonwealth and state governments in the former country having together contributed $f 22, \infty 00$. A British Treasury grant of $£ 2,000$ was received. The vessel (the "Aurora "), under the command of Capt. J. K. Davis, left London on July 27, I9 I, and Hobart in Tasmania for the south on December 2. A wireless telegraphic station was established at Macquarie Island, which was expected to be of service in obtaining the longitude of the principal base of operations in the Antarctic. On January 19, 1912 a party was landed in the previously unknown Commonwealth Bay, at the western extremity of Adélie Land. It had been intended also to put a party ashore on Knox Land. This was impossible, and the ship suffered some damage from the pack ice in the attempt to carry out the plan. But a party with provision for winter quarters was put on the barrier ice in $66^{\circ} 18^{\prime} \mathrm{S} ., 94^{\circ} 58^{\prime} \mathrm{E}$., and the " Aurora " returned to Hobart on March II. The landing parties were fully furnished for scientific work, and the Prince of Monaco provided an oceanographical equipment on board the "Aurora."

A Japanese expedition under Lieut. N. Shirase started from Wellington, New Zealand, on February II, IgI I, with the South Pole as its object. Judged by European standards, it was poorly equipped, and it returned later in the year unsuccessful.

Other projects for Antarctic work have been discussed. Dr. W. S. Bruce has proposed to cross the Antarctic land-mass from a base in Weddell Sea, meeting another party working from Ross Sea. Dr. A. Forbes Mackay, who accompanied Sir E. Shackleton's expedition, has made plans for the exploration of the coasts between Graham Land and King Edward VII Land with a small party. A scheme has also been under the consideration of the Peary Arctic Club and the National Geographic Society of Washington, for an attempt to reach the Pole from a base on the opposite side of the Antarctic region to Scott's base. Dr. H. F. Osborn has suggested that the American Department of Labor and Commerce should send an expedition to study the habitat of the southern fur-seal and to make other zoological observations, and $\mathrm{Mr}$. E. S. Balch has proposed the further investigation of Wilkes Land and the verification of Wilkes' discoveries.

Arctic: ${ }^{1}$-An American expedition was organised to explore Crocker Land, the northernmost land known, which was sighted by Peary in I906 to the north of Grant Land. The expedition was to be led by Professor D., B. MacMillan and George Borup, who both took part in Peary's expedition of 1909. But Borup was drowned in a canoe accident in Long Island Sound in April ror 2. He was educated at Yale University, had studied in the American Museum of Natural History at New York, had worked with the United States Geological Survey, and was also a trained astronomical observer and expert photographer. It was decided to proceed with the Crocker Land expedition, as a memorial to Borup. Under the Department of Naval Service of Canada, among other hydrographical investigations, a voyage to Hudson Bay was carried out in Igro for the study of the conditions of navigation, with particular consideration for the possibility of establishing a trans-Atlantic route from a port on the west coast of Hudson Bay. Port Churchill and Port Nelson on this coast, both of which have been spoken of as possible sites for a harbour and the terminus of a railway from the west, providing a new route of export for Canadian grain, were investigated by this expedition, and Port Churchill appeared to offer better prospects. Captain Bernier, a Canadian voyager, attempted but failed in I9I0-I I to make the north-west passage by way of Melville Island, but he carried out some valuable survey work, especially on the hitherto unknown coast of Baffin Land between Cape Kater and Fury and Hecla Strait. Mr. Stefansson's expedition returned in September r9 2 from four years' work on the Arctic shores

${ }^{1}$ See E. B. xxi, 938 et seq. Sir F. Nansen's "In the Mists: Arctic Exploration in Early Times" (London, I9I I), is a comprehensive history of early Arctic exploration. 
of Canada, where, in the ncighbourhood of Coronation Gulf, they discovered Eskimo tribes of a peculiarly light colour, with instances of blue eyes and red hair. Their physical characteristics and certain of their customs are identified by the explorer with those of the early Norsemen, and they are held to be descendants of emigrants from Scandinavia to Greenland (see E. B. xii, p. 547).

The Danish explorer Mikkelsen, who with a companion had been left in north-east Greenland in Igro when the rest of his party were brought back to Denmark, had been given up for lost when in July I9I 2 both were rescued by a Norwegian fishing vessel. They had recovered records of the lost explorer Mylius-Erichsen (see E. B. xxi, p. 953) dealing with his important work in the north of the island.

Spitsbergen has attracted considerable scientific attention. A Norwegian expedition under G. Isaachsen in June-September I9Io, in addition to oceanographical observations between Bear Island and Spitsbergen, carried out a number of journeys into the interior of West Spitsbergen and neighbouring islands, the expedition being divided into five parties. Valuable geological investigations were made. Other expeditions have been numerous. The discovery of coal in the district of Advent Bay and the attempts made to exploit it have drawn special attention to this locality. Three Russian expeditions were at work in IgII in Novaya Zemlya. Important geographical, botanical and zoological observations were made, and discoveries of some economic interest were those of naphtha and copper. Russian explorers have also been active in Siberia. The expedition of M. A. K. Volossovich between the Kolyma and the Lena and of M. T. A. Yolamchef east of the Kolyma in 1909 (which incidentally revealed considerable errors in existing maps) proved the possibility of a sea-route for trade between the Kolyma and Bering Strait; this route was successfully exploited in IgI I from Vladivostok, and is considered to be capable of commercial development.

Asin. ${ }^{1}$-Among recent journeys in Central Asia may be mentioned that of Mr. D. Carruthers, whose party, in nineteen months' work (I9IO-II), covered much ground in the upper Yenisei region, Mongolia and Dzungaria. In the same years the French traveller Dr. Legendre carried out important exploration in Western China, especially in the valley of the Yalung between $28^{\circ}$ and $30^{\circ} \mathrm{N}$. In India, Sir M. A. Stein has investigated (I9II-I2) numerous sites of archaeological interest in the course of an exploratory journey on the North-West Frontier. The punitive expedition (I9I2) against the Abors in the north-east added considerably to topographical knowledge in spite of extreme difficulties of transport, heavy forests, and misty and wet weather. One party explored the river Dihong as far as Shimong for the first time, and carried mapping above that point; another surveyed the Padam Abor country; others, again, broke new ground in the Galong Abor country and in the valley of the Subansiri. Considerable corrections were found necessary in existing maps. Major P. M. Sykes has continued his journey's in Persia. and in particular has studied the problems connected with the ancient territory of Parthia. Dr. A. Musil in rgro made further explorations in northern Arabia, in the region adjacent to the Hejaz railway. He claimed to have accurately identified for the first time the Mt. Sinai of the Bible.

New Guinca. ${ }^{2}$ - The great island of New Guinea offers some of the most extensive areas still unexplored in the world, and here the Dutch have been particularly active. The Mambaro river in the west, which had been visited by Capt. Herderschee in I909, was ascended in in10 by Dr. Moszkowski. He at first met with a mishap in the rapids of the river at the Vanrees Range, but subsequently reached the foot of the central Snowy Range, and estimaterl that its northernmost chain reaches an extreme height of ro.000 feet. The rapids again proved treacherous on his return, and he lost most of his collections in clescending them. In the same year the German and Dutch expeditions for the delimitation of the German-Dutch frontier covered much new ground. The Dutch Colonial Budget of $19 \mathrm{r}$ 1 contained an appropriation of 20,000 florins in aid of a new expedition to the Snowy Range, and in that year Capt. Schaeffer penetrated the heart of the central mountains by way of Island river from the south, but was unable

${ }^{1}$ See E. B. ii, $73^{8}$ et seq. ${ }^{2}$ See E. B. xix, 488. 
to cross the island to the north coast. An expedition which carried out work in I000-II on the south coast and the southern slopes of the Nassau mountains in Dutch New Guinea was initiated by the British Ornithological Union in commemoration of its jubilee; the party was under the leadership at first of Mr. W. Goodfellow, and after he was overtaken by illness, under that of Capt. G. C. Rawling. Capt. Herderschee started in August Igr 2 on a second journey, intending to follow the Lorentz river from the south coast, and to investigate the highland region in the neighbourhood of Mt. Wilhelmina. In British territory (Papua) the Hon. Staniforth Smith, administrator of the territory, led an expedition in I9IO-I I into the valley of the Kikor, in that part of the territory which lies east of the Fly river basin and north-west of the Gulf of Papua. Dr. Molengraaf in I9IO-II was at work in the eastern part of Dutch Timor.

Africa. ${ }^{1-I n}$ Africa, in the course of continued activity in the direction of opening up the various territories, many journeys of geographical importance have been made. On the recommendation of the Colonial Survey Committee, a party under Capt. W. C. Macfie has carried out a topographical survey of $\mathrm{I}_{4}, 000$ square miles in Uganda on the scale of $\mathrm{I}: 25,000$. Mr. R. L. Reid completed in IyIo a survey of the river Aruwimi from Basoko up to Avakubi, and Messrs. C. A. Reid and A. E. H. Reid have made surveys in the adjoining parts of the Congo basin. French investigations of considerable importance have been prosecuted in Morocco. In the comparatively little-known north-east, the Muluya, the largest river in the country, has been investigated by M. A.-Bernard, and previous maps rectified, while the region through which it flows, generally believed to be sterile, was found actually to contain fertile plains of considerable extent. French survey work has been continued in the Sahara under Capt. Cortier and Capt. Grosdemanger, who was killed in an encounter with raiders. An important expedition was despatched in I 9 Io to French Equatorial Africa under Capt. Périquet with a view to surveying a possible railway route from Libreville across the Ogowe basin and beyond. Some 3,000 miles of route-survey was made, and the project was favourably reported upon. In German South-west Africa Lieut. Trenk and others investigated in r 909 -1o the almost waterless dune-belt parallel to the coast, and in I9I I Professor H. Meyer brought back from the Ruanad country in East Africa the results of important physical, ethnographical and economic investigations. Topographical surveys of an improved character, on a scale of $1: 100,000$, were begun in Italian Somaliland in I9I0.

America.-A Report in I9Io from the Canadian government printing bureau, Ottawa, dealt with the survey carried out by Mr. J. Keele in one of the most important areas previously unexplored in the north-west of Canada, namely that between the Yukon and the Mackenzie, about the upper part of the river Pelly and its headstreams and the Gravel river. In the summer of roro Mr. Howard Palmer studied the orography of Mt. Sir Sandford and its vicinity in the Selkirk Range, B.C., of which not much was previously known, and exploration in the Canadian Rockies has been extended in various directions by several investigators, such as Dr. J. Norman Collie, who was travelling north of the Yellowhead Pass in I9i . The Research Committee of the National Geographic Society granted $\$ 5,000$ for the continuation in IgI I of the glacial investigations in Alaska by Prof. R. S. Tarr (b. I864; d. March 2I, 1912) and Prof. L. Martin, who led the Alaskan expedition of the Society in $1909-10$ in the region of Yakut Bay, Prince William Sound, and the lower course of the Copper river.

In South America, Major Fawcett undertook in I9 Io further exploration in Bolivia, in the valley of the Heath and adjacent territories. In January IgIr Col. A. J. Woodroffe led a party of British officers lent to the Peruvian government for the demarcation of the new frontier with Bolivia; this work was expected to take three years. The Yale Corporation sent an expedition to Peru in I9II, under the direction of Professor Hiram Bingham, with Professor I. Bowman as geographer and geologist and Mr. K. Hendriksen as topographer. It was divided into three parties, to carry out archaeological, topographical and geological exploration, and had three fields of operations--the Urubamba river and its affluents, a trans-Andean section from the head of navigation on the ${ }^{1}$ See E. B. i, 352. 
Urubamba to the Pacific, and the vicinity of MIt. Coropuna (the estimated elevation of which was reduced to about 21,700 feet) and lake Parinacochas. On the transAndean section physiographical and meteorological observations were made, in addition to notes on the human and economic geography of the region, and the expedition also obtained valuable results in archaeology and natural history. Professor W. Sievers, who in 1909 continued his researches in western Ecuador and southern Peru, decided that the main source of the Marañon is the stream draining lake Lauricocha, which, however, was found to be fed by a stream from still higher lakes, and he placed the true source in the glacier of Mt. San Lorenzo. Dr. Fritz Leichart has made a systematic study of the Andean glaciers south of Aconcagua (Mt. Juncal, etc.), where is found probably the most extensive field of snow and ice in the whole system excepting for southern Patagonia. The geographical and geological commission of São Paulo, Brazil, has caused explorations of the upper Parana river to be made by its engineers.

A series of investigations which have laid down the main lines of the topography of Dutch Guiana was brought to a close in I9ro, when Lieut. Kayser, taking the place of Lieut. de Haan, who died when about to continue the exploration conducted by him two years earlier, traced the Lucie, an important tributary of the Corentyn, down to its junction with the main river.

Cartography, etc. ${ }^{\text {L }}$-Resolutions of the International Map Committee, which met at the invitation of the British Government in London in November I909, were issued in 1910. They include provisions that a uniform set of symbols should be adopted by all nations for the map on the scale of $\mathrm{r}: \mathrm{I}, \infty 00, \infty 00$, that the limits of the sheet should be uniform, with international numbers, the boundaries being meridians at successive intervals of $6^{\circ}$, reckoning from Greenwich, and parallels at intervals of $4^{\circ}$ reckoning from the equator. The projection proposed is a modified polyconic with the meridians as straight lines. Altitude is to be indicated by a system of colour tints, and full provision has been made as regards other details of colouring, lettering and transliteration of names. A few sheets have already been published by the Ordnance Survey Office and elsewhere. The question of special aeronautical maps has been considered in different countries; an international commission was organised to compile such maps, and their requirements have been discussed by various aeronautical and geographical societies in France, Germany and Great Britain, and by the geographical section of the British Association (Portsmouth, I9I I). An aeronautical map of France has been published by the French Society for Aerial Investigation on the scale of $\mathrm{I}: 200,000$, and a series has been undertaken by the German Aeronautic Union.

A review of various directions in which progress has been made in geodesy in recent years was presented to the research department of the Royal Geographical Society by Mr. A. R. Hinks (Geog. Jour., August, I9I I).

A bill was passed in France on February ro, I9 I for the adoption, for ordinary purposes, of a standard time 9 minutes 2 I seconds behind that of Paris, - practically that of Greenwich.

Oceanography. ${ }^{2-T h e ~ " M i c h a e l ~ S a r s " ~ e x p e d i t i o n ~ u n d e r ~ D r . ~ J . ~ H j o r t ~ a n d ~ S i r ~ J o h n ~}$ Murray, which left Plymouth in April iوıо, made observations at seventy-four stations, from the west coast of Ireland along those of Europe and Africa as far as Cape Bojador, thence to the Canary Islands, the Sargasso Sea, the Azores and Newfoundland, and thence homeward across the Atlantic. Murray and Hjort have based principally on the results of this expedition their book The Depths of the Ocean (London, Igr 2) which, accorling to the sub-title, is a general account of the modern science of oceanography. The German survey ship " Planet " has carried on important work in the western Pacific in the ncighbourhood of the New Hebrides, the Loyalty Islands, New Mecklenburg, the Philippines, etc. A hitherto unknown series of deep trenches in the sea-bottom has been investigated in the last locality, and in June I0I 2 the deepest sounding ever recorded - 5.348 fathoms (upwards of six miles) —was reported east of Mindanao.

A scheme has been undertaken for oceanographical, geographical and biological 1 See E. B. xvii, 629 et seq.

${ }^{2}$ See E. B. xix, 967 et seq. 
investigations in the Adriatic under the auspices of the Austrian Adriatic Association and the Zoological Station at Triest. An institution similar to the Austrian association has been established as a department of the Italian Association for the Advancement of Science, and at a joint conference a plan of work on co-operative lines has been laid down. In connection with the Oceanographical Institute of Monaco, which was founded and is directed by the Prince of Monaco, an institute has been opened in the Rue St. Jacques, Paris, with a laboratory, lecture hall, aquarium and library, under the administration of Dr. P. Regnard.

The wreck of the "Titanic" in 1912, and the unusual southward extension of ice in the North Atlantic at the season when that disaster occurred, have indicated the desirability of a practical application of oceanographical study in particular reference to the temperature of the sea and the circumstances which govern it, and of further research to the north of the steamer "lanes:"

An elementary handbook of practical oceanography, entitled Science of the Sea (London, I912), has been written by members of the Challenger Society under the editorship of Dr. G. H. Fowler.

Education: Societies:-The teaching of geography in London elementary schools is the subject of a report ( I III) forming one of a series issued at the instance of the London County Council education officer; the schemes therein outlined are the outcome of conferences between teachers and leading authorities in the study of geography. At Berlin a chair of Colonial Geography has been established in the University in connection with the celebration of its centenary, together with a department dealing with this subject in the Geographical Institution, through the liberality of Dr. Hans Meyer. In Vienna a professorship of commercial geography was founded in igto in the Exportakademie of the Imperial Museum of Commerce.

During the presidency of Lord Curzon of Kedleston, active measures have been taken for the better housing of the Royal Geographical Society (London), and in July Igi'z it was announced that Lowther Lodge, Kensington Gore, had been acquired for this purpose. The Research Department of the Society, under which small periodical meetings had been held since I 903 for the discussion of specific problems, was brought to a close in I9I2, without causing any break in the continuity of the support afforded by the Society to research, but rather in order to widen its appeal, for such subjects as have hitherto been brought before the departmental meetings are now included in the programme of the general meetings. The death of Mr. John Coles (b. 1833) on June 24 , I910, removed a well-known figure from London geographical circles; he was map curator to the R. G. S. from 1877 to 1900 , and was also " travel editor" of The Field from 1884 .

The American Geographical Society celebrated its jubilee in $19 \mathrm{I} 2$, and in connection therewith a trans-continental excursion for the purposes of geographical study was planned under the leadership of Prof. W. M. Davis. The Servian Geographical Society was founded in I 9 Io at Belgrade, with the special purpose of promoting study of the Balkan lands; it was inaugurated under the presidency of Prof. J. Cvijič.

Geographical Literature.--Two important general works on geography may be specially noted. In La Géographie Humaine (Paris, rgro), Prof. J. Brunhes deals exhaustively with the influence of physical environment on the life of man and the conditions under which he lives, basing his study upon a simple classification of essential facts connected with the methods and conditions of cultivation, the working of natural resources such as minerals and various products, as well as the uses of animals, and of the erection of dwellings and the organisation of communications. In Influences of Geographic Environment (I9I I), Miss E. M. Semple approaches similar problems, but in great measure from a different point of view, drawing very freely upon historical examples and using illustrations from every part of the world.

From the beginning of I9I I the German geographical serial "Globus " was amalgamated with the serial "Petermanns Mitteilungen."

(O. J. R. Howarth.) 


\section{GEOLOGY ${ }^{1}$}

Volcanves.-Long-continued study of volcanic phenomena in various parts of the world, supplemented by much chemical and physical research in the laboratory, has led Dr. Albert Brun, of Geneva, to certain conclusions, which, if confirmed, will modify profoundly the generally accepted views on vulcanism (Recherches sur l'Exhalaison volcanique. Genève, I9II). From observations in the Mediterranean region, the Canary Islands, Java, Krakatoa and Hawaii, Dr. Brun believes that during a paroxysmal eruption no water is exhaled from the volcano. Examination of the gases evolved during an outburst at a high temperature invariably failed to show either water-vapour or the dissociated elements of water.

The great white cloud, which is so characteristic a feature of a volcano at its maximum temperature, is said by the author to be composed, not, as commonly assumed, of water-vapour expelled from the volcano and partially condensed on meeting the atmosphere, but of solid anhydrous particles of extreme tenuity, associated with certain dry gases. The solid matter consists chiefly of the chlorides of potassium, sodium, ammonium and iron, with ammonium fluoride and very finely divided silica. When the exhalation encounters the atmosphere, some of its hygroscopic salts may condense moisture, and in this way the erupted products may become more or less hydrated; but the water thus acquired is meteoric, not volcanic. In fact, the volcano instead of contributing water to the atmosphere subtracts water from it. It is notable that Dr. Brun's observations at Kilauea, in Igro, showed that the dew-point in the interior of the white cloud was lower than in the surrounding atmosphere. It was also noticed in Hawaii that the shadow of an observer projected on the white cloud was not accompanied by any trace of a glory, such as might have been expected had the cloud contained water-particles. Moreover, the volcanic vapours drawn through cold tubes deposited no moisture. Dr. Brun therefore concludes, contrary to general belief, that all paroxysmal eruptions are essentially anhydrous.

It is true that the vapour of water is present at low temperatures in the exhalations from certain fumaroles and solfataras, but it is maintained that such water is not derived from volcanic sources. It is practically pluvial water, its amount depending chiefly on the climate and on the capacity of the volcano to collect water from the atmosphere. Many igneous rocks yield water-vapour when heated to a moderate temperature, but it is held that this has been absorbed by the rock after cooling. Dr. Brun believes that whatever gases may be obtained from rocks on heating them to about $600^{\circ} \mathrm{C}$. are simply gases that have been so absorbed and are therefore not of true volcanic origin.

According to Dr. Brun, the nitrogen of lavas exists mostly as nitride of silicon, which he terms Marignacite, after Prof. Galissart de Marignac, of Geneva. The only volcanic nitride previously recognised had been that of iron.

Etna.-An eruption of Etna, of short duration but exceptional severity, occurred in rorr, and was the subject of scientific study by Prof. A. Riccò (Bolleltino d. Soc. Sismologica Italiana, vol. xv, p. 273) and Prof. Gaetano Platania, of Catania (Rivisha Geografica Italiana, Anno xix, Fas. 7). Evidence of approaching activity had been observed for several months in the early part of the year, and on May 27 the serious disturbance commenced by the opening of a vent in the upper part of the central cone, on the N.E. side. The activity culminated on September ro, resulting in the formation of a radial fracture, about five miles long, running in a N.E. direction. From numerous vents which opened along this line, cinders were thrown out in enormous quantity, forming a long chain of cones. Altogether I Io new vents are said to have opened. Lava was also extruded in two streams, partly blocking the Circumetnean railway, in places nearly 100 feet high. The eruption ceased after about a fortnight, though earthquake-shocks continued for a time.

Vulcanological Institute.-In accordance with a suggestion by Sig. Immanuel Friedlaent sr, of Naples, at the International Geological Congress held at Stockholm in

${ }^{1}$ For E. B. articles on Geological Subjects, see Index Volume p. 913. 
rgro, steps have been taken to establish an International Vulcanological Institute at Naples, for the systematic investigation of volcanic phenomena, especially those of Vesuvius. It is believed that the detailed observation of such phenomena, carefully recorded, may eventually lead to the determination of the successive stages in the approach of an eruption, and may thus become of much practical value. The gases exhaled from various volcanoes will be subjected to thorough analysis, and light may probably be thrown in this way on the origin of certain ore-deposits. Prof. Gaetano Platania is also establishing an institute in Sicily for the special study of Etna.

Earthquakes.-A valuable "Catalogue of Destructive Earthquakes," prepared by Prof. John Milne, has been published as an Appendix to the Report of the Seismological Committee of the British Association for I9I I. The entries, numbering nearly 6,000, extend from November IO, A.D. 7, to December 31, r899. The list represents extensive research carried on for many years, and is specially notable for its records of earthquakes in China and Japan. Feeble disturbances have been excluded, the items being confined to those of sufficient violence to effect structural damage. The order of intensity is indicated by reference to a definite scale. It is believed that the earthquakes recorded in this Catalogue have generally been connected with the formation or extension of lines of fault and fracture in the crust of the earth, and have consequently much interest to the geologist.

In the Report of the Seismological Committee of the British Association at Dundee and in the Halley Lecture at Oxford in I9I2 (Bedrock, No. 2, p. I37) Prof. J. Milne made an ingenious suggestion as to a possible cause of earthquake activity. It is found that large earthquakes, or megaseisms, resulting from a sudden relief of strain in the earth's crust, are most frequent in regions where the geothermic gradients are steepest, suggesting that the disturbances are connected with the outward flow of the earth's internal heat. Observation on the solidification of blast-furnace slag showed that the material suddenly contracted intermittently, and that the cooling mass cracked superficially, with extrusion of heated viscous matter, due to grip of the shrinking outer shell on the interior.

Such phenomena seem to admit of application to the rocks of the earth's crust. If the superficial shell contracts spasmodically at regular intervals in passing from the liquid to the solid state, or on cooling after solidification, it may suddenly fracture itself by a tight grip on the unyielding nucleus. Such action possibly throws light on many seismic phenomena, and may also explain the extrusion of lava in fissure-eruptions and dykes. Prof. Milne points out that volcanoes are too feeble to produce megaseisms, but that megaseisms often stir dormant volcanoes into activity.

The earthquakes of the Philippine Islands have been specially studied by the Rev. M. Saderra Masò, of the United States Weather Bureau. He shows that those of southern Luzon are connected with three great fractures, of which the most important runs through Taal volcano. This volcano was the seat of a disastrous eruption on January 30, I9I.

The first part of a seismic history of the southern Andes, by the Count de Montessus de Ballore, was published at Santiago de Chile in Igr $\mathbf{r}$.

The Zone of Rock Flowage.-It has been generally recognised of late years that the solid crust of the earth admits of division into an upper Zone of Fracture and a lower Zone of Flowage. Below a certain depth the pressure becomes so great that the existence of open spaces seems impossible, since the movement of the solid rock by flowagc must tend to close all cavities. At what depth the fractures cease is a question of extreme interest, and various estimates have been made from time to time, with more or less probability, by such geologists as Heim and Van Hise. The question has recently been studied experimentally, with much ingenuity, by Prof. Frank D. Adams, of Montreal, whose results are published in a paper entitled "An Experimental Contribution to the Question of the Depth of Flow in the Earth's Crust " (Journal of Geology, Chicago, Vol. xx, r9i 2, p. 97).

Two rocks were subjected to experiment, viz. an American red granite, representing 
a hard plutonic rock, and the lithographic limestone of Solenhofen, typical of a soft sedimentary deposit. The samples were worked into the form of short columns, carefully perforated axially and transversely, and were embedded in accurately fitting jackets of steel: intense pressure was then slowly applied by means of pistons. The period of pressure varied from a few hours to between two and three months, and the temperature ranged up to $550^{\circ} \mathrm{C}$. Any contraction of either the longitudinal or the transverse boring was ascertained by means of an accurately gauged wire fitting into the perforation. These experiments lead to the conclusion that empty cavities may exist in granite at a depth of at least eleven miles, which is a greater depth than previous estimates had suggested.

In connection with Prof. Adams's researches the subject has been discussed mathematically by Mr. Louis V. King, who concludes that, so far as hydrostatic pressure in the earth's crust is concerned, a small cavity at normal temperature will remain open at depths down to between 17.2 and 20.9 miles.

These researches have more than academic interest. When Sir C. A. Parsons (inventor of the steam turbine) proposed some years ago that an experimental boreshaft, for geological and mining exploration, should be sunk to a depth of perhaps I 2 miles, it was objected that such a depth was unattainable since the walls would collapse by the viscous flow of the rocks. This objection is now quite untenable. Prof. Adams's investigations have an obvious bearing on the question of the depth to which mineralveins and other ore-bodies may descend. Whether formed by deposition in fissures or by replacement of rock, it would seem that free spaces are required for reception of mineral matter. It is now seen that, in so far as fractures control deposition, oredeposits may well continue in depth to at least II miles, which is probably a greater depth than could ever be reached by mining operations.

The Planetesimal Hypothesis.-To the Journal of Geology (Vol. xix, I9r r, p. 673) Prof. T. C. Chamberlin, of Chicago, has contributed a paper in which he shows how his planetesimal hypothesis has been strengthened by the discovery of radioactivity. According to his view the earth originated in a nuclear knot of a spiral nebula, around which it was slowly built up by the aggregation of planetesimals, or discrete masses revolving in elliptical orbits around the common centre of the system. By the crossing of their paths, the planetesimals were gradually gathered into the immature earth. A certain amount of heat would be derived from the condensation of the original nucleus, and more would be developed by the infall of the captured planetesimals, but the chief source of the internal heat of the earth was found, according to the author, in the compression which the growing earth would suffer as the deeper parts were pressed by the rock-masses that gradually accumulated above. When this hypothesis was originally enunciated doubt was not unnaturally expressed as to the adequacy of progressive selfcompression to account for the earth's internal heat, but any doubt as to a sufficient supply of heat was dispelled on the discovery of an additional source of thermal energy in radioactivity.

As the earth was formed by the aggregation of all kinds of planetesimals derived from the original nebula, it must have presented from the beginning a very heterogeneous composition. On sufficient elevation of temperature, the less refractory substances would pass into a state of fusion, or rather mutual solution, but such liquefaction was essentially selective, local and temporary. At no period of the earth's history was there general fluidity, like that of a molten globe. It is held that the local liquid matter would be squeezed outwards by stress-differences in the body of the earth, forming threads or tongues which would flux their way upwards along paths of easy resistance, and thus transfer heat from the central parts towards the surface.

It seems a fair assumption that originally radioactive matter would be distributed through the heterogeneous mass of planetesimals quite promiscuously. But as the presence of any heat-generating bodies would favour the liquefaction of neighbouring matter, this matter would tend to rise towards the surface of the growing earth, carrying with it the associated radioactive substances. According, then, to the planetesimal 
theory there would be a tendency for radioactive mineral matter to become concentrated in or near the superficial part of the earth, thus offering an explanation of the results obtained by the Hon. J. R. Strutt in his well-known researches on this subject.

A theory of the evolution of the earth resembling in many ways that of Prof. Chamberlin seems to have been independently developed by Prof. E. H. L. Schwarz, of Grahamstown, and is set forth in his work on Causal Geology (London, Igro). In this work he discusses some of the fundamental problems of geology in the light of his experience gained during extensive field-work in South Africa. He concludes that the earth is throughout solid, rigid and cold. Local heat for volcanic phenomena is obtained by pressure and friction along lines of movement in the earth's crust, and from radioactive rocks. Such heat acting on water in the pores of the rocks gives rise to steam, producing explosive outbursts, whilst if the rocks are readily. fusible liquid lava may be formed. In explaining the formation of that type of volcano illustrated by the caldera, or pitcrater, of Kilauea, Prof. Schwarz assumes lateral movement of the rocks by simultaneous thrust along two crossed horizontal faults, with depression of the enclosed area. The origin of the depression is therefore similar to that of the fold-basins in many parts of Cape Colony.

As South Africa seems to have stood above sea longer perhaps than any other part of the world, it has suffered superficial denudation to an exceptional extent, and Prof. Schwarz believes that the crust is there so thin that the centrosphere has actually been reached by the diamond-pipes. These channels are now occupied by materials which may be regarded as samples of the highly basic rocks of the deep-seated interior, akin to meteorites.

Pacific and Atlantic Types of Rocks.-In a presidential address to the Geological Section of the British Association at the Portsmouth meeting of I9I , Dr. A. Harker, of Cambridge, developed his views on the geographical aspect of petrology, dwelling especially on the relation that may be traced between certain types of rock and the tectonic features of the regions in which they occur. So far as the younger igneous rocks are concerned, a curious relationship seems to govern their distribution over extensive geographical areas.

It was pointed out many years ago by Prof. E. Suess that the coastlines of the Pacific and the Atlantic basins were characterised by two distinct types of structure. The Pacific is bordered for the most part by mountain chains that are folded towards the ocean, so that the outer side of the fold looks seawards. On the Atlantic coast, however, such a structure is almost absent, and if folds exist the inner side generally faces the ocean. After this distinction had been recognised Dr. Harker called attention to the fact that the Pacific structure was characterised by igneous rocks of what is called the calcic type, and the Atlantic structure by rocks of alkaline facies. The petrological distinction indicated by these chemical expressions is now believed to be of fundamental or genetic significance. All igneous rocks admit of classification in two great branches, one of which is characteristically calcic or alkali-calcic in composition, while the other being rich in potash and soda is known as the alkali branch.

There is generally a regional separation between the two groups, the typical calcic and the typical alkali rocks being characteristic of distinct petrographical regions, each including subordinate provinces. The alkali group seems to be associated with areas of subsidence believed to be due to radial contraction, whilst the calcic group is connected with areas of folding, resulting from lateral compression. Viewed broadly, the calcic branch predominates over the alkali branch, but many rocks of the latter type may be hidden by submergence in sunken areas.

According to Dr. Harker, the variations in igneous rocks have been brought about mainly by differentiation of the original magma rather than by assimilation, or absorption of local rocks by the molten matter. But the relation between differentiation and assimilation is a subject on which petrographical opinion is still much divided.

(F. W. RudLER.) 


\section{METEOROLOGY ${ }^{1}$}

The events that have marked the progress of meteorology during the past few years may be briefly summed up under the following heads. (I) The great development of radiotelegraphy, by means of which our daily weather maps now cover the oceans and distant continents, so that every morning we have spread before us the general condition of the atmosphere over the whole northern hemisphere. (2) The remarkable development of the study of the atmosphere at altitudes of Io to 30 kilometers by means of kites, pilot balloons and sounding balloons, leading to the establishment of the existence of an isothermal or relatively warm layer at altitudes above 9 to 12 kilometres, due to the atmospheric absorption of terrestial radiations. (3) The publication (1907) of E. Gold's admirable survey of our knowledge of the upper atmosphere, the analogous summary by A. Wegener (I9I2), and the simultaneous publication (Ig09) by Gold and Humphreys of the importance of terrestrial radiation and atmospheric absorption in the formation of the isothermal layer. The radiation from the earth, ocean and air is mainly the same as that from water and aqueous vapour. Nearly all the rays that enter the gaseous and aqueous envelope of the globe in their passage outward are caught in the vapour atmosphere and radiated anew as from a water surface. The total resultant radiation is as though it issued from a total radiator or black surface at an elevation of 3 or 4 kilometres, which is about the centre of gravity of all the aqueous vapour floating in the atmosphere. Convective equilibrium and adiabatic control of temperature prevail up to 9 or I i kilometres or throughout the so-called convective region. Above this is Dr. Gold's advective region, or Leon Teisserenc de Bort's isothermal region, or his stratosphere. Humphreys (Mt. Weather Bulletin, Vol. 4, p. 408) concludes that the air above I I kilometres must have a uniform temperature of minus 55 degrees centigrade and is free from vertical convection, also that the volume percentages of gases at this altitude are the same as at the surface of the earth, but above this level the lighter gases gain in volume with elevation more than the heavy gases. (4) The determination by Humphreys of the zonal intensities of the earth's planetary radiation of heat, per unit of time and area at different latitudes, showing a maximum between latitudes $30^{\circ}$ and $65^{\circ}$ north but a minimum at the equator; this depends essentially on the atmospheric vapour and its radiating power. (5) The development, due to Bjerknes, of graphic methods of studying the dynamics of the atmosphere. The approximate solutions hitherto obtained by many scholars undoubtedly need revision in the light of the new methods devised at Christiania and now being published by the Carnegie Institution at Washington in Bjerknes's Dynamic Meteorology. (6) The increasing interest in precise climatology and its evident importance to the physiography of the globe and to all human labours. The publication by Hann of the enlarged third edition of his Climatology enables all interested therein to study this subject satisfactorily. (7) The publication of Hann's new edition of his elaborate "Lehrbuch der Meteorologie" and several general treatises by others, adapted to popular or educational purposes, such as the works of A. Wegener, Sir John William Moore, Willis L. Moore, W. H. Milham, A. Klossovski, and especially Forecusting the Weuther by W. N. Shaw, which is really an up-to-date meteorological memoir and summarises nearly all that is at present known of the dynamical problems bearing upon the practical art of weather forecasting. (8) The establishment of weather bureaus by the Commonwealth of Australia and by the South African Union. (9) The determination of the altitude of the aurora borealis by Stoermer, by photographic methods that give us for the first time some accurate knowledge on this subject; with this may be associated A. Wegener's co-existence of hydrogen and geocoronium at all altitudes above 50 kilometres. (ro) The publication of I'rof. Pernter's Meteorological Oplics (completed after his death by Dr. Felix M. Exner), the most comprehensive work on the subject now available.

International Ballooning.-In 1907 Professors Hellmann and Hildebrandsson compiled the "Official International Meteorological Codex" on behalf of the "International Meteor-

'See E. B. xviii, $26+$ et seq., and allied articles. 
ological Committee," which latter is the representative of the numerous meteorological congresses and conferences that have been held since 1872 . This Codex is a very convenient and useful codification of the numerous conclusions expressed by European meteorologists at these meetings. At Paris in 1896 an independent organisation was recognised, for purposes of collaboration, namely the "International Commission for Scientific Balloon Ascensions." This Commission held meetings in 1898, 1903, 1904, 1906, 1909 and 1912, its first report to the International Committee being made in 1906. The work of the International Commission for Scientific Ballooning has been much promoted by the discussions at Milan (1906), Monaco (1909), and Vienna (1912).

The study of upper strata in England has been greatly helped by the freedom with which W. H. Dines of Pyrton Hill, Wallington, and E. J. P. Cave, of Ditcham Park, Petersfield, have published their laborious observations with kites and balloons. Mr. Cave's work with pilot balloons can easily be repeated in any portion of the globe.

The observations with kites and balloons at the Royal Aeronautical Observatory at Lindenberg, under Assmann, have been continued steadily, and among the results summarised by Fischli we may mention that he finds the directions of the wind at various altitudes indicate changes in the weather very much as do the passage of areas of maximum and minimum pressure, or the so-called highs and lows, at the earth's surface. The atmospheric layers in which inversions take place vary with the season of the year and with the direction of the wind, and especially with the condensation of aqueous vapour. The changes of wind direction at different levels are one cause of variations from the regular diurnal periods of temperature. The upper layer of inversion, or the so-called isothermal stratum, was attained at an average height of a little over 12,000 metres in anticyclonic areas, while in cyclonic areas it was a little over 10,000 during I9I0; the mean temperatures were minus 9I.2 C. at the former altitude and minus 5 1.5 C. at the latter.

In European regions the limits of upper inversion at which the temperature begins to increase are higher in summer than in winter. The American observations by Rotch and Blair also seem to show that the isothermal stratum is higher in summer than in winter, which may be due to the greater dryness of the American climate. In the United States the limit is higher than in Central Europe, so far as the limited number of observations can justify an average. The warm layer exists above the ocean as well as above the land. The altitude of the layer over the North Sea is about the same as over Europe, whereas Hergesell found it much higher, viz. I3,000 meters over the South Atlantic. The general law seems to be that the upper inversion layer is lower near the poles and higher under the equator; a similar law seems to hold good for each of the cloud formations. Assmann is probably correct in considering the isothermal layer as a feature of the general atmospheric circulation, being the upper branch of the interchange of air going on between the equator and the poles, but this is only a partial explanation of its origin and temperature. In $1909 \mathrm{E}$. Gold of London and W. J. Humphreys of Washington published quite independently their proofs that the upper inversion must be due to the absorption, by the aqueous atmosphere, of heat radiated from the earth and the ocean. The total quantity of aqueous vapour contained in the atmosphere is sufficient to render the radiation from the atmosphere equivalent to that of a surface of water, or an absolute perfect radiator, at the altitude of 4,000 metres; therefore the effective surface of terrestrial radiation is at this altitude where the mean annual temperature is about 263 degrees absolute scale; so that the planet or combined earth and atmosphere radiates like a black body at this altitude. "The absorption of heat above 4,000 metres and its penetration beyond, explain the existence and the temperature of the stratosphere, while the changes in the quantity of aqueous vapour in the atmosphere explain the variations in the altitude of this layer, which must be higher in the summer and higher in dry climates but must surround the globe over continents and oceans and polar snows alike.

Teisserenc de Bort in his memoir of 1909 states as the result of his investigation at Trappes that the temperature of the thermal layer from 8 to 17 kilometres upward departs rarely less than 2 degrees, or more than ro degrees, and on the average only 6 degrees C., from the temperature appropriate to adiabatic diminution. His balloon ascensions, some of which attained $27 \mathrm{~km}$., show that in most cases after penetrating through the thermal zone the temperature returns to that which it had lower down when it entered the thermal zone. The same results are given by observations in Lapland and in the Atlantic Ocean, except only that the altitude of the stratosphere diminishes a few thousand metres as we pass from the equator to the Arctic zone. There are apparently precise relations existing between these altitudes and the lower meteorological conditions. The altitudes are in general higher within areas of high pressure than in those of low pressure. The greatest altitude is on that side of a high pressure area that is in advance of the low pressure. On the other hand the altitude of the stratosphere is lowest in the rear of a low pressure area and especially low in a trough of low pressure.

The important aeronautic expedition to Central East Africa led by Prof. Berson in I908 attained the isothermal layer or upper inversion stratum at about 17,000 metres. At these high altitudes Berson found a strong west wind, evidently a return current, that may possibly prevail over large areas in equatorial regions. while an easterly wind prevails below. 
The meteorologists of the Egyptian survey have contributed both to our knowledge of the climate of the country and to various problems of dynamic meteorology. Regular observations of the heat received from the sun have been made since 1907 with the Angstrom pyrheliometer and with the electric recorder of Callendar. Free air observations with kites, pilot balloons and captive balloons have also been prosecuted. The depth of the surface trade winds in lower regions and the character of the layers of air next above, up to 5,000 metres, have also been studied. The intermediate calm surface or transition surface, or the glide surface of Sandstrom, sometimes has a very steep inclination and sharp definition. In fact this glide surface, studied so carefully by Sandstrom in Norway, is undoubtedly a characteristic of the atmosphere in all parts of the world.

The late Dr. Rotch, by the use of kites and sounding balloons, studied the upper air at Blue Hill Observatory, Hyde Park, Mass. and in the central region of the Mississippi Valley. Up to 1,000 metres altitude there are many variations of pressure and temperature, but above this there is a steady diminution of temperature and increase of velocity, except that at 4,000 metres there is a rather sudden increase of velocity.

The behaviour of the winds in the trade region has been the subject of special studies by Mey, Campbell-Hepworth, Shaw, and of balloon observations by Hergesell, Rotch and Teisserenc de Bort, to which must be added the work by Dynes and Shaw on the anemometer records at St. Helena, and the work of Gold on the connection between air pressure and periodic variations of the wind. The studies of Wegener and Stoll on the trade winds in the neighbourhood of Teneriffe show that there are great irregularities produced by the presence of this island, and the same must be true of the island of St. Helena, therefore the study of the free trade winds in the open portions of the North and South Atlantic Oceans is especially needed.

Wagner- shows that the isothermal layer is higher above an anticyclone and lower above the cyclone, the difference amounting to 3,000 metres. The isothermal layer above a cyclone is colder than above the anticyclone by ten degrees.

A uroras.-In February and March 19ro Prof. Dr. Carl Stoermer was able to carry out satisfactorily the first precise simultaneous measures of the parallax and location of the beams and arches of auroral light. He accomplished this by making simultaneous photographs of the auroras and the brighter stars at stations a few kilometres apart connected by telephone. The general result is that out of 150 well determined altitudes the lowest cases of auroral light occur at about 40 kilometres altitude, thus showing that the solar corpuscles striking the earth's atmosphere penetrate far deeper than do the beta rays from radium. The upper limit of these I 50 cases was at 260 kilometres, with several cases occurring sporadically above this, showing that the study of our atmosphere and its fields of force, with its thermal and dynamic phenomena, must be extended outward to at least that altitude, or one tenth of the earth's radius.

Aerolites. - The study of the upper air by means of twilight phenomena and auroras is closely connected with its study by means of shooting stars and aerolites. A very complete summary of our knowledge of these bodies is given by Von Niessl of Vienna in Vol. vi of the Encycl. Math. Wiss., from which several facts are deduced bearing on the upper air. Out of 49 altitudes of August meteors or Perseids the average appearance began at I I 5 kilometres and disappearance occurred at 88 kilometres. In the same way $\mathrm{H}$. A. Newton found 39 meteors beginning at the average altitude 112 kil. and disappearing at $90 \mathrm{kil}$. Of the November shooting stars or Leonids 78 began at 155 and ended at 98 kil. Out of I59 miscellaneous shooting stars the average beginning was at lio8 kil. and the disappearance at 86 kil. The average appearance of 121 large aerolites was at 138.6 kil. and the average disappearance of 213 large ones was at $49.7 \mathrm{kil}$. The altitudes of first visibility, namely from $108 \mathrm{kil}$. to $155 \mathrm{kil}$, are of course smaller for larger meteors than for the small molecular masses involved in the aurora which may begin visibility at $260 \mathrm{kil}$., because of the smaller geocentric velocities of the heavy meteoric masses, whose average velocity is but 72 kil. per second, compared with that of electrons moving with the velocity of light. Evidently the total diurnal heat communicated to the earth's upper atmosphere by shooting stars must he a small but appreciable percentage of that absorbed directly by the air from the sunshine, even if it be inappreciuble compared with that received from the sun by the earth's surface.

Climatology. - The influence of climate on our physical condition, or the psychophysics of climate, is a study to which special attention has been given by Prof. Titchener of Cornell and by I.ehmann and Pettersen of Germany. The influence of climate on the nervous system is very pronounced, quite as much so as the influence of food, drink, companionship, or habitation in forests, among mountains or on islands in the ocean.

Arctowski maintains that the compensations in the annual changes of cold and warm, drought and Hood, do not balance each other perfectly year after year, but experience irregularities that nust be charged to sudden changes in the solar radiation.

The diurnal variation of the direction and strength of the wind in the Adriatic Sea has been analysed by Mazelle. The bora is defined as a wind of 50 kilometres per hour or over. (In days of such boras the maximum wind velocity occurs at 9 A.M. and the minimum at 4 P.M. On the scirocco days the maximum velocity of wind occurs at midday and a second 
maximum at 6 P.M., with a minimum at I A.M. During the bora the morning maximum occurs at IO A.M. at Trieste, but at 9 A.M. at Porer and at 8 A.M. at Lesina. On the scirocco days the principal maximum occurs at noon at Porer, but at I P.M. at Lesina, and this retardation of one hour also occurs in case of the I A.M. minimum. The greatest duration of a bora storm averaged 6.6 days at Porer in January. The greatest duration of the scirocco was 2.6 days in February. The strongest wind recorded during the 5 years, 1903-07, was 123 kilometres per hour, viz. for the bora of January 1906.

Temperature of the Globe. - The average temperature of ideal hemispheres of land or of water, and of the whole globe, which has been the subject of many theories since the days of Forbes, has recently been discussed by Liznar with the latest data from distant portions of the globe. He finds that the average temperature of a land hemisphere would be 16.99 and of water hemisphere 13.27; a difference that is much less than that found by Spitaler. He finds that a change of solar constant by one per cent would have a considerable change in the temperature of each zone the change being greatest at the equator. An equal effect would have been produced by a general change in the transparency of the sun's atmosphere, or in the sun's temperature, or by local changes in the temperature or the transparency of the sun's surface or of the earth's atmosphere.

Secular Change of Climate. - The variability. of temperature and the evaporation of moisture in the dry regions of South Africa have bien studied by $J$. $R$. Sutton. The relation of desert plants to soil moisture in the dry regions of Arizona has been studied by $R$. E. Livingston. The secular changes going on in the climates of various parts of the earth continue to attract both observers and theorists; most enthusiastic among these is Dr. Ellsworth Huntington of Yale University. His former studies in Asia Minor, Syria and Persia are now being supplemented by extensive explorations in the arid regions of America. He maintains his discovery of different periods of drought's and floods in ancient days in every country; some of these were undoubtedly followed by extensive national migrations and international wars. Dr. Huntington has even announced as a preliminary result of his study of the annual rings of growth of large trees, that precision can be given to the dates of the periods of drought.

With reference to the analogous phenomena of glaciation, Dr. Julius Hann, in his address at Innsbruck September 1905, remarked: "In connection with the many traces and observations of a progressive drying of Africa and the interior of Asia we have before us one of the greatest problems of terrestrial physics. This problem seems all the more difficult to solve since there are similar phenomena on a small scale that we may study completely as to time and space, and yet are completely powerless to explain them from a meteorological point of view: $e . g$. the progressive continued retreat of the Alpine glaciers that can be easily observed. Although this phenomenon is going on in a region from which it would seem that sufficient observations have continued for years, still it is not as yet possible to prove any direct connection between these variations and the variations of the meteorological elements. In such problems great results cannot be attained in a brief time but only through long continued labours prefaced by appropriate preliminary studies."

The great gorges traced out toward the middle of the Atlantic Ocean from the mouth of the Congo on the east, and from the mouths of the Hudson, Delaware, Susquehanna and Potomac rivers on the west, as well as the changes in the great lakes of America and Asia, and also the palaeontological evidence of oceanic and continental deposits that have been accumulating ever since the Permian era of the geologists, all agree with many other phenomena in showing that great climatic changes have been in progress in our atmosphere since the earliest ages, and it would not be strange if slighter changes should have continued to develop during the past 4,000 years of the world's history, quite independent of solar changes.

Glaciers.-Among climatological studies the formation of glaciers has received continued attention. W. Sievers at Carlsruhe, September I9I I, discussed the glaciation in South America: he attributes the secular variations to changes in temperature during the glacial period produced by changes in solar radiation, but apparently he does not take full account of the effect of the great changes on the earth's surface in altitude and moisture and the atmospheric changes due to volcanoes.

Dr. P. Paschinger after a careful study of the relations between the snow limit and the climate finds that these vary in different regions even during the same period of time; the variations of the snow limit are greater on isolated mountains than in mountainous regions and they are least between the tropics and on plateaus. The snow limit had its maximum in the northern hemisphere after 1890 and its minimum about I870.

In an elaborate study of the light and air of high mountain regions, Dr: C. Dorno has laid the basis for a physical study of the mountain climates of Switzerland, as minute and precise as has been hitherto devoted to lower altitudes. He has given special attention to the intensity and character of solar insolation, diffuse skylight radiation, terrestrial radiation and atmospheric electricity. Among the interesting results attained by Dr. Dorno are the determination of the great annual and diurnal variations of sunlight.

Sunspot Influences.-The last work from the pen of Prof. Simon Newcomb before his death in 1909 discussed the meteorological evidences as to variations of radiation of heat from 
the sun, ending with the conclusion that the minimum temperature on the earth occurs 0.65 year after the maximum of sunspots, whereas our maximum temperature occurs 0.33 year before the minimum of sunspots. He infers that there may be fluctuations of plus or minus two-tenths of one per cent in the earth's temperature, but whether this terrestrial phenomenon is due to variations of solar radiation or of atmospheric conditions is still problematical.

The Solar Commission under the presidency of Sir Norman Lockyer continues its energetic labours, bearing on variations in the physical relations of the sun and the earth. Such variations are delicate and obscure and apt to be deceptive; it is not as yet clear that any variations in the solar conditions exist whose effects are appreciable in comparison with the variations continually going on in our own atmosphere. Koeppen showed that the so-called sunspot period in local temperature records varied with the latitudes of our stations, and was essentially a transfer from the equator towarós the pole of waves of heat that may have had their origin in our own atmosphere; the obscuration of our upper atmosphere produced by the eruption of Krakatoa spread slowly for a number of years; analogous effects were produced by Skaptas Jokul in 1783; and the eruptions of 1912 in Alaska cut off appreciable amounts of insolation; similarly the short periods that have been worked out by W. J. S. Lockyer may have a terrestrial origin. The broader study of our atmosphere as a whole has been especially favoured by the great increase in the area of the daily weather maps now published in Europe, Asia, Australia and America, and still more light will be thrown on the subject when a daily map of Southern Africa is published by the South African Union.

\section{PHYSICAL SCIENCE ${ }^{1}$}

(Cleveland AbBe.)

While failing to chronicle any experimental discoveries of the first importance, the last few years have witnessed a tendency towards certain very radical changes in general physical theory. In their extreme form, these changes amount to a new definition of our units of space and time, the suppression of the interstellar aether as a physical reality, and the conception of a discrete or corpuscular structure of energy. None of these new principles has as yet been fully recognised, but the rapidly increasing number of their adherents renders it necessary to take them seriously into account.

The Principle of Relativity. - The uniform failure of all attempts to discover " absolute" motion through the aether, even under the promising conditions of the classical experiment of Michelson and Morley, ${ }^{2}$ was met in the first instance by FitzGerald and Lorentz's hypothesis of a shrinkage of all matter in the direction of such motion. Such an hypothesis, though not unreasonable, was entirely arbitrary, and open to the objection that the amount of shrinkage should depend in some way upon the substance in question.

A more radical solution was furnished in 1905 by Dr. Albert Einstein, of Bern, now Professor of Theoretical Physics in the German University of Prague. This solution is based on the "Principle of Relativity," a principle which extends to electromagnetic phenomena that independence of absolute motion which has been accepted for mechanical systems since the days of Newton. It makes two fundamental assumptions, which may be put concisely as follows: (I) It is impossible to discover absolute motion by means of electromagnetic (including optical) phenomena; (2) the velocity of light is a universal constant, independent of the motion of the source. ${ }^{3}$

Since this principle was put forward, a system of theoretical physics has been worked out in considerable detail on the new basis. This system is known as the Theory of Relativity. Among its chief exponents may be mentioned Minkowski, Laue, Herglotz, Noether, Tolman, Born, Frank, N. Campbell and Levi-Cività. The theory, though starting with a renunciation, leads to some very startling positive assertions. It involves a new definition of time, based upon the impossibility of synchronising two distant clocks by means of anything more rapid than light-signals. This limitation introduces the velocity of light as a disturbing factor in the synchronism of a clock "at rest" with a clock in (relative) motion. In fact, two clocks, originally

synchronous, will each, when viewed from the other, appear to lose $\frac{1}{2}\left(\frac{V}{c}\right)^{2}$ sec. per second, if we denote their relative velocity by $\mathrm{v}$ and the velocity of light by $\mathrm{c}$. A rigid sphere in motion, viewed from a system "at rest," appears flattened in the ratio of

"See generally F. B. articles on "Physics" enumerated in Index Volume, p. 940.

2 Philosophicul Magazine, 24, p. 449 (1887). 3 Annalen der Physik, 17, pp. 891 (1905). 
$\mathrm{I}: \sqrt{\mathrm{I}-(\mathrm{v} / \mathrm{c})^{2}}$. This is the Fitzgerald-Lorentz shrinkage, now no longer a physical reality, but an appearance due to physical limits of observation. The velocity of light plays the part of an infinite velocity, and any speed surpassing that limit becomes meaningless.

A notable consequence, already pointed out by Einstein, ${ }^{1}$ is that the inertia of a body depends upon the energy contained in it. This implies a fundamental identity of mass and energy. Thus, radiation must have a "mass." If a body in space were to emit radiation in a single direction, the recoil pressure of that radiation (the reality of which has been demonstrated by Poynting and Barlow), ${ }^{2}$ would exert a force equal to $\mathrm{E} / \mathrm{c}$, where $\mathrm{E}$ is the energy emitted per second. If we call $\mathrm{M}$ the "mass " of the radiation $\mathrm{E}$, its momentum is Mc. This momentum generated per second equals the force $\mathrm{E} / \mathrm{c}$. Hence $\mathbf{M}=\mathbf{E} / \mathrm{c}^{2}$. Thus $\mathrm{c}^{2}=9 \times 10^{20}$ represents in ergs a mass of $\mathrm{I}$ gram, and the solar system is filled with this new type of "radiant matter."

Once we admit the materiality of radiant energy, we are obliged to consider the question of it berig subject to gravitational force. Einstein, ${ }^{3}$ indeed, goes so far as to answer the question in the affirmative and boldly predicts the observation of the gravitational deflection : of a beam of light from a star by the sun's gravitational field, a deflection which, though only amounting to 0.83 ", ought to be unmistakable. Here, however, the relativity theory is on dangerous ground, for any such gravitational effect on beams of light contradicts its own second fundamental assumption, which postulates the absolute constancy of the velocity of light. This absolute constancy is all that remains of the properties of the luminiferous aether, which adherents of the relativity theory sometimes profess to have completely eliminated. As it stands, it really represents a modus vivendi by means of which the substance of the undulatory theory and the aether principle may be saved in spite of the overwhelming negative evidence which has accumulated against the latter. Should this attempt fail, there is always the alternative of assuming that the velocity of light is added to that of the source, as it is in the electromagnetic theory devised by Ritz. ${ }^{4}$ This, of course, means the total abandonment of the aether as a luminiferous medium, and the revival of the emission theory of light: ${ }^{5}$

Quanta of Energy.-The " materialising tendency" of present-day physics, to which Sir O. Lodge drew attention in his Becquerel Memorial Lecture (I9I 2), is nowhere more evident than in the new theory of radiation propounded by Max Planck, ${ }^{6}$ according to which radiant energy is emitted in discrete quantities proportional to the vibration frequency of the emitting atomic or molecular element. The formulation of some such theory was necessitated by a breakdown of the Maxwell-Hertz electromagnetic theory of radiation when molecular oscillators are considered. Imagine a closed vessel impervious to heat, and filled with gas. Let a hot and a cold body be introduced into the vessel. Heat will pass from the hot body to the gas and to the cold body until the temperature is equalised, and the entropy has become a maximum. But that final state will also be reached if the gas is removed and the inner walls are perfect reflectors. Then the transfer of heat is made exclusively by radiation, which behaves as if it had a temperature, like the gas. Equilibrium is again established, just as if the entropy had become a maximum, whereas we can hardly speak of the entropy of a vacuum, since it is the logarithm of a probability of collocation in space of discrete elements. Thus we are led to attribute entropy to radiation itself.

The only approach to a mathematical theory of the process is through the conception of molecular oscillators and resonators. If a number of these are contained in the vessel, their energies will be distributed as among the molecules of a gas, and, since each resonator has two degrees of freedom (corresponding to electric and magnetic

1 Tbid., 18, p. 639 (1905).

2.Proc. Roy. Soc., A 83, p. 534 (1910). ${ }^{3}$ Annalen der Physik, 35, 5, p. 898 (I9I I).

4 Annales de Chimie et de Physique, I3, p. 145 (1908).

"See Laue, "Das Relativitätsprincip" (Vieweg, Braunschweig, I9II).

'Deutsche Physikalische Gesellschaft, Verhandlungen, 13, p. 136 (I911). See also his "Theorie der Wärmestrahlung" (Barth, Leipzig, I906). 
energy respectively), the mean energy of a resonator must be $1.346 \times 10^{-16} \times \mathrm{T}$ erg, where $\mathrm{T}$ is the absolute temperature. Now, according to Maxwell's equations, the mean energy of a resonator exposed to a radiation of frequency $\nu$ and intensity $\mathrm{S}_{\nu}$ is $\frac{\mathrm{C}}{8 \pi \nu^{2}} \times \mathrm{S}_{\nu}$, where $\mathrm{C}$ is a constant. By combining these two results, we get $\mathrm{S}_{\nu}=\mathrm{C}^{\prime} \mathrm{T} \nu^{2}$. This result is obviously contradicted by experience, since it crowds the radiant energy into the shorter wave-lengths and makes the total radiation integrated over the whole spectrum infinite:

The only solution of this difficulty seems to be that proposed by Planck, who assumes that molecular oscillators are incapable of continuous radiation, but accumulate energy up to a certain amount proportional to their frequency, and then throw off the whole of that amount at once. The "quantum" thus thrown off is $h \nu$ ergs, where $\nu$ is the frequency in revolutions or complete vibrations per second, and $h$ is the universal "action constant," amounting to $6.55 \times 10^{-27}$ erg-seconds.

This is a grave departure from the postulate of the equi-partition of energy which has hitherto governed the dynamical theory of heat. The resonators of highest frequency obtain the greatest share of the incident energy. They absorb it without loss by radiation until the time has come to emit the whole of 'it. Radiation is as " chaotic" as are the molecular motions in a gas. The "temperature" of radiation is that of the emitting body, and its entropy is derived from the logarithm of the probability of its state just as it is in the case of a gas.

A difficulty arises as regards the aether, to which the energy of radiation is communicated by means of its pressure. The aether, with its infinite freedom, cannot be in equilibrium with an oscillator having only two degrees of freedom. Einstein ${ }^{1}$ sought to overcome this difficulty by supposing that light itself is propagated in discrete " cells " or quanta, which have a fixed and definite volume, and simply increase their mutual distances as they proceed outward into space. This, as Lehmann suggests, may account partly for the twinkling of stars, and even for their visibility at enormous distances. A discrete structure of light has also been suggested by Sir J. J. Thomson, on the basis of some photoelectric experiments, and by Sir J. Larmor in his Bakerian lecture ( 1909$)$.

"Natural" Units.-Planck's radiation formula is $\mathrm{S}_{\lambda}=\frac{c^{2} h}{\lambda_{5}} \frac{\mathrm{I}}{\mathrm{e}^{c h / k \lambda \tau}-\mathrm{I}}$, where $\mathrm{S}_{\lambda}$ is the energy in ergs per $\mathrm{cm}^{2}$ of radiating black surface at the absolute temperature $\mathrm{T}{ }^{\circ} \mathrm{C}$, the radiation being of wave-length $\lambda \mathrm{cm} ; c$ is the velocity of light in $\mathrm{cm} / \mathrm{sec}, h$ is the "action constant," and $k$ is the atomic gas constant expressed in ergs per degree, its value being $1.346 \times 10^{-16}$. If $h, k, c$ and the constant of gravitation $\left(\mathrm{G}=6.66 \times 10^{-8}\right)$ are each made unity. we obtain "natural " units for length, mass, time, and temperature which may be held in reserve for future use in case the C.G.S. system is ever to be superseded.

Atomic IIeats.-Planck's law, which for large wave-lengths resolves itself into Lord Rayleigh's, while for short wave-lengths it gives Wien's law, has been found to cover the whole range of infra-red spectroscopy, and E. Baisch (I9II) has confirmed it down to $3.30 \mu \mu$. 'The Stefan-Boltzmann law of total radiation and Wien's displacement law are simple deductions from it. It is therefore likely to become an important datum of physics. Whether the more speculative parts of Planck's theory are adopted or not, it is certain that its general method is fruitful. It has already led to some important results, and has become a valuable guide in physical and chemical investigations.

Thus, according to the older kinetic theory, the mean energy of an atom per degree of freedom must be $\frac{1}{2} \times 1.346 \times 10^{-16} \mathrm{erg}$ per degree. In a solid body, whose atoms possess 6 degrees of freedom ( 3 kinetic and 3 potential), each atom must have six times that amount of mean energy. In one gram atom, or $0.64+10^{24}$ atoms, the energy is, therefore, 5.95 .5 calories per degree. This figure, embodied in the law of Dulong and Petit, only applies to fairly high temperatures, and even at these it fails in carbon,

1 Physikalische Zeitschrift, 10, p. 185, 1909. 
boron, and silicon. At temperatures from $100^{\circ}$ abs. downwards there is a rapid fall in atomic heats, which tend to zero as the absolute zero of temperature is approached. This observation forms the raison d'être for the theory of heat quanta propounded by Einstein and worked out more fully by Nernst, ${ }^{1}$ which differs from Planck's (revised) theory by postulating not only a unitary emission, but also a unitary absorption of energy, - a modification for which E. Bauer has recently (I912) advanced some further theoretical reasons.

The smallness of specific heats near absolute cold is then accounted for somewhat as follows. Near $0^{\circ}$ abs. only very few atoms will possess any quanta of energy, but the few that do will determine the temperature of the aggregate. The remainder are simply at rest. Therefore a very small quantity of heat suffices to raise the apparent temperature of the body, in other words, its specific heat is small.

But this is only one of many useful applications of the theory: It enables us to calculate not only specific heats, but melting points and heats of transformation, besides giving a quantitative expression for chemical affinity. The atomic frequency $\nu$, which enters into all the formulae, is calculated either from absorption spectra, or from the selective photoelectric effect, as in the extensive work of Pohl and Pringsheim; or the cubic elastic compressibility. And Lindemann ${ }^{2}$ gives the formula $\nu=4.59 \times 10^{15} \sqrt{n d / A}$, where $\mathrm{A}$ is the atomic weight, $n$ the valency, and $d$ the density of the body.

F. Haber, ${ }^{3}$ who defines Planck's action constant $h$ as "the amount of work required to extract an electron from an atom or molecule having a frequency of $\mathrm{I}$ vibration per second," deduces the relation $\nu_{\mathbf{r}}=\nu_{\mathrm{v}} \sqrt{m / \mathrm{M}}$, where $\nu_{\mathrm{r}}, \nu_{\mathrm{v}}$ are the infra-red and ultraviolet frequencies respectively, $m$ is the mass of an electron, and $\mathbf{M}$ that of the atom.

The Revival of " Caloric."-How far the " materialising tendency" has proceeded in recent years is evidenced in a striking manner by Prof. H. L. Callendar's opening address to Section A of the British Association at Dundee, in which he pleaded, if not for a revival of the caloric theory of heat, at least for a recognition of the legitimate claims of some of its leading principles. The materiality of heat cannot be refuted by weighing if it consists of electrons whose mass is purely electromagnetic, or, better still, if it consists of doublets of positive and negative electrons, which would have no perceptible weight, no evident electrical properties, and no absorbing power for light. They might even constitute the aether of space, which, as Witte has shown, must not be a continuum, but have a discrete structure, if it is to exist at all. At all events, caloric would have a physical existence, instead of being merely the logarithm of a probability. It would be identical with entropy.

In this connection an observation by L. Dunoyer (19II) may be of interest. He finds that in very high vacua the vapours of potassium and sodium are precipitated on the walls of the vessels by a kind of radiation or straight-line trajectory in which obstacles produce sharply-defined shadows. This looks like a realisation of $\mathrm{R}$. W. Wood's "fourth state of matter," and suggests that neutral doublets of high velocity come into action at high temperatures and low pressures. Whether these doublets are identical with Wood's electronic doublets; or with Righi's " magnetic rays" (which consist of positive atoms attended by revolving electrons) cannot at present be discussed.

Shortest Sound Waves.-Advances into the region of shortest sound waves were made almost simultaneously by Campbell and Dye $e^{4}$ and by Lebedef and Neklepajef ${ }^{5}$ in rgrr. The former passed sparks of definite frequency close to the mouth of a Kundt's dust tube. They were able to obtain as many as 50 streaks per $\mathrm{cm}$, which means a frequency in air of 830,000 . The number agreed with the value deduced from the capacity and inductance of the spark circuit within 5 per cent: Lebedef calculated the shortest observable sound waves from Stokes's formula governing the attenuation of sound by the viscosity of the gas, introducing corrections made by Kirchhoff and

\footnotetext{
1 Physikalishe Zeitschrift, 12, p. 976 (1911):

2 Deutschen Physikalischen Gesellschaft, Verhandlungen, 13, p. 482 (1911).

${ }^{3}$ Ibid., I3, p. III7 (I9I I).

Annalen der Physik, 35, pp. I 7 I and 175 (I9II). 
Jeans. It appears that a sound wave $0.4 \mathrm{~mm}$ long decreases to one-hundredth of its strength within $10 \mathrm{~cm}$, while a wave $0.1 \mathrm{~mm}$ long does so within $6 \mathrm{~mm}$. Neklepajef, using spark waves concentrated by a mirror and analysed by means of a Fraunhofer grating of silver-steel rods, measured the absorption of waves down to $0.8 \mathrm{~mm}$ length by means of an Altberg pressure apparatus.

The measurement of the physical intensity of sound has been brought nearer to its full realisation. Heindlhofer (I9I2) has worked out the theory of a method of determining it by the heating of gold-leaf, while Zwaardemaker has found the energy required to sound $a h$ to be about 3 megergs per second.

Measurement of V'isible Light.-R. A. Houstoun ${ }^{1}$ proposes to measure light absolutely by means of a thermopile provided with an ideal light-filter to give it the same curve of sensitiveness as the human eye. The filter proposed is an aqueous solution of $\mathrm{CuSO}_{4}$. $\quad 5 \mathrm{H}_{2} \mathrm{O}$ of strength 0.2 gram-mols per litre, in a layer $3 \mathrm{~cm}$ thick, followed by an aqueous solution of $\mathrm{K}_{2} \mathrm{Cr}_{2} \mathrm{O}_{7}$ of strength $0.0025 \mathrm{gram}$-mols per litre, in a hayer $\mathrm{I} \mathrm{cm}$ thick. The light would then be measured in ergs per $\mathrm{cm}^{2}$ per second.

Meanwhile, Buisson and Fabry, ${ }^{2}$ using a Heraeus mercury lamp, have determined the minimum possible expenditure of energy on a lamp which entirely transforms the energy it receives into the most advantageous luminous radiations. They find the value 0.018 watt per Hefner candle, which is about one-fiftieth of the expenditure on a metallic filament lamp. This figure might be called the "mechanical equivalent of light."

As regards the maximum of visibility, we now have the wave-lengths indicated by Nutting, of the Bureau of Standards (I9II). They are $544 \mu \mu$ for strong light and $5 \circ 3 \mu \mu$ for very feeble light.

Advances in Spectroscopy. - The recent great activity of spectroscopists has been accompanied by the discovery of new methods of investigation and the devising of new aids. Thus we have Anderson's copies in collodion of Rowland's original gratings, rendered accurate by mechanical stretching where required; Féry's prisms with curved surfaces (I9I0), which offer a valuable saving of precious material like fluorspar, and eliminate the loss at additional optical surfaces; Lehmann's ultra-violet filter (1910) consisting of Jena " uviol " glass and a layer of dimethylnit rosoaniline, which only transmits light of wave-lengths below $380 \mu \mu$; and Wood's " echelette " grating, consisting of lines ruled about $\mathrm{I}, 000$ to the inch on metal. This new grating has been applied with great success by 'Trowbridge and Wood to the resolution of the extreme infra-red residual rays from quartz.

Longest Light I'aves.- The gap between the longest light waves and the shortest mechanical waves observable has been definitely bridged by Rubens and von Baeyer, ${ }^{3}$ who isolated a beam of the mean wave-length 3 I $3 \mu$ from the radiation of a mercury lamp consuming + amperes at 100 volts. This wave-length of about $\frac{1}{3} \mathrm{~mm}$ coincides with that of the shortest sound waves and closely approaches the shortest observable Hertzian waves.

The infra-red spectrograph recently devised by Lebedef, and Trowbridge's simple demonstration apparatus for the infra-red spectrum, in which the sensitive receiver is a stretched rubber band provided with a mirror to indicate its thermal expansion, will no doubt contribute to the advance of infra-red spectroscopy both in the laboratory and the lecture-room.

The theoretical analysis of spectrum lines by series has hitherto suffered from the presence of numerous lines which did not fit into any of the series specified by Kayser and Runge. 'This is now in a fair way towards solution, since Ritz indicated a principle of combination which enables us to deduce new wave-lengths from lines already fitted into a series. The principle in question has been very successfully applied by Paschen, ${ }^{4}$ with the aid of the Zeeman effect, which gives a valuable index to the mutual connection

${ }^{1}$ Royal Society, Proceedings A 85, p. 275 (1911).

3 Preussiche Akudemie, Sitzungsberichte, I4, p. 339

p. 689 (1911).

4 Annalen de Physik, 36, p. I9I (I9II).
2 Comples Rendus 153, p. 254 (I9II).

(1911). Philosophical Magazine, 21, 
between lines. This success is the more remarkable as Ritz's principle is almost purely empirical.

Koenigsberger ${ }^{1}$ has worked out a theoretical formula for finding the proportion of molecules taking part in any emission or absorption of light. He finds that only about one molecule in a thousand is active at any given instant. While this result is in agreement with estimates previously based on other data, an outstanding spectroscopic difficulty is still presented by the shifting of spectrum lines with a variation in the pressure of the gas in which the source is immersed. This effect, discovered by Humphreys and Mohler, has since been studied by Duffield, Rossi, King and others, but all that is clear up to the present is that this effect has no connection with the Zeeman effect, as was at first supposed.

Radioactivity.-The confidence with which the production of helium by the atomic disintegration of radium is now regarded by physicists is shown by Strutt's ${ }^{2}$ calculation of the age of some specimens of thorianite by comparison with the observed evolution of helium. He found that one specimen of thorianite was at least 280 million years old, - a figure which should satisfy all geological requirements.

A revised table of names of radioactive products has been put together by Rutherford and Geiger. ${ }^{3}$ Radium $\mathrm{C}$ gives rise both to Radium D and a new product called Radium $\mathrm{C}_{2}$, which, however, starts a side branch of the radium family. Radium emanation retains its somewhat clumsy name, although Ramsay proposes to re-name it "Niton," from its intense luminosity when solidified.

E. Regener $r^{4}$ counts the number of $a$-rays and slow cathode ray particles (" $\delta$-rays ") by allowing them to impinge upon a spray of fine oil-particles, which are then counted in the field of an ultra-microscope. This is interesting in view of Boltwood and Rutherford's definite proof that helium is monatomic, and each atom carries two elementary positive charges.

Chemical Analysis by Alpha-rays. - The combined magnetic and electric deflection of canal-rays (a-particles) gives rise to parabolic curves and other traces on a photographic plate which vary in a characteristic manner with the nature of the gas in the vacuum tube. This observation has been utilised by Sir J. J. Thomson ${ }^{5}$ to initiate a new method of chemical analysis whose sensitiveness shall greatly exceed even the spectroscopic method. It has been found possible to trace the presence of monovalent hydrogen and oxygen, as well as carbon molecules of various atomicities and charges, but the method is hardly ripe for general application yet, and the work of von Dechend, Hammer, Koenigsberger, Kutschevski, Kilching, Fulcher, Gehrcke, Reichenheim, Baerwald and Stark has not sufficed to clear up all the complex details of the behaviour of these important forms of radiant matter.

Photo electric Effects. - The photo electric currents generated by the expulsion of electrons from the illuminated surface (Hallwaehs), especially in the case of the alkali metals and their amalgams, have acquired a new significance since they are being used to discover selective absorption and atomic frequencies. Elster and Geitel, ${ }^{6}$ by covering the potassium cathode with a thin layer of colloidal potassium, succeeded in rendering the cell highly sensitive up to a region of the spectrum far in the infra-red. A cell of this kind would be suitable, as E. Bloch suggests, for use in a photophone.

Among substances whose resistance is affected by light must now be counted sulphur (Goldmann and Kalandyk); calcium sulphide (Vaillant); antimonite, both in the native macrocrystalline state (Jaegers) and as pure artificial sulphide $\mathrm{Sb}_{2} \mathrm{~S}_{3}$ (Olie and Kruyt); and even paraffin oil (Szivessy and Schaefer). It is significant that the action of ultra-violet light on paraffin oil is in every respect similar to that of gamma-rays. Probably we shall see this action before very long brought into a clear relation with

1 Physikalische Zeitschrift, I2, p. I (I9II).

${ }^{2}$ Royal Society, Proceedings, A84, p. 379 (1910).

3 Philosphical Magazine, 22, p. 621 (I9II).

4 Le Radium, 9, p. I50 (1912).

I Ibid., 20, p. 752 (1910).

- Physikalische Zeitschrift, 12, p. 758 (1911). 
Becquerel's photo-voltaic effect, which Samsonov ${ }^{1}$ has recently produced in chlorophyll, and in uranyl and quinine sulphates, by illuminating one of the two translucent plat+ inum electrodes.

Selenium.-The electronic theory of the light-action of selenium, first advocated by C. Ries, has acquired an additional value since both the photo-sensitiveness and the variation of resistance with the voltage (the "potential effect ") have been discovered on a smaller scale in other substances as well. Quite recently. (I9I2) Ries announces that the potential effect is a general property of photo-sensitive substances. The conductivity of selenium has been invested with a special interest since Kaempf ${ }^{2}$ succeeded in producing in it a saturation current with a gradient of 12,000 volts per $\mathrm{cm}$. This is the first time that a saturation current has been observed in a solid.

Selenium photometry, at which Stebbins, Pfund, and others have been working for some time, achieved a notable success when Stebbins (Igr I) discovered a slight luminosity of the "dark" companion of Algol by its means.

Another new practical application of selenium is Fournier d'Albe's "optophone,"3 which enables totally blind persons to recognise light by means of the ear, the light producing a change in a selenium resistance forming one arm of a Wheatstone bridge, and the resulting current being periodically interrupted and thus made audible in a telephone.

W, M. Thornton, who regards the eye as an electrical organ, gives (r9ro) 23 microamperes per $\mathrm{cm}^{2}$ of the retina as the minimum current required to produce visual sensation. He concludes that the eye can detect one-twentieth of the energy perceptible to the ear.

Magnetons.-Ampère's " molecular magnets " have acquired a new significance by a remarkable discovery made by $\mathrm{P}$. Weiss, ${ }^{4}$ viz., that the molecular magnetic moments of bodies differ from each other in simple ratios expressible by small whole numbers. Owing to thermal agitation, these molecular moments do not co-operate except at absolute zero, but measurements can be made in liquid hydrogen, or even at higher ranges of temperature when temperature coefficients obey a well-defined law. The common constituent of the magnetic molecular magnetic moments is called a "magneton," and its value is $0.174 \times 10^{-28}$ in $\mathrm{cm}$-webers. The magneton-number is for iron $\mathrm{II}$, for nickel 3 , and closely approaches whole numbers in a great variety of bodies.

Nickel-on-Gluss , Reflectors.-The silver-on-glass mirror, itself a great advance on speculum metal, is likely to give way before a nickel-on-glass mirror both as regards durability and capacity of reflecting ultra-violet light. R. W. Wood ${ }^{5}$ gives.instructions for depositing the nickel, which is best done electrically from a solution of a double sulphate of nickel and ammonia. In this connection it should be noted that the thinnest optically effective layar of lead peroxide on a platinum mirror is $0.84 \mu \mu$ thick, and must have the thickness of two molecules (Koenigsberger and Müller, I9I I).

Fused-Silica Shundard.--Owing to its low thermal hysteresis, fused silica is a suitable material for standards of length. G. W. C. Kaye ${ }^{6}$ describes those adopted in the Bureau of Standards. They have a very small expansion coefficient, and are light and inexpensive. They must be annealed for eight days at $450^{\circ} \mathrm{C}$. and cooled slowly for fourteen days. Annealing caused a shrinkage of about half a micron in the metre standard.

\section{CHEMISTRY 7}

(E. E. FourNIER D'AlBE.)

The increasing significance of chemistry as a factor in modern industrial and social progress is obvious to anyone who gives consideration to the matter. It is true that a great deal of the chemist's work seems to have no bearing on the practical side of life, but every now and then a convincing demonstration is given that laboratory research

1 Zeitschrift fur Wissenschaftliche Photographie, Ir, p. 33 (1912).

2 Physikulische Zeitschrift, I3, p. 689 (1912). ${ }^{3}$ Ibid., 13, p. 942 (1912).

4 Comples Rendus, 152, p. 187 (1911).

${ }^{6}$ Royal Society, Proceedings, A85, p. 430 (I9II).

7 See generally E. B. vi., 33 et. seq.; and the articles on particular chemical subjects and substances, as enumerated in E. B. Index Volume, p. 892. 
on purely scientific lines ultimately yields results which are of the highest utility to the community, and may have far-reaching effects on its industry and commerce. A striking instance of this lies to hand, for after much laborious investigation, synthetic rubber is now an accomplished fact, and no one can yet foretell what this discovery will mean to the community. Chemistry is contributing largely also to progress in other sciences, notably biology. At the present day, organic chemists are busy investigating and building up the countless substances which are normally the products of plant and animal activity, while physical chemistry, with its accumulated data bearing on the phenomena of solution, offers valuable assistance to the physiologist in the interpretation of vital processes. The present survey of the recent progress of chemistry deals only with the purely scientific aspect of the subject. If, further, it is borne in mind that the chemical investigations reported in recognised journals all over the world number about 5,000 per annum, it is plain that only some of the more outstanding points can be discussed here.

Inorganic Chemistry.-Since rgro two new elements have been incorporated in the table of International Atomic Weights. These are niton (radium emanation), atomic weight 222.4 (Gray and Ramsay, Proc. Roy. Soc., A., I9ro, 84, 536), and holmium, atomic weight 163.5 (Holmberg, Zeitsch. anorg. Chem., I9II, 71; 226). In the case of some other elements recent research has led to a revision of the values previously adopted. The most notable instance of this is mercury, for which the atomic weight 200.6 is now recommended (see $J$. Chem. Soc., I9I I, 99, I868: also Easley, J. Amer. Chem. Soc., I9ro, 32, I I 7 ; I912, 34, 137). Other recent and important investigations on atomic weights are those dealing with silver (Richards and Willard, J. Amer. Chem. Soc., I910, 32, 4; Baxter, ibid., I 59I), and chlorine (Gray and Burt, J. Chem. Soc., I 9o9, 95, 1633; Chem. News, I9I I, I03, I6I; Stähler and Meyer, Zeitsch. anorg. Chem., I9I I, $7 I, 378$ ). The claim to have fractionated tellurium (see $E$. B. xxvi, 577: also Flint, Amer. Journ. Sci., [IV], I910, 30, 209) has not stood the test of further experimental examination (Marckwald and Foizik, Ber., I910, 43, I710; Harcourt and Baker, $J$. Chem. Soc., I9I I, 99, I3II).

Of the 82 elements as many as 27 have atomic weights which are multiples of unity to within O.I, and this fact suggests that there may be something in Prout's hypothesis (see $E . B$. ix, 258). The bearing of the disintegration theory of radium on this point has lately been discussed by Sir W. Ramsay (British Association Reports, I9I r, Io). Of interest also in this connection is the Faraday lecture on the fundamental properties of the elements (Richards, J. Chem. Soc., I9 I I, 99, I 201).

Much interest has been aroused by the discovery of a chemically active modification of nitrogen (Strutt, Proc. Roy. Soc., A., I91 1, 85, 219; 86, 56; 1912, 86, 262). When a current of this gas at low pressure is subjected to the action of an electric discharge, it continues to glow in an adjoining tube, after passing out of the region of the discharge. The chemical change which gives rise to the glow appears to be accelerated by cooling and retarded by heating. Compression of the glowing gas increases the intensity of the glow. Ordinary phosphorus, exposed to the action of the luminous gas, is converted into the red variety. Sodium and mercury, gently heated in the glowing gas, combine with it; in both cases line spectra of the metals are developed. Hydrogen merely dilutes the glow, whilst oxygen destroys it, apparently without oxidation occurring.

Attempts are still being made to elucidate the mechanism of rusting. Pure iron does not rust in contact with pure oxygen and pure water, not even when carbon dioxide is present (Lambert and Thompson, J. Chem. Soc., 1910, 97, 2426). Commercial iron, however, behaves differently. The experiments of Dunstan and Hill (J. Chem. Soc., I9I0, 99, I835), who find that those dissolved substances which prevent iron rusting are those which induce the so-called "passive" state in the metal, give support, on the whole, to the electrolytic theory of rusting (see Tilden, J. Chem. Soc., I908, 93, I356. Compare Armstrong, Science Progress, I9I I, April and October; Friend, J. Chem. Soc., I9I $2, I O I, 50)$.

Much work dealing with the fundamental subject of combustion has been published 
recently. The ignition temperature of a mixture of hydrogen and oxygen out of contact with any solid material is about $600^{\circ}$ (Dixon and Coward, J. Chem. Soc., 1909, 95, 514), and the corresponding point for a mixture of carbon monoxide and oxygen is about $650^{\circ}$. Air may be substituted for oxygen without altering these ignition temperatures. Reference may be made here also to further experiments by Dixon on the ignition of explosive gaseous mixtures ( $J$. Chem. Soc., 1910, 97, 661; 1911, 99, 589), and to an investigation, with a practical bearing on mine-explosions, in which the authors have determined the limits of inflammability in mixtures of air with the simpler paraffin hydrocarbons (Burgess and Wheeler, J. Chem. Soc., r9II, 99, 2013). It is interesting to note that the experiments of Bone and others on the combustion of gases at hot surfaces have led to the development of practical methods for the raising of steam, the concentration of liquids, and the fusion of metals (see Journal of Gas Lighting, I9 I I, II4, 22, 98; Engineering, May rgr2). A general and exhaustive report on the subject of combustion was submitted by Bone to the Chemical Section of the British Association (B.A. Reports; r910, 469).

Mixtures of hydrogen and oxygen, submitted to the action of the silent electric discharge at the temperature of liquid air, give under certain conditions a high yield of hydrogen peroxide (Fischer and Wolf, Ber., I9I r, 44, 2956). The silent discharge has played a part also in the experiments of Dewar and Jones on the conditions of formation and the properties of carbon monosulphide (Proc. Roy. Soc., A., I910, 83, 408, 526; I9I I , 85, 574). When carbon disulphide vapour at low pressure is exposed to the silent electric discharge, it is decomposed into sulphur and gaseous carbon monosulphide, CS. Passed into a tube cooled with liquid air, the monosulphide is condensed, along with the unchanged disulphide. If the temperature of the tube is then allowed to rise, the monosulphide polymerises with explosive violence, forming a brown substance, which may be formulated as (CS)x. This latter may be obtained also from thiocarbonyl chloride, which reacts rapidly at the ordinary temperature with nickel carbonyl, according to the equation: $\mathrm{xCSCl}_{2}+\mathrm{xNi}(\mathrm{CO})_{4}=\mathrm{xNiCl}_{2}+4 \mathrm{xCO}+(\mathrm{CS}) \mathrm{x}$.

Some other interesting inorganic substances, prepared lately, are worthy of mention here. Cuprous sulphate, obtained by heating methyl sulphate with cuprous oxide in the absence of water (Recoura, Compt. rend, I900, I48, I105), is stable in dry air, but is decomposed immediately by water, with deposition of metallic copper and development of heat. It is noteworthy that the existence of the compounds $\mathrm{NH}_{3} \cdot \mathrm{H}_{2} \mathrm{O}$ and ${ }_{2} \mathrm{NH}_{3} \cdot \mathrm{H}_{2} \mathrm{O}$ in the solid state has been definicely proved by a study of the freezing-point curve for mixtures of ammonia and water (Rupert, J. Amer. Chem. Soc., 1909, 31, 866; Smits and Postma, Proc. K. Akad. Wetensch. Amsterdam, I909, I2, I 86). Another interesting achievement is the preparation of solid oxygen, by the evaporation of the liquefied gas (Dewar, Proc. Roy. Soc., A., I9 I 1, 85, 580).

Organic Chemistry. - The investigation of the carbon compounds is proceeding in a multitude of directions, but interest and importance attach mainly to research work along one or two lines. In the synthesis of those substances which are normally the products of vegetable or animal activity there is a special significance, as also in the preparation and study of physiologically active compounds which find application for medicinal purposes. A glance into the current chemical literature shows clearly also the extent to which organic chemists are occupied with problems relating to molecular structure. The general principles underlying the formation of organic compounds are, it is true, well established and regularly applied in practice, but in cases where two or more structural arrangements of the atoms in the molecule are possible there is less certainty of treatment and correspondingly greater interest attaches to their elucidation. In the attack on such problems organic chemists are using physical methods to an increasing extent, and are finding them successful where purely chemical methods have failed.

The investigation of the proteins and their degradation products, albumoses, peptones, and amino-acids, has been actively prosecuted in recent years. In his Faraday lecture on the relation of synthetical chemistry to biology (J. Chem. Soc., I007, 9I, I749) 
Emil Fischer enumerated nineteen amino-acids which were to be regarded as the chief hydrolytic cleavage products of the proteins (see E. B. i, I 53 et seq., article "Albumin "). One of these amino-acids, viz. histidine, which in 1907 had not been built up in the laboratory, has now been synthesised (Pyman, J. Chem. Soc., I9r r, 99, I386), and the racemic compound obtained in the synthesis has been resolved into the optically active isomerides.

Fischer and his pupils have combined amino-acids in a great variety of ways, and have thus prepared a large number of synthetic products, termed polypeptides, the simpler ones being similar to peptones, the more complex ones resembling proteins. The study of these polypeptides, moreover, has led to improved methods of isolating and detecting decomposition products of the proteins. In this direction much work is being done by Abderhalden, who finds that for the purpose of distinguishing proteins partial hydrolysis is preferable to total hydrolysis. The latter treatment applied to different proteins may yield the same amino-acids in equal quantities, without throwing any light on the different ways in which these amino-acids were linked together in the proteins. Partial hydrolysis, however, leaves the amino-acids still associated to some extent. From silk fibroin, for instance, three dipeptides and a tetrapeptide have been successfully isolated in this way (Zeitsch. Physiol. Chem., r9o9, 58, 334; 63, 401).

The constitution of the alkaloids has in some instances been settled by a complete synthesis; as, for example, in the case of laudanosine, the first opium alkaloid to be completely synthesised (Pictet and Finkelstein, Compt. rend., r909, I48, 925), papaverine (Pictet and Gams, ibıd., I49, 2 Io), narcotine (Perkin and Robinson, J. Chem. Soc., I9II, 99, 775), and berberine (Pictet and Gams, Compt. rend., I9I I, I53, 386). The structure of other alkaloids which have not yet been completely synthesised is being gradually elucidated (see, for instance, Perkin and Robinson, J. Chem. Soc., r910, 97, 305; г9г 2, IOI, I775; Rabe, Ann., r9ıо, 373, 85; Ber., r9i , 44, 2088; Pschorr and Knöffler, Ann., I9I I, 382, 50; Wieland and Kappelmeier, Ann., I9I I, 382, 306; Pyman, J. Chem. Soc., 191 1, 99, 668; Pschorr, Ber., I91 2, 45, 221 2).

The hydrolysis of tannin with sulphuric acid indicates that it is a compound of one molecule of dextrose with five molecules of digallic acid, and in confirmation of this result substances resembling tannin in all respects have been prepared synthetically (Fischer and Freudenberg, Ber., 191 2, 45, 9 1 5).

Recent research confirms the existence of a close relationship between chlorophyll and haematin (from oxyhaemoglobin). The amorphous natural chlorophyll is the ester of a tricarboxylic acid, termed chlorophyllin, in which two carboxyl groups are esterified by methyl alcohol and phytol respectively, the third probably remaining free (Willstätter and others, Ann., I910, 378, I, I8; I9r I, 380, I48, I 54, I 77; I912, 390, 269). Reduction of chlorophyll derivatives yields haemopyrrol, iso-haemopyrrol, and phyllopyrrol, and it is noteworthy that these compounds result also from the reduction of haematin (Willstätter and Asahima, Ann., I9I1, 385, I88. See also Piloty, ibid., I910, 377,3 I 4 ).

The remarkable progress made in the synthesis of the terpenes (see $F$. $B$. xxvi, 047 et seq.) bears witness to the value of the Grignard reaction. The synthesis of terpineol has been followed up by the preparation of the $d$-and $l$-isomerides. Attempts to convert these active terpineols into the corresponding active limonenes have been unsuccessful; apparently during the elimination of water from terpineol a migration of the double linking occurs and the optical activity disappears (see Chou and Perkin, J. Chem. Soc, rgr r, 99, 526).

The great majority of the naturally occurring members of the terpene group are derivatives of $p$-cymene, but all the thecretically possible menthenols and menthadienes of the ortho-series have been synthesised, with the exception of the $\Delta^{2}$-isomerides. All the possible inactive $m$-menthenols and $m$-menthadienes of the type of terpineol and dipentene have been prepared synthetically, including sylvestrene (Perkin and others, J. Chem. Soc., 1907, 91, 480; 1908, 93, 1876; Proc. Chem. Soc., 1910, 26, 97).

Certain menthadienes are found to be characterised by an abnormally high boiling 
point and molecular refraction. This has been connected with the occurrence of conjugated double linkings, a view confirmed by the fact that these menthadienes are able to combine with only one molecule of halogen or halogen acid, whereas the other isomerides can absorb two such molecules.

Much work has been done lately in connection with rubber, and there is no doubt now that synthetic caoutchouc, comparable in all respects with the natural product, can be produced by the polymerisation of the hydrocarbon isoprene and its homologues. This is best effected, as Matthews has found, by heating the hydrocarbon with metallic sodium at about $60^{\circ}$ for several days (see Perkin, J. Soc. Chem. Ind., I9I2, 3I, 6I6. Compare Harries, Ann., I9II, 383, I57). Isoprene is readily obtained from the isoamyl alcohol contained in commercial fusel oil. Iso-amyl chloride, obtained from the alcohol by the action of hydrogen chloride, is chlorinated under special conditions, so that the formation of products more highly halogenated than the dichlorides is avoided. When the mixture of dichlorides thus produced is passed over soda lime heated to about $470^{\circ}$, isoprene is obtained in 40 per cent yield. The possibility of turning out synthetic rubber on the commercial scale depends on an abundant and cheap supply of fusel oil. This problem appears to have been solved by Fernbach's work, which shows that the fermentation of starch may be so directed as to yield either acetone or fusel oil.

One or two other interesting compounds which have been prepared lately may be enumerated here: viz. azomethane, $\mathrm{CH}_{3} \cdot \mathrm{N}: \mathrm{N} \cdot \mathrm{CH}_{3}$, a colourless gas (Thiele, Ber., I 909 , 42,2575 ), diphenylene, $\mathrm{C}_{6} \mathrm{H}_{4}: \mathrm{C}_{6} \mathrm{H}_{4}$, melting at $74.5-75^{\circ}$ (Dobbie, Fox and Gauge, $J$. Chem. Soc., I II I, 99, 683), cyclo-octatetraene, $\mathrm{C}_{8} \mathrm{H}_{8}$, the eight-membered ring compound analogous to benzene (Willstätter and Waser, Ber., I9II, 44, 3423), and epicamphor,

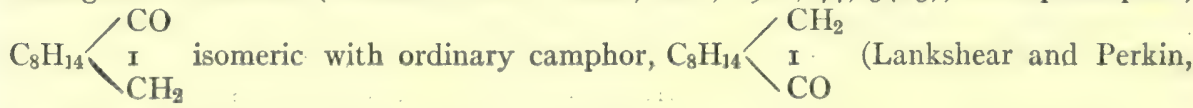
Proc. Chem. Soc., I9I I, 27, I66).

Discussion has long ranged round the question whether acetoacetic ester (see $E . B$. $\mathrm{i}, \mathrm{I} 35)$ is to be represented as possessing the " keto" form $\mathrm{CH}_{3} \cdot \mathrm{CO} \cdot \mathrm{CH}_{2} \cdot \mathrm{CO}_{2} \mathrm{C}_{2} \mathrm{H}_{5}$, or the "enol" form $\mathrm{CH}_{3} \cdot \mathrm{COH}: \mathrm{CH} \cdot \mathrm{CO}_{2} \mathrm{C}_{2} \mathrm{H}_{5}$, and latterly the view has been held that the liquid ester as ordinarily obtained is an equilibrium mixture of the two forms. Knorr has now succeeded, by carrying out operations at $-80^{\circ}$ and in the complete absence of moisture, in isolating both the ketonic and enolic isomerides in a pure state (Bcr., I I I I, 44, II 38 ). A comparison of the refractive indices of these two substances with that of the equilibrium mixture usually obtained shows that the latter contains 2 per. cent of the enolic form (compare, however, Meyer, $A n n$., I91 I, 380, 21 2; Ber., I9I I, 44, 2718). At the ordinary temperature both the enolic and ketonic forms change spontaneously into the equilibrium mixture, with great rapidity in the presence of certain catalytic agents. The isomeric forms of other tautomeric substances, such as methylbenzoylacetate and acetylacetone, have also been isolated (Ber., I9I I, 44, 2767).

In connection with optical isomerism much attention has lately been devoted to the Walden inversion. This term refers to a change of configuration occurring in an optically active compound when one of the atoms or groups attached to the asymmetric C-atom is replaced. Thus, for instance, the action of phosphorus pentachloride on 1-malic acid produces d-chlorosuccinic acid, from which in turn, on treatment with silver oxide, d-malic acid is obtained. Hence it is possible to convert l-malic acid into d-malic acid, and the reverse change can be similarly effected. Recent investigation of analogous cases has shown that change of configuration does not necessarily accompany any particular substitution, but is dependent on the character of the reagent employed to bring about the substitution. Thus the action of phosphorus pentachloride on l-a-hydroxy-a-phenylpropionic acid leads to the corresponding d-chloro-acid, while if the replacement is effected by thionyl chloride, the $l$-chloro-acid results (McKenzie, J. Chem. Soc., 1910, $97,1016,2566)$. It was thought at one time that a Walden inversion occurred only in cases where carboxyl was one of the groups attached to the asymmetric $\mathrm{C}$-atom, i.e. in the $a$-substituted acids, but recent work has shown that $\beta$-amino- 
and $\beta$-hydroxy-acids may also exhibit the phenomenon (Fischer and Scheibler, $A n n$., I9I I; 383, 337; McKenzie and Barrow, J. Chem. Soc., I9II, 99, 1910). It is noteworthy also that a Walden inversion is accompanied by racemisation to a greater or less extent.

In connection with the interpretation of the Walden inversion Emil Fischer has adopted the view that the $\mathrm{C}$-atom exerts an attractive force on atoms or groups outside the molecule of which it forms part (Ann., I9II, 38I, I23). That is, he assumes the existence of auxiliary valencies (see E. B. xxvii, 847 et seq., article "Valency ") and supposes that the formation of additive compounds precedes substitution. The position taken up by the replacing atom or group is not necessarily that of the atom or group which is replaced, so that in compounds containing an asymmetric C-atom substitution may be accompanied by a change of configuration. From this point of view the Walden inversion is a normal process which is as likely to occur as its opposite. Whether it occurs or not depends on the character of the reagent employed and on the nature of the groups attached to the asymmetric $\mathrm{C}$-atom. Should the change of configuration not occur in all the molecules involved then partial racemisation is observed. Werner proposes a somewhat similar interpretation of the Walden inversion (Ber., 191 I, 44, 873 . Compare Pfeiffer, Ann i, IgI I, 383, I23).

As regards new cases of optical isomerism, chief interest attaches to the preparation of active compounds of phosphorus (Kipping and Challenger, J. Chem. Soc., I9I I, 99, 626; Meisenheimer and Lichtenstadt,Ber., I9II, 44, 356), cobalt (Werner, Ber., I9 I I, 44, 1887, 2445, 3272), chromium. (Werner, ibid., 3231), iron (Werner, ibid., I9 2, 45, 433), and rhodium (Werner, ibid., I 228), and to the occurrence of optical activity in 1-methyl-cyclohexylidene-4-acetic acid and its derivatives (Perkin, Pope and Wallach, J. Chem. Soc, I909, 95, I789; Perkin and Pope, ibid., I91 I, 99, I510). It is claimed that the optical activity of this compound is due to the asymmetry of the molecule, not to the presence of any particular asymmetric C-atom (for discussion of this paint see also Everest, Chem. News, I909, 100, 295; Proc. Chem. Soc., I91 I, 27, 285; Marsh, ibid., 317).

Many workers are seeking to determine more definitely the quantitative connection between rotatory power and the various correlated factors, such as temperature, solvent, concentration, wave-length of the light employed, and the character of the atoms or groups attached to the asymmetric C-atom (see, for instance, Walker, J. Physical Chem., I909, I3, 574; Patterson and Stevenson, J. Chem. Soc., I910, 97; 2 I10, I912, I0I, 241; Frankland, ibid., r9I2, IOI, 654).

A physical method increasingly employed by organic chemists is the determination of refractive power. Refractometric investigations have yielded especially interesting results with unsaturated compounds, and recent work has confirmed and extended Brihl's conclusion that the grouping C:C.C:C or C:C.C:O in any molecule is associated with abnormally high refractive and dispersive power (see Brühl, J. Chem. Soc., I907. 9I, II 5; Smedley, ibid., I910, 97, I475; Anwers and Eisenlohr, J. prakt. Chem., I9I I, 84, I, 37; Refraktometrisches Hilfsbuch, by Roth and Eisenlohr, I9II. Compare Thiele, Ann., 1899, 306, 87). It is known that the mutual influence of contiguous unsaturated atoms finds expression also in anomalous rotatory power (Hilditch, J. Chem. Soc., Igo9, 95, 33I; ibid., 191. 99,224 ).

Another point worthy of notice is the publication of several papers demonstrating the applicability of the Barlow-Pope theory of valency volumes (see $E$. B. xxvii, 847 ; Le Bas, J. Chem. Soc., I907, 91, II 2; Phil. Mag., 1907, I4, 324; I908, I6, 60; Jaeger, J. Chem. Soc., 1908, 93, 517; Jerusalem, ibid., 1909, 95, 1275; 1910, 97, 2190 ; 191 2, I0I, I268; Colgate and Rodd, ibid., I9ro, 97, 1585; Barlow and Pope, ibid., 1910, 97, 2308).

Physical Chemistry.-In working out relationships between physical properties on the one hand and chemical composition and constitution on the other, much success has been achieved in the case of the refractive power of liquid substances. In this connection the recent thorough revision of the atomic refraction and dispersion values is noteworthy (Eisenlohr, Zeitsch. physikal. Chem., I910, 75, 585). The new figures (which take the place of those recorded in E. B. vi., 70), are as follows:- 


\begin{tabular}{|c|c|c|c|c|c|c|c|c|c|c|}
\hline & & & & & $\mathrm{H}_{a}$ & D & $D_{\beta}$ & $\mathrm{H}_{\gamma}$ & $\mathrm{H}_{\beta}-\mathrm{H}_{\alpha}$ & $\mathrm{H}_{\gamma}-\mathrm{H}_{a}$ \\
\hline Hydrogen & . & . & : & . & 1.092 & I. 100 & I. II5 & I. 122 & 0.023 & 0.0 \\
\hline Oxygen, hydroxyl & . & - & • & . & I. 522 & 1. $5^{2} 5$ & I. 531 & I . 54 I & 0.006 & 0.0 \\
\hline Oxygen, ether & . & . & . & 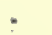 & 1. 639 & 1. 643 & I. 649 & 1. 662 & 0.012 & o \\
\hline Oxygen, carbonyl & . & . & . & . & 2.189 & $2.2 \mathrm{II}$ & 2.247 & 2.267 & 0.057 & o \\
\hline orine . . & . & . & . & . & 5.933 & 5.967 & 6.043 & 6.101 & 0.107 & \\
\hline romine & . & .. & 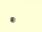 & . & 8.803 & 8.865 & 8:999 & 9.152 & 0.211 & o. \\
\hline dine & . & . & . & . & .13 .757 & 13.900 & 14.224 & 14.521 & 0.482 & o. \\
\hline arbon (singly bou & & - & . & • & 2.413 & 2.418 & 2.438 & 2.466 & 0.025 & \\
\hline ouble linkage of $c$ & arbon & . & 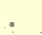 & • & 1.686 & I. 733 & I. 824 & 1: 893 & $0.13^{8}$ & \\
\hline linkage of $c a$ & rbon & & & & $2 \cdot 328$ & 2.398 & 2.506 & 2.538 & o. I39 & 0.1 \\
\hline en in prima & 1 & 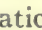 & & & 2.309 & 2.322 & 2.368 & 2.397 & 0.059 & 0.0 \\
\hline
\end{tabular}

The view that liquid water, on the ground of its peculiar physical properties, is a mixture of so-called "water-molecules " and "ice-molecules," the latter being more complex but less dense, has lately been strengthened by the preparation of new varieties of ice. When water at a pressure of about 3,000 atmospheres is cooled first to $-80^{\circ} \mathrm{C}$. and then to $-180^{\circ} \mathrm{C}$, , a specimen of clear ice is obtained which sinks in liquid air and is therefore denser than ordinary ice, but which swells up and crumbles to the ordinary variety when the temperature is allowed to rise to $-130^{\circ}$ (Tammann, Zeitsch. physikal. Chem., 1910, 72, 609). More lately still, two new forms of ice have been described, one of which appears only above $0^{\circ} \mathrm{C}$. (Bridgman, Proc. Amer. Acad., I912, 47, 44I). There is much to be said for another view that liquid water is a mixture of ice-molecules $\mathrm{H}_{6} \mathrm{O}_{3}$, water-molecules $\mathrm{H}_{4} \mathrm{O}_{2}$, and steam-molecules $\mathrm{H}_{2} \mathrm{O}$, the relative proportion of these varying with the temperature (Bousfield and Lowry, Trans., Faraday Soc., I910, 6, 85). According to Bose (Zeitsch. Elektrochem., I908, I4, 269) even steam contains a certain proportion of double molecules.

The notable work of Morse and his co-workers on the osmotic pressure of sugar solutions has lately been summarised (A mer. Chem. J., I9 I I, 45, 91 , 237, 383, 51 7, 554; 1912, $48,29)$. The ratio of osmotic pressure to gas pressure is constant for a given sucrose solution between $0^{\circ}$ and $25^{\circ}$ and tends to increase slightly with the concentration (reckoned in gm. mols. sucrose per $1000 \mathrm{gm}$. water) up to the value I.II4 for unit concentration. These results show conclusively that osmotic pressure is directly proportional to the absolute temperature. The Earl of Berkeley's work on calcium ferrocyanide solutions (Phil. Trans., A., 1909, 209, 177, 319) proves that the values of osmotic pressure measured directly are in close agreement with the values deduced from the vapour pressures of the solutions (compare E. B. xxv, 369 et seq., article "Solution").

New forms of apparatus for measuring osmotic pressure have been suggested by Fouard (Compl. rend., 1911, 152, 519) and Trouton (Proc. Roy. Soc., A., I912, 86, 149). A noteworthy case of a natural membrane giving rise to osmotic effects is furnished by the covering of certain barley grains (Brown, Proc. Roy. Soc., B., I909, 81, 82).

The view that hydrates exist in aqueous solutions is now accepted by the majority of physical chemists, but opinion differs widely as to how far their composition can be ascertained (see, for instance, Washburn, Tech. Quart., 1908, 21, 360; Jones, Amer. Chem. J., I909, 4I, 19; Hudson, J. Amer. Chem. Soc., I909, 3I, 63; Rothmund, Zeitsch. Physikal. (hem., I900, 69. 523; Armstrong, Chem. Neres, I9 I I, 103, 97). An analogous problem is presented by binary mixtures of organic liquids. The physical properties of a mixture of two nominally indifferent liquids may differ considerably from what is to be expected on the basis of the composition of the mixture and the corresponding properties of the pure components (see, for instance, Faust, Zeitsch. physikal. Chem., I91 2, 79, 97; Schulze, Zcitsch. Elcktrochem., I9I 2, 18, 77). Such deviations may be connected with the formation of a compound or with the association of similar molecules, and some noteworthy attempts have been made recently to estimate quantitatively the influence of these two factors in special cases (see Dolezalek, Zcitsch. physikul. Chem., 1908, 64, 727; 1910, 71, 191; Schulze, Physikal. Zeitsch., 191 2, 13, 425).

Much interest attaches to the study of organic liquids as ionising media. Of these, formamide resembles water most closely; as shown by Walden, its solvent power is very similar, its diclectric constant is somewhat greater than that of water, while potassium 
iodide and various alkylammonium salts are as highly ionised in formamide as in aqueous solution. The equivalent conductivity for a salt dissolved in an organic solvent increases with dilution, and the limiting value $\lambda_{\infty}$ may be deduced, as for aqueous solutions, on the basis of a linear relationship between the equivalent conductivity and the cube root of the concentration (see Philip and Courtman, J. Chem. Soc., roro, 97, I 26r; Walden, Zeitsch. physikal. Chem., r91 1, 78, 257). Waiden confirms the general validity of the rule according to which the product of $\lambda_{\infty}$ for a given salt and the viscosity of the solvent is a constant:

The evidence bearing on the validity of Ostwald's dilution law as applied to acids in aqueous solution (see E. B. ix, 2 I 7 et seq., article "Electrolysis") has recently been examined by Kendall ( $J$. Chem. Soc., I9I 2, IOI, I 275), who finds that the most probable value for the ionic conductivity of hydrogen is 347.2 at $25^{\circ}\left(313.9\right.$ at $\left.18^{\circ}\right)$. A new dilution formula, shown to be in harmony with the experimental conductivity data for acids of all types, is proposed, viz: $\frac{\mathrm{m}^{2}}{(\mathrm{I}-\mathrm{m})_{\mathrm{v}}}=\mathrm{k}+\mathrm{c} \frac{\mathrm{I}-\mathrm{m}}{\mathrm{m}}$, where $\mathrm{k}$ and $\mathrm{c}$ are constants for each acid, and $m$ is the coefficient of ionisation.

The position of colloidal solutions, relatively to crystalloidal solutions on the one hand and to mechanical suspensions on the other, has been made clear with the help of the ultramicroscope. The movements of colloidal particles are in harmony with the assumptions of the kinetic theory, and the agreement between the observed and calculated values for their velocity amounts to a proof of the kinetic nature of heat (see Brownian Movement and Molecular Reality, by Perrin, I9Io; Ostwald's Outlines of General Chemistry, p. 485).

In connection with the osmotic activity of colloids, the case of Congo red especially has been investigated (Bayliss, Proc. Roy. Soc., B., I909, 8I, 269; I91 1, 84, 229; Biltz, Zeitsch. physikal. Chem., I909, 68, 357; I910, 73, 481; I9I I, 77,9I). It seems, however, that peculiar inequalities of concentration are set up on two sides of the osmotic membrane, and it is therefore not permissible in this and similar cases to deduce the molecular weight from the recorded osmotic pressure (see Donnan, Zeitsch. Elektrochem., I9I I, I7, 572; J. Chem. Soc., I9I I, 99, I554; Moore, Roaf and Webster, Biochem. J., I9II, 6, 10).

The phenomenon of adsorption attracts much attention, especially since it has a bearing on such practical problems as the mfchanism of dyeing, the nature of the tanning process and the purification of sewage. Reference may be made here to investigations dealing with the adsorption of gases by charcoal (Homfray, Proc. Roy. Soc., A., I910, 84, 99; Titoff, Zeitsch. physikal. Chem., i9ro, 74, 641), of sugars by charcoal (Herzog and Adler, Zeitsch. physiol. Chem., r909, 60, 79), of acids by wool (Georgievics, Monatsch., I9I I, 32, 655; I91 2, 33, 45), of iodine by starch (Barger and Field, $J$. Chem. Soc., I9I2, IOI, I394) and of dyes by sand and natural fibres (Dreaper and Davis, $J$. Soc. Chem. Ind., I9I 2, 3I, 100). Experiments on the adsorption of acetic acid from its aqueous solutions by charcoal show the occurrence of a maximum of adsorption. The validity; therefore, of the usual adsorption formula $\mathrm{x}=\mathrm{kc}^{\mathrm{n}}$ must be limited (Schmidt, Zeitsch. physikal. Chem., r910, 74, 689; I912, 78, 667; Arrhenius, J. Chem. Soc., I912, I02, ii, I39).

It is well known that the course of a chemical change may be profoundly modified by the presence of foreign substances. Recent quantitative study of the photochemical reaction between hydrogen and chlorine has shown that this change is inhibited by oxygen, nitrogen chloride, nitric oxide, ozone and chlorine dioxide, while carbon dioxide, nitrogen, nitrous oxide and chlorine monoxide act only as diluents (see Chapman and MacMahon, J. Chem. Soc., I910, 97, 845). In several well-known cases the presence of water is necessary for the occurrence of chemical change. The rate of decomposition of moist ozone at $100^{\circ}$, however, is not appreciably different from that of the carefully dried gas (Chapman and Jones, J. Chem. Soc., I9r I, 99, I 8 I I ).

Analytical Chemistry. - From the mass of detail work published in this branch only one or two points of general interest and importance can be selected. 
In connection with the well-known method for estimating sulphates by precipitation with barium chloride a recent thorough investigation (Allen and Johnstone, $J$, Amer. Chem. Soc., I910, 32, 588) has shown that the barium sulphate precipitate as usually obtained is contaminated with alkali sulphate and barium chloride. The authors show how the errors can be reduced to negligible proportions.

For the rapid estimation of metals by electrolytic deposition it is advisable to keep the electrolyte stirred and many workers advocate rotating the electrodes for this purpose (see Price and Humphreys, J. Chem. Soc. Ind., I909, 28, I17). Others maintain that it is sufficient to pass a current of hydrogen or to work under reduced pressure; in the latter case, the gas evolved from the electrolyte occupies a much larger volume and effects thorough mixing (Fisher, Thiele and Stecher, Zeitsch. Elektrochem., I9I I, I7, 905).

In connection with volumetric analysis attention may be drawn to the use of titanium trichloride as a reducing agent (New Reduction Methods in Volumetric Analysis, I910, by Knecht and Hibbert). It may be used, for instance, in the estimation of iron, copper, tin, hydrogen peroxide, chlorates, organic nitro-derivatives, methylene blue and indigo. A useful paper has appeared recently in which the use of phenol phthalein as an indicator is discussed, more especially in connection with its sensitiveness to carbon dioxide (McBain, J. Chem. Soc., I912, IO1, 814).

The methods of gas analysis have been extended by the application of refrigerants for the purpose of fractional separation (Erdmann and Stoltzenberg, Ber.; I910, 43, I702, I 708). This procedure has been followed with very satisfactory results in the analysis of mixtures of ethylene and hydrogen, ethylene and oxygen, carbon dioxide and oxygen, nitrous oxide and oxygen. Attention may be drawn also to a valuable critical survey of modern methods for estimating carbon dioxide, moisture, methane or other combustible gas, and oxygen in air (Butterfield, Analyst, 1909, 34, 257).

Among recent books or new editions of old books, of special value to chemical students, the following may be noted: T. P. Hilditch, A Concise History of Chemistry; S. Arrhenius, Theories of Chemistry; W. Ostwald, Outlines of General Chemistry (new edition); Sir W. Ramsay's Textbooks of Physical Chemistry; J. C. Philip, Physical Chemistry and its Bearing on Biology; Wo. Ostwald, Grundriss der Kolloidchemie; J. W. Mellor, Modern Inorganic Chemistry; A. F. Holleman, Textbook of Organic Chemistry (3rd English edition); N. V. Sidgwick, The Organic Chemistry of Nitrogen; A. H. Allen, Commercial Organic Analysis (4th edition); Sir E. Thorpe's Dictionary of Applied Chemistry (new edition); Annual Tables of Physical and Chemical Constants.

(James C. Philiti.)

\section{BIOLOGY AND ZOOLOGY}

Biology and zoology are, fortunately, not like contemporary history; it seldom happens that a new discovery, like a new historical event, completely overthrows old land-marks, or transforms an account that is a year old to a halting record of knowledge. There is a vast annual output of new work with which the specialist must keep pace, each in his own branch, but the advance of knowledge is usually a slow progression, and it is even an advantage if general accounts, intended in the first place for those who are not working specialists, are a trifle belated, for there has been time for the new facts to lose some of their glamour of novelty and to fit into their appropriate and usually rather inconspicuous places.

How great is the actual output of newly published work, is not easy to realise. The annual volumes of the Zoological Record, published by the Zoological Society of London and by the International Catalogue of Scientific Literature, give only the titles of new memoirs and the barest indices of their contents, and yet each volume contains on an average about 1,200 closely printed pages. The Zoological Station at Naples issues each year a volume (Zoologischer Jahresbericht) intended to be a summary of the more important results of the period dealt with, selecting points of anatomical and morphological rather than purely systematic interest, and each of these reaches between six and seven hundred pages. A brigade of specialists is employed on the

1 See list of E. B. articles in Index Volume, pp. $889,890,891$. 
preparation of such records, and yet the complaint is sometimes made that by inadvertence, or even by want of appreciation, important contributions are overlooked.

In the following survey of the principal new points of substantial interest that deserve attention since the completion in 19 ro of the various articles on Zoological subjects in the Encyclopaedia Britannica, it is only possible to select amid a mass of detail, and to dwell on the questions of salient contemporary importance to the world at large. Many details appropriate for the consideration of the technical specialist are necessarily here passed over; for him, in his own subject, it would be impossible to select and reject: Similarly it would be superfluous to include here any of the technical descriptive matter relating to new species, mere extensions of known facts in anatomy, embryology and morphology and such subjects as. would require elaborate exposition. The attempt is, however, made to pick out what has seemed to be the opening of new subjects, to modify in any important way the general conceptions of the zoologist, or to show the tendency. of developing scientific opinion.

\section{Protozoa.}

Chlamydozoa.- One of the most remarkable additions to knowledge, or perhaps, it would be safer to say, to zoological theory, is associated with the name "Chlamydozoa," which has been given by S. von Prowazek to a highly problematical set of minute organisms, believed to be the cause of certain diseases in man and animals. It is well known that since the relation between disease and the semi-vegetable organisms termed bacteria ${ }^{1}$ was discovered, a very large number of different diseases have been traced to definite microbes belonging to that group, and the full life-history, mode of infection and propagation and so forth have been worked out. More recently still, the importance of parasitic Protozoa as the cause of many diseases,-such as malaria and sleeping sickness, was discovered. Next came knowledge of the part played by the slender thread-like Spirochaetes, which are frequently transported by blood-sucking ticks, and which cause special diseases such as some of the relapsing fevers, whilst others, like the spirochaete of syphilis, discovered by Schaudinn, pass direct from case to case. There remained, however, certain diseases such as vaccinia and variola, hydrophobia, scarlet fever, measles and foot-and-mouth disease, for which an organic cause seemed certain but had not been identified.

The supposed Chlamydozoa are smaller than any known bacteria; the virus containing them passes through ordinary bacterial filters, so that they must be studied by different methods, and elude safeguards that are efficient with other microbes. They are characteristically parasites of cells, living in the general cytoplasm, or in the nucleus, and stimulating the formation of special reaction-products of the cells they infest. They have a peculiar mode of multiplication, not splitting, like bacteria, by simple fission, but forming an elongated dumb-bell shaped figure. They have not yet been successfully cultivated, but artificial infections have been made from filtrates containing these bodies and not containing bacteria. So far they have been studied only in relation to disease, and even in this respect it cannot be said that their existence and properties have been definitely established. The work relating to them, however, is very promising, and appears to open a new subject of much practical and theoretical importance. If they are real entities, it is more than possible that they will be found living as free organisms as well as parasitically. They would represent the lowest known form of living being; they are certainly not cells, but are in a lower stage of organic evolution.

Spirochaetes.-Dr. H. M. Woodcock, in dealing with Trypanosomes in the $E$. $B$. (xxvii, 340 et seq.), discussed the affinity of the Spirochaetes with those organisms, and although admitting that there were reasons for the association, was disposed to be sceptical about it. Later work has confirmed his doubts. Some observers, such as Doflein, incline to regard them as a group transitional between bacteria and the Flagellata ( $E . B . x, 464$ et seq.); others; as closely related to the Oscillatoriae amongst 1 See E. B. iii, I56 et seq.; also "Parasitic Diseases," E. B. xx, 770 et seq. 
the bacteria; and others again as an entirely separate group of unicellular organisms showing little affinity either with bacteria or with any group of Protozoa. The balance of evidence certainly points to their exclusion from the animal kingdom.

Protozoa (General).-Dobell has raised an interesting but fine-drawn point in classification, relating not only to Protozoa but to all so-called unicellular organisms, animal, vegetable and on the borderland. The definition of a cell, he says in effect, is that it is part of an organism. Metazoa and Metaphyta are certainly cellular organisms, inasmuch as their bodies are built up of cells. But Protozoa and Protophyta are not unicellular, inasmuch as they are not cellular organisms at all. So also although gametes are cells, specialised cells of multicellular organisms, the fertilised egg-cell is not a cell but a whole organism.

E. A. Minchin, in a valuable new treatise on the whole group of Protozoa (see also E. B. xxii, 479 et seq.), discusses a similar problem from a wider standpoint. He suggests that there are three stages in the evolution of organisms. First there is the evolution of the cell itself from some primitive organism, such as for instance the Chlamydozoa, if these prove to be real, independent entities. In such evolution the cytoplasm and chromatin became distinct, and the chromatin became differentiated into a nucleus. The second siage was a further elaboration of the cell, with perfection of the processes of nuclear division and the establishment of syngamy and true sex. Only after these would have come the third stage, the evolution of ordinary multicellular animals and plants in different directions. In the same treatise, following separately published memoirs by himself and others, Minchin discusses the relations between parasitic and free-living protozoa.

Much of the brilliant work on pathogenic Protozoa has been carried out by medical men and specialists, acquainted chiefly with the forms that cause disease. From the broad point of view, parasites are abnormal and aberrant members of their race, and their life-history cannot be understood without knowledge of their normal relatives. Many parasites are new products of evolution. There is reason to believe that Trypanosoma rhodesiense, a trypanosome fatal to human beings, has come into existence quite recently, and many others show the marked disharmony with their surroundings that is characteristic of unsettled form and changing habit. From the vast assemblage of Protozoa that live free lives in the mud or water or air, some, from time to time, find their way into the bodies of living creatures and contrive to maintain existence in their new quarters. It can seldom happen that such intruders are by accident so nicely adapted to a particular host that they can live in it and in no other. They show a gencral power of tolerating parasitic life by being able to live in many different kinds of animals. But they also show a want for adaptation to their new habitat by multiplying unreasonably, and causing fatal disturbance in the body of their host. Plainly it can be no advantage to a parasite to kill its host, so destroying the living substance on which it subsists, and thus in course of time, partly by modification of the parasite and partly by modification of the host, a mutual toleration is acquired. The protozoon becomes accurately adapted to life in a particular host and causes it little or no harm. Parasites of such long-settled habit abound in all kinds of terrestrial and aquatic animals, but occasionally it happens, by a new intrusion from the stock of non-parasitic creatures, or by the migration of a possible host into a new country, that cases of organic disharmony occur, with a consequent catastrophic sweep of discase.

Isle of Wight Disease of Bces. - The cause of this disease, which has been extremely destructive in recent years, has been discovered by H. B. Fantham and A. Porter. It is a minute microsporidian parasite, named by its discoverers Nosema apis, and infesting the alimentary tract of the bee. A spore swallowed by a bee becomes amoeboid and enters one of the epithelial cells lining the gut. It then becomes nearly spherical, feeds, grows actively, and multiplies by binary fission in several ways, producing clusters or chains. The presence of the parasite deranges the digestive activities of its host, and is frequently fatal. Ultimately sporogony takes place and each of the pan- 


\section{BIOLOGY AND ZOOLOGY}

sporoblasts that are formed turns into a spore capable of passing to a new host. The symptoms of the disease in the bee are general ill-health, inability to fly, distention of the abdomen, and dry dysentery. Hives, honey, comb and pollen all may become contaminated with the spores, and the only mode of combatting the disease is complete destruction of the infected stocks. Dead bees, old combs and hives must be burnt. Warm weather is favourable to the bees, and cold and rainy seasons to the parasite. It seems to be the case that individual bees may become accustomed to the presence of the parasite and so form permanent reservoirs of the disease. Microscopic examination is the only method of being certain in the case of weakly or suspicious stocks. The parasite probably lives through the winter in hibernating bees, and there is no evidence of such hereditary infection as occurs in the case of the allied parasite of silkworms (Nosema bombycis).

\section{Porifera (Sponges).}

Most of the new work in this group (see $E . B$. xxv, 7r 5 et seq.) is too technical for summary here, consisting of descriptions of rew species, details as to geographical distribution, discussions of the minute anatomy, mode of origin and classification of the spicules, nature of the reproductive cells and structure of the tissues. H. F. Moore has published (in the Bulletin of the American Bureau of Fisheries, Vol. xxviii) two important economic memoirs. He shows that the Mediterranean fisheries still produce over half in value of the world's supply of sponges, but that the newer fisheries of the American coast produce by far the largest quantity, although a predominance of the lower priced kinds reduces the value to about one-third of that of the Mediterranean fisheries. All known and exploited sponge-beds, however, throughout the world, are showing more or less marked indications of depletion, and in some cases, especially in Florida, there has been a conspicuous falling off in the product under average conditions. This is due more to the intensity of the fishing, than to the taking of small sponges or to improper methods that could be suppressed. The demand is outrunning the supply; prices are rising, and the beds are being fished as they have never been before. Moore thinks that we must look to the development of sponge culture in territorial and extra-territorial waters as the chief hope for future progress. Experiments made under the direction of the Commissioner of Fisheries showed that the method of grafting superior varieties on inferior stocks failed in practice, the graft and the stock growing equally by simple processes of regeneration. Raising new sponges from eggs may be practical in future, but the most successful commercial process appears to be a simple propagation from cuttings. Sponges obtained in commercial fishing, that are too small or too badly shaped to be valuable, are reserved for propagation. The rather elaborate method, suggested by Dr. H. V. Wilson, of inducing the formation of degenerate bodies, which, on separation, grow up into little sponges, has been replaced by simply cutting up the sponges into pieces. From 100 to I 20 "plants," each readily capable of independent growth, were obtained by this method from a six-inch sponge, but in practice it was found more economical to divide the mother sponge into a smaller number of larger pieces, each about two by three inches. The mortality was smaller and the rate of growth greater in these larger cuttings. The cuttings are attached to concrete disks by lead-cased iron wires. Assuming a mortality of about 20 per cent, the net value, at the end of four years from the date of planting, was ascertained to be about four times the cost of planting, and it was estimated that an initial outlay of about 225 dollars an acre would yield about 200 dollars per annum. The calculations were based on actual experiments and Moore believes them to be conservative.

\section{Coelentera.}

The vast bulk of new literature published on the Coelentera (see E. B. vi, 640 et seq.) does not contain much of outstanding interest. The most notable publication is A. G. Mayer's great monograph on the Medusae of the world, consisting of three 
volumes containing over 700 pages, 428 figures and 76 plates. This memoir is in the first place systematic, but it contains many discussions of morphological, physiological and embryological points, and a very full list of reference to literature. The author insists that the medusa form has been acquired independently in different groups. F. Wood Jones has published an interesting contribution to the theory of coral-reef formation (see E. B. vii, 132 et seq.), the result of observations made during a prolonged residence on the Cocos-Keeling atoll. He thinks that Darwin's subsidence theory cannot explain the formation of this atoll, for the lagoon has become shallower since 1825 , and the structure of the reef shows no evidence of subsidence since its first formation. Equally he rejects Murray's theory of solution, as coral sand is constantly accumulating in the lagoon and calcium carbonate is being deposited. He thinks that the process of sedimentation is the chief factor. Corals are unable to grow where sediment falls on the zooids in any quantity, and accordingly the set of winds and waves and the limit of the slope on which sediment will lie quietly are the defining conditions of coral growth. Where there is a free wash of water, the zooids are kept clear of sediment and flourish; where there is an eddy or a quiet pool, or a depth of water beyond the reach of the waves, sediment lies and inhibits coral growth.

\section{Echinoderma.}

The most important new work on the group (see E. B. viii, $87 \mathrm{r}$ et seq.) is Mr. H. L. Hawkins' memoir on the Holectypoid sea-urchins, which he regards as forming an order intermediate between the regular and irregular urchins, but which have been characterised by a "persistently retarded progress in evolution," with the result that study of them throws much light on the relations and classification of the whole group.

\section{Pearl Oysters.}

Dr. Lyster Jamieson has published several memoirs dealing with the pearl-fishing industry in different parts of the world (see $E . B$. xxi, 25 et seq.), and the practical failure of attempts that have been made to improve it by biological investigations, a failure which he is disposed to attribute in the first place to the inexperience of the investigators with the practical side of the industry. In particular he throws doubt on an interesting theory which seemed to have a practical bearing. The pearly substance is frequently deposited round some adventitious foreign body which has found its way to the pearl oyster. In the case of the Ceylon pearl oyster, the foreign body was supposed to be the larva of a tape-worm, the adult stage of which infests a fish which preys on the oysters. It seemed a possible inference that if the fish were encouraged near the oyster beds, there would be a greater chance of oysters being infected by the eggs of the tape-worm, with a consequent increased production of pearls. Dr. Jamieson's observations lead him to dispute the fact and the inference. He thinks it more probable that the production of pearls in the oyster is the result of a pathological immigration of the epidermis into the tissues, the cause of which is unknown, and that if tape-worm larvae do really occur in the shell-fish, the case is one merely of the coincident presence of two diseases, one associated with pearl-production and the other with no practical relation to it.

\section{Disease-Bearing Arthropods.}

The new knowledge of the part played by biting and blood-sucking Arthropods in the carrying of disease from infected animals to man, from man to man, or from man to animals, has led to much careful work on the Arthropods themselver (see $E$. $B$. ii, $673 \mathrm{et}$ seq.). Of this the most important are a great monograph on ticks (Ixodoidea) by Messrs. Nuttall, Warburton, Cooper and Robinson; the fifth and completing volume of Theobald's monograph on the Culicidae, in which there are invaluable descriptions of tropical gnats and mosquitoes; and E. E. Austen's beautifully illustrated treatise on African blood-sucking flies. On the practical side, there has been an increasing trend of opinion towards incriminating large game animals, especially in Africa, as permanent reservoirs of disease, with the consequent demand for the relaxation or abolition of the 
game-laws for the protection of such animals. On the other hand it is urged that every excuse is taken for assaults on the game-laws, that the scientific indictment is far from complete, and that if the extermination of large ruminants were carried to its logical conclusion, it would be even more necessary to kill off the domesticated animals as these come into more immediate contact with man.

\section{Social Termites.}

Karl Escherich has published an unusually interesting volume on the habits of the social "white ants" or termites (see E. B. xxvi, 643 et seq.), based on studies made in Ceylon. He confirms the extraordinary fact that some of these insects cultivate fungi which they use as food, and, in the case of four Ceylonese species, describes and illustrates the fungus gardens in the termitaria. He found that two species of termites, or a species of termites and a species of ant, frequently inhabited the same nest. In every case, however, the relations appeared to be unfriendly; the actual chambers and fungus gardens of the different species were separated by walls, and if accidental breaches were made, the rivals fought bitterly. He confirms Holmgren's "exudate" theory, according to which the queen termite exudes from the surface of her body a substance that is eagerly sought by the workers. They lick her, not to keep her clean, but to obtain the coveted food, and they even distribute to other workers regurgitated morsels of it. Termites are one of the chief pests in tropical countries, all wooden structures, papers, books and cloth being attacked by them. Escherich describes a German apparatus, made for locating these insects and so marking them down for extermination. It consists of a microphone protected by a funnel-shaped guard and connected with a telephone receiver. The microphone is inserted in the earth, or in soft tree-stumps, and the crawling termites can be heard, even if they are at a considerable distance. When a termitarium has been discovered, it can be attacked in various ways. All apertures but one may be plugged with clay, and a stopping of tow soaked with carbon-bisulphide may be placed in the last opening. Still better is a device by which the fumes of arsenic and sulphur heated on glowing charcoal are blown through the nest by a small hand-pump.

\section{General Morphology of Mollusca.}

A. Naef has published the first of what is intended to be an elaborate set of invistigations into the morphology of molluscs (see $E$. B. xviii, 669 et seq., and allied articles). He rejects any idea of a relationship between flat-worms (Platyhelminthes) and molluscs, holding the latter to be intimately connected with annelid worms both by descent and by structure. He states that there is a sharp division between the Chitons, which he regards as not having reached the true molluscan grade, and the Eumollusca. The typical forms of the latter are the Gastropods and Cephalopods. In these the body is divided into two segments, the head-foot region and the visceral region, the two being joined by a rudimentary neck. The hind region shows traces of a primitive metamerism, and a retroflexion of the hind-gut with the mantle and shell is characteristic of it. The gastropods had primitively either a planospiral or a turbospiral shell, and it was only when swimming habits were replaced by creeping habits that the spiral was corrected by a torsion. In embryological development the appearance of the torsion has been pushed further and further back, until it appears even in the embryo. He recognises four stages in the phylogeny of gastropods:-Planospira stage (e.g. Bellerophon), Turbospira stage (Pleurotomaria), Prototrochus stage (Trochus and Patella), Metatrochus stage (Paludina, Atlanta, Actaeon, Limacina). He places Helicina and Nerita (on the morphology of which G. C. Bourne has also written an important memoir, regarding them as highly modified derivatives of a primitive type) between the last two groups.

\section{The Relations and Phylogeny of Mammals.}

W. K. Gregory has written (Bulletin of the American Museum of Natural History) a broadly-based study of the relations and phylogeny of the orders of Mammals (see 
$E . B$. xvii, 520 et seq., and allied articles). He insists on the importance of not being led by misleading analogies. 'The phylogenetic and systematic value of a character cannot be properly valued until its adaptive character has been understood; the trend of adaptation of the whole organism and of its race should be sought for. The intricate complex of homology and analogy, of adaptation and of change of function, must be analysed, and the little noticed " palaeotelic," non-adaptive characters must be looked for, as they often afford the best evidence of remote relationship. Gregory is restating in somewhat different terms what the present writer urged more than ten years ago (Trans. of the Linnaean Society, I901, pp. I 78 and 270 ), that a valuation of zoological characters must precede effective application of them to consideration of phylogenetic relationships. Unfortunately it often happens that the systematist, dealing with existing forms, finds notable distinguishing characters which sufficiently unite or separate existing animals, and is therefore content to base diagnoses on these. The first distinction to be made, however, if phylogeny is the goal, is between characters that are primitive and characters which have been modified from the primitive condition. It is plain that the common possession of primitive characters, however convenient a docket for a pigeon-hole, is no guide to affinity. If all the primitive mammals possessed five digits, there is no reason why those that still possess five digits should be more closely allied than any of them may be with those that have lost one or more of the digits. So also modified characters must be analysed; there is no reason to suppose that similar modifications imply affinity, as for instance adaptive modifications or losses of a numerical part of a common heritage. Gregory applies such reasoning in detail to the orders of mammals and has reached many interesting conclusions.

He thinks that it is unnecessary to have recourse to unknown Amphibian-like creatures of the Devonian in the search for the immediate ancestors of the Mammalia. Following Osborn and Broom, he thinks that mammals have been derived from the Triassic reptilian order Cynodontia, although not from any known member of it. He looks specially in these reptiles to the constitution of the temporal arch, the development of the secondary palate and of paired occipital condyles, the presence of teeth differentiated into incisors, canines, premolars and molars, and to the enlargement and functional importance of the dentary bone and the structure of the limb-girdles and limbs. The Cynodonts "structurally if not genetically" bridge over the gap between mammals and reptiles, for, in combination with the mammalian features that have just been mentioned, they possess many reptilian characters inherited from below. He thinks that the secretion of milk might have been a by-product of the change from coldblooded reptiles to warm-blooded mammals, and the young reptilian mammals, hatched from eggs carried on the ventral surface of their mother, licked or sucked the secretion becaluse " it tasted good," before it became of economic importance to them. He accepts the evidence that the primitive mammals possessed imbricated scales probably arranged in transverse rows, and that the first hairs were flattened structures protruding between the true scales.

With regard to the Monotremes, Gregory discusses but dismisses the tempting theory that they were derived from some family of Triassic or Permian reptiles other thin that which gave origin to the higher mammals, and holds that the common ancestors of Monotremes, Marsupials and Placentals were already mammals. The Monotreme stock, however, must have begun to diverge from the Marsupio-Placental remnant at an exceedingly remote period. Not only do the Monotremes retain many primitive reptilian characters not found in higher types, notably in the reproductive system, shoulder girlle and pelvis, but they have also had time to acquire so many deep-seated peculiarities in the skull, that the Monotreme skull may be set in a class by itself, in contrast with the primitive Marsupio-Placental type. There is a balance of evilence in favour of accepting Seeley's view that the Protodonts may be related to the Cynodonts, but in view of the lack of evidence for placing them in either of the mammalian sub-classes and of their progressive characters as compared with reptiles, Gregory treats them provisionally as representing a primitive group to which Haeckel's name 
"pro-mammalia" may be applied. The Multituberculata must be regarded as related with the marsupials, but were not diprotodont. The Triconodonts, excluding Peralestes, are also to be regarded as having marsupial affinities and to be distinct from the Multituberculata. The Trituberculata, although showing Creodont and Insectivore resemblances, are also more nearly related with the Metatheria. The primitive Marsupial skull on the whole approaches the Cynodont type more nearly than does that of the Monotremes, and the Marsupio-Placental remnant still retained some of these reptilian characters after the branching off of the Monotremes, but, owing to the assumption of semi-arboreal habits, it lost the Monotreme characters of the shoulder girdle. At such a point the divergence of the Marsupials and Placentals began, the former retaining and perfecting their arboreal characters. He gives a conception which he admits to be somewhat speculative, as the fossil history is obscure, of the ancestral Insectivores. These would be ordinally related with the contemporary ancestors of the Creodonts, but would be distinguished chiefly by smaller size and less robust structure, more clongate snout and premaxillaries, smaller canin`s, smaller and more sharply cusped molars, and perhaps by habits that were more arboreal, less predatory and more insectivorous-frugivorous. He removes the Tillodonts from their supposed relations with the Rodents, and places them near the Insectivore-Creodont stock.

The Creodonts are to be derived from Mesozoic Insectivora, and their relationship with polyprotodont Marsupialia rests chiefly on convergence. The Sparassodonts were very early separated from the Creodonts. The Fissipede Carnivora are descended from Creodonts by way of the Miacidae. The Fissipede Carnivora, as shown especially by the close relation between seals and bears, are derivatives of Arctoid Fissipedes.

The Menotyphla (Tupaiidae, Macroscelididae), Dermoptera (Galeopithecidae), Chiroptera and Primates are associated in a super-order to which Gregory gives the name Archonta ("A $\rho \chi \omega \nu$, chief, cf. German Herrenthiere). The separation of lemurs from apes and monkeys may date back to the Lower Eocene, but the close relationship of the two groups is accepted. The whole group Archonta is to be taken as a derivative from large-brained arboreal Insectivores resembling Tupaia in many ways.

The Rodentia form an extremely ancient order, perhaps going back to the Cretaceous, and it seems possible that their stem forms were Mesozoic Placentals, allied to the ancestors of the modern Insectivora and possibly to the contemporary ancestors of some of the Edentates. The extremely diverse character of the animals which are grouped as Edentata for convenience, is accepted, and Gregory thinks that there is a balance of evidence for the view that the Xenarthra, Tubulidentata and Pholidota are the highly modified descendants of some Mesozoic Placentals which branched off before the differentiation of Insectivores, Creodonts and Proto-ungulates. The various suborders of hoofed mammals are connected by " a tangled web of resemblances," a web which early caused the " order " Ungulata to be regarded as a natural group. It is probable, however, that convergent and parallel evolution accounts for many of the resemblances. The Artiodactyla are widely removed not only from the Perissodactyla, but from all other ungulate groups, and may be an offshoot from the ancestors of the Creodont Mesonychidae, or even from some Lemuroid-Insectivore group. Even in the lower Eocene, Artiodactyls and Perissodactyls are separated by deep-seated characters. All the remaining ungulate suborders may trace their ancestry back to a varied order of Cretaceous Proto-ungulates, which were primitive Placentals of small size, related with the Creodont-Insectivore stock, but falling under the original definition of the Condylarthra. By Basal Eocene times they had spread, probably from some Boreal Holarctic centre as yet unknown, into North America, South America and Europe, and had already split up into well marked families, such as Phenacodonts, Meniscotheres, Periptychids and Pantolambdids in N. America, Condylarths and Amblypods in Europe, and Condylarths, Periptychids and Homalodotheria in S. America. Later on the Amblypoda may have sprung from the N. American Pantolambdids, the Hyraces, Embrithopods, Barutheres, Proboscidea and Sirenia from a Lower Eocene African stock; the Perissodactyls and Chalicotheres from Holarctic Condylarths allied to the Phenaco- 
donts; and the Litopterna from the S. American representatives of the Meniscotheriidae.

The relations of the Cetacea, including the Zeuglodonts, seem to be with the Insectivore-Creodont group, but no good evidence of a specially great antiquity of the order, or of relationship with the Marsupials or Pre-Placentals, has been advanced.

\section{Longevity in Mammals and Birds.}

P. Chalmers Mitchell has published an elaborate memoir on longevity in Mammals and Birds (see E. B. xvi, 974 et seq.), with special reference to the viability of these animals in captivity. It is obviously impossible, except in the rarest cases, to obtain information as to the duration of life in wild animals, and therefore enquiry into the duration of life of animals in captivity is the best available means of reaching knowledge as to the relative longevity in different groups, and as to their viability in captivity, or power of resistance to new environment. He examined the records of duration of life in captivity of over 20,000 individual mammals and birds, and has collated and classified these systematically, giving in the case of each species the average duration and the maximum duration, comparing the figures with maxima otherwise known or suspected. He points oút, however, that the materials were defective in two important respects, inasmuch as the age and condition of the individuals at the time of their reception were unknown or unnoted.

Following Sir Ray Lankester, he distinguishes between potential longevity, the limit of age which an individual could reach if placed in the most favourable circumstances, and average or specific longevity, the average age to which the members of a species attain under the natural conditions to which a species has become adapted. The difference between the two is a measure of the severity of the conditions to which the species is subjected. When creatures of closely similar structure are compared, it appears that greater size is generally associated with longer life and higher viability. But the correlation completely fails when animals of different structure are compared; carnivores for instance, in proportion to their size, are much longer lived than herbivores; and, except for ostriches, which resemble herbivorous mammals in many respects, all birds, in proportion to their size, can attain much greater ages than mammals.

In dealing with animals in captivity, Mitchell replaces the terms " potential longevity" and "average longevity" by "maximum duration" and "average duration." He comes to the practical conclusions that the climate to which a captive animal is native has the smallest possible relation with its viability in captivity, and that the idea which has so long governed those who are responsible for captive animals, that it is necessary above all things to protect them from cold, leads to complete failure. Mammals and birds not only can endure considerable cold, but are favourably affected by frequent and rapid changes of temperature. In the long list of species that have been kept in captivity, there is no case of even reasonably good viability where the animals have been kept indoors and provided with artificial heat. All the cases of mammals and birds where there has been relative success are those where the creat ures either had no artificial heat at all, or had constant access to the open air from their warm shelters. These conclusions are in harmony with the methods which are beginning to find their way into zoological gardens and stock-breeding establishments, but many stubborn prejudices have yet to be conquered. Incidentally Mitchell points out that the presence of parasites has an important bearing on viability. 'The conditions of small well-heated quarters are most favourable to the preservation of parasites and to the chances of healthy creatures being infected by their neighbours, so that the temperature relations in many cases may act on the viability of animals through the intermediacy of parasites.

\section{A New Fossil Primate.}

Although no reasonable biologist doubts the descent of man from ape-like ancestors, geological evidence of the actual line of descent is vague and dubious to an extent that almost justifies the existence of the popular phrase "missing link." In s9ro our state 
of knowledge was roughly as follows. It was accepted on the one hand that even the lowest existing savage was much modified from any intermediate ancestor, and was truly a member of the species to which the highest civilised types belong, and on the other that the existing anthropoid apes were equally modified, probably in a degenerate or specialised direction, from the common man-ape ancestor. Human skulls like those of Neanderthal and Spy showed the existence of a race of cave-men with very low foreheads and prominent brow-ridges which in many respects were anthropoid in type, differing remarkably from the modern type and resembling adult gorillas and chimpanzees. These are of no great geological antiquity. Abundant fossil remains of a very much older date showed the existence, in Miocene and Pliocene times, of large creatures certainly apes, but more human than existing apes, and suggesting the degeneracy of the modern anthropoids. Finally Dr. Dubois's Javan discovery of Pithecanthropus. erectus $(E . B . x x i, 665)$ established the existence of a still more man-like ape, or of a more ape-like man than any form hitherto known. Its date was a matter of dubiety; Dr. Dubois was disposed to refer it to the Pliocene; a preponderance of expert opinion placed it later, in the Pleistocene. Mr. Charles Dawson has now discovered a skull that is more interesting and significant as evidence for the descent of man than any hitherto known. Four years ago, at Piltdown, near Fletching in Sussex, he discovered the first fragment in a bed of gravel usually worked for road metal. During Igr 2 he and Dr. A. Smith Woodward, the Keeper of Geology at the British Museum, searched the bed assiduously and discovered enough fragments to build up an almost complete skull and to make it possible to have an internal cast which showed something of the structure of the brain. The skull had the vertical forehead of a modern man with scarcely a trace of the prominent brow ridges of the cave-man, but the back of the skull and neck were shaped much more like those of an ape than of any human type. The size of the brain was not more than two-thirds that of a modern brain. The jaw, but for the presence of two distinctively human teeth, would certainly have been referred to a chimpanzee or gorilla. The skull in short was much more like that of a young chimpanzee, those of cave-men being like adult chimpanzees. Dr. Woodward's inference is that the Piltdown skull proves the existence of a real intermediate form, a true link between man and the ape, while the cave-men were degenerate offshoots of the ancestors of a modern stock. The gravel contained mammalian teeth of Pliocene age, and primitive shaped flints of the Lower Pleistocene. The unworn condition of the human remains suggests that the date is Pleistocene, not Pliocene, and the association with older mammalian relics accidental, but the similar staining of the human skull and the Pliocene relics is regarded as evidence for the older date.

\section{The Preservation of Fauna and Flora.}

It has long been acknowledged that in every part of the world the existing species of animals and plants are being sorely oppressed by man. Many species have become extinct within recent times, and the range of nearly every species is becoming restricted. It is no doubt part of a general biological process by which a dominant species, extending its range and becoming adapted to new and varied conditions, interferes with species already in possession. But man as a dominant species has a wider range and greater destructive powers than any of the lower forms. The danger of extermination presented itself in the most acute form with regard to well known game animals, especially in India, America and Africa, but is now being taken up on a wider basis. There is increasing evidence of a consensus of opinion throughout the civilised world that it is a duty of the present generation to preserve for the future all existing species that are not positively inimical to man. The late Lord Salisbury, so long ago as I 899, took an important initial step by arranging a convention of the Great Powers interested in Africa to consider the preservation of the "wild animals, birds and fish" of that continent. The scope of the agreement arrived at was practically limited to creatures of economic or of sporting value. Defining the number of each kind of game that can be killed, regulating the limits of size and sex within which it is permissible to shoot, or to sell the 
products of the chase, and the establishment of temporary or permanent reserved tracts within which the game may recuperate, have been the principal methods advocated and adopted. These methods, however, affect only an insignificant part of the existing species, and the absolute protection afforded to certain species often has led to harmful results, as it interferes with the balance of nature.

Opinion is moving more in the direction of the establishment in all suitable places of absolute sanctuaries where no animals or plants of any kind are allowed to be killed or taken, except for the direct advantage of the denizens of the sanctuaries, as for instance by the removal of noxious individuals, the controlling of species that are increasing beyond reason, and the extirpation of diseased and unhealthy individuals. The national parks of the New World are examples on a large scale. In the United States, moreover, chiefly by private munificence, a chain of small sanctuaries suitable for birds has been formed round the coasts. In Great Britain a new society was founded in ror 2 to educate public opinion and to endeavour to procure the formation of suitably placed sanctuaries and to arrange for their permanent preservation.

\section{Marine Plankton.}

"Pïlterism."-The greater number of marine species (see E. B. xxi, ;20 et seq.) are carnivorous, and the ultimate source of the food supply of the sea, besides its theoretical interest, may have an economic importance as bearing on the migration of pelagic fish. It has been supposed generally that the basis of the food supply consisted of microscopic plants, especially diatoms ( $E$. B. viii, I69 et seq.), which multiply in the presence of sunlight, building up their protoplasm from inorganic constituents like the green vegetation of the land. These are devoured by larger creatures, which in turn are preyed on by still larger animals. Professor Pütter, of Bonn, partly as a deduction from observations on the frequency of marine organisms, partly from examination of the contents of their digestive organs, and to a lesser extent on experimental work, has advocated the view that a large number of marine animals can obtain their nourishment directly from organic solutions present in sea-water, so living like many parasites in a nutritive fluid, or like fungi. So far, however, this view has obtained few adherents.

Artificial Rearing of Marine Larvae.-E. J. Allen and E. W. Nelson, working at the Marine Biological Laboratory at Plymouth since 1905 , have been investigating the methods of rearing the delicate pelagic larvae of marine animals. At an early stage they found it necessary to try to grow cultures of diatoms which should be either " pure," a result extremely difficult to obtain, or " persistent," by the latter term meaning a culture which can be carried on practically indefinitely by inoculating fresh supplies of sterilised water with the diatom required. Culture media, the basis of which is either natural or artificial sea-water, had to be sterilised by heat or filtration, and all the operations have to be conducted with bacteriological precautions. If normal seawater is the basis, the concentration of the nitrates, and probably also of the phosphates, has to be increased, and some further modification, the exact nature of which the authors have not yet discovered, has to be produced by treatment with peroxide of hydrogen or with animal charcoal. Light and temperature are extremely important, but the degree of salinity is indifferent within a wide range.

They have succeeded in making a very large number of persistent cultures on these line's. In the rearing of pelagic larval forms of marine animals, the young larvae are placed in pure, sterile sea-water, along with a culture of a suitable diatom to serve as food. As far as possible all other organisms are excluded from the vessels. To obtain the larvac, pieces of ripe ovary are taken from a female with sterilised forceps and are placed in sterile sea-water in a shallow glass dish, and then fertilised with active sperm from a ripe male. In a few minutes the eggs are filtered through silk and placed in larger vessels kept at a uniform temperature. In a few hours the healthy larvae rise to the surface and can be placed in still larger vessels, where they are fed with the culture found most suitable. The amount of food must be abundant from the first, but must be prevented from getting too thick in the water, by shutting off some of the light or by 
other suitable methods. In such a fashion very many delicate larvae of echinoderms and crustaceans have been reared:

\section{Heredity, Variation and Mendelism.}

The most active workers on all subjects connected with inheritance (see E. B. xiii, 350 et seq.) continue to be those who were stimulated by the rediscovery of Mendel's theories (see $E$. $B$. xviii, II 5 et seq.). On the experimental side their observations continue to increase in bulk, interest and importance. Biffen, for instance, has succeeded in producing a useful variety of wheat by crossing valuable wheats, liable to the attacks of rust, with less valuable but immune races, interbreeding the hybrids of the first generation, and selecting from their progeny a stock which combines the valuable qualities of the one set with the immunity of the other set. Other investigators have produced comparable results by other methods, but Biffen's work was prosecuted on the lines suggested by the followers of Mendel, and can be readily interpreted, as indeed Biffen interprets them, in the theoretical language of Mendelism.

From the point of view of theory, the sharp contrast with other views, which appeared to delight the Mendelian school in the early days of its exuberance, is becoming more and more blurred. It was urged, for instance, that Mendelian inheritance was almost a demonstration of the views of those who held that, because species are discontinuous, they had arisen by discontinuous variation (see E. B. xxvii, 906 et seq.). It now appears that amongst continuous variations some may be due to "fluctuation," and others may be Mendelian mutations. The argument from size of variation has gone, and with it the attractive suggestion of a causal connection between the discontinuity of species and that of variation. We are back to the theoretical position of Darwin, and have to make a choice, as he did, between the probability of the one set or the other being more important. Further experimental results have broken down the conception of the sharp contrast between "dominant" and "recessive" characters. If allelomorphs always exist in pairs, one possessing a factor absent in the other, the inheritance of colour does not fit the conception of dominance. It is supposed that the colourfactors stand in series, and that the presence of the higher member of a series obscures or prevents the development of a lower member. Thirdly, the Mendelian proposition that the members of an allelomorphic pair are completely segregated in the gametes, which was originally regarded as the distinctive feature of Mendelism, is breaking down. In some cases there is either incomplete segregation or even complete fusion of what were regarded as alternative characters, and if the conception of purity of the gametes is to be maintained, a new analysis of characters must be made.

It remains to be said, however, that by far the greater part of the modifications, attenuations and extenuations of the original theory of the Mendelians has come about not from the criticism of those who are hostile to their views, but as their own interpretations of the results they have obtained. They have found a new organon and are employing it to the lasting benefit of science.

(P. Chalmers Mitchell.)

\section{BOTANY ${ }^{1}$}

The past few years have witnessed important changes in the modes of the study of plants. Formerly direct observation was the means chiefly adopted in order to extend the fringe of knowledge, but at the present time, the method of advance by way of experiment has spread to almost every branch of the science, and the habits of thought thus induced are influencing the point of view even in departments from which the method itself is excluded from practice. Plant physiology from its inception has been avowedly experimental, but morphology and taxonomy are also yielding to a force which everywhere tends to render the too rigid ideas of a past time more fluid, and consequently more fitted to embrace the facts which a wider knowledge has disclosed.

Genetics.-The new science of genetics utilises plants no less than animals for its material, and is eminently experimental. The remarkable results which it has achieved

${ }^{1}$ See E. B. iv, 229 et seq. (and articless referred to, p. 302). 
are being illuminated by chemical investigations into the nature of the proximate substances which are becoming recognised as the agents responsible for some at least of the differences which separate nearly related forms. Mendelian analysis is proving a more complicated affair than many people at first anticipated, but the recognition that a character or a group of characters may require the interaction of two or more " factors" is a considerable step in advance. The researches on enzymes (especially the oxydases and peroxydases, specially investigated by Chodat and his school) in the determination of colour development and colour patterns are especially suggestive in this connection. Whiteness, for example, is a character which may be due to a variety of causes, in other words colour-absence is a term which includes more than one category. The development of a particular hue in the flowers of a considerable number of plants is recognised as depending on the simultaneous co-operation of several "factors " all of which must be present in order that the colour in question may be forthcoming, and in the absence of one or more of them the flower may be an albino or white. Oxydases and peroxydases above referred to, are known to play an important part in many of these colour productions. They clearly represent one of the factorial members of the complex, the others being made up of chromogens, substances ultimately derived, in all probability, from glucosides. But the matter is further complicated by the circumstance that whiteness may also result from the operation of a chemical "inhibitory" substance which arrests the colour production that ought to ensue from the interaction of enzyme and chromogen. The recognition of the influence of this factor, and especially its experimental investigation by Keeble and Armstrong, has served to clear away much that previously obscured the understanding of the occurrence and distribution of whiteness in flowers.

See M. Wheldale, "Plant oxydases and the chemical inter-relationships of colour varietics," Progressus rei botanicae, Bd. iii, 1910. Also Keeble \& Armstrong, papers in the Proc. Roy. Soc., vol. 85, 1912.)

Graft-hybrids.-Much light has, within the last few years, been thrown on the nature of the so-called graft-hybrids, especially by the work of E. Baur and H. Winkler. The general result of their investigations indicates that graft-hybrids consist of growths in which the cellular tissues of both stock and scion take a share, but the tissues, genetically derived from each of these two sources, however much they may be intermingled, remain organically distinct as far as the retention of their respective individual or specific characters is concerned. Sometimes the entire half of the "hybrid " shoot resembles one parent, while the other half obviously belongs to the other-or one (stock or scion) may be arranged so as to occupy a smaller sector of the shoot regarded in transverse section. These "sectorial chimaeras" are more easy to recognise than those belonging to the "periclinal" category. Periclinal chimaeras were first correctly explained by Baur, and arise when the tissues of stock and scion are so arranged that the one more or less covers the other in a concentric fashion. Although the apparent intermingling of characters especially in the periclinal chimaeras is sometimes intimate, it is to be understood that there is no fusion of the protoplasm of the composite structure of which the chimaera is made up. What has happened is the production of a sort of mosaic or interweaving of the tissues belonging to the respective constituents, each of which preserves its own characters intact, or only exhibits such modification as the correlative disturbance of nutritional conditions can effect. Thus it may happen, as in the wellknown example of Cytisus Adami, that the tissues of one of the two constituents may lag in development. The resulting shoot then resumes the habit and colour of the original constituent of which it is then composed, and if the separation has really been complete no reversion either to the hybrid form or to the character of the other constituent can or does take place.

Winkler, who has successfully produced a number of "graft-hybrids," clearly states that the two (o)-operating tissue systems of the respective constituents continue to retain their own specific characters. The composite organism is a mosaic of the cells and tissues of the grafted individuals only. In no instance (save in one doubtful one) does the union extend to a commingling of those finer elements which are ultimately responsi- 
ble for the adult characters of the future adult, even at the time when they are lurking within the confines of a single germ cell. Thus the difference between a "graft-hybrid" and a genuine hybrid is fundamental; the one depends on an accidental coalescence, as it were, of specifically distinct individuals, whilst the other owes its origin to the mingling of the parental characters in the germ cell from which it sprang. The example of Winkler's Solamum Darwinanum (hybrid) however may prove to be an example of a vegetative fusion of the nuclei of stock and scion since the number of its nuclear chromosomes is intermediate between those of the two parent plants.

See Baur, E. Einführung in die experimentelle vererbungslehre (Berlin, I I I I), a good account of the subject of graft-hybrids and also of other developments in genetic science; H. Winkler, 1907, Ueber Propfbastarde v. Pfanzliche Chimaren (Ber. d. Deutsch. Bot. Gesellsch., Bd. xxv). Winkler has published a number of more recent papers, and his larger work entitled Untersuchungen ueber Propfbastarde is in course of publication by G. Fischer, Jena.

Ecology.-Another modern development of botany, ecology, consists in the endeavour not only to systematise the older " Natural History." observations, but to utilise and extend them so as to throw light on the causes which underlie and determine the grouping and mode of distribution of the plants within a given area. This study is being prosecuted with vigour, especially in Great Britain and in America. So far as the former country is concerned the recent work has been brought together in A. G. Tansley's Types of British Vegetation. A considerable amount of experimental work has also been undertaken with the object of unravelling the relation between the plant and its surrounding, especially the soil conditions. Perhaps the most important of these results consists in the recognition of the importance of the physical and physico-chemical factors involved. The determination of the "wilting coefficient" by Briggs and Shantz has thrown light on the question of water availability of different soils. The percentage of moisture in the soil which is just below what was required to maintain the turgidity of the plant (" wilting coefficient ") varies definitely in different classes of soil according to its physical state of aggregation. This has of course long been known. They ascertained that if samples of these different soils, saturated with water, are placed in a centrifugal machine and the speed is so arranged as to exert a centrifugal force of $\mathrm{I}, 000 \mathrm{~g}$, that the percentage of water which they respectively retain (" moisture equivalent ") by virtue of absorption or surface tension, stands in a practically constant relation to the wilting coefficient, and they express this numerically by stating that within a very small margin of error, the ratio $\frac{\text { wilting coefficient }}{\text { moisture equivalent }}=\mathbf{1 . 8 4}$.

The ecological causes which determine the distributions of plants are not only physical but biological and are still for the most part obscure. Investigations, both in England and especially in Canada, have shown that grass is injurious to young apple trees, but a satisfactory and complete explanation of this has not so far been given. Indeed the mutual reactions of organisms provides a field for investigation as yet largely open.

Many of the supposed examples of symbiosis between plants and animals (e.g. ants) have not stood the test of investigation. - In the pitchers of nepenthes Jensen found living larvae of 9 species of insects which pass their laval period in these receptacles. They contain " anti-ferments," which render them immune to the action of the nepenthes digestive ferment, apparently in much the same way as intestinal worms escape digestion in the gut of their animal hosts, In such an example of course the grubs are utilising for their own purposes the animal food which, collected in the pitchers, would after digestion otherwise have become available for the plant.

See Briggs and Shantz, two papers on "Wilting Coefficient" in The Botanical Gazette, vol. liii, 1912; A. G. Tansley, Types of British Vegetation, Cambridge, I91 I; A. D. Hall and E. J. Russell, A griculture and Soils of Kent, Surrey and Sussex, Board of Agriculture \& Fisheries, London, igit.

Cytology.-One of the outstanding results of cytological research which has stood the test of criticism consists in the recognition of the importance of the chromosomes. These bodies are commonly very constant, both in form and in number for a given 
species, and as is well known they are doubled at every act of fertilisation and again reduced at some definite stage which intervenes between this act and the formation of new germ cells. But several instances are known in which the chromosomes appear to behave differently as regards their numerical constancy. Thus in the hybrid races of Primula Kewcnsis and in certain œnothera mutants the numbers normal for the parents are doubled, and in this duplicated fashion the corresponding numbers are retained during the succeeding generations. Moreover when again crossed with forms typical as regards the nuclear constituents the œnotheras at least behave in a manner different from that which the investigations of Rosenberg on Dorsera would lead one to expect. For at meiosis the chromosome number does not correspond with, but is as nearly as may be intermediate between, the two forms which are numerically different, as Gates, Geerts, and others have shown.

Opinions still differ widely as to how the chromosomes derived from the one parent normally pair with those originating from the other at meiosis, although nearly all investigators are united in concluding that such union actually does occur. There is almost overwhelming evidence to show that the chromosomes retain their physiological identity through the so-called resting periods of the nucleus, though they cannot then be structurally distinguished by any methods at present known to us. Furthermore that even during this period they have already passed through changes which culminate in their longitudinal fission at the next mitosis. It is not possible at present to explain at all fully either the meaning of this, or the mechanism by which it is effected. Formerly it was held that the chromosomes might themselves represent or be directly responsible for the production of the distinctive character of a species or variety. Further investigation has shown this to have been too crude a view, and although the chromosomes are almost unquestionably associated very intimately with the transmission of hereditary qualities, their precise relation in this respect still remains to be discovered. The principal evidence on which their claim to importance in the hereditary transmission of characters depends consists in (I) the exactitude with which the chromosomes are distributed between the sexual cells (and also between the cells of the whole body), (2) the probability, almost amounting to certainty, of their physiological permanence throughout the life cycle of an organism, (3) the paired arrangement which subsists between the chromosomes derived from the maternal and paternal parent respectively within the cells of the offspring, and the alternative distribution of the individuals of each pair between the sex cells to which this offspring may give rise, (4) the general harmony which exists between the results of such distribution and those observed to obtain in the breeding of hybrids and their descendants, (5) the remarkable discoveries by zoologists, and especially by E. B. Wilson on the existence of an " odd chromosome " and its distribution at meiosis among the germ cells. It is almost impossible to escape the conclusion that in this "odd chromosome" (to which many names have been given) we are witnessing the agent that is concerned in the determination of sex.

Němec and others have invest igated the effects of drugs on dividing nuclei. Chloral, for example, interferes with the completion of the process, and division of the nuclei may not be followed by division of the cytoplasm. When, as often happens, the nuclei resulting from this imperfect division subsequently fuse with one another again, the large cells in which this has occurred can readily be recognised by their larger nuclei. In fact the $\mathrm{K}-\mathrm{b}$ relation insisted on by Hertwig is very obvious. Such cells may continue to divide and contribute to the formation of the tissue in which they lie, and they retain their size characters as well as the increased number of chromosomes. Nermec further showed that a corresponding increase of chromosomes might be produced in the haploid gametophyte of Larix without influencing the prothalloid character of the cells. This is, of course, in accordance with the observations made by Farmer and Digby on aposporous fern prothallia as well as with those of El. and Em. Marchal on mosses. The enlarged cells tend to disappear during the further growth of the organ (commonly the root) in which they were induced to form. Nermec believes this to be effected partly by suppression of cell division, and consequently obliteration, partly by a "heterotype" 
or reduction division similar to the first one which occurs in ordinary meiosis. Further observations by others have, however, not confirmed the latter view.

A considerable literature has appeared in connection with the enigmatical bodies known variously as chondriosomes, nutochondria and chromidia. Probably a number of different substances have been confused, and whilst the chromidia proper appear to represent true nuclear constituents scattered in the cytoplasm, the significance of the rest is as obscure as their origin is uncertain:

See L. Digby, "The Cytology of Primula Kewensis" (full citation of literature), An. of Bot. 26 (1912); B. Němec, Das Problem der Befruchtungs vorgänge v. andere zytologische Fragen, Berlin, I9IO; H. Kemp, "On the Question of the Occurrence of 'Heterotypical Reduction' in Somatic Cells," Annals of Botany, vol. 24 (1910) El. \& Em. Marchal, A posporie et sexualité chez les mousses, Bull. Acad. Roy. Belgique (I9II); E. W. Schmidt, Pflanzliche Nutochondrien Progressus rei botanicae, iv (I9I2); E. B. Wilson, papers in the journal of Exp. Zool., Baltimore, from 1905 onwards.

Physiology. - Considerable advances have been made in our knowledge of protoplasm in relation to its permeability to substances in solution. Czapek especially has devised ingenious experiments which indicate that surface tension plays an important part in permitting or restraining the passage of solutes through plasmatic membranes. He finds that the semipermeability of protoplasm is one of the results of its surface tension properties, and has succeeded in showing that its value, as compared with the surface tension of water, is 0.68 . Any substance, in a concentration sufficient to lower the surface tension of the water in which it is dissolved to 0.68 will abolish the semipermeability of the protoplasm, and its contents will consequently stream out into the surrounding watery medium in question. There are strong grounds for supposing that the low surface tension of protoplasm is to be attributed to the presence of fatty bodies in a state of emulsion, these being necessarily distributed in the surface film, though not of themselves constituting the whole film in the sense of forming a fatty pellicle such as some have assumed to be present. This view renders it possible to account for the passage of salts in solution into the cell, a point which presented difficulties under the older lipoid theory of Overton, whilst it is in harmony with the fact that narcosis is produced, with great quantitative exactitude, by substances which dissolve the fatty constituents of the film. Exosmosis then is a physical consequence of immersion in any liquid the surface tension of which is 0.68 or less, but it may also be produced chemically by other substances, irrespective of their surface tension attributes, if they are able to attack and destroy the physical character of the protoplasm by combining with any of its constituent substances. Thus a poison may destroy life either by removing the conditions under which the contents of the protoplasm can be retained within the cell, or by destroying the organisation of the essential substance of which the cell consists, i.e. the protoplasm itself. Other important investigations bearing on the semipermeability of protoplasm and its abrogation have been conducted by Lepeschkin, and the results arrived at, though differing in detail, are not very dissimilar to Czapek's. Lepeschkin is inclined to agree with Overton in attributing to lecithin the role played by the lipoid, whilst Czapek regards a neutral fat (which irrespective of the amount present has the surface tension of 0.68 ) as being the substance more probably concerned. However this may be the recognition of the importance of surface tension in the whole matter certainly constitutes one of the most important advances made in our knowledge of protoplasm within recent times. Not only is it susceptible of quantitative analysis, but the suggestive speculations and researches which it opens up can be similarly checked and controlled.

Observations made in connection with root pressure and kindred phenomena appear to indicate the existence of a difference between the plasmatic membrane on the side of entry and of exit of a cell as regards its fluid sap. This especially affects the cells abutting upon the vessels and trachaeids of the primary wood of the young root. Lepeschkin in 1906 brought forward strong grounds for believing that a difference of this kind was accountable for the excretion of water from the surface of the sporangiophore of Pilobolus, one of the mucorine fungi. It appears difficult to resist the conclusion that a 
rhythmically recurrent alteration of this kind in the root-cells concerned is responsible for the flow of sap produced as the result of what is termed root pressure. The investigations of Adrian Brown have shown that grains of barley and other cereals possess in the dead cell layers of the pericarp a membrane which is semipermeable, and in this respect it recalls some of the physical properties of plasmatic membranes. If grains of barley are steeped in dilute sulphuric acid for example the water is able to pass through and swell the grain, but the acid is excluded. This will continue till a high degree of concentration of acid is produced such as would at once prove fatal to the living cells of the grain if they were directly exposed to its action. The membranes of certain fungi, e.g. Penicillium, have long been known to possess this property of semipermeability in a striking degree, thus accounting for the frequent development of the mycelium in solutions containing copper sulphate, sodium arsenite, and other poisonous substances.

The effects of temperature are of importance in influencing the rate at which chemical change occurs in the plant. They are complicated however by the invariable collateral action of other factors. They have been observed to accord with expectation in experiments which can be carried on in vitro, as for example in the study of enzyme action. But within the organism the events are more complex. Attempts to investigate the curious results of the effects of cold in retarding plants, and of a temporary immersion in a hot bath for forcing them into premature flowering have not as yet yielded conclusive results. Muller-Thurgau, who has recently investigated this subject, many years ago ascertained the fact that cooling potatoes to about $32^{\circ} \mathrm{F}$. led to the conversion of starch reserves to sugar, and that on raising the temperature increased respiration follows, some of the sugar undergoes reconversion to starch, but other changes also go on which render the potatoes unpalatable. Perhaps there is a resemblance here to the modified chemical change which was observed some years ago by Overton in the leaves of frog-bit (Hydrocharis) and other plants, when they were exposed to full light and low temperature; that is, to conditions under which photosynthesis was possible, but under which the means for the removal of the products of photosynthesis, either by translocation or by conversion to starch, were inadequate. The consequent abnormal concentration of sugars leads, under such circumstances, to the formation of glucosides and colour bodies characteristic of individual species of plants.

In plant metabolism important advances have been made by F. F. Blackman and his school, particularly in the processes of respiration and photosynthesis. A more complete analysis of the events included in photosynthesis has shown them to be more complex than they were formerly thought to be, and that whereas it is pretty certain that light is concerned in preliminary analytic effects, it is by no means so sure that it determines the subsequent syntheses that culminate in the production of carbohydrates. As a lateral extension of the study, particularly of the conditions that affect the metabolic processes here alluded to, a considerable clearing up has ensued of the obscurity that lurked in the old terms optima and minima. It has become recognised that any metabolic reaction (in the widest sense of the term) of plants is the net result of the interaction of a varying number of different factors. The word "optimum " therefore is not only without definite meaning, but is actually misleading, inasmuch as if used in a quantitative sense at all it entirely fails to recognise the limiting influence on a reaction which is imposed by new conditions. Thus the quantity of carbon dioxide that can be utilised in a given time by a given plant is not a necessarily constant quantity, but is affected by conditions of temperature and of illumination, and these two factors are in turn susceptible of modification in their results by others.

Many of the so-called vital processes of cells have resolved themselves into reactions that can be conducted in vitro, and especially is this true of reactions in which enzymes take a part. Unfortunately no enzyme has been prepared as yet in the pure state. It is always associated with extraneous, generally albuminous, matter, and it cannot be regarded as cert ain that each enzyme is to be considered as a specific and separable substance in the ordinary meaning of the word. The number of different enzyme actions is very large, and is still increasing, and while it is true that so far as we know at present 
each fermentable substance is only affected by its own particular enzyme this does not settle the question as to whether these bodies may not be resolved into fewer substances each more or less protean in form. For it appears to be tolerably certain that enzymeaction in general is a function of the surface properties of the substances which are responsible for its occurrence. It may happen (and often does) that the enzyme is located in more or less specialised cells adjacent to, but not identical with, those which contain the fermentable material, and in some seeds and fruits the two classes of substance may eyen be contained in quite different tissue systems. $\mathrm{H}$. E. Armstrong's investigations also show that there may exist a considerable range of variation in the accompaniment of enzyme and glucoside in nearly related varieties and species of plants. The glucoside may be very scarce, with a minimal quantity of the enzyme, or while the latter may be abundant the glucoside may be lacking. The suggestive bearing of such observations on the chemical differences between species is obvious, and the matter has already been referred to in connection with the colour inheritance of plants: of hybrid origin.

An excellent résumé of the physico-chemical aspect of plant physiology, and especially of respiration in its relation to fermentation, is given in Palladin's Pflanzenphysiologie, Berlin, I9I I, also Jost, Vorlesungen $\ddot{u}$. Pflanzenphysiologie, 2te aufl.; H. E. \& E. F. Armstrong, series of investigations on ferments in recent vols. of the Proc. Roy. Soc.; F. F. Blackman, numerous papers in the Phil. Trans. Roy. Soc. dealing especially with photosynthesis, and articles in recent volumes of. New Phytologist; F. Czapek, Ueber eine methode zur direkten Bestimmung der Oberfächenspannung der Plasmahaut von Pflanzenzellen, Jena, I9I I, and Chemical Phenomena in Life, London, $19 \mathrm{I}$; W. W. Lepeschkin, "Ueber die einwirkung anæsthesirende Stoffe auf d. Osmo. Eigenschaften d. Plasmamembran," Ber. Deut. Bot. Gesellsch., Bd. 29, I9II.

Angiosperms.-Although the past few years have produced no very startling changes in the views entertained as regards the phylogeny and interrelations of the angiosperms, several important works have appeared which continue to voice the divergent opinions entertained on these questions. The point of view adopted depends largely on the value placed on different criteria. Thus whilst Wettstein regards the Monocotyledons as having arisen from Dicotyledons viâ the Ranales and Helobiae, Lotsy in his large work, still in course of publication, while admitting the probability of this view for one group of Monocotyledons, considers the whole class as at any rate diphyletic. He sees a second point of contact, through the aroids, with the Dicotyledonous piperales. In this he is supported by some American writers who have approached the matter from another, the embryological, side. Lotsy goes further than many systematists will follow him in deriving the Dicotyledons, through the magnolia-like forms, from the fossil gymnosperm type of Bennettites. Most authorities are inclined to look with scepticism on a supposed origin of the angiosperms from any gymnospermic ancestors at present known to us, and the recent discoveries of angiospermic remains of a highly organised type in the Lower Cretaceous rocks adds weight to the negative position. For the plain indication is that the angiosperms were already a flourishing family even at the time when the Bennettiteae were in their prime, whilst evidence from other sides points to the conclusion that the importance of this group of fossils may easily be overestimated in framing large phylogenetic schemes.

Gymnosperms.-Considerable attention has been focussed upon the gymnosperm ever since the discovery of motile antherozoids, first in Ginkgo and subsequently in the Cycads. The study of the fossil seeds, and of the Bennettitian remains in America have further added to and consolidated our knowledge of a group which is now perhaps better understood than most of the other important sections of the vegetable kingdom. A very large share in the elucidation of the structure and development of individual living species has been undertaken by American botanists. The results of modern investigations have been well brought together by Coulter and Chamberlain in their recent volume on the gymnosperms. Still more recently, the thorough study of the morphology of the Podocarpoid alliance has cleared up much that was obscure in this important group of genera; and has thrown light on their relationship with the cone bearing species of gymnosperms. 
The mesozoic group of cycadophyta has become better known, and its range greatly extended, the researches especially of Seward, Nathorst, Wieland and others have served to show that the Williamsoniae were a very important and generalised group, of which the Bennettiteae, which formerly loomed largely in our outlook over these ancient forms, really only represented a somewhat specialised family. The strong anatomical evidence adduced by Scott and others as indicating the affinities between the Pteridosperms and Cordaitales of the palaeozoic period continues to receive. fresh support, and the linking up of that ancient plexus with the more modern gymnosperms, especially with the Cycadean alliance, has been made clearer by the investigations of Oliver upon the structure of several important Pteridosperm seeds.

Vascular Cryptogams. - In the domain of the Vascular Cryptogams the principal accessions to recent knowledge have come from the palaeontological side. One of the most important series of investigations is that of Kidston and Gwynne-Vaughan on the fossil Osmundaceae, the general result of which has been to link up this group with the palaeozoic primo filicean series. Considerable contributions have also been made by P. Bertrand, W. T. Gordon and others to our knowledge of the anatomy of the ancient Pteridophyta, and to some extent they tend to rehabilitate the importance of the palaeozoic ferns. Furthermore, the brilliant discoveries of Count Solms have conclusively demonstrated the true nature of the well-known and remarkable structure of the Psaronius root sheath. One result of Count Solms' researches, however, is somewhat to weaken the security of the foundations on which the ideas as to the systematic position of this group have been built up. For further information on recent work on the anatomy of fossil fern-like plants reference may be made to the excellent summary given by $\mathrm{P}$. Bertrand in the Progressus rei Botanicae, vol. iv (L'étude anatomique des Fougères anciennes et les problèmes qu'elle soulève), where the modern literature is fully cited.

Fungi, Bacteria.-Amongst modern advances of knowledge of the fungi perhaps the chlef point of interest is centred in the ascomycetes, concerning the fructification of which the views are still very divergent. Claussen has recently adduced strong evidence to show, in the forms studied by him, that no fusion of sexual nuclei occurs in the ascogonium, but that the fusion which takes place in the young ascus is, as Dangeard maintained, to be interpreted as the real sexual act. The cells of the ascogenous hyphae contain two nuclei apiece, which may represent either morphologically, physiologically, or both, the sexual nuclei which still remain separate but divide in pairs as they do in the uredineae after the nuclear approximation has occurred in the hyphal cells. It is not until the ascogenous hypha reaches its final stage, and bends over in the well-known hooklike manner that nuclear fusion occurs. The penultimate cell is observed to contain two nuclei, whilst the terminal one and the antepenultimate one have only received one apiece. The ascus is formed from the binucleate penultimate, and the previously distinct nuclei which, though in juxtaposition, have remained separate in descent finally fuse. This account is very different from that given by other competent investigators. But it is alluring, and has been worked out with great skill. The matter urgently needs to be settled as it affects not only our views as to the nature of the ascus, but also the morphology and affinities of the whole of the ascomycetes to other groups of fungi. The main lines of advance in the fungi myxomycetes and bacteria (apart from the physiology of the latter) is along cytological lines. The last have been carefully studied by Dobell (Quart. Journ. Micr. Sci., vol. 56, ro1 1), who believes that they are all nucleated organisms, but that these nuclei may be of "chromiclial " nature (i.e. granules scattered through the cytoplasm) whilst they may be filamentous or of spherical form in other species. It would seem that the actual nuclear character may differ in some of the bacteria at various stages of the life history.

The most recent studies of Jahn render it almost certain that reduction (meiosis) in the myxomycetes occurs at spore formation. He adduces evidence to show that conjugation occurs during the initial stages of plasmodial formation. and when this has occurred the new plismolium treats the non-conjugated amocbiform myxomycete 
individuals; as well as those which are still swarming, as foreign bodies, ingesting and devouring them instead of admitting them into the plasmodial organisation.

The nuclei of myxomycetes and of the fungi resemble the nuclei of higher plants, and in those which have a known sexual phase nuclear meiosis is intercalated at some stage in the life history.

See W. Bally, "Cytologische studen an Chytridineen," Prings. Jahrb., Bd. 50 (I9I I); Claussen, "Zur entwicklungsgesch. d. Ascomyceten," Zeitsch. für Botanik, Bd. iv (I9I2); J. H. Faul, "The Cytology of the Laboulbeniales," Annals of Botany, vol. 25 (I9II); E. Jahn, "Myxomycetenstudien," 8, Ber. Deut. Bot. Gesellsch,, 25 (I9II); A. Meyer, Die Zelle der Bakterien, (Jena 1912), a useful summary of our knowledge of the bacterial organism.

(J. B. FARMER.)

\section{ANTHROPOLOGY}

\section{Physical Anthropology. ${ }^{1}$}

I. Fossil Man; Homo Primigenius.--In the course of the last five years, additions of exceptional value have been made to the stock of material evidence bearing on the characters of early prehistoric man. The outstanding general result consists in the complete recognition now accorded to the remains of Homo primigenius as a distinct type differing from all others whether prehistoric or modern. Prior to the finding of the Piltdown skull, late in I9I2 (see under BIology above), the discoveries of greatest importance were made in France and Germany, ${ }^{2}$ and their significance may be summed up as follows.

For many years the skeleton from the Neanderthal (E. B. xix, 32I) remained almost isolated. The fossil jawbone from La: Naulette (Belgium) and the Forbes Quarry skull (Gibraltar) had been in evidence almost as long, but the former is but a small fragment, and the importance of the latter was neglected or ignored. Moreover the real significance of the Neanderthal skeleton was a subject of speculation, owing partly to the lack of precise information as to its exact surroundings. Thirty years after that discovery, the announcement that skeletons of comparable form had been found near Spy in Belgium ( 1887 ) restored the Neanderthal man to prominence, and revived all the interest of this department of prehistoric anthropology.

Yet another decade had to elapse before the Krapina specimens were added (I899) to the list, though in that interval Professor Dubois had made his wonderful discovery of Pithecanthropus at Trinil in Java ( 1892 ). The site at Krapina (in Croatia) continued. to reward the labours of Professor Kramberger until 1905, but from other regions no further records of importance are to be noted before the year 1907. From that time onwards, additional evidence has accumulated, and it is fair to say that if the Trinil fossils be excepted, the finds of the last five years are of more importance than the sum total of those made during the preceding half-century. Thus between I007 and the finding of the Piltdown remains the following examples were placed on record: (a) The fossil jaw from the Mauer sands near Heidelberg; (b) The skeleton from the Moustier in France; (c) The skeleton from La Chapelle-aux-Saints (France); (d) The fossil teeth from S. Brélade's Bay (Jersey); (e) The skeleton from La Quina (France); (f) The three skeletons from La Ferrassie (France).

The Mauer jaw claims by far the greatest interest of these specimens, and it was equalled indeed up to I I 2 by the Trinil fossils alone. With the exception of the Mauer jaw, the remaining "finds" are unhesitatingly referable to one and the same type, viz. that of the men of the Neanderthal, Spy and Krapina. The details upon which this conformity is established are accessible in the exhaustive accounts furnished by Professors Boule, Schwalbe, and Klaatsch, and it will suffice here to note that the advent of the new material is not merely confirmatory of views based upon the earlier finds, for it supplies information on numbers of details which were previously unknown. Thus the osteological characters of Homo primigenius can be illustrated now by a wealth of material which is almost comparable to that available for such extinct animals

1 See E. B. ii; 108 et seq.; and allied articles (see E. B. Index Volume, p. 883).

${ }^{2}$ Duckworth, Prehistoric Mun, 1912 (for a general review and bibliography). 
as the Tertiary ungulates of North America. Consequently, an ideal long cherished by students of human palaeontology seems to approach the point of realisation.

The new discoveries present still another feature of note, viz. the completeness and precision of information in regard to their position and surroundings when first exposed. In this respect also they far surpass the earlier examples, and their value in evidence is enhanced correspondingly.

From all this it results that the type of the Neanderthal man is now recognised as distinct, if not literally "specific;" in point of duration this type is shown to be remarkably limited, for it is especially characteristic of the period known as the "middle Palaeolithic" one. Ep to December I9I 2 no definite evidence was on record to show that this type as such was present either before or after that division of the Palaeolithic period. Although distinguished thus, the type of Homo primigenius is quite definitely human, and the problems of its precise relations to other human types, and of its origin and evolution; still remain to be solved.

2. Significance of the Mauer and Trinil Discoveries. - In relation to the whole question of the evolution of man, the Mauer jaw, together with the Trinil fossils, stands in a distinct category and transcends in value all other known. relics of the kind. It will suffice here to recall the general result of the discussions raised by its discovery and by its anatomical conformation. The title of Homo heidelbergensis, conferred on the skeleton by its discoverer, indicates that on the whole it apprcaches the human rather than the simian type. Yet the precise relation of $H$. heidelbergensis to $H$. primigenius and $H$. sapiens is still an open question. Most probably we have to deal here with an example of a collateral stock, but it is fair to regard the jaw as a piece of material evidence as to the conformation of an early human ancestor.

On the assumption that the Hominidae and the Simiidae (anthropoid apes) are derived from a common ancestral stock, the particular ancestor indicated by the Mauer jaw should be placed close to the point at which the human line (or lines) diverged from the simian line of descent. But the expression "close to " needs further qualification, for even thus three possibilities are evidently open, and all conform to that description. In fact, the exact point in question might be, (a) on the undivided line before the point of division, (b) on the simian line of descent, (c) on the human line of descent. The evidence of the Mauer jaw indicates a stage on the human side of the point of divergence, i.e. the position described here as (c).

We come now to the problem of the relation of Homo heidelbergensis (Mauer) to Pithecanthropus, the famous fossil specimen from Trinil in Java. The latter is to be regarded likewise as indicating the former existence and the osteological characters of another ancestral stage in human evolution. And like Homo heidelbergensis, again the Javanese form suggests a stage close to the parting of the ways just mentioned. No strong osteological evidence forbids the close association of the Mauer fossil with those of Trinil. But a difference is claimed to exist in the geological horizons of the respective deposits which yielded the specimens. In any case the difference is not very great; the recent work ${ }^{1}$ of the Selenka expedition to Trinil tends to reduce the interval, and further research may show that the geological evidence is less decisive than would appear on the claims now made for it.

The report of the Selenka Trinil-Expedition records also the finding of a tooth of human aspect, said to be derived from a geological deposit more ancient still than that which yielderl the remains of Pithecanthropus. The discovery is thus of the highest importance; for if this claim is substantiated, it would appear that a fully-evolved human being existed in Java before Pithecanthropus. The tooth from Sondé (a locality not far from Trinil) challenges therefore the most searching criticism. If this be applied, the evidence will be found lacking in completeness, so that no firm or final conclusions can be based upon the specimen.

3. Results as Regurds the Antiquity of MIn.-One general result of all the discoveries is to strengthen the demand made in certain quarters for increasing the antiquity of 'Selenka, Die Pithecanthropus-Schichten auf Java, 19I r. 
man, for assigning a date in the Pliocene epoch to even the later stages of human evolution, or for referring that phenomenon to a time still more remote. The former existence of a distinct type of mankind, Homo primigenius (neanderthalensis), is now firmly established. Yet as regards his forbears and associates, the evidence even now available leaves much desired. The characters of Homo primigenius provide many suggestions, but material confirmation in the form of actual specimens is limited to a few fragments. On the theory of evolution, the former existence of a primitive type such as Homo primigenius is in accordance with expectation. It is also reasonable to suppose that this primitive type was once the sole representative of humanity, unaccompanied by: any form more highly evolved. But doubt still persists as to whether the Homo primigenius known to us (through the various remains enumerated above) was always actually unaccompanied thus, even though it would seem that he alone was present in a particular period (that termed " middle Palacolithic"). Claims continue in fact to be made on behalf of the recognition of the equal, and indeed of the greater, antiquity to be assigned to another form of man, a type indistinguishable in essentials from that of the highest modern human beings.

Weak though such claims may be considered, they cannot be ignored. If admitted, they have the effect (in the present connection) of relegating the time of what may be termed the active evolution of the higher type of mankind, to a period so remote as to be almost incredible. Advocates of the greater antiquity of the higher types of man incline to regard Homo primigenius as a lingering representative of his kind. They do not agree as to his ultimate fate, i.e. whether the type died out, or, on the contrary, entered into a composite form which is represented in modern populations. Professor Klaatsch in particular holds that the primitive race was subjected to an invasion by representatives of higher type, and that the man of Aurignac provides a representative of the latter. Upon such assumptions, a far-reaching theory of the collateral development of two human stocks has been erected. A contrast of the Homo primigenius (of "African" affinities and origin) with the $H$. aurignacensis (of "Asiatic" relations) was instituted first (I909) on the examination of the fossil remains in each case respectively. Undismayed by the general disapproval with which this view was received, its author did not hesitate. ${ }^{1}$ He extended the contrast to the existing races of man, and from the bones of the skeleton to the brain (I9II). It will be interesting to learn whether the later extension can survive the crushing rejoinder which it has just elicited from an expert in cerebral anatomy (IgI2).

But the fate of such theories is after all of subsidiary interest. The evidence remains for what it is worth, and the essential evidence here in question is that on which are based claims of the modern type of human skeleton to great antiquity. For eighty years past, since Schmerling unearthed the celebrated Engis skull, records will be found of the renewals of discoveries of highly evolved human remains in suspicious association with animals now extinct, or at least unknown in European surroundings or a climate corresponding thereto. Nor are the records confined to caves, for many examples occur in widespread deposits considered on other grounds to have been laid down before the advent of the earliest human beings. In England, the specimen known as the Galley Hill skeleton furnishes a good example of this class of case, but suspicion has not yet been finally allayed concerning the exact circumstances of its discovery. A much more recent instance, viz. the skeleton found in IgI n near Ipswich, ${ }^{2}$ deserves very special mention. The bones in question were found beneath a stratum of boulder clay, and in fact at the horizon where this stratum overlies the so-called middle glacial sand deposit of the locality. The skeleton does not differ in essentials (with one exception, which does not however approximate it to any other known human type) from the most recent human forms. If it was deposited in situ before the advent of the boulder : clay, the specimen establishes the existence of a

${ }^{1}$ Klaatsch, Korrespondenzblatt der Deutschen Gesellschaft für Anthropologie, Ethnologie und Urgeschichte, in the Archiv für Anthropologie, I9I I, s. 84.

${ }^{2}$ Prehistoric Society of East Anglia, Annual Report, I9I2. 
highly evolved human type at a time much more remote from the present than is the middle Palaeolithic period, with which it has been noted the type of Homo primigenius is almost exclusively associated. But it is possible that the skeleton lay in a grave dug through the boulder clay, and extending (perhaps accidentally) just to the level of the upper surface of the underlying sand. Two problems, one geological, and a second which may be described as archaeological, are therefore presented by the discovery of the Ipswich bones.

On the geological side, it is believed that the crucial questions in dispute are, (I) Whether the boulder clay of the locality is identical with the widely-distributed stratum thus designated by geologists, (2) Whether the boulder clay was deposited under circumstances admitting of the preservation of the bones in close association and contact during that process, and lastly (3) Whether the local clay may not have been derived secondarily and comparatively recently from similar but adjacent material in such a way as to conform to the conditions suggested under the heading No. 2. The answers to the questions thus posed are conflicting, and the weight of authority is divided with remarkable evenness. It is appropriate therefore to recall the comment made in reference to such instances by Huxley, and to realise that on neither side is the evidence of an absolutely conclusive nature. But the validity of the claims pressed on behalf of the Ipswich bones will be affected also by the archaeological evidence. And in particular it is necessary to exclude as far as possible the question of an interment. For the latter might own a comparatively recent date. Again the evidence is not decisive in either sense, and it will thus be observed that if the claims to high antiquity have not been established satisfactorily, neither has the refutation of those claims been completely demonstrative. Consequently this instance, even if held in reserve, must be reckoned with in any discussion of human antiquity in general.

It is permissible to recall in this connection the claims now advanced in favour of the greater antiquity of the higher types of mankind, and based upon observations in another department of archaeology, viz. that which deals with the evidence provided by flint or other imperishable implements. The flints discovered below the Red Crag in Suffolk ${ }^{1}$ supply evidence distinctly in favour of the possibility of man's existence in the Miocene epoch if not even earlier. The suggestion is not novel, for Dr. Wallace ${ }^{2}$ advanced it distinctly more than fifty years ago. But however willing we may be to entertain such views, our adoption of these must depend after all upon the evidence. Unfortunately the palacontological record is still imperfect, at any rate so far as our museums are concerned. From Pliocene strata the only known specimens that possess a claim to rank as a human form is Pithecanthropus, and both the antiquity and the rank of this fossil have been disputed. With regard to the anthropoid apes it is otherwise. Many years ago, remains of a fossil form of anthropoid ape (Dryopithecus) were discovered in France. They occurred in strata considered then to be of Miocene age but now referred by some geologists to the subsequent Pliocene epoch. Later discoveries were made in India, and quite recently (IOII) the officers of the Indian Geological Survey have added considerably to the number of anthropoid apes found in that region. ${ }^{3}$ No fewer than four kinds of these apes are recognised now as having existed in the Pliocene epoch. They correspond, however, to the four existing kinds of anthropoid apes, being nearly if not quite so highly developed as these. Consequently it is not altogether reasonable to claim them as forms ancestral to the existing species, though they may serve to indicate some of the characters of those ancestors.

But a recent discovery of even greater interest is announced from Egypt. 4 There have been found in the Oligocene strata of the Fayum district, remains of monkeys, including a fossil remnant at tributable to a gibbon-like anthropoid ape. This Oligocene

${ }^{1}$ Lankester, Philosophical Transactions of the Royal Society, Series B., vol. 202, 1912.

${ }^{2}$ A. R. IVallace, Anthropological Review; Journal of the Anthropological Society, I864, p. clxvi.

${ }^{3}$ Pilgrim, Records of the Indian Geological Survey, 1910.

${ }^{4}$ Fraas, Korrespondenzblatt, etc. (cf. under Klaatsch), s. I9I, I9II; Schlosser, Beiträge zur Paläontologie und Geologie Oesterreich-Ungarns und des Orients, xxiv, s. 51, I9I1. 
Egyptian ape is considered to stand in an ancestral relation to another form called Pliopithecus, found in Germany and assigned to the Miocene epoch. And consequently each stage of the Tertiary period, from the Oligocene division onward, is now seen to possess one or more representatives of these animals. Moreover the oldest fossil form has at least a claim to represent an ancestor of some of the later types.

The precise bearing of these palaeontological discoveries upon the question of man's antiquity is by no means slight, yet it may be overlooked. The observations suggest that the various types of anthropoid ape were already and definitely divergent from each other even in late Miocene times. Such early divergence among the apes lends colour to the view that by that time the human line of evolution had become detached from the earlier common ancestral path. The most recent investigations into the characters of the brain in man and the higher mammals (including the apes) bring in confirmatory evidence from the side of comparative anatomy. Yet however clear the inference may seem to be, it is still a matter of presumption so long as we lack fossils which can be regarded confidently as having figured in the direct line of human descent. It may be too much to expect that the actual remains should be found; but in the absence of such fossils from Miocene strata, it is impossible on palaeontological grounds to say how far man had advanced in evolution by the commencement of the Pliocene epoch. Nothing is known of the speed with which the various possible phases were traversed, and yet the question of the rate of progress is all-important.

Where so much room exists for speculation, it is not surprising to find quite an extensive range of variety in the genealogical trees which have been advanced in explanation of the descent of man; and we may well pardon the indefiniteness of one of the most recent of those schemes, ${ }^{1}$ even though it be the outcome of patient research and well-balanced judgment.

But so far as it goes, the evidence of Pithecanthropus, having regard to its position near the end of the Pliocene epoch, suggests the earlier stages of this, rather than the Miocene division, as those which witnessed the final emergence of a distinctively human form. Thus the direct evidence of palaeontology, though it does not contradict, does not at present confirm the view which assigns the time of that event to the Miocene or even an earlier epoch.

4. Existing Types of Mankind.-The flood of anthropological researches into the physical characters of the various human types continues to increase in volume. The augmentation of the number of investigations undertaken by members of the various Slavonic nationalities and again by the Japanese forms a marked feature of recent literature. The Russian publications alone attain the most formidable proportions annually. ${ }^{2}$ It is a matter for regret that on account of linguistic difficulties, these memoirs are liable to be passed over by workers in Western Europe. Indeed it seems as though the necessity for some universal script, a written lingua franca, will become as urgent as in the Middle Ages.

Pygmies.-Some noteworthy researches bear on the distribution and affinities of the pygmy types of mankind. ${ }^{3}$. The discovery of pygmy tribes in New Guinea has given a fresh stimulus to speculation on the subject of the original unity or the independence of these diminutive Hominidae. Those who have studied the question may be divided conveniently into three groups. Of these one holds that the pygmy type represents an early stage in the evolution of the larger varieties of mankind. The latter are regarded in fact as modified descendants of pygmy ancestors, distributed, it is supposed, over the surface of the globe and now persisting only as widely-separated groups. An elaborate theory of the cultural relations of the pygmy types with their larger neighbours has been based on such considerations. On strictly anthropological grounds, however, this view, by which the pygmies are regarded as ancestral forms,

1 Vialleton, Morphologie des Vertébrés, I9I I.

2 Stieda, Aus der Russischen Literatur; Archiv für Anthropologie, 1906, and earlier volumes.

${ }^{3}$ Schmidt, Die Stellung der Pygmäen-Völker, etc, r 9 ro.

Poutrin, Les Negrilles du Centre Africain; L'Anthropologie, 19II-I2. 
can be severely criticised, and it lacks the support of palaeontological evidence. A second group of authorities regards the pygmies as varieties of the larger tribes of the respective localities in which they are met with, and a general appeal is made to their environment as the source of influences which have determined their persistence. Account is taken especially of conditions affecting nutriment. But pygmies are not necessarily starvelings, so that care must be taken to avoid laying stress on this particular argument. The third group of investigators holds the view that pygmies are neither "ancestral forms," nor stunted variants of their more bulky congeners, but that they constitute a distinct type of mankind, a collateral stock which has become modified in different areas, but which was nevertheless a parental form common to the modern pygmies. The evidence actually available at the present time seems to favour the two latter views almost equally. In the absence of any kind of experimental research, these problems will probably not receive a more definite elucidation. And even the excellent methods of employing anthropometric data for racial comparisons suggested by such recent writers as Drs. Mollison ${ }^{1}$ and Czekanowski ${ }^{2}$ provide approximations to solutions but not the actual solutions of these problems.

Apart.from all the foregoing instances are the sporadic cases of pygmies appearing in the midst of a population of the larger Hominidae. Such instances are studied advisedly from a pathological rather than from a purely biological standpoint. References are made to the irregular activity of glandular organs and to other deep-seated interferences with the normal processes of growth. And it is legitimate to foresee an epoch in which the accession of precise physiological knowledge will admit of descriptions expressing these aberrations in chemical terms.

Giants.- The study of giants will be found to present in its trend features similar to those just mentioned as influential in the case of pygmies of sporadic appearance. In default of races of truly gigantic stature, the chief material for researches is provided by sporadic examples of giants. But the materials are not exhausted thus; for certain cases are now brought into line with giants, on account of their presenting some of the characters typical of the latter, even though they may lack the prime feature, viz. excessive stature.

The literature of giantism is full of suggestions as to the pathological nature of this condition. And as in the case of pygmies, reference is made to general processes of nutrition, as well as to the activity of certain glands. The recent work of Professor Geddes ${ }^{3}$ is particularly illuminating on the relation between the growth of the sketeton and that of the sexual glands. And these researches have the particular merit of adducing the evidence of experimental tests devised and executed with a view to ascertaining the validity of conclusions based in the first instance upon purcly anthropological data. Thus Professor Geddes has been able to indicate with precision the chief factors concerned in the processes of excessive growth: he is able to classify examples of giantism according to the absence or presence of certain specified factors. He has contributed very largely to provide this study with a sound physiological basis. It should be added that this work contains suggestions bearing on certain features of other examples (such as the curious form and proportions of some of the limb-bones of Homo primigenius) which have long awaited elucidation.

Other observers have directed their investigations to the pituitary body in particular. The frequency with which this obscure glandular organ is enlarged in giants has been recognised for some years, but the exact mechanism of the processes involved is not yet fully known.

Andamanese and Malay Aborigines.-The human races threatened with extinction in the near future present a very special interest to anthropologists, and while the urgency of the matter is to be deplored, it is satisfactory to realise that investigators

1 Mollison, Archiv für Anthropologie, 1907.

${ }^{2}$ Czekanowski, Archie fur Anthropologie; Korrespondensblalt; Jahrgang xl, No. 6, 1909; ibid., 1910, p. 101.

${ }^{3}$ Geddes, Proc. Roy. Soc of Edinburgh, vol. xxxi, Part I, No. 6, I9ro. 


\section{PHYSICAL ANTHROPOLOGY}

of the highest ability are engaged in the study of the disappearing races while there is still an opportunity of so doing. In the Andaman Islands, Mr. A. R. Brown (Cambridge) has carried out extensive researches. In regard to the pygmy tribes of the Malay peninsula, the exhaustive works published by Professor Martin (of Zürich), and of Messrs. Skeat and C. O. Blagden still hold the first rank.

Bush Race.-The Bush race of South Africa has been studied minutely by Dr. Pöch ${ }^{1}$ (of Vienna) and Dr. Péringuey (of the S. African Museum ${ }^{2}$ ). Dr. Pöch lays stress on the necessity for a precise and definite diagnosis of the Bush type as contrasted with other adjacent varieties and especially with the Hottentots. Among the features employed as aids to drawing these distinctions, the form of the ears, of the eyelids and of the upper lip are regarded as possessing the first importance; for the true Bush native presents a distinct conformation in each instance. An interesting observation is to the effect that the parotid salivary glands are very large in the genuine Bush natives. No explanation of the condition has been advanced and its significance has remained obscure. (The present writer suggests that the development may be related to the employment of clicking sounds in speech, a fea ${ }^{+}$ure which is carried to its extreme by these natives. This suggestion is based on the observation that although Europeans may learn to employ clicks, yet a great difficulty is encountered in prolonged conversation owing to deficient saliva, the latter being essential to the proper production of the clicking sounds.) Dr. Pöch regards the well-known steatopygia of the Bush natives (it is found in both sexes) as a mode of storage of food-materials. (The present writer made this suggestion eight years ago, and even then was probably not the first person to do so.) In general, the position assigned to these remarkable representatives of humanity is that of a distinct and specialised form of mankind. It will be noticed that this view is identical with the last of the three mentioned above in connection with the pygmy tribes as a whole. Dr. Péringuey devotes a section of this work to the physical characters of the Bushmen, and Dr. Shrubsall has added a chapter on craniometry, which is an abstract of a larger report in preparation.

Australian Aborigines.-Mr. A. R. Brown has made extensive observations on the tribes of Western Australia but the results and summary still await publication. In other parts of Australia there has been a great awakening of activity and important memoirs on the craniology of the aboriginal natives have appeared quite recently. Particular attention may be directed to the work of Professor Berry ${ }^{3}$ (of Melbourne University), who has stimulated enthusiasm in a numerous band of students and colleagues. To Professor Berry credit is due also for rescuing from obscurity a fine collection of skulls of the extinct Tasmanian aborigines. Complete descriptions and admirable drawings are now available, and the additional material investigated by Professor Berry amounts nearly to as much again as all that had been previously described. An absolutely unique specimen is a desiccated Tasmanian brain, which has been studied by Professor Elliot Smith.

Professor Berry holds the view that the Tasmanian native represented a pure, if highly-specialised stock, which was modified in Australia owing to the advent of a second stock. The latter may be termed Papuan. The Tasmanians were distinct from this, and from the Melanesians also. Herein Professor Berry is in opposition to Professor von Luschan (of Berlin).

At the University of Adelaide, the study of physical anthropology is pursued actively by Professor Stirling, ${ }^{4}$ who has the advantage of access to a number of skeletons of the aborigines far greater than exists in any other scientific institution. But detailed accounts are not yet accessible.

Eskimo.-The Eskimo race has been investigated quite recently by two observers of the highest competence, Drs. Oetteking and Hrdlička. In view of the comparisons

1 Pöch, Korrespondenzblatt, etc., s. 75; Archiv für Anthropologie, I9II.

${ }^{2}$ Péringuey, Annals of the South African Museum, vol. viii, I911.

${ }^{3}$ Berry, Proc. Roy. Soc. of Edinburgh, vol. xxxi, Part I, No. I-4, I9Io.

4 Stirling, Trans. Roy. Soc. of South Australia, vol. xxxv, I9II. 
drawn so often between the Eskimo and certain early prehistoric European types, the conclusions of these authors are very important, and fortunately they are quite definite. Speaking of the skull, Dr. Octteking ${ }^{1}$ defines that of the Eskimo as a modification of the Mongolian type. Specific mongoloid characters are distinct, and in certain instances strongly marked. With these features others of a generalised or primitive type are blended. Dr. Hrdlička ${ }^{2}$ is even more direct in his statements. And although he clearly takes full account of environment and nutrition as factors capable of modifying the form of various organs, he states nevertheless that all Eskimo crania "present absolutely no racial affinity with either the diluvial or posterior European crania, and their comparison, except for contrasts should once for all be abandoned. The kinship of the Eskimo is with Asia and America." Whether Dr. Hrdlička ${ }^{3}$ will have any further information to give on the last point mentioned by him is not yet known, but in I9I 2 he made an expedition to Siberia, where he discovered examples of a blond Mongolian type. His detailed description of this is awaited with interest. A word of caution may be uttered meanwhile in reference to recent and widely-circulated reports announcing the discovery of a tribe of (so-called) "white" Eskimo.

Observations on the Brain.- The anthropological work thus far laid under contribution has been almost entirely anthropometric and craniometric. But investigation of the other anatomical systems makes steady progress. In particular, the brain has received much attention. In this connection the researches of $\mathrm{Mr}$. Bcan ${ }^{4}$ on the American negroes, of Dr. Sergio Sergi ${ }^{5}$ on the Hereros (South-west African negroes), of Professor Weinberg ${ }^{6}$ on the Poles and Esthonians, and of Dr. Kohlbrugge ${ }^{7}$ on the Malayan pcoples, have resulted in enormous additions to the stock of information previously collected. Yet it must be admitted that the naked-eye appearances fail to provide a basis for the satisfactory identification of a given specimen, so great is the variability in almost every detail of the surface anatomy. In fact, examples of lowly conformation may occur in almost any region of the surface, so that the racial factor, though doubtless present, cannot be regarded as very potent in comparison with other factors differing from the racial one in regard to their distribution. Such considerations, added to others based on a study of the weight of the brain in relation to the total body-weight, have had the tendency of directing attention more specially to the minute structure of the cortex of the organ. Conspicuous among recent publications on this subject, the latest work of Dr. Brodmann ${ }^{8}$ demands special notice here. Dr. Brodmann's researches have been directed to a large number of animal forms, and his conclusions are furnished consequently with a correspondingly solid basis. Of the results none is more important than that which confirms a claim already made in favour of recognising absolutely distinctive though microscopic features in a certain region of the cortical surface of the human brain. The relation of that region to certain markings of the cerebral surface is to some extent a matter of secondary importance. Further research is in progress with the object of ascertaining whether the features in question are modified by the factors of racial difference. But as yet no definite statement can be made as to the results of this enquiry.

5. The Study of Heredity and Environment.-It remains to consider some very striking developments of anthropological and more particularly of anthropometric research, which mav be regarded as the outcome of recent advances in the study of heredity and the influence of environment. It was inevitable that mankind should be recognised as a subject for enquiry in the novel researches generated by the redis-

${ }^{1}$ Oetteking, Abhandlungen der Königl. Zoologischen und Anthropologisch-Ethnologischen Museum zu Dresden, Band xii, No. 3, 1908.

2 Hrdlička, American Mus. Nat. Hist., Anthropological Papers, vol. v, Part II, I9Io.

${ }^{3}$ Hrdlička, XIVth Internat. Cong. of Prehistoric Anthropology, (icneva, IgI2.

4 Bean, American Journal of Analomy.

"Sergio Sergi, "Cerebra Hererica," in Schultze, Ergebnisse eine Zoologischen Forschungsreise, etc., Jena, I9o9.

${ }^{6}$ Weinberg, Zeitschrift für Morphologie und Anthropologie, Band viii, p. 123, 1904.

"Kohtbrugge, "Kultur und (iehirn," Biologisches Centralblatt, Band xxxi, No. 8, I9I .

${ }^{8}$ Brodmann, Anatomische Anzeiger. Ergänzungsheft, 1912. 
covery of Mendel's work, and also by the writings of Galton. Four years or more have passed since the inheritance of eye-colour in the white race was shown to conform to expectations based on the Mendelian theory. The question of hair-colour subsequently received attention, with results similar in kind though less marked in degree. Further evidence of the same sort was published next (1909) in relation to certain defects and diseases, of which the condition known as "night-blindness" provides a striking and instructive example. Another field of enquiry was successfully opened up in Igro by the results of Professor Davenport's ${ }^{1}$ observations on the offspring of white and negro parentage. Again (in I9II) the Jewish and Anglo-Saxon types of physiognomy ${ }^{2}$ were subjected to analysis, with the result that a strong claim (if not an absolutely convincing one) is made to the effect that in the offspring of mixed parentage these facial types segregate according to Mendel's law. The work of Dr. Eugen Fischer ${ }^{3}$ (I912) marks a further advance. Here the subjects are a hybrid population, the offspring of Dutch Boers and Hottentots in German South-west Africa. Many characters usually deemed distinctive of "race " were investigated, and the fact that such characters " mendelize" out in the hybrid offspring, furnishes an argument of enormous force against any theory of the origin of racial or sub-racial types through admixture. Other noteworthy results of Dr. Fischer's work include a clear demonstration of the complete and marked fertility of the hybrids inter se, and again the definite demonstration of the increased bulk of offspring of mixed parentage (as compared with their parents), even in the absence of all noticeable change in the environment.

Another and very different line of research has been opened up by Dr. Brownlee ${ }^{4}$ (III). He proposes to employ the Mendelian theory as a basis for the analysis of racial mixtures. Should the method withstand criticism and should the assumptions which are necessary be found justifiable, the anthropologist will have been furnished by Dr. Brownlee with an invaluable instrument of racial analysis.

The contribution to the study of environment provided by Dr. Boas in his report ${ }^{5}$ on the immigrants into the United States of America deserves special mention here. Two striking announcements are made in that report. In the first place, it is claimed that in regard to head-form, the offspring of immigrants stand in distinct and even marked contrast to their parents. Again the data are said to show that a change in every case takes place in the direction of convergence towards a common form or type. So that whether the parents themselves be long-headed or of the bullet-headed type, these characteristics are not transmitted. The offspring of either type tends towards an intermediate form. Environment is made prominent in the speculations as to the influences determining these results. The latter are extraordinary for two reasons. First on account of the intensity of the acting force, and again for the rapidity with which it acts. Acceptance of the conclusions in such a matter must depend on the nature of the evidence, including inter alia the method of collection and the actual numerical differences shown by the figures. Having regard to such points, the severe criticism ${ }^{6}$ which has been passed on these statements is not without justification, and it is clear that further support is needed before anything like complete recognition can be accorded to the conclusions. At the same time it would be of interest to learn whether Galton's law of regression finds any demonstration here.

\section{(W. L. H. DuckWorth.)}

\section{Cultural Anthropology.}

Prehistoric Archaeology. - In the domain of prehistorics the most recent discoveries are full of interest. As regards the supreme question of the antiquity of man, there must always be a point at which the certain shades off into the purely problematic. This

1 Davenport, American Naturalist, r9io.

${ }^{2}$ Salaman, Eugenics Review, vol. iii, No. 3, I9I I.

${ }^{3}$ Fischer, Die Rehobother Bastards, Jena, I9I2.

${ }^{4}$ Brownlee, Journ. Roy. Anthrop. Inst., I9II.

${ }^{5}$ Boas, The Immigration Commission, U. S. Senate Document, No. 208, 1910.

${ }^{6}$ Radosavljevich, American Anthropologist, p. 394, 1911. 
point, however, is being steadily pushed back by the aid of fresh evidence of a cultural kind. Formerly, for orthodox archacologists, the limit of historicity was represented by the horizon of Chelles. But now M. Commont's well-established stratigraphy for the Valley of the Somme includes a pre-Chellean level. It is characterised by the presence of very rough hand-axes and small implements derived from flakes, the associated fauna comprising hippopotamus, elephas antiquus, and an archaic form of elephas primigenius (Congrès préhist. de France, Tours, 1910). Indeed, Professor Sollas in his recent work, Ancient Hunters and thcir Modern Representatives (I9I I), is quite prepared to add another to the classical list of periods, and adopts for this pre-Chellean period the name Strepyian, derived from Strépy in Belgium. M. Rutot, the inventor of the term, claims a wide distribution for the characteristic industry of this epoch (Congrès d' Archéol. et d'Hist., Malines, IgIr). Further, at Torralba in Spain, at a height of some I 100 metres above sea-level, the Marquis of Cerralbo has found pre-Chellean implements, side by side with tusks and other remains of elephas meridionalis and elephas antiquus, in circumstances that suggest that there stands revealed the actual camp or "station" of these early denizens of the world (Congrès d'Anthrop. et d'Archéol. préhist., Geneva, I9I2).

Eoliths.-If, however, we try to get still further back, we plunge into the stormy waters of the cont roversy about "eoliths." The question arises whether man or nature is responsible for the pieces of stone shaped and chipped with a certain appearance of design that occur in various geological formations of early pleistocene or even of tertiary age. A while ago opinion perhaps tended to side with the opponents of " eoliths." M. Boule's attack, based on the production of pseudo-eoliths by the crushing machine of a cement-factory at Mantes ( $L$ 'Anthropologie, I905, p. 26I), had been reinforced by M. l'Abbé Breuil's discovery of other pseudo-eoliths, caused this time not by percussion but by pressure, at the base of the Parisian Eocene at Belle-Assise (L'Anthropologie, igro, p. 385). Now, however, Sir Ray Lankester comes forward as the champion of man-made implements from the basement-bed of the Suffolk Red Crag, a deposit which, at the latest, marks the very beginning of the Pleistocene epoch (Phil. Trans. of the Royal Soc., Series B, vol. 202, p. 283. Cf. Nalure, Oct. 31, 1912). They were discovered by Mr. J. Reid Moir from I 909 onwards at several sites in or near Ipswich; and very similar finds have been made by Mr. W. G. Clarke in the Norwich Crag which ranks as immediately subsequent to the Red Crag (Proc. of the Prchist. Soc. of East Anglia, Vol. i, parts I and 2). Indeed, Mr. Moir has lately claimed to have lighted on human handiwork, not only in the Red Crag, but likewise in the latter middle-glacial gravels and in the still later chalky-boulder-clay of Suffolk, and, in short, to have made out a long series of these very early forms (Times, Oct. I9, I9I2). Thus the question of "eoliths" is entering on a new and interesting phase; and, so long as they do not seek to dogmatise prematurely, the bolder spirits who are thus for putting back the beginnings of human culture, deserve a fair hearing and even encouragement

Palaeolithic Age.-Within the traditional limits of the Palaeolithic age, the main interest consists in securing greater accuracy of classification and an exacter correlation with the changes in the geophysical conditions. As regards the drift-period, whilst our collections of " amygdaloid " implements continue to swell, very little has recently been done, at any rate in England, to improve our knowledge of the stratigraphy; and M. Commont's researches in the Valley of the Somme remain unrivalled. Even where stratigraphy fails, however, much may possibly be done by paying more attention to patina, striations, and so on, as indicated by Dr. W. Allen Sturge in two important pioneer essays (Proc. of the Prehist. Soc. of East Anglia, Vol. I, parts I and 2). The cave-period, on the other hand, is fast yielding up its secrets. What, for instance, could be a more triumphant vindication of the classificatory methods of prehistoric archacology than what was lately revealed in the Cave of Castillo near Puente Viesgo in the North of Spain. Here M.M. Breuil, Obermaier and Alcalde del Rio (acting on behalf of the Institut de Paléontologie Humaine newly founded by the Prince of Monaco, to whom the science of prehistorics owes so much) actually brought to light, superim- 
posed one upon the other in a section of a depth of about thirty feet, ten archaeological strata proceeding from the Mousterian (two levels) to the Neolithic by way of the Aurignacian (three levels), the Solutrian, the Magdalenian (two levels), and the Azilian. Thus the classical seriation of cultural stages is no longer a matter of theory; it is a matter of palpable fact ( $L^{\prime}$ Anthropologie, I9I2).

Passing on to consider these stages in detail, there is, in the first place, not a little new information that relates to the Mousterian epoch. Thus M. Commont has discovered in the Valley of the Somme a well-developed Mousterian industry in conjunction with a warm fauna (Congrès d'Anthrop. et d'Archéol. prehist., Geneva, I91 2); thus helping to confirm, we may note, the hypothesis of Professor Sollas, who, despite the usual association of the Mousterian culture with a boreal fauna, is disposed to assign it to the interval between the last two glaciations. No less than three Mousterian caveoccupations have come to light between I9ro and I9I 2 in the Island of Jersey, and the fact that they occurred at a time when the bed of the Channel was sufficiently elevated for Jersey to be joined to France (as is proved by the presence of a Continental fauna, rhinoceros tichorhinus, reindeer, and so on) provides what may prove a useful datum for solving the chronological problem (Archaeologia, r9Ir, r912; Man, Nov. I912 and Bulletins de la Société Jersiaise). Mr. Reginald Smith has called attention to an extensive factory: of Mousterian implements of an unusual size situated at Northfleet in Kent in the middle-terrace gravels of the Thames; and it remains to be seen whether the terraces of the Thames and Somme and the evidences of oscillation of the bed of the Channel cannot be brought into some sort of correlation (Archaeologia, I9I I). Finally, the utilisation of bone in late Mousterian times found by Dr. H. Martin at La Quina in Charente helps us to understand how the transition took place from the Mousterian to the Aurignacian stages of culture (Recherches sur l'évolution du Moustêrien dans le gisement de La Quina, Charente, I9Io).

On the late Palacolithic period, comprising the Aurignacian, Solutrian, and Magdalenian cultures, light continually pours in. Fresh sites are reported from almost every part of Europe. In England, for instance, the Paviland cave at Gower in S. Wales, already suspected to be Aurignacian (see Sollas, o.c. $2 \mathrm{I}_{3}$ ), has been proved to be so by the discovery of characteristic implements, while even Aurignacian wall-paintings are suggested by certain remains in Bacon Hole in the same neighbourhood (Times, Oct. I4, I 5, 29, I9I2); and Mr. R. Smith, more doubtfully, claims an Aurignacian age for other English sites (Archaeologia, I912). Here, however, it must suffice to deal in some detail with the rapidly increasing extent of our knowledge of the evolution of latequaternary fine-art. In particular, the determination of the relative ages of various typical sets of cave-engravings and cave-paintings has recently made great strides. Whereas the contributions of the intermediate Solutrian period remain undetermined (though it is certain that the Solutrians were not artists merely in respect to flint, as witness the statuette of a mammoth in ivory discovered by Dr. Kriz at the Solutrian station of Predmost in Moravia, see L'Anthropologie, I912, 273), yet there are clear proofs that on the one hand such rudimentary graffiti as those of Gargas in Hautes Pyrénées are Aurignacian, and, on the other hand, that the far more evolved polychromes of Font-de-Gaume in Dordogne, or of Altamira near Santander in the North of Spain, are advanced Magdalenian (L'Abbé H. Breuil, "L'âge des cavernes et roches ornées de France et d'Espagne," Revue Archéol., r912). A method, not yet fully given to the world, of constructing as it were a stratigraphy of these works of art, consists in observing the superimpositions due to the fact that the ancient painters made light of utilising an already occupied rock-surface. The cave discovered by Col. Willoughby Verner in the Serrania Ronda. in the South of Spain (see Saturday Review, Oct. I9, 26, I9 I2) is destined to yield especially valuable results in this respect, having no less than a fourfold mural palimpsest to show. Apart from engraving and painting, new forms of art belonging to the late Pleistocene age are coming to light, the most notable being Dr. Lalanne's discovery of sculptured bas-reliefs representing human figures, male and female, at Laussel in Dordogne (L'Anthropologic, I9 I I, 257; I9 I 2, I 29); and the extraor- 
dinary find of M. le Comte Begouen and his son, who in the cave of Tuc d'Audoubert, in Ariège, some two kilometres from the entrance, came upon the bas-reliefs of bisons modelled in clay, the sandy floor in the vicinity showing the marks of many human footsteps (Times, Oct. 3I, I9I2). The human figures of Laussel, moreover, have more than an aesthetic interest. Here the male figure is finely shaped, but the female has the secondary sexual characters emphasised to the point of exaggeration, reminding us of the statuettes of Brasempouy and Willendorf. The question may be raised whether we have here the rendering of a racial trait, or are, rather, in the presence of some magicoreligious representation of fertility, it being perhaps significant that the female of Laussel raises aloft in the hand what might well be some sort of cornucopia. There are, again, human figures, both male and female, that in style remind us strongly of Bushman paintings, from a group of five Spanish sites (Cogul, Calapata, Albarracin, Ayora, Alpera) which have not yet been correlated with the classical French series, but are probably late Pleistocene (Breuil, o.c. II). The men, who for instance, comprise the greater part of the twenty-four figures of Alpera, are naked save for ornaments, and wield their great bows with the most animated gestures. The women wear petticoats, but leave the torso nude, and at Cogul seem to be engaged in a dance.

Azilians, and Neolithic Age.-We begin to cross the uncertain divide that separates the Palaeolithic from the Neolithic when we come to the Azilians. Their culture, marked especially by their horn harpoons (so different, even if, as M. Breuil thinks, derived by imitation from the bone harpoons of the Magdalenians) and their painted pebbles, has a somewhat wide distribution. For it seems undoubtedly to occur in Scotland (see R. Munro, Palaeolithic Man, First Munro lectures, Edinburgh, I912). Or, again, in Switzerland, at Birseck near Basel, Dr. Fritz Sarasin has found the characteristic painted pebbles, every one of them broken in two, as if, as he thinks, an enemy had tried to do away with receptacles or embodiments of the tribal stock of souls such as are the very similar churinga of the Central Australians ("Eine steinzeitliche Station bei Basel," Globus, I9ro). Lastly, in Spain at Castillo and elsewhere the numerous traces of them have led M. Breuil to construct a theory to the effect that they represent a wave of population driven through Spain northwards by the advance of the Neolithic peoples from North Africa (Breuil, o.c. 34). A further problem is whether we may connect with the Azilians, as M. Breuil is inclined to do, the numerous highly stylised and more or less geometrical designs recently found in many caves and rock-shelters in the South of Spain. On the one hand, they recall the designs on the Azilian pebbles. On the other hand they are not without analogy in certain early Neolithic idols discovered by M. Siret in the region of Almeria, which are made in the form of a sort of double triangle with lateral expansions (Breuil, o.c. 32); as well as in the decorations of certain dolmens of Portugal, and, it may be of other dolmens further north. Evidently we have here the results of various interpenetrations of peoples and consequent contacts of cultures which have still to be worked out fully. The study of the iconography of the dolmen period has, meanwhile, received an impulse from M. J. Déchelette's interesting interpretation of the figures of New Grange and Gavr'inis. He finds them to involve the schematised representation of a tattooed female personage, who in Brittany is associated with an axe; whilst solar symbols are also present ( $L^{\prime} A$ nthropologie, I9 2, 29).

Further, it is obvious that the theatre of this cultural evolution is not merely Western Europe, the North of Africa being likewise concerned and even primarily concerned therewith. Indeed, the prehistoric archaeology of Africa is beginning to compete in interest with that of Europe itself. 'Thus in the French Sudan painted grottoes in which geometric schematisation prevails, though there are a few realistic figures as well, suggest that, whilst a wave of Azilian or proto-neolithic culture went northwards through Spain, another may under the same influences have been diverted south ( $F$. de Zeltner, L'Anthropologie, IOII, I; compare Breuil o.c.). The common point of departure would on this assumption be north-west $\Lambda$ frica, the seat of the prehistoric flint-industry known as the Capsian, which seems typologically akin to the Aurignacian of Europe (Dr. E. Ciobert in Bull. de las Soc, préhist. de France, rgro). For the rest, atten- 
tion has been directed in England to the question of the part played by North Africa in the propagation of culture in Neolithic times by Prof. G. Elliot Smith's ingenious piece of synthetic work, The Ancient Egyptians and their influence on the civilisation of Europe (I9II). His point of departure is Reisner's theory that the utilisation of copper began in Egypt; and he suggests that one result of this was the spread of a taste for megalithic architecture, which worked its way round by North Africa to Western Europe. As regards other parts of Africa, prehistoric industries of a Neolithic facies are reported from many points, for instance, from the Anglo-Egyptian Sudan by Mr. Wellcome (Congrès d'Anthrop. et d'Archéol. préhist., Geneva, r912), and from Ashanti by Mr. Rattray and others (H. Balfour in J. of the African Soc., Oct. I9I2); whilst in South Africa the latest discoveries range in type from Neolithic celts to amygdaloids of riverdrift pattern (J. P. Johnson, The Prehist. Period in S. Africa, ro1o; L. Péringuey, "The Stone Ages of S. Africa" in Annals of the S. Af. Mus., viii, Igr I). The difficulty in respect to the African evidence throughout is that geological and palaeontological data are as yet not available for the determination of a chronological scale; whilst the backward state of many of the natives makes it possible that primitive and advanced types of stone-industry may have been more or less contemporary. Indeed, outside Europe and the immediate neighbourhood of the Mediterranean, prehistoric archaeology can scarcely boast the status of a quasi-independent interest, but tends to merge with cultural anthropology in general. As for proto-history, it is coming more and more to include the whole of the bronze-age and early-iron age cultures of Europe, as it already. does those of Eastern Europe. How much we are beginning to know about the development of bronze-age culture, even in so relatively backward a region as the British Islands, may be learnt from an admirable monograph, A Study of the Bronze Age Pottery of Great Britain and Ireland, and its associated Grave-goods (I912), by the Hon. J. Abercromby, who ascribes its introduction to invaders, mainly of Alpine stock, who had moved gradually from some region beyond the Rhine, not far north of Helvetia.

Ethnological Method.-When we turn to the consideration of cultural anthropology as it concerns itself with the primitive peoples of modern times, we can hardly expect to encounter dramatic surprises such as are occurring almost daily in the field of prehistorics. There are nowadays but few spaces on the ethnological map that are absolutely blank. If travellers' gossip is to count, we can claim to have covered most of the ground. On the other hand, there is to be noted on all sides a demand for intensive study that, from the standpoint of science, is a most striking and welcome sign of the times. It has become clear by experience that theory based on the observations of untrained and unguided field-workers comes to nothing. The endowment of anthropological research in connection with universities and government departments and the organisation of ethnographical museums have created a body of workers intent on obtaining accurate results. Hence interest now centres chiefly in questions of method. In England attention has been called to this subject by Dr. W. H. R. Rivers in a masterly paper entitled "The ethnological analysis of Culture" (Pres. Address to Section H., Brit. Ass., Portsmouth, I9I I). He there contrasts two methods, which he terms severally the psychological and the ethnological. The former rests on the tacit assumption of a general homogeneity of the human mind, and hence tends to explain such similarities as are found in different regions as due to the similarity of its workings; so that, given similar conditions, similar customs and institutions will develop along the same lines. The latter explains these similarities as due to the direct transmission of culture from one people to another. This new method is upheld in its most extreme form by $\mathrm{F}$. Graebner, Methode der Ethnologie, Heidelberg, I9i (compare his article "Die melanesische Bogenkultur und ihre Verwandten," Anthropos, I.909, iv, 726), who is herein supported by W. Foy (under whose editorship the annual Ethnologica is devoted to the illustration of this method) and, with certain restrictions, by Pater W. Schmidt (Mitt. d. anthrop. Gesellsch. in Wien, 1908, xxxviii, 73; and Denksch.d. Akad. d. Wiss. Wien, Phil.-hist. Kl., I9ro, liii). All German anthropologists, however, are not adherents of this school, as will be evident from the discussions published in Petermann's Mitt. I. I 3 
and II. I43; and in Korrespondenzbl. d. Deutsch. Ges. f. Anthrop. Ethnol. u. Urgesch., I9I I, Jahrg. xlii, 156. In America, again, whilst it is claimed that it has long been customary with Americanists to attach importance to the effects of the blending of cultures arising from racial mixture, it is contended that allowance must likewise be made for the results of what biologists know as "convergence" or "convergent evolution " (Cf F. Boas, Science, Dec. 8, rgr r; and R. H. Lowie, ibid., Nov. 3, IgI r; J. of Am. Folk-Lore, $\mathrm{xxv}$, No. xcv, I9I2): The fact would seem to be that the psychological and ethnological methods are in no sense fundamentally opposed to each other. Granted that the " adjacent anthropology," the cultural context, of each datum must be given for the latter to be understood, it is none the less possible that such a datum may ultimately serve to illustrate the evolution of human culture in general and of the mind of man in general; for, if " man " is an illegitimate abstraction, then so assuredly must " anthropology" be also. The ethnological method, in fact, stands chiefly for a self-denying ordinance on the part of the present generation of students, who are content to put off their all-embracing account of the history of culture until the history of cultures-of the developments confined to relatively discontinuous cultural areas-has been more completely worked out (cf. "The Present State of Anthropology," Athenaeum, Mar. I 2, 1910).

Totemism.-This question of method has been raised likewise in a more concrete way by recent discussions about totemism. It must be noted, in the first place, that an admirable survey of the facts relating thereto has been given to the world in Dr. J. G. Frazer's Totemism and Exogamy, I910; and it will be observed that, in accordance with modern tendency, his descriptive work is broken up into sections corresponding to geographical and ethnological provinces, though he likewise offers a general theory of totemic origins. Then, again, an important work embodying the principles of the school of thought represented by the writers in L'Année Sociologique has recently appeared in Prof. Emile Durkheim's Les Formes Elémentaires de la Vie. Religieuse (I9I 2), wherein the analysis relates especially to the "Totemic system" of Australia, though analogies from North America are allowed to play a secondary part in the argument. Meanwhile, Dr. A. A. Goldenweiser in Totemism, an Analytical Study (reprinted from $J$. of Am. Folk-Lore, xxiii, No. lxxxviii, rgro), instead of comparing, seeks rather to contrast the totemistic observances of Australia and of North America, insisting that each " totemic complex" is the result of a separate set of historical causes, so that to explain them on the assumption of common origins is methodologically unsound. On this point there has followed an animated controversy between Mr. Goldenweiser and the late Mr. Andrew Lang (A. Lang, Method in the Study of Totemism, Glasgow, I9I I privately printed, but published in a revised form in $A m$. Anthrop. N.S. xiv, No. 2, 191 2; A. A. Goldenweiser, ibid., xiii, No. 4 ; xiv, No. 2 ; cf. R. H. Lowie, ibid., xiii, No. 2 and W. 1). Wallis, ibid., No. I). Mr. Lang asks whether "convergent evolution" means "throug: a series of flukes," and maintains that the hypothesis of more or less parallel development from a common starting-point is sound, in that it "works." . No better criterion could be proposed. It may well turn out, however, to be the fact that, as intensive study proceeds, even the homogeneity postulated for totemism within a given area, say Australia, will have to be denied in favour of some theory of a mixture of ethnological elements, in short, a theory of the same type, if not necessarily the same content, as that which Graebner or Schmidt would offer. Meanwhile, the older method of classing the peoples of the lower culture together may still bear fruit when the broader conditions and functions of primitive mentality are in question: witness the brilliant essay of Prof. L. Lévy-Bruhl, Les Fonctions Mcntales dans les Sociétés Inféricures, igro. Even if his description of the primitive mind as "pre-logical " will hardly bear close examination (see W. H. R. Rivers, The Hibbert Journal, Jan. I912), the indistinct nature of the thinking associated with an undifferentiated social life comes out very clearly in his penetrating analysis, which includes a most valuable account of the relations between primitive thought and language. Another work on this subject, remarkable for its sanity and breadth of view, is Prof. Boas' The Mind of Primitive Man (Igr I).

Regional Anthropology.-Having considered the tendency towards ethnological 
specialisation which modern method recommends, we must conclude with a rapid glance at the recent advance made in our knowledge of the primitive culture of particular regions. America; perhaps, deserves to be placed first on the list, because here intensive work on regional lines has long claimed chief attention; though general theory, especially in regard to the psychology of religion, has by no means wholly been neglected, notable contributions to this subject being E. S. Ames, The Psychology of Religious Experience (гог); H. Webster, Rest Days (I9I1), and J. H. Leuba, A Psychologicul Study of Religion (I9I2).. Of outstanding importance are the results, still in course of publication, of the Jesup North Pacific Expedition, which took place under the direction of Dr. F. Boas. They are particularly interesting from an ethnological point of view, since they suggest that the peoples of N:E. Asia usually known as Paleo-Asiatics (Chukchee, Koryak, Kamchadale, Gilyak, Yukaghi) owe their indubitable affinities to the aborigines of America to the fact that they represent an ethnic reflux from the latter continent. It should be mentioned that Russian ethnologists, Messrs. Sternberg, Jochelson and Bogoras, took part in this expedition, and contributed not a little to its success. Moreover, a discussion of great interest concerning the ethnological status of the American aborigines has recently taken place, in which a number of distinguished Americanists have taken part (Am. Anthrop., Igr2). From the cultural point of view perhaps the most interesting contribution is that of Dr. W. H. Holmes, who reaches the same conclusion from the archaeological as does Dr. Hordlička from the somatological standpoint, namely, that the bulk of the aborigines are of Asiatic origin; though he would not wholly exclude cultural influences by way of Indonesia and Polynesia, and even, more doubtfully, from West Africa and North Europe (cf. also his paper in: $A m$. Anthrop., I910, 149). For the rest, it is impossible here to make more than passing mention of a few of the numerous additions to our knowledge of the natives of North America, present or past, especially notable being Miss A. Fletcher and F. La Flesche, The Omaha Tribe (гог I); Clark Wissler, Social Life of the Blackfoot Indians (I9гі) and Ceremonial Bundles of the Blackfoot (I9I 2), and E. Volk, The Archaeology of the Delavare Valley (I9II). Notice should also be taken of the recent anthropological activity displayed by the Canadian Government, which, by organising an ethnological department under the direction of Dr. Sapir, whose work, especially in the matter of linguistics, is of the highest value, has sent into the field a number of competent workers, Mr. Barbeau and others, of whom much may confidently be expected. For Central America with Mexico may be noted G. G. MacCurdy, A Study of Chiriguian Antiquities (r9I I); C. Lamholtz, New Travels in Mexico (I912); and K. Th. Preuss, Die Nayarit-Expedition. Erster Band: Die Religion der Cora-Indianer (I912), the last-named constituting a most important new source for the comparative study of religions. As regards South America, we must be content here to mention Sir C. Markham, The Incas of Peru. (I9Io); T. A. Joyce, South American Archacology (1912); W. B. Grubb, Indians of the Paraguayan Chaco (I9I I), and E. Nordenskiöld, Indianlif $i$ el Grun Chaco, Stockholm (I9I I).

Something has been said already of recent archaeological work in regard to Africa. As regards the study of the present-day natives, two monographs of first-rate quality, that deal especially with the subject of religion, are, be it noted, the work of missionaries, J. Roscoe, The Baganda (rgIr), and H. Junod, The Ba-Thonga (IgI2). Several important books upon the anthropology of the Belgian Congo have recently appeared, such as E. Torday and T. A. Joyce, Les Bushongo (I gro); F. Gand and C. van Overbergh, Les Mandja (I9I I); and T. H. Weeks, Congo Life and Folk-lore (I9I I). The former work discloses a quite remarkable state of native civilisation, the ultimate origins of which must be sought somewhere further north, probably in the neighbourhood of Lake Ghad, our speculations being assisted by historical records of the mnemonic order that would seem to be trustworthy for at least several centuries back. The increasing interest shown by the British Government in anthropology, as shown either in the direct appointment of ethnological investigators or in the encouragement of officials to prosecute such studies, has borne fruit in such works as N. W. Thomas, Ebo-speaking Peoples of Nigeria (I9Iо); A. N. Tremearne, The Tailed Head-hunters of Nigeria (I9I2); H. A. 
Macmichael, The Tribes of Northern and Central Kordofan (гіг 2); and C. G. Seligmann, The Cult of Nyakang and the Divine Kings of the Shilluk, in 4 th Rept.Wellcome Trop. Res. Lab., I II. Finally, W. S. and K. Routledge, With a Prehistoric People (Igro) contains much sociological and technological material concerning the Akikuyu of East Africa, that has been collected with remarkable skill and method.

Passing eastwards we come upon a mass of valuable new information relating to India. Especially noteworthy in point alike of form and of contents is the series of monographs issued under the authority of the Government of Eastern Bengal and Assam of which the latest volumes are T. C. Hodson, The Naga Tribes (I9I I), S. Endle, The Katháris (I II I) and J. Shakespear, The Lashei Kuki. Clans (IgI 2). Other interesting works relating to India are E. Thurston, Omens and Superstitions of Southern India (rgr 2), and L. K. Anantha Krishna Iyer, The Cochin Tribes and Castes, Vol. II (IgI 2), the latter work throwing much light on the curious social system of the Nayars (Nairs). Moving still further east we find two interesting books on Borneo, E. H. Gomes, Seventeen Years amongst the Sea-Dyaks of Borneo (rgri), and C. Hose and W. McDougall, Pagan Tribes of Borneo (I9I 2), the latter a most important contribution to science. From New Guinea, one of the least known parts of the anthropological world, comes news of pygmy tribes in A. F. R. Wollaston, Pygmies and Papuans (I912), and R. W. Williamson, The Mafulu Mountain People of British New Guinea (I9I 2), the latter work being somewhat rich in cultural particulars. C. G. Seligmann, The Melanesians of British New Guinea (1910), carries out an important survey of the coast-peoples in the S.E. area; whilst also about German New Guinea information is rapidly coming in (cf. M. Moskowski and R. Neubass in Zeitschrift f. Ethnol., I9ro, I9I I). A fresh instalment (Vol. IV) of the Report of the Cambridge Expedition to Torres Straits, edited and mainly written by A. C. Haddon, deals with the technology of this interesting area of transition. In regard to Australia there is to be noted a well-illustrated conspectus of the three expeditions of B. Spencer and F. Gillen (Across Australia, I9 2); but the fresh explorations of Prof. Spencer in the North and of Mr. A. R. Brown in the West are yet to be fully published. For Melanesia, again, we await the publication of the researches of Dr. Rivers, which are likely to shed much light on the problem of the peopling of the Pacific.

(R. R. MARETT.)

\section{PHILOLOGY}

In most branches of comparative philology there is little of substantial importance to record, representing progress since I9Io, and the various articles in the $E$. $B$. (for a summary of which see xxi, $437 \mathrm{et} \mathrm{seq.)} \mathrm{already} \mathrm{provide} \mathrm{a} \mathrm{sufficient} \mathrm{account} \mathrm{of} \mathrm{the} \mathrm{accepted}$ results of scientific scholarship. An exception may be made, however, for one series of little-known and scattered languages, which have now been studied for a long time without the results of much patient labour being made generally known, - what is now called the "Austric family," those namely of the Malay-Polynesian and other Oceanic people connected with S.E. Asia. The following article summarizes the results of recent research in this field.

\section{The Austric Family of Languages.}

The essential unity of the Oceanic languages, though partially recognized long ago by Humboldt in his Kawisprache, was not completely demonstrated until much more recent times. The connection between the Polynesian and Indonesian languages (including the geographically outlying Malagasy) met with ready acceptance, but the afiliation of the Melanesian was not so easy. The difficulty was partly due to purely linguistic differences, the Melanesian type of speech being superficially very different from the Indonesian and Polynesian, partly to the diversity of the races which raised the natural, but quite unjustifiable, presumption that the languages could not be of the same stock. It was, however, eventually proved that Melanesian could not be kept out of the Oceanic family, ${ }^{1}$ and it has since been shown that Micronesia, though

${ }^{1}$ Kern, De Fildji-taal in Indonesië en Polynesï̈, Verhand. Kon. Akad. v. Wet. (Amster(am, I886), Afd. Letterk., Deel XVI; Over de verhouding vian het Mafoorsch tot de MaleischPolynesische talen, Actes du VIe Congrès International des Orientalistes. 
different in race, falls linguistically into the Melanesian section. Also it ultimately became plain that of these three subdivisions Indonesian best represented the archaic family type, while Polynesian at the other extreme had gone furthest in the direction of simplification and decay. ${ }^{1}$. Thus was established, by the strictest scientific proof, the existence of the Oceanic or Malayo-Polynesian family of languages, extending from Madagascar in the west to Easter Island in the east, and from Formosa and Hawaii in the north to New Zealand in the south.

Meanwhile further exploration and research had revealed the existence in New Guinea and some of the neighbouring islands of a number of languages which could not be fitted into this scheme of classification, and did not even apparently form any family of their own, but only a number of distinct groups between which no ultimate relationship could be safely asserted. ${ }^{2}$ These so-called Papuan languages (which have since been found in portions of Dutch and German as well as British New Guinea) are therefore to be regarded as a purely provisional group, the time for their systematic classification not having as yet arrived. But it is quite certain that they have nothing whatever to do with the Oceanic family, though some of the neighbouring members of the latter have undoubtedly been influenced and to some extent modified by Papuan languages, and also vice versa, particularly in the matter of syntax. ${ }^{3}$ Moreover there exists in an outlying corner of Eastern Indonesia a small enclave comprising a number of closely related and very curious languages which differ profoundly from their neighbours of the Oceanic stock. These are the languages of the northern peninsula of Halmahera (or Jilolo), together with Ternate, Tidore, and a few other small adjacent islands. In spite of some attempts that have been made to show their ultimate connection with the Oceanic family, ${ }^{4}$ it cannot be said that the thesis has been proved or even rendered very probable. It is at least as likely that they are remnants of some archaic Papuan group, though the tribes that speak them are not Papuan in physical type. ${ }^{5}$

The Oceanic languages having thus been delimited, ${ }^{6}$ there remained the further question of their source of origin. By an ingenious comparison of purely linguistic data Kern had shown ${ }^{7}$ that the common mother-tongue from which they were derived must have been spoken on some long coastline in the Tropics, the east coast of Indo-China seeming on the whole to be the most likely one. Here there were actually languages, such as Cham and its immediate neighbours, which were plainly in some way connected with the Indonesian branch of the Oceanie family. But no really satisfactory attempt could be made to connect the Oceanic with any of the different groups of Indo-Chinese languages until the latter had been properly classified. This was done in part by Forbes $^{8}$ and carried further by Kuhn, ${ }^{9}$ but the final achievement was the work of IV. Schmidt. In a series of admirable monographs ${ }^{10}$ he succeeded in proving the intimate

${ }^{1} \mathrm{~S} . \mathrm{H}$. Ray, The Common Origin of the Oceanic Languages, "Hellas" Revue Polyglotte Internationale, VIe Année. Thalheimer, Beitrag zur Kenniniss der Pronomina der Sprachen Mikronesiens (Stuttgart, 1908); reviewed by Ray in Man (1908), 85.

${ }^{2}$ Ray, The Languages of British New Guinea, J. Anthr. Inst. XXIV, pp. I5-39; ibid. XXVI, pp. 204-5; Reports of the Cambridge Anthropological Expedition to Torres Straits, Vol. III, Linguistics:(1907).

${ }_{3}^{3}$ W. Schmidt, Man (1907) 106; Ray, J. Anthr. Inst. XXX (Anthr. Rev. and Misc. 50).

${ }^{4}$ Kern, Bijdr. tot de Taal-, Land-, en Volkenkunde van Nederlandsch-Indie (189I), Deel $\mathrm{XL}, \mathrm{pp} .493-530$. See also A. Hueting, Iets over de Ternataansch-Halmahèrasche Taalgroep, ibid. (I908), LX, pp. 369-4II.

${ }^{5}$ Schmidt, Die sprachlichen Verhältnisse von Deutsch-Neuguinea, Zeitschr. f. Afrik. u. Ozean. Sprachen, Jahrg. V \& VI, espec. VI, pp. 74-99.

6 It is hardly necessary to add that the languages of Australia and the now extinct dialects of Tasmania lie entirely outside this sphere.

${ }^{7}$ Taalkundige der Maleisch-Polynesische volken, Versl. en Med. Kon. Akad. v. Wret. (Amsterdam, I 889) Afd. Letterk., IIIe R., Deel 6.

${ }^{8}$ Comparative Grammar of the Languages of Further India.

${ }_{9}^{9}$ Beiträge zur Sprachenkunde Hinterindiens, Sitzungsb. d. K. Bayer. Akad. d. Wiss., Phil.hist. K1. (1889).

${ }^{10}$ Die Sprachen der Sakei und Semang auf Malakka und ihr Verhältnis zu den Mon-KhmerSprachen, Bijdr. tot de T. L. en V. v. Ned.-Indië, I9oI, Deel LII, pp. 399-583; Grundzige einer Lautlehre der Mon-Khmer-Sprachen, Denkschr, d. Kais. Akad. d. Wiss. in Wien, 1905, 
connection of the aboriginal languages (Sakai and Sermang) of the Malay Peninsula, the Mon-Khmer group, the Palaung-Wa-Riang group of the Shan states, Khasi in Assam, Nicobarese, and finally the Munda languages of India proper. All these are characterised by a structure based ultimately on monosyllabic roots from which more complex words are formed by means of prefixes and infixes (in the case of Munda and Nicobarese, suffixes as well). Both in structure and vocabulary they are altogether different from the large family, or agglomeration, of languages to which Tibetan, Burmese, Siamese and Chinese belong.

On the other hand a considerable amount of work had been done, mainly by Dutch scholars such as Van der Tuuk, Kern, and Brandes, to analyse the structure of the Oceanic languages; they succeeded in showing that the superficial dissyllabism characteristic of the family was really the result of an ancient agglutinative system building upon originally monosyllabic roots. ${ }^{1}$ This left the way open to Schmidt to show ${ }^{2}$ that his newly formed synthesis of languages, which he proposed to call Austroasiatic, was ultimately related to the Oceanic (or as he would style it Austronesian) family, so that the two could be conveniently grouped under the generic name "Austric." Schmidt's arguments were based both on similarity of structure and numerous cases of identity between the very roots of the two families; and so far as they. were confined to linguistic classification his conclusions have met with general acceptance at the hands of those best qualified to judge. But his attempt to establish a corresponding anthropological unity of the very diverse races speaking all these different tongues was not so successful and must be regarded as altogether premature. Most of these populations are blends, and though conceivably there may be some thin strain of common blood running through all of them, it is impossible as yet to define it or correlate it with the common element of their speech. Nor is any such assumption a necessary conclusion from the linguistic data. The synthesis of the languages has established a pureiy linguistic unity, implying no identity of race and admitting the existence here and there (e.g. among the Negritos of the Malay Peninsula, in Melanesia and even in parts of Polynesia) ${ }^{3}$ of traces of older aboriginal languages embedded, like flies in amber, in the prevailing type of speech.

Eliminating all such doubtful matters, the establishment of the " Austric " family of languages may well be considered the most important achievement in comparative philology during the last decade. It finally clinches the arguments in support of the Asiatic origin of the Oceanic languages, and thus sets at rest a question which had been long under discussion.

Supplementary Bibliography.--Brandstetter, Tagalen und Madagassen (1902); Ein Prodromus zu einem vergleichenden Wörterbuch der Malaiopolynesischen Sprachen (I906); Gcmeinindonesisch und Urindonesisch (1911); Das Verbum . . . in vierundzwanzig Indonesischen Sprachen (1912). Ferrand, Essai de phonétique comparée du malais et des dialectes malgaches (1909). Kern, Taulvergelijkende Verhandeling over het Aneityumsch, met een Aanhangsel over het Klankstelsel van het Eromanga, Verhand. Kon. Akad. v. Wet. (Amsterdam, I906), N. R., D. VIII, No. 2. Schmidt, Ueber das Verhültnis der Melanesischen Sprachen zu den Polynesischen und untereinunder, Sitsungsb. d. Kais. Akad. d. Wiss. in Wien, Phil.hist. Kl., Bd. CXLI, No. VI; Die Jabim-Sprache (Deutsch-Neu-Guinea), Ibid., Bd. CXLIII, No. IX. Mayer, Die Papuasprache in Niederliendisch-Neu-Guinea, Globus, XCIV, pp. 18992. Finot, Les études indochinoises, Bull. de l'E. F. d'Extrîme-Orient, VIII, pp. 22I-33. Cabaton, Dix dialectes indochinoises, Journal Asiatique, Mars-Avril, 1905, pp. 265-344. Aymonier \& Cabaton. Dictionnaire čam-français (1906).

\section{(C. O. Blagden.)}

Phil.-hist. K1., Bd. III; Grundzüge einer Lautlehre der Khasi-Sprache in ihren Beziehungen zu denjenigen der Mon-Khmer-Sprachen, Abhandl. d. Königl. Bayer. Akad. d. Wiss., 1905, I Kl., Bd. XXII, Abt. III, and op. cit. inf.

(onveniently summed up in Brandstetter's Wurzel und Wort in den Indonesischen Sprachen (1910).

${ }_{2}^{2}$ Die Mon-Khmer-Völker, Archiv f. Anthr., XXXIII, pp. 59-109; and in French, Les peuples Mon-Khmêr, Bulletin de l'École Française d'Extrême-(Orient, VII, pp. 2I3-63, VIII, pp. I-35.

${ }^{3}$ Skeat and Blagden, Pugan Races of the Malay Peninsula, Vol. II, Language; Ray, The Common Origin of the Oceanic Languages, loc, cit., and J. Anthr. Inst., XXVI, pp. 204-5. 


\section{MEDICINE ${ }^{1}$}

In the following survey of the advancement of the art and science of medicine and surgery during I9IO-I 2 it is only possible to note the outstanding facts of progress, and no attempt is made to trace out the innumerable observations which preceded each discovery and each theory. An excellent account of medicine and surgery, from year to year, is to be found in the Medical Annual (John Wright \& Sons, Bristol).

The deaths of Florence Nightingale, on August 13, I910, and of Lord Lister on February IO, I I 2 , remind us of the very origins of modern surgery and modern nursing. Long ago, they had finished the work of their lives, and had given it into other hands to be carried further; and death came to them as a quiet release from old age. They won the gratitude and the reverence of mankind; and it is no light honour to the medical profession to have these two names in its calendar. To them must be added the name of Robert Koch, who died on May 27, r9ro. We associate his name so closely with his later studies of tubercle, malaria, and sleeping-sickness, that we are apt to forget his earlier study of the infective diseases of wounds, his discovery of gelatin-media for the growth of bacteria in pure culture, and his use of differential stains in bacterislogy. He advanced the new learning in Germany, as Lister advanced it in England.

Next to Lister's name, we may fitly notice some of the most recent developments of operative surgery. Many operations have been performed, with very satisfactory results, for the relief of intra-cranial pressure, e.g. from intra-cerebral growths; or for the relief of intra-spinal pressure; e.g. in chronic spinal meningitis. Division of the posterior nerve-roots has been performed, with success, in some cases of spastic paralysis. ${ }^{2}$ In another field of surgery, Alexis Carrel's work, at the Rockefeller Institute, on the direct suture of arteries, is leading to good results in practice: and his study of the transplantation of organs and the aseptic storage of organs and of tissues ${ }^{3}$ is of so great importance that one of the Nobel prizes for IgI 2 was rightly awarded to him. In the surgery of the heart, there is by this time a large number of operations, under conditions of emergency, for the suture of stab-wounds. G. T. Vaughan, ${ }^{4}$ in 1909 , was able to collect records of I 50 such cases, with 35 per cent recoveries: and more cases have been published since.

But these and other achievements of operative surgery, made possible by Lister's work, are but a small part of the medical history of the last few years. In physiology, in general medicine, and in pathology, the multitude of new facts and methods is so great that it hardly gives itself to any proper arrangement. Nothing more can be done than to note, in the order of the alphabet, some results which have been of especial interest alike in science and in practice.

Anthrax.-For some years, Sclavo's serum has been used for the treatment of anthrax in man: and we now have an authoritative statement of the value of this treatment, in the sixth Annual Report of the Anthrax Investigation Board for Bradford and District, whose medical adviser is Dr. Eurich (Brit. Med. Journ., April 20, I912). The authority of Dr. Eurich on all questions relating to anthrax may safely be called final. The Report gives evidence that Sclavo's serum is useful in cases of infection not only through the skin, but also through the lungs (wool-sorters' disease).

Appendicitis.-Of many theories to account for the great frequency of this disease, none has yet come to general acceptance. The frequency of appendicitis may be judged by the fact that five cases were admitted during one night into one of the London hospitals, all of them in need of immediate operation. The evidence is by this time almost irresistible, that delay in operation, reckoned over large groups of cases, is not advisable. Thus, among 687 operation-cases in a hospital in New York, ${ }^{5} 20$ underwent

${ }^{1}$ See E. B. xviii, $4 \mathrm{r}$ et seq. , and $\mathrm{xxvi}, \mathrm{I} 25$ et seq., with allied articles enumerated under "Medical Science" in E. B. Index Volume, pp. 937, 938.

${ }^{2}$ See, inter alia, the paper by Prof. Foerster, of Breslau, Proc. Roy. Soc. Med., July I9I I.

${ }^{3}$ See "The Preservation of Tissues, and its Applications in Surgery." By Alexis Carrel, M.D., Journ. Amer. Med. A ss., lix, 7, August 7, 1912.

${ }^{4} \mathrm{G}$. T. Vaughan, Journ. Amer. Med. Ass., February 6, 1909.

${ }^{5}$ McWilliams, Annals of Surgery, June 1910. 
operation within 16 hours of the onset of the attack. Only one of these 20 died, and that from another disease. Of I 5 who underwent operation between 16 and 24 hours after the onset, 4 died $=3.5$ per cent. Of 145 who underwent operation on the second day, 9 died $=6$ per cent. Of 103 operations on the third day, the death rate was 7.7 per cent. Of operations on the fourth day, the death rate was 18 per cent.

Beri-beri.-Few events in pathology, during late years, have been more notable, or more happy, than the discovery of the cause of this endemic disease. Beri-beri, a form of peripheral neuritis, with loss of muscular power, emaciation, and exhaustion, has been one of the scourges of the tropics. In the Federated Malay States, the estimate has been made of 45,000 deaths from beri-beri in the course of 30 years. In the Philippines, it has been a long-standing evil. During the Russo-Japanese War, it accounted for a very large part of the sickness among the Japanese. ${ }^{1}$

In 1909 Fraser and Stanton published their Etiology of Beri-beri. Working on the lines suggested by $\mathrm{C}$. Hose and Braddon, they traced the cause of the disease to the use of " milled " rice, i.e. rice which has been "polished" by the removal of its husk and outer layers. Fowls or pigeons, fed on polished rice alone, quickly showed signs of the disease: but, if the polishings of rice were added to their food, they quickly recovered. Further observations, by De Haan, Chamberlain, Eijkmann, and others, showed that the disease was not due simply to the absence of phosphates from the rice. It was due to the loss of a substance which is present as a mere trace in the husks: indeed, there are no more than ro grains of it in a ton of rice. Funk, working at the Lister Institute, has lately isolated this substance, and has given it the name of "vitamine." A pigeon, on polished rice alone, will in three or four weeks show signs of the discase. If, a few hours before death, a minute dose of vitamine be given to it, then it will quickly recover.

The wonder does not end here. For this work on beri-beri throws light on scurvy, epidemic dropsy, scurvy-rickets, etc. Indeed, Funk has isolated from limes a substance similar to vitamine, and present in about I in $100, \infty \infty$ parts of the fruit. This "vitamine of the lime" has a favourable action alike on beri-beri and on scurvy. The practical result of this brilliant series of studies is bound to be very great. We may take for example, the Philippines. President Taft, speaking on May 4, IgI I, of the American occupation of these islands, said, "The change of their food from polished to unpolished rice has practically stamped out the disease." Dr. Heiser (Journ. Amer. Med. Ass., I9I I, i, I 237) reports on a leper colony at Culion. The disease had been so common in this colony, since its founding in 1906, that, in one year, one-third of the deaths in the colony had been due to it. After the use of unpolished rice was made compulsory, no deaths occurred from the discase: moreover, cases of the disease were quickly cured by the addition of rice-polishings to their food. In May, Igro, the use of polished rice was forbidden in all civil public institutions: with the result that only 2 cases of the disease have since occurred in these institutions, and in neither case had the prohibition been strictly obeyed.

Cancer.-The Imperial Cancer Research Fund, in rgro, published its Third Annual Report, giving facts as to the production of immunity, among mice, against mousecancer. In its Fourth Annual Report, I9I r, it upholds the theory of " the individuality of cancer" as hardly open to doubt. On this theory, "each tumour is peculiarly and genetically related to the individual in which it arises. . . . The relation of each malignant new growth to the affected animal is an individual one, parallel to that obtaining between the organs of the body and the organism as a whole." And again: "The individuality of cancer, both as regards the organism attacked and the tumour, would appear to have been placed at last beyond all further doubt. Such a relationship has long been maintained in various forms on the basis of deductions drawn from histological examination of the tissues at the site of the primary lesion, and from the nature of dissemination, but this interpretation of the findings has been as vehemently

${ }^{1}$ A very important discussion on beri-beri, with papers by Dr. Schaumann. Prof. Axel Holst, and others, is published in the Transactions of the Society of Tropical Medicine and Hygiene, v, 2, December I9I 1 . 
combated. The combination of the results arrived at by microscopical investigation and experimental study appears to complete the demonstration. A long step has thus been taken in defining the direction in which the future investigation of cancer is alone likely to be profitable." Out of the multitude of recent observations and doctrines concerning cancer, we have to note the following. (I) Much attention has been given to the subject of the biological characters of the "cancer cell," its place in nature, and what may be called its natal and prenatal conditions. See, inter alia, the lectures by the late Sir Henry Butlin on "Unicellula Cancri," Lancet, November 25 and December 2, I9I I, and Mr. C. J. Bond, Lancet, 19I I, ii, 349. (2) H. C. Ross has published a book on "Induced Cell-Reproduction and Cancer," describing his observations on leucocytes suspended in citrate solution and examined in contact with a colloid film. (3) Carrel has succeeded in cultivating particles of normal tissue, embryonic tissue, and cancer tissue, outside the body, in vitro, on a medium of the blood-plasma of an animal of the same species, and has been able to observe certain exchanges of influences between the plasma and the still living tissue. (4) Wassermann has obtained results of considerable significance, in mouse-cancer, by the intra-venous use of an eosin solution of selenium (See Brit. Med. Journ., January 6, I912).

Diphtheria.-Great attention has been given lately to the subject of diphtheriacarriers. How long, after recovery from diphtheria, may the patient still be harbouring the germs of the disease at the back of his throat? What is the risk of infection from such cases? What measure of virulence is still present in these lingering germs? How far are "carriers" responsible for the prevalence of diphtheria in Great Britain? At the I9I I Annual Meeting of the British Medical Association, these questions were fully discussed. It appears that about 50 per cent. of all cases of diphtheria are free from diphtheria-bacilli within three days of the disappearance of the diphtheritic membrane; and a further 25 per cent are free within another week or ten days. It is not improbable that the bacilli, in some of these cases, are of lowered virulence. The risk of infection must depend, more or less, on the patient's age, surroundings, and personal cleanliness. There seems to be, on the whole, a considerable weight of evidence that, with such precautions as are suggested by common sense, and with bacteriological examination of all especially suspicious cases, the chance of infection from diphtheriacarriers is not a very grave danger to the community. "In my opinion," says Dr. Goodall, "one of the principal factors in the persistent prevalence of diphtheria is not the carrier, but the mild, unrecognised case."

As regards diphtheria antitoxin, the latest Report (I9II) of the Metropolitan Asylums Board states that "the amount of antitoxin supplied, the number of cases treated, and the amount of antitoxin used for each patient, all show a considerable increase." As compared with a death rate of 30 per cent before the introduction of antitoxin, the death rate for I9Io was 7.7 , the lowest on record: the death rate for Igri was 8.5 .

There is no need here to praise diphtheria antitoxin. Securus judicat orbis terrarum. But every serum-treatment has this imperfection, that the serum has other qualities of its own, beside its antitoxic action: and some persons are abnormally sensitive to illeffects from the serum itself. We must not set the risk of these ill-effects against the legions of lives which are saved: still, there the risk is, such as it is. With many patients, the serum "disagrees" (if this word may be pardoned): it gives them a rash, a high temperature, and pains in the joints, for a few days. This is the so-called "serum sickness." Much work has been done, of late years, in the hope of annulling these drawbacks without impairing the antitoxic strength of the serum: see, inter alia, Dr. Bauzhaf's paper on "The Preparation of Antitoxin," Bull. Johns Hopkins Hosp., April, I9.II. In a very small minority of these cases of "serum-sickness," the effects of the serum are more grave: and, in a few cases, they have even been disastrous. More than one method has been devised against this very rare emergency. The remoteness of the danger, in any given case, may be judged by the fact that millions of doses of antitoxin have been given without harm of any kind (see Brit. Med. Journ., May I8, I9I2). 
The name " anaphylaxis," which is now given to this abnormal sensitiveness to the properties of a serum, was first used by Richet, in another connection, in I902. In its widest sense, the word covers such idiosyncrasies as the occurrence of a rash from eating shell-fish. In relation to serum treatment, there are two types of this hyper-sensitiveness. In the one type, the patient is naturally hyper-sensitive. In the other type, the patient showed no ill-effects from a first use of serum, but was found, on a second use, not less than a fortnight after the first, to have become, in the interval, markedly hypersensitive.

So far as the treatment of diphtheria is concerned, it is probable that not one case in a thousand is put to any serious trouble by antitoxin: and it is certain that the lives saved must be reckoned, every year, in thousands. In August I9I0, the Local Government Board issued an Order empowering the metropolitan Borough Councils to provide diphtheria-antitoxin for the poorer inhabitants of their districts. This good example has been followed by municipal authorities all over Great Britain. 'The value of the antitoxin is well shown, in London, by the annual Reports of the Metropolitan Asylums Board. In the Board Hospitals, the antitoxin was first used about November 1894 . Before its use the average death-rate of the disease had been 30 per cent: it now is 8.5 per cent. In the more serious cases, the laryngeal cases, it was 62 per cent in 1894 , and now is 14.9 per cent. In the tracheotomy cases, it was 70.5 in 1894 , and now is 29.3 per cent.

Dysentery.-In bacillary (not amoebic) dysentery, the value of a serum-treatment, such as Shiga's, seems by this time to be widely recognised. The earlier results with Shiga's serum were brought before the Royal Commission on Vivisection by Dr. C. J. Martin, Director of the Lister Institute (see Minutes of Evidence, iii, 22 I, July 10, 1907). Rüffer and Willmore have lately published, in the Brit. Med.Journ., r910, ii, I519, some good results, with a serum-treatment, in cases of bacillary dysentery at the El Tor pilgrim-camp; even in the "very severe and frequently gangrenous type of the disease found in the aged and worn-out class of pilgrims." In those cases which were of a purely bacillary type, the death-rate in I909 had been 64.4 per cent; but during I9Io, when the serum treatment was used, the death rate was only 10.8 per cent. It would be wrong to put great emphasis on one set of experiences even so favourable as these; but they do not stand alone.

Heart, Diseases of the.-The disorders and diseases of the circulatory system are of themselves sufficient for the study of a life-time: and the literature concerned with them is immeasurable. Among the more important subjects of recent investigation are (I) the bacteriology of ulcerative or septic endocarditis, (2) the tonic action of adrenalin on the heart, (3) the causes of diverse forms of arrhythmia. During I910-12, arrhythmia has been studied to its finest issues, and the many constituent forces of the heart-beat have been sorted-out and measured and recorded, with wonderful minuteness, by the methods of electro-cardiography.

"The principles of electro-cardiography," says Dr. Coombs, "may be briefly stated thus. (I) A contracting muscle is comparable to a galvanic cell; the active end of the muscle is the negative pole, the passive end is the positive; and a current passes through the muscle as through the cell, from positive to negative-that is, from passive to active. It follows that when the contraction-wave reaches the middle of the muscle there is no current; and that as it passes this equator the direction of the current becomes reversed. (2) These 'action-currents' are set up in the heart-muscle in the course of each rhythmic contraction, and can be 'led-off' from the body by attaching suitable electrodes. Different 'leads' are used; the best leads-off are from the right arm or hand (corresponding to the base of the heart) and from the left leg or foot (corresponding to the apex). (3) By connecting these electrodes with a delicate recording instrument - it is the delicacy of Einthoven's stringgalvanometer ${ }^{1}$ which has made electro-cardiography applicable to clinical researchgraphic records of the variations in the electrical potential of the heart may be obtained."

Dr. Waller, in his Hitchcock Lectures, Physiology the Servant of Medicine (University of London Press, I gro), gives a full account of this method, of which he may indeed be called one of the discoverers:

"To complete an effective circuit between one's heart and a galvanometer, all that is

'See Proc. Roy. Soc. Med., April 1912. 
necessary to do is to dip the right hand and left foot into a couple of pots or pans containing salt-solution, from which wires lead off to the two ends of the galvanometer. I did this some twenty years ago, and I remember, as if of yesterday, the keen pleasure with which I first witnessed the electrical pulsations of my own heart."

Malta Fever.-As in Malta, so in Gibraltar, Malta fever-it is called "Rock fever" in Gibraltar-has been stamped out from the British garrison by prohibition of the goats' milk which was the source of infection. More recently, it has been stamped out at Port Said: all imported goats were tested for the disease, and those which showed signs of infection were slaughtered. (Ross, Journ. R.A.M.C., IgII, p. 6I8). The fever is very widely distributed; thus, it is not uncommon in South Africa (Garrow, S. African Med. Journal, I9I I, p. 5I); and a little group of cases was lately found, under the usual conditions of occurrence, in south-west Texas (Ferenbaugh, Journ. Amer. Med. Ass., I9I I, ii, 730). Sir David Bruce, at the annual meeting, I910, of the Research Defence Society, described the discovery of Malta fever in the district of Ankole, on the eastern shore of Lake Albert Edward. The native name for the fever, in this part of Uganda, was "muhinyo." He examined some 50 cases of the disease. The symptoms were those of Malta fever; the micrococcus Melitensis was found in the blood of two of the cases; the tests and reactions were those of Malta fever, and the usual evidence of infection was found among the goats of the district (See also Journ. R.A.M.C., I9Iо, p. $527)$.

Meningitis, Epidemic Cerebro-spinal.-In this terrible disease, the use of a serum treatment is by this time generally recognised as the best possible method. The first use of Flexner's serum-it is his work at the Rockefeller Institute which founded the present understanding of the nature of epidemic meningitis and the present treatment - was in igo5; the earlier results of the serum treatment (New York, Belfast) are already noted in $E . B . x v i i i$, I3 Ib. Later results, in France, were published in the Annales de l'Institut Pasteur, February I9Io. Of 402 cases with a serum treatment, 66 died $=x 6.4$ per cent. The ordinary death-rate from the disease, under other methods of treatment, is 70 per cent. Figures collected far and wide, from many contributors, are sometimes viewed with distrust. But, with cerebro-spinal meningitis, we have that best of all object-lessons, the continuous experience of a good hospital. In the Children's Hospital, Boston, U.S.A., the death-rate in cases of epidemic meningitis, year after year, without the serum treatment had ranged between 60 and 80 per cent. In I908, with the serum treatment, it came down with a run to 20 per cent.

For recent facts in Great Britain, see Reports to the Local Government Board on Public Health and Medical Subjects, new series, No. 61 (Brit. Med. Journ., 1912, i, 383).

As with diphtheria, so with this cerebro-spinal fever, much attention has lately been given to the subject of "carriers." By long study and experiment, it has been found certain that persons who have been in close association with cases of the disease, or have themselves suffered from an "abortive attack," may be able to spread the infection: and there seems to be valid evidence that the number of carriers, in time of an outbreak of the disease, may be as high as 20 or even 30 per cent of the persons bacteriologically examined: it may be even higher, among members of a family in which there has been a case. The spread of the knowledge of these facts will doubtless make people careful to take precautions, and to submit themselves for bacteriological examination, if there is any reason to think that they may be carrying the germs.

Mental Disorders (Neuropathology).--It may sound old-fashioned, and unscientific, to use the phrase " mental disorders," seeing the magnificent work which is being done on the chemical, physical, structural changes which attend diseases of the brain, and the steady advance towards a comprehensive statement of these diseases in terms of general pathology. The researches of Dr. F. W. Mott and others hardly leave room for doubt that the best work, henceforth, will be done on these lines. Still, the work of the psychologists has a distinctive value of its own: and the full time has not yet come for chemistry and bacteriology to administer the new kingdom which they appear to be entering. 
In the purely psychological study of mental disorders, much interest has lately been roused by Freud's system of "psycho-analysis "- that is, the slow and exhaustive tracking-out and uncovering of some forgotten or hidden experience which was the startingpoint of the present ousession of the patient's mind. The past is dissected back and back - and the process may go on for years-till something is found which explains everything and may itself be explained to the patient as the primal cause of his or her perversion. This underlying or subconscious something which is at last reached and detected-it may be after a year or more-is something sexual. "I can only repeat afresh," says Freud, " the principle which I have never found otherwise than true, that sexuality, in the main, is the key to the problems both of the psycho-neuroses and of the neuroses. He who disdains to use this key will never be in a position to solve them.'

Freud's position has been hotly criticised: and, though his contention were true, yet the fact remains that very few have either the skill or the desire to be inquisitors on this grand scale: and the danger remains, that the inquisitor into "psycho-neuroses " may put into the patient's mind what he subsequently finds there.

Among those who suffer from obsessional habits or thoughts, many receive benefit from treatment by suggestion. It is perhaps in cases of this kind that this treatmentwhich may or may not be with "hypnotism"-gains some of its most signal and valuable successes.

Pellagra.-To heighten the interest of the problems of pellagra, a few cases of the disease have recently been found in the British Islands; see the paper by Dr. Sambon and Dr. Chalmers, "Pellagra in the British Islands," Brit. Med. Journ., October 26, I9I 2. It is but a very few cases, at present, which have been found: but we may be sure,seeing the endemic nature of the disease, its insidious onset, and its resemblance, in the final stage, to other forms of delusional insanity, - that where a few cases have been found, more are waiting to be found. In Italy, pellagra has been endemic for centuries. It occurs, also, in Spain, southern France, Hungary, Rumania, and Algeria. So far back as I893, Dr. Sandwith recognised its presence in Lower Egypt; and his paper on the subject (Brit. Med. Assn., Edinburgh Meeting, I898) is the earliest full account in English of pellagra.

The story of the finding of pellagra in the United States is a remarkable chapter in the history of diseases. Before 1907 , its existence was not generally known. "It was not until I907, when Drs. J. W. Babcock and J. J. Watson raised the alarm, that pellagra became a subject of inquiry in the United States." Now, we know that the disease prevails in no less than thirty-three States, and that there are thousands of indubitable cases on record. "Recent importation, and spontaneous origin, are quite out of the question. Only centuries of the prevalence of the disease can explain the wide range of pellagra in North America, extending from the Atlantic to the Pacific Ocean and from the Gulf Coast to the Great Lakes; especially when we consider the peculiar topographic distribution of the disease, which, in America as in every other affected country, is limited to the foreland or 'Piedmont Section' of mountain ranges, and more particularly to the valley tracts of swift-flowing streams." A full account of the disease in the United States has been published by Dr. Niles, Pellagra, an American Problem (Saunders. Philadelphia, I912).

The Transactions of the Society of Tropical Medicine and Hygiene, v, 3, 19 1 2, contain two important papers, (r) "Pellagra in Nyasaland," by Dr. Hugh Stannus, (2) "Pellagra in Thirt y-five States of America," by I)r. Sandwith. In the discussion on these papers. Dr. Sambon referrecl to the researches which he and Dr. Chalmers had lately made in Italy, Rumania, Iungary, and Spain. It is evident, as he says, that "this grave disease is much more widely distributed and far more prevalent than had been imagined."

Sambon's theory-founded on years of careful study of pellagra in many countries. with special regard to its geographical conditions and its mode of incidence-is that the disease is an infection, probably protozoal, like malaria, and probably conveyed by Simulium, a species of mirlge: and there is evidence that this view of the disease is gaining more acceptance than the older view, that pellagra is due to the eating of infected 
maize or corn. Still, it is not impossible that, years hence, some modified form of the maize-theory may be put forward which shall be more or less adaptable, at some level not yet reached, to the theory of an insect-borne infection. At present, the latter theory is rapidly growing in favour: and the discovery of undoubted cases of pellagra in the British Islands strengthens its claim.

Phlebotomus Fever (Sand-fly fever).-In Malta, Crete, Dalmatia, Egypt, and India, there has long been known a common type of fever, which mostly went by the name of "simple continued fever." Its chief months of occurrence are between June and October: it is characterised by sudden onset, with pain and stiffness of the muscles: it is of short duration, and not dangerous to life: it leaves no permanent ill-effects; and the patient rarely suffers a second attack. During the past few years, the nature of this fever has come to be clearly understood. - Its distribution, seasonal prevalence, and conditions of occurrence indicated an insect-borne infection: and suspicion rightly fell on the sand-fly (Phlebotomus) as the probable agent. By a long series of experiments on volunteers (see Birt, Journ. R.A.M.C., Feb. I9IO) this suspicion was verified. It was proved, that sand-flies do convey the infection from man to man; that the blood is infective on the first day of the fever; that the fly becomes infective seven days after biting, and remains infective for ten days, or longer; that the incubation-period of the fever may vary from three days and sixteen hours to seven days; that the fever may also be induced by direct transmission of infective blood, and that the virus of sand-fly fever, like those of yellow fever and of cerebro-spinal fever, will pass through a fine Chamberland filter. The habits and breeding-places of Phlebotomus have been very minutely observed: and some progress has been made toward a reduction of the fever by protective measures. For example, the Journal of the R.A.M.C., xix, 4, October I9I2, contains an article by Col. Robinson and Major Blackham, on "Sand-flies and Sand-fly Fever on the North-West Frontier of India." To the fever, in this part of India, the name of "Chitral fever" was given, in rgo6, by Col. McCarrison. Two types of the fever are found in the Peshawar Valley, a three days' and a seven days' fever. The writers recommend, as preventive measures (I) the use of netting of an extra-fine mesh, (2) the use of a strong punkah or electric-fan, (3) the counter-attraction of a bright lamp, (4) early isolation of cases, (5) evacuation of barracks. This last measure " has been tried extensively in this Division at Drosh. The Fort, which has hitherto been a hot-bed of sand-fly fever, was evacuated by June I, I9II." The number of cases, which in I9ro had been 75 per cent among the native troops, was in I9I I only 27 per cent. " Other factors contributed no doubt to this happy result, but the evacuation of the barracks was undoubtedly the main one."

The Pituitary Body.-From the time of Pierre Marie's classical work, some thirty years ago, on acromegaly, the fact has been recognised that the pituitary body, a minute glandular structure at the base of the brain, exercises a profound effect on the general growth; and, as science gained more insight into the activities of the thyroid gland, the suprarenal capsules, and the parathyroid bodies, so the pituitary body likewise became an object of exact study by all possible methods of scientific observation. Within the last few years, it has been brought within the range of operative surgery. Certain operations have been performed in cases of disease of the pituitary body in man; and, for therapeutic use, an extract has been made of pituitary substance.

Much has been learned by the experimental removal of the pituitary body in animals. See the very important papers in the Bulletins of Johns Hopkins Hospital, May I9ro and June I9I. For a detailed study of the whole subject, from all points of view, we now have Dr. Harvey Cushing's book, The Pituitary Body and its Disorders (Lippincott, Philadelphia and London, I9I2).

Plague.-In the winter of I9ro-rgri, came the outbreak of septicaemic and pneumonic (not bubonic) plague in Manchuria. For this outbreak, see the Report of the International Plague Conference held at Mukden, April, I9 I , Pp. 483 (Manila, Bureau of Printing, r912). See also Dr. Douglas Gray, Lancet, I9 I , i, I I 52.

The Proceedings of the Royal Society of Medicine, November IgI I, contain Dr. 
Reginald Farrar's account, from personal observation, of this Manchurian plague; they contain also the discussion on his paper. He gives the evidence of plague occurring among the marmots.

"The first human victims claimed were probably trappers who hunt and trap this animal for the sake of its fur. After an explosive outbreak in Manchu-li, the frontier town of Siberia and Manchuria, and in Harbin, it was rapidly carried south along the railway and the ruads by the hordes of Chinese coolies from Shantung, who migrate every year into Manchuria for the soya-bean harvest, and return home to worship their ancestors at the Chinese New Year. - . The difficulties of sanitary administration were enormously enhanced by international diplomatic complications. The virulence of the infection was such that in many instances whole families and large households were mown down by the disease; and its fatality so appalling that out of more than 40,000 cases only three recoveries are claimed. . . None dared give shelter to a stricken patient, and the sick were often thrust out into the streets to die. Those who died were often hidden under the roofs of their houses, or in other places of concealment. Burial was impossible, for the temperature of Manchuria in winter is often $40^{\circ}$ below zero, and the ground is frozen hard to a depth of more than 3 feet.

". . When, however, we come to consider in cold blood the actual extent of this epidemic, we are surprised to note that its real proportions were, in fact, relatively small; we find that it was brought under control with comparative ease, despite the complete absence at the moment of its outbreak of an organised sanitary service in China; and the limitation of the epidemic rather than its extension is found to be the factor that requires explanation."

Dr. Farrar is of opinion that the limitation of the epidemic was due to the absence of rat infection, and to sanitary administrative measures.

In Suffolk, in the autumn of 1910, four cases of pneumonic plague suddenly occurred in one household; see the paper by Dr. Brown and Dr. Sleigh, Brit. Med. Journ., November I2, Igro. The bacillus pestis was found in two of them, and there seems no reason to doubt that they were typical cases of the disease. A memorandum was accordingly issued by the Local Government Board, giving instructions as to the danger of rat infection. It will be remembered that small outbreaks of the disease, during the last twelve years, have occurred in more than one of the chief British ports.

Polio-myelitis, Epidemic--Polio-myelitis (infantile paralysis) accounts for a very large proportion of the inmates of Cripples' Homes; and cases of it come daily to the out-patient departments of the great Hospitals. Yet, in Great Britain, the fact has only lately received general recognition, that infantile paralysis, like epidemic meningitis, must be reckoned among the infective diseases. In Great Britain it never attains to the ways of a great epidemic disease; but in other countries-America, Australia, Norway and Sweden-it reveals, by the severity of its epidemics, the sure signs of infection from child to child. Indeed, there are instances of the utmost infectivity, e.g. during an epidemic of 200 cases in a town in Nebraska, July 1909. "Numerous families had several children, all of whom were attacked by the disease: thus, in one family of six children, all were affected; in another family of six, four cases occurred; in a family of five, four cases occurred; and in a family of four, all were attacked. Some of the cases illustrate the infectivity of the disease. Thus, a woman went with her child to the wedding of a sister, in whose house a younger sister was ill with the disease. The mother with the child returned home, and nine days later one of her own children showed symptons of paralysis. In an adjoining house there lived a family of six children, all of whom developed the disease. A woman who came to visit this family brought her baby; in four days it died of the disease." (Seidler, Journ. Amer. Med. Ass., Jan. 22, $1910)$.

For a short historical review of some of these epidemics, see Dr. Batten's paper on "The Epidemiology of Polio-myelitis," Proc. Roy. Soc. Med., June ror r. For a minute study of the clinical and pathological aspects of the disease, see the monograph by Drs. Peabody, Draper, and Rochez, A Clinical Study of Acute Polio-myelitis (Rockefeller Institute, New York, June IgIr.) Finally, we have the Huxley Lecture, given by Dr. Flexner, in November I 912 , at Charing Cross Hospital. It is to him, more than to any man, that we owe our present knowledge of the nature of epidemic polio-myelitis. From his laborious and successful study of epidemic meningitis, he advanced straight to this 
further series of problems: and his Huxley Lecture (Brit. Med.Journ., Nov. 9, I91 2) is likely to be one of the classics of medical literature. No excuse is needed for quoting from it:- -

"Polio-myelitis has been endemic in northern Europe for many years, but it is only five years since it started on that unique, and as yet unexplained movement that has carried it around the globe. . Some significance attaches to the fact, that the first two foci of the present epidemic-I say present, because since 1907 the disease has prevailed severely each summer and autumn at some places in the United States and Canada-arose in the Atlantic Coast cities and in the State of Minnesota in the middle West. The former receive the mass of emigrant population from Europe, and the latter, secondarily, the large contingent of Scandinavian emigrants.

"Five years ago the mystery of the disease was wholly unfathomed. The outlook was suddenly brightened when Landsteiner and Popper, in 1909, announced the successful transmission of polio-myelitis to monkeys; but the high hopes raised were as quickly damped by the failure to propagate the experimental disease beyond the first generation. This obstacle was immediately removed when intracerebral was substituted for intraperitoneal inoculation, as was done by Lewis and myself, and by Landsteiner and Levaditi. By this means the disease could be, and has been, transmitted through an indefinite number of monkeys.

"The virus of polio-myelitis passes readily through the more coarse and slightly through the finest filters. It is highly resistent to drying, heat, and chemical action. In dust, especially within protein matter, it survives weeks and months; in diffuse daylight indefinitely, and resists the action of pure glycerine and carbolic acid in one-half per cent solution for many. months. When animal tissues containing the virus suffer softening and disintegration or disorganisation by mould, the virus survives. Recovery from polio-myelitis in man and monkey is attended and produced by an immunisation of the body. During this process microbicidal substances appear in the blood that are capable of neutralising the active virus.

Dr. Flexner goes on to give the evidence that the nasal mucous membrane is the usual way alike of ingress and of egress of the virus in cases of the disease. He discusses also the question of insect carriers, and of human carriers; the possibility of "reservoirs" of the virus among domestic animals, and the present position of treatment.

Relapsing Fever.-The infecting agent of relapsing fever (famine fever), the "spirillum Obermeieri," is conveyed from man to man, like the infecting agents of many. other fevers, by the bite of insects. The fever is thus akin to other forms of spirillum infection, or "spirochaetosis," such as the spirochaetosis of fowls. Mackie, in India, first showed that body-lice are capable of conveying relapsing fever; and Bousfield (Jour. R.A.M.C. I9ro, ii, 444) has published evidence of a similar way of infection in the Sudan. Other observations, e.g. in Russia, tend to prove that bugs convey the disease. And in the Western States of America, e.g., Montana, California, Idaho, there seems to be some evidence that it may be conveyed by cattle-ticks. Major Marjoribanks, I.M.S., speaking of the transmission of the fever by body-lice, puts the matter well:-

"What is the practical use of this discovery? Simply this, that the subject of relapsing fever has been lifted from the sphere of curative medicine into the far higher sphere of preventive medicine. Formerly, all we could do was to send our native assistants into infected villages with febrifuges and other paraphernalia of curative medicine. But now we can strike at the disease at the root, and, by destroying the lice on the bodies of patients, prevent its spread. The details of the campaign have still to be worked out. My own suggestion to village officers so far has been that a cauldron should be set up in each infected village, and the clothes of the patient boiled in it to destroy the lice. Other methods will suggest themselves as we gain experience: this is a bit of preventive medicine in the making."

Sleeping-Sickness.-Dr. Sandwith, in his Gresham Lectures for I9 $2,{ }^{1}$ has told the whole story of Sleeping-Sickness, from the time of Livingstone till now. Under " Present Research Work," he writes as follows:-

"Important investigations are being carried out under the re-constituted Sleeping-Sickness Commission in Central Africa appointed by the Royal Society, consisting of Sir David and Lady Bruce, Captain A. E. Hamerton, D.S.O., and Major D. Harvey, to find out the reason why, although man and his domestic animals have been removed from the shores of the Lake Victoria Nyanza for some three years, Glossina palpalis, caught on the north shores of the lake, still continues to infect susceptible a nimals when allowed to feed on them for experimental purposes. Their prime object is to investigate the part played by African fauna in the maintenance and spread of sleeping-sickness.

${ }^{1}$ Sleeping-Sickness, by F. M. Sandwith, M.D., F.R.C.P. Macmillans, I9I2. 
"The effect of the depopulation of the country was to make a two-mile area on the north shore of the lake practically a game preserve, frequented by many kinds of antelope, hippopotami, and wild pig. The late Commission set themselves the task of finding out whether this game, and especially the antelope, were capable of harbouring the parasite, being thus a perpetual reservoir from which the fly could get fresh infective material. Very complete experiments were carried out, and it was found that antelope are very readily infected with trypanosomes from flies previously infected with human trypanosomiasis, and that the blood of the artificially infected antelope again infects other susceptible animals if the Glossina palpalis acts as an intermediary carrier. In no single case, among many animals experimented on, was the health of the antelope in any way affected. From a paper published by the Royal Society in February 19I2, we learn that one of Sir David Bruce's artificially infected antelopes still contains, after 327 days, Trypanosoma gambiense in its blood.

"It has now been proved that antelope living in fly-areas in N. Rhodesia and Uganda are naturally infected by the two human trypanosomes of sleeping-sickness. This is a sufficient explanation for the continued infectivity of the fly round the lakes. It is important to find out whether other wild game can, and do, act as a host of the parasite. It has already been suggested that the wild game in sleeping-sickness areas should be destroyed, but the British Government is unwilling to authorise any such wholesale extermination of animals, which might be wanted for food, until it has been more satisfactorily proved that the game are the chief reservoir of the parasite.

". Every fresh discovery tends to increase the complexity of the problem how to deal with the question of prevention. It is now known that the fly remains infective, after feeding on infected blood, for 96 day's, and possibly for the entire course of its life; that not only the Glossina palpalis, but also the far more plentiful Glossina morsitans is implicated; and now we must assume that an inexhaustible supply of infective material can be drawn by both these flies from innumerable reservoirs among wild game, and also among cattle and other domestic animals, because they can be infected so easily by experiment."

Happily, the work of protective administration has not been annulled by these further problems of science: and good work has been accomplished, under conditions of the utmost difficulty, toward holding the disease in check. It is worthy of note, that since the way in which the disease spreads was discovered, the annual death rate from sleepingsickness on the Uganda shores of the Victoria Nyanza has fallen from 8,000 to 500 . There are several causes for this happy reduction; but chief among them may be reckoned the present measures of protection and prevention to which men of science have been led by the help of experiments on animals.

Again, though no specific treatment has yet been discovered for the disease, such as quinine for malaria or antitoxin for diphtheria, there is much to be gained by treatment, if the conditions allow of continuous treatment. Unhappily, these favourable conditions, as Dr. Sandwith points out, are to be obtained in the few European cases, not in the vast multitude of the native cases:-

"The native does not usually come under treatment till he has developed the final and most serious symptoms, when his fate is sealed, and when the treatment can do no more than alleviate his sufferings and make his death less painful. Even if the negro presents himself for treatment at an earlier stage, and is apparently cured, he returns to the infected area, and his naked body is again a target for every hungry tsetse-fly, so that he may succumb to a fresh infection at once.

"But in the European the outlook is more hopeful. In most cases he comes to the doctor when he feels the first symptoms, and directly trypanosomes are detected in the blood he is sent out of the country and is safe from fresh infection. He submits to continuous treatment, and does not attempt to escape from his advisers-as the negro does when his condition begins to improve and he yearns for liberty from hospital confinement." (Sandwith, loc. cit.)

Sir Pat rick Manson has reported two European cases: one, after $2 \frac{1}{2}$ years of treat ment, has gained $30 \mathrm{lbs}$. in weight, and, though not absolutely cured, is well enough to walk three miles without fatigue: another, a lady, is in good health more than ten years after the onset of the disease. Among European cases which have ended fatally, there is the case of I.t. Forbes 'Tulloch, R.A.M.C., of the Royal Society's sleeping-sickness Commission in Lganda: he cut himself, dissecting an infected rat; trypanosomes soon appeared in his blood, and, after an unusually rapid course, the infection ended in death (June, I()06), within a few months. If any student of tropical medicine wishes to form an estimate of the volume of work done in the last few years on sleeping-sickness, he must 
look at the Bulletins of the Sleeping Sickness Bureau. (This admirable Bureau, in July I9I2, moved from Burlington House to the Imperial Institute: and it now is called the Tropical Diseases Bureau.)

Syphilis.-Great help has lately been given, toward the detection and study of the germs of this disease, the Spirochaeta pallida, by the use of lateral illumination of a dark microscope-field. The lateral rays of light are condensed by a parabolic reflector, and the central rays are cut off by a diaphragm. The spirochaetes show white against a black background. By the addition of micro-photography to this method of lateral illumination, "living pictures " have been obtained for the cinematograph.

For the diagnosis of past syphilis, and for the differential diagnosis between syphilitic and non-syphilitic lesions, the Wassermann test is of great importance, and has already become the subject of an extensive literature. See, inter alia, "The Wassermann Serum Reaction and Ehrlich's Salvarsan," by Carl H. Browning, M.D., and Ivy Mackenzie, M.B. (Constable, IgII.) See also a paper by Lt.-Col. Birt, in the Journal of the R.A.M.C., September I9I 2 , with a series of cases where, without the use of this test, " treatment would have been inappropriate, diagnosis would have been haphazard, prognosis mistaken, and the claims of the patient against the public would have been wrongly assessed."

The discovery and study of Spirochaeta pallida made it possible to observe the direct action of drugs on the living cause of the disease, under the microscope, and in the blood and tissues of experimental animals: the disease was brought into line, for the work of science, with other forms of spirochaetosis. In the latter half of I909, came the news of Ehrlich's discovery of "salvarsan." Ehrlich gives an account of his own work in Die Experimentelle Chemotherapie der Spirillosen (Berlin, Julius Springer, I9Io), by himself and S. Hata. Ehrlich had long been working at the arsenical compounds, e.g. atoxyl, arsacetin, in their bearings on syphilis: and, from these compounds, he and his fellow-workers advanced to the discovery of salvarsan. This arsenical compound (dioxydiamidoarsenobenzol, $\mathrm{C}_{12} \mathrm{H}_{12} \mathrm{~N}_{2} \mathrm{O}_{2} \mathrm{As}_{2}$ ) has also been called "606," and EhrlichHata; a later modification is called neo-salvarsan, or " $9 \mathrm{I}_{4}$."

No event in therapeutics since the discovery of diphtheria antitoxin has caused more wonder than the rapid and powerful action of this new weapon against syphilis. Even a single dose is capable of bringing to a sudden end the manifest signs of the disease. To be able to see; under the microscope, the destruction of spirochaetes by one dose of salvarsan, is to realise that the use of this "therapia sterilisans magna " is the greatest advance that has been made, within the memory of man, in the fight against syphilis.

It would be, in the common phrase, "too good to be true," if the use of this drug were absolutely free from risk. Salvarsan is not a drug to play with. A careful estimate of this risk has been made by Lt. Col. Gibbard, Major Harrison, and Lt. Cane: see the Journal of the R.A.M.C., September I9I 2, for their paper on "Salvarsan and Neo-salvarsan in the Treatment of Syphilis." They point out the shortening, by salvarsan, of the period of "inefficiency" in Army cases of the disease. They refer as follows to the element of risk in the use of salvarsan: "We may say at once that in 43 subcutaneous or intra-muscular and $\mathrm{I}_{6} \mathrm{r}_{3}$ intravenous injections, we have not experienced any untoward incident; while Wechselmann states that, in the course of over I 2,000 injections, he has not had any death which could be attributed to salvarsan. When we consider that probably more than a million injections must have been given, all over the world, fatalities amounting even to a fraction per thousand of the injections could not have been concealed, and would have filled a prominent place in the literature." (For the whole subject of syphilis, see Proc. Roy. Soc. Med., v, 9, October 191 2: Supplement. Pp. 214).

Tuberculosis. - In July rgr I the British Royal Commission on Tuberculosis, after no less than ten years of enquiry, ișsued its Final Report, founded not only on the experimental work done at Lord Blyth's farms and elsewhere, but on a vast extent of clinical, pathological, and statistical evidence. The principal findings of this Final Report are to the following effect: (I) In many cases, human tuberculosis is identical with bovine tuberculosis. (2) Tuberculosis is transmissible from mammals to man 
and from man to mammals. (3) Tuberculosis is transmissible to man in the milk or the meat (pork or beef) of tuberculous animals. The risk of infection from birds (avian tuberculosis) is negligible. (4) There are three types of the bacillus of tubercle: human, bovine, and avian. (5) The bacillus of lupus is of the bovine order, but is of a modified type, and is not identical with bovine tuberculosis. (6) Strict supervision of the meattrade and the milk-trade is of the utmost concern to the public health, especially in regard to infants and young children; and no relaxation of the present restrictions is permissible.

On January I, I9I2, pulmonary tuberculosis (consumption) was made one of the compulsorily notifiable diseases in England. The preliminary steps towards this measure are of interest. The municipal system of voluntary notification, with partial isolation, introduced by Dr. Newsholme in Brighton, gave encouragement toward further action. In 1908, the Local Government Board, taking advantage of its powers under the Public Health Act, issued the Public Health (Tuberculosis) Regulations, 1908, making the notification of consumption compulsory in all Poor-law cases of the disease, whether institutional or district. In I9II, it issued similar Regulations for all inpatients and out-patients of Hospitals and Dispensaries other than Poor-law institutions. Having thus covered two-thirds of all cases, it covered the remaining third on January I, I9I2.

In the last few years, great attention has been given to the use of "auto-inoculation " as a factor in the treatment of tuberculous disease; and to the relation of graduated exercises to auto-inoculation. Much work has also been done on the efficacy of bovine tuberculin for the treatment of tuberculosis of human origin, and the efficacy of human tuberculin for the treatment of tuberculosis of : bovine origin. Along these lines, a notable advance has been made, in Germany and in the United States, toward the saving of calves born of tuberculous cows. The principle of the method has been stated as follows: "If a calf is born of a tuberculous cow and left with its mother, the calf dies. If the calf is inoculated with small doses of bovine tuberculin the calf will also die. But if that calf is taken away from its mother and inoculated with small doses of human tuberculin, the calf will live and will be able to return to the herd from which it came."1

Typhoid Fever.-During I9IO-I2, the house-fly has been marked down as an important agent in the spread of typhoid fever, and, probably, of other infections. The fly does not act as an intermediate host of the bacillus typhosus: it does not afford such opportunities to these germs as the Anopheles mosquito affords to the protozoa of malaria: it simply conveys the germs, on its feet, from infective substances to our food. A full account of the subject will be found in Dr. L. O. Howard's book, The House Fly, Disease Carrier (Murray, I9I2). The use of a protective vaccine against typhoid fever is steadily gaining ground, and there is no longer any room to doubt its validity. II e have only to hope that it may be made, by further work, more efficient and more lasting. Meanwhile, we have reason to be glad of the good results which have already been obtained. Two sets of figures come to be noted here: they are concerned with the British Army in India, and with the Army of the United States.

(a) Sir William Leishman, in his address to the Glasgow Medico-Chirurgical Society on "Anti-typhoid Inoculation" (Brit. Med. Journ., Feb. I7, I9 2), said that "for 17 years prior to 1907 the annual number of admissions had averaged I406, with an average of 35.3 deaths. In 1005, anti-typhoid inoculation was introduced as a voluntary measure; and, while at first not largely utilised, was by 1007 being taken advantage of by the troops in increasing numbers. Since that date, the admissions from enteric had fallen steadily, till in Io 10 they numbered only 296 , with 45 deaths." Col. Firth, in his paper on "Recent Facts as to Enteric Inoculation and the Incidence of Enteric and Paratyphoid Fevers in India" (Journ. R.A.M.C., Aug. roI2) says that the whole series of facts indicates "that against enteric fever the value of inoculation as now

1 See Major Cummin's paper on "Primitive Tribes and Tuberculosis, ' with discussion: Trans. Soc. Trop. Med. and IIyg., June 1912. 
practised is most marked, and the case in favour of the procedure much strengthened by our experiences during Igr.."

(b) President Taft, at a medical banquet given to him in Philadelphia, on May 4 , Igr I, spoke as follows:-

"We have a division of 18,000 men in Texas and California. They have been there for two months, living under canvas, and in a country soaked with rain and deep with profanityprovoking mud. But so effective have been the regulative and preventive methods adopted to reduce sickness, that the percentage of sick men is less than it was in the posts from which these men were mobilised. I need not recall the dreadful record of sickness from typhoid fever in the camps at Chickamauga and other camps established during the Spanish-American war. The percentage of typhoid cases was so high that it is hard to believe. Of I20,000 men there were 20,000 cases, with a mortality of 7 per cent. Of the volunteer regiments mobilised during the Spanish-American War, 9o per cent became infected with typhoid fever within eight weeks from the date of mobilisation. To-day, two monthis after moliilisation, with the modern health regulations, and by the use of vaccination against typhoid, not one case of typhoid fever has appeared in the entire force, except that of one teamster who was not vaccinated."

A few weeks later, in the autumn of I9 I , an Army Order was issued, that the protective treatment against typhoid fever was to be made compulsory in the United States Army on all officers and men under 45 years of age; excluding, of course, those who had already suffered from the fever. The total number of men to receive the treatment was 76,000 .

In I9I2, it was stated that a similar measure was to be adopted in the United States Navy (See Brit. Med. Journ., Feb. 3, I9I 2). See also, on this point, Dr. Ford's paper on "The present status of the anti-typhoid campaign in Germany" (Johns Hopkins Hosp. Bulletin, Sept. I9I2), and Dr. Vincent's results with anti-typhoid inoculation in Morocco: (Brit. Med. Journ., Jan. 6, I9I2).

Much attention has lately been given to the important subject of carriers of typhoid and paratyphoid fever. See, inter alia, Dr. Bainbridge's paper, with discussion, on "The Etiology and Epidemiology of Paratyphoid Fever and "Food-poisoning'", (Proc. Roy. Soc. Med., Feb. I9I I) and Dr. Hamer's paper, with discussion, on "Typhoid Carriers and Contact-Infection" (ibid., April I9II). The whole subject has been reviewed in an authoritative volume by Dr. Ledingham and Dr. Arkwright, of the Lister Institute, The Carrier Problem in Infectious Diseases (Arnold, London, I912).

This question of carriers came into public notice, in rgIo, over an outbreak of illness in Wrexham, which affected 107 persons, with 5 deaths. The cases presented signs of paratyphoid infection; and the epidemic was associated with the eating of pork pies from a certain bakery. The bakehouse was sanitary; the meat was wholesome; the pies had tasted all right, and no chemical poison was found in them. But paratyphoid bacilli were found in them, and in blood from the heart of one of the fatal cases; ${ }^{-1}$ and, in several cases, after recovery, a blood-test gave evidence that they had suffered from paratyphoid infection. One of the staff at the bakery, apparently in perfect health, was found to be a carrier of paratyphoid bacilli identical in type with those found in the pies and in the blood from the fatal case. The opinion of the experts was, that this outbreak of "food-poisoning" was a genuine epidemic of paratyphoid fever, due to infection with "paratyphoid B bacilli;" and that the probability was "practically conclusive" that the carrier was the source of the infection.

The existence of typhoid carriers is a sure fact; but opinions differ as to the measure of danger of infection from them. Dr. Theodore Thomson, in his address on "The Enteric-fever Carriers" (Proc. Roy. Soc. Med., Nov. I9ro), estimates that 3 per cent of typhoid cases continue, after recovery, to be "chronic carriers;" and he thinks the estimate would be higher if more general use were made of bacteriological examination of the excreta after recovery from the disease. On a few occasions, evidence has been brought forward as to typhoid carriers which may, without offence, be called sensational. "The most noteworthy example," says Dr. Theodore Thomson, "is that of the Folke-

1 It is to be noted, as a sign of the virulence of the infection, that this fatal case seems to have infected three persons attending on her, one of whom died. 
stone cowman. There is every reason to believe that to this man might be attributed $6+$ per cent of the cases of enteric fever that occurred in Folkestone during the period ISo6-1909; the total number of cases during this time was 222." A similar case, in New York, was that of "Typhoid Mary," to whom many cases of typhoid were traced; she was compelled therefore to submit to a very long period of isolation. But the authorities are not agreed that every typhoid carrier is dangerous to the community: and much may be gained by enforcing strict rules of personal cleanliness, and by preventing any handling of other people's food. It seems not improbable, also, that proper treatment may make the typhoid carrier a safe member of society.

Vaccine-Therapy.-Two recent contributions, of special interest, to the literature of vaccine-therapy, are (I) "Vaccine-therapy: its Administration, Value and Limitations," Proc. Roy. Soc. Med., October I9 Io: Special Supplement; (2) Report of the Inoculation Department, St. Mary's Hospital, Paddington, I9 2.

Among recent extensions of this method of treatment, we have to note Gabritschewsky's streptococcus-vaccine as a protective against scarlet fever (sce Boston Med. \& Surg. Journ., Feb. 24, I010). This method was used in several Russian towns and villages during outbreaks of the fever; and the results appear to be very good. Thus, of 528 persons "vaccinated " once, 8 subsequently had the fever: of 106 "vaccinated" twice, and of 149 " vaccinated" thrice, none had it. In villages without this protective treatment, I6 per cent of the children had the fever: in villages with the treatment, $\mathbf{1 . 4}$ per cent.

For the cure of certain infective diseases, vaccine-therapy has by this time won general recognition as a safe and efficient method, and, in some large groups of cases, as one of the best of all methods: e.g. in many cases of streptococcic or staphylococcic infection of the skin. Good results have also been obtained with a vaccine-treatment in cases of pneumonia and of typhoid fever. (Reference has already been made to tuberculin, which is a vaccine.) Good results are reported (Ziegler, Brit. Med. Journ., Nov. $\mathrm{I}_{3}, \mathrm{I}(000)$ ) from a vaccine-treatment in a case of chronic glanders. In cases of hay-fever, benefit has been gained by what may be called a vaccine-treatment with pollen-extract, given some time before the hay-season. The advantages of vaccine-therapy, with its autogenous vaccines, over sero-therapy, are obvious: but, till science is able to give us a vaccine treatment for diphtheria and epidemic meningitis, we must be content to be thankful for the serum-treatment of these infections.

Conclusion.-Finally, a few points of special interest to the medical profession in Great Britain may be noted.

The final Report of the British Royal Commission on Vivisection, issued on March I2. I912, was the result of five and a half years of enquiry. Happily, it is unanimous: there are "reservation memoranda," but there is no minority report. The Commissioners are all agreed "that experiments upon animals, adequately safeguarded by law, faithfully administered, are morally justifiable, and should not be prohibited by legislation." They recomriend certain additional safeguards; which come within the power of the Home Office, and do not require the intervention of Parliament. They are all agreed that, by experiments on animals, "Valuable knowledge has been acquired in regard to physiological processes and the causation of disease, and useful methods for the prevention, cure, an I treatment of certain diseases have resulted." Of certain statements made to them by " anti-vivisection" witnesses, they say: "After careful consideration of the above cases we have come to the conclusion that the witnesses have cither misapprehencled or inaccurately described the facts of the experiments.

So far as we can judge, we believe that holders of licences and certificates, with rare exceptions, have endeavoured with loyalty and good faith to conform to the provisions of the law." And they give an emphatic warning to the public:-

"We desire further to state that the harrowing descriptions and illustrations of operations inflicted on anmals, which are freely circulated hy post, advertisement, or otherwise, are in many rase's calculated to mislead the public, so far as they suggest that the animals in guestion were not uneler an anaesthetic. To represent that animals subjected to experiments in this country are wantonly tortured would, in our opinion, be absolutely false." 
In the Hospital world in England, one of the most important events of late years has been the removal of King's College Hospital to a site in the neighbourhood of Denmark Hill. The new buildings were almost complete in November I9 12, and the Hospital was expected to be in full working-order by the beginning of the winter session, October I9I3. Westminster Hospital, likewise, is preparing to move.

The International Medical Congress meets in London, in August, 1913, under the Presidency of Sir Thomas Barlow.

(Stephen Paget.)

\section{DENTISTRY!}

The progress of dentistry during recent years has been characterised by marked advance in the technical procedures of its several departments and a corresponding development of its underlying scientific principles. The stimulus towards scientific investigation furnished by the publication of the results of Miller's studies of the nature and causation of dental caries during the latter decades of the past century has not only produced a large number of workers in related fields of research, but has created an appreciative interest in scientific investigation throughout the dental profession, so that the factor of empiricism so evident in earlier dental methods is being rapidly eliminated and replaced by a more rational and scientific practice.

An extensive study has been made of the problem of dental caries, not only as related to the individual, but in its broader aspects as a public health question. Carefully gathered statistics in all civilised countries point definitely to certain conclusions. First, that tooth decay is practically a universal disease among civilised peoples. Second, that between 92 and $95 \%$ of people in all nations are more or less subject to it. Third, that it is essentially a disease of youth and adolescence. Fourth, that in the life cycle of the individual there appear to be well marked periods of immunity and susceptibility. Fifth, that there appears to be a relation between the food habit of the individual and susceptibility. Sixth, not only statistics but experimental observation have demonstrated that decay of the teeth, its concomitant mouth conditions and its direct pathological results, are the cause of a degree of physical and mental deficiency in school children which, apart from humanitarian considerations, involves an economic factor of the highest importance. Dental disabilities are a cause of lowered physical and mental efficiency in children of school age, thus depreciating the value of the most important asset of the state in its future citizens, and, purely from a pecuniary point of view, it can be shown that it costs much less to remove this preventable cause of inefficiency and mental backwardness in school children than it does to continue them in school for the added time which the dental disability entails.

The extent and importance of the problem of dental disease, in its relation to public health and therefore physical and intellectual efficiency, is attracting the serious consideration of sanitarians, educators, military and naval authorities, criminologists, authorities of eleemosynary institutions and large manufacturing industries, generally speaking, in all countries. The attention of the dental profession has been focussed not only upon the improvement of all of its operations and procedures that have for their object the arrest and repair of the ravages wrought by dental disease, and the devices for restoration of lost dental organs, but also on the investigation of the causation of dental disease and particularly caries with a view to its preventative or prophylactic treatment. Much important work has already been done in connection with the fundamental aspects of the subject of dental prophylaxis, upon which later a scientific scheme of prevention of dental decay can be wrought out, mainly in the direction of so changing the composition of the mouth fluids as to render them unsuitable for the localised growth and propagation of the bacterial influences that are the direct cause of tooth decay, a change which at present is most hopefully sought in the direction of improved dietetics.

While the underlying principles of the preventative treatment of dental disease present problems of great intricacy, these are the subject of active investigation, and

${ }^{1}$ See $E$. B., viii 50 et seq. 
encouraging progress is being made toward their ultimate solution. Incidentally the resources of dental art are being enlarged in all departments, with a corresponding improvement in operative and restorative procedures.

Notable advances have been made in the control of pain in the performance of dental operations by the intelligent use of both local and general anaesthesia, so complete a success having been achieved that there is no longer any proper justification for the obligatory infliction of pain in the performance of any dental operation. The scientific study of the physiological action and therapeutic application of the large number of local anaesthetic drugs now available, and the improved methods of technique devised for their rational use by numerous investigators, notably by Prof. Guido Fisher, Prof. Hermann Prinz and others, has made it possible to use them safely for anaesthetising any predetermined area about the mouth and jaws, while the element of danger from toxic effects has been practically eliminated. Moreover it is now possible to maintain for an indefinite length of time a preliminary or peripheral stage of general anaesthesia, in which the sensory nerve terminals are anaesthetized while consciousness is in no appreciable degree interfered with, or to produce a state of " analgesia " (the elimination of pain) by carefully graded administration by inhalation of a determinate mixture of nitrous oxide and.oxygen. The patient breathes the requisite amount of mixed gases through a speciallyicontrived inhaler through the nostrils until the analgesic state is produced, leaving the mouth unobstructed for the required operation, which is performed without sensation of the slightest pain by the patient, yet without disturbance of general consciousness. The administration of the mixed gases for the production of the analgesic stage of anaesthesia may be continued without danger throughout the operation.

Notable advances have been made in the study of the nervous relations of the teeth and their relations to disturbance of reflex character in other parts of the body. Many stubborn and severe neuralgias about the head and neck, some of the choreas of childhood, epilepsy, dementia praecox, lesions of the ocular muscles, tic douloureux, arrested development of the jaws, of the nasal chamber and facial region, have in a variety of instances been found to have their origin in malpositions, impeded eruption or impaction of certain of the teeth, prompt relief of the disorders having followed the removal of the source of their dental origin.

The group of inflammatory disorders that disastrously affect the supporting and retentive tissues of the teeth, referred to as gingivitis, phagedenic pericementitis, pyorrhea alveolaris, etc. or commonly referred to as "Rigg's disease," have been the subject of close and careful study for many years, but the application of modern methods and the advances made in bacteriological science have done much to clear up their pathological nature. Among the important results thus attained is the knowledge that the destructive process is not a single disorder with a specific bacterial organism as its exciter, but a mixed infection giving rise to a group of inflammatory processes having a variety of expressions, due to differences in the nature of the infecting organisms concerned in their production, and to differences as well in the character of the tissues which are the seat of the disorder. Two broadly distinguished classes of disorders are now recognised as leading to the loss of the teeth by destructive inflammation of their supporting tissues. First, those which are primarily due to the accumulation of tartar of salivary origin upon the exposed tooth surfaces, which deposits impinge upon the gum margins about the necks of the teeth, act as a mechanical irritant to the soft tissues, thus rendering it susceptible to infection by pus-producing bacteria, and, second, the class of infections of the alveolar tissues which occur in connection with a weakened condition of the body due to malnutrition in some of its many forms, in which there is a general lowering of resistance to bacterial invasion, the gum tissues because of their relatively low resistance being in these cases the selected point of entry for the disease-producing germs commonly found in the mouth cavity. The better understanding of the causation of these gingival and alveolar inflammations has made possible their more rational, and, therefore, their more successful treatment. 
Thoroughness of local treatment by which every vestige of foreign matter adherent to the exposed tooth surfaces is completely removed is now recognised as essential to the cure of the disorder.

In order to achieve the necessary thoroughness of instrumental cleansing of tooth surfaces, great improvement in the number, character and adaptation of special instruments has followed, and the necessity for continued prophylactic treatment both by the dentist and the patient is recognised and insisted upon. In the more serious forms of alveolar disease, those complicated with a systemic or general nutritional disorder, attention must necessarily be directed to the correction of the impaired constitutional state; and as in such cases the general resistance of the individual to bacterial infection of the pus-producing variety is usually found to be less than normal, much therapeutic value has been derived from the administration of properly graded doses of autogenous vaccines derived from cultures of the organisms taken from the pus exudate about the affected teeth. The application of serum therapy to the treatment of alveolar pyorrhea must, however, be made with intelligent regard to the nature of the case if curative effects are to be derived from its use. In properly selected cases where the selection is based upon a correct diagnosis of the origin and nature of the disorder the use of serum therapy has given most satisfactory results.

The restorative procedures of operative dentistry have been greatly improved in usefulness and artistic quality by the development of the "inlay method" of filling cavities resulting from tooth decay, and by the improvements made in the composition of plastic filling materials, which make possible the restoration of lost tooth structure by materials so closely simulating the texture of the teeth as to render the repair unnoticeable.

The so-called inlay may be of metal or of porcelain. Gold is the metal used almost exclusively when a metallic inlay is to be constructed. The procedure is the invention of W. $\mathrm{H}$. Taggart of Chicago, and consists essentially of making a stopper of specially prepared wax to fit the previously cleaned and shaped cavity in the tooth, in all respects of the same form as it is desired that the finished inlay shall assume. The wax model of the inlay is then withdrawn from the tooth cavity and embedded in a mixture of clay and plaster of Paris contained in a small ring-like flask, so arranged that a gateway reaching from a concavity formed in the free upper surface of the investing mass shall communicate with the wax form embedded in the centre of the flask so as to permit the passage of the molten gold to the matrix left in the investing mass after the wax model has been removed by heating the apparatus to a temperature that completely dissipates the wax. Pure gold fragments are then melted in the concavity in the surface of the investment by means of the flame of a compound blast lamp burning a mixture of nitrous oxide and illuminating gas. At the moment of fusion of the gold the cover of the flask is forced down upon it by means of a lever which simultaneously opens a valve admitting nitrous oxide gas, under about $40 \mathrm{lb}$. pressure, to the surface of the melted gold, forcing it into the finest intricacies of the mold. The cast filling thus made is cut free from the casting head or sprue, and its outer surface is finished with a fine polish; it is then cemented to place in the tooth cavity with a suitable fine grained cement. The cast metallic inlay, while not universally applicable in all classes of cavities, especially where the color of gold would be objectionable on aesthetic grounds, has, however, a large usefulness in restoration of molar teeth weakened by extensive caries and where great strength of material is required to withstand the stress of mastication. The porcelain inlay has its special application to the filling of cavities in exposed positions in the front teeth where the insertion of gold restorations would be unsightly. The porcelain inlay is made by first forming a matrix in platinum foil of extreme thinness (.001 of an inch) by burnishing the foil into contact with the cavity walls and then filling the matrix thus made with porcelain paste and fusing it to homogeneous mass. Any tint or texture may be thus produced, enabling the skilful operator to imitate perfectly the texture and color of the tooth into which the inlay is to be inserted.

While fillings of gold foil have for all time demonstrated their utility and trustworthiness in the saving of carious teeth, gold has nevertheless distinct disadvantages for the purpose, the recognition of which has constantly stimulated the search for an acceptable substitute that would possess its valuable tooth-saving qualities without its objectionable feature of color, high thermal and electric conductivity, and the difficulties of its manipulation. A number of plastic substances, the amalgams, various cements and gutta percha, have been in use for years, but each has been defective in certain qualities, and though used in large quantity they have nevertheless had but a limited range of usefulness. Recently considerable advance has been made in connection with the plastic filling materials by the introduction of so-called silicate or silicated cements, combinations of calcium and zinc phosphate with silica, which give promise of a decidedly nearer approach toward the long-sought ideal plastic filling material. The peculiarly desirable feature of the silicated cements is their translucency, which closely simulates that of tooth structure in appearance, and their high 
resistance to the solvent action of the buccal fluids. The extensive use now made of the inlay methods and the improvements in tooth filling cements has had a marked effect in reducing the use of gold foil as a filling material, and while accurate figures are wanting, it is probably a safe conjecture that the average number of gold fillings done is to-day not over $50 \%$ of the average number performed ten years ago. The change represents the elimination of a large amount of operative discomfort both to the patient and to the dentist.

The significant feature which marks the more recent advance in prosthetic dentistry is the broader recognition of the fact that its ideal is not so much that of mechanic art as it is that of a restorative art related to vital activities. This feature is particularly noticeable in connection with the construction of artificial tooth crowns and crown-and-bridge work. Abundant evidence has accumulated to show that badly constructed mechanisms of this character are a fruitful source of disease action in the living tissues with which they are related. Recognition of this fact has led to the more rational designing, construction and application of these prosthetic appliances, so that the intelligent and skilled operator is now able to make these restorations so that they are not only free from disease-producing defects, but completcly and satisfactorily fulfil their purpose as restorers of impaired masticatory function. A marked advance may also be noted in the artistic reproduction of lost dentures, a result attained by the systematic study of the principles of physiognomy and the factors entering into the harmonious balancing of the several expressional features of the countenance, of which the dental apparatus constitutes a most important part.

The importance of correct alignment and of normal occlusion of the teeth is not only generally recognised, but is claiming the attention of a large body of specialists who devote their time and energies exclusively to that important department of dentistry. Apart altugether from the question of unsightliness, investigation has shown that malposition and malocclusion of the teeth interfere seriously with the efficiency of the masticating mechanism; they interfere with bodily health by preventing oral cleanliness, by inducing mouth breathing by preventing proper oxygenation of the blood, by causing nose and throat troubles, and by inducing a variety of nervous and nutritive disorders. The demand is now justified that malpositions of the teeth shall be corrected on hygienic grounds for the same, or even stronger, reasons that apply to the correction of visual defects.

Dentistry has altogether passed beyond the stage where it may be properly regarded as an art of handicraft. The mouth and its contained organs and tissues not only present for study and treatment a variety of disease conditions all of which are important in themselves and not a few of which are a serious menace to health and even life itself, but, because of their close nutritive, vascular and nervous relations with the rest of the body, frequently contain the first indications of ill health and general disease and enable it to be diagnosed in an unmistakable way. Because of these vital relationships the education of the modern dentist includes the study of all the fundamental medical sciences that form the basis of the science of healing, and the training now required of the student corresponds in plan to that required of the medical specialist.

(EDWARD C. KIRK.)

\section{OSTEOPATHY}

Note.-The distinctive school and system of medicine to which this name has been given has become so prominent in recent years that an authoritative statement of its principles and claims appears desirable. 'This is contributed in the following article by a leading American osteopathist.-ED.

Osteopathy passed its thirty-eighth birthday in June Ior 2. It is the science of the prevention and treatment of diseases of the human body, based upon the recognition of the human body as a vital mechanism, a living machine, which, given wholesome physical and mental environment, good food, proper exercise, pure air and pure water, will be healthy, i.e. will function properly, so long as all the cells and parts of that vital mechanism are in normal adjustment. Ostcopathy teaches that structural derangement of the body is the predisposing cause of disease. Faulty mechanism causes functional perversion of the vascular and nervous systems, weakening the powers of resistance of the body, producing congestion either general or local, thus making the body subject to climatic changes, unhygienic and unsanitary surroundings, and a hospitable medium for the invasion and propagation of germs.

Dr. Still, the founder of osteopathy, says, "A disturbed artery marks the beginning to an hour and minute when disease begins to sow its seeds of destruction in the human body. 'The rule of the artery must be absolute, universal and unobstructed, or disease will be the result." Osteopathy teaches that a cure is induced and effected by the correction of these derangements, thus permitting a free exercise of the auto-protective and recuperative powers of the mechanism itself. It recognises the mechanical, rather 
than the chemical, as a primary factor in etiology. Integrity of mechanical structure determines the fullness, the completeness of function. If a machine is complete in its structure, and the structural relation of all its parts is perfect, it performs its function in a perfect manner; if, however, it is not plumb, if some of its parts are not properly adjusted, it will not function properly, it will not perform its proper work as a machine. So it is with the human body. If the structural relations of the various cells, tissues, and parts of this vital mechanism are in perfect harmony, and if there be an unobstructed supply of blood, lymph and nerve to all these cells and tissues, then the purposes for which these cells, tissues and parts are designed will be carried out, i.e. function will be normal; but if the structure be perverted in any manner, then the function must also be perverted. This structural perversion is the basic cause of functional disturbance or disease - a distinctive and fundamental principle of osteopathy.

Centuries old is the idea that man is a machine, and that his operations are dependent upon mechanical laws; but to Dr. A. T. Still, the founder of osteopathy, is due the honour of recognising the unity of the body, and the law that any derangement of its structure is followed by disordered function or disease, and that the vital mechanism, through a force inherent in protoplasm, possesses the auto-protective power to restore the normal function, without chemical, electrical or any other artificial stimulation, as soon as complete alignment and adjustment have been made.

These derangements of the body are technically known as "lesions." A lesion is defined as "any structural perversion which by pressure (or irritation) produces or maintains functional perversion." All the tissues of the body are subject to such perversions. They are produced by both external and internal forces. Those of the former variety are the result of mechanical violence, such as falls, blows, strains, illfitting clothing and the like, and temperature changes. Those of the internal variety result from postural influences, abuse of function, and nutritional disturbances. When the body is closely studied, the wonder is not that lesions are produced and that some persist, but that when the strains, exposures and abuses to which the mechanism is subjected are considered, there are not more produced.

One of the gross, very frequent, and more palpable and easily distinguishable lesions is that of the sacro-iliac articulation. It is very productive of functional perversions of the sciatic nerve, pelvic viscera, and the body equilibrium. Prior to Dr. Still's founding of osteopathy in 1874 , anatomists described this as an immovable joint. Ever since then he has recognised and corrected this lesion. It was among his very first citations and teachings as an example of the osteopathic lesion. Only within the last decade has it been recognised by other schools of medical practice.

The more frequent, and consequently the more important lesions are those of the bony, muscular and ligamentous tissues. Owing to their intimate mechanical relation with the nervous and vascular systems, these tissues along the area of the spinal column are the ones most subject to lesions. Clinical experience also proves that a very large majority of lesions are found in the region of the spine. Hence the importance of maintaining the integrity of the spinal area, both as a prophylactic and a curative measure. As contributive factors in the etiology of disease osteopathy recognises climate, germs, abuse of function, unhygienic and unsanitary surroundings, etc.

Osteopathic diagnosis means but one thing: find the cause. Its diagnosis includes the complete examination of the entire body and its excretions. Symptoms are noted, and all chemical, microscopic, hygienic, sanitary, and other findings are studied, to aid in determining the existing condition of tissue, viscera and function. Of supreme importance, however, is the physical examination to discover existing lesions. In this respect osteopathy stands alone among schools of medicine.

Osteopathic therapeutics has to. do with but one thing, the removal of the cause. To attain that end it may require the employment of one or more of many means. It may and usually does consist of the specific adjustment of the lesion, the structural perversion, which frees the remedial, antitoxic, and auto-protective resources of the organism itself, and permits its maximum exhihition of physiological recuperative and 
reparative processes; or it may consist of correcting hygienic, dietetic, enviromental and psychic conditions; or surgery for fractures, lacerations, abnormal growths, or organs so diseased as to be dangerous to life; or it may be antidotes for poisons, and other dangerous substances physiologically extraneous to the body. In osteopathic therapeutics the fundamental principle is "Find the lesion, repair it and let it alone."

Some confusion has arisen in the minds of those unfamiliar with osteopathic practice as to the exact meaning of osteopathic treatment. It consists solely of specific physical correction of structural maladjustments, or lesions. This is done by manual adarljustment of the particular tissues involved in the lesion, and no others. This corrective work is of the highest technical order, and presupposes an absolute knowledge of the tissues involved and their mechanical relations, collectively, and one with another. Some have confused it with massage. For this confusion there is no justification. The principles of osteopathy are as different from those of massage, as the principles of surgery are different from those of massage. Nor does it mean simply "bonesetting." Correction of bony lesions is a part of the treatment, and is a large and very important part. But osteopathy is broader than that. Whatever the cause, osteopathy tries to remove it. If abuse of function is a contributive factor, that must be corrected. If there are unsanitary surroundings, they must be removed, etc.

Osteopathic prevention or prophylaxis comprises systemic examination for incipient lesions, and their correction before function becomes disordered; individual hygiene and right-living; public education in the correct use of the body to avoid structural injury, and in sanitation and all conditions conducive to favorable environment of life. It is a complete system of the healing art.

Osteopathy teaches the self-sufficiency of the normal vital mechanism. In other than normal conditions this principle powerfully manifests itself; the hypertrophy of the heart muscle in valvular insufficiency, the healing of a wound, the recovery of the body from "light attack" diseases without any treatment, are all instances of the self-sufficiency of the body to repair pathological conditions, traumatic and otherwise. Fvery healed wound, every hunch back, every particle of cicatricial tissue, every adhesion, is but a mute witness of the self-sufficiency of the mechanism, of the efforts of nature to heal disease, and they bear further witness that it was only due to the severe and persistent impairment of the mechanism of the body that complete repair was not effected. The more intensive the study of the minute mechanics and functioning of the body, the clearer becomes the law of its self-sufficiency.

The discovery of opsonins and antibodies and their efficacy, together with that of the thyroid and other glandular preparations, is a mark of gradual recognition and acknowledgment of the self-sufficiency of the body, when normalised and mechanically stimulated to the maximum exhibition of its reparative and auto-protective processes. One of the missions of osteopathy is so to normalise and stimulate the vital mechanism that it will manufacture in all necessary abundance its normal supporting and protecting chemical compounds absolutely pure and sterile.

The discoverer of the principles of osteopathy, Dr. Andrew Taylor Still, of Kirksville, Mo., was born August 6, I 827. He was a practising allopathic physician at the beginning of the American (ivil War. He served as an officer during that struggle, but at the close of the war returned to his home in the territory of Kansas and resumed the practice of his profession. He had served as a member of the territorial legislature in $1857^{-58}$. Being blest with an insatiably inquisitive mind, an indomitable spirit of perseverance and independent thought, he accepted no statement as true without its proofs. Gradually his confidence in the efficacy of drugs as a means of healing weakened, and his faith in the inherent curative power of the body strengthened, until June 22,1874 , when he publicly announced that he would henceforth discard the use of drugs as a curative measure, and would dedicate the remainder of his life to aiding nature in the alleviation of disease by the mechanical readjustment of the disordered body. The immediate result was the loss of his entire practice, and the estrangement of friends and relatives. For years he pursued his chosen path alone, 
but gradually the results began to count. Success begat success. Patients came from afar, and the practice of osteopathy became known throughout the land.

Could he impart his knowledge, his power to others, was the question asked by all. The answer was the opening of the "American School of Osteopathy" in the autumn of 1892 . There are now over five thousand graduate practitioners of osteopathy, located in the United States, Canada, British Isles, France, Germany, Mexico, Japan, India, Italy, Sweden, Argentina, South Africa, Cuba, Porto Rico and Hawaii. The following eight colleges in the United States are devoted to the teaching of its principles:- The American School of Osteopathy, Kirksville, Mo.; The Philadelphia College of Osteopathy, Philadelphia; The Still College of Osteopathy, Des Moines, Ia.; The Pacific College of Osteopathy, and The Los Angeles College of Osteopathy, Los Angeles, Cal.; The Littlejohn College of Osteopathy, Chicago, Ill.; The Central College of Osteopathy, Kansas City, Mo.; and The Massachusetts College of Osteopathy, Boston. All these colleges are recognised by the American Osteopathic Association. The student enrolment is second only to that of the allopathic colleges. The curricula of the osteopathic colleges embrace all the subjects taught in the other medical schools except materia medica. Osteopathy is recognised and regulated by law in forty states of the United States. The other states, through court decisions or exemptions in the laws, make its practice legal. There is an Osteopathic Association in every state of the Union, a national organisation, the American Osteopathic Association, associations in the provinces of Canada, and also a British Osteopathic Association. Ten or twelve magazines and periodicals are published by the profession, notably the Journal of the American Ostcopathic Association, Journal of Osteopathy, Osteopathic Physician, Osteopathic Health, Ostcopathic Herald, Osteopath, Western Osteopath, and Bulletin.

Much excellent experimental research is being done by members of the profession under the direction of the A. T. Still Research Institute located at Chicago. The work is chiefly along the line of osteopathic fundamentals and similar subjects, such as the production of lesions; the study of perverted function and pathological conditions resulting therefrom; the correction of the produced lesions; and the study of the results following that. Thesc experiments, through clinical observations and post-mortem dissections on various animals, have demonstrated, among other things, that when a spinal lesion is produced, pathological changes in the tissues of the various viscera involved result, for example in that of the stomach, kidney, liver, intestines, pancreas; and that abnormal functioning of these viscera also results, such as diarrhea, constipation, glycosuria, increased susceptibility to infection, etc. Further, the experiments have demonstrated that the correction of the produced lesion is followed by a return to normal functioning. The produced lesions also show profound pathological changes in the vascular mechanism of the posterior ganglion, the cells of the grey matter of the cord, and the sympathetic ganglia, all of which affected their functioning.

Experiments have also been made to determine the effect of osteopathic treatment upon the opsonic index, showing that the increase varied from 6.6 to 21.7 per cent, and that this increase began at once and continued from three to five hours. The experiments were followed by no untoward results.

The clinical use of radiography in practice has demonstrated the existence of bony lesions prior to osteopathic treatment for their correction, and then their non-existence following such correction.

Bibliography.-Booth, History of Osteopathy; Burns; Studies in the Osteopathic Sciences; Clark, Applied Anatomy; Diseases of Women; Hazzard, Practice of Osteopathy; Hulett, Principles and Practice of Osteopathy; McConnell and Teall, Practice of Osteopathy; Still, Autobiography; The Philosophy and Mechanical Principles of Osteopathy, Osteopathy, Research and Practice; Tasker, Principles and Practice of Osteopathy; Woodall, Osteopathic Gynecology; Young, Surgery.

(G. W. Riley, PH.B., D.O.) 


\section{SECTION III. ART AND LITERATURE}

\section{ENGLish Literature ${ }^{1}$}

In literature as in politics and arms the tendency in all old civilizations is to repose an undue faith in the achievements of ancestors and to harp with an uncritical accent upon the great Elizabethans and great Victorians. Discernment of the new elements in English imaginative literature is confined to a narrowing circle of organs of opinion. There is nothing more difficult at the present than for the great mass of readers to discover what competent judges consider to be the really vital literature of our time. Fortunately there are still some book advocates whose love of literature prevents them praising anything they know to be bad. It is by the diligent pursuit of these atone that the booklover may learn to discover the new corn in ear.

To this higher criticism in Great Britain the weekly "Literary Supplement " of the I.ondon Times has in the course of its ten years of existence established itself as on the whole the surest guide. A file of the "Supplement " supplies a corpus of English criticism without a rival in any contemporary literature, and of this periodical alone among its literary rivals today it may be said with certainty vires acquirit eundo. Young as it is, the "Literary Supplement " is a veteran among those very few English organs which make any claim to stimulate cultivated opinion by means of new ideas and vivid writing, e.g. The Nation, The New Age (Igo8), The English Review (I909), The Round Table (rgro), The Eye-Winess (rgri), The New Witness (rgr2). Increasingly difficult to please, the journal readers of today are correspondingly fatigued no less by the literary barrenness and denudation of ideas of the older journals, perpetually masticating the dogmas of a dowdy age, than by their newborn reticence in domestic criticism and their lack of tonic quality in matters of national concern. ${ }^{2}$

Belles Lettres.-The tendencies in England during the past two or three years have not been at all clearly marked. There has been no severance in continuity-the general aspect of the ripples on the stream has nevertheless insensibly changed.

The Irish movement has found certainly no authorised exponent, but a chronicler of candour with a gift of revelation that almost if not quite amounts to genius. in $\mathrm{Mr}$. George Moore. ${ }^{3}$ His two incontinently communicative volumes $H a i l$ and Farewell exhibit a movement which among all the doublings and turnings of the human harlequinade is perhaps the most interesting of the present day. Mr. W. B. Yeats, ${ }^{4}$ who, inspired by his Egeria, Lady Gregory, was believed to incarnate the Irish movement, in Mr. Moore's pages takes on the semblance of a corvine prophet, seriously immersed in poetical incantations over a caldron from which genuine poetic wreaths are dispersed from Ireland; and a rival protagonist to the movement has been found in J. Millington Synge (18-I-I 909), the dramatist of Shadow's of the Glen, Riders to the Sea and The Playboy of the Western World, whose Poems and Transhations (issued in Ioro) exhibit a quality of vivid energy and life comparable to that of A. E. Housman's Shropshire Lad. The best of his poems as of his prose connect with the peasant life of the Aran Islands. Reality and joy are at their highest in "Beg-Innish," but some of the ballads have rarely been surpassed since ballad-making became an anachronism. Vivid personal record, local jatriotism, the homing instinct, folk sentiment, the desolation of wild glen and mountain earth, and the spume of mist and rain in the mild island climate breathe through these poetic emanations-The Shadowy W'aters of Yeats, The Wild Earth of Padraic Colum, the dialect poems of Moira O'Neill, the Deirdre poems of Yeats, Synge, Herbert

${ }^{1}$ See E. B. ix, 607 et seq.

2 It has yet to be seen whether the newly constituted Academic Committee, brought into being in 1910-II in connection with the reorganisition of the Royal Society of Literature (previously a bedy of no particular importance) will establish its influence as a critical authority. It began boldly by awarding in 1911 to Mr. W. De la Mare, and in I9I2 to Mr. John Masefield, the first two annual prizes of fioo (founded by the Princesse de Polignac) for the best original work of the previous year.

${ }^{3}$ B. I853; see E. B. xviii, 808 .

${ }^{4}$ B. I865; see E. B. xxviii, 909. 
Trench (b. 1865) and "A.E." (George W. Russell), a mystical poet and patriot who is in a sense the hero of George Moore's wonderful impressionist portrait group.

A remarkable feature of much of this verse is that although written in English it derives its inspiration from Gaelic themes and often reproduces the dialect of speakers who have retained the expiring habit of thinking in Gaelic. The whole movement fits in with a latent conviction, parallel to that of the Ossianic and Chatterton period, initiated by Gray, that vital poetry must be sought among the solitary places and primitive folk of the earth, that legendary lore must be re-explored and romance redeemed from old crones at the spinning wheel or a remote provincial peasantry crooning over old-world poetry by a peat fire. The poetic idiom of England, it was held, showed signs of being exhausted. New fountains were in request which might peradventure be discovered in old Irish. Literature was sick of the polished speech of the academies and needed refreshment to be sought in a renewed contact with mother earth, nature, primitive people and prehistoric fragments like those exhumed by Irish mediaevalists such as Dr. Kuno Meyer. Mr. George Moore commits himself to the movement with the ardour of an agnostic realist turned Catholic neophyte, and chronicles his sensations in the confessions of a literary Rousseau in whose regenerate conception Art and Nature have become mystically reconciled-only to be confronted in the end with a terrible dilemma: Ireland stood revealed as the proper cradle for this rebirth of letters, but Ireland was Catholic in the modern narrow, post-Tridentine sense, and Catholic dogma was antipathetic to literature. Catholic Ireland must be regarded as stony ground.

Meanwhile the poetic soil of England has exhibited an unexpected richness. The daring of Synge in delineating the live human soul has been at least equalled by Mr. John Masefield (author of that intense drama of $\mathrm{Nan}$ ), whose strangely imaginative yet realistic poems, contributed to the English Review, have renewed the faith of the most sceptical in the compelling power of poetry. Putting aside the folk-song, chanty or lyric, in which his earlier experiments at verse were mostly made, Mr. Masefield (b. 1875) has astonished every one by the powerful thrust of his narrative, a narrative thrown in the unlikely medium of the old eighteenth century rhyming heroic to which he has lent a vitality wholly unexpected in poems such as "The Everlasting Mercy," "The Widow in the By-Street" and "Dauber." In lyric spontaneity and charm, again, these last years have found nothing to surpass the bird-like lyrics of Mr. H. Davies, "the supertramp," unless it be in the delicate, spritish and faerie songs and poems of Mr. Walter De la Mare (b. 1873). His intonation in his Songs of Childhood and The Listeners and other Poems has a bitter sweet of this writer's unaccountable own, haunting and strangely original, but the mould is essentially of folk origin. The workings of his fancy are to be seen in their richest luxuriance in the singular and delightful fantasy known as "The Mullah Mulgars," in which are embedded some perfect little nuggets of enchanted verse. Katharine Tynan and Lascelles Abercrombie have increased their poetic reputations in New Poems and Emblems of Love. Sidney Royse Lysaght has given a fine "Jean Christophe" type of poem in Horizons and Landmarks, characterised by real beauty of retrospective picturing. Maurice Baring (b. I874), the clever parodist, has produced some pensive Collected Poems, French perhaps in their inspiration, but of sincerity and beauty. Mr. Sturge Moore has not quite sustained his claim to a massive simplicity in A Sicilian Idyll. A poet emerges from the Fifty Poems of John Freeman. The grave satirist and studious social reformer John Galsworthy (b. 1867), though, having established himself as novelist (The Man of Property, I go6; The Country House, 1907; Fraternity, 1909), he has concentrated his best attention lately on the drama (The Silver Box, I906; Strife, I909; Justice, I910), has also aspired to lyric honours and has written one or two stanzas of rare beauty, almost lost it is true in pallid speculations, to gladden the heart of the anthologist. Mr. Henry Newbolt, ${ }^{1}$ in Songs of Memory and Hope, and Mr. Alfred Noyes (b. I880) in his Collected Poems, have on the whole well sustained their positions as foremost among writers of ballads and of patriotic, heroic, occasional and rhetorical verse. Mr. Hilaire Belloc (b. 187o),

${ }^{1}$ B. 1862 ; see E. B. xix, 463 . 
as sparing in verse as prolific in prose, strikes the lyre now of Tyrtaeus, now of Theocritus, and again of Martial, in his slender but memorable tome of Verses. The issue of a collective edition of Mr. Rudyard Kipling's ${ }^{1}$ poems has awakened many glorious echoes. Mr. Gosse's Collected Poems has stirred some memories. Mr. Thomas Hardy ${ }^{2}$ in his Time's Laughing Stocks has assured the world of a depth of reflection and a stock of vigour and modernity of feeling as yet wholly unclouded and uneclipsed. A splendid anthology of Victorian Verse has been chosen by Sir A. T. Quiller-Couch, ${ }^{3}$ the new Literature Professor at Cambridge.

In imaginative prose the place of honour falls to George Meredith's posthumous work, a fragment merely of his long incubated novel Celt and Saxon, in which Meredith ${ }^{4}$ groups many of his standing ideas on the racial contrast's of the Anglo-Celtic family. The story is one of several that he had planned at a much earlier period of his career; it embodied much of an earlier design to write a study of the activities of the modern journalist and publicist in the great days of journalistic independence as illustrated by such a type as Frederick Greenwood. ${ }^{5}$ Several stories had simultaneously been on the stocks. Lack of sympathy with his public had led to their being discarded. Celt and Saxon remains, a trumpet through which Meredith executes some of his finest and most characteristic fantasias, but not in any sense a finished example of his art. Of far greater value as a legacy to posterity are the two volumes of Meredith's Letters, edited by his son. These exhibit for the first time in its full grandeur the splendour of a noble mind struggling through adversity towards expression of that aristocratic philosophy of living which seems likely to form the main substance of Meredith's contribution to literature. The high literary ideals and ambitions enshrined in the vibrating prose of these letters constitutes them the first and most majestic literary monument of the new age. Next to them in historic and documentary interest one might be inclined to place the strangely revelatory Note-books of Samuel Butler (I835-I902), a "philosophical writer" whose Way of All Flesh has perhaps made more way in the minds of thoughtful people during the last decade than any other work of fiction. Butler's mind is peculiarly, and one might almost say exclusively English, and there is often in his style something reminiscent of the hammer and, at times, of the tintack. But the saw-like rasp of his observation has penetrated the wooden complacency of the nation, and the sound of it is heard in the most unexpected places.

Since Mr. Hardy has refrained from the laying on of hands in fiction, the primacy has fallen upon two writers whose closeness in age, ambition, energy, writing power and friendly rivalry is likely to impress the future. After passing through a period of extraordinary imaginative fertility culminating in Ioro respectively in The New Machiavelli and Clayhanger, Mr. H. G. Wells ${ }^{7}$ and Mr. Arnold Bennett (b. I867) have in I9I II 2 produced interim novels, the former writer Marriage and the latter writer Hilda Lessways. Mind as usual is more conspicuous in the work of the first, method in that of the second; yet both novels, dictated though they may have been in a measure by the necessity de reculer pour mieux sauter, are representative of their writers and of the full-blooded and realistic manner which holds its own far better in England than elsewhere in Europe. Mr. Bennett's wonderful Old Wives Tale (1908), following as it did a rapid succession of sketches of the romance underlying the life of the midland pottery district (his "Five Towns"), made his work the chief new interest to novel-readers during I909-II. Other established favourites in literary fiction such as Rudyard Kipling, Mrs. Humphry Ward, ${ }^{8}$ Mr. Galsworthy, Henry James, ${ }^{9}$ Joseph Conrad, ${ }^{10}$ R. S. Hichens (b. I 864), De Morgan, ${ }^{11}$ Anțhony Hope ${ }^{12}$ and Maurice Hewlett ${ }^{13}$ have done nothing notably to add to their reputation.

\footnotetext{
1 B. 1865 ; see E. B. xv, 825 .

${ }^{2}$ B. 1840 ; see E. B. xii, 946 .

${ }^{3}$ B. 1863 ; see E. B. xxii, 750 .

${ }^{4}$ See E. B. xviii, 160 .

- See E. B. xii, 554 .

'See E. B. iv, 887 c.

${ }^{7}$ B. I866; see E. B. xxviii, 5 I4.
}

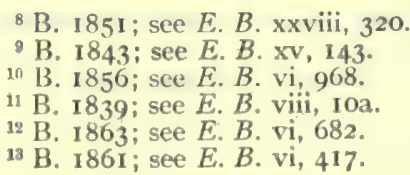

${ }^{8}$ B. $185 \mathrm{I}$; see E. B. xxviii, 320 .

9 B. I 843 ; see E. B. Xv, 143.

10 B. 1856 ; see E. B. vi, 968

12 B. I863; see $E$. B. vi, 682.

${ }^{13}$ B. 1861 ; see E. B. vi, 417 . 
Founded by Ford Madox Hueffer (b. 1873 ) - a versatile and inventive writer, author of a tour de force of historical picturing in fiction entitled Ladies whose Bright Eyes, dealing with the England of Edward II-the English Review has discovered and brought into notice (under Mr. Austin Harrison's editorship in its later period) some short story writers of exceptional accomplishment and force, among them Richard Middleton (The Ghost Ship, and The Day before Yesterday), a writer whose unhappy end cut short prematurely a career of unmistakable promise and partial achievement. A writer of philosophic originality in fiction has also been revealed in the person of Prof. L. P. Jacks (b. I860; editor of the Hibbert Journal), whose Mad Shepherds disclosed a power of discernment beneath the surface comparable to that of Mark Rutherford ${ }^{1}$ and Thomas Hardy. Work of singular promise has been published by J. P. Beresford, author of Mr. Perrin and Mr. Traill, and by Mr. Compton Mackenzie, whose Carnival was one of the most commented on novels of 19r2. Mr. Farnol, Mr. Oliver Onions, Mr. "George Birmingham " and Mr. De Vere Stackpole have also done distinguished work in the variant avenues of fiction, the level of which has been maintained steadily without much to stimulate prophecy or to provoke astonishment. The tendency most worthy of remark upon the confines of the novel proper has been the unceasingly sincere and sympathetic interpretation of the life, thought and habit of the predominant poor. The country peasant has found a loyal and constant spokesman: in Mr. George Bourne, who has completed the series of Bettesworth books, and Mr. W. H. Hudson, whose Shepherd's Life has impressed his many admirers as perhaps the truest and most attaching of all his, exquisite prose pastorals. The longshore fisherman has discovered a spokesman of shrewd vigour and outspokenness in Mr. Stephen Reynolds (b. I88I), whose Poor Man's House is one of the outstanding books. Mr. Pett Ridge ${ }^{2}$ and Mr. Barry Pain, ${ }^{3}$ whose work retains all its old vivacity, have also found recruits in the observation of struggling city workers and outcasts, in Mr. Harold Begbie (b. I87r), Mr. Neil Lyons, and Mr. Robert Halifax. The studies of these social observers and poignant reporters merit attention. Excellent prose, at times brilliant; rejoices the honorable minority of essay readers in the collective work of $\mathrm{H}$. Belloc (This and That), E. V. Lucas (London Lavender), G. S. Street, H. W. Nevinson, and G. K. Chesterton. ${ }^{4}$ That arch-anthologist Mr. Lucas has done an anthology of his own writings, modestly entitled $A$ Little of Everything.

The English critics of the past few years have not been much marked because little observed by public opinion. But their work has been of a high order and has lost little, perhaps gained in certain respects, by the fact that it is done in demi-obscurity. Of the older school who combine synthetic and analytic methods, Sir Sidney Colvin, ${ }^{5}$ J. W. Mackail (b. I 859 ), Augustine Birrell, ${ }^{6}$ Herbert Paul (b. I 853 ), Edward Dowden, ${ }^{7}$ remain on the active list along with Mr. Edmund Gosse, ${ }^{8}$ who has put forth a fine blossom in his Portraits and Sketches, enshrining a kit-cat of Swinburne which has a rare quality of humanism and literary experience. Like Andrew Lang, ${ }^{9}$ he is at his best when displaying his capacities as a featherweight. Of the polyphonic.writers of the period Lang will probably rank first, and his loss has been felt as almost a personal one by hundreds of refined readers. There was certainly too much of the rainbow about his literary palette in later days. At his best he wrote English prose of the purest and most flawless. But a capricious literary fairy presided at his christening, who decreed that whenever he laboured, researched; documented and dogmatised he should be mediocre, but that whenever he improvised in careless mood, pearls, real pearls should drop from his pen. His two last efforts, his History of English Literature and Shakespeare-Bacon, are not among the most prosperous productions of this fascinating polymath. A great loss has ensued to this branch of English letters by the health-enforced silence of Arthur Symons ${ }^{10}$ the first of adepts in literary impressionism; though his place may be partially

${ }^{1}$ See $E$. B. xxiii, 94 o.

${ }^{2}$ B. 1864 ; see $E$. B. xxiii, 317 .

${ }^{3}$ B. 1867 ; see $E . B . x x, 456$.

B. I $874 ; E$. B. vi, III.

${ }^{5}$ B. I 845 ; see $E . B$, vi, 748 ; knighted 19 I I.

${ }^{6}$ B. 1850 ; see $E . B$, iii, 989 .

${ }^{7}$ B. 1843 ; see $E$. B. viii, 456 .

${ }^{8}$ B. I 849 ; see E. B. xii, 268.

${ }^{9}$ B. I 844 ; d. I91 2 ; see E. B. xvi, I7 I.

${ }^{10}$ B. 1865 ; see $E . B$. xxvi, 287. 
filled by able disciples and students of pure literature such as Edward Thomas (on Hearn, Swinburne and Borrow), Arthur Ransome (on E. A. Poe) and Darrell Figgis. Systematic criticism of the motived, scientific school has not made very much headway, though works of erudition, enthusiasm and co-ordinated speculation have been completed by Prof. W. J. Courthope ${ }^{1}$ (History of English Poetry) and Prof. George Saintsbury ${ }^{2}$ (English Prosody and Prose Rhythm). Prof. Oliver Elton (b. I86I) has achieved a book of arduous critical chronicling on the English Literary period, $1780-1830$, and Sir Sidney Lee $^{3}$ has successfully continued his researches into the cross currents of French and English literature in his book on England and the French Renaissance. Prof. Sir Walter Raleigh, in his two short studies on Johnson and Halifax, has confirmed his unique position as a humorous professor who is at the same time a scholar and a wit. Specially good work either editorial, biographical or commentary has been done on Herrick (Delattre), Suckling, Thomas Deloney, Ruskin, Morris, Swift, T. L. Peacock, Scott, Goldsmith, Boswell, Borrow and George Gissing (The Private Life of Henry Maitland by Morley Roberts is a pastel of G. G.). Some valuable monograph series have been set on foot to chronicle the fluctuating fame of recent reputations (Secker's Critical Studies, Constable's Modem Biographies), and some suggestive chapters and papers have been contributed to the Cambridge History of English Literature, which has now been brought down to Dr. Johnson, and to collected papers by the English Association.

History.-In history and biography the years 1910-I2 have seen a good many important works already well under way brought a stage or two nearer completion. The Hon. J. W. Fortescue (b. I859) thus brought his monumental history of the British Army down to the verge of the Peninsular War, in other words to within eight years of its concluding point, and he accompanied it by a volume of hardly less importance, vindicating the Statesmen of the Great War. His championship of Portland, Perceval and Castlereagh, which goes far to destroy the ex parte indictment of Napier, receives valuable confirmation in the History of the Peninsular War by Prof. C. W. Oman (b. 1860), whose fourth volume brings the narrative down to Salamanca. Sir George Trevelyan ${ }^{4}$ completed his History of the American Revolution in a fourth volume, the scene of which is laid mainly in the court and capital of England; it brings the writer home from America to the commerce of the contemporaries of Fox and North, a subject in which he has few rivals and certainly no superiors. This last volume takes us back by a most happy reversion to the author of The Early History of (harles James Fox. Sir George's historically gifted son, Mr. G. M. Trevelyan (b. I876), has added another excellent volume to his series on Garibaldi,-Ney's successor to the proud title " bravest of the brave." His history of Garibaldi and the Making of Ituly may not quite achieve the vital interest of the history of Garibaldi and the Thonsand, but this is owing to no declension of st yle, but merely to the fact that the subject is inferior in dramatic interest. Here, at any rate, there is little justification for the prehistoric lament "Les grands talents vieillissent, rien ne se prêsente pour les remplacer." Another work of signal historical value is the completion or continuation of Gardiner's Protctoratc by his old ally, Prof. C. H. Firth, ${ }^{5}$ who brings the narrative down from 1657 to the death of Cromwell. Mr. Firth writes no less minutely, but interprets history in a wider sense than his predecessor. He exhibits, some may complain, a certain lack of temperament, but his two volumes are worthy in every way of an historical erudition and equipment second to that of no living historian. Since death has removed the four Academic historians, Sorel, Vandal, Houssaye and Monod, and the great Philadelphian, H. C. Lea, it may be doubted whether any universities are so happily provided in this respect as are Oxford and Cambridge. Pursuing his former Byzantine explorations, Prof. J. B. Bury ${ }^{6}$ of Cambridge has produced his II istory of the Eastern Empire from Irene to Basil I, a work of absolutely the highest rank both as regards research and presentation. Another Oxford historian, in the very front rank, Mr. Herbert Fisher (b. 1865 ), not content with an able edition of his kinsman

${ }^{1}$ B. 1842 ; see E. B. vii, 327 .

${ }^{2}$ B. I 845 ; see $E$. B. xxiv, 45

${ }^{3}$ B. 1859; see E. B. xvi, 363 .
${ }^{4}$ B. 1838 ; see E. B. xxvii, 255:

${ }^{5}$ B. 1857 ; see E. B. x, 425 .

B. $186 \mathrm{I}$; see E. B. iv, 867 . 
F. H. Maitland's Posthumous Papers and Studies, has also produced a valuable monograph on Democracy in Europe and a priceless little memoir of the great $N$ apoleon. The editor of the Historical Review, Dr. R. Lane Poole (b. 1857), has produced a work of much erudition in his History of the Exchequer in the twelfth century. A solid crown has been added to the series of somewhat unequal posthumous studies by Lord Acton by the issue of the Lectures on the French Revolution. The Esprit frondeur in contemporary history is well represented in Mr. Wilfrid Scawen Blunt's ${ }^{1}$ uncompromising Secret History of the English Occupation of Egypt. Two succès d'estime in historical biography have been achieved by Lord Rosebery ${ }^{2}$ and Mr. Holland Rose (b. I 855 ) in their respective lives of Chatham and Pitt. For different reasons they seem unlikely to occupy a place among the greatest of biographies, but both fill important gaps and are invaluable to the historian. The life of Chatham is in the strict sense preliminary only; it closes with the year I756. Holland Rose's first volume exhibits Pitt as intendant, the second as pilot. Mr. D. A. Winstanley has done a promising book on Chatham and the Whig Opposition. A word of recognition is due to Miss Kate Norgate's work on The Minority of Henry III, in which she continues the destructive criticism of the baronial party commenced in her book on John Lackland, and to the completion and continuation respectively of Longmans' Political History (I 2 vols.) and Methuen's English History (5 vols. completed out of $\eta$ ). Scotland has suffered a heavy blow in the loss of her accomplished historian, Andrew Lang. England has experienced a doubtful gain in the accession of Mr. Rudyard Kipling to the ranks of her historians ( History of England, I9r r, with C. R. L. Fletcher).

In biography proper some notable volumes have appeared, almost overwhelmed, it is true, by the enormous multiplication of mechanically made Lives. The two volumes of Mr. Monypenny's Life of Disraeli, Wilfrid Ward's Life of Newman, and Sir E. T. Cook's Life of Ruskin, are destined, it must be supposed, to occupy positions on the highest plane in a form of literature which many people regard as the most interesting of all. Mr. Monypenny's first volume hardly obtained the credit due to it, but the second shows that his selection as Disraeli's official biographer was entirely justified. The qualities of concentration, brevity and self-effacement are rare in modern biography, and the author's premature death in IgI 2 has left a difficult task to the writer who shall complete his work. More even than the Life of Disraeli, the Life of Newman had been discounted by anticipatory speculation. It is a noble and conscientious monument of biographic piety, though it cannot be said that the Newman legend has gathered quite so much brightness from it as in the corresponding case of the Life of Disraeli. Sir E. T. Cook's Life of Ruskin is a splendidly able, judicious and enduring estimate of a great Victorian, whose fame, like Gladstone's, is at present in a trough of depression, consequent upon a range of contemporary activity and influence almost too varied to be coherent. The only other cognate work which can claim to rival these in documentary value and standard quality is Mr. Aylmer Maude's Life of Tolstoi.

Two biographies of great brilliance, which derive a unique interest from the temperament of their writers, are Mr. Hilaire Belloc's Marie Antoinette and Mr. Walter Sichel's Sheridan. The first is an interpretation of the revolutionary, democratic and military forces of $\mathrm{I} 789$ concentrated upon the prismatic personality of Marie Antoinette; the second a suprème of the social aspects of England in the penultimate phase of aristocracy, grafted upon a new valuation of the sentimental and Pierrot-like character of Richard Brinsley Sheridan. The causticity and candour, which supply the differentiating quality of the hardiest stock of autobiography, are well illustrated in Goldwin Smith's Reminiscences and Sir William Butler's Autobiography: well too, though more diffusely, in the Reminiscences of H. M. Hyndman, and of Oscar Browning. A passing tribute should further be paid to three interesting revelations of personality; the first strictly historical, Mr. Snead Cox's Life of Cardinat Vaughan; the second partly imaginative, Miss Marie Hay's Winter Queen (Elizabeth of Bohemia); the third largely autobiographical, Mrs. ; Mills's Life of Frederic Shields, the artist (I833-I9I I), a " human document " of curious

1. B. 1840 ; see E. B. iv, 93 .

${ }^{2}$ B. 1847 ; see $E$. B. xxiii, 731 . 
interest, accompanied by a series of reproductions of his pictures which draw new attention to his originality and power. The centenaries of Browning, Thackeray and Dickens can hardly be said to have elicited much authorship of permanent value. Mr. Hall Griffin's Early Life of Browning is a laborious enumeration and itinerary without very much illumination; Mr. Chesterton's Introductions to Dickens are in part a working over of material which found its most savoury expression in his Life of Charles Dickens. A valuable portrait of Dickens as editor has been disclosed in the Letters faithfully edited by Mr. Lehmann; an effervescence of curiosity respecting the mystery of Dickens's last unfinished novel Edwin Drood has found interesting expression in speculations by Prof. Henry Jackson, Cuming Walters, Chesterton, Andrew Lang, William Archer and Sir W. Robertson Nicoll.

General.-The simultaneous publication of the 28 volumes of the I Ith edition of the Encyclopaedia Britannica early in $191 \mathbf{I}$, under the aegis of the Cambridge University Press, stands out as a unique event in the literary history of the last two years, on which it would be unbecoming here to dwell further. Much literary energy and research has also been concentrated upon such standard works of reference as the second supplement (for I900-II) to the Dictionary of National Biography, the progress of the great Oxford New English Dictionary (still incomplete), Hastings's Encyclopaedia of Religion and Ethics, the revised edition of "G.E.C.'s" valuable historical Peerage, and important subject-indexes such as those of the British Museum and London Library.

Among the reprint series of the day Everyman's Library has steadily extended its titles towards the promised goal of one thousand, most of them judiciously chosen. It has found a serious rival in enterprise in Nelson's Shilling Library, comprising for the most part more recent books, the majority of them still protected by copyright; this shilling library has also incorporated in its list a number of French and German books of standard value.

Of more original interest than these is the new series of miniature monographs known as the Home University Library. The title is not particularly happy in these days when a university is brought to almost every door, and the editors of the series, Gilbert Murray, Herbert Fisher and Prof. J. Arthur Thomson, are hardly self-taught prodigies of homeculture. But the series is cleverly conceived, and the volumes both well-informed and remarkable for lucid exposition. One of the most promising literary signs, indeed, in England is the steadily increasing excellence both of such small manuals and also of the larger standard works of reference upon which the general staff of the world's activity has so often to put its reliance.

Among the general tendencies of the commerce of books the comparative absence of really good books about books and their authors has been hardly less marked than the excessive duplication and reduplication of colour topographies, anthologies, nature and open-air books, books of maxims, books on education and military science, expanded centenary articles and heavily padded memoirs, many of these'last by complete amateurs, most of them useless and nearly all of them quite superfluous. Book society, like that of the beau monde, has increased beyond self-knowledge. The publishers are probably right in maintaining that the career of more than half the books now issued is made, not by the ability of the authors, but by the vague appetite for new books stimulated if not created by their own cleverness in tuning the public. As the tendency of the age is certainly not to increase the amount of time devoted to reading, the position of the printed book approximates more and more to that of the periodical. Books tend to become less and less carefully differentiated and assessed, less cherished, and a good deal more transitory both in their appeal and their impact than they were a quarter of a century ago.

(Thomas Seccombe.)

The Press. - In London journalism (see E. B. xix, 557-563) two important recent changes are to be noted. In August 1912 Mr. G. E. Buckle (b. 1854) retired from the editorship of the Times, which he had held since 1884 , and was succeeded by Mr. Geoffrey Robinson (b. I 874 ), a Fellow of All Souls, Oxford, who had joincd the staff a year or so before, after having been editor of the Johannesburg Star in South Africa, where he had originally gone in 1901 as private secretary to Lord Milner. In this connection reference may also be made 
to the enterprise of the Times, under Lord Northcliffe's ownership, in various new directions, and notably in its publication in September 1912 , in celebration of its 40,000 number, of a remarkable "Printing" supplement, dealing in a series of expert contributions with the history of journalism, typography, and everything else that goes to the making of a newspaper, and again in December of an equally elaborate "Shipping" supplement. The other important change was Mr. J. L. Garvin's transference to the editorial chair of the Pall Mall Gazette, while still holding that of the (Sunday) Observer, both papers being owned by Mr. Astor. Mr. Garvin (b. I 868), who first became known in London as a leader-writer on the Daily Telegraph, had in recent years come to occupy a unique place among Unionist journalists; a brilliant and inexhaustible writer, one of the inspirers and best exponents of $\mathrm{Mr}$. Chamberlain's Tariff Reform policy, and deep in the councils of the leaders of the party, he had made the Observer the contemporary "Thunderer" of the Press; and in taking the Pall Mall as his week-day organ he gave new vitality to this evening journal, which showed signs of enterprise in every direction under his editorship. The amalgamation in May I9I2 of the Daily News and Morning Leader, the two Liberal half-penny morning dailies, both owned by Mr. Cadbury, may also be noted.

\section{Shakespeare, and the Elizabethan Drama.}

During 1909-12 great activity has been shown in ransacking archives, public and private, in pursuit of matter bearing upon dramatic history which might have escaped the scrutiny of earlier investigators, such as Malone, Collier and Halliwell-Phillips. A considerable share in this enterprise has been taken by European and American scholars, more scientifically trained than those of England in the methods of research. One of the most successful contributors has been Prof. A. Feuillerat of Rennes University, who has just published in the Shakespeare Jahrbuch for I9I 2: a set of valuable documents from Loseley Hall, telling the story of a Blackfriars theatre earlier than that built by James Burbage, the existence of which has only been dimly suspected. This theatre was in use from $x 577$ to 1584 and was managed first by the Masters of the Children of the Chapel Royal, and afterwards by the playwright John Lyly under the patronage of the Earl of Oxford. Much new light has also been thrown upon the history of the Elizabethan and Stuart organisations of actors by Mr. J. T. Murray of Harvard, who in his English Dramatic Companies (гіл) has brought together for the first time, in many cases direct from municipal records, a mass of notices bearing upon the tours of the companies in the summer or plague times, and their entertainment in the provincial towns. which they visited. But the most untiring archivist has been Prof. C. W. Wallace of Nebraska University, who has ranged widely in the Record Office, and is now pouring forth an apparently inexhaustible stream of new material, largely derived from the records of the extinct Court of Requests, which had a special mission to compose the differences of players in their capacity as servants of the royal household. Prof. Wallace's researches have centred round the boy companies, and in a quite recent work, The Evolution of the English Drama up to Shakespeare (1912), he has been able to supplement Prof. Feuillerat's Blackfriars discoveries, and also to furnish much fresh information with regard to the Tudor and earlier Elizabethan court drama. He has also earned the gratitude of scholars by publishing in the.Nebraska University Studies for 1909 and rgIo the original documents on which his newspaper and magazine articles making known new facts about Shakespeare and the stage were based. Unfortunately, Prof. Wallace's judgment as an historian is not equal to his flair and perseverance as a researcher, and while the learned world has appreciated his documents, it has too often found it necessary to repudiate the inferences with which they have been garnished.

English students, however, have not been altogether unmindful of their duties to the archives. A good piece of work has been done by Mr. Ernest Law in Some Supposed Shakespeare Forgeries (rgII). Here he reviews the evidence for and against the authenticity of the lists of plays presented at court during the winters of $\mathrm{I} 604$ and I 6 I I as published by Peter Cunningham in 1842 , and comes to the important conclusion that, in spite of the scepticism aroused by Cunningham's shady character, the documents are genuine. His view is accepted by competent palaeographers, and he has been able to maintain it against a vigorous and detailed criticism in the pages of the Athenaeum. 
The rehabilitation of the lists restores confidence in the evidence which they furnish as to the court performances of some of Shakespeare's plays, but it does not affect the approximate dates assigned to those plays in the article on "Shakespeare " in the Encyclopaedia Britannica, ${ }^{1}$ since it was assumed in that article that, even if the lists were forgeries, they probably rested upon genuine originals. Several original documents have also been published in the Collections of the Malone Society, which was founded in 1907 for the express purpose of assisting the study of the drama, and has continued to produce an annual output of volumes. This society has also printed from the manuscripts accurate texts of many important documents for which scholars have hitherto had to rely, not without fear and trembling, on the versions of J. P. Collier.

The new material described above, while illuminating as to the conditions in which Shakespeare's work was done, adds practically nothing that bears upon his personality. In this direction there is but little to record. Dr. Paul Wislicenus in Shakespeares Totenmaske (I010) and Dokumente zu Shakespeares Totenmaske (I9I I) has revived the old controversy with regard to the so-called Kesselstatt " death-mask," but has not succeeded in bridging the evidential hiatus which separates that interesting work of art from any claim to be an authentic presentment of the poet's features. Some attention has also been called to the theatrical tradition preserved by Aubrey with regard to Shakespeare's private life. The Malone Society in its Collections for I0I I has published a facsimile of Aubrey's original memorandum, together with a critical notice which renders possible some correction of the references to the subject in the Encyclopaedia Britannica. Two main points emerge. One is that the reading of Aubrey's statement, first made known a good many years ago, and since overlooked, is not quite accurate. What Aubrey learnt of Shakespeare was not that, "if invited to court, he was in pain." The word " court " is a mistake for "writ," quite intelligible on a hasty reading of the manuscript, and the tradition really is that Shakespeare was thought "the more to be admired because he was not a company keeper, lived in Shoreditch, would not be debauched, and if invited to, writ he was in pain." The amended version is no less favourable to the decency of Shakespeare's demeanour and perhaps makes him out a little less churlish in his attitude towards a royal command. The other point is that the passage, from its place on a page of rough notes not wholly devoted to Shakespeare, might conceivably refer to John Fletcher, who is also dealt with on the page. But the probability is still that it refers to Shakespeare. Aubrey's informant was evidently not John Lacy, who first came to London long after Shakespeare, but an actor of an older generation, William Beeston, whose father, Christopher Beeston, had been a "fellow " of Shakespeare in the Chamberlain's company, and who himself, as a boy, might well have known the poet.

The most notable contribution to the critical study of Shakespeare has been that of Prof. A. C. Bradley, whose Oxford Lectures on Poctry (I 900) and subsequent British Academy lecture on Coriolanus have confirmed the high reputation won by his Shakespearean Tragedy. Mr. John Masefield's William Shakespeare (I9I I) has the interest which always belongs to the interpretation of one poet by another. A courageous attempt at a complete Shakespeare Bibliography (IorI) has been made by Mr. W. Jaggard; and an acute and searching study of the bibliographical problems surrounding the early editions of the plays is to be found in Shakespeare Folios and Quartos (1009) by Mr. A. W. Pollard of the British Museum. It is Mr. Pollard's avowed object to bring about a more: optimistic judgment than has sometimes prevailed with regard to the circumstances in which the early erlitions and particularly the Folio of 1623 came into existence, and $t(1$ the probabilitics that the texts handed down in them represent a reasonable approxi . mation to what Shakespeare actually wrote. In this task, with the aid of a wide: knowledge of seventeenth century printing methods, he is fairly successful, although he: perhaps rather exaggerates the extent of the antecedent pessimism which he sets ou: to vanquish. In a fascinat ing chapter, which sets out the results of earlier investigations by himself and I)r. W. W. Greg, he tells the almost romantic story of the train of bib-

${ }^{1}$ E. B. xxiv, 772 el seq. 
liographical reasoning which established the position that some of the Shakespeare quartos, which bear the dates 1600 and 1608 on their title pages, were really printed in I6I9, and form part of an endeavour, earlier than that of 1623 , to produce a collective edition of some at least of the plays. This is of course a discovery with which the critical editor of Shakespeare, no less than the bibliographer, must make his account.' Following up the same train of research, Dr. Greg in an edition (IgIo) of the First Quarto of The Merry Wives of Windsor has produced some interesting speculations as to how that piratical text may have come into being, probably with the aid of a blackleg actor who played the part of the Host.

The structure of the Elizabethan theatre and the methods of staging plays upon its boards continue to be the subjects of minute investigation. But the ground has by now been fairly covered, and there is not likely, so far as existing material is concerned, to be much to add to the exhaustive monographs of V. E. Albright, The Shakesperian Stage (I909) and B. Neuendorff, Die englische Volksbiihne im Zeitalter Shakespeares (Igro). These are of American and German origin respectively; the most important recent English contribution to the solution of the problems involved is to be found in the erudite and well-reasoned papers by Mr. W. J. Lawrence collected in his The Elizabethan Playhouse and Other Studies (I.912). The mounting of plays at court has been treated, on the basis of the accounts of the Revels office which he edited in I 908 , by Prof. Feuillerat in Le Bureau des Menus-Plaisirs et la Mise en Scène a la Cour d'Elizabeth (I9Iо); and a cognate subject by M. Paul Reyher in Les Masques Anglais (I909), wherein the importance of the part played by Inigo Jones in the spectacular development of the masque under the Stuarts is very fully established.

Two comprehensive works on the history of English drama in its literary aspect have appeared. One is the first part of the fourth volume of Prof. Creizenach's monumental Geschichte des neueren Dramas (I909), which is wholly concerned with England and covers the period I 570-1 593. The other consists of a number of chapters by various writers forming volumes $\mathrm{v}$ and vi of the Cambridge History of English Literature, issued together in I9ro. These range from the origins of the drama to $164^{2}$ and are supplemented by three chapters on the Restoration drama in volume viii, issued in I9I 2. As might be expected from the method adopted, the treatment lacks continuity, but several of the chapters and of the bibliographies by which they are accompanied are of individual value. Amongst special monographs Prof. Feuillerat's John Lyly (IgIo) and Miss M. L. Hunt's Thomas Dekker (I III) call for mention. The critical editing of texts has made some progress. The long desired edition of Ben Jonson by Prof. Herford and Mr. Percy Simpson has not yet made its appearance, and editions of Dekker and of Thomas Heywood are still to seek. But Dr. Waller's ro volume reprint of the Second Folio of Beaumont and Fletcher reached completion in Ig 2 , and the fourth volume of the more elaborate "Variorum" edition supervised by Mr. A. H. Bullen is on the point of issue. Mr. C. F. Tucker Brooke has published a useful text of Marlowe (I Iro), preparatory to a full edition; Mr. R. W. Bond, a volume of Early Plays from the Italian (I9II); and Prof. J. W. Cunliffe, a volume of Early English Classical Tragedies (IgI2). Particularly welcome is the first volume of an edition of George Chapman's plays (I9Io) by Prof. T. M. Parrott of Princeton University. Little has been done for mediaeval dramatic texts; but Dr. Karl Young has contributed some valuable versions of liturgical plays to the Publications of the Modern Language Association of America and other periodicals. The careful facsimile reprints of plays issued by the Malone Society under the editorship of Dr. W. W. Greg continue to appear in annual instalments. Two of the series, The Second Maiden's Tragedy (I909) and Sir Thomas More (I9I I) are not strictly reprints, but are of singular interest as being attempts to exhaust the resources of typography in reproducing the palaeographical peculiarities of complicated manuscripts, upon which several hands have been at work. 'These texts, with Dr. Greg's introductory notes, render possible some estimate of the extent and methods of official censorship as exercised by Edmund Tilney and Sir George Buck; and that of Sir Thomas More also affords opportunity for the reopening of the old controversy as to whether one of the passages 
inserted into the original manuscript is or is not the composition, and perhaps even in the handwriting, of Shakespeare. Some useful reprints, together with illustrative matter bearing on the English drama, have also appeared in the Materialien zur Kunde des älteren Englischcn Dramas, edited by Prof. W. Bang of Louvain.

\section{British Colonial Literature}

(E. K. Снамве RS.)

Australian.-Australia's beginning was from a literary standpoint unfortunate. The primitive aborigines had no history and no legendary lore which, finding expression through some of the first colonists, might have added to the world's stock of romance. The exploring of the continent-the siege of the Blue Mountains with their baffling natural fortifications, the conquest of the great fastnesses of the sun on the dry inland plains-might have inspired an epic, but no one of the explorers nor of their contemporaries attempted more than a bare record. The sordid convict era inspired one book,For the Term of His Natural Life, by Marcus Clarke,- which is made notable by its subject rather than its treatment. The bushranging era inspired another,-Robbery Under Arms, by "Rolf Boldrewood" (T. A. Browne, b. London, I 826), - of which the same may be said. Those are the two master works of early Australian letters. Yet neither is distinctively Australian in the sense of showing a different outlook on life, or a different sense of literary values, to that of the average contemporary English writer. The same may be said of the poems of Adam Lindsay Gordon, who wrote in Australia of Australian subjects from the standpoint of an English squire.

To-day, with less notable books to cite, the observer may see the beginnings of a characteristic Australian literature. The people-bred from the wilder and more enterprising of English, Scottish and Irish stock, responding to the influence of the bountiful, sometimes fierce, sunshine, and conditions of life which are singularly free from any bonds of convention and are singularly levelling of social conditions-begin to depart from the home type. They are gay and debonair, whilst a little inclined to be cynical, irreverent and vainglorious; enduring and brave, even to the point of being somewhat ruthless. The qualities of these new people, the Australians, begin to show in their literature, which is as yet more impressive in quantity than in quality. There are at least one hundred minor poets of some skill and originality of thought in Australia (with less than five million inhabitants), and nearly that number of prose writers of some distinction-all showing to the close observer some signs to distinguish them from writers of the same class in Great Britain and in America. A hedonistic joy in life, a disrespect for authority, a wit tinged with cruelty, a freakish humour founded on wild exaggeration-those are the qualities which outcrop most often in exploring the fields of contemporary Australian literature. There is to be found, too, a tinge of mystic melancholy, a sense of bitterness - a loving bitterness-inspired by the harsh realities of life in the "Bush" where Nature makes great demands on human endurance before: permitting her conquest, but enslaves her wooers by her very cruelty.

This modern Australian literature owes very much to one man, Mr. J. F. Archibald (b. Vic., 1858 ). He was of partly Scottish, partly Irish, partly French forbears, with : touch of Semitic blood. Editor for a quarter of a century of a notable Australian paper, he made it his mission to encourage young Australians to write of the life that was peculiar to Australia. IIe was a wit with a finc flair for a phrase; a sentimental cynic; and passionately Australian. Mainly under his aegis there came forward a young school of writers which included Mr. Henry Lawson (b. N.S.W., I867), who has given in short stories and verse faithful, sometimes terrible, glimpses of the "Bush;" Mr. A. B. ("Banjo") Paterson (b. N.S.W., I864), a singer of the racketty horsey life of Australian sheep stations; Mr. Louis Becke (b. N.S.W., I 857 ), who pictures South Sea Island life; Mr. A. H. Davis ("Steele Rudd") (b. Queensland, 1868), who writes broadly comic and yet sympathetic studies of life on the small farms of Australia; Mr. Roderic Quinn ( $h$. N.S.IV., I 860 ), and the late Victor Daley (both of Irish extraction and giving in their verse two different and yet both characteristically Australian modifications of Celtic melancholy); Mr. Edwin J. Brady (b. N.S.W., 1869), writer of sea-songs; Miss Ethel 
Turner (b. England, I872), a graceful novelist of Australian childhood; Mr. Bernard O'Dowd (b. Vic., I866); Mrs. Barbara Baynton, Mrs. Mary Gaunt and many others who make the Australian literature of to-day. Some of these owed much, some little, directly to Mr. Archibald and his newspaper. But without a doubt he was the chief founder of a new Australian literary movement.

Australian letters to-day suffer from diffused energy. There are numberless writers of some ability, but no commanding figures. The future holds out a hope of Australian works of the first rank, inspired perhaps by the "Bush "- the mysterious Neolithic-age forests, hills and plains, perhaps by the giant work of the early explorers, perhaps by the extremely fluid social conditions of a young country full of self-confidence as it grapples with the old, old problems of civilisation.

Australia has a vigorous newspaper press. In all the state capitals there are fine journals, and those of Sydney and Melbourne rival in wealth and influence the great dailies of England. The Argus (editor, Mr. E. S. Cunningham) and the Age (editor, Mr. G. F. H. Schuler) are the chief Melbourne dailies; the Morning Herald (editor, Mr. T. W. Heney) and the Daily Telegraph (editor, Mr. F. W. Ward), the chief Sy dney dailies.

(FRANK Fox.)

English-Canadian ${ }^{1}$ - The outstanding feature in any survey of Canadian literature during the last few years must be its serious and practical tone. A decade ago one was constantly coming upon new books of verse and fiction by Canadian writers. To-day we find in their place books of history, biography and travel, essays in which instruction is the dominant motive, and scores of works on every branch of the great modern subject of economics. Canada takes herself seriously in the twentieth century; she faces gigantic problems, relating to her own very rapid development, to the relations of the two radically different races that constitute the bulk of her population, to the assimilation of alien groups, to her future place in the British Empire, and her attitude toward other countries. To questions such as these the best thought of many of her most able students has been turned during the last few years, and the result embodied in several notable books. Of these one may mention Macphail's Essays in Politics (1909), Denison's Struggle for Imperial Unity (I909), Ewart's Kingdom of Canada (1908), and The Kingdom Papers (IgII), Robinson's Canada and Canadian Defence (I9ro), Porritt's Revolt in Canada against the New Feudalism (I9II), and, among many important articles in the reviews, Dr. Crozier's " A Warning to Canada" (Fortnightly, Sept. IgI I).

The publication in I9I of an Index and Dictionary of Canadian History completed the series of biographies known as the Makers of Canada. Shortt's Sydenham (I9o8) and Parkin's Macdonald (I908), in this series, Saunders' Three Premiers of Nova Scotia (I909), and the admirable reprint of Howe's Speeches and Public Letters (I 9o9), are all vitally important to the student of Canadian political history.

The memorable celebration of the Tercentenary of the founding of Quebec brought in its train, with a flood of purely ephemeral stuff, several books of permanent value. First of these is the King's Book of Quebec (I9II), edited by the Dominion archivist (Dr. Arthur Doughty), and Colonel William Wood, author of several important Canadian historical works. Another book that should be mentioned is Tracy's Tercentenary History of Canada (I908), a very readable and well-balanced history, in three volumes. Doughty's Cradle of New France (I908), Bradley's The Making of Canada ( 1908), Lucas's History of Canada $I 763_{3}-1812$ (I909), following his Canadian War of 1812 (I906), and Griffith's Dominion of Canada (I9II), are all the work of well-informed scholars.

Of agencies which, each in its own way, are making for the development of intellectual life and scholarship in Canada, none is more important than the Dominion Archives, the Royal Society of Canada, the Champlain Society, and the University Magazine. The Archives perform a triple service, in collecting and safeguarding the manuscript treasures of Canada, in affording facilities for research to students, and in publishing selected documents from its collections. A list of the papers published in recent volumes of Transactions of the Royal Society would afford ample proof of the praiseworthy activities of its members. The Champlain Society, with headquarters at Toronto,

${ }^{1}$ See E. B. v, 165 et seq. 
devotes itself to the publication of important works bearing upon Canadian history, and the reprinting of old works in the same field. Wood's Logs of the Conquest of Canada (1909). Ganong's new edition of Denys' Gaspesia (1908), Munro's Documents relating to the Seigneurial Tenure in Canada (1908), and Tyrrell's edition of Hearne's Journey from Prince of Wales's Fort to the Northern Ocean (rgri), are admirable examples of Canadian scholarship. The establishment of the University Magazine, under the control of three of the principal Canadian universities, has offorded a medium, hitherto lacking, for the discussion of Canadian problems by Canadian writers in a Canadian review. Not the least important element in the success of the magazine has been the personality of its brilliant editor, Dr. Andrew Macphail.

As regards purely imaginative literature, the output in Canada within the last few years contains little worthy of record. The older Canadian poets and novelists have been comparatively silent; and it remains only to mention the work of two new writers, both women, Miss L. M. Montgomery, whose novels of life in the little "garden province " of Prince Edward Island are deservedly popular, and Miss Marjory Pickthall, who has published, though not yet in book form, a number of charmingly musical verses.

(L. J. BURPEE.)

French-Canadian. ${ }^{1}$ - French-Canadian literature received a decided stimulus from the École Littéraire de Montréal, a self-constituted academy of young authors which exercised most influence during its formative period, between 1895 and 1900 . Poetry became less local in theme, expression and the point of view. Good homespun verse is written still; but with a difference. Albert Ferland (b. I872) is faithful to the older gods and the country of the habitant in Le Canada Chanté ( 1908 et seq.). Louis Joseph Doucet (b. 1874) follows the changing seasons with more wistful questionings in La Chanson $d u$ Passant (1908) and La Jonchée Nouvelle (1910). His pronounced love of animals marks him off from most of his compatriots, who are like the rest of the Latin world in this respect. In Les Blessures ( I 1 I 2 ) Jean Charbonneau (b. I 876 ) sings one long dirge over the minor poets who have to live in contact with the grosser side of commercial Canada. Émile Nelligan et son œuvre ( $\mathrm{I}_{903}$ ) commemorates a boy whose astonishing poetic genius suffered the total eclipse of insanity at the age of nineteen. Half Irish, half French-Canadian, Nelligan (b. 1882) expressed the yearnings of an Old-World symbolist in Parnassian French. He had a wonderful intuition for the musical suggestiveness of words; and his carefully wrought poems, no less than his abrupt, weird snatches, are full of that haunting sense which only comes with haunting sound. 'L'Âme Solitaire $(1907)$ is the aeolian harp that Albert Lozeau (b. 1878) set in his sick-room window for so many years. It is a little vague; but contains the promise of better things to come, when the poet can interpret a wider world with more developed powers. In Le Paon d'Émail (rgri) Paul Morin (b. r886) leaves the New World for the Old, like his model, Heredia. He heaps up a superabundance of sumptuous material, wanders into frequent preciosities, and lacks Heredia's master art of concentration. But both he and his poetry are young enough to grow into what may yet be truly great.

The whole drama of French-Canadian history was summed up in the Quebec Tercentenary Pageant of I908. The excellently apt libretto-Pageants $d u$ Tricentenaire de Québec-was by Ernest Myrand (b. 1854), author of several qualifying works-Une Fête de Noël sous Jucques Cartier (1888), Noëls Anciens de la Nouvelle France (1898), Phips devant Québec (1893), and Frontenac et ses A mis (I go2). The history of the whole Tercentenary was admirably written by a brilliant scholar, the Abbé Camille Roy (b. 1870), in Les Fêtes du Troisième Centenaire de Québec (rgrI).

Sir A. B. Routhier (b. I 839), author ot several books of travel and a noted conférencier has written the principal novel of recent years, Le Centurion: roman des temps messianiques ( 1909$)$. The action moves through the very difficult medium of letters from contemporary witnesses. But it moves well; and the great trial scene is full of legal insight and dramatic feeling. Hector Bernier (b. I 886) writes an equally ardent Christian a pologiu in Au Large de l'Écueil (IgI 2); though he and his work are vastly different from

${ }^{1}$ See E. B. v, I67-8. 
Le Centurion and its author. He is young, his scene is Quebec, and his time to-day. If he would argue less he would convince more; and perhaps he might then rise into true art with a story that tells its own tale.

Le Père Beaudé (b. I870), a Dominican whose nom de plume is Henri d'Arles, writes remarkably keen and beautifully expressed appreciations of aesthetic subjects in Propos d'Art (1903), Pastels (i905), and L'Âme Antique (I907).

The death of Sir James Le Moine (1825-I9I2) was a loss to both French-Canadian and Anglo-Canadian literature of the commemorative kind. Historical writings have been too numerous even for the barest mention. A Review of Historical Publications relating to Canada is issued annually by the University of Toronto.

The chief new works on French-Canadian literature, to be added to the Histoire de la Littérature Canadienne (1874) of Edmond Lareau (1848-1890), are the Études (1904) and Nouvelles Etudes (1907) of Charles ab der Halden, a Frenchman (b. 1872). The local peculiarities of the language have engaged the attention of many scholars. In addition to the handy little Glossaire franco-canadien (1880) of Oscar Dunn (1844-1885), a much larger and more important volume has been produced by N. E. Dionne (b. 1848) in Le Parler Populaire des Canadiens-Français (1909); and a still larger work is now in course of publication through the Bulletin du Parler Français au Canada.

(W. WOOD.)

\section{American Literature}

American literature continues to impress "by its mass rather than its details." The sheer bulk of output increases steadily from year to year; but Americans are appreciably raising that high level of "average workmanship" from which William Dean Howells expects so much. To less sanguine observers, less will seem to be promised by the multiplication of literary craftsmen. The disheartening thing to them will be the vast number of books now published which are almost good or fairly good. It remains to be seen whether America will prove what the world hitherto has not been able to prove-that works of genius are more likely to spring.from a soil of enlightened mediocrity than from the wayside.

Unless in the field of dramatic writing, little fresh vigour has manifested itself between I909 and r9I3. A number of the older figures have passed from the stage. Most notable of them was Samuel Langhorne Clemens ("Mark Twain ") (I835-I9I0), chief exponent of the American joke, and possessor of a strain of genius which never quite adequately expressed itself. William Vaughn Moody (1869-19ro) was among the handful of genuine poets whom the America of later years may justly claim, and was by way of becoming a dramatist of unusual power. Sydney Porter ("O. Henry ") (I867-I9Io) was the most versatile of recent American short story writers and humorists. David Graham Phillips (I867-I9II) had a rude force and a conscious but sincere Americanism which differentiated him from the mob of novelists who write with skill. By the death of Thomas Wentworth Higginson (1823-19II) America lost the last important survivor of the New England group which half a century ago gave American literature its first wide recognition abroad.

Colonel Higginson carried into this century the tradition and practice of the familiar essay. The Atlantic Monthly, in which most of his work was printed, is now almost the only surviving repository of that obsolescent form. In the hands of Agnes Repplier (b. I 857) and Samuel McChord Crothers (b. 1857) it has lost nothing of its flexibility and inherent charm, but it has lost its wider audience for the moment, at least. Frank Moore Colby (b. 1865) is the wittiest of American writers of those little leaders which, on their smaller scale, retain something of the function of the familiar essay. Mr. Howells still contributes informal papers to the "Easy Chair" of Harper's Magazine. In the more formal and extended essay William Crary Brownell (b. I 85 I) and Paul Elmer More (I864) are preeminent. Whatever may be true of the light essay, there is no doubt of the steady demand for careful criticism. In such work the lifting of the average quality is of undoubted importance, and it is a hopeful sign that among the rank and file of newspaper reviewers there is a growing tendency to take their work seriously.

I See E. B. i, 83 I et seq. 
The influence of the newspaper on popular forms of literature is increasing. The Sunday supplement has developed into a Sunday magazine which is issued in connection with a very large number of newspapers all over the country. The standards of Sunday journalism have become the standards of the cheaper magazines, so that the distinction now is hardly more than that the magazines are published monthly instead of weekly, and are of greater bulk. The methods of the newspaper "story " are imposing themselves upon the special articles and fiction of American magazines as a whole. A cheapening of the national sense of humour through the coarse ministrations of the comic supplement may be held responsible in part for the small amount of genuinely humorous writing now being done in America. One humorist of the first order, Finley Peter Dunne ("Mr. Dooley") (b. I857), continues to hit off the foibles of the hour, and to scrutinize its idols, with unflagging keenness and kindness.

In poetry as in other forms of expression "workmanship " improves. The younger performers are prone to experiment with odd metres, which they manage with ingenuity. Two of the older singers have been heard from, but with increasing faintness, "Joaquin Miller" (Cincinnatus Heine Miller) (I84I-I9I3), and J. Whitcomb Riley (b. I854). The latter published two new books of verse in I9II. Edith Matilda Thomas (b. I854) has not exhausted her pure if slender vein of song, and among younger women, Josephine Preston Peabody and Anna Hempstead Branch have each re-expressed, in recent books of verse, a genuine and delicate lyrical power. In The Town Down the River (I910) Edward Arlington Robinson (b. I 869), perhaps more indisputably a poet than any of his generation, shows increased strength. Percy Mackaye (b. 1875 ), with a true poetic impulse, betrays in his later verse the effects of divided allegiance; he is determined to be a playwright against nature, which meant him for a singer.

In fiction the activity is very great. Every season outdoes its predecessor in the actual number of novels issued. With barely one or two exceptions, the best of them have been by authors already known. Margaret Deland (b. I857) still adds to her delightful group of "Old Chester" stories, which have a place of their own in the American fiction of the past quarter-century.

Other writers of gènre stories, Ruth McEnery Stuart with her tales of the South, Mary Noailles Murfree ("Charles Egbert. Craddock") (b. I850), the earliest interpreter of the mountain whites, Mary Hallock Foote (b. I847) and Owen Wister (b. 1860), exponents of the Western miner and ranchman: these and other story-tellers of their generation are still doing strong and characteristic work. Volumes of both prose and verse from Henry van Dyke (b. I852) and Silas Weir Mitchell (b. I829) bear witness to the continued productiveness of two writers who have been sure of their audience for a generation. Robert Herrick (b. 1868) is a novelist of powers which he has not yet succeeded in getting under full control. In his latest stories there is still a wealth of unassimilated material: he writes too much and too often. This is in direct contrast to his contemporary, Winston Churchill (b. 1871), who restricts himself to a novel every two years, and whose work, crude at first, has shown a steady growth in quality as well as a steady improvement in form. The recent novels of Meredith Nicholson (b. I 866) and of Mary Johnston (b. 1870) have also shown a striking advance in power. Miss Johnston's Civil War stories, written from the Southern point of view, while not free from exuberance of manner, have a panoramic quality which gives them a place of their own in the literature dealing with that period. The art of Mary Stanbery Watts (b. 1868 ) is of finer texture, and her Nathan Burke (1910) is a war-time story likely to outlast Miss Johnston's more emotional narratives. Among all the novels of recent date by new writers none stands out more distinctly as of merit, both in substance and in form, than The Squirrel-Cage (I9I I) of Dorothy Canfield.

In Sydney Porter ("O. Henry") (1867-I9I0) America lost her acknowledged virtuoso of that most popular of American literary forms, the short story. His range and versatility were remarkable, and his handling of the chosen form had much of the precision and orderliness which belong to the playwright rather than the writer of narrative. Among his chief successors are Jack London (b. 1876) and Edna Ferber. 
A general accession of interest in the art of the playwright as something to be studied in the printed page as well as in the theatre, is a striking development of the hour. A few years ago it was a rare thing for a play to be printed, at least until it had achieved exceptional good fortune on the boards. Now the public is interested to apply the test of reading alongside the test of hearing and seeing. American publishers are putting forth not only translations of the best European plays, but issues of new American dramatic efforts. Not only the best plays of Clyde Fitch (1865-rgog) and Augustus Thomas (b. .1859) have been printed, but numerous plays by younger playwrights, like (to cite a single example) "The Nigger," by Edward Sheldon. This new tendency to publish plays does not indicate a return to the "closet drama," but a new realisation that a good play is not merely a " show," but a very important form of literature. The very large number of persons in America who are now trying to write plays, and even trying to learn how to write them, is a sign of awakening. Already a number of young playwrights have made notable progress towards a drama of sincerity and power.

Literature of the solider (and not necessarily less imaginative) types is also finding an increased audience. Publishers say that there is a growing demand for books of biography and history for "summer reading." The autumn of Igr 2, for example, saw the completion of John Bigelow's (I8I 7-rg I I) Retrospections of an Active Life; Mark Twain's Biography (by Albert Bigelow Paine, b. I86I), the life of George Palmer Putnam, by George Haven Putnam (b. I844); and Personal Traits of Abraham Lincoln, by Helen Nicolay (b. I866); books of considerable merit dealing with special periods of American history, or with special aspects of her development, have been many of late. It is noteworthy that American scholars in general are following the example of the late John Fiske and the late William James in cultivating a style such as to give their work a chance of survival as literature.

(HenRy Walcott Boynton.)

\section{French Literature}

There are periods that pass and leave little changed in the literature of a nation, and others which are a veritable springtime full of burgeons and new voices. Since Igog the progress of the Idealist Renaissance in France has changed the character of its literature. Zola and the Goncourts-the names of a dozen years ago--are as though they had not been. If the refined and philosophic scepticism of the seventies linger with a few great writers-Anatole France, Jules Lemaître, Pierre Loti, Henri de Regnier-we see no young men on their track. Always in France the spirit of Racine has warred with the spirit of Rabelais, or, to put things on a lower level, the art of Octave Feuillet has contradicted the art of Zola. To-day the classics and the idealists have come to the front. Ten years ago literature was positive, objective, and, if we may say so, visual; for that phrase of Gautier's: "Je suis un homme pour qui le monde visible existe," was still the motto of the hour. The younger men are writers for whom the invisible world exists and occupy themselves chiefly. with the interior sphere. The other day, M. René Boylesve expressed very happily this change of front to a reporter of the Revue des Français (Sept. 25, I9I2). He said "In my young days I used to visit Alphonse Daudet whom I greatly admired. He encouraged me, and we would talk of literature. He used to say gently, 'I have never described anything that I have not seen.' I felt he was offering me a piece of advice, discreetly, and I used to go away incapable of writing anything for long afterwards, since at every turn I caught myself on the point of describing things I had never seen "-such things for instance as emotion, beliefs, traditions, opinions, the moral atmosphere of a society. And M. Boylesve showed the journalist the plan or scenario for a novel lying on his writing table - no project of a plot, no list of personages, but a sequence of maxims and reflections. "Take care of the moral atmosphere," he would say, "and the characters will take care of themselves." So soon as he begins to write he forgets his notes, which transpose themselves into persons and actions, but all his care is to invent the moral world which brings them forth, just as Daudet would proceed from a description of physical reality to the spirit within.

1. See E. B. xi, n lo et seq. 
There is something English in the talent of M. Boylesve (b. I867), something that recalls at times the minute interior art of George Eliot or Mr. Galsworthy-precise small touches disengage the character of a soul, of a society. In the last three or four years M. Boylesve has risen to one of the highest places in the fiction of France. Continuing La jeune fille bien élevée, his last novel, Madeleine, jeune femme ( 1912$)$ is the story of a pure minded solitary girl, convent bred, pious, quietly reared in a small town of Touraine, suddenly cast by her marriage with a rising architect of Paris into that vortex of contractors, speculators, moneymakers and pleasure hunters which eddied round the great exhibition of 1889 . The refined and sensible Madeleine passes unscathed among the booths of Vanity Fair. But by a friendly hearth (the one spot which recalls the peaceful surroundings of her early years) she meets a man of letters, a student of subtle moral problems, a lover of Pascal, an inhabitant of her own intellectual world. And almost without a struggle Madeleine succumbs-succumbs morally, we hasten to add, and in the very secret of her soul, for in the world of fact she never succumbs at all and her aureole of virtue effectually protects her. M. Boylesve is a traditionalist, a lover of the ancient faiths and disciplines of France, a lover perhaps rather than a believer. Yet if Madeleine is saved it is not, he seems to say, the beautiful quality of her soul that saved her, but the regularity and nobleness of her early education; and to make the example clearer, he sets face to face with Madeleine a charming madcap, a child of nature, Pipette Voulasne, without a bad instinct in her composition, but without a principle, a faith, or an ideal. Pipette is marked out for Fate, and here no sudden angel intervenes. M. Boylesve loves to show us the neat well ordered world of civilized society but in his magic mirror the figures that move therein become sometimes transparent and reveal behind them the great primitive forces, never completely disciplined, which drop into our neatest systems some soul irreducibly irregular, a grain of sand throwing all things out of gear. All his novels are " une invitation a réfléchir sur la vie."

The art of M. Boylesve has made a strong impression on the young; among those who walk in his traces we may mention M. René Behaine, M. Alphonse de Chateaubriand, and M. André Lafon, to whom was awarded in the summer of IgI 2 the first Grand Prix de Litterature $\left(£_{400}\right)$, recently inaugurated by the French Academy.

Still more important than $\mathbf{M}$. René Boylesve is $\mathbf{M}$. Maurice Barrès (b. I862), his elder by a few years. Boylesve was one of the young writers (with Hugues Rebell, René Ménard and Charles Maurras) who collaborated on La Cocarde, the odd little review which Barrès edited in 1894 and 1895 , a review which was at once Boulangist and socialist, patriotic and individualist, military and literary; in brief, as Barrès defined it, the production " d'un groupe d'hommes passionnés pour le développement historique de notre pays." La Cocarde was not long lived, but its authority and inspiration, promulgated by a band of thoughtful young writers, with an ideal and a discipline of their own to propose to a somewhat disorganized literature, was enduring. La Cocarde was to the literature of the early twentieth century in France all that The Germ had been to Mid-Victorian England.

The sentiment of national traditionalism, which these writers elaborated, has proved the finest, the most stimulating tonic to French literature. Their shibboleth: "Nôtre terre, nos morts," is the pass-word of modern letters. The sense of responsibility, the dream of order, the feeling for continuity, the belief in the persistence and perpetuity of an ideal, are motives which inspire most of the principal writers of the present day in France. The Colette Baudoche (1909) of Maurice Barrès is one of the evangels of this doctrine, written with an ease, a measure, a liberty and grace which form a little masterpiece. It is one of those books (romantic by their sentiment and classic by the simple: purity of their form) which outlive schools and their gospels. We may place it on the shelf near P'dul el Virginie, The Surrows of Werther, or The Vicar of Wakefield.

This local life, this "regionalism" which the traditionalists offer as a remedy to the excessive importance of Paris, has its evident danger, - the dispersion of national feeling, the dissociation of the provinces. It is an evil against which they propose to guard by the restoration of the (atholic Church and the cult of great men. In two short studies 
( $L$ 'Angoisse de Pascal, I910; Il Greco, I91 2) Barrès has written in praise of natures with whom his own has obscure but intimate affinities. The great figures of history are the natural educators of a nation, its intercessors, its patrons and its patterns: A Pascal or a Corneille is surely more to France than St. Denis. In $I l$ Greco the writer inquires into the secret of the spiritual life. Il Greco is emphatically a painter for whom the invisible world exists. His faults, his voluntary distortion of the human figure, the flame-like fragility and aspiration of his personages are not repugnant to $\mathbf{M}$. Barrès, who maintains that an artist may sacrifice the detail of external truth in view of obtaining a greater intensity of emotional expression; he esteems such aberrations to be fortunate errors if they prove a condition of the utterance of certain spiritual states. Il Greco, like Blake, takes a poet's licence with anatomy, but he admits us to a mystical world of rushing spirits, of flooding light, of joy and fire, a world of adoration, bliss, eternal space. And so he has the praise of M. Barrès, who is far removed from the doctrines of Naturalists. In the last weeks of rgr2 M. Barrès completed a new novel, La Colline Inspirée. We may mention in the wake of $\mathbf{M}$. Barrès, the brothers Tharaud, novelists distinguished for a literary style singularly pure, firm and brilliant; the fanciful and ingenious critic and romancer, André Beaunier, and that profound and singular young genius, Mademoiselle Marie Lenéru.

Another modern Plutarch (who, like M. Barrès, seeks to propose to his contemporaries, in the Lives of Great Men, a discipline and an ideal) is M. Romain Rolland (b. I866), the author of studies of Beethoven (1903) and Michael Angelo (r9o6), which reveal his intense and dreamy genius, but especially known for his biography of an imaginary German musician, Jean Christophe; it is, in fact, a biography rather than a romance. Jean Christophe, a huge novel in successive books (the first, L'A ube, published in 1904), as long as Clarissa Harlowe or War and Peace, is perhaps the most remarkable work of contemporary fiction, as well known in Italy, almost as well known in Germany and England, as in France. A singular moral fervour, a rare imagination, an extraordinary alternation of sarcasm, rancour, revolt and tenderness breathe from the pages of this disconcerting book. M. Rolland is the Rousseau of our times, and he has the defects of his model: a negligence and diffuseness in the style, alternating with chapters so beautiful and touching that we may rank them with the best contemporary work; a lack of proportion and measure; an irritating spleen; sometimes a shrill-voiced choler almost shrewish in its denunciation, its polemics. But there is a greatness in M. Rolland's outlook, a penetrating quality in his insight, which is his own peculiar gift. No great question leaves him incurious. What is genius? Why does its production so often dislocate and jangle the nature which gives out the spark? In what degree is that creative force a thing distinct from the personality that harbours it? What is that dualism in the mind-partly a trained intelligence, partly the capricious play of a free unconscious instinct? What is that simultaneous working of intuition and understanding which goes to produce a masterpiece? No psychologist, we think, has noted these questions more finely than M. Rolland in the volume of Jean Christophe entitled La Révolte (I906). And what tenderness he brings to describe the ephemeral beauty of a girl's life who dies voung, an Antoinette or a Sabine; all the pathos of human destiny is there. With how intense a passion, a rancour, a fatality, he treats the overmastering force of love in Le Buisson Ardent. There is something of the wild tragedy of Tristan and Isolde in this episode (and here, we feel, his musician, who in his childhood reminded us of Beethoven, resembles Richard Wagner). At every turn our author treats the difficult problem of the artist's relation to his environment. Jean Christophe knows what it is to be one single cell, aching with individuality, in the national body of which, nolens volens, he forms a part; and he knows the attraction, too, which draws together the members that form a whole. He has learned the two great lessons: revolt, which strives and creates; acceptance, which assimilates and transforms. At the end of $19 \mathrm{I} 2$ the final volume of Jean Christophe,- the tenth,-closed on a note of peace this contemporary epic.

M. André Gide (b. I 869) is a very different artist, narrow but exquisite. "Le goût exquis craint le trop en tout." These words of Fénelon's rise into our mind whenever 
we open a book by M. Gide. Of all of them the best is La Porte Etroite (1909), the story of a rare soul drawn into the abyss of the mystical life " as waters are by whirlpools suck'd and drawn," through a mistrust of the excess, the vulgarity, the transitoriness of mortal happiness. There are natures which need the liberty, the solitude, the rapt interminable progression and ideal refuge of the inner life. They are, as Sainte-Beuve put it, marked with "la griffe de l'archange." Alissa has only to stretch out her hand to take her happiness. A sort of disgust of reality, a dread of disenchantment, paralyses her:

\section{"Enough, no more}

'Tis not so sweet now as it was before!"

Alissa was one of those Jansenists whom Ninon de l'Enclos mocked as " les précieuses de l'amour." M. André Gide, like M. Maeterlinck, like M. Barrès, like M. Boylesve, like most of the considerable writers of his generation, has entered religion through the gate of symbolism. He is a mystic rather than a dogmatist, a well-wisher to religion rather than a believer. Their last word is not said. The current which has borne them already so far from their starting point may land them within a chosen fold, but so far they are champions of the faith (M. Maeterlinck is an avowed materialist, M. Gide of Protestant origin, but M. Boylesve and M. Barrès are formjdable Catholic champions) "jusqu'à la foi, exclusivement," like those pious improfessi, those God-fearing metuentes, who in the primitive Church, though neither Jew nor Christian, ran the risks and fought the battles of Paul and Peter.

There is a vast difference between their novels-even between a book so avowedly orthodox as Madelcine, jeune femme and the real thoroughgoing religious novel written out of a fervour of faith, with the imagination of an apostle, perhaps the rarest and most difficult form of art. The last two years, however, have brought us several even of these; and we speak of real works of art, not merely tracts for the times. Of these the noblest is by a poet, Charles de Pomairols (b. 1848 ), who has been called the Wordsworth of contemporary France. Ascension (I gro) has all the defects of a poet's prose, but also a natural idealism, an air of noble reverie, a dreamy wandering grace, singularly poignant and fresh. Often in reading the volume we lay it down and think: how Pater, how Turgénieff, how Meredith would have appreciated this penetrating langour. But. it is certain that the ordinary novel reader would be bored. (A second novel of M. de Pomairols, Le Repentir, Igr2, does not reach quite this high level.) There is more fire, more force, more grip in an extraordinary book of a young writer, M. Emile Baumann (L'Immolé, I909). We may also mention La Barrière, by M. René Bazin (I9I0), Leur Royaume, by M. Robert Vallery-Radot (I9IO), and La Cité des Lampes by "Claude Silve" (IgI2). The last name veils the identity of Mademoiselle de Lévis-Mirepoix, the daughter of the Duke.

We have shown that the principal trend of French literature in Igro-i 2 has been towards a Renascence of idealism and indeed in great part toward a Catholic Revival, but this is not saying that the writers of yesterday have abandoned their positions or that they have ceased to produce; one of them indeed has produced a masterpiece. But we have preferred to indicate the present state of things and the promise of to-morrow, and to draw attention to the new writers who, with every season, are coming to the front.

And having performed our duty towards literary history, we may own that, for interest and charm, few of these newer books can compete with certain productions of the old stagers. Pierre Loti (see $E$. B. xvii, Iq) has seldom written a finer page than the concluding passage of Le Pélerin d'Angkor (1912). M. Jules Lemaitre (see E. B. xvi, 408), resuming the rôle of critic, has given us, following his Rousseau (1907), a Racine (Igo8), a Fénclon (1910), a Chateaubriand (IgI2). All of these are interesting and valuable, and the Racine especially is full of charm. In describing Rousseau, Fénelon and Chatcaubriand (the three great Romantics avant la litlic), the critic's habit is piquant. He sets his author on a pillory, vituperates him, attributes to his evil influence the degeneracy of France, then softens, as he tells his story; discovers him to be charming after all; crowns him with new plucked laurels, till, on the last page, author and critic 
kiss again with tears. If M. Lemaitre has struck forth no new line, developed no new faculty, at least he has lost nothing of his wayward originality. But M. Anatole France (see $E . B . x, 775$ ) has gone on from strength to strength. He has never produced a more brilliant book than Les Dieux ont soif, which, in its neat light form, is a psychology of the French Revolution - a psychology in action, with no visible apparatus of historical or philosophical knowledge but singularly penetrating and illuminative. Age has weakened none of the charming and redoubtable arts of the author of l'Orme du Mail. $\mathrm{He}$ is terrible or delightful, gay or sinister, exquisite or harshly, tragically moving, turn by turn. The same unparallelled style, supple, opulent, exact and sober, adorns the same philosophy - as the loveliest flower may hide the brink of an abyss. For the mind of M. France is full of contempt for human nature, derision of human destiny, and a sombre cynical satisfaction in contemplating lust and frenzy and horror. It is not unlike the mind of Swift. And yet M. France has looked on life and has seen that it was good. Like his philosopher Maurice Brotteaux, "il admire la nature en plusieurs de ses parties, et spécialement dans la mécanique céleste et dans l'amour physique." He might also add that he admires the complication of the human character, and finds a secret pleasure in verifying its paradoxes and disharmonies. His Evariste Gamelin will recall to the reader familiar with the history of the times that strange figure of François Sergent, most candid of mortals, most ferocious of revolutionaries, an implacable Jacobin, a delicate artist, who organised the September massacres and also the picture gallery of the Louvre, and who, all his life, was the faithful and devoted lover of one woman. But instead of the honest Mme. Sergent, Anatole France has given his Jacobin, for a vis-à-vis, a woman whose wiles, whose frailties, whose successive sincerities, remind us of the beautiful wife of Greuze, the daughter of the printseller.

Somewhere at the feet of M. France (children of nature and not grace), opposite to that band of idealists of whom we have already spoken, we must place a group of unconventional young writers whose extreme right would include the delightful poet Francis Jammes (whose Georgiques Chrétiennes have the charm of Pan, on his pipe, mimicking the church-bells), while their extreme left extended to the gifted Charles Louis Philippe, who died prematurely at the very opening of the period under consideration. There is Madame Marcelle Tinayre, who has never quite recaptured her first delicate mastery in La Maison du Pêchê, yet who in L'Ombre de l'A mour shows a sombre magnificence of style, and a violent poignant beauty of her own; there is Colette Willy, the actress, whose Vagabonde is a brilliant study of the eccentric sphere of the music halls; there is Marguerite Audoux, the dressmaker, whose Marie Claire was so astonishing a revelation of idyllic charm, primitive grace and exquisite poignancy. Before the prose of a Marguerite Audoux, as before the painting of her friend Madame Marval, the skilled artist, suddenly humbled, remembers a theory dear to Browning that the real man of genius should rise untaught. Their ignorance at all events is bliss.

And somewhere we must place the literary manifestations of the drama, too various to co-ordinate. We must note the metamorphosis which, in Le Tribun, has made of M. Paul Bourget (see E. B.iv, 33I), a successful playwright; we must recall the brilliant reception given to Rostand's theatrical fairy tale of Chantecler (see $E$. $B$. xxiii, 754); we must direct the reader to $M$. Charles Péguy's ample and powerful Mystère de Jeanne d'Arc (the English reader may imagine Walt Whitman turned a Christian mystic, and endowed with ten thousand-fold his original flux of words), and we must point out the original talent of Mademoiselle Marie Lenéru in her Affranchis. All these four writers join at different points the camp of the idealists.

(Mary Duclaux.)

\section{German Literature}

There is a peculiarly incalculable element in the German literary movement of the last generation; in spite of its being guided and preached at to an excessive degree by the critics, it has persisted, time and again, in freeing itself from their leading-strings, and

1: See E. B. xi, 783 et seq. 
going its own way. This has been more than ever the case during the past few years. Germany rose into prominence as a power which had to be reckoned with in literary Europe, towards the end of the eighties of the last century. The first phase of the literary revival resulted from a combination of three powerful forces in European literature: the French naturalistic movement, the influence of the Russian novel of Tolstoi and Dostoievsky, and the drama of ideas on a realistic basis which came from Scandinavia. But no sooner had an amalgamation of these three outside forces been effected, and Germany had begun to evolve a literature of her own from the union, than the wind of popular favour changed. The phase of undiluted realism gave place to a movement analogous to the symbolistic movement in France, but more deeply immersed in mysticism than the French movement. With daring originality, the young quondam realists introduced, side by side with the most painstaking and even sordid descriptions of actuality, elements of faery lore, of idealism and symbolism, which resulted in the most fantastic and incongruous combinations. But now it may be said that realism is virtually a thing of the past in Germany.

As time goes on, the significance of the work of Friedrich Nietzsche for the literary achievement of modern Germany becomes ever plainer. One can no longer regard this influence as restricted to the unfettering of individualism noticeable in the lyric poetry of the eighties and nineties. Nietzsche appears now rather as a force which is keeping German literature in touch with the needs and demands of the actual life of the present and is preventing it - as has so often happened in the past, when a healthy realism became a dead letter in Germany-losing itself in the clouds of an unworldly idealism.

The modern lyric has shown no abatement of its quest for new and original expression. And although neither Richard Dehmel nor Stefan George--no doubt the two most original of modern German singers in widely different fields-has added to his laurels in these years, younger men like Max Dauthendey (b. 1867), Rainer Maria Rilke (b. 1875 ) and Alfred Mombert (b. I 872 ), have been establishing their claims to a place in literary history. In epic poetry, the importance of the Swiss writer Carl Spitteler (b. 1845), as one of the strong talents of his time, is now very generally recognised, more especially since the republication in 1909 of his remarkable poem Olympische Frühling in a revised form. With the death of Detlev von Liliencron (July 22, 1909), the modern German lyric lost its first master; and with that of Otto Julius Bierbaum (Feb. I, I 9 IO) the leading spirit in that lighter phase of the modern lyric, which came to Germany with the French cabaret, the so-called "Uberbrettl." Further losses have been Martin Greif (Hermann Frey) (March 29, I9II), and, in other than lyric poetry, Wilhelm Busch (Jan. 9, I908) and Julius Wolff (June 30, 1910).

With the waning of Dostoievsky's influence and that of naturalism generally, the German novel has fallen back once more into an experimental stage. It is here, perhaps, that the decentralizing tendencies have most surely made themselves felt, the socalled "Los von Berlin" movement. The novel has entered the service of that "Heimatkunst" of which the Alsatian writer, Fritz Lienhart (b. I865), has been the most persistent advocate; it has fled to the country and the dialect; the novel of the large city has given place to that of the province, and the gain in variety and poetic strength has been undeniable. But along with this movement, there has also gone a tendency towards idealizing symbolism, similar to what has taken place in drama. This is to be seen notably in the work of the more promising younger writers, such as Hermann Icsse (b. 1877 ), who is restricting himself more and more to the short story, Emil Strauss (b. 1866), and Bernard Kellermann (b. 1879); while a distinctly novel note in the fiction of the day has been struck by Hanns Heinz Ewers (b. I87 r), a former contributor to the literature of the "Uberbrettl," who, with his Der Zaubcrlehrling (г 910), harks back to the manner of E. A. T. Hoffmann, and is influenced by Baudelaire. Of the writers of established reputation, Gustav Frenssen (b. 1863) has published one novel, Klaus Hinrich Baus ( $\mathrm{I} 900$ ), which, however, rather justifies our doubts as to whether the author of $J \ddot{r} n U \mathrm{Hl}$ has any higher poetic mission to fulfil towards his generation. Thomas Mann (b. 1875) has produced only one novel, Königliche Hoheit (1909), which 
is hardly worthy of the author of Buddenbrooks, while Hermann Sudermann (b. 1859) has remained faithful to the French realism of his earlier period in his Das hohe Lied (Igo8), and the short stories of the volume Die indische Lilie (IgII). Gerhart Hauptmann (b. 1862) has also in the last few years turned seriously to the novel and published two books, Der Narr in Christo, Emanuel Quint (I9II), a powerful reproduction of the gospel story in modern Silesian surroundings, and Allantis (1912), a novel of little distinctive literary quality. New novels by Jakob Wassermann (b. I873; Die Masken Erwin Rainers, I910), and by Arthur Schnitzler (b. I862; Der Weg ins Freie, 1908), show no conspicuous advance on these writers' earlier work; and the same is true of the recent work of the leading German women writers, Clara Viebig (b. I860; Kinder der Eifel, I909); Helene Böhlau (b. I859; Isebies, I9I I); Gabriele Reuter (b. I859; Das Tränenhaus, I909). Death has thinned considerably the ranks of the older generation of novel-writers. Hans Hoffmann died on July i I, I 909; Hermann Heiberg on February 16, I9ıо; Wilhelm Raabe on November 15, I910; Friedrich Spielhagen on February 25, I9I I; Adolf Wilbrandt on June I0, I9II; Wilhelm Jensen on November 24, I9 I ; Felix Dahn on January 3, I912. A promising talent in fiction has also been lost by the death of Wilhelm Holzamer (1870-1907).

The drama remains, as it has always been, the most interesting feature of recent German literature, and the one which reflects most faithfully the movement of ideas. In many ways the chief dramatic writer of the period, Gerhart Hauptmann, is representative of his time. In his work we see precisely that experimental spirit, that want of a definite poetic policy, and one might also add, of strong, dominating ideas, which is so characteristic of contemporary German literature. Since I 909 Hauptmann has hardly added to his reputation as a dramatist; he has written Kaiser Karls Geisel (I9o8), Griselda (igog), Die Ratten (I9ro), the latter in his earlier realistic manner, and Gabriel Schillings Flucht (I912), a weak and ineffectual play. These books cannot for a moment compare in incisive power with his early works. Hermann Sudermann, who was Hauptmann's brother-in-arms in the early days of the literary revival, has less to his credit: Strandkinder (I909), and a poetic play, Der. Bettler von Syrakus (I9I2). The latter fails, however, to rise much above the iambic " drama of ideas," as it was cultivated by Adolf Wilbrandt in the earlier generation. But the last few years have brought a new group of dramatic writers to the front. The leading spirit here is Hugo von Hofmannsthal, who is mainly responsible for the movement which has as its object a renascence of the works and forms of older literatures. One cannot, however, ascribe a like success to his latest original works, Christines Heimreise (IgII) and Der Rosenkavalier (IgII), to the latter of which Richard Strauss has written the music. Arthur Schnitzler has added to his reputation with the fine historical play, Der junge Medardus (IgIo), and with a modern drama in his old manner, Das weite Land (IgII); Hermann Bahr (b. I 863) has become one of the popular dramatists of the day with his Das Konzert (rgo9); and Karl Schönherr, a native of Tirol, has won a no less striking popular success with his tragedy, Glaube und Heimat (I9I0), the broad popular pathos of which is, however, more in evidence than higher literary qualities. The most promising developments of the drama in these years have taken two forms, the first a kind of modern romanticism in classic form, to some extent influenced by Hofmannsthal, and the second, ironic and satiric. To the first group belongs the work of Ernst Hardt (b. I876), author of Tantris der Narr, which received the Schiller Prize in I 908, without altogether meriting so high an honour, and of Gudrun (I I I ); further, that of the gifted and promising young dramatist Herbert Eulenberg (b. I876); but it remains to be seen whether this return to a poetic drama of a traditional type will escape the shallows on which such attempts usually come to grief in Germany. Meanwhile, the most prominent new man in the drama of to-day is a representative of the second form of innovation. This is Frank Wedekind (b. I864), whose work has in these years been advancing rapidly in popular favour. Wedekind is the most notable product of the "Uberbrettl" movement, with which he was formerly closely associated. He is grotesque rather than realistic, a dealer in irony and paradox, a fighter against the disease of excessive "liter- 
arism " in the theatre. But here, too, it remains for the future to show whether Wedekind's work has itself enough of the enduring qualities of literature to maintain its place; his latest plays, Oaha (1908), Musik (I908) and Der Slein der Weisen (1900), hardly, it must be confessed, justify very high hopes. By death the German drama has lost in these years A. L'Arronge (May 26, 1908), Ernst von Wildenbruch (Jan. 15, 1909) and Arthur Fitger (June 28, rgo9).

See K. Martens, Literatur in Deutschland (Berlin, r9ro); A. Soergel, Dichtung und Dichter der Zeit. Eine Schilderung der deutschen Literatur der letzten Jahrzehnte (Leipzig, 19II); G. Witkowski, Die Entwicklung der deutschen Literatur seit 1830 (Leipzig, 1912).

\section{ITALIAN LITERATURE}

Italian literature has not been very prolific during the last few years, and while a certain amount of good work has been produced, few books have appeared that are likely to hold their own in the first rank. In the field of fiction the two most important novels are the Leila of Antonio Fogazzaro (d. I9II), and the Forse che si forse che no of Gabriele D'Annunzio (b. 1863 , see $E$. B. ii, 78). The latter carries on the author's studies of the psychologically abnormal and of sensual passion, but in style and descriptive power it shows us D'Annunzio at his best; it is a novel of ultra-modern life in which motoring and aviation loom large. The novel of local colour, concerned rather with the ambiente than with character drawing or plot, maintains its popularity; Grazia Deledda, the talented Sardinian authoress, has brought out several new volumes belonging to this class of fiction, such as $I l$ nostro padrone, Sine al confine, etc., in which the primitive customs and interesting life of her native island are admirably rendered. The chief fault of her tales is their almost unrelieved gloom and sadness, a defect common, however, to a large part of modern Italy's literary output. It is therefore with relief that we turn to the reasoned optimism of Luigi Sicilian's Giovanni Francisca, a novel of Calabrian life, in which the virtues and attractive qualities of the people of Calabria are set forth as well as their faults; the conclusion is full of hope. Dora Melegari, one of the leading personalities of the Italian feminist movement and author of several novels, volumes of memoirs, literary criticism, etc, both in French and in Italian, has in La cilta d cl giglio-the second of the series Le tre capituli-produced a picture of life in Florence at the time when it was the capital of Italy; she has drawn the political and social milicu of the time as well as her characters with a steady hand and charm of style which make us look forward with interest to the appearance of her next volume on Rome. A young authoress who writes with an agreeable and straightforward simplicity and with a high moral purpose is "Paola Stafenda" (Lina Trigona), whose first novel $\mathrm{La}$ dritta via appeared in roro.

In poetry no new writers have risen to fame, but some well known poets continue to produce. D'Annunzio has been inspired by the Turco-Italian war to write ten poems collected in the volume Canzoni della gesta d'oltremare, which contain some of his most admirable verse. Although at times unduly involved and too full of allusions to obscure episodes, his poctry rises to a greater height of lyrical beauty and genuine inspiration than anything which he has yet produced. The muse of Ada Negri (b. I87o; sec $E$. $B$. xix, 34.3) has become less melancholy and less bitter now that her life has been happier, and in $\mathbf{M}$ aternita, a collection of songs of motherhood, she takes a more cheerful view of life than she did in her earlier poems. Dialect fills an important place in modern Italian literature, for it still holds its own among the people, and many poets have choser that medium of expression. Cesare Pascarella, the Romanesco poet, and one of Italy's greatest writers, has produced very little of late, but his new cycle on the Risorgimento, which his friends have been privileged to hear recited, will it is hoped soon appear. "Trilussa" (Carlo Alberto Salustri), who writes in the same dialect, has published sev. cral volumes of satires and fables, in the style of $\mathbf{G}$. C. Belli, but his work is inferior to that of Pascarclla. The Neapolitan dramatist Roberto Bracco has brought out some good verse in his native Neapolitan dialect, in which he paints the character of the

1 See E. B. xir, 897 et seq. 
Neapolitan people, sometimes wild, noisy and scapigliato, but often melancholy in its love songs. Another Neapolitan, Salvatori Di Giacomo, after a long silence, is beginning to write once more, and his poetry often contains high lyrical qualities.

Political movements in Italy have usually had literary beginnings, and Italian Nationalism, which arose as a reaction against the predominance of socialism and internationalist anti-patriotic ideas and proclaimed the necessity of a greater faith in Italy and of a more virile policy, has as its advocates a number of brilliant and enthusiastic young writers. The most remarkable of them is undoubtedly Enrico Corradini, the precursor and apostle of the movement; his two novels La patria lontana and La guerra lontana, although not without artistic faults, are vigorous, effective and sound, and inspired by lofty patriotism. His more recent books on the campaign in Tripoli are also remarkable. Such writers as "Giulio De Franzi " (Luigi Federzoni), Goffred Bellonci, Maurizio Maraviglia, also play an active part in the movement.

Of the other more purely literary and artistic movements none seem likely to make their mark on contemporary thought. The "Futurists," of whom F. T. Marinetti is the chief exponent, while professing to create a new literature, a new art and new music, are hardly to be taken seriously, while the same may be said of the shrieking and somewhat bumptious group of writers who centre around Giovanni. Prezzolini and his organ $L a$ voce, and wish to reform the world by substituting invective for argument.

Journalism continues to make great strides; the modern sensational style, with "scare" headings, etc. has been generally adopted, but the papers are larger, fuller of news and better written than before, and have an ever increasing circulation. Many of the most eminent authors, university professors, scientists and statesmen contribute to their columns. Among the best Italian journalists Luigi Barzini of the Milan Corriere della sera occupies a high place, and his vivid articles and telegrams from many lands where wars, revolutions and other exciting events occur, will always be read with interest. "Rastignac" (Vincenzo Morella) of the Rome Tribuna is one of the best known leader writers, and Enrico Scarfoglio, proprietor of the Naples Mattino, is also a very clever journalist. Giuseppe Bevione, for some years London correspondent of the Turin Stampa, is one of the most serious of the younger newspaper men. Plenty of literary talent gathers round the Rome Giornale d'Italia, to which the above-mentioned Nationalist writers contribute, as well as Diego Angeli, the art critic, translator of Shakespeare, novelist, and satirist of society's shortcomings, whose. witty and slightly malicious articles delight the readers of the same paper. Another writer de omnibus rebus et de quibusdam aliis is Ugo Ojetti.

Little has appeared worthy of note on the Italian stage. The one real success of the last few years is Sem Benelli's brilliant historical tragi-comedy La Cena delle beffe. D'Annunzio has written two new plays-Fedra, an attempted revival of the classical drama, and Il Martirio di San Sebastiano; originally written and produced in French; but although both contain many beautiful passages they are lacking, like the author's other tragedies, in dramatic quality. The most characteristic productions of the modern Italian stage are the dialect plays, which are associated with the various dialect conpanies touring about the country.

(LUIGI VILLARI.)

\section{Dutch Literature ${ }^{1}$}

The stagnation, if not decline, of Dutch literature after the flourishing period of r $880-1890$ must for a great part be ascribed to the fact that criticism came too strongly to the fore, and the discussion of literary method and ideals took the place of original production. Moreover, naturalism, introduced into Holland through Zola's powerful influence, had triumphed too much, and when the reaction came no definite path lay clear. In this way there came a certain anarchy in feeling and in thinking, and only in the last few years has imagination begun to occupy a prominent place in Dutch literature. The discord between what used to be congenial minds was made apparent by the constant appearance of new periodicals. So by the side of the Nieuwe Gids, the Twee-

1. See $E$. B. viii, 7 I9 et seq. 


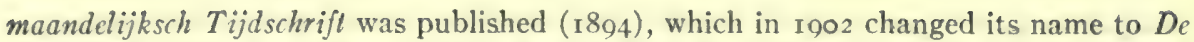
Twintigste Eeuw, and was combined in 1909 with the Nieuwe Gids. On the other hand Albert Verweij (b. 1865) had already left the latter in 1905 , and founded De Beweging. in which a large place was given to poetry, and naturalism was not admitted at all. Already in I903 Groot Nederland had been started, strictly limited to literary work, whereas in Onze Eeuw science and politics were also treated. Van Onzen Tijd (rgor, a weekly since I910) became the paper of the younger Roman Catholic authors, Ons Tijdschrift (1897) that of the younger Calvinists, Stemmen (I9II) that of the Orthodox Calvinists; the Nederlandsche Spectator stopped in 1908, but Elsevier's Geillustreerd Maandschrift was rejuvenated under the editorship of Herman Robbers (b. I 868).

Among the poets of the last few years were some of great promise, but many were mainly imitative and showed little originality. Against these Frederik van Eeden's articles about Literary language ( 1902 ) were directed, by the side of which must be mentioned Adama van Scheltema's book The Foundations of a New Poetry (1907). Van Eeden (b. 1860) followed up his Dante and Beatrice (1908) with the second part of Het Lied van Schijn en Wezen (the Song of Illusion and Reality, Part I, I895, Part II I9ro). Albert Verweij (b. 1865) whose poetry is too obscure ever to become popular, published Het Blanke Heelal (The Lucid Universe, I9o8), the dramatic poem Cola Rienzi (19ro) and a volume of poems called The Feast of Life (I9II). The poetess Helène Swarth (b. I859) added to her previous volumes Pale Skies (I009), Gossamer (1910), Eveningclouds (rgII), together with two poems in dramatic form Dolorosa and Mara (IgrI). Herman Gorter (b. I864) published the long socialistic poem Pan (I912), and the socialistic poetess Henriette Roland Holst-van der Schalk (b. 1860) gave utterance to her feelings in The New Birth (1903); U proard Roads (1907) and especially in the lyrical tragedy The Rebels (rgro). There must also be mentioned Tom's Diary (roro) by Willem Levinus Penning (b. I840), which contains fine poems, reminding us of Staring and Potgieter, Forgotten Songs (IgIO) and Carmina (Igr2) by P. C. Boutens (b. I870), From Silence and Strife (1909) by C. S. Adama van Scheltema (b. I877), Poems (I I I), by A. Roland Holst and Moods (rgro) by J. Reyneke van Stuwe (b. I874).

Much more distinctly than in the case of poetry, the want of a definite school is felt in Dutch prose literature, so that the most diverse tendencies find expression. In the flood of novels only a few can be pointed out which will probably attract more than temporary attention. Frederik van Eedən published a series of lectures under the title of The Joyous World (1903), followed by the novels The Bride of the Night (1909) and the fictitious Reminiscences of Vico Muralto, while in 1912 his Sirius and Siderius appeared, as the first part of a trilogy. L. van Deyssel's (b. I 864) From the Life of Frank Rozelaer (I II I) contains philosophical contemplations besides beautiful descriptions of nature and fine psychological analysis. Weirdly phantastic are The Strange Adventures of Zebedeus (I910) by J. van Looy (b. 1855). Cyriel Buysse (b. I 859) maintained his literary reputation by publishing The Full Life (1008), I remember (1909), The Donkey (IgIO) and Moods (I9II); J. de Meester (b. I 860) published a volume of stories, called Light Lines (1009) and G. H. J. van Hulzen (b. 1860) the two novels Love's Intermezzo (1 1 Iо) and The Nest of our dear Lord (IоI I). G. F. Haspels (b. 1864) wrote Lnder the Branduris (1908), Penance (1010) and The Town at the Ferry (1912); J. Eigenhuis (b. 1866) Growth and The rough Furm (rgII) and also four shorter stories called From the Village by the Sea; Herman Robbers The Happy Family (rgog), with the sequel One by one ( 1010 ); Israel Querido (b. I 873) was most successful with a novel about the diamond-cutters' world, The Course of Life (I)OI), but was guilty of great realistic exaggeration in Human Woe (1903), while The Jordacu (the name of a poor quarter in Amsterdam, I912), the first part of a cycle of novels about the life of the poor classes in Amsterdam, is judged very differently by different people but is widely read. Stories of which the scene is laid in the Indies are those of Fenna de Meyier, Under the Indian Sun, and the novels II hen the Sennahs are in Flower by Mrs. Overduyn-Heyligers, and Deep Currents by J. E. Jaspers.

The most prolific of Dutch writers is still Louis Couperus (b. I863); his novel On the 
Road of foy (rgo8) was followed by the volumes of sketches and stories called About my'self and others (Igro), Ancient Stories of Gods and Emperors, Poets and Hetairs (I9II), Short Arabesks (I9ri), The Swallows flown down (I9I1) and Ancient Tourism (I9I2), a travelling story from old Egypt.

Amongst women novelists J. Reyneke van Stuwe (b. 1874) is still very productive. She has published Behind the World (1908), Free Power (1909), The Illusion of the dead (I9I0), The Children of House Ter A ar (I9II) and Mater Triumphatrix (I9I I), the latter as the third volume of the series "Poor Woman." Next to her must be mentioned Margo Antink (b. 1869), who in collaboration with her husband Carel Scharten wrote A House full of People (I908) and Foreign Rulers (I9I I); Ina Boudier-Bakker (b. I875) to whom we owe the beautiful books Poverty (1909), The Withered Plant (19ro) and Blossom (I9I2); Anna van Gogh-Kaulback, the author of Mother, Tides (I9II), For Two Lives (19 2); and Anna de Savornin Lohman (b. 1868), who wrote Reminiscences and For the Honour of God with the sequel From Christian Circles (IgIr).

Very few Dutch dramas have been written of late years that lay claim to something more than transitory value. The public was much interested in Frederik van Eeden's social-satiric dramas: Y sbrand and The Promised Land (1908). Ina Boudier-Bakker's The Highest Law (I907) met with great success, as was also the case with Marcellus Emants' The Power of Dullness and Odours (rgog) and with Willem Schürmann's Forty and The Violiers (IOII). Excelling all these, however, especially as regards the technical qualities of his plays, there is Herman Heyermans, though his dramas are far from being of equal value. He put on the stage The Rising Sun, The Sleeping Beanty (I909), Beschuit met Muisjes (a rusk with aniseed comfits, the customary delicacy when a child is born; I9IO) and Gliick Auf (IgII), the latter a stirring picture of the misery and dangers of the mine-workers' trade.

See Dr. G. Kalff, Geschiedenis der Nederlandsche Letterkunde (7 vol.; 5 vol. have appeared, Groningen, 1905-1912); Dr. J. te Winkel, De Ontwikkelingsgang der Nederlandsche Letterkunde (4 vol.; 2 vol. have appeared, Haarlem, I908-1912); Dr. C. G. N. de Vooys, Historische Schets van de Nederlandsche Letterkunde (5th edition, Groningen, 1912) and Tijdschrift voor Nedor. landsche Taal en Letterkunde (Leyden, 1881-1912).

(H. ZONDERVAN.)

\section{Belgian Literature}

Maurice Maeterlinck's play L'Oiseau Bleu (IgII) is the outstanding contribution of Belgian French literature during I9I0-I2. It was first performed at Moscow, then in London (translated as The Blue Bird) and later in Paris and New York. The writer's poetic imagination and serene philosophy have contributed to make his play intensely popular. Emile Verhaeren's tragedy Hélène de Sparte was published first in German, translated by Stephan Zweig, then in Russian, and appeared in French, in 1912, when it was performed in Paris. Verhaeren's forcible and rather rugged style is perhaps not absolutely suited to the subject he treats. His new poems, however, Les Rythmes souverains (rgro), Les Villes à pignons (I I10), Les Fleures du Soir (I9I I), Les Blés monants (I9I 2) and Les Plaines (rgII), are as intense in feeling and vitality as his earlier work. In Les Libertins d'Anvers, Légende et Histoire des Loistes, Georges Eekhoud has told the story of the heretic sects in Antwerp in the XVI century. In this book, Eekhoud, according to his custom, exalts his native city in her vices as well as in her virtues. A tragedy in four acts by Camille Lemonnier, Edénic, set to music by Léon du Bois, was performed in Antwerp in r 912 with great success. The poem, written in blank verse, has all the charm of Lemonnier's vivid imagination and forcible style. Albert Giraud's La Frise empourprée ( $\mathrm{rg}_{2}$ ) is a collection of poems, in which their author remains faithful to the Parnassian tradition. Iwan Gilkin published in I9I I, poems called $L a$ $N$ uit, the first of three volumes, of which the others will be called $L ' A u b e$ and La Lumière. Grégoire Le Roy, in his collection of poems called Le Rouet et la Besace, illustrated by himself, deals with the sufferings of the poor. "Jean Dominique" (pseudonym of Mlle. Marie Closset); whose last volume of poems is called Le puits d'Azur (IgI 2), is undoubt${ }^{1}$ See E. B. iii, 680 . 
edly one of the most gifted of contemporary women writers. Her verses, written in classical form, are full of the most poignant sensibility. Mlle. Closset is a teacher and lives in Brussels. Amongst other contemporary French authors in Belgium, the following may be mentioned: Louis Delattre (Petits contes en sabots, La parfum des buis); Blanche Rousseau (Le Rabaga); Louis Dumont-Wilden (La Belgique illustrée, and, in collaboration with L. Sougenet, La Victoire des vaincus); Franz Hellens (Les clartés latentes); Jean de Bosschiere (Dolorine et les ombres). The best new Belgian plays include Kaatje by Paul Spaak, Les Étapes and Les Liens by Gustave van Zype, and Le mariage de Mlle. Beulemans, by Fonson and Wicheler, a picture of the life of the lower middle class in Brussels.

In Flemish literature there has been marked activity. Stijn Streuvels, a nephew of Guido Gezelle, and by profession a baker at Avelghem, a village in Flanders, has made a considerable reputation both in Belgium and in Holland. His descriptions of rural life are both poetic and realistic, and he has been compared to Tolstoi, whose psychological subtleties and epic amplitude Streuvels however does not possess. His style is of rare perfection, and this remark applies to the whole of the modern Flemish school of writers. Streuvel's last work is Het glorieryke Licht ("The glorious light").

Cyriel Buysse may be called the Flemish Maupassant. He is a realist. His works, which deal with the life of the people both in towns and in the country and, to a lesser degree, with that of the middle classes, form a complete picture of Flemish life. Buysse is passionate, robust, full of revolt and of pity, very human. His De vrootyke thocht ("The joyous expedition"), Stemmingen ("Impressions"), and, in collaboration with Virginie Loveling, a popular woman author, Levensleer ("Education through life"), appeared between rgro and I9 2.

Maurice Sabbe (De Nood der Bariseele's; "The plight of the Bariseeles "), whose writings deal exclusively with Bruges, and E. Vermeulen (Herwording; "Renaissance ") who deals with the life of the peasants in West Flanders, may also be mentioned as well known contemporary Flemish writers.

René De Clercq and Karel van de Woestijne are the most typical Flemish poets of the present generation. René De Clercq proceeds directly from the inspiration of Guido Gezelle (1830-1899). His poems are essentially popular, vigorous, full of life and good spirits, although through these one feels his tenderness, his pity for the misery of the Flemish peasants. A volume of Gedichter: "Poems") is his latest work. Karel van de Woestijne has a more complex personality. His poems are very varied in feeling, sometimes simple and direct, at other times complicated, full of metaphors. His sphere is that of the soul, and for him things are real in so far only as they partake of the spiritual life. It is necessary to add that there are contrasts in van de Woestijne's nature which he does not always dominate and which give a certain want of harmony to his works. His last volume, containing prose essays on Flemish painters and writers, is Kunst en Leven in Vlaanderen ("Art and life in Flanders "). His last volume of poems is De gulden Schadenn ("The golden shadow").

(LALla VAndervelde.)

\section{Danish Literature ${ }^{1}$}

No great new literary work or new literary name of surpassing merit can be said to have come forward during the period since I008. Danish literature has, however, lost one of its most distinguished representatives, Herman Joachim Bang (1857-1912), who died suddenly in a train on January 29, I9I2, while he was on a lecturing tour in the United States. The body was brought home for burial in Copenhagen. Amon; the later works of Bang were De uden Facdreland (Those without Country), I905, and Masker og Mennesker (Masks and Men), I9 Io, a volume of theatrical and dramatical essays. The death of Vilhelm Bergsöe ( $835^{-191}$ I) also occurred during this period.

The trend of Danish literature has been a continued revolt against realism, and a return to nature with works more redolent of the soil and of the national characteristics. Side by side with the revival of romantic literature in a modern form has been a growing ¿ See E. B. viii, 39 et seq. 
interest in historical works and memoirs, the chief among them being a series of biographical memoirs - at present some twenty volumes-dealing with Danish life in town and country, in camp or at court, at various periods from I600 to I870. While Henrik Pontoppidan (b. 1857 ) has been silent since he completed his great novel of eight volumes, Lykke-Per, he has found a competitor in the same field in Martin Andersen-Nexö (b. 1869), whose Pelle Erobreren (Pelle the Conqueror), still incomplete, secured for this author a place in the first rank among the popular writers of Denmark.

The agricultural labourers of Denmark, for whom the high schools, the agricultural colleges, intended especially for them, and the small-holding movement have proved a boon in more than one sense, have found two authors, who in poetry and prose describe their struggle for existence on the Jutland heaths or on the newly acquired state smallholding. Jeppe Aakjaer (b. I 866) bids fair to become a second Steen Steensen Blicher (see $E . B$. viii, 42 ) both in his prose in the Jutland patois, and in his poetry. His Rugens Sange (Songs of Rye)-a volume of poetry showing him to be a true disciple of Robert Burns, some of whose songs have been translated by Aakjaer-have become popular in wide circles and several of them have been set to music.

Johan Skjoldborg (b. I86I), formerly a village school teacher, has found favour by his novels on life among the small-holders. A many sided writer of great freshness and originality has appeared in Johannes V. Jensen (b. 1873), whom enthusiasts compare with Kipling. His rapid output includes such prominent works as Myths, of which the fourth volume appeared in I9I2, Stories of Himmerland, the author's native district in Jutland, a series completed in I910; Braeen (The Glacier), a novel dealing with neolithic man, and stories of the Far East.

Valdemar Rordam (b. I872) has followed the great success of Den Gamle Kaptain (The Old Captain), a cycle of songs in three volumes dealing with various episodes of the disastrous war of $\mathrm{I} 864$, by similar works appealing to Danish patriotism to look to the defence of the country, e.g. Luft og Land (Air and Land) rgio. Prominent among the playwrights besides Gustav. Wied (b. 1858), whose Satyrspil (Satiric Plays) and novels show a tendency to humour of a very coarse type, are Hjalmar Bergstróm (b. r868), and Baron Palle Adam Vilhelm Rosenkrantz (b. 1867 ). The voluminous literary output of the latter includes several successful plays, detective stories with plots well spun, and some historical novels dealing with the Tudor Period, e.g. Anne Boleyn.

Karl Larsen (b. I 860) has temporarily forsaken novels and plays for other literary work. His Under vor sidste Krig (During our Last War), a psychological study of war during its various phases, based on the numerous letters and diaries placed at the disposal of the author, proved a great success in Denmark and in Germany, and in roro was followed by Danske Nybyggere (Danish Colonists), also based on letters telling of their struggles on the prairies and backwoods of the United States a generation or more ago. Det Tabte Land, I I I (The Lost Country, i.e. Sleswick), has been the principal work of J. J. Jörgensen (b. I 866) during the last four years. The leading woman writer of the period has been Mrs. Karin Michaëlis (b. I872)-now Mrs. Stangeland. Her much discussed work Den farlige Alder (The Dangerous Age) ran into eight editions in rgio. This study of the life of woman at the age of forty was quickly translated into French. German and English, and has been followed by a continuation, Elsie Lindtner (I9I2).

Sophus Michaëlis (b. I865) struck out a new line by his dramas relating to the French Revolution or to Napoleon, Et Revolutionsbryllup (A Wedding under the Revolution), and St. Helena (I9I I), and also by Den evige Sövn (Eternal Sleep), a romance of the retreat from Moscow.

The celebrated critic Georg Morris Cohen Brandes (b. I842) celebrated his 7oth birthday on the fourth of February ror2. Besides the complete works of Brandes a volume of his essays and newspaper articles has been published in book form, Fra mange Tider og Lande (From Many Ages and Countries) I9Io. A younger literary critic and historian, Professor Vilhelm Andersen (b. 1864) has commenced the publication of Tide og Typer af dansk Aands Historie (Periods and types from the history of Danish Culture), a work on a large scale, the first volume of which was published in I909. A series of excel- 
lent studies of various phases of medieval life has been completed by Professor Valdemar Vedel (b. I 865); and Axel Olrik (b. 1864) has finished his work on the heroic age of Denmark, the northern lore and legend of the Eddas, Beowulf, etc.

Among Danish historians Professor Troels Frederik Lund (b. 1840) brought out in rgro-r 2 four volumes of historical essays, some of them new, dealing with the renascence period of Denmark and other European countries, a companion to his standard work on the history of Denmark and Norway during the sixteenth century. Edvard Holm (b. 1833 ) has once more returned to the field of historical study in his two volumes on the foreign history of Denmark and Norway $1800-{ }_{4}$ ( ( 9 I 2 ), based on the latest researches of the Napoleonic period. The question of Sleswick has found an impartial historian in M. Mackeprang, Nordslesvig I864-Igog (I910), and H. Rosendal has also published two volumes on the history of this Duchy in ancient and modern times.

\section{Norwegian Literature ${ }^{1}$}

(W. R, PrIOR.)

The furst decade of the twentieth century will forever be memorable in Norwegian literature for the passing away of the four great classics of the preceding epoch: Ibsen, Björnson, Lie and Kielland. Since their death Knut Hamsun (b. I859), Hans Kinck (b. I 865) and Gunnar Heiberg (b. 1857), are the leading literary figures, the two former chiefly as novelists, the latter as a dramatist. Of the generation of authors who entered literature during the nineties and a little earlier few others can be said to have made permanent reputations. After the constitutional crisis of 1905 economic and social problems came to the forefront in Norwegian public life, and the new ideas became prominent in the field of fiction. Johan Falkberget (b. I879), originally a mincr, introduced the modern industrial worker into Norwegian literature, painting with great talent, especially in Black Mountains (1907) and Blasting of Rocks (1908), the life of the miners and of the lumberers, with a striking background of natural scenery. Krist ofer Uppdal (b. 1878 ), writing in the landsmaal (the composite dialect of the peasants), describes in The Dance through the Mists (I9I I) the hard life of the navvies, which he knows from personal experience, while Oskar Braaten (b. I88I) in The Factory and its Surroundings (I910), also in the landsmaal, sketches the conditions of the industrial workers in a factory district in the neighbourhood of Christiania. Broader in their conceptions of life and its phenomena than these authors are Eilert Bjerke (b. 1887 ), whose Free Birds is one of the most powerful works in recent Norwegian literature, and Rolf Hjort Schöyen (b. 1887), who in his Masquerade (1910) indulges in whims and striking thoughts in an exuberant style; and their older contemporary Sigmun Rein (b. 1873), in his fine novel W $\mathrm{W}$ anderings (1910), has shown marked literary power. The chief contemporary lyric poets are Herman Wildenvey (b. I886), who especially in his Poems (1908) and his Round-Abouts (I 10) displays a troubadour talent, highly appreciated, and Olaf Bull (b. I882), whose first volume of Poems (I II I) is remarkable for beauty and maturity.

One of the most characteristic features in Norwegian literature within the last ten years is the growing tendency in the direction of developing a particular county or district literature, as it were, nearly each county getting an author of its own familiar with its life and manners, its way of thinking, and its special dialect, through which the whole composition takes a peculiar colour. The most important of these authors are Jacob Bull (b. 185.3), of Österdalen, with his Eline V'angen (1907), Andreas Haukland (b. 1873), of North Norway, with his Settlers (1907), and Ove Arthur Ansteinsson (b. I884), of the midland counties round Lake Mjösen, with his Ener Tuve (rgro). Among the landsmaal representatives of the county literature Jens Tvedt ranks highest with his sketches from West Norway country life. His most characteristic works are Madli under the Apple-tree (I900) and its continuation God's Reward (igo6). The chief mallyrist is Anders Hovden (b. 1860). Among the novelists mention may be made of B. Lie (b. I 868), whose best work is Against Superior Odds (1907).

The psychology of Woman has become an element of importance in recent Norwegian literature, especially as analysed by female authors. Ragnhild Jölsen ( $1875^{-1908)}$ in her

1 See E. B. xix, 817, 818 . 
Rikka Gran (1904), Regine Norman (b. I867) in her Krabvaag (-1905), and Sigrid Undset (b. I882) in her Jenny (IgII), are conspicuous in this respect.

Norwegian memoir literature, which up to a comparatively recent date was rather poor, has been greatly enriched within the last few years, the posthumous letters of Björnson (Aulestad-Brwe) to his daughter.Mrs. Ibsen, and of Kielland to his daughter Mrs. Krag, being among the chief contributions. Besides these may be mentioned several memoirs by Professor Yngvar Nielsen, the historian, the last one being Under the Reign of Oscar II, (I9I2). Sigurd Ibsen (b. I859), with his Human Quintessence (I9II), stands in the first rank of Norwegian essayists. Professor Gerhard Gran (b. I856), whose great work on Rousseau (Vol. I, r9I0; Vol. II, I9II) has been translated into English, is the leading literary critic of Norway. Hjalmar Christensen (b. I 869) formerly best known in the field of criticism, has lately shown remarkable gifts as an original author in A Life (I9I0) and Sheriff's Farm (I9II).

H. J. Haffner's Norsk Bokfortegnelse, IOOI-IDIO (I912) gives a complete list of all books published in Norway within the period.

(S. C. HAMmer.)

\section{SPANISH LITERATURE}

Few new names of importance occur in the record of Spanish literature for the last six years. In drama, poetry, fiction and literary criticism, there is abundant work indicating high average talent, but only in poetry are fresh tendencies revealed. The novel methods introduced by French and German poets between I 885 and I900 were tardily adopted in Spain, and owe their present vogue to Spanish poets born on the other side of the Atlantic.

Poetry.--Francisco Villaespesa (b. I877), whose literary career began before 1905, has become one of the most striking personalities in modern Spanish poetry. With a delicate tact he has contributed to the renovation of rhythmical forms; his verse renders an exquisite vision of the world, and his unaffected diction, while judiciously assimilating innovations, preserves its individuality, its vividness and rich colouring-qualities displayed to advantage in Bajo la Lluvia (гіг) and El Espejo Encantado (гіг). The copious verses of Juan R. Jiménez (b. I 88I), reveal a sad lucidity of soul. This Andalusian Amiel - a recluse to whom the tumultuous struggle of modern life is abhorrentproduces effects of evocation by means of suggestive half-tones which enable him, through the medium of landscape, to impart the intimate minutiae of his brooding melancholy. This faculty is eminently manifest in Arias Tristes (1903) and in the triple series of Elegias (1908-09-10). Prominent among the newcomers is Antonio Machado (b. I 875 ), a poet of austere imagination, placid and yet informed by the spirit of modernity, as may be seen in Soledades (I903) and Campos de Castilla (I9I I), in the latter of which certain Proverbios y Cantares recall the philosophic mood of Omar Khayyám. The representative of an earlier school, Eduardo Marquina (b. 1877), is distinguished for force and facility, and he handles blank verse with a ductile power rare in Spanish. The works: most characteristic of his talent are the Églogas and Elegias: his latest productions - Doña Maria la Brava (1909), En Flandes se ha puesto el sol (1910) and El Rey Trovador (I9I2)-are dramatic poems dealing with historical themes.

Drama.-Though Jacinto Benavente (b. I866) produces more frugally than in his first period, his supremacy as a dramatist is uncontested. His fine observation and mastery of scenic effect are undiminished in Los Intereses Creados (I907), wherein the great game of sordid motives is portrayed with engaging fidelity, and in Senora Ama (1908) the author has achieved a legitimate triumph. An acquisition to the theatre is Gregorio Martínez Sierra (b. I88I), who, in La Sombra del Padre (I9Io) has given a somewhat diffuse but effective study of inadaptability; still more deservedly successful, Cancion de Cuna (I9II) is an original effort which bespeaks shrewd observation of convent life, and interprets with almost feminine insight elusive and concentrated motives. Less subtle in analysis, Manuel Linares Rivas (b. I 866) fascinates his public by virtue of his technical dexterity and the Gallic vivacity of his dialogue: Maria Victoria will

\footnotetext{
${ }^{1}$ See E. B. xxv, 578 et seq.
} 
probably outlive his other pieces. The brothers, Serafin Alvarez Quintero (b. 187r) and Joaquín Alvarez Quintero (b. 1873 ). have fulfilled their early promise: in El Genio Alegre their collaboration has contrived a masterpiece which depicts with seductive exactitude the joy of life in an Andalusian atmosphere.

Fiction.-The most conspicuous novelist of the day is Felipe Trigo (b. I868), a physician whose autobiographical reminiscences enhance the value of El Médico Rural. He recounts the course of criminal passion with an unsentimental, scientific precision unprecedented in Spanish literature, and he writes with a profusion of detail which has laid him open to the charge of licentiousness. Though deliberately incorrect at times, his style is plastic, and he can evoke a landscape in terms of pellucent beauty. $L a$ Sed de Amar (1903), Sor Demonio (I908) and El Médico Rural (IgII) are among his most popular books. Ricardo Léon (b. I877) has captivated the public with Casta de Hidalgos (1908) and Alcala de los Zegries (1910); racy of the soil, fastidious, intentionally archaic at whiles, his limpid phrasing tends to become monotonously symmetrical. Abounding in ideas, Pío Baroja (b. I872) works on a large scale, not in single volumes, but in trilogies, the ample scope of which is implied by such titles as La Raza, La Tierra Basca, El Mar and Las Ciudades. His attempt to dissimulate his emotions produces a momentary impression of cynicism: his diction is metallic, harsh and rigid.

Literary History.-Scholarship and literary history have lost their foremost representative in Marcelino Menéndez y Pelayo (I856-I9I 2), who leaves behind a vast body of useful work, unfortunately incomplete. His successor as Director of the National Library is Francisco Rodríguez Marín (b. 1855), whose biographies of Barahona de Soto (1903) and Pedro Espinosa (1907) are authoritative. The death of Joaquín Costa (1846I III) deprives Spain of a patriot, an orator and a courageous thinker, who alienated the upholders of secular tradition by his propaganda to induce Spain to enter into the current of European culture.

Journalism.-The talents of several admirable writers are absorbed by journalism: thus Miguel de Unamuno y Jugo (b. r864) employs an alert intelligence well adapted to discuss questions that press for an early solution; José María Martínez Ruiz (b. I876), best known by his pseudonym of "Azorín," portrays certain phases of Spanish culture with rare felicity, knowledge and picturesque conciseness; José Ortega Gasett discusses with the stimulating freshness of a trained dialectician, the ideas and theories which bid fair to affect mankind in the near future.

(B. Sanin Cano.)

\section{Portuguese Literature ${ }^{1}$}

During the past five years Portugal has been passing through a revolutionary period, and the prevailing unrest has been disastrous to letters. A decline had already set in during the closing years of the igth century and became evident to all at the beginning of the present. Among the poets and prose writers who shed lustre on the reign of King Carlos, João de Deus, Antonio Nobre and Eça de Queiroz died, while Ramalho Ortigão, Guerra Junqueiro, Gomes Leal and Fialho d'Almeida produced nothing comparable to their earlier work. Their successors, lacking faith and high inspiration, have attempted no sustained llights. The destructive theories preached throughout the last thirty years hastened and have accompanied the national decadence, which is reflected in an anarchy of thought and a profound pessimism. Certain Republicans have striven to react against the disease by announcing a new gospel, but as it consists of French radical ideals without a sound philosophical or moral basis, they have but added to the confusion. Others of their co-religionists have entered public life and become lost to letters. Political journalism, being the easiest road to fame and fortune, largely absorbs the energies of the younger writers, and never was the press so intellectually sterile. The Revolution has raised no echo in literature, for the pamphlets it has suggested are without value, save as historical documents.

Were it not for Brazil, where twenty millions speak the language of Camoens, the output of imaginative books, other than poor romances and commonplace verse, would

${ }^{2}$ See $E$. B. xxii, I55 et seq. 
have nearly ceased. The new edition of the writings of Fialho d'Almeida is destined principally for the former colony, and the Jornal do Commercio of Rio de Janeiro has opened its columns to men who under existing conditions could hope for neither an audience nor a reward at home. Madam Vaz de Carvalho, the leading contributor to that paper, has been joined by the Count de Sabugosa, whose recent articles have been published in book form under the title of Donas de Tempos Idos.

The popular editions of Garrett, Herculano, Rebello da Silva, Camillo Castello Branco and Castilho, recently issued or in course of issue, are mainly for American consumption, though the middle classes in Portugal read more than they did. Unfortunately they usually prefer modern French books to their own, while a narrow species of "freethought" turns them from the old classics, products of a society essentially Catholic. It is to be feared that the new orthography, decreed in I9I $\mathrm{r}$, will in time increase the difficulty of studying the authors of the great period, the i6th century.

In order to acquaint the nation with its famous men a biographical series has been inaugurated with lives of D. João de Castro and Gil Vicente. The last is by General Brito Rebello, an authority on the subject and editor of the best text of Mendes Pinto.

While Corrêa d'Oliveira and Lopes Vieira have not materially added to their reputation as poets, the latter has made himself the apostle of an interesting Vicentian revival. His editions of the Barcado Inferno and Mofina Mendes were admirably staged and played, and drew public attention to Gil Vicente, whose Autos, previous to the celebration in 1902 of the $4^{\text {th }}$ centenary of his first piece, had been known only to students. Julio Dantas, Director of the Conservatoire, has revived there the best of the old comedies, among the authors represented being Camoens, D. Francisco Manuel and Antonio José da Silva. His charming one-act piece, Roses all the Year Round, was given in London in the spring of I9 1 2, the first version from the Portuguese seen on English boards.

The death of D. João da Camara has left only two playwrights of account, Marcellino de Mesquita and Julio Dantas, and the romance has sunk into extreme naturalism with Abel Botelho. But if creative writing in nearly all departments has died, criticism has shown a marked advance in power. To the quality of insight found in Moniz Barreto are added impartiality and a sense of proportion in the case of Fidelino de Figueiredo who is in touch with the best work of his foreign confrères. The psychology of Camillo Castello Branco has been discussed in some remarkable monographs, and a study on the expression of anger in literature by Dr. Henrique de Vilhena has received deserved commendation abroad.

Fortunato de Almeida brought out in the summer of I9I 2 the second volume of a useful compilation, Historia da Igreja em Portugal, and Dr. Gama Barros had in the press the third volume of his Historia da Administracão Publica em Portugal.

Two good omens for the future are the activity displayed by the Academy of Sciences thanks largely to Colonel Christovam Ayres, historian of the Portuguese army and secretary of the Class of Belles Lettres, and the creation of an Historical Society. The Academy has issued some unpublished letters of D. Francisco Manuel de Mello, and has in the press the parish registers of the Church of Santa Cruz in Lisbon, which cover the years I 536 to 1628 . This will mark a new departure in Portugal. It has also reproduced, under the editorship of the Romance scholar, Madam Michaëlis de Vasconcellos, an autograph MS. of some lyrics of Sa de Miranda, and has a long list of publications projected for the fourth centenary of the capture of Ceuta in I9r5. The Society of Historical Studies issues a Quarterly Review, and is doing good work.

Another important new Review is that of Coimbra University, which is giving (inter alia) a full and excellent biography of the epic poet Braz Garcia de Mascarenhas. The directors include Dr. Mendes dos Remedios, who has recently added to his classical reprints one of the Chronica do Infante Santo. From Coimbra comes also a new edition of the Cancioneiro de Resende, which the rarity of the Stuttgart edition made necessary. The sciences of folk lore and philology flourish exceedingly, and the Revista Lusitana continues under the editorship of the distinguished scholar Dr. Leite de Vasconcellos, whose Licoes da Philologia Portugueza (IgII) are beyond praise. (Edgar Prestage.) 


\section{Russian Literature ${ }^{1}$}

During the last few years, especially since the revolutionary upheaval of 1905 , Russian literature has immensely increased in quantity and proportionately declined in quality. If judged by extent of output only, it would appear to be in a most flourishing condition. From the point of view of material profit to the producers and the publishers, this could hardly fail to be the case when we consider the influences now at work in educating the Russian masses and thus continually increasing the number of actual and potential readers. As soon as restraint is removed, and the necessity of instruction is once admitted for a vast population like that of Russia, most of whom have hitherto been shut off from the advantages of printing, the reading public is sure to grow with leaps and bounds, there as well as elsewhere.

The pecuniary prospects of literature and the press generally in Russia are as brilliant to-day as they were hopeless and despairing in the more or less recent past. Even British capital has begun to seek profitable investment in Russian literary enterprises. Book illustrators are also reaping the benefit of a parallel development of their particular art. All this, however, does not seem to improve the literary quality and character of the production, in which, on the contrary, there is a noticeable deterioration, and, with one or two exceptions, the great bulk of it is no doubt destined to be soon forgotten. The better class of Russian readers are tired of the group of inferior pessimists and minor poets, who, having been flushed up on the tide of revolution, have done nothing else but probe the social and political vices of the nation. The growing disgust for the new style of revolutionary and erotic literature was intensified by the tragic death of Count Tolstoy, which reminded the Russians of the enormous contrast between the works of the modern favourites and the masterpieces of Tolstoy and his early contemporaries. There was consequently a revival of interest in Tolstoy's writings and a plentiful supply of posthumous 'Tolstoy literature, which threw into the shade modern celebrities like Maxim Gorki, and Leon Andreyeff. As one critic expressed it, the appearance of each volume of Tolstoy's literary legacy was like a day of glorious sunshine in a long period of depressing gloom. Two volumes of fresh stories, which were not published during the Count's lifetime, probably because of his change of views on art and fiction in general, made their appearance in I9II, including "A Living Corpse," "The Devil," "Father Serge," and "The False Coupon." This Tolstoy literature was further enriched by the reminiscences of the widowed Countess, by the notes of the Count's former secretary, N. Goosieff, and by Tolstoy's letters covering the period I848-19ro, edited by P. A. Sergeyenko.

Amongst the remarkable literary productions of I9I0-I I were Our Crime by Radionoff, an act of indictment against the intelligent classes of Russian society for their indifference to the brutalisation of the lower orders, and Alexander the First, an historical novel by D. Merezhkovsky, published in the Russkaya Mysl. This new work of Merezhkovsky's is the result of a careful study, based on documentary evidence, of the enigmatical personality of the Imperial "Emancipator of Europe" and of the strange legend concerning his death. Another historical romance was published in the Historical Viestnik under the title of Kolychevskaya Volchina by V. Kilshtet, treating of the epoch from the emancipation of the serfs and the Polish insurrection down to the end of the reign of Alexander II. Attention may also be directed to Two Lives and Days of Sedition, pictures of the downfall of Russian society, by Von Wiesen; the dramatic poems Bekh Ulla and Bab, with reference to religious movements in Persia, by Mrs. J. Grinevskaya; a love story, The Gurnet Bracelet, by A. Kuprin; and Altar of Victory by V. Brusoff.

A great many descriptive accounts, memoirs and documents were published in IgI II 2 in connection with the celebration of the centenary of the national war against Napoleon's invasion and the battle of Borodino. In I 9 Io the interesting announcement was made that an unpublished work by the great novelist Turgéniev, called Life for

${ }^{1}$ See $E$. B. xxiii, 914 et seq. 
Art, had been handed over for safe keeping to the Russian Academy of Sciences with the request to withhold it from publication for some time to come. Maxim Gorki began to write again, but without any of his former success. In I9I I he continued his story of Matvey Kozhemiakin, which belongs to the usual kind of "Liberation," i.e. revolutionary, fiction. Leon Andreyeff produced a symbolical tragedy called Ocean, of rather inferior quality, and also Sashka Zhaguleff, an attempt to idealise the leader of a gang of brigands.

A great deal of serious historical matter has been published in Russia during the last 3 or 4 years, amongst which the following deserve to be noticed: Archives of the Brothers Turgéniev, edited by the Academy of Sciences; Alexander the Second, by the late S. Tatischeff; researches of Professor Kaptereff regarding the lives and doings of The Patriarch Nikon and the Tsar Alexey Michailovich; Population of Russia in the time of Peter the Great, by M. Klochkoff; History of Russia in the XIX Century, by Professor Pokrovsky; History of Musical Development in Russia, by M. Ivanoff; translation from the French of several new works by Vlaishevsky; History of Russian Public Opinion, by Ivanov Razoomnik; History of Finland, by Borodkin; Tsar Ivan Shuisky, by Professor Platonoff; I3 volumes of History of the Russo-Japanese War, compiled officially; and Russia for the Russians, by General Kuropatkin. It may be said indeed that, during recent years, more value has been attached in Russia to historical work than to purely imaginative literature.

(G. Dobson.)

\section{CLASSICAL LITERATURE AND SCHOLARSHIP ${ }^{1}$}

The losses sustained of late through the death of distinguished classical scholars have been severe. A special tribute is due to the memory of S. H. Butcher and Andrew Lang, two leading Homerists and literary critics; of A. W. Verrall, a notable interpreter of Greek drama; of J. Adam, an accomplished writer on Greek philosophy and religion; of W. W. Goodwin, the well-known grammarian and archaeologist. Fr. Susemihl will be remembered as a learned critic of later Greek literature and philosophy; L. Friedländer as an authority on Roman society and manners; L. Traube as an expert in palaeography; Fr. Bücheler and H. Wölfflin as distinguished philologists and collaborators on the Thesaurus Linguae Latinae.

On the other hand proof is not lacking of the vitality of classical scholarship. Discussion on the aims and methods of classical teaching has been brisker than ever, and good results may be expected in particular from the meetings of the classical section at the Imperial Conference of Teachers' Associations, held in London in July I9I 2. The number of classical societies is steadily increasing. A new Society for the Promotion of Roman Studies has recently been formed in London as a complement to the Hellenic Society, and it can hardly fail to achieve a similar success in promoting classical scholarship.

New Texts. - Classical literature continues to be enriched with papyri recovered from the soil of Egypt. Drs. Grenfell and Hunt have followed up their previous successes by bringing to light some 400 lines of Callimachus' 'Airca and meliambic poems, ${ }^{2}$ and an equal length of a Satyric play of Sophocles entitled the 'I $\chi v \in v \tau a i^{3}$ This lastnamed piece, which dramatises the epic of the infant Hermes' pranks, affords some valuable evidence on the character and structure of Satyric dramas. To Dr. Hunt we further owe the publication of some new scholia on Homer, ${ }^{4}$ and of numerous fragments of minor Greek writers. ${ }^{5}$ A complete text of the new passages from Menander's 'E $\rho$ rár $\eta$ s has been provided by their discoverer, Dr. Lefebvre; ${ }^{6}$ and the recently discovered rem-

1 See generally E. B. articles enumerated in Index volume, p. 932.

${ }^{2}$ The Oxyrhynchus Papyri, vol. vii (London, íro).

a Ibid., vol. ix (1912).

"Ibid., vol. viii (I9I I).

${ }^{5}$ Catalogue of the Greek Papyri in the John Rylands Library, vol. i (Manchester, I9I I).

- Catalogue général des antiquités égyptiennes du Musée du Caire. Papyrus de Ménandre (Cairo; I9II). 
nants of Alcaeus, Sapphó and Corinna have been collected in a critical text by J. M. Edmonds. ${ }^{1}$

Editions and commentaries.-In the preparation of new editions Greek writers have of late received most attention. Theognis' poems have found a new interpreter in Prof. Hudson Williams, ${ }^{2}$ who contends that they are a miscellaneous collection by various pre-Alexandrine writers, and that Theognis was their editor rather than their author. The dramatists are represented by a posthumous work of the late W. G Headlam on Aeschylus' Agamemnon, ${ }^{3}$ the choicest part of which is a highly finished translation into rhyming English metres; and by Mr. B. B. Rogers' editions of the Acharnians, $K$ nights and Lysistrata of Aristophanes, ${ }^{4}$ whose English renderings follow the original Greek metres. Of the Greek historians Herodotus and the new author from Oxyrhynchus have been the chief objects of study. The former has received an up-to-date historical commentary by Messrs. How and Wells; ${ }^{5}$ the latter has been annotated in an authoritative manner by Ed. Meyer. ${ }^{6}$ Among the new works on Greek philosophy we may note a separate edition and translation of the fragments of Heraclitus by Diels. ${ }^{7}$ The study of Greek literary critics has been pushed forward actively. The Poetics of Aristotle are presented in quite a new light by Prof. Margoliouth, ${ }^{8}$ who argues that the obscurities of the text are for the most part intentional. This remarkable thesis is based on a comparison of Aristotle's avowedly technical treatises, and on a study of the Syriac and Latin translations. Another elaborate piece of work is contained in Prof Rhys Roberts' edition of the treatise On Composition by Dionysius of Halicarnassus. ${ }^{9}$ Of the new editions of Latin authors it may suffice to mention a greatly improved text of Ammianus Marcellinus by Mr. C. U. Clark, ${ }^{10}$ and a revised issue of Dr. Rice Holmes' authoritative commentary on Caesar's Bellum Gallicum. ${ }^{11}$

Translations.- The wide diffusion of interest in the ancient classics is clearly betokened by the greatly increased number of translations into various modern languages. In addition to the works of this kind mentioned in the previous paragraph, special attention is due to the Loeb Classical Library of texts and translations, ${ }^{12}$ the Oxford Library of Translations ${ }^{13}$ and the Oxford Translation of Aristotle. ${ }^{14}$ In each of these cases the versions have been prepared by thoroughly competent scholars. Interest also attaches to Prof. Gilbert Murray's free renderings of Sophocles' Oedipus Tyranmus and Euripides' Iphigenia in Tauris, ${ }^{15}$ and to Prof. Platt's translation of Aeschylus' A gamemnon into biblical English ${ }^{16}$ - a promising experiment. We may also welcome Mr. Cyril Bailey's ${ }^{17}$ new and more accurate version of Lucretius.

Criticism.-The "Homeric question" has again become a fruitful source of cont roversy. The main question at issue is whether the poems in their prescnt form represent the work of one man. The "unitarians" have been mainly engaged in detailed criticism of their opponents' theories; ${ }^{18}$ the "separatists " have replied by revising their arguments

1 The new fragments of Alcaeus, Sappho and Corinna (Cambridge and London, 1909).

2 Theognis (London, 1910).

Cambridge, 1910.

London, 1910-11.

${ }^{5} \mathrm{~A}$ Commentary on Herodotus (Oxford, 1912).

'Theopomp's IIellenika (Halle, 1909).

7 Herakleitos von Ephesos (Berlin, 1909).

8 The Poetics of Aristolle (London, 1911 ).

${ }^{9}$ London, 19 I0.

${ }^{10}$ Berlin, 1910 sqq.

"Caesar's Conquest of Gaul (Oxford, 1911).

${ }^{12}$ Ed. T. E. Page and W. H. D. Rouse (London \& New York, 1912 sqq.)

13 Clarendon Press, 1908 sqq.

14 The latest three vols. are the IIstoria Animalium, by D'Arcy W. Thompson, De Gencratione Animalium, by Prof. Platt, and De Partibus Animalium, by W. Ogle (Clarendon Press, I910-II)

${ }^{15}$ London, Allen, I910-II

16 London, Grant Richards, 1911.

17 Oxford, 1910.

19 Andrew Lang, The World of IIomer (I.ondon, 19ro); C. Rothe, Die Ilias als Dichiung (Iaderborn, 1910); F. M. Stawell, Homer and the Iliad (London, 1909); A. Shewan, The Lay 
and adding fresh ones. ${ }^{1}$.A less contentious but perhaps more promising topic has been dealt with by Mr. Chadwick in his comparison of the Homeric poems and the Teutonic sagas, and of the respective societies of which they were the product. ${ }^{2}$

The accepted theories concerning the rise of the Greek drama have been vigourously assailed by Prof. Ridgeway, ${ }^{3}$ who traces its origin back to funeral rites established in Greece long before the advent of Dionysus. A partial reply to this view has been put forward by Prof. Gilbert Murray, ${ }^{4}$ who contends that the structure at any rate of the Attic tragedies contains features peculiar to the Dionysiac cults. Of recent treatises on particular plays special attention is due to the late Prof. Verrall's essay on the Bacchae of Euripides, ${ }^{5}$ which he represents as an objective study in the workings of religious faith, betraying neither sympathy nor aversion. Dramatic technique is the subject of a work by Stählin, ${ }^{6}$ who discusses the part assigned by Greek playwrights to oracles in the construction of their plots.

Among Greek philosophers Plato continues to be the chief object of study. His relations to Socrates ${ }^{7}$ have been presented in a new light by Prof. Burnet, who contends that the doctrine of Ideas was taken over by him from his master, and developed rather than created in his hands. Another attractive and bold theory is mooted by Prof. Stewart, ${ }^{8}$ viz. that Plato's Ideas fulfilled a double function, being at once laws of thought and objects of imaginative contemplation. A more severely logical trend of thought is ascribed to Plato by Ritter, who has carefully re-examined the crucial passages in the Dialogues. ${ }^{9}$. The same scholar has also begun a more extensive but popular work on Plato $;^{10}$ and a similar study of Plato as a humanist and leader of thought is contained in a posthumous collection of essays by Prof. Adam.11 Aristotelian scholarship has of late been less productive, but an up-to-date criticism of the master's treatises on natural science has been provided by Mr. Lones. ${ }^{12}$ The collection of minor works by the late Prof. Zeller ${ }^{13}$ comprises articles covering the whole range of Greek phliosophy.

The Latin authors have been discussed profitably if not copiously. Sir A. Geikie's book on the Love of Nature among the Romans ${ }^{14}$ is full of acute observations, and should help readers of the Latin classics to appreciate many of their finer points. Another substantial addition to Latin scholarship has been made by Prof. Arnold, whose researches on Roman stoicism ${ }^{15}$ serve to place this branch of study on a thoroughly scientific basis. Of ancient historians the new author from Oxyrhynchus continues to attract most attention. His personality remains uncertain, in spite of a vigorous attempt by Ed. Meyer $^{16}$ to identify him with Theopompus; but the general trustworthiness of his work is now acknowledged in most quarters. A substantial new contribution concerning Thucydides has been made by Dr. Grundy, ${ }^{17}$ who accumulates proof that his History was a composite piece of work.

of Dolon (London, I9II); D. Mülder (Die Ilias und ihre Quellen: Berlin, 1910) adopts a more constructive line of reasoning.

${ }^{1}$ Gilbert Murray, The Rise of the Greek Epic, and ed. (Oxford, I9II); P. Cauer, Grundfragen der Homerkritik, 2nd ed. (Leipzig, I909); M. Croiset, Observations sur la légende primitive d'Ulysse (Paris, 1910). Fick (Die Entstehung der Odyssee: Göttingen, 1910) brings forward some new linguistic criteria.

${ }_{2}$ The Heroic Age (Cambridge, 1912).

${ }^{3}$ The Origin of Tragedy (Cambridge, 1912).

${ }^{4}$ Proceedings of the Classical A ssociation, vol. viii (London, 1912), pp. 45-69.

${ }^{5}$ The Bacchants of Euripides, and other Essays (Cambridge, I910).

- Das Motiv der Mantik im antiken Drama (Giessen, 1912).

${ }^{7}$ Plato's Phaedo (Oxford, ro11).

${ }^{8}$ Plato's Doctrine of Ideas (Oxford, 1909).

${ }^{9}$ Neue Untersuchungen über Platon (Munich, 1910).

10 Platon (vol. i, Munich, I9Io).

11 Platonism (Cambridge, 1911).

12 A ristotle's Researches in Natural Science (London, I912).

${ }^{13}$ Kleine Schriften (2 vols., Berlin, I9Io).

${ }^{14}$ London, 1912.

${ }_{15}$ Cambridge, I911.

${ }^{16} \mathrm{Op}$. cit.

${ }^{17}$ Thucydides and the History of his Age (London, I9II). 
Grammar.-Pioneer work is heing accomplished by Prof. Bennett in his exhaustive treatise on the Synlax of Early Latin. Attention is also due to Prof. Gildersleeve's Syntax of Clussical Greek, ${ }^{2}$ which proceeds by inductive methods and avoids theoretic speculation. From Prof. Sonnenschein's pen we have an ingenious attempt to classify all subjunctive usages under a single head, ${ }^{3}$ and a new primer ${ }^{4}$ which applies a standard terminology recently established by a joint committee of British teaching associations. ${ }^{5}$

Palaeography.--The materials for the study of palaeography have been increased by the publication of facsimiles of several notable MSS., e.g. the Palatine Anthology of Greek Verse, ${ }^{6}$ the Verona palimpsest of Gaius, ${ }^{7}$ and the Codex Theodosianus. ${ }^{8}$ The output of modern manuals has meanwhile kept pace with this growth of materials. Gardthausen's standard text-book of Greek palaeography is being issued in a revised edition, of which the Introduction has recently appeared. ${ }^{9}$ A similar service is being rendered for Latin palaeography by the publication of the late Prof. Traube's authoritative studies on that subject. ${ }^{10}$

History. - The outlines of Greek and Roman history have been sketched in a summary but highly suggestive form in a joint volume by U. Wilamowitz-Moellendorff and Niese, ${ }^{11}$ of which Wilamowitz' section on Greek history contains many new touches. A large work on post-Alexandrine Greece is being carried out by Kaerst, ${ }^{12}$ whose second volume (Igr2) deals mainly with the general features of Hellenistic statecraft. The history of the Roman Republic has been rewritten, with some new suggestions as to detail, in a three-volume work by Mr. Heitland.13 The Roman Empire is discussed in a series of stylish but sketchy essays by v. Domaszewski, ${ }^{14}$ and in a discursive yet stimulating disquisition by Dr. Bussell. ${ }^{15}$

Athenian history in its constitutional aspect is treated at length in a monograph by de Sanctis, which combines sound learning with venturesome speculation. ${ }^{16}$ Later Athenian history is dealt with in a series of acute researches by Kahrstedt, mostly on topics of the fourth century. Hellenistic Athens is the subject of an important book by Prof. Ferguson, ${ }^{17}$ whose information is largely derived from inscriptions skilfully interpreted. The outlines of Spartan history are retraced on an ingenious if not always convincing scheme by Mr. Dickins. ${ }^{18}$ Many new contributions have also been made to the study of the Hellenistic states. Chief among these are Jouguet's volume on the municipal government of Egypt under the Ptolemies and the Caesars, ${ }^{19}$ and Zucker's essay on jurisdiction in the same country. ${ }^{20}$

The opening chapters of Roman History have been rewritten by Modestov ${ }^{21}$ and $\mathrm{T}$. E. Peet, ${ }^{22}$ who have put to account the accumulations of archaeological evidence in order to

1 Vol. i (the Verb): Boston, I9ro.

${ }^{2}$ Vol. ii (the Attribute): New York, 191 I.

3 The Unity of the Latin Subjunctive (London, 1910).

- A New Latin Grammar (Oxford, 19I2).

5 The report of the committee is published separately (Murray, I9II), and in a volume entitled The Teaching of Latin and Greek (Murray, 1912), which contains a series of reports recently prepared by the Classical Association.

${ }^{6}$ Leiden, 1911.

7 Leipzig, 1909.

8 Paris, 1909.

${ }^{9}$ Griechische Palaeographie, and ed. (Leipzig, I9II sqq.).

10 Vorlesungen und Abhandlungen, 2 vols. (Munich, 1909-I I).

1 Stat und Gesellschaft der Griechen und Rümer (Leipzig, 1910).

${ }_{12}$ Geschichte des hellenistischen Zeitalters (vol. ii, pt. I; Leipzig, 1909).

${ }_{13}$ Cambridge, 1909.

14 Geschichle der römischen Kaiser (Leipzig, 1909).

15 The Roman Empire A.D. 81-1081 (London, 1910).

${ }^{16}$ Atois. Storia della repubblica ateniese, 2 nd ed. (Turin, 19II).

17 London, 1911.

18 Journal of Hellenic Studies, 1912, pp. I-42.

${ }^{19}$ La Vie If unicipale dans l'Egypte Romaine (Paris, I9II).

${ }_{20}$ Philologus, Beiheft xii (1911).

${ }^{21}$ Introduction à l'histoire romaine (French transl., Paris, 1906).

22 The Stone and Bronze Ages of Italy (Oxford, 1909). 
compose a coherent narrative of Italy's prehistoric development. Mr. Peet's book should become a standard work. The earliest literary records of Rome have been re-examined by Soltau, ${ }^{1}$ who upholds their substantial accuracy against radical critics. The later age of the Republic has not been a prolific field of research, but attention is due to the third volume of Jullian's History of Gaul, ${ }^{2}$ which describes the Roman conquest under Julius Caesar from the point of view of Caesar's victims. A useful companion to the history of the late Republic will be found in Mr. Hardy's excellent edition of the chief extant statutes of this period. ${ }^{3}$. Among the numerous treatises on the Roman Empire special interest attaches to Lord Cromer's studies in Ancient and Modern Imperialism, ${ }^{4}$ which is based on wide reading as well as first-hand experience. The conquest of Britain is illustrated by Mr. Macdonald's useful book The Roman Wall in Scotland, and a convenient summary of recent exploration of the South German frontier forms part of the late Prof. Pelham's Essays.

The private life of the Greeks and Romans is described afresh in the light of recent archaeological discoveries in Blümner's Technolngie und Terminologie der Gewerbe und Künste bei Griechen und Römern.7 Archaeological evidence also figures largely in Mr. Norman Gardiner's learned and practical treatise on Greek Athletic Sports and Festivals, ${ }^{8}$ which should long remain a standard authority. Roman society is accurately portrayed in Mr. Warde Fowler's ${ }^{9}$ and Prof. Tucker's ${ }^{10}$ new manuals.

Ancient economics have been discussed of late with unusual zeal. Beside Mr. Zimmern's book (quoted above) we may notice a luminous essay by Ed. Meyer, ${ }^{11}$ which emphasises the high level of economic development attained by the Greeks and Romans. The part played by capitalism is also insisted upon, perhaps rather unduly, in Dr. Grundy's ingenious disquisition on slavery in Greece. ${ }^{12}$ Special problems of economics are discussed in Francotte's Finances des Cités grecques, ${ }^{13}$ in Rostowzew's learned treatise on land tenure under the Hellenistic kings and Roman emperors, ${ }^{14}$ and in a masterly monograph by Preisigke on the banking system in Ptolemaic Egypt. ${ }^{15}$

Law. - Two substantial contributions to this subject need to be recorded. Mr. Strachan-Davidson's Problems of Roman Criminal Law ${ }^{16}$ is a supplementary treatise to Mommsen's Strafrecht; Mr. Phillipson's International Law and Custom of Ancient Greece and $R_{0 m} e^{17}$ is a promising enterprise in a little explored field of studies.

Religion.--Some suggestive speculations have been made by Miss Jane Harrison ${ }^{18}$ on the fundamental contrast between the "Olympian " and "pre-Olympian " gods of Greece, and by Mr. Cornford ${ }^{19}$ on the fusion of religion with early Greek philosophy. A more categoric resuit is attained by Dr. Farnell in his book on "Greece and Babylon," 20 which denies any connection between the cults of these two countries. The development of religious belief among the Romans is traced with much insight and sympathy by Mr. Warde Fowler. ${ }^{21}$ The survival of primitive beliefs and rites in Greece and Rome,

1 Die Anfänge der römischen Geschichtsschreibung (Leipzig, 1909).

${ }^{2}$ Paris, 1909.

${ }^{3}$ Six Roman Laws: (Oxford, 1911).

4 London, I9IO.

${ }^{5}$ Glasgow, I9I I.

${ }^{6}$ Oxford, igri.

7. Vol. i, Leipzig, 1912.

${ }^{8}$ London, I910.

${ }^{9}$ Social Life in Rome in the Age of Cicero (London, I908).

${ }^{10}$ Life in the Roman World of Nero and St. Paul (London, I910).

11 Kleine Schriften (Halle, I9I0), pp. 79-2 I 2.

12 Op. cit:

${ }^{13}$ Paris, 1909.

14 Studien zur Geschichte des römischen Kolonats (Leipzig, 1910).

15 Girowesen im griechischen Ägypten. (Strassburg, 1910).

16 Oxford, 19r2.

${ }^{17}$ London, I9I I.

${ }^{18}$ Themis (Cambridge, 1912).

19 From Religion to Philosophy (London, 1912).

${ }^{20}$ Edinburgh, 19I I.

21 The Religious Experience of the Roman People (Oxford, I9I I). 
and the reaction of riper thought upon them, is discussed from divers standpoints in a series of stimulating essays by Oxford students of anthropology. ${ }^{1}$

General.-A new survey of ancient culture, containing brief but comprehensive monographs on the various branches of classical study, has been commenced under the supervision of Profs. Gercke and Norden. ${ }^{2}$ A brief résumé of Roman culture is contained in a new Companion to Latin Studies, edited by Sir J. E. Sandys. ${ }^{3}$

(M. O. B. Caspari.)

\section{PALAEOGRAPHY ${ }^{4}$}

The largest field in which palaeographical discoveries are to be expected at this present time and, indeed, in the future is that of papyrology. The vast possibilities that ancient sites in Egypt offer for the recovery of the lost remains of Greek literature has been demonstrated by the prolific results which have already rewarded excavation. In other countries, which have been so thoroughly searched, it is only occasionally that an early vellum codex, accidentally hidden or temporarily overlooked, may be recognised and brought to notice by some travelling scholar or by the compilation of a new catalogue in some neglected library. But instances of such finds have been so rare that, when they do occur, they come as a surprise.

In Egypt, since the great successes achieved a few years ago, when large hoards of papyri, notably such as the Oxyrhynchus collection, were recovered, there has been something of a lull in respect of new discoveries. A period of digestion has set in, resulting in the output of an ever-growing number of papyrological publications. Not that the flow of material has actually ceased, for excavations of greater or less extent still continue to feed public and private collections of Europe and America. In this connection, evidence of the increasing number of local museums and libraries that, following the fashion, lay themselves out for securing a share in the spoils is to be found in the many useful publications which they issue describing their treasures.

In England the scholars who devote themselves to the study of papyri have not been idle during the past three years. The publication of the Oxyrhynchus Papyri by the Egypt Exploration Fund has gone on steadily under the editorship of Dr. A. S. Hunt, each year contributing its tale of new classical and other fragments, of more or less importance, and its series of non-literary cursive documents. In Part vii, roro, among new discoveries there are considerable fragments of Callimachus; in Part viii, I9I I, some remains of the cynic poet Cercidas; and in Part ix, I912, a large portion of the Ichneutae, a satyric drama of Sophocles. To Dr. Hunt likewise is owing the commencement of the catalogue of the Greek papyri in the John Rylands Library at Manchester, the first volume being published in ro I r. In that library we may notice in passing the existence of a large portion of an uncial MS. of the Odyssey as early as the fourth century. But the most important publication of cursive papyri is the fourth volume of the British Museum catalogue of papyri, rgro, edited by Mr. H. J. Bell. In this volume is described the collection of documents from Aphroditopolis (Kom Ishgau), which have the advantage of being, not a miscellaneous gathering, but a compact group from one locality and representing a limited period at the end of the seventh and beginning of the eighth centuries, and of providing, in official correspondence and documents relating to the financial administration of the district, a valuable insight into the methods of the earlier years of the Arab government of Egypt, while Greek officials were still employed there.

Outside England such well-established periodical publications as the Griechische Urkunden of the Berlin Museum and the Berliner Klassikertexte in Germany, and the Papiri Florentini in Italy have made their natural progress; and great activity has been shown in the launching or prosecution of catalogues or descriptions of collections at

1 Anthropology and the Classics (ed. R. Marett: Oxford, 1908).

${ }^{2}$ Einleitung in die Altertumswissenschaft (Vols. i-iii: Leipzig, 1910-11.)

${ }^{3}$ Cambridge, 1910.

"See E. B. xx, 566 et seq. 
Heidelberg, Leipzig, Giessen, Hamburg, Strassburg, Lille, Geneva and Cairo, as well as by the Italian Society " per la ricerca dei papiri greci e latini in Egitto." Among facsimiles issued specially with an educational object, Dr. W. Schubart's Papyri Graecae Berolinenses, published in I9II, a useful and representative selection of specimens from the earliest dates to the eighth century, which is issued at a very moderate price, is much to be commended.

The study of papyri has also now advanced to the stage when the material, accumulated and published in the busy years since the new discoveries lent it such an impetus, can be utilised for works of generalisation. Dr. G. Milligan's Selections from the Greek Papyri, r9ro, composed of texts drawn from the publications of the British Museum and the Egypt Exploration Fund, and from Berlin, Paris, and other places, and provided with translations and notes, is a book principally intended for students of the New Testament, but it also serves the purpose of an introduction to the study of papyri. But the most important publication that has appeared in this direction is the Grundzige und Chrestomathie der Papyruskunde. which Professors Mitteis and Wilcken have just completed: this is a great work comprising 550 texts of historical and social interest and nearly 400 legal texts, with exhaustive apparatus of descriptive and explanatory matter.

In the domain of general palaeography I9I 2 has witnessed the completion of the First Series of the Facsimiles of the New Palaeographical Society, consisting of 250 plates drawn from MSS. in Greek and Latin and modern languages, the work of the ten years' existence of the Society, which will forthwith enter on a second series. After a long interval of more than thirty years since its first appearance, Professor Gardthausen has commenced the issue of a second edition of his Griechische Palaeographie. The Clarendon Press, Oxford, has published.(Igr2) an Introduction to Greek and Latin Palaeography by Sir E. M. Thompson, an enlarged work on the lines of his Handbook. The valuable Vorlesungen und Abhandlungen of the late Ludwig Traube are slowly appearing in a collected form, two parts having been issued, in Igog and IgII. Among students prosecuting researches in special branches of palaeography, Professor W. M. Lindsay of St. Andrew's, following up his treatise on Contractions in early Latin minuscule $M S S$. which appeared in I908, has turned his attention to the Insular MSS., especially noting their systems of abbreviation and contraction, and has produced his Early Irish Minuscule Script, rgı̣, and Early Welsh Script, ror 2. Dr. E. A. Loew has contributed to the Bavarian Academy a valuable Contribution to the History of Early Latin Minuscule and to the dating of Visigothic MSS., I9ro.

Among publications of facsimiles, a second cdition has appeared of Steffens' Lateinische Palaeographie, I909; followed by a collection of Proben aus griechischen $H$ andschriften und Urkunden, I9I2. The Vatican collections have been represented by the Specimina Codicum Graecorum Vaticanorum of Franchi de' Cavalieri and Lietzmann, I9ı, and the Specimina Codicum Latinorum Vaticanorum of Ehrle and Liebart, I9I2, both useful works of limited extent and very moderate in price. Of wider scope is Staerk's book on the Latin MSS. of the fifth to the thirteenth centuries in the Imperial Library of St. Petersburg, roro.

The production of facsimiles of entire MSS. has grown to such an extent as to have become a feature in palaeographical publications. In Igog were issued the New Testament volume of the Codex Alexandrinus, ed. F. G. Kenyon; the Graeco-Latin Codex Boernerianus of the Pauline Epistles at Dresden, ed. A. Reichardt; the palimpsest Gaius of Verona, ed. A. Spagnolo; the Etymologiae of Isidore at Toledo, ed. R. Beer; and the Paris Theodosian Codex, ed. H. Omont. In roro, the MS. of Deuteronomy and Joshua of the sixth century, belonging to Mr. C. L. Freer of Detroit (one of the few uncial Biblical MSS. recovered within the last few years), ed. H. A. Sanders; the Tibullus of Wolfenbuittel, ed. F. Leo; and the Roman and Leiden MSS. of Ordericus Vitalis and Robert of Torigni, ed. J. Lair. In I9I I, the New Testament portion of the Codex Sinaiticus at St. Petersburg, ed. K. Lake; the Anthologia Palatina, from the Heidelberg and Paris MSS., ed. C. Preisendanz; the recently recovered papyrus of Me- 
nander at Cairo, ed. G. Lefebvre; the Wolfenbuittel Propertius, ed. T. Birt; and a further instalment of the great Florentine Pandects of Justinian.

Illuminated MSS. ${ }^{1-}$-An instructive book, Illuminated Manuscripts, has been written by Mr. J. A. Herbert (Methuen), Igr r, dealing with the different mediaeval schools and their productions. Besides this, a fair number of reproductions of choice MSS. have been published during the last few years. Three codices of the Byzantine School were issued in I909. The first is the Vatican MS. of the Topographia Christiana of Cosmas Indicopleustes, of the ninth century, ed. C. Stornajolo, the paintings in a broad illustrative style; the second is the Octateuch of Smyrna, containing from three to four hundred miniatures of conventional type, of the twelfth century, ed. D. C. Hesseling; the third is a Syriac Gospel Lectionary of the twelfth or thirteenth century, from Malatia on the Euphrates, now at Paris, illustrated with a series of miniatures of conventional art, the subjects being replicas of those in similar MSS. of Greek origin, ed. H. Omont.

In England three famous MSS, have been dealt with. The Benedictional of St. Ethelwold, Bishop of Winchester, the most important extant example of Anglo-Saxon art, of the later part of the tenth century, the property of the Duke of Devonshire, has been reproduced for the Roxburgh Club, ed. G. F. Warner and |H. A. Wilson, I910; for the same club the wonderful Apocalypse of Trinity College, Cambridge, of about A.D. I 230, perhaps executed at St. Alban's, has been edited by Dr. M. R. James, I909; and the MS. known as Queen Mary's Psalter, one of the most precious volumes in the Royal Collection of the British Museum, and of extreme artistic value, not only for its illuminated miniatures, but also for its wonderful series of tinted outline drawings of the best English art of the early years of the fourteenth century, has been brought out by the Trustees, ed. Sir G. F. Warner, rgr 2.

French illumination has been represented by several reproductions. The miniatures and initials of the two Bibles of Charles le Chauve in the Bibliothèque Nationale have been issued by $\mathbf{H}$. Omont, Igrr. The Psalter of St. Louis and Blanche of Castile, of the thirteenth century, one of the choice MSS. of the Arsénal Library, Paris, ed. H. Martin, appeared in I909; a section of the Bible Moralisée, from a MS. in the Bodleian Library of the thirteenth century, ed. Count A. de Laborde, in I9II; the Book of Hours of Jean Pucelle, of the fourteenth century, belonging to Baron M. de Rothschild, ed. L. Dilisle, in I9ro; the Livre de la Chasse of Gaston Phébus, Comte de Foix, from a MS. in the Bibliothèque Nationale, of the early fifteenth century, ed. C. Couderc, in r9o9; the Arsénal Cas des noblis hommes et femmes from Boccaccio, which belonged to John the Fearless of Burgundy, of the early fifteenth century, ed. H. Martin, in I9II; the Breviary of Philip the Good of Burgundy, now in the Royal Library at Brussels, of the first half of the I 5 th cent., ed. J. Van den Gheyn, in 1909; and the Munich Boccaccio, of the school of Jean Foucquet, c. A.D. I458, ed. Count P. Durrieu, in rgog.

Of the Flemish school are the following: The Chronicques et conquestes de Charlemagne with upwards of a hundred miniatures by Jean le Tavernier of Oudenarde, A.D. 1460, and the Histoire de Charles Martel with a like number of miniatures by Loyset Liédet, A.D. I $463-1465$, both MSS. in the Royal Library of Brussels, ed. J. Van den Gheyn, Iyog and I9IO; and the completion of the Grimani Breviary of Venice, in the Leiden series, igro. The reproduction in honour of Sir G. F. Warner of the miniatures and borders of a Flemish Book of Hours in the British Museum (Add. MS., 24098), of the beginning of the sixteenth century, may also be mentionad.

Only two examples of Italian art have to be recorded: the Romuleon, a MS. in the Arsénal of Paris, with miniatures of the late fifteenth century, ed. H. Martin, rgog; and the Psalter of Paul III, A.D. I 542, with miniatures and initials attributed to Vincenzio Raimondo, in the Bibliothèque Nationale, ed. L. Dorez, I909.

See E. B. xiv, 312 et seq.

(E. Maunde Thompson.) 


\section{DRAMA'}

For those who watch the course of events in the theatrical world from a dispassionate standpoint, the history of drama, in England specially, during the last few years is full of interesting and significant points. On the whole, the general tendency must be admitted to be both promising and healthy. Indeed, as compared with previous periods of dramatic history, it would seem that a new spirit has come over English Drama-a little vague and chaotic perhaps in character, and not thoroughly understood even by contemporary students, but, nevertheless, presenting several important features.

The New Realism. - The new spirit tends distinctly in the direction of greater simplicity, and a sincerer realism. It is now being claimed for the British stage that it should represent British life as it is actually lived, and give us faithful transcripts of real existence indeed of the melodramatic structures of romance. From this point of view it is interesting to observe the success of two piece:, "Bunty Pulls the Strings " at the Haymarket, London,-a success, both dramatic and pecuniary - and "Hindle Wakes," performed by the Manchester Repertory Theatre, which was without doubt an artistic success. "Bunty Pulls the Strings," by Graham Moffat, has enjoyed a vast amount of popularity, not because it tells an exciting story, but because it reveals with admirable veracity the daily life of Scotsmen and Scotswomen. In "Hindle Wakes," by Mr. Stanley Houghton, we deal with a veritable slice of life, "une tranche de la vie," taken from the experience of Lancashire folk. It is a singularly faithful transcript, in which the dramatis personae are obviously modelled on life types, and the story has all the more trenchant force because we are certain that it represents a definite experience, and not a more or less imaginative creation. If we contrast plays of this description with some of the conventional dramas produced at the leading London theatres, we observe that, in however tentative a form, a divergence in ideals is taking place between the so-called commercial theatre and those who are aiming at other and more artistic ends. The commercial theatre is regulated by the box office. The younger school of dramatic writers aim at truth-sometimes in very uncompromising fashion. The contrast in aims and dramatic methods is easily illustrated if we put side by side a melodramatic piece like "Bella Donna"-to which reference will presently be made-in the St. James's Theatre, and either of the two plays just referred to, "Bunty" or " Hindle Wakes." The first is a drama more than a little artificial and conventional; the two latter aim at simple veracity. There is a similar contrast to be found between two other interesting non-commercial plays- "Rutherford and Son," by Miss K. G. Sowerby, and "The New Sin," by Mr. B. Macdonald Hastings, as compared with pieces like " The Perplexed Husband," by Mr. Alfred Sutro, or "Jelfs," by Mr. H. A. Vachell. The last class of dramas is, at present, favoured by theatrical managers, who, naturally enough, guide their policy by the records of their "booking " and the demand of the libraries. The other class represents a newer movement which, indeed, is not indigenous to London but comes largely from the provinces. For a curious feature of the present situation is that London is no longer the dramatic capital of England. Some of the most interesting recent plays have either come from the provinces, or been acted by private societies for the benefit of special audiences.

Irish Players and Others.- Thus, during the last two years, the metropolis has constantly been invaded by groups of players belonging, as Matthew Arnold would say, not to "the centre" but to the circumference. Early in February rgr 2 Mr. Rutherford Mayne brought out "The Drone" at the Royalty Theatre, in order to prove that the drama is alive in Belfast as well as in Dublin. In June the Abbey Theatre company, whose business it has been for some time past to recommend native Irish drama, played at the Court Theatre not only some old accepted favourites, but some new studies of life. Mr. Synge's " Playboy of the Western World," which has had a mixed reception in the land of its birth, as well as in England and America, has now become tolerably familiar

See E. $B$. viii, $475-546$. 
in London. Besides this and Mr. Yeats' dramatic poem "Countess Cathleen," the Abbey Theatre company produced Mr. Lennox Robinson's "Patriot," Mr. T. C. Murray's " Maurice Harte," Mr. William Boyle's " Family Failing " and Lady Gregory's clever little farce "The Bogie Men." Miss Horniman's well-known company from Manchester also made its appearance at the Coronet Theatre, and has since established its position as one of the best and smartest of companies which has ever visited London. It is to Miss Horniman that we owe "Hindle Wakes," by Mr. Stanley Houghton, to which reference has already been made, and a second piece by the same author, entitled "The Younger Generation." There were also one or two sincere and capable artists engaged in these ventures, whose names deserve mention-Miss Sara Allgood and Mr. Arthur Sinclair, of the Abbey Theatre, Miss Irene Rooke and Miss Goodall, of the Manchester company.

Repertory Theatres.-We have already touched the fringe of one of the great modern movements of our time in England-the rise of the Repertory Theatre. In the old days -only known by the verbose reminiscences of actors long past their prime-stock companies used to be an admirable training school for young aspirants to the stage. Then came a period in which the provincial towns only received with gloomy acquiescence the theatrical successes of the Metropolis represented by touring companies of often mediocre excellence. Nowadays many provincial centres have started their own theatre, and have supported companies of their own. For instance, there are repertory theatres at Dublin, Manchester, Glasgow and Liverpool, and the movement is making headway in many directions and by many methods. Birmingham, for instance, was actively at work in I9I 2 preparing for its repertory theatre shortly to be opened. Leeds was securing a local guarantee for an experiment of the same kind. Bradford has founded a Playgoers Society, with somewhat similar objects, while Edinburgh, Bolton, Stockport, Sheffield, and other towns are showing much activity in the same direction. Movements of this kind cannot fail to be beneficial to the cause of drama, and they apparently justify the assertion already made that London, which, of course, has no repertory theatre, has ceased to be, in any true sense of the word, the dramatic capital of England. What is, however, often forgotten in this reference is the patent fact that London has a population drawn not only from many classes, but from many countries-a floating cosmopolitan population which, perhaps naturally, looks upon the theatre solely as a place for whiling away a few idle hours after dinner, and which, therefore, is inclined to prefer a musical comedy, or even the turns at a music hall, to sterner and more indigestible dramatic fare.

The Censorship.-One other feature of general interest to every English Drama may be added to those already mentioned. For some time past there has existed a certain impatience with the control which the Lord Chamberlain has exercised through the dramatic censorship on the production of plays. A Parliamentary committee appointed for the purpose of examining into this matter sat for a considerable time, with $\mathbf{M r}$. Herbert Samuel, afterwards Postmaster General, as charrman, but its recommendations remain a dead letter. Meanwhile, certain changes have occurred. Lord Sandhurst became Lord Chamberlain, with Sir Douglas Dawson as the chief of his staff. Mr. G. A. Redford, who undoubtedly made some mistakes, has retired from the office of Reader of Plays, and the vacant post has been given to Mr. Charles Brookfield, a clever and talented man who has been more identified with the lighter than the serious drama, and who is the author of a well-known piece of somewhat dubious ethical tendency called "Dear Old Charley." After the lapse of a few weeks an assessor was appointed in the person of Mr. Ernest Bendall, who had been for years a dramatic critic. The reorganised oftice has, on the whole, worked smoothly, and the friction between drama and censor, notorious in recent years, has become inconsiderable. There are two cases, however, in which some injustice probably was done to leading authors of distinction. Mr. Eden Phillpotts' play "The Secret Woman" was refused a licence, whereupon twenty-four authors issued a public protest and the play was performed six times in the afternoons, under the management of Mr. Granville Barker. Mr. Israel Zangwill's play "The 
Next Religion," which suffered a similar fate, was twice privately performed by the New Players at the London Pavilion. On the whole, however, it would be true to say that a wider toleration has sprung up, or, perhaps, a greater amount of tact has been exhibited in the Lord Chamberlain's office. One important change that has been made seems likely to work well. In order to put music halls and theatres on the same footing, so far as dramatic representation was concerned, the Lord Chamberlain decided to issue Stage Play licences to the music halls under his jurisdiction, a much needed reform which has given a great opportunity for the production of short and telling dramatic episodes at all the leading "variety" houses.

Recent Plays in London.-As we survey the various productions in the London theatres for the last two years we are struck with their prodigal variety. It may be very difficult to say precisely what kind of play an English audience instinctively prefers, but it seems on the whole likely, if we judge by much past experience in English dramatic history, that the English people like a touch of melodrama, that they are wedded to the old idea that virtue must be shown to prosper and vice to fail, and that in consequence new forms of realism have not as good a chance with them as the varieties of sentimental idealism. Confronted, however, as we are by a vast mass of material, our only plan will be to divide it, so far as it is possible, into groups, marking, at the same time, the relative success or failure of the various ventures.

Let us take the Shakespearian drama first. The great home of Shakespearian drama in London is, of course, His Majesty's Theatre, and it has been the good fortune of Sir Herbert Tree to prove that Shakespeare, so far from spelling bankruptcy, brings material gains to the booking office. "Henry VIII" was brought out with no little success, the part of the burly monarch being sustained by Mr. Arthur Bourchier, whilst Sir Herbert Tree, following the example of Sir Henry Irving, kept for himself the rôle of Cardinal Wolsey. "Macbeth" was another venture, which did not, however, enjoy the same prosperity. In the case of "Othello," which had a run for some time at His Majesty's, it was generally recognised that the young actress, Miss Phyllis Terry, as Desdemona, earned well-deserved laurels, while Mr. Laurence Irving as Iago gave, at all events, an interesting and a refreshingly youthful rendering of the part. Sir Herbert Tree's Othello had, undoubtedly, good moments. In the autumn of Igri Mr. Fred Terry produced "Romeo and Juliet" at the New Theatre. He was himself to have appeared in the part of Mercutio, but was, unfortunately, incapacitated by illness, and principal honours were won by his daughter Miss Phyllis Terry in an extremely able and promising performance of Juliet. The only other item in our Shakespearian list to which we need refer is the recent production of "The Winter's Tale " at the Savoy Theatre, by Mr. Granville Barker. Probably no piece of modern times has given rise to a greater amount of controversy; for Mr. Barker boldly challenged traditional methods and produced a spirited version of the play which had a kind of pre-Raphaelite, or perhaps, Post-Impressionist effect, both in design and in execution. Its chief features were, first the performance of the whole play as Shakespeare wrote it, with the exception of some eight lines; second, a great rapidity of utterance in the delivery of the speeches, which for many theatregoers afforded a welcome change from the stately and dilatory phrasing of the conventional method; and, thirdly, the rearrangement of the stage, which brought it back nearer to the conditions of the Elizabethan playhouse. Thus, for instance, there was what is technically known as an "apron" in front of the regular stage, enabling a number of scenes to be enacted before a curtain hiding the main stage. In the general effect produced, it was possible to discern several contributory influences. Mr. Granville Barker very cleverly made use of a good deal of modern experience. Some debt was incurred to Professor Max Reinhardt, something was due also to the exertions of Mr. William Poel and his Elizabethan enterprises. But, perhaps, the main influence came from the Russian ballet and M. Leon Bakst. Mr. Granville Barker carried his policy a step further in the production of "Twelfth Night," a very beautiful and noteworthy spectacle, admirably acted by Miss Lillah McCarthy, Mr. Henry Ainley, Mr. Leo Quartermaine and others. 
A characteristic feature of the London seasons of $191 \mathrm{I}$ and 1912 was the success of spectacular exhibitions, designed on oriental lines. Thus, for instance, we had "Kismet " at the Garrick Theatre, an eastern fantasy by Mr. E. Knoblauch which had a very lengthy run, "Sumurûn " and "The Miracle," due to the constructive imagination of Max Reinhardt, while the Russian ballet not only introduced such artists in dancing as Karsavina, Pavlova, Nijinsky and Novikoff, but revealed extraordinary cleverness on the part of the producer, Bakst, in his handling, for example, of "Schéhérazade." When "King Oedipus" was enacted at Covent Garden, with Mr. Martin Harvey in the principal part, it was a reproduction in most respects of the Max Reinhardt version in Berlin, and especially struck English audiences by its bold and free manipulation of large crowds, forming both chorus and populace in the arena. Other Greek plays produced were the "Iphigeneia in Tauris" at the Kingsway Theatre and at Bradfield College, and the "Medea" at the Kingsway Theatre. To this list may be added "A Venctian Night" produced by Max Reinhardt at the Palace Theatre. Some of these productions were not a little exotic in character, which gave them a touch of the eccentric and the bizarre. At all events they gave an opportunity for the "producer " of the show, who is becoming a most important figure in all modern theatrical history.

Theatrical Successes. - We must return to plays of a more ordinary type. In this department the outstanding successes have been undoubtedly "Bunty Pulls the Strings," by Graham Moffat, "Fanny's First Play," by Bernard Shaw, and " Milestones," by E. Knoblauch and Arnold Bennett. If "Fanny's First Play" revealed Bernard Shaw at his best, it is also true to say that no single play in London has been more unanimously praised by every class of theatregoers than "Milestones." The idea of the piece was to take a single family through three distinct phases of its career, and exhibit the prejudices inseparable from each stage in turn. The family in question was engaged on shipbuilding enterprises, and we had presented to us in turn the obstinate belief of the grandfather in wooden ships, succeeded by the faith of the father in iron ships, and followed in due course by the son's acceptance of the value of steel in naval construction. The two authors had woven a very interesting story round this framework, and as the figures were well drawn, and typical in each case of their own period, the piece has enjoyed the largest measure of popularity. A popular success has also attended the production at His Majesty's Theatre of Louis N. Parker's " Drake." It is a version of the life of the great Elizabethan seaman, and, although mainly spectacular in character, it yet has two acts of strongly dramatic interest, which, quite apart from its general popularity, appeal on the score of patriotism and national pride in the British navy. The St. James's Theatre has been remarkable for three pieces, all more or less melodramatic in their nature. "The Witness for the Defence," by A. E. W. Mason, was succeeded by "Bella Donna," founded on a novel by Mr. Robert Hichens, and dramatised both by the author and Mr. J. B. Fagan, in which both Mrs. Patrick Campbell and Sir George Alexander won an undoubted triumph. The third piece at this theatre is entitled "The Turning Point," based on "La Flambée" of M. Henry Kistemaeckers. We must pass more quickly over other dramatic ventures. Mr. Arnold Bennett's " The Honeymoon " had, perhaps, not as much success as it deserved, but Mr. Haddon Chambers' comedy " Passersby " ran for a long time, thanks to Mr. Gerald du Maurier, and "The Perplexed Husband " of Mr. Alfred Sutro also kept the boards for many wecks. Sir Arthur Pinero has been represented by three plays in the period under consideration- "Preserving Mr. I'anmure," the oddly named "Mind the Paint Girl," and a short play "The Widow of Wasdale Head," besides a successful revival of "The Amazons." Miss Marie Tempest, thanks to a most engaging personality, managed to make a success both of Mr. Anthony Wharton's "At the Barn" and Mr. Harold Chapin's "Art and Opportunity." Mr. Henry Arthur Jones' "The Ogre " did not hit the popular taste, but Mr. Henry Hubert Davies, the clever and ingenious author of "The Mollusc," seems once again to have secured a popular verdict by his rather thin piece entitled " Doormats." The titles of other plays may be rapilly run through, as, for instance, "The Easiest Way," by Eugene Walter, in which Miss Sarah Brooke had a "star" part; "The Five Frank- 
forters," translated from the German of Karl Roessler; "Jelfs," by H. A. Vachcll; " The Bear Leaders," by R. C. Carton; "Lady Patricia," by Rudolph Besier; " The Butterfly on the Wheel," a melodramatic version of a trial for divorce, by Messrs. Hemmerde and Neilson; "Little Miss Llewelyn," founded on the Belgian play "Le Mariage de Mdlle. Beulesmans"; "A Scrape of the Pen," by Graham Moffat, author of the evergreen "Bunty;" " Rebecca of Sunnybrook Farm," by Kate Douglas Wiggin; and "The Great John Ganton," which gave the American actor Mr. George Fawcett an opportunity for a singularly vivid piece of characterisation. "Everywoman " at Drury Lane requires a line to itself, because of its peculiar character. Instead of bringing out its usual melodrama, Drury Lane produced in I9I 2 a kind of modern morality play, in which "Everywoman," a name for the eternal womanly, is shown surrounded by youth, beauty, flattery, wealth, and other personified abstractions, and scolded from time to time by "Nobody," who acts the part of chorus to the piece. It was written by a young English author, Walter G. Browne, but he died before its production could take place in America, and the English version, transplanted from the United States, was made by Stephen Phillips working on the original material of the author. One of the most curious of recent productions was the triple bill (Nov. I9I2) at the Duke of York's Theatre, consisting of three items, "Overruled " by Bernard Shaw, " The Widow of Wasdale Head " by Arthur Pinero, and "Rosalind" by J. M. Barrie. Mr. Barrie was the only one of the three authors who kept up his reputation. Mr. Bernard Shaw's piece (called "a demonstration ") dealt in cynical and garrulous fashion with the old question of philandering with friends' wives, and Mr. Pinero's play, though called a fantasy, was singularly devoid of imaginative and fantastic elements. Mr. Galsworthy has been represented by a new piece "The Eldest Son" at the Kingsway Theatre, which is mainly a study of country house morality.

Needless to say, there has been the usual number of new musical comedies, of which it is only necessary to recall the names- "Princess Caprice," " Grass Widows," " The Girl in the Taxi," "The Sunshine Girl," "Gipsy Love," "The Dancing Mistress,"all more or less of the accustomed type.

English Actresses and Actors.-Before leaving the English stage, it may be interesting to mention the names of those contemporary players whose success has been most conspicuous in I9I I and I9I2. Of the younger actresses there can be no question that most mark has been made by Miss Phyllis Neilson Terry and Miss Marie Löhr, though they are of very different types, Miss Neilson Terry is better in romance and tragedy, and her chief honours were gained in the parts of Juliet, Desdemona, and Queen Elizabeth in "Drake." Miss Marie Löhr is a born comédienne, with a light pleasant youthful touch which stood her in good stead in such pieces as Pinero's " Mind the Paint Girl," the same author's "Preserving Mr. Panmure" and Mr. H. H. Davies' "Doormats." Mrs. Patrick Campbell still remains the most picturesque and accomplished actress on the English stage. Her technique is never perfect, but she has magnificent moments, and her intuitions are always right. Once more she proved her powers in Mr. Robert Hichens' "Bella Donna,"--on the whole a very remarkable performance on the part of the heroine. Miss Lillah McCarthy's successes have been gained as Jocasta in King Oedipus, as Iphigeneia in Euripides' play, and more recently as Hermione in "The Winter's Tale " and "Viola " in "Twelfth Night." Miss Alexandra Carlisle has taken a grea step forward in her representation of "Everywoman " at Drury Lane, and Miss Irene Vanbrugh revealed once more the extent of her charm as a comedy actress in $\mathrm{Mr}$. Barrie's play " Rosalind."

It would be true, however, to say that the English stage is not so richly endowed with actresses as it is with actors. Rarely in its history has the theatre possessed so many capable male artists. We need only mention here the names of those who are steadily winning fame by careful and intelligent work. Probably the actor with the largest following is Mr. Gerald du Maurier, who has attained a wonderful degree of popularity with his audiences, and often finds himself able to carry through an indifferent play to success by virtue of his personality.

Mr. Dennis Eadie is one of the cleverest actors in 
England, versatile and ready in resource. Mr. Henry Ainley is, perhaps, the best romantic actor; his recent performances as Leontes in "The Winter's Tale " and Malvolio in "Twelfth Night " confirmed once more the judgment passed on him by many critics. To this list of younger artists may be added the name of Mr. Robert Loraine. It need hardly be added that both Sir Herbert Tree and Sir George Alexander have retained the position which they have won by many years of conscientious work. Mr. Forbes Robertson, in some respects the most distinguished of English actors, has been absent from London, and so too has Mr. H. B. Irving, both having had successful tours far from home; while Mr. Frank Benson has continued his strenuous work at Stratford and in the provinces.

The American Stage.-Turning to the American stage, we find that it still retains some of those features which have marked it for some time past. In many respects it is crude, immature and imitative, and, as before, depends largely on the successes of the English stage. Nevertheless, it would be true to say that a few authors of independence and originality have arisen, and that the general level of American acting has decidedly improved. There are a number of good character actors, although the supply of jeunes premiers is decidedly scanty. Here we need only refer to some of the more conspicuous events of the past two years.

A good deal of interest was taken in the New Theatre, subsidized by wealthy private guarantors, which was opened with a great flourish of trumpets in New York. Built originally as an opera-house regardless of expense, it was found to be sadly deficient in acoustic properties for the purpose of drama, and to be much too large for the presentation of comedies and domestic pieces. Under Mr. Ames as producer and Mr. E. Hamilton Bell as art-manager, some excellent work was done in presenting and staging new pieces which otherwise would hardly have had a chance in America; but the experiment of providing continual novelty and avoiding "runs" gradually broke down, and the enterprise came to an end in the summer of IgII. The building was changed by the Lieblers into the Century Theatre, and modifications of the original structure were made, to adapt it for more ordinary requirements. Among other general events of theatrical interest we may mention that the Old Bowery Theatre was sold at auction, and that Miss Ellen Terry's lectures on Shakespearian heroines, were everywhere received with the greatest enthusiasm.

Of new dramas produced perhaps the most original were "As a Man Thinks," by Augustus Thomas, "The Wo:nan," by William C. de Mille, "The Return of Peter Grimm," by David Belasco, "The Price," by George Broadhurst, and "Bought and Paid For," by the same author. The oddly named "Get-Rich-Quick Wallingford" enjoyed much popularity at the Gaiety, and has since been given in London. "Everywoman." originally produced at the Herald Square, a modern moralist play by Walter Browne, has already successfully traversed the Atlantic, and perhaps the same good fortune will attend Mr. Louis Parker's play " Distaeli," in which Mr. George Arliss has won in New York such conspicuous success. "The Garden of Allah," by Robert Hichens, gave a fine opportunity for Mr. Lewis Waller, who has also been seen in "The Butterfly on the Wheel," "Discovering America" and "Henry V." "The Piper," Mr. F. R. Benson's Stratford prize play, by Josephine Preston Peabody, was produced in the New Theatre and greatly praised as literature, though its dramatic value was less evident. In "Thaïs," founded on the novel of Anatole France, Miss Constance Collier carned a considerable reputation, and Miss Ethel Barrymore won well-deserved praise in a production of Mr. A. E. W. Mason's "The Witness for the Defence." "Kismet," "Nohody's Daughter," "Passers-By," "A Single Man," "The Twelve Pound Look" and "The Perplexe 1 Husband," were other plays borrowed from the English stage; but "The Master of the House" by Edgar James, which came out at the 39 th Street Theatre, revealed a good deal of native American talent. It may be added that, when the Irish Players appeared in New York, Mr. Synge's piece "Playboy of the Western World" aroused as much opposition in America as it had done in Ireland, especially from Irish critics who denounced it as a libel on the Celtic character. Apart from this drama, 
however, the company produced several plays of interest by Yeats, Lady Gregory. Bernard Shaw, and others. Mr. John Drew is still to the fore as an American actor of rich attainments, especially in comedy.

The French Stage.-On the whole the French stage, within recent months, does not appear to be in so flourishing a condition as it has been in past years, and, indeed, it seems a little deficient in vitality as compared with the English stage. We notice a greater readiness to accept foreign importations, and a greater leniency of judgment in estimating their merits. Thus, for instance, so thoroughly; an English book as Pickwick was adapted under the title "Monsieur Pickwick," and produced at the Athenée with some success. "Kismet," too, has been transplanted from England and America to Paris, under the care of M. Guitry. Of authors well-known in the French dramatic world we may mention Pierre Wolff, Paul Bourget, Henri Lavedan, George de PortoRiche, and Henry Bernstein. From the last named writer have come two pieces"Après Moi," and "L'Assaut," together with a'revival of "Le Détour," all more or less successful. Paul Bourget's Drama "Le Tribun"' saw the light at the Vaudeville Theatre, and in conjunction with M. Beaunier, M. Bourget also produced "La Crise." M. Alfred Capus has been represented by "Les Favorites" at the Variétés, and those two capital comedians, De Flers and De Caillavet, have delighted the Parisian public with "Primerose," "Papa," and still later with "L'Habit Vert." Gabriel Trarieux's "La Brebis Perdue," Henri Lavedan's "Gout du Vice," Pierre Wolff's "L'amour Defendu," and George de Porto-Riche's "Vieil Homme," were all fairly successful productions, whilst Henry Kistemaeckers' "La Flambée," which came out at the Porte St. Martin, has since been seen in its English version at the St. James's Theatre. A very peculiar and powerful Hungarian play entitled "Le Typhon," and written by Lengyell, which came out in Paris, has already been adapted and produced by Mr. Laurence Irving in the English provinces, although it has not yet appeared in London. Another adaptation is "The Little Café," from M. Tristan Bernard's enormously successful farce " Le Petit Café," at the Palais Royal. Perhaps in Paris the most popular contemporary dramatist is Sacha Guitry, who made his fame in "Le Beau Mariage," and has certainly confirmed it in his most amusing recent piece "La Prise de Berg-op-Zoom." Towards the end of Igr 2 Paul Hervieu's "Bagatelle" was successfully produced at the Thêatre Français, Georges Duhamel's "Dans l'Ombre des Statues" at the Odéon, Henri Bataille's "Les Flambeaux" at the Porte St. Martin, and Brieux's "La Femme Seule" at the Gymnase (Dec. 22). Madame Sarah Bernhardt's success in "Lucrezia Borgia," and in "Elizabeth Reine d'Angleterre," was confirmed by the extraordinarily warm welcome accorded to her when she appeared at the London Coliseum.

(W. L. Courtney.)

\section{PROGRESS OF THE CINEMA THEATRE}

Though it is now nearly twenty years since R. W. Paul and others first evolved the cinematograph ${ }^{1}$ from Edison's kinetoscope, and though numerous patents relating to it have been granted in Great Britain and elsewhere, the machine remains essentially the same as it was then, and it is only in matters of detail that great improvement has been made. The film is now standardised and is $\mathrm{I}^{\frac{3}{4}}$ " in width, bearing I 6 pictures, each I" $\mathrm{x} \frac{3}{4}$, to the foot and having eight sprocket holes, four on each side, to every picture. The projector mechanism has been modified, the intermittent movement of the film being now usually effected on a " maltese cross " or Geneva stop principle instead of by the old cam or " dog " motion; and this has led to greatly increased steadiness of picture, as the film is positively locked except when the pictures are being changed. Another advantage from its use is that the change from one picture to the next is reduced to less than one-fifth of the whole cycle; thus minimising the "flicker." This has also been reduced by modifying the shutter, which now has three blades, instead of one, as formerly, of which one serves to cut off the light while the change is effected and the other two increase the frequency of the alternations of light and darkness thus rendering them less

${ }^{1}$ See E. B. vi, 374 . 
noticeable. The intensity of the light is of course increased to preserve the brilliancy of the picture. Minor improvements have also been devised in the nature of the screen on which the image is thrown, in the rapidity of the lenses fitted, and in the arc lamp which is always used to illuminate the film pictures, until, at the present time, films in good condition properly projected by the most modern apparatus worked by a firstrate operator show pictures which leave little to be desired as regards brilliancy, steadiness and freedom from flicker.

The camera in which the negative film is taken, from which all the subsequent prints are made, is practically the same mechanism as is used in a projector, but it is placed in a light tight box. The lens used in taking is an extremely rapid one of the highest quality so that the utmost detail may be secured. The pictures are invariably taken at 16 per second, or one foot of film, and the necessary alteration of the exposure is made by stopping down the lens. This taking speed is never altered, as the films are always projected at this speed and thus a natural effect of motion is always secured. If the film is projected faster than it was taken the effect is very hurried, and if slower an opposite but equally unreal effect is attained.

The films after exposure are mounted on frames (holding from 150 to 300 feet), developed, fixed and washed in large tanks, and then wound on drums about 4-5 feet in diameter and dried by being rapidly revolved in warm dry air. The positives are then printed from these in a special printing machine in which the positive is successively exposed to light behind the negative pictures. It is developed, fixed, washed and dried in the same way as the negative, and is then ready for the market. One or two of the largest French film manufacturers produce their positives by means of automatic machinery, but this has not yet been generally adopted.

In the early days, the subjects of the films were of the simplest possible character, scenery taken from a moving train, a woman washing a baby, boys bathing and so forth: but they have become more and more complex until at the present time no expense is spared to render the pictures correct in every detail. The actors are dressed with every. attention to historical accuracy and the plays are in many cases acted in the places where the scenes depicted actually took place, large numbers of people being continually employed by all the film companies in preparing, rehearsing, and acting the various scenes depicted. A French firm employed 2,500 people to act a film of "The Siege of Calais," and an American company spent $£ 20,000$ and employed sixty actors for months in Palestine to act "From Manger to Cross."

The business has developed into an enormous one all over the world, and has reached its highest development in the United States. There the most insignificant villages have their picture "show," and more than five million people go to see the plays every day, at least $£ 26, \infty 00, \infty 00$ being taken at the doors in a single year. In England, though the progress has not been so rapid, the business is an important one. There were over 4,000 theatres licensed in Great Britain for pictures in I9I2. Each of these shows 5,000 to 6,000 feet a day, so that over $20,000, \infty 00$ feet are projected every day. The life of a film is only six weeks in constant running, so that over $3, \infty \infty, \infty)$ feet come in and go out of circulation every week. As this film is supplied by the manufacturers at an average price of $3 \frac{1}{2} \mathrm{r}$. it follows that a large amount of capital is invested in this business, even though it has not yet reached its fullest development. All the countries of Continental Europe have adopted the new form of entertainment.

The most important countries for manufacturing the film are in order France, the United States, Italy, Great Britain and Germany. In the early stages, England had a monopoly of this branch of the business, but this was lost partly because climatic conditions were unsuitable and partly because the fear that the craze would be a transient one frightened capitalists. There is now no doubt that this form of entertainment will continue to attract: there were go picture theatres licensed in London in 1909 , but in 1912 there were over 400 . It attracts audiences partly from those who previously never went to places of amusement at all and partly from music-hall and theatregoers. It has recently been shown that the seven leading London music-halls made on the average 
$£ 3,000$ less profit in $19 I^{1-1} 2$ than they did in the preceding 12 months, and a similar drop would be shown in the theatre receipts if the figures were available. Many of the local theatres and halls in the London suburbs have either closed or been converted into picture palaces. Unfortunately the cinema theatres have shown less desire to use their opportunities for high-class educational purposes, and more to provide simply sensational entertainments, than they did three years ago. Then it was the custom to include at least one educational picture in each programme; it might be the growth of some well known flower, or perhaps the circulation of the blood, or a tour round some foreign city, or the manufacture of a familiar article, while now it is the exception to find such a film included. A wearisome round of pictures are exhibited, farces based on crude practical jokes, and melodramas mixed with maudlin sentimentality; the only leaven is an occasional historical play.

The cause of this failure to take advantage of the enormous educative possibilities of the cinematograph is twofold. Firstly, the majority of the leading film manufacturers are self-made men who have made all their money out of the business; and secondly, until lately it was fashionable to ridicule the cinematograph picture. The fact that the leading actors and actresses of Europe, for instance, Sir H. Beerbohm Tree and Madame Sarah Bernhardt, have not considered it beneath their dignity to act before the film camera shows that the second no longer applies. Time no doubt will remedy the first, and when the men arrive who will raise the tone of electric theatres in the same way as the late $\mathrm{Sir}$ Edward Moss and others have done for that of the music halls, the cinematograph will become a great influence for the public good.

There is a great field open too for the use of film pictures as an aid to teaching. Children are always more interested in the concrete than they are in the abstract; lessons in geography, history, natural science, etc., so illustrated, would interest and instruct them to a far greater extent than mere text-book teaching, and knowledge so acquired would be much more likely to be retained. The inflammability of the film has, however, up till now prevented any serious move being made in this direction. The Home Office and County Council regulations in England have rendered electric theatres very free from danger; but it would be difficult to apply these rules to schools. Children are highly susceptible to panic, and a fire-and-smoke-proof operating box would be a necessity, especially as school teachers could hardly be expected to be expert operators and so would be more likely to fire the film. The London County Council and others, however, have recently taken steps to consider how these difficulties can be overcome.

Many attempts have been made to make a non-inflammable celluloid film, but so far without success. Films have been made with tanned gelatine as a basis instead of celluloid, and inventors have also endeavoured to denitrate the nitrocellulose from which celluloid is manufactured; but in both cases the film has lost transparency and also strength. This is one of the problems awaiting solution. Another is that of obtaining a film in natural colours. G. A. Smith and Chas. Urban in their Kinemacolor process show very beautiful colour effects; but the film is not in itself coloured and so must be shown by special apparatus. Relying as it does on persistence of vision, much higher running speed than usually employed is required and considerably more light. The ideal colour film should consist of a series of pictures, each a complete colour rendering of the subject in itself; so that the film could be exhibited on any machine at the normal speed. No film fulfilling these conditions has yet been produced on the market, but of the numerous inventors who are investigating colour cinematography one, at least, is working on these lines and the problem should shortly be solved.

Another problem is the synchronising of the gramophone and cinematograph. This had been done but with very partial success, but late in I9I 2 seemed to have been successfully accomplished by Thomas A. Edison.

The one thing certain is that ten years ago the moving picture was an object of ridicule, yet to-day it has effected a revolution in the world's amusement; and its influence will continue to increase as more theatres are opened and better programmes are produced.

(T. P. Middleton.) 


\section{MUSIC 1}

The more recent developments of music have been concerned with performance rather than creation and invention. The truth is that, with the death of Wagner, an end came to a long period of inventive development in the art-the period, in fact, of developed music which may be said to have begun with Bach and ended with Wagner and Brahms. It is probable that to future historians this period will be known as the "equal temperament period," in which music was universally written on the basis of the whole-toned scale. The general tendency of music of the post-Wagner period has been to search for some new scale or tonal basis and consequently to express this in terms which at first seemed strange to ears trained to the old scale. With Wagner a certain period of composition may be said to have ended, and a new period of performance and interpretation to have begun; and it is that period which, in its turn, seems to have come to its own development and close in the last year or two-probably to give birth, in its turn, to a new period of original composition.

Whether this turn out to be true or not the expectation of it seems to be logical. A long and fertile period of creative production means almost certainly that less time and care can be devoted to interpretation and performance; there are more works claiming a hearing than can easily be heard; and musicians are more engaged in the business of presenting the new works than in perfecting their renderings of the old. In time, therefore, the actual technique of interpretation falls short of the demands made upon it; attention is drawn to it; and with the pause in the tide of production comes greater leisure to study the technique of performance and the consequent development in that branch of the art. The link between two such periods is curiously represented in the person of Wagner, who found that existing means of interpretation were not sufficient for the adequate performance of his own works, and he had therefore to evolve for himself a new orchestral technique by means of which his scores could be made intelligible to the world. He may be said to have invented the modern art of conducting - an art which arose entirely from his own works. Wagner had by long and patient study of Beethoven, Mozart and Weber, arrived at the conclusion that the orchestral works of the great masters had hardly ever been properly heard, and his essay on conducting marked an epoch in the history of music. But when his own scores came to be examined, they were pro.rounced unplayable. By the old methods, moreover, they were unplayable, and ghastly indeed must have been some of the performances of opera orchestras in Germany at their first rehearsal of his scores. No amount of merely beating one, two, three, four in a bar could produce melody and harmony out of the chaos presented by the score. The thing seemed hopeless. Like every creator or originator, Wagner had to begin at the beginning and form the tools with which his work was to be done. Liszt and von Bülow, the greatest contemporary masters of the technique of the pianoforte, were the first to realise that there was at least a possibility of the performance of Wagner's works; they had learned from him how to conduct Beethoven, anci the knowledge thus gained was applied to the interpretation of his own scores. And after them he trained a whole band of disciples in the interpretation of his operasRichter, Seidl, Levi, Richard Strauss, Mottl, Weingartner, and Nikisch were the chief of them; all these became great exponents of the new art of conducting. These men had many varieties of quality and talent, but it will be seen that one thing was common to the equipment of all of them: they were all trained in the interpretation of one set of works-Wagner's own operas. And that fact gives us the key to the new art of conducting as compared with the old art of beating time; for they had these scores absolutely in their heads. They lived with them; their lives were spent in rehearsing and copying and drilling until every note was as much their own as if they had themsclves composed the score; thus when they came to conduct they were not merely reading the music of the printed page a bar in advance of the orchestra; they were leading the orchestra in something that was within themselves, something that came from their own inner being.

${ }^{1}$ See E. B. xix, 72 et. seq.; and articles enumerated on p. 885 of Index Volume. 
They knew every note of the part, often knew it better than the player himself; and if he stumbled or made a mistake they could sing the right note for him through all the maze of other parts.

The interpretation of the Wagnerian scores was also a great training ground for conductors in the actual instrumental technique of the orchestra; and in the extension of this, and the first modern definition of it in the form of an authoritative monograph, the work of Hector Berlioz is pre-eminent. It was of old the invariable excuse of the lazy orchestral player to pronounce a passage presenting any unusual difficulties " unplayable," and the ignorant conductor, hesitating to contradict the player on a matter concerning the technique of his own instrument, was obliged to accept his verdict. But Berlioz and the disciples of Wagner changed all that. They armed themselves with an exact knowledge of what was and what was not possible for every instrument in the orchestra; they were careful not to write anything physically impossible. They thus abolished a great piece of bluff with which orchestral players had hitherto been able to oppose the exacting conductor; for composers had often written without any regard to the construction of the instrument employed, had even written notes which did not exist on the instrument; so that the conductor who should have demanded their execution would have been laughed at by his band, which would not fail to take advantage of this state of affairs when presented with a passage which was merely difficult and not impossible. But under the new régime the conductors very often knew as much about the technique of the instrument as did the players themselves; they were firm in demanding the execution of passages which were only difficult because they were unusual; and the natural pride of the artist, responding to the challenge, was found equal to the new demands. The old phrase "I can't do impossibilities," or "I can't play notes that are not on the instrument " gave way to "If the instrument can play it, I can play it."

The first result of this was a great increase in the efficiency of orchestral players, who began to find that their work was not a mere dull, slovenly, and rhythmic scraping and blowing, but a new and intricate art in which their artistic pride was challenged, a task arduous indeed and involving hitherto unheard-of labour and study, but rewarded, as all true artistic labour is, by the new interest and intrinsic joy found in the doing of the work. Thus the conductors improved the orchestras; the orchestras reacted on the conductors; the public found new pleasure in listening to orchestral performances; composers found a limitless field of possibilities in orchestration, and the whole art of music, borne high on this great wave, was swept forward to a new stage in its development.

This aspect of the matter is enlarged upon here because, as has already been said, the last three years have seen the culmination of the period of musical interpretation. The technique of orchestral playing has become so perfect that it seems almost impossible to carry it farther. Instruments have been improved, and families of instruments completed, and a first class orchestra of to-day is really an association of virtuosi, each of them a master of his own instrument. It is the period of style. Even the student of to-day is a master of orchestral resources that would have astounded Berlioz, and has an astonishing facility in using and blending them.

In the other great branch of interpretative music, the pianoforte has been mechanically developed along with the manual technique of the pianist to a point which leaves little if any room for further development. Even mechanical players, the universal use of which is one of the features of the day which cannot be ignored, have been so wonderfully perfected that they have brought practically the whole range of pianoforte music within the grasp of the ordinary uninstructed person. This has had the immediate effect of removing many of the barriers within which the art of music was enclosed, and of making it less and less a cult for the initiated and more and more a possession of the world at large. The benefit of this is obvious; obvious also is the unfortunate defect which it shares with all short cuts and with attempts to provide by rough and ready means high pleasures which can only be attained in perfection by a path of long and consistent study.

We stand now as regards symphonic and orchestral music at the threshold of a new 
period. The interpretative technique having been developed beyond the needs of what may be called classical music, a new school is springing up, the art of which seeks to take full advantage of the new resources thus afforded.

So far as one can judge in what is necessarily a transition period the centre of creative musical life seems to be shifting westward. The long and glorious annals of modern German music came to an end with Wagner and Brahms. The promise of an important Russian school heralded by Tschailkovsky has so far not been fulfilled. The first signs of a new life in music appeared in France, principally in the works of Debussy, Ravel, and others of their school, but it appears to have died down again or dissipated itself into a morbid and precious trifling with the exquisite interpretation of things not worth interpreting. A little later a new and promising school of composition sprang up in England, more solid in its basis than that of France and at first not so exquisite in technical mastery; but it has during the last three years developed to a point which has left the French trifling far behind and promises to broaden into a creative art of first rate importance. Such names as Granville Bantock, Joseph Holbrooke, Cyril Scott, Hamilton Harty, William Wallace, Hinton, Ethel Smyth, Vaughan Williams, York Bowen, Delius, Dale, Gardiner, Grainger, and von Holst, represent the most modern group of this English school, while composers like Stanford, Parry, Cowen, Mackenzie, ColeridgeTaylor, Walford Davies, Somervell, Hamish MacCunn, Edward German, and Hurlstone represent a type of music not so ultra modern but still full of an increasing freedom, while yet retaining enough of the old classical forms to take a stronger hold of the conservative public than is possible with the newer music. The work of Elgar can hardly be separated from either group; in a sense it belongs to both. The high degree of excellence attained by English orchestras has had much to do with the development of symphonic music; and the services of the two most eminent English conductors, Sir Henry Wood and Mr. Landon Ronald, have greatly stimulated and helped it.

The new development of music, arising from its perfection of the means of interpretation, is as yet hardly definite enough in its direction for us to predict with any certainty the course likely to be taken in its stream, but enough has happened in the last year or so to make clear the general lines on which composers of the new school are proceeding. The most striking characteristic which is common to them all is a great freedom of form. The classical form of the sonata and symphony has been expanded and modified almost beyond recognition. The modern composer does not, when he sets about a work, confine himself within the limits of form which have hitherto been characteristic of the greatest music. He seeks to interpret mood rather than to achieve structure or outline; in the slang of the arts he is more concerned with "atmosphere " than with construction. And here also comes in another striking quality in the new music. There were, roughly, three elements in the old music: rhythm, melody and harmony. To these has now been added a fourth, which for want of a better English term one must call colour. Tone colour is arrived at by the use of the different sound qualities of the different instruments; and the perfection of modern instruments, and the high degree of virtuosity achieved by their players, have greatly extended the resources of the composer. In the old music instruments were used more with regard to their compass than to their tone colour. Melody was assigned to such instruments as violins, oboes, and clarinets, on account of the facility of executing rapid passages upon them, and of their considerable compass in the higher scales. To the less agile instruments such as horns, trombones, and the lower strings, were assigned the task of filling in the harmonies, while drums and even trumpets were used as instruments of percussion to accent the rhythm. The modern tendency of music is to change all this. Melody, once almost a monopoly amongst the instruments named, has been distributed amongst all the instruments of the orchestra, even kettle-drums. The dream of Berlioz that every family of instruments should form a complete orchestra in itself has now been realized, with the result that by using their distribution of tone qualities, either separately, or blended one with another, the modern composer has on his palette a series of gradations of tone which correspond with the colours on a painter's palette. And it is this new use of colour, this 
making of sound for the sake of its quality, quite apart from melody or harmony, that is one of the most striking developments in recent music. It enormously extends the range of music in the expression of emotion, and, in the establishment of what is called " atmosphere," it carries the art as a means of human expression to lengths which have never before been attained and which neither language, nor painting, nor any other means of expression can find corresponding terms to describe. Music is getting farther and farther away from the expressing of intellectual ideas, and is more and more dedicated to the expressing of pure emotion.

With the emancipation from form, and as a consequence of it, has come emancipation also from the old harmonic laws. The principles of thorough bass on which music was written until the end of the nineteenth century are gradually being abandoned, and the long reign of tonic and dominant harmony is coming to an end. And as the ear becomes educated to these new forms, one discovers that principles which seemed to be immutable, like the laws of nature, may be abandoned not only without distress to the musical sense, but with positive increase to its giatification. As an illustration take the following close in the key of $\mathrm{F}$ major.

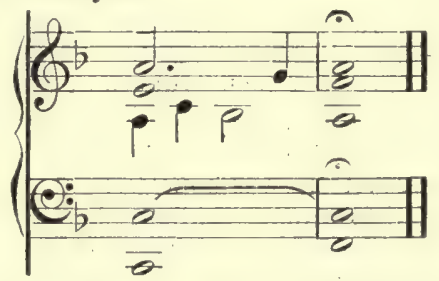

Up till quite recently no ear would have tolerated or found finality in anything but the tonic chord of F. But the modern composer would, if it suited him, without any hesitation write the passage thus, leaving the leading note unresolved:

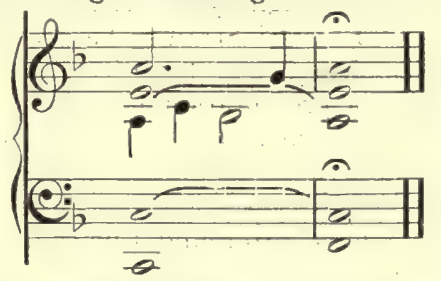

Anything more impossible under the old ideas than an unresolved leading note in the final chord could not be imagined; yet if the chord as it has been written here be held on an organ or any other tone-sustaining instrument and listened to attentively, it will be found that it comes to a quite natural close; that there is no essential unrest or desire for completion; and that as a final chord it has only a darker, more complex, more mysterious quality than a plain common sense chord of F major. The truth is, that the modern ear treats all notes as harmonies or overtones of some fundamental which is possibly not physically heard; and that the increase in the harmonic range of modern music is simply due to the fact that our ears have become educated to imagine and reconcile a far wider series of these harmonics than were the ears of an earlier generation.

Although, as has been said, the most immediate promising school of new composition is the English, the work of this school is almost entirely confined to instrumental and symphonic music which no modern school or opera has developed. The works of the popular Italian ccmposers such as Mascagni, Leoncavallo, and Puccini make a great appeal to the public which frequent fashionable opera houses; but so far as real artistic progress is concerned they are almost negligible. Their appeal is spectacular and sensational rather than artistic. From every point of view they are a retrogression from the position attained by Wagner. The characteristics of the recent successes in this school are absurdity of plot, crude delineation of character, and careful subordination to the 
requirements of the prima donna and the star tenor, and sufficient opportunity for spectacular mounting to make them acceptable to the managers of metropolitan opera houses. If the few attempts made at modern English opera have been negligible, it is no doubt partly due to the difficulties against which English composers have still to contend in getting a hearing for elaborate works; and if the demand for English opera continues to meet with little or no response, it is because the public at large has not really as yet developed a serious taste for opera.

Many experiments have been made in running a season of opera in English at popular prices, but they are almost always financially unsuccessful, although they meet with enough encouragement from the public to foster the hope that in this respect also the musical sense of England will continue to develop. The most conspicuous experiment in this direction was made by Mr. Oscar Hammerstein, who, at the cost of $£ 200,000$ built and equipped the London Opera House, a handsome and luxurious building situated in Kingsway. Here he conducted three seasons of grand opera, but failing to secure the necessary support he abandoned the enterprise in the spring of 1912. His failure has been variously explained, but it was chiefly due to his attempt to combine two quite opposite interests, due to his imperfect knowledge of London social conditions. $\mathrm{He}$ tried on the one hand to rival Covent Garden and to attract part at least of the fashionable audience to whom the opera is a social function, and also to attract the musical public which has learnt to demand a high standard of performance and repertoire. The standard of performance in Mr. Hammerstein's house was excellent, but the judgment shown in the selection of the repertoire was hopelessly at fault. Money was poured out on the lavish mounting of old-fashioned and obsolete operas which had never been really alive, and are more than dead to-day. Mr. Hammerstein was artistically in this respect some half a century behind the time. The fashionable world failed to support him; as a result, his project was abandoned and his opera house converted into a Cinematograph theatre. The enterprise of Mr. Thomas Beecham met with far more artistic, but no greater financial success, although by his seasons of modern opera (and his productions included the works of Richard Strauss) he proved that there was a steady popular support for opera in English at popular prices.

A quite new development in the presentation of opera is worth mentioning, as it may indicate a certain movement of popular taste. It is the performance of short operas in full on the music-hall stage. Mascagni conducted his Cavalleria Rusticana nightly at the London Hippodrome for a long season, and other short works adequately performed with a full chorus and orchestra have also found a place in recent variety programmes. But none of these conditions are at all likely to help in the development for which all musicians are eagerly looking, a truly modern art of opera. The works of Strauss, of which much was expected, have not succeeded in filling this want. It is just possible that with the development of spectacular dancing and the great impulse given to the new conception of scenic decoration by Gordon Craig and Prof. Reinhardt, the new opera may emerge, as did the old, from the dance and the ballet.

(FILSON Young.)

\section{PAINTING ${ }^{1}$ SCULPTURE $^{2}$ AND ARCHITECTURE ${ }^{3}$}

Painting.-On November 8, rgro there was opened at the Grafton Galleries in London an exhibition which has exercised the most far-reaching influence upon every phase of artistic activity in England. The movement illustrated Postimpres - by that exhibition has been an active force in France, and indeed all
sionism. sionism. over Europe, for some years, although it had only sent a faint echo across the Channel, where it was given the somewhat vague and meaningless name of "PostImpressionism"-.in preference to "Synthesism" and other terms suggested for it. This Post-Impressionism is a revolt against the tyranny exercised by realistic representation over the art of the later nineteenth century, just as earlier in the century

1 See E. B. xx, 459 et seq. and allied articles enumerated in Index Volume p. 886.

${ }^{3}$ See E. B. xxiv, 488 et seq. and allied articles enumerated in Index Volume p. 887.

${ }^{2}$ See $E . B$. ii, 369 et seq. and allied articles enumerated in Index Volume p. 884. 
Realism had been a revolt against the tyranny of academic classicism. Post-Impressionism derives from Impressionism (see $E . B$. xiv, 343) and is at the same time the negation of Impressionist principles. It is an art of expression rather than of impression. It derives from Manet's mass-impressionism, which had already done much towards eliminating chiaroscuro and simplifying the planes in pictorial work. It also derives from Monet's colour-impressionism with its analysis of light into the constituent spectral colours and insistence on colour vibration as the principal factor in the painter's art.

In the hands of such neo-impressionists as Signac, Seurat and Cross, Monet's application of the discoveries of spectral analysis had become purely scientific and mechanical, their canvases being filled with a system of round dots or square touches of identical shape and regular intervals. The first Post-Impressionists shrank from the imitative objectivity of these Neo-Impressionists, and used colour and form as symbols for the expression of their personal emotions. One of the best definitions of Post-Impressionism is " a new recognition of the principle that objects cannot be depicted as they exist in reality, but only as they appeal to the spirit of the individual; that their emotional significance - the bond that links man to his surroundings - can be expressed only by a full confession of personal experience."

The three founders of the new movement - the dominant personalities whose achievement stands out from the bulk of eccentric, incompetent and often absurd productions of the lesser men who sailed under the same flag - were Paul Cézanne (1839-1906), Paul Gauguin (1848-1903), and Vincent Van Gogh (1833-1890).

Cézanne, born in 1839 at Aix in Provence, the son of a prosperous banker, was educated for the law, but felt strongly drawn towards art and was allowed to enter the cézanne. Académie Suisse in Paris in 1862 . Having failed to gain access to the École des Beaux-Arts he had for a time to work in his father's bank; but he eventually returned to Paris and art, the influences to which he submitted being those of Courbet, Manet and Pissarro. An allowance from his father enabled him to follow his passionate love of art without having to depend on the very remote chance of selling his pictures. He worked with real passion, struggling with all his might to arrive at " the coherent architectural effect of the masterpieces of primitive art," and caring little for what became of the pictures upon which he had spent his fiery energy. But it was only on rare occasions that he was able to express his ideals. He was insufficiently trained, and remained to the end heavy and clumsy in his manipulation of the brush. Cézanne took part in the Communist rising of $187 \mathrm{x}$. He died at Aix on September 22, I906. The character of Lantier in Zola's "L'Oeuvre" was partly drawn from Cézanne

Paul Gauguin was born in Paris in 1848 , the son of a Breton father and a Creole mother. It was only at the age of thirty, after having been a cabin-boy and a bank Gauguin. clerk, that under the influence of Pissarro, Degas and Cézanne he took to painting, his early work being closely akin to that of Pissarro. His whole temperament made it impossible for him to live and work in Paris. He went first to Brittany, then to Martinique (in 1887 ), whence he only returned to go with Vincent Van Gogh to the South of France, where the two collaborated until Van Gogh after a murderous attack on his friend was removed to a lunatic asylum. In r80r Gauguin finally broke away from Europe and civilisation and went to Tahiti, where he took a native wife and lived the primitive life of the natives, interrupted only by a few visits to his native France, until he died on May 9, I903.

In the primitive surroundings of the South Sea Islands he endeavoured, with a good deal of success, to regain something of the decorative grandeur and expressive simplicity of primitive art. That the barbarous splendour of his colour has great decorative value, and that there is a certain archaic monumentality in his design, cannot be denied. Yet it is equally certain that with him, too, the achievement fell frequently short of the intention. Although trained in the Impressionist School, Gauguin, in his later work, has nothing in common with its practice. His colouring 
is conventional and arbitrary, his outline heavy and emphatic, his treatment of the human form synthetically simplified.

Vincent Van Gogh, who is in many ways the most interesting figure of this group, was born at Groot Zundert, in Holland, in 1853 , the son of a Lutheran clergyman. Van Gogh. He began life as a salesman at Goupil \& Co.'s, the well known art dealers, then went to England as a teacher, and returned to Holland in 1877 to study theology. Impatient of the narrowness of the school teaching, and impelled by real religious ardour, he took up missionary work among the rough miners at Boringe in Belgium. It was in this milieu that he began to practice drawing, and on his return to his parents in I88I he was sent to his brother-in-law Anton Mauve to receive instruction in painting. His passionate impulsiveness and restlessness made him again impatient to work independently, but four years later, recognising the disadvantages of insufficient training, he submitted himself - for a few months only - to the discipline of the Antwerp Academy.

In 1886 he went to Paris, where he entered the circle of the Impressionists and became friendly with Gauguin. In the next year Van Gogh went to Provence, and induced Gauguin to join him at Arles for the purpose of collaboration. The two artists, united only by their revolutionary tendencies, were wholly at variance in their disposition. Frequent quarrels between them reached their climax when Van Gogh attacked Gauguin with a razor and subsequently in a fit of remorse mutilated himself and was taken to a lunatic asylum. He had many lucid intervals and continued to paint with unabated enthusiasm. In I889 he was taken charge of by Dr. Gachet, at Anvers-sur-Oise, in whose garden he shot himself on July 28, I890.

Van Gogh's undisciplined, erratic, tragic life is reflected in his art. Of his absolute sincerity, of the intensity of his emotions, there can be no doubt. That his frenzied brushwork, his furious hatchet strokes of paint, his concentration upon the essential significance conveyed to him by each subject, served their purpose is equally certain. But not only are his paintings marred by an absolute contempt of surface quality and of what is commonly called beauty, but both his conception and his execution frequently, and especially in his later work, suggest an unhinged mind. His insanity in itself is no excuse for condemning his best work, which has qualities that entitle Van Gogh to a position among the great artists of the nineteenth century.

In the art of Cézanne, Gauguin and Van Gogh, who have already been called the "old masters" of the new movement, is to be found the germ of all the later developments. It is extremely difficult to draw a line of division between The later
Post-Impres. those recent attempts that are based on the confusion of art with science, Post-Impres-
sionists. which are either the expression of insanity or at least abnormality, or those which owe their origin to mere fumisteric and sensationalism. What they all have in common is contempt of mere representation of natural facts. At the second PostImpressionist exhibition, held in London at the Grafton Galleries in 191 2, Henri Matisse and P. Picasso represented the extremes to which art may be led by the application of these new principles. Matisse, an artist of immense ability, endowed with a rare sense of rhythm in line and colour, can scarcely be taken seriously in his grotesque contortions and simplifications. He tried to look upon nature with the unsophisticated eyes of a child, and his paintings, whilst betraying the experienced hand that simulates incapacity, too often succeed in suggesting the achievement of the nursery.

I'icasso, the head of the so-called "Cubist" school, has in his latest phase cut entircly adrift from anything that approaches recognisable representation. His cublsm. recent pictures are merely indescribably tangled geometrical diagrams. Cubism is supposed to be based on searching for the volume of objects and to "render unspeakable cosmic sympathies perceptible"; but it is really the outcome of an absolute misconception of the function of art. Even if it be taken for granted that the advanced Post-Impressionists are sincere and actually feel the amotions they try to express, this alone does not constitute art. The purpose of a work 
of art is not only to express, but to communicate emotion, and the mathematical science of cubism cannot possibly communicate any emotion.

The Italian Futurist movement, at the head of which are the painters Boccioni and Severini, is an outcome of Post-Impressionism and Cubism, although the Futurists themselves profess to regard even Cubism as antiquated and academic. The Futur- An exhibition held by the Futurists in London in the Spring of 1912 achieved
ists.

a succès de scandale and evoked an outburst of derision and indignation, the public refusing to take these artists seriously. Like Cubism, Futurism fails because it is too scientific, and in addition too literary, to have any close connection with pictorial art, the appeal of which must depend upon visual evidence.

Post-Impressionism, leaving aside its more extravagant recent offshoots, is really an attempt to approach the art ideal of the Far East, with its contempt for literal representation, its insistence on rhythm and on the spiritual significance that underlie the outward appearance of nature. But the refinements of a calligraphic style of expression are essential for the attainment of this end; and Post-Impressionism was bound to fail, because it had adopted the coarse technical language of Impressionism. It is for this reason that the real importance of Post-Impressionism lies not in its actual achievement but in its stimulating effect upon all recent art. In England, where the Grafton Gallery exhibition followed close upon an exhibition of Early Chinese painting at the British Museum in Igro, this effect was far-reaching and wholesome. Evidences of new vitality, of a more lively emphasis of structure, design and colour, immediately appeared at all exhibitions, and even at that stronghold of tradition, the Royal Academy. Artists like Augustus John, a masterly draughtsman and a painter gifted with a rare sense of decorative and expressive design, and Prof. C. J. Holmes, remarkable for the structural emphasis of his mountain landscapes, had already independently moved in the same direction as the French Post-Impressionists, without falling into their glaring faults. But in the last few years Post-Impressionism has taken firm root among British artists, the most notable group being the painters and illustrators connected with the magazine Rhythm (Peploe, Fergusson, Anne Estelle Rice, etc.), and the so-called "Camden Town group," to whom, under the guidance of Mr. Roger Fry, is due the decoration of the London Borough Polytechnic.

Whilst modern art has been feverishly searching for new channels of expression, the attention of the wealthy picture-buyers has been more than ever centred in the old Masters. masterpieces of the great dead. During I9I I and ror 2 scarcely a month was allowed to pass without bringing news of the further depletion of England's artistic heritage to swell the collections of American museums and financiers. The passing of Rembrandt's masterpiece " The Mill " from Lord Lansdowne's collection to that of Mr. Widener, in Philadelphia, was deplored in England as a national loss, for which the acquisition by the National Gallery of the Castle Howard Mabuse, "The Adoration of the Magi," was scarcely sufficient compensation. Still, Mabuse's famous picture is a work of eminent importance, since it marks in brilliant fashion the close of the great period of Flemish art which was so gloriously initiated by the brothers Van Eyck's "Adoration of the Lamb" at St. Bavon, in Ghent.

A feeling of consternation, akin only to that which was experienced by the whole civilised world on the occasion of the collapse of the Venice Campanile, was caused by the news, in August rgrx, that Leonardo da Vinci's portrait of Mona

The Mona Lisa theft. Lisa, known as "La Gioconda," had been stolen from the Salon Carré at the Louvre. The whole world shares the loss of this unique masterpiece, of the recovery of which there is but little hope.

On the occasion of the International Exhibition at Rome in I9r I, British art, both ancient and modern, scored a distinct triumph, the British section meeting with general approval and admiration. This section was arranged by the newly created

The Rome Exhibition. Exhibition Department of the Board of Trade. The building, the design
Exh for which is an adaptation of the façade of St. Paul's by Mr. Lutyens, is to be used as the permanent headquarters of the proposed British School in Rome. 
Extensive structural alterations have been effected during the years ror r and ror 2 at the National Gallery in London, the west wing being considerably extended and The Nation the east wing rebuilt. The additional space thus provided has made it Gallery.

possible to re-arrange the vast collection in a more satisfactory manner, and to find place for the numerous recent additions to the National collection without having to overcrowd the walls. The National Gallery now compares favourably with the best arranged public galleries of the world.

Sculpture.-The revulsion from academism, realism and impressionism has in the art of sculpture led to a movement that has much in common with Post-Impressionism in painting. This movement is far more widespread on the Continent of Post-Impres- Europe than in England. The dominating feature of its main current is
sionism. sionism. a return to archaic massiveness and simplicity, which is particularly noticeable in the recent monumental sculpture of Germany and Austria. In France little encouragement has been officially given to this archaistic art, which harps back upon ancient Egypt, Assyria and Cnossus, and which, with all its affectation of primitive rude strength, has not sufficient real vitality and sincerity to exercise a permanent influence, although its more eccentric manifestations naturally attract considerable attention at exhibitions. Maillol and Bourdelle are the most gifted sculptors of this synthetic archaistic group. The grotesque plastic contortions and malformations of Henri Matisse are so obviously produced with the intention to startle and shock, that they do not deserve serious consideration.

Strangely enough it was left to one of the very few English Post-Impressionists for Jacob Epstein, though Russian by birth, lives and works in England and is generally counted as an English artist - to shock French officialdom to such an extent by his Oscar Wilde tomb for the Père Lachaise cemetery, that steps were actually taken to prevent the unveiling of the monument, which, not without good reason, was considered unfit for exposure to public view.

Perhaps the most important event connected with the sculpture of I9II-IgI 2 was the completion of Stevens's Wellington Monument in St. Paul's Cathedral. After a miserable history of blundering extending over 45 years the screens were The Wellington removed from round the completed memorial on January 24, 1912. It Memorlal. will be remembered that Alfred Stevens ( $E . B$. xxv, 905) died leaving
the work completed with the exception of the bronze equestrian statue that surmounts the whole. Fortunately he had prepared a model for this, and Mr. John Tweed, who was commissioned to complete the work, has followed and developed the suggestions of the great sculptor. The result is, however, hardly as happy as could be wished. The Renaissance style of horse is in keeping with the rest of the monument; but the figure of the Duke is perched high upon the horse's withers, and the little stumpy legs are drawn up, making the figure of ill proportions and unpleasing gesture. The light moreover is too bad properly to illuminate the monument. It is significant of the heightened interest now taken in sculpture, that attempts are being made to discover and preserve the scattered works of Stevens. During November and December I II and January IO I 2 an exhibition of his paintings and drawings was held at the Tate Gallery; and on November I5, I9 I I Sir William Richmond, on behalf of the Stevens Memorial Committee, presented to the trustees a bust of Stevens by Professor Edouard Lantéri. A cast of Stevens's magnificent chimney piece at Dorchester House has also been placed in the 'Tate Gallery. The interest in Stevens has been largely promoted by the labours of the Memorial Committee, and more especially by the inspiration of the late Alphonse Legros.

The revolutionary influence of Auguste Rodin has become more marked during the last three years, and the publication of several books dealing with the work of Rodin's this sculptor has stimulated the desire to break away from traditional influence. orthodoxy. This movement has been felt both in Europe and America, and though due in part to the influence of the great French sculptor, it must be regarded as the outcome of the general state of unrest and upheaval which 
has marked the early years of this century. With the loosening of authority and discipline has grown the desire for individual expression; and, except in a few instances of men of strong character and genuine ability, the movement has fostered a disregard of technique and often of those fundamental principles which cannot be dissociated from the making of good sculpture. Roughly the position of sculpture may be regarded as of three factions: the steady and often uninspired though financially successful academic; the revolutionary and frequently chaotic, making appeal to journalistic exploitation; and those few artists of intelligence who have in their strong individualism been misunderstood by the lesser intelligences.

In a letter to the Times April 5, r910, Professor Waldstein replied to those few utilitarians who would devote subscribed funds to the building of refuges and to the assistance of hospitals in preference to the embellishment of cities with Memorial sculptural monuments. This letter would appear to typify the general
art. feeling for public statuary and the appreciation, both public and private, of good modern sculpture. In England the last two years have seen great advance in general demand. As a case in point it is worth noting that no fewer than four memorials were proposed in connection with the loss of the "Titanic," and subscription lists opened within three months after the disaster.

Foremost amongst recent European monuments are the important memorial to Victor Emanuel in Rome (inaugurated in I9II), that of Queen Victoria by Sir Thomas Brock in front of Buckingham Palace, and the Quadriga by Captain Adrian Jones placed in I9r 2 on Burton's arch on Constitution Hill, London. While these three works must be identified with the academic school, the Memorial at Buckingham Palace reveals the influence of that unhealthy searching for swirling lines that made its appearance in the schools a decade ago. These works are in no way calculated to have influence upon modern sculpture.

The original design by Bertram Mackennal for the King Edward Memorial, which was adopted March Igri (but subsequently abandoned), and the model for which was exhibited in the Royal Academy I9I2, revealed little that is personal in conception, and though Mr. Mackennal is one of the least academic amongst eminent British sculptors, his work must find its place between that which bears the influence of Alfred Stevens and that which bears the impress of the so-called " art nouveau." More than a touch of this " art nouveau " feeling is to be found in Sir George Frampton's recently erected " Peter Pan" monument in Kensington Gardens.

The sculpture at the National Gallery of British Art received a valuable addition through the presentation by Mr. and Mrs. E, Sadler of Havard Thomas' statue " LyciGallery das," whilst the same artist's " Thyrsis," which was the most remarkable art. statue of the Royal Academy of I9I2, was acquired by the Felton Bequest Committee for the National Gallery of Melbourne, Australia, a rare instance of sound judgment on the part of a collective body. Havard Thomas belongs neither to the Academic school nor to any strictly modern movement. His art is based on a sound understanding of the best Greek tradition and distinguished by the greatest perfection of tooling.

Great bodies are ever slow of movement. This borne in mind, no surprise can be evoked by the predilection shown for the academic work by those elected to represent the public taste. Academism will never die. It may be modified and altogether changed, but it will always represent the art of the preceding generation. Having the public to serve, and the public having learnt to admire the work of their previous generation, the representative of public taste finds no security except in buying that which has been improved upon. The outcome of this public buying - purchasing by committee - is the prolongation as far as possible of the life of a decrepit art, and consequently almost every public monument represents the art of the age preceding that of its erection.

France, the traditional pioneer of all things new and revolutionary, countenanced Auguste Rodin, and Rodin being a Frenchman, the British official mind has accepted 
him. Setting aside the political nature of such invitations as might be inspired by the Foreign Oflice, a debt is due in the case of Rodin to those whose initiative, through the National Art Collections Fund, has secured for London a bronze cast of "The Burghers of Calais," which is to be erected in Westminster. Rodin has in addition been commissioned to execute a memorial to Whistler for Chelsea.

Nowhere has Rodin won greater admiration than in America. In the last two years the change has been remarkable. G. Borglum, the greatest sculptor perhaps that America has produced (though Saint-Gaudens would usually be ranked American above him), and himself a disciple of the French master, has been to a
sculpture. great extent the leading spirit of revolt. But unlike England, where only that is accepted which has borne the test of time, America has no apron strings of tradition to hold to, and with youthful enthusiasm the work of Rodin has been bought for most of the important galleries throughout the United States.

The influence is immediate, but not altogether received with understanding. The exhibitions at the Pennsylvania Academy at Philadelphia have included some fine small works and many that are unintelligible. The New York Academy, which must rank second to Philadelphia, is no better. Here have been shown works in marble and bronze that ape the general appearance of Rodin's work, but show much ignorance of the art of sculpture and a lack of ordinary culture. The tightness and hard appearance of much American work must be ascribed to the employment of plasticine, a modelling paste of an oily nature, that does not require the constant damping necessary to clay, but which has none of the freedom and looseness which clay affords.

Architecture.-In present-day English architecture it is exceedingly difficult to differentiate between the efforts which have been purely individual and spontaneous in their inception and those which have been inspired and brought about by something of a general movement, however sluggish or ephemeral. This is due to the lack of any cult or fashion such as the genuine or emotional and hysterical secessions and movements in the related arts. There has been, and in some of the Continental European cities there is still, a movement akin to Post-Impressionism; but in England it has never taken root and is already practically dead. As in painting and sculpture, it took the shape of a return to severe archaic simplicity. The British Medical Association building in the Strand is the most typical of the few examples in London.

Perhaps the most encouraging feature of recent development has been the shedding of much of the affectation of the archaic and a return to the classical examples of the ornamental, if not always of the structural, in the art of building. In

Continental Europe. discarding the academic and searching vainly for a synthetic basis of design, have returned to the classical forms of their forbears with perhaps a fuller understanding of their application. Berlin and Munich, with their heavier handling of the same themes, have developed a romantic manner of expression which is distantly, yet quite evident$1 y$, related to the great period of the South German principalities, such as Würzburg, Carlsruhe, etc. The influence set in motion by such achievements as the Kursaal and environment at Wiesbaden, the Law Courts at Munich, and Reichstag and other buildings in Berlin, and the Opera House in Stuttgart, has overborne the secessionist protest whilst taking some suggestions from the life which was undoubtedly inherent in so much, and to this extent at least it is now clear that it is indebted. The evolution and development of modern comfort and convenience, and the added intricacy involved, have brought the modern architect in his search for suggestion to a livelier appreciation and a more catholic view of much of the later Renaissance.

The plastic treatment of classical forms, at one time decried like other art expressions of the period, is now being absorbed by the European architect to the full in his distraction at having to treat a complexity of inward utilitarianism with façades of any grace. "Baroque" has ceased to be a byword for all that is licentious and ungoverned in fancy, and the best examples are fast being recognised as peculiarly fit and purpose- 
ful, as one might have expected from those materialists who devised them. The Jesuit Churches of Venice and Vienna, the pleasure houses of the Romans and the palaces of Louis XIV. and Charles II., have an austerity and reticence until recently unsuspected, and it is modern complexity of life that has called for a style so adaptable. It may be in addition that the lighter spirit now pervading the Protestant countries has evoked a free and more demonstrative manner of expression, and the literary motive so much in evidence in modern music, and the didactic element in the plastic arts have their equivalent in a freer expression in architecture, with its details of sculpture and decoration.

In English and American architecture the " grand manner" quoted by Reynolds was a motive which was bound to recur. The recent researches made in the early eighteenth century and the period just before are in the art of architecture England. likely to have full effect. The works by Professor Reginald Blomfield (who succeeded Leonard Stokes as President of the Royal Institute of British Architects) and W. H. Ward in this field have been rotable influences. The great draughtsmen, such as Marot and Le Pautre, are now as familiar to us as Piranesi. Their fantasies, though so seldom materialised, yet proved a mine of wealth for those in search of new motives. The wealth of invention which never degenerated into the bizarre has placed the French School of the Baroque first as an influence in this revival. Already in America, where architects have for so long been obsessed with the sophistry of the Ecole des Beaux-Arts, one can see the influence of this earlier and more elastic manner, founded perhaps on a desire for the expression of a more racial character, as much as to escape from what was rapidly becoming a formula.

The lack of scholarly training characteristic of the last generation in English architecture is still the deterring factor in the progress which has here been outlined, but the evidence of a definite trend is apparent even in the unaccomplished efforts of recent years. It is true that public works of the importance of the new approach to Buckingham Palace, the New London County Hall now in progress, the very large commercial buildings in London such as Whiteley's new premises and the West-End establishments rebuilt, all show a wavering spirit and a tentative handling of the themes drawn upon from the sources described. Yet there is underlying them a distinct flavour of the early eighteenth century or late seventeenth century spirit, and an attempt to embody the strength of handling characteristic of the masters of these periods.

London buildings such as the new Hall built by the Wesleyan body at Westminster, the new Automobile Club, the Christian Scientists' Church in Curzon Street, and certain business premises in the West-End of a smaller scale than the large emporiums, show a far less hesitant manner, a complete knowledge of the style and possibilities, combined with discriminating use of modern sculpture.

But enough has been said to show the direction in which the architectural art not only of England but of Europe generally is now moving. France, with her academic leaning strengthened by a revulsion from the lapses of the past ten years,

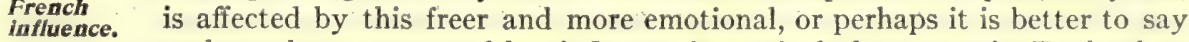
sculptural, manner; and her influence is particularly strong in England at present owing to such schools as the one at Liverpool University, the training of which is so largely based on the Beaux-Arts School; whilst the work of certain French architects in London, and especially the interior work of French decorators, is leaving a definite influence which is not to be escaped. We have had the Greek phase, then the Gothic cult, and later the Early Renaissance; but in the present period it seems to be natural to revert to the phase of the Renaissance nearest to us. The afterglow is now more powerful in its appeal than the once brilliant sun of the meridian of its power. Its slanting rays reach out to us, and by their nearness apparently have more power to revivify than the more intense but more distant flame at its zenith.

Considerable public.interest was aroused towards the end of 1912 in the designs prepared by Sir Aston Webb, and adopted by the Office of Works, for the refacing of 
Buckingham Palace. It had long been generally recognised that the old, dingy and rather featureless façade was unworthy of the residence of the British monarch. At the same time, when Sir Aston Webb was asked to prepare his designs, the Buckingham restrictions and conditions were such that the result was bound to be an
Palace. unsatisfactory compromise. The design for the new façade, with its raised cornice and balustrade and its rows of pilasters introduced between the windows, is certainly richer and more ornate, but is lacking in clear articulation and in that breadth which, despite all shortcomings, distinguished the original building.

The violent manifestoes issued by the leaders of the Italian Futurist movement, who advocate the wholesale destruction of old buildings, museums and monuments, should not be taken in too literal a sense. They are meant to express The nothing more than a patriotic desire that Italy should take her place among Campanlle
in Venice. the bounty of foreign tourists. That the growing consciousness of power and the spread of a new imperialism are accompanied by respect of the great achievements of Italy in the past is proved by the adherence to the best tradition of the $R e_{-}$ naissance in the many fine buildings that have been erected all over Italy in recent years, and in such works as the restoration, or rather rebuilding, of the Campanile in Venice. The decision to undertake the formidable task of rebuilding this tower brick by brick, exactly as it was before the fall, was taken immediately after the catastrophe of July I 2, I902; and the new Campanile, in every way an exact replica of the original building, but on stronger foundations and provided with a passenger lift, was inaugurated on April 25, I9I2. Over I,200,000 twelve-inch bricks, 24,000 cwt. of cement, 58,000 cubic feet of Istrian stone and I,000 cwt. of iron were used for the gigantic structure, the total cost, including the laborious reconstruction of Sansovini's Loggetta with all its sculptural adornments, being not more than $£ 88,000$.

(P. G. Konodx.)

\section{American Painting and Sculpture}

In the conditions promoting the development of these arts in the United States it has become peculiarly necessary to recognise certain civic influences. Large plans for the beautification of great centres like Washington, Chicago and San Francisco, plans embracing new streets and park systems as well as monuments of architecture and sculpture, have reacted upon the ambitions of smaller communities, and out of a national movement for the improvement of taste there have come richer opportunities for artists. This movement has also stimulated the activities of the museums, which have increased in number and are steadily exercising more and more useful functions. 'The most important of the museums built between 19ro and 1913 is the one at Toledo, Ohio, which was dedicated with a remarkable loan exhibition in January I9 12 . In addition to the educational work done through their permanent collections of old and modern works of art the museums are more than ever leavening public taste and encouraging native talent by the organisation of special exhibitions. Thus the annual shows at the Carnegie Institute in Pittsburg, the Pennsylvania Academy in Philadelphia, and the Art Institute in Chicago, and the biennial exhibition at the Corcoran Gallery in Washingt on, have had a profound effect upon painters and sculptors and upon the interest of the people in artistic matters. It is now customary, too, for some exhibitions to be carried about the country, the season from the autumn to the spring being divided up amongst half a dozen of the larger and smaller museums. The result is to widen the artist's audience, multiply the prizes for which he may compete and extend his market.

The Metropolitan Museum of Art in New York, the principal institution of its kind in the Cinited States, has successfully assumed as one of its special tasks the arrangement of those commemorative exhibitions which consecrate in some sort the genius of the country's leading artists. Following its memorial exhibitions of works by Whistler and Saint-Gaudens, it has more recently paid similar tribute to the late 
Winslow Homer and has made an important display of early American portrait painters. It has also shared in the development of the international projects which have latterly brought new currents into the artistic atmosphere. It was an exhibition of modern German art at the Metropolitan that led to the holding of a kind of return exhibition of American art in Berlin. The aim of the Hispanic Museum in New York, restricted in its gallery space, has been to present more especially the work of Europeans. It has shown the paintings of the two Spaniards, Joaquin Sorolla and Ignacio Zuloaga, and the sculptures of the Russian Troubetskoy. The Albright Art Gallery in Buffalo brought over in the winter of $19 \mathrm{I} I-\mathrm{I} 2 \mathrm{a}$ collection of modern French paintings which was later exhibited elsewhere in the country, and since then the AmericanScandinavian Foundation has made in New York and other cities an exhibition of I50 paintings from Sweden, Norway and Denmark. In the early summer of 1912 Mr. Charles L. Freer of Detroit, who has given his collection of Orientalia and of works by Whistler to the Federal government, showed $\mathbf{1} 75$ of his treasures in the National Museum at Washington.

The exhibitions of the National Academy of Design in New York and those which appear with similar regularity in other large cities have testified to an excellent average in American art rather than to the rise of new and original figures. It is in landscape that the school is perhaps most advanced, continuing profitably to study the problems of light which the French Impressionists long ago brought forward, but remaining faithful also to the Barbizon tradition and to that established by the native pioneers and masters, George Inness, Alexander H. Wyant and Homer Martin. On the basis of these varied inspirations the landscape painters express a warmly individualised feel.ing for nature. Looking at the mass of recent work the inevitable conclusion is that the artists who interpret the sentiment of the American countryside form the contingent that is most sensitive, most skilful, and most legitimately popular. The figure painters producing easel pictures are chiefly contented with the morceau, painting from the single model, posed in the studio, works purely decorative in motive; but a few more venturesome artists have followed a realistic trend, seeking their subjects out of doors, in the country and in the streets of cities. Two names may be cited, both from amongst the younger men. George Bellows (b. I 882) has found good material among the ragamuffins of New York and has used it to good purpose. Charles W. Hawthorne (b. I 872), painting the fisher folk of Cape Cod and types of ordinary American life, has lifted himself well above the ruck both in his technique and in the fresh personal force of his work. The only really notable sensation provided by an American painter in the period under review was one due, however, to a veteran, John S. Sargent. The exhibition of his Italian water colours in New York in March, I9I 2, was a memorable demonstration of the possibilities of the medium in the hands of a brilliant master.

In mural decoration American figure painters have been zealous and effective, rising with authority to the chances offered them by the civic developments already noted. Kenyon Cox and Edwin $\mathrm{H}$. Blashfield are notable amongst those who have produced for public buildings handsome and workmanlike symbolical schemes, faithful to earlier European conventions. Admirable experiments have been made by Frederick D. Marsh (b. I872) and Everett Shinn (b. I873) in the free utilisation of subjects available in everyday life. The outstanding achievement in this direction is that of the late Edwin A. Abbey in the Capitol at Harrisburg, Pennsylvania, where he has illustrated the mining and oil industries of the region in an elaborate and impressive series of monumental compositions. It is at Harrisburg, too, against the façade of the same building, that George Grey Barnard, in some colossal groups, has put to his credit the most important of recent American designs in plastic art associated with architecture. Amongst public monuments the statue of William Cullen Bryant in New York, modelled by Herbert Adams, may also be mentioned. Adolph A. Weinman (b. I 870) struck a new and promising note when, in collaboration with the architects, McKim, Mead \& White, he produced a polychrome relief for the pediment of the Madison Square Presbyterian Church in New York. In view of the thorough 
success of this pediment it is to be expected that colour will ultimately play a larger part than at present in American sculptural decoration.

Women have been extending their scope in the field of American art. They preponderate, as hitherto, amongst the miniaturists, and they are making progress in other spheres. Good sculpture on a large scale has been produced by Janet Scudder, whose fountains have won high appreciation, and by Mary Evelyn B. Longman, whose bronze doors for the Naval Academy at Annapolis marked her as an artist of distinction. The impression left by these docrs has since been confirmed by others, also in bronze and on an heroic scale, which she designed and modelled for Wellesley College. There has been a revival of interest in the United States in small sculptures, portrait busts and reliefs of children, studies of animals, paper weights, bowls, and the like, and in the group of artists occupied with these things Abastenia Eberle is conspicuous. She has disclosed an uncommonly attractive talent in picturesque figurines of familiar types. The juniors who have of late won attention in painting are Ellen Emmet (Mrs. Rand), and M. Jean McLane (Mrs. Johansen). Both have proved themselves very adroit and decorative in the making of portraits.

Through death American art has latterly suffered some of the heaviest losses in its history. The list includes John LaFarge (d. r9ro), landscape and figure painter, mural decorator, master of the art of stained glass, traveller, lecturer and author; Winslow Homer (d. Igro), perhaps the raciest of all painters of American life and famous for his marines, done on the New England coast; J. Q. A. Ward (d. I Iro), who modelled the "Indian Hunter" and one of the noblest of the statues of George Washington, and produced many other important statues of great Americans; Edwin A. Abbey (d. I9II), long renowned as an illustrator in black-and-white and later richly fruitful in historical paintings and mural decorations; Frederick P. Vinton (d. I9II), a strong painter of portraits, and Frank D. Millet (lost in the "Titanic," 1912) who had been a war correspondent, painted subjects from old English life, and at the close of his career was active as a mural decorator, taking his themes from American history.

(Royal Cortissoz.)

\section{American Architecture}

The public and monumental architecture of the United States increasingly tends to become a mere reflection of the official architecture of France. This tendency has been produced by the increasing number of Americans who have made their professional studies at the Parisian School of Fine Arts. Returning home to practise, these graduates have, by their ability, zeal, and close and efficient organisation, practically extruded all competition, so far as public architecture is concerned. It would at present be hopeless for any architect, in a competition for an important public building, to submit a design in any other than the authorised version of the antique, or of the Italian Revival of the antique. The prevailing tendency has lately been powerfully reinforced in the arrangement of the most costly and important project of public architecture now in course of execution in the United States. This is the construction of three new buildings for the executive departments of the Federal government in Washingt on, at a total cost of some $\$ 10,000,000$. The "style" of these buildings may plausibly be held to be fixed by the style of the existing department buildings, designed between 1835 and 1840 , of which two, respectively of the Doric and the Ionic orders, were examples of the Greek Revival at that time prevalent, while the third, in which the Corinthian order was employed, was an example of the Italian Renaissance. At any rate, the condition was imposed upon the competitors that their designs should be "classic." The designs chosen for execution show no architectural features which may not be found in the official buildings of two generations earlier, although the later buildings are much superior in magnitude and costliness.

Public and quasi-public buildings, elsewhere than in the capital, show the same subjection to French academic influences, whether in the compilation of the details of antique architecture or in the modern Parisian variations upon them. Of the former, 
the Pennsylvania railway station in New York is perhaps the most noteworthy of recent examples. This edifice is of great area, roughly $450 \times 750$, but of moderate height, except in the central transept, containing the "concourse" and the main waitingroom. The exterior walls are impressive by their great length and breadth, effectively emphasized by the simplicity of the treatment, which consists in a repetition of similar members. In the shorter but architecturally more important front, there are columns of the Tuscan order, forming a colonnade, continuous but for the central and terminal pavillions. Of the features of the interior the main waiting-room is a reproduction, on a considerably enlarged scale, of the Thermae of the Baths of Caracalla in Rome, while the structure of the concourse is an undisguised example of modern engineering in iron and glass. The second in importance of recent public buildings in New York is the Public Library. This shares with the Pennsylvania station the unusual advantage of a main frontage of over 400 feet, in each case obtained by closing a street, whereas the street system of New York limits the normal frontage of a building to 200 feet. As in the other case, the unusual length is effectively emphasized, and by similar means. The design of the library is derived from a "project" which obtained the grand prize of the Beaux Arts in 1893. Necessarily, it does not proceed from the actual requirements of the building, which are accommodated as best they may be to a preconceived envelope, insomuch that one of the principal interior divisions is cut by a cornice midway of its height and has no expression at all on the outside. A like inexpressiveness characterizes all the recent public architecture. The architectural feature of the new Court House in Chicago is a colonnade including five of its ten storeys, though these storeys are nowise superior in importance or different in function to the storeys not included. In the recent Education Building of the state of New York at Albany, a colossal colonnade, of which the columns, 65 feet in height, are metallic skeletons surrounded by marble shells, all the storeys are included in the "order," which thus constitutes the entire structure, with the exception of a tall blind attic. Yet interiorly the structure is an "office building," an aggregation of separate and equal cells. This mode of design, abandoning specific expression in favour of the artificial unity of a grandiose architectural mask, allows no scope for individuality, and abandons all hope of a characteristic or national expression in architecture.

In commercial building a national type has perforce been evolved out of the "skeleton construction," developed under the absence in the United States of any restriction of law or custom upon the individual owner of the height to which he may carry his building. In these many-storeyed buildings it is manifestly impossible to apply the formulas or canons of the modern academic interpretation of classic architecture. In one "skyscraper," (the new building of the Western Union Telegraph Co.) now under construction in New York, the architect has indeed undertaken to subdivide a wall of some thirty storeys by a superposition of two classic "orders." More commonly, the architect is content to emphasize, by separateness of material or treatment, the separateness of the beginning, middle and end, of his wall, more or less corresponding to the classic subdivision of base, shaft, and capital, and to garnish the more conspicuous parts of the resulting structure with classic detail. This practice, however, is not invariable. The latest of the very tall commercial buildings of New York (the Woolworth building), thus far the tallest of them, and, next to the Tour Eiffel, the tallest building in the world, rejects the classic subdivision into base, shaft and capital, or at least the classic proportion between these three members, and chooses what may be called, at least in comparison, a Gothic treatment. The metallic skeleton is distinctly felt through the necessary protective envelope, in this case of terra cotta, and the envelope is attenuated to the utmost, in disregard of the accepted classical proportions. The success of the attempt, as of previous attempts at expressional treatment on a less conspicuous and imposing scale, gives some ground for hope that the American "skyscraper" may become a typical work of art, as well as a typical embodiment of the modern commercial spirit.

Meanwhile, the successes of American architects have been mainly in dwellings, 
and in dwellings of moderate size and cost rather than in "palatial " erections. This success has been obstructed, in recent years, by the imposition of a fashion of stuccocoating the surfaces of dwelling houses so as to conceal their construction. This equable coating, concealing the articulation of the structure which may be underneath it, is in fact the expression of the construction of concrete, or reinforced concrete, which is one of the modes facilitated by the combination of the increasing demand for fire-proof buildings, and the increasing narrowing of the margin of cost between construction in timber and in fire-proof materials. It cannot be said that construction in concrete has thus far issued in much that is interesting or anything that can fairly be called typical or characteristic. But it has obstructed the development of such a typical construction in its chief rival in incombustible building-that in hollow tile. Hollow tile has for many years been currently in use as the most eligible material for the interior partitions of structures intended to be fire-proof. Of late years it has been extensively employed in the exterior walls, especially of dwellings. In neither case has it been expressively treated, except in a few cases of its internal use. The rule is that it is covered with an equable coat of plaster, so as to conceal material and construction. It is thus impossible to distinguish a house of hollow tile from one of concrete, or from one of which the material to which the coating is applied is a frame of timber or of "wire lath." Necessarily none of these dwellings has the interest of an expressive treatment, and none is of consequence in considering architectural development, though many examples show skill in composition, and all denote a reaction in favour of simplicity. Meanwhile, rural or suburban dwellings, constructed of the familiar building materials, continue to comprise the most interesting examples of architecture in America. Of no mode of domestic building can it be said that it rises to the importance of a "school," unless an exception be made of the country house constructed of rough stone. In this a high degree of success has been attained. Particularly is this the case in the suburbs of Philadelphia, where the architects have been impressed by the remaining stone farm houses and barns of the colonial period, and have refined the design of these to successful, attractive, and distinctive results. The Dutch colonial houses of Long Island and New Jersey have also furnished suggestions to the architects of dwellings, particularly in the neighbourhood of New York. The American derivative of British building of the Georgian period continues, however, to be distinctively known as "Colonial" and to furnish suggestions for the most prevalent mode of domestic architecture.

(Montgomery Schuyler.)

\section{The Arts and Crafts Movement in America}

In May Igr 2, there met in Philadelphia and in Washington two important associations-the National Federation of Arts, organised in 1910, which embraces in its programme both the so-called fine-arts and those included in the term handicraft, and the National League of IIandicraft Societies, wholly in the interests of these latter. The League, organised in 1907 , now represents about forty arts and crafts societies from all parts of the United States, some having a membership well into the hundreds. Its aim is to form a kind of clearing-house for the movement, and to take up statistical and educational work, not within the scope of any single society. It supports a travelling exhibition of articles of handicraft sent on request to places in which excellent work of this character is not easily seen, and a travelling library of technical and other appropriate books not easily obtained nor so well selected outside of the great cities. The existence of the League indicates a wide-spread interest and the establishment of many socicties, a few of which have been strong or enterprising enough to see the advantages of such a union and make the necessary effort to carry it on.

The arts and crafts movement has had two sources in America. It was early preached by Ruskin disciples, students returning from England, but with apparently little direct result at the time. The old Art Academy, however, at 23rd Street and Fourth Avenue, New York, was built under the influence of these teachings. A very practical incentive to craftsmanship was found in the remains of Colonial industries, 
- weaving, embroidery and other - not unfamiliar then in many households. 'The development of the movement was spontaneous and real, although fitful and unorganised; differing in this from that of England, where it was initiated by artists and had a comparatively swift flowering. Societies in England were largely exhibition societies of these artists and their followers; and the industries grew from classes among workingmen, or by the deliberate gathering of peasant groups, appreciative of the traditions of beauty and docile to leadership. Their results have done much to encourage leaders in America.

It is to the intelligent and energetic middle classes in America that the movement owes its growth. The artists were, as a rule, the last to be interested in a view of art in no wise exclusive; nor had American artists, as a class, such influence and position as in England. Those who carried on the work, therefore, were for the most part untrained. They at once began to group themselves into societies for mutual encouragement. The society of arts and crafts as here described is peculiar to America. Its form is elastic and suited to varied conditions, from informal meetings of a village group to complete city organisation with sales-rooms and committees.

The first arts and crafts society in America was that of Hull House, Chicago; but the Boston society was formed nearly at the same time, a few months later in the same year, 1897 . Societies multiplied rapidly and there is now scarcely a town or village but has its local group. Each began individually and spontaneously, and there was little or no relation, one with another. To bring these together and to record general progress, the League was organised, and ten years after the founding of the first society over twenty societies came together as charter members.

The first effort of an arts and crafts society is usually to establish a sales and exhibition room, and then to have classes. In several instances these latter have developed into a thriving school of craftsmanship. The management of a society is in all cases cooperative, and the work exhibited is individually contributed by members or consigners outside, and sold on a commission. Besides the regular arts and crafts societies there have grown up lately numberless little shops for the sale of handicraft. These, known as gift-shops, are usually in partnership with tea-rooms. They are already a familiar thing in cities, and the summer automobile travel is making them possible upon every country highway. Excellent craftsmanship is constantly in demand on all sides. A craftsman generally belongs to one or several regular societies, and contributes to exhibitions and shops when producing enough to enable him to do so. There is a natural tendency to form groups of workers, occupying adjoining studios; and this is found to be beneficial in every way. Rural groups of this kind, already occurring here and there, tend to multiply, affording a wider range of thought and inspiration.

The industrial village, so characteristic of the English development, is known in America, but with a difference. Deerfield, Massachusetts, will occur to everyone (see $E . B$ : vii, 924). But although these have had, at starting, their patrons who made the work possible, the individual worker has been generally independent, and this has always been the aim. Industries more nearly after the English pattern have been tried. The most notable, probably, is that of the Abnake rug. This was a hookedrug made by the women native to the place, Pequaket, New Hampshire, superintended by Mrs. Albee, who furnished the designs, the material, and marketed the rugs, paying for the work by the square foot. The rug was excellent in kind and quality and sold well, but the enterprise proved too burdensome and has been given up. A similar industry was carried on in Cranberry Island, Maine, and an extensive undertaking is that of Bourne, Mass. At the Sophie Newcomb College, New Orleans, an industry was attempted with the graduate students in pottery and needlework, with excellent results. The difficulties in these efforts, however, seem great, and the American development would seem rather to lie in the line of individual development and association. This is in close harmony with the ideals of the movement and those of democracy, and should result, eventually, in indigenous and vital forms of art-expression.

Semi-commercial industries have also done much to further the art-impulse in 
America. The earliest and best known of these is the Rookwood Pottery in Cincinnati (see E. B. vi, 373). The Grueby Pottery (South Boston) produced most excellent designs. The Dedham, Massachusetts, tableware enjoys a deserved reputation.

Besides the actual achievements of the arts and crafts movement, it has exerted an influence upon the thought of the time which it is difficult to estimate. Manufacturers, from direct copying, have come to reconstruct and improve their whole manufactured output. Simplicity has been the watchword in house furnishing, to its great improvement. Education, in introducing manual training in the schools, has apprehended the lessons inherent in relating head and hand, and in the new consideration of educational methods all these lessons will not be forgotten. (Mira Burr Edson.)

\section{ILLUSTRATIVE PROCESS-WORK ${ }^{1}$}

The development of the methods of manufacture of the process block has been very rapid. Some twenty years have turned a mere experimental effort into a vast business which has revolutionised the publication of illustrated works of all kinds. Progress at this rate of development was bound to slacken, and at the present moment, owing to causes we need not go into, stagnation has taken the place of development. It seems to be assumed that the process block, as we know it, has arrived at a state of perfection, and such improvements as have been introduced have mainly had for their object the cheapening of production by simplifying and speeding up the methods of working.

The introduction of panchromatic plates, sensitised to a greater range of spectrum colours, has done away with the old tedious system of indirect three-colour negatives, which required nine operations against three by the direct process. These plates have improved results as well as shortened the time of working.

Collodion emulsions have been specially sensitised and speeded up for direct three-colour work, but much has yet to be done in improving colour sensitiveness both in emulsions and dry plates. Especially in the matter of green tones, which are yet so imperfectly reproduced photographically, that in order to maintain a true balance, much handwork in the shape of fine etching is required.

The Acid Blast Machine for etching has come very much to the front; the introduction of the Levy machine, named after its American inventor, has shown that better results can be obtained in much shorter time than by the old rocking bath, and it is being largely adopted. For both blast etching and the ordinary rocking acid bath the old method of employing successive rollings up of the metal plate with fatty ink, to form a protective resist, has been superseded by powdering the first ink coating with "Dragons Blood" and heating the plate until the powdered gum melts into and with the ink, thus forming a homogeneous resist which reduces the time required for etching and produces sharper and deeper results.

The use of the Lumiere Autochrome plates for three-colour work is also a great advance. Many subjects, especially such as are liable to movement-growing flowers out of doors for example-were impossible so long as the necessity for making three separate negatives existed. The Lumiere plate gives a record of the whole scheme of colour, and the record is so good that it can be used as the original from which the necessary three negatives can be made.

Beyond these matters the most important developments have resulted from experiments upon printing papers, the aim of which has been to find a method for the printing of process blocks upon ordinary paper.

The great drawback to the use of the process block has been the necessity for printing it on a special paper with a prepared surface, a surface coated with a preparation of white clay. This surface, while giving the best result as regards the printing, has rendered the paper inconveniently heavy, liable to cracking and breaking, and is costly to produce. Continued efforts have been made to find a paper which should be free from these drawbacks. but the object seems to have been accomplished not by the invention of a new paper, but by the introduction of a new machine, and a new method of printing.

${ }^{1}$ See $E . B$. xxii, 408 et seq. 
The Rubber Offset Machine is being installed somewhat largely in printing establishments. It is an adaptation of lithography, and the principle of it is that, instead of printing from the lithographic stone or metal plate direct onto the paper, the inked print is impressed upon a sheet of rubber, stretched over an intermediary cylinder, and from thence is transferred, or "offsetted," on to the paper, which is carried round the impression cylinder by grippers in the ordinary way.

The offset method can be applied to flat bed machines for printing from stone, but usually the machine is rotary, and prints rapidly, as many as eight thousand impressions per hour being obtained when the machine is mechanically fed. The results are excellent, the finest lines and dots of the process block being reproduced on almost any quality of paper. It is somewhat of an irony that lithography should come to the help of its old enemy the half-tone block. A good deal, however, has still to be done in improving the quality of the inks used for the offsets, in securing rubber which shall be more sympathetic with the inks, and in other directions.

Transfers from process blocks are not so rich and full in colour as could be desired, and successful experiments have been made in the use of intaglio plates for this transfer process. An ordinary half-tone negative is made, from which a positive or transparency is prepared. This positive is etched on copper or zinc in the same way as for a photogravure. A print is pulled from this plate in lithographic ink, which is transferred to the zinc or aluminum plate for printing on the offset machine, and an impression taken therefrom is offsetted on to the rubber sheet, from which it is printed on any quality of paper, with admirable results, the colour from these offsets being rich and velvety similar to those produced by the Rembrandt photogravure work.

Up to the present three-colour work by the offset machine has not been so successful as black and white. The coloured inks are a greater difficulty, and the true register, so necessary for three-colour ink, is far from a certainty. When these difficulties are overcome there will be a vast field of operation open to this new development.

The Mertens Process. - A most interesting application of this use of intaglio gravure with letter press has been made in Germany by Dr. Mertens, who for newspaper work has coupled up his rotary intaglio printing machine with a rotary newspaper machine. The paper from the roll or web first takes the impression from the intaglio plate, passing on to the type machine which prints the letter press from the stereo plates. The two machines work of course at the same rate, and the result is a newspaper in which the illustrations have the rich qualities of photogravure work, produced (it is claimed) at a rate of twelve thousand an hour.

Coupled Up Machines are being applied to the printing of three, four or more coloured work. The machines to the required number of colours are coupled up to one driving shaft, and the sheets pass from one machine to another, all the colours being printed one after another in quick succession, instead of each colour being left some hours to dry before imposing another. The use of dryers in the specially prepared inks permits of a second, third or fourth printing following immediately on the first without producing the muddy effect resulting from the admixture of two colours both equally wet. The invention has greatly extended the possibility of the use of colour blocks for ordinary illustration by reducing the time necessary for the printing of large editions.

An interesting application of the Rembrandt intaglio process is in the direction of colour work. Attempts to print colours on the rotary intaglio machine have not been successful owing to the difficulty of obtaining accurate register on a rotary, but a compromise has been effected in what is known as the Widdop process by printing the colours lithographically from stones or plates over a gravure print. The results are rich, and blend very harmoniously with the soft monochrome of the gravure print. Reproductions of watercolour drawings by this method are particularly successful.

The success of the Rembrandt photogravure process has produced many rivals. Most of them work on the principle of the rotary machine, but an interesting development-not far advanced at the present moment, though full of promise-is that of flat bed machines for printing gravure plates. 
The Mezzograph Screen is another attempt to substitute something more interesting and less mechanical than the ordinary cross line screen. It is the invention of $\mathrm{Mr}$. Wheeler, and the feature of it is that although the grain is etched into the glass no pigment is used to fill up the spaces; the screen presents the appearance of finely frosted glass and the breaking up of the image is effected by diffraction caused by each minute grain in the chemically etched screen forming microscopic lenses. It is now used with good results for colour and also for general black and white reproduction.

Posters. - The application of half tone work to posters is of recent development. The production of half tone blocks for colour or black and white of the size required by poster work is a costly matter if they are made from large negatives, and this is only done by important firms. The common method is to enlarge up from small half tone negatives or transparencies, and it is found that in the large poster the coarseness of the grain resulting from the enlargement is not a drawback. When combined with colours applied by lithography or letter press the enlarged half tone key yields admirable results, which are cheap to produce and very effective. These colours are usually drawn on the stone or plate in chalk when they are to be printed by lithography, and the coarseness of the chalk work entirely disguises any rankness that might be apparent in the enlarged key block.

(EDWIN BALE.)

\section{SECTION IV. ARCHAEOLOGY AND EXCAVATION}

\section{BABYLONIA AND ASSYRIA ${ }^{1}$}

The three years I9IO-I9I2 have been prolific in discoveries bearing on the history and chronology of Babylonia and Assyria, particularly during the earlier periods. Three dynasties of kings, two in Northern Babylonia, and one in the south, have been recovered, not a single name of which had previously been known; a large gap has been filled in our knowledge of events in the north during the first great period of Semitic supremacy; following on this period, we now for the first time have information of an invasion, and a domination of the whole country, by a foreign Semitic power long settled on its eastern border; and linally a remarkable inscription, discovered and published in I0I2, records how this domination was brought to an end, and the way prepared for the later Sumerian supremacy which preceded the rise of Babylon to power. Such an accession of new material has naturally brought with it a series of fresh problems which still await a final solution. These will be briefly stated and a provisional scheme outlined by means of which the new data may be reconciled with the old. The discussion will best be followed by reference to the accompanying Reconstructed Chart of the Early Babylonian Dynasties. It should be noted that in the later periods the title " patesi," as opposed to that of "king," implied a condition of dependence, but in the earlier periods this distinction was not so marked.

\section{Reconstructed Chart of the Early Babylonian Dynasties.}

N. B. - The names of kings recovered in the years $1910-12$ are printed in italics, those previously known in ordinary type. $p .=$ patesi; $k$. =king; a comma after a ruler's name indicates that he was succeeded by his son. A dotted line (....) joins the names of kings who are proved to have been contemporaries; the position of names within parentheses is conjectural. The figures which follow the name of a king represent the number of years he ruled.

\begin{tabular}{|c|c|c|c|}
\hline \multirow{2}{*}{$\begin{array}{l}\text { Approxi- } \\
\text { mate } \\
\text { Ditle's, } \\
\text { B. ('. }\end{array}$} & Northern Babylonia. & \multicolumn{2}{|c|}{ Southern Babylonia. } \\
\hline & Kish, Opis, and Akkad. & Lagash. & Umma, Erech and Ur. \\
\hline & $\begin{array}{l}\text { Early Rulers of Kish } \\
\text { (Utug p.) } \\
\text { Mesilim k........ } \\
\text { (Urzage k.) } \\
\text { (Lugal-tarsi k.) }\end{array}$ & $\begin{array}{l}\text { Lugal-shag-engur p. } \\
\text { (Badu k.) } \\
\text { (Enkhegal k.) }\end{array}$ & \\
\hline
\end{tabular}

isee E. B. iii, 99 et seq. 


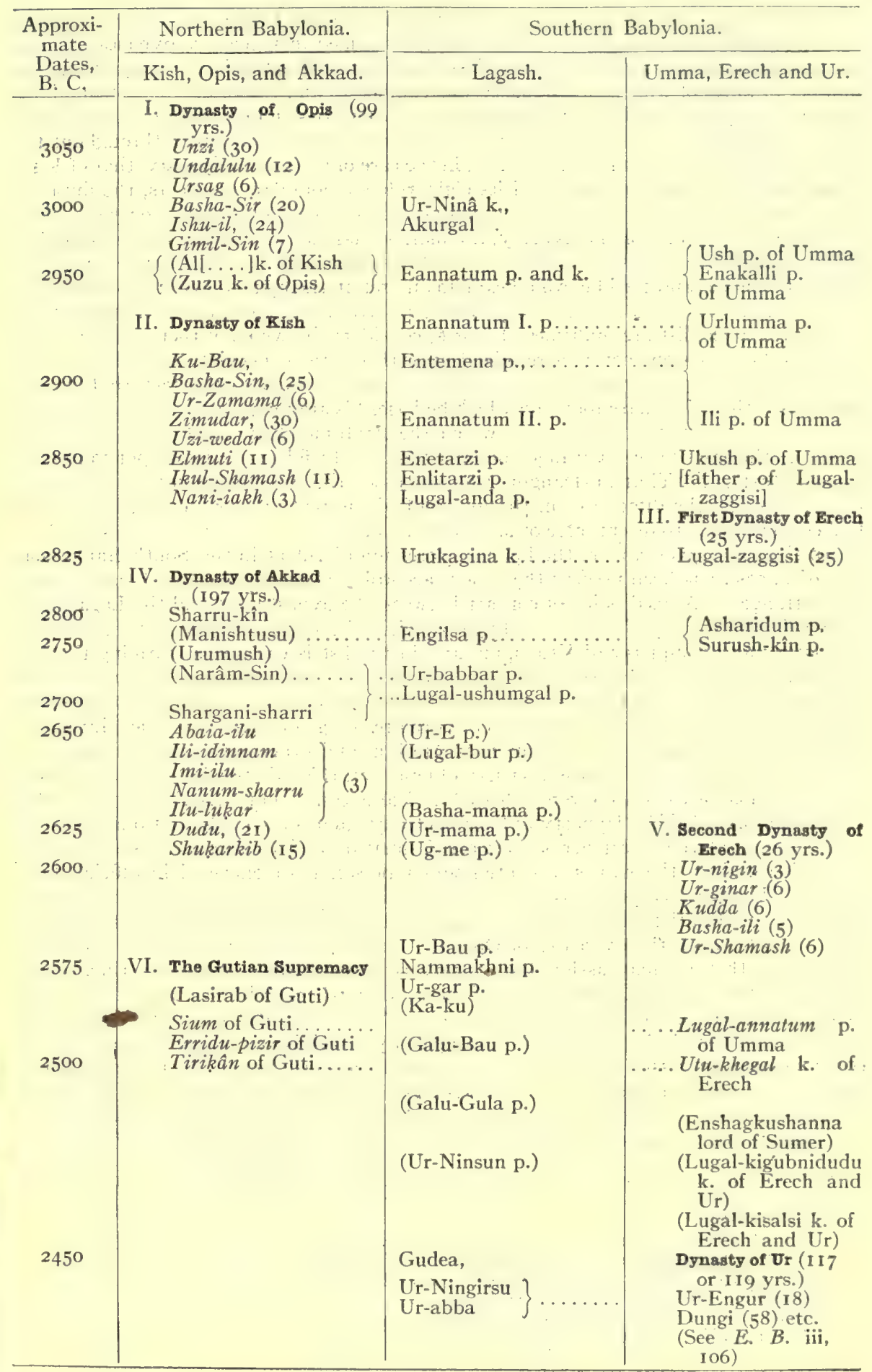


The principal source of our new information is an early Babylonian tablet inscribed in the Sumerian language with a list of kings arranged in successive dynasties. ${ }^{1}$ The text resembles other documents of its class in giving the length of each king's reign, the number of kings of which each dynasty was composed, and the total length of its duration; in two places, with regard to founders of dynasties, notes are added as to their former occupations before they secured the throne. The figures given throughout the text are consistent with the totals, except in the case of the second dynasty, that of Kish. Here, though the separate reigns of its eight rulers amount to 192 years, the duration of the dynasty is stated to have been 586 years; moreover, out of the 192 years of its existence, the founder of the dynasty, a female wine-seller named $\mathrm{Ku}-\mathrm{Bau}$, is stated to have occupied the throne for no less a period than too years. Scheil ${ }^{2}$ and Sayce, ${ }^{3}$ by theories of hiatus and the like, would explain and retain the figures; Peiser boldly emends them to what he considers the scribe meant to write. ${ }^{4}$ Kugler, noting that many of the figures in the list are multiples of 3 or 6 , considers the whole of them artificial; and he suggests the chronology is here mixed up with mystical speculations with regard to numbers in the manner of Berossus. ${ }^{5}$ But he has overlooked the fact that certain numbers with their square roots, on which he bases his argument, really occur on a fragment of quite a different tablet, with which the Arab merchant in Bagdad, the former owner of the inscription, had ingeniously attempted to fill in a missing portion of the original text. To Thureau-Dangin, who discusses the missing names of one of the later dynasties, the difficulties in the first half of the text appear inexplicable, and he makes no attempt to disentangle or assimilate its data ${ }^{6}$

In the chart given above, the known succession of rulers in the South Babylonian city of Lagash has been used as the canon, according to which the new dynasties have been arranged. A fixed point of contact between the dynastic list and the Lagash succession is afforded by the name of Lugal-zaggisi, who was already known as the contemporary and conqueror of Urukagina and in the list is counted as forming the first "Dynasty of Erech," between the dynasties of Kish and Akkad. It is remarkable that among the kings of Opis and Kish, in the first two dynasties of the list, none of the names are included which we know were borne by kings of these two cities during the earlier period of Lagash. It is true that Mesilim and other early kings of Kish are certainly to be placed before the Dynasty of Opis, but this is impossible with the ruler of Kish and Zuzu of Opis, who were defeated by Eannatum. For Peiser's suggestion that Eannatum preceded the Dynasty of Opis ${ }^{7}$ entirely ignores the evidence from Lagash as to the comparatively short period between Eannatum and Urukagina, based on direct succession and on the names of contemporary personages mentioned in official documents. ${ }^{8} \quad$ The hundred years assigned to the reign of $\mathrm{Ku}$-Bau in the list and the strange figure for the duration of her dynasty suggest the possibility that a period of confusion intervened between the dynasties of Opis and Kish; and to such a period it seems not improbable that we may assign Eannatum's contemporaries. From the time of UrNinā to that of Urukagina the activity of these two northern cities was not felt at Lagash except during Eannatum's reign, and none of the recently discovered northern kings succeeded in emulating Mesilim's example by establishing a dual empire. A comparatively successful attempt was made from the south under Lugal-zaggisi, but it was reserved for the Dynasty of Akkad to secure a real hegemony throughout Babylonia.

The important part played by Agade, or Akkad, at this period has long been recognised, and the list affords valuable information as to the kings who composed the

1 See Scheil, Comples rendus de l'Académie des Inscriptions et Belles-lettres, I911 (October), pp. $606 \mathrm{ff}$.

${ }^{2}$ Ibid., p. 612.

a Proc. of the Soc. of Bibl. Arch., xxxiv (1912), pp. $165 \mathrm{ff}$.

+ Orientalistische Literaturzeitung, 1912, No. 3 (March), Col. $108 \mathrm{ff}$.

5 Zeilschrift für Assyriologie, xxvii (1912), pp. $242 \mathrm{ff}$.

${ }^{6}$ Revue d'A ssyriologie ix (1912), No. II, p. 37.

'Orient. Lileraturzeit. (1912), Col. II3.

${ }^{8}$ Cf. King, Hist. of Sumer and Akkad, pp. 157 ff., $168 \mathrm{ff}$. 
dynasty of that name. It was formerly imagined that Sharru-kin, its founder, as well as Manishtusu and Urumush were kings of Kish, not Akkad, on the strength of their title which was read as "king of Kish" (shar Kish). In later periods this title was certainly a general one, "king of the World " (shar kishshati)," and Hrozný's sugges tion $^{2}$ that it always had this meaning is now proved to be correct. The list adds an interesting note that Sharru-kîn, or Sargon I. was at first a gardener by profession, and afterwards a cupbearer in the temple of Zamama, before he obtained the throne, thus confirming the Neo-Babylonian tradition of his humble origin. The suggested arrangement of the three missing names in the dynasty (Manish-tusu, Urumush and Narâm$\mathrm{Sin})^{3}$ makes it difficult to retain the further late tradition that Narâm-Sin was Sargon's son, but he may well have been a grandson or other near relative. Of the last seven kings of the Akkadian dynasty, as of the five kings who formed the succeeding "Dynasty of Erech," we know nothing beyond their names.

The invasion of Babylonia by the Semitic kingdom of Guti to the east of the Lower Zâb, which is now attested by the list, is an event of the first importance. The puzzling stele of victory found at Lagash, on which Semites are depicted slaying Semites, ${ }^{4}$ may well commemorate the event. Moreover, we have proof that the invasion was followed by a complete domination of Babylonia for some considerable time. The ceremonial mace-head of Lasirab, King of Guti, which was found at Sippar, is evidence in point, as also is the still unpublished text of Erridu-pizir, King of Guti, from Nippur. ${ }^{5}$ From a text recently found at Jôkha we also know that Lugal-annatum, patesi of Umma, owed allegiance to Sium, King of Guti. ${ }^{6}$ To this period we may also probably assign the bronze tablet, recently found at the celebrated Arab town of Samarra on the lower Tigris, ${ }^{7}$ containing a text of Ari-Sen, king of a district in the neighbourhood of Guti. The end of the Gutian domination came about through the valour of Utu-khegal, King of Erech, who, in a recently found inscription, ${ }^{8}$ records how he overcame "Guti, the dragon of the mountain," defeating and capturing Tirikân, its king, after having sought the assistance of the great Babylonian gods in their shrines upon his line of march. His success marks the first wave of a Sumerian reaction, and was followed up not long afterwards by the establishment of the powerful Dynasty of Ur.

Of discoveries bearing on the later historical periods, it will be necessary to speak quite briefly. The Semitic tablets discovered from time to time in Cappadocia have long been regarded as evidence of the spread of Babylonian culture northwards and westwards, of which we have such striking evidence during the second millennium in the El-Amarna and Boghaz-Keui documents. The date of the Cappadocian tablets may now be definitely fixed as early as 2300 B.C. by the discovery of one at Kara-Enyuk, to the north-east of Caesarea, bearing a seal-impression of Ibi-Sin, King of Ur. ${ }^{9}$ The circumstances which led to the founding at Larsa of the dynasty of Kudur-Mabug, whose sons gave so much trouble to Sin-muballidh, and Khammurabi of Babylon, have now been ascertaied; 10 and the names of two other petty rulers of the time of the First Babylonian Dynasty have been recovered." An attempt has also been made to settle the chronology of this period astronomically, ${ }^{12}$ but the texts on which it is based are late and corrupt copies and the result is consequently not conclusive. During the later Assyrian period by far the most important discovery is a long historical text of Sennacherib on

${ }^{1}$ Cf. King, Studies in Eastern History, i, p. 7 I.

${ }^{2}$ Wiener Zeitschrift f. $d$. Kunde des Morg., xxiii (1909), p. 196 f., n. I.

${ }^{3}$ Cf. Thureau-Dangin, Rev. d'Assyr., ix (1912), pp. 81 ff.

4 Sum. and $A k k$, pp. $247 \mathrm{ff}$.

${ }^{5}$ Hilprecht, Bab. Exped., Ser. D., v, i (I9Io), pp. $20 \mathrm{ff}$.

${ }^{6}$ Scheil, Comptes rendus, I9 I I (May), pp. 3 I 8 ff.

${ }^{7}$ Thureau-Dangin, Rev. d'Assyr., ix (1912), pp. I ff.

${ }^{8}$ Op. cit., ix, pp. I I I ff.

$O$ Op. cit., viii, pp. 142 ff.

${ }^{10} \mathrm{Op}$. cit., ix, pp. I2I ff.

11 Op. cit., viii, pp. 65 ff., and Ungnad, Orient. Literaturzeit., I 909 (Nov.), Col. 478 f.

12 Kugler, Sternkunde und Sterndienst in Babel, ii, Teil ii, Hft. I (I912), pp. 57 ff. 
a clay prism acquired by the British Museum. ${ }^{1}$ It is dated in the year 694 B.c. and includes records of two campaigns to the north-west in the years 698 and 695 B.C. The former was undertaken to suppress a revolt in the Taurus, and the new text confirms the traditions preserved by Alexander Polyhistor and Abydenus with regard to Sennacherib's conquests in Cilicia and his rebuilding of the city of Tarsus. It also gives new and valuable information on the topography of Nineveh, enumerating the names and positions of its fifteen gates; and it contains the earliest record of the cultivation of cotton, which Sennacherib succeeded in acclimatizing for a time at Nineveh, so that the Assyrians were able to use it for the weaving of garments. The plant was probably not the tree-cotton of India (Gossypium arboreum), mentioned by Herodotus, but the annual plant G. herbaceum, which, in Sir George Watt's opinion, originated in Arabia, whence it eventually spread northwards to the shores of the Black Sea and the Mediterranean.2

(LEONARD W. KING.)

\section{EGYPT $^{3}$}

In the past three years the study of ancient Egypt has been progressing in every branch, and in Nubia especially large extensions have been made. The results will be most easily referred to if stated in their historical order.

Prehistoric. - The most northern cemetery of the second prehistoric age (s.D. 50-70) was found at Gerzeh about forty miles south of Cairo, and excavated by Mr. Wainwright. It showed that the various products which are known some hundreds of miles to the south extended also to this region, and that the civilisation was general. The main result was finding iron beads alternately with gold on a necklace: these had certainly been metallic iron (probably native iron), and date between S.D. 53-63, or probably about 6500 B.C. This is by far the oldest wrought iron known, the next being in the IVth Dynasty; another new instance is in the XIIth Dynasty (see below). Another cemetery in the South, at Mahasneh near Abydos, was excavated by Mr. Ayrton ${ }^{5}$; it extended over nearly all the prehistoric civilisation, but did not give any new ideas.

Earliest Dynasties. - Two cemeteries of this period, and the most northerly known, are those of Turah ( 7 miles S. of Cairo) recorded by Dr. Junker, ${ }^{6}$ and Tarkhan ( 37 m. S. of Cairo) recorded by Prof. Petrie. ${ }^{7}$ The objects found at Tarkhan have shown much of the civilisation, owing to the perfect condition of the woodwork, baskets and clothing. The general result is that the size of graves and wooden coffins, and amount of copper tools, was greatest in the age of Mena and the kings just before him, and dwindled throughout the Ist Dynasty. This accords with the decay seen in the series of Royal Tombs, and shows that such a change was general. The whole of the burials were contracted in position; and though the prehistoric have head to south, and the historic the head to north, yet no progressive change went on during the three or four centuries examined. At Abydos the Tombs of the Kings have been re-excavated by 1)r. Naville, ${ }^{8}$ but no further facts have been obtained, nor was any other tomb found in the area which had already been fully searched by Prof. Petrie in rgor.

In Nubia a thorough clearance of the cemeteries has been in progress in order to secure their contents before the region was sulmmerged by the reservoir. The results published by Dr. Reisner and Mr. Firth ${ }^{9}$ show that the prehistoric civilisation of Egypt extended over Nubia in much the same style, the pottery and the art being

${ }^{1}$ King, Cuneiform Texts in the Brit. Mus., xxvi, pp. $7 \mathrm{ff}$., and Journal of IIellenic Studies, $\mathrm{xxx}(1910), \mathrm{pp} .327 \mathrm{ff}$.

2 King, Proc. Soc. Bibl. Arch., xxxi, pj). 339 ff., and Journal of Hellenic Studies, xxx, p. 33 I f., n. I4.

${ }_{3}$ See E. B. ix, 65 el seq.

4 Wainwright in The Labyrinth Gerzeh and Mazghuneh.

"Ayrton, Predynastic Cemetery of Fil Mahasneh.

6 Junker, Bericht über die . . friedhof in Turah, K. Akad. Wiss., Wien.

7 Petrie, Tarkhan.

${ }^{8}$ Griffith, Archaeological Report, 1910-II.

- Reisner, Archaeological Survey of Nubia. 
mainly like that of Egypt, but apparently rather later in historic times, as if the growth originated in Egypt and took some time to pass from tribe to tribe. The intrusive styles found after the XIIth Dynasty in Egypt are now shown to have come down from Nubia.

II-III Dynasties.-A large cemetery between Sakkara and Abusir has been cleared by Mr. Quibell, ${ }^{1}$ containing a variety of fine mustabas, including that of Ra-hesi from which came the celebrated wooden panels. This series will clear the development of all this period.

At Medum ${ }^{2}$ the tomb chambers of the nobles Nefermaat and Atet were discovered, and showed that the bodies had been more or less smashed up by the masons before closing the chambers. The pyramid of Snefru was tunnelled, and most important dates found on the stones. These show that the quarrying season was from the 6 th to the Irth month of the calendar; as by the inundation this must be from April to October, the period of the shifting calendar in the seasonal year is thus fixed. This proves that somewhere between II 38 and I683 years passed between the IIIrd and XIIth Dynasties; showing that Manetho's II98 years cannot be reduced to 3 or 4 centuries as Meyer has proposed.

Chronology. - The discussion of the above result has led to a complete recalculation of the astronomical data by $\mathrm{Mr}$. Knobel, ${ }^{3}$ fuller than before. The details of the application of this to history, and the explanation of the fact that the year formerly began with Mesore and not with Thoth, are given by Prof. Petric, ${ }^{4}$ with diagrams connecting the years, seasons, Egyptian shifting calendar, and rising of Sothis, so that any question can be at once solved to a single day. The results for the main periods (A) by purely external evidence of a physical nature, and (B) by Manetho are:-

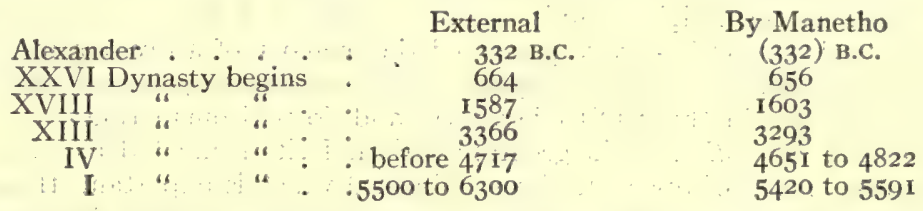

The differences in the lower figures show the range of uncertainty; but as a whole the close agreement is remarkable, and not a single fact in Egyptian history proves any different result, so that there is no conflict of statements to be weighed. The whole data of the Turin Papyrus, Manetho and Herodotus show that the Egyptians from I 500 B.C. down to 200 A.D. used 'a uniform and consistent chronology, which agrees as closely as possible with external physical data back to the beginning of the kingdom. More pieces have been found of the great historical register, known as the Palermo stone. This was a national record of the reigns to a single day, during the first five dynasties, and it shows the perfection of historical reckoning at that earliest age.

IV-VI Dynasties. - The granite temple near the Sphinx has been cleared in front, and the upper temple which is connected with it has been entirely cleared; both are of Chephren, and are excellently published by Dr. Hölscher. ${ }^{5}$ In restorations of these and other temples it must be remembered that the cultivation was about 20 feet lower, and perhaps a quarter of a mile further away, when they were built. The temples of Menkaura have been cleared by Reisner and fine portrait figures found, but not published.

The temples of Sahura, Neferarkara and Neuserra have now been fully described, ${ }^{6}$

${ }^{1}$ Griffith in Arch. Report, roro-r r, p. 22.

2 Wainwright in Meydum and Memphis III.

${ }^{3}$ Knobel in Historical Studies.

${ }^{4}$ Historical Studies.

' Hölscher in Grabdenkmal des Königs Chephren.

${ }^{6}$ Burchardt in Grabdenkmal des Königs Sahu-re, Grabd. K. Nefer-ir-ke-re, Grabd. K. Neuser-re. 
and give important examples of the temple sculptures of this age. Some more decrees of the kings of this time have been found at Coptos and published by Weill. ${ }^{1}$

$X I-X I I I$ Dynusties. - The publication of the funeral temple of king Mentuhotep Neb-hapt-ra by Dr. Naville ${ }^{2}$ has been finished, and gives the only complete plan of such a building in that period. It contained 260 columns and 160 pillars. The temple of the Osirification of King Sankhkere was found on the top of the Theban mountain, and an account published by Petrie. ${ }^{3}$

The last remains of the Labyrinth have now been excavated. The sculptures show that it was a centre for all the local deities and worship of the Fayum, as well as the funeral temple of Amenemhêt III. Two immense shrines of granite were found here by Petrie with statues of the king in them. The remains are all published. ${ }^{4}$

At the Second Cataract a cemetery of this age was cleared by Dr. Randall-MacIver, ${ }^{5}$ and two new points may be noted here. An iron spear head, of a broad leaf form, was found in a cave tomb with an undisturbed burial containing jewellery, and with three equally undisturbed burials in front of it, all dated to the XIIth or XIIIth Dynasty by the style; this is the earliest iron weapon known. An iron chisel in this cemetery had a pot of Roman date in the same tomb, and so was doubtless a late deposit, especially as it is of the form known in the XXVIth Dynasty. The other notable point is the keeping of fine jewellery of Amenemhêt III. in use for twenty reigns, or much over a century, before burying it in the reign of Noferhotep; it is seldom that such long use of jewellery can be proved. Unhappily it has all been stolen from the Philadelphia Museum.

Nomes.-In connection with this age may be noted the gradual growth of the political divisions of the country: ${ }^{6}$ by this time the division had extended to the 22 nomes of Lpper Egypt and 20 nomes in the Delta, which is regarded as the standard, and continued as the religious division of late times. But the ceremonial lists of festivals, and relics of Osiris, have preserved the memory of a division into 13 nomes in prehistoric times, and $x 6$ in the Ist Dynasty; this increased to 42 in the XIIth Dynasty, probably nearly 100 in the XIXth Dynasty, and 6o in Roman times.

XVIII-XX Dynasties.- The geography of the Delta is much debated in reference to the Exodus. A list of towns has been published which is important, though as late as the demotic period. It gives a list of places along the Wadi Tumilat, and the crux is that no place is named between Saft-cl-Henneh and Pithom, on the strength of which Daressy ${ }^{7}$ proposes that Pithom was near the west end of the valley. Beyond Pithom eastward are mentioned four places named from frogs - which might apply to any part of the valley - and then four places which cannot be identified, before reaching Pihahiroth, then two Migdol fortresses and the Migdol of Baalzephon. As there is some twelve or fifteen miles between the recognised Pithom and Pihahiroth it is possible that the eight places named might be all east of it, or the position of Pithom might have been put earlier in the list as the chief place of the district, and minor places named after it not in strict order of position. Either of these chances seems more probable than the shifting of Pithom from the large fort ress and town where it is named, and supposing it to have been where there are no noticeable ruins. In the eastern connection may be noticed a collection of all the Egyptian equivalents of Semitic names by Burchardt ${ }^{8}$; from this it is clear that the value $a$ or aleph formerly used for the flowering-reed sign is almost the only one used in such equivalents, and yod is never used; hence the new value of $i$ given to that, and the recent habit of calling it yod, is only a philological and not a practical matter. The same is shown by Ranke's comparison of cuneiform versions of Egyptian words; there the reed is often aleph or is represented by the termination $-i a$, where it is as likely to be aleph as yod; never is it rendered by yod alone. A revision of the practical rendering at Berlin is

1 Weill in Decrees of the Old Kingdom.

2 Naville in XIth Dynasty Temple at Dier el-Bahari.

Petrie in Qurneh.

1 Petrie in The Labyrinil.

s Randall-MacIver in Buhen.

- Petrie in Histoncal Studies.

${ }^{7}$ In Sphinx, xiv, 155 .

${ }^{8}$ Burchardt in All Kanadäischen Fremdworte. 
therefore needed, apart from theoretical rendering of earlier values; happily the French and many English have kept to the older custom of using $a$, which is the general equivalent. At Thebes the great and priceless series of painted tombs has been gradually put into safer condition. Walls have been built, doors put on, and Mr. Robert Mond has added to his provision for these tombs by supplying a custodian to conserve and photograph the paintings. The risks of vandalism are therefore lessened. The largest Sphinx ever moved has been found by the British School at Memphis; it is of alabaster, 26 feet long, and probably represents Amenhotep III. In Nubia near Amadeh an entire castle of the age of Thothmes III. has been cleared by Randall-MacIver ${ }^{1}$; it is not of Egyptian style, but shows the native system. At Abu Simbel a shrine has been found containing the altar and temple furniture in place.

$X X V-X X X$ Dynasties.- Another historical novel of the princelets of the XXVth Dynasty in the Delta has been published by Dr. Spiegelberg, ${ }^{2}$ republishing also the novel of the same period already known. These are most interesting pictures of the social life of the feudal princes of the time, only second in fullness to the late romances of Heliodoros and Achilles Tatius.

The palace of Apries has been found at Memphis by Prof. Petrie; ${ }^{3}$ it covered two acres, the gateways and dados were of stone, and the brick walls were nearly Ioo feet high, half filled up by a raised floor. The plan had the same position of quarters as that of the mansions in the XIIth Dynasty. Much armour, a silver and gold furniture ornament; Aramaic labels and Persian seals were found.

At Philae the great temple is ruined as to its unique colouring, and whenever the water rises to the full holding of the dam, the roofs will collapse and the whole be ruined. This barbaric fate was not in the least necessary; Sir John Aird had offered to transport the whole to a higher level above the water, and there would have been no difficulty in doing so. Thanks to the care of Professors Schäfer and Junker all the sculptures of Philae, and other temples that will be injured, have now been com. pletely photographed.

The new railway has opened up the Kharga Oasis, and the American expedition has been clearing and copying the temple of Darius.

A development of the history of Nubia has taken place. Dr. Reisner ${ }^{4}$ summarised it thus: Nubia and Egypt were on one level in the prehistoric age; in the Dynasties Egypt advanced; by the XII-XIIIth Dynasty Nubia had progressed in a native culture; in the XVIII-XXth Egypt occupied Nubia and largely modified it. There is no trace of the Ethiopian XXVth Dynasty. Nubia remained Pagan after Egypt, and remained Christian four centuries after Egypt was Muslim. In the 2nd and 3rd cent. A.D. there was a large invasion of a foreign people.

At Meroe Prof. Garstang ${ }^{5}$ has cleared much of the palace, and gives the history of it thus: From 700 to 300 B.C. there is the sun temple of Aspelut, and the palace; later the temple of Ammon. From 300 B.C. to I00 A.D. there were palaces, and a classical temple with Meroitic Venus figures, pottery, and glass, and the Roman bronze head of Augustus. From 200 to 700 A.D. there is the decay, the invasion by Axumites in 340 , and the destruction about 700 . Mr. Griffith has also been largely excavating in Nubia, finding the peculiar painted pottery of the Roman age. His great work is a corpus ${ }^{6}$ and study of the Meroitic inscriptions, of which he has almost completed the alphabet and obtained many words and phrases; the resolution of the language of it is yet to be settled.

Dr. Randall-MacIver ${ }^{7}$ has also published a splendid output of the Christian Nubian pottery and other remains.

1 Randall-MacIver in Areika.

2 Spiegelberg in Sagenkreis der Königs Petubastis.

3 Petrie in Palace of Apries and Meydum and Memphis III.

${ }^{4}$ Reisner in Archaeological Survey of Nubia.

${ }^{5}$ Garstang in Guide to XIth Annual Exhibition.

'Griffith in Karanog \&c.

7 Randall-MacIver in Areika and Karanog. 
Of the Christian period is a new form of fortress found by Prof. Petrie at Scenas Mandras, south of Helwan, probably due to the Gothic mercenaries settled there. The great Coptic monastery of St. Jeremias at Sakkara with both paintings and sculptures has been now completely cleared and published by Mr. Quibell, ${ }^{1}$ and gives an excellent idea of an unaltered early monastery.

(W. M. Flinders Petrie.)

\section{PALESTINE AND THE SEMITIC AREA}

Prof. Macalister's complete report on his work at Gezer (see E. B. xi, 91 5 , "Gezer ") appeared in 1912 (London, 3 vols. $4^{\circ}$ ), giving an admirable account of the excavations. He distinguishes ( $\mathrm{I}$ ) a pre-Semitic period, $(2-5) 4$ Semitic periods, (6-II) the Persian and subsequent periods down to the present day. The various methods of burial used in Palestine (including that of the Philistines) during all the early periods, are well represented. But the most remarkable discovery is that of the "High Place" or sanctuary. Its site was originally in the middle of the town, and was chosen not because it was already sacred (as so often in the East) but apparently because it was free from the contamination of graves, and also because of its proximity to the caves which were used for religious purposes. Its most striking feature is a row of (at one time ten) upright monoliths, arranged in a slight curve at irregular intervals along the middle of the site, having on one side a double cave, and curious cup-shaped indentations on the surrounding rock. The cult of the upright stone was, however, not the earliest form of worship at Gezer. It seems to have been introduced by the Semites about 2000 or 2500 B.C. From the fact that there is no sort of uniformity in the size of the stones, Prof. Macalister conjectures that the High Place was not built at one time on one plan, but was formed gradually by the additions made by successive "Kings." The rites practised there appear to have been much as described in Isaiab lvii. $5+$. They clearly included human sacrifice, especially the sacrifice of the first-born, as shown by the large number of newly born infants buried in jars within the sacred area. Foundation sacrifice was also customary in all the Semitic periods. In some cases the victims were adults but more commonly they were infants, or very young children, who were buried (also in jars) under the corners of houses. Among the very large number of articles of daily use; only two cuneiform tablets were found.

The best account of the German excavations at Jericho (Er-rihâ), begun on January 2, 1908 (see E. B. xv, 325, "Jericho"), is that of S. A. Cook in the P.E.F. Quarterly Statement, 1910, p. 54. See also the Mittheil.d. Deutsch. Orient-Gesellschaft, 1908, No. 39.

In August I 909 a private association began excavations on Mt. Ophel. A preliminary report of the work was published, under the title of Underground Jerusalem . . . by H.V. (London, I9II), and also in French. It is understood that the initials represent H. Vincent, the well-known archacologist of the Ecole Biblique et Archéologique at Jerusalem, whose name is a sufficient guarantee for the value of the account. The names of the persons responsible for the undertaking are, however, not revealed, and an unusual secrecy has been observed about it, giving rise to a number of strange rumours. It seems that the explorers were chiefly interested in the subterranean passages, of which they cleared several, including the Siloam tunnel. Some early pottery was found in the course of these operations, but no inscriptions. Ultimately trouble arose with the natives and local authorities, and the work was stopped, but there seems to be some intention of resuming it. Undoubtedly there is still much to be done.

After the close of the work at Gezer, the Palestine Exploration Fund Committee decided to excavate 'Ain Shams, believed to be the site of the ancient Beth Shemesh. The act ual digging began on April 6, I0I I under Dr. Duncan Mackenzie. A preliminary account of the results was given in the Fund's Quiterly Statement, I91 2, p. I25, and more fully in the Annual for I9II, p. 4I. Dr. Mackenzie distinguishes 3 strata: (I) that of the indigenous population, in cont act with Canaanites. Towards the end of this period the influence of Egypt (especially under the I Sth Dynasty) and of the Aegean begins to appear. Then (about 1200 B.c.) when the Cretan civilisation broke up, the trade routes ${ }^{1}$ Quibell in Excavations at Saqqara. 
changed and communication with the Aegean ceased. (2) The stratum of painted Philistine pottery; side by side with native Canaanite work, but with no admixture of imported Aegean ware. The pottery was indeed under Aegean influence, but was made in Palestine by Philistines (I 200 to I roo B.C.). (3) The stratum of Canaanite pottery, with no Philistine admixture. Chamber tombs were introduced from upland Judaea by Israelitish conquerors, who destroyed the Philistine rule but left the Canaanite population as it was. Traces of the conquest are probably to be seen in the burnt débris encumbering the south gate. The city was finally destroyed in the 7 th cent. B.C.

Inscriptions. - There have been no discoveries of Phoenician inscriptions of any importance. In Hebrew the newly published material is of little interest. At Gezer Prof. Macalister found some jar-handles inscribed in the usual manner with one word or two, and also a sort of rough calendar, all of which are fully described in his report. The "calendar" (op. cit. ii, p. $24+$ ) consists of 7 lines (and some letters in the margin) scratched on a piece of limestone, $4^{\frac{1}{4}} \times 2 \frac{3}{4}$ inches, and seems to be a table of rural occupations month by month, but the interpretation and object of it are alike obscure. An agriculturist would hardly require such a document to remind either himself or his labourers of the ordinary routine of farm work. Macalister is therefore probably right in suggesting that the stone was inscribed as a tour de force by some partly educated peasant who was proud of his knowledge of writing. He dates it, on archaeological grounds, in the 6 th century B.c. Others, judging from the forms of the characters, put it as early as the 8th century. But if it was written by a peasant, the ordinary palaeographical criteria will not apply. The writing is very unskilfully dore-in fact one letter is unlike any known form - so that it is wisest to accept the archaeological evidence. A very full discussion of the tablet, by H. Vincent, appeared in the Revue Biblique, 1909, pp. 243, 493, with a photograph: See also the P.E.F. Quarterly Statement, rgog, p. 26.

Much more important is the discovery at Samaria, by Dr. Reisner and the Americans, of early Israelitish remains including some which are inscribed. The official report has not yet appeared, but as a very much exaggerated account was published in Germany, Prof. Kittel made enquiries and printed a short statement of the facts in the Leipziger Neveste Nachrichten for January 23, rgr I, and the Theologisches Litteraturblatt for roIr. A summary was also published by Dr. Driver in the Guardian for February Io, I9I1. The following account is derived from Hölscher's article in the Mittheilungen d. Deutschen Palästinavereins for I9I I (p. 22), which is based on Lyon's report in the Harvard Theological Review (Jan. I9II) from Reisner's information.

The inscribed material consists of labels serving probably as records of oil and wine received for the royal household. They are mostly in the form of ostraka. The writing is in the old Canaanite alphabet, similar to that of the Moabite and Siloam inscriptions, done with a reed-pen and ink. The ostraka are dated in the year, presumably, of the king's reign. As they were found in the same stratum with a vase bearing the name of Osorkon II (874-853) it is conjectured that the king was Ahab. When the full account of the excavation is published, there may be other grounds for or against this identification. The texts are quite short, and of the following form: wine."

"In the 9th year. From Shaftan: For (or belonging to) Baal-zamar. A jar of old

"In the roth year. From Yazath. A jar of fine oil. For Alaino'am."

Their chief interest is in the forms of the names. Those compounded with "Baal" are about as numerous as those with $m$, showing the prevalence of Baal-worship. Also the divine name is always in the form " (never ' ${ }^{\prime \prime}$ ), and usually at the end of the compound, whereas in the massoretic text of the OId Testament $r$ (or i i is only to begin, a compound (but cf. Ahio) and $\boldsymbol{r}$ (or $\boldsymbol{N}^{\text {) }}$ at the end. Palaeographically the find is important as giving perhaps the earliest specimen of Canaanite writing.

The recent discoveries of Aramaic inscriptions (including papyri) have been of the utmost importance. After the publication (in r 906) of the papyri from Assuan, a large number of similar documents were found at Elephantine (whence no doubt the first lot originally came) by Dr. Rubensohn and Dr. Zucker in 1907-08. They were published by Sachau (Leipzig, IgII), and in a shorter form by Ungnad. 
The find consists of 62 leaves of papyrus, more or less complete, besides a number of fragments, ostraka and jar-inscriptions. The last are mostly Phoenician names, probably of persons trading with Egypt, not settlers. The papyri, which are mostly dated, cover nearly the whole of the $5^{\text {th }}$ century B.c. Three of the most remarkable were published by Sachau in a preliminary edition in 1907. They contain a detailed description of the Jewish temple at Elephantine, from which it appears that animal sacrifices were offered there. Another document gives directions for the celebration of the Passover in $4 \mathrm{I} 9$ B.C. The relation of these facts to the law of Deuteronomy and their bearing on the question of the date of the book, are still matters of discussion. One of the most startling texts, however, is a list (also dated 4 I 9 B.C.) of contributors to the temple funds, in which the sum collected is divided between Yahu (Jehovah) and two other deities Asham-Bethel and "Anath-Bethel.

Other important documents are fragments of an Aramaic version of the Behistun inscription and of the story of Abikar, to which reference is made in the book of Tobit (i, 21, 22, and xiv, Io). As this papyrus, though not dated, is clearly of the same age as the rest, it shows the story to be very much older than had been supposed. It is evidently of Babylonian origin, so that the Greek tradition that Democritus derived some of his

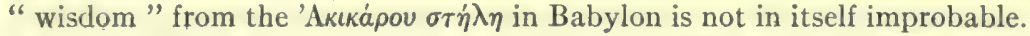

Under Aramaic must perhaps be classed another inscription from Zinjirli, discovered by F. v. Luschan and published by him in the Mittheilungen aus d. Or. Samml. XIV Ausgrabungen in Sendschirli,iv,"p. 374. See also Lidzbarski, Ephem. iii, p. 218. It was erected by Kalammu, king of Ya'di, in the reign of Shalmaneser II (859-829 B.c.), and gives the names of previous kings, with some historical facts about them. The text is, however, extremely difficult and cannot be said to have been fully elucidated yet. Kalammu himself is mentioned in the house-inscription of Bar-rekub, son of Panammu, king of Sam'al (line $\mathrm{I}_{7}$ ), found in $\mathbf{r} 89 \mathrm{I}$ at Zinjirli, but the passage was misunderstood. His father Hayya is no doubt the same as Haian son of Gabbar, king of Sam'al in an inscription of Shalmaneser. II.

In this connection must also be mentioned a curious inscription from Ördek-Burnu about eight miles south of Zinjirli, and therefore belonging to the same cycle as the above. Though written in the Aramaic character, and containing some Semitic words, it is clearly not in a Semitic language. This fact, coupled with the bad condition of the stone, makes the reading very difficult. For the present, all that can be said with certainty as to its contents is that we find the Semitic names Shamash and Rekub-el followed by the Semitic title (god) as in the other inscriptions of Zinjirli, and that some points seem to indicate, as we should expect, that the language is Cappadocian or Hittite. From the absence of Assyrian influence in the ornamentation, Lidzbarski thinks that it may perhaps belong to the roth century B.C., though the forms of the characters hardly seem to be so early. The stone is in the Museum at Constantinople. Its text was first published by Peiser (O.L.Z., I898), and again (rgrr) by Luschan (op. cit.p. 329) and by Lidzbarski (Ephem. iii, p. I92) after a careful re-examination.

In 1903 Pognon found an inscription of Zakir, king of Hamath and La'ash (the Lasha of Gen. x, I9), which he published in his Inscriptions Sémitiques, Paris, 1907, p. I56. Cf. also Nöldeke in Z.A. r908, p. 376. The stones were found built into a wall, but their precise situation is (doubtless for good reasons) not yet disclosed. Though the language may be classed as Aramaic, it might perhaps be better described more generally as a Canaanite dialect, since, besides purely Aramaic forms, it uses $e$.g. the peculiarly Hebrew construction of the "Vau consecutive," and its style in other respects strikingly recalls that of the Old Testament. It relates a war with Bar-hadad son of Hazael (cf. ii. Kings xiii, 3. 24) king of Aram, and his allies (who include the king of Sham'al), in which Zakir was successful. Its date must be early in the 8 th century, i.e. less than roo years after the inscription of Mesha. It is not complete, but Pognon hopes to find the rest of it. The same volume also contains a large number of Syriac inscriptions of minor interest.

(A. E. COWle Y.) 


\section{HITTITES ${ }^{1}$}

New light has been thrown on the Hittites by excavations at Jerablus (Carchemish) begun by the British Museum in I9II, and at Sakjegeuzi, begun by the University of Liverpool in 1908 but not continued after I9I2. Also by discovery or re-examination of sporadic monuments, and further study of sites.

The re-excavation of Jerablus, so far as it has gone yet, has resulted in (I) Re-examination of the ground in the lower walled city at the S.W. foot of the Acropolis, where a stairway and several sculptured and inscribed monuments were found $1878-188 \mathrm{r}$. The stairway is now seen to be approached from a courtyard lined with reliefs representing triumphant warriors, divinities, etc., and to be engaged in a block of buildings to left and right which probably represent the palace. Most of the sculptures belong to a comparatively late period (Ioth or gth cents. B.c.) and the staircase has been reconstructed. Many sculptured and inscribed fragments (over . 00 new texts or parts), proving wholesale destruction, probably after the Assyrian capture ( 7 I 7 B.C.), as well as terra cotta figurines, pottery, etc., have been recovered here or elsewhere. (2) Discovery of a water gate, connected with the above block of buildings and leading to the Euphrates S.E. of the Acropolis. It was lined with reliefs and entered between great inscribed lions. Here also are two periods of construction, and sculpture of two periods, one of Cappadocian character, the later more purely Mesopotamian. (3) Discovery of an Assyrian fortress in crude brick with stone façade on the northern end of the Acropolis. Two important Hittite monuments indicate the presence of an earlier building below. The strata of the Acropolis mound have been tested down to 50 feet below the summit, where lie neolithic implements and painted sherds. Below these again should be more primitive strata. The south end of the Acropolis carried a very massive Syro-Roman temple, whose deep foundations have greatly destroyed earlier remains. (4) Discovery of numerous graves, partly in the Acropolis mound, partly in the surrounding district, especially near Amana, where rises the large mound, Tell el-Ghanim. Most are of later Hittite period; but some, of pot-burial type, are probably of the Cappadocian time. (5) Discovery of isolated Hittite inscriptions and sculptures in the surrounding district. (6) Examination of the remains of the important post-Assyrian city which stood on the site and was inhabited up to Arab times,--perhaps the classical Europus or Oropus.

The results as a whole tend to show that only a small area on the rocky knoll by the Euphrates, which afterwards was raised artificially to make an Acropolis, was inhabited in pre-Hittite times; that there was a Cappadocian Hatti occupation from about the I 5 th cent. B.C., during which the city was enlarged and fortified, and Hatti art, strongly influenced by Babylonian, was introduced on the top of a native Syrian culture; that some cause produced collapse and reconstruction about I 100-1000 B.c., and the subsequent civilisation, still of Hittite character, owed much to Assyria and acknowledged other gods than the Cappadocian, notably Sandan. The invasion of the Muski about IroO B.C. was doubtless the cause of the Hatti collapse, and possibly the subsequent reconstruction was also the work of the Muski, who are known to have adopted Hatti writing and art and to have succeeded to Hatti dominion in Eastern Asia Minor. If not, then Carchemish resumed existence as a local capital independent of Cappadocia after I000 B.C. Reliefs in the palace court seem to commemorate victories over Assyrians, and if so, these must have been won in the interval of Assyrian weakness between Tiglath Pileser I (I roo B.C.) and Ashur-natsirpal ( $88_{3}$ B.C.).

The excavations at Sakjegeuzi have resulted in thorough examination of one mound (Jobba) and partial examination of two others, including the largest (Songrus). In the first has been laid bare a large fortified building with chambers inside the wall and inner residence in one angle, approached by a portico with good wall reliefs and architectural sculpture. Egyptian objects date this building to the gth or 8 th century B.C. No Hittite inscriptions have come to light here or elsewhere on the site, though a few small Hittite objects have been found, with pottery ranging from neolithic to so-called

1 See E. B. xíi, 534 et seq. 
late Hittite. Provisionally it may be said that the site was probably, like Sinjerli (Shamal), not a town of the Hatti at any time, but may have been one of the Kummukh (Commageni) who adopted Hatti civilisation:

At Tell Halaf in mid-Mesopotamia excavations were begun by Max Freiherr von Oppenheim in rgr2; sculpture, jewellery, etc., are said to have been found. The monuments found in 1902 seem not purely. Hittite, and perhaps the site is that of a town of the Khani (capital Harran), who may have used Hatti script and arts. This people came successively under Babylonian and Assyrian domination after having held all N. Mesopotamia before the rise of the first Assyrian empire.

The results of the Cornell expedition, published in I9I I, have proved inferior to expectation. By finding monuments in the Tokhma Su valley near Darande, the members of the expedition (Charles, Olmstead and Wrench) show connection between known areas of Hittite civilisation in the Gurun-Albistan and Malatia districts; and an inscribed spheroid seal, procured near Kharput, suggests that the latter area extended eastwards across Euphrates towards the Vannic borders-which is quite credible. The inscriptions published by the Expedition as from the middle Halys basin, the Kaisariyeh and Ekrek districts, the Tyana neighbourhood, Marash, Samsat, the Carchemish district and Aleppo, were, with two exceptions, already known, and the new copies of the stones, which in most cases are very badly weathered, are not more authoritative than those previously published. A copy of the great Nishan Tash inscription at Boghazkeui, obtained with great patience and labour, proves the text Hittite, but is too imperfect to place it among legible inscriptions. Hittite texts which have not been buried are usually so weathered that their existence in certain localities is of more scientific significance than their contents will ever be. Hittite history will have to read (if at all) from better preserved stones recovered by excavators:

The late O. Puchstein's posthumous report on the architectural remains at Boghazkeui (IgI2) is the most important contribution to Hittite archaeology which has appeared recently. It gives authoritative plans and details of the fortifications, as cleared by Winckler's expeditions in I906-7; of four temples, inclusive of the large building on the W. formerly supposed to be a palace, and of a "palace" on the S.E., etc. For lack of observation (or record) of the relation borne by small finds, e.g. pottery and inscribed tablets, to architectural remains, the age of the latter is not clearly proved.

A fragment of inscription in relief characters, found at Restan (Arethusa) on the middle Orontes by Père Ronzevalle, is the only Hittite monument known in mid-Syria except the Hamah stones. Two new stones have been seen by D. G. Hogarth west of the Sajur, an incised inscription at Ain es-Suda r hr W. of Arab Hassan, and a relief at Tell Khalid. Others at villages east of the Sajur, found and recorded by the British excavators of Jerablus, may have come from the latter site; but more probably from local tells. In Asia Minor, beside the Cornell expedition's stones at Tekir Devrent and Egri Keui in the Kaisariyeh district, and at Isbekjur and Kotu Kale near Darende, and their inscribed lion at Ordasu (Malatia), Garstang's stela from Hadji Bey Keui near Marash (Ann. Anth. Arch. iv, p. I $26 \&$ pl. 23) is a new discovery. Hittite characters have been newly found on the necks of large jars at Boghazkeui; on a clay tablet, otherwise in cuneiform, from Cappadocia; on a basalt weight at Jerablus; and on numerous seals and sealings, found in all parts of the Hittite area, but chiefly at Boghazkeui, Jerablus and Sakjegeuzi.

The history of Hittite power and civilisation, as supplemented by the Boghazkeui archives, has been well set forth by J. Garstang in his Land of the Hittiles (roro). The general bearing of recent discovery has been to emphasize the division of Hittite history and remains into two main periods; the first, imperial Hatti rule radiating from Cappadocia; the second, not of Hatti rule but of either Muski empire or Hatti civilisation surviving in small states of Eastern Asia Minor and North Syria (c.g. Tyanitis whose monuments show non-Hittite bearded figures). In the latter period fell the relations of the Hebrew monarchies with "Hittites," who, resigning mid Syria to the Aramaean powers of Damascus and Hamah, ceased to be an imperial power in the I2th cent. B.C. It 
should be added that the hostile relations of the Hatti with Assyria began at least as early as the reign of Shalmaneser I at Calah (I 4 th cent. B.C.).

See J. Garstang, Land of the Hittites, 1910; and Sakjegeuzi, 2nd report in Ann: Anth. \& Arch., v. p. 63. Report of Cornell Expedition to A sia Minor etc,, vol. i, pt. 2, 19 I I. O. Puchstein, and others, Boghazköi, Die Bawwerke etc., I9I2. F. v. Luschan and others, Ausgrabungen in Sendschirti, new parts, I910. F. v. Reber, Stellung der Hettiter in der. Kunstgeschichte, 1910. D. G. Hogarth, Carchemish and its Neighbourhood in Ann. Anth. \& Arch. ii, 4, p. 165; and Hittite Problems and the Excavation of Carchemish in Proc. Brit, Acad,, v.

\section{CRETE ${ }^{1}$}

(D. G. Hógarth.)

The principal excavations of Minoan sites in Crete since 1909 have been at Cnossus, at Tylissus, at Hagia Triada, and at three points near Gournia. At Cnossus, Sir Arthur Evans, assisted by Dr. Duncan Mackenzie, conducted excavations on an extensive scale in I910. In the palace itself, the difficult work was attempted of placing what remained of the fourth and fifth flights of the grand staircase in their original position. An interesting conclusion follows from the restoration, that the upper landing of the fifth flight does not lead on to the ground floor of the central court, but answers in height to what must have been the first floor of the rooms on the other or western side. It must itself, therefore, have led on to some raised building, probably a terrace, that ran along the eastern side of the court. On the south of the palace, the huge cavity, filled with débris of pottery of the Middle Minoan I period, which had at first been thought to be a truncated beehive tomb, proved on final excavation to be a cistern or reservoir. It has a circumference of 95 and depth of 56 feet and was apparently supplied with water from springs in the hill itself. To within 9 feet of its floor, where we may imagine was the average water level, it was accessible by a spiral staircase with shallow sloping steps and a low balustrade. It must, have been built in Early Minoan times, and filled in when a solid foundation was needed for the Middle Minoan Palace.

Further progress was made with the excavation of the Little Palace, 300 yards to the west of the Theatral Area, and joined to it by a paved road. Two pillar rooms were here found, and two staircases, leading to upper storeys. A fresh piece of Minoan road also came to light, with the ruts of the chariot wheels marked in the stone slabs. The excavation, however, is obviously and dramatically unfinished, and fine Minoan walls run straight into the olive grove on the hillside, while frescoes of Roman houses, high above them, emerge from amid the tree roots. About half way between the Palace and the sea, just north of the "Royal Tomb" at Isopata, were discovered six chamber tombs, whose vases had their colours unfixed, and were clearly made expressly for funeral purposes. Some of these vases were polychrome, not of the Middle Minoan type, but with spirals of brilliant rose red and light blue; others were covered with a resinous black, in imitation of Egyptian alabastra. One of the tombs, about 20 feet square, has been christened by its discoverer, "The Tomb of the Double Axes:" On one side of the entrance was a raised stone platform, and in this was cut the pit in which the body itself was laid. On the outer face of this platform, and along the other sides of the tomb, were ledges, clearly intended for sitting on, and perhaps originally furnished with benches. From the back wall jutted out a stone pier, the front of which was carved in low relief into a half column. Near the pillar, and apparently fallen from the platform, lay two thin ritual double-axes, the remains of a bull's head rhyton and one of the bright blue and red jars already described. The axes probably stood, socketted in plaster horns of consecration, at the head of the grave, and the jar was to hold libations poured from the bull's head. The ledges were for the family when taking part in this memorial service. An interesting problem is raised as to whether the tombs may have been reopened at intervals for a repetition of such a service.

No actual excavation was undertaken at Cnossus in I9II and I9I2, but much work has been done, especially on the frescoes. A short article on the light that is

${ }^{1}$ See E. Bi vii, 42 I et seq. 
thrown by the miniature frescoes on the plan of a shrine in the central court has been published by Sir Arthur Evans in vol. xviii of the Journal of the Royal Institute of British Architects, third series, pp. 289-95, and a general study of Minoan Lime Plaster and Fresco Painting by Mr. Noel Heaton in the same vol. pp. 697-710.

At Tylissus, on a high plateau about eight miles west of Cnossus and four miles from the sea, Dr. Hatzidákis, the senior Ephor of Antiquities in Crete, has continued in three successive seasons the work which he began in 1909. The site proves to contain, not, as was first suggested, a small palace with dependencies round it, but three large noblemen's houses, which lie close together, and are of the same date, but, in the excavator's opinion, are separate unconnected buildings. They may have been built in Middle Minoan III., as they contain pithoi that were commonest at that period, but they were in occupation throughout Late Minoan I. and II. Below them are traces of an Early Minoan settlement, and above them of Late Minoan III. buildings. Of special architectural interest are two rooms, each with two free-standing pillars, like those in the Little Palace at Cnossus; some double axes incised on outer walls; and a great cistern about ro feet in diameter and $r_{3}$ in depth, with a narrow stone staircase leading down into it. The most noteworthy of individual finds are a bronze figurine of a square-set male figure 8 inches high with the right hand raised to the forehead in a gesture of adoration and a kilt in the manner of the Petsofà figurines (Annual of British School at Athens, ix, pp. 363-4 and Pl. X) but more capacious; a beautifully worked filler (or strainer) of obsidian, about 9 inches high; fragments of miniature frescoes; a bronze ingot like those from Hagia Triada; four magnificent bronze cauldrons with three vertical handles, the largest of them four feet in diameter and 18 inches high; and a clay tablet of the earlier form of the linear script of Cnossus, showing not the familiar two-wheeled chariot, but a four-wheeled waggon.

These excavations had not been published up to the end of I9I2, and the above description is due to the kindness of Dr. Hatzidákis, supplementing a personal visit.

At Hagia Triada on the south coast near Phaestus Professor Halbherr of the Italian Mission has conducted excavations in I910, I9II and I912. He has proved that so far from the site containing only a "Royal Villa," as was first held, the Villa or Palace was only the centre of a town. Traces of this have been found dating from the Middle Minoan age, and some buildings of this date were incorporated in the Late Minoan $\mathbf{I}$. Palace. Throughout the latter period both palace and town were prosperous, but at the end of it both were destroyed. The extensive remodelling which we find on the site of both palace and town took place at a date which Prof. Halbherr places in Late Minoan III., though it may be remarked that it would have to be very early in that period. Of the same date is the remarkable "Agora " northeast of the Palace and below it, a large space about 50 yards long, with 8 long chambers, each about 17 feet long by 13 feet broad, opening out from one side of it. The staircases that led to an upper storey still exist, and also the bases of 8 pilasters, about 2 feet nine inches square, running down the length of the Agora; while between them, opposite the doorways of each chamber, have been discovered foundations of the bases of small round columns. There can be no doubt that these are the remains of a covered portico, the second storey of which rested on these alternate columns and pilasters and was reached at either end by the stairways. We seem to have here a covered market place, a portico with shops leading out of it like the famous Laura, or Arcade, of classical times at Samos. On the high ground south of the palace, Prof. Halbherr has found what seems to have been a small sanctuary, with a bench or dais like that of the shrine of the Double Axes at Cnossus (Annual of British School at Athens, viii, pp. 95-105). A short notice of some of these excavations appeared in Ausonia roro, p. 36, but the above description is mainly due to a personal visit and further details kindly given by Prof. Halbherr.

In the east of Crete Mr. R. B. Seager, the American explorer, has been conducting several small excavations near his headquarters at Pachyammos. At Sphongará, a few hundred yards from the town of Gournia, and between it and the sea, he discovered 
in 1910156 pithoi, a few of which date from the Middle Minoan 1 . period, but most from Middle Minoan III: and Late Minoan I. The pithoi rarely contained anything but bones and an occasional seal-stone. The body was trussed up like a fowl, with the knees under the chin and the arms folded tight. It was thrust into the jar head foremost, and the jar was then placed in the ground upside down. Some of the jars were painted, but the greater number were a tall slender type of unpainted jar, with a base so small that they were top heavy and could not stand upright without support. A few Early Minoan burials that were found on the same site, though often disturbed by the later pithoi, were sufficiently preserved to show that they were originally as rich as the great graves of that epoch found by Mr. Seager at Mochlos.

A hill about five miles west of Gournia called Vrokastro, short for Hebraiokastro, or Jews Castle, was excavated in rgro by Miss Edith Hall and in ror 2 by Miss Hall in company with Mr. Seager. In the latter year a settlement was found in the valley below, and seems to have existed there from the Early Minoan age; but the chicf remains, dating from Late Minoan III. and the Geometric age, were found on an extraordinarily steep peak overlooking the sea, almost inaccessible except on the south or land side. The chief point of interest is that the transition between Late Minoan III. to Geometric is made without any definite break or direct signs of a racial change.

On the other side of Gournia, south of Kavoúsi and just north-east of Vasilikí, there is a steep gorge above the village of Monasteráki. High up on the north side of the gorge itself, called by the appropriate name of Chaos, a narrow and precipitous path leads to some ledges, on which are ruins of ancient walls, called Katalumata. Mr. Seager conducted a small excavation here in I9II, which showed that the spot was used as a place of refuge from the earliest times onwards. The actual remains of the walls seem to be of Late Minoan III. date, but Early Minoan III., Middle Minoan I. and Late Minoan I. potsherds were all found there. These excavations in East Crete have not yet been published, and their description here is due to the kindness of Mr. Seager and a personal visit to the sites.

If we turn to the classical period, the discovery of a 5 th century Doric metope of Herakles and the Calydonian boar (Times Nov. I6, I910) on the high ground west of the Little Palace of Cnossus promises well for future excavation. Prof. Halbherr has excavated at Lebena, the harbour of Gortyna. At Gortyna itself he has diverted the millstream which flowed by the great inscription of the Laws, discovered in $\mathrm{I} 884$, and is exploring the neighbouring buildings.

Authorities.-The only final publication of Minoan Excavations that appeared during 1910-12 is R. B. Seager's Explorations in the Island of Mochlos (American School of Classical Studies at Athens, Boston and New York, I912). See further G. Karo's introduction to a 2me série of G. Maraghianis's Photographs of Antiquities Cretoises (Candie); A. Mosso's The Dawn of Mediterranean Civilisation (Tr. Fisher Unwin, I910); R. Dussaud's Les Civilisations Prehelléniques (Paris, I9I0); E. Reisinger's Kretische Vasenmalerei (Berlin, 1912); and the 3 rd and illustrated edition of R. M. Burrows's The Discoveries in Crele (J. Murray, 1913). "The Hymn of the Kouretes" discovered at Palaikastro in 1904 has been published by R. C. Boșanquet, G. A. Murray and J. E. Harrison in Annual of British School at Athens, Vol. xv.

(R, M. Burrows.)

\section{AEGEAN CIVILISATION ${ }^{1}$}

Since Igro there has been much new discovery in the field of ancient Aegean civilisation, and more has been learned about older discoveries, not only in Crete (sce above) but also in the Greek islands, on the Greek mainland, and in Asia Minor. Among the Greek Islands, Phylakopi (Melos) has been re-examined by the British Athenian School and a further landward part of the site has been excavated. The distinction of periods and classification of pottery confirm those arrived at by the previous diggers. Some graves containing L.M. III ware have been opened on Leukas by Dörpfeld and held by him to support his theory that here was the Homeric "Ithaca." On the Greek mainland important remains of L. M. frescoes have been found by the German Institute at Tiryns, and the pre-Hellenic Argos, explored by Vollgraf and others, has yielded a local

i See E. B. i, 245 et seq. 
variety of the native Boeotian "Minyan" ware. An L.M. III settlement with large painted jars has been found at Pylos, and similar ware has been recovered by the British School from the site of the Menelaum at Sparta. L.M. III graves have been opened on Aegina and similar graves at Thebes by Keramopoulos, together with: remains of a building at the last named with frescoes which the discoverer regards as the "House of Cadmus." In the uppermost prehistoric level on several Thessalian sites Wace, Thompson and Tsoundas have found L.M. III ware. In Asia Minor, Wiegand has found a neolithic settlement at Kiliktepé near Miletus, and many L.M. III sherds under later remains on the city site, especially near the shrine at Athena. Macalister, who had found both L.M. III and Cypriote ware, etc., in considerable bulk at Gezer (Philistia). in Syria, has now published his results. There is nothing new of importance from Cyprus, but vessels either of Aegean make or of Egyptian imitation (mostly L.M.) have continued to be found in Egypt as far south as Thebes.

So far as concerns Crete, the general results of these fresh discoveries and of the new study and new publications may thus be summarised. (I) More abundant and varied material for judging E.M. civilisation, which is now seen to have been more advanced, and nearer to M.M. brilliance than was supposed, in several arts, metallurgy, plastic (stone vases) and ceramic; very early trade connections with Egypt and Aegean isles (probably Cyprus also) are demonstrated. (2) Clearer knowledge of the course of Minoan history, beginning with local independent foci of civilisation in the centre and east, on which followed successive imperial dominations of Phaestus and Cnossus, the first in M.M. II, the latter in L.M. II. Each of these, at its acme, reduced the E. Crete foci to a low ebb, but they revived during L.M. I between the two imperial periods. (3) Surer chronology. The recent tendency of authorities is to protract the Minoan Age to about i I00 B.C. and to bring down also the first destruction of Cnossus and the other Minoan towns far into the I $4_{\text {th }}$ century. The coincidence of M.M. II with Egyptian Dyn. XII stands, but the later date (2000-I 800 B.c.) is preferred. (4) Increased knowledge of the Dispersion period (L.M. III) in which Cretan civilisation spread to Asia Minor and through Cyprus as far as South Syria on the one hand, and to Sicily, Italy and North Greece on the other; but the chief radiating centre was on the South Greek mainland. (5) Fuller evidence for funerary practices, and better knowledge of the origin and earlier development of the Cretan script, the last thanks to publication of Evans' Scripta Minoa I. Outside Crete, discoveries at Tiryns confirm the belief that "Mycenaean" culture, like that of Phylakopi from the Middle Cycladic Age onwards, was due in the main to Minoan Crete; while the excavations in Laconia, Boeotia and Thessaly show that Aegean influence pervaded all Greece up to Thermopylae in L.M. II and III times, but only reached Thessaly late and never greatly affected an indigenous civilisation long established there. Boeotia had also a pre-Mycenaean art, which gave way to Aegean influence earlier and more considerably. The chief lesson from Miletus is that the site had none but few and rude inhabitants till settled from Crete in the Dispersion period (L.M. III); while Gezer has strengthened the hands of those who have maintained that mid and south Syria owed far more to Cyprus and Crete than these islands owed to Syria. Doubts have been raised about the hitherto accepted identifications of the Minoan Cretans with the "Keftiu," and about the supposed early relations of Crete with Egypt; and no clearer light than before has been thrown on the racial character or linguistic affinities of the Aegean peoples, or on the links which connected their civilisation with the archaic Greek.

See R. M. Burrows, The Discoveries in Crete, $3 \mathrm{~d}$ ed. (1912) revised and illustrated. C. H. \& H. B. Hawes, Crete the Forerunner of Greece, 1909. R. B. Seager, Pseira, I9I0; and Mokhlos, 1912. A. J. Evans, Scriptr Minoa I, 1909; and Atlas of Cnossian paintings. D. Fimmen, Zeit und Dawer der Kretisch-Mykenischen Kultur, 1909. E. Reisinger, Kretische Vasenmalerei, 1912. A. Mosso, The Dawn of Medilerranean Civilisation, 1910. A. J. B. Wace and M. S. Thompson, Prehistoric Thessaly, 1912. A. Frickenhaus, W. Müller and F. Oelmann, Tiryns, 1, 1912. Ephemeris Arch. since I909 (minor excavations in Greece and Crete). R. A. S. Macalister, Gezer, 3 vols., 1912. R. M. Dawkins and J. P. Droop, Excavations at Phylakopi in Melos, 19II, in Ann. Brit. Sch, at Athens, xvii, D. G. Hogarth, Ionia and the East, 1909.

(D. G. HOGARTH.) 


\section{MISCELLANEOUS SITES OF THE NEARER AND MIDDLE EAST}

Cyrene.-(E. B. vii, 704). Excavations were begun in r910 by an American expedition representing the Archaeological Institute of America and the Boston Museum of Fine Arts. The members, led by R. Norton, had great difficulties to contend with owing to the suspicion and indiscipline shown at first by the local tribes; but these had been largely overcome when, in March I9II, the second in command, H. de Cou, was shot by three strangers from the Tolmeita district, sent to murder the leader. The other members of the American party, however, stayed on till May, and were about to return to the site in October in A. V. Armour's yacht, when the outbreak of war between Italy and Turkey in Tripolitana and Cyrenaica foiled their plans. Cyrene became inaccessible from the coast, and the objects discovered by the Americans remained on the spot in the hands of Enver Bey's force. They include two very fine pieces of sculpture, a torso of a dancer or a Victory, and a head of Atheria, the first of the earlier part, the other of the later part, of the $4^{\text {th }}$ century B.C. Besides these much sculpture of the Roman period was discovered including a great number of conventional figures for sepulchral use, whose faces were left blank to be painted with features as required. A large deposit of terracottas, mostly representing the city goddess bearing the silphium, was partly cleared, and much pottery etc., chiefly late, was extracted from tombs half robbed in antiquity. The main work of excavation was done on the hill above the Apollo spring, where a large building of uncertain nature and Ptolemaic date was in process of exploration when work stopped. The digging had not penetrated deep enough except in one or two pits to tap early strata and the promising virgin field below the Apollo spring, occupied by the grounds of the Senussi Convent, was not touched.

An important site of the earlier Greek period was discovered at Messa, about five hours S.E. of Cyrene, by the party under J. W. Gregory who in I 908 visited Cyrenaica to inquire (reporting adversely) into its possibilities as a field for the Jewish Territorial Organisation; and it was revisited by R. Norton and also by an Italian expedition under F. Halbherr in rito.

Didymi.-(E. B. viii, 207). The temple has now been disengaged from débris by the German excavators under Th. Wiegand. A small township is found to have encircled it, leaving a clear precinct. Of the earliest shrine some scanty remains have been found at the E. end with a fragment of an archaic inscription. The rest of the remains are Hellenistic in the main, and of Roman date in part. Several inscribed marbles record details about the building, towards which kings and other rich men contributed during a long period (e.g. Ptolemy XIV gave 34 elephant tusks to meet the cost of the great central E. door); Other marbles record the treasures deposited in the temple, oracular responses, etc. There were no architectural sculptures beyond heads ornamenting capitals, etc. of columns and the beautiful enrichment of bases at the E. end; and few remains of free sculpture have been found. The main additions to the work aone by Pontremoli and Haussoullier have been: ( $\mathrm{I}$ ) discovery of outlying dependencies such as a semicircular terrace for the deposit of offerings and an altar on the E., and a stadium on the S.; (2) clearing of the 122 columns, almost all of which stand at half height or more; (3) elearing of the pronaos with its I 2 columns and wonderfully preserved W. wall; (4) opening out of the stairs leading to the two subterranean chambers of the adyton under the pronaos; one of these stairways is perfectly preserved even to its ceiling, decorated with maeander design; (5) clearance of the spacious stairway which leads down to the cella at a level six metres below the pronaos; (6) discovery of many details of the enrichment of the upper members of the colonnades. There was no opisthodomos. The Byzantine castle, into which the cella was converted, and spoliation by natives have done much damage; but even as it now stands, this temple is by far the best preserved of the greater Hellenistic buildings. Many dedications to Artemis, who was here associated with Apollo, have come to light; and the sacred way to Panormus has been explored more thoroughly than by Newton (See Vorlaiuf. Berichle ïber die. . . in Milet $u$. Didyma Ausgrabungen nos. vi, vii, Igro, I9ri i, by Th. Wiegand). Miletus.-(E. B. xviii, 443). The excavations carried out by Messrs. Wiegand, 
Pernice and Knackfuss for the Berlin Museum are now virtually at an end. Little prior to the destruction of the city in 944 B.C. has come to light; but a primitive settlement has been located on Kiliktepé, S. of the later walls. This has rude constructions of small stones and graves yielding implements of obsidian and other stone, and painted pottery (red on black). Though neolithic in character these graves can hardly be very early in time since Greek geometric sherds were found in them. Much pottery of L.M. III (or Sub-Minoan) character has been found elsewhere on the site. Immediately above this stratum begin Ionian remains; a small part of the archaic city with its wall has been revealed at Kalabaktepé not far from the position of the early Athena temple. The sherds here found are not later than the opening of the 5 th century. A few graves of the archaic period have been opened near by. The rest of the discoveries are of the Hellenistic and Roman ages. The Hellenistic city was planned gridiron-wise, like neighbouring Priene, but with a slightly larger insular unit ( 170 feet in length as compared with I60). The south market, a vast square with halls and porticoes, was the last important site cleared. It was rebuilt and rearranged in the Ist century B.c. A temple of Serapis, some heroa, the stadium, and the baths, built at the expense of the empress Faustina, have also been explored. In the last was found a fine recumbent statue of the River Maeander. On the whole not much interesting sculpture has come to light and the inscriptions are disappointingly late; but a good deal of light has been thrown on local history in Hellenistic and Roman times, and on local cults. It appears that Miletus had no existence until settled by fugitive Cretans not long before I000 B.C.

Sardis.-(E. B. xxiv, 2I 7$)$. Systematic excavations were begun in I9Io by an expedition from Princeton University led by H. C. Butler. The main field of operations was the so-called Temple of Cybele or Cybebe, which is now proved by numerous inscriptions to have been called a temple of Artemis from the 6th century onwards. Clearance has praceeded systematically from the W. end by the removal of débris layer by layer. The opisthodomos was found to be the most ruined portion; but its north wall stands to a height of 2 metres and bears the greater part of an important Greek inscription, a mortgage deed of unique character drawn up at the end of the 4th century B.c., whereby specified lands, etc., were secured to the temple in consideration of a loan made from the treasury to a certain Mnesimachus who held the greater part of his real estate from a king, presumably Antigonus. This chamber with the cella had been converted into a cistern in late Roman times. The eastern end, protected by the talus of the hillside, proved in better preservation. Here two columns still stand to their full height, and many others to half height; but most, if not all, had been restored, probably after the great earthquake of 17 A.D., and many details, e.g. fluting, were never executed. Three varieties of Ionic architecture were employed in the external and internal colonnades. The temple was one of the very largest in the Greek world. No architectural sculptures, but many beautifully carved bases of columns have come to light, and in the joints of the central cult-statue pedestal-a survival apparently from a primitive temple-a considerable find of unused coins was made; the majority, of Hellenistic time, may have formed part of a foundation deposit, inserted at a time of reconstruction; one, of Croesus, found much lower down, must belong to a more original deposit. Greek inscriptions on the pedestals of statues of priestesses were found, and also texts in Lydian script and language, one with an Aramaic bilingual. The whole plan of the temple, which was pseudo-dipteral, has been recovered with certainty. A great many tombs, mostly used more than once in different periods, have been opened, and fine jewellery, intaglios. bronzes, terracottas and pottery have been found. The excavation is still proceeding and it is hoped that the whole agora, as well as other parts of the earliest city, may be explored. (See Amer. Journ. of Archuealogy, I910-r 2).

(D. G. HOGA RTH.)

\section{ARCHAEOLOGY OF OTHER GREEK SITES}

In Greece Proper, during 1010-12, continuous progress has been made in archaeological research, either by fresh discoveries or through the re-examination of previously kuuwn monuments, which is frequently due to the influence of new excavations. 
Athens.-In Athens itself (E. B. ii, 832 et seq.), and in connection with the Parthenon (E. B. xx, 869) and Pheidias (E. B. xxi, 36r) fresh facts have come to light. Mr. Hill, the director of the American School at Athens, has re-examined the foundations of the earlier Parthenon and shown that previous reconstructions of it were wrong. It was a temple with sixteen columns on the sides and six at the ends instead of nineteen and eight. This is proved by re-measuring the foundations themselves which form part of those of the later Parthenon, and by the discovery of several marble blocks built into the north wall of the Acropolis on which the curved lines drawn to guide the masons in putting the columns: in position are still visible. Further evidence derived from papyri and inscriptions tells us that Pheidias made the Zeus at Olympia after the completion of the Parthenos at Athens. Also since the records of the payments for the making of the pediments of the Parthenon continue after the date of his exile, it appears that he, although their designer, cannot have taken part in their completion, which was probably left to his pupils. Excavations on the Pnyx have shown that the supporting wall of the theatral area in front of the bema or platform dates from the fourth century. Consequently the problem of where and how the Athenian Assembly met during the fifth century remains unsolved. At the Dipylon cemetery excavations have shown that the graves were in family groups, each being enclosed by a high boundary wall. The tops of the platforms within these walls stood about six feet above the level of the roadway and consequently the marble grave reliefs, many of which are still in situ, were meant to be seen from below. This cemetery was in use during the fourth century, but nearer the city gates is a series of monuments erected over the graves of men who were given public funerals, and these date from the latter part of the fifth century. During the excavations many potsherds that had been used for voting during ostracism were found. Thirty of them bear the name of Thucydides, the son of Melesias, who was exiled in 442 B.C. and is well known as an opponent of Pericles.

Olympia.-At Olympia ( $E . B . x x, 93)$ the results of recent excavations have been surprising. It has been shown that underneath the centre of the shrine of classical times lie the ruins of a prehistoric Olympia. This extended below the Heraeum, the Pelopium, the Metroum, and the terrace on which the treasuries stood. This was a small village of the later bronze age and is marked by the presence of ellipsoid houses. One of these was in fact found during the original excavations and called the Altar of Zeus. Above the prehistoric stratum comes another of the Dipylon age which is characterised by numbers of small votive offerings in bronze similar to those found in the earlier excavations. Finally the third or uppermost stratum is the classical Olympia which we know. This discovery is typical as showing how much the science of excavation has progressed and emphasizes the necessity of the careful examination of the stratification of a site.

Corfu (E. B. vii, I45).-At Corfu (the ancient Corcyra) the chance find of a sculptured slab has led to excavations which have resulted in the discovery of practically the whole of the pedimental sculptures of a temple of the sixth century. Eight of the eleven slabs have been found; for, as is the case with nearly all early pedimental groups, the sculpture is in high relief. In the centre is a great Gorgon over six feet high with snakes on her hair and about her waist. : On either side is a figure on a much smaller scale; on her left a nude youth, probably Chrysaor, and on her right her offspring Pegasus. The next places on the right and left are occupied by two great panthers with their heads $\mathrm{en}$ face, but with their bodies in profile. They separate the central group from the smaller scenes which fill the angles. On the left is a fallen warrior. His opponent was probably represented on a slab which is missing, and between this gap and the panther is a slab with an altar and an enthroned goddess. On the right the two corner slabs are lost, but that next to the panther is occupied by a nude Zeus and a giant at whom he is hurling a thunderbolt. The striking feature of the pediment is the great size of the Gorgon and of the panthers compared with that of the other figures. At a distance the group must have appeared merely as a Gorgon supported on either side by a panther. This composition bears a strong resemblance to one of the favourite motives of Minoan art, as shown for instance by the Lion Gate at Mycenae, and goes to confirm the theory, which is 
daily gaining ground, that archaic Greek art was merely a renaissance of Minoan. Of the temple itself little or nothing has been found beyond the altar, but further excavations may give better results.

The Homeric Ithaca.--In the Island of Leukas (Santa Maura; E. B. xxiv, I89) Dörpfeld has been excavating in the hope of proving that it was the Homeric Ithaca. In a cave in the south of the island painted neolithic pottery has been found which has a distant resemblance to the painted prehistoric wares of Apulia and Thessaly. In the plain of Nidri where Dörpfeld places the city of Odysseus plentiful remains of habitation of the later bronze age have been found. The pottery, with the exception of a few imported Mycenean and Minyan sherds, is of local fabric and resembles the local wares from Pylos, Cephallenia and Olympia. It is also to be noted that late Mycenean ware was found in connection with these local wares at the first two sites. Further it is similar to some early pottery found in Acarnania at Stratus. Apparently this corner of north-western Greece had a local bronze age culture which was influenced towards the end of the late Minoan period by the imported Mycenean culture. At Nidri two important groups of tombs have been found. One consisted of cist graves within a rectangular enclosure. They contained pottery, bronze weapons and flint arrowheads, and apparently date from the same period as the shaft graves at Mycenae and the cist graves of the fourth prehistoric period in Thessaly. The other group consisted of burnt interments. The ashes were placed in large stone jars surrounded by circular enclosures of stone, perhaps once the bases of tumuli. The best grave, that of a woman, yielded seven vases, a necklace of gold beads, a silver bracelet, and a bronze tool.

Corinth (E. B. vii, $\mathrm{I}_{4} 8$ ). - At Corinth the main results of the American excavations go to show that the fountain houses of Peirene and Glauce probably date back to the age of the tyrants in the sixth century. This is of great interest, for we know that the tyrants of Athens, Samos and Megara about the same time busied themselves in improving the water supplies of the cities under their rule. Some scanty remains of the prehistoric period have been found round the hill on which stands the temple of Apollo. The painted pottery found here is remarkable, for it is of the North Greek style and belongs to the second and third prehistoric periods in Thessaly. Amongst these sherds are a few of a style which extends as far north as the banks of the Danube near Belgrade, where it is plentiful.

Delos (E. B. vii, 971). - At Delos the systematic progress of the French excavations under Holleaux has produced important results. The clearing of the streets and houses, many of which are in an excellent state of preservation, has made this once desolate site a Hellenic Pompeii. The wall paintings and mosaic floors of the houses are of great interest, while the details of their plans and the fact that the better houses had upper storeys may go far to solve some of the problems connected with Greek domestic architecture. To the north of the Apollo temple the so-called Temple of the Seven has been brought to light with seven bases for cult statues in the cella. To this temple, which is frequently mentioned in inscriptions as the Temple of the Athenians, belong the fine: acroteria now at Athens, which were formerly attributed to the Temple of Apollo. To judge by its stylistic likeness to the Parthenon and the temple at Bassae it probably dates from the fifth century. The Asclepieion has been cleared and a headless cult statue, perhaps that executed by Scopas, has been found. Further fresh research shows that what was originally called the older Artemisium is really the later. On the east of the valley of the Inopus the sanctuary of the foreign gods has now been completely excavated. This comprised two sections, one for Egyptian deities such as Isis, Anubis and Serapis, and another for Syrian divinities. The former, it seems, was built on the site of an earlier temple dedicated to a goddess. Not far off an older sanctuary of the Egyptian deities was found, apparently of the third century. These shrines throw much valuable light on the introduction and adoption of Oriental cults by the Greeks.

Thessuly, Phocis, Boeotia, Macedonia.-In Thessaly great advances have been made in our archacological knowledge. At Pagasae a large number of painted grave stelae of marble which date from the third and second centuries were found built into the foun- 
dations of towers of the city wall which had apparently been strengthened in the first century. They are the first good examples of Greek painting found on Greek soil, and their technique is especially interesting as illustrating the encaustic method. But as art they cannot rank high, for they are the productions of an industry rather than of an art. As in marble grave reliefs so also in these painted stelae the same motives constantly recur. The drawing in many cases is inaccurate, and in only one instance is there any attempt at atmosphere. Another important find is that of some silver plate and gold jewellery in a tomb at Metropolis. This belongs to the Hellenistic and Roman periods. The heavy gold necklaces and bracelets set with large stones display ostentatious vulgarity rather than good taste, but some of the work on the silver plate is exquisite. Further all over Thessaly careful exploration has brought to light a large number of new inscriptions which are an earnest of what yet remains to be found.

But more important than these, the recent Greek, Bavarian and British excavations in Thessaly, Phocis and Boeotia have given us a far clearer picture of the condition of the country in prehistoric times. The principal sies are: in Boeotia and Phocis, Orchomenus, Chaeroneia, Dhrakhmani and Ayia Marina; in Thessaly, Lianokladhi, Dhimini, Sesklo, Tsangli, Marmariani, Rakhmani, and Zerelia. The period of time occupied by this prehistoric civilisation has been divided into four periods. The first two are neolithic, though bronze may have been known as an import, the third is chalcolithic, and the fourth is of the full bronze age and comes to an end at the close of the third Late Minoan age. In the first period throughout the region mentioned there was a uniform neolithic culture characterised by an abundance of well made pottery decorated with elaborate red designs on a white ground. In the second period the region is split in two, and Thessaly north of Mount Othrys remains isolated, and the standard of culture as illustrated by the pottery gradually degenerates during the succeeding periods, though there is some progress in technical skill shown by the change from stone to bronze, and at the end from bronze to iron. In the second period the pottery shows kinship with that found in Moldavia and the adjoining districts, and in a more distant way, as mentioned above, with that found in Leukas and Apulia. The prehistoric remains of Macedonia and Thrace (Bulgaria) should provide a connecting link between Thessaly and the Danubian area and there are indications that such may eventually be found. In the third period the pottery is related to that so common in prehistoric sites in Servia, which as noticed above is found in Greece as far south as Corinth. In the fourth period there are for the first time definite signs of a connection with the Minoan civilisation of the south, for in this period Minyan and Mycenean (L. M. II and III) pottery are found imported into Thessaly, implying that not till then did the north come within the orbit of Cretan culture. Another sign of connection with the south is provided by the cist tombs which are common in Thessaly in this period and from their contents belong to the same date as the shaft graves at Mycenae and the Leukas tombs. At the end of this period there seems to have been an infiltration of influence from the north as shown by the resemblance between some Thessalian finds and those from an early iron age cemetery on Lake Ostrovo in Macedonia. These may well indicate the general direction whence came the invaders who overthrew the domination of the Minoan civilisation in Greece.

But in Phocis and Boeotia after the end of the first neolithic age a different state of affairs prevailed. The culture of the south spread northwards and settled in the land, but apparently without entirely displacing the old local culture. This southern culture seems to have originated mainly in the Argolid and to have been allied to that in the Cyclades. It is characterised by a kind of pottery known to archaeologists as Urfirnis, the name given to it by its German discoverers. This advance northward took place during the Middle Minoan age and may have been influenced by pressure from still farther south. This in its turn in the area in question gave way to another phase of civilisation which is marked by a peculiar grey wheel-made class of pottery known as Minyan. The main centre of this culture seems to have been Qrchomenus, but the pottery in question has a wide range, being found in Thessaly, the Troad, Attica, Melos, 
and the Argolid and Leukas. Finally at the beginning of the Late Minoan age the Mycenean or Cretan civilisation became dominant in the Argolid, and then spread northwards, becoming supreme first in Boeotia and Phocis and later in Thessaly. Apparently a backward and isolated. Thessaly acted as a barrier behind. which the Minoan civilisation was able to reach its high state of development undisturbed. It was not till the bearers of the Minoan culture had themselves removed this barrier by trade or conquest that the way was opened for the hardy tribes of the north to overrun and plunder the seats of an old established and wealthy civilisation.

In Macedonia itself, the country-where we must look for the solution of some of the problems indicated in the last paragraph, much exploratory work has been done. Many prehistoric sites have been noted, and it is to be hoped that their excavation will not be long delayed. We shall then be able to link up the prehistoric culture of northern Greece with that of Servia and Bulgaria, where many important finds have already been made. There are indications that the prehistoric folk of Thessaly were akin to the early inhabitants of those countries, and this gives special point to the Greek legends of Thracians in Thessaly and Phocis. Macedonia is rich also in remains of the classical period. The French excavations in the island of Thasos have laid bare a large temple on the acropolis, the city gates which were decorated with archaic reliefs, and the shrine of Artemis Polo. Some important pieces of archaic sculpture have also been found. Near Salonica a tumulus has been opened and found to contain a vaulted chamber tomb with double doors of marble and wood, the latter being remarkable for their fine bronze ornaments. The tomb dates from the Hellenistic age, but unfortunately it had been robbed in antiquity. Many new inscriptions have been found in various places. The most interesting is a decree of the emperor Trajan, fixing the boundary between Macedonia and Thessaly. In the course of the decree it is stated that it is based on a previous decision of King Amyntas III, the father of Philip II, which was found inscribed in the market place of Doliche. Another important regal inscription dated to the thirty-sixth year of King Antigonus Gonatas contains three letters of his son Demetrius, then apparently acting as regent for his aged father, sent to the governor of the city of Berrhoea.

\section{(A. J. B. WAGE.)}

\section{CYPRUS ARCHAEOLOGY}

Since the close of the survey of Cypriote archaeology, in the E. B. (vii, 697 et sey.) nothing of the first importance has been either discovered or published. A new Antiquity Law, passed in 1905 , has had the effect of restricting facilities for legitimate excavation; but the Berlin Academy of Sciences has examined a site at Rantidi near Old Paphos. Reports which appeared in the press in I9IO- I are exaggerated, ${ }^{1}$ and have been in part contradicted by the excavator $;^{2}$ but there is as yet no official statement of the results. The earlier German excavations are also still unpublished.

The general bearing of earlier work in Cyprus on the history of the island itself and of adjacent mainlands is discussed afresh in Eduard Meyer's Geschichte des Alterthums (2nd ed.) vol. i, 2, \$ 498-500; by D. Fimmen, Zeit $u$. Dauer der Kretisch-Mykenischen Kultur (Leipzig, 1909); by R. von Lichtenberg, Mitth. d. Vorderasiatischen Gesellschaft, 1906 and I911, and more popularly by M. Ohnefalsch-Richter, Contemporary Review, Nov., Dec., I9I2.

Cyprote objects figure largely in the British Museum's Catalogue of Terracoltas (1903), of Jewellery (I9II) and of Vases (vol. i, part 2, Cypriote, Elruscan, etc.). The pottery from the British Museum's excavations at Enkomi is discussed in detail by F. Poulsen, Jahrbuch d. Archaeol. Institute, xxvi (I9II), and the origins of the Mycenacan style of pottery in Cyprus and elsewhere by E. J. Forsdyke, Journ. Hellenic Studies, xxxi, p. IIo. The vast Cesnola Collection in the Metropolitan Muscum of Art in New York has been rearranged: uncertainty as to the circumstances of discovery does not affect the genuineness, value, or technical interest of its numerous masterpieces: ${ }^{3}$ a handbook is in preparation.

'In 1910: Phone tes Kyprou, June 25; Patris, June 23, 26; Tägliche Rundschau, July 6, 7; Ilellenic IIerald, July; Times, July 27, Aug. 27 , Oct. 18, Nov. 12. In 1911: Times, Sept. 11.

${ }^{2}$ Berlin Philol. Wochenschrifi, February $14,1911$.

' 3 Bulletin. Met. Mus. Art, June and Sept. 1909, Oct. 1910 (interim reports by J.L. Myres). 
Special problems of archaeology are discussed as follows:-(I) the date and affinities of the well-known silver bowls of "mixed oriental" style by F. Studniczka, ${ }^{1}$ who thinks them all alike Phoenician, and by $\mathrm{F}$. von Bissing, ${ }^{2}$ who claims the Berlin bowl as a genuinely Egyptian work of the New Empire, and emphasises the early date and Egyptian affinities of the rest of the series: (2) a peculiar form of spear, called sigynna by the Cypriote Greeks, is identified, and dated by J. L. Myres, ${ }^{3}$ who also discussed (3) an unusual fibula from the same Early Iron Age culture. ${ }^{4}$ (4) The influence of Cyprus on Palestine both before and during the Philistine occupation ( $1200-1000$ B.C.) is well illustrated (for the Palestine Exploration Fund), by R. A. S. Macalister. ${ }^{5}$

After long neglect the Government Museum of Antiquities at Nicosia has been provided with a new building and a trained curator. Illicit excavation and needless damage to antiquities are still far too frequent; but in I9I I a joint memorial on this subject from the principal learned societies of Great Britain received a favourable reply from the Colonial Secretary. The mediaeval buildings are inspected and maintained in as good condition as financial limits allow; and a collection of architectural fragments and movable monuments has been begun.

(J. L. MYres.)

\section{NEW LIGHT ON GREEK ART 6}

During the last four or five years there has been a great deal of activity in the fresh study of Greek monuments, their classification, and their restoration.

Period I, Before B.C. 480 . - One of the most pleasing discoveries of recent times is due to Dr. Premerstein, who has succeeded in better reading the inscriptions on the bases of the two archaic nude figures found at Delphi, and usually supposed to be Apollos (E. B. xii, 480, fig. 76). They are now proved to be, what M. Homolle had from the first conjectured that they might be, the very statues of Cleobis and Biton dedicated at Delphi by the Argives after they had dragged their mother's chariot. Everyone will remember the delicious tale as told by Solon in Herodotus.

The British excavations at Sparta have revealed to us the history of art at that city. The results are recorded in the Annual of the British School at Athens. It appears that in the archaic age Sparta, though never the home of a great art, was not unreceptive of the art influences which flowed from Ionia... The city is even supposed to have carried on a considerable export of painted pottery; and objects in ivory and bronze are not inferior to those of other Greek cities: The rising power of Sparta strangled art, as it strangled all humanism, in the times when Athens was greatest.

At Athens there are not many new statues; but the piecing together of the abundant fragments of the early monuments of the city which have been unearthed in the diggings of the latter part of the last century has occupied the full attention of distinguished German savants. The very archaic temples of limestone, with their uncouth sculptural adornments, have been elaborately published by. Wiegand and others; while Schrader has devoted his attention to the sculptural remains of the times immediately before the Persian wars, horsemen, dedicated female figures and the like. Wolters and others have begun the publication of the vase fragments found among the débris left by the destroying Persians. In this connection must be mentioned Mr. Guy Dickins' recent Catalogue of the Sculpture of the Acropolis Museum.

Period II, B.C. 480-400.-Among ancient sculptors who have recently come to be better understood we must especially mention Myron. His Discobolus and Marsyas have long been familiar to us in Roman copies. Recently a new torso of the Discobolus, in some respects superior to any known, has made its appearance. And the Marsyas is no longer a detached figure, as the Athena belonging to the same group (Athena throwing away the flutes, Marsyas picking them up) has been identified in a statue of a girlish Athena in the Museum of Frankfort. This figure has a singular' charm: the archaic severity of the head, the simplicity of the drapery, and a wonderful expression of girlish freshness are together captivating. This restoration has been generally

1 Jahrbuch. d. Archaeol. Institute, xxi (Igo6).

2. Jahrb. xxv (I9I0).

${ }^{3}$ Anthropological Essays, 1907, p. 255 ff. Liverpool Annals of Archaeology, iii, 107.

4 Liverpool Annals of Archaeology, iii, 138; v, 129.

6 Extavations at Gezer, 3 vols. I9I2.

${ }^{6}$ See E. B. xii, 470 et seq. 
accepted, and the group added to the stock of received masterpieces. Less certainty attaches to an attempt of Dr. Amelung to constitute out of the Medici torso of Athena at Paris and a head which can be shown to belong to the same type, a new restoration of the Athena Lemnia of Pheidias. These reconstructions afford an excellent exercise for the talents of archaeologists, but they must stand the test of time and criticism before they can be worked into the tissue of the history of Greek art.

A work of a very different kind is the publication by Mr. Arthur Smith, for the Trustees of the British Museum, of new and splendid volumes giving precise representations and detailed discussions of the sculpture of the Parthenon. This was a work quite due: equally due is a complete publication of the sculpture of the Mausoleum, which is to be Mr. Smith's next task.

A great controversy has arisen over some reliefs now acquired by the museum at Boston, U. S. A., which evidently correspond in size and arrangement to the beautiful set of reliefs in the Ludovisi Gallery, which represent (as is supposed) the birth of Aphrodite, with two Hours to receive her and two votaries seated at the sides. The main subject of the new reliefs is the weighing of two human souls-or destinies-by a winged Eros, while a draped lady or goddess sits on either side awaiting the result of the weighing. All these reliefs are supposed by Studniczka, who has published them in the Jahrbuch of the German Institute for I9I I, to come from the same altar. He supposes the weighing scene to represent the contest of Aphrodite and Persephone for the person of the young Adonis. The puzzle is a fascinating one. Certain differences in the style of the two sets of reliefs have caused some archaeologists to doubt whether they belong to.the same monument; or at all events whether they were executed at the same time. They belong precisely to that period of art, when archaic style is bursting its swaddlingbands, which appeals to the intelligence as well as to the aesthetic faculty.

Period III, B.C. 400-300.- Under this head we may range what is alike for its abundance and its importance among the most remarkable discoveries of recent times. At Pagasae in Thessaly Mr. Arbanitopoulos has succeeded in extracting from a tower, into which they had been built in ancient times, a large number of grave monuments which are now set out in the museum at Volo. These stelae are decorated with subjects similar to those used in the great Athenian cemetery of the Ceramicus; but instead of the decoration being sculptural (in relief) it is painted. Painted stelae are not unknown at Athens and elsewhere; but in such abundance they have not been found before. We have here painted groups of seated men and women, scenes of farewell and the like; and they are of the period of the great painters of Greece, painting probably touching its highest point with Apelles in the age of Alexander the Great. Thus the stelae of Pagasae claim attention. But few of them are as yet published, ${ }^{1}$ and from the examples thus made known it is clear that they are the work of very poor artists. This is confirmed by those who have seen the museum at Volo. Greek painting seems always to elude the student.

Period IV , B.C. 300-50.-Our knowledge of the Hellenistic age of Greek art has. progressed more rapidly than that of earlier periods. A number of books and papers by Schreiber, Strzygowski and other writers have fairly embarked us on the search for the bridges leading from the art of the great period of Greece to that of the Roman age. We can here only mention a few works of this period which have been the subject of fruitful investigation. We ought perhaps to place first a statue now in the Terme Museum at Rome which has exercised a fascination upon visitors to the eternal city, the Girl of Antium. Disclosed by a landslip at Antium, and bought for a great price by the Italian Government, the Girl not only has the charm arising from freshness of design and originality, but she also offers the archaeologist great difficulty in attribution. On a tray she bears a laurel twig, a scroll and a small box. It is impossible to detail the various interpretations of the figure which have been suggested. One point, as the writer is convinced from a careful inspection, is quite clear. The girl is a girl, and not, as some have fancied, a boy in girl's raiment. This suggestion is singularly in-

1 See Arbanitopoulos, Description of the Painted Stelae at Pagasae (Greek), 1909. 
appropriate: every part of the body as well as the total impression which it produces is thoroughly girlish. She is an attendant at a sacrifice, or entrusted with some religious function to which with naïve simplicity she devotes her whole attention.

To Mr. Guy Dickins we owe an important series of papers in which he has not only studied the remains of the colossal group at Lycosura, consisting of Demeter, Persephone, Artemis and Anytus, but succeeded in restoring the design of the group, a restoration more recently confirmed by the evidence of a coin of Arcadia which reproduces the group. These figures were by Damophon of Messene, and Mr. Dickins has conclusively fixed the date of the artist, who used to be given to the fourth century, to the early part of the second century B.C. Such fixed points are of the greatest value. The date also of the Laocoon has been by Danish archaeologists fixed, on the testimony of inscriptions, to about B.C. $5^{\circ-30}$, just before the time of the Aeneid, thus settling for all time a memorable controversy.

The Hellenistic age has many attractions to the researcher, and presents a vast range of interesting problems. From the artistic point of view, new lights could scarcely be more illuminating than that offered by the recent appearance of statue after statue from the workshop of Aphrodisias in Asia Minor, which seems to have supplied Italy, under the earlier emperors, with original types of the Greek deities. This school can best be studied in the magnificent $\mathrm{Ny}$-Carlsberg Museum of Sculpture, presented to the city of Copenhagen by Mr. Jacobsen.

A few of the many important books on Greek art which have appeared in the last few years may be mentioned. Among the most valuable are the volumes on archaic Greek art which form part of the great Histoire de l'art dans l'antiquité of Messrs. Perrot and Chipiez. We have here a more detailed general account of early architecture, sculpture and vases than has before appeared; and M. Perrot's work is marked by conspicuous good sense and moderation. Another valuable French work is Collignon's Statues funéraires dans l'art grec, a book which goes over the whole history of sculpture in Greece: In English we have some important new works, such as the great work on the Parthenon, already mentioned; Walters' Arl of the Greeks; Mr. E. Gardner's Six Greek Sculptors, and the Catalogue of the Sculpture of the Museum of the Capitol, a work of great research and much value, edited by Mr. Stuart Jones. In the very important and much neglected province of Greek portrait sculpture we have Hekler's Greek and Roman Portraits, the numerous plates of which bring for the first time ancient portraits within the ken of people of moderate means. The notable work of Furtwängler and Reichhold on Greek Vases makes it possible to study these admirable works of art outside the galleries of museums.

\section{PROTECTION OF ANCIENT MONUMENTS ${ }^{1}$}

United Kingdom.-The question of the protection of monuments has come prominently before the general public in England during I9IO-I9I2. This is due partly to the action of antiquarian societies and the great publicity given by the press when any monument is reported to be for sale or demolition, partly to the activity shown by the Office of Works and Mr. C. R. Peers, the official Inspector of Ancient Monuments, in making known the provisions of existing legislation, and partly to the interest roused by the publications of the Royal Commissions in England, Scotland and Wales.

Inventories with full descriptions and illustrations have been published by these Commissions of the Monuments of Hertfordshire and South Buckinghamshire in England; Berwickshire, Caithness, Sutherlandshire and Wigtownshire in Scotland; and Montgomeryshire and Flintshire in Wales; and the number and interest of the monuments there described have been a surprise to all but the most experienced archaeologists. On the whole, the enquiries show that, with few exceptions, architectural monuments of known interest receive careful treatment and that a far greater number suffer from ignorant restoration than from neglect.

From the English Inventories, evidence was adduced in 1912 before a Joint Committee of both Houses of Parliament, showing that $95 \%$ of the ecclesiastical monuments in Hertfordshire and South Buckinghamshire were in "good " or "fair" structural condition, while $5 \%$ were in bad condition or in ruins; of the secular monuments (including barns and cottages) $88 \%$ were in good condition while $12 \%$ were in bad condi-

${ }^{1}$ See $E$. B. xiiii, 796 et seq. 
tion or ruinous; and of the earthworks $52 \%$ were in "good " or "fair" condition while $48 \%$ were in "bad" condition. All the monuments to which these figures refer were of a date anterior to 1700 .

The Scottish report on Wigtownshire calls attention to the damage that is being done to prehistoric monuments, more especially cairns, by the removal of the stones of which they are composed for road metal, and also to the obliteration of original structures by the practice of utilising the sites of such monuments for the disposal of pebbles and boulders gathered from the fields.

In Wales special attention is called in the Report on Flintshire to the fate pending for the ruins of Diserth Castle, which ultimately must be blown to pieces with the advance of quarrying operations on the hill on which it stands.

For each county visited, the three Commissions append a list of those monuments which in their opinion are most worthy of preservation, and when complete the country will be fully seised of the nature and number of its ancient monuments and will be able to form some idea of their comparative value. In the meantime, the Office of Works has appointed a special staff to deal with the monuments brought under its charge, and is collecting from county councils and learned societies a preliminary list of the monuments in each county to form a basis for its work under the existing Monuments Acts. Further, a Bill for the consolidation and amendment of these Acts has lately been under the consideration of a Committee of Parliament, and it seems probable that some system of local correspondents will be established together with Advisory Boards for England, Scotland and Wales to assist the First Commissioner of Works in the problems connected with the acceptance and care of the monuments brought under his charge. The joint Committee recommends that monuments placed under the guardianship of the Commissioners of Works or the council of a county or county borough or the equivalent authorities in Scotland, should be exempt from liability for probate or death duties, and suggests that cathedral churches should be included within the scope of the Bill. Amendments are also suggested giving power to local authorities to regulate the display of advertisements, and power to the advisory boards to give gratuitous advice as to maintenance and repair, to owners of ancient monuments who invite their assistance. In the Bill the expression "monument" is interpreted to mean "any immovable monument, in the widest sense of the word, whose preservation is desirable in the interests of the public on account of its importance in the history of the country, the history of civilisation, or the history of architecture or art, or on account of its aesthetic value. And it may include any earthwork, excavation, structure or erection as well as any prehistoric or historic work of craftsmanship or art made or apparently made or excavated in the United Kingdom the preservation of which is a matter of public interest by reason of the historic, architectural, traditional, artistic or archaeological interest attaching thereto, or to any remains thereof, and the expression 'monument.' may include the site of any such monument, structure or erection, and any part of the adjoining land which may be reasonably required for the purpose of fencing, covering in or otherwise preserving from injury the monument, structure or crection, and it may also include the means of access thereto."

With regard to "chattels," which are not included in the Bill, the Committee was of opinion that such movable property as plate and other articles of historic and artistic interest as belong either to a municipal corporation or to the Established Church should be subject to protection similar to that extended under the Bill to fixed objects.

The following monuments were voluntarily placed under the Office of Works during the year ended March 31, I012: Old Machar Cathedral (ruined parts), Aberdeen, Aberdecnshire; Gateway Tower, Chester Castle, Cheshire; Richard III's Tower, the curtain walls, etc., Carlisle Castle, Cumberland; Blackfriars' Church (remains), St. Andrews, Fifeshire; Weobley Castle, Gower, Glamorganshire; St. Martin's Church, Haddington, Haddingtonshire; Kirby Muxloe Castle, Leicestershire; Maclellan's Castle. Kirkcudbrightshire; the Bishop's and Earl's Palaces, Kirkwall, Orkney; the Old Church, Westray, Orkney; the Old Bridge, Stirling, Stirlingshire. In all the Office 
of Works has charge of 53 ancient monuments and historic buildings in England and Wales, and 62 in Scotland.

Apart from State action, the committee for the survey of the Memorials of Greater London has published volumes on Bromley-by-Bow, Chelsea, and Lincoln's Inn Fields; and the National Trust holds properties amounting to 3,400 acres and 13 structures of historic or architectural interest.

Austria-Hungary.-The Central Commission of the Austrian Government for the preservation of Historical Buildings, Monuments, etc., was reorganised under new statutes to which the Imperial assent was given on July 3 I, I9II. Under these the Commission's sphere was extended to all monuments whose preservation is desirable in the interests of the public, whether on account of their importance in the history of the country, the history of civilisation, the history of art, or by reason of their aesthetic value. Separate arrangements are made for the care of written memorials, but all questions of "Heimatschutz," e.g. preservation of scenery, etc., so far as these are connected with the preservation of monuments, are dealt with by this Central Commission, which also supervises excavations and has charge of such prehistoric monuments as have not already been placed in the State Museums.

The Commission consists of a Chief Commissioner, a Chairman and Vice-Chairman appointed by the Emperor, an Advisory Board of Monuments of 50 members, and an office for State Monuments. Its headquarters are at Vienna. A History of Art Institute and possibly also institutes for prehistoric and numismatic research are projected in connection with it. For the separate kingdoms and countries of the Empire, local conservators are appointed who are civil servants versed in the history of art, technically trained and possessing legal knowledge. Further, the Chief Commissioner has power to appoint honorary wardens of monuments and correspondents with the duty of assisting local conservators. These conservators are under the Central Commission, which in its turn is under the control of the Ministry for Public Worship and Education.

Bavaria.-The entire care of the national monuments in Bavaria rests with the General-Konservatorium der Kunstdenkmäler und Altertümer Bayerns, which is placed directly under the Ministry of Education. The General-Konservatorium is composed of specialists in prehistoric archaeology (the term "prehistoric" covering the whole period up to A.D. 700), specialists in the later history of art, and practical artists experienced in the work of restoration. By a law of July 6, Igo8 national monuments were placed under legal protection and a penalty imposed for all damage done to them. The provisions of the law are extremely drastic with regard to the preservation of all prehistoric objects, though they only apply to such as are pronounced " remarkable" in the case of periods later than the Merovingian. Thus the right of the landowner to excavate or explore for monuments on his own estate is dependent on the permission of the administrative authorities of the district, and further, anyone who desires for any purpose whatever to disturb the ground in a place where monuments may be expected to be concealed must obtain leave from the same authorities before he can begin work. The General-Konservatorium, however, is free from any such restrictions, and is merely obliged to give notice to the district authorities of any investigations which it is going to undertake on its own account. Honorary local correspondents keep the General-Konservatorium informed of the condition of all historical monuments within their districts, and here the term " historical monument " is interpreted in a large sense and includes not only churches, fortifications, city gates, towers, castles and town walls, but even cottages, small chapels, fountains, old bridges, wayside calvaries and pillories. Great weight is also laid on the local associations, and a cottage may be saved because it is an integral part of a beautiful or typical landscape.

In addition to the above, the property of the Church is subject to the supervision of the State, and most districts have regulations of their own concerning the erection of new and the restoration of old buildings. Thus at Würzburg, the local by-law makes the employment of red roofing tiles obligatory "so as not to interfere with the beauty of the landscape by the erection of differently-coloured roofs." 
Belgium.-The State refers all matters concerning the restoration and preservation of monuments (i.e. religious or secular buildings possessing a special value from an architectural or artistic point of view) either to the Department of Bridges and Highways (a branch of the Ministry of Agricultural and Public Works) or to private architects, or to the Department and private architects in association. The expenses incurred in connection with cathedral churches, episcopal residences and diocesan seminaries, are included in the annual budget of the provincial councils. Recommendations by parochial councils which would result in altering the style or character of monuments must be submitted for the approval of the permanent committee of the provincial council and the sanction of the Sovereign. The Royal Commission for Monuments (founded in 1835) superintends the preservation of monuments and examines plans for their restoration. Each province and each commune can make appropriations for the restoration of monuments, and the Department of Fine Arts disposes annually of a sum of $£ 5, \infty 00$ for the restoration of secular and $£ 8, \infty 00$ for the restoration of religious buildings classified as monuments. Works of art in churches may not be removed without the sanction of the Crown or the public authorities designated for the purpose; and a communal law of 1836 , laying down special regulations with regard to architectural monuments, has been extended with a view to preventing the alienation of any works of art belonging not only to the communes, but also to vestries and other public institutions, without the sanction of the Government.

Denmark.--The protection of antiquities and monuments of the prehistoric period is under the supervision of the First Division of the Danish National Museum, which receives for this purpose an annual grant from the budget. Full compensation is paid for treasure trove, and the Museum considers that further legislation would be detrimental to the excellent relations subsisting between itself and the rural population. National monuments of a secular character, such as old castles and ruins, etc., of historic interest, are not protected by special laws nor has the State any right of supervision. But ecclesiastical buildings are subject to a law of February I9, I86 I enacting " that every church shall be maintained, both as regards interior and exterior, in a manner corresponding to its original style and that restorations shall be carried out in that style." Further, by the same law, cathedrals and other important churches are placed under the supervision of a special council, consisting of two architects and an archaeologist, and the duty of an annual inspection is imposed on the dean and two master craftsmen. All important questions of repairs and alterations, including the treatment of frescoes, are referred to the inspectors of royal buildings and to the authorities of the National Museum.

France.-A bill was at the end of 19 I $_{2}$ before the Council of Ministers amending the existing legislation. Some discontent is expressed with the present system, owing to the fact that local authoritics have been known to allow interesting buildings to fall into disrepair in the hope that the State may be induced to take them over as " monuments historiques" and thus save the locality the cost of their upkeep and repair.

Netherlands. - There are no laws on this subject in the. Netherlands, but the Communal authorities have been requested to notify the Ministry of the Interior in due time of any proposed demolition, reconstruction or restoration of ancient monuments, townhalls, churches, towers, castles, gates, interesting façades, etc., in order that it may be possible to reproduce them or take their dimensions.

Russia. - The number of buildings now standing, erected before 1650 , which are neither churches, monasteries nor fortifications, is insignificant. Legally, the care of the historical buildings is entrusted to the Academy of Fine Arts, a dependency of the Ministry of the Court, but as practically speaking all the ancient monuments are in the hands of the Ministries either of the Interior, War or Holy Synod, the control of the academy is nominal. () recent years there has been a great revival of interest, and a society has been founded on the lines of the English Society for the Protection of Ancient Buildings, but immensely more wealthy and influential; a bill was before a Committee in the Uuma at the end of 1912 , proposing that a Commission controlling 
the preservation of ancient monuments should be formed, consisting of 18 members, five to be recognised experts and I 3 representatives of government departments.

Saxony.-In I 894 a Royal Commission was appointed for the preservation of monuments. This body consists of a Councillor of the Ministry of the Interior who acts as chairman; two members nominated by the Evangelical Lutheran Consistory; two experts entrusted with the duty of cataloguing artistic monuments; and a member selected by the Antiquarian Association of Saxony. The Commission is in direct communication with the 28 administrative districts of Saxony, and is empowered to issue instructions to their officials. It deals with enquiries addressed to it by the Ministries and the Evangelical Lutheran Consistory with regard to the destruction, preservation and restoration of artistic monuments: The existing national monuments are subject to its supervision, and it gives advice as to their protection. It issues instructions with regard to continuing the work of cataloguing, and has published reports on general questions dealing with the care of antiquities, and three small volumes of advice with regard to the preservation of objects made of wood, metal, ivory, earthenware, glass and textiles, the preservation of pictures in oils and distemper and the preservation of prints.

In addition; the territorial offices of public works are expected to acquire, as far as possible, precise knowledge as to the existence and condition of ancient buildings and monuments of historical and artistic interest situated in their districts, and to notify the Commission when the buildings and monuments in question are in any way endangered. The same officials are also required, when repair or restoration of such buildings is undertaken, to make drawings of inscriptions, dates, masons' marks, etc., and to display the greatest care in preserving these from destruction by scraping or from disfigurement by paint or plaster; and further, they must report immediately when the demolition of a public building of artistic or historic importance is contemplated. The Commission also has local agents of its own. The Evangelical Lutheran Consistory has also taken steps to prevent the alienation of ecclesiastical monuments, and has instructed its subordinates to use experts in all additions to or restorations of ecclesiastical buildings or to apply to the Association for Ecclesiastical Art. The Saxon Government has established a "Denkmalarchiv," or collection of records relating to monuments, designed to serve scientific as well as practical purposes. In I909 a law was enacted "against the disfigurement of urban and rural landscapes," in which wide powers are given to the police to prohibit advertisements and even new buildings in streets where their presence would be a disfigurement.

Spain.-The preservation of ancient monuments is at present a part of the work of the Ministry of Public Instruction and Fine Arts. There is no law on the subject, though a number of Royal orders and decrees have been issued. In subordination to the Ministry there exists in each Spanish province a "Provincial Commission of Historic and Artistic Monuments," whose chief duty is to make recommendations to the Government as to what ancient buildings, etc., lying in their provinces, shall receive the title of " national monuments." . After such a recommendation, the Government consults with the Royal Academies of History and of Fine Arts, and if accepted, the building becomes a national monument and its preservation a direct charge on the State.

Sweden.-There have been provisions for the preservation of monuments of antiquity in Sweden since the early part of the I 7 th century, and all carved stones, ancient graves and treasure, have been since then regarded as, in a manner, State property, or at least under the direct protection of the State. This protection has since been extended to old church monuments and to vestments of the pre-Reformation era, as well as to the fabrics of ruined churches, such as exist in abundance in Gotland. It is probable that a new law will soon be passed making it impossible for the owners of old church treasures to sell them without direct State authorisation. At present they have to be offered to the State before sale, but there is no guarantee against their sale. The law of 1867 provides that "all monuments preserving the memory of the Fatherland's inhabitants in ancient times are put under the protection of the law, so that they cannot be altered, injured or destroyed by the owner of the land under other conditions than those speci- 
fied." The definition of ancient monuments includes everything which is of such antiquity that it cannot be regarded any more as belonging to any particular owner, and embraces all kinds of sepulchral monuments, sites of old towns, ruined churches and walls, etc. If the site is already in use for agriculture, the owner must not dig down further than he or his predecessors have done without special permission. If the construction of any public work is expected to interfere with any existing monument the authorities must be informed so that a competent person may be sent to examine the work "without undue interference." Destruction of monuments is punishable by fine. All ancient objects must be brought to the Historical Museum to be valued. Monuments, painted or otherwise, in churches must not be disturbed or injured without leave of the proper authorities. An inventory must be taken of Church property, which, if required, may be periodically examined by the Royal Antiquary (an office which dates back to the time of Gustavus Adolphus) or his deputy.

United Siates. - An Act of Congress was approved on the June 8, igo6 for the preservation of American antiquities. Under it the President is authorised, in his discretion, to declare by public proclamation historic landmarks, historic and prehistoric structures and other objects of historic or scientific interest that are situated upon the lands owned or controlled by the Government, to be national monuments. If such objects are situated upon a bonâ fide unperfected claim or held in private ownership, the tract, or so much thereof as may be necessary for the proper care and management of the object, may be relinquished to the Government, and the Secretary of the Interior is authorised to accept the relinquishment of such tract on behalf of the United States. Permits for the examination of ruins, etc., under their jurisdiction may be granted by the Secretaries of the Interior, Agriculture and War, to competent institutions, provided that the enquiry is undertaken for the benefit of reputable museums, universities, etc., with a view to increasing the knowledge of such objects, and that the "finds " shall be handed over for permanent preservation in public museums. The Secretary of the Interior reports that the only practical work carried out by his Department for the preservation of ruins, etc., has been in the Mesa Verde National Park, Colorado.

Conclusion.-It is evident that there is no lack of regulations in civilised countries for the preservation of ancient monuments. But in despite of them not a few memorials, both chattels and structures, disappear yearly owing to preventable causes; they perish by neglect, or they are sold and removed from their original surroundings, or it may be that they lose their character owing to ignorant restoration. In England the public conscience has been shocked by proposals to remove the mantelpieces at Tattershall Castle and the Globe room from the Reindeer Inn, and demands have been made for State interference. But the Inspector of Ancient Monuments is very near the truth when he declares in his annual report (I9I2) that "the ultimate protectors of national antiquities are the people themselves." The State indeed is powerless to preserve monuments except within a limited sphere without the sanction of an educated public opinion. Such dangers as the deadening of the public conscience due to the feeling that someone else is or should be responsible for the care of monuments, the tacit assumption by many that any monuments but those adjudged to be of "national " value may safely be allowed to decay or be sold out of the country, the encouragement towards careless treatment if it is felt that the State will more readily accept responsibility for monuments that are in a bad condition, and the power of arresting natural architectural development, are real dangers inherent in State action; and, unless particular care is taken to guard against them, largely counterbalance the value of the State's good example in selected cases and its ability to use the public purse freely on great occasions.

See Inventories issued by the Royal Commissions on Ancient and Historical Monuments for England, Scotland and Wales; Reports from H. M. Representatives abroad showing the systems adopted in certain foreign countries (Cd. 6200; 1912); Report of the Inspector of Ancient Monuments for the year ending March 31, I912; Report from the Joint Select Committee of the House of Lords and the House of Commons on the Ancient Monuments Consolidation and Amendment Bill, etc. (Nov. 1912).

(X.) 


\section{SECTION V. PHILOSOPHY, EDUCATION AND RELIGION}

\section{PHILOSOPHY ${ }^{1}$}

Any sketch of the general march of Philosophy during rgro- 2 is bound to be, in the main, impressionistic. The ground covered by the philosophical sciences is so vast that any one writer can see only a small portion of it in clear perspective; and even within the partial field where he is most at home, he may well find it hard to catch the real drift of tendencies which have not yet fully disclosed their ultimate scope. It is clear that the next generation or so will see some striking developments in Western philosophy, but the movements from which most may be reasonably expected are yet too undeveloped to admit of confident prophecy as to the precise direction they are likely to take in the near future. There seems to be at this moment no one type of philosophical thought which promises to be dominant even for the next few decades. The general impression one derives from the recent literature of the subject is rather that the day for the dominance of the main stream of thought by any single tendency is temporarily over, and that in the most immediate future, at any rate, philosophy is likely to witness a struggle for existence between two or three types of doctrine, each of which will presumably become seriously modified as it develops itself in conflict with its rivals.

There have been few outward signs lately of definite breach with the traditions of the opening years of the century. No startlingly new figure has appeared above the Shadworth horizon, though we have to chronicle the deaths of at least three distinHodgson. guished representatives of already established types of thought, William James, Shadworth Hodgson, and Alfred Fouillée. In Shadworth Hodgson there has passed away from the scene perhaps the last survivor of the classic "British" succession of thinkers, whose characteristic method in philosophy was the direct psychological analysis of the given " moment of experience" as distinct from metaphysical or epistemological enquiry into the "transcendental" implications of Being or of Thought. His philosophy seems likely to be the last attempt to develop a system in entire independence of the influence of Kant's " Copernican revolution," unless, indeed the recent work of Prof. S. Alexander should prove capable of development into something like a system. William James's work in general philosophy is of too recent a date to pass a judgment upon it with any confidence of anticipating the William final verdict of history. To the present writer it appears to exhibit three James. distinct strains, none too closely connected with one another: (I) a fundamental metaphysical pluralism, (2) a radical empiricism in method, (3) the adoption in logic of a purely utilitarian theory of truth and falsehood. It is this peculiar view of truth as "that which works," or "that which produces practically useful results" which, from its apparently paradoxical character, has made the principal sensation among James's contemporaries for the moment, and from which he has chosen the name ("pragmatism") for his type of thought, but it is open to question whether his abiding place in the history of philosophy will not depend primarily on his brilliant defence of pluralism against the singularism of philosophies of the " one substance " and "absolutist " types. His reaction against the type of speculation which denies substantial reality to finite individuals, by resolving them into phases, appearances, or predicates of a single all-inclusive individual, is equally manifest in schemes of thought so different from his own and from one another as those of Dr. Rashdall, Dr. McTaggart, Prof. Varisco, and the "new realists". of Great Britain and the United States." None of these thinkers, in fact, would accept the view that unqualified empiricism is the sole method of philosophical enquiry, and most of them would hardly acknowledge it as a valid method at all. Nor do any of them adopt the special theory which identifies truth with fertility in "practical" consequences (see particularly for a criticism of this view, the fifth essay in Mr. Bertrand Russell's Philosophical Essays, I9ro). The disappearance from Continental journals of philosophy of the discussions of "Pragmatism,"

${ }^{1}$ See generally the E. B. articles enumerated in Index Volume, p. 939. 
which were singularly numerous two or three years ago, seems to indicate that in Europe at large "Pragmatism" and its off-shoots, as distinguished from the more general return to Pluralism, is regarded as a movement which has already "done its do," and taken its place side by side with other manifestations of dissatisfaction with a purely intellectualistic attitude in Philosophy. ${ }^{1}$ Its former place as the champion of a positively anti-intellectualist interpretation has passed to the doctrine of M. Bergson.

The outstanding event of recent years, as far as philosophy is concerned, has certainly been the rapid rise of Bergson to a European reputation. Of the three works Bergson.

which constitute together the full exposition of his interpretation of experience, so far as it has yet been carried by the author, Les Données Immédiates de la Conscience had been published as long ago as I889, Matière et Mémoire in 1896 , and L'Evolution Créatrice had reached a fourth edition in 1908 , but the author's ideas can hardly be said to have attracted universal attention much before I910. The English translations, Time and Free Will, Matter and Memory, and Creative Evolution all belong to I9IO-II. A great amount of work in various European languages has appeared in exposition or criticism of Bergson's special tenets. Special reference may perhaps be made to H. W. Carr's Henri Bergson, The Philosophy of Change (Igri), and J. McNellar Stewart's A Critical Exposition of Bergson's Philosophy (rgr2). Without attempting to pronounce on the permanent value of Bergson's ideas, it may at least be said that his works contain the most systematic and brilliant exposition of Irrationalism since Schopenhauer, and that his presentation has the advantage of exhibiting the irrationalist position unencumbered by the temperamental pessimism with which Schopenhaver entangles it:

Bergson's main doctrine may perhaps be briefly summarised as follows. The human intellect is itself a product of evolution, a tool fashioned by natural selection Bergson's for the purpose of enabling mankind to find their way about among the inDocirine. animate bodies which make up their physical surroundings. Hence the crowning achievement of the intellect is the creation of the science of geometry, which therefore furnishes the ideal model to which human science in general is everywhere striving to approximate. The aim of all sciences is to become exact sciences, $i: e$. , sciences of number and measure. But the only magnitudes which we can measure directly are straight lines. Consequently all measurement of other magnitudes has to be effected by artifices which enable us to substitute lengths for the various " intensive " magnitudes (lapses of duration, degrees of temperature, electric charges, and the like), which meet us in the "real world" of actual life. In particular, the measurement of time only becomes possible by the artifice of representing the real duration through which we live by the image of a line on which we can measure off different lengths. This device, though indispensable to science, inevitably falsifies the facts of living experience. For it gives rise to the belief in a "Newtonian" time, which is homogeneous, like the straight line, and "flows equably," whereas the "real duration " of experience, which is the very stuff of which our inner life of feeling and conation is made, is non-homogeneous and "flows" with very varying rapidity according as we are well or ill, interested or bored, pleased or pained, and the like. From the initial substitution of the unreal "uniform " time of science for the infinitely varying " real duration" out of which the processes of life and consciousness are made further arise all the illusions characteristic of a mechanical and statical theory of the universe. It is our tendency to envisage time under the form of a line, which leads to the belief in permanent "substances" or things as the bearers or supports of change, and further conducts us to the notion of a rigid determinism by producing the illusion that what happens in the various moments of time is all completely "given" at once, as all the points on a straight line are given simultaneously. This again leads to a radically false conception of "evolution." It creates the belief that nothing radically new is ever produced in the evolutionary process;

${ }^{1}$ For an atfempt to write the full history of the conflict between rationalistic and antirationalistic types of philosophical thought during the last few years, see A. Aliotta's La Reazione Idealistica coniro la Scienza, Palermo; 1912. 
whatever emerges in the course of the process, on a determinist theory, must be alraady completely contained in its antecedent conditions, and adequate knowledge of those conditions must enable you to say beforehand exactly what will emerge from them. Hence for science, which to be true to its geometrical ideal must be strictly mechanical, the whole process of evolution can be nothing but the rearrangement, according to mechanical law, of self-same and permanent units. Real life, as we know it at first hand in the act of living it, is of a wholly different kind: It is a single continuous process of becoming, in which there is no permanent substratum; it presents us at every moment with the emergence of the qualitatively new, fresh qualities, fresh adaptations to environment; which could never have been anticipated, from any knowledge of what had gone before, until they had actually emerged. You cannot expect to know the direction this élan vital, as Bergson names the impulse which Schopenhauer had called the "will to live," will take until it has been actually taken; life is thus essentially contingent. (It follows, of course, that determinism is false as regards that special manifestation of the élan vital which we call will, or choice: To speak of our decisions as necessitated or determined by our past is virtually to think of them as already made for us before we make them.) Instinctive or impulsive activity is thus but a manifestation of the forward-going élan vital; the tendency of the process which is life to exhibit itself in ever newer forms. Science is the inevitably unsuccessful attempt of the intellect to reconstruct the process in "geometrical" form by reversing its sense. It looks back at a process which has culminated in the appearance of something new (e.g. a new modification of an animal species), notes what the earlier stages of the process have been, and then assumes that it could have predicted from a knowledge of antecedent conditions the new manifestation of the élan vital with which it had, in fact, to be already acquainted before it could think of the antecedent events as conditions of this result. Hence, if philosophy is to understand life, its method must be the reverse of that of the scientific intellect. It must renounce the intellect and its logic, which latter is indeed merely the abstract schematism of the "geometrical" procedure, and surrender itself without reserve to the intuitions and presages which attend on complete immersion in the stream of the élan vital.

It may perhaps be suggested that the real test of Bergson's ability to construct an irrationalist Philosophy on this basis must-be sought in the success with which it can

\section{Some}

Crittisms.

be applied to the interpretation of the spiritual life of humanity, a task with which Bergson has not as yet grappled. Meanwhile there appear to be some reasons for doubting whether the foundations of his thought are themselves securely laid. The condemnation of the intellect is based upon the assumption that because it is a "product of evolution" it can have no function but that of enabling us to find our way about among things; this is why geometry, which deals with the "surfaces of solid things," is declared to be its highest achievement, and why it is denied all value for the interpretation of life. But it might reasonably be contended that from the dawn of time men have had to occupy themselves at least as much with reaching a common understanding of one another as with learning their way about among "solid bodies," and that we should therefore expect an intellect which is a " product of evolution" to be competent to deal with life as well as with the surfaces of solid bodies. Again it is plain that the alleged necessity for science of a spatial schematism which inevitably misrepresents the facts of "real duration" depends entirely on the results of the one chapter (Données Immédiates de la Conscience, C.I) which expounds the author's peculiar theory of measurable magnitudes. Now this chapter bears evident marks of hasty construction. The author seems to have forgotten that even in geometry straight lines are not the only measurable magnitudes. It is indispensable that we should be able to measure angles, a consideration which of itself should have given the author pause. In fact the whole treatment of the distinction between "extensive" and "intensive" magnitudes upon which so much depends for Bergson's development of his theory, is, as it stands, at least perfunctory. Again the very language employed to distinguish "real duration" from the unreal time of science, viz. that the portions 
of real duration flow with varying rapidity, seems to imply that these varying rapidities are comparable with one another and consequently that "Newtonian" time has, after all, the significance for real life which Bergson refuses to allow. Thus it can hardly be said that Bergson has been successful in showing that logic and the intellect need to be sacrificed by a Philosophy which recognises the reality of contingency and moral freedom, and the origination of the genuinely moral in the course of "evolution."

There has been much discussion in philosophical quarters of Bergson's place in the classification of philosophers. William James, in his latest works, claimed him as a Pragmatist, and it has been maintained on the Continent of Europe that his doctrine is not only a form, but the one really coherent form of Pragmatism. There is, of course, a real affinity between Bergson and the Pragmatists, which rests on their common distrust of the intellect. On the other hand, whereas Pragmatism, at least in its inception, made it a fundamental point to insist on a pluralistic theory of the world, Bergson's doctrine of the élan vital is definitely singularist. Thus he touches Bradley on one side of his doctrine as closely as he touches James on the other. In fact the complaints which Pragmatists used to make a few years ago of the miraculous feats ascribed by "idealists" to the Absolute might be easily urged totidem verbis against the élan vital. According to another view Bergson is most correctly described as a "mystic," though he can hardly be called so if the word is used with any precision. Mysticism is primarily not a peculiar way of thinking but a peculiar way of being. What the great mystics of the past have aimed at is first and foremost a transformation of human character by which it becomes responsive to stimuli from a "transcendental " world, inaccessible to ordinary perception. Since no such transcendental world is recognised in the Bergsonian scheme, it seems merely misleading to speak of his philosophy as Mysticism.

A second feature of recent philosophy has been, in Great Britain and America, the rise of the so-called " new realism." This also may be regarded as a conscious reThe New action against the idealistic doctrines of the last generation which go back Reallsm. for their inspiration to Fichte and Hegel, but it is a reaction which is in many ways the direct antithesis of the movement represented by Bergson. The New Realism, though it manifests itself in a great variety of forms, is in all its various guises definitely intellectualistic. This is shown by the general dissatisfaction of its representatives with the Kantian strain in-the thought of their older contemporaries. What is particularly objected to, as the source of "idealistic " or " mentalist " fallacies, is the Kantian view that both sense, in virtue of the pure forms of intuition, and thought, in virtue of its scheme of categories, are in part constitutive of the objects they apprehend. The tendency common to all the writers who may be fairly classed together as typical of the latest forms of realism is to regard both sense and thought as simply apprehensive of data which do not depend on the percipient mind either for their existence or for their apprehended qualities and relations. The degree of consistency with which this doctrine is held varies with its individual representatives, but, thought out consistently, it plainly tends in the direction of ultra-intellectualism, since it leads to the view that the specific task of philosophy is simply to apprehend as completely as possible objects and relations which exist and have the characters and relations which they are discovered by science to have quite independently of the perceiving or knowing mind. On the psychological side this tendency shows itself in its extreme form in the doctrine that known relations between objects are purely non-mental, but the "work of the mind," as T. H. Green had taught. The function of the intellect is not to create relations between its objects, but simply to discover what the relations between them are. On this point there seems to be general agreement between such writers as Alexander, Russell, and Moore in England, Woodbridge and Fullerton in America, and Couturat in France. It is a natural development of the same view that the attempt should be made to deny the existence of what are commonly called "presentations," and to hold that in sense perception we have only two distinguishable factors, an extra-mental presented thing and the process of apprehending it. Presentations, i.e. mental contents, which psychologists have usually regarded as immediate objects of cognition from which 
we may go on to infer propositions about the extra-mental things which are the exciting causes, are then dismissed as unnecessary fictions. This is the point of view adopted by Prof. Alexander, according to whom there are, strictly speaking, neither contents of cognition nor cognitive states or processes. The contents of the mind consist solely of conations of various types, and the universe is thus reduced to conative tendencies and the objects in which they terminate and find their satisfaction. ${ }^{1}$

This extreme view that presentations have no existence is not shared by all the writers who exhibit the realistic tendency. Mr. G. E. Moore and Mr. Bertrand Russell both appear to admit their existence. Thus in the latest statement of his

\section{Moore and} Russell. Library), Mr. Russell maintains that apart from the general predicates of things and the relations between them, which are universal and must not be said to exist, what we know is composed of minds, physical things, and sense-data, i.e. what are more usually spoken of as sense-qualities, red, sweet, salt, and the like. Sense-data are neither mental (processes of consciousness) nor physical. We are acquainted directly with our own minds and also with sense-data. But we have no acquaintance either with physical things or with minds other than our own. Any knowledge we have of the minds of others or of physical things is merely knowledge of description, and its possibility depends on the truth that things with which we have no acquaintance can be indirectly known if it is possible to describe them in terms of sense-data with which we have acquaintance. Since Mr. Russell accepts the familiar arguments against the physical reality of sensible qualities, it follows on his theory that we have no acquaintance with physical things. I know a physical thing only by inference, as $e . g$. "the cause of such-and-such a definite group of sense-data." This is a description obtained by a combination of sense-data which I know at first hand by acquaintance with the universals " the" and "cause of," and with these universals I have also immediate acquaintance. My acquaintance with the meaning of "the" secures that the otherwise unknown physical thing signified by the descriptive phrase shall be strictly individual. Thus my knowledge through sense-data of physical objects is like the knowledge I have e.g. about the "magnates of the Education Department," when I know that there is such a body, and what it does, but have never met any of its members. For science the most important point in the theory of knowledge is that we can be directly acquainted with relations and universals, though these entities do not properly exist. Immediate knowledge of this kind is. what we mean by a priori.knowledge, i.e. knowledge which does not involve awareness of any proposition about what actually exists. As the principles of inference are among the relations with which we have acquaintance $a$ priori, we are able to have a derivative a priori knowledge of all truths which are deduced by correct inference from a priori principles with which we are directly acquainted. This covers the whole domain of the sciences of logic and pure mathematics, as, contrary to the Kantian opinion, all pure mathematics can be shown to consist of propositions deduced logically from premises which involve only logical concepts and relations with which we are directly acquainted. It is added that we must also include under a priori knowledge our direct acquaintance with the relative intrinsic worth of various goods. This is why there can be a science of Ethics. The chief special work of the particular type of realism represented by Mr. Russell and his associates has been done, in close connection with the earlier work of mathematicians like Peano and Frege, in the field of mathematical logic, with a view to the exhibition of pure mathematics as a vast body of deductions from the principles of the logic of relations, first treated with due elaboration in the third volume of E. Schröder's Algebra der Logik (189.5), and applied with particular thoroughness to Arithmetic in Frege's Grundgesetze der Arithmetik (1893-1903). The unfinished magnum opus of Messrs. Whitehead and Russell, Principia Mathematica (vols. I and 2, I9:IO-I2), represents the latest and fullest development of logic as a calculus of relations.

${ }^{1}$ See the continued controversy between Prof. Alexander and Prof. Stout as to the reality of presentations in the Proceedings of the Aristotelian Society, vols. for 1908-09 to $1911-12$; and articles on the same subject in Mind for the same years. 
The most brilliant general account of the principles and methods of the mathematical logicians is, perhaps, that of Couturat (Principes des Mathématiques, 1905).

Messrs. Moore and Russell have also made some application of their doctrine to Ethics (see G. E. Moore, Principia Ethica, r903; Ethics, in Home University Library, I9I 2 ; and Russell, Philosophical Essays, I910), but without any very satisfactory results. From their point of view the principal business of Ethics is to discover true propositions about the relative intrinsic worth of different "goods." As both writers assume that there are a plurality of such propositions, and that each of them is known a priori independently of the others, the impression they leave upon a reader not previously committed to their theory is that they have really no better standard for determining the worth of various goods than their own personal preferences. It is characteristic of both writers that they assume without serious enquiry that conduct can only be good in a derivative sense as leading to the production of some good other than itself. Hence, though both reject the older forms of Utilitarianism as ascribing a fictitious worth to pleasure, their own doctrine is itself utilitarian in its general character. Beyond discovering true propositions concerning the relative worth of goods, Ethics seeks to furnish rules of right conduct, i.e. conduct which produces good results, but these rules are always of the most rough-and-ready sort and constantly require modification to suit special cases. Hence the ground is left open in practice for an enormous development of reflective casuistry. Messrs. Moore and Russell have furnished us with some acute observations on the relative goodness of various objects, but because of their refusal to look at human life as a whole they cannot be said to have advanced the study of Ethics as an interpretation of life. In their ethical writings, slender as they are in bulk, one cannot see the wood for the trees; they are too much occupied with the search for true propositions about "goods" to develop a satisfactory theory of "the good."

Besides the Irrationalism of Bergson and the atomistic intellectualism of the new realists, one may mention as characteristic of the present day a third tendency, which is powerfully represented in contemporary philosophy, and holds in some Theism. respects a middle place between the former two. This is the revival of philosophical Theism, in connection with which important work has been done, especially by Prof. James Ward, Dr. Rashdall and Prof. Bernardino Varisco. Ward and Varisco agree in refusing to accept the unfavourable verdict of Pragmatism and Bergson on the worth of the intellect in philosophy, and are so far pronounced rationalists as to require of any philosophical theory of the world that it should be able to justify itself before the bar of reason; neither is, however, an " intellectualist," since neither ascribes to cognition a primacy in importance for the philosophical interpretation of the world over feeling and conation, and both admit, like Kant, our right to believe what we cannot demonstrate, provided that such belief, if accepted, would form the natural completion of the conceptions to which strictly logical analysis of the contents of science points. Both hold in common with Bergson and the Pragmatists the reality of contingency and the production of the genuinely " new," but both deny that there is anything irrational or repugnant to the intellect in these conceptions. Ward's views find their latest development in his Realm of Ends (IgII), Varisco's are expounded in I Massimi Problemi (Iоro) and Conosci te stesso (Igr2). Both thinkers show very markedly the influence of Lotze, whose final results in the main agree with theirs; Ward is, on the whole, Kantian, Varisco Leibnitzian in manner.

Ward's starting point is afforded by the contrast between the unity which thought demands of its world and the apparent plurality which meets us in the world of sense James perception. The problem which Philosophy has to solve is, according Ward. to him, on what lines the world of experience can be thought of as one without our ceasing to recognise that it is also truly many. The history of the postKantian "idealist" schools has demonstrated that the problem is insoluble if we attack it from the side of the "one." Since the world of perception is not primarily given to $u s$ as one but as many, we have to start from its given multiplicity and work toward such a final conception of its unity of plan as our data will permit. Ward 
thus begins by a tentative inquiry how far the metaphysical assumptions of Pluralism will allow us to recognise the experience-world as exhibiting unity. This leads him, inter alia, to a brilliant criticism of the concepts of mechanism and " evolution " as they figure in singularist philosophies. The result of the criticism is much that of Bergson's critique of the "geometrical " bias ascribed by him to the intellect. A mechanistic Monism must reduce " evolution"' to a process by which things unfold what has all along been in them in an " incapsulated " form; but the process known to genuine science by the unhappy name of evolution is really more properly " epigenesis," the growth of the qualitatively new, and therefore unpredictable, out of the old. Starting with an original pure Pluralism which resolves the course of things into interactions between agents, each of whom is independent of any other, we can see that a pluralistic universe would develop a tendency to unity in the very process by which its members establish a modus vivendi among themselves, but it is uncertain whether such a tendency would give us the amount of unity we presuppose in the real world when we assume the validity for it of general laws, and it certainly dot.s not warrant our ascribing to it such a unity as would justify the belief that the universe is such as to permit the realisation of our moral and spiritual ideals. If, however, the Pluralist should modify his hypothesis by regarding one member of his universe as a God from whom the rest derive their real but dependent existence, we could find in the existence of such a God good ground for faith in the persistence of spiritual life after bodily: death, and the final victory of good over evil; the alleged difficulties of Theism, in particular the alleged impossibility of reconciling the goodness of God with the presence of evil in His world, have no conclusive force. Thus we are free, as Kant held, to exercise a reasonable faith in God and in immortality; and such a faith, while meeting the demands of morality and religion, involves no breach with the intellect, as it amounts only to a further step along the road which the Pluralist is forced to tread in accounting for the presence of even so much unity of plan and order as he has to admit in the visible:world.

Varisco reaches a very similar position as the result of a polemic against the empiricist metaphysic of the ordinary Comtist. He begins with an analysis of the actual Varisco. moment of sense perception. The objects apprehended in such percepVarisco. tion stand at once in two sets of relations. On the one hand, they are connected in various ways with one another, and as so connected they form a system which lies open to the perception not only of the special "I" who speak of apprehending them, but to the perception of innumerable other beings, each of whom can equally say "I apprehend " them. Considered from this point of view the system of sense-data and their interconnections may be said to form the common perceived world of mankind at large. But also a given sense-datum which $I$ apprehend is, at the moment of its apprehension, present along with experiences (feelings, conations), which are intimate and private to me and directly accessible to no other being which calls itself "I." In this sense the perceived objects may be said to be my objects. Thus there is a sense in which the whole world of fact to which the individual has to adjust himself in action is inseparably bound up with the individual's inner life. Varisco develops this idea in a way which may remind us strongly of T. H. Green, but is at least equally reminiscent of Leibnitz, the one great philosopher whom Green persistently misunderstood. It is fatal to the empiricist theories which regard the "external world" as simply given in sensation, that the world reveals itself to science as a complicated network of relations between terms, and neither the universals which pervade it nor some at least of the terms they connect are sense-data. The universals are apprehended by thought, and the self to which they are known, the only thing which we apprehend directly as it is, is also no sense-datum. It is our immediate non-sensuous apprehension of the self which owns its "states" that supplies us with our standard of real Being. Hence Varisco is led to postulate as indispensable factors in the scheme of the universe not only the sense-data and the system of relations between them, but the plurality of persons whose sense-data they are and whose thought apprehends their complicated relations. From these considerations follows the reality of freedom and contingency. 
For each individual has its unique qualitative character, by which it is distinguished from every other, and the course of phenomenal events thus depends on two factors, the unique characters of individuals and the universal relations between them, and the former factor is obviously incalculable with certainty just because it is what is not common to two or more individuals. Hence the actual course of things is only partly calculable, and this admission of contingency, or spontaneity in the individual, involves no breach with the principle that it is for Philosophy to satisfy our intellectual demands. We may call the element of spontaneity a-logical (since logic is concerned solely with the universal laws of interconnection and interaction), but not irrational.

At this point arises the supreme issue for a philosophical interpretation of the universe, an issue which is one of value or worth. The question is whether we regard the principle of organisation in the universe as immanent, and manifesting itself in an endless succession of individuals which are all transitory, or whether we are to think of it as itself a transcendent individual, and of the finite individuals in which it exhibits itself as permanent factors in the universe. In the former case, the values of the individuals will be all relative, and there will be no meaning in attaching value or purpose to the world-order itself, as it is only the individual which properly has either; in the second case, there will be a meaning in regarding the values we ascribe to human personalities as absolute, and we shall be able to ascribe value and purpose to the universe as a whole, no less than to its various members. Varisco's view is that Philosophy as such cannot decide this issue between an impersonal immanent principle of order and " the traditional Christian conception of God." Our decision will turn upon the intensity of our faith in the correspondence between the order of facts and our spiritual ideals. His own preference is for the Christian solution, as an expression of personal faith.

In the sphere of Ethics, the attention of philosophers of all schools seems to be more concentrated now on the inquiry into the presuppositions and methods of science than Ethics. on the interpretation of our inner life. Erkenninisthcorie is at present more in the fashion than "discourses on conduct." This is, as has always been the case, specially true of the work of the Neo-Kantians, who are always with us as a testimony to the exceptional eminence of Kant in modern thought. Special notice is perhaps due to the important volume, Substanzbegriff und Funktionsbegriff (Igro), by the distinguished Neo-Kantian writer, E. Cassirer, which is specially valuable for its insight into the real character of the universals, or laws, of exact physical science, and for its criticism of the work done on the philosophy of mathematics by distinguished " new realists." In the sphere of "philosophy of religion" one may perhaps give special commendation to Evelyn Underhill's brilliant attempt to make a thorough study of the meaning and worth of the mystic "way of life" (Mysticism, Igro), as well as to the important and elaborate restatement of the principles of "idealism," with special application to the problems of religion, by Prof. Bosanquet in his Principles of Individuality and Value (the Gifford Lectures at Edinburgh for 1911 ) and its sequel, The Value and Destiny of the Individual (Gifford Lectures, I912).

Some note should be made of the remarkable vitality exhibited by the Thomist philosophy as pursued particularly at Paris and Louvain. The achievements of Neo-

Thomism. Thomism in adapting itself to the criticism of scientific methods and principles and in contributing to the positive advance of such studies as Anthropology and Experimental Psychology, have chiefly to be studied in the yearbooks of the centres where it is cultivated, such as $e . g$. the newly founded Annales de l'Institu Supérieur de la Philosophie (tom. I, Louvain, I9I 2), but we may perhaps mention as a work of general interest to students, Prof. Sertillanges' S. Thomas d'Aquin (Paris, I9ro, in the series of Les Grands Philosophes.)

The interest in the historical study of the great ancient and modern philosophers continues to be maintained. It is worth noting that Io 12 has seen the publication of the first two volumes of another handsome edition of Kant under the general editorship of E. Cassirer, following hard on reissues (published by Meiner, of Leipzig) of the principal works of Fichte (6 vols. I9I I-I2), Schelling (3 vols.), and Hegel ( 2 vols). 
British interest in Hegel has been exhibited by the appearance of Dr. M'Taggart's Commentary on Hegel's Logic (rgro) and Prof. J. Baillie's translation of the PhenomeThe Classical nology of Mind (I9IO): In the history of ancient Philosophy the main inSystems.
Sysal terest, as for some years past, has lain in the study of Plato, who seems at last to be receiving the minute and careful attention which scholars in the last half of the nineteenth century reserved chiefly for Aristotle. As indications of the revived interest in Platonism may be mentioned the two publications of the veteran Constantin Ritter, Neue Untersuchungen über Platon (Igro) and Platon, sein Leben, seine Schriften, seine Lehre (vol. I, I9IO); G. Werner, Aristotle et l'Idéalisme Platonicienne (I9I0); J. Adam, The Vitality of Platonism (I9II); to which the present writer may be pardoned if he adds A. E. Taylor, Varia Socratica (Series I, I9I I). . The steady progress made with the Oxford complete translation of Aristotle continues to make it easier for the English-speaking student to enter into the thought of the second great philosopher of antiquity.

(A. E. TAYLOR.)

\section{EDUCATION ${ }^{1}$}

\section{The Montessori System}

In connection with the theory of education the chief point of new interest during I9I0-1 2 has been the attention aroused by Dr. Maria Montessori's work in Italy. It is not too much to say that, since Froebel, no such stimulus has been given to a revolution in the elements of educational method as her success in connection with the Case dei Bambini in Rome; and the Montessori system has given a new direction to the whole "Kindergarten" idea. In The Montessori Method (trans. Anne E. George, rgr2) Dr. Montessori has now published a full account of her own principles and experiments, excellent short accounts of which were given by Miss Josephine Tozier in the Fortnightly Review for August I9I I and McClure's Magazine for May rgi I (see also A Montessori Mother, by Mrs. Dorothy Canfield Fisher, New York; 1912); the Board of Education in England, in October I912, issued a Special Report on the subject by Mr. E. G. A. Holmes. From these the main points of interest are here summarised.

Maria Montessori (b. I 870 ) came to the study of educational theory after a thorough training in practical medicine. She was the first woman to whom (in 1894) the University of Rome gave the degree of M.D., and as assistant doctor in the "psychiatry" clinic at the university she had become specially interested in the question of the treatment of the feeble-minded. At the Pedagogic Congress at Turin in 1898 she gave an address on this subject, which led the Italian Minister of Education, Signor Barcelli, to ask her to give a series of lectures to teachers in Rome; the result was the foundation of a new school for feeble-minded children, the Scuola Ortofrenica, of which she was made directress. Her ideas as to the proper way of awakening a defective intelligence had been founded on a study of what Dr. Itard, physician to the Institution for the Deaf and Dumb in Paris, had attempted early in the roth century in the case of the muchdiscussed "wild boy of Aveyron," and particularly of the later work of Edouard Séguin ( $1812-1880$ ), author of the Traitement des idiots ( 1846 ), who opened in 1839 the first school for idiots in France, and who in 1850 made his home in America and there did so much for the education of defective children. In carrying on Séguin's principles at the Scuola Ortofrenica for the two years that she was directress, Dr. Montessori had such remarkable success that it was borne in upon her that something must be wrong with the methods of education ordinarily applied to normal children. Idiots sent to her from the asylums were being taught to read and write so that they passed just as good examinations as pupils of the same age in the public-schools; and, as she says, "while everyone was admiring the progress of my idiots, I was wondering what could keep the normal children on so low a plane." The reason, in her opinion, was clear; the children from the asylums, under her treatment, had been helped in their psychic development, while

${ }^{1}$ See E. B. viii, 95 I et seq. and allied articles enumerated in Index Volume, p. 894. For progress in various national systems, see under country-headings in the Local Part of the YEAR-Book. 
the normal children, taught by ordinary methods, were retarded. If the same methods were applied to good material that were successful with bad, much better results ought to be attainable; and she determined to investigate the whole subject afresh.

In 1900 she left the Scuola Ortofrenica, and turned her attention definitely away from the question of the feeble-minded to that of the normal child-mind and its development. She returned to the University of Rome as a student of philosophy, and devoted herself to experimental psychology, then in its infancy at the Italian universities, at the same time making a prolonged and careful study of the actual practice of teaching at the primary schools. The result of several years of child-study and practical pedagogy was to establish her conviction that the master-principle in any proper system is "self-education," - that the work of mental growth must be done by the child itself, according to its own direct initiative and inclination, not in mechanical obedience to dogmatic dictation from a teacher; and she set herself to devise new methods for making the child-mind shape its own channels instead of the teacher telling the pupil what to do.

After six or seven years of enquiry and study, a unique opportunity arose in Rome for putting her theories into practice. During the building "boom " at the end of the I 880 's, a whole new quarter of apartment houses had been run up by speculators outside the Porta San Lorenzo. It was from the first a complete fiasco, the houses failing altogether to attract the superior class of tenants for which they were intended; and the district gradually developed into the worst of slums, the flats being farmed out room by room to the poorest families, so that at last a serious condition of insanitary overcrowding had resulted, which seriously engaged the attention of social reformers. In order to remedy this evil, an association was started on philanthropic lines, the Instituto Romano di Bene Stabili, with Signor Edoardo Talamo as director-general. It bought up a large part of the San Lorenzo quarter, and reorganized it in 1906 in separate and convenient working-class tenements, with proper air-space; prizes being instituted for the best-kept dwellings. A novel part of the scheme was the provision of infant-schools (Case dei Bambini) for the children of each block, the supervision of which was entrusted to Dr. Montessori; the first of these being opened in January 1907. These "Houses of Childhood". for children between 3 and 7 are themselves a very interesting social experiment, apart from the new methods of teaching which Dr. Montessori introduced: They provide a crêche and something more, taking the children off their mothers' hands during working hours. Each school has a directress living in the block which it serves and in touch with the parents, who can at any time come and see how the children are getting on; and it is thus part of the home life.

The Montessori system of education was first put in practice in these tenement schools, under teachers following Dr. Montessori's methods. ${ }^{1}$ Its fundamental aim and object is self-education by the pupils themselves. There are no timetables, no set lessons, no classes. There are no rewards or punishments of the ordinary kind. The pleasure of succeeding and getting things right is the only incentive. "Each child," says Mr. Holmes, "is doing what, for the time being, pleases him best. When he is admitted to the school, he sees small groups of children playing at various 'games,' and he joins the group which happens to take his fancy. Then and there his education begins. All kinds of interesting 'occupations' are going on, and wherever he goes he will get help and guidance from the teachers. If he gets tired of playing at this thing; he goes off and plays at that. But he is never idle, for whatever he does interests him." "The children are provided with light and comfortable chairs, which are easily moved about. There are also rugs, laid on the floor, for them to sit, kneel or recline upon, should they prefer those attitudes. Low and light tables are provided in abundance, but there is also plenty of open floor-space, and many of the 'occupations' are carried on on the floor." An extensive variety of apparatus, elaborately devised by Dr. Montessori, is provided for the educational games by which the children are stimulated to acquire knowledge; and this " didactic material " constitutes a distinctive part of the originality of the system, which can only be roughly indicated in a verbal description.

${ }^{1}$ At the end of 1912 they were no longer under her direct supervision. 
The first stage is to develop the senses of touch, sight and hearing; this is done both by games of various sorts and by guiding the attention systematically to the association of things, names and ideas. When a child washes its hands, for instance, it is given first cold and then hot water, and led to observe and understand the difference; the distinction of rough and smooth is emphasized by the provision of different qualities of cards for fingering and sorting. In each case the teacher gets the child to know the word, " hot," " cold," " rough," "smooth;" and thus the knowledge of language is extended in all directions (" high," "low," " thick," " thin," " round," " oval," etc.) before any question of writing or reading arises. Ideas of form and colour are given precision by games with blocks, cylinders, etc., of varying sizes, to be fitted into frames, or with shades of silk to be arranged to match; touch is practiced by playing the games blindfold; hearing by playing in the dark, and by games with stones of different weights to be rattled and arranged in size according to the sound, and so forth. Skill and neatness in the use of the fingers and movement of limbs are stimulated, partly by the mobility of the light furniture, which the children learn to re-arrange for their own comfort, and partly by games at tying and untying, hooks and eyes, dressing and undressing, waiting on one another at table, washing up, and so on. All such occupations are preliminary to writing and reading, but lead naturally up to both.

Writing comes essentially before reading, on the Montessori system, in any proper sense of " reading." Emery-paper letters gummed on cards are provided, with which the child is familiarised by games of hide-and-seck etc., so that, without any active teaching of the alphabet, he not only knows them by sight and by name, but also by feeling. He learns how to imitate them, partly by a touch-game of passing the fingers over the paper letter, thus making the actual motion of writing, and partly by playing at pencilling and colouring with specially devised cards on which an outline is given. The child thus learns to write before he knows that " writing " is what he is learning; the sounds and the shapes of the letters being known, it is a natural transition to build up the letters and their sounds into words. On this point Mr. Holmes says: "The usual interval between the first preparation for, and the accomplishment of, writing, is about a month and a half in the case of children of four years of age. When the period of preparation is over the average child finds that he can write any simple word, using ink almost from the beginning. After three months most of the children write a good hand; and those who have been writing for six months are as a rule quite on a par with children of the third elementary class in the public schools, i.e. schools for older children."

The next thing is for the child to " read "-not merely to retranslate into sound a word he has translated into symbol, which goes with the acquisition of " writing," but to extract a previously unknown idea from written or printed symbols of the same sort not put together by himself. It is found however-at any rate in so easy and phonetically-spelt a language as Italian-that, after-what has gone before, this is very quickly learnt. Numbers of words, already well-known to the children, are written on cards, and various games are played in identifying them with their objects; and from single words the children pass to phrases and sentences, the teacher writing on the blackboard, for instance, questions or orders which form part of a game. The success of this method, by all accounts, is extraordinary. Miss Tozier gives an example of one boy of only $3^{\frac{1}{2}}$, who "without realising that he has yet done anything more than play " could read and write both in English and Italian. This was a child of Dr. Montessori's American friend, the Marchesa Ranieri di Sorbello, whose case may perhaps be thought exceptional; but Mr. Holmes appears to be satisfied that on the Montessori system there is nothing more extraordinary, and no more strain involved, in such young children learning to read and write than in their having learnt to walk and talk. Arithmetic is similarly introduced to the children's minds by the employment of counting-games, in which an apparatus of striped poles, counters, etc., is used.

The detailed application of the Montessori system has not gone, so far, beyond the infantile curriculum, though Mr. Holmes insists that "the principle is applicable to children of all ages, and will bear its best fruits in the higher classes," and Dr. Montessori 
herself has recently started a class for older children. Her energies have naturally been devoted in the main to establishing her fundamental principle, and recruiting teachers to carry out her ideas in that part of the educational sphere where their success has already been so remarkable. In the light of what has been proved with children from 3 to 7 , she claims that " the old-time teacher, who wore herself out in maintaining the discipline of immobility, and who wasted her breath in loud and continual discourse,". must pass away. "For this teacher we have substituted the didactic material, which contains within itself the control of errors and which makes auto-education possible to each child. The teacher has thus become a director of the spontaneous work of the children. She is now a passive force, a silent presence." What this change means is indicated as follows by Mr. Holmes: "The function of discipline, in a school of the conventional type, is to shut down and sit upon the safety valve of "naughtiness" which the children's spontaneous energies, when wantonly repressed, instinctively try to use. In a school in which the energies of the children are constantly and happily employed, that safety-valve has never to be used, and the need for repressive discipline ceases to be felt. In a Montessori school each child is given the maximum of freedom that is compatible with his not hurting or incommoding others; and so long as he is busily and suitably employed, he is not likely to hurt or incommode others, or make himself a nuisance to the school as a whole.

The first impulse of the ordinary teacher is to tell a child how to do something which he has never attempted before. The second is to rush to the child's aid when, having been allowed to try his hand at something new, he is confronted by some difficulty and is in doubt as to his next step. The third is to correct his mistakes for him, instead of leaving him to correct them by himself. The Montessori teacher must keep all these impulses under complete control. When a child in a Montessori school is going to make his first attempt at a given problem, he is left to his own devices."

The Montessori system is undoubtedly a distinct step forward, on Froebelian lines, in the history of educational method. Dr. Montessori, in Mr. Holmes's words, has "rediscovered " Froebel's master principle; and by giving practical effect in a highly original way to some of the most solid conclusions of modern experimental psychology she has shown that, properly handled, the normal child will respond to an impulse towards growth from within, with a readiness commonly unsuspected. What has still to be discovered is to what extent the Montessori system requires exceptional capacity in the teacher, and how far the teaching profession is capable of supplying (or being content to supply) the " passive force" and " silent presence "which the system postulates. It is worth noting that Mr. Holmes, who inspected five schools where the Montessori system was supposed to be employed, found that in one of them the work was anything but satisfactory: " the Direttrice had got hold of some details of Dr. Montessori's method without having any sympathy with or understanding of her principle, and the results were so comically bad that a frank abandonment of the whole system was obviously the only remedy for the more glaring defects of the school." Unfortunately the suggested new type of teacher does not as yet grow on every bush.

According to Mr. Holmes, a Montessori infant school is somewhat costly both to build and to run. "Instead of 9 square feet per child, at least 15 ought to be allowed if the children are to have the freedom of movement which the system demands, for the amount of floor-space ought to be as large as the space which is covered with chairs and tables. The apparatus is costly and demands much storage room; and the cupboards should be so arranged that the children can have easy access to them. The staff ought to be large and a majority thoroughly trained. A teacher of great ability and wide experience tells me that under the Montessori system no teacher can do justice to more than about 20 children." He adds however, that compensation would, he thinks, be found in the schools for older children if the system were also introduced there: "my experience has convinced me that where children are trained to educate themselves the number of children per teacher may be steadily increased as we ascend the school."

(Hugh Chisholm.) 


\section{The Care of the Mentally Deficient}

One of the most pressing needs in social and educational reform in all countries that are organised on modern lines is the proper separation of the " mentally deficient " from those who are normal on the one hand and those who are already provided for as "lunatics " on the other, and the taking of consistent steps by the state for their treatment, both in their own interests and in those of Society. An important step forward was taken by the Government in England in I9r2 by the introduction of the Mental Deficiency Bill, which, though not passed that year owing to parliamentary time not permitting, was sufficiently discussed to become to some extent a model for future legislation; and its main provisions are therefore worth noting. It was the result of the report (Aug. rgo8) of a Royal Commission which had sat from rgo4; and its need in one country alone may be gauged from the fact that, according to this report, there were in England and Wales 149,628 mentally defective persons in addition to certified lunatics, and that nearly half of them were in an unprovided condition and a standing menace to public safety. The mischief done by leaving this class of people at liberty to propagate has received general recognition, and it is well-known that the absence of any proper supervision results in some of the worst sorts of crime. To put them in prison after the offences are committed is to shut the stable-door when the horse has been stolen; moreover prison is not the right place for defectives. Neither however is a lunatic asylum the right place for people who are not actually insane, while it is quite unfitting to mix them with the sane people in workhouses under the poor law. Special homes are required for what is a special class, and it was the object of the Government to organise such institutions, compulsion being put on local authorities for this purpose.

The bill was introduced by the Home Secretary on May 16, I912, and its second reading was carried on July ig by a large majority. It was then referred to a standing committee, and subjected to much valuable criticism; but on November 2 Ist Mr. M'Kenna had to announce that time would not suffice to pass it before the end of the session. It was agreed however to finish the discussion on the more important clauses, so that a new bill might be introduced in 1913 .

As introduced, the hill consisted of 66 clauses, in ${ }_{4}$ Parts. It set up a new Commission as a central authority under the Home Office, "Commissioners for the care of the mentally defective," not exceeding 6 , one to be a woman; they were to be independent of the Commissioners in Lunacy, and have nothing to do with the insane or idiots who were under the Lunacy Commissioners, though a possible future amalgamation was contemplated. They were to have general control over the arrangements made for "defectives," supervising the local authorities, providing and inspecting institutions, and administering Parliamentary grants. Subject to them, there were to be local authorities in the shape of committees of the county and county borough councils, who should deal directly with all defectives within their districts, in carrying out the provisions of the Act, but their expenditure was to be met by government grants to the extent of a half to two-thirds. Machinery was provided for having the feeble-minded medically certified before a judicial authority; and among other provisions clause 49 made it a criminal misdemeanour to marry with a congenitally defective person.

The bill did not interfere with the feeble-minded who were properly cared for in their own homes; its operation was confined to those defectives who are described in clause I6:

(a) who are found wandering about neglected, or cruelly treated;

(b) who are charged with the commission of any crime, or are undergoing imprisonment or penal servitude or detention in a place of detention or a reformatory, or industrial school, or an inebriate reformatory;

(c) who are habitual drunkards within the meaning of the Inebriate Acts 1879-1900;

(d) in whose case, being children discharged on attaining the age of 16 for a special school or class established under the elementary Education Act I899, such notice has been given by the local education authority as is hereinafter mentioned;

(e) in whose case it is desirable in the interests of the community that they be deprived of the opportunity of procreating children;

(f) in whose case such other circumstances exist as may be specified in any order made 
by the Secretary of State as being circumstances which make it desirable that they should be subject to be dealt with under this Act.

The following were to be deemed "defectives" within the meaning of the Act (as originally introduced):

(a) Idiots; i.e. persons so deeply defective in mind from birth or from an early age as to be unable to guard themselves against common physical dangers;

(b) Imbeciles; i.e. persons who are capable of guarding themselves against common physical dangers, but who are incapable of earning their own living by reason of mental defect existing from birth or from an early age;

(c) Feebleminded persons; i.e. persons who may be capable of earning their own living under favourable circumstances, but are incapable, through mental defect existing from birth or from an early age -

(i) of competing on equal terms with their normal fellows, or

(ii) of managing themselves and their affairs with ordinary prudence;

(d) Moral imbeciles; i.e. persons who from an early age display some mental defect coupled with vicious or criminal propensities on which punishment has little or no deterrent effect;

(e) Mentally infirm persons; i.e. persons who, through mental infirmity arising from age or the decay of their faculties, are incapable of managing themselves or their affairs.

In Committee however some of these definitions were altered after discussion, and the following were the revised definitions under the headings $b$ and $c$ :

Imbeciles.-Persons in whose case there exists from birth or from an early age mental defectiveness not amounting to idiocy, yet so pronounced that they are incapable of managing themselves or their affairs, or, in the case of children, of being taught to do so.

Feeble-minded.-Persons in whose case there exists from birth or from an early age mental defectiveness not amounting to imbecility, yet so pronounced that they require care, supervision, and control for their protection or for the protection of others, or, in the case of children, of receiving proper benefit from the instruction in ordinary schools.

In the case of (d), " moral imbeciles," the word " permanent " was introduced before " mental defect." It was agreed to omit class (e), i.e. " mentally infirm " altogether, the case of senile decay appearing to be one which was not ejusdem generis.

The only oppasition to the bill of any moment came from a section of Liberals, led by Mr. Wedgwood, who denounced it as an invasion of individual liberty, and as giving a dangerous power to so-called medical specialists or cranks on " eugenics " to shut up people whom they arbitrarily considered to be "wanting." It was objected also that it would be to the interest of all connected with the new institutions, which would be run for profit, to keep them full. But it appears unlikely that the safeguards provided under a system of government inspection would not be ample to prevent misuse of the new powers provided for benefiting both the defectives and the community; and the announcement that the bill was to be dropped, even temporarily, created widespread disappointment.

\section{THE BLIND ${ }^{1}$}

(Hugh Chisholm.)

The last census figures for the blind in several important countries, including the United Kingdom, France, Germany, Austria-Hungary, Russia, Italy, Spain, Canada and the United States (where the census was found to be inaccurate), were not available up to the end of 1912: and the following statistics are the latest then procurable.

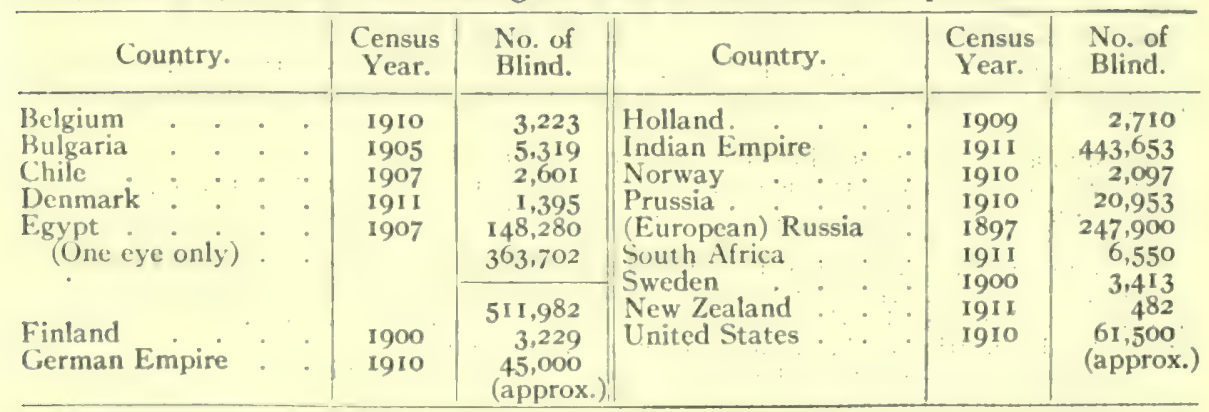

1 See E. B. iv, 59 et seq. 


\section{THE BLIND}

Belgium. -8 schools; 6 workshops. Most of the blind work in their families. Education is not compulsory, but facilities are given by the government to send children to institutions. The state and provinces pay 600 francs a year for any child between 6 and I 8 so sent. The law of $189 \mathrm{I}$ regulates the manner of payment, and the freedom of parents in choosing an institution.

Denmark. -2 schools; 4 workshops. Education is not compulsory. The schools are supported by the state, the workshops by private associations. On leaving school at. I 8 or 20 pupils are apprenticed to a seeing master for 3 years, the institution paying 300 kronen, and young musicians are given further training for 3 or 4 years; they are furnished with tools or musical instruments, and looked after by different societies. Since 1901, to counteract ophthalmia neonatorum, midwives are ordered to use the Credé method, and blindness from this cause has decreased.

France.-30 schools; I I workshops. One school is national, and five departmental, the rest private, receiving pupils with bursaries from departments and communes. The "Institution Nationale des Jeunes Aveugles" gives assistance in obtaining situations, and so does the "Association Valentin Haüy" of Paris. The law of 1909 provided compulsory assistance up to 16 , and two new laws are being proposed. Ophthalmia neon. is decreasing in many mairies; notices are distributed pointing out its danger and the need of immediate treatment.

Norway. -2 schools. Education is compulsory, and schools receive state aid. There is a Union for assisting the blind. Midwives are instructed to treat antiseptically for ophth. neon.

Sweden.-6 schools; 4 workshops. By act of 1896 , education is compulsory up to 14 . Four schools are state-supported. On leaving school, pupils receive grant of tools; and the state gives 25,000 kronen to an Association for After-care. Ophth. neon. is decreasing; the Credé method is prescribed by law in maternity hospitals and is in general use.

Switzerland. - 3 schools; 7 workshops. All institutions are private except the school at Zürich. Special Associations have been created in cantons which have no schools or workshops. The new Civil Code prescribes that all abnormal persons if teachable shall receive instruction, but all cantons are not yet able to carry out this provision. Each canton has special legislation covering ophth. neon. In Vaud, where the strictest measures have been taken for over 40 years, it has almost disappeared.

A ustria-Hungary.-17 schools; 2 workshops in Austria; 6 schools, 4 workshops in Hungary. Also II Homes, partly workshops. Instruction is compulsory between 6 and i4 The Austrian Ministry of Instruction provides annually 17,000 crowns for the blind; and the "Imperial Royal Institution" has its own funds under state administration. Four schools are supported by Austrian provinces, and one by city of Vienna, while others receive small grants. In Hungary 2 schools are partly state-supported; and the Society for the Relief of the Blind in Budapest receives 8,00o crowns from the city. Ophth. neon. is a notifiable disease, and pamphlets about it are largely circulated.

German Empire.-According to Taschenbuch für Blinderlehrer IOI2, there are 33 institutions, providing instruction for 2,763 persons. In Saxony, it may be noticed, the school in Dresden has been moved to Altendorf, a suburb of Chemnitz, where a colony of 300 blind and 500 feeble-minded are housed in 40 associated buildings. This combination of the blind and the feeble-minded is much to be deplored.

Russia.-32 schools; 7 workshops. The schools are supported to the extent of 5 per cent by the state, and 25 per cent by municipal grants, besides invested funds.

Egypt. -4 schools; helped by State and municipal funds. A Society for After-care has been formed at Cairo. Ophthalmologic hospitals have been created, fixed and ambulatory.

United Kingdom.-A new impetus has been given to the education of the blind in the United Kingdom, by 'Triennial Conferences of all those who are interested in their welfare, and the founding of "The College of Teachers of the Blind" in I9o8.

Previous to I902, conferences had been convened at irregular intervals; but in that year the Gardner Trust arranged for one to be held in London, and since that date important gatherings have taken place in Edinburgh, Manchester and Exeter. An important result of the Edinburgh Conference was the appointment of a National Employment Committee to discuss means of providing more work for those who had received manual training. It is estimated the workshops in the United Kingdom supply places for about 3,210 , and there are large numbers who would gladly work if more accommodation were provided. The National Employment Committee drafted a bill, which, if passed, will make it the duty of borough and county councils to provide adequate and suitable provision for the technical training and employment of needy blind persons over sixteen years of age who are capable of receiving instruction.

The College of Teachers was founded in I908, to raise the status of teachers of the 
blind, and give them an opportunity of submitting their qualifications to the judgment of an accredited body, for the purpose of examination. The College is recognised by the Board of Education, and certificates are issued to successful candidates. Each year the executive committee choose a board of examiners from those who are recognised experts in teaching the blind. The College of Teachers has raised its standard of examination each year, and soon the children in all schools for the blind will receive an education equal, or superior, to that given to normal pupils in elementary schools.

The progress in musical education is shown by the increasing number of students who take advanced musical examinations. Since 1909 two have received the Degree of Bachelor of Music at Durham, and five have taken the first musical examination preparatory to this degree. Seven have received their diplomas as Fellows, and fourteen as Associates of the Royal College of Organists. Seven have passed the licentiate examination of the Royal Academy of Music in pianoforte playing.

A notable change in recent years has been the separation of the children of school age, from the adults employed in workshops on the same premises. In several instances this has meant the removal of the school from its contracted city quarters where there were no playgrounds, to large open sites in the country. The "School for the Indigent Blind," established in Southwark in 1799, has been removed to fine new buildings with ample grounds at Leatherhead, while the workshops for adults remained in London. The Elementary Department of the "Bristol School of Industry" was removed to new premises at Westbury-on-Trim in 1911. In Manchester and Birmingham it was found more convenient to remove the adult inmates to the country, and remodel the existing premises for the Element. ary Department.

The counties of Norfolk, Suffolk and Cambridge opened a new School for the Blind and Deaf-Mutes at Gorleston in 1912.

The Kindergarten Branch of the Birmingham Institution at Harborne, and the Staffordshire Council School at Stoke-on-Trent, have erected shelters for open-air classes.

On account of the Employers' Liability Act, it is undesirable that any child who is to be regarded as weak-sighted rather than as blind, should be educated in a blind school. It is also a waste of time for such children to learn to read and write by the Braille system. There. fure, the London County Council have established experimental classes for children suffering from high myopia, the teaching being carried on jointly by the staff of the elementary schools and a special teacher. In the special class, the reading, writing and arithmetic are taught by means of large characters, written on a blackboard which runs round the classroom. The lid of each desk forms a smaller blackboard on which the children write their exercises, holding the chalk at arm's length. For oral teaching, they join with the normal children in the elementary schools; their manual training is given partly by the special teacher, and partly in the centres for cooking, carpentering, etc. of the Council Schools. In the scheme of work provided in these experimental classes, all work likely to be detrimental to the eye is eliminated.

There are at present 39 schools for blind children in England and Wales certified by the Board of Education, with accommodation for 2,355; the total number of day schools on the register for the year ending July 3i, I9I 1 , was 550 .

The British and Foreign Blind Association has done new and valuable work since Mr. Henry Stainsby was appointed Secretary General in 1908. Mr. Stainsby was connected with the Birmingham Institution for the Blind for 28 years, as Secretary and General Manager. He brought to the work in London a comprehensive knowledge of the needs of the blind, an indefatigable zeal, and great organising and business capabilities. He has introduced many improvements in the method of printing books, which have largely increased the output. Formerly each page was damped before printing, and the drying process was cumbersome and lengthy. The books are now printed on specially made paper, which softens as it comes in contact with the electrically heated plates, and quickly hardens as it leaves them. When the furst copy of the English Bible was printed in Braille (39 large foolscap volumes) every dot of the 6,000,000 letters was punched by hand on metal plates, but these plates are now produced by stereotype machines. The printing presses are driven by an electric motor, and the embossed plates open and close automatically to receive the paper. By the new method 6,000 pages can be embossed per hour, as against 320 by the old.

Mr. H. M. Taylor, M.A., F.R.S., Fellow of Trinity College, Cambridge, a member of the Executive Committee, has established a fund for the production of scientific books; each book is profusely illustrated by diagrams prepared under Mr. Taylor's supervision. The cost of a set of plates for one book averages 630 which shows the great expense incurred in producing books for the special needs of the blind. The recent publications include works on Astronomy, Botany, Geology, Physiology, Psychology, Chemistry, Electricity, Magnetism, Heat, Mechanics, and Acoustics. The Association issues four embossed Magazines, (Progress, a Literary Journal, a Musical Magazine, and Comrades for the Juveniles); the books, pamphlets, magazines, and papers published in ral I amounted to 150,189.

In this connection must be mentioned the great increase in the circulation of books by 
the "Incorporated National Lending Library." It now comprises between I5,000 and I6,000 volumes of general Literature in Braille and Moon, and over 3,000 pieces of music. There is an Esperanto Section containing $22 \mathrm{I}$ volumes, as well as books in foreign languages. About 1,300 volumes are added annually, most of them transcribed by some 500 voluntary writers. During the last three years there has been a 20 per cent increase of individual subscriptions, and periodical consignments of books are sent to 34 Public Libraries, and to 48 Institutions. The postage on embossed books has been reduced in the United Kingdom, and the Postmaster General has promised to bring the matter of international reduction before the next conference of Postal Authorities at Madrid.

Between 1906 and 1908 , seven Unions were formed of the existing Institutions, Societies, and Agencies for the Blind, in England and Wales. The Unions undertake to promote the general welfare of the blind, to enlist fresh sympathy on their behalf, and to befriend them in every possible way, so that no blind person shall be left uncared for. An important feature of their work has been the increased attention given to the prevention of blindness.

Ophthalmia neonatorum has been added to the list of notifiable diseases, and notification has been made compulsory in 29 metropolitan boroughs, 59 other boroughs, and 125 rural and urban districts-a total of $2 \mathrm{I} 3$, representing a population of $1 \mathrm{I}, 469,652$. It is hoped that this notification will soon be compulsory throughout the United Kingdom. In 1908 Dr. Walker of Liverpool instituted the plas of at once removing the infant whose eyes were affected and the mother to a hospital. In $2 \frac{1}{2}$ years time, out of 434 cases of ophthalmia neonatorum that were treated, only seven became blind. In the potteries district of Staffordshire, as soon as notice is given, a nurse is appointed to visit the infant in the home. During nine months' experience, out of 75 cases, only 2 per cent became blind. If like results follow in all the boroughs where notification is compulsory, the number of blind children in the United Kingdom will rapidly decrease.

United States.-In America liberal provision has been made for many years for the elementary and secondary training of every blind child; including schools for the coloured, there are 45, and in some large cities the public schools have departments for blind children. The efforts of the newly appointed state commissions have been chiefly directed to registering the adult blind; and as far as possible providing employment for them. An active propaganda for the prevention of blindness has been started. In December r 9 ro a National Association for the Conservation of Eyesight was founded. Its aims are (I) the prevention of infantile blindness, (2) the prevention of blindness from industrial and other accidents, and from disease, (3) the conservation of vision through improved hygiene during school life and in industrial occupations. The presence at the first Conference of leading ophthalmologists, physicians, social workers, statisticians, representatives of civic and labour organisations, illuminating engineers, and representatives of Institutions and Societies for the Blind, give proof of its wide practical usefulness. The Russell Sage Foundation has made an appropriation for this field of work, and appointed an able secretary to organise committees throughout the United States. In many public schools labels are posted in all text-books giving directions for the care of the eyes in reading. The Massachusetts legislature has passed a bill empowering the State Board of Health to investigate industrial eye diseases, and to enforce the use of safety devices. It will not be long before other state legislatures do hikewise.

The large city schools are removing to the country. The Pennsylvania School, opened in Philadelphia in 1833 , has new buildings at Overbrook, and its grounds comprise 2 I acres. The Perkins Institution at Boston, famous for the long continuance of Dr. S. G. Howe as its Director, has erected new buildings costing $\$ I_{1,019,000}$ in a suburb of Boston, where 37 acres bordering on the Charles River were purchased. The Maryland School has been moved from Baltimore to a site in the country covering 92 acres. A new feature is the opening of homes for blind babies in Massachusetts, New Jersey, New York and Arizona.

Canada.-In Canada there are 3 schools, and a new one for the Protestant blind of the province of Quebec was opened in 1912. The building and grounds have cost \$100,000, and the money has been raised mainly by the efforts of Mr. Philip Layton, a graduate of the Royal Normal College for the Blind, Upper Norwood, England. (F. J. CaMPbell.)

\section{The Deaf: And Dumb ${ }^{1}$}

The British Registrar General stated in October I 912 that the tabulation of statistics relating to deaf and dumb persons, as returned at the rgr census, would not be complet-

${ }^{1}$ See E. B. vii, 880 et seq. 
ed for some considerable time. It is therefore impossible to make any comparative statement as to the increase or decrease in the numbers of deaf people in the United Kingdom since I90I. But even if these figures were available; they might prove of little value, as the wording of the census question relating to deafness varies each decade, and in the last form was couched in language which will probably render it valueless. The information asked at the I9I I census was: "If any person included in this schedule is totally deaf, or deaf and dumb, state the infirmity opposite the person's name, and the age at which he or she became afflicted." Now total deafness, whether acquired or congenital, is comparatively rare, and even among the so-called "deaf and dumb" it is generally recognised that there are from I5 per cent to 25 per cent with a "useful" amount of hearing. The returns can only be misleading, unless indeed a supplementary enquiry be held, such as that conducted by the United States Census Bureau in 1906 , in which a special schedule was sent to the 29,544 persons returned as "deaf" in the first enquiry, and further particulars in the form of replies to specific queries asked for. Mr. B. St. John Ackers, member of the Royal Commission on the education of the blind and deaf, and Chairman of the International Statistics Committee (on the Deaf), has pointed out that "Statistics to have their full value, should not only be full, accurate and reliable, but should be on the same plan in all countries. This should apply both to census and school statistics." With this end in view, a "Form of Inquiry " has been compiled for adoption in all countries represented on the International Committee, and was issued at the end of IgI 2 to all the School Medical Officers in Great Britain. In this way it is hoped that better information may be secured.

The Report of the Chief MIedical Officer to the Board of Education in England for 1910I I gives the following figures: number of children examined in 23 educational areas, 122,854; percentage with slight defect in hearing, 2.7; marked defect I.3; number of schools in England and Wales for the deaf, 48 , with accommodation for 4, I83 children, and average attendance 3,5I4. In Scotland there were 12 schools with accommodation for I,0I4 children, and 714 pupils; in Ireland 4 schools with accommodation for 580 , and 525 pupils.

From an inquiry into the training of 947 deaf children in six typical schools the report finds that 70 per cent are taught by the oral method, Io per cent by mixed or combined systems, Io per cent by pure manual alphabet, and Io per cent by manual alphabet and gesture. The report states that about 80 per cent of the deaf children are normal mentally, and a comparison of the figures of the various schools and institutions shows that about two-thirds are being educated in residential schools, chiefly managed by private committees, and one-third are being educated in day schools managed entirely by the local authorities.

The most recent American return (The Volta Review, Feb. 1912) gives the following figures: number of schools for the deaf I48; total pupils 12,588; number taught speech 9.302 (73.9 per cent); taught wholly" or chiefly by the "Oral " method 8, I I9 (64.5 per cent); taught by the Auricular method I58 (1,25 per cent).

In the opinion of the Chief Medical Officer in England, "the degree of knowledge, skill and tact possessed and exercised by the teacher are factors which do more to make or mar success in the case of the deaf than in the case of ordinary children;" and teachers of the deaf appear to have recognised the supreme importance of periodically reviewing the methods and plans for ameliorating the lot of the deaf child. The biennial conferences of the National Association of Teachers of the Deaf have focussed the attention of teachers and workers on behalf of the deaf on the necessity for advance in certain directions. The International Conference held in Edinburgh in 1907 was attended by representatives from the British Colonies and all countries where education of the deaf is properly organised, and at this gathering a full review was made of the methods adopted for dealing with the education of the deaf. In I I I a very important conference was held at Manchester, under the presidency of Lord Sheffield, when resolutions were adopted: (a) in favour of provision for the higher education of the deaf; (b) the training of teachers for the deaf; (c) the compulsory education of the deaf in Ireland; (d) the moditication of the questions concerning deafness in the next census schedule; (e) increased government grants to schools for the deaf; $(f)$ the segregation of the feebleminded deaf; and $(\mathrm{g})$ the carlier compulsory education of deaf children.

An entirely new feature in the education of the deaf during the past three years has

${ }^{1}$ Report of the Manchester Conference on the Education of the Deaf, 1911 . 
been the establishment of classes for "hard-of-hearing" children at Glasgow, Bristol, Tottenham and London. The children admitted to these schools are too deaf to be dealt with even if placed in the front row of an ordinary class, yet they possess too much hearing and speech to warrant their inclusion in a class with the ordinary deaf child. They are therefore placed in these special classes or schools, and taught on "Oral" lines, utilising what residual hearing power they possess, and at the same time supplementing it by "lip-reading." As statistics in connection with all phases of deafness become more complete there will be a great extension in the provision for the education of this class of child, and this may lead to a more complete system of classification of children who are "educationally." deaf, i.e. too deaf to be taught with hearing children.

This question of classification received a great impetus from the discussion of the Danish system at the International Conference in 1907 , and it is to some such modification of English methods that those interested in the education of the deaf look for a cessation of the war of systems. Steps in this direction have been made by the segregation of all backward and physically and mentally deaf children, from the L.C.C. Schools for the Deaf to the residential school at Homerton (London), and also by the establishment of "Clyne House School " for the backward deaf of the Manchester Institution. At Homerton the combination of other defects, such as total or partial blindness, with deafness, presents unique conditions for the study of psychological problems in conjunction with physiological abnormalities.

In February I9I I Mr. Macleod Yearsley, aurist to the London County Council, wrote a series of articles in the Lancet dealing with the conditions of the education. of the deaf in London, and in making suggestions for classification for education on a physiological basis he strongly supported the feeling among teachers of the deaf in favour of "Earlier education," and recommended that Kindergarten Schools should be established to which deaf children from the age of three years upwards could be sent, and that by means of play, prattle about games, toys, and similar matters of infantile interest, the hereditary tendency to speech should be retained, and the habit of speech should be developed and utilised from these early years onwards. A reference to these articles in the "Educational Supplement" of the London Times (April-October I9I I) led to a long correspondence, in the course of which the whole question of "systems " was again discussed by the Rev. Arnold Payne, Dr. Kerr Love and others.

In Great Britain the Elementary Education (Blind and Deaf Children) Act, r893, makes the education of the deaf compulsory at seven, though grants are paid on their education from the age of five, when it is optional for local authorities to send such children to school, and provision for dealing with them has already been made at Manchester (where an Infant School and Home has been opened in connection with the Institution) at Fitzroy Square, at Moseley Road Deaf School, Birmingham, and under the L.C.C.; and other developments of the same kind are in contemplation at Doncaster and other places, following on the lines of the experimental schools at Boston, Chicago and Philadelphia.

The establishment in London in I9II of "The National Bureau for Promoting the General Welfare of the Deaf" was a step of the greatest importance. The famous "Volta Bureau," established in Washington, D.C., by Dr. Graham Bell, with the money he received from the "Volta" prize for the invention of the telephone, is well known, and it is confidently expected that this National Bureau, founded through the generosity of Mr. Leo Bonn, will do for Great Britain even more than its American predecessor. Full particulars of the 60 schools and institutions for the deaf, the 60 or 70 missions to the adult deaf, and the 15 or 16 large organisations, all interested in the advancement of the deaf in various ways, have been filed at the Bureau, and the Council consists of representatives of every organisation working on behalf of this afflicted class, both in child and adult life. The main objects of the Bureau are (I) (Centralisation) to get into touch with and promote co-operation between all existing agencies; (2) (Information) to collect, classify, and disseminate information; (3) (Investigation) to promote investigation. Already statistics and particulars are being prepared relating to all branches of work among the deaf for publication, in a form easily accessible, and when public bodies and private individuals realise that complete and accurate information on all matters connected with the deaf may be obtained through the Bureau, it will become a "clearing house". for this branch of effort.

In a letter sent out to institutions and schools for the deaf in Great Britain, Dr. J. Kerr Love, Aural Surgeon to the Glasgow Infirmary, states: "By a curious coincidence the writer 
has been asked by the two great bureaus which exist for promoting the welfare of the deaf; the American Volta Bureau, and the English National Bureau, to take up the question of the prevention of deafness. The requests came within a few weeks of each other, and were entirely unconnected. Only one conclusion can be drawn from this coincidence, i.e. that the time is ripe for the consideration of this large and important subject." In response to this request Dr. Kerr Love has given a series of lectures in London on the subject of the prevention of deafness, and the same subject has been dealt with in two articles by $\mathrm{Mr}$. Macleod Yearsley in the Lancet (July 20 and 27, 1912).

(F. G. BARNES.)

\section{RELIGION}

\section{Church of England and Anglican Communion}

Welsh Church Commission.-The Royal Commission appointed in 1906 to " inquire into the origin, nature, amount and application of the temporalities, endowments and other properties of the Church of England in Wales and Monmouthshire, and into the provision made and work done by the churches of all denominations in Wales and Monmouthshire for the spiritual welfare of the people and the extent to which the people avail themselves of such provision," did not report until December 19ro. It then presented majority and minority reports. The former was signed by seven of the nine Commissioners, five of whom gave a qualified adhesion to some of the opinions of their colleagues. The Commission received a mass of evidence as to the finances and the numerical following of the Church as compared with the Nonconformist bodies. The statistics presented on behalf of the Church showed that the actual number of communions made at Easter rose from 134,000 in $1905-06$ to 144,000 in $1908-00$ and that the total number of persons upon all the Welsh communicant rolls was, in the latter year, 193,000 . These returns were based upon lists for each parish, with the name and address of each communicant. The Nonconformist lists of "full members "gave the Congregationalists 175,000 , the Calvinistic Methodists 170,000 , the Baptists 143,000 , the Wesleyans 40,000 and the smaller Protestant denominations I9,000 among them. Other figures prepared on behalf of the Church showed that in every diocese in Wales there had for many years past been a constant and substantial increase in infant baptisms, confirmations, and Sunday-school scholars, and that in most cases the numbers had grown in a larger proportion than the population, the inference being that the Church was expanding by conversions from Nonconformity. In the diocese of Bangor, where the population decreased, the Church communicants increased. The Commission found that the Church in Wales provided I, 546 churches and mission-rooms, with seating accommodation for 458,917 . The officiating clergy numbered $\mathbf{I}, 597-968$ incumbents, 56I curates and 68 others. There were 2,393 English services, I, I03 Welsh services, and 228 bilingual services every Sunday. The seating accommodation provided by the Church in Wales was 22.8 per cent of the population, a fraction above the percentage for England and Wales together. The accommodation in the Nonconformist places of worship provided for more than double the total of Nonconformist adherents; the chapel-building debt of the Calvinistic Methodists amounted in 1906 to $£ 668,000$, and of the Congregationalists to $£_{31} 8,000$. On the other hand the Church accommodation failed to keep pace with the increase of the population. Between $183 \mathrm{I}$ and 1906 the population increased 9 I per cent, but Church sittings by only $i_{1}$ per cent. Resident clergy, however, grew by in per cent and regular Sunday services by 176 per cent. Much controversy arose as to the accuracy of the figures presented on the one side or the other, but in the end it appeared to be clear that the Church of England was numerically the largest single religious body in Wales. The Commission found the total gross endowments of benefices in Wales in 1906 to be $£_{242,669}$. (A Parliamentary Return issued in November 1012 showed it to be then $f_{2} 60,037$.) Of this sum $f_{1} \mathbf{1 3 5}, 980$ is income of endowments believed to have been in existence in $\mathrm{I} 703 ; \mathrm{f} 37,34+$ is income derived from Queen Anne's Bounty; $f_{49}, 669$ is income derived from the Eucharistical Commissioners; $£_{19}, 672$ comes from private gifts since 1703 . In $1905-06$ voluntary contributions were $\ell+8,972$ towards clerical stipends; $£ 62,26$ I for church expenses or church maintenance; $f_{0} 68,8,53$ for church building and burial grounds. 
Welsh Disestablishment.-Without waiting for this report the Government in Inog brought in a bill for the disestablishment and disendowment of the church in the four Welsh dioceses and the county of Monmouth, generally similar in its provisions to the bill of 1895 , but withdrew it after the first reading. The date after which private benefactions were to be exempt from the operation of the measure was fixed at 1662 , instead of $\mathrm{r}_{703}$ as in the former bills. It was argued on the side of the Church that the bill would take away eighteen-and-sixpence in the pound of the endowments. These funds were to be used for the provision of libraries, technical institutes, public halls, hospitals, dispensaries, convalescent homes, etc., for which no provision is made from public funds. In April rgr 2 a fresh disestablishment and disendowment bill was introduced which admittedly took away thirteen-and-fourpence in the pound of the endowments. Under this measure the vested interests of incumbents were preserved for their lives, instead of during their tenure of office, and the Ecclesiastical Commissioners and Queen Anne's Bounty were empowered to continue paying to the Welsh Church their existing allowances of $£ 68,600$ a year, which the bill of I 909 forbade them to do. A representative body was to be formed to receive and administer the whole of the property left to the church. The parliamentary proceedings in connection with the bill are dealt with elsewhere (Part II. UnITED Kingdom: History).

Prayer-book. Revision.-The Royal Letters of Business first issued in 1906 and since renewed to the two Convocations enjoining them to consider "the desirability and the form and contents of a new rubric regulating the vesture of the ministers of the Church at the times of their ministrations, and also of any modification of the existing law relating to the conduct of divine service, and to the ornaments and fittings of churches" were still under consideration at the end of $\mathrm{x} 9 \mathrm{I} 2$. The proceedings under these injunctions are necessarily slow and complicated. Each of the four Houses of Convocation has appointed a committee to draw up proposals, each of which has to be debated in public session; the two primates have, moreover, undertaken that the proposals finally accepted by the Convocations of the Clergy shall be submitted in the end to the Representative Church Council, which consists of the four Houses of Convocation and the two Houses of Laymen. Thus six bodies, four of them with powers of legislation dependent upon Parliamentary sanction, and two which have no power to do anything but debate, have to accept every proposed emendation of the Prayer-book. Many of these emendations are merely verbal; others raise questions the most sharply controverted between sections of opinion in the Church. The recommendations reached by the Convocations can therefore be regarded only as provisional, since alterations supported by the whole body of the Church must necessarily be regarded by Parliament with far greater respect than those upon which there is acute controversy. The sharpest of these controversies has raged round the Athanasian Creed, of which a new translation, prepared at the request of the Archisishop of Canterbury, was published in 1909 . In the same year Canterbury Lower House resolved that the Creed should be retained in the Prayer-book without the existing rubric, and that provision should be made for its use without the warning clauses. York Lower House decided that no change ought to be made in the use of the Quicunque Vult. York Upper House, on the other hand, favours the retention of the Creed in the Prayer-book but desires that it should no longer be recited in public worship, and that if its public use be continued it should be obligatory. only on Trinity Sunday. The question of vestments has caused an almost equally definite division of opinion. In Igog the York Upper House recommended that the bishop should have power, under safeguards, and in parishes where it was thought. desirable, to sanction the use of alternative vestments in the Holy Communion, provided that they should all be white, and in ror 2 the House voted equally for and against this arrangement, the Archbishop of York refraining from giving a casting vote in favour on the ground that the final step had not been reached. The Committee of York Lower House has also reported in favour of alternative vestments, but without limitation of colour. York Upper House has decided in favour of a book supplementary to the Prayerbook containing alternative lessons and psalms, forms of prayer and thanksgivings for 
special occasions, and alternative and additional forms of service, the Communion Office to remain untouched. Upon another much controverted question, the Communion of the Sick, Canterbury Lower House decided that it should be lawful for the priest to set apart at the public Communion a sufficiency of the consecrated elements for the communion on the same day of such sick persons as may not desire a separate celebration. Canterbury Lower House decided in I III that while it is undesirable to alter the Ornaments Rubric, provision ought to be made for a diversity of use as regards the wearing of vestments at the Holy Communion. In November 1912 the Lower House of both Convocations refused to modify the question put to deacons at their ordination, "Do you unfeignedly believe all the Canonical Scriptures of the Old and New Testaments?" In one or other of the four Houses of Convocation numerous minor amendments in the Prayer-book have been approved. Many of them have been hotly contested, both of the extreme wings in the Church being opposed to revision, either entirely or save within very narrow limits. The High Church party has issued a "Declaration " setting out an "irreducible minimum " of demands, which comprise the preservation of the Ornaments Rubric and the Athanasian Creed, and the Rubric requiring that no person shall be admitted to communion who is unconfirmed or is not desirous of being confirmed. Other demands are the restoration of the unbroken Canon, the provision of a form for the anointing of the sick, the sanctioning of continuous reservation and direct prayer for the dead. The Archbishop of Canterbury has appointed a committee of liturgical experts to advise on proposed alterations in the Prayer-book. Canterbury Lower House in I9I 2 approved the retention of the existing course of the Psalter, but later asked the Primate to procure an "authoritative revision of the Psalter for use in Church." In Canada a Committee of General Synod has been appointed to consider "Prayer-book adaptation and enrichment;" in South Africa various experimental modifications of the Prayer-book are in use; the Churches of China and Japan are also contemplating revision.

The Scottish Revision.-Meanwhile the Church in Scotland has actually revised its Prayer-book. In Igro the Episcopal Synod prepared a revised Scottish Communion Office, and in the same year the Consultative Council on Church Legislation prepared a schedule of permissible additions to and deviations from the Book of Common Prayer. After extensive discussion the new and revised forms were finally sanctioned and came into operation in a permissive form in I 9 I 2. In the Communion Office according to both the English and the Scottish rite, either of which may be used in Scotland, the Commandments may be omitted, and replaced by Our Lord's brief Summary of the Law. The Collects for the King may also be omitted. When there are many communicants the words of administration may be said once, the first half of the words only being recited to each person. New Proper Prefaces have been provided for festivals which hitherto lacked them, and for marriages and funerals. Proper Lessons are prescribed for the Evensong of Festivals, and other special occasions. Considerable freedom is accorded in the use of the Psalter, and there is now power, with the bishop's consent, to omit the Litany altogether on the three great festivals. The concluding portions may be omitted at other times, but on the other hand new suffrages have been added for the King's forces, for Missions and for Parliament. A variety of additional prayers for special needs have been added, together with commemorations of the dead. In the Marriage Service the exhortation has been altered and abbreviated, and there are alternative Lessons in the Burial Service. A committee has been appointed to consider the propriety of a thorough revision of the Psalter and Lectionary.

Reform of Church Finance.- The chaotic condition of the finances of the Church of England, the overlapping and waste of effort resulting from innumerable more or less isolated endeavours to accomplish a given end, the existence of many Societies with aims and policies of their own, led in I 1909 to the appointment of the Archbishops' Committee on Church Finance. After more than two years inquiry and deliberation this Committee reported in I9II. The key-note of the report is the recommendation that the diocese and not the parish should be the unit of Church life and that respon- 
sibility for the work of the Church should be brought home to every member. Among many instances of overlapping and lack of organisation mentioned by the Committee perhaps the most striking is the fact that there are over eighty separate societies seeking to provide for the needs of poor clergy. They insist that the underpayment of the clergy and the lack of provision for their superannuation discourages recruits for Holy Orders and that the laity have withheld support from Church funds on account of the lack of business-like administration. They further point out the singular circumstance that, since the Church of England has no corporate existence, it is unable to hold property; there may be, and are, innumerable parochial and diocesan funds, and a vast number of voluntary societies all of which have a legal existence, whereas the Church itself, quâ Church, has none. The Committee recommended that there should be an Incorporated Board of Finance in every diocese, elected by and affiliated to the Diocesan Conference, with a permanent secretariat. This Board is to arrange a system for the assessment of every parish according to its means and population in such a way that every individual is brought under contribution. There would be a Central Incorporated Board of Finance, attached to which would be a Central Building Loan Fund, on the lines of the Funds already existing in two or three dioceses; a Council of Maintenance of the Clergy; a Central Pensions Council, and a Central Advisory Council of Training for the Ministry (the last-named was established by both Convocations in November I9I 2). These general provisions include arrangements for recruiting and training ordination candidates who are unable in whole or in part to provide the cost of their own education; for maintaining the ministry by the endowment and augmentation of benefices etc.; for the provision of clergy pensions of not less than $£_{\mathrm{r}}$ roo per annum, especially for those invalided after twenty years' work in Great Britain; for providing for the widows and children of the clergy and making grants to clergy in difficulties through misfortune; for the erection of new churches and other parochial buildings, and the repair of those already existing. These recommendations have been discussed by the Representative Church Council, the Houses of Laymen, the Diocesan Conferences and other deliberative assemblies, and have, on the whole, been received favourably; the least popular provision is that for the assessment of parishes. In many Dioceses preliminary, and in some extensive, steps have been taken towards carrying out the proposals.

Increase of the Episcopate.-During the last four years the movement for the division of unwieldy dioceses has acquired increased momentum. It is proposed to divide the Diocese of Oxford into three portions, roughly co-extensive with the three countiesOxford, Berkshire and Buckinghamshire-of which it mainly consists, with new seetowns at Reading for Berkshire and at Aylesbury for Buckinghamshire. Steps are being taken to secure an endowment for a Diócese of Coventry, taken out of the straggling See of Worcester, which has already been relieved of Birmingham and its immediate district. It is hoped to create a third new Midland diocese, with its seat at Stoke-onTrent or Stafford, for the relief of Lichfield, with an ultimate further division of that diocese by the erection of Shropshire into a See of Shrewsbury. Further North preparations for separating Sheffield and its district from York are well advanced. The division of the Diocese of Winchester, rendered exceptionally difficult by the impossibility of a bishop with a reduced income living at Farnham Castle, is under consideration. The rearrangement of the East Anglian sees, under which Suffolk will be taken from Norwich and Essex from St: Albans, is almost ready to take effect. These plans are, however, hampered by the failure of Parliament to pass the Bishoprics Bill, a measure enabling new dioceses to be created by Order in Council without the necessity for an application to legislation in each case. Meanwhile the increasing necessity for episcopal supervision is being clumsily and inadequately met by the creation of additional suffragan-bishoprics, which are now almost as numerous as substantive dioceses." Thus the three dioceses of which Greater London consists-London, St. Albans and Southwark-have among them eight suffragans. Between 1909 and. I 912 five suffragan bishoprics were created: Lewes (Chichester); Stafford (Lichfield); Taunton (Bath \& Wells); Willesden (London); and Whalley (Manchester). 
The Church in the Empire and Abroad.-During the last four years there has been great activity in the Church of Canada, in consequence of the enormous influx of English settlers, especially into the North-West Provinces. The first service of the English Church in what is now the Dominion was held at Annapolis Royal in ry ro, and the bicentenary was marked by the opening of a new Cathedral at Halifax, Nova Scotia. To meet the strain of a rapidly growing population unable to provide for its own spiritual needs the Archbishops' Western Canada Fund was established in Ig Io for the provision of men and money to meet these needs, and the Rev. W. G. Boyd, one of the chaplains of the Archbishop of Canterbury, went out at once with five clergy and four laymen, and others have followed. On the whole, however, the response both in men and money. has been disappointing. In rgr 2 a Mission of Help was sent to the Province of Rupert's Land. In I9I I British Columbia was erected into a Province, and in October I9I 2 it was decided that instead of one Province for the whole of Canada east of Manitoba, a new Ecclesiastical Province of Ontario should be formed, to include the Dioceses of Ottawa, Algoma, Huron, Niagara, Ontario and Toronto. There are consequently now four Canadian Provinces. In Australia the serious "Question of the Nexus " arose in Ior2. Distinguished counsel have stated their opinion that the Church in Australia is an integral part of the Church of, and in, England and that it is bound by the judgments of the Judicial Committee of the Privy Council. A powerful movement in the direction of independence has been set on foot, but considerable opposition has been manifested to any disturbance of the status quo. A more local yet important disturbance of harmony was caused by a question of vestments at Sydney in rgro. The only churches in that city in which vestments were used were St. James's and Christ Church, and the incumbencies of both fell vacant within a few months of each other. The Archbishop of Sydney refused to institute any clergyman who declined to give an undertaking not to use, or allow to be used " the chasuble or other vestment in any church under his charge until, in the judgment of the Archbishop of Sydney for the time being, they have become legal." In each case this requirement caused a long delay in making an appointment, and the incident toduced a serious division of opinion in the Diocese. The first portion of Brisbane Cathedral, which when completed will have cost

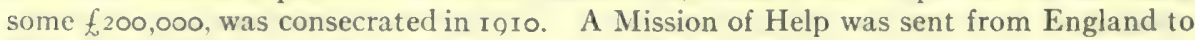
New Zealand in Iorr. In India the most important subject which has engaged the attention of the Church is the position of the Eurasians, whose education has been greatly neglected. Roman Catholic and Nonconformist schools have provided for large numbers of what is now called the Domiciled English Community, and it is thought desirable that this leakage should be reduced. Accordingly special funds are being raised for improving and strengthening the Anglican schools in the great centres of population. In consequence of the intended removal of the capital to Delhi the Provincial Synod of Calcutta has prepared a memorandum suggesting the formation of two new Archbishoprics-one of Madras to include the Sees of Madras, Tinnevelly, Travencore, and Colombo; and another of Delhi to include Delhi, Lahore, Lucknow, Bombay and Nagpur. In IoI 2 a native priest was, for the first time, raised to the Episcopate, the Rev. V. S. Azariah being appointed assistant bishop of Madras. In South Africa a new Diocese of George, taken out of the Sees of Capetown and Grahamstown, was created in IOI 1 , and in $19 \mathrm{r} 2$ the Diocese of Kimberley and Kuruman, taken out of the Diocese of I3loemfontein, was formed; in Ior 2 Khartum Cathedral was consecrated. In I900 the Missionary Church in China constituted itself under the title of "The Holy Catholic Church of China," and in Ior 2 the Church in Japan took a similar step.

Miscellancous Events.-During the period under review two important events, one affecting the discipline, and the other the doctrine of the Church of England, have occurred. 'The first turned upon the interpretation of the Deceased Wife's Sister Marriage Act of $\mathrm{I}()_{07}$, and led to the suits of Banister $v$. Thompson. The plaintiff married his sister-in-law in Canada, where he had no domicile, under the Colonial Act before the passing of the English Act and was refused communion by his vicar, the defendant. The Court of Arches found in 1908 that the passing of the Act of 1907 validated the 
marriage as a civil contract, and that therefore the parties could not be repelled as "notorious evil livers," to use the language of the Rubric which the defendant held to justify his refusal. The High Court by a majority upheld this decision, which was endorsed by the Court of Appeal, and confirmed by the House of Lords in June Igr 2. In rgi I the Rev. J. M. Thompson, Fellow, Tutor and Dean of Divinity of Magdalen College, Oxford, published Miracles in the New Testament, which produced an animated controversy. In the result the Bishop of Winchester, as Visitor of the College, withdrew Mr. Thompson's licence as Dean of Divinity on the ground that the book denied the articles of the Creed affirming the Incarnation and the Resurrection. In IgI the Church of England took part in the undenominational World Missionary Conference at Edinburgh. The Standing Committee of the S.P.G. decided in I 908 not to be officially represented at the Conference, but reversed its attitude in I9ro. In reply to a remonstrance from a large number of the members the Committee affirmed its determination "to uphold in all parts of the mission field the principles, order, discipline, doctrine and sacraments of the Church." In I 908 the Rt. Rev. A. H. Mathew was consecrated by the Old Catholic Church of Holland as Bishop for the Old Catholics in England, and at first much sympathy was expressed among those members of the Church of England who had long been anxious for an Anglican-Old Catholic entente; but when Dr. Mathew a year or two later declared against the validity of English Orders the budding understanding died a sudden and violent death. The movement for inter-communion with the Swedish Church had a happier issue. In I9I I a committee appointed in accordance with the desire of the Lambeth Conference of I908 reported that the Church of Sweden was a true Episcopal church and recommended the admission of its members to communion at English altars. The Church Congress kept its Jubilee in I 9 ro at Cambridge, the place of its birth.: One of the most important results of the Lambeth Conference of I 908 has been an increased interest in the spread and efficiency of Sunday Schools, and the Bishop of London in I9r I established a Sunday School Council and appointed a Director of Sunday Schools. When this example has been generally followed it is reasonably believed that the Sunday Schools of the Church, which in many places are conducted upon old-fashioned and ineffective lines, will become valuable aids to the spread of Churchmanship. The dissatisfaction of the unbeneficed clergy with their status generally, and especially with their exclusion from representation in, or the right to vote for, the Convocations has led to an organised attempt to obtain these things, and to make curates diocesan rather than parochial officers. During the past four years the magnificent undertaking of building a cathedral at Liverpool-only the second Anglican cathedral erected in England since the Reformation, the first being Truro-has made substantial progress. The lady chapel was consecrated in I910, and other large portions of the work are in hand. Winchester Cathedral, which in 1906 was found to be in imminent danger owing to the insecurity of its foundations, has been completely under-

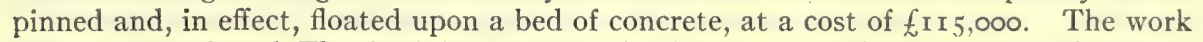
was completed and Thanksgiving services held in rgr2. The important church of Selby Abbey, which was almost completely burned in r 906, has been rebuilt and was reopened in I909; additions have since been made which have practically restored it to its pristine condition.

(J. Penderel-Brodhurst.)

\section{The Roman Catholic Church, igio-roi 2}

IgIO.- The death of King Edward VII in IgIo revived, and in an acute form, the old controversy in England about the Royal Declaration, with its antiquated terms of vituperation against Roman Catholic beliefs. At first it seemed that

\section{Britlsh} accession oath. the Roman Catholic demand for remedial legislation would have to be met by the same plea which had proved fatal to the hopes of Cardinal Vaughan in I9or. At that time Lord Chancellor Halsbury in reply to a question put to him by the Catholic Peers, explained that only Parliament could modify the Declaration, and that the making of the Declaration was a condition precedent to legislation. The Bill of Rights required that the Declaration should be made either at the 
Coronation or " on the first day of the meeting of the first Parliament next after his or her coming to the Crown." In this reply it was assumed that the Parliament which met on February 14, Igor was the first Parliament in the reign of King Edward. In I9ro a different view prevailed. It was successfully contended that the last Parliament elected under King Edward, and sitting at the time of his death, continued to be a Parliament of the old reign, and therefore was not "the first Parliament next after": the accession of George V. There was, therefore, plenty of time to amend, or to abolish, the Declaration. On their side the Roman Catholic body did all they could to facilitate legislation by making it clear they had no wish in any way to weaken the existing securities for the Protestant succession. All they asked was that the fundamental doctrines of their faith should no longer be selected for special repudiation by the sovereign. In these circumstances, Mr. Asquith had no difficulty in inducing the House of Commons to substitute a new formula, by which the king simply declared himself a faithful Protestant, prepared to uphold the Protestant succession. A bill giving effect to this change was passed on August 3, roro.

In September I9Io, for the first time, the International Eucharistic Congress was held in the New World. As the most Catholic city in the British Empire, Montreal made great efforts to welcome the Papal Delegate, Cardinal Vincent Eucharistic Vanutelli. The national, provincial and municipal authorities all worked
Congress. Congress. together for the success of the greatest Roman Catholic demonstration ever held in Canada, or indeed in the American hemisphere. The culminating scene was the mass said by the Cardinal Legate in the open air, at an altar built on the slopes of Mount Royal. The next day a vast procession, headed by the Cardinal Legate carrying the sacred host, passed through the streets of the festooned city to the same spot. It is estimated that 50,000 people, including the Canadian Prime Minister and other members of the Government, and representatives of every phase of the public life in Canada, walked in the procession three and a half miles to the mountain side, where a crowd of 200,000 men and women were waiting the Benediction of the blessed sacrament. The success of the Congress from the Roman Catholic standpoint is sufficiently attested by the emotional declaration of the Archbishop of Montreal, Monseigneur Bruchesi, at its close: "To me it seems like a dream, for the like of that demonstration ending to-night was never seen before, and probably never will be seen again in this or in any other country." Unfortunately some of the speeches and sermons were af a rather flamboyant nature, so that a good deal of anti-Catholic feeling was aroused.

On August 8, I910 an important decree of the Sacred Congregation of the Sacraments was issued in Rome, fixing the age at which children are to make their first communion. A child must begin to go to confession and communion First Com- when it begins to use its reason, that is " about its seventh year, or later.
munion or even sooner." The decree goes on to prescribe frequent communion for" children in these words: "Those who have charge of children must take the ut most care that after their first communion the said children should approach the holy table very often, and if it be possible, even daily."

The solemn consecration of Westminster Cathedral in London took place on Tuesday, June 28,1910 . At the beginning of the year the debt on the Cathedral had been $£ 7,340$, Westminster and this had to be paid off before the building could be consecrated. $A$ Cathedral.
special appeal was made to the Roman Catholic public, and before the end of April it was cleared off.

In Belgium, the elections in May roro for half the Chamber kept the Catholic party in power. They lost one seat at Nivelles, but returned with a majority of six. As i. Belgian Belgium there are no such things as by-elections, this majority though election. small was sufficient.

In August iо го Pius $\mathrm{X}$, in a letter addressed to the archbishops and bishops of France, condemned the principles which underlay the teaching of the organisation known as Le Sillon. Founded about I 898 by M. Marc Sangnier, Le Sillon represented a democratic movement at once social, political and religious. Described as "more 
advanced than Socialism," it at once made a strong appeal to the Roman Catholic masses, and soon spread over France. The Archbishop of Albi, writing in its defence,

\section{Le SHon}

in France. claimed that it represented an effort to " break down the prejudices which separate the majority of Republicans from Catholicism, to overcome the anti-clericalism which claims a monopoly of democratic zeal, and to destroy the association of ideas which in France seems to identify social progress with irreligion." But the extreme democratic theories advocated by some of the members of Le Sillon, and their indifference to ecclesiastical authority, soon got the organisation into difficulties, Cardinal Andrieu, the Archbishop of Bordeaux, being specially emphatic in his warnings. It was accused of substituting a vague philanthropy for religion, and the service of Man for the service of God; and teaching that all forms of government should be condemned which are not directly dependent upon the people. Pius $\mathbf{X}$ called upon the leaders of the movement to stand aside and to give place to the bishops. Its members were invited to group themselves in diocesan associations. "For the moment these diocesan groups will be independent of earh other; and to mark clearly their break with the errors of the past, they will take the name of Catholic Sillons, and each of their members will add the word Cathotic to his title of Sillonist.". The founder of Le Sillon a few days later announced his withdrawal from the direction of the movement.

IgII.-At the beginning of I9I I the Sacred College of Cardinals had only forty-six members, and the work which devolved upon the Cardinals living in Curia had become New very heavy. Seventeen new cardinals were created at a consistory held cardinals. in Rome in October. As had been generally anticipated in England the red hat came back to Westminster, and on the 27 th of November Cardinal Bourne became Titular of S. Pudenziana, one of the most venerable of all the sanctuaries of Rome. The other new cardinals were Archbishop Farley of New York, and Archbishop O'Connell of Boston, and Monseigneur Falconio, Apostolic Delegate at Washington, who though Italian by birth is a naturalised American citizen; Archbishop Cos y Macheo of Valladolid, Archbishop Amette of Paris, Archbishop Dubillard of Chambery, Bishop Cabrières of Montpellier, and Father Billot the Jesuit Professor of Dogma at the Gregorian University in Rome, Archbishop Nagl of Vienna, and Archbishop Bauer of Olmutz; Holland received a representative after a long interval in the person of Father Van Rossum; the diplomatic service of the Holy See supplied two names to the list-those of Monseigneur Vico, the nuncio at Madrid, and Monseigneur Granito di Belmonte, formerly nuncio in Vienna and more recently the envoy of the Pope to the Coronation of King George V; finally three members of the Roman Curia, Monseigneur Bisleti, for many years Maestro di: Camera and Majordomo, Monseigneur Lugari, one of the assessors of the Holy Office, and Monseigneur Pompili, secretary of the Congregation of the Council. Before the consistory the proportion of Italian to non-Italian cardinals was 28 to $\mathrm{I} 8$, after it the proportion became 33 to 30 .

The consistory was made memorable in the history of the Church by reason of the oath taken by each of the new cardinals pledging himself to disregard the right of veto over the election of the Pope claimed by the Catholic Powers, and commonly believed to have been successfully used by Austria to exclude Cardinal Rampolla from the Papacy. The oath repudiated in emphatic terms the interference of lay Powers.

In October IgI I two new ecclesiastical provinces were created by the Holy See in Great Britain, those of Liverpool and Birmingham. Something of the sort had long New British been expected. The province of Westminster, under an archbishop with sees.
fifteen suffragans, was an anomaly in the Church. Under the new arrangement the dioceses of Northampton, Nottingham, Portsmouth and Southwark are grouped with Westminster; with Liverpool go Hexham and Newcastle, Leeds, Middlesbrough and Salford as suffragan sees; while with Birmingham are associated the sees of Clifton, Menevia, Newport, Plymouth and Shrewsbury. At the same time the Holy See was careful in several ways to safeguard the position of pre-eminence which had so long belonged to the see of Westminster. Its archbishop is the permanent president at all meetings of the whole hierarchy, and it rests with him to summon such 
meetings. He takes precedence of the other archbishops, and is entitled to the use of the pallium and the throne, and to have the archiepiscopal cross carried before him in all parts of England and Wales. Finally to the archbishop of Westminster is entrusted the duty of representing the wishes of the whole hierarchy whenever it is necessary to approach the civil authority. To the archbishops of Birmingham and Liverpool were given all the rights and privileges ordinarily belonging to metropolitans.

By a decree of April 20, I9I the Portuguese Government declared the separation of the Church from the State. After confiscating ecclesiastical property to an estimated Separation in Portugal. value of several millions, the Republican Government handed over the control of public worship to associations of laymen. Priests were declared ineligible. It was made illegal to read a bishop's pastoral in church, or to publish it in any way without the previous permission of the Government. Processions were interdicted, and the clergy forbidden to wear their cassocks in the streets. Young ecclesiastics before they begin to study theology are required by the new law to attend the public lycées, in which the text books and the professors are selected by the Government. Finally no priest is allowed to exercise his functions if he holds a degree in any sacred science conferred by a university founded by the Holy See. In an Encyclical Letter addressed to all the bishops throughout the world in communion with the Holy See, and dated the $24^{\text {th }}$ of May, Pius X protested against this violation of the Concordat, and at the same time congratulated the Portuguese bishops on their faithfulness under trial and their constancy under persecution.

In the United States the Golden Jubilee of Cardinal Gibbons' priesthood, and the Silver Jubilee of his episcopate, were celebrated in Baltimore in June I9I I, with almost national rejoicings. Among those present to do honour to the Cardinal occasion were President Taft, Vice President Sherman, Mr. Roosevelt, ambons' the Governor of Maryland, the Chief Justice of the United States, the
jubilee. British Ambassador, the Speaker, a score of Senators and three times that number of Congressmen.

The Sacred Consistorial Congregation at Rome, at a general meeting held on February 23, I91 1 , considered the doubt whether the decree "Maxima Cura " issued in August of the previous year, applied to Great Britain and North America. "Maxima The answer in both cases was in the affirmative. The effect of the decree decree. is to abolish the distinction between permanent and removable rectors. No rector of a parish or mission is any longer liable to be removed from his post ad mutum episcopi. The hands of the bishops however are strengthened in the case of those who were formerly known as permanent or missionary rectors. The decree sets out nine causes which may justify administrative removal. Each case is to be considered by the bishop and two examiners who are to be chosen jointly by the bishop and the chapter. An appeal from this disciplinary council lies to a court consisting of the ordinary, and two parish priest consultors, who must be different from the two examiners previously engaged in the case.

In July r9 I a Motu Proprio was issued in Rome limiting the number of the weekday holidays of obligation throughout the church to eight-Christmas Day, the Cir-

\section{Church}

holidays.

cumcision, Epiphany, Ascension, Immaculate Conception, Assumption,

SS. Peter and Paul, and All Saints. The result, as far as England is concerned, is to reduce the number of holidays of obligation by one. The feast of the Immaculate Conception was never a holiday of obligation in England, and the feast of Corpus Christi ceases to be one. In the same way the feast of St. Patrick ceases to be a holiday of obligation in Ireland.

I9I2.- - In view of the fact that, at both the general elections in January Ioro and December roro, the members returned to the British House of Commons represented a majority in favour of denominational education (the Irish members and the Unionists being in agreement in this respect), the Catholic body had some reason to expect a cessation of Liberal Nonconformist hostility in regard to their schools. The old attacks, however, were renewed this year under cover of a bill introduced by Sir George Marks, 
which sought to suppress denominational schools in single-school areas. Under the bill, in those areas the only schools to be recognised for maintenance from public funds were to be the Council schools, in which teachers were to be appointed

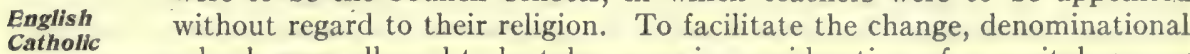
schools. schools were allowed to be taken over in consideration of a capital sum or annual rental. In that case, certain hours might be set aside for the giving of denominational instruction, provided that it was not given by the teachers of the school. The bill passed its second reading on the 8th of March, and received the support of a section of the Nationalist members. From the English Roman Catholics the bill met with uncompromising opposition from the outset. At their annual meeting in Low Week the English bishops endorsed a resolution passed a few days before by the Catholic Education . Council, in which the bill was condemned as "fundamentally unjust" inasmuch as "it seeks to deprive our children in certain districts of the distinctive education. we have provided for them; it would prevent the establishment of Catholic schools in the so-called single-school areas; with Catholic education where they may be sufficient numbers to warrant it; and it again seems to create a position of privilege for Cowper-Temple education." The resolution ended with a declaration that the bill should be "strenuously opposed." The bill was referred to a standing committee but its fate was already sealed. When the word "Where" at the beginning of the first clause had been passed, the whole bill was abandoned.

To the state of feeling aroused by the Home Rule controversy, specially in the North of Ireland, must be attributed the very unusual attention paid by the British Motu : public to two Papal documents, the Quantavis diligentia, commonly spoken Proprio of as the Motu Proprio, and the Ne Temere. The former was in fact a very decree. harmless document setting at rest a point which had long been in dispute among canonists with regard to an old Decree of 1869 , by which Catholics were censured who caused clerics to appear before the civil courts praeter canonicas dispositiones. The point in dispute was whether the prohibition applied to the individual plaintiff or to the legislative and judicial authorities. Owing to a misunderstanding of the Latin text, it was announced in some of the Dublin papers that the Pope had forbidden Catholics to bring a priest before the civil courts "without a canonical dispensation." But praeter canonicas dispositiones means only "contrary to the provisions of canon law." In other words, Catholics are required before bringing a priest into court, to comply with the rules laid down by canon law. It is not necessary here to consider in detail what those rules are, because the decree of . 860 does not apply either to the British Isles or the United States. To put the matter briefly: in the few countries to which the decree applies, an aggrieved Catholic is required, before bringing a priest into a secular court, to approach the bishop, and so try to get the dispute settled amicably. If the bishop cannot bring about a friendly settlement, he is bound to allow the case to go into the civil court. But the decree, which in Igr 2 was forty-three years old, applies only to countries in which the privilegium fori-the ancient custom by which the clergy were tried in their own courts-still prevails. That state of things has not existed in the British Islands since the Reformation.

The $N e$ Temere decree, on the other hand, raised serious issues affecting every count ry in the world, except Germany, and certainly was among the causes which contributed to the defeat of Sir Wilfrid Laurier's government in Canada, at the general "Nemere" election in September IgII. . The object of this decree, which came in

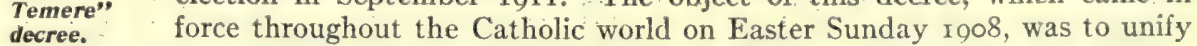
the canon law relating to marriage. Its effect was to simplify, and in some important ways to make less stringent, the legislation of the Council of Trent against clandestine marriages. Henceforth a marriage which is Catholic or mixed must be celebrated in the presence of the parish priest, or the ordinary, of the place where the ccremony is performed, and in the presence of two witnesses. This rule has no application to marriages contracted by non-Catholics between themselves, but a Catholic must be married in accordance with the Catholic form, whether the other contracting 
party be a Catholic or not. The essential difference between the new law and the old, between the legislation of Trent and the Ne Temere, is that, while the former made it necessary that every marriage should be contracted in the presence of the parish priest of one of the parties, the latter requires the presence of the parish priest of the place in which the marriage is solemnised. In the famous Hebert case in Canada, the marriage of two Catholics who had been married in the Province of Quebec by a Protestant clergyman was declared void, first by an ecclesiastical tribunal, and then by a civil court. The marriage was in any case canonically void, because the law of the Council of Trent, requiring the presence of the parish priest of one of the parties, prevails in Quebec, and had not been complied with. The decision in the civil court was based upon the belief that, upon the issues raised, the law of the Church and that of the State are identical. The case was still in November 1912 waiting the decision of the Superior Court in Montreal on appeal. The Ne Temere had nothing to do with this case one way or the other. But the public controversies to which the Papal Decree had given rise had inflamed public opinion, and the Hebert case became a party watch-word. While the Liberals were still in power in Canada great pressure was brought to bear upon Sir Wilfrid Laurier to induce him to bring in a bill in the Federal Parliament imposing a uniform marriage law in all the provinces. It would have meant a struggle full of peril for the peace of the Dominion, and Sir Wilfrid Laurier refused to consider the question, on the ground that in the opinion of the minister of Justice, Sir Allen Aylesworth, the legislation asked for would be ultra vires of the Dominion Parliament. After the election, when Mr. Borden had taken office, the new minister of Justice, Mr. Doherty, being faced with the same problem, gave the same answer, that questions concerning the solemnisation of marriage fell under the exclusive jurisdiction of the provincial legislatures. That ought to have been decisive, but opinion ran high, and the hand of the new Government was forced when a private member in the Parliament at Ottawa introduced a bill on his own account. It was then decided to take the opinion of the Supreme Court of Canada as to whether or not the proposed legislation would be within the jurisdiction of the Federal Parliament. Four out of five of the Canadian judges held that the proposed legislation in the Dominion Parliament was ultra vires. As soon as the decision of the Supreme Court of Canada was known, it was at once resolved to carry the case to the supreme arbitrament of the Judicial Committee of the Privy Council. The importance which all parties in Canada attached to the immediate settlement of these vexed issues may be measured by the urgency of the steps which were taken to speed the case across the Atlantic. The Supreme Court gave its decision on the r 7 th of June, and on the 22nd of July the case was being argued before the Privy Council in London. The bill was declared on July 29 to be ultra vires. Though the $\mathrm{Ne}$ Temere was freely invoked during the argument, it was not directly in issue. It was, however, the probably unfounded fear that the Papal decree might be incorporated with the civil law of Quebec which gave a theological colour to the whole discussion.

The elections for the German Reichstag in February I 12 found the Catholic party, the Centre, in a position of great disadvantage. The Borromeo Encyclical and the German "Motu Proprio," Quantavis diligentia, had been used to create a cloud of German
electlons. prejudice. Then the high price of food, largely due to the prolonged drought, was attributed by the Socialists to the Protectionist policy of the

Centre. They came back 93 strong, having lost nine seats; in fact, every party paid tribute to the Socialists. In the Rhincland the Centre polled 19,000 more votes than in I007. Taking the country as a whole, the Catholic poll showed a falling of something like 100,000 votes. This loss, however, is seen to be more apparent than real, when we: note the number of cases in which the C'entre abstained from setting up its own candi-. dates, in order to avoid "false second ballots." It is estimated that between 250,000 and 300,000 votes were in this way given by the Centre to their allies of the Right.

In Belgium the Catholic party, which had been in power continuously for twentyeight years, were in some apprehension as to their prospects at the general election in 
June 1912. They had long held office, and their majority in the Chamber was only six. The Liberals and the Socialists had formed a working alliance, with a programme

\section{Belgian} elections. which declared war against the denominational schools, and sought to amend the electoral law by the abolition of the plural votes hitherto allowed in respect of paternity, education and financial position. An additional element of uncertainty was due to the fact that owing to the increase of the population there were twenty new seats to be contested. In the result the Catholic party were again returned to power, with a majority over the Cartel of sixteen. The fact that the Liberals had identified themselves so closely with the Socialists during the struggle, seems to have driven a good many moderate Liberals into the Ministerial camp. Certainly the political constancy which granted a new vote of confidence after nearly thirty years of office is a phenomenon new in the history of democracy.

\section{(J. G. SNEAD-CoX.)}

\section{The Free Churches 1}

Doctrinal.-The disquietude caused a few years ago by what is known as the "New Theology " movement has very largely passed away. At the meetings of the Congregational Union in Nottingham in October 19I I, Dr. Forsyth and the Rev. R. J. Campbell, who had figured most prominently in the controversy, appeared on the same platform. Theologically the Free Churches may now be said to be marking time, though a good deal of constructive activity is going on beneath the surface. The attacks on the historicity of Jesus put forward by Dr. Arthur Drews in Germany and his translators and sympathisers in England, have been met with thoroughness and skill, especially by Dr. Estlin Carpenter, principal of Manchester College, Oxford. To the doctrine of the person of Christ a noteworthy contribution has just been made by Dr. H. R. Mackintosh of Edinburgh, and his book may be taken as presenting generally the position taken up by all except a comparatively small left wing of Free Church divines. The question of miracles, brought into prominence by a book written by the Rev. J. M. Thompson (Dean of Divinity at Magdalen Coll., Oxford), has furnished a theme for frequent discussion, but neither it nor Dr. Schäfer's pronouncements on the origin of life (British Association, Dundee I9I2) have ruffled the waters to any extent. There is no disposition among those churches that dispense with formal creeds to introduce anything of the kind, and where confessions are already in existence the tendency is to modify and adjust them, or to regard them as declaratory rather than binding. Thus the English Presbyterian Church at its General Assembly in May I 12 had before it the statement of Church principles made at the ordination of ministers and the form of the questions put to the candidate. These have been re-drafted so as to lay greater emphasis on the minister's message and less on his theory, and the proposals are now before the different presbyteries in the country. On the other hand the proposed union of the Methodists, Presbyterians and Congregationalists of Canada into one great church which shall more effectively grapple with the problem of the rapidly opening West and North-West, involves the last named denomination in a creed, which many churches of the order will accept for the sake of union, while others will prefer to retain their independence, feeling that the price is too high.

Union and Federation.-The movement in Canada just referred to had a certain quickening through the remarkable co-operation recently agreed upon by the theological colleges of Montreal. Certain influential laymen were struck by the anomaly that three institutions were doing practically the same work within a stone's throw of each other, with comparatively small classes and at the cost of an over-burdened staff. "They laid

1 The expression "Free Churches" is not strictly correct, but it is difficult to find a better one for the various Christian denominations outside the Roman Catholic Church and the Anglican Communion. In Ireland there is no Established Church; in Scotland the Established Church is of the Presbyterian polity. For churches in America, see under "United States" in Part II of the YEAR-BOok.

Apart from the Year Books of the several Churches, the Free Church Year Book, published annually in April, and the Scottish Church and University Almanac, are commended to those wishing further information. 
before the governing bodies a scheme by which all but the purely denominational work should be taken in common, thus giving the members of the professoriate time and opportunity for specializing, and bringing the students of the three churches into closer fellowship with each other. Not only so, but the Episcopal College when approached fully and gladly entered into the scheme, which was launched in October I 1212 and seems full of promise. It is possible that the same line will be followed in England, at least among the Free Churches, before long. Already in the theological faculties of Manchester, London and Wales there is a certain amount of co-operation; but there are isolated colleges of most of the denominations in different parts of the country that cannot do the best possible work under present conditions.

There is no sign on the horizon of any new organic union of churches in England. The directions from which such may be expected sooner or later to appear are of course the three great Methodist Churches (Wesleyan, Primitive and United) on the one hand, and Baptists and Congregationalists on the other. For the present however, and probably for several years to come the aim will be closer federation rather than the merging of denominations in larger units. Meanwhile there is a great deal of over-lapping in the smaller towns and in the villages which makes for weakness and is a cause of grave anxiety to the leaders of the denominations.

In Scotland friendly consultations have for some time past taken place between the Established Church and the United Free Church. These two communions embrace nine-tenths, if not more, of the church-members in the northern kingdom and thoughtful men on both sides have long been anxious for closer fellowship in the face of decreasing rural populations and the increasingly serious problems of the large towns. Holding the same standards of faith and church order these two great wings of Presbyterianism have practically everything in common except their views on the relation between Church and State. It is not easy to see how this gulf will be bridged, but it is not so wide as that which exists in England between the Established (Episcopal) Church and the Free Churches, for there is a large measure of intercommunion regularly practised in Scotland. Wisdom and mutual forbearance may, however, be able to accomplish an understanding which may ultimately lead to union. Meanwhile, it should be noted that many leaders in the United Free Church will not readily agree to any scheme which would ostracise or disparage such comparatively small Scottish churches as the Baptist, Methodist and Congregational.

Relations with the Anglican Church.-It may fairly be said that in spite of the acute tension raised here and there by the question of Welsh Disestablishment and the celcbration of the Ejectment of $\mathrm{I}_{662}$ there is on the whole a growth of sympathetic and amicable feeling between the Anglican and the Free Churches and no small amount of co-operation. British Nonconformists still believe that they are entitled to more real recognition at state festivals and would value further instances of the fellowship exemplified at the installation of the Prince of Wales at Carnarvon in July IgII. The few cases of intolerance and bigotry on the part of individual clergymen are more than offset by courtesy and kindliness on the part of others. In the academic world churchmen of all denominations work together in harmony and full trust on the Theological Boards of the newer universities, and the proposals emanating from Oxford (passed on Dec. 3 , I9I 2), Cambridge (passed on Nov. 22, I9I 2) and Durham, that their degrees in divinity should be no longer restricted to Anglican clergy or laymen have been warmly appreciated. The placing of a Bunyan memorial window in Westminster Abbey and its joint dedica. tion by the Dean and representatives of the Free Churches is one of the happy signs of the time. And if Lord Halifax can persuade other High Churchmen to agree with hin that the word "churches" may safely be applied to the non-conforming communities, headway will be made. Interchange of pulpits is not yet in sight, but there seems a growing inclination among Anglicans to regard modern diocesan episcopacy as the bene esse rather than the esse of a church. Meanwhile there are abundant opportunities for united service which do not entail the slightest abandonment of conviction and principle on either side, and three lines of approach are touched upon in different parts of this 
article. In the mission field, in theological study, and in social service there is already manifest a degree of co-operation and fellowship which are of the highest promise for the consummation of a unity that is not to be confounded with uniformity.

Sustentation Funds.- One of the signs of the times is the attempt made by the three churches of the independent order in England to raise central funds for increasing the stipends of the more poorly paid ministry. Congregationalists and Baptists are each aiming at $£ 250,000$ for this purpose; the former after three years have raised $£ 205,000$; the latter in one year $£ 70,000$. The Unitarians aim at $£ 50,000$, of which nearly $£ 40, \infty 00$ has been promised. The proposals vary, but what is intended is roughly speaking that every fully-recognised minister may receive not less than $£ \mathrm{r} 50$ per annum in town churches or $f$ I 20 in rural districts. The Presbyterians of course have long had their Sustentation Fund and the various Methodist churches, where the organisation is akin to the Presbyterian order though the terminology is different, are able to secure greater equality of income among their ministers than is possible in communions where the pastor is chosen by the local church without reference to synodal or presbyteral authority. Some of the much cherished traditional independency will perforce disappear as these augmentation funds come into practice, for behind the question of grants-in-aid lies that of an efficient ministry, and no help is likely to be given in the case of men whose ability does not commend itself to the central authority, however well satisfied the local church may be with its choice. In this way there seems to be the beginning of an approximation to the Presbyterian system of church government. Many Unitarian churches still bear the name Presbyterian, and not a few now called Congregational used to bear it.

Other Denominational Activities.-Two great ecumenical conferences were held in I0II; both in America. The Baptists met at Philadelphia in June; one of the most striking features of the gathering was the presence of a group of ministers from Russia and South-East Europe where the Baptist cause is-making phenomenal headway. The Methodists of all shades met in Toronto in October. Another noteworthy Methodist event is the opening of the new Wesleyan Church House in Westminster (October rgr2), a remarkable addition to ecclesiastical architecture and already taking its place as the headquarters and focus of the multiple organisation of the Connection. It is an outcome of the Million Guinea Fund raised at the beginning of the century and is a monument of the unwearying care and ability of Sir Robert Perks.

The Congregationalists, and to a less extent the Baptists, Presbyterians and Unitarians, have been celebrating the 25 oth anniversary of the Act of. Uniformity and the consequent ejection of 2,000 ministers in 1662 . Here and there the occasion was used somewhat aggressively againșt the Anglican Church, but on the whole attention was drawn to the positive lessons of the ejectment, fidelity to conscience and the dawn of the modern idea of a free church in a free state. In this connection may be mentioned a notable crop of sound historical research in which most of the Free Churches have taken part and which contrasts favourably with the comparatively uninformed productions of past generations. For Elizabethan Puritanism and Separatism we have the work of Mr. Champlin Burrage, while Rev. W. Pierce has done much to clear up the Marprelate mystery, Rev. Ives Cater that attaching to Robert Browne, and Rev. W. H. Burgess has investigated anew the story of John Smith, 'the Se-Baptist.' As regards the $I 7$ th century the Rev. B. Nightingale has pointed the way to a very necessary revision of Calamy's story of the ejected ministers and brought to light many facts respecting Cumberland and Westmorland, and Prof. Lyon Turner has made a special study of the indulgences granted in 1672 . Mr. W. C. Braithwaite has written a standard history of early Quakerism in England, and Dr. Rufus Jones has performed a similar service for America. Rev. H. W. Clark is engaged on a comprehensive history of Nonconformity, of which.the first volume has appeared.

Statistics of Membership. - The Free Churches in the United Kingdom are not having a happy time with their figures, and for some years most of them, especially Baptists and Wesleyan Methodists, have had to lament a decline of numerical strength. The 
Welsh Revival of 1904-5 brought into the churches an immense number of recruits whose stability has been in inverse ratio to their enthusiasm, and many of them have fallen away. This accounts for the greater part of the decrease, but there are other causes. Emigration has something to do with it, and also the movement from the rural to the urban districts. People change their residence more often than they did and are not always careful to transfer their church membership. Often there is not a church of their own order in the new locality, and where there is they hesitate to incur the responsibilities attaching to membership. The increase of Sunday pleasure and the general "spirit of the age" have also to be taken into account. In the Wesleyan Methodist Church possibly the regulations concerning attendance at class-meeting may have alienated a number of adherents. The exact definition of what should constitute membership in the Wesleyan Church has been a matter of repeated discussion in district synods and in Conference for some years past, and proposals to make the class meeting a more elastic exercise that shall be adaptable to different sections of the members have found much favour.

The Table of Free Church membership in England and Wales may be found of interest, though it must be remembered that such statistics can only be approximate. The meaning of the term "members "varies in the different denominations, and it has also been impossible to include in it any figures for the many unattached missions and evangelistic agencies.

Statistics of the Evangelical Free Churches of England and Wales.

(From the Free Church Year Book, 1912,)

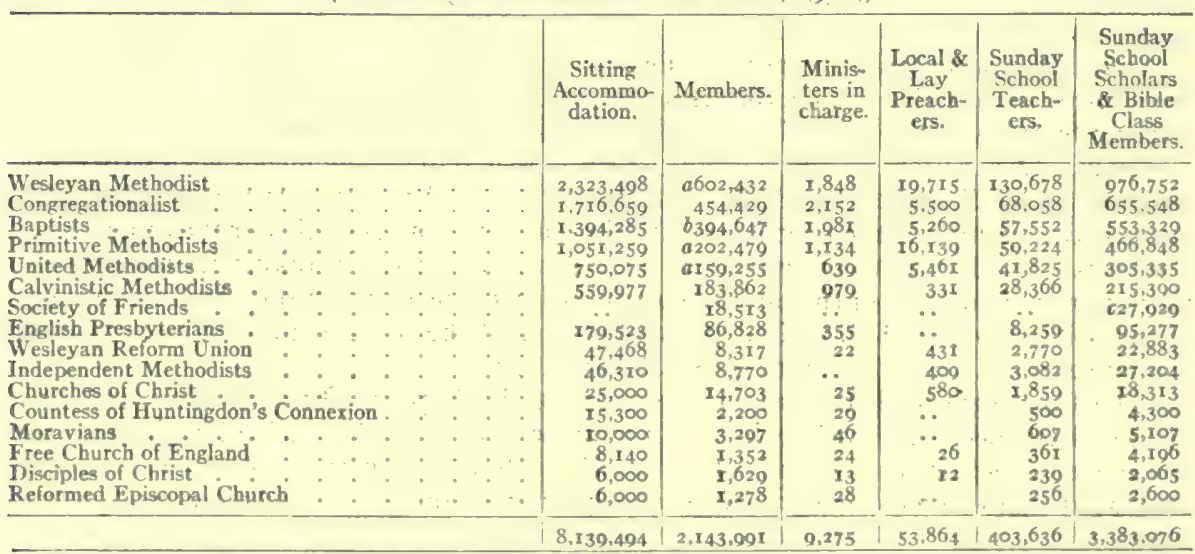

a This is inclusive of members on probation.

b 304 churches have not sent any returns.

Includes teachers.

The Salvation Army has some 9,000 halls with seating accommodation for about 500,000, and employs 16,000 ufficers. But they give no returns as to adherents. The Unitarians have some 375 churches (seating 100,000 ) and about the same number of ministers, with a membership of say 45,000 and about 40,000 Sunday scholars.

The following fizures give some idea of relative strength in Scotland:-

\begin{tabular}{|c|c|c|c|c|c|c|}
\hline & & & $\begin{array}{l}\text { Ministers \& } \\
\text { Evangelists. }\end{array}$ & $\begin{array}{l}\text { Churches } \\
\& \text { Halls. }\end{array}$ & $\begin{array}{l}\text { Church } \\
\text { Members. }\end{array}$ & $\begin{array}{l}\text { Sunday } \\
\text { Scholars. }\end{array}$ \\
\hline $\begin{array}{l}\text { Church of Scotland } \\
\text { United Free Church } \\
\text { Free Church } \\
\text { Episcopal Church } \\
\text { Congregationalists }\end{array}$ & $\vdots$ & $:$ & $\begin{array}{r}1,741 \\
x, 700 \\
190 \\
350 \\
210\end{array}$ & $\begin{array}{r}1,643 \\
1,603 \\
189 \\
410 \\
218\end{array}$ & $\begin{array}{r}714,915 \\
504,672 \\
54,000 \\
36,214\end{array}$ & $\begin{array}{c}230,967 \\
235,929 \\
\cdots \\
35,519\end{array}$ \\
\hline
\end{tabular}

There are also minor Presbyterian churches, e.g. original 'Seceders, and Reformed Presbyterians, and the Baptist, Wesleyan and Primitive Methodist churches are represented especially in the larger cities.

In Ireland the (disestablished) Episcopal Church claims about 600,000 of the population, 
the Presbyterians 450,000, the Methodists 65,000. Congregationalists and Baptists are very thinly represented.

Wales. - In view of the discussion on Welsh Disestablishment it may be convenient to set out the figures supplied to the recent Royal Commission on the basis of the rool census:Communicants of the Anglican Church, 193,081; Members of Congregational Churches, 175,147; Members of Calvinistic Methodist Churches, 170,6I7; Members of Baptist Churches, 143,835; Members of Wesleyan Churches, 40,8I I; Members of smaller denominations, 19,870; Roman Catholics, 64,800. There are 4865 Free Church ministers, 1,597 Anglican clergy; 61 1,083 nonconformist Sunday scholars and 168,786 Anglican.

Free Church Commission.-In view of the decrease in membership and of other problems of related but more general interest, e.g. the relation of the Free Churches to the spiritual and other needs of the present day, a commission of inquiry has been arranged which is representative of every shade of Free Church polity. The initial step was taken by Rev. F. B. Meyer, and his plan of a number of boards each charged with some definite task after the fashion of the Edinburgh Missionary Conference of rgro was approved at the annual meeting of the National Free Church Council at Cheltenham in March I9I2. These boards have now been constituted and will consider such questions as (I) the Free Church message, (2) the ministry and its training-including lay and feminine agencies, (3) the Institutional Church, (4) overlapping and co-operation (5) auxiliary agencies, (6) the laws of spiritual revival, (7) relationship to other churches. At the head of the whole investigation is Dr. J. Scott Lidgett, and there is every reason to believe that the enquiry will result in such a body of evidence and opinion that will enable the conference and the churches which it represents to arrive at a cool and reasoned appraisement of the situation, and to formulate some definite lines of action. The task in hand is much more than a question of "Why people do not attend church;" it is a consideration of the place and function of the church in modern civilisation.

Public Activities. - The Free Churches are keenly alive to current sociological problems and every denomination has its Social Service Union or Association. These organisations work largely through study circles in individual churches and through conferences, and have produced some pertinent literary contributions. This is especially true of the Wesleyan Methodist Union. Some of the best known University Settlements in London are directly connected with the Free Churches, e.g. the Leysian Mission and the Bermondsey Settlement (Wesleyan), and Mansfield House in Canning Town (Congregational). In Manchester and Bradford too the students of theological colleges engage in settlement work, and the various Institutional Churches (E. B. xiv, 650) and Central Missions may also claim to be working along kindred lines. Incidentally this branch of endeavour is proving a remarkable factor in drawing together churches separated in creed and polity. A very significant gathering of all the Social Service Unions was held at Swanwick in June I9I2, when representatives of the Free Churches met Unitarians; Angliçans and Roman Catholics in mutual confidence and friendship. The churches have been accused of callousness in standing apart from social questions, and of futile inexperience when they have attempted to intervene. Continued study and conference along the line indicated above should help to remove both these reproaches, while it must always be remembered that the function of the churches is to quicken conscience and sympathy rather than to frame programmes.

Separate churches have also been concerned directly with special problems. The Congregational. Union has drawn together in Conference a number of employers and employés to discuss the question of labour unrest, and the Society of Friends has been concerned with the problem of religion and business, which was raised in a somewhat acute form by the connection of some leading members of the Society with newspapers that publish betting news. The Free Churches as a whole have given hearty support to all movements for securing a weekly rest-day for all workers, and for the ending of the rubber atrocities on the Congo and in the Putumayo. They have also done their part in the endeavour to suppress the white slave traffic; and it was largely due to the efforts of the Rev. F. B. Meyer, who enlisted the support of the Archbishop of Canterbury and other leaders, that the proposed prize-fight between Johnson and Wells at Earl's Court, London, in September rgr I was abandoned. 
Foreign Missions. - The World Conference on Foreign Missions which met at Edinburgh in June 1910 (E. B. xviii, 598d) did much to educate and stimulate the Free Churches as well as the Anglican in this important department of their activities. Its work is being made permanent by a Continuation Committee and by the International Review of Missions, a quarterly periodical of high merit. In many churches small study circles have been established for the regular and systematic discussion of the different missionary fields and problems. It cannot however be said that there has been any considerable increase in subscriptions for foreign evangelistic enterprise, and most of the societies have to declare a succession of deficits in their budgets. They are all alive to the importance of the hour in China, and in India, even in the South Seas where, with the advent of the trader, problems unknown a generation ago are causing some perplexity. In Africa it is difficult to say how far Christianity is holding its own against Islam. South America is another field to which increased attention is being paid, and there will be not cnly a Roman Catholic but a Protestant mission to the Indians of the Putumayo. We may also note the effort of the Wesleyan Methodist church to raise $£ 250,000$ in celebration of the centenary of its Missionary Society. For the rest it is pleasant to record the comity that exists among the different Christian Churches on the mission field itself. One of the missionary events of $19 \mathrm{I} 3$ will be the Iooth anniversary of the birth of David Livingstone.

Some Personal Changes.-The Salvation Army mourns its founder William Booth. who died in I912, and is now under the command of "General "Bramwell Bonth, who was appointed to that office by his father's will. A good many changes in "divisional commanderships" have followed. It is significant that the memorial to the late "General "is to take the form of an institute or institutes where officers shall be inore efficiently trained for public service than hitherto.

The Rev. Dr. Jowett after fifteen years ministry in Birmingham has become pastor of Fifth Avenue Presbyterian Church in New York. The pulpit of the Metropolitan Tabernacle in London, on the other hand, so long associated with the name of C. H. Spurgeon, is now filled by an American, Dr. A. C. Dixon. Another well-known American preacher, Dr. Leonard Broughton, is at Newman Hall's Church in Westminster Bridge Road. In the academic world, the late Dr. Fairbairn has been succeeded at Mansfield College, Oxford, by Dr. W. B. Selbic (IgIo), formerly minister at Cambridge. That college has also appointed to its chair of New Testament studies Dr. James Moffatt, formerly United Free Church minister at Broughty Ferry. Dr. Campbell Morgan of Westminster Chapel has combined (I9II) with his pastorate the presidency of the Countess of Huntingdon's Institution, Cheshunt College, Cambridge, where new buildings are being erected.

Allied Organisations in the United Kingdom.-The Brotherhood movement, in some places known as the P.S.A., continues to attract large numbers of men on Sunday afternoons for brief and bright services where addresses are given on Bible subjects or on themes of current: interest from the Christian point of view. Much stress is laid on the obligations of Christiant (itizenship. The movement has extended to the mainland of Europe and is having remark. able success in Canada. Similar meetings for women are in many churches held on Mon. day evenings. The Adult Schools, a much older institution and one in which Friends have been particularly active, are rather hampered by the lack of suitable local leaders and clas; teachers, but exercise a very potent influence through the men who meet usually on Sundav mornings about 9 c'clock. Sunday Schools have suffered in the number of scholars mainly through Anglican aggression, but the quality of the work done is rapidly improving, as better methods of grading and instruction are introduced. All the churches are increasingly alive to the importance of this branch of their work; the difficulty is to get teachers who are as intellectually equipped for their task as those of the day school are. Boys' Brigades hav: perhaps suffered temporarily through the Boy Scout movement.

The $Y . M$. C. A has been more vigorous of late years and is trying to emulate the success of the American Association. Excellent new premises have been opened in London, and there, as in Leeds, Manchester and Edinburgh, "lightning campaigns" have been organised with fair success with a view to clearing off debts in ten or twelve days.

The Student Christian Iforement is one of the most vital Christian agencies in existence and affords a happy meeting ground for the educated youth of all the churches. It has widened its earlier scope, when it was chicfly concerned with forcign missionary aims, and 
is now placing alongside those as of equal prominence, the claims of social service at home.

The British and Foreign Bible Society and the Religious. Tract Society are the willing handmaids of all the churches. The chief event of moment is the celcbration by the former in March I9I I of the 3ooth anniversary of the issue of the English Authorised Version. With regard to the question of Bible revision a number of Free Church scholars issued a manifesto in October 1912 stating that in their opinion the time was not ripe in view of the work yet to be done in getting an approximately true text of the original Hebrew and in utilizing recent linguistic discoveries affecting New Testament Greek. A number of them also joined with representative Anglican scholars in a public protest against the issuing of the revised Bible of $\mathbf{I} 88 \mathbf{I}-85$ without the revisers' marginal readings.

(A. J. Grieve.)

\section{SECTION VI. LAW AND JUSTICE}

"In the mechanism of modern states," says Sir Henry Maine, " the capital fact is the energy of the legislatures." In the British Empire alone there are 6o legislatures busy at work: in the United States some 5o: besides the legislatures of foreign countries -Austria has at least a dozen. Looked at superficially the legislative output of these parliaments or legislative councils appears what Cromwell called " a Godless jumble:" but to the philosophic eye, in those multifarious acts and ordinances each several community is writing its history, recording its aspirations and ideals so far as they fall within the sphere of practical politics, readjusting its life to the changed and changing conditions of its environment and national development. There is no more faithful reflection of a people's life in its many sided activities than the pages of its statute-book.

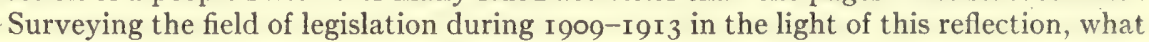
are the subjects which we find more especially occupying the minds of the nations at the present moment? Pre-eminent among them are the status of the worker, and the amelioration of his condition, the care of children-the rising generation as spes gentis, the prevention as distinguished from the punishment of crime, the health of the community in all its many aspects, the control of the drink traffic, the protection of public morals, marriage and divorce, the segregation and guardianship of the feeble-minded, the assimilation of commercial law, the encouragement of agriculture, the organization of trades and professions, and immigration.

Immigration.- - To take the last first, one of the rights possessed by the supreme - power in every state is, says Chief Justice Griffith of the Australian Commonwealth ( $Y$ en v. Christie), "the right to refuse to permit an alien to enter that state and to annex what conditions it pleases to the permission to enter it and to expel or deport home from the state at pleasure." This power of self-protection a large number of states have been freely exercising of late. It is obviously in vain a nation doing all it can to promote the physical, mental, moral and spiritual welfare of its citizens, if a stream of "undesirables" - the pauper, the feeble-minded, the criminal, the diseased, the drunken, the illiterate-is constantly flowing into the state, to weaken or contaminate it.

United States legislation probably makes the high-water mark in this policy. It prohibits admission of all idiots, imbeciles, feeble-minded persons, epileptics, insane persons, paupers, persons likely to become a public charge, professional beggars, persons afflicted with tuberculosis or with a loathsome or dangerous contagious disease, or any persons certified by the examining surgeon as mentally or physically defective, if such defect is of a kind to disable them from earning a livelihood, as well as polygamists and anarchists. The duty is cast on the master of a vessel bringing an alien into the United States of furnishing the immigration officer of the port with information as to the character, antecedents and position of the alien. By way of checking the "white slave "traffic foreign prostitutes may be deported.

In Australia the determination to keep out the undesirable settler has shown no sign of abating. British Honduras has been providing for the expulsion of aliens convicted of felony or other penal offence. The question of immigration and naturalization is still being agitated between Japan and the United States.

Concurrently with this policy of keeping out undesirables there is a strong desire among the young countries-illustrated by the South Australian Act of I9II-to encourage immigrants of the right sort. 
Public Morals.-Quid leges sine moribus? New Zealand, impressed with this truth, has recently passed an Act to repress effectually the publication, sale and distribution of indecent and offensive literature. "Indecent document." in the Act has a very wide meaning, and includes any "book, newspaper, picture, photograph, print or writing or anything having imprinted, written or otherwise exhibited thereon; any indecent word, statement, picture, illustration or representation." In Holland an Act has been passed to combat immorality. Immoral pamphlets and pictures are not to be disseminaied. Drugs or instruments for preventing conception are not to be sold or advertised. There are rigorous measures for suppressing the "white slave" traffic, and houses of ill-fame are absolutely prohibited. A drastic act against the "white slave" traffic has just been passed too in England.

In New Brunswick an Act has been passed providing that no cinematograph, movingpicture machine, or other similar apparatus, is to exhibit any films which have not been stamped by the board of censors. Manitoba has also been providing for the licensing and regulation of moving pictures. Grenada now requires the licence of the governor for cincmatograph performances. In Austria the whole subject of cinematographs is being reported upon by a Government commission. Meanwhile in England the manufacturers have agreed on a censor-entirely unofficial-for their films, and have secured Mr. Redford (formerly official censor of plays) in this capacity.

Gambling is one of the most deeply rooted instincts of human nature. It is preeminently the vice of this age, and against it, in all its Protean forms, Legislatures seem to strive in vain. A number of the states of the American Union have passed laws to stop betting on horse-races, and some have gone great lengths, notably California. An Act of that state provides that any person who engages in pool selling or book-making, or kceps or occupies a building or place or stand upon any public or private grounds within the state for that purpose, or for the recording or registering of bets or wagers upon the result of any trial or contest of skill, speed or power of endurance of man or beast, or between man or beast or upon the result of any lot, chance, casualty or unknown or consequent event whatsoever, shall be punishable by imprisonment for thirty days without the option of a fine. This is drastic indeed.

In Holland not only have all gambling houses been prohibited, but the prohibition extends to "the offering to the public the opportunity of participating in gambling."

Western Australia, like the Transvaal, has been sanctioning the use of the totalisator -as, presumably; the least objectionable form of betting.

The state of Virginia has made it a misdemeanour to swear over the telephone or to abuse a person or his female relations in such a way as to lead to a breach of the peace.

Marriage and Divorce.-The so-called feminist movement has exercised and is exercising a very unsettling effect on marriage, divorce and the matrimonial relations generally. In particular equality is claimed for wives in regard to the grounds of divorce. In England, as things stand, a husband can be grossly unfaithful to his wife, but so long as he does not add cruelty or desertion to adultery she is without any redress. This is a grievance against which women may fairly protest. But there is another ot equally long standing, the denial of the remedy of divorce to those wives or husbands whe are too poor to pay the costs of a suit in the divorce court: a state of things which $\mathrm{Mr}$. Justice Maule years ago satirised in a strain of exquisite irony. And there is yet a third, that the grounds of divorce as they stand in England to-day are too narrow and need enlargement. All these grievances or alleged grievances have been the subject of very careful consideration in England by a strong Royal Commission on Divorce under the chairmanship of Lord Gorell. Some 386 witnesses were examined, and never were mor 3 varied or conflicting ideas expressed on any subject.

The report of the commission appeared on November II, I I I 2, and it fully recognised, by a majority of 9 commissioners to 3 , that the above grievances were well founderi. Its recommendations were briefly as follows: the placing of men and women on an equal footing as regards divorce; the decentralization of sittings for hearing divorce cases so as to enable persons of limited means to obtain redress; the addition of five new 
grounds of divorce, (a) desertion for three years, (b) cruelty, (c) incurable insanity, (d) habitual drunkenness, (e) imprisonment under commuted death sentence. A serious factor in the situation has been the large number of judicial separations-rising in one year to over 7000-granted by magistrates under the Married Women's. (Protection) Act. The commissioners recommend the entire abolition of this jurisdiction.

Three distinguished members of the commission, the Archbishop of York, Sir William Anson and Sir Lewis Dibdin, presented a minority report, dissenting strongly, in particular, from any enlargement of the existing grounds of divorce. Adultery alone they think ought to constitute a ground for dissolution, and they point to America as an object lesson, where facilities of divorce have so " cheapened" marriage that there are now in the states 86 divorces to every I00,000 inhabitants This danger of "cheapening" marriage by facilitating divorce is what emerges most strikingly from the whole controversy. It is a danger not confined to the United Kingdom. Nearly all foreign nations recognize it (see Burge, Colonial and Foreign Law, and ed., Vol. iii), not necessarily on the sacramental view of marriage but for the sound practical reason that marriage forms the basis of family life. The state is founded on the "hearthstone." If the marriage bond is to be relaxed or dissolved, it ought only to be for reasons which make the married life of the spouses intolerable or defeat the ends of marriage.

Western Australia, legislating on lines similar to those of New South Wales and Victoria, has provided for diyorce of either husband or wife in case of adultery or desertion for five years, or in case either is an habitual drunkard, or in case of imprisonment or confinement in a lunatic asylum for certain specified periods. Panama has also passed a law authorising divorce $a$ vinculo, and making mutual consent with certain qualifications a ground, and also habitual adultery on the husband's part.

A very difficult question of the respective jurisdiction of state and church in relation to marriage arose in the English case of Thompson v. Dibdin (I912; A.C. 533), where a man had married his deceased wife's sister and the clergyman of their parish church repelled them from holy communion as " persons of notorious evil life." The House of Lords held that since the passing of the Deceased Wife's Sister Marriage Act 1907, it was impossible so to brand persons whose union was directly sanctioned by the Act. But the attitude of a very large number of Churchmen is still summed up in the Archbishop of York's words-"No trespassing on the spiritual discipline of the Church."

On the whole the proportion of divorces to the sum total of married life is remarkably small among the European nations. The most dangerous period for matrimonial happiness is from ro to 20 years after marriage; next to that, 5 to 10 years after. As the age for marriage grows later the ratio of divorce decreases. Romance must reckon with this fact as best it can. A significant feature in Germany is the growing number of divorces granted on the ground of mutual agreement. 'Children are evidently the best preventive of divorce. In more than half the cases in England there were no children: and the more the children the fewer the divorces. Husbands come for a dissolution of marriage much more frequently than wives. On the other hand petitions for judicial separation and restitution of conjugal rights are nearly all presented by wives. Magisterial separations in England under the Summary Jurisdiction (Married Women's) Act I895, s. 5, have declined to 48 I 9 - even then a large number.

Public Health.-For a long time past now, ever since Disraeli uttered his famous epigram-' sanitas sanitatum omnia sanitas, states and municipalities have been busy ing themselves with questions of health, and still are; A decent environment for every citizen is now a postulate of political science. Pure water, light open spaces, proper drainage-much has been accomplished in these matters but much remains to be done. Workers' dwellings for instance ${ }^{1}$ closely associated with the tuberculosis questionhave been too long neglected in England, though both political parties are committed to deal with the question. Here as in so many other matters New Zealand has been leading. In the Workers' Dwellings Act of roro the legislature of New Zealand has provided for the setting aside of land as sites for workers' dwellings, and for the erection, 'See E. B. xiii, 814 et seq., "Housing." 
improvement and enlargement of such dwellings thereon. The dwellings are not to exceed $f_{1} \infty \mathrm{in}$ capital value, and may be let on a weekly tenancy or lease or sold, the purchase money in that case to be partly equal instalments spread over 25 years. The Act is administered by a superintendent acting under the authority of the Minister of Labour, and for each land district there is established a board of control.

Western Australia has also been passing an Act to enable workers of limited means to provide themselves with homes by state advances.

Closely associated with workers' dwellings is the town planning movement. Narrow streets and crooked alleys are a damnosa hacreditas in Europe from the walled town of the Middle Ages, with no room to expand. The general idea of the movement is to safeguard the inhabitants of towns from being pent up in overcrowded, sunless and insanitary areas, and it is significant of the sense of the importance of healthy surroundings that the movement has spread with extraordinary rapidity. Italy led the way, and has been followed by Germany, Sweden, New Zealand, the Transvaal, the Orange River Colony, Southern Nigeria and Great Britain. In Germany the Act contemplates the remodelling of cities already in existence. This is not so with the English Act, except so far as it may be said to apply to areas condemned as unfit for human habitation. Another characteristic of the English Act is that it provides for compensation being paid to any person whose property is injuriously affect ed by a town planning scheme; and when the scheme enhances the value of property the local authority may recover half such increased value. The subject will be found fully discussed in two articles contributed to the Journal of Comparative Legislation (Nos. xxiv and xxv) by Mr. R. E. Willcocks. A Town Planning Conference was held in October I9I I under the auspices of the Royal Institute of British Architects, and the results are published in a volume of Transactions full of valuable information on the subject. British Columbia has been enacting sanitary regulations for lumber camps, mining camps, saw mills, railway construction camps, and other places of labour, to prevent nuisances and the outbreak of disease.

Queensland has passed an Act in very stringent terms against adulteration or false descriptions of food or drugs. All packages must be labelled with the description, weight and contents of the food and the name and address of the maker. All milk sellers must have licences. Precautions are taken that only pure beer shall be sold. New Brunswick has also legislated against adulteration.

An International Liquor Conference was held at Brussels in I9II, to secure united action by the Powers as to the supply of drink to natives. Unfortunately no agreement was reached, but pending such agreement the British Secretary of State for the Colonies has directed that distilling apparatus is not to be imported into the West African colonies and the zone of prohibition in Nigeria has been extended 3000 square miles. Illicit stills have been suppressed in Ceylon. The duty on imported spirits has been raised to the very high point of $5 \mathrm{~s} .6 \mathrm{~d}$. per gallon in Sierra Leone, the Gold Coast and Southern Nigeria. Heavy duties have also been imposed in Hong-Kong and in Malaya.

In all parts of the United States temperance legislation has been making great strides. Newfoundland, British Columbia, Grenada, Papua, Western Australia, British Honduras, Basutoland, British Guiana, Manitoba, and the United Kingdom also, have all in different ways been regulating and restricting liquor licences.

In England a bill has been introduced, backed by several eminent statesmen, to lessen drinking by levelling up the public house to something of the standard of the Continental cufé. The idea is to encourage certain improvements-space, comfort, cleanliness, sanitary conveniences, the supply of food, provision of chairs and tables in lieu of bars, together with accommodation for lawful games, papers, music, gardens and any other reasonable recreations.

Canada has followed up her campaign against drugs by a $£ 50$ fine on any person who makes or deals in drugs-meaning thereby opium, cocaine or any salts thereof-except for scientific or medical purposes. Patent medicines have been made the subject of inquiry by a Select Committee in England. Queensland has enacted that toys and wallpapers are not to be sold containing arsenic, lead or antimony. 
In America the states of Mississippi, New Jersey, Virginia and Massachusetts have all entered upon an anti-tuberculosis crusade; so have Saskatchewan and Newfoundland. The provision for sanatoria under the National Insurance Act is part of a similar movement in the United Kingdom.

The Eugenics Congress in London in r 912 - attended by no less than 500 delegateswas a striking manifestation of the consensus of the nations that the subject of race improvement needed to be scientifically treated, by the encouragement of fine families and the elimination of the unfit. The ideals of the eugenists are excellent, but the matters they touch are still very much in the domain of theory, and hardly ripe for legislation. "At present," as Major Leonard Darwin, the President of the Congress, said, "the most urgent need is for more knowledge." That sums up the situation. In the United States however a beginning has been made. Marriage by epileptics and feebleminded persons has been forbidden in some states, and in about one-third of the states of the Union marriages between first cousins are also banned. A number of statesIndiana, New York, Connecticut, California, Iowa, Utah, Nevada, New Jersey and Washington-have gone further and passed laws for the sterilization of certain classes of defectives and degenerates, such as habitual criminals, confirmed drunkards, epileptics and drug habitués. It is only in Indiana and California however that the law has been actively enforced. In the former state, which led the way in this heroic remedy, about 125 compulsory operations have been performed in two years. The operation is said to have no effect practically on sex instincts and little on sex habits. $A$ different method of dealing with the unfit and one less open to controversy is that illustrated in the Mental Deficiency Bill which was before the British Parliament in I9I2 (see under Education, in Section V. of the YEAR-Book). A Defectives Act very similar in its provisions has already been passed in New Zealand. The decline of the birth rate among the classes with whom children should be most abundant, the blighting of the harvest of human life, is a fitting text for the eugenist, full of solemn warning to society. But it is much to be feared that private selfishness will thwart his best efforts in the cause of race improvement. The maternity provisions in the British National Insurance Act may perhaps do something to check what has been called the "tragedy of spoiled babies." Spain has been securing the better protection of infant life by providing for the care of pregnant women, nurse agencies and proper milk supply.

The Worker and the State.- Undoubtedly the most striking social phenomenon of late has been the pervading Labour unrest. "Underneath all this unrest," as the Archbishop of York truly said, "is the movement of a true and right ambition to better the conditions of individual life," to secure a fairer distribution of the proceeds of industry. To solve this problem Australia has been trying the compulsory submission of industrial disputes to courts of arbitration. These courts have to do what is " fair and reasonable," and incidentally to determine what is "fair and reasonable " in relation to a living wage. The decisions of the courts are discussed in an interesting article by Professor Harrison Moore in the Journal of Comparative Legislation, No. xxvi. It must be sufficient here to say that the "fair and reasonable" in relation to the living wage is defined as "the normal needs of the average employee regarded as a human being living in a civilised community." This definition has been accepted generally in Australia without any serious adverse criticism. The living wage is there regarded as "sacrosanct." In England the fixing of a minimum wage in the coal industry by the CoalMines Act of r 912 makes a precedent which is pretty sure to be followed in other industries. Saskatchewan has been establishing a Labour Bureau in connection with its department of Agriculture. This Board has very wide functions-to collect and publish information and statistics relating not only to employment, wages and the hours of labour in the province, but to strikes, co-operative trade unions, labour organisations, the relations of capital and labour, in fact the whole commercial, industrial and sanitary conditions surrounding the working man.

The Shops Act of ror 2 in the United Kingdom, providing that " every shop shall, save as otherwise provided by this Act, be closed for the service of customers not later 
than one o'clock in the afternoon on one day in every week," is a welcome boon to that numerous and hard worked class the shop assistants of the country. South Australia has been passing a similar Act, the times fixed for closing being one o'clock on Saturday, nine o'clock on Friday, and six on other days. In Western Australia Wednesday has been made the early closing day, and Saturday the late day. Trinidad and Tobago have fixed a nine-hours day for shop assistants, with a half holiday once a week. In Manitoba, children under twelve are not to be employed between nine in the evening and six in the morning; anyone employing a child under sixteen in any occupation likely to be injurious to life, limbs, health, education or morals, is liable to a fine of $\$ 50$. In New York no minor under sixteen is allowed to work in any mercantile establishment more than fifty-four hours a week. The International Bulletin of Labour Legislation, issued quarterly, shows in a striking way how much has been done and is being done to protect the worker from injury by deleterious trades and from excessive hours of labour.

By the National Insurance Act some 75 per cent of the adult male population of the British Isles and nearly. 25 per cent of the women will be insured in a contributory scheme against sickness and disablement. For the first time in its history the United Kingdom finds itself organised to face the risks of disease and misadventure. Much criticism has of course been directed against the details of the scheme, some of it wellfounded. The marvel is that such a vast and complicated scheme should have been launched and should have started working with comparative smoothness. Experience will disclose the minor imperfections of the Act, and they can be rectified by an amending Act. In the meantime the Act may be described as the most solid experiment for the social betterment of the British working-classes which the last half-century has witnessed. An instructive comparison of the English with the German scheme by Dr. E. J. Schuster will be found in No. xxv of the Journal of Comparative Legislation, p. 30. Switzerland has been establishing a similar system of national insurance.

In the British crown colonies and protectorates recruiting of native labour for other colonies has been forbidden. It has been found that migration led to the dissolution of family and tribal ties, and often to the demoralization of the emigrant. In Mauritius the introduction of indentured labour from India has been abolished. The cost of the immigration of coolie labourers in the West Indies is now being put upon the employers, and also the cost of repatriation. Newfoundland has been prohibiting contracts with Eskimos or Mountaineer Indians to leave the colony for service anywhere except service such as fishing, hunting or exploring in the Canadian Labrador. South Africa requires native labour agents to be licensed, and regulates contracts for native labour. Australia has also passed a measure for the protection of aboriginals and half-castes.

Much dissatisfaction was caused in British labour circles by the decision of the House of Lords in what is known as the Osborne Judgment. Briefly the effect of that judgment was that a rule which purports to confer on any trade union under the Act of 187 I a power to levy contributions on members for the purpose of securing parliamentary representation, whether it be an original rule of the union or a rule subsequently introduced by amendment, is ultra vires and void. The result of this decision was of course to reduce Trade Unions to impotency for political purposes, and as it was only by political pressure that the interests of the workers could be protected and furthered, the restriction imposed by the judgment on the legitimate activities and aspirations of Trade Unions as Labour organizations seemed unreasonable and unfair. The Government has introduced a bill for the purpose of legalising - subject to certain conditionspayments made by a Trade Union for any lawful objects or purposes for the time being authorised under its constitution, including of course payments made for political purposes. Such a power, it may be said, operates unjustly towards a dissentient minority of members, but it must be remembered that they join the Union with their eyes open, with notice, that is, of its constitution and the possible application of the funds to political objects with which they are not in sympathy. Such coercion of a minority by a majority is a normal incident of the management of corporate undertakings. 
Children and the State.-Nothing is more striking in the legislation of all civilised nations to-day than the concentration on the child-the care that the youthful citizen shall not be corrupted by drink or tobacco or indecent publications, shall not be sent, if he or she does wrong, to prison or herded with common criminals, shall not drudge in factories, or hawk articles in the street or be exploited for public entertainments, shall be protected against cruelty and outrage, shall have free meals at school if underfed, and be sent to foster-homes if neglected. The recent Children Act of the United Kingdom, familiarly known as the Children's Charter (see $E . B$. vi, 138, 139), is a notable instance in point. The system of children's courts-that is, courts where charges against children and young persons are tried separately,-spread with remarkable rapidity all over the British Empire, the United States and many foreign countries. So too the prohibition against the passing of the death sentence on young persons. A kind-hearted judge under the old law, when people could be hanged for stealing to the value of a shilling, was passing sentence of death on a girl who had taken a bit of ribbon out of her mistress's wardrobe, when the poor girl fainted. "How dreadful! Tell her I don't mean it," said the kind-hearted judge, "will nobody tell her that I don't mean it?" Such scenes are to be no longer possible. Not that one any longer imagines the youthful mind to be the sheet of white paper postulated by Locke on which anything may be written. Heredity has already written there in its own invisible ink.

By a recent Manitoba Act, advertisements dealing with the adoption, boarding out, or care of any infants under the age of thirteen months have to be accompanied by a recommendation, signed by the advertiser with his or her name and address, and this memorandum has to be forwarded to the Superintendent of Neglected Children, - a salutary preventive against the abuses of baby-farming. Kentucky now punishes any person who directly promotes or contributes to conditions which render any child dependent, neglected or delinquent. Difficulties often arise-they did notably in Dr. Barnardo's case-from parents, who have surrendered their children to the charge of a philanthropic sơciety, wanting to get them back. Manitoba has met this difficulty by providing a Children's Superintendent. No surrender by a parent can be made without the consent of the Superintendent, but when once made it is final.

Commereial Law.- One of the resolutions passed at the British Imperial Conference I I I affirmed the desirability of securing greater uniformity in the company laws of the Empire, and well it might. In Canada there are no less than eleven different systems of company law contained in 67-Acts and Ordinances. In South Africa there are I 6 dealing with company law. In Australia there are 54 Acts, but an important step towards assimilation has been taken by the Victorian Consolidation Act, which practically adopts the whole of the English law on the subject of companies. Further progress towards uniformity has also been made by the Acts recently passed in the Transvaal, and in British Columbia. In the United Kingdom the number of companies registered shows on the latest available returns the same steady increase. The total number for I I I was 6444. The most remarkable feature however was the large proportion of the companies registered as " private companies," no less than 5 I 94 being of this description. In addition $\mathrm{r}, 860$ companies were converted from public into private companies. The superior attraction of the private company lies in the fact that it is exempt from the obligation of filing a balance sheet under s. 26 of the Companies Act rgo8 with the Registrar of Companies. The British trader likes to keep his affairs to himself. The neglect of the Limited Partnerships Act, as compared with the popularity of the private company, is also very striking. The number registered in the United Kingdom in I908 was r44. By I9I it had dwindled to 77 . There can be no question that as between the two kinds of organisation, the limited partnership and the private company, the latter is incomparably the safer, the simpler and the more efficient.

The company wreckage is still unfortunately very large. Taking together British companies that liquidated and that were struck off the register as defunct, the number for I9I I was 4353. This is more than ought to be, with all allowance for the enterprise of promoters and the sanguineness of human nature. 
It has long been an anomaly that foreign companies should be allowed to trade in the United Kingtom without disclosing anything as to their constitution and financial resources. This has been rectified by s. 274 of the Companies Act I908, requiring from these alien immigrant companies the filing of a copy of that constitution, a list of their directors and the name of a person to accept service. If the foreign company is limited, further requirements are made. One hundred and ten foreign companies complied with these conditions in rgrr. A large number of the British dominions and colonies are adopting similar precautions. Argentina has recently done the same. In connection with this subject a very serious situation has arisen in Egypt owing to the attitude of the Mixed Courts there as to English companies. An English Company which is carrying on business in Egypt may efficiently be treated by a Mixed Court as "null and nonexistent.' The question was very fully considered in all its bearings by the Judicial Adviser to the Khedive in his Annual Report, and will be found reproduced in No. $\mathbf{x x v}$ of the Journal of Comparative Legislation, p. 85 .

The unification of the law of bills of exchange has been engaging the attention lately of English business men and lawyers, and the Board of Trade has consulted the Institute of Bankers on the subject. The view of the Council of the Institute is that whilst any fundamental alteration in the general legal principles or customary usages underlying the existing law in the United Kingdom would not be acceptable either to the bankers or the mercantile community of this country, many existing differences between the laws of various countries could be adjusted by international agreement.

At the Hague Conference on Bills of Exchange a draft uniform code on the subject was accepted by the delegates of more than 30 nations. This draft code approximates more nearly to English law than to any existing continental code. The reconciliation of the English point of view with the continental is discussed in a paper contributed to the Journal of Comparative Legislation (No. xxiii, p. I43) by Dr. E. J. Schuster, one of the highest authorities on the subject, and also by Sir M. Chalmers in No. xxiv of the same Journal. Profit-sharing as a mode of reconciling the interests of Capital and Labour has been a good deal discussed, and many schemes have proved to have worked successfully. The system merits special attention from companies, for there can be no doubt that shareholders are becoming more and more mere dividend-drawers, and too negligent of their obligations as principals in the business to their employees.

In connection with commercial law it is noteworthy that the United States has created a Commerce Court with jurisdiction over all matters relating to inter-state commerce.

Criminal Law. - The old ideas of criminal law have been undergoing of late years a rapid and complete transformation. The very foundations of the old system seem to be crumbling away. The idea of retribution or vengeance, so long the animating principle, is fading into the background and is giving place to a desire to reform rather than punish the criminal. He, it is felt, is not so much to blame as heredity and his environment, and for that society is largely responsible. Of course society must be protected. That. principle remains unshaken, but does society benefit under our present system? "As a matter of fact," says Professor Willoughby, "so far as regards the reformatory ideit there would probably be a consensus of opinion that, upon the whole, criminal law as it. has actually been administered in the past was far more corrupting than elevating to the individual punished. Prisoners are for the most part composed of the feeble-minded, physical weaklings, vagrants, casual offenders, habitual criminals. For all but this last class - the hardened in crime-prison is a failure. The modern tendency is therefore to discriminate. For the young, for first offenders, for the weak, for those who ar: yet undepraved and can be reclaimed to honest citizenship, it provides such agencies as the industrial school, the reformatory, the Borstal institution. ${ }^{1}$ But for those who have adopted crime as a profession and are really irreclaimable, the main principle is an 1 must be the protection of the community. and in pursuance of that policy the Prevention of Crimes Act was recently passed in England. Under this Act those who have been convicted of crime and who are persistently leading a dishonest or criminal life may, See E. B. xv, 61 3 et seq., "Juvenile Offenders." 
upon being sentenced to penal servitude for a fresh offence, be further sentenced to preventive detention for a period not exceeding ten years, to take effect after the determination of the sentence of penal servitude. Convicts undergoing preventive detention are confined in prisons set apart for the purpose, with some amelioration of the usual prison treatment. In I9Io- the latest year for which statistics are available- 778 convicts were dealt with under this preventive system. Similar provisions have been introduced by amendment into the criminal code of Western Australia: and the Union of South Africa has adopted a similar line of legislation.

A treatment of criminals which has found much favour in the United States is that of the "indeterminate sentence." This is strictly a misnomer-there is no "indeterminate sentence" in the sense of a sentence without a limit, a maximum or a minimum. The "indeterminate sentence" is used as a catch-phrase to indicate opposition to the "retributory" element in the punishment of crime. It is for making, not the guilt of the criminal but his potentiality for reformation the test for the duration of his punishment, in other words it stands for the individucilisation of punishment, and it entrusts the power of judging the potentiality of reformation not to the judiciary but to boards of parole. But, as Sir Ruggles Brise has justly remarked, there is fixed in human nature a moral indignation against the perpetrator of an anti-social act which demands punishment when there is full responsibility for the deed, and it is a fallacy to call such a healthy moral sentiment a desire for vengeance or confound it with the old idea of expiation.

The Probation system is closely allied to that of the indeterminate sentence, but it is differentiated in this respect that it dispenses with imprisonment altogether. The system has spread with remarkable rapidity. Started in Massachusetts in I875, it has extended to about three-fourths of the States of the United States of America, to Great Britain, Germany, Hungary, Canada, Austria and New Zealand. It saves the offender from the stigma of imprisonment, his family from loss of wages, and the public from the expense of his support. Japan has lately adopted the system and applies it freely -whenever there is a chance of bettering the offender without sending him to a state penitentiary. Trinidad and Tobago have recognised its wisdom.

An International Penitentiary Congress is to be held in London in I9I5, and the result of its discussions will be awaited with much interest.

Everywhere there are complaints as to the increase of young criminals. In Italy, for instance, in Naples, Rome, Genoa and Milan, the juvenile offenders are 32 per cent of the total convicted. Between the ages of $\mathrm{i} 8$ and $2 \mathrm{I}$, offenders are nearly twice as numerous as between 40 and 50 . In this case want of education may be the cause -half of these juvenile criminals could neither read nor write: in other cases education itself, it is to be feared, may be the cause-perverted to the purposes of roguery. In Egypt the number of juvenile offenders has increased, but the greater vigilance of the authorities may have something to do with the rise in the statistics. In England and Wales the total number of juvenile offenders for the last year for which statistics are available was 34,087 -nearly all, it may be remarked, boys or youths. The proportion of girls was only 1899 - some six per cent. Juvenile offences fall mainly under a few heads-petty thefts, acts of mischief, disorderly behaviour, begging and loitering. Of these 34,087 youthful offenders only 90 , it is satisfactory to find, were sent to prison: I I 43 were sent to reformatories, $I_{5} 62$ were ordered whipping: but the large majority were fined, such fine to be paid by the parent or guardian. This is an excellent device, for it visits on parents and guardians the just consequences of their neglect.

The codification of the English criminal law is still afar off, but like the codification of the English civil law it is proceeding piecemeal. The consolidation of the law of perjury by an Act of I9I I was an excellent piece of work, and a bill has been introduced to consolidate and simplify the perplexed law of forgery. The agitation against capital punishment seems to have died out for the time, both in the United States and in the British dominions and colonies.

Licences.-A very noticeable feature of recent years has been the growth of the licence system. A great many states have adopted this method of securing control over the 
conduct of acts and undertakings in lieu of special legislation, and it has much to recommend it for the state can thus fix the terms of its sanction. The control of the liquor trade is of course an old example of the use of licensing: so is the control of public entertainments: but in recent times the licence has been used for an infinite variety of matters - to carry or sell firearms, to use the totalisator, to sell milk, to deal in coco-nuts and nutmegs, to run a cinematograph show, to act as a private detective, to buy gold, to deal in offensive weapons, to recruit labour, to sell morphine injection needles, for a salmon cannery or salmon curing establishment.

Analogous to this system is the growing organisation of professions and trades. Acts are being passed everywhere to protect the public and the professions against unqualified persons practising, ignorant pretenders, quacks and charlatans. Thus chartered accountants are being organised in Ontario, medical men in Quebec and New Brunswick, dentists in New Zealand, pharmacists in Saskatchewan, veterinary surgeons in Western Australia, and a movement is on foot to do the same for architects in England.

Newspapers.-The arch mischief-maker is a newspaper when unscrupulously conducted. Sierra Leone has recognised this, and provided a penalty for publishing statements which are " misleading or calculated to do harm on matters of public interest or importance." Some such provision might not be amiss elsewhere in restraint of the sensational newspaper press. Uganda has devised another check on enterprising journalism. The proprietor of every newspaper started in the Protectorate must give a bond for 3000 rupees, to meet any fine that may be imposed for criminal libel.

Agriculture. - This is the age of the ubiquitous microbe. We are quite used to waging a perpetual war with it in the human body, but we have only awakened slowly to the malignant potency of plant pests in the domain of agriculture. Now we are realising it, and the result is a large amount of legislation throughout the British Empire, in Canada, South and East Africa, Australia, the West Indies, Mauritius, the Seychelles, British Guiana, Nova Scotia. The Union of South Africa has prohibited importation of exotic products; precautions have been taken to prevent the spread of infection from plants, and notification of plant-disease is required. South Australia has been dealing with the phylloxera in its vineyards. Bees too have come in for attention in St. Lucia, Bechuanaland, Jamaica, Nova Scotia and Newfoundland; also noxious weeds. Canada has been legislating for the inspection of sceds to secure that the germs of such noxious weeds are not included. Great care is also being taken to secure the purity of dairy products, and the non-adulteration of fertilizers and foodstuffs. The prevention of cattle disease has been engaging the attention of many American states. Rural industries are being encouraged, homesteads and small holdings made easy of acquisition on periodical payments, in the United Kingdom, Canada, Australia and New Zealand.

A book full of instruction on the subject is the Annuaire International de Legislation Agricole, published by the Institut International d'Agriculture at Rome.

Native Law and Custom.-The value of the historical method in jurisprudence has long declared itself, and as it has made itself felt we are awakening to the importance of native law and custom as the origin of juridical ideas and as a side-light on their development. The awakening has come not a moment too soon, for with the spread of civilization these primitive customs with their rudimentary notions of justice are fast fading like a dissolving view. Mr. R. W. Hamilton, a Judge in British East Africa, has done excellent service in collecting some of the native customs there, and very curious many of them are. The fundamental ideas amongst most of the native tribes in East Africa regarding family relationships are: (1) that individual members of a family form the wealth and strength of the united family; (2) that the females cannot inherit and cannot dispose of property; (3) that females are themselves property to be bought and sold in marriage, to be assigned in payment of debt and to be owned and inherited by their male relations. In fact the female members of a man's family are as much a part of his property as his cattle, and often the most important source of his income. "Given" says Mr. Hamilton, "this conception of society in the minds of primitive savages whose 
crimes are commonly the instinctive crimes of passion, it naturally follows that such offences as murder and rape are regarded by them in a very different light from that in which we look at them. Murder is regarded as a loss of strength caused to the family of the person murdered, which may be compensated by the murderer replacing the murdered man with others. Rape of an unmarried woman is regarded as so much loss caused to her owner in the price procurable for her in the marriage market." In short they are looked on as offences not against the person but against property. The idea of a crime against society has no place in the native mind.

In Mr. Northcote Thomas's “Marriage Customs of the Edo-speaking Peoples of Nigeria" he cites a curious parallel to Jacob serving his father-in-law Laban for Rachel. In addition to payment for a bride he says: "when the bride is young the suitor does a certain amount of work on the farm of his future father-in-law and helps him in such tasks as bouse-building."

In Albania the system of accepting money payment for homicide is still in full force (see Miss Durham's book High Albania). In a case of misadventure or manslaughter the fI4 which is the standard tariff will as a rule be accepted: but when bad blood is aroused-in a case of honour or vital interests - the tender of cash is rejected and the tribes enter upon a long blood feud. It might be supposed that such a feud could only end with extermination, but there is a limit, though somewhat undefined. Thus, the Kastratione and Hoti tribes being at feud, a Kastratione accompanied Miss Durham as guide to the enemy's country. " All drank healths with him," she says, " he was the honoured guest and they discussed pleasantly how many 'bloods' would be required before peace could be made. The house-master was quite frank: five was the number he thought necessary. And the Kastran thought that five would satisfy them too." What is so curious is the absolute reverence of these untamed mountaineers for law co-existing with these bloodthirsty feuds: but the anomaly vanishes on a moment's reflection. The vendetta is to them the law-a family or social duty of primary obligation as it was to. Hamlet the Dane.

Witchcraft is still a potent force among the native tribes of Africa. Laws and magistrates are powerless to stamp it out. One of the latest criminal cases in the East Africa Protectorate arose out of the elders of a tribe in solemn conclave having clubbed and stoned a witch-doctor.

Ancient Monuments.-There is a growing seuse of the importance of protecting ancient monuments and national works of art before it is too late. The natural beauties of a country are being protected, and they run less risk of being spoilt than historic or architectural buildings or ruins. Austria, France, Holland, Germany, Italy and the United States have all legislated on the subject, and in the United Kingdom the Ancient Monuments Act I9ro, c.3. enables the Commissioners of Works to accept the ownership of any "structure, erection or monument of historical or architectural interest or any remains thereof." Two more English Bills on the subject are pending, one of which proposes that all ancient monuments, - - sites as well as artistic treasures - should be put under the protection of Government by being officially scheduled. In the meantime the Union of South Africa has provided for the preservation of Bushman relics in the shape of drawings or paintings on stone: while Spain has been creating. a "centre " of historical studies for the scientific study of Spanish history. Cyprus has also been protecting its unique classical antiquities.

Administration of Justice.-At the annual meeting in I.ondon of the Law Society in I9I 2 , the address of the President was chiefly occupied with the decline of British litigation and its causes. Such decline, it should be premised, is confined to the High Court. In the County Court the volume of litigation has increased and is increasing. For the decline in the High Court several causes are assigned-delay, uncertainty, costs; but these are nothing new. For centuries all these causes have been operating as deterrents. The true reason seems rather to be a decline in the litigious spirit of the old times. There is more of a disposition to-day to admit that the rights of the matter are partly on one side and partly on the other, and to compromise them accordingly, instead of fighting 
them out to the bitter end. There is nothing to regret in this-no denial of justice, though the lawyers may suffer in pocket. But this and other problems will, it is to be hoped, be solved by the lately appointed Royal Commission on the administration of justice. The existing English procedure in civil cases leaves much to be desired. There are too many interlocutory proceedings, too many appeals, a want of uniformity. Why should proceedings commence sometimes with a writ, sometimes with an originating summons? Expert witnesses are an enormous expense to the parties, and generally contradict one another. Why should not the Court have a list of assessors-engineers, merchants, doctors, architects, chemists and others whom it can summon to its aid, just as it now does Brethren of the Trinity House in Admiralty cases, and Bishops or other Church dignitaries in ecclesiastical cases?

Hearing in Camerâ.-The English divorce case of Scott v. Scott in rgra raised an interesting new question as to the effect of an order for hearing in camcrâ. A lady instituted a suit for nullity of marriage. The case was ordered to be heard in $\operatorname{camer} \hat{a}$, and in the result the Court made a decree on the ground of the husband's impotence. The ex-wife thereupon-to show that she was the aggrieved party-sent a transcript of the shorthand notes taken at the hearing to her father and sister. For this alleged violation of the secrecy of the hearing a motion was made to commit her for contempt, and Mr. Justice Bargrave Deane held that the publication did constitute a gross contempt. The lady appealed, and was met by a preliminary objection that the order was in a "criminal matter" and not appealable. The case was heard before the full Court of Appeal, with the result that four Judges held the preliminary objection good: two dissented, and of the latter one-Lord Justice Fletcher Moulton (now Lord Moulton)delivered a very striking judgment. In his opinion the order related to the hearing and the hearing only, and when that was concluded its effect was at an end. There was therefore no contempt by the lady in what had been done, and he pointed out the danger to the administration of justice if the Court - the guardian of the liberty of the subject-itself encroached on that liberty. Hearing in camerâ, it must be remembered, is ordered not only to avoid the scandal of indecent evidence being given in public, but because such evidence often cannot be obtained at all except in private.

Recent Legal Literature.-A book of great value now nearing completion is The Commercial Laws of the World. Here we have the Lex Mercatoria grown into a library of fifteen massive volumes, the mustard-seed into a tree overshadowing the whole earth.

In Professor Maitland's Collected Papers we have had another book of remarkable interest, the gleanings of the rich harvest of F. W. Maitland's genius. Maitland - as his editor $\mathrm{Mr}$. Fisher well say's - was not only "a great discoverer in history," but an "incomparable populariser of his own and other men's knowledge."

A notable work is the 2 nd edition of Burge's Colonial and Foreign Law, under the editorship of Mr. Justice Wood Renton and Mr. (.. G. Phillimore. The scope and thoroughness of this work is illustrated in the latest volume, which is entirely devoted to marriage and divorce and contains a detailed survey of the law'systems of nearly all civilized nations. The voluminous Laws of England, proceeding under the auspices of Lord Halsbury, is a notable achievement for comprehensiveness and accuracy; and second editions of the Encyclopaedia of the Law's of Englend and the Encyclopaedia of Scots Lave show the appreciafion which those works have met with. A work of remarkable erudition is Buckland's Roman Law of Slavery, and with it may be coupled the Master of Balliol's Criminal Law of Rome.

The Great Jurists of the World, appearing under the auspices of the Society of Comparative Legislation, is a collection of artjcles contributed to the Journal of the Society by a number of distinguished lawyers. It should help to form the basis of a history of jurisprudence-a history teaching by examples.

A new departure which promises well is the establishment at Berlin of an International Institute for a Bibliography of Jurisprudence. The Inst itute will deal not only with books but with periodical literature. A great amount of valuable work is in these days buried and lost in periedicals and fugitive pamphlets, such as Sir Erle Richards's recent Lecture on the "Sovereignty of the Air," or Sir John Macdonell's "Historical Trials,"

In connection with legal bibliography, a good idea comes from New York in the shape of a Guide to Germun Lati". Popularly it may be described as " ierman Law and where to find it." It is the first of a series, admirably planned and ably executed, designed to constitutea library of comparative law. 
Local Legislation.- The main currents of the past year or two in law and legislation having been indicated, a brief notice may be added of some of the special matters with which individual nations have been concerning themselves. Reference should be made, in this connection, to the accounts of separate countries in Part II of the YEAR-Book, notably in the case of the various states of the United States.

Austria.-Austria has lately been celebrating the centenary of its Civil Code. An interesting account of its history is given by Dr. Tisch. Divorce law in Austria, which is founded on the Code, still retains, Dr. Tisch says, the "confessional or ecclesiastical basis." In the case of Catholics, or even where one spouse only is a Catholic, the bond of marriage can only be dissolved by death. Where both spouses are non-Catholics the marriage may be dissolved by mutual consent if an insuperable disinclination is proved before the tribunal, or on complaint of one of the spouses for certain matrimonial offences.

A Code for Domestic Service in Vienna has lately been enacted by the Austrian Parliaments, defining concisely the respective rights of master and servant, mistress and maid.

The regulation of the Bar in Austria is also before the House of Deputies. The object is to prevent overcrowding by exacting higher qualifications and to prevent retired Judges swelling the competition.

Belgium.-Belgium has amended the whole of its Maritime Commercial Code.

Brazil.-Legislation here has been mainly concerned with bankruptcy and negotiable instruments. A copyright law has also been passed in favour of foreign authors, giving them the same privileges as native authors.

France.-France has been establishing old age pensions for workmen and peasants. Regulations have also been made for the health and safety of miners. Another law facilitates the acquisition of small rural holdings by allowing the agricultural banks to spread their advances over a period not exceeding fifteen years.

The growing importance of comparative law is illustrated in the fact that France has created an office of foreign legislation and international law. The full text of the decree will be found in No, xxv. of the Journal of Comparative Legislaition, p. I75.

Germany.-Germany has completed her scheme for compulsory insurance of workers. A new scheme of similar insurance for persons such as clerks with a higher scale of income is now being formulated.

In the matter of copyright, Germany, while adopting with a number of useful innovations the modifications of the Bern Convention of 1908 , has not seen its way to lengthen the period of protection to 50 years as the British Copyright Act I9I I has done.

Another noticeable statute is that extending the liability of the Imperial Exchequer for breaches of duty on the part of Imperial officials.

In England a person keeping an animal not ferae naturae is only liable for its mischief if he had reason to know that it is savage. This is expressed in popular language by saying that a dog is entitled to its first bite. This "scienter" doctrine is too lax owing to the difficulty of proving knowledge. In Germany on the other hand the law was too strict. A person keeping an animal was liable for all damage caused by it. Under a new law a person keeping a domesticated animal for purposes of his profession or trade or of his maintenance, is not liable for any damage caused by such animal if in keeping watch over it he has used reasonable diligence or if the damage could not have been avoided by the use of reasonable diligence. This is fair. But the protection, it may be noted, is not extended to animals kept for sport or otherwise.

India. - The Indian Councils Act has made great changes in the constitution and functions of the Legislative Councils ( see Sir C. Ilbert in Journal of Comp. Leg., No, xxiv), and the Press Act has been passed to check the licence of some native newspapers.

Italy. - The state has been taking over all life insurance business.

Japan.-Harcily anything in the development of nations. has been more remarkable than the rapid transformation in Japan of the old régime into the new: but with all its innovations it would be misleading to say, as it has been said, that Japan in its new Civil Code has "thrown over its whole existing legal system." Sir Henry Maine has noted in his Ancient Law the remarkable persistency among the Romans of the patria potestas. No less remarkable is its sway in Japan under what is called "the power of the family head." It still dominates all rival legal conceptions. In the political sphere this is illustrated in the Japanese fidelity for $255^{\circ}$ years to the Imperial dynasty as head of the great family of the statethe supreme pater familias. But it is "pretty to observe," as Mr. Pepys would say, how this doctrine of the patria potestas-this imperium in imperio-is, under the influence of modern ideas, passing through the same changes as in ancient Rome. Roman opinion tempered by degrees that strange domestic despotism, and there were duties attaching to the patriarchal head, such as the moral obligation to provide for all members of the family out of the common fund, which balanced the rights. In modern Japan the old feudal absoluteness of the family head has gone; the Japanese Court of Appeal has decided that his powers are to be exercised "only for the best interests of, and when necessary for the administration of, the house," and "if injustices are alleged the Court is to investigate them and set aside, if neces- 
sary, any unfair exclusion of a member by the family." If a family head abuses his powers, such powers may be suspended. In short, the rights incident to the patria potestas are fading while its duties are emerging into clearer relief.

Some other matters may be noticed: An old age pension scheme has been passed, the age being fixed at 70 . Selling intoxicating liquors to a minor has been made punishable. Horse racing has lately been prohibited,- the Government, which had at one time authorised it in the hope of improving the horse, being convinced that it was productive of more evil than good to the community. A censorship has also been established over the irresponsible newspaper, by requiring the publishers to make a deposit varying in amount with the population of the place where it is published.

Russia.- A new extradition law is one of the features of recent Russian legislation. The new law does not affect the provisions of existing treaties, but lays it down that subsequent treaties must be concluded on the basis of this law. To constitute an extraditable crime, it must be one punishable by imprisonment in both the countries in treaty. Extradition may be granted not only for the crimes enumerated in the treaty but for other crimes. It may be granted where the crime was committed for a political purpose. A Russian subject cannot be extradited. An interesting account of the new copyright law in Russia is given in No. xxvi of the Journal of Comparative Legislation.

Spain.-Spain has been legislating quite in the eugenist spirit for the good of babies,providing for nurse agencies, homes for infants, milk supply, and in the same interest, regulating the work of women and chilaren. It has been establishing a tribunal for the settlement of civil disputes between employers and employees. A usury law has also been passed making void all contracts of loan stipulating for a rate of interest notably higher than the normal value of the money and manifestly disproportionate.

Switzerland.- The new Civil Code has recently come into operation. It is based on the German Civil Code, but with original features of its own. The framers, for example, have preferred to leave much to the Judge, and where the text of the Code fails as a precise guide its spirit is to prevail. In default of this the judge is to be guided by custom or the rule which he would if legislating have adopted.

United States. - One of the most noticeable features in the United States is the effort to secure uniform legislation among the states. The evils of the cristing diversity are notorious and are specially felt in the case of commercial laws. The first of these proposed American uniform Commercial Acts deals with the law of negotiable instruments. Others will be the Sales Act, the Bills of Lading Act, the Uniform Desertion Act, the Uniform Divorce Act the Uniform Boiler Inspection Act.

(Edward Manson.)

\section{THE BRITISH LAW OF ARTISTIC COPYRIGHT}

On July I, I9I 2, there came into operation an entirely new British Copyright Act. Mr. Sydney Buxton's Imperial Copyright Bill (the general terms of which were given in the article "Copyright" in E. B. vii, I28, I29) became law in I9I1. The passing of this Act not only consolidated and amended the British law of Literary Copyright, on the lines there indicated, but has entirely altered the conditions of Artistic Copyright and repealed the previous Acts dealing with it; the statement of law on that subject as set forth in $E$. B. vii, I25 et seq. no longer therefore holds good, and we shall state here what the law now is. The changes effected by the Act were very great, the chief being the unification of the law in regard to every branch of the Fine Arts, the abolition of all formalities for securing copyright to the artist such as registration or the signing of works or documents of any kind, the extension of the term of copyright for all forms of art, the inclusion of architecture, and the return of the copyright to the legal representatives of an artist twenty-five years after his death.

Scope.-The application of the Act extends to the whole of the British Dominions except when specially restricted to the United Kingdom, but to be effective in the self-governing 1)ominions-Australia, Canada, New Zealand, South Africa, Newfoundland - the legislature of the Dominions must declare the Act to be in force either with or without modifications relating to procedure and remedies which the Dominions are at liberty to make. British possessions which are not self-governing Dominions have the same liberty to modify the Act or to adopt it as it stands. An order in Council may also extend the operation of the Act to Protectorates-as Cyprus-and to foreign countries. The old law protected all works of art produced in any part of the British Dominions, but it only protected them in the United Kingdom. British works of art appear to have had no protection in the self-governing Dominions and possessions unless under special local provision, or unless, as illustrations to a book, they were protected as being parts of a book under the Literary Copyright Act of 1842 , which unlike the Fine Arts Act extended its scope to the British Dominions.

Rights. - There is copyright in every original work of art, but if the work is published it 
must be first published in some part of the British Dominions to which the Act extends, and if unpublished the author must, at the date of the making of the work, be a British subject or resident within such part of the British Dominions as aforesaid. If the making of the work has extended over a considerable time it is only necessary that the author should have been for a substantial part of that time a British subject or resident or domiciled within the British Dominions or a foreign country to which the Act extends.

The change made by the new Act affects paintings, drawings and photographs to this extent. Publication did not affect copyright which existed from the making of the work, and which was protected by common law right, so long as it remained unpublished. On publication the copyright became subject to the terms of copyright enacted by the 1862 Act. The new law abolishes common law protection entirely, but gives protection for unpublished works; under the statute an unpublished engraving retains its copyright so long as it remains unpublished, but it becomes amenable to the terms provided for posthumous works if published after the author's death.

"Copyright" means the sole right to produce or reproduce the works or any substantial part thereof in any material form whatsoever, and to publish the work; it includes also the right to dramatise a work of art in the form of a living picture or otherwise. "Publication" means the issue of copies to the public. The exhibition of a work is not publication, nor is the construction of a work of architecture, nor the issue of photographs or engravings of works of sculpture or architecture.

Under the old law engravings and sculpture acquired statutory copyright on publication, by the addition of the name of the proprietor and the date of publication on each original or copy issued to the public.

In paintings, drawings and photographs there was statutory copyright from the making and quite apart from publication, but registration was necessary prior to any action at law in defence of copyright. Registration is now abolished.

Architecture is introduced into a copyright Act for the first time, and solely at the instigation of the Berlin Convention. It is very uncertain how it will act or what is protected, and its inclusion was by no means unanimously desired by architects. But the protection of architectural designs has been put in operation abroad, and certain claims have been dealt with. The use of the expressions "architectural drawings" and "drawings of architecture" seems to have caused some little confusion, but perhaps unnecessarily. An "architectural drawing or plan" may be taken to be a constructional drawing made by the architect for the use of the builder. A "drawing of architecture" may be made by anybody of a building already constructed, and while showing the superficial character of the building would not be in any sense a constructive drawing.

Infringement is the doing without the consent of the owner of the copyright anything, the sole right to do which belongs under the Act to the owner of the copyright. The following acts are exceptions:

(A) Any fair dealing with a work for purposes of private study, criticism or review is not an infringement.

(B) An artist who has disposed of his copyright in a work may use any mould, cast, sketch, plan, model or study, made for the purpose of the work, provided he does not thereby repeat or imitate the main design of the work.

(C) Paintings, drawings, engravings or photographs may be made and published of a work of sculpture or artistic craftsmanship permanently situated in a public place or building, or of an architectural work if they are not in the nature of architectural drawings or plans.

(D) Photographs may be made of paintings, drawings or engravings, situated in a public place or building, maintained in part or entirely by public funds, unless the copyright in them is private property:

Infringement is committed by anyone who sells, lets for hire, offers for sale or hire by way of trade, or widely distributes or exhibits in public, or imports for sale or hire into any part of the British Dominions, any work which to his knowledges infringes copyright.

These exceptions clear up points to which no reference was made in the old Acts, though some of them were assumed to be permissible, such as the use by the artist of his sketches and studies, and the making of complete copies of works for purposes of private study. "Fair dealing" is a new element which may have to be defined by the Law Courts.

Terms of Copyright.-Copyright endures for the life of the author and fifty years after his death. But the Act renders it impossible for an artist to dispose of his copyright for more than his life and twenty-five years after his death. No matter what agreement he may make to the contrary, twenty-five years after his death the copyright returns to his legal personal representatives as part of his estate.

A provision is made whereby in the case of a work which has been published, it is possible, twenty-five years after the death of the author or in the case of an engraving thirty years, for any person to reproduce and publish the work, on giving notice of his intention and on payment of a royalty of 10 per cent on the published price in respect of copies sold, the notice and the payment of royalties to be regulated by the Board of Trade.

Photographs have copyright for fifty years from the date of making the negative. 
The change in the duration of the term of copyright is one of the most important effected by the Act. Under the old law the terms were for engravings 28 years; for sculpture 14 years, with a possible additional 14 ; for paintings, drawings and photographs, the life of the author and 7 years after his death. The term of life and 50 years was decided upon to enable Great Britain to fall into line with the other countries of Europe, the great majority of these already having accepted this term.

Ownership of copyright. - The author of the work is the first owner of its copyright. There are two exceptions:-

(A) A person giving a commission for valuable consideration for a portrait, an engraving or a photograph, is the first owner of the copyright therein; (B) Where a work is made by a person in the employment under a contract of service of some other person the copyright belongs to the employer.

This is without doubt as regards the painter and draughtsman the most important change made by the Act. Under the old law it was necessary for the mere existence of a copyright in a painting or drawing that on the first sale of the work a document be prepare 1 stating to whom the copyright should belong. If it remained with the artist the document had to be signed by the purchaser, if it passed with the work to the purchaser it had to be signed by the artist, and in the event of no agreement in this form being made on the first sale the copyright ceased to exist, and the work could be reproduced by any one able to gain access to it for this purpose. The photographer came under the same law, but as the copyright in a photograph lies in the negative which is very seldom sold, the photographer was but slightly affected. Up to the clate of sale the copyright was protected by common law. The passing of copyright to a person giving a commission is now restricted to the case of a portrait, an engraving or photograph; previously it passed without agreement in all cases of commission of a painting, drawing or photograph, but not of an engraving or sculpture.

Licenses. - The owner of a copyright may assign his rights wholly or partially either for the whole term of his copyright or any portion of it, and may grant any interest in his rights by license. These grants must be in writing signed by the owner of copyright.

There was some doubt under the old law as to the righi of a copyright owner to split up and part with portions of his right, i.e. whether he could grant a right to one person to reproduce his work in black and white, and to another in colvur or to use it for post-cards, while the right to make a large coloured Christmas supplement went to another. It is clear under the new Act that he may also grant licences for a time or for the whole term of his copyright. It also does away with the provision in respect to the sculpture copyright that it could only pass by deed signed and sealed and by the attestation of witnesses, and also with the necessity in the case of an engraving copyright to have the written agreement attested by credible witnesses.

Civil Remedies.- When copyright has been infringed, the owner, except in the case of an infringing work of architecture, is entitled to an injunction or interdict, to damages and to an account of sales. In the case of a work of architecture the construction of the alleged infringing building cannot be stopped by injunction. Infringing copies of a work, except a work of architecture, are leemed to be the property of the owner of copyright. When proceedings are taken against an infringer who alleges in his defence that he did not know of the existence of copyright in the work, the onus of proof that he did not know and had not reasonable means of making himself aware of its existence lies on the infringer.

An action in respect of infringement of copyright must be begun within three years after the infringement.

If a work is signed or the authorship otherwise indicated on the work in the usual manner it is presumed that the person whose name is signed or so indicated is the author of the work If the work is published the name of the publisher, if the name of the author is not given, is accepterl as prima facie proof of ownership of copyright. The great change effected in the aw is the doing away entirely with registration, which was formerly necessary as primu facie proof of copveright in the case of paintings, drawings and photographs.

The innocent infringer was unknown under the old law. Absence of knowledge was no defence. The common law protected copyright from infringement, as it protected property from trespass. The limitation of time for the beginning of action was practically the six years prescribed by the statute of limitations.

Summary Remedies.-Any person who knowingly infringes copyright is liable on conviction to a fine not exceeding forty shillings for every copy dealt with, but not exceeding fifty pounds in respect of the same transaction. On a second offence the infringer is liable to imprisonment, with or without hard labour, for a term not exceeding two months. Infringing copies made out ide the IInited Kingdom and imported may be stopped at the port of entrance on notice being given in writing to the commissioners of Customs and Excise.

Clatuse's 7 and 8 of the 1862 Fine Arts Copyright Act remain operative under the new law. They impose penalties for (I) the fraudulent signing of paintings, drawings and photographs, with names or signs misleading as to authorship; (2) the fraudulent publishing or selling such fraudulently signed works; (3) the fraudulent putting forth copies of works, as original works by the author of those from which the copies have been made; $(4)$ the 
alteration of works after they have passed from the author's possession, and the putting forth such altered works as the original unaltered works of the author or copies of such altered works, as copies of the original unaltered works, without the author's consent The penalty for these offences is a fine of ten pounds, or a sum not exceeding double the full price at which all such fraudulent works have been sold or offered for sale. This penalty is contingent upon the author whose name has been fraudulently signed or work altered, etc. having been living within twenty years of the committal of the offence.

Joint Authorship.-The copyright in a work executed by two or more artists subsists during the life of the author who first dies and for a term of fifty years after his death, or during the life of the author who dies last, whichever period is the longer.

Designs.-The Act does not apply to designs capable of registration under the Patents and Designs Act 1907, that is to say designs which are intended to be multiplied by an industrial process.

Posthumous Works.-In the case of an engraving in which copyright subsists remaining unpublished at the time of the author's death, copyright remains until publication and for fifty years thereafter.

Existing Copyright. - Where any person at the time of the coming into operation of the Act was entitled to any copyright, he became from that date entitled to the substituted rights provided by the Act as if it had been in existence at the date when the work was made; but if the author of a work has assigned his rights entirely or partially for the whole term of his rights, then at the date when but for the passing of the new Act the right would have expired, the substituted right conferred by the Act passes to the author and the interest of the assign terminates $\cdot$ but the assignee is entitled at his option to (I) an assignment of the further rights on a consideration to be agreed, or (2) without such assignment to continue publication as before subject to the payment of a royalty to be agreed. Failing agreement, the terms in both cases must be settled by arbitration.

Common Law Right.- All protection at common law ceases to exist, and no right can be claimed other than those provided under the Act, or by any uther act which may be in force.

(EDWIN BALE.)

\section{SECTION VII. ENGINEERING AND INDUSTRY}

AERONAUTICS ${ }^{1}$

Since 19ro Aeronautics has definitely taken its rank among the sciences. Though precise knowledge is meagre as yet, the fundamental principles which determine the laws of air-resistance and the properties of the air in motion, on the proper utilisation and application whereof aerial navigation-is based, have once and for all been laid down in their broader aspects. Whereas, therefore, even in I9I0 the design of an aeroplane proceeded largely by guess-work and its construction by rule of thumb, to-day the science of aerodynamics, founded partly on theoretical considerations and partly on the data derived from extensive experiment and research, is sufficiently exact to enable the qualities and capabilities of an aeroplane of given design to be forecast with accuracy. Within this short space of time the aeronautical engineer, formerly content merely to produce a machine that would fly, has already begun to design aircraft with a given object, which has led to a marked differentiation of types.

If vast strides have been made in the science of aerodynamics, the kindred aspects of the science of meteorology have made little progress. From the point of view of aerial navigation the great general movements of the atmosphere, and their ology. causes have little immediate interest, whereas the structure of the wind is of vital importance. Since the publication of Langley's Internal Work of the Wind, this branch of meteorology has remained almost stationary, but in the year I 12 ithere was established at South Farnborough a new branch of the (British) Meteorological Office, acting in conjunction with the Advisory Committee on Aeronautics and the Royal Aircraft Factory, the chief function of which, in addition to supplying weather forecasts for the use of military aviators, is to carry on research work in what may be

'See E. B. i, 260 et seq. ("Aeronautics"), and x, 502, et seq. ("Flight and Flying"). 
termed "gust-meteorology." This work has already led to valuable results, more especially in recording the sudden deflections of the wind from the horizontal, and the relatively small area of gusts. Observations have also confirmed Langley's exposition of the structure of the wind as consisting of a series of rapidly succeeding gusts and lulls of approximately equal intensity; on rare occasions, however, a sudden increase or drop in the velocity of the wind may be sustained for several minutes, a phenomenon which has been held to explain one form at any rate of the aerial disturbances encountered by aviators and known as "holes in the air."

Recent aerodynamical research has largely substantiated in practice the former theories of air-resistance based on the general laws of fluid motion. In broad terms the

Aeroresistance of the air has been proved to vary directly as the area of the surdynamics. face opposed to it (with the necessary reservations regarding the shape of the surface), and as the square of the velocity of motion. The coefficient of air-resistance has further been laid down with accuracy; this coefficient, denoted by the symbol $\mathrm{K}$ in the case of a flat square plate placed normally to the wind, has a value of 0.075 in metric units, and of 0.00143 in British units (lbs., sq. ft.; ft. per. sec.). The fundamental equation of air-resistance (making due correction for the density of the air) therefore reads $\mathrm{R}=\mathrm{KSV}^{2}$. The variation due to the shape of the body is, however, very considerable; thus, in the case of a well-designed, curved aeroplane wing, the coefficient rises from 0.075 to 0.4 , and even more - a result due to the curve or camber of the wing and its large span. On the other hand; by adopting a shape approximating as nearly as possible to a perfect "stream-line" form, it is possible to reduce resistance to a very low figure, and this is now taken full advantage of in the design of all parts whose resistance to motion through the air impedes progress, as in the case of the hull of a dirigible, or the vertical struts of an aeroplane. Broadly speaking, therefore, recent research has led to a considerable increase of that portion of air resistance which, in the case of an aeroplane, is converted into the lifting force, and an important reduction of the detrimental portion of resistance, usually termed the "drift." Further experiment must lead to improvement of the ratio of the lift to the drift and involve corresponding modifications of design, which are already clearly foreshadowed.

The research work which constitutes the present basis of the science of aerodynamics has been carried out at various laboratories founded and supported either by private generosity and enterprise, or by the public funds. The chief of these Provision acrodynamical laboratories are those of M. Eiffel in Paris, the Aero-Technifor research, cal Institute founded by M. Deutsch at St. Cyr, the military laboratory at Chalais-Meudon, Dr. Riabouchinsky's institute at Koutchino in Russia, the laboratory of the University of Göttingen directed by Dr. Prandtl, and the new aeronautical branch of the British National Physical Laboratory at Teddington. The work of this latter institution, which was established in I9I0, has given particularly valuable results, due both to its exceptionally fine and complete equipment, and to the fact that its experiments are largely initiated and controlled by the Advisory Committee for Aeronautics, a body appointed by the British government under the presidency of Lord Rayleigh, in toro, whose reports are annually published in the form of a blue book. The equipment of this laboratory may serve as the general example of the methods whereby aeronautical research work is nowadays carried out. The principal part of the installation consists of two large wind tunnels in which scale models of the objects to be tested are suspended in a current of air drawn through the tunnel by an electric fan. Special care is taken to prevent the formation of eddies, pulsations and other forms of turbulence, and the speed of the air-current can be accurately regulated up to $50 \mathrm{ft}$. per second. The wind-tunnel is used to determine the air-resistance and pressure distribution on bodies of various shapes, from the hulls of dirigibles to the smallest portions of the structure of an aeroplane. A water channel, on a similar principle, provides the means for studying and photographing the flow of fluids past different forms of bodies. In a separate building is mounted a large whirling arm for testing models of propellers. In addition the equipment comprises machinery for testing the materials employed. 
Recent experiments having shown that the results of tests on scale models may be applied, in accordance with the known law of correspondence, to full-size machines, the work of the laboratory has become increasingly valuable and rendered superfluous the hazardous and often inconclusive experiments with full-size machines in flight.

While scientific experiment and research work have played a part of inestimable value in the development of aeronautics in general and of aviation in particular, this development has also called forth a new branch of engineering. In Great Britain the aeronautical engineering profession is represented by the Aeronautical Society, which grants Associate-Fellowship and Fellowship degrees of proficiency.

While both the aeroplane and the dirigible have made vast progress in recent years, the balloon, from its very nature, has reached the limit of its development and lost some Balloons. of its popularity in the face of the advance of the other forms of aerial navigation. From the military point of view it has been supplanted by motor-driven aircraft. For purposes of sport, however, the balloon remains in favour, stimulated to a great extent by the balloon races held in many countries. The following figures, representing the cubic feet of gas consumed for balloon ascents during the years I909, I9I0 and I9I 1 , in the four principal countries, reflect with fair accuracy the position of ballooning during recent times.

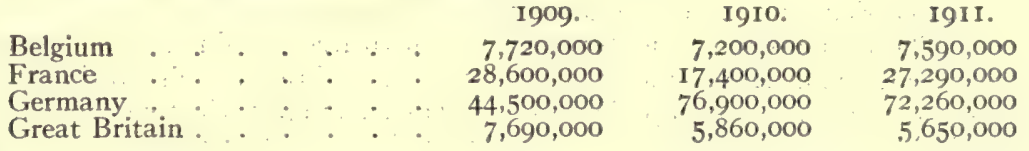

The chief sporting event of the year, the International Gordon-Bennett Balloon Race, in Igr 2 produced two new world's records. The race started from Stuttgart on October 27 th, and was won by M. Bienaimé; a French representative, who landed in Russia after having covered I,360 miles; M. Leblanc, the second French representative, also beating the former record by covering I,243 miles.

Some few years ago, in the face of questionable results and repeated disasters, it was commonly thought that the dirigible, too, had attained the limit of its development and Dirigibles. utility. But in recent years progress has been enormous in this direction. It is difficult to explain the reasons of this progress, save on the score of improvements in detail and in structural methods, based largely on accumulated experience. The one factor which, no doubt, has been chiefly responsible for the slow development of the dirigible has been that of expense. From its very nature, this type of aircraft is enormously costly, not only in the primary cost of materials, but in upkeep and by reason of the elaborate accommodation required for its harbourage. While an acroplane is practically independent of a fixed base, a dirigible requires vast halls for shelter, since, once on the ground, it becomes, in default of suitable harbourage, the prey of the least gust of wind. Nevertheless, the enormous progress realized with this type of aircraft, and its indubitable advantages, which an aeroplane can never possess, have rendered it a military instrument of potent value.

The three types of dirigibles which have always existed have been developed, each according to its special nature and purpose, to a high degree of efficiency during recent years. Their classification is based on their structural nature: the rigid, in which the hull consists of a rigid wood or metal skeleton, wherein the gas envelopes are contained; the non-rigid, forming in effect an elongated motor-driven balloon, comprising no rigid members or frameworks of any kind; the semi-rigid, a type intermediate between the previous two, in which the lower part of the hull is strengthened by a rigid framework forming the point from which the car is suspended and to which the organs of direction and control are attached. The latter type, however, is tending to disappear and to become absorbed in that termed non-rigid. The relative advantages of the three types are expressed in their denominations. The two a ms pursued by designers are speed and lifting-power. The former object demands considerable structural strength to resist the high air pressure exerted upon the hull at high speeds. . The rigid type of craft, 
consisting of a rigid indeformable framework, possesses a considerable degree of strength, moreover, the cars containing the engines, the propellers and the controlling organs, can be rigidly attached to the hull and in close proximity thereto; so that the rigid dirigible realises most nearly that ideal condition wherein the centres of resistance and propulsion coincide. On the other hand, the rigid framework implies a great increase in weight; hence a rigid dirigible must necessarily be of large size. Again, it can only be deflated slowly, so that in case of accident or involuntary landing, it always stands in danger of destruction by the wind. Lastly, being incapable of being transported, it can only act from a fixed base. The non-rigid type, on the other hand, while it can be easily deflated and transported, is of inferior structural strength and efficiency, for its gas-containing hull is constituted by fabric-the shape being maintained by keeping the gas under a pressure in excess of that of the surrounding atmosphere-while the propelling plant and controlling surfaces must be situated in or near the car.

The rigid dirigible, which owes its development chiefly to Count von Zeppelin, has realised the more important progress. The last Zeppelin dirigible built before the end of I9I2, and acquired by the German navy, possessed a volume of 776,000 cubic feet divided into I 8 gas compartments; its length was 525 feet, its diameter 49 feet; driven by three motors developing 5 ro total horse-power, it was capable of a speed of 52 miles an hour, and carried a useful load of approximately 7 tons, sufficient to provide fuel for 96 hours. The framework of the Zeppelins is constituted by aluminium girder work. In the Schüte-Lanz dirigible, and in the recent French dirigible built to the designs of M. Spiess, the skeleton is built up of wood. As passenger craft, the two Zeppelin dirigibles owned by a private German company, rendered an excellent account of themselves during the year I9I2, making over 300 ascents and carrying about 5,000 passengers.

Both the French and German armies possess a considerable fleet of dirigibles, the numbers of efficient vessels being, at the end of 1912 :

Rigid. Semi-Rigid. Non-Rigid. Total.

$\begin{array}{lllllll}\text { Germany } & 5 & 3 & 5 & 13 \\ \text { France } & \vdots & 3 & 8 & 12\end{array}$

In addition both countries possess several privately-owned airships, available for emergency service, which bring the German and French flects up to 25 and 21 units respectively. Further, both countries possess a large number of permanent airship stations, situated principally in strategical centres. During manoeuvres of recent years, and during the Tripolitan war in $19 I^{1-12}$, military dirigibles took part with good results and demonstrated their special adaptability for night-work, for detailed observation over long distances, and for maintaining uninterrupted communication with their base by means of wireless telegraphy. In Great Britain progress has been comparatively slow. Three small dirigibles built at the Royal Aircraft Factory for experimental purposes have only proved partially successful, while the rigid dirigible constructed for the Navy at Barrow was wrecked by the wind in I9 I on its first appearance in the open. These failures were followed by the British Government ordering, for the use of the Navy, a German dirigible of the Parseval system and a French dirigible of the Astra-Torres type, towards the end of ror 2.

The wonderful progress in aviation during the last two years, and its transition from the experimental to the practical stage has been due principally to the improved aerodyAeroplanes. namical knowledge resulting from scientific research work previously alludAeroplanes. ed, to and, though in lesser degree, to the increased skill and experience of aeroplane pilots. In essential principles no radical alteration has taken place since the days of Wilbur and Orville W'right, and the early Fench experimenters. By the side of improvements in details of design, highly improved methods of construction have contributed to increase the efficiency, reliability and safety of the aeroplane to a vast extent.

Most noteworthy of morlern technical features in aviation are the gradual introduction of steel where wool was the constructional material a most exclusively used a few years ago, the substitution of a long covered-in body, forming the back-bone of the 
aeroplane and enclosing both the engine and the passengers, for the simple open framework of former days, and a considerable improvement in stability. In consequence, the aeroplane in which the propeller revolved in the rear of the planes has been largely replaced by the type known as the "tractor," in which the engine, mounted in the bow of the body, drives by direct transmission a propeller rotating in front of the planes. Generally speaking, the above features apply both to monoplanes and to biplanes, the former type consisting of a single plane or pair of outstretched wings, whereas in the latter two lifting planes are superposed and interconnected by struts. The relative advantages of these two main types are chiefly constructional; the girder shape of the framework rendering the structure stronger in the biplane, and leading to its general employment where heavy weights have to be carried. In the case of a monoplane, the wings are stayed by means of steel wires or cables attached to the landing chass.s and to an overhead staymast, an arrangement which, while reducing head resistance, presents obvious engineering difficulties of a constructional nature. The controlling surfaces are usually situated in the tail, fixed to the after end of the body; they consist of an ordinary vertical rudder for steering in a horizontal plane, and of a horizontal rudder or " elevator" for steering upwárds and downwards and for maintaining longitudinal balance. Lateral stability is usually controlled either by the process originated by the brothers Wright and known as "warping" the planes, i.e. twisting their rear outer extremities to produce an increase in lift on the lowered side and to reduce the lift on the raised side, or by the equivalent means of operating balancing flaps attached to the rear edge of the planes or mounted in between them.

Two further distinctive features mark the recent development of aviation: the vastly increased reliability of the aeroplane motor and the evolution of the hydro-aeroplane, Motors. by which is denoted a craft able to rise from and alight upon the surface of the water. Two distinct types of aeroplane motors have been created, the rotary air-cooled engine and the water-cooled stationary type, of which the former, generally speaking, is most effective for comparatively low powers, while the latter is usually employed for the heavy passenger-carrying class of aeroplanes. The power developed ranges from 25 h.p. in a small school machine to 140 h.p. in a racing aeroplane, or one designed for extended flights. These motors, with the exception of the rotary type, show little difference from the average motor-car engine, save only in a considerable reduction in the weight, which ranges from 2 to $6 \mathrm{lbs}$. per horse-power.

The hydro-aeroplane owed its first development to the American, Glenn Curtiss, who equipped his aeroplanes with floats as early as I9Io. Two main types have already been evolved, though with countless modifications. In the first the only feature Hydro-
aeroplanes. substitution of one or more floats for the ordinary landing chassis, though this is sometimes retained in the shape of disappearing wheels. The second class, variously termed "flying-boat" and "air-boat," consists essentially of a long boatshaped hull, wherein the passengers' seats are contained, and on which the planes are built up in the form of a superstructure. This latter type of craft seems destined to a greater sphere of utility than the former, by reason of its being better able to withstand the battering of waves and the shock of alighting on rough water. General technical opinion foresees a greater future for the marine aeroplane than for the terrestrial type, owing to the fact that it can be used in the colonies and in undeveloped countries where suitable alighting grounds are scarce; while, on the other hand. it would solve the difficulty and danger of alighting in a heavy high-speed aeroplane.

In the sport of aviation, as evidenced in the record of performances during the last two years, progress has been startlingly rapid. The year IgI I was marked by the organisation of a series of long-distance cross-country races, among the

The

sport of

aviation. England with Paris as the starting and finishing point; and the 1000 miles circuit of 
Britain which was won by A. Beaumont, who beat J. Védrines by one hour in $22 \frac{1}{2}$ hours' net flying time. In the same year the International Gordon-Bennett Aviation Cup was won by C. Weymann on a roo-h.p. Nieuport monoplane at a speed of 78 m.p.h. In I 19 I 2 the same race was won by J. Védrines on a I40-h.p. Deperdussin monoplane at I0 $5 \frac{1}{2}$ m.p.h., which formed the world's speed record at the end of IgI 2 .

In other respects performances have been no less remarkable. On December II, IgI 2, at Tunis, R. Garros created a world's altitude record by ascending to I 9,000 feet. On September i ith of the same year, G. Fourny established the latest record for a continuous flight, by covering 627 miles in $13 \mathrm{~h}$. I 7 min. The longest flight across-country on a single day was made by P. Daucourt, who flew from Valenciennes to Biarritz, a distance of 530 miles, on October 27, I9I2. A new British duration record was established on October 24,1912 by H. G. Hawker, who, piloting a Sopwith biplane, remained in the air for $8 \mathrm{~h} .23 \mathrm{~min}$.

But the significance of these achievements fades before the truly wonderful development in the aeroplane from a military point of view. In I9I 2 aviation was definitely Use in war.' introduced, as a new arm, into the establishment of all the great armies. The first impetus to this movement was given by France, where aeroplanes have been employed in the army manoeuvres for several years past. Under the aerial law passed in March I9I2, the aviation establishment of the French army numbered, at the end of I I I 2, a total of 344 effective aeroplanes divided into 43 sections, distributed on a territorial basis, 234 efficient pilots, an equivalent number of trained observers and 2,200 men. Since then, the number of army aeroplanes has been considerably increased as a result of a popular subscription which realised over $f 100, \infty \infty$ in twelve months. The French budget for the same year included a vote of $£ 880,000$ for military aviation.

In Great Britain an effective forward step, on similar lines, was made in I 9 I 2 by the creation of the Royal Flying Corps. This body forms a separate entity from cither of the two services, from both of which its members are recruited. It comprises a Military Wing and a Naval Wing, each divided into sections of 8 aeroplanes. The chief training centre is situated at the Central Flying School at Upavon, and its main depot at the Royal Aircraft Factory at Farnborough. At the end of 1912, the establishment of the Military Wing consisted of one airship and kite section, and three aeroplane sections, the personnel and material of which, however, were not complete. Greater progress had then already been achieved by the Naval Wing, which had at the end of the year established flying stations on the Isle of Sheppey, at Rosyth and in the Humber. In I 12 the acroplane was first employed in actual warfare, by the Italians in 'Tripoli and by the Balkan states and the Turkish army in the Balkan war. In both cases, however, though valuable services were rendered, the results were somewhat inconclusive, owing to the absence of serious opposition in the first case and lack of organisation in the second.

That the aeroplane will be called upon to play a part of ever-increasing importance in warfare of the future is no longer open to doubt; but for the present its function appears to be confined to scouting and reconnaissance, both tactical and strategical, experiments with bomb-dropping having proved ineffectual hitherto.

The active and industrial development of aviation is clearly shown in the following list of aeroplane pilots at the end of the years 1910 , I9I I and IgI 2, the figures for the latter year being approximate only:

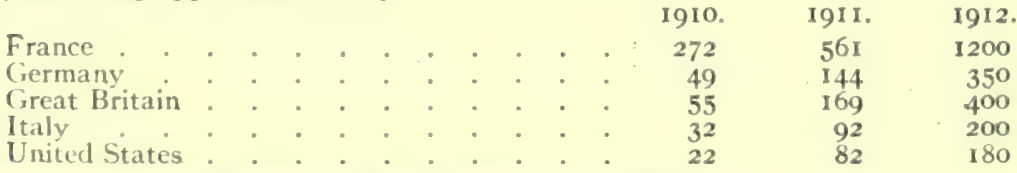

Military pilots are not, however, in all cases included in the above list. 


\section{SHIPS AND SHIPBUILDING 1}

Prosperity and disaster combined to make the years I9IO-I 2 very notable in the annals of British shipbuilding. The output of Merchant Ships in the United Kingdom in I II reached I, 803,844 tons-almost double that of I 908 ; and of this total, I, 400,000 tons were for United Kingdom owners, 60,000 for British Colonial, and 344,000 tons for foreign owners, as shown in Column 2 of Table I. In addition 695,300 tons of shipping were sold abroad. The world's output in IgII exceeded $2 \frac{1}{2}$ millions, as in Col. 3 . Glasgow, Newcastle and Sunderland districts each reported more than Germany; Greenock and Belfast more than the United States; Middlesbrough and Hartlepool more than France. Notwithstanding large additions the total tonnage (Col. 5) increases but slowly, as the annual reduction due to vessels being broken up, lost, etc., amounts to about 900,000 tons, including 350,000 tons British Shipping. Table I also shows the relation between Merchant and War shipbuilding in I9I I, Col. 6 the amount launched in each country, and Col. 7 the portion thereof for foreign owners.

Table I. Shipping of Various Countries (in thousands of tons).

\begin{tabular}{|c|c|c|c|c|c|c|}
\hline \multirow[t]{2}{*}{. } & \multirow{2}{*}{$\begin{array}{l}\text { Ownership } \\
\text { of U. K. } \\
\text { output in } \\
\text { I9I I }\end{array}$} & \multirow{2}{*}{$\begin{array}{l}\text { World's } \\
\text { output in } \\
\text { I9II }\end{array}$} & \multicolumn{2}{|c|}{$\begin{array}{l}\text { World's Shipping } \\
\text { in } 1912\end{array}$} & \multicolumn{2}{|c|}{$\begin{array}{l}\text { Warships built } \\
\text { in I II I }\end{array}$} \\
\hline & & & Numbers & Tonnage & Total & $\begin{array}{l}\text { For } \\
\text { others }\end{array}$ \\
\hline $\begin{array}{l}\text { (I) } \\
\text { United Kingdom } \\
\text { Dominions and Colonies }\end{array}$ & $\begin{array}{r}(2) \\
1,400 \\
60\end{array}$ & $\begin{array}{r}(3) \\
1,804 \\
20\end{array}$ & $\begin{array}{l}(4) \\
9,279 \\
2,165\end{array}$ & $\begin{array}{c}(5) \\
18,214 \\
1,660\end{array}$ & $\begin{array}{c}(6) \\
23 I \\
2\end{array}$ & $\begin{array}{l}(7) \\
9 \\
\cdots\end{array}$ \\
\hline Total $: \quad \therefore \quad:$ & $\mathrm{I}, 460$ & $\mathbf{I}, 824$ & $I I, 444$ & 19,874 & 231 & 9 \\
\hline $\begin{array}{l}\text { U. S. A.:- } \\
\text { Seaboard \&c. } \\
\text { Great Lakes : }\end{array}$ & $\therefore$ & $\begin{array}{l}96 \\
76 \\
\end{array}$ & $\begin{array}{r}2,820 \\
622 \\
\end{array}$ & $\begin{array}{l}2,899 \\
2,359\end{array}$ & 116 & $\begin{array}{c}5^{8} \\
\cdots\end{array}$ \\
\hline Total & $\cdots$ & $17^{2}$ & 3,442 & 5,258 & 116 & $5^{8}$ \\
\hline $\begin{array}{l}\text { Germany } \\
\text { Norway } \\
\text { France } \\
\text { Italy } \\
\text { Japan } \\
\text { Holland } \\
\text { Sweden } \\
\text { Russia } \\
\text { Austria } \\
\text { Denmark } \\
\text { Spain } \\
\text { Greece } \\
\text { Other Countries }\end{array}$ & $\begin{array}{l}21 \\
90 \\
17 \\
9 \\
20 \\
27 \\
19 \\
13 \\
51 \\
15 \\
5 \\
13 \\
44\end{array}$ & $\begin{array}{r}256 \\
35 \\
125 \\
17 \\
44 \\
93 \\
9 \\
3 \\
38 \\
19 \\
4 \\
10 \\
\end{array}$ & $\begin{array}{r}2,213 \\
2,132 \\
1,491 \\
1,090 \\
960 \\
701 \\
1,409 \\
1,207 \\
395 \\
829 \\
590 \\
433 \\
1,980\end{array}$ & $\begin{array}{r}4,629 \\
2,293 \\
2,053 \\
1,399 \\
1,345 \\
1,130 \\
970 \\
937 \\
993 \\
757 \\
772 \\
668 \\
1,612 \\
\end{array}$ & \begin{tabular}{l}
132 \\
59 \\
75 \\
37 \\
.6 \\
$93^{-4}$ \\
20 \\
1 \\
3 \\
\hdashline \\
1
\end{tabular} & $\begin{array}{l}3 \cdot 6 \\
\because 4.7 \\
: 3 \\
: 4 \\
\cdots \\
\cdots \\
\cdots \\
\cdots \\
\cdots \\
\cdots \\
\cdots\end{array}$ \\
\hline Total $\quad \therefore \quad \ldots$ & 1,804 & 2,650 & 30,316 & 44,600 & 769 & 76 \\
\hline
\end{tabular}

The United States output fell to I72,000 tons in I9II. The amount building fell from I30,000 tons in June I9I0 to 97,000 tons in June I9II, but increased to 215,000 tons by October I9I 2, due to the construction of vessels to engage in traffic through the Panama Canal. The last three years have seen rapid increases in Germany: the total for I9II-255,532 tons-was however still 63,000 tons less than the record made for that country in I906. The tonnage under construction rose to 467,700 tons in October I9I2 (see also Count Reventlow, Cassier's Mag., December I9II). The output of France in thousands of tons has been as follows: (I802) I7; (I902) I92; (Ig06) 35; (IgIO) 8I; (IgII) I25; but since March IgII building has remained fairly steady at about 120,000 tons. The output of Holland continues to increase; in October I 12 I 2 she

${ }^{1}$ See E. B. xxiv, 867 et seq. 2 2 The statistics are based on Lloyd's Register of Shipping. 
had 103,000 tons building, a number of vessels being equipped with I. C. engines, using suction gas and light and heavy oil fuels.

Lloyd's Register shows that in I9I 2 there were II British, 35 German, ir American, and 20 other vessels of over 10,000 tons, and on September 3 oth 36 such vessels were being built in the United Kingdom. The largest British vessel afloat in 19r 2 was the "Olympic," $852.5 \mathrm{ft}$. long, $92.5 \mathrm{ft}$. beam, 45,300 tons gross, 52,300 tons dispt. at $34 \mathrm{ft}$. 7 in. draught, 55,000 H.P. and $22 \frac{1}{2}$ knots speed (for description and drawings see Shiphuilder, IgII); but " Aquitania," building by John Brown \& Co. of Clydebank for the Cunard Co., "Britannic," building by Harland \& Wolff for the White Star Co., "Imperator" and two similar vessels building at Hamburg, are all larger still (see Sir William White on "Maximum Dimensions of Ships," Am. Soc. N. A.; and Foster King, Int. Mar. Congress, IgrI). Among German ships, the "Imperator" (Hamburg-American line), launched May 23, I 9 I 2 , is $88 \mathrm{I}$ feet long, 96 feet beam, $65 \mathrm{ft}$. depth, about 5I,000 tons gross, has accommodation for over 4,000 passengers and I, $200 \mathrm{crew}$, is fitted with Parsons turbines of 60,000 H.P., driving 4 screws at 185 revs. per min., and a speed of $22 \frac{1}{2}$ knots is expected. One vessel of 35,000 tons and five of $16-19,000$ tons are also being built in Germany. The largest Dutch vessel (being built at Belfast for Holland-Amerika Line) is $740 \mathrm{ft}$. long, 32,500 tons, has combination T. and R. engines for 17 knots, and will carry 3,600 passengers. The same firm has in hand the "Ceramic" of 18,000 tons for the White Star Australian service. The "France," the largest French vessel (Comp. Gen. Transatlantique) is $68 \mathrm{gt}$. long, $75.6 \mathrm{ft}$. beam, $53.4 \mathrm{ft}$. depth, 23.666 tons gross, has turbines of 45,000 H.P., for 24 knots speed, carries I926 passengers and a crew of 600 , and is now the fastest foreign vessel on the Atlantic. The Austrianbuilt “Kaiser Franz Josef I," 477.5 ft. long, I 2,567 tons, I 3,000 H.P., I 9 knots, carrying 2,000 passengers, is the largest Austrian vessel. The largest Spanish vessel, the " Reina Victoria Eugenia," built by Swan, Hunter \& Co., is $480 \mathrm{ft}$. long, $6 \mathrm{I} \mathrm{ft}$. beam, 32.7 ft. depth, I0,000 tons gross, I0,000 H.P., $17 \frac{1}{2}$ knots speed. The Allan liners "Alsatian" and "Calgarian," being built for the Canadian Atlantic service, are $570 \mathrm{ft}$. long, 18,250 tons, and 21,000 H.P. for 18 knots sea speed. The "Empress of Russia," and "Empress of Asia," built by Fairfield for the Can. Pac. service between Vancouver and Japan, are $590 \mathrm{ft}$. long, $68 \mathrm{ft}$. beam, $46 \mathrm{ft}$. depth, $\mathrm{I} 5,000$ tons gross, 20 knots trial and I $8 \frac{1}{2}$ knots sea speed, carry I, I00 passengers and $475 \mathrm{crew}$, and will replace the original "Empress" vessels of 6,000 tons in that service. The "Niagara," built by John Brown \& Co., for the Union Shipping Co. of New Zealand for service between Vancouver and Australia, is $522 \mathrm{ft}$. long, $66 \mathrm{ft}$. beam, $37 \frac{1}{2} \mathrm{ft}$. depth, I 3.500 tons, I 2,000 H.P., carries 667 passengers and a large cargo. The Japanese liner "Shinyo Maru," of 13.377 tons and 18,500 H.P., turbines as well as hull built in Japan, has been completed (sister vessel to "Tenyo Maru;" see E. B. xxiv, 887, and I.N. A. I gr I).

The "Medina" (P.\&O.), which on her first voyage (November IgII) took King George and Queen Mary to India for the Durbar, is I 2.358 tons and $18 \frac{1}{2}$ knots speed. The "Balmoral Castle" (Union Castle line), which took the Duke of Connaught to the Cape on her first voyage in $19 \mathrm{I} \mathrm{I}$, is $\mathrm{I} 3,36 \mathrm{I}$ tons and of $\mathrm{I} 8 \mathrm{knots}$ speed. The "Cape Finisterre," I 4,503 tons, I 7 knots, of the Hamburg-South Amerika Line; the "Arlanza," I 4,760 tons, I6 hnots, of the Royal Mail Fleet; the "Orama," I 2,927 tons, I 8 knots, of the Orient Fleet; and the "Cameronia," ro, 063 tons, I 7 knots, of the Anchor Line, are other examples of the new ships of increased size and power recently added to other well known lines and in most cases still larger vessels are on order.

The "City of Detroit," 6,06r 'ons gross, the largest Great Lake passenger boat (see Int. Mar. Eng. October I I 2), is similar in type to the "City of Cleveland" (E. B. xxiv, 88.3). The "Col. J. M. Schoonmaker" of 8,603 tons, $6 \mathrm{I}_{7} \mathrm{ft}$. long over all, $64.2 \mathrm{ft}$. beam, $34.2 \mathrm{ft}$. depth, 2.600 H.P., launched in 1012 , carrying 13,200 tons at Io knots, and her sister vessel are the largest Lake freighters yet built.

Recently a great demand has arisen for vessels to carry oil in bulk, and 90 such vessels, exceeding 500,000 tons gross, were being built in November 1912, nearly all under the survey of Lloyd's Register, about $\frac{2}{3}$ rds being for British owners and four for the 
British Admiralty. Ten of them are about $525 \mathrm{ft}$. long, $66 \mathrm{ft}$. beam, $34 \mathrm{ft}$. depth, ro, 000 tons gross, I 5,000 tons D.W.; seventeen are being built in the U.S.A. The "Gulfoil," built by the New York S.B. Co., is $392 \mathrm{ft}$. long, 5 I ft. beam, $30 \mathrm{ft}$, depth, 5, I 88 tons gross, constructed on the longitudinal system and fitted with $\mathrm{T}$. E. engines for ro knots. (For details see Montgomerie, Cassier's Mag., December I9I I.)

Propulsion.-The total Horse Power of machinery afloat is about $26,000,000$. The adoption of the turbine has been much more general for naval $\left(7,200,000\right.$ H.P. $\left.{ }^{1}\right)$ than for commercial vessels $\left(1,300,000 \mathrm{H} . \mathrm{P}^{1}\right)$, but $\mathrm{I}_{5}$ vessels of $100,000^{1} \mathrm{H}$.P. have now been built (chiefly commercial) having high speed turbines and mechanical gearing. This system has proved to be convenient and efficient in cargo steamers ("Vespasian "; I.N.A. I III), also in light high speed vessels of the cross-Channel type, as in the "Hantonia" and "Normannia," built for the S.W. Railway Co.'s service between Southampton and Havre, which showed an economy of about 20 per cent compared with that Company's direct turbine ships "Caesaria" and "Sarnia" built a year before (Prof. Biles, I.N.A. I912). Increasing numbers of vessels are being fitted with a combination of reciprocating engines and turbines: the "Laurentic," "Olympic," "Niagara" and "Arlanza" are fitted with three, the "Rochambeau" (see Engrg., Nov. 22, I9I2) and "Britannic" with four propellers; the large Spanish liner "Reina Victoria Eugenia" will also have four, while the sister "Infanta de Borbon," built by Denny, will have three screws and will thus afford an interesting comparison; all these vessels have reciprocating engines on two shafts.

In the "Aquitania," "Imperator," "France," "Empress of Russia," and some other large high powered vessels, turbines are fitted on four shafts; a high-pressure turbine is fitted on each wing shaft, the steam passing to an intermediate turbine on the opposite wing shaft and thence to a low pressure turbine on one of the inner shafts, thus giving three expansions.

The American navy is carrying out a great experiment in propulsion in three large colliers, each of about 20,000 tons displacement, 6,000 H.P., I4 knots speed, I 2,000 tons cargo. The "Jupiter" has one Curtis turbo-generator, 2,000 revs., giving alternating currents at 2,200 volts, and motors driving two propeller shafts at I Io revs., reported engine weight 156 tons, compared with 280 tons in the "Cyclops," which has two reciprocating engines. The "Neptune" has steam turbines and Westinghouse floating frame mechanical gearing (Engineering, August. 23d and September 20th I9I2). See also Mavor, Brit. Assoc. Igr I-12: Emmet, Am. Inst. Elec. Engrs. I9I I: Durtnall, I.N.A. r9ro and Soc. of Engrs. November 19r2: and Catterson-Smith, Liverpool Eng. Soc. I9I2, concerning proposals for Electric Ship Propulsion. Increasing numbers of vessels, including U.S. battleship "Nevada" and one of the 6,000 H.P. Japanese cruisers, are being fitted with Brown-Curtis turbines, and the Rateau, Zoelly and German turbines are making good progress in European countries.

Great advances are being made by connecting a high speed turbine to a slow running propeller by means of the Föttinger transformer, up to I8,000 H.P. (Föttinger, I.N.A. I9I2), very great savings in space, weight, and fuel consumption being obtained as with mechanical gearing, but with an efficiency of about $90 \%$ compared with $98 \%$ for Parsons's gearing. The economy and convenience of the turbine for all classes of vessels has now been well established. Sir Charles Parsons has stated (I.N.A. I gI2) that with oil-fired boilers, superheated steam (see Yarrow, I.N.A. I9I 2), and a proper arrangement of mechanical gearing, the consumption of fuel can be brought down to .6 lbs. per I.H.P. per hour, compared with .44 for I. C. Engines. "The Unaflow Steam Engine" (Constable \& Co.) describes a new type of reciprocating engine invented by Prof. Stumpf of Charlottenberg and fitted up to $\mathrm{I}, 000 \mathrm{H}$. P. in small vessels.

The use of oil for fuel under boilers continues to increase (the latest U.S. battleships will burn oil only), and the development of the I. C. engine for ship use is proceeding very rapidly (see Milton, I.N.A. I912). Lloyd's Register reports that, in Sept. 1912, 34 vessels were being built with I.C. engines, 23 being above 2,000 tons gross.

${ }^{1}$ These figures refer to Parsons turbines only. 
For modern developments of the Marine Steam Engine, and comparative possibilities of I.C. engines, see Hamilton on "Steamship Propulsion," Liverpool Eng. Soc., I91 I; HallBrown, Inst. Eng. and Ship. Scotland, I9I ; Anderson, American Soc. N. A., I9I I Rosenthal, Brit. Assoc., I91 I; Orde, Parsons, and others, N. E. Coust Insin., 1912; Dr. Diesel, Inst. M. E., 1912; and Sir Chas. Parsons's address to N. E. Coast Instn., October 12, I912.

The Motor Ship of September 26, I9I2 published a list of 32 vessels then under construction in which heavy oil (Diesel) engines were being fitted, the aggregate H.P. being 59,600 and average 1870; 17 were single-acting, four-stroke reversible; 9 were singleacting two-stroke reversible; three were of Junker's type; two were single-acting fourstroke non-reversible; and one only double-acting, - a two stroke M.A.N. engine for a Woermann liner by Messrs. Blöhm and Voss (See Engineer, October I I, I9I2). The non-reversing engines are for the "Tynemount" (see Mavor, Brit. Assoc., IgII and I9 I 2) of 600 H.P., and g knots, having electric transmission gear giving 80 revolutions of the propeller for 400 revs. of the engines, and a shallow draught vessel of $\mathrm{I}, 300 \mathrm{H}$.P. for service on the Congo, in which the engines run at 280 revs. and Föttinger tzansformers are fitted to drive the propellers at 440 revs., giving the boat a speed of $15 \frac{1}{2} \cdot k n o t s$. The largest engines named are of 6,000 H.P., and are for a twin screw vessel of 8,000 tons gross and 16 knots speed to be built by Barclay, Curle \& Co.

Motors of various powers have been fitted as auxiliaries in numbers of sailing vessels; the large French sailing vessel "France," of 6,500 tons D.W. capacity, has I.C. engines of $\mathrm{I}, 800 \mathrm{H} . \mathrm{P}$. and twin screws for ro knots. Motors are being fitted in rapidly increasing numbers of river steamers (see Syren and Shipping, August 21, I912), river tugs (see Motor Boat, March 9, I9Ir), lifeboats (see Int. Com. Eng., October 2, I91 2), fishing craft of all descriptions (see Report of Fishery Board for Scotland, I912), as well as in small coasting vessels, of which eighteen are being built in Scotland for one firmthe Coasting Motor Shipping Co. Lloyd's Register of I9r 2 includes 6r yachts of 3,733 tons having I.C. engines, and indicates a falling off in the building of large steam yachts.

Table II contains some particulars of a few of the earliest motor ships fitted with Diesel Engines of various types:-

Table II.

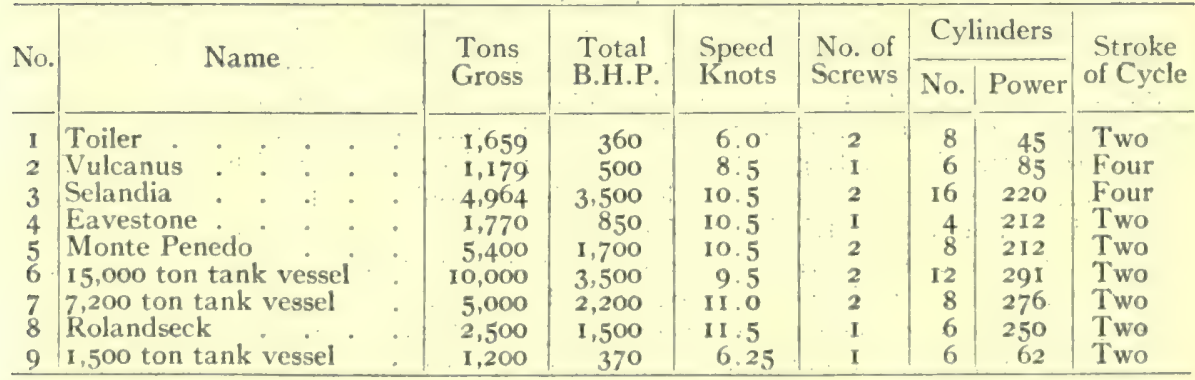

Notes. (1) First motor ship to cross the Atlantic, built by Swan, Hunter \& Co. for Canadian Lakes; Polar (Swedish) engines; estimated saving on machinery, 60 tons; fuel about 2 tons a day instead of 8 (sec also Engineering, May 5, 1911; similar engines 520 H.P. in Calgary, and 1600 H. P. in tanker building by Caledon Co.) (2) First seagoing motor vessel regularly employed in European waters, built in Holland for Anglo-Saxon Petroleum Co. Werkspoor (Dutch) engines. (I.arger engines of same type in "Juno," "Emanuel Nobel," "L.ourton," "Eburna" and "Jules Henry;" and smaller in "Sembilan," "San Antonio" and "Cornclis"). (3) First large ocean-going motor ressel, built at Copenhagen, Burmeister and Wain (Danish) engines. Sister vessels- "Jutlandia," first British-built ocean-going motor vessel, and "Fionia," purchased by Hamburg-American Co. renamed "Christian X" in honour of King of Denmark, and the first motor ship to arrive in New York. (4) First British owned ocean-going motor vessel, built by Sir Raylton Dixon \& Co. for Furness, Withy \& (o. Carels (Belgian) mahinery, reported to be 68 tons less than if steam, and fuel for 30 days 120 tons oil instead of $450^{\circ}$ tons coal, gain of a knot speed (see also Engineer, Oct. 25, 1912). Similar engines 750 H.P. in "Fordonian." (5) Built at Hamburg, Sulzer (Swiss) engines, total engine room weights 160 tons or less than half for steam engines, fuel consumption about one third, engine room complement half for steam machinery (see Int. 


\section{SHIPS AND :SHIPBUILDING}

Mar. Eng., Oct. 1912).

(6) The largest oil tanker yet built, to carry 15,000 tons D. W., Krupp (German) engines, $527 \mathrm{ft}$. long, $66 \mathrm{ft}$. beam (see also Engineering, April 19, 1912). (7) To carry 7200 tons D.W. building by Frerichs \& Co., Germany, for British ownersthe Petroleum Steamship Co. The Junkers (German) engines are of peculiar construction, two pistons in each cylinder, the fuel being ignited between them (Junkers, German Soc. N.A., I9II, and Int. Mar. Eng., July I912), (8) Cargo boat for Hansa line. TecklenborgCarels Engines, largest I. C. Engine yet afloat, viz. I500 B.H.P., cylinders $19 \frac{1}{2}$ inch diam., $35^{\prime \prime}$ stroke, II 15 revs. on one shaft. (9) To carry 1500 tons. First American Diesel-engined commercial vessel. M.A.N. (German) engines. Ship constructed by Staten Island Shipbldg. Co., and engines by the New London Ship and Engine Co. of Groton, Conn. (see Motor ship, June 6, I912).

Suction gas plants have been installed in two small experimental vessels, the "Electric Arc," in conjunction with electric drive (see Shipping World, January 3, I9I 2), and "Holzapfel I," in conjunction with Föttinger transformers (see Holzapfel, I.N.A. I9I 2). In both cases after a period of trial the plant has been removed. An auxiliary surveying vessel launched by Napier and Miller in IgI 2 is fitted with suction gas plant and a six cylinder 225 B.H.P. gas engine. In Cas and Oil Power, October 3, I9I2, an account is given of a roo H.P. engine by Mr. A. M. Low which runs on solid coal direct; and the case for alcohol fuel is stated in "The Motor," August 27, I9r 2.

Many firms are perfecting the Diesel engine for marine purposes (see Engineer, October i8, I912, for German ), and others are using Gas turbines to obtain the advantages of the low consumption of the $\mathbf{I}$. C. engines without reverting to reciprocating machinery (see Dugald Clerk and Hans Holzwarth, Brit. Assoc. I9I2).

Improvements.-For a review of 50 years progress see Dr. Thearle, I.N.A. I9I 2. Recent methods for ensuring sufficient strength with increased cargo capacity or speed comprise (I) a development of longitudinal construction, (2) raising the middle portions of the ship on arches, (3) forming fore and aft ridges in the side.

Details of (I) were given by Mr. J. W. Isherwood, I.N.A. I908. Clearer holas, greater strength and a saving of about $10 \%$ of weight of structure, are obtained, as well as decreased cost of building. The system has been adopted for three-fourths of the tank vessels now building, as well as for many other types of vessels in Europe and U.S.A. (see Cleveland, Marine Review, September 1912; also Standard, October 23, I91 2). The system had been adopted in 43 vessels of 176,000 tons by June I9Io, rapidly increasing to about 250 vessels of $1,200,000$ tons by December I9I2. (2) The "Arch" system of construction was described by Mr. Maxwell Ballard at the Institute of Naval Architects in I9I I (see also Shipping World, April 27, roro). Three vessels of I,500-2,000 tons each have been already built on this system, and two others were under construction at the end of rgr2. (3) The " Monitoria," built in I909-10, was the first vessel built with "corrugated sides" and gave the name to the system isee papers by Mr. Haver, N.E. Coast Inst. I9ro and I9I I, and Captain MacIlwaine, R. U.S. Inst. r912). Four vessels of the type were afloat at the end of I9I2, and three others under construction, all of about 3,000 tons D.W. capacity.

Anti-rolling tanks (see E. B. xxiv, 938; Watts, I.N.A. 1883-5; and Frahm, I.N.A. I9I I) are now being fitted in many large liners and war ships. Large chambers built on opposite sides of the ship are about half filled with water, a transverse water channel connecting the lower parts of the tanks, and air pipes the upper parts. Valves in the air pipes regulate the movement so as to prevent synchronism with wave periods and consequent rolling. Tanks were so fitted in the "Inflexible" and other warships of very large metacentric height 30 years ago, and proved very useful, but the practice has not been continued in later war vessels where smaller metacentric height is practicable (see also "Effect of Bilge Keels on Rolling," Messrs. Idle \& Baker, I.N.A. I9r 2; and "Applied Stability of Ships,":Heck, Inst. Mar. Engrs. Oct. I91 2).

Increasing attention is being given to the study of Naval Architecture and Marine Engineering in Germany and America as well as in England. Chiefly owing to the advocacy of Sir W. H. White and the generosity of Mr. A. F. Yarrow, a national experimental tank has in England been provided at Bushey. There is evidence of increased power of adaptability of designers to produce vessels specially fitted for the trades on 
which they ply, and of greater readiness on the part of the Classification Societies to regard such designs on their merits without too hard and fast adherence to well worn rules. It is a compliment to Great Britain that the Austrian Veritas Society has arranged with Lloyd's Register to adopt their Rules for building ships in their entirety, and that authorised translations in French and German have become necessary.

The "Titanic" Disaster.--Notwithstanding great progress recent years have been notable for serious disasters, such as the disappearance of the "Waratah" in I go9, the wrecks of the "Delhi" and "Oravia " and the sinking of the "Oceana" in IgI 2 , but the foundering of the "Titanic" in mid-ocean on April I5, 1912, after collision with an iceberg, when out of 2,224 persons on board only 7 II were saved, has eclipsed all previous experiences, and has led to much searching of heart as to means of providing better security. Enquiries were conducted in New York under Senator W. A. Smith of Michigan, and in London under Lord Mersey sitting as Wreck Commissioner with five experts as assessors. In both cases recommendations were made that liners should have boats for all, regular boat drill, more efficient Wireless Telegraphy arrangements, and improved sub-division in construction. Lord Mersey's Report covers 74 pages and deals exhaustively with all the circumstances, as well as the details of the "Titanic;" it showed that six out of fifteen of the main compartments of the vessel were damaged, that the ship filled and went gradually down by the head without capsizing, and recommended (a) improvements as above, (b) supervision of ship designs. The recommendations (a) were generally endorsed by the Merchant Shipping Advisory Committee of the Board of Trade, who did not however concur in (b). The Board of Trade appointed two committees, - one (Bulkheads), with Dr. Denny of Dumbarton as chairman, to consider the best means of improving the subdivision of new ships, the second (Boats and Davits), with Professor Biles as chairman, to consider questions relating to design and handling of boats, supply of motor boats, \&c. The Board of Trade also laid draft rules before Parliament (Parl. paper Cd. 6402 of I9I2), requiring (I) great increases in the numbers and capacity of boats to be carried by all classes of passenger vessels, and (2) the submission of the designs of new ships for examination of stability, proposed subdivision \&c.; and the Board also took steps to secure international agreement as to Wireless Telegraphy and all questions affecting safety at sea. The draft rules went considerably beyond the recommendation of the Advisory Committee, and met with very serious opposition from many quarters, but many steamship companies proceeded even before official action was taken to suppiy boats for all on board their vessels, while the White Star Company announced that improved subdivision would be built into the "Britannic," and that the "Olympic" would be similarly improved.

The collision between the "Olympic" and H.M.S. "Hawke" in Spithead on September 20, rgI I led to a legal inquiry before the Admiralty Court which showed that the interaction (due to "suction ") between two vessels passing each other was much greater than was generally known (see Taylor, Am. Soc. N.A. 1909; also Gibson and Thompson, Brit. Assoc. IgI 2). The President, Sir Samuel Evans, found that the cause of the collision was the faulty navigation of the "Olympic" by her pilot in going dangerously near the "Hawke." On the Government's case for damages, he entered judgment however for the owners of the "Olympic," since the pilot was solely responsible, and their plea of "compulsory pilotage" was therefore a good defence. Both parties appealed against the findings.

Warships.-The introduction of the Dreadnought design and the development from this vessel to the "Neptune," in which the broadside guns are placed en echelon so that both pairs of midship guns may fire on either broadside, and then to the Orion, in which all the heavy guns are placed on the middle line with a good arc of training on each side, were fully discussed by Sir Philip Watts in E. B. xxiv (art. "Ship"). This arrangement has been adopted in all the U. S. ships, and in other navies it has been closely followed. Particulars of the later vessels of the Orion type-the "King George $V " \& c$ as well as of recent foreign vessels, are given in Table III. Table IV shows the several vessels grouped according to Class. The "Invincible" has remained as 
the standard type for battle cruisers; higher speeds, heavier guns and better armour protection, entailing larger dimensions (Table V). With the growth in the sea lieeping power of destroyers, and the increase in range, speed and power of torpedoes, more powerful anti-torpedo guns have become necessary in battleships and battle cruisers.

On August I, I91 2, Mr. E. H. Tennyson D'Eyncourt succeeded Sir Philip Watts as Director of Naval Construction in the British Admiralty. His predecessors in the office had been educated in the Dockyard Schools and trained in the Dockyards and at the Royal School of Naval Architecture or the Royal Naval College. Mr. D'Eyncourt was educated at Charterhouse, and trained at Elswick Shipyard and the Royal Naval College, Greenwich; and he had very extensive experience in warship design and building at Fairfield and Elswick (see Shipbuilder, October 1912). Sir Philip Watts's connection with the Admiralty was however not entirely severed, as he was retained as Adviser to the Board on Naval Construction. During the II years 1902-12 he was responsible for the design and construction of no less than I 80 fighting vessels (battleships, cruisers, destroyers and submarines), aggregating about 1,350,000 tons displacement, 4,250,000 Horse Power and $\ell_{\text {II }}$ 7,000,000 cost,-besides a large number of Fleet Auxiliaries and small craft of very great variety and interest. Certain characteristic features are found in practically all these vessels; all the guns are fought on the weather decks, the vessels have high forecastles, no poops, and no topsides, so that the silhouette of the T.B.D., the unprotected cruiser, the battle cruiser and the battleship herself have the same general features, while in the preceding designs the torpedo boats and destroyers had low forecastles, the cruisers had topsides and poops, the battleships had topsides and no forecastles, and battleships and cruisers carried much of their armament on the main deck. All classes are also notable for great advances in speed.

The progress of other than British battleships and battle cruisers may be gathered

Table III. Particulars of Typical Battleships.

\begin{tabular}{|c|c|c|c|c|c|c|c|c|c|c|}
\hline Name of & Shi & & & $\begin{array}{l}\text { Laun- } \\
\text { ched. }\end{array}$ & Tons. & H.P. & $\begin{array}{l}\text { Speed } \\
\text { Knots. }\end{array}$ & Guns. & $\begin{array}{c}\text { Side } \\
\text { Armour. }\end{array}$ & Remarks. \\
\hline $\begin{array}{l}\text { Dreadnought } \\
\text { (British) }\end{array}$ & $\therefore$ & & . & 1906 & 17,900 & 23,000 & $21 \cdot 5$ & $\begin{array}{l}10-12^{\prime \prime} \\
24^{-1} \mathrm{i} 2 \mathrm{pdr}\end{array}$ & $1 I^{\prime \prime}$ & Cost $£_{1}, 8 \mathbf{1}_{3}, 000$ \\
\hline $\begin{array}{l}\text { King George V } \\
\text { (British) }\end{array}$ & & & & IgII & 23,600 & $31, \infty 00$ & 21.0 & $10-13,5^{\prime \prime}$ & $12^{\prime \prime}$ & $\begin{array}{l}\text { Total cost } £_{\mathbf{1}}, 96 \mathbf{1}, \infty \infty \circ \text {. Hull, engines } \\
\text { and all incidental charges } £ 893,000 \text {. }\end{array}$ \\
\hline$\underset{\text { (German) }}{\text { Kaiser }}$ & $\therefore$ & $\therefore$ & - & IgII & 24,310 & 28,000 & 21.0 & $10-12^{\prime \prime}$ & $13^{\prime \prime}$ & Cost $£_{2,327,000}$ \\
\hline$\underset{\text { (French) }}{\text { France }}$ & $\therefore$ & : & - & 1912 & 23,100 & 28,000 & $\begin{array}{c}20.0 \\
(\mathrm{e})\end{array}$ & $\begin{array}{l}12-3 \cdot 4 " \\
12-12^{\prime \prime} \\
22-5 \cdot 5^{\prime \prime}\end{array}$ & $\mathbf{I} \mathbf{I}^{\prime \prime}$ & Cost $£_{2,604,000}$. \\
\hline $\begin{array}{l}\text { Bretagne } \\
\text { (French) }\end{array}$ & $\therefore$ & . & & Bldg. & 23,600 & 28,000 & (e) & $\begin{array}{l}10-13 \cdot 5^{\prime \prime} \\
22-5 \cdot 5^{\prime \prime}\end{array}$ & $\mathbf{I} \mathbf{I}^{\prime \prime}$ & Cost $£_{2,910,000}$ \\
\hline C. di Cavour & - & $\therefore$ & 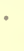 & I9II & 22,340 & 24,000 & 22.0 & $\begin{array}{l}13 \sim 12^{\prime \prime \prime} \\
18-4 \cdot 7^{\prime \prime}\end{array}$ & $10^{\prime \prime}$ & Cost $£_{2}, 600, \infty 00$. \\
\hline $\begin{array}{c}\text { Viribus Unitis } \\
\text { (Austrian) }\end{array}$ & - & . & - & Igr2 & $20, \infty 00$ & 25,000 & 20.5 & $\begin{array}{l}12-12 " \prime \\
12-5 ; 9^{\prime \prime} \\
18-3 ; "\end{array}$ & $\mathrm{II}^{\prime \prime}$ & Cost $£_{2,500, \infty 00}$ \\
\hline$\underset{\text { (Spanish) }}{\text { Espana }}$ & $\vdots$ & - & & 1912 & 15,460 & 15,300 & I9.5 & $\begin{array}{l}8-12^{\prime \prime} \\
20-4^{\prime \prime}\end{array}$ & $9^{\prime \prime}$ & \\
\hline $\begin{array}{l}\text { Reshad V } \\
\text { (Turkish) }\end{array}$ & . & . & - & Bldg. & $23, \infty 00$ & $31, \infty 00$ & 21.0 & $\begin{array}{l}10-13 \cdot 5^{\prime \prime} \\
16-6 "\end{array}$ & $\mathrm{I} 2^{\prime \prime}$ & \\
\hline Texas (American) & $\cdot$ & - & & Bldg. & 27,000 & 28,100 & 21.0 & $\begin{array}{l}10-14^{\prime \prime} \\
20-55^{\prime \prime}\end{array}$ & $12^{\prime \prime}$ & $\begin{array}{l}\text { Total cost not known. Hull and } \\
\text { engines only, } f_{\mathrm{r}, \mathrm{r} 66,000} \text {. }\end{array}$ \\
\hline $\begin{array}{l}\text { Sevastopol } \\
\text { (Russian) }\end{array}$ & 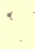 & • & & $x g r 1$ & $23, \infty 0$ & 42,000 & 23.0 & $\begin{array}{l}12-12^{\prime \prime} \\
16-4 \cdot 7^{\prime \prime}\end{array}$ & II" & Cost $£_{2,800,000}$ \\
\hline $\begin{array}{l}\text { Alexander III } \\
\text { (Russian) }\end{array}$ & : & $\therefore$ & & Bldg. & 22,150 & 25,000 & 21.0 & $\begin{array}{l}\text { 1 } 2-12^{\prime \prime} \\
\text { 1 } 2-6^{\prime \prime}\end{array}$ & $12^{\prime \prime}$ & \\
\hline $\begin{array}{l}\text { Settsu } \\
\text { (Japanese) }\end{array}$ & : & $\therefore$ & & I9II & 20,800 & 25,000 & 20.5 & $\begin{array}{l}x 2-12^{\prime \prime} \\
10-6 " 1\end{array}$ & $12^{\prime \prime}$ & \\
\hline Fuso (Japanese) & $\therefore$ & - & & Bldg. & 30,000 & 45,000 & 22.5 & $\begin{array}{l}x 2-4 \cdot 7 " \\
10-15^{\prime \prime} \\
16-6 "\end{array}$ & $12^{\prime \prime}$ & 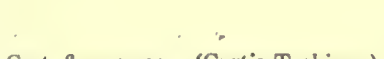 \\
\hline $\begin{array}{l}\text { Moreno } \\
\text { (Argentine) }\end{array}$ & . & $\therefore$ & ". & I9II & 27,600 & 40,000 & 22.5 & $\begin{array}{l}12-12^{\prime \prime} \\
12-6 " 1 "\end{array}$ & $\mathbf{x} 2^{\prime \prime}$ & Cost $£_{2,200, \infty 00 \text {. (Curtis Turbines.) }}$ \\
\hline $\begin{array}{l}\text { Rio de Janeiro } \\
\text { (Brazilian) }\end{array}$ & $\cdot$ & & & 1912 & 27,500 & $45, \infty 00$ & 22.0 & $\begin{array}{l}12-4^{\prime \prime} \\
14-12^{\prime \prime} \\
20-6 "\end{array}$ & $9^{\prime \prime}$ & \\
\hline $\begin{array}{l}\text { Ad. Latorre } \\
\text { (Chilean) }\end{array}$ & & & & Bldg. & 28,000 & 45,000 & 23.0 & $\begin{array}{l}12-3^{\prime \prime} \\
10-14^{\prime \prime} \\
22-4.7^{\prime \prime}\end{array}$ & $I x^{\prime \prime}$ & \\
\hline
\end{tabular}

(e) Probably continuous speed.

Nole.-Particulars of warships taken chiefly from The Naval Annual by kind permission of Viscount Hythe, and the Navy League Annual. 
from Tables III, IV and V. The triple turret has been exterisively adopted in Italy, Austria and Russia, and is under experiment in America, while France is proposing turrets to carry four I 2 inch guns in each, but turrets containing more than two heavy guns have not yet found favour in Great Britain.

Table IV. The World's Dreadnoughts.

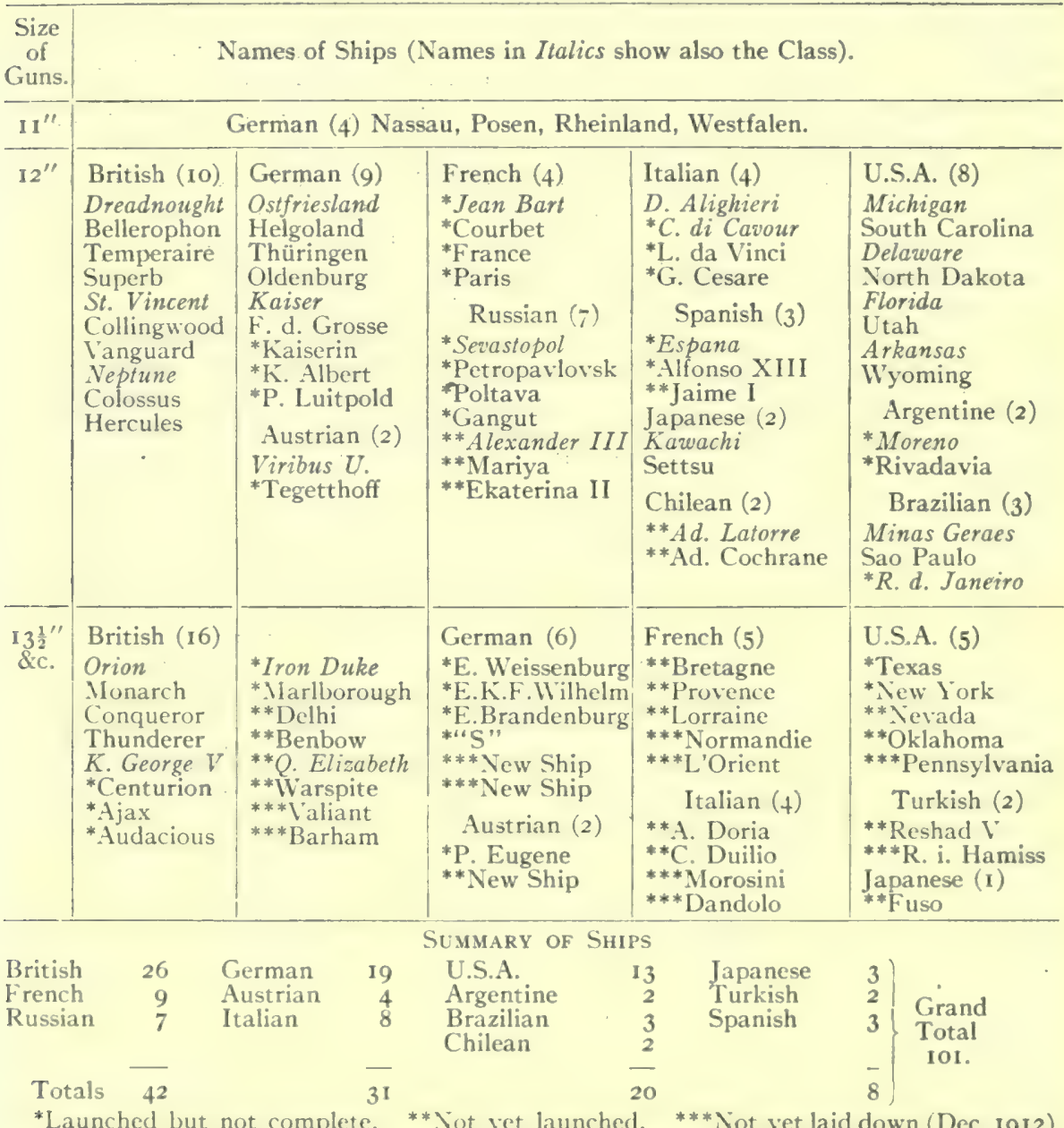

*Launched but not complete. ** Not yet launched. ***Not yet laid down (Dec. 1912).

The Armoured cruisers "Edgar Quinet" and "Waldeck Rousseau " (E. B. xxiv, Q1 2) have been completed by France. The "Giorgios Averoff " of 9956 tons, 24 knots, 7 inch armour, four 9.2 inch, eight 7.5 inch guns, \&c., has been completed by Orlando of Leghorn, and another vessel of 19.500 tons has been ordered of the Vulcan Yard, for Greece. Germany has completed several cruisers of the "Augsburg" type (E. B. xxiv, 9 I ) but new vessels will probably be of 5,000 tons and 27 knots and carry 4.I inch guns of improved type. A number of ressels of the "Dartmouth" type (E. B. xxiv, (009), including the "Melbourne " and "Sydney" for A ustralia, have been built in Great Britain, and the sister vessel "Brisbane" is being built at Sydney, but eight light armoured vessels of a new type are now being built for the British Navy. Italy is completing scouts of the "Quarto" type (E. B. xxiv, 9r3). 
Table V. Battle Cruisers.

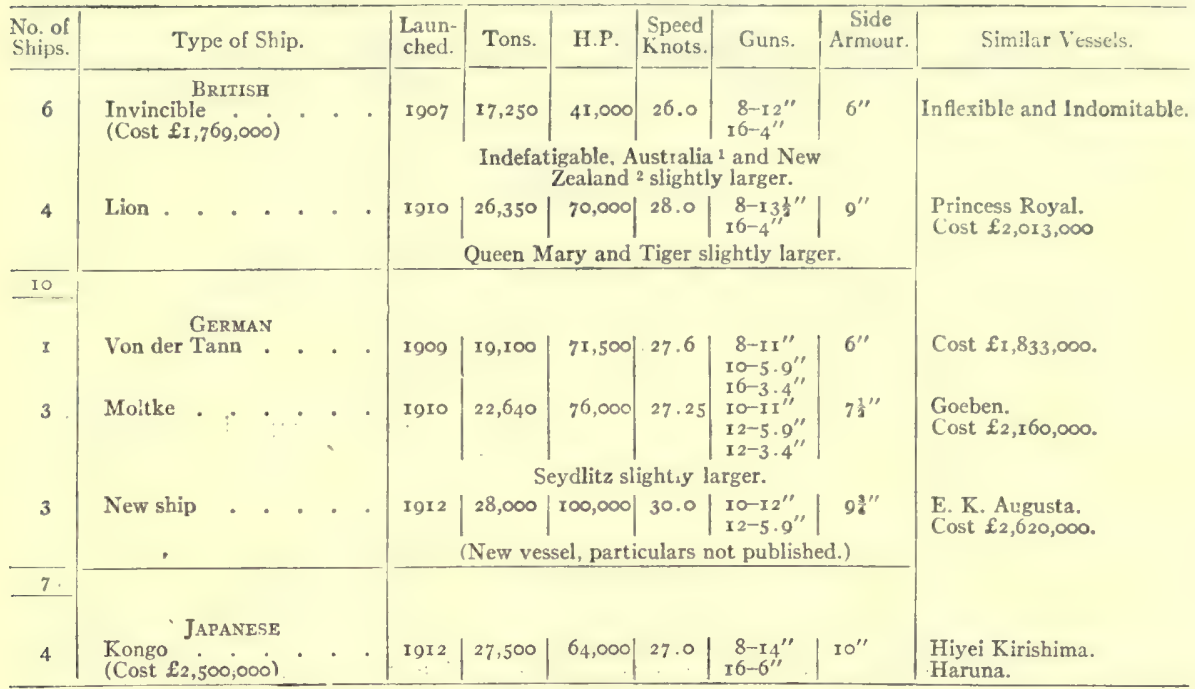

1 For Australian Govt. ${ }^{2}$ Presented by New Zealand Govt.

Destroyers are being built in great numbers by the various Powers. Particulars of several are given in Table VI. The "Parramatta " and "Yarra" were built to Prof. Biles's design and steamed out to Australia; a sister vessel "Warrego " was built at Fairfield, taken to pieces, sent out by steamer and put together in Australia, where three similar vessels, "Derwent," "Swan" and " Torrens," are being built.

Table VI. Destroyers.

\begin{tabular}{|c|c|c|c|c|c|c|c|c|c|c|}
\hline & & & & $\begin{array}{l}\text { Laun- } \\
\text { ched. }\end{array}$ & \begin{tabular}{|} 
Length. \\
ft.
\end{tabular} \mid & $\begin{array}{l}\text { Dispt. } \\
\text { Tons. }\end{array}$ & H.P. & $\begin{array}{l}\text { Speed } \\
\text { Knots. }\end{array}$ & Guns. & Remarks. \\
\hline $\begin{array}{l}\text { British- } \\
\text { Acasta Class }\end{array}$ & . & - & . & I912 & 260 & 935 & 24,500 & 29.0 & $3-4^{\prime \prime}$ & Admiralty design $(31-3)$ knots on \\
\hline Lurcher : & . & $\therefore$ & . & I9I 2 & 255 & 780 & 20,000 & 32.0 & $\begin{array}{l}2-4^{\prime \prime} \\
2-12 \text { pdr. }\end{array}$ & 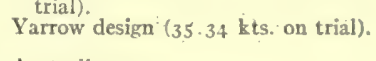 \\
\hline Parramatta & . & - & . & roro & 245 & 700 & 9,500 & 28.5 & $\begin{array}{l}\mathrm{I}^{-} 4^{\prime \prime} \\
3-\mathrm{I}^{2} \mathrm{pdr} \text {. }\end{array}$ & Australien type. \\
\hline $\begin{array}{l}\text { GERMAN- } 186, \text { V. } 192 \\
\text { \&c. }\end{array}$ & 2, & I7 & 6, & $\begin{array}{l}\text { I910- } \\
\text { IgI } 2\end{array}$ & $233^{\circ}$ & 640 & 16,000 & $32 \cdot 5$ & $\begin{array}{l}2-23 \mathrm{pdr} . \\
2-\mathrm{M}\end{array}$ & $35.3 \mathrm{kts}$. reported on trial. \\
\hline $\begin{array}{l}\text { FrENCH- } \\
\text { Bisson \&c. }\end{array}$ & - & - & . & 1912 & 243 & 750 & 18,000 & 31.0 & $\begin{array}{l}2+4^{\prime \prime} \\
4-9 \text { pdrs. }\end{array}$ & 35.3 kts. reported on trial. \\
\hline $\begin{array}{l}\text { RussIAN- } \\
\text { Novik ... }\end{array}$ & . & - & . & I9II & 329 & $x, 260$ & 30,000 & 35.0 & $4-4^{\prime \prime}$ & A.E.G. turbines, 36 knots on trial. \\
\hline $\begin{array}{l}\text { IraLIAN- } \\
\text { Indomito. }\end{array}$ & . & $\because$ & . & 1912 & 246 & 650 & $15, \infty 00$ & 30.0 & $\begin{array}{l}4^{-1 / 2} \\
\mathrm{I}^{-4} \cdot 7^{\prime \prime} \\
4^{-12} \mathrm{pdr}\end{array}$ & $35.1 \mathrm{kts}$. reported on trial. \\
\hline $\begin{array}{l}\text { Austrian- } \\
\text { Six Bioats : } \\
\text { AyERICAN- }\end{array}$ & . & . & . & 1912 & 266 & 800 & i $7, \infty 00$ & 30.0 & $2-3 \cdot 9^{\prime \prime}$ & \\
\hline $\begin{array}{l}\text { Beale \&c. } \\
\text { JAPANESE- }\end{array}$ & - & : & . & I $91 \mathrm{II}$ & 289 & 742 & 12,000 & 29.5 & $5-3^{\prime \prime}$ & \\
\hline Yamakase. & . & . & . & $-x 9 \ln$ & & 1,200 & 20,500 & $35: 0$ & $\begin{array}{l}2-4 ; 7^{\prime \prime} \\
5-3\end{array}$ & - \\
\hline $\begin{array}{l}\text { ARGENTINE- } \\
\text { San Luis }{ }^{1} \text { : } \\
\text { CrinLAN- }\end{array}$ & . & . & . & IgII & .285 & $x, 050$ & $19, \infty 00$ & 32.2 & $4-4^{\prime \prime}$ & \\
\hline Tome . & . & . & . & I9I 2 & 320 & $\mathbf{r}, 500$ & 27,000 & 31.0. & $\begin{array}{l}6-4^{\prime \prime} \\
2-M\end{array}$ & Six building by J. S. White. \\
\hline
\end{tabular}

1 Four built by Laird, sold to Greece September x 912 , and renamed: "Eagle," "Panther," "Lion," "Falcon."

France still takes the lead in developing Submarines, which are being built with success by all the Great Powers. Particulars of a few recent boats are given in Table VII, but very little is published about these craft. 
Table VII. Submarines.

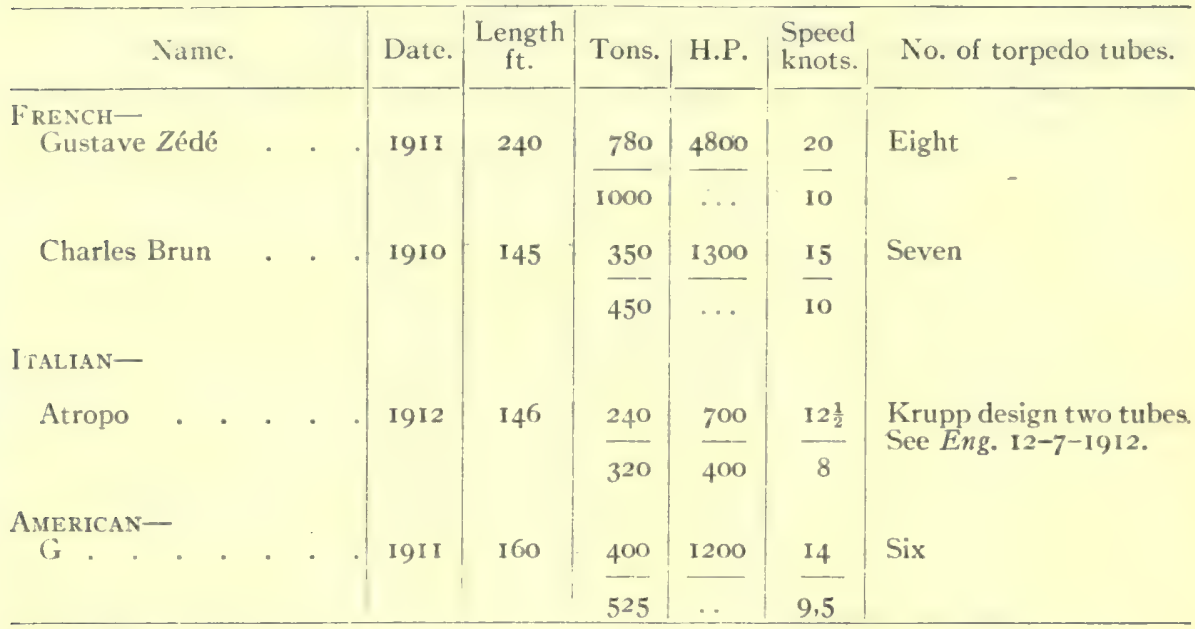

The Engineer of December I9 I gives photos of the German U.S. Recent boats are fitted with wireless telegraphy, armed with small disappearing guns, and are capable of long sea voyages in any weather without escort. British boats "E, I" to "E, I6" are being built to Admiralty design. (See Sir P. Watts's paper, I.V.A. r gr 2.)

Diesel Engines for Warships.--Russia has built several river gunboats of 600 to 950 tons propelled by heavy oil engines of rooo H.P. Germany has fitted experimental engines in an old torpedo boat, and also in a small tender named "Mentor "which has two Krupp engines of 350 H.P. each. Holland is building gunboats - "Brinio " of 540 tons with two Werkspoor engines of $600 \mathrm{H}$. P. each, to give r6 knots. The British destroyer "Hardy" is to be fitted with two Thornycroft engines for economical cruising, in combination with steam turbines for high speed. In England the First Lord of the Admiralty, Mr. Winston Churchill, has informed Parliament that "oil as a fuel offers enormous advantages to ships of all kinds and particularly to the smallest kind;" and a Royal Commission was appointed in I012, with Lord Fisher as Chairman, "to report on the means of supply and storage of Liquid Fuel in peace and war and its application to warship engines whether directly or by Internal Combustion."

(J. H. NaRbETH.)

\section{INTERNAL-COMBUSTION ENGINES ${ }^{1}$}

Considerable progress has been made during roro-I3 in the development of the various types of internal-combustion engines, more particularly in the smaller petrol engines for motor-cycles, motor-cars, and aeroplanes, and in oil engines (Diesel) for land and marine purposes. At the same time, the large gas engine using producer gas or blast-furnace gas has been increasing its reputation for reliability and economy, and is daily finding new applications where formerly steam-power plants were used.

Petrol Engines. - The classic racing competitions in England, France, and America have given an invaluable impetus to the improvement of the smaller petrol engines for cycles and cars. In England particularly, the racing-track at Brooklands enables manufacturers in the course of a few hours to subject their engines to a more crucial test for endurance than could be obt ained by months of trial on the road. Such engines in everyday use are working normally at a small fraction of their maximum power, the full power only being called upon for short periods when climbing steep hills. Hence the value of (say) an hour's run on a racing track in a race or an attempt at record-breaking.

The motor-cycle industry in Great Britain and America is expanding by leaps and

1. See E. B. xi, 495 et seq. ("Gas Engine"), and $x x, 35$ et seq. ("Oil Engine"). 
bounds. For motor-cycles an air-cooled four-cycle single-cylinder engine of $3^{\frac{1}{2}}$ H.P. (not exceeding 500 cubic centimetres cylinder capacity) is the type most widely used. Such an engine as made by Rudge Whitworth Ltd., bore $85 \mathrm{~mm}$., stroke $88 \mathrm{~mm}$., has given 8.4 brake H.P. at a speed of 3,060 revolutions per minute, in a bench-test of 87 minutes' duration. The corresponding mean effective pressure on the piston, calculated from the brake H.P. is 69 lbs. per square inch. Twin-cylinder engines are also much in favour; while water-cooling and the two-stroke cycle are used on many motor-cycleengines. England and America are pre-eminent in the motor-cycle industry. In France, the home of the motorcar, its use of the motor-cycle is not so widespread as in England. In Germany, Belgium, and Switzerland, excellent motor-cycle engines are manufactured.

In motor-car engines, the four-cylinder water-cooled type ${ }^{1}$ is pre-eminent. As an example of modern performances of such engines, that of a 15 H. P. engine, $3 \frac{1}{8}$ inch bore, $4 \frac{3}{4}$ inch stroke, by Crossley Motors Ltd., may be noted. The brake-tests show 40 H.P. at 2,400 revolutions per minute, 16 H.P. at 800 revolutions per minute, the corresponding M.E.P's. on the piston calculated from the B.H.P. being respectively 90 and ro8 lbs. per sq. in.

The sleeve-valve engine ${ }^{2}$ is made by a few firms, but there are no signs of its wider adoption by engine makers in place of the usual poppet-valve engine.

An interesting petrol engine, designed by Dr. A. M. Low, has been recently made by F. E. Baker, Ltd., the object being to obtain more power from an engine of given cylinder capacity. The principal feature in the Low engine is that petrol vapour under high pressure is injected into the cylinder, in which a charge of fresh air has previously been compressed. Liquid petrol is pumped into an annular jacket surrounding the cylinder, when the engine has been warmed up the petrol is vapourised, and the pressure in the jacket rises to I,O00I,500 lbs. per sq. in. A valve controls the rate as well as the period of admission of the vapour, which burns immediately it mixes with the air. This double control has the effect of rendering the engine extremely flexible, that is, it runs smoothly under all conditions of speed and load. The engine made is of single-cylinder, four-cycle type, $78 \mathrm{~mm}$. bore, $104 \mathrm{~mm}$. stroke, 499 c.c. capacity, and is rated at 15 H.P.

Commercial motor-vehicles are coming daily into wider use. In London the number of motor-buses running in 1912 was over 2,000 , and is still being increased almost daily They provide facilities for passenger carrying which previously did not exist, and are gradually changing the character of the street traffic. The motor-bus has established itself in successful competition with the electric tramway; in fact it may be said to have given a halt to any further considerable extensions of tramway systems. The growth of the motor-car industry is phenomenal. One American firm alone, The Ford Company, is said to have prepared for an output of 200,000 cars for the year 1913.

Gas Engines.-Great activity is manifest in the production of large gas engines. Germany led the way, and a few American makers, $e . g$. the Allis Chalmers Company, Milwaukee, and the Snow Steam Pump Company, Buffalo, were early in the field; but until a few years ago, British makers kept aloof from the production of large gas engines. The Lilleshall Co., Ltd., Oakengates, Shropshire, however, have supplied for a railway electric power station, near Yokohama, Japan, four engines of the Nürnberg type each rated at 2,130 brake $H$.P. when running at 94 revolutions per min. Each cylinder is 1,200 $\mathrm{mm}$. ( $47 \frac{1}{4}$ in.) bore, $1,300 \mathrm{~mm}$. ( $51 \frac{1}{8}$ in.) stroke. This type was first developed by the Maschinen-Fabrik Augsburg-Nürnberg A.G. and is now made by numerous licensees in various countries. It works on the four-stroke cycle, is double-acting, has water-cooled pistons and piston rods, and is usually made when space permits with two cylinders in tandem. There are thus two effective strokes for each revolution of the crank-shaft. In contradistinction to the usual practice in gas engines of moderate power, the cylinder, with its water-jacket casing and the valve pockets, is made in one casting. The design of the cylinder casting is such that there are no abrupt changes of form, and the water space between the inner and outer cylinders is ample. The old trouble of cracking of castings, exposed on one side to the heat of combustion of the gaseous fuel and on the other side to the cooling action of the water, has been successfully overcome in the sizes of engines made up to the present. For successful design of large gas engines, such castings should be of as simple and symmetrical form as possible. The large gas engines of modified Oechelhäuser type, ${ }^{3}$ made by W. Beardmore \& Co., Ltd., Glasgow, have their long cylinders in which two barrel-pistons work, made each of three plain-flanged pipes, the middle piece being short and forming, when the two pistons are closest together, the combustion chamber. Separate annular castings for the inlet and exhaust boxes sur-

See E. B. xx, 38, fig. 5 .

2 See E. B. xx, 39 fig. 6.

${ }^{3}$ See E. B. xi, 500. 
round the ports in the cylinder, which are uncovered by the piston barrels when furthest apart. The cylinder and annular exhaust box are immersed in a water-tank.

Messrs. Mather \& Platt, Ltd., Manchester, have recently made "Duplex " gas engines up to 500 B.H.P. on a modified Koerting-Clerk type ${ }^{1}$ with no valve-gear, and the type seems to be suitable for gas engines of very large power. The whole cylinderunit, consisting of a pair of equal side-by-side cylinders, presents extremely simple forms of single-walled castings particularly suitable for use in gas engines. It is made up of two U-tube castings placed end to end, the inlet and exhaust ports being at the joints, while flanges on the cylinders some distance from the joint retain between them the inlet and exhaust boxes. The cylinder-unit is placed in a water-tank. Each piston uncovers the cylinder port at both ends of its stroke, as in the Koerting-Clerk type. The two cranks are set nearly parallel, one having a slight angular lead so that the exhaust port is uncovered before the inlet port. When both ports are uncovered the charge of air and gas from the pump displaces the exhaust gases before it, the gases in the inlet cylinder passing through the connecting passage to the exhaust cylinder and thence through the exhaust port.

The cheapest fuel for gas engines is the gas given of from iron blast furnaces and from coke-ovens, formerly a waste product. In Germany and America blast furnaces and rolling mills for the production of steel plates and rolled sections are usually associated in the same or neighbouring works; hence the extensive use of large gas engines. In Great Britain the same conditions do not hold to the same extent, but the continual endeavour to reduce costs of production will compel the rearrangement of iron and steel works, so that large gas engines may profitably utilise the tremendous power now running to waste. ${ }^{2}$

Oil Engines. - The most rapid progress is being made in the application of the Diesel engine $^{3}$ for stationary and marine power-plants. Fishing-boats, barges, yachts, and large ocean-going ships are now running successfully with Diesel oil engines. The large marine oil engines have usually 4, 6, or 8 vertical cylinders, working either on the twostroke or four-stroke cycle. The pistons are usually air-cooled; starting and reversing is effected by a supply of compressed air at a pressure of $250-400 \mathrm{lbs}$. per sq. in. The "Selandia," built by Burmeister \& Wain, Copenhagen, and the " Jutlandia," built by Barclay, Curle \& Co., Ltd., Glasgow, are sister ships of 5,000 tonnage, 7,500 tons carrying capacity, with a service speed of 12 knots. The propelling machinery consists of twin screws, each shaft being driven by an eight-cylinder single-acting four-stroke cycle engine. Each cylinder is 20.87 in. bore, 28.74 in. stroke. The indicated horse power is 2,500 at a speed of 140 revolutions per min. The Werkspoor Works, Amsterdam; the Augsburg-Nürnberg Works; Sulzer Bros., Winterthur, and many other firms in Germany, Italy, and England are also building marine oil engines of large power.

For marine propulsion, the Diesel oil engine offers considerable advantages as compared with steam turbines and boilers. The boiler space is saved, and the oil fuel-tanks can be arranged in positions that cannot be used for cargo, whereas coal-bunkers occupy space that might otherwise be available for cargo. A separate set of steam turbines is required for reversing, while for naval purposes in which the maximum power of the machinery is only required for short periods, a third set of "cruising" turbines is usually installed, on account of the low economy of steam turbines running at less than full power. One set of Diesel engines can perform all three functions; the fuel-injection valve-gear being arranged to admit the oil spray during a longer or shorter period of the piston's stroke, giving full or low power as required, while the valve-gear for reversing is an integral part of the engine, just as with piston steam engines.

Fuel for Oil Engines.-The growth in the demand for oil fuel, from the volatile petrol to the heavy residue left after distillation of the purer grades from the crude petroleum, due to the motor-car industry and the development of the Diesel engine, has been more rapid than the increase of the supplies; the effect being that at present the prices of all grades of oil fuel are nearly double what they stood at three years ago. The future of the internal. combustion-engine industry in all its branches depends largely on an adequate supply of cheap fuel. The high prices have stimulated the production of oil fuel from hitherto neglected sources. Creosote oil, a by-product in the manufacture of coke, is being used in

1 See E. B. xi, 499.

${ }^{2}$ See E. B. xi, $497^{-8}$.

${ }^{3}$ See E. B. xx, 43 
Diesel engines. In Germany alone, the output during 1912 was estimated to be 450,000 tons, the average price 45s. per ton. 3,000 new coke-ovens were installed in 1912 , and for I915 in Germany alone the estimated output of creosote oil is 900,000 tons. These figures, large as they seem, are small in comparison with the total amount of coal now used for steamship propulsion. The evolution of a successful internal-combustion engine using coal power as fuel may be another great step in the forward progress of power production.

\section{STEAM BOILERS 1}

(Archibald Sharp.)

There has been very little change in $\mathrm{I}_{909-\mathrm{I}} 3$ in the design or construction of the various types of steam boilers used. Modifications have been due either to the use of somewhat higher steam pressures or to the more general application of superheating.

The increase of steam pressures is more noticeable in marine practice than in other cases. At the present time many marine boilers are being made to work at pressures of from $2 \times 5$ lbs. to .225 lbs. per square inch, supplying steam to quadruple expansion engines. Where triple expansion engines are used the most common pressure is $180 \mathrm{lbs}$. per square inch. The strength necessary for the extra pressure is generally obtained by using thicker plates for the shells and more closely pitched stays for the combustion chambers. In numerous boilers for large ocean liners, where the question of weight to be carried assumes an exceptional importance, steel plates having a tensile strength of from 35 to 38 tons per sq. in. have been used for the cylindrical shells, whereas that of ordinary boiler shell plates is from 28 to 32 tons per sq. in.

An improvement has been introduced by one firm of steel plate makers, who now roll long plates having two different thicknesses, the two end portions being thinner than the part near the middle of the length. The variation of thickness is made gradual over a space of about six inches. The thicker portion can be arranged in position and in dimensions with precision. Such plates can be made in widths up to, but not exceeding seven feet. They are used for the wrapper plates of the combustion chambers of marine boilers, the thin parts being employed for the sides of the chambers, which are supported by numerous screwed stays, whilst the thick central portions form the bottoms of the chambers which are unstayed.

The use of superheated steam has become more frequent in marine and stationary work, but more especially so in locomotive boilers. In practically all cases the superheaters are formed of pairs of headers made of cast steel, connected together by numerous steel tubes which form the superheating surfaces. One header of each pair is connected by a steam pipe with the stop valve on the boiler, and when in use the saturated steam from the boiler enters this header, then traverses the small superheating tubes and passes into the other, whence it is conducted through suitable steam pipes to the engine.

The steam pipe arrangements are sometimes made so that all the steam must pass through the superheaters; in other designs regulating valves are provided which permit of any desired proportion of the steam passing through the superheater, the remainder being mixed with the superheated steam before passing to the engine. This plan permits of the temperature of the steam entering the cylinders being regulated through a certain range so that the temperature which experience shows to be most advantageous can be used. About $600^{\circ} \mathrm{F}$. is generally considered to give the best result.

In locomotives the regulation of the temperature of the steam is effected by more or less throttling the passage of the heated furnace gases in their passage across the superheating tubes. It is customary to use only iron or steel for the superheated steam pipes to the exclusion of copper. It is also necessary to fit a safety valve to the superheater if the arrangement permits of its being shut off from the boiler at any time.

In the $E . B$. article, figures I I and I 2 , superheaters are shown of the types used and in the positions adopted with stationary boilers of the Babcock and Wilcox and of the Stirling types. In some marine boilers the superheaters are fitted in the uptakes, where they are exposed to the heat of the products of combustion after the gases have left the ordinary boiler tubes. In such cases as the temperatures to which the superheating surfaces are exposed are not very high only a low degree of superheat is possible. The

${ }^{1}$ See E. B. iv, I4I et seq. 
superheater most frequently fitted in marine boilers is, however, that known as the "Schmidt" superheater. This is a modification of the Schmidt superheater so generally employed on the Continent of Europe, for locomotive boilers, which is also now being introduced for the same purpose into England.

In the marine type, the pairs of headers are placed in the smoke boxes of the boilers. The superheating tubes are of small diameter and are made of seamless steel. 'They are formed in a series of hair-pin loops, each loop being placed in one of the smoke tubes of the hoiler, extending to within about nine inches of the fire box end. The arrangement is such that each of the series consists of 4,5 or 6 loops according to the design of the boiler, the total number employed being sufficient to provide each of the smoke tubes with its superheating tube. In a two furnace boiler only one pair of headers is used, placed in front of the space between the nests of tubes, and the superheating tubes are symmetrically placed on hoth sides of the headers. In three furnace boilers two pairs of headers are used, and the superheater tubes are more closely placed on one side of the header than on the other to suit the arrangement of the smoke tubes.

For use in smoke tubes $2 \frac{1}{2}$ inches outside diameter the superheating tubes are made $18 \mathrm{~mm}$. outside diameter and $2 \frac{1}{2} \mathrm{~mm}$. thick. Where $3 \frac{1}{4}$ inch smoke tubes are used the superheater tubes are $23 \mathrm{~mm}$. outside diameter and are $3 \mathrm{~mm}$. thick. The total superheating surface is usually about two fifths of the heating surface of the boiler proper.

The employment of this form of superheater makes very little difference in the design of the boiler, with the exception that the ratio of heating surface to grate surface is somewhat less than where no superheating is employed.

In lócomotive boilers the design has to be considerably modified. Many of the usual upper small tubes are replaced by three rows of large tubes which are generally from $4^{\frac{3}{4}}$ inches to $5 \frac{1}{2}$ inches in diameter for the greater portion of their length, reduced about $\frac{1}{2}$ inch in diameter for about 10 inches at the firebox end to permit of better water circulation over the tube plate. In each of these large tubes one section of the superheater is placed. This consists of a long seamless steel tube shaped as a four-fold bend. The two ends of the tube are bent upwards and are expanded into one rectangular flange which by means of one central stud and nut is secured to the header. In this case one header only is used, placed in the smoke box. It is made of cast iron of the special quality used for cylinders, and is formed with two passages, one serving as the inlet for the saturated steam and the other as the outlet for the superheated steam.

The practice with locomotive boilers is to make the superheating tubes with about one fifth of the total heating surface of the boiler. The damper retards or entirely cuts off the flow of furnace gases past the superheating tubes when there is little or no demand for steam from the boiler. Whenever the Schmidt superheater is used arrangements are made for keeping the superheating tubes and the enclosing smoke tubes free from soot and scoriae by means of a steam jet from a flexible tube.

(J. T. Milton.)

\section{ELECTRICAL ENGINEERING ${ }^{1}$}

\section{Electrical Measurements}

The importance of exact measurement in all electrical work has led to great attention being paid to improvements in methods for measuring electric currents, voltages, and power, especially in connection with alternating currents of low and high frequency. The direct reading potentiometer has been of such use in all direct current measurement that the invention of a similar instrument for alternate current work has long been desired. This has now been provided in Dr. Drysdale's alternate potentiometer.

This instrument consists of an ordinary direct current potentiometer, but has an electrodynamometer in series with the slide wire to adjust an alternating current to the same ront-mean-square value as the direct current, which makes a known fall of potential down a certain length of the wire. In addition to the usual resistances for regulating this current, the alternating current is supplied through a phase-shifting transformer, which enables it phase to be varied through $180^{\circ}$. If then it is desired to measure an alternating current voltage, which may be reduced in any required ratio by a transformer, this voltage is balanced against the fall in voltage down the slide wire which is produced when the slide wire is traversed by an alternating current taken from the same source so as to have the same frequency. To do this the phase as well as the strength of the alternating current in the slide wire must be capable of adjustment. The balance is determined by using a vibration galvanometer in place of the movable coil galvanometer employed with direct currents. The absolute value of the fall in potential down known lengths of the slide wire is obtained in the usual way by a direct current and the aid of a standard Weston cell. Hence if we

1 See E. B. articles referred to under Pursics: Electricity in Index Volume, p. 940. 
always work with one standard value of either direct or alternating current the slide wire can be graduated to show voltages directly from either alternating or continuous currents. By the use of an appropriate vibration galvanometer of the Tinsley type the Drysdale potentiometer may be used for measuring alternating voltages even up to a frequency of $\mathrm{I}, 000 \mathrm{p} . \mathrm{p} . \mathrm{s}$. It is therefore extremely useful in telephonic measurements. By the use of low resistance inductionless shunts it can measure large alternating currents.

Another recent alternating current instrument of considerable utility is the iron cored wattmeter of Dr. Sumpner.

In this instrument an electromagnet of laminated iron is wound over with coils of thick wire of low resistance. These coils are connected as a shunt across the terminals of the appliance in which the power is to be measured. The field of the magnet is therefore proportional to the time integral of the voltage when the terminals are connected to an alternating current supply. In the field of this magnet moves a pivotted coil with index needle, the coil taking current from an air core transformer the primary circuit of which is in series with the power absorbing circuit. Hence the secondary current in the coil varies as the time rate of change of the main current. The coil is constrained by a controlling spring and its deflections are then proportional to the mean value of the field of the magnet and the current in the coil. When the frequency of these is the same this mean product is proportional to the mean product of the voltage drop across the terminals and the current in the power absorbing circuit and therefore to the power taken up by it. Hence the instrument can be graduated to read power directly and can be arranged to read very small powers.

Another recently devised arrangement for alternating current measurement is the capacity bridge of Fleming and Dyke, by means of which the capacity of condensers having considerable leakance can be measured and the leakance or conductivity determined at the same time for alternating currents.

It consists of three condensers connected like the arms of a Wheatstone's Bridge. Two of these condensers $\left(\mathrm{C}_{3}, \mathrm{C}_{4}\right)$ are simple adjustable air condensers and the third $\left(\mathrm{C}_{2}\right)$ has in series with it a variable resistance $R_{2}$. The fourth arm of the bridge consists of the leaky condenser to be measured. In the bridge circuit a telephone is inserted and the conjugate points are connected to an alternator giving a simple sine curve electromotive force. The adjustment consists in varying the capacities and resistance until silence is produced in the telephone. The capacity $\mathrm{C}$ of the condenser under test is then given by the expression $\mathrm{C}=\frac{\mathrm{C}_{2} \mathrm{C}_{3}}{\mathrm{C}_{4}} \frac{\mathrm{I}}{\left(\mathrm{I}+x^{2}\right)}$, and its conductivity $\mathrm{S}$ by the expression $\mathrm{S}=\mathrm{pC} x$, where $x=\mathrm{pC}_{2} \mathrm{R}_{2}, \mathrm{p}=$

$2 \pi n$ and $n$ is the frequency. By the use of this appliance the above named investigators have examined the conductivity of numerous dielectrics for alternating currents of telephonic frequency and proved that the conductivity is in general greater than the direct current conductivity and is a linear function of the frequency $n$ of the form $\mathrm{S}=\mathrm{A}+\mathrm{Bn}$.

\section{Electrochemistry and Electrometallurgy}

The applications of the thermal and chemical properties of an electric current in industrial manufacture have become very extensive of late. Many products of great commercial value can now be prepared electrically in virtue of the high temperatures attainable which could not otherwise be produced. A good example is the substance called carborundum, which is a carbide of silicon first prepared by E. G. Acheson in I89I. It is extremely hard and now largely used as a substitute for emery in grinding wheels and polishing. It is produced at Niagara Falls by passing a current through a mixture of sand coke and sawdust which is thereby raised to a temperature of $1950^{\circ} \mathrm{C}$. The chemical reaction is, $\mathrm{SiO}_{2}+{ }_{3} \mathrm{C}={ }_{2} \mathrm{CO}+\mathrm{SiC}$. The carbon monoxide escapes and is burnt outside the furnace. More than 3,00o tons of this are made annually at Niagara. Acheson also prepares in the same manner graphite from coal (anthracite) and various lubricating materials are in turn made from this graphite. All forms of carbon pass into graphite at a sufficiently high temperature. Over 2,000 tons of graphite per annum are now produced at Niagara Falls by this electrical process, and Acheson has discovered methods of manufacturing not only the hard graphite suitable for electrodes, crucibles and other objects, but a soft oleaginous graphite for making lubricants.

Another extremely large electrothermal industry, in fact one of the largest, is the manufacture of calcium carbide by electrically heating to a very high temperature lime and pure coke or coal. The chemical reaction is $\mathrm{CaO}+{ }_{3} \mathrm{C}=\mathrm{CaC}_{2}+\mathrm{CO}$. The calcium 
carbide is employed for the production of acetylene gas for illumination which it yields by treatment with water reproducing calcium hydrate $\mathrm{CaC}_{2}+{ }_{2} \mathrm{H}_{2} \mathrm{O}=\mathrm{CaH}_{2} \mathrm{O}_{2}+\mathrm{C}_{2} \mathrm{H}_{2}$.

Another large use of calcium carbide is in the manufacture of calcium cyanamide or nitrolime, which is produced when nitrogen gas is passed over calcium carbide at a high temperature. This substance is used as a fertiliser for soils. The manufacture of calcium carbide is carried out on a large scale at Odde in Norway, where 23,000 horse power are taken from the river Tysse and used for creating electric current. Air is liquefied and the nitrogen gas separated from the oxygen and used for the production of nitrolime. In I9ro the total production of calcium carbide amounted to nearly 250,000 tons, and some I 5,000 tons were used for making nitrolime. An industry of immense importance which is wholly dependent on the cheap supply of electric encrgy is the manufacture of aluminium from cryolite and bauxite. The modern process of aluminium production is the result of the work of Hall in America and Héroult in France. The mineral cryolite is a double fluoride of aluminium and sodium. If it is crushed and mixed with powdered fluorspar (calcium fluoride) the mixture can be used and in the liquid state dissolves alumina. In the manufacturing process the alumina is prepared from bauxite, a crude aluminium hydrate. A mixture of cryolite, fluorspar and pure alumina is placed in an iron crucible lined with graphite and melted. When fluid a graphite electrode is placed in the mixture and made the anode by which an electric current is passed through the liquid. The alumina is decomposed and metallic aluminium is deposited at the bottom of the crucible. The success of the process depends on the fact that molten metallic aluminium has a greater density than the fused electrolyte, and hence falls to the bottom and is protected from oxidation. If the voltage used per cell is not more than 5 or 6 volts the alumina alone is electrolysed and the cryolite and fluorspar remain unaltered. This process is now carried out on a large scale at Niagara Falls, and also at the extensive works of the British Aluminium Company at Loch Leven in Scotland and at the Falls of the Foyers on Loch Ness, where 30,000 horse power are utilised for this purpose. By proper adjustment of the current the heat created keeps the charge of salts fluid, and the pots only need aluminic hydrate to be added at intervals and the pure metallic aluminium to be drawn off at the bottom. At Niagara each pot has a current of 7,000 to ro,000 amperes passed through it at about 5 volts, or takes nearly $60 \mathrm{H} . \mathrm{P}$., and produces I I 2 lbs. of aluminium per day. This process has now killed all other chemical processes and reduced the price of the metal to something near is. rod. alb., with an annual output of nearly i 5,000 tons.

Another very large industry dependent on the electric furnace is the production of ferro-alloys. Metallurgists have discovered the remarkable change in properties produced in carbon steel by the addition of a small fracture of I per cent of certain other metals such as chromium, vanadium, tungsten, or nickel. Thus 0.6 per cent of vanadium added to ordinary steel nearly doubles its tensile strength and resistance to vibration. If chromium is added, the chrome-vanadium steel has most valuable properties in resisting shock and is largely used for motor car axles. In the manufacture of such steel the small percentage of special metal is best added in the form of an iron alloy. The manufacture of these ferro-alloys of iron, tungsten, nickel, vanadium, etc., is now conducted in electric furnaces on an immense scale at the Girod works at $\mathbf{U}$ gines in France and elsewhere, also the preparation of an alloy called ferro-silicon used for imparting special qualities to cast iron and steel.

Another electro industry of vast importance is the manufacture of nitric acid from the nitrogen of the air. A few years ago Sir IV. Crookes drew attention to the approaching exhaustion of natural fertilizers such as guano and the natural nitrates, and the necessity for making them from atmospheric nitrogen to maintain the world's supply of wheat. This is now carried out on an immense scale in Norway and Switzerland by hydroelectric power. One process, as worked out by Birkeland and Eyde and Schönherr, depends on the fact that when air is blown through an electric are nitric oxide (NO) is produced, and this can take up oxygen from the air and form nitrogen peroxide $\left(\mathrm{NO}_{2}\right)$, which by action on water produces nitric acid. In the Birkeland-Eyde process a power- 
ful alternating current arc is formed between two water cooled electrodes with high voltage. This arc is spread out into a flat disk of flame by a magnetic field at right angles, and the arc itself is formed in a flat furnace chamber. Air is blown through the chamber, and the issuing gases are allowed to take up oxygen in a reaction chamber and then conducted up towers filled with lumps of quartz down which water trickles. The nitrous fumes produce nitric acid, which is concentrated and neutralised with either soda or lime water, this producing sodic or calcic nitrate. This artificial nitrate has now obtained a sale as a fertiliser. At Notodden in Norway the process is conducted on a large scale, water power amounting to 30,000 H.P. or upwards being used for generating the electric currents. Each arc furnace takes 700 kilowatts through which 25,000 litres of air pass per minute, the whole plant being capable of $\mathrm{I}, 500$ kilograms of 100 per cent nitric acid per day. This factory has been open since 1905. In the apparatus of Schönherr used by the Badische Anilinfabrik an arc is formed in a tubular furnace between metallic electrodes, and air is sent up the tube with a whirling motion which keeps the arc in the centre line. Each tube absorbs $1,0 \infty 0$ H.P. The Badische Anilinfabrik has combined with the Birkeland-Eyde Company, and altogether some 400,000 h.p. will shortly be utilised in Norway in the fixation of nitrogen.

\section{Railway Electrification and Power Transmission}

The great progress made in the generation of electric currents on a large scale is shown in the immense number of Power Stations now existing in the world, partly hydroelectric or deriving their energy from water power, and partly coal-steam electric stations.

The hydroelectric stations have obtained much their greatest development in Canada, Switzerland, Norway, Sweden, Italy, the United States, and other countries where water power is abundant. The hydraulic arrangements depend essentially on whether a low or high fall of water is available. If a high fall is utilised the power station may be located at the lower level and the water brought down to it by large iron tubes from an upper reservoir or lake. In this case the water motors, Pelton wheels or turbines, are placed at the base of the fall pipes and discharge the water into a river or channel. In other cases, such as Niagara, the turbines are placed at the foot of the penstocks and a long shaft extends up to the power house at a higher level. The dynamos are in all cases direct coupled to the water motors and may be direct current dynamos or single or polyphase alternators. The cost of such a hydroelectric installation varies very much according to the preliminary engineering work necessary to utilise the water, also with the size of the water motor units and whether the fall of water is low or high. In round numbers it may vary from $£ 25$ per horse power of output for low falls to $£ 5$ with high falls. An increase in the size of unit tends to economy. In the latest additions to Niagara Falls power house the sizes of turbines installed are from Io,000 to I 2,000 H.P., whereas the earlier units were 5,000 H.P. size.

The chief item of cost in connection with distribution of power electrically is the transmission line. The reduced cost of aluminium has now made it economical to employ that metal for conductors, since its specific gravity is one third that of copper and its electrical conductivity only half as much again. The improvements made in high tension oil switches and the control of large high tension currents, as well as in the construction of transformers for raising voltage, have rendered it possible to transmit at voltages such as 60,000 or even 100,000 volts and thus economise in the size of conductors for a given power. Thus the transmission of power from Niagara to Auburn, I63 miles, is carried out at 60,000 volts by 3 -phase currents over two lines, one of aluminium on wooden poles and one of copper on steel towers. In California the Great. Western Power Company have carried out a scheme for the transmission of power electrically at a pressure of 100,000 volts over a distance of several hundred miles. The Southern Power Company in the United States now distribute at 100,000 volts over a distance of 164 miles. A line from Cook Falls in Michigan to Battle Creek, 190 miles, is now operated at 135,000 volts, the power transmitted being I0,000 H.P. or more. The Ontario Hydroelectric Commission recently placed contracts for 300 miles of I I0,000 volt transmission line. In Europe there is at least one I IO,000 volt transmission line in Saxony, the station being a steam-coal station in contiguity to a colliery, the owners of which have agreed to supply power up to 12,000 kilowatts for 30 years. The transmission 
line is of copper, and in the course of the run rivers and railways are crossed. Hence the engineering difficulties of electric transmission of power at 100,000 volts over distances of IOO or 200 miles are now largely overcome. In Great Britain with a few exceptions a transmission pressure of 6000 volts is now usual in large coal-steam supply stations. It is transmitted as two or three phase alternating current and may be then transformed down to low pressure alternating or to 500-600 volt direct current for traction purposes.

A good example of a recent coal-steam electric power station is the Dunstan Power Station at Dunstan-on-Tyne for supply of power in Northumberland and Durham. The station is laid out for 6 generating units of 10,000 kilowatt capacity, 3 of which have been already installed. The engine units are steam turbines of the A.E.G. impulse type and Brown-Boveri-Parsons type, and drive alternators giving a three phase current at 5.750 volts and 40 periods. The feature of the station is the care with which the switchboard gear has been designed. This is contained in a separate fire-proof house I50 yards away from the engine room, and contains the oil switches and controlling gear for governing the distribution. The boilers are provided with automatic stokers and the steam is superheated to $570^{\circ} \mathrm{F}$. It is intended to supply electric energy at low rates for metallurgical and chemical operations.

The problem of railway electrification for other than short suburban railways and with the aim in view of main line electrification is now attracting the attention of engineers. There are four competitive systems-

I. The low pressure direct current (D.C.) system, working at 500-600 volts.

2. The high pressure D.C. system working at $1,200-2,000$ volts.

3. The single phase alternating system.

4. The polyphase (3-phase) alternating system.

System I has abundantly proved its applicability for electric urban traction and short urban or interurban railway lines, as for instance in the Metropolitan Railway (London) and in innumerable cases in urban and interurban tram lines all over the world. The low voltage used limits the economical use to a few miles unless coupled with the employment of transformer stations. Thus in the case of the Metropolitan Railway the energy is transmitted by alternating current at 5,000 or 6,000 volts from the generating station to transformer stations along the line and there changed to D.C. current at 500 volts.

The great contest at present is between the single phase alternating system and the direct current system. Single phase traction motors having commutators, called respectively compensated series and compensated repulsion motors, have now been invented, and these can be accelerated and reversed with the same ease as continuous current motors. The A. C. motors are, however, about half as large again as the D.C. motors for the same power output and the switching arrangements are heavier, and the motor has generally to be associated with a transformer. One difficulty with the A.C. motor is the sparking at starting; but the advantage of being able to transmit and pick'up current from the overhead trolley wire at high voltage and transform down on the locomotive to low voltage is very great.

Several railways are now operated with single phase line voltages of 11,000 volts at 25 periods per second; for example the Rock Island Southern Railroad 52 miles, Denver and Interurban Railroad 55 miles, and the Hoosac Tunnel on the Boston and Maine Railroad, and also the New York, New Haven and Hartford Railroad, all in the United States. The single phase system has also been adopted in England for the electrified section of the London and Brighton Railway, London Bridge to Victoria, and for the Heysham-Morcambe line of the Mirlland Railway. In (iermany engineering opinion inclines to the single phase system. The P'russian Chamber of Deputies has recently voted two million marks for electrifying the Bitterfeld-1)essau railway, and this is part of a scheme for electrifying a large number of Cierman state railway's with the single phase alternating system. On the other hand some railways in the United States which installed this system have now changed over to the high tension direct current system $(1,200$ volts). There are some 10 or 12 lines electrified on this latter system in the United States, the largest of which (6o miles) is the Washington, Baltimore and Annapolis Railroad. The capital costs are said to be slightly less than for the 600 volt I). (. system and the operating difficulties are no greater. In Italy and parts of Switzerland the three phase alternating current system seems to be preferred. The success of the Valtelina line on this system, and that of several similar north Italian lines, has encouraged an extension, and a Pitliamentary appropriation of 12 million pounds sterling has been made for elect rification of Italian main line railways on the 3 -phase system. The greater complications of the nverhead line involving a double trolley wire and those of the arrangements for speed regulation have been arguments against the 3 -phase system.

The future of railway electrification lies between the single phase alternating and high trnsion direct current systems for main line work. The horse-power output per ton of electrical equipment has been estimated at II H.P. for D.C. as against 6 H.P. for A.C. metors. The operating costs for A.C. systems are certainly higher than for D.C. For suburban lines and in competition with electrie tramwass railway electrification is necessary and advantageous, but for long main lines steam locomotion will continue to hold its own. 


\section{Electric Lamps and Electric Lighting}

Notable improvements have recently been made in the metallic filament electric lamps, in the flame arc lamp, and in the application of electric lamps to street lighting.

The metallic filament glow lamp made with drawn tungsten wire is now rapidly replacing the carbon filament lamp. In 1907 this lamp had hardly begun to affect the sales of carbon lamps, but in the United States in Igr 2 the sales of carbon lamps had fallen off to 52 per cent of the tótal, and that of metallic filament lamps correspondingly increased. Of these latter 25 per cent were tungsten, only about 3 per cent tantalum, and about I 9 per cent the gem or metallised carbon filament lamps. The original process of manufacture of tungsten lamps was to provide the metal in a finely divided condition, bind it with starch, sugar or camphor, squirt into a thread and then volatilise and burn out the binder, leaving a metallic filament composed of tungsten granules sintered together. The modern process is to draw down through diamond dies a wire of tungsten alloyed with some other metal as fine as .oor in $h$ diameter and to wind this on a frame which is inserted in the bulb. Lamps are thus made taking only I watt per candle.

The metallic filament lamp requires a more perfect vacuum than the carbon lamp or else blackening of the bulb soon takes place. A considerably larger percentage of the total power supplied is converted into light by the metallic filament. The carbon filament radiates 2.9 per cent of its total energy consumption as light, the osmium 5.2 per cent, the tantalum 6.5 per cent and the tungsten 75 per cent. 'This improved efficiency is due to higher temperature, but a greater percentage of ultra violet radiation which affects some eyes unpleasantly. The metallic filament lamp has, however, by its reduced energy consumption increased the demand for electric lighting. It has also given economy in street lighting by incandescent lamps, as it has, in addition to increased efficiency, an excellent life and therefore renewals are not large. The wire lamp has destroyed the domestic use of lamps such as the Nernst, which are not instantly illuminated on switching on.

In addition to improvements in metallic filament or wire lamps a good deal of work has been done in endeavouring to utilise vapour lamps.

The mercury vapour lamp consists of a glass or quartz tube provided with two electrodes highly exhausted but containing a little mercury. The lamp is started by tilting it so that the two electrodes are connected together for an instant by liquid mercury and the current then flashes through it and continues to travel in the mercury vapour, when the tube is again tilted back into an inclined position. The vapour is rendered incandescent and glows with a greenish light giving light at about 4 candles (mean spherical) per watt. The colour of the light is, however, a great disadvantage, and efforts to improve it by alloying the mercury with other metals have not yet been very successful. Another vacuum tube lamp is the Moore Lamp consisting of a long glass tube containing rarefied air or $\mathrm{CO}_{2}$. The particular improvement consists in a device by which the increase in the vacuum due to working is made to admit a little more air or gas. This automatic valve is essential to success. The use of neon as a gas for filling vacuum tube lamps is recommended on account of the high luminosity and low dielectric strength of the gas when traversed by a current.

In out-door lighting the use of flame arc lamps has now become very general. The carbons are impregnated with certain salts such as fluoride of calcium and sodium, which give great luminosity and a reddish yellow colour to the light. The efficiency is increased to about 4 to 5 candles (mean hemispherical illumination) per watt.

The question of effective street lighting and its cost has given rise to great discussion. The open plain carbon arc lamp is unable to hold its own with high pressure gas illumination, but the flame street arc lamp taking 360 watts and giving a mean hemispherical illumination of 2,200 candles costs about $f_{\mathrm{I}} 4$ per annum for energy and maintenance, and its colour gives an effective illumination for main streets.

The proper use of electric light and of illuminants generally has recently attracted much attention, and "Illuminating Engineering" has almost become a separate branch of electrotechnics. This is more necessary now that artificial light of greatly increased intensity is demanded and its safe and economical use has to be considered.

\section{Electric Heating Appliances and Furnaces}

The power of an electric current to produce heat is now utilised technically in electric heating for domestic purposes, e.g. cooking, house warming and water boiling, and also in manufacturing processes in electric furnaces of various kinds. There are two ways in 
which such heat can be generated, viz. by passing the current through a high resistance wire in some enclosure from which heat does not readily escape, and also by using the current to make an electric arc in some enclosed space.

The first method, called "resistance heating," is alone used for domestic heating. The simplest form of electric heater is a so-called radiator comprising an ornamental frame carrying several large electric lamps or else some coils of wire through which the current passes. If lamps are used it is called a luminous radiator, and if coils of wire a non-luminous heater or convector. If one electric unit (costing generally Id.) of electric energy is passed through such a radiator it creates 3,400 British thermal units (B.Th.U.) of heat, or enough heat to raise 18 pints of water from $60^{\circ} \mathrm{F}$, to $212^{\circ} \mathrm{F}$. The complete combustion of $\mathrm{I} \mathrm{lb}$. of good coal liberates 12,000 to I4,000 B.Th.U., but only a small fraction of the total calorific energy of coal is sent out into a room by a coal fire. Hence on the mere basis of fuel cost electric heating cannot compete with coal fires, yet in indirect advantages it can do so, especially if the electric energy is supplied at $0.5 \mathrm{~d}$. per unit. In the case of electric cooking two classes of apparatus are in use. In one, each utensil, say a kettle or saucepan, has a resistance wire contained in a double bottom or embedded in the sides. By means of a flexible wire and plug it is connected to the electric supply circuit, and the heat generated in the wire is imparted to the contained water or other liquid. In the same way an electric oven of this type has coils of resistance wire embedded in the sides and bottom. A good electric kettle so made can impart to the water 90 or 95 per cent of the heat created by the electric energy given to it. Thus about 60 watt-hours would be required to raise I pint of water from $60^{\circ} \mathrm{F}$. to boiling, costing at Id. per unit I th of a penny for the operation. Similar arrangements on a larger scale, as in the Therol heater, are used for heating bath water, etc.

In the alternative arrangement an insulated resistance wire is embedded in a closed flat plate of iron, and the passage of a current through the wire raises the plate to a high temperature. Ordinary kettles or saucepans with flat bottoms are then placed on this hot plate and cooking done in them. The "hot plate system" is somewhat less economical in energy consumption, but much more convenient in practice, as each cooking vessel does not require an electric connection. In the Berry "Tricity" system the oven is a light polished sheet metal box which has two hot plates applied to apertures at the top and bottom. Electric cooking by this method is cleanly and better than gas cooking in that the meat, poultry, etc. do not lose nearly as much weight in cooking as by gas or coal and preserve a better flavour. Everything that can be cooked by gas or coal can be cooked as well or better by electricity. With electric energy at Id. per unit the cost of electric cooking is not greater than gas cooking with gas at $2 \mathrm{~s}$. $6 \mathrm{~d}$. per thousand cubic feet. The convenience and comfort to the cook is, however, far greater. Where electric energy is supplied at $0.5 \mathrm{~d}$. per unit the advantage lies with electric cooking in every way.

Turning to larger operations we find that electric furnaces have now come into use in many branches of metallurgy, especially in steel and iron manufacture. There are several types of such furnace. Sir 11 . Siemens was the first to construct in 1879 an arc furnace for smelting iron, consisting of a crucible having one carbon electrode passing through its bottom and another which passed through the lid. Nearly 20 years later the matter was again taken up in 1898 by Major Stassano, who invented one of the earliest large electric arc furnaces, consisting of an iron cupola lined with fire clay in the interior of which a large electric arc was formed between carbon electrodes. Lumps of steel placed on the hearth were melted by the radiant heat so that the steel itself was not contaminated by the carbon.

Another form of arc furnace has been invented by Paul lléroult. It consists of an iron basin on trunnions, having a lining of refractory material and a cover through which pass two massive carbon electrodes. When the furnace is filled with a charge of pig or scrap iron, lime, and oxide of tar, the carbons are brought down on to it and a powerful arc formed between them which melts the charge and oxidizes the impurities, sulphur, phosphorus, carbon, etc. and finally converts the mass into licuid steel which is drawn off. An arc furnace of this type invented ly Paul Girod has only one carbon electrode passing through the lid, the other clectrode being one or more water conled steel plugs inserted in the bottom of the furnace. An arc furnace for smelting iron ore and producing pig iron has been devised by the French firm keller ledeux \& ("ie, in which the reduction of haematite iron ore by coke can be carried out electrically. In all these are furnaces there is a considerable combustion or loss of the carbon electrodes, and to some extent carbon is introduced into the charge. Hence their chief use is in the preparation of a material from scrap or pig iron which is approximatcly free from sulphur, phosphorus and carbon, and can be subsequently refined into a high class of steel.

A form of eleetric furnace without electrodes was originally devised by S. Z. Ferranti, called an induct ion furnate. It consists of a closed rectangular ring of laminated iron having wound round it at one part a magnetising coil through which an alternating current is passed. This ring is cmbiraced by a circular annular trough formed of refractory material, in fact a sort of groove in a mass of brick and fire clay. This trough is filled either with scrap iron or with crude liquid steel. It forms the secondary circuit of a transformer of which the iron 
ring is the core and the coil the primary. Hence powerful currents are induced in the material placed in the trough, thereby heating it. Various forms of this induction furnace have been designed by F. A. Kjellin and by the firm Hermann Röchling \& Co. (called the RöchlingRodenhauser furnace), in which induced heating is combined with direct resistance heating by passing an external electric current through the charge. By means of the induction furnace and by suitable admixtures of fluxes (lime) and oxidising agents (iron ore) crude steel or scrap can be refined into a high grade of steel. For laboratory purposes forms of resistance furnace have been devised by Heraeus, which consist of a porcelain tube wound round with a platinum strip and enveloped over this with a non-conducting covering. When a current is passed through the strip the tube is soon brought to a red heat. Crucible and muffle furnaces are similarly made. Small arc furnaces in which an arc is formed between two carbon electrodes included between two massive blocks of lime or dolomite are used in chemical laboratories. The scientific work of $\mathrm{H}$. Moissan was done with one of this type.

Electric heating and metallurgical processes can be conducted in some cases by passing a powerful electric current through the materials operated upon. The heat so produced effects some desired chemical change. In other cases a crucible may be packed round with high resistance material such as "kryptol," through which an electric current is passed and heat thereby produced. The great advantage of such electric heating is that the heat can be produced exactly where it is required and there are no products of combustion.

In the case of electric arc furnaces there is a necessary loss of heat through the electrodes. The rules for the most economical size have been discussed by C. Hering and A. E. Kennelly. Electric arc furnaces are used extensively in France at La Praz and Ugines for producing ferro-alloys, whilst induction furnaces are largely employed in steel manufacture.

\section{TELEPHONY}

In the last few years considerable attention has been paid to the theory of the propagation of electric currents along wires and cables, especially with reference to the rapidly alternating currents employed in telephony. The necessity for this arose from the costly nature of long telephone lines and cables, and the importance of being able to predict the performance of such a line from its specification before construction.

The mathematical theory has chiefly been developed by O. Heaviside, M. I. Pupin, A. E. Kennelly, G. A. Campbell and others, and has been put into a form intelligible to practical engineers by A. E. Kennelly and J. A. Fleming. The electric current which flows in a telephone cable when transmitting speech is a very complex ebb and flow of electricity. In accordance with Fourier's theorem this motion can be analysed into the sum of a number of simple harmonic motions of various amplitudes and frequencies in the ratio $\mathrm{I}: 2: 3 \mathrm{etc}$. These are called the harmonics of the current. That which gives the sound its meaning to the ear when transmitted telephonically is the wave form of this variable current. This depends upon the relative amplitude and phase of the harmonics. In an ordinary telephone wire or cable the harmonic oscillations of high frequency travel faster than those of low frequency, especially if the cable has much electrical capacity. Also the higher harmonics are more rapidly degraded or attenuated in amplitude than the lower. Hence after travelling a certain distance the wave form of the current becomes distorted so much that when it flows through the receiving telephone it no longer reproduces the sound uttered to the transmitter. Heaviside showed that this distorsion depended upon the relation of the resistance, capacity, inductance, and leakance of the line, and that if a line were constructed in which the product of the capacity and resistance per mile was equal to the product of inductance and leakance in homologous units the line would be distorsionless. It is always found that for ordinary lines the first named product is larger than the second.

The practical problem of making a telephone cable more or less distorsionless was found to depend upon the possibility of increasing considerably the quality called its inductance, which is in other words the electric inertia of the line, or the quality in virtue of which electric currents when created in it tend to persist and not die away instantly. This can be done by "loading " the line or inserting in it coils of wire of high inductance. It can also be achieved by winding over the telephone line with iron wire, which process is called uniform loading. The first method was proposed and worked out by M.I. Pupin, who showed that if the loading coils were placed at such distances that 8 or 9 of them were covered by one wave length of the current in the line 
the effcet was practically the same as if the added inductance were uniformly distributed. In subterranean lines the loading coils used are rings of iron wire wound with insulated copper wire, and are placed a mile or two apart. The difficulties of introducing the coils into a submarine telephone cable have only recently been overcome. A coil-loaded cable about 9 miles long was laid in 1906 by Messrs. Siemens and Halske across Lake Constance, and its improved telephonic qualities stimulated a larger experiment.

In r g го Messrs. Siemens Bros. made and laid for the British Post Office a coil-loaded cable across the English Channel. This cable contains two complete telephone circuits, each loaded with coils placed I nautical mile apart. This cable enables very excellent telephonic speech to be maintained between London and Paris; and in a paper on "Submarine Cables for Long Distance Telephone Circuits" (see Journal Inst. Elec. Eng., I 9 I I, vol. 46, p. 309) Major O'Meara stated that with suitably heavy land lines of copper conductors, 800 lbs. to the mile, conversation through it between London and Astrakhan on the Caspian Sea would be possible. A similar loaded cable has since been laid by Messrs. Siemens Bros. between England and Belgium. In this last cable a very great advance has been made in the quality of the gutta percha used for insulation. In connection with the transmission of telephonic speech the ratio of the leakance (S) of the dielectric to its capacity $(\mathrm{C})$ has a great influence. The ratio of $\mathrm{S} / \mathrm{C}$ for most gutta percha is a number near I 20 , but Messrs. Siemens have reduced the value to 12 for the Anglo-Belgian cable. In the Anglo-French the loading coils have an inductance of roo millihenrys and are placed I nautical mile apart, and the value of $\mathrm{S}$ C is I I 5 . In the Anglo-Belgian the coils have an inductance of $100 \mathrm{mh}$. and are also spaced I nautical mile apart. The attenuation constant for the loaded cable is nearly o.or 8 .

In addition to coil-loaded or Pupinised cables much work has been done with cables uniformly loaded by winding them over with iron wire as carried out by Krarup in Denmark. Many cables of Krarup type have been employed in Germany, and telephonic engineers differ in opinion as to the relative advantages of cables of the Pupin and Krarup type in respect to efficiency and cost, but evidence seems to show that for equal efficiency the Pupin method is cheaper. In any case an improvement from ro per cent to 100 per cent or more can be obtained by uniform loading and more by coil loading in the speech transmitting qualities. The problem of loading cables for short lengths of 20 to 50 miles may be considered as solved, and the advantage established.

Inother important advance in practical telephony is the introduction of the Automatic Exchange system. In the manual method an operator (generally a girl) is required at the central exchange to take from a caller his number and that of the desired correspondent and connect the two wires by a flexible conductor with end plugs. The delays and difliculties involved in this human element have led to the introduction of automatic exchanges. Each customer has on his telephone a dial or indicator with pointer which he sets successively to the integers, say four, composing the number of the person he desires to call up. Each subscriber is connected to the exchange by a double wire ending in a so-called ist selector switch, and the first movement of his index connects him to a group of wires the numbers of which lic in that particular thousand. The next movement of his index needle connects him to a 2 d selector switch which picks out a connection with a group of wires corresponding to the hundreds in the number called, and this in turn operates a 3 d selector switch which connects to the subscriber desired. The power to work the switches is obtained from local accumulators and the whole operation takes only a few seconds. The advantages of the automatic system are that the selector switches can be housed in basements or underground rooms unsuitable for manual operators. The aut omatic system which has come into most generahuse is the Strowger system. Although new to England, it has been for some years in use in the United States very successfully. In Los Angeles there are 47,000 subscribers in automatic connection; in ('hicago 30,000, and in San Francisco 25,000. The first exchange of this type set up by the General Post Office in England was installed at Epsom, the second at the General P'ost Office itself. Leeds is to have the third, and probably Portsmouth and Brighton will soon be provided with automatic exchanges. The automatic system 
lessens the cost of working and provides a more speedy interconnection. It can be combined with some manual interconnection in a semiautomatic system. Complete improved Strowger automatic systems are at work in Hildesheim, Altenburg, Munich, Graz and Krakow, and a semiautomatic is being prepared for Amsterdam.

\section{Wireless Telegraphy and Telephony}

In the increasingly important department of wireless telegraphy great progress has been made by G. Marconi in overcoming the difficulties of long distance radiotel graphy so as to maintain an efficient commercial service. Although some radiotelegraphic work is carried on ${ }^{1}$ by means of the Poulsen arc generator, up to the end of 1912 by far the greater part of all the wireless telegraphy in the world was conducted by the spark system, employing intermittent condenser discharges to create long electromagnetic waves. It has been found that for the accomplishment of long distances high antennae or aerial wires are necessary, and in the principal long distance stations the height of the masts or towers which carry these radiating wires is being increased. In Paris the Eiffel Tower is used as a support for antenna wires nearly I,, feet in height, and at Poldhu and elsewhere the Marconi Company employ masts 400 feet high. In these wires powerful oscillatory electric currents are set up by the intermittent discharges of large condensers, either air condensers (Marconi) or else glass plate condensers.

Great improvements have been made in the form of spark gap used. Marconi employs as a spark gap a rapidly revolving disk with studs on it to create several hundred discharges per second in the form of a spark called a musical quenched spark. In Germany a type of discharger due to $M$. Wien is employed, consisting of flat metal plates in close proximity, which has the property of instantly arresting the electric arc which tends to form between the plates. In the recent forms of spark transmitter producing a quenched spark, the effect is to impart to the antenna wires a sudden electrical impulse which sets up in them free electrical vibrations. These impulses are repeated several hundred times a second, and result in the radiation from the antenna of corresponding groups of electric waves. The signals are made by interrupting these intermittent wave trains into long or short groups in accordance with the dash and dot Morse code signals. At the receiving end these waves are picked up or absorbed by a receiving antenna and caused to create similar oscillations in a circuit comprising an adjustable condenser and inductance coil. The signals are mostly read by ear by a telephone receiver, which has placed in series with it a rectifier or valve to convert the rapid electrical oscillations into gushes of electricity in one direction. These gushes coming at the rate of the spark frequency in the transmitter give rise to a musical note which is interrupted into long and short sound interpretable as Morse code signals.

Much research has been carried out to discover and explain the action of these oscillation rectifiers. It has been found that certain crystals such as carborundum, an artificial carbide of silicon, conduct electricity better in one direction, and also that a contact between a metal or carbon point and certain metallic sulphides has a similar property. Thus a plumbago point lightly pressed against a surface of galena (lead sulphide) will rectify; also a gold point against a surface of pyrites (iron disulphide). By using a very sensitive galvanometer in series with a crystal of carborundum the radiotelegraphic signals can be photographed on paper slip. The action of these rectifying contacts does not appear to be thermoelectric, and the full reason for the asymmetrical conductivity has not yet been found. Prof. G. W. Pierce discovered that a copper point pressed against a surface of molybdenite is a very excellent oscillation rectifier.

As regards long distance radiotelegraphy Marconi has had in operation for some years stations conducting transatlantic communications, one at Clifden near Galway in Ireland, communicating with one at Glace Bay in Nova Scotia or with one at Cape Cod

${ }^{1}$ Before the Select Committee of the British House of Commons in November I9I2 evidence was given of further results of work between San Francisco and Honolulu. But here it is only possible to deal with the situation as known up to that time. See also under Part I, Sect. i., "Extension of Telegraphic Communication." 
in Massachusetts, and also long distance stations in Italy near Pisa and in South America. The scientific explanation of this long distance radiotelegraphy is even now imperfect. It is tolerably certain that if the earth were a metallic sphere and destitute of any atmosphere long distance wireless telegraphy on it would not be possible. Mr. Marconi not only sends electric waves across the Atlantic but has received signals in South America from his station in Ireland, a distance of 6,000 miles. The problem then is to explain how these electric waves travel one quarter of the way round the earth. The waves used in such work are from 2 to 4 miles in wave length and can undoubtedly bend or be diffracted like light rays to some extent round obstacles. The researches of several mathematicians such as Lord Rayleigh, M. Henri Poincaré, Prof. Macdonald and Dr. Nicholson, have, however, shown that diffraction alone will not account for such long distance radiotelegraphy. One attempt to explain it has been advanced by Prof. A. Sommerfeld. He has shown that in the case of a Hertzian oscillator placed at the boundary of two medii of different dielectric constant and conductivity, such as the earth and the air, there are surface electric waves which follow round the surface irrespective of curvature. Another theory is put forward by Dr. Eccles. He has given reasons for believing that in a medium such as the upper atmosphere, which is in a state of ionisation due no doubt to the absorption of ultra violet light from sunlight, a long electric wave travels faster than in ordinary un-ionised air. Hence his view is that the upper portion of the wave front advances faster than the lower when radiation takes place from an ordinary vertical antenna. The electric ray may therefore bend to some extent round the curvature of the earth.

Another question of great importance is the reason for the longer distances which can be covered by radiotelegraphic communication at night than in the day with certain wave lengths. This is in some way connected with the greater ionisation of the air by sunlight during the day. It can be shown that it is not due to mere conductivity imparted to the air by the ionisation, at least unless this is far greater at high levels than at any altitude at which it has yet been measured. It is probably due to the deflection either upwards or downwards of the electric radiation in virtue of the difference in the velocity of the wave at various levels in the atmosphere. For the waves as used for inter-ship and shore communication the range is about 3 times greater by night than by day, but by the use of a longer wave this difference can be reduced. There are also curious differences in the greater facility of transmission North-South than East-West.

Another matter to which much attention has been paid is the invention of high frequency generators for the production of undamped oscillations especially required for the achievement of wireless telephony. 'The inventions of Goldschmidt for multiplying up frequency by the use of a polyphase alternator are important. Duddell and Fessenden have also devised high frequency alternators.

The prohlem of wireless telephony requires not only means for producing persistent trains of electric waves but a microphone or means for modulating them in accordance with the wave form of the speaking voice. Such large current microphones have been devised by (). Majorana, W. Dubilier, E. Ruhmer and V. Poulsen, and by their aid speech has been transmitted for two or three hundred miles without wires. R. A. Fessenden has transmitied specch in this manner from Brant Rock to New York City, U.S.A., 200 miles; Poulsen from Lyngby to Eshjerg in Denmark, 200 miles; Lieuts. Colin and Jeance and M. Mercier from P'aris to Finisterre, 300 miles; Majorana from Monte Mario to Porto Danzig in Italy. More recently speech has been transmitted radiotelephonically between Monte Mario and a wireless station on Maddalena Island, I6o miles. The apparatus for conducting it generally involves a Poulsen arc generator or some modification for producing undamped clectric oscillations. It has not yet been adopted to work as a practical method of intercommunication like wireless telegraphy by ordinary operators. The invention of a simple efficient high frequency alternator producing electric oscillations or some equivalent device is a necessary preliminary to the establishment of wireless telephony on a commercial basis.

A reversion to the older system of magnetic induction telegraphy has been lately 
introduced under the name of the "Railophone" for effecting telephonic communication with moving railway trains. It is based on inventions by Von Kramer and Gisbert Kapp.

(J. A. Fleming.)

\section{MILITARY ENGINEERING}

\section{i. Heavy Field and Siege Ordnance Equipments ${ }^{1}$}

Since the introduction of quick-firing field guns, it was to be foreseen that inventors would apply the same principles of construction to equipments of heavy field and siege artillery. In fact there now exist several equipments which have common characteristics, i.e. the long recoil of the gun on the mounting, the reduction if not suppression of movement of the sights, and the simplification of loading and laying.

Heavy Field Armaments. - The size and weight of heavy field equipments have not been limited to a train in which the gun travels on its firing carriage attached to a limber, but have developed to such an extent that a train may necessarily be comprised of more than one carriage, the gun being dismounted for travelling and not merely drawn further back on the trail for the balance of the load. With a gun so much heavier and more powerful the application of the principle of the long recoil is faced with some difficultythe length of the recoil when the gun is in the neighbourhood of the horizontal being necessarily very considerable in order to obtain the desired stability. With howitzers also the application of the principles which have given such a happy solution for the field gun is full of serious difficulties, of which the chief is the necessity of obtaining angles of elevation of $40^{\circ}$ to $45^{\circ}$. The height of the trunnions is limited by considerations of stability and weight of equipment, and with this limitation a long recoil at high angles of elevation would cause the breech to foul the ground.

Two solutions present themselves: (I) to arrange trunnions at the rear end of the cradle, as near the breech of the piece as possible; (2) to arrange a variable recoil. Krupp favours the first, with springs compensating for preponderance; such springs, however, cause uncertainty and unevenness in laying for elevation, as they vary in tension. Ehrhardt favours the second. Cockerill has tried to combine the advantages of both but not quite satisfactorily. Schneider, while constructing with the variable recoil, has made an original application of the rear trunnions.

Schneider $15 \mathrm{~cm}$. Gun.-With this carriage the expression "variable recoil" is not exactly accurate. In reality the buffer is disposed in a manner to give a long recoil of a fixed length at all angles between maximum depression and $14^{\circ}$ elevation; and a reduced recoil, also of fixed length, at all angles between $20^{\circ}$ elevation and maximum elevation. Between $14^{\circ}$ and $20^{\circ}$ elevation the recoil is variable. Two steel valve keys are fixed to the buffer cylinder and engaged in slots in the piston. Their height varies, modifying at each instant the holes for the passage of the liquid. Their breadth being constant but less than that of the slots in the piston allows of a slight rotary movement to the piston. At high angles of elevation the liquid escapes through the slots only and the recoil is reduced. But when the angle decreases, holes in the head of the piston open, and the length of recoil increases. To obtain this effect, on the piston rod and against the piston itself is mounted a disc, with slots of exactly the same breadth as the valve keys, so that the disc cannot turn. There are holes in this disc, which according to the position of the piston, either do not correspond with the holes in the piston, so producing a reduced recoil; or partially correspond, with intermediate variable recoils; or entirely correspond, with a long recoil. The position of the piston is controlled through a rack and a toothed sector on a lever, the lever being worked by a bar actuated by a roller moving in two arcs of different radii concentric with the trunnions and connected to one another. For travelling the train consists of two carriages; the gun is raised out of its firing carriage by a screw and wound off by means of a windlass on to a four-wheeled block carriage; the mounting with cradle complete is attached to a limber, forming the first carriage of the train, of which the block carriage forms the second.

Schneider I2O mm. Howitzer.-There are three models of howitzers built by Schneider: light (I05 mm.), medium (120 mm.) and heavy (I50 mm.), of which the $120 \mathrm{~mm}$. may be taken as typical. The piece rests in a saddle which recoils with it; the buffer cylinder and recuperator form part of the saddle. The buffer allows of a variable recoil, regulated by variation of the holes for the passage of the liquid. The piston is attached to the cradle and the cylinder is pulled off it on recoil. The recuperator takes the form of a cylinder connected with air reservoirs, the air being compressed during recoil and, reasscrting itself,

1 See $E, B . \mathbf{x x}, 223$ et seq. 
runs the gun up again into the firing position. The general arrangement of the cradle and carriage is very similar to that of the field gun carriage, but the cradle is extended some distance further to the rear to ensure equilibrium about the trunnions which can thus be brought nearer to the breech of the piece. This extension of the cradle also protects the breech mechanism, preventing elevation beyond the point when the gun would strike the ground on recoil, and also gives a longer sliding surface and support to the saddle.

Howitzers travel on their firing carriages, the heavier being drawn back on the trail and anchored to the traversing lever after the buffer has been disconnected.

Heary Sicge Armaments. - The same principles are again introduced as far as possible in these equipments. And the principle of the long recoil, with siege equipments, must conduce to modifications, the advantages resulting being numerous. In the first place it affects the obviation of the platform, or at least its simplification in such a manner that the work preparatory to coming into action may become insignificant in comparison with what it used to be. In the second place, with equal weights the power of the piece can be increased in large enough proportion whereby can be obtained increase of effective range, accuracy of fire and finally striking effect.

Schneider $28 \mathrm{~cm}$. Mortar.-The mounting for this piece is designed to be brought into action on a platform rapidly laid, and also to form, for transport, carriages of such a weight as to allow of animal draught. The saddle forms two large buffer cylinders with the recuperator between them. The recuperator is of the compressed air type. The general arrangement of the cradle is similar to that of the howitzers described. The carriage is built up of plates and is arranged so that the cradle trunnions are carried on springs until the actual moment of firing, when the shock of discharge compresses the springs, bringing the weight down so as to be taken in the trunnion holes. The carriage lies with the fore part on a spring pivot on the platform. The hind part is carried by two rollers lying between the carriage sides and mounted on springs, so that on firing the carriage is supported directly on the platform. The platform is of the shape of a rectangular box with a pivot to receive the carriage, and lies upon a plough-shaped spade which holds up the recoil of the whole system. It is necessary to dig a hole for the reception of the box part of the platform and the spade. For travelling the equipment forms four separate carriages, each consisting of a limber with a false trail attached to that part of the mounting which, carried on an axle, forms the after part of the carriage. The parts are dismounted by means of hydraulic jacks or a capstan, each part being lowered on to its own axle.

Garrison Mountings.- The types of mountings for coast defences have not varied. But a new design has been manufactured by Cockerill and adopted by Belgium.

The deșign is of a completely shielded embrasure mounting. It consists of three principal parts: the trunnion ring with the hydraulic buffer; the carriage brackets; the frame. The gun slides in a trunnion ring of which the trunnions are pivotted about a horizontal centre line of the embrasure. The recuperator consists of springs carried inside the buffer cylinder. Metal segments mounted on the trunnion ring take up exactly the spherical form of the embrasure, and are held up to their work by springs, allowing of slight movement radially so as not to affect the laying of the gun. Projections on the trunnion ring form clutches attached to the carriage brackets, which thereby take the shock of recoil and also act as arcs for elevating. The carriage brackets are firmly connected together and pivotted on the frame about a vertical centre line of the embrasure. The frame closes the embrasure and is securely anchored. The gun is balanced by means of a spiral spring contained in a cylinder situated under the mounting, variation in the tension of the spring and the displacing moment at different angles of elevation being corrected by means of a fusee. Laying is arranged by means of a telescope supported on the left carriage bracket and laid through a small window in the frame, the axe's about which the telescope can le moved being horizontal and vertical centre lines of the window.

(F. M. RickARD, Captain, R.A.)

\section{Field Artillery Material}

Field Cuns.-With the exception of Italy, the principal European States had completed their armament with quick-firing ficld guns by the year 1906, and only slight changes have since been marde in their equipment. In the case of Italy, the $75 . \mathrm{A}$ semiquick-firing gun was superseded in 1906 by a Krupp 14.3 pr. of the standard Krupp type, and 600 of these guns were issued. The total number of field guns required by the Italian artillery on mobilisation is 1,746 , and it was proposed to make up this number by re-mounting the $75 \mathrm{~A}$ guns on quick-firing carriages. It was found, however, that these guns were so badly eroded by the nitro-glycerine powder (filite) used in Italy as to be

1 See generally E. B. xx 218 et seq. 
not worth converting, and competitive trials were therefore held in I9 I $\mathrm{I}-\mathrm{I} 2$ to select a new gun. The three guns selected for the competition were a Krupp, a Schneider, and the Deport gun. The latter was preferred, and 600 of these guns have been ordered, to be manufactured in Italy, leaving some 500 guns still to be provided. Of these 500 , some will be replaced by light field howitzers and some by heavy field guns.

The Deport gun is the invention of Colonel Deport, of the Forges de Chatillon, the designer of the present French service gun. The carriage is on a novel principle, known as the "scissors trail." The trail is in two halves, hinged to the axletree, and capable of being opened out at an angle of about $60^{\circ}$ when the gun is brought into action. In place of the ordinary spade, the point of each half of the trail is nailed to the ground by a stout steel spike, driven down by a hammer. This wide anchorage renders the carriage unusually stable, and allows the gun, upon its vertical pivot, to be pointed nearly $30^{\circ}$ on either side of the central line. Moreover since this construction leaves an open space between the two halves of the trail, it allows the breech to be depressed, so that the muzzle can be elevated to $45^{\circ}$ above the horizontal plane. Three advantages are claimed for this "enlarged field of fire;" in the first place, targets in widely divergent directions can be engaged without shifting the carriage; in the second place, air-craft can be engaged without the necessity for a special gun; and in the third place, the gu n can be used as a howitzer, for vertical fire, by withdrawing a portion of the charge. The recoil gear is of novel design, known as compound recoil gear; the gun recoils 14 inches in its cradle, and the cradle is mounted on a pedestal which recoils 40 inches on the lower cradle. The breech action is the Nordenfeldt eccentric screw, as used in the French service gun; it is, however, fitted with semi-automatic gear which throws open the breech and ejects the cartridge case during the recoil. The breech then remains open till the fresh cartridge is introduced, when it is closed automatically by a spring. The gun itself, in the Italian Deport equipment, is exactly similar to the Krupp gun already in the service, firing the same am munition and giving the same ballistics.

The Greek Artillery.-A competition between French and German makers was held in Greece in 1907 , as the result of which the Greek authorities ordered 30 four-gun batteries from Messrs. Schneider of Creusôt. This gun is a I4.3 pr. with compressed air gear, generally similar to the Spanish Schneider gun.

South America. - The Argentine Government held competitive trials between Krupp, Schneider and Vickers-Maxim guns in I908. The committee expressed a slight preference for the Schneider gun, but for financial and political reasons the order was given to Krupp. The gun selected is a light Krupp 13 pr. In the following year the Chilean Government ordered field guns from Krupp, without competition; the Chilean gun is very similar to the Rumanian Krupp.

Field Howitzers.-Field artillery with modern shielded guns suffer very little from the shrapnel fire of field guns, while the increasing employment of the concealed position renders it difficult to make direct hits upon the guns or wagons with high-explosive shell. The result has been the development of the field howitzer, whose shrapnel bullets, descending at angles of from $45^{\circ}$ to $30^{\circ}$ to the horizontal plane, are effective against men behind gun-shields. All the great nations are introducing these weapons; but the only two Powers whose armament is completed are England and Germany.

The English Field Howitzer.-The details are secret, but it is a 35 pr. quick-firer, designed by the Coventry ordnance works. It has variable recoil, the length being automatically reduced at high elevations by valves which increase the resistance in the buffer, to prevent the breech from striking the ground. It has a full shield giving good overhead cover, and has the panorama all-round sight. The weight behind the team is somewhat less than that of the $18 \mathrm{pr}$. field gun. This howitzer is said to be far more accurate than any produced on the Continent, possibly owing to the excellence of the ammunition.

The German Light Field Howitzer. - The German army have for some years past had a 6-inch heavy howitzer and a 4.2-inch light field howitzer. The latter weapon has now been replaced by a 4.2 -inch quick-firer, firing a $3 \mathrm{I}-\mathrm{lb}$. "Universal" shell. It is of the Krupp pattern, with the trunnions at the rear end of the cradle, allowing of long recoil at all angles of elevation. The weight in action, with 4 -millimetre hooded shield, is $22 \frac{1}{2} \mathrm{cwt}$.

Heavy Field Guns.-The principal Continental armies are now equipped with heavy 6-inch howitzers, firing $90 \mathrm{lb}$. shell, and ranging 3 to 4 miles. In some cases, as with the French Rimailho howitzer, the gun itself travels on a separate wagon, in order to lighten the carriage and to enable the battery to move at a trot. The modern tendency is to supplement these heavy howitzers by heavy field guns, throwing a 6o-lb. shell over 6 miles; but financial considerations have prevented their introduction on any large 
scale. In Austria a 9-inch howitzer, firing a $250-1 \mathrm{~b}$. shell, was recently made available as a field weapon, the equipment being mounted on three motor lorries.

Mountain Guns.- In view of the prospect of a war in Central or Southern Europe, where fighting must largely be in mountainous country, the importance of quick-firing mountain guns has been generally recognised: yet the greater powers have been very slow to introduce them. The principal modern development in the construction of mountain guns is the system of weighing the gun with a removable jacket, carried separately, in order to reduce the recoil and so to enable a more powerful shell to be fired. This system is used in the Schneider-Danglis gun, adopted by Russia and Greece.

The breech ring, carrying the breech-block, is prolonged forward into a loose jacket surrounding the gun, and secured to it by a bayonet joint; this enables the weight of the shell to be increased to I 4.3 lbs., with a muzzle velocity of I, I 50 fs. This gun forms 6 muls loads with shield. Other nations use lighter guns; thus Servia and Bulgaria have II pr. Schneider guns, and Turkey a 12 pr. Krupp.

Balloon Guns.- Guns for the armament of dirigible balloons have been designed, but none had in 1912 been constructed. The nearest approach to such a weapon is the machine gun carried on top of the structure of the latest military Zeppelin, and the bomb-launching tubes of the Italian semi-rigid dirigible launched in I9I 2 at Milan. Guns for the attack of dirigibles from the ground have not yet been manufactured on any large scale, as it still appears doubtful whether the military dirigible will not be superseded by the aeroplane, at which the fire of land guns would be no more effective than snipe-shooting with a rifle. The standard pattern of field guns for the attack of balloons is the Krupp high-velocity I 2 pr; this gun has differential recoil, rear trunnions, and semi-automatic breech action, and fires a high-explosive shell which leaves a smoketrail behind it, and has a sensitive fuze designed to act on the envelope of a balloon. Messrs. Ehrhardt have a similar gun, which however fires universal shell in place of high explosive shell. Messrs. Schneider of Creusôt have proceeded on different lines, and have built a 1.47 -inch pom-pom mounted on a motor car, producing effect rather by the number than by the individual efficiency of the projectiles fired from it.

Ammunition.-During the last few years the combined shrapnel and common shell, or " universal " shell, has attracted much attention, especially since its adoption in roro as the sole projectile for the new German light field howitzer. The best known pattern of this projectile is manufactured by Ehrhardt. It consists of a shrapnel with separate high-explosive head; when burst in air as a time shrapnel the shrapnel portion acts in the ordinary way, while the head flies forward and acts as a percussion high-explosive shell on its own account. When burst on impact, the head detonates, and the detonation is also communicated to the explosive (trinit rotoluol) in which the bullets are packed. Experiments conducted in Austria and elsewhere have show that the head of the shell alone produces good destructive effect on a shielded gun, while the shrapnel effect, as compared with ordinary shrapnel, is in proportion to the weight of bullets. Since ordinary shrapnel contains 50 per cent of its weight of bullets, while the latest patterns of universal shell contain about 43 per cent, the new projectile entails a loss of 14 bullets in a hundred, or 14 per cent of shrapnel effect. This consideration, together with the extra expense, has so far stood in the way of its general introduction.

Stores and Appliances. - Writhin the last three years, the increased employment of the concealed position for field artillery has led to the general introduction of sights and appliance's for indirect laying. The panorama sight, which enables the gun to be layed on an aiming point to the tlank or rear, has been adopted by Great Britain, Austria, Russia, Italy, and several minor States; the battery director, which is similar in principle to a theodolite, has been introluced for measuring target angles, and so crabling the guns to be layed on a target invisible from the battery; and telephones for connecting the observing station with the guns have been issued to batteries and brigades. Thus in (iermany every battery has now an observation wagron carrying a ladder which can be set up in the battery, so that the commanding officer can see the target while keeping his guns concealed; and this wagon contains a complete set of telephones and indirect laying stores.

(H. A. Bethell, Col., R.A.) 


\section{SMall ArMs}

Since I909-Io there has been no technical development worth notice in regard to the sword ( $E$. B.xxvi, 269 et séq.) or bayonet ( $E$. B. iii, 557-8); but further progress has been made in regard to rifles and pistols.

Rifte ( $E$. B. xxiii, 325 et seq.) - In I9I I a new cartridge, known as Mark VII, was introduced for the British service. The bullet has a sharp point like that of the German " $\mathrm{S}$ " bullet. Its weight is I74 grains as compared with the 2 I 5 grains of the roundnosed bullet, and its core is a compound one, the rear portion being a cylinder of lead while the front portion is a cone of aluminium. While reducing the weight, the length of the bullet has thus been kept the same as that of the Mark VI bullet, and a change of magazine has been avoided, while the surface which bears on the bore is kept long enough to ensure accuracy. The propellant is cordite, but the modified form of that explosive is used in which the proportion of nitro-glycerine is much diminished and the heat produced by its ignition is thus considerably reduced. The charge, which is in tubular form, has been increased in weight by about 25 per cent. This increase, and the reduction in the weight of the bullet, have led to an increased velocity of about 400 foot seconds, and to a consequent lowering of the trajectory. The battlesight range, covering a man $5 \mathrm{ft} .3$ ins. high, is now about 675 yards as against 500 yards with the Mark VI cartridge, and the vertex of the 800 yards trajectory is $9 \mathrm{ft}$. as against $\mathrm{I}_{3} \mathrm{ft}$.

The introduction of this cartridge has necessitated the re-sighting of the rifles, the shape of the ramp of the backsight being altered and a new dial plate fitted. The opportunity has been taken to issue rifles having a " $U$ " notch in the backsight and a blade foresight, a combination much superior to the "V" and barley-corn of the old sight. The action is unchanged, but a bridge charger guide is fitted in place of the sliding charger guide on the bolthead. The breech has not been strengthened to withstand the higher pressure though the bridge charger guide does something towards strengthening the body.

No nation has undertaken re-armament since the issue of the Japanese 38 th year rifle in 1907, but all the military powers except Austria and Italy have adopted a high velocity cartridge, and this has necessitated re-sighting, which has in all cases been a more complicated and costly process than in the case of the British rifle.

No trustworthy automatic rifle has yet made its appearance. Rumours of the adoption of a rifle of the kind by Continental European powers are probably due to a confusion of ideas, the "rifle" referred to being really a rifle-shaped portable machine gun. Military opinion in all nations is agreed that the disadvantages of an automatic rifle outweigh its advantages, and the possession of one would be a constant anxiety owing to its liability to fail, though the increased rate of fire possible at a critical moment, averaging perhaps 20 to 25 rounds a minute, and the diminution of fatigue to the firer would be notable gains. The distribution of ammunition to men in the firing line would tend to become a more difficult problem than ever, and the allowance of ammunition for peace training would have to be increased materially if an automatic rifle were adopted.

The title of "Portable Machine Guns" has been given to a type of weapon which, though rifle-shaped and fired from the shoulder with a forked support for the muzzle, is too heavy to be carried and used by the already heavily loaded infantry soldier. It occupies a position between the machine gun and the automatic rifle. Such guns are fed with ammunition by hoppers, magazines or flat clips, either device holding about 25 rounds. A considerable volume of fire can be produced by these guns, but as the provision for cooling the barrel, owing to considerations of weight, cannot be thoroughly efficient; the duration of fire is somewhat limited.

Several types of portable machine-guns are in existence or under trial, the best known being the Madsen or Rexer, recoil-operated and fed by hoppers, and the Hotchikiss (known in the United States as the Benet-Mercie), gas-operated and fed by flat clips. The former was used considerably and with effect by the Russian cavalry in Manchuria, but seems likely to be displaced by the Hotchkiss, which has been adopted by the United States and is being studied by several European powers. Both these guns can be operated by one man, though a more continuous fire can be obtained, particularly with the Hotchkiss, if two men are employed, one to supply ammunition and the other to fire. The Madsen weighs 18 lbs. and the Hotchkiss $26 \mathrm{lbs}$. Both can be adapted to fire any small-arm cartridge.

The Lewis gun recently produced in the United States belongs to this family, though more cumbrous. It weighs $25 \frac{1}{2} \mathrm{lbs}$, is gas-operated, and is fed by a drum-shaped hopper. 
A weapon of this type seems admirably fitted for carriage on a motor-cycle, when it would be easy to arrange for an adequate supply of ammunition. For other arms the provision of a sufficient supply of ammunition presents considerable difficulties.

The question of which is the best military rifle was raised in Great Britain in I0I 2 in both Houses of Parliament during the discussion of the Army Estimates. The broad points which decide the value of a rifle for military purposes are (I) accuracy, (2) good ballistics, (3) handiness, and (4) reliability under all the accidents and stresses of active service. With the round-nosed type of ammunition accuracy and ballistics were practically identical with all the rifles in use. The introduction of the pointed bullet has modified the situation as regards accuracy, because the portion of the barrel which serves as a guide to the bullet as it passes from the cartridge case to the rifling was designed for a round-nosed bullet, and cannot do its work so effectively with a pointed one, and as regards ballistics because some nations have not been able, and some have not thought it desirable, to go as far in the matter of flatness of trajectory as others. Accuracy with the German, United States, and British Mark VII cartridges is about equal to that obtained with the old type of ammunition, but all other nations are faced with diminished accuracy, though the old standard is being approached as light is thrown on the details of manufacture by experience. Ballistics, so far as the design is concerned, depend on the strength of the action and the capacity of the chamber.

In the Lee-Enfield rifle, between the point where the stress is applied and the point where it is taken by the body of the rifle, is interposed a hollow cylinder in the shape of the bolt, which is liable to compression. The amount of stress which can be safely applied is thus limited. In non-British rifles the locking lugs are part of the front end of the bolt and the shock is thus transferred directly to the rifle and not through the intermediary of the bolt. The chamber capacity of the rifle again is small, the design having been made for a cartridge containing a compressed pellet of black powder. It is thus not sufficient to allow of any large increase in the amount of the charge while still retaining the proportion of air space which is necessary with a smokeless propellant if pressures are to be kept within reasonable limits. It has therefore not been possible to obtain a lower trajectory than one giving a height of $9 \mathrm{ft}$. over 800 yards as against the $6 \mathrm{ft}$. of the German cartridge for the same distance. The cartridges of other nations using a pointed bullet lie between these two extremes. At long ranges a heavy bullet, such as the British or French, behaves better than a light one such as the German.

In the matter of handiness the Short Lee-Enfield is good. Its length and balance give it a great advantage for snapshooting, while its being cased in wood throughout enables it to be handled even when the barrel is heated by continuous firing. 'The shortness of the rifle is in some quarters held to be a disadvantage for bayonet fighting, but a short handy weapon may well be better than a long unwicldy one.

As regards reliability the only charge which can be brought against the British rifle is that the butt is liable to work loose owing to the stock being in two parts. In the pattern now in use however this tendency has been overcome.

Pistol (E. B. xxi, $654 \mathrm{et} \mathrm{seq.)} \mathrm{-} \mathrm{The} \mathrm{bullet} \mathrm{now} \mathrm{used} \mathrm{in} \mathrm{revolver} \mathrm{cartridges} \mathrm{is} \mathrm{a}$ heavy leaden one with a head so slightly convex as to be almost flat. 'This construction listributes the shock of impact over a greater area, and the man-stopping qualities of the bullet are thus much increased.

The automatic pistols produced till quite recently have been of small calibre and therefore deficient in stopping power. The Colt Company have however now produced one of $.45^{\prime \prime}$ calibre, and Messrs. Webley and Scott one of $.455^{\prime \prime}$ calibre, which are satisfactory in this respect. Both have a "grip" safety, consisting of a lever in the butt, pressure on which is necessary before the firing mechanism can be operated by the trigger. 'The lever is thus in the firing position only when the butt is gripped.

Sights (E. B. xxv, 65 et seq.) - The aperture backsight, preferably in conjunction with a blade foresight, is now recognised as being the best sighting device for small arms. To be most effective the aperture should be placed in such position on the rille that it is as close as possible to the firer's cye wbile not being close enough to strike his 
face when the rifle recoils on firing. The sight radius is thus increased and greater ease and accuracy of alignment are consequently secured. Again, the fact that the firer looks through the aperture and has not to focus his eye for anything nearer than the foresight removes the main cause of the eye-strain felt with the open sight. The method of aiming is easier to learn than that with the open sight, while, if the aperture is large and is not surrounded with a mass of metal it is effective when the light is bad or the target indistinct. The system has of course long been in use for sporting rifles, but the only military rifle at present equipped with it is that of the United States. Its application to that rifle is however so defective that all the advantages named above seem to be lost.

(G. Browne, Major.)

\section{Naval Ordnance Construction ${ }^{1}$}

During the past rew years, nearly every maritime nation has been making great efforts to increase the power of its naval armament. Larger ships with greater speed and heavier guns have been built, and the progress made even in two or three years has been considerable. The Dreadnought type has developed into the "super-Dreadnought." Some authorities contemplate still larger ships, whilst others think the risk of putting so many eggs into one basket too great, and that therefore smaller vessels, but more of them, are what would suit existing conditions best. Both admit, however, that the armament should be made as powerful as circumstances allow.

The power of the armament depends on four factors: (I) the calibre and weight of the projectile; (2) the initial velocity; (3) the maximum weight of the bursting charge which can be exploded behind the armour of a hostile vessel; and (4) the number of guns; but various considerations arise in connection with these, which must be taken into account.

The diameter of the bore of the gun is governed to a great extent by the thickness of armour borne by the rival ship; this armour, owing to its weight, is however strictly limited both as regards thickness and extent; in consequence the thick plating is confined to a belt along the water line, to the protection of the ammunition hoists, the necessary working gear of the guns, and of the guns and gun's crew.

Of late years, much has been done to increase the resistance of armour, and to this must be added the difficulty of obtaining direct hits in action, owing to the target being almost always an oblique one. Moreover, improvements have enabled the range of torpedoes to be greatly increased, and this has helped to increase the probable battle ranges from the 3,000 or 4,000 yards of a few years ago to 8,000 yards or perhaps more. Even with the aid of telescope sights and the modern devices applied to the sighting gear for correcting for wear of gun, for temperature, for wind etc., much experience and practice are required to ensure hitting the target at these distant ranges.

It is now well known that in the Russo-Japanese war the thick belt armour was never perforated in any of the Russian or Japanese vessels, even at the short ranges of 3,000 metres to which the Japanese finally closed at the battle of Tsu-shima; this remarkable fact was no doubt due to the projectiles striking the armour obliquely and not at right angles. Had the firing been direct, no difficulty would have been experienced in perforating the armour on the latest built ship at this short range, and still less difficulty with the armour of the older ships.

Until recently, too, it was generally taken as an axiom that armour would be attacked by a gun of a calibre somewhere near its thickness, and armour was tested from this point of view; thus a 9-inch plate would be tested by a 9.2-inch gun and a 6-inch plate by a 6 inch gun. After all, the actual perforation of the armour of a ship would not, in all probability, seriously damage any vital structure unless the projectile was provided with a large bursting charge of high explosive which could be detonated behind the armour. The real damage to the Russian ships was done, not by armour piercing projectiles from the heavy guns, but by the incessant rain of high explosive shell from the Japanese secondary armament of 6 -inch guns. These were fired at the unarmoured portions of the Russian ships, and, bursting with terrible effect within, greatly damaged the ship

1 See E. B. xx, 189-2 I $8,230-235$. 
and completely demoralised the crew. With this significant result before them, authorities have not been slow to recognise that the bursting of very few large high explosive shell behind the armour might speedily decide an engagement.

Supposing for the moment that the calibre of the gun was approximately equal to the thickness of the plate, it is evident that as the quality of the armour improved the perforating energy of the projectile had to be increased, and, as the fighting range became more distant, a higher initial velocity was required. Both these conditions operate in the same direction, i.e. in an increase in the muzzle velocity of the gun. Moreover, some authorities were manifestly reluctant to increase the calibre on account of questions of interchangeability, and the additional weight to be accommodated.

For these reasons, the muzzle velocity of heavy guns up to and including $\mathrm{I} 2$ inches diameter has had to be considerably increased by (a) making the gun longer, (b) increasing the weight of the charge; and as it is generally admitted that the length of the gun bore should not exceed 50-calibres, but should be shorter if possible owing to the tendency to vibration and a consequent loss of accuracy of long guns on firing, the gun maker has to face an augmentation in the weight of the charge. This, however, he endeavours to keep as small as possible, by increasing the chamber pressure and making the gun and projectile stronger to withstand it.

The addition to the weight of the charge, to the chamber pressure, and to the length of the gun, all tend to increase erosion and to shorten the life of the gun. Speaking broadly, the erosion of equally proportioned guns is, for similar velocities, dependent on some function of the calibre, and the high velocities until recently demanded may be regarded as responsible for the comparatively short life of the guns designed to produce these velocities. Naturally, the life of the gun, i.e. the number of full rounds it is capable of firing before it is worn out, has a most important bearing on its efficiency, especially at the present time when many rounds are fired annually for exercise purposes.

It has therefore been necessary to consider some means of increasing the life of the gun, of ensuring perforation of improved armour at fighting ranges of 8,000 yards, and of bursting behind that armour a high explosive shell containing a powerful bursting charge. These conditions were met in the British Navy by the introduction in Igro of the 13.5 -inch gun. This gun, with a moderate velocity, has, owing to its heavy projectile, a considerable surplus of perforating energy over that of the high velocity I 2inch gun at the fighting range of 8,000 yards, and this surplus increases with the range. The I3.5-inch gun with its comparatively low velocity requires a charge no larger than that of the 12 -inch gun, and in consequence this gun can fire from $2 \frac{1}{2}$ to 3 times the number of rounds that the $\mathrm{r} 2$-inch gun is capable of firing. As first designed, the weight of the projectile was exactly the same as that for the I3.5-inch B.L. gun of I 885 , viz. I, 250 libs.; recently, however, a tendency to increase the relative weight of the projectile has set in, on account of the larger bursting charge which they may be made to contain, and in accordance with this the projectile has been increased in weight to $\mathrm{I}, 400 \mathrm{lbs}$.

Formerly, it was supposed that the length of projectile which could be relied on to give accurate results was limited to about 4 calibres, and that any increase in its weight simply implied thicker walls and a smaller bursting charge; but recent experiments with heavy guns give accurate results with projectiles up to 5.5 calibres in length. One argument aggainst a relatively high weight of projectile therefore vanishes.

It is not to he supposed that the calibre of the gun will be limited to 13.5 inches. (iermany and the Lnited States are already manufacturing I 4 -inch guns, and the Japanese (iovernment, besides constructing guns of this calibre, are also acquiring in England a number of similar guns. Oher nations are following this powerful lead, and signs have not been wanting of further developments.

Gun power has also been increased by improvements in the shape of the head of the projectile. Lntil two or three years ago, the radius of the ogive had been 2 calibres, but experiments with pointed bullets having a ratlius of head of from 6 to 8 calibres had shown that the sharper form of head gave, owing to the reduced air resistance, higher remaining velucities at all ranges; and consequently for any given range a much flatter 
trajectory was ensured. Experiments were then carried out with gun projectiles in order to obtain similar advantages, and it was found that the remaining velocity increased with the radius of the head, but that the accuracy became less if the point was unduly acute. A radius of head of about 4 calibres was finally decided upon as giving the advantage of increased remaining velocity, or longer range with good accuracy.

The perforating power of the armour piercing projectile has been much increased by the introduction of the cap. The cap as first introduced was solid with a flat nose of considerable thickness in front of the actual point of the shell. Lately this thickness has been greatly reduced, but in order to preserve the external form of the large radius ogive the cap is provided with a hollow point.

By the use of a higher grade of steel, the thickness of the walls of armour piercing shell can be slightly reduced; thus the internal capacity of the projectile is increased and a larger bursting charge of high explosive can be used.

The high explosive bursting charge for the various kinds of projectiles has also increased in weight; so that modern shells are more powerful than those of older types. In these a bursting charge of lyddite, i.e. melted picric acid, was employed. This material, although a most powerful explosive, has certain drawbacks, of which the following may be mentioned: it requires a somewhat high temperature to melt it for the purpose of running it into the shells, and it readily forms dangerous combinations with certain metallic salts should these be present; great care has therefore to be observed to prevent any possibility of their presence. An alternative chemical substance "trinitrotoluol" has come into favour; this melts at a very much lower temperature, and has the further advantage of not forming dangerous compounds as picric acid does. On the other hand, it is more inert, so that a powerful exploder is required to properly detonate it; but this inertness is otherwise an advantage in as much as it enables an armour piercing shell filled with trinitrotoluol to perforate armour, even at a striking velocity of over 2,000 f.s., without exploding the shell. Thus, with a well designed fuze and exploder, it is possible to burst the shell after it has passed through the armour into the interior of the ship.

(A. G. HADCOCK.)

\section{ARMOUR-PLATE 1}

Progress of $M$ anufacture.-Improvements in armour-plate manufacture, with a view to increasing the resisting power of plates, are the jealously guarded secrets of the manufacturers and their respective Governments. As far as can be ascertained, however, there have been no further developments during the last two or three years comparable in importance with those introduced in the past by Harvey or Krupp. Minor improvements have no doubt been made, and the actual quality of an average plate is probably better than it was three or four years ago; but, relative to the attack, it is doubtful whether any progress has been made in the resisting power of armour.

It is claimed, however, that in the United States, at least, a considerable advance has been made in the case of the thinner plates, up to 3 or 4 inches in thickness, including those used for decks, splinter-proofs, roofs of turrets, conning towers, etc., by the adoption of a nickel-chrome-vanadium steel subjected to a special heat treatment. In view of the possibilities of aerial attack, the importance of horizontal armour, especially in the form of light over-head cover, is greater than ever, and for this reason alone any development in the resisting power of thin plates is to be welcomed. In the case of the thicker plates no definite advance of any importance has been reported, except in the matter of surface flaking when struck, which is said by Rear Admiral N.C. Twining, the Chief of the United States Bureau of Ordnance, to have been very greatly reduced in recent years (see Scientific Americain, December 9, I9II).

In the above remarks, no account has been taken of the Simpson process, which would seem to be still in the experimental stage. The process is one of welding together steel plates of varying hardness by means of copper. As described in the Times (London) of March 29, I9I I, the weld is effected as follows. The plates to be united are placed,

${ }^{1}$ See E. B. ii, 578 et seq. 
with a layer of copper between, in a mixture of carbon, brown sugar and water of the consistency of compressed snow, and the whole mass is heated to a temperature of $2,000^{\circ}$ F., when the copper melts away into the adjacent steel, forming a perfect weld. The advantage to be gained by such a process is obvious. One of the limitations of the cementation process is that the carbon, upon which the hardness of the face mainly depends, only penetrates to a depth of about one inch and, consequently, there is a dificulty, in the thicker plates, of getting the best relation of thickness between hard face and tough back. By the Simpson process-if successful-it would be possible to obtain any desired relation between the two and to use any class of steel which might be preferred. Further it would appear possible to employ one or more intermediate layers, if it should be found desirable, to prevent too abrupt a change in the character of the steel. The possibilities of the process depend upon the soundness of the weld-the point in which the earlier compound plates failed.

An interesting account of the Krupp process as carried out at Essen was given in Engineering of August I6, I9I2. It is noteworthy as giving the approximate temperatures of the various stages, including the differential heat. The account differs in some details from earlier descriptions, notably in the use of illuminating gas instead of solid carbon in the cementation process and in the method of the final chill.

Modifications in Thickness etc., of Plates.-The increased power of the attack, which, apart from the tendency to adopt heavier primary guns, is due partly to improvements in the projectile and cap, considered merely as perforating or punching tools, and partly to increased ranging power due to the elongated form of head now universally adopted, is having the inevitable effect, in the absence of any revolutionary change in the character of plates, of increasing the maximum thickness of the main armour; and it has been stated that in the U.S. battleship "Nevada" the maximum belt thickness is to be I $3 \frac{1}{2}$ inches as against the I I inches of the "Wyoming." and her foreign contemporaries, while armour of as much as i 8 inches thick is to be used on the port plates of the 3-gun turrets. During Igr trials are known to have been carried out in the United States with $\mathrm{r} 8$-inch plates. On the other hand there would appear to be a tendency in America to drop light vertical armour for the protection of the secondary armament on the ground that it merely serves as an effective shell burster. In the latest British battleships it is reported that light armour for the secondary guns is reverted to.

Another modern feature of interest is the use of plates of varying thickness vertically, for belt armour. There is thus no marked line of cleavage, as formerly, between the thicker and thinner horizontal layers of the belt.

The use of cast steel-such as Hadfield's "Era" steel-for gun shields, armoured tubes etc., is increasing. Its resisting value is high, a recent example of a 2.7 -inch plate showing a figure of merit well over 2 against capped 4 -inch armour-piercing shell.

This class of material is specially adapted to cases where a monolithic form is desirable, and enables the thickness to be graduated in the most economical way to suit the exposure of the various faces to attack.

In connection with the penetration of armour, a point of considerable interest,-whether, as is usually held, the projectile remains sensibly at a tangent to the trajectory during flight, or whether, as has been occasionally maintained by certain ballistic heretics, it remains parallel to the initia! direction of projection, - has recently been discussed (see Scientific American, August 10 and 17,1912 ) by Admiral Twining, who shows both theoretically and from actual firing trials at long ranges against armour that the orthodox theory is correct. The importance of the point is olvious when we consider that no projectile could withstand the cross breaking strain to which it would be subjected on impact, at any but very close ranges, if it retained its original direction, so that the employment of projectiles specially designed to perforate armour would be a sheer waste of money.

Caps.-Complete agreement as to the exact way in which the cap assists penetration has not yet been arrived at. All authorities concur in attributing great importance to the lateral support which it affords to the point on impact above a certain velocity. which varies in all probability with the particular plate and projectile involved (there is a general agreement that the minimum velocity to render the cap effective varies from about 1,600 to I. \$00 f.s.): but while some, following Tresider (see the latter's lecture, 
April 8, 1908, before the Institution of Naval Architects), think this the main if not the sole function of the cap; others, such as Chladek and Bahn, attribute considerable importance to its (supposed) action in breaking up or otherwise weakening the hard surface layers of the plate before the undamaged point impinges upon them. Those, now-adays in the majority, who hold the view of Tresidder, naturally use all the weight available in giving lateral support to the cap and put little or no metal in front of the point. Those, on the other hand, who believe that the cap can weaken the plate before the actual impact of the projectile itself, will place some of the metal of the cap in front of the point. From the point of view of external ballistics it is desirable that the external contour of the projectile should be continued to the point, and this is against the flat ended cap suggested by Tresidder. This difficulty can however be met by using a hollow cap with the bulk of the metal giving lateral support to the point and practically flush with it, but with what may be termed a false head to give it a suitable ogival outline, as for example in the Firth cap shown on page 29I of Brassey's Naval Annual (I9I2).

(W. E. EDWARDs.)

\section{MINING ${ }^{1}$}

So far as mining processes and operations are concerned, the principal new developments in the last few years have been connected with coal mining, ${ }^{2}$ and reference is chiefly made in the following sections to that industry.

Legislation.- The passage of the Coal-Mines Act, igri, which came into force, as regards the bulk of its provisions, on July $\mathrm{I}$, I9r2, has been the event of outstanding recent importance in the British coal-mining industry. It introduces radical changes in the control and management of coal-mines, and has entailed considerable alterations in the mechanical equipment and methods of working collieries. In France, new coalmines regulations became operative on February 25, I9 12. New Belgian regulations were issued in December I9ro in regard to travelling roads and shafts. A new CoalMines Regulation Act was passed in British Columbia during I9I I, and a movement was on foot in I9I 2 to consolidate the various Provincial Acts in Canada relating to coal-mining. The United States Bureau of Mines was established by Act of Congress on July I, I9I0, its purpose being to investigate methods of mining. The headquarters of the Bureau are at Washington, and the mining experiment station is situated at Pittsburg with an experimental mine at Bruceton, Pa., and six mine-safety stations and seven mine-rescue cars distributed one in each of the principal coalfields.

CoAl SuPPLy.- The three years igro- i 2 have been notable for the deepening interest that has been shown in regard to the question of coal resources. During rgr 2 the Royal Commission on Conservation appointed by the Canadian Government issued voluminous reports (see also An Investigation of the Coals of Canada, Ottawa, I9 2, in 6 vols.), and similar enquiries have been prosecuted in the United States, under the auspices of the Geological Survey and the Bureau of Mines.

In British Columbia, at the headwaters of the Skeena river in what is termed the Groundhog Mountain area, enormous deposits of anthracitic coal have been located, a conservative estimate placing the resources of the coalfield at 3,072,000,000 tons; other smaller basins have also been prospected. The development of the Rocky Mountain Coalfields - in British Columbia, Alberta and Manitoba-has proceeded apace. D. B. Dowling has estimated that the known areas in Canada underlain by workable coal beds (excluding the Skeena district) cover little short of $30,000 \mathrm{sq} . \mathrm{m}$. and contain a total of i 72,057,000,000 tons, sub-divided as follows: Nova Scotia, 6,250,000,000 tons; New Brunswick, I 55,000,000 tons; Manitoba, 330,000,000 tons; Saskatchewan, 20,000,000,000 tons; Alberta, 104,932,000,000 tons; British Columbia, 38,976,000,000 tons; Yukon, 9 r 4,000,000 tons; Mackenzie District, 500,000,000 tons. Further prospecting has taken place in Alaska, but transport difficulties have still to be overcome, and the same consideration delays the utilisation of the deposits in Siberia and China, in which the existence of enormous quantities of high-class coal is established. In Victoria, Australia,

See E. B. xviii, 528 et seq., and allied articles. ${ }^{2}$ See E. B. vi, 579 et seq. 
whose known coal supplies have previously been of a lignitic character, large deposits of good coal have been discovered in the Powlett River district, and pits have been established under government direction; these are now producing quantities of coal.

On the Continent of Europe, further knowledge has been derived by borings of the extent and character of the deposits in the French and German Lorraine. In Belgium a number of shafts were in I 9 I 2 nearing completion in the Campine region in the Limburg province, and borings in Hainault had succeeded in locating coal at workable depths, to the south of the Eifelian fault, the boundary of the existing coalfields. Dutch state enterprise has been extended in the Netherlands Limburg, by the discovery of further areas on the banks of the Meuse.

In Great Britain some of the new large collieries sunk in the S.E. portion of the South Yorkshire coalfield have reached the stage of active work, of which mention may be made of Maltby, Edlington, Bentley, Bulcroft and Askern; sinking operations also were in I9I 2 either in progress or contemplated at Rossington, Barnborough, Thorne, Hatfield, Barnby-upon-Don, Kelham, South Carr, Harworth, Howden and Thurcroft. When in full operation, they should add some $\mathrm{I} 2,000,000$ tons per annum to the existing output of the coalfield or about five per cent to the national output. Developments have also been in progress in South Staffordshire to the west of the boundary fault, Warwickshire, Fifeshire, the Lothians, Monmouthshire, Kent and South-East Durham.

The table shows the world's output of coal during 1910 (figures for 1909 and 1908 being given in certain cases as the latest procurable):

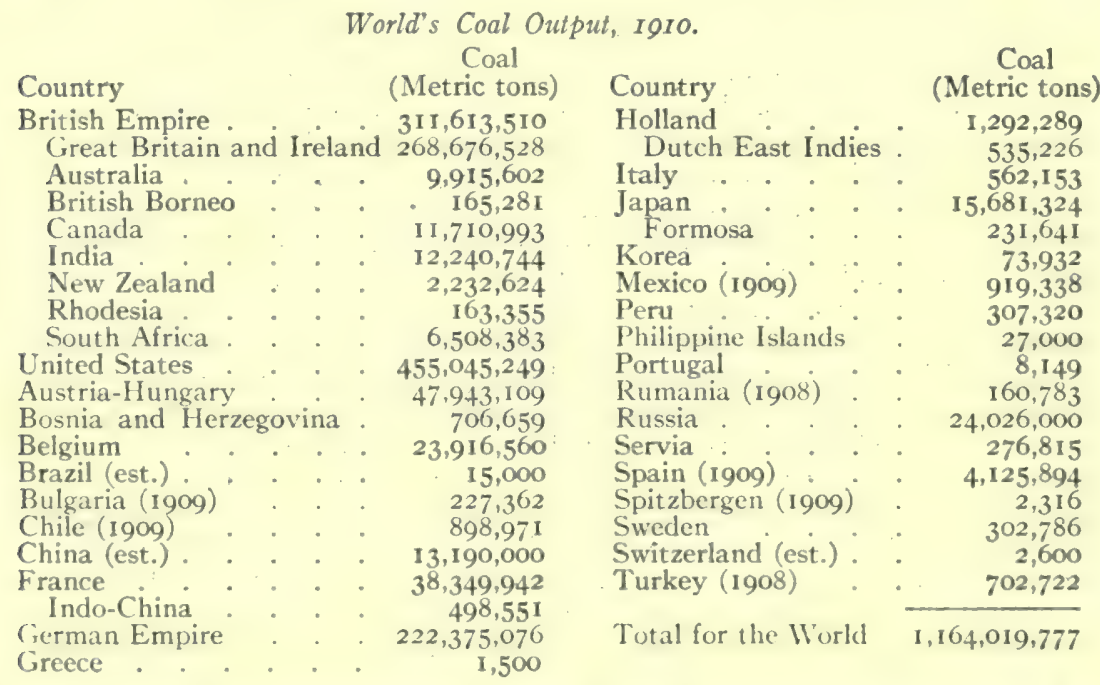

Coal-Cutting Miscminery. - At the time the Fight Hours Act of rgo8 (E. B. xvi, r8b) was under discussion in England it was persistently claimed that a great mitigation for the loss of output due to the restriction of the hours of labour would be forthcoming in the more general use of coal-cutting machinery. This anticipation has not been borne out; the application of machinery in Great Britain increases but slowly, the governing factors continuing to be the condition and lie of the strata and the relative cost of hand labour. The principal developments have been in the direction of improved design and mechanical efficiency.

Coal-cutting machines may be broadly divided into two classes-percussive and rokary machines-and there is a tendency to employ increased numbers of the former type, especially of the small character similar to the caulking hammer. Continued efforts have been made to produce a satisfactory electrical machine of the puncher type, but so far without conspicuous success. In America the pneumelectric puncher has been 
uset to some extent; in this machine the actual reciprocating motion is produced mechanically by an electric motor, and is transmitted by compressed air to the percussive tool, the whole apparatus being practically self-contained. The Ingersoll-Rand Company produce a similar machine. The percussive coal-cutter has gained from the development of the rock drill, and several of the modern machines, such as the Hardy, Ingersoll and Siskol, embody economical improvements in valve construction.

A novelty has been introduced in the United States in the shape of the HoadleyKnight coal-cutter. This machine, which is of the tunnelling or breast type, comprises swinging cutters rotating with great rapidity. The rotation is effected by electricity, whilst the swinging and feeding movements are directed and controlled by hydraulic means. The machine is especially designed for the getting of coking or gas coal in which the size of the product is not a consideration.

At the mines of the United States Coal \& Coke Co., Gary, W. Va., a system of pneumatic transport has been tested: a machine cuts out the entire thickness of the seam, removing the coal as it is cut to the outside by means of currents of air at high velocity.

A concomitant of the increased use of coal cutting machinery has been the more extensive adoption of coal face conveyors.

Mechantcal Ventilators. - The principal changes in the British Coal-Mines Act relating to methods of ventilation are the compulsory provision of an adequate ventilating system on the surface, with, after January I, I913, means for reversing the air current. A revolution in construction has taken place in colliery fans, the principal features of which are the great reduction in diameter, the adoption of high-speed engines, a quickrunning electric motor, and the use of short peripheral blades, in place of long blades attached to the boss shaft. Another development has been the increase in the number of blades, several of the modern quick-running fans having no less than 60 , as compared with about ten in the older type of fan. The modern inlet is nearly equal to the external diameter of the fan, giving a free entry of air into the centre of the fan. In the new fans the scoop blade is adopted; in the Bumsted and Chandler fan, however, the extremities of the blade are curved backwards from the direction of rotation. Examples of the modern type are the Sirocco and Barclay fans, and the former has given the high manometric efficiency of 0.9 .

Reversing fans have been in use for some time in the American coalfields; their use in Great Britain is comparatively recent. A simple method is so to arrange the fan that it can either exhaust from or blow into the shaft at which it is located; or drifts may be so arranged that the fan may exhaust either from the upcast shaft or from the downcast shaft, by means of a kind of damper. As a modification a stand-by fan is connected to the downcast shaft, which is started when a reversal of the air current is desired. The other fan at the same time is stopped. In France small helicoidal fans have been employed, driven by the shaft of an electric motor.

SHAFT-Sinking.-A steady extension has recently been witnessed of the patent processes of sinking shafts through water bearing and shifting strata. In the main these processes may be classified under three headings: (I) the drop-shaft system, as represented by the Kind-Chaudron process, the principal feature of which is the use of telescopic tubing; (2) the freezing system, developed from the Poetsch process; and (3) the cementation process, originally applied by Portier at Bethune, in the Pas-de-Calais, and developed by Lombois, Saclier, François, Gevers-Orban, and others.

As regards the drop-shaft system the most notable example in recent years is perhaps that at the Astley Green Colliery, near Manchester, when a depth of 3,000 ft. was attained (See Pilkington \& Woot, Trans. Inst. Min. Eng., Vol. 39, p. 529).

With the freezing system, for the development of which Messrs. Gebhardt \& Koenig have been largely responsible, much greater depths have been reached than was at one time considered possible. Thus in the Campine coalfield, where the freezing process has been adopted in seven of the eight shafts, the depth of frozen section has varied from I, I 80 to $I, 590 \mathrm{ft}$.; at Beeringen, where the latter depth was reached, 37 boreholes were necessary in order to secure an uninterrupted circumference of frozen strata, and altogether eleven miles of tubing were employed. In England the freezing system has been applied in seven instances-in 
the Durham and South Yorkshire coalfields. At Bullcroft Main it was found possible to deal with running water and at Easington with sea water and tidal variations in level.

It is in the cementation system that the greatest improvements have been made. It would seem to have certain advantages in cost, while the preliminary estimates are more likely to be accurate. At the Viktoria Colliery, in Westphalia, the cost was fr5o per yd. of depth. The system, as now applied, may be sub-divided into (I) the "systematic" process, in which liquid cement is injected into surrounding boreholes from the surface, much as in the case of the freezing system, with the object of filling up fissures and waterlogged cavities in the strata, the pressure being varied according to the necessities; (2) the "methodical" process, in which the pressure is automatically regulated by the pressure of the water; and (3) the "progressive" process; in which the ordinary drop-shaft system is pursued, fissures being filled with cement injected under pressure by means of inclined advance boreholes driven from the shaft bottom.

In addition to the freezing system, mention may be made of the Stockfisch system, which is a combination of percussion and flushing, the flushing liquid being of sufficient density to keep out of the shaft any quicksand or loose rock liable to cave in. An installation at the Diergardt Colliery is described by Krecke (Glückauf, No. I4, 1912). In this system, as in the Hoenigmann system, which has also been applied in Germany, and in the KindChaudron system, improvements in the boring trepan have been effected.

By the ordinary methods some exceptionally rapid work has been done in the more recently opened shafts, although, generally speaking, the increasing difficulties of depth and strata militate against speed in sinking. At the Askern Main Colliery, near Doncaster, a shaft of $23 \mathrm{ft} .6 \mathrm{in}$. in diameter (total excavation) in the middle coal measures was sunk 29 yds. I ft. in 7 days, at a labour cost of $£ 9.0 s \cdot 3 \frac{1}{4} \mathrm{~d}$. per yd.

For preliminary protection from surface water, use has been made (as at Bentley and Hatfield Main) of interlocking channel steel piling with satisfactory results.

In the equipment of finished shafts, which now range up to $22 \mathrm{ft}$. diameter finished, increased use is being made of concrete.

ThE USE OF ELECTRICITY.-The most profound change in mining since the opening of the present century has been the extension of the use of electricity. It has found its principal application for haulage, pumping, ventilation, signalling and shot firing, but its employment for lighting and winding is also steadily growing, and the "All-electric Colliery" is now an accomplished fact. New British regulations governing the installation and use of electricity in mines have been issued by the Home Oflice as provided for by the Coal-Mines Act (Section 60) which also prohibits the use of electricity underground-telephone or signalling wires and approved handlamps excepted-wherever the percentage of inflammable gas in the air is found to exceed $I_{4}^{1}$. Taken generally, the main object and intention of the new British rules is to make armouring compulsory in the future, although in some cases exempted until I920. The new French regulations also impose special restrictions on electric installations.

The liability of the electric spark to ignite firedamp has formed the subject of many experiments, but they have failed to establish the precise limits of safety. E. Lemaire (Ann. Mines Belgique, InI I Vol. xvi, p. 32I) has shown that explosive mixtures of air and firedamp can be ignited by the finest filaments provided their temperature be sufficiently high and quite independent of any break of contact spark. Such experiments have enforced the use of strong globes with air-tight joints.

The Coal Dist Question.-During recent years there has been much investigation of the part played by coal dust in colliery explosions. These investigations, which have been attended by research on many collateral subjects, have been conducted at a number of centres, by means both of large-scale experiments in galleries and also of laboratory tests. The testing stations are now for the most part under the cont rol of the Governments of the various countries concerned, but were started through the enterprise of the mine-owners. In Fingland the gallery erected hy the Mining Association of Great Britain at Altofts, in Yorkshire, has heen transferred to the Home Office, and reconstructed on a new site at Eskmeals, ('umberland. The Mining Association in roto published their first record of experiments; in Ior 2 the committee in charge of the experiments at Eskmeals issued two reports, as well as an outline of the scheme upon which it was proposed to conduct future investigations. In France the experimental station at Liévin, erected by the Comité Central des Houillères de France in 1907 and extended in I gor), has been the scene of further researches; under the direction of $\mathrm{J}$. 
Taffanel, which form the subject of several reports. An experimental mine has now been secured by the French Government at Commentry. In the United States, in addition to the existing installation at Pittsburg, a drift at Bruceton, Pa., has been equipped for experimental purposes, under the charge of the Bureau of Mines. It remains to mention the gallery erected in 1908 at Babitz, near Segengottes, by the Vienna Permanent Firedamp Committee, and the Frameries testing station of the Belgian Comité de Grisou, since transferred to the neighbourhood of Charleroi, at which some important results have been achieved by Victor Watteyne and his collaborators.

In the first instance the experiments at the large galleries were principally devoted to demonstrating the inflammability and explosibility of mixtures of coal dust with air and to testing the adequacy of certain suggested remedies such as water; deliquescent substances, and inert dust, and the arrangement of the same in zones, barriers, collapsible troughs, etc. The possibility of producing a coal dust explosion in the absence of firedamp may be said to have been firmly established in Igro. Latterly research has been principally devoted to establishing the conditions that promote or hinder the full development of explosions, as well as ascertaining their real nature. Amongst the points considered have been the velocity, pressure, and temperature of explosion waves, the relative inflammability of various dusts and their behaviour under certain conditions.

One of the results of the British experiments has been to show conclusively that the relative ignition temperatures of a series of coal dusts have no fixed relationship to the percentage of volatile matter as usually determined. In determining the chemical constitution of coal, the chemist has hitherto relied upon two different modes of procedure, viz: (I) the action of solvents, and (2) fractional distillation. The method of fractional distillation, as recently applied by Burgess and Wheeler, has afforded valuable results which have led those authors to a definite conclusion as to the nature of coal. They maintain that all coals contain at least two different types of compounds of different degrees of ease of decomposition. They regard coal as a conglomerate consisting of cellulose degradation products embedded in a cement of altered resins and gums. It is, in their view, the latter which first distils by heat, yielding mainly the paraffin hydrocarbons. The cellulose products are decomposed later, and, at a higher temperature, yield proportionally large quantities of hydrogen. In the second Eskmeals report strong evidence is adduced to show that the paraffin-yielding constituents are identical with Bedson's pyridine extract, for it is proved that in the series investigated there is a marked, although not rigid, relation between the ignition temperature of coal dusts and the percentage that can be extracted by pyridine. Taffanel, Floch and Durr, describing certain investigations undertaken at Liévin upon the oxidation and distillation of coal dusts, found that at 700 degrees all the ethylene and four-fifths of the methane had already been expelled. These gases are also those which possess the greater heat of combustion, that for ethylene being given by Taffanel as $34 \mathrm{I}$ calories, methane 213 , hydrogen 58 , and carbon 68 . It is interesting also to note that these same gases which are most readily distilled from coal dust have the lowest "limit "value for inflammability in air. As in other distillations the produits de tête differ markedly from the produits de queue, and the danger of coal dust is vastly enhanced by the fact that the carly distillates are the more readily inflammable.

The present feeling is that in stone dust lies the principal hope of a remedy. W. E. Garforth, in delivering his presidential address before the Institution of Mining Engineers on June 6, I9г2, expressed the opinion that the dangers of explosion of coal dust from electrical causes could be completely counteracted by the vigorous application of this remedy. Investigations have shown that suitable diluents exist which satisfy the considerations of health, efficiency and economy. At Altofts the cost of stone-dusting was $\frac{1}{2} \mathrm{~d}$ d. per ton raised.

At the Clarence colliery, where an explosion occurred on September 3, 1912, the collapsible arrêts-barrages (arresting barriers), proposed by Taffanel, failed to arrest the course of the explosion, in the one instance in which they have been put to a test under actual working conditions. This failure however may have been due to the improper application of the barriers, to the presence of fircdamp, or to the exceptional slowness of the explosion. 
Rescue APPliances-The organisation of rescue operations has made great advances since roro. In Igro the Mines-Accidents (Rescue and Aid) Act was passed in England, providing for the organisation and equipment of rescue brigades at all collieries and the erection of private and central rescue stations. An order was finally promulgated in r 912 defining the requirements under these heads. In the meantime central rescue stations have been erected or are in course of erection in all the British coalfields, and valuable services in the direction of recovery work have been rendered by the trained brigades at Darran, Hulton, Bignall Hill and Cadeby.

In the United States rescue stations have been established by the United States Bureau of Mines at Urbana, Illinois; Knoxville, Tennessee; Seattle, Washington; McAlester, Oklahoma; Birmingham, Alabama; and Pittsburg, Pennsylvania. In extension of these stations are seven mine-safety cars. In I9I I over 100,000 miners attended lectures and demonstrations, and over 7,000 received training in mine rescue and firstaid work in addition to the arrangements made by independent companies.

The principal types of apparatus in use at the present time are the following: oxygen regenerative appliances,-Draeger, "Proto" (or Fleuss), "Meco" (or "Westfalia "), Tissot, and "Weg;" liquid air appliances,--"Aerolith" (or Suess) and Claude. An investigation in the Rhenish-Westphalian districts under the mine regulations of May I, I9I 2, showed that 847 portable sets of apparatus were in use, of which $38 \mathrm{I}$ were of the Draeger type, and 449 of the Westfalia type. Broadly, the improvements in apparatus have taken the form of modifications in design accommodating them to the convenience of the wearer; increased attention has been paid to the effects of heat, and in the "Proto " apparatus experience at the Howe Bridge station has resulted in the addition of an emergency by-pass arrangement, which may be used for cooling the air in the breathing bag. Lung-governing valves have also been introduced similar to that first employed by Garforth in the "Weg " apparatus, used at Altofts and Cowdenbeath.

In the liquid air appliances, a new feature is the use of regenerative purifiers. At Newcastle a new liquid air apparatus, entitled the aerophor, has been developed by W. C. Blackett, which is able to supply air to persons in distress, independent of the wearer. In this apparatus, which is a development of the Suess or Acrolith apparatus, the pack and breathing bag are united and the pack is built to fit across a man's loins. There is a by-pass between the liquid air pack and the mouthpiece, and the regenerative properties of the purifier have been improved (Colliery Guardian, August 16, I912).

At the Singles colliery in the south of France safety chambers have been provided as places of refuge for men in the event of explosions. Similar steps have been taken in Austria, and it may be noted that the Herrn Draeger, of Lübeck, have proposed the construction of such chambers, equipped with purifying materials.

Lighring.- - In the illumination of the working face in collieries the chief development has been the increased adoption of portable electric lamps. The provision of these is now compulsory in connection with rescue operations in Great Britain, and there is a growing tendency to employ them for all purposes, where other means exist for detecting firedamp or at pits where this consideration is of lessened importance. One reason for this change is the restriction placed upon the use of flame safety lamps by recent legislation, which by their indifferent lighting capacity impose heavy burdens upon the worker.

According to the British Coal-Mines Act r9I I, locked safety lamps are to be used in any seam in whith the air in the return airway is found normally to contain more than $\frac{1}{2}$ per cent of inflammable gas, and, with certain exceptions, in any seam in which an explosion of gas has occurred. At the same time an official test for safety lamps has been instituted, and the government experimental station at Eskmeals in Cumberland is equipped with appliances for this purpose. Towards the end of $19 \mathbf{I 2}$, new regulations for lamps were issued by the Home ()ffice. According to Article 146 of the French regulations, safety lamps must conform to one of the types approved by the Minister of Public Works. Spirit lamps may only be furnished with internal igniters of approved design. The igniting bands must be disposed so that only one relight can be made at a single time, and must be composed of substances that are inflammable but not explosive. In British mines the use of internal igniting apparatus in connection with spirit safety lamps is limited by law from disciplinary considerations, but in Continental mines their use has extended considerably. 
Some important researches were communicated in I9I2 by J. S. Haldane and T. Lister Llewellyn, to the South Staffordshire Institution of Mining Engineers (Trans. Inst. Min. Eng., Vol. xliv, p. 267). Their experiments were designed with the view of producing a vitiation of the atmosphere similar to what occurs in the ordinary working of a mine. The result showed that every diminution of o.I per cent in the oxygen present lowered the illuminating power of a safety lamp, burning a mixture of colza oil and paraffin, by as much as 3.5 per cent; and the striking fact is deduced that with the oxygen reduced to 19.0 per cent, the minimum percentage allowed by the CoalMines Act for purposes of ordinary work in the pit, the light would be diminished by 70 per cent, under the conditions of the experiment. It has been found that for every increase of I per cent in the moisture of the air the illumination of the standard pentane lamp and also of the Hefner amylacetate lamp falls off by 6.25 per cent, and the light from a spermaceti candle falls off by 5 per cent. The authors also call attention to the confusion which has arisen through attributing to carbon dioxide the premier rôle in producing dimness of illumination. In their view it is only the variation in true oxygen percentage that matters in a practical sense, and how this percentage is diminished is of small importance, although it is true that added carbon dioxide does produce rather more effect than added nitrogen.

A point which has not yet been covered by the above experiments is the relative behaviour of various kinds of illuminants. Burrell and Seibert (U.S. Bureau of Mines, Technical Paper 13 , 191 $x$ ) found that there was a remarkable difference in the composition of the residual air that extinguished the flame of a Wolf spirit lamp as compared with that of an acetylene lamp. Thus, acetylene will apparently only cease to burn in an atmosphere containing as much as 6.3 per cent of carbon dioxide and as little as II.7 per cent of oxygen, whereas 3 per cent of carbon dioxide and 16.5 per cent of oxygen marked the limiting composition of air capable of supporting combustion of a Wolf lamp. The general use of acetylene lamps in coal-mines is frequently asserted to be impracticable; but this scarcely agrees with the experience recently recorded in a Spanish mine, where a Tombelaine acetylene lamp has been found to work satisfactorily in a very fiery pit, and also to be capable of being used as an efficient gas detector.

One result of these experiments is to point more strongly to the fact that the only satisfactory solution of the illumination problem in mines will ultimately prove to be the electric lamp; which is free at least from the deterioration arising from atmospheric influences. If ever a means is found whereby the electric lamp can be adapted to the detection and accurate estimation of firedamp, it will be at once established par excellence as the miner's lamp. A handsome prize has now been offered by the German mineowners with a view to the invention of some satisfactory device of this nature.

In May IgI I the British Home Office announced a prize of $£ \mathbf{I}, \infty 00$ for the best electric lamp suitable for miners. The judges (Messrs. C. H. Merz and C. E. Rhodes) awarded the first prize of $£ 600$ to the "Ceag" lamp sent in by F. Farber, of Dortmund. In the "Ceag" lamp the bulb is protected by spiral springs so arranged that the circuit it is broken when the surrounding dome glass is shattered.

An important feature of the work of Haldane and Llewellyn is its relation to the prevalence of miners' nystagmus. A paper on this subject was read before the Royal Society by Dr. Llewellyn, who is the first Tyndall Research Mining Student. He concludes that, whilst the disease is one of extreme complexity and one in which many factors are at work; the chief factor is strain caused by deficient light, and that the most important preventive measure is improvement in the lighting power of the miner's lamp. This view was adopted by the Ophthalmological Congress at Oxford I9I 2.

An interesting new safety lamp of great power, the Goulet incandescent lamp, has been tried at the Frameries Station, in which an Auer mantle is raised to incandescence by the flame of a mixture of air and benzine.

WINDING. - The use of electricity for winding purposes has made rapid progress during the last three years, and is now being applied to plants of much higher capacity. There are, broadly speaking, two systems, using in the one case an alternating-current 
motor, either geared or direct-coupled to the drum shaft, with rheostatic control, and, in the other, a direct-current motor, on the Ward-Leonard system, with the use of a flywheel accumulator. The field of the former has been greatly extended by the introduction of efficient and durable machine-cut helical gearing.

The Brown-Boveri system, installed at the Hcinitz Colliery, Upper Silesia, comprises the conjunction of high-pressure turbine, Ward-Leonard generator and A.C. generator, the turbine having considerable overload capacity by means of relay-operated by-passes if necessary, the A.C. generator supplying the general load of the colliery or as much of it as it can, and the Ward-Leonard generator the winding-engine. Another system is the series system, due to Prof. Thury.

The three-phase commutator motor has also been advocated for work of this description. Two types of such motor are obtainable-the series motor and the double-repulsion motor. In both cases speed regulation is obtained by brush displacement.

In I9 I a valuable report was issued of trials carried out by a joint committee appointed by the German Engineers' Association, the Dortmund Mining Association, and German Boiler Inspection Association (Glïckauf, Nos. 42 to 52 , I9II). The trials were carried out with the electric winding plants at the Deutscher Kaiser, Rheinelbe, Mathias Stinnes and Emscher-Lippe collieries; and with the steam plants at Schürbank and Charlottenburg, Julia, Helene and Amalie and Wilhelmine Victoria collieries. The report states that on general principles the working of a steam engine is the more satisfactory, as the mean net load approaches that for which it was built; and therefore the smaller the load the lower the efficiency. The electrical winder however adapts itself better than the steam engine to reductions in the net load. It cannot be deduced from the different values obtained that any given type or either of the forms of energy is unconditionally the best in general. In deciding which method of winding is to be preferred, the prime cost, depreciation and upkeep, must be borne in mind, as well as the consumption of steam or energy; and, in addition, how the method fits in with the general working conditions of the colliery.

At the Great Western colliery the Westinghouse winder on the converter-equaliser system is capable of raising $2 \frac{1}{2}$ tons of coal from a depth of $1110 \mathrm{ft}$. in $37 \frac{1}{2}$ secs. at a speed of 70 winds or 175 tons per hour. The maximum shaft speed is $40 \mathrm{ft}$. per second and at full work the winder requires 4.8 units per wind.

Considerable improvements have been effected in the steam winding-engine, and the large compound condensing engines installed within recent years represent a high efficiency. A notable economy has been obtained from the utilisation of exhaust steam in mixed pressure turbines, with or without accumulators on the Rateau principle: examples of such installations are to be seen at the Hulton, Maypole, New Hucknall and other collieries. They are very suitable for driving large compressed air plants in connection with coal-cut ting machines, where it is not desirable to take clectricity to the face of the coal. Tests at the Königsborn mine at Unna-Königsborn in the Dortmund district have shown that when working with low-pressure steam having an initial pressure of 1.2 atmosphere and a final pressure of 0.1 atmosphere, $2_{4}^{3}$ lbs. of steam are used for every cubic metre of free air compressed; and $1 \frac{1}{2} 1 \mathrm{lb}$. when working with fresh steam having an initial pressure of 7 atmospheres and the same final pressure of 0.1 atmosphere. At Penallta colliery in South Wales, the sinking engines were fitted with throttle valves on the high and low pressure cylinders, to obtain a starting torque equal to a pair of engines without the admission of live steam into the low-pressure cylinders. The engines were designed to wind from a depth of $800 \mathrm{yds}$. in 45 secs.

The provisions in the British Coal-Mines Act in regard to shafts and winding have entailed considerable alterations in the equipment at many collieries. After the beginning of I9I3 every vertical shaft is to be provided with a detaching hook, and where more than 100 yds. in depth, with an effective automatic contrivance to prevent overwinding. Detaching hooks have been in common use at British collieries for many years; overwinding controllers, howcver, have been employed in but few instances, although many of the largest Continental mines are equipperl with them. Generally speaking, these gears are mechanical contrivances which automatically cut off steam and apply the brakes when the limits of speed are exceeded at certain points in the shaft, or in cases where the engineman starts his engine the wrong? way in the shaft. During 1912 numbers of these gears were invented. Some of the bes: known of those used in British mines are the Barclay, Whitmore, Wilde \& Petrie, "Visor, Shaw, Wallace, Jackson \& Staley, "Profile," Melling, Futers I)aglish, Walker and Ingli; controllers. In France the principal types are the Reumaux, Sohm \& Burg devices.

The same section of the Coal-Mines Act provides for the use of guides in sinking shafts, and of "keps" at the surface, the periodical capping and limited employment of winding; ropes and the equipment of cages with catches, covered tops, gates and hand bars.

The new French regulations draw a distinction in the testing of winding ropes, in respect of the numbers wound at a single journey. Where more than four persons are wound in the shaft at the same time the ratio between the resistance to rupture by tension and the total foad must at least correspond to the factor of safety. The rope is to be discarded when the Inss of resistance exceeds 30 per cent of its original value, and no winding rope may be used for a load greater than one sixth of its breaking strain, if of wire, or one fourth if of hemp. 
According to the French regulations, safety catches, for holding the cage in the shaft, in the event of a breakage of the winding rope, are compulsory, in this respect differing from British practice. Many British inventors have during the past few years endeavoured to provide a satisfactory catch, but the rope and rail guides almost universal at British collieries are not suitable, and there is a considerable prejudice against the use of such appliances, especially under the exacting conditions met with at many of the new collieries. Several of the recently-opened shafts in Yorkshire and Nottinghamshire are equipped with four-decker cages, capable of raising 70 men. On the Continent the practice is to sink a greater number of shafts in proportion to the mineral area and the engines are designed for lower duties.

At the Maltby colliery steel rail guides have been fitted across the centre of the shaft, owing to the depth and increased demands of the loads. The cost per yd. was f6.I7s.8d.

At modern collieries the use of hydraulic lifts at pit tops and bottoms is now general.

Blasting Explosives.-On May 21, r91 2 the Home Secretary issued in England a new order regarding the use and storage of explosives in coal-mines. The main features of the order are the more detailed restrictions respecting the use of explosives in mines, the standardisation of cartridges, regulation of the size of rock-drill bits, precautions to be taken in the case of miss-fires, special stringent provisions for fiery mines, and regulations in the case of sinking operations. After March 31 , I9I3, the standardisation of cartridge diameters is made imperative. The sizes of drill bits are also specified, and this is provided for by the regulation that the drill bit must afford a clearance exceeding the diameter of the cartridge for which the hole is intended. The standard sizes of the cartridges are to be $\frac{7}{8}, \frac{10}{8}, \frac{11 \frac{1}{8}}{8}, \frac{14}{8}, \frac{16}{8}$ inches, and the drill bits for each size must not be less in diameter than $\frac{1}{8} \mathrm{in}$. in excess. The diameter of a drill bit for the smallest permitted size of cartridge must not be less than $\mathrm{I}$ in.

In Belgium and France further tests have been carried out with a view to establishing the safe limit-charges of explosives under varying conditions.

The United States Government has for some time past conducted experiments at their testing station at Pittsburg, in order to discover which of the many grades of shortflame explosives possess the qualities that render an explosive most effective and least dangerous for mining coal. As a result a "permissible" list has been issued.

A new type of instantaneous fuze has recently been introduced known as "Cordeau Detonant," or, "Cordeau Bickford," consisting of a core of trinitrotoluol enclosed in a lead sheath, which has a speed about 15,000 feet per second. This requires a detonator to initiate the explosion, but is sufficiently powerful in its action to induce detonation in a cartridge through which it is threaded. It is largely used for certain experimental work as a standard for comparing the speed of detonation of other explosives.

Deep Minrng.-Of all physical causes that underlie the development of mining the question of depth may be said to be the most important and far-reaching. Its influence upon the operations of winding and pumping, the methods of working, the transmission of energy, ventilation, and last, but not least, the support of the surface, is of ever-increasing gravity. The question of temperature is of particular importance. A differentiation in the conditions of labour where abnormal temperatures are encountered is a feature of recent industrial mining legislation, and in this respect the earlier example of Germany has been followed by Belgium and France. By the new French regulations work is prohibited in places where the temperature reaches 35 degrees $\mathrm{C}$. on the dry thermometer or 30 degrees $\mathrm{C}$. wet bulb reading, but any temperature exceeding 25 degrees C. wet bulb is considered high.

Some valuable records are given by G. J. Young as to the conditions encountered on the Comstock lode ("Ventilating System at the Comstock Mines, Nevada," Trans. Amer. Inst. of Min. Eng., Vol.4I, p. 3, roro). He finds that moderately high temperatures from 95 to ro5 degrees $\mathrm{F}$., with moderate humidities from 50 to 70 per cent relative humidity and with air currents of velocities from 200 to 300 feet per minute, do not prevent work nor are particularly uncomfortable. A higher temperature, from iro to I 5 degrees, with high humidity and moderate velocity air-currents, very greatly impairs efficiency, and a still higher air-velocity, under the same conditions, renders work more bearable, though miners cannot work very long at one time. A moderately high temperature, from 95 to 105 degrees in a saturated atmosphere with no current, becomes very trying. Prolonged exposure with much exertion is dangerous. A moderate tem- 
perature from 90 to 98 degrees, and saturated air currents of a velocity of from 400 to 500 feet per minute, with more or less vitiated air, are conditions which are very trying, and give a low labour efficiency. Vitiated air will impair labour efficiency to a greater extent than a high temperature.

Observations made with the object of determining the rate of increment of temperature with depth have shown considerable divergence in different places. The following results of temperature observations (quoted in the Report of the New Zealand Royal Commission on Mines, I9I2) show the depth in feet required in various localities for an increase of I deg. F.: Comstock, U.S.A., 33; Witwatersrand, Transvaal, 208; British collieries (mean), 64; Bendigo, Victoria, 77; Ballarat, Victoria, 80; Thames, New Zealand, 43.5; Waihi, New Zealand (approx.) 32.8. In a valuable paper by J. Whitehouse and W. L. Wotherspoon (Jour. Chem. Met. \& Min. Soc. of S.A., May Igr I) the mean temperature rise in the deep level mines on the Rand is given as I deg. F. for 253.9. ft.

Efforts have been made to counteract high temperatures in mines, by compressed air refrigerators, water-injectors and increased ventilation. Dr. Dietz (Oest. Z. f. Berg. u. Hittenwesen, I9I I, Vol. lix, p. 430) advocates the thorough cooling of a small portion of the incoming air and then mixing it with the remainder. He uses for this purpose a refrigerating-engine, air turbine, turbo-compressor, and a steam-turbine.

Prof. Jacob Koenigsberger, of Freiberg, while conducting investigations regarding the depth of the boreholes, found that the increase in temperature does not take place uniformly, but that it proceeds much more rapidly in boreholes sunk in the neighbourhood of ore deposits, the reason being presumably that, owing to certain chemical processes, heat is constantly generated there. In the vicinity of coal measures the temperature increased by one degree for every 26 to 30 metres. The change was particularly rapid near mineral oil deposits, where every 8 or I I metres of increased depth advanced the temperature by I degree. Prof. Koenigsberger draws from his observations the conclusion that from the change in the temperature of boreholes the occurrence of coal or mineral oil within 200 metres of the bore may be prognosticated. (See also Koenigsberger and Mühlberg, Trans. Inst. Min. Eng., Vol. 39, p. 61 7, I910).

A borehole at Czuchow in Austria, for the purpose of proving coal, in r9og reached the great depth of $7,350 \mathrm{ft}$.

Ventilation.- Ventilation questions have during the past two or three years engaged much attention, especially in view of the requirements of recent enactments in regard to the quantity and character of the mine air. The Coal-Mines Act, I9I I (Section 29 (3)) for the first time in Great Britain provides for a definite standard of ventilation; i.e., a place shall not contain less than Io per cent of oxygen or more than $1 \frac{1}{4}$ per cent of $\mathrm{CO}_{2}$, whilst the samples taken in an intake airway must not show an average percentage of inflammable gas exceeding one quarter. There are exemptions from the former provision in the case of mines liable to spontaneous combustion. The Act also provides for the classification of mines according to the amount of inflammable and noxious gases in the main return airway, thus paving the way for a system of division, as followed in France and Belgium, for imiting the use of certain types of illuminants and explosives. In France and Belgium the system has been extended so as to provide a classification in which due consideration is given to the dual factors of firedamp and coal dust.

According to the new French regulations a percentage of more than 2 per cent of gas is to be considered dangerous in a working place. The permissible limit in headings is I.5 per cent measured in the return, and I per cent in the return from other working places, but the regulations are more elastic than those now in force in Great Britain.

With the tightening up of the restrictions and the new requirements as to the qualification of officials, increased attention has been paid to the apparatus for measuring and testing the atmosphere of the mine. Briefly, the apparatus used for the detection of firedamp may be classified as follows: (1) Instruments depending on the comparative rates of diffusion of methane and air. (2) Instruments dependent on specific gravity. (3) The observation of the glowing appearance of a platinum wire rendered incandescent by electricity. (4) Instruments depending on the fact that the electrical resistance of 
a platinum wire increases in the presence of methane

(5) The saféty lamp.

(6) Chemical analysis. The feeling at present is that the only reliable indicators are the safety lamp for routine observations, and chemical analysis for the more elaborate calculations. Numerous ingenious appliances however have been devised of late to provide an efficient substitute.

The apparatus invented by Philip and Steele (Journ. Society of Chemical Industry, Vol. 3o, p. 867, 19II) depends on the sensitiveness of a relay containing iron, and as the hysteresis lag in the iron tends to reduce the sensitiveness of the instrument, this lag is removed or reduced either by mechanically vibrating the relay, or by passing intermittent pulsating currents through it, superimposed on its normal currents. Somewhat similar apparatus have been devised in the Holmes-Alderson gas-detecting apparatus and the Holmes-Ralph portable electric lamp (G. J. Ralph, Trans. Inst. Min.Eng., Vol. 40, p. 282, and vol. 42, p. 20I). In actual practice however it has been found that such apparatus, which depend upon the conductivity of platinum, have given less satisfactory results in a normal firedamp mixture than in coal gas or "petroleum vapour. The "interferometer," devised by Professor Haber of Karlsruhe, and Dr Lowe of the firm of Carl Zeiss, of Jena, depends upon the refraction of light in firedamp and other media. The apparatus is in daily use at Gelsenkirchen for the examination of gases passing out of the upcast.

Several devices have been introduced with the view of increasing the sensitiveness of the ordinary safety lamp. Of these mention may be made of the Cunynghame and Cadman device by which the cap on a safety lamp is converted from an indistinct blue to a distinct orange yellow by introducing a little asbestos paper soaked in carbonate of soda into the flame (Trans. Inst. Min. Eng., vol. 39, p. 13). Briggs has also proposed the use of a copper loop (Trans. Inst. Min. Eng., vol. 43, p. 64).

Turning now to the more accurate determinations obtained from chemical analysis, it may be observed that J. S. Haldane has recently designed an apparatus for estimating percentages of firedamp, in which the potash solution is dispensed with, the percentage of fredamp being given simply by the contraction on combustion (Colliery Guardian, Sept. 27, I912). In the United States a modified Orsat apparatus has been employed by Burrell and Seibert (U.S. Bureau of Mines, Technical Paper I3, I9 I ) for use in connection with mine fires, with which, it is stated, $\mathrm{CO}_{2}, \mathrm{CO}$ and $\mathrm{CH}_{4}$ can be determined within about 0.2 per cent.

New views have quite recently been advanced by physiologists as to the influence of oxygen and $\mathrm{CO}_{2}$ upon human life, and it has been urged by Leonard Hill and Harger amongst others that the existing standards might be varied without dangerously affecting health, even when due consideration has been given to alterations in barometric pressure. The object is to produce an atmosphere in which the liability to firedamp explosions and fires would be reduced, owing to the incompatibility of the media. Objections raised, apart from the suspected dangers to health, are, the effect upon lighting, and the difficulty of obtaining $\mathrm{CO}_{2}$ free from dangerous quantities of $\mathrm{CO}$, if introduced in the form of flue gas as proposed. Harger claims to have obviated the latter difficulty by the use of small gas engines. The former difficulty may be overcome in specific cases by the use of acetylene lamps or portable electric lamps. The value of inert gas as a means of combatting fires has been recognised, and it was used in the recovery operations following the Cadeby explosion ( $\operatorname{Ig} \mathrm{I}_{2}$ ), which was due to the existence of gob fires. In the United States the influence of carbon dioxide on the explosibility of mine gases has been investigated, primarily for the purpose of determining the practicability of introducing carbon dioxide into mine workings to extinguish fires and prevent explosions. The results have led to the following conclusions. (I) Carbon dioxide, owing to its higher specific heat, is more effective than nitrogen in preventing explosions. . (2) The addition of 25 parts (by volume) of $\mathrm{CO}_{2}$ to 75 parts of the most explosive mixture of methane and air renders the mixture non-explosive. (3) When carbon monoxide is introduced in place of oxygen, 7 per cent of $\mathrm{CO}_{2}$ is sufficient to prevent explosion.

The rapidity with which coal absorbs oxygen has been shown by Porter and Ovitz (U.S. Bureau of Mines, Technical Paper 2, I9ri). Ten kilograms (22 lbs.). of coal from Connellsville absorbed during first day after mining nearly one-half the oxygen in ro litres of air. Slightly more than one-tenth as much carbon dioxide was produced as would have been produced had all the oxygen absorbed combined with carbon to form 
carbon dioxide. Burrell and Seibert ( $i d .$, Technical Paper I3, I $9 \mathrm{r}$ ) find that oxygen is absorbed by the coal in mines. Samples of gases collected by the same authors near a fire, where the coal was intensely hot and the oxygen content of the mine atmosphere was only 2 per cent contained $\mathbf{1 . 5}$ per cent of $\mathrm{CO}$.

Our knowledge of the composition of "blackdamp" has been greatly extended by the researches of Haldane. In a paper on "A Flame-Test for the estimation of Oxygen and Blackdamp in Naked Light Mines" (Trans. Inst. Min. Eng., Vol. 4I, p. 455), he describes a series of laboratory experiments with an apparatus consisting of a glass tube and thin tapers. When a lighted taper is held inside the tube, the flame is extinguished by the draught so produced at a point lower down or higher up the tube, according to the percentage of oxygen. The tube is graduated to indicate various percentages of oxygen and blackdamp.

R. Nowicki (Oesterreichische Zeitschrift für Berg-und Hïtlenwesen, I9I I, p. 587) describes an apparatus for detecting $\mathrm{CO}$, using palladium chloride. Many, however, prefer the use of animals to chemical tests, and G. A. Burrell (U.S. Bur. Mines Tech., Paper II, I9I2) gives a preference to canaries as against mice.

(Allan Greenwell; Hubert Greenwell.)

\section{METALLURGY}

The period I000-I 2 has not been marked by any great or revolutionary development in either metallurgical science or practice; or rather, if any of the developments which have taken place should be destined to carry important changes in their train, no striking signs of such changes have as yet become visible. In general terms progress here, as in most industries, has been in the direction of increased production, increased economy of labour, and more efficient utilisation of raw materiais and of by-products, and in some cases this has led to the installation of plant on an astonishingly large scale. In other directions, the systematic and scientific exploration of the available materials and their products has led to the evolution of new and valuable materials, principally in the form of novel alloys. The developments of metallurgical practice in reference to the several groups of metals may be more conveniently considered before dealing with the scientific aspects of metallurgy in general.

Iron and Steel (E. B. xiv, 8or et seq.).-Ore resources are being further developed, and the beginnings of iron and steel industries have been made both in South America and Australia. Progress has also been made in the utilisation of finely divided ores and such materials as blast-furnace flue-dust by improved methods of briquetting; in the Schumacher process the addition of a small percentage of magnesium chloride solution to the flue-dust serves to release a latent power of setting, while in the Dwight-Lloyd system the material is sintered by mixing it with finely-divided carbon which is caused to burn, thus partially reducing the ore and producing a porous sintered mass.

In biast-furnace practice, the use of thin-lined and water-cooled furnaces has increased, while the drying of the blast is becoming universal. For this purpose several new methods have been used, including refrigeration by the use of ammonia without the intervention of brine, and the use of calcium chloride as a drying agent. The latter is used for six or eight hours and is then regenerated by drying in the heat of the fluegases. The former process has been used in Wales and the latter in Luxemburg, while at one Belgian plant the use of blast enriched with oxygen has been tried, and if the price of oxygen can be further reduced this may prove to be an important improvement. In this connection the use of an oxy-acetylene torch for burning out tapping holes may also be mentioned. The utilisation of blast-furnace gases has been pushed further, so that these furnaces now constitute important sources of power; the use of the gas in openhearth furnaces has been contemplated, but its calorific value is too low to allow of its use alone. Mixed with producer gas or with gas from coke-ovens, however, success has been attained. Quite recently the utilisation of the waste heat of blast-furnace slag has been accomplished by running the molten slag into water and allowing it to generate steam for driving turbine engines. 
In steel-making, the general progress of the open-hearth processes as compared with the Bessemer is the most prominent feature, especially as regards the basic open-hearth process. In America even for rail-manufacture the open-hearth has largely supplanted the converter. The open-hearth furnaces themselves are steadily increasing in size, the 50 and 75 ton furnaces of previous years being replaced by roo-ton units. This increase in size is accompanied by devices for prolonging the life of the furnace, principally by the more extensive use of water-cooling and the introduction of removable furnace ports. The importance of maintaining the shape and position of the ports having been recognised, water-cooling has been employed; on the other hand the use of removable ports makes the life of the furnace independent of the life of the ports. Thus a basic open-hearth furnace which formerly had a life of 350 to 500 heats now runs up to 1,000 heats with three changes of ports.

Rolling-mill practice $(E . B$. xxiii, 468$)$ has developed concurrently with the development of the furnaces; in America particularly, the tendency for obtaining very large outputs by installing plant of great power and speed has been strongly marked. The rolling-mill installed at Gary, Indiana, may be taken as an example. This mill is driven by a 6500 horse power electric motor working on a circuit at 6000 volts threephase current at 25 cycles; a I 2 -inch ingot can be broken down in this mill and rolled into a $\frac{1}{2}$-inch plate in 22 passes in approximately two minutes. It is however doubtful whether the market can dispose of the enormous full-power output of these very large mills, and the question of the quality of the resulting products is also a serious one. It is claimed, however, that there is now a strong tendency for American steel-makers to pay greater attention to the quality of their products than has hitherto been the case. The serious troublesvexperienced with steel rail fractures in recent years have no doubt produced some such effect. The mill just referred to is typical also of the tendency towards the increased use of electric motors for driving rolling mills.

An important feature in recent development in siderurgical practice is the steady progress of the electric furnace. At Tröllhattan in Sweden electric iron ore smelting has been in continuous use and it is claimed that under the favourable conditions as to water-power which prevail there the process is profitable. More frequently the electric furnace is employed simply for refining or rather "super-refining" steel which has been roughly freed from its impurities either in the converter or the open hearth. For this purpose one or two American steel works have installed combined open-hearth and electric furnaces, in which the steel is first "roughed down" under gas heating and electric heating is employed only for the final stages. The use of electrically melted steel for the production of steel castings has developed considerably and a steel foundry working entirely with Stassano electric furnaces has recently been put down in England. The advantages of "electric" steel in regard to freedom from gases, oxides, etc. are now widely admitted, but excessive and ludicrous claims on behalf of this material are still put forward at times. An interesting special use for the electric furnace has recently been found in melting the ferro-manganese or ferrosilicon prior to its addition to the molten steel in the ladle or the furnace; considerable advantages are claimed for the practice of making these additions in the molten state.

The difficulties experienced with steel rails in America and elsewhere have drawn attention to the question of soundness of ingots and the effect of blow-holes. In regard to the latter Stead has shown that deep-seated blow-holes certainly, and even superficial ones probably, weld up completely when the ingot is rolled, provided that the holes are not associated with sulphide enclosures. Hadfield, on the other hand, regards complete freedom from blow-holes as essential and prefers a steel which settles well and "pipes," but he counteracts the piping tendency by supplying the ingot during cooling with hot liquid steel from a "feeding head" placed on top of the ingot-mould, in which the steel is kept molten by a layer of charcoal kept in active combustion by the aid of an air-blast. Talbot, again, consolidates his ingots by giving them a few passes through the cogging-mill while their intérior is still liquid, thus claiming to produce in a simple and inexpensive manner the same results as the Harmet compression process. Goldschmidt claims that soundness may be insured by the introduction of a cartridge of thermit into the bottom of the solidifying ingot, and quotes examples from an extensive practical trial in support of his claim.

The use of alloy and "special" steels has extended very considerably, notably in the case of steels to which vanadium and titanium have been added during manufacture. In the case of vanadium this has become possible by the fact that the price of vanadium alloys at one point dropped to one half of the former figure, and the use of vanadium steels has increased considerably. The use of "titanium steels" has however increased - particularly in America - more widely than that of any other special steel. American metallurgists regard 
titanium as a "cleansing" addition which removes oxygen, nitrogen and other impurities, rather than as an actual alloying element. The value of titanium was first established in the case of rails, but its use has since extended to other classes of steel. As regards alloy steels proper, the use of nickel, nickel-chrome and chrome-vanadium steels has extended, chiefly through the growth of the automobile industry. The use of manganese steel and of nickel steel rails has also been tried.

The question of the corrosion of iron and steel has continued to receive much attention: apart from the general controversy between the "electrolytic" and the chemical (carbonic arid) theories of corrosion, the electrolytic theory has received a serious check from the researches of Heyn, who has shown that while the existence of local cells determines the rapidity with which corrosion commences, it does not affect the ultimate rate of corrosion. In America a new material, known under the name of American ingot iron or "open-hearth iron," has been produced for the purpose of resisting corrosion; it is claimed that this metal is the nearest practical approach to chemically pure iron and that it resists corrosion better than mild steel. The material, however, has an appreciable content of copper - it is even suggested that copper is intentionally added to it, and that its non-corrodibility is due to the copper. The addition of copper to steel for this purpose has also been introduced. Some progress has also been made in the production of actually acid-resisting varieties of cast-iron, such as the high silicon iron of Jouve and the material known as "tant-iron." The use of approximately pure silicon metal for this purpose is also contemplated.

The subject of the cementation of iron and steel has received much attention, the most notalble advances being probably those made by Giollitti and his collaborators at Turin: by the use of charcoal and a mixture of carbon dioxide and carbon-monoxide gases under pressure in a furnace where both temperature and pressure can be varied, these workers obtain a wide power of regulating both the intensity and depth of cementation and also the width of the transition zone between carburised and non-carburised material.

Copper (E. B. vii, ro2 et seq.). - The most marked feature in the metallurgy of copper during the past three years has been the great development of basic converting. causing a radical change in equipment, durability and tonnage of converters and in general practice. Even standard shells of the older type have been re-lined with basic material. Apart from this feature, progress has also been made in the handling of ores; as regards transport, troughed conveyor belting has proved eminently successful as compared with the electric car even for distances of four miles. The use of fine ores, flue-dust etc. has also been advanced, so that ores for the blast-furnaces are now generally screened so that the coarse charge can be worked at a higher rate. One interesting development is that of blowing fine material into the converter through the twyers by means of a jet of air at higher pressure than the blast. In the treatment of metallic copper itself, the use of boron sub-oxide has been introduced. Boric anhydride is reduced by metallic magnesium, yielding magnesium borate, and boron sub-oxide. The latter acts as a very satisfactory reducing agent on the copper and for castings intended for electrical purposes removes oxygen so well that conductivities up to 97.5 per cent have been obtained. The use of the boron sub-oxide to replace " poling " has also been tried, but although the results are satisfactory there are practical difficulties on the ground of expense and attack on the furnaces.

Among the alloys of copper, Monel metal - a natural alloy of copper and nickel - has received extended use owing to the remarkable combination of strength with resistance to corrosion which it presents. It has been used for screw propellers in battleships (U.S.S. "Dakota") and for roofing large buildings (Pennsylvania terminal in New York). A remarkable test at $1000^{\circ} \mathrm{F}$. has shown the alloy to retain 80 per cent of its normal strength. The alloys of copper with aluminium and manganese have also been studied very closely (Ninth Report, Alloys Research Committee); one of these attains, in the form of rolled and drawn rod, a tensile strength of 52 tons per sq. in. with 10 per cent elongation on two inches. These alloys are remarkable for their resistance to corrosion and to abrasion. Another special "Ironze" is that of "Rubel," which contains 58 per cent of copper, 41 per cent zinc, and I per cent chromium, and possesses remarkable mechanical properties.

Aluminium (E. B. i, 767 et seq.).--The production of this metal has increased and a steady improvement in quality is heing obtained; when the metal is excessively pure, however, difficulties arise in working it. Its uses have developed considerably, principally in the direction of cooking utensils and of large tanks for breweries and similar purposes. The latter development has been facilitated by the established success of methods of joining aluminium sheets by autogenous welding. Extruded aluminium shapes, as well as the sheet metal, are also extensively used in carriage construction. 
Light alloys of aluminium have received much attention and marked progress has been made. In the Ninth Report to the Alloy Research Committee the alloys of aluminium with manganese and with copper plus manganese have been studied. Derived from the best of these alloys is the metal known as duralumin, developed in Germany by Wilm; this alloy contains from 3 to 4 per cent of copper and from $\frac{1}{2}$ to $\mathbf{I} \frac{1}{2}$ per cent of manganese together with $\frac{1}{2}$ per cent of magnesium. This latter addition gives the alloy the remarkable property of undergoing a gradual spontaneous hardening after suitable heating and quenching - at first the mechanical properties are unchanged, but in the course of four days the tensile strength is doubled while the ductility is only slightly affected. In this hardened condition the alloy combines mechanical properties similar to those of mild steel with a specific gravity slightly less than 3 , but these properties are destroyed by even moderate heating. This alloy was used in the construction of the ill-fated British naval air-ship of the rigid type at Barrow-inFurness. Quite recently a detailed study of the alloys of aluminium with zinc and with zinc plus copper has been published in the Tenth Report to the Alloys Research Committee. One of the alloys there described, containing 25 per cent of zinc and 3 per cent of copper, attains mechanical properties similar to those of steel or of duralumin but entirely without any special quenching or other heat-treatment; this alloy, however, has a specific gravity slightly higher than duralumin (3.25). The demand for materials combining strength with lightness arising from aeronautical construction has given a fresh impetus to the study of light alloys, and further important developments are to be anticipated.

Gold and Silver, Platinum etc.-Apart from the general tendency towards perfection in detail, resulting in greater efficiency and increased output, few remarkable developments are to be recorded with regard to the precious metals. The cyanide process $(E$. $B$. xii, I99) has received increased application, and is becoming standardised to some extent. A novel proposal was that of Clancy to replace the expensive alkaline cyanides by the cheap product of atmospheric nitrogen fixation, calcium cyanamide, coupled with the application of electrolysis. No large practical developments of the process appear to have taken place as yet. Efforts are being made to render the cyanidation process truly continuous, but the resulting gain is somewhat doubtful. On the other hand the method of agitating slimes by means of air-jets is now wide-spread and successful. The treatment of sulphide ores by this process is also receiving greater attention, and as the chemistry of the process is better understood simplifications have become possible.

In regard to the metallurgy of the remaining metals similar general tendencies have manifested themselves, and only a few special matters need be referred to here.

In connection with the use of lead for accumulator plates, or for any purpose where large reacting surface area is desirable, the process invented by Hannover for producing porous metals becomes of importance. Hannover utilises the fusibility of the eutectic alloys by casting an alloy consisting for instance of lead and tin in such a way that the metal consists of lead crystals whose interstices are filled up by eutectic; at a suitable temperature this eutectic is fluid and can be expelled by such means as centrifuging, when porous lead is left behind. Lead, tin, and especially zinc as required for the cyanide process, can now be obtained in the form of "ribbon metal" produced by allowing a jet of the molten metal to fall upon a rapidly rotating cooled iron drum; the metal runs off as a continuous flat ribbon. By the use of very wide jets, sheet-metals can be produced in the same way. More remarkable still is the process of Schoop, in which a jet of molten metal meets a jet of highpressure gas and is atomised so as to form a metallic cloud.. This finely-divided metal can be sprayed upon any object which it is desired to coat and yields a strong coherent deposit which can be made either to adhere firmly to the matrix or to leave it in the form of a cast. The metallic spray does not burn or injure even delicate articles, so that silk or wax can be readily coated. Quite recently it has been found that finely-divided solid metal (powder) can be similarly made to adhere and to cohere by a spraying process.

In regard to zinc, the efforts at electric smelting are still being continued in Sweden, and although it is considered in most quarters that the process is still in an experimental stage, definite success, particularly in the production of spelter of high purity, is claimed. Extremely pure spelter, said to be of electrolytic origin, is at present produced in small quantities in England, but the demand for very pure zinc appears to be increasing. Efforts to meet it are taking the direction of improved methods of refining, and although much secrecy is observed, it is probable that vacuum processes of distillation are being introduced.

Some reference must also be made to the advance in the metallurgy of the very refractory metals, such as chromium, molybdenum and tungsten. The latter metal is now produced in approximate purity by the electric furnace, and for the purpose of electric incandescent lamps drawn tungsten wire is now used in place of the agglomerated filaments formerly employed. Both tungsten and molybden find increased uses in "high speed" tool steels, while chromium is finding a wider application in the production of new alloys. Among these an alloy of nickel, with chromium and manganese, known as "nichrome," has achieved 
considerable success as an electric resistance heater at high temperature; the newest grade of this alloy is claimed to withstand continuous heating at $1100^{\circ} \mathrm{C}$. An alloy of chromium and cobalt is described as having a white colour and being practically incorrodible, being unattacked even by nitric acid. It is said to have the hardness of steel and to take a cutting edge. Its incorrodibility indicates that the material would be particularly useful for such purposes as fruit knives and table cutlery. Its use for razors is also suggested, but it remains to be ascertained whether it shares the tendency of modern high-speed tool steels to produce undesirable symptoms in any small wounds inflicted.

Physics and Physical Chemistry. - The period under review has been particularly rich in scientific investigations on metals and alloys which come under the heading of "Metallography" in the wider sense of that word, but this sense has now become so wide that "Physical Metallurgy " is a preferable name for the rapidly expanding science, which now embraces the study of all the physical properties as well as the physicochemical relations of metals and alloys. Typical of this development is the existence, since I gr I , of an "International Journal of Metallography " published in Berlin, and the rapid rise of the Institute of Metals, founded in England in rgro. The wide-spread activity in this subject is also typified by the fact that, in a report on progress presented by Heyn to the International Association for Testing Materials, references are given to over 500 papers bearing dates later than rgog.

The equilibrium diagram of the iron-carbon system has been the subject of continued research and controversy on minor points, but the main features of the diagram are now accepted by all except a few extremists. Among researches bearing upon it the work of Gutowsky may be mentioned which indicates the necessity of revising the position of the "solidus" curve for the low-carbon end of the diagram. Rosenhain and Humfrey have demonstrated the existence of a relatively hard modification of iron above the critical points, while Baykoff has shown by means of etching with gaseous hydrochloric acid at high temperatures that steel is a homogeneous solid solution at those temperatures, as required by the accepted diagram. Controversy and difficulty still centre around the true relations of graphite and cementite, and the names of Ruff and Goecke, Ruer and Iljyn and Hanemann are associated with important work on this question. Another important step in the metallography of steel is denoted by the adoption, at the recent New York Congress of the International Association for Testing Materials, of a uniform nomenclature for the microscopic constituents of iron and steel. The fact that Howe and Sauveur have been able to prepare such a report indicates that a substantial agreement has now been reached by the majority of the world's leading experts. Increased attention has also been given to the foreign bodies, such as slag, sulphides and silicates of manganese and iron etc., which are met with in steel. Recent research is summarised in a report to the above-named Congress by Rosenhain.

Copper and its alloys have received much attention. In the copper-zinc series (brass) Carpenter has drawn attention to a thermal point at $470^{\circ} \mathrm{C}$. and has demonstrated its nature, as a decomposition of the $\beta$ into the $a$ and $\gamma$ phases, in an elaborate series of papers. The constitution of copper-arsenic alloys (Hudson) and of the phosphorbronzes (Law) has also been studied. The Ninth Report to the Alloys Research Committee of the Institution of Mechanical Engineers (London) contains an elaborate study. of the ternary group of alloys of copper with aluminium and manganese, and a detailecl metallographic study of portions of the system (Rosenhain and Lantsberry). This attack on the problem of the constitution of ternary systems of alloys is typical of a very large amount of work which has been undertaken, principally in Germany, during the past two years. Most of this work, however, although of great interest as yielding it first rough idea of the constitutions of these systems, must be regarded as strictly preliminary, since the methods and apparatus used are in many cases in adequate for the complete study of such complex problems. The manner in which early investigations of alloys are apt to be inaccurate has recently been illustrated in the aluminium-zinc system, where a research carried out with the greatest available refinements has led to a complete revision of the formerly accepted diagram (Rosenhain and Archbutt).

Many other fields of enquiry which have begun to yield important results can only 
be mentioned. These include the study of the gases dissolved or occluded in metals and removed by heating or even melting in vacuo, of the behaviour of metals in high vacua, especially in the light of the theory of an amorphous inter-crystalline cement in metals, of the magnetic properties of alloys, both of iron and of copper-aluminium-manganese, and of the electrical resistance of alloys and its variations with temperature.

For these and allied researches reference should be made to the original publications, many of which exist only in foreign languages. In English, many original papers, and abstracts of many others, including most of the more important foreign ones, will be found in the Journal of the Iron and Steel Institute, the Journal of the Institute of Metals, the Proceedings of the Faraday Society and of the Institution of Mechanical Engineers, and in the pages of Science Abstracts, devoted to physical chemistry. In French the Revue de Métallurgie, and in German Stahl u. Eisen, Metallurgie, and the Internationale Zeitschrift für Metallographie, may be consulted, as well as the more recent text-books upon this subject.

(W. Rosenhain.)

\section{SOLID, LIQUID AND GASEOUS FUELS ${ }^{1}$}

\section{Solid Fuel.}

Coal.-In the middle of the roth century a large amount of scientific work was done concerning the composition of coal, and the view was held by many observers that the New views variations in the properties of coals were dependent as much upon the on the com character of the vegetable matter from which they had been formed as position of upon the conditions of formation. These views however were more or less coal.

lost sight of until the last couple of years, when they have again been brought to the front, and are now shown to give a far more satisfactory explanation of many obscure points with regard to the thermal value and chemical decomposition of coal than was possible before. In rgr I M. J. Burgess and R. V. Wheeler published the results of a series of experiments on the distillation of coal at various temperatures, which led them to conclude that coal contained two types of compounds of different degrees of ease of decomposition, the one a degraded product of cellulose, the other derived from the gums and resins of the coal plants, and that the character of the coal is determined by the proportion in which these two types exist in coal.

V. Lewes puts forward the general theory of the formation and composition of coal as follows. Carbon is practically non-existent in the primary rocks constituting the crust of the globe; hence all the free carbon and compounds containing carbon that we now find have been produced by secondary actions from carbon dioxide in the atmosphere, the amount present showing that the atmosphere in times prior to the carboniferous period consisted of a high percentage of carbon dioxide, nitrogen, oxygen, and water vapour. Human life under these conditions was impossible, but as the crust of the cooling globe reached a sufficiently low temperature, a vegetable life of a low order started and grew with a luxuriance and rapidity that could never again be equalled, owing to the conditions of moist heat and plentiful carbon dioxide. As the vegetation grew it absorbed the carbon dioxide and moisture, and under the influence of the sun's rays built up the plant structure and evolved oxygen, thus in the course of geological ages creating an atmosphere fitted for lower forms of animal life, which gradually became of a higher order as the necessary oxygen increased in percentage. Owing to the paucity and dilution of oxygen in the earlier periods, decay, as we now know it, could take place only to a very limited extent, and this, with the rapidly growing flora of the carboniferous period, gave rise to the enormous vegetable deposits and drifts from which eventually all fuel was formed.

All the plants of which there are fossilised records in our Coal Measures consisted of sedges and reeds, tree ferns, club mosses or lycopodia, and trees akin to the pine; but in these prehistoric days the conditions of growth were such that the plants grew with a succulent freedom and rapidity since unknown, and this later rendered their tissues an easy prey to fermentation-an action which left only the more resistant unchanged. The work of Morris, Carruthers, Fleming and Huxley has shown that the bituminous

1 See. E. B. xi, 274 et seq. 
matter in coal is derived largely from the spores of fossil mosses akin to the lycopodia, and spores of this character, from the giant growths of the carboniferous period, together with the more resistant portion of plants akin to the pine, are the substances which have best resisted the actions taking place during the ages that have elapsed in the formation of coal.

The vegetable matter consisted chiefly of a basis of celluloses and lignose, together with the extractive matters rich in resin, and as these were unable to undergo rapid decay owing to the low oxygen content of the air, fermentation became the chief factor of change, and, the mass being overlaid gradually by sedimentary and other deposits, pressure and heat added their forces to the actions taking place, the celluloses and lignose becoming converted into humus bodies, having the general percentage compositioncarbon 63 , hydrogen, 5 oxygen 32 . During these periods the resins-which have the general composition: carbon 79, hydrogen I I, oxygen Io-underwent but little change, but in the long ages that have passed some of the resin bodies have been converted into such hydrocarbons as retene and hexahydrides, while the humus bodies have undergone general degradation, resulting when completed in residual carbon. All these constituents are found agglomerated in the coal-the humus bodies and residual carbon being luted by the resin bodies and hydrocarbons, the properties of the coal being dependent upon the proportions in which they are present.

The lignites or tertiary coals, being of younger age, were formed at a period when the air contained a higher percentage of oxygen, so that direct oxidation played a more important part, and as the resins are the bodies most affected by this they were reduced in quantity, but the great difference between the lignite and true coal is that the humus bodies have undergone a minimum of degradation, so that the free carbon is lower than in any other class, while the humus bodies still retain their attraction for water, which is always present in considerable quantity in the Tertiary coal.

During the formation of coal the gases evolved are carbon dioxide, methane and water, and where the roof of the seam has been impermeable to gas, methane is found occluded in the coal together with some carbon dioxide, but the bulk of the latter gas has dissolved under pressure in water and formed bicarbonates in the sedimentary deposits, and has then helped in such other changes as the dolomiting of limestone.

Many classifications of coal have been suggested, some based on their chemical, some on their physical, and others on their coking :properties. Of the latter, the most Classif- generally adopted is that of Gruner, in which he tabulates bituminous coals cation of into five classes. Although M. Schondorf, F. Muck, and others have shown coals. that it is not applicable to all kinds of coal, still this criticism applies to all classifications that have been proposed.

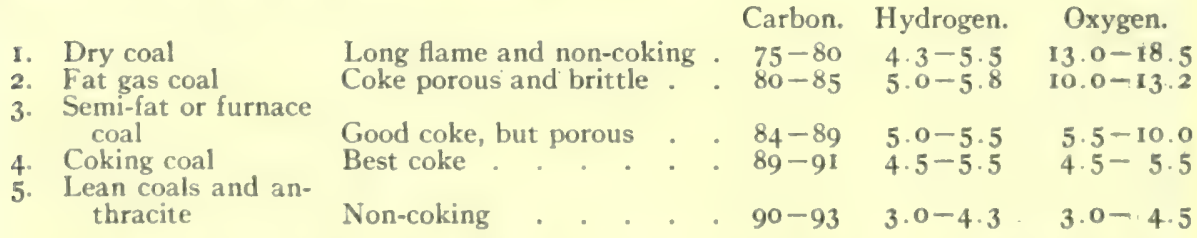

This arrangement shows not only the coking properties, but also the changes in composition which the coal undergoes, the concentration of carbon, and reduction in highly oxidised bodies. In the first class there are the dry coals, yielding large volumes of gas and liquid products on distillation; and these - as might be expected-most resemble the lignites, and share with them the property of non-coking or binding together of the residue on carbonisation. This is due to the fact that the humus-like bodies are still present in much larger quantities than the resinic compounds and hydrocarbons; and as on distillation they leave no binding material in the residue, the resinic bodies cannot supply enough to give more thas a friable mass. In the second class of coals, altered conditions of temperature, pressure and time have led to further decompositions of the humus bodies, and, the resinic constituents and hydrocarbons having increased in ratio by concentration, a point is reached at which coking takes place, although not of a really satisfactory character. In the third class, the action has continued with further concentration of the resin bodies, hydrocarbons 
and residuum, with the result that the former bodies are so increased in comparison to the humus and residuum that a good coke results, although rather too porous and bulky. In the fourth class, the proportion of resin and hydrocarbon bodies has reached the right ratio as compared with the humus and residuum, and the best coking coal is obtained. Bituminous coals of the kind classified by Gruner may therefore be looked upon as an agglomerate of humus and the degradation products of these bodies down to carbon, luted and protected by resin bodies and their derivatives; steam coal and anthracite as the degradation products of humus which has nearly completed its decomposition owing to the small quantity of resin bodies in the original vegetation; cannel coal as consisting mainly of resin bodies, derived from accumulations of seed spores which, having been brought down by streams, have mixed with sedimentary earthy matter, and are therefore often high in ash.

Such a theory has an important bearing upon the consideration of the thermal value of coal as well as its other properties, as it is manifestly the ratio of the coal constituents and

Effect of composition on thermal value. not the percentage of the elements in the coal that governs these. In all attempts to calculate the calorific value from the percentage composition it is found that, with coals poor in oxygen, such as steam coal or anthracite, there is a very fair agreement between the calculated value and the value as determined in a bomb calorimeter, but that directly the coal contains much over 5 per cent of oxygen, the value as determined rapidly rises above that calculated.

This is due to the humus bodies in the coal still retaining the endothermic character of the cellulose and lignose from which they were derived, and it is found that whilst the calculated heat values for the carbon, resin bodies and hydrocarbons in the coal are in close agreement with the determined values, an artificially prepared pure humus will have its calorific value as determined 16 or 17 per cent higher than when calculated from its percentage composition. It is clear therefore that direct determination in a bomb calorimeter is the only accurate method for determining the thermal value of coal.

The proportions of the constituents in the coal also govern the nature of the products when it is subjected to carbonisation. The humus bodies during carbonisation yield a

\section{Effect of}

composition

on products

of carbonjsation.

large: proportion of the gaseous products, and under the influence of heat show no sign of melting, but begin to break up at about $300^{\circ} \mathrm{C}$. The decomposition becomes more rapid as the temperature rises. Water distils over in the early stages; the tar is thin and poor in quantity, and the gases up to $600^{\circ} \mathrm{C}$. consist of hydrogen, methane and carbon dioxide, with smaller quantities of carbon monoxide and traces of other saturated hydrocarbons. The decomposition can be completed below $800^{\circ} \mathrm{C}$; but if the temperature is run up to $1000^{\circ} \mathrm{C}$. the carbon dioxide is reduced in quantity by the action on it of the red hot carbon. Carbon monoxide increases correspondingly, whilst hydrogen and methane are still evolved.

The decomposition of the humus is also largely affected by the rate of heating. If slowly heated, a large proportion of the oxygen is given off in combination with hydrogen as water vapour; whilst if quickly raised in temperature, more combines with carbon to form carbon dioxide and monoxide. The residue shows no sign of caking, whilst, like the naturally formed residue-mother of coal-it requires a large proportion of cementing material to make the particles cohere. The resin bodies and hydrocarbons which form the cementing portion in the coal melt between $300^{\circ}$ and $320^{\circ} \mathrm{C}$.; and if a coarsely powdered sample of the coal becomes pasty or semi-fluid at this temperature, it is a strong inference that the coal will coke on carbonisation - a fact noted by C. Anderson. About these temperatures also the resin bodies and hydrocarbons begin to decompose.

The resin bodies at low temperature yield saturated hydrocarbons, unsaturated, chiefly hexahydrides or napthenes, together with some oxygenated compounds; whilst the hydrocarbons yield paraffins and liquid products-all these primary constituents undergoing further decomposition at slightly higher temperatures. The liquids produced begin to distil out as tar vapours, and leave behind with the residuum pitch, which at $500^{\circ} \mathrm{C}$. forms a mass already well coked together if the residuum from the humus is not too great. The coke formed is soft; but if the heat be raised to $1000^{\circ} \mathrm{C}$., the pitch residue undergoes further decomposition, yielding gas and leaving carbon, which binds the mass into a hard coke.

Coke and "smokeless" fuels.- The efforts'of the Smoke Abatement Society in England have led to many attempts being made to introduce smokeless fuels like coke for domestic consumption, and there is no doubt that if a fuel of the character of "Coalite "easy to light and burning with a bright cheerful combustion-could be produced economically and sold at a reasonable price, it would not only command an enormous sale, but, in conjunction with gas fires, would go far to solve the problem of smoke prevention. The combustion of bituminous coal as a national domestic fuel brings in its train consequences so objectionable that every effort should be made to bring about a more rational state of things.

In order to overcome the trouble of smoke whilst using solid fuel, many forms of grate have been suggested, the most successful of them being dependent upon the principle of 
feeding fresh fuel to the bottom of the fire instead of to the top, so that as the tar, hydro. carbon vapours and steam distil out from the coal, they have to pass through a mass of incandescent carbon above, which decomposes the complex tar vapours into simple hydrocarbons. These are then completely burnt up on reaching the fresh air supply at the top of the fuel. The fact however that any special form of grate would require the removal of the old type and introduction of the new, has been sufficient to prevent any success in this direction, and what is really needed to make smoke prevention a practical possibility is the introduction of a fuel which could be treated in every way like coal, which would be as easy to ignite, would burn with a cheerful flame, and would in reality commence its combustion just at that period when, in a fire, the smoke has ceased and the fire has burnt clear.

"Coalite" was a fuel which fulfilled these conditions exactly, and consisted of coal carbonised at $420^{\circ} \mathrm{C}$. instead of at $1000^{\circ} \mathrm{C}$.; it was in fact a half-coked coal of uniform composition, with enough volatile matter left in it to give it the needed properties. For various reasons, unconnected with the nature of the fuel itself, coalite has not so far proved a commercial success; but it has convinced everyone who has used it that it is infinitely superior as a fucl to any bituminous coal, and has created such a demand for a smokeless fuel that some imitations, which differ from gas coke only in name, have been able to find a market. The best known of these is "Coalexld," made by mixing a very small proportion of alkaline nitrates with the coal before carbonisation. These evolving small traces of oxygen on their decomposition give small areas of high temperature during destructive distillation, and so give a slight increase in the gas yield. Another is made by cooling the hot coke when it is drawn from the retort by smothering it with a layer of coke breeze, instead of quenching it by water in the usual way, and is known as "Charco." Both these cokes contain about the same amount of volatile matter as ordinary coke made from the same coal.

Ordinary gas coke is not a popular domestic fuel; it is often over-quenched at the gasworks and sent out too wet, whilst its ignition point, if made at a high temperature, is nearly double that of coal, so that it is difficult to light and gives a dull fire, unless the chimney draught is exceptionally strong. With the introduction of continuous carbonisation in vertical retorts (see under GAS MANUfACTURE) the quality shows distinct improvement in dryness, and it would be easy for the gas manager so to regulate the heat of carbonisation as to leave 3 or 4 per cent of volatile matter in the coke to fit it tor domestic use.

Peal.-The vast area of the recorded peat bogs existing in the world, which in Great Britain alone amounts to 800,000 acres, and the fact that dry peat, especially in the form of briquettes, is a pleasant and efficient form of fuel, have led to many attempts being made to utilise this enormous store of latent energy. So far all attempts to solve the problem have been commercial failures, as the mass of raw peat existing in the bogs contains approximately 90 per cent of its weight of water, most of it so held in a condition of feeble combination that it cannot be pressed out mechanically, whilst if heat is employed to drive it off, as much is needed as remains in the residual solid, and the attempt ends in a loss equivalent to the money expended on labour.

In countries where coal has been abnormally expensive and the climatic conditions good, cutting and stacking the peat in such a way as to allow air-drying to reduce the moisture to about 50 per cent, and then driving off some more of the remaining moisture by artificial heat and briquetting the product with 10 to 20 per cent of moisture still in it, has yielded small profits, but the enormous area needed for the air-drying, the amount of labour needed to cut the peat, and the fact that it is possible to do so only for a few months in the year, have prevented anything like commercial success, whilst in most countries the humid climate of the peat districts renders such a process impossible.

In 1906 Dr. M. Ekenberg discovered that peat, consisting as it does of partially decomposed vegetable matter, contains cells which are filled with and coated by a slimy substance, which he called hydrocellulose, and that this jelly-like compound held the water in such a way that mechanical drying of the peat by pressure was not possible, but that when heated to $150-200^{\circ} \mathrm{C}$. the slime became "hydrolised" and went into solution, and that the peat so treated could be made to part with its water under hydraulic pressure. Starting from this point the Ekenberg process of "wet carbonisation " was elaborated, and works have been erected on a peat bog near Dumfries, the working of which has been designed to obviate both the climatic and labour difficulties.

In this process the peat is mixed with sufficient water to render it fluid enough to pump through tubes, and with a dry bog extra water would have to be added; at Dumfries however the bog is sufficiently wet for the purpose. The peat is dug by an ordinary mechanical digger of the type used in civil engineering operations, mounted on a pontoon which floats in the 
space excavated by it on the bog. This digger raises the material into a disintegrator of special design, whence it is pumped through pipe lines to the works.

The power required at the peat getting station is supplied by generating electric current in the works and transmitting it to the plant at the bog. The peat pulp is then passed through the carboniser, which may consist of an arrangement of two concentric tubes, such as is found in the Nichlausse boiler, heated in a gas furnace. The raw peat is pumped continuously into the space between the outer and inner tube, and the carbonised peat, flowing back in the reverse direction through the inner tube, thus parts with its heat to the entering raw pulp. Under the pressure existing in the carbonising plant the pulp passes into the filter presses, which squeeze out much of the water, leaving the peat in a condition ready to go into the producer for ammonia recovery, or, after further drying by the waste heat of the gases from the producer, to the briquetting press.

One of the chief points in the process is that double the quantity of peat is treated that is required as briquettes, one half being taken as press cake, and used in producers of the Crossley type for conversion into producer gas, which, after the ammonia in the gas has been absorbed by sulphuric acid, is then partly employed in a battery of gas engines to give the necessary power for working all the apparatus used and bringing the peat from the bog, and also for supplying the heat for drying the remaining half of the peat that is to be briquetted, down to about 5 per cent of moisture.

Peat contains nitrogen in amounts which vary from I to 3 per cent, and theoretically for every one per cent of nitrogen present it should be possible to obtain to5 lbs. of ammonium sulphate per ton, but in practice with gas producers of the Crossley type about 75 to 80 per cent of this quantity is recovered.

The calorific value of the peat blocks made in the briquetting press is about 5,490 calories or $9,882 \mathrm{~B}$ Th $\mathrm{U}$, and as the amounts which can be carbonised for ammonia recovery or can be briquetted are very elastic, the output can be arranged to meet local requirements. This process is undoubtedly far more promising than any that have been before attempted.

\section{Liquid Fuel.}

During I II and I 12 the use of liquid fuel has again received an impetus from the successful results obtained with it in practically all the naval services in the world. The American Government are safeguarding the supply for naval purposes by taking control over an area of the Californian oil fields, which will be held in reserve. In Great Britain the shortage of fuel oil supply, due largely to difficulties in transport, will probably disappear when the large number of new tank vessels now building are completed, and these will allow of the utilisation of the large supplies of fuel oil which will be available from Mexico, the Dutch East Indies and Burma, as well as from Texas and California. The price of liquid fuel limits its use to a great extent, as it is only where the advantages to be gained by its employment are so great as to overshadow the question of cost that it can possibly compete in Great Britain with coal, and the factor which prevents its adoption in very many directions is the impossibility of getting any guarantee as to constant supply. Freights have recently been so high as to make the price of the oil in England almost prohibitive, and the question is whether the carriage can be so reduced as to bring the price down. The great hope of the fuel oil market at the end of I 9 I 2 rested in the enormous demand for petrol, which during the next few years promises to lead to the development of all possible sources of oil; after the portion possible to use for motor-car fuels has been distilled off, the residuum, which is the portion of the oil available for fuel purposes, will be correspondingly large; but it must be remembered that in most of the countries on which Great Britain relies for oil supply the use of liquid fuel is advancing rapidly. In America, Russia, Austria and other countries producing oil or close to the oil fields, liquid fuel is now replacing solid fuels in the locomotives on the Government lines, as well as for manufacturing and other purposes, so that the supply from these sources for export is only what is left over after the home consumption has been satisfied. This of course does not apply to the Indian and Mexican fields, from which large supplies of fuel will probably be available.

Oil Fuel Burners.--Most of the earlier burners used for the consumption of oil in place of coal in marine boilers rely on the principle of injecting the oil as a fine spray into the furnace by means of steam, air or pressure. These burners answered well when the combustion space was large, but where a considerable amount of oil had to be burnt in a small space their action of driving forward the oil supplied rendered the passage of the burning oil through the combustion space too rapid to allow of complete combustion, and large quantities 
of smoke were formed. Further trouble arose because steam had to be supplied, and as on a Service vessel this would mean extra boilers this was a great drawback.

Of the burners which sprayed the oil under pressure without the use of either steam or air, the Korting and Swensson had already proved successful in many cases, but a great improvement was introduced by I. I. Kermode, who designed a burner in which the oil under pressure issued from the nozzle in a swirling cone of mist, the particles not being driven straight forward as in other types by the spraying, and the rate at which it traverses the combustion space is thus reduced. Air injection for the oil, although on theoretical grounds it might be expected to be the most advantageous, has never found much favour for marine work, as auxiliary power has to be provided to drive the pumps for the air compression, but where an intense temperature is required it has been used largely, and especially in furnace work on land has proved very successful. One of the most successful forms of burner for this purpose has also been designed by Kermode and may be used with either steam or air.

At the present time the use of liquid fuel direct in the internal combustion engine has occupied a large amount of attention, and the Diesel engine has already shown itself well adapted for marine use where the power required has not been very high. The successful installations in the tank steamer "Vulcanus" and in the "Selandia" have demonstrated its great possibilities, whilst the fact that one B.H.P. can be obtained with a consumption of something like 0.45 of a pound of liquid fuel of much the same character as that used for burning under a boiler gives very high economy in its employment.

The first British destroyer fitted with Diesel engines for propulsion was the "Hardy," launched in October 1912, in which, for full speed, turbines fed with steam from boilers fired with oil fuel are used, whilst the Diesel engines are employed for cruising speeds, at which the turbine shows a marked falling off in efficiency.

In Germany, where there is a heavy import tax upon oil, the use of tar and tar oils in the Diesel engine has attracted considerable attention, and for the last ten years tar and creosote oils have been satisfactorily used. The troubles that at first arose with tar oils were that the pipes and nozzles of the burners were found to become choked with muddy deposits of solid hydrocarbons, consisting mainly of napthalene, which formed a crust also at the mouths of the burners. These deposits made the working of the feed pumps difficult, and the solid hydrocarbons increased the temperature of ignition. The crude tar oils varied in composition and quality with differences in the temperature of carbonisation, even when the same coal had been used, which necessitated constant alteration in the feed and air adjustments of the engine. Of recent years, however, improved methods of fractionation and refining the tar oil, together with careful selection of the material, have ensured a supply of fuel of constant and regular quality, without the drawbacks incidental to the use of crude tar oils.

\section{Gaseous Fuel.}

The most important development in the use of gas as fuel that has taken place since the invention by Bunsen of the atmospheric burner promises to arise from the so-called principle of "surface combustion." Although a mixture of hydrogen and oxygen in the proportions in which they combine to form water has an ignition point of about $550^{\circ} \mathrm{C}$. at ordinary atmospheric pressure, yet the two gases will combine in contact with certain metals at lower temperatures, but the rate of combination is so slowed down that the ignition point may never be reached. This power of inducing combination between gases at comparatively low temperatures has been known to be possessed by metals of the platinum group, since Sir Humphry Davy first established the fact in r8r6, whilst Dulong and Thénard afterwards proved that all solid bodies possess in varying degrees the power of accelerating combustion below the ignition point. It is only within recent years that the study of this phenomenon has been revived by the researches of Professor W. A. Bone, and the phenomenon of surface combustion is now receiving a considerable amount of attention, and promises to lead to most important commercial developments.

If a mixture of coal gas and air in the explosive ratio of $I$ to 6 be directed on to the surface of red hot nickel gauze or incandescent fireclay and asbestos, it is found that the acceleration of the 'combustion is not confined to low temperatures only, but flameless combustion ensues on the incandescent refractory surface, producing there a more in tense combustion, with the result that the material is raised to a high degree of incandescence, and a much greater proportion of the heat energy of the gaseous mixture is converted into radiant heat.

There are two possible conditions under which gaseous combustion may take place - the first, homogeneous combustion, in which the velocity of the chemical change is 
dependent on the order of the reaction, and combustion occurs equally throughout the system as a whole, and secondly, heterogeneous combustion, in which the combustion takes place in layers immediately in contact with a hot surface. This second condition constitutes what is known as "surface combustion," and is governed by the rate of combustion, the diffusion factors of the components of the gaseous mixture and the products of combustion, the effect of the " activity " of the refractory surface, the physical texture of the surface, and the retarding effect of films of inert gas.

The "activity" of a given surface can be varied by special treatment within wide limits; but the nature of the causes of the variation is still somewhat obscure. For instance, using a mixture of hydrogen or carbon monoxide with oxygen in conjunction with a non-oxidisable metal or non-reducible oxide, if the surface be previously treated by contact with the combustible gas, the "activity" of the surface is considerably stimulated, whereas if treated with oxygen it is diminished. The activity of a surface also increases rapidly with rise of temperature, the difference in activity possessed by various substances being reduced until at bright incandescence it disappears.

Diaphragm Process.-If an explosive gaseous mixture be forced under pressure through a porous refractory incandescent body, combustion in a greatly accelerated form takes place within the pores, and the heat developed by this combustion keeps the surface in a state of incandescence without the formation of flame.

This principle may be employed in two ways. The first is to fit a slab of porous refractory material in the front of a fuel chamber into which the gas and air, in proportions necessary to give complete combustion, are forced under the pressure necessary to drive them through the porous plate; the mixture is then ignited on the outer surface, which rapidly becomes heated, and the mixture burns within the pores of the slab and close to its exterior surface, which being raised to incandescence emits great radiant heat. The degree of porosity and size of the pores of the slabs can be arranged to suit the quality of the gas, fine pores being used with rich gases, whilst a coarser grade is necessary with gases of low calorific power, the pressure also being regulated to ensure the rate of flow of the gas being sufficiently high to prevent any risk of back-firing or explosion. This method of applying the principle is generally known as the Diaphragm process, and as, being flameless, the slab can be fixed in any position, it can be used to throw the radiant heat on the surface of evaporating liquids, for the concentration of acids, and for many forms of industrial and domestic heating.

Granular Bed Process.- The second method, known as the Granular bed process, consists in making a granular mass of the refractory material, and blowing the mixed gases on to it or through it under pressure, so that the combustion takes place on the surface of the granules, and a temperature of $2,000^{\circ} \mathrm{C}$. can be obtained. The granules can be packed into tubes directly immersed in water for steam raising, into the space round crucibles in processes for the melting of metals, or formed into a bed for furnace work. In a special form of boiler designed for this process an efficiency of 95 per cent has been attained, that steam can be raised from cold in 20 minutes, and that the normal evaporation is $20 \mathrm{lbs}$. per square foot of combustion surface per hour, which can be increased to 30 with a slight loss in efficiency.

Gas Stoves.-Ever since Bunsen in the middle of the last century gave to the world his atmospheric burner, the use of gas for heating and power has progressed more and more, until nearly as much gas is now used for these purposes as for illumination.

The earlier forms of gas stove had many defects which created a strong prejudice in the minds of the public against them, more especially as custom and comfort had created a firm affection for the open coal fire. In the modern gas stoves however due regard has been paid to overcoming the drawbacks found with the older forms, and their improved efficiency together with the absence of smell, \&c, have resulted in a steadily growing popularity.

The greatest objection raised against the use of gas for domestic heating is that of cost. If the open fire and the gas stove be compared on the price of fuel and the number of heat units present, the use of gas is shown to be about five times as costly as coal but if the question of efficiency be taken into consideration, the difference between the two methods of warming is found to be but slight. With a coal fire in an open grate only about one fifth of the heat units are utilised in warming a room, whereas with a modern gas stove nearly four times as great an efficiency can be obtained. Moreover, in favour of gas one can place cleanliness, absence of dust and labour, and convenience of lighting and extinction.

Heating by radiation is the only true and hygienic method of warming a room, as in this way the temperature of the air is not directly raised, but the walls, furniture and other solid bodies in the room absorb the radiated heat and in turn slowly give off a portion of this heat to the air around them; consequently the walls \&c are at a higher temperature than the air. If however the room be heated by hot water pipes, steam or any other such system, the temperature is raised by convection: the air around the pipes or radiator is heated, expands and sets up convection currents until the whole mass of the air is at the one tempera- 
ture. The solid bodies in the room however are not raised in temperature to the same extent, with the result that a sensation of chill is experienced by a person sitting near a wall, owing to the heat of the body passing by radiation to the wall.

In the modern gas fire a large percentage of the heat is converted into radiant heat, and the convection heat is reduced to a minimum, whilst the efficiency has been so improved that a large proportion of the heat in the gas is utilised. Provided that the stuve be fitted in a proper manner the ventilation of the room is effected quite as thoroughly as with open coal fire, but to do this the space between the stove and the fireplace must not be filled in with a sheet of metal, as was the old accepted procedure, but the exit pipe should be carried for some little distance up the chimney, when the outrush of hot gases will be drawn up with them, by a sort of injector action, and nearly as large a volume of air can be withdrawn from the room as with an open fire.

Hygienic Effect of Gas Heating.-Careful researches have demonstrated that the use of gas in incandescent burners and stoves is by no means detrimental to health, but is a valuable adjunct to vencilation, owing to increased circulation of the air.

In the old forms of gas stove convected heat was relied on for raising the temperature of a room, but this decreased the percentage of humidity to such an extent as to produce rapid evaporation from the plants and occupants in the room, the results being drooping in the former and discomfort to the latter. This is always the case where convected heat is the sole method of warming, but if a combination of the two systems be adopted it will be found very useful in the case of large spaces where enough radiant heat could not be given by an open grate, or gas stove. With a factory or schoolroom, for instance, radiators or hot water pipes could be fixed below the windows and inlet ventilators, and in this way the entering current of air would be warmed up two or three degrees, and the fire would then be able to complete its work of warming the solids in the room by radiation in a much shorter time.

(VIVIAN B. LEWES.)

\section{ILLUMINATING GAS MANUFACTURE'}

In no large industry have such fundamental changes taken place during the past few years as in coal gas manufacture, a complete revolution of the old ideas upon the carbonisation of coal having led to the introduction in Great Britain of vertical retort processes, while on the European Continent and in Ameriça carbonisation in bulk or chamber processes have made rapid headway.

The beginning of the present form of vertical retort, in which gravity is brought into full play to aid the filling and discharging of the retort, was in 1902 , when at the Exeter

\section{Vertical}

retorts.

gasworks a retort on this principle was erected and worked by T. Settle and W. A. Padfield, and in the same year vertical retorts began to be experimented on in Germany, by Dr. J. Bueb who by 1904 had got a good-sized installation at Mariendorf working successfully. In July roo3 however Messrs. H. W. Woodall and A. M. Duckham had patented in England a form of vertical retort on a totally different principle to the German retort, inasmuch as they embodied the principle of working continuously, so rendering possible the uniform treatment of coal during carbonisation, instead of putting in a full charge of coal, carbonising, drawing the coke and recharging, as is done in the Continental type of vertical.

Messrs. William Young and S. Glover in I 905 patented a continuous vertical process, which differed from the Woodall-Duckham. In the latter the principle is adopted of a continuous column of carbonising material, the inlet of fresh coal at the top being dependent on the withdrawal of coke from the bottom, the retort being so proportioned with regard to time and temperature that the carbonisation of the coal was completed by the time the bottom was reached; whilst in the Young and Glover system the discharge of coke was independent of the coke feed, and a space was left in the top of the retort above the coal so as to form a chamber in passing through which tar vapour might be gasified and fixed by radiant heat: in this respect resembling the procedure adopted by Settle and Padfield.

In I 900 the Glover-West retort took the place of the Young and Glover, a cooling chamber for the coke being constructed at the bottom of the retort, and the heat utilised for raising the temperature of the secondary air supply to the flues, whilst the empty space at the top of the retort was done away with, and the coke-withdrawal made to govern the feed, thus reverting to the principle introduced by Woodall and Duckham.

${ }^{1}$ See E. B. xi, 483 et seq. 
The transition from the experimental to the practical stage proved fatal to the SettlePadfield system, whilst the Young and Glover became merged in the Glover-West process, but since I 909 the three remaining systems have been working continuously, and with later improvements are so successful that there is no doubt as to their gradually largely supplanting the older forms of retort in English practice.

The German intermittent verticals, or Dessau retorts, have been at work at Sunderland since 1909, where at the Ayres Quay works there is an installation of a bench of six beds of Dessan ten retorts each. The retorts are $I_{3}$ feet $I_{2}^{\frac{1}{2}}$ inches high, tapering from 9 Dessau inches by $22 \frac{1}{2}$ inches at the top to $13^{\frac{3}{4}}$ by $27 \frac{1}{4}$ inches at the bottom. The bench verticals. carbonises 400 tons of coal per week, and yields between I 2,000 and 13,000 cubic feet of gas per ton. The coal is charged into the retorts from an overhead hopper, each taking a little under half a ton, which requires twelve hours for complete carbonising, and during the last two hours steam is passed at a slow rate through the charge, partly to increase the volume of gas, and partly to prevent any sticking of the charge due to carbon deposited on the inner face of the retort, which might interfere with the discharge of the coke when the bottom door of the retort was opened. The use of steam naturally increases the amount of fuel used in the carbonisation, this amounting to 13.96 per cent of the weight of coal carbonised when no steam is used, and rising to 17.8 per cent when steam is employed, the average of fuel used being about is per cent.

Of the two continuous processes, the Woodall-Duckham has been the longest at work, and there are numerous installations in Great Britain and other countries. The retorts are Woodall- 25 feet in height with a sufficient taper to ensure the slip of the charge. The Duckham verticals. time occupied in the travel of the coal from the hopper to the coke extractor at the bottom of the retort is seven or eight hours. The coke is removed by an extractor, actuated by a ratchet and pawl arrangement on a grooved wheel, and driven by a rocking shaft, and the coke then falls into a watersealed hopper, which is large enough to take the amount drawn out during three revolutions of the extractor, or about three hours' discharge. The coke can be quenched, if necessary, by a small spray of water in the storage hopper, but the amount of water is limited, so that the coke is ejected in practically a dry state and at a temperature of $140^{\circ} \mathrm{F}$. The passage of the coal through the retort is governed by the speed of the extractor, the supply of coal at the top of the retort being arranged to keep the retort full, with the exception of a small space at the top where the gas is led off, and which can be regulated in size by a sliding partition. The top of the built-up retort is closed by an iron casting carrying the coal feed, the gas exit pipe, and the sliding partition. The coal feed is a gas-tight hopper fixed eccentrically to the retort and closed by a gas-tight valve, through which the hopper can be filled from another store hopper above. This operation takes a very short time and is necessary only once in three hours, the size of the lower hopper being so calculated as to hold the coal to give the charge of coke removed by the three revolutions of the extractor at the bottom of the retort.

In any process where automatic and continuous action is arranged for, the working parts of the apparatus are apt to become rather complex, but in spite of the objections raised from time to time against continuous carbonisation, the system is an established success, being at work also in America and on the European Continent.

The other process based on the continuous carbonisation of coal is the Glover-West. In this system an economy is obtained by utilising the heat from the cooling hopper for Glover-West
verticals. the coke to regenerate the air for the secondary combustion in the flues, this making a slight decrease in the fuel consumption, which is given as 10.3 per cent. Complete installations have been at work for some time at St. Helens and at Droylsden, the latter consisting of two settings of eight retorts, each setting being subdivided into two sections of four retorts, for convenience in working. The output of the plant is rated at 500,000 cubic feet of gas per twenty-four hours.

The retorts are 20 feet long, oval in section, and with a slightly increasing taper from the top to the bottom. The coke falls into a cast iron chamber at the bottom of the retorts, and round it the secondary air supply is led. Beneath the coke chamber is the extractor, a slowly revolving vertical screw, driven from a small gas engine by means of an arrangement of levers and ratchet wheels. The coke is discharged into a bottom hopper, from which it is removed about every two hours. The top of the retort is similar to that of the WoodallDuckham, being provided with the coal feeding hopper, gas exit pipe, and partition.

Extended experience with these systems has shown that in spite of their apparent complexity, they work smoothly and noiselessly, with complete absence of smoke and steam, which is in sharp contrast with the old methods of carbonisation. The wear and tear, also, are very small. A great advantage of the process is the uniformity in composition of the gas, whereas in the old horizontal retorts the composition of the gas evolved at the commencement and at the end of the carbonisation varied enormously, and uniformity in composition was left to the mixation of the gas from many benches in the holder.

Intermediate between the old processes of carbonisation and coke oven recovery plant comes what is known as "chamber carbonisation." By this method charges of three to 
eight tons of coal can be dealt with at a time, and it has met with considerable success, especially on the European Continent, where a number of installations have been erected.

Chamber carbonisa. tion. The first chamber setting was erected in 1901 at the Munich works by $\mathrm{H}$. Ries and E. Schilling, who converted an old setting for inclined retorts by building into it three chambers, each taking a charge of one ton of coal, the floors of the chambers being at an angle of $35^{\circ}$ to facilitate charging and discharging. This plant was so successful that the chambers were enlarged, and later on in 1906 an installation of fifteen chambers in groups of three per setting was erected. Each chamber takes a charge of two and a half to three tons, and the carbonisation is continued for 24 hours. A regards results, Dr. Bunte in 1907 reported that he obtained $11,3+2$ cubic feet per ton of Saar coal, having a gross calorific value of $626 \mathrm{~B}$ Th U per cubic foot.

The success of the Munich plant was followed by the erection of a larger installation at Hamburg. The chambers consisted of ten settings of three chambers each, the chambers being 24.6 feet long by 7.4 feet high, the width varying from I foot 8 inches in the outside chambers to 2 feet in the central chamber. Carbonisation takes 24 hours, and the capacity of the three chambers is $\mathbf{1 7 . 5}$ tons. A still larger installation of twelve settings of three chambers each was erected at Moosach, the length of the chamber being increased to 28.7 feet. At many other places on the European Continent chamber ovens were erected by H. Koppers, A. Klönne and Knoch, and the Koppers system is now to be tried at Birmingham. Horizontal, vertical and inclined chambers have all been tried, and each has its advocates, but the tendency seems to be to revert to the horizontal chamber with mechanical coke pusher.

The great advantage of chamber carbonisation is that it reduces the cost of handling and labour, and it has been stated that a labour charge of $9 \mathrm{~d}$. has been reduced to $\frac{3}{4} \mathrm{~d}$.; on the other hand the candle power of the gas is below the English standard, although the calorific value is satisfactory, and the initial cost of erection is very high.

Mr. Charles Carpenter, at the South Metropolitan gas works in London, carried out some experiments with ordinary horizontal retorts by filling them full of coal, as had been sugFull charges gested by Kunath in I885, instead of only partially filling them, an operation Full charges which became a possibility only with the perfecting of charging and discharging in horizontal machinery. He found that a considerable improvement was effected in the retorts. make and quality of the gas as well as in the tar. This is no doubt largely due to the elimination of the large space that was left above the charge of coal in the old practice, which led to the degradation of the gas and tar vapours owing to contact with the red hot crown of the retort, and the fully charged horizontal is being adopted at many works not yet prepared to instal verticals.

All the various systems of carbonisation in general use-fully charged horizontal retorts, intermittent vertical retorts, and continuous carbonisation retorts-show but little variation in the amount of gas they yield per ton of coal carbonised, but if the fuel consumption be taken for comparison, the continuous vertical retorts show a decided gain, the following figures giving the amount of fuel consumed per $100 \mathrm{lbs}$. of coal carbonised:-

$$
\text { Horizontal. }
$$

\begin{abstract}
Continuous Woodall-Duckham.
\end{abstract}

\section{Carbonisation Glover-West.} 10. 3

The low figure obtained in the Glover-West system is accounted for by the regeneration of the secondary air supply by the waste heat from the coke.

The continuous vertical retort also has other minor advantages. In the ordinary gasworks practice and with intermittent vertical installations the surrounding air is periodically rendered offensive by outbursts of steam and smoke from the charging and discharging of the retorts and the quenching of the coke, but in the continuous vertical there is none of this annoyance; the plant works with perfect cleanliness and absence of nuisance, whilst the coke, owing to being cooled before exposure to the air, requires no spraying with water. The quality of the coke and tar and the yield of ammonium sulphate also are improved, so that continuous carbonisation in vertical retorts offers the most advantages.

The great improvements in gas and residuals alike brought about by the introduction of the vertical retort and the fully charged horizontal are due to the elimination of the overdecomposition of the hydrocarbon gases and vapours that used to take place with the old practice of only about half filling a horizontal retort with the charge of coal to be carbonised. Inder these conditions, as the heat began to penetrate the charge, the gas that was evolved passed up into the empty space in the crown of the retort, and was there subjected to radiant heat from the retort wall.s, which are at a temperature of upwards of $1000^{\circ} \mathrm{C}$., and also to contact with them, the latter being destructive to the more easily decomposed hydrocarbons, breaking them up into simpler hydrocarbons, hydrogen and free carbon, the latter forming deposits of retort carbon on the interior of the crown of the retort and soot, found as free carbon in the tar. As the heat penetrates the carbonising mass, the outer portion of the charge becomes redhot coke, and the gas distilling from the inner core has to force its escape through this, so that not only contact but catalytic action of the carbon surface adds to the destruction of the hydrocarbons; as this action increases with the thickness of the red 
hot envelope of coke the gas gets poorer and poorer as the carbonisation proceeds, so that for the last hour during which gas is coming off it is practically non-luminous.

In the vertical retort and full horizontal the space above the coal is done away with, and as the heat penetrates the charge, gas, tar, vapour and steam distil inwards from the exterior portions, and the vapours condensing in front of the zone of heat form a pasty tube through the cool coal core of which the gases escape without undue degradation to the mouthpiece. In this way about two thirds of the charge is distilled under conditions favourable to the formation of good gas and tar, whilst a larger proportion of ammonia escapes destruction, but as soon as the central core gets tar-logged the remaining gas and vapour are forced back through the red hot column of coke and undergo complete degradation.

During the last few years no very marked improvements have taken place in the purification of coal gas, but a very interesting revival of an old process under new conditions has taken place at the Cheltenham gasworks, which may prove of great value. Coal liming. About thirty years ago the Cooper process of mixing lime with the coal before carbonisation, in order to increase the yield of ammonia, was extensively tried, but abandoned on account of the increase in ash it gave in the coke. J. Paterson and Twycross have now tried moistening the surface of the coal after crushing with a small steam jet, and dusting 2 per cent of lime over it, which adheres uniformly to the moistened surface, and shows a marked result not only in the amount of ammonia obtained, but in the purification of the gas from bisulphide of carbon, the sulphur compounds other than sulphuretted hydrogen being reduced to 20 grains per Ioo cubic feet, instead of being double that amount, whilst the increase in the ash of the coke is practically negligible.

Attempts are also being made to introduce direct processes for the recovery of the ammonia as sulphate, by washing the gas after removal of the tar with dilute sulphuric acid, as is

Burkheiser's done in some coke oven plants, whilst a vęry interesting system of recovering process. the ammonia as sulphate and at the same time utilising the sulphur of the sulphuretted hydrogen in the crude gas is also under trial. This is known as W. Burkheiser's process, and consists of removing the tar and passing the gas with the ammonia and sulphuretted hydrogen in it through porous hydrated ferric oxide warmed to $60^{\circ} \mathrm{C}$. which removes the whole of the sulphuretted hydrogen, but not ammonia; when the purifier is saturated with sulphide, a current of air and steam is led through it, the sulphur burns, forming sulphur di- and tri-oxide, mixed with the residual nitrogen of the air: these gases are then passed in small quantities into the gas containing ammonia flowing from another purifier of the same kind, and the sulphate and sulphite of ammonia so formed is washed out of the gas in a scrubber with a dilute solution of ammonium sulphate, which is used until concentrated, when a mixture of two thirds ammonium sulphate and one third ammonium sulphite crystallises out.

(VIVIAN B. Lewes.)

\section{THE COAL-TAR INDUSTRY ${ }^{1}$}

The history of coal-tar and its utilisation has undergone an interesting phase during the past few years. It is well known that the quality and value of coal-tar is as dependent upon the temperature at which the coal is carbonised as upon the character of the coal, whilst the amount of heating and contact with red hot surfaces that the tar vapours are subjected to after their formation also influences its composition; as a result the tar has shown distinct changes with every alteration in gas manufacture, these changes affecting the amounts of the products that can be obtained from it on distillation.

These changes are best seen by the percentage fractions obtained from the tar:-

Period

Process of carbonisation

Temperature of carbonisation

Yield of gas, cubic feet per ton.

Composition of tar by weight Ammoniacal liquor

Crude naptha

Light oils

Creosote oil

Anthracene oil . Pitch

Specific gravity of tar
I 820 to 1850.
Iron retorts.

$800^{\circ} \mathrm{C}$.

9,000

I. 04

3. 73

$4 \cdot 47$

27.29

18.13

41.80

I. 140
I 850 to 1898 .

Fireclay retorts.

$\mathrm{I}, 000^{\circ} \mathrm{C}$

10,500

I. 02

3.45

2.59

$27 \cdot 33$

I3. 77

47.67

I. I54
I 898 to I9II.

Fireclay retorts.

$\mathrm{I}, 050^{\circ} \mathrm{C}$

II, 500

o. 383

0.995

0.567

19.440

I2. 280

64.080

I. 206

1 See E. B. vi, 595 et seq. 
The results show that higher temperatures seriously diminished the amount of the more volatile distillates upon which the value of the tar largely depends.

In the first few years of this century the reduction in England of the Parliamentary standard of illuminating value, and the introduction of the No. 2. standard Argand as a test burner, led to a further pressing of temperatures in order to obtain a large volume of gas, and brought about such a deterioration in the quality of the tar that the market price fell to 3 d. a gallon; and had it not been for the enormous demand for tar that arose at this period for preparing the surface of roads tar would have fallen probably still lower, as it contained the minimum of valuable products and anything up to 30 per cent of free carbon, which deteriorated the pitch.

Luckily for those industries that are dependent upon tar products, a marked improvement in the quality of the tar has taken place with the introduction of vertical retorts, fullycharged horizontals and chamber carbonisation (see under GAS MANCFACTURE), as is shown by the following analyses:-

Specific gravity

Free carbon

Distillate up to $170^{\circ} \mathrm{C}$. $270^{\circ} \mathrm{C}$.

Pitch
Dessau
verticals.

I: 113

4.0

I3. 0

24.0

9.0

50.0
Continuous

Verticals.

I. 074

3. I

9. I

$25 \cdot 7$

24.9

46.0

Road Tarring.-The use of tar for road surfaces now occupies so much attention that a short description of the methods employed will be of interest.

The tar used should be coal-tar, either from gas-works or coke ovens, and should be partially distilled before use, in order to get rid of water and volatile oils; the specific gravity should be 1.2 to 1.25 and high temperature tar, containing much napthalene and free carbon, shuuld be avoided, as these bodies have no binding effect and lead to disintegration.

Crude tar should never be used for surface work; the complaints which arise from the contamination of water in streams, \&c. from tar-treated roads nearly all arise from this source, as the trace of water and ammoniacal liquor together with the volatile oils prevent rapid drying, and if rain falls shortly after the tar has been used, slight emulsifying of the surface takes place, and the water that flows into the gutters and streams becomes contaminated and shows itself by films on the water. The presence of water in the crude tar is also a serious drawback, because the porous road material absorbs water more quickly than tar, and this weakens the adhesion of the tar and leads to crumbling of the surface. Where partially distilled tar cannot be obtained, the best way to prepare the crude tar is to heat it in coppers to a temperature of $65^{\circ} \mathrm{C}$. $\left(150^{\circ} \mathrm{F}\right.$.) for several hours, when most of the water will be driven off, but great care must be taken in doing this, as if the temperature rises above this point frothing over of the tar and ignition from the fire below is very apt to take place.

There are three methods by which the tar may be used in preparing the surface of the road:- (1) Simply tarring the surface, as is done in most rural districts; (2) Making the surface of the road with tar macadam; (3) Grouting the macadam whilst making the road with tar. The first method is the one employed to the largest extent, and depends for its success on choosing a period of dry weather to carry it out; the surface of the road must be dry and all dust removed, the tar is then run on, preferably hot, from a tank on wheels with any form of sprayer that will give an even distribution, or it may be applied by hand, which allows of more attention being paid to local conditions in the road surface, and sand or stone screenings may be dusted sparingly over the surface of the tar, and all excess swept off when the tar sets. The advantages of this system are low cost, suppression of dust, increased life of roadway, economy in watering and good surface, whilst the disadvantages are that it gives a slippery road for horses with frost, and if the tar contains too much free carbon and napthalene, a black mud in wet weather. The second system consists in mixing the macadam with the prepared tar before making the road. Limestones absorb a very much larger proportion of tar than granites and make a more adherent mass when rolled, but granite road metal can be used guite sucessully. The procedure is to grade the road metal roughly into $2 \frac{1}{2}, \mathbf{I}_{2}^{\frac{1}{2}}$ and $\frac{1}{2}$ inch sizes: these are well dried and are mixed with the prepared tar and made up into heaps that are allowed to stand for a week or ten days, and a layer of the $2 \frac{1}{2}$ inch metal is put dewn and rolled, the operation is repeated with the $1 \frac{1}{2}$ inch metal, and the surface is marke of the $\frac{1}{2}$ inch size. The third or "grouting " system is to put down the macarlam in the usual way, but dry; and after light rolling, to mix hot prepared tar with sand and float it over the surface, brushing the grout into the interstices of the macadam, and lightly sifting a little screening over the surface. The great demand for coal-tar for this purpose has created a shortage in the supply, but the improvement in price will probably lead to a rapid extension in the use of coke oven recovery plant, thousands of tons of tar being burnt to waste annually in the bechive coke ovens. which still are used in the North of England to a very great extent.

(VIVIAN B. LEWES.) 


\section{GAS LIGHTING ${ }^{1}$}

The incandescent gas mantle, both in its upright and inverted forms, has made steady headway during the past few years, and the great increase in light that can be obtained by increase of the pressure under which the gas is supplied to the burner has been taken advantage of in constructing lamps for the illumination of large spaces.

The most important outcome of the last few years with regard to gas lighting is the change of opinion that is gradually taking place with regard to its hygienic effect on the air of enclosed spaces. When the electric light was first introduced as a domestic illuminant, the fact that it took no oxygen from the air and gave off no products of combustion led to the assumption that it must be more healthful in a dwelling room than gas; which not only abstracted oxygen but evolved as products of combustion water vapour and carbon dioxide, the amount of which latter gas in the air of a room had always been taken by the sanitary authorities as an indication of its hygienic condition. The researches of Dr. S. Rideal and others have shown conclusively however that the air in the breathing zone of an inhabited room lighted by the incandescent gas mantle is always fresher and less oppressive than with electric incandescent burners; and that the increase in carbon dioxide and humidity which one would expect is not to be found, whilst a large decrease in the organic matter takes place. This is explained by the fact that the uprush of heated air and products from the burner draws up the emanations from the skin and lungs of the occupants, charring and sterilising any germs and organic matter that are present, and, reaching the ceiling at a temperature $I 2^{\circ} \mathrm{C}$. higher than when electric light is used, diffuses so rapidly through the plaster as to draw in fresh air below the door of the room, and whilst so diffusing filters off the carbonised organic matter and dust on the surface of the plaster, so giving the blackening that is always found above a gas burner, which is often erroneously attributed to imperfect combustion.

Air movement, coolness, humidity, and reduction in the mass action of pathogenic bacteria, are now recognised as being of far greater importance to health than the chemical purity of the air, and the convection currents and change of air set up by the heat of the incandescent gas burner lead, it is held, to a fulfilment of these requirements far better than the electric light.

(Vivian B. Lewes.)

\section{OIL LGHTING ${ }^{2}$}

There has been but little change in either the construction of oil lamps or the use of oil for lighting during the past few years, and the production of a successful lamp using ordinary lamp oil and an incandescent mantle still awaits solution.

In lighting by oil gas a marked improvement has been made by Messrs. Pintsch in railway carriage lamps. Attempts were made for many years to devise oil gas burners fitted for use with incandescent mantles, but whilst upright mantles only were available no great success was achieved, as the shaking of the train rapidly destroyed them, and no anti-vibration device seemed to have any effect in preventing this. When however the inverted mantle was introduced, it was found that the method of suspending it by its steatite base from lugs on the burner nozzle rendered it far more resistant to shock, whilst in case of the mantle breaking the fabric was suspended in a fine platinum wire basket, which kept it in position until it could be renewed. Using the ordinary Pintsch compressed oil gas in small inverted atmospheric burners, a consumption of 0.6 of a cubic foot per hour gives with the mantle a light of 24 candle power, or three times the amount of light for half the gas consumption with small flat flame burners.

An interesting development of compressed oil gas for portable use, buoys, motor lamps, etc., is the introduction on the European continent of what is known as "Blau gas." When ordinary oil gas is compressed, as in a Pintsch cylinder, a considerable amount of liquid hydrocarbons, which were present in the gas as vapours, separate out, the liquid consisting of benzene, toluene, hexane, heptane, etc., and the gas suffers considerable reduction in illuminating power. The gas thus freed from vapours contains hydrogen, methane of little or no illuminating power, and the higher gaseous

1 See $E . B$. xvi, 655 et seq.

2 See E. B. xvi, 65 I et seq. 
members of the paraffin and ethylene series, such as ethane, propane, butane, ethylene, propylene, etc., of high illuminating power, and by cooling and compressing these under high pressure in a steel cylinder they are liquefied, whilst the hydrogen and methane remain gaseous and pass on. This liquid gasifies entirely when the valve of the cylinder is opened, and constitutes the "Blau gas," and is largely used when high light values are needed from jets or flat flame burners.

Of late years there has been a great influx of so-called " air-gas " or " petrol air gas " machines on the market, intended for the lighting of country houses where coal gas or electricity is not available. In nearly all these the principle first introduced by Hooker of adding only enough petrol vapour to the air to make it combustible and not enough to make it explosive, has been adopted, so that any leakage of the gas, instead of forming an explosive mixture as would be the case with coal gas, becomes non-combustible from over-dilution. The principle of all the machines is to evaporate a given weight of petrol into a definite volume of air, and to bring this about a large number of automatic devices are employed, driven by water power, hot air engines or falling weights. The "gas" so formed consists of a mixture of about 98 per cent of air with 2 per cent petrol vapour, and burns in specially constructed burners as a non-luminous flame which is used with an incandescent mantle. A gallon of petrol in a good machine will make from 1400 to I 500 cubic feet of "gas," having a heating value of between 80 and 90 B Th U per cubic foot.

(VIvian B. Lewesi)

\section{ACETYLENE}

The progress of the past two years in the use of acetylene has been chiefly in the direction of oxy-acetylene welding and cutting. As an illuminant, the number of new installations in Great Britain keeps a steady average. In other countries, where central installations for the lighting of small towns and villages are more often met with, the increase is more marked. Welding and cutting by means of the oxy-acetylene blowpipe, however, is advancing with great rapidity, America leading the way both in quantity and quality of the work done; Germany occupies the second place, France the third, and the United Kingdom a bad fourth. A school of acetylene welding has however been started in England, and more rapid progress is expected.

A noticeable feature is that in France and Germany nearly two-thirds of the oxy-acetylene welding done is in manufacturing work, while in America the extreme value of the process for rapid repairs has been fully realised, and nearly three-quarters of the work acetylene done is of that character. The size of the work which can now be undertaken welding. has enormously increased with extended knowledge of the requirements, and two examples will suffice to indicate the saving that can be effected by the rapidity with which the work is done. A section of the frame of a steam hammer, weighing about four tons, was fractured, and by means of the oxy-acetylene torch new metal was filled into the break, the whole of the welding completed, and the section delivered within 48 hours. The "Commonwealth," a large passenger steamer, was in collision with a warship and had her bows badly crumplea up, but by the oxy-acetylene cutting torch the damaged portion was removed, the repairs executed, and service resumed within a week.

In the early days of welding by the oxy-acetylene blowpipe many cases occurred which seemed to point to the steel being rendered hard and brittle in the neighbourhood of the heated portion. Investigation however has shown that this is due to careless adjustment of the ratio of acetylene to oxygen in the blowpipe flame, which with any excess of acetylene increased the carbon in the steel and so hardened it, and that if a properly designed and adjusted blowpipe is used the tensile strength of test pieces cut from a plate with the oxyaretylene flame is higher than when sheared. Some recent Austrian experiments on two mild steels however show that when a chrome nickel steel, hardened for armour plate, is cut by the flame a softening of the steel takes place, this being most noticeable close to the cut and gradually diminishing as the distance became greater, whilst a nickel steel, unhardened, was perfectly unaffected.

The American Naval Department was one of the first to adopt the oxy-acetylene process, and in building one of the recent battleships expended over $\$ 70,000$ in welding and cutting by it. The system has also been adopted widely at many European ports, and at Marseilles, Genoa and Antwerp has been in use for several years. The use of acetylene dissolved in acetone under pressure, the acetone being contained in porous material packed into strong steel cylinders, has largely extended the scope of autogenous soldering, as both acetylene

${ }^{1}$ See $E . B$. i, 137 et seq. 
and oxygen under pressure can be obtained in portable cylinders, and repairs executed in the confined space of a ship's hold or even in the boilers themselves.

The trade in cylinders of dissolved acetylene has, as might be expected, expanded rapidly both in $G$ reat Britain and elsewhere, this being due partly to the advance in oxy-acetylene Dissolved welding, but more largely to the enormous increase in the number of motoracetylene. vehicles, the headlights from which are most conveniently supplied with acetincidental to a portable generator.

Another direction in which the use of acetylene has made enormous strides in America is for self-starters for motor-cars, of which some fifteen different kinds are in use in the United States. In one class of self-starters the pressure existing in the acetSelf-starters. ylene cylinder is used to force a charge of gas and air into the explosion cylinders of the motor engine, where it is fired by the spark and starts the engine, the "Disco" automatic self-starter being one of the best of this class; while the "Prest-OStarter" may be taken as the type of a second class, in which low pressures only are used, the mixture of gas and air being pumped into the cylinders in proper firing order.

In 1896 it was shown that when acetylene is passed through a red hot tube it undergoes instantaneous decomposition with deposition of carbon and liberation of hydrogen, the Polymerisa - carbon being rendered incandescent by the exothermic decomposition, and that
tion of tion of hydrogen; when this was done the acetylene underwent condensation into acetylene. hydrogen; when this was done the acetylene underwent condensation into tions.on a larger scale. The apparatus consisted essentially of two vertical tubes, electrically heated, and a mixture of acetylene and hydrogen was passed slowly through them, the temperature being so arranged that separation of carbon was to a large extent avoided. The first tube was heated to $650^{\circ} \mathrm{C}$., and the second to $800^{\circ} \mathrm{C}$., when it was found that a quantity of a light brown tarry liquid was formed, and that the gases leaving the apparatus contained methane. In some cases the yield of liquid was about 60 per cent of the weight of acetylene used, and contained nearly 20 per cent of its weight of benzene. Other hydrocarbons identified were toluene, napthalene, anthracene, indene, diphenyl, fiuorene, pyrene and chrysene; and further experiments with acetylene and hydrocyanic acid confirmed Sir W. Ramsay's observations that these bodies condensed to form pyridine bases.

A considerable amount of work has been done in utilising calcium carbide for the fixation of atmospheric nitrogen. In order to do this crushed calcium carbide is heated to a temperaFixation of ture of $800-1000^{\circ} \mathrm{C}$. in an electric furnace, and nitrogen, generally obtained Fixation of by liquifying air by the Linde process and allowing the nitrogen to distil off,
aitrogen. is then passed through the red hot mass and converts the calcium carbide into calcium cyanamide, $\mathrm{CaCN}_{2}$. This is now recognised as an extremely valuable manurial matter, as it slowly evolves ammonia under the influence of moisture, according to the equation: $\mathrm{CaCN}_{2}+3 \mathrm{H}^{2} \mathrm{O}=\mathrm{CaCO}_{3}+2 \mathrm{NH}_{3}$. There is a large installation at Odda, in which I96 electric furnaces are employed, and about $3^{\circ}$ tons of calcium cyanamide, containing 18 per cent of nitrogen, made per 24 hours, whilst the world's production for the past year amounts to nearly 200,000 tons.

(VIVIAN B. Lewes.)

\section{THE PETROLEUM INDUSTRY ${ }^{1}$}

The winning of petroleum in regions of proved productivity, and, concurrently, the discovery of new sources of supply, are being greatly stimulated by the rapidly increasing employment of oil fuel for power purposes, both as a substitute for solid fuel in steamraising, and through the medium of the internal-combustion engine.

Since its inception half a century ago the petroleum industry has advanced to a position of great importance, mainly in supplying a cheap, convenient and efficient light, and an excellent lubricant for machinery. During the past few years it has also furnished the motor-spirit which drives our automobiles, motor boats, submarines, hydroplanes and aeroplanes. Now, however, it is entering upon a new era, in becoming a great fucl industry, and its further expansion promises to be far more rapid, for it is evident that if there is to be any large substitution of oil for coal as a source of power the output of oil will have to be greatly increased. At present the world's production of petroleum does not amount to much more than 5 per cent of the output of coal, even allowing for the higher calorific value of the liquid combustible. The general employment of motorspirit has, of itself, contributed largely to the present profitable character of the business, though the high price at which this product is now sold is leading to the use of distillates of higher specific gravity and lower volatility, of which a far larger percent-

${ }^{1}$ See E. B. xxi, 316 et seq. 
age can be obtained from the crude oil. Probably the owner of the private motor car will always prefer to have the product which he has been accustomed to use, even if he has to pay a high price for it, but for use in public-service and commercial motor vehicles an increasing substitution of the less volatile product may be looked for, and it is desirable that this should be so, for the supply of motor-spirit may otherwise become inadequate to meet the increasing demands, though at present the United States and the Dutch East Indies, which are the chief sources, show no signs of failure in this respect.

In regard to the industrial use of oil for power purposes it is instructive to consider the remarkable changes which have been effected in the United States within very recent years by the provision of liquid fuel. As was pointed out by Dr. David T. Day, in an instructive article published in The Times (London) for June 28, 19 2, the supply of oil fuel has been a potent factor in State development. It has made Oklahoma a state abundant in prosperous cities, and has developed the railroads and manufacturing industries of Texas. In Louisiana it has made the sugar industry ready for the free list, and corresponding changes are in progress in Illinois and further west in Wyoming. Oil fuel has completely revolutionised California, so that the state is in the midst of a startlingly rapid transformation from a mining and agricultural community to a manufacturing centre, and the keynote of the Panama-Pacitic Exposition of 1915 in San Francisco, originally intended to be a tribute to the extension of commerce through the opening of the Panama Canal, will be the change of San Francisco from a future Liverpool to a future Birmingham.

For marine purposes, as well as in industrial establishments, the most potent factor in the replacement of coal by oil is, however, unquestionably the Diesel engine, which possesses great economic advantages over other types of internal-combustion engines. Not only can a much greater amount of power be obtained with this engine from a given quantity of oil, but in addition the less volatile hydrocarbons of which petroleum is chiefly composed, and even the crude oil itself, can be used with it.

For use on railroads the Diesel engine has not, as yet, been substituted for the steam locomotive, but the employment of oil fuel, which for many years has been common in Southern Russia, has been extended to other countries, especially the United States.

According to the figures compiled by Redwood and Eastlake, the world's production of crude petroleum amounted in 1909 to $40,070,832$ metric tons, and in 1910 to 43,986 ,53 I metric tons, while in I9 I (from Day's figures) it was 46,526,334 metric tons. Details of the production in different areas for 1909 and I9I0 (Redwood and Eastlake), and Igri (Day), are shown in Table A.

It will be observed that the Lnited States continues to occupy a predominant position in the industry, having contributed in ror I no less than 63.8 per cent of the world's output, the next in order being Russia, with 19.16 per cent of the total. During I9I I the production of Mexico increased so largely as to bring that country into the third place, and as soon as there are adequate transport facilities the increase will probably be far greater. ()ther countries of very considerable commercial importance in the industry are the Dutch East Indies, Rumania and Galicia. To the aggregate output of the United States, California contributed far more largely than any other state, and may be expected to provide sufficient oil for the inclustrial needs of the whole Pacific stope for many years to come. The similar requirements of the Atlantic coast will probably be met by the importation of the surplus production of Mexico.

Ihe older oil-fields of Russia, in the Baku region, which in the past have produced immense quantities of oil from a comparatively small area, are showing signs of exhaustion, but other districts are being actively exploited with highly promising results. In the Lral Caspian region, lying eatst and west of the Lral river, there are over 30,000 square miles of territory, where already some very productive wells have been drilled, and a large proportion of which may prove to be richly petroliferous. The island of Cheleken has also become commercially important as a source of oil. The sanguine anticipations expressed in regard to the Maikop oil-field have not been fulfilled, but its prospects will be better understood when we know the results of the deep-drilling 
Table A-World's Production in Metric Tons of Petroleum, I909, 1910, 1911.

\begin{tabular}{|c|c|c|c|c|c|c|}
\hline & \multicolumn{2}{|c|}{1909.} & \multicolumn{2}{|c|}{1910.} & \multicolumn{2}{|c|}{ I9II. } \\
\hline & Production. & $\begin{array}{l}\text { Per cent } \\
\text { of total. }\end{array}$ & Production. & $\begin{array}{l}\text { Per cent } \\
\text { of total. }\end{array}$ & Production. & $\begin{array}{l}\text { Per cent } \\
\text { of total. }\end{array}$ \\
\hline United States:- & $24,422,783$ & 60.949 & $27,940,806$ & $63 \cdot 5^{2 I}$ & $29,393,252$ & 63.80 \\
\hline $\begin{array}{l}\text { Appalachians } \\
\text { Lima-Indiana } \\
\text { Illinois } \\
\text { Mid-Continent } \\
\text { Gulf } \\
\text { California } \\
\text { Other fields }\end{array}$ & $\begin{array}{r}3,538,113 \\
1,094,859 \\
4,119,779 \\
6,640,656 \\
1,588,274 \\
7,396,213 \\
44,889\end{array}$ & $\because$ & $\begin{array}{r}3,585,517 \\
967,182 \\
4,419,115 \\
7,183,343 \\
2,003,063 \\
9,734,741 \\
47,845\end{array}$ & & & \\
\hline Russia & $9,003,4 \mathrm{I} 6$ & 22.469 & 9,$599 ; 304$ & 21.823 & $9,066,259$ & $19 \cdot 16$ \\
\hline Galicia & $2,076,740$ & 5.183 & $1,762,560$ & 4.007 & $1,45^{8,275}$ & 3.04 \\
\hline Eastern Archipelago & $\mathrm{I}, 4 \mathrm{I} 3,74 \mathrm{I}$ & $3 \cdot 528$ & $1,435,240$ & 3.263 & $1,670,668$ & $3 \cdot 5^{2}$ \\
\hline Rumania . . & $1,296,403$ & 3.235 & $1,352,289$. & 3.074 & $1,544,072$ & 3.21 \\
\hline British India & 879,755 & 2. 196 & 808,794 & 1. 839 & 897,184 & 1.87 \\
\hline Mexico & 331,832 & 0.828 & 444,373 & I. 010 & $1,873,522$ & 4.07 \\
\hline Japan & 251,505 & 0.628 & 257,021 & $0.5^{84}$ & 221,187 & 0.48 \\
\hline Peru .... & 175,482 & 0,438 & 177,347 & 0.403 & 186,405 & 0.40 \\
\hline Germany . & $143,244$. & 0.357 & 145,168 & 0.330 & 140,000 & 0.29 \\
\hline Canada & 57,446 & o. 143 & 43,129 & 0.098 & $3^{8,813}$ & 0.08 \\
\hline Italy & 5,895 & 0.015 & (est.) 6,000 & 0.014 & 10,000 & 0.02 \\
\hline Hungary & 2,590 & 0.006 & (est.) 2,500 & 0.006 & & \\
\hline Other countries & (est.) 10,000 & 0.025 & (est.) 12,000 & 0.028 & 26,667 & 0.06 \\
\hline
\end{tabular}

operations recently in progress. Attention has also been directed to exploratory work on the Taman Peninsula.

Among other countries which may be confidently expected to add largely to the world's supplies of petroleum in the near future is Persia, where there is an immense area of presumably petroliferous lands, a portion of which has already been proved by the test of the drill to be highly productive. Drilling operations in Egypt, on the Gulf of Suez, have also been attended with results which are regarded as sufficiently promising to justify the provision of a large capital for the development of the industry. The island of Trinidad is being systematically examined, and sufficient has been done to lead to the belief that large stores of oil exist there; in I9I I it produced I 7,07 I metric tons. Among other potential sources of supply which have attracted the notice of the prospector are'Turkey (Mesopotamia), New Zealand, New Brunswick, Newfoundland, Canada (north-west), Alaska, Venezuela, Barbados, Madagascar, China, Argentina, Algeria, Nigeria, Colombia, Ecuador and Bolivia. There are also sources of oil in the bituminous shale deposits of France, Servia, Spain, South America, New Sout'n Wales, New Zealand, New Brunswick, Nova Scotia and Newfoundland. (Boverton Redwood.)

\section{AGRICULTURE}

\section{Progress of Scientific Research}

During recent years notable advances have been made in agricultural science and especially in the application of chemistry and biology to agricultural practice.

The perennial question of the source of the combined nitrogen utilised by vegetation has received fresh light from the discovery by Beijerinck of a group of bacteria The
question of living free in soil and water and possessing the power of bringing the free aitrogen.

nitrogen of the atmosphere into combination. These organisms, known as Azotobacter, are powerful oxidisers of carbohydrate material, from which process they derive the energy necessary to effect the fixation of the nitrogen, and they have been identified in cultivated and virgin soils from all parts of the world. They are however only practically effective in soils containing carbonate of lime, though they have been found in all the steppe soils where black soil rich in nitrogen 
has accumulated to a considerable depth, such soils for example as are found in Manitoba, the Russian steppes, and the Pampas of South America. Despite the fixing action of the bacteria associated with the leguminous plants it has always been difficult to regard the enormous accumulation of nitrogen in virgin soils as the result only of past vegetation, since the higher plants are only capable of taking already combined nitrogen from the soil and restoring it again as they die down. When, however, the vegetation falls back to the soil carbohydrates are added which have been manufactured by the green leaf from the carbon dioxide of the atmosphere by the help of light, and it is by the subsequent oxidation of this non-nitrogenous material by Azotobacter that free nitrogen is drawn into combination and the stock in the soil is added to.

The examination at Rothamsted, England, of the soil of a wheat field under arable cultivation for more than half a century shows a steady decline in nitrogen content approximately equivalent to the removals in crop, any recuperative actions

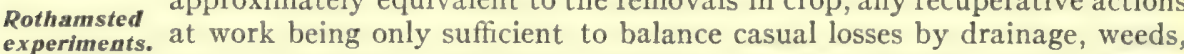
etc. A portion of the wheat field was, however, allowed to go to waste some thirty years ago, and became covered with a natural vegetation of weeds and grasses, which are never cut but allowed to die down each year in situ. The soil of this portion was found to have gained nitrogen at the rate of nearly roo lbs. per acre per annum, the greater proportion of which must have been fixed by Azotobacter working on the carbonaceous matter of the dead vegetation. With this clue we can interpret the accumulation of nitrogen in virgin soils carrying a grassy vegetation; similarly forest soils which annually receive carbonaceous matter from the fall of the leaf become enriched in nitrogen, though in both cases the process will only be effective if the soil contains carbonate of lime. Again when land is laid down to grass for a period there will be a regeneration of the nitrogen stock by the action of Azotubacter, utilising the carbonaceous matter in the roots and stubble of the grass.

The last decade has also seen the resources of agriculture enriched by two new nitrogenous fertilisers in which the nitrogen is derived from the atmosphere by artificial Articlal means. Sir William Crookes had drawn attention to the possibilities of the fertllsers fixation of nitrogen by means of the electric: spark, but the process only attained commercial realisation through the methods devised by Birkeland \& Eyde, now worked on an enormous scale at Notodden in Norway. In this process an alternating current of about 5,000 volts, derived from water power, is set to form an arc between U-shaped copper electrodes, water cooled. The arc is spread out into a broad flat flame by means of a powerful magnetic field, and through it is blown a current of air at gentle pressure. The issuing air at a temperature of $600-700^{\circ} \mathrm{C}$. contains about I per cent of nitric oxide, which after cooling combines with more oxygen from the air and is dissolved out by water and finally by milk of lime. The final products are nitric acid and nitrate of lime, which latter with about 3 per cent of combined nitrogen is now being sold as a fertiliser. The lime base gives it certain advantages over nitrate of soda on heavy soils deficient in lime, and as the nitrogen is equally effective unit for unit, nitrate of lime forms a valuable addition to the stock of nitrogenous fertilisers.

The other fertiliser depends upon a different principle, the combination of nitrogen with bodies of a metallic nature to form compounds which will give rise to ammonia on decomposition with water. A metal is not, however, the starting point but calcium carbide, now manufactured on an enormous scale for the generation of acetylene. At a temperature of about $700^{\circ} \mathrm{C}$. it combines with free nitrogen to form calcium cyanamide, which by the action of water becomes converted into calcium carbonate and free ammonia. The process is now extensively carried out in conjunction with various calcium carbide works situated where water power is available, as at Odde in Sweden, in Savoy, and at Piano d'Orte near Rome. The roughly ground carbide is heated in tubes through which is passed pure nitrogen obtained by the fractional distillation of liquefied air. The product contains I $8-20$ per cent of combined nitrogen with about 20 per cent of free lime; it is sold under the name of nitrolim or kalk-stickstoff and forms an effective nitrogenous fertiliser, especially valuable on soils poor in lime. 
Another series of investigations that may have considerable outcome in practice deal with the results of the partial sterilisation of soil. Various observers had noticed from time to time that a soil which had been heated to the temperature of boiling water was thereby markedly more productive than before. A similar increase of fertility follows treatment with volatile antiseptics such as chloroSterilisation of soll.

form, toluene, etc. Russell \& Hutchinson, working in the Rothamsted Laboratory, arrived at an unexpected solution of the problem. They found that the increased productivity was due to the rapid rate at which the soil developed ammonia after the treatment; the ammonia did not change further to nitrates because the nitrifying organisms had been destroyed, but the plants utilised the ammonia directly. The treatment moreover did not completely sterilise the soil; a small number of organisms, capable of decomposing the nitrogenous residues in the soil into ammonia, are left and multiply with great rapidity, until within a few weeks the numbers of bacteria within the soil are far in excess of those prevailing in the untreated soil. These bacteria account for the increased production of ammonia and therefore fertility of the treated soil. Further investigation led to the conclusion that normal soil contains agencies restricting the development of bacteria and therefore the rate of ammonia production and consequent fertility, which negative agencies are wholly removed by the heating and treatment with antiseptics, and these agencies were identified as protozoa, amoebae, etc., living in the soil, large organisms which feed upon living bacteria. They are killed off by the partial sterilisation, and on the removal of this check the bacteria are enabled to increase their numbers to an extent previously impossible, thus raising the rate of production of plant food from the otherwise unavailable nitrogenous material in the soil. It has been found practicable to apply these principles with commercial success to the treatment of greenhouse soils, which rapidly degenerate and have to be replaced because the conditions of warmth and moisture are especially favourable to the development of protozoa. Again the soil of sewage farms rapidly deteriorates and becomes ineffective towards the purification of sewage from the same causes, but can be restored to its proper character.by partially burning the soil or treatment with antiseptics. Much progress has not been made with the treatment of ordinary farm land, as heating is out of the question; the desideratum is a cheap antiseptic of the right degree of volatility.

The rediscovery and extension of the Mendelian theories of inheritance have placed the question of breeding new varieties of domesticated animals and plants upon a new

Mendelism and cereals basis, insomuch as they offer a method by which the attainment of a particular desired result can be foreseen. While animals present certain special difficulties because of the complexity of the factors involved in such characters as meat, milk or wool, plants are simpler, and considerable progress has been made in the application of breeding on Mendelian lines to the production of new varieties of cereals, which afford particularly easy material for work because they are naturally self fertilised. The English and West European varieties of wheat for example are distinguished by their capacity for heavy cropping, but they do not command the higher range of prices because flour made from them is not "strong," i.e. it does not make large loaves and is starchy rather than nitrogenous in comparison with the wheats grown in the east of Europe, Manitoba, Kansas, etc. Some of the latter wheats preserve a considerable measure of their strength and high nitrogen content on English soils, but the yield is too low to enable them to be profitable even at the higher price per bushel. Biffen at Cambri lge has shown that this high nitrogen content and strength is a Mendelian character that segregates in the offspring of cross-bred parents, and has succeeded in breeding one or two varieties which combine to a marked degree the cropping powers of the English wheats and the strength of other varieties, and one at least of these new cross-breds is now being grown commercially in England. Other experiments that promise success on a working scale deal with the breeding of wheats proof against rust, a disease which seriously affects the yield of wheat in many of the warmer countries and may indeed prohibit their growth, as over much of S. Africa. A rust-proof species had been found, and though its miserable yield deprives it of all commercial value it transmits its 
immunity on Mendelian lines when crossed with other varieties; hence by suitable crossing and selection a rust-resistant variety yielding normal crops has been obtained. Another line of attack has led to considerable improvement among existing races of cereals, and that is the process of selection of "pure lines " associated with Nillsen and the experimental station of Svalof in Sweden. If a field of any variety be examined, putting aside accidental admixtures, a considerable range of variation will be observed in such characters as the length of ear, the stiffness of the straw, the size of the grains, etc., etc. The majority of these differences are due to accidents of nutrition and are not inherited, but by selecting a number of ears from plants possessing the desired characteristics and growing the corn from each separately a few will be found to transmit the variation, and by raising a stock of seed from the best a permanent improvement in the variety can be effected. Moreover such a pure strain will be found to possess a great uniformity in the time of ripening and similar factors, which alone may make it of more value than the composite out of which it originated. The success of such breeding along pure lines is in marked contrast to the failure of many attempts to improve crops by mass selection, i.e., by picking out a large number of the best ears or the heaviest corns and raising a stock of seed from this aggregate. So large a proportion of the improved material owes its character to nutrition alone and falls back in the next generation, that the resulting mixture of strains is very slightly better than the unselected mass.

The scientific advance in the theory of the nutrition of animals has been of too technical a nature for discussion here, especially as it has resulted in no modifications of Soya practice; but the advent of a new and valuable feeding stuff into Europe may be noted. This is the soya bean, which has been long grown for both human and cattle food in China and Japan. At the close of the RussoJapanese war, when Manchuria was opened up to Japanese traders, it was found that large quantities of this bean were obtainable, and the firm of Mitsui embarked on its importation into Europe. The bean contains up to 17 per cent of a neutral tasteless oil, valuable for food, soap making and other purposes to which vegetable oils are applied, and this oil is extracted by pressure in the usual way. The residual cake forms a valuable food for all classes of stock, containing about 6 per cent of oil and over 40 per cent of proteins. Its advent has been particularly fortunate in that it occurred at a time when linseed cake, for which it is almost an equivalent, was rising to an exceptional price.

(A. D. HALL.)

\section{Agricultural Organisation in the United Kingdom}

The increasing demand for state assistance for agricultural research and education, improvement of live stock, furtherance of co operation, etc., led Mr. Lloyd George, Work of as Chancellor of the Exchequer, to introduce the Development Act in rooo, British under which a Commission was appointed to make recommendations Development to the Treasury of grants for the promotion of rural industries. The Commision. grants are to be made either to a government department or to a university or other association not trading for profit, and a sum in the first instance of $£ 2,500$,oo has been set aside for the purposes of the Commission. Under this Act schemes have already been approved and grants made for the furtherance of research and education, for the promotion of co-operation, for the improvement of live stock and horses, for experiments in the cultivation of tobacco, flax, hemp, etc., etc.

Lip to I9 I the Board of Agriculture was charged with the administration of agricultural affairs in England. Scotland and Wales. In I I I a separate Board was created for Scotland, to which were transferred the duties appertaining to the old Board as regards Scotland, higher agricultural education, and the administration of a scheme of land purchase for the creation of small holdings. 'To this Scotch Board of Agriculture an annual grant of $£ 200,000$ is made.

Owing to the increased grants derived from the Development Commission the organisation of agricultural education and research has been considerably advanced of late years in the ['nited Kingdom, and very shortly it will possess a complete system 
making provision for all grades of instruction. The schemes to which effect is now being given deal with research, higher and intermediate agricultural education. Provision for research is being made by the foundation of a number of institutes, as a rule attached to a university, each dealing with one branch of agricultural science.

As regards higher agricultural education, England and Wales are divided into 12 provinces in each of which an Agricultural College or Department of a University is located, where long courses of instruction are given leading to a degree or diploma in agriculture. These colleges receive grants from the Board of Agriculture of about $£$ IOoo each for education, and in addition grants of $£$ IOOO each to provide a staft available for advisory work and local investigation within its area, together with a further grant for a Live Stock officer charged with the organisation of certain schemes for the improvement of live stock.

As regards intermediate agricultural education, all forms of agricultural education below the colleges were formerly under the supervision of the Board of Education, the county being the unit of area and the County Council the authority, but in rer I the control was transferred to the Board of Agriculture, who administer a grant from the Development Commissioners for the setting up of Farm Institutes. A farm institute may be established by a single county or a group of counties and may take the form of a Farm School receiving pupils for a year or less, a winter school giving short courses of instruction in the winter months, or an institute serving as a centre for short courses of instruction in special subjects and for the itinerant lecturers employed in the county. Travelling dairy schools and similar practical instruction also form part of the programme of the institutes.

In Scotland the whole of the agricultural education is supervised by the Scotch Board of Agriculture, and is carried out under Colleges of Agriculture, associated with the Universities of Edinburgh, Glasgow and Aberdeen. These colleges possess in addition to their resident staff, which gives instruction leading up to the degree of $\mathrm{B}$. Sc., a large extension staff of whom one or more is resident in each county included in the province appropriated to the college. These instructors give lectures, conduct experiments and generally advise the farmers within their area. Many of the primary schools have developed a strong agricultural side to their teaching but no farm institutes exist in Scotland.

The provision of agricultural education in Ireland is administered by the Department of Agriculture, working as regards intermediate and lower education in conjunction with the County Councils. A three years' course of instruction in agriculture and the applied sciences is given at the Royal College of Science, Dublin, and a one year's course of a more immediately practical character at the Albert Agricultural College, Glasnevin, to both of which institutions the Department grant scholarships. The Munster Institute, Cork, and the Ulster Dairy School provide instruction in dairy work and creamery management, while at Athenry, Co. Galway, Ballyhaise, Co. Cavan, and Clonakilty, Co. Cork, are agricultural stations at which short courses of instruction, chiefly practical, are annually given. In addition the Department maintains a service of itinerant instructors in agriculture working in conjunction with the county councils.

The most notable movement of late years has been the revival of interest in small holdings. The returning prosperity of the agricultural industry consequent on the

Small

Holdings.

rising prices of farm produce became noticeable about 1904-05; a demand began to spring up for farms, until about 1908 it was rare to find farms in hand in any parts of the country, and a year or two later so numerous were the enquiries that increased rents could be obtained for all land that fell vacant. In I9Io rents were in some cases raised to the sitting tenants, and despite the fact that IgII and 1912 proved bad seasons in certain parts of the country, there are still more applicants for farms than can be satisfied and rents are everywhere rising. This demand for land on the part of working men resulted in 1907 in the passing of the Small-Holdings Act, amending the previous Act of $\mathbf{1} 892$. The new Act gave county councils the power not only to buy land and resell it to small holders but to take land on lease and let it on such terms as would repay the councils for their expenditure. The county councils were given compulsory powers for both purchase and hiring of land and a number of commissioners were appointed to stimulate and assist the councils, the Board'of Agriculture being given powers to put the Act in operation wherever it was found that the county council was backward. Under this Act a large number of statutory small holdings have been created, the success of which cannot as yet be estimated, though there is evidence that the expenses incurred by a public body in purchase, division, the erection of buildings, etc., are burdening the holdings with rents that are difficult to earn. Under the operations of this Act holdings of between $I$ and 50 acres, which had fallen to their lowest number in 1908 , increased from $287, \mathrm{I} 76$ to 292,488 in I9II. The Small 
Holdings Act with its compulsory powers, followed by the Finance Act of 19ro, created a feeling of distrust among owners of land, which with the rising values due to the returning prosperity of agriculture, prompted an unprecedented number of estate sales. During I 910 and Igrr the sales both of large and small estates went on in increasing volume, and many tenants found themselves in the difficult position of having either to give up their farms, which they had worked up into a profitable condition from their previous depressed state, or to find the capital for their purchase. Many cases of hardship occurred, until there was a call for legislation, and a Departmental Committee which reported in 1912 was appointed to consider the advisability of state assistance towards enabling sitting tenants to purchase their holdings.

During the period of depression the British farmer may be said to have emancipated himself from the covenants as to the course of cropping that proved so characteristic a Cropping. feature of the old agreements, whether for a lease or for a yearly tenancy. Freedom of cropping and sale has been rendered possible by the introduction of artificial manures and imported feeding stuffs, which enable the farmer to restore to the farm the elements of fertility which are being sold away in the crops. Under the old four course rotation all that was lost to the land was the nitrogen, phosphoric acid and potash contained in the corn and meat sold, and the losses of the first named element were replaced by the nitrogen of the atmosphere brought into combination during the growth of the clover crop; the roots, the hay and the straw, which make the chief demands upon the soil, were all returned, and under such a conservative system of farming the fertility of the land could be maintained almost indefinitely, though the level of production attained was not high. The sale of the so-called recuperative or green crops, or even the introduction of additional corn crops into the rotation, disturbed this equilibrium, and the losses had to be repaired by imported fertility as manure or food. Still it can hardly be said that the British farmer was emancipated from his old restrictions because of any increased appreciation of the scientific issues involved; in the bad times he became able to make what bargain he pleased and could force his landlord to accept any scheme of cropping that would yield a profit.

The old fashioned farming on which the covenants were based assumed that the crops were taken out of the soil; modern intensive farming only uses the soil as a medium to

\section{Intensive farming.} transform certain raw materials, manures and feeding stuffs, into saleable produce. Big crops do not in practice prove exhausting to the land, because they can only be attained by getting the soil into high condition and supplying an overplus of manure. The last decade having been a period of advancing prices has encouraged British farmers to raise the fertility of their land and aim at systems of cropping that would ensure larger returns per acre. It cannot be said that any new rotations have been introduced, for the underlying principles are of course not subject to change, but such systems as permit of more than two years corn in four, or the introduction of a paying crop like potatoes, or the reduction of the labour bill, have resulted in widespread modifications. For instance the five course shift-roots, barley, seeds, wheat, barley or oats-nowadays more characteristic of Norfolk than the rotation called " the Norfolk," has become very general, or even a six course, like wheat, oats, roots, oats, wheat, seeds, found in the maritime plain of West Sussex, is now regularly followed because thereby the land yields two saleable crops in three years. As examples of cropping dictated by the potato crop we may instance a characteristic East Lothian rotation-potatoes, wheat, seeds, potatoes, turnips, barley, or a Lincolnshire onepotatoes, oats, wheat, with seeds every seventh year. On the other hand we find in Scotland a tendency to increase the duration of the grass in the rotation; as prices fell and labour grew more costly it became common to leave the seeds down for two or three years, the five or six shift. Indeed the longer system has been forced upon many farmers by the increasing trouble with " finger and toe " in the turnips, which, however, becomes greatly reduced during the comparatively long rest from cruciferous plants the land obtains when laid down to grass. Near large cities, where market gardening prevails or where there is a demand for hay and straw, and root crops and green meat for the town 
dairies, farmers have often lost any idea of rotations; they consult their convenience and the promise of the market entirely, though cleaning the land and arrangement of labour necessitate some alternation of green and straw crops. With the need for heavy manuring the necessity for a sequence of crops largely disappears; near Penzance for example farmers have for forty years grown year by year a crop of early potatoes followed by one of broccoli, and on the Ayrshire coast early potatoes are similarly repeated on the same land and followed up by some sort of catch crop to be eaten off by sheep.

The intensive growers of market garden and other produce in the neighbourhood of the large towns are beginning to find their operations curtailed by the rapidly increasing difficulty of getting town manure. For example near London one great mar-

Decrease in town manure.

ket gardening district is the strip of light Lower Greensand that is found in Bedfordshire by Sandy and Biggleswade; another lies upon the thin Bagshot Sands and the alluvials derived from them in Surrey; another upon the equally poor sands of the Eocene in North Kent; all soils naturally of the poorest quality but easy to work early and grateful when liberally supplied with dung. The potato growers on the gravels of Hertfordshire, which Arthur Young described as " the jaws of a wolf," and the hop growers of Kent, are equally dependent upon London manure, as the Lancashire and Cheshire potato growers look to the Lancashire towns and the Ayrshire men to Glasgow. But the advent of the motor-car, particularly its displacement of horses in omnibuses, trams, and the vans of the big carrying companies, has already enormously reduced the amount of manure produced; London manure for example, which six or seven years ago could be bought at Is. a ton on rail or on barge, has now risen to over $4 \mathrm{~s} .6 \mathrm{~d}$., and become of much inferior quality. At the same time the town market for straw and hay has declined, so that considerable changes in the farming methods near the large towns are inevitable. It is difficult to see how the market gardeners can easily replace the dung they are losing; on the light soils an abundant supply of humus is as essential as the fertilising elements that are also supplied by farmyard manure. Failing the latter the only alternative method of obtaining humus is to turn in green crops, but the market gardener cannot as a rule afford to leave his land idle even for the time in which to grow a catch crop like mustard or tares. ${ }^{1}$

It cannot be said that any new staple crops have been introduced into the United Kingdom. Some considerable experiments, have, however, been made in the direction of reintroducing tobacco, experiments mainly conducted in Ireland and

British tobaccogrowing. owing their substantial progress chiefly to Sir Nugent Everard of Randlestown. Tobacco was at one time grown freely in England, Scotland and Ireland, but the cultivation was put down, partly in the interests of the Virginia settlement and partly because of political objections to the excise that had to be applied as an equivalent to the customs duty. Permission having been obtained from the Treasury, who granted a bounty of $£ 50$ an acre and an excise rebate of $2 \mathrm{~d}$. per lb. of manufactured tobacco, experiments began in I904, and I24 acres were in I9I 2 under crop in Ireland. Corresponding experiments did not begin in England until I9I I, 39 acres being so cropped in rgr 2. It has been demonstrated that certain grades of smoking tobacco, particularly a Virginian variety known as Blue Prior, will grow with great vigour in the British Isles, crops as large as 1600 lbs. per acre of merchantable tobacco having been obtained, but it has not yet been demonstrated that the culture will succeed on a commercial scale without any bounty. Further experiments extending to 50 acres in Ireland and about the same area in England have been sanctioned.

Considerable interest has been aroused in the question of whether the sugar beet crop can be given a footing in British agriculture, largely through the efforts of Mr. Sigmund Stein, who for many years has organised the growth of trial plots of sugar beet in various parts of the kingdom, and by the analysis of the roots had demonstrated that crops can be grown as large as or larger than those obtained on the Continent, and

'In view of the decline in the supply of manure, the chief engineer to the London County Council suggested in December 1912 that attention should be directed to the utilisation of the London sewage, which at present is simply carried out to sea and destroyed. 
of equal richness and purity. During I 900 and r910 crops on a commercial scale were grown in East Anglia and exported to Holland for manufacture, but owing to the large amount of capital required for a modern factory none of the projected underBrttsh takings was able to make a start. The Government were precluded from growing. extending any assistance so long as they were bound by the provisions of the Brussels Convention, but in r 912 a branch of a Dutch company established a factory at Cantley in Norfolk. It may be taken as established that profitable crops may be grown in England at prices equivalent to those paid by the Continental factories. The question is whether the manufacturing process can be conducted cheaply enough to make the industry profitable.

(A. D. HALL.)

\section{DRY FARMING}

The term "Dry Farming" has come into use to meet the need for a descriptive name for that type of farming which has been developed without irrigation in semiarid regions where irrigation is desirable but impracticable. No infallible rule can be laid down as to the range of annual precipitation which will include the dry farming regions and delimit them from humid regions on the one hand, and from arid regions on the other. It is however fairly well recognised that, in most parts of the United States and Canada, the minimum requirement for dry farming is represented by about I 2 inches annual precipitation, and that 20 inches or more is sufficient, when properly distributed, for crop production, on most soils of the Middle West, by ordinary methods of humid agriculture.

For several years past annual international congresses have been held in the western states of the United States in the interest of the dry farming movement. The $5^{\text {th }}$ congress, held at Spokane, Wash., October 3-6, 19ro, was attended by 1,200 delegates and the 6th, held at Colorado Springs, Colo., October I6-20, I9I I and presided over by President J. H. Worst of North Dakota Agricultural College, was even more satisfactory. The seventh was held at Lethbridge, ${ }^{1}$ Alberta, Canada, October 2I25, I 12 and was attended by delegates from is nations. W. R. Motherwell, minister of agriculture for Saskatchewan, was chosen president for the ensuing year and resolutions were adopted favouring the raising of a fund of $\$ 1,000,000$ for the purpose of maintaining permanent headquarters and inaugurating a world-wide propaganda. Oklahoma City, Okla., was selected as the place for holding the Igr 3 congress. An important part of the work of the U.S. department of agriculture and of many state agriculture experiment stations in I9I 2 related to the subject of dry farming.

The most distinctive feature of dry farming, as compared with other types of farming, is that it recognises the conservation and utilisation of moisture as the aim and end of all agricultural practices having to do with soil preparation and crop production. Even the problems involved in the quality of the crop produced, and the maintenance of soil fertility, which are of major importance in most systems of agriculture, assume a minor importance in dry farming. It is more important that a variety be selected that is reasonably certain to grow and produce a moderate crop of fair quality under semi-arid conditions than to select one that might produce a superior quality and quantity of crop if climatic conditions happened to be favourable, but would fail to produce any crop under adverse conditions. The problems of soil fertility under dry farming conditions are relatively simple as compared with those of humid agriculture. Dry farming soils are usually rich, especially in the mineral elements of plant food, for the reason that they have been formed under arid or semi-arid conditions which, instead of leaching out the soluble salts formed from the disintegration of rock material, have caused an accumulation of these salts near the surface. The same climatic conditions which have produced these fertile soils will tend to preserve these salts under dry farming methods, which take from the soil but small quantities of mineral plant food for the production of the moderate crops usually produced. The

'Dry Farming and Rural Homes (founded 1906), the official bulletin of the congress, is published monthly at Lethbridge, Alberta. 
deterioration in the soil under dry farming is therefore likely to be mainly in the loss of the organic matter. In most virgin diy farming soils the organic matter is low in quantity but high in nitrogen content, and it may be rapidly destroyed under faulty methods of farming, particularly where bare fallow is frequently practiced, and where the amount of organic matter which is restored by plcwing under some portion of the crops grown is small. Here occurs another contrast between dry farming and humid farming. The main object usually sought in increasing the organic matter in soils of the humid regions is to provide nitrogen, while under dry farming the main purpose is to improve the physical condition of the soil in its relation to water, with the addition of nitrogen as a secondary consideration.

Many attempts have been made to elaborate some general system of dry farming that would meet all conditions. Such attempts could be made only by those with an entirely inadequate conception of the magnitude and complexity of the problems involved and the diversity of soil and climatic conditions to be encountered, or by those having some ulterior motives in promulgating such theories. The soils of the dry farming regions range from the lightest sands and silts to the heaviest clays, and the annual precipitation from severe drought to humid conditions. Even in years of normal precipitation the daily distribution of the rainfall in relation to the stage of development of the crop and the character of the soil may under some combinations of these factors result in the production of an abundant crop, and in others a total failure. Practically every detail of dry farming practice must be predicated upon the particular combination of soil, climatic and economic conditions with which the farmer is confronted at the time, nor can he disregard the conditions that are likely to exist at some future time. For instance, some have advocated early deep fall plowing as an invariable practice. Some soils under some climatic conditions are in such conditions at that time of year as to make deep plowing, and in some instances even shallow plowing, utterly impracticable. The dry farmer must then look forward and attempt to form an opinion as to what combination of conditions is likely to exist during the following spring, and to calculate how much spring plowing he can do with his available teams before seeding time. He may come to the conclusion that he must disk some of his land without plowing at all, and it is not impossible that he may get his best crop on his disked land. A few years ago the "dust mulch " was recommended by many as the only proper means of conserving moisture. Practical farmers, however, soon discovered that on some soils the heavy winds would remove the entire "dust mulch" and not only ruin the field from which it was blown but in some instances the adjoining fields upon which it was deposited. Such have been the results of many attempts to maintain a dust mulch on the wind-swept prairies of the Great Plains. At Nephi, Utah, during the summer of rgoo a different result was obtained on a summer tilled field which was supposed to be in ideal condition, being covered with a fine "dust mulch." A heavy, beating rain of 2.5 inches occurred and it quickly reduced the dust mulch to a pasty impervious covering, which allowed but $20 \%$ of the rainfall to be absorbed, while on an adjacent stubble field $40 \%$ of the rainfall was absorbed. Similar results have been noted in many other instances. It has been found that both of the above mentioned difficulties can usually be avoided either by leaving the land unplowed and protected by the stubble of the previous crop during the fall and winter, or, if plowed, by keeping the surface, until seeded, in an uneven or cloddy condition. Subsoiling or very deep plowing is now being very strongly recommended by some, but many experiments on a great variety of soils and under varying climatic conditions have shown that frequently as good and sometimes better crops can be grown on shallow plowing, or even on land that has been disked but not plowed since the previous crop was harvested. This practice is particularly applicable where small grain is to follow a crop of corn. Alternate cropping and summer tillage is a favorite practice in some dry farming districts, especially in Utah and Eastern Oregon and Washington and in some of the Canadian provinces, but dry farmers are learning that a properly planned system of crop rotation in which corn or some other inter- 
tilled crop alternates with untilled crops of grain gives better returns than alternate cropping and summer tillage in many localities. The occasional plowing under of a green manure crop in such a rotation has been found very useful in many instances.

From the above considerations we deduce the following general rules concerning the practice of dry farming:

(I) While some very successful dry farming has been done on heavy clay soils, a sandy loam soil which is naturally receptive to precipitation, which can be made sufficiently retentive by proper methods of tilling, through which soil water moves freely, which yields up readily to the plant a large proportion of its water, and which affords a favorable medium for an extensive root development, will usually give better results.

(2) In the selection of strains, varieties and species of crop plants, choose those which have become adapted to semi-arid conditions, giving preference, other things being equal, to the smaller and earlier maturing strains.

(3) Practice thin seeding - from one-quarter to one-half the amount commonly used in humid regions.

(4) Having selected crops which will grow and which can be profitably utilised, work them into a rotation which will, so far as possible, allow an alternation of intertilled crops with untilled crops, and will insure some return of organic matter to the soil at frequent intervals.

(5) Study the soil, the climate, and the crops, and adopt such methods of tillage as will insure the most complete utilisation of the precipitation, bearing in mind that the dry farmer is dealing with an ever-changing combination of factors, and that no invariable rules or systems ever have, or ever can be, formulated that will be of any assistance to him unless he learns by careful observation on his own farm to know the problems involved, and can, as they arise from day to day, intelligently adapt available means to desired ends in their solution. ${ }^{1}$

(Ellery Channing Chilcott.)

\section{The Dairy. Industry ${ }^{2}$}

The most notable features in the recent development of the dairy industry, as exemplified especially in America, are as follows:- the marvelous increase in the demand for cream for ice cream manufacture: the revolutionary changes in methods of pasteurizing and handling milk for city distribution, together with the attention given to milk problems by municipal authorities: the development of the centralised creamery, receiving and handling hand-separator cream from a large territory as distinguished from the cooperative creamery dependent upon a comparatively restricted community; the testing of pure bred dairy cows for yearly production under the supervision of state agricultural experiment stations; the organisation of cooperative associations for ascertaining the production and cost of feeding dairy cows, and the organisation of communities with a view to predominance of single dairy breed in that community, with its advantage of large numbers of high class animals of one breed; and lastly, a growing recognition of the impossibility of taxing fraud out of the sale of oleomargarine, and an increasing demand for legislation requiring oleomargarine to be sold on its own merits as such.

Ice Cream.--In the United States ice cream has changed from an occasional luxury to being a common beverage or confection sold at every corner drug store, and a regular dish on the public and private dinner table; and this has taken ice cream making from the domain of the cook and the chef to the factory, where the cream and flavouring material are mixed in great vats, then conducted by pipes to power driven freezers, frozen by mechanically chilled brine and stored in hardening rooms held

${ }^{1}$ See the articles "Dry-Land Farming in the Great Plains Area" and "Some Misconceptions Concerning Dry Farming," by E. C. Chilcott, in the Year-Books for 1907 and 191 I of the U.S. Department of Agriculture; A Study of Cultivation Methods and Crop Rotation for the Great Plains Area (Bulletin No. 187, Bureau of Plant Industry, 1910), by the same author; and J. A. Widstoe, Dry Farming (19I1).

${ }^{2}$ See E. B. vii, 737 et seq. 
at zero to five degrees above by mechanical refrigeration so that ice is not used until the ice cream is packed in tubs for delivery.

The hand driven quart ice and salt freezer has been superseded by batteries of a score or more of ro gallon, often individually electric driven, brine freezers. It was estimated that $138,000,000$ gallons of ice cream were made in the United States in I9I II2, representing over I 50 millions of dollars paid by the consumers.

Market Milk.-In cities of any size the milk man who delivers the milk produced by his own cows within driving distance of town has been displaced by the distributor, who buys milk by the car or even train load from the country as many as 400 miles distant, and employs wagons in many cases to the number of 500 and over to distribute it to the consumer. An increasingly large proportion of this milk is pasteurized before distribution to guard against dissemination of disease and to prolong keeping quality. Recent investigation has convinced the thoughtful student of the problem that flash pasteurization, heating to ${ }^{6} 65$ degrees momentarily and immediate cooling, ordinarily fails to remove the danger of disease due to bacteria. This method is rapidly being superseded by the " holding system," i.e. heating to a temperature of I45 to I 50 degrees for from twenty minutes to half an hour, then cooling and bottling or bottling hot and cooling in the delivery container. Establishments equipped to pasteurize two to three hundred thousand quarts of milk, and to wash and fill as many bottles within a few hours each day, are to be found now in every large American city.

"Certified" Milk is milk produced under such conditions of cleanliness of cows, barns, attendants, freedom from disease, promptness in cooling and delivery, that in America the milk commission or the county medical society will "certify" to the public that the milk meets the bacterial and sanitary standard established for a milk suitable for infant food. The making of machinery for the bottling of milk, washing of bottles, pasteurization of milk and freezing of ice cream and manufacture of butter on a large scale has recently assumed gigantic proportions.

Butter Making. - The demand for milk and cream for retail delivery and ice cream manufacture has stopped the creamery butter-making in most territories tributary by railroad to the large cities, especially in the eastern United States. The centrifugal hand-separator is now found on a large proportion of the farms where butter is made, and has made possible the recent development of the centraliser creamery, each of which receives cream produced and separated on several thousand farms within two or three hundred miles radius, in many instances superseding the skimming stations to which the farmer hauled his milk and cream and from which he took home the skim milk.

Moisture Test.-The establishment in America of a Federal maximum moisture content of $16 \%$ for butter has brought to the front the moisture test, and made possible its convenient determination.

Artificial Buttermilk.-The writings of Metchnikoff on the influence of lactic acid bacteria in prolonging life by lessening the putrefactive fermentation in the intestine has stimulated the production of artificial buttermilk under such trade names as Fermillac, Heltho, Vitalc, Bacillac, Zoulak and others. They are made from skimmilk, or that with a low fat content, soured to the point of coagulation of the casein by the lactic acid produced by a combination of pure cultures of lactic acid forming bacteria, such as Bacterium lacticum and Bacillus bulgaricus, after which it is thoroughly agitated to break up the curd and make a smooth product.

Feeding Standards.-German scientists first promulgated the idea of supplying the animal body with the required constituents in definite proportion and in terms of composition of the feed, i.e. protein, carbohydrates and starch. Under the direction of Dr. H. P. Armsby of the Pennsylvania State College, and in co-operation with the United States department of agriculture, was built the first respiration calorimeter for accurately determining the disposition of food eaten by animals, by recording and analysing all ingo and outgo of air, food, water and excreta. This work has resulted in a method of indicating the relative value of foods and standards of daily requirements in terms of net energy (i.e. power to do work) after deducting from total energy of feeds 
that lost in faeces, urine and gas voided, and that required for mastication and digestion of food. A short method of computing rations to supply the daily need of dairy cows has been outlined. ${ }^{1}$

Production Records.-Recent advances in the price of feed and labour have rendered unprofitable the cow producing a low yield of milk and butter fat, and have stimulated interest in the securing of accurate data as to actual production by individual cows, through the Advanced Registry, local cooperative test associations and private records. The elimination of unprofitable cows and the increased consumption of dairy products have stimulated the demand for profitable cows until prices are from 50 to $150 \%$ higher than five years ago.

Advanced Registry Testing of pure bred dairy cows is the result of a demand for accurate, impartial knowledge of the year's production of milk and butter fat by individual cows. The agricultural experiment stations of most American states send a representative to see the milk from each cow weighed for two days per month, and determine its fat content, which with the owner's daily record furnishes the basis of milk yield for the month's estimate of butter fat production. Compared with the average production per cow for the United States of less than I 50 pounds of butter fat in one year, the highest individual records in each of the leading breeds are significant:Holstein cow, Banostine Belle De Kol, 27,404.4 lbs. milk, I058.34 lbs. fat; Jersey cow, Jacoba Irene, I 7,253.0 lbs. milk, 952.95 lbs. fat; Guernsey cow, Spotswood Daisy Pearl, 18,602.8 Ibs. milk, 057.38 lbs. fat; Ayrshire cow, Netherhall Brownie 9th, r 8, r ro.o lbs. milk, 820.9 r lbs. fat.

Mechanical Milkers.-Scarcity and high price of labour has stimulated a demand for the mechanical milker. The Burrell, Lawrence, Kennedy and Sharples mechanical milkers seem now to have reached a degree of efficiency where it may be said that they will milk most cows as well as or better than the average man, though not as well as the best hand milker, while a few cows cannot be milked thoroughly by either machine. They require more intelligent attention to operate and clean than the common labourer ordinarily is competent to give, though within the reach of the better grade of farm labour; they are usually most successful in the hands of the intelligent farm owner who operates his own machine instead of depending on employés.

National Dairy Show.-In America a National Annual Exposition of the dairy industry has become firmly established in Chicago. The show of 1912 brought together nearly 1,000 of the finest dairy cattle, every kind of mechanical device from stable fixtures to pasteurizer, churns and laboratory equipment, and attractive displays of butter, cheese, milk and cream from many states. Commercial demonstration of latest methods of bottle washing, pasteurization and bottling of milk for retail delivery and making of butter, occupied much space, as did the United States government demonstration of feeding methods with profitable and unprofitable dairy cows and municipal exhibits of the influence of bad housing, poor milk and preventable diseases on infant mortality in great cities. Visitors were present from every section of the United States, Canada and England.

(H. E. VAN Norman.)

\section{Poultry Farming}

Within the last few years the abandonment of a number of the largest spectacular poultry farms in America has had a marked effect upon the general attitude there toward large poultry projects. People are not so ready to engage in them, or to take reports of quick successes on a large scale at their face value. The public is learning to discriminate as qualified observers acquainted with the history of various enterprises of this kind have always done, between the real and the fictitious successes. There are many large poultry farms in the United States and the number may greatly increase, but too many of those kept prominently before the public as practical poultry farms have used the publicity that could be thus secured to advertise something that they had to sell, not to consumers of poultry produce but to producers.

${ }^{1}$ Bulletin No. 114, Pennsylvania Experiment Station. 
The lines in which operations on a large scale have been undoubtedly successful for long periods are the growing of ducks for the market, and sale of exhibition and breeding fowls. Duck growing has been developed on a very large scale on independent farms. Several of these for many years have produced about 50,000 ducks a year. One grower who operates two large farms sorne miles apart produces from 70,000 to 80,000 ducks a year. Farms producing from 10,000 to I5,000 ducks a year are much more numerous than those making a larger output. The successful farms are all operated by owners who have built up from small beginnings. The plants established on a large scale at the start, as investments, invariably fail.

The larger plants doing a business in exhibition and stock fowls grow only a part (sometimes a small part) of the birds that they sell. This is a necessary condition because selling ability and judicious advertising develop a demand far greater than can be supplied from the stock grown upon one farm. This class of poultry cannot be crowded but must have ample range. So as the business grows the breeder usually puts out as much stock as possible on cther farms, and often also buys stock from smaller breeders. The latter practice leads to some abuses, but on the whole is to the advantage of all concerned. Very large plants of this type are not numerous.

By far the greater number of poultry farms of all types are small, requiring the services of only one or two men. The plants for growing roasting chickens are on this scale, or smaller. Only a few of these have an annual output exceeding 2,000 or 3,000 chickens. The special egg farms of Petaluma, California, are on about the same scale. In the roaster growing section of Massachusetts and on the egg farms of Petaluma troubles due to carrying large stocks of fowls continuously on small areas of land are increasing. The same condition is apparent on many of the scattered farms. This and the gradual increase of interest in poultry among general farmers and those residents of towns who have room to keep poultry constantly tend to restrict the growth of exclusive poultry farms. With variations due to differences in customs and economic conditions in different countries, the conditions of poultry production are much the same the world over. With the decline of confidence in mammoth poultry projects an unusual interest arose, as if in reaction, in methods of keeping small flocks of fowls in very close confinement. This plan was exploited largely by the sale of books, each of which described a "system " devised by its author, whereby a very small number of fowls might be made enormously profitable Such ideas had often before been exploited in a small way. At this time skillful advertising on a very large scale enabled some of the promoters to realise very large profits. In America, where the movement started, it made quite a sensation for several years. In England it was at first ridiculed as characteristically. American, but before long English promoters were exploiting similar ideas. The interest in these highly intensive methods still continues, but greatly abated. The indications are that the net result of the movement will be to add many recruits to the number of poultry keepers who use more rational methods.

Production and Distribution.-The increased production of poultry and eggs in all progressive countries is marked. Statistics for the United States attract most attention because of the magnitude of the totals, and the impression is often conveyed that progress is more rapid there than elsewhere. A more correct view is that most progressive movements acquire an initial impetus more easily in America than elsewhere. Comparisons of production in the United States with that of different European countries does not fairly represent progress in Europe. Comparing Europe as a whole with the United States and Canada there is a remarkable parallellism. In Europe England has been the principal market for the surplus of the Continental countries, just as in America the New England and Middle States have furnished a market for the surplus of the West and South. The general history of the extension of interest in poultry culture in recent times on either continent is in nearly all essential particulars very like the history of development on the other. In the United States as a whole production and consumption have been very evenly balanced; but within the United States too there have been backward regions-just as there have been in Europe. 
The tariff on imports restricting movement of poultry produce from Canada to the natural market in the States for a time prevented the development of poultry culture in Canada. It was well advanced in Ontario but backward in other parts of the Dominion. Efforts to build up an export trade with England had the unexpected result of stimulating home consumption to such an extent that, although production greatly increased, the surplus which could be profitably exported dwindled to exceedingly small proportions.

In England and Scotland the question of future supplies of poultry produce has become important, because it has long seemed plain that without some concerted effort for a general increase of production on farms the falling off in imports would not be offset by increased production at home. Within the last year the figures for the census of poultry on the farms of Great Britain, taken in June 1908, have been published. These show a total of $36,728,000$ head of poultry of all kinds, divided as follows: fowls, 32,356,000; ducks, 2,963,000; geese, 71 2,000; turkeys, 697,000. " Statistician," writing in the Illustrated Poultry Record, August I9I2, observes that the number of fowls is almost precisely one to the acre of cultivated land in Great Britain, and that an average of three fowls per acre might be kept without the displacement of any other crop.

In Germany the consumption of poultry and eggs is increasing much faster than the home production. The increased demands of Central and Western Europe have especially stimulated production in Russia, and it seems apparent that that country will soon occupy a position in poultry production in Europe like that of the agricultural regions of the West in America.

The figures for the number and values of poultry in the United States as obtained in the census of rgro were also issued during rgr2. Those showing egg production have not yet appeared. According to this census the number of fowls of all kinds has increased from $250,624,038$ in 1900 to 295,880 , 190 in 1910 , an increase of $18.5 \%$; and the values have increased from $\$ 8_{5}, 807,818$ to $\$ 154,66_{3}, 220$, an increase of $80.2 \%$. The increase in population in this period was $21 \%$. It would appear that the poultry population had not increased as fast as the human population, but as the rules of enumeration of poultry in 1900 and rgro were not the same, close comparison is not possible. The conditions under which the enumerations of poultry have been made are not favourable to accuracy, and as no account is taken of the poultry not on farms it is apparent that a great deal of poultry is not enumerated. In Buffalo, N. Y., a canvass made by a local poultry association discovered that there were over 5,000 persons keeping poultry within the bounds of this city of 423,000 population. The ratio for all cities and towns would undoubtedly be found higher than this.

With progress general and the total of supplies well maintained, the years ror I and 1912 have been poor years in poultry production both in Europe and America. The increased numbers of those giving special attention to poultry account for the fact that there has not been a reduction of products over wide areas. Climatic conditions are commonly considered the fundamental cause of the poorer winter egg yields and bad hatches in the spring. Unseasonable and extremely changeable weather affects egg production unfavourably and impairs the vitality of the breeding stock. Lessened yield was in part made up by higher prices for market products, but these seasons werc very discouraging to novices. In America the year 1912 is likely to be memorable as a year of hard times for breeders of exhibition poultry, manufacturers of and dealers in poultrymen's supplies, and poultry journals. There was some depression in Europe, but it was most severe in America where all lines dependent upon advertising have been greatly overdone. The close of the year gave many indications of improvement, but it is the consensus of opinion that healthy conditions will not be fully re-established until the elimination of weak concerns and the natural increase of business bring about a more even balance of supply and demand in these lines.

Education. - The most important factor in poultry culture at the present time is the educational movement. This includes not only the work of instruction at colleges 
and schools, and the work of experiment stations, but the work of government departments, of poultry associations of many different types, and even of associations of other kinds which are in various ways engaged in education. This movement began to take definite form when poultry courses were introduced into colleges and schools, and to show continuous growth soon after the first such course was established in America, in 1898 . It did not, however, make strong headway until near the end of the last decade, and even then many believed that it would soon decline. Within the last few years the permanence of this movement has become assured. Nearly all states and provinces in the United States and Canada now provide instruction in poultry culture at their agricultural colleges, and there are poultry departments at many secondary agricultural schools and industrial schools. Some privately endowed universities are preparing to establish poultry departments. In a number of states poultry culture is taught in special high schools and in a few some instruction in the subject is given in all schools of certain grades. It is generally recognised that this is the branch of animal husbandry best adapted to school work. The wider introduction of practical courses halts for want of qualified instructors and suitable text-books. In other parts of the world the movement is not so marked, yet in nearly every country where poultry production is an important interest beginnings have been made,--in some cases earlier than in America. It will not be long before opportunities for instruction in the subject in all progressive countries are nearly equal.

The most notable events in the educational field in 1912 were the organisation at London of the International Association of Poultry Instructors and Investigators, and the completion of the administration building of the Department of Poultry Husbandry of the New York State Agricultural College at Cornell University, erected at a cost of $\$ 90, \infty 00$. The reports of experimental work with poultry which in recent years have attracted most attention are those on the inheritance of egg production from the Maine experiment station, and those on white diarrhea in chicks from the Connecticut experiment station. In these experiments popular interest in the subjects allowed a concentration and continuity of effort which are not often permitted to Station workers.

Another example of the results of concentration of force has been given in the work of the United States department of agriculture for the improvement of commercial eggs. This work developed several years ago from investigations of the bureau of chemistry in connection with problems of legislation relating to cold storage. The department of agriculture has used both the bureau of chemistry and the poultry experts of the bureau of animal industry in it. It has been found that there is an annual loss, estimated at $\$ 45,000,000$, due to improper handling of eggs, especially in hot weather. Through both the bureaus mentioned a campaign of education to check this loss is carried on by the department.

Current Discussion.-The matters of greatest fundamental importance to poultry keepers which have been prominently discussed in recent years and especially within the past year, without definite results, are:- the fox question, efficient organisation of poultry interests, and international standards for exhibition poultry. The fox question has become more acute in England because of the general increase of interest in poultry on farms, and the special increase due to the recent multiplication of small holdings. In America it has not had much attention except in Massachusetts. In England the Poultry Club, and in America the American Poultry Association are subjects of constant controversy because of their alleged failure to adapt themselves to the needs of the poultry interests which they are respectively to represent. The discussion of international standards has been rather a question of Anglo-American standards. The absurdity of having different standards for the same breed in different countries is on all sides admitted, but as they exist the possible effects of changes of standards upon business have to be considered. While there does not appear to be any prospect of immediate action, interest in this question is significant as an indication of the tendency to standardise poultry culture throughout the world.

(J. H. Robinson.) 


\section{Horticulture ${ }^{1}$}

The most important event during $19 \mathbf{I}_{2}$ in the horticultural world was the great International Exhibition held in the grounds of the Chelsea Hospital, London, from May 22nd to May 3oth. The exhibition embraced every phase and every department of modern horticulture with the important exception of market gardening, which, however, was represented in some fine exhibits from Belgium and Holland. As an exhibition of the marvellous skill possessed by the British gardener in bringing fruits, flowers and vegetables to the highest perfection, nothing has ever been seen like it before. The exhibits were divided into eleven main groups and four hundred and $t$ wenty-eight different classes. A large area under canvas contained the more tender stove and greenhouse plants from all parts of the globe, as well as roses, carnations, orchids, aroids, crotons, dracænas, palms, ferns, begonias, foliage plants, hardy herbaceous perennials and alpines, choice fruits and vegetables, etc.

Rock Gardening.--Although specimens of rock gardening have become a feature at exhibitions of late years, no one had any conception of the marvellous popularity of this kind of gardening until the International Exhibition at Chelsea. Several acres were devoted to rock gardens, and hundreds of pounds were spent in their formation. Thousands flocked to admire the rockeries and the charming alpines growing in them, and it was evident that other classes of plants were for once put in the background by the public. At last people are beginning to recognise that it is possible to beautify with appropriate vegetation any piece of land, whether large or small in area. Indeed, it is possible to make quite a charming rock garden in the back-yard of the humblest suburban dwelling, providing one has taste and a certain amount of knowledge of the right kind of plants.

Hall Gardening.-This is of even more recent development than rock gardening, of which, however, it is a variety. It consists in building lcose walls with slabs or boulders of stone, filling up the central space between the outside walls with soil, and then filling the outer spaces with plants that naturally flourish in the chinks and crevices of walls. The tops of the walls are, of course, also furnished with suitable flowering subjects, and a quite new garden may be given an ancient appearance by the judicious erection of a wall garden.

IV ater Gardening. - This may be looked upon as a modern adjunct to the rock garden, and has become very popular during the past few years. At exhibitions, by means of water-tight tarpaulins and a stream of artfully concealed water from the "tap," some exquisite water gardens have been made and have attracted much admiration. A great trade is now done in the beautiful hardy hybrid water-lilies of various shades, and in other water-loving plants that have hitherto been sadly neglected. Closely associated with the water garden is the bog garden, and many plants that love swampy or marshy soil are now grown on the margins of the water garden.

Moraine Gardening.- This is a still more modern phase of rock gardening. It indicates a style of growing alpine plants amidst rocky débris as seen at the foot of glaciers, etc., on the Alps. 'To make a moraine garden, the natural soil is deported, and its place is taken by a mixture of rock, sand, loam, peat, chalk, lime, etc., so that plants which naturally flourish in one or other of these " soils " may be accommodated as near as possible to their natural surroundings. Moraine gardens are made on slopes or terraces, and the gritty or rocky soil is prevented from being washed down by having the bottom of each slope or terrace shored up with larger boulders of rock. While stagnant water would be fatal, there must however be a good supply of moisture, the idea being to secure a kind of subterranean trickling as from the melting of ice during the summer months.

Japanese Gardening.- This name has now become attached to a particular style of gardening in which an attempt is made to reproduce the peculiarities of Japanese landscape gardening. Thousands of dwarfed specimens of conifers, oaks, maples, etc., are

'See generally $E$. B. xiii, 74I et seq. 
exported annually from Japan, and are employed in the formation of Japanese gardens in England and elsewhere. In landscape gardening eastern and western ideas are quite dissimilar. 'The western idea is to clothe the landscape with vegetation suitable to its aspect, altitude, soil, undulations, etc. In the Japanese style Nature is copied in such a way that plants from the mountain tops are never planted in the plains or valleys, and vice versa. In a small garden, therefore, everything is dwarfed to such a degree to represent as it were in scale, trees, shrubs, buildings, etc., reduced to corresponding dimensions. Hence pigmy trees, the miniature bridges of bamboo, the stone lanterns, the kiosks, the rivulets, rocks, and other objects on the landscape are all arranged to accentuate the governing idea. Deciduous trees are rarely used, the principal exception being in favour of the double flowered cherries, and the wistaria-both conspicuous objects in Japanese gardens. Water or bog plants like the Japanese iris (Kæmpferi), the water lilies, the lotus, etc., are much in evidence in and at the sides of streams and lakes, while clumps of bamboos give a luxuriant and subtropical effect.

Advance of the American Carnation.-Notwichstanding the many admirers of the hardy border and the Malmaison carnations, these sections are becoming more and more eclipsed by the American or perpetual-flowering varieties. These are now grown in hundreds of thousands and are actually pushing out other crops that have long held a place in the high esteem of cultivators. From a purely market point of view, the American carnation has signed the death warrant of the orchid, many kinds of which had just begun to be grown rather extensively for the floral trade. The extraordinary popularity of the American carnation is due to the ease with which it may be cultivated, its long stems and the beautiful shape of the blossoms, its many shades of delicate colour, its delicious fragrance, its cheapness, and to the fact that it blooms profusely during what in England are the worst months of the year, from October to April (but also during the summer months) and that it may be, and is, used for such a great variety of floral decorative purposes. At present it stands without a rival in these respects; added to which is the fact that the colours always seem pleasing under any condition of light, natural or artificial.

Development of the Dahlia.-In addition to the older sections like the singles, the show, fancy, pompon and cactus varieties, the last year or two have seen the rise of quite new forms--or what are claimed as new, for it is probable that they, or something like them, may have been seen by the first dahlia raisers nearly a century ago, but were discarded because they did not conform to the hard and fast outlines that were regarded as ideals in those days. The "cactus" dahlia is still perhaps the most popular of all sections, but even it is undergoing a change from the original types that were so fashionable a few years ago. Now there is the "miniature" or "pompon " cactus dahlia, in which the blooms, although retaining the perfect "cactus" shape, are much smaller, about 3 inches across, and are borne on long stiffish stems in great profusion. The plants are also much dwarfer than the ordinary kinds, being only about 3 feet high. They flower profusely and embrace every shade of colour almost, except blue.

Another new section of the dahlia is that known as the "collarette." The flowers resemble those of the ordinary single varieties in general appearance, but they differ conspicuously in having a secondary row or "collarette" of small forked petals interposed between the large outer ray florets and the small tubular ones in the centre or disc. The little petals forming the collarette are usually distinct in colour from the others. The "giant-flowered" dahlias with huge double flowers, and the "paeonyflowered " dahlias, having very large single blooms, are both making headway in popular favour, as newer and better forms are being developed.

Evolution of the Gladiolus.-Since the appearance of the first hybrid gladiolus in I 837 , under the name of gandavensis, gardeners have worked unceasingly to evolve other new strains. At first the work was slow and spasmodic, and the second hybrid of note, the still popular scarlet-flowered brenchleyensis, did not appear till 1848 . The Lemoinei hybrids were put into commerce in 1875 , and were followed in 1882 by the Childsi section, and in 1889 by the Nanceianus group. Since that time British, Conti- 
nental and American raisers have been busily engaged in mixing up the bloods of these different groups, all of which originated in the first place from South African species, far inferior to their descendants in size, shape, colouring and vigour. At first only a few well-defined colours appeared, but now there seems to be no limit to the shades and blendings, and hundreds of exquisitely tinted varieties are in cultivation. It was not, however, until IgI I that experts came to the decision that the time was ripe to establish a special society to encourage the more extended cultivation of the gladiolus, and to arrange and classify in some systematic manner the varieties already known, as well as to improve still further the various strains. In America a gladiolus society has been established some time, and growers are taking the keenest interest in this lovely bulbous plant, in conjunction with British and Continental holders of stock. To give some idea of the trade or the developing craze for the gladiolus, it may be mentioned that a Dutch grower recently gave $f r, 666$ for two corms (bulbs) of a variety with yellow flowers called "Glory of Nordwijk;" and there is no doubt that we shall soon be in the midst of a great gladiolus boom. At present the best white-flowered varieties include Albion, Europa, Duchess of Wellington, Prof. Hauber, and l'Immaculée. The finest yellow-flowered forms are Sulphur King, Golden Measure, Goldfinder; in addition to which there are many other lovely varieties.

Herbaceous Phloxes.-Amongst purely hardy flowers perhaps there is none making such progress of late years as the herbaceous phloxes. These plants now have thousands of admirers against dozens not many years back. The ubiquitous hand of the hybridist and cross-breeder is seen in these days among all classes of plants, and the phlox has readily responded to his art. There are now some magnificent varieties in cultivation. The colours vary from the purest white, as in Frau Anthony Buchner and Frau von Lasberg, and the pink, mauve, heliotrope, and the violet-purple of Le Mahdi, to the fine scarlet of G. A. Strohlein and Baron von Dedem. These belong to the " decussata " section and flower in the late summer and during the autumn; the earlier and dwarfer varieties belong to the "suffruticosa" section. Both groups are handsome, and when grown in rich and deeply dug soil they produce immense trusses of blossom.

Exportations of British-grown Apples.-The excellence of the British apple is at last beginning to make itself felt thousands of miles away from home. For many years the British grower has seen the large and increasing importations of apples from the United States, British Columbia, Canada, Australia, Tasmania, etc., and was beginning to think, not unnaturally, that his home markets were about to be swamped. Now, however, owing to the increasing prosperity of South Africa and Buenos Aires in South America, exportations of British apples are being made to these far-off climes. At present the industry is only in its infancy, but it is hoped that the solidity and flavour of the British apple, both due no doubt to a much maligned climate, will enable it to travel long distances and hold its own against all comers.

The season of 1912 completely upset long cherished views as to the necessity of a hot dry summer being essential for the development of high and rich colours in apples. Notwithstanding the cold and excessive wet, the fact remains that apples were, if anything, better coloured than they were in the hot season of Igrr, while the flavour is quite up to the standard. Other plants besides apple trees have been remarkable for their more than usually rich colouring, and the Virginian creeper may be cited as a particularly fine example. It is possible that the rains of $I 9 I 2$ were much needed after I I I to give the soil a thorough good soaking, to liberate those earth salts that go to produce richness of colour.

Potato Growing in America.-According to the latest official returns, 3,689,000 acres of potatoes were grown in the United States in Ior 2, and the estimated yield is put at 108 bushels per acre, that is, 2 tons I $4 \mathrm{cwt}$. if a bushel is reckoned at $56 \mathrm{lbs}$. In America this is considered a " bumper " crop, and " much above the average." The total crop for the United States in I9I 2 is estimated at 398 millions of bushels, that is $9,950,000$ tons. The price is estimated at 25 cents a bushel, or at the rate of just over $£^{2}$ per ton. The gross yield is therefore at the rate of about $£ 5 \cdot 1$ os.od. per acre-such a curiously low 
figure that the foreigner may wonder how it is possible to pay for labour, rent, manure, etc., and still yield a profit to the American grower. Against the American figures it may be stated that the British potato average works out at 6 tons to the acre, and the average price at $£ 3$ per ton, making a gross revenue of $£$ I 8 per acre, against the American $£ 5$. Ios. od. Under proper and intelligent culturai conditions it is possible to obtain from ${ }_{5}$ to 20 tons of potatoes to the acre. Evidently there is much to be learnt from modern scientific methods by practical potato-growers on both sides of the Atlantic, but especially in the United States.

Sterilisation of the Soil.-Amongst large growers of plants under glass this question is often discussed, and several carry out experiments in various ways to prove the advantages or otherwise of "sterilising" the soil, the object chiefly in view being to destroy eelworms and those bacteria that are said to be injurious to vegetation. To secure immunity from these evils, the soil is roasted in iron pipes or trays over a furnace fire, the heat of which is calculated to destroy the organisms referred to, as well as the seeds of weeds and the grubs of more conspicuous insect pests. Some cultivators attach great importance to the sterilisation of the soil for some of their crops, while others look upon the process as a fad, and not worth the time and trouble and expense of doing it. It is possible that when a soil is overdosed with rich organic manures, as it often is under glass, eelworms and injurious bacteria develop as a result of the soil becoming sour. Therefore, when heated, a good deal of the unnecessary organic material is driven off by combustion, and the soil is once more reduced to a clean and healthy condition, and will grow plants to perfection.

Some interesting examples of soil sterilisation were exhibited at the International Exhibition at Chelsea from the Rothamsted Experimental Farm. Eight specimens of tomato plants were grown in pots, the soil in which had been " sterilised" in various ways. The agents used were petrol, phenol, pyridene, formaldehyde, toluole, and calcium sulphide, in addition to which one pot contained steam-heated soil, and one unheated soil. The plants treated with phenol and toluole were very poor indeed. There was little to choose between those treated with formaldehyde, calcium sulphide, and steam; and although the weakest plant of all was in the untreated soil, the outstanding fact was that there was not a good tomato plant among them all. (JoHN WEATHERs.)

\section{BEE-KEEPING ${ }^{1}$}

Such rapid progress has been made in bee-keeping during the last sixty years, that it is not surprising to find that the advance has been maintained during $1909-12$. In Great Britain the most efficient means of advance, both in the art and science, have resulted from the institution of the British Bee-keepers' Association, 38 years ago. Among its objects were, the advocating of more humane and intelligent treatment of the honey-bee; the improvement and advancement of bee-culture; and the increase of the home supply of wholesome honey. The purposes thus set forth have been strictly kept in view, and have been successfully brought out. Help and advice have been given in the formation of county associations of bee-keepers, and forty-four of these are at the present time in affiliation with the parent association. Encouragement has been given to increasing the number of persons keeping bees, for although it is computed by the best authorities that there are over 90,000 bee-keepers in the British Isles, the honey imports from abroad, amounting in value to more than $£ 30,000$ per annum, show that the home production is not equal to the demand. The low price of the foreign product proves the superior quality obtained from British bees. The passing of the Small Holdings Act has opened a new field for bee-keeping.

The value of the industry has now been recognised by the British Government, which has made a grant to the British Bee-keepers' Association for the purpose of establishing an experimental apiary, where courses of lectures, illustrated by practical manipulation of hives containing bees, are given out of doors during the summer months. In winter the lectures are indoors, and are illustrated with suitable lantern slides. In addition

${ }^{1}$ See E. B. iii, 628 et seq. 
scientific lectures by specialists are given from time to time. The Government also make a grant for pioneer work and promoting bee associations, which the British Beekeepers' Association is able to do by sending its certificated experts and lecturers all over the country. Thirty-six county councils also make small grants in aid of technical instruction in bee-keeping, ten of them at their own agricultural colleges.

On the practical side progress has been made in queen rearing, and, by the adoption of Mendelian methods, bees have been improved both as regards hardiness and working qualities. The principal improvements in appliances have been for making old combs render a better quality and a larger quantity of wax.

The value of bees in the pollenation of fruit blossoms is now fully recognised, and the importance of having a sufficient number of them for this purpose has been brought prominently before the public, owing to a serious epidemic which has destroyed not only whole colonies of bees, but has also devastated entire districts, causing fruit growers anxiety with respect to their future crops. The United States of America, Canada, New Zealand and many other countries have legislated with respect to the control of bee diseases, and the British Government, realising the necessity for similar action, have introduced in Parliament a "Bee Diseases Bill " which it is hoped will enable them to cope with the two diseases which have caused such mortality among bees.

Respecting the disease known as "foul brood," recent investigations by Dr. White have shown that in one of the two forms of the disease, viz. the one known as "foul smelling " in which Bacillus alvei is usually present, the cause of the disease is not this microbe, as has hitherto been supposed, but one of several others found associated with it, to which Dr. White has given the name of Bacillus pluton.

An epidemic disease broke out in the Isle of Wight in 1906, about which little was known up to rgoo. Since then it has spread to the mainland, and has caused great losses of bees in many districts. The cause of the malady has been under investigation by the Board of Agriculture and Fisheries, and a full report has been recently issued, showing what has been done and the nature of the disease. European bacteriologists have also been investigating the cause of the great mortality among bees in various parts of the continent, and Dr. Zander in Bavaria, who made a very careful study of bees suffering from " infectious dysentery" in June 1907 , discovered as the infecting agent a protozoal parasite to which he gave the name of Nosema apis. His findings have been confirmed by other scientists in Germany and Switzerland, and in England it has been found by Dr. Graham-Smith and others associated with him that the same parasite is the cause of "Isle of Wight" disease, which is now called Microsporidiosis, since Nosema apis is a member of the group named the Microsporidia. Drs. Fantham and Porter had already observed a protozoan in the digestive tract of some bees obtained from the Isle of Wight in 1906, and in subsequent years Nosema apis was found in bees from Hampshire, Surrey, Middlesex, Cambridgeshire and Hertfordshire. By feeding experiments they were able to reproduce the fatal disease, both in bees and in wasps.

The life history of Nosema apis shows that it proceeds from a tiny germ which issues from the resistant spore, and gives rise to uninucleate daughter forms known as planonts, because of their migrating or wandering habit. They increase by division, and when they have penetrated between the epithelial cells, they may remain there in a resting condition for some time, or penetrate the gut direct from the lumen or from between the epithelial cells. The parasite is now called a meront, and is at first uninucleate. It has now entered upon the feeding stage, rapidly increases in size and multiplies by fission, ultimately forming spores. The main alimentary tract of the bee, particularly the chyle stumach and intestine, are the chief parts affected, although Nosema may occasionally be found in other organs.

The disease is one of the adult bees, larvae and young bees remaining healthy. The queen also appears $(0)$ be exempt and is frequently found as the last survivor of a colony. Bees suffering from the disease appear heavy and disinclined to move, the wings are frequently dislocated, and the abdumens swollen. They lose their power of flight, large numbers drop on the ground, and as the bees are unable to rise it is not long before they perish. The disease is infectious, and is introduced into healthy colonies by infected foragers, or infected foods. Affecterl bee's void excrements which contain the spores, while on the wing. Infected water grossly contaminated with excrement, and honey present in the hives in which bees have died, are stated to be the most important infected foods. 
The introduction of the parasite into the hive is not necessarily followed by the appearance of the disease, and some stocks remain healthy while the infected bees are gradually eliminated. At present no remedy is known, and it is recommended that where a stoch exhibits a heavy continuous mortality, it should be destroyed, as it never completely recovers and is a continual and serious source of danger.

All dead bees should be picked up and burnt and the ground disinfected. Hives that have contained diseased bees should likewise be disinfected.

Nosema has also been found in humble-bees and wasps, but it is not yet conclusive that it belongs to the species Nosema apis. New light has been thrown on the life history of humble-bees and their parasites by Mr. Sladen, who has succeeded in domesticat. ing, and keeping under observation, species of Bombus in artificial domiciles, to which queens were attracted.

The following are the most important works which have appeared during the last three years bearing on the subject: Dr. E. Zander's Der Bau der Biene, and Die Krankheiten und Schädlinge der erwachsenen Bienen; T. W. Cowan's Wax Craft, all about beeswax, its history, production, adulteration and commercial value; The Report on the Isle of Wight disease, by Dr. Graham-Smith and others, issued by the Board of Agriculture \& Fisheries; and F. W. L. Sladen's The Humble-Bee, its life-history and how to domesticate it.

(Thos. Wm. Cowan.)

\section{THE FUR INDUSTRY ${ }^{1}$}

So far as concerns the preparation of fur skins for the market, there is nothing new of importance since igro. One great change however has occurred in the primary conditions of the fur supply. In connection with the great importarce and necessity of enforcing close seasons and restrictions to prevent the total extermination of fur-bearing animals, a notable event has taken place as the result of the International Fur Seal Conference between the United States, Great Britain, Japan and Russia which was in session at Washington from May r 1 to July 7, I9 I 1 .

The conference concluded its labours on the latter date by the signature of a convention, which was ratified and went into effect on December I5, I9I I, and is to continue in force for a period of fifteen years from that date and thereafter until terminated by twelve months written notice given by one or more of the parties to all of the others. This convention was for the preservation and protection of the fur seals and sea otter, which frequent the waters of the North Pacific ocean, its essential object being to stop pelagic sealing, which was an international question. "Pelagic sealing " means " the killing and capturing fur seals at sea," which had long prevailed in spite of the constant and earnest efforts on the part of the United States Government to have it discontinued.

The Pribiloff Islands, which are the natural home and breeding places of the fur seals, were in former years leased by the United States to companies, who had the right to engage in taking fur seals on these islands. These leases expired by limitation on April 30 , I910, and it was found advisable to abandon the former system of leasing, the Government of the United States taking over entire control of the islands and the seal herds. It appeared that the seal herds on the islands have been reduced to such an extent that their early extinction had to be looked for unless measures for their preservation were adopted. A herd numbering 375,000 twelve years ago was reduced to 135,000 , and it was estimated that the breeding of seals had been reduced in the same period of time from 130,000 to 56,000 . The rapid depletion of these herds was undoubtedly to be ascribed to the practice of pelagic sealing, and by the convention signed by the four countries above named pelagic sealing is prohibited for I 5 years from December I 9 I I.

The countries who were until recently engaged in this wasteful and indiscriminate slaughter of fur seals have been induced after difficult and protracted negotiations to agree to abandon pelagic sealing on condition that they shall receive compensating interest in the skins taken by the United States Government on land.

In killing seals at sea all ages and sexes are killed indiscriminately, and a great waste thus takes place, as many, upon being shot, sink and are lost before the hunters can reach them; in fact it is well known that of all killed fully one half are lost.

The seals leave the islands in the autumn and make a most wonderful migration; it

${ }^{1}$ See E. B. xi, 346 et seq. 
goes on for nine months in the year and covers about 2,000 miles. The seal gets all its food in the open sea at great distances from land. It resorts to the land only to bring forth and nourish its young to self-dependence. It is resident for this purpose on certain islands in Bering Sea from May to November. The mother seal goes 150 to 200 miles from the rookeries to find her food, leaving her young behind, returning to nurse it, and again going away to feed. With the storms of winter all classes of animals leave the islands and make a long migration down through the Pacific ocean to the latitude of Southern California, the farthest point south reached by the fur seals about the month of January, when the course of their migration turns again northward along the western coast of Alaska, ending at the Pribiloff Islands sometime in the month of July.

It has been the custom of the Indians of the north-west coast of America from the earliest times to go out in their canoes a day's journey to hunt with the spear stragglers from the migrating herd on its northward journey. It was a precarious business and the number of animals taken was unimportant. In 1879 however sailing vessels began to be used to take the Indians and their canoes out to the main body of the herd and to enable them to follow its course. This new form of sealing was very successful. The fleet grew in numbers and the catch multiplied until it reached the total of 140,000 skins in a single season. The operation of the fleet gradually extended over the entire migration route of the seals and included their summer feeding grounds in Bering Sea. Until very recently at least the pelagic fleet contained about thirty vessels manned by about twelve hundred men using about three hundred boats. The sealers knew in general the locality of the fur seals at different periods of the year; the migration route has been determined by the logs of the various pelagic sealing vessels that have taken fur seals at various times of the year throughout that great course.

Between I 883 and 1897 a total of 304,7 I 3 skins of seals killed at sea were marketed, and undoubtedly an equal number were lost. The moment the mother seals left the islands the sealers were after them, and a mother seal, in order to get her food with which to suckle her young, was obliged to run the gauntlet of the vessels. The destruction of the mother seal meant the starvation of the offspring on shore, and uncounted thousands of young seals have perished on the islands from that cause. The males being reduced in numbers by land killing, the females predominated in the herd as found at sea. On land the young males are forced to herd by themselves through fear of the adult males. They can be readily distinguished and handled without disturbance to the breeding herd. At sea the sexes cannot be distinguished. On the spring migration the mother seal is heavy with young, and hence less swift in her movements. On the summer feeding grounds she must feed regularly and heavily through necessity of nourishing her young, and as a result the pelagic catch is made up chiefly of the breeding females. From 1879 to the present time this hunting of gravid and nursing females has gone steadily on, with the consequence that the herd of fur seals belonging to the United States has been reduced enormously.

This decline of the seal herd was established for the United States Government in 1898 by a commission of scientific experts. It was pointed out that only by the establishment of an international game law for the high seas which should protect the female fur seal,-in other words the abolition of pelagic sealing-could the herd be preserved and restored. The property involved is a very important one. With regard to the practice of killing bachelor seals for the natives' food it was decided that this should not be abandoned unless a cogent reason presents itself. No harm to the herd can result from the killing of surplus males. No benefit to the herd could accrue from the maturing of males unnecessary for purposes of reproduction, which when of adult age would have no female consorts, but which by incessant and furious fighting would destroy or cripple the breeding bulls and themselves as well.

Since signing this convention, the United States Government has passed a new measure with regard to killing fur seals on the islands, and has decided on a close season for five years from 1913. The section of the bill giving effect to the convention has therefore been amended to read as follows: 
"That from and after the approval of this act all killing of fur seals on the Pribiloff Islands or anywhere within the jurisdiction of the United States in Alaska shall be suspended for a period of five years, and shall be and is hereby declared to be unlawful, and all punishments and penalties heretofore enacted for the illegal killing of fur seals shall be applicable and inflicted upon offenders under this section; provided that this prohibition shall not apply to the annual killing on the Pribiloff Islands of such male seals as are needed to supply food, clothing and boat skins for the natives on the islands, as is provided for in article II of the said convention. The skins of all seals so used for food shall be preserved and annually sold by the Government and proceeds of such annual sales shall be covered into the treasury of the United States."

With regard to fur seals killed on the islands, so-called "Alaska fur seals," it is interesting to note that from 1870 , when the Alaska Commercial Company took charge of the islands under a lease for 20 years, roo,000 skins were taken annually.

With regard to the future of the so-called "South Sea seals," taken in the Southern Pacific and Indian oceans, it was reported in I9I 2 that the fleet which had been sailing from Halifax regularly for 27 years would abandon the enterprise in the coming season and that no ships would proceed to these regions, probably for several years.

Silver Fox,-During the last few years considerable progress has been made in the rearing of these animals in captivity in the United States and Canada. The fur has been found to compare favourably with those trapped and the skins are bringing very good prices.

Russian Sable.-In order to preserve the Siberian sable from entire extermination, the Russian Government passed a law in 1912 prohibiting sable hunting and trapping from February 14, 1913, to October 28, 1916, provision being also made for making it illegal between February I and October I 5 in subsequent years. It is doubtful, however, whether this action will be sufficiently effective to attain its object, as there are great possibilities in a vast country like Russia for smuggling the fur and exporting under an assumed name.

Chinchilla.-These animals are becoming so scarce that the Government of Bolivia has prohibited the exportation and killing of chinchilla. In Chile killing is also forbidden for a period of two years, but in spite of these restrictions the killing still goes on and the catch is smuggled out of the country. The collection of bastard chinchillas has been as high as 360,000 per year; the real chinchillas as high as 10,000 and chinchillonas 18,000 . In 1905 a total of 220,000 skins were exported from Bolivia alone; in 1906123,000 ; in 190758,000 ; and in 190838,000 . In I 1 I the collection was as follows:-Bastard chinchilla 30,000; Real chinchilla 1,200; Chinchillonas 2,400.

A ustralian Opossum. - The number of these animals has also been considerably reduced of late, and in consequence the Governments of New South Wales, Queensland and Western Australia have passed a law for a temporary close season, the duration of which, however, is uncertain.

\section{THE COTTON INDUSTRY AND TRADE ${ }^{1}$}

The Cotton Industry. - It was declared some years ago that the world's cotton spinning spindles were in excess of the world's requirements. But, in consequence of the fall in real cost of production, which is constantly taking place as a result of progress, combined with the development of backward places, the demand for cotton goods steadily expands, for they are the cheapest of textiles and, therefore, the first to feel the effects of advancing civilisation. Hence, considerable additions have been made to the world's facilities for spinning of late years, as the following figures show:

Spinning Spindles in Millions.

\begin{tabular}{|c|c|c|}
\hline & & \\
\hline Great Britain & 52.8 & 54.5 \\
\hline Germany & 9.9 & 10. \\
\hline France & 6.7 & \\
\hline Russia & $7 \cdot 9$ & \\
\hline India & 5.5 & 8 \\
\hline Austria . & 4.0 & \\
\hline Italy . & 4.2 & \\
\hline Spain & i. 9 & \\
\hline Japan & 1.6 & 2 \\
\hline Switzerland & I. 5 & \\
\hline Belgium & 1.2 & \\
\hline
\end{tabular}

Spinning Spindles in Millions.

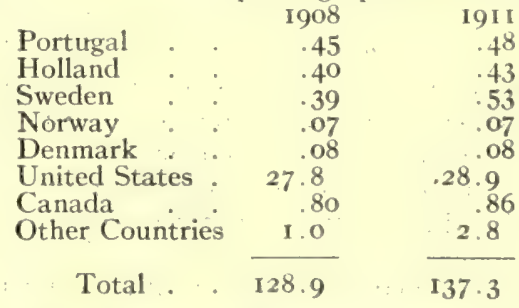

These figures are rough estimates only, but they are put forward with the authority of the International Committee of Master Cotton Spinners' and Manufacturers' Association, and are founded to some extent on collected statistics.

I See E. B. vii, 256 et seq. 
It is notable that, while spinning spindles would seem to have advanced in the world by more than 6 per cent between 1908 and $19 \mathrm{r}$, those in the United Kingdom only advanced by a trifle over 3 per cent. This result was however to be expected. In the course of the industrialising of the world, textile industries less developed than the famous Lancashire industry have been rapidly improving and increasingly satisfying home demands in the countries where they are placed, while spinning mills have been appearing in other countries where until recent times spinning was unknown. There is no reason to apprehend that the hand of the Lancashire operative is losing its cunning, or that slackness of management is preventing costs in English mills from being as low as they might; and it is beyond question that Lancashire still continues to enjoy differential advantages for the prosecution of the cotton industry. A cheap substitute for her climate is yet to seek; and nowhere else is an approach to be found to the systematic arrangement of her industry around marketing centres, in consequence of which a high degree of business specialism is rendered possible and the locking up in raw material of a great deal of capital is avoided. How great Lancashire's gain is with respect to the latter point, is indicated by the mill stocks of cotton. The average mill stocks in bales per I,000 spindles held on the 3 ist of August in the five years 1907-II amounted 10: Great Britain 6.6, Germany 35, France 24, Russia 65, India 93, Japan 192, United States 26. Russian bales are mostly of about 300 lbs.; American of 500 lbs.

It is remarkable that the cotton industry in the land from which most cotton comes must hold mill stocks four times as great as those held in the British industry which is divided from its supplies by the mighty Atlantic. One leading reason is that the American industry does not approach the Lancashire industry in completeness as an organic whole, and that the former is not peculiarly well placed with respect to means of transportation. The chief port of Lancashire, Liverpool, and, one might add, the secondary port of Manchester, ${ }^{1}$ lie so close to the spinning districts, and are so well connected with them by rail, that supplies of cotton can be obtained on the shortest notice as they cannot elsewhere; and Lancashire's cotton market is so highly organised, with its expert dealers and brokers and its system of 'futures,' that spinners can easily make arrangements for cotton to flow into their mills as they require it. Reservoirs of cotton, so to speak, need not be maintained in Lancashire mills. We may see in Lancashire, as nowhere else in the world as yet, cotton supplies travelling to the various mills according to almost immediate requirements, much as the blood in the body flows to the parts where it is needed, when it is needed, and in the proportion in which it is needed.

It must be remembered, moreover, when the number of spinning spindles in the United Kingdom is compared with the numbers elsewhere, that a year's working of an English spindle represents on an average a greater value than a year's working of any foreign spindle, because English spinning, as a whole, is becoming finer and the value of the fine work is greater than of the coarse work. Thus in the five years 1907-II the average consumption of cotton per spindle in different countries was:

\begin{tabular}{|c|c|c|c|c|c|c|}
\hline (ir. Brit. & Crermany. & France. & Russia. & India. & Japan. & IT. S. A. \\
\hline 71 & 173 & 137 & 250 & 371 & 685 & 170 \\
\hline
\end{tabular}

England has been steadily driven into undertaking more fine spinning (for which she enjoys special advantages) by foreign competition. It goes without saying that early attempts at spinning are made on the coarser and easier work.

It is impossible to put forward figures showing recent increases in looms, but they certainly still continue to increase enormously. In Lancashire and contiguous districts cotton looms were augmented by nearly 40 per cent between 1884 and Ior I, despite the extension of manufacturing in other countries; and it will be realised that countries which embark on the production of cotton textiles invariably begin with manufacturing

${ }^{1}$ The total imports of cotton into the United Kingdom amounted to (1907) 2387 million $11 \mathrm{s.}$, (1909) $2 \mathrm{I} 89$ million $1 \mathrm{bs}$; and (19II) 2207 million lbs. The amount shipped direct to Manchester via the Ship) (anal was (1907) 300 million Ibs., (I909) 340 million lbs., and (I9II) 350 million lbs. Nearly half the cotton consigned direct to Manchester came from Egypt. 
(as weaving is technically termed) and then pass on to spinning. It is notable, as regards manufacturing, that there are still no signs of an extensive adoption of the automatic loom in Lancashire, though its success in America appears to be assured. It is hardly conceivable that the main explanation is any lack of enterprise on the part of Lancashire manufacturers. The main explanation is far more likely to be (as is commonly alleged in Lancashire) that the automatic loom is not-at any rate, under the conditions now prevailing-suited to the character of the bulk of the British output.

The results of the British census of I9I I with respect to occupations are not yet available; but, in considering the changes in numbers employed in the cotton industry in the United Kingdom, we have factory inspectors' returns to fall back upon. These show as follows:-

Cotton Operatives in the United Kingdom in Thousands.

\begin{tabular}{|c|c|c|c|c|c|c|}
\hline 180 & $\begin{array}{c}\text { Half-timers. } \\
\quad 29.5\end{array}$ & $\begin{array}{c}\text { Under } 18 . \\
12.1\end{array}$ & $\begin{array}{c}\text { Over } 18 . \\
382\end{array}$ & $\begin{array}{c}\text { Males. } \\
204\end{array}$ & Females. & Total. \\
\hline 190 & 21.0 & II 5 & $3^{87}$ & 194 & 329 & $5^{2}$ \\
\hline Oด & 17.7 & 109 & 396 & 196 & 327 & 523 \\
\hline 1907 & 19.1 & 131 & 426 & 218 & 359 & 577 \\
\hline
\end{tabular}

The advance since 1904 is substantial and bears out the view that recent years have witnessed an accelerated growth of the British cotton industry. The inspectors' returns for I 907 are corroborated by the returns made for the census of production, which reveal a total of 560,500 wage earners occupied, on an average, on the last Wednesdays of January, April, July and October. Of these 560,500 wage earners about 14,000 were at work in Scotland. The returns of the census of production show that the number of salaried persons engaged in the cotton industry in the United Kingdom was 12,400 .

Among the operatives the proportion of males to females has remained about the same, males being in each period between 37 and 38 per cent of the total. Under 18 the proportion of males is less; which is, of course, to be explained by the fact that many women give up factory work when they marry. The augmentation of numbers between 1904 and 1907 is naturally most marked among those under I8. This does not necessarily mean that the young are substantially displacing adults; for, as a rule, when an industry suddenly requires more labour, the bulk of the new recruits are of the plastic age. Those already in the industry get promoted younger than they would have been otherwise, and fresh labour, new to the industry, tends to take the places vacated at the bottom.

The Cotton Trade.-In I 908 the cotton trade of the world was thrown into a state of collapse; for by that time the trade boom of the previous years had worked itself out and reaction had set in, particularly in the United States, where a severe financial crisis occurred in the autumn of 1907 . From this collapse, however, the cotton trade had by ror 2 recovered entirely, with the result, as regards the United Kingdom, that the high figure of exports of cotton goods in 1907 was actually surpassed in I9 I I (and again in I9I 2). The fact must be allowed for that all over the world the general level of prices has been rising, so that values for I 9 I I must be somewhat reduced to bring them into relation with those for 1907; but they still show an appreciable excess. The following figures represent approximately the recent foreign cotton trade of the four leading countries:

Foreign Trade in Cotton Goods in Million Pounds Sterling.

\begin{tabular}{|c|c|c|c|c|c|c|c|c|}
\hline & \multicolumn{2}{|c|}{ United Kingdom. } & \multicolumn{2}{|c|}{ United States. } & \multicolumn{2}{|c|}{ Germany. } & \multicolumn{2}{|c|}{ France. } \\
\hline & $\begin{array}{l}\text { Imports } \\
\text { less re- } \\
\text { exports. }\end{array}$ & $\begin{array}{c}\text { Exports } \\
\text { of home } \\
\text { manufac- } \\
\text { ture. }\end{array}$ & $\begin{array}{l}\text { Imports } \\
\text { less re- } \\
\text { exports. }\end{array}$ & $\begin{array}{c}\text { Exports } \\
\text { of home } \\
\text { manufac- } \\
\text { ture. }\end{array}$ & $\begin{array}{l}\text { Special } \\
\text { imports. }\end{array}$ & $\begin{array}{l}\text { Special } \\
\text { exports. }\end{array}$ & $\begin{array}{l}\text { Special } \\
\text { imports. }\end{array}$ & $\begin{array}{l}\text { Special } \\
\text { exports. }\end{array}$ \\
\hline $\begin{array}{c}1904-6 \\
\text { (average) }\end{array}$ & 6.2 & 9I & 10.6 & $7.9^{2}$ & 5.8 & 19. & 2.7 & I0. 8 \\
\hline 1907 & 6.8 & 110 & 14.5 & $5 \cdot 7$ & 10.7 & 23.9 & 3.7 & 14.8 \\
\hline 1908 & 7.7 & 95 & $13 \cdot 3$ & 4.6 & 7.4 & 19.7 & 3.0 & II. 6 \\
\hline 1909 & $7 \cdot 3$ & 93 & 12.3 & 6.0 & 8,2 & 18.9 & 2.9 & 13.7 \\
\hline r910 & 8.5 & 106 & 13.0 & 6.0 & 9: I & 21.7 & 3.5 & 13.7 \\
\hline I9II & 9.0 & 120 & I3. I & $7: 4$ & 8.6 & 23.4 & 3.4 & 14.0 \\
\hline
\end{tabular}

1 The pinnacle was reached in 1906 in America with exports over $f_{10,000,000}$.

In connection with the varying trade of the world, it is worthy of mention that it is usual in the British cotton industry for short time to be agreed upon when margins be- 
tween the prices of the product and the cost of material droop and show no sign of immediate recovery, the operatives, as a rule, readily falling in with the arrangement. The same policy is practised in countries other than England, but an attempt made in the late depression to secure concerted action throughout the world failed. The method of short time, when judiciously applied, is generally favourable to the interests of operatives as well as employers, as it causes under-employment to be spread over the industry, instead of unemployment being concentrated on a section of the working-class.

Since the issue in 1909 of the report relating to the cotton industry of the British census of production (taken in 1907), it has become possible to arrive at something more than intelligent guesses with regard to Great Britain's annual consumption of its own products. Taking the estimates put forward by the director of the census of productions, based on these returns, instead of the returns themselves, so as to avoid such sources of error as duplication, and placing side by side with them export returns for the same year, we have:-Yarn spun, I 826 million lbs. ( $£ 98,000,000$, including about $£ \mathbf{I}, 700,000$ for dyeing); Yarn exported, 24I million lbs. ( $f 15,250,000)$. So the proportion exported is about 13 per cent in quantity and I6 per cent in value. But the value of yarn exported includes the profits of the exporter. Consequently its value when it left the spinner would have been about $£$ I4,600,000 if these profits amounted on an average to 5 per cent. This is 14.5 per cent of the value of the total output; as compared with an export in quantity just over 13 per cent. The discrepancy seems only natural in view of the known fact that the yarns exported contain a large proportion of the fine counts, in which Lancashire far excels its competitors.

Coming to piece goods, we find an output of $709 \mathrm{I}$ million yards (value $f 95,000,000$, including $f_{1} 2,000,000$ for bleaching, dyeing and finishing), and an export of 6298 million yards $(f 8 \mathbf{I}, 000,000)$. The exports were nearly 89 per cent in quantity and about 85 per cent in value. But the export values include merchants' expenses and profits, and if we allow about 5 per cent for these we get a percentage of export in value of about $8 \mathrm{I}$. The probable explanation of the discrepancy between the quantity and value percentages of export is that the average value of the goods retained for home consumption is much higher than that of the exports. A large proportion of the exports are unbleached and unprinted, and the average quality of exported prints is pretty certain to be below that of prints for home use. Admittedly, there are sources of error connected with the census of production and with the collection of export figures; but they are not likely to have vitiated the results seriously.

Cotton Supplies.-The question of cotton supplies continues to agitate the English spinning world. It is still felt that dependence on the American supply is too great, and it is feared that the output of long staple cotton in America is much nearer its limit than the output of other kinds. Peculiar apprehension has been excited as regards the conditions of cotton-growing in Egypt. It is maintained that the yield of the plants is falling in quantity and quality. The yield of kantars ( $\mathrm{I}$ kantar $=98 \mathrm{lbs}$.) per feddan ( $\mathrm{I}$ feddan $=\mathrm{I} \mathrm{I} / \mathrm{I}$ oth acres) was on an average 5.29 in the period $\mathrm{I} 896$ - $\mathrm{I} 90 \mathrm{I}, 4.55$ in $190 \mathrm{I}-06$ and 4.24 in I906-II, according to statistics published by the Egyptian survey department. It is contended that the cause of the fall includes some or all of the following: (r) careless seed selection; (2) over-cropping, as a result of the reduction of customary rotation from three years to two, and also of the squeezing of the plants together; (3) insect pests; and (4) the water-logging of the soil. Some authorities are particularly insistent as to the gravity of the fourth case. Information, was laid before a cotton commission in $1909-10$ which reported in due course, made twenty-six recommendations and nominated a committee with a view to the carrying out of its recommendations. The committee had not met up to the time of the visit of Mr. Arno Schmidt (the secretary of the International Cotton Federation) to Egypt in IgI I but he states that he was informed by Lord Kitchener of an intention to institute a permanent cotton committee to take up the whole matter. Since then a committce to investigate the ravages of the cotton worm has been appointed. The question of the Egyptian supply is a serious one for England at the present time, for it has been estimated that of some twenty-one million spindles which are dealing exclusively with Egyptian cotton fifteen millions are in England-there are supposed to be no more than one million and a half in Germany, about one million and a half in France, and in no other country as many as a million. But the matter will become an increasingly important one to countries other than England as they push their way further into fine spinning.

The British Cotton Growing Association, which is specially concerned with the question of increasing cotton supplies, has now almost raised the capital of $£ 500,000$ 
which it first set out to obtain. In addition several subsidiary companies, in which the Association is interested, have been formed, some with the Association's assistance. Such are the British Cotton Ginning Co. Ltd. (capital $\left.£_{1} \infty 0, \infty\right)$ ), British East Africa Corporation Ltd. (capital $£ 200,000$ ), Sudan Plantations Syndicate Ltd. (capital £250,-

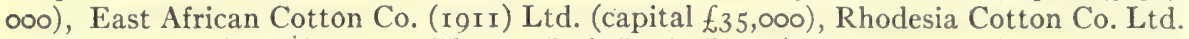

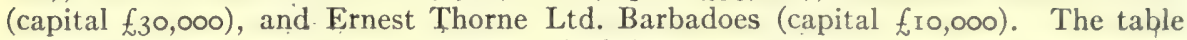
appended shows the amount of cotton which has come forward from new fields in the British Empire to which the Association has given its attention.

Cotton Grown in New Fields in the British Empire; Bales of 400 lbs.

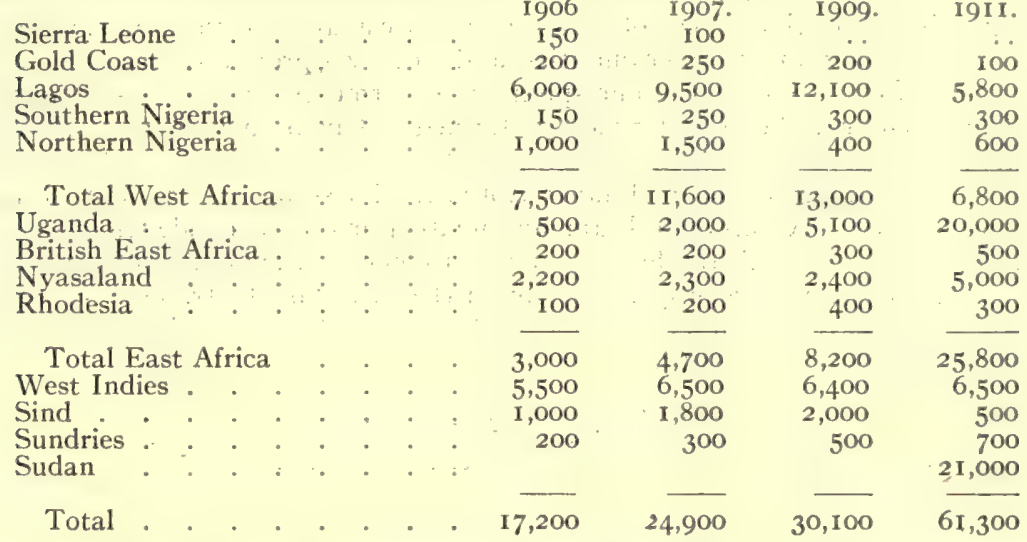

The present total is only a minute fraction of the world's crop, but it is approaching one and a half per cent of the imports into the United Kingdom; and, though the amount of cotton raised from the new fields is relatively small, it is absolutely large and is increasing by substantial percentages. High expectations have been formed of the possibilities of the Sudan. The total amount of cotton which passed through the hands of the Association (apart from that sold through other channels) in 1908 and the three succeeding years was respectively, in bales and in value:-(1908) $17,700(£ 224,900),(1909) 20,000$ ( $f, 225,100)$, (I9I0) 2I,400 (£296,200), (I9II) 27,700 ( $£ 373,600)$.

(S. J. Chapman.)

\section{LINEN AND LINEN MANUFACTURE ${ }^{1}$}

As indicated by the British Board of Trade returns, the linen trade is in a comparatively healthy state, and there has been a large increase in the number of acres in Ireland devoted to flax growing. This increase is due mainly to the gradual increase within the last few years, and the rapid rise in I9ro, in the price of the better qualities of flax. A glance at the average prices of flax in pounds per ton as supplied by the Flax Supply Association, indicates that the cultivation of flax may prove remunerative.

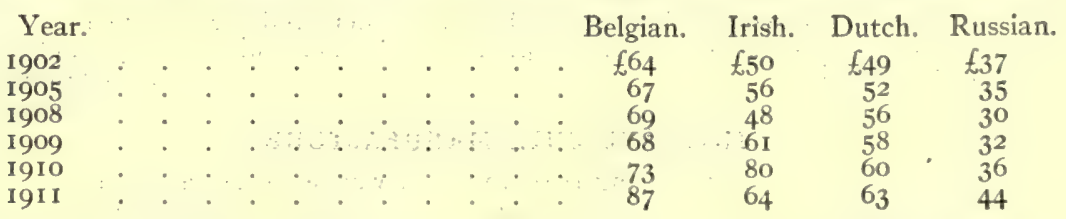

A rapid rise in the price of flax may be a healthy sign from an agricultural point of view, but it often checks not only the production of yarn but also that of cloth. It is all the more satisfactory to find that the trade has assumed such large dimensions.

The following table indicates the approximate number of acres under flax cultivation in the principal flax growing centres:

${ }^{1}$ See E. B. xvi, 724 et seq.; $\mathrm{x}, 484$ et seq. 


\begin{tabular}{|c|c|c|c|c|c|c|}
\hline Country. & I906. & 1907. & 1908. & 1909. & 1910. & I9II. \\
\hline $\begin{array}{l}\text { ussia including Cau- } \\
\text { casia and Poland. }\end{array}$ & 4,2 & 368,000 & 4,19 & 4.0 & 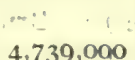 & \\
\hline a-Hungary & & 20 & 16 & 15 & 135, & \\
\hline Tace & 68 & 63 & $7 \mathrm{i}$ & $5 i$, & 54,000 & \\
\hline Belgium. & & & & 39 , & & \\
\hline reland & & & & & & 67 \\
\hline Ilolland & 38,000 & 42,000 & 36,000 & 25,000 & 29,000 & 39,000 \\
\hline
\end{tabular}

Within the last decade there has been a considerable development in the manufacture of linen cloths intended to be embellished by some form of hemstitch or embroidery. Although this type of cloth does not, as a rule, require a large weight of flax, it nevertheless creates a demand for the finer qualities, and moreover provides work for a considerable number of operatives in the fine spinning departments, and in those departments where hemstitching and embroidery are performed. This branch of the trade is now a very extensive one, the work being done mostly by mechanical means. Handkerchiefs, table covers, bed spreads, and small fancy cloths of all descriptions are adorned more or less by this method. A considerable amount of labour may be expended in comparatively short lengths of material, and hence a mere statement of the number of yards of cloth manufactured may not be a proper criterion of the extent of the trade. Nevertheless, along with other developments in the finer end of the trade, the British exports of linen goods show a satisfactory record.

British Exports of Linen Goods.

\begin{tabular}{|c|c|c|c|c|c|c|}
\hline Description. & 1906. & 1907. & I9o8. & 1909. & Igro. & Igrx. \\
\hline $\begin{array}{l}\text { Weight of linen yarn in } \\
\text { pounds } \\
\text { Length in yards of linen }\end{array}$ & $\mathbf{x} 4,978,200$ & $16,442,000$ & $13,705,900$ & $13,532,900$ & $18,548,900$ & $18, \infty 3, \infty 00$ \\
\hline piece goods, plain, & $173,3,34,300$ & $160,364,600$ & $1.32,987,100$ & $197.536,000$ & $105.001, \infty 00$ & $16,3,680,700$ \\
\hline $\begin{array}{l}\text { Length in yards of linen } \\
\text { piece goods, checked, } \\
\text { dyed or printed; also } \\
\text { damask and diaper } \\
\text { Length in yards of sail- }\end{array}$ & $13,372,100$ & $14,264,500$ & $14,967,200$ & $23,147,900$ & $21,626,400$ & $16,675,800$ \\
\hline $\begin{array}{l}\text { cloth } \\
\text { Total length in yards of }\end{array}$ & $4,251,400$ & $4,370,000$ & $3,939,600$ & $3,250,900$ & $3,850,600$ & $3,658,900$ \\
\hline $\begin{array}{l}\text { all kinds of linen cloth } \\
\text { Weight in pounds of lin en }\end{array}$ & $190,957,700$ & I $84,999,100$ & I $51,893,900$ & $223.934,800$ & $220,568,000$ & $194,014,800$ \\
\hline thread for sewing & $2,181,100$ & $2.381,700$ & $2,233.700$ & $2,263,800$ & $2,738,900$ & $2,595,400$ \\
\hline
\end{tabular}

The improvements in methods of manufacture which are mentioned with reference to Jute are applicable to flax machinery, and to all others where similar conditions obtain in regard to the roving, spinning, and twisting of long vegetable fibres.

Numerous attempts have been made from time to time to introduce quicker, and if possible more satisfactory methods of bleaching flax; and a new method, which claims to be a simple and inexpensive chemical process of preparing tlax straw for spinning, is the invention of Dr. R. R. Roberts, of Washington. It is stated that in this new process five hours are quite sufficient for the purpose, and that since the material is under complete control during the operation, there is no danger of the fibre suffering from ineffective treatment. The fibre bleacherl by this process has, we understand, been spun into yarn and woven into cloth for use as table cloths, napkins, towels, and similar articles, and compares well with Russian flax.

(T. WOOdHouse.)

\section{JUTE AND JUTE MANUFACTURE}

The state of the jute trade luring rgro and ror I was not very satisfactory. During I 9 I 2 however a great improvement took place, and towards the end of the year mills and factories were everywhere as busy as possible. The following table indicates the respective I) undee prices per ton of jute, per spyndle ${ }^{2}$ of weft, and per yard of cloth which were ruling in the middle of October in the years $1907^{-12}$.

1 See E. B. xv, 603 .

"A "spyndle" is a length of yarn equal to 14.400 yards; not to be confused with "spindle," the rod used in spinning. 


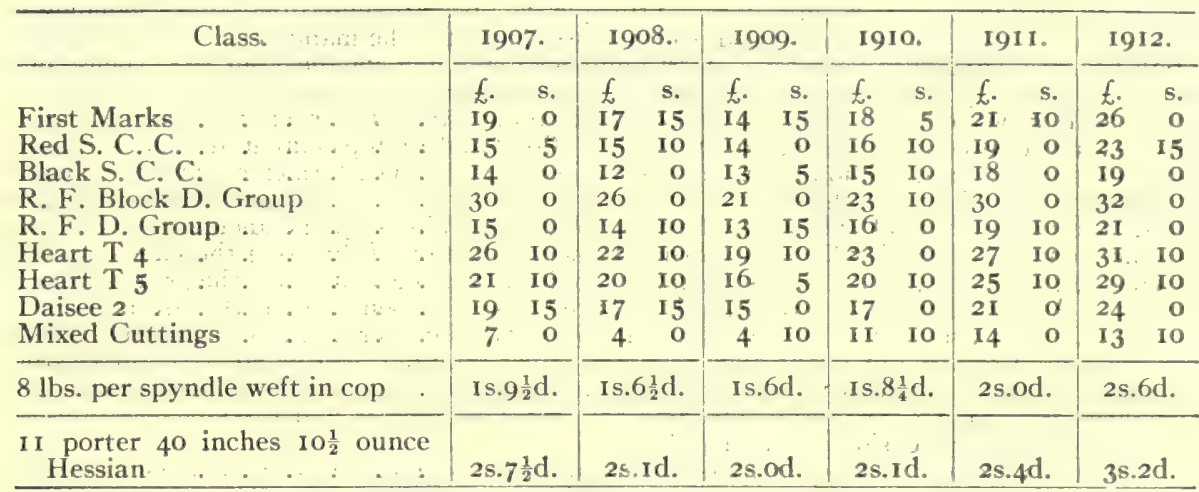

The fluctuation in the price of the raw material is often influenced by the size of the crop, but in spite of a forecast of practically a I0,000,000 bales crop, the prices for $19 \mathrm{I} 2$ were very high. New uses are continually being found for the jute fibre, so that the whole of the large crop is not available for what were originally the few typical types of simple yarns and fabrics. The crop in 1906 was a record one, but the figures compiled by Messrs. W. F. Souter \& Co. show that this has been exceeded since:

\begin{tabular}{|c|c|c|c|c|c|c|c|}
\hline & I906. & 1907. & I908. & I909. & I9I0. & I9II. & 1912. \\
\hline \multirow{2}{*}{$\begin{array}{l}\text { Acres } \\
\text { Est. crop in } \\
\text { bales }\end{array}$} & $3,336,400$ & $3,974,300$ & $2,856,700$ & $2,876,600$ & $2,842,600$ & $3,106,400$ & $3,353,800$ \\
\hline & $8,736,220$ & $9,867,000$ & $6,360,800$ & $7,295,580$ & $8,032,000$ & $8,339,000$ & $9,62 \mathrm{I}, 800$ \\
\hline
\end{tabular}

A good idea of the expansion of the jute trade in various countries can be gathered from the estimated consumptions in I906 and 1912:

\begin{tabular}{|c|c|c|c|c|c|}
\hline \multirow{2}{*}{ Country. } & \multicolumn{2}{|c|}{ Bales per annum. } & \multirow{2}{*}{ Country. } & \multicolumn{2}{|c|}{ Bales per annum. } \\
\hline & $1906-07$ & I912-I3. & & $1906-07$ & $1912-13$ \\
\hline $\begin{array}{l}\text { Scotland } \\
\text { England } \\
\text { Ireland } \\
\text { France } \\
\text { Belgium } \\
\text { Germany } \\
\text { Austria and Bohemia }\end{array}$ & $\begin{array}{r}1,250,000 \\
20,000 \\
25,000 \\
475,000 \\
120,000 \\
750,000 \\
262,000\end{array}$ & $\begin{array}{r}1,300,000 \\
20,000 \\
25,000 \\
620,000 \\
150,000 \\
800,000 \\
320,000 \\
\end{array}$ & $\begin{array}{l}\text { Norway and Sweden } \\
\text { Russia } \\
\text { Holland } \\
\text { Spain } \\
\text { Italy } \\
\text { America } \\
\text { India }\end{array}$ & $\begin{array}{r}62,500 \\
180,000 \\
25,000 \\
90,000 \\
160,000 \\
600,000 \\
4,400,000\end{array}$ & $\begin{array}{r}60,000 \\
230,000 \\
30,000 \\
150,000 \\
250,000 \\
600,000 \\
4,900,000\end{array}$ \\
\hline
\end{tabular}

The figures shows clearly that over half the total jute is used in India. Although the expansion in India was checked somewhat a few years ago, the new factory act has probably been the cause of many extensions which have been, and are still being made in that country. In 1906 , there were 26,799 looms and 520,980 spindles for jute, whereas at present there are over 32,700 looms and 650,000 spindles.

Within the last few years there has been a development in the spinning of finer jute yarns in the Dundee district, and it is hoped that this development will lead to a correponding movement in the manufacture of cloths from these yarns. They are used already for cloths intended for ladies' hats, and might well be adopted for other articles of clothing.

A new textile thread, or at least a combination of paper and fibre, termed " textilose," has recently been introduced for uses similar to those in vogue for jute yarns. So far as cloth is concerned, it appears to be used only for coarse sacking.

In the methods of spinning and weaving jute, improvements are constantly being introduced with the object of consuming less power, of improving the quality of the work and of facilitating the operations generally so as to increase production. 
A circular loom, on an entirely new principle, has been invented by $\mathrm{Mr}$. C. Whalley of Clitheroe, but has not yet been tried, so far as we know, for the manufacture of jute fabrics. Ball bearings have been used for a small number of spinning spindles, but the expense of a really satisfactory arrangement of this kind appears to stand in the way of a general adoption. A great improvement, and one which results in the saving of from 30 per cent to 40 per cent horse power, has resulted from the introduction of the Boyd and Phillips patent automatic tension cylinder, or the fixed tension cylinder to spinning frames. The former maintains an equal tension on the driving bands under all varying atmospheric conditions, and at the same time leads the driving side of the band off the spindle whorl almost perpendicularly to the axis of the spindle; the fixed cylinder performs the same function of directing the bands at right angles to the spindle, and it is this desirable condition which accounts for the great saving in power. A spindle drive is now being introduced which dispenses with the use of a guide cylinder. It consists of a solid drawn tube of small diameter suitably supported in ball bearings, and rotating at about 1000 revolutions per minute. The bands pass direct from the tube to the spindle whorls. Since the driving tube is mounted on radial arms and balanceci by hanging weights, it also acts as a tension cylinder and thereby maintains an equal and uniform tension on the bands.

For a considerable number of years endeavours have been made to simplify the method of imparting the necessary drag to the spinning bobbin as it is being filled. The latest invention, and one which appears to justify all that is claimed for it is that by Mr. J. M. Mallock, termed the "Turbo-Drag." It consists of an annular disc of thin steel, in the inside of which are flexible vanes. Its underside is provided with a renewable leather washer which rests on the bobbin board, while a loose leaden ring on the top supplies just the amount of weight which is essential for the empty bobbin. The drag is driven by the bobbin, to which it acts as a carrier, and as the bobbin is filled a uniform tension is maintained on the yarn by the combined action of plane friction (due to weight of drag, bobbin, and yarn), the air resistance induced by the vanes, and the increase of plane friction caused by the weight of the column of air in motion. There is no side pressure on the bobbin such as is always caused by the temper band and weight, hence the bobbin and spindle run more smoothly. With this drag the spinner is free to give her whole attention to the yarn since the tension or drag is applied automatically - this is a distinct advantage and one which is sure to appeal to employers of labour. The turbo-drag is capable of being utilised on all frames which are used for the roving, spinning or twisting of long vegetable fibres.

Another recent invention is an electrical rove stop motion by $\mathrm{Mr}$. P. Sharp. The apparatus is ingenious, and successful, as the rove is arrested immediately the yarn breaks. It has been in operation for some time in America, and is being experimented with in one or two Dundee jute mills.

(T. WOODHOUSE.)

\section{ROPE AND ROPE MANUFACTURE 1}

Recent changes in rope manufacture are of only minor importance. As in all other trades involving mechanical processes there have been various slight improvements in the machines employed. The price of the raw materials used has shown the same tendency as other fibres to rise, and, in consequence, attempts have been made to use larger quantities of the cheaper fibres. All sizes of ropes and twines from one inch downwards are now made of jute, and these are quite satisfactory where great strength is not essential, but the best ropes are made from the superior fibres.

The introduction of jute ropes and twines has caused a great development in the twisting of these yarns. In addition to being used alone, the twisted yarns are extensively used in connection with cables for all kinds of electrical purposes.

A new form of driving rope, made from 8 strands of sisal or similar fibre, is now being manufactured by plaiting - a process somewhat similar to that employed in the manufacture of box cords and the like. In some cases each of the 8 strands is composed of a large number of individual threads, whereas another style consists of 8 strands, each of which is in the form of a smaller rope. Although driving by means of ropes has been, and is still a very successful method, its position is being seriously threatened by the electrical method. Both the group drive and the individual drive by electrical motors appear to be making sat isfactory progress.

(T. WOODHOUSE.)

\section{WOOL AND WOOL MANUFACTURE 2}

Sheep and Wool.- In the British Home Wool Industry a freer interchange of opinion among sheep breeders has resulted since r909-10 in a more perfect adaptation of the animal to its environment, or rather the development of the various sheep districts to their utmost capacity through the introduction of the breeds yielding the most profit. Thus the rounded short grassed downs of the southern counties are now frequently

1 See E. B. xxiii, 713 et seq.

${ }^{2}$ See E. B. xxviii, 805 et seq. 
stocked with the Cheviot breed of sheep reared in a similar environment on the hills bordering England and Scotland; while the heavier sheep of the Down class have made more headway for crossing purposes in the richer pasturage lands of the northern counties. With wool fetching a better price more attention has been given by the farmer to its growing and "get-up," to the benefit of both himself and the manufacturer.

Reference must here be made to the attempts of the Wool Section of the Bradford Chamber of Commerce to impress upon both home and colonial wool growers the necessity for greater care in the packing of wool in order that the "vegetable fibre difficulty " may be eliminated. After experimenting with various wool packs the Chamber have made definite recommendations, and it seems probable that in the near future wool packed as recommended will fetch top price at the wool sales. The Chamber has also faced the difficulty of grey hairs in otherwise white fleeces, and has made certain recommendations to sheep breeders which may help to clear flocks of this defect.-

In Australia also some most interesting questions have been decided. Years ago the question of shipping wool in the "greasy" as opposed to the "scoured "state was hotly debated in the press, and a perusal of the correspondence on the matter left one absolutely in the dark as to which was the better method. Actually there was never a doubt, with few exceptions shipping in the grease being distinctly preferable. The question of the value of the Vermont breed in Australia has been fought out on very similar lines, and although from the correspondence of a few years ago in the Australian press it was impossible to decide for or against the Vermont, the past few years have shown that the Vermont is practically doomed so far as Australia is concerned. In the drought of 1902 the inability of the breed to withstand heat and dryness was only too painfully in evidence; but it has needed the experience of the past three or four years in washing, combing, spinning and manufacturing Vermont wools to bring the matter to a climax. Bradford, after trying to institute a coating trade based upon low and strong qualities of merino wools, has had a sudden awakening, and now demands nothing lower for these fabrics than a 64's or preferably a 70's quality. This has been the deciding factor, and so it comes about that the tendency of to-day is to grow a finer rather than a coarser merino, and for this purpose the Vermont strain is practically useless.

The following particulars taken from the Textile Mercury still show a result in favour of growing the "strong " merino, but a slight rise of price in the "fine " and a downward tendency in the "strong " would leave the advantage with the "fine."

Fine $\left(7 \frac{1}{2} l b.\right)-\frac{3}{4} l b$. locks at $4 d$. per $l b$.

$\mathbf{I} \frac{1}{2} \mathrm{lb}$. bellies and 2 nd pieces at $8 \mathrm{~d}$. per $\mathrm{lb}$.

$\frac{3}{3} \mathrm{lb}$. Ist pieces at rod. per $\mathrm{lb} . \quad \ldots \quad \ldots \quad \ldots \quad \ldots \quad \ldots \quad \ldots \quad 7^{\frac{1}{2}}$

$4 \frac{1}{2}$ lb. fleece at Is. $2 \frac{1}{2} \mathrm{~d}$. per lb. .......... . . . $55^{\frac{1}{2}}$

Total weight, $7 \frac{1}{2} \mathrm{lb}$. Value .

Medium (Io lb.) - I lb. locks at $3 d$. per lb.

$2 \mathrm{lb}$. bellies and 2 nd pieces at $7 \mathrm{~d}$.

I lb. Ist pieces at $9 d$.

$6 \mathrm{lb}$. fleece at Is. Id.

Total weight, ro lb. Value .

Strong (II lb.) $\rightarrow$ I lb. locks at 3 d.

$2 \mathrm{ib}$. bellies and 2 nd pieces at $6 \frac{1}{2} \mathrm{~d}$.

I $\frac{1}{2} \mathrm{lb}$. Ist pieces at $8 \frac{1}{2} \mathrm{~d}$.

$6 \frac{1}{2} \mathrm{lb}$. fleece at is. $0 \frac{1}{2} \mathrm{~d}$.

Total weight, i I lb. Value

d.

(n)

\begin{tabular}{ccc}
\hline & 7 & 4 \\
\hline 0 & 3 \\
1 & 2 \\
0 & 9 \\
6 & 6 \\
\hline & 8 & 8 \\
\hline & 0 & 3 \\
1 & 1 \\
1 & $0 \frac{3}{4}$ \\
\hline 6 & $9 \frac{3}{4}$ \\
\hline & $9 \quad 2 \frac{1}{2}$
\end{tabular}

Another most noticeable feature in the Australian flocks is the wonderful increase in numbers. The maintenance of the prices paid for the leading Australian brands in view of the large increase in wool shipments can only be explained by the vastly increased demand by a more numerous and wealthier world population for better clothing. 
Wherever sheep are reared as wool-producing rather than mutton-producing animals, at least some endeavour is made to improve the fleece in one or more of its characteristics. Of late some attention has been paid to the breeding of uni-fleeced sheep, i.e. sheep producing wool of one or two qualities only, as distinct from the five or six qualities frequently to be found even on well-bred sheep. This tendency is usually in evidence wherever attempts are being made to improve the merino or other breeds.

Attempts have been made to improve the breed of sheep in South Africa and in the West Indies. The connection of both these localities with Australia in the early days of Australian colonization adds interest to the recent importations of Australian merinos from accredited Australian stocks, and in the near future these localities may forward to Europe considerable quantities of the finer qualities of merino so much in demand.

Professor T. B. Wood, on the Cambridge University Farm, has applied Mendelism to sheep breeding; an endeavour being made to reshuffle the Shropshire and Merino characteristics and select the combination Merino wool and Shropshire carcase. By October I9I 2 Professor Wood had the third generation of the cross, showing marked segregation in wool characteristics. The effect of environment on the wool of Merino sheep kept for some years in England is also being investigated.

This attempt has stimulated other wool growers to work upon Mendelian lines and it is more than probable that in the near future much better control of flocks will result.

Wool Washing Processes.-In the preparation of wool for the subsequent manufacturing processes perhaps the most noticeable event since 1909-Io has been the débâcle attendant upon the attempt of a Bradford firm to introduce the solvent method of wool scouring on a large scale. Although the case was never proved against the firm in question the Bradford Beck explosion so clearly showed the dangers attendant upon the use of any of the volatile agents that on their own initiative the firm referred to gave up the attempt and dismantled their machines. This failure is to be regretted from more than one point of view. The solvent method is so useful for dealing with "tar-lots" and various stains on wools that its suppression almost amounts to the elimination of such special lots from the market.

From time to time new methods of scouring, or revivals of old methods, keep appearing. Solvent earths appear, disappear and re-appear again. Upon the whole it appears impossible to improve upon the emulsion method, especially if suitable emulsifying agents and well thought-out machines are employed. The most recent emulsifying agent introduced is "Sapon," for which the following advantages are claimed. (I.) The scoured wool dyes better. (2.) While dirt, etc. is cleared away the "wool-wax" is left in and gives the wool a most desirable "handle" and "lustre." (3.) There is no liberating of free caustic alkali and consequently no production of sticky, insoluble soap on the wool fibre. (4.) Economy in the scouring agent. (5.) Washing at $96^{\circ}$ to $100^{\circ} \mathrm{F}$. and consequently no clotting of blood cariying anthrax and a consequent minimising of liability of the workers to contract anthrax. U p to the present "Sapon" has proved its worth from the economical and efficiency point of view for the longer wools, but it has yet to prove its value for the shorter merino wools.

Attempts are being made to treat "wool-combers suds, washwaters" etc. Several methods have been or are being tried, and although it can not be said that any one has proved a marked success it seems probable that in the near future much will be done towards tne purification of certain of the Yorkshire rivers from these deleterious substances and that this may be effected along with a substantial financial gain.

Wool Preparing Processes.-The efficiency of carding engines has recently been improved by designing the framework to come close up to the revolving rollers, with driving wheels and pulleys on the outside. This amentrrange is more efficient owing to the absence of varying air currents towards the ends of the carding rollers. The hot-air backwasher has firmly established itself in the worsted industry, humouring the wool more and producing a better yield and a better "top" than that produced on the old ironing type of machine. Attempts continue to be made to improve the Noble comb, but little headway is to be recorded. The attempt to place three or four small circles within the large circle has not met with marked surcess, while mechanical dabbers to supplant the ordinary dabbing brush have been tried again and again and apparently found wanting, although there is one type making some headway. French combing has established itself for special types of work, but for bulk lots the Noble comb is still holding its own.

Spinning Processes. - French drawing and mule spinning are claiming increased attention in Yorkshire, and as a result drawers and spinners upon the ordinary English machines are being forced to study and if possible extend the capacities of their machines to meet the demand for soft spun yarn. A Yorkshire machine-making firm has put a useful gill box (the O.P.S.) upon the market for dealing with short fibred material to advantage, and various combinations of $\mathrm{French}$ and cone drawing-boxes are being tried in connection with ring and cap spinning and twisting. 
The most interesting development to be noted in the woollen trade is the attempt which is being made to introduce a continuous frame spinner in place of the woollen mule. Some remarkable yarns are being produced on this machine, and it seems probable that for at least a section of the trade the mule will be superseded by this simpler and quicker spinner.

Perhaps the most important development to note with reference to both cap and flyer spinning is the marked development of the self-doffing mechanism. Three years ago the self-doffing machine was considered a questionable advantage; to-day, owing in England to the shortage of half-time labourers, and also to certain incidental advantages, it is being adopted as the only possible solution to the difficulties by which the spinner is surrounded. The Arnold-Forster self-doffing flyer frame led the way and is now closely followed by Lister's, Prince Smith's and others for the flyer frame, and by Prince Smith and Hall and Stall self-doffers for the cap frame. When the self-doffer was first suggested its mechanical advantages were considered nil, and it has needed some years of experience to find out that there undoubtedly are such advantages. The latest cap frame doffer for example is so designed that there is no nicking of bobbins and no wearing away of cap spindles, and there are other advantages which are slowly being realised. Strange to say, "cap-doffing," which for some time after the introduction of "flyer-doffing" was considered impossible, is now the simpler of the two, and further has not necessitnted that change in the construction of the frame which is noticeable in the flyer-frame. The ring and mule self-doffers have yet to appear, but the demand for them seems inevitable.

Various attempts have been made to increase the production of wool spinning machines by the adoption of a variable drive. At present each machine is driven at the speed which will just yield a satisfactory result when the machine is spinning at its worst, say when the yarn is being wound upon the thin part of the bobbin or tube. Under the new arrangement the speed is not changed for this portion of this spin but the machine is automatically speeded up for the easier part. Possibly the extra expense of the variable speed motors has militated against any wide adoption of this method of increasing production.

The winding of yarn on to bobbins, tubes or spools seems unimportant, but the International Winder has proved its value; for by its means layer after layer of yarn can be so closely laid that about double the length can be got on to the spool or bobbin as compared with ordinary winding. Thus when such spools or bobbin come to be woven there are but half the stoppages for reshuttling, with a consequent greater production.

Reference should here be made to the difficulties of ten to be faced due to the electrification of wool while passing through the various machines. Two main systems to meet this difficulty have been tried. The most successful method seems to be to introduce humidity into the atmosphere and thus carry off the electricity. The other method is to employ a neutraliser throwing a continuous stream of the opposite sort of electricity into the electrified wool. The use of radium has also been suggested, but is too expensive.

Warping, Weaving, etc. Processes.-In the weaving section some few improvements are to be noted. The Scotch Warping Mill and the Warpers' Beam Systems are undoubtedly taking the place of the old upright mill, and more perfectly tensioned warps result. The tedious operations of drawing and twisting or tying-in have naturally claimed the attention of the inventor, and all these operations are being systematically and seriously attacked. The ease with which the Barber warp-tying-in and the automatic warp drawing-in machines work is a revelation in mechanical possibilities.

The most interesting loom development to note is an automatic shuttling mechanism introduced by Messrs. Robert Hall \& Sons, Bury. The warpstop motion, shuttling mechanism, etc. is so connected up to the lighting up of the loom that the moment anything goes wrong and it stops, in come the lights; the moment the loom is put to rights and set running, down go the lights and the loom does its work in an economical darkness.

In both automatic and ordinary looms a marked extension of the warp-stop mechanism is to be noted. Such a mechanism ensures greater perfection in the resultant pieces.

A shuttle-box control mechanism has been put on the market by two firms. Traps or double-shuttling are here obviated by the empty box controlling the picking.

The question of mechanical as against electrical driving of looms has been strongly fought. More electrical driving is certainly being introduced, but, upon the whole, under special circumstances only. It seems probable that if current can be supplied at $\frac{1}{4} \mathrm{~d} .(.25 \mathrm{~d}$.) per unit then electrical driving is as cheap as mechanical driving. Both the group and individual drive systems are advocated, but the group system seems to be gaining.

Dyeing and Finishing Processes. - In the dyeing industry marked advance seems to have been made in the dyeing of "tops" or wool in the combed state. Regularity of the dye has been considered an impossibility until quite recently, but the latest machines have certainly suggested the possibility of success. The Permutet water-softening apparatus is worthy of note, a good water supply being a desideratum both for scouring and dyeing.

In the designing section of the industry the two most noticeable features are the development of the worsted tweed trade-no doubt largely due to the introduction of the hobbleskirt-and artificial silk. In I9I2 tons of artificial silk were being employed in the Yorkshire manufacturing district alone, and the manufacturing firms were months behindhand with deliveries.

(A. F. BARKER.) 


\section{NEW FIBRES 1}

Through the "fibres" of the organic world mankind exhibits in a striking way his direct dependence upon natural products, both for the useful and the decorative and aesthetic elements of his life. It is in such regions of activity that we become aware that the arts have antedated "Science" by centuries, and moreover that our modern Science is contributing no few factors of primary importance. It might be presumed that the application of scientific investigation to the wealth of material presented by the organic world would certainly lead to the selection and industrial application of fibres outside the range of staple materials of natural empirical selection. The presumption however is not justified by the facts, and there are few elements of material and fundamental novelty in the present development of the textile and allied industries.

The only noteworthy exception is in the artificial fibres, which are chemical transformation products of the natural celluloses. These are manufactured in a large variety of dimensions, from a "monofil " of $0.5 \mathrm{~mm}$. diameter, to a unit thread of $0.5 \mathrm{mgr}$. per metre. The "artificial silks" are assemblages of the finer units, suitably twisted. The world's production of these yarns has steadily grown, and is advancing to 10,000 tons per annum. Hitherto, the artificial silks have not seriously competed with, or displaced, the true silks: they have rather made for themselves new applications. With increasing perfection of the product, however, the situation may be different. The industrial applications of cellulose derivatives have followed the lines of development indicated in E. B. v, 609. The viscose process is supplanting the nitrocellulose, and to a certain extent the cupr-ammonium process, for the production of artificial fibres. The acetates of cellulose are in certain directions supplanting the nitrate for films, and massive solids. The pure cellulose sheet or film in continuous length has developed into an important industry, and the product is on the market as "Cellophane."

The production of Phormium fibre (New Zealand "flax") is again engaging the attention of the colonial authorities, and the New Zealand Government offers prize money to the amount of $£ \mathrm{r} 2,000$ to inventors who shall improve the yield or quality of the fibre, or cheapen the production by utilisation of wastes or by-products.

In papermakers' raw materials there are supplies of new fibrous products on the market. The most important is the cotton hull fibre. Cotton hulls are the envelopes of the cotton seed, and they retain a residual proportion of cotton fibre, which escapes the ginning process of separation of the textile cotton from the seed. The treatment of the waste hulls, after removal of the endosperms for the purposes of oil and feeding cake manufacture, has been the subject of various inventions for the separation and concentration of the fibre (see Beadle \& Stevens, J. Soc. Chem. Ind. 28, ror 5). The machines invented by De Segundo (English Patent 3268 and II,I37 of I 908 ) effect a very complete separation of the fibre from shell residues, giving a raw material of 85 per cent cellulose concentration, and on a low rate of working costs. By this process a supply of 5000 tons of fibre per annum is already rendered available for European consumption, and bought at " rag " cellulose prices.

Bamboo has long been recognised as a potential source of papermakers' half-stuffs and cellulose. An important report has recently been published by Mr. W. Raitt, describing investigations carried out for the Forest Research Institute at Dehra Dun. This report puts the cost of production of unbleached bamboo pulp as $£ 6.5 \mathrm{~s}$. od. per ton (in India). It is also to be noted that a bamboo hall stuff is offering in the London market, and the present available supply is stated to be rooo tons per annum. This is produced in Tongking, where work has been started on a unit plant of 10 tons per day capacity. The undertaking is an Anglo-American capitalisation, and is projected for a possible extension to too tons a day.

Papyrus (Cyperus).-The massive reed growth on the Nile river is attracting attention as a possible source of paper-making cellulose. Practical investigations under the auspices of Sudan Industries Ltd., and Sudd Fuel (Suddite) Ltd., have established the

${ }^{1}$ See E. B. x, 309 el seq. 
industrial value of the compressed material in briquette form as a fuel: large shipments of the raw material to England have been worked up into paper, and the results establish an all round utility as a papermaking material. It remains to establish the important question of steady supply in convenient form for economical freights, and minimum rates of sale in European markets.

(C. F. C ROSS.)

\section{SECTION VIII}

\section{SPORT AND GAMES}

Internationalism.-In explaining the aspirations of his country towards sea-power, the new German Ambassador to England, Prince Lichnovsky, remarked at the end of I 912 that Germany had already adopted British manners, dress and sports. The assimilation of these and other features of social life throughout the portion of the world that affects the European form of civilisation is, of course, mainly the consequence of extended international intercourse and the growth of towns and commerce. It is a commonplace observation that nowadays the inhabitants of great cities in Europe and the countries colonised by Europeans are superficially very much alike; and it could easily be shown that their uniformity is no longer confined to appearances. But in the matter of sports and games, which reflect, besides modifying, character, other influences than the mere imitation of fashion have to be recognised.

In Great Britain it may be asserted that the passion for outdoor recreation is essentially hedonistic. While publicists, preachers and philosophers have for many years kept up a fierce controversy, the natural practice has been little, if at all, influenced by the questions whether games in moderation or excess waste the time and pervert the energies of school-boys or squires; whether physical culture is better advanced on the cricket ground or in the gymnasium; whether University oarsmen for the most part die prematurely of cardiac hypertrophy; whether the prevalence of football absorbs enthusiasm which ought to be given to national defence. There are, of course, thoughtful, unprejudiced and experienced educationalists who advocate athletic games as a necessary part of juvenile training, and are able to command practical assent to their views; while there are many thousands of sportsmen and players of games who are convinced by their experience of the immense utility of their favourite diversions. But on the whole it must be confessed that the general adoption during the last half-century of rural amusements by the British urban population has been caused, not by a conscious desire for culture, but simply by a desire for enjoyment; while the main retarding force has been a fast-decaying puritanism. The thing is first done and afterwards defended. At this point both the practice and the defence are seriously reinforced by the imitation of foreign nations. And it would seem that in their case the movement is to a considerable extent deliberately undertaken from a conviction that their own educational methods can be advantageously supplemented by a selection from the recreative customs of their neighbours. While increasing recognition is paid to the value of physical culture and curative exercise, it is now also understood that in sports of most kinds the senses are sharpened, and a mental as well as bodily kind of alertness and dexterity fostered. Further, the element of competition, -together with that conflict with the luck of a contest; which to the Anglo-Saxon race has so much to do with the pleasure of games,-is admitted to be in a high degree formative of character. In short, games and sports are in times of peace more or less useful substitutes for the normal military struggle for existence by which the nations have reached their present development.

Whether as an effect, as a cause, or as a concomitant of this new attitude on the part of the nations, the modern Olympic Games must be taken into account. They have certainly accelerated the growth of internationalism in sport. The celebration of the games in London in 1908 was practically the first revelation to some European peoples of a national opportunity. They found that they possessed champions worthy to stand up in an international arena; and thus was originated a new competitive 
patriotism, a kind of national consciousness, similar to that which is generated by warfare, though of much less intensity. At Stockholm, in 1912, international rivalry was even more vivid. The conviction that the credit of a state could be served by success in the Games had become so firmly established that Government subventions were granted to some of the competing teams, while others were assisted by public subscription or donations from wealthy patriots.

That international sport will occupy a still more important place in the future, provided that the general peace of the world is maintained, may be confidently asscrted. At present the obstacles to free and universal sporting intercourse are considerable, but they are not entirely insuperable. One of the greatest difficulties to be overcome is the establishment of an international code-perhaps necessitating international legislative conferences. It is only necessary to instance the defects of the fencing, rifle-shooting and wrestling contests at Stockholm in order to show what has to be accomplished in this direction. There also remain the vestiges of political barriers to be obliterated before French and German, Russian and Finnish, Austrian and Bohemian teams, for example, can freely engage in matches at such games as hockey and football.

At Olympic meetings hitherto the strictly athletic part of the programme has been the simplest to arrange and the most favoured, as well as the most conspicuously successful. Of what are called games in the limited sense of the word the most cosmopolitan, because most independent of different geographical conditions, are lawntennis, golf and football of the Association type. Both golf and lawn-tennis are finely adapted for the recreation of townsmen of sedentary occupations and restricted leisure. Association football, besides being simple, inexpensive and easily learned (though giving scope for great skill and speed), is assisted in its extension by attractiveness as a popular spectacle; since it affords the excitement of a combat to the spectators while demanding the smallest amount of practical comprehension of its technique. It would be tedious to catalogue the places where the game is played-let it suffice to mention that it has recently taken root in the United States, it pervades South America, and has been played by native Asiatic teams in Jerusalem, besides affording a moment of patriotic and ungrudged triumph to a Calcutta crowd when a native eleven defeated a British regiment. Similarly, it may be recalled that lawnt-ennis flourishes in St. Petersburg and in the Spanish Peninsula; that a journey across Africa has actually been described in the guise of a golfing tour; that a course has been laid out at Kabul for the Amir of Afghanistan. Both golf and lawn-tennis, in spite of the peculiar demands of foursomes and doubles, are essentially games for the individual. International competition in these games is accordingly carried on largely through the private enterprise of players who compete in the open tournaments and championships of foreign countries. But lawn-tennis matches, besides the Davis Cup contest, have recently taken place between teams representing London, Berlin and Paris; and the Dulwich Covered Court Club has received a visit from a Bremen team. In football, as in cricket, what are termed international matches are almost exclusively played by teams belonging to different sections of Great Britain, with occasional interchanges of visits between British and Colonial teams. But the Football Association has for some years chosen amateur elevens for matches with several Continental countries and English clubs have undertaken tours in the United States, Canada, South Africa, France, Belgium, Holland, Germany, Austria and Bohemia. The one Continental European country which enters largely into competitions in many kinds of sport with Britain is France, but Belgian rowing has been exemplified with great effect at Henley. Particulars of international contests in many sports and games will be found under the separate headings below.

The new movement towards competitive athletic games has been more highly exemplified in France than elsewhere. Though French athletes were not as numerous or as prominent at the Stockholm Olympic Games as might have been expected, the progress made in running on the track and across country has been sufficiently shown 
in matches between English and French clubs, and in the performances of French teams in the international cross country championships. French lawn-tennis players are capable of holding their own with All England champions on grass courts, and on hard courts have the advantage. But it is especially in Rugby football that the new French athletic spirit is most impressively declared. A priori no game seemed less likely to become acclimatised on the French side of the English Channel. A few years back, when the Parisian clubs, Stade Français and Racing Club de France, took up this form of football, the deficiency of school training, the want of personal dexterity, and the apparent ineptitude of the players for concerted play were the most obvious features of their matches. A sufficiency of courage and something more than a sufficiency of combativeness did not seem to hold out great promise for the future. Nowadays, Rugby football is popular throughout the country, and the Southern towns, Bordeaux, Nantes, Bayonne, Toulouse, Tarbes and Lyons, possess very strong clubs, backed by a local enthusiasm which is indicated by the large crowds of spectators at their matches. English club fifteens even of the highest reputation no longer play French teams in France with confident assurance of victory; international matches with the picked teams of France are considered to require the full force at the Rugby Union's disposal; a strong Scotland team has actually been defeated. In football is exemplified the modern French earnestness, the striving towards efficiency, the consciousness of the necessity for sustained national effort and sacrifice, that the present military phase of development has produced. But further, the practice of the game has already developed a genuine sporting love of it. Something like the old spirit of the knightly tournament is now discernible in the play of French fifteens; the delight in a fierce and headlong onset and the concentrated endeavour towards victory are now tempered by an appreciation of the technique of the game. Accordingly the self-possession and mutual reliance on which the concert of a team depends have been evolved, and a game is more likely to be won when the whole sum of enjoyment is not staked on victory. Probably the favour in which boxing is now regarded in France may be attributed to the national change of temperament. The acceptance of professional pugilism came about in spite of a fatal accident in the ring which might have been expected to prejudice the sport in the eyes of the public. The ordinary Continental European attitude towards boxing is such that no amateur contests were held at Stockholm in I9I 2 because of a doubt as to their legality. Pugilism is now so attracttive that a sum of more than 100,000 francs has been produced in Paris at one of Carpentier's matches. Boxing in the army and in amateur circles is also prospering under the impetus of a popular taste which is perhaps now at its climax.

Athletics - or competitive running, jumping and throwing-may be classified as lying between ordinary ball games and gymnastics. The readiness with which the athletic part of the Olympic programme was taken up by the Scandinavian nations was due to their excellent gymnastic discipline, based on the methods of P. H. Ling. ${ }^{1}$ This system, though it has made its way into all countries, is still cultivated more extensively and in higher perfection in Sweden than elsewhere; but an excellent gymnastic drill of the same type is used in Italy. It is significant of the expression of national feeling by the way of physical culture that the Bohemian Sokol societies, whose object is to preserve Slav-nationalism, make a peculiar mass-drill the chief featurc of their meetings. Nothing was more striking in the results of the Olympic competitions than the progress made in athletics by the Swedes and Finns, the latter excelling especially in wrestling and feats of strength. The Swedish National Union, subsidised by the state, is a great federation of clubs, having for its aim the enlisting of all adult citizens in an athletic discipline. Swedish citizens are encouraged to qualify for bronze, silver and gold badges by passing tests in five groups of exercises, which include jumping, running, swimming, fencing, weight, discus and javelin throwing, bicycling, skating and ski-running. There is no other country in which so near an approach is made to the old Spartan regimen. Hockey, football and lawn tennis are

${ }^{1}$ See.E. B, xvi, 728. 
also flourishing in Sweden, and not only are Swedish yachtsmen now famous, but considerable progress has been made in designing yachts of the smaller classes.

It would not be impossible to construct a scale of the nations arranged according to the degree in which active popular interest was taken in the despatch of competitors to the Olympic Games. This list would in no way represent the total amount of each country's devotion to athletic games, and, if Sweden were placed at the head of the table, Britain would occupy a low place. In Belgium, for instance, a taste for sport is very prevalent, but, as in England, it is not corporately manifested. It will probably, however, find its opportunity at the Ghent Exhibition. In America the doctrine of physical culture inspires a large amount of organised endeavour; the Athletic Union co-operates with the clubs in encouraging the systematic study of athletics; and it is supported by public interest, and, on occasion, by private munificence.

Olympic Results IoI2.- The Olympic Games were carried out in Stockholm in July I91 2 during exceptionally hot weather. Although the resources at the disposal of the Swedish committee did not admit of so large a programme as had been undertaken in London in I908, the whole festival was exceedingly successful. In regard to the presentation of internationalism, the Swedish capital had the advantage of not being so large as to engulf its visitors; and the spectacle of diverse nationalities was therefore most impressive. The stadium and its ornamentation were of striking and beautiful design and were situated in picturesque environment. There were several points in which the arrangements showed an advance on those of 1908, and though there were a few failures in the management of the competitions-partly through unavoidable defects in the programme, the conditions and the judging-very little cause was given for dissatisfaction. One of the most noteworthy innovations was the clectrical timing of the foot-races; and in view of the extraordinary speed attained by the runners, it should be recognised that the use of mechanical apparatus for this purpose can hardly have favourably misrepresented their performances in comparison with the old way of time-keeping with a stop-watch. The foot-races, on account of the facility with which they are exhibited in a stadium, once again were invested with a larger importance than they ordinarily attain in public esteem. By far the best results in this part of the games were secured by the United States contingent, who were also prominent in what are called field events, but not without strong rivalry from Sweden and Finland.

Comparison of the aggregate number of points gained during the whole series of contests by different nations is of no great utility, for the reasons that success in a team competition counts no more than the victory of an individual in a single race, and that the Olympic programme includes contests which are not in vogue in all the competing nations, while omitting others like cricket, baseball, Rugby football and (at Stockholm) boxing, on which hundreds of thousands of sportsmen concentrate their energies. There are slight discrepancies in the published returns, but it is substantially accurate to state that, three points being counted for a winner or winning team, two for a second place, and one for a third, the United States team gained 85 points in athletics and 45 in all other events; Sweden scored 30 points in athletics and 130 in other events; Great Britain 15 points in athletics, or rather foot-races, and 61 in other events. The British Dominions scored 13 , and 29 points; Finland 29, and 23 points. That Sweden was able to make the best total was mainly attributable to ability to undertake a greater number of competitions and to place in the field a greater number of competitors than any other country on account of the locality of the Games; but largely also to organised preparation. The United States had better results in proportion to the number of entries, and actually held the lead until the yacht races at the close of the meeting. These races, from geographical and other considerations, were practically limited to a very few countries. The Americans took no part in rowing or football, and sent in but one competitor for the gymnastics; the British were not represented in open-air lawn-tennis, the javelin, the discus and the weightevents which have never interested Englishmen,-the athletic decathlon and pentath- 
lon, certain of the shooting, wrestling and gymnastic competitions, etc. It is curious that while little or no public support was extended to the British Olympic Committee, and while the state of athletic in Great Britain furnished hardly any hope for success in the races, disappointment was loudly expressed by the British press and public when the anticipated results duly came to pass. The Swedish successes were widely distributed, points being gained especially in some of the less universally practised forms of athletics, in Swedish gymnastics, horse-riding, cycling, shooting, driving, wrestling and yachting. Finland, who came fourth in the order of aggregate with 52 points, profited by the assistance of the greatest long distance runner of modern times (Kolehmainen), and did well in discus-throwing and wrestling. Germany gained 47 points; Australasia, Canada and South Africa 42 -South Africa producing the winner of the much-esteemed Marathon race as well as the second man, and the winner of the curious cycling road-race. France scored only $3 \mathrm{I}$ points; Austria-Hungary 22; Denmark 19; Norway 16; Italy 13; Belgium I I; Russia 6; Greece 4; Holland 3. Entries were sent in, but no successes were obtained, by Iceland, Switzerland, Portugal, Luxemburg, Monaco, Servia, Egypt, Turkey, Argentina, Chile and Japan.

In the following sections on the progress of particular sports and games ${ }^{1}$ in $1911-12$, they are taken for convenience in alphabetical order, with the exception of the final section on American sport.

\section{Angling.}

Within the last few years there has been one remarkable development in the field of salmon investigation. It has been discovered, or rather re-discovered (for Anthony von Leeuwenhoek late in the seventeenth century was the first to suggest it - a fact which seems to have escaped notice until it was lately pointed out by Dr. W. J. Turrell in The Field); that it is possible to tell a fish's age from the markings of its scales. This has proved to be easier with salmon than most fish, and the results obtained by investigations have been noteworthy. Messrs. H. W. Johnston and W. L. Calderwood in Scotland, Mr. J. Arthur Hutton and Dr. H. Turnbull in Fngland, and Dr. Knut Dahl in Norway are the workers to whom the new knowledge of salmon is chiefly owed. Mr. P. D. Malloch of the Tay Salmon Fisheries Company has also done good service, and much interesting information is to be found in his book (see below), though some of his conclusions do not find general acceptance with other observers. The result of salmon scale reading, briefly put, is the following view of the fish's life history. The parr usually stays two years in the river (in Norway the river-period is sometimes longer, a fact which may be accounted for by differences of climate); after running down to sea as a smolt the fish spends at least a year in salt water and it may spend two, three, or even four years there, ascending a river again for the purpose of spawning as a three-yearold, four-year-old, five-year-old or six-year-old, as the case may be. This quite upsets the old idea that a grilse might return after only a few months in the sea. Another old idea must also be relinquished, that salmon spawn every year of their lives. Al] the data so far obtained go to prove that most of them spawn only once. A proportion (which has yet to be clearly determined) may spawn a second time; at present the data seem to show that this proportion is not more than ro per cent. A very few may spawn three times in their lives, but so far fish bearing evidence of three spawning seasons on their scales have been very rare indeed. There is obviously a good deal more to be learned, but the main facts cited may be considered proved. When the investigation has gone somewhat further, doubtless fresh problems of a practical nature, such as the treatment of kelts, will arise, but the time for them and for new legislation based on the new knowledge has hardly arrived yet.

In other fields of the angler's interest perhaps the most interesting is a revival of wet-fly:fishing on chalk streams. The practice as now carried on is really a development from the dry-fly; and those who practise the method go a step further than dry-fly men by imitating the nymphs of the Ephemeridae and using them under the surface. The book by Mr. Skues mentioned below is the chief authority for the method.

' See the corresponding $E$. B. headings for general accounts up to 19 Io. 
The following is a selection of recent angling literature worth noting.

Dr. IV. J. Turrell's Ancient Angling A uthors (London, 1910) dealing with angling literature down to the end of the eighteenth century, is a carefully compiled and useful book. Dr. H. M. Hall's Idylls of Fishermen (New York, 1912), a study of "piscatory eclogue" literature (of which there is a considerable mass, dating from Theocritus onwards), is the first attempt to deal with it at all fully.

On Salmon and trout-fishing A. H. Chaytor's Letters to a Salmon Fisher's Sons (London, 1910) is an excellent book of practical instruction. H. Lamond's The Gentle Art (London, I9II) contains useful chapters on legal and economic questions. G. E. M. Skues, in Minor Tactics of the Chalk Stream (London, 1910), deals with the use of wet-fly on dry-fly streams; with this may be mentioned F. M. Halford's Modern Development of the Dry-Fly (London, 19II). L. West's The Natural Fly and its Imitation (St. Helens, 1912), is perhaps the best book on practical fishing entomology since Ronald's; it contains excellont coloured pates.

H. T. Sheringham's Coarse Fishing (London, 1912) and C. O. Minchin's Sea Fishing (London, I9II) are excellent on their respective subjects.

C. Tate Regan's British Fresh Water Fishes (London, 19I I), W. L. Calderwood's Salmon Rivers and Lochs of Scotland (London, I909), and Life of the Salmon (London, 1907), P. I. Malloch's Life History of the Salmon, etc. (London, 1910), J. Arthur Hutton's Salmon Scale's (London, I909) and Salmon Scale Examination (London, 1910), and Dr. Knut Dahl's Age and Growth of Salmon and Trout in Norway (edited by J. Arthur Hutton and H. T. Sheringham, and published in English by the Salmon and Trout Association, I911), all deal more or less with the new science of salmon scale reading. Important papers on this subject by Mr. H. W. Johnston are also to be found in the twenty-third, twenty-fourth, twenty-fifth, and twenty-eighth Annual Reports on Scottish Salmon Fisheries. Dr. Francis Ward's Marvels of Fish Life (London, I9I I) is a remarkable study of fish as observed under water both with the eye and the camera. Dr. J. de Bellesme's La Pisciculture en France (Paris, 1910), is a study of French fish culture, with particular reference to the work of the Trocadéro Aquarium.

\section{Archery.}

In spite of much unfavourable weather several fine scores were made in England in I 9 I 2 by both ladies and gentlemen. The most notable was that of Mr. H. P. Nesham at the Southern Counties Mecting in September, when in the double York Round he obtained I,067 with 223 hits. This is the highest score made since I 868 when the late Mr. H. A. Ford at Leamington scored I,087 with 219 hits, and, except by Mr. Ford, it has never been beaten at any public meeting. The championships were shot for at the Grand National Meeting at Cheltenham and won by Miss Q. Newall with 7 I6 and Mr. R. Brooks-King with 829. In I9I I Miss Q. Newall at the Grand National Meeting, where she won the ladies' championship, scored 803. Mr. W. Dod, who won the gertlemen's championship, scored 885 . Flight shooting is now rarely practised, but a fine shot of 463 yds. was made by Mr. Ingo Simon in 1912 with a Turkish bow.

The opportunity may be taken here to correct the E. B. article on "Archery" in some particulars. The bow now used by men is from $6 \mathrm{ft}$. 1 in. to $6 \mathrm{ft}$. 4 in. in length; a lady's bow ranges from $5 \mathrm{ft} .6 \mathrm{in}$. to $5 \mathrm{ft} .8 \mathrm{in}$., measured between the nocks; these lengths according in the one case with an arrow of $27 \mathrm{in}$. to $28 \mathrm{in}$. and in the other with an arrow of 25 in. to 26 in. Exceptionally long arms may render necessary an arrow an inch longer and a corresponding adclition of one or two inches to the bow. The "weight" of a bow is the number of pounds required, when appended to the string, to draw to the head an arrow of $28 \mathrm{in}$. for a man's bow or 25 in. for a lady's. The weight of men's bows varies from $36 \mathrm{lbs}$. to 58 libs., of ladies' from I ' lbs. to 30 lbs., the lighter weights being sufficient for beginners. Bows are styled "self" or "backed" according as they are made of one wood or of two or more glurd tosether. "Self bows," if of yew, are usually made of two pieces joined by a double fish splice at the handle: as it is difficult to find a piece of this wond (incomparably the best) of sufficient length while free from knots. If made of lance they are invariably of a single piece. "Backed hows" may he of yew, backed either with the same wood or with hickory; or alternatively of washaba or of ruby, lance, or other woods backed with hickory; the back being the flat side of the bow, and the "belly" the rounded side. Three woods are sometimes ('mployed, a thin strip of fust ic being interposed between a belly of $y$ ew and a back of hickory. There should be an inflexible centre of about 2 inches, whence the bow should taper gradvally towards each end. It should be straight the back true, and, when strung, the strirg shouid appear to cut the belly into two equal parts. Self yew bows are the best. They are light in the hand, the sweetest to pull, and have the hest cast; but they require carefill handling. "They are also expensive, costing from $f_{5}$ to $\ell_{15}$, and they are liable to "crysals." or tiny cracks, which sradually spread until the bow breaks. A yew backed yew, which is next in merit, ran be bought for $f .5$ and is somewhat less liable to crysals. Between the others there is little to choose, provided that they are properly made, and not "reflexed," as 
they are said to be when the ends bend outward; for these jar the hand. Their price varies from 25 s. to 3 guineas. The string for a man's bow should be from 6 in. to $6 \frac{3}{4}$ in. from the back of the bow when strung, for a lady's from $5 \frac{1}{4}$ in. to 6 in., according to the length of the bow. The nock of arrows-it is never called the "notch"-should not be "cut square" but rounded. The feathers must be wing and not body feathers, which are quite useless. They should be from the same wing, $i$. e. right or left, about $I \frac{1}{2} \mathrm{in}$. long and tapering to the front from a depth of $\frac{1}{2} \mathrm{in}$. at the nock. If balloon-shaped, their greatest depth should be at one third of their length from the nock-end.

With regard to target scoring and handicapping it should be noted that a St. George's Round has never been shot at a public meeting, or, indeed, at any meeting held within the last 60 years. Handicapping by the loss of rings has been obsolete for more than 35 years, nor is there any system which can rightly be called handicapping by points. Handicapping is now carried out either by dividing the archers into classes according to their powers, or by deducting percentages from their scores for previous successes.

As regards the history of archery, some corrections may also be made. The bow was

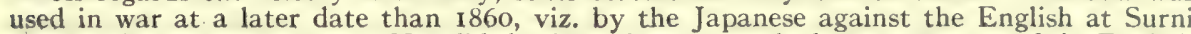
Nosake, September 5, I 864. Nor did the Armada year see the last appearance of the English archer. A company of archers was raised for the expedition to the island of Rhè in 1627. There were archers among the Russian troops in the Crimea. Again, the relation of Finsbury Archers, the Hon. Artillery Company and the Royal Toxophilite Society requires restatement. In July 1676 , William Wood, Marshal of the Finsbury Archers, was sent round with a paper, signed by Sir E. Hungerford and others, setting forth that the "officers and others of the Society of Archers, within the cities of London and Westminster" have determined "that the bearer shall have a silver badge and bear the same as Marshall to the Queen's Majesty's Regiment of Archers." The names of the subscribers were appended (Guildhall MSS. I93). Consequently this badge or shield had no connection with Oxford. The Finsbury Archers became extinct about I76I, but the Royal Toxophilite Society was not founded until i 78I, when Mr. P. Constable, the last captain of the Finsbury Archers, joined it and handed to it the shield and other valuables. There was, therefore, no combination of the two clubs in I 841. It is incorrect to assert that the Finsbury Archers were not connected with the Hon. Artillery Company. They were connected, and under their powers shot over the Finsbury Fields up to 1657 . The Archers' Division of the Hon. Artillery Company was formed by members of the Royal Toxophilite Society in 1784 .

It may also be mentioned that "the Championship" is not recognised as a term belonging par excellence to any of the public meetings; and that the list of public meetings should include the Southern Counties Meeting. The Crystal Palace meeting became extinct in 1902.

\section{Athletics. ${ }^{1}$}

It was to be expected that under the impulse of the Olympic Games prodigies of natural speed and strength would be forthcoming from several nations. On the other hand, while general improvement and an increase in the number of prominent athletes might be counted upon, the actual displacement of records, being apparently a matter of increasing difficulty, was considered improbable. In the course of the Olympic Games at Stockholm, and of the trial contests held in the United States, a number of feats were accomplished surpassing the best performances of exceptional and reputedly unapproachable athletes of former years. For example, if any record could be considered unassailable it was the high jump of $6 \mathrm{ft}$. $5^{\frac{5}{8}} \mathrm{in}$. of M. Sweeney of New York, and in another category, the long distance times of A. Shrubb and W. G. George seemed scarcely likely to be equalled. It was, however, precisely these records, together with the wonderful half-mile running of Lunghi, that were eclipsed either at Stockholm or in preliminary contests among American aspirants to Olympic medals. Systematic study and training in the United States, together with the large resources of athletic ability made available by the popularity of inter-club, inter-school, and inter-university rontests, have considerably enlarged the athletic horizon. At Stockholm the United States team, admirably organised and disciplined, carried off a considerable majority of the athletic medals. In many cases the struggle for the first two or three places was confined to the members of this team, and in several instances the failure of the expected winner did not impair the American chances of victory. On the other hand Finland, besides doing well in feats of strength, produced the most remarkable long-distance runner of modern times in $H$. Kolehmainen; and yet even he, in the most memorable race of the meeting over a course of 5,000 metres, was barely able to beat the French

1 See also under "United States" below. 
runner, J. Bouin, after running at his side for the whole of the distance. In the shorter races the Americans fully maintained their reputation for sprinting ability, and practically had the issue at their mercy, although W. R. Applegarth for Great Britain showed exceptional speed. In the subsequent English meetings of the year this runner achieved further distinction. On the whole, the British competitors, who had shown little or no promise at their preliminary trials, acquitted themselves better than had been expected. The ill fortune of G. R. L. Anderson, who might possibly have won the r 20 yards hurdle race, but fell when well placed towards the end of the final heat, was compensated by the victory of A. N.S. Jackson in the I,500 metres. A high jump of $6 \mathrm{ft} .4$ in. was accomplished by A. W. Richards, U.S.A., and a long jump of $24 \mathrm{ft} .11_{4}^{1} \mathrm{in}$. by Gutterson, U.S.A., and excellent performances were shown in the weight-putting and the throwing of the discus, javelin and hammer, as well as in the hurdle race. Although the American team gained so large a proportion of the Olympic medals, athletic ability of an exceptionally high order was forthcoming from several other countries. The German runner, H. Braun, like the Frenchman Bouin, was unfortunate in meeting men of phenomenal speed: Sweden and Finland produced many fine athletes, and Canada, besides producing the winner of the 10,000 metres walking race, Goulding, did very well in the long jump and the hammer. In the Marathon race two South Africans, McArthur and Gitsham, finished first and second, showing but wonderful endurance of the topical heat.

The previous best performances on record were excelled at Stockholm in the 800 metres (J. E. Meredith, U.S.A., I min. 5 I $9 / 1$ oth sec.) and the 5,000 metres (H. Kolehmainen, Finland, I 4 min. $363 / 5$ ths sec.) Meredith ran on and beat the half-mile record in $\mathrm{I}$ min. $52 \frac{1}{2} \mathrm{sec}$; and Kolehmainen ran 3 miles in $14 \mathrm{~min}$. I $3 \mathrm{sec}$. or $4 \mathrm{sec}$. less than $\mathrm{A}$. Shrubb's previously unbeaten time-in the course of his great exploit. Perhaps, however, the most wonderful of the Olympic victors was James Thorpe; an Indian from Oklahoma, who easily won the pentathlon and decathlon. His long jump was $23 \mathrm{ft} .2$ in., his high jump $6 \mathrm{ft}$, and he cleared $10 \mathrm{ft} .9 \mathrm{in}$. in the pole jump, besides running 400 metres in $5 \mathrm{I} .2 / 5^{\text {ths }} \mathrm{sec}$, 100 metres in $1 \mathrm{I} .1 / 5 \mathrm{th} \mathrm{sec.,} 1,500$ metres in $4 \mathrm{~min}$. 40 sec., and I 10 metres over hurdles in 15.3 isths sec., and throwing the javelin $155 \mathrm{ft}$.

Other amateur record performances, accomplished in the past two years, may be mentioned here. In the pole jump, M. S. Wright has done $13 \mathrm{ft} .2 \frac{1}{4}$ in. In the high jump, G. Horine has done $6 \mathrm{ft} .8 \mathrm{in}$. in the American Olympic trials. J. P. Jones at Cambridge, Mass., in May $191 \mathrm{I}$ ran a mile in $4 \mathrm{~min}$. $15 \% \mathrm{sec}$. or nearly $\mathrm{I}_{2}^{\frac{1}{2}} \mathrm{sec}$. faster than the British amateur record established in 1902; and A. Kiviat at Harvard in June 1912 covered 1500 metres in $3 \mathrm{~min} .55^{\mathrm{f}} \mathrm{sec}$. The hammer was thrown $187 \mathrm{ft} .4 \mathrm{in}$. by M. J. McGrath (afterwards Olympic winner) in 19II. The Swedish javelin thrower, C. Lemming, in September 1912 established the amateur record at $205 \frac{1}{2} \mathrm{ft}$. for the right hand and $146 \mathrm{ft} .4 \mathrm{in}$. for the lefi. At Herne Hill on May 20, I9 I , H. V. L. Ross walked I I miles in I hr. 25 min. 48 sec., and surpassed all records from this distance to $17 \mathrm{miles}\left(2 \mathrm{hr}\right.$. $18 \mathrm{~min}$. $29^{2} \mathrm{sec}$.): S. C. A. Schofield walked 22 miles in $3 \mathrm{hr} .9 \mathrm{~min} .48 \% \mathrm{sec}$, and 25 miles in $3 \mathrm{hr}$. $37 \mathrm{~min}$. $6 \frac{3}{5} \mathrm{sec}$. At Kennington Oval in September 1912, W. R. Applegarth ran 200 yards in $19 \%$ sec., and at Stamford Bridge a few days later the same runner covered $220 \mathrm{yds}$. in $21 \frac{4}{5} \mathrm{sec}$.

The Amateur Athletic Championships of 19 I I in England were undistinguished, but in $1912 \mathrm{H}$. Braun in the half mile, W. R. Applegarth in the 220 yds., G. H. Patching in the 100 yds., F. Owen in the mile, (i. R. I. Anderson in the hurdle race, contributed to make the meeting one of more than average quality. An international university match took place in I9II at Queen's (lub, West Kensington, between a team from Harvard and Yale, and another from (Oxford and (ambridge. The Englishmen won by 5 events to 4 . Cambridge won 6 events to 4 against Oxford in 1911, but the contest of 1912 resulted for the third tinie in the history of this annual engagement in a draw, each side winning 5 events.

\section{Ariation. 1}

With the advance of mechanical efficiency there came about in I 1 I a transition from closed aerodrome contests to cross country races. The Gordon-Bennett race was the only important one held under the old conditions, and it was won at Eastchurch by Weyman for the United States. The European Circuit-I, I25 miles of flight, which included a start and finish at P'aris and halts at Liége, Antwerp, Brussels, Calais, London and Calais en route - was won by André Beaumont, with Garros second. The

'See also "Aeronautics," p. 339 et seq. 
circuit-of-Britain race was also won by Beaumont, this time from Védrines, the:total distance being about 1,000 miles. . In I 12 the principal events were the various military aeroplane tests organised by the French, German and British War Departments. The Gordon-Bennett race held at Chicago was won by Védrines for France at a mean speed of 105 miles per hour. Legagneux put the altitude record up to 18,767 feet. The hydro-aeroplane has been considerably developed, and a number of competitions for it have been organised.

\section{Badminton.}

A steady, if not very great, increase in the number of clubs and players has been accompanied by a corresponding rise in the general level of proficiency. In the tactics of the players no change is observable. Success has attended what is called the " back and front "game in mixed doubles; but this depends on the ability of the lady to defend the net, and of her partner by means of great activity to take charge of the whole of the back of the court. The mixed doubles championship of the Badminton Association were gained in this manner by Mr. G. A. Thomas and Miss Larminie in I9I I, and by Mr.: E. Hawthorn and Miss Hogarth in ror 2:

In I9I I Mr. G. A. Sautter won the singles: Messrs. P. D. Fitton and E. Hawthorn the doubles: Miss C. Douglass and. Miss Orr the ladies' doubles. In I9I2 Mr. F. Chesterton won the singles; Messrs. G. A. Thomas and H. N. Merritt the doubles; Miss Cundall and Miss Gowenlock the ladies' doubles. Miss Larminie (Mrs. Tragett) in both years won the ladies' singles.

For Baseball see under "United States" below.

\section{Billiards.}

Since the prohibition of consecutive spot hazards and the push stroke, English professionals have relied chiefly upon the top-of-the-table game. An innovation, however, was introduced in I9I $\mathrm{x}$ by George Gray, a young Australian, who repeatedly made huge breaks by means of a series of losing hazards from the red ball. In all, he scored twenty-four breaks of four figures, of which the highest was 2, I96. "Gray invariably declined to play matches with ivory balls, and these breaks were not made under Billiard Association rules. H. W. Stevenson, though not at his best during this season, beat M. Inman twice for the championship of the Billiards Control Club.

In January 1912 George Gray met Stevenson and defeated him in two games out of three of 18,000 up. M. Inman beat T. Reece for the Billiards Control championship.

H. A. O. Lonsdale did not defend his title of amateur champion, and the cup reverted in Ig I I to H.C. Virr. An alteration was made in the arrangements, the champions of England, Ireland, Scotland and Wales meeting in competition in the finals.

H. C. Virr beat Major Fleming by only seven points in 3,00o for the amateur championship in 1912. The influence of Gray's example was plainly perceptible in this competition in the use made of the losing hazard. A break of 1016 made by Stevenson in October 1912, in the course of a match with W. Cook, is the highest yet recorded as having been achieved without series of spot strokes, anchor cannons, or long successions of losing hazards.

\section{Bowls.}

In the summer of I9I 2 a visit to England was made by a representative team from New South Wales, which won 30 matches out of 54 played. They were very strong on fast greens in sunny weather, but were unable to do themselves justice, when, during the latter part of their tour, rainy days and dull grounds became the rule rather than the exception. In the international matches Scotland won against Ireland and England, and England lost also to Ireland. A large extension of bowls as a club game; and of club and county matches, has recently been noticeable.

\section{Boxing and Pugilism. ${ }^{1}$}

Though boxing is cultivated in many English public schools, and has been encouraged in the British army and navy, with the result that it is more generally practised and appreciated at present than ever before, the standard of skill in England would appear to have fallen rather than risen in the past few years. The same thing is true of pro-

1 See also under "United States." below. 
fessional pugilists. English bantam and feather-weights have fairly held their own, but for weights above 9 st. America and France dispute precedence: The progress of boxing in France is worthy of particular attention. French pugilists were at first trained by Lavigne, the American light-weight champion, who defeated Burge at the National Sporting Club, and later by Erne, also an American:- The style of these men can be traced in their pupils, of whom Carpentier and Ledoux have been most prominent. Carpentier (b. 1894) is one of the most promising boxers of the day. In spite of his youth, he defeated the English middle-weight champion, J. Sullivan, in two rounds at Monte Carlo, and easily accounted for two of the best English welter-weights, S. Burns and Joseph. But he lost to F. Klaus at Dieppe in the spring 19r2, and in October to Papke in a fight for the middle-weight championship. He is a boxer of polished style, but not perhaps equal to some of his American rivals in in-fighting and hard hitting. Ledoux is a sturdy bantam-weight who has both stamina and hitting power. After losing to Stanley, the English champion, he took his revenge decisively. Pugilism is now much in vogue in France and may be said to have completely displaced the savate (la boxe Française). In England Bombardier Wells, a man of a remarkable reach of some 80 inches, holds a heavy-weight championship and the Lonsdale belt. He was not, however, regarded in IgI 2 as comparable to the heavy weights of the past, such as Jackson, Sullivan, Corbett and Fitzsimmons. His victory over Storbeck, a South African, who in I909 very easily won the amateur championship, is the chief basis of his reputation. On the other hand, in J. Driscoll of Cardiff, Great Britain is believed to possess the most skilful boxer of the day. He has won the Lonsdale belt for featherweights three times in succession, and has gained convincing victories in America, but failed in an ill-advised attempt to beat the light-weight champion, F. Welsh, who, when insufficiently trained, was defeated by Matt. Wells, an amateur ex-champion. This result was reversed in November ror 2. Stanley (b. I882) retains the bantam championship, chiefly by his height and reach and the facility with which he is trained for a combat. Whatever else may be said of the heavy-weight champion of the world, the negro, Jack Johnson, he is well qualified by physique, skill and quickness to compare with any boxer of the past; but another American negro, Langford, who in Australia twice beat McVea without being hit, though at a disadvantage of $2 \frac{1}{2}$ st. and 4 inches of stature, is perhaps even more wonderful as a boxer pure and simple.

Boxing has certainly suffered from the American use of rough tactics and clinching, as well as by the price which is demanded by champions for their appearance in the ring. Stipulations are made for a certain sum to be paid win or lose. In a match at Sydney, Burns, the loser, received $f 6,000$, and Johnson, the victor, $f, 1,100$. Difficulty has also been found in obtaining the services of qualified referees. In the reaction provoked by excessive clinching, what is called the "clean break" has been enforced in Australia and America, with the effect of preventing quite legitimate in-fighting.

The Amateur Boxing Association championships were won in 1911 by $W$. W. Allen (bantam weights) H. Bavers (feather weights), A. Spenceley (light weights), W. Child (middle weights) W'. Hazell (heavy weights). Allen regained his title in 1912: the other winners in the same order of weights were G. R. Baker, R. Marriott, E. V. Chandler, R. Smith.

\section{Bridge.}

A modification of the trick values in auction bridge has recently come into general use. The new values are as follows: spades 2 ; clubs 6 ; diamonds 7 ; hearts 8 ; "lilies" (or royal spades) 9; no trumps io. The advantages of this method are that (I) speculative declarations of no trumps are discouraged, (2) the preponderating value of red suits is diminished, (3) a situation is brought about in which the declaring side is placed at a disadvantage. On the other hand it is objected that in the bidding the strength and nature of the hands are often so thoroughly disclosed as to detract from the interest of the: play.

\section{Chess.}

While the number of chess players and of professionals entitled to the rank of masters increases continually and international tournaments are becoming common events, no very exact proportion exists between the demand for prize competitions and professional 
exhibitions and the supply. As a rule European tournaments receive so many applications from candidates that a selection is with difficulty made for the masters' contests, and supplementary classes are frequently ineluded in the programme. On the other hand, in England, though amateur talent abounds and opportunities for using first class play are eagerly welcomed, professional chess is by no means abundant.

Next to the veteran Blackburne, Burn is the most prominent English master. France is not nowadays represented in masters' tournaments: but Russia is prolific of players of every, degree, and so are the Dual Monarchy and Germany. But it is the "modern school" fathered by Steinitz, adopted by Dr. Tarrasch, and brought to perfection by Dr. Lasker, the present champion, which has for some years been predominant. It is characterised by academic soundness rather than brilliancy. In the indecisive matches between Lasker and Schlechter, and between Schlechter and Tarrasch, the players permitted themselves no variety of opening or of tactics, but were content with playing variations based on preliminary analysis, and with avoiding enterprise or complications in the middle game, unless forced upon them in some cases by exigencies of the battle. Of the younger masters, Rubinstein, who. has been conspicuously successful, has also of late years made sound position play his principal aim. Masters adhering to the romantic style (Morphy's), like the late Tchigorin, and to a modification tempered to modern demands, like Janowsky, Mieses, Spielmann and Marshall-in fact, masters with an individuality of style and a capacity for producing interesting games-save the game from degenerating into dull academic precision. Janowsky, though he did not do himself justice in his match with the champion, is, at his best, a player of commanding personality and exceptional strategic power; Mieses is distinguished by enterprise and tactical cleverness over the board; Spielmann is capable of producing specimens of both soundness and britliancy; Marshall's daring verges on recklessness, while on a high level of all round efficiency; Niemzovitch has displayed considerable ingenuity and originality.

At the San Sebastian tournament in 191 I, J. R. Capablanca, a young player from Havana, already famous, having beaten Marshall in a set match, accepted the place originally reserved for Dr. Lasker, and won the chief prize from the leading players of the day. His style, though at times tempered to the exigencies of the score sheet, was brilliant enough to cause him to be hailed as a new Morphy. It was hoped that he might be able to play a match for the championship; but hitherto Dr. Lasker has declined his challenge under the plea of having been insulted by Capablanca in the wording of a counter proposition to some clauses of the conditions proposed for the match. In the meantime Dr. Lasker has accepted Rubinstein's challenge, who of late has achieved several successes at San Sebastian, Postyén and in the Russian Championship Tournament. Teichmann won the Carlsbad Tournament of I9I I in grand style, while Niemzovitch and Spielmann ran Rubinstein at San Sebastian very close. Of younger masters Russia may boast a bevy, of whom Alechin is the best, while young Breyer of Budapest promises to take high rank among the masters of the day.

\section{Coaching and Driving.}

Undoubtedly the advent of the motor-car has caused a great diminution in the number of horses kept solely for driving. In London, in every continental European town, and in the cities of the United States, mechanical traction has practically taken the place of the horse. But motor-cars are still beyond the reach of the countryman who drives a gig, and of the small suburban tradesman who sends out his wares in a horsedrawn vehicle. In Great Britain few people now breed harness horses, except those of the hackney breed, the best of which are of considerable value, not only for the show ring, but because there still exists a small and wealthy public which will pay highly for possession of the smart stepper. The breeding and exhibiting of harness horses possessed of high action both in England and America is now quite a business, but it is confined to a not very large number of enthusiasts, and is in no way a national affair. In the United States there are the trotters, and the standard bred horses, and both these. breeds are in a flourishing condition, and not in the least likely to undergo a slump.

The pastime of driving, as is only natural with the motor-car so much to the fore, is in the hands of a few; but in London and its neighbourhood there has been, in the last four or five years, a considerable revival of four-in-hand driving, due in a great degree to the institution of the International Horse Show at Olympia, and to the establishing of the Coaching Marathons and Corinthian Cups. These contests, one of which attracted as many as twenty teams, have shown that the coach horses of the present day are better and more valuable animals than those of past generations, and that the art of driving four horses has by no means been impaired. Indeed the good "whip" of the present day has to contend with increased traffic everywhere, and with such fresh varieties of road users as the traction engine, the tramcar, the motor bus and the taxicab. Yet the driver of horses can hold his 
own; and this also applies to those who have charge of the public coaches, in which direction there has been some revival both in Great Britain and the United States. All over the world the best harness horses are better and more valuable than they have ever been before, though it is certain that in most countrics their numbers are decreasing.

\section{Coursing.}

Competition between greyhounds of different countries is attended with almost insuperable difficulties. Australians from time to time have sent dogs to the Waterloo Cup, meeting with but little success-perhaps through the effect of the long sea voyage. Coursing has become popular in France. The French Greyhound Club has leased a fine ground at Tremblay near Paris, where many meetings are held every year. Having purchased some of the best English blood for breeding purposes, French coursers are naturally anxious to send dogs to Altcar, and have more than once approached the Board of Agriculture and Fisheries in England with a view to the relaxation of the quarantine regulations. On the other hand English greyhounds are frequently sent abroad, even to countries as distant as Argentina, where many meetings have been held; and it is very rarely that they do not prove their superiority. In France for instance the majority of the stakes have been won by English bred dogs. Nevertheless some British breeders believe that the dogs now produced, while possessing speed, are deficient in stamina; and one breeder at least has decided to make the experiment of crossing with the Afghan hound, a slow animal remarkable for staying powers. One of this breed was imported by Lieut. M. H. Lucas, of the Indian Army (37th Lancers), who bought him from a caravan of Afghans passing through Zhob, Baluchistan. The dog is now at the stud in Northumberland, and the career of his produce will be watched with much interest. The pre-eminence of the English greyhound has been proved in Hungary, where coursing, or at least the pursuit of the hare with greyhounds, has been practised from time immemorial. The typical Hungarian dog was undoubtedly slow, but he was endowed with wonderful courage; and before the National Coursing Clubs (England) rules were adopted, the most sought after greyhound was the one that could bring his hare down, no matter what obstacles he might be called upon to negotiate. Since those days the Hungarian coursers have imported many English dogs; and the result has been highly interesting for the reason that few stakes are won but by an English bred dog, or one possessing English blood. Coursing has also been taken up in Russia with the support of the Grand Duke Nicholas, on whose estate at Perchino, about 200 miles south of Moscow, meetings are regularly held.

No other coursing event of importance in the world is held under such conditions as the Russian Waterloo Cup. After the snows have disappeared the sun exerts such power that coursing during the day is out of the question. It is therefore necessary that a start should be made at about two o'clock in the morning, or as soon as there is sufficient light; and as a rule eighty courses are decided before nine o'clock. In I9I I Dendromys, the winner of the Barbican Cup in England, was purchased by the Grand Duke Nicholas, and he was beaten in the final by Flower (ilen, also English bred. In 1912 Bachelor's Ball II, a prominent performer in England, and runner up for the Barbican Cup, was secured by Count Cheremèteff, and won the Russian IVaterloo Cup, defeating Thekan in the last round. Thekan was bred in Russia, but is by Prince Plausible who ran second for the Waterloo Cup at Altcar in 1905 . The borzois are frequently tested in Russia with hares. It has been held by many authorities that the English greyhound would beat the borzois if entered to wolves, being certainly much the quicker, while possessing quite as much courage; but the Russian dog has a great advantage in weight. In adclition to the stakes for greyhounds, at the last meeting hedel in Russia by the (irand Duke Nicholas there were several events for borzois.

(onsiderable interest was attached to the English Waterloo Cup both in $191 \mathrm{I}$ and 1912 owing to the fact that puppies played so important a part. In I9I the winner and runner up were in their first season, Sir R. WI. B. Jardine's Jabberwock, by Bachelor's Acre from Forrester's Favour, beating Mr. P. Storey's Silk and Scarlet, by Earl's Court from Gay Feather, in the final; and in 1912 Mr. E. L. Townshend's Tide. Time, by Friendly Foe from Fast Waves, beat another puppy in Mr. F. Alexander's Adversary, by Glenfield from Alternative.

\section{Crickel.}

For more than two years past public attention has been concentrated on international cricket. The visit of a South African team to Australia in 1910-I served.as 
a prelude to the so-called triangular tournament of 1912 , and in the meantime an English team under the management of the Marylebone Cricket Club carried through a wonderfully successful tour in Australia in I I I I-I.2.

$\therefore$ The South Africans in Australia hardly did as well as had been expected. Their strength was considered to lie chiefly in their bowling, but they were disappointed by the inability of A. E. Vogler, on whom much reliance was placed, to do justice to his reputation. On the other hand they found Australian batting in its prime. In eleven-a-side matches as many as fifteen Australian batsmen averaged more than 30 runs an innings against the South Africans, and eleven of them more than 40 runs. The most formidable were $V$. T. Trumper, who exceeded 75 runs an innings and in Test matches averaged 94.57, W. Bardsley, IV. W. Armstrong, C. Kelleway, C. G. Macartney and V.S. Ransford. The Australian bowling was of no very high quality, though $W$. J. Whitty was very consistent, and $H$. V. Hordern, who was able to match the South African "googly" bowling with a similar style, had a great share in winning two Test matches. For the South Africans, G. A. Faulkner, besides bowling well, batted with wonderful certainty, failing in none of the Test matches to make at least Ioo runs in the two innings. The South Africans won the third Test match by 38 runs at Adelaide, but they lost the remaining four; and they were also beaten once by Victoria and twice by New South Wales. Three of the twenty-two matches were drawn.

The tour of the M.C.C. team was extraordinarily successful. Of 18 eleven-a-side matches the first Test match, played at Sydney, alone was lost; four were drawn and 18 , including four Test matches, were won. The strength of the English team was found principally in the bowling of Barnes and F. R. Foster. Both these bowlers are above medium pace and of great accuracy. Barnes has a fine command of the leg break with the other break as a variation, and Foster, while often causing the ball to swerve in the air, has a remarkably quick rise from the pitch, and on that account is well suited by fast wickets. The batting of Hobbs, Rhodes, Woolley, G. Gunn and J. W. Hearne contributed much to the success of their side, while J. W. H. T. Douglas, who acted as captain, was of value both as a resolute and patient batsman and as a fast bowler of great precision and a mastery of the swerve. Douglas, who took up the captaincy on P. F. Warner being incapacitated early in the tour by serious illness, distinguished himself by his correct judgment and his unfailing presence of mind in the important matches. The batting of Hobbs has never been excelled in AngloAustralian contests. Invariably sent in first, he played innings of 187,178 and 126 not out in Test matches. His first-wicket partnership with Rhodes in the fourth match at Melbourne amounted to 323 runs-the greatest first-wicket partnership for a Test match-and the whole innings aggregated 589. The fifth match was won after the English team had been 144 runs in arrears on the first innings. The Australian bowling again seemed to be less dangerous than in previous years; but $\mathrm{H}$. V. Hordern was always formidable. He had a principal hand in winning the first match for Australia and took five wickets in each imings of the last match.

At the end of 1910 a team sent to South Africa by the M.C.C. won two and lost three Test matches. In spite of the brilliancy of Hobbs, the batting was weak on the whole, and it could not cope with the bowling of G. A. Faulkner and Vogler, who took 65 out of 85 wickets. Faulkner was also by far the best of the South African batsmen, having an average of 60.55 runs in the Test matches to the 67.37 of Hobbs.

In consequence of the exceptionally bad weather of the summer of I9I2 the Triangular Tournament in England was a complete failure. From the first the South African team was unlucky, several players, and notably Faulkner, being at one time or other more or less incapacitated, while they also seemed to be more adversely affected by the slow wickets than their opponents. They were without the assistance of Vogler. On the other hand Australia was unable to send to England a representative team. A dispute in which several of the foremost players were at variance with the Australian Board of Control prevented the inclusion in the party of Trumper, Hill, Armstrong, and Ransford. The weather, however, did not permit a convincing trial of strength between the English and Australian teams. Of three matches arranged only one was finished; and that one was much interrupted by rain; being concluded with difficulty in four days at the Oval on a treacherous wicket. It was decisively won by England, who had the advantage of greater experience of such conditions and bowling much better suited to them. England defeated South Africa at Lords, Leeds and the Oval, and Australia had two easy victories at Manchester and Lords. "Throughout this series of matches sudden spells of successful bowling were surprisingly common. In more than one of these Pegler (South Africa) was concerned; and it was curious that his periods of effectiveness would occur without any apparent cause when the batting had for some time been more or less dominant. In the first match between South Africa and Australia at Manchester, J. T. Matthews (Australia) performed the "hat trick" in both inningsan unprecedented feat: Pegler took six England wickets at Leeds for 16 runs when 308 had been scored for four wickets: G. R. Hazlitt (Australia) against England at the Oval closed an innings in which five wickets were down for 170 for the addition of 5 runs.

A team of Indians visited England in $19 \mathrm{I}$ I and played 14 matches, losing ten, but beating Leicestershire and Lincolnshire. Lord Hawke took a team to Argentina in I91 1-12. 
A new method of deciding the English County Championship was tried in Igrr, and although not giving general satisfaction was retained in 1912 . With the idea of discouraging the players from aiming at drawn matches, five points were given for a win, and three points (with one point to the losing side) for a first-innings victory. This purely arbitrary mode of reckoning, which had for some time been the rule of the minor counties, assisted Warwickshire to win the championship in $191 \mathrm{x}$, but they probably also profited by having no matches with some of the strongest counties. The fast wickets were favourable to several of the Warwick. shire batsmen, and still more to the bowling of F. R. Foster and Field. Kent would have been first according to the old reckoning; Middlesex were third, and Lancashire fourth. In 1912 the wet wickets were adverse to Warwickshire, but suited Northamptonshire, whose eleven showed great improvement in batting. This county was second to Yorkshire, who had a strong team, several of their younger professionals assisting materially in their success. Kent took the third place and Lancashire the fourth.

The Jam Sahib of Nawanagar (Ranjitsinjhi) played in several county and other first class matches in 1912 , and showed that he had lost little or nothing of his old skill in batting. Oxford beat Cambridge in ryI 1 through the excellence of P. R. LeCouteur's slow bowling, which was of varied style but was classed as belonging to the "googly" order. Cambridge won a very close match in 1912 largely by the fine all-round play and captaincy of E. L. Kidd. Eton in both years won against Harrow.

Good fast bowling is scarcer than ever in first-class cricket. Many bowlers have cultivated the delivery of the swerve, the ball being so held that the seam, while rotating vertically, lies a little to the right or left of the line from bowler to wicket. The "googly" has made little progress, though it was effectively used by H. V. Hordern in Australia. The plan of bowling at the leg stump, or even at the batsman's legs, originated by Hirst, has been perfected by other left-handed bowlers, notably Dean and F. R. Foster. In batting, back play and onside hitting are prevalent, and the right foot is shifted without compunction. In consequence of these developments the setting of the field has transcended all the old customs, and positions are assigned for which the game has no vocabulary.

\section{Craquet.}

One of the causes to which the decline-amounting almost to extinction-of croquet was attributed some thirty years back, was the modification of the conditions of the game to suit the requirements of the most skilful players. When the $3 \frac{3}{4}$ in. hoops were introduced the game became too difficult to be popular. The same difficulty has been reasserting itself. For many years the Croquet Association has been continually revising its laws to meet the increasing skill of the foremost players-nowadays by no means a small class. The small hoops no longer constitute any serious obstacle to the making of long breaks. In spite of the provision of "baulks," in order to secure an open shot for a player as soon as his opponent has finished a turn, it is realised that the player who first gets possession of the balls has the chances overwhelmingly in his favour. The laws committee of the Croquet Association has been discussing several proposals for making the game more difficult. The most favoured of these are: (I) playing with either ball of the side; (2) the reintroduction of a cage in the middle of the ground; (3) the turn to cease if any ball is sent off the ground after the first croquet has been made. The tactics of croquet have undergone but little change of late, except that the best exponents (and there is nothing which now shows the quality of a player more than the way the balls are left at the finish of a turn) almost invariably go out for a break, thus following the example of the present champion, Mr. C. L. O'Callaghan,- -and that the art of "peeling" - especially in handicaps-is greatly on the increase.

The principal competitions of 1911 and 1912 resulted as follows:- Open championship, (I911) E. Whitaker, (1912) ('. L. O'('allaghan; ladies' championship, (1911) Miss E. Reid, (1912) Miss Simeon; gentlemen's gold medal, (1911, 1912) C. L. ('Callaghan; ladies' gold merlal, (rorr) Miss N.S. L. (iilchrist, (1912) Lady Julian Parr; champion cup, (I9II) H. Maxwell Browne, (rol2) P. D. Matthews; ladies' champion cup, (19II) Mrs. R. C. J. Beaton, (1912) Miss D. M. Standring.

\section{Curling:}

The winter of Ioro-I I was soft ; that of IOI I-I 2, after beginning badly, later afforded excellent sport. During the latter part of January and the first week of February rer 2 there was unique activity both in Scotland and Switzerland; and at the same time the Scottish team in Canada reached the climax of their tour at Winnipeg.

In Scotland, for the second time since 1903, it was possible to hold the Grand Match. 
Though it was necessary to wait till the ice was five inches thick before announcing this event, and though considerable notice had to be given, yet the ice held long enough to enable 2,00o players to take part at Carsbreck on February 2. As usual the South beat the North. The International Match (England v. Scotland), fixed a day too late, was spoilt by the weather. It had not been played in the open since 1907. The rinks, or at least their skips, were deliberately selected, making the match genuinely representative, a place in the team having hitherto depended on inclination to enter and luck in the ballot. After several English victories (including I9II), Scotland wor in I9I 2 at Craigielands Loch by an average of six shots a rink, over 24 rinks. Curling facilities have been multiplied not only by the use of sprinkled asphalt rinks but by the opening of ice-palaces in Edinburgh and Aberdeen.

In Switzerland, curling has increased in popularity, it being possible to play in milder weather than suits most other winter sports. The centre of chief activity has moved from the Engadine to the Oberland, partly because of Grindelwald's victories in the Jackson Cup in I9I I-I2 necessitating the competition being held at Grindelwald (instead of Davos or St. Moritz) until they lose it. In the International Bonspiel Mr. McGeoch's Manchester rink won in 1911 and 1912 .

During their tour in Canada the Scottish touring team lost by $16,47,61$ and 31 shots on six rinks in their four international matches-an average of six shots a rink.

\section{Cycling.}

Interest in bicycle racing was maintained with difficulty during IgI , despite the continued increase in the use of the bicycle for utility and recreation. The World's Championships held at Rome early in June resulted in the Englishmen, Bailey and Meredith, winning the one kilometre and roo kilometres amateur contests, and Ellegard winning the kilometre professional race. In IgI 2 the World's Championships held at Chicago resolved themselves practically into duels between American and French professionals, out of which Kramer, the United States representative, emerged successful. The fact that the cycling contest at the Olympic Games was a road race gave a great fillip to that form of the sport and led to quite unexpected results. As the leading roadracing country England was looked upon as the inevitable winner, but anticipations were entirely falsified, for Lewis, a South African, accomplished the fastest tıme, and the Swedish team (Friborg, Malm and Persson) placed their country first. The race, however, was greatly influenced by the order of the draw for places.

Motor cycling made great progress in I9II, but mostly in Great Britain, Germany being a fair. second. The only international events of sporting importance were the Tourist trophy races held by the Auto Cycle Union of Great Britain in the Isle of Man on June 3 oth and July 3rd, On the former date Evans won the junior event for engines of less than about 3 H.P., and on the latter Godfrey won the senior race in which the power practically was limited to about 4 H.P. The expansion of motor cycling in I9I 2 was much more rapid, and general and international contests are likely to be multiplied. The chief sporting events, however, were again the Tourist Trophy races in the Isle of Man. The junior event was won by Bashall and the senior by Applebee. The chief mechanical development of the year was the evolution of the cycle-car-a four-wheeled motor cycle, which formed the feature of the London Olympic Motor Cycle Show in November I9I2.

\section{Fencing.}

For the advancement of international intercourse it is desirable, as recent events have demonstrated, that an effort should be made to assimilate both the rules and the accepted canons of foil and epic fencing as practised in different European contests. For instance, the rule as to the "target" adopted by the Swedish committee was regarded in France as so unsatisfactory that, by way of protest, no French team was sent to Stockholm for the Olympic contests, nor in fact was France even represented in the épée and sabre competitions. The Italians also declined the epée matches because the longer weapon which they affect was not admissible. In the French rules the upper part of the sword arm is assailable. The new rule adopted by the Amateur Fencing Association, but not yet applied to the foils championship, counts hits on the upper part of the sword arm, if in the judge's opinion it has intercepted the point when this would otherwise have reached the chest. Under the Swedish Olympic rule the sword arm was 
completely excluded, except that the jury could count a hit on the head, arm, or hand as valid, if the recipient had effaced the target by adopting an ungainly or irregular position, or, instead of making a parry, covered the target with head, arm or hand. Much of the fencing at Stockholm was open to the charge of being rough and ungainly. The gold medals were won as follows: individual foils, N. Nadi, Italy; individual épée, P. Anspach, Belgium; individual sabre, Fuchs, Hungary. The épée team contest was won by Belgium, with Great. Britain second, and Holland third, the sabre team by Hungary with Austria second and Holland third.

The Grande Semaine of $191 \mathrm{I}$ was held in Rouen instead of Paris. France retained the International Cup by beating Belgium (24-18) and Great Britain (26-12). In the Ostend week Great Britain beat Holland (I5-I4), but lost to Belgium (I6-II) and France (I7-II). A representative British team for the first time took part in the sabre contest and did well, losing to Bohemia, who took the first place $(5-4)$, Holland (5-3), and Belgium (4-2). No British team could be sent to the Grande Semaine of 1912 on account of the Olympic Games. France beat Belgium for the International Cup (22-18); Baron de Eynde carried off the épée championship, and Lieut. Perrodin the sabre championship. With the épée at Ostend France beat Belgium (I6-1I) and Great Britain (22-5). With the sabre Belgium defeated France and Italy: and France defeated Italy. M. Gravier, France, was first with the épée: M. Hennet, Belgium, with the sabre.

The British anateur foils championship fell in I9I I to E. M. Amphlett, in I9I2 to P. G. Doyne, after a tic with G. R. Alexander, R. M. P. Willoughby and P. M. Davson. The amateur épée champion of I9I I was J. P. Blake, in I9I2 the title fell to R. Montgomerie. W. Hammond, sabre champion of I9II, was replaced in I9I2 by Captain C. Van der Byl. Miss G. Daniell won the ladies' championship in I9I I and I9I2, after fighting off with Miss J. Johnstone in I9II and with the Misses C. A. Walker and A. B. Walker in I9I2.

\section{Football.}

The Rugby Game.-Although no distinct new phase has lately been observable in the manner in which Rugby football is played, the method of attack by means of concerted runs by half backs and three quarter-backs becomes yearly more indubitably stereotyped. The play of the forwards is subordinated to this leading idea. Even when the ground and the weather make the passing of the ball extremely difficult, while enhancing the effectiveness of dribbling, the same style of play is generally attempted and often with some success. On the other hand, as the counter moves are better understood, the attack has been varied by the artifice of kicking across the ground, and the forwards get some opportunity of using their skill in dribbling in the scrambling play thus brought about. So much depends on the first possession of the ball in the scrummage, whether for the purpose of heeling or wheeling, that various tricks and manoeuvres have been attempted. By an improvement on the tactics of the famous New Zealand team, the forwards on forming a scrummage sometimes bring up a man suddenly into their front row on the side nearest to the player who is about to put the ball in play. This forward, being unobstructed, is said to gain the "loose head," and is at an advantage in getting the ball with his feet. In order to check this trick, the International Board has declared that the ball is not fairly in a scrummage until it has passed a player on each side. It follows that the leading row of forwards must contain at least two, if not three players, though no rule exists to this effect; also that the outside forward who has the first chance of playing the ball may be penalised, if he does so. for preventing the ball from being fairly placed in the scrummage. This consequence, though logical, is not universally accepted. By new legislation penalties have been enacted for wilful knocks-on and throws-forward, and for wilful throws into touch.

The Rughy game, though exceedingly popular in some districts, has lost ground in the west of England, and even in South Wiales, through the rivalry of Association football. It: progress in france, however, has been unchecked. Early in $19 \mathrm{II}$, a French team for the first time was victorious in an international match, beating Scotland in Paris. French player:: are remarkatble for impetuosity, speed and quickness in starting, which last quality make. them strong in defence. In the same season Wales beat England, Ireland, Scotland and France; Ircland beat England, Scotland and France; England at Twickenham beat Scotlanel and France. In 1912 all the international matches that took place in the United Kingdom

'See alşo under "United States" below. 
were won by the fifteen playing in its own country. England defeated Wales and Ireland, but narrowly lost to Scotland. Ireland beat Scotland and Wales, and Wales beat Scotland. In no match was France victorious. The University match went in favour of Oxford in 1910 and I9I I, the disablement of a. Cambridge three-quarter-back; B. R. Lewis, apparently turning the scale in the first match. Cambridge won by 2 goals to a try in igi2. Rugby football was omitted from the Olympic programme at.Stockholm. A strong South African team began a tour in Great Britain in the autumn of I9I2. After gaining several decisive victories over counties the South Africans lost to Newport, were with great difficulty victorious over Llanelly, the United Services and London, beat both the universities, were narrowly beaten at Twickenham by another London fifteen and easily beat Scotland at Edinburgh, avenging the defeat sustained by the South African team in I906. They next gained their most decisive victory at Dublin, securing 36 points against Ireland, and beat Wales by a try at Cardiff, but lost to Swansea by the same margin.

Association Football. - The wide dissemination of Association football not only in Europe but also in the other continents is illustrated by the fact that a tour was undertaken in Brazil in IgIo:by the Corinthian F. C and another in North America in IgII12. There are now many clubs in Argentina, Uruguay, Brazil and Chile. Amateur international football has been affected by a dissension among English clubs dating from 1907. In consequence 'of the Football Association insisting upon the admission of professional clubs (so-called) to the district associations, a large number of amateur clubs, including the University College, and public schools clubs, seceded to form the Amateur Football Association. The officers of the army, while sympathising with the seceders, considered it advisable for the sake of regimental football to retain their connection with the Football Association... But in I9II-I2 they used their influence to promote a reconciliation. A conference was held at which the delegates of the two associations only failed to arrive at an agreement because the older body would not accept an arrangement by which the younger could receive the adherence of newlyformed amateur clubs. The Federation Internationale de Football Associations, commanding the support of most of the countries of Europe; including the Football Association, is necessarily cut off from intercourse with the Amateur Football Association. This, however, is in alliance with the Bohemian Football Association and with many French clubs belonging to the Union de Sociétés Françaises de Sports Athlétiques.

International matches played by England with other countries are no longer representative of English amateur football. The A. F. A., although allowed a representative on the British Olympic Council, was debarred from sending an eleven to the Olympic Games. Nevertheless an amateur team organised by the Fodtball Association was able to win the Olympic trophy, beating Denmark in the final round by four goals to two, after easier victories over Finland and Hungary. The Holland eleven gained the third place. The matches were played in very hot weather in. July. The playing strength of the English Football Association is largely professional, and therefore cannot be exhibited in contests with continental players, though occasional visits to the continent have been paid by professional teams. The amateur elevens of the Football Association won matches with Wales, Belgium, France and Holland in I9IO-II, but lost to Ireland and could only draw with Germany. In 191 I-12, besides their victories at the Olympic Games, they defeated Ireland; Wales, Denmark, Holland and Belgium. The Amateur Football Association teams were consistently victorious, beating Wales and France in both seasons and in October I9II winning a close match with Bohemia in Prague by 2 goals to $I$. The full representative elevens of the Football Association defeated Ireland and Wales in I9I I and drew with Scotland. Ireland lost to Wales and Scotland, and Scotland drew with Wales. In I9I2 England and Scotland again played an indecisive match, but both beat Wales and Ireland; Wales lost three matches. As an entertainment professional football is as popular as ever. More than 127,000 spectators attended the England $v$. Scotland match of 1912 in Glasgow. The Football Association Cup:was won in I9I I by Bradford City after a drawn match with Newcastle United; in I 912 by Barnsley after a drawn match with West Bromwich Albion. The championship of the Football League was carried off by Manchester United in I9II, by Blackburn Rovers in 1912. The principal trophy of the Amateur Football Association was won in Igr1 by the Old Malvernians, in 1912 by Oxford City. The Arthur Dunn Cup for public school clubs fell to the Old Reptonians in 1911 and to the Old Malvernians in I9I2. Oxford won the University match in I9II somewhat unexpectedly, but lost to Cambridge in I9I2. No substantial alteration has been made in the laws of the game or in the tactics of the players, except that the goal keeper in Football Association matches is now prohibited from using his hands outside the space called the penalty area. 


\section{Golf.}

By the introduction of the rubber-cored ball a phase in the evolution of golf was initiated which cannot yet be safely said to have culminated. The ingenuity of inventors has supplied balls with heavy cores of various materials, and these are tightly bound with rubber thread and an outer casing of gutta percha. A small ball of high specific gravity combined with great elasticity is now in general use, and is of course found particularly advantageous in a strong adverse wind. Not only have clubs and courses been modified to meet the development of the ball, but attempts have been made to obtair a reversion to the "gutty" or at least the adoption of a standard ball for important competitions. A memorial addressed to the committee managing the British amateur championship in 19I 2, though signed by a large number of leading players, failed to effect a reform, because the committee did not consider itself to be competent to pass what amounted to a legislative measure. There is a consensus among the most authoritative professionals, as well as amateurs, concerning this question. It is held that the new ball does not sufficiently penalise, and, in fact, does not invariably penalise to any extent the not quite perfectly delivered stroke. In this way it directly impairs the game as a test of skill. Indirectly, the action of luck is favoured by the elaborate hazards with which courses are often embellished, and the somewhat fantastic slopes given to putting greens in order that they may not be too easy. It is further argued by Vardon and other teachers that an undesirable kind of stroke is fostered by a ball which when driven low and "pulled " can be made to travel a great distance after pitching. On the other hand, it can hardly be maintained that the worse player is enabled habitually to defeat the better; and it is undeniable that the majority of golfers would be reluctant to abandon a ball which appears to flatter their skill. The rubber-cored ball indeed may be credited with much of the universal popularity of golf. In America the wonderfully rapid spread of the game has induced municipalities to lay out public courses, of which the long course in Jackson Park, Chicago-one of four belonging to the city-may be taken as an instance.

International intercourse is encouraged by open championships. After winning the British amateur championship in 1911 , Mr. Harold Hilton successfully essayed to carry off the amateur championship of the United States. He was less fortunate in I912, when the competition took place in very hot weather and Mr. J. D. Travers won. The American open Tournament was gained in both years by J. J. M'Dermott. The French amateur championship was captured by Hon. M. Scott, M. Castel being the foremost native competitor; but in spite of an invasion of British champions-Ray, Vardon, Taylor and Braid among them a French player, Jean Gassiat of Chantilly, was first in the professional championship of 1912 at La Boulie, with a score of 289 for four rounds of the course. A competition at Baden Baden, for which the title of championship of Germany was assumed, attracted a number of British and French professionals, and ended in Taylor beating Ray after a tie. H. Vardon was the British champion of I9II, E. Ray of 1912; and Vardon in the latter year beat Ray in the final round of the News of the World competition. Mr. John Ball supplanted Mr. Hilton as amateur champion, winning the title at Westward Ho in 1912 for the eighth time in his unparalleled career. The ladies' championship, which fell to Miss D. Campbell it I911, was won at Turnberry in the following year by Miss Gladys Ravenscroft.

Of the many noteworthy additions which have been made to the literature of the game it must suffice to mention The Royal and Ancient Game of Golf, by H. H. Hilton and Gordon G. Smith (1912): The Book of the Links, edited by Martin Sutton (1912): How to Play Golf by Harry Vardon (1912): The New Book of Golf, edited by Horace G. Hutchinson (1912).

\section{Hockey.}

Scarcely a year passes without some small alteration in the laws of hockey, if it be only the regulation of tlag posts, which are now obligatory. They must be four feet in height, and must be placed at the centre points of the side-lines and at the corners of the ground, one yard outside the line. In the "bully" each player must strike the ground on his own side of the ball and his opponent's stick alternately. Some latitude has been extended to the goalkeeper, who, except in a penalty bully, is allowed to kick the ball within the circle and is not penalised, if, when he has stopped the ball with his hand, it rebounds so as not to fall perpendicularly to the ground. It is no longer necessary in stopping a corner hit for an attacking player to make the ball absolutely motionless. 
Though hockey is largely played in several European countries it was excluded from the Olympic Games at Stockholm. To repair the omission a tournament was held at Hamburg in October I9I2, but this was only partially successful; as but four teams took part in it. An English team found strong opponents in a German team but defeated it, besides easily accounting for an Austrian contingent. In I9r I England beat Wales (7-0), Scotland (5-0), France (4-0) and drew with Ireland (2-2). In 1912 England beat Wales (6-3), Ireland (ro-3) and France $(9-1)$, but lost to Scotland $(1-2)$. Though Scotland defeated England for the first time, Ireland beat Scotland $(1-0)$ and Wales drew with Scotland $(2-2)$. Cambridge won the University match in I9II $(4-I)$ but lost in $1912(I-3)$.

Ice Hockey, so popular in Canada, is increasingly played on the Continent of Europe. In I909-10 a team composed of Canadians at Oxford took part in a tournament at Les Avants, and they have since made an annual tour through Europe during the Christmas vacation, visiting Belgium, Germany, Bohemia, Austria, Switzerland, France. On their last tour they noticed a vast improvement in the standard of play. In December I 9 I I and December I9I2 Cambridge teams beat Oxford teams at Mürren by 2-0 and $\mathrm{I}-\mathrm{O}$ respectively. International tournaments are frequently held at Swiss winter resorts, but the contesting teams are rarely representative.

\section{Horse Racing.}

The most important changes which have occurred in connection with international turf matters of late are the suppression of racing in nearly every part of the United States (see under "United States" below), and the extraordinary rise in the value of blood stock in the Argentine Republic. Doubtless there was room for improvement as regards the great meetings formerly held in the Northern States of America; and it is generally thought that some of the laws forbidding the meetings may be rescinded at an early date. Meantime there has been a fall in the value of thoroughbred stock in the United States, and valuable English and French stallions which had been sent to America at big prices not many years ago have now been brought back to Europe; while a fair number of American bred yearlings are also imported to England and sold by auction at Newmarket every year. The breeding industry in the United States is quickly dying out, but would be even more quickly resumed if racing were once more legalised. In the Argentine Republic four-figure yearlings are even more common than they are at Doncaster; and yet in September Igra Messrs. Tattersall sold by auction, at the annual Doncaster sales, yearlings of the value of $f_{1}$ to,, 00 . In every part of Europe the value of the highest class of stallions has enormously increased; and now the possessor of a really great performer can always be sure of $£ 30,000$ and more if he desires to sell. In other respects the English turf is pursuing the even tenour of its way. Every year there are more runners, and more money to be run for; and, though it is only occasionally that horses of the very highest class are forthcoming, it is probable that the average standard of excellence is thoroughly maintained. On the continent of Europe, and especially in France, Germany, and Austria, the thoroughbred flourishes, and racing becomes more popular everywhere; but whereas in France there is every encouragement for the long distance runner, the tendency in England is towards the development of speed, and important long distance races are by no means numerous.

The form of the most prominent horses on the English turf during the season of I9I I was more consistent than in I9I2. In the first place, Sunstar, by Sundridge-Doris, held his own against the best of the three-year-olds; and it is probable that he would have won the three leading events of the year but for breaking down after taking the Epsom Derby. He carried off the honours in the Two Thousand Guineas and the most important race of the year at Epsom, after which he was sent to the stud, much to the regret of his owner, who was justified in the hope that the colt would win the so-called "triple crown." In consequence of Sunstar's inability to compete in the St. Leger, this race at Doncaster was deprived of much of its usual interest, and Mr. T. Pilkington's Prince Palatine, by Persimmon-Lady Lightfoot, won easily from what was undoubtedly a mediocre field of opponents. A noteworthy incident in connection with the leading three-year-olds of I9I I was that Stedfast, the second in the Epsom Derby, and Prince Palatine, the winner of the Doncaster St. Leger, should have provided some of the most interesting racing of I9I2. As a matter of fact, the meetings of Stedfast and Prince Palatine were the leading features of the season; and it was a moot point which was the better four-year-old. The exciting racing provided by these two horses was very welcome, especially as the three-year-olds in I9I2 ran in so inconsistent a manner that in no case was any outstanding merit shown. Tagalie, a grey filly by CylleneTagale, after securing the first place in the One Thousand Guineas, won the Epsom Derby, 
a performance which led many excellent judges to the belief that she was likely to prove an exceptionally smart racehorse; but she failed unaccountably in the Oaks, a race, after her Derby victory, considered to be at her mercy. It was remarkable that in the Derby Tagalie led all the way and won with such ease that stamina was considered to be her strong point; yet in the Oaks she led for a part of the course and then failed to stay, finishing last. Tagalie also ran in a very disappointing manner in the St. Leger, which was won by Tracery, who had finished third to her in the Derby. It may be mentioned that Tracery was bred in America, as also was Sweeper II, the winner of the Two Thousand Guineas. The former was, however of English parentage. During the season of 1912 as many as eight owners won over $£ 10,000$ each in stakes, Mr. T. Pilkington, mainly by the aid of Prince Palatine, heading the list with $£ 20,822$ and Lord Derby coming second with $£ 17,333$.

\section{Hunting.}

British fox hunting still holds its own, in spite of such modern developments as barbed wire, increase of railways, excessive pheasant rearing; and the greater cost of maintenance of hunt establishments. In some districts the scene of operations of various hunts has been curtailed, owing to the expansion of the country towns, to the institution of small holdings near the towns, and to the fact that coal mining has greatly extended. But nevertheless every part of the country where hunting is possible has its pack of hounds, whether they be foxhounds, staghounds, harriers or beagles, and everywhere there are more people hunting every year, while the great expansion in the size of the fields is chiefly caused by the ever-increasing number of ladies who hunt. In this connection it can truthfully be said that there are a dozen lady foxhunters for every one that followed hounds a generation ago. Foxes are more plentiful than formerly; hounds are faster; and much of the hunting, especially in the most famous countries, is carried on at a higher speed than formerly. This means that hounds are taken from one covert to another at a canter, that there is no dawdling between the hunts, and that-at times-hounds are unable to do justice to their own hunting powers, because of the crowd pressing on from behind.

Creat Britain still takes the lead in foxhunting, but many hunt clubs have been established in the United States in recent years; there are in France over 300 hunts, the quarry for which is deer, wolf; hare, and occasionally fox; and in the British colonies and in India hunting is carried on wherever it is possible. The price of the best English foxhounds has risen enormously, and good hunters are only to be secured at high figures.

\section{Locrosse.}

It is generally held that the use of the lighter crosse with less rigid strings, introduced by Canadian teams into England a few years back, has made lacrosse a less difficult game to acquire and has improved the general quality of team play. In the north of England several clubs have attained a high standard of attack play: but defence seems to have slightly deteriorated, mainly through the disuse of the body check: and this may tell against English sides when international matches are undertaken.

The north of England is still uniformly superior to the south. The North and South match in 1911 and 1912 produced the identical score of 16 goals to 7 . The Stockport Club, having won in both years the Northern Flags, beat Lee in the Club Championship by $15-5$ and $18-8$, and the County (hampionship was twice taken by Cheshire. The runners up to Stockport in I9I I were the Old Hulmeians, who lost only after a tie; in 1912 Albert Park were beaten in the final by 7 goals to 3 . For the Southern Flags Oxford University fought out the final match with $\mathrm{L}$ ee in I9II, and West London reached the final in I912. The University match of I9I I was won by Cambridge at 8-3; in IgI 2 Oxford won at 9-4.

The competitions among the professional clubs of Canarla ended in Vancouver winning the Minto (up in I9I I after having beaten the holders (New Westminster) and the champions of eastern Canada (the Tecumseh team). In ig12 New Westminster regained the ("ur?, defeating Vancouver and Victoria, and then eacily answering the challenge of Cornwall. The Manx (up for amateur lacrosse is held by the Vancouver Athletics, who in 19 I I beat Toronto Juniors, and in Igre defeated Winnipeg (champions of the north-west) and S: Catherine (champions of the east).

\section{Lawn-Tennis. ${ }^{1}$}

In the count ries where good turf is not generally available lawn-tennis is satisfactorily cultivated on hard courts. The covered court form of the game was recognised by 'See also under "United States." below. 
inclusion in the Olympic programme in 1908; and the existence of a good covered court in Stockholm enabled similar competitions to be carried out in I9I2. Further, an open covered court championship has been instituted in Paris. French and German players, who are now able to hold their own with British champions on grass, have proved themselves superior in the hard court.

In Paris, O. Froitzheim carried off the French championship in singles, and (with $\mathrm{O}$. Kreuzer) the doubles: A. H. Gobert took the Olympic medals at Stockholm in singles and doubles, partnered by M. Germot, although the British champion, A. F. Wilding, competed, as the representative of New Zealand. Gobert visited London and won the Covered Court Championship in 1911 and 1912 . In the former year he was also victorious in doubles with M. J. G. Ritchie, but in $1912 \mathrm{~A}$. F. Wilding and S. N. Doust took the doubles championship. On the other hand, though Gobert and Decugis carried off the British doubles championship in I9I I at Wimbledon, no other successes fell to foreign competitors, the singles championship being retained by $A$. F. Wilding, who was again victorious in 1912 , when $C$. P. Dixon and H. Roper Barrett won the doubles.

The grass championships at the Olympic Games were fixed for a date which conflicted with the All England tournament, and the latter was preferred even by most of the leading foreign players. The medals were accordingly captured by Winslow (singles) and Winslow and Kitson (doubles), representing South Africa. Another international test of play on grass was afforded by the preliminary round of the Davis Cup, in which the English team beat the French in the summer of 1912 at Folkestone. But in two matches between England and Germany in 1912 each team was successful on its own ground, the English match being played on turf and the German on an artificial surface. In the previous winter Australasia, represented by. N. E. Brookes, R. W. Heath and A. W. Dunlop, had retained the Cup by beating an American team at Christchurch, New Zealand. England unexpectedly regained the Davis Cup at Melbourne on November 28-30, 1912. C. P. Dixon and J. C. Parke beat R. W. Heath and N. E. Brookes respectively on the first day, and on the third Parke beat Heath but Dixon lost to Brookes. The Australian pair Brookes and Dunlop beat Bramish and Parke; so that England won by the odd match. A team enlisted by the Drive L.T. C. (Fulham) made a tour in South Africa in $1910-1 \mathrm{I}$ and won two out of the three Test matches. A mixed team of men and ladies sailed from England for South Africa in the following winter and played three test matches, but unexpectedly lost one of them. The university matches of 1912 went in favour of Cambridge; in 1911 Oxford won the singles and Cambridge the doubles. A young Russian player, Count Saumarakoff-Elston, gained distinction by defeating C. Setterwall, the Swedish champion in the Olympic tournament, and made a close match with Kreuzer; a German player of the first rank. Many hard courts for autumn and spring play have been recently constructed in England and a new covered court is used for winter play at Dulwich. The difficulty of enforcing the foot-fault rule is still receiving attention. At an International Congress held in Paris in October 1912 preliminary measures were taken for a common understanding with regard to international championships.

The American lawn-tennis championships were won as follows:-men's singles: I9I I, IV. A. Larned; I912, M. E. McLoughlin; ladies' singles: I9I I, Miss H. Hotchkiss; 19I2, Miss M. Browne; men's doubles: I9I I R. D. Little and G. F. Touchard; I9I2, M. E. McLoughlin and Thomas C. Bundy.

\section{Motoring.}

The sport of motor racing, as distinguished from the competition of manufacturers in races for testing mechanical qualities, is best seen in France and America.

The chief French event of I9I I was the Light Car Race competed over the Dieppe circuit on June 25. The distance was 387 miles, and the contest was won by Bablot from Boillut at an average speed of about 55 miles per hour. In America some serious accidents caused a considerable restriction of high-powered racing. The principal event there-the Vanderbilt Cup - was won by Mulford.' In 1912 the revival of the French Grand Prix race and its fusion with the Small Car Contest-the Coupe de l'Auto-formed the chief event of the season. The Grand Prix was a race without any limitations of engine power, and was won by Boillat on a car of 175 H.P. from Wagner on a still larger car. Behind the pair'came three small cars of I2-I6 H.P. driven by Regal, Resta, and Medinger. The winner's speed was 70 miles per hour, while Regal and Resta, who were first and second in the Coupe de l'Auto, averaged about 66 . In America Hunery drove a 200 H.P. car at a speed equal to I 4 I miles per hour. The American Grand Prix was won by C. Bragg, and the Vanderbilt Cup Race by Ralph de Palma.

\section{Mountaineering.}

For the purpose of Swiss Alpine climbing, never were two successive summer seasons more unlike than those of rgrI and rgI2. The latter was perhaps the very worst within the memory of the oldest climber and the former was certainly the finest. 
I9I I will always be remembered for four great climbs carried out by Messrs. G. Winthrop Young and H. C. Jones. Mr. Todhunter joined these on the new route up the Grepon. Altogether this victorious party carried out six new expeditions, of which the Grepon marks the high water mark of rock climbing, though the two ridges of the Jorasses are only a little less severe. The Jorasses had previously been climbed by its south face, and the first object of this party was to find a route up the terrific wall that stoops down to the Col des Hirondelles. The ascent of this ridge was proved to be utterly impossible, but the descent was accomplished by an ingenious and daring combination of fixed ropes and pitons On this climb Joseph Knubel was the leading guide and Laurent Croux represented Courmayeur. The same party climbed for the first time the west ridge which had defied so many previous assaults. On this occasion Knubel was the only guide. Not content with this triumph Young, Jones, the famous Austrian climber Dr. Blodig, and Knubel defeated one of the last virgin ridges on Mont Blanc, the great Brouillard arête. And finally this unconquered party, with Todhunter in place of Dr. Blodig and an extra guide; Brocherel, forced a new direct route up the great northern face of the Grepon. The Grepon by the ordinary route is as hard as most climbs in the Alps or elsewhere, and it is scarcely a peak on which to look for variation routes. "Knubel's ascent of the last mentioned slab," wrote Mr. Jones, "relying solely' on an axe with its point inserted into a minute crack as hand-hold and merely on friction for the rest, is one of the most remarkable climbing feats I know of." As a member of the Alpine Club remarked after Mr. Jones had finished reading his paper, this kind of climbing can only be appreciated by about a dozen British mountaineers, and can be eclipsed by no living cragsman. The only other climb yet made which can be mentioned in the same category with these achievements was Dr. Piacenza's desperate ascent of the Matterhorn by the Furggen arête.

Other interesting new ascents of 1911 may be mentioned; the direct ascent of the Jungfrau from the Jungfraujoch by Herr Weber with the guide Schlunegar of Wengen, and the first passage of the Gletcherjoch by Dr. O. K. Williamson. This climb roused some comment, as Dr. Williamson introduced a practice which was first made use of in Welsh gullies. He climbed the pass from the easy side, and let down a rope on the top of the difficult section to facilitate the traverse of the pass on another day:

Beyond the Alps Captain Corry and Lieut. Squires did some interesting new climbs in the Himalaya, of which the North Peak of Kolahoi was perhaps the finest; and in the Andes Dr. Helbling made the first ascent of a virgin peak over twenty thousand feet in height.

The winter of 191 1-12 was as disappointing as the summer was satisfactory. British climbers, as usual, did very little, and such ascents as were recorded fell to foreign mountaineers. The Alpine Ski Club claimed the three ascents made by British ski-runners, and one of these, the Lauterbrunnen Breithorn, was probably a first winter ascent. It was climbed at the end of January by Mr. Edward Tennant and Mr. Arnold Lunn.

The summer of 1912 was remarkable for persistent bad weather. The indefatigable Mr. Young climbed the last of the Dames Anglais, and Messrs. Mallory, Pope, and Portman made without guides a fine variation ascent of the Dent Blanche, perhaps the finest guideless climb as yet'accomplished. The season was marred by an accident in which the brilliant young Cambridge professor and expert climber, Mr. H. C. Jones, was killed with his wife and the guide Truffer on Mont Rouge de Peuteret, not as originally stated on the Aiguille Blanche de Peuteret. Mont Rouge is not a difficult mountain, and the climb was well within the powers of Mrs. Jones. Truffer came away with a detached boulder, and the whole party were dragged from holds and killed. An unroped Austrian climber ahead escaped.

At the end of the season Hugh Pope (perhaps the finest rockclimber known) was killed on the Pic du Midi d'Ossau. He was climbing alone, and death was caused by rotten rock. The search party organised by Mr. Young found his body after a day's search.

\section{Polo.}

A noteworthy change in connection with polo in rgr 2 was the definite adoption by the Hurlingham authorities, who make the rules and govern the game in Great Britain, of the system of playing without penalty for offside, and with eight periods of seven and a half minutes each instead of six of ten. This system had been given an exhaustive trial the year before, but the change in the rules is directly traceable to the influence of the Meadow Brook team in 1909, when the International Cup, which for twenty-three years had rested on the English side of the Atlantic, was regained by the Americans. English players then learned that there were possibilities of the development of greater pace and greater accuracy of hitting, without real loss of combination, in the less restricted American game; and the victory of Mr. Whitney's team and their success in retaining the trophy against the challenge of the Hurlingham team under Captain Lloyd in Igr $\mathbf{I}$ have otherwise been far-reaching. In the United States, indeed, polo has received a decided stimulus, and there has been a marked increase of players and clubs, especially 
in the army. In rgr 2 new clubs were formed at Cincinnati, Lexington, and Islip (Long Island), among other places; and even American ladies have taken to playing polo. In England there has been a notable accession to the list of provincial clubs by the formation of the V.W.H. (Swindon), which had the rare success of winning the County Cup in its first season. In France a new club has been started at Le Touquet, sixteen miles from Boulogne; the Austrian Jockey Club, in order to encourage the game, has laid down a new ground in the centre of the racecourse at Kottingbrunn, near Vienna; and. among the most recent additions to clubs and grounds in India is that made by the Maharajah of Gwatior at his "rains" station of Sipri. Polo is now played in almost every European colony in Asia and Africa. It has spread to Northern Nigeria, Morocco, Rhodesia, Abyssinia, Arabia; and each year it finds fresh security in such countries as Canada, Australia, New Zealand, South Africa, and Argentina.

The most pronounced feature of the London polo season of 1912 was the success of the Old Cantabs in winning the Champion Cup at Hurlingham and the Open and King's Coronation Cups at Ranelagh; and no surprise was occasioned when the Duke of Westminster, undertaking the organisation of the challenging team to visit America in 1913, invited Mr. Walter Buckmaster (the captain of the Old Cantabs) and Mr. F. M. Freake and Captain George Bellville (members of the side) to accompany him. Captain Leslie Cheape, who tanks, with Mr. Buckmaster, highest in the official handicap list of British players, Captain R. G. Ritson, and Captain Hardress Lloyd, were also among the players invited.

As regards the international polo matches in I9I I it may be recalled that America (represented by the brothers L. and M. Waterbury, Mr. H. P. Whitney and Mr. D. Milburn) beat England (Captain Leslie Cheape, Mr. Noel Edwards, Captain Hardress Lloyd, and Captain Herbert Wilson) by $4^{\frac{1}{2}}$ goals to 3 in the first match, and by $4^{\frac{1}{2}}$ goals to $3^{\frac{1}{2}}$ in the second. Many who witnessed those two games were convinced that, if the Englishmen bad had half a-dozen more first-class ponies, their narrow defeat might have been turned into a narrow victory. England's goals were all scored by Mr. Edwards. In spite of the fact that several of the leading players were away in America during the major portion of the London season, English polo in IgI I was highly successful. A feature of the season was the brilliant success, to begin with, of the Royal Horse Guards (Captains G. V. S. Bowlby, Harold Brassey, and Lord A. Innes-Ker and Mr. J. F. Harrison). They won the Whitney Cup at Roehampton and the Open Cup at Ranelagh; but by trying themselves and their ponies too highly they fell between two stools, just losing the Inter-Regimental Cup to an admittedly inferior team of the 4th Dragoon Guards, and the Champion Cup to a splendidly mounted Eaton combination comprising Messrs. C. P. and P. W. Nickalls and G. A. and C. D. Miller. The King's Coronation Cup went to a powerful side representing the Indian Polo Association (Captains L. St. C. Cheape, Shah Mirza Beg, R. G. Ritson and V. N. Lockett). Another interesting feature of the London season of I9II was the playing of King Alfonso of Spain at Hurlingham, and of the Crown Prince of Germany at Roehampton.

\section{Rackets.}

Having taken measures to limit the ever-growing size of the racket ball, the Tennis, Rackets and Fives Association has recently made a few amendments in the laws of the game. A ball which in the course of a rally passes over without touching the cross-bars of the roof remains in play. A player's right to try to return a ball which he has missed at the first attempt is expressly recognised, but he may not claim a " let." In important matches an umpire is deputed to call the footfaults.

A match for the championship of the world was played in April and May I9I I at Queen's and Prince's clubs by Jamsitji of Bombay, the holder since 1903 , and C. Williams, the Harrow school professional, and was easily won by Williams. The English amateur championships were won as follows:-singles, (I9II) E. M. Baerlein, (r912) B. S. Foster; doubles, (I9II) B. S. Foster and the Hon. C. N. Bruce, (1912) H. W. Leatham and H. A. Denison. The Public Schools Challenge Cup was won by Rugby (C. T. B. Simpson and W. H. Clark) in I9II, and by Charterhouse (G. A. Wright and C. A. Leatham) in 1912. In both years Cambridge won the University matches-singles and doubles.

\section{Rowing. ${ }^{1}$}

International interest in oarsmanship has been considerably stimulated by the success of Belgian crews in the races for the Grand Challenge Cup at Henley. In May Igr I, an eight drawn from past and present members of Jesus College, Cambridge, defeated at Ghent a combined crew of the Ghent clubs, Sport Nautique and Club

I See also under "United States" below: 
Nautique, over a course of 2, I I m metres. The winners' time of $6 \mathrm{~m}$. $43 \mathrm{~s}$. was estimated as equivalent to $6 \mathrm{~m}$. $55 \mathrm{~s}$. or $7 \mathrm{~m}$. on a calm day at Henley. The English victory was made the occasion of an extraordinary ovation by the Belgians. The winning crew was composed of E. C. Henty, H. J. Shields, C. Hudson, H. E. Swanston, S. Hudson, H. M. Goldsmith, G. E. Fairbairn, T. M. Crowe (str.) and C. A. Skinner (cox).

In the University Boat Race of $191 \mathrm{I}$ Oxford won by $2 \frac{3}{4}$ lengths in record time: $18 \mathrm{~m} .29 \mathrm{~s}$. Cambridge also beat the old record, $18 \mathrm{~m} .47 \mathrm{~s}$., held by Oxford, 1893, and Cambridge, 1900. The names of the crews were:-Oxford: C. E. Tinné, L. G. Wormald, R. E. Burgess, E. Millington Drake, C. W. B. Littlejohn, A. S. Garton, D. Mackinnon, R. C. Bourne (str.) and H. B. Wells (cox); Cambridge: S. E. Swan, P. V. G. Van der Byl, F. E. Hellyer, C. F. Burnand, R. le Blanc Smith, J. B. Rosher, G. E. Fairbairn, R. W. M. Arbuthnot (str.) and C. A. Skinner (cox). The contest of 1912 took an unprecedented course, necessitating two races. In the original race both crews sank, and though Oxford re-embarked and reached the winning post, the umpire, Mr. F. I. Pitman, in the exercise of his discretion, declined to award them the victory. A second race was rowed two days later in almost equally rough weather and resulted in a victory for Oxford by six lengths in $22 \mathrm{~m} .5 \mathrm{~s}$. It was $\mathrm{R}$. C. Bourne's fourth year of stroking the winning screw, a record unparalleled in the history of the race. The crews were:-Oxford: F. A. H. Pitman, C. E. Tinné, L. G. Wormald, D. D. Horsfall, A. H. M. Wedderburn, H. F. R. Wiggins, C. W. B. Littlejohn, R. C. Bourne (str.) and H. B. Wells (cox); Cambridge: R. W. M. Arbuthnot, D. C. Collins, H. M. Heyland, R. S. Shove J. H. Goldsmith, R. le Blanc Smith, L. S. Lloyd, S. E. Swann (str.) and C. A. Skinner (cox).

At Henley Regatta both in 19 I I and 1912 the standard of oarsmanship was high. In the latter year the width of the course was reduced by ten feet, and the additional outside margin was located on the Bucks shore, with the object of equalising the value of the two stations by moving the boats to leeward of a "bushes" wind. The King and Queen visited the regatta and the Queen distributed the prizes. The most noteworthy feature of the racing was the capture of the Grand Challenge Cup by an Australian eight. The following is a list of Henley results:-Grand Challenge Cup, (I9II) Magdalen, (I9I2) Sidney R. C., N.S.W.; Ladies Plate, (I9II and I9I2) Eton; Thames Cup, (I9II) First Trinity, (I9I2) Rowing Club de Paris; Steward's Cup, (I9II) Thames R. C., (I9I2) New Coll.; Visitors' Cup, (I9II) Third Trinity, (I9I2) Christchurch; Wyfolds Cup, (I9I1) Pembroke, Cam., (I9I2) Queen's, Cam.; Silver Goblets, (I9II) J. Beresford and A. H. Cloutte (Thames R. C.), (I9I2) Bruce Logan and C. G. Wright (Thames R. C.); Diamond Sculls, (19II) W. D. Kinnear, (1912) E. IV. Powell. Of the Wingfield Sculls, W. D. Kinnear remains the holder.

The professional sculling championship of the world returned to England after many years through the victory in 1912 on the Thames of E. Barry over R. Arnst, who had beaten him in 1910 on the Zambesi. In I9I I R. Arnst defeated H. Pearce on the Paramatta. Barry was challenged by Durnan, a Canadian, but easily defeated him on October I4, I9I2 over the Putney-Mortlake course. Barry had twice rowed successfully in I9II for the professional sculling championship of England.

At the Olympic regatta in Stockliolm, over a course of 2000 metres, a Leander eight took the chief honours, defeating their Henley conquerors, the Sydney crew. England was less successful in the fours, rowed with coxswains, the Ludwigshafen Club being victorious; but Kimnear secured the Olympic trophy for sculling without great difficulty.

\section{Shooting.}

Game Shooting.- The report of the British Grouse Disease Inquiry Committec, published in I0I I, furnishes an important addition to the knowledge necessary for the proper management of a grouse moor. The committee, appointed in 1905 , was never empowered to draw public money, but its members gave voluntary work through six seasons, and succeeded in tracing beyond reasonable doubt the origin of the mysterious disease which at intervals has decimated the stock of grouse on many moors.

This grouse discase is due to a threadworm, Trichostrongylus pergracilis, with which all grouse are infected. Healthy grouse in a year free from disease throw off the attack, but there is a point at which infection becomes too strong for the hird, and it succumbs. The prectisposing cause to an outbreak of disease is a shortage during the winter and spring montlis in the supply of the young heather shoots which form the staple food supply of the grouse. At the end of a good shooting season it may happen that too many' grouse are left on the moor in uroportion to the heather supply. The grouse become crowded, the larvae of the threadworms accumulate from the droppings of the grouse on the patches of heather left uncovered by snow where the birds must congregate for food. These patches become intensely infected, and the tips to which the larvae find their way are eaten by the grouse. Thesc, when weakened by insufficient food, are unable to throw off the aggravated infection. The remedies are prophylactic:- ( I) reduction of the stock by harder shooting, (2) increase of food supply by burning old heather, (3) extensive draining, since the threadworn fourishes 
in damp soil. It remains to be seen whether, the cause being known, the disease can be checked with certainty.

Some progress has also been made in the study of the parasitic diseases of pheasants, especially coccidiosis, which of ten ravages the rearing-grounds. Experiments have been tried in the administration of drugs by which the coccidia are apparently to some extent repressed and the young pheasants are fortified and made sufficiently resistant to survive the attacks. If further trial confirm these expedients one of the chief difficulties in the artificial rearing of pheasants will be considerably diminished.

Rifle Shooting, etc.-To a considerable extent the shooting competitions at the Olympic festival at Stockholm were dominated by the conditions, which were more favourable to some of the national teams than to others. In the military rifle shooting the United States team took the first place. They not only possessed the best weapon, but were the only team to use aperture sights. Great Britain was placed second and Sweden third. The team shooting with any rifle was at the 300 metres range, and this produced the result that Sweden, Norway and Denmark occupied in this order the leading places. However Paul Colas (France) took the gold medals for the individual score both in the 600 metres military rifle and the 300 metres any rifle competition. The 300 metres military rifle individual competition was won by A. Prokopp, Hungary. In the miniature rifle matches no range of more than 50 metres was employed. At this range the United Kingdom team of four were first with a total of 762 out of a possible 800, P. J. Lessimore making the fine score of 192 . Sweden won the 25 metres disappearing target competition, with the United Kingdom only 8 points behind. The individual prizes fell to F. W. Hird, U.S.A., in the 50 metres, and Lieut. Carlberg, Sweden, in the 25 metres. The United States carried off the honours in the pistol and revolver shooting, winning the 50 yards team and individual contests. A. P. Lane took two gold medals, the second being in the duelling matches, in which Sweden was first in the team event. Sweden swept the board in the running deer competitions. The standardisation of rules is an essential preliminary if international contests are to be a perfect test.

At Bisley the chief trophy for the military rifle, the King's prize, was carried off in I9I I by Private W. J. Clifford, with a total score of 319: in 1912 the winner was A. G. Fulton, the son of a previous victor, and, although but: 24 years of age a marksman of great experience in important matches, having gained a place in representative British teams and regularly made his way into the last hundred for the prize which he at last secured. Mr. M. Blood took the grand aggregate (Hopton Challenge Cup) in I9II: in I9I2 it was captured by Corporal Mortimer (Canada) by the aid of the .280 Ross rifle, a remarkable weapon produced by a Canadian factory under the initiative of a well-known Scottish landowner.

Clay Bird and Pigeon Shooting.-The rules at Stockholm were not adverse to the chances of the British team, except in so far as the permission of a heavy shot charge may have handicapped competitors unable to use it. They were beaten for the first place by the United States team, but J. R. Graham, one of the members, made the best individual score of 96 birds out of roo. The shooting was of a very high standard.

The Clay Bird Shooting Association champion is W. Ellicott, who is also well known for his skill with the rifle at the running deer range, and is probably both with gun and rifle the best all-round shot in the United Kingdom. In I9I I A. Maunder, who had twice previously held the championship, regained it with a score of 34 points out of a possible 35 . The Pigeon Shooting Grand Prix du Casino at Monte Carlo fell to an Englishman, F. Moore of Newmarket, in 1911 after a most exciting contest: in I912 M. Des Chaux was the winner.

\section{Skating.}

The winter of I9ro-1 I was unfavourable to skating throughout Europe. ' In England it was impossible to hold any of the speed championships. But it saw a notable extension of artificial ice facilities in the opening of the Manchester Ice Palace, with a skating surface of $100 \mathrm{ft}$. by $\mathrm{I} 40 \mathrm{ft}$., enabling the National Skating Association to revive the championships in the English style of figure skating, abandoned since I904. Ice palaces have since been opened in Edinburgh and Aberdeen.

The international style of figure skating continues to make progress on the continent of Europe, especially in Germany and among English visitors to the Engadine and habitués of artificial rinks. A short but hard frost in February 19r 2 allowed the English 
Speed Championships, both amateur and professional, to take place, a new record (4 min. $444 / 5$ sec.), being set up in the latter by Greenhall. An open race for amateurs and professionals over a straight course of a mile was held in I 9 I 2 for the first time in thirty-one years, with the remarkable result that all the competitors; amateur and professional, beat George ("Fish") Smart's record of 3 min. made in 1881, F. W. Dix claiming the new record in $2 \mathrm{~min} .27 \mathrm{I} / 5 \mathrm{sec}$. The speed skating championships of the world produced two new records, viz., 500 metres in $44 \mathrm{I} / 5 \mathrm{sec}$. and 10,000 metres in 17 min. 46 3/ro sec. Oscar Mathiesen being the winner. Roller-skating has not maintained its sudden access of popularity, but has left a residue of increased proficiency. Practice on rollers is gaining recognition as useful for the ice skater when ice is wanting.

The winners of the principal championships of $1911-12$ were as follows:-

Speed Skating. - English amateur championship (I $\frac{1}{2}$ miles with three turns): 1912, F. W: Dix. English professional championship (same course): 1912, Sidney Greenhall. Both the winners were the holders. One mile straight-away: I912, F. W. Dix. World's championships: I9I I, N. Strunnikoff, all four distances (500, 1500, 5000 and 10,000 metres); 1912, Oscar Mathiesen, all four distances. European championships: 19I I, N. Strunnikoff; I912, O. Mathiesen.

Figure Skating.-English championships, English style:- Single skater's challenge cup, 19I I A. J. Davidson, 19I2 H. M. Morris. Combined skating: I9I I Combined Figure Skating Club team (A. J. Davidson, F. G. Fedden; H. M. Morris, R. Moxon), 1912 Wimbledon S. C. team (A. J. Davidson, F. G. Fedden, H. M. Morris, M. Teichmann). Pairs: 1912, Miss D. R. Jameson and A. J. Davidson. English championships, International style:singles, 19II Mrs. Greenhough Smith, I9I2 A. Cumming. Pairs (a new championship trophy presented by Mr. and Mrs. Johnson), I9I I Miss Harrison and Mr. G. B. Krabbé, 1912 Miss Harrison and Mr. Basil Williams. World's championship:-IgII V. Salchow, I9I2 Fritz Kachler. European championship:-1911 P. Thorén, 1912 Gösta Sandhal. Ladies' championship:-1911 Frl. L. Kronberger, 1912 Frl. Opika von Méray Horváth. Pairs championship:-I9II Frl. L. Eilers and W. Jakobsson, 1912 Mr. and Mrs. Johnson.

Roller Skating. - Amateur English championship (International style):-I9II, W. Stanton; 1912, D. Resta. (English style): I9II and 1912, R. S. Hewett.

\section{Ski-ing.}

As a competitive sport, running on ski is extensively practised in central Europe during the winter, especially in the Alps, the Black Forest, and Tirol, where there are many clubs, and several international open meetings are held. In the neighbourhood of Christiania the older and more famous meetings have for some years been carried out with difficulty, the weather having been on the whole exceptionally unfavourable Ski-ing is now the favourite amusement of visitors to Alpine winter resorts, and has increased in importance as a valuable aid to winter mountaineering. Its military value: is recognised by the nations that have Alpine frontiers, as well as by Norway and Sweden. The practical side of the exercise has also been illustrated by Amundsen's success ful rush to the South Pole.

Owing to the varying nature of the ground and of the condition of the snow, no purpose can be served by attempting to compare the times in which long distance races have been run. Jumping records are almost equally devoid of significance, as no standard angle of declivity is recognised. But it may be: mentioned that in the early part of 1912 the longest "standing jump"-i.e. jump in which the competitor kept his feet after landing-yet recorded was accumplished at Modum. Norway, by Gunnar Andersen, of Lyn, Christiania. The distance was 47 metres.

\section{Swimming.}

After the lapse of thirty-six years the feat of swimming from Dover to Calais, accomplished by Capt. Natthew Webb, was repeated on September 4 and 5, I9I I by 'T. W. Burgess, an Englishman resident in Paris. For some years frequent attempts had been made in vain by numerous swimmers. Burgess was fortunate in obtaining calm weather, but he was hampered by the tide in such a way as to be carried back over the larne sand; and his course, including a large loop, was thus considerably longer than Webb's. As his time ( 22 hrs. 35 min.) was but little inferior, his exploit must be considered equal to that of his precursor.

As a competitive sport, swimming has been brought to a high pitch by the Australians, who are favoured by their climate, and by Americans. Of the former, J. G. 
Longworthy has shown great speed at distances from 100 yards to a mile, and he is not unlikely to accomplish unprecedented performances, A Canadian, G. R. Hodgson, who won the I, 500 metres race at the Olympic Games of 1912 , is a swimmer of at least equal promise. At this meeting an Hawaiian, D. P. Kahanamoku, won the roo metres decisively, in time approaching the unparalleled performance of C. M. Daniels (U.S.A.). Great Britain unexpectedly found a young champion in J. G. Hatfield of Middlesbrough, who, profiting by the example of Kahanamoku, exhibited sudden improvement and almost succeeded in beating Hodgson. Since that time, Hatfield has beaten several records. In Great Britain swimming has made great progress in the public schools of all grades, and some degree of proficiency is attained by almost all the pupils. A satisfactory account of the present state of swimming whether as a sport or as a desirable accomplishment is to be found in The Complete Swimmer, by Frank Sachs (Methuen).

In the past two seasons new records have been made for the following distances:400 metres (free) by J. G. Hatfield (England); time, 5 min. $21_{5}^{3} \mathrm{sec}$; Shoreditch Baths, September 28, I9r2.

500 metres (free) by J. G. Hatfield (England); time, 6 min. $5^{6 \frac{4}{5}}$ sec.; Weston Super Mare, August 6, 1912 .

400 metres (breast) by W. Bathe (Germany); time, 6 min. $29_{5}^{3} \mathrm{sec}$.; Stockholm, July I9I 2. 1500 metres (free) by G. R. Hodgson (Canada); time, 22 min.; Stockholm, July 1912.

Ioo metres (breast) by E. Toldi; time, I min. 20 sec.; Budapest, September I 7 , I9I I. 200 yards (breast) by E. Toldi; time, 2 min. 3935 sec.; Budapest, August 20, 1912.

100 metres (back) by A. Barony; time, I min. $18 \frac{1}{5}$ sec.; Budapest, July 17, I9II.

400 metres (back) by S. Wendelin, time, 6 min. $38 \frac{4}{5}$ sec.; Budapest, August 5, 1911.

\section{Tennis.}

A match for the world's championship in 1912 between G. F. Covey and "Punch" Fairs (holder) ended in favour of the former, who had been defeated by the same opponent two years previously. The amateur championship in IgIr was won by the Hon. N. S. Lytton, but in I9I 2 he was defeated by E. M. Baerlein. The M.C.C. gold and silver prizes were taken in both years by E. H. Miles and Major Cooper-Key. Oxford won the University matches in both seasons, and was represented by the Hon. J. N. Manners and Hon. W. H. Grenfell; in the singles by the Hon. J. N. Manners.

\section{Tobogganing.}

At St. Moritz, tobogganing has been somewhat overshadowed by the many other diversions of the place and especially by ski-kjöring. In Switzerland generally it has given way to bob-sleighing. The Cresta run has been modified, the banks being built far higher and steeper than formerly, with the result that tobogganers, especially beginners, can make faster times. Throughout the two winters, I9IO-II and I9II-I2, the record for full bob-sleighs on the Schatz Alp course at Davos was continually being beaten. Herr Lüders on Torpedo frequently gained and regained the record, and finally retained it at $3 \mathrm{~min}$. I3 $\mathrm{sec}$. (March I5 $_{5}$ I9I2). A special prize is offered for a bobsleigh taking under 3 minutes.

Grand National:-191 I, Captain Webb. Bowen; 1912, Mr. E. O. Quicke. Symonds Cup: -V. Antoinetti (I9II and I9I2). Manchester Bowl:-19I1, Christmas Daisy (H. M. Jameson); I912, Vereina II (Th. Hew). Coupe de France;-I9II, Vereina II (Th. Hew); I912, Taffy (C. A. Longcroft).

\section{Wrestling.}

To the necessarily limited programme of the Olympic Games at Stockholm in I9I 2 the Graeco-Roman style of wrestling was alone admitted, as having the best claims to be cosmopolitan. The contests, however, proved unsatisfactory. It is the defect of this style that it encourages passive resistance; and when a bout lasted for eleven hours and it was considered necessary to allow intervals for rest and refreshment, it was felt that something like a reductio ad absurdum had been reached. This fiasco, however, was due in some degree to the intentional omission by the Swedish committee of a time limit such as had been enforced at the London Games of 1908. Some of the members

ISee also under "United States" below. 
of the jury withdrew, and a protest meeting was held by the competitors. The first prizes were won by Saarela, Koskelo and Wäre of Finland, with C. E. Johansson of Sweden, Ahlgren, and Böling of Finland receiving second prizes for the incomplete final round above-mentioned. A German, a Hungarian, and a Russian reached the prize list, which was otherwise confined to Finns and Swedes.

Professional wrestlers have assisted towards the present eclipse of this style. Gotch, the American champion, was victorious by a hold which gave his antagonist the choice of surrender or permanent injury. In a public match Gama, an Indian, and Zbysco, a Galician, helped to discredit wrestling as a popular spectacle by remaining on the mat for three hours and doing nothing. In Lancashire and Cumberland wrestling is still cultivated, and is seen at its best at the Grasmere and similar Fell meetings.

\section{Yachting.}

The progress of international yacht racing in European waters in the last few years has been considerable. The International Rule for yacht measurement and rating was introduced in England on January 1, 1907, and in all European countries on January I, I908. Since its introduction up to I9 2 about 650 yachts have been built to the classes which race under the rule. I76 of the vessels have been constructed under the survey of Lloyd's Register of British and Foreign Shipping; I 2 of this number have been built in Great Britain and 64 have been built abroad. The remainder, about 474 , have been built in Germany, Norway, Sweden, France, Denmark, Spain, Russia and Finland under the survey of foreign classification societies.

In I9I the first great European International regatta was held at Spithead; there were I9 events, of which Great Britain won 9, Germany 4, Spain 4, and Norway 2. 13 of the events were won by yachts of British design, and 6 by yachts of foreign design.

In 1912 the second European International regatta was held at Kicl. 24 events were sailed; German-owned yachts won 11, British 8, and Norway, Austria, Russia, Spain, and Belgium one each. I5 of the events were won by yachts of British design, 9 by yachts designed abroad.

All the yachts of the international classes of 23 metres ( 75.4 feet) and under have been single-masted vessels, and those from 23 metres down to 8 metres have been cutter-rigged. Those smaller than 8 metres have usually carried a triangular form of lugsail. The most successful designers of the cutters have been Fife, Mylne, and Nicholson (British), and Anker (Norwegian); and of small lugsail vessels, in addition to the designers already named, Morgan (iiles, Glen-Coats, Laws, and Linton Hope (British). Notable racing cutters have been "Shamrock" (Fife) 23 metres, "Octavia" (Mylne) I 9 metres, "Mariquita" (Fife) I 9 metres; and Nicholson in 1912 designed a splendid all round sea-going cutter in the 15 -metre class named "Istria."

The racing in Class $\mathrm{A}$ above 23 metres has been carried on by schooners, yawls having gone out of favour. Since the visit of an American schooner, the "Westward" (Herreshoff), to Europe in 1910 , which was most successful, the German schooners have been the best in European waters; "Germania," and the German Emperor's yacht, "Meteor," both designed by Max Oertz, winning all the prizes in their class at the International regattas of I9I I and 1912.

\section{Sport in the United States.}

Sport in America is constantly undergoing changes of more or less importance. This may be due in part to the nature of the amalgamated race or it may be due to the fact that sport has had such a short life in the United States as thus far to have no strong traditions. Every game is played by the letter of the rule, and the rules must therefore be exact; and with this exactness comes a pressing necessity for completeness that would hardly be recognised in England, where tradition governs so strongly. For this reason a brief summary of the changes that have affected American sports since 1909-10 will aid the reader in understanding the general situation in the United States.

Football. - The sport of American intercollegiate foothall has developed quite materially in method and rules in the last two or three years. First, the periods of play from two halves of thirty-five minutes each, separated by an intermission, have been altered into four periods of fifteen minutes each with an intermission of one minute between the first and second and third and fourth periods and an intermission of fifteen minutes between the second and third periods. The field of play has also been quite materially altered. The actual distance between the goal lines instead of $330 \mathrm{ft}$. as formerly is now only $300 \mathrm{ft}$., but there is an additional end zone at each end extending 30 feet back from the goal line, in which a man may 
legally receive a forward pass. It can really be said therefore that the middle line of the field is no longer the 55-yard line but the 50-yard line. Furthermore, a change in the rules has been made that makes the 20-yard line the limit of kick-out instead of the 25-yard line. Hence, the two lines that are marked more heavily than the rest on the field are now the 50-yard line and the 20-yard line instead of as formerly the 55-yard line and the 25-yard line. The longitudinal lines. of marking on the field have also been practically eliminated as they are now of no particular service. The latitudinal lines remain to mark the distance gained and lost. The scoring has also been altered; a touchdown counted five points and the conversion of this touchdown into a goal added one point more, a field kick goal counted four; now a touchdown counts six and its conversion one point, so that a goal and touchdown together count seven and a goal from the field counts only three.

The: method of play has also been somewhat altered, owing to certain changes in the rules. It has recently been enacted that a side shall have four trials to advance the ball the required distance of ten yards instead of three as formerly and this has increased the value of the running game. The restrictions upon the forward pass have also been rendered less severe. A man may now pass the ball so that it crosses the line of scrimmage at any point and he may make the pass as long or as short as he wishes provided he stands at least five yards back of the scrimmage line when he makes the pass. The onside kick has been entirely eliminated. The number of officials, formerly four, has been changed to three, but these three have so much to do that it is not improbable that there may be a return to the old method. However, the number of officials now stands at three, the referee, umpire and linesman. With all these alterations the play is more interesting and exciting and tends to an increase of scoring possibilities as well as giving an opportunity for the exercise of greater generalship. On the whole it is safe to say that the rules have been improved from the standpoint ' player and spectator.

The contests of greatest interest in : 19.12 were, as usual in recent years, those between the three Eastern universities of Harvard, Princeton and Yale. On November 2 at Cambridge Harvard defeated Princeton, 16 to 6; on November I 6 at Princeton, Yale and Princeton played a drawn game, 6 to 6 ; and on November 23 at New Haven, Harvard defeated Yale, 20 to 0 . On November 28 the University of Pennsylvania defeated Cornell 7 to 2 .

Association or Soccer football is being encouraged in the United States and has the support of many athletic directors throughout the colleges. It does not attract the large crowds but is popular as a pastime among those who do not care for the perhaps longer and more arduous training of the intercollegiate. It has added one more to the list of sports that help to attract out of doors during the fall and early winter months the student who otherwise would employ his time possibly in a less satisfactory manner. Rugby as such is not played in the United States except by two of the Pacific Coast universities.

Baseball. - In baseball the rules have not been materially altered, nor has the game taken on such distinct divergence as has football. The commanding feature of the baseball situation is that the public interest has not only been maintained, but has increased: and the attention given to the World's Series, that is, the annual contest between the winners of the American League pennant and the National League pennant, consisting of the winning of four games out of seven, has become a matter of national interest.

The series of I9I I was exciting, and ended in the victory of the Philadelphia American League Club over the New York National League Club. The series of 1912 was probably the closest ever known in a series of this nature, the Boston American League Club finally winning out in the concluding game of the series after each team had won three games. Public interest in intercollegiate games is also keen. In 1912, on June I3, Princeton defeatcd Yale at New York by a score of 19 to 6 and won the series between these two universitics. Princeton was easily first among all the college teams, winning 2 I out of 29 games played with other colleges in 1912. On June I9 Yale defeated Harvard at Cambridge 9 to 6, thus winning the deciding game in the series between these two universitics.

Boxing.-Boxing interest saw its height at the time of the Johnson-Jeffries match at Reno, Nev., July 4, I910, but the permitting of the sport in New York state under a certain board of commissioners has led in the last year or two to considerable development of interest in the so-called athletic-club promotions. On the whole, however, the meteoric career of "Jack" Johnson (the negro champion) has been typical of the ups-and-downs of the pugilistic profession in America.

Rowing. - Intercollegiate boat racing in the United States is represented by two principal regattas, the one at Poughkeepsie on the Hudson river and the other at New London on the Thames. Although Cornell at Poughkeepsie and Harvard at New London have now been monotonously winning for some years there has appeared no diminution of interest, and the crowd in the yachts assemble at the courses just the same, rendering the spectacle as brilliant as ever. There has continued the everlasting and apparently unending discussion of the merits of various strokes, but the subject seems to be one upon which opinions must always differ. Great respect is had in America for the theory as well as the practice of English rowing, and occasionally representatives of American rowing interests have, as in I9I2, visited the English crews and compared notes. Whether the two schools are coming gradually more nearly together is a question. It is more than likely that constant alteration will 
continue, although at times emphatically denied, and that after all the most successful crews will always be those whose stroke, boat and physique are best correlated.

Apart from intercollegiate rowing, an annual regatta is held of amateur oarsmen in which crews and boats of many kinds from singles to eight oars are represented and which is gradually gaining in importance and quality. In 1912 the Harvard-Yale race at New London, Conn., June 21, was won by Harvard by about 5 lengths. At the Poughkeepsie meet on June 29, in which for the first time the Far West was represented (by a crew from Leland Stanford Jr., University), all the races were easily won by Cornell.

Athletics.-At the Olympic Games of 1912 (July 6-15) in Stockholm, Sweden, many records were broken. In the event of perhaps greatest interest, the 800 metres run, the record was broken by the winner J. E. Meredith ( $1 \mathrm{~min} .51 .9 \mathrm{sec}$.) and by the second and third contestants, all of whom were Americans. America was first in 16 out of a total of $3 \mathrm{I}$ events and scored 85 out of I 84 points. The intercollegiate games, held at Philadelphia on June I, 1912, were won by the University of Pennsylvania with a score of 28 points. Five new records were established.

Cricket.-Cricket in certain quarters, notably the environs of Philadelphia and in some of the schools like Haverford, has kept up a specific interest among those devoted to the sport, but has not spread to any great extent. The Germantown (Pa.) Cricket Club visited England and Ireland in I9I I they won five games, lost five, and three were a draw.

Lawn-Tennis. - Lawn-tennis has more than held its own, and although the Davis cup matches have not proved sufficiently stimulating to draw new blood into tennis ranks in sufficient quantity to build up young players to take the place of the old, the general spreading interest in the game has been fully maintained. The chief events of 1912 were the winning of the national doubles title by Maurice E. McLoughlin and Thomas C. Bundy, both of California, in a challenge match with Raymond D. Little and Gustave F. Touchard at Newport, R. I., August $2 \mathrm{I}$; and the winning of the singles championship by McLoughlin on August 26; and the winning of the women's championships in singles by Miss Mary Browne, also a Californian, at Philadelphia, June 15. An important change made in 1912 was that the holder of the championship in singles was to be required to play through the championship tournament, instead of merely playing, in a "challenge" round, the winner of this tournament. W. A. Larned, who had won the championship in 1911 (and in several previous years), was prevented by his health from playing in the 1912 tournament. The year was notable on account of the success, for the first time, of the Western players.

Polo.- Polo holds its own, even though the cost of equipment is high and the game, in consequence, confined peculiarly to people of large means. Popular interest was greatly stimulated in the spring of 19 II, by the international matches between the American Meadow Brook Club and the English Hurlingham Club, at Westbury, New York. The Americans won two closely contested matches, the score being $4 \frac{1}{2}$ to 3 , and $4 \frac{1}{2}$ to $3 \frac{1}{2}$.

Horseracing.- Horseracing has been placed in an anomalous position in the United States in the last few years owing to legislation. The truth of the matter is that in order to stop the pool room betting, which certainly was a detriment to the youth who were exposed to its influence anci temptations, legislation piled up to such an extent as to affect the interest on the track and the owners. As probably betting has never yet been entirely dissociated from horseracing the attempt to carry through this divorce proved as usual to have unexpected results and one of these has been the cutting down very materially of the interest in this sport.

Wrestling. - In wrestling the important fact has been the still further victories of Frank Gotch, his decisive defeat of the Russian, George Hackenschmidt, at Chicago, Sept. 4, 1911, and his final retirement to his farm. The sport itself has been kept up very well in the colleges, although there have been some defections from the Intercollegiate League.

(Walter CaMp.) 


\section{SECTION I. THE BRITISH EMPIRE ENGLISH POLITICAL HISTORY ${ }^{1}$}

\section{The Crown.}

King Edward VII died on May 6, rgro, and was succeeded on the throne by his only surviving son as George.V, whose consort Queen. Mary, by the Regency Act I9IO, was at once nominated to be regent in the event of a demise of the Crown

Accession of George $V$.

before the next in succession arrived at the age of eighteen. As their eldest son, Prince Edward, was born on June 23, I894, a Regency Act was a temporary constitutional necessity; but he was created Prince of Wales on his sixteenth birthday, and, before attaining his majority in I9I 2 , he had completed his naval education at Osborne and Dartmouth (gazetted midshipman June 22, I9I I, and appointed to the "Hindustan" for a three months' cruise ending October 26th). The young Prince then returned to private studies, paying a visit in the summer of $19 \mathrm{I} 2$ to Paris, with his tutor, Mr. Hansell, as guest of the Marquis de Breteuil, and in the October term he went into residence at Oxford, as a commoner of Magdalen. The new Civil List for the Crown, as approved by Parliament in I910, was fixed at $£_{470,000}$ a year, but Parliament was not asked to provide for the Prince of Wales, his income from the Duchy of Cornwall $\left.(£ 87, \infty)^{\circ}\right)$ being sufficient.

An important change, which had been mooted but not proceeded with when King Edward came to the throne, was made at King George's accession, in the alteration of

Change

in the the Sovereign's declaration respecting his religion, the terms of which,

Accession Declaration. as provided in 1689 by the Bill of Right $\mathrm{s}$, had long been resented by Roman Catholics. After other unsatisfactory suggestions had been made, the Accession Declaration Act of igro finally substituted a short and simple formula for the more detailed "no-Popery" manifesto which, it was generally agreed, was no longer needed. The following were the new terms provided:-

"I (name of Sovereign) do solemnly and sincerely in the presence of God, profess, testify and declare that I am a faithful Protestant, and that I will, according to the true intent of the enactments which secure the Protestant succession to the Throne of my Realm, uphold and maintain the said enactments to the best of my powers according to Law."

At his first opening of Parliament, according to the practice, King George made this declaration, and the whole question was removed from further controversy.

At the death of so active, popular, and influential a sovereign as Edward VII, in the midst of grave parliamentary difficulties and a condition of social-economic unrest The Throne which was soon to be fertile in industrial conflict, the country was fortunate and the at any rate in this, that the Throne had already established itself in the Country. hearts of the people, as a central and unifying force, distinct from all party considerations. The Royal Family, without exception, were known to be active in all that their position enabled them to do for the furtherance of the public welfare; all classes of the community recognised the value of this factor in English social life, and took a proud and affectionate interest in the manifest determination both of the Throne and of individual members of the Royal Family to do their duty and to justify the public trust. The first two years of the new reign made in this respect an auspicious start, and it was soon realised that the consolidation of the Monarchy, begun under Queen Victoria and so remarkably continued under Edward VII, was being effectually carried on, with high ideals and in an earnest spirit, under the Sailor-King, whose' exhortation "Wake up, England," in his speech at the Guildhall when returning from his Colonial tour as Prince of Wales in Igor; had already made history as a general signal to the nation. At King Edward's death there were some who thought that, under his succes-

${ }^{1}$ For the course of events immediately preceding this narrative see Encyclopaedia Britannica, Arts. English History (vol. ix, pp. 532, 533), Edward VII (vol. viii), George V.. (vol. xi), Asquith, H. H. (vol. ii), Lloyd GEORGE, D. (vol. xvi), Balfour, A. J. (vol. iii), Chamberlain, J. (vol. v), Parliament (vol. xx), and British Empire (vol. iv). 
sor, the country would have a Court of more severity, less inclined to display, less sympathetic towards the joyous side of life, - - high-minded and worthy indeed, but rather dull. In so far as such doubts represented a fear that the new King and Queen, whose pure and happy domestic life was universally recognised and respected, would not enter into the amusements of the people and play a Royal part in the social life of the country, it was soon falsified and disappeared. As Prince of Wales, George $V$ had indeed shown no particular interest in horse-racing and some other kinds of national sport and amusement, though he was known to be one of the best shots in the country; but as King, he and his Consort, after the period of mourning was over, at once removed any misconception in this respect. Not only did they follow King Edward's example in attending race-meetings (the Royal training-stables entering horses for the principal races) and patronising the theatres, but in the summer of 1912 for the first time a state visit was paid to a London music-hall (the Palace) and to Henley Regatta, and the King went to Lord's on the occasion of the Test-match between the Australian and South African cricketers, and had the teams presented to him: so that the tradition of Royal interest in national sport and games was amply sustained.

The national inclination for pageantry and display, which King Edward had done so much to gratify, found in King George and Qucen Mary sovereigns who were ready,

The at any cost of personal sacrifice and fatigue, to go even further in making Coronation. public ceremony, on appropriate occasions, the magnificent expression of important acts of State. The Coronation at Westminster Abbey on June 22, I9I I, a solemnity of unparallelled grandeur, attended by representatives from all parts of the Empire and other countries, for which London was decorated as it never had been before, was followed on June 23 by a Royal procession through the streets both north and south of the Thames, on June 24th by a great Naval Review at Spithead, on June 26 th by a gala performance at the Opera, on the 27 th by a Royal gardenparty at Buckingham Palace in the afternoon and a gala performance at His Majesty's 'Theatre in the evening, on the 28th by a Royal visit to the Agricultural Show at Norwich, on the 29th by a thanksgiving service at St. Paul's and a luncheon at the Guildhall, on the 3 oth by an entertainment at the Crystal Palace given by their Majesties to 100,000 London Elementary school children, and by the King's presentation of medals at Buckingham Palace to 500 Indian and I 400 Colonial soldiers. On July 3 rd the King reviewed i 7,000 officers of the Territorial Army in Windsor Park, and on July 4th, 30;000 Boy Scouts gathered there from all parts of the country:

In order to complete the public assumption of Royal authority throughout the United Kingdom, the King and Queen, with the Prince of Wales and Princess Mary, Royal visit then made State visits to Ireland. (July 7 th-I 2 th), Wales (July 13 th) and Scotto Ireland. land (July i 7 th-2ISt). The fact that the Dublin Corporation refused to vote an Address, and that the leaders of the Nationalist party, as usual, held aloof, while "Sinn Fein" even got up local demonstrations against any. celebration of the new reign, only detracted in a very slight degree from what the King himself described as the "spontaneous and hearty loyalty" of his reception in Ireland. When the Royal party drove on July 8th from Kingstown to Dublin Castle they had a great popular welcome from checring crowds all the way; and in the course of the day the new College of Science was inaugurated, and visits were made to Trinity College and to the Phoenix Park races. On Sunday the gth their Majesties attended Service in St. Patrick's CatheIral, and in the afternoon paid a visit to Maynooth College. On the roth the King held a leve and received loyal addresses from deputations sent from various parts of the country, a special address of welcome from 165,000 Irish women being also presented to the ()ueen; in the afternoon their Majesties went to Leopardstown races, and in the evening gave a State banquet at Dublin Castle. On the morning of the r th the King reviewed over 16,000 troops in Phoeniz Park, in the afternoon their Majesties gave a garden-party at the Viceregal Lodge, and in the evening they held a Court at the Castle. On leaving Dublin next day the King gave $f \mathbf{r}, \infty$ for the relief of the poor, and the occasion was also taken by Lord Iveagh to distribute $£ 50,000$ among the Dublin hospitals. 
The Royal visit to Wales had for its centrabobject the Investiture of the Prince of Wales at Carnarvon Castle on July $\mathrm{r}_{3}$ th, a magnificent ceremony and an imposing

Investiture

of the

Prince of Wales. demonstration of Welsh nationalist sentiment, in the arrangements for which Mr. Lloyd George, who had been appointed Constable of Carnarvon Castle; had from the first taken a leading part. In the course of the proceedings a national address was presented to the young Prince by Sir John Rhys, Mr. Abraham, M.P., and the Archdruid; the Prince made part of his replies in Welsh: and in the religious services two Welsh Nonconformist ministers were associated with the two Anglican bishops. The whole affair was a great success. On July i 4 th, the King and Queen visited Bangor for the opening of the new buildings of the University College of North Wales; and on July 15 they visited Aberystwyth and laid the foundation of the new National Library of Wales.

From Wales the Royal party went to Edinburgh, where on July I 7 th a great procession escorted them to Holyrood Palace. Here again ancient Scottish ceremony and modern Scottish sentiment were duly observed and encouraged. A levée Royal visit a Scolland. and a state banquet were held on the I8th; on the Igth the King and Queen
to assisted at the dedication of the new chapel of the Order of the Thistle in St. Giles's Cathedral, and the King laid the foundation stone of the new City Hall; and on the 2oth reviews of troops and boy scouts were held in the King's Park, and a garden-party was given at Holyrood. On the 2 rst the Royal party returned to London, after having brought the whole of the United Kingdom more closely within the ambit of the Coronation festivities by their personal presence in all its capital cities.

But there still remained an important extension of the whole principle of the recognition of Imperial sovereignty, in the visit paid by their Majesties to India and the Coronation ceremonies at the ancient capital of Delhi. At the time of

The Royal visit to

India.

King Edward's death the native unrest in India had become a source of considerable political anxiety, and it was his successor's own idea that the personal presence of the King-Emperor, for the first time as such on Indian soil, and the compliment paid to his Indian subjects by his being crowned Emperor in their midst; would give new: life-blood to all the elements that made for loyalty to the British connection and for Anglo-Indian co-operation in the great work of administering India under the British Crown. The announcement that the King would go in person to India for this purpose, and that, instead of sending a representative, as had been done in the case of King Edward, he and his consort would themselves be crowned at a Royal Durbar, was made in the autumn of 19I0. It was understood that the King's decision was assented to at this time by his ministers with considerable hesitation, and when the Indian unrest continued to show itself during I9I I doubts were freely expressed as to its being prudent. Prophets of evil, as the time drew nearer to November I Ith, when the King and Queen were to leave England, were numerous; but the King's own courage and prescience were fully justified by the event, and the history of the Empire has included no more epoch-making act of State than was involved in all its circumstances. Embarking from Portsmouth on the P. \& O. steamship "Medina," and attended by Lord Crewe, the Secretary of State for India, and a numerous suite, with an escort of men-of-war, the Royal party arrived at Bombay on December 2nd (see INDIA), and were not back in London till February 5, I9I r.

From a political point of view the most remarkable part of the proceedings in connection with the Delhi Durbar was the Royal announcement of certain changes in the The changes Indian administrative system (see under INDIA). In celebration of the The changes
in India. Coronation itself various boons were granted, measures of relief and release for certain classes of debtors and prisoners, a large preliminary outlay towards a new scheme for the extension of popular education, extra pay to certain classes of native officers and civil servants, and the inclusion of native officers and men among those eligible for the award of the Victoria Cross. But all such concessions were overshadowed by the fact that occasion was taken for a public assertion of Royal power and authority in respect of the government of India, by the King's announcement that 
in future Delhi would replace Calcutta as the Capital, and that Lord Curzon's partition of Bengal, which had led to so much contention but which not long since had been described even by ministers in Parliament as res judicula, would be annulled, Bengal becoming a presidency, Behar, Chota Nagpur and Orissa being placed under a lieutenant-governor, and Assam being restored to a chief-commissionership. Not a word of this impending coup d'état had leaked out, though now the despatches of the Indian Government recommending it (August 25, I9IX) and of the Secretary of State sanctioning it (November I) were published. Without making any communication to Parliament, and without giving any opportunity for discussion-for when once royally announced in this way, the step, by common consent of all parties in England, was irrevocable, however muck it might be criticised-an English Radical Ministry had deliberately utilised the King-Emperor's position and prestige to carry out a great autocratic act of State policy, which otherwise certainly could not have been accomplished without considerable friction. So far as concerned the restoration of Delhi, the ancient centre of the Mahommedan Empire, as the capital, the announcement was undoubtedly an appropriate and effective accompaniment of the inauguration of a new Emperor, a dramatic exhibition of monarchical will; and it was made in a magnificent spirit, characteristic of Oriental ideas. Nobody outside the inner ring of the King's advisers, not even among important Anglo-Indian officials, had guessed at such a proposal; yet it had obvious advantages, both sentimental and administrative. Besides gratifying the Mahommedans and others to whom Delhi had immemorial associations with Indian Imperialism, whereas Calcutta represented rather the traditions of "John Company," it not only moved the seat of government away from the rather disturbing influences of Bengal politics, but also provided a central railway position, from which the annual migration to Simla in the hot weather could be made more conveniently and at half the cost. This latter point, combined with profit from the enhanced value of land available for building sites, could be off-set against the lavish outlay (estimated at $£ 4, \infty 00, \infty 00$ ) required to bring the new capital into existence. Bengal and the Hindus meanwhile were consoled for the removal of the Indian Government from Calcutta by the rearrangements made in partial satisfaction at all events of the opposition to Lord Curzon's partition of the province. From a political point of view this was the part of the announcement specially open to criticism, and to Lord Curzon himself it came as a personal rebuff of the bitterest kind; but though the opposing views were well expressed by him and others in subsequent debates in Parliament, the deed was done; in India the King's word had settled it. No single act of Government in the history of the British constitutional monarchy had ever exhibited so promptly the latent resources of the Throne as an extra-parliamentary factor in Imperial administration. That a Radical Ministry, supposed to stand for "democratic" methods and the responsibility of the House of Commons, should have had resort to the machinery of autocracy, was surprising, however, to a good many of their democratic supporters.

By a curious coincidence, just at the time of the Indian Durbar, the P. \& O. liner "Delhi," with the Princess Royal (the King's sister), her husband the Duke of Fife, and their daughters, Princesses Mlexandra and Maud, on board, was wrecked

\section{Desth of} the Duke of Fife.

in a gale off Cape Spartel on the Morocco Coast (December I 3 th) and became a total loss; and the boat in which the Royal passengers were taken to shore was upset in the surf, so that they had a somewhat trying experience. It was hoped that the party had escaped with nothing worse than a wetting and a shock, but after going on to Egypt, whither they were bound for the Princess Royal's health, the Duke of Fife fell seriously ill with pneumonia and he died at Assuan on January 2gth. His elder daughter now became Duchess of Fife in her own right. He and the Duke of Argyll (husband of the King's aunt, Princess Louise) bad been made Knights of the Garter at the Coronation; and his death removed from the Royal circle a Scottish noble of high character and patriotism, esteemed by all who knew him.

In any survey of contemporary English history it is only proper to dwell first on matters directly connected with the Crown and Royal Family, because of the interest 
attaching not only to the opening of a new reign but to the increasing importance of the activities of the Throne under modern conditions of British social and political life. Much inevitably depends on the extent to which popular respect

The Klog's Royal sup. porters.

members. In these respects King George was able to benefit from a continuous growth of mutual confidence, on the part of the Royal Family and the public at large. In his mother, Queen Alexandra, and his consort, Queen Mary, the national affection had always been unchangingly concentrated; and his aunts, King Edward's sisters, Princess Christian, Princess Louise (Duchess of Argyll) and Princess Henry of Battenberg, remained, as they had long been, active and popular figures in English social life. His one surviving uncle, the Duke of Connaught, a man admired and respected throughout the British Army and indeed among all classes, not only for his distinguished ability but also for his camaraderie and good sense, was still able and willing to take an important and most useful part in public life; he went in October, I9Io, to South Africa with great success to open the Union Parliament on the King's behalf, and in Ig I was appointed to succeed Earl Grey as Viceroy of Canada, where he and the Duchess quickly made themselves popular, and their charming daughter, Princess Patricia, not less so: The Duke of Connaught's son, Prince Arthur of Connaught, was meanwhile chosen by the King to be his representative on several important missions to foreign countries, and was appointed one of the four councillors of State (the others being the Archbishop of Canterbury, Lord Chancellor Loreburn and Viscount Morley of Blackburn) empowered to transact business in the King's stead while absent on the Royal visit to India. With such supporters among the Royal Family, the work of the Throne was ably assisted; nor was the support confined only to these. Queen Mary's brother, Prince Francis of Teck, a gallant officer whose death on October 22, I910, cut short a career of much promise, had thrown himself into social service at home by becoming chairman of the Middlesex Hospital, and his brother, Prince Alexander, followed his example. It was generally recognised as being the pride of English Royalty to use their position for public ends and to spare no effort on behalf of national causes.

But the character of the Sovereign himself is necessarily the central factor in the realisation of those potentialities for social and political influence which have become

King

George's

vindication.

so marked in the democratic development of the British Monarchy. At the very outset of his reign King George found it necessary to vindicate his personal character against certain remarkable aspersions, and in doing so he gave a proof of his own confidence in the public, which had excellent effect. It is now purely a curious episode in the history of scandal-mongering that, at the time when he came to the Throne, in spite of the genuine liking which existed in all classes for King Edward's sailor son, stories were current in various quarters, founded on irresponsible gossip, in the first place that he was addicted to drink, and in the second-a still more serious matter-that he had been secretly married before his marriage with the Queen and that this earlier wife was alive though for dynastic purposes the union was ignored. Even while King Edward was alive reports somehow became prevalent that the Prince of Wales drank too much. At "Grand night" at one of the Inns of Court the Prince bluntly told the Treasurer who was his host that people said so, and asked him how to get the impression removed, a question more easily asked than answered. Those more immediately in the Prince's entourage know that it was nonsense, but the more such things are denied the more publicity they generally get. When King George came to the Throne however it became desirable that the progress of this lie should be checked, and the Dean of Norwich in July, rgro, by the King's desire, spoke out plainly with excellent effect. Right-minded people felt moreover that a King who was prepared to abandon the usual reticence in such a matter had a straightforward way of acting which was preferable to the arts of diplomacy.

Reports with reference to the second allegation had indeed been spread at the time 
of the King's marriage to Princess Mary of Teck, as she then was, in 1893 , and had then been contradicted at Queen Victoria's desire, by Canon Dalton, in private letters to various people of influence; but gossip continued to make free with the story, The Myllus and it was revived, to the King's natural annoyance, and with the'danger
case.

of public misconception and ill-feeling if it were not finally disproved, in 1910. Nothing however is more difficult to deal with than private scandal for which nobody in particular can be made responsible. It was hoped that the further public contradictions authoritatively given by the Dean of Norwich in his speech in July, by Mr. Stead in the Review of Reviews for that month, and by Sir Arthur Bigge in Reynolds' Newspaper (October 30, 1910), would put an end to it; but it was repeated in a definite way by a certain Edward Mylius in November and December I910, in a " republican " paper called the Liberator, published in Paris and circulated in England under the auspices of the Indian revolutionary Krishnavarma. In this the writer declared that the King, when a midshipman, had in 1890 married at Malta a daughter of Admiral Sir Michael Culme-Seymour; his subsequent marriage in 1893 was therefore bigamous and shameful, and the Church, by conniving at it, had been guilty of subordinating its own principles to reasons of State. Copies of the Liberator were seized by the police, and Mylius was arrested and on February I, I9II, tried for criminal libel before the Lord Chief Justice and a special jury. Evidence was given by Sir M. Culme-Seymour and others absolutely contradicting the whole fabrication. The Admiral had no daughter whom the King could have married in 1890 ; one of his daughters died unmarried in 1895 without ever knowing him, the other (Mrs. Napier) had not met him between 1879 and 1898 ; the King was not at Malta between 1888 and I90r; the Maltese registers were produced and contained no record of any such marriage. Mylius refused to give evidence, his claim that the King ought to appear as a witness to be cross-examined by him being overruled; and the jury promptly found him guilty. He was sentenced to the maximum penalty of a year's imprisonment; and the Attorney-General then read a statement signed by the King that he had never been married to anyone but the Queen and that he would have attended in person to give evidence if the law officers of the Crown had not insisted that it would be unconstitutional for him to do so.

The whole affair caused naturally a great sensation, but again the effect was excellent, and the straightforward action taken by the King-for it was known that the Its effect. Government doubted the expediency of bringing the matter into Courtconfirmed public opinion as to the character of the new occupant of the Throne. He had insisted on having the truth told, and was not prepared to forgo his rights as a man simply because, as a King, he was above the law. That was not his idea of kingship. Good thus came of evil, and enhanced confidence in the Throne, which was strengthened, in all but one rather doubtful respect to be mentioned later, by the public work of King George and Queen Mary in IgI I and IgI2. They were not. content with the scenic side of Royalty; they were anxious to show their interest in all national activities and to enter sympathetically into the lives of the working-classes. While they mingled graciously with socicty at Court and at country house-parties, Queen Mary made herself equally at home in taking tea with a Welsh miner's wife (June 27, I I I2) after the Royal visit to the Dowlais steel-works at Merthyr, and during a tour through the industrial districts of Yorkshire King George went down the Elsecar ('olliery (July 9) and showed himself no less handy in wielding a pick than at bringing down the grouse on a Scotch moor. Moreover Royal visits were made to Harrow School on Speech 1)ay in July, I9 2 , and to Winchester just afterwards to celebrate the restoration of the cathedral; the King took an active part in various public functions, notably in I ying the foundation of the new London County Council ofices on the Embankment (March (), I() I 2), and opening the Immingham Dock near Grimsby (July 22, I9I2); and in the first two years of his reign he had made the Royal presence felt far and wide.

The doubtful excention already alluded to was in respect of the use of the Royal prerogative in passin $y^{2}$ the Parliament Act in IOII. The parliamentary aspects of this revolution in English constitutional procedure will be considered later, but the public 
intervention in party politics which it involved on the part of the King marks a distinct step in the history of the Throne itself, and one which affects the whole system of English parliamentary government. Whatever were the necessities of the case from

\section{The Royal} prerogative.

the point of view of the Liberal party, there can be no question that, politically, the successful use of the Royal prerogative in overcoming the resistance of the House of Lords to the Parliament Bill brought the Crown itself into open conflict with the passionate desires and convictions of a very large section of the community, - a minority indeed, so far as its representatives in the House of Commons were concerned, but a minority even then which, in the country at large, stood for nearly as many people as the majority. Under a sense of constitutional obligation, brought about by what the Opposition leaders indignantly denounced as ministerial trickery, the Crown lent itself to the last resort open to the party in office for forcing its demands through Parliament, by assenting to Mr. Asquith's demand that, if necessary, enough new peers should be created to vote down the resistance of the Upper House to a measure which practically wiped it out as an effective part of the machinery of legislation. Those who considered the use of the prerogative for such a purpose, and in such circumstances, a constitutional outrage, agreed in putting the responsibility on the Government and not on the King, who acted on the advice of his ministers; but this view, though undeniably correct, only emphasizes the fact that the King was made to appear to act simply as a ministerial puppet. The independent authority of the Throne, as a factor in the Constitution standing outside party politics, was to that extent publicly weakened, and it was only because all parties agreed in deploring such a result and desiring to minimize the effect of the action ostensibly taken by the Crown, that its bearing on the Constitutional position of the Monarchy was slurred over as much as possible. The question whether so drastic an assertion of ministerial power was justified depends, of course, for its answer on the point of view taken as to the merits of the Parliament Bill itself and the importance of passing it as introduced, without the amendments carried in the House of Lords; and from the point of view of the Liberal party the Government, no doubt was driven to the use of the last weapon in its armoury, unless it was to admit that the preceding steps taken, and apparently sanctioned by the results of two general elections, were to be stultified. But no competent observer of the working of British political machinery can deny that the use of the Royal prerogative for so violent a party purpose disclosed the subordination of the Sovereign to the Parliamentary Executive in all its nakedness, in a way which was directly contrary to the development of constitutional theory and practice concerning the functions of the Crown during the reigns of Queen Victoria and King Edward. With a less popular Sovereign on the Throne, and in circumstances less favourable to British pride and affection for the institution of. Monarchy, such a disclosure would have been a more serious danger.

As it was, while the Opposition levelled their denunciations at the ministry, and the Government justified themselves by the absence of any alternative, it was generally The State recognised that since the Lords' rejection of the budget in rgog the whole and the Crown: course of domestic politics had been quasi-revolutionary. In the prolonged crisis in parliamentary affairs, complicated by acute industrial unrest, which continued during I9IO, I III and I9I2, the political conflict in the United Kingdom was being waged under conditions dominated by the peculiar and almost unprecedented relations between parties, and the situation was such that the moderating influence of the Crown had practically no scope for its exercise. It was known at the time of King Edward's death that he had been gravely disquieted at the course which the constitutional crisis was taking; and though there was a strong hope that the parties might embrace the opportunity of the beginning of a new reign to settle their differences by some sort of agreement, it was perfectly clear that, if the dead-lock went on, King George himself must inevitably be placed in a position of serious embarrassment. When the conference of rigro broke down, and when immediately afterwards the second general election of that year gave the Liberal Government once more a majority, matters had to take their own course. The politicians on both sides, and their 
supporters in the country behind them, had created the problem, and its solution still remained for them to find. Between them, wherever the fault might lie, they had sown the whirlwind, and it must carry them where it blew. Meanwhile the Crown, outside domestic politics, remained by universal consent an Imperial and social factor of all the more potential value because of the warring of political factions. The consolidation of the Empire was making steady progress irrespectively of the political situation in the United Kingdom; and King George, though not the personal force in European diplomacy and statemanship that King Edward had been, was known throughout its length and breadth as no English Sovereign had ever been before. In spite of all the political difficulties in the mother country, the British Throne represented in his person a centre of Imperial authority, to which other peoples and Parliaments than those of the United Kingdom contributed: and whenever opportunity should serve for a judicious exercise of this authority, the extent of its influence, both on domestic and on international affairs, would not be limited by constitutional theories affecting the British Isles alone.

\section{The Empire.}

"English" history to-day cannot indeed be written without reference to the British Empire, as a unit greater than is represented by " home" (i.e. English, Welsh, Scottish and Irish) politics. The course of domestic affairs in the other British Progress of Dominions and Colonies is however dealt with in other sections of the Imperialism. $Y e a r-B o o k$, and here it is only necessary to refer to certain matters of common Imperial interest, which are also part of the recent history of affairs in the mother country as the centre of the Empire. The Imperial "idea," to which Mr. Chamberlain's administration of the Colonial Office and the emergency of the Boer War had given such a pronounced impetus, has progressed during these later years with rapid strides, both in Great Britain and the Dominions. It has done so irrespectively of English domestic politics, in consequence of the increasing consciousness in all quarters that the different parts of the Empire have a common interest in the maintenance of British power, and that this is only possible by mutual support. The persistent advocacy of the fiscal policy of Tariff Reform and Colonial Preference by the Unionist party in the mother country, and their agreement in this respect with the trade policy of the statesmen of the Dominions, has undoubtedly done much, directly and indirectly, to popularise the idea of closer union; but on these lines no advance was possible while an English government, committed to "Free Trade,"

Since 1909 however the question of Imperial Defence has become acute, in consequence of the rapid increase of the German navy and its manifest challenge to British Imperial sea-power. This new external pressure, and the strain it involved on the Defence. resources of the mother country at a point where the security of the outlying British Dominions was immediately affected, concentrated attention throughout the Empire on the problem of a fuller co-operation for Imperial defence; and during $191 \mathrm{I}$ and I9I 2 this aspect of Imperial consolidation brought the statesmen of the Empire increasingly into closer touch over a problem which raised no differences of political principle. The most remarkable incident during the Imperial Conference, which reassembled in London in $\mathrm{x} / \mathrm{I}$, was the confidential discussion of British international policy, at which the Colonial representatives were addressed by Sir Edward (irey with a detailed account of the situation in foreign affairs. For the first time. it was felt, the Empire as a whole had been taken into the counsels of the statesmen of the mother country, in order that a common understanding might prevail. A naval defence scheme was adopted, providing for the maintenance of the various naval services and forces under the control of their respective governments, but for making the training and discipline uniform with those of the fleet of the United Kingdom and for arranging an interchange of officers and men, while in war-time the colonial ships placed at the disposal of the Crown would be under the British Admiralty: The movement for increasing the Colonial naval forces, and combining their provision with the idea of

' See E. B. xi, 88 et seq. 
an Imperial Navy acting as a single unit, was also notably forwarded by the visit to England of the Canadian Premier, Mr. Borden, with other Canadian ministers, in I9I2, for the purpose of discussing the whole subject with the home government and the Committee of Imperial Defence. The public speeches made by Mr. Borden and his colleagues during this visit, and the references made to it by Mr. Asquith in the House of Commons, showed that, in this department of administrative policy at any rate, the goal of Imperial federation was appreciably nearer.

In connection with the Imperial Conference of I9I I it may also be noted that resolutions were adopted by it in favour of: (I) an Imperial Naturalisation Act, based on a

other questions at the Conference of 1911 . scheme to be agreed upon, but still undefined, for conferring an uniform British citizenship throughout the Empire, (2) the appointment (carried out in I9I2) of a Royal Commission, representing the whole Empire, to investigate and report on its natural resources, and the possibility of their development, (3) the establishment of a chain of British State-owned wireless telegraphic stations within the Empire (proposed under the Marconi agreement of I9I2). A somewhat elaborate scheme proposed by Sir Joseph Ward for setting up an Imperial House of Representatives for Defence, and an Imperial Council of State, was withdrawn by him, after both Mr. Asquith and various Colonial ministers had criticised it adversely.

\section{Domestic Politics.}

The history of domestic British politics in I9I I and I9I 2 was dominated by the state of the parties resulting from the general election which was precipitated Parties in in December I910 when the private conference between the Liberal and

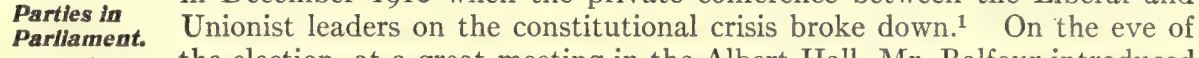
the election, at a great meeting in the Albert Hall, Mr. Balfour introduced a new issue on the Unionist side by advocating a Referendum on great constitutional questions, and declaring that he was prepared to refer Tariff Reform to the people by this method if the other side would do the same for Irish Home Rule. It was believed in some Unionist quarters that this declaration in favour of a Referendum on Tariff Reform (which was generally discussed without any question of its depending on the willingness of the Government to adopt the Referendum for Home Rule) would help to secure support among Unionist critics of the Tariff Reform policy; but it came too late in the day for that purpose, and was not much to the taste of the more ardent Tariff Reformers. Mr. Austen Chamberlain, for one, at once expressed his view of the difficulty of taking a Referendum on a question of finance; and after the elections the idea of qualifying the Tariff Reform issue by coupling it with a pledge not to proceed without a Referendum practically disappeared from the Unionist platform, though suggestions for its revival were occasionally made by Unionists who thought Tariff Reform unpopular. ${ }^{2}$ Its failure for electioneering purposes helped indeed to increase the criticism which was already rife in certain Unionist circles against Mr. Balfour's leadership. On the other hand the use of the Referendum for putting large constitutional changes before the electorate, and for thus solving the problem of conflicts between the two Houses of Parliament, was increasingly advocated on the Unionist side. A bill for this purpose, brought by Lord Balfour of Burleigh before the House of Lords in March I9II, made no actual headway, but the proposal, in one shape or another, became part of the Unionist alternative to the Parliament Bill. The Government, on their side, concentrated all their efforts on an appeal to the electorate to give them a majority for the Parliament Bill, as an essential preliminary to any Liberal legislation; and the result showed that the short interval since the general election of January rigro had made practically no difference in the balance of party power. The distribution of seats, and

1 See E. B. xx, 846,847 .

2 On November I4, I9I2, at the meeting of the National Unionist Association in the Albert Hall; at which Mr. Bonar Law and Lord Lansdowne both spoke, Lord Lansdowne specifically declared that the Unionist leaders regarded the proposal for a Referendum on Tariff Reform as abandoned. But see further below, ad fin. 
the strength of parties, may be shown best in tabular form (Table A). Party gains are shown in Table B.

\section{Table A. Result of General Election of December 19ro.}

Showing numbers of Liberals, Labour Party, Irish Nationalists, Independent Irish Nationalists, and Unionists returned.

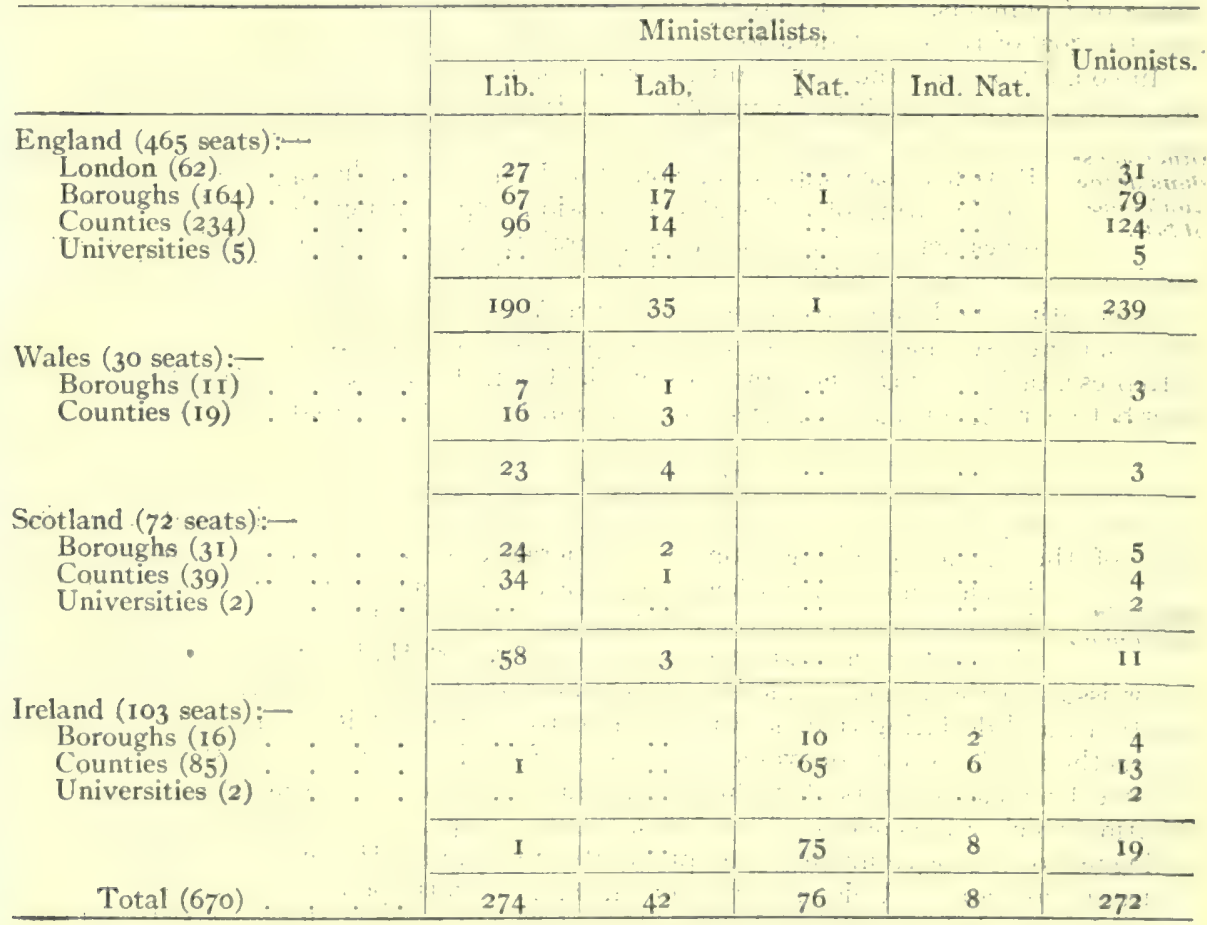

Allowing for the recount at Exeter, and the by-election at Cheltenham (April 28th) resulting from a successful petition, the new Parliament opened in IgIr with a Ministerial majority of I22, the coalition of Liberals (270), Labour Party (42) and Irish Nationalists $(84)$, numbering 396 , and the Unionists 274 . The precise balance of voting strength in the electorate cannot be stated, owing to the fact that $7 \mathrm{I}$ Unionist and 88 Ministerial seats were not contested; the Unionist votes recorded were 2,426,68I and Ministerialist 2,807,753; but if an allowance is made for the uncontested seats, the Ministerialist majority might be taken at between 240,000 and 350,000. In England alone the Unionists had a majority of I7 seats (24I to 224).

It may be convenient here to notice the results of the subsequent by-elections which for various reasons became necessary during IgII and Igr2. While the Parliament Bill By-elections was still the main issue, no change was made in the position of the parties, 1911, 1912. but afterwards the Unionists won three seats in I9I I at Oldham (Nov. I3th), South Somersetshire (Nov. 21st) and North Ayrshire (Dec. 2oth), and in IOI 2 gained further successes at South Manchester (Nov. 5th), Crewe (July 26th), North-West Manchester (Aug. 8th), Midlothian (Sept. roth), and Bow and Bromley ${ }^{1}$ (Nov. 26 th). This improvement in their position was marked still more by their gains in voting strength, which became particularly noticeable when the Insurance Act of I9I I was

${ }^{1}$ At Bow and Bromley, though the Unionist won a seat, the defeated candidate Mr. Lansbury was not actually standing as a supporter of the Government. He had resigned in order to vindicate his independence as a supporter of woman's suffrage, and the issues were consequently "mixed." 
added to the issues before the electorate. Between February IgI I and November 25, igi2, (before the Bow \& Bromley contest, which may here be ignored), in 30 straight contests between Unionist and Liberal candidates (including Cheltenham) they obtained a net advantage of 20,156 votes over the Liberals as compared with those given at the general election, the Unionists gaining 2 I,835 in 24 constituencies as against a Liberal gain of I,677 in 6; and in II three-cornered contests, where a Labour candidate also stood, they obtained an advantage of I 5,757 over the Liberals (as apart from Labour), gaining 21,069 in Io Elections as against 5,3 12 in I (Hanley). So that, in the aggregate, the Unionists, in 4I contests, improved their position, as compared with the Liberals, by 35,8 I 3 votes. The figures showing the differences from the previous pollings (and including Bow \& Bromley) are given in Table C.

Table B. Seats Representing Party Gains at General Election of December 1910

By Ministerialists (29)

Bedford.

$a$ Bow and Bromley.

Burnley.

Cambridgeshire, Newmarket.

$b$ Cheltenham.

Coventry.

Cumberland, Cockermouth.

c Dublin County, South. Essex, Saffron Walden.

$d$ Exeter.

Kent, Deptford.

Kirkcudbrightshire.

Lincolnshire, Louth.

Manchester. S. W.

Oxford, Banbury.

Peckham.

Radnorshire.

Rochester.

Southwark, W.

Staffordshire, Leek.

Stepney.

Suffolk, Lowestoft.

$e$ Sunderland (2 seats)

$c$ Tyrone, Mid.

Wakefield.

$a$ Whitehaven.

Wilts, Cricklade.

$a$ Woolwich. a. Labour.

b. Reversed at by-election after petition.
By Unionists (27)

Ashton-under-Lyne.

Birkenhead.

Cardiff.

Cheshire, Altrincham.

Cornwall, Bodmin.

Cumberland, Eskdale.

Darlington.

Derbyshire, High Peak.

Devonshire, Ashburton.

Devonshire, Tavistock.

Devcnshire, Torquay.

Dudley.

Great Grimsby.

Islington, W.

King's Lynn.

Lancashire, Darwen.

$f$ Lancashire, Newton.

Leicestershire, Melton.

Liverpool, Exchangè.

Plymouth (2 seats).

St. Andrews, Burghs.

$f$ St. Helen's.

St. Pancras, W.

Salford, S.

Warrington.

$f$ Wigan.

The Ministerialists, while representing a good many different shades of opınion, included a number of men of marked individual ability and parliamentary influence. Leading men In the Cabinet, Mr. Asquith ${ }^{1}$ (Prime Minister; b. I 852), Mr. Lloyd George ${ }^{2}$ of the (Chancellor of the Exchequer; b. I863), Mr. Winston Churchill ${ }^{3}$ (Home coalition.

Secretary from Feb. Igro till Oct. igri, and then First Lord of the Admiralty; b. 1874), Sir E. Grey ${ }^{4}$ (Foreign Secretary since I905; b. I862), and Mr. R. B. Haldane, ${ }^{5}$ who was created a Peer as Viscount Haldane in March I gI I (War Minister from I 905 till July I9I2, and then Lord Chancellor; b. I856), stood out first and foremost in dominating the manoeuvres of the party. Mr. Asquith, Sir E. Grey, and Mr. Haldane, with Lord Crewe (Sec. of State for India since Nov. Igro), Lord Morley (Lord President of his Council since Nov. I910) and Lord Chancellor Loreburn (who occupied the Woolsack till July I9 2 2) in the Upper House, gave a solidity to the Liberal counsels which was matched with the adventurous electioneering policy carried on by Mr. Lloyd George and Mr. Churchill along paths of their own.
$E$. B. ii, 769 .
I Ibid. xvi, 832
Ibid., vi, 347 .
Ibid., xii, 588 .
Ibid., xii, 831 . 
Table C. By-elcctions 1911 and 1912 , and changes in polling since last contest.

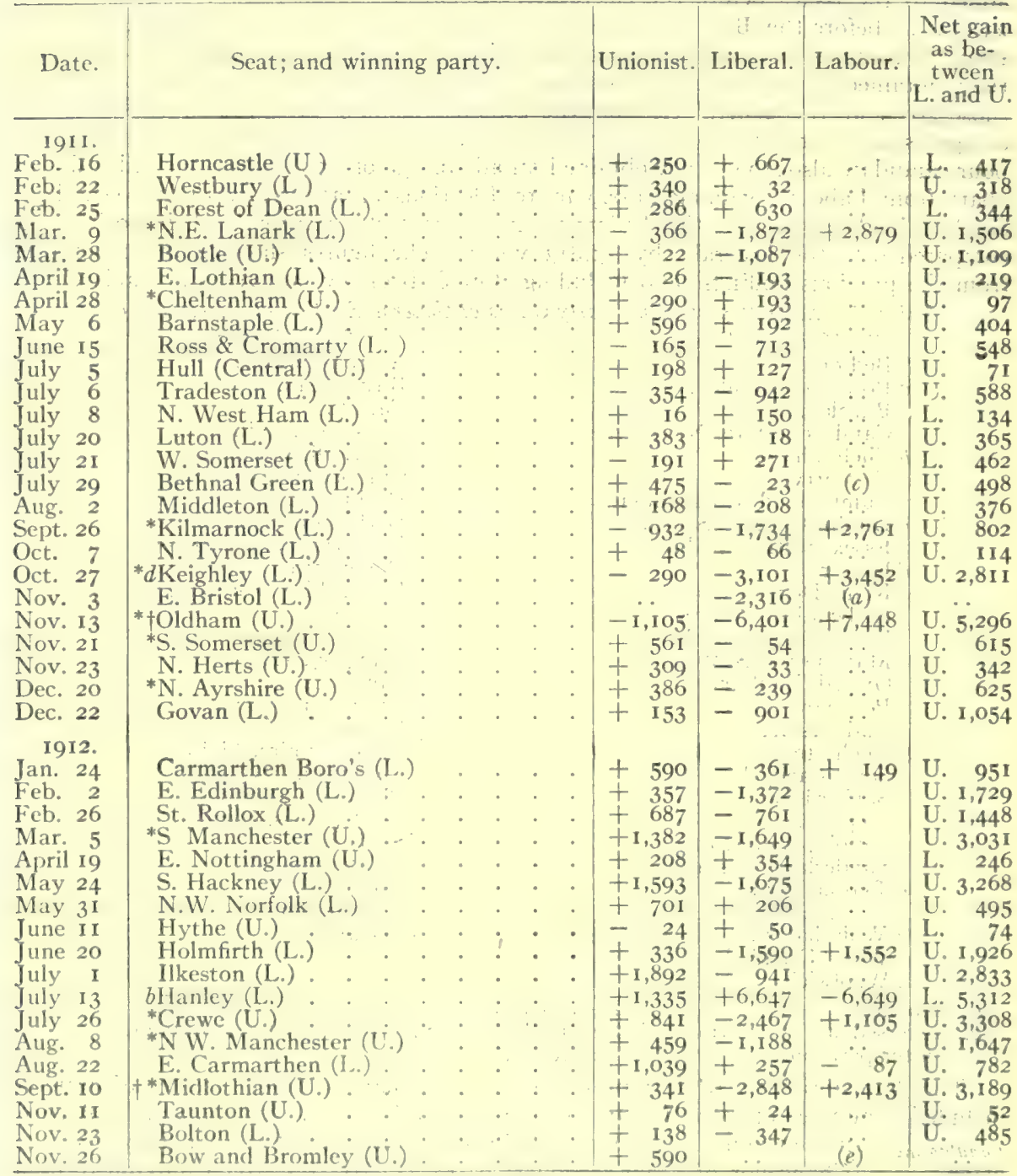

tNo Labour candidate at last general clection.

*Unionist gain from Liberal.

(a) No Unionist candidate. Ind. candidate polled 2,913 votes.

(b) Liberal gain from Labour

(c) Socialist candidate polled 134 votes:

(d) No contest in December I9I0. Figures compared with January I910.

(e) Independent Socialist and Woman's Suffrage candidate polled 3,291, or 1,024 less than he had polled in December 1910 when standing as a Socialist member of the Labour party with official Liberal support.

Behind them in the Ilouse of Commons the most prominent members of the Ministry holding major offices were: Mr. Birrell' (Irish Secretary since 1907; b. 1850); Mr. Johr Burns22 (President Local (jovernment Board since 1905; b. I858), Mr. Sydney Buxton (President Boarl of Trade since Feb. 1910; Postmaster-general 1905-1910; b. 1853); 
Mr. L. V. Harcourt ${ }^{1}$ (Colonial Secretary since Nov. I910; b. 1863); Mr. Reginald McKenna (First Lord of the Admiralty from r 908 till Oct. I9 I , and then Home Secretary; b. I863); Mr. J. A. Pease (Chancellor of the Duchy of Lancaster from I9ro till October I9I1, then Education Minister; formerly Chief Whip I908-I910; b. I860); Mr. Walter Runciman (Education Minister from I908 till Oct. I9I , then President Board of Agriculture; b. I870); and Mr. Herbert Samuel (Postmaster General; previously Chancellor of the Duchy, I909-Feb. I910; b. I870). Mr. Charles Hobhouse (b. 1862), who was Financial Secretary to the Treasury from I908 to October I9I I, then became Chancellor of the Duchy of Lancaster; Colonel John Seely (b. 1868), who, having seceded from the Unionist party with Mr. Churchill, was Under-Secretary first for the Colonies (I908-March I9II) and then for War, succeeded Lord Haldane as War Minister in July I9I 2 ; and Mr. T. M'Kinnon Wood (b. I855), formerly Progressive Leader on the London County Council, having been Under-Secretary for Education (1908), Under-Secretary for Foreign Affairs (rgo8-Oct. rgIr) and then Financial Secretary to the Treasury, became Secretary for Scotland in succession to Lord Pentland (who resigned and was appointed Governor of Madras) in I9I 2; while Sir Rufus Isaacs (Attorney-General since March I910; b. I860) was included in the Cabinet of I9r2. Sir John Simon (SolicitorGeneral since Mar. I9Io; b I873) had also come to the front as a politician of marked capacity.

Minor offices were filled by Mr.C. F. G. Masterman (Under-Secretary for Home Office since r9o9; b. r873), Mr. E. S. Montagu (Under-Secretary for India since Feb. r gro; b. r879), Dr. T. J. Macnamara (Financial Secretary for the Admiralty since r9o8; b. I86 r), Mr. F. D. Acland (Under-Secretary for Foreign Affairs from Oct. I II ; previously Financial Secretary to War Office I908-Feb. I910; b. I874), Mr. J. M. Robertson (b. 1856; Under-Secretary for the Board of Trade from Oct. IgI I, in succession to Mr. H. J. Tennant, b. 1865 , appointed Financial Secretary for War), Mr. C. Trevelyan (UnderSecretary for Education since 1908; b. I870), Mr. G. Lambert (Civil Lord of the Admiralty since I905; b. I866); and Mr: J. Herbert Lewis (Under-Secretary to Local Government Board since r 909 ; b. I858). The Master of Elibank (b. I870) was a popular and efficient Chief Whip (since Feb. Igro), and among the Junior Whips were Mr. P. H. Illingworth (his successor in August I912; b. I869), Mr. W. W. Benn (b. I877), Mr. Gulland (b. I864), and the Hon. F. E. Guest (b. I875).

Among the Liberal rank and file the men who figured most prominently in independent initiative or criticism were Sir A. Mond (b. I868), Mr. Chiozza Money (b. I870), Mr. J. C. Wedgwood (b. I872), Mr. P. Morrell (b. 187a), Mr. Ellis Griffith (b. I860), Mr. A. Ponsonby (b. I87 I), Mr. R. Harcourt (b. I878), the Hon. Neil Primrose ${ }^{2}$ (b. 1882), Mr. E. Crawshay-Williams (b. 1879), Mr. J. F. L. Brunner (b. 1865), Mr. Silvester Horne (the well-known Nonconformist minister; b. I865), Mr. A. J. Sherwell (b. I863), Sir A. B. Markham (b. I866), Sir W. P. Byles (b. I839), Sir J. H. Yoxall (b. I857), and Mr. T. Lough (Secretary to the Board of Education, I005-8; b. I 850); while Mr. Horatio Bottomley (b. I860), elected as a Liberal, but acting as an independent critic of an "unbusinesslike" parliamentary régime, pursued an impracticable but lively career until he resigned, having become a bankrupt, in I9 2.

Among the Labour party, led by Mr. J. Ramsay Macdonald (b. I866), the most notable figures were Mr. J. Keir Hardie (b. r856), Mr. G. N. Barnes (b. I859), Mr. W. Crooks (b. 1852), Mr. Philip Snowden (b. I 864 ), Mr. G. Lansbury (b. I 859 ), Mr. W. Thorne (b. r857), Mr. F. W. Jowett (b. 1864), Mr. C. W. Bowerman (b. I85 I), Mr. W. Brace (b. 1865 ), and Mr. W. E. Harvey (b. 1852 ).

Mr. John Redmond ${ }^{3}$ (b. I85I), as leader of the Irish Nationalists, found his most effective parliamentary support in Mr. John Dillon ${ }^{4}$ (b. I85 I), Mr. J. G. Swift MacNeill (b. I849), and Mr. T. P. O'Connor (b. I 848), though Mr. Joseph Devlin (b. I872) was an even more active force in the organisation of the party; Mr. William O'Brien (b. I852), and Mr. T. M. Healy (b. I855), meanwhile providing independent criticism from
${ }^{1}$ E. B. xil, 940 .
${ }^{2}$ Ibid., xxiii, 734 . 
the point of view of Irish Nationalists who were not satisfied that all was well with the Government policy:

In the Upper House Liberalism had but a small following, but was actively represented under Lord Crewe's ${ }^{1}$ leadership, by Lord Morley, ${ }^{2}$ Lord Loreburn (Lord Chancellor since 1905; formerly, as Sir Robert Reid, Attorney-General I804, and M.P. since $x 886$; b. 1846), Lord Pentland (Secretary for Scotland, I905-1912; till I909, as Capt. John Sinclair, M.P. for Fortarshire; b. I 869), Lord Beauchamp (Lord Pres. of Council JuneNov. rgro, then First Commissioner of Works; b. I872), Lord Burghclere (formerly, as Mr. Herbert Gardner M.P., Pres. of Bd. of Agriculture, I892-I895; b. I847), Lord Lucas (Under-Sec. for Colonies March-Oct. IgI r, then Sec. for Agriculture; b. 1876), Lord Welby (till 1894 the chief official of the Treasury; b. I832), Lord Sheffield ${ }^{3}$ (b. 1839), Lord Weardale (till i 905 Mr. Philip Stanhope, M.P.; b. 1847), Lord St. Davids (till r 908 Mr. J. W. Philipps, M.P.; b. I 860), and Lord Ashby St. Ledgers (till 19ro Capt. the Hon. Ivor Guest; M.P., eldest son of Lord Wimborne; b. 1873). Lord Rosebery (b. I 848), continued to plough a lonely furrow, and Lord Courtney of Penwith ${ }^{5}$ (b. 1832), to play the part of a political Aristides. In I9I I the Liberal Peers were reinforced by the elevation of Lord Haldane in March, and of Mr. Alfred Emmott as Lord Emmott (b. 1858 ; Chairman of Committees in the Commons since I906) in October, the latter being appointed Under-Secretary for the Colonies.

On the Unionist side, Mr. Balfour ${ }^{6}$ (b. I 848 ) had no rival as a parliamentary figure, but the party was sore with unsuccess, and the personal affection and admiration with Leading men which he was regarded were balanced by misgivings among the rank and on the Union-file and in the country as to his capacity to lead them out of it: No other ist side. Unionist leader however was prepared to be put in competition with him, and he was loyally supported in the House of Commons by ex-Ministers in Mr. Austen Chamberlain $^{7}$ (b. I863), Mr. Walter Long ${ }^{8}$ (b. 1854), Mr. Bonar Law (b. I858), Mr. H. Chaplin $^{9}$ (b. I84 I), Mr. G. Wyndham ${ }^{10}$ (b. I863), Mr.A. Lyttelton ${ }^{11}$ (b. I857), Sir R. B. Finlay (b. 1842 ; formerly Attorney-General), Sir E. Carson (ex-Solicitor-General, and leader of the Irish Unionists; b. I 854), Sir W. R. Anson ${ }^{12}$ (b. I843), Mr. J. H. Campbell (formerly Solicitor-General for Ireland; b. I85I), Mr. E. G. Pretyman (who had come prominently forward in i 909 as a critic of the new land taxes; b. I 859), and Mr. W. Hayes Fisher (fresh from leading the Unionists or "Municipal Reformers" on the London County Council; b. 1853 ).

In Mr. F. E. Smith, K.C. (b. I 872 ), who had made a rapid and brilliant success both at the Bar and in politics, the party had an indefatigable worker and an audacious orator, now taking a place in the front rank corresponding more or less to that of $\mathrm{Mr}$. Churchill on the other side; and a variety of political talent or experience was actively representer by Sir F. G. Banbury (b. 1850), Mr. G. Cave (b. 1856), Mr. H. E. Duke (b. 1855), Mr. J. G. Butcher (b. 1852); Sir Gilluert $\operatorname{Parker}^{13}$ (b. 1862), Mr. Charles Bathurst (b. 1867), Mr. A. H. Lee (b. I868), Lord Hugh Cecil'14 (b. 1869), Lord Charles Beresford (b. I846). Mr. E. A. Goulding (b. I863), Sir A. Griffith-Boscawen (b. I865), Mr. H. Stavely Hill (b. I 865), Mr. J. W. Hills (b. 1867), Mr. H. J. Mackinder (b. I86 I), Mr. F. Cassel (b. I 860 ), Mr. B. E. Peto (b. I862), Mr. L. Worthington Evans (b. 1868), Mr. H. Page Croft (b. 1881), Mr. George Sandys (b. 1875), Major Archer Shee (b. 1873), Mr. A. Burgoyne (b. 1880), Mr. W. Ormsby-Gore (b. 1885), Mr. W. W. Astor (b. 1870), Lord Winterton (b. 1883), Lord Castlereagh (b). 1878), Lord Ronaldshay (b. I876), Lord Tullibardine (b. 187 r), Lord Wolmer (b. 1887), and Lord Helmsley (b. 1887). The Irish Lnionists included Mr. W. Moore (b. 1864), Sir J. B. Lonsdale (b. I849), Capt. J. Craig (b. I87I), and Mr. W. Mitchell Thompson (b. 1877).

With Sir Alexander Acland-Hood (b. 1854) as Chief Whip-retiring with a peerage as Lord St. Audries in I0 I I - were principally associated Lord Balcarres (b. I $87 \mathrm{I}$ ), who
1 E. B. vii, 432 .
2 Ibid., xviii, 840 .
"Ibid., xxv, 777 ("Stanley" ad fin.)
'Ibid., iii, 250-254.
Ibid., v, 817.
I Ibid., xxiii, 73I
8 Ibid., xiv, 788.
s Ibid., vii, 328 .
9 Ibid., v, 852 .
${ }^{10}$ Ibid. iii, 252 ; xiv, 788 .
11 Ibid., xvii, 185.
12 Ibid., ii, 84 .
13 Ibid, xx, 827.
is Ibid., xxiv, 76 . 
succeeded him in the post, Mr. H. W. Forster (b. I866), and Mr. H. Pike Pease (b. r867); and as the result of a rearrangement of the machinery of the Conservative Central Office in rgr 1 : (carried still further by the fusion in rox 2 of the Conservative and Liberal Unionist organisations under Mr. John Boraston as "Chief Agent "), ${ }^{1}$ Mr. A. H. Steel Maitland, M.P. (b. 1876) was made "Chief Organizer" of the party, independently of the work of parliamentary "whipping."

In the House of Lords Lord Lansdowne ${ }^{3}$ (b. I845) was the recognised Unionist leader, actively supported by such ex-Ministers as Lord Halsbury ${ }^{4}$ (b. I825), Lord Londonderry $^{5}$ (b. I852), Lord Curzon 6 (b. I859), Lord Midleton ${ }^{7}$ (b. I856), Lord Selborne $^{8}$ (b. I859), Lord Cawdor (I847-I9Ix; First Lord of the Admiralty I905), Lord Salisbury $^{9}$ (b. I86r); Lord St. Aldwyn ${ }^{10}$ (b. 1837), Lord Balfour of Burleigh ${ }^{11}$ (b. I849), Lord Ampthill ${ }^{12}$ (b. I 869), Lord Derby ${ }^{13}$ (b. I865), Lord Onslow ${ }^{14}$ (1854-I9II), and the Dukes of Norfolk $^{15}$ (b. I 847 ) and Marlborough ${ }^{16}$ (b. I87I; formerly Colonial UnderSecretary): Lord Avebury ${ }^{17}$ (b. I834), Lord Cromer ${ }^{18}$ (b. 184I), and Lord Milner ${ }^{19}$ (b. 1854), were other important figures on the same side; and among Unionist peers of marked political talent and influence were Lord Ridley (b. 1874; Chairman of the Tariff Reform League), Lord Malmesbury ${ }^{20}$ (b. 1872), Lord Willoughby de Broke ${ }^{21}$ (b...869), and Lord Newton (b. 1857).

Among the members who were returned to the new House of Commons subsequently to the general election, the most notable personalities on the Liberal side were Baron de Forest (b. I879) for North-West Ham (July I9r r), Mr. W. G. C. Gladstone (b. I885) for Kilmarnock Burghs (Sept. Ior I), Mr. S. O. Buckmaster (b. I86I) for the Keigtiley division of Yorks (Oct. I0II); Mr. Hemmerde (b. x87I) for North-West Norfolk (May Igr2), and Mr. R. L. Outhwaite (b. r869) for Hanley (July ror 2); in the Ministry itself Mr. C. F. Masterman (b. I873) was returned in July I II for SouthWest Bethnel Green, after being unseated on petition for North-West Ham. On the Unionist side, the ablest of the Tariff Reform leaders, Mr. Bonar Law, who had been defeated for North-West. Manchester at the general election, was returned for Bootle in March IgIx; and other important additions to the Parliamentary personnel were represented by the return of Sir J. Larmor (b. I837) for Cambridge University. (Feb. rgII), Mr. W. Joynson-Hicks (b. I865) for Brentford, Mr. L. S. Amery (b. I873) for South Birmingham, Mr. Ronald McNeill (b. I86x) for the St. Augustine's division of Kent (July I9r I), Lord Robert Cecil (b. r864) for Hitchin (Nov. I9I I), and Mr. W. A. S. Hewins (b. 1865) for Hereford (March 8, r912). Mr. T. M. Healy, defeated as an Independent Irish Nationalist at the general election, was in July I9 I provided with a seat for North-East Cork, by the retirement of Mr. Moreton Frewen.

The Unionists were now united, after all the troubles over the Tariff Reform movement which started in 1903 , by the common bond of resistance to the Radical-Socialist The Union. programme of their opponents. The Unionist Free Traders had been comIst position. pelled by the course of events, - especially as in their opinion the Liberal Government had under Mr. Lloyd George's guidance pursued an economic policy disastrous to the essentials of Free Trade,- to accept the fact that Tariff Reform and Colonial Preference now stood officially in the forefront of the constructive programme of the party. In the House of Commons itself, when it met in February I9I I, Lord Hugh Cecil remained solitary as an Unionist Free Trader, in the peculiar conditions attaching to his seat for Oxford University. The precise form which the Tariff Reform policy would take if the party were returned to power,- whether the "food taxes"

${ }^{1} \mathrm{Mr}$. Percival Hughes, who had been "Chief Agent" on the Conservative side since 1907, resigned in January 1912. Mr. Boraston had been Liberal Unionist "Chief Agent" for some years.
${ }^{2}$ E. B. xxviii, 590 (art. "Whip").
3 Ibid., xvi, 184
4. Ibid, xii, 867.
5 Ibid., xvi, 969.
6 Ibid, vii, 665.
${ }^{8}$ Ibid., xxiv, 599.
${ }^{9}$ Ibid., xxiv, 76.
${ }^{10}$ Ibid., iii, 252.
11 Ibid, xviii, Ior 3.
' Ibid., xviii, 419.
12 Ibid., i, 894.
${ }^{13}$ Ibid., viii, 69.
${ }_{14}$ Ibid., xx, 113.
15 Ibid., xix, 744 .
${ }_{16}$ Ibid., xvii, 737 .
${ }^{17}$ Ibid., iii, 5 I.

${ }^{18}$ Ibid., vii, 484 .

${ }^{19}$ Ibid., xviii, 476

20 Ibid., xvii, 493.

21 Ibid., xxvii, I031. 
could be modified or dropped, whether the idea of a Referendum should be persisted in,was debated in some quarters, according to varieties of opinion on electioneering tactics; but it was sufficient for the moment for those Unionist politicians who had opposed it altogether, or still wavered as to details, to wait events. The solidarity of the party in opposition, in the immediate crisis, was of more immediate importance. On the other hand, while recognising this fact, the convinced Tariff Reformers were satisfied, from their point of view, with the progress of their movement. The party leaders and the party organisation were now identified with the whole policy, and its acceptance by Unionist candidates was therefore a matter of party loyalty. In the constituencies it was making continued headway, the winning back of eight seats in Lancashire at the general election indicating that an impression was being made on the industrial North of England. Above all, the general idea inspiring Mr. Joseph Chamberlain's proposals, - the federalisation of the British Empire and its closer union for fiscal as well as other purposes,- -was taking more definite shape in the common political consciousness. While a protective national economic policy was advocated by the Tariff Reformers as an essential condition of the improvement of industrial and social conditions at home, - and on those lines they were prepared to go considerable lengths to meet the demands of Labour,-its most active supporters had always in their mind its bearing on the policy of Imperialism. Faced with the inevitability of large constitutional and social reforms, a new constructive spirit had come to dominate the party, changing the whole outlook for democratic Conservatism, under the guidance of this vision of systematised Imperial unity. Fighting as they must to defeat the Coalition Government if possible, in order to preserve the integrity of the Imperial Parliament, menaced by Irish Home Rule, and the check of an effective Second Chamber upon Radical-Socialist legislation, put in jeopardy by the Parliament Bill, the most influential Unionist politicians and publicists were looking anxiously to the wider Imperial issues beyond the solution of immediate domestic problems. It would be unjust to the more Imperially minded individuals on the Liberal side to claim a monopoly in this respect for the Tariff Reform Unionists, but Liberal and Labour politicians and publicists were naturally engrossed with the purely domestic issues represented in their own party programmes. It was the predominant characteristic of all the Unionist activity, both at this stage and afterwards, that it centred round the Imperialist policy which was the end in view. The immediate danger to the cause of Imperial commercial unity which was threatened by the reciprocity treaty between Canada and the United States was therefore a matter of special concern, hailed as it was on the Liberal side as according with the Free-Trade fiscal policy. Grave as the position was for Conservatism and Unionism in English parliamentary politics, in Imperial politics as viewed by supporters of Tariff Reform and Colonial Preference this seemed even a more momentous development. Meanwhile hopes were still entertained that, either by agreement between the parties or through the failure of the Ministry to obtain the King's consent to actual coercion of the House of Lords, the immediate constitutional crisis might be solved or the Government forced to resign or once more dissolve in circumstances more favourable than before to a Unionist success at the polls. After the last two elections further defence of an unreformed House of Lords was out of the question.

It was clear from the first that the Government could rely on the support of the Irish Nationalist party. The passing of the Parliament Bill was an essential prelimThe position inary to the successful accomplishment of Home Rule, and it had been Mr. of the Redmond's policy ever since the elections of January rgro to press the deGovernment. struction of the peers' veto to its final issue for that purpose. The only doubtful element in the coalition was the Labour part $y,{ }^{1}$ whose parliamentary independence-partly as directly representing the Socialist movement, partly as representing the economic policy of the trade unions, and partly as advocating equally against Tory or Liberal " capitalists" and against the whole public of "consumers " the claims of the wage-earning classes as such, - was shown in the promotion of third-party candi-

${ }^{1}$ See E. B. xvi, 28. 
dates at some of the by-elections. Its parliamentary programme included a "Right to Work "Bill which the Liberal party could no more support than the Unionist, whatever individual members of either might do; and at the present moment, having successfully extorted the Trade Disputes Act from parliament in 1906 , it was set on obtaining from the Government a bill for reversing the "Osborne judgment," 2 and freeing the employ ment of trade union funds for political purposes. The fact however that the " independence " of the Labour party was dominated by reluctance to put Liberalism in a minority, in so far as it stood for causes with which the Labour party also identified itself,-Free Trade, the Parliament Bill, Irish Home Rule and Welsh Disestablishment, -made its parliamentary position more or less of a sham, and one over the manoeuvring of which the Government's Whips had the upper hand. 'The result was that the idea which had begun to prevail in 1906 that the power of the Labour party in Parliament (as distinct from the Labour " movement" outside) was likely to have a rapid growth was considerably modified. The industrial troubles of I9I I and I9I2, notably the railway strike, the coal strike, and the London dock strike (see IV below), were seen to be beyond their guidance or control, - they were indeed largely the consequence of a widespread feeling, shown in outbreaks of "syndicalism," that the Labour members in parliament were impotent, because their action was subject to their maintaining the Liberal Government in power. Moreover the wind was taken out of their sails by the extreme radicalism of Mr. Lloyd George and other Liberal electioneers, whose object naturally was to show that Liberalism could do all that Labour wanted. On the other hand, a considerable section of the Liberal party was either apprehensive of the alliance of Labour and Socialism or jealous of surrendering to the Labour party seats which were considered to be within the Liberal preserve. Between the claims of Liberalism and Labour, the Liberal party managers were unable to avoid friction in the constituencies as this situation developed; and though the Whips kept a majority for the Government together against every sort of Unionist attack up to the adjournment of Parliament in August I I 1 2, the possibilities of a serious breach between Liberalism and Labour were towards the end of that period clearly shown in the by-election at Hanley (July I3th), where a Liberal displaced a Labour member, followed by that at Crewe (July 26th), where the Unionist candidate was returned in a three-cornered fight, and still further in the rivalry of Labour and Liberal candidates for Midlothian (Sept. roth), resulting in a Unionist victory. In this last instance the local Liberals flatly declined to accept the Master of Elibank's suggestion-made just when he was retiring from the post of Chief Government Whip and was taking a peerage as Lord Murray,-that they should support the Labour nominee. But this particular weakness within the Coalition majority was of no advantage to the Unionists while the Parliament Bill was still under discussion. For their immediate purposes in I9I I the Government had complete control of the parliamentary machine when they started afresh after the general election, and they went "full steam ahead."

On February 6, I9II; the first Parliament of George V was opened, and its preliminary stages in the way of amendments to the address were soon over. On February The Parlia- 9th, an Opposition Tariff Reform amendment, moved by Mr. Austen ment Bill in Chamberlain, was defeated by Io2 votes, and on February I 5 th, an antithe House of Home Rule amendment was defeated by $\mathrm{rr}_{3}$. On February 2 Ist, the Parliacommons. mentBill ${ }^{2}$ was reintroduced in the House of Commons, and had a first-reading majority of 124 next day; and the second reading, moved on February 27 th', was carried by a majority of $\mathrm{I}_{2} 5$ on March 2d. The Committee stage lasted from April $3 \mathrm{~d}$, with an interval for Easter from the $\mathrm{r} 2 \mathrm{th}$ to the $\mathrm{I} 8 \mathrm{th}$, till May $3 \mathrm{~d}$; on May 8th, Mr. Asquith carried a motion to devote only four more parliamentary days to the Bill, and on the $\mathrm{I}_{5}$ th the third reading was carried by a majority of 362 to $24 \mathrm{I}$, and the Bill was sent up to the.House of Lords. A few trivial changes had been accepted in its wording, but all the substantial amendments proposed by the Opposition had been negatived; and the one attempt from within the Coalition to modify the Bill-a Labour party amendment
${ }^{2}$ E. B. xxvii, 143 .
${ }^{2}$ Ibid., xx, 846,847 . 
to omit the words in the preamble, pledging the Government to set up a reformed Second Chamber at all,-was rejected (May 2d). by 218 to 47 , Mr. Asquith declaring that the Government regarded it as an obligation, if time permitted, to propose a scheme for reconstituting the Upper House within the lifetime of the existing Parliament. This and other similar assurances subsequently gave occasion for passionate accusations of breach of faith from the Opposition, when in IgI 2 the Government proceeded with their legislative programme and left the reform of the House of Lords alone.

Every attempt of the Opposition to modify the operation of the Parliament Bill was met by dogged resistance. In the view of the Government it was a simple measure for destroying a veto upon the deliberate demands of the elected House, and therefore of the people, which had been shown to be inconsistent with modern parliamentary government, and for making impossible another rejection of a Budget; it gave statutory validity to what in their opinion was in any case the constitutional theory and practice, and was the minimum that the Liberal party could accept in the shape of fair play for their measures. The principal demand of the Opposition, put forward in a number of different amendments, that important new measures, especially constitutional changes like Irish Home Rule, should not become law, if rejected by the House of Lords, until they had been submitted to the judgment of the country either by a snecial Referendum or at a general election, was of no avail. The Coalition, by its very composition, was in office, as the Opposition were only too well aware, in order to try to pass Home Rule in spite of the Cnionist majority in the House of Lords. This was the essence of the political situation, and no arguments, however excellent, about the "horrid arbitrariness " of a House of Commons and its not really having the voice of the people behind it for such measures, were likely to be listened to. The Government's reply was that the country, in giving them a majority for the Parliament Bill, knew quite well what it would be used for, and that the two years' interval it allowed for delay, in which the feeling of the country would have scope for expression, was an ample safeguard against the passing of legislation to which the people were really opposed.

Meanwhile the alternative policy of the Unionist party was being made clearer in the more congenial at mosphere of the Upper House. On February $22 \mathrm{~d}$ Lord Lansdowne The action of gave notice of a Bill for reforming its constitution, which was read a first the House time on May 8th and a second time on May 22d. The whole principle of of Lords. this scheme of reform was that, while the composition of the Upper House would be changed and put on a representative basis, in accordance with the policy of Lord Rosebery's resolutions in $1910,{ }^{1}$ its powers would remain as they were. Under it, the reconstituted House would consist (except for Royal Princes) of "Lords of Parliament," summoned as such and not because of any hereditary title; I $\infty$ would be elected by the hereditary peers from such among their number as were qualified, under a schedule to the Bill, by having held various public positions or ranks in the public services; 120 would be elected to represent different districts of the United Kingdom by colleges of electors consisting of the members of the House of Commons for the constituencies within those districts; Ioo would be appointed by the Crown (i.e. the Ministry) so as to represent the proportional strength of parties in the House of Commons; 7 would be "spiritual Lords," i.e. the two archbishops and 5 bishops to be elected by the Anglican Episcopatc; and I6 would be peers who had held high judicial office. Except for the law lords, who would sit for life, and the spiritual lords who would sit while they occupied their sees, the lords of parliament would sit for twelve years, subject to onefourth in each class (sclected by ballot) retiring every third year. Peers who were not "lords of parliament" would be eligible for the House of Commons, but the creation of new hereditary peerages for commoners other than past or present Cabinet ministers was to be limited to five a year. In Lord Lansdowne's view, such a reform of the constitution of the Upper House, which followed on the lines of suggestions already thrown out by Lord Curzon and Lord Selborne, would provide a representative Senate, of which the existing Unionist party preponderance would no longer be characteristic.

${ }^{1}$ E. B. $\mathrm{xx}, 847$. 
The second reading of the Bill was begun on May I 5 th, and on May 2 d was carried without a division after debates which had disclosed considerable differences of opinion on the Unionist side. It was then quietly put on the shelf. The fact was that, as long as the Government flatly declined to accept any reconstruction of the Upper House as a substitute for the Parliament Bill, any such proposals were mere beating of the air. The actual scheme excited no particular interest on the Unionist side, and was assailed by Liberals on the ground that, according to their calculations, while pretending to be representative, it would simply stereotype a Tory majority. It was a well-meant effort on the part of the Unionist leaders to show that a basis existed for agreement between the parties, so far as concerned the willingness of the House of Lords to accept reforms; but a good many Unionists, and a good many peers, thought that it was a mistake in tactics. On the day after it was read a second time, the second reading of the Parliament Bill was taken (May 23d), and the real issue had to be faced; but the approach of the Coronation, and the prevalence of a feeling ihat, in spite of bellicose utterances in the Liberal Press as to the creation of 500 new peers for swamping opposition, the Government might still be forced to a compromise and could not possibly pursue their demands to the bitter end, made the debate still only a manoeuvre for position, and Lord Lansdowne decided not to divide against the Bill but to propose amendments in Committee.

The real fight only began when the Coronation was over. The Committee stage of the Parliament Bill lasted from June 28 th to July 6 th, and, in spite of warnings from Lord Morley that the Government would refuse, in the House of Commons, to accept them, Lord Cromer's amendment (June 28th) substituting a Joint Committee for the Speaker in deciding what a "Money Bill " was, and Lord Lansdowne's amendment (July 5th), providing for a Referendum in specific cases of measures attacking the existence of the Crown, the Protestant succession, or the establishment of National Parliaments with legislative powers in Ireland, Scotland, Wales or England, were carried by large majorities. On July zoth the Bill, so amended, was read a third time without a division, Lord Lansdowne declaring that the principal amendments were "so essential that we should certainly not be prepared to recede from them so long as we remain free agents." Lord Halsbury went still further: "but for the existence of the amendments, he would have himself moved the rejection of the Bill on third reading, and unless those amendments were accepted in substance, in meaning, and in operation, he would never consent without a division to the passing of the Bill."

The next day the Government exploded their bombshell. It had been a complete mystery up to this moment whether Mr. Asquith had obtained from the King a definite The use of assent to the use of the Royal Prerogative for creating peers in sufficient the Royal numbers to give a Government majority in the House of Lords, and the prerogative. question whether such a course could possibly be resorted to had been freely discussed from the time when the Parliament Bill was first proposed. All doubts were now set at rest. On July 2 Ist, a letter from Mr. Asquith to Mr. Balfour in the following terms, written the day before, was published:-

I think it courteous and right, before any public decisions are announced, to let you know how we regard the political situation. When the Parliament Bill, in the form which it has now assumed, returns to the House of Commons, we shall be compelled to ask that House to disagree with the Lords' amendments. In the circumstances, should the necessity arise, the Government will advise the King to exercise his prerogative to secure the passing into law of the Bill in substantially the same form in which it left the House of Commons; and His Majesty has been pleased to signify that he will consider it his duty to accept and act on that advice.

In the subsequent debates in both Houses of Parliament (Aug. 7th and 8th) on votes of censure moved by the Unionist leaders, the course taken by the Government was more fully explained, though with a decided economy of information, due to reluctance on both sides to bring the action of the Crown into political controversy. It appeared that the Cabinet had presented a Memorandum to the King on November I5; rigro, before the general election, as follows:-

His Majesty's ministers cannot take the responsibility of advising a dissolution unless 
they may understand that in the event of the policy of the Government being approved by an adequate majority in the new House of Commons, His Majesty will be ready to exercise his constitutional powers, which may involve the prerogative of creating peers, if needed, to secure that effect shall be given to the decision of the country. His Majesty's ministers are fully alive to the importance of keeping the name of the King out of the sphere of party and electional controversy. They take upon themselves, as is their duty, the entire and exclusive responsibility for the policy which they will place before the electorate. His Majesty will doubtless agree that it would be inadvisable in the interests of the State that any communication of the intentions of the Crown should be made public unless and until the actual occasion should arise.

The King had felt that he had no alternative except to assent, though he did so, as Lord Crewe now stated (as was understood) on his behalf, "with natural and legitimate reluctance." The Government, according to their own view, had hoped that, as the result of the general election, the Parliament Bill would be allowed to pass without amendments which would be fatal to its purpose, and therefore without a disclosure of the confidential understanding which all the time existed as to the use of the Prerogative, but this was no longer possible; and the only question now was whether the threat was to be sufficient by itself, or whether, by continued resistance, the Government should be forced to carry it into effect.

On this point a serious division of opinion at once was shown in the Unionist party. It was clear that, in the House of Commons, the Lords' amendments would be summariThe Die-Hard ly rejected by the Coalition majority, and any further development of the Movemeat political crisis depended on what would happen in the House of Lords when anditsresult. the Bill was sent back to it. A hurried meeting of Unionist Peers was held immediately (July 2 Ist) at Lansdowne House, at which Lord Lansdowne informed them that the Government had told the Opposition leaders that their intention was not to send the Bill up from the House of Commons unless an assurance was given that it would be passed, the assumption being that, failing this assurance, peers would at once be created in sufficient numbers for the purpose; and it was freely stated in the Liberal Press that the Government Whips had a list ready of persons who were prepared to accept peerages on condition that they voted for the Liberal programme. A state of extreme exasperation prevailed, but a considerable majority of Unionist peers agreed with Lord Lansdowne's view that, if this creation of peers was proceeded with, not only would the Parliament Bill be passed, but even such opportunities as it left open for subsequent resistance to Home Rule and similar measures would be nullified; the only prudent course, in the interest either of the Unionist party or of the peerage, was to sink further opposition, now that they were no longer "free agents." On the other hand a minority, whose view was strongly expressed by Lord Halsbury, the veteran ex-Lord Chancellor, bitterly opposed such a surrender; in their view they did not cease to be "free agents" until they were actually out-voted, and it was in this sense that they had understood Lord Lansdowne's use of the phrase on the third reading, and only on that condition that they had not rejected the Bill then; they still regarded the Government threat as a piece of bluff, which could not be carried into action; but even if it was not bluff, and a large number of new Liberal peers were actually created, such a violent course would bring ridicule and disaster on the Liberal party, and would make the country realise, as nothing else apparently could, the revolution that was contemplated. Moreover, from experience in the past, it was well within what might be expected that, when the 500 eligible magnates who were willing to take Liberal peerages had voted for the Parliament Bill, they would take a more independent view of their position so far as Home Rule and other measures were concerned. When the Government had finally shot their bolt, and by creating the new peers had reconstituted the existing House of Lords in such a way as to destroy the Liberal contention that it was simply a Tory preserve, it would, formally at all events, be actually strengthened as part of the constitutional machinery. It was impossible to suppose that, even in so wholesale a creation, the class of men whom $\mathbf{M r}$. Asquith was prepared to nominate for the purpose would be different from those who in recent years had been added, quite acceptably, to the House of Lords by Liberal initiation in considerable numbers, and who had in many cases come round there to a different 
way of thinking. ${ }^{1}$ A further argument was that if a creation of peers was avoided now, it would not prevent exactly the same situation arising if and when the House of Lords subsequently rejected a Home Rule Bill; the best thing therefore was to get the whole business over at once; and exhaust the credit which had been opened by the Ministry; matters had already gone too far for the House of Lords any longer to act as safeguard against single-chamber government.

Between these opposing views of the situation, a cleavage in the Unionist ranks was at once manifest; among the peers, the party in the House of Commons, the rank and file in the country, and in the Press. Mr. Balfour decided to " stand or fall " with Lord Lansdowne's advice, and they were followed by much the larger numbers; but public interest centred in the outcome of what was known as the "Die-Hard" movement, which was actively organised under Lord Halsbury's leadership and initiated at a largely attended and enthusiastic dinner in his honour at the Hotel Cecil on July 26th, at which Lord Selborne presided, supported by Lord Salisbury, Lord Milner, the Dukes of Northumberland, Marlborough, Bedford and Somerset, Mr. Austen Chamberlain, Mr. George Wyndham, Sir Edward Carson, Lord Hugh Cecil, Mr. F. E. Smith, Lord Wılloughby de Broke, and other prominent men. How many peers would follow the lead given by Lord Halsbury and vote against the unamended Bill when it was again sent up was still uncertain, but as Lord Lansdowne and the bulk of those who accepted his advice were only prepared to desist from further opposition and would not assist the Government affirmatively by voting for a measure they detested just as much as the "Die-Hards," it was impossible for him to give Mr. Asquith the assurance he had demanded. A period of extreme tension and uncertainty followed. On July 24 th, when Mr. Asquith was to move in the House of Commons that the Lords' amendments be disagreed with, he was howled down from the Unionist benches, amid a scene of great disorder in which Lord Hugh Cecil and Mr. F. E. Smith were specially prominent, and the Speaker was eventually obliged to adjourn the House; further disorder took place next day when Lord Hugh Cecil was howled down by the Ministerialists, and it was not till August 8th that, with Mr. Winston Churchill leading the House in the absence of Mr. Asquith, who was suffering from laryngitis, the motion for disagreeing with the Lords' amendments was carried by 32 I to 2 I5, after the Government had agreed to introduce a few minor changes. Meanwhile Mr. Balfour had endeavoured to placate the whole of the Unionist party by moving a vote of censure (Aug. 7 th), which was rejected by 365 to 246 , and in the House of Lords a similar vote of censure moved by Lord Curzon (Aug. 8th), was carried by 282 to 68 ; but the "Die-Hard " movement had gone on unfalteringly, and an active canvass had been in progress, both on the Unionist and the Liberal sides, with a view of ascertaining how the division might go if the Bill came again before the House of Lords under existing conditions.

The uncertainty whether the "Die-Hards" would outnumber the Liberal peers, if Lord Lansdowne's supporters simply abstained, as he advised them to do, made the situation very difficult, both for the Government and also for those Unionist peers who thought that a wholesale creation of new Liberal peerages would be worse even than the passing of the Bill without it. On the one hand, a considerable section of Radical opinion was in favour of settling the whole question, including the future of the Radical programme, by immediately making enough peers to ensure a Liberal majority; on the other, a section of. Unionist peers, led by Lord Cromer and Lord St. Aldwyn, were considering whether, to avoid this, they should vote for the Bill, bad as it was, while others, passionately resenting this suggestion, declared that if it were acted on they would desert Lord Lansdowne and join the "Die-Hards." Amid the confusion on both sides and the increasing bitterness of feeling among the Unionists, it was believed that Lord Knollys, the King's private secretary, who was in constant communication with Down-

${ }^{1}$ It is worth noting in this connection that between $x 868$ (when modern Liberalism and Conservatism practically started as organised parties) and October 1912, the new peerages created by Liberal Governments numbered 164 and those created by Conservative Governments 149. Mr. Asquith alone had created 52 new peers up to October 1912 since he became Premier in 1908 . See also E. B. xxiii, I 12 . 
ing Street, was counselling the avoidance of an extreme course as long as it could possibly be avoided, for the sake of the Crown.

On August $3 d$ it was known that the Government meant to take the risk of sending the Bill up, without any actual assurance of the result, and the debate on the question of the Lords' acquiescing took place on August 9 th and Ioth. In answer to Lord Rosebery, Lord Morley made the precise statement that if the Bill was defeated "His Majesty would assent to a creation of peers sufficient in number to guard against any combination of the different parties in Opposition by which the Parliament Bill might again be exposed to defeat;" and this declaration had a marked effect on the result. Up to the last moment the figures on the two sides were in doubt, but the division showed I $3 \mathrm{I}$ in favour of passing the Bill, and only II4 for insisting on the amendments, and the Government had won the day by the help of enough votes from peers who usually acted with the Opposition to counterbalance the "Die-Hards." Thirty-seven Unionist peers, the two archbishops, and eleven bishops, voted with the Liberals; but Lord Halsbury's followers were more than had been expected, several peers, including the Duke of Norfolk, joining them in protest against the action of the Unionists who helped to carry the Bill. Lord Cromer, who had been active in getting Unionist peers to support the Bill on the ground that only in this way could the damage likely to accrue from a creation of new peerages be avoided, was absent through illness; and Lord Curzon's was eventually the most powerful influence exerted in this direction, his action being all the more hateful to the "Die-Hards" because earlier in the year he had been specially prominent in counselling resistance to the Bill at all costs.

The Parliament Bill thus became an Act and duly received the Royal assent; and a statutory enactment defining the relations between the two Houses of Parliament was The Bill as substituted for an unwritten British Constitution. As compared with the passed.

original form in which it was introduced, ${ }^{1}$ various small drafting alterations were made, including an improved definition of a "Money Bill," and a more definite exclusion of Private Bills from the scope of the measure; but the only changes of any. substantial importance were the following. (I) A provision by which the Speaker, before giving his certıficate (to be endorsed on every Money Bill sent up to the House of Lords) that a Bill is a Money Bill, "shall consult, if practicable, two members to be appointed from the Chairman's panel at the beginning of such session by the Committee of Selection." This was the final result of various unsuccessful Unionist amendments for modifying the original provision by which the Speaker alone was to be the judge of whether a Bill was a Money Bill; in the House of Commons, Mr. Cave (April 8, I0II) had proposed that a Joint Committee of both Houses with the Speaker as Chairman should decide, and in the House of Lords (July 6th) Lord Peel's grave warning, as an ex-Speaker, against the danger of making the Speaker the sole arbiter, though unsuccessful in its support of Lord Cromer's proposal for a Joint Committee, induced the Government to move an amendment of their own, which, as amended by Mr. J. F. Hope from the Unionist side, was adopted on August 8th. (2) Provisions excluding from any Public Bills, as to which the Lords' consent would not be required after being sent up in three successive sessions, "a Bill containing any provision to extend the maximum duration of Parliament beyond five years " (an exclusion originally proposed unsuccessfully in the House of Commons by Mr. Cassel on April 2oth, and carried in the House of Lords by Lord Avebury), and also " any Bill for confirming a Provisional Order." (3) A provision altering the limits of the two years which must have clapsed during the three successive sessions to "between the date of the second reading in the first of those sessions of the Bill in the House of Commons and the date on which it passes the House of Commons in the third of those sessions." This was a Government modification of a Unionist amendment proposed in the House of Commons by Mr. Goldman (May Ist). (4) A provision requiring a certificate signed by the Speaker, stating that the provisions of the Act in this respect had been complied with, to be endorsed on any Bill so presented to the King for his assent notwithstanding

${ }^{1}$ See $E . B . x x, 846,847$. 
the opposition of the House of Lords. (5) A provision that "in every Bill so presented to the King, the words of the enactment shall be as follows:- Be it enacted by the King's most excellent Majesty, by and with the advice and consent of the Commons of this present Parliament assembled, in accordance with the provisions of the Parliament Act, and by authority of the same, as follows.' " This had substantially been proposed unsuccessfully in Unionist amendments, in the House of Commons by. Mr. L. Hardy on May ist; and in the House of Lords by Lord Camperdown on July 6th.

In all vital respects the Parliament Act remained as originally introduced in I9ro. While its preamble declared that reform of the House of Lords itself still remained a task for the future, the supremacy of the House of Commons, both for purposes of finance and for public legislation, was definitely enacted. If the House of Lords obstructed and rejected the Bills passed by the Commons, it could now only do so for two years if the Commons persisted, and at the end of that time a Government in control of the Lower House could pass its measures into law with the Royal assent without the Upper House having any further voice in the matter. The power of forcing an appeal to the electorate, which the House of Lords had hitherto had for all practical purposes, unless a Bill they rejected was dropped, was taken away; and what was virtually single-chamber government was thus established. It became possible for the first time, without any parliamentary check on a party in power, to pass measures into law simply because a majority in the. House of Commons (which might be quite unrepresentative of public opinion) could be secured for them. On the Liberal side it had been contended throughout that, when a Tory majority had control of the House of Commons, this was really the condition of affairs before, since the House of Lords always supported Tory measures; the cases however could only be considered parallel on the assumption that there was some fair correspondence in the character of the legislation proposed by the two sides when either was in power. While the Act, on the face of it, made the Government masters of the situation, it was recognised, on the other hand, by people who looked a little ahead, that in parliamentary practice it did not make things quite so easy. In order that its provisions should apply, to the extent of Bills becoming law over the resistance of the Lords, these Bills had to be sent up in time for two years to elapse during the same Parliament, and during these two years they had to be sent up again and again without being changed from their original form. As the duration of Parliament was cut down to five (practically four) years, this meant that nothing not sent up in the first year or two would benefit by the Act; and apart from that, it would be difficult to avoid changes in Bills sent up year after year. Even as regards "Money Bills" which the House of Lords was now to have no power of rejecting at all, the prospect was uncertain. - The Budget of 1909, the rejection of which was the cause of the whole revolution, was probably considered a Money Bill by most Radical politicians; but the Speaker (Mr. J. W. Lowther) upset any such calculations in December I9I 1 , by ruling, in answer to a question, that the Budget of that year was not a Money Bill within the Parliament Act-a fortiori therefore neither was that of I9o9.

On the very day that saw the triumph of the Parliament Bill (Aug. Ioth), yet another great alteration was being made in the essential conditions of parliamentary Payment of life. Following an invitation already given by Mr. Lloyd George, a members.

resolution was carried in the House of Commons, by 256 votes to 158 , providing "for the payment of a salary at the rate of $f 400$ a year to every member of the House, excluding any member who is for the time being in receipt of a salary as an officer of the House or as a minister, or as an officer of His Majesty's Household." Most of the Unionists were opposed to the proposal, and a good many Liberals did not like it, but the Government had determined to introduce payment of members as a way out of the difficulty they were in with the Labour party, owing to the Osborne Judgment having made.illegal the payment of salaries to working-class members out of . Trade Union funds. ${ }^{1}$ To legislate in the way the Labour party demanded,

${ }^{1}$ Ibid., xxvii, 143. 
so as directly to reverse the Osborne Judgment, was impossible, though the Government was prepared with a Bill-unsatisfactory to the Labour party and not proceeded with, a second edition being introduced in 1912 -for enabling Trade Unions to make special provision for voluntary political funds, separately from the general funds to which every member of the Union had to contribute; but it was hoped that payment of all M.P.'s out of public money would do away with the particular grievance of the Labour members. This was not however in fact the result, and the demand for a complete legislative reversal of the Osborne Judgment persisted. In the country generally a good deal of disgust was felt at the calm way in which M.P.'s had voted themselves $t+\infty$ a year, and a number of individual members, who were far too well-off to want the subsidy, did their best to refuse it. But the deed was done; provision was made in the Budget; and a new temptation was held out for the multiplication of parliamentary candidates among persons to whom $£ 400$ a year would be useful.

Meanwhile the National Insurance Bill, introduced by Mr. Lloyd George on May 4, IgI I, had introduced new issues into the political conflict, even when the constitutional The Insur crisis was at its height. This elaborate measure, in 87 Clauses, covered ance Acl. two distinct subjects, one being National Health insurance, under newly constituted Insurance Commissioners for England, Wales, Scotland and Ireland (with a joint Committee, formed from among them, for adjusting common affairs), assisted in each case by an Advisory Committee, with County and County borough Committees for local administration, and the other Unemployment Insurance, directly under the Board of Trade. As the latter excited comparatively little criticism, it may be dealt with first.

(x) Unemployment Insurance, administered largely throngh the Labour Exchanges, was limited to begin with to certain trades-building, construction of works (railroads, dock, etc.), shipbuilding, mechanical engineering, ironfounding. construction of vehicles, and saw-milling-but with power for the Board of Trade to extend the scheme to others. Workmen in these trades (others than foremen, clerks, indentured apprentices, and persons under sixteen) would be entitled under various restrictions to unemployment benefit (up to a standard of $7 \mathrm{~s}$. a week for not more than fifteen weeks a year, starting at the second week of unemployment), out of an Unemployment Fund formed by each workman compulsorily contributing $2 \frac{1}{2} \mathrm{~d}$. a week (paid by employer and deducted from wages), employers $2 \frac{1}{2} \mathrm{~d}$. a week per man, and the State adding an amount equal to a third of their total contribution.

(2) For National Health purposes, compulsory insurance was imposed on all persons (between 16 and 70) under contracts of service, with certain exceptions (including those employed otherwise than in manual labour, and paid over $£$ r 60 a year, or possessing $£ 26$ a year from property), provision being also made for certain classes of employed persons not compulsorily insured to come into the scheme as voluntary contributors. Under the compulsory insurance (except for certain lower rates) male contributors were to pay $4 \mathrm{~d}$. a week, female $3 \mathrm{~d}$. (employers making the payments and deducting them from wages), and employers $3 \mathrm{~d}$. for each male or female employed (special stamps for each amount having to be affixed to cards for this purpose), the State adding to the National Health Insurance Fund so constituted an amount (twoninths in the case of men, and a quarter in the case of women, of the cost of benefits and administration) which was reckoned to work out at $2 \mathrm{~d}$. a week per head. The benefits primarily secured were (I) free medical treatment at home, (2) sanatorium treatment for tuberculosis and other diseases specified by the Local Government Board, for which special arrangements were made, the Government allocating $\ell \mathrm{r}, 500,000$ for the building of sanatoria. (3) payment during sickness of ios. a week for men and $7 \mathrm{~s} .6 \mathrm{~d}$. for women up to 26 weeks, (4) subsequent payment during disablement of 5 s. a week, and (5) maternity bonus of 30 s. to women (including wives of insured persons) on confinement; provisions being made for granting these benefits (medical attendance, sickness, and maternity benefits not till six months, disablement not till two years after payments started) or modifying and extending them as funds permitted. The agencies for 
administering the benefits were made (I) "approved societies" i.e. the Friendly Societies, trade unions and such similar bodies as the Insurance Commissioners approved, the intention of the Government being to have as many as possible of the insured included as members of "approved societies," (2) the Post Offices, which would deal with those who would not join societies or whom societies would not admit, and who thus became " deposit contributors." The Local Health Committees, among their other duties (including the administration of sanatorium benefit) were left to arrange for the service of medical practitioners for insured persons, preparing lists of doctors from among whom the patients were to have their own choice, payment to the doctors from the general fund being estimated for at the rate of $6 \mathrm{~s}$. (including cost of drugs) per head per annum. This feature of the Bill, as explained by Mr. Lloyd George, quickly aroused the opposition of the doctors, who were organised under the British Medical Association to refuse their services unless a larger payment was made; and as a body the doctors stood out for better terms, month after month going by without any settlement being arrived at, even after the Act came into operation. As medical " benefits" under the Act became due on January I 5, I 913; it became a question for the Government whether, if no terms could be arranged, a regular State Medical Service would not have to be started; but this would take time to organise, and meanwhile it would be poor consolation to the prospective beneficiaries under the Act for the Government merely to hand them over the money proposed for the doctors and to leave them to make the best of it. On October 23, xor 2, Mr. Lloyd George announced the Government's "final" offer to increase the capitation fee to $9 \mathrm{~s}$. (including drugs and extras), representing a further increase in the remuneration of doctors by $£_{\mathrm{I}} \mathrm{s}, 650, \infty 00$; but on November Ioth the offer was rejected by an overwhelming majority of the profession at a representative meeting of the British Medical Association, and negotiations began again. (See below ad fin.)

The second reading of the Insurance Bill, debate on which began on May 24, Igr I, was carried without a division on May 29th, and the Committee stage went on intermittently from July 5 th to August 4 th, when, with the discussion on the 17 th Progress in clause finished, Mr. Lloyd George was still able to regard the Opposition as favourably disposed towards the Bill and co-operating, by useful criticism, in giving shape to what was necessarily a very complicated measure. Its remaining stages were then left over for the Autumn Session, which began on October 24th. But in the interval opposition had been growing, and the political situation in other respects was such that genuine co-operation with anything proposed by the Government was hardly possible if party capital could be made for the Unionists by what was unpopular in its programme. Not only were the doctors in full revolt against the terms the Bill proposed for their remuneration, but the working classes themselves were found to dislike exceedingly being taxed in such a direct way for benefits they were not able to appreciate. Mr. Lloyd George, ever an ardent electioneer, however sincere he might be as a social reformer, exasperated the Unionist party, sore enough already at his success with the Budget of Igog and the electioneering use made of the grant of Old Age Pensions, by his description of the Bill as giving the working classes " ninepence for fourpence;" but there was no doubt about the fourpence being a first charge on wages, and the man who paid it was perhaps only providing ninepence for somebody else, - this being the essence of any insurance scheme,-and was not so much impressed by the prospect of benefits as by the compulsory character of the contributions. Among domestic servants the scheme was cordially disliked. Though the Bill was planned so as to involve financial co-operation between the State and the Friendly Societies, there was considerable uncertainty as to how far a great many of the latter, especially the smaller local societies, would reap advantage rather than loss. The whole scheme, in spite of the excellence of its intentions, was seen to raise a number of new social and economic problems, the solution of which nobody could foresee, either before it became law or afterwards; and public discussion concentrated on the difficulties and objections. It was inevitable therefore that, so far as the political 
aspects of the Bill were concerned, the attitude of the Opposition should be affected by the discovery of its wide unpopularity. They had originally welcomed it in principle, but they represented, for organised political purposes; a growing body of hostile criticism as to details, and criticism which, in the circumstances, was becoming more and more incompatible with parliamentary support:

The result was decidedly unfortunate for a scheme which aimed at accomplishing so important a work of social reform. The Government had its programme for I91 2 Insurance full, subject to the way being cleared by the Parliament Act, by the political Act passed. necessity of proceeding with Home Rule and Welsh Disestablishment; and Mr. Lloyd George, whose influence on the parliamentary tactics of the Coalition was now supreme, determined to force the Insurance Bill through before Igr I ended. When the House of Commons resumed on October 24th Mr. Asquith carried a time-table resolution for closuring the remainder of its stages; and by this drastic method the Bill passed through Committee on November 2ist and was read a third time on December 6th. Under such conditions the opportunity for effective Opposition criticism and amendment was so limited that very little was possible, in spite of the activity of Mr. Worthington Evans and other Unionist members, and towards the end it became a question whether the Unionist leaders would actually divide against the third reading, a course to which they were openly challenged by Mr. Lloyd George. Instead of this, an Opposition front bench amendment was moved by Mr. H. W. Forster, proposing that the Bill should be postponed for further discussion, and this was defeated by 320 to 223 , the third reading then being carried in a division in which the Opposition as a whole took no part, 2I members recording their votes against it. On December IIth the Bill was read a second time in the House of Lords, and after various Government amendments had been inserted in Committee on December I4th it was passed and received the Royal assent next day when Parliament was prorogued.

During all this time, both inside and outside Parliament, opinion as to the scheme and its prospects had become more clearly crystallised. While Mr. Lloyd George and Public his supporters proclaimed it to be the most beneficial reform ever conceived

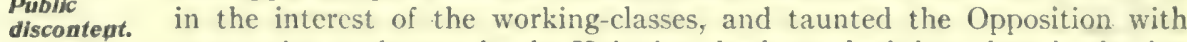
attempting to destroy it, the Unionists dwelt on the injury done by forcing through a measure which ought to have been more carefully considered bcfore it became law, and threw the responsibility on the Liberal party for everything that was objectionable and unworkable in it. The by-elections showed that its unpopularity was continually growing; and under the arrangement made in the Act that the Insurance commissioners should during roI 2 make regulations as to details, nobody knew yet what procedure would be adopted to overcome countless points of difficulty which under the Act itself remained quite unsettled. The medical profession, without whose co-operation, so far as could be seen, the Act would not work at all, continued to refuse it unless they were given better terms, to which Mr. Lloyd George was still unable to agree; "passive resistance" was being organised on their behalf by the British Medical Association, and threatened in various other directions. As time went on, the muddle only grew worse, and when the Act came into effect in the autumn of ror 2 most of its problems were still unsolved.

As a measure of social reform indeed the Insurance Act was undoubtedly one which ought to be of great value when in full operation; and, as usual in Great Britain, in spite of general discontent, most people combined to carry the Act out. Speaking on October I 2, I () I 2, Mr. Lloyd George was able to boast that, whereas the original actuarial calculations led to the expectation that 12 million stamps on the average would be fixed to cards every week, this number had been regularly and continuously exceeded, and had that week reached over ${ }_{5}$ million. In spite of all objections and much talk about resistance among employers and employed, though the benefits were not yet forthcoming and complete uncertainty existed as to the action of the medical profession. payment was being made for insuring between 13 and 14 millions of people against sickness and $2 \frac{1}{2}$ millions against unemployment. As a piece of Liberal electioneering, 
on the other hand, despite desperate oratorical efforts on Mr. Lloyd George's part and assiduous lecturing by his emissaries throughout the country on its advantages to the working classes, it was for the present a complete failure; and its unpopularity became the most prominent feature in the political life of the country, with the result of a marked improvement in the Unionist position. During the debate on the address, early in I9I 2, the leader (Mr. Bonar Law) of the Unionist party, being asked in debate by Mr. Asquith whether he would repeal it if he came into office, hastily replied " Certainly "-afterwards explaining that he meant "withdraw for amendment." It was considered at first by the Liberal Press (and even by many Unionists at the time) that he had made a faux pas; but as a matter of fact the unpopularity of the Act was such that the Liberals found it impossible to make any lasting capital out of the indiscretion.

Another piece of social legislation which caused considerable local irritation was the Shop Act, quickly passed in the autumn session, which many shopkeepers found

The Shop Ačt, 1911 . to work very inconveniently. It limited the hours of shop assistants to 60 (with one half-holiday) a week, regulated the overtime permissible, and while providing for Sunday closing gave power to local authorities, with the approval of two-thirds of the shops affected, to decide the closing hours on other days. It was, however, not only the stimulus given by the antagonism of the country to the Insurance Act that was causing a revival of Unionist confidence after the defeat over the Parliament :Act. During the autumn session the Unionist party Mr. Balfour's had started afresh under a new leader in the House of Commons. The
resignation. has "Die-Hard" revolt had been a fresh illustration of the dissatisfaction within the party at the way it had been led by Mr. Balfour for some time past. If the Parliament Bill had actually been defeated in the House of Lords by the "DieHards" it was an open secret that both Lord Lansdowne and Mr. Balfour had intended to retire from their positions at the head of the party, and it was largely the dislike of acting disloyally by them that confined the open revolt to a comparatively small section. Exasperation at the result, however, was general; and though, when the crisis was over, Unionist concentration was obviously dictated by all the circumstances, Mr. Balfour's authority had been seriously shaken. He himself did his best to smooth matters over, declaring in a public speech (Haddington, Oct. 7 th) that the question of the Peers' tactics was now a dead issue, of no more practical importance than the controversy as to the identity of Junius; and the "Die-Hards," though they started a Halsbury Club and kept their organisation in being, protested at the same time that the differences within the party were ended with the cause of them, and that they only meant to work for the common good. But after some weeks of reflection, when the hubbub was all over, Mr. Balfour made up his mind that the right moment had arrived for him to retire from the leadership, though not from Parliament, in view of the arduous political struggles still impending, and the unlikelihood of his being strong enough in health, should the Unionists again return to power, to conduct a Ministry. Since $189 \mathrm{I}$ he had led his party in the House of Commons, and at sixty-three it was time for him to make way for others. It would be better, he thought, to get a new leader into harness at once, so that he might be ready for the responsibility of office. His announcement to this effect was made on November 8th, at a hastily convened meeting in the City of London, and he made it clear that the step was irrevocable. For a few days the question of who would succeed him was uncertain. Mr. Austen Chamberlain, not only as principal leader of the Tariff Reformers and one whose very name would, on his father's account, be most representative of the Imperialist movement, but as ex-Chancellor of the Exchequer and officially Mr. Balfour's deputy on the Opposition Front Bench, had apparently the strongest claim; but, as a Liberal Unionist, his selection: was opposed by many Conservatives, who considered Mr. Walter Long a better choice; and Mr. Long's great popularity among all sections was much in his favour. It became clear to the partisans of both that if either were proposed, and votes were taken, it would only emphasise the division of opinion and create friction between their supporters, whereas unanimity was the first consideration. 
It was found that Mr. Austen Chamberlain and Mr. Long were both prepared to stand aside in favour of Mr. Bonar Law, ${ }^{1}$ nominally a Conservative and at the same time Mr. Bonar a strong Tariff Reformer; and on their joint proposal he was quickly Law, the new adopted, as leader in the House of Commons (Lord Lansdowne continuing leader. to be leader in the House of Lords), at a party meeting on November I3th. Their sacrifice of personal ambition to the party interest, and their loyal pledges of co-operation with the new leader, who himself enjoyed the admiration of all sections, set an example which did much to promote fresh confidence within the party; and $\mathbf{M r}$. Bonar Law had no sooner become leader than there were signs of improved Unionist prospects in the constituencies. In intellectual range, subtlety of exposition and criticism, and political experience, Mr. Balfour had, admittedly, no rival on either side, but he still remained in the fighting rank, ready to devote himself to the Unionist cause as much as anybody. His retirement from the formal responsibilities of leadership gave freer play to the respect and admiration felt for him personally as a public man, while relieving the party of the accumulation of doubt as to his policy and tactics, which, rightly or wrongly, had led to undercurrents of dissension. To the plain man his detached and philosophical outlook on public affairs had been rather too lofty; to be " had" or tricked, as the party was openly taunted by its opponents, over the Budget of 1909 or the Parliament Bill of I9I I, simply meant that its leader had failed in astuteness; ardent Tariff Reformers, enthusiastic for Mr. Chamberlain's policy and pining for Mr. Chamberlain's aggressive tactics, felt that Mr. Balfour's balancing support of their proposals was unpractical and was confined to economic generalities. He was perhaps "too much of a gentleman" as well as "too little of a business man" for the situation. Mr. Bonar Law, on the other hand, was more of the Chamberlain type,a successful man of business, the clearest and most convincing platform exponent of Tariff Reform, a speaker who was accustomed to calling a spade a spade. Though he had never sat in a Cabinet he had for several years been regarded by his party as one of their principal leaders. If Mr. Balfour, for his own reasons, had not decided to retire, it is certain that, however vocal the malcontents were,-and the National Review and Morning Post had for some time been in open mutiny,- - the party as a whole, and all his colleagues, would have remained loyal to his leadership; but as things were, it is equally certain that the change was regarded on all sides as marking an epoch in the fortunes of the Unionist party. With the selection of Mr. Bonar Law to lead them in the House of Commons came a new spirit of hope and zeal. He made an excellent start with his first public speeches after becoming leader, notably with a general attack on the Government at the Albert Hall on January 26, I9 2.

At the same time the result of the Canadian elections at the end of September, and the defeat of Sir Wilfrid Laurier's American Reciprocity proposals, had delighted the Unionists and given them fresh confidence for the future of Imperialism. Reciprocity Canada had shown that she meant to keep her place in the Empire, and in Canada. that antagonism to the prospect of becoming simply an annexe to the United States was more powerful than the temptation to secure immediate commercial advantages from Reciprocity. Up to the last the result of the Canadian elections had been very uncertain, and the Tariff Reformers in England, who had been thoroughly depressed and disheartened by the idea that, if reciprocity between Canada and the United States were established, their hopes for Imperial commercial union would be frustrated, had in Mr. Borden's success a legitimate triumph for their own views of Imperial policy. Imperial patriotism in Canada had averted the greatest danger yet

1 The Rt. Hon. Andrew Bonar Law was born in New Brunswick, Canada, on September 16, 1858, his father being a I'reshyterian minister, and his mother a native of Glasgow. He was sent $t()$ school in (Blasgow, and went into the business of his mother's family there, William Kidston \& Sons, iron merchants, from which he retired with a fortune. He entered Parliament for the Blackfriars division of (ilasgow in 1900, but did not contest the seat in 1906, being then returned for I) ulwich, where he sat till December 1910 , when he stood unsuccessfully in Manchester. In March 1911 he was returned for Bootle. From 1902 to 1906 he was Under-Secretary for Trade. 
threatened, in spite of the support given by the Liberal government at home and the British Ambassador at Washington. Every platform rang with Unionist rejoicings, and the Canadian victory put new heart into the Tariff Reform propaganda.

On yet another question of Imperial moment a rebuff was given to the Ministerial policy. Throughout I9I I the decision of the Government to ratify the Declaration of

The Naval Prize BIII:
London had led to a prolonged agitation. Most of the Unionist party, together with a strong body of naval opinion, were actively opposed to it, their argument being that under its provisions the advantages of British supremacy at sea in war time would be seriously diminished. The Government succeeded however (June I, IgII) in obtaining the support of the Imperial Conference, considerable weight attaching to Sir E. Grey's view that adhesion to the Declaration would be advantageous in Great Britain's foreign relations and to the cause of peace. As Parliament had no direct control over the action of the Government in the matter of ratification, political opposition centered on the Naval Prize Bill which was introduced to carry out the provisions of the Declaration of London, the second reading being taken on July $3 \mathrm{~d}$. So much headway was made in arousing antagonism to the Declaration itself that when the third reading of the Naval Prize Bill came on in the House of Commons on December 7 th the Government only managed to get a majority of 47 ; and the House of Lords promptly rejected the Bill.

The Government were meanwhile being perpetually worn and worried by the militant agitation for Women's Suffrage and by the difficulty of dealing with any legislaThe Fran- tion on the subject when the Cabinet was divided. The Prime Minister chise ques- himself was avowedly opposed to Women's Suffrage altogether, and tion. among other Ministers Lord Loreburn and Mr. Lewis Harcourt shared his views. On the other hand, Mr. Lloyd George, while professing himself a strong supporter of the cause, which was also advocated by Sir. E. Grey and Lord Haldane, objected to any Bill which was not thoroughly "democratic;" and because the " militants " regarded his attitude as obstructing the particular measure which they had in view and held him responsible for a Government Bill not being introduced as they desired, he was pestered as much as if he had actually been an open opponent like Mr. Asquith. The so-called "Conciliation" Bill, introduced by Sir G. Kemp, which assimilated the parliamentary to the municipal franchise for women and would give votes to about a million, had been read a second time in the House of Commons on May 5, IgII, Mr. Asquith himself pairing against it while Mr. Lloyd George and other Ministers supported it; and as there was no time for proceeding with the Bill in IgII the Government promised to give it "facilities" in the following year. But while the various sections of supporters of Women's Suffrage disputed about its prospects, and the "militants" raged together, Mr. Asquith suddenly gave a new turn on November 7 th by announcing the intention of the Government to add to its programme a Franchise Reform Bill on the lines of Manhood Suffrage. In answer to a deputation of Woman Suffragists on November $x$ th he declared that, while he was personally opposed to Women's Suffrage altogether, this Bill would be so drawn as to admit of amendment to include women on certain terms; and if an amendment, which the Government as such would not oppose, were carried, the Government would then adopt it. They would also, as had been promised, give facilities for the Conciliation Bill.

It had been generally supposed that the Government would take advantage of the passing of the Parliament Act to reintroduce the Bill against Plural Voting which the Lords had rejected in I906, but this larger measure was totally unexpected, and the announcement was widely construed simply as a device for "dishing."Women's Suffrage. It was at once denounced for that reason by the " militants," who began to make more trouble than ever. Their proceedings are chronicled elsewhere. So far as Parliament is concerned it is sufficient here to note that from this moment the internal divisions within the Cabinet on the subject of Women's Suffrage, and the necessity of taking administrative action against " militant " violence, remained a source of constant difficulty. When eventually, on March 28, I9I2, the Conciliation Bill was rejected 
by 222 to 208 , owing to disgust at " militant." tactics, the prospect of legislative action rested entirely with the question of an amendment of the Government Franchise Bill, which was read a first time on June I 7 , I9I2, by 274 to 50 , and a second time on July I 2 th, by 290 to 218 . In other respects this Bill, which abolished plural voting and University representation, made six months' residence by adult males the only qualification for votes, and did away with existing restrictions as to registration, handing it over for automatic action by the Municipal Authorities, excited comparatively little public interest. There did not seem likely to be time, even if there were inclination, to pass it into law before the session ended. The Unionists, while objecting to details; opposed it mainly on the old ground that Redistribution should accompany Reform; while the Liberal rank and file, who for their own electioneering purposes were principally anxious to destroy the plural vote, felt that a simpler measure with that object would have sufficed. A Bill, to abolish plural voting, introduced by a private member, Mr. Baker, was read a second time on March I, Igr2, and it was thought that the (iovernment might well adopt this if their own Bill had to be dropped.

Mr: Asquith's introduction of the Franchise Bill was, however, not the only parliamentary result of the continued blocking of the movement for Women's Suffrage. A The white desire to prove that measures demanded in the interest of women were not Siave Traf- neglected in the House of Commons, gave useful support to Mr. A. H. fic Bill.

Lee's Bill, aimed at the so-called "White Slave Traffic," which in June, I9I 2 , was adopted as a Government measure. Its object was to give power to any constable to arrest " procurers " summarily on good cause of suspicion without having to delay to get a warrant, to strengthen the law dealing with brothel-keepers and make landlords of such houses liable for their illegal use, to make the law as to solicitation apply to men as well as women, and to penalise more effectually men who lived on the earnings of immorality. The Bill was read a second time and then referred to a Standing Committee, where it met with a good deal of criticism, resulting in some of its provisions being weakened, the power of summary arrest, in particular, being altered so that it could only be exercised by special officers not below the rank of sergeant. 'The movement, however, outside Parliament was too powerful to be denied, and in October the Home Secretary promised a deputation of the Bill's supporters to use the Government influence to pass it with the original and more drastic provisions restored. The whole subject had aroused much public attention during I9 I 2 in England as well as in America, and it was widely felt that everything ought to be done, at any risk, to deny facilities in England for carrying on what had become an international traffic in women for purposes of prostitution, accompanied by systematic fraud and outrage which the existing law was powerless to stop. In accordance with the Home Secretary's advice, the House of Commons agreed, on the Report stage, to restore the Bill to its original more stringent form. By a considerable majority, flogging was made the penalty under Clause 2 for a second offence on the part of male procurers, and by a narrow division was extended also to a first offence against the advice of the Government; under Clause 6 flogging was made a penalty for the second offence, but the proposal to extend it to a first offence was defeated. On November I 2 th the bill was read a third time without discussion. On December 9, it passed the Lords, with minor amendments, in its most drastic shape; and on December II it became law, coming into operation at once.

The main problem however before the Government when Parliament met on February I4, I I 2, was Irish Home Rule, with Welsh Disestablishment and Disendow: Welsh Dis- ment in a secondary place. The latter measure, keenly as it was opposed establish - in the interests of the Church of England, may be dismissed in a comment

introduced by Mr. McKenna on April 23d, had been already explained by him in a speech at the Queen's Hall, London, on January 28 th. Its main interest lay naturally in the financial provisions, and their effect may be shown as follows. The income of the Welsh dioceses in 1 (1)06 was $£ 556,000$ ( $£ 206,000$ representing voluntary contributions, 
which would be unaffected), and of the $£ 260,000$ derived from endowments the Bill would take away $£_{172}, 500$, representing. (according to the Liberal view.) national property; but this reduction would only be gradually effected in about forty years by the Welsh Commissioners appointed to manage the transfer,- - existing interests being maintained and existing incumbents being paid their present stipends, $\rightarrow$ so that in that time the Church would have the chance of making good the loss of income by increased voluntary contributions. The disestablished Church was given power to set up a representative body, which might be incorporated by charter; and to this body the Welsh Commissioners would hand over the cathedrals, episcopal palaces, churches and parsonages, and also the modern endowments-and such part of the glebe as was not considered to be part of the ancient endowments-to which the Church as such was strictly entitled; as a dividing line the date of 1662 : was taken as that after which property of uncertain origin now owned by the Church might be regarded as her own. The funds which by degrees would be taken from the Church were to be applied partly: to charitable and public purposes by being handed over to the County Councils and partly to the colleges of the University of Wales (library, etc.).

The rather moderate extent of the disendowment thus proposed was somewhat of a surprise. Extreme Liberationists had to console themselves with the prospect of a success for the principle of disestablishment rather than any considerable acquisition of Church property for secular purposes. On the other hand, from a Church point of view, the smallness of the operation on its financial side made the whole transaction seem one of peculiar meanness; for a paltry result, the work of the Church-admittedly now well done, as had been proved before the Welsh Church Commission, whatever its shortcomings in the past-was to be crippled and hampered. Defenders of the Church, notably the Bishops of St. David's and St. Asaph's and Lord Hugh Cecil, could point with cogent force to the fact that the Church was the largest single religious body in Wales, and the only one which was represented in every parish by a regular organisation. Their argument for its being better entitled than any other denomination to be the national Welsh Church, and administer as such the "national " property it had so long possessed, represented one side of the case against the Bill. The ecclesiastical indivisibility of Wales and England was a more fundamental objection, the Welsh dioceses being from the Church point of view an integral part of the Church of England. The case for the Government, granted the principle of disestablishment at all, was however fairly simple. Their precedent was the case of the Irish Church in 1869: it was equally a part of the Church of England, and disestablishment and disendowment had done it good rather than harm. The answer to those who contended that the Church really was the national Church of Wales was that the Welsh people thought otherwise; at election after election, almost unanimously so far as political representation showed, they demanded the change as an act of justice. On the first reading of the Bill (April 25), which was carried by means of the closure by 33i to 253, Mr. Lloyd George emphasised this point in a somewhat rhetorical plea for the right of his own nationality to have the religion it chose and not to be nationally misrepresented by a Church which, however well it worked, was English and not Welsh. On. May I $3_{\text {th }}$ the second reading opened with a slashing criticism from Mr. F. E. Smith, but on the I 6 th it was carried by the closure by 348 to 267 , and the Bill was then hung up till the late autumn: Its introduction satisfied the Welsh party, but otherwise it excited no real parliamentary enthusiasm. In recent years disestablishment had ceased to interest any large section of Liberal politicians; and the Bill, while alienating many Liberal Churchmen and rallying to defence of the Church numbers of voters who are normally indifferent to ordinary political issues, was not of a nature to help Liberal or Labour electioneering: outside Wales itself.

In making an Irish Home Rule Bill their chief measure in I9I 2 the Government were more fortunate in one respect than Mr. Gladstone had been in 1886 and 1893 , when the whole Irish question was still associated in Great Britain with the prejudice and hostility aroused by the agrarian war, with all its incidents of cattle-maiming 
and boycotting, the "plan of campaign," the Phoenix Park murders and dynamiting outrages, the downfall of Parnell and the split in the Nationalist ranks. A new generaHome Rule. tion had grown up, to whom all this was ancient history, with no special application to the existing conditions. Ireland for years had been peaceful and growing in prosperity; the Unionist Government had given her both local government and the Land Purchase Act; and the idea of Home Rule (as apart from the forgotten Home Rule Bills) was now familiar, simply as one of the standing issues of party politics. Lord Rosebery's defection had not prevented Sir Henry Campbell-Bannerman from inscribing it again in 1905 on the banner of the Liberal Party; and though the Liberals then came into power, independently of the Nationalist vote, under a pledge not to introduce a Home Rule Bill during the I905-1910 Parliament, Mr. Asquith had been quite explicit in saying, when the elections of January I9 Io were taken, that if he got a majority this self-denying ordinance would be at an end. On the Unionist side the attitude of the Liberal party in this respect was indeed severely criticised; and it was true that at the elections of December I9I0 neither Mr. Asquith nor his colleagues in the Cabinet made Home Rule a direct issue either in their election addresses or in their speeches. On the contrary; when the Unionists warned the electorate that in voting for the Parliament Bill they were voting also for Home Rule, they were constantly told that this was only a "bogey." But the fact remained that, in spite of Unionist efforts and in conformity with what, from a Liberal point of view, was quite sufficient intimation that Home Rule was an integral part of the Liberal programme, a majority for the Parliament Bill had been returned; and within the coalition majority the Irish Nationalists held the balance of power. The Unionists taunted Mr. Asquith with being in office simply by the will of Mr. Redmond, and continued throughout the controversy to deny any Liberal mandate for Home Rule at all; but the parliamentary majority was the solid fact of the situation. Mr. Redmond, for his part, had been perfectly frank about the conditions of his support; on September 27 , I9ro, for example (to give only one instance out of many), at a moment when it was still uncertain to what lengths the Liberal Cabinet would go in framing a Home Rule Bill, he was reported as saying in a speech at Buffalo, U.S.A., "I believe the leaders of the Liberals are sincerely friendly to Home Rule, but, sincere or not, we have the power and will make them toe the line." Undoubtedly the Nationalists could have turned the Government out if it did not " toe the line;" but this would have done their cause no good. The strength of their position, for making a good bargain over the terms of the Bill, was really based on the willingness of the Liberal and Labour parties to concede, in all essentials, the Nationalist demand, representing as it did not only a solid vote from three-quarters of Ireland but also an important body of Irish opinion in America and the British Colonies. Apart altogether from the older arguments for Home Rule, the Liberals justified their policy by the success attending their grant of self-government to the Transvaal, and by the congestion of business in the Imperial Parliament, which in any case made it desirable to move in the direction of devolution. An Irish Parliament and executive of the colonial type for purely Irish affairs, subordinate to the Imperial Parliament, would not only satisfy the Irish claim but might be the beginning of a federal scheme for the whole of the United Kingdom. Arguing on these lines, - and Mr. Redmond carefully put the Irish case no higher in his speeches before British audiences-it was much easier in ro ro and I 9 I f for supporters of the Government than it was in I886 and I 803 to scout Unionist objections to the principle of Home Rule; they could even appeal to Unionist arguments in favour of an Imperial federal constitution. Whether the Bill to be introduced would reconcile Imperial interests and those of the United Kingdom with its proposals for Irish government had still to be seen; but meanwhile its consideration was approached this time under conditions more favourable than formerly. English Liberal Nonconformists were not now so much agitated about Home Rule meaning Rome Rule; and public opinion in Great Britain generally had become rather apathetic about Ireland altogether, being to a large extent out of touch with its problems. It was only in Ulster that the passionate resistance of a generation before was as yet reawakened. 
Mr. Asquith introduced the Government of Ireland Bill in the House of Commons on April II, IgI 2. He laid particular stress on its being intended to be the first step towards Parliamentary devolution and a system of federalised parliaments

The Home Rule BIII, 1912. within the British Isles, and on its maintaining the supremacy of the Imperial Parliament at Westminster over the new Irish Parliament equally with any that might later be set up in other divisions of the Kingdom. The essence of the Bill was that in Ireland an Irish Parliament and Irish Executive should be responsible for exclusively Irish affairs. Instead of saying precisely what these affairs were, the Bill specified what were the Imperial affairs which the Irish Government could not deal with, including certain Irish matters (Clause 2) "reserved " to the Imperial Government. There would be two Houses,-an elected House of Representatives of i64 members (of whom, on the existing basis, 39 would probably be Unionists); and a nominated Senate of 40 members, on which Mr. Redmond's view was that there would thus be the opportunity to secure the inclusion of Irish public men of eminence, without reference to their party colour. In case of a conflict between the two Houses they would sit and vote together. For Imperial purposes Ireland would still be represented at Westminster, but only by 42 members, subject to a special provision (Clause 26) for increasing this number in case the question of altering the financial relations should arise at some future time, and purely for that purpose. The acts of the Irish Parliament would be subject to veto or postponement by the Imperial Executive or Parliament, disputes as to their validity being adjudicated on first by the Irish Court of Appeal and secondly by the Privy Council. It might not enact privilege or disability, endowment or deprivation, for any form of religion, or make any religious belief or ceremony necessary to the validity of marriage. Irish taxes would be settled by the Irish Parliament but would continue to be collected (together with such Imperial taxes as remained) by the Imperial Government, and an annual sum corresponding to the cost of Irish services at the time of the passing of the Act would be "transferred" to the Irish Exchequer under the administration of a Joint Exchequer Committee, together with a grant beginning at $£ 500,000$, to be reduced as circumstances permitted; practically this meant an annual subsidy of $£^{2}, 000,000$ from the Imperial Exchequer. The "transferred sum " would provide a security on which the Irish Government could raise loans. The financing of Old Age Pensions, National Insurance, the Post Office Savings Bank, and the Royal Irish Constabulary, was reserved temporarily to the Imperial Exchequer, but the Irish Post Office (with the patronage attaching to it) was made a separate service under Irish administration. The powers given to the Irish Parliament to deal with Customs and Excise as well as other taxation contemplated the setting up of Irish custom-houses independently of Great Britain, and (within certain limits) the possibility of varying duties as between goods imported into Ireland or into Great Britain; and as the collection was to be made by the Imperial Government, and allowances for the Irish levy to be made to the Irish by the Imperial Exchequer, the procedure was necessarily rather complicated. The finance of the Bill was indeed admittedly and necessarily provisional, complete data being unavailable, in spite of the Government's having had the advice of a Committee of financial experts, whose report however was not disclosed. For I $19 \mathrm{I}^{2} \mathrm{I}_{3}$ it was estimated that the revenue derived from, and the expenditure incurred in, Ireland would be as follows, showing a deficit of $£_{\mathrm{I}}, 5 \mathrm{I} 5,000$.

\section{Revenue,}

Customs

Excise

Income Tax

Estate Duties

Stamps.

Miscellaneous

Post Office.

Total
$3,230,000$

$3,320,000$

I,512,000

939,000

347,000

I 37,000

$1,354,000$

Expenditure.

Not separately specified

Post Office

Old Age Pensions

Charges for Land Purchase

Nat. Insurance and Labour Exchanges

Royal Irish Constabulary

Collection of Revenue
$£$

$5,462,000$

I,600,000

$2,664,000$

761,000

I9I, 500

I, 377,500

298,000

Total 
In the next ten or fifteen years, it was contemplated, the charges for Land Purchase might well increase by $£_{4} 450,000$, and for National Insurance by $£ 300,000$, while the cost of Old Age Pensions within twenty years might decrease by $£ 200,000$; thus a normal increase might be expected in the deficit, bringing it up to over $f 2,000,000$. In arranging for Ireland to manage her own finances, England was bound to give her a fair start and not to expect to score by the change; and the subsidy now proposed was estimated accordingly. As against this, it was claimed on the Nationalist side that since I8I 7 Ireland had altogether contributed about $£ 330,000,000$ to what was strictly Imperial expenditure, so that she was justified now in getting even a larger subsidy back towards internal expenditure, the scale of which had been imposed according to English and not Irish ideas. According to the new system proposed under the Bill it was calculated that under Home Rule the first year's finances would work out as follows, in the Irish and (on Irish account) the Imperial Budgets:-

Irish Revenue.

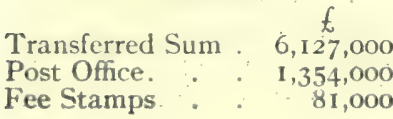

Total . . $\overline{£ 7,562,000}$

Imperial Revenue.

Irish Revenus, (ex- $\quad \ldots$ cluding Post Of- .. fice and Fee Stamps)

Deficit

9,404,000

$2,015,000$

Irish Expenditure.

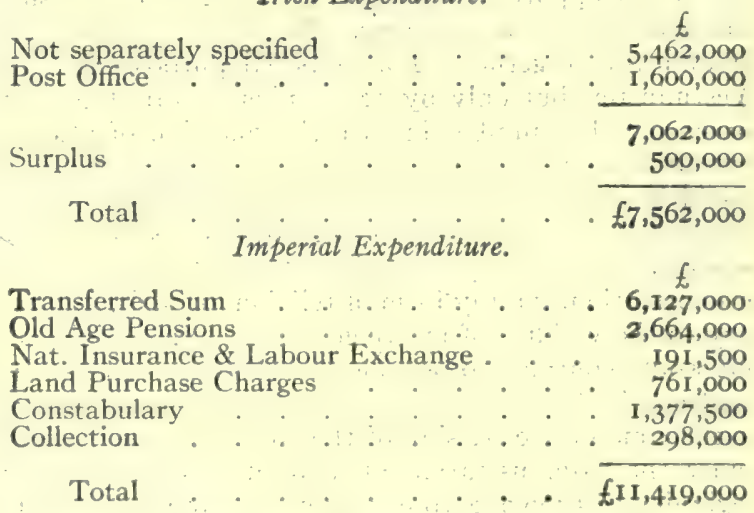

Total .

fII 419,000

Total

fII 419,000

For convenience a summary of the Bill is here given, clause by clause, omitting details as to the financial adjustment between the Irish and Imperial Exchequers.

\section{Précis of Government of Ireland Bill, Io12.}

(I) Sets up Irish Parliament, with two Houses; a Senate and a House of Commons. Supreme power of Imperial Parliament however to remain undiminished over all persons, matters and things, within $H$. M.'s dominions:

(2) Irish Parliament shall have power to make laws for the peace, order and good government of Ireland, but only in respect of matters exclusively relating to Ireland or some part thereof. It cannot legislate concerning the Crown, peace or war, army or navy, treaties or foreign relations, dignities and titles, treason, naturalization, foreign trade (except for taxation), quarantine, navigation, lighthouses, etc., coinage, weights and measures, trade marks, copyright and patents; nor on any "reserved matters," including the subject-matter of the Land Purchase Act, Old Age Pensions Act, and National Insurance Act, the collection of taxes, the Roval Irish Constabulary, the Post Office Savings Banks, and Trustee Savings Banks, Friendly Societies, or Irish Public Loans up to date of the Act. Any laws in contravention of these limitations to be void. [In Committee, the question of Trinity College, Dublin, was added to the "reserved" matters.]

(3) Irish Parliament shall not make any law so as, either directly or indirectly, to establish or endow any religion or prohibit its free exercise, or give a preference or advantage, disability or disadvantage, to any religious belief or status, or make any religious belief or ceremony a condition of the validity of marriage. Any law in contravention of this limitation to be void.

(4) Executive power in Ireland to continue vested in the King. As regards Irish services, the Lord Lieutenant or other chief executive officers approved in his place shall exercise any prerogative or executive power which may be delegated by the King; this power being exercised through such Irish departments as the Irish Parliament by its own Act may establish, and officers (i.e. ministers) to administer thes: departments being appointed by the Lord licutenant and holding office during his pleasure. Ministers must be members of the Irish Privy Council, and of the Irish Parliament (if in office longer than six months).

(5) After six years a transfer of the management of the Royal Irish Constabulary shall be made to the Irish Government. Also, if the Irish Parliament so resolves, the public 
services connected with Old Age Pensions, National Insurance, Labour Exchanges, and (after ten years) Post Office Savings Banks, Trustee Savings Banks, and Friendly Societies.

(6) Irish Parliament must meet once a year at least.

(7) Lord Licutenant shall give or withhold Royal assent to Bills passed by both Irish Houses of Parliament, but (I) shall comply with any instructions given by His Majesty (i.e: the Imperial Government) in respect of such Bill, and (2) if so directed shall postpone assent during the King's pleasure.

(8) : The Irish Senate shall consist of 40 members, the first 40 being nominated by the Lord Lieutenant on the advice of the Imperial Government, and subsequent members being nominated by him on the advice of the Irish Executive. They shall sit for eight years, one-fourth (selected by lot as provided in Clause 42) retiring every second year. [This was altered in Committee; see below.]

(9) The Irish House of Commons shall consist of 164 members, returned (as to the Imperial House of Commons) by the following constituencies (Ist Schedule): Boroughs: Dublin I1, Belfast I4, Londonderry 2, Cork 4, Limerick 2, Waterford I; University: Dublin 2; Counties: Ulster 43, Leinster 30, Munster 30, Connaught 25. It is limited to a duration of five years. After three years from the passing of this Act the Irish Parliament may alter the qualification of electors, mode of election, constituencies and distribution of members among them, but not the mumber.

(I0) Money Bills shall only originate in House of Commons after recommendation by Lord Lieutenant (i.e. proposal by an Irish minister). Senate may neither reject nor amend a Money Bill, and may not amend any bill so as to increase taxation.

(I I) If Senate rejects or fails to pass a Bill sent up by House of Commons, or amends it in a way the latter will not agree to, and the House of Commons next session repeats the Bill and the Senate repeats its action, the Lord Lieutenant may convene a joint sitting of both Houses; they shall vote together and a majority shall prevail.

(12) Peers (Irish or otherwise) are qualified to become members of either House. Ministers who are members of one House may also sit and speak, but not vote, in the other. Irish Parliamentary powers, privileges and immunities, to be as defined by Irish Act, but otherwise the same as at Westminster and no greater.

(13) Instead of the existing. Irish representatives in the Imperial Parliament, 42 Irish members shall be returned to Westminster for the following constituencies, under the election laws and qualifications of the United Kingdom, unalterable by Irish Parliament:Boroughs: Dublin 3, Belfast 4, Cork I; Counties: Ulster I I, Leinster 8, Munster 9, Connaught 6.

(I4) There shall be an Irish Exchequer and Irish Consolidated Fund, separate from those of the United Kingdom, but the proceeds of all Irish taxes shall be paid into the Imperial Exchequer, and out of the Imperial Consolidated Fund a "transferred sum" is annually to be paid to the Irish Exchequer. This "transferred sum" is composed of (a) an amount, to be determined by a Joint Exchequer Board (see Clause 16 et seq), representing the net cost of Irish services to the Imperial Exchequer at the time of the passing of this Act, (b) a sum of $f 500,000$, to be reduced eventually to $£ 200,000$ by annual diminutions of $£ 50,000$ beginning after the third year, (c) a sum equal to the proceeds, as determined by the Joint Exchequer Board, of any new Irish taxes imposed by the Irish Parliament. The Irish Parliament shall provide for the cost of Irish services within its own sphere of action, existing charges on the Imperial Consolidated Fund ceasing together with advances from the Public Works Loan Commissioners or Local Loan Fund.

(I5) The Irish Parliament may vary (add to, [reduce] ${ }^{1}$ or discontinue) any Imperia tax (except certain stamp duties) as regards the Irish levy, and may impose in Ireland any independent tax substantially different (in the opinion of the Joint Exchequer Board) from Imperial ones, but subject to certain limitations. It may not impose a customs duty (export or import) unless there is also an Imperial customs duty on that article; it may not levy a customs duty exceeding a corresponding excise duty; and (Clause $17,5.3$ ) no Imperial customs duty (except on beer and spirits), nor income tax nor death duties, may be increased by more than ten per cent.

(16-25) In these financial clauses detailed provision is made for adjusting Irish and Imperial customs duties and other financial relations, under the control of a Joint Exchequer Board, consisting of a Chairman appointed by the Imperial Government, two nominces of the Imperial. Treasury and two of the Irish Treasury.

(26) If in any three successive years the Joint Exchequer Board reports that the proceeds of Irish taxation and of any revenue to which Ireland is entitled exceed the "transferred sum," a revision of the whole financial arrangement is to be taken up by the Imperial Parliament. For this purpose alone the Irish representation at Westminster, as provided for in Clause 13 , is then to be modified; "there shall be summoned such number of members of the Irish House of Commons as will make the representatives of Irelard in the Commons House of Parliament of the United Kingdom equivalent to the representatives of Great Britain on the basis of population."

${ }^{1}$ This was afterwards eliminated, see below. 
(27) Irish judges shall in future be appointed by the Lord Lieutenant.

(28) For appeals to the House of Lords appeals shall be substituted to the Judicial Committee of the Privy Council.

$(29,30)$ Questions raised by the Lord Lieutenant or a Secretary of State as to Irish Acts being ultra vires shall be determined by the Judicial Committee of the Privy Council, to whom also shall be appeals on such points raised by decisions of the Irish Court of Appeal; and similar appeals shall lie to the latter from the Irish Courts.

(3I) The Lord Licutenant may be any British subject, irrespective of religious belief. His term of office shall be six years, and he shall be paid by the Imperial Exchequer, a deduction for this purpose of $£ 5,000$ per annum being made from the "transferred sum."'

$(32-36)$ Provision is made in these Clauses for safeguarding the interests of existing Irish judges and administrative officials, under the direction of a Civil Service Committee, consisting of a chairman nominated by the Lord Chief Justice of England, a nominee of the Imperial Treasury and a nominee of the Irish Ministry.

(37) Provision is also made for maintaining the existing interests of the Dublin Metropolitan Police and Royal Irish Constabulary.

$(38-41)$ General provisions, including that the Irish Parliament cannot repeal or alter this act, or any other that the Imperial Parliament extends hereafter to Ireland.

$(42-46)$ For the purpose of effecting the transition to a Home Rule system in Ireland, provision is made for details to be settled by Orders in Council.

(47) Definitions.

Even before the introduction of the Bill it had been seen that the greatest practical difficulty in the way of Home Rule, irrespective of controversy over particular details Ulster's in the scheme, would be the attitude of Unionist Ulster. Under Sir Edward opposition. Carson's leadership, opposition was already being organised in rgir; on behalf of the North of Ireland Protestants and Orangemen, which, it was openly avowed, would if necessary go to extreme lengths, even to a refusal to recognise a Parliament in Dublin ${ }^{1}$ and to the setting up of a separate " provisional government." The anxiety of the Government to counter this movement as far as possible had been shown early in the session by the announcement that Mr. Winston Churchill was going over to Belfast to speak on February 8th in the Ulster Hall, and violent opposition to the proceeding was at once taken in hand there. It was considered on the Unionist side that for the son of Lord Randolph Churchill, who had said that "Ulster would fight and LIster would be right," to preach Home Rule in a place associated with the campaign against it, was an outrage; and the leaders of the Ulster Unionist Council took steps to make the delivery of his speech in the Ulster Hall impossible. Eventually its engagement for the purpose was cancelled, and it seemed for the moment that the prospects of rioting and bloodshed if Mr. Churchill appeared in Belfast at all were so serious that the Government would be obliged to keep him away. Mr. Churchill however was not to be daunted. Arrangements were made for the speech to be delivered in a pavilion in a field outside the city, and for troops to be drafted there in large numbers for the maintenance of orler. The apparent denial of free speech at all on the Ulster Unionist side was severely commented upon elsewhere, and justified with some misgivings by English sympathisers, but when the leaders had been successful in defeating the plan for holding a Home Rule meeting in the Ulster Hall they went no further. Mr. Churchill duly arrived and made his speech with characteristic courage, dwelling particularly on the safeguards which the Home Rule Bill would contain against anything to which Ulster could object; but the city was in a ferment of dangerous antagonism and he had to be smuggled away afterwards to avoid the hostility of the crowd. Actual rioting was avoided, and peace was kept between Nationalists and Loyalists, at the cost of $\mathcal{L}_{2.7 .30}$ for the expense of the troops engaged, the Ulster leaders having eventually devoted themselves to keeping their supporters well in hand; but the whole incident was an unpleasint revelation of the rebellious spirit that was being aroused. A little later (April sth) Mr. Bonar Law was present at a great anti-Home Rule demonstration at Belfast, the special note of which was a solemn pledge of Loyalist resistance.

The Liberal Press in England made light of these warnings, but the organisation of

1 The anniversary of "Craigavon Day," September 23, 19I1, when Sir E. Carson was acclaimed the I Ister learter, and the Declaration of Ulster was published to the above effect, was publicly celebrated in 1912 . 
opposition in Ulster went steadily on. As controlled by the Irish Unionist leaders for a single purpose-to meet the situation arising if the Home Rule Bill became law

\section{Unionist} attitude.

-it was formally independent of actual parliamentary tactics, and therefore of the action of the Unionist party under Mr. Bonar Law's guidance; but Unionist opposition in Parliament and in the constituencies was inevitably concerned with what might take place in Ulster. Mr. Bonar Law, at a Unionist meeting at Blenheim on July 27 th, gave emphatic expression to the view he took of its meaning; which he was severely reproved by Mr. Asquith for repeating in the House of Commons on August 5th, while Mr. Churchill on August roth again took him to task in a published letter to which Mr. Law made a spirited reply (Aug. x 2th). He and his party were bound to side with the Unionists of Ulster. As Mr. Bonar Law put the case, if the Ulstermen were forced into open defiance of a measure passed under the Parliament Act without further appeal to the electorate, and by the dictation of a Nationalist vote which had in their view always been disloyal to the Empire, any attempt to coerce Ulster could only mean civil war, and this could not be confined to Ireland; it was incredible that the Government should contemplate the coercion of Ulster by British bayonets, but if they went to that length the situation would be intolerable,-ministers would be "lynched in London." Here was indeed the root of the Home Rule difficulty. Many Liberals hoped to find relief by proposing to leave Ulster out of the Home Rule Bill; at least temporarily, altogether; but Mr. Agar Robartes's amendment to this effect in Committee (July I8), after some ambiguous enquiries from the Government whether Ulster would be satisfied if it were adopted, was rejected by 320 to 252 ; the Nationalists could not do without the richest part of Ireland.

Criticism in Parliament meanwhile had gone on, for the present, along more or less stereotyped lines. On April 23rd an Irish National Convention in Dublin, with Mr. Progress of Redmond presiding, accepted the Bill, and the doubts as to whether Irish

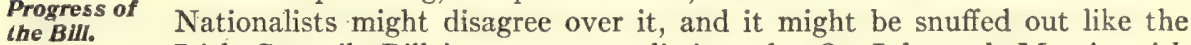
Irish Councils Bill in I907, were dissipated. On July Igth Mr. Asquith addressed an enthusiastic meeting in Dublin, and was received with fervour as the first English Prime Minister who had had a welcome there in Nationalist circles. The first reading of the Bill was carried in the House of Commons on April I6th by 360 votes to 266 , and the second reading (April 30 th) was carried on May 4 th by 372 to $27 \mathrm{I}$. The Committee stage began on June I Ith, and on July 3 rd the first clause had gone through; discussion was then suspended till the autumn. On the Unionist side the objections to any scheme for a separate Irish Parliament and Executive were fortified by criticisms of special features in the new Bill itself-the finance, the proposal for Irish representatives to remain at Westminster, the separation of Post Offices and Custom-houses, but these subjects had still to be further discussed when Parliament adjourned in August. On the Liberal side a good many members disliked the provision for the nomination of an Irish Senate, and this question arose in Committee on Clause I, but Mr. Dickinson's amendment to exclude it was rejected (June I9th) by 288 to $\mathrm{r} 99$.

The real opposition meanwhile went on in Ulster, not in Parliament. Serious rioting between Protestants and Catholics in the Belfast ship-yards during July showed the

The Solemn Covenant.

tension there; and on September I4th a free fight between partisans of both sides, in the course of a football match at Belfast at which 10,000 people were present, resulted in injuries to about roo, revolvers and knives being used. Active preparations were on foot for a series of Unionist demonstrations in Ulster, beginning at Enniskillen on September I8th, and leading up to the signing on September 28 th of a Solemn Covenant, pledging resistance to Home Rule. The perplexity on the Liberal side in face of Uister's determination was shown by a speech of Mr. Churchill's at Dundee on September r 2th, in which he suggested, purely on his own account, that, to secure a federal system of government for the United Kingdom, - to which Home Rule for Ireland, however, was an essential preliminary, - -it might be desirable to grant separate legislatures to large homegeneous areas in England like Lancashire, Yorkshire, the Midlands, and London; he would not shrink from the 
creation of ten or twelve such English bodies, all subordinate to the Imperial Parliament. The obvious comment on this suggestion was that Unionist and Protestant Lister was as much entitled to stand alone in Ireland as Lancashire in England; Mr. Churchill's speculation was effectively criticised by Mr. Balfour at Haddington on October oth, the scheme being described as " the application of decimal fractions to the United Kingdom." What Unionist Ulster demanded was to remain under the Imperial Parliament and not be at the mercy of a National Executive and Parliament in Dublin.

The text of the Solemn Covenant, promulgated by the Ulster Unionist Council, was as follows:-

Being convinced in our consciences that Home Rule would be disastrous to the material well-being of Ulster as well as of the whole of Ireland, subversive of our civil and religious freedom, destructive of our citizenship, and perilous to the unity of the Empire, we, whose names are underwritten, men of Ulster, loyal subjects of His Gracious Majesty King George $\checkmark$, humbly relying on the God Whom our fathers in days of stress and trial confidently trusted, hereby pledge ourselves in Solemn Covenant throughout this our time of threatened calamity to stand by one another in defending, for ourselves and our children, our cherished position of equal citizenship in the United Kingdom, and in using all means which may be found necessary to defeat the present conspiracy to set up a Home Rule Parliament in Ireland; and, in the event of such a Parliament being forced upon us, we further solemnly and mutually pledge ourselves to refuse to recognise its authority. In sure confidence that God will defend the right, we hereto subscribe our names, and, further, we individually declare that we have not already signed this Covenant.

Sir Edward Carson signed first, on September 28 th, at the head of a great gathering in Belfast. And when, just afterwards, he crossed with Mr. F. E. Smith to Liverpool, he had a remarkable ovation, violent speeches being made by sympathisers with the cause of Ulster, ${ }^{1}$ in favour of supporting her resistance by force of arms. It was announced later that the total signatures to the Covenent were:-Ulster, men 218,206, women 228,991; Outside Ulster, men I9, I62, women 5,055.

Parliament met again for the autumn session on October 7 th, and the political conflict was once more transferred to the House of Commons. The effect of the Ulster The autumn
session. demonstrations on the Government, up to this point, was not specially

terrifying; and Mr. Asquith, speaking at Ladybank on October 5 th, dealt somewhat scornfully with Sir Edward Carson's movement and the Unionist attitude towards it. The Government, he intimated, were ready to consider any proposals for safeguarding Ulster, but Ulster had nothing to suggest-she simply would not allow Ireland to have what the other four-fifths of Ireland demanded. It was impossible for the Government to give way to intimidation, prompted by the spirit of Orange ascendancy; they meant to go on with their Bill. On October Ioth he introducer in the House of Commons a series of resolutions for completing the various stages of discussion on it by Christmas under the closure. Including the time already occupied, fifty days (to which two were added a few days later) were, on this scheme, to be devoted to debate. An Opposition amendment, proposed by Mr. Bonar Law, was defeated by .32 .3102 .32 . The operation of the guillotine, combined with the "Kangaroo" system by" which the Chairman of Committees was left to choose which among the various amendments proposed should be discussed in the time available, made the resumption of the Committee stage simply a question of whether the Government could maintain their majorities; any effective debate was obviously impossible, and Mr. Bonar Law bluntly declared that the Government might just as well have moved that the Bill should be passed without further delay. On the other hand it was equally true that, without

"It must be remembered, of course, that "Tister," as an Trish political unit, does not mean the whole province, but only the N.F. portion, comprising the five counties of Antrim, Armagh, Down, Londonderry and Tyrone, with the cities of Belfast and Londonderry. As a geographical unit Ulster has a population (I9II) of $1,581,696$, but the N.E. purtion by itself has $1,188,695$. Out of the latter tutal, those of 16 years old and over were 387,241 males and 438,774 females. As the census classification showed that 33.1 per cent of the population in this. I.E. area was Roman Catholic, the number of adult male Protestants in Ulster who might be-expected to sign the Covenant was not much in excess of those who actually did so. 
such a time-limit, the Opposition would have protracted the debates till Doomsday; the Government had no option in the matter if they were to send the Bill up to the House of Lords during that session, as they must, in order to obtain the benefit of the terms of the Parliament Act. Even if the Home Rule Bill were to be passed through the House of Commons by January, the Government programme was overloaded, for they had announced their intention also to pass the Welsh Disestablishment Bill, the Franchise Bill and other measures, before the session ended.

Meanwhile, with Mr. Lloyd George's active encouragement, yet another political issue had been made prominent during the autumn throughout the constituencies, in The land the shape of an organised agitation for land-tenure reform and increased agitation. taxation of land-owners, promoted more particularly by a section of the Radical party who had long been advocates of the single-tax theory on Henry George's lines (see E. B. xi, 747). The Budget of I909, with its provisions for effecting a complete valuation of the land, paved the way for such a movement, and the land-reformers saw their opportunity now for pushing their views and preparing for legislation. The unpopularity of the Insurance Act made it opportune moreover for Mr. Lloyd George's section of the party to try to divert electioneering attention on the Radical side to something more attractive, and at the summer and autumn by-elections the new land campaign was made a leading feature by Radical candidates, notably by Mr. Outhwaite at Hanley. Intense exasperation was created on the Conservative side, representing as it did to so large an extent the landed interests of the country, by the organisation of an unofficial Committee of Inquiry under Mr. Lloyd George's auspices, with the authority of the Cabinet, in order to obtain evidence of various sorts of agrarian grievances in furtherance of a Radical policy. It was objected that any such enquiry for Government purposes should be by an impartial Royal Commission, which would act publicly and responsibly, and not by an unofficial body acting surreptitiously and in the interest of a partisan movement. Mr. Asquith, on behalf of the Government, repudiated entirely any sympathy with the single-tax theory, and insisted that any new land policy adopted by the Cabinet would be announced by them when the proper time came. But it was clear that, so far as Mr. Lloyd George was concerned, the next move forward in the direction of Radical social reform would be for "freeing the land," and that active preparations were being made by him with this object.

An important change in the Home Rule Bill was made when on October 3 oth the discussion in Committee reached clause 8 , concerning the composition of the Irish Senate. It was suddenly announced by Mr. Asquith that, while the

The pro: posed Irish Senate. proposed nomination of the first Senators by the Imperial Government would be adhered to, the Government had decided to abandon the idea of their successors being nominated by the Irish Government. Instead of this, the method would be substituted of election by the voters in the four Irish provinces, taken as units, on a plan of proportional representation, each elector having a "transferable" vote. ${ }^{1}$ The term of office for Senators would be five years, and all would retire together at the end of the fifth year so that the elections might then be taken; casual vacancies being filled by substitutes sitting only for the unexpired term, to be nominated if the vacancy is that of a nominated Senator, and elected if of an elected. The next day (October 3 Ist) the revised clause was introduced and carried. Mr. Asquith insisted that it would be an additional safeguard for the Unionist and Protestant minority in Ireland, but Mr. Bonar Law regarded it as worthless for any such purpose, and Mr. Healy frankly declared that in his opinion the Irish Unionists would have been better off with the method of nomination. Mr. Redmond, while accepting the Government's decision, expressed much the same view. The fact was that the whole idea of a nominated Senate was distasteful to most of the Liberal party, and it seemed a favourable opportunity for putting the experiment of proportional representation, which had recently made many converts, into practice. The Government refused however to adopt proportional representation for the Irish House of

1 See E. B. xxiii, I1 5 c. 
Commons. They also resisted the proposal, made in an amendment moved on November 5 th by Mr. Snowden, to make the local government register and not the parliamentary the basis of elections to the Irish Parliament and thus include women voters. The defeat of this amendment, by 3 I $_{4}$ to I4I, through Government and Nationalist pressure, caused considerable irritation among the more active supporters of women's suffrage, but the case against it was strong; if this was purely an Irish question it was one which, it was contended, the Irish Parliament itself should decide, while, if a decision was to be taken on the general question of women's suffrage for the whole kingdom, the proper occasion would arise when the Government's Franchise Bill came on.

On Friday November 8th a further step was taken to expedite the work of the session by the introduction of a "guillotine" time-table for the Welsh Church Bill. Mr. Asquith moved a resolution allocating I4 days to the Committee stage, Government 2 to Report, and one to third reading. So short a shrift excited much
defeat and its resull. bitterness on the Opposition benches, and it was hotly debated, the discussion that day being adjourned; and on the following Monday (Nov. IIth) the whole situation in the House of Commons was changed by an unforeseen event. The Resolution required as a preliminary to discussion of the financial clauses of the Home Rule Bill was in its Report stage, having been carried in Committee by a majority of 120 , and Sir F. Banbury now moved an amendment without notice, providing that the total payment from the Imperial to the Irish exchequer in any one year should not exceed $£ 2,500,000$. It was early in the afternoon, and the Government Whips had not realised that the Unionists were in unaccustomed force and had temporarily a majority in the House; but on a division the Government was defeated, the amendment being carried by 228 to 206. Mr. Asquith immediately moved the adjournment of the House in order to consider what action should be taken, but the idea of resignation was scouted at once; and next day it was announced that the Cabinet had decided to move a resolution rescinding the vote "notwithstanding anything in any Standing Order," and providing (so as to regularise further proceedings under the time-table, which was entirely upset by the incident) that the next day on which business was taken on the Home Rule Bill should count as the " 16 th allotted day," though, as previously fixed, the I 6 th day was November I Ith; when this had been done, they proposed to reintroduce their financial resolution and proceed as though nothing had happened. On Wednesday the 13 th Mr. Asquith accordingly moved to this effect, arguing that all the circumstances showed that the defeat of the Government had not been a genuine one and that they were not called upon to pay any attention to it. This proposal to rescind the vote and set up the resolution afresh was, however, as the Speaker agreed in reply to Unionist objections, absolutely unprecedented in Parliamentary procedure. It had always been held, and was laid down by Erskine May, that no question or Bill could be brought up in the House that was substantially the same as one on which judgment had already been expressed in the current session; and when the Speaker nevertheless ruled that Mr. Asquith's motion, though unprecedented, was in order, Opposition exasperation became intensified to a point beyond control. After Mr. Bonar Law had argued the case at length, and had moved the adjournment of the debate, which Mr. Asquith curtly declined to accept, a state of organised disorder prevented any further proceedings. With the approval of their leaders, the Opposition showed their resentment by keeping up a chorus of cries of "Adjourn," and refusing to allow any continuance of business. The Speaker at last took the only course open to him and adjourned the Housc. There seemed likely to be renewal of the same scene next day, since the Opposition were determined not to allow what in their view was a defiance of the "common law" of Parliament. Before the House met however on the r 4 th, calmer counsels prevailer owing to the exercise of the Speaker's influence. At the opening of the sitting he suggested that, if more time were given for reflection, a less objectionable way might be found for regularising the proceedings. Mr. Asquith promptly accepted this suggestion, and moved that the Ifouse shoukd adjourn for the purpose till Monday the I8th. As Mr. Bonar Law concurred, this course was accordingly adopted, and the 
anticipated storm was avoided. The air had previously been cleared to some extent by amends being made by Mr. Ronald McNeill for the most violent incident in the disorder of the previous evening. In the heat of the moment he had thrown a book at Mr. Winston Churchill which struck him a severe blow on the face; but he now offered a handsome apology, which was equally handsomely accepted.

The Liberal Press was inclined to treat the opposition to Mr. Asquith's motion as purely factious, and the organised disorder as a further mark of deterioration in parliaThe point mentary manners. But the historian of Parliament cannot well take this at issue. simple view. The defeat of the Government was certainly an accident, but it was the sort of accident that happens when a number of nominal supporters are not personally enthusiastic for the particular cause involved, or are being tired out by excessive demands on their attendance. The opinion of a high independent Liberal authority on procedure, Mr. James Caldwell, ex-M. P. and formerly Chairman of Committees, was moreover that Mr. Asquith's proposal for meeting the new situation was " clearly out of order" (Times, Nov. 16th), although not so ruled by the Speaker. Owing to the critical state of foreign affairs, consequent on the situation in the Balkan war, a change of government, as Mr. Bonar Law frankly admitted, was not at this moment desirable; and if the Government chose to ignore what was formally a parliamentary defeat their normal majority was still available. But the Opposition were naturally not prepared to forgo what, according to the practice and precedent of Parliament, was a legitimate opportunity for impeding the execution of the Government's programme of legislation for the session; and they gained their point. On Monday the I8th Mr. Asquith made an amended proposal, which was agreed to without further discussion, that the financial resolution should simply be negatived that day and the Committee stage on the financial clauses of the Home Rule Bill set up afresh on the Igth by the introduction of an amended resolution, the report stage of which would be taken on the 20 th, so that the next "allotted day" (the I 7 th day under the time-table) would be on Thursday November 2ist: This course was accordingly pursued.

The loss of a full week led to some questioning as to either the Welsh Church Bill or the Franchise Bill being dropped, but any such intention was firmly denied by Ministers. The only immediate victim to the necessity for lightening the ship was the Mental Deficiency Bill, an important social reform which a section of Radical members, in the supposed interests of individual liberty, were hotly opposing in Standing Committee; the Home Secretary on the Ioth announced that the hope of carrying this measure through must now be abandoned, though it would be reintroduced next session with the improvements suggested by the examination it had already received. Mr. Asquith, speaking at Nottingham at the annual meeting of the National Liberal Federation on November $22 \mathrm{~d}$, declared that the Government intended to pass Home Rule, Welsh Disestablishment, and Franchise Reform, before the prorogation. He vigorously denied that there was any justification for the Opposition contention that a majority obtained at the last general election for the Parliament Bill should not be used to carry these Liberal measures, to the introduction of which the destruction of the Lords' veto was well known to be a preliminary: The meeting was memorable for the appearance of Mr. Redmond side by side with Mr. Asquith, this being the first time that a Nationalist leader had been on a National Liberal Federation platform; and he made a speech insisting on the solidarity between the Irish and Liberal parties, and the cordial agreement of the Nationalists with the Government programme.

After the scare in the Government ranks caused by the misadventure of November It th and its immediate consequences, the resumption of proceedings on the financial

\section{Home Rule} Finance. clauses of the. Home Rule Bill saw their normal majority well kept up, and the guillotine fell with merciless regularity. Faced with a hostile and unreformed House of Lords, whose certain antagonism could only be defeated by sending the Bill up in time to obtain the benefit of the Parliament Act, the Coalition were compelled to restrict discussion in the House of Commons; and it might well be thought on their side that at this stage, since in any case the Parliament 
Act involved nearly two years' delay, it was futile to attempt to examine every detail in a scheme which was approved in principle, but which still had a long fight before it. On the other hand it was incontestable that, for a measure of such profound importance, supposing it to be one that might come into operation as it left the House of Commons, the discussion of the various difficult and obscure aspects of the new financial relations proposed between Ireland and Great Britain was entirely inadequate. The Insurance Act had been an unfortunate example of the results of insufficiently considered legislation, but here too clause after clause was carried, undiscussed, under the closure, full of complicated provisions, the working of which very few of the rank-and-file in Parliament even pretended to understand. The present scheme was totally different from anything proposed in Mr. Gladstone's Bills of 1886 and 1893; yet the one thing certain in 1912 was that if those Bills had become law their financial arrangements would have hopelessly broken down. And now the new proposals, fraught with revolutionary consequences alike to the finance of Ireland and of Great Britain, were being forced through with even less consideration. It was only natural that the Opposition should remain restive under conditions which made serious criticism impossible, if only because there was no time for ministers to reply in more than a perfunctory way. Mr. Herbert Samuel, Sir Rufus Isaacs, and Sir John Simon, for the Government, defended the finance of the Bill with marked ability, so far as time served; but the fact remained that on a single evening (Nov. 26th), after the guillotine had cut short a discussion on clause ${ }_{5} 5$ which left it quite uncertain to what extent it enabled a protectionist system to be set up in Ireland, clauses $16,17,18,19,20$ and 21 were then passed, with various amendments introduced by the Government itself, altogether undiscussed, most of the time available being consumed simply by taking division after division. Sir Edward Carson hotly denounced the whole proceedings as the gravest public scandal in the whole history of Parliament. On behalf of the Government it was contended that it was absurd to suppose that any Irish administration would be so foolish as to adopt the means which Mr. Amery and other Unionist speakers suggested that the Bill opened to them for introducing a protectionist policy. One variation only from the original draft of the Bill was proposed by the Government, in deference to remonstrances from their own supporters; under clause 15 the power to reduce an Imperial tax was omitted. But the Opposition amendments, proposing to reserve all power over Customs and Excise to the Imperial Government, and to prohibit the giving of direct or indirect bounties, were stoutly resisted. Mr. Bonar Law summed up the Opposition view by declaring that the Bill undoubtedly enabled the Irish administration to set up the worst form of Protection, namely bounties, and that the Government were really giving in to the demands of their Nationalist allies while professing to be the champions of Free Trade principles. Mr. Samuel, on his side taunted the Opposition with being advocates of Protection yet dwelling on the objection to a protectionist system in Ireland. Thus each party retorted on the other. But the clauses passed under the closure, with only the slightest consideration by Parliainent of the effects of its own legislation. For any judicial examination in debate, reflecting the careful conclusions of the House of Commons, was substituted the opinion of the ministers in charge of the Bill, alike as to the powers it gave and the way those powers were likely to be used. Just as the Insurance Act had left all sorts of obscure question: to be settled by the Commissioners, so the Home Rule Bill left some of the thornies! problems of the financial relations with Ireland to be solved by the proposed Join Exchequer Board, an entirely new official body, whose real status was highly question able; and clause 22 providing for this, with the remaining financial clauses, 23,24 and 25 . were duly guillotined on November 27 th. During 18 allotted days since the beginning; of the Committee stage, 78 lines of the 25 clauses passed had been discussed and 534 line: undiscussed, while 48 amendments had been discussed and 77 I ignored; on the financial clauses alone ( 14 to 25 ), $30 \frac{1}{2}$ lines had been discussed, and $260 \frac{1}{2}$ lines passed without discussion, the amendments discussed numbering $\mathrm{I} 2$ and undiscussed 210 . Eventually, under the guillotine, the Bill passed its third reading on January $\mathbf{I}_{7}, \mathbf{I}_{0.3}$. 
When Parliament adjourned for Christmas, from December zoth till December 3 oth, the two chief Government Bills, for Irish Home Rule and Welsh Church Disestablishment, were well on their way through the House of Commons. The Com-

Situation at end of 1912. mittee stage of the Home Rule Bill had ended on December I 2 th, clauses 26-48 and the final schedules having been carried since December 2 nd by the operation of the guillotine without any concession to Unionist criticisms. The Committee stage had lasted altogether 36 days, including the 25 provided under the time-table; two clauses ( $\mathrm{I}$ and 37 ) had been fully discussed, and 22 partly discussed, while 24 had received no discussion at all $(6$, I0, I 2, I6, I8, I I , 20, 2I , 23, 25, 28, 30, 32, $34,35,36,39,40,4 \mathrm{I}, 44,45,46,47,48)$. Seven days' discussion was reserved for the Report stage. For the Welsh Church Bill the time-table resolution had been carried on November 28 th, at the end of an all-night sitting, after a "reasoned amendment," "proposed by Mr. Lyttleton on behalf of the Opposition, had been defeated by 295 to $22 \mathrm{r}$; but the government agreed to give I6 days, instead of the I4 originally proposed, to the Committee stage, which began on December 5th. The discussions were marked throughout by much bitterness of feeling on the part of the defenders of the Church, among whom Lord Robert Cecil was specially prominent, but they were notable also for some important expressions of the desire of Liberal Churchmen to make the disendowment proposals less harsh than what the Welsh Nonconformists considered to be in accordance with their rightful demands. On December 5 th clause $\mathrm{r}$ was carried by 298 votes to I79, and clause 2 by 279 to I 83 , while clause 3 was carried on December 6 th by 259 to 145 ; but on December 13 th clause 4 was only carried by 269 to 202 , after an amendment moved by Mr. France and seconded by Mr. Gladstone (both Liberals), for leaving the Church all its endowments except tithe-rent-charge (thus proposing to reduce its funds by $\ell_{1} 126,000$ a year instead of $\oint_{1} 173,000$ ), had been rejected by 265 to $2 I_{5}$, the majority of 50 including 68 Irish Nationalists. And after clauses 5, 6 and 7 had been carried on December I6th and I 7 th by normal Coalition majorities, a concession was made on clause 8 , the government accepting (Dec. 18 th) amendments proposed by Sir Ryland Adkins and Mr. Atherley Jones (both Liberals), by which, much to the disgust of the Welsh members, the Church would retain possession of the Queen Anne's Bounty funds and property (see E. B. xxii, 729, 730). On another amendment, proposed by Mr. Ormsby Gore (Conservative), for keeping all the glebe as Church property, the government majority fell (Dec. roth) to 55 , the figures being 277 to 222 ; and clause 8 was only carried by 284 to $22 \mathrm{I}$. The fact that the majorities in both these cases were smaller than the number of Irish Nationalists voting with the Government showed that there was a good deal of sympathy with the Opposition among some sections of Liberals.

The actual proceedings in the House of Commons were being followed however with marked apathy in the country. Everybody felt that the real struggle had to come in

\section{Revival of}

Liberal

confidence.

rgr3. During the whole of December the critical state of European affairs monopolised public interest; and the party conflict took a secondary place when larger issues were at stake. Mr. Asquith and Sir Edward Grey, by common consent, were making British influence a powerful factor for peace in the settlement of the Balkan crisis. The Administration was strengthened for the moment simply by the fact that it represented the whole nation in the councils of Europe. Meanwhile trade was booming, and in some other respects also the position of the Government was more favourable than it had seemed likely to be a few months earlier. Since the Bolton by-election on November 23 rd, when the Liberal candidate had surprised his own party by retaining the seat with only a slightly diminished majority, the Liberal Press had taken a much more confident tone about the Coalition prospects. Moreover, in the middle of December, a flurry started in the Unionist ranks over a contentious question of electioneering tactics, which did much to assist a revival of Liberal confidence. Since Mr. Bonar Law had become the Unionist leader there had been, to all appearance, a concentration among all his followers on Fiscal Reform and Imperial Preference as the corner-stone of their constructive policy, and little had been heard of any wavering as to the principle of including low taxes on foreign wheat and other food- 
stuffs so as to give a preference to colonial imports. But the question of going to another election at all on a programme including food-taxes was now raised again on what started purely as a side issue. It was thought by the leaders of the party that the time had come when an explicit declaration should be made that Mr. Balfour's proposal; before the general election of December rgro, to submit the first Tariff Reform Budget after the Unionists returned to office to a Referendum, was no longer the party policy; and Lord Lansdowne accordingly made a statement to that effect at the Albert Hall on November 14th. No sooner had it been made than an agitation arose in certain Unionist quarters, especially in Lancashire, where it was contended that harm would be done to their electoral prospects by dropping the proposal; and the cry was taken up in circles where the food-taxes had always been disliked; with the result that pressure was put on Mr. Bonar Law to make a definite pronouncement on the whole scheme of Imperial Preference. This he did at Ashton-under-Lyne on December 16 th, but without the effect that was presumably intended.

A large part of Mr. Bonar Law's speech was devoted to combating the claims of the Radical party that they were the peculiar friends of the working classes; on the contrary he insisted that the party now in power were occupied mainly in work of Mr. Law's destruction, and that the real social needs of the community could only be Ashton speech.

met by a Unionist government. After criticising Mr. Lloyd George for offering what were only quack remedies, and declaring that the most important question of the day, so far as the industrial class was concerned, was to raise the level of wages throughout the country, which Tariff Reform would help to do, he proceeded to explain at length the main lines of the Tariff Reform programme, and particularly its relation to the policy of Imperial Preference. He repudiated the allegation that Tariff-Reform was simply old-fashioned Protectionism. It was not proposed to bolster up industries which were not naturally suited to the country, or to enable manufacturers to secure an artificial monopoly. Tariff Reform involved the imposition of duties smaller than in any other country, and its object was to give British workmen a preference in the home market over their foreign competitors. Similarly the object of Imperial Preference was to unite the Empire on lines of trade, and to secure for the United Kingdom the largest possible advantage in the British oversea markets. It was in connection simply with Colonial Preference that food duties were included in the Unionist programme, and he adhered to that policy in spite of all the misrepresentations to which it. lent itself. "For nine years we have kept the flag flying, and if there is any sincerity in political life at all, this is not the time, and I am not the man, to haul down that flag." But he wanted to make clear exactly what this meant; and here Mr. Law announced a new departure which to some extent appeared inconsistent with his previous utterance:

"If our countrymen entrust us with power, we do not intend to impose food duties. What we intend to do is to call a conference of the Colonies to consider the whole question of preferential trade, and the question whether or not food duties will be imposed will not arise until those negotiations are completed. . . We do not wish to impose them. They are not proposed by us for the sake of Protection, and there is no Protection in them. They are proposed solely for the sake of Preference, and if when the conference takes place the Colonies do not want them-I will put it far stronger than that, unless the Colonies regard them as essential for Preference-then also the food duties will not be imposed. All that we ask is that our countrymen should give us authority to enter into that negotiation, with power to impose certain low duties on foodstuffs, and within strict limits which will never be increased. - . . I hope it will be possible, and I think it may be possible, that if any readjustment is necessary it will only be a duty on wheat. I hope so, but I do not think it would be reasonable to ask the Colonies to meet us if our power of negotiation were limited. . . . If the Colonies do not think those duties necessary for Preference, they will never be imposed; if they do think them necessary, then I for one do not believe that the people of this country would not be ready to make that readjustment which is necessary to effect the purpose.".

As regards the Referendum, Mr. Law repeated Lord Lansdowne's declaration, and justified it on the ground that a pledge to submit the result of the negotiations with the colonies to a Referendum in the United Kingdom would not be fair to the colonies.

Next morning this speech had a "mixed" reception both in the Unionist Press and 
in the party. The Daily Mail took it quite plainly as meaning that no food taxes would be proposed at all, and approved of their being dropped. The Times, admiring "the

\section{Unionist}

internal

dissensions.

spirit, but not the letter," objected to making the taxation of the United Kingdom appear in any shape to depend on the decision of the colonies; the responsibility must be with the electors of the United Kingdom. In Lancashire and Yorkshire, and also in Ireland and Scotland, some important Unionist papers openly mutinied against the abandonment of the Referendum. Uncertainty as to what Mr. Law really meant-an unusual thing in his case-led to a revival, in the clubs and in the House of Commons, as well as in the Press, of the same sort of expression of hostile sectional views that had made Mr. Balfour's leadership so difficult between 1903 and 1906. There were "alarums and excursions" for several days. Mr. Garvin, in the Pall Mall Gasette and Observer, violently accused the Times and Daily Mail of leading a movement for repudiating the idea of food duties altogether, and fulminated against all and sundry who should split the party and betray the cause of Imperial Preference. Nothing that those papers had actually said really warranted any such invective, though the Times, both through its parliamentary correspondent and in its second leading-article on the subject (Dec. Ioth), encouraged the view that the majority of Unionists were averse from food taxes and would prefer to see Mr. Balfour's Referendum policy maintained, and that the section in favour of foodtaxes, though in control of the party "machine," was really a small minority. By giving currency to the report that the larger section was composed of followers of Mr. Walter Long and the smaller of those of Mr. Austen Chamberlain,-an analysis of the situation which was much too simple and very far from correct,- the Times moreover gave some ground for suspicion and irritation on the part of those who had always advocated the "whole policy:" But, while criticizing Mr. Bonar Law's suggestion that it would rest with colonial opinion to decide whether food taxes should be imposed, the Times had been quite firm in supporting Imperial Preference, including the possibility of new food duties; its real objection was to laying down any scheme of taxation in advance of precise knowledge of the conditions which might exist when a Unionist government should return to power. Nor was there theoretically any weakening in the Daily Mail, so far as the general policy of Tariff Reform was concerned: on the contrary, on December 24 th it announced that " the Daily Mail is frankly Protectionist, and is a firm believer in Imperial Preference," but it was " not over-enamoured of food taxes " and " hopeful that the Dominions do not wish Great Britain to tax corn." As consideration became cooler, it was recognised that nobody wanted to do anything that was not in the interest of a united party. Mr. F. E. Smith, speaking at Dudley on December 2oth, declared that the whole Unionist front bench in the House of Commons adopted the views expressed by Mr. Law, and that he had never meant that the decision as to food duties would be left to the colonies; all that he meant was that the decision must depend on what the colonies wanted. A duty on wheat; which seemed a vital matter in 1903 , might be much less so now; and while Mr. Law had taken the straightforward course of saying that the electors must leave the matter open for negotiation, the indications were that the colonies themselves would not ask for any measure which could be represented, even untruthfully, as likely to raise the cost of living to the working-classes in Great Britain. Mr. Austen Chamberlain also wrote a letter to a correspondent on December 23rd, expressing a general agreement with Mr. Bonar Law."

While this lively interlude was providing sport for the Free Trade party, the penultimate act of another drama, of more direct import to Liberalism, was also drawing to its close. On December Igth the result of the poll was published which had been taken among the medical profession, as to whether they would accept Mr. Lloyd George's latest terms for ordinary medical service under the Insurance Act, outside the special

${ }^{1}$ Eventually, as the result of a memorial from the bulk of the Unionist M.P.'s, Mr. Bonar Law, on January I4, stated in a letter that he and Lord Lansdowne, while remaining leaders of the party, were willing to agree that food duties should not be imposed without the approval of the electorate at a subsequent general election. 
terms made for the treatment of tuberculosis, which had already been accepted. Out of a total vote of 13,73 I only 2,422 were in favour of accepting, 11,300 being for rejection, an adverse majority of considerably more than 4 to $\mathrm{r}$. On December The doctors 2oth the representative meeting of the British Medical Association was held, and the In- to consider what action its members should take in view of the voting, and by $I 82$ votes to $2 \mathrm{I}$ a resolution was passed rejecting the Government proposal and advising the profession to decline service under the Act. In the previous February practically the whole profession-at all events 27,400 doctors-had signed an undertaking to stand together by the policy to be decided upon by the British Medical Association, and if they held to their pledge this meant a complete breakdown in the provisions of the National Insurance Act for medical benefit, which were to become operative on January I 5, I913. On the other hand, a scheme for an alternative policy was coupled with this flat refusal of Mr. Lloyd George's own proposals. It was recommended that the profession should express its willingness to treat insured persons, under arrangements to be made between local committees of doctors and the insured or their representatives (i.e. the approved societies) for a minimum capitation rate of $8 \mathrm{~s} .6 \mathrm{~d}$., inclusive of drugs, or a minimum fee of $2 \mathrm{~s} .6 \mathrm{~d}$. a visit, on condition that each insured person should have free choice of doctor and that the doctor should consent to act. Under this plan the doctors would not be dictated to by the lay insurance committees, but the financial terms would be practically the same that Mr. Lloyd George had last offered. It was promptly announced that the Government could not fall in with this proposal, which would involve handing over public money without public control; and the question now was whether there would be sufficient breaking-away from the pledges given to the British Medical Association for the insurance committees to be able to secure their panels of doctors in accordance with the regulations under the Act. Only about half of the 27,000 doctors who had ranged themselves with the Association in February had actually taken the trouble to go to the poll in December, and though this was generally believed not to indicate in itself any corresponding failure in the solidarity of the profession, there were now signs of a good deal of independent action in certain localities, and notably in Scotland. Already in November a few doctors who thought it a public duty to fall in with the Government scheme had started a new organisation in opposition to the British Medical Association, called the National Insurance Practitioners Association; and its influence, backed by Government support, was being exerted in the same direction. On Jan. 2, I9r3 Mr. Lloyd George, addressing the Advisory Committee, took a sanguine view of this situation, and declared that some 8,000 doctors were available. Nevertheless the strike now proclaimed against the Insurance Act by the recognised leaders of the medical profession was a very awkward fact for the Liberal party to reckon with. The year thus ended with the promise of a full crop of domestic political difficulties to be harvested in 1913 .

\section{The Labour "Unrest."}

(Hugh Chisholm.)

Allusion has already been made to the complications attending the political situation during I9II and I9I 2 on account of the industrial unrest, which had taken a peculiarly acute and dangerous form. Though trade generally was busy, and " unemployment," which had been a serious problem only a little while previously, steadily diminished, ${ }^{1}$ the demand of the wage-earning classes for a proportionately larger share of the good things of life-better pay and less work for it - had become more articulate and more organised than had been known before. Socialist - and particularly " Syndicalist "theories had for some time been getting a strong hold of the younger generation of tradeunionists; and a growing sense of the impotence of the Labour members in Parliament, added to increasing suspicion that Liberals and Tories alike were in league with the "money power," encouraged the idea that "direct action" by means of strikes was

1 The only official figures for "unemployed" issued by the Board of Trade are for the trade unions. In these the percentage of unemployment, which was 9 in 1908 and 1909 fell to $5 \mathrm{in} 1910$ and 3 in $191 \mathrm{I}$. For the first eleven months of 1912 it was as follows: January 2.7. F(t)ruary 2.6, March II.3 (coal strike), April 3.6, May 2.7, June 2.5, July 2.6, August 2.2, September 2.I, October 2.0, November 1.8 . 
the only way of successfully asserting the claims of the operatives to a larger share of the profits of industry. The fact that wages, under existing agreements, practically remained stationary, while the cost of living, owing to higher prices, was going up, gave a solid basis for discontent. The result was seen, not only in numerous local conflicts between Capital and Labour, of which it is unnecessary to give a detailed account, but in three more extended " general " strikes, which aimed at holding up whole industries throughout the country and compelling parliamentary intervention. These were the Railway Men's Strike of r9r I, and the Coal-miners' and Transport Workers' Strikes of 1912. A narrative of each of these is given below, in which allusion is made to the political incidents concerned with them. One outcome of the Railway Strike, and of the general unrest of which it was a symptom, was an addition made by the Government to the official machinery applicable at the Board of Trade to the working of the Conciliation Act of 1906 . In October rgr I an Industrial Council, representative of employers and workmen, was instituted, as a permanent body for considering and inquiring into matters referred to them concerning trade disputes, and for taking suitable action (but without any compulsory powers) on the same lines as the Conciliation Boards already adopted in particular industries. As Chairman of this Industrial Council, and "Chief Industrial Commissioner," the Government chose Sir George Askwith (b. I86I), head of the Labour department of the Board of Trade, who had just been knighted in recognition of the valuable work he had done in effecting peace in recent industrial conflicts. But during I9I2 at all events the deliberations of the new Industrial Council were not specially productive.

From a public point of view the worst feature of the industrial conflicts during I9II and I9I2 was the spirit of lawlessness so repeatedly shown in acts of violence and intimidation, and the apparent inadequacy of the law (partly owing to the Trade Disputes Act) to vindicate the "right to work" on the part of willing labourers outside the ranks of the unions. With a view to supplementing the protection available in the shape of the police and the military-limited as this might be by the unwillingness of the executive government to do more than appeared absolutely necessary in taking a side against strikers who were also voters, and even actually political supportersvarious arrangements were made in I II I for enrolling volunteers in private organisations for the purpose: but so far this movement has not had any important practical result. In spite of constant criticism on points of temporary difficulty both from employers and in Parliament and in the Unionist Press, the measures taken by the Government in calling out troops and supporting the local authorities were substantially effective. The complete failure of the Transport Workers' strike of May-August ig 2, following on the disappointing results of both the railway strike and coal strike, showed that when society as a whole was threatened, it could and would protect itself; and that the security of existing social order was the first consideration for the executive Government, however much it wished to be neutral in disputes between employers and employed. The necessity of using troops, however, as well as police, in such circumstances, has led to great bitterness on the part of the strikers and their sympathisers in Parliament; and in certain socialist quarters attempts have been made to put pressure upon soldiers themselves not to assist Capital against Labour and thus fight against their own class. In March 191 2 the Government prosecuted a journalist named Bowman, together with the two printers of a paper called The Syndicalist, for the publication of an article inciting soldiers to mutiny by telling them not to shoot at strikers if ordered to do so; they were found guilty at the Old Bailey, and sentences of nine and six months' hard labour was passed (March 22nd). On March I gth too, for making a speech to the same effect, Mr. Tom Mann, the well-known Labour agitator, was arrested on a warrant issued by the Salford magistrates, and he was found guilty at the Manchester assizes on May gth and sentenced to six months' imprisonment (reduced to two months by the Home Secretary.)

The year Igr 2 also saw the fruition of an enterprise long discussed at Trade Union Congresses, namely, the starting in England of a daily paper directly representing Labour. On October 8th the first number of the Daily Citizen was published, under the 
control of a board of directors appointed on behalf of the trade unions, the parliamentary Labour party and the Independent Labour party. Heretofore the principal organ of the movement-and particularly its socialistic side-had been the weekly Labour Leader; but the direct financing and control of a regular daily, combining the supply of general news with the attempt to forward Labour interests in particular, in competition with existing dailies, was a much more ambitious experiment, the results of which remained to be seen.

The Railway Strike of 1911.--For the first time in the history of English labour troubles a "national "strike was precipitated in I9II, and private war was made on the whole community by the members of the railway unions. In I007 there had been a violent agitation among members of the Amalgamated Society of Railway Servants for better wages and shorter hours, and, towards this end, for "recognition" of their Trade Union by the railway companies, which had been steadily refused by all except the North Eastern Company (after an arbitration in 1897). This struggle had gone on for many months, the companies insisting that their finances would not permit of any concessions, till in October 1907 a ballot of the Union was taken and preparations were made for a general railway strike. This was only averted on November 6th, as the result of negotiations carried on by Mr. Lloyd George as President of the Board of Trade, by an agreement between both sides to accept a scheme of conciliation and arbitration proposed by him. Under this scheme ${ }^{1}$ sectional boards were set up for each company, composed of representatives of employers and employed, to deal with disputes about hours and wages; a Central Conciliation Board, also representing both sides, was set up to adjudicate on points on which the sectional boards did not agree: and a final appeal was provided to a single arbitrator to be appointed by the Speaker and Master of the Rolls or one of them. The agreement to abide by this scheme was to remain in force for six years and then be terminable by either side on a year's notice.

Mr. Lloyd George was thought to have been highly successful in bringing it about, and it was hoped that a permanent remedy had been found for the unrest in the railway world. The companies had gone a very long way to meet the demands of the Union owing to the pressure put on them by the Government to accept the scheme. The actual working of the Conciliation Boards however proved as time went on very disappointing to the railway men; and the movement for shorter hours and better wages, persistently pressed by the forward party in the Union and associated with the socialist: propaganda throughout the Labour world, came to a head again in I9I. Strikes had been going on in Liverpool, Manchester, London and elsewhere, among various other classes of transport workers, - seamen, dockers and carters. In London a violent dock strike was only terminated early in August by an award of Sir Albert Rollit, increasing wages; and a carmen's strike, which had been accompanied by serious disorder and had driven the Government to order troops from Aldershot, was brought to an end with considerable difficulty at the same time by the intervention of the Board of Trade, the men securing concessions both as to hours and wages. At Liverpool a protracted dock strike had driven the shipowners on August 3 rd to agree to "recognise" the Dockers Union and make other concessions; but a number of strikers refused to go back to work; and the shipowners then announced a general lock-out to begin on August I4th. The answer of the Dockers Strike Committee, led by Mr. Tom Mann, was to call on all transport workers to assist them by striking in sympathy, and wild scenes of rioting resulted, requiring the assistance of troops to assist the Liverpool police. The general unrest now spread in an active form to the railway men too.

For some time past the discontent at the working of the Conciliation scheme had led to talk of a general railway strike; the Trade Union agitators were spoiling for a fight and the companies were preparing for emergencies. At Liverpool the goods porters at the Lancashire and Yorkshire stations struck on August $5^{\text {th }}$ because of the delay in dealing with their grievances, and at other stations the men came out in sympathy. On August isth, the joint executives of the four railwaymen's Unions,-Amalgamated So-

1 See generally E. B. ii, 33 I et seq. 
ciety of Railway Servants, Associated Society of Locomotive Engineers and Firemen, General Railway Workers' Union, and Signalmen's and Pointsmen's Union-decided to order a general strike unless in twenty-four hours the companies agreed to meet them and discuss terms. The Companies at once refused to do so, or to admit that the Conciliation scheme of 1907 could be thrown over in this way. The leaders of the men on the other hand contended that the spirit, if not the letter, of the agreement of 1907 had never been carried out, and that they must have direct recognition of their unions. Matters were now at a deadlock. However conciliatory the Government might be to Labour, its attitude was necessarily dictated, in the first place by the duty, in the event of a strike, of securing the transport of food and mails, the safety of property, and other public interests threatened, and secondly by its own responsibility for the agreement of 1907 which the railway men were openly intending to break. The machinery of the Board of Trade was set to work to try to bring both sides together and to delay the rupture, but meanwhile the companies, who engaged to provide for a restricted service by means of their non-union employés, were guaranteed military protection, and preparations were made for placing soldiers along the lines, at the stations and elsewhere for this purpose.

On August I 7th Mr. Asquith had an interview with the men's representatives, and offered a Royal Commission to inquire into the working of the Conciliation Scheme, but at the same time he warned them gravely and firmly. that the Government could not allow the railway service of the country to be paralysed. Resenting the tone of his speech, and suspicious of a Royal Commission as simply a means of shelving the whole matter-though it was explained too late that Mr. Asquith really meant a Commission of three to sit and report at once-they refused this offer and ordered the strike, which began next day in spite of continued efforts by Mr. Lloyd George (Mr. Asquith having left further action to him) to overcome what seemed to be a misunderstanding. As the result of his explanations to the men's leaders negotiations still went on; a vote of censure on the Government which the Labour Party at first decided to move in the House of Commons was not proceeded with; and instead of Parliament being adjourned on August I 8 th until the autumn session as had been arranged, it was decided to meet again on August $22 \mathrm{nd}$ in order to deal with the situation. Meanwhile the strike was in actual operation for practically two whole days and did not terminate till August 2oth., On Saturday (rgth) however a settlement was effected late at night, as the result of a conference at the Board of Trade between representatives of the companies and the men, Mr. Ramsay Macdonald, Mr. Lloyd George, Mr. Sydney Buxton, Sir H. Llewellyn Smith and Mr. G. R. Askwith. It was agreed that a Special Commission should at once investigate the working of the Conciliation Scheme and report quickly what changes were desirable, and that the trade-union leaders should persuade the men to return to work, the strikers being reinstated. There was some difficulty in certain districts in getting the men to go back at once, but the crisis was now substantially at an end, victory being claimed for the strikers at a mass-meeting in Hyde Park on Sunday. When Parliament met on the 22nd Mr. Asquith explained what had been done, and gave the names of the Special Commissioners,-Sir David Harrel (Chairman), Sir Thomas Ratcliffe Ellis, Mr. C. G. Beale, Mr. A. Henderson, M.P. and Mr. John Burnett; and though Mr. Keir Hardie and a few supporters insisted on a division against adjourning for the parliamentary holiday and attacked the Government for taking sides against the strikers - a charge warmly resented by Mr. Lloyd George,-the general feeling was that: a bad business was over as well as was possible.

The Special Commission started work on August 23 rd and took evidence from both sides up to October $3 \mathrm{rd}$, its report being issued on October 20 th. It was unanimously recommended that the Conciliation Scheme should be: amended in various ways, the central board being abolished and any differences within the sectional boards being settled by an independent chairman chosen from a panel drawn up by the Board of Trade; Trade Union " recognition" by the companies was not directly conceded-the Commissioners pointed out that the companies could not permit intervention on the subject 
of discipline and management,--but some satisfaction was given in this direction by a recommendation that the men should have anybody they wanted (e.g. a Trade Union official and not actually an employé) on the sectional boards as their secretary and advocate. Meanwhile however, though the men were back at work, there was still much unrest, and the Labour party and Trade Union leaders were by no means satisfied with the result of the Commission. When they accepted its appointment there was a general impression, shared in by the Government, that both sides had agreed to accept its findings, but on the men s side this was now denied, and threats of a renewal of the strike were made unless the companies agreed to specific demands for shorter hours and higher wages on a minimum scale. The union leaders decided to take a ballot in December on the question whether the findings of the Commission should be accepted or another strike for " recognition " started; and when the report of the Commission came up for discussion in the House of Commons on November 22nd the situation was still. a very difficult one. A resolution was moved by Mr. Lloyd George asking the Government to bring about a further meeting between the representatives to the agreement. of August rgth; but this was only carried after a contentious debate displaying obstinacy on both sides, Mr. Ramsay Macdonald insisting that the men had not agreed to accept the Report and that "recognition" was indispensable, while the view of the companies was that the Government ought to hold the Report as binding on both parties. It was not till December I Ith that, after a good deal of diplomacy on the part of the Board of Trade officials, a compromise was arrived at as the result of further conferences. A few days before, the ballot of the members of the unions had been taken, but the result was not made public, and now both parties agreed to accept the Report of the Commission as a basis for modifying the future working of the Conciliation Scheme, the "recognition" of the unions being accepted to the extent of allowing the men to have their Trade-Union Secretary as adviser. Matters were gradually arranged for continuing the conciliation boards on this amended scheme, and various concessions as to wages and hours were also made by the companies, which helped to keep the peace with the unions during I9I2; though discontent with their conditions of labour still continued among various classes of workers.

As regards the strike itself, while in actual operation, the state of the railways during those two or three days was unprecedented. Some 220,000 men altogether, about a third of the workers, were out, and trafific was much restricted, the worst dislocation being in the North of England, round Liverpool and Manchester. Troops were employed freely to guard the lines and give protection against violence, and in consequence there were only certain particularly disturbed districts where serious mischief occurred. On August r gth an attack was made by rioters on a train at Llanelly, and the soldiers had to shoot, two men being killed, while an explosion due to the mob setting fire to some trucks containing gunpowder resulted in five more deaths; and at Liverpool on the $15^{\text {th }}$ two men were shot in a riot. The employment of the military was furiously denounced by the Labour agitators, but the intimidation practised against non-unionists and the danger of extended sabotage were such that, on the whole, the comparative peaceableness of the stoppage, which occurred in a summer of unexampled heat, was rather remarkable. To a great extent, and particularly on the lines nearer London, this was due to the fact that a large proportion of the union-men who went out (a certain number remaining loyal to the Companies) only did so because they dared not disobey the union orders.

Simply on the issue as to more generous treatment of the railway-workers there was a fairly widespread sympathy on the part of the public with the men, ard it was against the method employed by their leaders for asserting their claims that public indignation was aroused. It is too early to estimate whether any substantial success was gained by the strike in improving the position of the men. One definite advantage was however secured for the railway unions as such; their membership before the strike had been steadily declining, and during the subsequent months they were joined by large numbers of men who had previously remained outside. 
The Knox Case, I9r 2.-In December rgr 2 a serious strike took place on the North Eastern railway over the case of Driver Knox, leading temporarily to a complete local dislocation of traffic and much injury to industry. Knox, who was a main-line driver, had been arrested at Newcastle on October 26 for being drunk and disorderly and assaulting the police; and when brought before the magistrates was fined five shillings for being drunk, though the charge of assault was dismissed. He was off duty at the time, but the company naturally took a serious view of such a conviction in the case of a man who was liable to be responsible for the safety of a passenger-train, and he was reduced in rank to that of driver of a pilot-engine only. He had apparently thought that no notice would be taken by the company, and had paid the fine and not appealed against the conviction; but when he was reduced in rank he protested that he had been wrongly convicted, and his case was taken up by the local branches of the men's union at Newcastle, Gateshead and elsewhere, their claim being that the company had no right to take cognisance of a man's action when off duty. Their demand that Knox should be reinstated was refused on public grounds by the company, and on December 6 the men decided to strike. The situation was altogether anomalous, since the strike was carried out without the sanction of the officials of the union, without legal notice, and contrary to the agreement made with the company for referring all disputes to a conciliation board; but by December 8 thousands of railwaymen at Newcastle, Gateshead, South Shields and other neighbouring centres had gone out, and the whole service was disorganised. It quickly became apparent that a settlement depended on whether Knox's conviction for drunkenness represented a serious offence or not. As matters stood the company were boutid to treat it as one, but if he could show that an error had been committed they were prepared to reinstate him. For this purpose an appeal was made by Knox to the Home Office, and on the roth of December the Home Secretary sent Mr. Chester Jones, one of the London police magistrates, to Newcastle to hold an official enquiry. He began to take evidence on the I 2 th, and issued his report on the I4th. It was shown that Knox was not quite sober on the occasion in question, and had been refused admission to a tramcar, with the result that an altercation took place, in which he had been roughly handled by the police; but the evidence was by no means satisfactory, and Mr. Chester Jones, in the circumstances, came to the conclusion, on the main point at issue, that Knox was not really either "drunk or disorderly" or "drunk and incapable" or even "drunk at all in the police-court sense." This being so, the Home Secretary announced that Knox would be granted a free pardon; and as this result wiped all the proceedings out the company immediately reinstated him. It was agreed that the strikers should resume their old places, which they had forfeited by their breach of agreement, on paying a week's wages as a fine, while the company paid compensation to the new men they had taken on during the strike; and on these terms the whole affair came to an end on December 16 with a minimum of further dissatisfaction.

The National Coal Strike of 1912.-In December Igro a strike began at the Cambrian Combine Collieries (of which Mr. D. A. Thomas was managing director), owing to the failure of the two referees (representing owners and men) appointed by the South Wales Conciliation Board to agree upon a tonnage price for the working of a seam at the Ely Pit, which had till then been worked on day-work. The rates offered by the owners were denounced by the strike committee as a "starvation" wage; but the strike was really a forward move on the part of the younger extremists among the men, who had obtained the upper hand and were influenced by socialistic doctrines. A general lock-out of the men working in other seams in the Ely Pit was the masters' reply. The Welsh socialists then sent delegates to enlist sympathy among the English and Scottish miners elsewhere, and to try to bring about a general strike; but the leaders of the Miners' Federation of 'Great Britain were not prepared to support the action of the Ely Pit strike committee, and financial support was withdrawn, so that the strike collapsed. But the propaganda which started in connection with it had an influence on what followed. 
For some little while the Miners' Federation had been putting a claim before the owners in the Federated area for the fixing of definite rates of payment in the case of " abnormal places." where the men were unable to earn an average day's wage for no fault of their own. The reasonableness of some such step could not be altogether denied, but the difficulty was to agree on satisfactory terms, and no conclusion had been arrived at. At the Southport Conference of Miners' Delegates in October Igr I the demand that, in abnormal places, a miner's remuneration should be made up to the district rate was given a different form. a claim now being made for an all-round minimum. The following resolution, proposed by the executive, was unanimously passed:-

That the Federation take immediate steps to secure an individual minimum wage for all men and boys working in mines in the area of the Federation, without any reference to the working places being abnormal. In the event of the employers refusing to agree to this, the 2 Ist rule to be put into operation to demand assent.

The delegates were instructed to report the result of their negotiations with the employers at a second Conference on November 14 th. At this conference, at which they reported their failure to obtain the minimum wage, an adjournment was resolved on (by 336,000 votes to 238,000 ) for future negotiations; and on December 2 Ist, the situation remaining the same, it was resolved that a ballot should be taken on January Ioth-I 2 th, I I 2, on the question "Are you in favour of giving notice to establish the principle of a minimum wage for every man and boy working in the mines of Great Britain?" A resolution was also passed "that each district send to Mr. Ashton [General Secretary of the Miners' Federation] a tabulated statement of what it desires to be its minimum wage, and that the Executive Committee of the Federation meet to consider the statements and report to a National Conference in Birmingham on January I 8, ro 2. ."

The result of the ballot, as declared at the Birmingham Conference. showed 445.80 r votes for giving notice, I15,72I against,-majority 330,080, South Wales alone giving a majority of 85,107 for stopping work. And on February 2, 101 2, after considerable discussion of the minimum rates asked for, the following schedule was approved:-

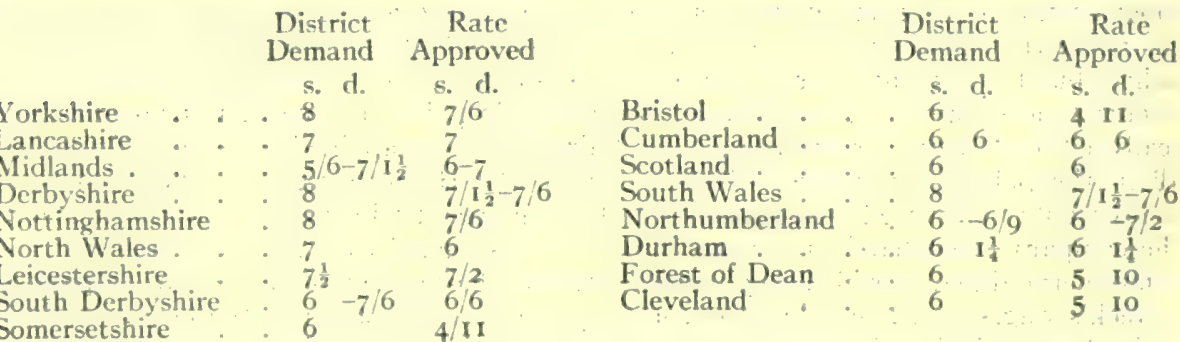

The coal-owners met on Fehruary 7 th, and the Welsh owners then refused to discuss the minimum wage and retired from the conference. This made a strike inevitable. since the miners were not prepared to settle with any but the whole Federated area, and notices were given accordingly, the public being faced with a prospect of a complete: cessation of coal supplies. The Prime Minister on February 20 th invited both sides to meet him to discuss means of averting a national stoppage, and their representatives, met him on February 2 2nd, but to no purpose; and on February 26 th the first miners: went on strike at Alfreton, the rest soon following: in spite of the announcement that. the principle of a minimum wage was now adopted by the Government and that they. would take steps to give it Parliamentary sanction unless an agreement were arrived at. (On this point a split occurred between the coal-owners, those of Durham and the Federated districts being prepared to fall in with the proposal of the Government, and the others refusing. On March Ist over a million coal-miners were out (Yorks and N. Midlands, 2.3.,000; S. Wales 220,000; Scotland 1 30,000; Northumberland, I 20,000; Durham, Iro.000; Midlands and South, 105,000; N. Wales, 70.000; N. and E. Lancs. $45, \infty 00$ ), and during the whole month the country was convulsed by the calamity. 
At last; after the Government had made a further unsuccessful attempt, by a conference, to bring owners and miners to agreement, on March Igth Mr. Asquith introduced in the House of Commons a Minimum Wage Bill as their last resort. It provided that, in the coal industry, every contract for employment should involve the payment of a minimum rate, to be settled for each district by a joint board set up under the auspices of the Board of Trade. The Bill was read a second time on March 2 Ist, after a motion for its rejection by Mr. Balfour, on behalf of the Opposition, had been defeated by 348 votes to 225 , and it had passed both Houses on March 28th. Having made their protest against a piece of revolutionary legislation which introduced so novel and farreaching a principle into industrial economics, the Unionists left the responsibility to the Government, and the only Parliamentary difficulty was caused by the Labour party, who fought for the inclusion of a precise definition of the minimum in the shape of 5 s. a day for adults and 2 s. for boys; as the Government refused this and insisted on the rates being fixed by the district boards, the Labour party opposed the third readıng, which, however, was carried by $2 \mathrm{I}_{3}$ to 48 . There was acute dissatisfaction among the miners at the failure of the Labour party to get their own minimum schedule of rates adopted, and for a time the result was doubtful; but it was decided to take a ballot (April Ist) on the question of returning to work, and though a majority still voted for staying out $\left(244\right.$, or I to 201, or $_{3}$ ) it was not large enough (two-thirds being required by the rules) and the abstentions were significant.

The fact was, the funds were exhausted and the men had had enough of the struggle. The conclusion of Sir A. Markham, the Liberal M.P. and coalowner, writing in the Quarterly Review for April 1912, is probably the verdict of history; he considered that "the ground of attack was ill-chosen; the men should have stood to their original demand, the payment on account of abnormal places or losses due to bad management. If in addition they had asked for an increase of wages equivalent to 10\% on the basis rates, to meet the increased cost of living, they would have occupied strong ground. The great mass of men came out to obtain higher wages, and for no other reason; and when they voted for the formula 'minimum wage' nine-tenths did not know what they were voting for:" The result, as the year went on and the minimum rates were settled, not without friction, was a profound disgust among the coal-miners generally with the operation of the new Act, which was found to do very little to increase the amount paid in wages; but it had done its work for the moment, the crisis being over. In October moreover an agreement was arrived at between representatives of miners and coal-owners of the English Federated area, by which about 400,000 workers would at once receive an advance of a shilling a week in wages. This was the outcome of discussions before a Conciliation Board, which had been in existence for some years and was now renewed for a further period; and this addition of about $£ I, 000, \infty \infty 0$ a year to the wage-fund was worth more than all the haggling about minimum rates.

The 'Transport-workers' Strike of 1912.-In connection with the opening phases of the railway strike of I I I , allusion has already been made to the sporadic strikes of other sections of "transport workers " earlier in that year; and the general dock strike which began in London on May 20, r9 12, was really the concluding phase of the unrest which had only been partially quieted during the previous August. First the lightermen came out, and then a "sympathetic ". strike involved all the other unions of transport workers connected with the Port of London. The nominal reason for the lightermen ceasing work was their objection to one man employed as a watchman having no "Federation ticket;" he belonged to the Foremen's Society, a union not affiliated to the Transportworkers' Federation, but refused to join the Lightermen's Society, which was so affiliated, and when the lightermen demanded his dismissal, on the ground that they would work only with men who belonged to the Federation, his employers naturally refused. This was however in reality only the culmination of a number of "grievances " put forward by the men, who complained of being victimised under the terms of the existing agreements. Unsuccessful negotiations had for some time been going on between their secretary Mr. Gosling (himself actually a member of the Port of London Authority) 
and the Board of Trade, with a view to pressure being put on the employers; and the declaration of a strike on May zoth for the reason given was prompted by the hope that the hands of the Government would be forced. In taking this step the lightermen relied on their privileged position in the Port of London. Their Society held an old licence from the Watermen's Company, whose functions were transferred in I908 to the new Port of London Authority, and the law was that unlicensed men should not be employed so long as licensed men were available, so that, apart from the difficulty of obtaining substitutes in an emergency, the employers, as they knew, would have to reinstate them when the strike was over. (One result of the strike was that the Port of London Authority took steps to get this law altered.)

The Federation of Transport Workers now took up the Lightermen's cause, and in doing so put forward a further grievance on behalf of the Carters' Union, by whom an agreement had been made with the Master Carters' Association when the strike of the previous August was settled. The: complaint was that one firm which had joined the Association had dismissed their union men, contrary to the terms accepted, and had resigned from the Association when it called them to account, so that the agreement was useless. The Union demanded accordingly that all employers in the Port should be obliged to belong to a Masters' Federation, which would have power to guarantee the carrying out of agreements. As no concession on this point was forthcoming, notice of a general strike of all members of the Transport Workers' Federation was given.

The Government at once took action by appointing Sir Edward Clarke, K.C., to hold an enquiry on May 24 th, in order that the issues, which at the moment were decidedly confused, might be somewhat better defined, and in the hope of checking the development of the conflict. He sat to hear evidence from both sides at Fishmongers' Hall, and made his report on May 28th to the effect that, while the lightermen were wrong in supposing that the award of the previous August meant that none but members of their Federation should be employed, and they themselves had broken their agreement by striking without recourse to arbitration, still there were several points on which the Transport Workers had legitimate grievances, owing to the employers not having carried out certain terms of their agreements also. The Government on May 29 th suggested a conference between the two sides, which was however declined by the shipowners, who insisted that the only point really at issue was the lightermen's breach of agreement in suspending work and thus dislocating the whole business of the Port. Meanwhile a general strike of transport-workers was in progress at the docks, some $80, \infty 00$ men being affected, and the whole food supply of London was threatened; but the shipowners actively engaged "free" labourers in spite of trade union picketing and intimidation, and day by day managed more efficiently to get their ships unloaded. Public discussion, influenced by Sir Edward Clarke's report, and its criticism of both sides, centred round the apparent necessity of providing, alike for masters and men, some guarantee against breaches of agreements; and Mr. Lloyd George, who in Mr. Asquith's temporary absence in the Mediterranean dominated the Government policy, made proposals, which he explainer in the House of Commons on June 5 th, for a Joint Conciliation Board, combined with pecuniary guarantees on both sides. Mr. Gosling, on behalf of the Transport Workers, gave a general assent to this suggestion, but the employers and the Port of London Authority (with Lord Devonport,--formerly Mr. Hudson Kearley, a well-known Liberal M.P.,- - as chairman), after careful consideration, rejected it ou June roth. It was pointed out by them that there was no proper basis, under the conclitions prevailing at the docks, for such a Board, the trades concerned being very different and the employers (some of whom were foreign firms) themselves being competitors; the Port of London Authority moreover was a statutory body, with distinct obligations and responsibilities, and could not well enter into such an arrangement, any more than a Government Department could-the Post Office, for instance-with the men in its employment. This was not a case of a strike against some individual firm which had given legitimate cause of offence, but a general strike against the whole Port, on the part of a heterogeneous body of workmen, most of whom had no actual quarrel 
with their employers, and who had stopped work in defiance of existing agreements. Negotiations now broke down altogether, and the leaders of the Transport Workers' Federation declared a "national " strike and tried to call out all its allied members at other ports as well as London. But though some 30,000 men responded altogether at Manchester, Southampton, Bristol, Plymouth and Swansea, this appeal for a " national" strike was a thorough failure; the railway unions had had enough fighting the year before and the seamen and firemen, as a body, were not prepared to come out. Scenes of violence were of daily occurrence between unionists and free labourers at the London docks, and in the East End, where the cessation of employment was causing great distress, it became necessary to cancel the King's intended visit to open the Royal Albert dock on June I 7 th; but by June I 8 th it was clear that the Port of London Authority and the employers, aided by police protection (which Mr. McKenna, the Home Secretary, provided however somewhat grudgingly), had the strikers well beaten, having obtained a sufficient supply of labour for the handling of cargo. From this point the strike degenerated into sheer anarchism, under the leadership of Mr. Ben Tillett, the Secretary of the Dockers' Union, whose revolutionary and inflammatory speeches-and especially a passionate prayer uttered by him for Lord Devonport's death-disgusted not only the public but also the Labour party in Parliament, and embarrassed their attempts to get the Government to intervene. Serious conflicts occurred, in which revolvers were used in self-defence by the free labourers, notably on July 24 th and on July 3 Ist, but by degrees the Strike Committee realised that their efforts were in vain. They recommended a return to work on July 27 th, but a mass-meeting in Hyde Part next day refused to comply with this advice, and it was not for a week later that all pretence at continuing the strike was abandoned. On July 3 Ist the lightermen decided to give in, and the riot among the dockers that day was mainly due to their finding that their old places had been filled up and that it no longer rested with them to say whether they were wanted. any more or not. On behalf of the employers however and of Lord Devonport, a general assurance had been given that, if the strike were abandoned unconditionally, any outstanding grievances under the old agreements would be inquired into and reinstatement effected as soon as possible for men who had formerly. been in regular employment; and, as the Strike Committee and theleaders of the Transport Workers' Federation could hold out no longer, further resistance came to an end.

The real object of the strike; in so far as it aimed at being a " national " one, was to compel Parliament to legislate, as it had done for the coal-miners. In this case bowever the Labour politicians and their sympathisers were impotent. The discussions in the House of Commons turned mainly on Unionist criticism of the Home Secretary for the apparent disinclination he showed for using force to preserve order and protect the free labourers. On June I2th, Mr. Austen Chamberlain moved a vote of censure on Mr. McKenna, which was rejected however by 337 to 260 . On July Ist Mr. O'Grady (Labour M.P. for East Leeds) moved a resolution "that it was expedient that the representatives of the Employers and Working Men's organisations involved in the dispute should meet with a view of arriving at a settlement," and Mr. Asquith (who had now returned to England) left the matter to the House, saying that he himself would not vote on it, as he did not think Government intervention would be justifiable or expedient. Mr. Bonar Law, for the Unionists, having expressed his surprise that in those circumstances Mr. Asquith did not oppose the resolution, moved as an amendment " that this House regrets the continuance of the strike and the consequent suffering, and approves of the declaration of the Prime Minister that the constitutional and normal attitude of the Government should be one of complete detachment and neutrality, and is of opinion that the intervention of this House in this instance can serve no useful purpose." The amendment was rejected by 260 to 215 , and the resolution was carried by 254 to 188. This was the end however of any Parliamentary action. The strike was already collapsing, and its only political result was to focus public opinion on the desirability of compulsory arbitration, or at any rate some improved machinery of making agreements, once entered into, binding on both sides.

(Hugh Chisholm.) 


\section{United Kingdom Finance, $1905^{-1913} .^{1}$}

The history of English public finance for the period from 1905 to 1912-13 offers many aspects of interest and importance. The Salisbury-Balfour administrations of I 895-1905 have been followed by those of Sir Henry Campbell-Bannerman (1905-8), and of Mr. Asquith (I908- ), and the transfer of political power is reflected in prominent features of the public finance of these periods.

When Sir Henry Campbell-Bannerman became Prime Minister on December 9, 1905, the financial position was still affected seriously by the events and work of the Period period just closed. Public expenditure had been growing rapidly, and 1895-1905. had reached a total which was substantially higher than the level of 1895 , nor did there seem a prospect of any serious reduction. In $1895^{-6}$ the total expenditure was $\{97.7$ millions, with grants to local taxation of $£ 7.4$ millions-a total of fro5. I millions: in $1905^{-6}$ the expenditure was $f_{1} 40.5$ plus $£_{9} .88$ millions to local taxation, or a total of $£_{1} 50.4$ millions. The figures just given do not include sums spent on account of capital expenditure, though annuities to meet that expenditure were included in the various estimates. In 1895 there were only three items in this account, viz. those for the Imperial Defence and the Barracks Acts of 1888 and I89o respectively, and for the Telegraph Acts. The total was only $£ 8$ ro, 00 , of which $£ 670,000$ was under the Barracks Act. In $1905^{-6}$ the sum thus spent was $£ 6.1$ millions, but it had been higher for some years; and on these accounts there were pending among the liabilities of the State about $f_{4} 45$ millions. (In March 1912 the sum owing under this head had reached $£_{50}$ millions, but the only item added to those of 1905 was $£_{3}$ millions, in part payment for the purchase of the National Telephone Company.)

The growth of expenditure from $£_{105}$ to $£_{1} 50$ millions (with extras) in the decade had, however, been more serious than these figures themselves suggest. The South African War broke out in October 1899 , and has left its mark on the finances permanently, besides keeping expenditure at a higher level. Large sums were paid toward the war from current revenue, the rest being borrowed in various ways. The borrowings to the end of $1902-3$ (March) amounted to about $£_{1} 60$ millions, but the direct cost of that War must have exceeded $£ 230,000,000$. Internationally, moreover, relations were strained in Europe, leaving a legacy in higher expenditure on the services in time of peace, and British trade was checked in a career which had promised very favourably. The surpluses of 1895 to 1899 gave place to the deficits of the war time for five years (but reappeared before Mr. Balfour left office); and meantime new taxation had been imposed up to $1902-3$ to about $£ 75 \frac{1}{4}$ millions, which included additions to the tea, tobacco, beer, and spirit duties, the imposition of taxes on sugar, coal (export), corn and flour, and the raising of the poundage of the Income Tax first by $4 \mathrm{~d}$., then by $2 \mathrm{~d}$., and then by a penny more ( $7 \mathrm{~d}$. in the $f_{\mathrm{a}}$ altogether) to is. $3 \mathrm{~d}$. The South African War, in short, disorganised finances, and necessarily caused difficulties at home and abroad; nor can its effects cease for some years. On the other hand, it is a surprise to many how remarkably strong the recovery has been since peace was signed at Vereeniging in 1902 . 'To this period also, I $90 \mathrm{r}$ and I902, belongs the Boxer outbreak in China, which involved an expense to the United Kingdom of over $£ 6$ millions.

But the South African War does not account for the whole of the growth in expenditure up to $1905^{-6}$. The debt service at $£ 28$ millions was $£ 3$ millions higher and was Revenue war charge. The cost of the Army in $1895^{-6}$ was $f_{1} 18.4$ and in $\left.1905^{-6}\right)$

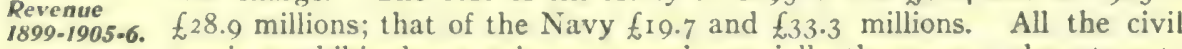
services exhibited a growing cost, and especially the revenue department.s which had heavier work in collection; but special mention of the education services is required, which went up from $£_{1}$ I to $£$ I6 millions; and of a sum of $£ 6.5$ millions in I90I-2, with another of $£ 8$ millions in $1902-3$ (or $£ 14.5$ millions in all), granted to the Transvaal and Orange River Colony to aid reorganisation. This last was virtually a part of the war's expense. It may be added that the revenue during this period was strong,

${ }^{1}$ See E. B. ix, $45^{8}$ et seq. 
though overwhelmed by war from 1899 to $1902-3$, and moved from frog.4 millions in I895-6 to $f_{153.8}$ millions in $1905-6$. The Corn Duty had been withdrawn, and the Income $\operatorname{Tax}$ at $1 \mathrm{~s} .3 \mathrm{~d}$. in war time reduced to $\mathrm{I} \mathrm{d}$. but raised again to $\mathrm{Is}$. Only the resources of a wealthy country could have borne the strain implied in these facts; and it seems as though the rapidly expanding expenditure which marks the period had been sealed and made permanent by the establishments set up during the War. It was acknowledged at the same time that the Army was in pressing need of reorganisation.

Mr. Asquith succeeded Mr. A. Chamberlain in December I905 as Chancellor of the Exchequer, and held the office until he became Prime Minister on the resignation of Sir Growth of Henry Campbell-Bannerman in April 1908, being succeeded in turn by Mr. Expenditure Lloyd George: The leading feature of the period from I905-6 to I9I 2-I3 1905-1913. is that for the latter year the total expenditure for revenue was placed at fir6.9 millions, to which $f_{900,000}$ more had to be added for Naval purposes. To this should also be added $£_{2}, 985,000$ on account of capital expenditure; but it is only fair to add that during the whole period such " extra " expenditure was discouraged, and in the case of military and naval outlay the year's expenditure was placed wholly on the estimates. For such a purpose as the undertaking of the National Telephone Company, which was taken over by the Post Office in January I912, resort was had to borrowed capital, $\AA_{3}$ millions being taken in $\mathrm{Ig}_{\mathrm{I}}-\mathrm{I} 2, \mathrm{f}_{1.7}$ millions more in $\mathrm{I}_{912-\mathrm{I} 3}$, while a much larger sum was due for the undertaking, the total amount being still in dispute at the end of ror 2 and subject to decision by an arbitration court.

It will be convenient to deal separately with Mr. Asquith's and Mr. Lloyd George's management of the national finances, though they seem to embody a continuous policy. It will be necessary to draw attention to the way in which $£ 38$ millions more were added to the annual expenditure of the United Kingdom between I 905 and I9I3, and to emphasize the fact that new state services have been undertaken.

Mr. Asquith was responsible for three budgets, I906-7, 1907-8 and I908-9, representing a period of consolidation. Retrenchment had been advocated by him in opposition; Mr. Asquith's and the expenditure was watched and checked carefully, as was essential three budgets after the costly war. The measures taken to this end may be judged by 1906-7-8. the following facts. From $\AA_{1} 5_{50.4}$ in $1905^{-6}$ the budget expenditure rose to fr 52.3 millions in 1908-9, though it had been below the $1905^{-6}$ level meantime. In the interval the Post Office charges rose from $£_{\mathrm{I}} 5.9$ to $£_{\mathrm{I}} 8$. I millions, but were more than covered throughout by: revenue. The Army estimates were reduced, though $\mathrm{Mr}$. Haldane was reorganising the whole service, and the cost fell from $£ 28.8$ to $£ 26.8$ millions. The cost of the Navy, too, was reduced-declining from $\ell_{33} .3$ to $£ 32.2$ millions in this period; and extras on capital expenditure were discouraged, nothing being added to former commitments. There was a growth indeed in the cost of the Civil Services, from $£ 28.4$ to $£ 32.3$ millions. The principal causes of this, apart from a normal tendency upward in the expense of administration, were the Education estimates, which showed a growth of about $\mathrm{fr}$ million; and the initiation of the Old Age Pension system at the opening of 1909 , toward which $£^{2}$.I millions were found necessary ultimately to meet the expense of the quarter from January to March. By this time the expenditure under capital during the year had fallen to $£ 2.6$ millions: but the outstanding total under this head was still $f_{5} \mathrm{I} .4$ millions.

The revenue fell from $£_{\mathrm{I}} 53.8$ in $1905-6$ to $£_{\mathrm{I}} \mathrm{5}_{\mathrm{r}} .5$ millions in $\mathrm{I908}-9$, but had been as high as $f_{5} 6.5$ millions the year before; and, when the circumstances are considered, it

\section{Fiscal}

changes. was surprising to find that surpluses aggregating $f_{1} 5$ millions had been realised from $1904-5$ to $1907-8$. The result of $1908-9$ proved eventually to have been a deficit of $£_{7}$ r 4,000 , as receipts were much lower than the estimate. This deficit may be accounted for in part by the changes made during this period in taxation, and on the other hand by the foundation of Old Age Pensions, for which only temporary provision had been made. Mr. Asquith's operations in taxation were important. In I 905-6 Mr. A. Chamberlain had reduced the Tea Duty from 8d. to $6 d$. per lb., and also some warehousing charges, at a total cost of nearly $f_{2} 2$ millions. In 
1906-7 Mr. Asquith fixed the Tea Duty at 5d., readjusted the rebate on stripped tobacco, and repealed the export duty on coal at a cost of about $£ 3.8$ millions. This was followed in $1907-8$ by changes of much interest. Income Tax was at a shilling in the $£$, at which it had been left by Mr. Chamberlain in 1904-5. Mr. Asquith now fixed the duty on earned incomes which do not exceed $£_{2}, 000$ at 9 d., provided the taxpayer claims the reduction by September 30 th, a concession which was computed to cost $\ell_{1} \frac{1}{4}$ millions. That was balanced, however, by reframing the scale of ascending charges for Estate Duty more severely ( $£_{\mathrm{I}}$ per cent up to $£_{500} \oint_{\mathrm{f}}$ Io up to $£_{\mathrm{I}}$ million, and $£_{\mathrm{I}}$ o for $£_{\mathrm{I}}$ million and $I 5$ per cent on sums above that when the total exceeds $f_{3}$ millions), to bring in $\ell_{\mathrm{r} .2}$ millions to revenue. Several minor concessions were also made on income-tax. The most important budget reform, however, was the power taken to pay the sums hitherto transferred directly to the Local Taxation Account into the Treasury, whence in future there should be paid to local authorities a fixed sum equal to their share in this year (1907-8); by this method an automatic growth of these grants was checked, and the taxation by which the money had been raised accounted for without any interception in the Consolidated Fund. In I908-9 again reductions of taxation were made. The Sugar Duty of rgor was reduced to Is. Iod. a cwt. from 4 s. 2 d., at a cost of $£ 3.6$ millions: the Establishment Licences transferred for collection to County and Borough Councils (which had received them before by transfer from the Treasury), and marine insurance stamps reduced from $3 \mathrm{~d}$. to Id. per cent. The Licences represented a loss of $£_{1}, 650,000$; and when the duty on glucose and on saccharine had been adjusted to the reduced sugar duty, the total concession for the year was computed at $£ 5,450,000$. During the three years, therefore, remissions of taxation (including the licences transferred) amounted to $£_{10}, 590,000$, the additions $£_{\mathrm{I} .2}$ millions, or a total reduction of $£_{9.3}$ millions; but it should be observed that this involved a shifting of a weightier portion to death duties, while duties on tea, coal, and sugar were either reduced or repealed. It may be added that provision was made for an excise duty on tobacco grown in Ireland, and for the transfer of the care of excise duties from the Inland Revenue to the Commissioners of "Customs and Excise."

Mr. Asquith's tenure of the Exchequer was distinguished also for his operations on the National Debt. During the South African War the Sinking Fund had been susReduction of pended for two years, but interest on War Loans had been paid; for two National other years the sum devoted to the service of the debt had been reduced from Debt.

$£ 25$ to $£ 23$ millions. From $1903-4$ interest on the War Loans had been included among the permanent burdens on this charge, which was raised first to $£_{27}$ millions in that year, and to $£_{2} 8$ millions in $1905^{-6}$. Mr. Asquith, pursuing the reinstatement of credit for the period I 906-9, kept this charge at $£ 28.5, £ 29$ and $£ 28$ millions respectively, thus devoting the largest amount recorded to swell the "New" Sinking Fund. The result of this policy may be gathered by the figures of the triennial period 1905-6 to 1907-8 (inclusive). These were years of large surpluses, allocated to the "Old" Sinking Fund, and amounting to nearly $£_{1} 4$ millions for the period; and these payments, together with large sums applied from the charge for the debt, "coupled with the purely financial operations of the Debt Commissioners, reduced the " dead weight " debt from $\ell_{755}$ millions at which it had been left in 1905 , to $£_{711} 1.4$ in 1908 (March): or a reduction of $£+3 \frac{1}{2}$ millions. On the other hand, the liabilities on capital expenditure had matured, and grown from $\ell_{4}$ r. 6 to $£_{5} 5.8$ millions; but as the policy by which they were incurred had been reversed by this time, the reduction on the "dead weight " debt was so much gained.

When Mr. Asquith handed over the work of the Exchequer to his successor in April I908, the financial position had undoubtedly improved very considerably since 1905 . Position in At the outset affairs were still in the shadow of the war, and though trade 1908.

was growing and even buoyant amid the shocks which it had to endure. public credit was low and public expenditure at a high figure. Consols. which had been at $113 \frac{1}{4}$ in May 1897 , were $89 \frac{\frac{1}{4}}{4}$ in December 1905 (but in 1903 had been reduced from a $2 \frac{3}{4} \%$ to a $2 \frac{1}{2} \%$ security). In that situation a policy of caution and re- 
trenchment was justified. As the revenue was elastic, and the wastage of the war had been great, it was wise to fortify the position by reducing debt and thus to aid, if only to aid, recovery. It is probable that the still expanding imports and exports owed something to this, though they dropped again in I908, as compared with the bounteous year, 1907. Still, amid undoubtedly great commercial prosperity Consols were only at $83 \frac{11}{16}$ in December 1908, and they had been as low as $82 \frac{1}{32}$ in prosperous 1907 . During the war years, however, the progress of social reform was checked, and while Mr. Asquith was strengthening the finances the demand for amelioration in the condition of the working-classes became insistent. Hence the.institution of the Old Age Pension system by Mr. Asquith in 1908 , followed by the provision of Labour Exchanges in Igog and later measures.' Mr. Asquith had left $f_{1}, 200,000$ to meet the cost of the Old Age Pensions during the first quarter of 1909 , but it was found that $f 2 . I$ millions were required.

The Old Age Pensions scheme was designed to supplement the Poor Law by giving pensions to qualified persons of 70 years of age and upwards. As originally passed it

\section{Old Age} Pensions. did not extend to persons who had been in receipt of poor relief, but after I910, by an amending Act, they were included. The chief qualification is that a pensioner shall not possess means above f3r.Ios. a year (or I2S. Id. per week) when a shilling a week will be payable, and a further shilling for every shilling per week by which the means are shown to be less up to $5 \mathrm{~s}$. each person, when the means do not exceed $£_{21}$ a year (or 8s. Id. per week). A weekly 5 s. is the highest pension per person. Up to March I9I 2 there were about 942,160 who had been awarded a pension; but from the first the number awarded in Ireland was relatively much higher than in other parts of the Kingdom. The total cost has been much higher than the original estimates, and apart altogether from the extension of the Act. The first quarter cost

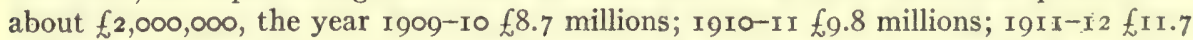
millions; and I9I 2-I 3 about $£_{12} 2.2$ millions. It is reckoned that the services rendered by other State departments to the Pension service cost $£_{450,000}$ in addition. On the other hand, the reduction in the number of paupers receiving poor relief should be set

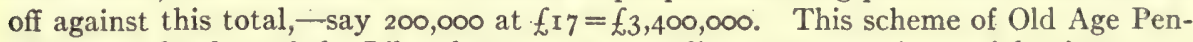
sions was the first of the Liberal attempts to realise a constructive social reform programme, the effect of which upon the finances will be noticed later.

In April $1908 \mathrm{Mr}$. Lloyd George went to the Exchequer (though the budget that year was Mr. Asquith's) and the "Social Reform programme" was further developed

Mr. Lloyd George at the Ex= chequer. under him. The season of careful retrenchment was over, and the Pensions Act was the harbinger of a still more important reform, involving increased expenditure. Under the Unemployed Workmen's Act, 1905, the Local Government Board had been entrusted with a sum of money annually to be used in relieving distress by assisting to open relief works. For some years that sum

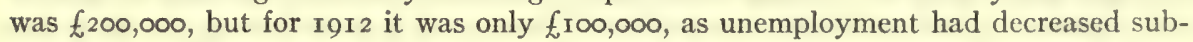
stantially. This was partly due to the Labour Exchanges Act, I909. But, apart from the great reform Mr. Lloyd George had in contemplation, which took shape in the National Insurance Act I9I I, it was his task, from the first, to finance a Liberal social programme, and this policy left its mark deeply on the revenue and expenditure from I $908-9$ to I9I 2-I3. Mr. Asquith had provided only for the first quarter of I 909 for the cost of the Old Age Pensions; and the new Chancellor of the Exchequer had at the outset to find means to defray an expenditure which was a novelty upon the estimates.

The total gross expenditure for I908-9 was $f_{152.3}$ millions, that for I 1 II I-I 2 was $\ell_{\mathrm{I}} 78.5$, and the estimates for I9I 2-I $3 f_{1} \mathrm{I} 86.9$ millions, which with a further $f_{900,000}$ for the Navy and other supplementary demands, brought the total to $f_{1} 88$

\section{arowing} expendilure, $1908-13$. millions. Nearly $£_{3} 6$ millions of the $f_{3} 8$ millions of increase since December I 905 fall therefore to be accounted for under the second Chancellorship of the Liberal Administration. Just as $£ 2$ millions were for postal purposes in Mr. Asquith's period, so may $f_{5} .8$ millions be accounted for, as the Post Office required $£_{23.8}$ millions in IgI2-I3, a sum including the administration of the newly acquired telephones. This comparison requires correction on the other hand; for though Mr. 
Asquith left the Debt service at $£_{2} 8$ millions, in $I_{912-I 3}$ only $£ 24.5$ millions were applied to that object. There is also the necessity to replace the $f_{I}, 650,000$ which the transfer of the Establishment Licences involved, which sum was now omitted from the gross expenditurc. This would leave about $f_{2} 35 \frac{1}{2}$ millions of increased expenditure to be provided for in I9I 2-I3, as compared with I908-9. For the reduction of the Sinking Fund it was pleaded that Mr. Asquith had provided so largely during the previous three years; but obviously the new expenditure which was decided upon called for a larger free income. As usual, such a transfer as that of the Licences and the suspension of the Sinking Fund disguised and understated the increase of expenditure.

As the Debt, the Consolidated Fund services, grants to local taxation, and such fixed services, show a decreased total, the increased total expenditure must be saught in the supply services for each year. Expenditure under "Capital " does The Trend not call for further notice, for with the exception of operations for telegraphs ture.

ing to the supply services, the Army took $£_{2} 28.8$ in I905-6; $£_{2} 6.8$ in I 908-9, and $£ 27.8$ millions in I9I $2-13$. We may look back usefully to 1895 , and find that the Army then cost $f_{17.8}$ millions: The Navy, too, which took $f_{\mathrm{I}} 7.5$ in $\mathrm{I} 895$, required $f_{33} .3$ in $1905^{-6} ; f_{32.2}$ in $1908-9$; and $f_{45}$ millions in $1912-13$. The Revenue departments, which cost $f_{3}$.I in I905-6, took $f_{3.3}$ in I908-9, and $f_{4.2}$ millions in I9I $2-13$. The general Civil Services, which took $f_{22} 2.4$ in I905-6, needed $£_{332.3}$ in $1908-9$, and nearly $f_{50}$ millions in I9I $2-13$. These facts enable us to trace the increased expenditure, and the swift channels in which it ran. Army expenditure is still below that of I ()$_{5}-6$, though $f_{1}$ million above $1908-9$; but since 1805 the cost had increased by over $56 \%$. Naval expenditure is now nearly $f_{12}$ millions more than $1005^{-6}$, and f.13 millions higher than in $1008-9$; comparing with 1805 , it has increased by $f_{2}-\frac{1}{2}$ millions, or I5) in a little over 17 years. As for the Civil Services and the Revenue departments, together, which cost $f_{3} I_{2}^{\frac{1}{2}}$ millions in $1005-6$ and in $1012-13$ about $f .54$ millions, we find that as the cost was only $f_{3} 35.6$ in 1 no $8-9$, some $f_{1} 8 \frac{1}{2}$ millions of the increase had been registered since then, and $£ 23$ millions or so (about 7 I per cent) since $1905-6$. If to the \{\}$_{2}^{\frac{1}{2}}$ millions taken from the Sinking Fund, and $f_{\mathrm{f}} \mathrm{r} .6$ millions less for licences placed in the total, we add the increases on Army, Navy, and Civil Services, the additions made from 1908-9 to $1912-13$ amount to about $f_{3} 3 \frac{1}{2}$ millions.

A further analysis of the $f_{1} 8 \frac{1}{2}$ millions added to the cost of the Civil Services, as shown in I0I $2-13$, is required. About $f_{\mathrm{I}}$ million was on account of the Revenue departments, a large portion of which, $f, 530,000$. means the Valuation department of the Inland Revenue. Old Age Pensions, $f\left(12 \frac{1}{1}\right.$ millions, is however the largest item. National Insurance and Labour Exchanges appear for $f_{2} .8$ millions (and the cost of medical benefits seemed likely at the end of IOI 2 to be f $\mathrm{I}^{3}$ millions more), while Education takes $f_{1} \frac{1}{2}$ millions. The rest of the $f_{0} I \frac{1}{2}$ millions of increased expenditure, about $\ell_{1} \mathrm{I} \cdot 3$ millions, may be traced to the various official bureaus.

This analysis of the trend of expenditure during Ino8-0 to roI 2-13 will serve to exhibit the position as conceived at the opening of this period. The House of Commons had been committed to a large and somewhat indefinite expenditure on Old Age Pensions for which no permanent provision had been made; a further extension of the social programme was in contemplation; there was uneasiness in the international situation, and a prospect of the growth of armaments; administration was becoming more expensive. What steps were taken to adjust the nationat finance to the national needs?

Fxpenditure depends largely on policy, and the taxation to meet it is intimately related to that policy. The measures taken to raise revenue in the budget of Igog, Revenue afterwards found in the Finance $A$ ct of roro, together with the Constitu-

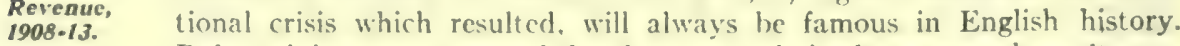
Before giving a summary of the changes made in the revenue laws it may be well, however, to give a brief account of the revenue to the end of this period.

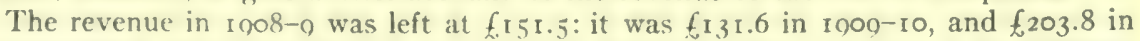
rgro-II (both abnormal figures, as explained below); and in I9II-I2, fr85 millions. 
The estimate for I9r2-r3 amounted to fr87.I millions, the borrowing for capital expenditure being about $£_{2} .9$ millions, principally for telegraphs and telephones. On I 908-9 there was a budget deficit of $f_{7}$ [4,000, but on the combined years 1909-IO-I I there was a surplus of $f 5.6$ millions, and on I9II-I 2 a surplus of $£ 6.5$ millions. The figures already given show that the relation between revenue and expenditure in I9 I 2-I 3 was tighter; but trade was favourable, the revenue returns showed much elasticity in certain directions, and yet expenditure, as has been shown, had not ceased to grow. These figures show plainly that this was a critical time, when the due working of the Treasury was much disturbed. An account of Mr. Lloyd George's budget of I909-10 and its changes in taxation will go far to account for that disturbance, especially as the Budgets of succeeding years made no changes of importance in the revenue laws.

The Finance Bill of r 909 was introduced on May 26th (after the discussions on the Budget statement of April 3oth), and was read a third time on November 4th, only to be rejected on the 3 oth by the Lords, who wished to have it submitted The Finance to the country. The budget statement anticipated a total revenue of Bill, 1909-10. $f_{162.5}$ millions, as against $f_{15} \mathrm{I} .5$ realised for I908-9. The actual revenue proved to be $f_{1} 3 \mathrm{I} .6$ in 1909 , consequent upon the rejection of the Bill by the Lords; for the custom of collecting the Income Tax and tea duty, which are annual taxes, on the authority of a resolution of the House only, had to be suspended, - a custom judicially declared since (Nov. I9I2) not to have any legal warrant. Some f30 millions of the huge revenue of I9IO-I I was, therefore, arrears of the revenue of I 909-10. After the general election of January rgro, which maintained the government in office, the Finance Bill (I909-10) was reintroduced on April 20 th and the Lords agreed to it without amendment on April 20th. There was a second Finance Act of I9I0, the ordinary one for the year, but it made no change in revenue laws.

According to Mr. Asquith (May 5th) the budget of 1909 contained proposals adequate for the year, and for the prospective necessities of years to follow, without deviating from the principles and practices of free trade, and without imposing Provisions additional burdens upon the necessaries of the people. The Chancellor of
of Finance Bill, 1909-10. the Exchequer, too, on the third reading (Nov. 4th) said that the taxes had been arranged to meet the requirements not only of the year, but also of the future. A summary of the provisions for new taxation may now be given, by which it was proposed to increase the revenue, while at the same time $f_{3} \frac{1}{2}$ millions were saved by reducing the Sinking Fund by that amount.

Beer duty was increased from 8 s. to 8 s. 3 d. per barrel: Spirits, home from Irs. to I4s. 9d. per proof gallon, and imported from Irs. 4 d. to I 5 s. Id: Tobacco, $8 \mathrm{~d}$. per lb. added to 35. with adjustments in Ireland and Scotland, and on cigars, \&c: Motor Spirit $3 \mathrm{~d}$. per gallon, with certain rebates: Liquor Licences were increased, and the whole code reframed. Motor Car Licences were also increased, and graduated according to horse-power. Estate and other inheritance duties were revised again more severely; especially the scalc on Estates exceeding $£ 5,000$ in value: Settlement Estate Duty was increased from I to 2 per cent, and powers of disposition were amended: the rates of Legacy and Succession duties were made higher. In Stamps the duties were doubled on Conveyances and Leases, and on Bearer securities, while those on Contract notes were increased and graduated from $6 \mathrm{~d}$. to $f_{\mathrm{I}}$ according to the amount in question. The Income $T$ ax was raised from IS. to IS. 2 d. in the $£$, and abatements on the income of those resident out of the United Kingdom abolished. A Super-Tax of 6d. was imposed on incomes over $f 5, \infty 00$, assessable on so much as exceeds $f, 3, \infty 00$. On the other hand the concession of a rate of Is. in the $f$ on earned incomes which exceed $f, 2, \infty 00$ but not $f, 3,000$ extended this innovation regarding earned incomes (this in 19ro-r I was a concession which involved $\left.f_{87}, 500\right)$ : there was an allowance of $f_{\mathrm{s}}$ ro on the assessment for every child under 16 on incomes between $£$ r6o and $£_{500}$; and additional relief was granted under Schedule $I$ on account of the cost of maintenance, repairs, insurance, \&c. The chief novelty of the Budget was the Land Value Duties, the provisions respecting which are somewhat complicated with regard to assessment, which also involved a scheme for securing a valua- 
tion of all land in the United Kingdom. The principle to be applied was easily stated, but in application is found very complex, while the terms of the Act in these sections are confessedly difficult, not to say obscure. The duties imposed were four, viz. the Increment Duty of $20 \%$ on the increase in value of the land site; the Undeveloped Land Duty of $\frac{1}{2} d$. in the $f$ on capital value: the Reversion Duty of ro per cent on benefits accruing at the termination of a Lease: and Mineral Rights Duty of $\mathrm{xs}$. in the $£$ on mineral rents, way leaves, \&c. These land value duties are not payable on agricultural land.

There were some general provisions touching this revenue which deserve notice, such as the instruction that premiums on the grant of new on-liquor licences shall be paid into the Exchequer; that $5 \%$ shall be paid to county councils in Ireland on the amount of the duty levied on motor-cars; and that the proceeds of the duties on motor spirits, and on motor-car licences, shall be paid to a fund as a grant (under the Development and Road Improvement Funds Act, I909) for road improvement. It may be added that when the House of Commons passed the Bill a second time provisions were added to confirm the collection of taxes while the Bill was passing the legislature.

Whatever might be the political objections to the Budget of 1909 , it has already been shown that its operation resulted in raising the gross revenue from $£_{1} 51.5$ in $1908-9$

\section{How the}

sources of

revenue

were af-

fected.

to $£_{1} 87$.I millions estimated in $1912-13$, thus showing a growth of $£_{35} .6$ millions in the interval. A certain amount of the increase arose, however, from non-tax revenue, $£ 7$ millions from Postal Services alone. The taxrevenue in I908-9 was $f_{125.5}$ : in I9II-I2 (a normal year) it was $f_{155}$ millions; in I9I $2-I_{3}$ about $£_{153.8}$ millions. The only change of substance in I III-I 2 was the withdrawal of the $2 \mathrm{~d}$. per lb. customs duty on ground cocoa, which involved about $£ 60,000$ only; but the tax revenue for I9I2-I3 showed an expectation of $f_{2} 28.3$ millions above $1908-9$. A revised estimate in 1909-10 of the anticipated effect of the new taxes gave a total of $f_{\mathrm{I}} 2 \frac{1}{2}$ millions for that year, and $\{77.7$ millions ultimately, but this last was exclusive of spirits, liquor licences, and the land value duties. A comparison of the differences between the revenue derived from various chief heads in I908-9, and in $1912-13$, will be instructive. Customs yiclded more by $£_{4.7}$ : Excise by $£_{4.1}$ : Estate Duties by $£_{7.1}$ : Stamps by $£$ I.7: and Income Tax (including Super Tax which yielded $£_{3}$ millions in 19I I-I2) by f, 10.2 millions. The House Duty also continues to show a growing yield. These are remarkable figures, no doubt, and speak much of the resources of the country. Each of these items, too, when compared with the expectation of I 900 , shows a fulfilment of hopes, with the doubtful exception of the Excise, while the changes in Income Tax, estimated to produce an extra $f_{6} \frac{\frac{1}{4}}{4}$ millions, actually produced $f_{\mathrm{r}} \mathrm{O}_{4}^{\frac{1}{4}}$ millions. The Land Value Duties, on the other hand, which were originally estimated to produce $£ 600,000$ in the first year (and much more ultimately), proved disappointing, the results being

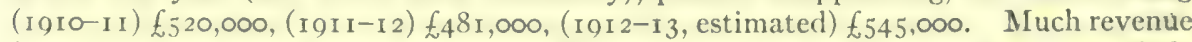
from this source could not be expected indeed, until the land valuation of the whole kingdom, affording a datum for the duties, had been completed, which could not be earlier than I 15 . Meanwhile the larger part of the revenue from those land value duties is derived from the Mineral Rights Duty, the yield of the others being small.

Both direct and indirect sources were appealed to for the additions to revenue. The new indirect taxes (tobacco, alcoholic drinks, and liquor licences) contributed $£ 8.8$ out of the $f, 28.3$ millions by which the revenuc of $I_{9} I_{2-1} 3$ exceeded that of $1908-9$. On the direct side there are additions to taxes on property, like the Estate duties, and largely the Stamps, and the half million from Land Value duties, and finally the high rate of Is. $2 d$. in the $f$ on income-tax (coupled with a super-tax) which in $1012-13$ yielded over $£_{44}$ millions. The concrete results of the Budget of I909-10, which for 1912-I 3 drew additional revenue of $f 8.8$ millions from indirect, and $f, 19.5$ millions from direct taxation, were naturally pointed to in I 2 I 2 by Mr. Lloyd George as justifying his policy.

Not unconnected with the incidence of the new taxation were some applications of the revenue to be raised, such as the provision of a Development Fund, and of a Road Improvement Fund. In 1909) an Act to form Boards, \&c., to manage these Funds was 
passed, which directed that a sum of $£ 500,000$ should be placed to the credit of the Development Fund annually for four years, beginning with I9ro-II; and the Finance

The Developmeat ana Road Im* provement Funds.

Act of I909-Io transferred a sum equal to the "net proceeds of the duties" on motor spirit, and on licences for motor cars, to the Road Improvement Fund. According to the Act of $1909, £ 400,000$, in addition to the $£ 500,000$ granted by that Act was voted to the Development Fund, and the Board in igro was made to consist of 8 members instead of five. The half million was paid into that fund again in I $9 \mathrm{II}_{\mathrm{I}} \mathrm{I} 2$; but by the Finance Act of I9II, $f_{\mathrm{I}} \frac{1}{2}$ millions were set aside from surplus revenue to be paid to this fund during the years ending in March I913, I914, and I915. To the Road Improvement Fund was paid in I9IO-II over $£ 860,000$, and in I9II-I $2, £_{1} I, 209,800$. In I9I $2-13$ this fund was estimated to reach $f_{1}, 225,000$. The functions and duties of the Road Board are indicated by its title. As for the Development Fund, that is used for the promotion, by government departments; colleges, institutions, or persons, not trading for profit; by means of a grant or a loan, of agriculture, forestry, drainage, harbours, fisheries, transport, stock, and so forth, in many cases by way of experiment. By means of these two Funds about $\ell_{1} \frac{3}{4}$ millions a year are now used so as to benefit property; and that aspect may have to be reconsidered in any reform of local taxation.

The National Insurance Act of IgI 1 , though a measure of great social and financial interest, does not enter into the finances of this period, beyond the appropriation of f2.8 millions in $1912-13$.

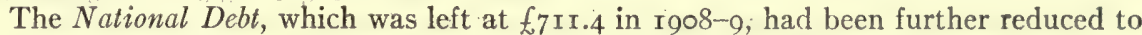
$\left\{674.7\right.$ millions in March, I9I2; the total " dead weight" Debt being lower by $£_{36.7}$ millions. Together with the $f 43 \frac{1}{2}$ millions paid off under Mr. Asquith (inNational cluding frr.8 millions for $1905^{-6}$, as provided in Mr. A. Chamberlain's Debt 1908-13. Budget), this makes a reduction of over $£ 80$ millions during seven years: The disposal of the surpluses of the second period is worth notice. The small deficit left by Mr. Asquith in I 908-9 was followed by the confusion of the finances in I $909-10$, at the rejection of the Finance Bill by the Lords, but the conjoint years I 909IO-I I yielded a surplus of $£ 5.6$, and I I I I 2 yielded $£ 6.5$ millions, which strictly should have gone to the "Old" Sinking Fund. From the first of these two, as already stated, $£ \pm \frac{1}{2}$ millions were placed to the credit of the Development Fund. Another $£_{1} \frac{1}{2}$ millions were used to provide Sanatoria for the treatment of tuberculosis, and $£ 250,000$ as a loan to the East African Protectorate. In June I9I 2 the Chancellor of the Exchequer announced that from the I9II-I 2 surplus of $£ 6.5$ millions nearly $f$ I million would be required for Naval purposes, and $£ 500,000$ would be advanced to Uganda and East Africa as a loan. In this connection also it should be recollected that not only was the action of the "New" Sinking Fund suspended in part in I909-10, owing to the confusion of that year, but that the Debt Service Charge was reduced from $£ 28$ to $£ 24.5$ millions.

The political controversies which have centred round "Lloyd George finance" are still too acute for final criticism. To it are attributed by its opponents the largely increased export of British capital and the fall in the value of Consols and other "gilt edged "securities. Whether the incontestable growth of British investments abroad is a good thing or a bad thing for the nation is, however, itself a matter of controversy. The price of Consols, whatever may have been the influence of politics, has undoubtedly been affected by a number of other causes, such as the extension of trustee stocks, and particularly the opportunities offered by a bounding commerce for more remunerative investments. The drop from $113 \frac{1}{2}$ in 1897 , when the interest was $2 \frac{3}{4}$, or even from $89 \frac{1}{4}$ in December 1905 , when the interest was $2 \frac{1}{2}$ per cent, to $72 \frac{1}{2}$ in October 19 I 2 , is in itself a serious one. But it points rather to the importance of maintaining the Sinking Fund than to any actual decline in British credit. In so far as the price of Consols is a test of British credit, they compare favourably with any national securities elsewhere. On November I 5 , I91 2, Consols at $2 \frac{1}{2} \%$ were $75 \frac{1}{2}$ (equivalent to over 90 at $3 \%$ ), and Ger$\operatorname{man} 3 \%$ were $76-78$. 


\section{British OBItUARY, : $910-12$}

I9IO

A few additions may be made here to the record of British obituary already contained in the $E$. B.. in respect of the period (1909-10) when the I Ith edition was passing through the press.

The deaths of Bishop Alfred Barry, formerly primate of Australia (b. 1826; d. at Windsor, April I, 1910; see E. B. iii, 444); General Sir William Butler, the Irish soldier and writer (b. 1839; d. in Tipperary, June 7, 1910 ; see E. B. iv, 888); Prof. J. E. B. Mayor, the classical scholar (b. I825; d. at Cambridge, December I, I910; see E. B. xvii, 937), and Sir Walter Palmer, Ist Bart., of "Huntley \& Palmer's" (b. 1858; d. in Berkshire, April 16, 1910; see $E . B . x x, 645)$, may be noted in connection with the biographical articles referring to them.

In the case of other people referred to in the $E$. $B$. as then living, the deaths occurred in I9Io of Lieut. Boyd Alexander, the African explorer (b. I873; killed by natives at Nyeri in Wadai, April 2; see E. B. i, 353); Col. Claude Regnier Conder, R.E., LL.D., the Palestinian geographer and archacologist (b. 1848; d. February I6; see E. B. xi, p. vi); Reginald Frank Doherty, the lawn-tennis player (b. 1874 ; d. in London, December 29; see E. B. xvi, 303); Sir Thomas Drew, the Irish architect, president of the Royal Hibernian Academy (b. 1838; d. in Dublin, March I3; see E. B. ii, 44I); Rev. Hereford Brooke George, the New College (Oxford) tutor, military historian, geographer and Alpine climber (b. 1838; d. December i5; see E. B. xv, 556, "Jungfrau"); Robert Walker Macbeth, the Scottish painter (b. 1848; d. in London, November $\mathrm{I}$; see E. B. xx, 500); Frank Podmore, the associate of Gurney and Myers in psychical research (b. 1856; d. near Malvern, August I4; see E. B. xxii, I5); Admiral Sir Harry Rawson, governor of New South Wales 1902-09 (b. I 843; d. in London, November 3; see E. B. iii, 738); and Dean Edward C. Wickham, of Lincoln, ex-headmaster of Wellington (b. 1834; d. in Switzerland August 18; see E. B. xii, 72).

Archbishop William Dalrymple Maclagan, who had resigned the archbishopric of York in 1908, died in London on the 19th of September, 1910. Born in Edinburgh in 1826, ho had begun life in the army, retiring as lieutenant in 1852 in order to enter the church; and after studying at Cambridge he became a London rector, first at Newington and then at St. Mary Abbott's, Kensington, where his success led to his selection as bishop of Lichficld in 1878 . In 1891 he was made archbishop of York. Both as bishop and archbishop, Maclagan did much to stimulate Church work both among the clergy and the laity; in 1899 he sat as assessor with Archbishop Temple of Canterbury when the decision was given against the use of incense and other "ritualistic" practices (see E. B. xiv, 352), and though personally a strong High Churchman he loyally upheld the Primate's "opinion" in his diocese.

Mention must be made here too of the death in London, on December 12, 1909, of the eccentric art-collector George Salting (b. Australia, I 836), whose name will endure because of his bequest to the nation of his unique treasures, porcelains, etc., now housed in several rooms of the Victoria and Albert Museum.

The premature death in London, on December 29, 1910, of Samuel Henry Butcher, the classical scholar and M.P. for Cambridge, calls for a fuller notice. He was the eldest son of Samucl Butcher, classical tutor and lecturer at Trinity College, Dublin, and subse(juently Bishop of Meath. Born in Dublin on the I6th of April 1850, he went to Marlborough in 1864 and won an open scholarship for classics at Trinity College, Cambridge, in 1869. In 1870 he won the Bell scholarship at Cambridge, in 1871 the Waddington scholarship, and in 1871 and 1872 the Powis medal. In 1873 he graduated as senior classic and won a Chancellor's medal. He took an assistant mastership at Eton for a vear, but returned to Trinity, Cambridge, as fellow and lecturer in classics. On his marriage in 1876 to Rose. daughter of Archbishop Trench of Dublin (see E. B. xxvii, 242d), he had to resign hi Trinity fellowship, and was then elected tutor and "married fellow" at University College. ()xfori. In 1882 he succeeded Prof. Blackie as professor of (ireek in the Iniversity of Edinburgh. During his tenure of this chair he became widely known, not only as a schular but as a judicious administrator and educational reformer. He was a member of the royal commission which was appointed after the passing of the Scottish Universities Bill in 1889 to reform the whole academical system in Scotland, and which reported in April 1900 . In 1902 Mrs. Butrher died, and two years later he resigned his professorship and went to reside in Jondon. He had been a member of the Royal (ommission of 1901 on University Education in Irclanfl, which produced an abortive report with 8 reservations in 1903; and he was alse included on the Royal (ommission of 1906 . In the latter vear, on the death of sir Richard Jebh, he was chosen as a I'nionist to represent the University of Cambridge in Parliament, where his brother J. (i. Butcher (b. 1853), a well-known harrister, had sat for mally vears as [ nionist member for York: he made an effective maiden speech on the Irish Iniversity Bill and frequently took a valuable part in debate. His grave and thoughtful style and gift of natural eloquence were combined with a charm and sincerity which won him universal respect and affection, no less in public than in private life. He was however, above all, a fine (ireck scholar, full of the true spirit of classical learning, with a remarkable 
power of literary expression, shown especially in such publications as his Aspects of the Greek Genius (1891), Aristotle's Theory of Poetry and Fine Art (1895), Greek Idealism in the Common Things of Life (1901), Harvard Lectures on Greek Subjects (1904), and his prose translation (with Andrew Lang) of the Odyssey (1879). In 1907 he was president of the English Classical Association, of which he had been one of the principal founders in 1903 . He was also the first president of the Irish Classical Association, and an original member of the British Academy, becoming its president in 1909 . In I908 he was appointed a trustee of the British Museum. Two years later his health began to fail, and he made his last public appearance and delivered his last speech on the 2 Ist of October 1910, at the dinner given to celebrate the publication of the IIth edition of the Encyclopaedia Britannica by the Cambridge University Press:

\section{IgII}

The following persons, of whom separate biographical notices are given in the $E$. $B$., diè in IOI I:

Edwin Austin Abbey (b. 1851, see E. B. i, I1), the Anglo-American painter, on August 1, in London. Besides bequests to the Corcoran Art Gallery, Washington, the Boston Art Museum and the British National Gallery, Mr. Abbey left his house in Chelsea, London, after the death of his widow, to the Royal Academy for the use of the president.

William Alexander (b. 1824; see E. B. i, 565), Protestant Archbishop of Armagh and Primate of Ireland, at Torquay on September 12. He had resigned his see on January 30, and had been created a G.C.V.O.

The 9 th Earl of Carlisle (b. 1844 ; see E. B. v, 34I), in London on April 16 th.

Edward Dicey (b. 1835 ; see $E . B$. viii, 178 ), the publicist, in London on July 7 th.

Sir Charles Dilke (b. I84I; see E. B. viii, 27I), the Liberal statesman and author, in Lóndon on January 26 th.

Sir Francis Galton (b. 1823 ; see E. B. xi, 427), the anthropologist and founder of "eugenics," at Haslemere on January 17 th.

Sir William Gilbert (b. 1836 ; see E. B: xii, ro), author of the Bab Ballads and collaborator with Sir Arthur Sullivan in the Savoy operas, on May 29th, being drowned in trying to rescue a lady from a pond in his grounds at Harrow Weald.

Sir Eldon Gorst (b. I86r; see E. B. xii, 26I), Lord Cromer's successor as British Agent and Consul-general in Egypt, on July I2th, at Castle Combe, Wiltshire. He had resigned his position in Egypt shortly before he died, being succeeded by Lord Kitchener.

Sir Robert Hart (b. I 835 ; see E. B. xiii, 30), long the head of the Chinese Customs, at Great Marlow on September 2oth.

Sir Joseph Hooker (b. 1817; see E. B. xiii, 671), the eminent botanist, at Sunnydale on December Ioth.

Baron James of Hereford (b. 1829; see E. B. xiv, 144), the Liberal Unionist statesman and lawyer, at Epsom on August i 8 th.

Thomas Rupert Jones (b. I819; see E. B. xv, 500), the geologist and palaeontologist, at Chesham, Bucks, on April 13 th.

Alphonse Legros (b. I 837 ; see E. B. xvi, 380; ix, 806), the artist, on December 8.

Sir Alfred Lyall (b. 1835 ; sec E. B. xvii, I48), the Anglo-Indian administrator and man of letters, in the Isle of Wight on April i Ith. 26th.

John Brown Paton (b. I83o; see E. B. xx, 930), the Congregationalist divine, on January

The Ist Baron Northcote (b. 1846; see E. B. xiv, 280), Governor-general of Australia 1903-08, at Ashford on December 29th.

The 4th Earl of Onslow (b. 1858; see E. B. xx, I13), formerly a Conservative Cabinct Minister, and governor of New Zealand, on October 23.

William Clark Russell (b. I844; see E. B. xxiii, 865), the writer of sea-stories, on November 8 th

Edward Whymper (b. I840; see E. B. xxviii, 617), the artist and Alpine climber, at Chamounix on September 16.

"John Strange Winter" (Mrs. Arthur Stannard; b. 1856; sec E. B. xxviii, 734), authoress of Boolles' Baby, in London on December I 3.

The Ist Viscount Wolverhampton (b. $183 \mathrm{I}$; sec $E$. B. xxviii, 78r), the Liberal statesman, on February 25. He had retired from the Asquith Cabinet early in 1910.

References are also made in the $E$. B. to the following who dicd in this year:

Hermann Adler (b. I839; d. July 18), the Chief Rabbi of the United Synagogue, London (see. E. B. xxvi, 292a).

James Aumonier (b. 1832 ; d. October 4), the landscape painter (sce E. B. xx, 501c). His." Sheep Washing" and "Black Mountains" are in the Chantrey Bequest collection at the Tate Gallery.

Charles Frederick Moberly Bell (b. I 847; d. April 5th), the managing director of the Times (see E. B. xix, 558a). Born in Alexandria, the son of an Egyptian merchant, he was educated in England, but in 1865 went back to Egypt and engaged in business. He 
soon began sending occasional correspondence to the London Times and from 1875 onwards devoted himself mainly to journalism. By 1880, when he founded the Egyptian Gazette, he had become the regular correspondent for the Times in Egypt. He also published Khedives \& Pashas (1884), Egyptian Finance (1887), and From Pharaoh to Fellah (1888). In I 890 he was summoned to London to take the post of manager (nominally assistant-manager) of the paper, at a time when it had suffered heavy. financial losses over the proceedings connected with the Parnell Commissions ( $E . B . x x, 858$ ). From that date he devoted all his masterful energies to the journal he served, and up to his death his was the personality most prominently associated with it in the public eye. When the Times Publishing Company was formed in 1908, and mainly through his personal exertions the financial control passed from the Walter family to Lord Northcliffe, he became managing director.

Sir Rubert William Boyce (b. 1863; d. June 16), the bacteriologist and pathologist (see E. B. xx, 779). Born in London, he was educated privately in Rugby and at Paris, and afterwards at University College, London, where he took his M.B. in I889, and was in 1892 appointed constant-professor of pathology. In 1894 he became professor of pathology in University College, Liverpool, and in 1898 bacteriologist to the Liverpool Corporation. He did much to promote the foundation of Liverpool University in I902, and the endowment of the four chairs of bio-chemistry, tropical medicine, comparative pathology and medical entomology. He had in 1898 worked with Sir Alfred Jones to establish the Liverpool School of Tropical Medicine, and in 1901 organised a series of expeditions to the tropics to investigate disease. In 1905 he went himself to New Orleans and British Honduras, and in 1910 to West Africa to examine epidemics of yellow fever. He published Mosquito or Man (1909), Health Progress and Administration in the West Indies (1910), Yellow Fever and its Prevention (19II), and many papers for scientific societies. He was knighted in 1906.

Sir Percy William Bunting (b. I836; d. July 22), editor of the Contemporary Review (see E. B. iv, 802 b.).

Sir Caspar Purdon Clarke (b. I846; d. March 29), the art-expert. Educated privately at Sydenham and Boulogne, in $\mathbf{1} 862$ he entered the art schools at South Kensington and was trained as an architect. In 1865 he entered H. M. Office of Works, and in 1867 was attached to the works department of the South Kensington Museum. He travelled extensively for the museum, purchasing objects of art, and at the same time carried on his profession as an architect. In 1883 he became keeper of the India Museum at South Kensington, in 1892 keeper of the art collections at South Kensington, in 1893 assistant director, and in 1896 director. This post he held until 1905, when he became director of the Metropolitan Museum, New York (E. B. xix, 614), resigning in 1910. He was knighted in 1902.

Ernest Crofts, R.A. (b. 1847; d. March 19), the historical painter (see E. B. xx, 50od). He had been keeper of the Royal Academy since 1898 .

John Passmore Edwards (b. 1823; d. April 22), newspaper proprietor and philanthropist. The son of a Cornish carpenter, and mainly self-educated, in 1844 he became London representative in Manchester of the Sentinel, an Anti-Corn Law weekly newspaper. A year later he went to London and began lecturing, together with the practice of journalism, starting several small periodicals which in succession failed, until in $\mathbf{1} 862$ he bought the Building News, which by 1866 had made a handsome profit. In 1876 he bought the London halfpenny evening newspaper, the Echo, and controlled it for 20 years. He was an ardent peace advocate, and supported a number of humanitarian and philanthropic objects, endowing various libraries and other institutions which bore his name, notably the Settlement in Tavistock Place, Bloomsbury. He also founded a Passmore Edwards scholarship at Oxford for the conjoint study of English and classical literature. He published privately an autobiography, A Few Footprints (2nd edition, 1906).

Edward Mills Grace (b. 1841, d. May 20) the cricketer. A brother of Dr. W. G. Grace (sec E. B. xii, $308 \mathrm{~d}$ ), he was a player', of first-class cricket for 35 years (see $E$. $B$. vii, 441). He had been Coroner for West Gloucestershire since 1875 .

Lady Hallé (Madame Norman-Neruda), the famous violinist (b. 1839; d. April 15). (see E. B. xii, 853b.).

John Lockwood Kipling (b. 1837; d. January 30), the Anglo-Indian artist, curator of the Lahore Museum 1875-93, and father of Mr. Rudyard Kipling (see E. B. xv, 825).

Sir Charles Bennet Lawes-Wittewronge, 2nd Bart. (b. 1843; d. October 6), the sculptor (see E. B. xxiv, 503b and 506). The only son of Sir John Lawes of Rothamsted (see E. B. $x v i, 300 h)$ he was educated at Eton and Cambridge, where he was a notable athlete. Subseruently he devoted himself to sculpture, while doing much also to further the scientific side of the Lawes Agricultural Trust, founded by his father, of which he was chairman. In 1882 he was defendant in a famous libel action, brought by another sculptor, Mr. Belt, for a criticism published in Vanity Fair, imputing dishonesty to Mr. Belt in taking credit for work done by another man. The question of how much a sculptor may be aided by others in work to which he attaches his name was inconclusively debated through a long and costly trial, and the verdict of the jury, awarding $f 5,000$ damages to the plaintiff, was much discussed at the time.

General Sir Robert Cunliffe Low, G.C.B. (b. I838; d. August 4), a famous soldier. Entering the Indian army in 1854 , he served through the Mutiny. As Director of Transpert 
he organised the mobilisation of troops for the campaign of $\mathrm{r} 880-8 \mathrm{r}$, including the march from Cabul to Kandahar. After some years of service as Lieutenant he commanded the Chitral Relief Expedition of 1895 (see E. B. vi, 252). Retiring in 1905 he was appointed Keeper of the Crown Jewels in I909.

George Robert Milne Murray, F.R.S. (b. I858; d. December I6), the well-known botanist, younger brother of A. S. Murray (see $E$. B. xix, 38). As keeper of the Department of Botany at the British Museum his researches were principally devoted to algae and cryptogams, in the pursuit of which he made several voyages, notably in I901 as scientific director to Capt: R. F. Scott's Antarctic Expedition.

Frederick William Pavy (b. 1829; d. September 19), the well-known physician. He was for years the chief authority in Europe on diabetes ( $E$. B. xviii, 62), and wrote various works upon digestion and the metabolism of the carbo-hydrates.

Sir Herbert Hope Risley (b. I85I; d. September 30), the Anglo-Indian Civil Servant and anthropologist. His principal work was done in connection with Indian ethnography, the discussion of the caste system, etc., and he published under Government auspices some important volumes of anthropometric data. He had charge of the Indian Census operations of I901. He was appointer Secretary of the Judicial Department of the India Office in r9ro.

General Sir Frederick. Charles Arthur Stephenson, G.C.B. (b. 1821; d. March Io) Constable of the Tower of London since 1898 . He fought in the Crimea, and served in China from 1857 to $186 \mathrm{I}$. From 1883 to 1888 he commanded the army of occupation in Egypt (see E. B. ix, 123, 126).

Meredith White Townsend (b. I83I; d. October 2I), the well-known journalist. Born in Suffolk, and educated at Ipswich grammar school, in 1848 he went out to India, and four years later became editor of the Friend of India, acting also for some years as Times correspondent. In 1860 he returned to England, and purchased the weekly Spectator ( $E$. $B$. xix, 562). With R. H. Hutton (E. B. xiv, I6d) he was joint-editor until 1898 , and he was largely instrumental in making it an established success.

Bishop John Wordsworth of Salisbury (b. I843; d. August I6), the classical scholar and divine, son of Dr. Christopher Wordsworth (afterwards Bishop of Lincoln) and grandnephew of the poet (see E. B. xxviii, 825c):

The obituary for I II also included the following names of people of public interest, concerning whom brief biographical data are appended:

Sir John Aird, Ist Bart., the famous engineer and contractor; d. January 6th. Born in London on the 3rd of December 1833, the only child of John Aird, contractor for gas and water plant, he joined his father's business at eighteen. He was entrusted with the removal of the Crystal Palace buildings for the Great Exhibition of 1851 from Hyde Park and their re-erection at Sydenham, and took part in many large enterprises at home and abroad, such as the Hampton and Staines reservoirs, the water-works of Amsterdam, Copenhagen, Moscow, Bahia, Pará, Calcutta, Simla and Berlin, and later (in the joint firm of Lucas \& Aird, afterwards John Aird \& Co.), the St. John's Wood Railway, the Hull \& Barnsley Railway and Docks, the West Highland Railway and the great Assuan Dam across the Nile (see E. B. xiv, 850a). He represented North Paddington in Parliament as a Unionist from I 887 to I905, and was its first mayor in 1900. In I9OI he was created a baronet.

William George Aston, a well-known authority on Japanese literature; b. 184I; d. Nov. 22nd. He entered the British consular service in Japan in 1864. His Japanese grammars and translations were the first good English books on the subject.

Harold Kyrle Bellew, the actor; d. at Salt Lake City, Utah, November 2. B. in 1855, in Lancashire, he first appeared on the stage in Australia in 1874; and after several London engagements he joined Henry Irving for two years at the Lyceum in 1878 . He had the reputation of being the handsomest man on the stage. In I888, with Mrs. Brown Potter's company, he toured round the world. For the last ten years of his life he had been playing in the United States, in romantic and modern plays.

Sir Nathan Bodington, vice-chancellor of Leeds. University; b. I848; d. May i2th. A graduate of Wadham, Oxford, he became a fellow of Oriel, and in 1882 professor of Greek and principal of Yorkshire College, Leeds. It was owing to his efforts that the college was endowed and chartered in 1903 as a university.

Colonel Sir Edward Ridley Colborne Bradford, Ist Bart., the Anglo-Indian soldier, and London Police Commissioner; d. May 13 th. Born in Buckinghamshire on the 27 th of July 1836 , and educated at Marlborough, in 1853 he went to India as a cadet in the East India Company's service and joined the 2nd Madras light cavalry. He served with distinction through the Indian Mutiny and till 1863 , when he lost an arm in tiger-shooting; he then accepted political offices, serving as political agent, chief of native police, and after 1878 , chief commissioner of Ajmere and in control of all relations with the Rajput chiefs. In 1887 he was recalled to the India Office in London, and from 1890 to 1903 he was commissioner of the London Metropolitan Police. He was created a baronet in 1902.

Henry Broadhurst, the English Labour Leader and Liberal politician; d. at Cromer, October IIth. Born at Littlemore, near Oxford on the I3th of April 1840, the son of a stonemason, he was educated at the village school, and at the age of 13 was apprenticed to 
his father's trade. Ho worked at it for nearly twenty years, going to I.ondon finally in 1865 where he was employed in the huilding of the House of Commons. In 1872 he was elected chairman of the mason's committee during a strike, and from that time was prominent as a trade union official. In 1875 he was elected secretary of the parliamentary committee of the trade union congress. He entered parliament in 1880 as liberal member for Stoke-onTrent. In 1885 he was elected for the Bordesley division of Birmingham, and in February I 886 was appointed under-secretary to the Home Office, going out with the Gladstone government later in the year. He belonged to the older school of trade unionism and was opposed to such demands as an 8-hours day fixed by law. His moderate policy was defeated at the trade union congress of 1890 , and he then resigned his secretaryship. Both in 1892 and 1893 he was unsuccessful in his parliamentary candidatures. In 1892 he was appointed a member of the Royal Commission on Labour, and in 1894 he was elected Liberal member for I,eicester, which seat he held until 1906, when he retired from ill health. He published the story of his life in I90I, and a book on Leasehold Enfranchisement in conjunction with Lord Loreburn in 1885 .

Lady Colin Campbell (née Gertrude Elizabeth Blood); d. in London Nov. IIth. In I886 she obtained a separation from her husband, a son of the duke of Argyll, after a long and painful suit; and subsequently she became well-known as an art critic and journalist.

The 3rd Earl of Cawdor (Frederick Archibald Vaughan Campbell), a prominent Unionist politician; d. at Stackpole Court, Pembrokeshire, February 8th. Born at Windsor on the 13th of February 1847, he was educated at Eton and Christ Church, Oxford. From 1874 to 1885 he was Conservative member for Carnarvonshire, and succeeded to the peerage in 1898. In 1890 he became a director of the Great Western Railway, and chairman in 1895 , and in this capacity earned a high reputation for business ability. On the 6th of March 1905 he became First Lord of the Admiralty in Mr. Balfour's cabinet, and held that post till the fall of the government in December. Under him the "Dreadnought" and "Invincible," the first ships of a new class, were laid down, and before leaving office he issued a programme for building four large armoured ships annually. His death deprived the Unionist party of a trusted statesman of whom much was expected. In 1907 he had moved for a select committee to consider the reform of the House of Lords, and he took a strong part in advising that House to reject the Budget in 1909; he was a member of the Conference of party-leaders in 1910 , which tried in vain to arrange a compromise on the constitutional question.

Prof. George Chrystal, the eminent mathematician; d. at Edinburgh November 3rd. Born near Aberdeen in 1851, he was second wrangler at Cambridge in 1875 , and was appointed successively professor of mathematics at St. Andrews in 1877 and at Edinburgh in 1879, holding the latter post till his death. He was the author of many publications on physical and mathematical subjects, and his researches into the surface oscillations of Scottish lakes won him a royal medal from the Royal Society.

Baron Collins of Kensington (Richard Henn Collins), the jurist and I.ord of Appeal, d. at Hove January 3 rd. Born in Dublin in 1842 , and educated at Trinity College, Dublin, and Downing College, Cambridge, he was called to the English bar in 1867 and joined the northern circuit. He edited the 7 th, 8 th and 9 th editions of Smith's Leading Cases, was made a Q.C. in 1883 and a judge in 1891 . In 1897 he became a judge of appeal, in 1901 Master of the Rolls, and in 1907 a lord of appeal (resigning in 1910). In 1899 he represented Great Britain on the tribunal appointed to arbitrate in the boundary dispute between British (iuiana and Venezuela; and in 1904 he was chairman of the commission which investigated the case of Adolf Beck $(E . B$. xiv, 287) and resulted in his conviction being annulled.

Canon Robinson Duckworth, the well-known divine; d. at Hawkhurst September 25th. Born at Liverpool in 1834 he took a first-class degree at Oxford in 1857 , and became a fellow of Trinity College, where, after being a master at Marlborough, he was tutor from 1860 to 1866. He was then appointed Instructor and Governor to the Duke of Albany (1866-70), and subsequently (haplain to Queen Victoria (1870). He was admitted into the most domestic Court circles, and accompanied the Prince of Wales (afterwards King Edward V'II) on his tour through India. He became a Canon of Westminster in 1875 (succeeding (harles Kingsley) and Sub-Dean in 1895 .

Sir Charles Alfred Elliott, the Anglo-Indian administrator; d. at Wimbledon May 28 th. Born at Brighton in 1835 , and educated at Harrow, he proceeded to Irinity ('ollege, Cambridge, but in 1856 , when the Indian civil service was first thrown open to public competition, abandoned his Cambridge career and went out as one of the first fifteen members. During the mutiny he was assistant magistrate of Mirsapur. He served at Cawnpore and Oonao, where he published Chronicles of Oonao, a collection of folk-lore; he accomplished the settement of the Hoshangabad district and the Farukhabad district, drawing up a model report of these operations. He administered famine relief at Mysore in 1878 , and in 1881 became chief commissioner of Assam. In 1886 he presided over a committee appointed by Lord Infferin to inquire into Indian public expenditure. From 1890 to 1895 he was lieutenant-governor of liengal. After his retirement he did valuable work as a member of the education committee of the London County Council.

Sir Hugh Gilzean-Reid, jurnalist and newspaper proprietor; rl. at Hendon November 
5 th. Born in Aberdeenshire in 1835 , he became a journalist, and founded several provincial papers, notably the first existing halfpenny daily, the North Eastern Daily Gazette. He was the first president of the Institute of Journalists I 888-90, and the first Liberal member of parliament for Aston Manor I885-86. He was knighted in I 893 .

Sir William Grantham, the well-known judge; d. in London, November 30th. Born in I835, he came of an old Sussex family; and inherited property in the county. After a successful career at the bar, and in parliament, where he represented East Surrey in the Conservative interest from $1874-85$, he was appointed in 1885 judge of the Queen's Bench division of the High Court.' He was never at pains to conceal his own views on politics, and after 1906, when he was on the rota of judges for election petitions, his decisions were sharply criticized: as biassed against the Liberal party, notably in the Great Yarmouth case, which led to a motion of cerisure in the House of Commons in July 1906. But in certain criminal cases he gained considerable credit, and in the Adolf Beck trial he was one of the first to suspect the mistake as to the prisoner's identity (see E. B. xiv, 287). He was chairman of the East Sussex Quarter Sessions, and as a landlord took a practical interest in the housing of the rural labourers. In Parliament he was a strong supporter of the establishment of the Criminal Court of Appeal.

The Very Rev. Robert Gregory, Dean of St. Pa'll's; d. August 2nd. Born at. Nottingham in 1819 , he was at first intended for business, but subsequently went to C.C.C., Oxford, and was ordained in 1843 . In $185 \mathrm{I}$, after holding various country curacies, he became Curate of Lambeth Parish Church, and from I 853-73 was rector of St. Mary's, Lambeth, becoming a Canon of St. Paul's in 1868. In 1890 he became Dean of St. Paul's, and to the end of his long life devoted himself to the service of the metropolitan cathedral. He was a High Churchman, a champion of Church Schools and of religious education, and was a member. of the first London School Board.

Sir Henry Harben, a pioneer of industrial life-insurance; b. 1823; d. Dec. 2nd. From 1848 he had been connected with the Prudential Assurance Company, and saw it increase from small beginnings till its income was over 14 millions sterling.

Samuel Henry Jeyes, a well-known journalist; b. 1857; d. in London June 25th. He had been assistant-editor of the Standard since I892, and was the author of a Life of Mr. Chamberlain and other books.

Alfred Peter Hillier, Unionist M.P. for Hitchin division of Herts; b. I858; d. Oct. 24th. Educated as a doctor at Edinburgh, he settled in South Africa in 1878 , and became a partner with Dr. (afterwards Sir Starr) Jameson at Kimberley and Johannesburg. He was a member of the Reform Committee in the crisis of $1895^{-96}$, and was one of the prisoners at Pretoria. In 1897 he settled in England and devoted himself to finance and politics. He contributed several articles on South African history' to the $E$. $B$.

Sir George Henry Lewis, Ist Bart, the famous solicitor; d. in London December $7 \mathrm{rh}$. Born in 1833, and educated at University College, London, he was articled in 1856, and became head of the firm of Lewis \& Lewis. He was engaged in a very large number of notable public cases, including the Bravo poisoning case, the Hatton Garden diamond robbery, and the Overend-Gurney and other banking prosecutions. Later he was solicitor for Mr. Parnell and the Irish party in the Parnell Commission (see E. B. ix, 579 and xx, 855). Sir George Lewis, who was made a baronet in 1893 , was for many years the most prominent man in his profession, and had a unique practice, especially in advising on difficult family affairs; he was the trusted confidential adviser of a host of important people.

Baron Lochee of Gowrie (Edmund Robertson), the jurist and Liberal politician; d. September I 3 th. Born in Scotland on the 28 th of October 1845 , and educated at Oxford, he became a fellow of Corpus Christi College in I872; he was called to the English bar, and became well-known as a jurist, filling the posts of examiner in jurisprudence at Oxford, professor of Roman Law at London University, and Reader in law to the council of legal education. He was Liberal member for Dundee from 1885 until he was raised to the peerage in 1908. In 1892 he became a Civil Lord of the Admiralty, and in 1906 was Secretary to the Admiralty: His writings included a book on American Home Rule, and numerous articles on legal and constitutional subjects in the $E$. $B$.

John Malcolm Forbes Ludlow, the well-known social worker; d: in London October I 7 th. He was born in I82I, and was called to the bar in 1843. Becoming associated with Kingsley, Hughes and F. D. Maurice, he helped to found the Working Men's College in Great Ormond Street, and was one of the first promoters of the Christian Socialist Movement. From 1875 to 1890 he was Chief-Registrar of Friendly Societies. He was one of the first members and subsequently president of the labour Co-Partnership Society.

The Rev. Dr. Norman Macleod, the Scottish divine; d. December IIth. The son of the Rev. John Macleod, D.D., he was born at Morven, Argyle, in 1838. He became one of the leading ministers of the Church of Scotland, always with a slight leaning towards the "High Church" section. Beginning his career as minister of St. Columba's, Glasgow, he was inducted to the first charge of Inverness in 1890 , was appointed clerk of the General Assembly of the Church of Scotland (an office in which his statesmanlike abilities were widely recognised), and in Igoo was elected moderator of the General Assembly.

John MacWhirter, the Scottish landscape painter; d. in London January 28th. Born 
near Edinburgh in 1839 , he began his art training under Robert Scott Lauder, and was elected a member of the Royal Scottish Academy in 1867, an associate of the Royal Academy in 1879 and R.A. in 1893. His June in the Austrian Tyrol was bought in 1892 out of the Chantrey bequest.

Margaret Macdonald (Mrs. Ramsay Macdonald); b. I870; d. in London Sept. 8th. A daughter of Dr. J. H. Gladstone (E. B. xii, 66), she devoted herself to social work, both before and after her marriage in 1896 to Mr. Ramsay Macdonald, who became leader of the Labour party. She was the first President of the Women's Labour League (1906).

Bishop Francis Paget of Oxford; d. in London August 2nd. The second son of the surgeon Sir James Paget (see E. B. 20, 45 I b), he was born on the 2oth of March 1851 . His brothers, Sir John R. Paget, K.C., 2nd Bart., the lawyer (b. 1848), the Rt. Rev. Luke Paget, Bishop of Stepney since 1909 (b. I85.3), and Stephen Paget, the surgeon and author (b. I855), all became well-known men. Francis Paget was educated at Shrewsbury and Christ Church, Oxford, where he had a distinguished career, taking first classes in classics, winning the Hertford scholarship (187I) and Chancellor's Latin Verse Prize (187I); he was elected a senior student of Christ Church (1873) and tutor (1876), taking holy orders in 1875. In $\mathbf{I} 885$ he was appointed Regius Professor of Pastoral Theology, and in 1892 succeeded Canon Liadell as Dean of Christ Church. He contributed the essay on the Sacraments to Lux Mundi. He became Bishop of Oxford in I9OI, and was a Member of the Royal Commission on Ecclesiastical Discipline from 1904-06.

Sir Cuthbert Quilter, Ist Bart., English financier and art collector, d. at Woodbridge, Suffolk, November $18 \mathrm{th}$. He was born in $184 \mathrm{I}$. He made a considerable fortune in business, and took an active interest in scientific agriculture, doing much to reclaim waste lands at Bawdsey, Suffolk, and also in the improvement of horse-breeding (he revived the all but extinct Suffolk "Punch"). He was a great picture-buyer, and acquired a collection of paintings which realised over $£ 87,000$ at his death. He sat in Parliament as Liberal Lnionist member for Sudbury from 1885 to 1906 , and for some years earnestly advocated the passing of a Pure Beer Bill, with the object of restricting the use of substitutes for hops; he himself started a brewery at Woodbridge in order to put his views into practice.

Alberto Randegger, the musical composer and conductor; d. in London December 18 th. Born in Trieste in 1832 , he had settled in London in 1854 after huiding various musical appointments in Italy. Both as an orchestral conductor, and as a teacher of music and singing he held for many years a leading position in London; he published a number of original compositions, and a host of prominent artists were his pupils, either privately or at the Royal Academy (from 1868) and Royal College (from 1896). Besides conducting on various occasions at the Royal Opera, musical festivals and elsewhere, he did much, as conductor of the Carl Rosa company from i 879 , towards the popular revival of opera in England.

The Rev. James Guinness Rogers, the Congregationalist divine, b. 1822; d. August 20th. He is best remembered for his close association with Dr. Dale in the Liberal-Nonconformist Education and disestablishment campaigns of $1865-75$, and for his friendship with Mr. Gladstone and Lord Rosebery, who consulted him as the foremost representative of Nonconformist statesmanship.

"Lord" George Sanger, the circus-proprietor; b. 1827, murdered at Finchley on Nov. 28th. He had at one time the largest travelling circus in Europe.

Elliot Stock, the Nonconformist publisher, bibliophile, and author; b. 1837 ; d. March Ist.

Mervyn Herbert Nevil Story-Maskelyne, the mineralogist; d. at Swindon, May 20th. Born in 1823 , he was descended on the mother's side from Nevil Maskelyne, the Astronomer Royal. He was Professor of Mineralogy at Oxford from I865-95, and also the first Keeper of the Minerals at the British Museum, relinquishing that post in 1879 . In 1880 he entered Parliament as Liberal member for Cricklade, and represented North Wilts as a Liberal Lnionist from 1885-92. He studied especially crystallography, meteorites and gem-stones, and was the author of many scientific papers, and of a book on the Morphology of Crystals.

"Hesba Stretton" (Sarah Smith), the authoress; d. near Richmond October 8th. She was horn at Church Stretton in 1832, and wrote for Household Words under the editorship of ( harles I)ickens, who became a personal friend. She was well known as the writer of Jessica's First Prayer and other religious tales.

Baron Swaythling (Samuel Montagu), the well known financier; d. in London January 12th. He was born at l.iverpool on the 2 ist of December 1832 , and came of Jewish family named Samuel, but afterwards took by royal licence the name of Montagu. Beginning in early life in a very humble way of business, he gradually acquired great wealth by enlarging it - seope, and he rose to the head of the most important arbitrage house in the City of London. A strong liberal in politics, he sat in parliament for the Tower Hamlets from 1885 to 1900 ; he was a member of the Gold and Silver Commission of $1887-90$, being himself a bi-metallist. He was created a baronet in 1894, and raised to the peerage in 1907. Throughout his life he was a zealous promoter of Jewish interests, founding the loan fund of the Jewish Board of (iuardians, the Jewish Working Men's Club and several synagogues, and for his work on emigration schemes for the persecuted Russian Jews he made many journeys in Europe and America, succerding Sir Julian Coldsmid as chairman of the Russo-Jewish committee. He also helped to establish a modern secular school for Jews at Jerusalem in $\mathbf{1 8 7 5}$. 
Katherine Cecil Thurston, the novelist; d. at Cork September 6th. The daughter of Mr. Paul Madden, she was born at Cork, and in 1901 married Ernest Temple Thurston, the novelist, the marriage being dissolved on her petition in I9I0. Her chief publications were The Circle (1903), John Chilcote, M.P. (1904), The Fly on the Wheel (1908).

Sir Samuel Walker, Ist Bart., Lord Chancellor of Ireland; d. at Dublin August I3th. Born in County Westmeath in 1832 , he was educated at Trinity College, Dublin, and called to the Bar in 1855 . He was Liberal Member for Londonderry from 1884-85, and was appointed Attorney General for Ireland in I885. From 1892 to 1895 he was Lord Chancellor of Ireland, and again from 1905 till his death.

Robert Spence Watson, a prominent Liberal politician; d. at Gateshead-on-Tyne, March 2nd. Born at Gateshead in 1837, he came of an old Quaker family. He was educated at the Friend's School, York, and London University, and then went into practice as a solicitor; but later he became well-known as an enthusiastic worker for the Liberal cause in politics. Though he never entered Parliament; he had a potent influence in north-country constituencies, and was president of the Newcastle-upon-Tyne Liberal Association (I 873-90) and also of the National Liberal Association (I89I-I902). He held the honorary degree of L.L.D. from St. Andrews and D.C.L. from Durham Universities; and in 1907 the Liberal Government made him a Privy Councillor.

Rosamund Marriott Watson, the authoress; d. December 29th. She was a daughter of Mr. Benjamin. Williams Ball, and was born in London in 1863. As Graham Tomson (the surname being that of her first husband) and also after her second marriage to the novelist H. B. Marriott Watson, she published some charming verse, besides books in prose and several anthologies, including a Selection from the Greek.Anthology (1889) and Concerning Cats ( 1890$)$.

James Galloway Weir, the Liberal politician; b. I84I ; d. May I8th. He had been M.P. for: Ross and Cromarty' since 1892 .

Charles J. Wertheimer, the art-dealer and collector; b. 1842, d. April 25th. His fine collection was sold for a large sum after his death.

\section{9 I 2}

During I912 the following persons died, on whom biographical articles are included in the E. B.:-

Sir Lawrence Alma-Tadema, the painter; b. 1836; d: at Wiesbaden on the 25 th of June. (See E. B. i, 712.)

Edward Arber, the Early-English scholar; b. 1836; d. in London, November 23 rd. (See E. B. ii, 323.)

William Blackwood, the Edinburgh publisher; b. 1836; d. November roth (see E. B. iv, 27); he had edited Blackwood's Magazine since 1879.

William Booth, "General" and founder of the Salvation Army; b. I829; d. in London on the 20 th of August (see E. B. iv, 239d; and for the Salvation Army, E. B. xxiv, Iood). Towards the close of his life he became blind through cataract, losing the sight of one eye in 1909 , and of the other after an operation three months before his death. But he had continued to direct the operations of the army and learned to write without the aid of sight. As late as 1909 he had undertaken his sixth motor-car campaign. His last public appearance was made at the Albert Hall, London, on the 9th of May I9I2 at a meeting to celebrate his 83 rd birthday.

Sir George Howard Darwin, professor of astronomy and experimental philosophy at Cambridge (see E. B. vii, 843 d.); b. I 845 ; d. December 7 th. The second son of Charles Darwin, he was 2nd Wrangler and Smith's Prizeman at Cambridge, and was elected to his professorship in 1883 . His principal work was on the subject of tides, on which he became the leading authority, and on other physical questions connected with the relation of the earth and moon; and the article "Tide" in the E. B. (xxvi, 938 et seq.) remains a unique expression of his matured researches on his special subject.

Andrew Martin Fairbairn, the Congregationalist divine, ex-principal of Mansfield College, Oxford; b. I838; d. in London on the 9th of February. (See E. B. x, I29.)

James Gairdner, the archivist and historian; b. I828; d. at Pinner, on the 4 th of November. (See E. B. xi, 390.)

George Grossmith, the actor and entertainer; b. 1847; d. at Folkestone on the Ist of March. (See E. B. xii, 6rig.)

Octavia Hill; the social reformer; b. $183^{8}$; d. in London on the $13^{\text {th }}$ of August. (See

E. $B$. xiii, 465 and 823 .)

Andrew Lang, the eminent writer; b. I844; d. at Banchory, N.B., on the 20 th of July. (See $\cdot E \cdot \cdot B \cdot x v i, 171$.

Lord Lister, the great surgeon; b. I828; d. at Walmer on the Ioth of February. (See

E. B. xvi, 777 ; and for his discoveries in antiseptic surgery, xxvi, 129 et seq.)

Justin McCarthy, the Irish politician, historian and novelist; b. I83I; d. at Folkestone on the 24th of April. (See E. B. xviii, 2ood.)

Lord Peel, ex-speaker of the House of Commons; b. 1829; d. at Sandy, Beds., on the 24th of October. (See E. B.:xxi, 39d.) 
W. S. Penley, the actor; b. 1852 ; 1. November inth. (See E. B. xxi, 99.)

R. Norman Shaw, the architect; ). 1831; d. at llampstead, November 17 th. (See $E$. $B$. xxiv, 8i3.)

Waiter William Skeat, the philologist; b. 1835; d. at Cambridge on the 6th of October. (See E. B. xxiv, 168.)

William Thomas Stead, the journalist; b. I 850 ; perished in the sinking of the "Titanic" on the 15 th of April. (See E. B. xxv, 817c.)

Edward O'Connor Terry, the actor; b. 1845; d. in London on the 3rd of April. (See E. B. xxvi, 660.)

Sir George Stuart White, the field-marshal; b. 1836; d. in London on the 24th of June. (See E. B. xxviii, 599b, and for his Natal Campaign, xxvii, 204a and 205d.)

Biographical notes may be added concerning others who died during the year:-

By the death of Henry Du Pré Labouchère, the Radical politician and proprietor of Truth, in Florence on the $15^{\text {th }}$ of January, a famous figure passed away. Born in London in 1831 , the son of John Labouchere of Broome Hall and nephew of Lord Taunton ( $E . B$. xxvi, 453a), he was educated at Eton, and, after spending a short time at Cambridge, entered the diplomatic service in 1854 , becoming in 1863 second secretary to the British Embassy at Constantinople. In 1864 he abandoned diplomacy for politics, and in 1865 was elected Liberal member for IVindsor, but was unseated on petition. In 1866 he won a by-election for Middlesex, but failed to be re-elected in 1868 . In 1880 he again entered the House of Commons as Radical member for Northampton with Mr. Bradlaugh as his colleague, and this seat he retained until his retirement in 1905 . He began his journalistic career with the Daily New's, of which he became part proprietor just before the Franco-German war, and he was himself the author of the Letters of a Besieged Resident, sent to it from Paris by balloon post during the siege, addressed to his wife in London. In 1874 he became associated with Edmund Iates on The World (see E. B. xxviii, 908b); but two years later he started Truth as a rival society paper, destined, as he himself said, "to be another and a better World." It had a remarkable record in the exposure of shams and organised impostures, especially frauds on the charitable. Many libel actions were brought against it, but in 25 between 1897 and 1907 only 3 verdicts were given definitely against the paper. For many years Mr. labouchere himself contributed racy articles and notes, and he was to the end popularly identified with Truth, though in fact he left the direction in later years first to Mr. Horace Voules and then to Mr. Bennett, and took no active part either in writing or editing. He was a thorough Bohemian, and after his death the whole story of his life connection with Truth was very candidly told in a series of admirable articles in its columns. As a politician "labby" was the chartered jester of the House of Commons, but his pungent and somewhat cynical speeches were the expression of highly independent democratic convictions, deeply opposed to all forms of social privilege or Jingo Imperialism. He was a strenuous advocate of the abulition of the House of Lords (see E. B. xx, 845(, 846b); at the time of the Parnell Commission (E. B. xx, 858d) he had much to do with the unmasking of P'igott; and he was a member of the Inquiry into the Jameson Raid, his hostility to Mr. ('hamberlain being as pronounced as against Lord Rosebery when the latter became leader of the Liberal party. He considered himself entitled to office when his party was in power, and was decidedly mortified at not getting it from Mr. Gladstone. In 1868 he had married Miss Henrietta IIodson, a popular actress. After 1903 he lived mainly in Italy, at a villa near Florence, where he died. He left a fortune of some two million sterling to his daughter, who had married a son of the Marquis di Rudini.

Among other people of political prominence the following may be noted:-

The 1oth Earl of Carlisle, who had succeeded to the title only in 1911 ; b. 1867; d. January 20th. As Lord Morpeth (E. B. v, 341 b) he served on the London School Board from 1894 to 1902 , and was Unionist member for South Birmingham 1904-II.

Enoch Edwards, the Labour leader and M.P. for Hanley (since 1906); d. at Southport on June $28 \mathrm{th}$. Born at Talk-o'-the 11ill, Staffordshire, in 1852 , he was the son of a pitman, and worked as a hoy in a coal-mine. He became first treasurer, then secretary of the North Staffordshire Miners' Assuciation, and in $188+$ went to Burslem, where he held various municipal pests and fintlly hecame maver. He was also president of the Midland Miners' Association, and latterly president of the Miners' Federation of Cireat Britain.

George Harwood, cotton manufacturer and member of parliament; $d$. in London on Vovember 7 th. Born at Bolton in 1845 , he entered his father's cotton spinning business, while still a student of ()wens (ollege, where he worked at classics and political economy until he could take the London M.A. degree. Later he read theology, and in conjunction with Dean Stanley and others founded the (hurch Reform I nion. Ender the intluence of

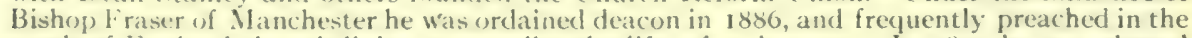
north of England though living outwardly the life of a layman. In 1895 he was elected Liberal member for Bolton, and held the seat till his death. He published The Coming Democracy, Essul's for the Times, Christianily dommon Sense and other works.

The 1 st Baron Holden (see $E$. B. xiii, $582(1)$, Liberal M.P. for Bradford 1885 , and the Buckrose division of Yorkshire I892-Igoo; b. 18.3.3; d. at Bolton Percy on March 25 th. 
Walter Stowe Bright McLaren, Liberal M.P. for Crewe 1886-95, and 1910-12; 4m of Duncan McLaren, Lord Provost of Lidinburgh, and ncphew of John Bright; b. 1853; d. June 29 th.

Sir Arthur John Otway, Bart., formerly for many years a Liberal M.P., Chairman of Committee in the House of Commons $1883-85$; b. 1822 ; d. June 8 th.

Lord Stalbridge, (cr. 1886), formerly, as Lord Richard Grosvenor, Liberal M. P. 1861-86, and Chief Whip 1880-85; Chairman of the L. \& N. W. Railway Company, 1891-1911; b. $1837 ; d$. May 18 th.

Lord Wandsworth (Sydney James Stern) cr. 1895, formerly Liberal M.P. for Stowmarket 1891 $\rightarrow 95$; b. : 845 ; d. February Ioth.

John Lloyd Wharton, Conservative M.P. for Ripon division of Yorkshire, 1886-1906; Chairman of N. E. Railway Company; b. 1837; d. July it th.

Sir George White, Liberal M.P. for West Norfolk, 1900-12; a prominent Nonconformist; b. 1840; d. May Irth.

In the public service the following had played prominent parts:-

Lord Wenlock (the 3rd Baron); b. I849; d. January 15 th. Governor of Madras I89I-96.

The Ist Baron Stanmore (cr. r893); b. 1829, younger son of 4 th Earl of Aberdeen; d. January 30th; Governor of Trinidad (1866-70), Mauritius (1871-74), Fiji (1875-80), New Zealand $(1880-82)$, and Ceylon $(1883-90)$.

Allan Octavian Hume, C.B.); b. 1829, son of Joseph Hume (E. B. xiii, 884); d. at Norwood July 3 Ist. Entering the Indian Civil Service in I849, he became Collector of Etwah, and rendered distinguished service during the Mutiny and later against Firoz Shah. Between 1867 and 187 I he carried out the negatiations with the Rajput chiefs for opening road and railway communications through the great belt of mountain and jungle which formerly cut India in two. He was made secretary to the Indian government in the Home department and afterwards in the Revenue and Agricultural departments, but returned to the NorthWest Provinces'as member of the Revenue Board in 1879 . In 1882 he retired from the service, and devoted himself to furthering the aspirations of native Indians. The Indian National Congress (see E. B. xiv, 4I $\mathrm{b}$ ), which held its first session at Bombay in 1885 , owes its existence to his exertions. He was the author of several works on ornithology, and presented his collections of bird skins and eggs to the British Museum.

Sir Richmond Thackeray Ritchie (see E. B. xxvi, 7I6d); b. I854; d. October 12th. Entering the India Office in I 877 , he rose to be Permanent Under-Secretary of State in I9IO.

Lt. Col. Henry Strachey; b. I8I6, brother of Sir Richard Strachey (E. B. xxv, 976); d. February 9 th. Entering the Indian service in 1835 , he made a notable journey in 1846 into Tibet $(E . B$. xxvi, $923 \mathrm{~d})$, and in 1847 he was a member of the Cashmere Boundary Commission.

George Strachey, brother of last-named; b. I829; d. February 25th. Minister at Dresden $1890-97$.

Admiral Sir Richard Vesey Hamilton; b. I829; d. September 18th. Entering the navy at the age of fourteen, he served in Captain Ommanney's Arctic expedition of 1850-5I, after. wards joining Captain Kellett ( $E . B$. xxi, 946a) and remaining in the Arctic regions for three winters. In 1856 he was promoted to command the gunboat "Haughty" and went to China. He was promoted captain 1862 , rear-admiral 1877 , vice-admiral 1884 , and admiral 1887. From $1885^{-87}$ he was commander-in-chief on the China station. In I 889 he was appointed Second Sea Lord of the Admiralty, becoming shortly First Sea Lord. In I89 I he became president of the Royal Naval College at Greenwich, and retired in 1894. He published Naval Administration (1896) and edited the Letters and Papers of Admiral of the Fleet Sir Thomas Byam Martin (3 vols.)

Admiral of the Fleet Sir Nowell Salmon; b. 1835; d. February I4th. Entering the Navy in 1847 , he served with the "Shannon" brigade in the Indian Mutiny, and received the V.C. for bravery at the second relief of Lucknow (1858). He became Commanderin-Chief at the Cape, 1882-85; and Commander-in-Chief at Portsmouth, 1894-97.

Admiral of the Fleet Sir Frederick William Richards; b. I833; d. September 28 th. Entering the navy in 1848 he served at first on the Australian station. In 1855 he was promoted lieutenant, in 1860 commander, and in 1866 captain. From $1870-73$ he commanded the Indian troopship "Jumna" and from I873-77 the "Devastation," the first sea-going turret ship. In 1878, being appointed Commodore and Senior Officer on the West Coast of Africa. he arrived at the Cape of Good Hope only to hear of the disaster at Isandhlwana. He promptly proceeded east and landed with a force of 250 men, who shared in the battle of Ginginhlovo and the relief of Eshowe, In I88I he was at the battle of Laing's Nek. He became rearadmiral in 1882 , and from $\mathbf{1} 882-85$ served as Junior Lord of the Admiralty. From I $885^{-88}$ he was Commander-in-Chief of the East Indies Station. In I 888 he was promoted viceadmiral. In 1890 he became Commander-in-Chief on the China station and in 1892 was appointed second Naval Lord of the Admiralty, being Senior Lord from 1893-99. He was promoted Admiral in 1893 and Admiral-of-the-Fleet in $\mathbf{1} 898$.

Major-General Sir John Frederick Maurice; b. 184I; d. January 12th. The eldest son of Frederick Denison Maurice (see E. B. xvii, 190); he entered the Royal Artillery in 1861 . Seven years later he was appointed Instructor at Sandhurst, and in 1873 went to the Gold 
Coast as private secretary to Sir Garnet (Lord) Wolseley. After seeing service in South Africa and in the Egyptian campaign of $\mathbf{1 8 8 2}$, he held the post of professor of Military History at the Staff College, and was gazetted a major-general in 1895 . It was, however, less on active service than as a student of war and national problems and as a thinker and writer that most of his work was achieved, between 1871 , when he was awarded the Welling. ton prize for his essay on field manoeuvres, and 1906-08, when he brought out the official history of the South African War. His published works include a Life of his father (r884). Hostilities without Declaration of War (1883), The Balance of Military Power in Europe (1888), National Defence (1897), War (1891), an expansion of his article in the E. B. (9th ed.), and the Diary of Sir John Moore, with notes. In 1907 he was awarded the Chesney Gold Medal of the Royal United Service Institution for his writings. One of his sons, Hugh Alexander, was killed at Delhi, in a railway accident, on the 22nd of January 1912, ten days after the death of his father.

General Sir Charles John Stanley Gough; b. 1832, grand-nephew of Viscount Gough (E. B. xii, 28I); d. September 6th. He went to India at the age of sixteen, where he joined the 8th Bengal Cavalry and served through the Punjab campaign of $1848-49$. . During the Mutiny he and his brother (afterwards General Sir Hugh Gough, keeper of the Crown Jewels) joined the Guide Corps, and took part in many actions, including the relief of Lucknow. He won the Victoria Cross. He served in the Bhutan expedition of $\mathbf{1} 864$, and commanded a cavalry brigade in the Peshawar Valley Field Force during the Afghan War of 1878. He commanded the Hyderabad contingent from 188I-85, and a division of the Bengal Army from 1886-90. He published The Sikhs and the Sikh Wars in 1897.

Major-General Sir Frederick Walter Kitchener; b. I858, brother of Lord Kitchener (E. B. xv, 838); d. March 6th. He was with Lord Roberts in the Afghan War of $1878-80$. From 189I-96 he was Deputy Assistant Adjutant General for Instruction in India. He accompanied the Dongola expedition of 1896 as director of Transport, and in 1899 filled the same post in Lord Kitchener's march to Khartum ( see E. B. ix, 130a). He served under Sir Redvers Buller in South Africa, taking part in the relief of Ladysmith. In 1908 he was appointed Governor of Bermuda, where he died.

Religion was represented by the following notable names:-

John Sheepshanks, formerly Bishop of Norwich; b. 1834; d. June 3 rd. Educated at the Grammar School, Coventry, and Christ's College, Cambridge, he was ordained in 1857 to a curacy under Dr. Hook, vicar of Leeds; but in 1859 he went out to British Columbia to be chaplain to its bishop and rector of New Westminster. His eight years' work amongst settlers, miners and lumbermen, taught him an unconventionality of outlook and methods which remained with him throughout his clerical career. He published his experiences under the title of $A$ Bishop in the Rough. In 1868 he returned to England, and after five years in the Yorkshire parish of Bilton, near Harrogate, he was presented to St.. Margaret Anfield, Liverpool, where he came under the notice of Mr. Gladstone, who in 1893 offered him the bishopric of Norwich. He held the see till 1910, when he resigned owing to ill health. Among his other publications were My Life in Mongolia and Siberia.(1903), The Pastor in his Parish (1908), and volumes of sermons and addresses.

Charles William Stubbs, Bishop of Truro; b. I843; d. May 4th. His father and grandfather were Yorkshire agriculturists, and throughout his life he took a strong interest in the welfare of the agricultural labourer. He published three volumes on the subject, Village Politics (1878), The Land and the Labourers (1890), and Christ and Democracy (1883). He was a strong liberal with somewhat socialistic views, and was preferred by Mr. Glarlstone to the living of Stokenham and Chivelstone in Devon in 1884. In 1887 he was transferred to L.iverpool, becoming rector of Wavertree. In I893 Mr. Gladstone made him dean of Ely. There he remained till 1905 when Sir Henry Campbell-Bannerman made him Bishop of Truro. He was Hulsean Lecturer at Cambridge in 1904, and published his lectures under the title The Christ in English Poetry (I905). His other published works include $A$ Creed for Christian Socialists (1896) and a Handbook to Ely Cathedral (1898).

George William Kitchin, Dean of Durham; b. 1827; d. October I3th. Educated at the Ipswich (jrammar School, King's College, London, and Christ Church, Oxford, he graduated in $185^{\circ}$, the only double first-class man of his year, and was ordained in 1852 . He became a schoolmaster, but returned to Oxford as tutor at Christ Church in 1863 . He undertook the organisation and control of the non-collegiate students, admitted by the University after 1868 , becoming their first Censor and holding the office till 1883 , when he became Dean of Winchester. In 1894 he was appointed Dean of Durham, becoming also first Warken and then (hancellor of Durham Iniversity. He published a History of France (1873-77), Life of Pope Pius II (1881), and various books on Winchester and Durham.

George Evan Moule, Anglican missionary Bishop in China; b. I828; d. March 3rd. Having graduated from C.C.C.. Cambridge, and taken orders in 1851 , he was sent out in 1857 to (hina by the Church Missionary Society. In $186 \mathrm{I}$ he was joined by his brother the Rev. Arthur F. Moule, and with him worked for over $5^{\circ}$ years, at first at Ning-po, but principally at Hang-chow. In 1880 he was consecrated first Bishop of Mid-China, and his work steadily developerl till his resignation in 1908 . Bishop Moule was a Chinese scholar, and translated the Prayer-book into classical Chinese. 
Father John Gerard, the Jesuit; b. I840; d. December 13 th. He was educated at Stonyhurst after becoming a Jesuit, spent a great part of his life as a master at his old school. In 1879 he was appointed its Prefect of Studies, but relinquished the post in 1893 to become editor of The Month. From 1897 to 1900 he was Provincial of the English Jesuits. He published a refutation of Haeckel in The Old Riddle and the Newest Answer, and various other works, notably The Gunpowder Plot (see E. B. xi, 729a).

John Griffith, the Welsh Congregationalist missionary in China; b. 1831; d. July 25th. He showed his religious bent very early. He was brought up a Congregationalist, and at the age of eight was admitted to full membership of his chapel, and when only i 4 he delivered his first sermon at a prayer meeting. At sixteen he became a regular preacher, and was subsequently trained at the Brecon Congregational College for the ministry. In 1853 he offered his services to the London Missionary Society, and after two years' training sailed for Shanghai in 1855 . His work in China covered a period of 55 years. In 1861 he went from Shanghai through the provinces of Central China, which he was the first Christian missionary to penetrate, and he claimed that with his colleagues he had established over 100 mission stations in Hu-peh and Hu-nan (see E. B.: xviii, 596). He acquired an intimate knowledge of the Chinese language and literature, and translated the New Testament and a great part of the old into more than one Chinese dialect. In the Yangtsze valley he founded a theological college for native preachers, which bears his name. At the end of 1911 his health finally gave way and he returned to England.

Arthur Wollaston Hutton, Anglican clergyman and author; b. 1849; d. March 25. A scholar of Exeter, Oxford, he took orders in the Church of England in 1872, but under Newman's influence became a Roman Catholic; and from 1876-83 was a member of the Edgbaston Oratorian Community. He changed his views, however, renounced Romanism, and became known as an agnostic and free-thinker; and for some years he was librarian at the National Liberal Club in London. In 1898 he again made a remarkable change, being readmitted to Anglican orders, and from 1903 to his death he was rector of Bow Church, London. His absolute sincerity, strength of conviction, and great intellectual ability and honesty, were recognised by all who knew him. He was the author of a Life of Manning ( 1892$)$, and of several articles in the $E . B$.

Charles Voysey, the Theistic preacher; b. 1828; d. July 20th. Educated at Stockwell Grammar School and St. Edmund Hall, Oxford, he was ordained in the Anglican Church and held various curacies up to I860, when he became curate of St. Mark's Whitechapel. Thence he was ejected for heterodox doctrine, and he went to St. Mark's, Victoria Docks, and later to Healaugh near Tadcaster, where he was first curate and then vicar. But in 1869 he was summoned before the Chancery Court of the Diocese of York for heterodox teaching, and deprived of his living. He appealed to the Privy Council, but the decision was upheld. He then established a Theistic Church in London; where he continued to preach and teach up to the time of his death.

In the medical world the following were of most interest:-

Sir William Henry Allchin, physician and author; b. 1846; d. February 8th. He was educated at University College, London, where he afterwards became Lecturer on Anatomy and Physiology, then he was principally associated with Westminster Hospital of which he became Senior Physician. He edited a Manual of Medicine (1903), to which he contributed articles on his special subject of abdominal diseases. He was Harveian Orator (I903); Bradshaw Lecturer (I9OI) and Lumleian Lecturer (I905); and was knighted in 1907.

Sir Henry Trentham Butlin, Bart., the surgeon and pathologist; b. 1845; d. January 24 th. He received his medical training at St. Bartholomew's Hospital, London; to which he returned after holding posts at the Children's Hospital, Great Ormond Street, and at the West London Hospital; and was successively demonstrator, assistant surgeon (I88I), and surgeon from I 892-I902. In I909 he was elected president of the Royal College of Surgeons. His investigations of cancer led him to the theory that the disease is a parasitic growth formed within and from the tissues of its host, which he announced at a Bradshaw lecture of the Royal College of Surgeons in 1905.

Clinton Thomas Denton, a well-known surgeon and Alpine climber; b. I850; d. August 26th. Educated at Eton and Trinity College, Cambridge, he was vice-president of the Royal College of Surgeons, senior surgeon to St. George's Hospital, and since 1904 chief surgeon to the Metropolitan Police. He made the first ascent of the Aiguille du Dru, after 18 unsuccessful attempts, and the first ascent of the Rothhorn from the Zermatt side. He also did much exploration in the Caucasus. Besides many works on surgery he published Above the Snow Line (1885).

Washington Epps, the homoeopathic physician; b. 1848; d. October 14th. The son of George Napoleon Epps (see E. B. ix, $708 \mathrm{c}$ ), he was for 38 years on the staff of the London Homoeopathic Hospital, and was president of the British Homoeopathic Society.

William Ogle, physician and author; b. I828; d. April I 2 th. He took his medical degree at Oxford and became a Fellow of Corpus. In medical circles he was well-known as chief secretary to the Royal Medical and Chirurgical Society, Lecturer on Physiology at St. George's Hospital Medical School; but his permanent fame rests on his remarkable edition of Aristotle's De Partibus Animalium, a work of great scholarship and learning. 
The following were prominent in the legal profession:-

Sir Gainsford Bruce, Judge of the High Court; b. 1834; d. January 23rd. He graduated at Glasgow Iniversity and was called to the bar in 1859. He joined the Northern and afterwards the North-Fastern circuit, and from $1869-82$ reported Admiralty and Feclesiastical cases for the Law Reports. His strength lay in Admiralty law, and he made several contributions to its literature; notably Williams and Bruce's Admiralty Practice, and the th edition of Maude and Pollock on Shipping. He was Recorder of Bradford from 1877-92, and successively solicitor-general (1879) and attorney-general (1886) to the County-Palatine of Durham. A Conservative in politics, he represented Holborn in Parliament from 1888 till he was raised to the bench in 1892 :

Sir John Compton Lawrance, Judge of the High Court; b. 1832 ; d. December 5 th. Called to the bar in 1859 , he became Q.C. in 1877 and Recorder of Derby in 1879 . In 1880 he was returned to Parliament as Conservative member for South Lincolnshire, and in 1885 was clected member for the Stamford division. He was made a Judge in 1890 , and sat on the Bench for 22 years, retiring March I912.

Sir Alfred Wills, Judge of the High Court; b. 1828; d. August Ioth. He was educated at University College, London, and was called to the bar in I85I. After some years on the Midland and North-Eastern Circuits, he was appointed to a judgeship in the Queen's Bench Division in 1884 , and four years later acted as the first ex-officio commissioner under the Railway Canal Traffic Act. Very few of his decisions or opinions were reversed upon appeal. His ability for dealing with complicated cases was notably shown in Cockerton $v$. London School Board, the point at issue being the power of the School Board to pay for higher technical education out of the rates. His judgment, adverse to the Board, was affirmed by the Court of Appeal; and in the case of Sharp $v$. Wakefield, when, with Mr. Justice Field, he asserted the unrestricted discretion of licensing justices to refuse, under certain circumstances, to renew a licence, the House of Lords upheld the decision. Sir Alfred Wills was a pioneer of mountaineering ( $\sec E$. B. xviii, 938c; and i, 748d), one of the founders of the Alpine Club in 1858 , third president in 1863 , and author of several books about climbing and other Swiss experiences. His father's treatise, Wills on Circumstantial Evidence, was cularged and editerl by him in book form, and went through several editions.

I.ord Stormonth Darling, Jurlge of the Court of Session in Scotland; b. 1845; d. June 2 nd. Educated at Kelso Grammar School and Edinburgh University, he was called to the Scottish bar in 1867 . In 1888 he entered the House of Commons as member for the Universities of Edinburgh and St. Andrews, and in the same year became solicitor-general for Scotland. In 1890 the was appointed a Lord of Session:

Thomas Hutchinson Tristram, a well-known ecclesiastical lawyer; b. 1825; d. March 8th. He took his D.C.L. degree in 1854 , and became an advocate of Doctors' Commons (see E. B. viii, 367). When that body was dissolved in 1857 he continued to practise as counsel, being eventually its last survivor. He was principally known in connection with ritual cases, several times representing $\mathrm{Mr}$. Mackonochie and other clergymen charged with illegal practices (see E. B. xiv, $352 \mathrm{~d}$, and $x v i, 678 \mathrm{a}$ ), and he appeared for the promotors in the ecclesiastical suit ended by the Iincoln Judgment (E. B. xvi, $712 \mathrm{C}$ ). He was (hancellor of the diocese of London, and also of the dioceses of Hereford, Ripon, Wakefield, and Chichester; and Commissary-General of the Diocese and City of Canterbury. He published Contentious Probate Practice (188I).

John Troutbeck, the coroner for Westminster; b. $186 \mathrm{I}$; d. February 29th. The eldest son of the Rev. Dr. Troutbeck, Canon and Precentor of IVestminster Abbey, he was educated at Westminster School and Queen's College, Oxford, was admitted a solicitor in 1884, and hecame coroner for Westminster in 1888 . His policy of employing an independent pathologist for post mortems, instead of the doctor in attendance, brought him on several occasion into conflict with the medical profession and was objected to by the British Medical Asso(iation. But he was master in his own court, and successfully defied opposition.

Sir Raymond West, the Anglo-Indian jurist; b. 1832; d. September 8 th. Educated at Gueen's College, (i.lway, he entered the Indian (ivil Service in 1856 , and during the Mutiny served under the resident magistrate of Belgaum. In $187 \mathrm{I}$ he became a Judge of the High rourt of Bombay, and in 1877 a member of the Bombay government. In 1879 he was appointed to the Indian Law Commission. In 1884 he accepted for a time the office of Procureur-(iencral in Egypt, and drew up a report on the French system of criminal procedure as applied to an oriental people. He then returned to India, where he remained till his retirement in 1892. He became reader in Indian Law to the University of Cambridge. holding that post till igor. He published The Bombay Code (3 vols.), and Hindu Law, at work which passed through many editions.

( )ne of the magnates of finance passed away in Sir Julius Charles Wernher, Bart., the South African millionaire; d. May 21 st. He was born at Darmstadt in 1850 , entered : banking house in lirankfort, and early in 1870 came to London as a clerk. On the outbreah of the Franco-(ierman War he returned to Germany to take his place in the army and was prement at the fall of Paris. At the end of $187 \mathrm{I}$ he was sent by Mr. Jules Porges, diamonel merchant of L.ondon and Paris, on a mission to Kimberley. There he remained till 1880 , when he was transferred to Lundon as English representative of the firm of Porges and 
Wernher, interested not only in diamonds but in the gold mines of South Africa. In 1888. when the Kimberley diamond mines were amalgamated by Cecil Rhodes and Alfred Beit, he became a life governor of the De Beers Corporation. Beit was now a member of his firm, and in 1889 , when Porges retired, the name of the firm was changed to Wernher, Beit \& $(u$. (See E. B. iii, 659a.) Out of his enormous fortune, Sir J. Wernher, who was created a baronet in 1905, spent large sums on public objects, including education; he gave $f_{10}, 000$ to the National Physical Laboratory, and together with Beit endowed the South African University with $£ 500,000$.

A captain of industry died in Baron Furness (formerly Sir Christopher Furness), on November Ioth. He was born on the $23 \mathrm{rd}$ of April 1852, the son of a provision merchant, and entered the family business in $\mathbf{1} 870$. By making a corner in food stuffs, whilst the French fleet was blockading the mouth of the Elbe, he made a profit of over $f 50,000$ for his firm out of the provisioning of ships. In 1877 he left the business and inaugurated the Furness line of steamships, and in I89I he amalgamated with Withy \& Co., iron and steel ship builders, founding the great shipbuilding firm of Furness, Withy \& Co. In I898, with others, he acquired extensive iron and steel works and founded the S. Durbam Steel \& Iron Cu. He had an interest in many other concerns, and was chief proprietor of a Liberal paper, the North Mail. In 1908 he established a profit-sharing scheme for his workmen, but in 1910 its continuance was put to the vote and rejected by a majority. In $\mathbf{1} 89 \mathbf{1}$ he was elected Liberal member for the Hartlepools, but in 1895 he lost the seat, winning it again in 1900 . In 1906 he was returned unopposed, and in January I9Io he was elected but unseated on petition. A month later he was raised to the peerage; he had been knighted in I895.

No fewer than four ex-Lord Mayors of London died during the year, three of whom had sat as Conservatives in the House of Commons:-

Sir Joseph Dimsdale, Bart. (b. 1849; d. August Ioth), who came of a Quaker family of bankers, was sheriff of London in 1894 , and from $1900-06$ was M.P. for theCity. In I90I-02, King Edward's coronation year, he was Lord Mayor; and from 1902 till he died he was City Chamberlain.

Sir John Whitaker Ellis, Bart. (b. I829; d. September 20 h), entered as a lad the office of an auctioneer and surveyor, and rose to be a partner and finally head of the firm; he was Lord Mayor in $188 \mathrm{I}-82$, and M.P. for a division of Surrey $1884-92$.

Sir Horatio David Davies (b. 1842 ; d. September 18 th), was a London merchant, who in 1889 was elected an Alderman and in 1897-98 was Lord Mayor. From 1895-1906 he was M.P. for Chatham.

Sir James Thomson Ritchie, Bart. (b. 1835; d. September 18th), was the son of a Dundee jute merchant, and carried on the same business in London. His younger brother was Lord Ritchie, the Conservative politician (see $E$. $B$. xxiii, $376 \mathrm{~b}$ ). He was elected an Alderman in I891, and became Lord Mayor in $1903-04$.

Mechanical science lost the following important representatives:-

Prof. Osborne Reynolds; b. 1842; d. February 21st. He was educated at Cambridge. and in I 868 became professor of Engineering at Owens College, Manchester, holding that post for nearly forty years. He was elected F.R.S. in 1877 . He was the author of over 70 papers on mechanies and physics published in the transactions of learned societies, notahly Sub-Mcchanics of the Universe, issued by the Royal Society. (For references to his work see E. B. iii, 58IC; v, 64a; viii, 783a; xiv, 6rc; xxii, 806c; xxv, 444c; xxviii, 428d.)

Prof. Henry Taylor Bovey; b. 1852 ; d. November 2 nd. He was educated at Queens College, Cambridge, of which he was afterwards a Fellow. Joining the staff of the Mersey Docks and Harbour Board, he became assistant engincer, but in 1887 was appointed Professor of Civil Engineering and Applied Mechanics at McGill University, Montreal. In 1909 he was appointed to be the first Rector of the Imperial College of Science and Technology in London, but ill-health obliged him to resign the post after a few months.

Valuable work in a special branch of science had also been done by the Rev. Francis Bashforth (b. 1819; d. February 12th). Second Wrangler in 1843 , he became a Fellow of St. John's College, Cambridge; and having taken orders, he was rector of Minting (Lincolnshire) from $1857^{-1908}$. His interest in ballistics led him to make a series of cxperiments between $1864-80$, upon which our present knowledge of air-resistance is founded (sec $E$. $B$. iii, 28ra). The Bashforth (hronograph for recording the velocity of shot (see E. B. vi, 303a). was his invention, and he received a pension from the government and a grant of $f_{2}, 000$ for his work. For some time he was professor of Applied Mathematics to the advanced class of Artillery officers at Woolwich:

Samuel Arthur Saunder, b. 1852, d. December 8th, was one of the leading authorities on Selenography (sce $E$ : $B$.'xxi, 525a).

A well-known naturalist passed away in William Bernhard Tegetmeier; b. 1816; d. November I9th. His special subject was poultry-breeding, on which he wrote in the 9 th ed. of the E. B.; and for forty years he was the poultry-editor of The Field.

Rowland Ward, b. 1848, d. December 28th, author of Record of Big Game, was famous all over the world as a taxidermist.

An eminent Scottish ichthyologist and palaeontologist died in Ramsay Heatley Traquair; b. I 840 ; d. November 24 th (see $E$. B. xiv, 248 b, 249c). 
The death also occurred on December 8th of Henry Dudding, famous all over the world as a scientific breeder of long-wool sheep and shorthorn cattle (see E. B. xxiv, 8I9d).

In Dr. Shadworth Holloway Hodgson (b. 1832; d. June I3th), there passed away an accomplished scholar and metaphysician. Educated at Rugby and Corpus Christi College, Oxford, he devoted himself from 1858 onwards entirely to the study of philosophy, and acquired a remarkable knowledge of the whole field of philosophical literature, ancient and modern. He helped to found the Aristotelian Society of London in 1880 , and was its first president. His published works include Time and Space (1870), The Philosophy of Reflection (1878) and a complete exposition of his philosophy (see E. B. xviii, 25Id) in The Metaphysic of Experience (1898).

English classical scholarship was notably poorer by the death of Arthur Woollgar Verrall (b. I851; d. June I8th). Educated at Wellington, and at Trinity College, Cambridge, he graduated as second classic in 1873 and became a fellow and tutor of his college. He published editions of many classical plays, especially the Medea, Agamemnon and Choephoroe. In 1895 appeared Euripides the Rationalist, followed in 1905 and 1910 by editions of most of Euripides' plays. He was an original critic with views of his own, often expounded in the Classical Review and other journals. In February I9I I he was appointed to fill the new King Edward VII professorship of Literature at Cambridge, which had been endowed by Sir Harold Harmsworth.

Cambridge University lost also two heads of colleges: the Master of Caius, Dr. Ernest Stewart Roberts (b. I847; d. June I6th); and the Master of Jesus, Henry Arthur Morgan (b. $1830 ; d$. September 3 rd).

Oxford University lost an able philologist in Dr. Henry Sweet (b. I845; d. April 3oth). He was a recognised authority on the subject of phonetics (see $E$. B. xxi, 460-6I; ix, 597c), a Readership in Phonetics having been specially created for him in 1901 by the University. His other published works include an Anglo-Saxon Reader, a Student's Dictionary of AngloSaxon, an English Grammar, The History of Language, and many editions of Old and Middle English Texts.

A widely known anthropologist passed away in Augustus Henry Keane (b. 1835; d. February 3rd). A native of Cork, he was educated at Dublin and in Rome for the Roman Catholic priesthood, but he declined to enter the church, and devoted himself to geographical and ethnological research (see E. B. i, 442c; ix, 90ob; xxii, 678c). He registered and classified almost every known language, and from these data worked out a system of ethnology. He edited Stanford's Compendium of Geography, and, besides many papers in the journals of learned societies and in encyclopacdias, published Man, Past and Present (r899), Ethnology (1896 and later"editions), The Gold of Ophir (1901), etc. He was professor of Hindustani at University College, London, till I 885 .

The literary world has lost also the following:-

James Beresford Atlay, barrister and journalist, author of Lives of the Victorian Chancellors and other works; b. $1860 ; d$. November 22 nd.

Robert Barr, the novelist; b. 1850; d. October 2 Ist. A native of Glasgow, he was taken to Canada when four years old, and educated at the Normal School, Toronto. He was headmaster of the public school of Windsor, Ont., until 1876 , when he joined the editorial staff of the Detroit Free Press. He had an adventurous career as a journalist for five years, and in $188 \mathrm{I}$ came to England. In 1892 he started the Idler together with Mr. Jerome K. Jerome. He published a number of novels and short stories, the best known being The Mutable Many (1897) and Countess Tekla (1899).

Capt. Frank Brinkley, the well-known authority on Japan; b. I $8+1$; d. at Tokyo, October 28 th. Having entered the British army, he went to Japan in 1867 in command of a battery of artillery. In 187 I he became Principal Instructor at the Marine College, Tokyo, under the Japanese government, and henceforth devoted himself to things Japanese. He left the army, married a Japanese lady, and in 188I founded the Japan Mail, of which he was proprictor and editor till his death. He was also correspondent for the London Times in Japan. He published Japan (1901), Japun and China (1903), as well as a Japanese-English Dictionary, and was the author of the article "Japan" in the E. B. He held a unique position among foreign residents in Japan, alike as a profound student of its history and art, and as a powerful factor in international politics,

The Rev. Alfred John Church, a prolific author; b. 1829; d. April 27th. Educated at Lincoln (ollege, ()xford, he took holy orders, and was assistant master at Merchant Taylors' School for many years; he was professor of Latin at Lniversity College, London, from I880-88. In partnership with the late W. J. Brodribb he translated Tacitus and edited Pliny's Letters, but he is best known by his English re-telling of classical tales and legends for young people (Stories from Virgil, Stories from IIomer, etc.). He wrote much Latin and English verse, and in 1908 published his Memories of Men and Books.

George Knottesford Fortescue, Keeper of the Printed Books at the British Museum; b. 1847 ; (1. () (o)ber 26th. Appointed an assistant in the British Museum Library in I8jo, he became Superintendent of the Reading Room in 1884 , and in 1886 began a valuable series of subject indexes to the modern works in the library, the last of which appeared in I9I. 
Thomas Kirkup, the sociologist and economist; b. 1844 ; d. May 23rd. Starting as a pupil teacher in the village school at Kirk Yetholm, he proceeded thence to Edinburgh University, and studied later at Göttingen, Berlin, Tübingen, Geneva and Paris. Besides many articles on economic subjects for reviews and encyclopaedias (including "Socialism" in the 9th edition of the E. B.) he wrote $A n$ Inquiry into Socialism (1887), History of Socialism (1892), South Africa, Old and New (1903), Progress and the Fiscal Problem (1905), and Primer of Socialism (1908).

Thomas Mackay, economist; b. I849; d. February 23rd. He was called to the bar but never practised, devoting himself to the study of economics and the English Poor Law, which was the subject of most of his writings.

Sir Frank Thomas Marzials, C.B., civil servant and man of letters; b. 1840; d. February 14th. He entered the War Office in the fifties and became Accountant-General in 1898 , retiring in 1904. As one of the editors of the "Great Writers" series, he contributed to it several volumes, and made an English version of the Chronicle of Villehardouin (1908).

William Flavelle Monypenny, the biographer of Lord Beaconsfield; b. I 866; d. November 23rd. Of Ulster birth, and educated at Trinity College, Dublin, and Balliol, Oxford, in I 893 he joined the editorial staff of the Times, and early in 1899 became editor of the Johannesburg Star in the Transvaal. He played an important part, as a publicist, on the side of the Reform party there, and when war came he joined thr Imperial Light. Horse and was one of the defenders of Ladysmith. Returning afterward to his position on the Star, he did much to promote Lord Milner's work of reconstruction, but resigned in 1903 owing to his hostility to the introduction of Chinese labour in the mines. He was then entrusted by the Times with the task of writing the official biography of Disraeli, and also did other work for that paper, becoming in 1908 a director of the company. Owing to ill-health the first volume of the Life of Beaconsfield (intended to be in four or five) only appeared in 1910, and the second shortly before his death.

Edward Williams Byron Nicholson, Bodley's librarian at Oxford; b. I849; d. March I7th. Educated at Tonbridge and Trinity College, Oxford, in 1873 he became librarian of the London Institution, and in 1877 he founded the International Conference of Librarians and the Library Association. In I882 he succeeded H. O. Coxe as Bodley's librarian, and did much to bring the library up to date. He published commentaries on the Gospel according to the Hebrews (1879) and St. Matthew (I88I), Keltic Researches (I904), papers on comparative philology, etc. and wrote the article on Mandeville in the E. $B$.

Dr. Frederic Seebohm, the historian; b. I833; d. February 6th. He was a native of Bradford and came of a Quaker family. His interest in problems of modern life, social and religious, led him to study the conditions of English rural life in the past, and the religious movements of the Reformation. In his English Village Community (1853) he dwelt on the survival of Roman influences in agricultural life; and in his Tribal Systems in Wales (1895) he reconstituted a Celtic society from i 4 th century evidence.

Bram Stoker, the novelist, for many years secretary to Sir Henry Irving; b. 1847; d. April 2oth. He was a native of Dublin and was educated there at Trinity College. . Besides Dracula and other novels, he wrote Personal Reminiscences of Sir Henry Irving, a valuable record of the theatrical history of the last quarter of the nineteenth century.

The Rev. Duncan Crookes Tovey, biographer and critic; b. I842; d. September 29 th. Educated at Trinity College, Cambridge, in 1868 he became assistant master at Haileybury; in $187 \mathrm{I}$ chaplain to Trinity College; in 1874 assistant master at Eton, and in 1886 rector of Worplesden. He was Clark lecturer in English literature at Cambridge in $1897-98$, and published Gray and His Friends (1890), an edition of Gray's poems, The Letters of Thomas Gray (I900-12), an edition of Thomson's poems, and Reviews and Essays (1897). He wrote the articles on 'Thomson and Gray in the $E, B$.

English music suffered a premature loss by the death of Samuel Coleridge-Taylor; b. I875; d. September Ist. Of Anglo-African parentage, his father being a native of Sierra Leone and his mother an Englishwoman, he was educated at the Royal College of Music, entering as a violinist in $189 \mathrm{I}$. In 1893 he won an open scholarship for composition, and studied for four years under Sir Charles Stanford. In 1898 his cantata Hiawatha's Wedding Feast was produced in London with marked success, and was followed by two other cantatas, The Death of Minnehaha and The Departure of Hiawatha (see E. B. xix, 85a). This trilogy was first given complete at the Albert Hall, London, in 1900. The Blind Girl of Castél Cuillé was given in Leeds in 1901, Meg Blane at Sheffield in 1902, and an oratorio, The Atonement, at Hereford in 1903 . He also produced Endymion's Dream and the Bon Bon suite (1908-09), and A Tale of Old Japan (I9I I).

In the art-world the following may be mentioned:-

Robert Wiedemann Barrett Browning (b. I849; d at Asolo, in Italy, July 8th), the only son of Robert and Elizabeth Barrett Browning (see $E$. B. iv, 668a et seq.). He became a painter, studying under M. Heyermanns at Antwerp, and in 1875 had his first picture, "The Armourer," exhibited at the Royal Academy. He had other pictures hung in the Paris Salon, and at Paris he also studied sculpture under Rodin. He bought and restored the Palazzo Rezzonico in Venice, where his father died, making it a museum to his parents memory, 
but it was subsequently sold and he lived at Asolu and Florence. His portrait of his father hangs in Balliol College, Oxford.

Edlardo de Martino, the marine painter (b. 1838; d. May 21st). He was a native of Italy, and was educated at the Naval College in Naples. After serving as an officer in the Italian naty until 1867 he went to Brazil, married a Brazilian lady, became a member of the Rio de Janeiro Academy of Fine Arts, and was attached to the Court of Dom Pedro II, Emperor of Brazil, for whom he painterl several pictures, besides making a number of sketches during the Paraguayan War. In 1875 he came to England and becane marine painter to Queen Victoria.

John Leighton, the designer and illustrator (b. 1822; d. September 15 th). The son of a London book-binder, at an early age he began designs for book-covers; in later life he was a prolific designer of book-plates (see E. B. iv, 233a), and wrote and illustrated the Book Plate Annual from 1894-99. He did much work as a book illustrator in the sixties and seventies, one of his best productions being The Life of Man Symbolised by the Months of the $\operatorname{Year}$ (1866.)

Charles Brinsley Marlay, a well-known art-collector (b. I83 I d d. June 18th). He inherit. ed extensive Irish estates from the last Earl of Belvedere, and his sister married the 7 th. Duke of Rutland. He was a connoisseur of Italian art, and a frequent exhibitor of pictures, porcelains, etc., at the Burlington Fine Arts Club and elsewhere. He bequeathed his collection of all kinds to Cambridge University, together with $£ 80,000$ for the Fitzwilliam Museum.

Sir John Edward Arthur Murray Scott, Bart., a trustee of the National Gallery (b. 1847: d. January I th ). The son of an English doctor at Boulogne, he became secretary to Sir Richard Wallace (see E. B. xxviii, 277a), heir of the 4 th Marquess of Hertford. He helped Sir Richard to organise relief for the sufferers of the siege of Paris in 1870 , and after the siege, to transport the treasures of the Hertford Art Collection from Paris to Bethnal Green Museum. It was largely through his influence that Sir Richard Wallace's widow left the collection en bloc to the British nation, together with Hertford House (see E. B. xix, 62l), and he acted as chairman of the trustees' committee until his death.

English sport lost well-known representatives in John Moyer Heathcote (b. I834; d. July I2th), formerly amateur champion at tennis (see E. B. xxvi, 630a, b); and William Storer (b. I868; d. February 28 th), the Derbyshire professional wicket-keeper and batsman, who played cricket for England against Australia in 1893 and 1899.

A magnate of the music-hall world died in Sir Edward Moss (b. 1852; d. November 25th), who had been the principal pioneer in the changes by which the modern "variety entertainment" has been so successfully established. His first Empire Theatre was opened at Edinburgh in 1877 , and gradually others were built elsewhere, till "Moss's Empires" (which became a company under that name) numbered in 1912 over twenty houses, and the business represented a capital of over $£ 2,000,000$. He was knighted in 1905 .

The deaths of several well-known women must also be recorded:-

Louisa Twining, the social reformer, b. 1820; d. September 25 th. In early life she was an artist, and published Symbols and Emblems of Mediaeval Christian Art (1852) and Types and Figures of the Bible (1854). In 1853 , however, she became interested in movements for social reform (see E. B. iv, 8I Ia), and began the work in connection with the Poor Law to which she devoted the rest of her life. In March $186 \mathrm{I}$ she helped to establish a home for workhouse girls sent out to service, and in 1864 a Workhouse Visiting Society. In 1867 an act was passed separating infirmaries from workhouses, and after twelve more years of work Miss Twining in 1879 established the llorkhouse Infirmary Nursing Association. She was a Poor Law Guardian for Kensington from $1884-90$, and for Tonbridge Union from 1893-96. She promoted the opening of Lincoln's Inn Fields to the public, helped to start the Metropolitan and National Asisociation for nursing the poor in their homes, did much to secure the appointment of police matrons, and was president of the Wiomen's Local Government Soriety. She published Recollections of Life and Work (1894), Workhouse and Pauperism (1898), and many papers on poor law subjects.

I)r. Sophia Jex-Blake, the pioneer lady (octor, b. 1840 , died at Mark Cross, Sussex, on the $7^{\text {th }}$ of January. From $1858-61$ she was mathematical tutor at Queen's College, London. She subseguently set out on a tour of inspection of girls' education institutions, and in America became a pupil of Dr. Flizabeth Blackwell (E. B. xxv, 957d). In I866 Miss Jex-Blake hegan a course of study in Boston under Dr. Lucy Sewall. In 1868 she returned io England and applied to the Iniversity of London for admission to their medical examinations. Being refused, she returned to the University of Edinburgh and was told that they could not admit one lady only. She got others to join her, and funally in 1869 they were admitted to classics, in 1870 to the hospitals, though here they encountered much riotous hostility from a section of the male students. The university, however, still refused to allow graduation, and after some legal proceedings and much expense Miss Jex-Blake in 1874 went to London, where she took a leading part in establishing the London School of Medicine for women. In 1877 this wats associated with the Royal Free Hospital, and in the same year Miss Jex-Blake obtained the M.D. degree of Bern. She was also admitted a 
licentiate of the College of Physicians, Dublin, and member in 1880 . She began prartice in Edinburgh in 1878 and opened a dispensary there for women and ehildren. In 1886 she founded the Edinburgh School of Medicine for. Women. She retired in 1899. Besides various medical works she published American. Schools and Colleges (1886), and Medicul Women (1872).

Victoria, Lady Welby, b. 1837 , died at Harrow on the 29th of March. She was the daughter of the Hon. Charles Stuart-Wortley, brother of the first Lord Wharncliffe, her mother being Lady Emmeline Manners, sister of the 6th and 7th Dukes of Rutland. She was in the household of the Duchess of Kent from 1858-6I, and from I86I-63 was maid of honour to Queen Victoria. In 1863 she married Sir William Welby-Gregory, Bart., who died in 1898. She published in I88I Links and Clues, a collection of religious papers. In later life she worked on the subject of significs, or the study of the correct philosophic and scientific. use of language. She corresponded with a large circle of scientific men and philosophers, and she published What is Meaning?, Significs and Language (I9II), and was the author of the article "Significs" in the $E . B$.

Rosa Morison, the educational pionecr; b. I841; d. February 8 th. She was one of the founders of College Hall, Byng Place, as a residence for women students in London; and was vice-principal (her friend Miss Grove being principal) from $1882-1900$. In 1883 she was appointed as the first Lady Superintendent of Women Students at University College, a post which she held till her death.

Catherine Marsh; b. I818; d. December 12th. Author of Memorials of Captain Hedley Vicars, English Hearts and English Hands, and well known for her philanthropic work among British navies.

Marian Rebecca Hughes, Mother Superior of St. Thomas's Sisterhood, Holy Trinity Convent, Oxford; b. I8I7; d. at Oxford on the 7 th of May. She became the first Anglican nun on the 6 th of June I84I (see $E . B . x x v, 160 \mathrm{c}$ ). At first she was directed by John Henry Newman, afterwards for fifty years by Edward Bouverie Pusey, who took an active part in establishing Anglican sisterhoods, and finally by Fidward King, Bishop of Lincoln. Under her rule the sisterhood prospered; schools were established for girls of all classes, a printing press was set up, and a Convent Magazine issued. Much work was also done amongst the poor of Oxford, and memorable service was rendered by the Mother during the cholera epidemic of 1866.

Lady Lindsay, the verse-writer and painter, died in London in August. The daughter of the Rt. Hon. Henry Fitzroy, who married Miss Hannah Mayer de Rothschild, and granddaughter of the 2 nd Lord Southampton, she married Sir Coutts Lindsay in I864, and for 30 years before her death had lived in London or Venice, gathering a circle of friends about her which included G. F. Watts, Alma-Tadema and Browning. She collected a number of fine pictures, some of which she left in the National Gallery. She wrote several volumes of verse, which hardly won the attention they deserved, among them From a Venetian Balcony, and Poems of Love and Death.

Margaret Hunt, the novelist, b. I831, widow of the painter A. W. Hunt (E. B. xiii, 934), d. in London on November Ist. Her best known book was Thornicroft's Model.

Mrs. De Courcy Laffan, the novelist, $d$. in London on the 5 th of September. She married first Surgeon-General Leith Adams and secondly the Rev. R. S. de Courcy Laffan, for some years headmaster of Cheltenham. As Mrs. Leith Adams she published a number of novels, beginning with Winstorve (1877) and including My Land of Beulah (1880), Louis Draycolt (189I) and The Peyton Romance (1894). She also published two plays in 1906 and a volume of poems in 1907 .

Mrs. Stanhope Forbes, the painter, b. I859; d. at Newlyn, Cornwall, on the I6th of March. 1 native of ('anada, hut educated in New York, as Miss Elizabeth Armstrong she became known as an etcher and a painter of the Newlyn School (sce E. B. xx, 499c). In 1889 she married Mr. Stanhope Forbes, R.A. Many of her pictures were exhibited at the Royal Academy and the Paris Salon, and she was an associate of the Royal Society of Painters in Water Colours.

Emily Soldene, the singer and actress, b. 1840; d. in London on the 8 th of April. She appeared in Genevieve de Brabant, her special rôle, in $\mathrm{I} 87 \mathrm{I}$, and in La Fille de Madame Angot in 1872 . Her greatest successes were made in opera-bouffe. She retired from the stage for some thirty years before her death.

Florence St. John, the actress, b. 1854 , d. in London on the 3oth of January. She went on the stage as a vocalist at the age of fourteen. Her chief early successes were made in light comic opera, notably as Cermaine in Les Cloches de Cornerille, and in Madame Favart, and for many years she played leading rôles in musical comedy and burleșque.

Beryl Faber, the actress, d. in London on the Ist of May. She married Mr. Cosmo Hamilton, formerly editor of the World, and began her stage career as an amateur. She was the original Clarice in The Masqueraders by H. A. Jones (1894) and Ellean in The Second Mrs. Tanqueray, and appeared in several of Sir Arthur Pinero's other plays.

Mrs. Lewis Waller (Florence West), the actress; b. $1862 ; \mathrm{d}$. November 14 th (see $E . B$. xxviii, 283b). 
Mention must also be made of the deaths of two well-known personages in "Society":--

The Duchess of Buccleuch, d. at Dalkeith, N.B. on the 17th of March. She was the daughter of the ist Duke of Abercorn, and one of the seven sisters depicted by Disraeli in Lothaire. In 1859 Lady Louisa Jane Hamilton married Lord Dalkeith, afterwards 5th Duke of Buccleugh (see E. B. iv, 712c). A great lady of the "old school," she was an intimate friend of the Royal family, particularly of Queen Victoria, to whom she was mistress of the robes in I885-92 and I 895-I901, and was continued in office by Queen Alexandra.

The Countess of Cork and Orrery, b. 1828 ; d. in London on the Ioth of October. She was the daughter of the first Marquis of Clanricarde, her mother being a daughter of George Canning. She was married in 1853 to Lord Dungarvan, afterwards 9th Earl of Cork and Orrery, and was the mother of three sons and five daughters. Possessed of great beauty and a brilliant talker, she gathered round her a wide circle of men of letters and politicians, especially among the Whigs, to which party her husband belonged. She was the writer of occasional papers, and of a little volume of verse, Memories and Thought (1886).

\section{ENGLAND AND WALES ${ }^{1}$}

\section{Including General Statistics for the. United Kingdom.}

Population.-The census of the United Kingdom in I9I I, of which tabular details are given below, revealed a greater aggregate increase in England itself during the decade $1901-1$ I than during that of I89I-I90I, but the increase per cent of the population declined. A tendency is suggested towards a state of equilibrium as between urban and rural districts, as was also indicated in the earlier decade. Thirteen administrative counties returned decreased populations in r90I, but these, with the exception of West Suffolk and Westmorland, showed an increase in I9II. In addition to these, Cumberland, Carnarvon and Radnor returned a decrease in I9I though not in I901; and among Welsh counties, Cardigan, Montgomeryshire and Merionethshire showed a decrease at both censuses. These counties indicate the existence of three main areas of decreasing or unstable population, a north-western, an East Anglian, and a Welsh area. But the census report points out that in the agricultural counties the "returns of increase for I gOI-I I compare favourably in nearly all cases with those recorded in the earlier period," and the fact is particularly noteworthy in Bedfordshire, Lincolnshire and Rutland, Buckinghamshire and Oxfordshire, and Dorset. On considering the chief mining and industrial counties, the argument is found to hold good, excepting in South Wales. A greatly enhanced rate of increase in the industrial area of South Wales causes the rate for the whole of Wales to grow from 13.3 per cent increase in I90 I to I8. I per cent in I9I. Otherwise, "in Nottinghamshire the rate is fairly steady, moving slightly up; in Northumberland and Durham, Lancashire, Staffordshire and the West Riding of Yorkshire, it is markedly down "(Geog. Jour., xxxviii, 309). The average rate of increase in the population of 98 towns with populations exceeding 50,000 has declined from $\mathrm{r} 5.3$ per cent in $I 89 \mathrm{I}$-o to 8.7 per cent in I90I-I I, and has fallen in all the 15 towns whose population exceeded 200,000 , except Portsmouth. "The greatest increase of all is at Southend-on-Sea (pop. 62,723; increase 117.4 per cent); Ilford, Ealing and Acton, Coventry, Wallasey, and King's Norton follow. Three of these towns are on the outer ring of London; Southend is practically so, and Wallasey and King's Norton are also 'ring' towns. The radiation outward from London and other great urban centres is going on; at the same time it is surging over some of the 'ring' towns which were at the height of their growth about rgor. Thus the rate of increase has fallen in Ilford from 277.6 per cent to 89.6 per cent, in Last Ham from 193.6 per cent to 39.1 per cent, in Walthamstow from 105.3 per cent to 3 I per cent. As to the gross decrease in the County of London, the report puts the matter geographically - The process of decentralization, which at first affected the inner districts of London only, has gradually affected a much wider area, until in I90I-I I only nine of the twenty-eight Metropolitan boroughs showed an increase of population. These boroughs, which are mainly those furthest removed from the centre, are Hampstead, Hackney, Fulham, Hammersmith, Wandsworth, Camberwell, Greenwich, Lewisham and Woolwich'" (Goog. Jour. xxxviii, 400).

'For earlier information on Fngland, see E. B. ix, 408 et seq.; for Wales, xxviii, $25^{8}$ et seq.; for general statistics for the Inited Kingdom, xxvii, 598 ef seq. See also $E$. $B$. articles on the counties and towns, and sections in articles on special subjects. 
The 19I I census figures for the United Kingdom, showing a combined area of I2I,39 I square miles and a total population of $45,360,822$ (22,010,004 males, $23,350,818$ females), with an increase of 9.1 per cent in population since $190 \mathrm{I}$, are analysed in Table I.

Table I.

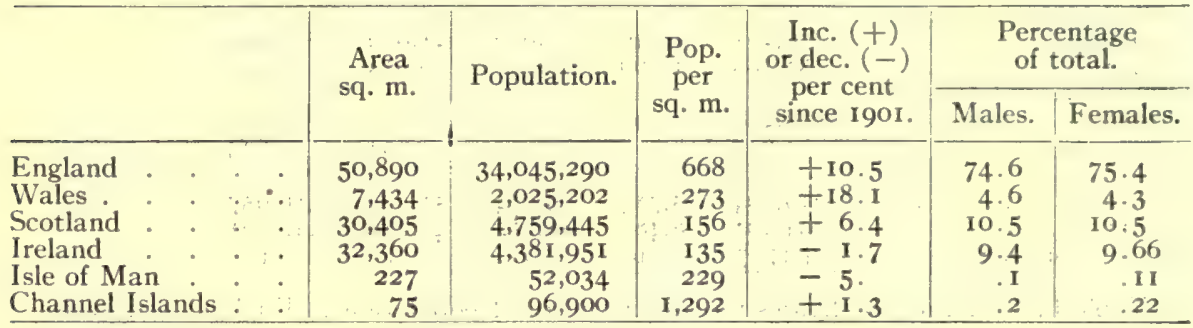

The births, deaths and marriages registered in I9IO and I9II are shown in Table II. Table II.

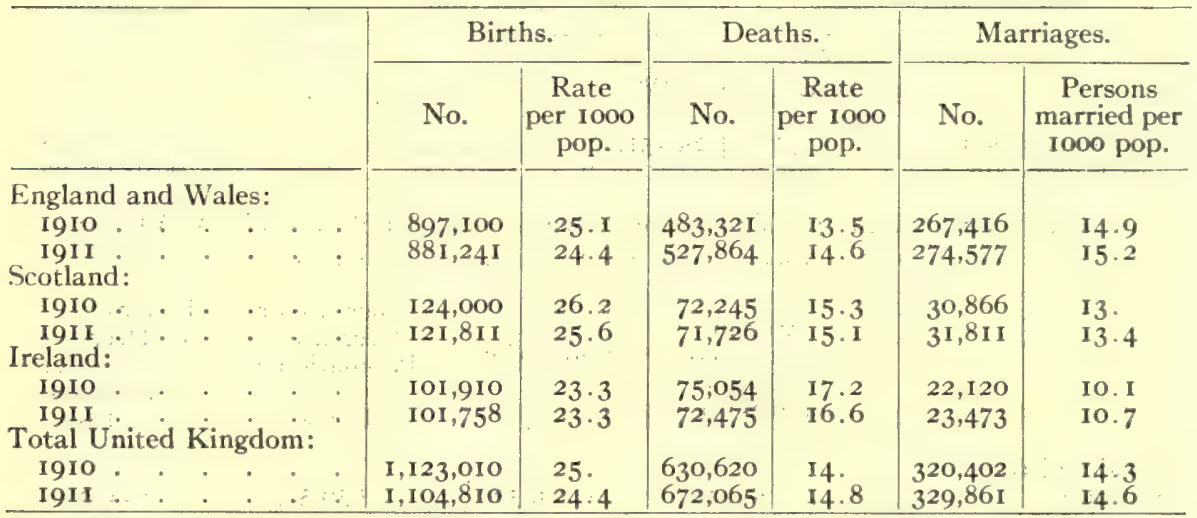

Table III shows the emigration from the United Kingdom.

Table III.

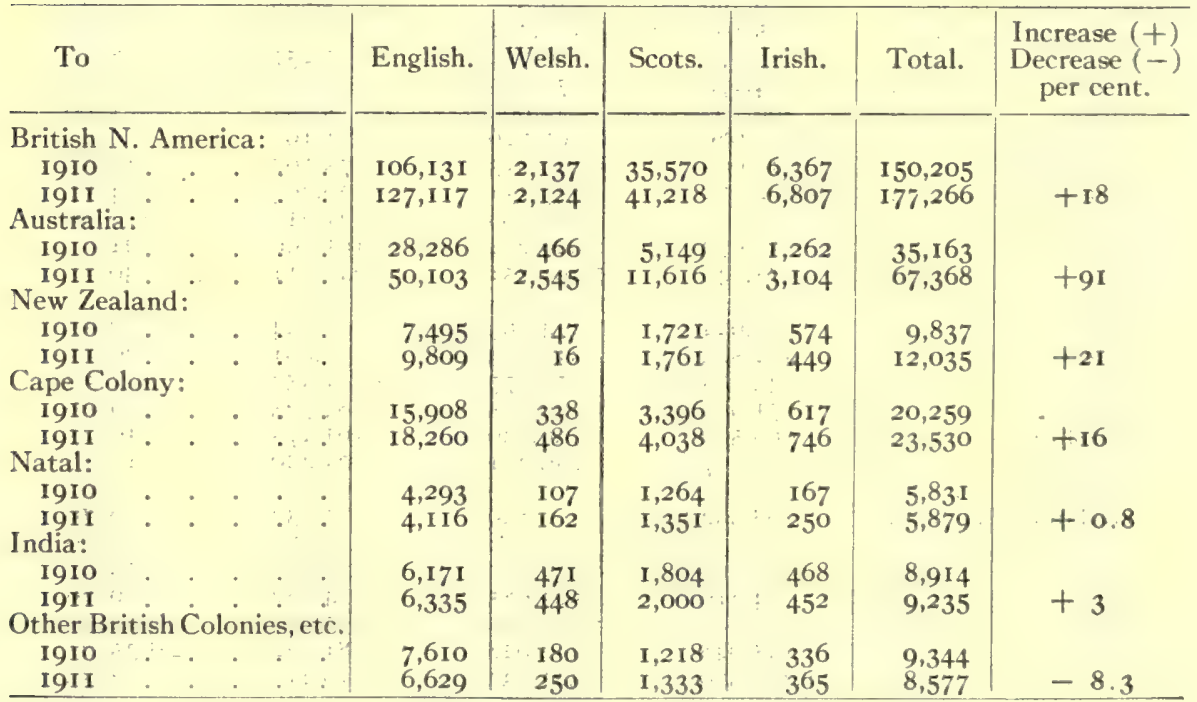


Table III - Continued.

To

United States:

1910

1911

Other Foreign Countries:

1910

I9II

Total:

1910

I9II

Inc. $(+)$ or Dec. $(-) \%$.
English.

\begin{tabular}{|c|c|c|}
60,481 & 1,646 & 27,918 \\
58,185 & 1,869 & 23,441 \\
13,429 & 393 & 1,744 \\
13,647 & 588 & 2,094 \\
& & \\
249,804 & 5,785 & 79,784 \\
294,201 & 8,488 & 88,852 \\
+17.7 & +46 & +11 \\
\hline
\end{tabular}

Irish. Total.

\begin{tabular}{r|r|l}
41,019 & 131,064 & \\
36,613 & 120,108 & -8.4 \\
474 & 16,040 & \\
494 & 16,823 & +4.8 \\
51,284 & 386,657 & \\
49,280 & 440,821 & \\
-4 & +14 &
\end{tabular}

Table IV compares the figures for urban and rural population in England and Wales. Table IV,

\begin{tabular}{|c|c|c|c|c|c|c|}
\hline \multicolumn{2}{|c|}{ England and Wales. } & \multicolumn{2}{|c|}{ Aggregate Population. } & \multirow{2}{*}{$\begin{array}{l}\text { Percentage } \\
\text { of increase. }\end{array}$} & \multicolumn{2}{|c|}{$\begin{array}{l}\text { Percentage of } \\
\text { Population in }\end{array}$} \\
\hline & $\begin{array}{l}\text { No. of } \\
\text { Districts. }\end{array}$ & 1901.: & 1911. & & 1911. & 1901. \\
\hline $\begin{array}{l}\text { Urban Population } \\
\text { Rural Population }\end{array}$ & $\begin{array}{r}1,137 \\
657\end{array}$ & $\begin{array}{r}25,351,118 \\
7,176,725\end{array}$ & $\begin{array}{r}28,162,936 \\
7,907,556\end{array}$ & $\begin{array}{l}\text { II. I } \\
\text { IO. } 2\end{array}$ & $\begin{array}{l}78.1 \\
21.9\end{array}$ & $\begin{array}{l}77 \\
23\end{array}$ \\
\hline
\end{tabular}

The figures for area and population are shown in more detail in Tables V: VI and VII. Table V.-English and Welsh Administratiz: Counties.

\begin{tabular}{|c|c|c|c|c|c|c|}
\hline & & & $\begin{array}{l}\text { Area in } \\
\text { Statute Acres } \\
\text { (Iand and } \\
\text { Inland Water). }\end{array}$ & $\begin{array}{l}\text { Population } \\
\text { 19II. : }\end{array}$ & $\begin{array}{l}\text { Increase or } \\
\text { Decrease of } \\
\text { Population in } \\
\text { Intercensal } \\
\text { Period. }\end{array}$ & $\begin{array}{l}\text { Increase }(+) \\
\text { or Decrease } \\
(-) \text { per cent } \\
\text { between I } 901 \\
\text { and I9II. }\end{array}$ \\
\hline \multicolumn{3}{|c|}{$\begin{array}{l}62 \text { Administrative } \\
\text { Counties }\end{array}$} & $36,820,226$ & $25,200,520$ & $2,656,525$ & +11.80 \\
\hline \multicolumn{7}{|l|}{ England:- } \\
\hline Bedford & . & & 302,942 & $1,944,588$ & $+22,881$ & +13.3 \\
\hline Berkshire & . & . & 456,491 & I95,8 I I & $+15,457$ & $\begin{array}{r}8.3 \\
+8.6\end{array}$ \\
\hline Buckingham & : & & 479,360 & $219,51 \mathrm{I}$ & $\begin{array}{r}22,505 \\
+\end{array}$ & +11.44 \\
\hline Cambridge. & . & & 315,168 & 128,322 & $\begin{array}{r}+8058 \\
+\quad 8,0\end{array}$ & +6.70 \\
\hline Isle of Ely & . & . & 238,073 & 69,752 & $+\quad 5.257$ & +8.16 \\
\hline Cheshire & . & & 644,172 & 676,275 & $+82,390$ & +13.89 \\
\hline Cornwall & . & . & 868,167 & 328,098 & $\begin{array}{l}+5.754 \\
+\quad 5\end{array}$ & +1.80 \\
\hline Cumberland & . & . & 973,086 & 265,746 & $-\quad 1,197$ & -0.43 \\
\hline Derbyshire & . & 。 & 645,097 & 560,013 & $+75,167$ & +15.53 \\
\hline Devonshire & . & . & $1,662,672$ & 457,331 & $+20,393$ & +4.67 \\
\hline Dorsetshire & . & . & 625,612 & 223,266 & $+2 \mathrm{I}, 2 \mathrm{II}$ & +10.50 \\
\hline Durham. & . & . & 637,672 & 929,214 & $+161,190$ & $+2 I$ \\
\hline Essex. & . & . & 974,849 & $1,061,851$ & $+245,211$ & $+30 \ldots$ \\
\hline Ciloucester & . & . & 786,016 & 329,014 & $+\quad 7,572$ & +2.4 \\
\hline Hereford. & 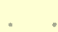 & . & 538,924 & 114,269 & 144 & +0.13 \\
\hline Heriford & . & . & 404.523 & 311,284 & $+52,861$ & +20.47 \\
\hline Iluntingdon & & 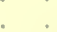 & 233.985 & 55.577 & $\begin{array}{r}1,452 \\
+\quad 1,\end{array}$ & +2.69 \\
\hline Kent & . & & $971,99 \mathrm{I}$ & $1,020,965$ & $+84,725$ & +9.06 \\
\hline I.ancashire & ${ }^{\circ}$ & . & $1,066,529$ & $1,739,330$ & $+161,175$ & +10.23 \\
\hline \multicolumn{7}{|l|}{ l.incoln: } \\
\hline Holland & . & . & 268,992 & 82,849 & $\begin{array}{l}5,239 \\
+\quad 5\end{array}$ & +6.76 \\
\hline Kesteven & . & & 465,878 & I I I, 324 & $+\quad 7,362$ & +7.09 \\
\hline Lindsey & & & 963,800 & 237.843 & $+31,315$ & +15.2 \\
\hline I.ondon & & & $74,8 \mathbf{1 6}$ & $4,521,685$ & $-14,582$ & -0.29 \\
\hline Mirkllesex & & & 148,701 & $1,126,465$ & +333.989 & +42.17 \\
\hline Monmouth & ${ }^{\circ}$ & & $3+5,048$ & 312,028 & $\begin{array}{r}+81,222 \\
\end{array}$ & $-+35.2 \mathrm{I}$ \\
\hline Norfolk & $\theta$ & & $1,303.570$ & 321,733 & $+10,418$ & $\begin{array}{r}+3.35 \\
\end{array}$ \\
\hline
\end{tabular}


Table V.-English and Welsh Administrative Counties.-Contimued.

\begin{tabular}{|c|c|c|c|c|c|c|}
\hline \multicolumn{3}{|c|}{ Names of Counties. } & $\begin{array}{c}\text { Area in } \\
\text { Statute Acres } \\
\text { (Land and } \\
\text { Inland Water). }\end{array}$ & $\begin{array}{l}\text { Population } \\
\text { I9II. }\end{array}$ & $\begin{array}{c}\text { Increase or } \\
\text { Decrease of } \\
\text { Population in } \\
\text { Intercensal } \\
\text { Period. }\end{array}$ & $\begin{array}{l}\text { Increase }(+) \\
\text { or Decrease } \\
(-) \text { per cent } \\
\text { between I } 190 \text { I } \\
\text { and I9II. }\end{array}$ \\
\hline \multirow{2}{*}{\multicolumn{3}{|c|}{$\begin{array}{l}\text { Notthants } \\
\text { Soke of Peterborough }\end{array}$}} & $5^{81}, 679$ & 213,733 & $+6,248$ & +3.02 \\
\hline & & & 53,464 & 4 & +3.596 & +8.75 \\
\hline \multicolumn{3}{|c|}{ Northumberland } & $\mathrm{I}, 278,69 \mathrm{I}$ & 371,474 & $+66,744$ & +21.92 \\
\hline \multirow{2}{*}{\multicolumn{3}{|c|}{$\begin{array}{l}\text { Nottingham } \\
\text { Oxfordshire }\end{array}$}} & 529,188 & 344,194 & $+69,478$ & +25.27 \\
\hline & & & 475,968 & 146,221 & $\begin{array}{l}+\quad 9,097 \\
\end{array}$ & $\begin{array}{r}+6.64 \\
\end{array}$ \\
\hline \multicolumn{3}{|l|}{ Rutland. } & 97,273 & 20,346 & 637 & +3.24 \\
\hline \multirow{2}{*}{\multicolumn{3}{|c|}{$\begin{array}{l}\text { Shropshire } \\
\text { Somerset. }\end{array}$}} & 861,800 & 246,307 & $+6,524$ & +2.72 \\
\hline & & 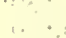 & $\mathbf{I}, 034,259$ & 407,304 & $+22,193$ & +5.77 \\
\hline \multicolumn{3}{|l|}{ Southampton } & 942,501 & 433,566 . & $+69,916$ & +19.23 \\
\hline \multicolumn{3}{|l|}{$\begin{array}{l}\text { Isle of Wight } \\
\text { Stafford }\end{array}$} & 94,145 & 88,186 & $\begin{array}{l}+5,768 \\
+\quad 5\end{array}$ & +7.01 \\
\hline \multirow{2}{*}{\multicolumn{3}{|c|}{$\begin{array}{l}\text { Stafford } \\
\text { Suftolk, East }\end{array}$}} & 710,844 & 738,990 . & $+67,500$ & +10.07 \\
\hline & & & $549,24 \mathrm{I}$ & 203,223 & $+14,053$ & +7.43. \\
\hline \multicolumn{3}{|l|}{ Suffolk, West } & 390,916 & I 16,905 & -648 & -0.54 \\
\hline \multirow{2}{*}{\multicolumn{3}{|c|}{ Surrey }} & $45^{2}, 817$ & 676,027 & $+156,261$ & +30.06 \\
\hline & & & 517,067 & 242,146 & +23.747 & +10.1 \\
\hline \multicolumn{3}{|l|}{ Sussex, West } & 401,839 & 176,308 & $+25,032$ & +16.56 \\
\hline \multicolumn{3}{|l|}{ Warwick. } & 563,117 & 408,227 & $+60,505$ & +17.42 \\
\hline \multicolumn{3}{|l|}{ Westmorland } & $505,33^{\circ}$ & 63,575 & 834 & $-\quad 1.29$ \\
\hline \multirow{2}{*}{\multicolumn{3}{|c|}{$\begin{array}{l}\text { Wiltshire } \\
\text { Worcester }\end{array}$}} & 864,101 & 286,822 . & +15.428 & +570 \\
\hline & & . & 472,487 & 427,026 & $+69,624$ & +19.49 \\
\hline \multicolumn{7}{|l|}{ Yorkshire- } \\
\hline \multicolumn{3}{|l|}{ E. Riding } & 741,172 & I 54,768 & $+10,020$ & +6.93 \\
\hline \multicolumn{3}{|l|}{ N. Riding } & $1,359,600$ & $3 \mathbf{I}$ & $+28,743$ & +10.06 \\
\hline \multirow{2}{*}{\multicolumn{7}{|c|}{ Wales:- }} \\
\hline & & & & & & \\
\hline Brecknock & & & $469,28 \mathrm{I}$ & 59,287 & $\begin{array}{r}322 \\
+\quad 5,074\end{array}$ & $\begin{array}{r}+0.07 \\
+9.38\end{array}$ \\
\hline Cardigan. & 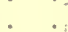 & $\therefore$ & 443,189 & 59,879 & - I,I99 & -1.97 \\
\hline Carmarthen & & $\therefore$ & 588,472 & 160,406 & $+25,078$ & +18.55 \\
\hline Carnarvon & & . & 365,986 & 125,043 & 606 & -0.48 \\
\hline Denbighshire & & & 426,084 & 144,783 & $+13,201$ & +10.04 \\
\hline Flintshire & • & & 163,025 & 92,705 & $+\mathrm{II}, 220$ & +13.79 \\
\hline Glamorgan & & & 489,529 & 742,998 & $+211,165$ & +39.73 \\
\hline Merioneth & & $\therefore$ & 422,372 & 45,555 & $-\quad 3,287$ & -6.71 \\
\hline Montgomery & . & $\therefore$ & 510,110 & 53,146 & - I,755 & -3.19 \\
\hline Pem & 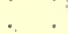 & & 393,003 & 89,960 . & $+\quad 2,066$ & +2.35 \\
\hline Radnorshire & & & 301,165 & 22,590 & $-69 I$ & -2.97 \\
\hline
\end{tabular}

Table VI.-English and Welsh County Boroughs.

\begin{tabular}{|c|c|c|c|c|}
\hline Names of Towns. & $\begin{array}{c}\text { Area in Statute } \\
\text { Acres. }\end{array}$ & $\begin{array}{l}\text { Population } \\
\text { I9II. }\end{array}$ & $\begin{array}{l}\text { Increase }(+) \\
\text { or Decrease } \\
(-) \text { in Inter- } \\
\text { censal Period. }\end{array}$ & $\begin{array}{c}\text { Increase }(t) \\
\text { or Decrease }(-) \\
\text { per cent in } \\
\text { Intercensal } \\
\text { Period between } \\
\text { IgoI and } 1911 .\end{array}$ \\
\hline 75 County Boroughs & 517,3 II & Io,869,972 & $+886,124$ & +8.89 \\
\hline Liverpool & 16,642 & $74^{6}, 42 \mathrm{I}$ & $+42,287$ & +6.0 \\
\hline Manchester & 21,645 & 71 & +69. & $+10,8$ \\
\hline Birmingham & 13 & & +2, & +0.5 \\
\hline Sheffield . & 23,662 & $454,63^{2}$ & $+45,562$ & $+I I . I$ \\
\hline Leeds : . & 21 & 445 & +16, & +3.9 \\
\hline Bristol . & 17,460 & 35 & $+\quad 18,006$ & +.5 .3 \\
\hline West Ham . & 4,683 & 289,030 & $+21,672$ & +8.1 \\
\hline Bradford & $22,88 \mathrm{I}$ & 288 & $+8,691$ & +3.1 \\
\hline Kingston-upon-Hull & 9,042 & 277,991 & $+37,732$ & +15.7 \\
\hline tle-on-Tyne ... : & 8,452 & 266,603 & $+\quad 19,5$ & +8.0 \\
\hline Nottingham & $\therefore 10,935$ & 25 & $+20, \mathrm{I} 6 \mathrm{I}$ & +8.4 \\
\hline n-Trent & $\mathrm{II}, \mathrm{I} 4^{2}$ & 234,534 & $+19,822$ & +9.2 \\
\hline Salford & 5,202 & 231,357 & $+10,400$ & +4.7 \\
\hline
\end{tabular}


Table VI.-English and Welsh County Boroughs:-Contimued.

\begin{tabular}{|c|c|c|c|c|c|c|}
\hline \multicolumn{3}{|c|}{ Names of 'Towns. } & $\begin{array}{c}\text { Area in Statute } \\
\quad \text { Acres. }\end{array}$ & $\begin{array}{c}\text { Population } \\
\text { I9I I }\end{array}$ & $\begin{array}{l}\text { Inc. }(+) \text { or } \\
\text { Dec }(-) \\
\text { since } 1901 .\end{array}$ & $\begin{array}{l}\text { Increase }(+) \text { or } \\
\text { Decrease }(-) \\
\text { per cent. }\end{array}$ \\
\hline \multirow{2}{*}{\multicolumn{3}{|c|}{$\begin{array}{l}\text { Portsmouth } \\
\text { Leicester }\end{array}$}} & 6,100 & $23 I, 14 I$ & $+42,213$ & +22.4 \\
\hline & & & $8,5^{82}$ & 227,222 & $+\quad 15,643$ & +7.4 \\
\hline Cardiff : & . . & $\therefore$ & 6,373 & 182,259 & $+17,926$ & +10.9 \\
\hline Bolton . & . & $\therefore$ & 15,279 & I 80,85 I & $+12,636$ & +7.5 \\
\hline Croydon & $\cdot$. $\cdot$ & $\therefore$ & 9,012 & $\mathrm{I} 69,55 \mathrm{I}$ & $+35,656$ & +26.6 \\
\hline Sunderland . & - $\cdot$ & $\therefore$ & 3,357 & I 51,159 & $+\quad 5,082$ & +3.5 \\
\hline Oldham :- & •. $\cdot$ & & 4,736 & 147,483 & $+10,237$ & +7.5 \\
\hline Blackburn : & . & $\cdot$ & 7,418 & 133,052 & $+\quad 3,836$ & +3.0 \\
\hline Brighton . & . & $\therefore$ & 2,536 & 131,237 & $\begin{array}{l}+7,759 \\
+\end{array}$ & +6.3 \\
\hline Birkenhead . & - & $\therefore$ & 3,848 & 130,794 & $+\mathbf{1 9}, 879$ & +18.0 \\
\hline Derby & . & $\therefore$ & 5,272 & 123,410 & $+\quad 8,562$ & +7.5 \\
\hline Norwich . & . & & 7,896 & $12 \mathrm{I}, 478$ & $+\quad 7,556$ & +6.6 \\
\hline Southampton & . & & 4,604 & 119,012 & $+14,188$ & $+13,6$ \\
\hline Preston & . & $\therefore$ & $3,971=$ & I 17,088 & $\begin{array}{l}+\quad 4,099 \\
\end{array}$ & +3.6 \\
\hline Gateshead . & . & $\cdot$ & 3,132 & I 16,917 & $+\quad 7,029$ & +6.4 \\
\hline Swansea & . & $\therefore$ & 5,202 & I I 4,663 & $+20,126$ & $+21 \cdot 3$ \\
\hline Plymouth & . & & 2,374 & 112,030 & $+\quad 4,394$ & $+4 \cdot I$ \\
\hline Stockport & . & $\because$ & 5,488 & 108,682 & $+15,850$ & +17.1 \\
\hline South Shields & . & 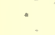 & 2,399 & I08,647. & $+\quad 7,789$ & +7.7 \\
\hline Huddersfield & . & 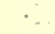 & 11,859 & $107,82 \mathrm{I}$ & $+12,774$ & $+13 \cdot 4$ \\
\hline Coventry & • & . & 4,147 & 106,349 & $+36,371$ & +52.0 \\
\hline Burnley : & is & $\therefore$ & 4,005 & 106,322 & $+\quad 9,279$ & +9.6 \\
\hline Middlesbroug & & 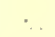 & 2,685 & 104,767 & $+13,465$ & +14.8 \\
\hline Halifax . & • & & 13,983 & Ior,, 553 & $-\quad 3,391$ & $-3 \cdot 2$ \\
\hline St. Helens . & : & . & 7,284 & 96,55 I & $+12,141$ & +14.4 \\
\hline Wolverhampt & ton & & 3,525 & 95.328 & $+\quad \mathbf{I}, \mathbf{1} 4 \mathrm{I}$ & +1.2 \\
\hline Walsall . & • & & 7,483 & 92, I 15. & $+\quad 5,685$ & +6.6 \\
\hline Rochdale & : & $\therefore$ & $6,44^{6}$ & $91,4^{2} 8^{\circ}$ & $+8,314$ & +10.0 \\
\hline Northampton & $n$ & . & 3,469 & 90,064 & $+\quad 3,043$ & $+3 \cdot 5$ \\
\hline Wigan & & 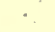 & 5,083 & $89,15^{2}$ & $+\quad 6,724$ & +8.2 \\
\hline Newport (Mo & on). & & 4,504 & $83,69 \mathrm{I}$ & $+16,421$ & +24.4 \\
\hline York : & -. & & 3,730 & 82,282 & $+\quad 4,368$ & +5.6 \\
\hline Devonport & & . & 3,152 & 81,678 & $+11,241$ & +16.0 \\
\hline Merthyr Tyd & fil . & $\because$ & 17,761 & 80,990 & $+11,762$ & +17.0 \\
\hline Bournemouth & h. & & 5,742 & 78,674 & $+18,912$ & +31.7 \\
\hline Reading. & & & 5,876 & 75,198 & $+\quad 2,98 \mathbf{I}$ & +4.1 \\
\hline Grimsby & 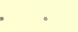 & . & 2,868 & 74,659 & $+11,52 I$ & +18.3 \\
\hline Ipswich . & . & . & 8,112 & 73,932 & $+\quad 7,302$ & +11.0 \\
\hline IVarrington & & . & 3,057 & 72,166 & $+\quad 7,924$ & +12.4 \\
\hline Smethwick & . & . & 1,929 & 70,694 & $+16,155$ & +29.6 \\
\hline Bootle . & & . & $\mathbf{I}, 947$ & 69,876 & $+9,641$ & +16.0 \\
\hline West Bromwi & ich. & ? & 5,859 & $68,33^{2}$ & $+\quad 3,157$ & +4.9 \\
\hline West Hartlep & oool & . & 2,684 & 63,923 & $+\quad 1,296$ & +2.1 \\
\hline Barrow-in-Fu & irness & 5 & I I , 02 & 63,770 & $+\quad 6,184$ & +10.7 \\
\hline Rotherham . & . & : & $6,00 \mathrm{I}$ & 62,483 & $+8,134$ & +15.0 \\
\hline Hastings & • & & 4,495 & 61,145 & $-\quad 4,383$ & -6.7 \\
\hline Tynemouth . & . & & 4,372 & 58,816 & $+\quad 7,450$ & +14.5 \\
\hline Bury i . & . & . & 5,907 & $5^{8,648}$ & 619 & +1.1 \\
\hline Blackpool & • & . & 3,601 & 58,371 & $+11,023$ & +23.3 \\
\hline I incoln. . & • & . & 3,755 & 57,285 & $+8,501$ & +17.4 \\
\hline (ireat Yarmo & outh & & 3,598 & 55,905 & $\begin{array}{l}+\quad 4.589 \\
\end{array}$ & +8.9 \\
\hline Oxford . & . . & . & 4,719 & 53,048 & $+\quad 3.712$ & +7.5 \\
\hline Eastbourne & 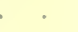 & 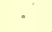 & 6,472 & $5^{2}, 54^{2}$ & 8,968 & +20.6 \\
\hline Southport & . & & 5,144 & 51,643 & $+3,560$ & +7.4 \\
\hline Dudley . & & . & 3.546 & $5^{1,079}$ & $+\quad 2,346$ & +4.8 \\
\hline Bath . . & & & 3.383 & $50,72 \mathrm{I}$ & 882 & +1.8 \\
\hline (jloucester & . & & 2,314 & 50,035 & $+2,080$ & +4.3 \\
\hline Exeter & $0^{\circ}$ & & 3,166 & 48,664 & $+\quad \mathbf{1}, 479$ & +3.13 \\
\hline Burton-on- $\mathrm{Tr}$ & rent & & 4,203 & 48,266 & $-\quad 2,120$ & $-4 \cdot 19$ \\
\hline IVorcester & . & & 3.185 & 47,982 & $+\quad 1,35^{8}$ & +2.92 \\
\hline Chester. & - & & 2,862 & 39,028 & 719 & +1.9 \\
\hline Canterbury & & & 3.975 & 24,626 & 273 & -1.09 \\
\hline
\end{tabular}


Table VII.-Other Large English and Welsh Towns.

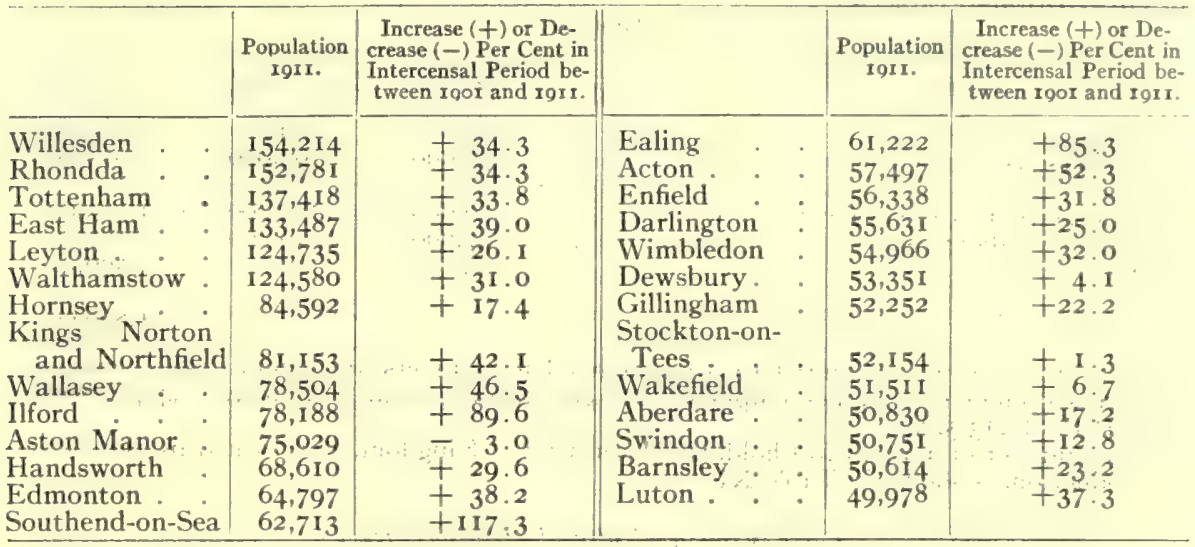

Agriculture.-According to returns of I9I2, out of a total area of 37, 143,953 acres for England and Wales, the average under all crops and grass was 27,169,462, a decrease of 0.3 per cent on the returns for the preceding year. The general Table VIII for the United Kingdom is given for purposes of comparison (increase or decrease per cent on the preceding year following the total acreage in brackets).

Table VIII.

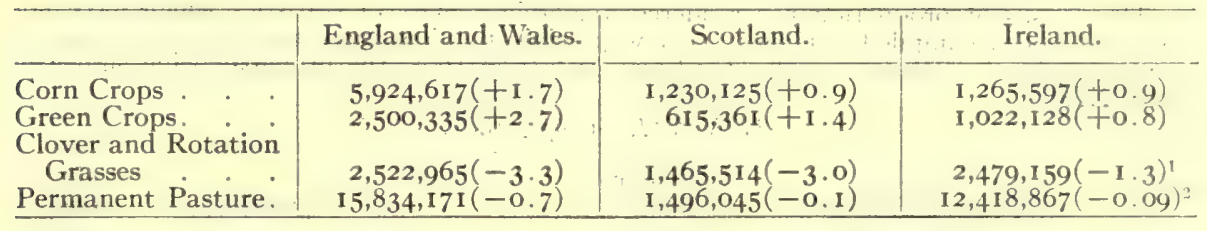

Live stock in England and Wales was returned as follows:-horses 1,406,099 ( -1.0$)$; cattle 5,84I,908 (-I.2); sheep I 8,053,584 (-6.6); pigs 2,496,358 (-5.8).

A return published in June 1912 (Census of Production ${ }^{3}$ ) relating to the year ending June 4 , I908, sets down the value of the produce of British agriculture at $£ 150,800,000$, as shown in Table IX:

Table IX.

\begin{tabular}{|c|c|c|c|}
\hline$\therefore$ & England and Wales. & Scotland. & Great Britain. \\
\hline $\begin{array}{l}\text { Farm Crops } \\
\text { Fruit, Flowers and Timber } \\
\text { Animals } \\
\text { Wool } \\
\text { Dairy Produce } \\
\text { Poultry }\end{array}$ & $\begin{array}{r}f 40,200,000 \\
4,700,000 \\
50,800,000 \\
2,100,000 \\
25,500,000 \\
4,350,000\end{array}$ & $\begin{array}{r}f, 400,000 \\
500,000 \\
10,600,000 \\
500,000 \\
4,500,000 \\
650,000\end{array}$ & $\begin{array}{r} \pm 46,600,000 \\
5,200,000 \\
61,400,000 \\
2,600,000 \\
30,000,000 \\
5,000,000\end{array}$ \\
\hline Total Sales . . . . & $f_{1} 127,650 ; 000$ & $£ 23,150,000$ & $f_{1}, 50,800,000$ \\
\hline
\end{tabular}

1 Hay area.

2 Pasture and mountain grazing.

- This census was provided for by the Census of Production Act, 1906. It is under the direction of the Board of Trade, and the first census was taken in I908. The results so far as applying to agriculture were issued by the Board of Agriculture.

"The total value of farm crops grown in 1908 is calculated at $£ 125,000,000$, but the portion actually sold realised (as shown in Table IX) $f, 46,600,000$, the remainder of the produce being used to feed the stock and maintain the fertility of the land. 
A further return of the Census of Production analysed the labour employed on the farm: of Great Britain (Table X).

Table $X$.

Members of Family

Other-Persons

Total permanently employerl

Temporary. Labourers

Occupiers

Grand Total

\begin{tabular}{|c|c|c|}
\hline Males & Females. & Total. \\
\hline $\begin{array}{l}313,000 \\
576,000\end{array}$ & $\begin{array}{r}189,000 \\
95,000\end{array}$ & $\begin{array}{l}502,000 \\
671,000\end{array}$ \\
\hline \multirow{4}{*}{$\begin{array}{l}889,000 \\
127,000\end{array}$} & \multirow{4}{*}{$\begin{array}{r}284,000 \\
\therefore \quad 40,000\end{array}$} & $1,173,000$ \\
\hline & & 167,000 \\
\hline & & 500,000 \\
\hline & & $\mathrm{I}, 840,000$ \\
\hline
\end{tabular}

The gross output amounted to fgo per head if occupiers are included and temporary labourers excluded. Engines employed in agricultural pursuits numbered 34,450 with a total H.P. of $2 \mathrm{I} 3.525$.

The number of agricultural holdings in the United Kingdom, as returned by the Census of Production, is shown in Table XI.

Table X1:-Agricultural Holdings, 1008 .

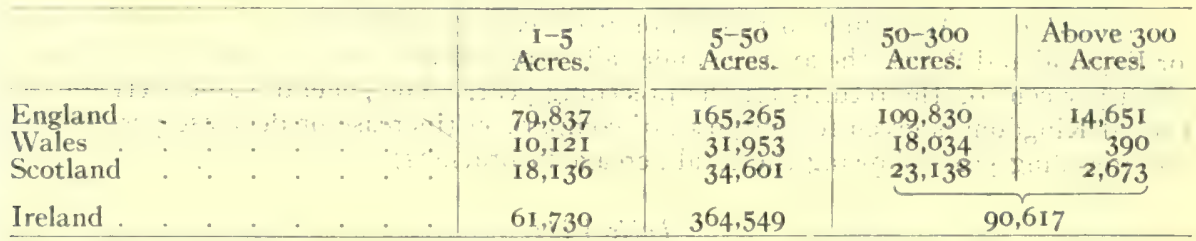

The census of production has rendered available a mass of statistics which have not previously been compiled. Thus it is now possible to view the estimated production of crops in order of their gross value for Great Britain in 1908, the principal being shown in Table XII.

Table XII-Crops, -1908 .

\begin{tabular}{|c|c|c|c|c|c|}
\hline & Quantity. & $\begin{array}{l}\text { Th } \\
\text { san }\end{array}$ & - & $\because$ Quan & $\begin{array}{l}\text { Value in } \\
\text { Thou } \\
\text { sands. }\end{array}$ \\
\hline $\begin{array}{l}\text { Turnips and } \\
\text { Swedes } \\
\text { Meadow Hay } \\
\text { Oats } \\
\text { Clover and "Seed } \\
\text { Hay" } \\
\text { Straw } \\
\text { IVheat }\end{array}$ & $\begin{array}{cr}\text { Tons } & 23,768,000 \\
\text { “ } & 6,213,000 \\
\text { Qrs. } & 15,453,000 \\
\text { Tons } & 3,507,000 \\
\text { " } & 7,000,000 \\
\text { Qrs. } & 6,567,000\end{array}$ & $\begin{array}{r}£ 23,768 \\
19,106 \\
13,264 \\
12,712 \\
12,660 \\
10,370\end{array}$ & $\begin{array}{l}\text { Potatoes } \\
\text { Barley } \\
\text { Mangold } \\
\text { Beans } \\
\text { Apples } \\
\text { Peas } \\
\text { Hops } \\
\text { Strawbrries }\end{array}$ & $\begin{array}{lr}\text { Tons } & 3,918,000 \\
\text { Qrs. } & 6,840,000 \\
\text { Tons } & 8,995,000 \\
\text { Qrs. } & 1,161,000 \\
\text { Tons } & 224,300 \\
\text { Qrs. } & 765,000 \\
\text { Tons } & 23,540 \\
\text { " } & 41,450\end{array}$ & $\begin{array}{l}6,892 \\
9,177 \\
7,196 \\
1,735 \\
1,490 \\
1,130 \\
1,059 \\
1,036\end{array}$ \\
\hline
\end{tabular}

Below the tabulated categrory follow cabbage $£ 760,000$; vetches or tares $£ 439,000$; nuts and mixed orchard fruits $£ 406,000$; plums $£ 357,000$; a group of vegetables including artichokes, cucumbers, marrows, etc., $£ 352$,000; raspberries f.309,000; lucerne $£ 276,000$; mixed small fruits $\{252,000$; rye $f 220,000$ and gooseberries $f 208,000$. Between $£ 200,000$ and $f_{100,000}$ follow cherries, rape, rhubarb, carrots, crops under glass, crops for seed, flowers and shrubs, mustard and onions; between $f_{100,000}$ and $f_{50,000}$ pears, kohl rabi, black currants, broccoli and cauliflower, celery, red currants and Brussels sprouts; and below the last figure asparagus, parsnips, lettuce, seakale, kale, beetroot (but the subsequent extension of beet (ultivation should be borne in mind), buckwheat, maize, and flax.

It is found that the number of cattle slaughtered for meat in Great Britain was $1,489,000$; calves 639,000) sheep 7,638,000; lambs 1,915,000, and pigs 4,418,000. The total British supply of meat amounted to $1,051,000$ tons, representing an average supply per head of the population of (ireat Britain of $26.3 \mathrm{lb}$ ) of beef and veal, $14.5 \mathrm{tb}$ of mutton and lamb, and $17.5 \mathrm{lh}$ of pig-meat (total $58.3 \mathrm{lb}$ ), the average of imports in the same year (1908) being $20.44 \mathrm{tb}$ of lee.f and veal, ir.23 of mutton and lamb, 18.69 of pig-meat (total $50.36 \mathrm{tb}$ ).

A "farm-yard census" has also been taken, which so far as concerns birds is summarized in Table XIII, the interesting comparison for Ireland being added. Table XIV gives particulars of dairy produce, and Table XV those of timber. 
Table XIII.

\begin{tabular}{|c|c|c|c|c|}
\hline & Fowls. & Ducks. & Gése. & Turkeys. \\
\hline $\begin{array}{l}\text { England } \\
\text { Wales } \\
\text { Scotland } \\
\text { Ireland } \\
\text { Eggs produced (Gt. Britain) }\end{array}$ & $\begin{array}{r}25,962,000 \\
2,287,000 \\
4,107,000 \\
17,664,000 \\
1,108,483,000\end{array}$ & $\begin{array}{r}2,395,000 \\
274,000 \\
294,000 \\
3,477,000 \\
27,260,000\end{array}$ & $\begin{array}{r}494,000 \\
192,000 \\
26,000 \\
1,838,352 \\
1,724,000\end{array}$ & $\begin{array}{r}541,000 \\
87,000 \\
69,000 \\
1,051,667 \\
1,826,000\end{array}$ \\
\hline
\end{tabular}

Table XIV-Dairy Produce, Ioo8.

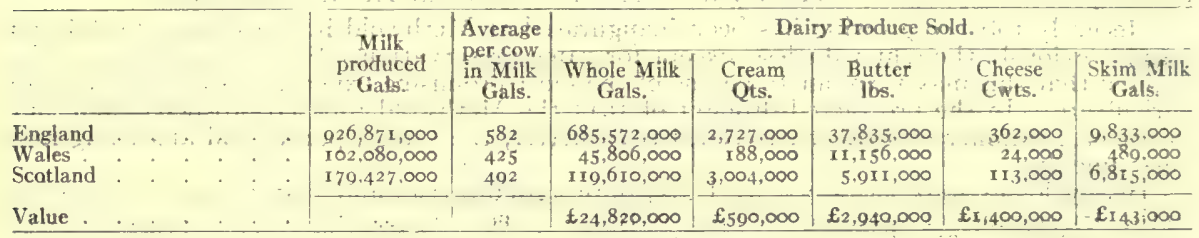

Table XV - Timber, 1908

\begin{tabular}{|c|c|c|c|c|c|c|}
\hline & \multicolumn{3}{|c|}{ Area planted, Acres. } & \multicolumn{3}{|c|}{$\begin{array}{c}\text { Trees felted for sale or sold standing. } \\
\text { Great Britain. }\end{array}$} \\
\hline & $\begin{array}{l}\text { England } \\
\text { and Wales. }\end{array}$ & Scotland. & $\begin{array}{l}\text { Great } \\
\text { Britain. }\end{array}$ & Number. & $\begin{array}{l}\text { Quantity } \\
\text { Cubic feet: }\end{array}$ & Value. \\
\hline $\begin{array}{l}\text { Scots Pine Coniferous Woods: } \\
\text { Larch } \\
\text { Spruce } \\
\text { Others and Mixed }\end{array}$ & $\begin{array}{r}49,000 \\
69,000 \\
1,000 \\
\quad 35,000\end{array}$ & $\begin{array}{r}r \\
56,000 \\
25,000 \\
8,000 \\
293,000\end{array}$ & $\begin{array}{r}205,000 \\
94,000 \\
9,000 \\
428,000\end{array}$ & \begin{tabular}{rr}
$\quad$ & 441,000 \\
\hdashline & 560,090 \\
$\quad$ & 77,000
\end{tabular} & $\begin{array}{r}3,895,000 \\
3,709,000 \\
587,000\end{array}$ & $\begin{aligned} & 81,000 \\
& 144,000 \\
& 12,000\end{aligned}$ \\
\hline Total Broad Leaved Woods. & 254,000 & 482,000 & 736,000 & & & 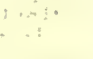 \\
\hline $\begin{array}{l}\text { Oak } \\
\text { Beech } \\
\text { Birch } \\
\text { Others and Mixed }\end{array}$ & $\begin{array}{r}130,000 \\
25,000 \\
1,000 \\
476,000 \\
\end{array}$ & $\begin{array}{r}9,000 \\
1,000 \\
10,000 \\
75,000\end{array}$ & $\begin{array}{r}139,000 \\
26,000 \\
11,000 \\
551,000\end{array}$ & $\begin{array}{r}210,000 \\
89,000 \\
66,000\end{array}$ & $\begin{array}{l}3,604,000 \\
1,349,000 \\
520,000\end{array}$ & $\begin{array}{r}237,000 \\
51,000 \\
15,000\end{array}$ \\
\hline & 632,000 & 95,000 & 727,000 & $\begin{array}{ll}\text { Ash } \\
\mathrm{E} / \mathrm{m}\end{array} \quad \begin{array}{l}4 \mathrm{r}, 000 \\
15,000\end{array}$ & $: \begin{array}{l}598,000 \\
583,000\end{array}$ & $\begin{array}{l}37,000 \\
2 \pi, 000\end{array}$ \\
\hline $\begin{array}{l}\text { Mixed Coniferous and Broad Leaved } \\
\text { Woods }\end{array}$ & $\mathbf{1}, 021,000$ & 298,000 & $\mathbf{1}, \mathbf{3} 19,000$ & Total $\overline{1,508,000}$ & $14,845,000$ & 598.000 \\
\hline Total Acreage of Woodland ..... & $1,907,000$ & 875,000 & $2,782,000$ & \multirow{2}{*}{\multicolumn{2}{|c|}{$\begin{array}{l}\text { Pit props, Faggots, Small } \\
\text { Thinnings, Cord Wood, \&c }\end{array}$}} & 202,000 \\
\hline & & & & & & $8 \infty 0.000$ \\
\hline
\end{tabular}

Development Commission.-The Development Commission was instituted in May I 10 under the provision of the Development and Road Improvement Fund Acts of that and the previous year. It consists of eight commissioners appointed for ten years, one (who is eligible for re-appointment) retiring every two years. In the order in which they were to retire, the commissioners were as follows: Mr. H. J. Davies, Sir S. Eardley Wilmot, Mr. M. A. Ennis, Mr. W. S. Haldane, Mr. A. D. Hall, F.R.S., Mr. Sidney Webb, Lord Richard Frederick Cavendish (chairman) and Sir Francis Hopwood (vice-chairman). Mr. Vaughan Nash, who had been private secretary to the Prime Minister, Mr. Asquith, succeeded to the vice-chairmanship in ror2. The function of the Commission is to consider the development of agriculture and other economic resources of the kingdom and to advise the Treasury as to the disposal of grants and loans for purposes connected with agriculture, forestry, reclamation of land, rural transport other than roads, canals, harbours and fisheries. The sums available are partly voted by parliament, partly charged on the consolidated fund, and partly received by way of interest on and repayment of loans, and of profits received (if so provided) on works started by a grant or loan from the Commission.

Agricultural Progress. ${ }^{1-}$ In Norfolk the inception of sugar-beet growing on a consider-

1 See also "Agriculture" in Part I of the YEAR-BOOK. 
able scale is the outstanding agricultural development. A large sugar-beet factory at Cantley, on the banks of the Yare, some tes stiles from Norwich, was opened in I9r 2. Despite the torrential rains in August of that year, samples of Norfolk-grown beet yielded as much as the average yield of roots grown in Holland. Farmers who have at first looked askance at the new venture, have since offered land freely. Beet-sugar experiments Lave also been made in Kent and Sussex: the Maidstone Farmers' Club reported in 1912 that satisfactory crops could be grown, and in Sussex it was proposed to form a company to develop the industry on condition that 2000 acres should be placed under the crop for five years. A factory has been established at Hayle in Cornwall.

Recently tobacco growing has been inaugurated at Methwold in south-west Norfolk on a soil previously thought valueless, except for game preservation. Some experts are of the opinion that this may turn out to be one of the most promising experiments in East Anglian agriculture. In the protracted drought of I9I I the Methwold tobacco prospered well, but in the wet summer of 1912 it succeeded even better, the sandy, porous soil absorbing rain very quickly.

Heavy losses were sustained by Hampshire agriculturists and market gardeners owing to the dry summer of I9II and the long continued rains of 1912 , but the cultivation of strawberries did well. The fruit is grown at Swanwick and at Sarisbury, and is sent to market a week or more before the Kent crop. In some cases the plantations yielded a profit of $\AA_{50}$ an acre, the culture not being confined to small holdings, but carried on extensively on large farms where strawberries have displaced some of the usual crops. The Hampshire County Council purchased 264 acres at Sparsholt near Winchester, for use as a farm school, and have established a system of agricultural scholarships.

Considerable disturbance in the agricultural industries of Cheshire and Shropshire is reported owing to the change in ownership of thousands of acres of agricultural land through owners of great estates putting them on the market.

A wide scheme for the reclamation of waste lands in the north of the Isle of Man, the creation of small holdings, and the development of an export trade in the produce to English markets, has been under consideration.

In the direction of agricultural education mention may be made of the extension of facilities by the university of Bristol in adjacent counties. A large technical school with an agricultural department has been established by the Essex Education Committee. The new buildings of the Cheshire Agricultural College and Norris Midworth Museum were opened on July 22, 1912.

Dr. Clement Stephenson, F.R.C.V.S., in February 1912, gave $£ 5000$ towards buildings for a new agricultural department at Armstrong College, Newcastle-upon-Tyne.

Mining and Manufactures.- Table XVI shows the total number of persons employed at mines in the four divisions of the United Kingdom in I9II.

Table XVI.-Miners, IgII.

\begin{tabular}{|c|c|c|c|c|c|c|}
\hline & & England. & Scotland. & Wales. & Ireland. & Total. \\
\hline vumber. . . & . & & I & & & $\mathrm{I}, \mathrm{I}$ \\
\hline $\begin{array}{l}\text { ac. or I)er. on } 1910 \\
\text { ac. or Dec. per cent }\end{array}$ & : & $\begin{array}{l}+8,531 \\
+1.2 \%\end{array}$ & $\begin{array}{r}-48 \mathrm{I} \\
-0.33 \%\end{array}$ & & $\begin{array}{r}+150 \\
+2.8 \%\end{array}$ & $\begin{array}{l}+15.181 \\
+1.3 \%\end{array}$ \\
\hline
\end{tabular}

Minerals were produced in 1910 to the value of $£ 82,090,108$ in England, $£ 23,604,416$ in Wales, $£_{16,155,377}$ in Scotland, $£_{2} 16,726$ in Ireland, and $£_{3} 8,955$ in the Isle of Man. The quantities of various minerals produced in $191 \mathrm{I}$ in the United Kingdom are shown in Table XVII.

Table XVII.-Mineral Production, I9II.

\begin{tabular}{|c|c|c|c|c|c|}
\hline & Tons, rorr. & $\begin{array}{l}\text { Increase } \\
\text { or } \\
\text { Decrease } \\
\text { on rora. }\end{array}$ & & Tons, yerx. & $\begin{array}{l}\text { Increase } \\
\text { or } \\
\text { Decrease } \\
\text { on 1910. }\end{array}$ \\
\hline $\begin{array}{l}\text { Coal } \\
\text { Iron Ore } \\
\text { Clay and Shale } \\
\text { l.imestone (not Chalk) } \\
\text { Igneous Rocks } \\
\text { Sandstone } \\
\text { Chalk } \\
\text { Oil Shale }\end{array}$ & $\begin{array}{r}271,891,899 \\
15,519,424 \\
13,835,038 \\
12,183,355 \\
6,524,696 \\
4,044,907 \\
4,884,020 \\
3,116,803\end{array}$ & $\begin{array}{l}+2.8 \\
+1.9 \\
-1.9 \\
-2.6 \\
-1.3 \\
-7.6 \\
+5.4 \\
-0.5\end{array}$ & $\begin{array}{l}\text { Gravel and Sand } \\
\text { Salt } \\
\text { Lead Ore: } \\
\text { Tin Ore } \\
\text { Copper Ore } \\
\text { Copper Precipitate } \\
\text { Zinc Ore } \\
\text { Cold Ore. }\end{array}$ & $\begin{array}{r}2,280,248 \\
2,082,688 \\
23,910 \\
7,746 \\
3,153 \\
109 \\
17,652 \\
2,752\end{array}$ & $\begin{array}{l}+3.6 \\
+1.5 \\
-16.3 \\
+2.2 \\
-20.9 \\
-43.3 \\
+57.0 \\
-55.3\end{array}$ \\
\hline
\end{tabular}


Coul.- The production of coal and its value in the four divisions of the United Kingdom in 1910 is given in Table XVIII.

Table XVIII.-Coal Productions, Ioro.

\begin{tabular}{|c|c|c|c|c|c|c|}
\hline & & England. & Wales. & Scotland. & Ireland. & Total. \\
\hline Tons . & & $183,913,5 \mathrm{II}$ & $39,104,583$ & & 79,802 & $264,433,028$ \\
\hline Inc. or Dec. on 1909 & . & $+437,115$ & $-1,335,576$ & $+1,566,767$ & $-9,590$ & $+658,716$ \\
\hline Value & . & $£ 72,301,746$ & $2 \mathrm{I}, 934,12 \mathrm{I}$ & $14,097,798$ & 43,902 & $108,377,567$ \\
\hline
\end{tabular}

Table XIX shows the coal production and value for the chief producing counties of England and Wales.

Table XIX:-Counties Producing Coal, rgro.

\begin{tabular}{|c|c|c|c|c|c|c|}
\hline$\because$ & Tons. & $\begin{array}{l}\text { Value at } \\
\text { Mine. }\end{array}$ & 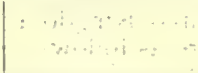 & & Tons. & $\begin{array}{l}\text { Value at } \\
\text { Mine. }\end{array}$ \\
\hline $\begin{array}{l}\text { ENGLAND } \\
\text { Chester } \\
\text { Cumberland } \\
\text { Derby } \\
\text { Durham } \\
\text { Gloucester } \\
\text { Lancaster } \\
\text { Leicester } \\
\text { Monmouth } \\
\text { Northumberland } \\
\text { Nottingham } \\
\text { Shropshire }\end{array}$ & $\begin{array}{r}348,464 \\
2, \mathrm{I} 74,755 \\
\mathrm{I} 7,276,94 \mathrm{I} \\
39,43 \mathrm{I}, 598 \\
1,477, \mathrm{I} 5 \mathrm{0} \\
23,4 \mathrm{I} 7,9 \mathrm{I} 3 \\
2,793,126 \\
\mathrm{I} 3,006,275 \\
\mathrm{I} 3, \mathrm{I} 2 \mathrm{I}, 69 \mathrm{I} \\
\mathrm{I} \mathrm{I}, \mathrm{I} 80,353 \\
837,541\end{array}$ & $\begin{array}{r}£ \\
142,289 \\
791,883 \\
6,182,773 \\
15,710,205 \\
726,265 \\
9,935,159 \\
977,594 \\
6,340,559 \\
4,993,897 \\
4,006,293 \\
324,547\end{array}$ & $\begin{array}{l}\text { ENGLAND:- } \\
\text { Somerset } \\
\text { Stafford. } \\
\text { Warwick } \\
\text { Worcester : } \\
\text { Yorkshire } \\
\text { WALES: } \\
\text { Brecon } \\
\text { Carmarthen } \\
\text { Denbigh } \\
\text { Flint } \\
\text { Glamorgan }\end{array}$ & : & $\begin{array}{r}1,208,046 \\
14,009,765 \\
4,654,336 \\
658,397 \\
38,300,000 \\
\vdots \\
738,725 \\
2,135,304 \\
2,598,370 \\
812,506 \\
32,878,827\end{array}$ & $\begin{array}{r}f \\
598,989 \\
5,136,914 \\
1,590,231 \\
227,696 \\
14,612,632 \\
412,527 \\
1,192,856 \\
1,061,001 \\
331,773 \\
18,905,326\end{array}$ \\
\hline
\end{tabular}

Coal was exported from the United Kingdom to the amount of $62,000,000$ tons in I9ro and $64,600,000$ in $19 \mathrm{II}$; while in addition $19,525,000$ tons in 1910 , and $19,264,000$ in I9II, were shipped on steamers engaged in foreign trade. Table XX shows the chief receiving countries.

Table XX.-Countries Receiving British Coal.

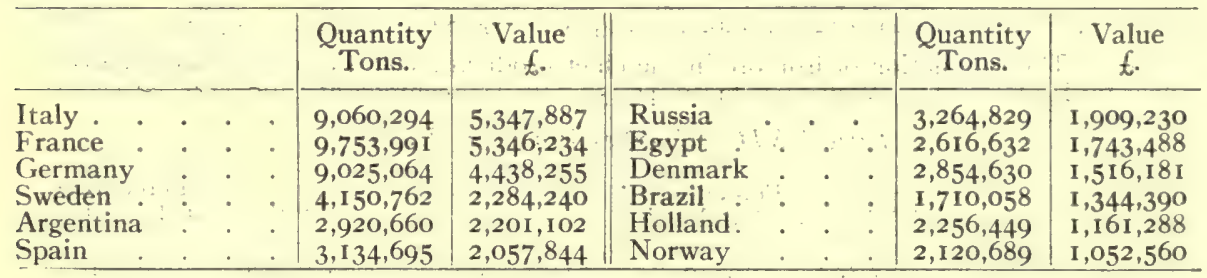

A national strike of miners lasted from March $x$ to April 6, Igr2 (see under History above). The following report from the northern coal-fields may be taken as an illustration of some of its effects. The Northumberland Miners' Association disbursed in strike pay $£_{156, \infty}$, its total funds, including investments from which it had been deriving $£ 4000$ annually in interest. The funds of the Durham Miners' Association, amounting to over $£ 400,000$, were also seriously depleted. The loss to colliery owners and to trades dependent on coal supplies was enormous. This strike occurred during a period of prosperity. Northumberland miners' wages in August I.9 I 2 were 36 per cent above the 1879 basis - the highest recorded for many years previously.

In the week ending July I3, I912, the King and Queen travelled in the West Riding of Yorkshire to inspect the social and industrial life of the people, including Halifax, Huddersfield, Rotherham, and many colliery centres, among them Cadeby Colliery, Conisborough, which they visited on hearing of a series of explosions which occurred on July 9, rgr 2, resulting in the loss of 86 lives. Among those killed were Mr. W. H. Pickering, chief inspector of mines for Yorkshire, Mr. H. R. Hewitt, government inspector for Sheffield, and Mr. J. Y. Tickle, government inspector of Doncaster. 
A remarkal,le colliery development has taken place in the Doncaster district in the last two years. Numerous pits have been sunk, and coal has been reached in several of them. Former villages have grown into populous places, and Doncaster is becoming the centre of a large population. Again, the developments which have taken place in the neighbouring north Nottingham coalfield have largely altered the industrial character of that part of the country. Within a radius of five miles of Mansfield eleven collieries have been sunk, and twenty others in the ten-mile limit. The Mansfield collicry itself was responsible for the output of $1,183,876$ tons in $191 \mathrm{I}$, an increase of 40,756 tons over the previous year. The leautíful "Dukeries" have been invaded, and in 1912 negotiations were completed for a pit between Warsop and the forest village of Budby, to be known as the Welbeck Colliery. To cope with this advance the Mansfield tramways have been extended, and a new railway, touching that town and Sutton, is in course of construction.

Progress has been made in the Kent coalfield, and four new seams were reported as proved within the boundary of the Kent Coal Concessions, Ltd. in August 19II.

The outlook in the South Wales coal was better towards the close of 1912 than it had been for some time. In I9II the trade suffered on account of a succession of strikes which probably affected this district more than any other. Thus while there was an increase of shipments of coal from the United Kingdom, there was a decline from South Wales. The details of foreign shipments were as follows:-Cardiff, I6,127,777 tons (dec. 829,979); Newport, 4,324,917 tons (inc. 550,555); Swansea, 2,929,982 tons (inc. 218,788); Port Talbot, $1,650,53^{8}$ tons (inc. 65,858 ). The coastwise trade was as follows:-Cardiff, $2,644,520$ tons (dec. 222,912); Newport, 689,960 tons (dec. 48,781); Swansea, 272,331 tons (dec. 39,516); Port Talbot, 164,791 tons (dec, 18,350 ). These decreases are unusual and due entirely to the unrest in the labour world. Their significance may be realized from the fact that the output of one coalfield despite the strike amounted to 50,200,000 tons as compared with $48,699,982$ tons in 1910 , and that the number of persons employed in one coalfield has risen from 150,394 in I90I to 213,252 in 1910. The North Wales coal mines have been holding their own, whereas metalliferous mines and slate quarries have, been doing badly.

Other Minerals.-Metals were obtained from British ores as in Table XXI.

Table XXI-British Metals, rgro.

\begin{tabular}{|c|c|c|c|c|c|c|c|}
\hline 4 & Iron. & Tin, & Lead. & Zinc. & Copper. & Silver. & Gold. \\
\hline Quantity & $\begin{array}{c}\text { Tons. } \\
4,975.735\end{array}$ & $\begin{array}{l}\text { Tóns. } \\
4.797\end{array}$ & & & $\begin{array}{l}\text { Tons. } \\
++9\end{array}$ & $\begin{array}{c}\mathrm{Oz} . \\
\text { I } 36,665\end{array}$ & $\begin{array}{c}\mathrm{Oz}_{2} \\
2,427\end{array}$ \\
\hline Value . . . & $\underset{17,008,812}{f}$ & $\underset{738,025}{f}$ & $\frac{f}{283,194}$ & $\begin{array}{c}f \\
99,823\end{array}$ & $\frac{f}{27.570}$ & $\underset{14,058}{£}$ & $\underset{8,088}{\mathcal{L}}$ \\
\hline
\end{tabular}

Iron.-The production of iron-ore in the rhief producing counties of England in I9Io is shown in Table XXII. Wales produced $4 \mathrm{I}, 455$ tons (percentage of total U.K., 0.3 ).

Table XXII.-Counties Producing Iron-ore.

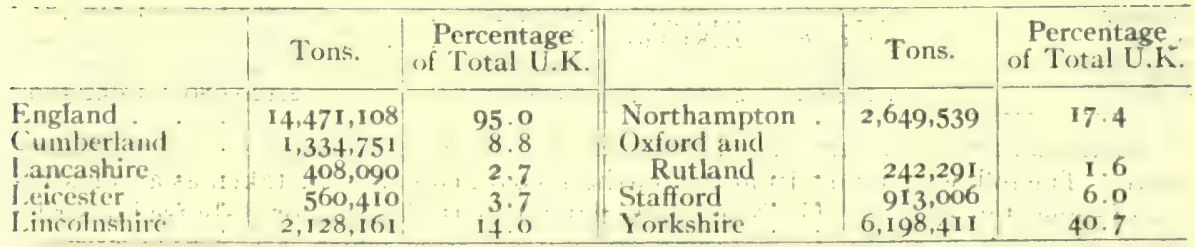

Salt.-Affecting the Cheshire salt industry, a parliamentary bill was promoted in rol 2 by the Cheshire County Council, and other bodies, to restrict the conveyance of brine by pipe from the salt manufacturing areas of Northwich and Winsford to Weston Point, which offers advantages of cheaper transport by Manchester Ship Canal and the rombined manufacture of salt and electricity. (At Weston, it was stated, the Salt Union was receiving $f_{I} 5,000$ a year from the sale of electricity made by steam going on its way to hoil the brine). By the House of Lurds' Committee the Bill was rejected. Incidentally there was mentioned a discovery of brine and large deposits of rock salt at Lymm.

Tin.-The steady rise in the already high price of tin has maintained the prosperity of the Cornish mines of established position, while the most noteworthy new progress has been the development of alluvial workings following on the success of this method of operations on the Coss Moors. A large electric power station at Hayle is now supply- 
ing current through west Cornwall from Camborne on the east to St. Just, with a branch to Penzance, on the west. The wires are carried across country on overhead standards. At present the chief users are the mines. The whole of the mining schools of Cornwall have been combined in one school of metalliferous mining at Camborne, and the local schools at Redruth, Truro and Penzance are now closed for mining education.

Important developments are anticipated from the recent discovery of radium in the famous hot springs at Bath. A discovery of gold was reported in Jersey in I9II.

Manufacturing Industries. The Midlands:-In all branches of trade in the Birmingham district there has been an improvement during the past two years. The South Staffordshire iron trade has experienced a remarkable revival. The former preference of steel aver iron has in many cases disappeared, whereas the open hearth process for steel has also regained favour, to the advantage of this district. In bars, billets and all other classes of semi-raw and finished material there have been repeated advances of selling prices, and during ror 2 the price of pigiron moved slowly but steadily upwards. The insufficient supply and high price of coke has seriously handicapped the iron trade during the past year. Ironworkers have received several advances in wages. Foreign competition in bar iron, steel billets, etc.; has diminished considerably during I9I 2.

In the copper, brass and metal trades, there has been constantly increasing activity. By the formation of associations and manufacturers combinations selling prices have been improved. Repeated advances in selling prices were declared in 1912 , though without a corresponding increase in profits, owing to the high prices of fuel and raw materials.

The selling prices of metal bedsteads have been increased, through the formation of an alliance embracing all the principal factories.

The cycle and motor trades have increased in prosperity. The trade in bicycles fell off a little in 19 I I but revived in 1912, while the popularity of the motor cycle has greatly augmented business. Many motor car manufacturers have turned their attention to vehicles for heavy traffic; others, again, are making special efforts to produce cheap cars in order to meet American competition. The amalgamation of the Daimler Company (Coventry) with the Birmingham Small Arms Company has proved successful.

The Birmingham gun trade has fully recovered its former prosperity. Both the home and the export demand for good sporting guns and rifles have steadily improved. A difficulty is found, however, in obtaining skilled men. Belgtan and other foreign competition has been largely met by the designing of cheap machine-made guns with standardised parts. The Gun Trade Technical School has been placed under the Birmingham Education Committee, though it still receives financial support from the guardians of the Proof House.

The jewellery trade of Birmingham has experienced some fluctuations, but the average volume of business tends to increase. Several new factories have been erected.

In the button trade; which has suffered from changes in fashion, employment at the end of 1912 was exceedingly good. All the fancy and miscellaneous trades have been busy.

In all the metal trades wages have been advanced, the advances ranging from 5 to 20 per cent. Strikes have been comparatively few and unimportant. The most notable was that of the Birmingham Small Arms Company's employés in October I9I I, which affected over 3,000 persons and lasted four weeks. It was ended by important concessions.

Electrical engineering and trades accessory to it have grown enormously in the Midlands during the past two years, and export business has been unprecedented.

In the saddlery and harness and general leather goods trades of Walsall, which was recently in a depressed state, there has been a return to prosperity especially in connexion with the export trade. Prices have advanced considerably, not only on account of demand but also through the very large increase in the cost of leather and other materials. The engineering and hardware trades of the town and neighbourhood have also prospered.

At Coventry the watch trade has been exceedingly busy owing to the growing preference for English-made watches. The artificial silk trade is increasing, and the general engineering trades have done well. A large electrical industry appears likely to grow up.

The trade of Leicester shows progress, boot and shoe exports being heavier than previously, and hosiery and elastic webbing employing many hands. Large works for general electrical engineering constitute an important new industry in Northampion. The growing industries of Peterborough include a large shop fitting factory. In Nottingham the tendency of lace-making firms to erect factories in outlying districts has acted as a stimulus to new industries. Blouse and robe-making have become of great importance, engineering and wood-working occupy much labour, and in 1912 there was introduced a new machine for the making of embroidery. It was announced in October I 12 that a large lace-manufacturing business would be removed from Beeston (Notts) to Rab in Hungary, as a result of the effect of hostile tariffs, and that facilities and remission from taxation had been granted by the Hungarian government. Through the activity of the Derby Borough Development 
Committee, new industries have been introduced there, one of great importance being the manufacture of filament electric lamps. The ironworks' industry at Hawarden Bridge, Flintshire, has continued to develop, and connected with it a garden city at Sealand has been partly built and occupied. Another ironworks industry is flourishing at Ellesmere Port, Cheshire, where water-transit facilities have also developed corn milling. The population has increased in ten years by 6,091 .

Lancashire and Yorkshire.-New cotton mills are building in such centres as Turton, Leigh, Nelson, Hastenlae and Livesey (Blackburn), Haslingden, \&c.; while steel works at Partington and salt works at Runcorn are to be included among other industrial developments. The Lancashire cotton trade enjoyed in I9r I its most prosperous year since 1007 , and this prosperity was reflected in the iron-founding and engineering industries which are more or less closely allied to the staple industry of the county. At the end of I9II, however, a dispute occurred in the cotton trade which was only brought to a close on January I9; I9I2, after a lock-out of the operatives lasting nearly a month.

All the Shefreld industries have shown remarkable activity, the volume of trade in the last three years being larger than at almost any previous period. To protect themselves against infringers of trade marks, a special fund of $£ 15,000$ has been raised by manufacturers, and several prosecutions have been successfully initiated. A new society called the Sheffield Electro-Metallurgical Society was formed in 1910. Many new mills have been erected at Huddersfield, where the cloth and other trades have been active.

Northern Counties.-Ship-building on the north-east coast from Blyth to the Tees has reached a very high point, 349 vessels of $1,071,743$ tons being launched in I9II, compared with 226 vessels of 654,789 tons in 1910 . After an interval of five years the "blue riband" for the largest amount of construction by one firm in the United Kingdom came to the Tyne in I9I I, this distinction being obtained by Messrs. Swan, Hunter and Wigham-Richardson, whose production aggregated I 25,050 tons. New methods of marine propulsion during the period under review include the geared turbine of Sir Charles Parsons, the Diesel oil engine, as exemplified in the Wallsend-built ship "Toiler," and the gas engined vessel "Holzapfel I" built at South Shields. At the close of r9I 2 Messrs. Swan, Hunter and Wigham-Richardson were building for a Scotch firm a vessel for the Canadian lakes on the new principle of a Diesel engine supplying electrical power.

Naturally, with ship-building so active in $19 \mathrm{I} \mathbf{I}$, the sister industry of marine engineering was correspondingly brisk. One firm on the Tyne, Messrs. R. J. W. Hawthorn, Leslie and ('o., held the record over the Kingdom for the year, their turn-out of engines amounting to 150,200 shaft horse power. Since 1910 the various sections of labour engaged in ship-building have had their wages increased three times, representing $3 \mathrm{~s}$. per week per man. Shipyard workers' discharge notes were discontinued at the request of the men in the early part of 1912 , and their demand, along with the engineering trades, is for an eight hours' day.

East Anglia, etc.-Among recent industrial developments in this part of England are the establishment of blast furnaces and rolling mills at Scunthorpe, Lincolnshire, and of electric steel furnaces at Braintree, Essex. Among industries recently established at Chelmsford are works of the Marconi Wireless Telegraph Co. and other electrical works, the National Steam Car works, etc. At Rochester large works for the manufacture of cement-making machinery were established by an Anglo-German firm in 1911 .

South Wales. - The revival of prosperity in the tin plate trade which began in 1898 continues unchecked. The annual amount paid in wages to South Wales tin plate workers is now about $\{2,300,000$. Of the 569 mills engaged on the manufacture of tin plates in England and Wales 96 per cent are situated in Glamorgan, Carmarthen and Monmouth. In I9I I the Welsh tin plate trade broke all records.

Labour Exchanges. - The system of labour exchanges was inaugurated on February I, IgIo. By the end of IgI I there were 26I exchanges at work, and during that year the number of vacancies notified by employers was 757,109 , and the number filled by the exchanges was 580,770 . The demand for workers exceeded the supply in the cotton, woollen and worsted trades, as well as, during certain seasons of the year, in the coachbuilding and engineering trades and the Clyde ship-building industry, while female workers were also found scarce in the clothing and laundry industries.

Fisheries.-The great herring industry at Yarmouth has now a fleet of 1000 boats, principally steam drifters. A Yarmouth boat broke all records in September I 9 I 2 with a haul of 320,000 herrings, a catch that realised $\ell_{52}$. Not less than 10,000 fishermen are engaged in the Yarmouth fishery. In the season of rol the catch at Yarmouth 
totalled just upon $550,000,000$ herrings, but the catch in 1912 exceeded that and all previous records. Protests have lately been made against the practice of trawling for herrings and the consequent destruction of immature fish; the matter was the subject of a deputation to the president of the Board of Agriculture and Fisheries (Mr. Runciman) in October $19 \times 2$, and the difficult questions involved may result in legislation and international action. A movement has been started to organize steam trawling on colonial fishing grounds in connection with Grimsby. A new trawling industry was initiated at the port of Blyth at the beginning of I912. A considerable number of Cornish fishing boats have been fitted with motors, including some of the larger craft engaged on mackerel fishing in the Mount's Bay ports, and new boats for the pilchard and inshore fisheries are being built with these engines along the south coast of Cornwall, especially in the eastern ports, and in Devonshire.

For the English and Welsh fisheries the total weight of wet fish landed in 1911 was I4,4I 8,$904 \mathrm{cwt}$., and the total value $f 8,05 \mathrm{I}, 486$, representing an increase in comparison with the previous year of practically 10 per cent in weight, lut only I per cent in value. The principal fish were-cod $2,562,182$ cwt. ( $\left.£_{1}, 291,095\right)$; haddock $2,114,287$ cwt. ( $£$ I $\left., 269,432\right)$; herring $4,995,976$ cwt. ( $(1,474,065)$; plaice 986, I65 cwt. ( $f 985,098)$; hake 732,365 cwt. $(£ 564,769)$; sole 61,817 cwt. $(£ 403,637)$. The total value of shell-fish was $£ 273,012$, making a grand total value for all fish of $£ 8,324,498$ (an increase of 3.7 per cent on the average for 1906-10). The principal shell-fish were $4,785,984$ crabs $(£ 54,034) ; 570$, I 74 lobsters $(£ 27,-$ $435) ; 26,358,115$ oysters $(£ 79,773)$. The imports of fish into the United Kingdom decreased by 10 per cent in value in $191 \mathbf{I}$, to $£ 3,906,020$, whereas the exports of fresh fish increased by 66 per cent to $\ell_{1}, 308,295$, and those of cured or salt fish by 15 per cent to $£ 5,118,825$.

Commerce.-British trade has had three "record" years in I9IO, I9II and I9I2, each surpassing all others before it in the figures for imports and exports. Those for I9II are analysed below; but the totals for I9I2, as disclosed by the final monthly Board of Trade returns issued on January 7, I9I3, may first be given. The imports were valued at $£ 744,896,5$ I4 (nearly 65 million pounds more than I9II), the British

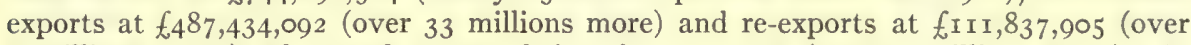
9 millions more), the total exports being $£ 599,271,907$ (over 42 millions more). It may be useful to show by comparison with previous years the enormous expansion that has taken place, as shown by the import and export figures (in million pounds), in British trade:-

$\begin{array}{llllllll} & & \text { 1912. } & \text { 1911. } & \text { 1910. } & \text { 1907. } & \text { 1902. } & \text { I } 897 . \\ \text { Imports } & & 744 & 680 & 678 & 645 & \mathbf{5 2 8} & 451 \\ \text { Total Exports } & : & 599 & 556 & 534 & 517 & 349 & 294 \\ \text { British Exports } & \cdots & 487 & 454 & 430 & 426 & 283 & 234\end{array}$

It will be seen that in fifteen years the exports of purely British products have more than doubled.

During I9I2 the principal increases in imports were recorded in the following groups:grain and flour, $+£ 12,746,268$; non-dutiable food and drink (other than meat, grain. and flour), $+£ 3678,390$; tobacco, $+f_{1} I, 088,933$; wood and timber. $+£ 2,489,144$; raw cotton, $+\{9,083,446$; textile materials o her than cotton and wool, $+£ 3,967,054$; oil seed, etc., $+f^{2}, 397,031$; hides and undressed skins, $+£ 2,613,386$; iron and steel, and their manufactures, $+f_{3}, 618,654$; cutlery and hardware, $+f_{1}, 717,532 ;$ machinery, $+f_{1}, 052,082$; chemicals, dyes, etc. $+£_{1}, 150,501$; leather, excluding boots and shoes, $+£_{2}, 1_{15}, 826$; railway cars, motor vehicles etc., $+£ 1,351,322$. The total increase of $£ 64,738,987$ for the year is divided broadly under Raw materials etc. $\{27,554,672$, Articles wholly or mainly manufactured, frg, 943,700, Food, Drink and Tobacco, $f 16,805,989$, and miscellaneous, $f 434,6 \mathrm{I} 6$.

In British exports the chief increases were in the following groups: food and drink (other than grain, flour and meat), $+£_{2}, 462,572$; coal, coke and fuel, $+£ 4,137,+20$; wool, $+£ 916$,474 ; iron and steel and their manufactures, $+£ 4,898,626$; other metals, and their manufactures, $+£ \mathrm{r}, 276,6 \mathrm{r}_{3}$; electrical goods, $+£ \mathrm{r}, 550,503$; machinery, $+£ 2,201,094$; new ships, $+£ 1,368,784$; cotton yarns, $+£ 2,164,560$; yarns other than cotton, wool and silk, $+£ 1,376,487$; apparel, $+£_{1} 1,892,758$; chemicals, $+£_{1}, 019,62 \mathrm{I}$; railway cars, motor vehicles etc., $+f_{1,641,546 .}$ The total increase of $£ 33,314,704$ is divided broadly under Articles wholly or mainly manufactured, $£ 22,996,368$, Raw materials and articles mainly unmanufactured, $f 5,702,023$, Food, Drink and Tobacco, $f 3,652,405$, Miscellaneous $f 963,908$.

The increase in trade was reflected also in shipping activity. Ships entered with cargoes exceeded those in 1911 by $4,401,543$ tons, and those cleared with cargoes by $2,746,369$ tons. 
The appointment was announced in April r9 2 , of a royal commission to inquire into the natural resources and improvement of the trade of the Empire, following upon a resolution passed at the Imperial Conference in May Igri. The following were appointed: for the United Kingdom, Lord Inchcape (Chairman), Sir Edgar Vincent, Sir Charles John Owens, Sir H. Rider Haggard, Mr. Tom Garnett (of Manchester), and Mr. William Lorimer (of Glasgow); for Canada, Mr. George Eulas Foster, minister of trade and customs; for Australia, Mr. Donald Campbell, formerly a member of the legislature of South Australia; for New Zealand, Sir Joseph George Ward; recently prime minister of the Dominion; for South Africa, Sir David de Villiers Graaf, minister of posts and telegraphs; for Newfoundland, Mr. Edgar Bowring, M.L.C.

Import and Export Trade (United Kingdom, I9II).-The total imports into the United Kingdom in 1911 were valued at $f 680,157,527$, an increase of $f 1,900,503(+0.27$ per cent) on 1910. Of this total, British possessions contributed $f_{171}, 453,587$ (an increase of $f_{8} 15,971$ or +0.47 per cent), and foreign countries $£_{508,703,940}$ (an increase of $f_{\mathrm{I}}, 084,532$, or +0.2 per cent). The total exports in I9I I were valued at $£ 556,878,432$, an increase of $£ 22,732,6$ Is $(+4.082$ per cent) on I9I0. Of this total, British possessions took $f 169,745,187$ (an increase of $f_{1} 12,289,933$, or +7.2 per cent), and foreign countries $f 387,133,245$ (an increase of $f_{1} 10$, 442,682 , or +2.69 per cent). The proportion per head of population of the value of import into the United Kingdom in 1910 was $£ I 5: 2: I$, and in I9II, $£ 15: 0: 4$; that of exports of native produce only ( $£+30,384,772$ in 1910 , and $\ell_{454}, 119,298$ in 1911 ) was $f_{9}: 11: 8$ in 1910 and $f_{10: 0: 7}$ in I9II, and that of net imports (i. e. less re-exports) was fI2:I5:10 in I9IO and EI2:15:0 in 19II. Bullion and specie are excluded. Table XXIII shows the trade with British possessions, and Table XXIV with foreign countries.

Table XXIII.-Imports from and Exports to British Possessions, I9II.

\begin{tabular}{|c|c|c|c|c|}
\hline Fron & Impo & & Exports. & $\begin{array}{c}\text { Inc. or Dec. } \\
\text { on } 1910 .\end{array}$ \\
\hline $\begin{array}{l}\text { India and Ceylon } \\
\text { Straits Settlements, Malaya and } \\
\text { Hong Kong } \\
\text { Africa } \\
\text { Canada and Newtoundland } \\
\text { West Indies } \\
\text { Australia } \\
\text { New Zealand } \\
\text { Other British Possessions }\end{array}$ & $\begin{array}{c}\underset{E}{E} \\
52,227,837 \\
15,485,064\end{array}$ & $\begin{array}{c}f \\
+3,392,+37 \\
+1,748,811 \\
-\quad 775,083 \\
-\quad 833,463 \\
-\quad 672,838 \\
+\quad 528,675 \\
+3,092,601 \\
+\quad 520,033\end{array}$ & $\begin{array}{c}\qquad \\
5^{6,499,051} \\
8,125,232\end{array}$ & $\begin{array}{c}f \\
+7,011,497 \\
-\quad 399,414 \\
+1,171,163 \\
+\quad 239,732 \\
+\quad 388,564 \\
+3,467,653 \\
+1,197,148 \\
-\quad 306,946\end{array}$ \\
\hline
\end{tabular}

Table XXIV.-Imports from and Exports to Foreign Countries, IgII.

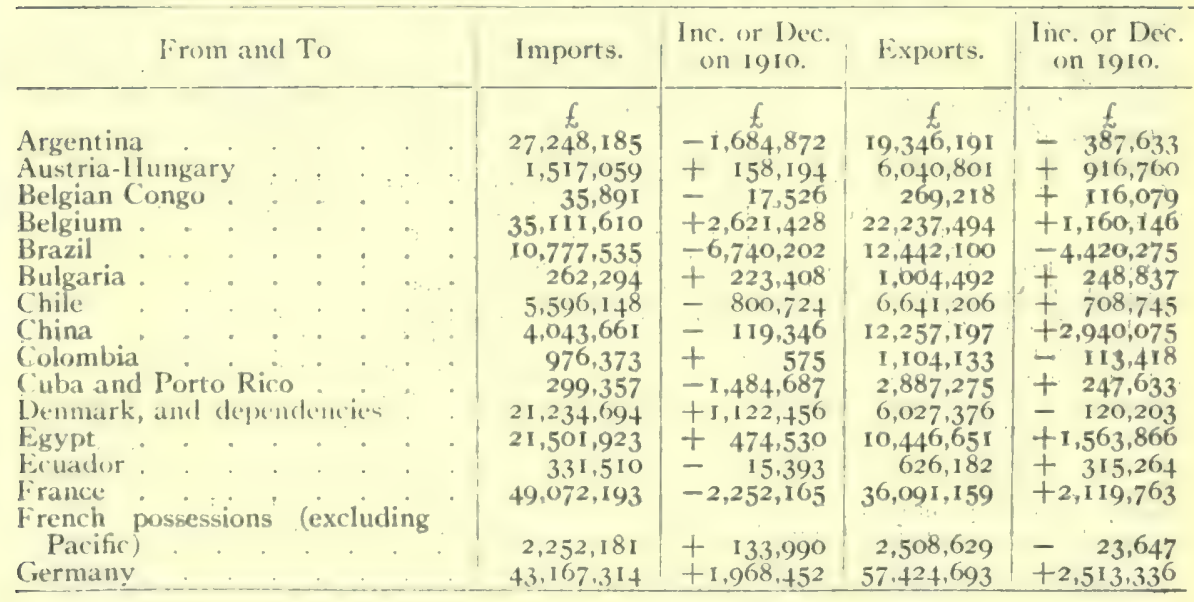


Table XXIV.-Imports from and Exports to Foreign Countries, rorr.-Continued.

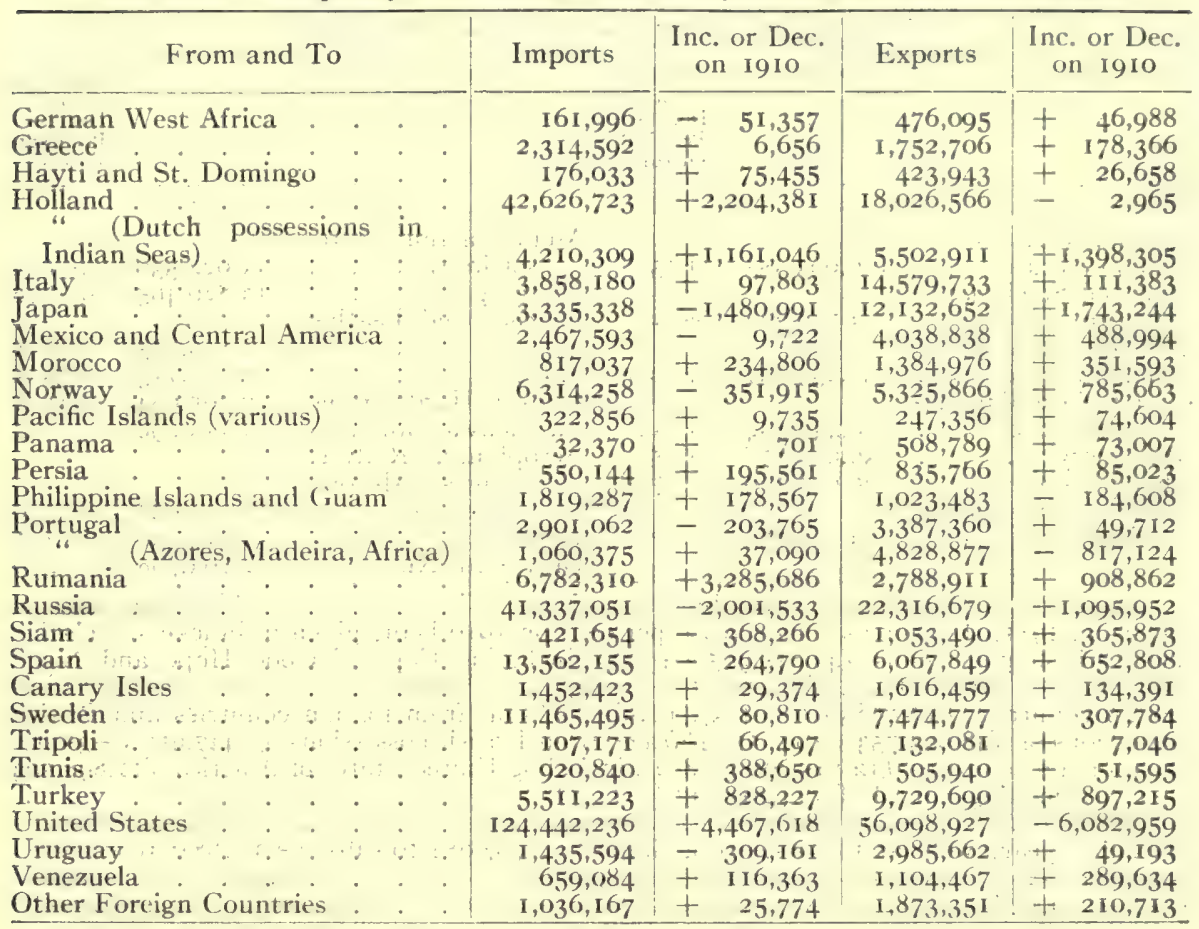

Table XXV shows the declared value of the principal articles imported:

Table XXV.-Imports, IgII.

\begin{tabular}{|c|c|c|c|c|c|}
\hline & I9II. & $\begin{array}{l}\text { Inc. }(+) \\
\text { or } \\
\text { Dec. (-) } \\
\text { Per Cent } \\
\text { on I gro. }\end{array}$ & & I9II. & $\begin{array}{l}\text { Inc. }(t) \\
\text { or } \\
\text { Dec. }(-) \\
\text { Per Cent } \\
\text { on I gro. }\end{array}$ \\
\hline ink, & 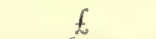 & & & & \\
\hline & $75,760,943$ & -2.0 & Hides and Skins & I 1 $, 106,664$ & -13. \\
\hline . . & .722 & +1.7 & excluding & & \\
\hline Butter & $?$ & +0.8 & $\because$ & 8,859 & -1. \\
\hline Igar :.. & 26,5 & +8.2 & Iron ore, etc. & 62 & -7.5 \\
\hline Tea . . & $12, \mathrm{C}$ & +14.0 & Manufactured & & \\
\hline $\begin{array}{l}\text { Wine } \\
\text { Coffee }\end{array}$ & 4 & -2.1 & cles:- & & \\
\hline (Cured or Salted) & $\begin{array}{l}2, \\
2,\end{array}$ & +6.2 & $\begin{array}{l}\text { Yarns and tex } \\
\text { rics }\end{array}$ & & + \\
\hline and Choce & & +4.4 & (excluding iron & 90 & \\
\hline 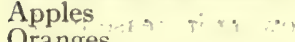 & & +2.0 & teel) & 27 & $+\mathbf{I I}$ \\
\hline 1 & & $\begin{array}{l}+5.1 \\
+8.1\end{array}$ & & & +3 \\
\hline & & $\begin{array}{r}+8.1 \\
+15.3\end{array}$ & $\begin{array}{ll}\mathrm{C} \\
\mathrm{Ir}\end{array}$ & & +1. \\
\hline aterials:- & & & machinery) & & +22. \\
\hline Cotton . . & 71 & -0.2 & Pap & & +2.3 \\
\hline $\begin{array}{l}\text { Wool } \\
\text { Oils etc. }\end{array}$ & 36,0 & $-3 \cdot 5$ & hinery & $5,768,662$ & +29 \\
\hline Wood and Timber & $\begin{array}{l}35,047 \\
25,621\end{array}$ & $\begin{array}{l}-0.7 \\
-1.5\end{array}$ & $\begin{array}{l}\text { Cutlery, Mardware, } \\
\text { etc. }\end{array}$ & & +12.8 \\
\hline $\begin{array}{l}\text { Textile materials ex- } \\
\text { cluding cotton and }\end{array}$ & & & $\begin{array}{l}\text { Apparel } \\
\text { Aeroplanes, Cycles }\end{array}$ & 99,932 & +1 \\
\hline Waoutchouc & $\begin{array}{l}14,611,045 \\
18,332,502\end{array}$ & $\begin{array}{l}+14.1 \\
-29.8\end{array}$ & & $6,500,046$ & +16.0 \\
\hline
\end{tabular}


The principal articles exported are similarly treated in Table XXVI.

Table XXVI.-Principal Articles Exported, I9II.

Cotton, yarn and manufactures

Iron and Steel manufactures

Woollen yarn and manufactures.

Coal, Coke and manufactured fuel

Machinery

Chemicals, etc.

Textile (not cotton, silk or wool)

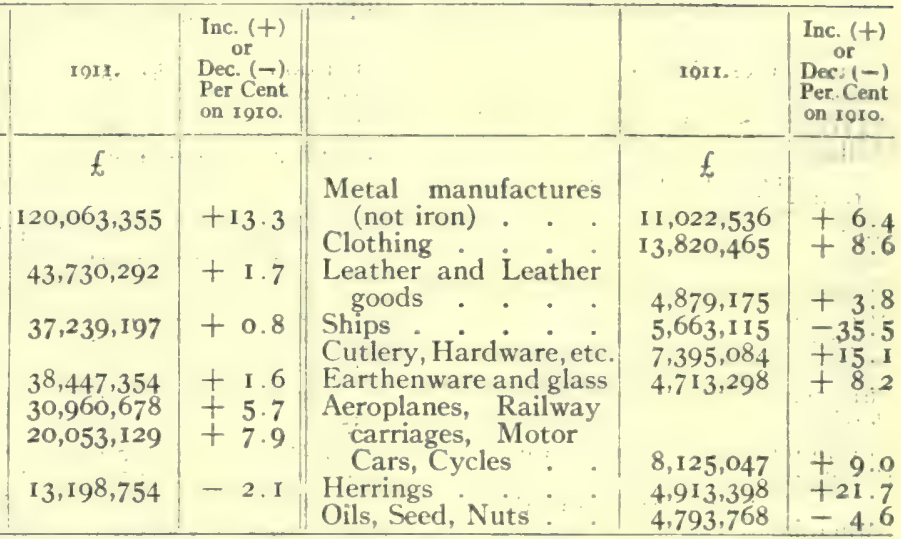

The imports of gold and silver bullion and specie into the United Kingdom were as follows in $19 \mathrm{II}$, the increase or decrease per cent on 1910 being given in brackets. Goldfrom British possessions $£ 42,815,915(+4.7)$, including Cape of Good Hope and Natal $f_{37,218,665}(+9.1)$; India $£_{2}, 245,761$ ( +1 . I 4$)$; and Australia $f_{1}, 534,965(-33.8)$ : from foreign countries $\{5,877,838(-64.3)$, making a total from foreign countries and British possessions of $£ 48,693,753$ (-I 5. I). Silver-from British possessions $£$ I , 447,957 ( -35.1$)$; from foreign countries $£_{1} 2,845,790(+8.2)$, including United States of America $£_{1} 1,898,503$ $(+4.02)$; making a total of $\{14,293,747(+1.37)$.

Textile Industries. - The imports of raw cotton in I9I I (with increase or decrease on the preceding year) were as follows:-total imports 2,207,088, 100 lbs. (+II .88); re-exported $291,180,600$ lbs. ( +13.6 ); retained $1,915,907,500$ lbs. (+I I.6). The United States supplied 1,682,000,000 lbs. (+14.4); Egypt 364,000,000 lbs (+10.6), and British India 79,000,000 lbs. $(-26.9)$.

Wool (sheep, lamb, alpaca and llama) was imported in I9I I to a total of $799,896,221$ lbs. $(-0.5)$; $304,525,9$ IO lbs. were re-exported $(-9.2) ; 495,370,3$ I I lbs. were retained $(+5.8)$. Table XXVII shows the countries of origin.

Table XXVII.-Countries of Origin for Wool Imports to U.K., $19 I I$.

\begin{tabular}{|c|c|c|c|c|c|}
\hline & $\begin{array}{l}\text { IgI } \\
\text { Million lbs. }\end{array}$ & $\begin{array}{l}\text { Inc. }(+) \text { or } \\
\text { Dec. }(-) \\
\text { Per Cent on } \\
\text { 19ro. }\end{array}$ & & $\begin{array}{l}\text { I9I I } \\
\text { Million lbs. }\end{array}$ & $\begin{array}{l}\text { Inc. }(+) \text { or } \\
\text { Dec. }(-) \\
\text { Per Cent on } \\
\text { rgro. }\end{array}$ \\
\hline $\begin{array}{l}\text { Russia } \\
\text { Germany } \\
\text { Belgium } \\
\text { France. } \\
\text { Spain and Portu- } \\
\text { gal } \\
\text { Turkey } \\
\text { Egypt. }\end{array}$ & $\begin{array}{r}2.856 \\
2.38 \\
3.215 \\
22.544 \\
1.77 \\
\text { II. } 94 \\
3.33\end{array}$ & $\begin{array}{l}-24.8 \\
-30.8 \\
-32.2 \\
-18.3 \\
-40.3 \\
+25.6 \\
-\quad 9.6 \\
\end{array}$ & $\begin{array}{l}\text { China } \\
\text { South America } \\
\text { United States } \\
\text { South Africa } \\
\text { India } \\
\text { Australia } \\
\text { New Zealand } \\
\text { Falkland Isles }\end{array}$ & $\begin{array}{r}2.98 \\
84.64 \\
1.77 \\
101.88 \\
56.58 \\
323.99 \\
174.12 \\
2.577\end{array}$ & $\begin{array}{l}+23.3 \\
+21.5 \\
-52.5 \\
-2.4 \\
+6.1 \\
+3.0 \\
-8.2 \\
-46.8\end{array}$ \\
\hline
\end{tabular}

Shipping.- In rgr i the total net tonnage of vessels entered and cleared with cargoes and in ballast at ports of the United Kingdom was as follows, showing increase or decrease per cent on 1910: Stcam, entered 67,253,999 tons $(+3.9)$, cleared $67,844,960$ $(+3.7)$; Sailing, entered 1,910,516 (-2.2), cleared 1,899,866 (-2.5); Total, entered $6(9,164.5 \times 5(+3.7)$, cleared $60,744,826(+3 \cdot 5)$. Of these the British vessels alone represented: entered $40,777,476$ tons $(+2.8)$, cleared $4 \mathrm{r}, 107,978(+2.3)$.

The total net tonnage of British vessels with cargoes entered and cleared in ports of foreign countries in IOII was as follows: entered 2I,534, I 26 tons, cleared 29,237,582. In British ports abroad: entered 7,920,081, cleared 7,856,500.

The principal ports of the IT.K., with the tonnage of vessels cleared and entered in I9I I, are shown as follows, with the increase or decrease per cent on 1910:- London, ent. 11,973,249 (-I.5), cl. 9,004,974 (+0.05); Liverpool and Birkenhead, ent. 7,887,719 (+3.9), cl. 
6,880,27I (+2.7); Cardiff ent. 5,526,426 (+o.04), cl. 8,328,047 (-2:8); Tyne Ports (Newcastle, N. and S. Shields), ent. 5,954,498 (+18.5), cl. 6,842,199 (+11.8); Southampton, ent. $4,466,314(+2.8)$, cl. $4,351,037(+3.7)$; Hull, ent. $3.534,964(-5.6)$, cl. $3,185,290$ $(-8.2)$; Glasgow, ent. 2, I46,5I2 (+5.3), cl. 3,418,77I $(+3.8)$; Dover, ent. $2,068,728(+15.2)$, cl. 2,060;391 (+15.5); Newport, ent. I,703,794 (+12.8), cl. 2,292,584 (+8.3); Blyth, ent. I,388,727 (+12), cl. 1,973,867 (+8.3); Middlesbrough, ent. 1,597,834 (-5.2), cl. 1,656,530 (+6.9); Plymouth, ent. I,670,446 (+1 I.9), cl. I,497,105 (+9.8); Sunderland, ent. I,42 I,748 (+19), cl. I,742,937 (+12.9); Swansea, ent. I,251,983 (+24.6), cl. I,843,624 (+9.9); Grimsby, ent. I, 446,777 (+9.8), cl. I,503,095 (+8.7); Leith, ent. I,4I 7,534 (+o.04), cl. I,448,498 $(+0.00)$; Manchester, ent. I,329,679 (+o.00), cl. I,095,478 (+1.3); Bristol, ent. 1,049,567 (+1.3), cl. 817,398 (+2.7); Methil, ent. 908,318 (+7.3), cl. I,191,052 (+1.3); Harwich, ent. $918,123(+4.6)$, cl. $867,666(+4.5)$; Grangemouth, ent. 820,855 (-14.2), cl. 906,283 (-12); Hartlepool, ent. 951,849 (+15.I), cl. 730,513 (+19.6); Goole, ent. 769,531 (-4.2), cl. 769,962 (-4.5); Port Talbot, ent. 590,802 (-1.4), cl: 888,990 (+2.9); Burntisland, ent. $529,435(+7.4)$, cl. 836,336 (+16.2); Folkestone, ent. $646,546(+82.4)$, cl. $640,267(+77)$; Newhaven, ent. $433,786(+4.9)$, cl. 423,626 (+5.3); Bo'ness, ent: $319,027(-6.5)$, cl. 308,569 $(-5 \cdot 7)$.

Recent Developments at English Ports:-London.-In I 909 the value of the imports into the port of London represented 32.9 per cent, and the exports 18.5 per cent, of the total for the U.K. The Port of London (Registration of Craft) Order Confirmation Act, rgro, authorised the Port of London Authority to impose fees in respect of the registration or licensing of craft on the river Thames. In IgII the Port Authority decided to construct a new dock estimated to cost $£ \mathrm{I}, 400,000$, and the King undertook to perform the ceremony of cutting the first sod on July I7, I9I2, but this was prevented by the Transport Workers' strike. On February I, I9II; H.M.S. "Thunderer," the first super-Dreadnought vessel constructed on the Thames, was launched from the yard of the Thames Ironworks Ship-building and Engineering Co.

Mersey.-Important developments of the north end of the Liverpool Dock Estate include the Gladstone Dock at Seaforth, begun in September I910. It was decided early in I9I 2 to construct a deep-water approach taking vessels I, IOO feet long. The Gladstone Dock is to be convertible into a graving dock; two branch docks and a halftide dock, together with a lock 645 feet long, communicating with the Hornby Dock, are included in the scheme, the estimated cost of which is $£ 3,000, \infty 00$. New works have also been undertaken at Brocklebank Branch Dock, including the extension of quayage, railways and sheds. The proposal to construct a bridge between Liverpool and Birkenhead was revived in I9I 2 , but the scheme for the erection of a custom house at the pier head has been abandoned owing to failure of the negotiations for the site. Facilities at the Port of Manchester have been extended at Trafford Park and elsewhere on the canal, and seed-crushing works have been undertaken at Partington and elsewhere. Cornbrook wharf was extended in I II . The Manchester Cotton Association is actively fostering the import trade in raw cotton.

Dee.-An improved waterway for shipping in the Dee estuary has long been contemplated, and in ror 2 a conference of representatives of Flint and Denbigh County Councils, Chester Town Council, Dee Conservancy Board, and other bodies, gave general approval to a scheme for a navigable channel near the Flintshire shore, and agreed to press the Development Commissioners to grant $£ 30,000$ towards the estimated cost of $f 75,000$.

Southampton.--Increased size of the Atlantic liners calling at Southampton necessitated the construction of a dock of 16 acres, which was used for the "Titanic." Considerable loss has been sustained by strikes of dockers.

At Dover, trials were made in roro for the running of trains serving passenger vessels on the Admiralty Pier extension. It was decided in September 1912 to close the western entrance to Dover harbour, with a view to improving the shelter in rough weather, and to extend or duplicate the eastern entrance.

Bristol continues to direct its chief effort to the development of the dock estate owned by the municipality. New traffic has been attracted. The Canadian Steamship Ltd. (Royal Line), established in I9ro, has been very successful, particularly in the emigration branch, and large numbers of agriculturists from the west of England have been 
settled in Canada. There has also been considerable increase of the imports of frozen meat. The port dues grew from $£ \times 46,565$ in 1911 to $£ 155,284$ in IgI2. The latter figures are the highest on record, and the trade has doubled since r882. Grain and provisions continue to be among the chief imports, and petroleum and fruit have been imported in increasing quantities of late: There is still a heavy call on the rates to meet the deficiency in dock revenue, the amount of aid in r 912 being $£_{140,000}$ compared with $f_{154,000}$ in I9II. The city's indebtedness considerably exceeds $f 8, \infty 00, \infty 00$, over $\$ 5,75^{\circ}, 000$ being for docks, after allowing for accumulations in the Sinking Fund.

Humber and Lincolnshire Coast.-At Hull an important addition to the facilities for the coal export trade was made in Igro by the installation of coaling beds at the Victoria Docks. This method of shipping coal, the appliance for which has a capacity of 600 tons per hour, had not previously been employed in England. The extension of the joint dock was completed in Igr 2 .

The greatest undertaking on the east coast has been the construction by the Great Central Railway of the Immingham Dock, opened by the King on July 22, I912. Six miles from Grimsby and nine miles nearer the North Sea than Hull, Immingham possesses many advantages, providing free ingress and egress at any state of the tide. The arca of the dock property, which is two and a half miles in length and one mile in breadth, is just over I,000 acres, and the railway sidings and lines extend to I 70 miles, being sufficient to take i I, 600 waggons carrying upwards of 10,000 tons. The water area is 45 acres. There are eight hydraulic steam hoists capable of shipping 5,600 tons per hour. From Grimsby itself the coal shipments to foreign ports in I9Ix exceeded $\mathbf{I}, 500,000$ tons. At Boston dock extension has been taken in hand.

Wrecks.-The number of vessels belonging to the United Kingdom totally lost at sea in 1910 was 319 , of 150,142 tons (sailing 195 of 32,547 tons, steam 124 of 117,595 tons).

Communications:--Railways.-Table XXVIII gives particulars for the railways of the United Kingdom in Igrr, the figures being also analysed under the three divisions of the kingdom for purposes of comparison.

Table XXVIII.-Railway Statistics, I9II,

\begin{tabular}{|c|c|c|c|c|}
\hline & $\begin{array}{l}\text { United } \\
\text { Kingdom. }\end{array}$ & $\begin{array}{c}\text { England } \\
\text { and Wales. }\end{array}$ & Scotland. & Ireland. \\
\hline at $t$ & & & & 9 \\
\hline (5) & EI & & & \\
\hline (millions) ${ }^{1}$ & 3 & & I & \\
\hline 910 & I. & 1 & 2 & 0.29 \\
\hline $\begin{array}{l}\text { (millions) of miner } \\
\text { ods }\end{array}$ & $5^{23}$ & 4 & 68 & 6.62 \\
\hline icrease per cent on igio. & I & & & 1. 4 \\
\hline otal receipts. & $f, 127,199,000$ & fiog, 18 & f. 3,489 & $f 4,511,000$ \\
\hline From passengers. & t $53,955,000$ & $£ 46,3$ & $£ 5,362,000$ & $\begin{array}{c}22,284,000 \\
f 671\end{array}$ \\
\hline From goods & $\begin{array}{l}t^{2}, 304 \\
f \quad 63,285,000\end{array}$ & $\begin{array}{r}t^{2}, \\
f 53,0\end{array}$ & $f, 7,281,000$ & $f_{2}, 082,000$ \\
\hline Per mile of line open & 2,703 & 3 & $f 1,909$ & $f 612$ \\
\hline $\begin{array}{l}\text { otal increase per cent } \\
\text { orking expenses }\end{array}$ & $\begin{array}{r}2.6 \\
f 78,617,000\end{array}$ & $\begin{array}{r}2,6 \\
f 68,252,000\end{array}$ & $\begin{array}{c}3.0 \\
\{7.551,000\end{array}$ & $\begin{array}{r}0: 8 \\
f 2,814,000\end{array}$ \\
\hline
\end{tabular}

The percentage of working expenditure to total receipts was 62 for the whole kingdom, 63 for lingland and Wales, 56 for sicotland and 62 for Ireland.

The Cireat Western Railway company, having shortened its route between Birmingham and I.ondon by making a new line ria Aynho, has spent upwards of $f 2,000,000$ in the Birmingham dist rict in widening and improving the line north and south of the city, rebuilding Snow Hill Station and constructing a new passenger station and a large goods station at Moor Sireet, near the public markets. The London and North-Western Railway company are preparing an important scheme for the improvement of New Street Station, Birmingham, and the extension of the adjoining Queen's Hotel. A new line is projected from Coventry to Arley in conjunction with the lithitacre and Nuneaton branch of the I,ondon and NorthWestern, for the purpose of developing the coalfield in the neighbourhood of Coventry. In connection with recent labour disputes it may be mentioned that the North-Western company

'Excluding season-ticket holders. 
appointed a "grievance-hearer" (Feb. 1912) to inquire into minor complaints. The extension of a branch line of the Great Northern Railway north of Enfield to Cuffley and beyond, is opening up a new residential district for London. Other railway enterprines include the reopening (April 13, 191 r) of the Shropshire and Montgomeryshire Light Railway from Shrewsbury to Llanymynech, after lying derelict for thirty years, and the opening of a line (July I, I912) $1 \frac{3}{4} \cdot$ miles long, connecting Holywell, Flintshire, with Holywell Junctirn! station on the L. \& N. W. line from Chester to Holyhead. An extension of the electrification of part of the Lancashire and Yorkshire railway system was opened in March I9I I between Maghull and Town Green, and a scheme for the electrification of the Manchester, Suuth Junction and Altrincham line is in hand. A bill was promoted in 1912 by local landowners for a railway between Richmond and Reeth in the valley of the Swale, Yorkshire.

Canals, etc.-The final report of the Royal Commission on Canals and Inland Navigation has received much attention in the midlands; and a Midland Waterways Association, representative of all the towns and interests concerned, has been formed to press forward the scheme of the Commission for improved water communication with Hull, Liverpool, London and the Severn ports. A committee has also been formed to promote the restoration of the Warwickshire Avoin as a commercial waterway.

London Traffic.- In I9I0 the mileage of tramways in London was I39.48. Motor omnibuses have practically superseded the horse omnibus; in 1899 there were five motor omnibuses licensed by the Metropolitan Police, while in rgro this number swelled to $I, 2 \infty$, and the number has greatly increased since. The streets of London extend to $2,15 \mathrm{I}$ miles. In some of these the congestion of traffic is exceedingly severe. The number of accidents and consequent agitation in parliament and elsewhere in the autumn of I9I 2 drew the serious attention of the Home Office and other authorities to the matter, and it was considered whether statutory powers should be created for the limitation of the number of public vehicles in certain thoroughfares. The recommendation of the Royal Commission on London traffic in favour of a Traffic Board for London was strongly revived, but did not receive the support of the government.

Practically all the drivers of motor cabs in London struck in October-November I 9. I, and the dispute was settled by an arrangement, the principal points of which were that the drivers should retain " extras," which are chargeable by statute upon passengers, and that "observers," whose duty it was to report to the cab companies any defalcation on the part of the drivers, should be abolished. A further dispute arose in March 19 I 2 with the drivers and two of the companies, and a settlement was only effected on April I 5th; and at the end of the year another strike took place.

The Piccadilly, the Baker Street and Waterloo, and the Hampstead "tube" railways were amalgamated as the London Electric Railway Company in I9Io, under the control of the Underground Electric Railways Company; the fusion of the latter company with the London General Omnibus Company (which has absorbed a number of competing omnibus companies since the introduction of motor traction) was subsequently arranged, and in November I9I 2 it was announced that it was intended to amalgamate the Central London and the City and South London "tubes" with the underground system, and the London United Tramways with the Metropolitan Electric Tramways. The chairman of the Underground company is Sir Edgar Speyer.

Road Board.- Under the Development and Road Improvement Act (rgog) the Road Board was created for the improvement of roads and the administration of a grant for that purpose, consisting of the proceeds of duties on motor spirit and of part of the duties in respect of carriage licences. The Commissioners appointed in May Igro were: Sir George S. Gibb (chairman), Lord Pirrie, Lord Kingsburgh (Sir J. W. Macdonald), Lord St. Davids, and Sir Charles D. Rose, Bart. The Board has power to act on its own initiative or through existing highway authorities; and has already carried out much important work, not only in the direction of improving roads but in such other directions as inquiry into the best forms of road-crusts.

One proposal, which has attracted wide attention and was the subject of a conference in February 1912, under the chairman of the Board and including representatives of the Board of Trade and local authorities interested, is that of a new approach to London from the west, extending from Hounslow to the West Cromwell Road, and avoiding among other crowded points the narrow High Street of Brentford. The cost was estimated approximately at 
f.1,750,000, hut alternative schemes are in the field. Mention may also be made of the adaptation of disused portions of the Roman Foss Way in Lincolnshire for modern traffic.

The system of propulsion of electric vehicles without rails, by means of overhead trolleys, has received much attention, and has an example in Leeds, where a public service on this principle was inaugurated in June 1911 .

Tramways of the United Kingdom. - The total length of tramways open at the end of I9I I was 2597 ; the paid-up capital $£ 7+725,440$; the gross receipts $£ 13,777,001$ (an increase of 5.3 per cent on the preceding year). Working expenses amounted to $f 8,500,94 \mathrm{I}$ (increase 4.5 per cent); net receipts to $£ 5,276,060$ (increase 6.6 per cent). The number of passengers carried during the year was $2,907,177,120$, an increase of 9.2 per cent.

Post Office.-With the close of the yenr rgi i the telephone system of the National Telephone Company passed under the control of the Postmaster-General, whose department under this arrangement entered into possession of some I,500 exchanges and undertook the service of 400,000 subscribers in addition to about 80,000 who were previously served by existing post-office exchanges. With very few exceptions, the company's staff was transferred to the government service, the total personnel amounting to about 18,000 . The rates were not immediately affected by the change, but public opinion was freely expressed that the efficiency of the service had deteriorated:

The following statistics relate to the year ending March 3I, I9I2. The total number of letters delivered in the United Kingdom was 3186.8 millions (in England and Wales 2729.8, Scotland 273.8 and Ireland 183.2 millions), an average per head of the population of 75 in England and Wales, 58 in Scotland and 42 in Ireland, or 70 for the whole kingdom. There were also delivered in the Kingdom 1265.5 million newspapers and halfpenny packets, $905,500,000$ postcards, and $124,254,092$ parcels with an average postal rate of $4.84 \mathrm{~d}$., providing a revenue of $f_{2}, 505,068$, of which $f_{1}, 122,605$ was paid to railway companies. The length of telegraph lines in I9I0-1I was 52,413 miles overhead, 5569 underground and 3314 submarine, but these figures represent lengths of wire of 440,315 miles overhead, 787,553 underground and 10,727 submarine. Telegraph business was transacted at I3,959 postal and other offices, and telegrams numbered 76,029,000 inland (a decrease of 596,000 ) and $15,585,000$ foreign (an increase of 478,000 on the preceding year). Receipts on telegrams and telephones amounted to $f_{5,1}$ I I,34I, including $£_{2,297,953}$ from inland telegrams and $\{1,952,537$ from telephones (including royalties); expenditure on this department amounted to $f 6,352,28 \mathrm{I}$.

Money orders were issued in I9I I-I2 to the amount of $f 35,260,390$ in England and Wales, $£ 4,467,975$ in Scotland and $£ 2,367,366$ in Ireland (total $£ 42,095,731$ ), and postal orders to the amounts of $£ 41,337,000, £ 4,432,000$, and $£_{2}, 261,000$ respectively (total $£ 48,030,000$ ).

The demolition of the old General Post Office in St. Martin's le Grand, London, was undertaken in July I912. It was hoped to preserve the façade, which is of some architectural interest ( $E$. $B$. xvi, 945 b), by its re-erection elsewhere.

Finance (see under "History" above, ad fin.) For I9I I-I 2 the total revenue for the United Kingdom was $£_{1} 85,090,286$, and the expenditure $£_{1} 78,545,100$.

The following were the details of revenue:-Customs, $£ 33,649,000$; Excise, $£ 38,380,000$; Estate Duties, £25,392,000; Stamps, £9,454,000; Land Tax, $£ 750,000$; House Duty, $£ 2,130,-$ oon; Income Tax, $£ 44,804,000 ;$ Land Value Duties, $£ 481,000 ;$ Post Office, $£ 19,650,000 ;$ Telegraphs, £3,105,000; Telephones, £2,945,000; Crown Lands, £530,000; Receipts for Suez Canal shares, etc., $f 1,281,497 ;$ Miscellaneous, $£ 2,538,789$;

The following were the details of heads of expenditure:-National Debt, $£ 24,500,000$; Development Fund, $f_{1}, 709,859$; To local taxation account, f9,636,399; Civil list, f470,000; Annuities and Pensions, $£ 317,745$; Salaries and Allowances, $£ 56,572$; Courts of Justice, f523,000; Miscellaneous, $f 325,525$; Army, £27,649,000; Navy, f $42,858,000 ;$ Miscellaneous Civil Services, $£ 46,001,000 ;$ Customs and Excise, $£ 2,297,000$; Inland Revenue, $£ 1,654,000$; Post Office (Telegraphs, etc.), £20,547,000.

The income brought under review for the assessment of income tax was stated as follows, for the year ending April 5, 1911:- Schedule A (ownership of lands, houses, etc.), England $\left\{233,906,688\right.$, Scolland $£ 26,944,348$, Ireland $f_{14,971,877}$. Sch. B (occupation of lands), England $f_{12}, 282,010$, Scolland $f_{1}, 925,858$, Ireland $f_{3}, 231,092$. Sch. C (interest on securities, ctc.), Lniled Kingdom $\{49,562,418$. Sch. D (profits from business, professions, ctc.), England $\left\{509,578,24+\right.$, Scolland $\left\{57,036,283\right.$, Ireland $£_{16} 697,54^{2}$. Sch. E (salaries, etc.), United Kingdom fi19,697,415.

The National Debt on March 21, 1912, consisted of:-Funded Debi, f602,200,092; Terminable Annuities, $\{33,044,389$; Unfunded Debt, $\{39,500,000 ;$ Other capital liabilities, £50,061,947. Total gross liabilities, $£ 724,806,428$.

Parliamentary Electors. - In Iог 2 the registered number of parliamentary electors 
was $7,984,600$, or an average of 11,917 per member of parliament (670 seats). They were distributed as follows: (A) England and Wales: counties (253 seats), 564,28 I owners, 3,106,370 occupiers, I30,302 lodgers, total 3,800,953; boroughs (237), 22,986 freemen, freeholders, etc., $2,445,387$ occupiers, 185,6 o I lodgers, total $2,653,974$; universities (5), 20,8 16. Total, 6,475,743. (B) Scotland: connties (39), 63,884 owners, 372,913 occupiers, 34,II6 lodgers, total 470,913; boroughs (3I), 30,265 freemen, etc., 255,429 occupiers, 32,044 lodgers, total 317,738; universities (2), 23,801. Total, 812,452. Ireland: counties $(85), 8,918$ owners, 556,535 occupiers, 4,926 lodgers, total 570,379; boroughs (I6), 2,535 freemen, etc., II 3,803 occupiers, 4,69I lodgers, total, I21,029; universities (2), 4,997. Total, 696,405.

Defence.-The cost of imperial defence, in relation to national wealth and income, is summarized in Table XXIX. ${ }^{1}$

Table $X X I X$.

\begin{tabular}{|c|c|c|c|c|c|c|c|}
\hline & & $\begin{array}{l}\text { National } \\
\text { wealth. }\end{array}$ & $\begin{array}{l}\text { Per } \\
\text { head. }\end{array}$ & $\begin{array}{l}\text { National } \\
\text { Income. }\end{array}$ & $\begin{array}{l}\text { Per } \\
\text { head. }\end{array}$ & $\begin{array}{c}\text { Expenditure } \\
\text { on defence } \\
\text { (est. 1912-13): }\end{array}$ & $\begin{array}{c}\text { Per } \\
\text { head. }\end{array}$ \\
\hline $\begin{array}{l}\text { England and Wales } \\
\text { Scotland } \\
\text { Ireland } \quad\end{array}$ & $\cdot:$ & $\begin{array}{r}\text { Millio } \\
13,7 \\
1,4 \\
7\end{array}$ & $\begin{array}{l}f \\
380 \\
305 \\
163\end{array}$ & $\begin{array}{r}\text { Millio } \\
1,7 \\
\text { I } \\
\text { I }\end{array}$ & $\begin{array}{l}f \\
48 \\
36 \\
23\end{array}$ & $\begin{array}{r}1 \\
65 \\
7 \\
7 \\
\mathrm{Ni}\end{array}$ & $\begin{array}{c}\text { t. s. d. } \\
\text { a. } \\
\cdots\end{array}$ \\
\hline United Kingdom & & & $35^{I^{\prime}}$ & & 44 & & 12 \\
\hline $\begin{array}{l}\text { Canada } \\
\text { Australia } \\
\text { South Africa } \\
\text { N.Zealand } \\
\text { India }\end{array}$ & $\therefore$ & $\begin{array}{r}1,3 \\
3 \\
3,6\end{array}$ & $\begin{array}{r}288 \\
287 \\
100 \\
320 \\
10\end{array}$ & $\begin{array}{r}259 \\
164 \\
75 \\
40 \\
608\end{array}$ & $\begin{array}{l}36 \\
36 \\
12 \\
40 \\
2\end{array}$ & $\begin{array}{r}2,285 \\
4,775 \\
843 \\
288 \\
20,249\end{array}$ & 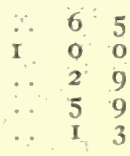 \\
\hline \multirow{2}{*}{\multicolumn{2}{|c|}{$\begin{array}{l}\text { Crown Colonies, etc. } \\
\text { Total }\end{array}$}} & & & 17 & 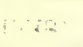 & 1,00 & . \\
\hline & & 24,986 & $\cdots$ & 3,332 & $\cdots$ & 102,440 & . . . \\
\hline
\end{tabular}

Navy (see also "Navies" in Part I: sect, i, of the YEAR-Book).-The creation of a Naval War Staff was announced in January I9I2. Its advisory functions were outlined in an important memorandum by the First Lord of the Admiralty, Mr. Winston Churchill, in which he foreshadowed a scheme of collaboration between the Naval War Staff and the General Staff of the army. Some staff officers were to be appointed immediately, and appointments were to be made subsequently after a special course of training at the War College. At the same time the appointment was announced of Sir Francis Hopwood as additional Civil Lord of the Admiralty to deal with the business and commercial transactions of the Board, the appointment being permanent and nonpolitical. Rear Admiral E. C. T. Troubridge was appointed Chief of the War Staff, Captain G. Ballard Director of the Operations Division, and Captain E. C. Jackson Director of the Intelligence Division.

Admiral-of-the-Fleet Sir A. K. Wilson, formerly First Sea Lord, retired from the active list on March 4, Igr 2, on attaining the age of seventy. He was succeeded as First Sea Lord, on November 29, I9 I r, by Admiral Sir Francis Bridgman, whose resignation on the ground of ill-health ${ }^{2}$ was announced on December 6, I912. He was succeeded

1 After Mr. Edgar Crammond in the Nineteenth Century and After (Aug., 1912).

2 The resignation of Sir F. Bridgeman on Dec. 4 th was the subject of several questions to $\mathrm{Mr}$. Winston Churchill in the House of Commons, and led to an animated debate on Dec. 20th. Mr. Churchill had originally stated that Sir. F. Bridgeman resigned for reasons of health, but, under pressure, admitted that he had himself taken the initiative in asking for the First Sea Lord's resignation; and he was sharply attacked by Lord Charles Beresford, who suggested that Sir F. Bridgeman had been improperly treated, and that he had been removed because he disagreed with Mr. Churchill on questions of naval policy. The full disclosure of the facts on Dec. 2oth showed that these charges were untenable. Mr. Churchill had reluctantly been forced to the conclusion that the Admiral's health was not equal to the grave responsibility attaching to his office at a time of severe strain, and he was bound in 
by Admiral Prince Louis of Battenberg, who was followed in the office of Second Sea Lord by Vice-admiral Sir J. R. Jellicoe. Among other recent appointments, Admiral the Hon. Sir H. Meux succeeded Admiral Sir A. Moore as Commander-in-Chief of Portsmouth, and Admiral Sir A. Berkeley Milne succeeded Admiral Sir E. Poë as Commanderin-Chief in the Mediterranean (announced in April I912).

The personnel of the Royal Navy for 1912-13 is shown as follows. (1) Sea Service: (a) Fleet:- -lag officers 28 , commissioned officers 4727 , subordinate officers 740 , warrant officers 2070 , petty officers and seamen 97,811 , boys (service) 2,601; total 107,977. (b) Coast guard:-commissioned officers 99, chief officers and second mates 205, petty officers and seamen 2796; total 3100. (c) Royal marines:-commissioned officers 420, warrant officers 67 , staff sergeants and sergeants 1300 , band ranks, buglers and musicians 1708 , rank and file 13,296 , band boys 272 ; total 17,063: total for sea service 128,140 . (2) Other services 7860. (3) Addition under supplementary estimate 1500. Total personnel 137,500.

Army.-In February I9r 2 a joint Army and Navy School of Aviation was established for the instruction of officers in both services. A British aeronautical service was instituted and designated the Royal Flying Corps, with naval and military sections, and a central flying school on Salisbury Plain administered by the War Office. The Army Aircraft Factory was renamed the Royal Aircraft Factory.

General Sir C. W. H. Douglas succeeded General Sir J. French as Inspector-General of the Home Forces on March 5, I9r2.

The following figures show the personnel of the Army on October I, I91 I, the numbers wanting to complete the strength being given in brackets where necessary:- $(a)$ Regular Army:-British establishment 176,539 (427I); Indian establishment 77,770 and 1,886 supernumerary; staff and departments, etc., 2474 (I06); army reserve 138,531 ; special reserve 60,931 (30,288). (b) Territorial Force:-officers, N.C.O's. and men 264,9 II $(49,445)^{\prime}{ }^{1}$ permanent staff $2786(35)$; reserve 656 . The above figures give a total of 724,598 . There are also to be added:- militia 1655; reserve 205: militia (Channel Isles, Malta and Bermuda) -permanent staff 178 (I) and militia 5243 (319): volunteers (Bermuda)-permanent staff 4 (1) and volunteer officers and volunteers 225 (89). Grand total 732, 108.

Local Affairs and Finance: Uniled Kingdom, I909-10.-For England and Wales the revenue of local bodies amounted to $£_{1} 68,157,555^{2}$ and expenditure to $£_{1} 66,104,559$; for Scotland to $£_{1} 8,854,650$ and $£_{1} 8,9$ I 8,681 respectively, and for Ireland to $£^{2}, 75_{2}^{2,498}$ and $f 8,598,435$ respectively. Outstanding local loans in England and Wales amounted to $£ 536,002,529$, including $£ 49,529,222$ in respect of loans taken over or raised by the Metropolitan Water Board; for Scotland the figure was $£ 65,827,182$, including capitalised values of annuities, and for Ireland $f_{2} 2,066,834$. Total, $£_{\leftarrow 2} 63,896,545$.

London Government.- The assessable value in the county of London in I 1 I amount. ed to $£ 44,669,4 \mathrm{I} 2$. The net outstanding debt of central and local bodies on March 3I: I0IO, was $£$ III,043,088. The central rates for the administrative county (excluding the City of London) for the year ending March 31, r91 2, amounted to 5s. 3.995d. in the pound; leaving to be raised locally differential rates in each borough. The amounts of the localised rates varied from Is. $0.005 \mathrm{~d}$. in Westminster (St. James) to 6s. $0.005 \mathrm{~d}$. in Poplar; the amount of the total rates varied from $6 \mathrm{~s} .4 \mathrm{~d}$. in West minster (St. James's) to I Is. 4 d. in Poplar. A return published by the London County Council in November I () I 2, compared the cost of the municipal services in London and six other large cities. The total net cost per head of the population was found to be highest in London $£ 3.3 \mathrm{~s}$. 9.5 c., against $£ 2.16$ s. I I.0d. for Manchester; $£ 2.8 \mathrm{~s} .9 .7 \mathrm{~d}$. for Leeds; $£ 2.5 \mathrm{~s} .5 .5 \mathrm{~d}$. for Liver pool; $£ 2.35 .6 .1 d$. for Bristol; $£ 2.35 .2 .9 \mathrm{~d}$. for Birmingham, and $£$ I.I8s.8.4d. for Sheffield), those circumstances to act as he did, after consulting with the Prime Minister and inform. ing the King, whose sanction had been obtained. After conveying his view to Sir $\mathrm{F}$. Bridge. man in so kind and diplomatic a letter that the gallant Admiral at first failed to realise the: situation, he had then put it so bluntly - as Mr. Bonar Law considered, "brutally" - that no misunderstanding was possible. But after the full explanation given by Mr. Churchill it was clear that, if his method was open to criticism, his artion was not, and that the attack: on him in other respects were unsupported by any material evidence.

1 Includes both permanent staff and territorial officers for O.T.C. The Territorial force was stated to include 9236 officers and 252,152 N.C.O.'s and men on October I, I9I2, giving a total of 261,388 , and a decrease of 3523 on the total of the previous year.

${ }^{2}$ Including $f 22,570,459$ of loans and $f, 2,679,183$ of other receipts accounted for by the Port of London Authoricy. 
but the cost per $f$ of assessable value is lowest in London (6s.5.9d., ranging up to ros.4d. in Leeds). Education is found to cost 6s.7.6d. per head more, and police 3s.10.2d. more in London than the average for the other cities. Higher prices, salaries, wages, and cost of lands and building are adduced as explanations of the higher total cost per head in London.

Alderman Sir David Burnett (an auctioneer and surveyor by profession, was elected Lord Mayor of London on September 28, 1912, in succession to Sir Thomas Boor Crosby. The London Borough Council elections took place on November I, I9I2, and as the result the Municipal Reform party retained the general ascendancy which it had previously held. To a total number of 1362 seats in the 28 borough councils there were returned 1002 Municipal Reformers, 252 Progressives, 33 labour representatives, I5 socialists, 23 independents and 37 non-party members (the borough of Stoke Newington electing a non-party council of 30 ). The Progressives outnumber Municipal Reformers in the councils of Bethnal Green, Southwark and Battersea, the result in the borough last named constituting a Progressive gain; on the other hand that party lost its previous majority over the Municipal Reformers in Hackney.

Municipal Boundary Alterations, England and Wales.-Among recent changes adopted or proposed in the boundaries or constitution of boroughs, the following may be noticed.

The area of the city of Bath was increased at the expense of the county of Somerset by $\mathbf{1} 767$ acres in $191 \mathrm{I}$; a population of 18,454 and a rateable value of $£ 8 \mathrm{r}, 043$ were thus added.

The Greater Birmingham scheme came into operation on November 9, I9I I. The effect of the scheme was to include in the city the borough of Aston Manor and the urban district of Erdington (Warwickshire); the urban district of Handsworth, with Perry Barr (Staffordshire); the rural district formed by the parish of Yardley and the greater part of the urban district of King's Norton and Northfield (Worcestershire). Quinton (Worcester) had been absorbed in 1909. The whole of these districts thus became part of the geographical county of Warwick. Birmingham, by this extension, was made the second largest city in the empire, but it only maintained that position until November I912, when the extension of the boundaries of Glasgow (q.v.) raised the Scottish above the midland city. The area of Birmingham was increased from 13,478 acres to 43,601 acres. The population in I9II was 840,202. Without the added areas it would have been 525,833 . The population at the end of 1912 was estimated at about 854,000 . The corporation now consists of a Lord Mayor, thirty aldermen and ninety councillors, and the city is divided into 30 wards. The water, gas and electric lighting, and tramway undertakings belong to the corporation. The whole of the city with the exception of Handsworth (which remains in the West Bromwich Union) forms one parish for poor law purposes.

Application has been made for a charter of incorporaion or Buxton. At Chesterfied, or which the Duke of Devonshire was mayor in 1910-11, the borough boundaries have been considerably extended, the area being increased from I2I2 to 26II acres, and the population by some Io,00o to 37,429 . A scheme for the extension of the borough of Dudley is under consideration. The borough of Eastbourne was extended in April I9II, to include part of the parish of Willingdon. A scheme is being promoted for the extension of the borough of Kidderminster. By a provisional order granted in May I9I2 Roundhay, Seacroft, Shadwell and part of Crossgates have been incorporated in Leeds, extending the area of the city by 4670 acres, and adding 7620 to the population, while the rateable value is increased by $f 56,640$. Northampton was redivided in 1912 into 12 wards instead of 9 , and the number of town councillors was increased from 36 to 48 . In I9II, besides being the scene of the coronation review and providing hospitality for ships of foreign navies, Portsmouth entertained the British Association, British Pharmaceutical Society, Institute of Auctioneers, National Free Church Council, Co-operative Congress, Incorporate Municipal Electrical Association, South-Eastern and Metropolitan Poor Law Conference, and smaller bodies. It was considered opportune that Portsmouth should be raised to the rank of a city, but the petition was refused. In 1912 Reading enlarged its boundaries by including Caversham and part of Tilehurst, in spite of some opposition. Its acreage has been increased from 5876 to 9107 acres, and its population from 75,214 to more than 88,000 . The union of Rochester, Chatham and Gillingham as a count y borough has been considered. In the census of I9I I Sheffield was found to be the largest city in Yorkshire, with a population of 454,603 as compared with 445,568 in Leeds, which had previously held the first position. On April I, I912, Tinsley was added to Sheffield, giving an additional area of 685 acres, a population of 5270 and a rateable value of $\{42,659$. A movement is on foot for the incorporation of Stourbridge. In Cheshire the urban district of Wallasey, virtually a residential suburb of Liverpool, which since I9OI has increased its population by 24,935 (pop. in I9II, 78,514), was constituted by charter, dated July 27,1910 , a municipal borough, and will become a county borough on April I, I9I3. The borough of Wallsend was increased in October I9IO 
by the addition of the former urban district of Willington Quay and part of the rural district of Tynemouth.

Channel Islands. - The Guernsey States (the legislative body) approved a resolution for the adoption of English weights and measures in 1910 to the exclusion of the old local standards, but a petition for the adoption of British coinage as the only legal currency was rejected in I9II. Major E. O. F. Hamilton, C.B., succeeded the late Major-General R. Auld, C.B., in April I $9 \mathrm{I}$ I as lieutenant-governor and commander of the troops in Guernsey and Alderney:

Isle of Man.-In April I9II the Home Secretary appointed a committee to report upon a petition from the House of Keys for reforms in the Manx: Government. It was proposed to limit the lieutenant-governorship to a term of years (seven or eight), to extend the powers of the Tynwald, and to constitute the legislative council of four members elected by the Keys, together with the Attorney-General, the Bishop and two judges. The Tynwald, with the approval of the Board of Trade, passed in April 1912 a resolution imposing a duty on passengers entering or leaving the parts of Douglas, Ramsey, Peel, Laxey and Port St. Mary, and devoting the proceeds to we improvements of the ports.

Water Supply. - In London the Metropolitan Water Board (New Works) Act, IgI ], authorised the Board to construct new storage reservoirs at Staines, Lalcham and Shepperton, new service reservoirs on Horsendon Hill, Greenford, and on Barn Hill, Wembley, and to construct numerous conduits and aqueducts. The Island Barn reservoir, near West Molesley, constructed by the Board, was opened on November 4, I9 I I.

The corporations of Derby, Leicester, Nottingham and Sheffield are jointly responsible for the Derwent Valley Water scheme, of which the cost is estimated at $£ 6,000,000$, and which began the impounding of water on January I, I9I2. The first two reservoirs are the Howden and the Derwent, the former having a capacity of I,886 million gallons and being 14 miles in length, and the latter a capacity of 2,000 millions, with a length of $I^{\frac{3}{4}}$ miles. The proportion of water allotted to Leicester is 35.72 per cent, providing for a daily yield of $9,800,000$ gallons, to Derby 25 per cent, to Nottingham 14.28 per cent, and to Sheffield 26 per cent. Derbyshire water has also been laid under contribution for the supply of Stockport, a new source at Kinder, Hayfield, being opened on July II, I9I 2.

Improvements undertaken in the Liverpool water supply system include the construction of a reservoir on Lake Vyrnwy aqueduct near Malpas, and a water-tower (IDII) and high level-tank at Woolton Hill. Similarly at Manchester, for which water is drawn from Thirlmere in the Lake District, it has been necessary to undertake extension of the works by laying a third conduit from the lake to the city. Works are in progress for a water-supply from the river Alwen in North Wales for Birkenhead.

On October 4, I9II, the new Lincoln water-supply was inaugurated, being obtained from the red sandstone near the village of Elkesley, Nottinghamshire, 22 miles from the city, at a cost of about $£ 250,000$.

Housing and Tozen-planning.-In London, improved communications and the working-class dwellings provided in the outskirts (as at Norbury, Totterdown and White Hart Lane) by the London County Council, have facilitated the efflux of population from the centre to the border of the county. The tenements in dwellings belonging to the London County Council on December 3I, I910, numbered 9,2 I7; the total number of rooms was $25,922 \frac{1}{2}$; the average rent per week per room was 2 s. Io $\frac{1}{2} \mathrm{~d}$. A scheme for the establishment of a garden city on land belonging to King's College, Cambridge, at Ruislip-Northwood, was authorised by the Local Government Board in March I9I I, and a plan was adopted after competition. It was proposed to devote two-thirds of the estate of r,300 acres to building and one-third to open spaces. The extension of the Garden City movement in the neighbourhood of London is also illustrated by the plan

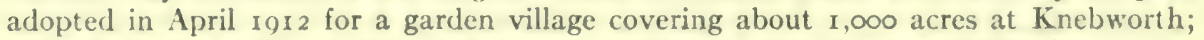
while at Letchworth, the first garden city, 28 factories have been established.

At Birmingham town planning schemes have been adopted for Quinton, Harborne, Edghaston and Fast Birmingham. In 19 I I the town council of Covenlry adopted a scheine for artisans' dwellings estimated to cost $f_{30,000}$. Portsmouth, Winchester and Bournemouth have adopted town-planning schemes, and at Portsmouth it was found feasible to clear a large slum area and erect model dwellings, without adopting the Housing Act. A garien village has been founded in the Far Cotton district of Northamplon, at Hunsbury Hill on the Bouverie estate. In Liverpool mention may be made of the laying of the foundation of a housing scheme, the largest of six undertaken by the Liverpool City Council, by the Rt. Hon. John Burns in November 19ro. Housing is provided for 1372 persons. The development of a garden city at Wavertree is in progress, and a number of streets have been 
widened in connection with this. The Town Planning Act is in operation at Sheffield, and various districts are scheduled, but not yet developed. A new road along the Rivelin Valley some three miles long has been made by the Water Committee of the corporation, and the surplus land on each side is to be developed in accordance with modern town-planning methods. The recent census returns confirm the trade statistics in their evidence of the prosperity of South Wales and Monmouthshire. The counties of Monmouth and Glamorgan show a higher percentage of increases of population than any other typically commercial and industrial county in England and Wales. Between I90I and I9I the increase per cent in Monmouthshire was no less than 32.8 , or nearly double that in any English county; Glamorgan makes a good second with 30.3 per cent. It is largely due to the rapid groivth of the chief centres of population that the housing conditions are so notoriously bad. The local authorities are now trying to meet the need with municipal housing schemes, but despite improvement in some towns the general conditions remain the worst in Britain. One result is that according to the most recent statistics the infantile mortality rate in Carmarthenshire, I 36 per rooo births, is the highest county rate in England and Wales, despite the fact that the chief industry there is agriculture.

Open Spaces.- In I 12 the London County Corncil and the City Corporation decided to co-operate with the King Edward VII Memorial Committee with a view to the conversion of the site of the Shadwell Fish Market into an open space for the purpose of a memorial in the East End of London to King Edward VII. On February I9, r9ro, twelve additional acres of land adjoining Ruskin Park, Denmark Hill, were thrown open for the use of the public. In the same year the London County Council decided to acquire and preserve the Sir Robert Geffrey's Almshouses in Kingsland Road and certain property in Maria Street. The open space has been laid out and is known as Geffrey's Garden. The Council have also decided to acquire the Grange estate, Kilburn. The estate extends to $8 \frac{1}{2}$ acres, 7 of which are laid out as a park.

The break up of large estates in the neighbourhood of Bournemouth, Lymington, Portsmouth, Gosport, and other Hampshire towns, has enabled the public bodies to acquire numerous open spaces, though it is to be regretted that around Bournemouth and in the New Forest the picturesque features have suffered. Near the first-named town, and on the Crown lands, woods have disappeared. A movement was started to make the New Forest a sanctuary like Epping Forest, but was not supported by the Hants County Council

Loxley Chase (74 acres) has been presented to Sheffield as a public park.

Public Buildings and Other Undertakings,-London. ${ }^{1}$ In October 1912, it was announced that the front of Buckingham Palace was shortly to be refaced in stone from designs by Sir Aston. Webb. The Queen Victoria Memorial, in front of the palace, was completed and unveiled by the King on May 16, I9II.

The King laid the foundation stone of a new County Hall, at the south end of Westminster Bridge (Belvedere Road, Lambeth) on March 9, I9 I 2. In the course of excavations on the County Hall site, the remains of a Roman boat were discovered, together with various Roman objects. The boat and objects are preserved at the London Museum, Kensington Palace, opened by the King on March 2I, I9I2. A stone bearing the inscription "Lambeth Boundary of Pedlar's Acre, I 777," was also unearthed.

Among other new London buildings may be mentioned the premises of the Royal Society of Medicine (Wimpole Street), opened by the King on May 2 I, I91 2; the lecture hall and museum at the Horniman Museum, Forest Hill (Jan. 27, I912); and the London Opera House in Kingsway (IgIr). Mr. Oscar Hammerstein of New York, for whom this opera house was built, decided to close it after his season in Igr 2. Cinematograph theatres are now subject to licence (Cinematograph Act, I900), and about 250 halls have been licensed in London. The Young Men's Christian Association has opened a new building in Tottenham Court Road, and with the object of disposing of the

${ }^{1}$.Among recent works on L.ondon, see:-Sir Waiter Besant, London North of the Thames (1911), London South of the Thames (1912); Sir Laurence Gomme, The Making of London (I912); E. Beresford Chancellor, Annals of Fleet Street (1912); Calendar of Letter Books preserved among the archives of the Corporation of the City of London as the Guildhall (A-K) (circa 1275-I464); The London County Council-Various annual publications; The Survey of London (Vol. iii: the Parish of St. Giles in the Fields) (1912); Indications of Houses of Historical Interest (parts i to xxxvi). 
debt upon it at the outset an attempt was made in January 1912 to raise a fund of $f 100,-$ ooo in I 2 days by means of an organised campaign, which was not, however, fully successful. The Port of London Authority adopted in July I9 2, a design by Mr. Edwin Cooper for chief offices to be erected in Trinity Square, E.C. In January IgI 2 the London County Council sold the site at the eastern junction of the Strand and Aldwych to the Commonwealth of Australia, for $£ 379,756$, for the erection of offices.

The Corporation of London (Bridges) Act I 9 I I, authorised the Corporation to construct a new bridge over the Thames between Southwark and Blackfriars bridges, to widen St. Paul's Churchyard, and to carry out other improvements in the city of London. The new bridge will be probably known as St. Paul's bridge. On June I, igir. the subways constructed to relieve the traffic at the Elephant and Castle were opened for pedestrian traffic, and on October 26, 1912, a tunnel beneath the Thames at Woolwich was opened for foot-passengers.

Other public buildings and municipal enterprises have been reported as under:-

Birmingham.-In July I9I2 was opened an extension of the Birmingham Council House upon land on the opposite side of Edmund Street. The scheme, still in progress at the enc: of the year, has cost upwards of $£ 200,000$, out of which $£ 50,000$ was provided out of a bequest by the late John Feeney (proprietor of the Birmingham Daily Post) for an extension of the Art Gallery. Provision has been made for a museum of Natural History.

Blackpool.- The new promenade known as Princess Parade was opened in 1912, extending from the north pier to Cocker Street: the cost was $£ 25,000$.

Cardiff.-The visit of the King and Queen to South Wales in I9II was an occasion of gratification to Welsh nationalist pride. The King laid the foundation stone in Cardiff of the National Museum, which with the University College and the National Library are the outward signs of a great Welsh renaissance. In two other important respects the right of Wales to be treated as a distinct autonomous unit has been recognised. For the purposes of the Insurance Act Cardiff has been selected as a centre for the principality with its own commissioners and staff; and the Welsh National Memorial Association, which has a fund of more than $£ 200,000$ publicly subscribed for a campaign against tuberculosis, has received a royal charter and the full status of a national institution.

Chester.-Municipal progress includes a hydro-electricity scheme (1912) for utilizing by means of turbines the water-power at the Dee Mills for an auxiliary supply of electricity.

Dudley. - The corporation received in 1912 a bequest of $£ 30,000$ from the late $\mathrm{Mr}$. Brooke Robinson (formerly M.P. for the borough) for an art gallery or museum.

IIereford. - The city library has been extended by the addition of an art gallery provided by the late Sir Joseph Pulley and Mr. C. T. Pulley, High Sheriff (1912). The Roman site of Dinedor Camp, near the city, has been purchased for a public pleasure ground.

Heriford.- In May I9I 1 Lord Salisbury offered the castle and grounds at Hertford to the corporation for public use at a nominal rent; and the transfer of the building, in which the municipal offices are established, took place in the following year.

II ull.-An art gallery was opened in I9IO by Mr. T. R. Ferens, M.P., who has largely contributed to its erection and upkeep, and also presented to the town in 1911 twelve almshouses as a memorial to King Edward VII, and a playing field near the East Park. A new museum has been designed to illustrate the shipping and fishing industries.

Leicester.-A great fire in October 19 I I destroyed St. George's Church and an important hosiery factory. A scheme has been put forward for a public hall near Victoria Park.

Liverpool. - The cathedral has been enriched by the gift of a reredos by Mr. Mark Wood, from designs of Mr. (;ilbert Scott. It was decided in the autumn of 1912 by the cathedril committee to proceed with the building of the first transept. A representative exhibition of the works of Albrecht Dürer was held in the Walker Art Gallery in April 19ro. Mr. Andrew Carnegie in August I9I I opened at Sefton Park a library worked by a staff of women.

Manchester.-Mr. Carnogie also in the same year presented $f_{15,000}$ to Manchester towards the estallishment of three branch libraries. A church house, with a hall seating 2,000 persons, was opened in October I9 I by the Archbishop of York.

Middlesbrough. - A transporter bridge across the Tees, erected by the Corporation, was opened by Prince Arthur of Connaught in October 1911.

Northamplon.-Among important new buildings are a Carnegic library, costing $£_{15}, 000$, in Abington Street, a theatre, and new buildings for the grammar school (891 I).

Norwich.-Serious clamage was caused, and much suffering occasioned, by a great rainstorm and floods on August 26, 1912. At Brundall near the city 8.06 in. of rain fell, and more than 7 in. over an oval area includling Norwich and the district of the Broads. The damage to communications was enormous. Large relief funds were raised.

Nottingham.-A number of improvements have been carried out in Nottingham, among the most noteworthy being the widening of Carrington Street and Great Friar Gate at a cost of $£ 60,000$. A still larger scheme is that in the ('arter Street area, estimated to cost $£ 139,000$ 
Penzance.-By a legacy under the will of the late Prebendary Hedgeland, the Penzance library received in I9II an addition of 7,000 books.

Plymouth.-In October I9Io a free library, art gallery and museum were opened; they had cost about $£ 25,000$, towards which Mr. Andrew Carnegie gave $£$ I5,000.

Reading.-The Berkshire County Council has built new offices at Reading, a fine building in the Queen Anne style, near the medieval gateway of the abbey.

Shrewsbury.-A weir has been constructed on the Severn to improve boating; and the Town Council resolved on June 24 , 1912, to apply for sanction for a loan of $f_{12,000}$ to widen the English bridge over that river.

Stoke-on-Trent.- In I9II the Duke of Sutherland offered Trentham Hall and a large portion of its grounds to the corporation, but the offer was declined. The hall was therefore demolished and its chimney-pieces and other carvings and fittings were sold.

Wakefield. - The County Hall has been extended at a cost of $£ 32,000$.

Worcester.-Important street improvements have been effected principally in the widening of The Foregate, High Street. The Corporation has acquired Pitchroft (including the racecourse) for a public pleasure-ground and has purchased land for a recreation ground.

Ancient Sites and Buildings.-London.-In the course of work on the fine Norman western porch of the Temple Church it was found that the carving had been coated over, and it has now been revealed in almost its original state by the removal of the coating.

Rochester.-The restored north aisle of Rochester Cathedral was dedicated on March Io, I9II.

Salisbury.-Old Sarum, the former city of Salisbury, lies buried a mile and a half from the present town, and interesting excavations were made in Igr2. The area is in the care of archaeologists, under Col. William Hawley, F.S.A., and the history of the site is gradually coming to light. The most recent excavations reveal a good outline of the south wing of the transept of the great church, and many graves have been met with, most of them very near the surface. Their depths vary considerably, but none seems to be more than three feet, while stone coffins must have been actually on the surface. For the present all the coffins have been covered up to receive attention later, but it is doubtful whether anything definite will be ascertained of the occupants, as the covering stones have in all instances been taken away and doubtless the contents have been interfered with. Other things unearthed include some very fine gargoyles found in the transept cutting. The intention of the excavators in 19 r 2 was to get a general outline of the close and the cathedral, and to open out the entire basement of the building when work was resumed in I9r3. It was hoped that the work would be completed by I9r 5 .

Lake House near Salisbury, a fine example of Elizabethan stone architecture, in the occupation of Mr. P. W. Illingworth, M.P., was destroyed by fire on March 29, I912.

After much public interest had been aroused, Tattershall Castle, with its famous carved stone fireplaces, was purchased in 1912 by Earl Curzon of Kedleston. The fireplaces were brought back in June, and Lord Curzon intimated that he intended to restore the mansion to its original condition and make it accessible to the public.

Winchester.-In July] I9I2 a service was held in Winchester Cathedral, at which the King and Queen were present, to celebrate the completion of the restoration of the cathedral. The eastern arm of the cathedral was practically built over a peat bog upon a raft, which, after eight centuries, subsided, and in 1905 the whole building threatened to collapse. Over fiI 3,0oo was raised to meet the cost of restoration. New buttresses were erected, and a diver, working in darkness for six hours a day for six years, and much hampered by subterranean springs, laid a solid bed of concrete under the piers and walls.

Education.-For the year ending July 3 I, I9 I I, the total number of pupils in schools comprised under the national system of public elementary and higher elementary education, in England and Wales, was 6,067,075; of these 350,621 were aged 3 to under 5, I,30I, 267 aged 5 to under 7, 3,3 I I,756 aged 7 to under I 2, I, 096,474 aged I 2 to under I 5 , and 6,957 aged I5 and over. There were 8,046 "Council" elementary schools with accommodation for $3,980,946$ pupils; I 2,734 "voluntary" elementary schools (maintained by local education authorities) with accommodation for $2,808,795$; and 66 "voluntary" elementary schools (not so maintained) with accommodation for I 7,799 . Also 46 "Council " higher elementary, and 285 other schools, with accommodation for I 2,207 and I9,39I respectively; and I "voluntary" higher elementary, and II 6 other schools, with accommodation for 240 and $\mathrm{I} 2,742$ respectively. Of the $\mathrm{I} 2,734$ "voluntary" elementary schools, I0,94I (with accommodation for 2,245, I43 pupils) were 
Church of England, 225 (for 60.322 pupils) Wesleyan, 1,075 (for 375,535) Roman Catholic, and 12 (for 9,863 ) Jewish. The parliamentary grant for elementary education was $£_{1} I, 445,055$, the additional amount provided by rates and borough funds being $£_{1} 1,635$,725 ; for higher elementary the receipts were $f_{1}, 129,699$ from parliamentary grants, and $£_{1}, 857,955$ from rates and borough funds.

It was announced on November 28, I 9 I I , that Sir R. Morant, who had been secretary and chief permanent official of the Board of Education since 1903 , had been appointed Chairman of the new Board of Commissioners under the National Insurance Act. He was succeeded at the Board of Education in I91 2 by Mr. W. A. Selby Bigge.

On July $2-5$, I 1912 , a congress of the universities of the empire was held in London, under the chairmanship of Lord Rosebery, Lord Curzon, Lord Rayleigh and Lord Strathcona. Fifty-two universities were represented. It was resolved to establish in London a bureau of information concerning the universities of the empire.

In local educational circles some of the principal events of I910-12 may be noted.

Oxford University. - The question of the continuance of the study of Greek by mathematical and science students has been much discussed, and at a large meeting of Convocation it was decided in the affirmative by a great majority. The preamble of a statute making Greek optional in Responsions was rejected however by 188 votes to 152 at a Congregation on November 22, 19ro. The new buildings of Oriel College, provided by the munificence of Cecil Rhodes, were opened on September 28, IgI I, and form a new feature of High Street, opposite St. Mary's Church. The Union Society new buildings were opened by Lord Curzon, the Chancellor, on June I, I9II. He also inaugurated some new buildings at Lady Margaret Hall on October 22, 19ro. A new electrical laboratory presented by the Drapers' Company of London was handed over to the University on June 22, 1910. The front of Christ Church has been restored. The Principal of Brasenose, Dr. C. B. Heberden, D.C.L., was elected Vice-Chancellor in 1912 in place of the President of Magdalen, Dr. T. H. Warren, D.C.L. A new financial board for the University has been formed. Mr. Falconer Madan, senior sub-librarian, was recommended in June I $9 \mathrm{I} 2$ by the curators of the Bodleian Library to the office of Bodley's librarian, vacated by the death of Mr. E. B. Nicholson. The Prince of Wales entered Magdalen College as an undergraduate in October I9I 2.

The millenary of the city of Oxford was celebrated at the beginning of July I9 I2, when a historical exhibition was collected, the city entertained members of the university and others, and degrees honoris causâ were conferred upon the mayor and the town clerk.

Cambridge University.-During rgr I Mrs. Butler, widow of A. J. Butler, Fellow of Trinity College, presented to the library a valuable collection of the early editions of the works of Dante. Mr. E. W. Hunnybun presented his unique collection of drawings of the flowering plants of the British Isles. Mr. J. Willis Clark, late Registrary of the University, bequeathed to the library his valuable collections relating to the town, county, colleges and university of Cambridge, including his manuscript collections. Sir Harold Harmsworth's offer to found a professorship in English literature took shape during the Michaelmas term of $19 \mathrm{I}$; in February $19 \mathrm{I} 2 \mathrm{Dr}$. A. W. Verrall was appointed, and on his death Sir A. Quiller Couch, the novelist ("Q"), was chosen professor in October. Following a promised anonymous donation of $f_{1} 125$ for ten years towards the stipend of a Reader in Modern History, the readership has been established. A new lecture rooms building was completed and brought into use in the year I9II-I2. A. munificent offer of the Drapers' Company to provide a physiological laboratory wa: accepted by the Senate, and the erection of the building was begun; with this is connect. ed a laboratory of experimental psychology.

Other Universities. - In the new buildings of Birmingham University at Bournbrook, a statue of King Edward VII (the gift of the pro-vice-chancellor, Alderman F. C. Clayton) has been erected to commemorate the opening of the buildings by his Majesty and Queen Alexandra un July 7,1909 . These buildings include departments of mining and metallurgy, mechanical engincering, chemistry and physics, together with foundries and other plant for experimental purposes on an unusually complete scale, and an experimental mine. There is also a large hall and library, and the buildings (from the designs of Sir Aston Webb and 
Mr. Ingress Bell) are surmounted by a lofty clock-tower. Alderman C. G. Beale, ViceChanccllor of the University, died on September I, I9I2.

The late Mr. H. O. Wills has been succeeded by Lord Haldane as Chancellor of Bristol University.

In December I9I I intimation was given of the decision of Durham University to admit all students professing the Christian faith to Divinity degrees, hitherto limited to the Church of England.

A large extension of the textile department of Leeds University has been made through the generosity of the Clothworkers Company. Sir Nathan Bodington, Vice-Chancellor of the university, died May 12, 1911, at the age of 63. He was succeeded by Professor M. E. Sadler, C.B., the well-known educationalist (b. 186I). Lord Airedale, formerly Mr. Jas. Kitson, one of the governing body of the university and head of the Airedale Foundry, Leeds, died in March 1911. Sir William Hepton, Lord Mayor of Leeds, who was knighted at the opening of the university extension, met with a fatal accident while fishing in France on May 23, I9II. A new training college for teachers has been established at a cost of nearly a quarter of a million.

At Liverpool University the foundation stone of a new engineering laboratory was laid on October 22, 1910. The Liverpool School of Tropical Medicine in I910 offered to the university the endowment of a chair in tropical entomology, and in the following year Professor R. Newstead was appointed from the school to the new Dutton Memorial Chair of Entomology. A new lectureship in education, preparatory for teaching in secondary schools, was filled by Mr. Kenneth Forbes (St. John's College, Oxford) in July I9I I. In the same year the cost of building a central hall for the Undergraduates' Union, and of furnishing the Union, was undertaken by Captain Gilmour. Sir William Hartley presented a wireless telegraphic installation for the purpose of experiment and research, in 1912. A plant for tests in connection with the erosion of metals has been established in the metallurgical department; a certificate in architectural design and a diploma in ophthalmic surgery have been instituted.

London.--Under the King's College, London (Transfer) Act, I908, this college, apart from the faculty of theology, was incorporated in the University of London on January I, I9IO. King's College hospital and medical school were separated from the college in the previous year. King's College for Women became a separate institution, and a site is under consideration for new buildings to include laboratories for a home science department in connection with Queen Mary's hostel for practical training in domestic arts, for which it was announced in February 1912 that $f_{100,000}$ had been privately subscribed. A further change in the arrangements of King's College took place in June I9 I when King's College School at Wimbledon became a separate corporation.

Proposals have been put forward for the acquisition of a site for London University to the north of the British Museum in Bloomsbury; and Lord Haldane, as chairman of the Royal Commission on university education in London, stated in May 1912 that large sums had been offered by private donors for this purpose; but alternative sites have been considered, and the whole question has given rise to some dispute, the reconstitution of the university being $s u b$ judice pending the report of the commission.

A building fund of froo,ooo was completed in February 1912 for Bedford College for Women, one of the "schools" of London University.

At Manchester University a new botanical laboratory was opened in I9I I and a physical laboratory in 1912. The engineering buildings have also been extended. An extension of the Manchester museum was opened on October 30, I912, providing accommodation for geological, anthropological and Egyptian antiquarian collections.

Sir Charles Eliot, first vice-chancellor of Sheffield University, accepted in. March I9I 2 the position of principal of the Hong-Kong University; and in November Mr. H. A. L. Fisher, of New College, Oxford, was selected to succeed him in the office. Sir Frederick T. Mappin, Bart., one of the first pro-chancellors, died in March 1909 . He was a generous donor to the university and the Mappin Art Gallery. The University Library erected at a cost of $f_{10,000}$ by $\mathrm{Mr}$. William Edgar Allen was opened in 1909. He has also given a medicomechanical institute, the first established in England, to work in connection with the hospitals. New buildings, to be used chiefly for the study of mining and non-ferrous metallurgy, were opened in 1912 in connection with the applied science department. The Company of Drapers contributed $f_{15}, 000$ to the cost, and the corporation make an annual grant of $f_{1,000}$ for ten years. A training college for teachers has been completed and equipped.

University Colleges.-Earl Grey, who returned to Northumberland at the end of October I91 I, after several years' governor-generalship of Canada, was shortly afterwards appointed president of Armstrong College, Newcastle-upon-Tyne.

At Brighton a movement was set on foot in I9I I to establish a university college, and in January 1912 it was proposed to make it a college of the University of London, with courses in the arts, sciences, education and pedagogy at first, and subsequently in medicine and law.

Hartley University College at Southampton, threatened with the withdrawal of the Treasury grants, owing to the lack of the usual support, was able to collect $f 3^{2}, 000$, partly by 
grants from the County Council and Southampton Town Council, for the erection of a college and school of art on Southampton Common.

Educational needs have been met in Nottingham by several new schools, and the university college is extending its utility by a mining department and a Byron Chair of Literature, in connection with which the American ambassador (Mr. Whitelaw Reid) paid a visit to the institution in November 1910.

The expansion of the work of University College, Reading, is a remarkable feature of the educational work of Berkshire. It has adopted the hostel system, the chief institution being Wantage Hall, built and permanently endowed by the generosity of Lady Wantage of lockinge. The Rt. Hon. G. W. Palmer and other members of his family have enriched the college with buildings and lands. The college has undertaken the important work of improving agriculture. It has a well-equipped experimental farm at Shinfield, and in I9Io in connection with the Berkshire County Council sent a deputation to visic selected centres of agricultural and horticultural education in the United States and Canada. The college has over $\mathrm{I}, 000$ students. The Berkshire Education Committee has made provision for the instruction of those engaged in agricultural and horticultural work and provided an expert to teach employees on farms. A travelling farriery school has also proved useful.

The opening of the new buildings of the University College of North Wales, Bangor, by the King, took place on July 14, 1911.

Among other recent educational developments may be mentioned the addition of a new textile department to the Bradford Technical College, opened by Lord Rotherham on October 25, 1911; a residential school for the blind has been established by the education committee in the same city. The Cheshire County Council's training college for teachers was opened on July 5, 1912. At Shrewsbury School a new speech hall was opened on May 5. I9II, and science buildings on October 20 of the same year. Evesham grammar school, one of the oldest in Worcestershire, opened new buildings in 19I1. An anonymous donation has been made (in July, 1912) of $f_{1} 10,000$ to the Chancellor of the Exchequer for educational purposes in Wales.

In September I9II a "strike" of school-boys took place in Newcastle-upon-Tyne and other places in the neighbourhood.

Crime.-The criminal statistics for I9I s show the following figures. England and Wales: committed for trial, I3,644 (males, I2,301; females, I,343); convicted, I 1,338. Scotland: committed for trial, I,401 (males, I,2I5; females, I86); convicted, I, I 22. Ireland: committed for trial, 2, I 4 (males, I,804; females, 3 I0); convicted, I,496.

Police numbered in $191 \mathrm{I}$-in England and Wales 51,203, in Scotland 5,654, and in Ireland I 1,865 .

Paupers. - The number of paupers (exclusive of casual paupers) in receipt of relief in the United Kingdom at comparable periods was as follows: England and Wales (July I, I9I I) 749,777; Scotland (Sept. I5, I9I I) 105,478; Ireland (first week of July I9II) 75,3 I 7. England and Wales (Jan. I, I912) 792,I49; Scotland (Jan. I5, I9I2) 109,060; Ireland (close of first week of Jan. 1912) 78,652. The proportion of paupers per I0,000 of the population of the United Kingdom in the summer period of I 9 I I was 205 , and in January $1912,216$.

In England and Wales for the year ending March 3I, I9I I, the total expenditure on relief of the poor by the Guardians and Poor Law authorities amounted to $£$ I $5,380,420$ (London $£_{3}, 888,684$ ). Of this sum in-maintenance represented $£_{3}, 600,327$ (London. $\left.£_{1}, 103,433\right)$, out-relief $£_{3}, 300,3$ I 9 (London, $\left.£_{2} 87,422\right)$, and lunatic asylums $£_{2}, 545,189$ (London $£ 505,265$ ), the balance being for salaries, buildings, loan charges, etc.

Old Age Pensions. - The Old Age Pension Act 1908, was modified by a further act of $19 \mathrm{I} \mathbf{I}$ The pauper disfualification was removed as from January I, I9II, and poer-law authorities in lingland and Wales were thereby relieved of the charge of 122,415 paupers in that month Qualifications for an old age pension include the age of 70 years, the status of a British suliject for 20 years previously to the receipt of the pension, and residence in the United Kingrom (subject to certain exceptions) for 12 years out of that period. The pensions are arranged on a sliding scale from $5 \mathrm{~s}$. a week for those who possess incomes not exceeding L21 a year down to 1 s. a week on incomes over $£ 28.17 \mathrm{~s} .6 \mathrm{~d}$. and up to $£ 31.10 \mathrm{~s} . \mathrm{od}$. The numbers of pensions payable on March 31,1912 , were-in England 602,44I; in Wales 40,083 in Scotland 9+.319; in Ireland 205.317, and the proportion of pensioners per thousand of the census population of $191 \mathrm{I}$ in that year was 17.81 in England and Wales, 19.82 in Scotland and 46.86 in Ireland. According to the appropriation amounts for the year ending March 31 , 1911, the grant for pensions was $f 9,820,000$, for expenses of pension committees $£ 100,000$, while the actual expenditure was-for pensions $£ 9,682,526$; for expenses $£ 74,155$; for sums irrecoverable $\int_{\sim} 798$, and for extra-statutory payments $£ 117$-total $£ 9,757,596$. The civil 
service estimates for pensions for 1911 - 12 were $£_{12}, 350,000$ and for $1912-13 £\{12,135,000$ (decrease $£ 215,000$ ), the pension committees in addition costing $£ 65$,000.

Hospitals, etc.-Memorials to King Edward VII have given an impetus to the building or extension of trospitals, and among other schemes the following have been reported. A new infirmary at Bristol, erected at a cost of $£ 70,000$, was opened by the King and Queen on June 28, 1912. The citizens of Birmingham have raised a fund out of which will be provided a new building in Ladywood Road for the Children's Hospital, in addition to a statue of King Edward by Albert Toft, R.A., a native of Birmingham. As a Warwickshire memorial a sanatorium on Binton Hill near Stratford-on-Avon was decided on; the Worcestershire memorial takes the form of an enlargement of the sanatorium for consumptives at Knightwick. The North Wales counties joined the scheme of national sanatoria for the treatment of tuberculosis; the Shropshire memorial took the form of a sanatorium; Cheshire's memorial fund was apportioned to existing hospitals; and Chester and Stockport embarked on infirmary extensions costing respectively $£ 40,000$ and $£ 10,000$. A subscription was promoted at Leeds to raise $f_{1}$ 50,000 for the reconstruction and extension of the General Infirmary, and, twothirds of this sum having been received, the work was started in I9I2. This also involves an extensive street improvement, undertaken by the City Council, in the neighbourhood of the Town Hall, clearing away a considerable amount of slum property.

Among other institutions, the erection of a home for consumptives, on a site between the Lickey and the Clent Hills, was started in 1912 at a cost of $f_{14}, 000$ by the Birmingham Hospital Saturday Committee as a memorial of the late Alderman Sir William Cook, who was chairman of the Committee (also of the Health Committee of the Corporation) for many years. To perpetuate the memory of Edwin James Oates, his sisters have presented $£$ I 0,000 to Halifax towards an open air school and a convalescent home. There was opened at Crewe (Dec. I8, 19II) a railway orphanage built and endowed out of the residue of the estate of the late Mr. F. W. Webb, chief mechanical engineer, L. \& N. W. Railway. The Berkshire Hospital has considerably enlarged its building, and now provides 200 beds and is one of the best equipped in the country. The Radcliffe Infirmary at Oxford has also begun some new buildings at a cost of $£ 20,000$.

Portsmouth was the first municipality in the United Kingdom to start a tuberculin dispensary (I9II), with treatment for out-patients, an open air hospital, and a stock of shelters, disinfecting appliances, etc., lent to patients visited at their own homes, the inclusive cost being frooo a year.

[For the above sections on England and Wales, the collaboration of the following local correspondents is acknowledged:- R. W. Brown (Northampton), J. B. Cornish (Penzance), T. A. Davies (Cardiff), Rev. P. H. Ditchfield (Berks.), W. H. Garbutt (Birmingham), Sir G. L. Gomme (London), J. E. Hooper (Norwich), E. Howarth (Sheffield), J. Jamicson (Newcastle-upon-Tyne), P. H. Maggs (Portsmouth), F. W. Parker (Chester), F. P. Pointon (Nottingham), A. E. Reynolds (Salisbury), C. Wells (Bristol). The general statistics have been compiled from official sources by Harold Macfarlane.]

(O. J. R. HOWARTH.)

\section{SCOTLAND ${ }^{1}$}

Population.-The most significant feature in the recent economic development of Scotland is the progress of the country in industrial enterprise and its gradual decline in agricultural activity. The townward trend of the rural population, which has been in progress for many years, is emphasised by the latest census returns. The population of the country in I9I I (details of which are furnished in Tables A and B) was 4,759,445. and of this total (of whom $2,302,865$ are males and $2,446,808$ females) about 77 per cent live in towns, and 21 per cent in the country. Scotland, like other parts of the United Kingdom, has felt the effect of a slackening birth rate, and in the last census year the number of births registered was smaller than in any year since 1873 , the year I 890 excepted, and the birth rate was the lowest recorded since 1885 . The total increased population was less than at any census since $186 \mathrm{I}$. The falling birth rate has of course a vital bearing on the comparatively moderate increase of the population generally, but the dwindling of rural communities cannot be wholly attributed either to it, or to the call of the towns. Scotland has suffered seriously within recent years from emigration. In IgI I alone 57,4 I 7 passengers of Scottish nationality left Scottish ports, in itself a disquieting enough fact. But in order to appreciate the effect on the country of the drain of emigration, it is necessary to take a more distant view. Going back a period of the years it is found that 354,056 Scottish people left their native shores for permanent residence abroad, and against that there was an immigration of 66,921. In other words, within the period mentioned Scotland was depleted by 287,135 persons. The cities,

1 See $E$. B. xxiv, 412 et seq., and articles on the various counties, towns, etc. 
Table A. Scottish Counties.

\begin{tabular}{|c|c|c|c|c|c|c|c|c|c|}
\hline & & & $\begin{array}{c}\text { Area } \\
\text { (exclusive of } \\
\text { Inland Water } \\
\text { Tidal Water } \\
\text { and Foreshore) } \\
\text { acres. }\end{array}$ & $\begin{array}{c}\text { Population } \\
\text { rgr }\end{array}$ & $\begin{array}{l}\text { Inc. or } \\
\text { dec. } \\
\text { per cent. } \\
\text { since } \\
\text { rgoI }\end{array}$ & : & $\begin{array}{c}\text { Area } \\
\text { (exclusive of } \\
\text { Inland Water } \\
\text { Tidal Water } \\
\text { and Foreshore) } \\
\text { acres. }\end{array}$ & $\begin{array}{c}\text { Population } \\
\text { I9rs. }\end{array}$ & $\begin{array}{l}\text { Inc. or } \\
\text { dec. } \\
\text { per cent. } \\
\text { since } \\
\text { IgeI }\end{array}$ \\
\hline $\begin{array}{l}\text { Aberdeen } \\
\text { Argyll : } \\
\text { Ayr } \\
\text { Banff : } \\
\text { Berwick : } \\
\text { Bute : } \\
\text { Caithness } \\
\text { Clackmanna } \\
\text { Dumbartons } \\
\text { Dum,ries } \\
\text { Edinburgh } \\
\text { Elgin : } \\
\text { Fife } \\
\text { Forfar : } \\
\text { Haddington } \\
\text { Inverness } \\
\text { Kincardine }\end{array}$ & $\begin{array}{l}: \\
: \\
\vdots \\
\text { in } \\
\text { shire } \\
: \\
:\end{array}$ & $\begin{array}{l}\vdots \\
\vdots \\
\vdots \\
\vdots\end{array}$ & $\begin{array}{r}724,5 \\
403,0 \\
292,5 \\
139,6 \\
438,8 \\
34,0 \\
157,4 \\
686,3 \\
234,3 \\
304,0 \\
322,8 \\
559,0 \\
170,9 \\
2,695,0\end{array}$ & $\begin{array}{r}70,901 \\
268,332 \\
61,402 \\
29,643 \\
18,186 \\
32,008 \\
31,121 \\
139,831 \\
72,824 \\
507,662 \\
43,427 \\
267,734 \\
281,419 \\
43,253 \\
87,270 \\
41,007\end{array}$ & $\begin{array}{l}+2.3 \\
-3.7 \\
+5.4 \\
=\quad .1 \\
=3.8 \\
=3.2 \\
=5.5 \\
+22.8 \\
+\quad 3.3 \\
+3.9 \\
+3.1 \\
+22.3 \\
+11.9 \\
+3.1 \\
+\quad .2\end{array}$ & $\begin{array}{l}\text { lnross } \\
\text { irkcudbright } \\
\text { anark } \\
\text { inlithgow } \\
\text { arin } \\
\text { rkney } \\
\text { eebles } \\
\text { erth } \\
\text { enfrew } \\
\text { oss and Cromarty } \\
\text { oxburgh } \\
\text { elkirk } \\
\text { hetland } \\
\text { irling } \\
\text { ltherland } \\
\text { ligtown }\end{array}$ & $\begin{array}{r}52, \\
575, \\
562 \\
76, \\
104, \\
240, \\
222, \\
1,595, \\
153, \\
1977, \\
426, \\
170, \\
352, \\
288, \\
1,297, \\
351,\end{array}$ & $\begin{array}{r}7,528 \\
38,363 \\
1,447,113 \\
79,456 \\
9,319 \\
25,896 \\
15,258 \\
124,339 \\
314,574 \\
77,353 \\
47,192 \\
24,600 \\
27,911 \\
161, \infty 03 \\
20,180 \\
31,990\end{array}$ & $\begin{array}{l}+7.8 \\
+2.6 \\
+\quad .8 \\
+20.9 \\
+\quad .3 \\
+\quad 9.8 \\
+\quad 1.3 \\
+17.0 \\
+1.2 \\
+3.3 \\
+5.3 \\
+13.9 \\
+5.9 \\
-\quad 2.1 \\
\end{array}$ \\
\hline & & & 82 & $4 \mathrm{I}, \infty 7$ & & Total & $19,070,46$ & $4,759,445$ & +6.4 \\
\hline
\end{tabular}

Table B. Scottish Burghs having over 30,000 inhabitanis.

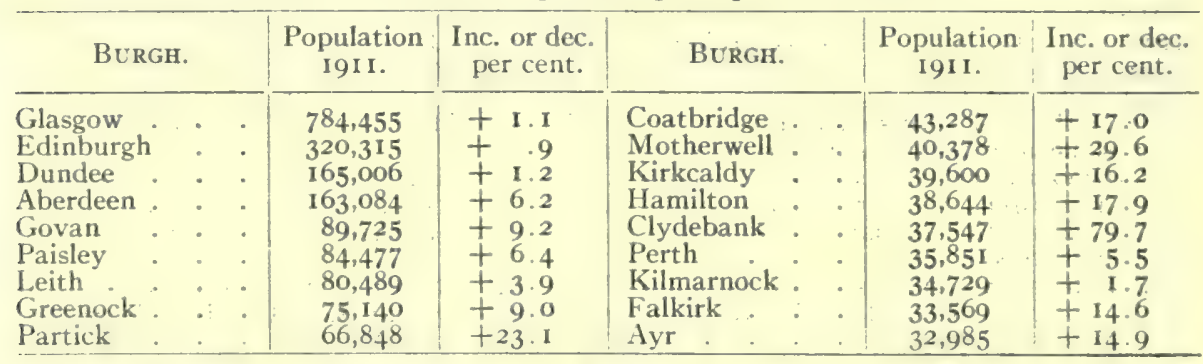

of course, have made contributions to the multitude of emigrants, but the effect of emigration has been chiefly felt in the purely agricultural counties. Thus, compared with the census returns of $\mathrm{rgor}$, at which period modern emigration enterprise had scarcely begun, decreases are to be noted (Table A) in the following counties:-Shetland, Orkney, Caithness, Sutherland, Inverness, Elgin or Moray, Forfar, Clackmannan, Argyle, Bute, Berwick, Roxburgh, Kirkcudbright, Wigtown. In those counties the staple occupations of the people are agriculture or fishing. A more cheerful state of things is revealed in the counties which contain the chief cities and towns, and where the people are engaged in industrial pursuits. Thus, Lanarkshire shows an increase of ro7,786, Fifeshire 48,894, Dumbartonshire 25,066, and Renfrewshire 45,594. Perhaps the most remarkable increase is in Fifeshire. The "Kingdom " is unique among counties, half of it being almost entirely rural, and the other half chiefly industrial. In East Fifeshire farming and fishing are the principal occupations, and its picturesque parishes and townships have suffered by the exodus of the sturdiest part of the population to other lands, a fact borne out by the decrease in the fishing communities, and the growing difficulty of procuring agricultural labour. The increase of population in Fifeshire is entirely in the West, the seat of coal mining, and the great linoleum manufactures.

The deaths in the eight principal towns of children under one year numbered 5907 . The births registered were 44,206 , and the aggregate infantile mortality for the year was 134 per thousand. It ranged from 156 in Edinburgh, 139 in Glasgow and Aberdeen, to 112 in Greenock, and $I I I$ in Paisley.

Agriculture.-The land system in Scotland is in some respects peculiar, and the huge estates and large farms on which it is based have proved a severe handicap to the enterprise of an uncommonly capable peasantry. The land agitation, a chequered history of economic struggle, which, particularly in the north, assumed a virulent and often violent form, has not however within recent years shown much vitality. The 
problem of the Highland crofter is at least in process of settlement, and the operations of the Congested Districts Board have certainly had beneficial effect. The number of new holdings formed since the establishment of the Board ( 1898 ) is $6 \mathrm{I}$ I, while 1068 crofters have obtained enlargement of holdings. The last notable intervention of the Board followed on the dispute between Lady Cathcart and her tenants at Castlebay, part of her Hebridean possessions, which resulted in what was known as the Vatersay Raid (1908). This, the latest crofter rising in the Islands, was at the time somewhat exaggerated, although events proved that the tenants had reason for their action. The inhabitants of Castlebay eke out a slender livelihood, partly by their labour on a peculiarly sullèn soil, and partly by fishing. The land is barren and scarcely adequate to maintain one family on each holding. The difficulty arose from "squatters," members of the crofter families, who set up huts on the family crofts. The inevitable congestion followed. Opposite Castlebay is the Island of Vatersay, then occupied by grazing farms. Some of the bolder spirits among the "squatters," the pioneers being three lobster fishermen, descended on Vatersay, erected huts, and proceeded to agricultural activity. There were some exciting encounters 'between the forces of law and the Vatersay " raiders," culminating in the imprisonment of half a-dozen of the latter, who were however released before the expiry of their term of sentence. The Congested Districts Board intervened, purchased the Island of Vatersay, where now is a contented crofter population, and thus the trouble ended. But, while the exertions of the Congested Districts Board and the Crofter Commissioners who fix fair rents have made for crofter contentment, the Highland land problem has not yet reached solution.

There is still considerable heart-burning over the question of deer forests. The latest returns show that of those there are 198 with a total acreage of $3,369,936$. The Sutherland "clearances" which resulted in the compulsory emigration of fifteen thousand people within a period of nine years, still rankle in the Highland memory. Doctrinaire land reformers are perhaps inclined to exaggerate the agricultural potentialities of the deer forest. However, the passing of the Smallholders' Act of ror I will enable the fertility of those sporting estates to be put to the test. This Act, the most important piece of land legislation in Scotland for many years, is a modification of the Pentland Bill, which aroused much controversy. It by no means goes the length of that drastic measure, although it retains its cardinal principle, enabling an agriculturist with small capital to obtain compulsorily a holding of 50 acres, the landlord being compelled to provide house and steading. But although now on the statute book it will be some time before the Act can be operated to any great extent. The leases of large farms will have to run out before the division of acres can be made. When, however, the Act does become operative, it cannot fail to break up the historic land system of the country. Among the smaller cultivators, whose position in Scotland has been peculiarly hard, their few and scattered acres being rented considerably in excess of the acreage of the great farms, the Act has naturally been hailed with satisfaction, nor has much opposition been displayed towards it by the large farmers.

The truth is that farming on an extensive scale is no longer the profitable business it was, either for landlord or tenant. Agricultural rent in Scotland has fallen enormously, the rental of large farms being on an average only half what it was twenty years ago. And this drop, while seriously affecting the land owner, has not benefited the tenant. The development of agricultural science and the growth of foreign competition have rendered farming on an extensive scale a costly, and even a hazardous undertaking, added to which the cost of agricultural labour has greatly advanced. The wages of ploughmen have doubled, and in some cases trebled, and with the flow of emigration and the scarcity of labour in the rural districts, they tend to increase. An important factor in the case is the altered standard of living among the rural population. The cheap and sustaining brose is now a rarity in cottar's house and bothy, and even porridge has ceased to be the staple of the morning meal. On the other hand, much tea is drunk and there is a large consumption of butcher meat, a commodity almost entirely unknown among the Scottish peasantry of the past. Moreover, the Scottish hind has recently 
become pervious to the influence of Trade Unionism, and in IgI 2 a rural Union was started which already numbers thousands of members. That being the condition of things, the Small Landholders' Act makes a timely appearance. It should have the effect of stemming the tide of emigration, checking the migration to the towns, and consequently re-peopling the rural districts. Notwithstanding the disadvantages indicated, the agricultural enterprise of Scotland shows astonishing vitality. ${ }^{1}$ The question of afforestation, in which Scotland, like other parts of Great Britain, is far behind other countries, has recently been a subject of agitation, and the Development Commissioners have recommended that grants should be given for the establishment of a central administration area, along with a school of forestry of not fewer than 5000 or more than 10,000 acres. The recommendation has already had practical effect, the Government having agreed to purchase a tract of land in Argyleshire.

Trade and Manufactures. - In regard to trade a retrospect of $1910-12$ reveals a period of prosperity tempered by the adverse influence of labour disturbances. Scotland is a country of multifarious industries, but the staple of her trade consists of shipbuilding, iron, and coal mining, all of which are interrelated. In the western part of Scotland, of which Glasgow is the centre, shipbuilding is of prime importance, and the measure of activity in the Clyde yards is the truest measure of the industrial prosperity of the district. The Clyde may be described indeed as the industrial pulse of the country, and the prosperity or otherwise of her yards is reflected in the national industry.

In the matter of shipbuilding, the Clyde, of course, dominates Scotland. During 191012, there were improvements in the trade on the Forth and Tay, but the increase of tonnage in those districts was infinitesimal when placed alongside the increase on the Clyde. The following table shows the work done by Scottish builders in I9I I and I9I 2:-

1912

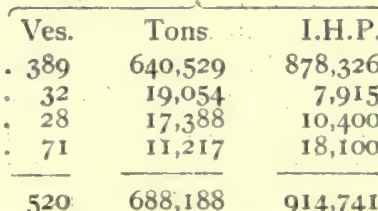

1911

\begin{tabular}{rrrr} 
Ves. & Tons. & I.H.P. \\
413 & 630,583 & 786,889 \\
31 & 11,319 & 9,355 \\
31 & 17,303 & 14,770 \\
82 & 12,419 & 23,614 \\
\hline 557 & 671,624 & 834,628
\end{tabular}

In the kindred branch of marine engineering a feature is the increasing share in the total output of turbines. In the record for Clydebank, a typical yard, the total engineering output in I9I I was 104,550 i.h.p. and of those 71,000 consisted wholly of turbines, and II,250 of combined turbines and reciprocating engines.

In coal mining ${ }^{2}$ the west of Scotland also continues to lead, although its supremacy in this branch of industry is less secure. The most notable advance in output was in Fifeshire, which in 191 I showed an increased production of 375,000 tons, and the industry in Fifeshire is advancing rapidly and is likely soon to outdistance. Glasgow and the west of Scotland in the matter of shipment. The reason is due to the fact that the extensive Fifeshire coalfield is still in process of development, whereas, in Lanarkshire, the coalfield is almost entirely covered with collieries, and there are naturally no new developments. By the application of machinery, however, notably in coal cutting, the capacity of the western mines has been increased. On the other hand, large new pits have recently been sunk in Fifeshire, and their present output will certainly grow enormously. A feature of the Fifeshire shipping trade is the large and increasing exports to South America. The total shipments of coal from scotland (export and bunker) amounted in I911 to 1,680,000 tons compared with 1,640,000 tons in the previous year, an improvement of fully 40,000 tons. The increase, however,

1 The following figures are taken from returns for 1912 , with the increase $(+)$ or decrease (-) per cent on the previous year. Acreage under corn crops 1,230,125 (+0.9); under green crops 6I5.36I ( $+\mathrm{I} .4)$; clover and rotation grasses $1,+65.514(-3.0)$; permanent pasture $1,496,0+5(-0.1)$; wheat 62,463 ( -1.6 ; but in 1911 the greatest increase was recorded since 1899 ); barley 183.477 ( +1 I .7); oats 949,143 (-I.5); turnips and swedes $439,185(+0.1)$; potaloes $149.710(+5.0)$; total under all crops and grass $4,821,249(-0.5)$. Livestock-horses 204,792 (-0.8); cattle 1,178,936 (-1.8); sheep 6,991,667 (-2.4); pigs $159.391(-6.9)$.

2 Production in 1910: Argyll, Dumlries and District, $4+4.033$ tons; Ayr, 4,018,119; Clackmannan, 405.912; Fife, 8,674,404; Renfrew, 132,756; Dumbarton, 558.381; Linlithgow, 2,059,433; Edinburgh, 2,991,81 I; Haddington, 1,088,364; Lanark, 17,886, I37; Stirling, $3,075,782$. 
was only about half that which took place in 1910, compared with 1909, and the falling off must be largely attributed to labour traubles. Glasgow and the west of Scotland took good position with an increase of fully 300,000 tons, and in Ayrshire between the ports of Ayr and Troon there was an increase of 150,000 tons. On the other hand the Forth (excluding the Fifeshire ports) made a comparatively poor show. At Grangemouth there was a decrease of 260,000 tons, and although Granton improved its position by 130,000 tons, due largely to an increasing trade with London, Leith showed a falling off of 120,000 tons. While the condition in the Scottish coal trade on the whole is satisfactory an unpleasant factor is to be reckoned with in German competition. At one time Germany constituted one of the best markets for Scotch coal, but now she is entering into active competition.

In the mineral oil industry, whose centre is West Lothian, the prospect is less bright. This is due chiefly to foreign competition, which was severely felt during the past year, with the result that prices of oil products never got a chance. The slackness of the Scottish oil market is best indicated by the drop in profits during 1909-I912. During that period Pumpherston dividend has fallen from 50 per cent to 30 percent; Tabrax from $7 \frac{1}{2}$ per cent to 5 per cent; Oakbank from ro per cent to 5 per cent; Young's Paraffin Oil Co. and the Broxburn Oil Company paying percentages respectively of $4 \frac{1}{2}$ and Io per cent.

Foreign competition is being felt also in steel manufacture. This is indicated by the action of Scottish makers in introducing rebates (the outstanding feature in recent developments of the industry) with the object of limiting outside competition. It would be premature to judge of its effects, and meantime it has not resulted in any marked improvement, there being a falling off in supplies, particularly to Canada, owing to American manufacturers' prices being lower than those of the home market. A contingent effect of foreign competition is indicated by the continued slackness in locomotive building. The Scottish industry chiefly depended on the foreign market, particularly the East, and the foreign orders are dwindling, although there is a slight improvement in colonial trade.

The three trades already mentioned are the vitals of industrial Scotland. Next to them may be ranked the various branches of textile manufactures. While the woollen trade of the borders has been in a state of almost unexampled prosperity, the jute trade of Dundee during I9II underwent one of the worst periods in its history, but entirely recovered towards the end of 1912 . The linen trade, although satisfactory, has been hard hit by foreign competition, which has been felt in its chief seat, Dunfermline, and the cotton trade has suffered chiefly from the same cause. It is still located principally in the east end of Glasgow, but many of the great mills of Bridgeton, where once it flourished, are now devoted to other enterprises, and stand, pathetic witnesses of a great decline. The thread industry, however, continues a huge industrial asset to the West, the headquarters of the great Coats' combine being in Paisley. Another branch of the textile trade, that of dyeing, has undergone a change. The Combine of a few years ago has resulted in the concentration of the industry, and many of the smaller works at different points in the west of Scotland have been closed. The total value of produce and manufacture from the chief Scottish ports was: Glasgow $£ 29,129,406$, Leith $£ 6,875,636$, Grangemouth $£ 2,239,581$.

A general consideration of the industrial outlook reveals the eastern part of the country as portentous of greatest development, and the increased activity here is almost entirely limited to Fifeshire. That county, in its western area, has grown enormously in industrial importance within recent years. The basis of its prosperity is the wealth and extent of its coalfields, and within the coal area many important manufactures have sprung up, notably. linoleum, the staple trade of Kirkcaldy, and now extending to other parts of the "Kingdom. Fifeshire ports also continue to grow in importance, notably Methil, which, with the completion of the new dock will contribute to make the Fifeshire ports of the Forth serious competitors with the west in the export of coal and iron. The establishment of the naval base at Rosyth, in process of construction since 1908 , will stimulate industry in the western part of the county, and already in the neighbourhood of the dock a town is developing.

Fishing.-The fishing industry of Scotland has changed greatly in the manner of its pursuit. Formerly, it was interwoven with the work of agriculture, particularly in the Western Highlands, where crofters profitably combined the harvest of the waters with the harvest of the land. Those were in the days of sailing boats, the possession of which was within the reach of thrifty fishermen. The advent of the steam drifter is gradually crushing out the modest sailing boats, and their humble owners, who find it impossible to compete against highly equipped drifters, which generally have behind them powerful capitalist influence. The industry is now largely in the hands of large combines, who own a fleet of drifters, and although the new order has doubtless proved beneficial to the consumer it has been detrimental to the economic welfare of the working fisherman, who has to be content with the position as member of a drifter crew, with little prospect of ever having a boat of his own. The combine system is rapidly spreading. Salmon fishing on the Tay, for example, is now monopolised by wealthy companies, whereas formerly the fishings were distributed among small fishermen. The effect is seen in the changed complexion of Newburgh, whose community until a few years ago was almost entirely engaged in the Tay fishings. It has sunk to a town of little importance in salmon fishing, and such prosperity as it still enjoys is based on the manufacture of linoleum. For administrative purposes the Fisheries Board 
of Scotland have divided the Scottish Coast into three districts, namely, ( 1 ) the East CoastEyemouth, Leith, Anstruther, Montrose, Stonehaven, Aberdeen, Peterhead, Fraserburgh, Banff, Buckie, Findhorn, Cromarty, Helmsdale and Wick. (2) Orkney and Shetland. (3) West Coast-Loch Broom, Skye, Fort William, Loch Fyne, Campbeltown, Rothesay, Greenock, Ballantrae, Stornoway and Barrow. The tonnage of boats belonging to those divisions is as follows: East Coast, IOI,721; Orkney and Shetland, 22,517; West Coast, I5.735, a total of 139,973 . While the Fishery Board has rendered good service to the industry the undoubted grievances of native fishermen in regard to foreign trawling remains unremedied. The Scottish Board in 1885 obtained statutory powers to close portions of the territorial waters against trawling, and a large area of east coast waters was closed in the interests of scientific experiment. It was found that the closing of those waters gave great satisfaction to both line and drift fishermen, and as the Board were anxious to encourage development of those methods of fishing in preference to beam trawling, they secured further powers under the Herring Fishing Act of 1889 , which enabled them to close against all forms of trawling not only the whole territorial waters of the Scotch coast but a large number of areas defined in the Scheduled Act as lying outside the territorial waters, properly so called. Among those scheduled areas were the Moray Firth, and the Firth of Clyde. By international law the power of a state to make regulations with regard to methods of fishing is limited to its territorial waters. There are a number of regulations existing with regard to the fishing boats working in the North Sea, but these regulations have been made under International Conventions, and are to be only obeyed by the subjects of the high contracting states. But apparently Parliament can make regulations which are only obligatory to British fishing vessels. Hence, while the latter cannot trawl within the Firth of Clyde, or the Moray Firth except in a very limited area, foreign trawlers may fish anywhere in the considerable area which lies outside the area known to International Law as Scottish territorial water. Thus Dutch and Norwegian vessels at Fleetwood fish in the Clyde. Some of them are doubtless bona fide foreign boats, but for the most part they are English vessels registered either in Norway or Holland. Foreign trawlers find it convenient to work Scottish waters and to land their catches in Fleetwood, and they are enabled to do so owing to a flaw in the Herring Fishing Act of i 889. A slight amendment prohibiting the landing of fish in England as well as in Scotland by such vessels, would remedy the difficulty.

The fishing fleet comprises 9889 vessels with an aggregate tonnage of 139,973 and a total value of equipment and fishing gear amounting to $f 5,000,028$, the number of persons employed in the Scottish fishing trade, and industries subsidiary thereto is 92,060 , and of those 39,208 man the fleet, the remainder being engaged in operations on shore. Eleven vessels, employing $42+$ men, 145 of whom are British, are engaged in whaling. In I9II, 730 whales were landed, and the value of the products amounted to $£ 71,223$. The outstanding feature is the continued decline in the number of boats, the quantity and value of the gear, and the numbers employed in the industry. The cause of this decline is chicfly due to the replacement of sailing boats by steam and motor driven vessels, but fishing, like agricultural, communities have suffered considerably from the drain of emigration. It is difficult to get fishermen to divulge their earnings, but the following figures may be regarded as authentic, relating to a particular Scottish district: Steam trawlers (highest) £1610, (lowest) f900, (average) £I 388 ; Motor Boats (highest) £1610, (lowest) £600, (average) £973; Sailing Buats (highest) 6910 , (lowest) $f_{120}$, (average) $f_{412}$. The output of sailing boats steadily declines, the number of vessels constructed in 1911 being 164 , valued at $f_{7} 940$, compared with 193 valued at $£ 8334$ in the previous year. The total quantity of fish, exclusive of shell fish, landed in Scotland was $8,709,655 \mathrm{cwts}$. valued at $£ 3,100,387$. Compared with 1910 this shows an increase of $1,286,470$ cwts. and an increased value of $£ 211,280$, the second highest result on record. In $1911,1,767,544$ barrels of herring were exported, 3 II, 188 being "Crown" branded. The total of cod, ling, and dried fish exported was 104,058 cwts., nearly all to Ireland. The total salmon carried on Scottish railways was 27,390 cwts.

Ruilways.-The profit earning capacity of the Scottish railways has declined, due in large measure to the development of the tramway enterprise and the increased use of motor cars. Through the industrial parts of the country there is now a complete system of tramway communication, linking districts many miles apart. The extent of the tramway undertaking may be gathered from the fact that the passengers carried in 1911 numbered 276 . 745.475 . The effect on railway enterprise is obvious, and in order to meet the compecition the different Railway Companies recently came to an arrangement which has resulted in a conciderable curtailment of competing trains, and a general increase in passenger fares. The most important decision in railway law in $1911-12$ was that given by the Railway Comnisioners sitting in Finburgh, on the demurrage case brouglit by the Scottish traders against the principal companies. The decision was almost entirely in favour of the Companies, and its importance lies in the fact that it gives them full use of their wagons for their legitimate furpose, thus setting loose a large capital, previously locked up in rolling stock, which had virtually been seized by the trader as free storage accommodation.

The Scuttish railways are behind those of England in regard to electrification, a beginning not yet having been made. On the other hand a series of successful experiments were carried out with a small electrical driven vessel, and it is probable that the next step will be 
the construction of a large ship for service. It is appropriate that this departure should find its home on the Clyde. which 100 years age witnessed the initiation of steam propulsion with the launch of the "Comet," an event which was elaborately celebrated on the Clyde in IgI2. While there has been little in the way of railway development, there has been a growing agitation for improved communication by water. An ambitious project has been advocated, notably by Sir Charies Campbell, that a ship canal should be constructed, uniting the Forth with the Clyde on the route of the present shallow canal, or by a new route embracing Loch Lomond in its course. : From a naval point of view it is urged that such a canal would be an important adjunct to Rosyth dock. So far, the scheme has failed to win much support from the commercial communities, and obviously the sum that would be required for its fulfilment is of such magnitude that it could not be ventured upon without Government subsidy.

Education.- The most remarkable feature of recent educational development in Scotland has been the growth of technical education. Technical schools are now established in every important town, and under the auspices of the county council the system has been extended to provide instruction for those in rural districts. The chief centre is naturally Glasgow, whose Royal Technical College (the " Royal " distinction was conferred upon it in $19 \mathrm{I}_{2}$ ) is the largest institution of its kind in the United Kingdom, and among the largest in the world. The work of the College is associated with that of the University, and an endeavour is being made to bring the relationship still closer. The Scotch Universities themselves are proving responsive to the new spirit in education, and although strong as always, in the "Humanities" they are extending their curriculum to include instruction of a more utilitarian sort. This tendency is most marked in Glasgow, whose greatest development has been in the direction of Engineering Science and Chemical Research. St. Andrews, the most ancient seat of Scottish learning, which celebrated its quin-centenary in I9IO, on an impressive, if less imposing scale than the sister University of Aberdeen, which celebrated her quatercentenary in I906, remains largely a centre of pure scholarship, but utilitarian tendencies are evident in the development of the seats of learning in Edinburgh and Aberdeen. The princely benefaction to the Scottish Universities made by Dr. Andrew Carnegie in I9or, has tended to strengthen the democratic character of Scottish Academic life, which never, indeed, has been so exclusive as in the great English universities. With recent developments in Secondary and Higher Grade Schools, and the elaborate system of Continuation Classes the Scattish educational system may now claim to link in an unbroken chain the Elementary School with the University:

The most notable legislative event of recent years was the Scottish Education Act of 1908. It greatly extended the powers of school boards in the direction of feeding necessitous children, the medical inspection of pupils, and the compulsory attendance at continuation classes. It has also, to some extent, checked the spirit of sectarianism, the great church training colleges being now controlled by representative committees. Sectarianism however has never been a conspicuous blemish in the Scottish educational system, and the great Presbyterian bodies, the Church of Scotland, and the United Free Church, who formerly controlled the Training Colleges, loyally fell in with the new National scheme. The Act has not, however, affected to any appreciable extent the old school board areas, and it retains the system of cumulative voting, which leads to many abnormalities in representation.

Administration.-Scotland has a comprehensive system of county and municipal government, but as regards the country generally there is a lack of co-ordination and greater national control is obviously desirable. Thus it is still necessary when any great scheme of county or city development is promoted to have it considered by Parliamentary committees in London. The Private Bill Legislation Act, passed some years ago, has mitigated only to a slight extent this old standing grievance. Perhaps, however, it is in educational affairs that the system of administration proves most irritating. The headquarters of the Scotch Education Department are still in London, although much of the clerical work hitherto done there has been transferred to Edinburgh. It is felt that the educational authority should be concentrated in Scotland, and the desirability of rearrangement seems obvious from the fact that there are in Scotland, including Inspectors, I 8 officers of the Education Department, and only 50 in London.

In the sphere of municipal activity the most notable event has been the extension of Glasgow boundaries. The total area of the city is now 19,082 acres, an addition of 6107 , and the population of the city has been increased from 784,456 to $\mathrm{I}, 010,000$. The scheme as 
originally formulated would have increased the area to 33,166 acres and would have embraced large tracts of rural land, the object of the promoters being to give effect to the provisions of the Town Planning Act. The original scheme was practically endorsed by the House of Commons Committee, but it was curtailed to the extent indicated when it came before the Committee of the House of Lords. Greater Glasgow now includes the adjacent burghs of Govan and Partick and portions of the county areas of Lanark and Renfrew. The places absorbed, however, are all populous, and the density of the population in the extended city is only slightly less, being 52.8 per acre against 60.4 ; and it is still largely in excess of the other large cities of the kingdom. The valuation has been greatly increased. The latest valuation for the smaller area was $£ 6,000,000$ and the extension of boundaries is estimated to increase this by about $\{2,000,000$. Under the Boundaries Act, however, it is stipulated that no increase of rates can be imposed on the places annexed, until the lapse of five years, so that during that period the cost of improvements will fall upon the ratepayers within the old city boundaries. Dunfermline has also extended her boundaries to include Rosyth, and an elaborate scheme of extension is at present under consideration by Dundee.

Poor Law.-The number of poor in receipt of relief in 191 I was 73,642 , and 40,370 dependents, and the burden of local rates which steadily advances, having increased during a period of 15 years by $1 / 5.4 \mathrm{~d}$. or 48.9 per cent is chiefly due to the increase of the poor rate, education and sanitation. The latest available returns, I9II, shows the total amount paid on local taxation to be $£_{1}, 286,396$. The most recent development in the relief of the poor is under the Unemployed Workmen's Act of 1905. The total population of the areas in which distress committees are engaged is I, $989,95 \mathrm{I}$, being $4 \mathbf{I} .8 \mathrm{I}$ per cent of the population of Scotland. The total receipts from all sources from operations under the act amounted in 1911 to $£ 29,182$ which includes $£ 14,300$ from the Parliamentary Grant, $£ 5737$ from the rates, $£ 2254$ from voluntary contributions and $£_{6315}$ from the work performed by the unemployed. The expenditure was $£ 29,701$.

Religion.-Presbyterianism continues the dominant faith in Scotland, but recent years have witnessed a considerable growth of the Roman Catholic community, and of the Scottish Episcopal Church. Latest returns give the membership of the Church of Scotland (I687 Churches) at 706,653; United Free Church (1,620 Churches) 501,573: Free Church (150 Congregations) 60,000: Episcopal Church (338 charges) 52,029. The Roman Catholic Church has 398 Churches, Chapels and Stations, 550 Priests, and the Roman Catholic community is estimated at $\mathrm{I}, 000,000$. Politically, Scotland has never manifested any aggressive desire for national self government, and she has undoubtedly benefited materially from the Union with England. There have been frequent attempts to stimulate interest in "Home Rule for Scotland," but they have proved abortive, owing to the apathy of the people. In another sense, however, there has been within recent years an undoubted revival of national sentiment, reflected in the widespread interest now taken in Scottish customs, language, and literature. It has found expression in the establishment of a Scottish Chair in the University of Glasgow, to further which project a Scottish Exhibition was held in the city in 1911 , resulting in a surplus of $£ 20,000$, which, with other contributions, has enabled the foundation of a Chair of Scottish History and Literature. And, although there cannot be said to exist a national demand for "Home Rule" in the form of a National Parliament, there is, as indicated, widespread dissatisfaction with the present conduct of national administration. The creation of the Scottish Office under a Secretary for Scotland has rather added to the confusion, and among all sections of the community, irrespective of party, there is a strong feeling that the Scottish department should be situated in Edinburgh, and under the control of a national administrative council.

(DONALD MUIR.)

\section{IRELAND ${ }^{1}$}

The material prosperity of Ireland reached a higher point in $I 9 I 2$ than at any period during the past century. It is true that, according to the census returns published in IgI , the population is still declining. but prosperity cannot be reckoned in terms of population alone. The population of Ireland, as given in these returns, which refer to the middle of 1910 , is 4,381,951. (Details are furnished in Tables A and B.) During: I 9 I I the marriages registered in Ireland numbered 23,473 , the births $101,75^{8}$, and the deaths 72.475 . The marriage rate was 5.37 per thousand of the estimated population, an increase of 0.32 on the preceding year; the birth rate was 23.3 per thousand, the sami: as the preceding year; and the death rate was 16.6 per thousand, 0.5 below the rate of the preceding year. Since the census of $I 90 \mathrm{I}$ the population has decreased by 76,824 , or 1.7 per cent. This is the smallest decrease known since the institution of the census. Not only the decrease, but the rate of decrease is rapidly slackening. The decrease is very unevenly distributed over the four provinces-36,966 in Connaught, 43,103 in Munster, $7+99$ in Leinster, and 4254 in Llster. There is a large growth in the population 1 See E. B. xiv, $7 \$^{2}$ et seq., and articles on the various counties and towns. 
of the cities of Dublin and Belfast-over I8,000 and 36,000 respectively. In these cases the increase is due to internal expansion.

Table A-Irish Provinces and Counties.

\begin{tabular}{|c|c|c|c|c|c|}
\hline \multirow{2}{*}{$\begin{array}{c}\text { Provinces and } \\
\text { Counties (includ- } \\
\text { ing County } \\
\text { Boroughs). }\end{array}$} & $\begin{array}{c}\text { Popula- } \\
\text { tion }\end{array}$ & $\left\{\begin{array}{c}\text { Inc or Dec. } \\
\text { per cent on } \\
1901\end{array}\right.$ & \multirow{2}{*}{\begin{tabular}{|} 
Provinces and \\
Counties (includ- \\
ing County \\
Boroughs)
\end{tabular}} & $\begin{array}{l}\text { Popula- } \\
\text { tion. }\end{array}$ & \multirow{2}{*}{$\begin{array}{l}\text { Inc. or Dec. } \\
\text { per cent on } \\
\text { IgoI. } \\
\text { Rate } \\
\text { per cent. }\end{array}$} \\
\hline & 1911. & $\begin{array}{l}\text { Rate } \\
\text { per cent. }\end{array}$ & & I9 11. & \\
\hline $\begin{array}{l}\text { Connaught:- } \\
\text { Galway } \\
\text { Leitrim } \\
\text { Mayo } \\
\text { Roscommon } \\
\text { Sligo } \\
\end{array}$ & $\begin{array}{r}181,686 \\
63,557 \\
191,969 \\
93,904 \\
78,850 \\
\end{array}$ & $\begin{array}{l}-5.6 \\
-8.3 \\
-3.6 \\
-7.7 \\
-6.2\end{array}$ & $\begin{array}{l}\text { MuNStER:- } \\
\text { Clare } \\
\text { Cork, E. R. } \\
\text { Cork, W. R. } \\
\text { Kerky } \\
\text { Lir.erick }\end{array}$ & $\begin{array}{l}104,064 \\
267,472 \\
123,718 \\
159,268 \\
142,846\end{array}$ & $\begin{array}{l}-7.4 \\
-1.9 \\
-6.2 \\
-3.9 \\
-2.2\end{array}$ \\
\hline Total Province & 609,966 & $-5 \cdot 7$ & Tipperary, N. R. & & -5.7 \\
\hline \multirow{3}{*}{$\begin{array}{l}\text { LeINSTER:- } \\
\text { Carlow } \\
\text { Dublin } \\
\text { Kildare } \\
\text { Kilkenny } \\
\text { King's }\end{array}$} & \multirow{3}{*}{$\begin{array}{r}36,151 \\
476,909 \\
66,498 \\
74,821 \\
56,769\end{array}$} & \multirow{3}{*}{$\begin{array}{r}-4.2 \\
+6.4 \\
+4.6 \\
-5.5 \\
-5.7\end{array}$} & rd . . . & 83,766 & $-3: 9$ \\
\hline & & & Total Province & $1,033,085$ & $-4: 0$ \\
\hline & & & $\begin{array}{l}\text { ULST } \\
\text { An }\end{array}$ & 478,603 & \\
\hline Longford & 43, & -6.2 & & & $\begin{array}{l}-4.6 \\
-6.6\end{array}$ \\
\hline Louth & 63 & $-3: 7$ & Donegal & & \\
\hline $\begin{array}{l}\text { Meath } \\
\text { Queen's }\end{array}$ & $\begin{array}{l}64,920 \\
54,362\end{array}$ & $\begin{array}{l}-3 \cdot 8 \\
-5 \cdot 3\end{array}$ & n,$\ldots$ & & \\
\hline Westmeath & & $-2,9$ & $\mathrm{Fe}$ & I & -5.5 \\
\hline Wicklow & $\begin{array}{r}109,287 \\
60,603\end{array}$ & $\begin{array}{r}-1.7 \\
-4\end{array}$ & $\begin{array}{l}\text { Londonderry } \\
\text { Monaghan . }\end{array}$ & & $\begin{array}{l}-2.6 \\
-4.3\end{array}$ \\
\hline \multirow{2}{*}{ Total Province } & \multirow{2}{*}{$1,160,328$} & \multirow{2}{*}{+07} & & & \\
\hline & & & Total Province & $1,578,572$ & $\therefore-0.3$ \\
\hline
\end{tabular}

Table B-Largest Irish Towns.

\begin{tabular}{|c|c|c|c|c|c|}
\hline $\begin{array}{lll}1 & 1 \\
- & 1\end{array}$ & $\begin{array}{l}\text { Popula- } \\
\text { tion }\end{array}$ & $\begin{array}{c}\text { Inc or Dec. } \\
\text { per cent on } \\
1901\end{array}$ & 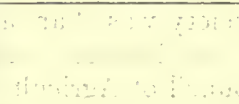 & $\begin{array}{c}\text { Popula- } \\
\text { tion }\end{array}$ & $\begin{array}{l}\text { Iric or Dec. } \\
\text { per cent on } \\
\text { I } 901 \text {. }\end{array}$ \\
\hline 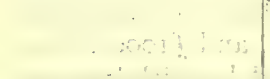 & I9II. & $\mathrm{R}$ & H & I9I I & $\begin{array}{r}\mathrm{R} \\
\text { per }\end{array}$ \\
\hline $\begin{array}{l}\text { DUBLEN AND SUB- } \\
\text { URBS:- } \\
\text { Dublin City } \\
\text { Rathmines and } \\
\text { Rathgar } \\
\text { Pembroke } \\
\text { Kingstown } \\
\text { Blackrock }\end{array}$ & $\begin{array}{c}309,272 \\
38,190 \\
29,260 \\
17,227 \\
9,081 \\
\end{array}$ & $\begin{array}{r}+6.4 \\
+17.1 \\
+13.4 \\
-0.9 \\
+\quad 42\end{array}$ & $\begin{array}{l}\text { alk } \\
\text { alk } \\
\text { neda } \\
\text { rn } \\
\text { down } \\
\text { dow }\end{array}$ & $\begin{array}{l}\text { I3 } \\
\text { I3 } \\
12 \\
\text { I2 } \\
\text { I2 } \\
\text { II } \\
\text { II } \\
\text { II }\end{array}$ & $\begin{array}{l}-1.3 \\
+\quad 0.4 \\
-\quad 2.6 \\
-\quad 3.0 \\
+\quad 6.2 \\
-\quad 3.6 \\
+16.2 \\
+\quad 2.6\end{array}$ \\
\hline Total & $40_{3}, 030$ & 474 & 4. & & $\begin{array}{r}+4.5 \\
+\quad 2.7\end{array}$ \\
\hline $\begin{array}{l}\text { Belfast } \\
\text { Cork } \\
\text { Londonderry } \\
\text { Limerick } \\
\text { Waterford }\end{array}$ & $\begin{array}{r}385,492 \\
76,632 \\
40,799 \\
38,403 \\
27,430\end{array}$ & $\begin{array}{r}+10.4 \\
+\quad 0.7 \\
+\quad 2.3 \\
+\quad 0.7 \\
+\quad 2.5\end{array}$ & $\begin{array}{l}\text { Kilkenny } \\
\text { Clonmel. }\end{array}$ & & $\begin{array}{r}-0.9 \\
+\quad 1.1\end{array}$ \\
\hline
\end{tabular}

In certain counties, howeverr, a slight but appreciable tendency on the part of the population to move from the rural to the urban districts may be noticed. This feature is especially marked in County Longford, the West Riding of County Cork, County 
Cavan and County Sligo, where the urban population has increased by 6 per cent at the expense of the rural, County Roscommon 7 per cent and County Leitrim 8 per cent. Allowing both for the natural growth of the more important towns and the urban expansion in these districts at the expense of the rural population, the gross decline of agricultural population for the whole country during the decade is approximately 146,000 . The total emigration represents a correspondingly large number, but the figures for I $91 \mathrm{I}-3 \mathrm{I}, 058$-are the smallest on record since early in the century.

Agriculture.-Most of the decline represented by these alarming figures must be allotted to the earlier years of the decade. Since rgog the rural decline has been substantially checked. The earlier years of decline in arable cultivation, and consequently in agricultural population, were reflected in the increased production from pasture lands and of cattle feed generally, and the material increase in the number of store cattle. The cattle industry no longer flourishes directly at the expense of cultivation.

The total area of corn and green crops, including flax and fruit, in Ireland in 1912 was $2,357,969$ acres, an increase of 9148 acres on the preceding year. The corn crop, growing on $1,265,597$ acres, showed an increase of 11,166 acres. There was a decrease of 211 acres in the total area under wheat, but this was entirely due to the heavy decrease-1II0 acresin Connaught. The area under oats showed an increase of 5736 acres; in Ulster the increase was 10,379 acres, while the acreage had decreased in the other three provinces. The increase in barley-7186 acres - was distributed over the four provinces. The total area of potatoes was 595,2 1 8 acres, an increase in the year of 3959 acres; there were increases in Leinster and Ulster ( 876 and 3670 acres) and decreases in Munster and Connaught (I 46 and I 441 acres). The acreage under turnips showed an increase of 956 acres to 271,761 . The total area of hay was $2,479,159-$ a decrease of 33,244 acres in all the provinces. The approximate yield per acre was oats 5 I.I bushels, barley 44 .I bushels, wheat 38 bushels. The total yield of potatoes was approximately 3.1 million tons, and of hay 5.1 million tons. The area under flax had decreased by 1 I,70I acres in 19 I 2 to 54,917 , the decrease being general throughout most of the flax-growing counties. The area of pasture, including mountain grazing, was $12,418,867$ acres-a decrease of 11,931 acres. There were in $19124,848,498$ cattle in Ireland, an increase in the year of 136,$778 ; 617,532$ horses, or +1201; 3,828,829 sheep, or $-78,607 ; 1,323,957$ pigs, or $-91,162 ; 25,525,724$ poultry, or $+77,923$.

Two factors have to be taken into account in a consideration of the rural regeneration of Ireland-the growth of co-operative principles and the effect of land purchase. In 1908 the Irish Agricultural Organization Society became involved in a dispute with the Irish Department of Agriculture and Technical Instruction. The political aspect of the question may be disregarded. Its economic aspect is contained in the charge that the Organization Society was "an association trading for profit." Mr. T. W. Russell ${ }^{1}$, who succeeded Sir Horace Plunkett ${ }^{2}$ as vice-president of the Department in 1907, informed the Council of Agriculture in 1908 that he had decided to withdraw the Department's subsidy to the Society, but he undertook to continue a diminishing grant for three years, $£ 3000$ for the first year, $£ 2000$ for the second, and $£ 1000$ for the third. The Agricultural Board later decided that the grant should be withdrawn at the end of Ig08. Under the provisions of the Development Fund Act of r9o9, the Development Commissioners were empowered to make advances for the organization of co-operation, either "to a Government Department or through a Government to a voluntary association not trading for profit." In accordance with this provision, the Irish Agricultural Organization Society, like the similar societies in England and Scotland, applied for a grant in aid. The application was referred to the Department of Agriculture, which reported adversely. Much delay ensued, but, nearly a year after the application was sent in, the matter was submitted to the Council of Agriculture. This body endorsed Mr. T. W. Russell's action. Mr. Russell then proposed to the Development Commissioners that a grant should be made to the Department for " noncontroversial co-operation." The Commissioners rejected this proposal early in ror 2, and decided a few weeks later to make the grant on their own responsibility to the Irish Agricultural Organization Society - a course which had been repeatedly advocated by

B. I8 1. Originally an Ulster Liberal Unionist (M.P. for S. Tyrone from I886), and in $1895^{-1900}$ parliamentary secretary to Local Govt. Bd. in Unionist ministry; but went pver to liberal side in 1905 . A well-known Temperance advocate.

${ }^{2}$ B. 1856; See E. B. xxi, 857 . 
the Chambers of Commerce of Dublin and Belfast, both of which bodies repudiated, as did the Society itself, the suggestion that the Society was entering into direct competition with legitimate traders. The Commissioners stipulated, however, that certain changes should be made in the composition of the governing committee of the Society as a condition to the grant of a subsidy. The temporary loss of State assistance does not appear to have injured the vitality or the financial stability of the society. According to the statement made at its annual meeting in IgIr, it has about 900 branches, a membership of 100,000 , and a turnover of nearly $£ 3,000,000$. In the spring of I 12 a Commission of Inquiry began to investigate the system of agricultural credit instituted by the Society: In the course of its proceedings it was found that the Department of Agriculture had lost only $£_{1} 100$ out of $£_{1} 8,000$ advanced to credit societies, and this loss was more illusory than real since it did not include reference to the interest paid on advances. It thus becomes clear that the department is making a handsome profit out of the agricultural credit societies, and that the system is working admirably.

The most interesting event of Irish economic history during 1910-12 was the establishment in I9ro of a society called the United Irishwomen. This body is affiliated to the Irish Agricultural Organization Society, and was founded in order to do on the social side of rural regeneration what the Organization Society has done, and is doing, on the economic. It was intended, in effect, to develop the principle of " better living", which is one tenet of the threefold faith of Irish rural reformers. Its policy includes the teaching of cookery, poultry management and dairying, and the encouragement of village crafts such as the making of furniture for cottages. Beginning with three branches, and finding the district of Connemara one which especially eagerly awaited development, the organizers of the United Irishwomen were able in a year to announce the existence of fifteen branches. This work is still rapidly expanding.

Two incidents may be noted as indicating the growth of popular appreciation of Sir Horace Plunkett and his work. In the early summer of IgIo the Department of Agriculture combined with the Estates Commissioners to reconstruct a little patch of rural life in Castlerea. The first action of the new land-holders was to combine with one another in order to apply co-operative principles. This Mr. T. W. Russell admitted was " but a sample of what is going on all over the West." The other incident was an "All-Ireland Model Election" conducted in December IgII by the Proportional Representation Society of Ireland. Intended as an "All-Ireland" election, it was ultimately confined in operation to Ulster and the immediate vicinity of Dublin. It resulted in the return at the head of the poll of a curious collocation of names-Mr. John Redmond, Sir Edward Carson, and Sir Horace Plunkett.

The new land purchase policy which was instituted by the Act of I gog has not been justified by results. The changes from the provisions of the Wyndham Act may be briefly reviewed. Instead of cash payments landlords were to receive stock at 3 per cent. This stock was issued on a falling market, and cannot appreciate owing to the embarrassment of Irish estates; about half of each issue has had to be thrown back on the market for the redemption of mortgages. Instead of paying $£_{3} .5 \mathrm{~s}$ per $£ 100$, tenants were to pay $£ 3$.Ios without any reduction in the period of repayment. A large propor-

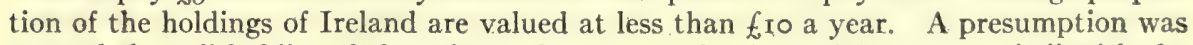
created that all holdings below that value were to be deemed "uneconomic," with the result that the whole of Connaught, with the counties of Donegal, Kerry, and part of Cork, became "congested." The Congested Districts Board, charged with conducting purchase in this area, is consequently swollen to unmanageable size. Comparisons between the work of the Wyndham Act and the Birrell Act show the following results: From 1903 to 1909 the number of potential purchasers was 217,299 ; from 1909 to I9II, or a third of the previous time, the number was only $8992-$ a decrease of over 80 per cent. Under the Act of 1903 landlords were assisted in the repurchase of their demesnes after selling their properties. Under the Act of 1903 the advances on resale to owners sanctioned by the Land Commission numbered 205; under the Act of 1909, up to the end of the financial year igri, only two. 
Manufactures.-Although agriculture still is, and must remain, the chief industry of the country, Ireland is continuing to fall into line as a manufacturing country. Irish expansion in this direction is largely due to the industrial revival movement. Great local forces have been at work in recent years in forwarding this revival. They received a considerable stimulus from the date (1907) of the International Exhibition in Dublin. There have since 1909 been exhibitions on a smaller scale, but of a similar nature, in Belfast, Cork, Limerick, Drogheda, Londonderry and elsewhere throughout the country. The Ui Breasil exhibition at Ballsbridge in the summer of I9I I gave another immense impetus to the movement. It is a common fallacy to suppose that the industrial life of Ireland is confined to Ulster. This is even less true at the present time than was the case four or five years ago. In many towns of the other three provinces thriving industries are to be found, small, indeed, when compared with the industries of Great Britain, but still appreciable. The "Made-in-Ireland" movement exercises an increasingly strong protectionist influence. It is supported by various political and economic associations such as the Gaelic League, Sinn Fein, and the Industrial Development Associations. Irish industry covers a far wider range than is commonly supposed. Industrial Development Associations have been formed, in addition to the original ones at Dublin, Belfast and Cork, in Limerick, Waterford, Wexford, Sligo and other smaller towns. The Cork Association in its annual report for IgI I speaks of an exhibition of Irish goods at its offices as including samples of woollens, linens, flannelettes, calicoes, threads, silk-gauze, maps, stationery, mosaics, marbles, lead-pipes, etc. The Dublin Association is, not unnaturally, more successful than any other. This is illustrated by the reports for two consecutive years. In the IgIo report articles which "could and ought to be manufactured in Ireland " include paper, bottles, stained-glass, church and school furniture and accessories, shop-fronts, general office requisites, soap, matches, candles and flour. In the report for the next year ( $\mathrm{IgII})$ it is stated that all these articles are now "obtainable in Ireland on competitive lines."

There are at present some twenty hosiery factories and as many tweed mills in Ireland. These new industries appear to be making progress, though it cannot be specifically estimated. The woollen-making industry has consolidated its position. A factory in Galway paid in 1912 a dividend of twelve per cent. There are cleven tobacco factories, besides the established ones in Belfast, scattered over the West and South, employing 3000 hands. All of them suffer from the competition of the Imperial Tobacco Trust; this reason was advanced for the closing of a Dublin factory, which employed zoo hands, in August I912. The Irish tobacco industry receives a small subsidy from the Treasury, but this ceases in I913.

The linen industry is by far the largest industry in Ireland. The number of spindles is returned approximately at 946,000 . The number of power looms shows a large increase to 36,892 , of which 21,000 are in Belfast, 13,000 elsewhere in Ulster, while the rest represent small factories in Dublin, Cork, Dundalk, Drogheda and elsewhere. Next in importance is the shipbuilding industry.

The industrial troubles of 19 I I and I 9 I 2 affected Ireland equally with the rest of the United Kingdom. In August rgi I a strike of the Dublin seamen and firemen interrupted the trade of the capital, though only for a brief period. A railway strike. (which had no connection with the strike in Great Britain but was begun in sympathy with a porterage strike) followed, and there were several local disputes, of which the most serious were a bakery strike in Dublin and a transport workers' stoppage at Wexford. The coal strike of March-April Igr2, which sent up the supply to famine prices, did an indirect benefit to Irish industry by causing a development, which has since been partially maintained, in the output from the collieries at Athy and Kilkenny.

Fisheries.- That the Irish fisheries are a valuable asset to the country is established by the fact that the total value of fish landed in Ireland, and sold, was, according to recent returns, $f 375,636$ against a total of $f 363,801$ in the preceding year. But there has been a serious falling away in the number of vessels engaged in the Irish sea fisheries-a decrease of 324 vessels to 5652 . The fisheries give employment to some 20,000 men. The Department of Agriculture and Technical Instruction has granted loans to fishermen for the purchase of boats and gear and the installation of peteol power. A station was established in 1910 at Courtmacsherry, where improved methorls of curing, classification and packing are taught. The whale fisheries of I nishkea and $\left.13\right|_{1}\left(\mathrm{k}_{\mathrm{s}} \mathrm{sel}\right.$, which were decaying, have also been fostered 
by help from the Department. Endeavours to extend the sale of fish in inland towns are being continued; in $191 \mathrm{I}$ there were about I50 towns on the Department's official list.

Commerce.-In the fiscal year of 1909 -10 the value of imports amounted to $f 63,779,709$, and of exports to $f 60,946,186$. In the fiscal year of I9I0-1 I the value of exports, for the first time on record since the institution of these returns in 1904, exceeded that of imports. Imports were returned at $f 65,044,477$ and exports at $£ 65,844,255$ - an aggregate of $£ I_{30}$,888,732 . This is nearly $£_{28} 8$ per head of the population, while the corresponding figure for

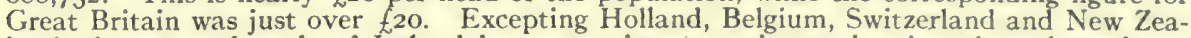
land, the external trade of Ireland is greater, in proportion to its size, than that of any country in the world. There is certainly no other country where the figures of external trade more closely approximate to a measure of the actual productive prosperity. The value of the export transit trade to Great Britain is officially estimated at four-fifths of the total, or about $f 52,600,000$. There has been a substantial increase in the export trade of yarns, especially to foreign countries. The value for 1910 was $£ 1,197,000$. The increase was especially marked in the exports to the United States; linen goods form two thirds of the Irish trade with that country. In recent years, largely as the result of the efforts of the "Made-in-Ireland" movement, certain foreign countries have begun to show separate details for Irish imports in their trade returns. These returns illustrate the present variety and extent of Ireland's foreign trade. Those for I9I0-II are the latest available. The value of French imports from Ireland was fr41,000 (mainly salted meat, pork, cereals and yarns); Belgian $£ 4000$ (iron, steel and linens); Dutch $f 234,000$ (yarn, malt, flax, wool and grass seed); Cuban $f_{216,000}$ (cotton, linen and woollen tissues). These figures represent the direct trade. The actual trade is many times greater, but the bulk of it passes through Great Britain and is credited under that heading by the Customs authorities.

The leading article of export from Ireland remains live-stock. Nearly all of it is imported by Great Britain. Reference has been made above to the causes of decline under this head. In the year ended March 3I, I9I2 the numbers of the live-stock export had decreased by more than 200,000 as compared with the preceding year. The numbers stood at $1,742,477$ and the value at $£ 13,520,754$. Cattle accounted for 689,550 of the numbers and for $£ 9,508$,083 of the value. At the end of June 1912 the export of cattle to Great Britain came to an abrupt standstill in consequence of the discovery of foot-and-mouth disease in cattle despatched from Swords, County Dublin, and the subsequent closing of English ports against Irish cattle. The weekly loss to Ireland while this embargo (which was imposed at the height of the fat cattle season) rested was estimated at a minimum of $f 20,000$. The disease was isolated with more success by the Irish Department of Agriculture than was the case in Great Britain, but during the first weeks after the outbreak the necessary "standstill" order resulted in the stagnation of the country fairs as well as the cessation of export. Six weeks after the outbreak all Irish ports except Dublin, Drogheda and Dundalk had been opened, but only for immediate slaughter at the English ports of landing. As a result the fat cattle trade suffered enormously, and as the season advanced the case of the store cattle trade became even worse. The calamity concentrated the attention of Irish stock-raisers on the merits of the dead-meat trade, whose establishment has been urged for several years past by the Irish Agricultural Organization Society. It was also recommended by a deputation of Irish farmers which in 1910 , at the instance of the Department of Agriculture, investigated the dead-meat trade of Scotland. A dead-meat trade was established experimentally at Wexford and Drogheda and has since flourished. Late in August 1912 a movement to organise the trade throughout the country was set on foot.

The principal items of the Irish import trade remain chiefly the same as those of Great Britain in the past two years. In the case of articles similar to those produced in Ireland, however, it is noticeable that the bacon import had declined in value (I910-I I) to $f 1,659,000$. The butter import for the same year valued $£ 478,000$. The decline during the past two years in the Irish butter export was not, as an enquiry conducted by the Agricultural Organization Society showed, due to a decrease in production, but to an increase in home consumption for which the "better living" in rural districts which the Society promotes is responsible. In this connection the increase of deposits and cash balances in the Irish Joint Stock Banks, Trustee Savings Banks, and Post Office Savings Banks ( $f_{1}, 910,000$ in 1909 to $£^{2}, 402,000$ at the beginning of 1911 ) is worthy of notice. Banking accounts also show much larger amounts under the head of advances to customers, made mainly for industrial purposes and land improvement.

Communications.-Railway traffic returns reveal similar features of expansion. The total receipts for I909-IO were $£ 41,180,023$, and for I9IO-II $f 41,302,720$. These returns are the highest on record. The railway strike in the summer of I9I I resulted in a slight setback, but this was successfully overcome. In 19 Io the main railway companies met, for the purpose of developing the inland sale of fish referred to above, the demand for reduced freights and through rates for this traffic. The Great Southern Railway has made arrangements for a junction with the proposed Athy and Queen's County Railway at Athy, a project whose completion will benefit the coalfield of the district. The Midland Railway has completed the doubling of the line between Athenry and Attymon Junction, and this 
is now being used for traffic. This company contemplates the opening of a new station in County Mayo, between Westport and Castlebar. The Dublin and South Eastern Railway has taken in hand the diversion of the line from Killiney round Bray Head to Greystones, since recent dangerous encroachments of the sea have rendered this course necessary. The Viceregal Commission on Irish railways issued its final report in I910. Its majority report advocated State purchase and nationalisation, but a minority report dissented from this recommendation. The Royal Commission on the Canals and Inland Navigation of Ireland issued its final report in the following year. Here again State purchase and control were recommended. This report strongly urged that the problem of arterial drainage and relief from floods should also be attacked by a central authority. The pressing nature of the drainage question has been emphatically evidenced by the flooding, during the winter of I9II-I2, of the basins of the Shannon, Barrow and Bann, and the consequent wholesale damage to property and public health. Nothing has ye $e^{-}$been done in any of these directions. Projects for no less than 83 new railways were brought before the Viceregal Commission, but even improvements of the existing light railway system had to be abandoned, since there is no means of raising new capital under the system of legislation by which they were constructed. Road improvement proceeds slowly, but surely, under the local authorities. The Local Government Board of Ireland during the year I9I I-12 made orders extending the limit of expenditure in 28 rural districts contained in 13 counties. In 16 cases the increase was required to permit road improvement by steam-rolling to be undertaken; in one case to provide for the repair of sudden damage by the sea, and in one case for the widening of dangerous bog roads. Loans of a total amount of $f 71,500$ were sanctioned. In these districts (all in the West) the extension of communication facilities has been rendered desirable by the fact that these parts of Ireland look for an increasing part of their prosperity to the tourist traffic. The operation of the Health Resorts (Ireland) Act has also assisted in the opening up of the remoter districts to the tourist; local authorities are now empowered to strike a rate for tourist development purposes.

Local Government.-The Local Government Board for Ireland had occasion up to I 9 I 2 to pass, in its annual reports, favourable judgment on the smooth working of the various bodies created by the Act of 1898 , but the report issued in August 1912 contains nothing under this head, from which it may be inferred that the Irish County Councils and District Councils are continuing to do satisfactory work. At the beginning of I9I2 the restriction preventing women from being members of County and County Borough Councils was removed, bringing the Irish law into harmony with that in force in England and Scotland. The new Act became operative for the first time at the municipal elections of January I9I2. Three women were successful at the polls, one in Dublin (Miss S. C. Harrison, well-known for her interest in distress work) and two in Waterford. New Acts in connection with local administration in Ireland which came into force at the same time were an Act empowering the Dublin Corporation to strike a halfpenny rate for the maintenance of the Dublin Municipal Gallery of Modern Art, and an Amending Act to the Irish Labourers Act, which granted another $f 1, \infty \infty, \infty, \infty$ for the building of labourers' cottages and enabled the Local Government Board to proceed with the scheme already lodged. The working of the Labourers Act gave an opportunity to the United Irishwomen to turn their attention to the provision of a proper water supply in the proximity of labourers' cottages, an object in which an active interest was also taken by the Women's National Health Association, the organization which the Countess of Aberdecn instituted in 1907 in order to combat the growth of tuberculosis in Ireland. This association has now 150 branches, with about 19,000 members; it has established two garden playgrounds in the most congested districts of Dublin, and a third is in course of preparation; it has established the Collier Memorial Dispensary for the prevention of tuberculosis, which centralises the work previously carried on by the Dublin Hospital Tuberculosis Committee, and formed the Dublin Samaritan Committee in connection with the dispensary, besides several such committees in connection with different branches; it has established a Preventorium at Sutton, a Pasteurised Milk Depôt, and numerous babies' clubs in Dublin and throughout the country. The association has also undertaken, in the interval before the County Councils construct the necessary machinery, to work the sanatorium benefit under the Insurance Act, and has received $\{25,000$ of the grant to Ireland for this purpose. The Registrar-General's return for ig I attributes some part of the fall in the death rate ( 16.6 for I000 or .5 below the rate of the preceding year) to these agencies. It is also due in part to the 
operation of the Old Age Pensions Act, which, under the original estimate in rgoo, affected some 70,000 persons in Ireland. This was exceeded by 28 per cent, but a large number of claims were subsequently disallowed. The number of appeals decided during I III was I I,727. The operation of the Insurance Act in Ireland cannot yet be estimated. Mr. Charles Kinnear was appointed Chief Commissioner. The number of insurable persons is estimated at $\mathrm{r}, 050,000$, and 674,000 persons were returned as members of approved societies when the Act came into force.

Religion. - In the census of $191 \mathrm{I}$ the population of Ireland is divided by religions as follows: Roman Catholics 3,238,656; Protestant Episcopalians (Church of Ireland) 574,489; Presbyterians 439,876; Methodists 61,806. The number of Roman Catholics had decreased by 70,005 , of Protestant Episcopalians by 5600 , of Presbyterians by 3400 , and of Methodists by 200 during the decadal period since the last census. In Dublin 83.I per cent of the population was Roman Catholic, I 2.9 per cent Protestant Episcopalian, I.4 per cent Presbyterian, and 0.8 per cent Methodist. In the county of Dublin (which includes the urban districts around the city) the percentages were $7 \mathrm{I}, 22.8,2.5$, and r.6. In Belfast Roman Catholics numbered 93,243, Protestant Episcopalians II 8,173, Presbyterians 130,575, and Methodists 23,782. In County Antrim the numbers were 39,$751 ; 42,118 ; 97,198 ;$ and 3813 .

Owing to the special interest attaching to the Ulster question, mainly a Protestant one, it may be noted that, in the N.E. counties constituting "Ulster" in the political sense, there were 394,42 I Roman Catholics (33.I per cent), as against 794,274 of other denominations: In all Ulster the Roman Catholics numbered 690,8 6 (43.7 per cent) as against 890,880 of other denominations. In Munster, the Roman Catholics constituted 94 per cent; in.Leinster 85.2 per cent; and in Connaught 96.3 per cent.

Notable changes occurred in the composition of the clergy in the Church of Ireland. Dr. Alexander, the Primate of Ireland, retired from the primacy in January I 1 I $r$, and died shortly afterwards. In February Dr. Crozier, bishop of Down, Connor and Dromore was elected Primate, the see of Down being filled by the transference of the bishop of Ossory. Dean Bernard, dean of St. Patrick's, was appointed to the vacant bishopric. In June Igriz a canonry of St. Patrick's fell vacant and was filled by the appointment of the Rev. James O. Hannay, Rector of Westport, better known as the novelist " George A. Birmingham.".

Justice and Law. - Ireland has been in a very satisfactory condition in respect of crime. In IgI I the prison population was the smallest on record. Drunkenness continued to supply a large proportion, the number of commitments under this and cognate charges being 9258 , or 40 per cent of the total number committed to prison. In I9ro the figures were 10,088. During the year 1077 male and 345 female offenders under the age of 2I years were received under sentence. A Borstal Institution for males was established at Clonmel in November r 909 under the Prevention of Crimes Act of rgo8; nearly all its past inmates placed out are doing well. During the period under review Ireland has been singularly free from serious crime. In I 909 there was a recurrence of agrarian crime - shooting outrages and cattle-driving-in certain counties, notably Tipperary, Clare and Westmeath. But since that year the number of Grand Juries congratulated by the judges of Assize on the satisfactory: state of their counties has continued to rise. In 1911 the number rose to 90 per cent; and in 19 I 2 it reached 95 per cent. The Recorders of the large towns have also been able to produce testimony as to their comparative freedom from crime. Almost without exception the judge of assize has vigorously protested year by year that agrarian outrage in the western countiesKerry, Clare and Galway-where it still sporadically appears, is largely due to the unrestricted sale and carriage of firearms. The Irish Game Protection Society and similar associations have also identified themselves with this protest. There have been several changes in the composition of Bench and Bar. In I 909 Lord Justice Fitzgibbon, who had for many years been judge of the Appeal Court, died. The Attorney-General, Mr. R. R. Cherry, was raised to the Bench, and was succeeded by Mr. Redmond Barry, whose place as Solicitor-General was taken by Mr. Charles O'Connor. Sir Samuel 
Walker, Lord Chancellor of Ireland, died towards the close of I9I I, and was succeeded by the Attorney-General, Mr. Redmond Barry. Mr. Charles O'Connor became Attorney-General, and Mr. Ignatius O'Brien was appointed Solicitor-General.

Educution.- So far as education is concerned, the situation is practically unchanged except for the establishment of the National University. Under the system of payment by results, the amount of the school grant paid to managers of intermediate schools in Ireland on account of the examinations in I9II was $\ell_{4} 6,46$ I. In June I 9 I 2 the Intermediate Board was requested by the Under Secretary for Ireland to draw up, in cooperation with the Board of National Education, a scheme of scholarship whereby suitable pupils might pass from the primary to the secondary schools. After conference between representatives of the board and of the teaching profession a scheme was drawn up and sent to the Treasury. The board suggested the extension of the scheme so as to provide increased facilities for agricultural and technical training. The Treasury refused to sanction the scheme. However, in July I9I 2 provision of $\ell_{10,000}$ was made for scholarships to enable primary school children to enter secondary schools. These scholarships were to be open to all National School children under I3 years of age, and the examination was to be competitive, regional and annual, conducted by the National Board's inspectors. (Provision of $£ 40,000$ was also made to improve the status of secondary teachers, an improvement which consecutive teachers' congresses have annually demanded.) It was proposed that, when the scholarships expired, the holders should be elected to County Council scholarships. The County Councils offered these only on condition that they should be held at the National University. The Chief Secretary insisted that they should be tenable at any Irish University, and, as a result of the deadlock, the scheme remained in abeyance at the end of Igr 2. The National University of Ireland was the creation of Mr. Birrell's Irish Universities Act. The Act instituted University College, Dublin, and reconstructed the Queen's Colleges of Cork and Galway as constituent colleges. Queen's University, Belfast, became a separate establishment. Dublin was allotted an annual grant of $£ 32,000$, Cork, $£ 20,000$, and Galway $£_{12,000}$ out of the new University's share of the original endowment of the Royal University. $£ \mathrm{I} 50,000$ was granted for building purposes to Dublin, $£$ I4,000 to Cork, and $£ 6000$ to Galway. The preparatory work of the Commission was completed in July I grr, but the authorities of the Dublin College experienced some difficulty in finding a suitable site. Eventually a site adjacent to that of the Royal University buildings was provided by Viscount Iveagh, the chancellor of Trinity College, Dublin. St. Patrick's College, Maynooth, has been " recognized " by the senate of the new university. The number of entrants to the university in I 912 was: 755 to University College, Dublin, an increase of 60 on the previous year; 425 to University College, Cork, an increase of 10 ; and 155 to University College, Galway, an increase of 5. An agitat:on in favour of making Irish compulsory for matriculation was begun by the Gaelic League, and the senate finally decided to make a course in Irish compulsory for those who did not take it at matriculation till $\mathrm{I}_{\mathrm{I}} \mathrm{I}_{3}$, in and after which year it is to be compulsory for matriculation. Mr. Dennis Coffey was appointed president of University College, Dublin. The five Connaught counties have struck a rate-in-aid of University College, Galway. Kerry, Waterford, Cork, Tipperary and Limerick have established scholarships to University College, Cork. It is estimated that when the County Council schemes are in full working order the National University of Ireland will derive an additional income of more than $£$ I 2,000 from this source. The demand for the development of the constituent colleges into independent universities, on the plea that a federal system is wasteful and cumbrous, has already made itself audible. The proposal is supported by the Cork College and its president, Sir Bertram Windle. It is resisted by the Galway College and its president, Dr. Anderson. Trinity College, Dublin, celebrated the bi-centenary of its Medical School in July rgr2. The recommendations in the report of the Science Schools Committee have now been completed by the gift of Lord Iveagh two months earlier of $£_{1} \mathrm{O} 0,000$ to the Trinity College department of geology and mineralogy, which had been prevented by lack of funds from acquiring the appara- 
tus, and meeting the expenses of research assistants, necessary to the carrying on of its work. There has been, contrary to expectation, no friction between the old and the new universities. The National University played a prominent part in the bi-centenary celebrations of Trinity College. The co-operative principle is working not only in agriculture. It is the key-note of the Ireland of to-day.

Among recent works on Ireland, see George W. Russell •("A. E."), Co-operation and Nationality, Dublin; S. J. Brown, A Guide to Books on Ireland (Dublin); E. Paul Dubois Contemporary Ireland, Dublin; Padraic Colum, My Irish Year (London); R. Mortimer Wheeler, Ireland To-day (London); W. P. Ryan, The Pope's Green Ireland (London); the Earl of Dunraven, The New Spirit in Ireland (London); Sydney Brooks, Aspects of the Irish Question, Dublin.

\section{INDIA ${ }^{1}$}

Census of IOII.-The census was taken in India on March Io, I9II, and showed a total population for the Indian Empire of $315,132,537$. Compared with the total for igor, the increase is $20,77 \mathrm{I}, 48 \mathrm{I}$, or $7.1 \%$. But part of this increase is due to the inclusion of tribal areas on both the N.W. and N.E. frontiers, with a population (mostly estimated, not actually enumerated) of I,73I,II6. In the British Provinces the rate of increase is only $5.5 \%$, while in the Native States and Agencies it is as high as $12.9 \%$. The intervening decade had been, on the whole, favourable to agriculture, and a recovery was to be expected in the areas affected by the famines of 1897 and 1900 . On the other hand, the visitation of plague had been severe and continuous, causing more than 6 million recorded deaths, chiefly in Northern India, where also an exceptional outbreak of malarial fever occurred. In the result, both the Punjab and the United Provinces show an actual decrease. The highest rates of increase are in the Central Provinces, Burma, and Eastern Bengal and Assam.

Classified according to religion, some interesting results appear. As on former occasions, the rate of increase among Mahommedans $(6.7 \%)$ is higher than among Hindus $(5 \%)$. So-called Animists $(20 \%)$ and Buddhists (1 $3 \%$ ) both have a high rate of increase. Jains show an unexpected decrease $(6 \%)$, while the reforming sect of the Arya Samaj in Northern India has grown from 92,4I9 to 243,5I4. But the most surprising results are in the case of Sikhs and Christians. The former have increased from $2,195,339$ to $3,014,466$ or by $38 \%$; the latter from $2,923,24$ I to 3,876, I 96 or by $33 \%$.

This increase of Christians, ${ }^{2}$ which of course means native converts, deserves explanation in detail. The great majority are still to be found in the extreme South, where in the two States of Travancore and Cochin more than one-fourth of the total population are now Christians, and the rate of increase during the past decade was $30 \%$. Though the actual numbers are much less, this rate of increase has been exceeded elsewhere. Taking native Christians alone, and thus excluding European troops, in the United Provinces the number has risen from 23,404 in $I 891$ to $68,84 I$ in $I 901$ and 136,469 in I9I I; while in the Punjab the number has risen from 19,561 in 1891 to 37,980 in 1901 and 163,220 in 1911 . The rate of increase during the past decade has been $90 \%$ in Assam, $45 \%$ in Burma, and $33 \%$ in Bihar \&c., while in the Mahommedan state of Hyderabad it has been threefold. Turning to the several denominations, Roman Catholics are still by far the most numerous, and their rate of increase has been $22 \%$. Next come Syrians of various rites, and then Anglicans, among whom the rate of increase has been only $8.5 \%$. Other Protestant denominations show extraordinary figures. Baptists, mainly in Madras and Burma, have multiplicd from $22 \mathrm{I}, 040$ to 336,596 ; Lutherans, in Madras and Bihar, from 155,455 to 218,499 ; Presbyterians, in the Punjab and Assam, from 53,931 to I8I,128; Methodists, in the United Provinces, from 76,907 to $17 \mathrm{I}, 754$; and Congregationalists, in Madras and Travancore, from 37,874 to 135,264 . Salvationists now number 52,407 , mostly in the Punjab, Travancore, Bombay and Madras.

The statistics of literacy are not strictly comparable, for the test has been changed, bcing now the ability to write a letter to a friend and read his reply. The total number of literate persons has risen during the decade from about $15^{\frac{1}{2}}$ to $18 \frac{i}{2}$ millions, the proportion per thousand having risen from 98 to 106 in the case of males and from 7 to II in the case of females. The total number of persons literate in English has risen from I, I 25,23 I to I, 670,387 , the proportion per ten thousand having risen from 68 to 95 in the case of males and from 7 to 10 in the case of females. Excluding the exceptional case of Buddhist Burma, Bombay

1 See E. B. xiv, 375 et seq, and allied articles.

2 Here it may be mentioned that those of mixed descent, formerly known as Eurasians, are henceforth to be officially styled Anglo-Indians. 
continues to stand first in respect of literacy and the United Provinces last. Among native states Travancore and Baroda are conspicuous.

Finance.-In India financial equilibrium varies with the monsoon, upon which agriculture is mainly dependent. In 1908-9, following upon two bad seasons, which culminated in famine throughout the United Provinces, there was a deficit of no less than $3 \frac{3}{4}$ millions entirely due to a fall in land revenue and in receipts from railways. Succeeding years have been favourable, though in I 1 I t the desired rainfall did not fall until as late as September. The consequence has been a succession of surpluses, a mount-

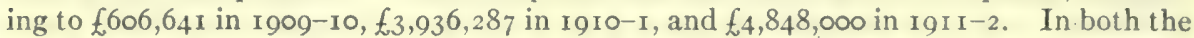
last two years, however, no less than two millions of the surplus was due to an unexpected windfall from opium. In I $I I-2$, the net revenue reached the unprecedented total of $5^{6}$ millions, compared with 49 millions two years before. During the interval, the only change in taxation was a new customs duty on silver, and increased duties on imported liquors, tobacco and petroleum. It should however, be added that the excise duties on liquors and drugs have likewise been raised throughout the several Provinces. As so large a portion of the recent surpluses has been derived from opium, a source of revenue that will shortly disappear, they have not been applied to the reduction of taxation, but have been utilised partly in extraordinary grants for education, sanitation, \&c., and partly in reduction of debt. The cost of the Royal visit (one million) was entirely defrayed out of revenue, and it is anticipated that some part at least of the expenditure on the new capital at. Delhi will come from the same source.

The Opium Question.-The subject of opium demands special mention. By arrangement with China, the Government of India undertook to reduce the quantity exported after January 1908 by amounts annually increasing until the export should entirely cease after ten years. Under a new agreement in $I 9 I I$, the total cessition was to be accelerated if China suppressed her own production of the drug, and a further limitation was placed on the export to Chinese ports, such exports to be specially certified. As a result, the number of chests exported was reduced from 61,900 in 1908 to 44,600 in 1911 , of which only 30,600 were certified for admission to China. In the meantime, of the two Government factories in the Ganges valley that at Patna has been closed, while the area under poppy has been reduced from about 500,000 to 200,000 acres, entirely in the Linited Provinces. A result not foreseen is that the restriction on export led to an increased demand and a doubling of the sale price. Thus is explained the windfall from opium which figures so conspicuously in the surpluses of the last two years. Finally, it should be stated that, in conformity with the international convention signed at the Hague in January 19 II the Indian Government has announced its intention of introducing legislation to discourage opium smoking. It is proposed to prohibit the practice absolutely in saloons or gatherings numbering more than two persons, to reduce the amount of the drug which a person may lawfully possess, and to increase the sale price to the public.

Agriculture. - The last three or four years have been characterised by favourable monsoons and consequently by wirle-sprearl agricultural prosperity. If prices still range high, this must be attributed to the foreign demand for such staples as cotton, wheat and oilseeds. A notable example of prosperity is presented by the Canal Colonies in the Punjab, where wheat for export is the chicf crop and horse breeding is also cncouraged. The colonists have been allowed to acquire proprietary rights in their holdings, and the cooperative credit movement is making rapid progress. It may be mentioned that as much as f.3,000 per acre has here been paid for market sites along the railway, that labour at harvest time fetches Rs. 2 (2s. 8(t) a dav, that sovereigns are common in circulation, and that in one year lyallpur remitted $f \mathbf{1} 47,000$ by money order to other districts.

The Inited Provinces recovered with unexampled rapidity from the famine of 1908, owing as much to their previous prosperity as to the efficiency of relief operations. Bengal and Bihar suffered somewhat in 1909 from a poor harvest. But the only real distress has been in Bombay. Here the monsoon of ig1 I failed almost entircly in (ivjarat, including a large area of Native States. No difficulty was experienced in providing work and food for the destitute people, and private charity was to some extent successful in saving the cattle alive; for, as often happens, the drought caused a fodder famine. In I9I2 the monsoon again failed in the Bombay. Decean, a tract particularly liable to drought.

The most notable feature of recent years, apart from the activity of the Agricultural Departments in the several Provinces, has been the steady growth of cooperative credit societies. Some of these are urban, for the benefit of artizans, \&c.; but the great majority are rural, numbering nearly 5,000 in $19 \mathrm{II}$, with a membership of 236,000 and a working capital of $f .730,0(x)$, of which $f 105,0(x)$ represents deposits by the members. The movement seems to have been mont sucesuful in the Inited Provinces, Madras and the Punjab. In 
Bombay a Central Cooperative Bank has been founded by a leading Hindu merchant, Sir V. D. Thackersey, with a Government guarantee on its $4 \%$ debentures. It lends, only with the approval of the official registrar, at an interest which must not exceed $8 \%$, and half of its surplus profits above $6 \%$ must ultimately be devoted to rebates on the interest payable.

Mines and Minerals. - The mining of coal, which is mainly concentrated in Bengal, has recently been subject to vicissitudes. While the total output increased from an average of Io million tons during the five years ending 1908 to 12 million tons in 1910 , the price fell ronsiderably. The difficulties of local transport by both land and sea have become so troublesome that the railways with headquarters at Bombay were compelled in 1912 to invite contracts from Japan and Natal. The production of the gold mines in Mysore remains constant at about 545,000 ounces a year; the Hutti mine in Hyderabad yields about $\mathbf{1 5}, 000$ ounces; but the mines in the Bombay district of Dharwar have all closed down, owing to disappoint. ing results at deep levels. The production of manganese, chiefly in the Central Provinces and Madras, has increased from an average of 500,000 tons during the five years ending 1908 to 800,000 tons in 1910; and India may now claim to be the largest producer of highgrade ore in the world. The production of petroleum in Burma has similarly increased from an average of 146 million gallons during the five years ending 1907 to 215 million gallons in 1910; while the refining of the crude oil and the manufacture of petrol, paraffin, \&c., have become an important industry at Rangoon. The iron industry, elsewhere languishing, has made a memorable start at Sachi, on the hilly borders of the Central Provinces and Orissa. Here the Tata Iron and Steel Company, with a capital of $I_{\frac{1}{2}}$ millions raised entirely in India, began work early in 1912. . Equipped with the most modern machinery for smelting, puddling, forging, \&c., it is intended to produce 87,000 tons of iron and steel in the year. The Government have erected a laboratory close by, at Kalimati, for testing the steel rails produced for use on the State railways, and Japan has already give a large order for steel.

Manufactures.-In manufactures, the most important event has been the passing of a new Factory Act, which came into force on July I, 1912. The chief provisions applying to textile factories are: that no person shall be employed for more than 12 hours, no woman for more than io hours, and no child for more than 6 hours in any one day; that no person shall be employed before 5:30 a.m. or after 7 p.m.; and that mechanical or electrical power shall not be used for more than 12 hours in the day.

The cotton mills, chiefly centred in the Bombay Presidency, have passed through a long period of depression, though the number of both spindles and looms increases year by year. While the spinning of yarn has been generally unremunerative, the weaving of cloth, especially of the finer fabrics, is steadily advancing. During the five years ending $1910-11$, the number of looms has risen from 55,000 to 79,000 , and the production of woven goods from I 59 to $23 \mathrm{I}$ million pounds. Another Tata company, with a capital of more than a million again raised entirely in India, has begun operations at Lonauli in the Western Ghats for providing elec. trical energy for the many industries of Bombay city. Jute mills, which are concentrated at Calcutta and mainly in English hands, have enjoyed almost unbroken prosperity. In I 10 the total number of factories under inspection in all India was 2,27 I, employing 800,000 persons, of whom I 16,000 were women and 52,000 children. Mention may here be made of the recent development of banks, under Indian management and with Indian capital, with their headquarters at Bombay. One of these subscribed for the greater part of the Government loan of three crores ( 2 millions) issued in 1912.

Commerce. - The foreign trade reflects the series of favourable harvests. During the four years ending $1911-12$, imports of merchandise have increased from 81 to 92 millions, exports of merchandise from 100 to 15 I millions, and the net imports of treasure from i I to 28 millions. The "balance of trade" in favour of India thus rose from 8 to 31 millions. Among imports, while cotton yarn shows a continuous decline, other cotton manufactures (almost entirely from England) have increased from 23 to 30 millions. Large increases are also shown in sugar (from Java), and in copper, the usual material for household vessels. Among exports, raw cotton continues to rank first, but the second place is now held by oilseeds, though raw jute and jute manufactures combined more than equal cotton. The export of rice depends upon the harvest in Burma, as that of wheat does upon the harvest in the Punjab. Within the last year barley has been sent in large quantities to England. About $62 \%$ of the total imports come from the United Kingdom, but only about $26 \%$ of the total exports are consigned thither. A notable feature during $1911-12$ has been a fall in the imports of silver, accompanied by a very large rise in the imports.of gold, both bullion and coin. Gold is no doubt hoarded and used for jewellery; but sovereigns are now common in circulation in some parts, while since I9I0 the amount of gold held by Government in the paper currency reserve in India has increased from 9 to 20 millions.

Railways.- Railways have fully participated in the favourable seasons which India has recently enjoyed. Contrasted with a loss of $x^{\frac{1}{2}}$ millions under this head in the financial year 1908-9, gains are shown of more than $\frac{3}{6}$ of a million in $1909-10$, of 2 millions in $1910-11$, and of more than 3 millions in $1911-12$. But; as all the railways do not belong to Government, it will be more convenient to take figures for the last calendar year. Between I909 and I9I I, the total length of line open increased from $3 I, 484$ to 32,839 miles, while the total mileage under construction or sanctioned at the close of 19 I I was 2,675; the total capital outlay on 
open lines increased from 286 to 300 millions; the total number of passengers carried increased from 329 to 410 millions; the total weight of goods carried increased from 61 to 76 million tons; and the net earnings increased from $13^{\frac{3}{4}}$ to more than 17 millions, the percentage of profit on capital rising from 4.81 to 5.71 .

The most important new line recently opened is that through Rajputana from Muttra to Kotah, which affords communication from Northern India to Bombay on the broad gauge of the Bombay and Baroda system. The most important work in hand is the construction of a bridge across the Ganges at Sara in Bengal, which will bring the traffic from the north of the river (at present ferried over) direct to Calcutta. The most interesting project sanctioned is that of connecting the railway systems of India and Ceylon by means of a ferry service, for which a bridge along Adam's Reef may possibly be substituted. Three turbine steamers were in 1912 being built on the Clyde for this ferry service. The passage is about the same distance as from Dover to Calais, through practically smooth water at all seasons.

Complaints have often been made of the inadequacy of the railways to carry the increasing goods traffic. These culminated in the spring of 1912 under a combination of exceptional circumstances: the recent Durbar, the coal strike in England, the demand for fodder in the famine districts of Gujarat, a deficiency of water in some places, and the heavy bulk crops for export. The provision of rolling stock has been the chief item of capital expenditure for several years past. It is now recognised that the most pressing need is the adaptation of the railways to heavier and more frequent traffic by the doubling of lines, strengthening of bridges, increase of sidings, and improvements at terminal stations.

Irrigation.- According to the financial accounts, the net revenue from irrigation remains pretty constant at about $£ 600,000$ a year. But this gives a most inadequate conception of the important works undertaken by the Government. During the four years ending I9I0-I, the capital outlay increased from $34^{\frac{1}{2}}$ to $39^{\frac{1}{2}}$ millions, while the total area irrigated and the net receipts showed little change, and consequently the percentage of profits fell from 6.74 to 6.33. Punjab is the province where the existing canals are the most necessary and also the most remunerative, and it is in the Punjab that the most important work is now under construction. This is known as the Triple Canal in the Upper Jhelum, the Upper Chenab, and the Lower Bari Doab, which will be completed in 1915 at a total cost of nearly 8 millions. In the United Provinces a series of minor canals have been constructed for the protection against famine of Bundelkhand, while a large scheme is under consideration to increase the supply of the Ganges and Jumna Canals from the overflow of the Sarda river in Oudh. The important project of throwing a barrage across the Indus at Sukkur, and thus effecting perennial irrigation in Sind, still awaits final sanction. These projects involve such heavy expenditure, in this case nearly 6 millions, that delay is justifiable. Minor works have been carried out on the Godavari river in Bombay, and also in the Central Provinces; but large schemes in Madras on the Kistna and the Kaveri rivers are still under consideration.

Education.-No subject connected with India has attracted more attention of late than education, starting from the reform of the universities in 1904 . This reform has been slow in accomplishment, but the aim has now been effected, by which the academical syndicates have gained control over the affiliated colleges and have themselves undertaken to conduct postgraduate courses and research. Towards the end of I9ro, a member for education in the person of Sir Harold Butler was appointed to the Viceroy's executive council. At the Delhi Durbar one of the boons announced by the King was a grant of 50 lakhs $(£ 333,000)$ for education, which has been devoted mainly to primary schools. The Hon. G. K. Gokhale, the recognised leader of Indian opinion, introduced a bill in the Viceroy's Legislative Council for the gradual introduction of compulsory education, which was rejected by a large majority in March IgI2. The alternative proposals of the Government were explained by Mr. Montagu, Under Secretary of State. in his budget specch to the House of Commons on July 30, I9r 2. Leaving compulsion for the future, it was pointed out that free education already exists for all girls and also for a proportion of boys varying from one-fifth to one-third in the several Provinces. What is now required is to augment the number of schools and to improve the teaching in the schools that already exist. The additional amount provided for education (higher as well as primary) in the estimates for $1912-3$ was $\frac{3}{4}$ of million.

During the ten years ending 1910-1 the total number of boys at school increased from. 3,5 r 3,000 to $5,489,000$, and the total number of girls increased from 446,000 to 866,000 , whilk. the total expenditure from all sources increased from $£ 2,700,000$ to $£ 4,800,000$. In I9II the proportion of pupils to the population of school-going age, which is taken at $15 \%$ of the: total population, was $28 \%$ for boys and $4 \%$ for girls. The attendance at Secondary schools, which is almost equivalent to education in English, increased during the ten years by $44^{\circ}$; and it is noteworthy that $t$ wo-thirds of the cost is derived from fees. The number of students at Arts colleges increased from 17,430 to 2.3 .714 . Of those who graduated B.A. in I9II, 
Brahmans numbered 530, non-Brahman Hindus 492, Mahommedans 173 , and native Christians 31. An interesting movement is that for the creation of new universities. The Government has resolved to found one at Dacca in Eastern Bengal, which will probably be followed by others - at Rangoon for Burma and at Patna for the new Province of Bihar. Meanwhile the Mahommedans have been collecting large subscriptions in order to raise the Aligarh college to the status of a university, and the Hindus for a college at Benares.

In this connexion mention may be made of the scheme organised by the Secretary of State for the benefit of Indian students who come over to complete their education in England. The number of these is estimated at nearly 2,000, of whom 800 are in London. Prof. T. W. Arnold, formerly at Aligarh and Lahore, was appointed in 1909 with the title of educational adviser to superintend an office in Cromwell Road, London, for information, guidance and guardianship. The house in Cromwell Road contains bedrooms for students on their arrival, and also provides accommodation for two associations which promote social intercourse. So successful has the scheme been that in 1912 it was found necessary to make the additional appointment of a secretary at the India Office, who will be responsible for making arrangements for students in universities \&c. outside London. Also a departmental committee was constituted to consider the means by which engineering and other technical students could obtain better facilities in England for practical experience in workshops and factories.

\section{Political History.}

The "Unrest."-Within the brief period of half a dozen years the political surface of India, usually so unruffled, has undergone two changes as sudden and as strange as the burst and the passing away of the annual monsoon. To assign their proper value to all the causes that contributed to provoke the spirit of political and social "unrest " would be a hopeless task. The Japanese victories over Russia, the "partition " of Bengal, racial antipathy, misdirected education, inflammatory publications and preachings each played their part. The result was an unexpected outbreak of anarchical crimes such as are really alien to the Indian character, and which could only be met by stern measures of repression. But while these crimes naturally attracted most attention in England, those responsible for the government of the country always recognised, as others can now see plainly, that the deepest and most permanent feeling beneath the " unrest" was a growing self-consciousness of nationality, with an inarticulate cry for greater sympathy in the administration. In 1909 , when sedition was at its height, the Imperial Parliament passed an act enlarging the legislative councils by the introduction of an elected element, and also authorising the appointment of an Indian member to the executive councils of Madras, Bombay, and Bengal. The following year, when officials and representatives of the people met in friendly debate and shared in the responsible work of legislation, ushered in a period of appeasement, transfigured into effusive loyalty by the Royal visit.

Nevertheless, out of regard to historical truth, it is necessary to summarise the chief incidents of the black period. Though it was only in Bengal that sedition and outrage became endemic, under the influence of secret societies and the preaching of a sort of religious anarchism, the first overt signs of trouble were manifested in the Punjab, the recruiting ground of the Indian army, and in the remote south of Madras. The Punjab soon quieted down, after one of the ring-leaders had been deported to Burma, and a real grievance in connexion with the canal colonies had been redressed. In Madras also order was restored by severe punishments on the offenders. Meanwhile, at Poona, in the Bombay Deccan, the Chitpavan Brahmans, of the same caste as the former Peshwa of the Marathas, had long been fomenting disaffection. Their leader, Mr. Tilak, a man of great ability and a Sanskrit scholar, traversed the country to promote the cult of Sivaji, the founder of Maratha nationality. He was responsible for breaking up the National Congress held at Surat in December 1907, when the Extremists definitely separated themselves from the Moderates. After he was sentenced in July I908 to six years' transportation for sedition, the local agitation suffered a check, but in truth it was only driven underground. In January 1909, the Queen Victoria Memorial at Nagpur was desecrated by a student of the agricultural college; on November 15 th a bomb was thrown at Lord Minto when entering the city of Ahmadabad; and on December 23d Mr. Jackson, magistrate of Nasik, was assassinated. The thrower of the bomb was nev- 
er discovered; but the actual murderers of Mr. Jackson were promptly tried and executed, though one of the conspirators (Savarkar), by escaping for the moment from a British steamer to the quay at Marseilles, furnished occasion for a reference to the international tribunal at the Hague, which decided against his extradition to France. It was also in 1909 that London was startled on July $2 \mathrm{~d}$ by the assassination of Sir W. Curzon Wyllie and a Parsi doctor at the Imperial Institute. The murderer, a student from the Punjab, was duly hanged on July 27 th. It may be emphasised that most of the anarchical crimes were committed by youths of imperfect education and morbid temperament. In January 1910 , a Mahommedan superintendent of police was shot in a corridor of the Calcutta High Court while the final appeal in the Alipur bomb case was being heard; and in the same month an attempt was detected to tamper with the fidelity of a native regiment in garrison at Calcutta. Subsequently, despite an isolated outrage here and there, however, the spirit of conciliation overcame the demon of " unrest." An Indian member had been admitted to the executive council or cabinet of the l'iceroy, and elected members sat on all the legislative councils. In February 1910, the government found themselves justified in releasing the nine persons who had been "deported," or imprisoned without any charge, two years before at a time when Bengal was honey-combed with samitis or secret societies. At the end of the year a further stage of conciliation was reached when Sir W. Wedderburn, a retired Bombay civilian of the highest character, went out to India to be president of the National Congress held at Allahabad, and to promote good will between Hindus and Mahommedans.

The New Viceroy. - With the arrival of the newly created Baron Hardinge of Penshurst (b. 1858) as Viceroy, in November I910, it was everywhere tacitly recognised that a new chapter had opened in the political history of India, though no one dared to foretell the Royal visit and its marvellous results. Lord Hardinge had from 1906 been, as Sir Charles Hardinge, at the head of the Foreign Office in London, and intimately associated with King Edward (see E. B. viii, $999 \mathrm{~b}$ ); and in succeeding Lord Minto, who had been personally popular with all classes, he brought a varied official experience to bear on the problems of Indian government. Though IgII was marked by one serious political crime, the murder of Mr. R. W. D. Ashe, a Madras magistrate, on June Igth, events proved that the end of an anxious period was in sight. Nor need this verdict be upset by the deplorable outrage on Lord Hardinge himself at the end of 1912 , when on December 22 a bomb was thrown at the Viceroy as he entered Delhi in state, injuring him somewhat severely and killing an attendant. The occurrence of such a crime is serious enough, no doubt, but represents the spent force of pure anarchism and not any widespread movement.

The Royal Visit.- The Royal visit to India, announced in the speech from the throne on February 6, I9II, is known to have been undertaken on the King's own initiative, in spite of some not unnatural warnings. Never before, since Angevin times, had an English sovercign left his own realm for a state progress through his dominions beyond the sea. From first to last its success exceeded anticipation, being marred by no untoward incident. The P.\&O. S.S. "Medina" was chosen for the Royal yacht and manned with a crew from the navy. She sailed on November $\mathrm{I}$ ith, and the first Indian port at which she touched was Aden, where the King and Queen landed. Bombay was reached on December $2 \mathrm{~d}$, and here three days were spent, the King and Queen sleeping on the "Medina." The chief public functions were a welcome on the Apollo Bandar, where a Saracenic archway and a pavilion had been erected; a procession through the streets of the city; and a children's fecte. On the night of December 5 th they departed from Bombay by the recently opened railway through Central India and Rajputana, arriving at I)elhi on the morning of December 7 th. Here ten days were crowded with ceremonial duties: first a procession from the Fort through the city to the Durbar camp; then the reception of ruling chiefs, whose visits were returned by the Viceroy; the laying of the foundation of the All India memorial to King Edward; the presentation of colours to British and Indian regiments; and a review of 50,000 troops. The culminating scene 
was the Durbar on December I 2 th, in an immense amphitheatre constructed for the purpose, within which the King and Queen in their royal robes received the homage of the ruling chiefs and their coronation was proclaimed to the assembled people. Among the boons then announced were a grant of 50 lakhs $(£ 333,000)$ for education, half a month's pay to all soldiers and subordinate officials, and the admission of Indian soldiers te the Victoria Cross. But what caused these to be ignored was the further announcement, altogether unexpected, that Delhi would henceforth be the capital of India in substitution for Calcutta, and that Bengal would be reunited under a governor-incouncil. From December I6th to 29th the King went for a hunting trip to Nepal, where the Maharaja-minister welcomed him in person, and many tigers and rhinoceros were shot, while the Queen visited Agra and several cities of Rajputana. After meeting again near Patna they arrived at Calcutta on December 30 th, and stayed there for nine days. Apart from the exuberant loyalty of the people, the most interesting incident was the historic pageant organised to represent the two festivals of the Hindu Dashara and the Mahommedan Nauroz. The return journey to Bombay was broken for an hour at Nagpur, and the "Medina" sailed on January I0, I9 I2, stopping at Port Sudan in the Red Sea and at Malta. The intention and the result of the Royal tour could not be better expressed than in the words which the King evidently uttered from his heart on leaving Bombay:-

"It is a matter of intense satisfaction to me to realise how all classes and creeds have joined together in the true-hearted welcome which has been so universally accorded to us. Is it not possible that the same unity and concord may in the future govern the daily relations of their public and private lives? The attainment of this would indeed be a happy outcome of our visit to India. To you .... I deliver this our loving message of farewell to the Indian Empire."

What may be taken as a reply was sent by the Viceroy to the Prime Minister on the day of the King's arrival in England:-

"The Princes and people of India desire to take the opportunity afforded by the conclusion of the Royal visit to convey to the great English nation an expression of their cordial goodwill and fellowship.... Their Imperial Majesties, by their gracious demeanour, their unfailing sympathy and their deep solicitude for the welfare of all classes, have drawn closer the bonds that unite England to India. ... We are confident that the great and historic event marks the beginning of a new era, ensuring greater happiness, prosperity and progress to the peaple of India under the aegis of the Crown."

Domestic Affairs.-The legislative council of the Viceroy, on which an official majority is required by the regulations, contains 60 "additional" members, besides those of the executive council or cabinet. Of these, 25 are elected by various representative bodies. For example, the non-official members of each of the provincial legislative councils, the Mahommedan community and the landholders in the larger provinces, and the chambers of commerce of Bengal and Bombay each have at least one representative. In the result, among these elected members, in I 12 there were I 2 Hindus, 9 Mahommedans, two Englishmen, one Parsi, and one Buddhist from Burma. Of 35 nominated members, 26 were officials; and the remainder included two Hindus and two Mahommedans, and a representative of the domiciled Anglo-Indian community.

Undoubtedly the most conspicuous among the Indian members, alike for his knowledge of affairs, his eloquence, and his moderation, has been Mr. Gopal Krishna Gokhale, C.I.E. (b. I866), one of the two representatives of the Bombay council. He is a Chitpavan Brahman from Poona, where he was for some years professor at the Fergusson College, and where he recently founded a society, called the Servants of India, for the study of social and economical questions and for their propagation by missionary effort. He has paid several visits to England, the latest in I9I2; and in October I91 2 he went to South Africa to examine on the spot the vexed question of the exclusion of Indian immigrants and to promote a conciliatory settlement.

The first Indian member to be admitted to the Viceroy's executive council was Mr. Satyendra Prasanna Sinha (b. 1864), a Hindu barrister, who had previously officiated as advocate-general for Bengal. He was appointed legal member in April I909, and on his retirement in November 1910 he was succeeded by Syed Ali Imam, a Mahom. 
medan barrister from Patna. It is perhaps worthy of note that both of these have sent their sons to be educated at public schools in England.

The enlarged legislative councils came into being in January roro, and as the period of membership was for three years, fresh elections and fresh appointments were due at the end of I912. Debates on bills and discussions on the budget have always been conducted without friction; resolutions proposed by Indian members have afforded useful opportunities for the pronouncement of official explanations; and the privilege of asking questions has been abundantly availed of. It is significant that almost the first Act passed by the legislative council of the Viceroy (in July I910) was one empowering the Government to prohibit indentured emigration to any country whenever it considers that sufficient reason exists. Such emigration has accordingly been prohibited to Natal. Nothing excites so much feeling among all sections of Indians as the disabilities to which they are subjected in some of the self-governing British colonies.

During I9I I three important Acts were passed: a Factories Act, which had been long under consideration and of which the chief provisions are specified above; a Patents and Designs Act, on the lines of the English measure; and a Prevention of Seditious Meetings Act, renewing an expiring Act of 1907 , with certain amendments, the most noteworthy of which permits the holding of meetings for the discussion of political subjects generally. A stringent Act for the regulation of the press, passed early in I9Io, still remains in force, its chief provision being the requirement of security, which may be forfeited and the press confiscated on the publication of seditious matter.

In IgI 2 swelling revenues resulted in a large surplus, part of which was devoted to the pressing needs of improved sanitation. The monsoon was, on the whole, very favourable, and trade was unusually brisk. In the Viceroy's legislative council the most important event of the year was the rejection, as premature, of the Hon. G. K. Gokhale's bill for a considered scheme of free and compulsory education. An Act passed Parliament for carrying into effect the new constitution of Bengal and also the formation of legislative councils in Provinces under a chief commissioner. A Royal Commission was appointed, with Lord Islington as chairman, and including the English labour leader, Mr. Ramsay Macdonald, to examine and report on all matters connected with the various branches of the civil service, with special reference to the further employment of Indians and the present division of the services into Imperial and Provincial.

Echoes of the recent troubles were aroused during the year by two legal judgments, given on appeal after prolonged litigation by the Privy Council and the Calcutta High Court, both of which justified executive action taken by magistrates at a time of crisis. In the Mymensingh case, which dates back to 1907 , the district magistrate had personally conducted a search for arms in a house near which an outrage had been committed the day before. No arms were found. The occupier of the house brought an action for trespass against the magistrate and obtained a judgment for 6.33 as damages, which judgment was confirmed by the High Court at Calcutta. Cltimately, after long delay, this judgment was reversed by the Judicial Committee of the Privy Council in July I) 12 , on the ground that the magistrate was acting within his powers as a criminal court of first instance. The circumstances of the Midnapur case are more complicated. Here there is littl: doubt that a seditious conspiracy existed in Ioos, when several suspected persons were arrested. One of these, who had been soon discharged, brought an action against the magistrate and two Indian police officers for illegal arrest. After a trial before a judge of the (alcutta High Court, which lasted for nearly 200 days, he was awarded $f 66$ as damages. Here it may be remarked that in India all civil actions are tried without a jury. (On appeal to three judges of the High Court, one of whom was an Indian, this judgment was unanimously reversed in August 19 I2, and the plaintiff was condemnerl to pay the costs, estimated at $f, 20,000$.

Foreign At thirs.- Foreign affairs, which for India are almost equivalent to frontier affairs, may be briefly treated. Anarchy in Southern Persia has required the despatch of a native cavalry regiment to open the roads and protect trade. In the Persian Gulf the traffic in rifles and ammunition has been suppressed by combined naval and military 
operations, supported by restrictions imposed by the Sultan of Muscat. The Amir of Afghanistan has continued to maintain a not unfriendly attitude. In I9 10 he agreed to the appointment of a joint commission for the settlement of boundary disputes, which resulted in an agreement for the removal of outlaws from both countries to at least fifty miles from the border. Tibet has suffered from more than one revolution, and the end is not yet in sight. In I9Io, the Dalai Lama, who had fled to China before the British occupation of Lhasa, took refuge in India from the tyranny of the Chinese, and was hospitably entertained, visiting the sacred sites of Buddhism. Afterwards, as a result of the revolution in China, the Tibetans rose against the Chinese with more or less success and invited the Dalai Lama to return. An agreement was concluded at Lhasa in August I9I2 between the Tibetans and the Chinese, in the presence of the representative of Nepal, in accordance with which the Chinese garrison was to be repatriated by way of India.. But fighting subsequently broke out afresh. In these troubles the Indian Government has taken no part, except by stopping a Mongolian mission that wished to proceed from Calcutta to Tibet. With Bhutan, on the other hand, relations have become more intimate. A formal treaty was executed in March, I9I0, with the new ruler or Zimpon, whose full style and name is 5 Sris Ugyen Wangchuk. In July I9I I, he was invested with the title of Maharaja and granted a salute of I 5 guns; and at the Delhi Durbar, where he was a conspicuous figure in his Tibetan dress, he was created K.C.S.I. Further east, at the end of the Assam valley, the wild tribe of Abors murdered Mr. Williamson, a political officer, and most of his party in April IgII. A strong military expedition, under the command of General Bower, moved into the Abor country in October, and succeeded in punishing the culprits. Though there was little fighting, the natural difficulties to be overcome were very great, owing to dense jungle, steep hills, unfordable rivers, and perpetual rain or mist. An attempt to survey the gorge by which the Brahmaputra cuts through the Himalayas-one of the few unsolved problems of geographers-was not successful. At the same time a survey party was sent out from Sadiya east through the Mishmi country toward Rima, where the Chinese were said to be encroaching.

Obituary.-Among the native Indians who have passed away during the period the most notable name is that of BeHramji MERwanji MALABari, the Parsi social reformer, who was born at Baroda in I853, and died at Simla from heart failure on July I8, r9 2. His boyhood was straitened by poverty, and he was unable to pass beyond the matriculation of the Bombay university. His first literary effort was a collection of Gujarati verse, entitled Nitivinodo (1875). This was followed by a volume of English poetryIndian Muse in English Garb (Bombay, I876)-which was dedicated to Miss Mary Carpenter, and attracted the notice of Florence Nightingale, Max-Müller, Lord Shaftesbury and John Bright. Encouraged by letters from these, he now became a journalist and devoted the rest of his life to the cause of social reform. In I 880 he became proprietor and editor of the Indian Spectator, which he conducted almost unaided for 20 years, Since Igor he had edited East and West. He will be remembered best for the agitation he conducted for many years on behalf of Indian women, touring throughout the country and thrice visiting England. The result was the passing, after bitter controversy, of the Age of Consent Act in I89I, by which the age for consummation of marriage in the case of a girl was raised from ro to 12 years. Later undertakings of his were to found the Seva Sadan, a society for the improvement of women by women, and to establish with the help of native princes and others a sanatorium for consumptives at Dharampur in Northern India. He also conceived, but did not live to carry out, the foundation of a Morley chair for the philosophy of history at Bombay. Latterly his health broke down and he lived the life of a recluse. He is understood to have refused the Kaisar-i-Hind gold medal and also knighthood.

A strong contrast is presented in SYEI) ALI BILGRAM, the most versatile Mahommedan of his time, who died at Hardoi in Oudh on May 23, I9r. A half-brother, younger by seven years, of Syed Husain, the first Mahommedan member of the Secretary of State's Council, he was born at Patna in 1851 . Educated first at Patna College, he 
graduated at the Calcutta University with double first class honours, taking Sanskrit as his second language. He then attended the Thomason Civil Engineering College at Rurki for a time; but having attracted the notice of Sir Salar Jung, the great minister of Hyderabad, he came in his suite to England in 1876 and joined the Royal School of Mines, where he passed the examination for the Associateship and was awarded the Murchison medal in geology. At this time he also travelled on the continent, and made himself proficient in French and German. Returning to India in 1879 , he served for many years in Hyderabad in the departments of public works, mines and education. In 1892 he went up for the law examination at Calcutta, passing at the top of the list and winning the gold medal. Retiring from service in I901, he settled with his wife in England, being appointed lecturer in Marathi at Cambridge, and also employed in cataloguing the Delhi collection of Arabic and Persian MSS. in the India Office. In I907, he was called to the bar at Lincoln's Inn, and then returned to India, to devote himself to work for the Muslim League and the Aligarh College. Among his numerous publications are a monograph on the Book of Kalilah and Dimnah, Notes on the Educational Value of Persian as compared with Sanskrit, and a translation into Urdu of Le Bon's Civilisation des Arabes.

Yet a third type is represented by Venkatarama Krishnaswami Atyar, C.S.I., a Brahman lawyer, who died on December 28, I9I 2, at Mylapore, a suburb of Madras, at the age of 48 . In 1909 he had been appointed a judge of the High Court and in January IgI I a member of the executive council. When attending the Durbar at Delhi his health broke down. Though a supporter of the National Congress and always maintaining very independent views, the esteem in which he was universally held was shown at a public meeting summoned by the Sheriff of Madras, at which the Governor was present, when it was resolved to erect a memorial statue of him. Another memorial is the Sanskrit college which he himself founded at Mylapore. Almost his last words are said to have been: "I want to do something yet for the country. I do hope God will not take me away before I have done it."

Bibliography.-Among recent books on India, the following are specially notable: Indian Unrest, by V. Chirol (1910); Administrative Problems of British India, by $\mathrm{J}$. Chailley (1910); India under Curzon and After, by L. Fraser (1911); Studies in Indian Life and Sentiment, by Sir B. Fuller (19I0); India and the Durbar, being a Reprint of the Indian Articles in the Times of May 24, I9II; The Awakening of India, by J. R. Macdonald (I9Io); Education and Statesmanship in India, by H. R. James (1911); The Renaissance in India: Its Missionary Aspect, by C. F. Andrews (1912); The Economic Transition in India, by Sir T. Morison (I9II); Der lleutige Indien, von Prof. Dr. Georg Wegener (Berlin, I9I2); The Indian Scene, by J. A. Spender (1912); Narrative of the Visit to India of Their Majesties King George $V$ and Queen Mary and of the Coronation Durbar held at Delhi, I2 Dec., I9I I, by the Hon. J. Fortescue (I912); The King and Queen in India, I911-2, by Stanley Reed (Bombay, 1912) In Abor Jungles: being an Account of the Abor Expedition, the Mishmi Mission, and the Miri Mission, by Angus Hamilton (1912); On the Track of the Abor, by Powell Millington (1912).

\section{Indian States, Provinces and Cilies}

Notes are appended giving recent information on the more important states, provinces, and cities, supplementary to the accounts given in the Encyclopaedia Britannica. For convenience of reference they are given in alphabetical order.

ADEN. - The population of Aden in 1911 was 46,165 , showing an increase of $5 \%$ during the decade. The trade, almost entirely a transit trade, does not increase, partly owing to troubles in the interior, but also to the development of French and Italian ports in the Red Sea. Aden was the first spot of Indian territory visited by the King and Queen on November 27 , I9II, when they came ashore for a few hours and received an address from Mr. Cowasji Dinshaw, the leading Parsi merchant.

Acira.-The population of Agra city in I9I I was $185,4+9$, showing a decrease of $1.4 \%$ during the decade. Both the district and the division show still larger decreases. On the orasion of the royal visit to India the Queen spent three days at Agra, including a trip to Fatehpur Sikri, while the King was shooting in Nepal.

AHMEISABA. - The population of Ahmedabad city in $19 x 1$ was 215,835 , showing an increase of 16.1 , during the decale, which follows upon an increase of $25.3 \%$ during the previous decade. This prosperity is mainly due to its cotton mills, which number 54 . The population of the district increased hy unly $4^{\prime \prime} \ldots$. The Arts College, formerly managed by a 
local society, has recently been transferred to Government. By the munificence of a wealthy merchant, Sir Chinubhai Madhavlal, a Science Institute, with separate buildings for a hall and a library, are now being added.

AJMER.-The population of Ajmer city in $191 \mathrm{I}$ was 86,222 , showing an increase of $16.8 \%$ during the decade. The minor province of Ajmer-Merwara shows an increase of only 5.I $\%$. On the occasion of the royal visit to India the Queen spent three days at Ajmer in December 1911, while the King was shooting in Nepal. She visited the Mayo College, Pushkar lake sacred to Hindus, and the tomb of the Mahommedan saint, Muin-ud-din Chisti.

AllaHABAD. - The population of Allahabad city in I9I I was I 7 I,697, showing a decrease of $2 \%$ during the decade. The population of the district likewise decreased by $1.6 \%$, due to the prevalence of plague. On November I I, I9IO theViceroy paid a visit to Allahabad to lay the foundation stone of a pillar in Minto Park, on which have been inscribed the two historic proclamations of Queen Victoria and Edward VII. In December of that year, while the National Congress was being held under the presidency of Sir W. Wedderburn, the largest exhibition yet held in India was opened by the Lieutenant-Governor. The agricultural court, which was a conspicuous success, has greatly stimulated the interest of landowners in the use of labour-saving implements, power-plant for pumping, and the manufacture of white sugar by machinery. A new bridge across the Ganges to connect with the Oudh and Rohilkhand Railway was opened in October 1912, while the railway bridge across the Jumna is being widened to carry a double line. Other public works in progress are a senate hall and a library for the university, while a new building for the High Court has been sanctioned. A trust fund has been formed for the purpose of opening out congested areas.

ALWAR.-The population of this native State in I9I I was 79I,688, showing a decrease of $4.4 \%$ during the decade. The Maharaja, Sir Sawai Jai Singh, was created K.C.I.E. at the Delhi Durbar.

AMrITSAR.-The population of Amritsar city in rorr was 152,756, showing a decrease of $6 \%$ during the decade. The population of the district also decreased by $14 \%$, due to plague and malaria. As a result of the malaria conference held at Simla in 1909, Amritsar has been selected for a laboratory; lectures are here given to medical officers, and a periodical is published.

ANDAMAN Islands.-The population of Port Blair (the penal settlement) in 19I I was 16,324, showing an increase of $4 \%$ during the decade, while in the rest of the Andamans only I,3I7 persons were enumerated, showing an apparent decrease of $30 \%$. In the Nicobar Islands, however, which are under the same jurisdiction, there was an apparent increase of no. less than $35.4 \%$.

Assam.-The population of Assam (which was incorporated with Eastern Bengal in 1905 , but was again constituted a separate Province under a chief commissioner in I9I2) was $7,059,857$ in 1911 , showing an increase of $17.1 \%$ during the decade. This high rate of increase, more than three-fold that for all British India, may be ascribed partly to the immigration of labourers on the tea estates, but still more to recovery from the results of a severe epidemic fever. The tea industry has been very prosperous in recent years, demand having exceeded production. The total number of labourers on the tea estates in 1911 was 763,239 , of whom only 20,868 were under the Act specially enforcing contracts, which it is proposed shortly to repeal. In 1912 Sir A. Earle was appointed chief commissioner of Assam, and it is proposed to give the province a legislative council under the powers conferred by the Act of Parliament passed in that year.

A valuable series of monographs on the more important tribes of Assam is being published by the Government.

BAHAWALPUR. - The population of this native State in I9I I was 780,641 , showing an increase of $8.3 \%$ during the decade. The Nawab, a boy of only 7 , was a conspicuous figure at the Delhi Durbar, riding at the head of his camel corps in the military review. In February I9 I I, a feeder railway of 22 miles, constructed at the expense of the state, was opened by the Jieutenant-Governor of the Punjab.

Baluchistan.- The population of British Baluchistan in I9I I was 4I4,4I2, showing an increase of $8.5 \%$ during the decade. In the Baluchistan states, the population of Las Bela likewise increased by 9.I \%, while that of Kalat (excluding Kharan) shows an apparent decrease of $10 \%$, due to the fact that the earlier figure was based upon an estimate, not upon actual enumeration. In British territory, the recent period has been peaceful, except for raids by Afghan outlaws from across the frontier, in consequence of which it has been found necessary to re-arm the levy corps with Martini-Henry rifles. The value of transfronticr trade, though still small, exhibits an increase. The state of Kharan was disturbed after the death of its old chief in June 1909, and his successor was assassinated in April I9II. The ex-Khan of Kalat, who was dethroned in 1893, died at Pishin on May 20, 1909. A severe shock of earthquake was felt throughout Kalat on October 2 I, 1909, causing great loss of life and property.

A Gazetteer of Baluchistan has been published in 8 vols.

BANGALORE. - The population of Bangalore city (including the civil and military station under British jurisdiction) was 189,485 in 1911 , showing an increase of $19.1 \%$ during the decade. The Mysore state proposes to introduce an electric tramway service for ten miles through the city and its suburbs. 
Banganapalle.-The population of this native State in I9I I was 39,344, showing an increase of $21.9 \%$ during the decade.

BARODA. - The population of this native State in I9I I was $2,032,798$, showing an increase of $4.1 \%$ during the decade; and the population of the city was 99,345 , showing a decrease of $4.3 \%$. The Maharaja Gaekwar, with the Maharani, was absent during the greater part of 1910, visiting Japan, the United States (where his second son was at college), and England. They again came to London in $191 \mathrm{I}$ for the Coronation. Concerning his act of homage at the Delhi Durbar the description of the official historian may be quoted: "One chief only marred the proceedings for a moment by a laboured ungainliness of bearing which lent itself to misinterpretation." His third son at Oxford has played cricket more than once for the university eleven. Baroda maintains its claim to be the most progressive state in India. In 1911 , the length of railways open was 300 miles, and 100 miles more were under construction. In addition, $£ 218,000$ was spent on other public works. Export and import duties generally have been abolished, and also octroi in municipalities. Education in primary schools is compulsory and free. A bank and many factories have been established with official encouragement. The legislative council is active in passing laws and regulations. There is also a state council, presided over by the minister. See $A$ Year with the Gaekwar of Baroda, by E. St.C. Weeden (1912).

BASTAR. - The population of this feudatory State in 191 I was 433,310 , showing an increase of no less than $41.4 \%$ during the decade, due partly to recovery from famine. In February 1910 there was a serious rising of the aboriginal tribes, which was not suppressed without the intervention of regular troops. Two British officers have since been deputed to assist the Raja, and many reforms have been introduced in the administration.

BEHAR AND ORISSA.- This is the name of the new province in India which was created on April I, I9I2, in accordance with the announcement of the King at the Delhi Durbar and the provisions of a subsequent Act of Parliament. Including Chota Nagpur in addition to the two historic tracts after which it is named, it has a total area (with native States) of about I 16,000 sq. m., and a total population (I9II) of about $38 \frac{1}{2}$ millions, among whom Hindus greatly predominate over Mahommedans. The capital has been fixed at Patna, and a hill station will probably be found on the Chota Nagpur plateau. The first Lieutenant-Governor is Sir Charles Bayley, transferred from Eastern Bengal and Assam; and the first Indian member of the executive council is the Maharaja of Darbhanga, a wealthy landowner in Behar.

BENARES. - The population of Benares city in I9I I was 203,804, showing a decrease of $4.4 \%$ during the decade, while the population of the district increased at the rate of $1.7 \%$.

In November I9Io it was announced that the Raja of Benares, Sir Prabhu Narayan Singh, G.C.I.E., who already possessed the rank of His Highness and a salute of 13 guns, would be recognised as a ruling chief, and he was formally invested in April 19II. The new native State thus created, the first in Indian history, consists of what were before known as the Family Domains, with a total area of nearly $1,000 \mathrm{sq} . \mathrm{m}$. in the two districts of Benares and Ghazipur, and a rent roll of about $£ 66,000$. In addition, the Raja owns private estates with a rent roll of about $£ 46,000$ subject to land revenue. He is descended from the father of Chet Singh, who rebelled against Warren Hastings and was dethroned in $178 \mathrm{I}$.

BENGal.- The Province of Bengal, while retaining the same official title, has undergone two fundamental changes of area within seven years. In 1905, the original province, practically identical with that comprised in the Diwani grant of 1765 , was reduced by the separatirm of Eastern Bengal from a total area of about 190,000 sq. m. to about 150,000 sq. m., while the population was reduced from over 78 millions to over 54 millions. On April I, I9I2, in accordance with the announcement of the King at the Ielhi Durbar and under a subsequent Act of Parliament, Eastern Bengal was reunited, while Behar, Orissa, and Chota Nagpur wrre separated to form a new Lieutenant-Governorship; and the province was at the sime time raised to the rank of a Presidency, under a Governor, with powers and privileges similar to those of the Governors of Madras and Bombay.

In IOI 1 , the population of the Province (as then existing, with the inclusion of native states) was $57,206,430$, showing an increase of $4.8 \%$ during the decade. The population of the Province as now reconstituted is about 46 millions, with Mahommedans in a slight majority over Hindus. The first governor is Lord Carmichael, transferred from Madras; and the first Indian member of the executive council was Rai Kisori Lal Goswami Bahadur, appointed in November Ig Io when an executive council was constituted under the Indian Councils Act of I)(x). The same statute authorised the enlargement of the legislative council, which now consists of 52 members, including 25 elected by variously composed constituencies. In the total there were 20 Hindus and 7 Mahommedans. Calcutta remains the capital of Bengal, with Darjiling as the residence of the Crovernor during the hot season; but it has been solemnly promised that Dacca, the former capital of Eastern Bengal and a centre of Islam, shall always be occupied by the entire administration for a certain period of every year. In 1912 , when the Province was reconstituted, the Indian member appointed to the executive council of the ( novernor was Dyed Shams-ul-Huda, a Mahommedan adiocate.

BHARATPIR. - The population of this native State in I I I was 558,785 , showing a decrease of $10.8^{\circ}$. during the decade. The Maharaj, who is still a minor, recently spent twa years in England, returning in ()(tober Ioro. He was a page of honour at the Durbar. 
BHopal.-The population of the Bhopal Agency in I9I I was $1,050,735$, showing an increase of $13.4 \%$ during the decade, due to recovery after famine. The population of the city was 56,204 , showing an apparent decrease of no less than $27 \%$, due to plague at the time. The Begam of Bhopal, who is a most enlightened ruler and travelled lady, was a conspicuous though veiled figure at the Coronation in London and also at the Delhi Durbar, where one of her sons acted as an A.D.C. and another as a page of honour. She received the decoration of G.C.S.I. on January I, I9IO, and that of C.I. in December I9II.

See A Pilgrimage to Mecca, by the Begam of Bhopal (Trans. Calcutta, 1906); and $A n$ Account of My Life, by the Begam of Bhopal (Trans. 1912).

BIKANER. - The population of this native State in 1911 was 700,983 , showing an increase of $19.9 \%$ during the decade, due to recovery after famine. The Maharaja, as A.D.C. to the King, was a conspicuous figure at the Coronation and also at the Delhi Durbar, where one of his sons acted as a page of honour. He was created G.C.S.I. on the occasion. In June I9II, he had received the honorary degree of LL.D. at Cambridge. In September I9I2, he celebrated the twenty-fifth anniversary of his own accession by opening the Dungar Memorial College in his capital, named after the elder brother to whom he succeeded, and by announcing the formation of a legislative council. He has recently converted an infantry regiment, 500 strong, into Imperial Service troops: and he has offered to contribute towards the construction of a railway through his state to connect Delhi more directly with Karachi. The town of Bikaner is now lighted throughout by electricity. An English officer has been lent to the state to reform the land revenue system.

BомвAY CITY.- The population of Bombay city in I9I I was 979,445, showing an apparent increase of $26.2 \%$ during the decade. But when the Census of I 90 I was taken plague was raging in Bombay, and a special enumeration in 1906 returned a total of 959,537. It is also suggested that again in I9II many persons had left the city owing to depression in the cotton industry or through fear of plague infection.

Bombay city has enjoyed almost unbroken peace and prosperity, its citizens being too well-to-do and too sensible to be affected by the "unrest" that manifested itself in other parts of the Presidency. The only serious trouble was caused in December 1909 by riots of a nonpolitical character between rival sects of Mahommedans at the Muharram festival. It was found necessary to call out the troops, who fired on the mob and 20 lives were lost. Bombay was the scene of the arrival of the King and Queen in India, and also of their departure; and it was there that the King delivered two of his sympathetic speeches. It has been decided to commemorate the Royal visit by erecting an archway on the historic Apollo Bandar.

Two undertakings of the first magnitude are in progress at Bombay. One is the work of the Improvement Trust, which has already reclaimed 90,000 sq. yards from the foreshore for buildings, opened two wide roads through former slums, and erected sanitary chauls or lodging houses for 15,000 poor persons. With the aid of a special grant of $£ 333,000$ from the Government of India, it is now engaged in opening out the north of the island, which is difficult of access and sparsely inhabited. The other is the work of the Port Trust, which should be completed in I $19 \mathrm{I} 3$ at a total cost of more than $f 5,000,000$. This consists in the construction of the Alexandra Dock, 50 acres in extent, with a dry dock $1,000 \mathrm{ft}$. long, and a mole where the mail steamers can lie alongside; and the reclamation of 600 acres for export traffic and a new railway station. Three other projects may be mentioned: the provision of electrical energy from water power in the Western Ghats, which has been commenced by a company with more than $f_{1} I, 000,000$ of Indian capital under the auspices of the Tatta firm; a grandiose scheme, still in embryo, for the reclamation of no less than 1,000 acres in Back Bay, at an estimated cost of nearly $f_{2}, 000,000$, to be taken in hand by the Government; and the proposed electrification of all the railways in the island.

See Gazetteer of Bombay City, 3 vols. (Bombay, 1910).

Bombay Presidency. - The total population of the Bombay Presidency in I9 I (including Sind, Aden and native States) was 27,084,3I , showing an increase of $6.3 \%$ during the decade, due mainly to recovery after famine. Agricultural seasons were on the whole favourable, except in Gujarat in I9II; but plague continued to be prevalent. In British territory alone (excluding Aden) the population was $19,626,477$ and in native States 7,41 1,675, the rate of increase in each being almost equal:

Bombay claims to be the province where education is most widely spread and also most efficient. Under the stimulus of encouragement from the Governor, Sir George Clarke (who retired at the end of I9I2, with a peerage as Lord Sydenham), great progress has been made in recent years, especially as regards the higher teaching of science. The university has revised its courses and made arrangements for post-graduate study. In Bombay city three wealthy merchants have subscribed $f_{126,000}$ for the establishment of a Science College, and their example has been followed at Ahmedabad ( $q . v$.$) . Conse-$ guently the Science College at Poona has been converted into a college for engineering. A first class agricultural college has been built at Poona. Nor has primary education been neglected. During the two years ending I9I I no less than I, IOO new schools were opened; but it is admitted that there are still $\mathrm{I} 00,000$ children whose parents would willingly send them to school if there were schools for them.

The first Indian member to be appointed to the executive council was Mr. Mahadev 
Bhaskar Chaubal, an advocate of high standing, who has since been nominated to serve on the Royal Commission to enquire into the civil service. The legislative council, as reconstituted in 1910 , contains a majority of non-official members. Of the total of 46 , Hindus number 20. Mahommedans 7 , and Parsis 3 .

See Rural Economy in the Bombay Deccan, by G. Keatinge (1912).

BCNDI.-The population of this native state in 1911 was 218,730 , showing an increase of no less than $27.7 \%$ during the decade, due to recovery after famine. In December I9I the Queen paid a visit to Bundi while the King was shooting in Nepal. There being no railway within the state, she travelled by motor from Ajmer (100 miles). She was hospitably entertained at the capital; and the Maharao, who afterwards came down to Bombay to bid farewell, there received from the King the decoration of G.C.V.O.

BURMA. - The population of the Province of Burma in 191 I was 12, I 15,217, showing an increase of $15.5 \%$ during the decade; more than double the rate of increase for all India. Of this increase about $\mathbf{5 3 , 0 0 0}$ is due to an estimate for tribes on the frontier not formerly included. It is noteworthy that the number of Chinese has risen from 62,000 to 123,000 , of whom only 17,000 are females.

Burma is happy in the possession of no exciting history. The wave of "unrest" which recently ran through India never reached its borders. Its prosperity depends almost entirely upon rice, and even when the harvest has not been good, this has been compensated by high prices for export. Teak ranks next in importance to rice; and by the extension of working plans over the virgin forests the supply of timber is being maintained. In 1910-1, the net revenue of the forest department amounted to $£ 440,000$. Petroleum is another valuable product, though the supply of oil is apparently not increasing. The ruby mines cannot be considered a success; but in $1910-1$ lead was produced to the value of $£ 168,000$, and rich discoveries of wolfram have recently been reported. What Burma most needs is an improvement in communications, for which purpose it has been proposed to levy a cess upon the rice exported from Rangoon. A line of railway is now being constructed into the Southern Shan States, and a small line has also been opened in the Northern Shan States by the Burma Mines Company. On the northern border, which marches with Chinese territory, occasional raids of Chins, Kachins, and other wild tribes occur; but these have never assumed a serious form. The Shan States are, on the whole, successfully administered by their own Sawbas or chiefs.

Under the recent reform, Burma has a small legislative council with a majority of nonofficials, but the elective system has not been introduced. In a total of 15 members, there are 4 Burmans, one Mahommedan, one Parsi, and one Chinese.

CALCUTTA.-The population of the city of Calcutta proper in 19 II was 896,067 , showing an increase of $5.7 \%$ during the decade; but if the suburbs and also Howrah on the opposite side of the Hugli be added, the total population would be raised to $1,222,313$ and the rate of increase to $10.4 \%$. The increase is entirely among Hindus, Mahommedans and Christians showing an actual fall, while females constitute less than one-third of the total.

Though the climate does not enjoy a favourable reputation, Calcutta is fortunate in escaping endemic plague. In 1911 , the registered death rate was only 27.2 per thousand, as compared with an average of 32 per thousand for the previous five years. The municipality has recently completed two large projects for doubling the supply of filtered water and for improving the system of drainage. It has also taken over the lighting of the city, and by-laws have been passed relating to dairies, stables, public buildings and markets. During the past ten years the rateable value has increased by $58 \%$ to $\{2,365,000$, while the total debt is $\{3,222,000$. In August I9I I an Act was passed by the Bengal legislative council, constituting an Improvement Trust (similar to that at Bombay) to undertake schemes for clearing congested areas and making street improvements, the cost to be met from an increased cluty on property transfers, a terminal tax on passengers, and a cess on jute, with contributions from the municipality and the government. The Port Trust has to provide for a trade that has doubled within the last ten years. The more important works completed or in progress are-the extension of docks and sidings, the acquisition and reclamation of land, and the provision of a coal depot, a landing stage, and four ferry steamers. In 1910-1, the receipts a mounted to $£ 855,000$, while the debt was $f 5,622,000$. Under the stimulus of recent reforms, the Calcutta University has advanced far towards becoming a teaching institution with no less than 49 lecturers and more than 500 students for post-graduate study. The newest college is one founded by Marwaris for commercial education, at a cost of $£ 60,000$; while a Hindu lawyer has promised f93,000 for the foundation of a College of Science.

The visit of the King and Queen to Calcutta from December 30, 19 I I, to January 8, 1912, was even more notable for a popular demonstration of loyalty than the Delli Durbar. It cannot, however, be disguised that the transfer of the imperial capital to Delhi has been badly received, especially by the English residents, who will lose not only the attractions of a seasonal court but also the advantage of contact with the heads of the administration. Indians, on the other hand, are glad that Bengal is reunited, and that a civilian Lieutenant-Governor has been replaced by a Governor from England. Apart from a possible fall in house rent. there is no reason to suppose that the material prosperity of Calcutta will suffer.

CAWNPORE. - The population of (awnpre city in I9 I was 178,557 , showing an apparent decrease of no less than $12 \%$; but plague was raging at the time, and a later enumeration 
raised the number to 195,498 . The population of the district likewise shows a decrease of $9 \%$, due to plague and malaria. An agricultural college has recently been opened at Cawnpore, and a trust fund formed for opening out congested areas.

CENTRAL INDIA. - The total population of the Central India Agency in I 9 I I was 9,356,980, showing an increase of $10.1 \%$ during the decade, due to recovery after famine. For the more important states, see Bhopal, Gwalioc, Indore and Rewa.

A Gazetteer of the Central India Agency has been published in 9 vols.

Central Provinces. - The total population of the Central Provinces and Berar (which form a single administration since. 1905) was 16,033,310 in 1911 , showing an increase of $17.9 \%$ during the decade, due to recovery after famine. In the feudatory states alone, with a population of $2,117,002$, the rate of increase was as high as $29.8 \%$. Native Christians have increased from 20,115 to 24,106 , among whom the Quaker mission counts I, I40 converts. The province, with its large Maratha population, did not altogether escape the prevalent spirit of "unrest;" and in January 1909 the Queen Victoria Memorial at Nagpur was desecrated by a student of the agricultural college. But, on the whole, prosperity has followed upon good harvests, the crops for export being cotton, oilseeds, and wheat. As a result of the Irrigation Commission, a number of small tanks have been excavated to protect precarious tracts, and sanction has been given for the construction of three large canal systems from as many rivers. On January 9, I9I2, the King and Queen, on their railway journey back from Calcutta to Bombay, stopped for an hour at Nagpur, to visit the fort and show themselves to the people. Under the Act of Parliament passed in 1912, it is proposed to give the Province a legislative council; but this can only apply with restrictions to Berar, which is not strictly British territory. The Viceroy visited Nagpur on December I7th, to lay the foundation stone of the council hall.

СнамвA. - The population of this native State in I9I I was 135,873 , showing an increase of $6.3 \%$ during the decade. A full account of the inscriptions found in the State, and also of the people and their dialects, is given in the Chamba State Gazetteer (Lahore, I9IO).

Cochin. The population of this native State in I9I I was 918,1 IO, showing an increase of $13.1 \%$ during the decade. Christians number no less than 233,092 , mostly Syrians of different rites and Roman Catholics. The state has been exceedingly prosperous of recent years, much attention having been paid to all departments of the administration, especially forests and navigable canals. In January 19II, the Raja's salute was increased to 19 guns as a personal distinction; and he was created G.C.I.E. at the Delhi Durbar.

COORG.-The population of this minor province in 19 I I was 174,976 , showing a decrease of $3.1 \%$ diring the decade, due to the decline in the coffee industry. Out of 3,533 Christians, no less than 2,830 were Roman Catholics.

CUTCH.-The population of this native State in 191 I was 513,429 , showing an increase of $5.2 \%$ during the decade. There are no railways in the State, and the proposal to construct a direct line from Bombay to Karachi through Cutch remains in abeyance.

DACCA.-The population of Dacca city in I9II was IO8,55I, showing an increase of $21 \%$ during the decade, while both the district and the division increased by more than II \%

Dacca was the capital of the new province of Eastern Bengal and Assam created in 1905; and now that Bengal has been reunited in 1912, a solemn promise has been made that Dacca shall be occupied by the government for part of every year. Important buildings have been erected for the residence of officials and for the secretariat. The remodelling of the waterworks has been completed, and schemes for improving the drainage are in hand. Education, especially in English, is making rapid advance. Hostels and a hall have been opened for Mahommedan students, and it is announced that Dacca will shortly have a local university. At the Delhi Durbar, the Nawab, Sir Khwaja Salimulla, was created G.C.I.E.

DELHI.-The population of Delhi city in I9I I was 232,837 , showing an increase of I1 $6 \%$ during the decade, due to the growth of commerce and industries, while the population of Delhi district fell by $4.6 \%$ and that of Delhi division by as much as $8.9 \%$, owing chiefly to plague and malaria.

An account of the Delhi Durbar is given above. Here it may be briefly said that the Royal visit, which lasted from December 7 to I6, I9 I I, was an unqualified success from the popular point of view. The canvas city along the historic ridge covered a total area of $25 \mathrm{sq}$. $\mathrm{m}$.; the amphitheatre erected for the crowning ceremony accommodated 100,000 spectators; and 50,000 troops were present at the review. To the Indian mind the most attractive incident was when the King and Queen showed themselves to the crowds below from a balcony in the Fort where the Mogul emperors had been wont to view spectacles.

The site of the new capital is not that of the Durbar, nor does it include the spot where the king performed the ceremony of laying a foundation stone. In accordance with the advice of an expert commission, which included the chairman of the London County Council, it will be on a high and unoccupied tract S.W. of the city, where convenient space and healthy conditions can best be secured. Here at a distance of about $3 \mathrm{~m}$. from the city walls, and separated from them by a wide belt of park, will be built the Viceroy's palace, the council chamber, and other government offices, at a cost provisionally estimated at $t+, 000, \mathrm{o}(0)$. The style of architecture to be adopted was still under discussion in 1912, though designs had been invited from architects in India. 
Meanwhile, as the Government will not return again to Calcutta, temporary residences and offices were erected at Delhi, at a cost of about $£ 333,000$, of which it is estimated that one-third will eventually be recovered. On October Ist, an enclave surrounding the city, with an area of $557 \mathrm{sq}$. $\mathrm{m}$. and a total population of about 392,000 , was by proclamation separated from the Punjab and constituted a new province under a Chief Commissioner, while the laws in force in the Punjab and the jurisdiction of the Chief Court at Lahore are preserved by an Act of the legislative council.

DHOLPUR.- The population of this native State in 19 I I was 263,188 , showing a decreasc of $2.9 \%$ during the decade. The Maharaj Rana, Captain Sir Ram Singh Lokindar, K.C.I.E.. died on March 29, I9II, and has been succeeded by his brother, Udaibhan Singh Lokindar.

EASTERN BENGAL. - The population of Eastern Bengal and Assam (which was created a separate province in 1905, but ceased to exist in 1912) was $34,018,527$ in 1911 , showing an increase of $11.5 \%$ during the decade. Under the reform, it received in 1910 a legislative council with a non-official majority. Of the total of 40 members, Hindus numbered 13 and Mahommedans 8 .

GARHWAL. - The population of the British district of Garhwal in I9I I was 480,167 , showing an increase of I I.7\% during the decade; and the population of the native state of TehriGarhwal was 300,819 , showing an increase of $11.9^{\circ}$. The Raja, Sir Kirti Sah, K.C.S.I., is a member of the legislative council for the United Provinces. For both district and State see Garhwal Gazetteer (Allahabad, 1910).

GWALIOR.-The population of the Gwalior Residency in I9I I was $9,356,980$, showing an increase of $10 \%$ during the decade, due to recovery after famine. The population of Lashkar or Gwalior city was 46,952 , showing an apparent decrease of no less than $47 \%$, for plague was present at the time of the Census. A later enumeration gave a total of $60,93 \mathbf{I}$. The Maharaja Sindhia was a conspicuous figure, as A.D.C. to the King at the Coronation and also at the Delhi Durbar. While in England he received the honorary degrees of D.C.L. from Oxford and LL.D. from Edinburgh. His personal salute has been increased to 21 guns, and he has been raised to the rank of honorary major-general in the British army.

The Grullior State Gazetteer consists of four volumes (Calcutta, Bombay, and Lucknow, 1908), one of which contains nearly 400 photographs of places of historical and archaeological interest, while another is an atlas of 15 maps.

HIIL TipPERA.- The population of this native State in I9I I was 229,613, showing an increase of no less than $32.5 \%$ during the decade, due to agricultural prosperity. Valuable deposits of limestone, kaolin, and red ochre have recently been reported. The Raja, Birendra Kishore Manikya, who succeeded his father in 1909, married in August 1910 a cousin of the Maharajadhiraj (nominal king) of Nepal.

IOWRAH.- The population of Howrah city in I9II was 179,006 , showing an increase of 13.6" during the decade; and the population of the district was $9+3,502$, showing an increase of $10.9 \%$. It has been determined to reconstruct the pontoon bridge connecting Howrah with Calcutta on the opposite side of the Hugli.

HYDERABAD. - The population of Hyderabad State in 19 II was $13,374,6,6$, showing an increase of no less than $20 \%$ during the decade. The population of Hyderabad city (including the British cantonment of Secunderabad) was 500,623 , showing an increase of $11.6 \%$.

The late Nizam (E. B. xiv, 32) died on August 29, 1911 , at the age of 45 , having succeeded when only two years old. He was always constant to the tradition of his family as the loyal ally of the British Government. One of his latest acts was to prohibit the dissemination of seditious literature in his state. Ile was succeeded by his son, Csman Ali Khan, to whom the Viceroy paid a visit of congratulation in October 1911. At the Delhi Durbar he was a conspicuous figure as the first ruling chief to pay homage, clothed in plain black with a green turban of Mughal pattern. On the previous day he had been created G.C.S.I. On the occasion of his birthlay, in July 1912, he announced a change in the administration. Salar Jung, grandson of the famous minister of the same name, was appointed to the office of prime minister, with the Nawab Imad-ul-Mulk (better known as Saiyid Husain Bilgrami, the first Mahommedan member of the Council of India) as his special adviser. The most important recent work has been the construction of the Musi reservoir, for flood protection and the water supply of the city, at a cost of about $£ 666,000$. There was a serious outbreak of plague in the early part of 1912.

IXDORE. - The population of Indore state in 191 I was 979,360 , showing an increase of $16.3 \%$ during the derade, due we recovery after famine. The population of Indore city was 44,947 , showing an apparent decrease of no less than $48 \%$, for plague was present at the time of the ('ennus. A subsequent enumeration gave a total of 68,733 . The young Maharaja Holkar, who harl spent the greater part of two years in England and on the continent, was installed with ruling powers in November I9II. He takes over a state that has been vastly improved by the administration of a council during his minority. The most important addition to Indore city has been the completion of Daly College for the sons of Central India chiefs.

JAIPIR.- The population of Jaipur State in 19 I I was $2,636,647$, showing a decrease of $8 \%$ during the decade. The population of the city (the only one in Rajputana with more than $5^{\circ, 000}$ inhabitants) was 137,098 , showing a decrease of $14.4 \%$. Jaipur city was visited 
by the Queen in December I9I r, while the King was shooting in Nepal. She was entertained by the Maharaja. An excursion was made to Amber, the former capital, now in ruins.

JAISALMER. - The population of this native State in I9I I was 88,31 , showing an increase of $20.4 \%$ during the decade, due to recovery after famine. The Maharawal, who was born in 1887 and succeeded in 1891 , was granted ruling powers in December, 1908.

JHALAWAR. - The population of this native State in I9I I was 96,27I, showing an increase of $6.7 \%$ during the decade, due to recovery after famine. The Maharaj-Rana paid a visit to England in 1912, when he was a conspicuous figure of the London season. His predecessor, dethroned for persistent misgovernment in 1896, died at Benares in October 1912.

See Picture Travels: The Record of a European Tour, by Sir Ghawani Singh, MaharajRana of Jhalawar (I912.)

JIND. - The population of this native State in I9II was 271,728 , showing a decrease of $3.6 \%$ during the decade. The state has recently suffered from repeated outbreaks of plague. See Phulkian States Gazetteer (Lahore, I909).

JoDHPUR. - The population of Jodhpur State in I9I I was 2,057,553, showing an increase of $6.3 \%$ during the decade, due to recovery after famine. Large sums have recently been expended upon irrigation, and many new schools have been opened. The Maharaja, who died in March I9I I, has been succeeded by his son, a minor, who acted as a page of honour at the Delhi Durbar, and has since been brought to England for education. A regent has been found in Sir Pertab Singh (b. I845) who had been regent to the boy's father, his own nephew. Sir Pertab Singh resigned for this purpose the state of Idar in Bombay, to which he had succeeded in 1902 . He was a conspicuous figure as A.D.C. to the King at the Coronation and also at the Delhi Durbar, when he was created G.C.V.O.

KalAT.-The population of this native State (excluding Kharan) was 335,227 in I9 I I, showing an apparent decrease of $10 \%$ during the decade; but in I 901 the figures had been based on an estimate, not on actual enumeration. While Kalat proper has enjoyed an uneventful history, serious troubles have occurred in the subordinate state of Kharan. The chief, Sir Nauroz Khan, K.C.I.E., died in June 1909, and was succeeded by his son, Sardar Yakub Khan, who repudiated the conditions imposed by the British representative on his accession, and was ultimately killed by his own troops in April, I9I I. The succession of his son, Habibullah Khan, has been recognised, and measures taken for the administration of the state during his minority. The ex-Khan of Kalat, Khudadad Khan, G.C.I.E., who had been deposed in I893, died at Pishin in May, 1909.

KAPURTHALA.- The population of this native State in I9I I was 268,133 , showing a decrease of $14.7 \%$ during the decade, due to repeated outbreaks of plague. The Maharaja is accustomed to pay frequent visits to England and the continent, leaving his state under an administrative council, presided over by an English official, lent by the Government. He was created G.C.S.I. at the Delhi Durbar.

KASHMIR. - The population of this native State in I9II was $3,158,126$, showing an increase of $8.7 \%$ during the decade. The population of Srinagar, the chief city, though the Maharaja resides at Jammu within the Punjab, was 126,344 , showing an increase of $3 \%$. The Maharaja is a British major-general, and was created G.C.I.E. at the Durbar.

Apart from a serious epidemic of cholera from June to November I9Io, the state has recently enjoyed a period of prosperity. The total revenue has risen from about $f 666,000$ to $f 76 \mathrm{I}, 000$, while the cash balance in 19 I I amounted to $£ 225,000$. In the meantime, large sums have been expended upon public works, especially upon an electrical power scheme on the Jhelum river; and education has been encouraged. The introduction of seri-culture has been a notable success, the number of rearers between 1910 and I II having increased from 27,000 to 36,000 , and the weight of cocoons produced from 37,000 to 42,000 maunds.

KHAIRPUR. - The population of this native State in I9I I was 223,788 , showing an increase of $12.3 \%$ during the decade. The Nawab, who succeeded his father in March 1909, was created G.C.I.E. at the Delhi Durbar.

KOLHAPUR. - The population of this native State was $833,44 \mathrm{I}$ in I 1 I I, showing a decrease of $8.4 \%$ during the decade, due to plague. The Maharaja was created G.C.I.E. at the Delhi Durbar. In 1912 his two sons were brought to England for education.

KOTAH.-The population of this native State in I9I I was 639,089 , showing an increase of $17.3 \%$ during the decade, due to recovery after famine. The Queen paid a visit to Kotah in December I9II, while the King was shooting in Nepal; and to commemorate the occasion the Maharao, who had been created G.C.S.I. at the Delhi Durbar, offered a lakh of rupees to be sent for the benefit of the women of India. It has been decided that this shall form the nucleus of a fund for founding the Queen Mary College and Hospital for Women at Delhi, towards which other princes and Indian noblemen have already contributed $£ 100,000$.

KUCH BEHAR.- The population of this native State in I9II was 592,952, showing an increase of $4.6 \%$ during the decade. The Maharaja ( $E . B . x v, 937$ ) who had come to England to attend the Coronation, died at Bexhill on September I8, I9II. As a colonel in the British army, his body was conveyed to the crematorium at Golder's Green with military ceremony, and a funeral service was read in accordance with the rites of the Brahmo Samaj. He was succeeded by his eldest son, educated in England. A legislative council has been 
instituted in the State, and one of its first measures was a Tenancy Act. The state railway has been converted from the $2 \mathrm{ft}$. 6 inch to the metre gauge.

LAFORE.-The population of Lahore city in I9II was 228,687 , showing an increase of 12.7 during the decade, due to its growing importance as a railway centre, with the workshops of the North-Western State Railway. In the district the population has slightly decreased, while in the division the decrease amounts to as much as $8.7 \%$, due to plague and malaria. A water supply for the city has recently been completed.

LuckNow. - The population of Lucknow city in I9I I was 259,798, showing a decrease of $1.6 \%$ during the decade; the population of both the district and the division likewise decreased at about the same rate. A trust fund has been formed for the purpose of opening out congested areas in the city, and improvements are being made in water supply and drainage. A medical college, the only one in the province, is now approaching completion, and the Canning College has been reconstructed.

Madras Presidency.- The total population of the Madras Presidency (including native States) was $46,217,245$ in 1911 , showing an increase of $9 \%$ during the decade. In native states alone the rate of increase was as high as $14.9 \%$. In British territory the population numbered $41,405,404$.

Madras, usually so tranquil, did not escape from the prevalent spirit of "unrest." Apart from isolated disturbances, the most serious occurrence was the assassination of $\mathrm{Mr}$. R. W. D. Ashe, collector of Tinnevelly, at a railway station on June I9, I9II. The actual murderer committed suicide; but several of his accomplices were convicted by a special tribunal of the High Court after a prolonged trial. The monsoons, and therefore the harvests, have recently been favourable, permitting an increase in the export of cotton and ground-nuts. The co-operative credit movement has taken a firm hold. As regards irrigation, a project is under consideration for constructing a reservoir in the valley of the Kaveri which (it is said) will be the largest in the world. Apart from indentured emigration to British colonies, labour flows freely from Madras to Ceylon, Burma, and the Straits Settlements. The number of emigrants to the Straits rose from 49,000 in I9 Io to 85,000 in I9 I I.

The first Indian member appointed to the executive council was the Raja of Bobbili, who resigned after a few months, being created G.C.I.E. at the Delhi Durbar. He was succeeded by V. Krishnaswami Aiyar, a Brahman judge of the High Court, who died in December I9I I, (see above), and was succeeded by P. S. Sivaswami Aiyar, an advocate of the High Court. The legislative council, as reconstituted in 1909 , consists of 46 members, with a non-official majority. Of the total, 19 are Hindus and 3 Mahommedans. Under revised regulations for the second election in December 1912, the number of elected members has been raised from 19 to $2 I$, and the number of nominated members correspondingly reduced, while the electorate has been increased by about $30 \%$. The new Governor, Lord Pentland, took his seat in October 1912, in succession to Lord Carmichael, transferred to Bengal. The districts in Madras are exceptionally large, so that it has recently been found necessary to create three new ones by redistribution: namely, Guntur, Chittoor, and Ramnad.

Madras CITY.-The population of Madras city in I 9 I I was 518,660 , showing an increase of $1.8 \%$ during the decade. As compared with Calcutta and Bombay, the notable feature is the equal number of males and females, for the workers here bring their families to reside with them. The registered death rate in 1910 was as high as 40 per thousand, due partly to the large proportion of children. The municipality completed in 19 II a scheme for distributing the water supply, and a project for drainage is in hand. The harbour has been so much improved that P. \& O. steamers now call at the port, and further improvements are being made. In 1911 , the debt of the Port Trust amounted to $f 558,000$.

Mandalay. - The population of Mandalay city in I9I I was 138,299 , showing a decrease of $24.8 \%$ during the decarle; and the population of the district was 340,770 , showing a decrease of $7 \%$, both of which decreases are due to the decay of the former capital, for in the agricultural country around the number of inhabitants largely increased. A scheme for water supply and drainage improvements is in hand.

Mand.-The population of this native State in $191 \mathrm{I}$ was 181,110 , showing an increase of $4.1 \%$ during the decarle. In May 1909 popular discontent in the state culminated in a serious disturbance which necessitated the despatch of troops from Simla. Order was quickly restored, and an official of the (ivil Service has been lent to the state to conduct a settlement of the land revenue. The Raja, Bhawani Sen, died in March 1912.

MrSORE.-The population of this State in 1911 was $5,806,193$, showing an increase of 4.8 during the derade. The populition of Mysore city was 71,306 , showing an increase of 4.7 . The most important event has been the renewal of all the leases on the Kolar Gold Fields for a further term of thirty years from March 22, 1910. In I911, the total production of gold was 547,746 ounces, all sent to London for refining. Another mineral product is manganese ore, of which 43,000 tons were raised in I910. Apart from an epidemic of plague, the condition of the state has been prosperous. An economic conference was held for the first time in June, I9I I, and cooperative societies have been placed upon a satisfactory basis. An interesting institution is the State Life Insurance Fund, in which policies are held by more than 7,000 persons, assuring a bonus of $f 447,000$ for a monthly premium of $f 1,500$. The 
government has proposed a bill for the tentative introduction of compulsory education.

The Yubaraja, brother and heir of the Maharaja, was created K.C.I.E. at the Delhi Durbar.

NABHA.-The population of this native State in I9II was 248,887 , showing a decrease of $16.5 \%$ during the decade, due to the prevalence of plague and malaria. The Raja, the honoured type of an old-fashioned Sikh chief, died on December 25, 19I I, at the age of 68, having been too ill to attend the Delhi Durbar. He was succeeded by his son, Ripridaman Singh, born in 1883 , who paid a visit to England in 1910, and who, as a member of the Viceroy's Legislative council, introduced the Anand Marriage Act (passed in I909) to validate a certain marriage rite of the Sikhs.

NICOBAR ISLANDS. - The population of the Nicobar Islands in 19 I I was 8,818 , showing an apparent increase of no less than $35.4 \%$ during the decade. For the first time most of the tribes were actually enumerated, while the savage Shom Pen, of whom not even an estimate could be formed, accidentally supplied the defect. At the very time of the Census they issued a declaration of war, accompanying it with two tally-sticks, on which notches were cut to indicate the number of fighting men in their settlements, the several settlements being marked off by lateral notches.

N.W. Frontier Province. - The total population of the North-West Frontier Province in I9II was $3,819,027$, showing an apparent increase of no less than $79.7 \%$ during the decade. But these figures are misleading. They include estimates of $\mathbf{I}, 084,824$ in the agencies and of 519,44I in the trans-border tribal areas under "political" control, which were omitted from the Census of 190I. In British and "administered" territories alone, the population was 2,196,933, showing an increase of $7.6 \%$. 2,039,994 were Mahommedans.

Agricultural seasons have been favourable, especially for the important wheat crop. There has, however, been a great increase in crime, not of a political nature and not connected with border feuds; and a regrettable outbreak of Mahommedans against Hindus occurred at Peshawar in March I910. Education is very backward, but the proposal to found an Islamic college at Peshawar has been warmly taken up.

The peace on the frontier has nowhere been seriously disturbed. The large agency tract to the north, consisting of Dir, Swat and Chitral, shows steady progress and development, and a high standard of discipline and behaviour is maintained by all the militia corps. Raids there have been, especially by the Mahsuds; but they are being conciliated, partly by the offer of work on roads and railways, and partly by enlistment in the army. The most important matter has been the appointment of a joint commission with the Afghan government, which met from May to October, I9:10, for the settlement of outstanding disputes, which came to an agreement for the removal of outlaws from both countries to a distance of fifty miles from the border. Caravan traffic through the Khyber Pass has gone on without interruption, and two of the Amir's motor cars ran through to Peshawar from Jalalabad.

PATIALA. - The population of this native State in I9I I was I,407,659, showing a decrease of $11.8 \%$ during the decade, due to the prevalence of plague and malaria. The young Maharaja was invested with full powers on November 3, I9I0, by the Viceroy, who visited the state for the purpose. In the following year he came to England for the Coronation, and on one or two occasions played cricket with success for the Indian team. At the Delhi Durbar, as the leading Sikh chief, he organised in person the Sikh religious service of loyalty that attracted much notice; and he was created G.C.I.E. The Maharani on the same occasion presented to the Queen an address from Indian ladies, with an historic jewel.

PatNA.- The population of Patna city in I9I I was 136,153 , showing an apparent increase of $I \%$ during the decade; but plague was raging at the time of the Census in I9OI, and if comparison be made with an enumeration taken later in that year, there would appear a decrease of $11.4 \%$. The district and of the division both show a small decrease.

Patna, or rather the adjoining civil station of Bankipur, has been chosen as the capital of the new province of Bihar and Orissa, constituted on April I, I9I2. In addition to the official buildings required, it is proposed to provide a High Court and also probably a University, both independent of Calcutta. The existing college has recently been equipped with hostels for students. The King twice passed in a steamer along the river front of the city in December I9I I, when going to, and returning from, his shooting trip in Nepal.

Poona.-The population of Poona city in 19 I I was 158,856 , showing an increase of $3.6 \%$ during the decade; the population of the district was $1,071,512$, showing an increase of $7.7 \%$, due to recovery after famine. The Agricultural College has recently been completed and official buildings for the secretariat \&c. are in progress. A water supply scheme, estimated to cost $f_{1} \mathrm{I} 6,000$, has been begun. Among the most interesting modern institutions are the Servants of India Society, founded by the Hon. G. K. Gokhale for preparing graduates by further study for careers of national usefulness; and the Seva Sadan sisterhood, under the direction of the widow of Justice Ranade. The memorial to King Edward VII has taken the form of a hospital for women and children.

PUDUKKOTTAI.- The population of this native State in 1911 was 411,886 , showing an increase of $8.3 \%$ during the decade. Owing to continued ill-health, the Raja has been absent in Europe for almost the whole of the last three years.

PunJAB. - The total population of this Province in I9I I was $24,187,750$, showing a decrease of $2.3 \%$ during the decade, due to the prevalence of plague and malaria. For the native 
States alone the rate of decrease was as high as $4.8^{\circ} \%$. In British districts the population was $19,974,956$, showing a decrease of $1.7 \%$. It is noteworthy that the number of native Christians has risen from 37,980 to 163,220 , mostly Presbyterians.

The spirit of "unrest," which found its first overt manifestation at Rawalpindi in 1907, died away very rapidly throughout the province, though there is still some friction between Hindus and Mahommedans. In this connexion it may be mentioned that the reforming Hindu sect of the Arya Samaj now number nearly 100,000, compared with only 9,000 males above fifteen who returned themselves as such in 1901. Despite heavy mortality from plague and malaria, the Punjab has enjoyed a large measure of prosperity, owing to the extension of irrigation and a succession of bountiful harvests. In 1910-1, the total area irrigated from government canals was 6 million acres, showing an increase of more than 400,000 acres in two years. The canal colonies are so prosperous that they can afford to hold up their wheat for a favourable price and at the same time to indulge in the luxury of hoarding gold. It is officially stated that $f 4,000,000$ in sovereigns was absorbed by the Punjab during two years. What is known as the Triple Canal Project, on the Upper Jhelum, Upper Chenab, and Lower Bari Doab, is now nearing completion, at a total cost of about $£ 6,500,000$. Education is making steady progress, especially education in English. The Sikhs, the Mahommedans, and the Arya Samaj each support an Arts college of their own. In I9ro the percentage of boys of school-going age attending public institutions was 23.3 for Sikhs, 17.7 for Hindus, and 11.3 for Mahommedans.

In accordance with the reforms of 1909 , the legislative council now consists of 24 members, of whom only 5 are elected. Of the total, 6 are Mahommedans, 5 Hindus or Sikhs, and one a Parsi. The Land Alienation Act of 1900 , designed to protect hereditary land-owning tribes from expropriation by money lenders, has been extended to certain small tribes who are really agriculturists; and it is believed that the old land-owners are now recovering part of what formerly passed out of their hands. Tenants in the canal colonies have been encouraged to purchase hereditary rights in their holdings. An Agricultural College was opened at Lyallpur in December 1910. See The Industrial Punjab, by A. Latifi (1911).

Rajputana.-The total population of the Rajputana Agency in I9II was I0,530,432, showing an increase of $6.9 \%$ during the decade, due to recovery after famine. For the more important states, some of which were visited by the Queen in December, 191r, see Bikaner, Bharatpur, Bundi, Jaipur, Jodhpur, Kotah and Udaipur.

RAMPUR. - The population of this native State in I9I 1 was 531,217 , showing a decrease of $.4 \%$ during the decade. The population of Rampur city was 74,316 , showing a decrease of $5.6 \%$ As A.D.C. to the King, the Nawab was a conspicuous figure at the Delhi Durbar, when he was created G.C.V.O. He has recently converted six companies of infantry into Imperial Service troops. Though a Pathan, he is a Shiah, and is honoured as the head of that Mahommedan sect in Northern India. Large sums have been spent on the improvement of the capitai, old mud houses and shops having been replaced by brick, while a new brick fort full of palaces has a circumference of nearly a mile. The library of Oriental MSS. has few superiors, and there is a large collection of pictures by European artists. A new sugar factory and distillery yield large profits, and the finances of the state are satisfactory.

RANGOON.-The population of Rangoon city, which forms a district by itself, was 293,316 in 1911 , showing an increase of $19.5 \%$ during the decade. In recent years the city has been almost reconstructed, partly by land reclamation and partly by rebuilding. In I9I I, the total debt of the municipality was $\ell_{1}, 245,000$, of which $\ell_{403}, 000$ was due to reclamation works. The incidence of direct taxation was 13s. per head. A new pumping station was completed. Rangoon now almost monopolises the trade of Burma, and conducts about $8 \%$ of the whole foreign trade of India. In 1910 the Port Commissioners, who found themselves in an embarrassed position, resolved to derive their revenue in future mainly from port and river dues, instead of from landing, shipping and warehousing charges. Their chief task is the construction of river training works, on which the welfare of the port must depend. In I9II, the debt amounted to $f_{1}, \epsilon_{34}, 000$. Within the last ten years the revenue has increased from froo, 000 to $\{225,000$. A local company with European directors, called the Bank of Burma, failed disastrously in 1912 , and a public prosecution has been ordered.

REWA.- The population of the Baghelkhand Agency (almost co-extensive with Rewa statc) was $1,772,57+$ in IgI I, showing an increase of $14.1 \%$ during the decade. The eldest son of the Maharaja acted as one of the pages of honour at the Delhi Durbar.

SANDER.- The population of this native State in I9I I was 13.526 , showing an increase of 20.8 "' during the decade. The Raja, who is a minor, is being educated in the Court of Virds (ollege in Madras. In 1909-10 the export of manganese ore from this little state by the General Sandur Mining Company reached 60,000 tons.

SIkKIM.-The population of this protected State in 191 I was 87.920 , showing an apparent increase of $49 \%$ during the decade, following after an increase of $94 \%$ in the previous decade. The Maharaja, in his quasi-Tibetan dress, was a conspicuous figure at the Delhi Durbar, on which oceasion he was created K.C.I.E. Both he and his son (educated at Oxford) take an active interest in extending education.

Sirmur (or Nahan).-The population of this native State in 1911 was $1.38,520$, showing 
an increase of $2.1 \%$ during the decade. The Raja died on July 4, I9II, and has been succeeded by his son, Amar Parkash.

Tonk. - The population of this native State in I9II was $303,08 \mathrm{I}$, showing an increase of $10.9 \%$ during the decade, due to recovery after famine.

TRAVANCORE. - The population of this native State in I9I I was $3,428,975$, showing an increase of $16.2 \%$ during the decade, which follows upon an increase of $15.4 \%$. No further evidence is necessary to prove the extraordinary prosperity of the state, which is likewise indicated by the high standard of education; but it is noteworthy that native Christians have increased faster than the general population, and now number more than one-fourth of the total. The revenue has reached $£ 780,000$, and the value of the exports $£ 3,658,000$. In August 1912 the Kodyar irrigation works were opened, constructed at a cost of 70 lakhs to irrigate about 70,000 acres; the area of the reservoir will ultimately be $7 \mathrm{sq} . \mathrm{m}$.

UDAIPUR (or Mewar).--The population of this native State in I9I I, was $1,293,776$, showing an increase of $25.6 \%$ during the decade, due to recovery after famine. At the Delhi Durbar the Maharana, as recognised first in rank of all Rajput princes, was appointed to the dignity of ruling chief in waiting on the King-Emperor, and was created G.C.I.E.

United Provinces. - The total population of the United Provinces of Agra and Oudh in I 191 , was $48,014,080$, showing a decrease of $1 \%$ during the decade, due to the prevalence of plague and malaria. The native state of Tehri-Garhwal alone showed an increase of $12 \%$. In British territory the population was $47,182,044$, the rate of decrease being $.7 \%$ in Agra and $2.1 \%$ in Oudh. It is noteworthy that the number of native Christians has risen from 37,980 to 163,220 , mostly Methodists.

The province has been happy in escaping almost entirely from the "unrest." This may be ascribed mainly to the efficiency of the local administration, under two popular Lieutenant-Governors. There is, indeed, some friction between Hindus and Mahommedans; and the numbers of the Arya Samaj, or reforming Hindu sect, have increased in ten years from 65,000 to 131,000 . The prosperous condition of the people is proved by their rapid recovery from the famine of 1907-8. Relief was so efficiently administered that deaths from starvation were practically unknown, and the large sums then advanced for agricultural improvements were quickly repaid. Harvests have since been generally good. Irrigation has been extended through the precarious tract of Bundelkhand, and a comprehensive scheme is now under consideration to supplement the system of canals that take their water from the Ganges and the Jumna by diverting the overflow of the Sarda river in Oudh. The exhibition at Allahabad during the winter of $1910-1$ was the means of popularising labour-saving implements and machinery for sugar making, and an agricultural college has recently been opened at Cawnpore. Special attention has also been paid to technical education and the encouragement of industries. It must, however, be admitted that the United Provinces still lag behind in the matter of primary instruction.

In accordance with the reforms of 1909 , the legislative council now consists of 48 members, of whom 18 are. Hindus and 9 Mahommedans. One of its most important measures has been a Court of Wards Act, for the disqualification of spendthrifts. Sir J. P. Hewett, whose term of office was marked by friendly cooperation with Indian sentiment, was succeeded as Lieutenant-Governor by Sir J. S. Meston in September I912. It was understood that an executive council with an Indian member, as in Behar and Orissa, would shortly be given to the United Provinces.

(J. S. Cotton.)

\section{CEYLON ${ }^{1}$}

The population of Ceylon in I9I I (census, March I0), inclusive of military and shipping, was $4,109,470$, as compared with $3,578,333$ in I90I, an increase of 531,137 , or nearly $15 \%$. The figures for the nine provinces of the island were as follows:-

Provinces.

Population.

Increase
per cent.
18.84
7.76
8.65
10.89
6.02

Southern $\quad \begin{aligned} & 369,654 \\ & 628,491\end{aligned}$

Eastern

183,720

0.89
6.02
Provinces.

North Western

North Central

Uva

Sabaragamuwa
Population. Increase per cent. 21.86 8.94 16.42 26.97
433,958

86,269

216,655

408,524

A feature of the decade was the movement of population into the towns. Colombo with its population of 2 I I, 284 increased by $32.5 \%$ and Kandy with 29,928 by $25.82 \%$. Newara Eliya, the health resort, with 7,412 , shows an increase of $36.43 \%$. The only town of any importance showing a decrease of population is Trincomalie, where the naval yard has been closed and the military garrison taken away. There has been a satisfactory increase of $21 \%$ in the number of Europeans, who are now twice as numerous as in $187 \mathrm{I}$. Of the native races the low Country Sinhalese show the highest percentage, 1 8.7, of increase. The Moors show 16.8, the Kandyans I4.2, the Tamils II.3, and the Malays 9.9. There has been an increase in the number of Buddhists and Christians and a decrease in that of Hindus. In 1901 there were 8,806 females to 10,000 males, and in I9II, 8,878 .

'See E. B. v, 780 . 
Agriculture.-Messrs A. M. \& J. Ferguson, the authors of the Ceylon Handbook and Directory, estimate that out of a total of $15,809,280$ acres in the island, there were in January 1912 about $3^{\frac{3}{4}}$ million acres under cultivation, a slight increase on the corresponding estimate made by them in July 1908. Coco-nuts occupy 770,000 acres, rice 620,000 acres, and palms, other than coco-nuts, about 300,000 acres.

The acreage under tea, about 395,000 acres, has not varied much since 1909 , any increase due to newly planted fields being cancelled by the dying out of those where rubber has been interplanted. The crop for $1911,187,674,990$ lbs., though $6,000,000$ lbs. in excess of that for 1910 , fell short of the record crop for 1909 by $4,000,000$ lbs. The estimate by the Planters' Association of the 1912 crop is $193,000,000$ lbs.

In rubber planting there has been very rapid development. An area of 184,000 acres in 1909 has risen to 217,000 acres in 1912 , while the shipment of $1 \frac{1}{2}$ million lbs. in the former year increased to over 7 million lbs. in 1911 . It was estimated that in 1912 the shipments would again be more than doubled. In cocoa, about 32,000 acres, and cardamoms, about 8,000 , there has been no increase of area under cultivation. Coffee and cinchona bark, once leading products, have practically disappeared from the list of exports. In cinnamon no change is recorded. Immigrant labour, brought over from southern India under a system of money advances, has from the first been the life blood of Ceylon planting. In 1910 the arrivals and departures were respectively 118,000 and 64,000 : in January to June 191 I they were 40,000 and 36,000 . The system has for the most part worked admirably. But in the last few years an excessive strain has been thrown on it by the vast area brought under cultivation for rubber both in Ceylon and in the Federated Malay States; and in the keen competition for coolies the amounts advanced have so increased as to leave small hope of recovery in full. To meet this proprietors of tea and rubber estates have formed "The Ceylon Proprietors' Labour Federation" with the object of limiting the amount of advances, and ultimately of substituting for the present system one under which all the initial expenses of the immigrant shall be paid in such manner that he shall start work in Ceylon free of debt.

Commerce.-The last Government Blue Book, in place of giving figures as previously for the calendar year, gives them for 18 months, January I, I9IO to June 30 , I9I I as follows: Imports, $164,864,703$; exports, $173,717,722$. The increase since 1900 is about $18 \%$.

Finance.- The public revenue has risen from Rs. $27,325,930$ in 1900 to Rs. $39,332,860$ in 1909 and to Rs. 65,612,640 in the 18 months, January I, 1910, to June 30, 1911. Assuming that the figures for 1910 must have exceeded Rs. 41,000,000 the increase in the present century has been fully $50 \%$. Public expenditure has risen to correspond.

The public debt on June 30 , I9II was: loans raised in London $£ 5,962,700$, equivalent, at Is. 4 d. to the R., to Rs. $89,440,500$; local loans, Rs. $3,064,027$; the total debt, Rs. $92,504,527$; less sinking funds, Rs. 12,425,330, making a net debt of Rs. $80,079,197$, or the equivalent of $\{5,338,613$, equal to about 2 years' revenue.

Railways. - The mileage open for traffic increased from 563 in 1908 to 604 in 1912, and I 30 miles more are either in course of construction or have been sanctioned. Sanction has been sought for other 72 miles which should be complete within four years. The railways have from the first been a fruitful source of revenue to the government, to which they belong. In the 18 months from January I, I9I0 to June 30 , I9I I the receipts were Rs. $13,583,160$ and working expenses Rs. $6,337,583$, showing a profit of Rs. $7,245,577$. It is calculated that this is a return of $7 \frac{1}{2} \%$ on the capital expended.

Shipping. - The total tonnage of vessels calling at Cevlon ports in 1910 was 9,371,097 as against $8,453,236 \mathrm{in}$ 1909. Over $90 \%$ was entered at Colombo, where the harbour, like the railways (though in a less degree), has become a source of government revenue. The estimated receipts for I9II-I2 (July I to June 30 ) were Rs. $2,609,380$, and the estimated expenditure Rs. $2,085,656$, showing an estimated profit of $\mathrm{Ks}$. 523,724 . As the, annual charge for the public debt only slightly exceeds Rs. 4,000,000, or not much more than half the profits of the railways and harbour, the financial condition is quite sound.

Political and Social Progress.-The Legislative Council, hitherto consisting of the governor, ten official members and eight unofficial members, has been reformed by Ordinance 13 of 1910. In the past the unoficial members were all nominated by the governor, who as a rule placed the nominations in the hands of the various representative bodies of the island. Three of the eight seats were held by Europeans, the other five by natives. The reformed council consists of the governor, eleven official members and ten unofficial members. The $n$ n. w official member is the government agent for the time being of the Southern Province. (I) the unofficials four are elected by constituencies created under the above ordinance and are styled the European urban member, the European rural member, the burgher member and the Educated Ceylonese member, the electors being (1) Europeans resident in Colombo, Calle and Kandy; (2) other Europeans resident throughout the island; (3) the Burgher community; ( $t$ ) native's who can read and write English. The other six unofficial members are nominated as before by the governor.

The first clections took place in November and Decenber igri. For the European seats there was no contest, ant as under the old system, leading members of the Chamber of Commerce and Planters" Ascociation were elected. The native seats were warmly contested. 1 he reformed council held its first sitting on January 16,1912 . The reduction of the num- 
ber of European unofficial members from three to two has been severely criticised. Com. mittee work is perhaps the most important part of the work of the council and no committee can be counted complete without one European unofficial member on it. With only two members available it will hardly be possible to provide a representative on every committee.

Under the Excise Ordinance of I9I I introducing the Madras system into Ceylon 1 I40 "toddy" taverns have been recently opened under Government regulation. This has led to protests being lodged with the Secretary of State in London by the Native Races and Liquor Traffic United Committee and by many influential native gentlemen.

Education has become more widely diffused with the increase of prosperity. In I9I I there were 299,620 pupils under instruction, an increase of about $63 \%$ since 1901. The government has a training college with about 100 students, but there is not yet any general provision for higher technical education. Sir. H. E. McCallum, G.C.M.G. (b. I852), resigned the governorship of the colony on Dec. 12, 1912, owing to a breakdown in health.

(W. Martin Leake.)

\section{BRITISH MALAYA, ETC. ${ }^{1}$}

Straits Settlements. ${ }^{2}$-Exclusive of the floating population, in 19 II the residents in the Straits Settlements proper (excluding Christmas Island and the Cocos-Keeling Islands) numbered 705,405, males being nearly 2 to I; Singapore had 303,32I; Penang, I4I,559; Province Wellesley, 128,978; Malacca, 124,081; The Dindings, 7,466. Chinese comprised more than half the total population, numbering 366,765 ; then came the Malays and allied races with 235,762; Indians, 81,928; and Europeans and Americans, 7,276. The military at Singapore (including dependents) numbered 3,714.

As regards religions, the census returns gave the following statistics: Non-Christian and non-Mahommedan Chinese 359,760; Mahommedans 26I, I54; Hindus 52,579; Christians 27,474 ; Buddhists (non-Chinese), 2,758; Jews 387 ; Sikhs 372 .

In 1910 there were 216,321 Chinese immigrants, but in 19 I I a fresh record was established with 269,854, made up of 226, I29 men, 22,738 women, 16,030 boys and 4,957 girls. Most of them proceeded to the Malay States to work in the tin mines and on rubber estates, and a few went to neighbouring Dutch possessions. The number of Indian immigrants also established a record- 108,471 in 1911 as against 83,723 in 1910 .

The large increase in the number of immigrants from southern India of the free coolie class is due to the requirements of the rubber-planting industry. In I9I I the system of indentured labourers ceased. In I9IO 37,829 adults and I,25I children returned to India, and in I9I I 46,754 adults and 5,614 children, so that the net gain to the Indian population of the Settlements in I9I I was 56,103 .

The number of births in the Colony in 1911 was 18,069 against 18,012 in 1910 , and the number of deaths 33,075 against 27,484 in 1910 . The birth rate was 25.38 as against 27.5 per mille, and the death rate 46.45 as against 41.88 per mille.

In I91 I, the police force had a total strength of 2,450 , made up of 100 Europeans, 372 Sikhs, and I,979 Malays, Tamils, and Chinese. The number of arrests during the year was I7,954, a decrease of 1,769 on 1910. There were 484 banishments, against 643 in 1910 .

During 1900 the Education Board was appointed to assist the government in the control of money spent for educational purposes. All school fees and other sums collected by the Department are credited to the account of the Board. The levying of an education rate, which was new in 1910 , has relieved the government of a large proportion of the expenditure on education. In I9I I Singapore had 33 schools, with an average enrollment of 7,714 pupils; Penang 102, with 10,469 pupils; Malacca 83 , with 6,183 pupils. The total amount expended $(\$ 427,225)$ was slightly higher than in 1910 , and the net average expenditure per pupil was $\$ 10.73$, as against \$1 I.03 in 1910 and $\$ 16.52$ in 1909 . The largest number of schools are for Malays. At the English schools the average attendance increased from I I,232 in 1910 to II,456 in I I I I. The number of girls attending school continues to increase, especially among the Chinese.

The years I 909 and I910 witnessed a remarkable development of agricultural activity, especially in Malacca and Province Wellesley. In Singapore considerable acres of waste land were put under rubber, which was planted also through the pine-apple fields. At the end of 19 I I there were 29,150 acres of rubber on this island alone. The expansion of rubber planting has led to the neglect of fruit cultivation and other forms of agriculture, but there is a slight increase in coco-nut planting, and several new plantations of pepper and gambier, which has been inclined to disappear, and a slight increase in indigo, citronella grass, ginger and ground-nuts. Sugar is going out as a product of Penang and Province Wellesley owing to the sale of plantations to rubber companies, and spices are still cultivated only to a small extent. In Malacca rubber planting expands at the expense of tapioca. At the end of I9II there were 80,000 acres alienated for rubber estates. The actual acreage planted in rubber in the whole of the Settlements was 80,629 as against 60,568 in 1910.

${ }^{1}$ For information contained in this section the Editor is indebted to the Malay States Information Agency, London.

2 See E. B. xxv, 980 . 
'There are 165 square miles of forest land; about $10 \%$ being forest reserves.

The trade shows a steady growth. The total imports in I9II were valued at $£ 46,437$, . 339 as against $£+2,521,576$ in 1910 ; and exports $£ 39,887,145$, as against $£ 37,822,142$.

The values of the leading articles of import and export in round figures were as follows:Imports: Tin and tin-ore, $£ 9,780,870$; rice and other grains, $£ 6,679,620$; cotton piece goods, $£ 2,600,385$; opium, $£ \mathbf{I}, 735,070$; fish, $£ 1,275,400$; provisions, $£ \mathbf{I}, 2 \mathrm{II}, 000$; coal, $£ 85 \mathrm{I},-$ 670: machinery, $£ 561,400$; silk piece goods, $f 428,050$; cycles, motor cars and accessories,

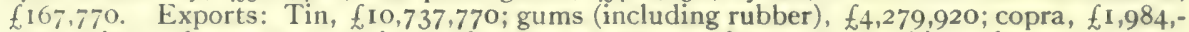
I50: spices, $f 1,600,090$; tapioca, $f 520,920$; rattans, $f 515,085$; gambier, $f 502,600$; sago, $£+86,735$; phosphate of lime, $\{383,485$; coco-nut oil, $£ 265,420$; preserved pines, $\{288,750$.

It should be stated that the trade of the ports is chiefly a transit trade, and that these statistics refer largely to the trade of the whole of the Malay Peninsula augmented by transshipments from and to neighbouring countries.

The merchant shipping entered and cleared (exclusive of native craft) in I9I I amounted to $24,086,904$ tons, including $14,277,754$ tons British.

Revenue in I9I I amounted to $\$$ I I,409,220, and expenditure to $\$ 9,085,389$. The position of the Loan Account-an additional sum of $£ 2,750,000$ having been raised in 1910-was as follows on December 31, I9I I :- $31 / 2 \%$ S.S. Inscribed Stock, $f 6,913,352 ; 4 \%$ S.S. Debentures $f_{1}, 030,100$, total $f 7,943,452$. Provision is made for repayment of this loan by a sinking fund which will come into operation in 1917. The charge on account of interest in I9II was $\$ 2,449,243$ as against $\$ 1,608,865$ in 1910 . The greater portion of this charge, however, is borne by the Tanjong, Pager Dock Board and other bodies to whom portions of the loan funds have been allocated. The actual sums paid by the Colonial Government in I9ro and 1911 respectively were $\$ 103,667$ and $\$ 806,961$.

The revenue and expenditure of the Singapore, Penang and Malacca municipalities for I9Io and I9I I were as follows:-

Revenue.

I9I0 I9II

$\$ 2,961,876$

$\$ 2,512,507$

$1,103,587$

$1,206,244$

Penang

76,853

91,828

Expenditure:

Malacca

The debt of the three municipalities at the en

$\$ 7,067,300$; Penang, \$2,630,000; Malacca, \$83,800.

In 1909 the excise farms were abolished. Towards the end of the year the Government Monopolies Department was formed and arrangements made for taking over not only the preparation and sale of opium but also the collection of duty on liquors; and at midnight on December 3I the "farmers" handed over premises, stock and utensils to the superintendent of the Department. In addition to supplying the Colony, the Department also arranged to supply the districts included in the Perak, Selangor and Negri Sembilan Coast Farms and also the State of Johore; and from January I, I9I I the whole of the Federated Malay States were included in the operations of the Department. In I9II the cash receipts for opium for consumption in the Colony were $\$ 7,707,068$, against $\$ 6,612,918$ in 1910 . The collections in respect of duty on intoxicants in I9II were:-Singapore $\$ 665,258$; Penang $\$ 505,537 ;$ Malacca $\$ 164,386$.

For five years extensive works have been in progress to increase the wharfage accommodation at Singapore and Penang, and otherwise to improve the harbour at Singapore, where a new graving dock, the largest in the Far East, has been constructed. The harbour works at Singapore include a new sea-wall and reclamation at Teluk. Ayer and a lagoon wet dock and additional wharfage at Tanjong Pagar.

A ferry now connects the railway system with the mainland at the straits of Johore, and a through service of trains, night and day, runs between Singapore and Penang, by way of Kuala I.umpur, the capital of the Federated Malay States. The journey occupies 23 hours.

Improvements have taken place in the postal, telegraph and telephone services since the new treaty brought Kelantan, Trengganu, Kedah and Perlis under British suzerainty.

The mean temperature of Singapore and Penang in 1911 was $82.6^{\circ}$. of Province Wellesley $8.7^{\circ}$; and of Malacca $82.1^{\circ}$. The rainfall recorded in 1911 was-Singapore, 88.10 inches; Penang, 77.25; Province Wellesley, 90.47; and Malacca 81.4I inches.

Labuan. ${ }^{-}$- By the census of I9 I I the population amounted to $6,546(3,662$ males, 2,884 females), of whom 34 were Europeans, 1,799 (hinese and 4,434 belonged to the Malay races. There were 189 births and 183 deaths, compared with 235 and 267 respectively in 1910. ("ensus returns gave I 6 inhabitants as Christians and 4,430 Mahommedans.

The revenue in 1910 was $\$ 82,926.44$, and in 191 I $\$ 78,990.44$; the expenditure S104,85.5 .98 in 1910 and $\$ 105.989 .87$ in 1911 . Imports in 1910 were valued at $\$ 1,+37.390$, and in $1911 \$ 1,258,884$; Exports $\$ 1,217,132$ in 1910 , and in $1911 \$ 1,074,737$.

The shipping ("ntering Port Victoria was 282,742 tons (British, 152,668) in 1910: in I9I I, 136,884 tons (British, 42,288).

1 See E. B. xvi, 3I. 
A noteworthy feature in the history of the island in I9I I was the closing of the mines at Coal Point belonging to the Labuan Coalfields Co., Ltd. In 1909 there was an output of 61,855 tons and of 86,689 in 1910 , the export in the respective years being 57,268 and 92,223 tons. Only 17,748 tons were exported as cargo and bunker coal in I9II. The shrinkage in trade was due entirely to the stoppage of mining.

A fortnightly mail service is maintained by German steamers between Labuan and Singapore. The rainfall was 151.25 inches in $1910 ; 99.82$ inches in 1911 .

Cocos-Keeling Islands. ${ }^{1}$-The annual official visit to the Cocos Islands was made in September-October 19 I I by Mr. Charleton Maxwell. A wireless telegraph installation had been erected on Direction Island in March. Messages have been sent a distance of 2,300 miles, and have been exchanged over a radius of 1,600 miles.

According to the census of I 11 I there was a population of 749 (4I I males, 338 females), of whom 39 were Europeans and 668 belonged to Malay races (including 33 Bantamese contract coolies). At the time of Mr. Maxwell's visit the population was recorded as follows:Home Island, 640 (3 Europeans); Direction Island, 64 (27 Europeans); total, 704. The Europeans on Direction Island are members of the Eastern Extension Telegraph Company's staff. There were 50 Christians and 669 Mahommedans when the census was taken.

There are no independent trades or industric:. Every able-bodied man and every boy over fourteen years of age is in the direct employment of the proprietor, Mr. Clunies-Ross. There are 172 . men and boys rated for pay according to their ability, apprentices receiving 1 rupee per week and competent artisans 7 rupees. Fishing is done only as a recreation in spare time. One man is rated as a fisherman and supplies the proprietor's household with fish. Soap, vinegar and salt are manufactured locally. The soap is made from coco-nut oil and the ashes of the coco-nut husks; the vinegar from the palm wine "tuwak," and the salt from sea-water evaporated over a fire in iron pans. Mr. Clunies-Ross proposes to start a small export trade in shark's liver oil for the manufacture of cod-liver oil. Since the typhoon of 1909 a large number of coco-nuts have been used as seed, and the replanting of the entire area of the islands was nearly completed in October I9I I. The area available for planting is Io square miles or 6,400 acres, and is planted with I,216,000 trees. In the typhoon there were over I,000,000 trees, and only 3 per cent were left standing. No copra was exported in 1911 , but export was expected to be renewed in I9I3. In I9I0 the export was $37 \mathrm{I}$ tons.

The rainfall of I9II was 70.25 inches.

Christmas Island. ${ }^{2}$ - In I9I I the population amounted to 1,369 (I,328 males, 4 females), I9 being Europeans, I,252. Chinese and 44 Malays. Christians 32, Mahommedans 46.

The rainfall of $I I 2.43$ inches in 1909 was a record, but was eclipsed in I910 with 136.93 .

In 1909 the only export was phosphate of lime (I05,48I tons), but in I9I0, in addition to $\mathbf{I} 37,700$ tons of phosphate, there were exported 1,200 lbs. of cotton. Extension works are in hand to increase the output of phosphate. As the present quarry will be exhausted in a few years, the Company is building a light railway, 15 miles long, to open up phosphate beds, hitherto untouched, on the south-east end of the island. Value of imports (I9II) \$229.5I3; exports $\$ 3,288,208$. Revenue (I9I0) $\$ 85,023.34$; expenditure, $\$ 14,107.25$.

British North Borneo. ${ }^{3}$ - According to the census of I9I I the population was 208, I 83 (79,141 men, 60,081 women, 35,774 boys and 33,187 girls), compared with 104,527 in I90I, an increase of 103,656 . In Sandakan, the seat of government, there were 8,256 inhabitants, and in Jesselton 2,686. The total of 208,183 included 355 Europeans, 167,586 natives of Borneo (of whom 87,951 were Dunsuns, 25,314 Muruts, and 22,587 Bajaws), 26,002 Chinese, 5,5 ro natives of the Dutch East Indies, 5,503 natives of the Sulu Archipelago, and 246 Japanese. Divided by religions there were 3, I56 Christians, 61, 165 Mahommedans, 24,076 Confucianists, 164 Buddhists, 150 Hindus, I 73 Sikhs, and I I9,299 pagans. Agriculturists numbered 74,469 , labourers $I 8,865$, and fishermen 3,528 . Steps are being taken to attract agricultural immigrants, and arrangements have been made for the immigration of labourers.

Recent years have witnessed an enormous development in British North Borneo, and the Court of Directors of the Chartered Company by which its affairs are administered have every reason to be satisfied. "Seconded" by the Colonial Office for the purpose, Mr. J. Scott Mason (b. I 873) in I9I2 assumed the governorship in succession to Mr. F. R. Ellis for a period of two years; but on December 5 he was killed by a fall from his horse, and $\mathrm{Mr}$. Aylmer Pearson, formerly acting-governor, at once returned from England to take up the office. To aid the governor and the staff of civilians in the local administration, a legislative council was created in I9II, upon which the commercial, planting, Chinese and native communities have representatives. Sanitary Boards have been established at Sandakan, Lahad Datu and other townships.

The reorganization of the medical department is in progress, and a hill station for Europeans is in contemplation. Increased grants-in-aid have been made to the missionary bodies in whose hands educational affairs are at present.

There are 125 miles of railway on the north-west coast connecting Jesselton with Weston, in Brunei Bay, and Tenom, inland. The gross earnings amounted to $f_{16,936}$ in I9II against $£_{1} \mathrm{I}_{3,2} \mathrm{I}_{4}$ in 1910. A sum of $£ 28,000$ was spent in improving and strengthening the

${ }^{1}$ See E. B. $\mathrm{xv}, 7 \mathrm{12}$.

${ }^{2}$ See E. B., vi, 294 .

${ }^{3}$ See E. B. iv, 262 et seq. 
line during the year. The Court has under consideration a scheme for the construction.of riads to supersede the present bridle-paths. There is a regular weekly service of steamers hetween Singapore and North Borneo ports. It is also hoped to arrange a weekly service between Hongkong and Sandakan in place of the present uncertain fortnightly service. Oiher schemes are for the reclamation of land at Jesselton, the improvement of its wharf and pier, the provision of adequate water supplies for that port and for Sandakan, and the lighting of the coast. There are about 800 miles of telegraph lines. Their maintenance is costly and the Court has decided to erect wireless installations at various points.

The revenue was $£_{247,599}$ in 1910 , and $£ 180,646$ in 1911 ; the expenditure $£ 95,107$ in 1910 , and $£ 96,745$ in 1911 . The revenue for 1910 included $f 60,000$ derived from concessions, $f_{1} 16,792$ from land sales, $£_{1} 3,593$ from railway receipts, $£ 54,257$ from customs, and $£ 39,587$ from excise and licences; while the expenditure included $£ \mathbf{1 7}, \mathbf{1} 80$ for railway working expenses and $£ \mathbf{1} 3,647$. for constabulary. In 1911 customs brought in $£ 59,005$, excise farms and licences, $£ 43,135$, and railway receipts $£ 17,040$; there was no income from concessions and only $f_{3} 37$ from land sales. The railway working expenses amounted to $£_{20}, 125$, and the cost of constabulary had fallen to $f 9,816$.

Following the policy of the Straits Settlements, the British North Borneo Company has created an Opium Monopoly Department as from January I, I9I3.

The total volume of trade in 1910 was valued at $f_{981,000}$ and in $191 \mathrm{I}$ at $£ \mathbf{I}, 101,000$, an increase of $f \mathbf{1 2 0}, 000$. Out of 47 headings 39 showed increases in I9II. Estate rubber heads the list, I 49,000 Ibs. exported being valued at $f 41,096$, as compared with 54,000 lbs. and a value of $f_{22,866}$ in 1910. Successive years should show a large increase as more estates come into bearing, but as cultivated rubber is free of export duty for another 43 years this item does not affect the revenue. At the end of July 1912, out of 30 companies operating in the territory, the majority were engaged in rubber growing, while others are engaged in coco-nut and tobacco cultivation. There were upwards of 23,000 acres under rubber. One company had a crop of 280,410 coco-nuts in I 91 I, and the export of copra was $1,183,866$ lbs. against $1,034,533$ lbs. in 1910 . The output of tobacco was 13,750 bales as compared with 13,508 bales in 1910. The export of timber amounted to I,3 I I,539 cubic feet against $\mathbf{1}, 218,967$ cubic feet in 1910 . The British Borneo and Burmah Petroleum Syndicate have acquired a large tract in the Klias peninsula, where they had located an oil-field. Following upon this discovery, they have taken up on lease 440 square miles of territory, and are prospecting extensive areas. The output of coal in $191 \mathrm{I}$ amounted to 38,920 tons. The Cowie Harbour Coal Company have satisfied the Court of Directors that the collieries are at present sufficiently developed to yield up to 500 tons of coal a day, provided that labour is availble and some expenditure incurred to put the surface coal-handling arrangements in order.

Brunei. ${ }^{1}$-The census of I9II shows 6,380 males, 7,193 adult females, 4,1 39 male, and 3.986 female children, with a total of 21,718 . Of these 20 were Europeans and 736 Chinese. The only town of any size, Brunei or Dar-ul-Salam (city of peace), has a population of 9,767. including 8 Europeans. It is composed of houses built in the river on nibong piles. With the establishment of peace and order the natives are gradually learning the advantages of cultivation and are migrating to terra firma. At Muara Damit (Brooketon), leased to Raja Brooke, where there is a colliery, there is a settlement of $\mathbf{I}, 447$ persons. Since the appointment of a resident British official, the common people have shown eagerness to take up land, and plant coco-nuts. The wild rubber tree, Jelutong (Dyera costulata), is common and is wrorked for export. Land suitable for cultivation of Pará rubber (Hevea brasiliensis) is alienated by the government at an extremely low rental, and several European companies have taken out grants, and are proceeding with planting. At Brunei Town, the Island Trading Syndicate has its cutch factory, employing several hundreds of hands. The value of the cutch exported in 1911 amounted to $\$ 262,216$.

Coal is worked on Berembang and at Raja Brooke's Brooketon collieries. The gross output of coal from these collieries in 1910 was 18,418 tons and in 191125,607 tons.

ihe principal imports are piece goods, tobacco, kerosene and sugar. The main exports are cutch, sago, hid's and jungle produce of various kinds. The imports at Brunei Town amounted to goods of a declared value of $\$ 70,000$ in 1909 and of $\$ 82,000$ in 1910 . The exports from Brunei Town for the same years reached a value of $\$ 237,000$ and $\$ 246,000$.

That oil in payable quantities is to be found in Brunei can no longer be doubted. Bores are heing sunk at Jenidong and in the Belait District, with every hope of success. Prospecting leases are granted on exceptionally easy terms.

Revenue (I9II) $\$ 261,865$; expenditure, $\$ 247,930$. There is a public debt of $\$ 400,000$, and the state has investments to its credit of a capitalised value of $\$+4+74+$.

Federated Malay States. ${ }^{2}$-Each year witnesses a steady growth in the progress and prosperity of the Federated Malay States. In I911, though the out put of tin was not greatly: in excess of I9IO, the enhanced value brought benefit, while the rapid expansion of the plantation rubber industry is reflected in the statistics of the various departments. The demands for labour in the mines and on the plantations have hampered to some extent the development of public works; but much has been done to construct new roads and

'See E. B. iv, 68I,

See E. B. xvii, 478 et seq. 
waterworks, to extend the railway system, to improve the harbours and to carry out other public works necessitated by the expansion of commerce and the growth of industries.

In 1912 Benker Semang, a small tract of territory, 20 miles square, between the states of Kedah and Perak, was formally transferred from Kedah to the latter state.

Between 1901 and I9I I the population of the Federated Malay States increased by $35^{8,404}$ persons, or 52.8 per cent. In the latter years of the decade, the extension of rubber planting was very rapid and labour was introduced to meet the demands of the numerous new estates. Towards the end of 1907 there began a slump in the tin-mining industry. The closing down of many of the lower grade mines threw numbers of Chinese out of employment, and led to much emigration. But the slump in the mining industry was well over before the last census was taken and the tide of immigration had set in with augmented force owing to the increased demand for Chinese labour on rubber estates. A comparison of the population enumerated in the censuses of I89I, I90I and I9I I shows the remarkable increase from 418,509 in 1891 to 678,595 in 1901 and then to $1,036,909$ in 1911 . Of the latter total, 725,062 were males and 311,937 females. The races represented were as follows:-Europeans 3,284, Eurasians 2,649, Malays 420,840, Chinese 433,244, Indians 172,465 , others $4,517$. The religions professed were:-Mahommedan 406,860, Hindu 140,068, Christian 22,902, Sikh 7,406 , other non-Christian religions $420,38 \mathrm{I}$, not given 12,164 . In $191 \mathrm{I}$ there were $108,47 \mathrm{I}$ Indian immigrànts (the highest number recorded) against 83,723 in 1910. The excess of Chinese immigrants over emigrants in I9I I was 38,033 against 7,794 in 1910.

The total amount spent by the Education Department in I9I I was $\$ 330,563$. Schools increased from 356 in 1910 to 369 , with an average enrolment of 22,566 pupils (I9,585 boys, 2,981 girls) and an average attendance of 18,384 . At the English schools 3,I7 I boys and 909 girls were in average attendance.

Throughout the year the battalion of Malay States Guides was kept up at full strength of 895, mainly Sikhs, Pathans and Mahommedans. The rank and file of the Malay States Volunteer Rifles, composed of Europeans, numbered 578. The police force was 2,882.

Revenue (I9II) $\$ 35,056,544$; expenditure $\$ 25,292,749$. The largest amounts collected were:-customs $\$ 11,313,173$, licences and excise $\$ 9,574,437$, railways $\$ 7,039,789$, land $\$ 1,771,317$, interest $\$ 1,383,981$, municipal $\$ 1,183,760$, land sales $\$ 519,646$.

The actual Federal revenue (as distinct from the whole Federated Malay States revenue) was $\$ 9,568,590$, an increase of $\$ 1,466,885$ over that of 1910 , of which railway revenue contributed $\$ \mathbf{I}, 043, \mathbf{I} 40$. The Federal expenditure was $\$ 15,144,696$, an increase of $\$ 1,993,77$ I over that of 1910 , of which $\$ 7,550,513$ was spent on railway account. The balance to the credit of the Federated Malay States is now \$52,537,647.

Rubber is now the principal agricultural product. The number of estates increased in I9I I to 700 against 435 in I9IO; the labour force to I66,0 I 5 from 128,446 ; and the output to $21,809,617 \mathrm{lbs}$. from $12,563,220$ lbs. For the first eleven months of 1912 the output was $3 \mathrm{I}, 024,086 \mathrm{lbs}$. Copra exports in I9I I reached approximately 8,000 tons, the value being $\$ \mathrm{I}, 553,000$. It was a bad year for padi; the acreage under cultivation shrinking from I I 9,224 in 1910 to 103,278 in I9II. The output was $3,313,437$ bushels. The following statistics show the agricultural acreages in I9I I, exclusive of padi and horticulture:-rubber 352,974; coco-nuts 142,774; coffee II,313; other cultivations I8,751. I53 square miles were added to reserved forests, bringing the total area reserved to I,I6I square miles out of a total area of 27,750 square miles. It was a prosperous year for mining owing to the high average price for tin. From all sources the revenue of the Mines Department was $\$ 9,416,779$ against $\$ 7,753,143$ in 1910 . Of this amount $\$ 8,818,764$ was on account of the export duty on tin and tin-ore against $\$ 7,162,026$ in I9I0. The output of tin was 44, I49 tons in I9I I, and the value $\$ 69,645,466$ against $\$ 57,116,989$ in 1910 . The total labour force in mines was 196,427 against $170,36 \mathrm{I}$ in 1910 . The output of wolfram was 88 tons, of a value of $\$ 84,500$ in I9II, against a value of $\$ 47,400$ in 1910. There was a falling off in gold production, the output being 9,228 ounces, valued at $\$ 306,514$, against 16,767 ounces in 1910 , valued at $\$ 574,868$.

In the states of Perak, Selangor and Negri Sembilan, 3,890 fishermen were employed in I9II on the fisheries compared with 3,765 in I9IO.

Again there was an increase of trade on the record for 1910, the aggregate value, including bullion and specie, being $\$ 182,812,966$, against $\$ 156,107,14 \mathrm{I}$ in 1910 . The leading exports were:-coffee $\$ 302,608$; rice $\$ 752,973$; sugar $\$ 235,343$; gambier $\$ 241,413$; tapioca $\$ 312,286$; copra $\$ 1,294,301$; Pará rubber $\$ 39,931,123$; tin and tin-ore $\$ 69,756,2$ I 5 (total $\$$ I 16,280,927).

The number of vessels, exclusive of native craft, entered and cleared in I9r I was $9,66 \%$, with a tonnage of $3,870,329$, compared with 9,014 and $3,504,667$ in 1910 .

The provision of means of communication with a view to the development of the natural resources of the country has been a consistent policy of the Federal Government, and in addition to the construction of new roads, every year sees an improvement in roads already existing. At the end of $x \mathbf{I I}$ : the lengths of roads and paths were:-Metalled cart-roads, I,988 miles; unmetalled, 234 miles; bridle roads and paths, I,542 miles. New roadways are under construction in all the states. The total mileage of railway open to traffic at the end of I9II was 560, an addition of 20 miles during the year, the capital account for railway and motor services being $\{6,383,200$, or $£ 340,074$ more than in 1910 . 
The profit in I9I I was equivalent to a dividend at the rate of 6.03 per cent. The department was authorised to expend nearly $£ 600,000$ in new construction work in 19I2.

Perak is the most populous of the four states, containing (I 9 I I) 494,057 persons $(344,238$ males, I 49,819 females). Of these I,396 were Europeans, 845 Eurasians, 199,034 Malays, 217,206 ( hinese, 73,539 Indians and 2,037 others. Religions were:-Mahommedan, 192,991; Hindu, 56,988; Christian, 9,734; Sikh, 3,918; other non-Christian 213,386; not given 3,690. Ipoh, in the mining district of Kinta, had 23,978 inhabitants, Taipeng (the capital) 19,556, and Kampar, I 1,604 . Ipoh and Kampar nearly doubled their population in ten years. The aboriginal population is given as 12,632 against 7,982 in 1901 . Births numbered 8,946 , or 17.95 per mille, against 10,306 in 1910 . Deaths numbered 14,026 , or 28.16 per mille, against 13,118 deaths, with a death rate of 33.03 , in 1910 . There were 6,498 deaths from malaria in 19II. There was an excess of 19,053 Chinese immigrants over emigrants.

The strength of the police force was 1,180 .

The total enrolment at 213 schools was 13,126 , with an average attendance of 78 per cent. English was taught at 15 schools to 2,246 pupils, the majority being Chinese. The expenditure on education was $\$$ I 49,025 .

The revenue in $191 \mathrm{I}$ was $\$ 19,081,190$; expenditure $\$ 13,071,195$. Balance of assets at the credit of the state, $\$ 33,194,1+6$. The revenue from land was $\$ 860,277$; land sales, $\$ 218,367$; customs, \$6,271,8 I3; licences, excise, etc., $\$ 4,584,938$. There was an increase of $\$ 3,106,837$ under the last, due mainly to the establishment of the government chandu monopoly.

A record was created in the value of both imports and exports:-Imports (I9II) $\$ 29,349,-$ 234 ; exports $\$ 55,535,590$. Of exports, the principal values were:-Rice, $\$ 725,724$; padi, $\$+63,458$; sugar, $\$ 233,196$; tin and tin-ore, $\$ 41,105,822$; copra, $\$ 973,8$ I I rubber, $\$ 10,994,087$.

There was an increased alienation of land for rubber and coco-nut cultivation over the areas so allocated in I 10 and 1909 . Of the 262,487 acres alienated for rubber I 24,681 were rcported to be opened and 31,532 acres to be producing. The total crop for the year was $6,041,763$ lbs. as against $2,962,218$ in 1910 . The total acreage under padi was 78,735 , and the yicld, in a year of poor crops, was $2,596,290$ bushels. The fruit harvest, on the other hand, was the best on record. Under coco-nuts there were 73,120 acres as against 66,088 in I9ro. Practically the whole delta between the Bernam and Perak rivers has been alienated for cultivation, and in a few years this vast plain, which was dense jungle four years ago, will present an unbroken field of coco-nut palms.

The total area of forest reserves is 422 sq. miles, an increase of $46 \mathrm{sq}$. $\mathrm{m}$. during $19 \mathrm{II}$.

The acting Resident (Mr. Oliver Marks) comments on the difficulty of obtaining contractors to undertake the construction of new roads, the prosperity in the planting industry having attracted both contractors and labourers. Nevertheless, $8 \frac{1}{4}$ miles were added to the metalled roads (now $7+5$ miles) and $6_{2}^{1}$ miles of earth-road were metalled. Several bridges were constructed, and waterworks for Taipeng and Kampar completed.

The number of vessels entered and cleared at the ports of the state (exclusive of native craft) was 3,990 as against 3,550 in 1910 , with a tonnage of 439,926 as against 383,976 in 1910 .

Taipeng recorded the largest rainfall, I +7.09 in.; Lenggong the lowest, $69.90 \mathrm{in}$.

In Selangor the population was 294,035 in I $91 \mathrm{I}$, a gain of 74.2 per cent. There were 220, 939 males and 73,096 females. Resident in the state were 1,348 Europeans, 64,952 Malays, 150,908 Chinese, 74,067 Indians, and Sakai (aboriginals) 1,739. Christianity was professed by $10,4+7$, Mahommedanism by 66,639 and Hinduism by $62,9+0$. Chinese immigrants numbered 46,598 and emigrants 24,512 . There were 46,718 inhabitants $(33,034$ males, 13,684 females) in the capital, Kuala I.umpur, the largest town in the Federation.

Births numbered 5,036 against 4,456 in 1910 , the rate per mille being 16.943 . Deaths numbered 11,903 against 10,797 in 1910 . The death rate was 40 per mille.

Pasture and agriculture employed 88,388 ; mining, 56,0;3.

The police force had a total of 681 of all ranks.

There were 58 schools- 49 Malay, I Tamil, I Chinese vernacular school maintained by the government, and the remainder English-teaching schools in receipt of a grant-in-aid. The average enrolment was 4,397 and the average attendance 3,837 , compared with 4,092 and 3,615 respertively in 1910 . 'Two girls' schools had an average attendance of $6 \mathbf{I}$. 'The expenditure on education was $\$ 62,548$.

Total revenue (I9II) $\$ 12,330,045$; cxpenditure $\$ 8,715,718$. The balance of assets amounts to $\$ 27,073,607$. A Chandu Monopoly Department was created on January $\mathbf{I}$, I011. Its total sales amounted to 67,067 tahils, and there was a net profit on the working of the Department of $\$ 2,206,6+1$. Land revenue was $\$ 695,906$ as against $\$ 659,705$ in 1910 .

The year was markerl by an expansion in rubber, coco-nut and coffee production. There were $413,+99$ acres alienated for agricult ure, comprising I 45,222 acres under rubber; coco-nuts, 33.355 icres: coffee, 9,575 ; rice, 4,312 ; and gambier, 746 acres. 253 estates produced 11,438 , 996 ibs. of rubber. Forest reserves totalled 201,265 acres. There were 71,353 acres alienated for mining, mostly for tin. The recently discovered coal-ficld at Rawang promises well. A manufacturing plant has been established at Batu Caves for high-class cement.

Imports (I9II) $\$ 30,196,834$; exports $\$_{47}, 433,952$. The principal exports were: - rubber, $\$_{23}, 852,273$; tin and tin-ore, $\$ 21,724,4,30$; copra, $\$ 20,6,66$; and wolfram $\$_{40,503}$.

()cean-going steamers using Port Swettenham numbered 469 , against 448 in 1910 , with 
a tonnage of $1,673,067$, against $1,503,510$ in 1910 . Altogether there entered 1,335 of coasting merchant vessels during the year with a tonnage of $1,422,74 \mathrm{I}$. All but six were British.

During I9II 22 miles of new roads were added to the state.

Sanitary Boards deal with such municipal affairs as roads and bridges, lighting, sewage and registration of vehicles at Kuala Lumpur, Klang and four other towns; and in April I9I I an Advisory Board was appointed for Port Swettenham, one of the members being nominated by the Selangor Chamber of Commerce.

In I9I I the Volunteers became a Federal force. Selangor contributed two companies totalling 209 officers and men.

The rainfall in I9 I ranged from 79.37 inches at Kuala Lumpur to III.26 at Kuala Kubu.

In Negri Sembilan, out of a population of 130,199 (87,651 males, 42,548 females), there were 403 Europeans, 69,745 Malays, 40,843 Chinese, and I8,248 Indians in I9II. There were 69,330 Mahommedans, 15,700 Hindus, and 2,212 Christians. On 89 estates 26,688 persons were employed, and in mining 9,657. The birth rate was 23.5 per mille, and the death rate 73.6 per mille.

The police force included 369 of all ranks.

In the 65 schools, 3,893 pupils were enrolled as compared with 4,253 in 1910. Of the schools 59 were for Malay boys and 3 for Malay girls; there were 2 English-teaching schools and I Tamil school. There is a growing desire amongst the Malays for English education.

A company of Volunteers was raised for the Federal battalion in 1911 , and 108 officers and men were enrolled.

Revenue (I9II) $\$ 2,512,002$; expenditure $\$ 1,768,733$. Land revenue amounted to $\$ 295$,989 against $\$ 272,578$ in 1910 ; and the new Chandu Monopoly Department collected $\$ 837,644$ against the $\$ 349,969$ derived from the spirit and opium farms in I9IO.

The balance of assets at the credit of the state amounts to \$1,47 I,644.

Rubber leads in agricultural produce, with I5I estates and a planted area of 75,356 acres. The output in I9II was 4,297,7 I $5 \mathrm{lbs}$. To rice 48,306 acres were devoted, to coco-nuts 19,584 and to gambier 15,049 . There is a tendency to abandon rice and gambier cultivation in favour of rubber and coco-nuts. The rice crop was a failure in I9II. There were $239 \mathrm{sq}$. miles of forest reserves. The total acreage of mining land was 22,837 .

Imports (I9II) $\$ 4,630,404$; exports $\$ 8,419,046$. These figures, however, are no true index to the total trade of the state, as much of the merchandise produced and consumed in the state is imported via Selangor. On the export side rubber was valued at $\$ 5,039,968$; gambier, $\$ 168,457$, and tin and tin-ore, $\$ 750,108$.

The number of vessels cleared at the ports (exclusive of native craft) was 1,328 , with a tonnage of 363,362 , against 1,548 and 496,380 respectively in 1910 .

The rainfall in 19 I I ranged from 64.35 inches at Jelebu to 96.50 at Port Dickson.

In Pahang the population was II 8,708 . in I9I I ( 72,234 males and 46,474 females). Of these I 37 were Europeans, 87,I09 Malays, 24,287 Chinese, and 6,6 I I Indians. There were 509 Christians, 77,900 Mahommedans, 4,440 Hindus, and 967 Sikhs. Aborigines numbered 10,2I3. With the smallest population of the four states Pahang has the highest birth rate and the lowest death rate. It is the only state in which the birth rate exceeds the death rate. The birth rate, per mille, was 27.13 and the death rate 26.40 .

The police strength is 384 .

The country is being opened up steadily by the extension of the road and railway systems. 20 miles of new trunk railway through the eastern states were opened on the GemasKuala Semantan section between Triang and Semantan, $34^{\frac{3}{4}}$ miles of the permanent way laid from Semantan to Kuala Tembiling, and progress made with the extension into Kelantan. Out of 173 miles of telegraph lines in course of construction, 125 miles were completed.

Revenue (I9II) \$I, I33,307; expenditure \$1,647,102. The state debt stands at \$9,201,749. Revenue from the new Chandu Monopoly Department amounted to $\$ 335,595$.

The acreage alienated for agriculture amounted to $I \mathrm{I}, 945$, but the acreage planted was only as follows:-Coco-nuts, I6,7I5; rice, 8,201; rubber (3I estates), 7,7I5; tapioca, 500; coffee, 97 . There were $3 \mathbf{I}, \mathbf{I} 44 \mathrm{lbs}$. of rubber exported. The live stock comprised 28,348 buffalos and 3,274 cattle, being 340 buffalos and $45^{8}$ cattle fewer than in I9IO. Forest reserves amounted to 106,208 acres. For mining, 44,439 acres were alienated.

Imports (I III) $\$ 2,277,768$; exports $\$ 4,890,639$. Among the exports, tin and tin-ore accounted for $\$ 4,129,974$; dried fish, \$174,8I7; rattans, \$54,008; getah grip, \$47,I92; rubber, $\$ 28,319$; tapioca, $\$ 24,645$, and copra, $\$ 17,185$.

Rainfall in I9I I ranged from 81.20 inches at Temerloh to 553.14 at Sungei Lembing.

Non-FEDerated States. ${ }^{1}$ - Johore. ${ }^{2}$ Great progress has to be reported since the Sultan obtained the services of a General Adviser from the Governor of the Straits Settlements in his capacity of High Commissioner to the Malay States. Mr. Douglas Campbell, C. M. G., was lent by the Federated Malay States in 1909, and several officers were also seconded from the same service to organise and conduct government departments. Legislation was at once introduced, and the outcome is increased prosperity in the finances of Johore, while vast improvements are reported in administration, the opening up of roads and other means of

i See E. B. xvii, 482 et seq.

2 See E. B. xv, 475 . 
communication and increased cultivation. A trigonometrical survey of the country is in progress, road and railway extensions are being carried out, and newly-created Town Boards in Johore Bahru, Bandar Maharani and Penggaram (Batu Pahat), have been able to effect improvements in sanitation, etc.

The census of I9I I showed a population of I80,4I2 (I22,I29 males, 58,283 females). Of these 205 were Europeans (16I British), 71,315 Malays, 63,405 Chinese, 30,904 Japanese, and 5,659 Indians. By religion, I 10,939 were Mahommedans, 843 Christians, 847 Pagans, 251 Buddhists, and 4,455 Hindus. The capital, Johore Bahru, has 22,636 inhabitants. Milarial fever was rife in 1910 and I9I I, and in I9I I there was a severe outbreak of smallpox. Two government vaccinators have been appointed and are doing good work.

As yet little attention has been devoted to mining in Johore, which is largely covered by jungle, but in I91 1276 tons of tin were exported. Under the new Land Enactment, grants of land are now made in perpetuity on conditions similar to those in force in the Federated Malay States. Gambier, pepper and tapioca are going out of cultivation. Coco-nuts and areca nuts are greatly favoured by Malay and Javanese agriculturists, and the export value of these crops in 1910 was $\$ 2,150,000$. The area under rubber at the end of I9I I. was 75,205 acres, and the export of rubber in that year amounted to $1,244,500$ lbs., against $613,600 \mathrm{lbs}$. in 1910. The total area leased, mostly by rubber companies, is $28 \mathrm{I}, 900$ acres, and a large amount of land is taken up by Japanese. Most exports pay a specific export duty. Rubber and coco-nuts, however, if grown on land held on a title on which annual rent is reserved to the state pay $2 \frac{1}{2}$ per cent ad valorem; if otherwise, 5 per cent.

Revenue (I9I I) $\$ 3,954,90$ I ; expenditure $\$ 3,469,57$ I. The expenditure for I9I I includes the repayment of $\$ 500,000$ of the capital sum lent by the Federated Malay States on account of the Johore State Railway. The Public Debt is $\$$ I I , 168,578, representing capital outlay on the State Railway.

The railway through the state, connecting Singapore with the Federated Malay States system, was completed in 1909 . Along its 120 miles it provides access to the extensive areas of valuable forest lands not conveniently reached by the natural waterways. In I910 some 295 square miles of land adjoining the railway were alienated for cultivation. The expenditure on the railway was $\$ 388$, 09I in I9I I and the profit on the last quarter's working was $\$ 6,683$. A narrow gauge railway, I I miles long, has been constructed to facilitate the shipment of produce from the district south of Bandar Maharani. Its extension for a further 28 miles is in progress. This railway made a profit of $\$ 12,336$ in 1910 , and of $\$ 4,026$ in I9I. Road construction is being pushed on, and in 1910 the Sultan sanctioned the construction of a main road across the peninsula, about 88 miles long, from Batu Pahat on the west to Mersing on the east, crossing the railway at Mengkibol.

The government maintains 39 schools, at two of which (Johore Bahru and Muar, with attendances of 300 and 140 ) English is taught. It is proposed to start an English boarding school on the lines of the school for the children of well-to-do Malays at Kuala Kangsar, in Perak. At the 37 vernacular schools, 2,529 pupils were enrolled.

Consisting solely of Malays, the police force, made up of 23 officers, i 16 non-commissioned officers, and 450 constables, is distributed over 42 stations. It was arranged in 1912 that an European officer should take charge. The Sultan maintains and commands a regiment of Malays, comprising 220 regulars and 300 volunteers, as well as a force of 65 Pathan artillerymen.

In 1910 the rainfall was 106.05 inches.

Kelantan. - The most important event in the history of Kelantan since the British Adviser (Mr. J. S. Mason) took over the supervision of its affairs from Mr. W. A. Graham, the Siamese Commissioner, on July I 5, I909, was the determination in 1912 of the agreement bet ween the Sultan and the Duff Development Company, and the resumption by the government of the sovereign powers conceded to the company over nearly two-thirds of the state. A new working agreement has been prepared under which the government of Kelantan undertakes to pay the company $£ 300,000$ and to grant to them the following rights: $(a)$ The sole right to select blocks of land for agricultural purposes, amounting in the aggregate to not more than 50,000 acres; $(b)$ the sole prospecting rights for minerals over the area of the concession; (c) the sole prospecting right over an area of approximately $78 \mathrm{sq} . \mathrm{m}$. in the Sokor district, and the right to take up mining leases and certain other rights.

(ireat activity has characterised the administration, with a view to bring about a more effective centralised government of the country. In 1909 the State Council held 10 meetings and passed six important enactments; in 1910 , when 12 meetings were held, 18 enactments were passed. In Igog a beginning was made with an educational system. A government school was started at Kota Bahru with II 9 pupils, and the enrolment had risen to 277 at the end of the year, 29 of the pupils taking up the study of the English language. Only four members of the royal house attended-one in the English class; but in 1910, when the average attendance was 117 , a son of the Sultan was amongst the students. Three new schools were opened in that year, and a night school for clerks at Kota Bahru. The Kelantan Malays are keen on education; the boys are industrious students, and there is great eagerness to learn English. The Mosque school at Kota Bahru, a sort of theological institution with a great reputation in the peninsula, has a daily average attendance of 42 . 
Regular steamship communication has been established with Singapore and Bangkok. On August I, 1909 postal rates were reduced from 9 cents to 3 cents between Kelantan and the Straits Settlements and the Federated Malay States, and in November to 8 cents for places within the Imperial Penny Postage Union. In spite of the reduced rates, the postal revenue has steadily increased. At the end of the year, the cash-on-delivery system was introduced for parcels and a money order system established with the Federated Malay States. The telephone and telegraph systems were extended, and the rate for telegrams to the Straits Settlements and the Federated Malay States reduced from I 5 to II cents per word. In I9ro commission on money, orders was reduced to half per cent, with a substantial increase of business. A start was made with the construction of roads, and at the end of I 909 there were 11 miles of gravelled roads and 6 of earth roads, and several hundreds of miles of foot tracks and bridle paths. In 1910 the road making was continued, and the most important work of the year was the beginning of a trunk road through the state.

The population (19II) is $286,75 \mathrm{I}$. There were rog deaths from cholera in 1910 .

The police force, numbering 232 men, with a European as Chief Police Officer, was reorganised on the Federated Malay States system in 1910 . As the administration of justice had fallen into an unsatisfactory state, the opportunity was taken on the resignation of the Siamese judge in 1909 to appoint the Assistant Adviser as judge. The result was an immediate improvement in the personnel and conduct of the Courts.

Revenue (I9I0) \$419,327; expenditure $\$ 403,552$. Principal sources of revenue: customs $\$ 129,560$; licences, $\$ 197,508$; land, $\$ 104,474$. The public debt at the transference of the suzerainty was $\$ 150,000$ upon which Siam charged 6 per cent. This debt was taken over by the Federated Malay States, interest being reduced to 4 per cent.

In 1910 only about 124,200 acres were reported to be under cultivation in a country of approximately 6,500 square miles. This comprised 95,000 acres devoted to padi, I 8,250 to coco-nuts, and 5,400 to rubber. Rubber planting, however, is spreading, and 64,500 acres were alienated in 1910 for this purpose, mostly to European companies. 3,763 tons of copra were exported, and 7,261 head of cattle, I, 480 sheep, II 5,044 poultry and 684 pigs were exported to Singapore. Arrangements are being made to improve the breeds of cattle and sheep. The revenue from land in 1910 amounted to $\$ 104,474-$ a large increase in the collection under the Siamese régime. A sago factory was installed at Kota Bahru in I9Io. Many unworked mining concessions were cancelled in that year. The dredging operations for alluvial gold in the Galas, Nenggiri and Lebir rivers were scarcely so successful in I9I0 as in the previous year, the gold won amounting to $3,698 \mathrm{oz}$., against $8,507 \mathrm{oz}$. in 1909 . On the other hand the output of tin-ore, though small, showed an increase.

The total value of trade in I9Io was returned at $\$ 3,003,935$, against $\$ 2,648,57$ in 1909 . Chief among the exports were-Copra, \$632,040; cattle, \$217,830; betel nuts, \$I 43,048; gold, \$1 29,465 ; fish, $\$ 64,904$; rice and padi, $\$ 45,342$. The principal imports were-Cotton piece goods, \$14I,337; kerosene, \$III,886; opium, tobacco, salt, and woollen goods. Shipping amounted to 206,560 tons, an increase on 1909 .

In 19 ro the rainfall was 123.4 inches.

Trengganu. - Though the suzerainty was transferred from Siam to Great Britain on July 14, 1909, it was only on April 22, I9 I0 that the Sultan signed an agreement providing for a British agent to reside at Kuala Trengganu, to fulfil the functions of a Corisular official, for the control of the foreign affairs by Great Britain, and for the limitation of mining and agricultural concessions to persons other than natives and subjects of Trengganu.

The population (I9II) is I46,920; of Kuala Trengganu, I3,99I.

In 19 Io the Sultan issued his "kuasa" empowering the British agent to adjudicate as a magistrate, jointly with the Hakim, according to Mahommedan law and the state regulations, and five suits were disposed of in that year.

Several Europeans have taken up concessions for rubber planting, in which industry the Sultan shares, and a Japanese subject obtained a concession for coco-nut planting in I 910.

No less than 1,986 fishing boats were on the register at Kuala Trengganu in 1910, as well as 385 sailing vessels of a burden ranging from 25 to IO0 tons. These sailing vessels were all built by native Malays for trade in the Archipelago. A bright future is predicted for Trengganu as a mining country, tin, wolfram and gold having been found, while traces of natural oil are reported near Dungun in the north-east.

The following were the values of imports and exports in 1910:-Imports: Rice, \$209,528; cotton goods, $\$ 69,73 \mathrm{I}$; opium , $\$ 60,909$; sugar, $\$ 49,420$; sarongs, $\$ 38,52 \mathrm{I}$; raw silk, $\$ 36$, roo; tobacco and cigarettes, $\$ 31,936$; petroleum, $\$ 21,645$. Exports: Tin-ore, $\$ 313,177$; fish, $\$ 464,288$; copra, $\$ 281,8$ I 3 ; padi, \$1 74,295 ; black pepper, $\$$ I $_{52}, 707$.

Revenue is raised by means of "Farms" and duties on all kinds of exports.

Mr. W. D. Scott's report for I9ro says: "The area is estimated at 6,000 square miles. There are no main roads, railways or telegraphs; communication with the interior is by means of the rivers and by good native paths." Regular steamship communication is maintained with Singapore, and in order to obtain a good port of call a survey is to be made of Chendering, lying seven miles south of Kuala Trengganu. The state joined the Imperial penny postage system and the Postal Union on January I, I 9 I I.

Rainfall in r9I0 (for nine months): IOI.98 inches. 
Kedah.-The years 1909 and I9ro were devoted largely to a reorganisation of the internal affairs of this state with a view of bringing its governmental system into line with the Federated States of Malaya. With the transfer of the suzerainty under the Anglo-Siamese "Treaty of 1909, Mr. IV. G. Maxwell, of the Federated Malay States Civil Service, as British Adviser, succeeded Mr. G. C. Hart, the Adviser appointed by the Siamese government. In that year the state council held 25 meetings and passed 13 enactments or decisions, by some of which forced labour was abolished and new methods introduced for raising revenue for state purposes. The administration is entrusted to departments, and in each district there are now district officers who interest themselves in the work of the land office, mines office, hospital, gaol, public works, etc. A sanitary board was brought into existence in the capital (Alor Star), and is doing good work. In 1910 the State Council held 75 meetings; 16 enactments were passed. They enable the central authorities to exercise closer control of finance and a more thorough management of business. Special mention should be made of the legislation for the speedy abolition of "debt bondage," a peculiar feature of ancient Malay life.

A survey department has been constituted. Road making, bridge building and canal extension are features of the new régime, and a tracing has been made of an extension of the railway from Province Wellesley into Kedah as far as Alor Star. New post offices have been established throughout the country, the money order system introduced and telegraph and telephone systems extended. The telephones are being connected with Penang.

Education is making rapid progress. Before 1905 there was only one school in Kedah. In 1910 there were 20 Malay schools, with 37 masters and 1,675 pupils enrolled. There is a growing demand for schools and the extension of accommodation in existing schools. An English school at Alor Star had 97 boys on the register in 1910 and an average daily attendance of 80 , including two of the Sultan's sons. 'There is a girls' school at Alor Star.

There are 37 police stations, with a total police force of 419 men, of whom 2 are Europeans and 335 Malays. A Courts Enactment, passed in 1910 , constitutes the various courts of the state and defines their powers. The Court of Appeal, which had formerly consisted of the State Council without the President and Adviser, but with the Assistant Adviser and two experts in Mahommedan law in their place, now consists of officers specially selected to be judges. At any appeal at least five judges must be present. Members of the State Council are not eligible to be the judges, but if any case appears to be of exceptional difficulty or importance, the Court may ask the State Council to sit with it. The enactment provides for a judge of the High Court sitting with two Assessors at the hearing of any murder case or criminal case of unusual importance or difficulty. It also gives the High Court full powers of revising on its own initiative the decisions of the District Courts. The powers of the Adviser in sitting in civil and criminal cases in which British subjects are defendants are the subject of special sections of the enactment. The efficiency of the High Court has been much improved, and the arrangements for the Chief Justice to go on circuit saves much trouble, expense and delay. Most of the work is done by the nine District Courts.

Population (I9I I) 245,986 (males I37,I 39, females I08,8.47); of these 195,4 I I were Mlalays, 33,746 Chinese, 8,135 Siamese, 6,074 Indians, and 136 Europeans (128 British). There were 198,720 Mahommedans in the state, 5,002 Hindus and 642 Christians. A smallpox epidemic in 1910 caused 36 deaths, and over 33,000 persons were vaccinated. The Kedah Malass believe in the efficacy of vaccination.

Revenue (I9IO) \$I,449,116; expenditure $\$ 1,285,3+2$. Seventy-three per cent of the revenue is derived from the opium monopoly, land revenue, and export and import duties. The revenue from land in 1910 was $\$ 398,034$ against $\$ 242,873$ in 1909 .

In 1910693 tons of tin were exported as against $7+4$ tons in 1909; and 12 tons of wolf ram.

Agriculture is the mainstay of Kedah at present. An epidemic of rinderpest having swept the country in 1908-9 carrying off 9,000 head of cattle, valued at $\$ 300,000$, left many villages in the north without animals enough to plough the rice-fields. The State Council in 1910 came to the rescue of the cultivators, lending money against the security of title deeds at 6 per cent interest (against the 24 per cent formerly charged by native money lenders), the principal buing repaid in instalments. An excellent harvest induced many of the cultivators to repay half the principal in the first year. The state veterinary surgeon reports that Koch's anti-rinderpest serum is less efficacious in Kedah than it appears to be in India, which is possibly due to the Indian cattle possessing a modified immunity through their ancestors having had rinderpest or to the deterioration of the serum in the Kedah climate. During 1910 16,741 head of cattle were licenced either as imported or born in the country as against II, 125 in 1909; 15,808 sales were registered as against 6,599 in 1909. Exports (1910) of rice were 614,080 gantangs; of padi $13,653,936$ gantangs ( 1 gallon = I gantang).

Canals have been extended for irrigation in the rice-growing districts.

There has been great activity in rubber planting, and out of 40 agricultural estates registered at the end of 1910 only one had no rubber trees. The total acreage was 9.4,005, of which 20,034 acres were under rubber, 3,679 coco-nuts and 10,005 tapioca.

The passing of a Timber and Furest Produce Passes Enactment was the first step towards protecting the forests of the state. No forest reserves have yet been created.

The rainfall in 19 in ranged from $89.92 \mathrm{in}$. in South Kedah to $135.38 \mathrm{in}$. in North Kedah.

Perlis. - The chief work of the British Adviser (Mr. Meadows Frost) in 1909 and 1910 was 
to reorganise the administrative departments of this small state. The population (I9II) numbers 32,746 persons ( 16,808 males and 15,938 females)., Of these 29,497 are Malays 1,627 Chinese, 1,388 Siamese and only 5 Europeans (3 British); 29,665 are Mahommedans and 8 Christians.

The state is governed by the Council, consisting of the Raja, the Adviser, and three - other members. In I9I0 it passed 8 enactments, one abolishing debt bondage. The State Council is the Appeal Court. There is a police force of 65-Malays and Indians.

As there was no proper register of titles for land and no rent-roll, Mr. Frost, soon after his arrival in 1909, set himself to draw up both, with the result that the collection of land rents in 19 Io realised $\$ 20,586$ as compared with $\$ 14,875$ in 1909 . The land office has issued a notice that no unregistered grant will be considered valid after a certain date.

Revenue (I9IO) \$I 14,834; expenditure \$1OI,493. When the transference of suzerainty from Siam to Great Britain occurred in 1909 there was a debt of $\$ 474,796$, which the Federated Malay States took over. In 1910 the debt was reduced by $\$ 20,000$.

In 1910 the State Council abolished the miscellaneous import duty of 3 per cent on all imported goods not specifically mentioned, and now the only duties raised are on spirits, beer, wine, tobacco, and kerosene or other oils used for heating or lighting purposes. The miscellaneous export duty of 5 per cent on all goods not specifically mentioned (such as tinore and guano) has also been abolished.

Except in the Coast districts, where there were excellent crops and plenty of cattle, the padi season of I9IO was a failure. Owing to the lack of bullocks the cultivators could not plough and they left off hand tillage till it was too late. Rinderpest wiped out the cattle, upwards of 7,490 head succumbing to the disease. The direct loss to the small cultivators was $\$$ I 13,000 , but there was a large indirect loss as well. The State Council came to the aid of the people, and loans are granted for restocking against land titles.

In I9Io there were 150 tons of tin-ore exported.

Many of the limestone hills of Perlis contain caves rich in deposits of guano. A company has been formed by some Dutchmen in Penang, called the Straits Guano Company, to work the deposits, and they have obtained a lease of seven hills. (The government retained the best-known hill for the use of the local cultivators.) The company has made two miles of earth road, which opens up good country, where people are anxious to take up land. The quantity of guano exported in I9IO was $838 \frac{1}{2}$ tons, which paid export duty at the rate of $\$ 2.00$ per ton. After a certain date the company is bound to extract not less than 500 tons per month, and the export duty will be 10 per cent ad valorem of the market price in Penang.

\section{HONG-KONG ${ }^{1}$}

According to the census taken on May 25, I9II, the civil population of the colony numbered 456,739. The non-Chinese community numbered I 2,075, while the Chinese population was thus distributed:-city of Victoria (including the Peak) 219,386; villages of Hong-Kong r6, I06, Kowloon (including New Kowloon) 67,602; New Territories 80,622; population afloat 60,948 . The general death rate for I9II was 2 I.I3 per I000 among the Chinese community and 13.38 among the non-Chinese.

Public Health.-The colony has outlived its former notoriety for unhealthiness. The influence of the young pine forests created by the Afforestation department and the training of nullahs on the slopes have tended to check malaria, while the attention recently bestowed on sanitation has also had beneficial effects.

The gradual replacement of old Chinese dwellings by new premises, erected in accordance with the Public Health and Building Ordinance of I903, is effecting an improvement in the healthiness of the native quarters, but the abnormal influx of refugees, estimated at some 20,000 , who arrived in Hong-Kong during the revolutionary movement in south China, somewhat discounted the improvement by contributing largely to the number of cases of plague and smallpox which occurred towards the end of I9I I. The number of deaths from beriberi during I 91 I was only 320 as compared with 566 during I9IO. This reduction was in some measure due to the dissemination of a circular of information among employers of coolie labour, which set forth the cause of beri-beri and advised the use of beans for food with rice in the absence of fresh meat or fresh fish.

The records at the Observatory, Kowloon, showed in I9I a highest temperature of 93. $1^{\circ} \mathrm{F}$. in August, a lowest temperature of $47.1^{\circ} \mathrm{F}$. in February, and a rainfall of 90.55 inches, occurring on 145 days.

Industries.-Of the total area of the colony, which, including the New Territories, is estimated at $249,55 \mathrm{I}$ acres, some $4 \mathrm{I}, 967$ acres are cultivated; that is, practically the whole available area, the remainder being steep hillsides. The government Pine Plantations occupy 6800 acres and there are about 43,000 acres of Licensed Pine Plantations. With the exception of brewing, the manufacturing industries of the colony under European supervision increase in importance yearly, although the Chinese revolutionary disturbances in 1911 were adverse

'see E. B. xiii, 657 . 
to trade. The manufacture of lard is one of the important Chinese industries in the colony, most of the lard being sent to the Philippines, and during 191 I a lard and meat factory was started for the Philippine trade. Since the middle of 1910 a steam trawler has been engaged in the fishing industry and has contributed its hauls to the local markets.

Commerce.-Hong-Kong is a free port. The total reported imports during I 9 I I amounted to $3,995,793$ tons as against $4,292,194$ tons in 1910 . The exports for 1911 show an in-crease of 71,672 tons or 3.1 per cent. Transit cargo shows an increase of 66,109 tons or I.6 per cent. Of the more important articles of import, kerosene oil shows a remarkable increase. The imports of raw opium and the trade in compounds of opium have decreased considerably owing to recent legislation. The failure of the southern rice crops in I9II caused a decrease in the rice imports and a corresponding increase in the import of American flour, which is used as a substitute for rice and rice-flour.

The demand for labour in the rubber plantations of Malaya is responsible for the con. tinued increase in the number of Chinese emigrants to the Straits Settlements. The table which follows illustrates the extent of the Hong-Kong immigrant and emigrant trade:-

\begin{tabular}{|c|c|c|c|}
\hline Year. & $\begin{array}{l}\text { Emigrants to } \\
\text { Straits Settlements. }\end{array}$ & $\begin{array}{l}\text { Total Number } \\
\text { of Emigrants }\end{array}$ & $\begin{array}{l}\text { Total number of } \\
\text { Immigrants } \\
\text { (returning } \\
\text { Emigrants). }\end{array}$ \\
\hline $\begin{array}{l}1909 \\
1910 \\
1911\end{array}$ & $\begin{array}{r}48,016 \\
76,705 \\
100,906\end{array}$ & $\begin{array}{r}77,430 \\
111,058 \\
135,565\end{array}$ & $\begin{array}{l}\text { I } 44,82 \text { I } \\
\text { I } 49,564 \\
\text { I } 49,894\end{array}$ \\
\hline
\end{tabular}

The total of the shipping entering and clearing at ports in Hong-Kong during the year I9IO was the highest reached in the history of the colony. The number of vessels engaged in foreign trade was 40,714 , of $23,160,256$ tons in 1910 , and 44,978 of $23,063,108$ in 1911 , when 24.0 per cent by number and 50.7 per cent of the tonnage was British.

Finance.-In I9I the revenue was $f 7,497,23 \mathrm{I}$ and the expenditure $£ 7,077,177$. The amount of the Consolidated Loan (Inscribed Stock Loans of 1893 and I906) at the end of I9I I stuod at $f_{1}, 485,732$, and, in addition, the advances by the Crown Agents for railway construction amounted to $£ 340$,ooo. The rateable value has doubled since $1900-01$ and for I9II-12 stood at $t_{1} I, 16 I, 390$. The colony pays a military contribution fixed at 20 per cent of the revenue; the cost of volunteers is borne entirely by the colony.

Communications.-Hong-Kong has unrivalled steam communication with all parts of the world and there is a weekly European Mail service. During I 9 lo the Hong-Kong Post Office began to forward parcels to Great Britain and (ermany via Shanghai, Dalny and the TransSiberian railway. The cash-on-delivery service for parcels exchanged with the United Kingdom was adopted on May I, I909. From Jan I, I9I I the Hong-Kong government was relieved by the Imperial government of the charge of the postal agencies in China.

Extensive resumptions of land at Kowloon Point were effected during 1909 to provide a site for the terminal station of the Kowloon-Canton Railway. The British section of this railway, 21.78 miles in length and of $4^{\prime} 8_{2}^{1 \prime \prime}$ gauge, was opened on October I, I9I0, by Sir Henry May. A two-foot gatge branch from Fan ling to Sha Tau Kok, a distance of $7^{1}$. miles, was commenced in May 1911 , and a length of 61 miles of this branch was opened for traffic on December $2 \mathrm{Ist}$. The Chinese section of the railway was opened, and through traffic between Kowloon and Canton established on October 4, I9I I.

Gonernment.-Sir Frederick Lugard, who was appointed Governor in July roo7, left the colony in March I9I2, to become Governor of Nigeria. He was succeeded by Sir Francis Henry May, K.C.M.G., formerly Governor of Fiji and High Commissioner for the Western Pacific, who had previously been acting Governor.

In accordance with the resolutions of the International Opium Conference which met in Shanghai in February rgog, the opium ordinances have been amended and consolidated, and additional restrictions and safeguards have been imposed in respect of morphine, compounds of opium and cocainc. Twenty-six opium divans were closed in $\mathrm{I}(\mathrm{O})$, and all that remained both in the island of Hong-Kong and the New Territories were closed in roro. A grant of foooo was made to the colony by the Imperial Government for the year 1010 on account of the loss of opium revenue, and a grant of $f_{12,000}$ for the same purpose for the year IOII-12. In order to replace the revenue lost on opium, a law was passed by the Legislative Council on September r 7 , r 909 , imposing duties on intoxicating liquers consumed in the colony. The 34 ordinances passed in yoro were chiefly concerned with the consolidation of the ordinances relating to the New Territories, copyright, crown suits, lepers, midwives, oaths and the volunteer 
reserve. In I9I I the ordinances passed numbered 65 , the largest number ever dealt with in one year. They related chiefly to defence, the consolidation of the liquor laws, the university, stamp duties, civil procedure, laws for the more effectual control of clubs and societies, and for the registration of Chinese partnerships with limitation of liability.

A conference lasting from June till November I909 was held in Hong-Kong between the Portuguese and Chinese Commissioners for the delimitation of the boundaries of Macao. In July Igog there was trouble in Macao with pirates on Colowan Island, in which Portuguese troops and gunboats were engaged. Some of the pirates escaped and were afterwards arrested at Cheung Chow Islands in the New Territories.

Police and Crime.- The strength of the police force in Igr I totalled I080; the force is composed of 134 Europeans, 399 Indians and 547 Chinese. The District Watchmen Force, composed of I 24 Chinese, patrols the Chinese quarters of the city of Victoria under the supervision of European police. The daily average of prisoners confined in the Victoria Gaol in I9I I was 595 as compared with 726 in I904, the highest previous average. The average percentage of prisoners to population for the last ten years has been 0.14 , but owing to the large floating population which is constantly moving between the colony and Canton, this percentage does not convey an accurate idea of the comparative criminality of the residents of the colony. The Chinese community in Hong-Kong was profoundly stirred by the revolutionary movement in China, and for some days in the early part of November I9I I great excitement prevailed. A proclamation under the Peace Preservation Ordinance was issued November 29th, and remained in force until February 26, I9I2. The police succeeded in preventing any serious outbreak of lawlessness, though the influx of undesirable characters from Canton and other parts of China caused many cases of disorderliness, assaults and petty thieving. Military assistance had to be provided and special constables enlisted.

Education.-Education is provided at 67 government and Grant Schools comprising 20 upper grade schools (average attendance 4IO7) and 74 lower grade schools (average attendance 2196). On September 7, I9II, a Board of Chinese Vernacular Primary Education was constituted to promote efficient Chinese vernacular education and to collect funds to supplement the government subsidy made to the Board. The amount of the government subsidy for the year $19 \mathrm{I} 2$ was $£ 4 \mathrm{I}$ Oo. Higher education is represented by the Technical Institute where instruction is given in scientific, technical and commercial subjects. The Hong-Kong University building was opened on March 12, 1912. The first chairs were to be those of medicine, engineering and the arts; the medium of instruction will be English. The primary object of the University is to train the character and morals of students and, so far as is possible, to inculcate western ideals. It will be open to all races and creeds, but owing to the position of Hong-Kong it is chiefly intended for the Chinese. At the end of I9I I the University endowment fund amounted to $f 40,098$. The British government has promised a sum of $£ 300$ a year scholarships ("King Edward VII Scholars").

Social.-The Victoria Recreation Club, which, under the style of the Victoria Regatta club, held its first regatta in 1849 , celebrated its 60 th anniversary on July 10 , 1909 , in a new club house which had been built on an extension of what was formerly Murray Pier. The Club Germania commemorated its fiftieth anniversary on November 27, 1909. On June 22, I9I I the coronation of King George $V$ was celebrated by a public holiday. The whole of the colony was illuminated for three nights, all the men-of-war in the harbour combining in the display.

During the past three years the colony has lost several of its prominent men by death, including Mr. George Murray Bain, who came to the colony in $\mathbf{1} 864$ as sub-editor of the "China Mail" of which paper he ultimately became proprietor; he died April 21, 1909. Sir Hormusjee Mody, the donor of the Hong-Kong University buildings, died on June 26, 19II. On October 28, I9I I, Mr. W. D. Barnes, the Colonial Secretary, who had only recently been transferred to Hongkong from the Federated Malay States, met with an untimely death on the polo ground.

\section{Weihaiwei ${ }^{1}$}

The population in I9r w was $147, x_{77}$ ( 146,840 Chinese and 293 of other nationalities). This gives a density of about 5 to per square mile. The European element numbers 2 I 5. It consists chiefly of the Royal Naval contingent on the island of Liu Kung, and of school-boys most of whom have their homes in Shanghai. Of the native male population about one-fifth is engaged in occupations other than agricultural. This frac-

1 See $E, B$. xxviii, 494 . 
tion includes merchants (shopkeepers and employees), fishermen, carpenters and builders, smiths, boatmen and teachers-named in order of their numerical importance. As the inhabitants are mostly small-holders, many of them combine several occupations.

Weihaiwei is now a regular port of call for many China coasting steamers sailing northwards from Shanghai, and there is also a regular weekly service, carrying mails and passengers between Shanghai and Weihaiwei, subsidised by the Government. The mails are landed and shipped at Port Edwar:', where the main Post Office has been established and which is now the principal anchorage for steamers, instead of, as formerly, on the Island of Liu Kung. The shortest time in which a mail has arrived from London via Siberia is 15 days. The number of steamers that called during I9I I was 6I5, net tonnage 5I9,399.

Of the total area, which is 285 square miles, it is estimated that not more than two-fifths is arable land. The principal export crop is ground-nuts (Arachis hypogaea), the export of which amounted in I9I I to 547 tons of nuts and 85 IO tons of seeds. Shark fishing has been carried on by the Japanese since 1908, but only seven boats were engaged during 19I I.

Revenue in $1911-12$ was $\$ 74,673$, expenditure $\$ 153,591$, and grant-in-aid $£ 6000$.

The I9I I census returned 8637 males and 40 females of the Chinese population as able to read and write; that is, just below 6 per cent of the total population, or over I I per cent of the male population. The people of the territory have voluntarily agreed to levy a small tax on theatrical performances for the improvement of the standard of education in village schools, which is very low. The government Free School during the year I 9 I I had an average attendance of 60 pupils. There are several other schools for boys and girls under the management of Europeans. From the Chinese treaty ports and Hong Kong, boys are now sent to the Weihaiwei School for European Boys. The average attendance is about 50 and the school is now the home of the First North China Troop of Boy Scouts.

The inhabitants of the territory are, for the most part, of an orderly nature, and crime is rare. In I9I I there were 786 convictions. Gambling is responsible for a large proportion of these. The prisoners are employed on labour of a useful kind, such as roadmending and treeplanting. The total strength of the police force is 3 Eurnpean inspectors, 3 Chinese sergeants and 52 constables; an average of one policeman to 2830 of the population.

The territory is remarkable for the number of suicides-3I males and 63 females in 1911 .

In 1909 the Provincial Assemblies were inaugurated in China. On the Weihaiwei register of the electors entitled to vote or to become members of the Provincial Assembly of Shantung, appeared about 500 names.

An ordinance was introduced in 1909 , prohibiting generally the importation, sale and smoking of opium, or any other hypnotic except on medical grounds. A refuge was opened under the control of a medical officer for those who desired to rid themselves of the opium habit. The number of persons licenced to smoke opium in IgI I was 42 as compared with 50 in 1910 and 110 in 1909 . The licensed smokers are either over 50 years of age or suffer from a chronic disease. The opium habit is becoming less prevalent and there are few young men who indulge in it. On the other hand cases of drunkenness, which till recent years were very rare among the Chinese of Weihaiwei, are now becoming more numerous.

The Revolution in China in I9 I caused an outloreak of disturbances on the Weihaiwei frontier, which necessitated employing marines to guard the boundary. On the withdrawal of the marines a force of a hundred men of the Royal Innis-killing Fusiliers was sent from Tientsin to take their place. The city of Weihaiwei, following the lead of the Treaty port of Chefoo, declared itself in favour of the Republican party on the Ifth of November.

The Commissioner of Weihaiwei is Sir James Haldane Stewart Lockhart, K.C.M.G.

(H. SPOONER.)

\section{Fiji ${ }^{1}$}

The total population at the end of I9I I was $142,76 \mathrm{I}$, as compared with 137,588 in I0) 10. During 1011 4,216 Indian immigrants entered as against 3,879 during roro.

The colony continues to progress satisfactorily. A large area of native land has been taken up on leasehold and the industries have increased. The Sigatoka district, now opened up, promises to be one of the principal sugar-producing districts. The field work of the trigonometrical survey of Viti Levu was completed during ror I.

In March in ro the colony was visited by a hurricane which did considerable damage to buildings and plantations. Banana plantations and many acres of sugar-cane were entirely destroyed, the latter being affected more particularly by floods in the low-lying country where cane is principally grown. Damage to coco-nut plantations was also considerable, but rubber plantations were unaffected by the wind.

Finance.-The revenue for 1911 amounted to $£ 240,395$ or $£ 28,442$ more than for 1910 ,

1 See E. B. x, 335 . 
and $f 33,098$ in excess of the original estimate. $£ 265,347$, which was $£ 28,686$ in excess of 1910 . for Public Works Extraordinary.

Trade.-The bulk of the colony's trade continues to be conducted through Australia and New Zealand. The total trade during I9I I amounted to $£ 2,233,285$. In I9IO the figures were $f_{1}, 833,847$. The total trade with the United Kingdom and British possessions, which is 88 per cent of the total trade, increased from $£ 1,747,283$ in 1910 to $£ 2,138,827$ in I9II. An extraordinary increase in the quantity of green fruit exported is noticeable. This is due to the fact that the banana industry was not in I9II affected by any serious cyclonic disturbance. The total area of land under sugar cane in December I9I I was estimated at 43,358 acres, from which was produced 488,534 tons of sugar cane. The estimated cultivated area under banana and pine apples was 4,692 and 230 acres respectively. The area under coco-nuts was estimated at 37,562 acres. The principal minor export in I II I was trocas shell, locally known as "sici." It is found abundantly on the reefs surrounding the greater part of the colony and is exported for use principally in France and Japan for the manufacture of buttons. It was placed on the list for the first time in I9Io and the export for I9I I amounted to $£_{14}, 252$ in value.

Government.- Sir Francis Henry May, K.C.M.G. was appointed Governor of Fiji and High Commissioner for the Western Pacific in I9II, to succeed Sir Everard im Thurn, K.C.M.G., C.B., who retired in I9I0. In 1912 Sir Ernest Bickham Sweet-Escott, K.C.M.G. succeeded Sir F. H. May, who was appointed to the governorship of Hongkong.

Among legal enactments during I9I0 and I9I I was an ordinance providing for the raising of a loan of $f_{\mathrm{I}} \mathrm{IOO}, 000$ for the reclamation of the Suva harbour, and of harbour works at Suva and of works for the general sanitation of the town. Other ordinances relate to the taxation of buildings, the extension of restrictions regarding the sale of spiritous liquors, and the consolidation and amendment of laws relating to lepers and the constitution of a Central Board of Health.

Education.-During I9I I a special grant of $£ 300$ was allowed the Suva Public School for building purposes. The school has five teachers with an average attendance of 137.2. The Levuka school has two teachers and an average attendance during I9I I of 142.7 . The education of natives is conducted mainly by the Wesleyan and Roman Catholic Missions. The former has 1002 schools with a total attendance of 16,525 . The Roman Catholic Mission has 124 schools and in I9II 2293 native children were on the school rolls. The general question of education within the Colony was the subject of a commission which sat throughout I909, but the steps to be taken are still under consideration.

Judicial. -The total number of offences reported to the police was 6160 , which was 14 more than in I9IO. Of these reported offences 776 were offences against the person, 372 larceny, I4I offences against property (other than larceny), and the greater portion of the balance were offences-against labour laws by indentured labourers.

Climate.-The rainfall recorded at Suva during I9I I was I08.346 inches. In the previous year the rainfall was 107.812 inches. The greatest rainfall in any one day throughout the ycar was 15.907 inches on November I2th.

Shipping. - The number of vessels visiting the Colony during 19I I was I5I with a tonnage of 295,477 as against 140 , with a tonnage of 262,273 in 1910 .

\section{Gilbert ${ }^{1}$ and Ellice ${ }^{2}$ Islands Protectorates}

The population of these Protectorates in I9I0 was about 30,000 of whom I50 were Europeans and 50 Asiatics. The natives are nearly all engaged in the copra industry but about 700 are employed by the Pacific Phosphate Company at Ocean Island and 100 by the owners of Fanning Island. An epidemic of dysentry caused a heavy death rate in I908-09. The financial statement for roro showed an excess of liabilities over assets amounting to f5966. This adverse balance was caused by the purchase of the S. S. "Tokelau" and the erection of several residences for Government officials in 1909. The trade of the Gilberts was very much affected during the year by the prevailing drought which reduced the export of copra. But little progress was nuade during the year, the energy of the native officials being concentrated on combating famine. The export of phosphate of lime from Ocean Island amounted to 166,695 tons as against 119,425 tons in 1909 .

\section{TONGaN ${ }^{3}$ Islando Protectorate}

The population in 1909 was 21,958 . The latest report, dated 1910 and issued in I9I2, stated that the islands are in a satisfactory financial and commercial condition, a condition of affairs brought about by the absence of drought and hurricane for a number of years. The general revenue for 1910 amounted to $£ 44,007$ as compared with $£ 40,456$ in 1909 . The expenditure for these years amounted to $f 42,6$ I 7 and $f 34,739$ respectively. The imports in 1910 totalled $£_{1} 160,543$ as against $£_{1} 5_{2}^{2,870}$ in 1909 and the exports $£_{245,946}$ in I9IO as compared with $£_{2} \mathbf{1} 7,155$ in the previous year. The trade of the Protectorate could be considerably increased if the native government exercised a more efficient administration and made provision for an adequtae supply of labour. Climate and soil are greatly

${ }^{1}$ See E. B. xii, Ir.

${ }^{2}$ See $E, B$. ix, 29r.

${ }^{3}$ See $E, B$. xxvii, 3 . 
in favour of agricultural development but labour is scarce and expensive. Copra continues to be the principal export, 12,998 tons valued at $£ 232,866$ being sent away in 1910 . About one quarter of the total output is shipped to Europe, the balance going to Australia. The Tongan Islands are now a place of call for a line of steamers running between Australia and San Francisco. The shipping returns for rglo consequently show a considerable increase. In that year 59 vessels, with a tonnage of 104,403, entered. The Government College at Nukualofa was advanced by the appointment of a technical instructor in carpentry and the commencement of a Technical School.

\section{SOLOMON IsLANDS ${ }^{1}$}

The natives of the Protectorate are estimated to number 150,000. In March 1911 the white and foreign population numbered 443, as against $25 \mathrm{I}$ in 1909 . The number of indentured labourers employed in the Protectorate at the end of March I9I I numbered 4500. In 1909 the number was only 2284. The revenue for I9IO-II amounted to $£ 14,130$ and the expenditure to $£ 9493$. The loan of $£ 2000$ made from the funds in the hands of the High Commissioner for the Western Pacific for the purpose of extinguishing certain claims to land preferred by German claimants in the islands ceded by Germany to Great Britain in 1900 was paid off in 1909-10 and the Protectorate is now free from debt. The imports for I9IO-II were $f_{103,147}$ and the exports $£^{8} 88,890$. Almost the whole of the import and export trade is with New South Wales. The coconut plantations in the Protectorate are developing rapidly. It is estimated that the area of these plantations, owned by white men amounts to about $\mathrm{I} 8,000$ acres. The quantity of copra exported during $19 \mathrm{I} 0$ amounted to 4030 tons and seems likely to increase. Ivory nuts rank next in importance to copra among the agricultural products. The nut is the fruit of a species of sago palm (Calococcus solomonensis), peculiar to the Solomon Islands. It grows naturally in swampy ground, where it is also being cultivated. The nuts are used in the manufacture of buttons and other similar articles. Bananas of high quality are now being produced and have lately come upon the Sydney market, but this industry is only in infancy. Rubber, cotton and other fibres are still in an experimental stage, but give promise of development. The shipping returns show that the number of British and other foreign-going vessels entered and cleared in the Protectorate during I9I0-I I numbered 82, with a total tonnage of 63,257 . The total rainfall registered at Tulagi in 1910 was 133.40 inches. (A. BRUCE JACKSON.)

\section{Gibraltar $^{2}$}

The population on April 2, 19II, was 25.367 (14, I 45 males; I I,222 females), in addition to 8,050 men on board H.M. ships in harbour.

Revenue (1910) $£ 80,929$; (1911) $£ 94,573$. Expenditure (1910) $£ 76,410$; (1911) $£ 73.390$. The shipping, entered and cleared, amounted in 1911 to $I I, 704,163$, of which $7,143,083$ tons were British. A scheme is in hand for the improvement of commercial facilities at W'aterport. In August I9I I the removal of coal hulks was considered as their presence, as offering shelter to torpedo boats, was held to be dangerous in war; on the other hand, their removal was viewed with concern by those interested in the coal traffic of the port.

The naval establishment was inspected on June 6, 1912, by Mr. Asquith, Mr. Winston Churchill, and Admiral H.S.H. Prince Louis of Battenberg.

\section{Cyprus $^{3}$}

The census of April 2, ror I, gave a total of 274:108, including the military population; of this number 56,428 were Mahommedans and 217,680 non-Mahommedans. There were 4658 males in excess of females.

Agriculture.-As the result of two bad harvests in succession the year I910 was not a prosperous one for Cyprus. There was a serious falling off in revenue and a trade depression which reacted on every industry and activity in the island. Wheat was below the average of the preceding five years; barley was a poor crop. The production of cotton on the other hand was almost double that of the previous year and there was a substantial increase of olives, carobs, grapes, pomegranates, oranges, lemons and silk. An exceptionally severe winter, succeeding late rains, had a disastrous effect on the flocks; in the Famagusta district there was a decrease of nearly 12,000 sheep and 1500 goats. The outlook for the wine industry was gloomy; and the relief works were continued in the Limassol district for the benefit of the vine growers. The crisis in the wine industry was suddenly relieved, however, by events in France and Italy which caused a brisk demand there for Cyprus wines. The output of wine was good and satisfactory prices were obtained.

In the seven nursery gardens in various parts of the island more attention is now given to the production of fruit trees, vegetables and economic plants than to the cultivation, as heretofore, of purely forest trees. In the experimental garden at Nicosia several thousand

1 See E. B. xxv, 364.

2 See E. B. xi, 938. sec E. B. vii, 695 . 
fruit trees were planted during the year and a number of vines were also planted to provide cuttings later on. The cotton experiments with the varieties previously tried again gave good results. The distillation of essential oils is an important item in the work of the Agricultural department, though the market appears to be somewhat limited. The art of basket-making is now taught and a number have been made for fruit transport. The export of potatoes to Egypt has shown considerable expansion, $36,27 \mathrm{I} \mathrm{cwt}$. (value $£ 8472$ )

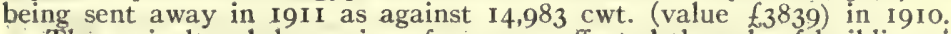

The agricultural depression of I910-II affected the sale of building timber, the receipts from which amounted to $£ 3592$ as against $£ 3762$ during the previous year. Two new forest stations have been started in the Famagusta and Nicosia districts. The expenditure on the forestry department amounts to about $£ 13,000$ per annum, exclusive of the vote for special tree planting, and the revenue represents at present only about 35 per cent. of the cost, though the foundations are being gradually laid of a large revenue in the future. Now that the destruction of trees has been stopped and systematic planting undertaken the island may again become one of the best timber-producing areas in the Levant.

Mining.-The asbestos mining industry is progressing steadily under considerable difficulties as regards labour and transport. During the year 417 tons of dressed asbestos were exported. It is hoped to increase production with the aid of improved machinery. Asbestos is present in practically unlimited quantities but the fibre is for the most part very. short, and the output does not in consequence possess a high market value.

Trade.-The value of imports during the year I910, exclusive of specie, was $£ 493,475$ and the value of the exports $f_{5} I I, 84 I$; an excess of exports over imports of $f_{1} 18,366$ whereas in 1909 there was an excess of imports over exports amounting to $\ell_{1} 30,643$ due to importations of flour and the partial failure of the cereal and carob crop. The imports from the United Kingdom represent 26 per cent. of the whole; the exports to the United Kingdom. 27 per cent of the total. The total number and tonnage of steam and sailing vessels entered and cleared in the foreign trade was 2,268 with a tonnage of 742,584 , being a decrease of 90 steamers, with 48,967 tons and an increase of 180 sailing vessels and 6517 tons.

Finance. - The revenue collected in $1910-$ II was $£ 286,848$ grant in aid $f_{40}, 000$, total $£ 326,848$. Expenditure $£ 251,521$, tribute $£ 92,799$, total $£ 344,320$. The excess of expen: diture over revenue was due to the fact that surplus balances of $f_{1} 17,670$ were drawn on to meet a special Forest Estimate of $£ 5000$, and a special Public Works Estimate of $£ 12,670$.

Political.-Major Sir Henry Hamilton John Goold-Adams, G.C.M.G., K.C.B., was appointed High Commissioner in succession to Sir Charles A. King-Harman, K.C.M.G., and arrived in October ror I to take over the administration.

On September 5, I9I I, the Legislative Council was dissolved and elections for a new council subsequently took place.

On May 27, I9I2, the troops had to be called out to quell a riot between Greeks and Turks. Four persons were killed, 80 wounded. No Englishmen were hurt.

In August I9I 2 a deputation from the Greeks of Cyprus conferred with the British Colonial Secretary and asked for administrative reforms, including an increased proportion of Greeks to Turks on the Legislative Council, and also for the abolition of the tribute to Turkey of $£ 42,000$ a year.

Several measures of local utility were passed during the session of Igro. Of the most important was the law providing for the registration of trade marks.

Education.-In 1910-II there were 583 primary schools, with 707 teachers and 30,779 scholars; an increase of 12 schools, 25 teachers and 1,203 scholars over $1909-10$. The average daily attendance, excluding harvesting time, is estimated at 26,910 . The schools were supported at an expense of $f_{1} 16,859$ raised locally by assessment, contributions from religious funds or individuals. The schools are apportioned amongst the following religious communities: Moslem (187); Greek Christians (387); Armenian (5); Maronite (4). The average attendance in Moslem schools was 4659, and in Greek Christian schools 22,1 59.

Public Health:-At the end of 1910 an outbreak of smallpox occurred but this was checked by vigorous measures of isolation and vaccination. Malarial fever was less prevalent than in former years, 6074 cases being returned as compared with 7450 in 1909 , and 10,476 in 1908. The hospitals of the islands show an all-round increase in attendance and admissions, and important improvements have been made. At the close of the year the inmates of the Leper Farm numbered 99 and their lot has been considerably relieved by a substantial increase to the grant allowed them by the government.

Climate.-The weather in Cyprus during 19 I I was extremely varied as regards heat and cold. Snow fell on the central plains and remained on the ground some days, an event which had not occurred for 13 years. The average rainfall over the whole island was 23.49 inches.

(A. BRuCE JACKSON:) 


\section{Malta ${ }^{1}$}

The civil population of Malta on April I, I9I2, was estimated at 215,332 , as against 2I 5,395 on the corresponding date of I9II. The total number of births in the two years was $72 \mathrm{II}$. The birth rate in $\mathrm{I}_{9} \mathrm{II}-\mathrm{I} 2$ was 33.49 as compared with $36 . \mathrm{I} 2$ per thousand in the previous year. The total number of deaths was 5286 , as compared with $46 \mathrm{ir} 2$ in I910-II. The death rate of the civil population in I9II-I 2 was 24.42 per thousand, as against 21.42 in $1910-11$. The general state of health in the island during the year was satisfactory, except for an extensive epidemic of measles and some cases of cholera. Cholera broke out in an encampment. which was formed to shelter refugees from the war in Tripoli. There were I 6 cases, 85 of which proved fatal. The preventive meașures taken were successful in stamping out the disease.

Agriculture.-The total area of land under cultivation in 19I I-I2 was 4I,866 acres, while the area of uncultivated land was estimated at 4707 acres. The total area under cereals was 13,444 acres. The total yield of cereals including wheat, barley and mischiato (a mixture of both) was 22,457 quarters. The area under beans and other pulse was 2004 acres, with a total yield of 3902 quarters. The area planted with potatoes was 4147 acres and the total yield was 448,454 cwts. Cummin seed was planted on 1594 acres. The total yield amounted to $\mathrm{ir}, 430 \mathrm{cwts}$. The total quantity of oranges, lemons and mandarines gathered is estimated at 176,000 dozen. The acreage of land under cotton was I I0O acres; the total yield was 187,340 lbs. The average price obtained was $6 \frac{\mathrm{k}}{4} \mathrm{~d}$ per $\mathrm{lb}$. The quantity exported was $122,04 \mathrm{I}$ lbs: of this $22,015 \mathrm{lb}$ were exported to the United Kingdom.

Finance and Trade.-The revenue for I9II-I2 amounted to $f 448,1 \mathrm{I} 4$ and the expenditures $f_{4} 67,783$. The total expenditure on the garrison (including Militia) was $f_{5} 1 \mathrm{I}, 649$. In $1910-11$ the expenditure was $£ 510,033$. The total declared value of goods imported, exclusive of bullion and specie and of goods imported for transhipment was $\{2,413,687$. The total declared value of goods exported (exclusive of transhipments) was $f 750,422$.

Shipping. - The number of British steamers which called during $19 \mathrm{II}-\mathrm{I} 2$ was 997 , tonnage $2,219,643$. The number of foreign steamers was 1427 , tonnage $1,871,595$.

Royal Commission.-In I9I a Royal Commission sat to enquire into the unsatisfactory economic condition of the island and as to the best means to restore its prosperity. The conditions show a financial deficit, a decline in the shipping trade and an increasing population above the economic capabilities of the island. Malta has suffered severely from the gradual reluction of the Imperial garrison, naval and military, since I9o 2 - a reduction which includes two battalions and six battleships. Morcover, the fleet has for the past few years been more or less frequently absent from Malta, and it is estimated that this absence means a loss to the island of at least frooo a day. On the whole the reduction of the garrison must mean a loss to the industries of Malta of not less than $f_{400,000}$ annually. The financial position is now such that while the government expenditure continually increases, the revenue diminishes.

In $\mathbf{I} 906$ when the Admiralty works were completed, the extra demand for labour which had arisen a few years before ceased and there began the growth of unemployment fron which. Malta is now suffering and which has been aggravated by a rapid increase in population. The former prosperity depended to a large extent upon Imperial expenditure in connection with the fortifications and military works and upon the expenditure of the garrison and the fleet. In 1905,9175 men were employed in the Naval establishment as compared with $518 \mathrm{I}$ in $19 \mathrm{IT}$, while the reduction of employment under the War department has also been considerable. The demand for Maltese lace has greatly fallen off in recent years, owing to the competition of machine-made lace, chiefly from Germany. It has been susgested that a government agency for the sale of genuine Maltese lace should be establisher.

The Commission, composed of Sir Francis Mowatt (chairman), Mr. Russell Rea, Sir Mackenzie Dalzell Chalmers and Mr. D. L. H. Baynes (secretary), emphasized in their report the fact that the difficulties, both financial and economic, from which Malta is at present suffering, can be traced almost entirely to the growth of her population without a corresponding increase in the means of subsistence, no alteration in the system of taxation or other measure serving as more than a temporary palliative. The Commission also refers to the density of population and the impossibility of providing adequate employment by the development of existing industries or by the introduction

1 See E. B. xvii, 507. 
of new ones. This condition is yearly intensified by the high birth rate, and thus the standard of living tends continually to fall and poverty to increase.

The Commission makes the following recommendations among others:- that in view of the importance of the agricultural industry to Malta this department should be developed and placed under an officer who would give his whole time to the work; that a committee should be appointed to conduct a thorough investigation into the expenditure of the government and to report what economies can be effected; that the scale and amount of expenditure on public works extraordinary should be cut down; that the annual contribution of $£ 5000$ paid to the Imperial government in aid of military services should be discontinued or that alternatively the island government should be authorised to charge a fair rent for all sites or buildings required by the Army or Navy for purposes other than fortifications; that the tax on imported grain should be reduced by half, the revenue thus lost being made up by increases in the duties on imported tobacco, beer, and sugar, and the liquor license duties, and by the imposition of a general ad valorem duty on imported articles at present untaxed; and that information with regard to opportunities for emigration should be made readily accessible.

Legislation:-Twelve ordinances were passed by the Council of Government during I9I I. The most important of these relate to the management and regulation of customs, the criminal laws and the manufacture of spirit and artificial wine in the island.

Education.- There are IOI day schools and 42 night schools. The enrollment in the day schools in September I9I I was I9,282. The night schools were attended by 2666 pupils. The strength of the teaching staff during the year was 766 . The total cost of the elementary schools was $£ 28,265$. An average of $I 75$ students attended the secondary school for girls. The average daily attendance in the secondary school for boys was 66 . The daily average number of students in the Lyceum was 484 . The average number of students who attended the University was 149 , as against 222 in the previous year.

On January 24, 1912, the islands were visited by King George V and Queen Mary, who remained from the 24 th till the 27 th and received an enthusiastic reception.

Climate. - The meteorological returns show a mean temperature for the year of $63.02^{\circ} \mathrm{F}$. The total rainfall was 24.230 inches. Earthquakes were felt locally on September. 30, October 16, and November $15 ; 1911$.

(A. BRUCE JACKSON.)

\section{BRITISH EAST AFRICA}

British East Africa comprises (I) the East Africa Protectorate; (2) the Uganda Protectorate, (3) the Sultanate of Zanzibar. The furst two are administered through the Colonial Office and in status closely approximate to crown colonies. The Sultanate of Zanzibar is a protected State, its affairs being supervised by the Foreign Office. The East Africa Protectorate by itself is popularly known as "British East Africa," but all three protectorates come strictly under the designation.

The East Africa Protectorate. ${ }^{1}$ - In IgI 2 the white population of the East Africa Protectorate was about 4,000; the Indian about 20,000 . The native population was estimated at 4,000,000. The period Igog-I 2 witnessed a great development in the Highlands, that part of the protectorate suited for permanent occupation by Europeans. The area so available does not exceed Ireland in size. Nairobi, the capital, had (IgI I) I 4,, 00 inhabitants ( 800 whites, 3,000 Indians). It contains handsome public and private buildings. A wireless telegraphy station was erected in I9I2. The whites are almost wholly engaged in agriculture, including dairy farming and stock raising. Sisal hemp, black wattle (for tanning) and coffee are the chief products. Wheat, barley, maize, vegetables and cotton are also cultivated. Besides cattle, sheep and pigs, there are ostrich farms. During I907-10, 62,000 acres of freehold and 1,718,000 of leasehold land were taken up; I, I4I, ,oo being for grazing. Large areas near the coast have been planted for coco-nuts, rubber, tobacco, \&c. The only mineral exploited is carbonate of soda, but coal was found in Igr i near the railway at Mackinnon Road Station.

Excluding government stores and specie exports rose in value from $f 515,000$ in $1907-8$ to $f 962,000$ in $1910-11$; imports (chiefly cotton goods, foodstuffs and agricultural implements) in the same period rose from $f_{799,000}$ to $f_{1}, 000,346$. In I9II $60 \%$ of the imports came from the United Kingdom or British possessions and Io \% from Germany. Of the exports

${ }^{1}$ See E. B. iv, 6oI et seq. 
$40 \%$, went to the United Kingdom; France, Germany and the United States taking nearly all the remainder in about equal proportions. The revenue rose from $£ 485$,000 in $1908-9$ to over $£ 700,000$ in $1911-12$. In the same period expenditure was approximately $£ 700,000$ each year. Up to 1912 grants in aid were made by the British treasury, the amount so found in I010-II being $f_{1} 130,000$. In 1912 the Protectorate became self-supporting.

Traffic on the Uganda railway increased very rapidly, as a result of the great agricultural development in Uganda as well as in the East Africa Protectorate. The total tonnage handled advanced from 60,000 tons in 1909-10 to 77,000 tons in $1910-1$ I and 100,000 tons in $1911-12$. In 1912 nearly half a million passengers were carried; double the number of three years previously. A new railway, 93 miles long, starting from the Uganda railway 282 miles from Mombasa was built in I9II-I2 to the Magadi Soda Lake, which lies towards the German frontier. It is owned by the company exploiting the soda, but worked by the government. Another railway $(30 \mathrm{~m}$. long) was built from Nairobi N.E. to the Thika river, opening up one of the best parts of the Highlands. The Imperial government made in 1912 a loan of $£ 750,000$ towards railway improvements and the provision of a deep water pier at Kilindini. On July 2, I912 Mr. H. A. F. Currie, C.M.G. (b. 1866), who had been manager of the Uganda Railway since 1903 , died. He was succeeded (in Oct.) by Mr. H. B. Taylor, Superintending Engineer, Indian State Railway.

The passing of ten years since the first settler (Lord Delamere, the 3 d baron) made the Highlands his home has proved that climate and soil admirably suit the European constitution. The bulk of the farm work is done by the Kikuyu, a race which has distinct aptitude for agriculture. The settlers were largely recruited from the upper and middle classes of England, and by the end of the decade the Highlands were furnished with churches, schools, roads, race courses, fenced farms and substantial farm houses, newspapers, etc.

Sir J. Hayes Sadler, the governor, was in July igog succeeded by Sir Percy Girouard. He achieved the somewhat difficult task of working in harmony with the white settlers, who chafed under crown colony administration and the long delays in obtaining land grants. In September IgI I the indignation of the whole white community was roused by the deportation of Mr. Galbraith Cole (a pioneer settler and brother-in-law of Lord Delamere) by order of the British Colonial Secretary. Mr. Cole, after vainly seeking protection from native stock thieves, shot dead a Kikuyu caught sheep stealing who attempted to escape. Tried at Nairobi for murder the jury had acquitted Mr. Cole without leaving the box. One result of this episode was an endeavour by the administration to afford the settlers better protection. On July I 7, I $9 I_{2}$ the resignation was announced of Sir Percy Girouard, who had accepted an offer to join the engineering firm of Armstrong, Whitworth \& Co., in England. Mr. H. C. Belfield, the new governor, who had served for 25 years in the Malay States, reached East Africa in October 1912.

Uganda. ${ }^{1}$ - The delimitation of the western and south-western frontiers of the Uganda protectorate, where they adjoin Belgian Congo and German East Africa, was completed in I912. As a result a large tract of country north of Lake Kivu was brought under British administration while that part of the protectorate west of Lake Albert was handed over to Belgium. The area of the protectorate is now given as II 7,68I sq. m.

At the I9I census the population was returned at $2,843,325$, including an estimate. of 378,000 for natives in districts not under administrative control. The European population was 640 (including 203 government servants and I 87 missionaries); Asiatics numbered 2,216 (chiefly traders and clerks). The increase in population, despite the ravages of sleeping sickness ${ }^{2}$ was testimony to the prosperity of the country. The Baganda (most of whom are Christians) totalled 558,000 , the Banyora, the next largest race, 270,000. Mengo had 32,44I inhabitants, Entebbe, on Victoria Nyanza, 9,569.

The years 1909-12 witnessed an unexampled development of cotton growing, the firm establishment of coffee plantations and a general expansion of trade. Besides cotton and coffee there is a large trade in chillies and in hides and skins, and in 1911 plantation rubber, as apart from wild rubber, first appeared in the export list. Wheat is grown in Toro and on the foot-hills of Mt. Elgon. The cultivation of the cotton is almost entirely in the hands of natives, the purchasing and collecting being the work mainly of Indians, while the ginning and exporting is done by European firms. In 1912, as the result of three year investigation, pure long staple varieties of cotton-"Sunflower" and "Allen's Improved" -

1. See E. B. xxvii, 557 et seq.

${ }^{2}$ By 1910 , in which year the deaths from the disease were 1,546 , sleeping sickness had bcen got under control. 
were substituted for the hybrids previously cultivated. The value of the cotton crop, $f_{41,000}$ in $1908-9$, was $£_{165,000}$ in $1910-11$ and over $£ 250,000$ in $1911-12$. The imports (merchandise only) rose in value from $£, 288,000$ in $1909-10$ to $\$ 347,000$ in $1910-11$, and exports increased from $£ 225,000$ to $£ 340,000$. In $1909-10$ revenue (including a grant in aid of $f_{103}, 000$ ) was $f_{268}, 000$; in $1910-11$ it was $£_{287}, 000$ though the grant in aid was reduced to $f 96,000$. The expenditure in the two years was $£ 240,000$ and $£ 252,000$.

The railway from Jinja, near the Ripon Falls, along the Victoria Nile was completed to

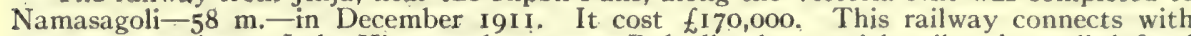
a steamer service on Lake Kioga and opens up Bukedi, where a rich soil and a well defined dry season provide exceptional opportunities for cotton growing. In I9I2 the Imperial parliament voted $£ \mathrm{I} 00,000$ for the provision of metalled roads suitable for motor traffic in this region. A railway from Port Bell to Kampala $(20 \mathrm{~m}$.), built 1912 , marked the beginning of a trunk line from the Victoria to the Albert Nyanza.

The Baganda continue to prove themselves a most progressive type of negro. Some 8,000 are in government service; over 32,000 of their children were in Anglican schools alone in Igrt. The native government is in the hands of Sir Apolo Kagwa, K.C.M.G., and two co-regents. The Kabaka (king), Daudi, was I6 on August 8, I9I 2.

In March Igr I Mr. F. J. Jackson, C.B., succeeded Capt. H. E. S. Cordeaux (who was appointed to St. Helena) as governor of Uganda. Jackson had played an important part in bringing Uganda under British protection and since 1889 had served continuously either in Uganda or in the East Africa Protectorate.

Zanzibar. ${ }^{\text {- }}$ The Sultan of Zanzibar, Ali bin Hamud, abdicated November I5, I9 I , and on December 9 th his son, Khalifa bin Harub, a child of six, was proclaimed Sultan by the British. Ali-bin-Hamud had been educated in Europe and he preferred the freer life and wider interests of Europe to his throne. The native administration is under the general control of the British Agent-Mr. Edward A. W. Clarke, who succeeded Mr. Basil S. Cave (appointed consul general at Algiers) in I909. Capt. F. R. Barton, C.M.G., is First minister to the council of regency.

The population of Zanzibar island at a census taken in I9ro was II4,069, that of Pemba being 83, I30. Zanzibar city had 35,262 inhabitants. The Arab aristocracylarge land-owners-number about 20,000; there are an equal number of British Indians and about 300 Europeans. The transhipment of goods to and from the mainland of East Africa and the growing of cloves are the main sources of wealth. The value of cloves exported in roro was $£ 253,000$, compared with $£ 330,000$ in 1909 . In I9II the crop was estimated at $£ 300,000$ Copra cultivation is increasing; the export in roro was $f_{2}$ I 9,000, almost double the figure for I 909 . Nearly all the other exports figure also as imports; they are goods in transit. Zanzibar has been to some extent replaced by Mombasa (British East Africa) and Dar-es-Salaam and Tanga (German East Africa) as the distributing centre for Indian and European goods. This is due to the extension of direct steamship communication between India and Europe and the mainland of East Africa, and to the establishment of equal rates of freights to Zanzibar and the coast town. The exports from Zanzibar to the mainland of East Africa, piece-goods, petroleum, rice, sugar, \&c. received from abroad and transhipped fell in the ten years IgoI-I gIo from $£ 574,000$ to $£ 348,000$. In the same period the value of goods received from the mainland decreased from $£ 34 \mathrm{I}, 000$ to $£ 242,000$. But Zanzibar retains its position as the chief city of East Africa in native estimation; and it remains the headquarters of the principal Indian merchants trading with East Africa, and the centre of the dhow traffic on the coast. The tonnage of vessels clearing the port in r 9 ro was 682,000 ; the external trade was valued at $£ 2,026,000$. The British proportion of the trade declined from $55 \%$ in 1908 to $47 \%$ in 1910 . Customs revenue in 1910 was $f_{107, \infty 00}$ the total revenue $£ 181,000$ and the expenditure $£_{1} 92,000$.

See the Colonial Office reports on East Africa Protectorate and on Uganda, and the Consular reports on Zanzibar; Lord Cranworth, A Colony in the Making (London, 1912); Ward and Miligan, Handbook of British East Africa (Nairobi and London, 1912); John Roscoe, The Baganda (London, I9II).

(F. R. CANA.)

${ }^{1}$ See E. B. xxviii, 957 et seq. 


\section{BRITISH SOMALILAND ${ }^{1}$}

During Igro the British troops were withdrawn from the interior of Somaliland. The arrangenents made for organising the tribes in the protectorate and providing them with arms for defence against the Mullah Mahommed-the "Mad" Mullah-led only to inter-tribal fighting and anarchy. The Mullah remained in Italian territory, and in October I 912 was officially reported to be suffering from an incurable disease.

The revenue for the years I909-I2 varied from $£ 30,000$ to $£ 32,000$; the expenditure, f192,000 in $1909-10$ (owing to military operations), had dropped in $1911-12$ to $f 74,000$. Deficits are met by grants. The trade was valued at $f 490,000$ in .1909-10 and $f 484,000$ in $1911-12$.

Gums (Arabic, myrrh, etc.), hides and skins, ghee, coffee and pearls are the chief exports. The decrease of trade between Zaila and Harrar continued owing to the competition of the railway from Jubiti. The pearl fisheries at Zaila increased in value. Berbera was placed in wireless telegraphy communication with Aden in I9II.

Mr. H. A Byatt, C.M.G., who became commissioner of the protectorate in I9I ; had served in Somaliland since 1905. 1912).

See the Colonial Office Reports, and R. E. Drake-Brockman, British Somaliland (London,

\section{NYASALAND ${ }^{2}$}

(F. R. Cana.)

The period 1910-I2 was one of prosperity in Nyasaland. The population in I9II was, natives 969,183 , (as against 927,355 in 1907 ), Europeans 766 , Asiatics 481 . The natives proved both peaceful and contented. Witchcraft and trial by ordeal were rendered illegal in 1911 . Sleeping sickness slowly extended despite every effort to arrest it. The spread of the tsetse fly involved the closing of many roads to animal transport. This difficulty is being met by the construction of metalled roads along which motor vehicles can ply, but of the 3,156 miles of road in the Protectorate in I9II, only 23 miles-between Blantyre, the chief commercial centre, and Zomba, the administrative capital-were macadamised.

The external trade of the Protectorate in 1910-1 I amounted to $£ 368,000$ and in 191 I-12 to $f 446,000$. To the United Kingdom in $1911-12$ went produce valued at $f 179,000$ and from it came goods valued at $f_{194}, 000$. The cultivation of coffee, at one time Nyasaland's staple product, gradually diminished since I 899-I900. In 1909-10 the export of coffee was valued at $f_{15}, 500$; in $1910-1$ I it had dropped to under $f_{7,000}$. In $1911^{-12}$ it rose to f 16,000 , a temporary increase due to exceptionally suitable weather conditions. Cotton $(£ 59,000)$ was the chief export in I9IO-II, having more than doubled in a year. Owing to late export of part of the crop there was a drop in I9I I-I 2 to $f 58,000$. Tobacco exports were $£ 42$,000 in I9IO-I I and $£ 53,000$ in I 9 II-12. Rubber exports in 19 II-12 were $£ 10,000$.

A great obstacle to the expansion of trade was the inadequate communication with the outer world, due to the persistent diminution of water in the lower Shiré so that steamers ascending the Zambezi were frequently unable to reach Port Herald, whence a railway runs to Blantyre. During 1912 the Imperial Government arranged to extend the railway south from Port Herald to the Zambezi; the line to be continued eventually to Beira. In October 1912 the Portuguese government signed a contract with a Belgian group of financiers for the building of the part of the line from Beira to the Zambezi.

The revenue of the Protectorate was $f_{94,980}$ in I910-II and $f_{97,356}$ in I9II-I2. Ex. penditure was $£_{112}, 369$ in $1910-11$ and $£_{11} 8,070$ in $1911-12$. Deficits are made good from the British treasury. The institution in 1911 of a land tax of one halfpenny an acre per annum on all lands held by non-natives became a valuable source of revenue. The tax on native huts was raised in I9I I from 35 to $4 \mathrm{~s}$ and from $6 \mathrm{~s}$ to $8 \mathrm{~s}$ for "low and high" grades respectively. The tax yielded in $1911-12 \quad\{50,900$.

Sir Alfred Sharpe (b. 1853), who had served in official capacities in Nyasaland since I891, and had governed the Protectorate since 1897, retired in 1910. He was succeeded by Sir W. H. Manning (1. 1863), the officer who raised the Central Africa regiment and commanded the Somaliland Field Force in $1902-3$ (see F. B. xxv, 382a), and who from January to November I9Io was Commissioner of that Protectorate.

(F. R. CANa.)

\section{MAURITIUS ${ }^{3}$}

The population of Mauritius at the census of I9II was 368,791 , a decrease of 2,232 compared with 1901. Males exceeded females by 22,000. Port Louis, the capital, had a pop. of 50,060, a decrease of 2,680. As Mauritius has an area of only 716 sq. mile:; the density of population-5I4 per sq. mile-is one of the greatest in the British Empire: Indian immigrants and their descendants constituted about $70 \%$ of the total population, while the negro type had almost disappeared. The dependencies had 6,690 inhabitants in 1911; Rodriguez, the largest (area $t^{2}$ s(1. miles), had a population of 4,829 .

Mauritius continues to yield practically nothing for export besides the products of the

1 See E. B. xxv, 381 .

¿See E. B. iv, 595 et seq. ("British Central Africa").

${ }^{3}$ See $E . B$. xvii, $913 \mathrm{el} \mathrm{seq.}$ 
sugar cane. Moreover it produces little else for home consumption. Dependent on a single industry, the colony suffers when that industry is depressed. Owing to the high price fetched by sugar the colony during 1910-12 attained however a sounder position than it had held for years. The value of imports in 1909 was $\ell_{1}, 800,000$; in 19 lo it had increased to $\{2,333,000$. Exports in 1909 were valued at $£ 2,295,000$ and in 1910 at $£ 2,435,000$. About $79 \%$, of the total imports came from the United Kingdom and British Possessions, to whom went nearly $99 \%$ of the exports.

The sugar crop of I9IO-II, exclusive of sugar for local consumption, was 214,372 tons (metric) as compared with the "record" I909-I0 crop of 246,560 tons; the value was $£ 2,000$,000. Over 144,000 acres, one-third of the whole area of the island, were in 1910 under sugar cultivation. There were at the same time sixty-two sugar factories working. : The colony's three largest customers for sugar were in I910: British India, 146,510 tons (metric); the United Kingdom, 47,3 I6 tons, and Cape Colony, I9, I37 tons. Great improvements have been made in the manufacture, and steam ploughs have been introduced for work in the cane-fields, but much of the land under cultivation is rocky and hand labour has not been superseded. Aloe-fibre and vanilla are the only other exports of any note. Imports of tea have increased considerably, although locally-grown tes has been found very satisfactory, and nearly $t_{60,000}$ worth of culinary oils, etc., was imported in 1910 notwithstanding that the soil and climate are eminently suited to the cultivation of oil-bearing plants and trees. Experiments in the cultivation of cotton have been made.

The revenue for the financial year I909-10 was $f 720,000$, considerably exceeding that of any previous year. The expenditure was $£ 630,000$. In I9I0-II the revenue was $£ 742$,000 , and the expenditure $£ 638,500$. The net debt of the colony in I9I I was $£ \mathbf{I}, 296,000$.

Sir Cavendish Boyle (b. I849), after serving as Governor of Mauritius for eight years, retired in 1911. He was succeeded by Major John Robert Chancellor (b. 1870), an officer who had served with distinction in the Tirah Expedition (1897-98) and in other campaigns, and who had been Secretary to the Imperial Defence Committee.

See A. Walter, I01 I Census Report (Port Louis, 1912); and Report of the Mauritius Royal Commission (Cd. 5186 ) issued in I9I0, a valuable guide to the economic condition of the colony.

\section{SEYCHELLES 1}

The population of Seychelles at the I9I I census was 22,69 I (I48 per sq. m.) of whom only 2,159 were not born in the islands; the increase in ten years was 3,454 , or I 8 per cent. 85 per cent are Roman Catholics.

The value of exports in I III fell to $£ \mathbf{I} 26,867$ from fI 149,467 in Igro and imports were $f 90,126$ as against $£ 98,460$ in the previous year. The United Kingdom and British Possessions took about a quarter of the total. France, with purchases to the extent of $£ 47,000$, was the colony's best customer. The chief article of export was copra, valued at $£ 5 \mathrm{I}, 000$, guano $(£ 43,800)$ coming second. It is estimated that at the present rate of exploitation the supplies of guano will not last beyond 1920. Vanilla $\left(f_{1} 5,533\right)$ was spoilt by unseasonable rainfall, and the crop was one of the smallest on record since 1907, when the value of the harvest was nearly $£ 67,000$. Cinnamon bark comes fourth on the list; the trees were introduced during the French rule about $\mathbf{1 7 7 5}$, but their cultivation was abandoned almost immediately and the trees spread through the forest and were neglected until I 908 . A ton of tortoise shell was exported to London and Paris. Experiments have been made in the rearing of young turtles from the eggs in enclosed areas. The turtles grow more quickly in confinement and the weight of the shell is proportionately greater. Most of the imports came from the United Kingdom and British Possessions, the total for 191 I being $£ 74,067$ as against $f_{1} \mathrm{6}, 047$ from other countries. The chief import was rice, which India supplied to the value of $f \mathbf{I} 6,333$. Methods of agriculture have been improved, and coco-nut plantations in particular show the results of more scientific treatment. Many thousands of seedlings have been planted out from the seeds of rubber trees growing in Seychelles, and in $191 \mathrm{I}$ rubber appeared for the first time as an export.

The revenue in 1911 was $f_{3} 6,333$ and the expenditure $f_{34}, 133$.

In October I912 Mr. W. E. Davidson (b. I 859), who became Governor of Seychelles in 1904, was appointed Governor of Newfoundland, and Lieut-Col. C. R. M. O'Brien (b. I859), Colonial Secretary of the Gambia (who had served with distinction throughout the AngloBoer War 1899-I903); was: made Governor.

(F. R. Cana.)

\section{BRITISH WEST AFRICA}

In West Africa the British colonies and protectorates form separate governments directly dependent upon the Colonial Office in London. They are (I) the Gambia; (2) Sierra Leone; (3) the Gold Coast, with Ashanti and the Northern Territories; (4) S. and N. Nigeria. In every part of British West Africa the outstanding features of the period I9Io-I 2 were practically unbroken public peace and a remarkable development of trade

1 See E. B. xxiv, 751 et seq. 
and improvement of means of communication. But the need of securing the natives in the unfettered enjoyment of their lands, as a condition necessary for the permanent prosperity of each of the colonies and protectorates, led to the appointment (June 26, 1912) of a Committee by the Colonial Secretary (Mr. L. Harcourt) to consider the laws relating to the transfer of land in British West Africa, with a view to seeing how far it was feasible to extend the system adopted in N. Nigeria, where the whole of the country is held in trust for the native inhabitants. Sir Kenelm Digby was appointed Chairman of the Committee, whose members included Sir F. M. Hodgson, an ex-Governor of the Gold Coast, and Mr. E. D. Morel, well known for many years' persistent advocacy of native rights on the Congo and elsewhere in tropical Africa.

Gambia. ${ }^{1-}$ The census taken in igr I showed that the population of the Island of St. Mary at the mouth of the Gambia, on which is built Bathurst, the capital, was 7,700 , compared with 8,807 in 1901 . The population of the protectorate, mainly Jolloff and Mandingo, was 138,401 , or 15,000 fewer than was estimated for 1907 . In I $91 \mathrm{I}$ for the third successive year the revenue $(£ 86,454)$ exceeded previous records, the expenditure being $£ 7 \mathrm{I}, 390$. In 1910 , for the first time, the value of the trade reached over a million sterling, the figure being $£_{1}, I_{34}, 460$; and in $191 \mathrm{I}$ it rose to $£_{1}, 499, \infty 00$, imports being valued at $£ 807,000$ and exports $£ 682,000$. The ground-nut industry is the main occupation of the people, and while it continues so lucrative the efforts of the Administration to widen the basis of prosperity meet with little success. In the five years I907-I I the value of the crop varied from $£_{245,000}$ to $£ 437,000$ (IgI I tonnage $47, \infty 00$ ).

Consisting of a narrow strip of land on either side of the lower Gambia the protectorate is hemmed in by French West Africa, and the commerce( though not the shipping) is largely in the hands of French firms established at Bathurst. The trade in ground nuts is almost wholly with France, and in I 91 I 84.8 p.c. of the exports (excluding specie) went to France and her Colonies. The British Empire took 6.3. p.c. and Germany 5.6. p.c. France had also about 45 p.c. of the import trade, Great Britain coming next with about 30 p.c.

In September 19I I Sir George Denton (b. 185I) who had administered the Gambia for nearly eleven years, retired. He was succeeded by Col. Sir H. L. Galway (b. 1859).

See H. F. Reeve, The Gambia (London, 1912), an excellent monograph by a retired official; Sir G. Denton, "Twenty Three Years in Lagos and the Gambia," Inl. African Soc., Vol. xi (1912); and the Annual Reports issued by the Colonial Office.

Sierra Leone. ${ }^{2-B y}$ a treaty with Liberia signed on the 2 Ist of January I9I t, the south-eastern district of Sierra Leone lying south of the Morro river was ceded to the Republic in exchange for the district of Kanre Lahun (see map in E. B. xi, 204). Immediately north of the Anglo-Liberian frontier the Anglo-French boundary underwent a modification (exchange of notes July 6, 19II), resulting in the transference to Sierra Leone from French Guinea of a narrow strip of territory with an area of $125 \mathrm{sq} . \mathrm{m}$. The census of I II I gave the population of the Colony at 75,572, while that of the Protectorate was estimated at $1,327,560$. The figures for the chicf tribes were: Mendi 442,000 , Sherbro 107,000, both pagan; Timini 347,000, Limba I10,000, Konnoh 61,000, the last. three Moslem (more or less). The European population was 650 (as against 309 in i ()or), while the Syrians (who have obtained a considerable share of the petty trade of the country) had increased from 47 in Igor to 175 . Freetown, the capital, and one of the finest ports in West Africa, had a population of 34,09o. There has been a general increase both in commerce and in agriculture, but the primitive and wasteful methods of farming adopted by the natives are leading to the disappearance of the dense forest land; -with unfortunate results, especially on the mountain slopes and tops, where in two years virgin forest may be turned into bare rock (see "Forestry" by Mr. G. B. Haddon Smith in the Colonial Office report on Sicrra Leone for I910.) The first step towards the reservation of forest land was made in igt 1 .

The commercial prosperity of Sierra Leone continues to be bound up with the products of the oil palm-constituting 72 p.c. of the domestic exports in 19II. Next in importance comes the Kiola nut, a universal article of diet among the natives of West Africa; scarcely any of the nuts reach Europe. In the five years 1907-II, the value of the exports rose from $f_{831}, 000$, to $f 1,300,000$; that of the imports from $f_{9} 88,000$ to $\ell_{1}, 267,000$. The total revenue for the same peried increased from $£ 359,000$ to $£ 457,000$, the corresponding figures for ${ }^{1}$ See E. B. xi, 437 et seq. ${ }^{2}$ See E. B. xxv, 54 et seq. 
expenditure being $£ 345,000$ to $£ 432$,000. At the close of 19 I 1 the colony had a funded debt of $\{1,255,000$. Great Britain's share of the import trade in I9I I was $75 \%$; of the export trade $24 \%$. Germany ranks first $(30 \%)$ in the export trade, as a result of the gravitation of the palm kernel trade to Hamburg, where there are large factories with the most modern machinery for extracting the oil from the kernels and making use of the waste products. The shipping. statistics for I9I I showed a total tonnage of $I, 246,000,68 \%$ being British, compared with a tonnage of 993,000 in 1910 when the British percentage was $77 \%$. The German tonnage rose from 13.55 in 1910 to 18.67 in $191 \mathrm{r}$.

The expansion of trade depends largely on opening up new oil palm districts, and as the tsetse fly renders animal transport impossible attention is directed to other means of locomotion. A branch line ( $90 \mathrm{~m}$. long) from the main railway, begun in 1910 and completed in 1912 , runs northward from Boia (S.E. of F reetown), and crossing the Rokell river reaches Makene, the centre of one of the richest palm belts in the country. The opening up of the Hinterland by "feeder roads" also continues. A notable feature in the history of the country is the spread of Islam, coupled with a general desire for education. During I9II-I 2 a Government Model School was built at Freetown. In districts where Moslem influence is strong a high degree of sobriety and of amenability to good order prevails.

The visit of the Duke of Connaught to Freetown in December 1910, was an event of more than ceremonial importance. There were present from the Protectorate chiefs of many tribes which had fought hard against British dominion, and the cordial manner in which they were received by the uncle of King George has been told in every corner of the country. In April I9I I Sir Edward Marsh Merewether (b. 1858), formerly Lieut. Governor of Malta, became Governor in succession to Sir Leslie Probyn, transferred to Barbadoes. By the death of Dr. E. W. Blyden, at Freetown on February 7, 1912, at the age of 80 , the British Empire lost a distinguished negro scholar and official (see $E . B$. xxv, $56 \mathrm{~d}$; and xvi, $54 \mathrm{Id}$ ).

See the annual reports on Sierra Leone issued by the Colonial Office; J. T. Aldridge, "Sierra Leone and its Commercial Expansion," United Empire, Vol. 2, I9II; Major R. G. Berry, "The Sierra Leone Cannibals," Proc. Ryl. Irish Assn., 1912.

Gold Coast. ${ }^{1-}$ The census of I9I I gave the total population of the Gold Coast, Ashanti and the Northern Territories as $1,503,386$ equal to 18.7 per square mile. 'The number in the Gold Coast proper was 853,766, in Ashanti $287,8 \mathbf{r}_{4}$, in the Northern Territories, 361,806 . In all there were 1,625 Europeans. The increasing prosperity of the Gold Coast is shown in the returns of trade and revenue, in the absence of inter-tribal disputes, in the development of agriculture, and in marked improvement in sanitation.

The revenue for the financial year I9II, which amounted to $f$ I, I II,000, surpassed that of all previous years, and exceeded the expenditure by $f_{1} 197,000$. The revenue in 1910 had been $f_{I}, 006,000$ and the expenditure (including $f_{\mathrm{I}} 49 ; 380$ repayment of loans) $f_{924 ; 862}$. The public debt on December 3I, I9II, was $\{2,489,000$. The value of the seaborne trade increased from $f 5,049,000$ in 1909 , and $f 6,137,000$ in 1910 , to $£ 7,576,000$ in 1911 . The

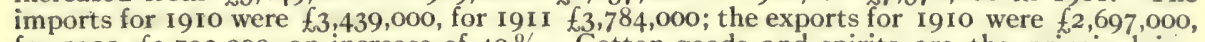
for $191 \mathrm{I} \cdot\{3,792,000$, an increase of $40 \%$. Cotton goods and spirits are the principal imports; the Gold Coast in addition imports much machinery and lumber for the mines. Cocoa, gold, rubber, and palm oil and kernels are the chief exports. The cocoa industry, which is entirely in native hands, has had a great development. In the two years I910-II the export was almost doubled in quantity and more than doubled in value. The figures for the three years I909-II were: I909, quantity $45,277,000 \mathrm{lbs}$, value $f 755,000$. I9I0, quantity $50,692,000 \mathrm{lbs}$., value $£ 866,000$; I 9 I I, quantity $88,987,000 \mathrm{lbs}$, value $£$ I $, 513,000$.

The gold mining industry is firmly established. The value of the gold mined during the first ten months of 1912 was $\ell_{1}, 215,000$ as against $\ell_{1}, 069,000$ for the whole of 1911 , which was itself an increase of $£ 3$ I 3,000 over the figures of 1910 . The mines of the Ashanti Goldfields Corporation export nearly half the total yield. About 20,000 natives are employed in the mines or in dredging the river beds for alluvial gold, $15 \%$ of the gold being obtained from alluvium. Besides cocoa and gold, rubber, lumber and oil palm products are the chief exports. Some $80 \%$ of the total trade is with the United Kingdom; but Germany has a large share of the shipping, the tonnage of the German ships cleared in I9I I being 438,000, British ships 773,000 and French ships $113,000-$ the total tonnage being $1,326,000$,

Sir John Pickersgill (185I-1910), who had been Governor for seven years, retired in September r9ro, and shortly afterwards died in England. He was succeeded by Mr. J. J. Thorburn - who had previously. served in Ceylon and Lagos. Mr. Thorburn retired from the Colonial service in August rg12, and Sir Hugh Clifford (b. I866), then Colonial Secretary of Ceylon, was appointed Governor. During I9I , Sir William Brandforth Griffith, Chief Justice since 1895, who had done much to codify the colony's laws, retired and was succeeded by Sir P. C. Smyly, Chief Justice of Sierra Leone.

1 See $E . B$. xxi, 203 et seq. 
A new and valuable direction has been given to education by the adoption of a combined system of literary and technical instruction in every Government assisted primary school. A Government Training Institution for teachers and a Technical School have been opened at Accra. The new system has the cordial co-operation of the missionary societies, on whom has fallen hitherto the bulk of the burden of education.

The history of Ashanti ${ }^{1}$ has been one of marked development. Much of the success of the administration is attributable to the wise guidance of Mr. F. C. Fuller, Chief Commissioner since 1905. The Ashanti and allied tribes, having a comparative high mentality, have adapted themselves more readily than was expected to the changed conditions following the establishment of British rule, and have become keen agriculturists-cultivating cocoa, rubber and kola nuts. The town of Kumasi (pop. 18,853 in $19 \mathrm{rr}, 93$ being Europeans and 23 Syrians) is a great trade centre and contains many handsome buildings, some of them owned by Ashanti chiefs. Christianity is making progress-the Christian population in I 9 I I was 6,000 -while Islam finds few converts.

In the Northern Territories of the Gold Coast-an open park-like country for the most part-there is a marked improvement in the condition of the people, the last tribe to dispute the authority of the British-the Zouaragu-having been subjugated in I9ro. The protectorate is purely agricultural and pastoral; the chief exports, which are sent mainly to Kumasi, being live stock, shea butter, and dawa dawa. A small amount of cotton is raised. The energies of the Government have been largely directed to establishing and maintaining the legitimate authority of the chiefs, the country formerly being in an anarchical condition when each man did what was right in his own eyes.

See the Annual Reports on the Gold Coast, on Ashanti, and on the Northern Territories, published by the Colonial Office, London; Major F. G. Guggisberg, "Mapping the Gold Coast and Ashanti" in Trans. Liverpool Geo. Soc., I9I0; Mary Gaunt, Alone in West Africa (London, 1912); J. A. Barbour James, The Agricultural and Other Industrial Possibitities of the Gold Coast (London, 1911); L. P. Bowler, Gold Coast Palaver, London, 1911).

Nigeria. ${ }^{2}$ - The unification of the protectorates of Southern and Northern Nigeria was decided upon early in I912. Sir Frederick Lugard (E. B. xvii, I I5) was selected as Governor of both protectorates, succeeding Sir Walter Egerton in S. Nigeria and Sir Hesketh Bell in N. Nigeria. Sir Frederick (whose appointment was gazetted on May I 7 th) did not arrive in Nigeria till October I912. In both protectorates there was a marked development of trade in the period $1910-12$, while the social condition of the people underwent rapid changes. The only part of S. Nigeria not brought under administrative control by the middle of 1912 was a small area in the N.E. corner inhabited by Munshis, a wild pagan tribe.

The population of Nigeria is approximately r 8,000,000, of whom 2,400 are Europeans. The census of I9I I gave S. Nigeria 7,858,689 inhabitants; and $\mathrm{N}$. Nigeria 8,1 I0,63 1 , but $9,270,000$ is considered a more accurate figure for the northern protectorate. The pop. per sq. m. is 98 in S. Nigeria and about 40 in N. Nigeria. Yoruba numbers about 2,000,-

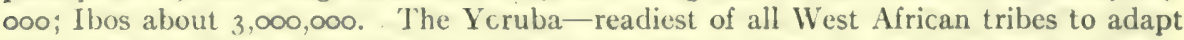
themselves to Western civilisation-inhabit the Western Province of S. Nigeria, through which the railway from Lagos to the Niger passes. Their chief towns are Ibadan (pop. 175,000, in I911), Ogbomosho (80,000), Abeokuta (51,255), Oshogbo (59,821). In contrast to the Western Province, where Yoruba is practically the only language, the census of Ior r revealed in the Central and Eastern provinces of S. Nigeria 57 different languages with 82 distinct tribes. In N. Nigeria two to three hundred different languages are spoken, Hausa being the widest spread. The only towns of more than 30,000 inhabitants in N. Nigeria are Kano $(39.368$ in roI I) and Ilorin $(36,343)$.

In $\mathrm{S}$. Nigeria the energies of the administration were chiefly concentrated on sanitation, the clearing of the network of waterways which form the Niger delta, the building of roads, and the putting down of inter-tribal disputes. At Lagos, the capital (pop. 73,766 in IOII), great harbour works were begun to enable steamers dra vir.g $24 \mathrm{ft}$. to lic alongside the quay. Large areas of swamp land have been reclaimed at Lagos and

${ }^{1}$ See E. B. ii, 724 et seq. ${ }^{2}$ Sce E. B. xix, 677 et seq. 
Forcados (pop. 3,189), the port for steamers ascending the Niger. Throughout Yorubaland increased attention has been paid to education-several technical schools being established,-and there is springing up a group of intelligent, thinking men, born and educated in Southern Nigeria, who are imbued with love of their country and are devoting themselves to its service. In the Hausa States and Bornu in N. Nigeria-as among the Yoruba in S. Nigeria-the administration rules through the native governments. The establishment in Igr of a Beit-el-Mal.(State Treasury) in all the Hausa Emirates was an important step towards securing purity in the public services. From the Beit-el-Mal the native judges and other functionaries receive fixed salaries. At the same time the Emirs were given civil lists in lieu of depending upon what share they could get from the imposts levied on the people. The Land and Native Rights Ordinance, IgII, established the system of native land tenure on an inalienable basis.

Nigeria, with 80,000 sq. m. of dense forest, still depends mainly upon its sylvan products, but since 1910 its mineral resources have leapt into importance. The mineral survey of S. Nigeria revealed the existence of lignate at Asaba, $15 \mathrm{~m}$. W. of the Niger, and of enormous deposits of coal at Udi, some $50 \mathrm{~m}$. E. of the Niger at Onitsha. A survey for a railway to connect the Udi coalfield with Onitsha was made in 1912. In N. Nigeria the exploitation of the tin fields in the province of Bauchi attained large proportions. Mining, which began in a small way in 1902 , attracted little attention till 1909 . Since then over $f 3,000,000$ capital has been invested in the field, which is alluviat and covers some 2,500 sq. m. Exports of tin ore rose from $£ 38,000$ in 1909 to $f 72,000$ in 1910 , and $f_{181,000}$ in 1911 . In that year $\mathbf{I}, 470$ tons of tin were exported; from Jan Ist. to July 3I, I9I2 the export was I,489 tons (value not stated). In October I9I2, the Colonial Office announced that pending a systematic survey of the tin mining area no mining leases or prospectnig licences would be granted to new applicants. ${ }^{1}$ Rich reefs of galena carrying a considerable silver return have been found in the province of Muri, along the middle Benue.

The completion of the railway from Baro to Kano in March I9II, proved a potent factor, not alone in the development of trade, but in its influence on native life and thought. In the first year of working the receipts on the Baro-Kano railway came to about $£ 70,000$. The railway is $3 \mathrm{ft} .6 \mathrm{in}$. gauge and 356 miles long. In 1911 also the railway from Lagos was extended till it joined the Northern Nigeria line at Minna (250 miles from Lagos), the Niger being bridged at Jebba. A $2 \mathrm{ft} .6 \mathrm{in}$. gauge railway was built in 19 I I from Zaria, on the main line, eastward to Rahamma, at the foot of the Bauchi Plateau and $40 \mathrm{~m}$. W. of Naraguta, the headquarters of the tin field. It is $90 \mathrm{~m}$. long and cost $f 2,000$ a mile, Like the other Nigerian railways it is State owned and State worked.

During I909-I I the volume of trade passing through S. Nigeria rose from $£ 8,600,000$ to fro, 588,00o, excluding the goods in transit to Porto Novo in Dahomey. In I9I0, 5546,000 , and in I9II, $\_726,000$, of the total was credited to $\mathrm{N}$. Nigeria as the value of imports and exports by commercial firms. Palm kernels, valued in I9I I at $\{2,574,000$, and palm oil $\left(f_{1}, 696,000\right)$, were the chief exports. Rubber and cocoa were next in importance. The export of cocoa in I9I I $(9,858$,000 lbs.) showed an increase of $50 \%$ over I9IO; its value was $f_{1} 64,000$. Cotton, despite fluctuations in the crops, gave promise of expansion. Cotton cultivation for export also progressed in Northern Nigeria. Up to 1912 the price fetched by native cotton for local manufacture exceeded one penny per lb., the highest price offered by the British Cotton Growing Association. From N. Nigeria the chief exports during I9IO-I2 were palm kernels, shea nuts, rubber, gum and tin. The bulk of the trade of Nigeria, as also the shipping, is in British hands, though increasing competition is being met with from German and French firms.

In I9I I the revenue of S. Nigeria was $f_{1}, 956,000$, the highest on record. Of this $f 975,000$ was derived from duties on imported spirits, and $f 307,000$ ( $f I 30,000$ net profit) was railway revenue. Expenditure was $£_{1}, 717,000$. On March 31 , 1912, the public debt of $S$. Nigeria was $£ 6,47 I, 000$. A loan of $f 5,000,000$ was floated in 1911 , calls to the end of the year being $f 3,223,000$. In $N$. Nigeria in the financial year 19I0-II the total local revene was $\ell^{275,000}$ compared with $f_{178,000}$ in $1908-9$. In $1911-12$ it was $£ 545,000$ (including a sum of $f_{1} 196,000$ on account of native local administration, the corresponding sum not being shown in the $1910-11$ statement). The expenditure in I910 was $f 565,000$, compared with $f 540,000$ in $1908-9$. In 191 I-I2 it was $f^{2} 7,000$. In $N$. Nigeria the importation of trade spirits is forbidden and the chief source of revenue is the land tax-in reality a pro rata property tax-which increased from $f_{124}, 000$, in $1908-9$ to $f_{2} 17,000$ in $1911-12$. (The land revenue is really double the figures given, one-half the amount collected being retained by the native government for local needs.) Deficits on the N. Nigeria revenue were met by grants in aid from the Imperial government, and as to $£ 70,000$ from the S. Nigeria treas-

${ }^{1}$ In some districts the presence of prospectors was resented. Mr. Campbell, a mining engineer, was murdered in June 1912 at Ninkada, Nassarawa province, by Mada pagans against whom a small force was sent, the Mada sustaining about 180 casualties. 
ury. The revenue of the Beil-el-Mal amounted to over $£ 200,000$ in the first year of its institution. In N. Nigeria in the Moslem regions (i.e. the Hausa States and Bornu) are government schools where purely secular education, including crafts and agriculture, is given. Hausa is taught in Roman characters. As among the Yoruba and the Beni of S. Nigeria the chiefs in N. Nigeria are keenly interested in the schools.

See Capt. C. W. J. Orr, The Making of Northern Nigeria (1911); E. D. Morel, Nigeria: Its Peoples and Its Problems, (I9I I); Major A. J. N. Tremearne, The Tailed Head Hunters of Nigeria (1912); C. L. Temple, "Northern Nigeria," in Geog. Jnl. (Aug. 1912); Prof. Wyndham Dunstan, Southern Nigeria: Mineral Survey (Colonial Reports, miscellaneous nos. 8I and 83); J. D. Falconer, The Geology and Geography of N. Nigeria (I9I I) and On Horseback Through Nigeria (1911); A. F. Calvert, Nigeria and Its Tin Fields (1912) and The Nigerian Tin Manuel (1912); Colonial Office Annual Reports on S. and N. Nigeria; S. Nigeria Census Reports 1911 (Lagos, 1912).

\section{St. Helena ${ }^{1}$}

The population in I9I I was 3,520 ( 1,658 males; I,862 females). Revenue (I9I0) $£ 9,306$ (including a grant-in-aid of $f 2,500$ from the Imperial Exchequer); (I9II) $f 8,622$. Expenditure (1910) £9,596; (I91 I) $£ 9,129$. The Government flax fibre mills have been working only intermittently; having been opened in 1907 they were closed in 1910 , the supply of leaf being exhausted, and they have remained so since, except during a few weeks. There is a lace school, but it does not support itself. Jamestown was visited by 5 I ships in 1910 and 64 in 1911. On October 24, 1910, H.R.H. the Duke of Connaught visited the island, no member of the Royal Family having done so since the Duke of Edinburgh in 1860 . Capt. H. E. S. Cordeaux, C.B., C.M.G., became governor in 191 I in succession to Lt.-Col. Sir H. L. Galway, K.C.M.G., transferred to Gambia.

\section{Falkland Islands ${ }^{2}$}

According to the census of I9I r, the population, including South Georgia, was 3,275. The large increase since Igor (pop. 2,043) is due to the development of the whaling industry. The population in rgr I was thus distributed:-East Falklands and adjacent islands, r,608; West Falklands (including New Island), 664; South Georgia (including a shipping population of 563 ) I,003-in I901 it was uninhabited.

The average number of births during 1908-1912 was 52 and of deaths 18 . The average density of population was:- Falkland Islands (6,500 sq. miles) 34; South Georgia (1000 sq. miles) 1,003. The total number of males and females was 2,370 and 905 respectively; or an average of only 38.2 females to every 100 males. The small population of females is due to the large number of men engaged in the whaling industry. In the statistics relating to religious beliefs 1,82 I persons are returned as belonging to the Church of England, 769 as Lutherans and 63 as Baptists. Of the total population 2,107 were returned as British subjects; 13 of these being naturalised. Of the I,093 foreigners 980 were natives of Sweden and Norway, the majority of these being engaged in the whaling industry.

With the exception of small government reserves the whole of the land of the colony is in the hands of sheep farmers. Closer settlement is thus rendered impossible and in spite of the high wages paid for labour there is no opening for new settlers. About one-fifth of the colony is composed of peat, but nothing has yet been done to develop it.

The rainfall registered at Port Stanley during $191 \mathrm{I}$ amounted to 37.06 inches as compared with 27.68 inches in 1910.

Industries.- Sheep farming and whaling continue to be the principal industries. The number of sheep in the colony during 19 II was 706,170 , which is 18,566 less than in 1910. The number of sheep slaughtered in I9II was 76,3 I5 as against 69,704 in the previous year. This increase is partly due to the establishment of two mutton-canning factories, capable of dealing respectively with 600 and 300 sheep daily. They began work in 1910 , employing 100 men and producing 25,000 tins of preserved meat.

Whaling round the Falkland Islands was not so successful in I9II as in former years, one company producing only a total of 7,400 barrels of oil and 50 tons of whalebone. In the dependencies, however, the whaling industry has developed rapidly and appears to be. rivalling sheep-farming as the mainstay of the colony. In South (ieorgia eight companies, are now established and employ rono men in their factories ashore and afloat. During: the I9I0-I I whaling season oil and guano were produced worth $£ 534,715$. The South Orkneys and the Sandwich Islands were each visited by one company, and ten companies held li.cences for the South Shetlands and (iraham's Land. The total catch from these dependencies was 156,770 barrels of oil and 400 tons of whalebone, together worth over $£ 468,500$. The total value of the products during IgII was $f I, 026,415$. The export of whale oil in 1911 was 13.174 tons, valued at $£ 270,762$, more than double the export in 1910 .

Trade is expanding steadily. The exports during 1911 amounted to $£ 471,156$ as co-m

See E. B. xxiv, 7 .

${ }^{2}$ See $E, B, \mathbf{x}, \mathbf{1 5}$. 
pared with $f 308,930$ in 1910. The imports were valued at $f 93,913$ as against $f 94,294$. The principal exports are whale oil and wool. Over $4 \frac{1}{2}$ million $t_{b}$ of wool, valued at $£ 150$,I34, were sent away in 1911, a slight decrease on 1910. The other articles of export are tallow, sheep-skins, hides, seal-skins, whale oil, whalebone, whale plates and tinned meat.

The total general revenue during I9I I amounted to $f 36,146$, exceeding that of I9I0 by £9,566. The total general expenditure amounted to $£ 23,407$, an increase of $£ 5,464$ over I9I0. The average excess of ordinary revenue over expenditure during I908-I2 was $\{2,910$. At the end of IgIr the assets of the colony were $f 167,727$, and the liabilities $£ 76,546$.

Communications.-The Pacific Steam Navigation Company's steamers call at Stanley on their voyage out to Callao and on their return voyage a fortnight later, thus making a monthly communication by letter with England, and fortnightly by cable via Monte Video and Chile. The hitherto isolated state of the colony will shortly be terminated by the erection of a wireless telegraph station, the tender of the Marconi Wireless Telegraph Company having been accepted for a 5 kilowatt installation capable of communicating at night with Buenos Aires or Monte Video.

The number of sailing vessels that entered inwards in I9I was I4 with a tonnage of I2,940; an increase of 6,159 in tonnage but no increase in the number as compared with 1910. The number of steamers entering was 64 with a tonnage of 141,929; an increase of 6 in number but a decrease of 7,192 in tonnage:

Social Progress.-Among legal enactments of the year I9I were new regulations concerning whaling, sealing, and the importation of animals, an ordinance dealing with the sale of liquor in the Falkland Islands and South Georgia, the imposition of an export duty of $3 \mathrm{~d}$ a barrel on whale oil, and a publication of a new edition of the laws of the colony.

The volunteer force on December 3I, I9II, had two officers and II 7 non-commissioned officers and men. The "Boy Scouts". held their first meeting on July 23, I9I I.

The results of the educational year in the government school are satisfactory. There is a further advance in the numbers on the roll, and a considerable improvement in the average attendances. The number of children educated during rol I was 435 .

The new hospital to be erected from a fund subscribed by the colonists as a memorial to King Edward VII was begun towards the end of I9II; it will have accommodation for 12 patients. A new town hall to take the place of the Stanley Assembly Room, recently destroyed by fire, is also in the course of erection.

In 19 I I there were only 60 convictions for various offences as against 81 in 1910.

The reports of the medical officers indicate a general improvement in the public health of the colony.

\section{THE BRITISH WEST INDIES}

The history of the British West Indies is still that of the several colonies, no practicable scheme for federating the islands, British Guiana and British Honduras, having been forthcoming. During I9ro-I 2 steady progress has, however, been made in the direction of securing greater uniformity in all matters concerning these colonies. The question of closer trade with Canada has helped to bring the various units together.

The preference of $37 \frac{1}{2}$ per cent given by the Dominion on British sugar had continued to attract West Indian produce to the Canadian market; the value of the preference was, however, reduced by the privilege given to the best refiners of Canada for three years from rgog of importing at the British preferential rates two tons of sugar for every ton of Canadian beet refined, and by the further privilege extended to the Canadian refiners generally in the same year of importing foreign sugar to the amount of 20 per cent of their requirements, on the terms of the British preference, in view of an alleged combination of the West Indian producers to raise prices. In August 1909 a Commission consisting of Lord Balfour of Burleigh, the Hon. William Stevens Fielding, the Hon. William Paterson, Sir John Poynder Dickson-Poynder, M.P. (now Lord Islington), and Sir Daniel Morris, with Mr. H. R. Cowell as Secretary, was appointed to enquire into the question of trade relations between Canada and the West Indian colonies. The terms of reference included improvement of transportation and telegraphic communication. The Commissioners visited Canada in September I 909 and the West Indian colonies in January I9Io. Evidence was also taken in London. In their Report they warmly advocated the establishment of reciprocal trade arrangements between Canada and the West Indies, and the improvement of steamship and telegraphic communication. With regard to steamship communication, they advocated the establishment of a service between the West Indies and the Mother Country via Canada, but this did not commend itself to the West Indian colonies, and the scheme was dropped in favour of 
direct steamship communication. In April igro a conference of delegates from British Guiana and the West Indian islands (the Bahamas, Jamaica and Grenada excepted) met at Ottawa, and an agreement was arrived at on the basis of the grant of mutual preferential terms on the principal articles of import into the West Indies from Canada, and vice versa. During 1912 the agreement was approved by the Legislatures of all the West Indian colonies concerned, and by the Imperial government. A resolution approving of it was passed by the Dominion House of Commons in November I9r 2.

Since 1905 , when the transatlantic mail contract was abandoned, the Royal Mail Steam Packet Company had carried the transatlantic mails on a poundage basis. In I gIo the Company gave notice to terminate the arrangement, and in November the direct service ceased, causing much inconvenience and loss to trade. On November I 8 th an intercolonial conference was held in Barbados, and the West India Committee strongly urged upon the Imperial Government the need for a mail subsidy. The government at last agreed to offer a subsidy of $£ 40,000$, and a contract was entered into with the Royal Mail Company for a transatlantic service to run until I 9 I 7 or concurrently with the intercolonial service (conducted for a subsidy of $£_{2} 5,000$ payable half by the Imperial Government and half by the colonies served) for a subsidy of $£_{63}, \infty$, to which Trinidad contributes $f_{1} 16,300$, Barbados $£_{4} 000$ and British Guiana $£_{2} 700$. Under the new service, which was inaugurated in I IIr, Trinidad succeeded Barbados as headquarters and port of transhipment for the intercolonial steamers. In I9I I the direct service carried on since I gor by the Imperial Direct West India Mail Service between Avonmouth and Jamaica under contract with the Imperial and Jamaica Governments ceased, the subsidy of $f_{40,000}$ not being renewed. In the same year the Imperial Government discontinued the subsidy of $f_{\mathrm{r}} 3,500$ to the mail service between Canada and the West Indies, which is now conducted by the Dominion alone.

\section{THE LEEWARD ISLANDS ${ }^{1}$}

The census of rgr I disclosed the population of the islands constituting this colony to be as follows: Antigua 22,265; Barbuda 775 ; St. Kitts 26,283; Nevis I 2,945; Anguilla 4075; Dominica 33,863; Montserrat I2, I 96 ; Redonda I20; Virgin Islands 5562 . During the financial year I910-II there were 4649 births and 3456 deaths. Of births 1762 were legitimate and 2,887 or 62 per cent illegitimate. The death rate of the Colony is conspicuously low, Montserrat enjoying the minimum with I3.I5 per Ioo0. Next in order come Anguilla (14.64), the Virgin Islands ( 15 ), Barbuda (18), Nevis (23.62), Dominica (23.99), Antigua (27.38) and St. Kitts (29.37).

Sugar is the chief industry, and the principal source of revenue in Antigua and St. Kitts. Antigua during 1910-1 I exprorted 13,488 tons (6397 tons of $96^{\circ}$ grey crystals and 7091 tons muscovado). The central factory at Gunthorpe's (Antigua) manufactured 5400 tons of crystals, and Bendal's Factory IoI5 tons. Extensions at Gunthorpe's during the year increased its manufacturing capacity to about 8000 tons of grey crystals in a crop. Conserguently more estates have abandoned the muscovado process and now sell canes to the factory. The quantity of peasants' canes purchased in Antigua was 7718 tons as against 4.579 in 1909 , the price paid averaging $12 \mathrm{~s}$ Id per ton in 1910 as against 9560 a ton in the previous year. In St. Kitts a central factory has been established, with a maximum output of 10,000 tons of crystals. Further extensions of the central factory system, the success of which has been so pronounced, are also contemplated. In the cotton industry during 1910II prices fell somewhat from the high figures prevailing during the previous year, and trade depression in England early in $191 \mathrm{I}$ also affected the sale. From the cultivators' standpoint, however, yields gave no caluse for disappoint ment. The area planted was extended and there was comparative freedom from insect pests, a freedom not enjoyed by sugar planters, who were handicapped to a certain extent on this account. In the Presidency of Antigua, where 560 acres-an increase of 215 -were cultivated, the average return amounted to 173 th of lint per acre. In St. Kitts I600) acres-an increase of $600-$-were planted, the average yield being $2(x) \mathrm{lt}$ ) of lint per acre. A like yield was obtained in Nevis (the highest since the island turned its attention to cotton), where I $f(0)$ acres were cultivated-an increase of 500 acres. A similar return is reporterl in the case of Mont serrat, which possesses the largest area under cotton-2(non acres. In the V'irgin Islands there is no estates cultivation, the cotton being purchased from growers and ginned and exported by the Government.

${ }^{1}$ See E. B. xvi, 371, and allied articles. 
Ever increasing prosperity attends the cultivation of the lime (citrus acida var. medica), the principal industry of Dominica. In I910-I I lime crop for the year, 369,000 barrels, showed an increase of 85,000 barrels as compared with I909-10. The export of citrate of lime amounted to $5194 \mathrm{cwt}$. valued at $£ 16,880-$ an increase of $1747 \mathrm{cwt}$. A second citrate works was established and the operations of an existing works extended. In Montserrat the total export of limes was valued at $£ 9000$. In a minor degree, Antigua, Nevis and the Virgin Islands devote attention to this industry.

Dominica also exported cacao to the extent of 11,012 cwt. valued at $£ 23,769$. Cacao also engages a certain measure of attention in some of the other islands. Dominica has also embarked on rubber cultivation, a considerable area having been planted with Hevea brasiliensis. It is estimated that 40,000 plants are already in various stages of growth.

The cultivation of coconuts attracts attention in Antigua and Nevis, and in the latter island and in Dominica vanilla is receiving notice.

The only manufactures of importance are connected with sugar in Antigua and St. Kitts, Nevis and the cultivation of lime in Dominica. In St. Kitts rum is distilled.

The total imports were valued at (Ig09) f471,016, (I910) $£ 541,713$; and exports (I909)

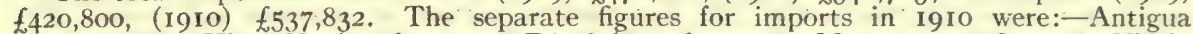

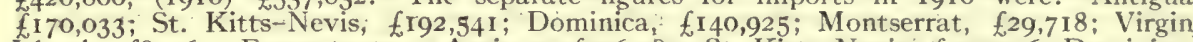
Islands, f8496. For exports:- Antigua, f196, 184; St. Kitts-Nevis, fi95,506; Dominica, flog, 529; Montserrat, f30,003; Virgin Islands, f66ro. The imports came chiefly from:the United Kingdom, $f_{229}, 193$ in 1910 (an increase of $\left.f 45,667\right)$, British Colonies $£_{102,738}$ $\left(+f_{2} I, I 30\right)$, and the United States $f_{19 I, I 48}\left(+f_{104 I}\right.$. The exports went chiefly to: the United Kingdom, $f \mathbf{1} 88,984(+f 41,666)$, British Colonies $f_{271,020}(+£ 68,934)$, and United States $£ 43,462(+£ 5175)$.

The total revenue was (I909-IO) fI49,670, (I910-II) £I64,375; and expenditure (I90910) $f_{149,906)}$, (1910-I I) $f_{159,263}$. The revenue was raised by the respective Presidencies in $1910-11$ in the following proportions:-Antigua $£ 52,326$; St. Kitts-Nevis $£ 52,748$; Dominica $£ 41,473$; Montserrat $f_{12}, 262$; Virgin Islands $£ 5566$.

The surplus of assets over liabilities on March 3I; I9I I, amounted to $f_{54,845}$. The public debt of the Colony amounted to $£ 273,250$; the sinking fund stands at $f 80,688$.

There are 24,573 children on the registers of the Government and grant-aided schools of the Colony, the average daily attendance being 12,082 . There are 7 secondary schools in receipt of grants from local funds. The Colony also asșists a Moravian Training College for females in Antigua, and furnishes an allowance for the training of local male students at the Mico College, Jamaica. From Imperial funds grants are made towards Antigua and St. Kitts Grammar Schools and Dominica Agricultural School. 'The Presidencies maintain in Antigua an industrial school to which boys are sent from each Presidency.

The total number of persons committed to prison during I9I0 was i i 44;3140 offences were reported to the police; $13,45^{8}$ persons were brought before the magistrates, and the summary convictions numbered 6802 . Convictions in the Superior Court totalled 39.

Sir Henry Hesketh Bell, K.C:M.G., was appointed Governor of the Leeward Islands in 1912. The Administrators were: St. Kitts-Nevis, Hon. T. L. Roxburgh, C.M.G.; Domin. ica, Hon: L. Douglas Young, C.M.G.; Montserrat, Lt. Colonel L. B. Dåvidson-Houston, C.M.G. (Commissioner); and the Virgin Islands Hon. T. L. H. Jarvis.

\section{BRITISH GUIANA}

During roo9-r 2 the Government continued to obtain information with regard to the extent and value of the vast forest resources of British Guiana, and an officer of the Department of Lands and Mines with special qualifications for the work was appointed to make a systematic and detailed examination of the Forest Lands. In IgIO-I I the Commissioners appointed to enquire into the question of the sea and river defences of the colony presented their report. Their recommendations, which included the execution and maintenance in future of the sea defences by the Public Works Department and the division of the colony into sea defence districts, were approved by the Combined Court, which decided that the cost should be met by the estates, villages and other properties within each district, and by the Government in the proportion of $\frac{3}{4}$ for the estates, villages and other properties, and $\frac{1}{4}$ from General Revenue.

The census of April I9I I showed a population of 295,7 I3, exclusive of the aboriginal Indians in the unfrequented portions of the Colony. During ig ro there were 8332 births registered $(27.5$ per 1000), a slight decrease on the previous year. Of the births so registered, 6o.r per cent were illegitimate: The deaths registered were 10,424 (or 1057 more than in the previous year), giving a death rate of 34.4 per thousand. Mortality amiong children continues high: 234 per thousand.

${ }^{1}$ See E. B. xii, 676 et seq. 
The acreage devoted to the principal products of the Colony stood as follows at the end of 1910:-sugar cane 69,736; rice 31,680; cacao 2200; coffee 2546; rubber 1700 , coconuts 9466. Sugar and its by-products constitute 72 per cent of the export of locally grown produce, and 64.01 of the total exports. The export for 1910-11 declined by 7579 tons and the prices realised were below those of the previous year. The cultivation in certain districts suffered to such an extent from the ravages of insect pests that it was decided to obtain the services of an economic biologist. The experimental cultivation of canes was continued during the year by the Board of Agriculture, and on the plantations the area planted with varieties of cane other than Bourbon increased from 39,850 to 45,484 acres. Excellent rice is grown-largely by East Indians who settle in the colony after the expiration of their indentures on the sugar plantations. The export, which is absorbed mainly by the British West Indies, has risen from a few thousand pounds to a quantity running into seven figures. There is an enormous area available for rice cultivation, and although the output for 1910-II was below that of the previous year, the industry is firmly established. The export of cacao fell considerably during I9IO-II, but this is explained principally by an increased local consumption of sweets. Rubber as a local industry is still in its infancy. Cultivation is being prosecuted vigorously and the Government carries on experimental work. The export of coconuts has increased considerably. Cattle rearing is an important branch of local industry, and a low estimate gives the number of cattle as 71,500 .

In I9ID-I I the output of rum was upwards of $2,515,000$ gallons, a falling off of half a million gallons as compared with $1909-10$. This decline is attributed to the downward tendency in the price in the United Kingdom.

The output of gold for 1910 - I I was 54,989 ozs. - a decrease compared with the previous year of 9841 ozs. The search for diamonds was actively prosecuted, although the output (3035 oz.) was below that of 1909-10.

Perhaps the most striking success has attended the balata industry, the amount collected in I910-II-I,340,924 tb-being the highest on record. Four new companies were floated and commenced work, and new areas are being prospected.

The forest resources of the Colony are practically limitless, and of those resources timber is of the first importance. During 1910-I I 256,845 cubic feet were exported, showing an increase of 58,648 cubic feet on the previous year. Woodcutting licences to the number of 218 were issued, covering an approximate area of 70,000 acres.

The total imports were valued (I909-IO) at $£_{1}, 774,457$ and (I9I0-II) $£_{1}, 749,766$; the exports (I909-IO) $£_{1}, 985,337$, and (I910-II) $£_{1}, 820,198$. Of the imports in I9IO-II, the United Kingdom sent 47.64 per cent, the United States 24.4 I per cent, and Canada 8.23 per cent. Of the exports the United Kingdom took 40 per cent, Canada 3 I.60 per cent, and the United States 14.20 per cent.

The revenue was (1909-IO) $£ 540,269$, and (1910-II) $\$ 563,100$; the expenditure (1909I0) $£ 546,711$, and (I9IO-1I) $\{542,757$. The excess of assets over liabilities on March 31 , 1911, was $€ 48,116$. The public debt of the colony was then $£ 887,115$. Of this amount $\{817,115$ represents sums borrowed for public purposes, the balance $£ 70,000$ having been raised for immigration purposes. $£ 280, \mathbf{1} 86$ stood at the credit of the sinking fund account.

During the financial year I9I0-II, the sum of $f .28,294$ was distributed in grants in aid among 224 schools with an average daily attendance of 21,555 , the number on the rolls being 34,562 . Secondary education is provided for in the case of girls mainly by private enterprise. For boys, the Government maintains Queen's College. There are also two or three private schools. There is a system of scholarships under which pupils from primary schools can pass to the secondary schools; these scholarships being open both to boys and girls. In a country pre-eminently agricultural, like British Guiana, instruction in the principles of agriculture is of the first importance, and this fact is fully recognised by the covernment. Model gardens, and gardens attached to schools are found throughout the colony. The establishment of an Agricultural School has also been determined upon. At the school founded for the reception and training of vagrant boys and youthful male offenders, the large najority are educated in agriculture, the institution being worked as a farm school and possessing 80 acres of land under cultivation.

During 1910-11, 8795 offences were reported to the police. There were committed to prison 4562 persons; and there were three cases of capital punishment.

In 191 I the Combined Court voted an increased salary for a (iovernor of tried administrative ability, and Sir Walter Egerton K.C.M.G., received the appointment in 1912 ,

\section{WINDWARD ISLANDS ${ }^{1}$}

Grenada. - This island is the headquarters of the Government of the Windward Islands, the governor in 1912 being Sir James Hayes-Sadler, K.C.M.G. The population on December 31 , I910, estimated on the basis 'of natural increase, was 75,254 The census of 19 I r however disclosed a total of 66,750. The discrepancy is attributed to emigration. The birth rate in 1911 was 39.92 per thousand, and the death rate 19.66 .

${ }^{1}$ See $E$. B. xii, 578 . 
Cocoa, nutmegs and cotton represent the principal products, and in past years have practically absorbed the attention of the agricultural population. A healthy tendency however is now being manifested to open up other sources of development. The record cocoa crop of the island-73,863 bags-was reaped in the year ending September 30, 1910. In the following year it was 67,144 bags. Land settlement schemes have been initiated in the dependency of Carriacou, where a lime industry has been established, and also in Grenada itself, where rubber cultivation is extending. Practically the only manufacture is rum, of which 63,356 gallons were made in I9I 1 ; a soap factory is also in operation. The total imports for I910 were valued at $£ 279,368$ and for 191 I at $£ 309,227$ and the exports at (1910) $£ 291,760$ (including cocoa $£ 259,365$ ) and (I9II) $\left\{264,640\right.$ (cocoa $£_{223,104}$ ).

The revenue was (1909-10) $£ 71,224$, (I910-I1) $£ 81,413$, (191 I-I2) $£ 98,645$; the Expenditure (1909-10) $£ 73,282$, (1910-1I) $£ 75,561$ and (I9II-12) $\ell^{81,012}$. The Colony's assets stood on March 31, 1912, at $£ 56,419$. The public debt was $£_{123,670}$; and the accumulated sinking fund for its redemption between 1917 and 1942 amounted to $£ 30,270$. The Government owns and maintains 9 of the 49 existing schools, the remainder being grant-in-aid schools (22 Roman Catholic, 11 Anglican, 5 Wesleyan and 2 Church of Scotland). The number of scholars on the roll was 10,905, and the average attendance 5377.

St. Lucia. ${ }^{2}$ - The census of April I9II showed a population of 48,637 as compared with 49,883 in I901. The birth rate for I9lo was 30.1 per thousand and the death rate I6.6. In 1910 the Government made its first comprehensive attempt to combat the malaria problem by means of the free distribution of quinine.

The principal products are sugar and cocoa, which represent 92 per cent of the domestic exports. Lime cultivation is steadily increasing, while honey and cotton are also produced, though cotton does not appear to find favour with the planters. The Botanic station and special agricultural services involved an expenditure during 1910 of $£ 638$, and $£ 507$ was spent on the maintenance of the Agricultural School. Plants to a total number of 54,929 were distributed by the Agricultural Department. Local sulphur deposits are worked, but the quantity obtained in I9lo was so small that none was exported. The position of the rum industry is indicated by the following returns: distilled, 49,256 gallons; consumed, 42,456 gallons; exported, 4692 gallons. In 1909 the experiment was tried of shipping rum to Canada. In 1910 however this was found unprofitable owing to the low prices obtainable. Consequently less rum has since been manufactured. The outlook in regard to the trade of the port of Castries is encouraging. This remark applies especially to the extending coal trade. The total value of all imports was (I909) $£ 266,228$, (1910) $£ 277,208$; and of exports (1909) $\{250,674$, and (I9I0) $\{238,955$. The revenue was (1909-IO) $f 65,739$, and (I9I0-I I) $£ 65,066$, and the expenditure (r909-10) $£ 64,446$, and (1910-II) $£ 67,288$. The Colony's surplus on March 3I, I9II, stood at $f_{25}, 014$, in addition to the Public Buildings Insurance Fund ( $f 3895$ ). The Public Debt amounted to fi46,929. There were 53 elementary schools in I910, having 7259 scholars on the roll, with an average attendance of 4625

The Administrator in 1912 was the Hon. Edward J. Cameron, C.M.G.

St. Vincent. ${ }^{2}$-The census of April I9I I showed a population of $4 \mathrm{r}, 877$. The births in I9I0-I I totalled I66I (83I males, 830 females), $58.2 \mathrm{I}$ per cent being illegitimate. Deaths totalled 835 (r9.93 per thousand), infant mortality standing at $24.9 \mathrm{I}$ per cent.

During recent years St. Vincent has taken up the cultivation of cotton with enthusiasm. The extent of the acreage and the quantity of the export in I9Io were the largest since the revival of the industry in the island. Sea Island cotton was planted over 3,587 acres, and $56 \mathrm{r}, 526 \mathrm{fb}$ of lint were produced, the average yield of lint per acre being I $56 \mathrm{lb}$. The total cotton production was $521,956 \mathrm{lb}$, valued at $£ 38,409$.

The success attending this cultivation has set up a serious rivalry with arrowroot, which has held pride of place in the exports for many years, but so long as cotton retains its average value of $\mathrm{r} 8 \mathrm{~d}$. per $\mathrm{tb}$ of lint, it must constitute the staple crop of the Colony. Arrowroot can be grown on any land where cotton is cultivable, whereas the production of cotton is confined to the coast lands. Meanwhile arrowroot continues to receive increased attention. Towards the end of I9I0 a Growers' and Exporters' Association began work, and it is notable that the price has advanced from $1 \frac{7}{8} \mathrm{~d}$. to $3 \frac{1}{2} \mathrm{~d}$. per lb. The soil and climate of the Colony appear to be better suited to arrowroot production than those of any other West Indian island. Sugar is produced chiefly in the Carib country, the only noticeable feature being an increase in the export of the crystallised, and a decrease in that of muscovado. Land settlement continues satisfactory.

The ginning of cotton is the principal industry, the Central Ginnery established by the Government in 1903-04 having proved a profitable-and indeed indispensable factor in the success of cotton culture. The working of the establishment in 1910 yielded a profit

1 See E. B. xxiv, 27 .

2 See E. B. xxiv, 50. 
of $£ 480$. The sale to the ginnery of seed cotton is compulsory in the case of lots of less than rooth weight. Any amounts up to $4000 \mathrm{tb}$ may also be sold by anyone to the ginnery. This cotton is bought on a profit-sharing basis. The law providing for this method of sale and purchase has proved highly popular among small cultivators. In actdition to the Government establishment there are three private ginneries. The price of lint during the year was good, reaching $26 \mathrm{~d}$. per $\mathrm{lb}$. in the case of some special bales. The average price, however, was $17 \mathrm{~d}$. to $20 \mathrm{~d}$. for Sea Island cotton, Marie Galante selling at from $6 \mathrm{~d}$. to Iod. per. Ib.

The whale oil industry would appear to be in a decadent state, there being a great fall in the value of the export. Efforts are being made to establish a sponge industry in the Grenadines. Turtling is carried on, but here again the exports disclose a conspicuous decrease. The total value of the imports was (1909) 887,810 , (1910) $f .97,737$; and of exports

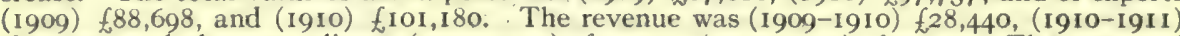
$£ 30,125$; and the expenditure (1909-1910) $£ 31,330$, (I910-1911) $£ 30,343$. The excess of assets over liabilities amounted on March 31 , I9II, to $\ell^{6524}$. There is no public debt, the last loan instalment having been repaid in May 1910. The Colony is responsible for the unpaid balance of the Hurricane loan to planters from the Imperial Treasury, which on March $3 \mathrm{I}$, I9II, stood at $f_{10}, 450$, but against that amount there is a sinking fund of $£ 2335$. This loan is being steadily redeemed.

There are 28 primary schools, and $\mathbf{4 5 5 2}$ scholars on the rolls with an average attendance of 2260. There is also a secondary school, and satisfactory results are obtained from the Agricultural School. Special effort is made to teach the cultivation of cotton.

The Administrator in 1912 was the Hon. C. Gideon Murray.

\section{BRITISH HONDURAS ${ }^{1}$}

The development of British Honduras proceeds slowly. The Stann Creek Railway, begun in 1907, was nearing completion in 1912. It runs 20 miles inland, and opens up an extensive area suitable for banana cultivation. In Igr I a Town Board was constituted for the City of Belize. The population according to the census of I9II was 40,809 (20,526 males, 20,283 females). The birth rate in I9I I was 42.393 and the death rate 24.8 , malarial fever being the principal cause of mortality. Tuberculosis has seriously increased, and preventive measures are being adopted with some success.

The iotal imports for I9I I were valued at $\$ 2,886,677$ ( $-\$ 67,460$ on I9I0), and the exports at $\$ 2,685,849(-\$ 341,469)$, the bulk of the trade being with the United States. The revenue in $1910-11$ was $\$ 459,295$, and the expenditure $\$ 542,810$. The loan debt on December 31 , I910, amounted to $f 168,815$. Provision for the repayment of loans has been made by the investment of sinking funds which total $\$ 92,173$. There were 46 primary schools in 1911 , with 4725 pupils. The cost of primary education was $\$ 34,259$. Of this sum the Government contributed $\$ 20,103$.

The Governor in 1912 was Sir E. J. E. Swayne, K.C.M.G.

\section{BARBADOS ${ }^{2}$}

In ig 2 the House of Assembly voted $£, 900$ to defray the cost of a complete survey of the island, with a view more particularly to the investigation of the extent and position of the petroleum deposits. The existence of petroleum has been proved, but the industry has not yet been placed on a commercial footing. The survey was entrusted to Mr. E. H. Cunningham Craig. In IgI2 the Legislature passed a Bill granting to the Anglo-Mexican Petroleum Products Co. Ltd. the exclusive right of supplying imported fuel-oil to calling steamers for a period of twenty-five years.

With an area of 166 square miles, Barbados is for its size the most densely populated British possession. The census of April I9I I showed a population of I 7 I,4 I 7 (69,9 I 2 males and IOI,505 females). The population and prosperity of the island are affected by two factors - the emigration of labourers to the Panama Canal Zone and the influx of visitors from abroad. The Panama Canal has been constructed mainly by West Indian labourers, of whom no fewer than 20,000 were natives of Barbados in 1909. It is claimed that any disturbance of the local labour supply has been more than compensated for by the remittances sent home by Barbadians from the Panama Canal Zone, and by the money brought back to the island by returning emigrants. In I $909 £ 80,000$ was

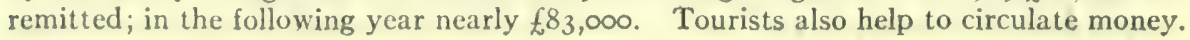
In 1910549 I first and second class, and 12,44 I steerage and deck passengers reached the

1 See E. B. iv, 615 . See E. B. iii, 380, 381 . 
island. The tourist business is assuming considerable dimensions; with a view to stimulating it a Barbados Improvement Association was started in I 1 I.

The birth rate in 1910 was 37.2 per thousand and the death rate 25.5 per thousand. Of the births 58.8 per cent were illegitimate. Infantile mortality stands at 268 per thousand.

Sugar has always been the chief product of Barbados. The crop for 1910 amounted to 35,906 hogsheads of muscovado, 3993 hogsheads of vacuum-pan crystals, and 77,722 puncheans of molasses, or 22, I04 hogsheads of sugar and 8686 puncheons of molasses more than that of the previous year. Barbados was one of the first West Indian Colonies to participate in the revival of the cotcon industry in the West Indies, and remarkable results were obtained within a comparatively brief period. In 1910 however the acreage reaped declined from 5768 to 4121 , the decrease being due to the low price and poor yields obtained in 1908. The remunerative prices obtained during 1909 and I9Io resulted in an increase of the acreage from $4 \mathrm{I} 2 \mathrm{I}$ to $474 \mathrm{I}$. Bananas are cultivated to some extent, and during $1910,13, \mathrm{I} 37$ bunches were exported. 226, I69 gallons of rum were manufactured in 1910 , as compared with 207,239 gallons in 1909. Sea Island cotton is ginned locally.

The imports and exports in 1909 and 1910 were valued as follows:- (I909) exports, f888,086, imports fI, I19,343; (I910) exports $f_{1}, 058,830$; imports $f_{1}, 345,194$. United Kingdom imports, $f_{480,823}$ in 1909 , rose to $f_{1592,641}$ in I910; United States, $f_{n} 355,809$ in

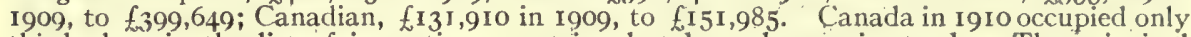
third place in the list of importing countries, but her advance is steady. The principal commodities purchased from Canada in I9Io were flour $\left(f_{3} 3 \mathrm{I}, \mathrm{I} 44\right)$ and white pine $\left(f_{3} \mathrm{I}, 409\right)$; other articles, all of which show an increase, include oats, iron nails, staves and shooks, beef, cordage, fruit and vegetables, grain and shingles. Fish, butter, sulphate of ammonia and hay are also obtained from Canada. Of the total exports in I9I0, f783,125 represented produce of the colony, and $\{305,705$ the produce of other countries. Exports to the United Kingdom, $f 70,487$ in 1909 , rose to $f_{11} 1,223$ in 1910 ; those to Canada, $f 348,707$ in 1909 , to $£ 484,108$; those to the United States, $f_{37,219}$ in 1909 , to $£ 77,650$. Exports of sugar $(£ 396,004)$ showed an increase of $£ 243,092$, as compared with 1909 , Canada alone taking $\AA_{268,455}$ as against $\oint_{107,222}$ in 1909 .

The revenue in $1909-10$ was $£ 195,803$, and in $1910-11 \quad f_{2} 13,298$; the expenditure in I909Io was $f 199,625$, and in I9IO-II, $t 2 I I, 949$. Public debt stood at close of the year at $£ 422,900$, and the sinking fund at $f 85,940$.

The primary schools number I66 (Anglican I32, Wesleyan I8, and Moravian 16), scholars on the rolls numbering 27,658 , and the average attendance being 16,829 . The government

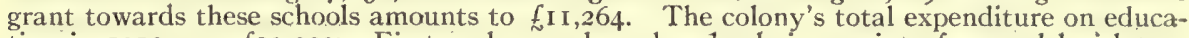
tion in 1910 was $f, 19,209$; First and second grade schools in receipt of annual legislature grants number 9 ( 7 boys' and 2 girls') the largest grant ( $f 1000$ ) being made to Harrison College (boys). The number of pupils on the rolls of these schools totals 635 . The colony makes provision for scholarships tenable by students enrolled at Codrington College, and for a further scholarship tenable at a European or Canadian University. At the close of 19I0 there were 4 ragged schools, having 285 scholars, with an average attendance of 173 .

During I9I0 there were 9888 . summary convictions land 40 convictions in Supreme Couris. The percentage of convictions to population is 5.79 . The daily average number of prisoners in Glendairy prison was 210 for I9I0; the number of persons committed to penal imprisonment, I785. There were 134 boys in the Industrial school on December 31, 1910. The proceeds of its agricultural work amounted to $f 1937$, and the expenditure to $f_{2} 283$.

The Governor in 1912 was Sir Leslie Probyn, K.C.M.G.

\section{JAMAICA ${ }^{1}$}

The census of April rgi I showed a population of 831,383 (females 433,944, 'males $397,439)$. Compared with the previous census of 189 I this return reveals an increase of I 91,892 or 30 per cent compared with an increase of 26.3 per cent between $187 \mathrm{I}$ and I891, Every parish except Port Royal contributed to this increase, notably St. Mary 70 per cent and Portland 53.7 per cent. Labour requirements on the Panama Canal, in Cuba and in Costa Rica have affected the emigration and immigration returns; I3, Io9 labourers set out from the Colony during the year ending March.3 I, I9I 2 and 8,984 arrived at Kingston. The marriages celebrated during the financial year I 9 r I $-\mathrm{r}_{2}$ numbered $3607-\mathrm{a}$ rate of 4.2 per thousand as compared with 4.0 in 1910-II. Both these rates show a remarkable decline when compared with $1907-08$, when owing to the emotional effects of the earthquake at Kingston in January 1907 the rate rose to 7.4 . As a result, in $1908-09$ the return of illegitimate births declined to 60.59 per thousand. The total births registered in I III I 2 numbered 32,750 , representing a rate of 39.0 per thousand, the rate for illegitimate births being 64.I per cent. The death rate stood

${ }^{1}$ See E. B. xv, 132 et seq. 
at 22.I per thousand, the total number of deaths registered being $\mathrm{r} 8,63 \mathrm{I}$. Of these 8,871 were due to infantile mortality; 38.9 per cent of the children born in Kingston and 35.5 per cent of those born in St. Andrew dying before the age of 5 .

The total acreage under cultivation returned in $1911-12$ was $2,171,709$, distributed as follows:- tilled lands, 280,286 , guinea grass 143,592 , commons 517,830 , wood and ruinate $1,230,001$. This return shows an increase over the average for the four preceding years of 24,552 acres or 8 per cent in tilled lands; an increase of 3,902 acres or 3 per cent in guinea grass; of 28,589 or 6 per cent in commons, and of 2488 acres in wood and ruinate.

Tilled lands, classified under the agricultural products, give the following returns:sugar cane 34,766 , coffee 24,473 , coconuts 16,691 , bananas 82,435 , ground provisions 74,723 , mixed cultivation 30,167 , cocoa 13,355 , minor products 3676 . These returns diclose an increase over the average for the four preceding years of 4450 acres in cane; of 3440 acres in coconuts; of 14,862 in bananas; of 3163 in cocoa. Ground provisions including mixed cultivation show a decrease of 146 acres, coffee 668 acres and minor products 603 acres.

During 1910-I I the Sugar Experiment Station was operated, the Imperial Grant enabling the station to be equipped with laboratories and an experimental distillery and to provide for experimental plants on estates. The operating expenses of the station were also provided for a period of 7 years. A central sugar factory at Rose Hall in St. James, recently completed, will deal with the prodice of nine sugar estates. The work of agricultural instruction received considerable impetus, as the result of the appointment of four additional instructors. The rubber industry engaged attention during I9I I, Castilloa, of which three distinct species have been established, giving the most promising results.

The total value of the imports and exports for 1909-10, and 1910-II was:- (1909) imports, $f_{2}, 561,674$, exports $£_{2}, 628,307$; (1910) imports $\ell_{2}, 614,943$, exports $£_{2,568,222}$. and (I9II) imports $\{2,865,553$, exports $£ 2,948,067$.

The principal articles of import were textiles $\left(f^{6} 38,331\right.$, in 1911$)$, hardware $\left(f_{3} 04,128\right)$, wheaten Hour $(f 255,207)$, dried and salted fish ( $f_{150,746)}$, and lumber $(£ 106,893)$.

The principal articles of export were bananas $\left(£_{1}, 456,58 \mathrm{I}\right.$ in $\left.191 \mathrm{I}\right)$, sugar $\left(£_{247,413}\right)$,

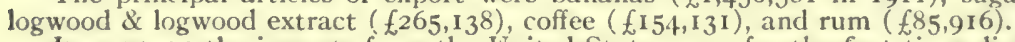

In 1910-1 I the imports from the United States were for the first time slightly in excess of those from the United Kingdom. In the following year, however, imports to the value of $f 1,291,923$ or 45 . I per cent came from the United Kingdom and $f I, 200,345$ or 41.8 per cent from the United States and $f_{249,546}$ or 8.5 per cent from Canada.

Of the exports the United States took 61.9 per cent in 1911 , as against 54.1 in 1910; the United Kingdom 14.7 per cent as against 20.6; and Canada 8.6 per cent as against 8.4.

The revenue was (1909-10) $\$ 992,976$, (I910-1I) $f 990,399$ and (I9II-I2) EI,I6I,o14; and the expenditure (I909-10) fI,033,794, (I9I0-II) $£ 987,304$ and (I9II-12) $£$ I,155,208. The Government closed the financial year I9II-I2 with a surplus of $\ell_{190,191 \text {, having also }}$ froo,000 invested as an insurance fund to provide for the repair of damage to Government property by hurricane, fire or earthquake. The Public Debt of the island, most of which is represented by productive investments, amounted to $f 3,871,305$ on March 31,1912 . The sinking funds amounted to $£_{759,865}$, leaving a net liability of $£_{3}$, I I I 440 .

In I9I I there were 698 schools on the annual grant list, average number of scholars 98,576 , average attendance 61,669 , percentage 62.55, total payments to elementary schools and teachers $f 60,503$. On January I, I9II, the regulations for compulsory education in Kingston district, Falmouth and lucea, came into effect. The work of school inspection was facilitated in 1911-12 by the addition of an Assistant Director, and of three Inspectors: A reduction from 100 to 70 of the number of schools in each inspector's district improves the oversight.

Serious crime finds no place in the social life of Jamaica. No execution of capital punishment took place in 1911-12. Committals to prison totalled 5676, a decrease of 1oI as compared with r910-II but an increase of 716 as compared with 1909-10. Reconvictions during the year amounted to I442. Persons bound over as probationers numbered 103 .

Work is proceeding on an extension of the Jamaica Government Railway from May Pen to Chapelton to be constructed at an estimated cost of $f 90,000$; it will open up the fertile valley of the Rio Minho, and render $I 7,000$ atres available for cultivation.

The western end of the island was visited by a destructive storm of hurricane violence in November 1912.

The Governor in 1912 was Sir Sydney Olivier, K.C.M.G.; but at the end of the year he resigned on being appointed secretary of the Board of Agriculture in England.

\section{TRINIDAD ${ }^{1}$}

The estimated population on March 31, I9I I, was 368,or4. Arrivals in the Colony during the year numbered 22,845 , and the departures 16,719 , giving a net increase to the population by immigration of $6 r_{26}$. Included in these figures were 3286 East

1 See F. B. xxvii, 284 . 
Indians brought to the Colony under indenture, and 622 who returned to India after the expiration of their indenture. The birth rate was 31.8 per thousand, and the death rate 20.5. The health conditions show steady improvement. During I9II there were only two fatal cases of yellow fever, and twelve cases of plague.

Cocoa and sugar represent the chief products of Trinidad. Coconuts also engage widespread attention, and this remark holds good with regard to rubber,-large areas being planted under Castilloa, Funtumia and Hevea brasiliensis. During I gro-II $7376 \mathrm{lb}$ of rubber, valued at $£_{\mathrm{I}} 395$, were sent out of the Colony. Fruit, principally bananas, is cultivated, but the progress of this industry was arrested during I 910-I I by the uncertainty (now remedied) as to the continuance of a regular steamship service providing cold storage. Minor industries are greatly encouraged in Trinidad by means of the distribution of plants and seeds from the Botanic Stations, at reasonable rates.

The establishment and progress of the oil industry represents one of the most striking developments within recent years of industrial activity in the tropics. The most important borings are located in the South-western portion of the island, in the vicinity of the celebrated Pitch Lake, which for many years has provided immense quantities of asphalt exported largely to Great Britain and the United States,-a principal source of the Colony's economic wealth. The use of oil fuel in the British Navy promises to enhance the importance of Trinidad as a British possession. During the financial year Igro-II considerable advance was made in the industry, drilling being commenced on private lands at five centres. An aggregate depth of I5,347 feet was drilled, the number of wells in progress being 22. Thirteen have yielded fair results. Since prospecting commenced a total depth of 32,972 feet has been drilled, the number of wells being 44 . The area affected by approved licences comprises 78,237 acres.

In addition to the oil and asphalt industries, maniak mining is carried on, and limestone quarries are worked. The manufacture of sugar and rum and molasses is an important characteristic of the colony's industry; apart from the quantity exported, about 8,000 tons of sugar (valued at $f_{1} 35,000$ ) and 335,045 gallons of rum (valued at $f_{3} 29,000$ ) were manufactured for local consumpion in I910-II. Also five million coconuts were used locally in the manufacture of 85,000 gallons of oil, valued at $f_{1} 16,000$, nearly all of which was consumed in the colony.

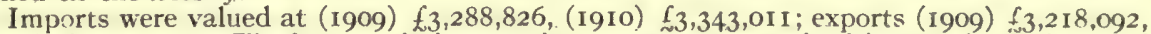
(19I0) $f_{3}, 467,588$. The increase in imports in 1910 as compared with 1909 is made up of $f 3^{\circ}, 743$ under raw materials (principally coal and lumber) and $f 83,719$ under manufactured articles (chiefly machinery for the oil fields), less a decrease of $f 6,657$ under live stock, food, etc. The growth of the coaling business of Port of Spain, the capital, is a striking feature of the Colony's trade. In 1910, 80,067 tons were imported (as compared with 23,235 tons in $1906-07$ ); 44,295 tons being supplied to vessels (as against 6,703 tons in $1906-07$ ). The value of machinery imported in 1910 was $£_{122}, 788$, as compared with $f_{52}, 676$ in the previous year. The raw material chiefly imported is coal, patent fuel, manure and lumber. The chief importing countries were:- the United Kingdom, f936,427 ; United States, $f_{8} 860,903$; Venezuela $f_{0} 233,086$; Canada, $f_{1} 34,609$. The principal exports were:-cocoa, $f_{1}, 230,097$; sugar, rum and molasses, $\_7.43,969$; coconuts and copra, $f 85,35^{8}$; fruit, $f 19,95^{2}$; asphalt, fi79,I46. The chief countries taking the exports were:- United States, E919,047; United Kingdom, f599,240; France, f 483,211 ; Canada, $\{354,484$.

The revenue in $1909-10$ was $£ 853,565$, and in $1910-11, £ 948,383$; the expenditure (I909-IO) $£ 863,253$, (I9IO-II) $£_{927,033}$. The revenue for I9IO-II was the largest ever collected in the colony, the chief increases being under customs $\left(£_{6} 67,340\right)$ and licences $\left(£_{24},-\right.$ 770 ). As regards expenditure, the recurrent expenses amounted in I9IO-II to $£ 843,050$ as compared with $f 798,262$ in the previous year, whilst the extraordinary (public works, roads and bridges) amounted to $f 83,984$ as against $f 64,99 \mathrm{I}$ in $1909-10$. The surplus balance was fro4,925 on March 3I, 19II; assets totalling $f 606,630$ and liahilities (exclusive of funded debt) to $f_{591,705}$. The funded debt stood on the same date at $f_{0}, 051,093$, and the sinking funds at $f_{1} 174,426$; a loan of $f_{4} 450,000$ has also been authorised by Ordinance.

The elementary schools, exclusive of private schools, numbered 263 on March 3I, I9II, Government schools totalling 53, and assisted schools 2 IO. The assisted schools are as follows:--Roman Catholic: 79, Anglican 5I. Presbyterian Canadian Mlission 56, Wesleyan I2, Moravian I2. Children on the rolls totalled $47,66 \mathrm{I}$, the average daily attendance standing at 27,083 . The expenditure on elementary education from public funds amounted to f II,III. Practical agriculture and nature study are taught in nearly all primary boys' or mixed schools. Secondary education for boys is provided from public funds at Queen's Royal College (Port of Spain). and two affiliated schools, St. Mary's College (Port of Spain) 
and Naparima College (San Fernando). St. Joseph Convent School for Girls is now affiliated to Queen's Ruyal College. A Board of Industrial Training carries on small night classes for apprentices, artisans also ảttending.

Offences reported to the police during 1910-I numbered 20,928 , the total number of persons arrested or brought before the magistrates being 23,787. Summary convictions numbered 15,857. Convictions in the supreme court totalled 18.5 . The death penalty was imposed in 4 cases. Persons were conmitted to prison to the number of 4,780 . The cost of prison administration during the year was fI 2,365 . Prisoners' earnings were $£ 7,749$.

During I9I I the first sod of the Tabaquite-Foole Railway exiension, which will open up 10,500 acres of fertile land, was turned; and work on an extension to Siparia, which will serve an area of 14,100 , is in progress.

The Governor in 1912 was Sir George Le Hunte, K.C.M.G.

\section{The Bahamas ${ }^{1}$}

In I9Io the Legislature passed a resolution authorising the Governor to ascertain on what terms the Canadian Dominion could incorporate the Bahamas; but the resolution was purely tentative. The Bahamas did not participate in the reciprocal Trade Conference at Ottawa in I9I2. During I9IO-I2 the tourist business continued to ncrease, and the Legislature voted $£_{\mathrm{I}, 000}$ for advertising the Islands in I909-Io.

The census of April I9I I gave a population of 55,872 , a net increase of 2137 since 1901 . The islands showing an increase were Andros $\left(1,25^{2}\right)$, Abaco $(1,1.66)$, and New Providence $(1,020)$. On the other hand Eleuthera showed a decrease of 2,203. During I901-I I about 6,000 labourers (accompanied in some cases by their familics) emigrated to Florida, Mexicn and Yucatan. The births during 19 I I numbered 34.I per thousand, and ihe deaths 21.7 per thousand. Nearly every industry has recently shown a decline. The export of tinned pineapples has fallen off, owing to poor stock, Hawaiian competition, and the effect of the American tariff. Sisal fibre cultivation is the most important industry, some 20,000 acres being planted, but the price is low and the rapid extension of the indusiry in other countries has had its effect on the Bahamas. The sisal is all shipped to the United States.

The exports of grape-fruit, which amounted to 365,000 in 1909 , fell in 1911 to 309,194 . The ontput of oranges, which in 1907 amounted to a million and a half valued at $f_{3}, 000$, fell in IIII to 15,400 valued at $f_{20}$. The feeling with regard to agricultural prospects is reflected by the decision of the Legislature to abolish the Board of Agriculture, after an exisience of six years and the expenditure of $f 5,000$ of public money. The one industry which has shown signs of progress has been sponge fishing. The sales of sponges during I9I I reacherl $£ 79,102$, as against $£ 70$, 000 in 1910 , and the total exports $£_{1} 10,740$ as against $£ 87,657$.

The trade figures are-(I909), exports $t 171,44^{2}$, imports f 343,489 ; (I910) exports fi 193,803 , imports $f_{329,014}$; (1911) exports $£ 200,25 \mathrm{I}$, imports $t_{311} 1,095$.

Out of a total of $f_{3} \mathrm{II}, 095$, imports to the value of $\ell^{203.550}$ came from the United States, and imports to the value of $f 82,360$ from the United Kingdom in 19Ir. It should be explained, however, that in the alsence of direct communication with the United Kingdom, many goods from the mother country being transhipped in America are classified as American. The Linited States is also the best custumer of the Bahamas, having taken produce to the value of $f_{9} 88,975$ out of a total of $£_{174,895}$, the United Kingdom ranking next with $£_{20} 9,349$. Here again, it must be remembered that as New l'ork is the port of transhipment, many goods destined for (anada and the United Kingdom are classified as going to the United States.

The financial;ifigures are: (1909-10) revenue $f 77,578$, expenditure $f_{92,858}$; (1910-11) revenue $f^{8} 4,391$, expenditure $f 85,315$; (19II-12) revenue $f_{85} 592$, expenditure $f_{82,675}$.

The excess of assets over liabilities on March $3 I_{1}, 19 I_{2}$, stood at $f .15,482$. The public debt stands at $f 51,568$, the annual charge for interest and sinking fund being $f_{6} 6,580$. The existing debt wili be wholly liquidated by 1926 unless anything unforeseen arises.

The number of primary schools (exclusive of private and denominational schools) is 64 ( 46 board schools and 18 grant-in-aid schools). Pupils number as follows:-Board Schools, 6,594; Aided Private Schools, 1,492; Church of England, 1,625; Roman Catholic, 531; Private Schools, 222; Wesleyan, 167, total 10,621.

The annual vote to the Board of Education amounts to $f 6,000$. There is no State secondary education, but five private organisations provide instruction for 153 pupils.

The number of persons committed to Nassau Prison in 1910 was 189, as against 214 in $1 y(x)$. The police force-largety recruited from Barbados-numbers $8 \mathbf{I}$ men.

Mr. (i. Hadlden-Smith was appointed to sucreed Sir William Grey-Wilson, K.C.M.G. as governor in 1912 .

\section{Bermuda ${ }^{2}$}

The population of Bermuda at the Census of 1911 was 18,994 . The revenue for $191 \mathrm{I}$ was $f 79,24 \%$, and the expenditure $£, 90,10 r$. No official report on the colony has been issued since 1907 , but in 1910 the exports totalled $\ell_{106,508}$ and the imports $f_{517}, 074$.

${ }^{1}$ See E. B. iii, 207 el seq.

' See E. B. iii, 793 . 


\section{CANADA ${ }^{\mathrm{i}}$}

Area. - In rgir the fifth decennial census was taken. The area is given as 3,729 ,665 sq. m: of land and water, 15,909 sq. m. less than in r 901 , the reduction being partly due to the Alaska award and partly to the new map measurements.

The areas of the separate provinces in sq. m. are:-Alberta, 255,285; British Columbia, 355,855; Manitoba, 73,731; New Brunswick, 27,985; Nova Scotia, 21,427; Ontario, 260,862; Prince Edward Island, 2,I84; Quebec, 35I,873 . The population per square mile was I.93 in I9I I, as against 1.44 in I90I; the corresponding figures for the provinces being as follows: (I901 in parentheses)-Alberta I.47 (.28), British Columbia r.o9 (.50), Manitoba, 6.18, (3.46), New Brunswick, I2.6I (I I.83), Nova Scotia, 22.98 (21.45), Ontario, 9.67 (8.37), Prince Edward Island, 42.9I (47.27), Quebec, 5.69 (4.69), Saskatchewan, 1.95 (.36); in Yukon and the North-West Territories there have been decreases.

Population.-The population of Canada according to the census of Igr $\mathrm{r}$ was $7,204,-$ 838 , an increase of $r, 833,523$ since $190 \mathrm{r}$ or 34.13 per cent. The following were the populations of provinces and territories, with the increase or decrease per cent since I90I in parentheses: Alberta, 374,663 (+4I3.08); British Columbia, 392,480 (+ I I9.68); Manitoba, 455,6I4 (+78.52); New Brunswick, 351,889 (+6.27); Nova Scotia, 492,338 (+ 7.13); Ontario, 2,523,274 (+15.58); Prince Edward Island, 93,728 (-9.23); Quebec, 2,002,712 (+21.46); Saskatchewan, 492,432 (+439.48); Yukon, 8,512(-68.73); NorthWest Territories, $17,196(-15.79)$.

The rural population in $19 \mathrm{I} I$ was $3,924,394$ and the urban population $3,280,444$, the increase since I90I being 17.16 per cent for the former and 62.25 per cent for the latter. In Alberta the increase of rural population in the ten years was 180,327 and of urban 121,314. In British Columbia the increase of rural population was 100,318 and of urban II 3,505, and in Manitoba the rural increase was 70,5 II and the urban 129,892. New Brunswick lost I,493 rural and gained 22,262 urban, while Nova Scotia lost 23,981 rural and gained 56,745 urban. Ontario lost 52, I 84 rural and gained 392,5 I I urban. : Prince Edward Island gained I5 urban, but lost 9,546 rural. Quebec shows gains of both rural and urban population, being $39,95 \mathrm{I}$ for the former and $3 \mathbf{I} 3,863$ for the latter. Saskatchewan also shows gains in both classes, being 287,338 for the former and $\mathbf{I}_{3} 3,815$ for the latter. In Yukon the rural loss was 13,430 and the urban loss 5,277. In the North-West Territories, whose population is wholly rural, the loss was 2,933 .

The cities with populations exceeding. 24,000 in I9I I were: Montreal, 470,480; Toronto, 376,538; Winnipeg I43,518; Vancouver, I00,401; Ottawa, 87,062; Hamilton, 8г,969; Quebec, 78, г90; Halifax, 46,6r9; London; 46,300; Calgary, 43,704; St. John, 42,5II; Victoria, 31,660; Regina, 30,2 I3; Edmonton; 24;000.

The total Indian population of the Dominion on March 31, I9I2, was 104,956, and in addition there were 4,600 Eskimos within the confines of Canada, making a total native population of 109,556 , a slight increase on the previous year. Of the Indians 43,382 were in Ontario, Quebec and the Maritime Provinces, 36,793 in the three Prairie Provinces and the northern territories, and 24,78I in British Columbia.

Immigration. - The total immigration to Canada during the fiscal year I9II-I 2 was as follows: From the United Kingdom.138, I. I ; U.S.A. I 33,7 I0; other countries 82,406; For I910-II the total was 3 II,084 (British I23,0I3; U.S.A. I 21,451 ), and for 1900-10, 208,794 (British 59,790, U.S.A. 45,206). The British immigrants in I9I I-I 2 included 96,806 English and Welsh; 32,988 Scotch; 8,327 Irish.

Boundaries.-Important measures, extending the boundaries of the provinces of Quebec, Manitoba and Ontario, were passed by the Canadian parliament during the session -I9II-12. The boundary of Quebec was extended to include the whole of the mainland north of her old boundary, excepting such territory over which Newfoundland has lawful jurisdiction, the additional territory being approximately 355,000 square miles. The eastern boundary of Manitoba was extended northerly to the 6 oth degree of latitude, and the eastern boundary north-easterly to the point where the eighty-ninth meridian of west longitude intersects the southern shore of Hudson's Bay, an addition of about 178 , 100 square miles. Additional territory to the north was also given to Ontario, amounting to approximately $\mathbf{4} 6,500$ square miles. This arrangement gave to Manitoba possession of the two ports on the Hudson's Bay--Fort Churchill and Port Nelson.

1. See E. B. v, 142 et seq. 
It was, however, provided by Order in Council that access to the Bay should be provided for the Temiskaming and Northern Ontario Railway, a line belonging to the Ontario government. For this purpose Ontario is to be given a strip of land five miles wide, running from the new Boundary of Manitoba to the Nelson River, and terminating in a half mile strip along the east shore of that river. Should the Dominion government decide to extend the Hudson's Bay Railway to Fort Churchill, Ontario is to receive an additional strip 200 feet wide from the Nelson River to the nearest point on that railway, and to have running powers over that line to Hudson's Bay. On April 2I, I9I2 it was officially announced that the new district of Ontario is to be known as "Patricia."

A griculture.-The details of area, yield, and value of the principal crops for I 91 I were as follows: Wheat I0, 373,958 acres, $215,851,300$ bushels, value $\$ 138,567,000$; oats, $9,219,920$ acres, $348,187,600$ bushels, value $\$ \mathbf{1} 26,8 \mathbf{I}_{4}, 000$; barley, I, $404,35^{2}$ acres, 40 ,$64 \mathrm{I}, 000$ bushels, value $\$ 23,004,000$; hay, $7,903,242$ acres, $12,694,000$ tons, value $\$ 146,-$ $596, \infty 00$. The total estimated wheat production of Canada for I9I2 was 205,685,300 bushels, oats $38 \mathrm{I}, 502,000$ bushels, and barley $43,895,300$ bushels, the quality of these three crops being above the average of the two preceding years.

At the close of the fiscal year I III-I2, fifteen government experimental farms and stations were in operation throughout the Dominion, in addition to sub-stations. While much of the work done has been a continuation of years past, some of the features are practically new, especially in connection with the encouragement of mixed farming.

Conservation.-In February 1908, an international conference on the conservation of the natural resources of the North American continent was held at Washington, when the United States, Canada, Newfoundland and Mexico were represented by delegates. A declaration of principles was adopted respecting the use, development and conservation of land, water, forests, minerals and game, and the conference advised the establishment in each country of a permanent commission for the conservation of natural resources. The question having come before the Canadian parliament, a Commission of Conservation was created by statute. This body consists of thirty-two members, including the Dominion Ministers of the Interior, of Agriculture and of Mines respectively, and the member of each of the nine provincial governments who is charged with the administration of the natural resources of the province, together with twenty other members appointed by the Governor in Council. Of these twenty appointed members at least one from each province must be a member of the faculty of a university (if any) within the province. It is the duty of the commission to take into consideration all questions which may be brought to its notice relating to the conservation and better utilisation of the natural resources of the country, to make inventories, collect and disseminate information, and frame recommendations. The first annual meeting of the Commission was held in Ottawa in January rgro. Seven committees of the Commission were formed for lands, water and water powers, minerals, forests, public health, fisheries, game and fur bearing animals and press and co-operating organisations. A staff has been appointed and constituted as a department of the government at Ottawa, and in addition to the work of the Committees, numerous important subjects have been investigated and reported upon. One instance of a recommendation acted upon is that of setting aside the eastern slope of the Rocky Mountains as a forest reserve. This has been embodied in an Act of Parliament, and some 14,600 square miles will be reserved and protected. An exhaustive work containing the various regulations in force throughout Canada bearing upon lands, fisheries and minerals has been compiled and published under the auspices of the Commission, and a report has been issued dealing adequately for the first time with the extensive water powers of the country. Other reports bear on agriculture, insanitary housing, etc.

Fisheries.-An amendment to the Fisheries Act, R.S. I906, c. 45, provides for the licensing in British Columbia of salmon canneries, and manufacturers of oil from sea lions, hair seals, sharks or dog fish, and alterations are made in the method of calculating the license fees to be paid by lobster canners.

Commerce. - The value of the total exports, imports and goods entered for consump- 
tion in Canada, with the duty collected thereon for I9ro, I9Ir, and I9r2, are shown below. The figures in each case are for the fiscal year ended March 3ist:

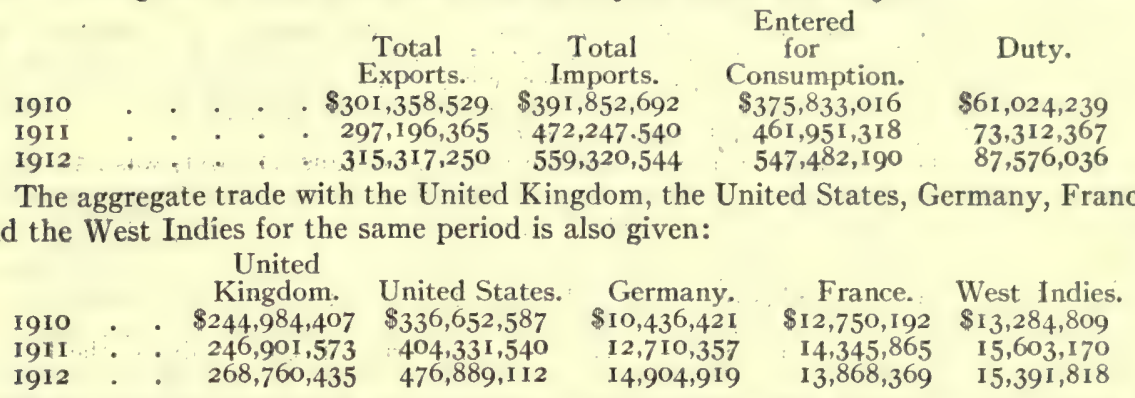

Manufactures.-Although the complete details showing the results of the census of rgi i are not yet available, some useful preliminary figures have been made public by the census and statistics office at Ottawa. Every factory in operation during the whole or part of the census year, which had given employment during any part of the year to five or more persons was required to make a report. Some places, such as brick or tile works, butter and cheese factories, electric light and power plants, fish curing plants, flour and gristing mills, lime kilns, saw and shingle mills may, however, be operated to yield large products with less than five hands. With these exceptions, factories employing five hands and over in I910 made an average product of $\$ 60,67 \mathrm{I}$ as compared with $\$ 45,483$ in 1905 and $\$ 26,2$ I 3 in 1890 , being an increase per factory of 25 per cent in the ten years 1890 to 1900 and 84 per cent in the ten years 1900 to I9Io. Or, compared by the production per head of the whole population, it was $\$ 76$ in 1890 , $\$ 89$ in I goo and $\$ 161$ in I9Io. The total value of products of this class of factories grew from $\$ 481,053,375$ in 1900 to $\$ 718,352,603$ in 1905 , and $\$ 1,165,975,639$ in 1910 . In the five years 1900 to 1905 , the growth was 47 per cent and in the next five years it was 61 per cent. For the same class of factories the earnings of salaries and wages were in I9IO $\$ 241,008,416$, being an increase of $1 x_{2}$ per cent in the decade. The average of wages and salaries in r9ro was $\$ 467$, in wages alone $\$ 418$.

Classified by provinces, the values in dollars of manufactured products were as follows: Alberta, (I900) 1,313,375, (I910) 18,788,826; British Columbia, (1900) I9,447,778, (1910) 65,204,235; Manitoba, (I900) I 2,927,439, (I910) 53,673,609; New Brunswick, (I900) 20,972,470, (I9IO) 35,422,302; Nova Scotia, (I9O0) 23,592,5I3, (I910) 52,706,184; Ontario (I900) 241,533,486, (1910) 579,810,225; Prince Edward Island, (1900) 2,326,708, (1910) 3,136,470; Quebec, (1900) I58,287,994, (I910) 350,901,656; Saskatchewan, (1900) 65I,667, (1910) $6,332,132$. It will be seen that Ontario and Quebec more than doubled their values, showing increases respectively of $\$ 338,276,739$ and $\$ 192,613,662$; but the four western provinces have shown rates of increase considerably higher, ranging from $1,323.78$ per cent for Alberta to 871.68 per cent for Saskatchewan.

The principal manufacturing centres, with the values in dollars of products in I9ro, are:Montreal 166,296,972. (71,099,750 in 1900); Toronto, I 54,306,948 (58,415,498 in I900); Hamilton; 55, 125,946 (17,122,346 in 1900); Winnipeg and St. Boniface, 39,400,608 (8,616,248 in 1900); Ottawa, 20,924,331 (7,638,688 in 1900); Maisonneuve, 20,813,774 (6,008,780 in 1900); Quebec 17,149,385 (12,779,546 in 1900); London, I6,273,999 (8,122, I 85 in 1900); Brantford, I5,866,229, (5,564,695 in 1900); Vancouver, I5,070,105 (4,990,152 in 1900); Halifax, 12, 140,409 (6,927,552 in 1900); Windsor and Walkerville, 12, 1 1 3,279 $(3,278,126$ in 1900); Berlin and Waterloo, 12,078,783 (4,359,690 in I900); Peterborough, I0,633, 119 $(3,789,164$ in 1900); St. John, 10,081,667 (6,712,769 in 1900); Sydney, 9,395,017 (631,396 in I 900); Sault Ste. Marie and Steelton, $7,842,384$ (738,472 in I900); Calgary, 7,75 I , o I I (599,444 in 1900); Guelph, 7,392,336 (3,689,183 in I900); Hull, 7,259,301 (3,182,050 in 1900); Lachine, $6,295,716(2,909,847$ in 1900); St. Catherines, 6,024,217 (2,070,543 in 1900); Galt, 5,252,600 $2,225,343$ in 1900); Stratford, $5,133,840$ ( $1,935,176$ in I900); Chatham, $5,023,560(2,714,977$ in 1900); Edmonton, 4,493,304 (243,7.78 in 1900); Victoria, $4,244,034$ (2,617,573 in 1900).

Capital increased from $\$ 331,635,499$ in 1890 to $\$ 446,916,487$ in 1900 and to $\$ 1,247,583,609$ in I9I0; salaries and wages in the same years from $\$ 79,234,311$ to $\$ 113,283,602$ and to $\$ 241,008,416$; and products from $\$ 368,696,723$ to $\$ 481,053,375$ and to $\$ 1,165,975,639$. The averages of the values of twelve out of fifteen groups of products were greater at the end of the first decade than in 1890 , and at the end of the second they were greater for all groups, 
the lowest showing an increase of $8 \mathbf{I}$ per cent. At the end of twenty years the increase in the values of all products was 216.54 per cent as compared with an average of 30.47 per cent in the first decade and of 142.13 per cent in the second.

In 1910 there were three hundred kinds of manufactures as compared with 264 ten years before. The cost of raw materials in 1900 was $\$ 266,527,858$, which when deducted from the value of products gave $\$ 214,525,517$ or 80.26 per cent as the value added by manufactures, compared with $\$ 601,509,018$, as the value of raw materials and $\$ 564,466,62$ I or 93.76 per cent as the value added by manufactures in 1910 .

Railways. - The total railway mileage for the year ended June 30 , I9II, was 25,400 , an increase of 669 miles over 1910. Seventy per cent of this increase was in the western provinces. On the same date there were about 1600 additional miles of railway in actual operation, which were officially regarded as being still under construction. The mileage under construction was:- graded or being graded, 6,223; track laid or being laid, 3,833. In addition to these figures some 2,500 miles of additional line were located, surveyed or being surveyed.

New construction on the Canadian Pacific Railway system between June 30, I9I0 and June 30 , I9I2 amounted to 1,753 miles. On the Grand Trunk Pacific Railway, the Prairie Section (main line, Winnipeg to Wolf Creek, 916 miles) was completed at the beginning of 1910; of the Mountain Section (main line, Wolf Creek to Prince Rupert, 837 miles) 100 miles from Prince Rupert eastward to Copper River were completed at the beginning of 1910 , the remaining 257 miles being under contract; from Copper River eastward to Bulkley Summit, 175 miles, were to be completed in the spring of I913; from Wolf Creek westward, 185 miles is completed, and a further distance west ward to Second Crossing of Fraser River (120 miles) was also completed at the end of 1912.

From 1909 to the end of 1912,849 miles of branch lines (of which 747 were graded) were constructed, as follows:-Regina Boundary Branch, 155 miles; Regina Moose Jaw Branch, 40 miles; Moose Jaw North-West Branch, 48 miles; Weyburn Branch, I 5 miles; Prince Albert Branch, II I miles; Battleford Branch, 48 miles; Cut Knife Branch, 50 miles; Harte Brandon Branch, 25 miles; Biggar Calgary Branch, I05 miles; Calgary Branch, 202 miles; Alberta Coal Branch, 50 miles.

During the year 1912 over 586 miles of newly constructed tracks were added to the Canadian Northern system, the average mileage operated being 3,888 miles. Great progress has been made in the construction of the transcontinental line of the Canadian Northern System, which was expected to be completed by the end of I9I3; the line through British Columbia to connect the western lines of the railway with tidewater at the Pacific coast has advanced rapidly. In addition to the advantage of easy gradients, the location of the line enters without competition into a large territory, the physical characteristics of which are expected to attract a desirable class of settlers. The line will also give access to a hitherto unknown section of the Canadian Alps,

During the year $\$ 61,650,300$ was added to the stock issue of railways operating in Canada, and $\$ 56,741,2$ I 4 to funded debt. These additions brought the aggregate capital liability up to $\$ 1,528,689,201$. The aggregate earnings from all sources for the year were $\$ 188,733,-$ 493, an increase of 8.7 per cent over 1910 .

Porls.-Much attention has been and is being devoted to the provision of adequate dock accommodation and other shipping facilities. The harbour at Montreal has been vastly improved, and a new floating dry dock was launched by the Governor General on November 18, 1912, thus providing complete modern equipment for the repair and examination of large. vessels. At Victoria, British Columbia, a contract has been let to an English firm for the construction of a breakwater as a first instalment of an important scheme of harbour improvement, and at Courtenay Bay, St. John, New Brunswick, another English firm of contractors were in 1912 undertaking dock and breakwater works on a large scale so as to enable the port to meet the demands that would be made upon it through the great railway extensions.

Postai Development.-During $191 \mathrm{I}-12$ a very considerable expansion was witnessed. The number of post offices increased by 437 , and there was an increase of 670 miles in the extent of the system over which mails were carried by railway. The number of miles over which mails were carried by railway and water routes and ordinary land routes was greater by $3,422,080$ mile's than it was for the year before. The increase in the number of letters and postcards sent during the year was over fifty-two millions and a quarter, or more than ten per cent greater than the year before. An ()reler in Council was passed during the year increasing to $\$ 1500$ the amount the Post Office Savings Banks are authorised to accept in any one year, and increasing the maximum limit of an account to $\$ 5000$, exclusive of interest. Formerly the maximum amount that could be accepted from a depositor in one year was 81000 , and the maximum limit of an account was fixed at $\$ 3000$. The increase in value of postage stamps sold was $\$ 1,068,607$, or about $10 \frac{3}{6}$ per cent.

Finance.-The feleral revenue increased from $\$ 71,186,072$ in 1905 to $\$ 136,108,217$ in 1912 , and the expenditure from $878,804,1,38$ to $8137,142,082$. A large amount of this expenditure is chargeable to capital, and represents outlays in respect of railways, canals and public works, bumties, etc. The total debt in 1912 was $\$ 508,338,591$; the total assets $\$ 168,419,131$, and the net debt $\$ 339,919,400$. 
The Governor General. - The Earl and Countess Grey embarked at Quebec for England on October I3, I9I1, when His Excellency relinquished the office of Governor Gen. eral. Appointed on Șeptember 26th, and assuming office on December 10, I904, Lord Grey's tenure of office was in I 909 extended beyond the usual term of five years, and again for another year after the death of King Edward in Igro. He had thus held office longer than any of his eight predecessors since Confederation. In January Igr I it was notified that the Duke of Connaught would be appointed to succeed Lord Grey, and on March 2Ist, he was formally gazetted as Governor General and Commander in Chief for a period of two years. On October I2, I9II the Duke and Duchess were welcomed at Quebec, where the new Governor General was formally sworn in.

Imperial Conference, I9I.-At the Imperial Conference in London in May and June IgI I, the Canadian representatives were Sir Wilfrid Laurier, ${ }^{1}$ Prime Minister, Sir F. W. Borden, ${ }^{2}$ Minister of Militia \& Defence, and Mr. L. P. Brodeur (b. I862), Minister of Marine \& Fisheries.

Among the resolutions adopted of particular interest to Canada was Resolution I, proposed by the Imperial government, which provided that (a) the Dominions shall be afforded an opportunity of consultation when instructions are being framed for British delegates at future meetings of the Hague Conference, and that Conventions affecting the Dominions provisionally assented to at that Conference shall be circulated among the Dominion governments for their consideration before any such convention is signed: (b) that a similar procedure, where time and opportunity and the subject matter permit shall, as far as possible, be used when preparing instructions for the negotiation of other international agreements affecting the Dominions. Moreover, in connection with the most-favoured-nation clause in certain Treaties still in force between Great Britain and other countries, Resolution XIX was adopted on the motion of Sir Wilfrid Laurier, as follows: "That His Majesty's Government be requested to open Negotiations with the several foreign governments having Treaties which apply to the Overseas Dominions with a view to securing liberty for any of those Dominions which may so desire to withdraw from the operation of the treaty without impairing the treaty in respect of the rest of the Empire." Steps were subsequently taken by the Imperial government towards the opening of negotiations with the countries concerned.

Resolution XX, also adopted on the motion of Sir Wilfrid Laurier, suggested the appointment of a Royal Commission to investigate and report upon the natural resources of the Empire and the development of mutual trading relations. Effect was given later in the year to this suggestion, and Mr. George E. Foster, the Minister of Trade \& Commerce in Mr. Borden's cabinet, was appointed on the Dominions Royal Commission.

Parliamentary Politics. - The political history of Canada in Igro-r 3 centres round the two great questions of Reciprocity with the United States and Canadian naval policy in relation to the Empire. On July I8, I9II parliament reassembled after the Coronation adjournment, and on July 29 th the government of Sir Wilfrid Laurier, who had been Premier since I896, decided to recommend the dissolution of parliament, and to submit their proposals for commercial reciprocity with the United States (see below) to the judgment of the Canadian people at a general election, which was fixed for Septem- ber 2 Ist. While the chief question before the electors was the Reciprocity Agreement, the question of Canada's Naval Policy (see below) received much attention, especially in the province of Quebec. The result was a complete defeat for the government and the Reciprocity party. What had been a Liberal majority of 43 was converted into a Conservative-Liberal and Anti-Reciprocity majority of 49. Mr. Fielding and Mr. Paterson, who were responsible for the negotiations with the United States, were both defeated, together with Sir F. Borden and four other ministers. On October 6th Sir Wilfrid Laurier and his administration resigned office. Sir Wilfrid Laurier retained his seat, however, and decided to remain at the head of his party, now in Opposition.

Mr. R. L. Borden, ${ }^{3}$ leader of the Conservative party, being called upon to form an Administration, accomplished this task on October IO, I9II, and the new ministry was

${ }^{1}$ B. 1841 : see $E$. B. xvi, $286-7$.

B. 1847 : see E. B. iv, 245 .

${ }^{3}$ Robert Laird Borden (see E. B. iv, 245) was born in Nova Scotia in 1854 . Becoming a leading lawyer in his province, he entered the Dominion parliament in 1896, and in I90I became leader of the Conservative Opposition. 
constituted as follows: R. L. Borden, Premier and President of the Privy Council; George Eulas Foster, ${ }^{1}$ Trade and Commerce; Robert Rogers (b. 1864), Interior; F. D. Monk (b. 1856), Public Works; Francis Cochrane (b. 1852), Railways and Canals; William T. White, ${ }^{2}$ Finance; Louis P. Pelletier (b. 1857), Postmaster General; John D. Hazen (b. I860), Marine and Fisheries and Naval Service; Charles J. Doherty (b. I855), Justice; Samuel Hughes (b. I853), Militia and Defence; William J. Roche (b. 1859), Secretary of State; Thomas W. Crothers (b. 1850), Labour; Wilfrid B. Nantel (b. 1857), Inland Revenue and Mines; John D. Reid (b. 1859), Customs; Martin Burrell (b. 1858), Agriculture; George H. Perley (b. 1857), Albert E. Kemp (b. I858), and James A. Lougheed (b. 1854), members without portfolios. On October 22, Igr2 Mr. Monk resigned on the question of Mr. Borden's naval policy (see below) and his portfolio was taken over by Mr. Rogers, Mr. W. J. Roche becoming Minister of the Interior in his place. The office of Secretary of State was filled by Mr. Louis Coderre (b. 1865), the member for the Hochelaga division of Montreal. On October 23, I9II the Hon. Auguste Landry was appointed Speaker of the Senate, and on November I 5th Dr. T. S. Sproule was elected Speaker of the House of Commons.

The twelfth parliament of the Dominion of Canada was opened on November I 5, I 9 I I by the Governor General in person. The address in reply to the speech from the throne was voted on November 29, and on December 7 th parliament adjourned over the Christmas recess until January Iо, I9I2. On resuming, the main business was financial, estimates including supplementaries being submitted for $\$ 169,389,7$ I 6 divided as to $\$$ I 77,98 I, 83 I to Consolidated Fund Account, and $\$ 51,407,885$ to Capital Account. On April I, I9I 2 parliament was prorogued.

When the new session opened on November 2I, I9I2, it was known that the announcement of Mr. Borden's naval programme would be the business of outstanding importance. The Governor General in the speech from the throne stated that, his advisers having consulted with the Imperial government, it had been concluded that it would be the duty of Canada at this juncture to afford aid for the purpose of strengthening the effective naval forces of the Empire; and on December 5 th (see below) the Premier announced an Emergency Contribution Bill, leaving the permanent Naval Policy for future consideration.

The Reciprocity Question.-Sir W. Laurier's government had begun their official negotiations for Reciprocity with the United States in January I9II, as the result of private discussions in the previous year. The terms of the proposed Agreement were announced in the Canadian parliament by Mr. W. S. Fielding, the Finance Minister in Sir W. Laurier's cabinet, on January 26 , I9I. It aimed at more free interchange of products by removing duties on certain articles and reducing them in others.

Among those which were to enter free in each country, if of the growth, product or manufactures of the other, were live animals, poultry, wheat and other grain, vegetables, fruit, dairy products, honey, cotton seed, oil and certain oil seeds, grass, garden, field and other seed, fish except those preserved in oil, certain fish oils, timber (not sawn), brass (not polished) rolled iron or steel sheets 14 gauge or thinner, galvanised, coated with zinc or tin, crucible cast steel, galvanised iron, steel or wire, typewriting and typesetting machines, barbed fencing wire, coke (round), wire rods, wood pulp, and cream separators. Among the articles to be admitted into Canada from the United States and into the United States from Canada at identical rates were the following:--Fresh meats $1 \frac{1}{4} \mathrm{cts}$. per $1 \mathrm{~b}$.; bacon and hams, not in tins or jars, $1 \frac{1}{4}$ cts. per lb.; meats dried and preserved $1 \frac{1}{4} \mathrm{cts}$, per lb.; canned meats and poultry 20 per cent; lards, etc., I cts. per lb.; barley, malt, per Ioo lbs. $45 \mathrm{cts}$. ; cereal fords $12 \frac{1}{2}$ cts. per 100 lbs.; biscuits, wafers, cakes, 25 per cent; confectionery $32 \frac{1}{2}$ per cent; farm wagons $22 \frac{1}{2}$ per cent; farming implements of various kinds 15 per cent; portable engines with boilers and traction engines for farm purposes 20 per cent; roofing slates $55 \mathrm{cts}$. per $100 \mathrm{ft}$.; cutlery plated or not $27 \frac{1}{2}$ per cent; clocks, watches, etc. $27 \frac{1}{2}$ per cent; automobiles 30 per cent. Arrangements were made for special rates of duty on a moderate scale to cover a large number of other commodities.

${ }^{1}$ See E. B. x, 732. Born in New Brunswick in 1847. In 1885 he was Minister of Marine and Fisheries, and in $1888-96$ Minister of Finance.

2 Born at Bronte, ()ntario, in 1866 . He became a successful financier in Toronto, occupying until recently the position of Vice-President of the National Trust Company. 
The case presented for the adoption of this agreement was that reciprocal trade relations had been the policy of all parties in Canada for generations, that many efforts had been made to secure a treaty without success, and that Sir John Macdonald's National Policy Tariff (1879) contained a standing offer of reciprocity with the United States covering a large portion of the products included in the present agreement. The United States having approached Canada with fair offers, it was claimed that they should be fairly met, and that in making the arrangement the government were realising the desires which the Canadian people had expressed for half a century, and also that in promoting friendly relations with the neighbouring republic the best possible service to the empire was being done. As Canada was seeking markets everywhere for her surplus products, subsidising steamship lines, and sending out commercial agents, it would be absurd to refuse to avail herself of increased facilities in the markets at her doors.

A denial was given to the expressed fear that the imports from Great Britain would be seriously affected. It was pointed out that the greater part of the agreement dealt with natural products which did not come from Great Britain, and that the range of manufactures affected was small. It was further denied that there was any foundation for the assumption that the tariff rates agreed upon discriminated in favour of the United States and against Great Britain. The promoters of the agreement promised that in every case Great Britain would have the same rate or a lower one, and held that Canada's right to deal with the British preference as she pleased remained untouched.

The opposition to the agreement took the ground that the arrangement had been entered into hastily without its effects being fully appreciated, and that the question should be referred to the people. Attention was drawn to the success which had attended the efforts to build up a nation and bind the country together from east to west, and it was contended that, as the arrangements proposed would primarily affect the question of transportation by promoting a tendency to make trade move north and south, the immense efforts which had been made would be sacrificed, and the markets which had been secured in Great Britain abandoned. The action of the United States in approaching Canada with a desire to make such an agreement, after declining on so many occasions to consider the question when asked to do so by Canada, was looked upon with suspicion, and it was suggested that the balance of advantage would remain with the United States, the speeches of some of her most prominent public men being freely quoted in support of this view,-notably one by Mr. Champ Clark in Congress, and another by. President Taft himself. It was held that the impelling cause was the desire of the United States to have access to the abundant natural resources of Canada, her own reserves of wood, coal and other minerals, and much of her farm land, having shown signs of exhaustion. It was thought the better plan was to conserve Canadian resources for Canadian use. A further objection to the proposals was that while they would change the whole current of Canadian industries, and be likely to dislocate the national development, the new markets proposed would be so entirely unstable and insecure that, after having had the benefit of them for a few years, they might be withdrawn, causing a reversion to the position of 25 years ago, and necessitating the rebuilding of home industries and re-making their reputation in markets which in the meantime had been entirely occupied by old competitors. Great importance was attached to the restriction on legislation which it was alleged this agreement would cause, as no trade aggrieved under it could obtain redress without the arrangement as a whole being upset. It was also urged that under it concessions in the tariff would have to be made, in accordance with existing treaties, to countries from which no equivalent advantages could be obtained; and it was declared that if this Reciprocity policy was pursued the ties of empire would eventually be cut, for it would lead to complete commercial union and in the end the political domination of the United States, to which Canada would simply be an annexe.

The debates in connection with the matter lasted for almost the remainder of the session; but on February 22, I9II, on the motion of Mr. F. D. Monk, the House adopted unanimously the following as an amendment to the motion for going into Committee 
of Ways and Means: "But, before resuming the discussion of the terms of the agreement concluded between the government of Canada and the President of the United States, and with a view to dispel the feeling of unrest created in Canada by comments made in both countries as to the political consequence of the agreement, the House wishes to affirm emphatically its determination to preserve intact the bonds which unite Canada to the British Empire and the full liberty of Canada to control her fiscal policy and internal autonomy."'

A Bill to give effect to this Reciprocity Agreement on the part of the United States was introduced in the American Congress on January 29th, and in due course passed the Senate on July 22 nd, it being enacted that its provisions should become operative as soon as the necessary counterpart legislation had been passed by the Canadian parliament. Discussion continued in the Canadian House of Commons, but no progress was made towards the adoption of the proposals, and on July 29 , I9 I I the government decided to recommend the dissolution of parliament and to submit the matter to the judgment of the people at a general election. The defeat of the government followed, the result being greatly influenced by the strong opposition to Reciprocity which was shown by such well-known Liberals as Mr. Clifford Sifton (b. I86r; formerly Minister of the Interior in the Laurier cabinet), Mr. Lloyd Harris, and Mr. Wm. German, and by the steps taken by a body of prominent Liberals of Toronto, assisted by Sir Edmund Walker, President of the Canadian Bank of Commerce.

Sir W. Laurier's Naval Policy.-An outcome of the Imperial Conference of Igog had been the determination of the Canadian government to establish a naval service; and on January I 2, rgro a Bill for this purpose was introduced into the House of Commons, and became law on May 4, I9ı. It provided for the creation of a Naval Department, and transferred to it from the Department of Marine and Fisheries the wireless telegraph, fisheries protection, hydrographic, and tidal survey branches. It empowered the government to appoint a Naval Board to advise the minister, and to organise and maintain permanent, reserve and volunteer forces, and to place at the disposal of His Majesty, for general service in the Royal Navy, ships or men of the Canadian naval service. Provision was also made for a naval college. During the debate on the Bill, Sir Wilfrid Laurier announced that it was the intention of the government to construct, in Canada if possible, four cruisers of the improved "Bristol" class, and six destroyers of the improved "River" class. At conferences with the British Admiralty it was agreed that the naval stations for Canada should be two-one on the Atlantic to include the waters north of $30^{\circ} \mathrm{N}$. lat. and west of the meridian of $40^{\circ} \mathrm{W}$.; and one on the Pacific to include the waters north of $30^{\circ} \mathrm{N}$. lat. and east of the meridian of $180^{\circ}$. Halifax Dockyard was taken over from the Imperial authorities on January I, 1906, and the dockyard at Esquimalt on November 9, I010. On August 28, I9I it was announced that the King had approved of the naval forces of Canada receiving the style of "The Royal Canadian Navy," and of the ships of war of that navy being designated as "His Majesty's Canadian Ships." On December r6th the following regulations were published with regard to the flag and pennants to be flown by the Royal Canadian navy: " All ships and vessels of the Royal Canadian Navy shall fly at the stern the white ensign as the symbol of the authority of the Crown, and at the jack-staff the distinctive flag of the Dominion of Canada, such distinctive flag being the blue ensign with the Arms of the Dominion inset in the fly. The white pennant will be flown at the masthead."

In pursuance of Sir Wilfrid Laurier's naval policy, H.M.'s cruisers "Niobe." and "Rainbow" were purchased and taken over in the autumn of rgro. On July 29, rgri. however, H.M.C.S. "Niobe" sustained damage by grounding on the coast off Cape Sable; her repairs were undertaken at IIalifax and took fifteen months to complete. The building of the proposed new cruisers and destroyers had, however, not been commenced at the time of the resignation of Sir Wilfrid Laurier's government.

Mr. Borden's Naval Policy. - The naval policy of Sir. Wilfrid Laurier's government was that of a Canadian-built and Canadian-controlled navy, but this was criticised by the Opposition as involving a large expenditure, a disunited Imperial navy, and the construc- 
tion of obsolete types of ships. Upon Mr. Borden's acceptance of office, the naval question became one of renewed interest. Mr. Borden stated that in his view the question of permanent co-operation between the Dominion and the rest of the Empire ought to be fully debated, and that the Canadian people should be given an opportunity of pronouncing upon it; pains would be taken to ascertain in the meantime what were the real conditions confronting the Empire. In pursuance of this object, Mr. Borden, with several of his colleagues, visited London in July igi 2, and were cordially welcomed by Mr. Asquith's government, who enabled them, at meetings of the Imperial Defence Committee and otherwise, to obtain all the information available as to the problems of British foreign policy and the naval situation as it presented itself to the British Admiralty. The proposals which the Canadian government founded on the understanding thus arrived at were left, however, to be made public first in the Dominion Parliament after it met in November.

Mr. Borden's speech on December 5, I9I 2 must always be historic in the relationship between Canada and the Mother-country. It was notable for announcing two steps forward in a common Imperial policy. In the first place his "Bill to Authorize Measures for Increasing the effective Naval Forces of the Empire" proposed to contribute $f_{7} 7,000,000(\$ 35,000,000)$ for the constrüction and equipment of three first-class battleships, to be under the control of the British Admiralty as part of the Royal Navy, subject to arrangements for their being at the disposal of the Canadian government if ever a separate Canadian Navy were established. And in the second place, by the agreement of the Imperial government to include a Canadian Minister as one of the permanent members of the Committee of Imperial Defence, the principle was recognised that, if the Dominions took their share in Imperial defence they must also have a share in determining Imperial policy.

The proposal for an "emergency contribution" of three battleships to the British Navy was founded on a memorandum (published in England on Dec. 5th, as a Parliamentary paper) drawn up by the Admiralty for the information of the Canadian government as to the existing international situation from a naval point of view; and $\mathrm{Mr}$. Borden read this out in the course of his speech. It is given in full elsewhere in the YEAR-BOoK (see Part I. sect. i, "The World's Navies") and need not here be repeated. But the view taken by the Canadian government can best be shown by quoting the salient passages of Mr. Borden's speech.

As regards the vital need of naval security for the very existence of the Oversea Dominions as part of the British Empire, and the grave danger to that security indicated by the relative decline in the power of the British navy, owing to the growth of other navies, Mr. Borden said:

"This Empire is not a great military power, and it has based its security in the past, as in the present, almost entirely on the strength of its. Navy. A crushing defeat upon the high seas would render the British Islands, or any Dominion, subject to invasion by any great military Power; loss of such a decisive battle by Great Britain would practically destroy the United Kingdom, shatter the British. Empire to its foundations, and change profoundly the destiny of its component parts. . . There is, therefore, grave cause for concern when once the naval supremacy of the Empire seems on the point of being successfully challenged.

"The great outstanding fact which arrests our attention in considering the existing conditions of naval power is this. Twelve years ago the British Navy and the British Flag were predominant in every ocean of the world and along the shores of every continent. To-day they are predominant nowhere except in the North Sea. The paramount duty of ensuring safety in home waters has been fulfilled by withdrawing or reducing squadrons in everry part of the world, and by concentrating nearly all the effective naval forces in close proximity to the British Islands. . In 1902 there were 55 British warships on the Mediterranean station; to-day there are 19. There were I4 on the North American and West Indies station; to-day there are three. There were three on the south-east coast of South America; to-day there is one. There were 16 on the Cape of Good Hope station; to-day there are three. There were eight on the Pacific station; to-day there are two. There were 42 on the China station; to-day there are $3 \mathrm{I}$. There were I 2 on the Australian station; to-day there are eight. There were ten on the East Indies station; to-day there are nine. To sum up, in 1902 there were 160 ships on foreign and Colonial stations against 76 to-day. Do not imagine that this 
result has been brought about by any reduction in expenditure, for the case is practically the reverse. Great Britain's total naval expenditure in 1902 was less than $\$ 152,000,000$ ( $f_{30}$,$400,000)$. For the present fiscal year it exceeds $\$ 220,000,000(f 44,000,000)$. Why then, has the naval force of the Empire been so enormously reduced while at the same time the expenditure has increased nearly 50 per cent? For the simple reason that the increasing strength of other navies, and especially of the German Navy, has compelled Great Britain not only to increase her fleet, but to concentrate it in the vicinity of the British Islands. ...

"It is neither necessary nor desirable to debate or discuss the probability or imminence of war. The real test of our action is the existence or non-existence of absolute security. It should never be forgotten that without war, without firing a shot or striking a blow, our naval supremacy may disappear, and with it the sole guarantee of the Empire's continued existence.

"The fact that trade routes, vital to the Empire's continued existence, are inadequately defended and protected by reason of the necessary concentration in home waters is exceedingly impressive, and even startling. Even during the present year the battleships of the British Mediterranean Fleet, based on Malta, have been withdrawn and based on Gibraltar, in order that they might become more easily available for necessary aid in home waters. The Atlantic Fleet, based on Gibraltar, has been withdrawn to the vicinity of the British Islands for the same reason. Under such conditions the British Flag is not predominant in the Mediterranean, and with every available exertion of the whole Empire it may be impossible to regain the necessary position of strength in that great highway before 1915 or I9I6. Austria-Hungary, with only 140 miles of sea coast and absolutely no colonial possessions, is building in the Mediterranean a formidable fleet of Dreadnoughts which will attain its full strength in about three years, and which will be supported by strong battleships of the preDreadnought type, and by cruisers, torpedo craft, and other necessary auxiliaries. The fleet of Italy in the same theatre will be even more powerful and more formidable. The withdrawal of the British Flag and the British Navy from so many parts of the world for the purpose of concentration in home waters has been necessary, but unfortunate. Our Navy was once dominant everywhere, and the White Ensign was the token of naval supremacy in all seas. Is it not time that the former conditions should, in some measure, be restored? Upon our own coasts, both Atlantic and Pacific, powerful squadrons were maintained 12 years ago. To-day the flag is not shown on either seaboard. I am assured that the aid which we propose will enable such special arrangements to be consummated that, without courting disaster at home, an effective fleet of battleships and cruisers can be established in the Pacific, and a powerful squadron can periodically visit our Atlantic seaboard and assert once more the naval strength of the Empire along these coasts. I do not forget, however, that it is the general naval supremacy of the Empire which primarily safeguards the Oversea Dominions. New Zealand's battleship is ranged in line with the other British battleships in the North Sea, because there New Zealand's interests may best be guarded by protecting the very heart of the Empire."

As regards the three Canadian battleships now to be added to the navy, Mr. Borden pointed out that, under the Admiralty, the Empire now had what he had convinced himself was the most thorough and effective naval organisation in the world, of which it was the best Canadian policy to make use. The hazardous and costly experiment of building up a separate naval organisation for Canada was quite unnecessary, and in any case could only provide a poor and weak substitute. In the present emergency the Canadian ships were best employed as part of the Empire navy under the Admiralty of the mother-country:

"Those ships will be at the disposal of His Majesty the King for the common defence of the Empire. They will be maintained and controlled as part of the Royal Navy, and we have the assurance that, if at any time in the future it be the will of the Canadian people to establish a Canadian unit of the British Navy, these vessels can be called by the Canadian government to form part of the Navy, in which case, of course, they will be maintained by Canada and not by Great Britain. In that event, there will, necessarily, be reasonable notice, and, indeed, Canada would not desire or suggest the sudden withdrawal of so powerful a contingent from any important theatre in which the naval forces of the Empire might be exposed to severe and sudden attack. In the meantime I am assured that special arrangements will be made to give (anadians an opportunity of serving as officers in these ships.

"The ships will be built under Admiralty supervision in the United Kingdom for the reason that, at present, there are no adequate facilities for constructing them in Canada. The plant recuired for the construction of Dreadnought battleships is enormous, and it would be imposibible at present to have shipbuilding in this country on such a scale. In any case, only half could be built in Canada, because the machinery for armour and guns would, necessarily, be constructed or manufactured in the United Kingdom. The additional cost of construction in Canada would be about 12 million dollars for three, and it would be impossible to estimate the delay. No one is more eager than myself for the development 
of the shipbuilding industries in Canada, but we cannot, upon any business or economic considerations, begin with the construction of Dreadnoughts, and especially we could not do so when these ships are urgently required within two or three years at the outside for rendering aid upon which may depend the Empire's future existence. According to my conception, the effective development of the shipbuilding industries in Canada must commence with small beginnings and in a businesslike way. I have discussed the subject with the Admiralty, and they thoroughly realise that it is not to the Empire's advantage that all shipbuilding facilities should be concentrated in the United Kingdom. I am assured, therefore, that the Admiralty are prepared in the early future to give orders for the construction in Canada of small cruisers, oil tank vessels, and auxiliary craft of various kinds. The plant required is relatively small as compared with that which is necessary for Dreadnought battleships, and such an undertaking will have a much more secure and permanent basis from the business standpoint. For the purpose of stimulating so important and necessary an industry we have expressed our willingness to bear a portion of the increased cost for a time at least. I see no reason why all the vessels required in future for our government service should not be built in Canada, even at some additional cost. In connection with the development of shipbuilding I would not be surprised to see the establishment of a high class of engineering works which will produce articles now imported and not at present manufactured in Canada. Therefore, although the sum which we propose to devote for necessary naval aid at this critical juncture is to be expended in Great Britain, yet we believe that this step will result, under the conditions which I have described, in the very marked development of more than one industry in Canada, and that, even from a purely economic and material standpoint, the step has much to commend it."

The Canadian expenditure now proposed was, in Mr. Borden's view, a moderate one, regarded not as the beginning of a system of periodical contributions, but as an emergency aid at a moment of crisis:

"If we should neglect the duty which I conceive we owe to ourselves, and if irreparable disaster should ensue, what will be our future destiny? Obviously as an independent nation or as an important part of the great neighbouring Republic. What then would be our responsibilities, and what would be the burden upon us for a protection on the high seas much less powerful and less effective than that which we enjoy to-day? Take the case of one nation whose territory, resources, population, and wealth may fairly be compared with those in Canada. The naval estimates of Argentina for the four years from 1909 to I912 inclusive amounted to $\$ 35,000,000(£ 7,000,000)$. No information is available as to the exact proportion of the last-mentioned sum which has been appropriated for naval purposes, but it is understood that the far greater portion is for naval construction. It is safe, therefore, to estimate that during the past four years Argentina has expended for naval purposes not less than from $\$ 65,000,000$ to $\$ 70,000,000$ ( $£_{13}, 000,000$ to $£_{1} 4,000,000$ ). The Federal and State expenditure of the United States comprises a total outlay for armaments of between $\$ 250,000,000$ and $\$ 300,000,000\left(f_{50}, 000,000\right.$ and $\left.f 60,000,000\right)$, or at the rate of $\$ 2.75$ per head. Similar expenditure by Canada would mean an annual outlay of some $\$ 20,000,000$ to $\$ 25,000,000$, or between $\$ 80,000,000$ and $\$ 100,000,000$ during the same period.

"It is apparent, therefore, that the aid which we propose to bring at this juncture is of a moderate and reasonable character. For 45 years as a Confederation we have enjoyed the protection of the British Navy without the cost of a dollar. . . . So far as official estimates are available, the expenditure of Great Britain on naval and military defence for the provinces which now constitute Canada during the nineteenth century was not less than $\$ 400,000,000(f 80,000,000)$. Even since the inception of our Confederation, and since Canada attained the status of a great Dominion, the amount so expended by Great Britain for the naval and military defence of Canada vastly exceeds the sum which we are now asking parliament to appropriate. From 1870 to 1890 the proportionate cost of the North Atlantic Squadrons which guarded our coasts was from $\$ 125,000,000$ to $\$ 150,000,000$ ( $f 25,-$ $000,000$ to $f 30,000,000)$. From I 853 to 1903 Great Britain's expenditure on military defence in Canada runs closely to $\$ 100,000,000$.

As regards the voice which it had been arranged that Canada should have on the Committee of Imperial Defence, Mr. Borden said:

"With increasing power and influence there has necessarily come, by sure and gradual steps, a certain development in our relations with the United Kingdom and the other Dominions. . . . In this constitutional development we are necessarily confronted with the problem of combining co-operation with autonomy. It seems most essential that there should be such co-operation in defence and in trade as will give to the whole Empire an effective organisation in these matters of vital concern. On the other hand, each Dominion must preserve in all important respects the autonomous government which it now possesses.

"The responsibility for the Empire's defence upon the high seas, in which is to be found the only effective guarantee of its existence, and which hitherto has been assumed by the United Kingdom, has necessarily carried with it the responsibility for and the control of 
foreign policy.

When Great Britain no longer assumes sole responsibility for defence upon the high seas she can no longer undertake to assume sole responsibility for and sole control of foreign policy, which is closely, vitally, and constantly associated with that defence in which the Dominions participate. . . . The great Dominions, sharing in the defence of the Empire upon the high seas, must necessarily be entitled to share also in the responsibility for and in the control of foreign policy. Not only His Majesty's Ministers but also the leaders of the opposite political party in Great Britain, have explicitly accepted this principle.

"I have alluded to the difficulty of finding an acceptable basis upon which the great Dominions co-operating with the mother-country in defence can receive and assert an adequate voice in the control and moulding of foreign policy. We were brought closely in touch with both subjects when we met the British Ministers in the Committee of Imperial Defence. That committee is peculiarly constituted, but in my judgment is very effective. It consists of the Prime Minister of Great Britain and such persons as he may summon to attend it. Practically all the members of the cabinet from time to time attend its deliberations, and usually the more important members of the cabinet are present. In addition, naval and military experts and the technical officers of the various departments concerned are in attendance. A very large portion of the work of the committee is carried on by subcommittees, which often are composed in part of persons who are not members of the general committee itself, and who are selected for their special knowledge of the subjects to be considered and reported upon. The amount of work which thus has been performed during the past five or six years in particular is astonishing, and I have no doubt that it has contributed largely to the safety of the whole Empire in time of peril.

"The committee is not technically or constitutionally responsible to the House of Commons and thus it is not supposed to concern itself with policy. As so many important members of the cabinet are summoned to attend the committee, its conclusions are usually accepted by the cabinet and thus command the support of the majority of the House of Commons. While the committee does not control policy in any way and could not be undertaken to do so as ii is not responsible to parliament, it is necessarily and constantly obliged to consider foreign policy and foreign relations for the obvious reason that defence, and especially naval defence, is inseparably connected with such considerations.

'I am assured by his Majesty's Government that pending a final solution of the question of voice and influence they would welcome the presence in London of a Canadian Minister during the whole or a portion of each year. Such minister would be regularly summoned to all meetings of the Committee of Imperial Defence and be regarded as one of its permanent members. No important step in foreign policy would be undertaken without consultation with such representative of Canada. This means a very marked advance both from our standpoint and from that of the United Kingdom. It would give us the opportunity of consultation and therefore influence which hitherto we have not possessed."

In opposition to the Government proposals, Sir Wilfrid Laurier on December I 2th moved an amendment which, while not negativing the first clause of the Government resolution providing for a vote for increasing the effective Naval forces of the Empire, would have substituted for the remaining clauses a resolution declaring it necessary that Canada without further delay should enter actively upon a permanent policy of naval defence, and that any measure of aid to Imperial naval defence which did not embody a permanent policy of participation by ships owned, manned and maintained by Canada, was not an adequate expression of the aspirations of the Canadian people. Mr. Borden, said Sir Wilfrid, had asserted that before she enacted a permanent policy Canada must have a voice in all questions affecting war or peace. But that was a large contract, and the question before them was that of emergency and immediate: defence. If Canada was represented in the councils of war and peace the other Dominions and dependencies must be also. That question might take years to solve. It must be discussed by itself, and in' the meantime Canada shouid continue in her preparations for defence. Sir Wilfrid Laurier condemned the Government's policy oi direct contribution as un-Canadian and un-British, and as unsuited to the real need:s of the Empire.

Other Legislation, 1910-12.-Among important acts passed during the session 1910-1 were the Opium and Drug Act, which prohibits the importation, manufacture, sale or possession for other than scientific or medicinal purposes of opium, cocaine, morphine anc! eucaine, or any salts or compounds thereof; a new Seed Control Act; and an Act confirminy and sanctioning the treaty signed at Washington on January II, I909, relating to the bound. ary waters and to the questions arising along the boundary between Canada and the United States. In the session $1911-12$, an act was passed amending the Dry Docks Subsidies Act of 1910 , and providing that any dry dock shall not be deemed, for the purpose of subsidy, 
to be a dry dock of the first class unless there can be received and repaired therein the largest ships or vessels of the British navy existing at the time at which the contract is entered into. Another Act of this session provided for the constitution of a new Department under the First Minister, to deal with all official communications in connection with the external affairs of Canada, the administration of all matters relating to the foreign consular service in Canada, etc. A measure of great importance, dealing generally with grain inspection, was also passed; it provides for the appointment of Grain Commissioners, the establishment of inspection divisions, and the appointment of a Grain Standards Board for the purpose of establishing commercial grades, and defines the various established grades. Acts providing for the extension of the boundaries of Manitoba, Ontario and Quebec were also passed.

Under the Canadian Medical Act, chapter I37, Revised Statutes I906, and the-amendıng Act, chapter I6, I9II, provision was made for the formation of a Dominion Medical Council as soon as the Legislatures of the various provinces of Canada had enacted legislation accepting the provisions of the Acts. The object of the legislation is to provide for one central council consisting of representatives of the different provinces, for the purpose of (a) the establishment of a qualification in medicine, such that the holders thereof shall be acceptable and empowered to practise in all the provinces of Canada; (b) the establishment of a register for Canada of medical practitioners, and the publication and revision from time to time of such register; (c) the determination and fixing of the qualification and conditions necessary for registration, the examinations to be undergone with respect to professional subjects only, and generally the requisites for registration; (d) the establishment and maintenance of a board of examiners for examination and granting of certificates of qualification: (e) the enactment, with the consent and at the instance of the medical councils of the various provinces of Canada, of such provincial legislation as is necessary to supplement the provisions of this. Act and to effect the foregoing purposes. The Secretary of State summoned a meeting on November 17, I912 for the purpose of organising the Council, and a number of appointments were subsequently made.

The "Ne Temere" Decree.-On January 23, 1912 the House of Commons decided to refer to the Supreme Court of Canada, and later to the Judicial Committee of the Imperial Privy Council, the question whether the Dominion parliament may constitutionally pass a marriage law applicable in all respects in every province in Canada. On July 29, I912 the Lord Chancellor delivered judgment, which, speaking generally, upheld the decision of the Supreme Court of Canada. It was ruled that the Dominion parliament is not entitled under the British North America Act to pass a uniform federal law legalișing all marriages performed by authorised clergymen. The matter is in the jurisdiction of the provinces.

Anglo-American Peace Celebrations.-On June 4, I9I2 at a representative meeting at Ottawa, a Committee was appointed to act for Canada in preparing a programme of the celebration of the Ioo years of peace between the branches of the English-speaking people.

Fur Seat Convention. - The International Fur Seal Conference which was held at Washington from May II to July 7, I9I I resulted in a Convention being signed by which Great Britain, the United States, Russia, and Japan undertook that pelagic sealing should cease for a period of 15 years from December I5, I9II, and thereafter until terminated by one year's notice. Canada was represented by the under-secretary for external affairs, Mr. Joseph Pope, who in 1912 was created a K.C.M.G. Provision was made for an apportionment of the annual proceeds from the seals killed on land, the share payable to Canada being I 5 per cent of the gross takings of the United States and Russia, and Io per cent of those of Japan.

Provincial Governments.-On June I4, I9I I a general election was held in Nova Scotia, the result being the return of the government, which had been Liberal since 1884 . The elections for the British Columbia Legislature took place on March 28, 1912, the result being the return of the government, 40 Conservatives and 2 Socialists being elected. The Hon. Richard McBride, K.C. (b. I870), the Premier of British Columbia since I903, was created a K.C.M.G. in I9I2. The election in Ontario was held on December II, I9I $\mathrm{r}$, when Sir James Whitney's government was returned by a majority of 60. In January I9I2 the Prince Edward Island elections resulted in the return of 27 Conservatives and 3 Liberals. The Premier is Hon. J. A. Mathieson, K.C., who had formed a government in December I9I1. The general election in New Brunswick took place on June 20, 19.12, resulting in the return of 44 Conservatives, 2 Independents, and 2 Liberals. On May 15,1912 the elections were held for the Quebec Legislature and resulted in the return of Sir Lomer Grouin's government with a slightly reduced majority. On July I I, I9I2 the generäl election took place for the province of Saskatchewan. The chief issue was the Reciprocity agreement, as in the Dominion elections, and the overwhelming majority by which Mr. Scott's government was returned, was looked upon as a striking victory for the Reciprocity party.

The appointment of members of provincial governments to the new federal cabinet in I9I I necessitated some re-arrangements in the provincial cabinets.

In Manitoba the vacancy caused by the Hon. Robert Rogers joining the Dominion cabinet was filled by the inclusion of Mr. George Lawrence, as Minister of Agriculture. In 1912 the. Hon. Rodmond Palen Roblin (b. 1853), Premier since 1900, was created K.C.M.G., and the retiring Chief Justice, Joseph Dubuc (b. I840), was knighted.

In Ontario, Mr. W. H. Hearst, K.C., M.P., became Minister of Lands, Forests and Mines 
in succession to the Hon. Frank Cochrane, the new Federal Minister of Railways and Canals. In 1912 the lieutenant governor, Col. John Morison Gibson, was created a K.C.M.G.

In New Brunswick, owing to the appointment of the Hon. J. D. Hazen, Premier and Attorney General, to be Federal Minister of Marine and Fisheries, the Hon. J. K. Flemming, Provincial Secretary, was called upon to form a government. Mr. Flemming took the office of Surveyor General, and the Hon. W. C. H. Grimmer was appointed Attorney General; Hon. H. F. McLeod, Provincial Secretary; Hon. John Morrissy, Commissioner of Public Works; Hon. D. V. Landry, Agricultural Commissioner; and the Hon. Robert Maxwell and Hon. John A. Murray, without portfolios.

New Lieutenant Governors.-On August I, rgrr Mr. D. C. Cameron was sworn in as Lieutenant Governor of Manitoba, in succession to Sir D. H. MacMillan retired. A native of Vankleek, Ontario, he was elected to the Ontario Legislature in 1902.

Sir Francis Xavier Langelier, Acting Chief Justice of the Supreme Court of Quebec, was appointed Lieutenant Governor of the Province of Quebec in succession to Sir C. A. Pelletier, deceased. Born in 1838, he has held several offices in Quebec Ministries, and sat in the Dominion House of Commons from 1884 to 1898 .

In New Brunswick the term of office of the Hon. I. J. Tweedie expired on March 1, 1912, and he was succeeded as Lieutenant Governor by Senator Josiah Wood, who was born at Sackville, New Brunswick, in 1843 .

Judiciary.-In succession to Sir Lous Jette, resigned, the Puisne Judge of the Court of King's Bench, the Hon. Horace Archambault, became Chief Justice of Quebec in 1912. Born at L'Assumption, Quebec, in 1857 , he was educated at Laval University. In 1888 he was called to the Legislative Council, Quebec, and from 1897 to 1905 was Attorney General of the Province. Appointed a Q.C. in 1889 he was raised to the bench in 1908 .

On the death of Sir Charles Moss, Chief Justice of Ontario, in 1912, he was succeeded by Sir Wm. Meredith, who was born at London, Ontario, in 1840 , and was educated at Toronto University. He was member for London in the Ontario Legislature from 1872 to 1896. He was appointed Chief Justice of the Common Pleas in 1904.

The Hon. F. W. G. Haultain, formerly Premier of the North-West Territories, was gazetted on November 2, I9I2, as Chief Justice of Saskatchewan. He was born in I857 at Woolwich, England, going to Ontario in 1860 . He was called to the Bar of Ontario in 1882, and to the Bar of the North-West Territories in I884, being appointed a K.C. in 1902

The Hon. Francis L. Haszard, K.C., Prime Minister of Prince Edward Island, was appointed Judge of the Canadian Supreme Court on May 4, 1911, being succeeded in the Premiership by the Hon. H. J. Palmer. The new Judge of the Supreme Court was born in Prince Edward Island in 1849 and was admitted to the Bar in 1872 . From 1893 to 1900 he was Stipendiary Magistrate and Recorder of Charlottetown. Elected a member of the Provincial Legislative Assembly in 1904, he became Prime Minister of the Province in 1908.

In April 1912 four new Judgeships were authorised by parliament, and were filled as follows:-Mr. Alexander Haggart, ex-M.P. for Winnipeg, to the Manitoba Court of Appeal; Mr. W. L. Walsh, K.C., of Calgary, to the Supreme Court of Alberta; Mr. Hector Chauvin, K.C.., of Hull, as Judge of the new judicial district of Labelle; and Mr. Haughton Lennox, M.P., for South Simcoe, to one of the extra judgeships of the High Commission of Ontario.

As Chief Justice of the Superior Court of Quebec, Mr. Justice Davidson has succeeded Sir Melbourne Tait. The new Chief Justice was born in Huntingdon, Quebec, in 1841 ; he was educated at McGill University, and was made a Q.C., being raised to the bench in 1887 . where he has been a Puisne Judge of the Superior Court.

Personalia.-On October 22, 1912 Major G. W. Stephens resigned the position of Chairman of the Montreal Harhour Commission.- On March I, I912 Dr. J. G. Rutherford resigned his position as Veterinary Director General and Live Stock Commissioner. He was Appointed Chief Veterinary Inspector in 1902, Veterinary Director in 1904, and Live Stock Commissioner in 1906.- On March 3I, 1911 Dr. William Saunders, C.M.G. retired aftes nearly 25 years service as Director of Experimental Farms in Canada, during which time he showed a keen and enlightened sympathy with all that tended to assist in the development of the agricultural resources of the Dominion. Born in Devonshire. England, in 1836, he went to Canada in 1848 . He is succeeded by Mr. J. H. Grisdale.

Obituary. - The Canadian obituary for I9I I included the following:- Thomas Mayne DALY (b. 1852), police magistrate at Winnipeg; d. June 24th. He was formerly a member of parliament, and was Minister of the Interior from 1892 to 1896 . - DESIRE GIROUARD, the judge and man of letters; $d$. at Ottawa on March $22 \mathrm{ndl}$. He was born at St. Timothée, Quebec on July 7,1836 and was educated at Montreal College, afterwards studying law. He stoor for the Canadian House of Commons for several constituencies from 1872 to 1878 , and wa: finally elected for Jacques (artier in that year. He held the seat until 1895 , when he became a judge of the Supreme Court. At the time of his death he was Senior Judge. He published a work on the Civil Laws of Marriage, one on the law of insolvency and one on bills of exchange; also Lake St. Louis, Old and New, and Chevalier de la Salle. He was an editor of La Rerue C'ritique.-Sir (hari.es Alphonse Pantaleon Pelletier, K.C.M.G., the judge and statesman; d. at Qucbec on May Ist. He was born at Rivière Ouelle on January 22 , 1837 and educated at Laval University. He was called to the Bar in 1860 and became Q.C. 
in 1879 . In 1892 he was Batonnier of the Quebec Bar. He commanded a battalion of volunteers during the Fenian rising of 1866 . He sat in the Dominion House of Commons from I 869 to 1877 , when he was called to the Senate. From I 896 to I 901 he was Speaker of the Senate. In 1902 he was appointed a Judge of the Supreme Court of Canada and in I908 Lieut.-Governor of the province of Quebec.-SIR HENRI EL7EAR TASCHEREAU, the judge; d. at Ottawa'on April igth. He was born at St. Mary's, Beauce Co., Quebec, on October 7, 1836 and educated at Quebec Seminary. He was called to the Quebec Bar in 1857. became Q.C. in 1867 , Judge of the Superior Court, Quebec, in 1871 , Judge of the Supreme Court of Canada in 1878 and Chief Justice in 1902. He was knighted in 1902 , and made a Privy Councillor in 1906, when he resigned his Chief Justiceship. From 1861 to 1867 he had represented Beauce Co: in the Canadian Legislative Assembly. He published Criminal Law of Canada and Code Civil Procedure of Province of Quebec.-Sir John CARLING, K.C. M.G., the agricultural administrator; b. at London, Ontario, I828; d. November 6, 19 II. Prior to Confederation he had held the positions of Receiver General, 1862, and Minister of Works and Agriculture, 1867-71, in the local government. From 1885 to 1892 he served as Minister of Agriculture in the Dominion Ministry of Sir John A. Macdonald, and to him is due the credit of establishing a number of Experimental Farms throughout the country.

The following are the more memorable among those who died in 1912:-ADAM CARR BELL, formerly Senator; b. I847; d. at Picton, Nova Scotia, on October 3 Ist. He entered the Nova Scotia legislature in 1878 . In 1896 he was elected to the Dominion parliament, but was defeated in 1904.--EDWARD BLAKE (b. 1833), formerly prominent as a Canadian statesman, whose later career in the Imperial Parliament was of less account; d. at Toronto on March Ist (for biography see $E . B$. iv, 35a).-Sir Richard Cartwright (see $E . B . v, 435$ ), the statesman (b. I 835); d. at Kingston, Ontario, on September 23rd.-Sir Edward Clouston, Bart., the financier, general manager and vice-president of the Bank of Montreal; b. I849; $d$. November 23rd. He had been connected with the bank for nearly 50 years.-George RALPH RichaRDSON COCKBURN, the educationalist and politician; d. in London on January 24 th. He was born in Edinburgh on February 15, I832 and educated at the Royal High School and University there, afterwards going to France and Germany. He went to Upper Canada in I 858 and from I 86I was Principal of the Upper Canada College for over twenty years besides being Senator of Toronto University. From 1887 to 1896 he sat in the Dominion House of Commons as Conservative Member for Central Toronto. He was chief Canadian Commissioner at the Chicago World's Fair, I893.-Charles M. Hays (b. I856 at Rock Island, Ill., U.S.A.), president of the Grand Trunk Railway; lost in the "Titanic" in April. Formerly general manager of the Wabash Railway, he was appointed to be manager of the Grand Trunk in 1896 , and subsequently president. He was also president of the Grand Trunk Pacific.-George Holmes, missionary bishop in the North-west; $d$. in London on February 3rd. He was born in England on November 23, I858 and educated at St. John's College, Winnipeg. He was afterwards trained at the Church Missionary College, Islington, whence he returned to Canada in I 885. In I 887 he was ordained and worked as a missionary in the North-West Territory till 1905. In $190 \mathrm{I}-05$ he was Archdeacon of Athabasca, in I905-09 Bishop of Moosonee, and from 1909 till his death Bishop of Athabasca.-SIR JAMES MaCPHERSON LEMOINE, the lawyer and author; d. at Quebec on February 5 th. He was born at Quebec on January 24, I825, and educated there. He was called to the Bar in 1850 , but devoted himself chiefly to the writing of historical and ornithological works. In 1894 he was elected President of the Royal Society of Canada. His publications included L'Ormithologie du Canada (1861), Les Pecheries du Canada (1862), Maple Leaves (6 vols. 1863-94), Quebec Past and Present (1876), Annals of the Port of Quebec (I901), etc.-James PitT Mabee, the judge; d. at Toronto on May 7 th. He was born at Port Rowan, Ontario, on November 5, 1859 and educated at Toronto University. He was called to the Bar in I882, made Queen's Counsel in 1899 and Judge of the Ontario High Court in 1905 . He resigned his position as Judge in 1908 to become Chief Commissioner of the Board of Railway Commissioners for Canada.-JAMES MACDONALD, the politician and judge; d. at Halifax, N.S., on October 4th. Born in 1828 , he entered the Dominion parliament, and was Minister of Justice in Sir John Alexander Macdonald's cabinet in I 878. Latterly he had been Chief Justice of his province. - Sir Charles Moss, the judge; d. at Toronto on October I2th. He was born at Cobourg, Ontario, on March 8, 1840 and educated at the Ontario Law School. He was called to the Bar in 1869 , became K.C. in 1881 and Judge in 1897 . In 1902 he became Chicf Justice of the Province of Ontario. He was knighted in 1907 . From 1900 to 1906 he was Vice-Chancellor of Toronto University. He published, together with Mr. R. Sullivan, a handbook of Commercial Law for Upper Canada.-JAMEs OBoRNE, a well-known railway official; d. at Vancouver on April 3oth. He was born at Montreal on September 19, 1862 and was educated at the Montreal Public School. At thirteen years of age he began railway work and rose to be general superintendent of the British Columbia division of the Canadian Pacific Railway. -William OGilvie, first governor of Yukon; b. at Ottawa, I 846 ; d. November I 3 th. Formerly a Dominion Lands Surveyor and astronomer in the service of the Canadian Department of the Interior, he carried out important surveys in the Mackenzie and Yukon regions and also in connection with the Alaska boundary. As representative of the Dominion government in the Yukon during the exciting period of the Klondike gold rush, Mr. Ogitive 
performed excellent service for which he was justly esteemed.-WiLLIAM Ross, the Senator; b. I 825 ; d. at Halifax on March 17 th. He became a member of the Legislative Assembly of Nova Scotia in 1859 and of the Dominion House of Commons in 1867 . In 1874 he left parliament and became collector of customs at Halifax. In 1889 he was returned again to the Dominion parliament and in 1906 was appointed to the Senate. He was Minister of Militia in the Mackenzie government in 1873.- Frederick William THOMPSON, manufacturer; b. 1862 ; d. May 7 th. At the age of fifteen he entered the Exchange Bank of Montreal. When twenty-one he joined the Ogilvie Milling Co., becoming general manager of their North-Western business in $\mathbf{1 8 9 9}$, and general manager of the whole business in 1900 . In 1902 he re-organised it as the Ogilvie Flour Mills Co., Ltd. He had considerable political influence, and worked hard against the reciprocity agreement with the United States.

\section{NEWFOUNDLAND ${ }^{1}$}

(W. L. GRIFFITH.)

Population.-The provisional returns of the census of I9II show a total population of 242,966 persons ( 124,485 males and 1 i 8,48 I females), of whom 239,027 are domiciled in Newfoundland, and 3,939 in Labrador. This constitutes an advance of $9.95 \%$ over the figures for I 90 I. The population of St. John's City has increased from 29,594 in I 901 to 32,292 in I9II. The religious classification includes Roman Catholics 8I,914; Church of England 78,140; Methodists 68,1 27, and Salvation Army Io, 27.

Economic Conditions.-The marked progress of Newfoundland during the last few years is in the main to be attributed to three factors, viz., improved means of communication, the development of mineral resources, and the foundation of an important pulp and paper-making industry. The immediate results of these undertakings have been to give employment to large numbers of people hitherto dependent solely upon the great fishing industries as a means of livelihood, and to turn the attention of capitalists and administrators to the possibilities of the land as opposed to the sea.

Recent international and imperial events have brought Newfoundland much before public notice. Sir Edward Morris (b. 1859), Prime Minister since I909, accompanied by special delegates, attended the Imperial Conference of IgI I. The Colonial Government took a prominent part in the Festival of Empire held in London during the same year: the extensive collection of Newfoundland products there exhibited has been transferred to the Newfoundland Court at the Imperial Institute. The award of the Hague Tribunal in Igro has been brought to a satisfactory conclusion by the AngloAmerican Fisheries Treaty ( $I$ gI 2), which settles outstanding difficulties between the Colony and the United States. The question of reciprocity between Newfoundland and the United States has been the subject of official discussion.

Fisheries.-The fisheries must for long remain the primary interest of Newfoundland; and measures have recently been taken to place the industries upon a thoroughly stable basis. Important work has been done by the newly-established Board of Trade in the official inspection, grading and branding of products. The Government has had under consideration the offers of the Booth Fisheries Company (U.S.A.) to undertake operations in Newfoundland, the proposal being to apply modern methods of cold-storage to the cod catch, and thus render available the extensive markets for fresh fish in the central and western states of America and elsewhere. Similar methods are proposed in connection with the lobster fishery. The award (1910) of the Hague Tribunal has been found to work satisfactorily and with the gratifying result of an increase of trade in fishery products with America. An agreement has recently been arrived at between the (iovernments of Newfoundland, the Lnited States and Canada, which settles, among other difficulties, the delimitation of bays on the Newfoundland coast. The total value of the fishery exports in 19I I was $f_{1}, 807,226: \operatorname{cod} f, 1,344,689$, cod oil $f_{61} 1,833$, cod liver oil $\ell_{12}, 04 \mathrm{I}$, herrings $f_{79}, 97 \mathrm{I}$, lobsters $f_{74,069,}$ salmon $f_{14}, 535$, other fish $f 45,523$, seal skins (undressed) $£ 56,562$, seal oil $£ 79,155$, whale oil $£ 29,790$, whale fertiliser $f 6,124$. whale bone $£ 2,934$.

Forest Resources.-Fxploitation of the forest wealth of the colony is developing rapidly in the pulp and lumber industries. It is stated that natural regeneration is sufficient to assure a jermanent supply of raw material, but steps are being taken by the Government with regard to reafforestation. Advance has been made in the lumber industry chiefly owing ti) the operations of American companies. Profitable markets have been developed in South and Nurth America, the exports in I9I0-I I being valued at $E_{25,683}$. The forest resources of Labrador remain practically untouched. In its extensive forests and abundant and readily available water-power, Newfoundland possesses remarkable facilities for the establishment of it pulp and paper-making industry, and important advances have already

${ }^{1}$ See E. B. xix, 478 . 
been made. The Anglo-Newfoundland Development Company, in which Lord Northcliffe is so largely interested, commenced operations in 1909 and now controls over 3,000 square miles of forest land yielding a fine quality of pulpwood. The mills erected at Grand Falls, on the Exploits River, are the second largest of their kind in the world and possess the most modern equipment. The whole of the power required is obtained from the Falls. At Bishop Falls, also on the Exploits River, and eleven miles distant from Grand Falls, Messrs. Albert Reed \& Co., of London, have established a similar plant of only slightly smaller dimensions. Schemes are being framed for the erection of further mills by American and other companies in the Fortune Bay, Gander River and Grand Lake districts. The export of pulp and paper during I9IO-I I was valued at $£ 5$ I,582 and $£$ I 93,898 respectively. The whole of the trade was with the United Kingdom.

Agriculture.-The Government is prosecuting an active agricultural policy with a view to meeting the demand for farm produce which will arise from the industrial development of the country. The programme provides for the supply, at Government expense, of improved stock, seeds and implements, and considerable inducements are offered to agriculturists. Attention is also being given to agricultural education. Farm colonies are to be established by the Salvation Army. Mixed farming offers the best inducements, while the prospects for cattle, sheep and poultry are considered good. Special encouragement is being given to sheep-farming with a view to the establishment of a local woollen manufacturing industry. The average annual output of farm produce is valued at over $£ 800,000$, the principal crops being cabbages, turnips, hay and oats. Development of the fruit (berry) industry is anticipated. A successful Agricultural Show was held in St. John's in 1910.

Mineral Resources.-During the last twenty years the annual value of minerals exported has averaged nearly $£ 257,000$, the chief ores being those of copper and iron. The Government has recently concluded agreements with certain companies in respect of the development of coal, iron and petroleum resources, and has offered financial rewards to successful prospectors. The principal copper mine is that at Tilt Cove in Notre Dame Bay, but promising discoveries of ore have recently been made at points in White Bay, and on the north-east coast. The iron mines at Bell Island, Conception Bay, have been successfully worked by two companies, and it is estimated that $40,000,000$ tons of haematite ores are in sight, with an unknown quantity in the extension of the beds seawards. Haematite has been found at River Exploits and at various points on Notre Dame Bay. Rich bessemer ores occur at White Bay, and extensive deposits of magnetic ore have been located along the west coast. Operations with iron pyrites have been commenced at Pilley's Island, in Notre Dame Bay. Developments are expected with regard to the west coast chromite deposits; the silver-lead ores near Placentia; and the slate beds at Bay of Islands, Smith Sound and elsewhere. Operations at Parson's Pond oil-field have advanced sufficiently to permit of a regular supply of oil to the gas works of St. John's for illuminating purposes. Favourable agreements have been concluded with certain English companies for the exploitation of the coal resources of the Island. During the last few years the valuable seams near Grand Lake have received considerable attention from the Reid Company.

Communications.-Progress has been made with the construction of the branch railways sanctioned by the Government in I9I0. Steamship communication has been improved, and the telegraph, telephone and wireless services augmented.

Finance.-The trade and revenue returns (the highest ever recorded) for the year ending June 30 , I9II, were: revenue $£ 725,020$; expenditure $£ 689,587$; imports $£_{2}, 75^{1}, 137$, and exports $\{2,461,68 \mathrm{I}$. During 19 ro-I I the British Empire (chiefly Canada and the United Kingdom) supplied $60.8 \%$ of the imports, and received $39.7 \%$ of the exports.

Administration.-Sir Ralph Champney Williams, K.C.M.G., was to retire from the Governorship in February I9I3, and to be succeeded by Mr. Walter Edward Davidson, C.M.G.; Governor of the Seychelles.

The principal measures recently dealt with by the Legislature have reference to railway extension and steamship services, mining development, agriculture, and the fishing industry; while others are concerned with education, the extension of telegraph, telephone and wireless facilities, road development, woollen manufactures, the provision of sanatoria for consumptives, and old age pensions.

The death occurred at Ottawa on October 7, I9II, of Sir James Spearman Winter, formerly Premier ( $1897-1900$ ). Born in Newfoundland in 1845 , he became a barrister and in 1874 entered the Newfoundland legislature, being its speaker in $1877-78$, and subsequently holding other offices. In 1910 he was one of the British Counsel in the Fisheries Arbitration.

See Year-Book of Newfoundland (I9I2); Newfoundland Guide Book, IoIT (ed. D. W. Prowse); Nerwfoundland in IOII (P. T. McGrath); Mineral Resources of Nerefoundland (James P. Howley, St. John's, I909).

(S. E. Chandler.) 


\section{AUSTRALIA ${ }^{1}$}

Including as it does the adjacent island of Tasmania, the area of the Australian Commonwealth is now computed at 2,974,58I square miles, I, I49,320 of which are within the tropical zone (about five-thirteenths of the total). Since the Commonwealth was proclaimed in Igor there have been three changes affecting the political boundaries of Australia. In 1905 Papua (the British portion of the island of New Guinea) was taken over from the British Government and constituted a Territory of the Commonwealth. In 1909 the Commonwealth took over an area in the south of New South Wales which was constituted a Federal Territory, and on which will be built the Federal Capital. In I910 the Northern Territory was taken over from South Australia and constituted a Federal Territory.

Papua.-Soon after taking control of Papua the Australian Government appointed Colonel Murray as Lieutenant-Governor, with Mr. Staniforth Smith as a special officer to encourage industrial development. The suitableness of Papua for various forms of tropical agriculture is undoubted, but there is a "labour difficulty" in the way of progress. The Papuan, like most South Sea Islanders, has an aversion to steady work. In Fiji, a British Colony in the South Pacific, a position similar to that existing in Papua has been met by the importing of industrious coolies from India to develop the sugar plantations. The Australian Government, however, is determined to keep Papua for the Papuans. It was proposed in 1908 that the Papuan should be forced to do a certain amount of work, either for himself, for private planters, or for the Government, the argument being advanced that since Nature was so bountiful as to keep him in reasonable comfort without work, he would never be driven to labour by necessity and must, therefore, be brought under some other form of compulsion. The Australian Government vetoed the proposal. The officials responsible for the government of Papua state now that they have hopes that the natives will be tempted into the paths of industry by desire for the white man's cloth, steel, etc.; ordinances have been framed to regulate the conditions of native labour; and during 1911 nearly 8,000 natives were engaged under contract in some form of labour. But the labour position does not hold out much hope of the growth of a great sugar-growing or cotton-growing industry.

The white population of Papua is about 1,000 and the native population about 500,000. There are about 15,000 acres under cultivation, mostly planted with coco-nut trees. Rubber, cotton, sisal, coffee are also grown and mining and pearl-shelling are considerable industries. The system of land tenure is by leasehold; freeholds are not granted; the conditions of leasing are not onerous.

The Federal Territory and Federal Capital Site.-The Constitution having provided that the capital of the Commonwealth should be within the State of New South Wales, at least one hundred miles from Sydney, the New South Wales Government in 1909 surrendered to the Commonwealth Government some 900 square miles of territory around Yass-Canberra, and also an area of two square miles on the shores of Jervis Bay for the construction of a Federal port; and with these areas went the right to construct a railway from this port to the Federal territory.

In 1910 the Federal Government took possession of the Territory. It established there in I9I I a military college, and instituted a competition among the architects of the world for the best plans for building a new Federal city. Unfortunately, because of a disagreement, many British architects of the first standing did not take part in the competition. The design which found most favour was the work of a Chicago (U.S.A.) architect, Mr. Walter Burley Griffin. At the proposed Federal capital will be housed the GovernorGeneral, the Parliament, and as far as possible all the Federal government departments. The preliminary work of construction is in hand.

The Northern Territory. - With an area of 523,620 square miles (more than one-sixth of the continent), having some very fertile land, and with a better river system than most other parts of Australia, the Northern Territory is almost empty and undeveloped. The total population (other than aborigines) was 2,846 in 1910 , of which the largest element was Chinese, the total white population being $\mathbf{1}, \mathbf{1 8 2}$. The backwardness of the Territory as compared with the rest of Australia is due chiefly to political causes. When the Australian colonies first set up separate households it was convenient to none of them to include the Territory, and it was left in the hands of the Imperial Government. In 1863 South Australiat tork over the responsibility for the Territory, having formed a plan to connect it with Adlelaide by a north-to-south trans-continental railway. With such a railway it would have been brought within the ambit of South Australian development. Without that railway it was actually more remote from communication with South Australia than with any other of the States. The railway was begun. It reached Pine Creek from Port Darwin at the north end, and Oodnadatta from Adelaide at the south end; then hope of its completion was abandoned. As soon as the Commonwealth came into existence it sought a

1 See E. B. ii, 941 et seq. 
transfer of the Northern Territory from South Australia. But it was not until January 1, IgI I that the final stage of the negotiations was reached and the Territory assumed by the Commonwealth. The terms of transfer were that all the past deficits incurred by South Australia in the administration of the Territory should be taken over by the Commonwealth, and that the trans-continental railway should be completed from Port Darwin in the north to Port Augusta (near Adelaide) in the south. The Commonwealth purchased the existing state railway from Port Augusta to Oodnadatta.

In 1912 the Commonwealth Government appointed an administrator for the Northern Territory and took preliminary steps for its development and colonisation. A scientific inquiry as to the possibilities of a white population flourishing in this tropical part of the continent is proceeding, and, so far, the evidence on that point is reassuring. There is very little malaria in the Northern. Territory, and other specific tropical diseases are absent. The land is generally considered to be suitable for cattle-grazing (there are great herds of wild buffalo) and tropical farming on the coast, for sheep farming and dairy-farming on the tablelands. There are said to be possibilities of mineral wealth, but mining results in the past have been usually disappointing. In its policy of development the Australian Government does not propose to allow any further complete alienation of Crown lands. (There have passed into private hands already 473,990 acres.) In future all titles will be leasehold, but the leases will be in perpetuity, with reappraisement every 14 years in the case of town lands, every 21 years in the case of agricultural and pastoral lands. Political difficulties stand in the way of pushing on boldly with the north-to-south trans-continental railway, which is the chief need of the Territory. Some favour a direct route, some a route deviating so as to cross Western Queensland and New South Wales.

\section{The Commonwealth}

The Federal Act of July 1900 (see E. B. ii, 966) united in an indissoluble Australian Commonwealth six self-governing colonies, organised as British settlements between 1770 and $\mathrm{x} 859$, which retain their individuality and, for certain purposes, their independence. The federating States, New South Wales (E. B. xix, 537 et seq.), Victoria (E. B. xxviii, 37 et seq.), Queensland (E. B. xxii, 732 et seq.), South Australia (E. B. xxv, 492 et seq.), Western Australia (E. B. xxviii, 539 et seq.) and Tasmania (E. B. xxvi, 438 et seq.), were left with certain self-governing powers and preserved their own political institutions. Separate notes are added later as to certain details in the internal affairs of the individual states, but in the following account Australia will be considered substantially as a whole, in its aspect of a single national unit.

Population.-Public opinion in Australia has at different times condemned as unsatisfactory the rate of growth of the population both by natural increase and by immigration. The feeling that the natural increase of the population was not sufficient led in New South Wales to the appointment of the Birth Rate Royal Commission (1903). An outgrowth of that Commission was a Federal Royal Commission on Secret Drugs and Cures which reported in 1907 and devoted much attention to the matter of artificial limitation of families. It was established fairly clearly by the first of these Commissions that there was no natural cause predisposing to sterility in Australia, but that the desire for comfort conduced to a fairly general artificial limitation of families. As a consequence of this Commission some public opinion against the tendency to "race suicide" was aroused; and certain administrative measures were adopted by the Customs and Police Departments which sought to lessen the facilities "for artificial limitation of families. It is a coincidence, if not a case of cause and effect, that since 1903 " the natural increase " of population in the Commonwealth has steadily improved. Possibly a healthier public opinion following on the report of the Birth Rate Commission was in part responsible. Other possible contributory causes were a great increase in material prosperity following upon Federation, and an influx of immigrants from lands where artificial limitation of families was not so much practiced. The natural increase per I,000 of mean population in I906-Io was 15.93 , which was higher than that of any European countries, except the Netherlands and Bulgaria, and compared with I'r.58 for England and Wales. A natural increase which is almost the highest in the world must be accounted fairly satisfactory - even though the "crude birth rate" (number of births per 1,000 of mean population) is rather low (26.7 as 
compared with 48.1 in Russia, 25.6 in England and Wales and 19.6 in France). But with a somewhat low birth rate (for a new country) Australia has a very low death rate; the lowest in the world except for New Zealand. The Australian death rate of 10.4 compares with 14.5 for England and Wales, 30.0 for Russia and 19.3 for France.

In regard to immigration, Australian public opinion has undergone a marked change within the last few years, a change due in the main to a fuller appreciation of the danger of leaving the lonely outpost of the Empire in the South Pacific so bare of population. There was for many years a desire on the part of the exceedingly prosperous working people of Australia to keep out immigrants as much as possible, lest a rush of population should cause a reduction in the wage rate or a hardening of the conditions of life. That desire survives in some quarters, and is still a force to be reckoned with in a country where the Labour voters have the controlling power in politics. But it is being recognised, by Labour leaders as well as by others, that a great access of population is necessary to the safety of the country and need not affect the general prosperity of a continent which has a population of under $5,000, \infty 00$, and which has room, at a low estimate, for $100,000,000$ people. In the beginning of Australian colonisation state-aided immigration brought a great influx of people to Australia who otherwise would never have been able to afford the expenses of the long journey from Europe. Since Igo6 the policy of state-aided immigration has been re-established in Australia by several of the States.

The effects of a better natural increase and a better increase from immigration are shown in the following figures since rgor.

$\begin{array}{cccc}\text { Year. } & \text { Natural increase. } & \text { Migration. } & \text { Total gain. } \\ \text { 190I-1905 } & 284,431 & \text { dec. 16,793 } & 267,638 \\ 1906-1910 & 334,828 & \text { inc. } 57,278 & 386,106\end{array}$

On April 3, I9 I the decennial censưs was taken in Australia, and the population ascertained to be $4,455,005$, showing a rate of increase for the Federal decennium of $18.05 \%$ as against a rate of increase of 18.88 for the previous decennium. But whilst. the annual rate of increase from I $90 \mathrm{I}-\mathrm{I} 906$ was only I. $39 \%$ the annual rate of increase I906-IgII was 2.03. The year Igri showed a total increase of I43,624, to which natural increase contributcd 74,324 and immigration 69,300 , exceeding in one year by over $50 \%$ the total immigration gains of the previous ten years.

It is clear that Australia has "turned che corner" in regard to immigration. For I 912 it was officially computed that the total immigration would be 100,000 persons from the United Kingdom alone; as emigration from the Commonwealth has almost ceased, this will represent a clear gain. The difficulty experienced in 1912 was not in persuading people in Great Britain that there were better chances of prosperity in Australia, nor in overcoming any Australian objection to new-comers, but in securing accommodation on ships to take British emigrants to Australia.

Social Conditions. - The Australian people are almost wholly British in character; a full $96 \%$ of the total are of British origin, $2 \%$ come from foreign European countries and $2 \%$ from foreign non-European countries. The standard of average education is high and illiteracy almost unknown. The wage rate is generally high and has shown lately a marked tendency to increase. Thus the average wage of females in the clothing trade (taking the lowestpaid class of labour) in lictoria was 10 Iod per week in 1897 , but in 1910 the average wage was 21 s gd per week. From a West Australian Lahlour return endorsed by the Trade Union officials the following current average rates of wages in that state are taken: bakers $f 3$ per week, blacksmiths ins to I2s fod a day, hricklayers I2s to I 4 s a day, carpenters Ios $6 d$ to I2s a dily, domestic servants $8 \mathrm{~s}$ to $25 \mathrm{~s}$ per week, engine drivers $\{2.8 .0$ to $f 3.7 .6$ per week, navies \&s to 8 s $\sigma d$ per day, shoemakers f.2.14.0 to f.3 a week, waitresses from $x 2 \mathrm{~s} 6 \mathrm{~d}$ to $25 \mathrm{~s}$ per week., These figures are fairly representative of Australia.

The rost of living in Australia is affected favourably on the one hand by the low price of food items which are local products, unfavourably on the other hand by the high wage rate ruling in the huilding trade and the loral manufacturing industries. On the whole, it compares well with the cost in most civilised countries. In $19 \mathrm{I}$ the statistician to the Commonwealth (iovernment, Mr. (;. H. Knibbs, instituted an inquiry into the cost of living, from which sime valuable facts were gleaned. Taking four sets of family budyets, (a) of families with $£ 200$ a year and over, divided into families of four members and under four 
members, (b) of families with less than $£ 200$ a year, divided similarly, he found that the average percentage of income spent on housing was 13.70 , on food 29.30 , on clothing 12.72 , on fuel and light 3.46, on "other items" (including amusements, thrift, etc.) $40.82 \%$. This last figure gives the best indication of a general prosperity, i. e. of a substantial margin out of wages and salaries for non-essential outgoings. The percentage of income expenditure on food in working class families in Australia is 36\%, as compared with $57 \%$ in the United Kingdom, and a general average of over $50 \%$ in all other countries for which statistics are available. The indication this gives is of a good margin between wages and cost of subsistence, and it is strengthened by the fact-which cannot be supported by official statistics but is apparent to every observant traveller in Australia-that the working classes indulge in more varied, plentiful and luxurious food than the same classes in Great Britain. Thus of a total of $4 \mathrm{~s}$ Iod spent in food the Australian apportions $6 \mathrm{~d}$ to bread, Is Id to meat, $7 \frac{3}{4} \mathrm{~d}$ to vegetables and fruit, $6 \frac{3}{4} \mathrm{~d}$ to milk, $7 \frac{1}{4} \mathrm{~d}$ to butter, cheese etc., $3 \frac{1}{2} \mathrm{~d}$ to sugar, $2 \frac{1}{4} \mathrm{~d}$ to tea, coffee; etc, and is to "other food."

The Australian birth rate was 27.21 in 1911 . The percentage of illegitimate births to total births was 5.84 in 1910 . There has been a very slight decrease in this rate during the last decennium. The Australian population is predominantly masculine, the proportion being 108 males to every 100 females. The marriage rate (number of marriages per $\mathbf{I}, 000$ of mean population) was 8.79 in $19 \mathrm{II}$. The rate has improved steadily since 1908 . (The rate for England and Wales calculated in the same way is 7.30). The most favoured ages for marriages are between 18 and 30 . The average age of bridegrooms is, in the professional classes 31.26 years, the mercantile classes 29.74 , the industrial classes 28.76 and the agricultural classes 30.93 . The average age of brides in 1910 was 25.77. The celebration of a marriage is more easily effected in Australia than in England. The facilities for divorce differ in the various states, divorces being granted more readily in New South Wales and Victoria than in the other states. The total of Australian divorces in 1910 was 451, of which 254 were granted in New South Wales and I4I in Victoria.

A disquieting feature of Australian social life is the preponderance of the urban over the rural population. In South Australia nearly one half of the total population of the State (380,000 square miles in extent) is concentrated in the city of Adelaide. In Victoria $44 \%$, in New South Wales $38 \%$ of the total population, is in one city, and in the whole Commonwealth $38 \%$ of the population is contained within six cities. The charm of the cities is great; the conditions in the "back country" are often hard. By cheap railway rates for the farmers' goods, by pushing such of the conveniences of civilisation as are under state control as far forward as possible, and by other means, the states and the Commonwealth strive to counterbalance the call of the cities. But all effort seems to be in vain. The proportion of the urban to the total population is growing. In I 906 Sydney had $35 \%$ of the total population of New South Wales, in $191 \mathrm{I}$ it had $38 \%$; in 1906 Melbourne had $42 \%$ of the population of Victoria, in I9I I $44 \%$; and in the whole Commonwealth six cities held 35.49 of the population in 1906 and $38 \%$ of the population in $19 \mathrm{II}$.

At the last census 4,274,4I4 of 4,455,005 people were returned as Christians (Church of England 1,710,443, Roman Catholic 921,425, Presbyterian 558,336, Methodist 547,806, being the chief denominations). Of Hebrews, Pagans, : Mahommedans, etc., there were 36,785 ; and some 25,000 were returned as agnostics, atheists or freethinkers. There is no established church.

Public Health.- Though part of Australia is within the tropics there is practically no tropical disease, and there is an absence also of small-pox, hydrophobia and other diseases which are known in some parts of Europe. The death rate from all causes in I9I I was 10.66 (including the death rate for the tropical Northern Territory, 19.58). It is the lowest death rate in the world except one. Lately there has been a betterment in regard to the infantile death rate, which the hot summers ruling over the greater part of the Commonwealth make the chief cause of public health anxiety. In I90I it stood at 103.6I per thousand, in 1910 at $74.8 \mathrm{I}$ per thousand. It is noticeable that an abnormally hot summer forces up the infantile death rate; but this rate has been brought down to as low as 7 I.56 per thousand in I909. To lessen infantile mortality, and at the same time to encourage the birth rate, there are two remarkable proposals (both likely to be carried through) before the Australian public to-day. One is that of the Commonwealth government to pay a bonus of $£ 5$ to the mother of every infant born in the Commonwealth whether legitimate or illegitimate. The other is that of the New South Wales State government to provide a free and compulsory medical service in childbirth. Apart from infantile mortality the chief foes to human life in Australia are tuberculosis, cancer, diseases of the heart and violence. The deaths from malaria (tropical) numbered forty in Ig Io.

Education.-The Australian system of elementary education is free, compulsory, undenominational and usually secular. Secondary education is not free, but a generous system of bursaries makes education to the stage of a University degree available to the poorest in most states. There is also a good system of agricultural and technical colleges. Slight differences as regards religious teaching exist in the various States. In Queensland "undenominational " teaching of the Bible is allowed, and clergymen may give religious teaching within school hours to children of their respective denominations. In New South Wales 
and Western Australia "general religious teaching" is part of the course. In other states the system is more rigorously secular. In no state is denominational religion taught in the state schools; but private denominational schools exist, being maintained especially by the Roman Catholic Church. The compulsory age for school attendance is in the largest States from six years to fourteen years, in no State less than six years.

Production and Industry. - Australia, down to the end of 1912, had enjoyed seven fairly good years. The early stage of the Federation was marked by a severe drought which checked for a time the development of prosperity. But since 1905 the growth of prosperity in the Commonwealth has been very great. A valuation of the total production of the Commonwealth shows in 1907 a value of $f_{114}, 585,000$ (average per head $f 30.2 .6$ ), in 1909 $£ 174,503,000$ (per head $£ 40.16 .6$ ), and in $1910 £ 187,734,000$ (per head, $f 42.19 .2$ ).

In 1906 the total value of the pastoral products of the Commonwealth was $f, 45,389,000$; in $1907, £_{50,660,000}$; in 1908, $£ 47,259,000$; in $1909, £ 50,064,000$; in $1910, £ 56,993,000$. These returns from the chief Australian industry afford a safe index to the growth of prosperity in others. The area under crop in 1905-06 was 9,433,455 acres. It amounted in 1906-07 to $9,552,800$ acres, in $1907-08$ to $9,358,902$ acres, in $1908-09$ to $9,891,243$ acres, in $1909-10$ to $10,972,299$ acres, and in $191 \mathrm{I}-12$ to $12,105,125$ acres. The production of wheat increased from $68,520,772$ bushels in $1905^{-06}$ to $95, \mathrm{I} I \mathrm{I}, 983$ bushels in $1910-1$ I of a value of $£ 16,458,187$. The figures for I9II-I2 are not so good, the estimated yicld being 7I,664,97I bushels; the falling off was due to a somewhat unfavourable season. The growth of sugar cane, in spite of the great change made in its conditions by cutting off the supply of coloured labour, has held its own. In all other crops-fruit, vines, oats, hops, potatoes - there was either progress or stability. Some promising indications were gleaned of future success in the cultivation of coffee, tobacco, cotton, oil plants and fibres. In dairy farming there was great progress. The export of butter in 1906 was $75,802,856 \mathrm{lbs}$, in I9IO it was 87,928 , I I I lbs., and the value of dairy farm exports increased from $£ 3,352,803$ in 1906 to $f 4,127,074$ in 1910. The total yield from agriculture, including dairy, poultry and bee farming, was $f 38,960,000$ in 1906 and $£ 57,139,000$ in 1910 . In mineral production, Australia kept a high place, in spite of the dwindling gold returns from Victoria and West Australia. The mineral production of the Commonwealth reached to its highest point $(£ 28,301,346)$ in 1907 . In 1908 it was $£ 24,580,303$; in 1909 (the year of a disastrous coal strike) $£ 23,074,935$; in 1910 it was $\{23,215,191$. The chief items in this total were gold $£ 11,553,840$, coal $£ 3,684,-$ o4I, copper $£ 2,389,4 \mathrm{I} 2$, silver-lead bullion and ore (shipped abroad to be refined) $£$ I,934,735, tin $£ 950,768$ and zinc $£ I, 289,78 I$. The great mineral resource of the future in Australia will, doubtless, be coal. A conservative estimate of the amount of coal available for easy working in the state of New South Wales alone is over a thousand million tons. Mineral oil shale exists also in Australia, and the Commonwealth Government is now offering bounties to the extent of $£ 20,000$ a year to encourage the local production of kerosene and paraffin wax. Up to I9IO the value of the products of oil shale in New South Wales had reached $£ 2,251,08 \mathrm{I}$, and the actual year's production was worth $£ 33,896$. Queensland and Tasmania have also deposits of oil shales.

There has been a steady progress in manufactures in Australia since the Federation. In 1907 the total of wages and salaries paid in factories was $£ 18,323,977$, with an average wage of $£ 77.32$. In 1910 the total of wages paid was $£ 23,874,959$, with an average wage of $f \times 7.11$. The total value of the output of factories in 1909 was $f 107,409,733$; in 1910 $f_{120,770,674}$. The value added in process of manufacture was $£ 42,216,493$ in 1909 and $f_{48,048,032}$ in 1910. The factory industries are not, so far, of a highly organised type. Great iron industries are yet to be created, though the presence in many parts of Australia of deposits of iron ore and the cheapness of coal have invited their establishment for many years. In 1909 the Australian Government offered bounties to a total of $f 150,000$ for pig iron, puddled bar-iron and steel made from Australian ore; and further bounties to the extent of f.30,000 for galvanised iron, wire-netting and iron pipes. So far, however, no very great results have followed. During 1912 there were reports that great iron-smelting works were alout to be estathlished in New South Wales by a company which had been before chiefly interested in silver-mining.

Forests and fisheries bring an amount of nearly $£ 5,000,000$ to the Australian purse. But in neither case is there creditable progress. The timber resources are usually prodigally wasted: and until very recently there was no attempt at reforestation. The fisheries are not exploited in any systematic fashion, there being little or no deep-sea fishing or fishcuring. In both these matters, however, better things are promised in the future. Bounties were available during 1912 to the extent of $£ 10,000$ for Australian preserved fish, and there are 13 fish-curing estahlishments. In 1909 the Federal Government launched the "Endeavour," a vessel specially built to investigate and chart deep-sea fishing grounds. The "Endeavour" has since been engaged in the collection of information regarding the migration, feeding grounds, etc., of fish in the waters off the Australian coast, and it is hoped that the ultimate result will be the foundation of a great fishing industry.

Trade and Commerce. - Since Federation the overseats trade of the Commonwealth has increased rapidly. In 190 I the total was valued at $f 92,130,000$; in 1911 at $f 146,456,000$ The records since 1906 have been:- 


$\begin{array}{lcccc}\text { Year. } & \text { Imports. } & \text { Exports. } & \text { Total. } & \begin{array}{c}\text { Value per } \\ \text { inhabitant. }\end{array} \\ 1906 & 44,745,000 & 69,738,000 & 114,483,000 & 28.3 .10 \\ 1907 & 51,809,000 & 72,824,000 & 124,633,000 & 30.4 .5 \\ 1908 & 49,799,000 & 64,311,000 & 114,110,000 & 27.4 .1 \\ 1909 & 51,172,000 & 65,319,000 & 116,491,000 & 27.5 .0 \\ 1910 & 60,014,000 & 74,491,000 & 134,505,000 & 30.15 .6 \\ 1911 & 66,973,000 & 79,483,000 & 146,436,000 & 32.12 .5\end{array}$

The unfavourable figures for 1908 were due in a large measure to the financial crisis in the United States causing a lower range of world prices for wool and metals. The total public indebtedness of Australia is $£ 267,127,283$ - most of it borrowed abroad-on which an average rate of interest of $f_{3} .14 .4 \%$ per annum is paid. The payment of this interest affects the export figures. The import figures on the other hand are swollen by the continuance of public borrowing from abroad, which averaged for the nine years to I9I I about $£ 6,000,000$ a year. Probably in a normal year one item nearly balances the other.

The bulk of Australia's trade is with Great Britain and with British possessions. Of the imports in I9ro, totalling $£ 60,014,351, £ 36,646,441$ were from the United Kingdom, $f_{7}, 865,649$ from British possessions, and $£_{1} 5,502,26 \mathrm{I}$ (not much more than one quarter) from foreign countries. Of the exports in I910, totalling $£ 74,491,150, f 37,698,312$ were to the United Kingdom, $f 8,323,486$ to British possessions, and $f 28,469,352$ (more than one third) to foreign countries. British imports to Australia have preferential tariff treatment. A profitable future is promised for Australian trade in supplying Asiatic countries with food products, minerals, and raw materials for textiles. Steps are being taken to foster this trade, and it has grown in value from $£ 2,298$,000 in 1904 to $£ 3,121,000$ in 1910 .

Communications. - There were at the end of I9I I a total of 18,012 miles of railways open for traffic in Australia, showing an increase of nearly $\mathbf{I , 0 0 0}$ miles over the previous year. Practically all the railways are owned by the state governments. There are four different gauges in use, broad, standard, narrow and very narrow. The Commonwealth has constitutional power, with the states' consent, to take over the railway systems and unify the gauges; but the power is not likely to be exercised for some time. At present Queensland and New South Wales are foremost in railway development. The Commonwealth Government has acquired from South Australia the railway line from Port Augusta to Oodnadatta, and has taken over with the Northern Territory the short railway from Port Darwin to Pine Creek. It is intended to connect Pine Creek with Oodnadatta, thus making a north-tosouth trans-continental railway. Other proposed Commonwealth lines will connect the new Federal Capital with the Sydney to Melbourne main line, and with the Federal port of Jervis Bay. In a more advanced stage is the line which will complete railway communication between east and west. This trans-continental line from Port Augusta in South Australia to Kalgoorlie in West Australia will stretch over I, roo miles; and the estimated cost is $f 3,988$, ooo. The work is being carried out by the Government without the intervention of contractors, and was put in hand in September 19r2.

The capital cost of the Government railways in Australia had reached to $f_{152,855,000}$ in I9IX. They are the chief asset standing against the public indebtedness of various states. The net revenue of these railways provides $4.44 \%$ for interest and sinking fund on the capital invested. After payment of all working expenses and interest there was calculated to be a profit of $f_{1}, 424,000$ in $19 \mathrm{I} I$ available for debt redemption.

Several great shipping companies have arisen in Australia to carry on the coastal trade; the trans-oceanic trade is mostly in the hands of British companies, though Australian, German, French, Italian, Norwegian and American lines have some share. The policy of the Australian Government is to seek to secure as much as possible of the coastal trade for Australian vessels, and to banish coloured labour from all ships trading to Australia. Since shipping legislation can only be carried out with the assent of the Imperial Government, these ideals cannot be fully realised, but the Commonwealth enforces white labour conditions to some extent by refusing postal subsidies to vessels employing coloured crews. A new Navigation Bill, drafted after several consultations with the Imperial Government, passed through its final stages in the Commonwealth Parliament in I9I2. In this measure there are elaborate provisions for the safety of ships and the comfort of crews. The coastal trade is confined to Australian ships and to foreign ships licensed to engage in that trade; licenses are subject to the payment whilst on the Australian coast of Australian wage rates to seamen, and a further condition is that the ship receives no bonus or subsidy except from the Australian Government.

The proportion of British to foreign shipping entering and clearing Commonwealth ports is roughly 77.4 to 22.5 :

Finance (Public). - The prosperity of Australia during the last quinquennium is reflected in the public revenues. The Commonwealth collects the revenue from Customs, Excise, Land Tax, Posts, Telegraphs and Telephones, Coinage (including Bank-note issue), and fees from various small services such as the Patents Office. It has to meet from this revenue the cost of naval and military defence, of its services (such as postal and telegraph), and of 
its administration, and to pay a fixed annual subsidy to the state governments of $25 \mathrm{~s}$ per head of the population resident in each state. In addition it has to meet the cost of the trans-continental railway from west to east already in process of construction; of the proposed trans-continental railway from north to south; and also of the administration of the Northern Territory, taken over from South Australia.

The early years of Federation were hampered by the want of revenue owing to the operation of the "Braddon clause" of the Constitution. But it was possible to make great changes in the financial position when Mr. Fisher took office in 1910. The lapsing of the Braddon clause gave him a larger share of the Customs and Excise receipts. The Land Taxes he imposed brought in a revenue of $f I, 370,344$ in the financial year $1910-11$. The Australian Notes Act which he passed made the Commonwealth Government the issuing authority for bank notes up to the value of $£ 7,000,000$, against which a gold reserve of one fourth that amount was to be kept. The issue might go above $£ 7,000,000$, but for any sum above that limit a gold reserve equal to the full issue had to be kept. A subsequent Act abolished this qualification, and left the amount of the issue unlimited provided that a gold reserve of $25 \%$ of the total was maintained. Serious objection was taken to this amendment in financial quarters, and Mr. Fisher undertook not to put the amending Act in force until after the General Election of 1913. At the same time as the Australian Government note issue was authorised, a tax of $10 \%$ per annum was imposed on the amount of all notes issued by private banks and any note issues by state governments were prohibited. Also a Commonwealth Bank, having all the ordinary functions of a bank, with a Savings Bank Department superimposed, was established, and opened its doors in 1912. In I9I2 the Commonwealth note issue had reached to $£ 10,048,472$, against which a gold reserve of $£ 4,841,536$ was held.

The growth of Commonwealth revenue since 1906 is shown below in thousands of pounds, which disregards small items, except in the computation of the grand totals:-

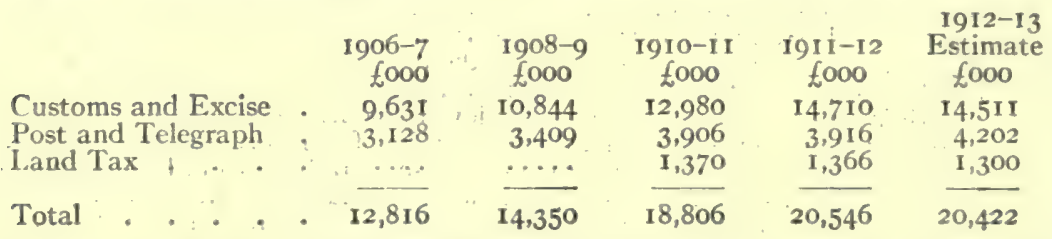

The expenditure has also grown. Excluding the subsidy paid to the states, the Australian Government spent $\ell 4,987,317$ in $1906-07, £ 7,499,516$, in $1909-10$, and $£ 13,158,529$ in $1910-$ II (the chief increase that year being in respect of the construction of the Australian Navy), $£ 14,297,572$ in $1911-12$, and (estimated) $£ 16,604,791$ in $1912-13$, of which. however, $£ 2,261,541$ did not come out of current revenue. Expenditure grows in all departments as new responsibilities call for outgoings. The deficit on Northern Territory administration for example was $f_{166,856}$ in I9I I (a half-year only). On the other hand the subsidy to the states, which in $19 n 6-07$ was $£ 7,8+5,574$ and in 1909 -10 $£ 8,492,436$ under the Braddon clause, dropped in I 9 I I-12 to $\{5,824,423$ under the new system of a definite subsidy of 25 s per capita.

The debts of the various states can best be referred to here because the Commonwealth Government sought in I9IO, and was granted by Act of Parliament and Referendum, the right to amend the Constitution so as to take over all the State debts and make them into one Federal debt. The total of the State debts outstanding in I9I I was $f 271,750,944$, and they have largely increased during 1912. The total is represented in the main by such solid assets as railways. The transfer of these debts to the Commonwealth would involve, presumably, the transfer of the assets which stand against them, and would also necessitate some arrangement for Federal control of future borrowing. The Prime Minister announced in September 1912 that he was devoting earnest attention to the matter.

Finance (Private).-There are twenty-one private banks trading in Australia. Their paid-up capital totals $\{20,181,758$, and their reserved profits total $£ 10,330,457$. Their total deposits in 1911 were $\{143,446,910$, and the total of the advances made by them $£ 108,578,774$. Their total liabilities were $\ell_{1} 48,835,219$ and their total assets $£ 159,565,443$. The last dividends of the four greatest banks were $10^{\circ} \%, 10^{\circ}, 14^{\circ}$, and $12 \%$ respectively

The Savings Banks' figures show a prosperous and thrifty working population. In 19II there were $1,600,1$ I 2 individual depositors in the Savings Banks of Australia, a proportion of 362 to every thousand of the population. The total of deposits was $\{59,393,682$, giving an average deposit of $\{37.2 \mathrm{~s}$. $4 \mathrm{~d}$. per depositor, or of $£ 13.8 \mathrm{~s} .5 \mathrm{~d}$. per head of the whole population. The life assurance figures impress the same lesson. There were nearly a million life assurance policies in force in Australia for I9I0. More than half of these were for small amounts, but the total sum assured, exclusive of bonus additions, was about firo,000,000. Further the Friendly Societies have a total membership of 400,000 and a yearly revenue of $£ 1,538,532$. 
Government and Politics.-Under the Federal Constitution the Commonwealth is governed by a Governor General appointed by the British Crown and acting on the advice of a Cabinet which is responsible to an Australian Parliament of two Houses. The Senate represents the states and is composed of six members from each state, elected for six years by the adults of the state voting en masse every three years to return three Senators; the House of Representatives is about double the Senate in numbers (75), represents the people numerically, and is elected every three years by the adults of Australia voting in single-member electorates, which are approximately equal in population. The number from each state varies with the growth of population. The Australian Parliament can only act within the powers set forth in the Constitution. The High Court is the final interpreter of that Constitution and may veto any legislation, either of the states or of the Commonwealth which is ultra vires.

It was not until the election of the fourth Parliament in I9Io that the political system of the Commonwealth of Australia began to have an aspect of permanency,

\section{First}

Parliament,

1901-03.

and it is necessary to refer back to $190 \mathrm{I}$ to understand fully the position of I912. At the outset there had been some promise that the early years of the Union would have been marked by a truce among all political parties, during which the machinery of the new Government would be established firmly. This promise had been illustrated in the choice of the first Ministry. The first Governor General of the Commonwealth (the late Marquis of Linlithgow), in a situation which offered him the guidance of no precedent, had followed a sound constitutional course :by "sending: for" the Premier of the senior of the Federating states, Sir Wm. Lyne. But public opinion did not endorse the choice. Sir William Lyne (born in Tasmania in I844) was a type of the politician who had served well in the days of the states. He had been the first champion of a Protective tariff in New South Wales, had risen to be her Premier, and had marked his term of office by a programme of social reform which had endeared him to the powerful Labour Party. But he had not been enthusiastic for Federation: rather otherwise. Public opinion demanded that the first government of the Union should be formed by its champion Sir Edmund (then Mr.) Barton (born in New South Wales in 1849). Mr. Barton had never been at home in state politics, though he had early devoted himself to a Parliamentary career, entering the New South Wales Assembly as member for the University of Sydney in 1879. His enthusiasm waited for the cause of the Federation of Australia. After the death of Sir Henry Parkes he assumed the leadership of the Federal movement, having for his chief lieutenants Mr. Alfred Deakin in Victoria, Sir Samuel Griffith in Queensland, Mr. B. R. Wise in New South Wales, and the late Mr. Kingston in South Australia. The Convention which framed the Federal Constitution had recognised Mr. Barton's services by electing him as its leader. Now there was such an unmistakable demand that he should be Federal Prime Minister that Sir William Lyne was unable to form a Government and advised that Mr. Barton should be "sent for." The latter called to his side all the Premiers of all the Federating states; with one exception they responded, and this Ministry of "all the talents" appealed to the people for support ion a non-party platform.

But this fair promise at the outset was not fulfilled. Party warfare broke out at the first elections with great violence. Sir George (then Mr.) Reid led one opposition party. He had been the chief opponent of Federation. Born in Scotland in 1845, he went to Australia as a boy with his father, a Presbyterian clergyman, entered the Civil Service, ventured on a political career somewhat late in life, and entered the New South Wales Parliament as a champion of Free Trade, which was just then being attacked in its last Australian stronghold. Federation was to him anathema, for he saw that it would be fatal to Free Trade in New South Wales. But he finally recognised that the movement for Union was too strong, and as Premier of New South Wales he had convened the Federal Convention of 1899 which framed the Commonwealth Constitution. Now that Federation was achieved, he went to the polls in a Free Trade attack upon the Barton administration. 
Another attack came from another quarter. In the various states there were labour parties of varying strength, very influential in New South Wales, Queensland and South Australia, weaker elsewhere. These combined in a Federal organisation, and, as a third independent party, went to the polls under the leadership of one of the remarkable men of Australian public life, Mr. J. C. Watson. Born of poor Scottish parents in 1867 whilst on the voyage to Australia, Mr. Watson was in boyhood deprived of nearly all the advantages of education, but taught himself enough to become a printer. Sagacious, tactful, resolute, he came to the front in the Australian Labour movement and was elected first leader of the Federal Labour party. The success of the Labour party under his leadership at the polls was extraordinary. The first Parliament of the Commonwealth was divided as between the Government followers and Mr. Reid's Opposition party almost equally; but with the Labour party (I6 strong in the Representatives, 8 strong in the Senate) holding the balance of power.

This made a position of grave difficulty for the Government. The common-sense and moderation of Mr. Watson saved the situation to some extent. He gave a general support to the Government and assisted them in their most pressing tasks. Nevertheless the first Parliament was hampered by party fighting, the opposition seeking to win the Labour party over to their side, and the Government being forced to postpone a good deal, to modify a good deal, in order to keep in office. Sir Edmund Barton was deeply disappointed. He had looked to a first patriotic Parliament completing without any "scuffling on the steps of the temple" - to use his own phrase - the measures necessary for the stability of the Federation. He experienced a first Parliament in which party rancour had been extraordinarily rife. He retired to accept a Federal judgeship, and Mr. Deakin took his place (September r903).

Mr. Alfred Deakin (born in Victoria in 1856) had cherished an enthusiasm for Federation not inferior to that of Sir Edmund Barton. But he had resolutely put away from him the idea of competing for the Federal leadership, recognising that it was best in the hands of a citizen of New South Wales, the chief citadel of anti-Federalism. He now took over the government at a time of great difficulty. Mr. Watson had led his Labour forces with moderation and with a sense of patriotism as distinguished from "partyism." Nevertheless the Labour member, and even more exigently, the Labour voter, had to be placated with some "Labour legislation." One of these Labour measures, the Industrial Arbitration Bill, had almost wrecked the Barton Government. The opposition fostered a point of division. between the Government and its Labour allies, and on this point there arose a crisis, which was interrupted by the General Election of rgo3.

Mr. Deakin met the Second Parliament of the Commonwealth in 1904 with his own following reduced, the following of the Labour party increased ( 23 in the Representatives, 14 in the Senate), and with party feeling embittered by the Second recriminations incidental to a contest at the hustings. Business was Parllament, impossible, though Mr. Deakin proved to be an able and tactful leader.
1903-07. 1903-07. In April $1904 \mathrm{Mr}$. Deakin went out of office and was succeeded by Mr. Watson. In August of the same year Mr. Deakin gave his support temporarily to Mr. George Reid, and a Reid-McLean coalition administration supplanted Mr. Watson's. This lasted through a long recess and a few days of Parliamentary life, and in July I905 Mr. Deakin came back to office with the support of Mr. Watson. Mr. Watson was even at that time determined on resignation. But he was strongly convinced that a measure of tariff reform was necessary, and determined to remain in Parliament until it was effected. 'The first Federal tariff had had to make concessions to Free Trade sentiment. The second tariff was completely protectionist, and introduced a new principle into Australian politics by granting a "preference" to British imports. At the third (ieneral Election in 1907 the Labour party again improved its position, mostly at the expense of its allies.

Mr. Watson kept the leadership of the Labour party, and kept that party solidly behind Mr. Deakin, until the tariff was settled. Then he retired and Mr. Andrew 
Fisher took his place. Born in Scotland in 1862, Mr. Fisher was brought up as a coalminer. He went to Queensland in $\mathbf{1 8 8 5}$, entered the state Parliament and later the Federal Parliament. He had been included in Mr. Watson's Cabinet. Third Now, assuming the leadership, he very quickly gave Mr. Deakin notice to Parliament, quit, and in 1908 formed his own administration. It lasted however little
1907-10. more than six months. Mr. Deakin then formed a coalition with the remnants of the Free Trade opposition, no longer now led by Mr. George Reid, but by Mr. Joseph Cook, his lieutenant, and the Deakin-Cook administration came into office; one of its first acts was to send Sir George Reid to London as High Commissioner for the Commonwealth. Mr. Cook, like Mr. Fisher, had been a miner. He entered New South Wales Parliament as a Labour member, drifted away from his party and entered the Federal Parliament as a Free Trader, was the chief supporter of Mr. Reid in an Anti-socialist party, and now joined with Mr. Deakin to oust the Labour party from office, one ground of attack being their lack of proper sympathy with the cause of Imperial defence.

This was at the time of the European crisis over Austria's annexation of BosniaHerzegovina, when public interest throughout the British Empire was being stirred over the question of maintaining British supremacy at sea and strengthening the hands of the Imperial Government in view of increasing international complications. New Zealand had promptly offered to provide a "Dreadnought" for the British navy. It was objected that Mr. Fisher had not done likewise. He claimed that his Imperial patriotism was not wanting, but that in his judgment more useful action could be taken by hurrying on with the creation of an Australian navy. This navy, he stated in a despatch to the British Government, would be organised and controlled by Australia in times of peace, but on the outbreak of war would pass automatically to the control of the British Admiralty. Mr. Fisher's direct following, though he was helped by Sir William Lyne, who now left Mr. Deakin's party, could not maintain him in office, and in June 1909 the Deakin-Cook administration came into power. Amid bitter party wrangles the third Australian Parliament closed its life, expiring by effluxion of time in January rgro.

The General Election of IgIo resulted in a sensational victory for the Labour party under Mr. Fisher. The party captured a working majority in both the Senate Fourth and the House of Representatives. The position of parties was: DeakinParliament, Cook followers, - Representatives 3I, Senators I3; Labour party,1910-13. Representatives 42, Senators 23. In the House of Representatives there were two independents. On April 29, roro Mr. Fisher formed his second administration under circumstances unique in Australian Federal history. In the Senate and the House of Representatives the opposition was powerless, the more completely so because the Labour party majority was bound solemnly to party fidelity. No opposition criticism on any issue could hope to detach a single Labour member from his allegiance to the Government, which in regard to all its measures consulted a caucus of its supporters beforehand as to both principles and details.

The decision which gave Australia's destinies completely into the hands of the Labour party (and that not the Labour party of Mr. Watson, but of Mr. Fisher much mcre of a " party " man) was influenced very largely by negative considerations. The people disliked deeply the coalition of Mr. Deakin with Mr. Cook, who had before seemed to represent absolutely irreconcilable ideas in politics; and a vote for the Labour party was in many cases a vote of no-confidence in the coalition rather than actually an endorsement of Labour policy. An indication of this fact was given a little later, when the Labour Government (May I9II) submitted to a direct poll of the people amendments of the Federal Constitution, without which it could not carry out its Labour policy. These amendments sought: (a) to give the Commonwealth Parliament full power to legislate with respect to trade and commerce instead of the limited power it had under the Constitution (the limitation stood in the way of Federal legislation dealing with the conditions of labour); (b) to give the Commonwealth 
Parliament full power over all trading corporations; (c) to give the Commonwealth Parliament specific power to deal with the wages and conditions of labour and labour disputes; (d) to give the Commonwealth Parliament power to deal with all combinations and monopolies. A further proposed amendment of the Constitution gave the Commonwealth Parliament power to declare that any business was a "monopoly," and following such declaration to acquire it, paying on just terms for any property used in connection with it. By a majority of about a quarter of a million votes in-a total poll of about $1,155,000$ votes the people declared against these amendments of the Constitution. Thus a Labour Government was left in office without power to carry out its Labour policy. It was announced that these amendments would be submitted again at the General Election of I9I3.

Thwarted by the safeguards of the Constitution and the refusal of the people to allow amendments removing those safeguards, in an effort to move further towards the ideal of a socialistic state, the Fisher Government was yet able to carry out much advanced legislation. Its first task, however, had been to clear itself very completely of any suspicion of a lack of earnestness regarding the defence of Australia and the Empire. In I009, whilst Mr. Deakin was Prime Minister, an Act of Parliament had been passed enforcing military training on all able-bodied male citizens. Tlis enactment of universal service had not been opposed by the Labour party. Indeed their criticism was that the system proposed to be enforced was not thorough enough; and the Government of the day promised that an expert from Great Britain should be asked to report on the system. Field-Marshal Viscount Kitchener accepted an invitation to visit Australia, and his report was before the Parliament of rg1o with a Labour Government in power. That Government not only accepted all his recommendations but in some cases crossed his " t's" and dotted his "i's." There was established a system of universal training for military defence which Lord Kitchener guarantees as adequate and which the Fisher Government has enforced against various protests with a resolute courage. In the matter of naval defence the Fisher Government was equally firm in dissociating itself from any faltering policy.

Mr. Fisher, in carrying on and extending the defence policy of his predecessors, gave the opposition no reason for hostility. But his Land Tax was hotly contested. During his brief administration Mr. J. C. Watson had foreshadowed a Land Tax, the purpose of which was to be economic rather than fiscal; that is to say, it was to be designed chielly to make the holding up of big estates against closer settlement unprofitable, and the collection of revenue was to be but an incidental matter. Mr. Fisher's Land Tax kept this " bursting up " of big estates in the foreground, but owned to a material interest in securing additional revenue to finance the great defence schemes which harl been entered upon. Estates of under $f, 5,000$ in unimproved value were exempted if their proprietors were resident in Australia (absentee landlords had wo exemption); upon estates of over $f, 5,000$ in unimproved value the tax was at the rate of one penny in the $f$, rising rapidly with the value of estates until at $£ 75,000$ unimproved value the rate was $6 \mathrm{~d}$. in the $f$, beyond which it did not go. In case of absentees the rate is higher, culminating in a tax of $7 \mathrm{~d}$. per $€$ of unimproved value.

Another highly important financial measure carried through by the Fisher. Government was a re-arrangement of the financial basis between the Commonwealth and the states. The original financial basis of the Commonwealth Government was absurd, but it had been furced upon the makers of the Federation by circumstances. It was found during the various sessions of the Convention which sat to frame a Constitution that Fecteral enthusiasm was apt to evaporate, and to be replaced by a hard bargaining spirit, as soon as the allocation of revenues came to be discussed. There were six states to be united, two of them (New South Wales and Victoria) rich and powerful; two others (Tasmania and II est Australia) poor in revenue and in population; two others (Qucensland and South Australia) occupying middle places. As soon as the issue came up as to how the Commonwealth revenues were to be collected and distributed, the representatives of the large states began to fear that the small states 
would "live upon them "; the small states began to fear that their revenues would be destroyed in the interests of the big states. Tasmania and West Australia won a large proportion of their income from the Customs taxation of goods from the other states, and that source would disappear with inter-state Free Trade. The difficulty was finally solved by a clause called the "Braddon clause" (or in party polemics " the Braddon Blot"), after its author, the late Sir Edward Braddon, Premier of Tasmania.

The Braddon clause provided that the Commonwealth Government, after collecting the Customs and Excise duties, should pay back at least $\frac{3}{4}$ of them to the revenues of the various states. The idea was ingenious. The Commonwealth Government in order to get $5 \mathrm{~s}$ for itself would have to collect ${ }_{5} 5 \mathrm{~s}$ for the states, and thus the smaller states could rely on no starveling policy of Customs and Excise taxation. Almost everybody said that the clause was absurd without being able to suggest an alternative. It was put in the Constitution with a proviso that it should last but ten years. During the first three Parliaments several efforts were made to secure, by agreement with the states, a less crippling arrangement. But party strife prevented resolute action on the part of any Federal treasurer. On their part the states were firm to maintain a system which in some cases they thought to be the only safeguard against bankruptcy, while in other cases they recognised it to be a source of most abounding revenues, which they had the pleasure of spending but not the odium of collecting. The DeakinCook administration, on the eve of going to the country in rgog, made an arrangement with the state Premiers to amend the constitution, so that in place of the provisions of the Braddon clause the Commonwealth should pay to the states $25 \mathrm{~s}$ per head of population per annum out of the Customs and Excise collections. This amendment was sanctioned by Parliament. To come into force, however, it required the endorsement of the people at a referendum. That endorsement was refused. The position, then, when Mr. Fisher took office for the second time, was that the Braddon clause of the Federal Constitution was on the point of expiry and that the whole of the Customs and Excise revenues would then be at the unfettered disposal of the Commonwealth. He could have destroyed the financial independence of the states absolutely. He took a moderate course, and by an Act of Parliament of Igro the states are allowed subsidies of $25 \mathrm{~s}$ per head of population per annum, out of the Customs and Excise revenue for ten years. At the end of that time the Federal Parliament can make any other disposition that it thinks fit. since there is now no Constitutional provision on the subject.

Mr. Fisher with two of his colleagues attended the Imperial Conference of Igr. He was apparently impressed by the degree of confidence with which the British Government consulted the representatives of the overseas dominions. A first indication of the intention of Australia to take an active part in the foreign policy of the Empire was furnished in August I9I 2 by a protest against the United States policy in regard to the Panama Canal.

Australia at the end of Igr 2 was on the eve of her fifth General Election. The Labour party intended to ask for a renewal of confidence and for such amendments of the Constitution as would enable them to carry further their socialistic policy. The Opposition, under Mr. Cook,-Mr. Deakin announcing in December his withdrawal from the leadership,- - raised a warning against this policy and condemned the administration of the Government as tinged with favouritism and inefficiency. "The Opposition party was not as well organised as the Government party and it showed some signs of internal dissension. Many of its friends feared that it would succeed only in weakening and not in defeating the Labour Government. It was impossible for it under any circumstances to secure a majority in the Senate, even if it won all the 18 seats to be contested, for all the 18 Senators who were not retiring at the election of $19 \mathrm{I} 3$ were Labour members. A by-election in I9I2 at Werriwa (N.S.W.), at which the Labour party held the seat by a greatly decreased majority, seemed to foreshadow this result. 
The Governor General of the Commonwealth in 1912 was Lord Denman. The follow. ing were the names of the Cabinet still in office at the end of the year:

Prime Minister and Treasurer
Attorney General
Minister for External Affairs
Minister for Home Affairs
Postmaster General
Minister for Defence
Minister for Trade and Customs
Vice-President of Executive Council
Honorary Ministers

Andrew Fisher

W. M. Hughes

J. Thomas

K. O'Malley

C. E. Frazer

G. F. Pearce

F. G. Tudor

G. McGregor

E. Findley and E. A. Roberts

The Constitution and the High Court.- The Federal Constitution, in safeguarding the Federal power from trespass by the states and the power of the states from tres: pass by the Federation, necessarily set up a system of conservative check. But the full extent of that check was only understood when a High Court began to interpret the statutes in the light of the Constitution. Already a considerable amount of the legislation of the Australian Parliament has been declared ultra vires by the High Court. Some of the decisions affected political issues so deeply that it was sought to amend the Constitution so as to facilitate "Labour" legislation, but this effort failed. The power to amend the Constitution is in itself subject to many safeguards. A proposed amendment must first have the approval of an absolute majority of both Houses of Parliament; it is then submitted to a poll of the people, and to pass it must secure (a) a majority of the total votes cast, (b) a majority of the votes cast in a majority of the states. If the three largest states voted "Yes" and the three smallest states voted "No," though the total Australian vote was " yes," the proposed amendment would still fail.

In 1906 the Australian Parliament had passed an "Excise Act "which was intended to enforce what was called "the New Protection." A high protective Customs Duty had been placed on agricultural machinery, and at the same time an Excise Duty on the same machinery manufactured locally, with the provision that the Excise Duty should be remitted if the manufacturers paid "fair wages." On June 26, I908 the High Court declared this Act invalid, on the ground that it was not what it purported to be - a taxing Act, but rather an Act to regulate wages within a state, a thing which the Federal power was not competent to undertake under the Constitution.

The first two Australian Parliaments devoted much time to discussing a Federal Industrial Arbitration Act, which included in its control state railway servants. This inclusion was nullified by a High Court decision that it was an unconstitutional interference by the Federal power with the affairs of the states. In the Trade Marks Act the Australian Parliament gave Trade Unions the right to register what is known in the United States as the "Union label," a mark showing that certain goods were manufactured by Trade Union labour only. 'The Australian High Court (August I908) set this part of the statute aside on the ground that such a "Union label " was not a genuine trade mark, and the proposal to register it as a trade mark was really a subterfuge to assume control of labour conditions which were outside the province of the Commonwealth.

Not only Federal legislation but state legislation has been vetoed. An Arbitration Act in New South Wales had sought to give the widest powers of regulating industrial disputes. In a series of five appeals the High Court gave such a strict interpretation to the provisions of that Act that it was more than half destroyed. (The High Court is the only Court of Appeal in cases affecting the Constitution, and is with the I'rivy Council an alternative Court of Appeal in all other cases.)

In Ig 13 an effort was to be made to secure from the people a reversal of their verdict in 1911 , when they refused to give endorsement to amendments of the Federal Constitution which would legalise for the future the Federal and Labour legislation which the High Court har vetoed. Meanwhile the Australian Constitution, as interpreted by the High Court, is a barrier against any great development of socialistic enterprise on the part of the Commonwealth Government. 
Since the beginning of the Federation there have been two alterations of the Constitution sanctioned: one, unimportant, was designed to improve the electoral machinery; the other gave the Commonwealth power to take over all the states' debts. Three proposed alterations have been rejected: one which proposed to make constitutional provision for a subsidy to the states; one which proposed to give the Commonwealth Parliament control of labour legislation; and one which proposed to give the Commonwealth Parliament power to take over monopolies and conduct them under state control.

The Australian High Court was originally constituted (1903) of three Judges, Sir Samuel Griffith (chief), Sir Edmund Barton and Mr. R. E. O'Connor. In 1906 two other Judges were added, Mr. Henry Bournes Higgins and Mr. Isaac Isaacs. In I 9 I 2 it was proposed to strengthen further the Court to seven Judges. Sir Samuel Griffith (born in Queensland in 1845 ) had a distinguished career as a politician in his native state. He took an early interest in the Federal movement, was President of the Federal Council (which preceded Federation) from 1888 to 1893 , and was chiefly responsible for the framing of the first Federal Constitution on which the more "popular" Constitution subsequently adopted was modelled. Sir Edmund Barton's services to Federation have been already noted. Mr. Richard E. O'Connor (born in New South Wales in 1851) was also one of the first advocates of Federation; he died on November I8, I9I2. It was a curious circumstance that all three members of the first High Court were graduates of Sydney University. Mr. Higgins (born in Ireland) was leader of the Equity Bar in Victoria and accepted office as Attorney General in Mr. J. C. Watson's first Labour Ministry (rgo4). Mr. Isaacs (born in Victoria in 1855) had a distinguished career in state politics and was Attorney General in Mr. Deakin's second administration.

Industrial Disputes.-In spite of much advanced "Labour" legislation the industrial situation in Australia has not been altogether peaceful recently. The strike on the Victorian State Railways in 1903 was followed in 1908 by a strike on the Sydney State Tramways. Both of these strikes against state employment failed. New South Wales in I908 altered its Industrial Arbitration system, and, this alteration being resented by the Trade Unions, various small strikes followed. The next year (rgog) more serious strikes broke out on the Broken Hill (N.S.W.) silver-mining and the Newcastle (N.S.W.) coal-mining fields. Stern measures were taken by the New South Wales Government to repress these strikes, and the leaders in the strike movement were arrested and some of them punished with imprisonment. In IgIo there were strikes of tramway employees at Perth (W.A.) and of transport workers at Adelaide (S.A.). In Igr 2 the tramway employees of Brisbane came out on strike because of a slight grievance against their employers (a private company). The leaders fomented a sympathetic strike on "Syndicalist" lines, calling out the workers in every industry with the avowed object of preventing all business. Serious riots accompanied the strike. The state Government acted however with decision, and the strike disorders were crushed and the Syndicalist movement defeated. This strike had not the general sympathy of Labour leaders in Australia. Shortly after, the Queensland Premier, Mr. Denham, went to the country to ask for sanction for a policy of dealing sternly with labour disorder. The General Election gave him a substantial majority, and he passed legislation (I9I2) making strikes illegal without due notice and without a secret ballot of the Trade Union affected.

The Labour Government of the Commonwealth has amended the Federal Industrial-Arbitration Act (introduced by the Deakin Government and passed by the Reid-McLean Government). It originally forbade the employment of Trade Union funds for political purposes. That restriction has been removed.

The Tariff.-The first Australian Tariff Act of rgor was introduced by the late Mr. Charles Kingston, then Minister for Customs, in a form very like that of the later Tariff Act of 1908. In I90I Free Trade opposition and Labour party criticism cut down Mr. Kingston's proposals materially, and his Tariff did not satisfy the Protectionists. But party divisions prevented reform for seven years. During I906 however several small Tariff Acts were passed, the chief of which provided for a measure of Preferential Trade with South Africa. The I908 Tariff Act raised the tariff generally and provided for a preferential rate on certain goods imported from Great Britain. 
In rgro the system of Customs book-keeping between the states was abolished in consequence of the substitution for the Braddon clause of a fixed subsidy from the Commonwealth to the states. Since then there have been no material changes in the Tariff, and the Customs Minister, Mr. Tudor, has expressed the view recently that the Government: would not be willing to raise the Tariff further unless there were a certainty that labour conditions would be thereby bettered, a certainty which could not be provided by the Commonwealth legislature under the present constitutional limitations.

The preferential tariff treatment of British imports does not show any very marked effect on the trade figures as yet. The proportion of imports from the United Kingdom has remained fairly steady; it was $51.52 \%$ in $1908,51.50$ in $1909,51.21$ in 1910 . Previous to 1908 the proportion of British imports was dwindling. British goods admitted at a preferential rate in 1910 paid $\{2,485,497$ in duty, whereas if they had come under the general tariff they would have paid $£ 3,457,67 \mathrm{I}$ in duty. The rebate was thus $f 972,174$. In regard to $£ 6,425$,260 of British imports the Commonwealth admitted them frec; foreign goods of the same classes and value would have paid an average tariff duty of $5.18 \%$

Defence.-When the Commonwealth Government took over the defence of Australia from the states in I 901 there existed for land defence in the various states very small forces of regular troops, used as instructional cadres and as garrisons for the forts; small forces of militia, enlisted under a voluntary system and paid for about i 6 days of drill and camp training a year; further small forces of volunteers, not paid at all, and giving usually but scanty time to training. The total of these forces was 25,873 , of whom a proportion could be counted as efficient. Naval defence, apart from the existence of various small craft, was entrusted to the British Navy, and a yearly subsidy (up to $£ \mathrm{r} 26, \infty 00$ ) was paid to the British Admiralty on condition that a fleet of a certain strength was maintained in Australian waters and certain facilities given to Australians wishing to enter the naval service.

At first the Federation did little to disturb these arrangements. The fleet subsidy was continued and extended. The military forces were taken over as they were. But the Defence Act of 1903 gave an indication of a new spirit. I It made provision for the enlistment of all able-bodied males for defence service in case of war. An amendment proposed by Mr. W. M. Hughes, one of the leading members of the Labour party, that this universal obligation to military service should be accompanied by a universal obligation to training for service, was rejected. But it was inevitable that in time the one should follow the other. Mr. Hughes (born in Wales in I864), a very advanced Socialist at the outset of his political life, constituted himself the Parliamentary champion of compulsory training for service, and - assisted outside the House by the National Defence League, of which Colonel Gerald Campbell, a volunteer officer of distinction, was the moving spirit - eventually secured the acceptance of the principle. A series of Acts in I009, I0IO and I0I I gave Australia a military system under which, with few exceptions, the whole manhood of the country will be trained to the use of arms. Under this system, at the age of twelve, a boy must begin training (chiefly physical culture) as a junior cadet. Training as a senior cadet begins at 14, and lasts until I 8 ; it comprises drills equivalent to 16 full days a year. At the age of 18 the obligation to undergo adult training begins, and lasts until the age of 25 , through seven years. This adult training consists of the equivalent of 16 full days drilling a year, of which not less than eight shall be in a camp of continuous training. In the case of the artillery and the engineers the training extends to 25 days a year, of which not less than I $_{7}$ must be in camp. There are certain exceptions, including one making provision for those who have conscientious scruples against bearing arms; these however are trained for the hospital and ambulance services. The thinness of the population in some districts forces another class of exemption: the residents of far "out back" camnot be economically mobilised for training, and for the present are left out of the scheme. A Staff College in the Federal Territory is provided for the training of officers, and its organisation is on severely practical lines. Cadets are accepted after examination. The whole cost of their college training is borne by the Army Estimates, and parents are forbidden to supplement the messing allowance by private pocket- 
money. Even railway fares to and from the College when cadets go on holiday leave are paid by the Government, as are also all costs of uniform and equipment. A severe but not unwholesome discipline is exacted; the drinking of alcoholic liquors and cigarette smoking are both forbidden in the College.

It was not to be expected that a compulsory military system should be carried through altogether without protest. It had some opponents, influenced by religious objections or by those pacific ideals which would seek to abolish the possibility of war by abolishing all organisation for national defence. But the first stage and the second stage of the scheme dealing with the cadets have now (1912) been successfully surmounted, and the training has been put in hand of the first draft of 20,000 of adult citizen soldiers. An official statement published in September ror 2 showed that $81 \%$ of those affected had.complied with the provisions of the Act, and that there were in New South Wales only 643 offenders; "-in the other states a considerably less number," who were'so recalcitrant that it was necessary to prosecute them. In October IgI 2 the Defence Minister stated that the Opposition to the Act was no greater than to the Compulsory Education Act. Penalties of fines and imprisonment are provided for disobedience.

The numbers under training when the system is in full operation are estimated at 100,000 senior cadets and 120,000 citizen soldiers. But as after training the citizen soldier will pass into a reserve, the potential military resources of the Commonwealth in the future are only to be calculated by the total number of males of "military age" minus those who had been exempted from training. On the basis of the present population there would be 366,000 males between the ages of 18 and $26,330,000$ between 26 and 35 , and a further 614,000 between 35 and 60 . Exemptions, at a broad guess, might be $25 \%$. The organisation of the establishment proposes at present 28 regiments of Light Horse, 56 batteries of Field Artillery, and 92 battalions of Infantry, and a due proportion of Engineers and Army Services Corps.

In regard to naval defence there was strong criticism of the subsidy policy at the very outset of the Federation. But that policy was warmly supported by the British Admiralty and the Imperial Defence: Committee; and the impression was given that the only alternative to an Australian cash subsidy towards the British Navy was no co-operation at all in the naval defence of the Empire. Indeed the early advocates of an Australian Navy were met in their own country with charges of disloyalty to the mother country. But Australian public opinion steadily hardened on the subject. The British Admiralty was ultimately converted, in part at least. On December 19, 1907 Mr. Deakin as Prime Minister of Australia outlined a scheme by which Australia would devote the amount of the naval subsidy, then $£ 200, \infty 00$ a year, to the building of an Australian fleet, under the control of the Commonwealth Government but trained to co-operate with the British Navy. He proposed, in short, that in naval defence Australia should set up an independent but loyal system corresponding to the one she had adopted in military defence. Mr. Deakin announced that the British Admiralty did not altogether endorse his views, especially in regard to the control of the Australian Navy in time of war, which was kept with the Commonwealth Government unless it chose to pass that control over to the British Admiralty.

No great advance was made in regard to naval defence until the general anxiety as to the European situation in 1909 made the subject of Imperial Defence of the first importance. Australia was represented at an Imperial Defence Conference in Igog which showed a remarkable change of opinion on the subject of "local navies" on the part of the British Admiralty. They brought down to the Conference, as a substitute for an Australian subsidy to the British Navy, a proposal for the building of an independent Australian fleet unit with the help of a British Treasury subsidy of $£ 250,000$. The Australian Government adopted the scheme in its entirety, except that it refused to accept the subsidy and decided to put the whole cost on the Australian taxpayer. Under this scheme Australia was to provide a fleet unit with a "Dreadnought ". cruiser as its chief vessel. There was no provision for the automatic transfer 
of the fleet to British control in the outbreak of war, that point having been allowed to drop out of sight. It is argued in Australia that a special provision. of the sort is not needed, as full co-operation may be safely assumed.

In March I9I I, at the request of the Australian Government, and at the close of a visit to Australia, Admiral Sir Reginald Henderson reported on the naval needs of the Commonwealth. His report was accepted, and it represents the present aim of Aus. tralian Naval Defence, though, according to a statement made by one member of the Australian Ministry (Mr. Roberts), the acceptance of Admiral Henderson's proposals was subject to ratification by the electors in 19I3. But there seems to have been no division of opinion in the Cabinet as to its acceptance. "We have called in a doctor: we must take his prescription," was the statement made by one member of the Cabinet, discussing the expenditure that Admiral Henderson demanded. His proposed Australian navy would consist in 22 years of 52 vessels manned by 15,000 men. The highest annual vote would be $f_{4}, 794,000$, and the ultimate cost would be $f 88,500,000$. The strength of the fleet would be 23 ships in 1918,42 . ships in 1923,48 ships in 1928 , and 52 ships in 1933 .

At present the Australian building programme is confined to the fleet unit decided upon in 1909: a battle cruiser, of the "Indomitable" class, three unarmoured cruisers of the "Bristol " class, six destroyers of an improved "River" class, and three submarines of " $\mathrm{C}$ " class, and the necessary auxiliaries. In I9I 2 there were in actual commission the "Parramatta," "Yarra Warrego" (destroyers); and in the water, the "Australia" (a battle-cruiser completed in I9I2), and "Melbourne" and "Sydney" (cruisers, one of which was due for completion in 1912). Construction of the fleet is proceeding simultaneously in Great Britain and in Australia. The personnel for the fleet will be largely drawn from the British Navy at the outset. But Australian officers and crews will be recruited and trained as quickly as possible. A site has been chosen for a naval college for the training of officers at Jervis Bay (N.S.W.), and a temporary college established at Geelong (Vic.). New Zealand is co-operating with Australia in the maintenance of the college for training naval officers. The provisions of the Act compelling universal training for service affect the naval manning, for young citizens may elect to train as naval cadets. The official report on the training of the first batch of naval cadets, issued September I912, was satisfactory.

The cost of this great naval and military preparation is shown in the growth of the Australian Defence votes. In $1905-6$ the Commonwealth devoted $f 970,345$ to defence, in 1906-7 $£_{1}, 035,795$, in $1907-8 \quad £ 1,334,744$, in $1908-9 \quad £ 1,050,590$, in $1909-10 \quad £ 1,534,881$, in $1910-11$ f $f, 008,705$. The estimates for $1911-12$ provide for an expenditure of $£ 4,775,136$. Administration of both the military and naval systems is by Boards.

ObItUARy. The Australian obituary for I9I included the following names:-

Sir Richard Chaffey Baker, President of the First Senate of the Commonwealth; d. at Adelaide, Australia, on the 18 th March. He was born in North Adelaide in 1842 , educated at Eton and Trinity College, Cambridge, and called to the Bar in 1864 . He was president of the Legrislative Council of South Australia from 1893 to 1901 , and special envoy to London from the Australian Governments for the mail contract negotiations in 1885 .

Sir JENkiN Coles, speaker of the South Australian Assembly since 1890; b. 1842; d. at Adelaide on the 7 th of December.

SiR (iEORge HeNRY Jenkins, Clerk of Parliaments in Victoria since I89I; $d$. at Colombo, Ceylon, on the 17 th July. He was born in $18+3$ at Abergavenny in Monmouthshire, and becoming connected with the government department of Victoria made a special study of parliamentary procedure and became an authority in Australia on Constitutional questions. He was Clerk of the Legislative Assembly of Victoria from I882 till I89I, and was knighted in 1904 .

Cardinal Patrick Francis Moran, third Archbishop of Sydney, New South Wales, and the first Australian (ardinal; (see E. B. xix, 543c); d. at Sydney on the I6th August. He was born in County Carlow, Ireland, on the 16 th September 1830 , and educated at the Irish (ollege at Rome, where he became Vice-President and Proiessor of Hebrew. In 1873 he was consecrated Bishop of Ossory, and thence went in 1884 to Sydney as Roman Catholic primate of Australia. The cathedral of St. Mary, Sydney, was built under his direction.

WILliam LloYid MIRIDOCH, the cricketer; d. suddenly during a cricket match at Melbourne, on the 18th February. Born in 1855 at Sandhurst, Victoria, he went to England as 
captain of the Australian eleven in 1880 , and in the historic test match of that year made I53 not out (see $E$. B. vii, 444 b). He was captain of the Australian eleven in 1882 and 1884 . From I 893 to 1899 he lived in England and played for Sussex; and, returning to Australia, he played for New South Wales.

In 1012 the following well-known Australians died:-

GEORGE JOHN BONNOR, the cricketer; d. at Sydney on the 28 th June. Born in 1855 in Victoria, he first went to England as a cricketer in I880, attracting special attention by his unusual height and strength. He played for Australia again in England in 1882, 1884, 1886 and 1888 (see E. B. vii, 444 b).

James Francis CoRbett, Roman Catholic Bishop of Sale, Victoria; d. in Melbourne on the 29th May. He was born at Limerick in 1840 , and educated in France. After a few years spent in Ireland as a priest he went to Melbourne as secretary to Archbishop Goold. He acted as Assistant Secretary to the Primary Australian Synod of his church in 1885, and in 1887 was consecrated first Bishop of Sale.

Sir Matthew Henry Davies, Speaker of the Legislative Assembly of Victoria from 1887 to 1892 ; b. 1850 ; d. November 26 th.

JoHN Hughes, member of the Legislative Council of New South Wales, was born at Sydney in I 857 , and died I 8 th December. He was Vice-President of the Executive Council in I 898-99 and again from I904 to I9IO. In 1899 he was for a few months Minister of Justice.

Martin Howy Irving, a prominent educationist; d. at Albury in Surrey, England, on the 23 rd July. The son of Edward Irving (see $E$. $B$. xiv, 854 b), the founder of the "Catholic Apostolic Church," he was born in 1831. After leaving Balliol College, Oxford, he was for a year a master at the City of London School, but went to Australia and was appointed to the Chair of Classics and English at Melbourne University. In 1876 he became head master of the Hawthorn Grammar School, and in 1884 commissioner of the new constituted Public Service Board. He was also for some years chairman of the Melbourne board of the Australian Mutual Provident Society, and a promoter of the volunteer movement.

Samuel Edward Marsden, former Bishop of New South Wales, d. at Clifton, England, on the 15th October. He was born at Sydney, N.S.W. in 1832, and educated privately and at Trinity College, Cambridge. He was ordained in 1855 and in 1861 was appointed diocesan inspector of schools for Worcester. In 1869 he was consecrated Bishop of New South Wales, and held the see till 1885 . After his retirement he returned to England and became assistant bishop in the diocese of Gloucester and Bristol.

RichaRd Q'Connor, Judge of the High Court, d. at Sydney, on the I 8 th of November. Born at Sydney in $\mathbf{1} 85 \mathrm{I}$, he gradually made a position at the N.S.W. Bar, and entered the state legislature; and he was an enthusiastic supporter of the movement for Federation. When this was accomplished in I90I, he became vice-president of the Council and leader of the Federal Senate; and in 1903 he was made a judge of the new High Court. From 1905 to I 908 he was president of the new Court of Conciliation and Arbitration.

Sir William Owen, formerly Judge of the Supreme Court of New South Wales; b. I834; d. November 22.

\section{New South Wales}

The area of New South Wales is now computed at 309,472 . square miles. The state has progressed rapidly since Federation. The population in I 900 was I,364,590 and in I 1 I I

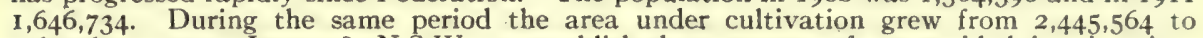
$4,611,672$ acres. In 1908 N.S.W. re-established a system of state-aided immigration. Its net gain from immigration was, however, only 438 in 1911 . But since then the increase has been greater. The city of Sydney has shown a remarkable growth since Federation, and in 1912 a "Million Club" was formed to foster the growth of the city to I,000,000 inhabitants. The estimated population in I9I I was 629,500 .

At the General Election of I9 Io the Labour party carried the day and Mr. J. C. T. McGowan formed a ministry which still held office at the end of 1912. Parties are very evenly divided, and the years I9I I and I 9 I 2 were marked by perpetual political fighting and very little legislative work. By securing from a member of the Opposition acceptance of the office of Speaker the Government was able to make its position more secure (his vote, of course, was lost to the Opposition), and this incident led to many remarkable scenes of disorder and violence in the House. An incident of the political situation has been a growth of unfriendly feeling between the state Government and the Federal Government. The state Government in 1912 decided that the Government House building could no longer be reserved for the use of the Federal Governor General. In consequence the Governor General will not live in Sydney in future during the Parliamentary recess.

Lord Chelmsford, appointed in 1909 , was still Governor in 1912, but Sir Gerald Strickland was nominated in October to succeed him in 1913.

\section{VICTORIA}

Since Federation the population has increased from I, I97,206 to $1,337,678$. State-aided immigration was re-established in 1908 and a vigorous policy of closer settlement has been adopted. Victoria is now the most forward of all the states in encouraging immigrants. 
Alone of all the Australian states, Victoria has never yet been governed by the Labour party. At the end of 1912 the Premier was Mr. W. A. Watt. His ministry is the successor of Mr. W. H. Irvine's (I902) which was very strongly opposed to the Labour party. After Mr. Irvine, Mr. Bent, then Mr. Murray, then (1912) Mr. Watt led this Government. As temporary seat of the Commonwealth Government, Melbuurne, the capital of Victoria, has been also the political capital of Australia, and the housing of the chief of the Federal departments there has given some impetus to the city's growth. Since the inauguration of the Federation it has been improved greatly in appearance by a scheme of tree decoration applied to the river banks and the chief streets.

The Governor in 1912 was Sir John Michael Fleetwood Fuller.

\section{SOUTH AUSTRALIA}

South Australia has now an area of 380,070 square miles and a population of 408,558 , having been relieved of the care of the Northern Territory. The state is facing the development of its "dry-belt" where wheat-growing has been found to be possible with a very low average rainfall. In I90 I the area under wheat was $1,743,452$, in I910-1 I 2, I04,7 I9 acres, in $1911-12$ (estimated) $2,190,782$ acres with an average yield of 9.29 bushels to the acre. A great access of prosperity is expected in South Australia as a result of the new transcontinental railway to Perth (W.A.).

In politics South Australia has always been very progressive in spirit. It was the first state to enfranchise women, and most of the "social reform" legislation of Australia originated here. The Labour party has often formed the Government. But since a strike of transport workers in 1910 there has been a reaction against that party in the state.

At the end of 1912 the Governor was Admiral Sir Day Hort Bosanquet, and the Premier the Hon. A. H. Peake.

The population of Queensland is now 505,813; the state has progressed greatly since Federation, the population having increased in the last decade by $21.62 \%$. The state is committed to a vigorous policy of railway development and immigration. Alone among the Australian states it develops its railways from several maritime centres instead of from the one capital city. The sugar industry is a great source of Queensland wealth, and some anxiety was formerly felt as to whether the "white labour" policy of the Commonwealth would not ruin this industry. That anxiety no longer exists. In I9IO-I I there were I08,535 acres under sugar in Queensland, in I9IO-II I I I,779 acres, and the estimates for I9II-12 were extremely favourable. The sugar produced in 1910 was $1,840,447$ tons. Agricultural farm applications in 1901 were 661 , in 19101,733 , showing the rapid progress of land settlement. Under all forms of settlement there were applications for 364,766 acres in I90I and for $1,951,170$ acres in 1910 . The figures in each case represent new settlement.

Pulitically, the state was for long one of the strongholds of the Labour party, which shared the Government under a coalition system. Since 1907 (when woman suffrage was adopted) there has been a drift in the other direction. The Philip ministry (1907-8) was hostile to the Labour party. The Kidston ministry (1908) was, as regards its head, strongly pro-I ahour at one time, but became more Conservative as a tortuous and troubled political sit uation developed. The Denham ministry (I9II) was quite opposed to the Labour party. It had to face in 1912 a fierce "Syndicalist" labour strike; and, following the defeat of the strike, appealed to the countrv for a renewal of confidence. The General Election resulted in the decisive defeat of the Labour party. An Industrial Peace Bill was then brought forward to limit the right to strike, and was passed by the Legislative Assembly in September 1912. At the end of that year the Governor was Sir William MlacGregor, and the Premier the Hon. Digby Frank Denham.

\section{WEST At'stralia}

The population $\left(282,11_{4}\right)$ shows an increase since Federation of $53 \%$. The state has kept for many ycars a system of state-aided immigration, and in 1910 , the number of immigrants was 6,655 .

The backwardness in development of this, the largest of the states, is now being met by a vigurous land settlement policy and the pushing on of the trans-continental railway to connect the state by land with the eastern states. The wheat-growing industry has developed very greatly of recent years. In Igor there were 94,710 acres under wheat, in I $10-11581,862$ acres, and the estimated area for I9I I-12 is 559,195 acres. The gold yield is decreasing. In $191 \mathrm{I}$ it was $1,370,868 \mathrm{oz}$.

IV est Australia with its large population has a strong Labour party, which was in power at the end of 19 I2 with the Hon. F. Scaddan as Premier. The Covernor in I9I2 was Sir Gerald Strickland, whose successor in 1913 was designated in November in Sir H. Barron.

\section{TASMANLA}

With a very mild climate, in which drought is unknown, Tasmania (pop. I9I,2II) is destined to be the garden orchard and small-culture farm of the mainland. But it has not 
yet shared in the tide of the Commonwealth's prosperity, and during the last decade increased its population by only $10.86 \%$, though its natural increase was almost the highest in the Commonwealth. It lost more by emigration than it gained by immigration.

In 1912 the Governor was Major General Sir Harry Barron (transferred I9I3 to West Australia), and the Premier Sir Elliott Lewis; Mr. W. G. Ellison Macartney, deputymaster of the Royal Mint, was nominated on Dec. II to succeed Sir H. Barron as governor. (FRANK FoX.)

\section{NEW ZEALAND ${ }^{1}$}

Population.-The population, according to the quinquennial census of April 2, I9I I, was (exclusive of Maoris) r,o08,468, of whom 53r,9 10 were males and 476,558 females. This shows an increase of II 9,890 in five years - the largest in any quinquennial period in New Zealand's history. The density to sq. m. is 9,690; number of persons to an inhabited dwelling 4.68. The populations of the principal cities (including suburbs) were: Auckland I02,676; Wellington (the political capital) 70,729; Christchurch 80,I93; Dunedin 64,237. Excluding suburbs the city populations were: Wellington 64,372; Christchurch 53, II6; Dunedin 4I,529; Auckland 40,536. The number of Maoris (including half-castes living as Maoris) was 54,025. Of the total population 996,4I8 were British subjects (born and naturalised), and only 12,050 were of foreign nationality. The birth-places of the British subjects were as follows: New Zealand 702,779; United Kingdom 228,684; Australia 50,693; other British possessions 4,570.

Births and Deaths. - The birth rate in 1886 was 35.40 per $\mathbf{I}, 000$ of population, but it declined steadily from year to year until in 1899 it was 25.12 -the lowest percentage reached in the history of New Zealand. The rate increased yearly until 1907, when 27.30 was recorded. In I9I I the rate fell to 25.97 . The number of children to a marriage for the twenty-year period I892-I9I I shows a decline from 4.54 to 3.07. Of every I,000 children born in 1911, 41 . were born out of wedlock as against 45 in 1910.

The death rate per 1,000 of population has been as high as 10.95 (in 1907), but fell to 9.39 in I9II, which is slightly below the New Zealand average of the previous ten years, slightly below that of Australia and much below that of all European countries. The principal causes of death in 191 I were: cancer, 7.97 per 10,000 of mean population; phthisis, 5.58; pneumonia; 5.14; gastritis and enteritis, 3.69.

Although the birth rate in New Zealand is low as compared with that of some European countries the death rate (particularly among infants) is the lowest recorded by any country in the world. As a result, the natural increase of population-by excess of births over deaths-is exceptionally high. The natural increase per 1,000 of mean population for the decennial period ended I9I I was 17.00 as compared with II.7 I for England and Wales during the same period.

Migration.-The migration returns show considerable fluctuations. For instance the net increase by migration in the years I907-I I was:- (I907) 5,730; (I908), I4,26I ; (I909), 4,719; (1910), 3,408; (I9I1), 4,200. In the same period the natural increase remained consistently steady: (I907); 15,028; (I908), I6,897; (1909), I 7,565; (I910), I6,345; (I9II), 16,820. During the same years, arrivals from the United Kingdom were: (I907), 7,449; (I908), II,348; (I909), II,I 84; (I9I0), 9,367; (I9II), I I 379. Departures for the United Kingdom were: (I907), 2,446; (I908), 2,635; (I909), 2,676; (I9I0), 2,509; (I9II), 2.755.

Religion:-The New Zealand census includes the religions of the people. An analysis of the I9II returns gives the following percentages:-Church of England and Protestants not otherwise defined 41.I4; Presbyterian 23.32; Roman Catholics and Catholics undefined 13.97; Methodist 9.43; Baptist 1.99; Hebrew 0.21 . The number who objected to state their religion represented 3.57 per cent.

Agriculture. - The census for I9I i showed the total area of land under occupation to be $40,238,126$ acres, of which $16,265,890$ acres were under cultivation. The principal crops were: wheat, 8,290,22 I bushels; oats, I0, I I 8,9 I 7 bushels; barley, 927, I I 2 bushels; potatoes, 141,510 tons. Of the total production of wheat 7,000 bushels were rcquired for home consumption and seed in I9I. There is no regular export of wheat. Butter and cheese were exported in $191 \mathrm{I}$ to the value of $f_{1}, 216,137$ - an increase of about 200 per cent in ten years. Frozen meat exports doubled in value in ten years. The exports in I9I were valued at $£ 4,173,014$.

Trade. -The value of imports has been:-(I909), £15,674,719 (from United Kingdom $f_{9,287,786)}$; (I9I0) $f_{17,05 I, 583}$ (from United Kingdom fIO,498,77I); (I9II) $f_{1}$ I $9,584,789$ (from United Kingdom fII $1,787,300$ ). Exports:-(I 1909$)$ f I $9,661,996$ (to United Kingdom $f 16,193,188) ;($ I 110$) \cdot\{22,180,209$ (to United Kingdom $£, 18,663,1$ 1 8); (I911) $£, 19,528,490$ (to United Kingdom $\left.£_{15}, \mathbf{1} 34,743\right)$. The total trade per head of population was:-(rgog)

1 See. E. B. xix, 624 et seq. 
$£ 36.7 .3$; (1910) $£ 39$. 10.4; (19I1) $£ 38$.o.2. The imports and exports for the first six months of 1912 were:-imports, $f_{1} 10,281,641$; exports, $£ 14,339,086$.

The Preferential Tariff takes the form of a surtax on certain goods not being the produce or manufacture of some part of the British Dominions. Out of the total of 486 items on the Tariff 193 are scheduled under the surtax. The surtax was legalised in 1903 . The New Zealand Official Year Book says:- "The value of imports from foreign countries has never assumed large proportions, ranging from 13.5 to 17 per cent. of the total during the past ten years. From 1899 to 1904 there was a steady increase, but since the latter year the proportion has fallen - a result no doubt in a large measure due to the preferential treatment of British goods.'

Reciprocity is provided for under the Customs Duties Act 1908, where any country, being part of the British Dominions, agrees to reduce or abolish a duty against New Zealand products or manufactures. Treaties under this Act are in force between New Zealand and the Union of South Africa, Southern Rhodesia and Canada.

Railways. - The chief asset in which loan money has been invested in the Dominion is the Railways. It is also the most profitable. According to the Railways report for the year ended March 3I, I9I2 the year's earnings (which exceeded those of the previous year by $\left.f_{1} 82,327\right)$ were $f 3,676,509$, and the expenditure $\ell_{2}, 465,896$, showing a net profit on working of $f 1,210,613$, equal to a return of 3.98 per cent on the capital invested in the opened lines and 3.70 on the opened and unopened lines. The lines opened for traffic were 2,808 miles, and the capital cost $f 30,506,089$; the capital cost of opened and unopened lines was $\{32,689,179$ in 1912 . The entire railway system, with the exception of a few miles of private lines used for specific purposes, is now owned and controlled by the government.

Defence.-The most interesting fact in connection with the Defence Forces has been the operation of the rompulsory training provisions of the Defence Act of I909 (amended r9ro). That Act provides for the gradual military training of every male New Zealander from the age of 12 years to the age of 25 , after which he must serve in the Reserve up to the age of 30 . There are no distinctions and no exemptions; but those who, in consequence of religious convictions, have a conscientious objection to bearing arms, may be trained as far as possible in the non-combatant branchès, of which ambulance work is made a special feature. From $\mathrm{I} 2$ to $\mathrm{I} 4 \mathrm{a}$ boy is a junior cadet; then he is transferred to the senior cadets and becomes a member of the Military Forces, although not liable to be called out to fight. He remains a senior cadet until $\mathbf{r} 8$, at which age he is drafted into the Territorial Force and is liable to be called out at any time for service within the Dominion. At 25 he is transferred to the Reserve till 30 , when he is discharged but is still liable to be called back to his regiment in case of war. The number of Territorials and senior cadets registered or serving up to March 25, I9I 2 were as follows: Territorials under $2 \mathrm{I}-6,309$; registered for enrolment-22,214; senior cadets $-30,560$; territorials over age but desirous of continuing service-2,862; total 6r,945. The training of the cadet and soldier is strictly territorial, - that is to say, except for the one week a year spent in camp, training is carried out within reach of the man's home and at convenient times. It is pointed out by the military authorities that the New Zealand Territorial Force cannot be fairly compared with the Territorial Force of the United Kingdom, which has the regular army and special reserve in front of it. The New Zealand Territorial Force is the New Zealand Army, and the Permanent Force (officers, warrant and non-commissioned officers) are its auxiliaries to control, guide and instruct it. The Force will be about 30,000 strong, and is organised in field and coast defence units, with practically the same establishment for peace as for war. Nine officers of the New Zealand Staff Corps were in 1912 undergoing instruction in England and two in India; the number of imperial officers interchanged and on loan from the imperial army, serving with the New Zealand forces, was I 5.

Finance.- The budget of the new Minister of Finance was presented in the House of Representatives on August 6, I9I2. The actual revenue for I9I I-I 2 was $f_{1} 1,032,544$, being $£ 603.534$ in excess of the estimate, and the actual expenditure $£$ ro,604,677, being $\{264,309$ under the estimate. The gross public debt at the end of the financial year (March 3I, I9I2) amounted to $£_{24}, 352,913$, and the net debt (i.e. less accrued sinking fund) to $£ 82,10,3,310$. The following were the principal purposes for which the various amounts were borrowed and applied: Maori War, $£ 2,537,000$; Defence $£ 3,369,952$; Railways $£ 26,154,970$; Roads and Bridges Construction and Lands Improvements 
$£_{7,240,676 ;}$ Public Buildings $£_{55}, 643,912$; Telegraph and Telephone lines $f_{1}, 601,767$; Immigration $\ell_{2}, 477$, I 19; Harbours and lighthouses $£ 586,942$; Purchase of Native lands $\ell_{2,715,217 .}$ "Opinions may differ," said the Minister of Finance, " as to how much of the total is self-supporting, but the amount expended in the construction of railways, the purchase of native lands and the acquisition of lands for settlement are of this nature, and the amounts spent on telegraph and telephone lines, loans to local bodies, and reserve fund securities must be regarded as revenue producing. Other amounts, such as those expended on purchasing the Bank of New Zealand shares and for advances to settlers and workers, bring in more income than is paid out for interest." Loans were to fall dure in the seven years ending Igig amounting to $£_{23}, 176,47.8$, of which there was payable $£ 10,568,550$ in London, $£_{2}, 133,550$ in Australia and $£ 10,474,378$ in New Zealand. "A very large proportion of our public debt," said the Minister, "will require to be either renewed or paid off by fresh loans."

Political History. - The years $1909-\mathrm{I} 2$ are important in the political history of New Zealand, which in 1907 became a "Dominion." In I909 the government offered Great Britain " at least one first-class battleship (and, if necessary, two) of the Dreadnought or latest type," and took the lead in the movement in the Oversea Dominions for imperialising the British navy. In IgI I the Imperial Conference in London was attended on behalf of New Zealand by Sir Joseph Ward (Prime Minister since I906; b. I857) and Sir John Findlay (Attorney General; b. 1862 ), and of the 52 resolutions which made up the Agenda-for that Conference no fewer than 23 stood in the name of New Zealandincluding one which aimed at the re-constitution of the Colonial Office and the constitution of an Imperial Council but was eventually withdrawn. Sir Joseph Ward and Sir John Findlay (the former having been created a baronet and the latter a knight during their attendance at the Conference) returned to New Zealand in the latter part of I9I I, to face a general election at which the party which had ruled New Zealand uninterruptedly for more than twenty years under the leadership of John Ballance, Richard Seddon and Joseph Ward in succession, was shattered. The Prime Minister refused to accept the verdict of the elections, and met the new parliament with a new policy, but was defeated in the House of Representatives and resigned. He was succeeded in February I912. by a member of the same party and a former colleague, Mr. Thomas MacKenzie (b. - 854 ) who formed a Ministry as follows: Thos. MacKenzie, Prime Minister and Minister of Lands; A. M. Myers, Minister of Finance and Defence; W. D. S. MacDonald, Minister of Native Affairs; J. A. Hannan, Minister of Education; G. Laurenson, Minister of Customs; G. W. Russell, Minister of Internal Affairs; James Colvin, Minister of Mines; Thomas Buxton, Minister without portfolio; Te Rangihiroa, Minister representing Native Race. Mr. MacKenzie's government lasted however only five months, being defeated in July. And thus ended the ultra-Radical régime which had existed from Tanuary I89 I to July I912-a period of over 2 I years.

The most interesting incident in the short-lived career of the MacKenzie Ministry was in connection with the request of the Imperial government to include the battleship "New Zealand " (the Dominion's gift to the Imperial Navy) in the Home Fleet. In the early part of May I9I 2 the Colonial Secretary telegraphed to the New Zealand government: "In the event of the increases of the naval programmes of European Powers which now seem imminent and likely, in the interests of naval supremacy it would be desirable that the battle cruiser 'New Zealand,' instead of serving in China, should be appointed to the Home Fleet in the North Sea, where alone she would be matched against vessels of her own size and quality." The Premier of New Zealand replied: "The government approves your proposals and considers 'New Zealand' should be stationed where Home Government consider her of most value." This message was acknowledged by the Colonial Secretary in these terms: "His Majesty's Government convey their deep gratitude and appreciation of your patriotic action in accepting so readily the suggestion of the Admiralty in the interests of the Empire at large."

Mr. W. F. Massey (b. I856), Leader of the Opposition for several years, who succeeded to the Premiership, was a Conservative in New Zealand political nomenclature but 
a Moderate Liberal from an English point of view. He surrounded himself with colleagues who collectively made up the strongest cabinet New Zealand had possessed for a generation. More than half the members of the cabinet were university graduatesa distinction unique in the history of New Zealand Ministries. The Ministry, which had a good working majority, was constituted as follows: W. F. Massey, Prime Minister, Minister of Lands, Agriculture and Labour; J. Allen, Minister of Finance, Defence and Education; W. H. Herries, Minister of Railways and Native Affairs; W. Fraser, Minister of Public Works and Mines; A. L. Herdman, Attorney-General and Minister of Justice; F. M. B. Fisher, Minister of Customs and Marine; F. H. D. Bell, Minister of Internal Affairs and Leader of the Legislative Council; R. H. Rhodes, PostmasterGeneral and Minister of Public Health; Dr. Pomare, Member of the Executive Council representing the Native Race.

The Massey government announced their determination to bring about closer settlement of the land and to make this the most important plank in their policy. They proposed to lessen the graduated tax on estates of $£ 5,000$ unimproved value, and to provide that the graduation should be regular and increasing with every $f_{\mathrm{I}}$ increase in unimproved value, while increasing the tax payable on estates of over $£ 30,000$ unimproved value. The new law was to provide that the 25 per cent additional tax now imposed on estates of $£\{0,000$, or more in unimproved value should apply to estates of more than $£ 30,000$.

One of the first executive acts of the Massey Ministry was the appointment of Mr. Thomas MacKenzie to the position of High Commissioner in London in succession to Mr. C. Wray Palliser, who on Mr. MacKenzie's appointment resumed his office of secretary to the High Commissioner's Department, which he had held during Mr. W. Pember Reeves' and Sir William Hall-Jones' tenures of office as High Commissioners.

Obituary.-Sir John Logan CaMpbell, known as "The Father of New Zealand," died at Auckland on the 2Ist of June 1912. He was born in Edinburgh on the 8th of November I 817 , and educated at Edinburgh University. After taking a medical degree he entered the service of the East India Company, but in I 839 he left it and emigrated to Sydney. A year later he went to New Zealand and there founded at Auckland the firm of Brown \& Campbell. In 1856 he joined the Stafford government as a member of the Executive Council. From $186 \mathrm{I}$ to $187 \mathrm{I}$ he was in England; but he returned to New Zealand, and there held many important posts, including the chairmanship of the Board of Education in Auckland and of the Board of the Bank of New Zealand. He was the author of Poenamo, a book on early life in Auckland. He was knighted in 1902.

SiR WilliaM SteWARD, ex-Speaker of New Zealand House of Representatives, died at Wellington, N.Z., on the Ist of November 1912. He was born at Reading, Berks., on the 20 th of January $184 \mathrm{I}$, and went to New Zealand in 1862, where for 30 years he was a journalist and newspaper proprietor. He was elected to the House of Representatives in 1870 and was its oldest member. From 1893 to I90I he was Speaker of the House, and in I901 he was knighted. He published Carmina Varia (1867) and The Vision of Aorangi and Other Poems (1906).

\section{SOUTH AFRICA}

(L. J. BRIENT.)

The area of British South Africa, according to I 9 II official figures, is I, 204,358 sq. $\mathrm{m}$. In the same year the census returns gave the total population as $8,196,224$ of whom 1,305,5.3 were Europeans or whites. Administratively British South Africa consists of: (I) The Union of South Africa, a self-governing dominion comprising the Cape, Natal; Transvaal and Orange Free State provinces; (2) The Territory of Rhodesia, administered by the chartered company of British South Africa; (3) The Native ProtectoratesBasutoland, Bechuanaland and Swaziland, administered as crown colonies. South Africa, however, forms one Customs Union, and the interests of Rhodesia and the Native P'rotectorates are so intimately connected with those of the Union that it is best to treat the whole arca as a unit. This plan has been adopted below, but certain particulars regarding Rhodesia and the Protectorates are given in separate sections.

Vital Statistics. - Table I, compiled from the ror I census return, gives details of the area and population. Compared with the census of 1904 the increase in the white population wats 172,390 . Of this increase 123,285 was in the Transvaal alone, the in-

${ }^{1}$ See $E . B . x x v, 463$ et seq. and allied articles. 
Table I. Area and Population of:British South Africa.

\begin{tabular}{|c|c|c|c|c|}
\hline . & $\begin{array}{l}\text { Area } \\
\text { Sq. } \mathrm{m} .\end{array}$ & $\begin{array}{l}\text { Pop. } \\
\text { I9II } \\
\text { White. }\end{array}$ & $\begin{array}{l}\text { Native } \\
\text { and } \\
\text { Coloured. }\end{array}$ & Total. \\
\hline \multicolumn{5}{|l|}{ Union of S. Africa: -} \\
\hline Cape Province & 276,995 & $5^{82,377}$ & $\mathbf{I}, 982,588$ & $2,564,965$ \\
\hline $\begin{array}{l}\text { Transvaal Province } \\
\text { Natal Province (includes Zulu- }\end{array}$ & & 420 & 50 & 212 \\
\hline land) & & 98, & $\mathbf{I}, 0$ & $\mathbf{I}, \mathbf{I}$ \\
\hline Orange Free State Province. & $5^{\circ}$ & I75, & & \\
\hline Total Union . . . . & 473,954 & $1,276,242$ & $4,697,152$ & $5,973,394$ \\
\hline $\begin{array}{l}\text { Territories - } \\
\text { S. Rhodesia } \\
\text { N. Rhodesia }\end{array}$ & $\begin{array}{l}148,575 \\
290,000\end{array}$ & $\begin{array}{r}23,606 \\
1,497\end{array}$ & & $\begin{array}{l}\mathbf{I}, 077 \\
2,599\end{array}$ \\
\hline Total Rhodesia , . & $43^{8,575}$ & 25,103 & $1,568,573$ & $\mathbf{x}, 593,676$ \\
\hline rotectorates:- & & & & \\
\hline Bechuanaland & 275 & & & 125 \\
\hline $\begin{array}{l}\text { Basutoland } \\
\text { Swaziland }\end{array}$ & & & & \\
\hline Total Protectorates . . . . & 291,829 & 4,186 & 624,968 & 629,154 \\
\hline Total British South Africa . & $1,204,35^{8}$ & $\mathrm{I}, 305,53 \mathrm{I}$ & $6,890,693$ & $8,196,224$ \\
\hline
\end{tabular}

crease in the white population in the other provinces of the Union being slight. In Rhodesia the white population had nearly doubled in the seven years. The increase in the native and coloured population was $88_{5}, 660$. With respect to the coloured population two important factors must be remembered. (I) The Cape province total of native and coloured includes 391,000 persons with a marked strain of white blood, officially classed as "mixed", the total "mixed " population being 435,000 . (2) The Natal province total of native and coloured includes I33,000 Indians. There were also 10,048 Indians in the Transvaal, the total Asiatic population being I 52,000.

The increase in the total population in the Union between I 904 and I I I I was I $5.12 \%$; in the white population $14.44 \%$, in the native population $16 \%$, in the Asiatic and other coloured races $9.84 \%$. Among the whites there were 86.18 females to roo males in I $9 \mathrm{Ir}$, compared with $75.85 \%$ in 1904 . For all races there were 94. II females to 100 males in I9II, compared with 92.97 in r904. Increase by immigration is slight. In I9II, 55,000 passengers landed at S. African ports and 46,000 embarked.

The population of the chief towns at the I9II census was: Cape Province.Cape Town, with suburbs, I6I, 579 (85,442 whites); Port Elizabeth and suburbs, 37,063 (20,007 whites); East London, 24,606 (I4,899 whites); Kimberley (including Beaconsfield, the municipalities were amalgamated in I9I 2), 44,433 (17,507 whites); Graham's Town, I3,830 ( 7,323 whites); King William's Town, 9,028 (5,570 whites). Natul Pravince.-Durban and suburbs, 89,998 (34,880 whites); Pietermaritzburg, 30,555 (14,737 whites); 'Ladysmith 5,595 (2,287 whites). Transvaal Province.-Pretoria and suburbs, 57,674 (35,942 whites); Johannesburg, 237,104 (II9,953 whites); Germiston, 54,325 ( 15,579 whites); Boksburg, 43,628 (II , 529 whites); Benoni, 32,560 (8,639 whites); Roodepoort-Maraisburg, 32,578 ( 7,657 whites) - these four last named are all towns on the Rand as is also Krugersdorp, 55, 144 ( 13,132 whites). Orange Free State Province.Bloemfontein, 26,925 ( 14,720 whites); Jagersfontein, 9, 0I9 (2,067 whites); Harrismith, 6,799 (3,447 whites). Rhodesia.-Bulawayo, whites 5,199; Salisbury, whites 3,479.

Commerce and Agriculture.-While gold and diamonds are still the chief sources of wealth there was during 1910-I2 a marked development in other mining industries (coal, - copper, tin, \&c.) and in agriculture. The value of external trade for the whole of British South Africa (excluding specie and government stores) is shown as follows:- 
1910

Exports

Imports
I9I I

$£ 57,734,000$

$36,423,000$
1912

(Ist nine months only)

$£ 46,512,000$

$27,460,000$

Compared with 1907 the export figures for 1911 showed an increase of over $£ 10,000,000$ or 21 " in 19 I I it was officially estimated that $£ 6,351,000$ or $17 \%$ were taken by native or coloured consumers, a significant indication of their economic importance to the country. In I9II the United Kingdom supplied $58 \%$ of the imports, those of the British empire as a whole being $64 \%$. Germany and the United States came next as importers. By reason of the preference tariff granted them British goods benefited in $19 \mathrm{II}$, in the Union alone, by $£ 538,000$, Australian goods by $£ 46,000$ and Canadian goods by $£ 16,000$. Nearly all the exports $(92 \%$ in I9II) go to the United Kingdom. The following were in I9I I the chief exports: gold $£ 37,608,000$; diamonds $£ 8,282,000$; wool $£ 3,900,000$; ostrich feathers ${ }^{\natural}$ $£ 2,253,000$; angora and mohair $£ 917,000$; hides and skins $£ \mathbf{I}, 216,000$; coal $£ \mathbf{I}, 079,000$; copper $\{615,000$. These figures do not, however, represent fully the agricultural development. The export of maize, bark (for tanning) and of fruit has greatly developed, while much of the increased production in I9I I was consumed locally. The imports of agricultural machinery, $f_{148}, 000$ in 1910 , rose to $f_{196,000}$ in I9II. But the development of industries besides gold and diamond mining is best shown by the value of other goods exported; valued at $f 9,500,000$ in 1908 , they were worth $£_{1} 3,300,000$ in 1910 and $£_{13}, 700,000$ in 1911 .

The gold output from the Transvaal mines for 1911 was $\{35,041,000$; for the first ten months of 1912 it was $£ 32,242,633$. The issued capital at the end of 19 I I was $£ 62,325,000$, and $f 8,066,000$ represented dividends. The diamond output was, from the Cape Province (including $£ 346,000$ from river diggings) $£ 5,506,000$, an increase of $£ 298,000$ over 1910; the Transvaal diamond output in I9I I (mostly from the Premier mine) was $£ 1,628,000$. In May I91 I alluvial diamonds were discovered at Mooifontein on the Transvaal side of the Vaal in the Bloemhof district, and $17 \mathrm{~m}$. N.IV. of the river bank in a great gravel covered area. Alluvial diamonds had never previously been found so far from the river. A mining town of 10,000 inhabitants (half whites) has sprung up and there is every likelihood of the diggings having a iire or several years. By the middle of 1912 diamonds worth over $f 300,000$ had been found. Of more importance was the proof afforded in 1912 that there were rich copper fields in the Messina district, northern Transvaal.

Finance.-The following are the figures for the revenue and expenditure of the Union (Rhodesia and the protectorates being dealt with separately below). The financial year ends March 3I, and as the Union was established on May 3I, 19I0, the first financial "year" contained ten months only. It should also be pointed out that the account of the Railways and llarbours Board is not shown in the budget statements, only the contribution from the board to the consolidated fund. Revenue: (I9I0-II) $£ 14,392,000$, (I9II-I2) $\{17,336,000$,

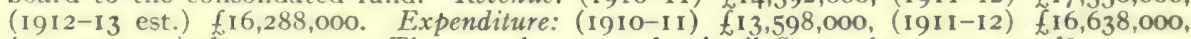
(1912-13 est.) $\ell_{17}, 129,000$. The actual revenue for April-September 1912 was $f 8,473,000$; the expenditure for the same period $£ 7,629,000$. The public debt on March 3 I, I9I I was $f_{11} 4,236,000$; the yearly interest $£ 3,876,000$. The Union government, to the end of I912, had contracted no permanent loan; the indebtedness being that incurred previously to Union.

The following figures for I9I I-I2 show the main sources of revenue: Customs $£ 4,508,000$; mines (part proprietory profits, part $10 \%$ tax on profits, imposed 1911 ) $£ 2,305,000$, licences, stamp duties, transfers \&c. $£_{1}, 653,000$; taxes on natives $\ell_{1}, 181,000$; contribution from Railways and Harbours fund $f^{\prime}, 159,000$. In I9I0-II the Board's contribution had been $\{1,520,000$; it was reduced in $1912-13$ to $£ 500,000$, and is intended to cease altogether, profits from railways and harbours being allocated to developing industries, by reduction in rates and fares, and in improving means of communication. Expenditure is practically wholly on the civil service. In I9II-12 the sum of $f 418,000$ was spent on defence. The provincial administrations cost the Union $£ 3,315,000$. (No permanent arrangement as to provincial finance had been reached by the close of 1912.) Up to March I9I2 the sum of $\{5,889,000$ was spent by the Railways and Harbours Board on capital and betterment account; of this $£ 2,400,000$ was allocated to building new railways. Reductions in railway rates to the end of 1912 represented a loss in revenue of $f 1,335,000$. In 1911 the Railways Bisard showed a revenue of $f_{12}, 163,000$ and expenditure $f_{12}, 056,000$; the Harbours Board a resenue of $\{852,000$ and expenditure $£ 729$,000. The state owned harbours are Cape Town, Port Elizabeth, East London, Durban and Mossel Bay.

Communications. - The contract for carrying ocean mails by the Union-Castle boats expired in September 1912. Meantime the company's fleet had been purchased by the Eller Dempster Shipping Company which 'on September 9, 1912 concluded a new agreement (to last ten years) with the government, framed to meet the requirements of an act passed in April 19 I I by: the Union Parliament forbidding the entry into any contract with any person or company which granted rebates to shippers. This act was aimed at the "shipping ring"

1 South Africa supplies the world's markets with about $85 \%$ of their requirements of ostrich feathers. 
which controlled freight rates to and from South Africa. The contract with Elder Dempster (who in October placed orders for two new liners for the S. African service, each of over I 5,000 tons) left the time for the mail boat service unaltered, namely 16 days 15 hours, between Southampton and Cape Town. Over $80 \%$ of the shipping is British. The net tonnage of vessels entering and clearing Union ports rose from $11,494,000$ in 1910 to over $12,550,000$ in 1.9II. Another 2,000,000 tonnage represents the trade of Lourenço Marques and Beira with British South Africa.

Wireless telegraphic stations have been established at Cape Town and Durban. The inland telegraphic service was in I9I I connected with German S. W. Africa.

In October 1912 the total mileage of the railways open was, in the Union 8,400 (of this mileage 7,646 was state owned); belonging to the Rhodesian Railway Systems 2,357. The Rhodesian system includes the railway running through the Bechuanaland protectorate (it is part of the trunk line north from Cape Town) and the Beira railway. There was in I9I2 through communication from Cape Town to Katanga (Belgian Congo) a distance of 2,3 I6 miles, all save 167 miles being in British territory. With the following exceptions the railways built since I9Io were mainly short lines to serve rural districts. The railway from Ermelo to Piet Relief (70 m.) opened in July I9II, was in 1912 being extended to Vryheid $(69 \mathrm{~m}$.) to give a direct route from Durban to the Eastern Transvaal. In October 1912 the Johannesburg-Zeerust line was completed to Mafeking, thus reducing the railway distance from the Rand to Bulawayo by 240 miles and making Durban the Union port nearest to Rhodesia. In the northern Transvaal, the Pretoria-Pietersburg line was continued to Bandolier Kop (7o m.) and, after lying derelict many years, the old Selati railway was continued to Messina, on the Transvaal side of the Limpopo.

Public Buildings and Monuments.-During $1910-12$ over $£ 1,300,000$ was spent on public buildings. The most notable are the Union government offices at Pretoria expected to be completed in I 1 I 4. The new General Post Office at Pretoria (opened Oct. I 1 I I) is a handsome and commodious Renaissance building. The museum, government library and University College at Pretoria have also been completed. The Houses of Parliament at Cape Town have been enlarged, as have also the Law Courts in that city. New Law Courts have been built at Johannesburg and Durban. A University College has been built at Pietermaritzburg. Over $£ 500,000$ was spent on harbour improvements, notably at Durban where a permanent quay wall was built at the harbour entrance while the harbour at Congella was opened up.

A memorial to Cecil Rhodes has been placed in the Groot Schuur estate on the slopes of Table Mountain. It is a granite temple in the Doric style approached by a flight of steps on either side of which are four lions sculptured by J. M. Swan. At the foot of the steps is G. F. Watts's statue of "Physical Energy" (of which the cast is in Kensington Gardens, London) and in the centre of the temple is a gigantic bust of Rhodes.

Progress has been made with the new Anglican cathedral in Cape Town. In it was placed in 1912 a magnificently illuminated MS. vellum volume bearing the names of the British slain in the war of $1899-1902$.

In November 1912 it was announced that Mr. Max Michaelas, formerly a partner in the firm of Wernher, Beit \& Co., had purchased from Sir Hugh Lane a collection of 46 pictures by old Dutch masters, including paintings by Rembrandt, Frans Hals, Jan Steen and Vandyck. These he presented to the Union government to form the nucleus of a national gallery. Sir Hugh Lane had previously formed a collection of modern masters at the Johannesburg Municipal Gallery, of which he was the first honorary director. The Michaelas collection is to be housed at Cape Town.

Rhodesia.-In July rgх N.E. and N.W. Rhodesia were amalgamated under the title of Northern Rhodesia, a change indicative of the recognition that N.E. Rhodesia would follow the fortunes of South Africa rather than those of Nyasaland. The census of April I9I I showed that the white population of Rhodesia had nearly doubled since I904, but was still very sparse-25,000 persons to $438,000 \mathrm{sq}$. $\mathrm{m}$. In the I 8 months following the taking of the census there were fully 2,000 new European settlers. Over $90 \%$ of the white inhabitants are natural born British subjects - a higher percentage than in any other part of South Africa. The administration remained in the hands of the British South African Company, whose charter does not expire till rigr4. Rhodesians were divided in their views of the future form of government between three policies (I) a renewal of the charter, (2) entry into the Union of South Africa, (3) a modified form of crown colony government. The party advocating the third alternative was most vocal. It was represented by the Southern Rhodesian League, which formulated its views in November IgI2. In December IgI 2 the Chartered Company announced that the elected members of the Southern Rhodesia Legislative Council would be increased from seven to twelve, and the nominated members from five to eight.

The revenue figures in Southern Rhodesia are: (I9IO-II) $f 784,000,($ I9II-I2) $f 864,000$, 
(1912-I 3 est.) $f 853,000$; and the expenditure (I910-II) $£ 684,000,($ I9II-I2) $£ 838,000$, (1912-13 est.) f 894,000 .

The imports of "ordinary merchandise" (i.e. excluding railway material, government stores and specie) were valued at $f_{2}, 222,000$ in 1910 and at $f 2,569,000$ in 1911 . The exports (excluding goods in transit) were $f_{3}, 018,000$ in 1910 and $f_{3}, 098,000$ in 1911 . For the first eight months of 1912 the figures were: imports $£_{1}, 745,000$, exports $£_{2}, 081,000$. In 1910 British imports were $69 \%$ of the whole; in I9I I they were $68 \%$. One-fifth of the imports came from the Union of S. Africa. Germany and the United States each had about $5 \%$ of the import trade. Northern Rhodesia in 1911 -apart from transit trade-sent exports worth $f_{150}, 000$ into Belgian Congo. This was consequent on the opening of railway communication with Katanga. Gold is the chief export. The output in 1910 was valued at $£ 2,568,000$, in 1911 at $£ 2,647,000$, for Jan-Oct. 1912 at $£ 2,262,000$. The export of chrome ore in 1910 was $f 100,000$, in I9I I $f$ I I 8,000. The output of coal from the Wankie mines was 180,000 tons in 1910 , and 212,000 tons in 1911 .

Rhodesia is, however, pre-eminently a stock-raising and agricultural country and most of the new settlers are farmers. Maize is largely grown for export, but the chief export ather than minerals was tobacco, valued at $£ 31,000$ in 1910 , and $£ 34,000$ in 1911 . Scarcity of native labour led to the establishment in October I9I I of an official Native Labour Recruiting Bureau which secured uniformity of recruiting conditions for all classes of employers and better conditions for the natives. A uniform tax of one shilling per native was imposed on all employers by an ordinance passed in December 1911. This tax the farmers refused to pay and to save the situation the ordinance was revoked by the Secretary of State for the Colonies, June 1912, at the request of the Chartered Company. The Legislative Council, in lieu of the tax, granted a subsidy to the Labour Bureau.

Complaints of the high cost of living and of excessive railway rates were rife during the last half of 1912 , and led to vigourous protests against the increased duties on foodstuffs and clothing proposed by the Union commission on trade and industries. Suggestions to make Dutch an official language in Rhodesia were strongly resented. Owing to large gifts from Cecil Rhodes and Alfred Beit there are as good facilities in the country for elementary and secondary education of Europeans as in England. High schools for girls and for boys have been opened at Bulawayo and Salisbury.

The Native Protectorates.- The Bechuanaland Protectorate, Basutoland and Swaziland remain under the control of the Imperial Government, represented by the High Commissioner for South Africa, and are administered by Resident Commissioners. They form, in whole or in greater part, native reserves. The history of all three protectorates in 1910-12 was one of peaceful development, the fear of the Basuto and Bechuana that they would be immediately handed over to the Union having been allayed.

Basutoland in 1912 changed its financial year to end at March 3I (instead of June 30) to bring it in line with the rest of British South Africa. Its prosperity is shown by the fact that for the nine months which constituted the financial year $1911-12$ the revenue was $f_{1} 138,000$, compared with $£ \mathbf{1 4 5}, 000$ for the full twelve months on the preceding financial year. Expenditure in 1910-1I was $£_{134,000}$ in I9II-12 $£_{111}, 000$. At the time of the census of I9I I over 2 I, 000 male Basutos were absent from the territory, I I,800 being engaged on the Rand mines. Agriculture and stock-raising are the occupations of those who stay at home. Strenuous efforts were made by the administrator to improve agricultural methods, and in 1912 there was a marked increase in the quality and quantity of wool and mohair produced. Education is fairly general; 17,400 scholars, the majority girls, were in attendance at the mission schools of the Paris Evangelical Society and other bodies. In 19 I I the hut tax was abolished and a tax of $£ I$ per annum on adult males substituted, or if a native has more than one wife he pays $f_{1}$ p. a. for each wife up to a maximum of $f 3$ a year for himself and his wives. This tax yielded $£ 92,000$ in 1912 . The Basutoland national council met at the capital, Maseru, in March 1912. This council consists of 99 members (all natives) and the paramount chief (I.etsie); 94 members are nominated by the Basuto themselves, 5 by the government. This council is an advisory body and keenly critical. The Resident Commissioner (appointed I90I), Mr. H. C. Sloley, was made a K.C.M.G. in I9II.

Bechuanaland is a much poorer country than Basutoland, and the Bechuana a much less virile race than the Basuto. They suffered in $19 \mathrm{I}$, and again in 1912 , from prolonged drought. Financially Bechuanaland approached an equilibrium in $1911-12$, when the revenue was $\{59,000$ and the expenditure $£ 65,000$, the deficit, made good by the Imperial Government, being the smallest on record. This was due to the fact that the staple product of the protectorate-cattle (which between 1904 and 19 I I increased from 139,000 to 323,000)-had for the first time access to a good market, Johannesburg and Kimberley, restrictions previously enforced owing to fear of cattle disease being removed. A sum of f,70,000 was realised by the natives through the sale of surplus cattle. Bathoen, paramount chief of the Bangwaketsi died in July 1910 and Sebele, paramount chief of the Bakwena died in January I9I 1 . Montsiva, chief of the Baralong, died in April 19t1. All these chiefs were noted men in the early struggles between the Boers and British for the possession of Bechuanaland, Sebele being 
son of the chief Sechele, the friend of David Livingstone. Khama survives and rules his tribe - the Bamangwato - with undisputed authority.

Swaziland is steadily recovering from the state of chaos into which it had fallen (see $E$. $B$. xxvi, I 86). The white inhabitants are engaged in agriculture and in gold and tin mining. In 19 I I-I 2 the gold output was $£ 62,000$; that of tin $£ 32,000$. The staple agricultural product is maize. During I9II-I2 there was a considerable development in fruit growing especially citrus fruits. The Swazis raise maize and other crops and own large stocks of cattle. From 7,000 to 10,000 Swazis obtain work on the Rand mines. The partition of rights between the European concessionaires and the Swazis was completed in I911. Altogether f, 182,000 was expended on the settlement of this question. In $191 \mathrm{I}-12$ the total revenue was $f, 57,000$; the expenditure $£ 62,000$. In I9I I a National Fund was established, to be used for purposes beneficial to the Swazis. To this fund every adult male Swazi pays a direct tax of 2 s. a year. Naba Tsibeni, the "queen regent" continued to act as chief of the Swazis. Sobhuza, her grandson and nominally paramount chief, was in 1912 about fourteen years old.

Political History.--The most salient feature in the history of South Africa since the establishment of the Union has been the endeavour made to develop the material resources of the country, especially its agricultural and general trade. The results achieved have been indicated in preceding sections of this article.

The parliament of South Africa legislating for the whole Union, the provincial councils took a purely secondary position. Racial questions, as between the British and Boer sections of the community, tended to occupy a less conspicuous position, though the indiscreet actions and utterances of General Hertzog, the minister of Justice and an ardent champion of Boer nationality, caused much embarrassment to his colleagues and disquiet among the people.

General Botha,${ }^{1}$ the Prime Minister in the first session of the Union Parliament (opened November I9ro), had the support not only of his own party, the Nationalist or "South African" party (predominantly Boer), but that of the four Labour members from the Rand and of several of the Natal members, elected as Independents. The opposition, known as the Unionist party (and mainly British), was led by Dr. Jameson (see E. B. xv, I47), who was created a baronet in January IgI I. Owing to ill-health Sir Starr Jameson resigned the leadership in April IgI 2 and was succeeded by Sir Thomas Smartt, an ex-Cape minister, and like Jameson a medical man. In October Igr 2 Sir Starr Jameson retired from parliament altogether, resigning his seat for Albany (Graham's Town).

General Botha made one important change in the cabinet during the first session, Sir.F. R. Moor, ex-Premier of Natal, being succeeded on February $22 \mathrm{~d}$ as minister of Commerce and Industries by Col. George Leuchars, also a Natal representative. This first session was devoted mainly to putting the Union machinery into working order. The most controversial issue considered arose out of the Education Acts of the former Orange River Colony (see $E . B . \mathrm{xx}, \mathrm{I} 60$ ) which enforced bi-lingualism. Elementary education was by the act establishing the Union left in the control of the provincial councils. The Union parliament could therefore only advise. A select committee on which both parties were equally represented considered the subject, and on the $I$ th of April Igr I presented a majority report recommending that up to standard IV instruction in schools be given in and through the " home language," with the optional use, on the demand of parents, of the other language, and that above standard IV freedom of choice be left to the parents; also that teachers should be free to qualify in either language. On April 24th the Union parliament approved this compromise, though General Hertzog (formerly minister of education in the Orange River Colony) was not in full agreement. The success of an action for slander brought against Hertzog (August I9I I) by Mr. Wm. Fraser, an ex-inspector of schools-whom that minister had dismissed in May I909-caused considerable scandal, which was intensified by the success of another slander action (November I9II) against Hertzog, the plaintiff in the second case being Dr. Ward, president of the O.F.S. medical council. The situation was rendered piquant by the fact that Hertzog was minister of Justice. Hertzog's resignation was

${ }^{1}$ General Botha was on August 16, 1912 appointed an honorary general in the British army. 
tendered, but Botha, fearing to alienate the more extreme Boer element, of which Hertzog was the leading representative, did not accept it.

General Botha had delayed till October Igr I to urge, officially, that the educational compromise advocated by the Union parliament be adopted by the provincial councils. ${ }^{1}$ Meantime the Transvaal provincial council had passed (August I9II) an ordinance in which the terms of the compromise were adopted, but with a modification which favoured the Dutch language. The Free State province passed an ordinance containing the same modification, and in August I9I2, the Cape provincial council by a majority of three passed a similar ordinance. Meantime the Natal council in view of the departure of the inland provinces from the strict terms of the compromise had refused to alter its education law. But in the Free State the new ordinance was so far accepted that on June 30 , I912, the free schools spened in 1910 as a protest against General Hertzog's compulsory bi-lingual system were handed over to the provincial administration.

Besides the language problem, the Union parliament during $\mathrm{I} 9 \mathrm{I} \mathrm{I}_{-} \mathrm{I} 2$ attempted to grapple with great social and political issues which as separate colonies the various provinces of the Union had been unable to solve. They concerned the relation of the Europeans to the native population; the position of Asiatics in South Africa (nearly all the Asiatics in the country were British Indians); and national and imperial defence. In regard to the relation of the white and Kaffir races to each other some little progress was made. Assaults on white women by Kaffirs both on the Rand and in Rhodesia attracted much attention. On the Rand in the first half of IgI I three Kaffirs were shot by white women whom they had attempted to assault. This shooting followed the commutation, in January I9II, by the High Commissioner (Lord Gladstone) of a death sentence on a Rhodesian native convicted of an attempt to assault a white woman; action $w$ hich roused much indignation against the High Commissioner. Feeling was intensified by the acquittal in August I II, by a Rhodesian jury, of a white man who had shot dead a Kaffir. ${ }^{2}$ In all during the year ending March 31, I912, there was in the Union alone (i.e. Rhodesia excluded) 85 cases of outrages upon Europeans by natives, as compared with 69 during I9ro. On the initiative of Sir Thomas "Smartt a commission was appointed June I9, I9I 2 " to enquire into the prevalence of sexual assaults on women by men of the same or of different race and colour, the extent to which they are attributable to economic and social factors, and to report means for their suppression." Mr. Melius de Villiers (exChief Justice of the Orange Free State and a brother of Lord de Villiers) was appointed chairman of the commission, whose membership included four ladies, one from each province. On the Rand the evil was attributed in part to illicit liquor selling and in part to the fact that the mine labourers were without their women-folk, and a petition signed by 52,000 Rand residents (presented to parliament May 1912) asked inter alia for the provision of compounds in which natives should be permitted to keep their wives, as well as for facilities for training native female servants and for the importation of European domestics.

This aspect of the case was recognised as but a part of a problem of vital importance, namely, the position of the natives in the body politic. South Africa at present is dependent on the native for unskilled labour. But even the position of the European as an overseer of blacks is threatened. In the Cape province the coloured population already competes with the whites in skilled labour, such as carpentry work, harnessmaking and boot-making (see e.g. Report on Trade of British South Africa for IgII). The pure African too has entered the skilled labour market, and is making many sacrifices in order to become well educated. Moreover in the Cape province-and to a slight extent in the other provinces-coloured and native men have entered the profes-

1 The administrators of the various provinces were: Cape, Sir N. F. de Waal; Natal, the Hon. ('. J. Smythe (b. 1852), an ex-premier of Natal; ()range Free State, Dr. A. E. W. Ramsbottom; Transvaal, Hon. J. Rissik (formerly member for lands and native affairs, Transvaal).

${ }^{2}$ Subsequently a special jury list was made for the trial of these cases, it being recognised that the ordinary jury could not be trusted to administer impartial justice. 
sions. They are lawyers, doctors, land surveyors and journalists. One native was elected (I9IO) a member of the first Cape provincial council. A clash between the two races is feared by many thoughtful leaders of the white community. One solution of the problem favoured is the keeping of whites and blacks in separate areas. General Botha in a speech in parliament (May 9, r912) stated that " the time was coming when the native question would have to be considered most seriously in the direction of keeping whites and natives apart and preventing their intermingling. They would have to fix attention closely on the question of segregation, while treating everyone with absolute justice."

The segregation plan also received the support, among many others, of Sir Mathew Nathan, an ex-governor of Natal, and General Hertzog. But it was opposed by those who, like Mr. P. W. Schreiner and Mr. Patrick Duncan (a leading member of the Unionist party); believe that it is both wrong and impolitic to put hindrances in the way of the advancement of the natives in civilisation and industrial efficiency. Mr. Duncan in a striking pamphlet published in October r9r2 ("Suggestions for a Native Policy") admits the dangers foreseen by the segregationists, but sees a remedy in European immi. gration on a large scale. "Nothing else" he declares "will save South Africa for the European race." A motion brought forward at the Unionist Congress in Johannesburg (Nov. 2I, I9I2) to commit the party to the policy of segregation was defeated, the previous question being carried by $9 \mathrm{r}$ votes to 7 .

Consciousness of the peril of the native problem caused the white inhabitants of South Africa to determine not willingly to add to it an Asiatic problem of equal perplexity. They exhibited a rigid determination to prohibit the immigration of Asiatics in the future alike on racial and economic grounds. The only dissentients were tea and sugar planters of Natal who were accustomed to depend upon coolies for labour. In I9II and again in I9I 2 the government introduced an Immigrants Restriction Bill. General Smuts, Minister of the Interior, in moving the second reading of the bill, May 30, ror2, said that without excluding Asiatics by name the government had adopted the suggestion of the British Colonial Office (a suggestion supported by the government of India) to apply to immigrants an educational and medical test based on the Australian model. That test admitted of elasticity in its application so that whites might be encouraged to come in while Asiatics were kept out. An arrangement had been come to with the Imperial Government to allow the entry of educated professional Asiatics in limited numbers. Objections to any concessions to Indians were raised by the Free State supporters of the ministry and the bill was dropped, but in September rgr 2 the intention of the cabinet to introduce an amended bill in I9I3 was announced. In October I9I 2 Mr. Gokhale, an elected member of the Indian Legislative Council, visited South Africa and in November went to Pretoria as the guest of the Union government to confer with them on the matter. The Indian government on its part had meantime (I9Ir) prohibited the importation of indentured Indians to Natal.

Little indication was given of the mann $r$ in which the Union government meant to deal with " the Indian peril " in Natal. There are in Natal 133,000 Indians; they are more numerous than the whites; they are moreover not only labourers, they have monopolised several branches of trade. It would seem that they must remain a permanent factor in the life of Natal. But to prevent the same problem arising in the Transvaal the law of 1907 prohibiting the immigration of Asiatics into that province, and enacting the registration--by finger prints-of Indians already in the province, was enforced (see $E$. B. xxvii, 209, 210). In many cases the provincial administration applied the law in an unnecessarily objectionable form. The Indians replied by a campaign of passive resistance. Many of their leaders, high caste Hindus, were imprisoned and great indignation was aroused in India by what Mr. Gokhale called "the continued ill-treatment of Indians in South Africa." Before the end of I9I I, however, certain modifications in the registration laws were agreed to by the provincial council, the exact status of British Indians in the Transvaal being left over for decision with the larger question of Asiatic immigration. 
The session of IQII-I 2 revealed acute differences in the cabinet and in the ministerial ranks. Mr. J. X. Merriman, ex-Cape Premier, the most accomplished parliamentarian and ablest financier in the House of Assembly, was a very candid friend of the ministry, as when in June 1912 he denounced their financial proposals as predatory and extravagant. The ministry itself was divided on personal and provincial and also progressive and retrogressive lines. Chief among Botha's colleagues were Mr. H. C. Hull and Mr. Jacobus Wilhelmus Sauer. Mr. Hull (b. I860) after being in the Cape civil service had practised at the bar, served in the war of $1899-1902$ and was afterwards treasurer of the Transvaal and he entered the Union cabinet as minister of finance. Mr. Sauer (b. I850) had been 30 years a member of the Cape House of Assembly and had frequently held office. On the establishment of the Union he became Minister of Railways and Harbours and Chairman of the Railways and Harbours Board created by the Union Act, the largest revenue producing department of state. Mr. Sauer became head of one section of the cabinet; General Botha or rather Mr. Hull head of another. As early as July I9II cabinet dissensions occurred, but there was no open breach until May I8, 1912, when Mr. Hull resigned. The ministerial differences were aired in two set debates in the House of Assembly. Mr. Hull alleged that railway expenditure was not previously sanctioned by the Treasury and that there had been a tendency to regard railway administration as something for which the government had no collective responsibility. General Botha (May 22d) admitted that the cabinet had not been sufficiently considered in railway matters.

As a result of this episode within the ministry itself General Botha's authority was weakened. The reconstruction of the cabinet was postponed until after the close of the parliamentary session, on June 24th. After two days' negotiations, Mr. Sauer and his friends threatening to resign if their demands were not granted, a compromise was reached. Mr. Henry Burton, K.C., another ex-Cape Colony minister, took over the Railways and Harbours; General Smuts (Transvaal) was transferred from the Ministry of the Interior to that of Finance; Mr. Sauer became Minister of Agricult ure (an office General Botha had held in conjunction with the premiership); Mr. Fischer (Orange Free State) became minister of the Interior, while retaining his portfolio as minister of Lands, while General Hertzog, in addition to his duties as Minister of Justice, undertook those concerning Native Affairs, which Mr. Burton had previously administered. The cabinet-whose other members were Col. Leuchars, Mr. F. S. Malan (Cape) and Sir David de Villiers Graaff (Cape) - was thus reduced to nine members, 4 of them being representatives from the Cape, 2 from the Transvaal, 2 from the Orange Free State and one from Natal.

The question of defence came prominently before the country in connection with the Imperial conference held in London in I I I I, which General Botha attended as representing the Union. It was decided that South Africa should provide for its own internal defence, and a Defence Act was passed in the Union parliament in June 1912, creating a citizen force at a cost of about $£_{500,000}$ a year; this is in addition to a permanent force of five regiments. The act provided for the military training of $50 \%$ of the young men between 18 and $2 \mathrm{I}$; the other $50 \%$ being compelled to join rifle clubs and similar associations. The $50 \%$ for training are obtained in the first place by voluntary enlistment, but if sufficient numbers are not forthcoming by this method, then by ballot. Members of the Citizen Force with the colours are paid. Provision was made for artillery, cavalry, infantry, engineer and transport units, uniformity with the units of the other over-sea Dominions being aimed at. General C. F. Beyers, one of the Transvaal commandants in the Anglo-Boer War was appointed Commandant General, while the Council of Defence created by the act consisted of General Schalk Burger (Transvaal), Col. ('rewe (Cape), General de Wet (Orange Free State), and Col. Sir Duncan Mackenzie (Natal).

Objections to the act came chiefly from the "back-veld" Boers who entertained strong dislike to compulsory service. The force being established, the reduction of the strength of the British Imperial forces in South Africa from II,500 to about $7, \infty 00$ 
was announced in November rgr2. The Union government had also under consideration proposals for a naval defence policy, General Botha educating his followers on this matter in several speeches made during rar 2.

A notable event in the history of the country was the inauguration of the Rhodes memorial at Groot Schuur on July 5, I9I 2 by Earl Grey, a former director of the Chartered Company and ex-governor general of Canada. The ceremony was attended by Lord de Villiers, Chief Justice of South Africa, Mr. Merriman, and Mr. Burton, minister of Railways. General Botha was absent, but he subsequently wrote a foreword to the pamphlet containing Earl Grey's speech, in which he (Botha) paid a warm tribute to Rhodes' lofty conceptions and achievements.

Lord Gladstone, who filled the dual offices of Governor General of the Union and High Commissioner of South Africa, was subjected to much criticism over his action with regard to natives charged with assaults on white women, but he met his critics fairly and won their respect. In February igi I he was made an LL.D. of Cape Town University. ${ }^{1}$ In May of that year he visited Basutoland, in September he went to Rhodesia (where he received Lewanika, the paramount chief of the Barotse), extending his journey into Katanga (Belgian Congo). In the summer of I9I2 Lord Gladstone paid a long visit to England, returning to South Africa in October.

The promotion of trade and agriculture occupied much attention, especially as the country suffered from prolonged drought, the severest experienced since 1862. Beginning in October I9I I, it affected chiefly Natal, the Transvaal and Transkei, where thousands of natives were reduced to the verge of starvation. The severe losses sustained turned attention to the need of more scientific farming and to large irrigation works, upon which the government expended $£_{500,000}$ in I9I2. In October I9I 2 a government Land and Agricultural Bank began operations in the Union, and a similar institution was established by the Chartered Company in Rhodesia. Great relief was experienced in Natal and in the Rand by the break up of the drought in November 1912. Meantime the export of cereals from South Africa had fallen off considerably, while a new and formidable competitor for the European maize market was being found in Argentina.

Early in I9I 2 a commission, of which Sir T. M. Cullinan was chairman, appointed to enquire into the conditions of trade and industries reported in favour of increased duties on wheat, flour, sugar, tea, clothing and furniture, declaring that it was "not only necessary that a policy of protection should be adopted, but that there should be continuity of policy." Two influential members presented minority reports in favour of "the open-door." Rhodesian feeling was in favour of a lower tariff, and with reference to the increased duties proposed by the Union commission the Bulawayo Chamber of Commerce declared (August r912) that it was to the interest of Rhodesia to withdraw from the Customs Union rather than bear greater fiscal burdens. The other Rhodesian Chambers of Commerce passed similar resolutions. At Johannesburg on November 19, I9 2 Sir Thomas Smartt deciared that a plank in the Unionist party's platform was a tariff primarily for revenue purposes, combined with a policy for the encouragement of industries for the general benefit and the extension of the existing imperial preference.

In December г гі 2 a political crisis involving the reconstruction of the ministry occurred. It was precipitated by the by-election in the Albany division to fill the vacancy caused by Sir Starr Jameson's resignation. (The election on Dec. Io resulted in the return of the Unionist candidate Mr. Van der Riet by a large majority over the Ministerialist, Mr. Espin.) General Hertzog had already (Oct. IgI2) created anew a feeling of political antagonism by describing, in a speech at Nylstroom, Sir Thomas Smartt and other Opposition leaders as "undesirable political foreign adventurers," and during the Albany election he made a speech-at Rustenburg on December 8,pointedly against the Imperial policy advocated by General Botha, declaring that

${ }^{1}$ George $\mathrm{V}$ after his accession resigned his position as Chancellor of the Cape University, being succeeded in 1912 by the Duke of Connaught. 
Imperialism appealed to him (Hertzog) only when it was useful to South Africa. He had a short time previously also pronounced in favour of the Dutch and British remaining "two nationalities flowing each in a separate channel." On December 13, Col. Leuchars, Minister of Public Works, resigned as a protest against General Hertzog's "Anti-Imperial and Anti-British sentiments." As Hertzog was not prepared to resign, General Botha tendered his resignation on December 15 , and was at once asked by the Governor General to form a new ministry. This was accomplished on December 20; Mr. Fischer, a minister who had usually acted with General Hertzog, deciding after much hesitation to join the new ministry. The cabinet was reconstituted as follows:-General Botha, Premier and Minister of Agriculture, Mr. Sauer, Minister of Justice and Native Affairs; General Smuts, Minister of Finance and Defence; Mr. Fischer, Minister of the Interior and of Lands; Mr. Malan, Minister of Mines and Education; Mr. Burton, Minister of Railways and Harbours; Sir Thomas Watt, Minister of Posts, Telegraphs and Public Works; Sir D. de Villiers Graaff, minister without portfolio. The only new member was Sir T. Watt, who, as a Natal member of the House of Assembly, replaced Col. Leuchars. General Botha described the new ministry as aiming first "at building up a new country on non-racial lines."

OBITUARY.-The deaths of some prominent South Africans may here be noted:-

Sir THOMAS EkiNs F LlLLeR, formerly agent-general for Cape Colony, died at Tunbridge Wells on the $5^{\text {th }}$ of September 19I0. Born at West Drayton, Midulesex, in I83I, he was for some time a Baptist minister, leaving England to edit the Cape Argus in I864. He was subsequently general manager of the Union Steamship Company; Chairman of the Cape Town Harbour Board, a director of the De Beers Mining Company and member of the House of Assembly (see E. B. v, 248). In 1902 he was appointed agent-general for Cape Colony in London, and knighted in 1904 . "Tommy" Fuller was one of the most esteemed and respected men in South African circles.

Piet Arnoldus Croxje, the Boer general (see E. B. vii, 50Ic), died at Klerksdorp, Transvaal, on the 4th of February I9r, aged 75. Since the war ended he had sunk into comparative obscurity.

Sir Jacobrs Albertus De Wet, Member of the Legislative Council of Cape Colony, died at his home in Cape Colony on the 26th of March I9II, aged 7I. He came of an old South African family. He was appointed British Agent at Pretoria in 1890, during the critical period (see E. B. xxvii, 200 et seq.) which ended with the closing of the Vaal River Drifts, and his name was familiar in connection with the proceedings after the Jameson raid in 1896 .

Sir Henry George Elliot, born in I826, died at Cape Town, 29th of November 1912. He entered the Royal Marines in I 847 and served through the Crimean War. In 1877 he became chief magistrate of Tembuland, and for 26 years he took a great share in the government and development of Kaffraria (see E. B. xv, 630a).

Sir Thomas Charles Scanlen, the Cape Colony politician, died at Cape Town, on the 15th of May 1912, aged 77. He was admitted Attorney of the Supreme Court of Cape Colony in I 866 , sat in the House of Assembly from $1870-96$, and was Prime Minister of the Colony from $188 \mathrm{I}-84$ (see $E . B . \mathrm{v}, 248 \mathrm{~b}$, and $242 \mathrm{c}$ ). In 1894 he was appointed Legal Adviser to the British South Africa Company, and held the position of Acting Administrator of Rhodesia at intervals from $1898-1907$. He was knighted in 1884 .

Arth'r Jesse. Shepstone, the Natal politician, died at Pietermaritzburg on the zoth of Septemler 1912, aged 59. He was born in 1852, the son of Sir Theophilus Shepstone (see E. B. xxiv, 840), and was educated in Natal. He was a digger at the Kimberley Diamond Fields in 1871 , and served as a trooper in the Natal Carbineers during the Langalibalele rebellion in I873. In 1876 he was appointed Labour Agent for the Natal railways. In 1887 he lecame a resident maysistrate, and served in various districts. In 1909 he became Secretary for Native Affairs in Natal.

See The South African Almanack (Cape Town, yearly) edited by E. Glanville, a good general reference book; A. S. Brown and (;. C. Brown, The Gitude to South and East Africa (Londin, vearly); The South African Municipal Year Book (Cape Town, 1912); The Report of the Commission on Trade and Industries (Pretoria, 1912) and other Lnion Blue Books (particulars may be obthined at the office of the lligh (ommissioner for South Africa, Sir Richard Solomon 72, Victoria Street, London, S. W.); E. H. L.. Schwarz South African Geology (London, I912). For histury see Sir Edgar Walton, The Inner History of the National Conerention of S. Africa (London, ig) 12) mainly a summary of speeches; Basil llorsfold, Union of South Africa (London, 1912); Sir William Butler, An Autobiography (London, 1911), contains S. African chapters.

(F. R. CANa.) 


\section{SECTION II. THE UNITED STATES OF AMERICA \\ THE UNITED STATES ${ }^{1}$}

Population.-In Igro the population of the United States and possessions (the latter estimated) was IOI,100,000; the actual enumeration (including Alaska, Hawaii and Porto Rico) was 93,402,I5I ; and the inhabitants of "continental " United States (including Alaska), 9I,972,266, the figure used as a basis of comparison here. Of this total three-fifths $(60.6 \%)$ was contained in the three-tenths of the country's area in the "Northern" states:2 i.e. New England (one-fourteenth of the tctal population); the Middle Atlantic group (more than one-fifth); the East North Central group (nearly one-fifth); and the West North Central (more than one-eighth). In this group the proportion of population was twice the proportion of area. In the Southern states the proportion of population (nearly one-third) was about the same as the proportion of area, not quite three-tenths; in the South Atlantic group it was two-fifteenths ( $3.3 \%$ ); in the East South Central one-eleventh (9.1\%), and in the West South Central nearly a tenth $(9.6 \%)$ of the total. The Western states with nearly two-fifths $(39.6 \%)$ of the area had less than two-twenty-fifths $(7.4 \%)$ of the population-relative population being to relative area as one to five; in the Mountain states there was about $2.9 \%$ and in the Pacific states about $4.6 \%$ of the total population. Roughly three-tenths of the area and seven-tenths of the population was east of the Mississippi river; and seventenths of the area and three-tenths of the population west of it.

Of the separate states eleven had each more than two and a half million inhabitants, and together they contained a larger population than the other 37 states (and the District of Columbia); in order these were: New York, Pennsylvania, Illinois, Ohio, Texas, Massachusetts, Missouri, Michigan, Indiana, Geórgia and New Jersey. Only two of these states are west of the Mississippi-Texas, the largest state of the Union in area, and Missouri, an important manufacturing state. The only one in the "Old South" is Georgia, the great producer of coal and iron in the South.

The relative increase for the entire country in the decade was $21 \%$, - little more than in $1890-1900$, but less than in any other decade, even $1860-70$, when the rate was $22.6 \%$ (or a little more). The actual increase in $1900-10$ was $15,977,69 \mathrm{I}$, a much greater one than ever before, and equal to the entire population about 1835 .

The decade's growth was largest in the West, $66.7 \%$, as compared with $19.8 \%$ for the South and $17.7 \%$ for the North. In the groups the greatest increase was $73.5 \%$ (only 28 in $1890-1900$ ) in the three Pacific states; and least in the East South Central group (Kentucky, Tennessee, Alabama and Mississippi; II.4\% (in I890-I900, I 7.4\%). In the most populous group, the three Middle Atlantic states, the rate was $25 \%$. Three states, Washington, Oklahoma (both comparatively new states) and Idaho, doubled in population, and Nevada came near doubling; the growth in the last two states was partly due to changes in mining. Iowa, alone, decreased $(0.3 \%)$ in the decade. The lowest rates of increase were in rural New England (Vermont, 3.6\%; New Hampshire, $4.6 \%$ ), where economic conditions resemble those in the East South Central group.

In roro the Middle Atlantic states ranked first and the East North Central states second, changing positions since rgoo. In the same way the West South Central, fifth, and the East South Central, sixth in IgIo, exchanged rankings in the decade.

' See E. B. xxvii, 612 et seq.

2 The classification of states is as follows: Northern, including New England Group (Maine, New Hampshire, Vermont, Massachusetts, Rhode Island and Connecticut), Middle Atlantic (New York, New Jersey, and Pennsylvania), East North Central (Ohio, Indiana, Illinois, Michigan and Wisconsin), West North Central (Minnesota, Iowa, Missouri, North Dakota, South Dakota, Nebraska and Kansas) Southern, including the South Atlantic Group (Delaware, Maryland, District of Columbia, Virginia, West Virginia, North Carolina, South Carolina, Georgia and Florida), East South Central (Kentucky, Tennessee, Alabama, and Mississippi), West South Central (Arkansas, Louisiana, Oklahoma, Texas), and Western, including the Mountain Group (Montana, Idaho, Wyoming, Colorado, New Mexico, Arizona, Utah and Nevada) and Pacific Group (Washington, Oregon and California). 
The other groups did not change in rank. South Atlantic, third; West North Central, fourth; New England, seventh; Pacific, eighth; and Mountain, ninth.

The average density of population in 1910 was 30.9 . persons to the square mile-nearly thrice that (10.6) in 1860 . The variations in different parts of the country are great; from 3. I persons to the square mile in the Mountain Group ( 0.7 in Nevada) - a much smaller density in r9ro than that (4.5) for the original thirteen states in I790-to I93.2 in the Middle Atlantic states (337.7 in New Jersey), 418.8 in Massachusetts and 508.5 in Rhode Island. The greatest density is in the District of Columbia (i.e., Washington) 5,517.8.

The centre of population in 19 Io was in Bloomington, Indiana ( $39^{\circ}$ I $^{\prime}$ I $^{\prime \prime}$ N. lat.; $86^{\circ}$ $32^{\prime} 20^{\prime \prime} \mathrm{W}$. long.), or rather over 39 miles north of where it was in 1900 ; in 1790 it was $23 \mathbf{m}$. E. of Baltimore, only $6^{\prime} 18^{\prime \prime}$ further north, but about $557 \mathrm{~m}$. to the east. The median point of area of "Continental United States" is $657 \mathrm{~m}$. further west and about $50 \mathrm{~m}$. to the north, in Smith county, northern Kansas.

The number of males to roo females was 106 in 1910 (104.4 in 1900; increase due to immigration), and the variation in different parts of the country was marked; 99.3 in New England, but 127.9 in the Mountain states and 129.5 in the Pacific states. More illuminating is the ratio of males to Ioo females in different "nativities" and colours of the population: 98.9 among negroes; 99.5 among native whites of foreign parentage; ro 4 among native whites of native parentage; I 29.2 among foreign whites; and 185 among all others-mostly Asiatics and temporary immigrants. These ratios differ little from those in I900. In the West the ratios in each state were much higher than this average. Five states, comparatively the older communities,-Massachusetts, Rhode Island, Maryland, and North and South Carolina, - and the District of Columbia, had in 1910 more females than males. New Hampshire, New York, New Jersey, Virginia and Georgia, -also of the earlier-settled territory-were in this group in 1900 but not in I9I0. In I9I0 the males of voting age numbered 26,999, I5I, or $29.4 \%$ of the total population (in I900, 2 I , I 34,299; or $27.8 \%$ ).

In the decade $1900-10$ the rate of increase of the white population was $22.3 \%$ and that of the negro population 11.3\%, the former a little more and the latter a great deal less than the rate $(2 \mathrm{I} \%)$ for the entire population. So that the white population increased relatively from $87.9 \%$ to $88.9 \%$ of the total population, and the negroes decreased from I I.6\% to $10.7 \%$ $(8,833,994$ in I900; $9,828,294$ in I9IO). In I9I0 the Indian population was $265,683(237,196$ in 1900); the Chinese, 70,944 (89,863 in I900); and the Japanese, 71,722 , nearly thrice the number $(24,326)$ in 1900 . The percentage of whites was highest in New England ( $98.9 \%$; in New Hampshire, 99.8\%) and lowest in the South Atlantic group $(66.2 \%)$, where, however, it was higher than in I900 (64.2); and, for any one state, lowest in Mississippi (43.7; in I900, $41.3 \%$ ). The relative decrease in the negro population is not due merely to the more rapid increase of population in the North, for there was such a decrease throughout the South Atlantic states, where they were $35.7 \%$ in 1900 and only $33.7 \%$ in 1910 , and in Mississippi (58.5 and 56.2) and Alabama (45.2 and 42.5). In the South Atlantic states the highest percentage of negroes was in South Carolina, 58.4 in 1900 and 55.2 in 1910 . In the New England and Middle Atlantic groups, manufacturing States fed by constant immigration, the whites of foreign birth and of foreign parentage made up more than one-half the total (59\% New England; $53.9 \%$ Middle Atlantic). The Pacific states, with their strong appeal to the immigrant, come next with $45.7 \%$ (48.5 in California). The New England and Middle Atlantic states rank highest in both foreign-parentage and foreign-birth, i.e., in the immigration of the last and present generations. The East and West North Central states $(28 \%$ and $27.6 \%$ of foreign parentage) rank next highest in the immigration of the last generation; and the Pacific states (20.6\% of forcign-born whites) next in more recent immigration. In the South the foreign element is small: $6 \%$ (3.6 foreign-parentage and 2.4 foreign-horn) in the South Atlantic states (only 1.1\% in South Carolina); $3.6 \%(2.6$ and 1 ) in East South Central (only 1.6 in Mississippi and $2.4 \%$ in Alabama); and $10.9 \%(6.9$ and 4 ) in West South Central (3.4 in Arkansas).

Immigration. - Immigration is more and more from southern and eastern Europe. Austria-Hungary, Italy and Russia supplicd one-sixteenth of the immigrants in $1871-80$, onesixth in the next decade, one-half in the next and nearly two-thirds in I90I-10. In I9I0 the percentage to the total population of foreign-birth from Russia and Finland was i2.8 (6.3 in 1900$)$, from Austria-Hungary 12.4 (6.2 in I900), and from Italy I0.I (4.7 in I900). In 1900 there were 8,5 I3.3 (ireeks; in I9IO IOI, I00. Although there were large percentages in 1910 of foreign-born whites from Germany (18.7), from Ireland (I0.I), from the Scandinavian countries (9.4), from Great Britain (9.2) and from Canada and Newfoundland (9), this is much less important than the fact that these percentages were smaller than in I900, when they were 27.5, 15.8, I0.4, II.t and I I.5, respectively. In mill work Slavs and Ármenians are employed where, a generation ago, there were Irish and French-Canadians; and in small shop)s, especially in the Fast, Creeks are rapidly displacing the Italians, who were themselves new-comers, in the sale of fruit and in the ownership of boot-blacking and small barber shops fifteen years ago.

${ }^{1}$ This proportion is not typically American, but is nearer the ratio in Europe. 
Urban Growth.-In I9I0 the urban population (in 2,405 incorporated places each of 2,500 inhabitants or more) was $42,623,383$, about six-thirteenths of the total population and in this territory the increase in the preceding decade was $34.8 \%$, in rural territory, $11.2 \%$, and in the whole country, $21 \%$. The increase in urban population (nearly $12,000,000$ ) made up about seven-tenths of the total increase in the decade. More than two-thirds of this urban population in 1910 was in the three groups (New England, $12.8 \%$; Middle Atlantic, $32.2 \%$; and East North Central, $22.6 \%$ ), which were comparatively early-settled and are pre-eminently manufacturing. In New England (where the census includes townships or "towns" among urban territory) the urban population was five-sixths of the total; it was more than nine-tenths of the whole in Rhode Island (96.7\%) and Massachusetts. (92.8) and was less than half only in Vermont (48.6). In the Middle Atlantic states seven-tenths ( $7 \mathrm{I} \%$ ) of the total population was urban; in New York, $78.8 \%$; in New Jersey, $75.2 \%$, and in Pennsylvania, $60.4 \%$. In the East North Central the urban population made up more than half $(52.7 \%)$ of the total; the ratios were highest in Illinois $(61.7 \%)$ and Ohio $(55.9 \%)$. Other states in which the urban population was greater than the rural were: California (61.8\% urban), Washington $(53 \%)$, Maryland $(50.8 \%)$ and Colorado $(50.7 \%)$. The percentage in the Pacific Group, where city growth has been very rapid, was 56.8 in 1910 but only 46.4 in 1900 and 36.2 in 1880 ; the urban population from 1900 to I9IO more than doubled and the percentage of increase in Washington was $166 \%$, in Oregon, $1.15 \%$ and in California, $81.4 \%$.

Nearly one-ninth of the country's urban population was in New York City $(4,766,883)$, and about one-fifth $(8,501,174)$ in New York City, Chicago $(2,185,283)$ and Philadelphia $(1,549,008),{ }^{1}$ taken together. In I9I0 there was 5 (in 1900,3 ) cities between 500,000 and $1,000,0000$; II (in 1900,9), between 250,000 and 500,000; and 31 (in 1900, 23), between $100,-$ 000 and 250,000 . The 50 cities each with more than 100,000 inhabitants included I 4 which had less than 100,000 in 1900 (when Spokane had only 36,848 ); their total in 1910 was $20,302,-$ $138,-$ nearly one-half the urban population.

Illiteracy. - In spite of the great increase in I900-10 of population especially in large cities, the growth of immigration and especially of immigration from southern and eastern Europe and from Asia, the number of illiterates (10 years old and over) decreased from 6, I 80,069 to $5,516,693$. The percentage of illiterates was 10.7 in 1900 and 7.7 in 1910 . In the latter year the rate was highest in the South: 17.4 in the East South Central, 16 in the South Atlantic and $\mathbf{1} 3.2$ in the West South Central. But these percentages showed immense progress over I900 (when the corresponding figures were $24.9,23.9$ and 20.5). In each of the other groups of states the rate was lower than the average for the entire country-ranging from 6.8 (9.6 in 1900) in the Mountain states to 3 (4.2 in 1900) in the Pacific and 2.9 (4. I in I900) in the West North Central groups. In New York and Connecticut the actual number of illiterates increased in the decade and the percentage remained 5.5 in New York as it was in I900 and increased in Connecticut from 5.9 to 6 ; this was due to large immigration of a non-Teuton class. The presence of a large proportion, and, in a few states, of a majority, of negroes in the South makes the rate of illiteracy high there; but the improvement in the decade is more marked in the negro than in the white population-the actual decrease during the decade in the number of all illiterates in the country was 663,376 , of negro illiterates, 625.107. The highest rates for the entire population, over 10 years, in 1910 were: 29 in Louisiana (38.5 in 1900) and 25.7 in South Carolina (35.9 in 1900). In the former state the rate for whites was 14.2 (I8.4 in I900) and for negroes 48.4 (6I.I in I900); and in South Carolina the rate for whites was 10.3 (13.5 in I900) and for negroes 38.7 (52.8 in I900). In the South, the number of white illiterates increased only in Texas and Louisiana; the number of negro illiterates increased only in Oklahoma.

AGRICULTURE. ${ }^{2}$ - In I9I0 the number of farms was $6,361,502$, being $10.9 \%$ more than in 1900 , but the area in farms, $878,798,325$ acres $(46.2 \%$ of the land area of the country), was only $4.8 \%$ more than in 1900 . Considerably more than half of this area $(478,451,750$ acres $)$ was improved and it is a true index of the progress of agriculture that this improved area was $\mathbf{1 5 . 4} \%$ greater than ten years before. The average farm acreage decreased from 146.2 to I 38 . I acres, and both this fact and the increase in the average value of farm land per acre from $\$$ I 5.57 to $\$ 32.40$ ( I08. I \% -due, in part, no doubt, to the increased cost of living and general rise in prices) and in the average value of farm property per farm from $\$ 3,563$ to $\$ 6,444 .(80.9 \%$ increase-for a farm 5.5\% smaller) show gradually intensified farming. The rapid increase in all prices can explain only a part of the increase, $100.5 \%$, in the total value of farm property, $\$ 40,991,449,090$ : of this total the items were: land $\$ 28,475,674$, I69 (I I 8 . I $\%$ increase);

${ }^{1}$ A more exact idea of this centralisation of the urban population in these cities may be gained by taking the population of the three metropolitan districts, that is of the territory within ro miles of the charter boundaries of each. The total for these three cities and their immediately adjacent districts was I0,913,83I: New York (including Newark and Jersey City), 6,474,568; Chicago, 2,466,92I, and Philadelphia, I,972,342. On the same basis the population of the Boston district was $1,520,470$, of the Pittsburg district $1,042,855$, and of St. Louis and its immediate vicinity, 828,733. Twenty-five such metropolitan districts each containing a city with more than 200,000 , contained $22,088,33$ inhabitants.

2 See E. B. i, 4 I 4 et seq. 
buildings, $\$ 6,325,451,528(77.8 \%)$; implements and machinery $\$ 1,265,149,783(68.7 \%)$; and domestic animals, poultry and bees, $\$ 4,925,173,610(60.1 \%)$

In 1910 east of the Mississippi were $41.7 \%$ of all farm land and $45.6 \%$ of improved farm land; in $1900,43.8 \%$ and $51.1 \%$. The land in farms was divided in 1910 between North, South and West in proportion of $47.1,40.3$ and $12.6 \%$; the corresponding figures for 1900 being $45.6,43.2$ and $11.2 \%$. Of the improved area $60.6 \%$ was in the North, $31.5 \%$ in the South and 7.9 in the West in 1910; the percentages in 1900 were $63,30.4$ and 6.6.

Acreage of Farms. - Of the total increase in farm acreage in the decade more than threefourths was in the West North Central states, where the percentage of increase was $15.7 \%$ An even larger percentage but a much smaller total increase was in the Mountain group $(28.3 \%)$. There was scarcely any increase in the East South Central group $(0.3 \%)$, and actual decreases in the West South Central (4.2\%), in New England (4. I) and in the Middle Atlantic group $(3.7 \%)$. Only in the two groups last named were there decreases in the improved acreage, $10.8 \%$ in New England and $4.8 \%$ in the Middle Atlantic group. In each state of these two groups there was a falling off both in total area and in improved area: in Vermont there was $23.2 \%$ less improved farm land in 1910 than in 1900 . The greatest decreases in farm land for the separate states were: Arizona, 35.6\% (but $37.6 \%$ increase in improved area); Utah, $17.5 \%$ (but $32.6 \%$ increase in improved area); Texas $10.6 \%$ (but $39.8 \%$ increase in' improved acreage); West Virginia 5.9\% (but a slight increase $0.4 \%$ in improved acreage). The greatest increases in area of all farms were: in New Mexico, $119.7 \%$ (and $348.9 \%$ increase in improved land); North Dakota, $82.9 \%$ (and $112.1 \%$ increase, improved land); Idaho, $64.9 \%$ (and $96.6 \%$ in improved land); Colorado, $42.8 \%$ (and $89.2 \%$ in improved land); Washington, $37.8 \%$ (and $83.9 \%$ improved); South Dakota, $36.4 \%$ (and $40.2 \% \mathrm{im}$ proved); Nebraska, $29.1 \%$ (and $32.3 \%$ improved); and Oklahoma, $25.5 \%$ (and $104.7 \%$ improved). The great increase in improved land is shown by the fact that in 1900 it was $49.4 \%$ but in $191054.4 \%$ of all farm land, and by the fact that although the percentage of the total farm land improved decreased slightly in the decade in New England (from 39.6 to 36.8) and in the Middle Atlantic states (from 68.6 to 67.9), this decrease was in two distinctly nonagricultural (but manufacturing) groups. In every other group there was increase; East North Central from $74.5 \%$ to $75.4 \%$ (in $1910,56.6 \%$ of all land was improved farm land); West North Central from $67.5 \%$ to $70.6 \%$ (in $1910,50.3 \%$ of all land was improved); South Atlantic, from $44.2 \%$ to $46.7 \%$; East South Central, from $49.5 \%$ to $53.9 \%(38.2 \%$ of all land improved); West South Central, $22.5 \%$ to $34.4 \%$; Mountain, $18.1 \%$ to $26.7 \%$ (only $2.9 \%$ of all land); and Pacific, from $39.6 \%$ to $42.9 \%$. In $191059.5 \%$ of all farm land and $39.8 \%$ of all land was improved east of the Mississippi; and $50.8 \%$ of farm land and $19.2 \%$ of the entire land area, west of the Mississippi. In the North 70.1 \% of farm land and $49.3 \%$ of all land was improved; in the South, $42.5 \%$ and $26.8 \%$; and in the West, $34.2 \%$ and $5 \%$.

The average farm is larger in the newer than in the older part of the country; in the West, 296.9A. (386. I in 1900), in the North, 143A. (133.2 in 1900), and in the South I14.4A. ( 138.2 in 1900); but the figures for the South are somewhat misleading, as the census classifies as separate farms the several tenant holdings of a large plantation. East of the Mississippi the average acres of land per farm was 93 (99.8 in 1900); and west, 211.3 (229 in 1900).

Farm Values. - In $191067 \%$ of the value of all farm property was in the North $(33 \%$ in the West North Central and 24.7 in the East North Central group); $21.9 \%$ in the South (9.4 West South Central; 7.2, South Altantic; 5.3 . East South Central); and $\mathbf{I} 1.1 \%$ in the West (6.8, Pacific and 4.3 , Mountain). East of the Mississippi was $46.5 \%$ of the whole value; west, 53.5. But, east, the value of land was only $43.1 \%$ and the value of live stock only $43.8 \%$; the value of buildings, $62.8 \%$, and the value of implements $52.2 \%$ of the total of each of these items, the first two being less and the second two more than the percentage of the value of all property in the West. The percentage of increase in the value of all farm property was 69.1, east, and 139.3 , west of the Mississippi; or, by the three-fold division, $90.1 \%$ in the North, IIO.I in the South, and $164.7 \%$ in the West. The average value of all farm property per acre was $\$ 46.64$ in 1910 and $\$ 24.37$ in 1900 for the entire country; in the North it was $\$ 66.46$ (76\% more than in 1900$)$; in the South, \$25.31 (114.7\% increase); and in the West, $\$ 40.93$ (123.9\% increase).

The average value of farm property per farm, east of the Mississippi, increased in the lecade from $\$ 3,067$ to $\$ 4,849$; and west of the Mississippi from $\$ 4,448$ to $\$ 9,030$. In I9Io the average in the North was $\$ 9,507$; in the South $\$ 2,897$, and in the W'est, \$1 2, I 55 (Pacific group \$14,643; California, \$18,308; Nevada, \$22,462). But comparisons are misleading. becituse the average acreage differs so much in the different parts of the country and the number of live stock is so much greater in the West (and, to a less degree, in the North) than in the South. The average value of buildings per farm, it is to be noted, was higher in the North $(\$ 1,564)$ than in the West $(\$ 1,009)$ and much higher than in the South $(\$, 61)$; but in land, malhinery and live stock, the rank of the three regions was: first, the West; second, the North, and third, the South.

Production. ${ }^{1}$ - The crops of 1911 were unusually small and those of 1912 remarkably large.

1 Statistics for 19I are from the Year-Book of the U.S. department of agriculture; those for 1912 are preliminary estimates made by that department. 
In May and June I9I I the country east of the Rocky Mountains suffered severely from a series of hot waves in May and June I9I I and from January to June I9I I from a sub-normal rainfall. The Weather Bureau reported that in a half century there had not been such a continuous high temperature as in these two months. The rainfall was $27.8 \%$ less than usual in New England, $21.6 \%$ less in the West South Central states, $21.2 \%$ below normal in the Pacific Northwest, $25.4 \%$ in the Dakotas, Nebraska and Kansas, $19.7 \%$ in Minnesota, Iowa and Missouri, $12.4 \%$ in the Middle Atlantic group, and $10.3 \%$ in the East South Central states. The result was that the total value of the crops of 1911 , estimated at $\$ 5,504,000,000$, was only $\$ 44,000,000$ greater than in 1910 , in spite of higher farm prices for all crops-except cotton, cotton-seed and flaxseed. The total value of all farm products in I9 I I was $\$ 8,417,000$,000 , being $\$ 277,000,000$ less than in 1910 . The loss of $\$ 321,000,000(\$ 277,000,000$ net loss plus $\$ 44,000,000$ increase in value of crops) was in animal products-eggs, wool, butter and poultry being less and only dairy cows more valuable than in 1910; in I9I I the value of animal products was $\$ 2,913,000,000(\$ 3,234,000,000$ in 1910$)$.

In 1912 there was no such damage from inclement weather. The value of animals slaughtered was less than in the preceding year (or in 1909, but more than in any other year since

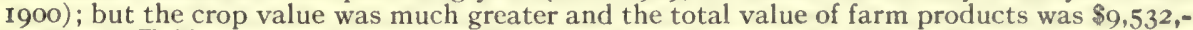
ooo,ooo. Taking 100 as the value of farm products in 1899 , the United States department of agriculture estimates the products of 1905 at 133 , of 1910 at 184.3 , of 1911 , at 178.4 (being less than in 1909 or the preceding year) and of 1912 at 202.I.

In I9II nearly all crops were less than the average for the preceding five years; but in 1912 nearly every crop was greater than ever before. Wheat and tobacco had twice been greater, and cotton and rice once.

Indian Corn. - The crop of Indian corn in I9I I was estimated to be 2,53I,500,000 bushels, with a farm price per bushel higher than in any year, except 1883 , in the records of the United States department of agriculture; and the total value was greater than in the previous year, was twice the value of the cotton crop and was hardly exceeded by the value of cotton, wheat and oats combined. In I9I2 the crop was $25.2 \%$ greater than in I 9 II.

Cotton.-The cotton crop of I9II, about 15,700,000 bales (only II,610,000 in I910), grown on $36,045,000$ acres (only $32,403,000$ in 1910 ), was probably the largest ever grown in the country, but its value, though above the average for the five preceding years, was less than that of 1910 , lint being nearly 5 cents a pound cheaper and cotton-seed being correspondingly lower in price. In I9I 2 the crop was smaller than in I9II or in 1904 and was exceeded in value by the crop of I9IO.

Hay. - Third in value in I9I I was the hay crop, 47,444,000 tons. The average crop for the five years preceding was one-third greater and the crop since 1888 was each year larger. The crop was so small that there was an increase in farm value of $\$ 2.50$ a ton, and the total value, $\$ 694,570,000$ was exceeded only in 1910 and 1907 , and was a little more than the five years average. In 1912 the hay crop was greater in value than the cotton crop or the great hay yield of 1910 , being $\$ 861$, 000,000-nearly as much as wheat, tobacco and potatoes together.

Wheat. - The I9II wheat crop, about $621,340,000$ bushels, was less than the five-year average; in the preceding decade the crop of 1904 only was smaller. The value of the wheat crop, about $\$ 543,000,000$, also was far below the average; it exceeded the value of the crop of 1906, when the average price a bushel was nearly one-third less. In I912 about 730,267,000 bu. $(\$ 555,280,000$, farm price) was grown (less than in: I90I or I906), the spring crop being much better than the winter yield and the total being one-ninth more than the average for the preceding five years.

Oats.-In oats, as in hay, the crop was so small in rgli that the price was unusually high and the total farm-value above the five-year average. It was $922,000,000 \mathrm{bu}$. valued at $\$ 414,000,000$ (about $\$ 408,000,000$ in 1909 and in 1910 ). But in 1912 the crop was $46 \%$ greater than the previous maximum crop of $1909,51.5 \%$ more than the five-year average. The large crop, I , 4 I $8,337,000$ bushels, forced the price down and the value was $\$ 452,469,000$, only $22.2 \%$ more than the preceding five-year average.

Potatoes. - The I9I I crop of potatoes was about $290,000,000$ bu. $(349,000,000$ in I9I0; $376,500,000$ in 1909), but the farm price was nearly one-half greater than in 1910 , and the farm value, $\$ 233,800,000$, was far greater than the five-year average, or than in any preceding year of record. In 1912 the production was much larger, $420,647,000$ bu., $-29 \%$ above the fiveyear average; the farm value was $\$ 212,550,000$.

Barley. - The barley crop of $191 \mathrm{I}, \mathbf{1 6 0}, 000,000 \mathrm{bu}$, was much less than for any one of the years 1908, 1909, 1910; but the price was high and the total farm-value, about \$139,000,000, was a third greater than that of the I9I0 crop. The I9I2 crop was the largest on record, $223,820,000$ bu., $35.7 \%$ more than the five-year average, but the price declined and the total value was $\$ 112,957,000$, much less than that of the small crop of 19 II.

Tobacco. - The tobacco crop of I9I I not merely was short but commanded a price only a little higher a pound than in 1910 and considerably less than in any year between 1906 and 1909, inclusive. The crop, grown on $1,013,000$ acres (in $1910,1,366,000$ ), was 905, 109,000 lbs. (1,103,415,000 lbs. in 1910), valued at $\$ 85,210,000,-$ nearly one-sixth less than in 1910. In 1912 the crop was $962,855,000 \mathrm{lbs},-7.1 \%$ more than the five-year average; the average price per pound also increased, so that the gain in value will be greater. 
Flax. - The most valuable of the smaller crops was flaxseed with an acreage in IgI of 2,757,000 (about two-thirds in the Dakotas; most of the remainder in Montana and Iowa), - which is more than in any preceding year except 1902, 1903 and 1907,- - a production of $19,370,000$ bu., - which was more than in 1910, but less than in any other year in the preceding decade. The value, $\$ 35,272,000$, was exceeded only by that of the record crop of 1909 , and the average farm price was greater than in any year except 1910 , when the short crop made it phenomenally high. In 1912 the crop was much larger, 28,073,000 bu. (or $44.1 \%$ above the five-year average), valued at $\$ 32,202,000$ (about $32.4 \%$ above).

Rye. - The rye crop of I9II was 33,1 I 9,000 bu. $(34,897,000$ in 19 Io) from $2,127,000$ acres, being smaller than in 1902,1906 , or 1910; but the farm price per bushel, 83.2 cents, was greater than in any year except 1867,1868 and 1881 , and the total farm value, $\$ 27,557,000$, was the highest known. The 1912 crop was $35,664,000$ bushels, the largest on record, being $10 \%$ above the five-year average. Prices fell, and the total value was only $\$ 23,636,000$.

Sugar. - The sugar beet crop of I 9 I I was 599,500 tons, worth more than $\$ 24,000,000$; both in quantity and value it was nearly one-fourth greater than the five-year average. In 1912 the crop was nearly 700,000 tons. Of cane sugar the crop in 1912 was small because of floods in the Mississippi Valley.

Hops. - The crop of hops in I9I I was small, only 40,000,000 lbs., compared with 49,634,000 in 1910 and $57,510,000$ in 1907 , but the average price a pound was nearly twice the average of preceding years, and the crop value, $\$ 15,500,000$, was much more than twice as great as the average for the preceding five years. In 1912 the crop increased to $44,500,000$ lbs., but prices fell and the total value was only about $\$ 11,000,000$.

Rice.-Rice was grown in 191 I on 696,000 acres (720,000 in 1909 and 723,000 in 1910) and the crop, $22,934,000$ bu., though less than that of 1910 or 1909 , was considerably above the five-year average. The farm value of the crop, $\$ 18,274,000$, was more than in any other year except 1909 , when the price per bushel was higher. In 1912 the crop suffered from floods but was probably larger than in any year except 1909; its value was \$23,423,000.

Buckwheat. - The buckwheat crop of $1911,17,549,000$ bu., was a little less than that for I910, 17,598,000 bu. (grown on 860,000 A.; I9I I acreage, 833,000), but much larger than for any other year in the last decade. The average farm price a bushel was $72.6 \mathrm{c}$., exceeded only in $1908(75.6 \mathrm{c}$.), and the farm value of the crop much above the five-year average. In 1912 the crop was even larger, -about 19,124,000 bu.; value about \$12,000,000.

Animals. - The total value of animal products in 1912 was about $\$ 3,395,000,000$; being more than in $191 \mathrm{I}$ but less than in 1910 . The number of horses on January $1,1912,20,509$,000 , was larger than in 1911 or in any other year except 1909 and 1910 and the average value and the total value $(\$ 2,172,694,000)$ larger than in any year except 1910 and 1911 . The number of mules, $4,362,000$, was greater than in any preceding year, and average value $(\$ 120.5 \mathrm{I})$ and aggregate farm value $(\$ 525,657,000)$ were exceeded in $191 \mathrm{I}$ only. The number of milch cows, $20,699,000$, was the smallest since 1906 ; the average value $(\$ 39.39)$ and the total $(\$ 815,414,000)$, were exceeded only in $191 \mathrm{I}$. Other neat cattle numbered $37,260,000$, - much less than for any year in the decade, but the average value, $\$ 21.20$, was higher; the total value was less than for any year since 1906. The number, 52,362,000, and total value, \$181, 170,000, of sheep, also, were less than since 1906; and the average value, $\$ 3.46$, was far below the five-year average, - that for 1909 alone was lower. Swine numbered 65,410,000 , a little less than in 1910 , but far more than in any other year; the average farm price was exceeded in I9IO and in I9II, and the aggregate value only in I9II.

Plant Indtestry. - The U.S. department of agriculture established about twelve years ago its bureau of plant industry whose work has consisted largely of searching the world for grain, fruits, grasses, etc. and ascertaining by experiments which of them might be useful in the United States. Recently a force of 25 trained explorers have been busy in this work and some 34,000 varicties of plants have been imported and experimented with, their seeds and progeny leeing sent out to private breeders and experimenters. Mr. E. H. Wilson, of the Arnokl Arboretum, Boston, Mass., who has distinguished himself in similar work and is said to have introluced into America more new plants than any other man, in 1912 received from the Royal Horticultural Society of (ireat Britain the Victoria Medal of Honour -never befcre conferred on any one outside of the British Isles.

The other activitie's of the Federal department of agriculture are manifold: the forest service and the weather bureau are sublivisions; meat inspection and the enforcement of the federal food and drugs act are quasi-police functions of the department carried on by a burcau of animal industry, which, besides, investigates and eradicates diseases of animals, experiments in breeding and feeding, and works for the improvement of the dairy industry; and the department has experiment stations and co-operates with state agricultural experiment stations, and through its burcau of soils makes soil surveys-sometimes with the aid of state organisations. Other bureaus in the department are those of chemistry, entomology and biological survey. About 2,000 publications of the department appear each year in these different fields and the total number distributed in the year $1910-11$ was $27,595,000$.

Minerai. Products. - Total value, 1911, \$1,918,326,253. This was $3.65 \%$ less than in 1910 and 7.4 " less than in 1907 , the only year when mineral products were valued at more than $\$ 2,000,000,00 \%$. But the value in 1911 was greater than in 1908 (following the panic 
of 1907$)$ or 1909. The decrease as compared with 1910 was $\$ 72,584,882$ and this was more than covered by the decrease in pig-iron, ${ }^{1}$ which was $\$ 84,827,862$. The same item explains the decrease $(\$ 75,611,118)$ in the value of all metals from $\$ 747,790,718$ in 1910 to $\$ 672,179,-$ 600. In other words, apart from pig iron, there was an actual increase from r9I0 to I9I I of $\$ 12,278,980$ in the value of all other mineral products, and of $\$ 9,216,744$ in the value of all other metals. The difference between these two increases, about $\$ 3,050,000$, is the increase in the value of non-metals in the year; and it is to be noted that this increase was in spite of a decrease of $\$ 18,104,235$ in the value of bituminous coal, so that, apart from bituminous coal, there was in the year an increase of $\$ 21.155,000$, approximately. ${ }^{2}$

Metals. - Of pig iron the output in I9I I was $23,257,288$ tons (one-eighth less than in 19ro), valued at $\$ 327,334,624$ (one-fifth less). The average price per ton was $\$ 14.07$ in I9II, $\$ 15.57$ in $1910, \$ 16.25$ in $1909, \$ 20.56$ in 1907 . Even greater was the decrease in iron ore marketed: in 191 I, 40,989,808 tons (nearly one-fourth less than in 1910), valued at \$86,419,830 (more than three-eighths less), - the decrease in average price per ton being marked.

Second in value of the metals was copper, $1,097,2,32,749 \mathrm{lbs}$., valued at $\$ 137,154,092$ (quantity $1.58 \%$ more, value $0.02 \%$ less, than in 1910 ; about one-seventh more in quantity and one-eleventh less in value than the average for the five years, I905-09). In copper and in iron the United States outranked any other country.

The output of gold was $4,687,053 \mathrm{oz}$., valued at $\$ 96,890,000\left(\frac{2}{3}\right.$ of $\mathrm{I} \%$ more than in 1910$)$. The value of silver, $\$ 32,615,700$, was $5.71 \%$ more than in 1910 , but was nearly $2 \%$ less than the average for the five years, igo5-09.

Ranking immediately above and below silver in value among the metals were lead and zinc, respectively, with 406,148 tons $(\$ 36,5,53,320$, - one-ninth more than in I910) and 271,62 I tons $(\$ 30,964,794,-$ nearly one-seventh increase). This is exclusive of antimonial lead, 14,078 tons, valued at $\$ 1,380,556$ (3\% increase).

The only other metals of importance were: aluminium (consumed), 46, I25,000 lbs. (onethirtieth less than in 1910 ), valued at $\$ 8,084,000$ (nearly one-tenth less); quicksilver, valued at $\$ 977,989$ ( $2 \%$ increase); tin, $\$ 56,635$ (two and a half times as much as in 19I0); and platinum, $\$ 40,890$ (three-fifths increase).

Fuels. - Of the non-metals, - and of all the minerals-by far the most valuable was coal with an output of $496,221,168$ tons $(501,596,378$ tons in 1910$)$, valued at $\$ 626,366,876$ (\$629,557,02 I in I9I0). The U.S. Geological Survey divides this total between Pennsylvania anthracite and bituminous coal (including brown coal, lignite and anthracite mined in other states than Pennsylvania). Using "bituminous coal" to include all this, the value was $\$ 451,177,484$ ( $3.86 \%$ less than in I9IO: see above) and the output, 405,757 , IOI tons $(2.72 \%$ less). There was an increase $(7.08 \%$ in quantity and $9.31 \%$ in value) in the output of Pennsylvania anthracite, $80,77 \mathrm{I}, 488$ tons, $\$ 175,139,392$. Not so large was the increase $(5.2 \%$ in quantity and $4.8 \%$ in value) in petroleum; the output was $220,449,39 \mathrm{I} \mathrm{bbls.,} \mathrm{valued} \mathrm{at}$ $\$ 134,044,752$. Other fuels were, coke, $35,55 \mathrm{I}, 489$ tons, valued at $\$ 84, \mathrm{I} 30,849$ (nearly onęsixth less than in 1910); natural gas, $\$ 74,127,534$ (4.76\% increase); and peat, $\$ 272,114$.

Structural Materials. - Third in value, - to coal and iron,- -were clay products, $\$ 162,236$,I 81 ( $4.63 \%$ less than in 1910 , but considerably more than the average for 1905-09). The more valuable building materials were: stone, $\$ 77,108,567(0.77 \%$ more than in 1910, but about one-seventh more than the five-year average) and cement, $79,547,958 \mathrm{bbls}$. $(2.27 \%$ more than in I910), valued at $\$ 66,705$, I 36 (nearly $3 \%$ less than in 1910). Almost all of this $(78,528,637$ bbls.; value, $\$ 66,248,817)$ was Portland cement. Natural cement was valued at $\$ 378,533$ and puzzolan at $\$ 77,786$. Minor building materials were: sand and gravel, $\$ 19,614,850$; lime, $3,392,887$ tons, valued at $\$ 13,688,970(2.83 \%$ less than in 1910 , but nearly one-eighth more than the five-year average); gypsum $\$ 6,462,035$ (a very little less than in 1910); slate, $\$ 5,728$, org (one-twelfth less than in 1910); glass sand, $\$ 1,543,733$ (1.78\% more than in 1910); and sand-lime brick, $\$ 897,664$ (nearly one-quarter less than in I9IO).

Chemical Materials. - The output of phosphate rock was 3,053,279 tons ( $15 \%$ more than in 1910$)$, valued at $\$ 11,900,693$ (9\% increase). The value of salt was $\$ 8,345,692(5.64 \%$ increase over I910); of sulphur, $\$ 4,787,049$ (4\% increase); of sulphuric acid, $\$ 2,733,696,-$ first reported in 19 II from fumes of copper and zinc smelters; of pyrite, \$1, I64,87I (nearly one-fifth increase); of borax, \$1,569, I5I (three-tenths increase); of fluorspar, \$6II, 477 (twofifths increase); of calcium chloride, \$9I,2I5 (two-ninths increase); of bromine, \$110,902 (more than thrice that of 1910 ); and of arsenious oxide $\$ 73,408$ (two-fifths more than in I9IO; value more than twice as great). The Geological Survey is making an elaborate search for potash salts, drilling for saline residues at great deptbs and examining brines, alunites and igneous rocks. The Soils Bureau of the department of agriculture is studying the kelps of the Pacific Coast, for the same purpose, and is making a field survey of arid lands.

Pigments. - Mineral paints were valued at $\$ 7,84^{2}, 5^{83}$ (31/2 times as much as in 1910$)$.

1 Pig-iron and not iron ore is the basis of valuation adopted by the United States Geological Survey and the value of iron ore is not included in the total value of minerals given here.

2 Exact figures are not given because the Geological Survey does not make "metals" and "non-metals" the only classes, but adds "unspecified products," mostly rare metals. 
This excludes zinc oxide, not separately reported in I9II, but valued at $\$ 5,238,945$ in 1910 and $\$ 6,156,755$ in 1909 . Crude barytes was valued at $\$ 122,792$, a little more than in 1910. Abrasires. - Artificial abrasives were valued at $\$ 1,493,040$, about one-fourteenth less than in 1910 . Grindstones were worth $\$ 907,316$, about one-seventh less than in 1910; oilstones and whetstones, $\$ 214,991$, less than in 1910 or than the average for the five-year period; and abrasive garnet; \$121,748.

Miscellaneous. - The output of asphalt (including bitumens and hydrocarbons not classified as petroleum) was 360,004 tons (almost two-fifths more than in 1910 ), valued at $\$ 3,828$, 751 (one-fourth more than in 1910, and over double the annual average in I905-09). Other products valued at $\$ 500,000$ or more were: mineral waters, $\$ 6,837,888$ ( $7 \%$ increase); talc and soapstone, $\$ 1,032,732$ (one-fifth increase) and fibrous talc, $\$ 613,286$ (about $16 \%$ decrease); bauxite, $\$ 750,649$ (4.8\% increase), and felspar, $\$ 579,008$ (15\% increase).

Manufactures.-In " continental " United States (excluding Alaska) there were in $1909268,49 \mathrm{I}$ manufacturing establishments ( $29.4 \%$ more than in 1899 ), which employed $7,678,578$ persons, of whom $6,61_{5}, 046$ were wage-earners $(40.4 \%$ increase); had a capital of $\$ 18,428,270,000$ (105.3\% increase); and manufactured products with a gross value of $\$ 20,672,052,000$ ( $81.2 \%$ increase) and a net value (gross, less cost of materials) of $\$ 8,530,26 \mathrm{I}, 000(76.6 \%$ increase). The increase in value, gross or net, must be interpreted with the increase of prices in view, or its meaning will be exaggerated.

The ten leading manufacturing states, ranked according to the gross value of products, and with the percentage of the total contributed by each, were: New York, 16.3; Pennsylvania, I 2.7; Illinois, 9.3; Massachusetts, 7.2; Ohio, 7 ; New Jersey, 5.5; Michigan, 3.3; Wisconsin, 2.9; Indiana, 2.8, and Missouri, 2.8. (See the separate state articles.) The three Middle Atlantic states reported more than one-third $(34.5 \%)$, the East North Central states about one-fourth $(25.2 \%)$ and the New England states, more than oneeighth $(12.9 \%)$, a total of nearly three-fourths $(72.6 \%)$ of the total gross value of the country. Ranked on the same basis the ten leading cities in Igog were: New York, Chicago, Philadelphia, St. Louis, Cleveland, Detroit, Pittsburg, Boston, Buffalo, and Milwaukee. The total gross value of manufactures from these ten cities was more than $\$ 5.800,000,000$, - nearly three-tenths of the total for the nation. In 50 cities which had 100,000 or more inhabitants the value of manufactures was more than twofifths $(42.3 \%)$ of the total; and the 603 cities over 10,000 contributed nearly seventenths of the total product value, employed nearly two-thirds of the wage-earners in manufactories, and contained more than half the establishments, although their combined population was only three-eighths that of the entire country.

Chief Industries. - The largest single industry, according to the census classification and judged by gross product, was slaughtering and meat packing with one-fifteenth of the total product value and more than one-half increase in the decade. Second of the single industries is that of foundries and machine shops, with nearly $6 \%$ of the total product value, in I 909 ; with this industry should be mentioned iron and steel from steel works and rolling mills $\left(4.8^{\circ} \%\right.$ of the total) and iron and steel from blast furnaces $\left(1.9^{\circ} \%\right.$ ). Third in value was lumher and timber $\left(5.6^{\circ}\right.$ of the total), with a product more than one-half greater than in 1899 Flour and grist mill products were valued at one wenty fourth of the total product value The more important textile products were: cotton goods $\left(3^{\circ}\right.$ o of the total), woollen, worsted and felt goods $\left(2 . I^{\circ}\right)$ ), hosiery and knit goods $\left(I^{\circ}{ }_{0}^{\circ}\right)$ and silk goods $\left(I^{\circ}{ }^{\circ}\right)$. The value of men's clothing was $2.7 \%$ and of women 's clothing $1.9 \%$, of the total of all industries; that of boots and shoes, $2.5^{\circ}$; that of tobacco, $2^{\circ}$; that of cars and shop construction by steam railway companies, $2 \%$ and by other manufacturers $0.6 \%$ A metallurgical group of industries includes: copper smelting and refining $\left(1.8^{\circ} \mathrm{o}\right)$, lead smelting and refining $\left(0.8^{\circ} \%\right)$, copper, tin and sheet iron products $\left(1^{\circ} \%\right)$, and brass and bronze products $\left(0.7^{\circ}{ }^{\prime}\right)$. Malt liquors are reported as $\mathbf{I} .8 \%$ and distilled liquors as $\mathbf{I} \%$ of the total; but a Federal revenue tax, included in the reported value, makes it misleading. Other items, all valued at more than $\$ 100,000$, $(x)$, with the per cent of the total for each, were: leather $\left(1.6^{\circ}\right)$ and leather goods $\left(0.5^{\circ}\right)$; sugar and molasses, not including beet sugar $(1.4 \%)$; butter, cheese and condensed milk $\left(1.3^{\circ}, \ldots\right)$; paper and wood pulp $\left(1.3^{\circ} \%\right)$; automoliles $(1.2 \%)$ and wagons and carriages $(0.8 \%)$; furniture (1.2 $\left.{ }^{\circ}\right)$; refined petroleum (I.1 $\left.{ }_{0}^{\prime}\right)$; electrical machinery (I.I $\left.{ }_{0}^{\circ}\right)$; illuminating and heating gats $\left(0.8^{\circ}\right)$; canning and preserving $\left(0.7^{\circ} \%\right)$; cottonseed oil and cake $\left(0.7^{\circ} \%\right)$ and agricultural implements $(0.7 \%)$.

Of the manufactures specifically named in the preceding paragraph only one, smelting and refining of lead, showed a decrease $\left(9.9^{\circ} \%\right.$ in the gross value between 1904 and 1909 , and only two others, sugar and molasses, and wagons and carriages, a decrease in the value added 
by manufacture in the same five years-and these decreases were small, $2.7 \%$ and much less than the increase, $77.5 \%$ and $9.6 \%$, in the years $1899-1904$. The gross value of automobiles increased $532.6 \%$ from 1899 to 1904 and $729.7 \%$ in $1904-09$. Other high percentages of increase in gross value during the years $1904-09$ were: $68.8 \%$, iron and steel from blast furnaces; $66.6 \%$, copper, tin and sheet-iron products; $63.2 \%$, butter, cheese and condensed milk; $57.3 \%$, copper smelting and refining; $57.2 \%$, electrical machinery and apparatus; $\mathbf{5 5 . 9} \%$, distilled liquors; $\mathbf{5 5 . 4} \%$, women's clothing; $\mathbf{5 3 . 4} \%$, cottonseed oil and cake.

Ownership. - In 1909 of 268,49 I manufacturing establishments, 69,5 OI $(25.9 \%$; in 1904 $23.6 \%$ ) were operated by corporations, and these establishments reported nearly four-fifths (in 1904 not three-fourths) of the total product value. In the Mountain Group of states $90.2 \%$ of the product value was from establishments owned by corporations, largely smelters; in the East North Central group the percentage was 85.I; in the West North Central, 83.9; in the Pacific states, 82.4; in New England and in the West South Central group, 81.4 for each; in the East South Central, 78.5; in the South Atlantic, 76.7; and in the Middle Atlantic, 71.9. The highest per cent in any state was 96. I, in Arizona. More than twice as many establishments were operated by individuals as by corporations, but their product value was less than one-eighth as large. Establishments operated by firms numbered about four-fifths as many as by corporations and had a product value a little more than one-eighth as large. In 1904 establishments operated by individuals reported $11.5 \%$ of the total value; in $1909,9.9 \%$. In I904 establishments operated by firms reported $14.4 \%$; in I909 I0.6\%. The advance of corporation control is marked.

Establishments. - Establishments with an output of more than $\$ 1,000,000$ each numbered $1900(0.9 \%)$ in 1904 and 3,06I (I.I \%) in 1909 ; in the former year their product value was, $38 \%$, in the latter $43.8 \%$ of the total for all establishments; in 1904 they employed $25.6 \%$, in $1909,30.5 \%$ of all wage-earners in manufacturing. In I909 $67.2 \%$ of all establishments had each an output less than $\$ 20,000$ in value; but these establishments produced only $5.5 \%$ of the total product value and employed only $9.3 \%$ of the wage-earners.

It will be surmised that the increase of large establishments is accompanied by greater efficiency, because the ratio of wage-earners to product is smaller in the large establishments; but it is more probable that this difference is due to the presence of more labour-saving machinery (and machinery that saves more labour). in the large establishments. And it should be noted that the million dollar establishments producing $43.8 \%$ of the gross value, produced only $35.7 \%$ of the net value (gross, less value of raw material); but that the establishments producing less than $\$ 20,000$ each and contributing $5.5 \%$ of the gross product, produced $7.7 \%$ of the value added by manufacture. Even from this, however, no generalisation may safely be drawn, since many establishments with large gross outputs are in industries which, from the nature of the raw material, add comparatively little by manufacture. This is shown in a striking way by the slaughtering and meat-packing industry, which ranks first in the country in gross products $(\$ 1,370,568,000)$ but twelfth in "value added by manufacture" $(\$ 168,740,000) ;$ or by flouring and grist-mills, with a gross value of $\$ 883,584,000$ (5th of all industries) and a net value of $\$ 116,008,000$ ( 18 th). Both these industries have a large proportion of large establishments: in the former, 166 out of $\mathrm{I}, 64 \mathrm{I}$ had each an output of more than $\$ 1,000,000$. There were even larger percentages of million dollar establishments in copper smelting and refining (84.2, with $99 \%$ of product value); steel works and rolling mills (4I.7, with $91 \%$ ); blast furnaces (4I.3, with $85.8 \%$ ); refining petroleum $(23.8$, with $88 \%$ ); and steam railway car construction and repairs $(22.7$, with $80.7 \%$ ).

In Rhode Island $3.5 \%$ of all establishments produced each more than a million dollars' worth a year, with a total value nearly half the entire product value for the state. In Arizona $84.1 \%$ of the entire product value was from such establishments, in Montana $68.1 \%$, and in Utah, 53.4\%-almost all these being smelters; in Nebraska, 68.9\%, and in Kansas, $62.9 \%$, mostly slaughter houses and meat-packing establishments; in Illinois, $56.2 \%$, meatpacking and iron and steel; in Pennsylvania, 50.7 \%, largely iron and steel; and in New Jersey, $56.7 \%$, from copper smelters and petroleum refineries. New York, the first manufacturing state in the Union, reported only $37 \%$ of all product values from million dollar factories; this is partly due to the diverse character of manufacturing industries in that state and partly to the large number of clothing establishments, mostly very small.

Of the total population of "continental" United States, $7,678,578$, about I in I2, were engaged in manufacturing; 487,173 being proprietors and officials, 576,359 clerks, and 6,61 5,046 wage-earners. Of wage-earners about I out of 5 were females, and about I out of 40 $(162,246$ in all) were under I6,- -by official reports; the actual number was probably greater.

In dairy industries, flour-milling and baking the percentage of proprietors and officials was unusually high $(33.3,28.4$ and 20.2 , respectively), the dairy establishments being largely co-operative and in flour milling much labour-saving machinery is used which requires comparatively few wage-earners. Absolutely, the largest number of wage-earners in any one industry was 695,019 (more than one-tenth of the total) in the manufacture of lumber and timber. Other industries employing more than 200,000 wage-earners were: foundries and machine shops, 531 , oI I ; cotton factories, 378,880 ; steam railway companies' car construction, 282, I74; printing and publishing, 258,434; steel works and rolling mills, 240,076; and men's clothing, 239,696. The percentage of children under 16 to all wage-earners is largest 
in three textile industries: cotton goods, 10.4; hosiery and knit goods, 8.1 and silk, 8-the number of girls being much more than that of boys in the last two. In canning and preserving, in the woolen goods industry and in the manufacture of bags (not paper), of cigar boxes, of paper and fancy boxes, of cordage and twine, of needles, pins and hooks and eyes, of lead pencils, and in a few other comparatively unskilled industries, more than $5 \%$ of the wage-earners are under 16 years. Geographically, child labour is strongest in the South Atlantic group, where $6.3 \%(7.9 \%$ in 1899$)$ of wage-earners were less than 16 years old. In South Carolina the percentage is 12.9 (in 1899, 18). The recent establishment of manufactories, especially cotton factories, the small percentage of immigrants to be employed, and the comparative laxness of child labour laws explain these high percentages. In general and particularly in the larger industries the proportion of women and children employed decreased markedly between 1899 and 1909 .

TRANSPORTATION.-Railway mileage, January I, I912, 246,572.73, exclusive of I I 4,940 m of second track and sidings. In the preceding year 3,292.66 miles of steam railway track were added; 793.40 in the Southwestern group, 729.34 in the Pacific states, 500.33 in the Northwestern, 460 in the South Atlantic, $318.5 \mathrm{I}$ in the Central Northern, 310.33 in the Gull and Mississippi Valley, I80.87 in the Middle States and 2.85 in New England. For loca building operations see articles on separate states and for the Grand Trunk in New Englanc see RHODE ISLAND, for the Western Maryland see MARiland, for the Key West railway see FI,ORIDA, for the barge canal see NEw York, for the Cape Cod Canal see MASSACHCsetTs, etc. See AlASKA, also. River and harbour improvements also are dealt with in separate state articles. The total appropriation for rivers and harbours in the last fiscal year was $\$ 40,559,620$. The only sign of economy in this respect is the growing tendency to make Federal appropriations contingent on local expenditures and co-operation.

\section{Foreign Commerce}

For the twelve months ending June $1912^{1}$ the total imports of merchandise were valued at $\$ \mathrm{r}, 653,264,934$ (as compared with $\$ 1,527,226,105$ for the preceding year and $\$ 1,556,947,430$ for the year ending June r910), and the total exports at $\$ 2,204,322,409$ (in I9II, $\$ 2,049,320,199$; in I910, $\$ 1,744,984,720$ ). The excess of exports was $\$ 551$, 057,475 in the year ending June $1912 ; \$ 522,094,094$ in the preceding year, and only $\$ 188,037,290$ in 1910.

The duties collected on imports were $\$ 311,257,348$ (in $1911, \$ 314,497,071$, and in 1910 , $\$ 333,683,4+5)$. Of the imports $53.33 \%$ were free of duty. More than one-third the total imports was classified as crude materials for manufacture, valued at $\$ 555,059.586$, more than one-fifth (value, $\$ 360,655,409$ ) was manufactures ready for consumption, and the other large items were manufactures for further use in manufacturing, $\$ 294,260,981$; foodstuffs in crude condition, \$229,565,515; and foodstuffs partly or wholly manufactured, $\$ 196,759,741$. Of exports nearly one-third in value $(\$ 722,488,53 \mathrm{I})$ was crude materials for use in manufactures, and the other major items were: manufactures ready for consumption, \$674,302,903; manufactures for further use in manufacturing, $\$ 347,451$, o1 5 ; foodstuffs partly or wholly manufactured, \$31 8,262,524; and crude foodstuffs and food animals, \$99,659,023.

(of the world trade of the United States the major part of course is with Europe-in 1912 a little less than half the imports $(\$ 819,585,326)$ and more than three-fifths of the exports $(\$ 1,3+1,732,789)$. Of imports from Europe nearly one-third were from the United Kingdom $(\$ 272,9+0,700)$ and of exports to Europe a little more than two-fifths goes to the United Kingdom $(\$ 564,372,186)$. (iermany and France rank next: Germany, imports to United State' $\$ 171,380,380$, and exports from United States $\$ 306,959,021$; France, imports $\$ 124,548$, 458 and exports $\$ 135,388,851$. (Other countries with American imports or exports of \$100, $0(0,000$ or more were: Netherlands, exports from U.S. \$103,702,859 (imports to U.S. \$35, $5(6,8,+36)$; (anada, exports from U.S. $\$ 329,257,302$, imports to U.S. $\$ 108,813.368$; Cuba, impurts 10 L.S. $\$ 120,15+, 326$ (exports from U.S. \$62,203,05I); and Brazil, imports to U.S. $\$ 123,881,6+4$ (expmerts from U.S. $\$ 34,678,081$ ). The excess of imports over exports in the last two cases is due to the larger sugar and coffee trade.

The trule of continental I nited States with Alaska was: exports, domestic \$ $8,809,270$

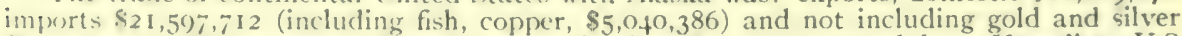
$\$ 20,732,597$. Shipments to Hawaii were valued at $\$ 24,418,67 \mathrm{I}$, and from Hawaii to U.S at $\$ 5,5,05,816$ (principally sugar, fruits and nuts, $\$ 2,744,0+2$ ). To Porto Rico $\$ 37,424,545$ and from Porto Rico to the mainland $s_{42,873,401}$ (sugar, coffee, tobacco and fruits). Te the Ihilippines $\$ 23,703,935$, and from the Philippines to U.S. \$23,257, 199 (including sugar fibres, fruits and nuts, cigars and cigarettes).

The Tithle shows the value of foreign commere for the year ending June 1912 by the principal ports and customs districts, arranged by states.

${ }^{1}$ For the calendar year 1912 , imports, \$1,817,662,340 and exports, 82,399,995,973; for the calendar year 1911 , imports, $\$ 1,532,931,861$ and exports, $\$ 2,092,373,141$. 
Value of Imports and Exports by States and Districts, for the Year ending June I9I2.

\section{STATE}

Alabama .

Alaska

Arizona

California

Colorado

Connecticut

Delaware

District of Columbia Florida

Georgia

Hawaiian Islands

Idaho (see Montand

and Idaho)

Illinois : . Chicago

Indiana

Iowa

Kentucky

Louisiana .

Maine

Maryland

Massachusetts

Michtgan.

Mobile

Arizona

Denver

Tampa

Atlanta

Chicago
Peoria

Machias

Castine

Bangor

Belfast

Bath
DIST RICT

San Diego .

Los Angeles

San Francisco

Humboldt .

Stonington

New London.

Hartford

New Haven

Bridgeport

Delaware

Georgetown

Fernandina

Jacksonville

St. Augustine.

Key West

St. Marks.

Apalachicola

Pensacola.

Savannah.

Brunswick

St. Marys.

Evansville

Indianapolis

Council Bluffs

Des Moines

Dubuque

Sioux City

Louisville .

New Orleans

Aroostook.

Passamaquoddy

Frenchman Bay

Waldoboro

Wiscasset .

Portland \& Falmouth Portland

Baltimore

Gloucester

Salem \& Beverly

Marblehead

Plymouth.

Barnstable

New Bedford.

Fall River.

Springfield

Grand Rapids

Michigan .

Huron.

Detroit

Superior

Minnesota

Port Huron
PORTS OF ENTRY

Mobile

Juneau

Nogales

San Diego.

Los Angeles

San Francisco

Eureka

Denver

Stonington

New London.

Hartford

New Haven

Bridgeport

Wilmington

Fernandina

Jacksonville

St. Augustine

Key West

Tampa

Cedar Keys

Apalachicola

Pensacola .

Savannah .

Brunswick

St. Marys

Atlanta

Honolulu .

Chicago

Peoria .

Evansville

Indianapolis

Council Bluffs

Des Moines

Dubuque.

Siouxx City

Louisville .

New Orleans

Houlton

Eastport

Machias

Ellsworth .

Castine

Bangor

Belfast

Waldoboro

Wiscasset .

Bath

Baltimore.

Gloucester

Salem

Marblehead

wn, Boston

Plymouth.

Barnstable

New Bedford.

Fall River

Springfield

Grand Rapids

Grand Haven.

Detroit

Marquette

St. Paul
IMPORTS

$\$ 4,633,907$

563,503

I $0,989,32$ I

I,076,990

$3,225,618$

$59,235,47$ I

7,622

495,520

22,559

37,693

$2,217,247$

417,574

I,7 I 9,353

I $, 935,1$ IO

I,I31,9I5

45,774

I $, 354,000$

II, 012

I, 123,028

$4,752,475$

6,327

I, OIO

I $, 534,125$

$5,129,979$

76,618

……

$5,598,444$

$28,748,742$

80,290

187,224

$\mathbf{5 2 0 , 7 8 3}$

84,833

89,89 I

78,102

I I 7,148

757,060

$75,089,887$

424,996

I , 099, I 85

10,303

19,093

6,593

$3,527,633$

25,037

105,674

3,418

150,378

I, 686,205

$26,438,400$

455,830

6,667

43,756

I 29, 293,0 I 6

7,664

6,808

I 33,215

224,125

I,320,609

319,869

60,099

$5,961,597$

$7,774,662$

$3,078,389$

$7,841,660$
EXPORTS

$\$ 31,230,117$

$1,010,072$

$6,88 \mathrm{I}, 034$

I,092, I 59

I $6 I, 735$

$49,249,734$

I ,23 I, 44 I

3,196

29,822

. . . . .

$\ldots \ldots$

$2,83^{8}$

$6,529,640$

$2,329,322$

I ,599,292

$4,409,640$

I, 026,300

701,095

$23,886,645$

104,286, 925

I $9,689,838$

57,699

373,273

$7,664,928$

.......

.......

$\ldots \ldots$

$\ldots \ldots$

19,90I

I $49,160,910$

62,829

$1,238,465$

313

I $, 873,163$

I 26,43 I

I 53

270

$7,114,350$

$92,210,877$

I 0,182

I, 852

210

$69,692,17$ I

38,553

333,398

$32,199,443$

$55,911,967$

$8,829,661$

$25,128,304$ 
Value of Imports and Exports by States and Districts, for the Year ending June 1012-continued.

\section{STATE}

Minnesota

Mississippi

Missouri

Montana \& Idaho. Nebraska.

New Hampshire.

New Jersey

New York

North Carolina

Duluth

Pearl River

Kansas City

St. Joseph.

St. Louis

Montana \& Idaho

Lincoln

Omaha

Portsmouth

Newark

Perth Amboy.

Sag Harbor

City of New York

Champlain

Oswegatchie

Cape Vincent .

Oswego

Genesee

Niagara

Buffalo Creek

Dunkirk

Albany

Syracuse

Pamlico

Wilmington

North \& South Dakota N. \& S. Dakota :

Ohio

Oregon \& Washington,

Miami

Sandusky

Cuyahoga

Cincinnati

Columbus.

Dayton

Coos Bay

Yaquina

Astoria

Portland

Pennsylvania

Rhode Island

South Carolina

Puget Sound

Philadelphia

Erie

Pittsburg

Newport

Bristol \& Warren

Providence

Charleston

Beaufort

South Dakota (See N. \& S. Dakota)

Tennessee

Texas

Itah

Vermont

Virginia
Chattanooga

Knoxville.

Memphis

Nashville

Houston

Galveston .

Saluria

Corpus Christi

Brazos de Santiago

Paso del Norte

Sabine

Salt Lake City

Vermont

Memphremagog

Alexandria

Newport News

Norfolk \& Ports-

mouth

Petersburg
PORTS OF ENTRY

Duluth

Gulfport

Kansas City

St. Joseph.

St. Louis

Great Falls, Mont

Lincoln

Omaha

Portsmouth

Newark

Perth Amboy.

Sag Harbor

New York

Plattsburg

Ogdensburg

Cape Vincent.

Oswego

River Genesee

Niagara Falls.

Buffalo

Dunkirk

Albany

Syräcuse

Newbern

Wilmington

Pembina, N. D.

Toledo.

Sandusky

Cleveland

Cincinnati

Columbus .

Dayton

Coos Bay.

Yaquina

Astoria

Portland

Port Townsend

Philadelphia

Erie

Pittsburg .

Newport

Bristol \& Warren

Providence

Charleston

Beaufort

Chattanooga .

Knoxville.

Memphis

Nashville

Houston

Galveston

Eagle Pass

Corpus Christi

Brownsville

El Paso

Port Arthur

Salt Lake City

Burlington

Newport

Alexandria

Newport News

Norfolk \& Portsmouth

Petersburg to City Pt.
IMPORTS

I, 634,298

65,850

I, 838, I 50

235,191

$6,054,566$

I, 222,067

64,356

536,480

3I,99 I

I , I O4, I 3 I

$8,069,060$

I, 250

$975,744,320$

$9,795,23 \mathrm{I}$

$18,770,409$

303,486

971,901

$2,012,791$

$5,802,8$ I 8

$14,703,523$

45,570

I $, 895,200$

228,663

663

$3,090,703$

3,679, I 40

967,751

$4 \mathrm{I}, 767$

4,80 I, 98 I

$2,332,59$ I

359,33 I

368,649

.......

29,62 I

$2,739,8+1$

39,0 I I 250

$85,038,185$

312,666

I ,953,899

I 56,258

......

$2,495,677$

$5,024,674$

.

$57.57^{2}$

11,835

I 75,28 I

92,345

444,670

$4,309,758$

$5,142,795$

I, 480,835

218,912

$4,680,366$

728,156

59,095

$8,356,004$

$6,349,170$

I, 500

I ,964,586

$28,705,4+8$

$23,003,662$

2,007 , I I

I, 477,247

I $6,202,24^{\circ}$

..........

$\ldots$

$47, I_{12}$

$65 \mathrm{I}, 0 \mathrm{I}$ I

$9,980,222$

$63,7+5,572$

$69,069,730$

428,514

$\ldots . .$.

1,244

$12,423,035$

45,000

2 I $8,146,097$

$2,694,307$

I0, 404,250

I, 041,780

$6,172,436$

$22,964,28 \mathrm{c}$

$7,050,167$

$20,223,921$

$6,34^{8,751}$

I ,809,37 I

372,775 
Value of Imports and Exports by States and Districts, for the Year ending June 1912-continued. STATE
DISTRICT
PORTS OF ENTRY
IMPORTS
EXPORTS
Richmond.
Richmond.
926,516
7,800

Virginia

Washington (See Oregon and Washington)

Wisconsin

Milwaukee

Porto Rica

Porto Rico

Milwaukee

$4,646,399$

$4,501,928$

120,174

$6,832,012$

FinANCE.-The balance in the general fund on June 30 , I I I I, was $\$ 140,176,926$ and on June 30, I912, \$167,152,479 (and on Nov. I1, 1912, \$147,982,307). For the fiscal year the receipts were: ordinary, $\$ 691,778,465$ (preceding year, $\$ 701,372,375$ ), Panama Canal bonds sold, $\$ 33,189,104$ (in $191 \mathrm{I}, \$ 18,102, \mathrm{I} 70$ ) and public debt, $\$ 20,537,645$ (in I9I I, $\$ 40,232,555$ ). The disbursements were:-ordinary, $\$ 654,553,963$ (I9II, $\$ 654$, r 37,998), Panama Canal, $\$ 35,327,37$ I (I9I I, $\$ 37,063,5$ I 5) and public debt, $\$ 28$,648,327 (I91 I, $\$ 35,223,336$ ). The principal items in "ordinary" receipts were:customs, \$3II,32I,672; ordinary internal revenue, \$293,028,896; corporation tax, $\$ 28,583,303$; and of "ordinary" disbursementc: pensions, \$1 53,590,456; war, \$148,795,422 ; navy, $\$ 135,591,956$; interest on public debt, $\$ 22,616,300$; Indians, $\$ 20,134,-$ 840 ; civil and miscellaneous, $\$ 173,824,989$.

The appropriations by annual acts (exclusive of postal; payable from postal revenues) were $\$ 634,549,56$ I for I912 and $\$ 6$ I 7,382, I 78 for I9I3 (permanent appropriations: for I9I2, $\$ 68,575,924$, and for $1913, \$ 72,556,424)$. The Democratic Congress cut down the appropriations for public defence: army, from $\$ 93,374,756$ for 1912 to $\$ 90,958,7$ I 3 ; navy, from $\$ 126$,405,509 for 1912 to $\$ 123,151,539$ for 1913 ; fortifications, from $\$ 5,473,707$ to $\$ 4,036,235$; and Military Academy, from $\$ 1,163,424$ to $\$ 1,064,668$. It is true that the total of annual appropriations for 1913 compared with that for 1912 showed retrenchment and an apparent effort for economy, but the decrease in the items just named and the "cut" of $25 \%$ in the "Sundry Civil" act (from \$1 $35,241,935$ to \$ I02,538,934), even if they were entirely laudable economies, do not hide, although they overbalance, the enormous increases in the Rivers and Harbors acts (almost one-third: from $\$ 30,883,4$ I 9 to $\$ 40,559,620$ ) and in the Pension Act (nearly onetwelfth; from $\$ 153,682,000$ to $\$ 165,146,146)$, - both items notoriously for political purposes.

On June 30 , I9I2 the outstanding debt was $\$ 2,849,373,874$ (June 30, I9I I : $\$ 2,765,600$,$607)$, but more than half of this $(\$ 1,524,535,369)$ was in certificates and treasury notes, offset by an equal amount of cash in the Treasury, so that the difference, $\$ 1,343,838,505$ is a less misleading figure. This sum is made up of the following items: interest bearing debt, $\$ 963,776,770$ (including $\$ 646,250,150$ in $2 \%$ consols of $1930 ; \$ 134,631,980$ in Panama Canal loans of 1906 and 1908 - both $2 \%$-and of I9I I, $\$ 50,000,000$ at $3 \% ; \$$ I I $8,489,900$ of the $4 \%$ loan of $1925 ; \$ 63,945,460$ of the $3 \%$ loan of I908-I 8 ; and two issues of postal savings bonds at $21 / 2 \%$, the first, 19 I I-3I for $\$ 41,900$, and the second $1912-32$, for $\$ 417,380)$; debt on which interest has ceased since maturity, $\$ 1,760,45^{\circ}$; and debt bearing no interest, $\$ 378,301,285^{-}$ not including the certificates and treasury notes, mentioned above.

A system of postal savings banks was put in operation January 3 , I9I I and at the beginning of November 19I2 there were banks in 12,773 post-offices (out of a total of 58,133 in the country), including 644 branch offices and sub-stations, in every state of the Union; the number of depositors was 290,000 , and the total deposits were \$28,000,000.

On June 27, 1912 President Taft sent to Congress a report of the president's commission on economy and efficiency ${ }^{1}$ entitled The Need for a National Budget (submitted June 19; printed as 62nd Congress, 2nd Session, House Document No. 854) with a message approving the commission's recommendation that a budget be submitted to Congress by the President and that appropriations not based on this budget be acted upon in a separate bill. On July Io heads of departments and establishments were instructed by the President to prepare for the year I9I4 estimates and summaries not only in the form previously used, but in the uniform manner suggested by his commission. A letter from the President to the Secretary of the Treasury (Sept. I9) supplemented this order. Congress seemed prone to consider that the President was encroaching on its powers and in this letter the President said that he questioned not "the constitutional right to Congress to prescribe the manner in which reports . be submitted" but "the practical wisdom of continuing to operate the Government under 90 different statutes, passed at 90 different times, which prescribe 200 different forms.'

1 This commission was organised March 8, I9I I and took over work begun under Charles D. Norton, secretary to the President. Its chairman was Frederick A. Cleveland, formerly. director of the New York City bureau of municipal research. See his paper in Vol. 3, No. 2 (1912) of Proceedings of the Academy of Political Science; and, for other activities of the commission, Hearings before the House Sub-committee in charge of the Sundry Civil Appropriation Bill for 1913 (Washington, I9.12). The distribution of all departmental documents by the Superintendent of Documents instead of by the separate departments is an accomplished reform proposed by the Committee, and improved and uniform filing is another. 
Not only did Congress object to the work of the committee but in the legislative, executive and judicial bill (which President Taft twice vetoed) it required estimates to be submitted in the same way as before and in another way. Hence the President's letter of September 19.

The problem of rural credit has attracted much attention and in October I9I 2 the Federal government published a Preliminary Report on Land and Agricultural Credit in Europe, with a letter to governors of the states by President Taft recommending the introduction of co-operative credit on the lines of the Raiffeisen banks of Germany. ${ }^{1}$

The National Monetary Commission (which terminated March 31, 1912) presented in October I9I1 and on January 8, I91 2 its recommendations, ${ }^{2}$ notably for a National Reserve Association, formed of 15 district reserve associations, each made up of local associations of Io banks or more, each local association with a combined capitalisation of $\$ 5,000,000$. To secure membership banks must subscribe for $20 \%$ of their capital in stock of the National Reserve Association and must fulfill certain requirements regarding capital, surplus, reserves and examination which put state banks and trust companies under supervision similar to that now in force for national banks. Earnings of the association are to be divided between the stockholders and the United States, a certain part, however, going to a surplus reserve for the association. No more national bank notes would be issued, their place being taken by notes of the association, based on bonds, and by additional circulating notes based on bankable commercial paper, etc. The association would be required to make weekly public reports to the comptroller of the currency and full reports five times a year. Its advocates think that the plan would be of particular value in financing crops and argue that as fiscal agent for the treasury the association would effect a more satisfactory relation between the treasury and the banks. In general opposition to the plan was: partisan, arising partly from the unpopularity of the reactionary or stand-pat wing of the Republican party with which Senator Nelson W. Aldrich, the chairman of the commission, was affiliateda party group which was inextricably connected in the popular mind with tariff iniquities and favouritism to "Wall Street," the "interests " and the "Trusts"; or based on economic or political theory, which distrusted the management of a central institution and Federal interference in banking. The popular aversion to Wall Street immediately urged that the association could not fail to be under the control of this interest, in spite of the large size of the board of directors (47) and of the probable effect of the association to minimise the influence of the stock exchange on business conditions. The plan has practically the undivided opposition of the Democratic party, and the incoming administration will almost certainly not adopt it or any part of it.

The attitude of the Democratic party towards financial questions is hinted at by the "Money Trust " investigation carried on by the "Pujo committee" on banking and currency ${ }^{3}$ of the Federal House of Representatives (resolutions of February 24 and April 25. I012), although it was charged that this was prompted not merely by hostility to organised finance but largely by a desire to make political capital to be used in the presidential campaign. Besides prominent bankers, including J. P. Morgan, the committec called before it Mr. Roosevelt, who testified on the action he had taken in the panic of 1907 (see E. B. xxvii, 734d); much of the testimony before the committee was of great interest and importance.

In 1912 Professor Irving Fisher of Yale ${ }^{4}$ suggested a gold seigniorage, adjusted by reference to price index numbers, as a means of reducing the cost of living through restoration to the gold dollar of its purchasing value. Woodrow Wilson had previously

${ }^{1}$ See O. R. Hobson, Agricultural Credit Banks (Washington, 1912).

'See Iudwig Bendix, The Aldrich Plan in the Light of Mfodern Banking (New York, 1912, and in (jerman); J. L. Laughlin, Banking Reform (Chicago, 1912), a defence of the plan of the monetary commission, and the unfavourable criticism of Albert A. Bowles in North Americin Review, March 1912, vol. 195, pp. 310-318, on the ground that the system is too complicated and tries to securc the maximum of profit. V'ictor Morawetz, The Banking and Currency Problem and its Solution (New York, I911) opposes the note-issue plan.

${ }^{3}$ ('hairman, Arsène Pujo (b. 186I), representative from Louisiana since 1903.

4 In a paper before the International Chambers of Commerce at Boston, printed in the Independent (New York) of September 26, 1912. 
suggested an actual increase in the bulk of the coined dollar. Professor Fisher's plan would increase the bulk of the "uncoined dollar" without changing the coin dollar, once or repeatedly; and would substitute for the present uncoined dollar of fixed weight an uncoined dollar of variable weight but would make the coined dollar of fixed instead of variable value.

ARMy.-At the close of 1912 the regular army, limited by law to a maximum enlisted strength of 100,000 , included 4,781 active commissioned officers (including 244 detached line officers, 127 first lieutenants of the Medical Reserve Corps and 60 dental surgeons) and $81,5+7$ enlisted men, excluding provisional force and hospital corps. The branches of the force were: cavalry, 15 regiments with 765 officers and 13,823 men; field artillery, 6 regiments, with 252 officers and 5,417 men; coast artillery corps, 170 companies, with 715 officers and I 8,47I men; infantry, 30 regiments, I,530 officers and 30,340 men; Porto Rico infantry, I regiment, 32 officers and 591 men; Indian scouts, recruits, etc., 7 officers and 8, I4 2 men; native Filipino scouts, 52 companies, I 80 officers and 5,732 men; and engineers, 3 battalions, $\mathrm{I}, 942$ men. The estimated strength of the organised state militia for the same year was 9,437 commissioned officers and I 12,940 men.

The army is organised in four divisions: Eastern, including departments of the East and of the Gulf; Central, including departments of the Lakes, of the Missouri and of Texas; Western, including departments of California, of the Columbia (with Alaska) and of Hawaii; and Philippines, including departments of Luzon and Mindanao. There were I54 garrisoned posts and sub-posts, including two military prisons ( $\mathrm{Ft}$. Leavenworth, Kansas, and Alcatraz, California) and the Walter Reed General Hospital at Washington, D.C.

By Act of Congress of August 24, I9I2, the term of enlistment after November I, I9I2 was increased from three years to seven, of which the active service is four years and the other three years are in the Army Reserve (thus established) on furlough without pay. After four years' service an enlisted man may re-enlist for seven years, with higher pay; and after three years' service he may upon request be furloughed and put on the Reserve. - After two years' service enlisted men, unmarried and under 30 years of age, may take examinations for promotion to second lieutenant. Enlisted men, retired after 30 years' service, receive three-fourths pay and $\$ 15.75$ a month. The Army Appropriation Bill, carrying a clause aimed at Major-General Leonard Wood, Chief of Staff, and making him ineligible for this office, was vetoed by the President on June I7, I9 I2, and an appropriation measure without this clause was finally passed. There was a strong effort in the House, which did not succeed, to reduce the number of cavalry regiments from 15 to 10. On February 15, 1912, Adjutant-General Fred C. Ainsworth was removed from office by the President's order, pending trial for insubordination; on the 16th he was placed upon the retired list, on his own application. Gen. Ainsworth opposed the reorganisation scheme suggested by Major-General Leonard Wood, Chief of Staff. The opponents of the chief of staff in Congress and the friends of the adjutantgeneral demanded an investigation, and the committee on military affairs of the House of Representatives (House resolution 4I5, Feb. 23, 1912) asked the Secretary of War for all records in the case. In sending these records to the House the Secretary said that he had been directed by the President that their transmittal was "not to be construed as a recognition of the authority or jurisdiction of the House . . . to require of the Chief Executive a statement of the reasons of his official action in such matters or of a disclosure of the evidence upon which such official action is based." The majority report of the Committec (Report No. 508, 62nd Congress, 2nd Session) objected to the attitude of the Executive and declared that the Secretary of War had flagrantly abused his official authority; a minority report (Part 2 of same document) defended the President, the Secretary of War and the Chief of Staff, and criticised the adjutant-general.

The movement, especially strong in I 1 I I and I9I2, to pay state militia from Federal funds is blocked by a technicality - the constitutional provision that militia shall not be required to serve beyond the limits of the United States. A bill has been prepared authorising the president to transfer to the army state militias in time of war or when war threatens, and providing for their payment.

In 19I2 the principal administrative officers of the army were: Henry Lewis Stimson, secretary of war; Robert Shaw Oliver, assistant secretary of war; Major-General Leonard Wood, chief of the general staff; Brigadier-General George Andrews, adjutant-general, successor to F. C. Ainsworth in 1912; Brigadier-General E. A. Garlington, inspector-general; Brigadier-General E. H. Crowder, judge-advocate general; Brigadier-General J. B. Aleshire, quartermaster-general; Brigadier-General H. G. Sharpe, commissary-general; BrigadierGeneral G. H. Torney, surgeon-general; Brigadier-General George R. Smith, pay-master general, succeeding C. H. Whipple in 1912; Brigadier-General William H. Bixby, chief of engineers; Brigadier-General William Crozier, chief of ordnance; Brigadier-General James Allen, chief signal officer; Brigadier-General Frank McIntyre, chief of bureau of insular affairs, succeeding C. R. Edwards in I9I2.

NAVY. - The principal vessels of the American navy, in service, under construction and authorised, may be classified as follows: first class battleships, 38; armoured cruisers, I2; 
protected cruisers, 22; unprotected cruisers, 3; scout cruisers, 3; single-turret harbour defence monitors, 4; double-turret monitors, 6; gunboats, 13; light draught gunboats, 3; composite gunboats, 8 ; torpedo boat destroyers, 56; steel torpedo boats, 28 ; submarine torpedo boats, 49 ( 8 authorised); tugs, 45 ; auxiliary cruisers, 5 ; converted yachts, 17 ; colliers, 25 ; transports and supply ships, 15. For technical 'details see under SHIPS AND SHIPPING and The WORLD's NAVIES. There are three fleets: Atlantic, with four divisions; Asiatic, with four divisions; and Pacific. In 1912 there was a naval militia in each of 22 states and in the District of Columbia, with a total of 558 commissioned officers, 29 warrant officers, I, 361 petty officers and 5,372 men. Thirty-two vessels of the U.S. Navy are assigned to state naval militias. The navy active list of officers includes 2,796 commissioned, 273 warrant officers and 768 at the Naval Academy. The maximum number of enlisted men by law is 51,500 .

In Congress there was a long struggle over an appropriation for battleships; on May 28 , 1912 the House passed an appropriation bill with no provision for battleships; the Senate voted for two on July 5; and the conference report for one battleship was adopted by the Senate, August 19, 1912.

The secretary of the navy since March 6, I909, was George von Lengerke Meyer (b. I 858) of Massachusetts. In 1912 Admiral George Dewey was president of the general board, and the administrative bureaus with their heads were: navigation, Rear Admiral Philip Andrews; yards and docks, Civil Engineer Homer R. Stanford; ordnance, Rear Admiral Nathan C. Twining; construction and repair, Chief Constructor Richard $\mathbf{M}$. Watt; steam engineering, Engineer-in-Chief Hutchinson I. Cone; supplies and accounts, Paymaster General Thomas J. Cowie: medicine and surgery, Surgeon-General Charles F. Stokes; marine corps, MajorGeneral William Phillip Biddle.

\section{EDucation}

At the close of the first decade of the 20 th century there were in the United States about $25,000,000$ children of school age, and about $20,000,000$ enrolled in public and private schools, with an average daily attendance of about $14,0 \infty, \infty \infty 0$. The average school year was about 8 months of 20 days each. In the decade 1900-10 the school population increased at a much smaller rate than the entire population, as the birth rate has continually decreased. But this decrease has been much larger in the North than in the South or West, and, in general in the older parts of the country than in the newer. It is equally true that all averages for the entire country are misleading, because there is so great a variation between different states, and even between different parts of the same state. Less than two-thirds of the school population was enrolled in r gro in ten states; and, in the same year, less than two-thirds of the enrolled number was in average daily attendance in 17 states. With an average of 160 days for the country's school term, 26 states fell below the average and several had only about roo days of school a year. The average attendance of the total school population was less than 100 days in 42 states, less than 75 days in I 9 of these, less than 50 in 5 states, and not more than II 4 in any state; of the total enrollment it was less than Ioo days in 19 states and less than 75 in 5 states.

For similar comparisons in regard to illiteracy see Population above. But it must be borne in mind that, even if such averages are misleading in many respects, they are approximately correct for purposes of comparison with previous years. The percentage of enrollment to total school population was $68.6 \%$ in 1900 and $72.5 \%$ in 1909 . The length of the average school term increased from 144.3 to 155.3 days in the same period, and the average attendance of each pupil from 99 to I 12.6 days. In spite of a steady tendency during the ast part of the decade to consolidate small country districts, the number of public schoolhouses increased from 248,279 to $257,85 \mathrm{I}$, and the value of public school property increased from $\$ 5,50,531,217$ to $\$ 967,775,587$. The cost of public schools increased from $\$ 214,964,618$ to $\$ 401,397,747$, or $86^{\circ}$; ; and the cost per pupil increased from \$20.21 to $\$ 31.65$. The per'entage of the total cost expended for teachers' salaries was $64 \%$ at the beginning and only $59.2 \%$ at the end of the decade. The average monthly salary of men teachers increased aheut $35 \%$ and of women teachers about $25 \%$. Because the school year is longer the average varly salary shows an even greater increase. Even thus the increase is probably less than the average increase in cost of living and scale of prices during the decade. This is no doubt one reaten for the decreased proportion of men teachers: in 1900 they were about $30 \%$ and in Ig() alwut $2 I^{\circ} \%$ of the total. What effect the growing tendency to pay women teachers as much as men will have upon the proportion of men to women is a question on which experts disagree and which the next decade may decide.

The public school system has been growing up and down. In the decade the number of children in public kindergartens increased 40.\% (from 131,657 to 185,471 ) in cities with 
4,000 inhabitants or more, and not merely have the large cities extended their kindergarten work but smaller cities and country districts have adopted the methods of the kindergarten. In the same period the number of public high schools increased from 6,005 to $10,213\left(70^{\circ}\right.$ ), the number of pupils from 519,25I to 915,06I $(76 \%)$ and that of high-school teachers from 20,372 to 41,667 . Private secondary schools decreased in number, and the number of teachers increased only $10 \%{ }^{1}$ Besides there can be no doubt that the public high schools have gained in efficiency absolutely and relatively to the private schools. Indeed it is a common1place among university and college teachers that a majority of the best students come from the public schools and not, as a generation ago, from the private secondary schools.

During the decade the universities have done increasingly much for the secondary schools. The increasing growth and importance of the state universities and normal schools, in almost every instance under the same control (state board of education) as the public high schools, the dependence in a greater degree of higher institutions of learning upon the public secondary schools for the best part, qualitatively and quantitatively, of their clientele, and, above all, the new and wider study of education as a science and of the interesting special psychology of adolescence, - have been notable factors in this change. The unsettled problem of college entrance examinations is not the only one that is being carefully studied by the faculties of the higher schools-it is rather a part of the great question of curriculum.

Even more striking is the independent attitude toward the college of the secondary school, which considers itself more and more as a school preparatory for business and the trades rather than for college. Although the number of pupils in secondary schools increased $200 \%$ between 1890 and I9IO (when the total population increased $50 \%$ ), only one-fifteenth of the pupils in secondary schools now go to college. First the commercial high-school, or the commercial course in a general high-school and manual-training high-schools, and now agricultural high-schools, mark the progress of this movement toward satisfying the practical needs of the present American population. To a large degree this has been effected by the work of the Morrill "land grant" agricultural and mechanical arts colleges, to a rapprochement between state departments of agriculture and education, which was promoted by the mere existence of these agricultural colleges, and to such movements in the schools as the Boys' Corn Clubs and Girls' Tomato Clubs, and the Farmers' Cooperative Demonstration Work, which began in the early part of the decade under Dr. Seaman Asahel Knapp and which at the close of the decade was symbolised in the establishment in connection with Peabody College for Teachers at Nashville of the Seaman A. Knapp School of Country Life (see TENNESSE: Education). The spread during the last two years of agricultural and vocational education in primary and secondary public schools, and the provisions for courses in agriculture and domestic science in public normal schools, is shown in the articles on the different states. ${ }^{2}$ It may be noted here that the General Education Board (Rockefeller Fund) in October I9I 2 appropriated money for agricultural schools in northern New York and in Maine; and that in I9I I and 1912 Senator Carroll S. Page of Vermont introduced a bill in Congress for Federal aid to secondary schools teaching agriculture, home economics, trades and industries, and for training teachers in state normal schools for these vocational subjects. Similar measures were introduced by C. R. Davis, Representative from Minnesota, William B. Wilson, Representative from Pennsylvania, and Senator L.S. Overman of North Carolina. In 1911 , 12 states required instruction in agriculture in the common schools, 4 in rural schools and 3 in rural high schools; I6 gave aid to special agricultural schools and 12 to departments of agriculture in high schools; and $3 \mathbf{I}$ had agricultural colleges maintaining secondary courses (or schools) in agriculture. New York, Ohio, Massachusetts, Connecticut, New Jersey and Wisconsin had definite systems of vocational education - all but the first two the direct result of reports by state commissions on the subject. In Indiana and in Illinois the ilegislature of 1913 will be called to act upon reports from similar commissions.

Especially during the latter half of the decade, state laws have been stricter in regard to compulsory schooling and to such limitations of child labour as literacy requirements for children's certificates to work. Closely related to the movement for agricultural education is the greater attention paid to rural schools, ${ }^{3}$ state aid granted to "weak" school districts to assure full school terms and a fair teacher's wage, and the consolidation of small rural districts, often accompanied by free transportation of remoter pupils.

Urban schools are being more efficiently organised, school boards being reduced in size and removed from political control, and the appropriations and expenditures are more nearly adequate. Especially in the city public schools have experiments in testing efficiency of the educational plant been made and provisions made for sub-normal or defective children, ${ }^{4}$

1 The increase of teachers proportionally to pupils, or rather the decrease of numbers in classes, in all branches of education--even in the face in large cities of enormous increases in population and lack of class-room-is.a significant and promising phenomenon.

2 See the summary, "Legislation for the Last Three Years on Vocational Education" by R. R. Simpkins, in The School Review for June I9I2.

${ }^{3}$ See E. Benjamin Andrews, "The Crusade for the Country School," Educational Review, Nov. I9I2; C. B. Fishpaw, "The Training of Rural Teachers," Education, Oct. I9I2.

${ }^{4}$ The National Association for the Study of Exceptional Children (Plainfield, New Jersey), 
and for the physical welfare of all children-notably in physical training and examination, abolition of common drinking cups and towels, better cleaning and ventilating apparatus and more hygienic school furniture. A movement for holding city schools the year round seems to be gradually gaining favour. In $1911-12$ investigations of the school systems of Baltimore and New York City were made by experts outside the municipal system.

Upon the colleges the utilitarian tendencies of secondary schools - and of other agencieshave had their effect, which may be seen negatively in the rapid minimisation in the college (as in the secondary school) of the humanities, particularly Greek, and, positively, in the establishment of schools of finance and of journalism in addition to the previous "professional" schools. The improvement of the professional schools, especially of law and medicine, though hampered by the licensing of lawyers and physicians under different requirements in different states, has still advanced. The requirements are being raised (and thus approximately standardised) by the legislatures of the different states. The wretched conditions in some medical schools and the wasteful multiplication of these institutions was pointed out in I910 by Abraham Flexner in a report to the Carnegie Foundation for the Advancement of Teaching. This report, and the standards of efficiency required by the Carnegie Foundation in institutions to whose teachers it grants pensions, have promoted the cause of higher education, both special and general, by putting a premium on the best. ${ }^{1}$

The principal change in recent years in the matter of college entrance requirements was a scheme adapted at Harvard in I9II to be tested with the former scheme; it requires the satisfactory completion of an approved (but not a university ruled or supervised) course of secondary studies and examination in four subjects: English; Latin (arts course) or French or German (science course); mathematics or science (physics or chemistry); and one of Greek, French, German, history, mathematics, physics or chemistry, not chosen from the preceding three classes. This method had been proposed in 1910 at a meeting of the Association of New England Colleges, when it was summed up as "a certificate for quantity and an examination in a limited number of substantial subjects for the quality of school work." Vocational subjects may be offered for entrance to the University of Wisconsin and the University of Chicago, but both universities (and the University of California) limit a student taking entrance examinations in such subjects and require him to combine them with more abstract and disciplinary subjects; and the University of Chicago announced as an "offset to this increased freedom" that students would no longer be admitted with conditions.

The growth of the large colleges and universities has made the problem of the small college, ${ }^{2}$ and especially of the rural college, a difficult one. Amherst College definitely decided to adhere to a liberal arts curriculum. Hamilton College, Clinton, New York, in much the same difficulty, seriously considered the opposite course, dropping Greek from the requirements for the degree of Bachelor of Arts and building up a literary scientific curriculum, but in 1912 no very radical action was taken. In February and April I9I I representatives of several denominational boards of education decided to co-operate in the founding of colleges.

The most interesting and important new institutions opened during the years $1911-12$ were: Rice Institute (see TEXAS) and Reed College (see OREGON).

Bibliography.-Gene Ral: Paul Monroe (ed.), A Cyclopaedia of Education (New York, I9I I ; -3 vols. now published) is a remarkable evidence of the work of Columbia University and its Teachers College for general education; and G. E. Partridge's, Genetic Philosophy of Education (New York, 1912) is an epitome of the writings of G. Stanley Hall of Clark University. Of historical importance, especially for education in New York state, is Edward A. Fitzpatrick, Educational Views and Influences of De Witt Clinton (New York, 1911); and on women's education papers in the October and November numbers of the Educational Review by James M. Taylor of Vassar. The annual reports of the U.S. Commissioner of Education and the reports of state superintendents cuntain important statistical matter.

On the special topics mentioned above the following are some of the more important recent publications. Secondary Schools: C. H. Johnston and others, High School Education, (New York, 1912) and Julius Sachs, The American High School (New York, 1912). RuRAL Schools, Agricultural and Vocatronal Education: E. P. Cubberley, The Improvement of the Rural Schools (Boston, 1912); B. M. Davis, Agricultural Education in the Public Schools (Chicago, 1912); G. A. Bricker, The Teaching of A griculture in the High School (New York, I9II); Part II, on agricultural education, of the Eleventh Year Book of the National Society for the Siudy of Education (Chicago, 1912); Edwin G. Cooley, "The Need for Vocational Schools"

The New Jersey Training School (Vineland) and the State University of Pennsylvania with its psychological clinic are the pioneers. The State University of Washington has a fund (Catzert foundation) for training and studying mental defectives. There is a tendency to take the control of state schools for fecble-minded and other defectives from charitable (and penal) hoards and to give it to state boards of education. See Frederick E. Bolton, "Public Education of Exceptional Children," Educational Review, June 1912.

${ }^{1}$ On efficiency tests see various articles, including one by Clyde Furst, Secretary of the Carnegie Foundation, in the May 1912 School Review.

${ }^{2}$ See T. Morey Hodgman, President of Macalester College, St. Paul, Minnesota, "Functional Changes in the College," Educational Review, October 1912. 
in Educational Review, December 19r2; C. H. Robison, Agricultural Instruction in the Public High Schools of the United States (New York, I9II). SANitation AND STUdy OF BACKWARD ChILdRen: Russell Sage Foundation, What American Cities are Doing for the Health of School Children (New York, I9II); Walter S. Cornell, Health and Medical Inspection (Philadelphia, 1912) and William Hawley Smith, All the Children of all the People (New York, 1912).

(RICHARD WEBSTER.)

\section{Churches and Denominational Statistics}

The most marked contemporary tendency among the religious bodies in the United States, particularly those ranking as Evangelical Christian, is that toward co-operation, federation and unity. Churches of similar faith are drawing closer to one another, and while they do not surrender that which is peculiar to each in doctrine, polity, discipline and method, they do emphasise their points of agreement and insist above all that they are engaged in a common task, that this common task is immense in extent and importance and that it cannot be accomplished except by most strenuous and united effort. The field of this effort is not only the United States and its colonies, but the entire world; to the leaders it is one and all-embracing. But, for convenience, we may distinguish between the work at home, or home missions, and the work in the rest of the world, or foreign missions.

The conditions in the foreign field present a problem so stupendous that the effort of individual denominations appears utterly inadequate and inefficient, and the logic of the situation drives the missionary societies to co-operation and combination. The work has gradually broadened in scope so that while evangelistic effort has increased, educational, publication, hospital, and industrial institutions have multiplied in number and importance. The demands from Asia for a western system of education and other adjuncts of Christian civilisation bear heavily and persistently upon the minds and hearts alike of the missionaries and of the directors at home; the hundreds of millions of non-Christian peoples appear to be drifting from the moorings of their ancient religions, and "immediate urgency" every where faces society and worker. Therefore universities and colleges, publishing houses, hospitals, etc., have become union organisations, with from two to half a dozen different denominations supporting and conducting each. Moreover by common agreement the native Church, when it shall become autonomous and independent of the societies, is not to reproduce all the denominational divisions of America and Europe, but is to have for its ideal complete Christian unity. So, following the example in Japan, half a dozen Presbyterian and Reformed bodies have united their mission churches into one organisation in India and China, and the three branches of the Anglican Communion operating in China have done likewise. In West China bodies as diverse as Baptists, Friends and Methodists have come to an agreement to create an undivided comprehensive native Christian Church. The World Missionary Conference at Edinburgh in 1910, representing all Protestant bodies, became the mount of vision, so to speak, for an exhaustive survey of conditions in the non-Christian world, for the purpose of sounding an advance for the missionary forces of all Protestantism. A Continuation Commission, serving for all, is studying the problem with the view of securing a more perfect comity, co-operation and unity, and a more adequate occupancy of the whole field and of strategic centres. A considerable saving in means and effort has resulted, and combination has increased efficiency and power many fold. This economy in expenditure has not reacted in smaller contributions by the American home churches for foreign missions; but the aggregate becomes constantly larger, reaching in 1912 nearly $\$ 15,000,000$ for the United States and Canada alone; about a half of the entire income from all countries.

The missionary problem in the United States appears from the evangelical point of view to be quite as important and urgent as that in the rest of the countries of the world. The coming to America of a vast stream of immigration, approximating a million souls a year, of whom probably a minority only may be regarded as professing any form of the Christian faith, makes a moving demand upon all the denominations-the Jewish, to care for those of their own religion, the Roman Catholic and Eastern Orthodox, to meet the needs of the multitudes of the Latin and Greek rites, and the Lutheran and Reformed, to provide for those adhering to the Augsburg and Heidelberg Confessions. Great numbers of immigrants have practically no religion, and Protestant missionaries are endeavouring to reach these in particular. While most of the newcomers are drawn to the cities, vast numbers of Italians, Poles, Hungarians, Slavs and Greeks find their way into the smaller cities and towns, and even into villages. The service to be given, therefore, is extensive as to territory and numbers, and comprehensive as to language. Add to this foreign-speaking conglomerate the pioneers in newly-settled sections, the negroes and the Indians, and the inhabitants of those older rural pariskes which are weakened by the migration to cities, and the Churches feel that an extraordinary task confronts them. Combination of Protestant home missionary societies in a Council for conference, co-operation and united action, as far as possible, is the 
outcome. The principle of comity, the prevention of waste by doing away with rivalry' overlapping, over-churching small communities, and the joint study of difficult problems' are some of the achievements aimed at.

The missionary spirit thus dominates all Protestantism as well as the relations of one denomination to another. It has made possible the Federal Council of the Churches of Christ, the second quadrennial session of which was held in Chicago, early in December 1912. The Council is a consulting and advisory body composed of official delegates appointed by the chicf judicatories of the various evangelical churches, including Baptist, Congregational, Disciples of Christ, Friends, Lutheran, Mennonite, Methodist, Presbyterian, Protestant Episcopal and Reformed bodies. The purpose of the Council is to express the common consciousness of the united churches upon matters of mutual and public interest, and to render such service in their behalf as may be possible; to co-ordinate and correlate the work of the churches so as to secure a more perfect distribution of effort and prevent duplication; to bring about the formation of state, city, town or other local federations of Churches, and to co-ordinate their work.

The affairs of the Council are directed, in the interval of its quadrennial sessions, by a large Executive Committee. Important commissions and committees deal with such subjects as evangelism, social service, peace and arbitration, temperance, Sabbath observance, family life and divorce, and theological and primary education. The Social Service Commission covers a wide field of activity, and has a broad policy for the moral and spiritual uplifting of the working people, of the vicious, criminal, unfortunate and depressed classes, for the improvement of industrial conditions for men and women and for the abatement of poverty, better housing, etc. In other words, by careful investigations and surveys and the thorough study of unsatisfactory conditions the commission seeks to find effective measures for the alleviation of unnecessary human suffering and human misery, and to apply the Gospel of Christ, in the Spirit of Christ, for salvation in the largest sense. Social service has also been done by the Men and Religion Forward Movement, the aim of which is to interest men in the Church and the Church in men. It has endeavoured by a series of conventions to arouse the churches, particularly in the cities, to the necessity of organised effort to secure social justice and civic reforms, to make Bible study interesting and profitable, to surround boys with good influences, etc. The Federal Council meeting at Chicago was very successful and showed no signs of denominational cleavage. The new president is Prof. Shailer Matthews, a Baptist, succeeding Bishop Eugene R. Hendrix, a Methodist. The general feeling was that this Council, which represents $16,000,000$ communicants or more, is no longer an experiment, and that its province is to secure a wider and more complete practical unity.

Another movement aiming to bring about as far as possible the corporate union of Evangelical and Orthodox Christian Churches has been started under the auspices of the General Convention (I9IO) of the Protestant Episcopal Church. A large commission, of which Bishop Charles P. Anderson, of Chicago, is president, was appointed to invite all Christian Churches which "confess our Lord Jesus Christ as God and Saviour" to unite in arranging for and conducting a Conference for the consideration of questions of faith and order, with the reunion of Christendom as the ultimate object. Most of the Protestant bodies have responded cordially to the invitation, and have appointed commissions to confer with the Episcopalian Commission; the Church of England and the Episcopal Churches of Scotland, Ireland and Canada have agreed to co-operate. It is expected that individuals of the Roman Catholic and Oriental Orthodox Churches will assist in the arrangements for the conference and some of these bodies may participate officially in the conference itself. A circular issued late in 1912 in the name of the commission says that important preliminary questions, such as the basis of representation, the time and place of meeting, the method of procedure, may require years of discussion.

Reunion of bodies of similar faith, order and history has not made much progress in recent years. The Northern and Cumberland Presbyterian bodies voted in 1906 to consolidate, but only a minority of the ministers, churches and communicants of the latter entered the United Church. Much property litigation and consequent bitterness of feeling have resulted. Some important projects of union are pending. (I) Between the Methodist Episcopal, Methodist Episcopal, South and Methodist Protestant Churches. A plan in outline has been prepared, proposing that the three churches unite in one body with three or four territorial divisions, each to have a quadrennial conference for jurisdiction over its local affairs, and all to have a general conference with jurisdiction over the general affairs of the United Church. The plan contemplates the possibility of the union of the negro constituents of the Methodist Episcopal and Methodist Protestant bodies with the Colored Methodist Episcopal Church and other colored Methodists under a quadrennial Conference. The new Church would have from 5,000,000 to 5,500,000 communicants. The plan has received little general discussion sn far. (2) Between the Church of the United Brethren in Christ and the Methodist Protestant (hurch, bodies similar in docirine, discipline, polity and usage. (3) Between the Free Methorlist and American Wesleyan Churches, small bodies not far apart. (4) Between the Evangelical Association and the I'nited Evangelical ( hurch, Methodistic bodies which separated about twenty years ago. (5) The Presbyterian (Northern) and the Reformed Church in the United States (German). (6) The Preshyterian (Southern) and the 
United Presbyterian Church. (7) Between the Northern Baptists and the Free Baptists, long separated by their Calvinistic and Arminian Confessions; the two bodies have consolidated their denominational missionary, publication and educational boards, but the merging of churches, conferences, associations, etc., will, it is expected, be a gradual process.

The Roman Catholic Church is steadily growing in America, having a population of over I5,000,000, not including Porto Rico, the Philippines, and the Panama Canal Zone. This population, embracing representatives of many of the peoples, races and languages of the world, stands for a communicant membership of about 12,750,000 (end of 1911), eliminating unconfirmed baptised children; this indicates a net gain of about 675,000 communicants in the last five years. The Pope, appreciating the freedom, loyalty and prosperity of the Church in the United States, gave it in 1908 a complete ecclesiastical status. Before that year it had been treated as a missionary organisation under the general supervision of the Congregation de Propaganda Fide, in Rome. Now it has the same measure of autonomy as is enjoyed by the Roman Catholic Church in England or Germany. The pope has appointed three new cardinals for the Church in the United States-Archbishop Farley of New York, Archbishop O'Connell, of Boston, and Monsignor Falconio, Apostolic Delegate at Washington. The Papal decree of September, I9Io prescribing rigorous measures to prevent "Modernism" from getting a footing in the Church, evoked no protest in the United States, and the oath required of the clergy was loyally given.

The group of Eastern Orthodox Churches having congregations in the United States has increased in number by immigration. In addition to the Russian, Greek, Armenian, Servian, and Syrian bodies, the Bulgarian and Rumanian Churches have organisations, the seven reporting an aggregate of about 434,000 communicants.

The Church of Christ Scientist, or Christian Science, appears to be gaining in number of branches, or churches, in "readers" and in practitioners. For some years no returns have been given of members. The death of the founder and director of the movement, Mrs. Mary Baker Eddy, in I910, left the Board of five directors, which had been appointed by her, as the governing body of the denomination. Her fortune, amounting to $\$ 2,500,000$, was left for the benefit of the organisation. The withdrawal of a few branches and the organisation of a Reformed Christian Science Church is one of the events of I9I2.

The fourth decennial Ecumenical Methodist Conference, for the discussion of problems common to Methodism was held in October, I9I I in Toronto. There were present about 500 delegates, 200 from the Methodist Churches of Great Britain, Ireland, France, South Africa and Australasia; and 300 from the many branches of Methodism in the United States and Canada. The questions treated in papers and discussions took a wide range, the newer phases of Church life and Church work, including missionary endeavour, social service, training and care of the young, evangelism, international peace, receiving much attention. Higher biblical criticism evoked expressions of acquiescence in ascertained results, although there was an undercurrent of dissent. Delegates from Great Britain and Australasia had enthusiastic reports to make of the results of the consolidation of a number of branches. An Ecumenical Methodist Commission, to act for the Methodism of the world in the interval of the decennial Conferences, and especially to cultivate a more intimate fellowship between the various branches, was created. Reports from the Eastern and Western Sections showed that Methodism in America has entered a period in which the rate of increase is lessening; while the British branches are encountering net losses. The larger bodies of the United States have all gained in communicants since 1906, the Methodist Episcopal reporting 3,293,526 in 1912, the Methodist Episcopal Church, South, I,919,873 in 1912, the Methodist Protestant 183,318, the African Methodist Episcopal, 620,234 the African M. E. Zion, 547,216 and the Colored M. E., 234,72x. In all, the 17 bodies have a total of about $6,905,000$.

The Baptist World Alliance held its second Congress in Philadelphia, in June I9II. Delegates of the Northern, Southern, Colored and Free Baptist bodies of the United States and from the Baptist Churches of Canada, Great Britain, Russia and other countries of Europe, and from Africa, Australia, and countries of Asia were present. The sessions were crowded, and great enthusiasm was evoked by the Russian delegation, who told of persecution and progress and great opportunities. The Congress raised over $\$ 60,000$ for a theological seminary in St. Petersburg, and the American Baptists agreed to increase the fund to \$1 25,000. The Rev. R. S. MacArthur, D.D., of New York, was elected President, and he subsequently visited Russia, dedicated a Baptist Tabernacle in St. Petersburg and bought ground for the Seminary. The larger Baptist bodies of the United States are growing steadily. The Northern Baptists number about I, I 76,000, the Southern 2,475,600 and the Colored over I,912,000. A dozen other Baptist bodies bring the total up to about 5,894,000.

The Congregational Churches have under consideration a plan for the co-ordination of their benevolent societies and for changes in their national triennial Council which would give it administrative functions, with a permanent Secretary. The denomination is growing moderately, having at the close of 1912742,000 communicants.

The Disciples of Christ, notwithstanding the division of some years ago into two bodies show a healthy growth. In this denomination at the close of 1912 there were about $1,340,000$ communicants, besides the $\mathbf{1 5 7 , 0 0 0}$ or more belonging to the conservative branch known as the Churches of Christ. 
The Evangelical Association and the United Evangelical Church have 184,866 members, the Friends ( 4 bodies) 124,216, the German Evangelical Synod 258,911, the United Brethren in Christ ( 2 bodies) 320,960, the Reformed (4 bodies) 459, 106.

The Protestant Episcopal Church, which, as a new feature for large city dioceses, has suffragan bishops, grows steadily. At the end of 1912 it had 970,45I communicants.

The Presbyterian bodies show a steady growth in numbers and in finances. The Northern Church has $1,368,150$ communicants, the Southern 292,845 , the Urited 139,617 , and the Cumberland 120,000 . The twelve bodies returned in $1912,1,982,000$ communicants.

Jewish immigration adds about 70,000 to 75,000 annually to the Jewish population in the United States, now about 2,000,000. Great activity in the organisation of societies and in the prosecution of various lines of work characterises the denomination.

The Lutheran Communion has an encouraging annual growth. Independently of the kindred Swedish Evangelical bodies $(68,500)$ it has an aggregate of $2,353,702$ communicants. It is developing steadily its missionary and other interests. Of the general bodies the Synodical Conference has 807,693 communicants, the General Council 473,295 , the General Synod 309,702, and the United Synod, South, 50,669.

The grand total for all denominations in the United States, chiefly on the basis of the returns for 1912 , rises above $36,675,000$ members, including Christians, non-Christians and Jews.

(Henry K. Carroll.)

\section{Political History 1909-12.}

During the administration of President Taft, which began in the spring of r 909 , the tariff assumed a place of first importance in the work of Congress and in public discussion. Called into special session for the purpose of revising the

Payne-

Aldrich
Tariff 1909. tariff, Congress passed in August the Payne-Aldrich act. It was by no means a radical measure. There were some reductions in duties, as in the case of iron and steel, wood pulp and printing paper, and manufactures of leather; hides were placed on the free list. But there were also increases, notably in the finer grades of cotton and silk goods; and the woollen and sugar schedules, which had been the subjects of general criticism, remained virtually unchanged. Aside from such readjustments of the duties, the act had several notable features. It provided for free trade between the United States and the Philippines (q.v.), with the exception that certain imports from the islands were to be limited in quantity; it erected a customs court of appeals to review the findings of the Board of General Appraisers; it established a minimum and maximum system under which the President was empowered to impose an additional $25 \%$ ad valorem upon imports from countries which should discriminate against American imports; and it levied an excise tax of one per cent upon the net income of corporations. The constitutionality of this tax was upheld by the Supreme Court in Igrr. Its imposition marks an advance in Federal control of corporations, entailing as it does supervision over annual accounts and business transactions. Congress also initiated an amendment to the Constitution which would permit the government to levy an income tax without apportioning it among the states according to population. Thirty-seven states had ratified the amendment ${ }^{1}$ up to February I9r3. It was officially proclaimed on February 25 th.

The tariff act also empowered the President to "employ such persons as may be required " in securing the information necessary to the execution of the maximum and minimum provisions. Under this vague authority he appointed a tariff The Tariff board for the purpose, among other things, of investigating the difference
Board. in the cost of production in the United States and abroad, since the Republican platform of 1908 had promised tariff revision on the basis of equalising this cost (see E. B. xxvii, 735a). He urged Congress to make the board permanent and to actopt the policy of revising the tariff schedule by schedule in accordance with the findings of the board. He did manage to secure annual appropriations for the board until 1912; but though the board made exhaustive reports upon the paper, wool, and cotton schedules, Congress gave little heed to them in framing its tariff measures.

'The amendment becomes Article XVI of the Amendments to the Constitution and reads: The Congress shall have power to lay and collect taxes on incomes, from whatever source derived, without apportionment among the several States, and without regard to any census or enumeration. 
The passage of the Payne-Aldrich act marked a turning-point in the fortunes of the Republican party. Nineteen Republicans had opposed this party measure in the House, seven in the Senate; and it was soon evident that their course was Dissatisfac- widely approved by the people, especially in the Middle West. It did not tion with Taft's policy. appear that any real attempt had been made to revise the tariff in accordance with the pledges of the party platform. The President failed to understand the temper of the country. He declared, on signing the bill, that it was a sincere effort to make a downward revision, and again, somewhat later, that it was " the best customs law that has ever been passed." His attitude separated him from the progressive wing of the party, creating the impression that he had become dominated by reactionary influences. The breach became still wider when he laid before Congress, on January 26, I9Ir, a Reciprocity Agreement with Canada

\section{Cansdian} Reciprocity.

which required legislative adoption by both countries. The agreement provided for the free exchange of all primary food products and a reduction of duties upon secondary food products and certain manufactured articles. The progressives denounced it as a discrimination against the farmer: he would receive no real relief from the extortions of American trusts while having to meet the competition of Canadian food-stuffs. Opposed by the progressives for one reason and by the high-tariff Republicans for another, the Tariff bill failed in the Senate; and though the President carried it through the Sixty-second Congress in the spring of IgI , he had to rely mainly on the Democrats. His measure for reciprocity with Canada, with which he had expected to recover the prestige lost in I909, still further irritated the Northern farmers. As a climax to this bitter disappointment the Canadian Parliament withheld its consent as a result of the election of IgIr (see CANADA), the ever-present fear of absorption by a powerful neighbour weighing heavily in the decision.

When the Sixty-second Congress convened in IgI I popular disapproval of the Taft administration was written large in the altered composition of the houses. The Democrats had a majority of sixty-seven in the House of Representatives and The Demo- were only eleven votes below the majority in the Senate. For the first crats and the tariff.

time in fourteen years they had broken Republican control of Congress.

They had also wrested seven states from the Republicans, electing the governor in Maine for the first time in thirty years and in New York for the first time ir eighteen. Since their campaign had been conducted on the tariff issue, they clearly had received a mandate to proceed with the work of revision. Led by Oscar W. Underwood, ${ }^{1}$ chairman of the committee of Ways and Means, and combining with the progressive Republicans in the Senate, they carried through Congress in the special session of IgII a "farmers' free list bill " (August I) which removed the duties from certain manufactures and food products; a bill which made considerabe reductions in the duties on wool and woollens; and a bill cutting in half the duties on cotton goods. All three the President vetoed, condemning them as "empirical and haphazard" and holding that Congress should not touch the wool schedule until it received the report of the tariff board. In ror 2 he followed the same course, vetoing reductions in the wool, cotton, and metal schedules; and the Democrats could not command the necessary majority of two-thirds in the Senate to override the veto. The Senate, in fact, rejected House bills revising the chemical schedule and placing sugar on the free list. Though protesting indignantly, the Democrats were not sorry to have so definite an issue to present to the electorate in the presidential campaign.

All through his administration President Taft vigorously enforced the Sherman anti-trust act which was passed in 1890 to protect interstate commerce from restraint

${ }^{1}$ Underwood (b. 1862), a native of Kentucky and educated at the University of Virginia' had represented the 9 th Alabama district in Congress, since 1895 . He was chairman of the state Democratic campaign committee which drafted the constitution of Alabama adopted in I90I. In I9II W. J. Bryan in his weekly, The Commoner, charged that Underwood prevented the revision of the steel and iron tariff schedules because he was interested in the iron industry in Alabama. Underwood denied this, and in spite of the public break with Bryan retained the party leadership in the House which he had assumed that year. 
and monopoly (see E. B. xiv, 7 гza). On May I5, I9I r, the Supreme Court gave a new interpretation to this act, distinguishing for the first time in a majority opinion between reasonable and unreasonable restraint. Chief Justice Edward D.

The trust White ${ }^{1}$ asserted the doctrine that combinations were illegal only when exquestion. ercising an unreasonable restraint upon trade or when their "direct and necessary effect "was to stifle competition. Although Justice John M. Harlan sharply dissented from the opinion, pointing out that the court had expressly rejected the "rule of reason" fifteen years before, yet he joined his eight colleagues in decreeing the dissolution within 6 months of the Standard Oil Company (May I 5) and the American Tobacco Company (May 29). Shortly afterwards these great corporations dissolved into their component parts. But the belief widely prevailed that their obedience to the court decree was only colourable. Justification of this view appeared in the suit which the government brought against the Standard Oil Companies of New Jersey and New York, August 29, I9I 2, charging conspiracy to ruin the business of the PierceFordyce Oil Association of Texas and in the proof, adduced by proceedings in the state of Missouri, that control over the Waters-Pierce Company still rested with John D. Rockefeller and his associates of the Standard Oil. Among Republicans there now began to appear a definite cleavage of opinion as to the best methods of dealing with the trusts. President Taft wished to secure "competition without monopoly." He expressed satisfaction with the Sherman act, suggesting that amendments be adopted defining improper acts of restraint or monopoly as criminal offences. Mr. Roosevelt, on the other hand, regarded as chimerical the attempt to regulate trusts by means of a succession of lawsuits. He wished to have an administrative commission which would supervise other interstate corporations very much as was already being done in the case of railroads. This would preserve the advantages of large-scale production and give certainty to business. In the presidential campaign this question, though overshadowed by the tariff issue, was much discussed. The Democrats, with their laissezfaire notions, differed radically from Mr. Roosevelt, denouncing his scheme for a commission as state regulation of monopolies and emphasizing the function of the states in dealing with the problem. They also differed from Mr. Taft in wishing to reverse the interpretation which the court had placed upon the Sherman act.

During I910-I 2 important questions came to the front with respect to the control of railroads. In Igri the conflict between national and local authority became acute.

\section{Control of}

By court decisions severe restrictions were placed upon the states. The railroads. Supreme Court held that the equipment of a railroad which conducts an interstate business comes exclusively under the jurisdiction of the Interstate Commerce Commission, even in the case of cars moving entirely within the boundaries of a single state. The circuit court at St. Paul held invalid (April 2I, I9I I) a Minnesota law fixing the passenger rate at two cents a mile, the ground being that, while the law applied only within the state, it nevertheless discriminated against interstate passengers who had to pay a higher rate. Against this decision, as an encroachment upon state rights, the state governors protested on the occasion of their annual conference at Spring Lake, New Jersey, on September I 2, I9 I. In April, I9I 2, when the case came before the Supreme Court on appeal, three of the governors presented briefs. The decision, which will have far-reaching effects, had not been handed down in February I013. In roro Congress adopted an amendment to the Interstate Commerce act. This extended the jurisdiction of the Interstate Commerce Commission to telegraph and telephone companies, increased its powers in fixing rates, created a commerce court to review its orders, and authorised the President to create a board to investigate railroad capitalisation. The new Commerce Court proceeded, in a series of decisions, to override the Commission, only to have several of the decisions reversed in I0I 2 by the Supreme Court which criticised it for exceeding its powers. Public

1 Edward Douglass White (b. 1845), a native of Louisiana, a Democrat, and a former Confederate soldier, had become a justice of the Supreme Court in 1894 , and in Dec. 1910 was appointed (hief-Justice. He had served in the U. S. Senate in $1891-94$. 
suspicion of the court was reflected in the refusal of Congress to authorise any grant for its maintenance until the President had twice returned the general appropriation bill for I9I3 without his signature. Against one of the judges, Robert W. Archbald, who was charged with having used his position to secure favours from litigants, impeachment proceedings were brought (see below). The Railroad Securities Commission reported in December rgI I that it would be impracticable to place the issue of railroad securities under Federal control; it recommended full publicity under the supervision of the Interstate Commerce Commission, with power to make physical valuations.

Almost from the beginning of the Taft administration its attitude toward the conservation of natural resources was bitterly assailed. This was one of the chief circumstances which alienated the progressive wing of the Republican party from The Con- the President. In I 909 the Chief Forester, Gifford Pinchot, ${ }^{1}$ attacked the

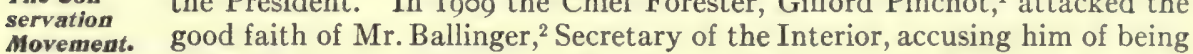
opposed to conservation and of supporting fraudulent claims to Alaskan coal lands. The charges were investigated by a Congressional committee. The majority report, laid before Congress in December, I910, completely exonerated Mr. Ballinger as "a faithful and efficient public officer;" but, being dictated apparently by partisan motives, the report had no substantial effect upon public opinion. On March 6, I9I I, Mr. Ballinger resigned, the victim, the President said, of "one of the most unscrupulous conspiracies for the defamation of character that history can show." He was succeeded by Walter L. Fisher, ${ }^{3}$ a pronounced conservationist. Nevertheless criticism of the land policy of the administration continued, in one case taking the form of unjustified imputations against the President and his brother in connection with the sale of land on Controller Bay, Alaska, to a coal-mining syndicate. See Alaska.

The principle of conservation may apply not only to natural resources, but also to the people themselves and to the processes of government. The phenomenal increase

Labour legislation. of labour legislation shows that men have come to realise the social peril of the old laissez-faire attitude. Down to I I I only three states had enacted workmen's insurance or compensation laws; and in two of these cases (Montana and New York) the courts, adhering to an ancient doctrine, held the acts unconstitutional as taking property without due process of law. In the past two years, on the other hand, fourteen states have taken action. Similarly, with reference to child labour, laws were passed in roI I by thirty of the forty-one legislatures then in session, and the next year by eleven out of twenty. Among the other subjects covered in I 9 I $2{ }^{4}$ were: the reporting of industrial accidents and diseases, woman's labour, wages, and hours of labour. In Massachusetts a commission was established with power to establish wage boards in any industry in which it may appear that the wages received by women are insufficient to supply them with necessaries and maintain them in health; but the boards may simply recommend a minimum wage and publish the names of

${ }^{1}$ Pinchot (b. I 865) graduated at Yale in 1889 and after studying forestry in Europe devoted himself to this subject, doing the first systematic forestry work in the United States at Biltmore, North Carolina, in 1892. He was Chief of the bureau of forestry, U. S. Department of Agriculture, in I898-I9Io and then became president of the National Conservation Association. In 1903 he became professor of forestry at Yale. He and his brother Amos were deeply interested in radical reform movements and in the I9I2 presidential campaign supported La Follette and then Roosevelt. He wrote much on forestry, including the article "Forests and Forestry" in the IIth edition of the E. B.

2 Richard Achilles Ballinger (b. 1858), a native of Iowa, graduated at Williams Cullege in 1884 , practised law in Kankakee, Illinois, New Decatur, Alabama, and Port Townsend and (after 1897) Seattle, Washington, was mayor of Seattle, 1904-06, and Commissioner of the Federal General Land Office, 1907-09; and became Secretary of the Interior in President Taft's cabinet March 4, I909. He wrote on Community Property (I 895) and edited and annotated the Codes and Statutes of Washington (I897).

${ }^{3}$ Fisher was born in Wheeling, West Virginia, in 1862; studied at Marietta College, Ohio, and Hanover College, Indiana; was admitted to the bar in 1888; practised law in Chicago, where he was special traction counsel in I906-I1; and was an officer of the Conservation League of America, of the National Conservation Association, etc.

${ }^{4}$ See separate state articles under Legislation and Government. 
employers who refuse to adopt it. Federal legislation is notably increasing in volume. In I9I 2 the manufacture of poisonous phosphorus matches was prohibited (April 9) by an exercise of the taxing power; a commission established to examine into the relations between capital and labour; and the scope of the eight-hour and accident compensation laws applying to government employees enlarged. The welfare of wageearners received unusual attention in the presidential campaign on account of the position accorded it in the platform of the Progressive party.

The sentiment against intemperance has been growing rapidly in the United States. A systematic agitation has given wide publicity to the economic waste and the social evils which it entails. At this time, by state or local action, the sale of The liquor is prohibited in two-thirds of the whole country and among nearly Prohibition
movement. half of the population. That the prohibition movement made no great progress and suffered no reverses in I9I 2 may be set down to the fact that it was a presidential year, and that the people were occupied with other questions, as may be seen from the losses of the Prohibition party in the I9I 2 campaign, partly to the Progressives. In New York the members of the legislature, fearing to compromise themselves, made no concessions either to the liquor interests or to their opponents. In the November elections, however, the state of West Virginia went "dry" by a large majority $(92,342)$. It is also worthy of mention that several railroads in Pennsylvania, urged by the anti-saloon league of that state, discontinued serving drinks on their dining cars; that in Illinois (q.v.) certain railways did the same thing because of local prohibition; and that the Southern Pacific Railroad began the construction of recreation houses along its lines with the idea of keeping its employees away from the saloons. The new movement in politics which looks to the elimination of the boss and his corrupt affiliations will help the prohibition cause. Hitherto the control which the bosses have exercised over the government, and the liquor men over the bosses, has resulted in a general defiance of the law and a popular saying that "prohibition does not prohibit." It is also true that under Federal law liquor may be shipped from" wet" states into "dry" states and that the state authority may assume jurisdiction over it only when the original package (see $E . B . \mathrm{xx}, 273$ ) has been broken or its contents have left the hands of the consignee. In February 19I 3 a bill to do away with this immunity was vetoed by President Taft.

Health laws are another phase of conservation. Not only have the states been seriously backward in legislation, but enforcement has been still more lax. Unfortunately the great hope which was placed in the Federal Pure Food and Drugs

Protection of public health. act of 1906 has not been altogether realised. By a decision of the Supreme Court, May 29, I9I (U.S. v. Johnson), it was held that extravagant claims might be made for worthless patent medicines without any contravention of the act. Apparently the Secretary of Agriculture was not in sympathy with its strict enforcement. The intrigues against Dr. H. W. Wiley, ${ }^{1}$ chief of the bureau of chemistry, attracted public attention in I9Ir. When he resigned (March I5, I9I2), he announced that conditions in the department made it impossible for him to remain. There was a general feeling that the President should have intervened to eliminate the influences which drove Dr. Wiley out.

${ }^{1}$ Harvey Washington Wiley was born in Kent, Indiana, in 1844 ; graduated at Hanover College in 1867. Indiana Melical College in 1871 and Harvard in 1873 . He taught Latin and (ircek in Butler College, Indianapolis, in 1868-70; from 1874 to 1883 was state chemist of Indiana and professor of (hemistry in Purdue University; and from 1883 to I9I2 was chief chemist of the U. S. Department of Agriculture. His opposition to the use of benzoate of soda as a food preservative aroused the hostility of certain food packers, and a chemistry board (of experts) was appointed which disagreed with him in regard to the injurious effects of this preservative. On July I3, I9I I, the Attorney-General recommended Wiley's dismissal on the ground that he had employed at a rate higher than the legal per diem a consulting expert, H. H. Rusby. President Taft sustained Dr. Wiley in a letter of Sept. 15, I9I I. An impression prevailed that the incident was the outgrowth of a personal quarrel between Dr. Wiley and (i. P. Mrcabe, solicitor and member of the personnel board of the Dept. Dr. Wiley was succeeded in December 1912 by Dr. Cari L. Alsberg. 
The public conscience has also been much exercised over the prevalence of prostitution. In a number of cities careful investigations have been made, notably in Chicago where a commission has reported that there are more than a thousand houses of illfame with an income of $\$ 16,000,000$. Congress, in r910, passed a law which makes the transportation of women for immoral purposes a felony. Half the states have passed laws to combat the "White Slave" traffic.

Conservation in government is efficiency. This has been notoriously lacking in the United States. For example, it was stated by Senator Aldrich that the loose methods of the Federal government wasted $\$ 300,000,000$ every year. To remedy Government this, President Taft appointed in December rgro an Economy and
efficiency.

Efficiency Commission, which investigated the organisation and accounting systems of the departments. One of their recommendations, that the President should submit an annual budget to Congress, met with anything but a kindly reception among those numerous Congressmen who profit politically by the wasteful diversion of public moneys. Accordingly, in r9r2, they reduced the salaries of the commissioners and provided in another bill that only the usual departmental estimates should be submitted. President Taft, however, took a different view of his powers; and he made known his intention of sending his budget to Congress at the opening of the regular session. (See Finance above.) He showed the same commendable zeal in the improvement of the civil service. In several messages he urged that practically the entire Federal service, with the exception of the cabinet officers and their assistants, should be placed in the competitive classified list; and in October, I9 2, he classified all unclassified fourth-class post-masters and in December many.skilled labourers in navy-yards. By courageous use of the veto he prevented Congress from limiting the civil service tenure to seven years. Throughout the country there were marked advances in civil service reform during I9I2, not only in the adoption of the merit system, but in the recognition of the importance of taking higher administrative officers out of politics. Not less worthy of notice is the founding of numerous legislative reference bureaus and bureaus of municipal research. In New York, Philadelphia, Cincinnati, and other large cities the methods of public accounting have been transformed; and the most modern business practices have been introduced into the departments.

The increased efficiency. of the Federal government is illustrated by the fact that the chronic deficit in the post-office department ${ }^{1}$ has been stopped and that Congress Changes in has been willing to entrust new functions to it. In roro, a system of the Post- postal savings banks was established (see E. B. xxii, I96), such post-offices Office $\quad$ as a board of trustees may indicate paying two per cent on deposits of Department. from $\$$ I to $\$ 500$, or giving in exchange for the deposits government bonds which bear two and a half per cent interest. The trustees may place moneys in state and national banks under guarantee of certain prescribed securities. Put gradually into operation, the system has worked splendidly. In May I9I 2 a limited parcel post for rural and city delivery routes was established, effective January I, I9I3. The maximum weight is eleven pounds; and the charges, beginning with five cents for the first and one cent for each additional pound, vary with the distance. A large discretion in modifying the original regulations is left with the Postmaster-General acting under the control of the Interstate Commerce Commission. Agitation for the parcel post has been largely due to the excessive charges made by the express companies. In July, I9 2, however, the Interstate Commerce Commission ordered a reduction of about fifteen per cent, particularly affecting parcels under twelve pounds.

A few phases of American foreign relations deserve attention. In August I9I I, as

${ }^{1}$ Many improvements in this department were due to the postmaster-general, Frank Harris Hitchcock (b. I 867), who graduated at Harvard in 189I, was admitted to the bar in I 894, and was Ist assistant postmaster-general in 1905-08. He managed Taft's presidential campaign in 1908 and was chairman of the Republican National Committee in 1908-09. Hitchcock's efforts to increase postal rates on periodicals brought on him and on the administration the sharp criticism of many popular and influential periodicals. The introduction of the parcel-post system was opposed by the powerful express companies. 
the result of suggestions made by President Taft, general arbitration treaties between the United States on the one side and Great Britain and France on the other were signed at Washington. Questions of national honour were brought withArbitration treaties. in the scope of the treaties; all " justiciable" disputes which could not be settled by diplomacy were to be submitted to the Hague Tribunal or some other body. In some quarters the treaties were regarded as heralding the dawn of universal peace; in others as a dangerous step in advance of public opinion, likely to breed friction and misunderstandings. Mr. Roosevelt opposed them. The Senate committee on Foreign Relations asserted that they would rouse into malign and dangerous activity a series of disputes now happily set at rest. Amendments were adopted in Igr 2 which left the Senate free in each case to determine whether the matter were justiciable or not, and which altogether excluded from arbitration under the treaty the alleged indebtedness of the states and other questions. Thus devitalised, the treaties remained unratified.

In the autumn of $\mathrm{I} g \mathrm{I} 2 \mathrm{a}$ controversy arose with England which remained unsettled at the end of the year, but seemed likely to raise the question of arbitration in concrete form. The matter at issue depended upon the interpretation of the Hay-

\section{Panama}

Canal tolls.

Pauncefote treaty. Congress passed on August I6, I912, a bill providing

for the government and regulating the use of the Panama Canal. The bill empowered the President to fix and alter tolls, admitted free of tolls American ships engaged in the coast wise trade, gave the Interstate Commerce Commission authority to exclude ship lines financially affiliated with railroads, and admitted to free registry under the American flag foreign-built ships owned exclusively by Americans. The English government protested while the bill was before Congress, urging that a subsidy calculated especially with reference to the use of the canai would not be in accordance with treaty obligations, and that it would be impossible to frame regulations for the exemption of ships in the coast-wise trade which would not constitute a preference to American shipping and therefore an infraction of the Hay-Pauncefote treaty. President Taft, however, signed the bill. Opinion in the United States was sharply divided both on the question itself and on the procedure adopted; but without doubt a large part of the American people held either that, as the President believed, the terms of the treaty were being observed or that the circumstances attending the construction of the canal were so different from those contemplated in the treaty that the treaty itself should be regarded as having practically lapsed.

American relations with the Latin-American Republics have been complicated by revolutionary movements in Mexico, Nicaragua, Cuba, and elsewhere. So serious did

Latia -

American

republics. the disturbances become in Mexico during the early part of IgII, that an army of 20,000 was for a time mobilised on the frontier to prevent violation of neutrality and protect American interests, should occasion arise. Again, a year later, several regiments had to be despatched to patrol the border; and in September I 912 , when armed bands of revolutionists came into conflict with the troops on American soil, the situation became exceedingly critical. Only the forbearance of President Taft saved the country from the perils of intervention. In May rog several hundred marines were hurried to Cuba, where a negro insurrection had assumed serious proportions. But again intervention proved unnecessary, President (jomez showing himself able to suppress the rebels. In October marines were landed in Santo Domingo to protect the customs houses, some of which had been seized by revolutionists. The collection of the customs revenue on that island has been superviserd by agents of the Linited States Government for the past five years. In order to restore the finances of Honduras and Nicaragua in the same way President Taft negotiated treaties with them in IoII, under which the United States would make arrangements for a loan, supervise the customs service, and apply a certain part of the receipts to the payment of the foreign debt. Although the Senate refused to ratify the treaties, some of their provisions were carried out informally, an American being placed in charge of the Nicaraguan customs and a considerable loan being made by American bankers. 
During the summer of I9I 2, 2,500 marines were sent to Nicaragua to protect the lives and property of Americans; they took part in several engagements.

In December I9II the treaty of 1832 with Russia was abrogated because of the refusal to give proper recognition to the passports of American Jews in Russia.

The high cost of living has naturally led to demands for increased wages and to labour disturbances throughout the country. Acts of violence attended many of the strikes. Early in I9I 2 some 25,000 operatives employed in the mills of Labour Lawrence, Massachusetts, left work on account of a reduction in wages disturb- following the passage of a state law which limited the hours of labour. The strike ended with the concession of higher wages, but not before the militia had been ordered out and some bloodshed had occurred. In this struggle the operatives were led by a new organisation known as the Industrial Workers of the World. This organisation, though it has been in the public eye little except in I9I I-I 2, dates further back. Its prototypes were the Knights of Labor, the Western Federation of Miners which struck in Idaho in 1899 , the American Railway Union, which carried through the great railway strike of $\mathrm{I} 894$, and, in form, the United Mine Workers. Each of these attempted to unite all the workmen, skilled and unskilled, in an industry. As a result of a conference of six active labour leaders in the autumn of 1904, the Industrial Workers of the World, with Debs of the American Railway Union and Haywood of the Western Federation of Miners, attempted to organise the workers of all industries, and in January roo5 published an Industrial Union Manifesto. There was a serious split in the Industrial Workers of the World, in 1906, when the radicals broke with the officials, whom they accused of too great conservatism but who kept control of the organisation. The Goldfield strike of $1907-08$ (see E. B. xii, 210) centered about the I.W.W. In Igog there was another schism; Daniel De Leon (b. I852), a member of the Knights of Labor in $1888-95$ and a leader in the Socialist Trade and Labor Alliance from I895 to its fusion (I905) with the I.W.W., founded an "indirect" (or political) action branch with headquarters at Detroit, which is very different from Industrial the direct action policy of the Chicago School. There is the bitterest
Workers Workers
of the World. feeling between the two branches,-almost as strong as their enmity to the trades unions. The Detroit branch nearly coincides with the Socialist Labor party, of which also De Leon is the leader. The Chicago branch would probably have amounted to little had not William D. Haywood been disowned early in 1908 (after his acquittal on the charge of murdering Governor Steunenberg) by the Western Federation of Miners. He thereupon devoted himself to the I.W.W. In I9o9 the organisation engineered the McKees Rocks (Penn.) strike of the workers of the Pressed Steel Car Company including I6 nationalities, where success was largely due, as in Igr 2 in Lawrence, Massachusetts (q.v.), to the arousal of public sympathy, partly because of gross errors of the authorities in dealing with the trouble. In I9II-12 the workers campaigned for "free speech" in Oregon and California (q.v.).

There are two national unions, the Textile and the Lumber, affiliated with the I.W.W., and its appeal has been to the lower paid and more unskilled workman, the newer immigrant, and-in its free speech propaganda on the Pacific Coast-to the tramp. The basic principles of the I.W.W. are that "the working class and the employing class have nothing in common" and that between them a struggle must go on, through the organisation of all the members of all industries if necessary, until capitalism is overthrown and the wage system abolished. It considers a strike a mere incident in a prolonged warfare, to be followed, when strikers return to work, by "sabotage," i.e., idling at work, the British "ca' canny," and various ingenious methods of spoiling the machinery, business, market, etc., of the capitalist employer. The question of right and wrong is not to be considered. No agreements with an employer are sought and none are final.

The dynamiting work of the McNamaras and their associates (see CALIFORNIA and INDIANA) was done, not by members of the I.W.W., but by officials of unions affiliated with the American Federation of Labor which the I.W.W. has always opposed. 
In the American Socialist party, the leaders Debs and Haywood were founders of the I.W.W. Besides Haywood, two other members of the Executive Committee were in sympathy with the I.W.W.; but the other four, Victor Berger (former Congressman from Wisconsin), John Spargo, the author, Morris Hillquit, the historian of Socialism, and Job Harriman, late candidate for mayor of Los Angeles, were opposed to it.

In the 1912 convention of the American Federation of Labor at Toledo, Ohio, on November 20, delegates from the United Mine Workers introduced, and those from the Western Federation of Miners supported, a resolution approving industrial organisation, the scheme of the I.W.W. The resolution was defeated two to one, but it is important to note that there is a movement of some strength in this craft organisation for a general industrial organisation of the I.W.W. type, which the Federation has always opposed. The I.W.W. has six publications at the present time. It has "National administrations " in Hawaii, Australia, New Zealand and South Africa.

Dissatisfaction with the economic conditions in the country and with the failure of the great political parties to face them seriously has greatly strengthened the Socialists. In I910 they cast 605,000 votes, a gain of nearly 200,000 over 1908; and Socialism in I9I2. the Socialist vote for president was large (about 896,000),

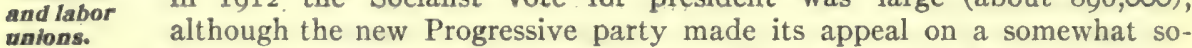
cialistic programme. In IgII they had 392 elected officials, including the first socialist Congressman, Victor Berger (defeated in I9I2), I8 legislators in five states, 32 mayors (including Emil Seidel of Milwaukee and G. B. Lunn of Schenectady), and $34 \mathrm{I}$ minor officials. On the other hand, the Socialist Labor party, with much more radical principles, has steadily diminished in popular strength. ${ }^{1}$ The trade unions have been increasing in number and in membership. The American Federation of Labor had, at the end of 1912 , an enrollment of $1,841,268$; and, during the year, 260 certificates of affiliation had been issued to unions. Injury was done to the labour cause in IgI I, however, by the discovery that numerous dynamiting outrages had been planned and executed by men connected with the International Association of Bridge and Structural Ironworkers (see CaLIforNIA; INDIANA).

These outrages, extending over two years, culminated in the loss of $2 \mathrm{I}$ lives by the destruction of the Los Angeles Times building in October I910. Their purpose was to discourage the use of non-union materials and the employment of nonThe union labour. Ortie McManigal, who turned state's evidence, James B McNamara
case. McNamara, and J. J. McNamara, secretary of the Association, were

indicted. The American Federation of Labor, warmly espousing their cause, collected a large sum of money for the defence and placed a committee in charge In December I9I I before the tedious process of selecting the jury had been completed the McNamaras confessed. They were sentenced to imprisonment for life and for fifteen years respectively. Their attorney, Clarence Darrow, was afterwards brought. to trial for attempting to bribe a prospective juror, but acquitted; at the end of $19 \mathrm{I} 2$ he was awaiting trial on another similar charge. As a sequel to the McNamara case: forty-five officials or former officials of the Association were brought to trial at Indianapolis in October, 19ז 2, upon the charge of conspiracy to transport explosives from state to state upon passenger trains. One of the defendants pleaded guilty. As the trial advanced, there was unfolded a remarkable story of criminal machinations, and eventually a verdict was returned for the prosecution.

During the past two or three years the growing alertness of public opinion has been illustrated by the exposure of political corruption in all parts of the country and in the Political electorate as well as in the government service. One of the most disturbcorruption. ing revelations occurred in Adams county, Ohio, where, largely on the testimony of political workers who turned state's evidence, more than a quarter of the electorate were convicted of selling their votes. They were sentenced to a fine and disfranchisement for five years. Judge Blair, who conducted

${ }^{2}$ The vote for Reimer, Socialist Labor candidate for president in 1912, was less than 40,000 . 
the inquiry, declared that similar conditions prevailed in other parts of Ohio and in neighbouring states. In the same year, I9ri, detectives employed by a citizens' committee found evidence which led to the indictment of nineteen members of the Ohio legislature on charges of accepting bribes, and up to the end of Igr 2 the sergeant-atarms and one senator had been convicted. In Illinois (q.v.) the confession of several members of the legislature indicated that William Lorimer had been elected to the United States Senate in I909 by the use of bribery; and for over two years progressives of both the leading parties made a determined effort to have the election invalidated. The Senate first decided in March, I9I I, that there was no evidence to connect Lorimer with the bribery, and that, even without the votes known to be tainted, he had been elected by the proper majority. This decision was generally regarded as a set-back for the cause of clean government. In deference to public protests and in view of the disclosure of new evidence the case was reopened. In May, r91 2, the investigating committee reported once more in favour of Lorimer; but two months later the Senate voted to unseat him. Senator Stephenson of Wisconsin (q.v.), who admitted spending more than $\$ 100,000$ in his primary campaign, was allowed to keep his place. Instances of municipal corruption have been revealed in Detroit, Pittsburg, New York, and other cities. In New York (see NEW YORK), the murder of a gambler who was about to expose the system of police graft led to the indictment of four " gunmen " for the actual shooting, and of a police lieutenant named Charles Becker as the instigator of the crime. In trials which were remarkable for the absence of the usual delays and technical rulings, Becker was convicted in October, I912, and the four gunmen in November. An investigation of the police administration, conducted by the board of aldermen, disclosed some facts of a disquieting nature; and the mayor, by way of a counterblast, charged members of the board with corruption in the granting of licences.

While the probity of judges is not often impugned in the American press, it is well enough known that they sometimes pay large sums for their nomination, and that their decisions sometimes show a tender regard for corporations. Corruption Recently the courts have been criticised with unusual freedom. Mr. Roosevelt and obscur has been chiefly instrumental in directing public sentiment against the antism in corrupt or merely obscurantist action of certain courts in erecting constitutional barriers to the enactment of necessary social legislation. Surely it is pertinent to ask why the court of appeals in New York should be allowed to prevent the legislature from enacting an employers' liability law such as the Supreme Court of the United States has declared valid under the "due process of law " clause of the Federal Constitution. In Igr 2 two Federal judges were involved in scandals. The House of Representatives presented to the Senate, in July, articles of impeachment against Judge Robert W. Archbald (b. I 848) of the commerce court, the charges relating generally to business transactions with railroad companies at times when the companies were litigants before his court or the Interstate Commerce Commission. The trial before the Senate began in December I9I 2 and he was found guilty early in I9I3. The House also investigated the conduct of Cornelius Hanford, a district judge in the state of Washington, who was charged with " a long series of corrupt and unlawful decisions" and with being guilty of intemperance. Threatened with impeachment, he resigned. The public are also showing increasing impatience with the delays of justice and the technicalities of procedure. The widespread recognition of this evil will undoubtedly bring substantial reforms within the next few years. Congress, however, has as yet made no response to the demands which the President has frequently made for legislation upon this subject. Late in I9I 2 the Federal Supreme Court made important changes in its rules of procedure.

The existence of corruption is coming to be recognised as one of the chief obstacles to social and political advancement. The men who have felt this most strongly, believing that the sinister alliance between business and politics must be terminated and that the people must resume control of the government, have been styled "progressives." There have been progressives within both the Republican and Democratic parties; 
but the movement within the Republican party is more interesting because it led to a definite political schism in 1912 and the formation, under Mr. Roosevelt's leadership, of a new National Progressive party. The creed of the insurgent or proRise of the gressive Republicans was not well understood at first, even by themselves. Progressives. But, early in I9II, Senator Jonathan Bourne, Jr., of Oregon (see Oregon), with Senator Robert M. LaFollette (b. 1855) of Wisconsin (see WisconSIN) and various radical members of both Houses of Congress, formed the National Progressive Republican League. It formulated a definite programme and gave coherence to the aims of the progressives. The essential feature of that programme was popular control of the government; and this it designed to establish by various methods.

It advocated the direct primary. Either by mandatory or by optional laws or else by party rule the system has, in some form, made its way into all but half a dozen of The direct the states, sweeping away the old nominating conventions and substitutThe direct ing an election within each party. The object is to eliminate the boss, to
primary. primary. bring the plain citizen into participation, and to let the voice of the majority govern in the choice of candidates. Names are placed upon the primary ballots by petition, although in some states (as New York) the party committees may make designations and have them appear under the party emblem. It cannot be said that experience has demonstrated the superiority of this plan over the simpler arrangements which prevail in Canada and England. The number of signatures required for the petition and the limited time allowed for circulating it sometimes handicap poorer men or men who are not backed by an active organisation. It is also true that where a man must make a declaration of party affiliation in order to enter the primary, the secrecy of the ballot is impaired, and where no test is exacted, the primaries may be flooded by voters from other parties. But whatever the defects, it has at least met with popular approval; and it has enabled the people, in striking instances, to drive out the disreputable element and assume control.

The selection of the presidential candidate of the party has come within the scope of the direct primary. In 19ro Oregon took the lead in prescribing the choice of delegates to the national convention by that method. A considerable

Presidential preference pripuaries. for them. It was in Oregon also that voters were first permitted to express their choice for President directly. So keen was the interest in the primary campaign of 1012 within the Republican party, that thirteen other states-all but one of them in the North-provided for the presidential preference vote, legislation which had a decisive effect upon the future of the Republican party. There are objections to this plan. The delegates would be morally bound to vote as a unit in accordance with the expressed will of the majority in the state; and the unit rule in national conventions promotes deadlocks and boss control. Senator Albert Baird Cummins of Iowa (see Iowa), therefore introduced into Congress a bill establishing a national presidential preference primary; but it met with scanty support. As the new practice spreads, national conventions will do little more than register the popular verdict.

The Progressives also advocated the direct election of United States senators as against the present system of choice by the state legislatures. This would improve the Direct election of U.S. personnel of the Senate and save the legislatures from prolonged deadlocks; but it would also have the disadvantage of strengthening the Senate and senators.

thus accentuating the dispersion of power in the American system of government. The reluctance of Congress to initiate the necessary amendment to the Constitution has led to the adoption under state law of practices which actually violate the spirit of the Constitution. By the rules of the Democratic party throughout the South, and by statute in eight Northern states, a moral obligation rests upon the members of each party in the legislature to vote for the party candidate success- 
ful in the primaries. Ten Northern states have adopted the "Oregon plan," under which each candidate for the state legislature must stipulate whether he will follow implicitly the popular choice for senator expressed in the general election. Thus in 1909 the Republican legislature in Oregon felt constrained to choose a Democrat. In response to the general demand, a resolution providing for the popular election of Senators was brought into the Senate in July, I9I I. Apparently in the hope that the measure thus amended would be beaten by Democratic votes, an amendment was adopted giving the national government supervision over such elections. The Southerners took alarm, fearing the enfranchisement of the negro. But though they managed to defeat the resolution twice in I9II, they accepted it in IgI 2 believing that the Federal government would not assert its right to control the elections. This proposed I th amendment was ratified by Massachusetts, May 22, Arizona, June 3, and Minnesota, June 12, 1912, and by several states early in 1913.

A determined effort is also being made to prevent the lavish use of money in the elections, especially the money of corporations, which not infrequently subsidise both the leading parties in order to make doubly sure of favourable consideration Corrupt
Practices acts. afterwards. The legislation on the subject is, for the most part, very recent. The Federal law of 1907 prohibits all corporations from assisting candidates for national office and all corporations chartered by the United States from making any campaign contribution whatever; the law of rgro requires publicity in the case of expenditures made by individuals and organisations which take part in the Federal election campaign in two or more states; and the law of I9I I requires publication of the accounts of candidates for Federal office before and after the primaries and elections, and limits to $\$ 10,000$ and $\$ 5,000$ respectively the amounts which candidates for the Senate and the House may spend personally. More than three-quarters of the states have passed campaign publicity laws. Of these $2 \mathbf{I}$ prohibit corporations from contributing, and require the publication of accounts after the primaries as well as after the election. About the same number of states limit the amount of expenditures, either by fixing a definite maximum for each office or a percentage of the first year's salary or a sum varying with the number of votes cast for the office in the last election. The Wisconsin law of IgII is considered very complete. In conformity with the most approved tendency it enumerates the purposes for which expenses may be incurred, instead of merely forbidding, as state laws used to do, certain specified acts such as intimidation and bribery. Candidates and their agents must both file itemised statements. An interesting feature is the publicity pamphlet, published by the state and sent to all voters, in which candidates may print their biographies and indicate the policies for which they stand.

None of the reform ideas promise more for the improvement of American politics than the Short Ballot principle. The multiplication of elective offices which took place

The short ballot. toward the middle of the nineteenth century has overburdened and confused the voter, making him accept the straight party ticket without considering the merits of the candidates. Some of the primary ballots in New York in I912 were fourteen feet long. It is now proposed to strike at the power of the political boss and the political machine by placing in the hands of the voter a ballot which he can mark more simply and intelligently. In state government the tendency is to bring the administrative officers directly under the control of the governor, thus centring executive responsibility and power. California has eliminated two officers from the elective list; Illinois; Ohio, and New York are expected to follow suit. A beginning has also been made toward the reform of county government along the same lines. The short ballot idea was endorsed by the three leading candidates for president in I9I2. The idea has won its chief success, however, in the adoption of what is known as commission government. Up to the end of I9I 2 more than 200 cities in thirty-four states had substituted for the mayor and council a small board elected on a general ticket and wielding both executive and legislative power. Recently two large cities, New Orleans and St. Paul, have adopted this form of government. 
Whether or not the small board will be permanently retained, respect for two cherished American theories has been seriously impaired-the election of both political and administrative officers, and the separation of executive from legislative power.

In view of the attitude taken toward the question in the campaign of 1912, woman suffrage may be regarded as another of the Progressive principles. Presumably it has

Woman suffrage.

a bearing upon the movement for the uplifting of politics. Down to I9I2 women enjoyed a limited suffrage, chiefly in relation to the schools, in twenty-three states, and full suffrage in Colorado, Idaho, California, Utah, Washington, and Wyoming. In that year proposed constitutional amendments conferring the privilege were defeated in Ohio, Michigan and Wisconsin, but ratified in Arizona, Kansas and Oregon. The nine suffrage states cover about a quarter of the entire Union and contain nearly three million women of voting age. During the presidential campaign the National Progressive party incorporated a woman suffrage plank in its platform; in five states all the parties did so.

The direct primary, the corrupt practices acts, and other reforms are calculated to improve the quality of public officers. A process of rehabilitation is going forward. But meanwhile state legislatures and even executive officers, far from The Initiative, enjoying prestige, are viewed popularly with a profound distrust. This is

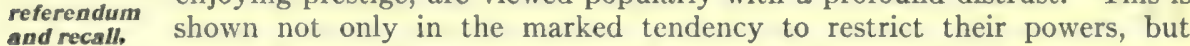
and recall, also in the assumption by the people of a more immediate share in government. No political phenomenon of the time is more significant than the spread of the Initiative, Referendum, and Recall. Under the Initiative, measures may be submitted to popular vote on the petition of a varying proportion of the voters (usually eight or ten per cent); under the Referendum, statutes passed by the legislature may be subjected to a popular vote upon the petition of a smaller proportion of the voters; under the Recall, the plebiscite may be invoked to determine if the people wish to remove a particular official and to effect such removal. In I9I 2 the Initiative and Referendum were adopted in Ohio, Mississippi, Nebraska, and Washington, thus making a total of fifteen states which employ this method of direct legislation. Three other states have partial systems; Wisconsin and North Dakota will vote upon the question in 19I4. The Recall has not spread so widely. Oregon adopted it in rgo8, California in I9II, Arizona and Washington in IgI2. North Dakota and Wisconsin will decide in I9I4 whether or not to adopt it. In Oregon, California, and Arizona the recall extends even to judges. Conservative men have denounced this as a fatal impairment of judicial independence. When, in IgII, Arizona (q.v.) applied for admission to statehood, the veto of President Taft forced the provision for the recall of judges out of the constitution, but, on acquiring statehood, Arizona took the first opportunity to restore it. In view of the reactionary decisions which the courts have so often given, and of the political power which they wield in interpreting general clauses of the constitution, the demand for a popular check upon them has increased. Mr. Roosevelt suggested in Igr 2 the recall of judicial decisions ${ }^{1}$ instead of the recall of judges, the people being allowed by plebiscite to determine whether a statute, pronounced invalid, should nevertheless become law under the state police power. This proposal appears to many to preserve judicial independence and open the way for social legislation.

The rapid progress in the adoption of the Initiative, Referendum, and Recall illustrates the growing impatience with constitutional restrictions and with " the check and balance system." There is no country in the world of Western civilisaThe decay tion where so many obstacles are raised as in the United States to the enactof constitu. ment of social legislation. Not only must executive and legislature agree, Honalism. but the courts must consent to an interpretation of the supreme law which will recognise the validity of an Act. Now, although the votaries of popular government will not admit it, their proposals are destined to work a fundamental change in American institutions. Not that the legislature will be supplanted; experience in

${ }^{1}$ In 1912 Colorado adopted a constitutional amendment for a popular recall of decisions by the state supreme court that laws were unconstitutional. 
Oregon has shown that the radicals are really bent on rehabilitating the legislature. ${ }^{1}$ But the distinction between constitutional and statutory law, which is a unique feature of the American system, is bound to break down. Already state constitutions have lost in substance, in many states, the character of constitutional law; they have become little more than bundles of statutes distinguished from other statutes only in name. The distinction in method of adoption is also breaking down; under the Initiative and Referendum in several states precisely the same method may be followed in amending the constitution or in passing ordinary laws. Will the judges care to say, especially with the Recall looming ahead, that a statute adopted directly by the people yesterday must give way to some vague provisions of the so-called fundamental law adopted a generation ago?

The effect of the popular propaganda was abundantly seen in the primary campaign for the presidential nomination. As delegates to the convention were to be chosen by The pre- direct vote in a considerable number of states, and as a presidential prefconvention erence primary had been established in twelve of them, the various aspirants campaign of both parties showed a deference to public opinion quite unusual at such of 1912 .

an early stage in the campaign. To an unprecedented extent they travelled about the country making speeches; enormous quantities of literature were circulated; money was spent with as much profusion as in the regular election campaigns. This was mainly due to the contest for control of the parties by conservatives and progressives. Senator LaFollette had come forward in December, I0I I, as the progressive candidate against President Taft; but following his temporary collapse in February, the governors of seven states united successfully in urging Mr. Roosevelt to accept the progressive leadership. It was felt that he alone could have good prospect of defeating the President for the nomination and of saving the party from disaster in the election. By the Democrats and by the conservative Republicans he was assailed for ignoring the tradition that the presidency should not be held by any man for more than two terms and he was charged with ignoring a specific pledge (differently interpreted by Mr. Roosevelt and his opponents), made by Mr. Roosevelt in I904, upon being elected to the presidency, that he would under no circumstances accept a renominationmeaning, according to his followers, that he would not accept a nomination in 1908 . That these attacks carried little weight with the people was evident from the fact that Roosevelt secured the great majority of those delegates who were elected directly, and completely outdistanced Taft in the preference vote. The latter denounced the progressives as "emotionalists and neurotics," who would " hurry us into a condition which would find no parallel except in the French Revolution." With Mr. Roosevelt he had a bitter exchange of personalities; and some thought that his participation in the campaign had impaired the dignity of the presidential office. Within the Democratic party the prominent candidates were Oscar W. Underwood, leader of his party in the House of Representatives; Speaker Chamb Clark, ${ }^{2}$ a man of great popularity rather than of intellectual distinction; Governo. Judson Harmon ${ }^{3}$ of Ohio; and Governor

\footnotetext{
${ }^{1}$ But see OREGon for the proposed (but defeated) constitutional amendment for a onechamber legislature.
}

${ }^{2}$ Champ Clark was born in Anderson county, Kentucky, March 7, 1850; studied at Kentucky University, Bethany College, and Cincinnati Law School; was president of Marshall College, West Virginia, in 1873-74; and was admitted to the bar in 1875 , practising after 1880 in Bowling Green, Missouri. He was a Democratic representative in Congress in 1889-91, $1893-95$ and since 1897 ; being minority leader in 1907-I I and becoming speaker in 1911. In 1904 he was permanent chairman of the Democratic National Convention.

${ }^{3}$ Harmon was born near Cincinnati on February 3,1846 , the son of a Baptist minister of New England descent. He graduated at Denison University, Granville, in 1866 , and at the Cincinnati Law School in $\mathbf{1} 869$. He was judge of the superior court of Cincinnati in 1878-88, attorney-general in Cleveland's cabinet from June 8, 1895, to March 5, I897, and governor of Ohio since I909. In October $\mathbf{I} 896$ he argued the first great anti-trust case, the Trans-Missouri freight case (see $E . B$. xiv, 7 I $3 \mathrm{~d}$ ), and secured a reversal by the U. S. Supreme Court of a decision for the railway in the lower courts. Attorney-General Moody retained him as special counsel in the Santa Fe case. 
Woodrow Wilson ${ }^{1}$ of New Jersey, formerly president of Princeton University, whose political administration had been characterised by great vigour and independence, and whose reputation as a publicist stood very high. Mr. Bryan (see E. B. iv, 697) announced that he would not offer himself as a candidate; but his attitude toward the various aspirants was felt to be important. In a series of speeches he denounced Governor Harmon as " a reactionary and the choice of the predatory interests," saying that either Speaker Clark or Governor Wilson would meet with his approval.

As the primary campaign proceeded, the public utterances of President Taft and Mr. Roosevelt were marked by increasing bitterness; and the irreconcilable differences between these leaders spread to the rank and file of the party. When the The Republican convention met at Chicago on June 18, 1912, it was evident nominating
conventions that everything depended upon the decision of more than two hundred and - Republican fifty contests. Mr. Roosevelt denounced as theft the action of the national and Progres- committee in placing only 19 of his contestants upon the temporary roll.
sive.

But an appeal to the convention was lost by more than fifty votes; and it was by about the same margin that the selection of Senator Elihu Root (see E. B. xxiii, 7II) as temporary chairman was made. When the committee on credentials decided against the seating of his contesting delegates, Mr. Roosevelt denounced their conduct as fraudulent and advised his followers to take no active part in the proceedings. Accordingly most of them sat in silent protest while the platform was adopted and the nominations made. President Taft received 56r votes on the first ballot, or twenty-one more than the necessary majority. Vice-President Sherman (see Obituary, below), who was also renominated, died a few days before the general election. ${ }^{2}$

The disruption of the Republican convention led to the birth of a new party which took the name of National Progressive and appealed for the support of Democrats and Progressives alike. Its convention was held in Chicago early in August.

The new Progressive party.

There Mr. Roosevelt made a declaration of his political views, which were received with enthusiasm and embodied in the platform. He was nominated for president, and Governor Hiram Johnson of California (see CALIFORN1A) for vice-president. The convention was remarkable for several things: the absence of professional politicians, the prominent part taken by women and social workers, and the quasi-religious fervor which pervaded it.

1 Woodrow Wilson was born in Staunton, Virginia, on December 28, 1856, the son of Joseph R. Wilson, a Presbyterian clergyman and professor of theology. He graduated at Princeton in 1879 , studied law at the University of Virginia and practised in Atlanta, Georgia, in $1882-83$, and in 1886 received the degree of doctor of philosophy at Johns Hopkins University. He was associate professor of history and political economy in I885-88, at Bryn Mawr. and in $1889-90$ at Wesleyan University, where he acted for a time as foot-ball coach. From I 890 to 1902 he was professor of jurisprudence and politics at Princeton, of which he became president on August I, 1902. This position he resigned on October 20, 1910 and in November he was elected governor of New Jersey (by 233,682 to 184,626 votes for Lewis, Republican). As president of Princeton he attempted to democratise the University and aroused the opposition of many wealthy alumni by his criticism of the upper class clubs. In a controversy over the site and plan of a graduate school he argued for buildings on the present campus, and the faculty and alumni were divided between him and Andrew Fleming IVest (b. 185.3), dear: of the graduate school, who wished a separate campus for the elaborate graduate school he planned. At the age of twenty-three Wilson had published in the International Recienv (August 1879) the outline of his Congressionai Government, which appeared in I885. His The State (I889) has become a standard work. He wrote, besides, Division and Reunion, I820-18\$0 (I893), a short volume in a series on U.S. history; two volumes of (Msays, An O)d Muster and Mere Literature (1893); a life of Washington (1896), and a popular IIistory of the American People (1902). As governor of New Jersey (q.8.) his administration was marked by legislative reforms and by the defeat of the "machine" element in the Democratic party. In 1912 he favoured the Initiative and Referendum, which he had formerly "spposed. See the biography (1912) by IV. B. Hale; H. E. Hosford's Woodrow Wilson and Vene Jersey Made ()ere (I9I2); A. I. P. Dennis in Contemporary Review, Dec. I9I2, and W. G. McAdoo and Bliss Perry in The Century, Mar. 19I3.

${ }^{2}$ The electoral votes of Utah and Vermont were formally cast for Taft for president, and for Nicholas Murray Butler of New York (president of Columbia University) for vicepresident. 
The cleavage between the conservative and radical wings of the Democratic party was clearly exposed when the national convention met at Baltimore on June 25. AlThe though a conservative, Alton Brooks Parker (b. 1852; chief justice of the

nominating conventions Democratic New York court of appeals in I898-I904; Democratic candidate for the presidency in 1904), was chosen temporary chairman over Mr. Bryan, the latter's influence proved decisive in the choice of the permanent chairman and in the passage of a resolution attacking members of the party connected with Wall Street. Moreover the " unit rule," under which state delegations deliver a solid vote, was modified so as not to apply to delegates elected by districts under state primary laws. The permanent chairman was Ollie M. James of Kentucky (senator elect; representative in Congress since I903), who was a lieutenant of Mr. Bryan. It required forty-six ballots to select the presidential candidate. On the first, Clark had $440^{\frac{1}{2}}$, Wilson 324 , Harmon 148 , Underwood $117 \frac{1}{2}$, Marshall 31 , Bryan I. When, on the tenth ballot, the Tammany-controlled New York delegation transferred its ninety votes from Harmon to Clark, Bryan declared that, as long as that situation lasted he would withhold his vote from Clark. That declaration had much to do with the final success (on the 46th ballot) of Governor Woodrow Wilson. Governor Marshall $^{1}$ of Indiana was nominated for the Vice-Presidency. Among the minor parties neither the Independence League nor the Populists put a national ticket in the field The Prohibition party nominated Eugene W. Chafin (b. I852) of Arizona, its candidate in 1908 , and Aaron S. Watkins (b. 1863) of Ohio, candidate for governor in I905 and for vice-president in 1908; the Socialist Labor party, Arthur E. Reimer of Massachusetts and August Gilhaus of New York, the party's candidate for president in I908; the Socialist party, Eugene V. Debs (b. 1855) of Indiana, candidate of the Social Democrats in 1900 and of the Socialists in 1904 and 1908 , and Emil Seidel (b. 1864) of Wisconsin, Socialist candidate for governor in 1902 and mayor of Milwaukee in I9ro-12.

The platforms of the three leading parties held similar views upon a number of points, such as the reform of legal procedure, the establishment of a parcel post, and the maintenance of an adequate navy. But they had, of course, distinctive

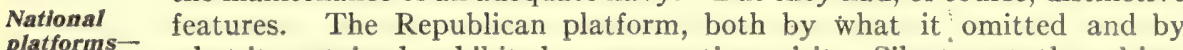
platforms-
Republican. of social legislation and the methods of bringing government nearer to the people, it laid emphasis upon the necessity of preserving the integrity and authority of the courts as the protectors of individual and property rights. It reaffirmed belief in a protective tariff high enough to furnish a revenue and give protection to American industries, readjustments to be made in accordance with the findings of an expert commission. With respect to the anti-trust law supplementary legislation should "define as criminal offences those specific acts which uniformly mark attempts to monopolise trade." In his speech of acceptance, President Taft made it appear that there were two issues in the campaign: the preservation of representative government supported by an independent judiciary, and the encouragement of business expansion through the free use of capital.

The Democrats and Progressives agreed on a number of points: the physical valuation of railroads, a regular Territorial government for Alaska, trial by jury for indirect

1 Thomas Riley Marshall was born at North Manchester, Indiana, on March I4, I854; a grandnephew of John Marshall, chief justice of the United States, and on his mother's side a descendant of Charles Carroll of Maryland, signer of the Declaration of Independence. He graduated at Wabash College, Crawfordsville, in 1873 , was admitted to the bar in 1874 , was prominent in local politics but ran for office only once, in I880, when he was defeated for prosecuting attorney, before his nomination in 1908 for governor of Indiana. He was elected by 14,800 plurality over James E. Watson, Republican. As governor his principal work was the proposed state constitution which the Indiana supreme court decided could not be submitted to the voters of the state in I9I2; see INDIANA. He enforced local laws against racetrack gambling. He favoured the direct election of U.S. Senators; and opposed ship subsidies, protective tariff and a Federal inheritance tax. For his views of reform by legislation and of the curse of over legislation see his "Automatic Citizen," Atlantic Monthly, Sept. I9I2. 
contempt of court, limitation upon the use of injunctions, the spread of the direct primary and other instruments of popular rule, etc. But the Democratic programme was much less comprehensive and, except for the tariff, much less radical. Democratic It insisted upon the old doctrine of state rights, a single term for the Presiand Progres" dent, the abolition of protective duties (but by legislation which "will sive. not injure or destroy legitimate business "), and supplementary legislation to give the anti-trust act more definiteness and override the court's interpretation.

The most characteristic feature of the Progressive platform was the attention which it gave to the subject of social welfare and industrial justice. As a means to this end it advocated a more expeditious method of amending the Federal Constitution, the recall of judicial decisions, the right of appeal to the Supreme Court in cases where the highest state court should hold laws invalid under the Federal Constitution, and the bringing under effective national jurisdiction of those problems which have expanded beyond the reach of the states. The proposals with respect to the labouring class included minimum safety and health standards, prohibition of child labour and night work for women, minimum-wage standards for women, and much else. On the tariff, the Progressives differed from the Republicans only in demanding the immediate downward revision of excessive duties. They did, however, take a very different position with respect to the trusts, wishing to place their regulation under an administrative commission. They advocated woman suffrage.

The campaign presented peculiar features from the fact that it was a three-cornered contest. Each party had to fight the other two. The Republican cause, for which there seemed little hope, was badly managed; its appeal was addressed to The came the conservative class, who were told that Mr. Roosevelt and his party paignand
the elections. menaced the time-honoured institutions of the country. The Democrats the elections. emphasised the evils of the protective tariff, holding it responsible for the high cost of living and the corrupt alliance between business and politics. On this issue the other two parties opposed them, while, with respect to the trusts, Democrats and Republicans held to fairly similar positions as against the Progressives. The latter directed attention to the need of a constructive social policy. Their desire to break the "Solid South" and to attract Democratic voters was shown by Mr. Roosevelt's attitude towards the negro. He announced that the new party could not be built up in the South "by relying on and appealing to the negroes;" and in the settlement of contests between Southern delegates the national convention acted upon this principle. Although Mr. Roosevelt was received with enthusiasm during a speaking tour through the South, he managed to divert very few Democratic votes in the election. The concern expressed through the country when he was shot by a fanatic at Milwaukee on October 24 evidenced his great personal popularity. He addressed a mass-meeting for an hour and a half after being wounded. Democratic success in the elections, though foreshadowed by the disruption of the Republican party, was more complete than had been generally expected. Taft won only two states, Utah and Vermont, with 8 electoral votes; Roosevelt won California (i I of I 3 vutes), Michigan, Minnesota, Pennsylvania, South Dakota, and Washington, with 88 electoral votes. All the other states went for Wilson, who received 435 electoral votes. Sweeping though the victory was, it seems to have been mainly due to the split in the Republican party. Wilson had a plurality of more than two millions over Roosevelt, but he did not have a majority of the popular vote. The new Congress is Democratic in both branches. In the House almost exactly two-thirds of the members are Democrats; and the capture of state legislatures which had previously been Republican insured a small Democratic majority in the Senate. Out of 28 governors elected all but ten were Democrats. Mr. Wilson was formally inaugurated, March 4, I9r3. His cabinet is: W. J. Bryan, State; W. G. McAdoo, Treasury; Lindley M. Garrison, War; J. C. McReynolds, Attorney-General; A. S. Burleson, P'ostmaster-General; Josephus Daniels, Navy; F. K. Lane, Interior; D. F. Houston, Agriculture; W. C. Redfield, Commerce; W. B. Wilson, Labor.

(E. M. SaIt.) 


\section{American Obituary}

The following persons, separately noticed in the Encyclopaedia Britannica, died between the publication of that work and the end of 1912.

Thomas Ball (b. I819; see E. B. iii, 263), sculptor, on December 11 , I9r 1 .

Clara Barton (b. I82 I; see E. B. iii, 452), philanthropist, on April 12, I9I2.

John Bigelow (b. 1817 ; see $E . B$. iii, 922), diplomat and journalist, in New York City, on December I9, I9II.

Cornelius Newton Bliss (b. 1833 ; see $E . B$. iv, 72 ), merchant and politician, on October 9, IgII.

Robert Collyer (b. I823; see E. B. vi, 694), Unitarian preacher and author, in New York City, on November 30 , I912.

Mary Baker (Glover) Eddy (b. 1822; see E. B. vi, 29Ia and 830c), founder of Christian Science, at Boston, on December 4, 1910.

George Cary Eggleston (b. I839; see E. B. ix, I6b), writer, on April I4, 1911 .

Horace Howard Furness (b. I 834 ; see E. B. xi, 362), Shakespearean scholar, at Walling. ford, Pa., on August 13, 1912. He edited Anthony and Cleopatra in the Variorum Shakspeare in 1907.

William Watson Goodwin (b. I831 ; see E. B. xii, 240), Greek grammarian, at Cambridge, Massachusetts; on June I5, I912.

Frederick Dent Grant (b. 1850 ; see E. B. xii, 358c), army officer, commanding Eastern Division, in New York City, on April 11 , 1912.

John Marshall Harlan (b. 1833; see E. B. xii, 954), justice of U.S. Supreme Court, on October I4, I9I I.

Edward Harrigan (b. I 845 ; see E. B. xii, I7), actor and playwright, on June 6, I9I I.

Jonathan Scott Hartley (b. I 845 ; see E. B. xiii, 35), sculptor, on December 6, I9I2.

Thomas Wentworth Higginson (b. 1823; see E. B. xiii, 455), author, on May 9, I.9I I.

Henry Christopher McCook (b. I 837 ; see E. B. xvii, 205d), naturalist, on October 31, I9II.

John James McCook (b. I845; see E. B. xvii, 205c), soldier and lawyer, on September I7. $191 \mathrm{I}$.

Francis Davis Millet (b. I846; see E. B. xviii, 466), painter and author, in the "Titanic" disaster, April 15, 1912. He had been recently appointed head of the American Academy at Rome.

Roger Quarles Mills (b. I832 ; see E. B. xviii, 475), legislator, on September 2, I9I I.

Sara Agnes Pryor (b. I830; see E. B. xxii, 533b), author, on February 15, 1912

Howard Pyle (b. 1853 ; see E. B. xxii, 679), artist and author, near Florence, Italy, on November 9, I9II.

Whitelaw Reid (b. 1837; see E. B. xxiii, 52), diplomat, in L.ondon, on December 15, I9I2.

Winfield Scott Schley (b. 1839 ; see E. B. xxiv, 34c), naval officer, in New York City, on

October 2, I9II.

Frederick Porter Vinton (b. I 846 ; see E. B. xxviii, IOI), portrait painter, on May 20, I9I I.

Elizabeth Stuart Phelps Ward (b. 1844; see E. B. xxviii, 319), author, on January 28, 1911. Among her later books were: The Oath of Allegiance (I909) and Comrade (1911).

James Baird Weaver (b. I833, see E. B. xxviii, 439), politician, on February 6, 1912. In 1904-06 he was mayor of Colfax, Iowa.

The following is a series of brief sketches of some of the more important Americans ${ }^{1}$ not separately treated in the itth edition of the Encyclopaedia Britannica, who have died since its publication:

John Arbuckle, business man, died in New York City on March 27, 1912. He was born in Scotland in 1838, and in I871 established in New York the house of Arbuckle Bros. which sold sugar and imported and roasted coffee for retail sale in packages, and in the sale of sugar and of coffee competed successfully with the "Sugar Trust." A terminal warehouse and a large towing and salvage business grew out of the coffee importation, and the house was very successful in raising wrecked vessels. Arbuckle established a farm-colony for the unemployed at New Paltz, N. Y. He was interested in horse-breeding and owned a large ranch in Wyoming. He left a large bequest for a memorial building under the care of Plymouth Church, Brooklyn, to be a home for young men and women.

Sidney Gillespie Ashmore, Latinist, professor at Union College since. 1881 , died in Schenectady, N. Y., on May 22, I9I I. He was born in London, April 15, 1852, graduated at Columbia University in 1872 , taught at Lehigh University in $1873^{-76}$ and at Columbia from 1876 until he went to Union, and wrote The Classics and Modern Training (I905) and edited with notes a complete text of Terence (I909), based on Tyrrell.

John Jacob Astor, capitalist, died when the "Titanic" sank, April I5, I9I2. He was born at Rhinebeck, New York, on July 13, 1864, the great grandson of John Jacob Astor (see

${ }^{1}$ Other obituary notices are included in articles on separate states of the Union. 
E. B. ii, 793), founder of the family. He graduated at Harvard in 1888 . He was colonel on the staff of Governor Levi P. Morton of New York and, in the Spanish-American War was lieutenant-colonel of volunteers, serving in Cuba, with a battery of field guns equipped and organised by him. The Waldorf-Astoria, St. Regis, Knickerbocker and Astor hotels in New lork City were built by him. He invented a turbine engine, a bicycle brake, etc., and wrote A Journey in Other Worlds (1890). His wife, née Madeline Force, whom he married in September 1911 after being divorced in 1909 by his first wife, Ava Willing, whom he had married in $189 \mathrm{I}$, was rescued from the "Titanic" and bore him a posthumous son. Almost all his enormous estate, probably $\$ 80,000,000$ at the least, was left to his son by the former marriage, Vincent Astor, who came of age November 15, 1912.

Francis Bacon, physician, died April 26, 1912. He was born in 1831, graduated at Yale Medical School in 1853 and, after service as a surgeon in the Civil War in $1861-64$, was professor of surgery at Yale in I $864-77$ and lecturer on medical jurisprudence from 1899 to his death. He was known as an alienist and an authority on yellow fever.

Henry Carey Baird, publisher and author, died in Wayne, Pennsylvania, December $3 \mathbf{I}$, 1912. He was born in Philadelphia, September I0, 1825, a grandson of Henry Carey (see $E$. B. v, 329), and was an exponent of Carey's protectionist views. On this subject and on the currency he wrote several tracts and his Philadelphia publishing house, Henry Carey Baird \& Co., specialised in technical and industrial books.

Willis Judson Beecher, Old Testament scholar, died, in Auburn, N. Y., on May 10, 1912. He was born at Hampden, O., April 29, 1838 and was ordained in the Presbyterian ministry in 1864, after graduation from Hamilton College in $185^{8}$ and from Auburn Theological Seminary in $186 \mathrm{I}$. With the exception of two charges of short duration, his life was spent in teaching. He was professor of moral science and belles-lettres at Knox College, 1865-69, and of Hebrew language and literature at Auburn Seminary, I87I-I908. He was president of the Society of Biblical Literature and Exegesis in 1904. He wrote: Father Tompkins and II is Bibles (1874), The Prophets and the Promise (1905), The Teaching of Jesus Concerning the Future Life (1906), The Dated Events of the Old Testament (1907), and Reasonable Biblical Criticism (191r).

Joel Benton, author, died September 15, 1911. He was born at Amenia, N. Y., May 29, 1832. He taught for a few years and then became a journalist and popular lecturer. He wrote: Emerson as a Poet (1882); The Truth about Protection, (1892); Greeley on Lincoln (1893); In the Poe Circle (I899), and many popular poems.

Emil Leopold Boas, American resident director and general manager (since 1892) of the Hamburg-Amerika Steamship Company, died at Greenwich, Conn., on May 3, I9I2. He was born at Görlitz, Germany on November I 5, I 854, and was educated in Breslau and Berlin. He came to the United States in 1873 , and was a prominent member of important clubs and organisations of a public character.

Lewis Boss, astronomer, director of Dudley Observatory (Union University), Albany, since 1876, died on October 5, 1912. He was born in Providence, R. I., October 26, 1846, and graduated at Dartmouth College in 1870 . He was assistant astronomer to the U.S. Northern Boundary Commission (1872) and a member of the American expedition to observe in Colorado the total eclipse of 1878 and chief of that to observe the transit of Venus in Santiago, Chile, in 1882; edited the Astronomical Journal (I909) and received the gold medal of the Royal Astronomical Society in 1905 and the Lalande prize of the French Academy of Sciences in I9II. His most important publications were star catalogues and essays on The Physical Nature of Comets (188I) and Solar Motion (I90I).

Amory Howe Bradford, Congregational clergyman, died February 18, I91 I. He was born in (iranby, N. Y., April 14, 1846, graduated at Andover Theological Seminary in 1870, and studied at Oxford. He became pastor of the First Congregational Church at Montclair, $\mathrm{N}$. J., in 1870 , and was associate editor of The Outlook from 1892 to 1899 . He was a prominent member of Congregational councils and missionary bodies in the United States and in Europe. He published more than fifteen books on religious subjects, including Spirit and Life (1888), Heredity and Christian Problems (1895), The Return to Christ (1900), The Age of Faith (1900), The Ascent of the Soul (1902), and The Inward Light.

Gamaliel Bradford, financier and publicist, died August 21, 1911. He was born in Boston, Mass., January 15, 1831 , and after graduating from Harvard in 1849 entered the banking husiness. In 1868 he retired and devoted the remainder of his life to the study of American institutions and government, especially the state and the municipality. He was an independent in politics and an ardent opponent of the colonial extension of the United States. He wrote The Lesson of Popular Government (1898), and many articles and monographs.

Edward Stuyvesant Bragg, soldier and legislator, died June 20, 1912. He was born at Unadilla, N. Y., February 20,1827 , studied at Hobart College in $1844-47$, and was admitted to the New York bar in 1848 . He removed to Wisconsin in 1850 . In the Civil War he was commissioned brigadier-general of volunteers, June 25, I864. He became a prominent member of the 1 ) emocratic party and was a representative in four Congresses (1877-83). When seconding the presidential nomination of Grover Cleveland, in 1884 , he used the famous phrase, "We love him for the enemies he has made." He was American minister to Mexico 
in 1888-89. He supported the candidacy of McKinley (1900), and was consul-general at Havana (1902) and at Hong-Kong.(1902-06).

George Jarvis Brush, American mineralogist, died February 6, 1912. He was born in Brooklyn, N. Y., December I5, I83I. He studied chemistry and mineralogy in New Haven and in Europe; and after teaching at the University of Louisville and the University of Virginia, became professor of metallurgy (1855) and of mineralogy (1864) at the Sheffield Scientific School of Yale University. From I 872 to 1898 , when he became professor emeritus, he was director of that institution.

Charles Stedman Bull, physician, died April 17, I9I1. He was born in New York City, graduated at the medical school of Columbia in 1868 , and completed his studies at several European universities. His specialty was ophthalmology, which he taught at the Cornell University Medical College, and practised in St. Luke's and other hospitals in New York City. He was president of the American Ophthalmological Society in 1903-07.

Daniel Hudson Burnham, architect, died in Heidelberg, Germany, June I, 1912. He was born in Henderson, N. Y., September 4, I846. He studied architecture in Chicago, and established himself there. Many famous buildings in American cities, including the Rookery and Temple, Chicago, and the "Flatiron," New York, as well as Selfridge's, London, were designed by him. He was chief architect of the Columbian Exposition, Chicago, I893. He was chairman of the national commission for beautifying Washington, D. C., and of the committee for remodelling Cleveland, Ohio. He also planned extensive alterations for Manila, San Francisco, and Chicago.

Silas Wright Burt, civil-service reformer, died in New York City, November 30, 1912. He was born in Albany, N. Y., April 25, 1830, graduated from Union College in 1849 , and practised as a civil engineer for some years. About $\mathrm{I} 867$ he began to take deep interest in civil-service reform and when, two years later, he was appointed special deputy naval officer of the port of New York he had the opportunity of studying the evils of the spoils system. He induced the naval officer to permit a competitive examination for promotion, which was however limited to persons whose applications for promotion were on file, and this was practically the beginning of the merit system. He was chairman of the supervisory examining board in New York, 1872-75, and was twice naval officer (1878-83; I885-89) of the port of New York, chief examiner of the state civil service (1883-85), and a member of the state civil service commission from 1895 to 1900 , and president in 1900 . One of the founders (1880) of the Civil Service Reform Association of New York, he was its president in 1907.

Arthur Tracy Cabot, surgeon, died in Boston, November 4, 1912. He was born there on January 5, 1852, graduated from Harvard College in 1872 and from Harvard medical school in 1876 , and studied in Vienna and Berlin. He was a fellow of Harvard University, chairman of the state commission on hospitals for consumptives, consulting surgeon of many hospitals, and a member of the American Association of Genito-Urinary Surgeons, etc.

Will Carleton, verse-writer, died in Brooklyn, New York, on December I8, 1912. He was born in Hudson, Michigan, October 2I, I845; graduated at Hillsdale College in I869; was in newspaper work in Chicago and Detroit in 1870 and I87I and in the latter year published in the Toledo Blade a poem "Betsy and I are out," which won such great popularity by its colloquial style and simple homely character that he left the Detroit Tribune to write verse and to be a lecturer and public reader of his writings. His published volumes, which had a large sale, include Farm Ballads, Farm Legends, Farm Festivals, City Ballads, Rhymes of Our Planet, In Old School Days.

John Merven Carrère, architect, died in New York City from injuries received in a cab accident, March I, I9II. He was born in Rio de Janeiro, Brazil, November 9, $185^{8}$. $\mathrm{He}$ was one of the first Americans to study at the École des Beaux Arts, Paris. In New York he' became associated with McKim, Mead \& White, and in I 885 formed a partnership with Thomas Hastings. Their first important work, the Ponce de Leon Hotel at St. Augustine, Fla., placed them in the front rank of their profession. Among their other noted buildings are the New York Public Library, and the Senate and House of Representatives Office Building in Washington.

Henry Beebee Carrington, soldier, died in Boston, Mass., October 26, 1912. He was born in Wallingford, Conn., March 2, 1824, and graduated from the Yale law school in 1847. From I848 to I86I he practised law in Columbus, Ohio, and then took a prominent part in the Civil War, being appointed brigadier-general of volunteers in 1862 . After the close of the war he entered the regular army as colonel. He was in command at Fort Phil Kearny at the time of the Fetterman massacre (December I866) by the Sioux Indians. Wounded in a subsequent skirmish, he was retired from active service in 1870 , and was appointed professor of military science at Wabash College. In 1875 he began to map the battlefields of the American War for Independence, the basis of his valuable Battles of the American Revolution (I876) and Battle Maps and Charts of the American Revolution. From I 889 to I 89 I he was employed by the American Government to treat with the Indians. In 1904 he received the rank of brigadier-general, U.S.A. He also wrote Washington the Soldier (1899) and other works on American history, especially military.

William Campbell Clark, manufacturer, president of the Clark Thread Works of Newark, New Jersey, died on November 14, 1912. He was born in Paisley, Scotland, in 1863, of a 
family of thread makers, and in 1879 went to the United States, where he succeeded his uncle as president of the Clark Company, which introduced British methods of manufacture in the United States, and became one of the largest concerns of the kind in the country.

Charles Finney Cox, railway officer, died at Yonkers, N. Y., January 24, 1912. Born in Richmond Co., New York, January 16, 1846, he graduated at Oberlin College in 1869. He was for many years treasurer of the New York Central lines west of Buffalo.

William Demos Crum, negro physician, minister resident and consul-general to Liberia since June 1910, died in Charleston, S. C., of African fever, on December 7, 1912. He was born in Charleston on February 9, 1859, graduated at the Avery Institute there in 1875 and at the medical school of Howard University in 1881 , and practised medicine in Charleston. President Roosevelt appointed him port collector of that city in 1903, and in spite of local opposition and of the Senate not confirming his nomination, Crum administered the office from 1904 to 1910 , when he resigned. He was managing commissioner of the negro exhibit at the South Carolina Interstate and West Indian Exposition of $1901-02$ at Charleston.

William Bayard Cutting, lawyer and philanthropist, died March I, 19:12. He was born in New York City, January 12, 1850, graduated at Columbia College in 1869 and at the Columbia law school in $\mathbf{1 8 7 1}$, and practised law in New York City. With his brother, Robert Fulton Cutting (b. 1852), he was interested in the work of the Association for Improving the Condition of the Poor, in building model tenements, and in many movements, notably the Citizens' Union, for the improvement of municipal politics. 'He was an active member of the Protestant Episcopal Church.

Homer Calvin Davenport, cartoonist, died May 2, 1912. He was born in Silverton, Oregon, March 8, I 867, and was reared on a farm. He was a jockey, a railroad fireman and a circus clown before his talent for caricature found him employment on a San Francisco newspaper in 1892 . Three years later he went to New York, where he drew cartoons for the American and Journal, notably in the presidential campaign of I900, when he originated the dollar-mark suit of clothes in his cartoons of Mark Hanna, and a gigantic figure of the trusts which became well-known. He was interested in the breeding of Arabian horses in the United States, and imported a number of them from Arabia. His cartoons have been published in book form, and he wrote The Bell of Silverton and Other Short Oregon Stories.

George Davidson, geographer, died in San Francisco, Deccmber 2, I9I I. He was born in Nottingham, May 9,1825 , removed to the United States in 1832 , and was educated at the Central High School of Philadelphia. He became honorary professor of geodesy at the University of California in 1870 and professor of geography there in 1898 , and took a leading part in the study of the geography of western America, serving on government coast surveys on the Pacific Coast (in charge 1868-95), transit of Venus expeditions of U.S. government in $187+$ (Japan) and 1882 (New Mexico), and as president of the Pacific Geographical Society. In 1908 he received the Daly gold medal of the American Geographical Society.

Sarah S. Platt Decker, a national leader in the women's suffrage movement, died at San Francisco, Cal., July 7, I9I2. She was born at McIndoe Falls, Va., October I, I852. She worked successfully in Colorado for women's suffrage (adopted 1893), was president of the Women's Club of Denver, and served four years as president of the General Federation of Women's Clubs. In Colorado she was the first woman member of the state board of pardons, and later was appointed to the Colorado board of charities and corrections. She was also a member of the National Child Labor Committee and the state civil service committee. She was an earnest advocate of a sweeping anti-child-labour law, and urged the appointment of women to offices in institutions for juvenile delinquency. She had been twice a widow when she married Judge Decker of Colorado in 1901 .

John Fairfield Dryden, insurance official, died November 24, 1911. He was born at Farmington, Me., August 7, I839, and spent his youth at Worcester, Mass. He studied for two years at Yale University, but was prevented from graduation on account of ill health. Entering the insurance business as an agent, he made an exhaustive study of industrial insurance as practised in England, and in 1873 founded the present Prudential Insurance Co. of America, which, beginning as the Widow's and Orphan's Friendly Society, was the first successful industrial insurance institution in the United States. After 1881 he was president of the company. In 1880 by special act of legislature the right of policy holders to vote was withdrawn and the financial control came largely into his hands. He was. U.S. senator from New Jersey in $1902-07$.

Daniel Cady Eaton, art-critic, professor of the history and criticism of art in Yale University in 1869-76 and 1902-09, died on May 11 , 1912. He was born in Johnstown, N. Y., Junc 16,1837 , graduated at Yale in 1860 and at the Albany Law School in 1861, practised law until 1866, and then studied art in Berlin and Paris. He wrote handbooks of Greek and Roman sculpture ( $188_{4}$ ) and of modern French painting (I909).

Alice Morse Earle, author, died February 16, 1911 . She was born at Worcester, Mass., April 27, 1853 , and was married to Henry Earle, in 1874 . She wrote Customs and Fashions in Old New Iingland, Home Life in Colonial Days, Two Centuries of Costume in America, and many other works on similar subjects.

Samuel Franklin Emmons, economic geologist, died in Washington, D. C., March 28, 1911. He was born in Boston, March 29, 1841, graduated at Harvard in 1861 and studied 
in the schools of mining in Paris and Freiberg. He took part in the Fortieth Parallel Survey, and worked with Arnold Hague on the Descriptive Geology of that survey. In 1879 he was put in charge of economic geology in the Rocky Mountain Division of the U.S. Geological Survey, and worked at Leadville, preparing statistics on precious metals for the Ioth Census. The scene of his last labours was Leadville again, but final results of his investigations had not been published at his death.

Robley Dunglison Evans, naval officer, died January 3, 1912. He was born in Floyd county, Va., August 18, 1846. He was commissioned ensign in the American Navy in 1863 after graduation from the Naval Academy. He served with the North Atlantic Blockading Squadron, and was permanently crippled by a wound in the right leg in the land attack by sailors on Fort Fisher (December 25, 1864). In I 891 -92, commanding the "Yorktown" at Valparaiso, Chile, he displayed great ability and firmness in settling the trouble arising from the killing of several American sailors in that city. At this time he received the sobriquet "Fighting Bob." In the Spanish-American War he was captain of the battle-ship "Iowa," which took a prominent part in the destruction of Cervera's fleet off Santiago, Cuba. He was appointed rear admiral in I90I. He commanded the Asiatic station in I902-04 and the Atlantic fleet in 1905-08. On August 18, 1908 he was retired, and on account of ill health gave up command of the Atlantic Fleet, then on tour of the world. He wrote A Sailor's Log (I9OI), and An Admiral's Log (1910).

Arthur Henry Ewing, missionary, died at Allahabad, India, on September I3, 1912. He was born at Saltsburg, Pa., on October 18, 1864. He graduated at Washington and Jefferson College (1887), at Western Theological Seminary (I890) and at Johns Hopkins University ( 1891 ), was ordained to the Presbyterian ministry in 1890 , and became a missionary in India, where he was principal of a boys' boarding school at Ludhiana in I89I-08 and established the Christian College at Allahabad in I901. He was chairman of the united council on work among young people in India from 1907 until his death.

Rose Eytinge, actress, died December 30, 19r I. She was born in Philadelphia, November 21,1838 , and acquired great popularity in emotional rôles, in the United States and England, playing with Edwin Booth (1862), in Lester Wallack's company (1868) and with Augustin Daly, but seldom appearing after 1884 . For several years after 1870 she lived in Egypt where her husband (George H. Butler) was American consul-general. She dramatised several of Dickens' works, Browning's Colombe's Birthday, etc., and wrote a few novels and recollections of her life in Egypt.

Harry Fenn, artist, died April 24, I91 I. He was born in Richmond, Surrey, September 14, 1838, but went to the United States in 1857. He was best known as a book illustrator, especially of gift books (poetry, travels, etc.), but he also acquired considerable reputation as an aquarelle painter and was a founder of the American Water Color Society.

Isaac Nelson Ford, journalist, died in London on August 7, 1912. He was born at Buffalo, N. Y., June II, I848, graduated at Brown University in 1870 , and in the same year became a reporter for the New York Tribune, which he served as leader-writer, and, from I 895, as London correspondent. He was the founder of the London Pilgrims' Club. He wrote Tropical A merica (1893).

Sam Walter Foss, poet, died February 26, r9II. He was born at Candia, N. H., June I9, 1858, graduated at Brown University in 1882 , and was an editor and later a lecturer and public reader of his own verse. He was librarian of the Somerville, Mass., Public Library, from I 898 until his death. He published five volumes of verse (Songs of the Average Man, Dreams in Homespun, etc.) of a popular nature.

Paul Caspar Freer, chemist, died April 17, 1912. He was born in Chicago, I11., March 27, 1862 , graduated from Rush Medical College in 1882 , and subsequently studied chemistry in Germany (Ph.D., Munich, 1887) and in Owens College, Manchester, England. He taught at Tufts College in $1887-89$, and then became professor of chemistry at the University of Michigan. In I90I the American government sent Dr. Freer to Manila as superintendent of government laboratories. This organisation became, in 1905, the Bureau of Science of the Government of the Philippines, and he was made director. He was the pioneer in general scientific work in the islands, and built up a great research institution that is now classed with the best in the world. He was founder and editor-in-chief of the Philippine Journal of Science. The Philippine Medical School, founded in 1906 and now part of the University of the Philippines, was largely his own creation. He was dean of the College of Medicine and Surgery, and professor of chemistry in the University. He wrote several text-books of chemistry and many articles on the structure of ring compounds, etc.

William Pierce Frye, politician, died at Lewiston, Me., August 8, I9I I. He was born there September 2, 1831. He practised law after his graduation from Bowdoin College (1850) and after studying under W. P. Fessenden. Affiliated always with the Republican party, he was a member of the state legislature (1861, 1862, 1867), mayor of Lewiston (1866-67), attorney-general of Maine (1867-69), representative in Congress in $1871-81$, and successor to James G. Blaine in the U.S. Senate, where he served from 1881 until his death and was chairman of the commerce committee after $\mathbf{1} 889$. He was president pro-tem. of the Senate in 1896 and after I9OI and was a member of the Paris Peace Commission (I898) to negotiate terms of peace between Spain and the United States. 
Isaac Kaufman Funk, publisher and author, died April 4, I9I2. He was born in Clifton, O., September I0, I839, studied at Wittenberg College, and entered the Lutheran ministry in 1861. He edited (1872 seqq.) several ecclesiastical weeklies, notably The Homiletic Review. In 1877 he, with A. W. Wagnalls, formed the publishing house of Funk \& Wagnalls Company. The firm produced such noteworthy works as $A$ Standard Dictionary and the Jeruish Encyclopaedia, of which Dr. Funk was editor-in-chief or chairman of an editorial board; and published the Literary Digest. He was a Prohibitionist and in $\mathbf{1} 880$ established The Voice as a party organ; and he was much interested in the problems of psychic phenomena, and wrote, The Next Step in Evolution (1902), The Widow's Mite and Other Psychic Phenomena, (1904) and The Psychic Riddle (1907).

Jacques Futrelle, author, was lost with the "Titanic," April 15, 1912. His wife was saved. He was born in Pike county, Georgia, April 9, I875, and engaged in journalism (1890-1902) and theatrical management (1902-04). He wrote fiction of a popular nature, and his best known books are: The Chase of the Golden Plate (1906), The Thinking Machine (1907), and, published after his death, My Lady's Garter.

George Augustus Gates, educator, president of Fisk University (Nashville, Tenn.) from 1909, died at Wintershaven, Florida, on November 20, 1912. He was born in Topsham, Vermont, January 24, 1851, graduated at Dartmouth College in 1873 and at Andover Theological Seminary in $\mathbf{I} 880$, and in the same year was ordained a Congregationalist minister. After a pastorate of seven years in Lpper Montclair, New Jersey, he served as president of Iowa College in I887-I90I and of Pomona College (California) in 1902-09.

John Warne Gates, American capitalist, died in Paris, August 8, 1911. He was born near Chicago, Ill., in I855, and first displayed his great business ability as a travelling salesman, introducing barbed wire into Texas. He established himself in this business, and organised the Southern Wire Co. and later the Braddock Wire Co., which absorbed other companies. This was sold to the Federal Steel Co. in $\mathbf{I} 898$, and Gates organised the American Steel and Wire Co. now a part of the U.S. Steel Corporation. His activities were also extended to deals in railway and industrial stocks. He had undoubted talent, although his methods were often severely criticised, and he died possessed of a large fortune.

William Washington Gordon, soldier and merchant, died at White Sulphur Springs, Va., on September 12, 1912. He was born at Savannah, Ga., on October 14, 1834, and graduated at Yale in 1854. At the beginning of the Civil War he became 2nd lieutenant in J. E. B. Stuart's cavalry (the Georgia Hussars), and was afterwards captain and inspector of Mercer's brigade, and then captain and adjutant of Anderson's brigade, in Joseph Wheeler's cavalry. He was senior partner in the cotton firm of W. W. Gordon \& Co., and from 1876 to 1879 was president of the Savannah Cotton Exchange. From 1884 to 1890 he was a member of the Georgia House of Representatives. He served in the Spanish-American War as brigadier-general of volunteers, and was a member of the Porto Rican evacuation commission.

Charles Chapman Grafton, Protestant Episcopal bishop, since I889, of Fond du Lac, died August 30, 1912. He was born in Boston, April 12, 1830, graduated at the Harvard Law School in 1853, studied divinity with Bishop Whittingham of Maryland, and was ordained deacon in 1855 and priest in 1858 . He spent $1865^{-72}$ in England where he founded in 1865 with R. M. Benson the Society of the St. John the Evangelist, better known as the "Cowley Fathers," described in Hall Caine's The Christian. In 1872-88 he was rector of the Church of the Advent, Boston. He established the St. Margaret's Sisterhood in Boston, the Sisters of the Holy Nativity in Providence, R. I., and Grafton Hall, a school for girls at Fond du l.ac. He was a leader of the High Church party in America, and wrote Fond du Lac Tracts; Christian and Catholic (1905) and The Lineage of the American Catholic Church (I9I).

Benjamin Henry Grierson, military officer, died September I, 19II. He was born at Pittsburg, Pa., July 8,1826 , and entered the Union cavalry at the opening of the Civil War. He captured Baton Rouge in May 1862 with forces from Tennessee, as a part of Grant's opera. tions on Vicksburg, and the raids of his troops in Mississippi and Alabama in 1863-64, among the most brilliant minor performances of the great conflict, won him the brevets of brimadier and major-general, respectively. He became a colonel in the regular army in 1866 , and was retired in 1890 after reaching the rank of brigadier-general.

Clement Acton Griscom, financier, died November 10, 1912. He was born in Philadelphia, Ya., November 15, 1841, and in 1857 entered the shipping business, in which he rose to be general manager (1894) of the International Mercantile Marine (o. (originally International Vavigation $\mathrm{Co.}$.). This office he resigned in 1904 , assuming the chairmanship of the bard of directors. He was a director in many financial and industrial corporations.

Benjamin Guggenheim, capitalist, perished in the wreck of the "Titanic" on April 15 , 1912, ageel +7 . Ile was a member of the firm of M. Cuggenheim's Sons and of the American Smeltink \& Refining (o., with great interests in Colorado and Alaska.

Benjamin Morgan Harrod, civil engineer, died September 7, 1912. He was born in New Orleans, Fithruary 19,1837 , graduated at Harvard in 1856 , served in the Confederate army, becoming captain of engineers, and was state engineer in $1877-80$, member of the Mississippi River (Commission 1879-1094 and of the I'anama Canal Commission in 1904-07, city engineer of New (Orleans in $18 \times x-92$, and in charge of that city's drainage construction in 1895-1902. In $1897-98$ he was president of the American Society of Civil Engineers. 
Frank Davis Hill, consular official, died at Frankfurt-am-Main, Germany, on May 23, 1912. He was born in Minnesota, May 28, 1862, and was educated at the University of Minnesota, and at the Columbian and National Law Schools, Washington. He was admitted to the Bar in 1884 , and became consul at Asunción, Paraguay, in 1887 , in Montevideo (1890), La Guayra (1893), Santos (1896) and Amsterdam (1899). In I907 he became consulgeneral at St. Petersburg, in 1908 at Barcelona, and in I9IO at Frankfurt.

Edward Hitchcock, physician and teacher of physical culture, died February I I, I9I I. He was born at Amherst, Mass., May 23, 1828, a son of Edward Hitchcock (see E. B. xiii, 533), geologist and president of Amherst College. He graduated at Amherst College I849 and later at the Harvard Medical School. From I86I he was professor of hygienic and physical education at Amherst, being the first physician in the United States to take up this work. He was acting president of Amherst in 1898-99. He wrote Anatomy, Physiology and Anthropometry (1860) and A Manual of Gymnastic Exercises (1884).

Herman S. Hoffman, bishop of the Reformed Episopal Church since June I903, died in Philadelphia on November 23, I9I2. He was born near Salem, N. C., on June 9, I84I, studied in the Moravian theological seminary at Bethlehem, $\mathrm{Pa}$., was fordained to the Moravian ministry in 1864 , and founded five churches of that denomination in Philadelphia before I88I, when he became a member of the Reformed Episcopal Church. In I905 he became assistant bishop in charge of the New York and Philadelphia synods. He wrote Life Beyond the Grave (1898).

Edwin Eugene Howell, geologist and cartographer, died in Washington, D. C., April I6, 191 I. He was born in Genesee county, N. Y., March 12, 1845, and studied at the University of Rochester under the geologist Henry A. Ward; was geologist of the United States Geological surveys west of the Rocky Mountains in 1872-73, and was with the government survey of the Rocky Mountain region under Powell in 1874. In I870 he made a relief map of the island of San Domingo, and in I875 produced his famous relief map of the Grand Cañon of the Colorado, for the government. In his later years he devoted his time to the manufacture of geological models and maps first in the Rochester. Museum and then in an establishment at Washington which he called the Microcosm. He wrote on meteorites, and was a founder of the Geological Society of America.

John Wesley Hoyt, administrator and author, died on May 23, 1912. He was born near Worthington, Ohio, on October I3, I83 I, graduated at Ohio Wesleyan University in I849, studied law and then medicine at the Eclectic Medical Institute (Cincinnati), where he taught chemistry in 1853-57, and was editor and publisher of an agricultural paper at Madison, Wisconsin, in $1857-67$. He was an early member of the Republican party and in $1878-82$ was governor of the Territory of Wyoming. His interests and activities were varied: he was president of the international jury of awards on education and science at the Vienna Exposition of 1873 , at the Philadelphia Centennial Exposition of 1876 and at the New Orleans Exposition of $\mathbf{1} 884$, and special representative for foreign affairs at the World's Columbian Exposition of 1893; worked for the founding of a National University; and wrote, besides reports of the Wisconsin Agricultural Society (I860-72), of the same state's railway commission ( $1874-75$ ), and Federal reports on education in Europe and America (1870), Studies in Civil Service (1878) and histories (1893-95) of the universities of Bologna, Paris, Oxford and Cambridge in the Middle Ages.

Thomas Augustus Jaggar, Protestant Episcopal bishop, since May 1908, in charge of American churches in Europe, died December 13, I9I2. He was born in New York City on June 2 , I 839 , was a bank clerk before entering the ministry in I863, and held among other charges one at Yonkers, N. Y., where he established St. John's Riverside Hospital. From I 875 to I905 he was bishop of Southern Ohio. In 1900 he delivered the Bohlen lectures (Church of Holy Trinity, Philadelphia) on the personality of truth.

Edward Gamaliel Janeway, physic nn, died February IO, I9II. He was born in New Jersey, August 3 I, r 84I. He left his medical studies at Columbia University to act as medical cadet at the army hospital at Newark, New Jersey, during the Civil War, but took his degree in 1864 . His long connection with the University and Bellevue Hospital Medical College (from I 868) as curator and professor ended in 1905 with his retirement as professor of medicine and dean. He was a noted specialist on nervous diseases and in $1875^{-82}$ was health commissioner of New York City. He was the author of Clinical Points in the Diagnosis of Hepatic Affections.

Tom Loftin Johnson, capitalist and administrator, died in Cleveland, O., April Io, I9I I. $\mathrm{He}$ was born at Blue Spring, Ky., July i 8,1854 . He was a street railway owner and promoter in several large cities, including Detroit and Brooklyn. He became an ardent believer in the "single tax" doctrines of Henry George, and did much towards spreading them. He served as a Democratic representative in Congress in $1891-95$ and was mayor of Cleveland, Ohio, in I90I-I909, in which office he was partially successful in establishing a three-cent street railway fare (see $E . B_{\dot{*}}$ vi, 504d). See his autobiography, My Story (New York, I9II) and Carl Lorenz, Tom L. Johnson (ibid., I9II).

Adrian Hoffman Joline, American lawyer, died October 15, 1912. He was born in Sing Sing (now Ossining), N. Y., June 30, I850, and graduated at Princeton in I 870 and at the Columbia Law School in 1872 . He was admitted to the bar in 1872 , and became one of the best 
known corporation lawyers in the country. He was especially active in the management of railroad properties, and was receiver for the Metropolitan Street Railway Co. of New York after 1907. For some time he was a trustee of Princeton University. He was an ardent collector of autographs, and wrote Meditations of an Autograph Collector (1902); Diversions of a Book Lover (1903); At the Library Table (1909) and Edgehill Essays (1910).

James Otis Kaler, writer of juveniles under the pen-name "James Otis," died in Portland Maine, December II, I912. He was born in Winterport, Maine, March 19, I848, and after 1865 was in newspaper work, first on the Boston Journal and then on the New York Sun, until he was employed (1870) on Leslies' Boys and Girls. In I877 he wrote Toby Tyler as a serial in Harper's Young People and then devoted himself to books for children, notably the "Minute-Boy Series," writing nearly 150 volumes, including serials for St. Nicholas.

John Steinfort Kedney, professor of divinity in Seabury Divinity School, I87 I-I908, died at Salem, New Jersey, March 8, I9II; he was senior priest of the American Episcopal Church. He was born in Essex county, New Jersey, February 12, I819, graduated at Union College in 1838 , and at the Union Theological Seminary in 1841 , and was ordained priest in 1843. He was rector of several churches and lectured in the Concord School of Philosophy and in the Cambridge Episcopal Theological School. He wrote The Beautiful and the Sub. lime (1884), Hegel's Aesthetics (1886), and Problems in Ethics (1899).

John Mills Kendrick, Protestant Episcopal bishop (since January 1889) of Arizona and New Mexico, died in I9I2. He was born in Gambier, Ohio, graduated at Marietta College in 1856 , was admitted to the New York bar in 1858 , served two years in the Civil War, and in 1865 was ordained to the priesthood. He was rector of churches in Fort Scott and Leavenworth, Kansas, and in Columbus, Ohio, and in 1878-89 was general missionary of the diocese of Southern Ohio.

Frederick Keppel, art-dealer, died in New York City on March 5, 1912. He was born at Tullow, Co. Carlow, Ireland, on March 22, I845 and was educated at Wesley College, Dublin, and in England. In New York City he became a bookseller and then a print dealer and importer of pictures. He was an art critic of ability, and lectured on art at the Metropolitan Museum of Fine Arts and in Yale, Columbia, and Harvard universities. He published The Golden Age of Engraving, A Day with Whistler, and many articles in periodicals, especially in The Print-Collector's Quarterly.

Vaughan Kester, novelist, died July 4, I9II. He was born in New Brunswick, N. J., September I2, 1869, and was reared in Ohio. He portrayed types characteristic of the South and Middle West. Among his books are: The Manager of the B. and A. (I9OI); John o'Jamestown (1907); The Prodigal Judge (1911), and The Just and the Unjust (1912.)

Herman Knapp, physician, died May 1, I9I1. He was born at Dauborn, Prussia, May 17,1832 , and practised as an eye-and-ear specialist in New York after I868. He taught in the medical school of New York and Columbia universities, and founded the New York Ophthalmic and Aural Institute. He wrote a book on intraocular tumours, many papers on eye-and-ear surgery, and excellent text-books, and founded the valuable Archives of Ophthalmology and Otology.

James Proctor Knott, lawyer and legislator, died June 18, 191 1. He was born in Kentucky, August 29, 1830, and was educated at home. He practised law in Missouri and after 1863 in Kentucky, was a member of the Missouri state legislature in 1858 and state attorney. general in 1858-61. He was a Democratic representative in Congress from Kentucky in I 867-7I and $1875^{-83}$, and governor in $1883-87$. Between 1892 and I9OI he taught economics and law at Centre College (now part of Central University), Danville, Kentucky.

George William Knox, theologian, Union Seminary lecturer on Christianity in the Far East, died at Seoul, Korea, April 26, 1912. He was born at Rome, N. Y., August I1, 1853, graduated at Auburn Theological Seminary in 1877 , and was ordained in the Presbyterian ministry in the same year. The first years of his professional life were spent in missionary work and teaching in Japan, where he was, for a time, professor of philosophy and ethics in the Imperial University, Tokio, and where he received the Order of the Rising Sun. In 1897 he became a lecturer on apologetics in Union Theological Seminary, New York, and after 1899 , was professor of the philosophy and history of religion there. He wrote many books, mostly on religious subjects, both in Japanese and English-including The Direct and Fundamental Proofs of the Christian Religion (1903; N. W. Taylor Lectures at Yale), The Spirit of the Orient (1906), The Development of Religion in Japan (1907) and The Religion of Jesus (1909), - and contributed the article "Christianity" to the IIth ed. of the Ency. Brit.

William Mershon Lanning, judge of the U.S. Iistrict Court, for New Jersey, since June 1904, died February' 16, 1912. He was born in Ewing township, Mercer county, New Jersey, January 1,1849 , studied at Lawrenceville, and was admitted to the bar in 1880 . He was city solicitor of Trenton, 1883-87, judge of city district court, 1887-91, and (Republican) representative in Congress, 1903-04. He was a trustee of the General Assembly of the Presbyterian Church (North) and of Lawrenceville School, and a director of Princeton Theological Seminary.

Homer Lea, author, died at Los Angeles, November 1, 1912. He was born in Denver, November 17, 1876, and was educated in California, at Occidental College, the University of the Pacific and Leland Stanford Jr. Iniversity. Stories of his holding high rank in the 
Chinese reform army seem to have no basis of fact except his unsuccessful mission to China in 1900 and his militaristic ideals. He wrote The Vermilion Pencil (1908), The Valor of Ignorance (1909), urging the necessity of military training in the United States in case of Japanese invasion, and The Day of the Saxon, predicting the fall of the British Empire.

Ida Lewis, American lighthouse keeper, died October 24, I9II. She was born in Newport, R. I., in 1841 . In 1857 , when her father was incapacitated, she took up his work as keeper of the Lime Rock Light, Newport Harbor. Her official appointment by act of Congress (the first given to a woman) was dated I889. An expert rower and swimmer, she saved I 8 lives from drowning, receiving many medals, and a pension from the Carnegie Fund. In 1870 she married W. H. Wilson.

Morris Loeb, chemist, died in New York, October 8, 1912. He was born in Cincinnati on May 23, I863, graduated in I 883 at Harvard, where he studied under Wolcott Gibbs, whose assistant he was in I 888-89 after his return from Germany, where he worked under Hoffman in Berlin and Ostwald in Leipzig. He taught at Clark University in 1889-91 and then until his death was professor of chemistry in New York University. His principal chemical investigations were on the kinetics of substances in solution, osmotic pressure and crystallization of sodium iodide from alcohols. He was a member of a wealthy family and was prominent in Hebrew charities, to some of which he made large bequests, as well as to the American Chemical Society, the Smithsonian Institution, Cooper Institute, the American Museum of Natural History, the Metropolitan Museum of Art, and Harvard University.

Charles Battell Loomis, author, died September 23, I9II. He was born in Brooklyn, N. Y., November 12, I86I, and was a writer of humorous fiction and verse, his best known volumes being Yankee Enchantments (I900) and Cheerful Americans (1903).

Eben Jenks Loomis, astronomer, died at Amherst, Mass., December 2, 1912, He was born at Oppenheim, N.Y., November II, I 828, and was educated at the scientific school of Harvard University. He spent 50 years in work on the American Ephemeris and Nautical Almanac. He was also a naturalist, a Shakespearian scholar, and a poet.

Patrick Anthony Ludden, Roman Catholic bishop of Syracuse since May I 887, died in that city, August 6, 1912. He was born near Castlebar, Ireland, in 1836 , studied at St. Jarlath's College, Tuam, and at the Grande Séminaire, Montreal, and was ordained priest in 1864 . He was rector of the Albany cathedral and vicar-general, 1877-80, and after seven years at St. Peter's, Troy, New York, was consecrated first bishop of Syracuse. In I9 I I he urged the election of William F. Sheehan as U.S. senator from New York and declared that the opposition to Sheehan was due to his being a Catholic and of Irish descent.

Arthur MacArthur, army officer, died in Milwaukee, Wis., September 5, 1912. He was born in Springfield, Mass., June 2, 1845, but was educated in Milwaukee. He served in the volunteers in the Civil War, distinguished himself at Stone River, received a Congressional medal for bravery at Missionary Ridge, and became major at 19 and colonel before he was 20. He continued in the regular army and reached the high rank of lieutenant-general in 1906. As brigadier-general of volunteers he went to the Philippines during the SpanishAmerican War of 1898 , and was made major-general of volunteers for his service at the capture of Manila. He was military governor of the islands in r900-or, the most critical period of American occupation. On his return he commanded different military departments in the United States before he was retired in 1909.

Robert Lee MacCameron, portrait painter, died December 29, I9I2. He was born in Chicago, January I4, I866, and was brought up in Necedah, Wis., where he worked as a lumber jack when he was I4 years old. He became a newspaper illustrator in Chicago and later in New York and in London, on The Boys' Own, and in 1889 went to Paris, where he studied under Gerôme. He was made a chevalier of the Legion of Honor in July rgiz. Besides portraits of celebrities, English and American, his best-known pictures were "Absinthe Drinkers," "The Dancers" (honourable mention, Paris Salon), "The Daughter's Return" (in the New York Metropolitan Museum), and in general scenes from the slums.

Alexander Mackay-Smith, Protestant Episcopal bishop, died November 16, I9 I I. He was born in New Haven, Conn., June 2, 1850, and was ordained priest in 1877 , after studying at the General Theological Seminary and in England and Germany. In I902, after service as rector in South Boston, New York (where he was first arch-deacon in 1887), and Washington, he was made coadjutor-bishop of Philadelphia, and bishop in I9IO.

Willard Francis Mallalieu, Methodist Episcopal bishop, died at Auburndale, Mass., August I, I9II. He was born at Sutton, Mass., December II, I 828, and entered the ministry after graduation from Wesleyan University in 1857 . He held several charges in Massachusetts and in 1882 was made presiding elder of the Boston district. In 1884 he was elected bishop. He was a prominent member of many church boards and commissions, and advocated total abstinence and Sabbath observance. He wrote The Why, When, and How of Revivals, The Fullness of the Blessing of the Gospel of Christ, etc.

John William Mallet, chemist, died November 6, 1912. He was born in Dublin, Ireland, October Io, 1832 , and studied at Trinity College, Dublin and at Göttingen. He came to the United States in 1853 , and taught chemistry at Amherst, at the universities of Alabama, Louisiana, Virginia, and Texas, and at Jefferson Medical College in Philadelphia. During the Civil War, he had charge of the ordnance laboratories of the Confederate States. 
W J McGee (his full name), anthropologist and geologist, died September 4, I912. He was bnrn at Dubuque, Ia., April 17, 1853, and was self-educated. After studying mathematics. astronomy, law and other subjects, he turned his attention about 1875 to archaeology and geology. Without public aid he made a geological and topographic survey of northwestern Iowa, and later became attached to the U. S. Geological Survey. He was in charge of the Bureau of American Ethnology in $1893-1903$, resigning in order to undertake the work of assembling a collection of races for the St.'Louis Exposition, 1904. His later years were devoted to the inland water-ways commission, and he was an expert in the U.S. department of agriculture. He wrote on anthropolngy, geology and hydrology.

George Wallace Melville, naval officer, died March 17, 1912. He was born in New York City, January 10, I8+I, was educated at the Brooklyn Polytechnic Institute, entered the nary as assistant engineer in 1861 and served through the Civil War. In 1879 he sailed with the De Long Arctic expedition, and commanded the boat's crew that escaped from the Lena delta. He later headed the parties which recovered the records of the expedition and De Long's remains. After 1887, he wasengineer in chief, L.S. Navy, and became rearadmiral, 1 899 (retired, 1903). He invented many mechanical appliances, and wrote In the Lena Delta. a narrative of the De Long expedition after the loss of the "Jeannette."

Richard Wilde Micou, theologian, died at Oxford on June 4, I9I2. He was born on June I 2, 1848, at New Orleans, and after studying at the universities of Georgia and Alabama, he went to Erlangen, to Edinburgh, and to the General Theological Seminary in New York City. He was ordained in 1870 . In 1892 he became professor of systematic divinity in the Philadelphia Divinity. School, and in 1898 professor at the Virginia Theological Seminary.

Philip Verrill Mighels, author, died October 13, I9II. He was born in Carson City, Nevada, April 19, I 669 , was admitted to the Nevada bar in I890, was a journalist in San Francisco and New York, and in I 895 began writing fiction. He published about a dozen books, of which the best known is Brwver Jim's Baby.

Darius Ogden Mills, American financier, died at Millbrae, California, on January 4, 1910, aged 84 . Born at Salem, .. . Y., on September 25,1825 , he was a clerk in . Vew York, went to California during "the gold rush" of $18+9$, became a storekeeper at Sacramento, and founded the Gold Bank of Sacramento. After doing much for the development of the Comstock lode region, he was president of the Bank of California from 1864 (when he founded it) until 1873 , and in 1875 , when the bank was wrecked under other management, he returned and placed it on a sound basis. In California he had endowed a chair of philosophy in the state university and had been a trustee of the Lick estate and Observatory: He sent an astrnnomical expedition to Chile to observe stars not visible in the northern hemisphere. In New York (after I880) he was a trustee of the Metropolitan Museum and of the Museum of Natural History and president of the New York Botanical Society; and he built the Mills Hotels, lorlging-houses for working men. His daughter married Whitelaw Reid.

Paul Morton, administrator, died in New Fork City, January 19, 1911. He was born in Detroit. Mich., May 22, 1857. At the age of fifteen he began his business career as a clerk in the land office of the Burlington and Missouri R.R. He showed great executive ability as a railroad man, and rose to be second vice-president of the Santa Fe system in 1898. He was secretary of the navy in Mr. Ronsevelt's cabinet in I904-05. In I906 he was made president of the Equitable Life Assurance Society, and by his able administration helperl to restore the impaired fortunes of that company. He became vice-president of the Pan-American R.R. in 1910.

Francis Philip Nash, professor of Latin at Hobart College in $1871-76$ and $1882-1907$, died un February 5. 1911. He was born in Florence, Italy, December 5. 1836 . graduated at Harvard in 1856 and at Harvard Law School in 1859 , and practised law in New York City before becoming a teacher. He edited Two Sutires of Jucenal, translated the American Prayer Book into Italian, and contributed to the Nation (New York)

John Willock Noble, Secretary of Interior in President Benjamin Harrison's cabinet, 1889-93, dier March 22, 1912. He was born in Lancaster, Ohio, October 26, 1831, graduated at lale in 1851 and at the (incinnati Law School in 1852 , and was admitted to the bar in 1853. He practised in St. Louis (I855) and then in Keokuk, Iowa, until the outbreak of the (ivil War, during which he became colonel and brevet brigadier-general. He was L.S. di-trict attrorney in St. Louis in $1867-70$ and prosecuted whisky and tobacco frauds.

Edward Payson North, civil engineer, died on July 20, 1911. He was born in Hartord, Conn., July 16, I 835 . studied engineering at Lnion College, became assistant engineer of the Saratuga \& Hudson Kiver railway in 1864 , and in 1866 chief engineer of the Stamford \& New (anaan Railroad, on which he used, probably before any one else in the United States, nitro-glyerine in rock-excavation. In 1868 he became connerterl with the Union Pacific and in is , 3-75 with U.S. Army engineering work on the upper Mississippi. He was superintendent of ruads and streets in New lork City in 1876 and, after being chief engineer of the Sinalua \& Durang' railway in Mexico ( 1881 ), was engineering expert on many municipal projects, including the electric subways in New lork, where he was head of the work on paving and repairing streets in 1895 and cunsulting enginter of the department of public works in 1897 . He was a prominent member of the American Society of (ivil Engineers and contributed many papers to its Trunsuctions and to technical and other journals. 
John Alsop Paine, archaeologist, died July 24, 1912. He was born in Newark, N. J., January I4, I840, and studied at Andover for the Congregational ministry (ordained 1867). He also studied science at several universities of the United States and Germany. He was engaged in research work on the flora of New York state, 1862-67, and afterwards taught natural science at Robert College, Constantinople, Lake Forest University, Ill., and the College of Physicians and Surgeons, New York City. In $187 \mathrm{I}-72$ he was associate editor of The Independent (New York). He was archaeologist of the first expedition of the Palestine Exploration Society in 1872-74; edited and conducted the Journal of Christian Philosophy (I882-84), was curator of the Metropolitan Museum, New York, I889-1906, and was also on the staff of the Century Dictionary.

William Paret, Protestant Episcopal bishop of Maryland since I884, died on January I8, 1911. He was born in New York City, September 23, 1826, graduated at Hobart College in I849, was ordained in 1852 upon leaving the Hobart Divinity School, was rector successively in Clyde and Pierrepont Manor, N. Y., East Saginaw, Michigan, Elmira, N. Y., Williamsport, Penna., and Washington, D. C., and wrote_St. Peter and the Primacy of the Roman See and Our Freedom and our Catholic. Heritage.

Daniel Kimball Pearsons, philanthropist, died April 27, I9I2. He was born in Bradford, Vt., April I4, I820. He practised medicine in Mussachusetts from 1842 to 1857 , was a farmer in Illinois until $\mathbf{1 8 6 0}$, and then engaged in the real-estate business in Chicago, from which he retired in 1887. He was childless and gave away his entire fortune-he lived on an annuity during his last years-to 30 colleges in 20 different states (especially Chicago Theological Seminary, Beloit College, Whitman College, Berea College) and to a public library and museum for Hinsdale, Ill., the village in which he made his home. A larger sum had to be raised from other sources before his donations were available, and he gave only to smaller institutions. He was an alderman in Chicago from 1873 to 1876 .

William Alfred Peffer, politician, died at Grenola, Kansas, October 7, I912. He was born in Cumberland county, Pennsylvania, September I0, 1831. He served as a private in an Illinois regiment during the Civil War, and in 1870 removed to Kansas where he practised law and edited newspapers in Fredonia and Coffeyville. He became a member of the state senate in $\mathbf{1 8 7 4}$. In $\mathbf{1} 89 \mathrm{I}-97$ he was United States senator from Kansas, being the only member of the Populist party in the Senate. He had been a Republican before the establishment of the Populist party, which was largely due to him. In 1898 he was the Prohibitionist candidate for governor. He wrote Myriorama, a National Poem, several novels, The Farmer's Side (I89I) and Americanism and the Philippines (1900).

David Graham Phillips, novelist, died January 24, I9II. He was born in Madison, Ind., October 3I, I 867, and graduated at Princeton in 1887. After a short career as a journalist he devoted his time to the writing of fiction. He wrote The Great God Success (I90I); The Golden Fleece (1903); The Cost (1904); The Plum Tree (1905); Light Fingered Gentry (1907); The Second Generation (1907); Old Wives for New (1908); and, posthumously published, The Grain of Dust (I9II) and The Price She Paid. He presented, rather crudely, the social and economic problems of modern American life, especially in high society. He was murdered by a deranged man who imagined that his family had been satirised in Phillips's novel, The Fashionable Adventures of Joshua Craig.

Arthur Tappan Pierson, Presbyterian clergyman and editor, died June 3, I9I I. He was born in New York City, March 6, I837 and was ordained in the ministry upon graduation from the Union Theological Seminary in 1860. He filled pulpits in Detroit, Indianapolis, Philadelphia, and elsewhere, and in I 888 became editor of the Missionary Review of the World. His knowledge of the missionary field was very extensive and he was prominent in religious conferences at Northfield, Mass., of which he was a leader after the death of D. L. Moody. A trip around the world in the interest of foreign missions was interrupted by ill health in Korea. Dr. Pierson published about 30 wooks on missions and other religious subjects. See the biography (New York, I9I2) by Delavan Leonard Pierson.

Louis McClellan Potter, sculptor, died in Seattle, Washington, August 29, I9 I2, possibly as a result of treatment by a Chinese physician. He was born in Troy, New York, November 14, 1873, graduated at Trinity College (Hartford) in I 896 and studied in Paris under Luc-Olivier Merson and Jean Dampt. In Tunis and Alaska he studied native types. His work, first realistic and then imaginative, includes a memorial in Hartford (1909) to Horace Wells and "Earthbound," a symbolic piece for the New York Child's Welfare Exhibit.

Joseph Pulitzer, editor and journalist, died October 29, I9I I. He was born at Budapest Hungary, April I0, I847. He emigrated to America practically penniless in I 864 , served in the Union army through the Civil War, and became a reporter on the St. Louis Westliche Post in I868, rising to be editor and part owner. This paper he combined with the St. Louis Dispatch, which he bought in 1878 . He served in the Missouri House of Representatives in 1869 and was connected with the Liberal Republican movement in Missouri in 1872. In I 876-77 he reported for the New York Sun the proceedings of the Electoral Commission. In 1883 he bought from Jay Gould the New York World (see E. B. xix, 569c) which, although sensational, through a fearless editorial policy of combatting political evils became one of the most influential journals of the United States. In 1885 he was elected a Democratic member of Congress but resigned after a few months' service. His later years, owing to failing eye- 
sight and a high state of nervous irritability, were spent in long cruises in his private yacht on which he died in the harbour of Charleston, S. C. But up to the end he was most active in directing the World. He founded the School of Journalism at Columbia University, New York City, and made bequests of $\$ 500,000$ each to the New York Philharmonic Society and the Metropolitan Museum.

Myrtle Reed, author, died August I7, I9I1. She was born in Chicago, Ill., September 27, 1874 , and married J. S. McCullough in 1906. She wrote popular fiction, essays and verse, including Love Letters of a Musician (1899); Later Love Letters of a Musician (1900); The Spinster Book (1901); Lavender and Old Lace (1902); Pickaback Songs (1903); The Shadow of Victory (1903); The Master's Violin (1904); The Book of Clever Beasts (1904); At the Sign of the Jack o' Lantern (1905); A Spring in the Sun (1906); Love Affairs of Literary Men (1907); Flower of the Dusk (1908); and the Weavers of Dreams (I9I I).

Eugene Lamb Richards, professor of mathematics at Yale in $189 \mathrm{I}-1906$ and a director of the Yale gymnasium in I 892-1902, died at Beach Haven, N. J., August 5, I912. He was born in Brooklyn, December 27, 1838 , graduated at Yale in 1860 , and became tutor in mathematics there in I868. He wrote on college athletics and published text books of Trigonometry (1879) and Elementary Navigation (1902).

Maurice Howe Richardson, surgeon, died on July 3I, 1912. He was born in Athol, Mass., on December 31, 1851, graduated at Harvard College in 1873 and at the Harvard Medical School in 1877 , practised in Boston, and taught anatomy and surgery at Harvard after 1879, becoming Moseley professor of surgery in 1907. In $191 \mathbf{1}$ the post of surgeon in chief to the Massachusetts General Hospital was created for him.

Theophilus Francis Rodenbaugh, soldier and author, died December I9, I912. He was born in Easton, Pa., November 5, 1838; served as a volunteer in the Civil War, losing an arm and being made brigadier (March I3, 1865) for gallantry at Cold Harbor; entered the regular army in 1866 , and retired in 1870 with rank of colonel; and in 1904 was made brigadiergeneral retired. He wrote: From Everglade to Cañon with the Second Dragoons (1875), Afghanistan and the Anglo-Russian Dispute (1885) and Sabre and Bayonet (1897), and edited in 1899 the Journal of the Military Service Institution.

Abbott Lawrence Rotch, meteorologist, died at Boston, Mass., April 7, 1912, where he was born January 6, I861. He graduated from the Massachusetts Institute of Technology in I 864, and became professor of meteorology at Harvard in 1906. After I885, he maintained from his private fortune the Blue Hill Meteorological Observatory near Boston. Here he first introduced the use of kites in exploring the upper air. He also obtained valuable data with registration balloons five to ten miles above the earth. He collaborated with Teisserenc de Bort (1905-06) in sending a steam yacht to explore the tropical atmosphere, and took part in scientific expeditions to South America, Europe and Africa. He wrote Sounding the Ocean of the Air (1901) and The Conquest of the Air (1909). Upon his death the Blue Hill Observatory became the property of Harvard.

Patrick John Ryan, Catholic prelate, died February II, I9II. He was born in Thurles, County Tipperary, Ireland, February 20, I83I, and removed to the United States after graduation from Carlow College and ordination as a sub-deacon in 1852 . He taught English Literature at Carondelet Seminary in St. Louis, was ordained a priest in 1853 , and became rector of St. John's Cathedral there. He was made coadjutor-bishop of St. Louis in I872; was promoted to an archbishopric eleven years later; and in I 884 was transferred to the see of Philadelphia, where he remained for the rest of his life. President Roosevelt appointed him to the board of Indian Commissioners in 1902. He wrote What Catholics Do Not Believe, and Causes of Modern Religious Skepticism.

Charles Robert Sanger, chemist, director of the Harvard laboratory after September 1903, died on February 25, 1912. He was born in Boston, August 31, 1860, graduated in $188 \mathrm{I}$ at Harvard, where he was assistant in chemistry in 1882 and $188+-86$ and (after teaching the same subject at the U.S. Naval Academy in 1886-92 and at Washington University, St. Louis, in 1892-99) assistant professor in $1899-1903$ and then professor.

Margaret Elizabeth (Munson) Sangster, editor and author, died at Glen Ridge, N. J. June 4, 1912. She was born at New Rochelle, N. Y., February 22,1838 , and was married to (jeorge Sangster in 1858 . At an early age she began contributing to current periodicals, and became one of the best known writers in the United States on topics of special interest to women and girls. She was staff editor on many women's and children's periodicals. She wrote Winsome Womanhood, Fairest Girlhood, The Queenly Mother in the Realm of Home, etc.

William Lindsay Scruggs, diplomat and authority on South America, died in Atlanta, Georgia, on July 18, 1912 . He was born near Knoxville, Tennessee, September 14, 1836, was admitted to the bar in 1858 , edited the Columbus (Georgia) Sun in I862-66 and the Atlanta New Era in 1870-72, and was minister to Colombia in 1872-77 and (after being consulgeneral in (China) in $1882-87$ and to Venezuela in $1889-93$. In $1894-98$ he was legal adviser of Venezuela and agent for the settlement of the boundary dispute with Gireat Britain, arbitrated in 1897. He wrote The Colombian and Venezuelan Republics (3 ed., I905), Origin and Meaning of the Monroe Doctrine (1902), and several books on the boundary dispute.

William Hall Sherwood, pianist and composer, died in (hicago, January 7, I9Ir. He was born at Lyons, N. Y., January 31 , 1854 , the son of a music teacher, and studied music 
under William Mason, Kullak, and Liszt. He was an organist in Stuttgart and Berlin, and became well-known as a piano soloist in Europe and America, being perhaps the first American who could be ranked as a first-class pianist. His merits as a composer for the piano were recognised in professional circles, and he wrote Music Study and the Mutual Relation of Interpretation and Technic. For many years he directed the Sherwood Music School in Chicago, where he settled in $\mathbf{I} 889$ as head piano teacher in the Conservatory, and his University Extension Course of Music Study and Piano Playing was in many respects a new depárture. He gave summer normal courses at Chautauqua.

James Schoolcraft Sherman, vice-president of the United States after 1909, died at Utica, N. Y., October 30, I912. He was born on his father's farm near Utica, October 24, I 855, and graduated from Hamilton College in 1878 . Admitted to the bar, in I 880 , he established a law firm in Utica which continued until 1907 . His savings were first invested in a canning factory founded by his father, and the enterprise prospered greatly under his guidance. Although at first he followed his family in its allegiance to the Democratic party, he soon became a Republican. He was mayor of Utica in $1884-85$. In the winter of 1887 , when only thirty-two years of age, he began a career in the House of Representatives which was uninterrupted until 1908 except during the term of the 52 nd Congress (I89I-93) to which he failed, by a small number of votes, to be elected. In the political campaigns of 1895,1900 , and 1908, he was chairman of the New York Republican State Convention, and in I906 was chairman of the Republican National Congressional Committee. It was in the latter capacity that he appealed to Republicans throughout the country for one-dollar subscriptions, and obtained a large sum of money. For many years he was chairman of the Congressional committee on Indian affairs - he was related to Henry Schoolcraft, the well-known writer on American Indians-and it was on this committee that his most important legislative work was done; he also was a member of the committee on interstate and foreign commerce. In 1908 he was elected Vice-President of the United States on the ticket with Mr. Taft, and he was re-nominated at the Republican National Convention of 1912. He was one of the most expert parliamentarians in Congress in his time. "His sympathies were with the conservative or "stand-pat" wing of the Republican party.

Albert Keith Smiley, philanthropist, died at Redlands, Cal., December 2, 1912. He was born of Quaker parentage at Vassalboro, Me., March I 7, I828, and graduated at Haverford College, in 1849 . Until 1879 he was a teacher, but then began to develop a large tract of land in Ulster Co., N. Y., including the beautiful Lake Mohonk, which he had purchased ten years previously. It became a popular summer resort, and Smiley, who was now a member of the board of U.S. Indian Commissioners, arranged at his own expense for a conference each autumn for the discussion of the problems of the Indians and later of other dependent peoples, the Filipinos, Hawaiians, and Porto Ricans. The first of these was held in $\mathbf{1 8 8 2}$. Likewise, after 1894 , he called an annual spring conference in the interest of international arbitration. In I 889, he and his brother Alfred H. (d. I903) purchased a large property at Redlands, Cal. In I 898 , he presented a public library to Redlands, and he served as trustee for Brown University and Bryn Mawr College.

Gerrit Smith, composer, professor of music in Union Theological Seminary, New York City, died July 21, 1912, in Darien, Connecticut. He was a grand-nephew of the abolitionist of the same name, was born in Hagerstown, Maryland, December I I, I 859, was educated at Hobart College, where he was chapel organist, studied music in Stuttgart and under Haupt and Rohde, in Berlin, and was successively organist of St. Paul's Cathedral, Buffalo, St. Peter's, Albany, and (I 885) Old South Church, New York City, where he gave many organ recitals. He composed songs, notably "The Night Has a Thousand Eyes" and a cycle Thistledown, and ecclesiastical music, including a cantata King David.

John Bernhardt Smith, entomologist, died on March 12, I912. He was born in New York City, November 2I, I 858 , had a common school education, and was admitted to the bar in 1879 . In 1884 he became a special agent of the Entomological Division of the U.S. Department of Agriculture and in 1889 professor of entomology in Rutgers College and entomologist of the New Jersey Agricultural College experiment station. As state entomologist, after 1898 , he was in charge of the extermination of mosquitos in New Jersey. He wrote Economic Entomology (1896) and Our Insect Friends and Enemies (1909).

Paul Smith, guide and hunter, died in Montreal, December 15, I9I2. He was born in Milton, Vermont, August 20, 1825, and in $185^{2}$ built a Hunters' Home at Loon Lake in the Adirondacks of New York, whence about $185^{8}$ he removed to St. Regis Lake, where he built a hotel and where the whole region came to be known by his name. The development of the Adirondack country was largely due to him.

John Russell Soley, lawyer and naval historian, died September I0, I9I I. He was born in Boston, Mass., October I, I850 and graduated at Harvard in I870. He made a specialty of international law, taught at the Naval Academy, was assistant secretary of the navy in 1890-93, and wrote a number of books on naval and maritime subjects. Among them are The Blockade of the Cruisers (1883), in a series on the American Civil War, Foreign Systems of Naval Education (1879) and Life of Admiral Porter (1903).

Julius Stahel, American soldier, died in New York City, December 4, I9I2. He was born, November 5, 1825, in Hungary, and was educated in Budapest. After fighting for Hunga- 
rian independence under Kossuth in 1848 he came to the United States (1856) and engaged in journalism until the Civil War broke out. In this he participated, first as lieutenantcolonel of a New lork regiment, and rose to be major-general of volunteers in March $\mathbf{1 8 6 3}$. He was prominent at the first battle of Bull Run, in Fremont's operations in the Shenandoah Valley, in Pope's Army of Virginia, and for a 'short 'time thad command of the IIth Army Corps. In March 1863 he held a command in the defence of Washington. He was American consul at Yokohama, and consul-general at Shanghai in $1884-85$.

Isidor Straus, merchant and philanthropist, was a victim of the "Titanic" disaster April 15. 1912. He was born in Rhenish Bavaria, February 6, 1845, went to the United States when nine years of age and was educated in Georgia. In 1863 he went to Europe to assist in purchasing steamers and supplies for the Confederate Government, and three years later joined his father in New York City in the business of importing pottery and glassware. He was also a partner in several large department stores in New York City. He was a strong supporter of tariff reform and sound money, took a prominent part in the Democratic presidential campaign of 1892 , and in $1894-95$ served in the Federal House of Representatives, where he assisted in drafting the Wilson Tariff. He was connected with many charitable and philanthropic institutions, notably the Educational Alliance of New York City.

Ralph Stockman Tarr, geographer, died March 21, I912. He was born at Gloucester, Mass., January I 5, I864 and graduated at the Lawrence Scientific School of Harvard Lniversity in $189 \mathrm{I}$. He was assistant professor of geology at Cornell University in $1892-97$, professor of dynamic geology and physical geography in 1897-1906, and thereafter professor of physical geography. He had an international reputation through his work in geology and geugraphy, especially in the field of glaciology, in the study of which he made several expeditions to Greenland and Alaska,-one to Alaska under the auspices of the National Geographic Society shortly before his death. He was president in I9I I-I2 of the Association of American Geographers, and was an associate-editor of the Bulletin of the American Geographical Society and the Journal of Geography. He wrote a number of valuable papers and monographs and was the author of a widely-used series of geographical text-books, of a New Physical Geography (1904), etc.

Denman Thompson, actor, died April I4, I9II. He was born at Girard, Pa., in I833, but was reared in New Hampshire. He began his professional career with a travelling circus in New England about 1850 . His work on the stage was inconspicuous, until, in 1875 , he wrote a short play, Joshua Whitcomb, portraying characteristic types of rural New England, which was immediately successful and was expanded by its author to larger proportions and renamed The Old Homestead. This medium, peculiarly fitted to his abilities, was his sole dramatic resource until he abandoned the stage in 1910 , and it brought him a large fortune.

Bradford Torrey, naturalist, died at Santa Barbara, California, on October 7, I9 I2. He was born in Weymouth, Mass., on October 9,1843 , and had a common school education. He was an editor in I 886-190I of the Youth's Companion (Boston), and among his books were: Birds in the Bush (1885), A Rambler's Lease (1889), A Florida Sketch-Book (1894), Every-Day Birds (1900), The Clerk of the Woods (1903) and Nature's Invitation (1904).

Eugene F. Ware, lawyer and poet, widely known as "Ironquill," died at Cascade, Colo., July I, I9II. He was born at Hartford, Conn., May 29, 18+1 and was reared in Iowa. He served in the Union cavalry in the Civil War and was admitted to the Kansas bar in $187 \mathbf{I}$. He held public office as (Republican) state senator in 1879-84 and was U.S. pension commissioner in 1902-05. His newspaper verse was afterwards collected in the Rhymes of Ironquill which has run through many editions. Among his other works are The Rise and Fall of the Saloon (1900); The Lyon Campaign and IIistory of the First Iowa Infantry (1907) Ithuriel (1909); From Court to Court (1909). He also made translations of French and Latin works, including Justinian's Roman Water Law.

Henry White Warren, bishop of the Methodist Episcopal Church, died in Denver, Colorado, on July 23, 19I2. He was born in Williamslurg, Massachusetts, on January 4, $183 \mathrm{I}$, and was a brother of William Fairfield Warren (b. 1833; president of Boston University, 1873-1903). He graduated at Wesleyan Cniversity in 1853 , was ordained in 1855 , filled pastorates in Massachusetts in $187 \mathrm{I}$, in Philadelphia in $187 \mathrm{I}-74$ and from 1879 to 1880 when he was elected bishop. He edited The Study (1896-1900) and was a prolific writer, publishing Recreations in Astronomy (1879), The Bible in the W'orld's Education (1892), etc.

Alexander Stewart Webb, military officer and educator, died February 12, 1911. He was horn in New York City, February I5, I83 I, and was graduated from the U.S. Military Arademy in 1855 . In the (ivil War he served in the Army of the Potomac, being made brighlier-general of volunteers in June is6,3. He was wounded at Gettysburg, on the Rapidan, and at Spottsylvania. At the time of I.ee's surrender he was General Meade's chief of staff. After the war he was brevetted major-general in the regular army. In 1870 he was discharged at his own reguest because in the previous year he had been chosen president of the college of the ("ity of New lork. Here he remained until rgoz, when he retired. He wrote The Peninsula, an excellent sketch of the McClellan Campaign of 1862.

Frederic Cope Whitehouse, lawyer and archaeologist, died November 16, 19I1. He was born at Rochester, $\mathrm{i}$. I., November 9, 1842 , graduated at Columbia University in $186 \mathbf{1}$, studied in Europe, and wis admitted to the New Jork bar in 1871 . He spent much time 
in Egypt, investigating Semitic traditions in regard to that country, and attempting to identify localities mentioned in the Bible. In 1882 , he discovered the depression in the desert now known as the Wadi Raiyan and advocated unsuccessfully its use as a storage reservoir for the water of the Nile. The khedive granted him the Mejidieh order for his efforts in behalf of Nile regulation, and he was also a commander of the Osmanieh order.

Ozi William Whitaker, Protestant Episcopal bishop, died February 9, I9II. He was born at New Salem, Mass., May I0, I830, and was ordained deacon and priest, in 1863, after graduation from the General Theological Seminary. After serving two years as rector at Gold Hill, Nev., he held a charge in Englewood, N. J., but returned to Nevada in 1867 , and was rector at Virginia City for two years. He was then (I 869) consecrated missionary bishop of Nevada, and became assistant bishop of Pennsylvania in I886. In I887 he succeeded Bishop Stevens. He laboured assiduously for the extension of the diocese until failing eye-sight compelled him to relinquish the charge in I9I0.

Wilbur Wright, aeronaut, died at Dayton, Ohio, on May 30, 1912. He was born near Millville, Indiana, on April I6, I867, and was the son of Milton Wright, a bishop of the United Brethren in Christ. He was educated in the high schools of Richmond, Indiana, and Dayton, Ohio. He and his brother, Orville, were early interested in problems of flying, and about I900 began experiments on the coast of North Carolina in "gliding" from some high points. In 1903 they ventured to fit a petrol molor to their machine, and at the end of the year accomplished a flight of 260 yds., the first successful experiment of the kind with a motor-propelled aeroplane. On October 5, 1905, they established a record by flying $24 \frac{1}{5}$ miles at a speed of 38 miles an hour. They unsuccessfully tried to sell their patents to some one who would develop them, without any public exhibition. They were therefore obliged to come out into the open, and Wilbur went to France, where his great flight of 56 miles on September 21, 1908, established his fame. He set up a school at Pau and trained pupils. On December 3 Ist of that year he flew 77 miles, remaining 2 hrs. 20 min. in the air. After that his advice and his machines were in great demand. He visited Italy and England in 1909, and on his return to America devoted himself to tests, which resulted in the sale to the War Department of a machine for $\$ 30,000$. From then till his death he worked mainly on the mechanical side of the business.

Walter Wyman, physician, died November $2 \mathbf{I}$, I9II. He was born at St. Louis, Mo., August 17,1848 , and graduated at Amherst College (1870) and the St. Louis Medical College (1873). He entered the Marine Hospital Service in 1876. His career was one of great activity in promoting better sanitary conditions among seamen and the prevention of epidemics, and he established the first government sanatorium for consumptives, at Fort Stanton, N. M. After 1902 he was surgeon-general of the U.S. public health and marine hospital service. He was instrumental in securing the government regulation of serums, toxins, etc., and the establishment of a leprosy investigation station in Hawaii.

\section{ALABAMA 1}

Population (I9I0), 2, I38,093 ( $16.9 \%$ more than in I900); average number per sq. $\mathrm{m}$. $4 \mathrm{I.7}(35.7$ in I900). Of the total $56.6 \%$ were native whites ( $1.5 \%$ native whites of foreign parentage), $0.9 \%$ foreign-born whites, and $42.5 \%$ negroes $(45.2 \%$ in $\mathrm{I} 900)$. In I I counties running from East to West across the central part of the state (the " black belt "), negroes made up $75 \%$ or more of the population, and in Io others $50 \%$ or more. Negroes constituted $42.3 \%$ of the urban population (45.3\% in I900), and $42.5 \%$ (45.2\% in 1900$)$ of the rural, including towns of less than 2,500 . The " rural " population was $82.7 \%$ of the total. The cities with 2,500 inhabitants or over were: Birmingham, I32,685; Mobile, 51,521; Montgomery, 38,136; Selma, I3,649; Anniston, I 2,794; Bessemer, Io,864; Gadsden, I0,557, Tuscaloosa, 8,407; Huntsville (town), 7,6I I; Dothan, 7,or6; Florence, 6,689; New Decatur, 6, I I8; Talladega, 5,854.

A griculture.-In I900-I910 the number of farms increased $17.8 \%$ and the acreage of improved land $12 \%$, although the total area of farm land increased only $0.2 \%$. The average number of acres in a farm was 92.7 in 1900 and only 78.9 in 1910 . The value of farm property increased from $\$ 179,399,882$ to $\$ 370,138,429$ (\$2I6,944, I75 land; $\$ 71,309,416$ buildings; \$16,290,004 implements; and \$65,594,834 domestic animak). In 19 10 the average value of farm land per acre was $\$ 10.46$; and $60.2 \%$ (in $189048.6 \%$ ) of the farms were operated by tenants.

In 1912 (preliminary estimates) the state ranked below Texas and Georgia in production of cotton-1,330,000 bales (173 lbs. per A.). Other crops were; Indian corn, 54, I 80,000 bu. (3, I 50,000 A.); wheat, 3 I 8,000 bu. (30,000 A.); oats, 5,200,000 bu. (260,000 A.) rye, 12,000 bu. (I,000 A.); rice, 9,000 bu. (300 A.); potatoes, 1,2 1 5,000 bu. (15,000 A.); hay, 261,000 tons (209,000 A.); and tobacco, 225,000 lbs. (300 A.). In I 909 (U. S. Census) the value of all vegetables (excluding potatoes) was $\$ 5,379,577(69,468 \mathrm{~A}$.) and of orchard fruits, $\$ 1,818,508$

' See E. B. i, 459 et seq. 
(peaches and nectarines, \$1,055,971; apples, \$620,745). On January I, 1912 there were on farms 143,000 horses, 265,000 mules. 396,000 milch cows, 540,000 other neat cattle, 140,000 sheep and $1,533,000$ swine.

Besides the staple fruit crops, especially peaches, the Alabama farmers have recently experimented with pecans, Japanese persimmons, Satsuma oranges (usually planted with pecan trees) etc., and many cotton farmers are turning to horticulture or truck-raising because of the advance of the boll-weevil. The same cause tends to promote the selection of hardier cotton and more scientific methods of cultivation. The Alabama experiment station at Tuskegee in 1911 and 1912 carried on important studies in feeding beef-cattle and swine; it has bred two new varieties of cotton, notably "Carver's hybrid," and had experimented with Indian corn to produce a breed which will resist weevil. There is a state department of agriculture and industries, and a board of agriculture (established in 1911) supervises appropriations for farm demonstration work. County commissioners are authorised to appropriate funds for farm demonstration work or "farm life clubs" in counties where such work has been undertaken by Federal or state authorities.

Minerals.-Natural gas and petroleum were discovered at Fayette in the W. part of the Warrior coal field, early in 1909 , when gas was found $475 \mathrm{ft}$. below the surface. Wells drilled early in $1910-$ some $2,200 \mathrm{ft}$. deep-had varying success. The field is undeveloped and the find has not yet been of commercial importance. In I9I I the total value of mineral products was $\$ 28,005,278$. The largest items were: coal, I5,021,42I tons, valued at $\$ 19,-$ 079,949 , nearly $10 \%$ less than in 1910 , but ranking Alabama 5 th in the Union; and iron, $1,617,150$ tons (pig), worth $\$ 17,379,171$ (not included in total given above), more than a quarter less than the value in 1910 , and $3,955,582$ tons of ore $(\$ 4,876,106 ; 3 d$ in the United States). The Woodward mine with $502,47 \mathrm{I}$ tons of ore ranked I 7 th of the iron mines of the country. Clay products, \$1,947,102-a slight increase over I910. Mineral waters were reported sold from Io springs ( 3 in Mobile county), and a little mica is found.

Manufactures.-In 1909 the number of establishments was 3,398 (in 1904, 1,882, the increase being largely in saw mills and timber plants); the number of persons engaged in manufacturing was 81,972 , of whom 72,148 were wage earners; the invested capital was $\$ 173,180$,$000 ;$ and the value of products, \$145,962,000. Among the more important manufactures were: lumber and timber products (mostly yellow pine), including the output of planingmills and wooden packing boxes, \$26,058,000; cotton goods, including small wares, $\$ 22,212,000$; cotton-seed oil and cake, $\$ 9,178,000$, ranking the state 6 th in this industry; iron and steel blast furnaces, \$2 I,236,000; foundry and machine-shop products, \$I I,550,000, and iron and steel, not separately reported; coke, $\$ 8,843,000$; steam railway cars and shop construction, $\$ 7,528,000$; fertilisers. $\$ 6,423,000(\$ 2,159,000)$ - Alabama ranking 7 th in fertilisers; flour and grist mill products, $\$ 2,779,000$; printing and publishing, $\$ 2,768$,000; and turpentine and rosin, $\$ 2,472,000$ - Alabama ranking 3 rd in this industry.

The principal manufacturing cities were: Birmingham $\left(\$ 24,128,000\right.$, nearly $\frac{1}{6}$ of the state's total and including $45 \%$ of the state's foundry and machine-shop products); Bessemer $(\$ 6, \mathbf{I 0 6 , 0 0 0 )}$; Montgomery $(\$ 5,442,000)$; Mobile $(\$ 5,429,000)$, and Anniston $(\$ 4,333,000)$.

Transportation.- Railway mileage, January I, $1912,5,295$. I I m. Under the Federal River and Harbor Act of 1910 work was begun on making a $4 \mathrm{ft}$. depth in the Alabama and Coosa rivers to Wetumpka and on the $27 \mathrm{ft}$. channel $(200-300 \mathrm{ft}$. wide) in Mobile harbour, to be finished about 1914 ; on the Warrior and Tombigbee rivers, three locks, in addition to 13 formerly built in a series of 17 , were practically completed in $1911-12$. The legislature has created a state highway commission, authorised to administer for good roads an annual appropriation of $\$ 154,000$, which may be increased at the option of the governor by not more than $\$ 4000$ a year for each county appropriating an equal amount.

Government.-The quadrennial regular session of the legislature was held January to April I9II. A state court of appeals of three members (salary, $\$ 5, \infty 0$ ), elected for six years, was created, to relieve the supreme court and to have final jurisdiction in certain minor cases. A constitutional amendment prohibiting the sale or possession of liquor was defeated at a special election, November 29, I910. The strict prohibitionist legislation of 1907 and 1908 (in effect January I, I909) was replaced by the Parks local (county) option bill (Feb. 2I, 19II), which provides that counties may vote not only for or against the sale of liquor but whether liquor shall be sold by dispensary, and prohibits the sale of intoxicating liquor except within the corporate limits of cities or towns which continually employ at least one policeman. This law was held constitutional by the state courts in I9I2, when it was attacked by the Anti-Saloon League. Under this law I 5 counties voted in I9 I and 2 in I9 I 2: 9 for no licence, 7 for licence and I for a county dispensary. The Smith Bill (I III) regulates strictly the licensed sale of liquor, forbiddling it between II P.M. and 6 A.M. and limiting the number of saloons in incorporated places according to population. 
Commission government was made mandatory for cities of 100,000 or over (only Birmingham in 1910) and for cities between 25,000 and 50,000 (only Montgomery in 1910); and permissive for all other cities above I,000 on petition and favourable vote. The "recall" of a commissioner is provided for. Cordova, Hartzell, Huntsville, Talladega, Tuscaloosa and Sheffield (Aug. 19, 1912; in effect Oct. 5) have adopted commission government-also Mobile, the only city in Class " $\mathrm{B}$," legislation not being mandatory for this class. Civil service regulations were provided for police in cities of 25,000 or more. In November 1912 the people adopted an amendment abolishing the fee system in Jefferson county.

Primary elections are taken under state control-although the party state committees still have much power and may fix assessments on candidates-and must be held throughout the state on the same day (four months or more before the regular November election) for state and county elective officers, representatives in Congress and presidential electors. Corporations are forbidden to contribute for or against nominations.

Among important labour measures is one requiring the appointment by the governor of an inspector of coal mines for each $2,500,000$ tons of coal mined; the inspectors must investigate accidents promptly and they may close mines and must oversee the re-opening of old mines; the law minutely prescribes measures for insuring safety, sanitation and ventilation, and forbids women and boys under 14 to work in mines. A state board of mediation and arbitration was created, and similar local boards were authorised.

On January 3, I9I I (219 U. S. 219, Bailey v. Alabama) the United States supreme court (Justices Lurton and Holmes dissenting) declared the Alabama "Contract of Service" (or peonage) Law counter to the I 3 th Amendment to the Federal Constitution and unconstitutional because the state rule of evidence gave the accused no opportunity to prove or testify to his uncommunicated motives, purpose or intention, and the law made breaking a contract on which a cash payment had been advanced prima facie evidence of intent to defraud. The legislature on March 9, rgIr, provided for the conviction and punishment of anyone entering into a written contract for service or rent of land with intent to defraud and with like intent obtaining money or property thereon; the new act omits the provision making breach of contract prima facie evidence of intent to defraud and a provision which gave one-half of the fine to the injured party.

The salary of the governor was increased from $\$ 5000$ to $\$ 7500$. A mansion for the governor was purchased in I9II, and the legislature appropriated \$100,000 (available in 1912-13) for the improvement of the state capitol at Montgomery. The capitol wing has been completed on this appropriation. An oyster commission was created to preserve and develop oyster, shrimp, terrapin and turtle fisheries and to control canneries of sea-food. Columbus Day (12 October) and Mardi Gras were made legal holidays.

Finance.-The bonded debt on September 30, 1912 was $\$ 9,057,000$; the balance in the treasury September 30, I9I I, \$7,07 I, the receipts for the following year, \$6,26I, 237; the year's disbursements, $\$ 6,34 \mathrm{r}, 852$. An act of rgi I taxes telephone and telegraph companies on the basis of mileage of lines operated; express companies, doing intrastate business; sleeping car companies, $\$ 5,500$ a year-besides a municipal privilege tax; insurance companies, $1 \frac{1}{2}-2 \%$ of gross premium less cancelled premiums,--besides municipal taxes; brewers, automobile owners, corporations (franchise), bottlers, rectifiers, theatres, ball-parks, travelling salesmen, peddlers, lawyers, doctors, brokers, freight lines, etc. A state banking department was created in I9I I.

Charities and Penal Institutions.-In 19I t the legislature provided for the Alabama home of refuge, at East Lake (Birmingham), for wayward and delinquent white females between 12 and $\mathrm{I} 8$, and for a reform school at Mount Meigs for juvenile negro law-breakers, taking over the reformatory formerly managed by the State Federation of Colored Women's Clubs. The office of state prison inspector was created, and a juvenile court of Jefferson county (including Birmingham) was established. Liberal provision was made for pensioning Confederate soldiers and sailors.

Education.-For public schools the state appropriated for the year ending September 30, I9I I, \$I,933,86I; county appropriations amounted to $\$ 389$, I64 and city appropriations to $\$ 405,108$. In addition $\$ 317,600$ was available from general property taxes, loans, bond sales, etc. The total income for the nine district agricultural schools was $\$ 56,365$; and for the normal schools $\$ 483,396,-\$ 102,761$ for the six schools for whites (at Daphne, Florence, Jacksonville, Livingston, Moundville and Troy), and $\$ 380,635$, largely from non-official sources, for the three negro schools (at Montgomery, Normal and Tuskegee). In I9II $\$ 100$ for each county was appropriated for public school libraries in towns of $\mathrm{I}, 000$ inhabitants or less. Connected with the work of the rural schools is the Boys' Corn Club (first organised in Alabama in 1910) for interesting boys in scientific agriculture. In I9 I the Girls' Industrial School became the Girls' Technical Institute. In I9I I the legislature established the North East Alabama Agricultural and Industrial Institute at Lineville for whites "over the age of seven years," and the Alabama School of Trades and Industry for Boys and Young Men (white) at Ragland (to be opened in 1913). In illiteracy the state's percentage, $22.9 \%$ of all Io years of age and more in 1910 ( $34 \%$ in 1900$)$, was exceeded only by that of Louisiana $(29 \%)$ and of South Carolina $(25.7 \%)$. Among whites the rate was $9.9 \%$ in 1910 ( $14.7 \%$ in 1900) and among negroes $40.1 \%$ in $1910(57.4 \%$ in 1900$)$. 
The school population in 1912 was 727,297 (399,273 white; $328,024^{\circ}$ negro); the enrollment, 445, 105 (298,648 white; 146,457 negro); and the percentage of full time attendance 6I for whites and 59 for negroes. The average school term was I32 days for whites and 96 for negroes. The receipts for schools were $\$ 3,703,7$ II and the expenditures, $\$ 3,547,955$.

History.-For several years preceding I9I2, the most prominent question in local politics was that of the prohibition of the sale of intoxicating liquors. The administration which came into office in January I9II, and especially Governor Emmet O'Neal (b. I853; his father Edward A. O'Neal was governor in I882-86), was opposed to statewide prohibition and enacted the Parks county option law. In February igi a negro who had accosted a white woman was lynched after being taken from officers on the way to the Eufaula jail; and on April 2, I 1 I , a negro accused of rape was taken from the sheriff of Bullock county and was lynched near Union Springs. Governor O'Neal preferred charges against the sheriff, who had said that he was kidnapped in daylight. He was removed from office (May 25, I9II). In I9r2 a negro was lynched at Bessemer (Jan. 28th), one at Hale's Station (Aug. 5th), one near Gadsden (Aug. 28th), one at Wetumpka (Nov. I 8 th) and one at Butler (Dec. 7 th), - all for murder. An international conference on the negro was held at Tuskegee, April I 7-I9, I9 2. There was no state election in I9 I ; the election in November I9I 2 resulted in a large majority for Woodrow Wilson for president $(82,440$ votes to 22,680 for Roosevelt, 9,730 for Taft and 3,029 for Debs, who received I,399 in I908), and in the choice of the regular Democratic nominees for members of the Federal House of Representatives, ro under the new apportionment, instead of 9 as formerly. In the Democratic National Convention the state delegates had supported for the presidential nomination Oscar W. Underwood (b. I 862), one of the congressmen from Alabama, who had won national prominence as the leader of the Democrats in the House of Representatives. John Hollis Bankhead (b. I842), who har succeeded John T. Morgan as United States senator in 1907, was re-elected in January I9I I for the term 1913-19.

Bibliography.-Laws (2 vols. Montgomery, 1911) and other official reports.

\section{ARIZONA ${ }^{1}$}

Population (rgro) 204,354, 66.2\% more than in r9o0. Density r.8 per sq. m. (ז.I in 1900). Foreign-born whites constituted $22.9 \%$ of the total (in $1900,18.2 \%$ ); native whites $6 \mathrm{I} \%$ (more than one-third born of foreign parents); negroes $\mathrm{I} \%$, Indians and Asiatics I5.I \%. Nine cities and towns each with 2,500 or more contained $31 \%$ of the total; in 1900 the four such places contained $15.9 \%$. Thirteen cities and towns with less than 2,500 each, made up $8 \%$ of the I9Io total; ten made up $7.2 \%$ of the I 900 total. The largest municipalities in I910 were: Tucson, I3, I93 (7,53I in I900); Phoenix, I I,I34 (5,544 in I900); Bisbee, 9,0I9; Globe, 7,083 (incorporated I907); Douglas, 6,437 (inc., r905); Prescott, 5,002 (3,559 in I900); Clifton 4,874 (inc. I909); Nogales, 3,514 ( 1,761 in 1900); Yuma, 2,914 (inc. 1902).

Agriculture.-In Arizona agriculture is more and more intensive; the acreage in farms decreased from $1,935,327$ to $1,246,613$ between 1900 and 1910 , but the improved land in farms increased from 254,521 to 350,173 acres; the average farm acreage fell from 333.2 to $135 . \mathrm{I}$, and the value of the farm property increased from $\$ 29,993,847$ to $\$ 75,123,970$ $(\$ 42,349,737$, land; $\$ 4,935,573$, buildings; \$1,787,790, implements; and \$26,050,870, domestic animals). Of the land area about $1.7 \%$ was in farms in 1910 . The average value of farm land per acre was \$33.97. In four counties crossed by the Gila river-Maricopa, Graham, Yuma and Pinal-there is the largest use of irrigation. The total acreage irrigated in 1909 was $320,05 \mathrm{I}(62.2 \%$ more than in 1899$)$; of this total 307.778 was supplied from streams. In (Octoler 1912 the Salt River project of the Federal Reclamation Service was nearly completed, the water coming from the reservoir controlled by Roosevelt Dam, which was formally dedicated on March 18, 1911. The Yuma project (partly in California) in October 1912, was nearly three-quarters completed. The total cost of irrigation enterprises to July I, I9 I0 was $\$ 17,677,966$, and the estimated final cost of improvements begun was $\$ 24,828,868$. Of cereals $85.2 \%$ by acreage in 1909 was grown on irrigated land and of barley $98.1 \%$ of hay and forage crops, $84.3 \%$ and of alfalfa, $98.9 \%$; of sugar beets $92.8 \%$. Farms were operated largely by owners $(8,203$ by owners, 163 by managers and 861 by tenants). In 1912 (preliminary estimates) the principal crops were; Indian corn, 528,000 bu. (16,000 A.); wheat, 707,000 bu. (23,000 A.); oats, 268,000 bu. (6,000 A.); barley, 1,440,000 bu. (36,000 A.);

1 See E. B. ii, 544 et seg. 
potatoes, 125,000 bu. (I,000 A.); hay, 384,000 tons (I I3,000 A.). In 1909 (U. S. Census), the total value of vegetables other than potatoes was $\$ 379,293$; of orchardfruits, $\$ 241$, I I0 (apples, $\$ 109,395)$; of grapes, $\$ 25,371$; of tropical fruits, $\$ 63,632$ (oranges, $\$ 52,341$ ). On Jan. 1,1912 there were on farms 104,000 horses, 32,000 milch cows, 741,000 other neat cattle, 1,510,000 sheep, and 22,000 swine. Dry-farm experiments are being carried on near Prescott and Snowflake and in Sulphur Springs Valley; and experiments in raising date palms (and in artificial ripening) at Tempe and intensive farming at Yuma, where acclimatised Egyptian cotton has been successfully grown. Tunis sheep and ostriches have been breck.

Mineral Products.-Total value, I9I I, \$44,I04,73I. The state ranked, as for several years, first in copper, 303,202,532 lbs. (more than one-quarter the country's output of blister copper), valued at $\$ 37,900,317$. In the Globe district and in Mineral Creek district there were new companies producing copper in 1912. The yield in gold and silver per ton of copper ore was $\$ 0.5 \mathrm{I}$, and the total value of all gold $\$ 3,52 \mathrm{I}, 400$, and of all silver from the state, $\$ 1,743,600$. Of zinc the total output was 2,476 tons $(\$ 282,264)$; and of lead 3,450 tons (by smelter reports; 5,137 by mine reports), much more than in I9IO. In I9I I asbestos deposits at Bass Camp, Grand Canyon, were being developed,

Manufactures. - The total value of factory products for 1909 was $\$ 50,257,000,79 \%$ more than in 1904; capital invested in manufacturing, $\$ 32,873,000$ ( $128.3 \%$ more than in 1904$)$; the number of establishments, $3 \mathbf{I}$, and the number of persons engaged in manufacturing, 7,202 . The value of the copper smelting and refining products was $\$ 41,059,000(81.7 \%$ of the total); of the wage-earners $48.6 \%$ were employed in this industry. Tucson's factory product was valued at $\$ 2,037,000$; that of Phoenix at $\$ 1,467,000$.

Transportation.-Railway mileage, Jan. I, I912,2,190.19. In I9I2 the legislature required the raising by tax annually of $\$ 250,000$ for the state road fund.

Government.-A convention at Phoenix (October I 5 th-December gth, I9Io) adopted a constitution, ratified by the people at a special election February 9, I9 I I. The opposition of President Taft to its provision for the "recall:" of judges led to the passage of Public Resolution 8 (62. Cong.), which required the people of Arizona to adopt an amendment omitting judicial officers from the clause providing for recall. This amendment was adopted at the general election held December I2, I9I I, but an amendment restoring the original clause by which the recall is applicable to all elective officers was adopted by popular vote ( 16,272 to $3,49 \mathrm{I}$ ), November 5, I9I2. Elections for recall follow a recall petition, giving the reason for removing the official (in 200 words or less), signed by at least $25 \%$ of the voters at the last election in the electoral district which elected the official, and not circulated until an officer has been six months in office. If an official is re-elected at a recall election, no second recall petition against him may be filed during his term of office until the petitioners pay into the treasury all expenses of the first recall election. At the general election in $19 \pm 2$ an amendment was adopted ( 14,928 to 3,602 ) giving the state and all municipal corporations " the right to engage in industrial pursuits." The constitution reserves to the people the initiative (petition for legislation by a minimum of $10 \%$ of the total number of electors voting for governor at the preceding election, and for a constitutional amendment by at least $15 \%$ ) and the referendum; the legislature or $5 \%$ of the qualified electors may require the submission to the people of any law or any part of a law, unless immediately necessary; and, except emergency measures, no law goes into effect within go days. The governor may not veto an initiative or referendum measure approved by a majority of the voters. The constitution provides for initiative and referendum in municipal and local elections.

The house of representatives consists of 35 members and the senate of 19 ; all must be at least 25 years old and residents of Arizona for 3 years and of the county from which elected for one. They are paid $\$ 7.00$ a day (for no more than 60 days in a session) and 20 cents a mile for mileage. The legislature meets biennially. At special sessions no business may be transacted not described in the governor's call for the session. Bills may be passed only by a majority vote of all members elected. Measures or items in appropriation bills may be passed over the governor's veto by two-thirds vote of all elected members; measures not returned with the governor's approval in 5 days (excepting Sundays) become law. The executive officers, elected for 2 years, must be at least 25 years old and citizens of the United States for 10 years and of Arizona for 5 : they are governor $(\$ 4,000$ a y ear), secretary of state $(\$ 3,500)$, auditor and treasurer $(\$ 3,000$ each $)$, attorney-general and superintendent of public instruction. There is no lieutenant-governor.

The supreme court is made up of three justices, with a six year term, one being elected at each general election. The names of candidates for judicial office must be in alphabetical order on the ballots without partisan or other designation. 
Suffrage except in school elections was originally limited by the constitution to male citizens of the Linited States, 2 I years of age, resident in the state one year, and not under guardianship, non compos mentis, insane, or convicted of treason or felony (unless restored to civil rights); but in November 1912 an amendment (proposed by initiative petition) for woman suffrage was adopted by $13,45^{2}$ votes to 6,202 . The legislature, following the instructions of the constitution, in 1912 provided for an advisory popular vote for United States senator (and for United States district judges; the returns of the popular vote being submitted to the president) and enarted a direct primary law providing for nominations for clective state, county and city officers and candidates for United States senator and representatives in Congress; a registration law (at the special session) making ability to read the constitution in English a requisite for suffrage'; and a law for "general publicity, before and after election, of all campaign contributions . . . and expenditures." The legislature ratified the proposed 16 th and 17 th amendments to the Federal Constitution (April 8 th and June 3,1912 ).

Constitutional amendments may be proposed in either house of the legislature or by a $15{ }^{\circ}$ initiative petition; they may be voted on by the people at special or general election after due publication. The legislature may not call a constitutional convention without the approval of the people on a referendum vote.

The constitution prohibits plural or polygamous marriages and the sale or gift of intoxicating liquors to Indians.

Municipal corporations must be by general statute; but any city of 3,500 inhabitants or more may frame its own charter to be approved by the governor, who may withhold approval only if the charter is in conflict with the constitution and the laws.

There is a strict article in the constitution governing non-municipal corporations and forbidding monopolies and trusts. A state "corporation commission" supervises public service corporations, except those in incorporated cities and towns, and issues certificates of incorporation and (to foreign corporations) licenses to do business in the state. The legislature in 1912 passed an elaborate Public Service Corporation Act.

The constitution makes 8 hours a lawful day's work in all employment by the state or any political division thereof; forbids the employment of children under i 4 during school hours and of children under 16 in mines, in an injurious or hazardous occupation, at night, or more than 8 hours a day; makes it illegal for employers to stipulate in a contract that employes give up claims against employers for personal injuries at work; abrogates the common law doctrine of fellow servant, as affecting the liability of a master for injuries to a servant; and makes the defence of contributory negligence or assumption of risk a question of fact to be left to the jury. By a provision of the constitution alien labour may not be employed by the state, by counties, or by municipalities.

The legislature, as required by the constitution, passed an employers' liability act applying to dangerous occupations and adding $12 \%$ interest per annum to original damages granted for the time consumed in appealing a case. (ompensation (not more than $\$ 4,000$ ) for temporary incapacity is one half of average earnings; for incomplete disability, one half the difference between earnings before and those after the accident; for death, I,200 times average daily wages, or, if there are no dependents, medical and burial expenses. Companies and corporations are required to pay their employes twice a month. Blacklisting is forbidden. Women are not to be employed in an occupation which requires constant standing, or in any mine, quarry or coal-breaker.

An eight-hour law was passed for mines and smelters and similar establishments and for electric light and power plants. Other laws provide in various ways for the safety of railway passengers and employes, and specify minutely requirements for the safety of mine workers. Suits against the state were authorised; the penal code was amended; and desertion of wife or failure to provide for wife or minor child was made a felony. Columbus Day was made a legal holiday.

Pandering was made punishable by a fine of $8 \mathrm{I}, 000$ and imprisonment from one to ten years. A state lahoratory for the analysis of food and drugs was established.

Finance.- The constitution provides for a state board of equalisation and for county bards of supervisors to act as boards of equalisation, but a substitute clause was ratifier $(15.967$ to 2,283$)$ by the people in November 1912 , allowing the legislature to prescribe a method of assessment, equalisation and levy. A state tax commission was created in 1912 and laws were passed for the taxation of private car companies, at the rate of $7 \%$ of the gross receipts, of express companies, at the rate of $5 \%$ of the gross receipts, and of all railways, telegraph and telephone companies, county by county. In 1912 a graduated collateral inheritance lax law was passed. The corporation commission is allowed to exempt at it: discretion any railroal from the three cent minimum fare law: The constitutional limit on municipal indetitedness was increased by a constitutional amendment adopted November 5 , 1912 by 15,357 votes to 2,682 .

The report of the state treasurer for the year ending June 20, 1912 shows receipts of

'As there is a large Spani-h-speaking (Mexican) dement in the population, the constitutionality of this requirement may be tested in the courts. 
$\$ 1,192,350$, expenditures of $\$ 1,300,85^{8}$, and a balance of $\$ 411,441$. The net state debt was $\$ 946,972$, exclusive of a funded county and city indebtedness of $\$ 2,098,303$.

Education.-The constitution leaves educational administration mostly to legislative provision and a school code was adopted in 1912 , but the constitution vests general conduct and supervision of public schools in a state board of education. The governor appoints regents of the university and the governing boards of other state educational institutions. A permanent school fund is derived from the sale of public lands, from escheated estates and from unclaimed shares and dividends of corporations incorporated in the state. Laws of 1912 give state aid for vocational education in high schools (and in normal schools); and provide for free text books in public schools; for county scholarships in the state university and for the retirement on a pension of $\$ 600$ a year of any teacher who has served in the public schools for 25 years or more.

In $1911-1912$ the school population was 42,381 ; the enrollment, 32,749 ; the average daily attendance, 22,812; and the length of the average school year, 8 months. The total revenue was $\$ 1,817,647$ and the expenditures $\$ 1,321,595$.

Of the total population Io years and over in I910, $20.9 \%$ were illiterate (29\% in I900).

Charitable Institutions. - In I910 a pioneers' home was opened.

History. - The proposed new state constitution was ratified by the people on February 9, I9I I by a vote of 12,000 to 3,500 . The first state election, on December I 2, I9 I I, resulted in the success of the Democratic ticket, headed by George Willie Paul Hunt (b. I 859 ), who had been president of the constitutional convention and whose four-year term of office began on December 31, I9II. The proclamation admitting Arizona as a state to the Union was signed on February 14, I9I2. On March 27 th the legislature (I 5 Democrats and 4 Republicans in senate; 30 Democrats and 5 Republicans in house) chose as United States senators two Democrats, Marcus Aurelius Smith (b. I 852), who had been a delegate to Congress from the Territory, and Henry F. Ashurst (b. 1875 ), who was speaker of the Territorial legislature in 1899 . There was no election for state officers in I9I2. In June the Republican state convention chose delegates pledged to President Taft, but there was a contesting Roosevelt delegation; the national convention decided against the latter. At the November election the state was carried by the Democrats with 10,324 for Wilson, 6,949 for Roosevelt, 3, I6 6 for Debs and 3,02 I for Taft; the Congressman chosen was a Democrat; and the people approved several railway bills passed by the legislature but "referred" on petitions, which were easily secured by the railways,--by far the largest employers of labour in the state.

On November 8, I912, Phoenix adopted a new charter with a commission of three and with provisions for initiative and referendum; but this charter was not approved by the governor.

Bibliography.-Session Laws (Phoenix, 1912) and reports of state departments; F. M. Irish, Arizona. (New York, I9I.I), - a state geography.

\section{ARKANSAS}

Population (1910) 1,574,449 (one-fifth greater than in 1900); $28.1 \%$ negroes $(28 \%$ in 1900$) ; 68.4 \%$ native whites of native parentage, and $2.3 \%$ of foreign parentage; I. I \% foreign-born. Density of population 30 per sq. $m$. In r 9 ro the 28 incorporated places with 2,500 or more each contained I $2.9 \%$ of the total; in I 900 the I 5 such places contained $8.5 \%$. In I9ro, 273 cities and towns with less than 2,500 each contained one-ninth of the total population; in $1900, \mathrm{I} 73$ contained $8.6 \%$. The strictly rural population, not in cities and towns, decreased from $82.9 \%$ in 1900 to $76.1 \%$ in 1910 . The largest cities in I910 were: Little Rock 45,94I; Fort Smith, 23,975; Pine Bluff, I5, 102; Hot Springs, I4,434; Argenta (Pulaski county; incorporated from part of Little Rock, in I904; Baring Cross consolidated with it in I905), II, I38; Helena, 8,772; Jonesboro, 7, I23; Texarkana, 5,655; and Paragould, 5,248.

Agriculture.--In $191051.8 \%$ of the state's area was in farms; $8,076,254$ out of $17,416,075$ acres were improved (one-sixth more than in 1900). The average number of acres in each farm was 81.1 ; average value per farm, \$I,864. The total value of farm property increased in $1900-10$ from $\$ 181,416,001$ to $\$ 400,089,303$ (land, $\$ 246,021,450$; buildings, $\$ 63,145,363$; implements and machinery, $\$ 16,864,198$, and domestic animals, $\$ 74,058,292)$. Of the farms, 107,412 were operated (1910) by owners and managers and 107,266 by tenants. In 1909 ,

i See E. B. ii, 551 et seq. 
232 farms (27,753 acres) were irrigated for rice-growing. During 1900-1910 the acreage of cotton increased about $30 \%$ and that of hay about $80 \%$, but that of cereals decreased. The farmers' co-operative demonstration associations and the agricultural college have organised boys' corn clubs. In 1912 (preliminary estimates) the crops were: cotton, 854,000 bales (I 90 lbs. per A.); Indian corn, 50,490,000 bu. $(2,475,000$ A.); wheat, 940,000 bu. (94,000 A.); oats, $3,482,000$ bu. (175,000 A.); rye, 10,000 bu. (1,000 A.); rice, 3,405,000 bu. $(90,800 \mathrm{~A}$.$) ; potatoes, I, 750,000$ bu. $(25,000 \mathrm{~A}$. $)$; hay, 352,000 tons $(286,000 \mathrm{~A}$.); tobacco, 520,000 lbs. ( $800 \mathrm{~A}$.). In 1909 (U. S. Census) the value of vegetables other than potatoes was $\$_{4}, 843,442$; of small fruits, $\$ 601,722$; of orchard fruits, $\$ 3,011,377$ (apples, $\$ 1,322,785$; peaches and nectarines, $\$ 1,502,996)$. On January I, 1912 there were 265,000 horses, 228,000 mules, 404,000 milch cows, 538,000 other neat cattle, .134,000 sheep, and 1,738,000 swine.

Mineral Products. - Total value, $1911, \$ 5,829,606$. Coal was the most important: $2,106,789$ tons $(\$ 3,396,849)$. Zinc from northern Arkansas amounted to 385 tons $(\$ 43,890)$ and 15 tons $(\$ 1,350)$ of lead were reported. In Sebastian and Scott counties there is a little natural gas. Mineral waters, bottled at 8 springs, were valued at \$118,994. The state is the foremost producer in the country of bauxite and of oilstones (novaculites and Ouachita or Arkansas stone). Phosphate rock in 1911 was mined near Batesville. Diamonds continue to be found in Pike county; in 1911 one weighed $8 \frac{1}{8}$ carats, another $3 \frac{11}{16}$ carats.

Manufactures.-In $1904-09$ the number of establishments increased from 1,907 to 2,925 and that of persons engaged in manufacturing from 37,557 (33,089 wage-earners) to 51,730 (44,982 wage-earners); capital invested from $\$ 46,306,000$ to $\$ 70,174,000$; and the value of products from $\$ 53,865,000$ to $\$ 74,916,000$. The value of lumber and timber products was $\$ 40,640,000$, more than half the state's total, and in their manufacture nearly three-fourths of the wage-earners were employed. The state produced in $190928.4 \%$ of the red-gum lumber, $20.5 \%$ of the cottonwood, $11.4 \%$ of the ash and $13.5 \%$ of the hickory cut in the United States; and in each it ranked first in the country, except in hickory, in which it was second. The largest cut-five-eighths of the state's total-was yellow pine. Other important manufactures were: cottonseed oil and cake, $\$ 7,789,000$, ranking the state 6 th in this industry; flour and grist-mill products, $\$ 5,615,000$; steam-railway cars, construction and repairs, \$4, 154,000; printing and publishing, \$2,082,000; carriages and wagons, \$1,664,000 (115.5\% more than in 1904); and foundry and machine-shop products, \$1,051,000. The following five cities produced together about one quarter in value of the state's total; Little Rock, \$6,882,000; Argenta, \$4,842,000; Fort Smith, \$3.739,250; Pine Bluff, \$2,387,000; and Hot Springs, $\$ 844,570$.

Transportation.-Railway mileage, Jan. 1, $1912,5,190.72 \mathrm{~m}$. In 1911 and 1912 the Federal government was building locks and dams on the Ouachita river, was removing obstructions on the upper part of that river and on the Saline, and was dredging the Arkansas (under the River and Harbor Act of 1910).

Legislation.-A constitutional amendment, declared in effect in January ror r, reserves to the people the legislative powers of initiative-by petition of $8 \%$ of the legal voters (for governor at the preceding election) filed at least 4 months before the general election at which the measure is to be voted upon-and of referendum, which may be ordered, except in case of emergency measures, by the legislature or by a petition signed by $5 \%$ of the legal voters (as above), filed within 90 days after the final adjournment of the legislature which passed the Act in question. The governor may not veto a measure adopted by the people on referendum vote.

The legislature met in regular session from January 9 to May 13, I91 I and in special session from May 22 to June Io, I911. The income tax amendment to the Federal Constitution was ratified on April 22nd. Acts were passed for a franchise tax on corporations doing business in the state. Railways and other public service corporations, including pipe-lines, are to be assessed for their franchises as for other property. An elaborate act is to reduce the rate of taxation.

For 1911 and 1912 \$1,250,000 was appropriated for Confederate pensions: provision was made for a census of Confederate veterans in the state; and $\$ 10,000$ was voted for a monument to the women of the Confederacy on the new capitol grounds at Little Rock.

The sale of intoxicating liquor without a county license, the giving or selling of it to an intoxicated person, and free lunches in saloons were prohibited. There may be a second primary election if no candidate received a majority at the first and a statute provides for the contest of primary elections. General clection days, the birthday of Jefferson Davis and Octolier i2 (Columbus Day) were made legal holidays. Concubinage of whites and negroes was made a felony, and the birth of a mulatto child prima facie evidence of guilt, justifying the conviction of the mother.

An art of 1911 regulates liability of common carriers for injuries to their employes. Contributory negligence does not bar recovery if the employer's disregard of the law has 
contributed to the injury. No contract of indemnity constitutes a bar to action for damages but any sum contributed for insurance, relief benefit or indemnity by the employer may be set off in trial of such an action. Contributory negligence of a person injured by a railway train is not to be considered if the railway fails to have proper lookout, the burden of proof devolving on the railway. The state law requiring full train crews has been declared valid by the Federal Supreme Court (31 S. C. R. 275).

Finance. - The state debt is $\$ 1,250,500$ in $3 \%$ thirty year bonds, maturing in 1929 , held by permanent school fund and University of Arkansas endowment funds. The total receipts for the two years ending September 30, I9I2 were $\$ 6,902,386$; disbursements $\$ 6,812,486$ (principally for general expenses, common schools and Confederate soldiers' pensions). The balance in the treasury on September 30,1912 was $\$ 800,77 \mathrm{I}$.

Education. - The legislature of 191 I created a state board of education and provided for state aid to high schools and for compulsory attendance at school for one-half the school year of children between 8 and I 6 (unless the family is destitute) and of children between 16 and 20, if they are not regularly employed-but this applies to only half the counties of the state. The Medical Department of Arkansas Industrial University in Little Rock was made part of the state university. A proposed constitutional amendment providing for uniform text books was defeated in September $19: 2$ by 64,898 votes to 73,701 . A commission of twenty; appointed by the governor, and with the state superintendent of public instruction as chairman, works with funds from the Southern Education Board; it made its first report in 1911 . In 1912 work began on an educational building at the state university, for which the Peabody Board gave $\$ 40,000$. Four district agricultural schools, at Jonesboro, Russellville, Magnolia and Monticello, created by an act of 1910, were opened in 1912. Of the total population Io years old and more $12.6 \%$ was illiterate in 1910 (20.4\% in 1900$)$. Of whites over 10, $7 \%$ was illiterate (I 1.5\% in I900); of negroes $26.4 \%$ ( $43 \%$ in 1900 ).

In the year ending June 30 , I9I2 the total school population was 603,226 ; the enrollment, 409,746; the average daily attendance, 26I,747; the average length of school year, I 17.9 days; the number of teachers employed, 10,175; the total number of school houses, $6,33^{8}$ (282 erected during the year); and the total value of school property, \$10,131,828. The balance on hand at the beginning of the year was $\$ \mathbf{1}, 398,699$, the income during the year, $\$ 3,876,954$, and the expenditures, $\$ 3,837,549$, leaving a balance of $\$ 1,438,104$.

Charities and Corrections. - The legislature of I9II established juvenile courts in the several counties of the state. Governor Donaghey's recommendation in his call for a special session that the convict labour system be abolished and that provision be made for the proper management and control of the state penitentiary had no legislative result. On December I 7, I912, Governor Donaghey, as a protest against the lease system, pardoned 360 convicts.

History.-Governor George W. Donaghey (b. I856), re-elected by the Democrats for I9ro-i I (by ror, 646 votes to 39,570 for the Republican candidate) did not secure a renomination in $191_{2},{ }^{1}$ his successor in $19 \mathbf{I}_{3}$ being Joseph Taylor Robinson ${ }^{2}$ (b. 1872 ), Democratic member of the Federal House of Representatives from I903 to I9I3, elected on the gth of September rgr2. The people at this state election voted against statewide prohibition of the liquor traffic $(85,358$ to 69,390$)$ and against the " grandfather " clause, or negro disfranchising amendment to the state constitution $(74,950$ to $5 \pi, 334)$, but adopted the "recall" 3 of elective officers (7 r,234 to 57,860) and limited sessions of the state legislature to 60 days (ro3,246 to 33,397). In November the state was carried for Woodrow Wilson (68,838 votes; Roosevelt 21,673; Taft 24,467; Debs 8, I53, -in I908, 5,842); and seven Democratic congressmen were elected-the complete delegation, as the number was not increased by the new apportionment. The election practically eliminated from the control of Federal patronage in the state Powell Clayton (b. 1833 ), governor in $1868-7 \mathrm{I}$, United States senator in $187 \mathrm{I}-77$, and long member from Arkansas of the Republican National Committee.

The new legislature is strongly Democratic (the only Republicans are four in the lower house); it chose (January 29, I913) Joseph Taylor Robinson, the newly elected governor, who had been inaugurated on the I4th, to succeed U. S. senator Jeff Davis (b. 1862; governor 1901-07), who died January 3, 1913 and who had been opposed by

1 The issue in the Democratic primaries was state-wide prohibition of the sale of intoxicating liquors. Donaghey favoured prohibition; Robinson, local option.

${ }^{2}$ Upon Robinson's entering the U.S. Senate the lieutenant-governor, W. C. Rodgers, became governor in March.

${ }^{3} \mathrm{~A}$ circuit judge has ruled that the recall amendment was not adopted because it did not receive a majority of the votes cast for state officers at the same election; and that it was illegally proposed, being the fifth amendment submitted, whereas only three amendments may be submitted at a time. 
Stephen Brundidge, Jr. (b. 1857), member of Congress I897-1909. On January 6, I013, the governor had appointed ad interim J. N. Heiskell, editor of the Arkansas Gazette of Little Rock, but on January 30 he was succeeded by Judge W. M. Kavanaugh, to serve until March 4. In the spring of I9I2 the Socialist party elected a mayor in Hartford, Sebastian county (pop. r910, 1,780).

There were several lynchings in the state in I9II-I2. In I9II a negro was killed at Benton in a race war growing out of an attack on a minstrel troupe; one was lynched at Augusta (Sept. 9) for rape and murder; two mulattoes were killed at Dumas (Sept. 27) in a fight in which they and their white father resisted arrest; a negro was lynched at Forest City (Oct. 16) sharged with rape and another at Hope (Oct. 20) for using abusive language. On March 23, I9 I 2 an apparently innocent negro was lynched at Fort Sinith by a mob excited at the shooting of a constable. The police made no effort to defend him and the chief, three officers, and six patrolmen were removed from sffice. On May 2, twenty-three indictments were returned by the grand jury for participation in the lynching, but no convictions have been secured. On the 4 th of July a negro was lynched at Plummersville, for killing a deputy; and on the I th of August another at Russellville for assault on a white woman.

The state suffered severely from the Mississippi flood in I912. The levee, at three places where it was i to $3 \mathrm{ft}$. below standard grade, broke early in April and flooded a large part of the lower St. Francis basin in N.E. Arkansas, about 2,500 sq. m., where people were cut off for days.

Bibliography.--Public Acts (Little Rock, I911) and official reports, especially of the department of education.

\section{CALIFORNIA ${ }^{1}$}

Population (rgro) 2,377,549, an increase of 60.1\% since 1900; $73.2 \%$ native whites ( $26.7 \%$ native whites of foreign parentage), $21.8 \%$ foreign born whites, $0.9 \%$ negroes, and $4 \%$ Indians and Asiatics. Density 15.3 to the sq. m. Roughly, the growth was relatively larger in the southern part of the state: in Los Angeles county it was $196 \%$, and in the two southern-most counties, San Diego and Imperial, II $4.5 \%$. In I910, $61.8 \%$ of the total was in the 70 cities with more than 2,500 each; in $1900,52.4 \%$ in the 40 cities of this size. The semi-urban population in 128 (76 in I900) cities and towns, each with less than 2,500 inhabitants, constituted $6.4 \%(6.1 \%$ in 1900$)$ of the total. The rural population decreased relatively from $41.5 \%$ in 1900 to $31.7 \%$ in I910.

There were 10 cities with between 5,000 and 10,000 each in 1910, 34 cities (and 5 other places) each with 2,500 to 5,000, and 60 cities (and 68 other places) each with less than 2,500. Twenty-one cities, as follows, had more than 10,000 each (the I900 populations are given in brackets): San Francisco, 416,012 (342,782); Los Angeles, 319, 198 (102,479); Oakland, I50,1 $74(66,960)$; Sacramento, the capital, 44,696 (29,282); Berkeley, 40,434 (13,214); San Diego, 39,578 (17,700); Pasadena, 30,201 (9,117); San Juse, 28,946 (21,500); Fresno, 24,802 (12,470); Alameda, 23,383 (16,464); Stockton, 2.3,253 (17,506); Long Beach, I7,800 (2,252); Riverside, I5,212 (7,973); San Bernardino, $12,779(6,150)$; Bakersfield, 12,727 (4,836); Eureka, I1,845 (7,327); Santa Barbara, I $1,659(6,587)$; Vallejo, I I,340 (7,965); Santa Cruz, xi, I 46 (5,659); Redlands, 10,449 (4,707); Pomona, 10,207 (5.526). It is noteworthy that four of these cities are in Los Angeles county. Los Angeles itself, which in Io I-I 2 had a population of some 400,000 , continues to grow with great rapidity; and the strect-car connection with Pasadena on one side and the "beach towns," Santa Monica, Redondo, etc., on the other, is creating a "Greater Los Angeles," by stimulating their development and that of the area between them and the city. In San Francisco the recovery from the ruin caused by the fire and earthquake of I006 has proceeded with striking results: what is practically a new and even finer city has come into existence, full of palatia! buildings; and active preparations are being made for the great Panama-Pacific Exposition to be held in ror 5 .

1 See E. B. v, 7 et seq. 
Agriculture.-In 1910 the farm acreage was 27,931,444 (I I,389,894 improved), and the average acreage of each farm was 316.7 -all these being a little less than in 1900 . In the decade the total value of farm property increased from $\$ 796,527,955$ to $\$ 1,614,694,584$ (land, $\$$ 1,317,195,448; buildings, \$133,406,040; implements, $\$ 36,493,158$; and domestic animals, $\$ 127,599,938)$, and the average value of a farm from $\$ 10,980$ to $\$ 18,308$ and of farm land per acre from $\$ 21.87$ to $\$ 47.16$. In 1910 about four-fifths of all farms were operated by owners or managers and only one-fifth by tenants. The most striking change in crop acreage was in wheat, of which in $1899,2,683,405$ acres (less than in 1889 ) were harvested, but in 1909 only 478,217 . In $1909,39,352$ farms (out of 88,197 ) were irrigated; in 24 of the 58 counties more than half the farms were irrigated; and of the total irrigated acreage $(2,664$,104) 961,136 acres were individual or partnership enterprises, 779,020 acres co-operative, 746,265 commercial, 173,793 in irrigation districts, 3,490 under the Indian service and 400 under the United States Reclamation Service. In its first season, I9I I, the (Federal) Orland project (begun 1906; 85\% finished in November 1912) irrigated 2,600 acres; and preliminary examinations for the Needles (Colorado river) project are not completed. The cost of irrigation up to 1910 was $\$ 72,580,000(\$ 20.05$ an acre) and the estimated final cost of enterprises begun is $\$ 84,392,344 .^{1}$

In 1912 (preliminary estimates) the principal cops, excluding fruits, were: Indian corn, I, 924,000 bu. (52,000 A.); wheat, $6,290,000$ bu. (370,000 A.); oats, $7,800,000$ bu. (200,000 A.); barley, 4I,760,000 bu.,-about one-fifth of the country's crop-(I,392,000 A.); rye, I4I,000 bu. (8,000 A.); potatoes, 10, I 40,000 bu. (78,000 A.); hay, 3,825,000 tons $(2,500,000 \mathrm{~A}$.); cotton, 9,000 bales; rice 70,000 bu. ( $1,400 \mathrm{~A}$.); sugar beets, $1,037,283$ tons $(99,545 \mathrm{~A}$.). In I 909 (U. S. Census) the value of tropical fruits was $\$ 16,75^{2}$, IOI (oranges, $\$ 12,951,505$; lemons, $\$ 2,976,57$ I ; olives, $\$ 401,277$; figs, $\$ 260$, I 53; pomeloes (grapefruit), $\$ 143,180$ ); of hemp, $\$ 39,000(300 \mathrm{~A}$.$) ; of vegetables other than potatoes, \$ 6,886,885$; of flowers and plants, $\$ 1,388,513$; of nursery products, $\$ 2,2$ I2,788; of small fruit, $\$ 1,789,2$ I 4 (strawberries, $\$ 1,149$,475 ; raspberries and loganberries, $\$ 304,169$; blackberries and dewberries, $\$ 282,383$ ); of orchard fruits, $\$ 18,358,897$ (apples, $\$ 2,901,662$; peaches and nectarines, $\$ 4,573,775$; plums and prunes, $\$ 1,660,963$; cherries, $\$ 5,473,539$; apricots, $\$ 2,768,921$ ); of nuts, $\$ 2,959,845$; and of grapes, \$10,846,812. On January 1, I912 there were on farms: 493,000 horses, 72,000 mules, 505,000 milch cows, I,515,000 other neat cattle, 2,656,000 sheep and 830,000 swine. In December I9II an act was passed for the promotion of horticulture and to prevent the introduction of insects or diseases injurious to fruit trees, etc.; it provides for the inspection of nursery stock, etc., brought into the state.

The University of California received an appropriation of \$30,000 to enable it to hold farmers' institutes; \$15,000 every two years for research work in viticulture; the same sum for the improvement of cereal crops and the same for the study of plant diseases not already arranged for by the Southern California Pathological Laboratory. Experiments in rice culture point toward the possibility of large crops of this cereal; important investigations have been made of orange thrips and scale insects; and it has been proved that the bubonic plague was carried by wood-rats and ground squirrels. In I9I I a new bird reservation was established at the Clear Lake reservoir, S. E. of Lake Klamath.

Mineral Products. - Total value, $1911, \$ 90,517,566$. The state ranked first in petroleum with an output of $8 \mathbf{I}, \mathbf{I} 34,39 \mathrm{I}$ bbls. $(\$ 38,719,080)$, in asphalt, mostly oil asphalt, $\$ 2,104,42$ I $(50 \%$ more than in I9IO), and in gold, $\$ 19,928,500$ (a little more than Colorado's output in I9I I or California's for I9Io). The North Star mine near Grass Valley and the Kennedy at Amador City ranked 9 th and 14 th respectively among the largest gold mines in the country. There was an increase in placer production and quartz mining, but a decrease in deep mining due to the decrease in mining copper and lead. In silver, \$686,300, there was a decrease of nearly one-third compared with the preceding year. The output of copper was $35,835,65 \mathrm{I}$ lbs. (20\% less than in I9IO), of lead, 6I5 tons (less than half that of 19I0), and of zinc, I,404 tons (mine reports; 959 tons, smelter reports; none reported in 1910). The state produced in I9I I about nine-tenths $(\$ 867,749)$ of all quicksilver, more than oneseventh of all pyrites, all the magnesite (including that from a new deposit at Bissell, Kern county), most of the crude platinum ( 5 I I oz.), practically all the borax $(\$ I, 569, I 5 I)$ and all the chromic iron ore $(\$ 1,629$; from Shasta, Siskiyou and Tehama counties) produced in the country. Important absolutely were: salt, I, 062,813 bbls. $(\$ 543,917)$; clay products $(\$ 4,915,866$, mostly brick and tile); Portland cement $(\$ 8,737,150$, ranking next to Pennsylvania); stone $(\$ 4,676,902$, ranking fifth), the larger items being granite, $\$ 1,738,094$, and trap rock, $\$ 2,055,930$; sand and gravel, $\$ 416,980 ;$ and lime $\$ 564,175$. Natural gas was valued at $\$ 800,714$, much more than in any previous year and about 12 times as much as in 190I. Mineral waters, bottled at 40 springs, including 18 resorts, were valued at $\$ 578,439$, almost a half more than in I910. Brine in Searles Lake, San Bernardino county, has 6.78\%? of potash and may furnish a supply for fertiliser.

Manufactures.-Between 1904 and 1909 the number of establishments increased from 6,839 to 7,659 ; the number of persons engaged in manufacturing from 120,040 (I00,355 wage-

${ }^{1}$ See F. W. Roeding, Irrigation in California, and Victor M. Cone, Irrigation in the San Joaquin Valley (both Washington, I9II). 
earners) to 141,576 (II5,296 wage-earners); the invested capital from $\$ 282,647,060$ to $\$ 537,134,000$; and the value of products from $\$ 367,218,000$ to $\$ 529,761,000$. The principal products were: lumber and timber products, $\$ 45,000,000$; slaughtering and meat packing products, $\$ 34,280,000$ (I $6.7 \%$ more than in 1899 ); canned and preserved fruits, vegetables, fish, etc., localised largely in Fresno, Oakland, Pomona and Redlands, \$32,915,000 (more than one-fifth the total for the United States and far more than for any other state); foundry and machine shop products, $\$ 26,731,000$; flour and grist-mill products, $\$ 25,188,000(93 \%$ more than in 1899 ); printing and publishing $\$ 25,032,000$; steam railway cars and construction, $\$ 18,719,000$; refined petroleum, $\$ 17,878,000$, about 25 times as much as in 1899; butter, cheese and condensed milk, \$12,761,000 (256.2\% more than in 1899); tanned, curried and finished leather, $\$ 9,367,000$; malt liquors, $\$ 9,319,000$; vinous liquors, $\$ 8,937,000(68.1 \%$ of the total for the United States); illuminating and heating gas $\$ 8,927,000 ;$ copper, tin and sheet iron, \$6,804,000; cement, $\$ 6,504,000$, manufactured principally in Solano, Santa Cruz and San Bernardino counties; roast and ground coffee and spice; $\$ 6,492,000$; food preparations, $\$ 5,508,000$; distilled liquors, $\$ 5,353,000$; and men's clothing, $\$ 5,121,000$.

In $1909,55.7 \%$ of the total value was reported from the $2 \mathrm{I}$ cities, each with 10,000 inhabitants or more. San Francisco was still the first manufacturing city, and the decrease in the value of manufactures from $\$ 137,788,000$ in 1904 to $\$ 133,041$,000 in 1909 was due partly to the fire of 1906 . Los Angeles $(\$ 68,586,000)$, the second city, showed an increase of $353.2 \%$ between 1899 and 1909 ; and Oakland $(\$ 22,343,000)$, third, an increase of $316.2 \%$. Other important manufacturing cities were Sacramento \$13,977,000; Stockton, \$1 1,849,000; Fresno, \$1 1,090,000; San Jose, \$5,610,000; San Diego, \$4,74I,000; and Berkeley, \$4,435,000.

Transportation.-Railway mileage, January I, I9I2, 7,5II.78. The department of engineering was reorganised in 1911 and now appoints a highway engineer. Many separate acts were passed to establish state highways, notably in Alpine county, which has long been without any westward outlet, the only roads leading $\mathrm{E}$. into Nevada. Much has been done to improve roads for motoring, especially near Los Angeles. The state contributed towards the improvement of the Sacramento and Feather rivers, and the Federal government appropriated (March 4, I9I I) \$ I 5,000 for the state débris commission and in 19 I I $\rightarrow$ I 2 was dredging the harbour of Los Angeles and building a breakwater there, improving San Francisco harbour by rock removal, digging a $30 \mathrm{ft}$. channel in San Diego harbour and another in Oakland, and improving the entrance channel at San Luis Obispo.

Legislation.-The 39 th session of the legislature met from January 2 to March 27, I9II, and on February 3 ratified the proposed 16 th amendment to the Federal Constitution. At an extra session, November 27 to December 24, the state was redistricted, into senatorial, assembly and congressional districts; and by joint resolution an amendment to the Federal Constitution to provide for a nation-wide direct vote for president and vice-president was urged.

A conservation commission was appointed by the governor to report laws and make regulations in regard to forestry, water, the use of water, water power, electricity, mines, mineral lands, etc., and $\$ 100,000$ was appropriated for this work, although no salary was allowed to the commissioners.

Provision was made for a presidential primary election to be held on the second Tuesday in May in the years of presidential elections. A primary law adopted the Oregon plan of pledging legislaturs to the people's choice for United States senator as shown in the primary or of having a legislator sign an alternative pledge, that he would consider the primary choice merely as a recommendation. Nominations other than by primary must be made by petition with a certificate for each signer. A law providing for a registrar of voters was referred to the people and defeated $(255,05 \mathrm{I}$ to 145,924$)$ in Nov. 1912 .

The law in regard to voting machines was revised; no machine may be used which makes it possible for a straight ticket to be voted without the separate motion of lever or button for each separate candidate. A ballot law provides for the office group form, with names arranged in rotation-but alphabetically for local offices-with the party name or the word "independent" following the name of the office and with a blank space in each party group for the addition of the name by the elector. A sample ballot and a card containing instructions must be mailed to each voter. Pamphlets containing arguments for or against referendum measures must be distributed to voters-until there is legislative action forbidding this-and pamphlets on proposed constitutional amendments must be distributed to public schools,

Twenty-three constitutional amendments were adopted by popular vote on October 10,1911 , the most important being for the initiative and referendum, providing for initiation directly to the perple if the petition is signed by $8 \%$ of the voters or more, but through the legislature if the petition is signed by more than $5 \%$ and less than $8 \%$, and giving the governor, as in Oklahoma, the power to call a special election for initiative measures; an amendment providing for woman suffrage; one for the recall of all elected officers (I78, II5 
votes to 53,755 ); one prohibiting the reversal of verdicts in criminal cases on mere technicalities; and one limiting biennial sessions of the legislature to 30 days with a recess of 30 days before re-assembling, no bill then to be introduced except with the consent of three-fourths of the members of the house and no member to be allowed to introduce more than two bills. Before the adoption of these amendments, the legislature had granted to voters of municipalities the right of initiative and referendum on municipal questions; providing for initiative on a petition of $15 \%$ of the qualified electors-in this case the measure must come before a general election, but if the petition is signed by $30 \%$ it must either be passed by the city council or must be brought up at a special election; only emergency measures passed by a four-fifths vote by the city legislative body are exempt from the referendum; appropriation measures do not go into effect for 30 days and they may be suspended by a petition signed by $25 \%$ of the voters until they are acted on by a special or general election. The provision for a recall was that a vote for the recall of any city official might be called by a petition of $25 \%$ of the voters at the last city election, after he had been in office for four months. A similar law provides for the initiative, referendum, and recall in counties, but the initiative petition must be signed by $20 \%$ of the qualified electors to secure the calling of a special election and a vote for the recall of an officer after he has been in office six months can be secured by petition of $20 \%$ of the voters at the last congressional election.

A law for local option in incorporated towns and cities and in supervisorial districts outside of a city or town requires a local option election on a petition of $25 \%$ of the qualified voters. This law has been held constitutional, and there were to the end of I9I2 about 160 elections under the act: of about 60 cities, two thirds voted for licence and of about 100 supervisorial districts, 3 out of 5 voted for licence: Two measures in regard to local officers and one (initiated) providing for consolidated city and county governments were defeated at the November I912 election--each by about 7 to 4 .

The municipalities of the state were re-classified ${ }^{i}$ and a law authorises the municipal ownership, construction, and operation of public utilities.

The commission form of government was extended in I9II-I2 to the following cities: Oakland (election Dec. 8, I910; in effect July I, I9II), Modesto (election Sept. I4, I9I0; in effect July I, I9I I), Vallejo (election Feb. 2I, I9I I; in effect July I, I9I I), Pomona (election Feb. I6, I9I I; in effect May 8, I9II), San Luis Obispo (election Sept. 12, 1910; in effect May 15, I9II), Monterey (election Dec. I2, 1910; in effect July I, I9II), Santa Cruz (election Jan. 3I, I9II; in effect July 3, I9II), Petaluma (election Feb. I4, I9I I ; in effect April 17, I9II; not a pure commission), Sacramento (election Nov. 7, I9II; in effect July I, I912), and Stockton (election Oct. I7, I9I I ; in effect Jan. 6, 1913). In every case the new charter was drawn by the board of freeholders or city council. San Mateo also has commission government, not a freeholder charter, and San Bernardino adopted it in 1912. Los Angeles rejected it December 3,1912 by nearly 2 to I, and Eureka by I,048 to 124 .

At a special election in San Francisco on November I5, I9IO, I 8 out of 35 amendments proposed to the charter were adopted: one for initiative and referendum and recall; one for direct nominations with no party name to appear on the ballot, but not less than ten or more than twenty sponsors must appear before the registrar to certify under oath to the qualifications of any candidate for office; and one for the minimum wage of $\$ 3.00$ a day for municipal employees in San Francisco. Of 37 amendments submitted December 10, I9I2 that for local-option by city districts was defeated but one extending the power of the civil service commission and one authorising the purchase of land for a civic centre were adopted. On December 20 five propositions for bond issues were voted upon, and all were rejected, except one for $\$ I, 700,000$ to complete the county hospital.

Fourteen amendments to the charter of Los Angeles were adopted on March 6, I9I I, at a special election. They provide for the initiative, referendum and recall, for primary nominations, for the regulation of expenses of candidates, for the creation of a commission on a city plan, for the establishment of a department of public utilities, a harbour department, a department of public service, playground department and a municipal art commission, and for the creation of pension funds for firemen and policemen. On December 5 , I9I I the people voted $(58$, I 34 to 43,937$)$ for a municipal newspaper but against $(88,395$ to 32,283 ) a measure prohibiting saloons; and on May 28, I9I2 voted for an aqueduct investigating board $(16,564$ to 15,697$)$ and against the improvement of a harbour boulevard $(20,415$ to II, I I $)$ - it is to be remarked that the vote on these initiated measures was much smaller in I9I2 than in I9II. In the latter year there were two referendum votes (May 28 ); one against ( 18,883 to 13,899$)$ an ordinance requiring the testing of milk for tuberculin, and one for $(2 \mathrm{I}, 085$ to $\mathrm{II}, 662)$ an ordinance regulating franchises.

${ }^{1}$ Cities over 400,000 are in the first class and those between 250,000 and 400,000 in the first and one'half class, cities between 100,000 and 250,000 in the second class, those between 23,000 and 100,000 in the third, those between 20,000 and 23,000 in the fourth, those between 6,000 and 20,000 in the fifth and those under 6,000 in the sixth; but cities already organised are not to be classified and municipal corporations are not to be reclassified on the basis of the Federal census without action of the state legislature. Another law classified the counties of the state and adopted a new county code. Laws provide for the recall of elective officers and for initiative and referendum in counties and in subdivisions of counties. 
A railway commission (later changed to a public utilities commission), was organised, and by constitutional amendments and statutes received important powers, - among others (by the Eshelman-Stetson law) to fix absolute (and not minimum) rates and to make physical valuations of railways; $\$ 210,000$ was appropriated for the work of the commission. A highway engineer is to be appointed by the department of engineering, reorganised in I9I I.

The state bureau of labour was re-organised. The term of the commissioner is no longer limited to four years but he holds office at the pleasure of the governor. In I9I I the state passed the first law in the United States requiring all physicians to report occupational diseases to the state board of health, the report to be transmitted to the commissioner of labour. The penalty for failure to report is not more than \$1o. One of the constitutional amendments adopted in October I9I I enabled the legislature to make compulsory the elective compensation laws for workmen; and an act of 1911, applying to all employments, but not to casual employees, is compulsory for state or municipality as employer. The compensation provided for is, in case of death, three years' earnings, not less than $\$ 1,000$ or more than $\$ 5,000$; if there are no dependents, \$10o. For total disability the compensation is $65 \%$ weekly of $\mathbf{I} \mathbf{- 5 2}$ of the average yearly earnings (if a nurse is required, $100^{\circ}$ ) with $\$ 333.33$ the minimum and \$1666.66 the maximum yearly earnings, the limit to be 3 times the yearly earnings or 15 years; and for partial disability $65 \%$ of the weekly wage loss with the same limits as for total disability. Child labour laws forbid any minor under 18 (formerly I6) to work between Io P.M. and 5 A.M. (formerly 6 A.M.) or more than nine hours a day; but children between 15 and 18 may appear on the stage. Fifteen years is the age limit for most employment and $\mathbf{I} 6$ the limit for employment during school hours. Children over 12 may work on special permit from a judge of the juvenile courts. The law making $\gamma$ hours a maximum working day for women in factories, stores, hotels, restaurants, public utility companies, etc. (but not canneries of vegetables and fruits) was held to be constitutional by the supreme court on May 27,1912 in a test case brought by a hotel keeper in Riverside who was imprisoned for making a woman in his employ work nine hours a day. All employers must pay their employees monthly or oftener. Employees discharged must be paid immediately and those that resign, within five days. The powers of the Industrial Accident Board were enlarged. Employers -were required to keep records of accidents. Hours on railways must be no more than 16 in succession followed by 6 hours off. A new law provides for full train crews and sets qualifications for engineers, conductors and brakemen. A law in regard to convict labour requires goods manufactured in state prisons to be marked with the name of the prison and not be sold but only be for public use.

The law for general vaccination passed in 1889 was amended by a clause exempting those that sign a statement they are conscientiously upposed to vaccination, but unvaccinated children may not attend school in a district where there is smallpox. The practice of medicine, surgery, osteopathy and other treatments of cure was regulated by two new acts. The state board of health received an appropriation of $\$ 5,000$ to spread a knowledge of tuberculosis through the state. Giving or selling tobacco to minors is made a misdemeanor. Dairy products must not be manufactured from unhealthy cattle and the sale of impure or adulterated products is forbidden. The Lnited States Department of Agriculture standard of purity for condensed and evaporated milk is proclaimed for the state. Cold storage eggs or butter kept for three months must have marked on the package the date of storage and any place in which they are sold must display a sign "Cold Storage Eggs of Butter Sold Here." It is made unlawful to dump garbage in navigable waters of the state or in the Pacific within 20 miles of land. The secretary of state is to keep standard weights and measures and countie's, cities and towns are to appoint sealers of weights anrl measures. A tenement code was passed for buildings in incorporated places.

The laws against pimping and pandering were made more severe than before and a wife's testimony against her husband in such a case is competent.

The law against pool-selling and book-making on races was amended; but an initiative measure for a state horsc-racing commission was defeated in November 1912 by 353,070 to 149,864 . A new section added to the Penal Code prohibited gambling by use of slot-machines and of dice having more than six faces.

A state flag was adopted showing a grizzly bear in dark brown on a white field with a red stripe at the bottom of the flag and a red star in the upper left-hand corner and on the flag the legend "California Republic."

Finance.-A state board of control was created in I9I I to be composed of three members appointed by the governor to hold office during his pleasure at a salary of $\$_{4}, 000$. This board is 10 itmine the books of every state institution and visit institutions; to investigate school land funds; to supervise the state's financial policy; to pass on contracts for supplies; to supervise a new department of public accounting: and to institute a uniform system of accounting. The board of examiners was abolished. In accordance with a constitutional amendment of 19 I0 public service corporations are taxed on their gross earnings for a state tax only and the state and local taxes were separated. Public service corporations were taxed from $2^{\circ}$ oto $t^{\circ}$ on gross earnings; insurance companies $I^{\frac{1}{2}}{ }^{\circ}$ or on their gross premiums and banks $I^{0}$, on their capital, surplus and undivided profits. These rates may be changed by a two-thirds vote of the legislature. The state banking law was revised in 1911 . An 
amendment (IVII) to the law in regard to non-resident taxation taxes anything left by the will of a resident of the state or by the will of a non-resident bequeathing property within the state or on a transfer without valuable consideration and makes the tax a lien on the property. There is a scale for the nearness of kin to the legatee; under $\$ 25,000$ the rate is I \% for those nearest of kin and $5 \%$ for those more remote; for sums between $\$ 100,000$ and $\$ 500,000$ the corresponding rates are $5 \%$ and $25 \%$. In 1912 the controller published the first annual report of the finances of municipalities and counties in the state, authorised by a law of April 21, I9II. An initiated amendment for local taxation was defeated in November I 912 by 243,959 to 169,32 I ; but one changing the system of depositing public funds was adopted, 307,199 to $128,4 \mathrm{II}$.

The cash in the state treasury July 1,1910 , was $\$ 7,201,220$. The receipts for the fiscal year ending June, I9I I, were \$18,843,854 and for the year ending June $30,1912, \$ 27,395,144$. The expenditures for these years were respectively $\$ 18,591,47$ I and $\$ 24,945,213$, leaving a balance on hand June 30,1912 , of $\$ 9,903,534$.

Educatian.-A new compulsory education law of I9I sets the age for school attendance from 8 to 15 , but there are many exceptions. In accordance with a constitutional amendment of 1910, the fund for the University of California is to be increased by $7 \%$ a year from 191 I until 1915. In November 1912 the people approved $(343,443$ to 171,486$)$ an amendment to the constitution giving free text-books to pupils in day and evening schools. A state normal school at Fresno was opened for instruction in September 19II. One high school in every first class city must teach French, Italian, Spanish and German and such a school is to be called a "cosmopolitan school." Athletics and military drill may be included in the high school curriculum and high school cadet companies may be organised with target practice under the supervision of an officer of the National Guard:

For the school year ending in the summer of 1912 the total enrollment was 423,824 ; the average daily attendance, 323,657 , and the length of the average school year, I 72 days. The total school revenue (excluding that of the University of California) was $\$ 32,265,79$ I and the expenditures $\$ 24,534,266$.

Illiteracy in the population Io years old and over was $3.7 \%$ in 1910 against $4.8 \%$ in 1900 .

The University of California in 1912 received a gift of $\$ 100,000$ for the endowment of scholarships for men. Late in the same year Prof. Merriam of the University began the excavation of remarkably preserved skeletons of prehistoric animals mixed in tar pools on Rancho La Brea, near Los Angeles. In April I9I2 the University Medical school was re-organised in three departments: gynecology and obstetrics, medicine, and surgery.

Charitable and Penal Institutions.-T The state board of charities and corrections received new powers in 1911 , and a state reformatory for first affenders between 16 and 30 was established; it is to be erected near Yountville, Napa county. Inebriates and those with drug habits may be committed to a state hospital for the insane. The juvenile court law was twice amended, in minor details, in I9II. On November 6, I9II, the Federal Supreme Court (Finley $v$. California) held that there was no unconstitutional discrimination in a law making death the penalty for assault with intent to kill on the part of a convict serving a life term. In I9I2 an effort was made to propose by initiative a constitutional amendment abolishing capital punishment.

History.-Hiram W. Johnson (b. I866) was elected in November I9 1o governor for the term I9I I- 5 by I 77, I9I votes to I $54,8,35$ for Bell (Democrat), 47,8 I 9 for Wilson (Socialist) and 5,807 for Meads (Prohibitionist). This was the result of a campaign in which Johnson toured the state in an automobile, attacking "special interests" and particularly the Southern Pacific Railroad, whose counsel (and vice-president since March rgro), William F. Herrin (b. 1854), he accused of having an undue and improper influence upon legislation and nominations for state office. Johnson's nomination and election gave the Lincoln-Roosevelt League and the progressives generally control of the Republican partisan machinery.

The Eshelman-Stetson law (see above) had for its object the lessening of the power of the Southern Pacific; the amendment for municipal home rule, resulting in the adoption of several free-holder charters with commission government, put the cities of the state on a better government basis than those of any other state; and Colonel Roosevelt said that Governor Johnson and the legislature put through " the most comprehensive program of constructive legislation ever enacted at a single session of any American legislature." An attempt was made to "side-track" the governor by electing him United States senator, but the choice fell (Jan. I I) on John Downey Works (b. I847), one of Johnson's aides in the campaign, justice of the state supreme court in I888-9 I, an authority on water rights and a prominent Christian Scientist. In the election of delegates to the National Convention the state law stipulated that the vote for district 
delegates should be by the state-at-large; the rules of the Republican National Committee that they should be by districts. There resulted a bitter contest in the Convention in the case of two seats, which the Convention awarded to Taft. Johnson's primary law was one factor, his name on the Progressive ticket and the votes of women were others, in the victory of Roosevelt in the Republican presidential primary; he received 70,000 votes more than Taft and 25,000 more than Taft and LaFollette combined. Champ Clark defeated Woodrow Wilson in the Democratic primary-William Randolph Hearst was one of Clark's strongest supporters and a power in the Democratic party in the state. On October 3 the state supreme court barred from the Republican ticket the electors pledged to Taft, at the same time calling the primary law a very bad one because it would practically disfranchise one-third of the voters of the state. This made it necessary for Taft electors to be nominated by petition with signatures of II, 000 voters who had not taken part in the primaries. The state was carried for Roosevelt by I 74 plurality for the highest Republican elector (283,610 for Roosevelt, and 283,436 for Wilson). Of the 13 presidential electors I I were for Roosevelt and 2 for Wilson. The Socialist vote was 79,20I (in I908, 28,659; in I9ro for governor 47,819) and the vote for Taft was only 3,914. The Congressional delegation, I I instead of 8 as for the last decade, contains 3 Democrats, 4 Republicans and 4 Progressives. The new state legislature contains enough Democrats and Taft Republicans to make difficulties for Governor Johnson. One Socialist was elected to the lower house from Los Angeles.

The municipal election in San Francisco in IgII-the first under the new nonpartisan plan-resulted for the first time in the victory of the "anti-Union Labour" party; at the primary James Rolph, Jr., received a majority of all votes cast (Sept. 26th), defeating Mayor McCarthy; who had the backing of the Union Labor party, and becoming mayor-elect without a general election. In the spring of I9I I a Socialist mayor, city commissioner, and member of the board of education were elected in Berkeley, - an educational and residential, rather than an industrial city; and in April r 912 , in Daly City, a suburb of San Francisco with 3,000 inhabitants, the Socialists elected a city clerk and three (out of five) members of the board of trustees, including the mayor - that is, gained the control of the city government. In Oakland the Industrial Workers of the World secured a petition (March I9r2) for the "recall " of the mayor and two commissioners on the ground that they protected vice, but the recall election resulted in favour of the incumbents. In San Francisco a municipally owned and operated street railway to Golden Gate Park (bonds issued in 1909) was opened December 27, I912. An extension to Ocean Beach is planned. A municipal opera-house in San Francisco seems assured. Los Angeles has a municipal cement mill built in 1908 .

The trial, beginning October 9, I9II, in Los Angeles, of John J. and James B. McNamara (arrested in Indianapolis April 22) for dynamiting the Los Angeles Times Building (Oct. I, Igro) and the Llewellyn Iron Works, was one of the most important events in the state's recent history (see United Stares, §. History). The Los Angeles election of December 5, I9I I was marked by the first participation of women voters, and by a contest between the Socialists, whose candidate, Job Harriman, one of the counsel for the McNamaras, suffered from their cause being discredited, and the "Good Government " party, which re-elected Mayor Alexander (83,978 to 52,293 for Harriman). Late in November IgI 2 a recall petition against the mayor was circulatedapparently for political purposes.

The experiences of Los Angeles with organised labour. aroused opposition in San Diego to the Industrial Workers of the World and other radicals, who in April I 9 I 2 made the place a centre for their propaganda and flocked thither from the whole Pacific Coast. In December I I I I the city council had abolished street meetings in a district where they had formerly been held. After the arrest of speakers at meetings called by a Free Speech League, ${ }^{1}$ a meeting, not in the forbidden quarter, was broken up by the

1 The demonstrations were nominally to test the right of free speech, as were meetings in February' I9I I in Portland (Oregon) and Spokane (Washington) and in Fresno (California) where 40 were convicted and put to breaking stone. 
police, March I7, rgr2. On May 7 th, two policemen watching a lodging house frequented by radicals were shot from ambush. Camps outside the city were established to turn back Industrial Workers, and a "vigilance" system was organised. Dr. Ben Reitman, an aide of Emma Goldman, was tarred and feathered and driven out of the city on May 15 ; Mrs. Goldman left the city immediately afterwards without lecturing on "free speech," as she intended; and there were riots in the city on the 27 th. Six leaders of the Industrial Workers were convicted of felony on August i I. In the meantime a special commissioner reported to Governor Johnson that the city authorities were blameworthy for arbitrary treatment of the speakers, and the governor instructed the attorney-general to restore law and order. He threatened to declare military law and began an action against the vigilantes, but the grand jury adjourned without finding an indictment. A negro was lynched at Bakersfield September 12, I912, for an alleged assault on a white woman.

A civil service system was established in Oakland in I9I 2 with the assistance of two members of the Chicago civil service board. In IgI I an efficiency department was established in Pasadena.

Bibliography.-Statutes and Amendments to the Codes (2 vols., Sacramento, 191 I-12) and other official reports. F. Hichborn, Story of the California Legislature of Igog. (San Francisco, 1909), and Story of the California Legislature of IOII (ibid., I9II); Helen T. Purdy, San Francisco: As It Was; As It Is; and How To See It (San Francisco, 1912); John Muir, The Yosemite (1912); J. S. Chase, Yosemite Trails (Boston, 1911); D. W. Johnson, "The Hanging Valleys of the Yosemite" in November and December 191 I, Bulletin of American Geographical Society; K. B. Judson, Myths and Legends of California and the Old Southwest (1912); J. B. Richman, California Under Spain and Mexico, 1535-1847 (Boston and New York, I9II); L. Eaves, A History of California Labor Legislation (Berkeley, 1910).

\section{COLORADO 1}

Population in 1910, 799,024 (48\% more than in 1900). The greatest relative increase since 1900 was $635.9 \%$ in Cheyenne county, on the E. boundary. In 14 counties in the central part of the state and near the S.W. corner there were actual decreases $(59.9 \%$ in Hinsdale county). In $191082.2 \%$ of the population were native whites and $\mathbf{1 . 4} \%$ negroes; ' $5.9 \%$ were whites of foreign birth and $22.7 \%$ were whites of foreign parentage. The average density of population was 7.7 to the sq. $\mathrm{m}$. There were 27 cities and towns with more than 2,500 inhabitants each, and these contained $50.7 \%$ of the total (in 1900,20 with $48.3 \%$ ). The purely rural population increased more than $45 \%$ in the decade, but was only $37.2 \%$ of the total. There were II cities with more than 5,000 each: Denver, 213,38I (I33,859 in 1900); Pueblo, 44,395 (28, I 57 in I900); Colorado Springs, 29,078; Trinidad, Io,204 (5,345 in I900); Boulder, 9,539; Fort Collins, 8,210; Greeley, 8, 179; Grand Junction, 7,754; Leadville, 7,508; Cripple Creek, 6,206; Canon City, 5, I62.

Agriculture.-The acreage in farms. increased from $9,474,588$ to 13,532, I 33 between I 900 and 1910 , and the improved land in farms from $2,273,968$ to $4,302,101$; the average farm acreage fell from 383.6 to 293 .I ; and the value of farm property increased from $\$ 161,045$, IOI to $\$ 491,47$ I,806 $(\$ 362,822,205$ land; $\$ 45,696,656$ buildings; $\$ 12,791,601$ implements; and $\$ 70,161,344$ domestic animals). In I910 one-fifth of the land area was in farms; 36,993 farms were operated by owners, 787 by managers and 8,390 by tenants. The average value of farm land per acre (exclusive of buildings) was \$26.81. The total acreage irrigated in 1909 was $2,792,032(73.3 \%$ more than in 1899 ); of this total $2,758,283$ were supplied from streams. The total cost of irrigation enterprises to July I, I9I0 was $\$ 56,636,443$, and the estimated final cost of improvements begun was $\$ 76,443,239$. Of cereals $42.6 \%$ by acreage in 1909 was grown on irrigated land, and of oats, $69.7 \%$; of barley, $68.3 \%$; of hay and forage crops, $74.8 \%$ and of alfalfa, $94.4 \%$; "wild, salt or prairie grasses," $75.9 \%$; of sugar beets, $99 \%$ and of potatoes, $69 \%$. There is an irrigation demonstration farm at Eads, Kiowa county. The Gunnison tunnel of the (Federal) Uncompahgre Valley project (see $E$. B. vi, $720 \mathrm{ob}$ ), was completed "for present use" in June 1910, and in November I9I 2 the entire project was $56.2 \%$ completed. Preliminary work is being done on the Grand Valley project (Mesa county) to irrigate 53,000 acres by tunnels from the Grand river. In 1912 (preliminary estimates) the principal crops were: Indian corn, $8,736,000$ bu. $(420,000 \mathrm{~A}$.); wheat, $10,968,000$ bu. (453,000 A.); oats, I 2,412,000 bu. (290,000 A.); barley, 2,964,000 bu. (76,000 A.); rye,

${ }^{1}$ See E. B. vi, 717 et seq. 
488,000 bu. $(25,000 \mathrm{~A}$. $)$; potatoes, $8,075,000$ bu. $(85,000 \mathrm{~A}$.$) ; hay, 1,905,000$ tons, $(870,000$ A.); flaxseed, 96,000 bu. (12,000 A.); and sugar beets, 957,142 tons $(86,437 \mathrm{~A}$.). In I909 the value of vegetables other than potatoes was $\$ 2,349,634$; of flowers and plants, $\$ 468,685$; of nursery products, $\$ 72,090$; of small fruits, $\$ 398,836$ (strawberries, $\$$ i 56,059 ; raspberries, $\$ 156,668$ ); of orchard fruits, $\$ 4,651,792$ (apples, $\$ 3,405,442$; peaches and nectarines, $\$ 764,561$ ). On January 1, 1912 there were on farms: 321,000 horses, 167,000 milch cows, 921,000 other neat cattle, 17,000 mules; 1,579,000 sheep and 211,000 swine. Carriage horses were successfully bred in $1911-12$ at the Agricultural Experiment Station.

The legislature of I9II amended previous irrigation laws; created the office of state dairy commissioner, and passed an elaborate act for dairy sanitation and for the branding of dairy products; it gave to the state board of agriculture authority over forestry and provided for the appointment of a state forester; passed a law requiring a health certificate for cattle over six months old brought into the state, and a law requiring railways to build fences to protect herds. A school of horticulture and forestry was established in $191 \mathrm{I}$ at the Grand Junction Indian School, and a School of Agriculture and Mechanical Arts at the Fort Lewis School, which was thereby put on a par with the Fort Collins School.

Mineral Products. - Total value, I91 I, \$51,958,239. In gold the state ranked second with $\$ 19,138,800$, less than that of California in I91 I and less than Colorado's output in 1910, when the state ranked first. There was a similar decrease in the value of silver, in which the state ranked fifth in 19 I I with $\$ 3,958,800$; in 1910 it ranked fourth, a position held by Idaho in I9Ir. Teller county, with the Cripple Creek district, was the principal gold producer and Lake county (Leadville) the principal producer of silver. Other metals were: copper, 9.791,86I lbs.; zinc, 42,233 tons; and lead, 30,62 I tons. Second in value to gold was coal, $10,157,383$ tons $(\$ 14,747,764$; less than in 1910$)$. The value of petroleum was $\$ 228,104$ $(226,926$ bbls.). A little natural gas was used commercially in Boulder and F remont counties. Clay products were valued at \$1,606,709; stone at \$1,51 4,827 (mostly marble and including small output of marble from several other states); and sand and gravel at $\$ 65,366$. Portland cement was manufactured at two plants. From the Boulder field 730 tons of tungsten were taken in 1911. Vanadium was found in San Miguel and Montrose counties. Sulphur deposits in Mineral county have not yet been worked commercially. Mineral waters, bottled at I 4 springs, including 5 resorts, were valued at $\$ 104,763$. Mica, fluorspar, graphite and grindstones were minor mineral products.

Manufactures.-From 1904 to 1909 the number of establishments increased from 1,606 to 2,034 ; the number of persons engaged in manufacturing from 25,888 (21,813 wage-earners) to $34,115(28,067$ wage-earners); the invested capital from $\$ 107,664,000$ to $\$ 162,668,000$ (5I.I increase); and the value of products from $\$ \mathrm{I} 00,144,000$ to $\$ 130,044,000$. The principal manufactures in 1909 were: smelting products (value not shown separately): slaughtering and meat-packing products, \$9,657,000 (190.5\% more than in 1904); flour and grist mill products, $\$ 7,868,000$; printing and publishing, $\$ 6,962,000$; steam-railway cars, construction and repairs, $\$ 6,559,000$; foundry and machine-shop products, $\$ 5,907,000$. The principal manufacturing cities, with the value of their products, were: Denver, $\$ 51,538,000^{\circ}$; Pueblo, \$3,345,000; and Colorado Springs, \$1,733,000.

Communications.-Railway mileage, January I, I912, 5,728.30 m. Beginning with I9II the second Friday in May became a state holiday under the name of "Good Roads Day." An act of 19 I I provided for a tumnel through James Peak to be used, but not exclusively, for fifty years by the Denver, Northwestern \& Pacific Railroad, with the option to purchase, but under the necessity of completing a through line to Salt Lake City; this was referred to the people in November 1912 and was defeated.

\section{Legislation.- The legislature met from January 4 to May 6, Igir. On February} 20 it ratified the proposed Federal income tax amendment. Amendments to the state constitution were proposed, making smelters public utility works; and providing for a state tax commission. An initiated amendment for prohibition was defeated in November I9I 2; this was the first measure of great importance brought before the people under the constitutional amendment (like that of Oregon) for initiative and referendum, passed in special session September ro. iо ro, arlopted at the November igro election by 8()$, \mathrm{I} f \mathrm{I}$ votes to 28.608 . declared invalid by the district court. August 23, I0 1 2, but held constitutional by the state supreme court on September 23. Other important amendments and measures voted on in 1912 were: for recall of officials, adopted by $5.3,620$ to 30.564 ; for popular recall of decisions of the state supreme court that laws are unconstitutional, adopted by 55.4 I 6 to 40.809 ; a new ballot law, adopted by 4.3 .390 to 30.504 ; and a measure for state compensation to deserted or widowed mothers of dependent children, adopted 82,337 to 37,870 .

Two new counties were created in InI : Crowley from Otero (temporary countyseat, Ordway), and Moffat from Routt (temporary county-seat, Craig). 
Voters, except for school elections, must register ten days or more before the election.

The legislature established a court of appeals for four years to be composed of five judges appointed by the governor and to supplement the overworked supreme court which may transfer cases to it.

Among labour laws passed were one establishing a workmen's compensation commission; and one providing for employers' liability. A department of factory inspection was created, and mining and working in smelters, stamp mills, reduction works, coke ovens, etc., are classed as injurious and dangerous occupations; eight hours (except in emergencies) is made a legal day in such work. A child labour law forbids any child under 14 being employed in a theatre, or in a place of amusement where intoxicating liquors are sold, mercantile institution, hotel, laundry, factory, bowling alley or elevator, or as a messenger or driver; a child of this age must have a permit to work on a farm or in an orchard. No child under 14 is to be employed during school terms or before. 7 A.M., or after 8 P.M., and eight hours is the maximum day for child labour. The age limit is set at 16 years (formerly I4) for hazardous and immoral occupations, and children may not be employed at all in the manufacture of paint, white lead, etc. Girls under 10 may not sell newspapers or engage in any street trade. An anti-coercion act forbids an employer discharging an employee for membership in a lawful organisation or society, or preventing an employee from joining such a society. For the use of armed guards in labour disputes written permission must be secured from the governor. Several labour laws, especially in regard to working hours, were referred to the people in November I9I2 and all were ratified.

The 1909 law in regard to prostitution was revised and made more severe, and there is a special clause making a husband or a wife a competent witness against the other. Maternity hospitals must be licensed by the state board of health and by the bureau of child and animal protection. Public drinking cups are forbidden unless they are properly sterilised. The sale of cocaine and similar drugs is forbidden except by druggists on prescription or by manufacturers (to registered physicians, dentists or veterinarians).

Among interesting miscellaneous laws are those making false statements about newspaper and periodical circulation a misdemeanor; making non-support a felony; and adopting a state flag of three horizontal stripes with a red $\mathrm{C}$ on the gold design in the field.

Municipal Government. - On September 19, I9I I Pueblo adopted a commission form of government with a provision, like that of the charter of Grand Junction, for preferential voting (on ballots for commissioners, "First Choice," "Second Choice," and "Third Choice" are to be entered if the candidates are more than twice and less than thrice as many as the number of offices to be filled), and provisions for initiative, referendum and recall. A similar charter was adopted by Durango in September 19r2. The validity of the Pueblo charter was taken to the courts: the district court decided that the commission form was valid; the supreme court in December 1912 had not yet handed down a decision.

In May I9I I the state supreme court reversed its previous decision that the merger under the charter of 1904 of the city and county of Denver was unconstitutional, so that the merger is now in force. Early in 1910 the people of Denver voted not to renew the franchise of a private water company and created the public utilities commission of the city and county of Denver; and on August 6 , I 9 Io they voted a bond issue of $\$ 8,000$,ooo for a municipal water plant. The New York Trust Company, a holder of the bonds of the private company, secured an injunction against the issue of the new bonds, first in the U.S. District Court and then in the U.S. Circuit Court of Appeals. The Trust Company argued that the franchise of $\mathrm{I} 890$ required the city to renew in I9Io or else to purchase the plant; the utilities commission that there was nothing mandatory in the terms of the franchise. ${ }^{1}$ On May 21 , I9I2 Denver adopted two charter amendments; one for a half-mill tax for five years for the purchase and improvement of mountain land for parks; and one for the trial of violators of the excise law in the county court; but voted against a mill tax for playgrounds and for a playground commission. An election on a commission charter for Denver was postponed from November I9I2 to the spring of 1913 .

Finance. - The legislature of I9I I created a state auditing board and a tax commission; revised the revenue laws of 1908 and I 902 ; created the office of state bank commissioner; and prescribed the amount of paid-up cash capital (varying according to the size of the place) for banks to be organised. On February 19, 1912 the United States Supreme Court (Atchison, Topeka \& Santa Fé v. O'Connor; 223 U.S. 280) decided that the state tax of 2c per \$ I,000 of capital stock of a foreign railway was invalid-the Santa Fé was a Kansas corporation.

Education.-An act of I9I I establishing 6 summer normal schools (instead of 13 as formerly) was defeated by the people at the November election in 1912. The normal school at Greeley was renamed in I9I I the State Teachers College of Colorado. Appropriations were made for a normal school at Gunnison, opened in September I9II, and for a State Home and Training School for Mental Defectives, opened for patients in July 1912 and for school work in September 1912. The state made an interesting experiment in appropriating money to

1 See C. L. King, The History of the Government of Denver (Denver I9II), wnich harshly. criticises public utility corporations. 
employ a state teacher of the adult blind. The General Education Board in October 1912 gave $\$ 100,000$ to the University of Denver. In 1910 the percentage of illiteracy in the population Io years of age and over was 3.7 (4.2 in I900). For the year ending June 30, I9 I 2 the school population was 227,142 , the enrollment 173,229 , the average daily attendance I 18,245 , and the length of the average school year I62 days. The total revenue was $\$ 7,089$,936 , and the expenditures $\$ 6,158,064$.

Charities and Penal Institutions.- Under an act of I9I the state soldiers' and sailors' home may admit Confederate veterans. The legislature provided for the parole of prisoners in county jails for good conduct and work, and for employment of prisoners in jails, half of any prisoner's earnings to go to his dependent wife and children. The State Home and Training School for Mental Defectives at Arvada (ro m. N.E. of Denver), authorised in 1909, was practically completed in 1912, the opening being planned for May 1913.

History.-There was an unbroken deadlock in the rgr I legislature over the election of a United States senator to succeed Charles James Hughes, Jr. (1853-19ro), Democrat, elected for the term ending I9r5. Senator Simon Guggenheim (b. 1867), Republican, the state's only representative in the Federal Senate in I9I I and I9I2, announced that for personal reasons only he would not be a candidate for re-election in I9I3. There was a bitter struggle in the Democratic party, also, for control: the "platform " or radical Democrats were led by John Franklin Shafroth (b. I 854), governor since I 909 , and Alva Adams (b. I $85^{\circ}$ ), governor in $1887-89$, and the "City Hall " wing was led by Robert Walter Speer (b. I855), mayor of Denver in I904-I2. The Republican state convention (April I912) was for Taft. The Progressive party was well organised in the state, with nominations for governor (E. B. Costigan) and Congressmen, but the Republican nominees (C. C. Parks for governor) ran better-the fact that the Roosevelt nominees were supported by three "parties," the Bull Moose, Roosevelt, and Progressive, was no advantage since the ballot is not of the party column form. In the November election the state went for Woodrow Wilson (i I4,232 votes to 72,306 for Roosevelt, 58,386 for Taft and I6,4I 8 for Debs); Elias M. Ammons, Democrat, was elected governor (receiving IOI,293 votes to 63,035 for Costigan and 54,720 for Parks) and the remainder of the Democratic ticket ${ }^{1}$ was successful, including James B. Pearce, Secretary of State, who ran behind the ticket because of criticism of his personal morality by a part of the press and of the clergy of the state-in this particular the campaign was singularly venomous. On January I4, I9I3 two Democrats were chosen as U. S. senators, ex-governor Shafroth, for the full term, and, for the short term, Charles Spalding Thomas (b. I 849), governor in I899-I90I. The legislature is Democratic by more than 40 on joint ballot. The four congressmen ( 3 under the previous apportionment) are Democrats. The municipal machine in Denver was defeated May 2 , I9 2 by a "Citizens' Ticket," on which Judge Ben Lindsey of the Juvenile Court was the bestknown name and Henry J. Arnold was the successful candidate for mayor with 40,87 I votes to 16,898 for J. B. Hunter (Democrat), of Mayor R. W. Speer's wing of the party, and I2,510 for United States Marshal D. C. Bailey (Rep.), whose candidacy suffered from his connection with William G. Evans, the Denver Street Railway magnate, who sued the Denver Post for $\$ 1,000,000$ for libel. In the campaign Mayor Speer bought the Evening Times so that he might have an organ with which to reply to the attacks of the Rocky Mountain News and of the Post.

A cloudburst on Cherry Creek caused a flood in Denver, July 15, I912, which did damage estimated at $\$ 2,000,000$ and resulted in the loss of two lives.

Bibliography.-Laws (Denver, I9II) and other official publications; E. Parsons, A Guide to Colorado (1911); E. A. Mills, The Spell of the Rockies (1911).

\section{CONNECTICUT ${ }^{2}$}

Populution (I010) I, I $4,7.56$ (008,420 in I900), Connecticut ranking 4 th among the states in density of population with $23 \mathrm{I} .3$ per sq. $\mathrm{m}$. (I 88.5 in I900). The percentage of increase in 1000-10 was 22.7 , greater than that for any decade since $1850-60$. Foreign-born whites constituted $26 . \mathrm{I} \%$ of the total in 1900 and $29.5 \%$ in 1910 ; native

${ }^{1}$ B. R. Montgomery, lieutenant-governor-elect, died December 29, 1912.

2 See E. B. vi, 95 I et seq. 
whites $72.1 \%$ in 1900 and only $69.1 \%$ in 1910 (of foreign parentage $31.1 \%$ in 1900 and $33.6 \%$ in 1910 ), and negroes $1.7 \%$ in 1900 and $1.4 \%$ in 1910 , decreasing in actual num. bers from 15,226 in 1900 to $\mathbf{I}_{5}, \mathrm{I}_{74}$ in 1910 . In $1910,89.7 \%$ (in $190087.2 \%$ ) of the population was in places ( 72 in $1910 ; 70$ in 1900) of 2,500 or more. The 18 cities with a population of over 5,000 contained together $57.6 \%$ of the total. The following cities, boroughs, and towns, each had 10,000 or more: New Haven, 133,605; Bridgeport, I02,054; Hartford, 98,9I5; Waterbury, 73,I4I; New Britain (city and town since I906), 43,916; Meriden (city), 27,265; Stamford (city), 25, 138; Norwich (city), 20,367; Danbury (city), 20,234; New London, I9,659; Greenwich (town), r6,463; Torrington (borough and town), I 5,483; Ansonia, I5,I52; Manchester (town), I3,64I; Naugatuck (borough

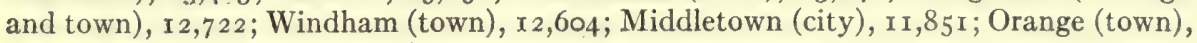
II,272; and Willimantic (city), II,230.

Agriculture.-The acreage in farms decreased from $2,312,083$ to $2,185,788$ between 1900 and 1910 , and the improved land in farms from $I, 064,525$ to 988,252 ; the average farm acreage fell from 85.8 to 81.5 and the value of farm propert $y$ increased from $\$ 113,305,580$ to $\$ 159,-$ 399,77 I (\$72,206,058 land; \$66, I I 3, I63 buildings; \$6,916,648 implements and \$ 14, I63,902 domestic animals). Of the land area $70.9 \%$ was in farms. The average value of farm land per acre was $\$ 33.03$. Farms. were operated largely by owners $(23,234$ by owners, 949 by managers, and 2,632 by tenants). In 1912 (preliminary estimates) the principal crops were: Indian corn, 3,000,000 bu. (60,000 A.); oats, 338,000 bu. (I I,000 A.); rye, I22,000 bu. (7,000 A.); buckwheat, $62,000 \mathrm{bu}$. (3,000 A.); potatoes, $2,461,000$ bu. (23,000 A.); hay, 436,000 tons $(379,000$ A.); and tobacro, $29,750,000 \mathrm{lbs}$. (17,500 A.). In 1909 (U. S. Census) the value of vegetables other than potatoes was \$1,965,635; of flowers and plants, $\$ 1,047,431$; of nursery products, \$26I,506; of small fruits, $\$ 316,75^{2}$ (strawberries, \$235,648); of orchard fruits, $\$ 1,327,074$ (apples, $\$ 833,168$; peaches and nectarines, $\$ 417,598$ ); of grapes, $\$ 43,523$. On January I, I9r2 there were on farms 47,000 horses, 120,000 milch cows, 71,000 other neat cattle, 21,000 sheep and 60,000 swine. The Storrs Agricultural Experiment Station published in 1912 important studies of the chestnut blight, showing that it was not imported, that its spread is due to weather conditions and that it will naturally die down; and continucd its important researches into nutrition.

Mineral Products. - Total value, I9II, \$3,151,588. The principal products of mines and quarries were: stone (granite and traprock mostly), valued at $\$ 1,2$ I 5,462; lime, $\$ 328,904$; felspar, 16,497 tons (less than in 1910 , but ranking the state third; value, $\$ 73,557$ ); clay products, \$I,284, I66 (entirely brick and tile); and mineral waters bottled at 28 springs, $\$ 182,744$, two-thirds more than in 1910 .

Manufactures. - In I909 the gross value of products was $\$ 490,272,000(\$ 369,082,000$ in I904, the increase being partly due to the increased price of raw material); there were $4,25 \mathrm{I}$ establishments $(3,477$ in 1904$)$ and 210,792 wage earners, $18.9 \%$ of the total population. More than 60 different industries had each an output valued at more than $\$ 1,000,000$. Among the principal manufactures are: brass and bronze products, $\$ 66,933,000$, being fourninths of the total for the United States; foundry and machine-shop products, including hardware, $\$ 65,535,000$; cotton goods, $\$ 24,232,000$; silk goods, $\$ 21,063,000$; firearms and ammunition, $\$ 19,948,000$ (the output of ammunition being nearly four-fifths of the total for the country and of firearms nearly one quarter); woollen, worsted and felt goods, $\$ 19,363,000$ and fur felt hats, $\$ 10,400,000$; silverware and plated-ware, $\$ 15,837,000$, more than one-third the total value for the country, and for plated-ware alone more than two-thirds; corsets, $\$$ I 2,8 I 5,000, more than one-third the country's total; automobiles, $\$$ I I , 668,000,-34I.3\% more than in 1904; cutlery and tools, \$10,717,000; electrical machinery, \$9,824,000; and clocks and watches, $\$ 7,390,000$.

In I $90968.1 \%$ of the state s product came from cities and boroughs, 5 in all, which had each a population of 10,000 or more. These were: Bridgeport, $\$ 65,609,000$, with $14.9^{\circ} \circ$ of the state's foundry and machine-shop products, $53.8 \%$ of the corsets, $33.8 \%$ of the electrical machinery, and more than half of the sewing machines and of the talking machines; New Haven, $\$ 5 \mathrm{I}, 07 \mathrm{I}, 000$, of which more than one-seventh was foundry and machine-shop products and other important items were clocks, automobiles, boots, malt liquors; Waterbury, $\$ 50,350$,000 , of which five eighths was brass and bronze ( $21 \%$ of the total for the country), the next item being clocks and watches; Hartford, \$40,680,000; New Britain, $\$ 22,021,000,52.9 \%$ of which was hardware; Ansonia, $\$ 20,088,000$, chiefly brass and bronze products, clocks and watches; Meriden, \$16,317,000, chiefly silverware and plated ware; Torrington, \$12,550,000, mainly brass and bronze products; Naugatuck, \$ I I,033,000, mainly rubber goods; Danbury, $\$ 10,3$ 18,000, about two-thirds of which was fur-felt hats (nearly a quarter of the country's output); Norwich, \$9,389,000, mainly textiles; Stamford, $\$ 8,740,000$; Willimantic, $\$ 6,733,000$, textiles and thread; Middletown, $\$ 4,955,000$, largely men's furnishing goods; and New London, $\$ 4,483,000$, largely textiles.

Transportation.-Railway mileage, January I, I912, I,015.98. The Federal River 
and Harbor Act of February 1912 appropriated $\$ 77,000$ (and empowered the Secretary of IVar to expend \$100,000 more) for improvement of the Connecticut river below Hartford. In 19 I the lederal improvements of the Bridgeport harbeur and the $12 \mathrm{ft}$. channel in the New Haven harbour were completed; and in the latter harbour breakwaters were practically finished and a $12 \mathrm{ft}$. anchorage basin more than half completed in 1912 .

Goiernment. - The regular session of the legislature was held in Igr I from January 4 to September 26. It rejected the proposed $x 6$ th (income tax) amendment to the Federal Constitution. The house of representatives proposed, on January 20, a constitutional amendment providing for two-thirds (instead of a plurality) vote in each house to pass a bill over the governor's veto; this is to come before the legislature of 1913. Amendments adopted by popular vote in I9I I and I9I 2 provide for the lieutenant-governor's succession to the gubernatorial office if the governor is unable to serve $(20,738$ votes to 4,$7 ; 0)$; and that the legislature adjourn sine die by the first Wednesday after the first Monday in June (30,349 votes to 4,865$)$, sessions thus being limited to 5 months. The salary of the governor after the 1912 general election was increased to $\$_{5}, 000$ a year, and that of the lieutenant-governor to $\$ 1,500$; and that of the attorneygeneral to $\$ 5,000$ after September I, I9II. A board of state bank commissioners was to report to the legislature in I913. Columbus Day was made a legal holiday.

The corrupt practices act and the Australian ballot law of 1909 were amended. Any political division of the state may vote for or against the merit system for all its officers and employees. The legislature created a public utilities commission. All public service companies must make return to the commission and immediately report all accidents to it. It controls rates and service of public utilities.

Commissions were created to report by April I, I9I3 on the employment of women and children and to investigate employers' liability and workmen's compensation. The eight hour day was made a maximum for mechanics in state institutions except in unavoidable emergencies. If workmen work on Sunday they must have one other day off in seven, but the act excepts "commercial occupations and industrial processes . . . by their nature : . continuous." No minor under 16 and no woman of any age is to be employed in a mercantile establishment, unless it is manufacturing or mechanical, more than 58 hours a week; but if the employer makes the hours 55 a week or less in June, July and August, the hours a week for the rest of the year may be 60; and the provision is not applicable between December I 7 th and December 25 th if the employee gets seven holidays during the year with full pay. No child under $\mathrm{I}_{4}$ is to be employed in a mercantile, mechanical or manufacturing establishment and no child under 16 unless he has a certificate of an elementary education. No child under 16 may run or adjust certain dangerous machinery or be employed in the manufacture of dangerous drugs or explosives and none under 18 may run an elevator. An claborate law was passed forbidding blacklisting. Damages for injuries resulting in death were limited to $\$ 10,000$, and suit must be brought within one year from the time of the neglect complained of. Physicians are required to report to the state commissioner of labour cases: of occupational discase. An act of $191 \mathrm{I}$, probably the first American state law dealing with. aeronauts, requires the registration of air-ships and the licensing of acronauts. An elaborate' act for sanitation in tenements, boarding and lodging houses, and several acts safeguarding public health, providing for purity of milk and other food and regulating the sale of liquor and drugs, were passed. Tobacco must not be sold or given to minors under 16 . Any com. bination to increase prices of necessities is punishable by a maximum fine of $\$ 1,000$ or by. imprisonment for 5 years or by both.

The town of Bristol in August I9I adopted a city charter (in effect Oct. I, I9I I), which contains some features usually found in the commission plan of government and provisions for the initiative and referendum.

Finance. - A commission appointed in I9 I to examine into the methods of taxation of railways and other taxable corporations was to report in 1913 . The treasurer, comptroller and tax commissioner constitute a board of equalisation of taxes. I and planted with forest trees, at least 1,200 to an acre, if the planting is approved by the state forester, is exempt from taxation, but this exemption cannot hold after the timber is cut nor in any case for more than 20 years.

The state treasury had a balance on hand October I, I91 I of $\$ 376,576$. The receipts for the year ending ()ctober I, I9I 2 (including $\$ 4,000,000$ bonds sold) were $\$ 9,915,418$, and the expenditures (including $\$ \mathrm{I}, 450,000$ temporary loans paid) $\$ 8,105,750$, leaving a balance in cash of $\$ 2,186,244$. The state debt in October 1912 was $\$ 7,064,100$.

Fducation. - For the school year I9II-12 the school population (between 4 and 16) was 255,692 ; the total enrollment in public schools. 197.852; the average daily attendance, 155,73. ; the average length of the school year i $4+$ days; and the total revenue for schools, $\$ 6,040,-$ 1,32 and the expenditures, $\$ 6,122,307$. The total indebtedness of towns and districts for school purposes was $\$ 8,81,3,998$ in $1912,-$ as compalred with $\$ 3,110,210$ in 1901 ; in the same 
period the enumerated school population increased less than one-fourth. Of the towns 129 provide (39 do not) free text books. The work of consolidation of small schools is going on. In Connecticut - as in no other state except New I'ork-there was an increase of illiteracy in $1900-1910$, from $5.9 \%$ to $6 \%$ of the population 10 years of age and more. This rate was the highest in New England, excepting that of Rhode Island. Morton F. Plant gave \$1,000, ooo in June I9I I for the Connecticut College for. Women. A site has been secured in New London, but late in 1912 building had not begun. With the autumn term of 1912 Wesleyan University (Middletown) ceased to be co-educational and received men only; in June it completed an endowment fund of $\$ 1,000,000$. In October $1912 \mathrm{~J}$. Pierpont Morgan gave money for a new library and administration building at Trinity College, Hartforrl. To Yale University M. C. D. Borden left $\$ 250,000$ in 1912 and the McPherson fund for indigent students will amount to $\$ 400,000$, or more.

Charitable and Penal. Institutions.-In $191 \mathrm{I}$ the legislature created (over the governor's veto) an annual pension of $\$ 30$ to veterans of the Civil War, their widows, their widowed mothers, etc; but the act was declared unconstitutional in April I9I2 by the state supreme court. An act of I9I I provides for the transfer from the state prison to the new!y completed reformatory at Cheshire (subject to the approval of the directors of these institutions) of male prisoners under 25 sentenced to less than 5 years. Contracts for convict labour may not be made for longer than 4 years. This law does not apply to inmates of county institutions in farm, domestic and casual service. A prisoner in the state prison sentenced for attempt to murder by assault or attempt to poison may be paroled after two years.

History.-On January 4, I9I r, Simeon Eben Baldwin (b. 1840), professor of constitutional and private international law in Yale University since $18 ; 2$, and chief justice of the state supreme court of errors, was inaugurated governor,- - the first Democrat to hold the office since 1895 . He had a Republican legislature (majority of 7 in senate, of 60 in house), which blocked some of his proposed legislation; and the senate refused to ratify the governor's nominee for state highway commissioner, although the Republican incumbent of that office had been much criticised. On January I7, I9I I the legislature elected a Republican, George Payne McLean (b. I857; governor I901-03), United States senator to succeed Morgan Gardner Bulkley (b. I838), also a Republican. Local opposition to the "boss" rule in the Republican party of Alberto Roraback contributed to the growth of a Progressive party, which was led in the gubernatorial campaign of I9I 2 by Herbert Knox Smith (b. I869), who resigned his post as federal commissioner of corporations to join the third party and received 31,020 votes to 67,531 for Judge John P. Studley, Republican, and 78,264 for Baldwin.- With Baldwin the entire Democratic state ticket was elected, including 5 congressmen (all from districts; formerly 4 districts and I at large). Ebenezer J. Hill (b. I845), Republican representative since I 895 and one of the "Old Guard," was defeated. The Democrats secured a majority of 7 ( 2 I to $\mathrm{r}_{4}$ ) in the senate; in the Assembly there are $\mathrm{r}_{30}$ Republicans, I 20 Democrats, 6 Progressives and 2 Progressive Republicans. But the Republican majority on the joint ballot is comparatively unimportant, as no United States senator had to be elected in I9I3. The Democratic presidential electors received 74,614 votes; the Republican, 68,099; the Progressive, 34,I43; and the Socialists 10,078, as compared with 5 , II 3 in 1908 and 12,179 in I910 (for Robert Hunter, as governor). In the spring of I9I 2 Socialists got control of the borough government of Naugatuck; in. I 9 I I they cast a large vote in Bridgeport, where they elected one alderman.

A short strike of Italian weavers in Middletown, led by representatives of the Industrial Workers of the World, began on June 5,1912 and was accompanied by so much disorder that the militia was called out.

The Federal district court at Hartford on October I I, I9 I2, handed down a verdict of $\$ 80,000$ and costs in favour of D. E. Loewe \& Co., hatters of Danbury, against the United Hatters' Union of North America for boycott (see E. B. iv, 353).

A city plan for New Haven, submitted by Cass Gilbert and F. L. Olmsted, has not been acted upon, but in I I 2 the city was planning approaches to a new railway station, and the commission made its fifth annual report. In Wallingford a private bureau of municipal research was established in February rgr.x.

During the year r9r 2, 6 towns formerly "no-licence" voted for the sale of intoxicating liquor, making $8 \mathrm{r}$ licence and 87 no-licence towns in the state.

In Waterbury on the night of April 22, I0I2, about a dozen fires were set by an incen- 
diary who afterwards confessed to setting 30 fires in Connecticut and western Massachusetts. The state militia was called out to control the panic.

Bibliography.-Public Acts (Hartford, I9II), Register and Manual (ibid., 1912), and other official publications; J. A. Stoughton, Corner Stone of Colonial Commerce (Boston, I9I I).

\section{DELAWARE ${ }^{1}$}

Population (1910) 202,322 (9.5\% more than in 1900); $76 \%$ were native whites, $12.8 \%$ whites of foreign parentage, $8.6 \%$ foreign-born whites, and I $5.4 \%$ negroes. The average number to the sq. $\mathrm{m}$. was $103(94$ in 1900$)$, the state ranking 9 th in density of population; $52 \%$ of the total lived in unincorporated territory or in incorporated places of less than 2,500 inhabitants. Wilmington, the only city with 5,000 or more, had 87,4 II; Dover, the capital, 3,720; and New Castle, 3,35x.

Agriculture. - The acreage in farms decreased from I, 066,228 to $1,038,866$ between 1900 and I9I0; the improved land in farms from 754,010 to 7 I 3,538 ; and the average farm acreage from I10.I to 95.9. The value of farm property increased from $\$ 40,697,654$ in 1900 to $\$ 63,179,201$ in I910 (\$34,938,161 land; $\$ 18,217,822$ buildings; $\$ 3,206,095$ implements and $\$ 6,817,123$ domestic animals). About four-fifths of the land area was in farms in 1910. The average value of farm land per acre was $\$ 33.63$. Farms were operated largely by owners ( 6,178 by owners, 123 by managers and 4,535 by tenants). In 1912 (preliminary estimates) the principal crops were: Indian corn, 6,630,000 bu. (195,000 A.); wheat, I, 942,000 bu. (I I I,000 A.); oats, I22,000 bu. (4,000 A.); rye, I4,000 bu. (I,000 A.); buckwheat, 64,000 bu. (4,000 A.); potatoes, I, 100,000 bu. (I I,000 A.); and hay, 96,000 tons $(72,000 \mathrm{~A}$.). During 19I2 the shipments of fruit, etc., over the Delaware Railroad, comprising most of that marketed, were: berries $18,626,793$ qts.; apples, 556,62 I baskets ( $\frac{7}{8}$ bu.); peaches, 336,037 baskets ( $\frac{5}{8}$ bu.); pears, I,026,620 baskets; grapes, 3,225,876 lbs., potatoes, 303,60I bbls.; canteloupes, $489,75^{2}$ carriers; watermelons, 478 cars. Except apples and peaches the crops were unusually large. In I909 (U. S. Census) the total value of vegetables other than potatoes was $\$ 1,102,620$; of flowers and plants, $\$ 71,429$; of nursery products, $\$ 39,057$; of small fruits, \$649,732 (strawberries, \$569,354; blackberries, \$6I,8I 7; raspberries, \$I 7,359); of orchard fruits, $\$ 195,766$ (apples, $\$ 1$ I 5,37 I and pears, $\$ 52,022$ ); of grapes, $\$ 43,967$. On January I, I9I2 there were on farms: 34,000 horses, 6,000 mules, 37,000 milch cows, 19,000 other neat cattle, 8,000 sheep and 59,000 swine. In I9:2 a study by the state experiment. station of the effect of various forms of lime in the soil indicated that ground limestone is as effective in promoting decomposition of organic matter as burned lime. A study of Bordeaux injury to the apple was completed.

Manufactures. - The total value of factory products in 1909 was $\$ 52,840,000$, an increase of $28.4 \%$ since 1904 ; capital invested in manufacturing, $\$ 60,906,000$, the number of establishments, 726 , and the number of persons engaged in manufacturing, 23,984 . The value of leather, tanned, curried and finished was \$12,079,000; foundry and machine-shop products, $\$ 4,781,000$; cars, steam railway, not including operations of railway companies, $\$ 3,628,000$; cars and general shop construction and repairs by steam railways, $\$ 3,25 \mathrm{I}, 000$; paper and woorl-pulp, \$2,292,000; products of canning and preserving, \$2, 106,000; and shipbuilding, $\$ 1,990,000$. The factory products of Wilmington were valued at $\$ 38,069,000(72 \%$ of the state's total).

Transportation.-Railway mileage, January I, 1912, 388.17. During 19 II T. Coleman du Pont offered $\$ 1,500,000$ to the state to build a state boulevard; and the legislature authorised the organisation of a boulevard corporation to build a boulevard from the northern to the southern part of the state. The corporation (the Colemandu Pont Road Incorporated) under the law was permitted to build and maintain telegraph and telephone lines, a street railway, lighting, heating and power plants. The constitutionality of the boulevard law was in question; the state supreme court unanimously decided (July 17, I912) that it was valid. but an appeal on a writ of error was taken to a Federal court by land owners who opposed the building of the road. No decision was handed down in roi2.

In I9I I-I 2 the Federal government was improving the channels in several streams in the state-the Appoquinimink, Murderkill, Mispillion, St. Jones, Leipsic and Broadkill.

Government.-The regular biennial session of the legislature was held from January 3 to March 30, Igr. It proposed constitutional amendments (to come before the legislature in IOI3 for ratification) giving the legislature the power of laying out such roads as are continuous highways through a part of the three counties of the state and making one superior court justice (instead of two) a quorum except in a court of oyer and terminer. The law of negotiable instruments was made uniform and ground rent s were extinguished. For capital punishment life imprisonment may be substituted at the option of the court if the jury recommends to mercy.

'See E. B. vii, 947 et seq. 
Commissions were appointed to report on child labour and on employer's liability to the legislature of $\mathrm{s} 9 \mathrm{i}$. The filling of prescriptions for intoxicating liquors for medical purposes was strictly regulated by law. Cold storage food may be sold only if it is marked with the date of storage; this act does not apply to fruit or fish. A state live stock sanitary board was created. Twenty acts of I9I I deal with fish, oysters and game and the provisions for the protection of fish, birds and game are made more stringent. A contract for a state armory in Dover was let in March 1912. A city charter for Wilmington proposed by the legislature was defeated June I, I9I 2 by 7,700 to 99 I votes. For Wilmington a public utilities commission was created in I9I I. The $\mathrm{r} 2 \mathrm{th}$ of October (Columbus Day) was made a state legal holiday.

Finance.-The outstanding indebtedness on January I, I9I3 was $\$ 826,785$; in January, 1912 the school fund was $\$ 944,407$, of which $\$ 712,500$ was the market value of shares of stock in the Farmers' Bank of the State of Delaware, in whose board of directors the state is represented. A revenue and tax commission was to report in I9I 3 to the legislature. New revenue laws require manufacturers to pay for an annual licence and to turn in an annual report; require gypsies to take out a licence for which they must pay \$300; and require a licence ( $\$ 300$ in large cities, less in small cities) for travelling shows and other licences for smaller concerns, and a licence to carry dangerous weapons.

The annual report of the treasurer shows a balance on January I, I9I2 of $\$ 49,987$; receipts, $\$ 843,572$; expenditures, $\$ 801,211$; and balance on hand December 3I, I9I2, $\$ 92,348$.

Education.-The legislature of I9I I abolished the old state board of education and provided for a new board (with increased powers) to be appointed by the governor and to receive no compensation. A special commission was created to report on the higher education of women in the state. Half an hour a week in public schools must be devoted to teaching morals and humanity, and experiments in public schools on live animals are prohibited; the act does not apply to Wilmington. A retirement fund is authorised for teachers in the public schools of Wilmington. A special appropriation was made for negro schoolhouses. In Delaware college the State Chair of History, a pathological and bacteriological laboratory and a division of agriculture extension were established. Of the total population Io years and over, $8.1 \%$ were illiterate in $1910,(12 \%$ in 1900): whites $5 \%(7 \%$ in 1900$)$; negroes $25.6 \%$ (38.1 \% in 1900$)$.

Charities and Corrections. - In I9I I the legislature provided for the appointment by judges of the superior court of a probation officer to act for the whole state and for a juvenile court in Wilmington. The state commission for the blind reports (1912) that there are in the state 378 feeble minded ( 246 under 25 ); 277 blind ( 46 under 25 and 12 in special schools); and 154 deaf ( 77 under 20 and 16 in schools for the deaf).

History.-There was delay in I9II in the organisation of the legislature and then a deadlock over the choice of United States senator, through the disaffection of state Senator Lewis A. Drexler, who complained that the party organisation had failed to keep a promise to make him president of the senate pro tem.; but on January 25 th $H$. Algernon du Pont (b. 1838 ) was re-elected to the United States Senate. The Republican governor, Simeon Selby Pennewill (b. I867) came out for Colonel Roosevelt's candidacy in March I912. There was not merely a progressive schism from the Republican party but two "Progressive" parties were formed-one calling itself the "Original Progressives ". was represented on the National Committee of the Progressive party and nominated a full state ticket; and the other, called the "National Progressive " party, had on its ticket the Roosevelt electors and the Republican state county and district nominations. The Republican candidate for governor, Charles R. Miller, endorsed by one Progressive faction, received 22,745 votes to $2 \mathrm{I}, 460$ for Thomas M. Monaghan, (Dem.); and 3,org for George B. Hynson (Prog.) third; but the Democratic candidates for other state offices were elected. Woodrow Wilson carried the state with 22,63I votes to 15,997 for Taft and 8,886 for Roosevelt, 556 for Debs (239 in 1908). A Democratic congressman was elected, and as the state legislature is Democratic on joint ballot (senate, 9 Republicans and 8 Democrats; house, I4 Republicans and 2 I Democrats), a Democrat was chosen in 191 3 to succeed Harry Alden Richardson (b. 1853), Republican, United States senator,-namely Willard Saulsbury (b. I86I), Democratic national committeeman from Delaware.

Bibliography - Lazes of Delaware, Vol xxvi (Wilmington, I9II) and other public documents; C. H. B. Turner, ed., Some Records of Sussex County (Philadelphia, 1909) and Rodney's Diary (19II); A. C. Meyers, ed., Narratives of Early Pennsylvania, Delaware and West Jersey, 1630-1708 (New York, 191.I). 


\section{DISTRICT OF COLUMBIA (WASHINGTON CITY) ${ }^{1}$}

Population (rgro) 331,069; distributed as follows: in original limits of Washington City, 230,630 (1 20.284 in "Northwest;" 40,959 in "Northeast;" 32,513 in "Southwest," and 36,8 74 in "Southeast "); in Georgetown, 16,046 ; and in former Washington county, 84,393. Whites numbered $236,128(71.3 \%$; in $190068.7 \%)$ and negroes, $94.446(28.5 \%$; in $1900,31.3 \%)$. Native whites of native parentage constituted $50.4 \%$ of the total, and those of foreign parentage, $13.6 \%$ and whites of foreign birth, $7.4 \%$. Of all foreign-born whites, $21.9 \%$ were born in Ireland, 2 I. 3 in Germany, I 3.9 in Russia; II. 3 in Italy, Io.8 in England, 4.6 in Canada, 2.9 in Scotland, 2.I in France, I.9 in Austria, $\mathrm{I} .5$ in Sweden, $\mathrm{I} .4$ in Greece and $\mathrm{I} .2$ in Switzerland. The ratio of males to females, 91.3 to 100 , was a little higher than in 1900 ( 90 to 100 ). This comparatively low ratio is only partly due to the large number of female employees in government departments; the ratio among whites is 94.9 , among negroes 82.2 . The death rate in I9II was 17.8 per 1000 (whites 14.61 ; negroes, 26.I2), and the birth rate was 19.86 .

Agriculture.-The acreage in farms decreased from 8,489 to 6,063 between 1900 and 1910 , the improved land in farms from 5,934 to 5,133 , the average farm acreage from 31.6 to 27.9 , and the value of farm property from $\$$ II, 535,376 to $\$ 8,476,533$ ( $87,193,950$ land; $\$ 1,037,393$ buildings, \$92,350 implements, and \$152,840 domestic animals). The principal crops were: hay and forage, 2,148 tons $(962 \mathrm{~A}$.); potatoes, 32,028 bu. (226 A.); sweet potatoes and yams, 19,662 bu. (126 A.); and Indian corn, 12,667 bu. (426 A.).

Manufactures.-Apart from establishments operated by the Federal government, the number of factories increased in $1899-1909$ from $49 \mathrm{I}$ to 518 ; the number of wage-earners from 6.155 to 7,707 ; capital invested from $\$ \mathbf{1} 7,960,000$ to $\$ 30,553,000$, and the value of products from $\$ 16,+26,000$ to $\$ 25,289,000$. The larger manufactures were: printing and publishing, $\$ 4,899,000$; malt liquors, $\$ 1,805,000$; foundry and machine-shop products, $\$ 1,175,000$.

Buildings.--The most important changes in the city of Washington are the new buildings for the departments of state, justice and commerce, for which commissions were made in April Igr r and which are to be grouped between Pennsylvania avenue and the Mall and Fourteenth and Fifteenth streets. All are to be of white marble. The Commerce building (architects, York and Sawyer) is to be five storeys high, is to stand between the other two (each three storeys) and is to cost $\$ 3,650,000$. The State building (architect. Arnold $\mathrm{W}$. Brunner) will cost $\$ 2,200,000$, and the building of the department of justice (architect, Donn Barber), \$r,000,000.

In Ig i Congress appropriated $\$ 2,000,000$ for a Lincoln Memorial, and appointed the Lincoln Memorial Commission, with President Taft as chairman, which, cooperating with the Federal Fine Arts Commission, appointed Henry Bacon to design a plan. The Fine Arts Commission, July r 7, ror r, recommended Potomac Park as the site of the memorial. Mr. Bacon's plan, as completed in I0I 2, is for a hall of white marble, resembling a (ireck temple, surrounded by 36 Doric columns, representing the 36 states of Lincoln's time, to be built in Potomac Park, in the cent re of a circular terrace, $500 \mathrm{ft}$. in diameter, rising $\mathrm{x} 6 \mathrm{ft}$. above another 1errace, $\mathrm{I}, 000 \mathrm{ft}$. in diameter and $\mathrm{Ir} \mathrm{ft}$. above the present grade. In the hall is to be placed a statue of Lincoln, and on the interior walls are to be inscribed his (iettysburg speech and his second inaugural. The memorial terminates the princinal axis of the city, and is intended to fit into the design for the revision and extension of the original plan of Washington which was undertaken hy a commission appointed in I0от. Early in I0I 3 the memorial was adopted by Congress. Plans for a memorial to Christopher Columbus, for which Congress appropriated $\$_{100,000}$, and to which the Knights of Columbus contributed, were drawn by the architect Daniel H. Burnham and the sculptor Lorado Taft. The memorial, made of Georgia marble. consists of a semi-circular fountain, $70 \mathrm{ft}$. wide and $65 \mathrm{ft}$. deep, adorned with a statue of Columbus behind which rises a stone shaft $45 \mathrm{ft}$. high surmounted by a globe. Figures typifying the new world, an American Indian, and the old world, a Caucasian. stand on either side of the shaft. Columbus is represented as standing on the prow of a ship, the figure-head of which is a female statue typifying discovery. The memorial was unveiled June 8, in 12 . The Memorial Continental Hall (architect, E. P. Casey)

${ }^{1}$ Sec E. B. xxviii, $3+9$ el seq. The District and the city are coterminous. 
was erected by the Daughters of the American Revolution. Among new monuments is one by William W. Bosworth, at the tomb of Major Pierre Charles L'Enfant, who planned the city, in Arlington Cemetery, unveiled May 22, I9I I. On April I7, I912, a statue of John Paul Jones was unveiled in Potomac Park. The corner-stone of Gibbons memorial hall of the Catholic University of America was laid October I2, I9I I.

Appropriations were made for the establishment in I9I3 of a park in the southeastern part of the city, including Forts Davis and Dupont, and to extend Rock Creek Drive from Massachusetts Avenue to Montrose Park. Proposed parks, for which no appropriations have yet been made, are Klingle Ford Valley ( 28.5 acres), Mount Hamilton (8r acres) and Piney Branch.

The Engineer Commissioner of the District of Columbia has urged an annual appropriation for permanent works of improvement beginning in I9I3 with $\$$ I, 230,000 and increasing annually by not less than $\$ 100,000$, this work to include the reclamation of the Anacostia Flats and the converting of this section into a public park, extension of the improvements of Rock Creek Valley, improvement of the harbour by means of public wharves and completion of the park system.

Finance-On June 30 , I9I2, the debt of the Federal District was $\$ 10,240,500$, of which $\$ 8,258,550$ was bonded. The cash balance at the beginning of the fiscal year was $\$ 337,712$, and at its end, $\$ 398,753$; the receipts for the year were $\$ 14,868,722$ and the expenditures $\$ 14,807,68 \mathrm{I}$. In the year an elaborate inventory of district property was begun. An Act of Congress dividing certain fees collected in the District between the District and the United States will probably reduce the District revenues about $\$ 65,000$ a year. The assessed valuation of real property for 1912 was $\$ 330,332,487$, and for 1913 was $\$ 339,198,990$; and for the former year the real-estate tax was $\$ 4,954,987$, and the personal tax levy, \$1, I3 1,946 . The tax for national banks and trust companies is $6 \%$ on gross earnings, on gas companies, $5 \%$ on gross earnings, on incorporated savings-banks, clectric-light companies, telephone companies $4 \%$ on gross earnings, and on strect railways, $4 \%$ on gross receipts.

Education.-For the school year ending June 30, I912, the school population (6-17 years) was 65,867 ; the enrollment, 57,781 (18,663 negroes); average daily attendance, 46,23I; average length of the school year, 36 weeks; the school revenue, $\$ 3,180,378$, and expenditures, $\$ 3,050,03 \mathrm{I}$. In I9I0 the percentage of illiteracy of the population over Io years was 4.9 (in 1900, 8.6); among negroes 13.5 ; foreign-born whites, 8.2 ; native whites, 0.5 . The percentage of illiterates between ro years and 20 was only $\mathbf{I}$.

Charities.-On February 15, I912, the penal farm at Occoquam, Virginia, the workhouse of the District of Columbia, was formally placed under the supervision of the District board of charities, taking the place of a workhouse in the city. An institution for feeble-minded negro children is projected.

\section{FLORIDA}

Population (1910) 752,$619 ; 41 \%$ negroes, $54.5 \%$ native whites $(4.8 \%$ of foreign parents), and $4.5 \%$ foreign born whites. The average number per sq. m. was $13.7 \%$. In I910, 23 cities and towns, each with 2,500 or more, made up $29.1 \%$ of the total; in 1900, I 2 municipalities of the same class contained $20.3 \%$. The semi-urban population in 125 places in 1910 ( 79 in 1900 ) each with less than 2,500 made up $11.6 \%$ ( $10.1 \%$ in 1900). The rural population decreased from $69.6 \%$ of the total in I900 to $59.3 \%$ in I9ro. The rate of increase during the decade was: $42.4 \%$ for the whole state; $73.5 \%$ for urban territory- III.4\% for cities having more than 25,000 and $52.4 \%$ for cities and towns between 2,500 and 25,000 ; and $32.6 \%$ for the rural remainder. There were Io cities each with more than 5,000; Jacksonville, 57,699 (28,429 in 1900); Tampa, 37,782 (I5,839 in I900); Pensacola, 22,982; Key West, I9,945; West Tampa, 8,258 (2,355 in I900); Gainesville, 6, I83 (3,633 in 1900); St. Augustine, 5,494; Miami, 5,47 I ( $1,68 \mathrm{I}$ in 1900); Lake City, 5,032; and Tallabassee, 5,018 (2,98 $\mathrm{I}$ in r900).

A griculture.-The acreage in farms increased from $4,363,89$ I to $5,253,538$ between 1900 and 1910 and the improved land in farms from $1,511,653$ to $1,805,408$; the average farm acreage fell from I06.9 to 105.0 and the value of farm property increased from $\$ 53,929,064$ to $\$ 143$. $183 ; 183$ (\$93,738,065 land; $\$ 24,407,924$ buildings; $\$ 4,446,007$ implements and $\$ 20,591,187$ domestic animals). Of the land area $15 \%$ was in farms. The average value of farm land per acre was $\$ 17.84$. Farms were operated largely by owners $(35,399$ by owners and I 3,3,2 by tenants). In 1912 (preliminary estimates) the principal crops were: Indian cor11, 8,515,000

${ }^{1}$ See E. B. x, 540 . 
bu.( 655,000 A.); oats, 740,000 bu. (43,000 A.); potatoes, I, 023,000 bu. (I I,000 A.); hay 54,000 tons (43,000 A.); cotton, 68,000 bales (I I9 lbs. per A.); tobacco, 2,604,000 lbs. (3, I00 A.) and rice, $15,000 \mathrm{bu}$. (600 A.). In 1909 (U.S. Census) the value of vegetables other than potatoes was $\$ 6,31_{4}, 3 I_{3}$; of nursery products, $\$ 478,174$; of small fruit, $\$ 302,383$ (strawberries, $\$ 301,056)$; of orchard fruits, $\$ 232,203$ (peaches and nectarines, $\$ 128,029)$; of tropical fruits, $\$ 7,092,150$ (oranges, $\$ 4,304,987$; pomeloes (grapefruit), \$1,907,816; pineapples, \$734,069). On January I, 1912 there were on farms: 52,000 horses, 25,000 mules, 123,000 milch cows, 758,000 other neat cattle, 120,000 sheep and 954,000 swine.

The legislature of I9II required the appointment of an inspector of nursery stock and appropriated $\$ 5,000$ for farmers' co-operative demonstration work. The shipment of immature citrus fruit was made unlawful. In I9I-I successful experiments were made in growing rice without irrigation in prairie districts, and in raising Rhodes grass for hay; and a representative of the Federal department of agriculture found in Saharapur, India, and brought to the United States parasites and insect enemies of the white fly pest in orange groves.

Mineral Products. - Total value, I911, \$10,250,228. The only important mineral product in the state is phosphate rock, more than two-thirds land pebble; the output in I9I I was valued at $\$ 9,473,638$, about $9 \%$ more than in I9IO. In this product and in fuller's earth the state ranked first. The value of mineral waters, from 9 springs, including 5 resorts, was $\$ 19,330,-$ one-third more than in 1910 .

Manufactures.-From 1904 to 1909 the number of factories increased from 1,413 to 2,159; the number of persons engaged in manufacturing from 46,985 (of whom 42,091 were wage-earners) to 64,810 ( 57,473 wage-carners $)$; the capital invested from $\$ 32,972,000$ to $\$ 65,291,000(98 \%)$; and the value of products from $\$ 50,298,000$ to $\$ 72,890,000$. In 1909 the most important single industry was the manufacture of tobacco (mostly cigars and cigarettes), valued at $\$ 2 \mathrm{I}, 575,000$, Florida ranking $3 \mathrm{rd}$; in Key West $93.7 \%$ of the total value of products $(\$ 3,965,000)$ and in Tampa $82.7 \%$ of the much larger total $(\$ 17,653,000)$ was the value of tobacco manufactures. Lumber and timber products (more than $90 \%$ yellow pine) were valued at \$20,863,000; and turpentine and rosin at \$11,938,000. The only other important distinctive industry was the manufacture of fertiliser, $\$ 3,878,000$ (I $43.9 \%$ more than in 1904 ).

Transportation.-Railway mileage, January I, I9I2, 4,467.09 m. On January 22, 1912 , the Florida East Coast Railway formally opened the last link, $45.5 \mathrm{~m}$. from Knights Key to Key West, completing its all rail route from Jacksonville to Key West; ${ }^{1}$ a car-ferry is projected to run from Key West to Havana $(90 \mathrm{~m}$.). The Federal government began work in I9I I on a channel $30 \mathrm{ft}$. deep and $300 \mathrm{ft}$. wide from Jacksonville to the Ocean, which makes it possible to ship naval stores to foreign ports direct from Jacksonville; and in I9I 2 nearly completed deepening the St. Johns river channel at piers opposite Jacksonville, the improvements across the bar and at West Pass channel in Apalachicola Bay, and a channel, $30 \mathrm{ft}$. deep and $500 \mathrm{ft}$. wide, from the Gulf to the docks at Pensacola.

Legislation.-The legislature met from April 4 to June 2, I9r. It enacted that no judgment in a state court should be set aside, and no new trial granted unless the error complained of actually resulted in a miscarriage of justice; and that a judge should charge a jury only upon the law. After January I9I3 there are to be only 5 instead of 6 justices of the supreme court. A constitutional amendment, adopted in November I 112 ( 18,051 to 3,057 ) provides for an additional circuit judge in Duval county. The state building commission, created in I9I I, chose a site near the capitol for a building for the state supreme court, the railroad commission and the state library, which was begun in April I912; \$100,000 was appropriated for this building. An appropriation of $\$ 50,000$ was made for a Florida exhibit at the proposed National Historical Exposition in St. Augustine in I9I3, to celebrate the 40oth anniversary of the discovery of Florida by Ponce de Leon; $\$ 6,000$ was appropriated for work on the valuable state archives; $\$ 10,000$ for a statue of Dr. John Gorrie (1803-55; see E. B. ii, I 59a), the invenfor of a machine for making artificial ice, in the National Statuary Hall in the Capitol at Washington, and $\$ 5,000$ for a monument to the Confederate women of Florida.

A new pure food and drugs act was passed; there are to be two inspectors and an assistant

1 This great enginecring triumph was the result of nearly seven years' actual work; construction south of Homestead (128 m. from Key West) began in April r905. The railway leaves the mainland at Everglade station (on Manatee Creek), crosses I ake Surprise to Key largo, goes by the two Matecumbes and on Long Key, to Grassy Key by a viaduct $2 \frac{1}{4} \mathrm{~m}$ long, and then by the $7 \mathrm{~m}$. Knights Key-l.ittle Duck viaduct which is followed by about $13 \mathrm{~m}$., sometimes piers, sometimes concrete arches and some embankment work protected by marl slopes, to líest Summerland. Some piers were built on foundations $30 \mathrm{ft}$. below tide level. Forty-nine miles of the road was constructed by submarine blasting of limestone and by dredges and traveling excavators. At Key West about 134 acres of land was filled in for a terminal and a concrete pier is building, $1,700 \mathrm{ft}$. long and $134 \mathrm{ft}$. wide. 
state chemist, and the previous offices of pure food and drug inspector and commercial stock feed inspector were abolished. The work of inspection is put under the chemical division of the state agricultural department.

Heavy penalties are imposed for the sale of intoxicating liquors in any prohibition county or precinct. In any county, on a petition by $25 \%$ of the qualified voters, a special election must be held to decide whether or not liquor shall be sold in the county. A bill closing saloons between 9 P.M. and 6 A.M., one prohibiting the use of screens, tables or chairs in saloons, and one forbidding soliciting orders for intoxicating liquor in "dry" territory were vetoed by the governor, separately, and again together in a general revenue bill. In 19i2, II counties in the state were "licence" territory"

The board of railroad commissioners has power to regulate telephone business and telegraph rates; and only with its permission may railways or canal companies be consolidated or lease or purchase other common carriers. Many game laws were passed, mostly for separate counties and localities, and many of them forbidding the taking of food fish except by hook and line.

A large part of the legislation of the year was local. Ten new towns were incorporated, Pass-a-Grille, in Hillsborough county, with a commission government and a provision for the recall of officials; and a new charter providing a commission form of government was granted to Green Cove Springs. The charters of Jacksonville, St. Augustine and Tampa (to which East Tampa was annexed) were amencied. A new county, Pinellas, was created from Hillsborough county, with Clearwater as its county-seat. In I9I2 Tampa adopted a commission charter with provision for advisory vóting.

Finance. - The tax levy for I9I I and 1912 was set at 2 mills for current expenses and for interest on the bonded debt, and $r$ mill for a school tax, but the governor was authorised to reduce these rates. If the assessment of the state and other sources of revenue permitted, the trustees of the internal improvement fund and the state board of education are required to retain a three-fourths interest in phosphates, petroleum or other minerals found in any lands sold by them. Building and loan associations were permitted to increase their capital stock to $\$ 2,000,000$, and a law was passed for the incorporation of trust and security companies. A constitutional amendment was adopted in November 1912 (16,348 to 4,014) empowering the legislature to provide for special tax districts and to issue bonds for free public schools therein. There was in the state treasury, January I, I9I2, a balance of $\$ 858,440$. Receipts for the year 1912 were $\$ 3,023,698$ and expenditures, $\$ 2,870,603$, leaving a balance on December 31 , 1912 of $\$ 1,011,535$.

Education.-For the year ending June 30, 1912 the school population was 225,000 , the enrollment 157,161 , the average daily attendance 110,364 . and the length of the average. school year $5 \frac{1}{2}$ months. The revenue for schools was $\$ 2,359,679$ and the expenditures were $\$ 2,327,395$. The board of commissioners of state institutions was made in I9I I a state school-book commission to adopt uniform text-books throughout the state there had already been uniformity in each county for about ten years. School-books are to be furnished free to any child under 15 whose parents are on the roll of the county poor or are indigent, or are dead. The trustees of the Peabody Fund gave: $\$ 40,000$ to the University of Florida for a school of education; the new department was opened in the autumn of I9IO and a new building was begun. The principal appropriations for higher education were for the University of Florida, \$177,000; for the State College for Women, \$1 36,500; for the School for the Deaf and Blind, $\$ 82,500$; and for the Agricultural and Mechanical College (1887) for Negroes, \$30,000. The first Friday in November is to be celebrated in the public schools each year: as Mothers' Day.

The percentage of illiteracy in the population ro years of age and over in 19ro was 13.8 (21.9 in 1900). Of whites it was 5.5 (8.9 in 1900); of negroes, 25.5 (38.4 in 1900).

Penal and Charitable Institutions.-The legislature of I9I I appropriated $\$ 50,000$ for the purchase of a state prison farm,- - about 17,000 acres were purchased but no buildings were erected in 1912 - and authorised the state board of health to establish a hospital for the treatment of indigent children or to send them to established hospitals; the latter course was still being pursued in I9I2. The board of commissioners of state institutions was forbidden to lease or release convict labour before July I, I9I3; the present lease expires on December 3I, I9I3. County judges are required to act as judges of juvenile courts, and keep a separate juvenile record, and the governor is to appoint a probation officer in each county for dependent and delinquent children. Newspapers are forbidden to print the name of a woman criminally assaulted, and 5 years' imprisonment or a fine of $\$ 1,000$ or both is made the maximum penalty for enticing girls for immoral purposes.

History.-Two primary elections (May 9 and June 7 , Igro) were necessary to secure a majority vote for a United States senator to succeed James Piper Taliaferro (b. I $8+7$ ), whose term expired in I9I I, but Napoleon B. Broward (I857-r910; governor in $1905^{-}$ o9), who defeated Senator Taliaferro in the second primary, died before he took office. There was no majority for any one of the four candidates at the primary of January ro, I9I I, but on January 3 I Nathan Philemon Bryan (b. I872) was chosen at the Demo- 
cratic primary, which was followed by his election by the legislature. The Democratic primaries for delegates to the national convention elected men pledged to Oscar Underwood; Albert Waller Gilchrist (b. 1858), governor since 1909,-possibly because he opposed the submission to the people of the amendment for initiative and referendumdid not secure a renomination from the Democrats, who nominated and in November elected Park M. Trammell, then attorney-general, with a full state ticket, and carried the state for Woodrow Wilson, who received 36,417 votes to 4,535 for Roosevelt and 4,279 for Taft. There was a Progressive state ticket in the field with 3 nominees for Congress and William C. Hodges for governor, and this cut heavily into the usually small Republican vote and the opposition of the Progressives to the negro and the success of the party over the Republicans minimised the political importance of the negro. The four Democratic nominees for representatives in Congress were elected ( 1 at-large). The Socialists made gains in the state, polling 4,806 votes for Debs $(3,747$ in 1908$)$, -more than for Taft or for Roosevelt. The Socialist candidate for governor, Thomas W. Cox, received 3,467 votes to 38,977 votes for Trammell (Dem.), 2,646 for William R. O'Neal (Rep.) and 2,3 44 for William C. Hodges (Prog.).

Peonage in the state received a severe blow when President Taft refused to grant the request of the Florida legislature in I9 I to pardon five officers of a lumber company convicted by a United States circuit court in 1906 of conspiracy to arrest and return to a condition of peonage foreign-born labourers. There seem to have been fewer lynchings in $19 \times 2$ than in Igri. In the former year a negro was lynched (March 4), at Cypress for attempting to shoot a marshal; and seven negroes accused of murder were killed (May 2 I) at Lake City by men in three automobiles. In IgI 2 on April I5 a negro was lynched near Tampa for murder, on July 4 another at Bradentown for alleged assault on a white woman, on September $\mathrm{I}_{4}$ one at Alton for assault and two at Ocala (Nov. 14 and I9) for murder. The presence of militia in Jacksonville on March 7, I9 2 prevented an attack on five negroes charged with murder and assault. In the first part of November I9I 2 there was a serious street car strike in Jacksonvillc with some violence, so that car-lines were tied up and militia was called out.

Bibliography.-Acts and Resolutions (Tallahassee, I9I I) and official reports; J. C. Gifford, Everglades and other Essays relating to Southern Florida (Kansas City, 1911); H. G. Rhodes and M. W. Dumont, Guide to Florida (New York, I9II).

\section{GEORGIA 1}

Population (roro) 2,600, I2 I, an increase of $17.7 \%$ since 1000 ; negroes were $45.1 \%$ of the total, foreign-born $0.6 \%$, whites of native parentage $5.3 .3 \%$. Density 44.4 to the $\mathrm{sq} . \mathrm{m}$. In the 45 cities and towns in 1910 (3I in 1000 ) each having more than 2,500 there was $20.6 \%$ of the total $(15.6 \%$ in 1000$)$; in the 516 incorporated places ( 344 in $\mathrm{I}(100)$ having less than $2.500,11 \%(8.7 \%$ in 1000$)$; and in the purely rural districts $68.4 \%(75.6 \%$ in 1900$)$. There were 23 municipalities with a population exceeding 5,000 at the Ioro census-Atlanta, I $54,8,30\left(80,87_{2}\right.$ in 1000); Savannah, 65,064; Augusta, 41.040; Macon, 40.665 (23.272 in 1000); Columbus, 20,554; Athens, 14.013; Waycross, $1+185$ ( 5,910 in 1000); Rome, 1 2,000; Brunswick, 10, 182; Albany, 8.100 (4.606 in I900); Inericus, 8,063; Valdosta, 7,656 ; Griftin, 7,478 ; Thomasville (town), 6,727 ; Elberton, 6.48 .3 (3.834 in I 900); Marietta, 5,949; Gainesville, 5.925; Cordele, 5,883; Dublin, 5,795 ( 2.087 in 1900); Fitzgerald, 5,795 (1,817 in 1900); La Grange, 5,587; Newnan, 5,548; and Dalton 5,324.

Agrisulture.-The acreage in farms increased from $26,392,057$ to $26,953,413$ between $19(0)$ and 1010 and the improved land in farms from 10,615.64t to 12,298,017; the average farm atreage fell from 117.5 to 92.6 , and the value of farm property increased from $\$ 228,374$,

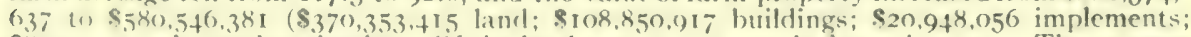
s.0.,39.3.90.3 domestic animals). (if the land area $71.7^{\circ}$ " was in farms in 1910 . The average value of firm land per acre was 813.74 . Farms were operated largely by tenants $(98,628$ hy owners, $1,+10$ by managers and 190,980 by tenants). In 1912 (preliminary estimates) the principal creps were: Indian corn, 53,958,000 bu. $(3,910,000$ A.); wheat, 1,228,000 bu. $(132,000$ I.); vats, $7,571,000$ bu. $(364,000 \mathrm{~A}$.); rye, $101,000 \mathrm{bu}$. (11,000 A.); potatues, 936,000 1 See E. B. xi, 751 . 


\section{GEORGIA}

bu. (12,000 A.); hay, 316,000 tons (234,000 A.); cotton, 1,701,000 bales (163 lbs, per A.); tobacco, $1,162,000$ lbs. (I,400 A.) and rice, 27,000 bu. (900 A.). In 1909 (U. S. Census) the value of vegetables (excluding potatoes) was $\$ 5,580,368$; of small fruits, $\$ 111,754$; of orchard fruits, \$2,930,793 (peaches and nectarines, \$2,182,613). On January I, 1912 therc were on farms: 124,000 horses, 310,000 mules, 406,000 milch cows, 667,000 other neat cattle, 174,000 sheep and 2,098,000 swine.

Spraying with Bordeaux mixture was recently proved a specific for the scab which had seriously threatened the pecan groves. The great increase in recent years of the Indian corn crop is partly due to the work done by the Boys' Corn Growing Clubs-in I9I I in the seventh congressional district 1,200 boys were engaged in this contest.

The legislature of I9I I authorised the veterinary department of the agricultural college to manufacture serum for hog cholera and to instruct the public in its use; and that of 1912 appropriated $\$ 15,000$ for the eradication of cattle tick. The appropriation for the board of entomology was increased in I9I I so that its work might be enlarged. Upon petition of 50 producers of cotton any county must appoint (1912) a weigher and grader of cotton.

In McDowell county 8, II3 acres were taken over in 1912 by the United States for a forest reservation under the Weeks Law (Mar. I, I9II) to preserve forests on upland watersheds; and 31,876 acres more (Fannin, Union, Gilmer and Lumpkin counties) were approved for purchase for the same purpose by the National Forest Reservation Commission.

Mineral Products. - Total value, I9I I $\$ 6,171,367$. Of iron ore the output was 207,279 tons $(\$ 315,704)$, and of coal, 165,210 tons $(\$ 246,208)$, - both less than in I9Io. Clay products were valued at $\$ 2,636,380$ (almost entirely brick and tile), stone at $\$ 1,967,077$, more than one-half being the value of marble, and sand and gravel at \$175,734. Most of the ochre in the United States came from Georgia; value, $\$ 69,447$. A little gold was still taken from placers and about half as much from siliceous ores; value, $\$ 35,070$. The output of asbestos was about $60 \%$ more than in 1910; and that of bauxite was less, although a new field was worked in Wilkinson cointy.

Manufactures.-In 1909 there were 4,792 establishments (3,219 in 1904); the capital invested was $\$ 202,778,000$ ( $50 \%$ more than in 1904$)$; and the total value of products $\$ 202$, $863,000(34.3 \%$ more than in 1904$) ; 25.7 \%$ was the value of cotton goods $(\$ 48,037,000)$, hosiery, knit goods, mostly cotton $(\$ 3,233,000)$, and woollen and worsted goods $(\$ 87 \mathrm{I}, 000)$. The value of lumber and timber (about $89 \%$ yellow pine), was $\$ 24,632$,000; of cottonseed oil and cake, $\$ 23,64 \mathrm{I}, 000$ (an increase of $193.2 \%$ since 1899); of manufactured fertilisers, $\$ 16,800,000$ (about one-sixth of the total for the United States, and about five times as much as in I899); of flour and grist mill products, $\$ 8,000,000$; of turpentine and rosin, $\$ 6,939,000$; steam railway cars and repairs, $\$ 6,535,000$; printing and publishing, $\$ 6,400,000$; and foundry and machine shop products, $\$ 5,808,000$. The principal manufacturing cities, with the value of their product in 1909, are: Atlanta, \$33,038,000; Macon, \$10,703,000; Augusta, \$10,456,000; Columbus, \$8,552,000; and Savannah, $\$ 6,734,000$.

Transportation.-Railway mileage, January I, I912, 7,382.19. The Federal government in 1912 had more than half finished increasing the channel depth of Savannah harbour to $26 \mathrm{ft}$. and clearing up the Savannah river below Augusta. Work on the river at Augusta was begun in I9I I by the Federal government and the state together.

Legislation.-The legislature met in regular session in I9II (June 28-Aug. I7) and in I9г2 (June 26-Aug. I4). In г9т 2 constitutional amendments were adopted: creating Bleckley county from a part of Pulaski $(28,7$ I 7 to 6,886$)$ and Wheeler county from a part of Montgomery $(68,627$ to 13,003$)$; increasing the governor's borrowing power for annual deficit from $\$ 200,000$ to $\$ 500,000$ ( 10,58 I to I 2,550 ); giving the legislat ture authority to require corporations to pay taxes on September I instead of December $20(21,499$ to 14,534$)$; permitting counties to levy taxes for high schools $(28,024$ to $6,970)$; empowering the legislature to replace with municipal courts justice courts in all cities (except Savannah) with more than 25,000 inhabitants (24,2 I I to I0, I9.3); exempting farm products from taxation while held for sale $(75,836$ to 10,577); and allowing judges of superior courts to grant charters in. vacation (74,119 to 8,084). Lobbying was prohibited (IgII) by a law which requires agents for bills to register the name of their employers, the purpose of their employment and an itemised account of their expenditures. Practice in courts of review was revised especially as regards review of judgment for lack of proof of venue and as regards service of bills of exception. Provision was made for the investigation of the judicial system of the state and defects in penal laws.

The state was divided into 12 Congressional districts in I9II under the new apportionment. A department of game and fish was established and a department of commerce and labour. Hours in cotton and woollen factoties were reduced from i I to Io a day and from 66 to 60 a week. In 1912 new laws were passed for calling out militia in time of riot and for declaration of martial law; and an insurance department was created. 
The powers of the state inspector of drugs were enlarged (19I I). An application for an internal revenue tax receipt or the possession of such a receipt is prima facie evidence of the violation of the state prohibition law. A bill, the Tippins law, to close "near-beer" saloons, was vetoed by the governor and could not be passed over the veto. Newspapers published in the state are forbidden to print the names of any victims of criminal assault.

A quasi-commission charter for Atlanta provided by the 1911 legislature was defeated by the electors of the city on September 27, I911. In 1911 Summerville (pop. 4,361 in 1910) was annexed to Augusta; a commission form of government was provided for Marietta; Macon was authorised to own and operate water works and a civil service system for the police and fire departments was added to its charter.

The cities of Baxley, Fayetteville, Glennville and Lilly (August 19II) and Albany, Lawrenceville, Springfield, Statesboro, Stone Mountain, Sycamore and Villa Rica (August 1912), received new charters and the cities of Blackshear, Bostwick, Folkston, Odum, and Woodville were incorporated in 1911 , and Rex in 1912. The governor was authorised in I 912 to bring suit to test the state's claim to a part of Tallulah river, Tallulah Falls and adjacent country as unsurveyed and not legally granted by the state.

Finance. - A joint committee of the house and the senate was appointed in I9I I to codify the state banking laws and the state insurance laws; but the bill which it drafted failed to pass in 1912. The maximum number of directors of any bank was increased from 15 to 25 (1912). The state debt (Jan. I, I913) was $\$ 6,734,202$ and the annual appropriation for interest on the state debt was $\$ 287,945$ for 1912 and $\$ 283,445$ for I9I3. The treasurer's report shows a balance on hand December 3I, I9II, of $\$ 727,076$; receipts of $\$ 6,014,109$; expenditures of $\$ 5,627,668$; leaving a balance on December 31 , I912, of $\$ 1,113,517$.

Education.- In 19 I I the school law of the state was revised by a remarkably brief and clear act, which however does not apply to Atlanta, to a few county districts or in most respects to especially incorporated local districts. The title of the chief executive officer has been changed from superintendent of schools to school commissioner. The state board of education is now professional rather than political in its character. An appropriation of $\$ 25,000$ a year and $\$ 5,000$ for equipment was made for the agricultural industrial normal school of South Georgia at Valdosta, which was to open early in 1913; and one of $\$ 25,000$ (1912) for an industrial building for the North Georgia agricultural college at Dahlonega. At Clarkston near Atlanta, Lamar College, under the auspices of the Christian Church, will be opened early in 19I3. The University of Georgia received in 1912 a gift of $\$ 12,500$ from the Phelps Stokes Fund to found a permanent fellowship for the study of the negro.

For the year ending December 3I, 19II, the enrollment was 565,071 $(222,942$ of whom were negroes), the attendance 352,059 (130,678 negroes), and the average length of the free school year was 118 days for whites and 107 for negroes. The number of teachers was 13,024 (4,070 negroes) and their average monthly salary ranged from \$1 18.70 for white male teachers in cities to $\$ 20.56$ for negro female teachers in counties.

The percentage of illiteracy in the white population lo years of age and over in 1910 was 20.7 (30.5 in 1900); among whites 7.8 ( 11.9 in 1900) and among negroes, 36.5 (52.4 in 1900).

Penal and Charitable Institutions. - In January 1912 of the 2,708 convicts serving time in the state prison, 1,487 had been convicted of crimes against life (812 for murder, 365 for manslaughter, I,3 I0 for attempted murder). Among the appropriations for 191 2 and for 1913 each were: \$530,000 for the Georgia state sanitarium; $\$ 20,000$ for consumptive patients in the sanitarium; \$515,000 to Confederate soldiers; $\$ 145,000$ to the indigent widows of Confederate soldiers; $\$ 100,000$ to widows of Confederate soldiers who died in action and $\$ 300,000$ to Confederate soldiers and their widows; and \$30,000 for the soldiers' home. The act of 19 Io pensioning Confederate soldiers and their widows was amended in 1912 so as to make the requirements for pensions less difficult; the pension of blind soldiers was increased from $\$ 60$ to $\$ 100$ a year.

History.-Hoke Smith (b. 1855), Secretary of the Interior in President Cleveland's cabinet in $1893-06$, and governor in $1907-00$, was again inaugurated governor July $\mathrm{I}$, InIr. On July i 2 th he was chosen United States senator to succeed Joseph Meriwether Terrell, who was in bad health and who immediately resigned. Governor Smith refused to accept Senator Terrell's resignation, as he wished to remain governor for a time at least; but Senator Terrell ${ }^{2}$ refused to return to Washington and for the remainder of the session of the 6rst Congress Georgia was represented in the United States Senate by

'In special systems where there was no local tax teachers were paid by patrons for additional teaching in some cases, so that the average for these special systems was I7o days ( 175 for white and 164 for negro), making the average for all'schools, 140 days.

"Terrell, horn in Greenville in 1861, died in Atlanta November 17, 1912. He served in the state leyislature, was attorney-general 1892-1902, governor 1902-07, and, after his political ally Joseph M. Brown succeeded Hoke Smith, his opponent, as governor, United States senator, heing appointed November 1910 by Governor Brown for the unexpired term of Senator Alexander Stephens Clay $(1853-1910)$. 
one senator only, Augustus O. Bacon. In the 6 nd session Hoke Smith took his seat as United States senator. He was succeeded as governor by Joseph M. Brown, who had been governor in rgog-II. Brown's term ends July I, I9I3, and the Democratic primaries on August 2I, I9I2 (by 104,857 votes against Hooper Alexander 39,037, Joe Hill Hall 24,856) named John M. Slaton (elected in October) to be his successor and re-nominated United States senator Bacon for the term I9I3-I9. Local politics centre around the liquor question; which splits the Democratic party. The newly elected state legislature will be nine-tenths (or more). Democratic. In November I9I2, I 2 Democratic congressmen were elected-formerly the Georgia delegation was Ir; and the state was carried for Woodrow Wilson by $93, \mathrm{I} 7 \mathrm{i}$ votes to 22,0 Io for Roosevelt, 5, I 90 for Taft, 1,028 for Debs ( 584 in I908) and 147 for Chafin.

On December I8; I9I2 the state protested (memorial of Aug. I9) to Congress against the adoption by a two-thirds vote of the quorum (and not of the total membership) of each house of Congress of the measure to submit to the states the constitutional amendment for popular election of United States senators.

In Igri there were 20 lynchings in the state, all negroes but one-a negro at Vera for murder (Jan. 29); two for murder at Warrenton (Feb. 25); three accused of murder (taken from jail) at Ellaville and one for rape at Lawrenceville (April 8); one for threatening to kill, in Bullock county (April 22); one for murder (May 14) and one for killing an officer (May 2I) at Swainsboro; one for murder at Crawfordsville (May 22); a white man for rape at Monticello ( $\mathrm{J}$ une $\mathrm{r} 8$ ); a negro for rape at Social Circle and one for suspicious loitering at Monroe (June 27); one for murder at Baconton (July II); one for rape at Dublin (Oct. 5); one, on no definite charge, at Vienna (Oct. 7); one for attempted rape (taken from bailiff) at Irwinton (Oct. II); one for murder at Washington (Oct. 28); and one for murder at Donaldsonville (Dec. 23). In I9I 2 three negroes and one negress were lynched at Hamilton (Jan. 22) for murder; a negro was lynched at Cordele (Jan. 30) for rape, one was burned at Macon (Feb. 4); one was lynched at Cochran (March 2I) for murder; one near Jackson (April 26); one for murder at Columbus (Aug. I3); one on suspicion of aiding a murderer at Cumming (Sept. Io); one for assaulting a white woman at Americus (Oct. 5); one was taken from the court house at McRae and was lynched (Nov. 30) for assaulting and shooting two white women:and on the same day one was lynched at Cordele for murder. Anti-negro night riders terrorised northern Georgia in December I9I 2.

Augusta was put under martial law in the last part of September I912, when street railway employees rioted and tied up car-lines; three were killed on the 27 th and on October I about 30 soldiers were put on trial for murder. The strike ended October I7, when the company granted a wage increase of one-eighth and shorter hours. On October I, I9I2, the Georgia Railroad was paralysed by a strike of conductors and trainmen, but on the $I$. th they returned to work, agreeing to arbitration.

Bibliography.-Lares (Atlanta, I9II and I9I2) and official reports; Georgia Code of I9Io (2 vols, ibid., I9II); Georgia Annual (ibid.); The Alexander Letters, I787-1900 (Savannah, I9I0); O. Wegelin, Bibliography of Georgia (1911).

\section{IDAHO}

Population (I910) 325,594 (Iог.3\% more than in r900). The greatest relative increase was in Iincoln county-610.5\%. Density 3.9 to the sq. $m$. The Indian and Asiatic element constituted I.7\% of the total (in I900 $4.3 \%$ ); foreign-born whites I $2.4 \%$; and whites of foreign parentage $23.1 \%$. There were I2 (in I900 only 2) places with 2,500 inhabitants or more, including $21.5 \%$ (in 1900 only $6.2 \%$ ) of the total, as follows (I900 figures in brackets): Boisé, I7,358 (5,957); Pocatello, 9, Iro (4,046); Coeur d'Alene, 7,29I (508); Lewiston, 6,043 (2,425); Twin Falls, 5,258 (inc. I908); Idaho Falls, 4,827 (I,262); Nampa; 4,205 (799); Moscow, 3,670 (2,484); Caldwell, 3,543 (997); Wallace, 3,000 (2,265); Sandpoint, 2,993 (inc. r907); Weiser, 2,600 (1,364). The pop. of smaller incorporated places made up $18.1 \%$ of the total (15.7\% in 1900 ).

'See E. B. xiv, 276 et seq. 
Agriculture.- In 1910 nearly one-tenth of the state's area was in farms $(5,283,604$ acres $)$, but hardly more than half the farm acreage $(2,778,740 \mathrm{~A}$.) was improved; this was $96.6 \%$ more than in 1900. The average number of acres in a farm in 1910 was 171.5; in 1900, 183.4. In the decade the value of farm property increased from $\$ 67,271,202$ to $\$ 305,317,185$ (land, \$219,953,316; buildings, \$25,112,509; implements and machinery, \$10,476,051; and domestic animals $\$ 49,775,309$ ); the average value of each farm from $\$ 3,850$ to $\$ 9,91 \mathrm{I}$, and the average value of farms per acre from $\$ 11.07$ to $\$ 41.63$. More than half the farms (and more than one-fourth the farm acreage) were irrigated in 1910; of the $1,430,848$ acres irrisated: 628,102 were by co-operative concerns; 403,600 by individuals and partnerships; 162,418 by Carey Act "enterprises"; and 47,500 by the U. S. Reclamation Service. The (Federal) Boisé project was $\mathbf{5 2} \%$ (excluding Boisé river storage, $98 \%$ ) completed in November I912, and was in 191 I irrigating 121,000 acres; and the Minidoka project, $90 \%$ completed, irrigated in 191291,000 acres. In 1910 more than $90 \%$ of the alfalfa and nearly half the wheat acreage was irrigated. In 1912 (preliminary estimates) the following crops were reported: Indian corn, 394,000 bu.; wheat, 14,566,000 bu.; oats, I 7,01 7,000 bu.; barley, $6,916,000$ bu.; rye, 66,000 bu.; potatoes, 6,475,000 bu.; hay, 1,938,000 tons, and sugar beets, 206,367 tons. In 1909 (U. S. census) the value of vegetables other than potatoes was \$1,007,667; of small fruits, \$201,525 (strawberries, \$92,904); of orchard fruits, \$863,516 (apples, \$610,504; plums and prunes, \$132,804). On January 1, 1912 there were 214,000 horses, 94,000 milch cows, 343,000 other neat cattle, 2,951,000 sheep and 212,000 swine.

In 19 I I agriculture was first taught systematically in the rural high schools of the state. The federal department of agriculture in 191 I established an experiment farm at Aberdeen, for the study of cereals in dry lands, in co-operation with the state experiment station. An irrigation demonstration farm at Gooding has done much to teach economic use of water.

Mineral Products. - Total value, $191 \mathrm{I}, \$ 17,588,340$. The principal products were gold and silver; of the former, 65,688 fine oz., valued at $\$ 1,357,900$, and of silver $8, \mathbf{1} 84,900 \mathrm{oz}$., valued at $\$ 4,+19,800$, mostly from lead mines in the Coeur d' Alene and Gilmore regions. The output of lead, in which the state ranked second in 1911 , was 117,159 tons ( 136,278 tons, on mine reports); of zinc, 3,180 tons; and of copper, 4,514,116 lbs. (less than for any year since 1904). I.ess salt was produced than in 1910. A little phosphate rock was found in $191 \mathrm{I}$ in the S.E. part of the state.

Manufactures. - The total value of factory products for 1909 was $\$ 22,400,000,155.4 \%$ more than in 1904 ; the capital invested in manufacturing, $\$ 32,477,000$, an increase of $235.2 \%$; the number of establishments, 725 , and the number of persons engaged in manufacturing, 9,909. Lumber and timber products valued at $\$ 10,689,310(240.2 \%$ more than in 1904$)$ made up $47.7 \%$ of the total value, followed by flour and gristmill products, $\$ 2,479,719$; cars and general shop construction and repairs by steam railway companies, $\$ 1,366,000$, and printing and publishing, \$1, I 48,033. Boisé had factory products valued at \$1,660,497.

Transportation.- Railway mileage, January $1,1912,2,550.88$.

Government.-The legislature met in regular session from January 2 to March 4, i $91 \mathrm{I}$, and in special session January II-3 I, J9I2. It ratified the proposed 16 th amendment to the Federal Constitution January 20, ro r r, and submitted several constitutional amendments to popular vote at the ror 2 general election. These include: one providing for the referendum (adopted, 43,658 to 13,490 ); one providing for the recall of state officers, except judicial officers (adopted, 37,875 to 13,469 ); one for the initiative (adopted, 38,918 to 15,195$)$; one making the limit of state indebtedness for work on the capitol $\$ 2,000,000$ (adopted, 31,7 I 2 to 18,083 ); one permitting convicts to work outside of prison grounds and on the other public works (adopted, 33,908 to 17,876 ), and one providing for an appointed board of education (adopted, 33,045 to 14,796), in place of the present ex-officio board.

In I II I, four new counties were created: Bonneville from the N.E. part of Bingham (county-seat, Idaho Falls); Clearwater from the N.E. part of Nez Perce (county-seat, Orofino); Adams from the N. part of Washington (temporary county-seat, Council); and Lewis from the central part of Nez Perce (temporary county-seat. Nez Perce).

The legislature passed a law revising and enforcing that of 1909 , declaring saloons in prohibition districts common nuisances, the discovery of liquor on the premises to be prima furie evidence of guilt. In 1912 four counties which had been "no-licence" for two years voted for licence. Saloons, dance-halls, etc, are not to be opened on Sunday.

The legislaturc enacted a commission charter for cities of 2,500 or more if they adopt the act at a sperial clection. The charter provides for nomination by petition, for initiative (on a $10^{\circ}$ petition), for referendum (on a $25^{\circ}$, petition) and for the recall of any local officer, after he has been in office three months, at an election called by a $20^{\circ}$ in petition. The charter may be ahandoned after 6 years by a vote at a special election called by a petition of $25^{\circ}$ " of the voter. Boise adopted the charter on February 23, 1912; in effect May 21 , 1912. I.ewiston has had a commission government since 1907. 
The state appropriated $\$ 750,000$ for work on the capitol building, which was ncarly completed in 1912 , and $\$ 12,000$ to purchase about 12,000 acres for a state park to be called Heyburn Park in what was the Coeur d'Alene Indian Reservation; the land was bought immediately. A Game Preserve was created in Cassia, Twin Falls, Oneida and Bear Lake counties.

Among important labour laws was one making 8 hours a day's work on public works. The state insurance department was organised and an act was passed to protect commerce against monopolies and to prevent rebating. Sanitary laws provide for the inspection of hotels and for sanitation in dairies and in peddling of dairy products; and forbid the sale of adulterated, misbranded or impure foods or drugs. Lotteries are declared unlawful. The white slave trade is forbidden and the penalty is imprisonment from 2 to 20 years, fine of $\$ 1,000$ to $\$ 5,000$ or both imprisonment and fine. Other miscellaneous laws organise the militia; make Columbus day (12th of October) a legal holiday, and forbid advertising on rocks or similar natural objects.

Finance. - The taxes collected in I9I 1 were $\$ 1,300,000$ more than in any previous year, and in 1912 the senate declared that the taxes had become oppressive and urged economy on state officers. An ad valorem tax of $\$ 900,000$ was laid for I9I I and 19I2. In I9II the legislature provided for the appointment of a state bank commissioner and for the control of bank organisations, and in I9I2 revised the tax laws. On January I, I9I I the balance in the treasury was $\$ 853,706$, and on October I, I $1912, \$ 1,280,654$; the receipts in the interval were $\$ 6,023,947$; the expenditures $\$ 5,596,999$. The debt (Oct. I, I912) was $\$ 2,364,250$.

Education.-The legislature of 1911 passed an elaborate educational code drafted by a commission. This was partly amended in 1912. Among the important changes are the following. The state board of education has larger powers and the superintendent smaller ones; a new class of school districts is formed with enlarged powers and graduated scale for the length of the school term in the different parts of the state. The system of certification for teachers is improved. The state board is empowered to draft rules and regulations for building schoolhouses and there is an important change in the method of apportioning the school fund. This "Idaho plan" distributes two-thirds of the total fund among the different districts on the basis of the school population-except that each district is assumed to contain at least 20 children; $5 \%$ of the remainder goes to rural high school districts in proportion to the number of actual high school teachers, not more than $\$ 300$ for each teacher; one half of the remainder goes to weak or poor school districts, and the other half to the districts in proportion to their school population. The law forbids the employment of children under 14 in any employment (formerly, only for certain stated employments) during school hours and before 6 A.M. or after 9 P.M. There are the same limitations on the employment of children between 14 and 16 unless they have met certain educational requirements. The code makes education compulsory for children between 8 and 18 unless they are excused on a doctor's certificate or are over I4 years old and have passed through the 8 th grade.

In 1912 the school population was 109,610 ; the total enrollment, 82,387; the average daily attendance, 57,359; and the average length of school year about 7 months. The revenues for the year ending in the summer of 1912 were $\$ 3,218,035$, and the expenditures $\$ 2,910,301$. The percentage of illiteracy in the population Io years and over in I9Io was 2.2 (4.6 in I900). The college of agriculture of the state university supervises agricultural extension work, including farmers" institutes, "movable schools" and demonstration trains.

Charities and Corrections. - In I9I I the legislature established the Idaho State Sanitarium for feeble-minded and epileptics near Nampa, and created a prison labour commission to investigate the state penitentiary. The punishment for murder in the first degree was made either death or life imprisonment.

History.-James H. Hawley (b. I847), Democratic governor in I9II-I2, was renominated but was defeated by John M. Haines, Republican, formerly mayor of Boisé, who received 35,056 votes to 33,992 for Hawley and 24,325 for G. H. Martin (Progressive) and II,094 for L. A. Coblantz (Socialist). The Republican nominees for Congress (2; instead of I as under the previous apportionment) were elected and in the state legislature the Republicans have very large majorities ( 56 to 4 in the lower house), so that William Edgar Borah (b. 1865) was re-elected U.S. senator, January If, I9I3. The governor appointed November I 8, i9 1 2, Judge Kirtland I. Perky, Republican, of Boisé, for the unexpired term (to March 4 , I9I5) of Weldon Brinton Heyburn (1852-1912; U.S.

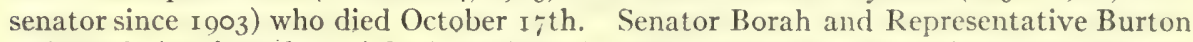
L. French (re-elected I9I2) had considered Taft's nomination fraudulent, but had not left the Republican party. Although the Progressive cause received a set-back when the Supreme Court of the state decided" (Octuber I, I9 I2) that electors of the National

1 This decision was called "trickery and chicanery" by Col. Roosevelt. The Boisé Capital News published this criticism and its editors were cited by the Supreme Court for contempt, and were found guilty. 
Progressive party could not be nominated by petition, as other methods provided by law had not been used, the Roosevelt ticket made a fair showing. Woodrow Wilson carried the state, receiving 33,92 I votes to 32,8 Io for Taft, 25,527 for Roosevelt and II,960 for Debs $(6,400$ in 1908$)$.

Bibliography.-Session Laws (2 vols., Boisé, I9II-I2) and official reports; H. L. Talkington, Political History, State Constitution and School Laws of Idaho (Lewiston, 1911).

\section{ILLINOIS ${ }^{1}$}

Population.-In I910, as in 1890 and 1900 , Illinois rasked third in population among the states. The total in I9I0 was $5,638,591,16.9 \%$ more than in 1900 , a smaller percentage of increase than in any previous decade. Of this total $98 \%$ were whites ( $76.7 \%$ native-born whites, $30.6 \%$ whites of foreign parentage, $21.3 \%$ foreign-born whites) and $1.9 \%$ negroes. In density the state ranked roth, in 19I0, with I00.6 inhabitants per sq. m.; the maximum density was 2,578 in Cook county (containing Chicago) and the minimum 25.9, in Henderson county.

In I9I0 there were 144 (in I900, II4) incorporated places having more than 2,500 inhabitants, and these contained $61.7 \%$ (in $1900,54.3 \%$ ) of the total. In the 920 incorporated places having less than 2,500 , there was only I $2 \%$ in I 9 ro. In rural territory there was not merely a relative decrease (from $33.2 \%$ in 1900 to $26.4 \%$ in I 910 ), but an actual decrease (from $1,598,385$ in 1900 to $1,486,422$ in 1910 ). Of the 144 municipalities with populations above 2,500, $7 \mathrm{I}$ were between 2,500 and 5,000 (total 239,887) and $4 \mathrm{I}$ between 5,000 and 10,000 (total 286,079). The 32 having over 10,000 were: Chicago, $2,185,283$ (in I $900, \mathrm{I}, 698,575$ ); Peoria, 66,950; East St. Louis, 58,547 (29,655 in r 900 ); Springfield, 5I,678; Rockford, 45,40I; Quincy, 36,587; Joliet, 34,670;. Decatur, 3I, I 40; Aurora, 29,807; Danville, 27,87I ; Elgin, 25,076; Bloomington, 25,768; Evanston, 24,978; Rock Island, 24,335; Moline, 24,199; Galesburg, 22,089; Belleville, 21,1 22; Oak Park (village), I9,444 (inc. I902); Freeport, I 7,567; Alton, I 7,528; Waukegan, I6,069; Jacksonville, I 5,326; Cicero (town), I4, 557 ; Cairo, I4, 548; Chicago Heights, I 4, 525 (5, I00 in I 900); Streator, 14,253; Kankakee, I3,986; Champaign, 12,421; La Salle, I1,537; Mattoon, II,456; Lincoln, I0,892; and Canton, ro,453.

Agriculture. - The acreage in farms decreased from $32,794,728$ to $32,522,937$ between 1900 and 1910 , but the improved land in farms increased from $27,699,219$ to $28,048,323$, the average farm acreage increased from 124.2 to 129.1 , and the value of farm property from $\$ 2,004,316,897$ to $\$ 3,905,321,075(\$ 3,090,411,148$ land, $\$ 432,381,422$ buildings; $\$ 73$,724,074 implements and $\$ 308,804,431$ domestic animals). Of the land area $90.7 \%$ was in farms in I910. The average value of farm land per acre was \$95.02. Farms were operated largely by owners ( 145,107 by owners, 2,386 by managers and 104,379 by tenants). In IgI2 (preliminary estimates) the principal crops were: Indian corn, 426,320,000 bu. (I0,658,000 A.); wheat, $9,819,000$ bu. (1,183,000 A.); oats, $182,726,000$ bu. $(4,220,000$ A.); barley, I, 796,000 bu. (57,000 A.); rye, 768,000 bu. ( 48,000 A.); buckwheat, 88,000 bu. $(4,000 \mathrm{~A}$.); potatoes, $13,837,000$ bu. ( $137,000 \mathrm{~A}$.); hay, $3,266,000$ tons $(2,512,000 \mathrm{~A}$.) and tobacco, 684,000 lbs. (900 A.). In I909 (U. S. Census) vegetables (except potatoes) were valued at $\$ 9,392,296$; flowers and plants, $\$ 3,694,801$; small fruits, $\$ 1,109,7+7$ (strawberries, $\$ 613,917$ ), orchard fruits, $\$ 3,857,743$ (apples, $\$ 2,111,866$; peaches and nectarines, \$999,516); and broom corn, $\$ 1,457,172(38,452$ A.). On January I, 1912 there were on farms: I, 497,000 horses, 15 I,000 mules, I, 049,000 milch cows, I, 266,000 other neat cattle, I, 068,000 sheep and $4,640,000$ swine. The office of state inspector of apiaries was created in I I I by a law which provides for the destruction of bees with foul brood or other contagious diseases; $\$ 60,000$ was appropriated for county fairs, $\$ 4,000$ for farmers' institutes, $\$ 8,000$ for demonstration work by the state entomologist and \$215,000 for buildings at the state fair. The second special session of 1912 appropriated $\$ 130,000$ to the Agricultural Experiment Station for a soil survey. Much important work on soils had already been done, especially by Professor Cyril George IIephins of the University of Illinois.

Mineral Products. - Total value, I9II, \$106,231,455. In value of coal, \$59,519,478, the state ranked 2 nd; in quantity, 53,679, II 8 tons, $3 \mathrm{rd}$. In petroleum, $31,317,038$ bbls., $\$ 19,734,339$, also it ranked 3 rd. Natural gas, $\$ 687,726$, was more abundant than in preceding years. (lay products were valued at $\$ 4,333,0$ I I $(\$ 832,813$ for yellow and stone ware); stonce at $\$ 3,467,930$ (almost entirely limestone), 8 th among the states; Portland rement at $\$ 3,583,30$ r ( 5 th $)$ - and a little natural cement; sand and gravel, \$1,990,922 (2nd). The output of pig iron was $\$ 31,152,927$ (not included in the total given above),

${ }^{1}$ See E. B. xiv, 304 et seq. 
(3rd); zinc, 4,2 I9 tons (mine reports; 2,884 tons on smelter reports); lead, 964 tons (mine reports; 308 tons on smelter reports). There are large deposits of tripoli. The value of fluorspar, $\$ 481,635$, was more than in any other state. Diamonds were found near Macomb and in Jefferson county -one of 7 carats. Mineral waters were valued at $\$ 82,330$.

Manufactures.-Illinois in 1909 was the most important manufacturing state W. of the Alleghany Mountains and ranked $3 \mathrm{~d}$ in the Union; the gross value of products was $\$ 340.38$ per capita, and the total value one-eleventh that of the whole country. From I904 to I909 the number of establishments increased from 14,92 I to 18,026 and that of persons engaged in manufacturing from 447,947 (379,436 wage-earners) to $56 \mathrm{I}, 044$ (465,764 wage-earners) the capital invested from $\$ 975,845,000$ to $\$ 1,548,17.1,000(58.6 \%)$; and the value of products from $\$ 1,410,342,000$ to $\$ 1,919,277,000$. Of separate industries the census reported 95 with products valued at $\$ 500,000$ or more, 8 more than $\$ 50,000,000$ each; 8 between $\$ 25,000,000$ and $\$ 50,000,000$; and 15 between $\$ 10,000,000$ and $\$ 25,000,000$. In slaughtering and meatpacking $(\$ 389,595,000)$ Illinois ranked Ist with $28.4 \%$ of the country's total. Nearly fivesixths $(\$ 325,062,000)$ of the state's output came from Chicago, and this was more than onefourth of that city's total $\left(\$ 1,28 I, \mathbf{I} 7 \mathbf{I}, 000^{1}\right)$. The other industries which had each a product valued at $\$ 25,000,000$ or more were: foundry and machine shops, $\$ 138 ; 579,000$ (Chicago, $\$ 89,669,000$ ); men's clothing, $\$ 89,473,000$ (Chicago, $\$ 85,296,000$ ); printing and publishing, $\$ 87,247,000$, ranking the state 2 nd to New York only (Chicago, $\$ 74,2$ I I,000); iron and steel, rolling mills, $\$ 86,608,000$, ranking the state 3rd (Chicago, $\$ 45,984,000$ ); agricultural implements, $\$ 57,268,000$, ranking the state Ist with two-fifths of the country's output; distilled liquors, $\$ 55,200,000$, being $27 \%$ of the country's product and consisting principally of corn whisky; flour and grist-mill products, \$5I, I I I,000; lumber and timber, $\$ 44,952,000$ (Chicago, $\$ 32,709,000$ ); iron and steel, blast furnaces, $\$ 38,300,000,9.8 \%$ of the total of the country and ranking the state 3 rd; steam railway car construction and repairs, $\$ 32,229,000$, and-not by railway companies $-\$ 27,001,000$; malt liquors, $\$ 28,449,000$ (Chicago, $\$ 19,-$ $5 \mathrm{I} 2,000)$; furniture, $\$ 27,900,000$ (Chicago, $\$ 20,5 \mathrm{I} 2,000)$; and electrical machinery, apparatus and supplies, $\$ 26,826,000$ (Chicago, $\$ 20,669,000$ ): Next to Chicago the most important manufacturing cities were: Peoria, $\$ 63,061,000$ (chiefly distillery products); Joliet, $\$ 38,8$ I 6 ,500 (chiefly steel); Rockford, $\$ 22,265,700 ;$ Moline, $\$ 20,891,700$ (chiefly agricultural implements); Waukegan, \$19,984,000; East St. Louis, \$18,228,000; Quincy, \$ I I 435,600; Elgin \$I I,1 19,700; Aurora, \$10,954,200; and Chicago Heights, \$10,839,200.

Transportation.-Railway mileage, Jan. I, $1912,12,132.10$, more than in any other state save Texas. The law governing the railroad and warehouse commission was amended and the commission's powers were increased. To it was given-jurisdiction over express companies, which were declared common carriers. A uniform bills of lading act was passed in 19II. The governor appointed a rivers and lakes commission to survey the waters of the state, to prevent pollution and to gather data in reference to navigability, deep waterways, reclamation and water power, etc. In igI I the Federal government completed the Black River pool (20 ft. wide; $7 \mathrm{ft}$. deep) of the Illinois and Mississippi Canal and began work on turning basins in the Calumet river.

Legislation.-The legislature met in regular session from January 4 to June I, I9I I; in special session from June I4 to November I4, I9I I, from March 26 to June 5, I9I2, and from April 24 to June 5, I9I2. The third special session was called after the beginning of the second and its proceedings were carried on on the same days (but not at the same time) as the second session. This was unprecedented in the state. The legislature urged on Congress a constitutional amendment giving to Congress the power to prevent and suppress monopolies. The state supreme court was authorised to appoint persons to aid the appellate judges. An amendment to the state constitution providing for initiative and referendum passed the senate but secured nine votes less than the necessary two-thirds in the lower house. A new ballot law provides that, when two or more persons are to be chosen for any one office, the names of party candidates are to be arranged in a party column, in order, according to the vote cast for each at primaries and the names of candidates nominated by petition in the order in which their names appear on the nominating petition. A direct primary law like that enacted in I908, but omitting clauses held unconstitutional by the state supreme court, was passed in I9II. A presidential primary election law $^{2}$ (approved 30 March, I9I2) provides that the vote of the state at large is to be considered advisory to convention delegatesat-large and the vote of each congressional district advisory to delegates of the district; and there is provision for advisory voting for candidates for United States senator.

1 The total value of the output of Chicago's factories exceeded that of any state of the Union except New York, Pennsylvania, Illinois, Massachusetts and Ohio.

${ }^{2}$ Principally to secure such a law, Governor Deneen called the special session. 
A commission for the study of public utilities in the state, and the Illinois park commission were created. The Staricd Reck State Park was set aside (formally opened May' I. 1911 ) between Ottawa and La Salle where in $177^{\circ}$ the Potawatomi besieged the Illinois as a sequel to the murder of Pontiac. The legislature appropriated $\$ 5,000$ for a monument at Edwardsville to commemorate the Iooth anniversary in 1912 of the beginning of republican government in the state, and \$5,000 for a monument at Equality to General Michael Kelly 1.awler (c. I 820-82), an early settler and a veteran of the Mexican and Civil wars.

The law of 1897 regulating the practice of architecture was amended and commissions were created to revise and codify the building laws and to investigate the coal mines of the state. Provision was made for strict sanitary inspection and sanitation of all places used for the preparation of foods, the act to be enforced by the state food commissioner; and the entire dairy and food products law was amended. Common drinking cups are prohibited in public places and on railway trains. Intoxicating liquor is not to be sold within twothirds of a mile of any soldiers or sailors home and the act forbids the drinking of intoxicating liquors on passenger cars or in railway stations or the boarding of a railway train by an intoxicated person. Under this law I I railways operating in the state stopped the sale of intoxicants on passenger trains. An attempt to repeal in 1911 the municipal and township local option law of 1907 was unsuccessful.

A workmen's compensation law of the elective type applies to certain dangerous industries only and election by the employer is presumed in the absence of written notice from him to the contrary. The law abrogates the defence of assumed risk (held constitutional by the state supreme court, June 6,1912 ) and of fellow service and requires that compensation be diminished for contributory negligence; if an employer intentionally fails to comply with the statute, a suit for damages is permitted in lieu of compensation. The employer may insure his employees or may maintain a benefit fund provided he does not reduce the liability fixed by law. To be compensated, disability must continue more than six working days. The maximum compensation for death is $\$ 3 ; 500$ or four years' earnings, and the minimum $\$ 1,500$. If there are no dependents, compensation is limited to \$150. For tutal disability the compensation is $50 \%$ of weekly earnings for 8 years (not less than $\$ 5$ nor more than $\$ 12$ nor more than $\$ 3,500$ in all) and, if complete disability still continues, a compensation for lif $\mathrm{t}^{2}$ (not less than $\$ 10$ a month) equal to $8 \%$ of the death benefit. For partial disability the crimpensation is $50^{\circ}$ of the wage decrease, not more than $\$ 12$ and not longer than 8 years. The ten hour law for women was extended to public institutions, public utilities, places of amusement, restaurants, mercantile, telegraph and telephone establishments and on June 21,1912 the state supreme court upheld the constitutionality of the law thus amended in a test case brought by a hotel proprietor. Physicians are required to report cases of occupational diseases, and employers must arrange for the examination once every calendar month by a licensed physician of all employees in dangerous processes likely to result in such diseases. Miners' and mechanics' institutes are established throughout the state to prevent "by clucational betterment" accidents in mines and other industrial plants; and \$30,000 was appropriated for the use of the mining rescue station commission in equipping rescue cars and stations and in carrying out educational work. A coal mining code provides for a state mining board of five (two owners, two miners and one hoisting engineer). It contains elaborate provisions for safety and forbicls the employment of boys under 16 without certificate. Pension fundls were created for park police, for employees of houses of correction and for municipal employees in cities with a population above I00,000. A law in effect July I, 19I I authorises county pensions to needy widows with dependent children.

The law for the commission form of government was slightly amended in $191 \mathrm{I}$ and a new scale of salaries for officers under this form of government was adopted. The constitutionality of the law was sustained (December 2 I, I9II) by the Illinois supreme court. To the close of 1912 the following cities had commission government; Braceville, Carbondale (in effect May 8, 1912), (linton, Decatur (election January 17, 1911 ; in effect May 1, 1911), Dixon, EIgin (election January 2I, I9II; in effect May I, I9II), Forest Park (election November 7. 1911; in effect April 30, 1913), Hamilton, Harvey, Hillsboro, Jacksonville (election January 3I, 19II; in effect Nay I, I9II), Kewanee (election January 27, 1911; in effect May 1, 1911), Marseilles, Moline (election January 3, 1911; in effect April 6, 1911), Ottawa (clection January 17, $191 \mathrm{I}$; in effect April), Pekin (election February 7 , 1911 ; in effect May 1. I9II), Roxhelle, Rock Island, Springfield (election, January 2, I9I1), Spring Valley and IIaukegan (election February 14, 1911). Cities may vote to discontinue minority representation. For counties of 150,000 inhabitants or more (in 1912 Cuok county only) the civil service law was extended to almost all county employees.

On September 27, 1912, a decision of a Federal district court, in an action brought by the receivers of the Chicago, Peoria \& St. Iouis Railway Co. involving the validity of the 2-cent fare act (in effect July 1,1907 ), held this law ineffective as to this railway, since its enforcement would compel passengers to be carried at a loss.

Finance. The general resenue fund for $191 \mathrm{I}$ and 1912 was $\$ 7,750,000$. On October $\mathbf{I}$, 10 to the balance in the treasury was $\$ 4,424,610$; the receipts for the two years following, $\$ 26,957,188$; the dishursements, $\$ 25,882,588$; and the balance September 30 , 1912, \$5,499,210.

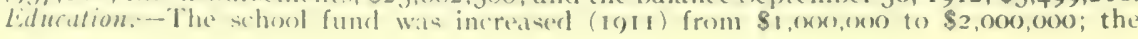


state educational commission had recommended its increase to $\$ 4,500,000$. The appropriation for the University of Illinois for the biennium was more than $\$ 2,000,000$ for maintenance and nearly $\$ 850,000$ for improvements. The legislature provided for a one mill tax thereafter for the university. Among the appropriations was one of $\$ 125,000$ for a training school building for the State Normal University, on which work began in the summer of 1912 and which will accommodate 700 children. Boards of education were authorised to establish and maintain classes for the deaf, dumb and blind and for delinquent children, the state to pay the excess cost. In 1912 a constitution for the University of Illinois was being prepared. The board of education in any district having more than $\mathbf{1}, 000$, and less than roo,000, inhabitants may establish and maintain a fund for the retirement of teachers upon an assessment basis. By a majority vote a district which does not maintain a pension fund may retire any teacher over 50 who has taught in the district for 25 years.

In 1910 the percentage of illiteracy in the population Io years of age and over was 3.7 (4.2 in 1900). In $1911-12$ the school population was $1,570,867$; the total enrollment in public schools, 987,379; the average daily. attendance, 865,009; the average school year, 158 days; the revenue for schools, $\$ 36,007,378$, and the expenditure, $\$ 34,869,457$.

A municipal bureau was established at the University of Illinois in I9II. The medical school of Northwestern University received in 1910 , I9I I and 1912 large gifts from James A. Patten of Evanston for a fund for medical research, especially on tuberculosis; and in 1912 Dr. A. I. Kendall was put in charge of this research. At the University of Chicago new buildings were begun in I9II for the departments of geology and geography and of classics and for a women's gymnasium. In 1912 cconomic conditions in Liberia were investigated by Frederick Starr of the University of Chicago. In December 19 I I N. IV. Harris, a Chicago banker, gave $\$ 250,000$ for school extension work of the Field Museum.

Penal and Charitable Institutions. - In the general appropriation act for charitable institutions in $1911, \$ 3,753,26+$ was appropriated besides special appropriations for the same institutions amounting to $\$ 1,184,250$. By separate acts $\$ 10,000$ was appropriated for the relief of the adult blind and $\$ 75,000$ for a building for the Illinois surgical institution for children, -if ground be donated-and $\$ 600,000$ for a new state hospital for the insane, for which Alton was chosen as the site in 19I2. In all courts having criminal or quasicriminal jurisdiction the probation system was introduced in I9I I for first offence prisoners. A law, approved June II, I9I2, shortens the official title of each charitable institution of the state, and provides for the appointment by the governor of a board of administration (five members, one an alienist), of a charities commission, also of five members to investigate the state's charitable system and to establish a bureau of criminal statistics, and of a board of visitors, which inspects and reports to the charities commission. All private institutions for mental and nervous cases must be licensed by the board of administration. A law of I9I I authorised courts with juvenile jurisdiction to fix the amount which will enable poor parents of a dependent child to care for the child properly; this amount is to be paid by the county board. A commission, created by an act of 1907 which appropriated $\$ 500,000$, has recently bought 2,500 acres (quarry and farm) N. W. of Joliet for a penitentiary to replace that at Joliet, condemned in 1906; plans had been drawn and accepted, but building had not begun at the end of 1912 .

History.-The principal political event of I9I $\mathrm{r}$, when there was no state election, was the mayoralty campaign in Chicago. Mayor Fred A. Busse (b. 1866; Republican), who went out of office that year, appointed the Vice Commission, whose report ${ }^{1}$ and recommendations were of great value. In the city primaries (Feb, 28, I9II) Charles Edward Merriam (b. I874), alderman in I909-II, chairman of a commission on city expenditures, and professor of political science in the University of Chicago (afterwards head of the Progressive Republican Club of Cook county), received the Republican nomination with more votes than both his more "regular" opponents; and Carter Henry Harrison (b. 1860), mayor in 1897-1905, defeated Edward Fitzsimons Dunne (t. I 853), mayor in I907-o9, for the Democratic nomination (about 55, I 20 votes to 53,700). Harrison was elected (April 4, I9II), receiving 177,900 votes to 161,000 for Merriam, whose promise to enforce laws about the sale of liquors lost him many votes; the Socialist candidate W. E. Rodriguez received 24,825 votes. Under Harrison the work of the Vice Commission was actively supplemented by the Civil Service Commission, which investigated the building department and the police, effected the discharge of many policemen for inefficiency, and was actually invited to Jakland, California, where two of its members organised a civil service system. Harrison had campaigned for an ordinance making 70 cents the maximum price for $1,000 \mathrm{cu}$. $\mathrm{ft}$. of gas; but experts who were to report on a fair price set 77 cents and 75 cents (with reductions until $6_{5}$

1 Published as The Social Evil in Chicago, 1911. 
cents for the fifth year under the new contract), and when the Council (July Iy, rorI) set the rate at 75, 70 and 68 cents (for first, for second and third, and for fourth and fifth years) the courts set 80 cents as a temporary rate. In O'Fallon the Socialists on April 13, I9I I, elected a mayor (281 votes to 277) and 2 of 3 aldermen.

The primaries of April 9, I 912 (provided for by an act passed at the special session called by Deneen) gave Roosevelt 266,9 I 7 votes to $127,48 \mathrm{I}$ for Taft and 42,692 for Senator La Follette, and Champ Clark 2 I 8,483 votes to 75,527 for Woodrow Wilson; chose Charles S. Deneen ${ }^{1}$ again as Republican candidate and Edward F. Dunne as Democratic candidate for governor; named Lawrence Y. Sherman (b. 1858), Rep., as candidate for United States senator to succeed Shelby Moore Cullom (b. I829), also Republican; and voted down woman's suffrage. The Progressive party nominated (Aug. 3) Frank H. Funk, a state senator, for governor, and a nearly complete state ticket. The opponents of Woodrow Wilson attempted to make political capital out of his failure to repudiate the state Democratic " boss," Roger C. Sullivan (b. I86r). At the November election the vote in Cook county (including Chicago) was for Roosevelt (I66,06I votes to I30,702 for Wilson), and the state was first announced for him, but the rural vote was overwhelmingly for Wilson, who received in the state 405,048 votes to 386,478 for Roosevelt, 253,593 for Taft, and 81,278 for Debs (who had 34,7 I I in I908). Wilson carried 64 counties, Roosevelt 28 and Taft ro. Republican Congressmen Joseph G. Cannon, ex-Speaker, and William B. McKinley, campaign manager for President Taft, were defeated, and 20 Democrats (including 2 at-large), 5 Republicans and 2 Progressives were returned to the House of Representatives. Dunne was elected governor (443, 1 20 votes), with Deneen second, $(318,469)$ and Funk third $(303,401)$, șo that the Republican.(and not the Progressive) party is the " second major" party with official recognition,--except in Chicago (Cook county). The Democratic nominees for state office were elected by smaller pluralities than for Dunne. The rgr3 legislature with 97 Democrats, 76 Republicans, 27 Progressives and 4 Socialists $^{2}$ (the last two groups holding the balance of power), will elect United States senators to succeed Cullom (at the beginning of March I9I3 it was in deadlock) and to take the place vacant by the Senate's declaration (July I3, I9I2) of the invalidity of the election of William Lorimer (b. I86I), Republican. Lorimer had been in the Chicago water department in 1887-93, and was a member of the Federal Housi of Representatives in 1895-1901 and in r $1903-09$. His election to the Senate in 1909 was attacked on the ground that he had bribed state legislators. He was first exonerated but finally (July I3, I9I2) unseated by the Senate (see United States $\$$ History). The incident was of great importance in the state and national campaign, each party leader attempting to make capital out of the relations of his opponent with Lorimer. In December ror 2 Deneen was prominent in an attempt to reorganise the Republican party in the state. The next legislature was instructed (by popular vote, Nov. 5, I912, on three "questions of public policy," in accordance with an Act of 1901 ) to submit an amendment for classification of property for taxation, to revise the primary law, and to create a commission for a short ballot.

Cairo, with the low lands about it, in sq. $m$. in all, was inundated, the Mississippi breaking the levees, March 25, r9r2.

Chicago City Plan. - The Chicago Commercial Club from rgo7 to rgog had a City Planning Committee, which published in rgoo an exhaustive study called "The Plan of Chicago;" later a Chicago Plan Commission was created by the city. Daniel H. Burnham, the architect, was particularly interested in this work. The commission estimates that 50 to 75 years would be needed to carry out its plans. The most immediate of its projects is to improve $\mathrm{I} 2$ th Street-an ordinance for widening this street (from 62 and in some places $50 \mathrm{ft}$. to $108 \mathrm{ft}$.) was passed by the city council on April 6, IgIr. Twelfth Street is the south side of a quadrangle planned by the commission. The South Shore Lake Front is to be improved, a Lakeshore Drive being planned from

'In July Deneen announced that he would support Taft instead of following Roosevelt into the third party.

'Contests may slightly change these figures. 
Grant to Jackson Park, and an Outer Island Park which will make lagoons along the front of the lake. The work on the South Shore Lake Front is not in the hands of the commission but of a Board of South Park Commissioners, which in July Igr I obtained riparian rights from the Illinois Central Railroad. East of the right of way of this railroad, facing the north on Grant Park, the Field Columbian Museum is to be built. The contract was let in I9I2. A new station of the Illinois Central is to be built, west of its tracks and facing north on Twelfth street. A third of the immediate plans of the commission is in regard to the Michigan Avenue connecting link, a two level street to join the South and North Parkway. Plan 3 calling for this was adopted by the Commission on July 6, I9ro. A Civic Beauty commission was appointed in September roI I . A city harbour and subway commission was created by the city council on December 4, I9II; and on December II, I9I2, the city council committee on local transportation tentatively adopted a scheme for presentation to the council and (if approved) to the voters in April 19r3. In I9I2 a Bureau of Information and Publicity was established in Chicago, absorbing the Bureau of Statistics. The Chicago drainage canal is proving inadequate for the growing needs of the city, and in I9I I a sewage purification plant was planned by the engineer of the Sanitary District. Land was bought for this in I9I 2 and the plant was expected to be built in I913. Freight terminal improvements to cost $\$ 200,000,000$ were planned in September I912, including the purchase of the Chicago Union Transfer Company and the erection of a freight and passenger terminal between Polk, Sixteenth, Park and State streets. In November IgI 2 Cook county voted $\$ 3,250,000$ for improvements; $\$ 1,750,000$ to widen Twelfth Street; $\$ 1,000,000$ for almshouses and a pauper cemetery; and $\$ 500,000$ for a new detention hospital.

Bibliography.-C. O. Gardner "The Working of the State-wide Referendum in Illinois, in American Political Science Review (August I9II); L. D. Upson, Municipal Revenues in Illinois (University of Illinois Studies in the Social Sciences); R. M. Haig, History of Taxation in Illinois (University of Illinois Studies, etc.); Charles B. Cory,. The Mammals of Illinois and Wisconsin (Chicago, I9I2); S. M. Cullom, Fifty Years of Public Service (Chicago, 19I I); and Laws (2 vols., Springfield, 19II-12) and reports of state departments.

\section{INDIANA, 1}

Population (I910) $2,700,876,7.3 \%$ more than in 1900 ; the actual increase and the percentage were lower than for any decade since I820-30. In 56 (out of 92) counties the population decreased; the greatest relative increase was $118.7 \%$ in Lake county. Density of population 74.9 per sq. m. Of the total $91.9 \%$ were native whites (about one-seventh of foreign parentage), $5.9 \%$ foreign-born whites, and $2.2 \%$ negroes. The population in the 88 incorporated places, of 2,500 or more, constituted $42.4 \%$ of the total; in 1900 , in 80 such places there was only $34.3 \%$. The semi-urban population was one-ninth of the total, and the rural was $46.6 \%$, nearly one-fifth less, relatively, than in 1900. Of the 88 municipalities, with a population above $2,500,37$ had less than 5,000 and 26 between 5,000 and 10,000. The 25 having 10,000 or more were: Indianapolis, 233,650; Evansville, 69,647; Fort Wayne, 63,933; Terre Haute, 58, I57; South Bend, 53,684; Muncie, 24,005; Anderson, 22,476; Richmond, 22,324; Hammond, 20,925; New Albany, 20,629; Lafayette, 20,08I; Marion, I9,359; Elkhart, I9,282; East Chicago I9,098; Logansport, I9,050; Michigan City, I9,027; Kokomo, I7,010; Gary, I6,802; Vincennes, I4,895; Mishawaka, I I,886; Elwood, I I,028; Peru, I0,910; Laporte, 10,525; Jeffersonville, 10,412; and Huntington, 10,272.

Agriculture.-The acreage in farms decreased from $21,619,623$ to $21,299,823$ between 1900 and 1910 , but the improved land increased from $16,680,358$ to $16,931,252$ acres; the average farm acreage increased from 97.4 to 98.8 and the value of farm property from \$978-, 616,471 to $\$ 1,809,135,238(\$ 1,328,196,545$ land; $\$ 266,079,051$ buildings; $\$ 40,999,541$ implements; \$173,860, IOI domestic animals). Of the land area $92.3 \%$ was in farms. The average value of farm land per acre was $\$ 62.36$. Farms are operated largely by owners (I48,501 by owners, 2,297 by managers and 64,687 by tenants). In 1912 (preliminary estimates) the principal crops were: Indian corn, 199,364,000 bu. $(4,947,000 \mathrm{~A}$.); wheat. $10,080,000$ bu. (I,260,000 A.); oats, 79,799,000 bu. (I,990,000 A.); barley, 266,000 bu.

1 See $E$. $B$. xiv, 421 et seq. 
(9,000 A.); rye, 928,000 bu. $(64,000$ A.); buckwheat, 95,000 bu. (5,000 A.); potatoes, 9.918,000 bu. $(87,000$ A.); hay, 2,582,000 tuns $(1,885,000 \mathrm{~A}$.); and tobacco, 14,960,000 lbs. (18,700 A.). In Igog ( $\mathrm{C}$. S. (cinsus) the value of mint was $\$ 58$, r $10(1,8 \mathrm{r}+\mathrm{A}$.); of vegretables (excluding potatoes), $\$ 7,498,024$; of smalt fruits, $\$ 612,725$; of orchard fruits, $\$ 3,709,275$ (apples, $\$ 1,720,811$; peaches and nectarines, $\$ 1,123,248$; cherries, $\$ 508,516)$. On January 1, 1912 there were on farms: 838,000 horses, 84,000 mules, 634,000 milch cows, 707,000 other neat cattle, 1,372,000 sheep and 4,031,000 swine.

Mineral Products. - Total value, I9II, $\$ 37,430,187$. In output of coal the state ranked 6 th with $14,201,355$ tons $(\$ 15,326,808)$ and of this product as of petroleum, I, $695,289 \mathrm{bbls}$. $(\$ 1,228,835)$ and of natural gas $(\$ 1,192,418)$, the product was less than in I9I0. Many gas wells were exhausted in 1911 . The value of clay products was $\$ 7,000,77$ I (including $\$ 549,470$ for sanitary ware $\$ 1,004,737$ for all pottery). In Portland cement the state in I9I I ranked 2 nd in quantity and 3 rd in value, $7,407,830$ bbls., $\$ 5,937,24 \mathrm{I}$. The value of stone was $\$ 4,413,655$ (mostly limestone); of lime, $\$ 324,950$; of sand and gravel, $\$ 1,133,829$. Mineral waters, bottled at is springs (including 6 resorts), were worth $\$ 653,64 \mathrm{I}$.

Manufactures. -From 1904 to 1909 the number of establishments increased from 7,044 to 7,969 ; the number of persons engaged in manufacturing from 176,227 (154,174 wagecarners) to 218,263 (186,984 wage-earners); the capital invested from $\$ 312,071,000$ to $\$ 508,717,000(63 \%)$; and the value of products from $\$ 393,954,000$ to $\$ 579,075,000-$ the state ranking 9 th in the Union. Among the principal manufactures in 1909 were: slaughtering and meat packing products, $\$ 47,289,000$, of which about four-fifths came from Indianapolis; flour, \$40,541,000, ranking the state 8th; foundry and machine-shop products, $\$ 39,884$,000 ; iron and steel mills, $\$ 38,652,000,128.4 \%$ more than in 1904; distilled liquors, $\$ 31,610$,000 , the state ranking 3 rd (in 1904,2 nd); automobiles, $\$ 23,764,000$; lumber and timber, $\$ 23,135,000$; carriages and wagons, $\$ 21,655,000$; furniture and refrigerators, $\$ 18,456,000$; railway cars, repairs, $\$ 17,128,000$, and manufacture, $\$ 9,498,000$; agricultural implements, \$1 3,670,000; and glass, \$1 1,593,000. The principal manufacturing cities were: Indianapolis, \$1 26,522,000; South Bend, \$27,854,000; Fort Wayne, \$23,687,000; Evansville, \$22,929,000; and Terre Haute, \$21,793,000.

Transportation.-Railway mileage, January 1, 1912, 7,496.72. In 1911 the powers of the railway commission were much increased; railway rates are subject to its decisions, and it may suspend any rate for 30 days. An act deals with the liability of common carriers and includes a bill of lading law. In IgI the Federal government began the improvement of the outer harbour at Indiana Harbor.

Constitution.-A new constitution was to have been voted upon in November I9 I2, but the constitutionality of this was in question and the matter was referred to the state supreme court, which had previously decided that an amendment was pending until a majority of the electors of the state had voted for it or against it, and which held (July 5, 1912) the act submitting the new draft unconstitutional because a single session of the legislature and not two consecutive sessions or a constitutional convention proposed the changes. The supreme court by three (I Democrat, the chief justice, and 2 Republicans) to two (Democrats), upheld the Marion circuit court (Remster, Democrat), which enjoined the state board of election commissioners, including the governor, from putting the constitutional question on the ballot; the decision was not on party lines. The constitution of $185 \mathrm{I}$ forbids the proposal of amendments (or an amendment) when action on an amendment is pending, and an amendment of 1897 giving the legislature power to prescribe qualifications for admission to the bar (every voter of good moral character may now be admitted to the bar) was voted on by the people in 1900 , 1906 and 1910 , each time not decisively, so that this pending amendment barred other amendments. It is a question whether revision by the creation of a new constitution is barred in the same way-as the constitution of $185 \mathrm{I}$ prescribed no mode of adopting a new one. The Republican party opposed the new constitution, and it was argued that it was not new but amended, that the legislature could constitutionally call a constitutional convention, but could not submit a constitution to the people, and that this was a "one man " draft-it was largely the work of Governor Marshall.

The principal changes in the proposed constitution were: in the bill of rights, a provision empowering the legislature to enact a workmen's compulsory compensation law, defining "hazardous employment;" in suffrage requirements, the increase from six to twelve months of residence in the state, the omission of a clause giving the suffrage to aliens living in the state six months and in the United States one year, who have declared their intention to become citizens and the addition of a clause requiring would- 
be voters not registered before November I9I3 to be able to read "in English or some other known tongue any section" of the constitution; the governor was empowered to veto items in appropriation bills and a three-fifths vote (instead of a majority) was required to over-ride a veto; the legislature might (on petition of $25 \%$ of the electors) enact laws for initiative, referendum, and recall (not applying to judges) and provide for qualifications for admission to the bar; and there was a definite provision for amendments, without the clause that new amendments (except on the same subject) might not be proposed when one or some were "pending."

Legislation.-The regular session of the legislature met on January 5, I9r. It voted to submit to the people the new constitution described above, and provided for a. method of voting for constitutional amendments, permitting the state conventions of political parties to approve or disapprove in their platform of any constitutional amendment, so that a straight party ticket might be voted including a vote on the amendment. The proposed I6th amendment to the Federal Constitution was ratified on February 6th. Probate, juvenile court and superior judges are to hold office hereafter for four years, elections for these judges being held in ISI4 and in I9I8-but none in I9I2. A rigorous corrupt practices act was adopted. The county option law of 1908 was repealed, and city and township option was substituted. ${ }^{1}$ A regulation law limits saloons to not more than I for each 500 and not less than I for each I, 000 inhabitants, - the limit to be fixed by the county commissioners. The offices of a state commissioner of weights and measures, and state food and drug commissioner were created. The pure food law of 1907 was revised. Cold storage food products, except for interstate shipment, must be marked with the date of storage and must not be kept in storage for more than 9 months. The medical inspection of children in schools was authorised and recommended, and the sanitation and ventilation of school buildings was provided for. The punishment for pandering was set at imprisonment from 2 to ro years and a fine of $\$ 300$ to $\$ \mathrm{I}, 000$, and, for a second offence, imprisonment of from 5 to I4 years; marriage is no defence and a wife's testimony is competent against her husband.

The factory inspection department was changed into a tripartite bureau: (I) for inspec. tion of buildings, factories and workshops; (2) for inspection of mines, and (3) for inspection of boilers with an inspector of locomotive boilers. The state established free employment bureaus in cities of 50,000 or more, and the law of 1909 governing employment agencies was entirely revised. Coal mining was classed as a dangerous industry. The law of 1887 in regard to the payment of wages was replaced by a new law which gives greater protection to employees. Various important public safety laws applying to railways were passed.

No child is permitted to work, except on a farm or in domestic labour, if he is under I4, but between June Ist and October Ist children between 12 and 14 may work in fruit and vegetable canneries; except at farm work and domestic labour no child under I 6 may work more than 48 hours a week or 8 hours a day without the written consent of parent or guardian. Under no condition may a child of this age work more than 54 hours a week or 9 hours a day, or before 7 A.M., or after 6 P.M. No minor under 16 may work in a tobacco factory, hotel or a theatre, and no boy under 16 and no girl under 18 in a saloon, brewery or distillery or in the manufacture of matches or explosives. No girl under 18 may work where she must stand constantly, and no child under 16 on certain dangerous machinery.

An employers' liability act applies to all employers of five or more workmen; abrogates the fellow servant rule and the defence of contributory negligence, restricts the rule of assumption of risk, stipulates that liability may not be avoided by contract, and permits an employer to set off any contribution to the insurance or relief of an injured workman. The act is not retroactive, but limits the amount of recovery to $\$ 10,000$, and the time of action to two years from the cause. On December 23, I9I2 the U.S. Supreme Court held constitutional a state law taxing shares of stock in corporations organised outside the state and held by residents. The 12 th of October was made a legal holiday as "Discovery Day."

Finance.-A state debt sinking fund for 1912 and 1913 was provided for by the levy of .or $\frac{1}{2}$ mills. The I 907 law for bank and trust company commissioners was revised; and the state auditor was made head of a state department governing building and Inan associations. On September 30, 1911 the balance in the treasury was $\$ 272,969$; on September 30, 1912 $\$ 339,4$ O5; the receipts during this period were \$I I, IOI , 456 and the disbursements, \$I I, 035,020. The state debt on September 30 , 1912 was $\$ 1,260,163$.

Education.-The governor was authorised in 1911 to appoint a commission to report

"Under this act, the "Proctor law," 48 cities voted, 30 for and 18 against licence, and 210 townships, 43 for, 166 against and 1 tie. 
by January I, 1913 on industrial and agricultural education in the state. This commission reported in December 1912 , recommending: the establishment of vocational schools and departments with state aid amounting to two-thirds the local expenditure; the presence on the state board of education of three vocational experts; the employment of an agricultural agent by the state superintendent, etc. Any city of the first class may establish and maintain a trade school. A tax of .02 mills may be levied in any city of 6,000 or more for the maintenance of kindergartens. Night schools were authorised (I9II) in cities of 3,000 or more. In cities of more than 100,000, schools may arrange with art associations, museums, etc. for art education. A minimum wage law for teachers provided that the pay of all beginning teachers should be the product of the average per cent on a licence examination multiplied by $2 \frac{1}{2}$ cents a day; and that for teachers who had taught more than 3 years the pay should be the average percentage on examinations and for success (with $2 \%$ added for attending teachers' institutes), multiplied by $3 \frac{1}{2}$ cents a day. The previous rate had been 3 cents. The compulsory education law of 1909 was extended to deaf and blind children, who must attend the state schools between the ages of 8 and 16 .

The Robert W. Long hospital was established in connection with the Indiana University School of Medicine on a gift of property (about $\$ 200,000)$ from Dr. Robert IV. Long and his wife; the building was not begun in 19I2. A state educational building or museum is to be erected to celebrate in 1916 the Iooth anniversary of the admission of Indiana to the Union. The legislature appropriated $\$ 100,000$ for a library building for Purdue University, which was practically completed in 1912 .

The school census for 1912 showed 76I,494 children of school age, an enrollment of 532,821 and an average daily attendance of 430,862 . The average school year was I 40 days in townships and 187 days in cities. The total revenue for the school year 1911-12 was \$19,354,565 and the expenditures $\$ 18,784,426$ (\$9,209,226 for teaching). In 19lo the percentage of illiteracy in the population 10.years and over was 3.1 ( 4.6 in 1900).

Charities and Penal Institutions. - The age of commitment to the Indiana Girls' School was limited to from 10 to $\mathbf{I} 8$; older girls are to be transferred to the women's prison. No life prisoner is to be sent to the reformatory. The state and the political divisions of the state must purchase goods made in the reformatory, except upon a release by the superintendent. The legislature appropriated $\$ 75,000$ for land for a colony for the insane in connection with one of the state hospitals (and in 1912 a site was chosen for the colony under the supervision of the Eastern Hospital at Richmond) and \$25,000 for a new industrial school for negroes; and it spent \$25,000 for the installation of electro-hydrotherapeutic apparatus in the Southern Hospital for the insane. In April 19 I I the State Tuberculosis Hospital (established 1907), $3 \mathrm{~m}$. E. of Rockville, was opened. In 1912 a former teacher of psychology in De Pauw University was appointed associate superintendent of the state reformatory.

History.-The political history of the last two years centres in the movement, led by Governor Thomas R. Marshall and opposed by the Republicans, for a revision of the state constitution. The Democratic legislature elected with Marshall voted in vain for his measure, which the supreme court decided could not be submitted to the people. On January 18, I9r I, it chose John Worth Kern (b. 1849), Democratic candidate for vice-president in 1908 , United States senator to succeed Albert Jeremiah Beveridge (b. I862), Republican, senator in I899-1911. Beveridge used his influence for the nomination of Roosevelt-he was chairman of the National Progressive Conventionand for his election, and was nominated (August I, I9I2) for governor with a full state ticket by the party; his opponents charged that he had the backing of the Steel Trust. But the conservative Republicans, led by Harry Stewart New (b. I $8_{5} 8$ ), a member of the party's National Committee, carried the Republican state convention for Taft. Twelve seats were contested by Roosevelt men, but all were awarded to delegates pledged to Taft. Governor Marshall was the choice of the Democratic Convention in the state for the presidency and of the national convention for vice-president. In the election of November 5, I0I 2, Samuel M. Ralston, the Democratic nomince for governor, received 275,357 votes to 166, I 24 for Beveridge, who did much better in the country districts than in Indianapolis, and $\mathbf{1 4 2 , 8 5 0}$ for Winfield Taylor Durbin (b. 1847), Republican, governor in $190 \mathrm{I}-05$. The new state legislature contains 40 Democrats, 9 Republicans and I Progressive in the senate, and 95 Democrats, 4 Republicans and I Progressive in the House. The Democrats carried all the 13 Congressional districts, including the roth, where Edgar Dean Crumpacker (b. 1851), representative since 1897 and the only Republican from Indiana in the House of Representatives in rgro-1 1 , was defeated by his Democratic opponent, John B. Peterson. Although the Democratic candidates were criticised because they did not break with Thomas Taggart (b. 1856), 
the reputed "boss" of the state, the presidential electors for Woodrow Wilson and Marshall received 28I,890 votes; those for Roosevelt, I62,007; those for Taft I5I,267; and those for Debs, a native of the state, 36,93 I (in 1908, 13,476; in 1910, Socialist vote for governor, about 19,600 ).

On October 22, I9I2 Governor Marshall sent three companies of state troops to the race track near Valparaiso to stop racing because gambling was going on; and on the 26th Judge Tuthill refused to grant an injunction forbidding this use of the militia.

About 50 officials of the Association of Bridge and Structural Ironworkers, arrested in February rgr 2 on evidence secured by William J. Burns and through information given by Ortie McManigal, who figured in the Los Angeles Times case (see CALIForNIA), were put on trial in Indianapolis, October $\mathrm{I}$, charged with conspiracy to carry dynamite on trains in interstate commerce. McManigal gave minute and circumstantial testimony tending to show that the Ironworkers had for 6 years systematically dynamited structures built by non-union men. A plot to blow up locks of the Panama Canal was disclosed, and evidence was brought to show that textile strikers in Massachusetts secured dynamiters from the Ironworkers. The judge ruled (October 22) that the conspiracy was proved; and on December 28,38 of the defendants were found guilty on each of the 52 counts of the indictments. Thirty-three of them were sentenced to the Federal prison at Leavenworth, Kansas, for terms varying from I to 7 years.

Bibliography.-Laws (Indianapolis, I9II) and various official reports; E. E. Moore, Century of Indiana (New York, 1910); Logan Eseray State Banking in Indiana 1844-73 (1912); N.L. Sims, A Hoosier Village (1912).

\section{IOWA ${ }^{1}$}

Population (I910) 2,224,77I ( $0.3 \%$ less than in I900, Iowa being the only state with a decrease). Negroes constituted $0.7 \%$ of the total; native born whites $87 \%$ and whites of native parentage $58.6 \%$. There were 69 (in 1900,70 ) cities and towns of 2,500 or more each, containing $30.6 \%$ (in I $900,25.6 \%$ ) of the total. Twenty-six had 5,000: Des Moines, 86,368; Sioux City, 47,828; Davenport, 43,028; Dubuque, 38,494; Cedar Rapids, 32,8I I; Council Bluffs, 29,292; Waterloo, 26,603; Clinton, 25,577; Burlington, 24,324;

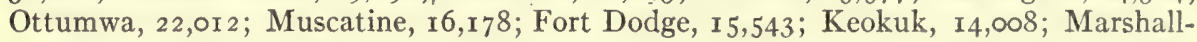
town, I3,374; Mason City, I1,230; Boone, I0,347; Iowa City, Io,ogr; Oskaloosa, 9,466; Fort Madison, 8,900;' Centerville, 6,936; Creston, 6,924; Oelwein, 6,028; Charles City, 5,892; Webster City, 5,208; Grinnell, 5,036; and Cedar Falls, 5, or 2.

Agriculture. - The acreage in farms decreased from $34,574,337$ to $33,930,688$ between I 900 and 1910 and the improved land from $29,897,552$ to $29,491,199$; the average farm acreage increased from 151.2 to 156.3 and the value of farm property from $\$ 1,834,345,546$ to $\$ 3,745$,$860,544(\$ 2,801,973,729$ land; $\$ 455,405,67$ I buildings; $\$ 95,477,948$ implements and $\$ 393,003$,196 domestic animals). Of the land area $95.4 \%$ was in farms; and the average value of farm land per acre was $\$ 82.58$. Farms were operated largely by owners $(133,003$ by owners, 1,926 by managers and 82, I 5 by tenants). In 1912 (preliminary estimates) the principal crops were: Indian corn, 432,02 I,000 bu. (10,047,000 A.); wheat, 12,850,000 bu. (650,000 A.); oats, $217,818,000$ bu. (4,928,000 A.); barley, II,570,000 bu. (470,000 A.); rye, 665,000 bu. (35,000 A.); buckwheat, 133,000 bu. (7,000 A.); potatoes, 18,966,000 bu. (174,000 A.); hay, $4,952,000$ tons $(3,537,000 \mathrm{~A}$.); flaxseed, 402,000 bu. (35,000 A.). In I 909 (U. S. Census) the value of vegetables. (excluding potatoes) was $\$ 5,266,4$ I I ; of small fruits, $\$ 966,894$; of orchard fruits, $\$ 4,283,873$ (apples, \$3,550,729; cherries, $\$ 455,022$ ). On January 1,1912 , there were on farms: I,568,000 horses, 57,000 mules, I,393,000 milch cows, 2,773,000 other neat cattle, I,201,000 sheep and 9,689,000 swine.

By acts of I I I the state dairy association and the beef cattle breeders association are made official state corporations with duties of inspection; a commission of animal health takes the place of the board of veterinary examiners.

Mineral Products.- Total value, I9II, $\$ 21,107,496$. By far the most valuable mineral product is bituminous coal, in which the state ranked 9 th in $191 \mathrm{I}$ with $7,331,648$ tons ( $\$ 12,-$ $663.507)$. It held the same rank (8th in 1910$)$ in clay products $\left(\$ 4,432,874 ; \frac{1}{6}\right.$ less than in 1910), almost entirely brick and tile. More than one-seventh of the gypsum product of the country came in I9II from Iowa $\left(354,204\right.$ tons; value, $\left.\$ 871,75^{2}\right)$. Building and other stone quarried in 19 I I was valued at $\$ 736,207$, mostly limestone; and lime at $\$ 80,914$. No

1 See E. B. xiv, 732 et seq. 
zinc was reported shipped to smelters in 1911 ; the lead mined was only 60 tons $(\$ 5,400)$. The value of mincral waters bottled was $\$ 20,500$, about ${ }_{4}^{1}$ less than in 1910.

Manufactures. - In 1899-1909 the capital invested in manufacturing doubled and the value of the mimufactured product increased nearly as much. Between 1904 and 1909 the number of establishments increased from $4,7 \times 5$ to 5.528 and that of persons engaged in manufacturing from 61,361 (49,481 wage-earners) to 78,360 (61,635 wage-earners); the capital invested from $\$ 1$ II,427,000 to $\$ 171,219,000$; and the value of products from $\$ 160$, 572,000 to $\$ 259,238,000(61.4 \%)$. In 1909 the value of slaughtering and meat-packing products, including sausage, was $\$ 59,045,000$, nearly twice the value in 1904 and more than one-fifth the value of all products, the state ranking 6 th in this industry. In dairy products (mostly butter), valued at $\$ 25,850,000$ ( $72 \%$ more than in 1904$)$, Iowa ranked 3 rd. Foundry and machine-shop products were valued at \$14,064,000 (122.1\% more than in 1904); flour and grist mill products at $\$ 12,871,000$. Other important products were: lumber and timber, \$12,659,000; car construction and repairs by steam railway companies, \$10,269,000; carriages and wagons, $\$ 4,786,000$; agricultural implements, $\$ 4,757,000$; brick and tile, $\$_{4,483,000}$; and buttons, $\$ 4,035,000$ (168.8\% more than in 1904 ), almost entirely made from "fresh water pearl." The principal manufacturing cities were: Sioux City, $\$ 37,424$, 000 (153.5\% increase over I904); Cedar Rapids, \$24,824,000; Des Moines, \$23.585,000; Davenport, \$18,802,000; Dubuque, \$15,376,000; Ottumwa, \$14,838,000; Waterloo, \$8,999. 000; Burlington, $\$ 8,443,000$, principally car construction and repairs; Clinton, $\$ 7,480,000$; Keokuk, \$7,399,000; and Muscatine, $\$ 6,166,000$, principally buttons.

Transportation.-Railway mileage, January I, I912, 9,988.24.

Legislation.-The regular session of the legislature was held from January 9 to April I2, I9II. On February 27 it ratified the proposed Federal income tax amendment; and on April 4 made application to Congress to call a constitutional convention to propose an amendment to the Federal Constitution providing for the direct election of United States senators. The Oregon plan of direct election of United States senators passed the legislature, but was vetoed by the governor.

The state was re-apportioned; there are now 50 senators and 108 representatives from 99 county districts - the nine largest counties each having two representatives, although some of these, notably Polk (I9I0 pop. I I0,438) and Woodbury (pop. 67,6I6) had populations more than twice 22,472 , the number set for the ratio of representation.

An employer's liability commission, appointed in 1911 , reported in September 1912 a bill creating an industrial commission to administer an elective compensation law. The law of workmen's compensation was amended in 191 I so that a woman may recover not merely for elements of damages recoverable by common law, but also for medical attendance, loss of time and other expenses resulting from an accident. The coal mining law was revised to insure safety and comfort of miners. The office of state fire marshal was established.

The board of railroad commissioners was authorised to appoint a commerce counsel with a salary of $\$ 5,000$, and this was done July I, I $9 \mathbf{I}$ I. A uniform bill of lading act was adopted.

For regulating the sale of milk and cream the new offices of dairy and food commissioner. deputy commissioner and state dairy inspector were created. New pure food laws and pure drug laws were enacted. The state dairy commissioner is required to inspect scales, weights and measures. Infantile paralysis is included in the list of diseases to be quarantined, and the disinfection of premises is required after a death from tuberculosis. An anti-toxin department, under the direction of the state board of health, is created. A law of I9II making the certificate of an internal revenue collector that he has issued a federal tax stamp to any person to sell intoxicating liquor prima facie evidence that the person is engaged in the sale of licjuor was held unconstifutional in 1912 by a district court as taking away the presumption of innorence. The Moon law of 1909 limiting the number of saloons to 1 for cvery 1,000 inhabitants was held constitutional on December I 8 , 19 I I by the supreme court.

(ities may establish, on the approval of $60 \%$ of the voters, a "department of publicity, development and general welfare." In cities under the commission plan fire employees are put under the civil service laws.

Finance.-A Tax Commission, appointed in 1911, made a report in October 1912, propouing a new tax colde with three commissioners appointed by the governor for 6 years, taking the place of the present executive council for taxation, assessment and equalisation. 'The state levy was set at $\$ 2,500,0)$ for the fiscal year I9II, and for 1912 . A limit is set on property exempt from taxation helonging to educational institutions or to army veterans. The inheritance tax law was revised; the tax was set at $5 \%$ : 10 " is the rate if the legated is a brother or sister and an alien non-resident in the United States; 20 " for other aliens nonresident in the Inited Siates; the exeeptions are: estates less than $\$ 1,000$ after debts have been deducted: if the legatee is husbinnl or wife, father or mother, lineal descendant or adopted chiid of the deceaserl, or if the levatee is an erlucational or a religious corporation or a charity or a municipality, the bequest being for public purposes. The tasation of moneys and credits was changed and a law fixing an annual rate was adopted. 
On July I, 1911 the balance in the treasury was $\$ 1,282,539$ and on July $1,1912, \$ 1,041,486$. The receipts for the fiscal year were $\$ 4,983,448$, and the expenditures $\$ 5,224,501$. The state debt (July I, 1912) was $\$ 65,969$.

Education.-For the year ending June 30, 1912 the school population was 672,940 ; the public school enrollment, 507,109; average daily attendance, 368,631; average length of the school year 8.6 months; revenues, $\$ 15,453,274$, and expenditures, $\$ 15,330,652$.

In 1910 the percentage of illiteracy of the population Io years of age and over was 1.7 (2.3 in 1900)-less than in any other state in the Union.

On February 23, I9I I John Gabbert Bowman (b. 1877), formerly secretary of the Carnegie Foundation for the Advancement of Teaching, was elected president of the University of lowa, succeeding George E. McLean (b. 1850), who resigned on February I. He took office August I, I91 I,

In 1912 there was a general reorganisation of higher education: new normal schools were planned; and advanced courses for teachers were transferred from the Teachers College, at Cedar Falls (which can no longer grant degrees) to the University, the general science course from the Agricultural College, at Ames, to the University, and the engineering department from the University to the Agricultural College. A new physics building at the University was completed in I912. In December I9I2 Grinnell College received a gift of $\$ 50,000$.

Charitable and Penal Institutions.-By a law of I9I the execution of sentence may be suspended for the first offender unless he is convicted of murder, treason, rape, robbery or arson. On the recommendation of the state board of control surgeons in state institutions are authorised, by a law operative July 4, I9I I, to sterilise criminals, idiots, feeble-minded, drug fiends, and epileptics; in 1912 the law had not been enforced, and its validity had not been tested. Boys and girls in the state industrial schools may be placed under contracts in good homes with the approval of the board of control. The state College for the Blind was transferred from the board of control to the board of education. In May 1912 a commission recommended many changes in penal administration, notably the abolition of the contract system and the purchase, for the use of first offenders and good conduct and short term convicts, of a farm of 2,000 acres, near the capital. At Knoxville there is a state hospital, with a 200 -acre farm, for inebriates.

History.-Beryl F. Carroll (b. I860). Republican, governor in I909-10, was re-elected for I9II-I 2 with a large Republican majority in the legislature. On the death of Jonathan Prentiss Dolliver (I858-I9IO), Republican, U.S. senator since rgoo, Carroll appointed (Nov. I2, I910) as his successor, until the legislature met, Lafayette Young (b. I 848 ), editor since 1890 of the Des Moines Capital. After a deadlock for nearly three months the legislature elected (April r 2, I9 r) William Squire Kenyon (b. I 869), who had been for a year assistant to the attorney-general of the United States. The other senator from Iowa, Albert Baird Cummins (b. 1860; governor in I902-08; senator, I908-15) was a radical, and so delegates to the Republican National Convention were instructed for him and 16 for Taft. Governor Carroll, also, was a progressive Republican and came out for Roosevelt in March I9I2. The strong Republican majority in the state was thus split, and in the first victory for a Democratic presidential candidate in the state's history 185,376 vot es were cast for Wilson, I6 I,783 for Roosevelt, I I9,8 1 I for Taft, and 15,9 I 4 for Debs ( 8,287 in 1908). But the state Republican ticket, in spite of Progressive nominations for governor and 8 congressmen, was successful; for governor George W. Clarke defeated E. D. Dunne, Dem., by 184,057 to 182,349 . The vote for John L. Stevens, the Progressive candidate, was 75,000. In the legislature there is a Republican majority of 38 ( 14 in senate, 24 in house), by which Kenyon was re-elected U.S. senator, January 21 , I9I3; and of the Congressional delegation of $\mathbf{I}$ (the same number as in the preceding apportionment) the Democrats got three seats (only I in $62 \mathrm{nd}$ Congress) 1

In Muscatine the factories making buttons from fresh water mussel shells shut down without notice February 25, I9 I. A week later non-union labourers were taken back to work. There was then some violence, and a more thorough organisation of the workmen began. The state commissioner of labour and the governor interposed, and on

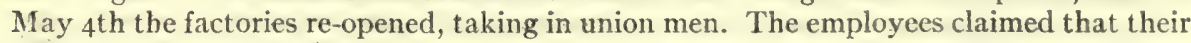
employers did not keep their agreement, and in August there was another strike; nonunion workers were imported, there was rioting and a policeman was killed. During

${ }^{1}$ Elbert Hamilton Hubbard (b. 1849), Republican, representative in Congress since I905, died June 4, 1912 . 
the winter some st rikers returned to work. A street railway strike in Des Moines was ended on August 5, I 9 Ir, by a court order reinstating a discharged union man.

In Des Moines a civic centre of twelve squares on both sides of the river, including a library, coliseum, post-office and city hall (dedicated Jan. I, I9I2), to be supplemented by an art institute, was practically completed in rgrr. A municipal bureau of public efficiency and economy was established in October ror I.

William Larrabee, born in Ledyard, Conn., in 1832, Republican governor of Iowa in 1886-90, died at Clermont, November 16, 1912. He wrote The Railroad Question (1893) and was responsible for much railway legislation and other progressive measures.

Bibliography.-Acts (Des Moines, I9I I); Report of Committee on Jail System (ibid., rgr2); other official reports, and on recent legislation, etc., see the monographs of the State Historical Society: J. E. Brindley, Tax Administration and Road Legislation; E. H. Downey, Regulation of Urban Utilities and Work Accident Indemnity; and H. J. Paterson, Corrupt Practices Legislation (all 1912); J. E. Brindley, History of Taxation in Iowa (I9I I); L. Pelzer, Life of Henry Dodge (19II); J. C. Parish, George Wallace Jones (Iowa City, 1912).

\section{KANSAS ${ }^{1}$}

Population (1910) I,690,949, I5\% more than in 1900. Density 20.7 to the sq. m. Of the total $96.6 \%$ were whites, $3.2 \%$ negroes, and $0.2 \%$ Indians and Asiatics; $88.7 \%$ were native whites, $17.3 \%$ were of foreign parentage and $8 \%$ were foreign-born. The rural population decreased between 1900 and I910 both actually (from 923,358 to 918,439) and relatively (from $62.8 \%$ of the total to $54.3 \%$ ). The urban population in places ( 53 in $1910 ; 40$ in 1900 ) of 2,500 or more increased from 330,903 in 1900 to 493,790 in 1910 , but was then only $29.2 \%$ of the total; the semi-urban, in incorporated places ( 418 , in $1910 ; 314$ in 1900 ) of less than 2,500 each, was $16.5 \%$.

Of the 53 municipalities with more than 2,500 each, 28 had less than 5,000 each. The 25 with more than 5,000 were: Kansas City, 82,33 I (5I,4I 8 in I900); Wichita, 52,450 (24,67I in I900); Topeka, 43,684; Leavenworth, I9,363; Atchison, I6,429; Hutchinson, 16,364; Pittsburg, 14,755; Coffeyville, I 2,687 (4,953 in I 900); Parsons, I 2,463; Lawrence, I 2,374; Independence, I0,480 (4,851 in I900); Fort Scott, I0,463; Salina, 9,688; Chanute, 9,272 (4,208 in I900); Emporia, 9,058; Iola, 9,032; Newton, 7,862; Ottawa, 7,650; Arkansas City, 7,508; Wellington, 7,034; Winfield, 6,700; Galena, 6,o96; Rosedale, 5,960; Manhattan, 5,722; and Junction City, 5,598.

Agriculture.-The acreage in farms increased from 41,662,970 to $43,384,799$ between 1900 and 1910 , the improved land from $25,040,550$ to $29,904,067$, the average farm acreage from 240.7 to 244.0 , and the value of farm property from $\$ 864,100,286$ to $\$ 2,039,389,910$ (\$1,537.976,573 land; \$ I 99,579,599 buildings; \$48,310,161 implements; \$253,523,577 domestic animals). Of the land area $82.9 \%$ was in farms. The average value of farm land per acre was $\$ 35.45$. Farms were operated largely by owners (III, IO 8 by owners; I, 335 by managers; and 65,398 by tenants). In 1909 (U. S. Census) 1,006 farms $(37,479$ acres: mostly in Finney and Kearny counties) were irrigated; and actual enterprises were capable of irrigating 139,995 acres and projects of irrigating I6I,300 acres. Alfalfa (10,470 acres) and sugar beets $(5,638$ acres) were the principal irrigated crops. The Garden City irrigation project of the Federal Reclamation Service was practically completed in I9I I-I2. It was authorised in October 1905 , secures water from shallow wells near the Arkansas river, has $3.8 \mathrm{~m}$. of publicly built canals and $32 \mathrm{~m}$. constructed by water users, and can irrigate 10,677 acres in Finney and Kearny counties. In 1912 (preliminary estimates) the principal crops were: Indian corn, I 74,225,000 bu. $(7,575,000$ A.); wheat, $92,290,000$ bu. $(5,956,000$ A.); oats, 55,040,000 bu. (1,720,000 A.); barley, 4,136,000 bu. (176,000 A.); rye, 477,000 bu. $(30,000 \mathrm{~A}$.$) ; buckwheat, I6,000 bu. (1,000 A.); potatoes, 5,740,000$ bu. (70,000 A.); hay, $2,440,000$ tons $(1,627,000 \mathrm{~A}$.) and flaxseed, 300,000 bu. (50,000 A.). In 1909 (U.S. Census) the value of broom corn was $\$ 593,947$ ( $+1,064$ A.); of vegetables (excluding potatoes), $\$ 2,963,733$; of nursery products, $\$ 948,493$; of small fruits, $\$ 454,200$; of orchard fruits, \$944,6.3I. On January 1 , 1912 there were on farms I, I69,000 horses, 218,000 mules, 698,000 milch cows, 1,872,000 other neat cattle, 326,000 sheep and 2,808,000 swine.

In 19 II an inspector of apiaries was appointed under the state entomological commission.

Mineral Products. - Total value I9II, \$24,987,807. By far the largest item was coal, $6,25+, 228$ tons $(\$ 9,6+5,572)$, more than one quarter increase over the 19ro output. The output of natural gas, valued at $\$ 4,854.534$, was less than for any year since 1906 , but ranked the state 5 th. Petroleum was valued at $\$ 608,756(1,278,819$ bbls.). Other important

See E. B. xv, 654 et seq. 
minerals were: salt, I,390,I68 bbls. (\$608,666), Kansas ranking 4 th; zinc, 6,843 tons ( $\$ 780,102)$; lead, 2,522 tons? $(\$ 226,980)$; building stone, $\$ 803,222$, mostly limestone; mineral waters (from 18 springs), $\$ 63,063$; and a little pumice from Phillips county.

Manufactures.-From 1904 to 1909 the number of establishments increased from 2,475 to 3,435 ; the number of persons engaged in manufacturing from 42,057 (including 35,570 wage-earners) to 54,649 (44,2I5 wage-earners); the capital invested from $\$ 88,680,000$ to $\$ 156,090,000$; the value of products from $\$ 198,245,000$ to $\$ 325,104,000$. The larger separate industries in 1909 were: slaughtering and meat-packing, $\$ 165,361,000,50.9 \%$ of the value of all products, the state ranking 2 nd only to Illinois in this industry; flour and grist-mill, $\$ 68,476,000,21.1 \%$ of the state's total product-value and ranking Kansas 3 rd in this industry; repair of steam railway cars, \$1 I, 193,000; zinc smelting and refining, $\$$ 10,857,000, ranking the state Ist in this industry with nearly $\frac{1}{3}$ the country's total product value. Among other important products are cement, \$4,682,000, Kansas ranking 4 th; glass, \$2,037,000, Kansas ranking $8 \mathrm{th}$; and salt $\$ \mathrm{I}, \mathrm{I} 06,000$, the state ranking 4 th. The principal manufacturing centres were Kansas City, $\$ 164,081,000(50.5 \%$ of the state's total); Wichita, \$22,564,000 $(200 \%$ more than in I904); Topeka, $\$ 17,821,000$; and Leavenworth, $\$ 4,875,000$.

Transportation.--Railway mileage, January I, 1912, 9,150.40.

Legislation.-The regular session of the legislature was from January io to March 1.5, I9I I. On March 6th it ratified the proposed income tax amendment to the Federal Constitution. An amendment to the state constitution providing for woman suffrage was adopted in November I9I 2 by I 75,246 to 159,197 . The legislature recommended (IgrI) the direct election of United States senators. Public utility corporations may not contribute to campaign funds. United States senators are to be voted for at primary and general elections and the candidates for the legislature must sign a pledge, as in Oregon, either to follow the choice of the people in a primary election or to consider it as a recommendation when they choose United States senators. Electors who are unavoidably absent from their election district on election day may vote in any other district, and the ballot must be forwarded to the home election officers.

The 12th of October (Columbus Day) was made a legal holiday. From funds received from Congress in $1908(\$ 97,466)$ and $1909(\$ 425,065)$ to reimburse the state for expenditures during the Civil War an appropriation was made to continue construction of the Memorial Hall, Topeka, for the use of the Department of Kansas, Grand Army of the Republic, and the Kansas State Historical Society. The board of railway commissioners was converted into a public utilities commission; it is to regulate the issue of bonds and stocks and only with its permission may corporations consolidate or may any corporation purchase the stock of a competitor. Unless the commission decides that it is a public necessity no public utility or common carrier may operate within the state. Public utility companies and common carriers wholly within the limits of any city are controlled by the municipality. The U.S. Supreme Court, December 2, 1912, held invalid for interstate commerce a state law requiring foreign corporations trading in Kansas to file annual statements.

The office of live stock sanitary commissioner was created, and a state fish and game warden is to be appointed under an act which is practically a new game code.

The cities which have more recently adopted the commission form of government are: Chanute, Council Grove, Manhattan and Pratt in I9II; and Arkansas City, Holton, Junction City, Olathe and Parsons in rgr2.

A law providing compensation for workmen injured in an accident is elective and appliès to especially dangerous occupations (enumerated), regularly employing 15 or more workmen. An employer must file his choice of action under the law. The act abrogates the defence of assumed risks and of fellow servant, and requires contributory negligence to be measured, but not if an employer who has chosen the compensation system is sued. Suits for damages in lieu of compensation are permitted and certain approved schemes may be substituted. There is no compensation for disability of less than two weeks. For an employee's death the compensation is set at a maximum of $\$ 3,600$, but $\$ 100$ is the maximum if he leaves no dependents. For total disability the compensation is $50 \%$ of the injured man's weekly earnings, not less than $\$ 6$, and not more than $\$ 15$, and the payment of this amount is not to be continued for more than 10 years. If the beneficiaries of the compensation are non-resident aliens $\$ 75^{\circ}$ is the maximum unless they are residents of Canada. An act makes railway corporations liable for accidents to their employees, abrogates the fellow servant rule, enumerates insufficiencies of railway equipment which places the liability for injuries on the employer and makes it impossible for liability to be avoided by contract, but permits an employer to offset any contribution or relief that he has made to the injured man. The U.S. Supreme Court, January $7,19 ! 2$, upheld the constitutionality of a state law regulating the sale of black powder.

Desertion by a husband or parent is punishable by a maximum imprisonment of 2 years at hard labour in the reformatory or penitentiary. 
Finance.-The Igog laws governing the bank depositors' guaranty fund, and building loan associations were amended in I9I I; and a new assessment and taxation law was passed. On July I, I9I I the balance in the treasury was $\$ 1,423,238$, and on June $30,1912, \$ 1,289,209$; and the receipts for the fiscal year were $\$ 7,758,070$ and the expenditures $\$ 7,892,099$. The only bonded indebtedness in 1912 was $\$ 370,000$ held by the permanent school fund.

Education.-In 1911, 7 months was made the minimum term for rural schools and 8 for schools in cities of the first and second class; and a complete re-organisation of the rural schools was planned. In I9II \$70,000 was appropriated for 1912 and $\$ 75,000$ for 1913 to carry out the work planned in 1909 for normal school courses in high schools. A state school of mines was opened in the autumn of 1912 at Weir City. In October 1912 the General Education Board gave \$125,000 to Baker University at Baldwin.

For the school year ending June 30 , I912, the school population was 510,273 ; the enrollment, 395,064; the average daily attendance, 298,128; and the length of the average school year, 170 days. The total revenue was $\$ 12,956,894$ and the total expenditures $\$ 11,158,256$.

In $19102.2 \%$ (in $1900,2.9 \%$ ) of the population 10 years and over was illiterate..

Charitable and Penal Institutions.-A board of penal institutions (three members) replaced the directors of the penitentiary and the managers of the Kansas industrial reformatory on July I, IgII. The legislature established an asylum to be used for the dangerous insane in the penitentiary, and provided for a western state insane asylum; Larned was chosen as its site in ro12. The penitentiary was authorised to buy coal rights adjacent to the penitentiary mine, in which 300 to 400 convicts worked in 1912. Convicts were employed in building roads. It was made unlawful for convicts to work for private citizens. Newton has been chosen as the site for a state tuberculosis hospital (authorised I9II).

History.-The control of the state by the Republican party, radical though the party was with Walter R. Stubbs, governor, and Joseph Little Bristow (b. I86r), United States senator, among its leaders, appeared to be weakening in I9I I and I9I2; in Fort Scott (.1pril 5, I I I I) 3 councilmen (of 5 elected; 3 of 5 elected in r 9 ro were Socialists) and the city attorney were Socialists, and a Socialist mayor was chosen in Girard, Crawford county; two Republican members of the Federal House of Representatives died in office and a Democrat was chosen to succeed each, by a majority in each case greater than $1, \infty 00$ votes in a light poll in a district usually strongly Republican. Stubbs was one of the seven governors who voiced the popular call to Roosevelt to contest the presidency. In May I 9 I 2 the Republican state convention instructed the four delegates at-large for Roosevelt; and the primaries of August 6th resulted in the choice of electors pledged to Roosevelt on the regular Republican ticket. Stubbs defeated Charles Curtis (b. 1860) for a re-nomination for United States senator (losing on the popular vote for the whole state by $\mathrm{I}, 200$ but carrying a majority of the legislative districts)William H. Thompson receiving the Democratic nomination for senator in the same way, carrying more legislative districts than Hugh P. Farrelly but receiving I,900 less votes in the state; and Arthur Capper (b. I 865 ; proprietor and editor Topeka Capilal since I 892) received the Republican and George M. Hodges the Democratic nomination for governor. No state "Progressive" ticket was nominated. The names of the National Progressive electors could not appear in the Republican column under a decision (Sept. Ioth) of the secretary of state, ${ }^{1}$ so these were put, alone, in a column headed "Independent." Possibly this circumstance, which made it necessary for "Progressives" to split the ticket if they wished to vote for Roosevelt electors, worked against the National P'rogressive ticket. The state was carried for Wilson with I 43,670 votes to I 20,123 for Roosevelt, 74,844 for Taft, and 26,807 for Debs ( 12,420 in 1908 ). Crawford county was carried by the Socialists who gave Debs a plurality and elected several county officers, a state senator and two state representatives. Hodges was clected governor, receiving $16 ;, 4,37$ votes to 167,408 for (apper and 24,767 for Kleihage (Socialist). The other state officers were elected by a larger margin; but Thompson (Dem.) defeated Stubbs (Rep.) for United States senator by about $2 \mathrm{I}, \infty 00$ votes, 5 Democrats ( 2 in 62 nd Congress in 1912) were elected and 3 Republicans-including D. R. Anthony and Victor Murdock-to the Federal House of Representatives, and

1 The state Supreme Court, and the Federal Courts, first the District Court, then the Circuit (ourt of . Ipleals (Sept. I6th) had held that they had no jurisdiction and dismissed a lill asking for an injunction to keep Roosevelt chectors off the Republican ballot, - practicully a victory for the Progressives, who did not take advantage of it. 
the Republicans lost the state legislature (Senate, 2 I Democrats, I 8 Republicans, I Socialist; House, 72 Democrats, 5 I Republicans, 2 Socialists).

At Pawnce Rock, May 24, ror2, a monument was dedicated commemorating the early settlers of the state.

Bibliography.-Session Lawe (Topeka, I9II) and departmental reports; Samuel J Crawford (governor, 1865-69), Kansas in the Sixties (Chicago, 1911).

\section{KENTUCKY ${ }^{1}$}

Population (roro) 2,289,905. The percentage of increase (6.6) and even the absolute increase in $1900-10$ were less than for any decade since 1820 . Density 57 to the sq. m. In I900-io the number of negroes decreased from 284,706 to 261,656 ( I $3.3 \%$ of the total in 1900 and only $11.4 \%$ in I9I0). The foreign-born whites were $2.3 \%$ in 1900 and only $1.7 \%$ in I9IO. In rig Io there were 40 incorporated places of 2,500 or more, containing $24.3 \%$ of the total; in 1900,34 such places contained $21.8 \%$. The population in purely rural territory was $70.4 \%$ of the total in 1900 and $67.5 \%$ in 1.910 . There were in I910 20 cities, with 5,000 or more. Louisvilie, 223,928; Covington, 53,270; Lexington, 35,099; Newport, 30,309; Paducah, 22,760; Owensboro, I6,0II; Henderson, II 452; Frankfort, 10,465; Hopkinsville, 9,419; Bowling Green, 9, I73; Ashland, 8,688; Middlesboro, 7,305; Winchester, 7,156; Dayton, 6,979; Bellevue, 6,683; Maysville, 6,I4I; Mayfield, 5,916; Paris, 5,859; Danville, 5,420; and Richmond, 5,340.

Agriculture. - The acreage in farms increased from $21,979,422$ to $22,189,127$ between 1900 and 1910 and the improved land in farms from 13,741,968 to $14,354,471$; the average farm acreage fell from 93.7 to 85.6 ; and the value of farm property increased from $\$ 47 \mathrm{I}, 045$, 856 to $\$ 773,797,880$ ( $\$ 484,464,6$ I 7 land; $\$ 150,994,755$ buildings; $\$ 20,851,846$ implements and \$I 1 7,486,662 domestic animals). Of the land area $86.3 \%$ was in farms. The average value of farm land per acre was $\$ 2$ I.83. Farms are operated largely by owners ( 170,332 by owners, 993 by managers and 87,860 by tenants). In 1912 (preliminary estimates) the principal crops were: Indian corn, I09,440,000 bu. $(3,600,000$ A.); wheat, $6,860,000$ bu. $(686,000$ A.); oats, 4,035,000 bu. (150,000 A.); barley, 78,000 bu. (3,000 A.); rye, 273,000 bu. (21,000 A.); potatoes, $5,151,000$ bu. (5I,000 A.); hay, I, 002,000 tons (815,000 A.); and tobacco, $343,980,000$ lbs. (44I,000 A.). In I 909 (U.S. Census) the total value of hemp was $\$ 348,386$ $(6,855$ A.); of vegetables other than potatoes, $\$ 8,287,497$; of flowers and plants, $\$ 392,409$; of nursery products, \$115,963; of small fruits, $\$ 357,597$ (strawberries, \$159,765; blackberries, $\$ 137,250)$; of orchard fruits, $\$ 4,506,950$ (apples, $\$ 3,066,776$; peaches, and nectarines, $\$ 1,062,-$ 138). On January I, 1912 there were on farms 443,000 horses, 234,000 mules, 398,000 milch cows, 561,000 other neat cattle, I,320,000 sheep and 1,724,000 swine.

In 1912 the legislature voted an annual appropriation of $\$ 10,000$ for the department of agriculture, $\$ 5,000$ of which was to be used to encourage corn clubs and similar clubs in public schools; and $\$ 50,000$ annually to the agricultural experiment station of the state university. A statute provides that the state industrial institute, practically a farmers' state fair, be held at Frankfort each year.

Mineral Products. - Total value in I9II, \$18,910,73I. The output of coal (bituminous) was $13,706,839$ tons $(\$ 13,617,217)$, - about twice as much as in 1902 . A little more petroleum was produced $(472,458 \mathrm{bbls}$., valued at $\$ 328,614)$ than in 1910 , but less natural gas $(\$ 407,689)$ than in any year since 1907 . and much natural gas is now piped into the state from West Virginia. The output of pig iron in I9II was 57,982 tons $(\$ 870,5+2$; not included in the total given above) one-third less than in 1910 ; and that of zinc ore 158 tons $(\$ 18,012)$, found with fluorspar, of which the value in I9II was $\$ 96,574$ (less than in 1910). No lead was reported shipped to smelters in I9II. In building-stone, especially oolitic limestone (value. $\$ I, 124,170)$, the state ranked 18 th, with an output valued at $\$ 1,227,609$ in $191 \mathrm{I}$. The value of all clay products was $\$ 2,368,094$ (almost all brick and tile; less than in I910). Mineral waters bottled from $\mathbf{I} 3$ springs ( $\mathrm{I}$ of these a resort) were valued at $\$ 49,82 \%$. A little barytes is found. The Leitchfield marls of Grayson county, containing about $3 \frac{3}{4} \%$ of potash, are being investigated as possible sources of potash for artificial fertiliser. In I9I I phosphate rock was found in the central part of the state.

Manufactures. - From 1994 to 1909 the number of establishments increased from 3.734 to 4,776; of persons engaged in manufacturing from 69,755 (including 59,794 wage-earners) to 79,060 (65,400 wage-earners); the capital invested from $\$ 147,282,000$ to $\$ 172,779,000$; and the value of products from $\$ 159,754,000$ to $\$ 223,754,000$. The more important separate manufactures in 1909 were: distilled liquors, $\$ 44,360,000$, more than one-fifth of the product for the entire country, Kentucky ranking 2 nd among the states; flour and grist-mill products, $\$ 22,365,000$; lumber and timber, \$21,381,000; tobacco, \$18,598,000, seven-eighths of which

${ }^{1}$ See E. B. xv. 740 et seq. 
was manufactured in Louisville; foundry and machine-shop products, \$9,627,000; iron and steel, $\$ 7,779,000$ (including blast furnaces, $\$ 9,258,000$ ); slaughtering and meat packing products, \$6,568,000; steam-railway cars, repairs, \$6,535,000; men's clothing, \$6,052,000; and carriages and wagons, $\$ 5,14 I, 000$. The principal manufacturing cities were: Louisville, \$101,284,000; Covington, \$8,712,000; Newport; \$6,490,000; Paducah, \$4,967,000; Owensboro, \$3,505,000; Frankfort, \$3,083,000, Henderson, \$2,932,000; and Lexington, \$2,851,000.

Transportation.-Railway mileage, January I, I912, 3,840.66. In I9I2 the Federal government began work on Lock and Dam No. I4, the last of a series on the Kentucky river; and in I9I I it repaired locks and dams on the Green and Barren rivers.

Legislation.-The regular session of the legislature was held in I9I 2 from January 2nd to March $\mathrm{I} 2 \mathrm{th}$. The pay of members was increased from $\$ 5.00$ a day with mileage to Sio a day and 15 cents a mile. The president of the senate and the speaker of the house receive an additional \$5.00 a day. For a new Governor's Mansion in Frankfort $\$ 75,000$ was appropriated. Constitutional amendments were preposed by the legislature for working convicts on public roads and providing for a referendum petition in regard to tax laws. These will be voted on at the next regular election.

An appropriation was made for the purchase of Jefferson Davis's birthplace near Fairview in Todd county and for building a memorial in Jefferson Davis park under the control of the Jefferson Davis Home Association. A cession of land to the Federal Government for a Mammoth Cave National Park was authorised.

A new county, McCreary, was created out of Pulaski, Wayne and Whitney counties, and Pine Knot was made temporary county-seat by the county commissioners. The name of Mt. Pleasant, Harlan county, was changed to Harlan. Lexington adopted commission government by vote on November $7,191 \mathrm{I}$; the first election under the new charter was in November 1912. Newport adopted it in I910 and Paducah rejected it in November I9II.

Women are allowed to vote for school officers and on school matters and may hold school offices-except those limited to men by the constitution. A primary election is to be held on the first Saturday of August of each year and nominations must be certified unless the nominating petition is signed by 3 to $10 \%$ of the party vote for presidential electors at the last election. This law does not provide for primary vote for presidential electors but it does require a preferential vote for United States senators.

The legislature created a state insurance board to take over the work of the insurance commissioner; a pension board, to pension indigent and disabled Confederate soldiers and widows of Confederate veterans residing in the state since January I, 1907; a department of public roads and state commissioner of public roads; a game and fish commission; a state board of agriculture, replacing the board of agriculture, forestry and immigration, part of the work of which is taken over by a newly created board of forestry; a state board of tuberculosis commissioners; a state geological survey to take over the work of the geological survey, formerly a part of the state university; and the office of state fire marshal.

The working hours of women under $2 \mathrm{I}$, except in domestic service and nursing, are limited to 60 a week and Io a day; and these hours were made the maximum for all women working in factories, stores, hotels, telephone and telegraph companies.

The possession of a U.S. special tax stamp was made prima facie evidence of violation of local option laws. It was made unlawful to buy, procure or deliver intoxicating liquors in local option territory ${ }^{1}$ where their sale is prohibited, but common carriers acting in good faith may deliver 5 gallons or more to licensed druggists and physicians. Intoxicating liquors must not be sold within $400 \mathrm{ft}$. of state normal schools or colleges. The tenement laws of the state were revised. A law was passed forbidding public drinking cups.

Finance. - The I9I 2 legislature created a state department of banking. The balance in the state treasury on June 30,1912 was $\$ 300,550$, and the amount of outstanding (unpaid) warrants, \$1,80I, 387; receipts for the year were $\$ 7,280,486$ and expenditures, $\$ 7,336,225$.

Education. - The legislature of 1912 made education compulsory for children between 7 and 12 unless excused by the county board of education for physical or mental condition. The State School for the Deaf is now classified as an educational (rather than a charitable) institution. Since the beginning of I9I I the department of education has had a rural supervisor of schools whose salary is paid by the Southern Education Board and a high school supervisor whose salary is paid by the General Education Board (traveling expenses by the state university) and who acts as professor of secondary education in the Western Normal School. A "school improvement league organiser" is paid by the Southern Education Board and the State Federation of Women's Clubs.

The percentage of illiterates in the population (10 years old and over) was 12.1 in 19 Io as compared with 16.5 in 1900 ; of negroes $27.6 \%$ in 1910 and $40.1 \%$ in 1900 .

For the year ending June 30,1911 (the last for which statistics are available), in rural schools the total population was 591,255 (59,900 negroes); the enrollment 424,976 (39,369

' In I9II-12 of 9 counties voting on liquor licence, only 3 were for licence and 1 of these will probably be contested (Boyd county; election of May 2, I9I2). 
negroes); and the average daily attendance 220,946 (19,920 negroes). Tha receipts were $\$ 4,220,193$ and expenditures $\$ 4,089,723$. In city schools (28 cities) the population was I 42,067 (25.849 negroes); enrollment, 69,887 (13,982 negroes); average daily attendance, 52,614 (7,863 negroes). The receipts were $\$ 2,459,213$ and expenditures $\$ 2,061,045$.

Charitable and Penal Institutions. - The last legislature made an appropriation to repcir the Kentucky Confederate Home (incorporated 1892) at Pewee Valley; and, besides the pension act for disabled and indigent soldiers, provided for pensions for city firemen and for teachers in public schools in first class cities. In I9IO and I9I I cases of pellagra were reported in the Eastern State Hospital for the Insane (Lexington). In the Central Hospital (Lakeland) a tuberculosis hospital was built in I9II-12 and at the Western Hospital (Hopkinsville) a tuberculosis colony was established in I9I0-II. The tuberculosis hospital at the Eddyville Penitentiary, authorised in 1906, was completed and opened for use in 1912.

History.-There was a state election in I9II, which resulted in the defeat of the Republicans, who had been in control for four years. Augustus Everett Willson (b. $\mathbf{1 8 4 6 )}$, Republican, governor in 1907-1 I, was not renominated, but the Republicans named Edward Clay O'Rear (b. I863), chief justice of the state court of appeals since 1907. He was defeated by James Bennett Mcreary (b. I838), who had been governor in $1875-79$, representative in Congress (1885-97) and United States senator (1903-09), and who received 226,77I votes to I95,436 for O'Rear. The Democrats secured a strong majority in the legislature. On January r6, г912, it elected as successor to Thomas $H$. Paynter (b. I85I), Dem., Ollie M. James (b. 187I), Democratic representative in Congress in $1903^{-13}$, who was chairman of the Democratic National Convention at Baltimore later in the year and who was affiliated with the Bryan wing of the party. In the presidential campaign the sentiment of the Democrats of the state favoured Champ Clark for the nomination. A conspicuous incident of the pre-nomination campaign was the breach between Woodrow Wilson and Henry Watterson, who had previousi- advocated in the Louisville Courier-Journal the nomination of Wilson. One Roosevelt delegate to the Republican national convention and I7 pledged to Taft were seated after a contest, June II, I9I2. In the election (Nov. 5, I9I2) Woodrow Wilson received 2I9,584 votes; Taft, II 5,5 I2; Roosevelt I02,766; and Debs, I I,647 (in I908, 4,000). The Congressional delegation, 9 Democrats and 2 Republicans, was unchanged-except that A. W. Barkley (Dem.) in the rst district succeeded James, elected to the Senate. There were Progressive candidates for Congress in every district but the first, and in the 5 th the Progressive candidate was defeated by 1,680 out of 54,000 votes.

In $19 \mathrm{I} I$ there were more lynchings in Kentucky than in any other state save Georgia: 3 negroes, 2 accused of rape and $\mathbf{r}$ of wife murder, were taken from the Shelbyville jail by a mob to which the jailer surrendered the keys (Jan. I 5th); a negro, accused of murder, was taken from a marshal at Livermore, McLean county, by a mob and was shot on a theatre stage (April $\mathbf{r} 2 \mathrm{th}$ ); and 4 whites were lynched at Campton (May 25 th).

The country around Hickman, Fulton county, was flooded (about 300 sq. m.) early in April 1912, when the Mississippi burst a levee (3 ft. below standard grade but built up by sack topping) when the water was I $\mathrm{ft}$. above the levee.

Bibliography.-Acts of the General Assembly (Frankfort, 1912) and state departmental reports; B. H. Young, The Prehistoric Men of Kentucky (Louisville, 1910); Mary Verhoeff, The Kentucky Mountains: Transportation and Commerce, 1750 to I9II; A Study in the Economic History of a Coal Field, vol. I (Louisville, I911).

\section{LOUISIANA ${ }^{1}$}

Population (1910) $1,656,388$, an increase of $19.9 \%$ since 1900 , the absolute numerical increase being greater than in any preceding decade. In rooo-ro the proportion of negroes decreased from $47.1 \%$ to $43.1 \%$ and that of the foreign-born whites from $3.7 \%$ to $3.1 \%$. Density of population, 36.5 to the sq. $\mathrm{m}$. The rural population was $68.7 \%$ of the total in 1900 and $63.4 \%$ in I9ro, and the urban $26.5 \%$ in Igoo (in I 5 incorporated places, each with more than 2,500 inhabitants) and $30 \%$ in 1910 (in 26 such places). There were in I9ro II places of 5,000 or more; New Orleans, 339,075; Shreveport, 28, or 5; Baton Rouge, I4,897; Lake Charles, I I,449; Alexandria, I I, 2 I3; Monroe, Io,-

i See E. B. xvii, 53 et seq. 
209; New Iberia, 7,499; Lafayette (town), 6,392; Morgan, 5,477; Crowley, 5,099; Houma (town), 5,024.

A griculture. - The acreage in farms decreased from $11,059,127$ to $10,439,48 \mathrm{I}$ in $1900-10$, and the improved land increased from $4,666,532$ to $5,276,016$; the average farm acreage fell from 95.4 to 86.6 , and the value of farm property increased from $\$ 198,536,906$ to $\$ 301,220$,988 (\$1 87,803,277 land; \$49,741,I 73 buildings; \$18,977,053 implements and $\$ 44,699,485$ domestic animals). Of the land area $35.9^{\circ}$ owas in farms. The average value of farm land per acre was \$17.99. Farms were operated largely by tenants $(66,607$ by tenants, 52,989 by owners and 950 by managers). In 1909, 2,690 farms including 380,200 acres devoted to rice growing were irrigated, the largest areas being in Calcasieu (131,208 A.), Acadia (107,466) and Vermilion parish $(52,196)$. In I I 2 (preliminary estimates) the principal crops were: Indian corn, 32,490,000 bu. (I,805,000 A.); potatoes, I, 460,000 bu. (20,000 A.); hay, 234,000 tons (142,000 A.); cotton, 435,000 bales (197 lbs. per A.); tobacco, 150,000 Ibs. (500 A.) and rice, $11,812,000$ bu. $(352,600$ A.). In 1909 (U.S. Census) the value of vegetables (excluding potatoes) was $\$ 3,000,864$; of small fruits, $\$ 486,988$; of orchard fruits, $\$ 314,027$; and the acreage in sugar cane was 329,684 . On January 1, 1912 there were on farms: 187,000 horses; 134,000 mules, 288,000 milch cows, 516,000 other neat cattle, i 76,000 sheep, and $1,642,000$ swine.

The production of long-staple Upland cotton has greatly decreased during the last few years through the prevalence of the boll weevil. Texas cotton boll weevil parasites were introduced into Louisiana in I9II. Partly because of difficulties in growing cotton and partly because of the work of the farmers' cooperative demonstration, and of the boys' corn growing clubs, there is increased cultivation of Indian corn. In I9I2 the police jury of each parish was authorised to establish and maintain an experiment farm under the supervision of the Federal and state departments of agriculture. A conservation commission was created which is to protect the natural resources of the state and for which \$125,000 a year was appropriated. Queen Bess Island, Barataria Bay, was set apart as a game preserve, and in October Mrs. Russell Sage purchased Marsh Island, Iberia parish, as a bird refuge. The legislature declared that wild game was the property of the state and gave the conserva. tion commission elaborate powers to protect game. It appropriated $\$ 50,000$ to purchase seed for needy farmers and planters in districts flooded in the spring of 1912; and \$15,000 for the expense of the militia during the flood.

Mineral. Products.-Total value, I9II, $\$ 12,710,958$. Two large items, sulphur and salt, were not separately reported. Louisiana is far the largest producer of sulphur in the United States and in I9II a large part of the total output, 265,664 tons, came from the state, mostly from (alcasieu parish. In salt the state ranked 5th. The output of petroleum, $10,720,420$ bbls. $(\$ 5,668,814)$, ranked the state 4 th in 1911 ; in 1910 it was 8 th. Natural gas was not separately reported; new wells were operated in De Soto parish in 1910 and near Shreveport in 1912, and some gas is piped into Arkansas. Mineral waters, bottled at 5 springs, including 3 resorts, were valued at $\$ 110,998$. Limestone was the only stone of importance. Sand and gravel were valued at $\$ 3+4,281$, and clay products at $\$ 531,949$.

Manufactures.-In I $904-09$ the number of establishments increased from 2,091 to 2,516 and that of persons engaged in manufacturing from $63,735(55,859$ wage-earners) to 86,563 $(-6,165$ wage-carners); the capital invested from $\$ 150,8 \mathbf{I}$ I,000 to $\$ 221,816,000(47.1 \%)$; and the value of products from $\$ 186,380,000$ to $\$ 223,949,000$. The recent development is attributable largely to cheap fucl from the oil ficlds in the state and in Texas. Of the product-value in $1909,28.5 \%$ was that $(\$ 63,775,000)$ of sugar and molasses and sugar refining, and almost as much, $\$ 62,838,000$, was the value of lumber and timber (yellow pine and cypress were the hargest cuts). Other important products were: cottonseed oil and cake, \$13,085,000; rice, cleaned and polished, \$12,529,000; bags (not paper), \$5,352,000; printing and publishing, $\$ 3,82,3,000$; malt liquors, $\$ 3,573,000$; foundry and machine-shop products, $\$ 2,998,000$; copper, tin and sheet-iron, \$2,899,000; repair and construction by steam railroads, $\$ 2,527,000$. New Orleans (product, $\$ 78,794,000$ ) was the most important manufacturing city in 19c9; its principal manufactures were bags $(\$ 5,352,000)$, rice, $(\$ 5,125,000)$, and copper, tin and shect-iron $(\$ 2,554,000)$. ()ther important cities were: Shreveport, \$3,642,000; Lake Charles, $\$ 2,251,000 ;$ Alexandria, \$1,279,000; Monroe, $\$ 1,255,300$, and Baton Rouge, $\$ 658,379$.

Transportation. - Railway mileage, January 1, 1912, 5,648.23. The Federal government by dredging in 1911 secured a depth of $31 \mathrm{ft}$. in the channel at Southwest Pass. The navigation of the Mississippi and its tributaries was much disturbed in 1912 by floods.

A constitutional amendment providing that a police jury may form a parish into a road district and may levy tax for roads was adopted in 1912 by 32,703 votes to 17,151 ; and one extending the time of the organisation of the Pan-American Steamship Company from 1913 to 1916 and still securing exemption from taxation was carried by 27,537 to 20,420 votes.

Legislation.-The legislature was in regular session from May I3 to July Ir, rgr 2, and in extra scscion from . August $\mathrm{r} 2 \mathrm{th}$ in 24 th. On July ist it ratified the proposed r6th amendment to the Fiederal Constitution providing for an income tax. It asked 
Congress to authorise the secretary of the interior to settle contests between settlers and the Texas \& Pacific Railway Company and also asked for the completion of the land survey of the state and for a final settlement of swamp land grants of March 2, 1849. It re-apportioned the state into eight congressional districts (formerly 7 ).

Lobbying was forbidden. A corrupt practices act sets the maximum of expenditures of candidates for different offices, in most cases $20 \%$ of one year's salary in office, but $\$ 2,000$ for all state wide offices and $\$ 6,000$ for candidates for governor or for United States senator. A "political party" of the primary law of 1906 was defined to be a party casting at least 5 \% of the total vote. The dominating political party must nominate all candidates by direct primary; minority parties may do so at the option of the executive committee. By a constitutional amendment adopted in November, 1912 (by 33,955 to 18 , I 44 votes) the time for final registration under the "grandfather" clause of the constitution of 1898 was postponed until September I, IOI3. An amendment permitting women to hold educational office was defeated at the same election ( 31,452 votes to 18,779$)$. Another, defeated by 29,852 votes to 22,607 , was for the recall of public officials (after January I, 1913) at an election not less than three nor more than five months after petition signed by $30 \%$ of the voters.

Vacancies in office in parish, district or other subdivision of the state are to be filled by election, if the unexpired term is more than one year; and an amendment to the same effect applying to the city of New Orleans was adopted in November $1912(27,998$ to 19,422). The legislature created a state printing board with authority to make contracts for state printing.

Three new parishes were created from Calcasieu-Allen from the N.E. part, Jefferson Davis from the S.E. part, and Beauregard from the N.W. part, and the parish seat of Boissier was removed from Benton to Boissier City.

The property of married persons was divided into separate property and common property and the wife was made a competent witness against her husband in cases of desertion.

An employers' liability commission is to report in 1914 on the advisability of compulsory compensation for workmen. A law of 1908 forbidding the appearance of children under I4 on the stage was repealed; the secretary of the national child labour committee calls this "the first backward step in child labour legislation in any state in 8 years." The manufacture and sale of white phosphorus single-dipped matches or blazer or wind matches was forbidden. The state board of health was authorised to revise the sanitary code. State boards of medical examiners were created by a law regulating the practice of medicine, surgery and midwifery. A nurses' board of examiners was created and unregistered nurses were prohibited from professional practice. Only registered nurses may use "R.N." after their names. A state tuberculosis commission was established.

Children under 16 must not be employed in any immoral or dangerous occupation, nor, except by permit from a judge of a juvenile court, in any theatrical exhibition or musical concert. Children under $\mathbf{I} 7$ are forbidden in pool and billiard rooms and several acts prohibited gambling (and four the sale of intoxicating liquors) within five miles of certain public schools or within a school district. The conducting of disorderly houses makes one liable to a fine of $\$ 10$ to $\$$ roo. The legislature authorised municipal corporations to withhold permits for building houses for negroes in communities occupied mostly by whites or houses for whites in negro communities.

The powers of the railroad commission were enlarged; it may award damages for violations of its rules, rates and classifications. The legislature passed a uniform bill of lading act and a new fraternal insurance law. A commission of two lawyers and two business men appointed by the governor is to report in I9I4 on revising the state corporation law.

The legislature provided commission charters for New Orleans and Natchitoches. In New Orleans there are a mayor and four councilmen at large each giving bond to the city in $\$ 50,000$. The city budget must be advertised and there is a provision for initiative and referendum on a $30 \%$ petition. The charter was adopted by New Orleans on August 28. The Natchitoches charter was to be adopted at an election called by a petition of $33^{\circ} \circ$ of the voters. The mayor and three commissioners are to be nominated at a primary and are subject to recall at an election summoned by a $30 \%$ petition under the unusual condition - "if a majority of the duly qualified electors . . . shall . . . vote for the recall." A general law for commission government was passed applying to towns above 2,500 inhabitants and cities (except New Orleans) above 5,000, to be adopted at an election upon a petition of $25 \%$. Shreveport had adopted commission government in 1910 , and Hammond and New Iberia adopted it in 1912 .

Finance. - The balance in the treasury December 3I, I9I I was $\$ 986,068$. The receipts for I912 were $\$ 7,2$ I 9,743 and the expenditures, $\$ 7,355,786$; the balance, January $1,1913, \$ 850,025$.

The tax rate for the general fund was 520 mills for 1913 and I9I4. A commission of 32 members (lieutenant-governor, speaker of the house, I6 representatives, 8 senators and 6 appointed by the governor) is to recommend amendments to the assessment and taxation laws of the state. New taxes were laid on theatres; on the sale of malt liquors ( $\$ 50$ to $\$ 100)$; on all "severers from the soil" of natural products-including timber, turpentine, minerals, oil, gas, sulphur and salt ( $1 / 2 \%$ on gross value less royalty interest). Traveling salesmen of stocks and bonds are required to pay a certificate fee and to give bond in $\$ 15,000$. 
In November 1912 the following constitutional amendments were defeated: one reorganising and remodelling the state's system of assessment and taxation; one for an issue of \$II,108,300 to refund the state debt; one giving parishes and municipalities the power to exempt from tax any industrial enterprises; exempting from tax for Io years from their completion railways or parts of railways built after June I, 1912; exempting for ten years irrigation, navigation and hydro-electric concerns expending not less than $\$ 5,000,000$ on their plants and in actual operation within five years of January I, 1913; exempting money in hand or on deposit; allowing parishes to decide by referendum whether cities or incorporated towns be exempt from parochial tax; and authorising parishes and municipalities by referendum to exempt $\$ 2,000$ of the value of dwellings used by actual owners as dwelling houses. An amendment was adopted $(29,609$ to 21,953$)$ exempting from tax corporations organised to lend money at not more than $6 \%$ on country mortgages, and one $(28,155$ to 21,480$)$ exempting the legal reserve of life insurance companies. The former may be the basis for a rural credit. plan benefiting farmers and planters. The state banking department was reorganised in 1912 and a new law limited to one year the liability of a bank for forged checks.

Education. - In illiteracy the state ranked first in the Union, the percentage for I910 of the population 10 years and over being 29 ( 38.5 in 1900). Among whites it was 14.2 (18.9 in 1900); among negroes 48.4 (61.1 in 1900). For the year ending July 1, 1912, the school population was 526,268 ; the enrollment 287,988 ; the average daily attendance, 173,797 ; and the length of the average school year, 7.86 months. Receipts were $\$ 5,867,968$ and expenditures $\$ 5,403,183$.

A new school code (1912) established a state board of education composed of the governor, the superintendent of public education, the attorney-general and one citizen from each congressional district. The annual appropriations for support and maintenance were $\$ 900,000$ for free schools; $\$ 72,500$ for the state normal school, and $\$ 100,000$ for the state university. The legislature authorised the Southern University and Agricultural and Mechanical College (a land grant college for the education of negroes) to sell its property in Jefferson and Orleans parishes, to acquire a new site in a rural community and to establish an industrial and agricultural normal school for the training of negro teachers and a model school. The trustees of the university are to be whites but all other officers and teachers are negroes.

Penal and Charitable Institutions. - A constitutional amendment giving a pension (not more than $\$ 8$ a month) to Confederate soldiers and levying a I mill tax for this purpose was adopted $(43,938$ votes to 13,049$)$ in November 1912 . For pensions $\$ 150,000$ was appropriated and a home was established for the wives and widows of Confederate soldiers. The employment of convicts for personal or private use outside prison walls or away from camps or penal farms was forbidden. The trustees of the state penitentiary were authorised to appropriate $\$ 250,000$ for penitentiary expenses, mortgaging the state farms if necessary. The legislature appropriated in 1912: $\$ 10,000$ for the tuberculosis sanitarium to be built by the AntiTuberculosis League; \$24,000 a year for the Lepers' Home; and \$ 176,000 for the Charity Hospital at New Orleans. On January 24, 1912 Edward Wisner gave New Orleans 50,000 acres of undrained alluvial land in the Mississippi delta, the revenue to be devoted to charitable purposes, if the city does not sell the land for 100 years.

History. - The political history of the state centres in the contest between a Democratic "machine" and a "Democratic Good Government League," formed in Igro and opposing the machine in the state and in New Orleans. Governor Jared Young Sanc'ers in July Igro was chosen United States senator by the legislature to succeed Samuel Douglas McEnery (I837-1010; governor 188I-88, and senator since 1897). After taking some time to put his affairs in order, he withdrew his acceptance so that he might promote the claims of New Orleans for the Panama Exposition, and with no apparent precedent appointed (Aug. 27 th) Judge John Randolph Thornton (b. 1846), whom the legislature elected (Dec. 7 th), although he had not been nominated by the primaries, as the state law requires. The legislature refused to submit the choice of Thornton to the popular vote. At the state election (April 30, 1912) Luther Egbert Hall, the candidate of the reformers, was elected, and only 4,96 I votes were cast for the Republican candidates. This was less than the percentage required by state law to give an organisation official standing, so that Republican candidates can be nominated only by petition; the law requires $\mathrm{r}, \infty 00$ signatures in each congressional district, and only in two districts (New Orleans) are there that many registered Republicans. In the November election the state was carried for Wilson by 61,035 votes to 9,323 for Roosevelt, 3,834 for Taft and 5,249 for Debs (2,538 in 1908). The state's representatives in Congress ( 8 instead of 7 as in the preceding decade) will all be Democrats. In New Orleans Martin Behrman (b. 1864), mayor since 1906, was re-elected to head the new commission government. Murphy James Foster (b. I849, Democrat, governor 
I892-I900) was succeeded as U.S. senator in I9I3 by Joseph Eugene Ransdell (b. 1858; Democrat, representative in Congress since 1899). In I9I2 Robert F. Broussard (b. I864; representative in Congress, I897-1913) was chosen senator for the term beginning I915, to succeed John R. Thornton. On January 5, 1912, died Francis T. Nicholls (b. I 834), who served in the U.S. Army.from 185., when he graduated at West Point, to 1857 and in the Confederate Army in 186r-65, and was governor in I $877-80$ and $1888-92$ and a justice of the supreme court of the state after 1893 .

The state supreme court (Jan. 25, I912) held that negroes may not be ejected from street cars reserved for whites if there are no seats in cars reserved for negroes-an important modification of the "Jim Crow" law. A negro accused of murder was lynched at Opelousas (Jan. 29, I9II); one on the same charge in Claiborne parish (July 24th) and one at Delhi (Nov. 3rd), and one at Winnsboro (Sept. I 5 th) for assault. At Shreveport (April 9, I9I2) a mob lynched a negro for insulting a white woman, and at Yellow Pine (May $3 \mathrm{rd}$ ) another was lynched for insulting a white woman over a telephone. At Delhi (April 25th) a negro was lynched; another at Grand Cane (Sept. 25th); three at Benton (Nov. 28th) for murderous assault; and one, convicted of murder, at West Baton Rouge (Dec. 23rd):

During a strike (called May I3, I9I2) of timber warkers at Grabow, there was (July 7 th) a riot in which 4 men were killed. The strike leaders were arrested and tried for murder but were acquitted (Nov. 2nd). They said that they were fired upon by employees of the lumber company.

In March and early April I9 2 heavy rains swelled the Mississippi and its affluents, already full after a long winter with a heavy fall of snow. The danger mark, $\mathrm{I} 8 \mathrm{ft}$. of water, was reached April 9th. Part of the U.S. Army, especially its engineers and commissary, had been ordered to the help of the threatened districts by President Taft on the 6th, and now Governor Sanders and Mayor Behrman began strengthening levees, organising patrols and getting relief for the homeless. The condition was aggravated by heavy rains in the lower course of the river which could scarcely be carried off by ordinary methods of drainage. A levee $6 \mathrm{~m}$. below Melville, St. Landry parish, on the W. bank of the Atchafalaya, was cut by some one who wished to save the E. bank. A large area was flooded and the patrols were strengthened. Pointe Coupée and parts of Iberville, Assumption and Feliciana parishes were flooded; in Pointe Coupée the water was above the telegraph wires in May. The damage was not confined to crops, especially sugar cane, which gives this low region the name of the "Sugar Bowl," but much live stock and hundreds of people were killed. Ten breaks in the Louisiana levees flooded about $2,800 \mathrm{sq} . \mathrm{m}$. and at least one of these breaks was probably due to weakening by crawfish holes. The flood was of unusual duration. In the second week in June nearly Ioo $\mathrm{m}$. of levees gave way and many railways were inundated; and the water was still high in July. Although the volume of the river may have been less than in the flood of 1897 , the water was higher at almost every point than at any time since $187 \mathrm{r}$ when gages were first used, and the provisional grades for levees will have to be changed all along the river. (See A. L. Dabney, in Engineering News for June 13, I912; N. C. Frankenfield, in same for April I8, I912; and R. M. Brown in Bulletin, American Geographical Society, Sept. I912).

On April 30, I9 2, the state celebrated the centenary of its admission to the Union.

Bibliography. - Acts Passed by the General Assembly (Baton Rouge, 1912) and other official publications; John Rose Ficklen, History of Reconstruction in Louisiana (Baltimore, 1910); J. A, Robertson, Louisiana Under Spain, France and the United States, 1785-1807 (I9II).

\section{MAINE 1}

Population (I910) 742,37 I (6.9\% more than in 1900); $84.9 \%$ were native whites, $\mathbf{I} 8.2 \%$ whites of foreign parentage, $14.8 \%$ foreign-born, and $0.2 \%$ negroes. Density $24.8(23.2$ in 1900$)$ to the sq. m.; $5 \mathrm{I.4} \%$ lived in cities or towns of 2,500 inhabitants or more. The cities or towns with 5,000 or over were: Portland, 58,57 I Lewiston, 26,-

1 See E. B. xvii, 434 et seq. 
247; Bangor, 24,803; Biddeford, 17,079; Auburn, 15,064; Augusta, 13,21 1; Waterville, II,458; Bath, 9,396; Sanford, 9,049; Westbrook, 8,28I ; Rockland, 8, I 74; South Portland, 7,471; Rumford, 6,777 (Rumford Falls, 5,427); Brunswick, 6621 (village 5,34I); Saco, 6.583; Old Town, 6,3 I 7; Calais, 6, 116; Houlton, 5,845; Brewer, 5,667; Caribou, 5,377; Skowhegan, 5,34I; Gardiner, 5,311; Presque Isle, 5, 179.

Agriculture.-The acreage in farms decreased from $6,299,946$ to $6,296,859$ between 1900 and 1910 and the improved land from $2,386,889$ to $2,360,657$; the average farm acreage fell from 106.2 to 104.9 and the value of farm property increased from $\$ 122,410,904$ to $\$ 199,271,998$ (\$86,481,395 land; \$73,138,23I buildings; \$14,490,533 implements; \$25, I61,839 domestic animals). Of the land area $32.9 \%$ was in farms. The average value of farm land per acre was \$13.73. Farms were operated largely by owners $(56,454$ by owners, 999 by managers and 2,563 by tenants). In 1912 (preliminary estimates) the principal crops were: Indian corn, 640,000 bu. (I6,000 A.); wheat, 70,000 bu. (3,000 A.); oats, 4,602,000 bu. (133,000 A.); barley, I05,000 bu. (4,000 A.); buckwheat, 412,000 bu. (I 4,000 A.); potatoes, $23,166,000 \mathrm{bu}$. (II7,000 A.); and hay, I, 428,000 tons (I,231,000 A.). In I909 (U. S. (ensus) crops were valued at $\$ 39,317,647$ : $\$$ I5, II 5,82 I, hay and forage; $\$ 10,224,714$, potatoes; $\$ 5,573,763$, forest products of farms; $\$ 3,100,902$, cereals; $\$ 2,2$ I 5,116 , fruits and nuts $(\$ 2,121,816$, appies); and $\$ 2,153,003$, vegetables other than potatoes. The value of poultry on farms was \$I, I3I,92I, and of poultry and eggs sold during the year, $\$ 3,386,865$. On January I, I9I 2 there were on farms: I09,000 horses, I55,000 milch cows, 98,000 other neat cattle, 186,000 sheep and Ior,000 swine.

In 1911 a live stock sanitary commissioner was appointed by the governor to improve breeds of cattle and to study and prevent contagious diseases among them. For protection from gypsy moths $\$ 20,000$ in 191 I and $\$ 15,000$ in 1912 was appropriated. The state experiment station in I9II-12 cooperated with the Federal department of agriculture in experiments in poultry breeding. In October 1912 the General Education Board granted \$8,000 for agricultural demonstration work in Washington, Kennebec, Oxford and Cumberland counties under the State College of Agriculture.

Mineral Products. - Total value, I9II, about $\$ 4,645,630$. The largest item was stone, valued at $\$ 2,263,200$, mostly granite. Lime was valued at $\$ 773,2$ I 2 (considerably less than in 1910), clay products at $\$ 625,2 \mathrm{r} 4$, and mineral waters, bottled at 28 springs (including 3 resorts) at $\$ 431,740$. In output of slate, \$263,516, the state ranked 3 rd, and in felspar, 25,976 tons, valued at $\$ 246,305$, it ranked ist.

Manufactures. - In I904-09 the number of establishments increased from 3, I45 to 3,546 and that of persons engaged in manufacturing from 82,109 (74,958 wage-earners) to 88,476 $\left(79,955\right.$ wage earners); the capital invested from $\$ 143,708,000$ to $\$ 202,260,000\left(40.7^{\circ}\right)$; and the value of products from $\$ 144,020,000$ to $\$ 176,029,000$. The six largest industries reported a little more than two-thirds the total value of products. These were: paper and wood-pulp, $\$ 33,950,000$ (more than one-eighth the total value for the United States); lumber and timber, including wooden boxes, $\$ 26,125,000$-more spruce and more balsam fir was cut in Maine than in any other state; cotton goods, \$21,932,000; woolen, worsted and felt goods, \$1 8,490,000; boots and shoes, \$15,509,000; canning and preserving, fruits, vegetables (sweet corn) and fish and oysters, $\$ 7,689,000$. Shipbuilding (largely at Bath), had a product valued at $\$ 3,062,000$. The value of marble and stone work was $\$ 2,565,000$.

The 7 cities of 10,000 inhabitants or more manufactured together about three-tenths of the state's total by value: Portland, \$ I I,950,400; L.ewiston, \$10,475,400 (two-thirds, cotton guods); Biddeford, $\$ 9,011,600$ (seven-tenths, cotton goods); Auburn, $\$ 8,842,600$ (seven. tent hs, boots and shoes); Augusta, $\$ 4,662,175$; Bangor, $\$ 3,345,700$ and Waterville, $\$ 3,179,000$.

Transportation.- Railway mileage, January 1, 1912, 2322.17. In 191 I the legislature defined the trunk line of state highways and substituted for the three-quarter mill tax for state highways an appropriation of $\$ 250,000$. In September 1912 a constitutional amendment was adopted $(80,619$ votes to $21,+54)$ for a bond issue of $\$ 2,000,000$ for improvement of ruads, the funds to be raised by tax on automobiles. The Federal government in I9II-12 completed the improvement between the mouth of the Kennebec river and Gardiner, with a flesed tirle depth of $20.5 \mathrm{ft}$., the removal of ledge at Rockport harbour entrance, the deepening of liast Boothbay harbour to $8 \mathrm{ft}$., of Camden harbour to 10 and $12 \mathrm{ft}$., and of Stockton harbour to $25 \mathrm{ft}$. (formerly $18-20$ ); the work of widening the channel of the Penobscot at Banger was more than half completed; and work had begun for a $7 \mathrm{ft}$. depth on the Saco river from the head of navigation to the sea.

Goremment. - The regular session of the legislature was held in Igi I from January 4 th to March $3 \mathrm{rcl}$; a special session in Ior 2 from March 2oth to April 6th. On March 31, 10I I it ratified the proposed i6th amendment to the Federal Constitution providing for a Federal income tax, which had previously been rejected in the state. An act for uniform ballot boxes at elections was passed by a referendum vote $(72,816$ to 33,884$)$ in September ror 2. (olumbus Day (1 zth of October) was made a legal holiday. A 
department of labour and industry was established in I9I I to take the place of the office of factory inspection and of the bureau of industrial labour statistics; at its head is a commissioner. Exemptions for debt no longer include bills for necessaries, but \$ro a week is exempt from execution. The law of I 909 making ten hours a working day for women and children in factories is amended so that it does not apply to the manufacturing of perishable products. Packers of food in tin or glass must pay annually, for a permit, \$roo to go toward the cost of a monthly inspection of food packed. The penalty for false marking of a container of food is $\$ 500$. A stricter law was passed against the adulteration of milk or cream. The laws for the sale of seeds, commercial feeding stuffs, fertilisers, drugs, foods, and insecticides were revised and codified. The state forest commissioner is to maintain fire patrol along railways, which must pay the expense.

The legislature of I9r I passed many private and special laws in regard to fishing and trapping, and prescribed closed seasons for scallops, mink, sable, fisher, otter, muskrat and eider ducks; the closed term for caribou was extended to 1917 and for wood ducks to 1915. Game commissioners were authorised to declare in open season for beaver upon a written complaint that beavers were doing serious damage. Towns may grant licences for the protection of clams and no clams may be taken in the licensed territory.

A charter giving a commission government to Gardiner, adopted by the city September II, I9II, was the first in Maine. The voters of Waterville defeated, October 2, I9I1, a charter providing for commission government, referendum, initiative and recall. Bangor adopted plans submitted by an expert for rebuilding the part burnt on April 30, I9I I (with a loss amounting to $\$ 3,500,000$ ), widening the streets and grouping public buildings.

Finance. - In 1909-I I the net debt increased $\$$ I,I5I,502, an amount greater than the previous total. Governor Plaisted urged the strictest economy, inasmuch as only $\$ 300,000$ a year could be raised by temporary loan. This amount was borrowed in I9II and I9I2. The governor pointed out that in I9II and I9I2 it would be necessary to raise $\$ 1,000,000$ more than the amount of actual current expenditures. The appropriation bill for I9II carried $\$ 4,044,140(\$ 1,497,500$ for school and mill fund tax due to townships). The net debt in January 1913 was $\$ 1,249,664$. Cash on hand January 1,1912 in the treasury was $\$ 502,202$. The receipts for the year were $\$ 5,32$ I, 7 I I and the expenditures $\$ 5,366,785$, leaving a balance of cash on hand January I, 1913 of $\$ 457,128$.

The inheritance tax law of 1905 and 1909 was slightly amended in 1911 ; and previous laws for the taxation of express companies, steam railways, insurance companies, and telegraph and telephone companies were revised. Foreign corporations must pay a fee of \$IO before doing business and the same annually, and their officers are liable jointly and separately. Banks and trust companies with savings departments must set apart assets equal to the aggregate-savings deposits, not liable for debts until all deposits are paid.

Education.- - A law of I9I I introduced manual training into all normal schools, and provided state aid for manual training in towns. The Washington state normal school at Machias, established by law in 1909, was opened in 1911. The percentage of illiteracy in 1910 among the population Io years of age and over was 4.1 (5.1 in 1900).

For the year ending June 30, I9I2 the school population was 214,348 ; enrollment, 139,957; average daily attendance, 107,768; length of the average school year, 163 days in primary and 173 in high schools; receipts, $\$ 3,509,269$ and expenditures, $\$ 3,151,917$.

In I9I2 a new gymnasium for Bowdoin College was completed and occupied.

Penal and Charitable Institutions. - In I.9 I I a board of trustees (five men and one woman) of juvenile institutions was created to manage the state school for boys and the industrial school for girls (formerly under separate management), and a board of seven hospital trustees, one a woman, to manage all state institutions for the insane and the feeble-minded. The wife, or the guardian of the children, of any prisoner convicted of desertion and employed at hard labour is to receive from the state 50 cents a day for the convict's labour.

History.-Frederick William Plaisted (b. I865; mayor of Augusta in 1906-10) was elected (I9ro) the first Democratic governor since 1882 , when his father held that office. $\mathrm{He}$ and the Democratic legislature were pledged to resubmit to the people the question of prohibition. The legislature repealed the Sturgis enforcement law of I905, under which a state commission enforced the prohibition clause; abolished the state agency for the sale of liquor; and (March $23 \mathrm{rd}$ ) submitted a constitutional amendment providing for local option and repealing the clause (adopted 1884 ) prohibiting the sale of intoxicating liquors. The amendment was defeated (Sept. II, I9II) by 60,853 to 60,095 votes. It was first reported adopted, through a clerical error. Every city, Calais excepted, voted for the amendment. At the same election the Davies direct primary law (for all state and county officers and United States senators) was adopted $(65,300$ 
votes to $2 \mathrm{I}, 700$ ), as was a constitutional amendment making Augusta the permanent capital. The repeal of prohibition was shelved for the time by the rejection in the legislature (March 23, I912) of another local option amendment (passed by senate 18 to 8 ; vote in house, $7 \mathrm{I}$ for, 64 against - a two-thirds vote was necessary), and by the defeat (Sept. 9, r912) of Governor Plaisted by 3,300 plurality $(67,748$ to 71,043$)$ for William T. Haines, Republican, state attorney-general in $1896-1900.1$ One seat in Congress (3rd District) was won from the Democrats by the Republicans, the seats now being held by three Republicans and one Democrat (2nd District). There was no state Progressive ticket, many of the Republican nominees being Progressive in sympathy. In the November election Wilson carried the state, by 5 I, II 3 votes to 48,493 for Roosevelt, 26,545 for Taft, and 2,54I for Debs (I,758 in I98).

In I9I I (Jan. I th) Charles Fletcher Johnson (b. I859), Democratic candidate for governor in 1892 and 1894 , was chosen U.S. senator to succeed Eugene Hale (b. 1836 ), Republican, who had served in the United States Senate since I88r; and upon the death of William Pierce Frye (I83I-I9II; Republican; senator since r88I and repeatedly president protem. of the Senate) Obadiah Gardner (b. I852), Democratic candidate for governor in 1908 and (against Johnson) for senator in I9II, was appointed (April 3, I9I2) for the unexpired term to March 4, I9I3. To succeed him, Edwin Chick Burleigh (b. 1843; governor, I889-93; representative in Congress, I897-I9I I), Republican, was chosen by the Republican primaries on June $\mathbf{I}$ th (when the Democrats renominated Gardner) and by the legislature January I5, I9I3.

Three ex-governors of the state died in I9I 2: on February 3rd, Frederick Robie (b. 1822), governor in $188_{3}-87$; on March 16 th, John Fremont Hill (b. I 855), a publisher and capitalist, governor in $190 \mathrm{r}-05$, and prominent in the national organisation of the Republican party; and on June 2 2nd, Henry Bradstreet Cleaves (b. I 840 ), who served in the Civil War and was state attorney-general in I880-85 and governor in $1893-97$.

Bibliography. - Acts and Resolves (Augusta, I9II); other state reports.

\section{MARYLAND}

Population (ז́г) 1,295,346; 9\% more than in 1900; the absolute increase (107,302) was less than in any decade since $1860-70$. The number of negroes decreased from 235,064 ( $10.8 \%$ of the total) in 1900 to 232,249 (17.9\%) in 1910 ; foreign-born whites increased from $7.9 \%$ to $8.0 \%$. In density of population Maryland ranked 7 th with 130.3 persons to the sq. $\mathrm{m}_{\mathrm{i}}$. The rural population (in unincorporated places) was $45.5 \%$ of the total in 1900 and $43.8 \%$ in 1910 ; the urban in 1900 was $49.8 \%$ (in $\mathrm{I}+$ incorporated places with 2,500 or more) and in 1910, $50.8 \%$ (in 15 such places). In 1010 these I 5 places nere: Baltimore, 558,485; Cumberland, 21,839 ; Hagerstown, I6,507; Frederick, I0,4II; Annapolis, 8,600; Salisbury (town), 6,690; Cambridge (town), 6,407; Frostburg (town), 6,028; Havre de Grace, 4,212; Brunswick (town), 3.72r; Crisfield (town), 3,468; Westminster, 3,295; Easton (town), 3,083; Chestertown (town), 2,735; Westernport (town), 2,702.

A griculiure. - The acreage in farms decreased from 5,170,075 to $5,057,140$ between 1900 and $I 910$, and the improved land in farms from $3.516,352$ to $3,354,767$; the average farm acreage fell from I I2.4 to 103.4 ; and the value of farm property increased from $\$ 204,645,407$ to $\$ 286,167,028$ (\$163,451,614 land; $\$ 78,285,509$ buildings; $\$ 11,859,771$ implements; and $\$ 32.570,134$ domestic animals). Of the land area $79.5 \%$ was in farms. The average value of farm land per acre was $\$ 32.32$. Farms were operated largely by owners (33.519 by owners, I 4,416 by tenants and 988 by managers). In 1912 (preliminary estimates) the principal crops were: Indian corn, $24,455,000$ bi1. (670,000 A.); wheat, 8,985,000 bu. (599,000 A.); oats, $1,350,000$ bu. ( 45,000 A.); barley, 108,000 bu. $(4,000$ A.); rye, 418,000 bu. $(27,000$ A.); luckwheat, 210,000 bu. (12,000 A.); potatoes, 4, I 44,000 bu. (37,000 A.); hay, 575,000 tons $(381,0 \%)$ A.) and tohacco, 17,160,000 llos. (26,000 A.). In 1909 (U.S. Census) the value of vegetables other than potatoes was $\$ 5.729,400$; of flowers and plants, $\$ 597,001$; of nursery products, $\$ 456,900$; of small fruits, $\$ 1,227,548$ (strawberries, $\$ 1,070,072$ ); of orchard fruits, $\$ 1,517,400$ (apples, $\$ 902,077$ ); of grapes, $\$ 53,498$. On January 1, 1912 there were on farms

1 The Sorialist candidate for governor received 2,I10 votes; the Prohibitionist, 1,204.

2 See E. B. xvii, 827 et seq. 
103,000 horses, 23,000 mules, I68,000 milch cows, I 19,000 other neat cattle, 230,000 sheep, and 345,000 swine. The Federal department of agriculture in I9I I-I 2 carried on breeding experiments of poultry, of Barbados sheep, and of native and Saanen goats at the experiment farm of the Bureau of Anima Industry at Beltsville. The state horticultural department has been campaigning against the importation to the state of nursery plants infested by brown-tail moth and other pests. In 1911 the legislature voted aid to the high schools which give instruction in agriculture. In 1912 the appointment of a Maryland country life commission of seven members was provided for. The legislature provided for a state biological laboratory (after 1912) to test serums, etc., and passed a law for the inspection, analysis and regulation of the sale of commercial fertilisers.

Mineral Products. - Total value, I9II, \$9,386,663. About two-thirds of this was the value of coal $(\$ 5,197,066 ; 4,685,795$ tons-considerably less than in 1910) and of iron ore (not separately reported). Clay products were valued at $\$ 1,772,434$, of which $\$ 1,518,023$ was the value of brick and tile. Mineral waters (bottled at 12 springs, including 2 resorts) were valued at $\$ 150,966,-47 \%$ more than in 1910 .

Manufactures. - In 1904-09 the number of establishments increased from 3,852 to 4,837 and that of persons engaged in manufacturing from 107,303 (94, I 74 wage-earners) to 125,489 (107,92I wage-earners); the capital invested from \$20I,878,000 to \$251,227,000; and the value of products from $\$ 243,376,000$ to $\$ 315,669,000$. In 1909 first in value among the prod-

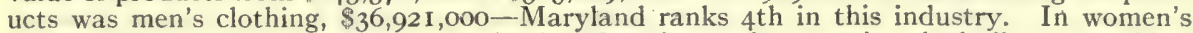
clothing $(\$ 4,35 \mathrm{I}, 000)$ the state ranked $8 \mathrm{th}$. Canning and preserving, including vegetables, fruits, fish and oysters, pickles, etc., is a typical industry; the value of the output was \$13,709,000. Among other larger products were: slaughtering and meat-packing products, $\$ 13,683,000$; lumber and timber products, $\$ 12,134 ; 000 ;$ foundry and machine-shop products, \$I I,978,000; tobacco, \$10,559,000; fertilisers, \$9,673,000; flour and grist-mill products, $\$ 9,268$,00o; steam-railway car construction and repair, by railway companies, $\$ 9,059,000$.

All industries are largely centred in Baltimore, the value of whose product was $\$ 86,978$,000 , ranking the city $\mathbf{I} 3$ th in the country. Other important cities were: Cumberland, \$4,534,0o0; Hagerstown, \$3; I97,000; and Frederick, \$2,9I I,000.

Transportation.--Railway mileage, January 1, 1912, I,473.II. In 1912 an extension of the Western Maryland was completed, $87 \mathrm{~m}$., connecting Cumberland and Connellsville and forming an important trans-Allegheny line with connections with New York Central lines. The legislature of 1912 appropriated $\$ 300,000$ a year for public roads and $\$ 50,000$ for the completion of State Road No. I; and \$75,000 to connect the Maryland system of good roads with the proposed State Boulevard of Delaware. In 19 II the Federal government finished widening the Fort McHenry channel near Baltimore.

Legislation.- The legislature met in regular session from January 3 to April I, I9r 2. It submitted for ratification at the general election in I9I3 constitutional amendments providing for the method of condemning private property for public use; and allowing the legislature to excuse from penalty the seller of a vote and putting all the penalty on the briber. Primary and election laws were repeatedly amended, but the old distinctions between different counties were kept in all these acts. A new registration with party affiliations was required; bribery, intimidation and corruption were forbidden at primaries. A provision was made for first and second choice vote for nominees for state offices. A presidential primary act requires delegates in the state convention to vote for the candidates chosen by the vote of the district or county "as long as in their conscientious judgment there is any possibility" of their being successful, and the same requirement is made of delegates to national conventions, but these delegates may go uninstructed, and on presidential preference ballots there must be a separate column headed "For an uninstructed delegate." A new corrupt practices act was passed limiting a candidate's expenditures to \$10 per thousand registered voters (qualified to vote for the office in question) up to 50,000 and $\$ 5$ per thousand above 50,000. Agents must file statements within 20 days and candidates within 30 days, of their expenditures at primaries or other elections, Any .promise made by the wife of a candidate is to be considered as coming from the candidate. Three voting machines were authorised for use in Baltimore.

In 1912 the "Rule in Shelley's case" (see E. B. xxiv, 832) was abolished, as had previously been done by almost every other state.

The powers of the public service commission were increased and it may order the issue of excursion, commutation or of joint interchangeable mileage tickets. Occupational diseases must be reported by physicians to the state board of health. Workmen and employers may contract that an employee may be insured against death or accident, and the employer is thus relieved from damages. The benefits under this act are in case of death three years' 
wages, but not less than $\$ 1,000$ (if there are no dependents not less than $\$ 75$ nor more than $\$ 100)$; in case of total disability $50 \%$ of the weekly wages after the first week during the period of disability. In manufacturing, mercantile, mechanical, printing, baking and laundering establishments women are not permitted to work more than to hours a day or 60 a week (the old to hour law applied to cotton and woollen mills only and was practically a dead letter); nor more than 8 hours a day if any work is done before 6 A.M. or after 10 P.M.; nur continuing more than 6 hours without a half-hour interval, unless the working day is only $6 \frac{1}{2}$ hours. Allegany county is excepted; in establishments in that county where the average number of hours for the year is not more than 9 hours a day, there may be overtime during 6 weeks because of seasonal demands. A new child labour law forbids the employment of children under 14 in most establishments except canneries and in any establishment during school hours. Children under 12 may not work in canneries nor children under 16 in dangerous employments, nor without employment certificates. Children under 18 may not be cmployed in certain very dangerous employments such as the manufacturing of explosives, nor in places where liquor is manufactured or sold, and no minor may be employed in a harroom. No girl under 18 is to be employed in work where she must stand continually. In cities over 20,000 no messenger under 18 is to be employed between 10 P.M. and 6 A.M. Boys under 12 and girls under 16 may not be employed in selling newspapers in cities of 20,000 or more except that boys may deliver papers on regular routes outside of school hours. laws were passed for the collection of vital statistics; regulating the sale of narcotic drugs; forlidding the use of common drinking cups in public places and on railway trains, and requiring the registration and licensing of midwives. A bill extending local option in regard to the sale of intoxicating liquor to counties not prohibiting such sale passed the lower house but was defeated in the senate (April I).

Finance. - Two acts of 1910 provided for an oyster tax-one levying a tax of one cent a bushel and the other a tax of two cents. The court of appeals declared the latter law unconstitutional and a considerable part of the taxes collected in I9I I were restored. A loan of $S_{1,000,000}$ dated January I, I9I4 was authorised to refund a state debt at $4 \%$ or less. A luan of $\$ 400,000$ for public buildings was authorised in 1912 and $\$ 600,000$ was appropriated for the payment of the interest on the public debt. On September 30, 1912, there was a b. lance of $\$ 1,826,230$ ( $\$ 1,471,521$ at the beginning of the fiscal year); the receipts for the year were $\$ 8,908,454$ and the expenditure, $\$ 8,553,745$. The state debt was: net $\$ 5,880,967$; gross $\$ 13,028,096$. In 1912 the banking department published the "first annual roll of honor" of state banks and trust companies, to encourage substantial surplus funds.

Education.-A general retirement law of I9I2 for public school teachers gives a pension of $\$ 200$ a year to disabled teachers over 60 , who have served for 25 years and who have no means of comfortable support. Special laws create boards of trustees for teachers' retirement funds in Baltimore county and in Allegany county. Teachers are to elect whether they come under the terms of the law or not. Funds are to be raised by assessments on teachers' salaries; the maximum assessment is $\$ 28.80$ a year in Baltimore county and $\$ 18.00$ in Allegany county. Retired teachers are to receive a salary (not a pension) equal to one half the average annual salary for the last 5 years (between $\$ 360$ and $\$ 600$ in Baltimore and between $\$ 200$ and $\$ 400$ in Allegany county). The minimum salary for white teachers of ten pupils or more, except in Garrett county, was set at $\$ 300$ a year. A stricter school attendance law was passed referring especially to the city of Baltimore but capable of extension to most of the other counties. A loan of $\$ 600,000$ was authorised for land and buildings (at Towson, probably open in 19I4) of the state normal school, which is to be moved from Baltimore.

'The annual appropriation for schools, including normal schools, the retired teachers' fund and the department of education, was $\$ 1,+50,000$. Johns Hopkins University received $\$ 600,000$, and an annual appropriation of $\$ 50,000$ for free scholarships in applied science or advanced technology; was required to erect a technology building (begun in 1912), to cost with its equipment $\$ 600,000$; and received its usual grant of $\$ 25,000$ a year for general schelarships. (On October 25, I912 the University received \$200,000 from James Buchanan Brady for a urological institute. On April 10, 1912 Ira Remsen (see E. B. xv, 46I, footnote) resigned the presidency of the university.

For the year ending July 3I, I9I2 the school population was 415,908; the enrollment in public schools, 228,425; average daily attendance, 146,408; and average length of school year, 9.35 months. The total receipts were $\$ 4,356,542$ and the expenditures $\$ 4,351,046$.

In 1910 of the totil population 10 years and over $7.2 \%$ were illiterate $(11.1 \%$ in 1900$)$. Or white's the percentage was 3.7 (5.2 in 1900); of negroes 23.4 (35.1 in 1900).

Penal and Charitable Institutions. - In 1912 a commission was appointed to investigate the penal laws and penal system of the state. The legislature made, as it usually does, large appropriations for private charities; appropriated \$15,000 for the purchase of Pine Bluff Sanitirium, near Salisbury, to be used as the Eastern Shore State Tuberculosis Sanitarium; $\$ 2(\%), 000$ for a state hospital on the Fastern Shore near Cambridge, Dorchester county; and for additional accommodations, buildings, etc., the following sums: \$150,000 for the training school for feeble-minded at Owings Mills, hereafter to be called the Rosewood state training school; $\$ 175,000$ for the Hospital for the Negro Insane (opened 19II) at Crownsville, hereafter to be called the Crownsville Hospital; \$100,000 for the Hospital at 
Catonsville, which is to be called the Spring Grove State Hospital, and $\$ 175,000$ for new buildings at the Springfield State Hospital at Sykesville. To cover these appropriations for state hospitals the I9I2 legislature authorised a loan of $\$ 800,000$, in addition to a loan of $\$ 600,000$ authorised in 19I0. A state miners' hospital is to be established at Frostburg. For maintenance $\$ 125,000$ was appropriated for the Maryland Tuberculosis Sanitarium at Sabillasville (1908).

History.-In Baltimore there was an exciting contest at the primary and regular elections in IgII. In the former (April 4) John Barry Mahool (b. I87o; mayor since 1907), a Democrat not entirely satisfactory to the "machine," was defeated for renomination by James Harry Preston (b. I 860 ; speaker, house of delegates, I 894 ) by 9,000 out of 50,000 votes cast; and the Republican "reform" candidate, Charles $H$. Torsch, was beaten by the nominee of the regular organisation, E. Clay Timanus (about 17,000 to 4,600 votes). Preston was elected by a small plurality. The first state primary (August 26) under the new law nominated for governor Arthur Pue Gorman (a son of the late Senator Gorman), whose supposed relations with Democratic boss rule in Baltimore worked against him in the campaign, and Phillips Lee Goldsborough, Republican, who was elected (November 7, I9II) by a plurality of 3,000 (I06,392 votes to 103,395 for Gorman) and who succeeded Austin L. Crothers ${ }^{1}$ (b. I860; Democrat) in January for a four-year term. All the other state officers and a large majority of the state legislature were Democrats. Goldsborough came out for Roosevelt early in the year, and Roosevelt carried the presidential preference primary (by 29,000 votes to 26,000 for Taft). Speaker Champ Clark was the Democratic choice for presidential candidate. The Democratic National Convention was held in Baltimore. The Progressive party nominated a full ticket for Congress but none was elected, the Democrats carrying the 6 districts including the 5 th, the only one which sent a Republican to the 62 nd Congress. The state legislature (to be elected in I913) in r914 will choose a successor to Isidor Rayner (I850-r912), United States senator from I905 to his death, November 25, I91 2; ad interim the governor appointed (November 29) a Republican, William Purnell Jackson (b. I868). Woodrow Wilson received the electoral vote of the state, with ri 2,674 votes to 57,786 for Roosevelt, 54,956 for Taft, and 3,996 for Debs (2,323 in I908). Taft ran third in Baltimore, but second (with nearly $60 \%$ more votes than Roosevelit) in the counties.

In St. Mary's county a campaign for higher liquor licence, led by the Roman Catholic clergy, was unsuccessful, 857 to 6I I votes (August 3, I9 I 2).

In Baltimore at the primary election of August 29, I9I I there were palpable frauds: in the 8 th precinct of the 23 rd ward no votes were returned for Thomas F. McNulty, who had opposed the party organisation candidate for sheriff and who secured affidavits from who had voted for him in the precinct. On September 22nd, a grand jury presented indictments against six election officials of the precinct; and on December 29 th, it indicted the officials of 38 other precincts in which Independent Democratic candidates seemed to have been defrauded. One judge (Republican) of the 8 th precinct of the 23 rd ward was acquitted (June Io I912); three others were found guilty and sentenced to imprisonment and fine (August $22 \mathrm{nd}$ ), but their cases were carried to the state court of appeals.

A new charter submitted to the legislature by the Baltimore Committee of Fifty was not passed. In April-July г 9г 2 there was a stevedores' strike in Baltimore, in which employees of the Baltimore Copper Smelting and Refining Company joined (May I.5), ending with a victory for the strikers. The stevedores received an advance of $2 \frac{1}{2}$ cents

${ }^{1}$ Crothers studied law at the University of Maryland, was admitted to the bar in 1880 , was state senator in 1897-1901, judge of the 2nd Circuit in 1906 and governor 1908-12. He died May 25, 1912.

${ }^{2}$ Rayner was of Bavarian ancestry, was educated at the University of Virginia, was state senator in $1886-87$, representative in Congress $1887-89$ and in $1891-95$, and state attorney-general in 1899-1903. He was counsel to W. S. Schley in the Santiago investigation (I90I). In state politics he opposed the Gorman machine but secured a Democratic nomination to the Senate; and in the United States Senate he worked for arbitration, for the abrogation of the treaty with Russia, for tariff reform, and against monopolies, and was a caustic critic of Roosevelt and one of the ablest debaters on the floor. 
an hour. A Baltimore ordinance (Dec. 1910) forbidding a coloured family to live in a block where the majority of the tenants were white, was declared invalid early in I9II, and on April 6th the city council provided that one " race " be excluded as soon as a block is inhabited entirely by the other, and-under a clause in the earlier law-forbade whites moving into blocks where the tenants were mostly negroes. A constitutional amendment (the "Poe" measure, prepared by Edgar Allan Poe, Democrat, attorney-general), practically disfranchising the negro, was defeated at the November election in I9II, largely through the efforts of Senator Rayner. On Christmas Day rigr a negro accused of murder was lynched at Brooklyn, near Baltimore.

In conformity with an act of the legislature of that year the mayor of Baltimore appointed on November 25, r910 a "Commission on City Plan." Plans for a civic centre have been tentatively approved, and in the autumn of IgI 2 actual construction of a street to serve as an approach to it was well under way:

Bibliography. - Laws (Baltimore, 1912); other state documents; Lady Edgar, A Colonial Governor in Maryland: Horatio Sharpe and His Times, 1753-73 (New York, 1912); B. C. Steiner, Maryland under the Commonwealth (Baltimore, I9I1).

\section{MASSACHUSETTS ${ }^{1}$}

Population (I910), 3,366,4 I6 (51.4\% of the total for New England), an increase of $20 \%$ since 1900 . There was an increase in I900-Io in the percentage of foreign born whites (29.9 to $3 \mathrm{r} .2)$ and of whites of foreign parentage ( 32 to 34.8$)$; but whites of native parentage decreased from $36.8 \%$ to $32.8 \%$, and negroes from $\mathrm{I} .2 \%$ to $\mathrm{I.I} \%$. In density of population the state ranked 2 nd to Rhode Island only (4I8.8 to the sq. m.). The highest density was $\mathrm{I}, 340.9$, in Suffolk county (including Boston). Incorporated places with less than 2,500 inhabitants each comprised $7.2 \%$ of the total $(8.5 \%$ in 1900$)$. More than half the total ( $46 \%$ in I900) was in cities or towns of more than 50,000 ; there were I04 cities and towns, each with 5,000 inhabitants or more, of which 55 had I0,000 or more each, and 25 had 25,000 or more. These 25 were: Boston, 670,585 (in I900, 560,892); Worcester, I45,986; Fall River, II9,295; Lowell, I06,294; Cambridge, I04,839; New Bedford, 96,652; Lynn, 89,336; Springfield, 88,926; Lawrence, 85.892; Somerville, 77,236; Holyoke, 57,730; Brockton, 56,878; Malden, 44,404; Haverhill, 44,I15; Salem, 43,697; Newton, 39,806; Fitchburg, 37,826; Taunton, 34,259; Everett, 33,484; Quincy, 32,642; Chelsea, 32,452; Pittsfield, 32,121; Waltham, 27,834; Brookline (town), 27,792; Chicopee, 25,401.

Agriculture.-The acreage in farms decreased from $3,147,064$ to $2,875,94 \mathrm{I}$ between 1900 and 1910 and the improved land in farms from $1,292,132$ to $1,164,501$; the average farm acreage fell from 83.4 to 77.9 ; and the value of farm property increased from $\$ 182,646,704$ to \$226,474,025 (\$105,532,616 land; \$88,636,149 buildings; \$11,563,894 implements; \$20,741,366 domestic animals). Of the land area $55.9 \%$ was in farms. The average value of farm land per acre was $\$ 36.69$. Farms were operated largely by owners $(32,075$ by owners, I, 863 by managers and 2,979 by tenants). In 1912 (preliminary estimates) the principal crops were: Indian corn, $2,115,000$ bu. ( 47,000 A.); oats, 272,000 bu. (8,000 A.); rye, 56,000 bu. (3,000 A.); buckwheat, 42,000 bu. (2,000 A.); potatoes, 3,380,000 bu. (26,000 A.); hay, 596,000 tons $(477,000 \mathrm{~A}$.$) ; and tobacco, 9,860,000 \mathrm{lbs}$. $(5,800 \mathrm{~A}$.$) . On January I, 1912,$ there were on farms 64,000 horses, I67,000 milch cows, 80,000 other neat cattle, 35,000 sheep, and 117,000 swine. In 1909 (U.S. Census) vegetables (other than potatoes) had an acreage of 37,220 and a value of $\$ 6,190,000$; flowers, plants and nursery products, 2,750 acres, $\$ 3,061,000$; small fruits, 9,552 acres, $\$ 1,676,790$ (cranberries, 6,577 acres; $\$ 1,062,205$ ); orchard fruits, \$2,074,270 (apples, \$1 780,290 ).

In place of the cattle bureau of the state board of agriculture a department of animal industry was created in I9I2. A law of I9II provides for the appointment of a state inspector of apiaries and for the suppression of infectious or contagious diseases of bees. For the suppression of gypsy and brown-tail moths $\$ 150,000$ was appropriated in 1911 and $\$ 325,000$ in 1912. An act of 1911 established a state bird and game preserve, and in October I912 the commissioners on fisheries and game reported 15,000 acres acquired for it.

Fisheries. - In 19 I I $93,760,109$ lbs. of fish with a total value of $\$ 2,575,282$ were landed at Boston; this included 13I,200 lbs. of salt fish, and of fresh fish, 47,687,300 lbs. haddock, $21,704,300 \mathrm{lbs}$. cud, 5,095,840 lbs. hake, 2,916,800 lbs. cusk, and 2,588,694 lbs. mackerel. At Gloucester the total was $91,393,258$ lbs. (value $\$ 2,449,215$ ), of which $40,157,577$ was

${ }^{1}$ See E. B. xvii, 850 et seq. 
salted; the principal varieties of fresh fish were: cod, 12,272,843 lbs.; pollock, 9,651, I78 lbs.; haddock, 9,024, I02 lbs.; hake, 6,759,243 lbs.; cusk, 3,516,703 lbs.

Mineral Products. - Total value, I9I I, \$6,623,077. The principal item was stone, valued at $\$ 3,692,000$, - granite being valued at $\$ 2,361,624$, and trap rock and sandstone being next in importance. Clay products were valued at $\$ 1,700,287$, of which $\$ 1,471,761$ was the value of brick and tile; lime at $\$ 695,662$, ranking the state 6 th; and mineral waters from 56 springs, at $\$ 2$ I 8,870 .

Manufactures. - In 1904-09 the number of manufacturing establishments increased from $I 0,723$ to $I I, 684$ and that of persons engaged in manufacturing from 532,481 to 644,399 (wage-earners from 488,399 to 584,559 ); the capital invested from $\$ 965,949,000$ to $\$ 1,2790^{-}$ $687,000(32.5 \%)$; and the value of products from $\$ I, 124,092,000$ to $\$ 1,490,529,000(32.6 \%)$. In 1909 the state ranked 4 th (as in 1889 and 1899 ) in manufactures.

There were reported 76 separate industries each with a product valued at $\$ 500,000$ or more; and of these 4 exceeded $\$ 50,000,000,6$ more exceeded $\$ 25,000,000$ and 16 more exceeded $\$ 10,000,000$. The most important industry with a value $(\$ 236,343,000)$ more than oneseventh the state's total, was the manufacture of boots and shoes; the state was the largest producer in the Union, with $46.1 \%$ of the country's total. Cotton goods ranked second with a value of $\$ 186,462,000$; in this industry, in woollen, worsted and felt goods $(\$ 141,967,000)$ and cordage, twine, jute and linen goods $(\$ 16,632,000)$, as well as in all textiles combined $(\$ 387,063,000)$, Massachusetts ranked ist. Other important manufactures were: foundry and machine-shop products, $\$ 86,926,000$; slaughtering and meat-packing, $\$ 44,403,000$; paper (especially fine writing paper) and wood pulp, $\$ 40,097,000$; tanned, curried and finished leather, \$40,002,000; electrical machinery, etc., \$28, I 43,000; lumber and timber products, $\$ 23,026,000$; rubber boots and shoes, $\$ 18,722,000$; men's clothing, $\$ 18,314,000$; confectionery, $\$ 15,266,000$; jewelry, $\$ 15,211,000$; and hosiery and knit goods, $\$ 14,736,000$. The principal manufacturing cities were: Boston, \$237,457,000; Lawrence, \$79,993,000 $(73.2 \%$ being woollen and worsted goods, ranking the city Ist in the United States in this product); Worcester, $\$ 77,148,000$; Lynn, \$71,503,000 (65.3\% boots and shoes); Fall River, \$64, I 46000 ( $757 \%$ cotton goods); Lowell, \$60,271,000 (41.1\% cotton goods); New Bedford, \$53,237,840 (79.8\% cotton goods); Brockton, $\$ 45,972,000$ ( $85.5 \%$ boots and shoes); Cambridge, $\$ 44,227,000$; Holyoke, $\$ 40,097,000$ (chiefly textiles and fine writing paper); Somerville, $\$ 38,687,000(80.8 \%$ slaughtering and meat-packing); Haverhill, $\$ 35,377,000(82.4 \%$ boots and shoes); Springfield, $\$ 31,773,000$; Fitchburg, $\$ 23,252,000(40.2 \%$ textiles); Chicopee, \$19,2 I 9,000; Chelsea, \$1 7,002,ooo; Peabody, \$1 5,549,000 (82.9\% leather); Taunton, \$15,380,000; Pittsfield, \$15,2 15,000; Attleborough, \$15, I60,000 (48.8\% jewelry); Salem, \$ 1 4,576,000; and Plymouth, \$ I I,61 8,000.

Transportation.-Railway mileage, January I, I912, 2,135.1. In May I9I I the electric installation in the Hoosac Tunnel was completed. In 1912 the highway commission was authorised to issue $\$ 5,000,000$ in scrip for construction of state highways in $1913-17$, inclusive, not more than $\$ 1,000,000$ to be expended in any one year. The Cape Cod Canal (see E. B. xvii, 854a) was five-eighths finished in 1912; the time for its completion was extended to June I9I4. In I9I I the state dredged in Hingham harbour an anchorage basin $6 \mathrm{ft}$. deep and a channel $75 \mathrm{ft}$. wide and $6 \mathrm{ft}$. deep to connect this basin and the channel made by the Federal government, which the state widened from 50 to $75 \mathrm{ft}$. The more important recent improvements in Massachusetts waters under Federal charge are: new jetties at Newburyport, under an Act of $1910,85 \%$ completed in 1912; the removal of ledges in Gloucester harbour, begun in 1911 and $10 \%$ completed in 1912; and the improvements of channel and turning basin in Lynn harbour, 37\% completed in 1912; deepening the lower Mystic river to $25 \mathrm{ft}$., completed in $191 \mathrm{I}$; widening and straightening Weymouth Fore river, under Act of February 27, 191 I (dredging $97 \%$, ledge $60 \%$ completed in 1912) and dredging Weymouth Back river, completed in 1912; removal of shoals in Fall River harbour, begun in I9II and 50\% completed; dredging the channel of Boston harbour to $35 \mathrm{ft}$. depth, completed 1912 and removal of ledges at the south edge of the channel, $25 \%$ completed in 1912 . A Board of Port Directors of Boston created in 1911 is to expend $\$ 9,000,000$ in improving the harbour; on December 24 , I912 they voted to expend $\$ 3,000,000$ for a drydock in South Boston large enough to accommodate vessels $1,000 \mathrm{ft}$. long and $\mathbf{r} 20 \mathrm{ft}$. wide. A state commission on a free ship canal between Boston and Narragansett Bay, to be built by the Federal government with the co-operation of the state, reported in May I9II adversely.

Legislation.-Regular sessions of the legislature were held both in I9I I and I9I2. In I9I I two constitutional amendments were adopted, after submission to popular vote; one providing for the use of voting machines if the right of secret voting be preserved, and the other authorising cities to take by condemnation proceedings more private property than might actually be required to widen public thoroughfares. The I 912 session submitted to the people an amendment to disqualify from voting those convicted of corrupt practices in respect to elections - carried, 204,892 votes to 85 , 689- and one permitting the legislature to tax wild or forest lands to "develop and conserve the forest resources of the Commonwealth," which was adopted by 200,819 
votes to 70,923 . Two other amendments-one making women eligible as notaries and one permitting the legislature to refer statutes to the people for their approvalwere referred to the next session. The legislature ratified (May 22, 1912) the proposed amendment to the Federal Constitution calling for the popular election of United States senators. In IgI I the lower house approved, but the senate defeated by one vote, the proposed Federal amendment providing for an income tax. In I9I the number of associate justices of the superior court was increased from 24 to 27. In I9I2 a commission of economy and efficiency was established.

In I9 I a direct primary was required for all state officers, excluding presidential electors but including the district members of state party committees and delegates to the state party conventions. A law of 1912 requires the primary election of delegates to national party conventions in presidential years and the preferential primary for candidates for the presidency. The corrupt practices act of 1907 was amended (I9I I) by the definition of "personal expenses" and by limiting expenditure for primary or local election to $\$ 25$ for each 1,000 voters qualified to vote for the office-but permitting an expenditure of as much as \$150 no matter how few voters there are and no more than $\$ 5,000$ no matter how many voters there are. In 1912 the law of 1908 prohibiting political contributions by business corporations was made more explicit.

The provisions of the civil service law in regard to police were extended to the superintendent or chief of police in all cities except Boston and in all towns accepting the civil service law, and the removal, suspension, or transfer of any member of the civil service (except in Boston police, the district police, or the Metropolitan park commission police) is to be reviewed on petition in a police, district, or municipal court.

The governor was required to set apart the 14 th of June as flag-day, each year, and the r2th of October (Columbus Day) was made a legal holiday.

In 1912 the legislature established a state board of labour and industries. A commission on the employment of women and children and especially on the establishment of wage boards and the question of minimum wage was created, and a 1912 law makes the commission permanent and provides that, if it decides that wages are too low in any industry, it may establish a wage board to report a minimum wage, which the commission may approve after public hearing and which may be reviewed by the superior court upon an employer's filing a declaration that the payment of this minimum wage would endanger the prosperity of his business. A minimum wage was set for employees of the Metropolitan parks and the water and sewerage departments. The 8 hour day must be observed by contractors working for the state or for a municipality that has adopted the 8 hour law, but the act excepts the printing of ballots and work in public institutions. Women and children under 18 are not to work in manufactories or mechanical establishments more than 54 hours (formerly 56) a week, nor more than 10 hours a day, but in seasonal employments they may work for 58 hours a week if the average is not more than 54 a week. Women and children under 18 are not to work more than 56 hours a week on the "altering or repairing of garments" in clothing factories owned by a store proprietor and in connection with a clothing store. The hours for street railway employees were made 9 or $9 \frac{1}{2}$ a day on car platforms and all work over 9 hours a day must reccive extra pay. No one under 21 may be employed in messenger service, except in newspaper offices, between IO P.M. and 5 A.M. No illiterate minor is to be employed in factories, workshops, mechanical, or mercantile establishments without a certificate that he is 16 or over (I9II), and illiterate minors under 21 (formerly I8) must attend evening school (1911). The age and schooling certificate must show that the child employed can read and write English as it is required for admission to the fourth grade (I9II). The board of education was directed (1911) to report in January 1913 on the need of vocational and part time schooling for working children, especially between the ages of 14 and 17 .

By far the most important recent labour legislation has been in regard to pensions and retirement of employees. A retirement sy'stem for state employees-practically an assisted old age pension - was provided. Contributions from employces for the fund are voluntary in the case of present employees but are compulsory for those entering the service after the passage of the act. Retirement may take place after service of 15 years on the recommendation of the head of the department. The employees share not only in the expenses but in the administration. One member on the board represents employees, as one does the employers; the third is the state treasurer. The system was extended to municipalities and to counties, and any town, on the acceptance of the act by the voters in 1912, is permitted (1) pension an employee incapacitated for labour who is 60 years old and who has been employed by the town for 25 years. Besides, several acts were passed providing for the retirement on half pay of veterans of the Civil War in municipal employ.

$\Lambda$ law for (elective) state insurance against accidents was passed in I9II and slightly amended in 1912. If the employers choose the insurance system, the common law defences are abrogated. To he compensated a disability must last for more than two weeks. The amount of damages recoverable was increased in 1912. In case of death, it is 300 times 
the half weekly wages, but not less then $\$ 4$ nor more than $\$$ io a week; and if there are no dependents, \$200; in case of total disability, 50\% of the weekly wages (not less than \$+ nor more than $\$ 10$ a week, with a limit of $\$ 3,000$ or 500 weeks); in case of partial disability, $50 "$. of the weekly wage loss, but not more than $\$ 10$ a week nor longer than 300 weeks. All accidents resulting in personal injury must be reported by the employer to the industrial accident board within 96 hours. The penalty for loss of life of a railroad employee through the negligence of the corporation employing him was increased from $\$ 5,000$ to $\$ 10,000$ (I9I2). The law of desertion and non-support was made uniform in I9II.

The state inspector of health is required to inspect factories for proper lighting and ordet necessary changes if he suspects damage to the eyes of employees (I9II). Women may nor work in mercantile, mechanical, or manufacturing establishments two weeks before or four weeks after childbirth (I9II). The state board of health is authorised to regulate the cmployment of women in core rooms (1912). A homestead commission was established to report (in 1913) on building homesteads for workmen in suburbs of cities and towns. A tenement house act for towns was passed (1912). The state board of health received $\$ 10,000$ in 1911 and $\$ 5,000$ in 1912 for the investigation of infantile paralysis. A state subsidy of $\$ 5$ a week was voted (I9II) for every indigent patient in a hospital (or ward, 1912) for tuberculosis maintained by a city or town; and cities and towns with more than I0,000 inhabitants must support dispensaries for needy tubercular patients. The law for the prevention of infantile blindness was made more definite in 19i2. A medical milk commission may be incorporated for the supervision of the production of milk for sick rooms or infants (I9II). The cold storage of certain food products was regulated (I9I2).

Local boards of health were required to establish sanitary stations in cities or towns with populations above IO,OOO (I9II). Drinking water and individual cups are to be furnished in all railroad cars in the state (I9I I and I9I2). The sale (except wholesale), the rental or the leasing of firearms is to be licensed by the mayor and council of each city, acting as a licensing board (I9II), and anyone who is arrested for felony and found in possession of a revolver or pistol without a licence is liable to imprisonment from one to ten years (I9II). The proposal to abolish capital punishment (which recurs annually) was defeated in 1912 by a much more decisive vote than usual ( 153 to 72 ).

Cities and towns were permitted (I9II) to establish art commissions. Boston was empowered to spend $\$ I_{1}, 000,000$ in six years for a high pressure fire service (I9I I). Justices of the Boston Municipal Court may retire at the age of 70 , if they have served 20 successive years, and may receive a pension equal to three quarters of their annual salary (I9II).

Hyde Park was annexed to Boston (19II). Lawrence (November 7, I9I I; 6,027 to 2,214 for change; 6,077 to 1,358 for commission charter over other charter subnitted) and Lowell (December I9, 19II) adopted new charters with commission form of government providing for recall, initiative and referendum and no partv names on municipal ballots; both went into effect on January I, 1912. The municipal board of control; a quasi-commission form of government, which had been in use in Chelsea for 3 years (ever since the fire of April 1908) was replaced November 7, I9II, by the old system of government by a mayor and aldermen; it is said that the large Jewish population thought itself insufficiently represented on a small board. Cambridge also defeated a commission charter drafted by the legislature (I9II) which provided for five department heads called "supervisors" (not commissioners) and for initiative, referendum and two choice nominations. The people of Pittsfield, with a choice between amending their old charter and adopting a new charter for government by mayor and aldermen or by commission form of government (1911) voied to amend the charter in force. The I9I2 legislature drafted a two plan act for Salem, giving the voters the choice between government by mayor and seven councilmen elected from districts and government by five commissioners elected at large. - Both forms provided for recall, initiative and referendum. At the state election in 1912 the voters chose the latter by $2,8,30$ to 746 votes. In 1912 the Metropolitan Plan Commission reported to the legislature recommending the constitution of a Metropolitan Planning Board.

Finance. - The state tax in I9I I was $\$ 5,500,000$ ( $\$ 1,880,395$ was on the city of Boston), and in $1912 \$ 6,250,000(\$ 2,137,000$ on the city of Boston). The I907 inheritance tax law was replaced by an act of 1912.1 False or exaggerated statements about business concerns

1 This act divides the beneficiaries into three classes and provides that in cases of those not near of kin - that is, not in the other two classes - the inheritance tax be $5 \%$ if the bequest be less than $\$ 50,000 ; 6 \%$ if it be between $\$ 50,000$ and $\$ 250,000 ; 7 \%$ between $\$ 250,000$ and $\$ 1,000,000$ and $8 \%$ if over $\$ 1,000,000$; that in cases of those in "Class $\mathrm{A}$ "- that is husband, wife, ancestor, descendant or daughter-in-law of the testator-the tax be $\mathrm{x} \%$ on a bequest below $\$ 50,000 ; 2 \%$ between $\$ 50,000$ and $\$ 250,000 ; 3 \%$ between $\$ 250,000$ and $\$ 1,000,000$, and $4 \%$ if the bequest is greater than $\$ 1,000,000$; and for those in "Class B" - that is brother, sister, nephew or niece of the testator, - $2 \%$ if the bequest is below $\$ 10,000 ; 3 \%$ between $\$ 10,000$ and $\$ 25,000 ; 5 \%$ between $\$ 25,000$ and $\$ 50,000$ and for greater amounts the same as for those not near of kin. In any case a bequest of $\$ I, 000$ or less is exempt from tax and so is a bequest to a charitable, educational or religious society whose property is exempt from taxation, or for the public use of any city or town in the Commonwealth. 
affecting the value of bonds are punishable by a fine of $\$ 500$, imprisonment for not more than ten years, or both. The office of supervisor of loan agencies was created and anyone who issues loans of $\$ 300$ or less at a rate, including interest and expenses, greater than $12 \%$ must secure a licence from the supervisor, who is authorised to fix the rates of interest. In I9II a law was passed against monopolies and one for the control and regulation of fraternal benefit societies. A new code for co-operative banks was adopted in 1912. There was in the state treasury December I, I9II, \$6,208,336. Receipts for the year were $\$ 48,054,457$ and expenditures $\$ 47,892,827$, leaving a balance, December 1 , $1912, \$ 6,369,965$.

Education.-A code adopted in $191 \mathbf{I}$ for state aided vocational schools, permits industrial schools to be established under the local school board (formerly only under special board) and to receive state aid, if approved by the board of education. The board of education was authorised to investigate the advisability of establishing and maintaining in Taunton or Attleborough a school for designing silverware and jewelry. ${ }^{1}$ The school committee of any city or town was empowered (I9II) to grant the temporary use of school buildings, out of school hours, for public educational purposes. Among the appropriations were: \$100,000 annually for ten years to the Massachusetts Institute of Technology in return for 80 free scholarshipsbut no appropriation in I9I7-2I unless by that time the Institute should have $\$ 1,000,000$ additional endowment; and $\$ 50,000$ annually to the Worcester Polytechnic Institute in return for 40 free scholarships, with a similar proviso in regard to I917-21, unless the Institute then have an additional endowment of $\$ 350,000$. The legislature authorised in 1912 the building of a model school for the Salem State Normal School, the contract for which was let in the autumn of I9I2; and the establishment of independent agricultural schools in Bristol county and in Essex county on the approval of the voters, which was granted in November 1912: in Bristol, 17,869 votes to 8,042; in Essex, 35,279 to 9,349 .

In the school year ending July I, I9I2 the school population between the ages of 5 and 15 was 577,160 ; the total enrollment (all ages), 546,914; the average daily attendance, 458,065; and the length of the average school year 9.35 months. Expenditures were $\$ 22,502,934$ $(\$ 3,733,729$ for new buildings, etc.).

The percentage of illiteracy in I9 Io of all 10 years and over was 5.2 ( 5.9 in 1900).

The Massachusetts Institute of Technology concluded arrangements in 1912 for removal to the Cambridge side of the Charles River Basin. It received several large gifts during 191 I-12: about \$500,000 from T. Coleman du Pont; the same amount from the widow of W. B. Rogers, the founder; $\$ 600,000$ from the Francis B. Greene Fund; $\$ 2,500,000$ from an anonymous benefactor; and $\$ 50,000$ from the bequest of Nathaniel Thayer of Lancaster, who left the same amount to the General Hospital and $\$ 250,000$ to the Boston Muscum of Fine Arts. It also received in 1912 from Theodore U. Vail the George Edward Dering collection (about 30,000 volumes) of electrical books; and a bequest (not available within $2 \mathrm{I}$ years) from C. H. Pratt of $\$ 750,000$ for a school of naval architecture and marine engineering. On October 10, 1912 work began on a new library (from plans by Horace Trumbauer) for Harvard University on the site of Gore Hall, the old library; it is to be a memorial to Harry Elkins Widener, who was lost on the "Titanic" and whose excellent collection of rare books was given to the University. In I9I2 work began on the new Germanic museum, and plans were approved and location fixed for three freshmen dormitories. A new house for the president was completed and occupied late in 1912. In March an anonymous gift was announced to the Graduate School of Applied Science of a new electrical laboratory for the study of high tension currents and a location and plans were decided on. In the same month the Collis P. Hluntington Memorial Hospital (for the study of cancer) was opened near the Harvard Medical School group of buildings on Back Bay, Boston. In April 1912, by the will of A. L. Rotch, the Blue Hill Meteorological Observatory with $\$ 50,000$ for maintenance was given to Harvard University. A bureau of research in municipal government was established at Harvard in 1911. Amherst College which has definitely returned to the humane or classical curriculum, in May 1912 chose as president, to succeed George Harris (b. 1844), who resigned November 16, I91 I, Alexander Meiklejohn (b. 1872), who graduated at Brown University in 1893, taught philosophy there and became dean in 1901. He was inaugurated at Amherst on October 16, 1912. On June 9, 1911 Ellen Fitz Pendleton (1). 1864), dean of Wellesley College, was elected its president, succeeding Caroline Hazard. Mount Holyoke College on October 8,1912 , celebrated with a pageant its 75 th anniversary and completed an endowment fund of $\$ 552,000$. Lemuel Herbert Murlin (b. I 86 I), president of Baker Iniversity, Baldwin, Kansas, in I894-19I1, was inatugurated president of Boston University, October 20, I9I1. By two acts of 1912 Wheaton Female Seminary (founded 1834 ) at Norton was authorised to hold $\$ 1,000,000$ of additional real and personal estate, to change its name to Wheaton College and to grant the degrees of A.B. and A.M.

Penal and Charilable Institutions. - The Board of Trustees of the Massachusetts Training Schools was established in I9 I to replace the separate boards controlling the Lyman School at IVestboro, the Industrial School for Girls at Lancaster and the Industrial School for Boys

1 No school had been established at the end of 1912, but certain evening courses were given in I9I I and 1912 in Taunton and North Attleborough schools for the benefit of silverware and jewelry designers-half the expenses being borne by the state. 
at Shirley (opened I909). Departments of defective delinquents were created at the Reform atory for Women, at the Massachusętts Reformatory and at the State Farm, and criminal defectives from other institutions are to be turned over to these departments. The supervision of wayward and delinquent children was transferred in 1912 from the state board of charity to a commission on probation. The use of solitary confinement rooms in reformatories was forbidden, and corporal punishment in the Lyman School was restricted. Prisoners of the state prison may be released on parole after serving two-thirds of the minimum term of two years, and the same provision was extended in I9I 2 to prisoners transferred from the state prison to the reformatory. The prison commissioner is required to arrange for the segregation of epileptic prisoners in any state institution. In I9I I Governor Foss frced so many convicts that the pardoning committee of the executive council adopted in I9I2 stricter rules governing pardons.

The state's appropriations for penal and charitable institutions are large and in almost every instance the appropriation carries a large amount from the receipts of the institution at the time in the treasury. The plan of making goods for public use by the labour of prisoners was enlarged in 1912. The Worcester. State Asylum is to be superseded by one on the Grafton Colony (opened 1903 as a branch of the Worcester Asylum), where additional build. ings are to be completed in 1915 . A commission was appointed in 1912 to report, in January, 1913, on the support of dependent minor children of widowed mothers. Experiments in the cases of inebriates and users of drugs which had been carried on for many years at the Foxboro State Hospital for the insane, led to the establishment in I9I2 of a separate institution for inebriates known as the Norfolk State. Hospital and comprising I,000 acres and three groups of buildings in the towns of Norfolk and Walpole. In 1912 the psychopathic department of the Boston State Hospital was established in its new building on the Fenway in Boston. In 1912 the Perkins Institution for the Blind became established in its extensive new buildings, begun in February, 1911 , in Watertown.

History.-In I9II and I9I 2 the majority of the legislature was Republican and so were all state officers except the Democratic governor, Eugene Noble Foss (b. I858), a prominent leather manufacturer and an advocate of tariff revision and reciprocity, who had been a member of the Federal House of Representatives in I9IO-II. In I9II he defeated Louis Adams Frothingam (b. I87I; speaker, state house of representatives I904-05; lieutenant-governor, I909), Republican, by 214,897 votes (36, r6o votes on Democratic Progressive ticket) to 206,795 ; the Socialist vote was 13,355 . All candidates for state office at this election (November 7 , I9I I) were chosen for the first time by direct vote at primaries, the later election of the conventions being a mere formal acquiescence in the primary nominations. In 1912 Governor Foss was renominated by the Democrats, getting 63,000 votes in the primaries to 36,000 for Pelletier, and was again elected, in November, by 193,184 to 143,597 for the Republican candidate, Joseph Walker, speaker of the state lower house in rgog-II, and I22,602 for Charles Sumner Bird (b. I 855), Progressive, a paper manufacturer. With Foss, a Democratic lieutenant-governor was elected (with 3,465 votes less than for Foss) for the first timeDavid I. Walsh, who had been defeated for the same office in I9I I by Robert Luce (b. I862), Republican. The Democratic candidate for secretary was elected, but the Republicans elected treasurer, auditor and attorney general. There will still be a Republican majority in the governor's council and a Republican plurality in the rgI 3 legislature (in which there will be I Socialist, from Haverhill, and 8 Progressives)-assuring the election of a Republican as United States senator to succeed W. Murray Crane (b. I853; governor I900-02; senator 1904-I3), who refused (May 2I) to be a candidate for re-election. The principal Democratic candidate for the senatorship had been John Francis Fitzgerald (b. I863; representative in Congress, I895-1901; mayor of Boston 1906-07 and I9I0-I.I). Republican candidates were ex-governor Eben S. Draper, William B. Plunkett and Congressmen John Wingate Weeks (b. I 86o; graduated U.S. Naval Academy $188 \mathrm{I}$; representative in Congress since 1905) and S. W: McCall. Weeks was chosen January I3, I9I3. On January I8, I9II, Henry Cabot Lodge, Republican, was re-elected U.S. senator.

The primary contest for the presidential campaign was marked by the speeches of President Taft and of ex-President Roosevelt in the state. Taft carried the preferential primary (May I, I91 2) by 3,655 votes but the 8 delegates-at-large for Roosevelt were chosen-apparently because $\mathrm{r}_{3}, 000$ ballots for the Taft candidates were invalidated on a technicality.: Roosevelt immediately instructed these delegates-at-large to vote 
for Taft. In November Woodrow Wilson carried the state, receiving 173,408 votes to I 55,948 for Taft, I 42,228 for Roosevelt and I2,616 for Debs (who got Io,78I votes in I908). Of the 16 congressmen ( 14 under the previous apportionment) 9 are Republicans (I0 in the last Congress).

Boston (January I0, I9I1), North Adams, Lowell and Lawrence (December I9, I9I I) voted for the licence of liquor. On October I4, I I I 2, Revere voted for annexation to Boston. On December 3, 1912, municipal elections were held in I4 cities and mayors were re-elected in more than half of these. "No licence" was voted in Quincy, and licence in Gloucester On December Io municipal elections were held in I 5 cities, I 2 of which chose mayors. On the liquor question there was but one change, Newburyport going "wet" (by 3 votes) for the first time in 7 years. The "bar and bot tle" law of I9ro, forbidding the sale of bottled liquors (or those to be taken away) in saloons where intoxicants are drunk, went into effect May I, I0II; this has. resulted in the immediate decrease of the number of licences issued and in force. In the rgr I election an unsuccessful attempt was made to recall Mayor John Francis Fitzgerald of Boston under the provision of the I 909 charter that in the middle of the mayor's four-year term there shall be a vote whether he be recalled.

An act reducing the maximum working hours for women and children from 56 to 54 hours a week--although the maximum was still 58 in New Hampshire and 60 in Vermont-went into effect January I, I9I2. Due notice of this change was given, but in the textile mills of Lawrence apparently no notice was given of a cut in wages following the reduction in hours (applied to all employees, as more than half were women and children). The cut in pay aggravated previous discontent with the bonus or premium system, giving extra pay for increased output if not more over one day's work were lost; and on January I I a strike began, in which I4,000 employees joined in the first few weeks; 23,000 were concerned at the most and about 1,000 were out when the strike practically closed March I4. There was little organisation when the strike began; a mule spinners' union and some other crafts, mostly English speaking, included 2,500 men,- - these were affiliated with the American Federation of Labor, which did not cooperate in the strike and whose representative, John Golden, head of the Textile Workers of America, left Lawrence as soon as the strike began and denounced it as revolutionary; and the Industrial Workers of the World had organised a few of the less skillful workmen regardless of crafts-projably it had 300 paid up members on its rolls at the beginning of the strike. The municipal police were unused to strikes, and on January 15 the local militia was called out for patrol duty. Five days later Joseph J. Ettor (b. I887) of New York City, one of the 5 members of the general executive board of the Industrial Workers of the World (I.W.W.), came to Lawrence to lead the strike. In a riot (January 29) Anna Lopizzo was killed-probably by a stray bullet, and two days later Ettor and his assistent, Arturo Giovannitti, were arrested as accessories to the murder; the control of the strike then passed to William D. Haywood, an I.W.W. leader formerly prominent in the Western Federation of Miners and in its strikes in Colorado and Idaho. On January 30, a Syrian boy was bayonetted because he did not " move on." The same day Governor Foss (and February 8 a joint committee of the legislature) attempted intercession. To secure sympathy and to lessen the number to be supported in Lawrence, a plan which had been used in Europe was adopted-partly on the suggestion of the (Socialist) New York Call-and children were shipped to sympathisers in other cities-about I 20 , February 10, to New York City, and later, 30 to Barre, Vermont, 40 to Philadelphia, go more to New York and 40 to Manchester, New Hampshire. A newly appointed chief of police stopped the sending of more children, and a city magistrate ruled that the parents' action might be considered neglect. A Federal enquiry into the action of the municipal authorities in preventing children from leaving the city was ordered February 27,1912 . After nearly ten weeks the strike ended with a victory for the workmen, an advance of wages in nearly all the textile mills of New England and a change of the premium system so that it applies to two-week (instead of four week) periods. The president of the American Woolen Company of Lawrence, 
William M. Wood, was arrested August 30, charged with "planting" dynamite during the strike to discredit the strikers. On a similar charge the city clerk, John J. Breen, was arrested in January, was convicted and, October I, was recalled from office by 3,373 votes to 2,269. As the time for the trial of Giovannittiand Ettor (at Salem, by change of venue) approached, trouble broke out again; Haywood was arrested in Boston (September 15) for inciting a strike of protest against the imprisonment of the two; there was an actual cessation of work, beginning September 27, with violence on the 29th and 3oth, but the mills reopened October 3. Ettor, Giovannitti and a workman named Caruso were acquitted on November 26. The conditions of the strike were unusual in that the workmen were of so many different nationalities-Italians, Portuguese, Belgians, Germans, Polish, Lithuanians, Syrians, Armenians, etc. Several nationalities had cooperative associations which helped support the strikers by loans, by maintaining soup-kitchens, and in other ways. ${ }^{*}$

During the year there were several other strikes in the state: on the Boston elevated railway (June 7 to July 29), a victory for the strikers who appealed to the state board of conciliation and arbitration; a peaceiul strike at New Bedford in the cotton mills (July I 5-Sept. Io), protesting unsuccessfully against a new system of grading, introduced after a strike in the spring; a textile strike in Lowell (March 25-April 22 with some rioting afterwards),-like the preceding marked by quarrels between the I.W.W. and the Federation of Labor, a victory for the employees; a strike of 2,000 cotton mill operatives in Clinton (March 20-April 22), resulting in an increase of $10 \%$ with an unsuccessful after-strike (June 26) for the reinstatement of one man; a strike a month long, ending April 9, at West Warren cotton mills, resulting in a victory; a weavers' strike (August 5-16) at Adams; in Lynn, a glaziers' strike (September) and a shoe cutters' strike (October 16 -November I); and a longshoremen's strike in Boston (January 4February 14), also successful.

In Boston the "Boston ror 5" movement, an elaborate plan for city betterment under the chamber of commerce, is doing much to improve the city and assist its growth. In IgIr subway leases were extended to 1936, and work was begun on the Boylstion Street and Dorchester tunnels and on an extension of the East Boston tunnel. On March 23, I9r2 the subway from Park Strect, Boston, to Harvard Square, Cambridge, 3 miles, on which work was begun July I2, I9o9, was formally opened to the public. In September rgr 2 work began on the Stadium Bridge, over the Charles River between Cambridge and Brighton, the gift of Larz Anderson. In Concord the Orchard house was purchased in I9I 2 as a memorial to Louisa May Alcott. In Pittsfield a company of 50 citizens established a community theatre for the presentation of good plays at low prices. In Northampton, where there has been a municipal hall for theatrical performances for nearly 20 years, the Northampton Players, a municipal company, was organised in the autumn of I9I 2 ; it is probably the first theatrical company owned, directed and managed by an American municipality. The town of Abington celebrated on June Io, I9 2 its 200 th anniversary and dedicated a memorial bridge and arch to the men who fought in the Civil War. The town of Hingham on November 25, I9I 2 dedicated a memorial bell-tower to its founders.

Bibliography.-Acts and Resolves (2 vols., Boston, I9I I and 1912); other official reports; the Manual of the General Court (ibid., 1912); C. J. Hilkey, Legal Development in Colonial Massachusetts, I630-1686 (New York, I910); Labor Laws and Their Enforcement in Special Reference to Massachusetts (vol. ii of Studies in Economic Relations of Women, Boston, 1912); Diary of Cotton Mather, I68I-1708 (Part I, Massachusetts Historical Society, 19I I); Grace G. Niles, The Hoosac Valley, its Legends and History (New York, 1912).

\section{MICHIGAN ${ }^{2}$}

Population (1910) 2,810,173 (r6.1\% more than in 1900 ) $; 43.6 \%$ were whites of native parentage, $21.2 \%$ were foreign-born whites, and $0.6 \%$ were negroes. Density

${ }^{1}$ See Report on Strike of Textile Workers in Lawrence, Mass.; Senate Document No. 87o, 6and Congress, 2nd Session (Washington, 1912).

${ }^{2}$ See E. B. xviii, 371 et seg. 
48.9 to the sq. m. The proportion in purely rural territory decreased from $49.9 \%$ to $42.6 \%$ in I900-10. In I910 the 24 places of I0,000 or more were: Detroit, $465,766(285,-$ 704 in 1900); Grand Rapids, I12,57I; Saginaw, 50,510; Bay City, 45, 66 (27,628 in 1900); Kalamazoo, 39,437; Flint, 38,550 ( 13,103 in 1900); Jackson, 31,433; Lansing, 31,229 (16,485 in 1900); Battle Creek, 25,267; Muskegon, 24,062; Port Huron, 18,863; Ann Arbor, 14,817; Pontiac, 14,532; Escanaba, 13,194; Ironwood, I 2,821; Alpena, I 2,706; Sault Ste. Marie, I 2,6r 5; Ishpeming, I 2,448; Manistee, I 2,38I; Traverse City, I 2, II 5; Marquette, II,503; Adrian, 10,763; Menominee, I0,507; and Holland, I0,490.

Agriculture. - The acreage in farms increased from I 7,561,698 to I 8,940,6 I4 between I900 and 1910 and the improved land in farms from II,799,250 to $12,832,078$; the average farm acreage increased from 86.4 to 91.5 , and the value of farm property from $\$ 690,355,734$ to \$1,088,858,379 (\$615,258,348 land; \$285,879,951 buildings; \$49,916,285 implements; \$1 37,803,795 domestic animals). Of the land area $51.5 \%$ was in farms. The average value of farm land per acre was $\$ 32.48$. Farms were operated largely by owners ( 172,3 I0 by owners, 1,961 by managers and 32,689 by tenants). In 1912 (preliminary estimates) the principal crops were: Indian corn, $55,250,000$ bu. (I,625,000 A.); wheat, 7,000,000 (700,000 A.); oats, $51,826,000$ bu. (I,485,000 A.); barley, 2,262,000 bu. (87,000 A.); rye, 4,92 I,000 bu. (370,000 A.); buckwheat, I,088,000 bu. (64,000 A.); potatoes, $36,750,000$ bu. (350,000 A.); hay, $3,185,000$ tons $(2,395,000$ A.) and sugar beets, $1,443,856$ tons (145,837 A.). In 1909 (IY.S. Census) the value of chicory was $\$ 70,020\left(1,5^{84} \mathrm{~A}\right)$; of mint, $\$ 194,391(6,360 \mathrm{~A}$.); of vegetables (excluding potatoes), $\$ 6,286,645$; of flowers and plants, $\$ 1,143,764$; of small fruits, $\$ 2,028,865$; of orchard fruits, $\$ 9,020,842$ (apples, $\$ 5,969,080$ ); of grapes, $\$ 1,531,057$. On January I, I9I 2 there were on farms: 634,000 horses, 4,000 mules, 806,000 milch cows, 701,000 other neat cattle, 2,276,000 sheep and $1,382,000$ swine.

Laws of I9I I permit the incorporation of mutual insurance companies against damage by hail; exempt private forest reserves from taxation; and permit county boards of supervisors to levy a tax to advertise the agricultural conditions of the county. Juvenile corn growing associations have accomplished much in the state since 1908 . Since 1904 there has been a Michigan Corn Improvement Association.

Mineral Products. - Total value, I9I I, $\$ 65,077,232$. The largest item was copper, 218 ,$185,236 \mathrm{lbs}$. $(\$ 27,273,155)$, a little less than in 1910 and ranking the state 3 rd in copper production. From copper lodes were taken $497,28 \mathrm{I}$ oz. of silver, about one-half more than in $19 \mathrm{Io}$. The state ranked 2 nd (to Minnesota) in the amount of iron ore, $8,944,393$ tons $(\$ 23,808,935)$, which was nearly one-half less than in 1910 . The output of pig iron was 304,654 tons $(\$ 4,-$ 672,799; not included in the total given above). When the state board of tax commissioners appraised the mining property of the state in 1911 it was estimated that the reserves of iron ore in mines were $124,598,164$ tons, omitting ores of $40 \%$ grade which can be mined in the Gogebic and Marquette ranges. The outplit of coal was $\mathbf{I}, 476,074$ tons $(\$ 2,79 \mathbf{I}, 46 \mathrm{I})$. The value of salt, $\$ 2,455,983$, was greater than that in any other state, though the amount was less than that of New York. Cement (all Portland) was valued at $\$ 3,024,676$, from 1 I producing plants. Clay products (almost entirely brick and tile) were valued at $\$ 2,083,932$. The state ranked 3 rd in the output of gypsum and 2 nd in grindstones and scythestones. A little graphite is prepared from graphitic slate.

Manufactures. - In $1904-09$ the number of manufactories increased from 7,446 to 9,159 and that of persons engaged in manufacturing from 200,196 (175,229 wage-earners) to 271,071 (231,499 wage-earners); the capital invested from $\$ 337,894,000$ to $\$ 583,947,000$ ) $(72.8 \%)$; and the value of products from $\$ 429,120,000$ to $\$ 685,109,000$. In 1909 the state ranked 7 th in the value of all products, and as in 1904, Ist in the manufacture of automobiles. with $38.8^{\circ} \%$ (in $1904,26.6 \%$ ) of the value of the country's total. The out put in $1909, \$ 96,651,000$, was more than 12 times as much as in 1904 . Nearly one-eleventh of the state's product value in 1909 was the value, $\$ 61,514,000$, of lumber and timber. Furniture was valued at $\$ 28,642$, oOo ( $\$$ I 2,630,000 from Grand Rapids). Other items were: foundry and machine-shop prod ucts, \$45,399,000; tobacco, mostly cigars and cigarettes, \$16,179,000; leather, \$15,331,000; paper and wood-pulp, \$1 3,922,000; brass and bronze products, \$13,890,000, ranking the state 3 rd in this industry; patent medicines, etc., $\$ 13,475,000-$ in this industry Michigan ranked 2nd; slaughtering and meat-packing, $\$ 13,435,000$; chemicals, $\$ 12,890,000$, ranking the stat: 4 th; food-preparations, $\$ 11,492,000$; beet-sugar, $\$ 10,477,000$, being more than one-fifth the output of the entire country. The principal manufacturing cities were: Detroit, $\$ 252,992$, 000 , in 1909 the 6 th manufacturing city of the country; Grand Rapids, $\$ 42,231,000$, of which three-tenths was the value of furniture; Flint, $\$ 24,118,000$, three-fourths being automobiles, carriages and wagons; Battle Creek, $\$ 20,174,000$, nearly one-half being food preparations; Saginaw, \$1 8,833,000, principally beet-sugar and lumber; Kalamazoo, \$1 7,904,000, paper and wood-pulp, and corsets; Lansing, $\$ 16,567,000$, one-half automobiles; Jackson, \$14,006,000, one-third automobiles; and Bay City, \$10,294,000, lumber.

Transportation, - Railway mileage, January I, 1912, 9, I00.98. The Federal government widened St. Mary's river in $19 ! 1$ and in 1912 practically completed improvements in 
the Amherstburg and Livingstone channels of the Detroit river and the 3,000 $\mathrm{ft}$. long concrete superstructure of the breakwater at Marquette, which by the River and Harbour Acts of 1910 and $19 \mathrm{II}$ is to be extended $1,500 \mathrm{ft}$. further.

Legislation.-Besides the regular session of the legislature in Ig I there were special sessions in I91 2 adjourning respectively on March 2oth and April Ioth. On February 23, I9II, the proposed r6th amendment to the Federal Constitution was ratified. In IgI 2 two amendments were proposed, one giving women the right to vote and the other giving to electors in cities and villages power to make or amend their charters. In November I9I 2 the latter was carried $(285,9$ I I to 138,579$)$, the former defeated by 248,135 to 247,375 votes.

A law of 1912 provides for a presidential preferential primary. In I9I I the legislature amended the registration law; created justice courts in cities of 100,000 inhabitants or more; and abolished the office of the commissioner of mineral statistics. The law in regard to concealed weapons was amended by including among prohibited weapons hatpins more than ten inches long. Married women have a right to their personal earnings. The legislature voted $\$ 15,000$ for the erection of a statue of Zachariah Chandler in the National Statuary Hall of the Capitol in Washington.

An employers' liability law of the pseudo-elective sort-the election both of employer and of employee being assumed unless notice to the contrary is given-was enacted in I9I2, and went into effect on September Ist. It does not apply to farm hands and domestic servants. There is no compensation for a disability lasting less than two weeks; and compensation begins on the I 5 th day, but on the first day if the disability lasts more than 8 weeks. In case of death the compensation is one-half the average weekly wage for 300 weeks, but not more than $\$ 10$ nor less than $\$ 4$ a week. If the family left is only partially dependent, compensation is proportional to the degree of dependence. If there are no dependents, $\$ 200$ is the maximum. In case of total incapacity, the compensation is one-half the average weekly wage (between $\$ 4$ and $\$ 10$ ) for not more than 500 weeks or $\$ 4,000$. For partial incapacity the compensation is one-half the difference between the wages before the accident and after the accident, - not more than \$10 nor for more than 300 weeks. The act specifies compensation for maimings on the basis of wages paid. Death terminates a disability indemnity, but a death benefit must be paid. One member of an industrial board (three members) and one person chosen by each of the parties to any dispute form a board of arbitration. Special provisions for the formation of mutual insurance companies of employers who elect to come under the employers' liability law. were passed in I9I2. The number of free employ. ment bureaus was increased from 8 to Io. The law of 1889 creating a state court of mediation and arbitration of labour disputes was repealed. All physicians are required to report to the state board of health the name, the address, the place of employment and the length of employment of those having occupational diseases.

A new child labour code of I9I I forbids children to work on the stage, in shows, pool-rooms or dance halls where liquor is sold, makes hours for children under 18, 10 a day (average 9) and 54 a week in factories, mills, warehouses and workshops, but not in canneries, and requires employment permits to be issued (only to those completing the fourth grade) by school officers or probate judges, instead of by employees of the state department of labour. No girl under 18 is allowed to work in a factory and no child under 16 in a factory, workshop, mine or messenger service between 6 P.M. and 6 A.M.; and no child under 18 in messenger service between IO P.M. and 5 A.M. City aid, not more than $\$ 3.00$ a week for each child or $\$ 6.00$ for a family, may be granted on the recommendation of truant officers to widows whose children's work is necessary for the support of a family. Free text books also may be supplied.

A law forbidding breweries to own saloons (directly or indirectly) was passed in I9I2. The supreme court held unconstitutional a clause in the local option prohibition law exempting from the prohibition the manufacture of wine and cider from home-grown fruits. A medical milk commission may be incorporated in any city, village or township to supervise milk supplies for infants and sick rooms. The office of state fire marshal was created and the marshal must enforce a law that schools have fire drills once a month. The sale and use of toy pistols, guns and cannon shooting blank cartridges was forbidden as well as the use of fireworks containing picric acid or fire crackers above specified size and explosive force. Immoral advertising is forbidden and pandering is made punishable by 30 years' imprisonment.

Telephone lines and companies are made common carriers under the control of the state railroad commission and express rates are regulated by an amendment to the common carriers act. A uniform bill of lading act: was passed.

Under a home-rule law East Jordan, Fremont, Pontiac (Jan. 3oth; in effect Apr. Ioth) and Wyandotte adopted commission governments in 191 I. Port Huron adopted a commission charter November 5, I9ro. Lansing adopted a home rule charter on August 27, 1912; in effect October 7, 1912; amendments may be proposed by initiative petition. A new charter proposed for Grand Rapids was defeated by 6,878 votes to 5,596 on February 20, 1912; it was a "Federal" plan with legislative (council of 12 aldermen, one from each ward), adminis- 
trative and judicial departments, - the mayor to appoint four general managers to be heads of departments of public works, health and safety, parks and public property, and finance and revenue. St. Joseph adopted a commission charter in 1912. Charter commissions in Holland and Saginaw have not yet reported.

Finance.-In I9I I a special tax commission was appointed to investigate the entire system of taxation; and a state board of equalisation was created. The board of tax commissioners under a law of I9II inventoried and appraised all mining property and mineral rights; these are all taxable under this act. The legislature provided for a tax of 5 mills on mortgages and liens and for taxes on railway stock, bonds, interest coupons, etc., by an act which requires corporations to deduct the tax from dividend, interest or principal to be paid to the holders of bonds. A uniform accounting system is to be adopted in all state departments, as well as institutions and boards; the system was not introduced throughout in I9I2. Maximum rates of interest to be charged by pawn-brokers were prescribed. In I9I2 a tax of $\$ 2,060,000$ for 191 I and one of $\$ 1,063,000$ for 1912 were made for appropriations for which the legislature had provided no special tax. The state treasurer's report for the year ending June 30 , r912 showed a balance on hand of $\$ 8,980,404$ (as compared with $\$ 2,235,425$ at the end of the preceding year), and receipts of $\$ 14,190,498$. Of the total amount on hand $\$ 5,466$,584 was primary school interest fund and $\$ 3,372,608$ general fund. Nearly one-half of the receipts was from county treasurers and nearly as large a proportion-partly included in the other class - was from business corporations, $\$ 5,317,205$.

Education.- The compulsory education law of 191 I has been described above. Districts that do not maintain high schools must pay tuition to one of the three nearest high schools for children who have completed eight grades. Any school district may establish a vocational school or a gymnasium and is empowered to accept gifts and legacies; this law enabled the schools of West Saginaw to accept a bequest for vocational education. In the autumn of 1912 an industrial co-operative department was opened in the Lansing high school. Physical training must be taught in public schools in city school districts with a population greater than I0,000 and in all state normal schools. The township unit law was amended by an act which permits women to vote on the question of reorganising under this law. Fraternities and school societies were abolished in all public schools. In 1910 the percentage of illiteracy in the population Io years and over was 3.3 ( 4.2 in 1900). In the school year ending June 30 , 1912 the number of children between 5 and 20 was 783,770 , the total enrollment 545,279 and the average daily attendance $75 \%$ of this number. The average length of the school year was 9.1 months in city and graded districts and 8.1 months in ungraded districts. The total number of teachers employed was 18,207 at an average monthly salary for men of $\$ 79.84$ and for women of $\$ 53.53$.

The excellence of the public school system is largely due to Luther Lamphear Wright (b. 1856), state superintendent since 1907 , who has attempted to discard text books in language-work and arithmetic and urges the adoption of a I2-months school system. (See Kathleen Nicholson, "The Michigan Schools" in Educational Review, June 1912.)

Penal Institutions. - The I9I I legislature provided that prison labour should be used on the state prison at Jackson and on the House of Correction and the branch of the prison in the Upper Peninsula. Convicts may be employed on state roads, but not to displace skilled labour, and are to be paid a minimum of $50 \mathrm{c}$ a day, plus a bid price bonus. A house of correction with a public account system and wages like the system in the Detroit House of Correction (which is a municipal institution) may be established in any city with more than I00,000 inhabitants. The governor may parole any life convict who has served 25 years or 25 years less a proportional time for good conduct. In September 1912 there were serious riots in the state prison at Jackson, where convicts got control of the institution and militia had to be called out. The warden's friends found the reason for the outbreak in the contrast between his strict discipline and previous slackness; his enemies, in poor food furnished to the convicts. Immediately after the riot the prison warehouse was burned.

History.-Chase Salmon Osborn (b. 1860), Republican, editor and proprietor since Igor of the Saginaw Courier-Herald, having defeated the Democratic candidate, Lawton Thomas Hemans (b. I864; author of History of Michigan, I906), by 202,863 to I 59,670 votes, became governor January I, I9I I. The legislature, elected on a radical Republican platform, chose (Jan. I8th) Charles Elroy Townsend (b. 1856 ; representative in Congress $1903^{-1} I_{\text {and }}$ anosen for I $_{91} \mathrm{I}_{-13}$ ) to be United States senator, to succeed Julius (.. Burrows (b. 1837 ), conservative Repul)lican, representative in Congress $1873^{-}$ $75,1850-83,1885^{-95}$, and senator $1805^{-1011}$, whom he had defeated in the first senatorial primary in the state, September 7, igro. In state and local elections, April 3, I9 I : the Republicans were in general successful; and in Flint a strong Socialist vote was cast and the Socialist candidate for mayor was elected. There were local option elections in April Ig12, and at the end of the year 35 (of 83 ) counties were " no licence." At the primaries (Aug. 2\%, 1912) about 1 50,000 Reputslican votes and only about 6,500 Progres- 
sive votes were cast, but the Republican organisation was Progressive in character. The presidential preferential primary law of 1912 (approved March 2oth) did not go into effect for go days (although it provided for a primary on the first Monday of April ror2) since it did not receive the two-thirds vote necessary to make it an emergency measure immediately in effect. At the Republican state convention at Bay City (April $\mathrm{I} I \mathrm{th}$ ) the Taft and Roosevelt factions quarrelled so violently that troops had to be ordered out. It chose two district delegations-at-large to the National Convention, where (June r 2 th) the 6 delegates instructed for Taft were seated in spite of the protests of the "Progressives." Amos S. Musselman was nominated for governor by the Republicans, Woodbridge Nathan Ferris (b. I 853; head of Ferris Institute, Big Rapids, since Igor; candidate for governor I904) by the Democrats, and L. Whitney Watkins by the Progressives, who put in the field a ticket of I 2 congressional candidates. Governor Osborn had first endorsed Woodrow Wilson but later turned to Roosevelt, who carried the state by 214,584 votes to $150,75 \mathrm{I}$ for Wilson, I 52,244 for Taft and 23,2 I I for Debs (II,586 in I008). But Ferris, the Democratic candidate for governor, was elected by 194, or 7 votes to 169,963 for Musselman and I 55,372 for Watkins, being far ahead of the rest of the state ticket, which was defeated. The (Republican) legislature re-elected (Jan. 14, I9I3) to the United States Senate William Alden Smith (b. I 859), who had succeeded Russell A. Alger in I907; the choice of the Democratic primaries was Alfred Lucking. The congressional delegation ( 13 under the new apportionment, including $\mathrm{I}$ at-large -instead of $\mathrm{I} 2$ as before) will be 9 Republicans, 2 Democrats and 2 Progressives.

The union employees, numbering 6,000, of the furniture factories of Grand Rapids, went on strike April I9, rgII and stayed out for I 7 weeks. Upon the report of a citizens' committee several employers agreed to a 9-hour day. The economic effect of the strike was felt immediately in reduced municipal appropriations for public schools, etc.

In Grand Rapids the City Plan commission submitted to the mayor and common council a report for a city plan made by Carrère and Brunner April 7, 1909. There has been no organised movement to carry this plan into effect. Detroit has a city plan and improvement commission, created in I909, and in I9I 2 this was considering a new city plan.

Bibliography.-Public Acts (2 vols., Lansing, I9II and I9I2); other reports, notably that of the Employers' Liability Commission; the Michigan Manual (I9II); Harriette M. Dilla. The Politics of Michigan, $1865^{-78}$, in Columbia University Studies.

\section{MINNESOTA 1}

Population (r910) 2,075,708 (18.5\% more than in 1900 ); $99.2 \%$ being whites, $0.3 \%$ negroes, and $0.5 \%$ Indians and Asiatics. The percentage of native whites changed from $70.4 \%$ to $73 \%$ in 1900-10, and of foreign-born whites from $28.8 \%$ to $26.2 \%$. Density 25.7 to the sq. m. The urban population in 48 municipalities each having 2,500 or more was $4 \mathrm{I} \%$ of the whole (in r 900 in 37 cities $34 . \mathrm{I} \%$ ). The purely rural population decreased from $50.8 \%$ to $43.3 \%$. There were in 191024 municipalities of 5,000 or more as follows: Minneapolis, 301,408 (202,7 18 in r900); St. Paul, 214,744 ( 163,065 in 1900 ); Duluth, 78,466 (52,969 in 1900); Winona, 18,583; St. Cloud, 10,600; Virginia, 10,473 (2,962 in I900); Mankato, I0,365; Stillwater, I0,198; Red Wing, 9,048; Faribault, 9,00I; Hibbing (village), 8,832 (2,48I in I900); Brainerd, 8,526; Rochester, 7,844; Chisholm (village), 7,684; Crookston, 7,559; Eveleth, 7,036 (2,752 in 1900); Cloquet, 7,031; Austin, 6,960; Fergus Falls, 6,887; Albert Lea, 6,192; Little Falls, 6,078; Owatonna, 5,658; New Ulm, 5,648 ; and Bemidji, 5,099 (2,183 in 1900).

A gricullure. - The acreage in farms increased from $26,248,498$ to $27,675,823$ between 1900 and 1910 ; the improved land in farms from $18,442,585$ to $19,643,533$; the average farm acreage from 169.7 to 177.3 and the value of farm property from $\$ 788,684,642$ to $\$ 1,476,4 I I$,737 (\$1,019,102,027 land; \$243,339,399 buildings; \$52,329,165 implements; \$161,6+1, 146 domestic animals). Of the land area $53.5 \%$ was in farms. The average value of farm land per acre was $\$ 36.82$. Farms were operated largely by owners (122, I04 by owners, I,222 by managers and $32,8 \mathrm{I}$ I by tenants). In 1912 (preliminary estimates) the principal crops were. Indian corn, $78,177,000$ bu. $(2,266,000$ A.); wheat, $67,038,000$ bu. $(4,325,000$ A.); vats, 122,

See E. B: xviii, 548 el seq 
932,000 bu. $(2,948,000$ A.); barley, 42,01 8,000 bu. (1,490,000 A.); rye, 6,026,000 bu. (262,000 A.); buckwheat, 126,000 bu. $(6,000$ A.); potatoes, $33,075,000$ bu. $(245,000$ A.); flaxseed, 4, 121 , 000 bu. $(404,000 \mathrm{~A}$.) and hay, 2,541,000 tons $(1,661,000 \mathrm{~A}$.). In 1909 (U.S. census) the value of vegetables (excluding potatoes) was \$3,359,052; of small fruits, \$493,406; of orchard fruits, $\$ 801$, I 12 (apples, $\$ 769,114$ ). On Jan. I, 1912 there were on farms 806,000 horses, 6,000 mules, I, 107,000 milch cows, I, I5 I,000 other neat cattle, 600,000 sheep, I,702,000 swine.

The legislature in 1911 created a state forestry board, which is to appoint a state forester. Railways must provide fire patrolmen, and use spark-arresters on railway locomotives for the prevention of forest fires. Sub-experiment and demonstration farms were established, one near Duluth, and one near Waseca. A new state fish hatchery was established near Detroit. The office of state inspector of apiaries was created, and a law provides for the prevention and suppression of contagious disease among bees. For experiments to rid the state of grasshoppers $\$ 6,000$ was appropriated, and $\$ 25,000$ for grass and clover seed to be distributed to farmers whose lands were burnt over in the fires of 1910 . An appropriation of $\$ 25,000$ was made for an experiment station for the dairy and food department, near Albert Lea. The experiment station recently originated new varieties of winter wheat, of oats, of Indian corn, and of flax, which have become commercially valuable.

Mineral Products. - Total value, I9I 1, \$53,460,561. The only large item is iron ore, of which the state was the largest producer, with $23,398,406$ tons valued at $\$ 48,447,760$; six mines each had more than I,000,000 tons output-all of hematite- and these and five other mines were the largest producers in the country. Clay products, almost entirely brick and tile, were valued at \$1,693,478; mineral waters, bottled at 17 springs, at 270,039 .

Manufactures.-In $1904^{-09}$ the number of establishments increased from 4,756 to $5,56 \mathrm{I}$ and that of persons engaged in manufacturing from $83,30 \mathrm{I}(69,636$ wage-earners) to I04,406 (84,767 wage-earners); the capital invested from $\$ 184,903,000$ to $\$ 275,416,000\left(49^{\circ}, a\right)$; and the value of products from $\$ 307,858,000$ to $\$ 409,420,000(33 \%)$. The principal manufactures in 1909 were: flour and grist-mill products, \$ $139,136,000$, Minnesota ranking Ist in this industry; lumber and timber products, $\$+2,353,000$ (about five-sixths of the timber cut was white pine and this was more than one-third of the white pine cut in the United States); slaughtering and meat-packing products, $\$ 25,754,000$; and butter, cheese and condensed milk, $\$ 25,287,000$ ( $\$ 24,581$,000 being butter), Minnesota ranking 4 th. Other important

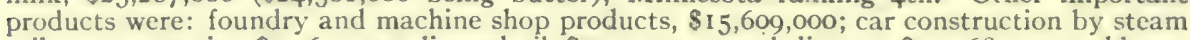
railway companies, \$1 2,631,000; linseed-oil, \$1 1,037,000; malt liquors, \$10,568,000; and boots and shoes, $\$ 7,568,000$. The manufactures of Minneapolis were valued at $\$ 165,405,000$, nearly three-fifths being flour and grist-mill products; nine-tenths of the linseed-oil made in the state was manufactured here. Othercities of importance were: St. Paul, \$58,990,000; Duluth, \$ I 7,I 80,000 (in $1899, \$ 7,81 \mathrm{I}, 000$ ), and Winona, $\$ 11,200,000$, chiefly flour and patent medicines.

Transportation. - Railway mileage, January I, I912, 8,832.92. In I9I2 the Federal government had about half completed work on Lock and Dam No I on the Mississippi between Minneapolis and St. Paul, where the lift is to be increased from 13.3 to $30 \mathrm{ft}$., with the intention of developing a passenger traffic on this part of the river; and had nearly completed improvements in Duluth-Superior harbour. A constitutional amendment, establishing a road and bridge fund and authorising an annual tax for roads and bridges, was adopted in November 1912 by 195,724 votes to 51,135 .

Legislation. - The regular biennial session of the legislature was held from January 3 to April I9, I9r. It submitted constitutional amendments which were voted on in November I 9 I 2 by the people: requiring the state auditor to levy an acreage tax on farm lands at the option of owners for an insurance fund against damage to crops from wind or hail (adopted: 145,173 to 60,439 ); authorising the investment of school funds in loans on improved Minnesota farm lands (adopted: 168,440 to 39,483 ); allowing incorporated cities or villages desiring incorporation as cities to frame charters, and classifying cities for general legislation (adopted: 157,086 to 41,977 ); and reapportioning the state, providing for $6_{3}$ senators, no county to have more than 7 , and empowering the legislature to determine the number of representatives (adopted: 122,457 to $77, \mathrm{I} 87$ ).

The legislature urged the adoption of Federal laws to prevent Federal courts from enjoining a state official from enforcing any state law before the constitutionality of the law had been passerl on by the state courts, "leaving the United States Supreme Court to correct any. decision of the state court;" and the creation of a permanent non-partisan Federal tarifif board. A special session (June 4-18, 1912) ratified on June 12 th the proposed 16 th and 17 th amendments to the Federal Constitution.

An act of I9) I provides for direct nomination of United States senators, and candidates for the legislature may promise to vote for the choice of the primary for senator, but need not sign any pledge. An elector may vote for presidential electors or state officers or on constitutional amendments in a precinct of the state other than that in which he resides and usually rasts his wte. The 1912 session passed a new registration, primary and general election law; it provides that judges and county superintendents of schools be nominated by 
non-partisan primary ballots, the two having the highest votes at the primary to be the nominees; for a method of rotation on primary ballots; and for second choice voting at primaries. In 1912 a new corrupt practices act was passed. Permitted expenses are specified by classes and the maximum expenditures for each office. Political advertisements must be headed "paid advertisements" with a statement of the amount paid and by whom. Any candidate or member of a political committee having a financial interest in any newspaper must file with the county auditor a statement of the amount of his interest. Campaign literature must bear the name of its author. Treating electors and wagering on elections are forbidden. All campaigning dispursements must be reported each calendar month. A board was appointed to promote uniformity of legislation in the different scates, especially laws on marriage and divorce, insolvency, the form of notarial certificates, the descent of property, acknowledgment of deeds, and the execution and probate of wills.

The legislature created the Fort Ridgely State Park (about 80 acres; opened I9II) in Nicollet county, and required the superintendent of public instruction to proclaim between October Ist and May Ist a day (Minnesota Day) on which special exercises should be held in public schools. The county of Pennington (county-seat; Thief River Falls) was created from the N. W. part of Red Lake county by executive proclamation on November 23, I9IO.

A new child labour law of 1912 forbids the employment of children under 14 at any time in factory, mill, workshop, mine or building construction or engineering. work, or during school hours in any employment. Children under 16 may not be employed more than 8 hours a day or 48 hours a week nor between 7 P.M. and 7 A.M.; nor in certain specified dangerous occupations. Theatrical exhibitions are excepted by the law, on the written consent of mayor or village president. In messenger service no boy. under 18 may be employed between 9 P.M. and 5 A.M., nor any girl under 21 at any time. A report on workmen's compensation was published in 1912 by the state bureau of labour.

The railroad and warehouse commission was instructed to make rules for joint rates between common carriers. Railways must keep accounts showing revenue per mile. Five cents is the minimum rate for carrying a passenger from one station to another. The state rate law setting 2 cents as the maximum per mile was held invalid (April 2I, I9II) by a circuit court as unfair to interstate transportation at higher rates; the case was carried to the Federal Supreme Court, which had handed down no decision by March 1913.

The state and not the Federal census is to govern the classification of cities. Cities of the first class under a home rule charter may establish a purchasing department. One city may join another to form a public corporation for the development of water power. By a law of I9I2 Minneapolis, St. Paul, and Duluth were required to have non-partisan primaries for municipal offices. Cities over 50,000 may issue $41 / 2 \%$ bonds for $\$ 600,000$ for land and buildings for public libraries. Cities of this size have a fire marshal, and the laws for fire protection in hotels, inns, etc., and to prevent fires started by locomotive sparks, are made much stricter. Railway crossings must be protected and inspected by the railroad and warehouse commission, and tracks at crossings must not be at different levels. In cities of 50,000 or more the mayor is to appoint a city chemist, and cities of this class with home rule charters may regulate the sale of liquor in hotels. It was made a gross misdemeanour to entice a minor into a saloon, and was declared illegal to sell liquor to a student in a state school, to an intoxicated person, to an Indian, to an habitual drunkard, or to a spendthrift for one year after a notice by any person annoyed by such a sale; and the selling or giving away of malt liquors, even if they are not intoxicating, was forbidden except in licensed places. Any one selling intoxicating liquors is liable to action for damage done by an intoxicated person to whom he has sold such liquor. No intoxicated person is allowed to enter a railway train; the drinking of intoxicating liquors on trains is forbidden, and a conductor on any train in the state may seize intoxicating liquor, but must give a receipt redeemable within ro days. A department of weights and measures under the supervision of the railroad and warehouse commission was established. A standard of pure milk was set. County boards are authorised to appropriate money to prevent the spread of tuberculosis.

Finance. -The inheritance tax law was amended in I9II. The tax levy for the general revenue fund for 1912 and 1913 is to be 1.9 mills or less, and $\$ 2,200,000$ was the amount to be raised in I9I2. A law of $191 \mathrm{I}$ requiring railways to pay a tax of $4 \%$ on gross earnings derived from all sources was repealed in 1912 by an act (in effect 1913 ) making the rate $5 \% i^{1}$ and the tax commission was bidden to report to the 1913 session on the property of railways and to have it assessed and taxed (including back taxes). In its third annual report, in preparation in December 1912, the tax commission proposes sweeping reforms in the direction of more equitable levying of taxes. An annual tax of 3 mills on each dollar of the fair cash value of moneys and credits was levied; no offset is allowed for debts, and the tax does not apply to money or credits of an incorporated bank situated in the state. On August I, I9I I, the balance in the treasury was $\$ 3,508,491$ and on July 31,1912 , it was $\$ 2,992,728$. The receipts for the fiscal year were $\$ 15,805,302$ and the expenditures, $\$ 16,321,065$. There is no state debt. Trust funds, invested and drawing interest, amounted to $\$ 27,210,768$.

1 This tax was put in the constitution by an amendment adopted November 1912 (184,612 votes to 41,130$)$. 
Education. - The legislature of I9I I passed a compulsory education law which was called by the Federal commissioner of education the most comprehensive one enacted in the year. It requires a complete school census, makes poverty no excuse for non-attendance, allows children to be excused from attendance if their bodily or mental condition necessitates it, or if they have finished the work of the eighth grade; and, except in cities of the first and second class, permits children over 44 to be excused between April ist and November Ist, if their help is needed "in any permitted occupation in or about the home." The state director of school hygiene in 1912 introduced a "health grading outline" for all school children. Instead of 10 high schools, 30 may now receive $\$ 2,500$ a year for courses in agriculture, home economics. and manual training, for which the state appropriated $\$ 105,000$ a year. A bonus of $\$ 1,000$ is given to each of 50 high schools with any one of the three special courses mentioned. An association for retirement fund pensions for teachers may be formed in cities of 10,000 inhabitants or more-the limit was formerly 50,000 or more. A new law regulates prices of text bonks, and on the vote of the district or of the school boand books may be supplied free or sold at cost. An educational and professional qualification for county superintendents was adopted by constitutional amendment $(167,983$ votes to 36,584$)$ in November 1912

On April I, I9I I, Cyrus Northrup, president of the University of Minnesota, was succeeded by George Edgar Vincent (b. I 864), who had been dean of the faculties of arts, literature and science in the University of Chicago, and president of the Chautauqua Institution since 1907. The schools of medicine and engineering occupied new buildings, and a chemistry building was constructed. There is a "university extension" movement on Chautauqua lines. In the law school the "case system" has been introduced.

In 1910 , of the population 10 years and over, $3 \%$ was illiterate (4.I $\%$ in 1900). The total school enrollment in $191 \mathrm{I}-12$ was 445,995 , the school revenue about $\$ 20,000,000$ and the expenditures about $\$ 17,000,000$.

Penal and Charitable Institutions. - A law of I9I I provides for the indeterminate sentence of prisoners convicted of any crime except treason and murder, and for a state board of parole. Life imprisonment was made the punishment for murder in the first degree. A new act was passed for the government of the hospital farm for inebriates, finished late in 1912.

History.-At the beginning of ror the governor, Adolph Olson Eberhart (b. 1870; elected lieutenant-governor, r9o7; succeeded on the death of Governor John A. Johnson September I909; re-elected, I910), all the state officers, and a large majority of the state legislature were Republicans. Moses Edwin Clapp (b. I85I), United States senator since Igor, was re-elected January I 7, I9II. In I9I2 before the actual opening of the presidential campaign Eberhart was one of the governors who urged Roosevelt's candidacy, but when the Republican National Convention, in which the state's delegates were instructed to vote for Roosevelt, nominated Taft, Eberhart refused to leave the party. He was re-nominated ${ }^{1}$ (Sept. I7, I0I2) by the Republicans, who it must be remembered were at least partially radical in their sympathies, and who re-nominated Knute Nelson (b. I 843 ; representative in Congress I $88_{3}-89$; governor $1893-95$; United States senator since 1895) for the Senate. The Progressives nominated P. V. Collins for governor and no other candidates save secretary of state and one railroad and warehouse commissioner-no candidate for Congress. Fherhart was re-elected, with the entire Republican ticket, getting I29,688 votes to 99,6 59 for his Democratic opponent, Peter M. Ringdal, and 33,455 for Collins. The congressional delegation (10, including I at-large; formerly only 9) will consist of 9 Republicans and (from the 2 nd district) I Democrat. Senator Nelson's re-election by the legislature (Jan. 21, 1913) was insured by a Repul)lican legislature and by a primary vote of 173,074 for Nelson to 102,691 for Daniel W. Lawler, Democrat. The first returns, coming from the cities, pointed to a plurality for Woodrow Wilson, but when the rural districts were heard from, it was found that the state was carried for Roosevelt; by 125,856 votes to 106,426 for Wilson. and 64,334 for Taft, and 27,505 for Debs," who had 14,527 in 1908 .

Duluth (May 7, 1012) adopted by 5,331 votes to 1,206 a charter amendment for initiation of legislation (the charter already provided for initiation of arrendments to the charter), for referendum and for recall. Immediately thereafter the municipal council adopterl a resolution for the purchase of a lighting plant, to which it had been opposed. There was a street-car strike in Duluth from September 9 to November 7, Ig I 2, when it

${ }^{2}$ At the state's first state-wide primary in which the second choice on the ballots caused much confusion to voters and to canvassers.

: One Socialist, from Two Harbors, was elected to the lower house of the legislature. 
was called off because the strikers were in actual need. This strike led to the serious consideration by the city council of the acquisition of the railway system by the city. On February 6, I912, the city adopted four charter amendments, one providing for a board of public welfare, and one for an issue of $\$ 700, \infty 00$ bonds for a lighting plant; and December 3 , r9r 2, it adopted $(5,500$ to 3,400$)$ a new charter of the commission form with provisions for referendum, recall and preferential voting. St. Paul (May 7, 1912) adopted the commission plan of government (by 20,640 to 4,137 votes), -this at the very time that a home rule charter commission had prepared a new charter (federal plan) for the city, which will be submitted at a special election. Ten days later the state supreme court upheld the constitutionality of the commission plan in the charter of Mankato and in an act of igoo. Faribault (Feb. 7, by 688 to I85; in effect April II, Igri), Tower, and St. Cloud (Nov. 28 , by 3 to I) adopted the commission plan in Igrr. At the November election in rors Wallace G. Nye was elected mayor of Minneapolis by 22,282 votes to I9,498 for Thomas Van Lear, Socialist, who had not entered the non-partisan primaries, in whichW.G.Nye received the largest vote; 2 Socialists were elected aldermen. In December I9I I the city of Two Harbors authorised the establishment of a municipal coal yard. In rgr a civic commission in Minneapolis submitted plans for a fourth diagonal highway and for neighbourhood parks at intersections.

Bibliography.-General Laws (2 vols., St. Paul, I9I I and I9I2) and other public documents; W. H. Winchell, ed., The Aborigines of Minnesota (Minn. Historical Society, 1912).

\section{MISSISSIPPI}

Population (I910) I,797, I 4 ( $15.8 \%$ more than in I900); whites constituted $43.7 \%$ (in I.900 4 I. 3 ), and $43.2 \%$ were native-born whites. The proportion of negroes was $58.5 \%$ in 1900 and $56.2 \%$ in I9Io (Indians and Asiatics $0.2 \%$ in I900 and 0.I \% in I9Io). Density 38.8 per sq. m. The urban population ( 29 municipalities each with more than 2,500 ) was $11.5 \%$ of the total, compared with $7.7 \%$ (22 municipalities) in 1900 . The I5 municipalities of 5,000 or more were: Meridian, 23,285; Jackson, 21,262 (7,816 in I900); Vicksburg, 20,8I4; Natchez, II,79I; Hattiesburg, I I,733 (4, I75 in I900); Greenville, 9,6ro; Columbus, 8,988; Laurel, 8,465 (3, r93 in I900); Biloxi, 8,049; Yazoo, 6,796; Gulfport, 6,386 ( 1,060 in I900); McComb, 6,237; Greenwood, 5,836; Brookhaven, 5,293; Corinth, 5,020 .

Agriculture.-The acreage in farms increased from $18,240,736$ to $18,557,533$ between 1900 and 1910 and the improved land in farms from $7,594,428$ to $9,008,310$; the average farm acreage fell from 82.6 to 67.6 ; and the value of farm property increased from $\$ 204,221,027$ to $\$ 426,314,634$ (\$254,002,289 land; $\$ 80,160$,000 buildings; $\$ 16,905,312$ implements; $\$ 75,247,-$ 033 domestic animals).: Of the land area $62.5 \%$ was in farms. The average value of farm land per acre was $\$ 13.69$. Farms were operated largely by tenants ( $8 \mathrm{I}, 49 \mathrm{I}$ by tenants, 825 by managers and 92,066 by owners). In I9I2 (preliminary estimates) the principal crops were: Indian corn, $56,840,000 \mathrm{bu}$. (3,106,000 A.); wheat, $96,000 \mathrm{bu}$. (8,000 A.); oats, I,966,000 bu. (I13,000 A.); potatoes, 890,000 bu. (I0,000 :A.); hay, 297,000 tons (201,000 A.); cotton, I, I09,000 bales (I 77 lbs. per A.); rice, 77,000 bu. $(2,200$ A.). In I 909 (U.S. Census) the value of vegetables (excluding potatoes) was $\$ 5,868,275$; of small fruits, $\$$ I07, 171 ; of orchard fruits, $\$ 1,325,506$ (peaches and nectarines, $\$ 925,288$ ); of figs, $\$ 107,609$; of nuts, $\$ 90,855$. On January I, I9I2 there were on farms 234,000 horses, 277,000 mules, 443,000 milch cows, 566,000 other neat cattle, 214,000 sheep, and $1,577,000$ swine.

The pest of crayfish in the Houston clay lands; where crops of cotton and Indian corn have often been destroyed just after the plant appears, has been investigated by an agent of the Federal department of agriculture, and poisoning them in their holes has proved the simplest and most effective way of ridding fields of them. Crayfish seriously weakened levees and dikes also. The I9I2 legislature passed elaborate acts in regard to drainage districts. In I9I I and I9I2 the experiment station reported on scale insects, apple-growing, cotton experiments and cut-over lands.

Mineral Products. - Total value, 19II, $\$ 1,052,842$. The value of clay products was $\$ 687,836,8 \frac{2}{3} \%$ more than in I9I0. Sand and gravel were valued at $\$ 286,206$; and mineral waters (from 8 springs, including 6 resorts) at $\$ 75,050$, being $71 \%$ more than in 1910 .

Manufactures.-From 1904 to 1909 the number of establishments increased from 1,520 to 2,598 , and that of persons engaged in manufacturing from 42,966 (38;690 wage-earners) to $56,76 \mathrm{I}(50,384$ wage-earners); the capital invested from $\$ 50,256,000$ to $\$ 72,393,000$; and

I See E. B: xviii, 599 et seq. 
the value of products from $\$ 57,45 \mathrm{I}, 000(\$ 33,718,000$ in 1899$)$ to $\$ 80,555,000$. Of the total, lumber and timber constituted 53.I \% $(\$+2,793,000)$; more than four-fifths of the total cut was yellow pine. In the manufacture of turpentine and rosin $(\$ 1,474,600 ; 37.7 \%$ less than in 1904$)$ the state ranked 4 th; in the manufacture of cottonseed oil and cake $(\$ 15,966,000)$, 3 rd. The value of railway car repairs was $\$ 3,233,000$; cotton goods, $\$ 3,102,000$, more than twice that of 1899 ; fertilisers, - excluding the by-product $(\$ 616,000)$ of cottonseed oil mills, $\$ 2,125,000$, more than thrice that of 1899 . Meridian, had a product of $\$ 4,237,500$, principally cottonseed oil and fertilisers; Jackson, \$3, I I3,000; Vicksburg, \$2,229,350; Hattiesburg, \$I 250,900; Natchez, \$ I I I 4,000.

Transportation.-Railway mileage, January I, 1912, 4,402.08. The Federal government by acts of 1911 and 1912 has secured a 23 -ft. basin and channel at Gulfport.

Legislation. - A special session of the legislature was held in I91 I (from Nov. Ist to I 5 th) and the regular session in I0I 2 from January 2 nd to March I6th. It submitted to the people, for approval in November I9I2, constitutional amendments allowing a verdict in civil suits from nine jurors; and providing for the initiative and referendum. Each of these failed to get the necessary majority of all votes cast at the election, though 28,964 votes were cast for and only 14,255 against the former, and 25, I 53 for and only $I_{3}, 3 \delta_{3}$ against the latter. A bribery immunity act of I9I I was repealed in IgI2. For a monument on the capitol grounds to the Mississippi women of the Confederacy $\$ 7,500$ was voted and the cornerstone was laid on June 3, Igr 2.

By an act of 1912 cities may adopt the commission form of government (with a charter providing for the recall and initiative) at an election held after a $10 \%$ petition therefor. After six years under commission government, any city may vote to abandon its charter. Gulfport had adopted a commission charter on December 12, I9I I; in effect January I, 1913; and Clarksdale on August 30, 1910. Charleston, Jackson (September 24; in effect January 6, 1913) and Meridian (May 9; in effect January 6, 1913) also adopted it, in 1912. Vicksburg amended its charter (July 1912; in effect, January 14, 1913) so that it has a commission government in all but name. A child labour law applying to factories making cotton, wool or other fabrics, and to canneries and establishments where children are employed indoors at work injurious to health or in operating dangerous machinery, and not applying to fruit canneries, prohibits the employment of any girl under 14 or any boy under 12 and for more than 8 hours a day, or 48 hours a week, or between 7 P.M. and 6 A.M.; or any boy under 16 or any girl under 18. No child under 16 may be employed without the consent of his guardian. Ten hours a day, except in cases of emergency, was made the maximum for employees in manufacturing or repairing establishments.

Railway corporations were made liable for damage from fire set by sparks from locomotives, and are permitted to have an insurable interest in property on the route. The state board of health was ordered to establish a bureau of vital statistics, which was in operation in 1912. Tips in hotels, restaurants, dining and other cars are forbidden; the penalty is not to exceed $\$ 100$, and copies of the act are to be posted in cars and eating places.

Finance.-The state tax for 1912 and 1913 was 6 mills. The proportion for annual interest charges on different state bonds and for the Chickasaw school fund amounted to $\$ 119,025$, and $\$ 610,500$ for 1912 and $\$ 615,500$ for 1913 was appropriated to repay money borrowed for the state by the governor. The special session of I9I I was devoted almost entirely to appropriations. Many privilege taxes were laid: those on sleeping and palace cars and on railways were increased; freight lines and equipment companies were taxed $3 \%$ on their gross earnings. An income tax of 5 mills on all incomes (that is, gross profits) in excess of \$2,500 a year was levied. New permanent factories of certain classes established before 1918 were exempted from tax for 5 years. The highest contract rate of interest was made $8 \%$ instead of $10 \%$. The biennial report of the treasurer for the year ending October I, 19I2 shows cash on hand October I, I9II, \$572,047. The receipts were \$4, I79,283; and the expenditures $\$ 4,500,33 \mathrm{I}$, leaving a balance in the treasury, $\$ 250,999$.

Education.- A normal school, authorised in 1910 , was established in I9r I at Hattiesburg. The legislature in 1912 voted \$1,500 a year for each county agricultural high school, or $\$ 3,000$ for a joint school; the special session of 1911 authorised municipalities to issue bonds for agricultural high schools. Crreek letter and other secret societies were abolished and prohibited in 1912 at the University of Mississippi. The governor and the state superintendent of education were made ex-officio members of the board of trustees of the higher educational institutions of the state (a law of 1910 had forbidden the presence on this board of any state officers or legislators); other members are to be chosen by the governor. The General Education Board (which had previously given \$25,000) in October 1912 gave \$100,000 to Mississippi College (1826; Baptist) at Clinton.

In 1910, of the total population Io years and over, $22.4 \%$ was illiterate $(32 \%$ in 1900$)$; whites $5.3 \%$ ( $8 \%$ in 1900$)$; negroes, $35.6 \%$ (49.1\% in 1900). For the school year ending in the summer of 1912 the school population was 737,356 ( 425,967 negroes); length of the average school year, 6 months; the total revenue for schools, about $\$ 3.500,000$. 
Charitable Institutions.-A law of 1912 requires that poor and needy persons be admitted for treatment in any "charity" hospital supported by the state. Among the appropriations were $\$ 450,000$ annually for Confederate veterans and their widows, and $\$ 98,000$ biennially for the Confederate veterans' home at Beauvoir.

History. - The chief political issue in IgII and IgI 2 was the United States senatorship. After a deadlock lasting seven weeks, Le Roy Percy (b. I861) was elected, February 22, I9IO, to serve the unexpired term (ending March 4, I9I3) of Anselm Joseph McLaurin (I848-I909; governor, I896-I900; senator, I90I to his death). State senator Theodore G. Bilbo (elected lieutenant-governor in rgii) testified that he had changed his vote from Percy's opponent, James Kimble Vardaman (b. 186r; governor in I904-08) to Percy for money paid him by L. C. Dulaney, another state senator, who was indicted for bribery. Percy urged a thorough investigation, and the case broke down completely; apparently the notes that Bilbo claimed he had been bribed with came from a local bank after the date of the supposed bribery. The state senate exonerated Percy and his campaign managers and came within one vote (two-thirds vote necessary) of expelling Bilbo. But in the primaries, August I, I9r r, Vardaman's candidacy for the senate was successful. ${ }^{1}$ The legislature elected on the senatorial issue asked (March 5, I9I2) for the resignation of Percy, who had offered at the time of the bribery charge to refer his claims to the voters of the state, who had received only $2 \mathrm{I}, 500$ votes out of a total of 132,400 at the August primary, and who was therefore considered discredited by Vardaman's followers. Percy had promised, immediately after the August I9I I primáries, to resign in January I 12 unless in self-defence he was forced to keep his seat by continued attacks upon him; and he refused to retire (March 9, I9I2). Vardaman's accession to the United States Senate was deprecated by many because as governor he had indulged in much severe criticism of negroes. In November I 9 I I a suit in chancery was brought against Vardaman for the restitution of public moneys, but the suit was dismissed, March 2, I9I 2, after an investigation by the legislature. Earl L. Brewer, governor for I9г 2-16,- - elected without opposition, - is a Democrat, and the legislature and the congressional delegation ( 8 as before) are Democratic. The Republican state convention split and chose rival delegations, one for Taft and one for Roosevelt, but the former was seated and many contests were withdrawn at the last moment. In the presidential campaign the state primary elections were for Underwood and in November the vote was overwhelmingly large for Woodrow Wilson, who received 57,164 votes to 3,627 for Roosevelt, 1,5 I I for Taft and 2,01 7 for Debs (978 in 1908).

There were several lynchings in the state in $19 \mathrm{I} \mathrm{I}-\mathrm{I} 2$ : of a negro for murder at Rockport (March 25, I9II); 2 negroes for attempting to poison a family at Louisville (May 5th); a negro accused of murder at Chunky (June I6th); one for murderous assault on a white man at Lockhart (Nov. 7th); one at Sucarnoochee (Jan. I 5, I9I2) for murder; one at Starkville (Feb. I 4 th) for rape; one at Greenville (May 7 th) for the same offence; and another on the same day at Macon for murder. A negro was killed in a gambling raid at Gunnison (Feb. I5, I9II) and a race war for a time seemed imminent.

The state suffered from floods in the spring of I9I2. A dike at Greenville burst April $\mathrm{I} 2$ th and about $\mathrm{I}, 300 \mathrm{sq} . \mathrm{m}$. in the lower Yazoo district was inundated.

There was a serious strike centering in the state on the Yazoo \& Mississippi Valley Railroad. A federation of railway employees in June IgI demanded recognition, not merely in Mississippi, from the "Harriman" lines. Of the 9 unions included in the federation, 7 had contracts which called for 30 days' notice before action on change in relations; the officials of the railway, on this ground refused to recognise the federation. The men went out, September 25, I9II, and there was violence at Vicksburg and McComb City, when new men tried to work, so that the militia had to be called out. No settlement of the strike was made in IgII or IgI2.

The state supreme court on December ro, rgiz ruled that the "Jim Crow" law (for separate cars for negroes) applies to through sleeping cars as well as day coaches.

${ }^{1}$ The other senator from Mississippi is John Sharp Williams (b. I 854; representative in Congress 1893-1909; minority leader 1903-09). He succeeded for 1911-17 Hernando de Soto Money (1839-1912), senator from I897 to I9I I, who died on September 18, I9I2. 


\section{MISSOURI}

Population (rgro) $3,293.335$ (6\% more than in rgoo). Negroes made up $4.8 \%$ $(5.2 \%$ in 1900$)$; native whites $88.2 \%(87.9 \%$ in 1900$)$, and forcign-born whites $6.9 \%$ (unchanged). Density to the sq. m. 47.9 ( $I I, 262.8$ in St. Louis). The urban population (in 62 municipalities of 2,500 or more) made up $42.5 \%$ of the total (in 1900,50 cities made up $36.3 \%$ ); there was a decrease from 53.7 to $46.6 \%$ in the purely rural population. There were 27 municipalities of 5.000 or over, as follows: St. Louis. 687.029 ( 575,238 in 1900); Kansas City, 248.381 ( 163,752 in I900); St. Joseph, 77,403; Springfield, 35,201; Joplin, 32,073; Hannibal, 18,341; Sedalia, I 7,822; Jefferson City, I I 850; Webb City, I I,8 I 7; Moberly, I0,923; Independence, 9,859; Columbia, 9,662; Carthage, 9,483; St. Charles, 9,437; Cape Girardeau, 8,475; Wellston, 7,3 I 2; Nevada, 7,1 76; Webster Groves, 7,080 (1,895 in 1900); Poplar Bluff, 6,916; Kirksville, 6,347; Chillicothe, 6,265; Mexico, 5,939; Brookfield, 5,749; Trenton, 5,656; Lexington, 5,242; Fulton, 5,228; Flat River, 5, II2.

Agriculture.-The acreage in farms increased from $33,997,873$ to $34,591,248$ between 1900 and 19I0; the improved land in farms from 22,900,043 to 24,581, 186; the average farm acreage from I I 9.3 to I 24.8 ; and the value of tarm property from \$ I , 033, I 2 I, 897 to $\$ 2,052$,917,488 (\$1,445,982,389 land, \$270,22 1,997 buildings, \$50,873,994 implements, and \$285,839,108 domestic animals). Of the land area $78.6^{\circ}$, was in farms. The average value of farm land per acre was $\$ 41.80$. Farms were operated largely by owners (192,285 by owners, 2,00 I by managers and 82,958 by tenants). In 1912 (preliminary estimates) the principal crops were: Indian corn, $243,904,000$ bu. $(7,622,000$ A.); wheat, $23,750,000$ bu. (1,900,000 A.); oats, $37,125,000$ bu. (I,125,000 A.); barley, I 49,000 bu. (6,000 A.); rye, 222,000 bu. (I5,000 A.); buckwheat, 30,000 bu. (2,000 A.): potatoes, 7,980,000 bu. (95,000 A.); hay, 4, 143,000 tons $(3,187,000 \mathrm{~A}$.); cotton, 59,000 bales (267 lbs. per A.); tobacco, 6,000,000 lbs. $(6,000 \mathrm{~A}$.); flaxseed, 72,000 bu. (I2,000 A.). In I909 (U. S. Census) the value of vegetables (excludirg potatoes) was $\$ 8,268,28 \mathrm{I}$; of small fruits, $\$ \mathbf{I}, 76 \mathrm{I}, 409$; of orchard fruits, $\$ 6,582,578$ (apples, $\$ 4,885,544$; peaches and nectarines, $\left.\$ 1,110,55^{\circ}\right)$. On January 1,1912 there were on farms: I,095,000 horses, 333,000 mules, 822 ,000 milch cows, 1,504,000 other neat cattle $1,755,000$ sheep, and 4,491,000 swine. In 1912 the agricultural experiment station pursued various studies of Indian corn and of hog cholera, and continued its rotation experiments conducted for more than twenty years on the same field. With the Federal department of agriculture it co-operates in investigations of farm management.

Mineral Products.-Total value, I9II, \$52,636,348. Of greatest importance were: lead, 182,207 tons $(\$ 16,398,630)$ being about $95 \%$ of the total output in 191 I of the Central States; and zinc 127,540 tons $(\$ 14,539,560)$, more than from any other state. About fivesixths of the lead comes from central and S. E. Missouri and almost all the zinc from the S. IV. part of the state. From the lead ores of S. E. Missouri there was recovered $49,100 \mathrm{oz}$. of silver $(\$ 26,500)$; and $640,4 \mathrm{II}$ lbs. of copper $(\$ 80,05 \mathrm{I}$; nearly seven times as much as in 1910). The coal mined in I9II was $3,760,607$ tons $(\$ 6,431,066)$. Clay products, almost all brick and tile, were valued at $\$ 6,274,353$; and sand and gravel at $\$ 1,0+2,674$, ranking the state 4 th. Mineral waters, bottled at $2+$ springs, were valued at $\$ 86,7+7$. The value of natural gas was only $\$ 10,496$ and that of harytes - of which more is found here than in any other state- $88 \mathrm{I}, 380$. In $19 \mathrm{II}$ new deposits of tripoli were found at Stella, about $25 \mathrm{~m}$. E. of Seneca, where deposits had already been worked.

Manufactures. - In $1904^{-09}$ the number of establishments increased from 6,464 to 8.375 ; the number of persons engaged in manufacturing from 156.585 (1 33.167 wage-earners) 11) 185,705 (152,993 wage-earners); the capital from $\$ 379,369$, 000 to $\$ 4+4,343,000$; and the value of products from $\$ 439,549,000$ to $\$ 574,111,000$. The most important industry was slaughtering and meat-packing $(\$ 79,581,000)$. In the manufacture of boots and shoes Missouri ranked 2 nd ( 4 th in $1904 ; 8$ th in 1899 ) with a product of $\$, 8,751,000$. Other important manufactures were flour and grist-mill products, $\$_{4+508,000}$; printing and publishing, \$29,651,000; malt liquors, \$27,447,000; lumber and timber, \$23,261,000; men "s lothing, \$15,407,000; foundry and machine-shop products, \$19,975,000; roasting and grinding coffee and spice, \$12,062,000; railway car construction, \$9,812,000; carriages and wagons, $\$ 8,469,000$; copper, $t$ in and sheet iron, $\$ 7,827,000$; and patent medicines, $\$ 7,639,000$. $S t$. Louis was by far the most important manufacturing city $(\$ 328,495.000)$ ranking + th among the cities of the Union. Other manufacturing cities were Kansas City, $\$ 54,705,000$; sit. Joseph, \$17,626,000); Hannibal, \$6,195,000; Jefferson (ity, $85.446,000$; Springfield, $\$ 5,382,000$; Jopplin, $\$ 4,1,36,000$ (chiefly lead-smelting); Sedalia, \$2,333,000; Moberly, \$1,984,ooo; and Webb City, $\$ 777,000$.

Transportation.--Total railway mileage, on January I, 1912, 8,22 1.17.

I See E. B. xviii, 607 el seq. 
Government.-The legislature met January 4 to March 20 , I9II. On February 5 th the state capitol building (built I838) was struck by lightning and burned. At a special election the people on August ist voted ( 144,644 to 45,468 ) an issue of $\$ 3,500$, 00 in I3 year bonds to rebuild the capitol on nearly the same site. Tracy, Swartwout \& Litchfield of New York were chosen architects on October 7, I9I 2.

The following constitutional amendments. were submitted by the legislature for vote by the people in November I9I2; to provide that free public education must be furnished for children between 6 and 20, and that it may be furnished for children between 5 and 6 and for those over 20 -defeated, 367,032 votes to 207,298; two amendments changing municipal limits of indebtedness, both defeated; one to change the qualifications for electors by omitting the clause in the constitution of 1875 which permitted males of foreign birth to vote if they had declared intention of becoming citizens of the United States,-defeated 378,263 to $x 72,140$; and one empowering the legislature to provide for registration of voters in St. Louis county (defeated, 385,698 to 151,694 ). Four constitutional amendments proposed by initiative were defeated; one changing the tax system so that land and franchises only would be taxable after I9I9 (508, ז 37 votes to 86,647 ); one substituting a tax commission, appointed by the governor, for the state board of equalisation $(475, \mathrm{I} 5 \mathrm{I}$ to $96,9 \mathrm{rr})$; one revising the election and registration law $(348,495$ to 197,643$)$; and for a one mill tax for schools $(401,843$ to 154,952$)$.

The legislature ratified on March I6th the proposed amendment to the Federal. Constitution providing for an income tax.

The supreme court was authorised to appoint four commissioners to assist it in preparing statements of fact and opinions, and to sit with it when required. Ballots for primary elections are no longer to have names arranged alphabetically, but in rotation in different districts, so that the advantage of position on the ballot will not be everywhere the same.

In factory, mechanical or mercantile estabblishments, including laundries and workshops, no woman is allowed (or "suffered") to work more than 9 hours a day or 54 hours a week. The working day for children under 16 is limited to 8 hours (not between 7 P.M. and 7 A.M.), and a working week to 48 hours. Children under 15 may be engaged only in agricultural and domestic service. Boys under 10 and girls under 16 are not allowed to sell on streets or in public places. The act strikes out the previous exemption of children from school attendance if it is shown that a child's labour is absolutely necessary for the family support.

Express companies are required to post schedules of tariffs and are placed under the supervision of the board of railroad and warehouse commissioners, which also fixes railway passenger rates. The liability of common carriers may not be limited by contract. The state anti-trust law was upheld, April I, I912, by the U. S. Supreme Court, in an appeal on the ouster of the Standard Oil Company and Republic Oil Company. In November I9I2 there was an ouster against the International Harvester Company. The adulteration and misbranding of foods was forbidden and provisions were made for the sanitation of bakeries, canneries, packing houses and other establishments producing foods. False statements tending to injure bank, trust or guaranty companies are punishable by a fine of $\$ 1,000$, imprisonment in the county jail for one year or less, or by both. The law permitting third class citics and special charter cities to erect and owh public utility plants was extended to include fourth class cities and towns and villages under special charter with a population less than 30,000 . The legislature of I9II appropriated \$5,000 for a monument to General Sterling Price in Price Memorial Park, Keytesville, and \$I, ooo for a marker at the birthplace, Florida, of Samuel L. Clemens (Mark Twain) and \$10,00o for a monument to him in Riverview Park, Hannibal,' for this monument Frederick C. Hibbard of Chicago was chosen as sculptor. The contract for the latter monument calls for its completion by June I, I9I 3 and the former is expected to be completed during the summer.

In St. Louis an ordinance of March 27, 19 II created a city plan commission, succeeding the (unofficial) city plan association, which was the outgrowth of a committee of the Civic League of St. Louis. In 1912 the commission reported favourably on a central traffic-parkway to be built by the city after condemnation of blocks bounded by Market, Chestnut and Twelfth streets and Jefferson Avenue; it began work on a report on the river front. St. Louis in November 1912 adopted a charter amendment $(62,359$ to 41,243$)$ for initiative and referendum. In I9II the city established a municipal reference library.

In Kansas City the board of public welfare has a research bureau which has charge of the charities registration bureau, the charities endorsement department, and of the sociological library and museum. It has published a Report on Housing Conditions.

Finance. - In IgI I a paragraph on the incorporation of mortgage loan companies to be under the supervision of the Bank Commissioner was added to the law in regard to banking

1. His early home was presented to the city of Hannibal, May 15, 1912. 
companies. The balance in the treasury on January 1, I9II was $\$ 1,829,546$; receipts for the calendar year, $\$ 7,598,067$; disbursements, $\$ 7,388,902$; and balance on January I, 1912 , $\$ 2,038,712$. The state debt was $\$ 284,000$ capitol building bonds and $\$ 4,398,839$ school fund certificates.

Educution.-For public schools the legislature appropriated one-third of the ordinary revenue paid into the treasury for the fiscal years July I, 1910-June 30, 1912; and for higher education for I9I and $1912, \$ 2,352,975$. Pupils living more than half a mile from a public schrol are to be carried to school free if the board of directors in the district approves. Boards in cities with more than 75,000 inhabitants and less than 500,000 (that is St. Joseph and Kansas (ity) may erect public libraries, art galleries, museums and auditoriums, even though these are not used strictly for school purposes. School districts may issue bands to erect library buildings. The requirements for teachers' certificates were raised in I911. In Octoher 1912 the General Education Board gave $\$ 75,000$ to Central College at Lafayette. In 1912 the total population of school age was 958,623 ; the total enrollment 696,893 ; the average daily attendance 488,619 ; the average length of the school term : 155.4 days; total school revenue, $\$ 17,101,000$, and expenditures, $\$ 14,200,000$

The percentage of illiteracy in 1910 of population 10 years and over was 4.3 (6.4 in 1900).

Penal and Charitable Institutions-- The labour of convicts, by a law of $19 \mathrm{I} I$, is not to be let, farmed or sold; convicts are allowed to work in the binding twine plant and in manufacturing for state institutions supplies, which are not to be purchased elsewhere if it is possible for convict labour to supply them. A law of I9I I allows counties with a population of 250,000 to 500,000 ( Jackson county, including Kansas City, was the only one in this class) which have a juvenile court, to appropriate not more than \$12,000 a year for the support of mothers (of children under 14), who are widows or whose husbands are prisoners and who would otherwise have to work away from their children. Cities of 500,000 or more (St. Louis only in'1910) may create a board of children's guardians to manage public institutions of the city for delinquent, dependent or defective children. Juvenile courts for children under 17 were established in counties with a population of 50,000 or more. Tuberculosis hospitals are to be established in special districts called "Tuberculosis Hospital Districts." In June, I9I I, two tuberculosis hospitals (for men and for women) were opened at the State Hospital at Nevada; in June, 1912, one was opened at Fulton. Buchanan county voted for a hospital in November, 1912; and in the same month in Kansas City, in accordance with an appropriation of $\$ 50,000$ made in 1911 , a site was chosen for a city hospital.

History.-The legislature, being strongly Democratic, chose (Jan. I8, I0I I) the nominee of the Democratic primaries (over David R. Francis), James A. Reed (b. I 86r; Reform Democratic mayor of Kansas City i900-04) as United States senator to succeed William Warner (b. 1840; Republican; representative in Congress I 885-89), whose term expired Merch 4, I9ir. Herbert Spencer Hadley (b. I872), Republican, governor in $1909-13$, was at one time suggested as a "compromise" Republican candidate for the presidency. ${ }^{1}$ In the National Republican convention ${ }^{2}$ he was considered the ablest and fairest of the speakers for Roosevelt, but eventually he refused to join the new Progressive party, definitely announced himself for Taft (Oct. 3, 19I2), and, after the death of Sherman, was the choice of most of the Republican National committeemen to succed him on the Taft ticket for vice-president. In the contest for governor the Republicans in the state nominated John C. McKinley, lieutenant-governor in 1905-09, whose suggestion in the party platform to use convict labour in printing school books roused the opposition of labour unions and publishers; but he was defeated by Elliott IV. Major (b. 1864), Democrat, attorney-general of the state in 1909-13. Major received more votes than McKinley (Rep.) and A. D. Nortoni (Prog.) together, while Mckinley received about twice as many votes as Nortoni (Major, 337,oro; McKinley, 21 7,819 ; Nortoni, I00, 146). The entire Democratic state ticket was elected,-an unusual thing in the state, where Hadley had some Democratic administrative officers and a Democratic majority in the legislature and Folk was the only Democrat on the state ticket clected in 1004 . The next legislature will be composed of 25 Democrats and 9 Republicans in the senate and I 3 Democrats, 28 Republicans and I Progressive in the house. There were no Progressive candidates for Congress and the delegation of 16 will have I $_{4}$ Democrats and 2 Republicans (in 62 nd Congress, 3 Republicans, ${ }^{3}$ all from

'Harlley's predecessor as governor, Joseph Wingate Folk (b. I 869), Democrat, was considered a posible Democratic candidate, but withdrew (Feb. 10, 1912) in favour of another Missourian, Champ Clark.

${ }^{2}$ Eight delegates for Roosevelt were seated by the National Convention after contests.

' One of these, Theron E. Catlin, was unseated (August 12th) by a partisan vote of the 
St. Louis). Woodrow Wilson carried the state with 330,746 votes t.3 207,821 for Taft 124,37 I for Roosevelt, and 28,460 for Debs ( 15,43 I in 1908).

In IgI I there were two Jynchings in the state on the same day (Ort. I 7th) at Caruthersville, where a negro suspected of robbery and one accused of an assault were taken from jail and shot.

The state suffered greatly from the terrible flood of the Mississippi and Missouri rivers. About 700 sq. m. in the Upper St. Francis Basin were inundated and New Madrid was entirely cut off in April ror.2.

In. St. Louis a joint committee on public morals, representing 30 organisations, recommended late in $\mathrm{I} 9 \mathrm{I} 2$ after an exhaustive investigation the creation of a permanent commission to fight the social evil. In November Ig I 2 charter amendments for initiative and referendum were adopted; but amendments for a bond issue for a free bridge and for an increase in salary of members of the municipal assembly were defeated. The League of Missouri Municipalities at its $5^{\text {th }}$ annual convention (December I 7, 19r 2) at St. Louis adopted resolutions favouring the calling of a convention to revise the state constitution:

Bibliography.-Laws (Jefferson City, I9II); the Official Manual for 1911-12; The Missouri Red Book for IOII (Part I, Labor Section); Missouri Historical Society of St. Louis Collections, vol. iii, No. 4 (1912); J. D. Elliff, Missouri (New York, 19Ir).

\section{MONTANA}

Population (1910) 376,053 ( $54.5 \%$ more than in 1900 ). Indians and Asiatics constituted $3.6 \%(6.4 \%$ in I 900$)$, native whites of native parentage $43.1 \%(38.2 \%$ in I900). Density 2.6 to a sq. $m$. The population was $55.2 \%$ rural (in $1900,58.8 \%$ ). In I9Io there were 14 cities and towns (with $35.5 \%$ of the total) having over 2,500 inhabitants each, as follows: Butte, 39,I65; Great Falls, I3,948; Missoula, I2,860 (4,366 in 1900); Helena, I 2,5 I 5; Anaconda, 10,134; Billings, 10,031 (3,221 in r900); Kalispell, 5,549; Livingston, 5,359; Bozeman, 5,107; Red Lodge; 4,860; Miles City, 4,697; Havre (town), 3,624 ( 1,033 in 1900); Lewistown, 2,992; and Deer Lodge, 2,570.

Agriculture. - The acreage in farms increased from $8,344,454$ to $13,545,603$ between 1900 and $19 \mathrm{IO}$ and the improved land in farms from 4725,720 to $3,640,309$; the average farm acreage fell from 885.9 to 516.7 and the value of farm property increased from $\$$ I I $0,225,423$ to $\$ 347,828,770$ (\$226,771, 302 land; $\$ 24,854,628$ buildings; $\$ 10,539,653$ implements; $\$ 85,663,187$ domestic animals). Of the land area $14.5 \%$ was in farms in 1910 . The average value of farm land per acre was \$16.74. Farms were operated largely by owners (23 365 by owners, 505 by managers, and 2,344 by tenants). In 1912 (preliminary estimates) the principal crops were: Indian corn, 61 2,000 bu. $(24,000$ A.); wheat, I9.346,000 bu. (803,000 A.); oats, $22,848,000$ bu. (476,000 A.); barley, $1,424,000$ bu. (39,000 A.); rye, 235,000 bu. (I0,000 A.); potatoes, 6,105,000 bu. (37,000 A.); hay, I,2 I6,000 tons $(640,000 \mathrm{~A}$.) and flaxseed $5,520,000$ bu. $(460,000$ A.). In 1909 (U.S. Census) the value of vegetables other than potatoes was $\$ 928,906$; of flowers and plants, \$104,601; of nursery products \$174,427; of small fruits, $\$ 86,586$; of orchard fruits, $\$ 609,078$. On January $\mathbf{I}, \mathbf{I} 912$ there were on farms 347,000 horses, 4,000 mules, 91,000 milch cows, 732,000 other neat cattle, 5,011,000 sheep, and 143,000 swine,

In 1909 about one-third of the farms of the state were irrigated (two-thirds in 1889 ) and dry-farming was used largely in Cascade, Chouteau, and Fergus counties. To rolo the total

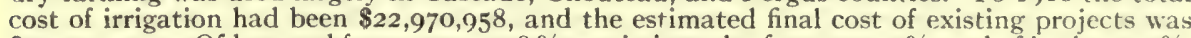
$\$ 32,407,452$. Of hay and forage crops $58 \%$ was irrigated; of oats, $47.9 \%$, and of barley, $34 \%$. Of the Federal projects the Huntley (Yellowstone county) and the Lower Ycllowstone (Dawson county) were practically completed in $191 \mathbf{I}-12$ and irrigated respectively 12,000 acres (sugar beets, cereals, alfalfa) and 2 I,800 acres, partly in North Dakota (wheat); the Milk River, I 5.5\% completed, irrigated 2,000 acres, and the Sun River, $9 \%$, with 7, I 70 acres. The Flathead project in 1912 was $15 \%$ completed; the Little Porcupine unit of the Fort Peck project was practically completed; and of the Blackfeet project the Two Medicine unit was $73 \%$ completed, the Badger-Fisher unit $25 \%$ and the Piegan unit $83.5 \%$.

The U.S. department of agriculture established in $19 \mathrm{I}$ I an experimental farm on the Huntley reclamation project; the bureau of entomology has worked successfully to control the bark-beetle pest near Columbia Falls; and this bureau, the biological survey and the state agricultural experiment station in $1911-12$ studied the origin of the spotted fever, so danger-

House, on the recommendation (July 19 th) of the Committee of Elections, because he spent $\$ 13,000$ in his campaign, $\$ 662$ being the maximum under the state law.

i See $E_{\text {. }}$ B. xviii, $75^{2}$ et seq. 
ous to domestic cattle and to man in the Bitterroot lalley, and discovered that the tick which carries it infosts most frequently the ground squirrel (Citellus columbianus), which is besides a pest in the grain fields. The state has 19 demonstration dry farms and two sub-stations for dry-farm work and one horticultural sub-station. A state board of poultry husbandry was established in $191 \mathrm{I}$. For 1912 the legislature appropriated \$22,500 for the experiment station and $\$ 20,000$ for dry land farm demonstration work.

Mineral Products. - Total value, 19II, \$53,454.926. In copper the state ranked 2 nd to Arizona, with $271,814,491$ lbs. Second in importance were silver (12, I63,900 oz.) and gold $(176,554 \mathrm{oz}$.), together valued at $\$ 10,218,200$. The output of zinc was 22,115 tons (40\% more than in 1910 ), of lead 2,499 tons (more than double that of 1909 ), and of coal 2,976358 tons $(\$ 5,342,168)$. New deposits of phosphate rock were found in $191 \mathrm{I}$ in the S.W part of the state. (iraphite property near Dillon, Graphite county, was being developed.

Manufactures. - From 1899 to 1909 the number of establishments increased from 395 tc 677 ; wage-earners from 9,854 to 11,655 ; invested capital from $\$ 38,225$,000 to $\$ 44,588000$ and value of products from $\$ 52,745,000$ to $\$ 73,272,000$. The principal manufactures were copper smelting and refining products (not valued separately); lumber and timber, $\$ 6,334,000$ (102.9\% more than in 1904); car construction and repairs by steam railway companies $\$ 2,8$ I I,000; malt !iquors, \$2,+40,000; flour and grist-milling products, \$2, I 75.000; and slaugh tering and meat-packing products, $\$ 2,054,000$. The largest manufacturing centres were Butte, \$2,464,010; (rreat Falls, with large copper smelters; Helena, \$1,303,000; B1llings $\$ 1,243,000 ;$ and Missoula, \$1,171,000.

Transportation. - Railway mileage January I, I912, 4,360.72. Hauser Lake Dam across the Missouri $18 \mathrm{~m}$. below Helena, was completed May 21,1911 .

Legislation.- The I 2 th regular session of the legislature was held from January 2 to March 2, I9I I. The proposed I6th amendment to the Federal Constitution providing for a Federal income tax was ratified on January 3I. The legislature memorialised Congress for a constitutional convention which should recommend an anti-polygamy clause in the Federal Constitution; urged an amendment to the Federal Constitution providing for the direct election of United States senators, and asked for the opening to settlers of the Crow Indian Reservation and for the segregation of agricultural lands in national forest reserves. The Oregon plan of direct vote for United States senators and for pledging state legislators for the choice of senators was adopted. The legislature ceded to the Lnited States Glacier National Park; created the county of Musselshell from parts of Fergus, Meagher and Yellowstone counties, making Roundup the temporary county-seat, and established a fish hatchery (partly built in I9I2) near Somers, Flathead county. An elaborate law for the registration of voters was passed.

The use of the "third degree" or of torture in obtaining confessions from prisoners was forbidden. Common councils of first or second class cities must (others may) provide free employment bureaus. Eight hours was made a working day except in emergency for men in underyround mines or tunnels. A new coal mining code raised the requirements and increased powers of coal inspectors; and included provisions for safe-guarding the lives and health of miners. At the October IgI I term the state supreme court declared unconstitutional the cral-miners' compensation act passed by the legislature of 1909 . The liability of railways for the death of their employees was increased; contributory negligence is no longer a lar to recovery lut damages may be diminished therefor; there is no assumption of risk if the accident happens through the negligence of an employee or of a fellow employee, and liability may not be avoided by contract. The secretary of the bureau of child and animal protection was authorised to appoint a deputy for each of the six more important cities.

The penalty for the white slave traffic was made imprisonment from 2 to 20 years in the state prison, or a fine of $\$ 1,000$ to $\$ 5,000$, or both imprisonment and fine. A statute forbids the drinking of introxicating liquors on passenger trains except in buffet, sleeping and dining cars. Vo city or county may issue more than one licence for every 500 inhabitants except that two salorns may be licensed in any city or town. In unincorporated cities or towns saloons are not to lee open letween I A.M. and 6 A.M. A statute forlids the sale and manufacture of adulterated fungicides and inserticides and all misbranded or adulterated food and drugs and regulates the sale of dairy proflucts. The offices of state fire marshal and state sealer of weights and measures were created. Teachers in public and parochial schools must instruct their pupils in the danger of fire, and a state text book was authorised for this purpose. Cities may arloyt the commission form of government (with provisions for recall, for referendum and intiative, for nomination by petition and for strict civil service regulation), at an election after a petition by $25 \%$ of the electors. Missoula adopted the commission plan May 26: in effect July: 27, IgII. On May I4, 1912 Polson adopted it; in effect July 20 th.

Finance.-For 1911 and 1912 there was a levy of $21 / 2$ mills for general state purposes and of $1 / 4$ mill for state sinking fund. A licence tax of srow was levied on every sleeping car operated within the statc. Lnincorporated lanks must he examined by the state examiner. 
and the commissioner of insurance may examine into the affairs of any insurance concern and if necessary publish the result of his examination. On December I, 191 I the balance in the treasury was $\$ 923,081$ and on November 30, 1912, \$1,401,64I The receipts for the fiscal year were $\$ 4,046,691$ and the expenditures $\$ 3,568,131$. The bonded debt was $\$ 200,000$, and $\$ 75,000$ was redeemed before January I, I913; there were outstanding warrants for $\$ 507,897$ at the close of the fiscal year. Capitol building bonds for $\$ I, 000,000$ are a lien on state lands.

Education.-In I9I I manual and industrial training was made a part of the public school curriculum and school districts with a population greater than 5,00o must (others may) establish one manual training school. A commission was appointed in I9I I to codify the school laws of the state. A law school was established (and opened in $\mathrm{Ig} \mathrm{r} \mathrm{I}$ ) at the University of Montana and $\$ 5,000$ was appropriated for a biological station at the university; this was opened in the summer of I912. The percentage of illiteracy in I9Io of the population 10 years and over was 4.7 (6.I in I900). For the year ending August 3I, IgI 2 the school population was 98,687 , enrollment 68,335 , average daily attendance, 49,330 , length of the school year, 7 months, revenue for school purposes, $\$ 4,966,756$, and expenditures, $\$ 3,519,933$.

In 1912, Edwin Boone Craighead (b. I86I), president of Tulane University of Louisiana since 1904 , was chosen president of the University of Montana.

Penal and Charitable Institutions.-By a law of I9I I district courts have jurisdiction as juvenile courts; county committees on juvenile improvement, appointed by the court, confer on jurvenile cases. A state tuberculosis sanitarium-especially for miners' consumptionwas established, and also an institution at the state insane asylum at Warm Springs to cure persons "suffering from mental affliction caused by the use of drugs or intoxicants."

History.-There was a long legislative deadlock over the election of a United States senator to succeed Thomas Henry Carter, ${ }^{1}$ Republican. The legislature was Democratic on joint ballot (by 6 votes), but Carter's political influence was so strong that he came near re-election. The deadlock was broken March 2 by the choice on the 79 th ballot of Henry L. Meyers (b. I862), Democrat and district judge. In November I9I 2 the state was carried by Woodrow Wilson, who received 28,230 votes to I 8,404 for Taft (who had carried the Republican primaries in May), 22,448 for Roosevelt (who was supposed to be bitterly opposed by the Amalgamated Copper Company, a great influence in the state) and 10,828 for Debs ( 5,855 in I908). The two congressmen elected are Democrats and the legislature, with a Democratic majority of 25 , on January I4, I9I3, elected Thomas James Walsh, Democrat, of Helena, United States senator to succeed Joseph Moore Dixon (b. 1867), who was the manager of the Progressive party's campaign for the election of Roosevelt, and who received less votes in the November election than Judge H. C. Smith the Republican candidate. The whole Democratic state ticket was elected with Samuel V. Stewart as governor, receiving 25,375 votes to 22,809 for Harry L. Wilson (Rep.) and r 8,858 for Frank J. Edwards (Prog.)

In Butte a socialist was elected mayor ( 1,834 plurality) and 5 (out of $\mathrm{r} 6$ ) councilmen of the same party were elected, April 3, r.9II; and the Socialist mayor of Butte, Lewis J. Duncan, running for governor, received more votes than Debs. On the eve of election in November I9I 2 there was a riotous attack on the governor and on the Democratic candidate for governor after a Socialist demonstration.

The Federal Supreme Court (Quong Wing v. Kirkendall; January 22, I9I2) decided that on the grounds on which the test was brought there was no unconstitutionality in a law taxing hand laundries employing less than two women; the ground that the law was aimed at the Chinese was not urged.

The confessed murderer of a woman was lynched at Forsyth, April I8, I9I 2.

Bibliography._Laws, Resolutions and Memorials (Helena, I91 I); other official documents, notably Montana (ibid., I9I2) issued by the Bureau of Agriculture, etc.

\section{NEBRASKA ${ }^{2}$}

Population (I910) I,I92,214; an increase of $\mathrm{II} .8 \%$ since I900. The foreign-born whites constituted $14.8 \%$ ( $16.6 \%$ in 1900$)$, and the native whites $84.3 \%(82.5 \%$ in I900). Density I 5.5 to the sq. m. The purely rural territory contained $53.5 \%(58.6 \%$

${ }^{1}$ Carter was born in Scioto county, Ohio, October 30, I854; died September 17, I9II. He was delegate from Montana Territory and then representative in the 51 st Congress, 1889 91, Commissioner of the (Federal) general land office, 1891-92, and United States senator I $895-190 \mathrm{I}$ - and $1905 \sim \mathrm{I}$.

${ }^{2}$ See E. B. xix, 323 et seq. 
in 1900 ); the semi-urban $20.4 \%$ ( $17.7 \%$ in 1900$)$; and the urban $26.1 \%(23.7 \%$ in 1900$)$. In I9 10 there were 13 incorporated places of 5,000 or more, as follows: Omaha, I 24,096 (102,555 in 1900); Lincoln, 43,973; South Omaha, 26,259; Grand Island, I0,326; Beatrice, 9,356; Hastings, 9,338; Fremont, 8,718; York, 6,235; Kearney, 6,202; Norfolk, 6,025; Nebraska City, 5,488; Fairbury, 5,294 (3,140 in I900); Columbus, 5,or 4.

A griculture.-The acreage in farms increased from $29,9 \mathrm{I}$ I, 779 to $38,622,02 \mathrm{I}$ between 1900 and 1910 and the improved land in farms from $18,432,595$ to $24,382,577$; the average farm acreage from 246.1 to 297.8 ; and the value of farm property from $\$ 747,950,057$ to $\$ 2,079,818$,647 (\$1,61 $4,5,39,313$ land; \$198,807,622 buildings; \$44,249,708 implements; \$222,222,004 domestic animals). Of the land area $78.6 \%$ was in farms. The average value of farm land per acre was 34 I.80. Farms were operated largely by owners $(79,250$ by owners, 987 by managers, and 49,44I by tenants). In 1909 I,852 farms (255,950 acres; 100,30I in Scotts Bluff and 34,760 in Lincoln county) were irrigated, and the acreage which actual enterprises could irrigate was 429,225 and that which was included in projects was 680,133 . The largest irrigated crop acreages were: wild, salt or prairie grass, 37,019; alfalfa, 31,842; Indian corn, 2 I,552; oats, 18,794; wheat, 9,015 ; potatoes, 6,077 ; barley, 3,495 ; sugar beets, 3,1 I 4 . In I 912 (preliminary estimates) the principal crops were: Indian corn, $182,616,000$ bu. $(7,609,000$ A.); wheat, $55,052,000$ bu. $(3,123,000$ A. $)$; oats, $55,510,000$ bu. $(2,275,000$ A. $)$; barley, 2,486,000 bu. (I 3,000 A.); rye, 880,000 bu. (55,000 A.); buckwheat, I 8,000 bu. (I,000 A.); potatoes, $9,440,000$ bu. (1 I 8,000 A.); hay, I 552,000 tons (I, I 50,000 A.); flaxseed, 19,000 bu. (2,000 A.). In 1909 (U.S. Census) the value of vegetables (excluding potatoes) was $\$ 2,118,393$; of small fruits, \$159, I69; of orchard fruits, \$1,932,124 (apples, \$1,612,765). On January 1, 1912 there were on farms: 1,059,000 horses, 85,000 mules, 61 3,000 milch cows, 2,002,000 other neat cattle, 382,000 sheep and $4,267,000$ swine.

In November 1912 the North Platte reclamation project (see E. B. xix, 327a) was $83 \%$ completed, and in I9I I irrigated 74,300 acres, partly in Wyoming.

Mineral Products. - Total value, I9II, \$1,316,168. Clay is the only mineral product of importance and in I9I the value of clay products was $\$ 795,894$. Limestone was valued at $\$ 263,501$, and sand and gravel at $\$ 156,777$.

Manufactures. - From 1904 to 1909 the number of establishments increased from 1,819 to 2,500 and that of persons employed from 25,356 (20,260 wage-earners) to $31,966(24,336$ wage-earners); capital invested from $\$ 80,235,000$ to $\$ 99,901,000$; and the value of the product from $\$$ I 54,918,000 to $\$ 199,019,000$. The principal manufactures were: slaughtering and meat-packing products, $\$ 92,305,000(46.4 \%$ of the state's total, and ranking Nebraska 4 th in this industry); flour and grist-mill products, $\$ 17,836,000$; butter, cheese and condensed milk, $\$ 7,681,000$ (130.9\% more than in 1904), mostly butter; car construction and repairs by steam-railway companies, $\$ 4,642,000$; malt liquors, $\$ 3.335,000$ (100.4\% more than in 1904 ); foundry and machine-shop products, \$2,930,000; lumber and timber products, \$2,02 I, 000. The principal manufacturing cities were: South Omaha, $\$ 92,436,000$, chiefly slaughtering and meat-packing $(96.9 \%$ of the state's product); Omaha, $\$ 60,855,000$; Lincoln, $\$ 7,010$,000 ; and Grand Island, \$1,837,000.

Transportation. - Railway mileage, on January I, 1912, 6,223.17.

Legislation. - The regular session of the legislature was held from January 3 to April 6, I9II. It re-districted the state into 28 senatorial and 77 representative districts. The legislature submitted several constitutional amendments to popular vote in November I912: for initiative and referendum, both statutory and constitutional, which was adopted by 180,200 to 15,3 I 5 votes; changing the pay of members of the legislature to $\$ 600$ a year (formerly $\$ 5$ a day) and Ioc a mile for mileage, and providing that no bills shall be introduced after 20 days (formerly 40 days) of the 60-day session had elapsed, except on the recommendation of a message from the governor-adopted, 173,225 to 26,355 ; creating a board of commissioners for state institutions-adopted, 174,939 to 25,439 ; and for biennial instead of annual general elections-adopted I 74, I 5 I to 25,048 . The legislature ratified the proposed income tax amendment to the Federal Constitution on February II, I I I and it sent a resolution to Congress asking for an amendment to the Federal Constitution prohibiting polygamy. An important primary law was enacted which provided a method of electing delegates to National Conventicns and a method of preferential voting for presidential and vice-presidential candidates. The governor was authorised to appoint a code commission to report a new code for 1913. The I 2 th of October was made a legal holiday as Columbus Day.

Trainmen's working hours are limited to 16 in succession, to be followed by 10 hours off; if any trainman is busy 16 hours not in succession, within a period of 24 hours, he must have 8 hours off before he is on duty again. Train dispatchers must work not more than 9 hours 
any day. Acts were passed to protect workmen on buildings, and for the sanitation of factories where eight or more workmen are employed; and employers who do not comply with these acts are held to strict liability for injuries or death of employees.

All schools are required to observe the first Friday in November as State Fire Day, and teachers must give at least 30 minutes in each school month to instruction in the danger of fire. A hotel commission insures the comfort and protection of guests, and the law provides for individual towels for all guests, for bed sheets 99 inches long, etc. The food, drug and dairy commission was reorganised. It was made unlawful for minors under 18 to smoke tobacco in any form. Houses of ill fame are declared a nuisance, and the act provides for the abatement thereof; on a permanent injunction for maintaining such a nuisance a tax of $\$ 300$ is assessed on the building and on the ground. Pandering is made punishable by imprisonment in the county jail from six months to a year, by a fine of $\$ 1,000$ or less, or by both; and a second offense by imprisonment from three to ten years in the penitentiary. A wife's testimony is competent against her husband and marriage is not a defence.

Cities of 5,000 or more, under a constitutional amendment (adopted November 5, I9I2 by 164,579 to 32,04 I) may frame their own charters. They may, by statute, adopt commission form of government. A special election is to be called on the petition of $25 \%$ of the voters, but, if the commission plan is not adoptc $\mathrm{d}$ at this election, the proposal may not be re-submitted within two years. Omaha adopted commission government on September 2 , I9II $(5,477$ to 2,29 I votes-out of a voting population of nearly 25,000$)$; the first election was held May 7, 1912 and the commissioners took office on May I4th. Commission government was adopted by Beatrice, October 4, I9II, in effect April 8, I9I2; Nebraska City, January 16, 1912, in effect April 8, I912; and Lincoln, April 19, I9I2 (1,982 votes to I,911), in effect May 1913. Grand Island voted against it, March 19, 1912.

Finance.- The state banking law was amended in I9II. The occupation tax for corporations was revised, the tax to be $\$ 5$ a year if the capital stock is $\$ 10,000$ or less, and $\$ 200$ if $\$ 2,000,000$ or more. The organisation of trust companies in the state was authorised; the requisite capital is scaled to the population of the city in which the company is to do business; and specified security deposits must be made with the state auditor. On December I, I9I0 there was a balance of $\$ 60$ I,290. The total receipts for the two years ending November 30, I9I 2 were $\$ 10,862$, I 42 and the expenditures $\$ 10,890$, I 22, leaving a balance of $\$ 573,310$.

Education.-In I9I I the legislature appropriated $\$ 75,000$ to enable all districts levying a maximum school tax to have a five-month school term. The method of instruction in the State School for the Deaf was changed to the oral or lip-reading method. A new school of agriculture was established and in I9I I-I2 was built at Curtis, Frontier county. So that the course in the medical college may be given entirely at Omaha (instead of two years at Lincoln and two years at Omaha) an appropriation of $\$ 100,000$ was made for a laboratory building in Omaha. The legislature created a legislative reference bureau, including a special department on municipal affairs, to be affiliated with the department of political science and sociology, and with the college of law of the State University. It is to give instruction and furnish facilities for training in legislative reference to students of the university.

In illiteracy, in I9IO, of the population Io years and over the percentage was I.9 (2.3 in I900), ranking the state third from the lowest (Iowa, I.7 \%; Oregon, 1.89\%).

For the year ending July 1912 the school population was 381 , r94; the enrollment, 285,220; the average daily attendance, 213,488 ; the average school year, 146 days; receipts for schools, $\$ 10,461 ; 720$, and expenditures, $\$ 8,757,288$.

Charitable and Penal Institutions. - The juvenile court law was amended in rgri and a board of control for dependent and neglected children was created. A law for an indeterminate sentence gives paroles to the charge of the state prison board. The 2 nd of September, the birthday of John Howard, is made a legal holiday in all penal and reformatory institutions, and is to be called "Howard 's Day." A state hospital for the indigent tuberculous was opened at Kearney in January 1912 . In the state penitentiary a deputy warden was killed by a convict on February II, I912, and on March I4th the warden, a deputy and an usher were murdered by three escaping convicts, two of whom were killed resisting capture. Investigation showed that appropriations had been small, that the office of warden had been a political gift, that prisoners' credits had been exchanged for cash, and that there had been a regular trade in liquor, drugs, etc. ${ }^{1}$

History.-In I9I I-I 2 the state had a Democratic legislature, but the governor, Chester H. Aldrich, and administrative officers were Republican. On January I 7, I9 Ir, as United States senator to succeed Elmer Jacob Burkett (b. I867; Republican; representative in Congress, 1899-r905; U. S. senator, I905-r.I), the legislature elected Gilbert Monell Hitchcock (b. I859; Democrat; editor Omaha World-Hcrald; representative in Congress I903-05, I907-II), whose father Phineas W. Hitchcock (I83I-8I) was senator from Nebraska in $187 \mathrm{I}-77$; he was chosen by primary vote (Nov. I9ro) and some Republican legislators voted for him who were pledged to follow the primary choice. 'See a paper by Judge Lincoln Frost in the March 19, I9 2 Nebraska State Journal. 
In the Democratic party there was a split on the liquor question; a county option law, resembling that urged by William Jennings Bryan, was defeated in the state senate in February I9I I, by a single vote. But in the state convention many party differences were glossed over and Mr. Bryan's followers did not insist on an endorsement of him by the state platform. ${ }^{1}$ In the Republican convention the Taft followers, fearing an open declaration for LaFollette, did not force the issue of re-nominating Taft. In the primaries Clark received 2I, 027 votes to $\mathrm{I} 4,289$ for Wilson and $\mathrm{I} 2,454$ for Harmon; and Roosevelt, 46,795 to 16,785 for LaFollette and $\mathbf{3} 3,34 \mathrm{I}$ for Taft. Governor Aldrich was one of the seven state governors who voiced the call for Roosevelt's candidature, and the state Republican primaries were carried by Roosevelt over Taft. Norris Brown (b. 1863; state attorney-general, I904-06; U.S. senator I907-I3) was defeated for renomination at the Republican primaries by a member of the more Progressive wing, George William Norris (b. I861; representative in Congress, I903-ri ), who received in November on the preferential vote for senator 126,022 votes to I I I, 946 for the Democratic nomince, Ashton C. Shallenberger (b. I862; governor, I909-II). Norris was chosen by the legislature, January 21, I9I3. Early in September the Progressives decided not to run a separate state ticket, ${ }^{2}$ but in spite of this governor Aldrich was defeated by the Democratic nominee, John H. Moorehead, president of the state senate, who received I 23,997 votes to II4,075 for Aldrich. The state senate will be Republican, the lower house Democratic; on joint ballot the Democrats will have a plurality of 5. The failure of the Republicans to "split "lost the Democrats two seats in Congress; the new delegation will be 3 Democrats and 3 Republicans, - that of IgII-I 2 was 5 Democrats and I Republican. Woodrow Wilson carried the state with I09,008 votes to 54,2I6 for Taft, 72,689 for Roosevelt, and I0,1 85 for Debs (in I $908,1,524$ ).

There was one lynching in the state in $x$ II (June Igth) at Valentime where a white man was killed after a quarrel with cattlemen over land rights.

Bibliography. - Laws, Joint Resolutions, and Memorials (York, 191 I); A. Watkins, ed., Collections of the Nebraska State Historical Society (Lincoln, 1912).

\section{NEVADA $^{3}$}

Population (1910) 8r,875, nearly double that of 1900 , the greatest increase being $559 \%$ in Nye county, the most recent rich ore district. Density 0.7 per sq. $\mathrm{m}$. The Indian and Asiatic element decreased from $16.1 \%$ to $8.5 \%$ of the total. Negroes increased in number from $\mathrm{I}_{34}$ to $5 \mathrm{I} 3$. In I9I0 the native whites constituted $68.7 \%$ $(63.3 \%$ in I900) of the total, and the foreign-born whites $22.1 \%$ (20.3\% in I900). The population in urban territory was $16.3 \%$. The larger places were: Reno (city), 10,867 (4,500 in I900); Goldficld (town), 4,838; Sparks (city), 2,500; Carson City, 2,466; Virginia City, 2,244; Ely (city), 2,055.

Agricullure.-Between 1900 and 19 ro the acreage in farms increased from 2,565,647 acres to $2,714,757$, and the improved land in farms from 572,946 to 752,117 , the average farm acreage decreased from $1,174.7$ to $1,009.6$ and the value of farm property increased from $\$ 28,673,835$ to $\$ 60,399,365(\$ 35,276,599$ land; $\$ 4,332,7$ to buildings; $\$ 1,576,096$ implements; $\$ 19,213,930$ domestic animals). Of the land area $3.9^{\circ}, w^{2}$ was in farms in 1910. The average value of farm land per acre was $\$ 12.99$. Farms were operated largely by owners $(2,175$ by owners, 181 by managers and 333 by tenants). In I9I2 (preliminary estimates) the principal crops were: Indian corn, 30,000 bu. (1,000 A.); wheat, I, I37,000 bu. (39,000 A.); oats, 400,000 hu. (10,000 A.); barley, 492,000 bu. (I2,000 A.); potatoes, 2, I36,000 bu. (12,000 A.); hay, $6,81.000$ tons $(227,000 \mathrm{~A}$.). In I 909 (IT.S. (ensus) the value of vegetables (excluding potatoes) was $\$ 264,122$; of small fruits, $\$ 5,683$; of orchard fruits, $\$ 82,695$. On January I, 1912 there were on farms: 72,000 horses, 3,000 mules, 20,000 milch cows, 429,000 other neat cattle, $I,+4+, 000$ sheep, and 30,000 swine. The total acreage irrigated in I909 was 701,833 (39.2\% more than in 1899); 661,862 were supplied from streams. The total cost of irriga-

1 For Mr. Bryan's part in the Convention and campaign see United States.

2 'The state supreme court, October 23, 1912, decided that only the Taft electors could appear on the official ballot as Republicans. In the 6th district the Progressive nominee for (ongress polled only $8+$ votes (out of more than 50,000 ). Elsewhere Republican nominees were "Repuhlican and Progressive," and Democratic were "Democrat and Progressive Independent."

${ }^{3}$ See E. B. xix, 450 et seq. 
tion enterprises to July 1, 1910 was $6,271,924$ and the estimated final cost of improvements begun was $\$ 12,188,756$. Of cereals $96.5 \%$ by acreage in 1909 was grown on irrigated land and of Indian corn $91.6 \%$, of oats $92.8 \%$, of barley $98.2 \%$, of rye $97.1 \%$, of alfalfa $99.7 \%$, of wild, salt or prairie grasses $98.8 \%$, and of potatoes $96.9 \%$. In I9I I a new state code was adopted for the organisation and government of irrigation districts. The Truckee-Carson project (see $E$. B. xix, 452b) was $72 \%$ completed in 1912 , and in $191 \mathrm{I}$ irrigated 34,000 acres, mostly in alfalfa. At Fallon, in the district irrigated by this project, a large beet-sugar factory opened in $19 \mathrm{II}$. The legislature of I9I I appropriated $\$ 12,000$ for a state agricultural experiment farm. The U.S. department of agriculture has an experiment station on the Truckee-Carson reclamation project.

Mineral Products.-Total value, I9I I, \$34,I48, I01. The largest items were gold, $875,438 \mathrm{oz}$. ( $\$ 18,096,900$; more than in 1910$)$ ranking the state 3 rd; silver, $13,185,900 \mathrm{oz}$. $(\$ 7,120,400)$; and copper, 65,561,015 lbs., ranking the state 5 th. Copper production from the Yerington district of Nevada began early in I912. The output of zinc was I,595 tons, mostly from Clark county. In the Lake Lahontan district at Fallon deep drilling for potash salts was begun in I9II, but there were no important discoveries.

Manufactures. - The total value of products in 1909 was $\$ 11,887,000(283.9 \%$ more than in 1904); the capital invested, $\$ 9,807,000(239.1 \%$ more than in 1904$)$; the number of establishments, 177; and the number of persons engaged in manufacturing, 2,650. Car construction and repairs by steam railroads was first in value, $\$_{1}, 033,000$; second, flour and gristmill products, $\$ 598,000$. Reno had a factory product of $\$ 1,862,000$.

Transportation,--Railway mileage, January 1, 1912, 2,207.63.

Legislation.-The state legislature met in regular session from January 16 to March I6, I9I I, and there was a special session February 23-29, I9I 2. On February I8, I9II, the legislature approved the proposed Federal income tax amendment. The legislature urged the adoption of an amendment to the Federal Constitution calling for a direct vote for United States senators. The following constitutional amendments were adopted by popular vote in November I9I 2; for initiative and referendum on a petition signed by $10 \%$ of the voters $(9,956$ to 1,027$)$; for the recall of any public officer six months in office at an election called on petition signed by $25 \%$ of the qualified electors $(9,636$ to $\mathrm{I}, \mathbf{1} 73$ ); allowing the attorney-general or district attorney to cause an arrest on information without action of the grand jury $(8,259$ to $\mathrm{r}, 504)$; and permitting women to be notaries $(8,603$ to $2,24 \mathrm{~F})$.

The primary law was amended: a single registration is required for primary and regular elections and on primary ballots all parties must appear on the same ticket. The signature of each voter is required in registration. Candidates for the legislature are required (as in Oregon) to promise whether they will follow implicitly or regard merely as a recommendation the people's choice at the primary for United States senator.

A state bureau of industry, agriculture and irrigation was created; it is required to advertise the state, to study industrial problems, and control the Carey Act lands. The railroad commission was made a public service commission. In I9I I the legislature requested the commission to take action to reduce the exorbitant express rates in the state; but no reduction has since been made. Eight hours was made the legal day for all miners. An accident compensation law (compulsory) for especially dangerous trades was passed: suits for damages are permitted in lieu of compensation; special contracts are forbidden; the burden of cost is on the employer; no compensation is allowed unless the disability continues more than Io days; the compensation for death is three years' earnings, not less than $\$ 2,000$ nor more than $\$ 3,000$, and $\$ 300$ if the workman leaves no dependents. For total disability it is $60 \%$ of the weekly earnings with certain specified increases for certain maimings, the maximum amount being $\$ 3,000$; contributory negligence is to be measured and the compensatión reduced proportionally.

Las Vegas, formerly a precinct, was incorporated as a city with commission government and provision for the recall of elective officers. Mineral county (county-seat, Hawthorne) was created out of the northern part of Esmeralda county: Yerington supplanted Dayton as the county-seat of Lyon county in igir?

A state board of health was established in 1911. The director of the Nevada agricultural experiment station was made the official sealer of the state, and treble damages are allowed to a sufferer by short weight. The sale of liquor is not to be licensed within $5 \mathrm{~m}$. of a construction camp and no house of ill fame may be within 800 yds. of a school house or church.

Finance.-Under the laws of I9 I the full value of property is to be assessed, less mortgages, deeds of trust or other obligations securing a debt, and these are to be assessed on the holder of the mortgage, etc. Express companies are to be taxed, and the cash value of their property and franchise is to be an amount on which the net profit for the preceding calendar year would pay a dividend of $8 \%$. The accounts of state, county and city officials are to be examined scmi-annually by expert accountants. A new banking act makes the 
minimum capital $\$ 25,000$, requires every bank to have available funds amounting to $15 \%$ of its deposits and requires the liability to be less than $25 \%$ of the capital stock and surplus. The governor is to appoint a bank examiner. A law of 1901 requiring the acceptance and collection of grants and gifts to the state was repealed in $191 \mathrm{I}$, because it was used as a cover for forcing the collection of repudiated bonds of Southern states, notably North Carolina. A constitutional amendment adopted in November $1912(8,418$ to 1,683$)$ permits the investment of school funds in bonds of any county in the state.

The cash on hand January I, 1912 was $\$ 522,065$; receipts for the year, $\$ 1,269,432$, expenditures, \$1,212,469; and the balance on December 3I, I912, \$579,028.

Education. - The legislature in I9II adopted a code drafted in the main by a committee of the state teachers' institute. The school tax rate was increased; Nevada already spent more than any other state per pupil in public schools. School districts may borrow money on bonds to complete and equip schools for industrial training, domestic science and agriculture. Better provision was made for enforcing school attendance. A non-partisan committee was appointed to prepare a law for free text-books in public schools. A college of education has been established in the University of Nevada.

For the school year 1912 the school population was 12,652 ; enrollment 12,403; length of the school year a little over 8 months; receipts $\$ 600,000$ and expenditures $\$ 587,508$. In I9I0 the percentage of illiteracy of the population Io years and over was 6.7 (13.3 in I900).

Charitable and Penal Institutions. - State convicts may be detailed for work on roads and for each month of faithful.work they are to receive an allowance of ten days extra time off, and besides they are to receive $25 \mathrm{C}$ a working day. Among the appropriations were: \$50,900 to the orphans' home in Carson City; and $\$ 7,500$ for the training of juvenile delinquents, still carried on in institutions of adjoining states.

History.-The legislature, although Democratic, re-elected (Jan. 25, IgIr) as United States senator, George Stuart Nixon, Republican, who carried the primary in November and whose Democratic opponent, Key Pittman, had made with him a "gentleman's agreement" to abide by the results of the primary, Nixon" died June 5. I I 2, and a week later Governor Tasker L. Oddie (b. I8?0, Republican) appointed, pending election by the r9r3 legislature, first Nixon's business associate George Wingfield, who declined, and then W. A. Massey, formerly chief-justice of the state supreme court. He was re-nominated for election by the Republicans for the term expiring in I0I7, Key Pittman being the Democrat candidate and Sardis Summerfield the Progressive. I'ittman was chosen by the Democratic legislature. The other senator is a Democrat, Francis G. Newlands (b. 1848; representative in Congress, I893-1903 and scnator since I903; prominent in reclamation legislation), whose term ends in I9I5. There was no election for governor in I9I 2: Oddie's term ends December 3I, I9I4. One Socialist was elected to each house of the legislature. In the presidential campaign the delegates to the Republican National Convention were instructed for Taft, and the state was carried for Woodrow Wilson by 7,986 votes to 5,605 for Roosevelt, 3,190 for Taft and 3,313 for Debs. E. E. Roberts, Republican, representative in Congress, was re-elected. The defeat of Judge William D. Jones, a candidate for re-election to the lower house of the legislature, may result in the repeal of his "open-door" and "timelock" law, requiring physical presence in the state (not intent) for divorce. If this law is repealed, Nevada, and particularly Reno, will no longer be a centre for the whole United States for securing divorces.

In October Ior 2 there was a strike of miners at Ely, beginning on the and and ending on the 28 th with a victory for the strikers. Martial law was proclaimed on the $\mathrm{I} 7 \mathrm{th}$.

Bibliography.-Statutes (Carson City, I9II); departmental reports; Agricultural Nevada, (San Francisco, 19II); C. M. Harvey, "Trail of the Argonauts," July I9I I, Allantic Monthly.

\section{NEW HAMPSHIRE 2}

Populution (rgro) 430,572 (4.6\% more than in r9o0). Density 47.7 to the sq. m. In $1000-10$ the native whites decreased from $78.4 \%$ to $77.4 \%$ of the total (whites of

1 Nixon was born in Newcastle, California, in 1860 , worked as a telegraph operator in (alifornia and in Nevada, where he built up a banking business in Winnemucca, Reno and Tonopah, and was prominent in irrigation developments. He was a leader of the silver purty and a member of the state legislature in 1890 , and $U$. S. senator after 1905.

John Percival Jones (b. 1829), U.S. senator from Nevada in 1873-1903, Silver Republican, died on November $27,1912$.

${ }^{2}$ See E. B. xix, 490 et seq. 
foreign parents, $19.5 \%$ in 1900 and $23.9 \%$ in 1910$)$ and the foreign-born whites increased from $21.4 \%$ to $22.4 \%$. In 26 municipalities with more than 2,500 there was $59.2 \%$ of the total ( $55 \%$ in I 900$)$. The cities and towns with more than 5,000 were: Manchester, 70,063; Nashua, 26,005; Concord, 21,497 ; Dover, I3,247; Berlin, I1,780; Portsmouth, II,269; Laconia, I0,I83; Keene, Io,o68; Rochester, 8,868; Claremont, 7,529; Somersworth, 6,704; Franklin, 6,132; Lebanon (town), 5,718; Derry, 5, 1 23.

Agriculture.-The acreage in farms decreased from $3,609,864$ to $3,249,45^{8}$ between 1900 and 1910 and the improved land in farms from $1,076,879$ to 929,185 ; the average farm acreage fell from I23.I to I20. I but the value of farm property increased from $\$ 85,842,-$ 096 to $\$ 103,704,196$ ( $\$ 44,519,047$ land; $\$ 41,397,014$ buildings; $\$ 5,877,657$ implements; $\$$ II,9I0,478 domestic animals). Of the land area $56.2 \%$ was in farms. The average value of farm land per acre was \$13.70. Farms were operated largely by owners $(24,493$ by owners. 681 by managers 1,879 by tenants. In 1912 (preliminary estimates) the principal crops were: Indian corn, I, 058,00o bu. (23,000 A.); oats, 468,00o bu. (I2,000 A.); barley, 28, 000 bu. (I,000 A.); buckwheat, 3I,000 bu. (I,000 A.); potatoes, 2,380,000 bu. (I7,000 A.); hay, 626,000 tons (50I,000 A.); and tobacco, 170,000 lbs. (I00 A.). On January I, I9I 2 there were on farms: 46,000 horses, 97,000 milch cows, 65,000 other neat cattle, 43,000 sheep and 53,000 swine. In 1909 (U. S. Census) the value of vegetables, excluding potatoes, was \$ I,07I,55I (from 8,855 acres); of orchard fruits, \$7I9,777 (apples, \$637,990); of small fruits, $\$ 107,365$. (strawberries, $\$ 68,552$ ); and of maple sugar and syrup, \$182,341. The decrease in acreage of cereals in 1899-1909 was more rapid than that in the acreage of vegetables.

Laws of I9I I provide for stricter protection of state forests, and regulate the sale of concentrated commercial feeding stuffs. In 1912 the National Forest Reservation Commission recommended the purchase of 72,252 acres in Coos and Grafton counties for a national forest, under the Weeks Act of March I, I9II.

Mineral Products. - Total value, I91 I, \$1,727,645. The only large item is granite, $\$ 1,017,272$. Clay products were valued at $\$ 430,748$. Mineral waters, bottled at 6 springs, including I resort, were valued at $\$ 139,130$. In each of these items the total was less than in the preceding year. In scythestones the state ranked first. Other products were garnets, used as abrasives, mica and fluorspar.

Manufactures. -From 1904 to 1909 the number of establishments increased from 1,618 to $\mathrm{I}, 96 \mathrm{I}$ and that of persons engaged in manufacturing from $69,758(65,366$ wage-earners) to 84, I9I (78,658 wage-earners); capital invested from \$109,495,000 to \$1 39,990,000; and value of products from $\$ 123,6$ I I,000 to $\$ 164,581,000$. The principal products were: boots and shoes, $\$ 39,440,000$; cotton goods, $\$ 33,602,000$; woollen, worsted and felt goods, $\$ 16,731$, ooo; lumber and timber products, \$15,284,000; paper and wood pulp, \$13,994,000; foundry and machine-shop products, $\$ 4,947,000$; hosiery and knit goods, $\$ 4,764,000$; four and gristmill products, $\$ 3,187,000$; and marble and stone-work; $\$ 1,818,000$. The principal manufacturing cities were: Manchester, $\$ 46,812,000$; Nashua, $\$ 17,326,000$; Concord, $\$ 6,476,500$; Dover, $\$ 6,370,000$; Berlin, $\$ 5,896,600$; Laconia, $\$ 3,818,500$; Keene, $\$ 3,483,000$; and Portsmouth, \$2,871,000 (not including \$1, 153,000 from Kittery Navy Yard).

Transportation. - Railway mileage, January I, I912, I,253.12. Freight rates in force were validated until July I9I3, after an investigation had started upon the charge that the Boston \& Maine railway, with a practical monopoly of the rail traffic in the state, was charging higher rates than in $\mathbf{1 8 8 9}$, when a law forbade the increase of rates by roads uniting or consolidating thereafter. The Boston \& Maine agreed to restore the previous rate if the legislature granted it no relief. On December 2, 1912, the public service commission recommended the establishment, with the railway's consent, of rational maximum rates. In I9II the Federal government began work on improvements of the Exeter river and on improving Portsmouth harbour on the Maine side at Pepperells Cove, where the depth over the ledge is to be increased from 5 to $I 2 \frac{1}{2} \mathrm{ft}$. and the harbour depth from $I-I$ I to $12 \mathrm{ft}$.

Government.-A constitutional convention (called by the legislature in igri) met at Concord in June I912, and submitted to the people for their approval at the regular election in November I9I 2 twelve amendments to the state constitution. Only four received the requisite two-thirds vote: (I) Disfranchising and making ineligible for office anyone convicted of treason, bribery or wilful violation of election laws, unless restored by the supreme court, to which this amendment gives this power $(22,383$ to $8,322)$; (2). Making the election of the governor, councilors and senators by plurality instead of majority vote $(2 \mathrm{I}, \mathbf{1} 20$ to $9,80 \mathrm{I})$ - this will render impossible a recurrence of the situation which arose in I9I2, when no candidate was chosen at the popular election (see History below); (3) Empowering the legislature to give police courts original jurisdiction to try criminal cases where the punishment is less than imprisonment in the state prison-subject to the right of appeal and trial by jury. (I 8,606 to 8,29I); and (4) Making the division of the state and of councilor districts dependent upon population 
and not upon the proportion of public tax (I9,Ig6 to 6,90I). Among the rejected amendments were one providing that representation in the senate (the membership of which was to be increased to 36 ) was to be based on population and not the proportion of direct taxes paid by different districts; two by which the legislature was empowered to impose a graduated inheritance tax, and an income tax on "public service corporations and voluntary associations in lieu of a direct tax upon their property;" one striking out from the Bill of Rights the word "Protestant" in a provision for maintenance of "public Protestant teachers of piety, religion and morality" and the phrase "rightly grounded on evangelical principles" which now modifies the words "morality and piety" in the same article; and one giving the governor the power to approve or disapprove any separate appropriation in any bill or resolution passed by the legislature. On all the rejected amendments there was a plurality vote for the amendment: the smallest vote for an amendment, I6,555 to I4,3 I5, was for the omission of the word "Protestant" and of the reference to "evangelical principles."

The legislature met from January 3 to April 15, 1911 and on March 2 the senate voted unfavourably on the proposed 16 th amendment to the Federal Constitution. The districts for state representatives were reapportioned: towns with a population of less than 600 choose a representative for a proportional time, that is for different sessions of the five occurring during the next decade. A public service commission of three members, serving for six years, was established (in place of the old railroad commission); it is to investigate railway affairs and to fix reasonable rates, to pass on any proposed extensions of railways or any exercise of eminent domain, and upon stock and bond issues of any public service corporation.

Political advertising in newspapers must be designated and signed. The giving or soliciting of campaign contributions by corporations is forbidden. The party circle is omitted from ballots, and there is no special provision for "straight" voting. Bribery at election was made a misdemeanour and conviction disqualifies for office and suffrage. Political committees must publish campaign receipts and expenses 3 days before, and within I5 days after, the election; violation disqualifies for nomination or election.

The state appropriated $\$ 100,000$ to take Crawford Notch as a forest reservation and state park; and the state took possession by eminent domain,-compensation of the owners is to be fixed by referees appointed by the supreme court.

An employer's liability law-in effect January 1, 1912 provides for elective compensation in dangerous employments which the act enumerates. The election of the employer must be made in writing with a proof of his financial ability or a bond. None of the common law defences is abrogated, but assumed risks, fellow service, and contributory negligence are restricted by the provisions for liability. The compensation in case of death is 150 times the weekly earnings, but not more than $\$ 3,000$ (or if there are no dependents only $\$ 100$ ); in case of total disability $50 \%$ of the average weekly earnings - not more than $\$ 10$ nor for more than 300 weeks; and for partial disability $50 \%$ of the wage loss with the same limitation as to the maximum amount and time.

A new child labour law provides that in mills, factories, workshops, telegraph. telephone or messenger service, etc., no child under 12 shall be employed, no child under 14 during school session, and no illiterate under 16 unless he is mentally incapable. Boys under Io and girls under 16 are not to be employed in the street trades; no child under 18 in messenger service between Io P.M. and 5 A.M., and no child under 16 in any employment without an employment certificate. To carry out labour laws, arbitrate in labour disputes and attempt to settle strikes and lockouts, a bureau of labour was substituted for the commission.

The state board of health was authorised to prohibit the use of common drinking cups in public places; and forbade their use, after July I, I9I2, on railway trains, in railway stations, in public and private schools, and in the state educational institutions. All cases of tuberculosis must be registered and recoveries of patients must be reported. The board of health is to draw up rules for certified and inspected milk. Renovated butter must be labelled. Food or drink containing wood alcohol must not be sold. Baby farms and lyingin hospitals are to be licensed, supervised and regulated, and a law was passed to prevent infantile blindness. A board of registration in optometry was established. Portable steam mills must be fitted with spark arresters, and a penalty of $\$ 50$ was decreed for failure to extinguish camp fires, and careless shooting by hunters was made punishable by a fine up to \$r,ooo or 2 years' imprisonment. A law forbids drinking of intoxicating licuuors on strect cars or railway cars, except buffet or dining cars. Pandering was made punishable by imprisonment from six months to one year, and by a fine of $\$ 300$ to $\$ 1,000$, or by both, and on second conviction by one to ten years in the state prison; it is punishable though partially committed outside of the state, the victim may testify, and marriage is no defence.

Finance. - In IgI I permanent tax commission was created; it is to determine the tax rate, to assess public service corporations and to equalise the state tax biennially. The act requires railways to le taxed at the average rate upon the actual value of the property in 
the state used in their business "which would not be exempt from taxation if owned by a natural person." The state tax for I9II was \$700,000; for 19I2, \$800,000 and for 1913 , $\$ 600,000$. A new law was passed for taxing savings banks; and money loaned at $5 \%$ or less and secured by a mortgage on real estate in the state, or by note, is exempt from tax. Trust and banking companies must have a cash reserve equal to $15 \%$ of their deposits and must put aside a guarantee fund of $10 \%$ of net annual earnings until this amounts to $25 \%$ of the capital stock. Stockholders in such companies are personally liable. The balance in the treasury on September I, I9I I was $\$ 283,987$; receipts for the year, $\$ 2,797,894$, and expenditures, \$2,5I4,054, leaving a balance August 31, 1912 of $\$ 567,827$. The net state debt was $\$ 1,387,038$.

Education.-The appropriation for weak school districts was increased from $\$ 80,000$ to $\$ 1$ I5,000. For the school year ending September 30, I9I2 the school population was 75,337; the enrollment, 63, I 86 ; the average daily attendance, 49,524; and the length of the average school year, 33.8 weeks. The revenue was $\$ 2,047,033$ and the expenditures $\$ 1,883,059$. In 1910 the percentage of illiteracy (10 years and over) was 4.6 (6.2 in 1900).

There are good industrial courses in rural high schools, notably Colebrook Academy: see H. A. Brown, The Readjustment of a Rural High School to the Needs of the Community (Washington, I9I2; U.S. Bureau of Education, Bulletin 492).

Edward Thompson Fairchild (b. 1854), state superintendent of schools of Kansas in $1907-12$, was elected president of the state college of agriculture and mechanic arts in 19 I 2 .

Penal and Charitable Institutions. - In 191 I a committee was appointed to investigate the operation in other states of the system of centralised supervision of penal and charitable institutions. Among the appropriations was one of $\$ 20,000$ for the treatment of tuberculosis.

History.-In I9 I I- 2 the state government was Republican of the "progressive" type and both party platforms in roro had contained promises of definite reform. legislation which were so slow in fulfillment that in March IgI I the legislature was upbraided for its failure to pass these measures by Governor Robert Perkins Bass (b. i873; prominent in improving forestry and farming). Bass was not renominated. The Progressives nominated Winston Churchill (b. 1871), a member of the state legislature in 1903 and I905, but better known as the author of Richard Carvel and other popular novels. The Democratic nominee was Samuel D. Felker, representative from Rochester; and the Republican, Franklin Worcester, former state senator. There was no choice of governor by the people as no candidate received the necessary majority of all votes ${ }^{1}$ cast, and the legislature (senate, is Republicans and 9 Democrats; house, 208 Republicans and I97 Democrats) early in I913 chose Felker. On March 13, r913, Henry French Hollis (b. I 869, Democrat) was chosen to succeed H. E. Burnham (b. 1844, Republican), United States senator. The four electoral votes of the state went to Woodrow Wilson, who received 34,724 votes to 32,927 for Taft (for whom most of the Republican delegates to the national convention had been instructed), $\mathbf{1 7 , 7 9 4}$ for Roosevelt (who was supported by Governor Bass and by Winston Churchill), and 1,98 I for Debs (who received I,299 votes in I908). Two Democratic representatives were elected to Congress to succeed two Republicans, Cyrus Adams Sulloway (b. 1839 ), who had served in Congress for 18 years and Frank Dunklee Currier (b. 1853) who had been in Congress since 1901. In I9I 2, 202 towns voted no licence, 2 I voted for licence and in I town there was a tie.

Bibliography.-Session Laws (Concord, I9I I) and other official reports; Allen H. Bent, A Bibliography of the White Mountains (Boston, I9II); J. O. Lyford, History of the Town of Canterbury N. H., I727-1912 (2 vols., Concord, 1912); Winthrop Packard, White Mountain Trails (1912).

\section{NEW JERSEY ?}

Population (roro), 2,537, 167, an increase of $34.7 \%$ over 1000 . The greatest increase absolutely for any county was 153,833 , in Essex; and, relatively, $75.9 \%$ in Bergen. The proportion of whites of foreign birth increased from $22.8 \%$ in i 900 to $25.9 \%$; that of native whites of native parentage decreased from $43.9 \%$ to $39.8 \%$. In density New Jersey, with 337.7 to the sq. m. ranks below Rhode Island and Massachusetts. The rural territory contained $18.9 \%$ of the entire population $(23.8 \%$ in 1900$)$; the urban comprised 88 places ( 67 in 1900 ) which had more than 2,500 each, making $75.2 \%$ of the

1 The popular vote was: Felker (Dem.), 34,203; Worcester (Rep.), 32,504; Churchill (Progr.) I 4,401 ; Wilkins (Socialist), I,674; and Morrill (Prohibitionist), 496.

${ }^{2}$ See E: B. xix, 501 et seq. 
total. There were 32 places, each with more than 10,000 inhabitants, as follows. Newark, 347,469 (246,070 in 1900); Jersey City, 267,779 (206,433 in 1900); Paterson. I25,600; Trenton, 96,815; Camden, 94,538; Elizabeth, 73,409; Hoboken, 70,324; Bayonne, 55,545; Passaic, 54,773; Atlantic City, 46,150; West Hoboken (town), 35,403; East Orange, 34,371; Perth Amboy, 32,121; Orange, 29,630; New Brunswick, 23,388; Montclair (town), 21,550; Union (town), 21,023; Plainfield, 20,550; Kearny (town), I8,659; Bloomfield (town), I5,070; Harrison (town), I4,498; Bridgeton, I4,209; Hackensack (town), I4,050; Phillipsburg (town), I3,903; West New York (town), I3,560 (5,267 in 1900); Long Branch, I3,298; Morristown (town), I 2,507; Millville, I $2,45 \mathrm{I}$; Irvington (town), II 877 ; West Orange (town), Io,980; Garfield (borough), I0, 213 (3,504 in I900); Asbury Park, IO, I50 (4,I 48 in 1900).

A griculture. - The acreage in farms decreased from 2,840,966 to $2,573,857$ between 1900 and 1910 and the improved land in farms from $1,977,042$ to $1,803,336$; the average farm acreage decreased from 82.0 to 76.9; and the value of farm property increased from $\$ 189 ; 533,660$ to $\$ 254,832,665$ (\$124, I 43, I67 land; \$92,99 I, 352 buildings; \$1 3, I09,507 implements; \$24,588,639 domestic animals). Of the land area $53.5 \%$ was in farms. The average value of farm land per acre was $\$ 48.23$. Farms were operated largely by owners $(24,133$ by owners, 1,060 by managers and 8,294 by tenants). In I 112 the principal crops (preliminary estimates) were: Indian corn, 10,374,000 bu. (273,000 A.); wheat, I,462,000 bu. (79,000 A.); oats, I, 849,000 bu. (67,000 A.); rye, I, 260,000 bu. (72,000 A.); buckwheat, 264,000 bu. (12,000 A.); potatoes, 9,936,000 bu. ( $92,000 \mathrm{~A}$.), and hay, 521,000 tons $(362,000 \mathrm{~A}$.). In I 909 . (U.S. Census) the value of vegetables other than potatoes was $\$ 7,566,493$; of flowers and plants, $\$ 2,857,709$; of nursery products, $\$ 681,814$; of small fruits, \$1,954, I25 (strawberries, \$929,I08); of orchard fruits, \$1,975,044 (apples, \$956,108; peaches and nectarines, \$652,771); of grapes, $\$ 132,957$. On January I, I9I2 there were on farms: 9I,000 horses, 4,000 mules, I50,000 milch cows, 68,000 other neat cattle, 30,000 sheep, and I65,000 swine.

In I9I I a department of poultry husbandry was established in the agricultural experiment station and the office of state plant pathologist was created. The pathologist is to examine nurseries, destroy plants incurably diseased and prevent the spread of disease. The state entomologist was required to inspect all apiaries for diseased bees.

Mineral Products. - Total value, I9I I, \$27,559,246. In clay products the state ranked 3rd, below Ohio and Pennsylvania, with a total value of $\$ 18,178,228$, of which $\$ 8,401,941$ was pottery, in which the state was exceeded only by Ohio. Almost all the zinc produced in the East comes from the Franklin Furnace mines in this state; the total was 15,128 tons, valued at $\$ 1,724,592$, in I9II. Pig iron was valued at $\$ 583,300$ (not included in the total given above), and iron ore, 359,721 tons, was valued at $\$ 1,158,271$. Sand and gravel were valued at \$1,058,926; Portland cement, at \$3,259,528; stone at \$1, 597,4 IO (of which \$1, 1 36,385 was the value of trap rock); lime, at $\$ 113,784$, and mineral waters, from 12 springs, at $\$ 210,123(58 \%$ more than in 1910). The greensand marls of the state with a potash content of $3 \frac{1}{2}$ to $6 \frac{1}{3} \%$ are being studied as a commercial source of salts for fertiliser.

Manufactures. - In 1904-09 the number of establishments increased from 7,010 to 8,817 and that of persons engaged from $296,262(266,336$ wage-earners $)$ to $371,265(326,223$ wage earners); capital invested from $\$ 715,060,000$ to $\$ 977,172,000$; and the value of products from $\$ 774,369,000$ to $\$ 1,145.529,000(47.9 \%)$, ranking the state 6 th in the Union.

In I 909,24 separate industries reported products valued at $\$ 10,000,000$ or more. The three most important manufactures were: copper refining and smelting products, \$125,65I,ooo (twice as much as in 1904, and much more than in any other state); silk and silk goods, $\$ 65.430$, 000 (52.6\% more than in 1904 ; one-third the country's total); and foundry and machine-shop products, $\$ 65,398,000(29.4 \%$ more than in 1904$)$. Other important manufactures were: slaughtering and meat-packing products, $\$ 37,583,000$; woollen, worsted and felt goods, including hats, $\$ 33,939,000$; wire, $\$ 28,858,000$ ( $\$ 17,777,000$ being copper wire - twofifths of the country's product); leather, $\$ 28,431,000$; electrical machinery, \$28,365,000; tolacco, \$24,177,000; chemicals, \$22, \$24,000, ranking the state 2nd; malt liquors, \$20, 184,oon; rubber goods, $\$ 19,543,000$, ranking the state 2 nd; cotton goods, especially thread, $813,-$ 729,000; soap, \$13,674,000; lumber and timber, \$1 3,5 I I, 000; jewelry, \$1 3,272,000; pottery, terracotta and fire-clay products, $\$ 13,139,000$ - the state was 2 nd in this industry; paint and varnish, \$12,767,000; iron and steel rolling mills, \$12,014,000; copper, tin and sheet-iron products, \$II, I I , 000; and oilcloth, $\$ 10,143,000,-$ in this industry New Jersey ranked Ist.

The leading manufacturing cities were: Newark, $\$ 202,511,500$, the IIth city in the Union in value of manufactures, its principal products being refined copper, leather $(\$ 18,858,000)$, foundry and machine-shop products $(\$ 15,482,000)$, jewelry $(\$ 13,152,000)$, malt liquors $(\$ 12,361,000)$, and paint and varnish; Jersey City, \$128,775,000, including slaughtering and meat-packing $(\$ 22,314,000)$, tobacco $(\$ 11,065,000)$, foundry and machine-shop products, soap; Bayonne, $873,641,000$, petroleum refining; Perth Amboy, $\$ 73,093,000$, copper refining; Paterson, \$69, 584,000 (silk \$ \$0,358,000); Camden, \$49, I3 38,000 ; Trenton, \$49,009,000; Passaic, \$41,729,250 (textiles \$20,536,000); Elizabeth, \$29, I 47,000; Hoboken, \$20,41 3,000. 
Transportation.--Railway mileage, January I, 1912, 2,350.5. In I9I2 a commission composed of the governor, the attorney general and Mr. Bennet Van Syckel (former supreme court judge) reported to the legislature in favour of the abandonment of all claims on the Morris Canal to the Lehigh Valley Railroad Company, the holder of almost all of the capital stock of the Morris Canal and Banking Company, the original owner of the canal which by its charter was to become the property of the state in 1973. The legislature arranged for the appointment of a committee of twelve, to report on the property owned, its use and its value, what the state would receive under the arrangement suggested by the previous commission, and what obligations it would incur in the taking over of the water rights as recommended by the previous commission; what the net proceeds to the state would probably be, whether a part of the canal could be operated and whether the Morris Canal and Banking: Company and its lessee had forfeited the charter.

In 19 I I the New Jersey ship canal commission was created to examine the plan and the route of a proposed canal from New York Bay to Bordentown on the Delaware river. Its preliminary report in 1912 recommended a $25-\mathrm{ft}$. depth and a bottom width of $125 \mathrm{ft}$.

A new code was adopted in 1912 for the improvement and maintenance of public roads. The county board of chosen freeholders may require any township through which a road passes to pay $10 \%$ of the cost of the road in the township, and two or more counties may cooperate in road improvement. Plans must be approved by the Commissioner of Roads. Certain roads are to be taken over by the state as state highways.

In 1912 the legislature passed a law requiring every railway in the state, within three months after the act went into effect (Sept. I, 1912) and within the same period yearly thereafter, to remove one grade crossing for every 30 miles or fraction thereof of road operated by it in the state. The bill passed the assembly (where it originated) on the 29 th of March, and the senate on the $28 \mathrm{th}$; on the IIth of April it was returned by the governor with his veto, because of the injustice, in his opinion, of the requirement that every railway remove crossings for every 30 miles, and because the act did not forbid the creation of new grade crossings, nor attempt to classify the present crossings. The legislature had been in recess from March 29th to April Ioth, and the attorney-general filed an opinion that the bill was not a law, and that the governor's veto was valid, but the assembly passed a resolution that "in the judgment of the House of Assembly said bill is now a law," since more than five days, excepting Sundays, had elapsed between the presentation of the bill to the governor and its return to the assembly, which had not been prevented by adjournment. On September 27, 1912 the supreme court held that the act had never become operative.

In December I9I I the Delaware, Lackawanna \& Western Railroad opened for passenger service a "cut-off" of $28.45 \mathrm{~m}$. between Hopatcong and Slateford Junction, which saved II m. (4I I m. reduced to $400 \mathrm{~m}$. from New' York to Buffalo) over the old route, reduced the maximum grade per mile from $60.2 \mathrm{ft}$. to $29.04 \mathrm{ft}$.; one fill, I Io ft. high and more than $3 \mathrm{~m}$. long, E. of Andover, is supposed to be the largest in the world.

The Staten Island and New Jersey channel was dug to a depth of $\mathrm{I} 4 \mathrm{ft}$. in $\mathrm{I} 9 \mathrm{II}$ and the $16 \mathrm{ft}$. channel from Staten Island Sound $10.8 \mathrm{~m}$. up the Passaic river was completed and work further up the river was begun by the Federal Government.

Legislation.-The legislature meets annually, and its regular sessions were held in IgIr from January Ioth to April 21st; in I9I 2 from January gth to April 2 Ist, with a recess from March 29 th to April Ioth. The new legal procedure act of I9I 2 is intended to insure speedy trials; it simplifies pleadings, abolishes bills of exception and writs of error, although allowing an appeal to be taken on error, and provides that no judgment be reversed on a technical error unless it injuriously affects the substantial rights of the party to the case; new evidence is admissible on appeal. A law of I9I2 permits a married woman to sue or be sued without joining her husband, if he would be an unnecessary party were he not her husband. A commission was appointed (rgr2) to report on the reorganisation and consolidation of state departments with unrelated functions, and one in I9I I to consolidate the law on primaries and general elections.

The Geran Election law of 19 I I substituted for separate party ballots a blanket ballot with an alphabetical arrangement of candidates by office groups. No election district is to contain more than 400 voters; candidates for boards of registry must take civil service examinations; candidates for governor and congressmen are to be nominated directly at primaries, at which there is to be a preferential vote for candidates for the presidency. The law includes the Oregon plan, putting candidates for the legislature on record whether they will follow implicitly or not the recommendation of the primary for United States senator. The law required a primary register, as well as registration for the general election, the register to be by house-to-house canvass in municipalities of less than 5,000 , but elsewhere to be personal. In I9I I all laws providing for the use of voting machines were repealed. A corrupt practices act of I9II (amended in I912) limits election expenditures to $\$ 200$ for an assemblyman and $\$ 2,500$ for a candidate for governor; requires a sworn statement of expenses to be filed within five days; and allows the party organisation to employ agents (but 
not watchers) at the polls and to provide transportation only for such voters as are physically unable to go to the polling place.

In 191 I a new law was passed for the government of the public utility commission, whose members are to have a six-year term and a salary of $\$ 7,500$ each. The commission is empowered to investigate and fix rates, to appraise property, classify service, standards, methods rtc., and the act regulates public utilities, forbidding unjust discrimination and unfair rate classification. On December 27, I912, it reduced the price of gas from \$1.10 to 0.90 per M cu. $\mathrm{ft}$. in the Passaic division; in effect February I, 1913.

In I9I I the competitive class in the civil service was divided and enlarged; the civil service commission was authorised to admit non-residents for examinations to posts requiring technical training; and in I9II and 1912 additional groups of state and local employees were brought under the civil service rules.

An employers' liability law of I9II was in most respects like the New York Act of I9IO which was declared unconstitutional on March 24, I9II, the objectionable clauses being omitted; it provides for an elective compensation system covering all industries. The election is presumed in the absence of written notice to the contrary. The act abrogates the defences of assumed risk, fellow service, and, unless wilful, contributory negligence. Suits for damage are not permitted after election for compensation. To be compensated, disability must be for two weeks at least, the compensation for death is 25 to $60 \%$ of the average wages; not less than \$5 nor more than \$IO for 300 weeks, and is limited to \$200 if the deceased leaves no dependents. For complete disability compensation is $50 \%$ of the average wage (not less than $\$ 5$ or more than $\$ \mathrm{ro}$ ) for 400 weeks, and for partial disability the compensation is proportional, on a fixed scale. Medical and surgical aid for the first two weeks of disability must be paid for by the employer, but the maximum cost of such service is to be $\$ 100$. The act excludes from this provision non-resident alien beneficiaries.

Children under 14 are not allowed to work in a mercantile establishment during school hours, and no child under 16 is to work more than $5^{8}$ hours a week, nor between 7 P.M. and 7 A.M., except that on one day in the week work may be continued until 9 P.M., and that these hours do not apply to the ten day's immediately before Christmas. No child under 18 (or under $2 \mathrm{I}$ in cities of the first class) is to be employed in messenger service between IO P.M. and 5 A.M., except on written permission from the commissioner of labour. Eight hours is a working day in state or municipal employ. A law of 1912 makes 10 hours a day and 60 hours a week the maximum for women in manufacturing or mercantile establishments, bakeries, laundries or restaurants, but not in mercantile establishments for the six days before Christmas - the act does not apply to canneries. A new law was passed (1911) for fire protection, and especially for fire exits in factory buildings. In 1912 a commission was appointed to revise and codify the laws relating to mechanics liens. Various important laws were passed (I9II and I912) to protect the lives and health of employees in factories. Occupational diseases, such as anthrax, compressed air illness, phosphorus, arsenic or mercury poisoning must be reported within 30 days to the state board of health under a penalty of $\$ 25$ by a law of 1912 following the California law of I9II. A state board of examiners of nurses was appointed in 1912 with authority to regulate and register nurses. Registered nurses are permitted to use after their names the letters "R. N." and these letters may not be used by any one else in the state. In I9I I the pure food law of I9OI and I 906 was supplemented by stricter requirements for the cleanliness of dairies and other places where food products are handled; and a law of 1912 forbids the adulteration and regulates the sale of skimmed milk. Goods placed in cold storage must bear the date of storage. The use of public drinking cups was restricted. A law of I9I2 provides for the establishment of county mosquito extermination commissions. A state superintendent of weights and measures was appointed in I9I I under a law for a uniform standard of weights and measures.

In I9I counties were re-classified; the first class contains all with a population greater than 300,000 , and the government of these was re-organised in 1912 ; the second class contains those between 50,000 and 300,000; the third those between 20,000 and 50,000, and the fourth all other counties. Cities of the first class were authorised to appoint a city plan commission to remorlel the city; in Jersey City the commission has done educational work mainly; in Newark several definite plans of improvement have been proposed. In cities of the first class a police pension fund was created in 19 II from an assessment of $\mathrm{r} \%$ of police salaries, the deficiency to be made up by the city. Anyone 60 years old who has been in the service for 20 years may be retired on half pay, and must be retired if he asks for retirement; and anyone who is 55 and has been in the service for 25 years is to be retired on half pay upon application. The law provides for retirement for disability and for a pension for a policeman's widow so long as she remains his widlow, and for his children under $\mathbf{6} 6$. The commission form of government may be adopted upon a favourable vote in any city, town or borough. An amendment provides for the recall, the initiative and the referendum. Cities which adopt the commission government may revert to their original charter after six years at an election called by a petition signed by $25 \%$ of the electors. Two or more cities may join to maintain garbage disposal plants. Any municipality may spend $\$ 5,000$ a year for publicity. The law for borough government was amended and codified. In IgI I commission government was adopted by Hawthorne, Margate City, Ocean City, Passaic, Ridgewood and 
Trenton; and in 1912 by Atlantic City, Deal, Long Branch, Longport, Nutley, Ridgefield Park and Wildwood. It was rejected in I9I I by Bayonne, Cape May, East Rutherford, Garfield, Hoboken, Irvington, Jersey City, Metuchen, New Brunswick, Orange, Paterson, Rahway and Salem; and in 1912 by Elizabeth, Emerson, Glen Rock, Ventnor City and Westwood.

In 1912 the legislature granted a pension of $\$ 1,200$ a year to the widow of any former governor, and $\$ 10,000$ for a monument in the National Cemetery at Arlington to Gen. Philip Kearny, whose remains were removed in I9I I from Trinity Churchyard in New York.

Finance. - In 1912 a commission was appointed to investigate assessments for taxes and the Department of Accounts was reorganised. An inventory and appraisal of railroad and canal property was begun in 1910 and completed in 1912. The balance in the treasury on November I, 19II, was $\$ 3,309,78 \mathrm{I}$ and a year later, $\$ 5,270,672$; the reccipts during the year, $\$ 9,657,366$, and the disbursements, $7,696,475$. The state has no bonded debt.

Education. - In I9I I as the result of a two years' investigation of the public school system by the board of education working with the legislature several important school laws were passed. A new board of education of 8 members with an 8 year term, was organised and took office on June 30, 191 I. The board is non-partisan, and besides having the powers of the previous board, is to appoint an inspector of buildings and district inspector of accounts, and to prescribe a uniform system of book-keeping for school accounts. The office of state superintendent of education was abolished and the governor appointed in I9I I as commissioner of education (to hold office for five years, and to receive a salary of $\$ 10,000$ a year) Calvin Noyes Kendall, superintendent of schools of New Haven (1895-1900) and of Indianapolis (I900-II). The commissioner appoints four assistant commissioners, one to supervise elementary schools, one secondary schools, one industrial education including agriculture, and one to hear controversies and disputes in regard to school laws, subject to appeal to the state board of education; and appoints also county superintendents of schools, who have a 3 year term. In 191 I the time of the distribution of school funds was set for the September following the receipt of taxes, so there might not be a delay such as there had been in the distribution of the funds.' A law of I9I2 specifies the manner in which the funds are to be apportioned by county superintendents. The commissioner of charities and corrections is required to prepare standaid plans for school houses of the different sizes, and on request to inspect any school building. After 35 years' service (of which 20 years must be with the board by which the teacher is retired), any teacher in the public schools of the state may be retired upon half pay. Special classes are to be organised in public schools for blind and deaf children who cannot be received in institutions for the blind or deaf.

The centennial of the Princeton Theological Seminary was celebrated on the 5 th and 6 th of May I9I2. On January II, I9I2, John Grier Hibben (b. I86I), professor of logic, was elected president of Princeton University; he was inaugurated on May II. George Brinton McClellan, formerly mayor of New York City, was appointed professor of economic history. Of the population Io years of age and over $5.6 \%$ were illiterate in $1910 ; 5.9$ in 1900 .

For the year ending June 30,1912 the total enrollment in public schools was 459,189 ; the average daily attendance, 348,238 ; and the length of the average school year, 9 months 2 days. Receipts were $\$ 26,436,005$ and expenditures $\$ 2$ I, 840,574 .

Charitable and Penal Institutions. - In I9I I cities of the first class were authorised to maintain detention homes for juveniles. A law was passed requiring the appointment of female guards in county jails and penitentiaries. Prison contract labour was prohibited: the prison contracts are not annulled, but prisoners must be employed in manufacturing supplies for public institutions and offices; this law was slightly amended in 1912 , so that prisoners may be employed on roads and children in state homes may be indentured. A prison labour commission was created, and in December 1912 the first experiments were made in working convicts on roads. A house of detention for convicts or criminal insane on the grounds of the State Hospital at Trenton was begun late in 1912. Indigents with incurable diseases, such as locomotor ataxia, paralysis and chronic rheumatism, are to receive from the state not more than $\$ 365$ a year. A new poor law code was enacted in I9I I and amended in I9I2, and a new law was passed in 1912 for the government of a state reformatory for women at Clinton (to be opened soon). Physicians are required to report to the township assessor cases of epilepsy and mental deficiency. In I9I I $\$ 100,000$ was appropriated for buildings of the New Jersey State Village for Epileptics at Skillman - 5 of which were nearly completed in November 1912. There is question as to the constitutionality of a law of I9I I requiring (upon recommendation of an expert board) the sterilising of feeble minded, epileptics, and criminal insane in state institutions. Counties of the first class were authorised in 1912 to establish parental schools and juvenile courts; and these courts are to hear cases affecting the domestic relation. The state is to give $\$ 200$ a year to any blind person who wishes to take a course in a higher cducational institution (not for the blind) in the state. A commission on old age insurance and pensions was created in I9I I but made no report in I9I2. The system of pensions for state employees was extended to employees of penal institutions and reformatories.

History.-With Woodrow Wilson (Democrat) as governor was elected a Republican ¿See John P. Murray "New Jersey School Conditions" Educational Review, Nov. I912. 
senate in IgIo. The primary vote for United States senator was for James Edgar Martine (b. 1850), but this did not pledge members of the legislature to choose him, and he was opposed by James Smith, Jr. (b. I851), the "boss" of the state organisation, United States senator in $1893^{-99}$ and a candidate for re-election. He argued that only a minority of the Democrats of the state voted for Martine and that under the constitution the choice of senators was the function of the legislature and not of the people. Governor Wilson defended the primary vote and roused public opinion so that on the first joint ballot in the legislature Martine received only one vote less than was needed to elect him, whereupon Smith (who had received ro votes) withdrew, assuring the election (Jan. 25, I9I2) of Martine, to succeed John Kean (b. 1852), Republican, senator 1899-IgIr. This contest made it evident that the governor considered himself the leader of the Democratic party in the state. In I912, after Wilson was nominated for the presidency, James Smith again became a candidate for the U. S. Senate, to succeed Frank Obadiah Briggs (b. I85 r), Republican, whose term ends March 4, I9I3. Governor Wilson used all his influence against Smith, and in the primary (Sept. 24, I912) William Hughes (b. I872; representative in Congress, I903-05 and 1907-13) was named by the Democrats and Briggs by the Republicans. In the (legislative) state elections in November I9II, although I60, I84 Democratic votes were cast and only $\mathrm{I} 57, \mathrm{I} 84$ Republican votes, in Essex county ${ }^{1}$ the Republicans were successful-possibly, as Governor Wilson's friends thought, because of the opposition to him of Smith and J. R. Nugent (city counsel of Newark), Democratic leaders in the county; both houses of the legislature were Republican (senate I I to ro; assembly 37 to 23); but the legislature in I 9 I 3 will have. 2 Democrats and 9 Republicans in the senate and 50 Democrats and ro Republicans in the assembly. Woodrow. Wilson's term as governor did not expire until January I9, I9I4; his successor for the unexpired term from March I9r3 is, under the constitution, the president of the newly-elected senate, chosen at the organisation of the senate in January r9r3. James F. Fielder was chosen president of the senate January I3, I9r3.

In the presidential campaign New Jersey was prominent because of the part taken by her governor, Woodrow Wilson, in his successful effort for the Democratic nomination for the presidency, and his election, and because, as in Massachusetts, before the primaries both Roosevelt and Taft made a speech-making tour of the state. In the primaries (May 28 th) Roosevelt received 17,000 votes more than Taft; and Wilson received 48,336 votes to 522 for Clark, 60 for Harmon and 47 for Bryan. In the November election Wilson carried the state with $r 78,289$ votes to 145,4 Io for Roosevelt, 88,835 for Taft and 15,80x for Debs (10,253 in I908). Of 12 congressmen (under the new apportionment) II are Democrats and I, from the ist district, Republican. The representation in the 6 2nd Congress was 7 Democrats and 3 Republicans. Throughout the state there were many voters disfranchised by the Geran election law, which the state supreme court (Nov. 4, I9I2) interpreted to require registration as well as enrollment.

In Newark, after being bitterly attacked on the charge that he permitted disorderly houses to remain open, Mayor Haussling (Dem.) was re-elected in 1912 by 25,831 to I 9,343 for Aronson (Rep.) and 2,142 for Reilly (Socialist). In I9I and I9I 2 corruption among city oflicials was discovered in Atlantic City by detective W. J. Burns.

In 1912 there were strikes among the textile workers in Paterson and Passaic. There was no violence in Paterson, where the broad-silk workers struck (March) under the learlership of the Detroit branch of the Industrial Workers of the World. In Passaic a strike lasted from the middle of April to May 9 th, when most of the strikers returned to work. They were led by Haywood and others of the Chicago (" direct " action) branch of the International Workers of the World. In Perth Amboy there were violent strikes during June among employees of the American Smelting and Refining Co., the Barber Asphalt Co., etc., and three were killed on the I 4 th, and one on the 25 th. In December striking coal-handlers of the New York, Susquehanna \& Western Railway at Edgewater

${ }^{1}$ The county was carried by the Democrats in 1912 in all state and local contests, but Roosevelt received $33,71+$ votes to 26,229 for WVilson and 16,981 for Taft. 
killed two detectives and wounded nine on the rith, but were driven off on the inth. They struck for an increase of pay from 20 to 25 cents an hour.

On November 19, I91 2 the Court of Errors and Appeals upheld the supreme court in its decision that women cannot vote for civil officers or presidential electors or on questions submitted to the people. The case rested on the claim that the provision of the first constitution ( 1776 ) which gave the suffrage to "all inhabitants of full age, . . . worth 50 pounds proclamation money," etc., had never been legally: rescinded.

In Hoboken the Robert L. Stevens Fund for municipal research was established in I9ro; and a Citizens' Federation in Hudson county and a bureau of municipal research in Jersey City in I91 2-all these are private agencies.

Bibliography.-Acts of the Legislature (Paterson, I9II and Trenton, I9I2); E. J. Fisher, New Jersey as a Royal Province from 1738 to 1776 (N. Y., I9I I).

\section{NEW MEXICO ${ }^{1}$}

Population (1910) $327,30 \mathrm{r}$, an increase of $67.6 \%$ since r 900 . The negro element decreased from $0.8 \%$ to $0.5 \%$. The foreign-born whites constituted $6.8 \%$ in 1900 and $6.9 \%$ in I9I0; the native whites $85.5 \%$ in 1900 and $86.1 \%$ in I9Io. Density 2.7 to the sq. m. The purely rural population was $80.4 \%$ of the total $(83.4 \%$ in I900); in Io municipalities, each having more than 2,500 inhabitants, there was $14.2 \%$ (in 1900, 7 places had $I_{4} \%$ ): Albuquerque, $I_{1,020}(6,238$ in 1900$)$; Roswell, 6,I72 (2,049 in 1900$)$; Santa Fé, 5,072; Raton, 4,539; Las Cruces (town), 3,836; Las Vegas (city), 3,755; Clovis, 3,255; Silver City, 3,217; Las Vegas (town), 3,179 and Tucumcari, 2,526.

Agriculture.-The acreage in farms increased from 5, I30,878 to II,270 021 between 1900 and 1910; and the improved land in farms from 326,873 to $1,467,191$; the value of property from $\$ 53,767,824$ to $\$ 159,447,990$ ( $\$ 98,806,497$ land; $\$ 13,024,502$ buildings; $\$ 4,122,3$ I 2 implements; $\$ 43,494,679$ domestic animals). Of the land area $14.4 \%$ was in farms. The average value of farm land per acre was $\$ 8.77$. Farms were operated largely by owners $(33.398$ by owners, 32 I by managers and I,957 by tenants). In I9I2 (preliminary estimates) the principal crops were: Indian corn, 2,083,000 bu. (93,000 A.); wheat, I, 232,000 bu. (59,000 A.); oats, I,839,000 bu. (53,000 A.); barley, 70,000 bu. (2,000 A.); potatoes, 900,000 bu. (9,000 A.); and hay, 436,000 tons (I87,000 A.). In I900 (U.S. Census) the value of vegetables other than potatoes was $\$ 567,154$; of orchard fruits, $\$ 519,677$. On January I, I 9 I 2 there were on farms: 185,000 horses, I 5,000 mules, 53,000 milch cows, 900,000 other neat cattle, 3,300,ooo sheep and 50,000 swine. The total acreage irrigated in 1909 was 461,718 (126.5\% more than in 1899); 398,592 acres were supplied from streams. The total cost of irrigation enterprises to July I, I9IO was $\$ 9,154,897$ and the estimated final cost of improvements begun was $\$ 11,640,091$. Of cereals $51.8 \%$ by acreage in 1909 was grown on irrigated land, and of wheat $79.6 \%$, of barley $68.9 \%$ and of alfalfa $96.4 \%$. The (Federal) Carlsbad project, completed in 1909 , irrigated 13,673 acres in 1911 ; and the Hondo project, 1,000 acres. The great Rio Grande project was $20 \%$ completed in October 1912 and in the preceding. year irrigated 25,000 acres, partly in Texas. The Federal department of agriculture has a station at Tucumeari for the investigation of dry-farming.

The constitution provides for a department of agriculture under the regents of the State College of Agriculture and Mechanic Arts. The legislature of 1912 created a state land office and the office of county inspector of bees and apiaries; appropriated annually \$ I 5,000 for gauging stream flow for irrigation purposes; passed a law for the organisation and operation of drainage districts and authorised the commissioners of community ditches to grant free irrigation of three acres or less to blind men or their widows.

Mineral Products. - Total value, I9II, \$7,869,918. The only important items were: copper, 2,860,400 tons (about $3 / 4$ of the output in I910; a new company hegan work in the Santa Rita district); zinc, 3,778 tons ( $40 \%$ less than in I9IO); and coal $3,148,158$ tons $(\$ 4,525$,925). Mineral waters from 5 springs (2 resorts) were valued at $\$ 41,833$. Salt, mica and fluorspar were found in small quantities.

Manufactures.-Between 1899 and 1909 the capital invested increased from $\$ 2,161,000$ to $\$ 7,7,43,000$, and the value of products from $\$ 4,06 \mathrm{r}, 000$ to $\$ 7,898,000$. The larger industries were: steam railway car construction, $\$ 2,251,000$; and lumber and timber, $\$ 2,162,000$. In Albuquerque there were one-tenth of all the establishments, with a product, $\$ 1,288,000$, nearly one-sixth of the total.

Transportation.-Railway mileage, January I, I912, 3,079. In I9I2 by a statute the Territorial roads commission became a state highway commission with control of the state

See E. B. xix, 520 et seq. 
road fund, and county road boards were created in place of road supervisors. of $\$ 500,000$ was authorised for constructing and maintaining state highways. authorised to issue bonds for roads and bridges.

Government.-The convention which met at Santa Fé from October 3 to November 2I, I II drafted a constitution (adopted Jan. 2I, I9II, by a popular majority of I8,000), to which one amendment in regard to the method of amending the constitution was made at the general election in November I9Ir. ${ }^{1}$ The bill of rights in the constitution is unusual only in that it alludes to the privileges guaranteed by the Treaty of Guadalupe Hidalgo. The capital may be removed from Santa Fé by popular vote, but not before 1925. The article (IV) on legislation provides that the people " reserve the power to disapprove, suspend and annul any law enacted by the legislature," except general appropriation laws and emergency acts; petitions of "disapproval " must be filed four months before a general election and must be signed by $10 \%$ at least of the qualified electors of each of three-fourths of the counties (the aggregate to be at least $10 \%$ of the total number of votes cast at the last general election). The measure is annulled if a majority (at least $40 \%$ of the number of votes cast at the last general election) vote against it. If a petition of disapproval is signed by $25 \%$ of the qualified voters and is filed within 90 days after the legislature adjourns, the measure disapproved is rendered inoperative until the general election. The senate consists of 24 members (each at least 25 years old) elected for four years; and the house of 49 members, elected for two years. In I 12 an amendment was adopted striking out the requirement that legislators and state officers must be able to read, write, speak and understand English. A statute of I 912 excludes from public office or employment persons convicted of felonious or infamous crime. Legislators receive $\$ 5$ a day during sessions and ro cents a mile for mileage. At special sessions, called by the governor, no business may be transacted not specified in his proclamation. Any bill may originate in either house. The governor may veto, within three days, Sundays excepted, any measure, or, in an appropriation bill, any item; and bills may be passed over his veto by a two-thirds vote of the members present and voting in each house. General appropriation laws and special emergency acts, if passed by a two-thirds vote, and containing an emergency clause, go into effect immediately; other laws not until go days after the legislature adjourns. The legislature is to "enact laws to prevent trusts, monopolies and combinations in restraint of trade." Bribery or the undue use of influence for legislation is declared a felony punishable by a maximum fine of $\$ 1,000$ or by one to five years' imprisonment; the statutes of I 9 I 2 include a corrupt practices act and a bribery law.

The executive officers are elected for four years, and must be citizens of the United States, at least 30 years old, residents of New Mexico for five years. They are: governor (annual salary $\$_{5}, 000$ ); lieutenant governor; secretary of state, state auditor, state treasurer, attorney-general, superintendent of public instruction and commissioner of public lands. In 1912 the governor was authorised to appoint a legal adviser; and a department of fish and game was created. There are a supreme court with three justices (the legislature may increase the number to five after 1920) elected for eight years (salary, \$6,000); eight district courts ( 1 judge in each district, term six years, salary $\$ 4,500$ ); and probate courts in each county.

Suffrage is granted to every male citizen of the United States over 21 , resident in New Mexico 12 months, in the county 90 days and in the election precinct 30 days; excepted are idiots, insane, persons convicted of felonious or infamous crime (unless restored to political rights) and Indians not taxed. By statute, railway employees, if necessarily absent from the precinct in which they registered and qualified, may vote elsewhere. At school elections, which must be held at different times from other elections, women possessing the same qualifications of age and residence may vote-unless a majority of the qualified voters of a district 30 days before the election petition the board of county commissioners "against woman suffrage." There must be a similar petition for women's voting before they are restored in suffrage. Women may hold office on boards of education, or be school directors or county school superintendents.

Amendments to the constitution may be proposed in either house and if passed by a majority vote in the legislature must be advertised in one newspaper in each county (both in English and Spanish, if there are newspapers in both languages) at least two weeks before the general efection, and at the general election must receive a majority of the votes cast on

I This amendment was adopted because Congress had refused to admit New Mexico to statchood unless the provision in the original constitution were changed. 
the amendment, to become operative. The requirements for franchise and sections in the article on education providing for instruction in Spanish can be amended only by a threefourths vote in the legislature and at the general election. Within 25 years a constitutional convention may be called by a three-fourths vote of the legislature; thereafter by a twothirds vote, if approved by popular vote. The draft of the convention is not valid until ratified by the people.

A state corporation commission of three members, elected for six years, charters and regulates corporations other than municipal, and is empowered to fix rates of public service charges. The constitution contains an employers' liability clause; forbids the lease of convict labour; and makes eight hours a day's work on state, county or municipal jobs. Statutes of 1912 forbid blacklisting, limit continuous hours of service on railways to 16 , and include a coal mining code, providing for a state inspector of mines to be appointed after examination.

The first regular session of the legislature was held from March I I to June 8, I9I2. It urged the United States Congress to allot and open the Navajo and other Indian reservations to settlers; to restrict making reservations by executive orders and to modify the law in relation to the Pueblo Indians which puts them on the same footing as "tribal Indians" and overlooks their treaty rights as former citizens of Mexico.

The I2th of October, Columbus Day, was made a legal holiday.

Finance. - The constitution provides for a reve.lue tax of four mills on the dollar, other state taxes may not be more than ten mills (I 2 mills for the first two years). The governor, travelling auditor, state auditor, secretary of state and attorney-general form a state board of equalisation. The state may borrow no more than $\$ 200,000$ to meet casual deficits or for necessary expenses. The legislature of 1912 created a board of loan commissioners to determine the Territorial debt and to arrange for the issue of refunding bonds by state and counties; the commission agreed to an issue of state bonds for $\$ 1,125,000$ in December I9I2 to take up railway bonds of Grant and Santa Fé counties, which had been declared invalid hy the Federal Supreme Court but were later validated by Congress. Provision was made for a uniform system of accounting, auditing and reporting for all public officers under administration of the travelling auditor and bank examiner.

The balance in the treasury on November 30, I9I I was $\$ 568.199$ and on November 30, I $912 \$ 655,376$; the receipts during the year were $\$ 2,382,275$ and the expenditures, $\$ 2,295,098$.

Education.-The constitution provides for a state board of education, and requires school attendance of every child of school age ("of sufficient physical and mental ability"). By statute the public school curriculum must include the study of the nature of alcoholic drinks and their effect on the human system; and a course of industrial education is prescribed.

For the school year $1911-12$ the school population was 100,045 ; the enrollment 57,436 ; average daily attendance, about 41,000; length of the average school year, a little over 6 months; total expenditures \$997,89I (\$265,766 for new buildings and improvements). Of the population 10 years and over $20.2 \%$ were illiterate in 1910 (33.2 in 1900)

Penal System. - The Territorial mounted police has been continued as a state force. Convicts who work as mechanics, foremen or 'trusties,' or outside of the penitentiary, receive ten days a month additional good time. Prisoners using explosives or deadly weapons in an attempt to escape from confinement are liable to imprisonment from 25 to 50 years.

History.-The state election of November 7, rgri, resulted in the defeat of the gubernatorial candidate of the Republicans (who had been uniformly successful in the Territorial elections) by a combination of Democrats and Progressive Republicans. William C. McDonald (b. I858), who had been chairman of the Democratic Territorial Committee, was elected governor by 3,000 votes plurality. The state senate contained I6 Republicans, 7 Democrats and I Progressive Republican (term ends Jan. I9I 7 ), and the house of representatives, 28 Republicans, i 7 Democrats, 3 Progressive Republicans and I Independent (term ends Jan. I9I5). The state was formally admitted to the Union January 6, I912. On March 27, I9I 2, the legislature chose Thomas Benton Catron and Albert Bacon Fall, both Republicans, to be United States senators. Fall drew the short term (one year) and was again chosen for 1913-19, by a joint session, June 6, I9I2, in which, after divided counsels, 22 members of the lower house (out of 49; including the Democrats and Progressives) refused to vote, and the election proceeded amidst much disorder. Governor McDonald doubted the legality of Fall's reelection and refused to sign the election certificate.

In the November I 912 election there was no vote for state officers. Woodrow Wilson carried the state, receiving 20,437 votes to 17,733 for Taft, 8,347 for Roosevelt and 2,859 for Debs. A Democratic representative in Congress was elected.

Bibliography.-R. E. Twitchell, Leading. Facts of New Mexican History (2 vols., Cedar Rapids, Iowa, I9I1-12); L. B. Prince, New Mexico's Struggle for Statehood (Santa I'é, 1910). 


\section{NEW YORK}

Population (I910) $9, \mathrm{I} 13,6 \mathrm{I} 4 ; 25.4 \%$ more than in 1900 . The greatest rate of increase was in Nassau, Queens and Westchester counties (in and near New York City) and in Schenectady county (each more than $50 \%$ ). There was an increase of the foreign-born from $26 \%$ to $29.9 \%$; of negroes, from $1.4 \%$ to $1.5 \%$. The density of population was I9r. 2 (in New York county 43,850 ) to the sq. m., the state ranking 5 th in this respect. In $\mathrm{r} 9 \mathrm{IO}, \mathrm{I} 7.3 \%$ of the total was in rural territory (in $1900,22.4 \%$ ). The urban population increased relatively from $72.9 \%$ of the total in 1900 to $78.8 \%$ in 1910 . Of 148 municipalities, each having more than 2,500 inhabitants in I9IO, 2 I had more than 25,000 each, 9 more than $50,000,4$ more than 100,000 and one (New York) more than 500,000 . The 21 with 25,000 or more were: New York, $4,766,88_{3}(3,437,202$ in I 900$)$; Buffalo, 423,715 (352,387 in 1900); Rochester, 218,149 (162,608 in 1900); Syracuse, I37,249 (108,374 in 1900); Albany, I00,253 (94, I $5 \mathrm{I}$ in 1900); Yonkers, 79,803 (47,93 I in I900); Troy, 76,813 (60,651 in I900); Utica, 74,419 ( 56,383 in 1900); Schenectady, $72,826$ ( 31,682 in I 900$)$; Binghamton, $48,443(39,647$ in 1900$)$; Elmira, $37,176(35,672$ in 1900); Auburn, 34,668 (30,345 in 1900); Jamestown, 31,297 (22,892 in I900); Amsterdam, 31,267 (20,929 in 1900); Mount Vernon, 30,919 (21,228 in 1900); Niagara Falls, 30,445 (19,457 in 1900); New Rochelle, 28,867 (14,720 in 1900); Poughkeepsie, 27,936 (24,029 in I900); Newburgh, 27,805 (24,943 in I900); Watertown, 26,730 (21,696 in I 900$)$, and Kingston, 25,908 (24,535 in I900). The population of the 5 boroughs of New York City was: Manhattan, 2,33I,542 (I,850,093 in I 900), Bronx, 430,980 (200,507 in I900), Brooklyn, ${ }^{2} \mathrm{I}, 634,35 \mathrm{I}$ ( $\mathrm{I}, \mathrm{r} 66,582$ in $\left.\mathrm{I} 900\right)$; Richmond, ${ }^{3} 85,969$ (67,02I in I 900); Queens, ${ }^{4}{ }_{284,04}$ (I 52,999 in I900).

Agriculture. - The acreage in farms decreased from 22,648, 109 to $22,030,367$ between I 900 and I9IO and the improved land in farms from I5,599,986 to 14,844,039; the average farm acreage increased from 99.9 to I02.2; and the value of farm property from $\$ 1,069,723$. 895 to \$I,45I,48I,495 ( $\$ 707,747,828$ lands; \$ $476,998,001$ buildings; $\$ 83,644,822$ implements; $\$ 183,090,844$ domestic animals). Of the land area $72.2 \%$ was in farms. The average value of farm land per acre was $\$ 32.13$. Farms were operated largely by owners $(166,674$ by owners, $4,05 \mathrm{I}$ by managers and 44,872 by tenants). In 1912 (preliminary estimates) the principal crops were: Indian corn, $19,763,000$ bu. (512,000 A.); wheat, $5,360,000$ bu. $(335,000$ A.); oats, 36,714,000 bu. (I,192,000 A.); barley, 2, I32,000 bu. ( 82,000 A.); rje, 2, I 12,000 bu. (128,000 A.); buckwheat, $6,593,000$ bu. $(277,000$ A.); potatoes, $38,160,000$ bu. $(360,000$ A.); hay, 5,900,000 tons $(4,720,000$ A.) and tobacco, 5,200,000 lbs. (4,000 A.). In 1909 (U.S. Census) the value of vegetables other than potatoes was \$15,963,384; of flowers and plants, $\$ 5,148,949$; of nursery products, $\$ 2,750,957$; of small fruits, $\$ 2,875,495$ (strawberries, $\$ 1,187,410$; raspherries, $\$ 1,168,062$ ); of orchard fruits $\$ 17,988,894$ (apples, $\$ 13,343,028$; peaches and nectarines, \$2,014,088; pears, \$1,418,218); grapes, \$3,961,677; and maple sugar $\$ 1,240,68+$. On January I, I9I2 there were on farms: 609,000 horses, 4,000 mules, I,495, 000 milch cows, 894,000 other neat cattle, 9 I I,000 sheep, and 777,000 swine.

In 1911 the legislature voted state aid for high schools giving courses in agriculture. In $1912 \$ 50,000$ was appropriated for a State College of Forestry (established in 1911 and now open) at Syracuse University and a new school of agriculture was authorised on Long Island (site between Babylon and Huntington chosen early in 19I3). In I9II another school of agriculture had been established at Cobleskill, the construction of which began in 1912; and a state advisory board in relation to agricultural education and country life advancement had been established. A commission was appointed to inquire into prices, purity, production, distribution and consumption of food, farm and dairy products in the state. In $1912 \$ 265,000$ was appropriated to Cornell University for the New York College of Agriculture: $\$ 50,000$ for the Veterinary College; $\$ 34,880$ for the State School of Agriculture at Morrisville (established 1908; opened 1910) and $\$ 35,000$ for the maintenance of a school of agriculture at St. Lawrence University. The Gieneral Education Board in October 1912 gave $\$ 1,500$ for agricultural demonstration in St. Lawrence county.

${ }^{1}$ See E. B. xix, 594 et seq.

2 Ward 29, formerly Flathush, had 73,048 in 1910; Ward 30, formerly New Utrecht, 77,1 16: Ward 3I, formerly (iravesend, 29,610; and Ward 32, formerly Flatlands, 17,412.

${ }^{3}$ Ward I, formerly Castleton, 27,201 in 1910; Ward 2, formerly Middletown, 15,501; Ward 3, formerly Northfield, 19,248; Ward 4, formerly Southfield, 12,596; and Ward 5, formerly West field, II,423.

"Ward I, formerly Long Island City, 61,763; Ward 2, formerly Newtown, 105,219; Ward 3, formerly Flushing, 37,171; Ward 4, formerly Jamaica, 67,412; and Ward 5, formerly part of Hempstead, $\mathbf{2} 2,476$. 
Mineral Products. - Total value, I9II, $\$ 42,392,180$. The output of pig iron was I,537, 201 tons, valued at $\$ 23,924,194$ (not included in the total just given), much less than in 1910. The state ranked 4 th in iron ore, $1,057,984$ tons (value, $\$ 2,959,009$ ). In stone its rank was 2nd, with a quarried output of $\$ 6,895,466$ (limestone, $\$ 2,857,797$; sandstone, $\$ 2,353,995$; trap rock, \$959,966). The value of clay products was $\$ 10,184,376(\$ 8,006,012$ being brick and tile, ranking 4 th); of Portland cement, $\$ 2,669,194$ (besides natural cement, of which the state is the largest producer); of sand and gravel, $\$ 2,4 \mathbf{I} 4,452$; and of lime, $\$ 524,845$. The state was the largest producer of gypsum, with 472,834 tons, more than one-fifth the country's total. The output of salt was larger than that of any other state, but less in value than that of Michigan. In the group of fuels, the output of petroleum was 952,515 bbls. $(\$ 1,248,950)$ and the value of natural gas, $\$ 1,4 I 8,767$. Mineral waters bottled at 5I springs were valued at $\$ 939,003$. In pyrite and in millstones the state ranked 2 nd. It is still an important producer of garnets, emory and graphite, both natural and, at Niagara Falls, artificial.

Manufactures. - In 1904-1909 the number of establishments increased from 37,194 to 44,935 and that of persons engaged in manufacturing from 996,725 (856,947 wage-earners) to I,203,24I (I,003,98I wage-earners); capital invested from $\$ 2,031,460,000$ to $\$ 2,779,497$, $000(36.8 \%)$; and the value of products from $\$ 2,488,346,000$ to $\$ 3,369,490,000(35.4 \%)$, ranking the state first in the Union. By far the most important industry in 1909 was the manufacture of clothing, its value being nearly one-sixth the total for all industries of the state, viz.: women's clothing, $\$ 272,518,000(\$ 256,558,000$ being the value of the product in Manhattan and Bronx boroughs of New York City and $\$ 266,477,000$ for the entire city); and men's clothing, including shirts, $\$ 266,075,000$, of which $\$ 218,411$, 000 was the value of the product of New York City. The state produced $56.5 \%$ of the clothing (in these two classes) manufactured in the country. Second in importance was printing and publishing, $\$ 216,946,000$, of which $\$ 183,509,000$ was in New York City. The output was $29.4 \%$ of that of the entire country, and the state and the city ranked Ist. . Other important manufactures were: foundry and machine-shop products, $\$ 154,370,000$, New York ranking 2nd; slaughtering and meat-packing, $\$ 127,130,000$, the state ranking 3rd; malt liquors, $\$ 77,720$,ooo, making the state Ist; tobacco, mostly cigars and cigarettes, $\$ 76,662,000$, the state ranking Ist; lumber and timber products, $\$ 72,530,000-$-in this industry the state was 2 nd; flour and grist-mill products, $\$ 69,802,000$, ranking New York next to Minnesota; hosiery and knit goods, \$67,I30,000, New York ranking Ist; millinery and lace goods, \$52, I06,000, being $60.7 \%$ of the total for the country; electrical machinery, apparatus, and supplies, $\$ 49,290$,ooo (New York ranking Ist); paper and wood-pulp, $\$ 48,860,000$ (I8.3\% of the output of the entire country and more than that of any other state); boots and shoes, $\$ 48,186,000$, the state ranking below Massachusetts and Missouri; butter, cheese and condensed milk, $\$ 42,458,000$ (15.5\% of the country's total, but less than that of Wisconsin); men's 'furnishing goods, $\$ 42,197,000$ ( $\$ 15,897,000$ collars and cuffs, being $92.3 \%$ of the total in the United States); furniture and refrigerators, $\$ 41,929,000$, ranking the state first with $17.5 \%$ of the country's product; fur goods, $\$ 4 \mathrm{I}, 30 \mathrm{I}, 000$, being $73.8 \%$ of the product value for the whole country; iron and steel, steel works and rolling mills, $\$ 39,532,000$, blast furnaces, $\$ 26,621,000-$ in these two industries the state ranked 4 th; copper, tin, and sheet-iron, $\$ 38,452,000$, ranking the state Ist; patent medicines, compounds and druggists' preparations, $\$ 37,343,000$, the state being Ist in this industry, also, as in chemicals, $\$ 35,346,000-30 \%$ of the country's total; musical instruments, $\$ 33,680,000$, being three-eighths of the country's product value and much more than the output of any other state; automobiles, $\$ 30,980,000$ $(627.2 \%$ more than in I904), ranking New York 3 rd; paint and varnish, $\$ 28,559,000$ (more than the product of any other state); tanned, curried and finished leather, $\$ 27,642,-$ ooo, New York being 5th; silk and silk goods, \$26,519,000, ranking the state 3rd; carpets and rugs (not rag), $\$ 25,606,000$, ranking the state Ist; and confectionery, $\$ 25,540,000$. In fourteen other industries New York ranked Ist among the states.

The principal manufacturing cities were: New York, \$2,029,692,600 (Manhattan, $\$ 1,388,408,000$; Brooklyn, \$4 7 7,222,800; Queens, \$I $51,680,000$; Bronx, $\$ 42,680,800$; Richmond, $\$ 29,701,000$ ), more than any state except Pennsylvania (2I industries producing more than $\$ 20,000,000$ each); Buffalo, $\$ 218,804,000-9$ th in the United States-(slaughtering, $\$ 25,416,000 ;$ foundry and machine-shop products, \$20,775,000; flour, etc., \$19,942,000; automobiles, $\$ 9,598,000$; soap, $\$ 8,653,000$; linseed-ail); Rochester, $\$ 112,676,000-20$ th in the United States-(men's clothing, \$1 8,879,000; photographic apparatus; boots and shoes, $\$ 13,450,000$ ); Yonkers, $\$ 59,334,000$ (sugar refining; carpets and rugs; foundry and machineshop products, $\$ 2,837,000$ ); Syracuse, $\$ 49,435,000$ (automobiles; foundry and machine-shop products, \$5,691,000; typewriters); Schenectady, $\$ 38,165,000$ (electrical apparatus; steam locomotives); Troy, \$37,980,000 (collars and cuffs, \$ $3,639,000$; men's clothing, \$6,976,000); Utica, \$31,199,000 (textiles, \$1 5,977,000); Niagara Falls, \$28,652,000 (chemicals, \$1 I,997,000 -mostly manufactured by electrolysis; food preparations; flour); Albany, \$22,826,000.

Transportation.-Railway mileage, January I, I9I2, II,639.72 m. The public service commission was authorized in 1911 to determine the maximum and reduce rates in railway fares and in 1912 to have the control of the reorganisation of corporations under its jurisdiction. In I9I I separate appropriations amounting to $\$ 12,945,000$ were passed for the improvement, completion or expedition of different state highways. In both years many 
routes of state highways were changed, and altogether more than a dozen routes or sub-routes were added to the previous list. There were large appropriations for the state proportion of repairs on highways; one bill in I9I I carried \$1,795,254 and another \$1,207,079 and in I9I2 separate bills carried respectively $\$ 2,519,399, \$ 95,641$ and $\$ 1,833,182$ for maintenance and repairs. In 191 1, \$1,030,000 was appropriated for interest on the debt for the highway and in 1912 two bills carried a total of $\$ 9,345,000$ for highway improvements. The highway law was generally amended in 1912 . At the regular election the people voted $(637,548$ to 281 ,265) for the issue of $\$ 50,000,000$ in bonds for highways. A commission was appointed to investigate the operation of a barge canal; $\$ 30,000,000$ was appropriated for the improvement of the Erie and Oswego and Champlain canals: $\$ 6,000,000$ for the Cayuga and Seneca Barge Canal; $\$ 3,230,000$ to pay off a part of the principal on the canal debt; $\$ 12,000,000$ for canal terminals and facilities and $\$ 2,883,850$ for interest on the canal debt. In $191 \mathbf{1}$ bonds amounting to $\$ 19,800$, o0o were authorised for terminals for barge canal traffic. At the close of 1912 the barge canal, on which it was expected that boats $275 \mathrm{ft}$. long, $30 \mathrm{ft}$. wide, $12 \mathrm{ft}$. draught will be used, was two-thirds completed, the final opening being set for 1916. A commission was appointed to act with the New Jersey authorities and the Federal authorities in the investigation of operating conditions, and a terminal station commission for Buffalo; and a freight terminal act was passed for New York City, giving the board of estimate the power to plan terminals approved by the commissioner of docks. A section on freight terminal corporations was added to the law on transportation corporations. A law regulating the terminal of the New York Central \& Hudson River R. R. in New York City provided for the abolition of the use by railways of streets at grade. In 1912 a revision of the rapid transit law gave additional powers to the public service commission and made possible an addition to New York City's rapid transit facilities. In June and July I9II a part of the new subway construction (mostly into the outlying parts of the city) was awarded to the Brooklyn Rapid Transit Company, and a part to the Interborough system, which had built the earlier subways; early in 1913 the terms of the contracts were still under discussion. The question of lengthening city piers for the accommodation of trans-oceanic passenger steamers aroused much public interest in I9I I-I2. The United States department of war in I9I I gave temporary permission to lengthen certain piers outward, $i$. e., toward the river channel. but in 1912 the Secretary of War refused to permit this permanently, and many new plans were suggested: for new piers along Riverside Drive, above $72 \mathrm{nd}$ St.; for piers running into the land obliquely - to save room in the river channel; for docks in South Brooklyn; etc.

The Federal government practically completed in 1912 the Ambrose and the Coney Island channels in New York harbour and the breakwater $(1,565 \mathrm{ft}$. long) at Plattsburg, had more than half finished the improvement of East River and Hell Gate, and had begun the improvement of the Niagara river (12 ft. channel), of Ogdensburg harbour and of Jamaica Bay (I $8 \mathrm{ft}$. entrance channel). On December I4, 1912, New York City began work in Jamaica Bay in co-operation with the Federal government.

Legislation.-The legislature met in regular session from January 4 to October 6 I9I I and from January 3 to March 29, Igr2. At the latter session the newly surveyed boundary line between New York and Connecticut was put on the statute books.

The I 9 I I session (April Igth and July I 2 th) ratified the proposed I 6 th amendment to the Federal Constitution providing for a Federal income tax, which had been defeated in the previous session, largely because of the opposition of Governor Hughes. All the amendments to the state constitution submitted by the I9I I session to the people at the November election in IgI I were defeated. Among them was one raising the salary of assemblymen from $\$ 1,500$ to $\$ 3,000$ and of senators to $\$ 3,500$ and making the milcage, instead of roc a mile for the trip once in each session, $3 \mathrm{c}$ a mile once in each week of actual attendance at the session; raising the governor's salary from $\$ 10,000$ to $\$ 20,000$; giving partial home rule to cities and changing the requirements as to condemnation procecdings. The I9I 2 session passed three amendments which go over to the I0I3 session: providing for condemnation "by the supreme court with or without a jury, but not with a referee," and giving the legislature power to authorise any city to take more land than it needs in condemnation proceedings to secure control of certain property-practically the same as two amendments defeated in I9I I; securing to the legislature the right to pass a workmen's compensation act; and revising the system of county courts.

An claborate election and primary law was passed in 1911. A clause (to prevent fusion) forbidding the repeating of the name of any candidate in different columns of a ballot was held unconstitutional on March 7, 1912; the clause requiring personal registration in rural districts was rleclared invalid on Octoher 10 , I9I (Hopper v. Britt 203 N. Y. I 44 Court of Appeals); and the repuirement of 1,500 names for a petition for independent nomination 
was declared unconstitutional in October 1912; the law contained a provision for direct primaries except for officers chosen by the state at large. In presidential years there must be separate ballots for presidential electors and state officers. The law was revised as regards party committees and delegates in I9I2. An act of I9II declares that no ballot is void because the cross made in voting is irregular in shape.

In 1912 a board was appointed to simplify civil practice. It has the same personnel as the board of statutory consolidation. Several important amendments to the law of procedure were passed in $191 \mathrm{I}$. A Conservation Department was created, in charge of a commission with powers and duties previously belonging to the forest purchasing board, the forest, fish and game commission, the commissioners of water power on Black river, and the state water supply commission; and in 1912 the law of lands, forests and public parks was revised and a new article on fish and game was added to the conservation law. In I9I I a state athletic commission was created by a law which regulates boxing and sparring. A new personal property law was passed (I9II) in relation to the sale of goods, in nearly the form desired by the commissioners for the promotion of uniformity of legislation in the United States. The office of supervisor of records was created, and that office and the office of state historian were put under the department of education. The legislature appropriated $\$ 40$, 000 to buy the house (built $\mathbf{I} 76 \mathbf{I}-62$ ) in Albany in which General Philip Schuyler had lived and which in I9II was the Saint Francis de Sales Asylum; it was bought on February 10, 19I2. After the capitol fire, $\$ 100,000$ was appropriated for the safety of the capitol and $\$ 2,000,000$ for the reconstruction and decoration of the building in I9I I and $\$ 1,000,000$ for the same purpose in 19.12 , when $\$ 550,000$ was appropriated for continuing the construction and $\$ 200,000$ for the equipment of the State Education Building (opened October 1912) and $\$ 500,000$ for the re-establishment of the State Library. The inferior courts of New York City were re-arranged in accordance with the report (I9I0) of the Page Commission. The mayor was empowered to create a public recreation commission. A relief and pension fund was created for street cleaners. The legislature passed a law making the Borough of the Bronx a separate county; and this was approved by the voters of the borough (about 39,350 votes to 27,870 ) in November 1912, but the appellate division of the supreme court declared the referendum invalid (January 17,1913 ).

In 19 ir the department of labour was reorganised, and a commission was appointed to investigate manufacturing conditions in first and second class cities. This report was to go in before January i5, I913. On March 24, I9I I the state court of appeals decided that the workmen's compensation law of 19 10 (applying to certain dangerous employments) was unconstitutional as taking property of employers "without due process of law." This ruling was harshly criticised-see for instance the statement signed by fourteen professors of law in the New York Outlook, July 29, I9II, and opinions of prominent lawyers in The Survey, April 29, 19II. The commission on employers' liability made a valuable report in four volumes but the legislature took no action on this except to propose the additional constitutional amendment already mentioned. Women may not work in factories or mills within four weeks after childbirth. The medical officer of the department of health must make a thorough physical examination before issuing employment certificates for children in first class cities. Working hours a day were reduced (beginning October I, I912) from Io to 9 and a week from 60 to 54, for males under 18 and all females in all factories-except where there is overtime so that there may be a short sixth day in a week or overtime not more than three times a week. The maximum hours for this exception are Io (formerly 12) a day and 54. (formerly 60) a week. The law does not apply to fruit canneries ${ }^{1}$ between June 15 and October 15. Its constitutionality was being tested in the courts at the close of I9I2. A law of IgII added to places in which children could not be employed more than 54 hours or six days a week, theatres, places of amusement, barber (and shoe polishing) shops, and forbids the employment of children between 12 and I4 during summer school vacation in villages and cities of the second and third classes. Misrepresentation in regard to employment was made a misdemeanour. Much stricter requirements for sanitation and inspection were adopted for bakeries and confectioneries. Doctors were ordered to report to the bureau of labour statistics all cases of industrial poisoning or other occupational disease. The use of compressed air in caissons was regulated in 1912 by a law which includes a schedule of working hours per day under different pressures.

In 19 I I the State Institute for the Study of Malignant Disease (succeeding the Pathological Laboratory of the University of Buffalo, and the Gratwick Laboratory) was established at Buffalo. The legislature appropriated $\$ 65,000$ for a cancer hospital adjacent to the Gratwick Laboratory and $\$ 35,000$ for maintenance in I9II (and $\$ 60,000$ for equipment and maintenance in 1912). The office of state fire marshal was created, and in 1912 a much stricter fire prevention law was adopted for factories. There must be fire drills in all factories and automatic fire sprinklers must be installed in factories, and in buildings more than seven stories or ninety feet high, which have wooden flooring or wooden trim. A general fire prevention law was passed applying to New York City only, supplementing an amendment

${ }^{1}$ Evidence brought before a legislative commission in 1912 showed that there were grave abuses in these canneries, -especially in regard to child labour. 
to the New York charter made in I9i I. The tenement house law was clearly made applicable to apartment houses - after the court of appeals February 13, 1912, Grimmer v. Tenement House Department of New York City) distinguished between tenement houses and apartment houses. A new vital statistics law was passed in $19 \mathrm{II}$. The discharge of sewerage into rivers was regulated. In 1912 the governor was authorised to appoint a board of three, a surgeon, neurologist and practitioner of medicine, to be examiners of the feeble-minded criminals and other defectives; they are authorised to recommend the sterilisation of dangerous criminals. The requirements for the practice of medicine were increased, and after September 1, 1912, chiropodists must be licensed. By a law of I9II the possession and use of false weights and measures creates presumption of knowledge of their falsity. A law of 191 I required that cold storage foods be labelled and be kept not more than one year. A commission was appointed to study market facilities and the prices of food, and in August 1912 it reported that distribution added $40 \%$ to the cost of foodstuffs and recommended the authorisation of cities to establish departments of markets. A strict law was passed regulating the sale or possession of dangerous weapons - more stringent in many respects than the previous law against concealed weapons. Among important measures defeated in the I9I I legislature were a new charter for New York City, a bill granting suffrage to women, and one relieving racing associations from the responsibility of gambling at race-tracks - a measure which would have lessened the effectiveness of the anti-gambling legislation of 1908 and 1910.

Finance. - The state tax for 1912 was .396 mills for the general fund; .383 for the canal debt sinking fund; .03 for the barge canal terminals sinking fund; .1 885 for the highway improvement sinking fund and .0I25 for the sinking fund for the debt for the Palisades Interstate Park debt sinking fund. In I9I I bequests to charities outside the state were made exempt; the previous law had applied only to charities within the state. The double taxation of inheritances was practically stopped. Money and securities of non-residents taxed in the state and their shares in New York corporations were made exempt, even if there is no reciprocal arrangement with the other state. Secured debts were taxed $1 / 2$ of $1 \%$ of their face value and thereby exempted from any other tax. The stock transfer tax was changed both in I9II and I9I2 and the person who makes the sale or transfer of stock must procure and affix a tax stamp. In New York City assessments begin on April $\mathrm{I}$ instead of the first Tuesday in September. Statements of valuation must be forwarded to the state board of tax commissioners, not to the comptroller as formerly, and the board certifies to the comptroller. He is required to collect statistics of taxation, revenue and debt.

For the fiscal year ending September 30, I9I 2 the revenue was $\$ 50,213,405$ (for the preceding year $\$ 38,045,353)$. Among the larger items were inheritance tax, $\$ 12,153,189$; corporations, $\$ 10,349,165$ (and $\$ 472,960$ for organisation of corporations); (new) direct state tax $\$ 6,326,823$; excise, $\$ 9,412,364$; stock transfer stamp tax, $\$ 3,653,037$; and (new) secured debt tax, $\$ 3,626,823$. The expenditures for the same year were $\$ 44,658,678$; and the cash surplus at its close, $\$ 8,808,265$.

Education.-In I9I I a teachers' retirement fund was created for all parts of the state except where there was local provision for a similar fund. Teachers are assessed $I \%$ of their salaries, and may retire after 25 years' service ( 15 of which must be in the part of the state covered by the act) on an annuity of half of the annual salary at the time of retirement, this to be not more than \$600. Any teacher retiring after I5 years for disability gets an annuity bearing the proportion to the retirement annuity that the number of years he has served bears to twenty-five. Annuities are to be granted only if the teacher has paid a sum equal to $30 \%$ of the annuity, but the difference, if any, may be made up by the teacher. In 1912 the law for retirement of teachers in state institutions was made more liberal. The previous age limit of 70 was omitted, and the requirement that the teacher must have been employed for 10 years immediately preceding retirement was changed by omitting the words "immediately preceding." The maximum allowance for teachers was raised from $\$ 750$ to $\$ 1,000$. In $191 \mathrm{I}$ the law in regard to the education fund was radically changed. The county loan commissioners were abolished and the complete control of the fund was vested in the state comptroller. In the same year a new salary law was passed for teachers in New York City which states that there shall be no discrimination based on sex; this went into effect January I, I9I2 and added nearly $\$ 3,850,000$ to the annual pay roll. A law of 1912 provides that cligible lists for vacancies in New York (ity schools should not be merged but that one list must be exhausted before nominations are made from a later list. On a question of teachers' licenses the state supreme court in November 1912 held that the state commission of education had jurisdirtion over all school departments in the state including that of New York City. One of the most discussed points in the proposed charter for New York City was a paid board of education, which Mayor Gaynor defended against the almost universal critIcism of educational experts. In 1912 was celebrated the 25 th anniversary of the service of William H. Maxwell (b. 1852) as superintendent of schools in New York City. (See his article in Educational Review, October 1912). In 1912 the principal appropriations for education were $\$ 125,000$ to secondary schools for training of teachers; $\$ 506,500$ for normal schools; $\$ 5,175,000$ for common schools and $\$ 650,000$ for secondary departments and libraries.

For the year ending July 31 , 19 I 2 the school population was $2,143,580$, the total enroll- 
ment, I,457,391, the average daily attendance, I, I64,992, and the average school year about 169 days. The total expenditures were $\$ 59,063 ; 976$.

In 19 Io the percentage of illiteracy (I0 years of age and over) was 5.5 , as in 1900 .

Elmer Ellsworth Brown (b. I86I), U. S. Commissioner of Education in 1906-11, was chosen chancellor of New York University on April 24, I9 I, and was installed on November 9. In I9I I Columbia University became closely affiliated with the Presbyterian Hospital, and received the bequest of Joseph Pulitzer for the establishment of a school of journalism, which opened for instruction in the autumn of I912, with Talcott Williams (b. I849) of the Philadelphia Press (since I88I) as its head. In I9I2 a dramatic museum was established in Philosophy Hall of Columbia University. A "Politics Laboratory" was established at Columbia in I91 I. A gift of George F. Baker (b. 1840), a banker of New York City, made in November 1912, will be used to ally the Cornell Medical College and the New York Hospital. The Crocker Research Fund of Columbia University for study of cancer was announced late in 1912 to amount to $\$ 1,565,635$; it was supplemented in the same year by a bequest of Augustus W. Openhym. The cornerstone of a dispensary at Syracuse University was laid December 14, 1912. Hamilton College, Clinton, celebrated its centennial in 1912 and planned to make its entrance requirements broader and, beginning in 1913 , to introduce a group system of electives in the second, third and fourth years of the course; Greek is still required for the degree of Bachelor of Arts, but the degrees of $\mathrm{Ph} . \mathrm{B}$. and B.S. are given without Greek. In September I9I2 the College of St. Francis Xavier in New York City became a part of Fordham University, though each kept its former name and charter.

Penal and Charitable Institutions.-In 19 I I an investigation of state prisons and prison industries resulted in the discovery of much corruption and mismanagement and in the resignation of the state prison commissioner Cornelius $V$. Collins. In I9I I a new law was passed for the government of Letchworth Village and in 1912 one for the Woman's Relief Corps Home at Oxford. The name of the commission in lunacy was changed to the State Hospital Commission; and its medical member became practically president of the commission. In I9I I a farm industrial colony for tramps and vagrants was established, and in 19 I 2 a state reformatory for misdeameanants, for which $\$ 50,000$ was appropriated. A site in Dutchess county, 821 acres, $20 \mathrm{~m}$. S. of Poughkeepsie, was approved by the governor in September 19i2. The Great Meadows prison, at Comstock, Washington county, was opened in I9II. A Bureau of Deportation, created in I9I2, may order the deportation of insane immigrants. The board of parole may issue an absolute discharge to any paroled prisoner - formerly this could be done only if the prisoner had an indeterminate sentence. In Nov. I912 a site for the New York City farm for inebriates (controlled by a board created in 1910) was chosen in Orange county, near Greycourt, $60 \mathrm{~m}$. from the city. In 19I2 work was begun on a laboratory of social hygiene at the Bedford (state) reformatory for women.

The legislature of I9I I incorporated the Phelps-Stokes fund for the erection of tenements, etc. under the will of Caroline Phelps-Stokes, who died in 1893; and the Carnegie corporation, to which Andrew Carnegic has delegated the work of carrying on his various philanthropies, to which he gave $\$ 25,000,000$, November 10 , 1911 , and $\$ 100,000,000$ in the following year, and which he has made his residuary legatee. In 1912 the principal appropriations were $\$ 770,000$ for the maintenance of the state prison; for the state hospitals $\$ 5,804,891$, and for charitable institutions including reformatories, asylums, etc., \$1,999,929. The total number of inmates in state charitable and reformatory institutions, not including insane asylums, on September 30, 1912 was 10,744 (10,625 in 191 I).

A Free Employment Bureau in Schenectady was established on January 24, I9I 2 and on March 7 was transferred from the charities department to the department of public works.

History.-On January I, I9I I John Alden Dix (b. I860; Democratic candidate for lieutenant-governor in I.908; manufacturer of wall paper and lumber), the first Democrat to hold the office since 1894 , was inaugurated governor. The legislature was strongly Democratic in both houses for the first time in $\mathrm{I} 7$ years. Its session, the longest in the history of the state, lasting until October 5 th, was broken by two recesses, one following the partial destruction of the state capitol by fire on March 29th, when the state library was almost totally destroyed and there was a loss of several millions of dollars, and another during the month of August. Under the control of the leaders of Tammany Hall, the Democratic organisation in New York City, a mass of partisan primary and electoral legislation was introduced; some of the bills were to eliminate bi-partisan boards and replace them with partisans appointed by the governor, and others were salary "grab" bills, especially for New York City. Some passed, but were subsequently partially invalidated by the courts, because of faulty drafting or flagrant violations of the constitution; others, notably the proposed New York City charter, which was backed by Tammany and favoured by Mayor Gaynor, and the cardinal aim of which was to increase the powers of the mayor and lessen those of the existing city officers elected on 
the anti-Tammany platform in 1909 , were defeated after a long and bitter fight $\rightarrow$ the charter on September 30, I9 I. Ten weeks in the early part of the session were occupied by a deadlock over the election of a succesșor to Chauncey M. Depew (see $E$. B. viii, 56), United States senator since 1899 . Neither of the original contestants, Edward Morse Shepard, ${ }^{1}$ supported by the independent and anti-Tammany elements who refused to enter the Democratic caucus, or William Francis Sheehan (b. 1859), a New York corporation lawyer and in I892-95 lieutenant-governor, was successful, the election finally going on March 3ist to James A. O'Gorman (b. 1860), a justice of the supreme court (since 1900), who, although at one time an active Tammany man, was not originally favoured by the Tammany leaders. In IgI 2 he was active in Woodrow Wilson's interests at the Baltimore convention and during the presidential campaign.

The character of the legislation passed at the session of I9I I was the principal cause of the overwhelming victory in the autumn elections (Nov. 7, I9I I) of the Republicans in the state and in most local and municipal contests. The Republicans, helped in some districts by fusion with other anti-Tammany elements and largely on the issue of the attempted Gaynor charter, carried for the first time a majority of the assembly districts in New York City. In Kings county (Brooklyn) a Republican and Independent fusion elected the entire county ticket. The senate, elected for two years in roro, remained Democratic, but the division in the lower house showed I02 Republicans to 47 Democrats and I Socialist-in the preceding session there were 83 Democrats, 65 Republicans, I Independent Democrat and I Independence Leaguer. The Socialists elected the Rev. George R. Lunn² mayor and a nearly complete city ticket, including 8 of 13 aldermen in Schenectady city, and gained control of the Schenectady county board of supervisors, electing 8 out of 18 members.

The control of the senate by the Democrats and of the lower house by the Republicans made partisan legislation impossible although the party machines sought, by bipartisan alliances, to divide the patronage. The primary in March, the first under the new law, brought out the defects in that statute. Uniformly the Roosevelt delegates to the National Republican convention at Chicago were defeated and delegates favourable to President Taft's renomination were chosen by the " regular" party organisation. The Democrats, by an alternative provision of the law, did not choose delegates by primaries in New York City. Both parties held state conventions in April, the Republicans adopting a "stand-pat " platform and declaring for President Taft's renomination, and the Democrats choosing state delegates to the Baltimore convention bound by the unit rule and selected largely by the Tammany leaders. At the national convention at Chicago the Republican delegation from the state cast 76 votes for Taft and 8 for Roosevelt, and 6 delegates did not vote. William Barnes, Jr. (b. I 866), publisher of the Albany Journal and the reputed "boss" of the Republican machine, was prominent in Taft's interests; and James S. Sherman, ${ }^{3}$ a leader in the conservative or "stand-pat" wing of the party in the state, was renominated for vice-president. Timothy Lester Woodruff (b. 1858), whom Barnes succeeded in I9II as chairman of the Republican state committee and who had been only less well-known than Barnes for his connection with the Republican organisation, identified himself with the followers of Roosevelt.

${ }^{1}$ Shepard was burn in New York City in 1850 and died on July 28, $191 \mathrm{I}$. Orphaned at six, he became the ward of Abram S. Hewitt, graduated at the College of the City of New York in 1869 and was admitted to the bar in 1875. He was a founder and leader of the Brooklyn Demorratic ('lub and of the Independent Democracy; opposed David B. Hill and Tammany Hall, but was Tammany's nomince for mayor of New York in 1901, when he wats defeated by Seth Low, whom he had supported against Tammany in I897; worked for the (sold Democrats in the presidential campaign of 1896 , supported Bryan in I90o, opposed his nomination in 1904 , but again supported him in 1908 , to secure tariff revision. He withdrew his name from the senatorial nomination, hoping to insure the election of some other independent Democrat. He wrote an excellent biography of Martin Van Buren (1899).

${ }^{2}$ He was formerly a Dutch Reformed clergyman. In June 1912 he appointed to the municipal board of public warfare Helen Keller.

${ }^{3} \mathrm{He}$ died immediately before the election (see Obituaries) and no name was officially substituted for his on the ballots. But the only electoral votes cast for Taft, those of Utah and Vermont, were for another New Yorker, Nicholas Murray Butler, for vice-president. 
The presidential campaign resulted in Woodrow Wilson receiving the 45 electoral votes of the state. The popular vote was: for Wilson, 655,475 ; for Taft, 455,428; for Roosevelt, 390,021; and for Debs, 63,38I (38,45 I in 1908). The Democratic machine, it was supposed, would not exert its utmost strength for Woodrow Wilson, whose nomination it had opposed at Baltimore, where the delegation voted (as a unit) for Judson Harmon on the first nine ballots and thereafter for Champ Clark ${ }^{1}$; and because Wilson had urged the nomination for governor of no machine candidate. ${ }^{2}$ The press of the state was less favourable to Wilson, much less favourable to Roosevelt and more kindly disposed to Taft than that of any other part of the country. And the Republican party organisation, which had long been hostile to Roosevelt, suffered less from schism and gave to Taft a stronger support than in almost any other state. The state's representation in Congress, ${ }^{3} 43$ under the new apportionment, instead of 37 , will be composed of 30 Democrats, ro Republicans and 3 Progressives. W. Bourke Cockran (b. I 854), a New York Democrat, who had campaigned for McKinley in I 896 and was representative in Congress in $1887-89,1891-95$ and $1904-09$, joined the Progressive party and was a candidate for Congress.

In August the new Progressive party organised separately. In the primaries of September 17 Progressives largely refrained from taking part. The anti-Tammany wing elected about a third of the delegates to the Democratic state convention. Early in September the Progressives met in an unofficial convention at Syracuse. A split threatened between the followers of two rival candidates for governor. One of these was William H. Hotckhiss, formerly state commissioner of insurance, chairman of the convention, who repeatedly refused to have his name considered, but who was still urged as a candidate by his followers; the other William A. Prendergast, comptroller of the city of New York, who had the backing of Timothy L. Woodruff. The convention was stampeded by a single speech (September 6) for the nomination for governor of Oscar Solomon Straus (b. 1850), ambassador to Turkey in $1887-89$, I 898-1901 and I909-10, a member of the Hague permanent court of arbitration since 1902, and secretary of commerce and labor (1906-09) in the cabinet of President Roosevelt.' A full state ticket and local Progressive candidates were subsequently nominated by petition. The Republican state convention met at Saratoga on September 25, adopted a state platform with many progressive features and nominated (September 27) for governor Job Elmer Hedges (b. 1862), a New York lawyer, known as a witty campaigner and after dinner speaker. The Democrats, at Syracuse, nominated (October 3) for governor William Sulzer (b. I863) who had been a member of Tammany but had not been closely identified with that organisation and who had been a representative in Congress in 1896-1912, where he was prominent on the forcign relations committee, especially in connection with the question of passports in Russia. Governor Dix was a candidate for renomination but his weakness and vacillation had made him unpopular. Most of the state officers elected with Dix in 1910 were renominated and at the general election, November 5 , the entire Democratic state ticket, including two judges of the state court of appeals, was elected. Sulzer received 649,559 votes (less than for any Democratic candidate for governor since 1898); Hedges, 444, I05; and Strauss, 393,183. In New York City the Progressives elected one representative in Congress and one state senator and polled many more votes than the Republicans, who elected no senators or assemblymen. The political alignment of the legislature in 1913 is: senate, 32 Democrats, I 7 Republicans, 2 Progressives; assembly, I03 Democrats, 4 I Republicans, 6 Progressives. As the Progressive party was not second in the state election it will be at a disadvantage on the ballot; and it will not be an "official" party until I9I4 when it may vote at a legal primary.

There were no local elections of importance in New York City either in I9II or 1912. In I9I I the anti-Tammany judicial and county officers were successful and the fusion forces won control of the board of aldermen from the Democrats, who elected a sheriff by only 2,200 votes. William J. Gaynor (b. 1851, justice of the New York state supreme court, I893-1909), over a divided opposition, was elected mayor in 1909 on the Tammany ticket, but he was from the Borough of Brooklyn, where there is no Tammany organisation, and his earliest political fame had been gained in crushing a corrupt ring in Brooklyn. On the whole he kept his administration free from extremely partisan control. In general he acted in harmony with the fusion majority in the board of estimate, elected with him, and furthered reforms in the direction of efficiency in many city departments. He delayed a decision in

${ }^{1}$ This solid vote of New York for Clark helped to turn Bryan and his followers against Clark and to lose him the nomination. See United States, Political History.

${ }^{2}$ But the Wilson and Marshall electors received more votes than were cast for the Democratic candidate for governor or for any state office except lieutenant governor and controller.

${ }^{3}$ Two congressmen died in 1912; on July 5 George R. Malby (b. 1857), Republican, in Congross since 1907; and on October 30 Richard E. Connell (b. 1857), Democrat. 
regard to subways by opposing the majority of the board of estimate and apportionment. In the Cullen-Folcy (modified Gaynor) charter there was a provision empowering the mayor to veto contracts let by this board. He insisted, it was generally believed, on being in actual control of the police and enforced his theories of personal liberty and of non-interference on the part of the police with gambling and other vice. Possibly as a result of the weakening of the power of the police came a wave of lawlessness and licence which culminated in "gang" terrorism on the lower east side of Manhattan and in the assassination of a gambler, Herman Rosenthal, July 16, 1912, who was on the point of making disclosures to the county district attorney of the relations between gamblers and the police. Charles Becker, a police lieutenant, was accused of instigating the murder because Rosenthal's disclosures would cuit off the income he was deriving from protecting gamblers. He was tried and convicted (October 24), and immediately afterwards four gangsters or "gunmen" were convicted as the actual slayers of Rosenthal. A Citizens' Committee was organised to study police problems and an enquiry was begun by a special committee of the board of aldermen (the Curran Committee), which at first was openly opposed by Mayor Gaynor, who upheld the administration of the police department. The city chamberlain Charles $\mathrm{H}$. Hyde was indicted by a grand jury on May I, I9I I for accepting a bribe from the Carnegie Trust Company. He was stoutly defended by the mayor, who urged him not to resign, but he withdrew on the ground that the charges made against him would embarrass the administration. After a long delay, procured by the counsel for the defence, he was convicted on November 29, 1912. This conviction and those in the Rosenthal case were largely due to the efforts of the county district attorney, Charles Seymour Whitman (b. 1868), assistant corporation counsel in $1901-02$, city magistrate $1904-07$, and judge of general sessions court, 1907, who was mentioned as a candidate for governor in 1912 and for mayor in 1913 . In December 1912 disclosures of corruption in the police department were made by owners of disorderly houses. In Queens borough, New York City, a former borough president was indicted, November 21 , 1911 , for corrupt conspiracy to secure the nomination of a candidate for the supreme court of the state; and on September 26 Governor Dix removed President Gresser of the borough for incompetency,

The Democratic senate through a committee in 1912 investigated the city government of Albany, the capital of the state, controlled by a Republican machine organisation led by William Barnes, Jr., the Republican state "boss," and showed the presence of corruption. On March 29 the senate adopted the report of the committee and recommended the removal of Mayor James B. McEwan.

There were several serious labour disturbances in the state in I9II and 1912. In New York City drivers and helpers in the street-cleaning department struck on November 5 , I9II, asking for the abolition of night work and for increased wages, but they were all employed under civil service rules and were tried and dismissed. The strike was broken by the end of the month. There was rioting on November 12. A coastwise shipping strike in New York City lasted from June 28 to the end of July I9I2. This strike and that of New York City hotel waiters (May 31 to June 25) were marked by violence. Other strikes in New York City were those of tailors (September I4-16, I9I I), of furriers (June 20-September 8 , 1912) and of theatre musicians (July 19-August 4); the latter was broken by the use in many theatres of mechanical pianos, etc. At the very close of 1912 a garment workers strike began. At the New York cotton mills near Utica there was a strike from March 28 to April 23, 1912; the militia were called out early in April to check disorder and the strikers went back to work having gained nothing. A strike at a knitting mill in Little Falls beginning October 23, 1912 was led by the Industrial Workers of the World; it was marked by rioting and by the attempt of the police to prevent Socialists from speaking in the streets Mayor Lunn of Schenectady was arrested (October 15 and 17 ) for addressing the strikers and was sentenced to fine or imprisonment. On December 28, 1912, there were two riots. Two days before this the State Department of Labor had begun an investigation of the strike. The strike ended early in January 1913.

In New York (it the completion of the Pennsylvania terminal ( 3 I -33 sts.; 7 th and 8 th Aves.) in 1911 and the opening in 1912 of part of the new Grand Central Station (42d st. and Park Ave.) were events of architectural and cconomic importance. The new city Public Library (Fifth Ave.; 40- $4^{2}$ sts.) was opened in May 1911 and the great Municipal ()ffice building (probably the largest municipal building in the world) immediately E. of City Hall park was nearing completion in 1912. New hotels completed in $1911-12$ were the Ritz(arlton (Madison Ave. and 46 st.) the Vanderbilt ( 34 st. and Park Ave.) and the McAlpin (Broadway and 34 st.). The two last call attention to the development of the city in the district near the Pennsylvania terminal. The Woolworth Building, $760 \mathrm{ft}$. high, was finished in I912. A city plan association in Albany was organised in I9I I and by an ordinance of January 15,1912 it employed as expert Arnold W. Brunner of New York City.

Bibliography.-Session Laws (5 vols., I911-12); Legislative Manual, 1912; S. D. Brummer, Political ITistory of New York State During the Period of the Civil War (New York, 19II); S. Jenkins, The Greatest Street in the World (19II); Z. R. Brockway, Fifty Years of Prison Service (1912); F. E. Pratt, Industrial Causes of Congestion of Population in New York City (I9I1); A. Chester, Legal and Judicial IIistory of New York State (.3 vols., I9II). 


\section{NORTH CAROLINA 1}

Population (I910), 2,206,287 (I6.5\% more than in I900). The proportion of negroes decreased from $33 \%$ in 1900 to $31.6 \%$. The native whites made up $66.5 \%$ of the total in I 1900 and $67.7 \%$ in I910 (foreign-born whites in 1910, $0.3 \%$ ). Density 45.3 to the sq. $\mathrm{m}$. Of the total $75.8 \%$ (in $1900,82.3 \%$ ) lived in rural (unincorporated) territory. There were 20 cities and towns which had more than 5,000 each, as follows: Charlotte, 34,0I4; Wilmington, 25,748; Raleigh, I9,2 I 8; Asheville, I8,762; Durham, I8,24I (6,679 in 1900); Winston, 17,167; Greensboro, 15,895; Newbern, 9,96r ; High Point, 9,525 (4,163 in 1900); Concord, 8,715; Elizabeth City (town), 8,41 2; Rocky Mount (town), 8,051 (2,937 in 1900); Salisbury, 7,153; Fayetteville (town), 7,045; Kinston, 6,995; Wilson (town), 6,717; Washington, 6,21 I; Goldsboro, 6,107; Gastonia (town), 5,759; and Salem (town), 5,533.

Agriculture.-The acreage in farms decreased from 22,749,356 to 22,439, I29 in 1900-1910 but the improved land in farms increased from $8,327,106$ to $8,813,056$; the average farm acreage fell from IOI.3 to 88.4 and the value of farm property increased from $\$ 233,834,693$ to \$537,7 I6,2 IO (\$343, I64,945 land; \$1 I3,459,662 buildings; \$ 18,44I, 619 implements; \$62,649,984 domestic animals). Of the land area $71.9 \%$ was in farms. The average value of farm land per acre was $\$ 15.29$. Farms were operated largely by owners ( 145,320 by owners, I, I I 8 by managers and 107,287 by tenants). In 1912 (preliminary estimates) the principal crops were: Indian corn, 51,106,000 bu. (2,808,000 A.); wheat, 5.322, 000 bu. (598,000 A.); oats, 3,794,000 bu. (204,000 A.); rye, 409,000 bu. (44,000 A.); buckwheat, I75,000 bu. (I0,000 A.); potatoes, 2,550 , 000 bu. (30,000 A.); hay, 38r, 000 tons (293,000 A.); cotton, 878 , 000 bales ( $27 \mathrm{I}$ lbs. per A.); tobacco, I I0,980,000 lbs. (I 79,000 A.) and rice, 10,000 bu. (400 A.). In I 909 (U.S. Census) the value of vegetables other than potatoes was $\$ 6,496,308$; of small fruits, $\$ 853,076$ (strawberries, \$712,126); of orchard fruits, \$3,248,036 (apples, \$2,014,670; peaches and nectarines, \$1,04I,767). On January I, 1912 there were on farms 173,000 horses, 182,000 mules, 312,000 milch cows, 380,000 other neat cattle, I93,000 sheep and I,405,000 swine.

In 1912 the National Forest Reservation Commission recommended the purchase of the "Mt. Mitchell" area (18,701 acres; McDowell county) and the Nantahala area (27,815 acres; Macon and Swain counties) under the Weeks Act of March I, I9I I, for national forests. The state experiment station in 1912 seemed to have succeeded in removing toxic properties from cottonseed meals.

Mineral Products. - Total value, I9r I, \$2,797, I55. Clay products were valued at \$1,280,I 26 and stone at $\$ 826,928$. In mica the state ranked Ist with an output valued at $\$ 217,299$. Gold mostly from siliceous ores was valued at $\$ 7 \mathrm{I}, 900$. Of mineral waters the value in $19 \mathrm{II}$ was $\$ 3 \mathrm{I}, \mathrm{ro}$, being $45 \%$ more than in 1910 . Valuable emeralds were found near Shelby in 1911 and amethysts near Raleigh and in Warren county. Graphite was found near Franklin. Monazite, zircon, barytes, millstones and garnets are minor products.

Manufactures. - The state is one of the most important in the South in manufactures. In 1904-09 the number of establishments increased from 3,272 to 4,93I, and that of persons engaged in manufacturing from 93,142 to 133,453 (wage-earners from 85,339 to I2I,473); the capital invested from $\$ 141,001,000$ (only $\$ 68,283,000$ in 1899 ) to $\$ 217,186,000$; and the value of products from $\$ 142,521,000(\$ 85,274,000$ in 1899$)$ to $\$ 216,656,000$. In 1909 more than three-fourths of the total was from the following: cotton goods, $\$ 72,680$, 000 ranking the state 2 nd (in I 889 , Ioth); tobacco, $\$ \mathbf{3 5 , 9 8 7 , 0 0 0}$; lumber and timber products, $\$ 33,525,000$, ranking the state 2 nd, and furniture $\$ 7,885,000$ (more than thrice as much as in 1899 ); cottonseed oil and cake, \$8,504,000 (over twice what it was in 1904); and flour and grist-mill products, $\$ 8,501,000$. Other important products were:-fertilisers, $\$ 6,316,000$ (four times as much as in 1899), a large part being complete fertilisers and the industry being dependent largely on the manufacture of cottonseed oil; tanned, curried and finished leather, $\$ 5,+15,000$; hosiery and knit goods, $\$ 5,152,000$; and carriages and wagons, $\$ 3,283,000$. In I 909 not quite two-sevenths of the total product-value came from cities; in I 899 about one-sixth. The principal manufacturing cities in 1909 were: Durham, \$23,27I,500; Winston, \$ I6,778,000; Charlotte, \$10,460,000; Asheville, \$3,250,000; Wilmington, \$3,005,000; Raleigh, \$2,376,000, and Greensboro, \$2,032,000.

Transportation. - Railway mileage, January I, I9I2, 5,000.98. The legislature in I9II incorporated the trustees of the Central Highway, $480 \mathrm{~m}$. long from Beaufort Harbor to the Tennessee state line. County commissioners may appropriate annually not more than $\$ 50$ a mile for the highway and municipalities may appropriate \$100 and \$25 for every I,000 inhabitants above the first one thousand in the municipality. In 1912 work on this highway in 18 (out of 19 ) counties was in progress and it was estimated that it would be completed

${ }^{1}$ See $E . B$, xix, 771 et seq. 
by the close of 1913. Similar appropriations are permitted for a state highway from Charlotte to Wilmington, but little work had been done on this in I9I2.'

The Federal river and harbour act of 1910 provided for slack water navigation on the Upper Cape Fear river, above Wilmington, with a depth of $8 \mathrm{ft}$. and work on this project was begun in I9II. The same act and a law of 1911 made appropriations for a depth of more than $20 \mathrm{ft}$. in parts of the lower river. The canal from Pamlico Sound to Beaufort Inlet, Io ft. deep, being the third unit of the inside route from Norfolk, Va., to Beaufort, was completed in January I911. The river and harbour act of July 25, 1912 appropriated $\$ 500,000$ to purchase the Chesapeake \& Albemarle Canal, and \$100,000 for improvement and maintenance.

Legislation.- The regular session of the legislature was held in Raleion beginning January 4, Igri. On February IIth it ratified the Federal income tax amendment. The governor's salary was increased from $\$ 4,000$ to $\$ 5,000$ a year.

Children under 18 are not to be "required" to work in manufacturing industries more than 60 hours a week; the law apparently permits a greater number of hours if the employee consents. There are the same exemptions as there were in the 66 hour law. The hours of railway employees are limited to 16 hours in succession to be followed by Io hours off. If an employee works for 16 hours (not consecutive) in any 24 hour period, he must have at least 8 hours off. Train despatchers are not to work more than 9 out of 24 hours in night and day offices nor more than 13 in day offices but in emergency they may work 4 hours more three days in a week.

Married women may contract as if they were unmarried, and if their husbands are insane are permitted to sell property for their support.

The health laws of the state were amended and a state board of health was created. The act provides for a superintendent of health who in some cases is a quarantine officer and medical inspector of schools, with special instructions to investigate hook-worm disease.

Procurers are to be punished by six months or one year in jail and by a fine of $\$ 300$ to $\$ 1,000$. The sale of substitutes for beer is forbidden. The law does not apply to sales to pharmacies or to sales of domestic wines and wines in sealed packages or of sacramental wine or of flavouring essences or carbonated drinks with ${ }_{10}^{1}$ of $I_{0}^{0}$ of alcohol. Clubs anu associations are forbidden to handle or sell intoxicating liquors.

Injuring or obstructing a railway is made a felony instead of a misdemeanour, as it was formerly. The powers of the corporation commission, which discharges the functions of railway commissioners, were increased; it may abolish grade crossings or require interlocking automatic signals at crossings or bridges, and may control ticket selling in railway stations.

The county of Avery was established (county-seat, Elk Park) from parts of Mitchell, IVatauga and Caldwell counties; it was named in honour of Gen. Waightstill Avery (1745I82I), one of the signers of the Mecklenburg Declaration. Hoke county (county-seat, Raeford) was established from parts of Cumberland and Robeson counties. All lakes in Bladen, Columbus and Cumberland counties containing 500 acres or more are to remain state property forever for the use of the public. The city of Wilmington was re-chartered with a commission government, which was adopted (March I5, I9II). The legislature drew up a commission form of government for Winston and changed the charter of Raleigh by providing for three commissioners, appointed from primary nominations, and for no party names to appear on municipal ballots; but Raleigh voted down the change by 886 to 437 (out of 2,5 o) voters) and the commission form was defeated in Winston also. The commission form with the recall was adopted in February 19 I I by popular vote in Greensboro, ratifying the.charter drawn by the legislature.

Finance. - In 1909 the legiskature appropriated $\$ 300,000$ more than the revenues for that year; and in I9II the treasurer was authorised to issue a two year note for this amount. An issue of $\$ 550,000$ in 44 year $4 \%$ bonds for refunding the state debt was oversubscribed in December 1912, although the plan was attacked by the ('orporation of Foreign Bondholders of London, which holds repudiated bonds of the state. The legislature authorised the governor to appoint commissioners to settle claims of indebtedness with the United States, after the appointment of commissioners by the Federal government. An act was passed making shareholders in any state bank which has become bankrupt, defendants in original action against that bank. The corporation commission was made a board of state tax commissioners with a general supervision of the tax system and with the powers of a board of equalisation; it is required to investigate other state systems of taxation. Real property is to be assessed at its true value. The tax levy for 1911 and 1912 imposes a poll tax on all males between 21 and $5^{\circ}$ of $\$ 1.29$ a year and an ad valorem tax of 4.5 mills, -2.1 mills for state purposes, 4 mills for pensions and 2 mills (formerly 1.8 mills) for schools. Without the authority. of the legislature municipal corporations may not lay a tax of more than 10 mills. Business corporations are subject to tax on their capital stock, payable to the state treasurer. The seneral tax law of $\mathrm{IgI}$, as for several years, provides for an inheritance tax, graded to degrees of relationship and amount of bequest $15^{\circ} .0$ on sums above 850,000 , if the legatee

'Sec "Highways of North Carolina" by Joseph Hyde Pratt, State Geologist, in A merican Motorist, April 1912. 
is not a relative) and for a tax of $1 \%$ on incomes above $\$ 1,000$ from property not taxed. In the fiscal year ending November 30 , 1912 receipts were $\$ 3,413,656$ and expenditures $\$ 3,341,021$, leaving a balance December 1,1912 of $\$ 290,856$, in face of unpaid obligations amounting to $\$ 1,095,709$. The total state debt was $\$ 7,832,950$.

Education.-In I9I the legislature voted to establish in each county, after a favourable vote therein, a country farm-life school, to which state aid is to be given. A school at Vanceboro, Craven county, under this law will open in 1913. Under a special act for Guilford county, there are three agricultural high schools. The name of the Baptist University for Women in Raleigh was changed to Meredith College, and the name of the Croatan normal school to the Indian normal school of Robeson county (the name of "Croatan Indians" becoming officially "Indians of Robeson county.") Among the appropriations in 19I I was $\$ 100,000$ for weaker school districts to bring their term up from four to five months a year.

For the school year 191 I-12 the school population was 762,607 ; the enrollment in public schools, 525,507; the average daily attendance, 332,546; the average school term, I09 days; the receipts for schools, $\$ 4,448,752$, and the expenditures, $\$ 4,078,768$.

Of the population Io years and over in $191018.5 \%(28.7$ in 1900) were illiterate; of whites, 12.3 (19.4 in 1900); of negroes, 31.9 (47.6 in 1900).

Penal and Charitable Institutions. - The legislature in 19ri appropriated $\$ 60,000$ for a school for the feeble-minded over 6 years of age; a site has been chosen at Kinston, Lenoir county. A reform and manual training school for negroes between 7 and 16 was established.

History.-Governor William Walton Kitchin1 (b. 1866), who had been a representative in Congress in 1897-r909, was not renominated for governor for the term 1913-17, but entered the campaign to succeed Furnifold McLendel Simmons (b. I854; senator I90I-I3), also a Democrat, as United States senator; he was defeated at the November election (which in this state includes what is practically a Democratic senatorial primary), Simmons receiving about 30,000 more votes and Chief Justice Walter Clark about 25,000 less votes than Kitchin. The ten (Democratic) representatives in the 6 and Congress were reelected in I9I2. In the campaign for governor, Locke Craig (b. r860; member state house of representatives, 1899 and r9or), Democrat, was elected by 149,975 votes to 43,625 for Thomas Settle (b. I 865 ; representative in Congress, I893-97), Republican, 49,930 for Iredell Meares, Progressive, of Wilmington, who had refused (Oct. 28th) the offer of the Republicans to withdraw the Taft electors if the Progressives would support Settle for governor. The Republican $(43,625)$ and the Progressive $(49,930)$ votes were so small that the parties cannot be officially recognised in the state $-50,000$ votes is the minimum for an "official "party. The next legislature will have 46 Democrats in a senate of 50, and Io6 Democrats in a lower house of I 20. Woodrow Wilson carried the state, with I44,507 votes to 60,130 for Roosevelt, 29, I39 for Taft and I,025 for Debs. In the presidential campaign, Josephus Daniels (b. 1862), editor of the Raleigh News and Observer, took a prominent part as a member of the Democratic National Executive Committee and in charge of the publicity bureau.

At Pinehurst a negress was lynched for murder on June 25, r9 2.

Charles Brantley Aycock, born 1859, Democrat, governor in r9or-05 and a leader in the campaign for state-wide prohibition, died April 4, ror2. He was a candidate for U.S. senator in rgrr. See his Life and Speeches by R. D. W. Connor and Clarence Poe (Garden City, N. Y., I912).

Bibliography.-Laws (3 vols., Raleigh, I9II); official and departmental reports; A. S. Salley, Jr., ed., Narratives of Early Carolina, 1650-1708 (New York, I9II); R. D. W. Connor, Makers of North Carolina History (Raleigh, I911).

\section{NORTH DAKOTA ${ }^{2}$}

Population (I910) 577,056 (80.8\% more than in I900). Foreign-born whites constituted $27.1 \%(35.3 \%$ in I 1900$)$; native whites of native parentage, $-28.2 \%(20.6 \%$ in I 900 ). Density 8.2 to the sq. $m$. The rural (unincorporated) territory contained $72.1 \%$ of the total (in $190077.7 \%$ ). The 1o places of 3,000 or more contained together II $\%$, of the total. They were: Fargo, I4,33I; Grand Forks, I 2,478; Minot, 6, I 88 ( 1,277 in 1900); Bismarck, 5,443; Devils Lake, 5,r 57; Valley City, 4,606; Jamestown, 4,358; Mandan, 3,873; Dickinson, 3,678; and Williston, 3,124 ( 763 in I 900 ).

${ }^{1}$ His father, William H. Kitchin $(1837-1902)$ was in the Federal House of Representatives $1879-81$; and his brother Claude (b. 1869 ) a representative in I90I-I3, reelected I9I2.

See E. B. xix, 779 et seq. 
Agriculture. - The acreage in farms increased from $15,542,640$ to $28,426,650$ in $1900-10$; the improved land in farms from $9,644,520$ to $20,455,092$; the average farm acreage from 342.9 to 382.3 and the value of farm property from $\$ 255,266,751$ to $\$ 974,814,205(\$ 730,380,131$ land; \$92,276,613 buildings; \$43,907,595 implements; \$108,249,866 domestic animals). Of the land area $63.3 \%$ was in farms. The average value of farm land per acre was \$25.69. Farms were operated largely by owners $(63,212$ by owners, 484 by managers and 10,664 by. tenants). In 1909, 69 farms (10,248 acres: 8,043 in Williams and 850 in McKenzie county) were irrigated; the acreage of which present enterprises were capable was 21,917 and that of projects was 38,173 . About one-sixth of the acreage irrigated was under the U.S. reclamation service. Wheat (I,268 acres) and wild grass ( 1,057$)$ were the largest irrigated crops. In I912 (preliminary estimates) the principal crops were: Indian corn, 8,758,000 bu. (328,000 A.); wheat, 143,820,000 bu. (7,990,000 A.); oats, 95,220,000 bu. $(2,300,000$ A.) ; barley, 35,162,000 bu. (I,I76,000 A.); rye, 864,000 bu. (48,000 A.); potatoes, 6,656,000 bu. (52,000 A.); hay, 510,000 tons (364,000 A.); and flaxseed, 12,086,000 bu. (1,246,000 A.). In 1909 (U.S. Census) the value of vegetables (excluding potatoes) was $\$ 1,069,125$. On January I, 1912 there were on farms: 691,000 horses, 8,000 mules, 272,000 milch cows, 446,000 other neat cattle, 287,000 sheep, and 359,000 swine.

The legislature in 19 I I appropriated $\$ 15,000$ to advertise the state's agricultural possibilities through the department of agriculture and thus offset the advertising of farm lands in Canada. A hail insurance department was created with the commissioner of agriculture and labour as hail commissioner. The Buford-Trenton unit of the (Federal) Missouri River pumping project was 38\% completed in November 1912 and in I9I I irrigated I,240 acres; and the Williston unit, on which the Federal department of agriculture maintains a field station, was $64 \%$ completed in November 1912 and in 1911 irrigated 3,800 acres. The state experiment station has recently bred successful new varieties of alfalfa, Indian corn, blue-stem wheat, and a hardy and fertile winter rye. Plant industry demonstration farms and trial gardens at Mandan were established in 1912 by an act of Congress passed in August.

Mineral Products.-Total value, I9II, \$957,425. The only important items were: coal, 502,628 tons $(\$ 720,489)$; clay products, $\$ 210,616$; and natural gas, $\$ 5,738$.

Manufactures. - In 1899-1909 the average number of wage-earners more than doubled $\left(1,35^{8}\right.$ to 2,789$)$, the capital invested increased from $\$ 3,512,000$ to $\$ 11,585,000$, and the value of the product from $\$ 6,260,000$ to $\$ 19,138,000$. The largest single industry in 1909 was flouring and grist-milling, \$11,685,000. Printing and publishing, \$1,910,000, and the manufacture of butter, cheese and condensed milk, \$1,029,000, were the only other industries with a product value greater than $\$ 1,000,000$. The products of Fargo were valued at \$2,477,000 , and those of Grand Forks at \$1,910,000.

Transportation.-Railway mileage, January 1, 1912, 4,703.21.

Legislation.-The $\mathrm{x} 2 \mathrm{th}$ regular session of the legislature was held from January 3 to March 3, IgII. On February 3 I it ratified the proposed 16 th amendment to the Federal Constitution, providing for an income tax. Three amendments to the state constitution, on which the preceding legislature had voted favourably, were submitted to the people for their approval, at the regular election in 1912; one empowering the legislature to erect, lease, purchase and operate terminal elevators for grain in Minnesota and Wisconsin or in either of these states was carried $(56,488$ to 18,864$)$; another governing the sale of school lands to railways was ratified $(47,717$ to 22,871$)$; and the third making the term of judges of the state supreme court ten years was defeated by 42,4 I 5 votes to 27,892 . Various amendments, referred to the next session of the legislature, provide in different ways for the initiative, both as regards statutes and constitutional amendments, for the referendum, and for the recall of public officals; and for the taxation of railway and public utility property, and for the permanent location of certain state institutions. The amendments for initiative and referendum are opposed by the Prohibitionists, who think that their cause would be endangered.

The legislature adopted a state flag. A commission was appointed to revise the probate corle, and district "juvenile courts" in counties were empowered to have jurisdiction over offenders, and to keep a separate juvenile record.

The state was re-apportioned into three congressional districts and the legislature is to consist of 50 senators and 112 representatives until the end of 1914 when there are to be 47 senators and II 3 representatives. United States senators are to be nominated at primaries like candidates for state offices, and delegates to national nominating conventions are also to be chosen at primaries. An act was passed requiring party affiliation registration. Lobly ing is forbidden and lobly ists are not permitted to go on the floor of either house of the legislature. Second choice nominations were provided for in the case of United States senators or congressmen or any oflicer of the state. If no candidate receives $50 \%$ of the first choice, the cne of the two having the most first choice votes is to be chosen who has more 
of the second choice votes. A rigorous corrupt practices act was passed. A publicity pamphlet is to be sent to all voters by the secretary of state. Space is sold in it to candidates at rates per page, proportional to the importance of the office. A ballot law provides for rotary arrangement of names when two or more persons are to be elected to an office.

A commission of three was established to investigate employers' liability and workmen's compensation and to report to the next legislature. Children between 8 and 15 must attend school but a child may be excused if his labour is necessary for the support of the family. The law says that no child shall be employed in "hours when" (formerly "any part of the term during which") school is in session, so that the requirement is made more lax than before. Children under 16 may be employed not more than 48 hours, formerly 60 hours a week.

An anti-pass law contains the usual exceptions to the provision that no free tickets or passes be granted. Public vehicles must be disinfected once every thirty days during the time they are used. Local boards of health must disinfect schools once every thirty days except in vacation time. Theatres and places of amusement are not to be opened on Sunday. Ball games and horse-racing are prohibited on Memorial Day before 2 P.M. The practice of medicine is regulated by. an act which requires a licence from a state board of medical examiners and there is a separate board of examiners for practitioners of osteopathy. A state board of dental examiners was established and the qualifications for the registration of pharmacists are prescribed. Disorferly houses are declared a nuisance and may be abated by an injunction. Intoxicating liquors must not be drunk on passenger trains in the state, except in buffet or dining cars. The penalty for the disposal of liquors at any private or public sales of property was made a fine of $\$ 200$ to $\$ 1,000$ and imprisonment in the county jail for ninety days to one year.

A bird reserve was created on the islands of Devils Lake. An act was passed for the inspection and regulation of nursery stock shipped into the state.

Any city or village with 500 inhabitants or more, may adopt the commission form of government, unless it has been rejected within four years immediately previous, if the majority of the voters so decide at an election called upon the petition of $10 \%$ of the qualified electors. Voters in cities under the commission form of government may exercise the right of recall, initiative or referendum. Any city after six years under the commission form of government may abandon it and return to the state law for cities of its class or to its previous special charter, after a favourable vote therefor at an election called by a petition signed by $40 \%$ of the qualified electors. Incorporated cities are empowered to fix and adjust reasonable rates for public utilities.

Finance.-A permanent non-partisan state tax commission was established in 1911; it made its first report in December I I I 2, pointing out that the assessment is only 15 to $20 \%$ of the actual value. Corporations issuing or selling bonds or other evidences of obligation must report to the state bank examiner upon his request, and the state banking board is to take charge of any such state corporation if it is satisfied that it is insolvent or mismanaged. The balance at the beginning of I9I2 was $\$ 2,121$ and at the end $\$ 60,940$; receipts for the year, $\$$ I,4I 8,664 and expenditures, $\$ 1,359,845$. In September I9I2 the city of Fargo declared a dividend of $6 \frac{1}{2} \%$ on the tax levy, credited to tax payers March Ist, I9I3.

Education.-The igr I legislature appointed a commission to report in 1913 on the educational system of the state and passed a school code which added one month to the minimum school year and made attendance, compulsory for children between 8 and 15 . Lessons in nature study and elements of agriculture were added to the curriculum for all common schools, and agriculture is an optional subject for a teacher's certificate. Another act contains excellent and strict provisions relating to the building, sanitation and fire protection of school houses. State aid of $\$ 2,500$ a year was voted to schools with agricultural departments, each to have at least ten acres of land for a school garden; this went into effect in June, 1912. County agricultural and training schools are to be established by the board of education, if approved by a vote taken after a petition of 300 or more freeholders, and are to be maintained in part by the state. Joint schools may be established by two or more counties. A state agricultural and training school board was created. Among the appropriations were: \$10,000 for the Public Health Laboratory (opened in 1907), Medical Department, State University, and \$25,000 for the Mining Experiment Station and sub-station.

In 1912 the school population was 167,326 ; the enrollment 139,361 ; the average daily attendance, 99,686; the average school year about 7.5 months; the total revenue, $\$ 5,666,934$, and the expenditures $\$ 5,597$, i 54 .

In 1910 the percentage of illiteracy (ro years of age and over) was 3.r ( 5.6 in 1900).

Penal and Charitable Institutions.-The superintendent of the Society for the Friendless was required in I9I I to assist convicts on probation or parole to find work. The legislature established a state board of control of charitable, reformatory and penal institutions. A State Tuberculosis Sanitarium at Dunseith, Rolette county, was opened on October 24, I912.

History.-In IgIr and Igr 2 the governor was a Democrat, John Burke (b. I859, governor since I907), but the legislature was Republican (senate, 44 Republicans and 5 Democrats; house, 87 Republicans and 13 Democrats). On the death of Martin 
Nelson Johnson' ${ }^{1}$ (Rep.) in October 1909, Governor Burke appointed as U. S. senator Fountain Land Thompson (b. I854), Democrat, who resigned for ill health February I, ז910, and was succeeded by William E. Purcell (b. .1856), Democrat, also appointed. Asle J. Gronna (b. I 858), Republican, representative in Congress in I $905^{-1}$ I , was the choice of the primaries for the unexpired term (ending March 3, 1915) and was elected by the legislature, January i 8, igri. On the same day Porter James McCumber (b. 1858; Republican, senator since 1899 ) was re-elected for the term I9I I-I 7 .

In I 9 I I Judge John F. Cowen of the Devils Lake District was impeached before the state senate on charges brought by Governor Burke. He was acquitted after a trial lasting two months and costing the state nearly $\$ 100,000$.

The first state-wide presidential preference primary in the United States, held March 19, 1912, gave Robert M. LaFollette 34,1 23 votes to 23,669 for Roosevelt and 1,876 for Taft. This result was a great surprise, as the LaFollette boom had seemed to die out; it was not, however, a sign that that boom was reviving, but probably expressed the intense radicalism of the state and possibly the antipathy of the farmers to Roosevelt's original support of reciprocity with Canada and to the support given to Roosevelt by George W. Perkins-because of the hatred of the North Dakota farmers for the "Harvester Trust," with which Perkins was identified. Governor Burke was the only Democratic candidate for the presidential nomination. Woodrow Wilson carried the state (5 electoral votes) with 29,555 votes to 25,726 for Roosevelt ${ }^{2} 23,090$ for Taft and 6,966 for Debs (2,42I in I 908). P. D. Norton, Republican, secretary of state of North Dakota in I9I I-I2, was elected as a third Republican Congressman, under the new apportionment, which makes three districts. The Republican nominees for Congress were endorsed by the Progressives. The legislature elected in I9I 2 will be strongly Republican in each house. In the campaign for governor Frank O. Hellstrom (Dem.) and W. D. Sweet (Progressive ${ }^{3}$ ) were defeated by the Republican nominee, Louis Benjamin Hanna (b. I861), who was representative in Congress in $1909-13$, and the remainder of the Republican state ticket was elected. Hanna received 39,8II votes; Hellstrom, 3I,544; Sweet, 9,406; and A. E. Bower, Jr. (Socialist), 6,835.

On November 7,1912 , a prisoner in the county jail at Steele, accused of murdering his wife and her father, was lynched.

A statue of Rollo the Northman, given by the City of Rouen to the Norse race in America, was unveiled in Fargo on July 12, I912.

Bibliography. - Laws (Fargo, 1911); "North Dakota Primary," in Literary Digest, March 30, 1912; F. O. Hellstrom. "North Dakota Penitentiary," in Survey, February 24, 1912.

\section{$\mathrm{OHIO}^{4}$}

Population (1910) $4,767,121$ ( $14.7 \%$ more than in 1900 ), a figure exceeded only by New York, Pennsylvania and Illinois; I 2.5\% were foreign-born whites (11\% in 1900), and $85.1 \%$ were native whites. In density, 117 to the sq. $\mathrm{m}$. $(\mathrm{I}, 376.7$ in Cuyahoga county), the state ranked 8 th. Rural (unincorporated) territory contained $34.6 \%$ of the total $(41.9 \%$ in 1900$)$. The 139 incorporated places with 2,500 or more inhabitants each contained $55.9 \%$ (in I900, I 26 such places had $48.1 \%$ ). The 37 places containing more than 10,000 inhabitants were: Cleveland, 560,663 (381,768 in 1900); Cincinnati, 363,591; Columbus, I81,511; Toledo, 168,497; Dayton, I16,577; Youngstown, 79,066; Akron, 69,067; Canton, 50,217; Springfield, 46,921; Hamilton, 35,279; Lima, 30,508; Lorain, 28,883; Zanesville, 28,026; Newark, 25,404; Portsmouth, 23,48I; Steubenville, 22.39I; Mansfield, 20,768; East Liverpool, 20,387; Sandusky, 19,980; Ashtabula, 18, 266; Marion, I8,232; Norwood, 16,185; Lakewood, I5,181 (3,355 in 1900); Alliance, 15,083;

'Johnson was horn in 1850 in Wisconsin, lived for a time in Iowa, where he was a member first of one and then of the other house of the legislature, and was representative in Congress from North Ilakota in I891-99. He was elected United States senator in 1909.

${ }^{2}$ The Rersevelt electors tried unsuccessfully to get on the official ballot in the Republican column; they were nominated by petition.

${ }^{3}$ The only other Progressive nominee was for commissioner of agriculture and labour.

${ }^{4}$ See E. B. xx, 25 et seq. 
Findlay, 14,858; Elyria, 14,825; Chillicothe, 14,508; Masisillon, 13,879; Piqua, 13,388; Middletown, I3,I52; Ironton, I3,I47; Lancaster, I3,093; Bellaire, I2,946; Marietta, I 2,923; Tiffin, II,894; Cambridge, I I,327; and Warren, I I ,08 I.

Agriculture. - The acreage in farms decreased from $24,501,985$ to $24,105,708$ between $I 900$ and I9IO, and the improved land in farms from $19,244,472$ to $19,227,969$; the average farm acreage increased from 88.5 to 88.6 , and the value of farm property from $\$ 1,198,923,946$ to $\$ 1,902,694,589$ (\$1,285,894,8 I2 land; $\$ 368,257,594$ buildings; $\$ 51,210,07$ I implements; $\$ 197,332,112$ domestic animals). Of the land area $92.5 \%$ was in farms. The average value of farm land per acre was $\$ 53.34$. Farms were operated largely by owners (192, I04 by owners, 2,753 by managers and 77,183 by tenants). In 1912 (preliminary estimates) the principal crops were: Indian corn, I74,410,000 bu. $(4,075,000$ A.); wheat, 9,760,000 bu. (I,220,000 A.); oats, $93,280,000$ bu. (2,120,000 A.); barley, 620,000 bu. (20,000 A.); rye, 884,000 bu. $(57,000$ A. $)$; buckwheat, 410,000 bu. (21,000 A. ); potatoes, 20,832,000 bu. (186,000 A.); hay, 4,026,000 tons (2,960,000 A.), and tobacco, 79,304,000 lbs. $(86,200$ A.). In I909 (U.S. Census) the value of vegetables, other than potatoes, was \$ I I, 393,79I; of flowers and plants, $\$ 2,384,830$; of small fruits, $\$ 1,296,343$; of orchard fruits, $\$ 5,691,530$ (apples, $\$ 2,-$ $970,851$; peaches and nectarines, $\$ 1,349,311)$; of grapes, $\$ 858,594$. On January 1 , I9I2 there were on farms 901,000 horses, 24,000 mules, 887,000 milch cows, 885,000 other neat cattle, $3,694,000$ sheep and $3,578,000$ swine.

Mineral Products. - Total value, I9 I I, \$97,090,284. The state ranked 2nd (to Pennsylvania) in pig iron with a value of $\$ 73,484,592$ (not included in the total above); and was Ist in clay-working industries (value $\$ 32,663,895$, - about one-fifth the total for the country) and also in the manufacture of pottery (value $\$ 14,775,265$, - included in the total for clayworking). In stone, $\$ 5,796,829$, Ohio ranked 4 th; about three-fourths was limestone. Coal was valued at $\$ 31,810,123(30,759,986$ tons) ranking the state 4 th; natural gas at $\$ 9,367,347$ (more than in any other year except 1909-there were new wells in Lorain, Medina and Ashland counties), ranking the state 3 rd; petroleum, at $\$ 9,479,542$ (8,8 I 7 , I I 2 bbls. ; less than in 1910$)$, ranking the state 6 th; and salt at $\$ 1,100,453(4,302,507$ bbls.), ranking the state 3 rd. The value of sand and gravel was $\$ 2,104,776$ and in the production of glass sand the state ranked 3 rd. Portland cement was valued at $\$ 1,228,680$ and one of the three puzzolan cement plants in the United States in operation in I9I I was that at Struthers. In grindstones and pulpstones the state ranked ist with $\$ 742,107$ out of $\$ 907,316$ for the entire country. Lime was valued at $\$ 1,607,524,2$ nd only to Pennsylvania. Mineral waters from 28 springs, including 4 resorts, were valued at $\$ 86,478$.

Manufactures.-From 1904 to 1909 the number of establishments increased from $\mathrm{I}_{3,785}$ to 15,138 and that of persons engaged in manufacturing from $417,946(364,298$ wage-earners) to $523,004(446,934$ wage-earners); capital invested from $\$ 856,989,000$ to $\$ 1,300,733,000$ $(51.8 \%)$; and the value of products from $\$ 960,812,000$ to $\$ 1,437,936,000(49.7 \%)$, ranking the state 5 th. Three closely related industries had product values amounting together to $29.7 \%$ of the total. These were: iron and steel from steel works and rolling mills, \$197,780,000; iron and steel from blast furnaces, $\$ 83,699,000$; and foundry and machine-shop products, $\$ 145,837,000$ Ohio ranking 3 rd in this industry and 2 nd in the two classes of iron and steel manufactures. In slaughtering and meat-packing $(\$ 50,804,000)$, the state ranked 8 th; in flour and grist-mill products $(\$ 48,093,000) 5$ th. Other products were: automobiles, $\$ 38,839,-$ 000 (more than 5 times as much as in 1904 and more than that of any other state save Michigan); lumber and timber products, $\$ 34,597,000$; boots and shoes, $\$ 31,551,000$ - the state being 5 th in this industry; tobacco manufactures, $\$ 28,907,000$, ranking the state 5 th; cars, construction and repairs by steam railway companies, \$28,690,000; malt liquors, \$25,332,000; men's clothing, \$24,869,000, and women's clothing, \$19,493,000; carriages and wagons, $\$ 21,949,000$, first in the Union; pottery, terracotta and fire-clay products, $\$ 21,173,000$, the state ranking Ist; copper, tin and sheet iron products, \$19,086,000; electrical machinery, apparatus and supplies, \$18,777,000; soap, \$17,077,000; paper and wood pulp, \$16,965,000; furniture, \$16,259,000; stoves and furnaces, \$15,358,000. The state ranked Ist in safes and vaults; flags, banners, etc.; pumps, not steam pumps; and grindstones.

The principal manufacturing cities were: Cleveland, 5 th in the United States, \$271,961,000; Cincinnati, I2th, \$194,516,000; Youngstown, \$8I,27I,000, Ist in the state in steel and iron; Akron, $\$ 73,158,000$, Ist in the country in manufacture of rubber; Toledo, $\$ 61,229,500$; Dayton, $\$ 60,378,000$, Ist in the country in the manufacture of cash registers and calculating machines; Columbus, $\$ 49,032,000$; Lorain, $\$ 38,987,000$; Canton, $\$ 28,583,000$; Steubenville, \$2 I, I 87,000; Springfield, \$19,246,000, and Hamilton, \$18, 184,000.

Transportation. - Railway mileage, January I, I9I2, 9,406. I. The legislature in I9I I voted to abandon the Hocking Canal and to sell or lease the lands connected with it. It gave to counties the power to issue bonds or give aid otherwise to the establishment of waterways and canals and it created a state highway department with a state highway commissioner and 3 deputy commissioners. Parts of the Ohio Canal were abandoned, sold or leased; a part of the Miami and Erie Canal was leased to Cincinnati as a public boulevard. The slack water in the Scioto river was abandoned for canal purposes and the rights transferred to Columbus, the Columbus feeder to the Ohio Canal being abandoned. 
The Federal government in $1911-12$ began work on six dams on the Ohio river and in 1912 had practically completed four others; it also had about three-quarters finished improvements on Toledo and Fairport harbours and about half finished Ashtabula harbour.

In Cleveland on June I, I9I I, as the street railway interest fund had increased to $\$ 700,000$ (from $\$ 500,000$ ), fares were reduced to 3 cents with I cent for transfer and a I cent rebate, the first of eight cuts provided for before the minimum is reached of 2 cents cash fare, I cent transfer and no rebate.

Constitution.-At the state election in November rgro the people authorised the legislature to provide for a constitutional convention. Members of the convention were elected in November I9I I, and the sessions began on January 9, I9I2, and ended on the last of May. The 42 amendments as drafted by the convention were voted on by the people on September 3 rd, at a special election. Eight were defeated; for woman suffrage (by 269,693 to 242,735 ), due partly to the opposition of liquor interests; for a bond issue of $\$ 50,000,000$ for good roads $(274,582$ to 272,564$)$; prohibiting certain out-door advertising $(262,440$ to $26 \mathrm{I}, 360)$; for statutes regulating labour injunctions and contempt proceedings (257,302 to 240,896$)$; abolishing capital punishment (302,246 to 258,706$)$; providing for the use of voting machines $(288,652$ to 242,342$)$; permitting appointment of women to certain offices $(284,370$ to $26 \mathrm{r}, 806)$; and omitting the word " white " from the suffirage requirement $(336,875$ to 249,420$)$.

Of the amendments adopted all go into effect on January I, 1913 except that for referendum and initiative (on October I, 1912), that for educational administration (on July 14, 1913) and that for municipal home rule (on Nov. 15, 1912). The Elson amendment $(345,686$ to 203.953) gives the legislature power to authorise by statute a three-fourths jury verdict in civil cases. The number necessary to form a grand jury and the proportion required for a verdict are to be provided by statute. A clause $(291,7$ I 7 to 227,547$)$ provides for depositions from witnesses unable to attend court and for the presence of the accused with counsel at the taking of a deposition. "No person shall be compelled, in any criminal case, to be a witness against himself; but his failure to testify may be considered by the court and jury and may be made the subject of comment by counsel." Statute is to provide for suit against the state $(306,764$ to 216,634$)$. Damages for death by wrong, neglect or default shall not be limited by law $(355,605$ to 195,216$)$. There is provision $(312,592$ to 231,312$)$ for state and municipal initiative (upon petition signed by $10 \%$ of the electorate for constitutional amendments, by $3 \%$ for statute laws-a very low percentage, which would make initiation possible by the Socialist vote), and for referendum upon $6 \%$ petition against all or part of any law, filed within 30 days of the passage of the law; but emergency measures passed by two-thirds of the elected members of each house are not subject to referendum. Other laws (or parts of laws) do not go into effect after a referendum petition is filed against them until they are ratified by popular vote. The veto power of the governor is limited $(282,412$ to 245,186$)$ by the requirement of a three-fifths instead of a two-thirds vote of the legislature to pass a bill over his veto; but he may veto items in appropriation bills. Each house of the legislature is empowered to make investigations $(348,779$ to 175,337$)$. Laws may be passed providing for mechanics' and builders' liens $(278,582$ to 242,385$)$, for minimum wages and general welfare of employees $(335,588$ to 189,728$)$, for workmen's compensation $\left(321,558\right.$ to $\left.2 \mathbf{I} \mathbf{I}, 77^{2}\right)$, for the conservation of forests and other natural resources $(333,307$ to 232,898$)$, for the recall ot state officers including legislators $(347,333$ to 185,986$)$, for regulating expert testimony $(336,987$ to 185,986$)$, for registering and guaranteeing land titles $(346,373$ to 171,807$)$, and for the occupation of prisoners-prison contract labour is abolished $(333,034$ to 215,208$)$. Eight hours a day and 48 hours a week is a maximum on public works, except in extraordinary emergencies $(333,307$ to 232,898$)$. The legislature when it is in special session may pass no laws not named in the call for special session by the governor (319,100 to 192,130). The judiciary is remodelled: in place of the circuit courts created by the amendment of 1883 , courts of appeal are created (so that there is "one trial and one review") each with three judges with a six year term and the present circuit judges become judges of the appellate court for the district in which they reside; the number of supreme court justices is increased to seven (chief justice and six judges) and the appellate jurisdiction of the court is in part defined by the constitution $(264,922$ to 244,375 ); common pleas judges for each county (no longer for common pleas districts) are elected for six years $(301,891$ to 223,287$)$. Justices of the peace are abolished in large cities where there are municipal courts other than mayors' courts $(264,8.32$ to 252,936$)$. Nomination for state, district, county and municipal offices must be by direct primaries, except in political units of less than 2,000 population, where direct primaries may he secured by majority petition; statutory provision is to be made for a preferential vote for United States senator, and delegates to national nominating coriventions must be chrosen by direct vote, and on ballots for delegates there must be given the name of each delegate's first and second chnice for president $(349,801$ to 183, I 12). A superintendent of pullic instruction, replacing the state commissioner of common schools (statu- 
tory official) in July 1913 , is to be appointed for four years by the governor $\left(256,6 \mathrm{I}_{5}\right.$ to $251,946)$. Statutes may provide for the regulation of insurance rates charged by companies organised or doing business in the state $(321,388$ to 196,628$)$. To the prohibition of a poll tax is added the prohibition of any service required by the state, "which may be commuted in money or other thing of value." The clausefor exemptions from taxation limits the exemption of public or school bonds "now outstanding," and the personal property exemption is increased from $\$ 200$ to $\$ 500$. There may be statutory provision for inheritance taxes (exempting a part of any estate less than $\$ 20,000$ in value), for income taxes (exempting a part of an income of $\$ 3,000$ or less), for excise and franchise taxes and for taxes on the production of coal, oil, gas and other mineral products; at least one-half of income and inheritance taxes collected must be returned to the local government unit from which the tax originated $(269,039$ to 248,684$)$. Bonded indebtedness may not be incurred or renewed without legisla- tive provision for a tax to pay interest on bonds and to create a sinking fund for their redemption. Corporations may be classified and controlled by statute $(300,466$ to 212,704$)$. Bankstockholders are liable for corporation debts in proportion to the amount of their stock at par in addition to the amount invested in their shares $(377,272$ to 156,688$)$; and statute shall provide for the inspection of private banks. State printing may be done by the state $(319,612$ to 192,378$)$. A clause permitting the grant of licences ${ }^{1}$ to traffic in intoxicating liquors (except where there was local prohibition under the Rose county option law of 1908 and the Beal municipal option law of 1902), but limiting the number of saloons to one for every 500 inhabitants, was voted on in a separate column of the ballot with space for a vote "for licence" and one for a vote "against licence." The vote was 273,36 I "for" and I 88,825 "against." Civil service appointments and promotions in state, county or city must be on merit, ascertained if possible by competitive examinations $(306,767$ to 204,580$)$.

Candidates for a constitutional convention must be nominated by petition and there shall be no emblem or party designation on the independent and separate ballot, on which their names appear. There must be a vote every twentieth year, beginning 1932, on the call of a constitutional convention $(271,827$ to 246,687 ). An entirely new article (XVIII) on municipal corporations (adopted by 30I,86I to 215,120 ) classifies corporations over 5,000 as cities and under 5,000 as villages and provides for home rule; statutes for the government of municipalities, other than general laws, become operative in a municipality only when they are approved by popular vote; municipalities may own, lease and operate public utilities (even without their corporate limits) if an ordinance therefor within 30 days after its passage is not opposed by a $10 \%$ petition calling for a referendum; and municipalities may frame their own charters (not in conflict with general laws) or adopt a commission form of government. The vote on the schedule for amendments was 275,062 to 213,979 .

Legislation.-The legislature met in regular session from January 2 to May 3I, I9 I and ratified, January I 9 th, the proposed amendment to the Federal Constitution for an income tax. It provided for a vote for United States senators on primary ballots and for statements by candidates (like those in Oregon) that they will follow the people's recommendation. The law in regard to registration for election was revised. A corrupt practices act requires the accounting of campaign funds, strengthens the law against bribery and specifies a maximum campaign outlay for candidates in different offices. Candidates violating the law may be disqualified for office. There is to be a separate independent judiciary ballot, to be marked "Judicial Ticket," for all elective judges and on this no names of parties are to appear.

The initiative and referendum are provided for in municipal corporations, giving the initiative by a petition of $30 \%$ of the qualified voters to be filed within 120 days of the date of the first signature. A measure thus initiated must be voted on at the next general election, if it is not passed within 60 days after its submission, without change, by the council. Franchise grants, bills providing for expenditures, etc. must be referred to the people if within 30 days of their passage a petition therefor is signed by $15 \%$ of the qualified electors. Acts of city councils do not go into immediate effect unless they are declared to be emergency measures and receive a three-fourths vote in the council, and even then may be vetoed by a referendum vote. A bill drafted by the Cleveland Chamber of Commerce provides that no city council may have more than 32 members; the minimum is 7 . The nuisance of noise and smoke in a city may be abated by the municipality. Cities are permitted to establish municipal pawn departments. An elaborate building code was adopted.

A public service commission was created to take the place of the railroad commission; it has power to supervise and regulate public utilities and railroads - not including street railways and other utilities operated by municipalities;- to investigate and fix rates; to establish uniform accounts and to grant permission after a public hearing for the consolidation of

1 The constitution of $185 \mathrm{I}$ forbade the grant of liquor licences but allowed the legislature by law to "provide against evils resulting therefrom." There was a state tax of $\$ 1,000$ on each person or corporation trafficking in intoxicating liquors. 
competing lines. Public utilities companies are forbidden to give rebates or unjust or unreasonable preferences.

The legislature created a commission to codify and revise laws pertaining to children; it reported in 1912 a new code which will be submitted to the next legislature. Ten hours a day and $5+$ hours a week was made the maximum for working women but canneries and establishments preparing perishable goods are exempted; the constitutionality of this law was upheld in January 1912 by the state supreme court.

A state insurance fund (elective) was created for the benefit of injured workmen and the dependents of killed employees, - to be administered by a state liability board of awards. The insurance fund is made up from premiums paid by employers and employees, $90 \%$ by employer and $10 \%$ by employees, the latter amount being deducible from the payroll. Employers who pay the premium are not responsible in damages under common law or statute, unless for injury received through wilful failure of employer or employer's agent to comply with law or ordinance, and in this case, the claim for damages may be made against the employer or may be for compensation under this act. The act provides that an employee receive two-thirds (if between $\$ 5$ and $\$ \mathbf{1}_{2}$ ) of his full wages during temporary disabilitythe total not to be more than $\$ 3,400$ nor to continue more than six years from the injury. fior permanent injury the payment is two-thirds of the average weekly wage (between $\$ 5$ and \$I2; if less than $\$ 5$ his whole wages) until death; as a benefit to dependents the rule is not less than $\$ 1,500$, nor more than $\$ 3,400$, for that part of six years after the injury beginning with the employees death, the payment being two-thirds the average weekly wage. This law was upheld by the state supreme court in a test case in January 1912.

The legislature appropriated $\$ 5$,ooo for the purchase of land for the Perry Memorial in Put-in-Bay, to be dedicated in 1913, the centennial of the Battle of Lake Erie.

The Cleveland Chamber of Commerce has a committee on municipal art and architecture (until I908 the Group Plan Committee). The Federal Building (dedicated March 20, 1912), the county court-house (completed Jan. I9I2), the city hall (begun I9II) and the public library were built in accordance with its recommendations. The city council made no appropriation for the work of the (official) municipal planning commission, so that, although not formally discharged by the mayor, it was in 1912 practically out of office.

Finance.-The annual interest on the irreducible debt (largely educational) is $\$ 325,000$. The 191 I legislature passed in important tax limit levy law. A budget commission was created for each county to pass on local appropriations. This consists of the county auditor, the prosecuting attorney and the mayor of the largest city in the county. The law of I9II provides for a depository for state funds, not more than $\$ 50,000$ to be kept as a reserve in the stite treasury vault. The tax commission law of 1910 was revised, and more power was given to the commission especially in enforcing the "excise" tax on corporations.

On November 16, 1911 , there was in the state treasury $\$ 3,768$, I I6. Receipts for the following fiscal year were $\$ 14,036,902$ and expenditures, $\$ 13,122,181$, leaving a balance (Nov. 15, 1912) of $\$_{4}, 682,838$. There is practically no state debt.

Education. - The legislature in 19 II appropriated $\$ 2,475,000$ to be distributed to the common schools. For normal school buildings at Kent $\$ 50,000$ was appropriated, and the same amount for buildings at Bowling Green. These normal schools were authorised in I910. Agriculture is to be taught in common schools except in city school districts and after September I, 1912 agriculture is a required subject for teachers in any village, township, or special school district. The legislature authorised the erection of a high school building on the grounds of the Ohio State Lniversity to be used as an observation and practice school for the university's college of education; this had not been built in 1912. The Cleveland School Board in I9I I voted that any. public school in the city, not in use in the evenings, might be thrown open for public meetings on the petition of 15 tax payers.

For the year ending August 3I, I9 22 the school population (between 6 ana 21) was I,231 946; enrollment in public schools, 853,002, excluding 90,000 in parochial schools; average daily attendance, 659,044; length of average school year, 34 weeks; total revenue for schools, $\$ 48,939,820$, and expenditures, $\$ 3 I, 031,678$.

In 1910 the percentage of illiteracy ( 10 years of age and over) was 3.2 ( 4 in 1900 ).

In 191 I llestern Reserve University completed an endowment of $\$ 1,000,000$ for its medical school. An attempt in 1912 to tax part of the endowment of Oberlin College was unsuccessful.

Charitable and Pena Instimtions. - The legislature in I9I I created a board of administration to take the place of separate boards controlling the seven state hospitals, the hospital for epilept is the institute for feeble-minded, the state schools for the deaf and for the blind, the Ohio soldiers and sailors home, the Madison Home (formerly called the Home of Ohio soldiers, sailors, etc.), boys' industrial home, girls' industrial home and the state reformatory, penitentiary and sanatorium as well as the Ohio reformatory for women (established in 19I I; not yet open). All employees of institutions under the board were put on the civil service classified list. A woman resident physician was appointed for the Girls' Industrial School and a chief matron of the school tikes the place of the superintendent. A committee of the legislature was authorised to investigate the Ohio penitentiary, to study convict labour, and especially the advisability of farm labour for convicts. 
History.-In IgI I-I 2 the Democrats controlled the state, the only state officer who was a Republican being the treasurer. Judson Harmon (b. I846), who had been attorney-general of the United States under President Cleveland (June 8, I895-March 5, I897), governor since 1909, was the choice of the Democratic state convention in 1910 for the Democratic nomination for the presidency in $1912^{1}$ and in the National Convention received $I_{4} 8$ votes on the first ballot, I 27 on the ninth, 3 I on the tenth, and I 2 (all from Ohio) on the 46 th and final ballot. The Democratic lieutenant-governor, Atlee Pomerene (b. I863) was elècted United States senator (Jan. I I, I9I I; two days after his inauguration) to succeed Charles Dick (b. I858), Republican, who had succeeded M. A. Hanna in 1904. The other senator from Ohio is Theodore Elijah Burton (b. I8.5I), Republican, whose term expires in I9I5, so that the legislature of I9I3 will not elect a senator. Pomerene's election was largely due to Harmon's influence and was opposed by the Democratic " machine," which preferred Edward W. Hanley. Late in the session the legislature carried, over Governor Harmon's veto, a measure calling for the immediate payment to legislators of their next year's salaries. The radical element of the Democratic party opposed Governor Harmon in his candidacy for the presidency and, January 2, I9I 2, organised a league against him. Both Roosevelt and Taft spcke in the state before the Republican primaries for district delegates to the National Convention, which were favourable to Roosevelt; but in the state convention the 6 delegatesat-large chosen were instructed for Taft. In November the state (24 electoral votes) was carried by Wilson who received 423 , r 52 votes to 277,066 for Taft (a native of the state), 229,327 for Roosevelt, 89,930 for Debs (33,795 in I908), and II,459 for Chafin (Prohibition). In the campaign, Dan R. Hanna, son of M. A. Hanna, was a prominent worker for Roosevelt. For governor the Republicans nominated (July 2, I9I2) Judge Edmond B. Dillon who declined (July 27th); and then chose (Aug. roth) Robert Burns Brown (b. I844), of the Zanesville Courier, commander-in-chief of the Grand Army of the Republic in I896-97; the Progressives (Sept. 5th), Arthur L. Garford; and the Democrats, James M. Cox (b. 1870; head of the News League of Ohio, composed of Cincinnati, Dayton and Springfield papers; and representative in Congress, I909-13), who was elected by 439,323 to 272,500 for Brown and 217,903 for Garford. Only 3 (out of 22) representatives ${ }^{2}$ in Congress will be Republicans. The state legislature will be Democratic by 72 on joint ballot.

In Cincinnati, George B. Cox, Republican "boss" of the city was indicted for perjury (Feb. 27 and Mar. 3I, I9II; the indictments were quashed, May 2oth); and in November, although the machine Republican nominee for mayor was endorsed by President Taft, a Democrat, Henry Thomas Hunt (b. I878), prosecuting attorney of Hamilton county in I 909-I I, was elected by a plurality of 4,000. In Cleveland, Newton Diehl Baker (b. 1871), Democrat, city solicitor since I902 and a friend and follower of Tom L. Johnson, was elected mayor by a plurality of I 7,838 votes; and the Socialist vote was large. Socialist mayors were elected in rgr in Barberton, Cuyahoga Falls, Lima, Lorain, Mansfield, St. Marys (with all other Socialist nominees) and Salem (by ro4 votes), and a Socialist mayor of Canton was elected in November I 9 I 2 by only two votes.

Following the indictments (Nov. I910) of hundreds of citizens of Adams and Hamilton county for corruption at the polls, $4 \mathrm{I}$ persons were indicted for vote-selling in Scioto county (Feb. II, IgII); and in I9I2, in an investigation of the state legislature, representative George B. Nye of Waverly pleaded guilty to bribery and revealed systematic corruption (Oct. 9, I912), and two state senators were convicted of taking bribes and were sentenced to 3 years and 9 months in the penitentiary. See UnIted STates, History.

At Cleveland in August I9I 2 the mayor opened a municipal dance hall.

Bibliography.-Legislative Acts, vol. cii (Springfield, 19II) official reports, especially Ohio Statistics, 191 I (ibid., 1912); Adelaide R. Hasse, Index of Economic Material in the Docu-

${ }^{1}$ In the primaries Harmon received 100,099 votes to 89,116 for Wilson, 2,490 for Bryan and $\mathbf{3}, 489$ for Clark.

2 Carl Carey Anderson, born 1877 , Democrat, mayor of Fostoria in $1905-09$ and representative in Congress since 1909, was killed in an automobile accident on October 1, I912. 
ments of the States of the United States: Ohio (Washington, D.C., I912); D. J. Ryan, The Civil War Literature of Ohio; a Bibliography (Cleveland, I9II); Isaac Franklin Patterson, The Constitutions of Ohio (Cleveland, 1912); E. L. Bogart, The Financial History of Ohio (1912), in Univ. of Ill. Studies in Social Sciences; George H. Porter, Ohio Politics during the Ciont War Period (New York, I9II), in Columbia University Studies.

\section{OKLAHOMA ${ }^{1}$}

Population (I910) I, 657, I55 (I09.7\% more than in I900); $8.3 \%$ (in I900 $7.0 \%$ ) were negroes; $84.8 \%$ (in $190082.2 \%$ ) were native whites, and $2.4 \%$ (in $19002.6 \%$ ) were foreign-born whites. Density 23.9 to the sq. m. The urban population (in 46 cities, each having more than 2,500 inhabitants) was $19.3 \%$ of the total (in 1900 , in 13 such cities, $7.4 \%$ ); and the rural decreased from $82.1 \%$ in 1900 to $66.8 \%$ in I910. In I9ro the 14 cities having 5,000 or more inhabitants were: Oklahoma City, 64,205 $(32,452$ in I907); Muskogee, 25,278 (I4,418 in 1907); Tulsa, 18,182 (7,298 in I907); Enid, 13,799; McAlester, I2,954; Shawnee, I2,474; Guthrie, I I,654; Chickasha, Io,320; Ardmore, 8,6 I 8; Sapulpa, 8,283 (4,259 in I907); El Reno, 7,872; Lawton, 7,788; Bartlesville, 6, I $8 \mathrm{I}$; and Durant, 5,330.

Agriculture.-The acreage in farms increased from $22,988,339$ to $28,859,353$ between 1900 and 1910 and the improved land in farms from $8,574,187$ to $17,551,337$; and the average farm acreage fell from 212.9 to 151.7 ; but the value of farm property increased from $\$ 277$, 525,433 to $\$ 918,198,882$ ( $\$ 649,066,668$ land; $\$ 89,610,556$ buildings; $\$ 27,088,866$ implements; $\$ 152,432,792$ domestic animals). Of the land area $65 \%$ was in farms. The average value of farm land per acre was \$22.49. Farms were operated largely by tenants (104, I37 by tenants, 85,404 by owners and $65 \mathrm{I}$ by managers). In 1909 (U. S. Census) 137 farms (4388 acres; 2,769 in Harper county) were irrigated by enterprises capable of irrigating 6397 acres. The acreage included in projects was 8,258 . Streams are almost the only source utilised $(97 \%$ in $\mathbf{1 9 0 9 )}$. Alfalfa $(\mathbf{I}, 383$ A.) and wheat (969 A.) are the largest irrigated crops. In 1909 (U. S. Census) the value of broom corn was $\$ 2,559,235(216,350 \mathrm{~A}$.), of vegetables (excluding potatoes), \$2,610,239; of orchard fruits, $\$ 943,464$ (apples $\$ 573,076$ ). In I912 (preliminary estimates) the principal crops were: Indian corn, IOI, 878,000 bu. $(5,448,000$ A.); wheat, $20,096,000$ bu. (1,570,000 A.); oats, $23,494,000$ bu. $(936,000$ A.); barley, 160,000 bu. $(8,000$ A.); rye 48,000 bu. $(4,000$ A.); potatoes, $1,740,000$ bu. $(29,000$ A. $)$; hay, $48 \mathrm{I}, 000$ tons ( 385,000 A.); cotton, $1,039,000$ bales (1 84 lbs. per A.); and flaxseed, 9,000 bu. (1,000 A.). On January 1,1912 there were on farms 750,000 horses, 272,000 mules, 504,000 milch cows, I, 242,000 other neat cattle, 72,000 sheep and I,410,000 swine.

A statute of 19 I I made the larceny of live stock a felony. In I9I I the legislature exempted from taxation for not more than five years anyone successfully using gravity underflow water for irrigation and domestic purposes; the act permits cities and towns to exempt such persons or corporations from municipal taxation on their property. The Federal Reclamation Service is investigating the feasibility of irrigating lands in Beaver and Woodward counties from the Cimarron river or from underground waters of the Cimarron Valley.

In November 1912 the people voted $(164,530$ to 63,586$)$ to amend the constitution so as to remove the present board of agriculture and to replace it with a new board.

Mineral Products. - Total value, I9ri \$42,678,446. In value of petroleum, \$26,451,767 (one-third more than in 1910), the state ranked 2 nd, and in natural gas, $\$ 6,731,770$ (about 16 times as much as in 1907$)$, 4 th. The output of coal was $3,074,242$ tons, valued at $\$ 6,291,-$ 494. Asphalt was valued at about $\$ 400,000$. The output of stone was worth $\$ 795,879$; of sand and gravel, $\$ 97,539$; and of clay products, $\$ 756,639$. The only important metals were: zinc, 2,247 tons, \$256, I58, and lead, 1,925 tons, \$173,250. Mineral waters, bottled at Io springs, were valued at $\$ 14,290$, nearly thrice as much as in 1910 .

Manufactures. - In $1904-09$ the number of establishments increased from I, 123 to 2,310 ; the number of persons engaged in manufacturing from $7,456(5,456$ wage-earners) to 18,034 (I3,I43 wage-earners); the capital from $\$ 16,124,000$ to $\$ 38,873,000$; the value of products from $\$ 24,459,000$ to $\$ 53,682,000$. The most important separate manufactures were: flour and grist-milling products, \$19,144,000; cottonseed oil and cake, \$5, 187,000; lumber and timber, $\$ 4,439,000$ (mostly yellow pine and oak); refining and smelting zinc, $\$ 3,002,000$; steam railway car construction, \$1,702,000; foundry and machine-shop products, \$1,371,000; artificial ice, \$1,273,000; butter, cheese and condensed milk, \$1, I50,000; and brick and tile, $\$ 1,029,000$. The principal manufacturing cities were: Oklahoma City, \$7,868,000; Enid, $\$ 2,453,000$; Muskogee, \$2,279,000; and Shawnee, \$2,081,500.

Transportation.-Railway mileage, January I, $1912,6,179,77$.

Legislation.-There was an extraordinary session of the legislature from November 28 to December I6, 1910, taken up almost entirely with the question of moving the state

${ }^{1}$ See E. B. xx, p. 57 et seq. 
capital. It passed a law giving to the state supreme court exclusive original jurisdiction in regard to the removal of the state capital or any state institution and declared Oklahoma City the permanent seat of government and created a state capitol commission. On May 29, 191 I in Coyle v. Smilh (221 U.S. 559) the Supreme Court of the United States decided that after it has come into the Union a sovereign state cannot be limited by conditions in the act " under which the new state came into the Union, which would not be valid and effectual if the subject of Congressional legislation after admission" -in other words that the state had the right to change its capital in spite of the provision in the enabling act. An initiative petition for moving the capital back to Guthrie was defeated in November I9I 2 by 103,106 to 86,549 .

The regular session of the third legislature was held from January 3 to March II, I9II. It asked for a Federal Constitutional Convention to propose an amendment prohibiting polygamy, and urged Congress to permit the sale of segregated coal and asphalt lands of the Choctaw and Chickasaw Nations and to distribute among the Osage Indians the tribe's mineral holdings.

A revised code compiled by a commission appointed in 1909 was adopted in I911. A commission was appointed to promote uniform legislation in the different states and to investigate especially. laws in regard to marriage and divorce, insolvency, descent and distribution of property, etc. A supreme court commission of six was appointed for two years to relieve and assist the supreme court.

A state flag was adopted with a red field and a white five pointed star with blue edges and with " 46 " in the centre of the star to show that the state was the forty-sixth to be admitted to the Union. The legislature appropriated $\$ 5,000$ for a statue of Sequoyah (see $E$. $B$. xiv, $482 \mathrm{c}$ ) to represent Oklahoma in the statuary hall in the capitol at Washington, D. C.; Mrs. Vinnie Ream Hoxie has been chosen as the sculptor. The r2th of October was made a legal holiday as Columbus Day. The state department of labour was divided into four bureaus: of statistics, of arbitration and conciliation, of free employment, and of factory inspection. An act for the sanitation of bakeries and food stuff factories and the ventilation of all factories gives the factory inspector police powers and permits him to order the repair of unsafe buildings. The office of state fire marshal was created.

The state law ${ }^{1}$ for enforcing the constitutional provision for the prohibition of the sale of intoxicating liquors (adopted when the state came into the Union) was made more strict, but the: governor is authorised to regulate the sale of pure grain alcohol and of denatured alcohol for medical and industrial purposes and to apothecaries who give a bond of $\$ 1,000$ or more that none is to be used except for compounding prescriptions and medicines, such as may be sold without paying a federal tax. The governor was authorised to establish warehouses to handle orders for industrial alcohol. "The possession in a place of business, amusement or resort of more than one quart of intoxicating liquor with one half of $1 \%$ (or more) of alcohol, by volume, was made unlawful by this act, except for bonded apothecaries, druggists, etc.; and it was made unlawful to keep more than one gallon of intoxicating liquor in one's residence. But these provisions were declared unconstitutional (I I 9 Pacific Rep. Iorg) by a court which pointed out that such possession might be made, by statute, presumptive evidence of intent to violate the law. Transportation companies are required to keep record of shipments of liquors and an original package containing intoxicating liquor may not be opened on the premises of the transportation company.

Finance. - The state banking law was amended in $191 \mathrm{I}$ mostly in details in regard to the depositors' guarantee fund. Provision was made for the issuing of $\$ 3,000,000$ worth of $5 \%$ public building fund bonds in 28 series. The United States Supreme. Court on May 13 , I9I2 decided that the state could not tax lands belonging to Indians of less than half-blood. It held the bank guarantee law (see $E . B . x x, 60 c$ ) constitutional (219 U. S. IO4), and on February 19, 1912, declared that the state law requiring a report of gross receipts of corporations and taxing them was valid only for receipts from intra-state commerce.

On December I, I9I0, there was a balance in the treasury of $\$ 653,710$. The total receipts for the two years ending November 30 , 1912 . were $\$ 7,688,435$ and the expenditures, $\$ 7,218$,$32 \mathrm{I}$, leaving a balance of $\$ 1,123,824$. There is no bonded debt.

Education. - The state board of education was newly organised in I9I I, to take over not merely the work of the old board of education, but also that of the state text book commission, of the board of regents, of the industrial state boards, of the preparatory schools at Tonkawa and Claremore and the boards controlling the state normal schools, the Oklahoma industrial school for girls at Chickasha, the school of mines, the school for the deaf, the school for the blind, the boys' training school, the orphans' home, the institution for the feebleminded, the deaf, blind and orphans' home for negroes, and the agricultural and normal university for negroes, - so that its work will be in the field of charity as well as education.

${ }^{1}$ On April 3, I9I I, the U. S. Supreme Court declared that it was not called upon to enforce the state prohibitory law. 
On October 21, 1912 Dr. Stratton Duluth Brooks (b. 1869), who had been superintendent of schools in Boston since 1906, was inaugurated president of Oklahoma University. For the school year ending June 30 , I9I I there were $\mathbf{5 5 6 , 8 5 2}$ children of school age, an enrollment of $443,227(37,35+$ negro $)$ and an average daily attendance of 260,018 . The average length of the school year was 6.5 months. The receipts for school purposes were $\$ 8,076,310$ and expenditures, $\$ 6,759,413$. At the election of November 1912 the people adopted (100,042 to $65,+36)$ a constitutional amendment for state aid to districts in which the local tax of 5 mills is not enough to keep school for 5 months.

In 1910 of the whole population ro years of age and over $5.6 \%$ (12.1 in 1900) was illiterate: of whites, $3.6 \%$ (7.9 in I900); of negroes, 17.7 (37 in 1900).

Penal and Charitable Institutions. - The penal and charitable work suffers from the newness of organisation and the lack of buildings for the institutions; and in I9I I large. appropriations were made for new buildings. An act gave to the commissioner of charities and corrections the authority to appear as "next friend" before a county court having probate jurisdiction for minor orphans, defectives, dependents and delinquents in public institutions. The state commissioner of charities and corrections is a woman, Miss Kate Barnard, to whom the success and efficiency of the department are largely due. She was largely responsible for constitutional and statutory provisions in regard to compulsory education, child labour, prison laws, etc. The department has a "public defender" who appears in cases for orphans and minors, whom the peculiar status of land-holdings, especially of Indians, in the state makes singularly likely to be defrauded of their property. A farm colony for discharged prisoners is proposed.

History.-In I9I I-I 2 the legislature was Democratic (by 57 on joint ballot) and all the administrative officers were Democrats. Lee Cruce (b. I863), Democrat, in rgro, was elected governor for I911-I 5 by 120,218 votes to 99,527 for McNeal (Rep.) and 24,707 for Cumble (Socialist); in I 907 a much larger total vote was polled, but only 9,303 votes were cast for the Socialist candidate for governor. In the elections of November I91 2 the Democrats were successful. Woodrow Wilson received 119,156 votes, the Republican electors ${ }^{1} 90,786$ and Debs 42,262 (in 1908, 21,734). The reapportionment of 1910 gave the state 8 representatives in Congress, instead of 5 . Of the five in the 6 and Congress, two were Republicans and three Democrats, and these five were re-elected from districts in 1912 , but the three chosen at large were Democrats. In the 4th and $5^{\text {th }}$ districts the Socialist candidates received only a few less votes than the Republican candidates-100 (out of $46, \infty 00$ ) in one and less than $1, \infty \infty$ (out of 52,000 ) in the other. Robert Latham Owen (b. I856), Democrat, United States senator in $1_{907-13}$, carried the senatorial primary (Oregon plan) by I 26,4 I 8 to 83,429 for his Republican opponent Judge H. B. Dickerson, and was the choice (Ian. 21, I9I3) of the strongly Democratic legislature (senate: 36 Democrats, 8 Republicans; house: 80 Democrats, I 8 Republicans). The other senator from the state is Thomas Pryor Gore (b. I870), senator since 1907 , whose term ends in I915; he is totally blind .

The adoption of the "grandfather" clause, August 2, I9ro (by 135,443 to 106,222), tending to disfranchise negroes, seemed likely to provoke a contest between Federal and state authorities. Under instructions from the attorney-general election officials refused to register negroes in certain districts or to allow them to vote, and in igro some election officers were indicted by Federal grand jury. The only conviction was of two officials ${ }^{2}$ for fraudulently hindering a voter - this was not a test of the constitutionality: of the "grandfather clause," which the state supreme court (27 Okla. 292) upheld, but which Federal judges in the eastern and western districts in obiler dicta denied. In the eastern district there were prosecutions for enforcing the "grandfather clause" in registration and at the primary of August 6, I9I2, and several officials were bound over to await the action of the grand jury. In the western district the Federal attorney before the general election of rgr 2 warned election officers that the "grandfather clause" was unconstitutional and the enforcement a violation of the laws of the United States.

There were several lynchings in the state in IgI I: a negress and her son, accused of murder, at Okameh, May $25_{\text {th; }}$ a negro, shot and burnt for rape at Durant, August I3th; another accused of rape, burnt at the stake at Purcell, August 23rd, when sheriffs

1 Of the Republican electors 7 were for Roosevelt and 3 for Taft.

2 Frank fuinn and J. J. Beal, convicted September I9I I and sentenced to 1 year in the penitentiary at Leavenworth and to pay a fine of $\$ 100$, appealed. 
attempting rescue were locked in the courthouse; one for robbery and killing officers, at Manford, December 3 rd; and one for rape at Valliant, December 5 th. A race riot in Coweta, October $22 \mathrm{nd}$, was averted by the presence of militia; the city attorney was shot and killed by a negro, who was lynched. On January I, IgI 2 a negro was lynched at Muldrow for murder.

In Guthrie a commission form of government was adopted, June 20, I9I I, and the commissioners took charge on a writ of ouster. But the aldermen were restored by the state supreme court's decision, September I3, I9I I, that the commission government was not in power. On a rehearing the same court restored the commissioners, March 13, I912. A freeholders' commission charter was adopted by Holdenville on April 25, I 9 I I ( 183 to IO3 votes) and went into effect on July 4, I9II; by Enid, September 22, I909, in effect December 20, 1909; by Oklahoma City on March 9, r91 r, in effect May $9^{\text {th; }}$ by McAlester on May 26, I9ro, in effect October 4, roro; by Kingfisher, April 5, I910; by Bartlesville, August 2, I910; by Tulsa, July 3, I908; in effect January 5, I909; by Wagoner, October 4, I9I0, in effect April 25, I9I I; by Ardmore, November I 7, I 908, in effect April 1909. In I9I 2 the commission government was adopted in Ada (April 3oth; in effect, July ist) and Okmulgee; in Collinsville it was defeated by 7 votes. The mayor of McAlester was recalled on April 24, igr 2.

Bibliography.-Session Laws, I9I0-I9II (Guthrie, I9II), and official reports, especially of the commissioner of charities and corrections. C. B. Galbreath on Initiative and Referendum in Annals of the American Academy, September 1912.

\section{OREGON}

Population (Igro) $672,765(62.7 \%$ more than in 1900). The proportion of Indians and Asiatics decreased in the decade from $4.3 \%$ to $2.4 \%$; that of the foreign-born whites increased from $13 \%$ to $15.3 \%$. Density 7 to the sq. m. (in Multnomah county 5०1.7). Unincorporated places or rural territory contained $4 \mathrm{I} \%$ of the total $(55.6 \%$ in I900). There were II incorporated places in I 900 which had each 2,500 or more $(32.2 \%$ of the total); in I $910,45.6 \%$ was in I 8 such places, as follows: Portland, 207,2 I 4

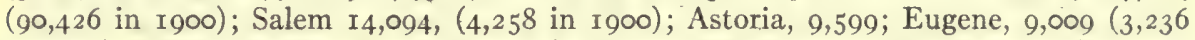
in I900); Medford, 8,840 ( $1,79 \mathrm{I}$ in I900); Baker City, 6,7.42; Ashland, 5,020 (2,634 in r 900); The Dalles, 4,880; St. Johns, 4,872 (ine., r9o3); La Grande, 4,843; Roseburg, 4,738 ( 1,690 in 1900); Corvallis, 4,552, ( $1,8 \mathrm{I} 9$ in 1900); Pendleton, 4,460; Oregon City, 4,287; Albany, 4,275; Grants Pass, 3,897; Marshfield (town), 2,980; and Klamath Falls (town), 2,758 (447 in r900).

Agriculture.-The acreage in farms increased from ro,07 I, 328 to $11,685,110$ between 1900 and 1910 and the improved land in farms from $3,328,308$ to $4,274,803$; the average farm acreage fell from 281 .o to 256.8 and the value of farm property increased from $\$ 172,761,287$ to $\$ 528,243,782$ (\$411,696, I02 land; $\$ 43,880 ; 207$ buildings; $\$ 13,205,645$ implements; $\$ 59,461,828$ domestic animals). Of the land area 19.1\% was in farms in 1910 . The average value of farm land per acre was $\$ 35.23$. Farms were operated largely by owners $(37,796$ by owners; 847 by managers, and 6,859 by tenants). In I9I2 (preliminary estimates) the principal crops were: Indian corn, 630,000 bu. (20,000 A.); wheat, $21,018,000$ bu. $(842,000$ A.); oats, I 3,7 I 4,000 bu. (359,000 A.); barley, 4,284,000 bu. (I I9,000 A.); rye, 352,000 bu. (22,000 A.); potatoes, $10,075,000$ bu. $(65,000 \mathrm{~A}$.); and hay, I, 738,000 tons $(790,000 \mathrm{~A}$.) In 1909 (U. S. Census) the value of vegetables except potatoes was $\$ 2,448,917$; of flowers and plants, $\$ 268,833$; of nursery products, $\$ 783,020$; of small fruits, \$64I, I94 (strawberries, \$395.349; currants, $\$ 150,729$ ); of orchard fruits, $\$ 3,339,845$ (apples, $\$ 1,656,944$; plums and prunes, $\$ 838,783$; cherries, $\$ 269,934$; pears, $\$ 366,977)$; of grapes, $\$ 98,776$. On January I, I9I 2 there were on farms 289,000 horses, I0,000 mules, I 80,000 milch cows, 457,000 other neat cattle, 2,592,000 sheep, and 258,000 swine. The total acreage irrigated in 1909 was 686, I $29(76.7 \%$ more than in 1899); 646,866 were supplied from streams. The total cost of irrigation enterprises to July I, 1910, was $\$ 12,760,214$, and the estimated final cost of improvements begun was $\$ 39,-$ 2 I6,619. Of cereals $5 \%$ by acreage was grown on irrigated land in 1909 , and of barley, $16.9 \%$; of alfalfa, $83.6 \%$; wild, salt, or prairie grasses, $63.3 \%$; and of sugar beets, $74.5 \%$. The Umatilla reclamation project ${ }^{2}$ (on which the Federal government has a field station) was in November $191282 \%$ completed and in I9II irrigated 8,600 acres. The Klamath project ${ }^{2}$ in November 1912 was $73 \%$ completed, and in I9I I irrigated 27,693 acres, partly in Cali-

1: See $E . B$. xx, 242 et seq.

See $E, B . x x, 244$ c. 
fornia. In I9I I a new experiment farm for growing grain on dry lands was established at Burns, Harney county. The legislature adopted (I9II) a new code for irrigation districts.

The office of state imnigration agent was created in I9II to work with the Oregon Development League in developing the agricultural resources of the state; and a state board of forestry was established. Besides appropriations for experiment stations, the state appropriated \$ I 5,000 for the investigation of crop and fruit pests and diseases and of horticultural problems by the State Agricultural College, and \$20,000 a year (in addition to the \$5,000 a year appropriated in 1905) for co-operation with the Federal government in making topographic maps and in investigating water resources. A survey fund was created from fees for licence for water power; it is to be used for the study of stream flow, etc.

Mining.-A state bureau of mines was created in $191 \mathrm{I}$ to be carried on by the department of mines of the state agricultural college. The total value of mineral products in I9I I was $\$ 3,198,796$. The value of gold was $\$ 634,200$ (more than twice as much as in 1909), mostly from the Republic district, Ferry county; and that of silver, \$24,200. The cutput of copper, $125,943 \mathrm{lbs}$., was thrice that of $19 \mathrm{IO}$; that of lead II tons. Of platinum I $17 \mathrm{Oz}$. were reported, partly from placers and partly from beaches. Of coal 46,66I tons were marketed, valued at $\$ 108,033$. Clay products were valued at $\$ 1,081,025 ;$ stone at $\$ 583,398$, and lime at $\$ 38,2$ I 6 .

Manufactures. - In 1904-09 the number of establishments increased from 1,602 to 2,246 , and that of persons engaged in manufacturing from 22,018 to 34,722 (wage-earners from $18,523$ to 28,750$)$; the capital invested from $\$ 44,024,000$ to $\$ 89,082,000(102.3 \%)$; and the value of products from $\$ 55,525,000(\$ 36,593,000$ in 1899$)$ to $\$ 93,005,000$. More than onehalf of the total product value was reported from the following industries: lumber and timber, \$30,200,000 (nearly twice as much as in 1904); flouring and grist milling. \$8,891,000; slaughtering and meat-packing, $\$ 5,880$,000 (more than double the value in 1904); butter, cheese and condensed milk, $\$ 4,920,000(57.6 \%$ butter, $13 \%$ cheese); and canning and preserving, $\$ 3,207,000$. Foundry and machine-shop products, $\$ 3,135,000$; malt liquors, $\$ 1,857,000$; leather goods, $\$ 1,629,000$; and copper, tin and sheet iron, $\$ 1,611,000$, were some of the other larger products. More than half of the product value was reported from Portland, \$46,$86 \mathrm{I} 000(63.6 \%$ more than in I904). The product of Salem was valued at $\$ 2,208,000$.

Transportation. - Railway mileage, January I, 1912 2,602. The Federal government in 1911 completed dredging in Tillamook Bay (co-operating with the Tillamook Port Commission) and in 1912 was dredging in the Coquille river and had nearly completed dredging operations in Coos Bay inside channels. An act, proposed by initiative, creating a state highway department, was defeated by 83,846 votes to 23,872 in November 1912, when an initiated law for county road systems also was defeated 56,713 to 49,699 , but an amendment excluding indebtedness for state roads from the constitutional debt limit of $2 \%$ of the taxable property of the state was carried $(59,452$ to 43,447$)$, and so was a similar amendment in regard to county roads and county debt limits $(57,258$ to 43,858$)$. A measure fixing the percentage that freight rates on small shipments bear to carload lots and establishing minimum weights and maximum freights was adopted in November 1912.

Legislation.-The legislature was in session from January 9 to February $\mathbf{1} 8$, I9I I. On January 30 it ratified the income tax amendment to the Federal Constitution.

Thirty-seven laws and constitutional amendments (including several amendments in regard to taxation; see Finance) were referred to the people in November I912. An amendment creating the office of lieutenant governor was defeated $(61,644$ to 50,562 votes). Another amendment would have radically changed the requirement for amending the constitution by substituting the words " majority of total number of electors voting or casting ballots at said election" for a majority of the votes on the amendment. This was favoured by a "Majority Rule League" but was bitterly opposed by the People's Power League and was defeated by 70,325 votes for 32,934. A similar proposed change in regard to initiative measures was defeated by 68,86 I to 35,721 votes. An amendment, approved by the People's Power League, but defeated by 7 I, I 83 to 31,020 votes, would have abolished the state senate, given to the governor and all defeated party candidates for governor membership of the one-chamber legislature, and empowered the governor alone to introduce appropriation bills. An amendment for woman suffrage (defeated 1900, 1906, I908 and 1910) was proposed by initiative petition and was adopted by 61,265 to 57,104 .

The legislature urged Congress to give Alaska an organised Territorial government; to submit to the states an amendment to the Federal Constitution providing for direct election of United States senators; to set aside 30,000 acres in the Klamath Indian Reservation and the Crater National Forest for army manoeuvres; to give to Oregon one-half of the proceeds from national forests within the state, in order to make up the loss in taxes to the counties; and to secure the completion of the Klamath and Umatilla projects.

On February 19, 1912 the U.S. Supreme Court (in Kiernan v. Portland, and Pacific 
Telephone \& Telegraph Co. v. Oregon) held that the effect of the adoption of initiative and referendum on the republican form of government guaranteed by the constitution was a political question to be determined by Congress.

A law proposed by initiative and approved by the people on November 8 , roro requires presidential preference primaries; the state pays the necessary experises up to $\$ 200$ of delegates to national party conventions. The legislature appointed a committee for the revision of the registration and election law. An act requires rotation on ballots of the names of candidates for the same office. A committee of seven was appointed by the governor to propose and recommend a revision of the judicial system and of state court practices. Judges must decide within three months upon any question submitted to them, unless sickness or unavoidable casualty prevent. In civil cases three-fourths of a jury may render a verdict.

The legislature created a state purchasing board (governor, secretary of state and state treasurer) to purchase supplies for state institutions, as far as practicable, from lowest bidders; a state printing board (composed of the same officers) to supervise a state printer to be elected first in 1914; and a state board of fish and game commissioners. The taking of any lobsters in the state before January 1, 1916 was prohibited; appropriations were made for several salmon hatcheries; and "wild bird and game refuges" were created.

Railways must not work their employees for more than I4 consecutive hours, after which the employees are to have Io hours off. Train despatchers in day offices are not to work more than 9 out of 24 hours. In an emergency an employee may work 4 hours above this schedule in any 24 but not more than 3 days a week. No child under 14 may work in a factory, workshop, mercantile establishment, restaurant, hotel, office, etc., or at all during the term of the public schools and no child under 16 to is work in telegraph, telephone or public messenger service; the certificate law for child labour is made more severe. Acts prohibiting boycotting and picketing in strikes and the use of parks or public places for speech-making without the mayor's written permit were referred to the people in November 1912 and were defeated. An amendment making 8 hours a day's work on state or municipal contracts and requiring contractors to give bonds against filing claims or liens on buildings was adopted.

An act empowering the railroad commission to regulate all public utilities was referred, on petition, to the people and was adopted in November I912, 65,985 to 40,956 votes. A law proposed by initiative petition and approved by the people on November 8, I9I0 requires, for the protection of workmen, that materials be inspected, that safety rails be used in construction and that there be a system of signals and that all supports bearing live wires be specially coloured. The law declares that there is no statutory limit of damages for its violation. Railways are forbidden to give rebates.

No saloon is to be located and no liquor is to be sold within 6 miles of public construction work (state or Federal), unfess in an incorporated city. The licence tax for the sale of liquor was set at $\$ 400$ a year $-\$ 200$ for the sale of malt liquors only. The use of intoxicating liquors was forbidden in engines, cars, trains and railway stations of common carriers. After June 15,1912 it is illegal to sell or explode a fire-cracker larger than $21 / 2$ in. $\times \frac{5}{8} \mathrm{in}$.

The legislature created a state board of examination and registration of graduate nurses; the law permits registered nurses to add after their name " $R$. N." and forbids the use of these initials by any other person. For protection against bubonic plague, cholera and other menacing Asiatic diseases \$5,000 was appropriated. White slave traffic was made a felony, punishable by a fine of $\$ 100$ to $\$ 10,000$, one to ten years in the penitentiary, or both.

The legislature passed two laws requiring uniform insurance policies against accidents and disease, and against fire; a law for the control of fraternal benefit associations and one increasing the powers of the state insurance commissioner.

Ports with more than 100,000 inhabitants (i.e., Portland) are to be governed by seven commissioners appointed by the governor with a four year term, instead of the regular city government.

The I2th of October (Columbus Day) was made a legal holiday. The legislature provided for the appointment of trustees to preserve the home of Dr. John McLoughlin in Oregon City (this was done in 1912) and authorised the erection in the national statuary hall in the Capitol in Washington of a statue of George Henry Williams (1823-1910), United States senator from Oregon in 1865-71 and attorney-general in President Grant's cabinet (1872-75).

Finance.-The situation in regard to taxes from November I9IO to November I9I2 was an impasse. In I9IO two amendments submitted by the legislature, repealing the uniform tax requirement on all property and permitting the legislature to classify property for taxation or to exempt it, were defeated at the polls; and a third constitutional amendment, submitted by initiative petition, was adopted. This provided that no poll tax should be imposed, that no statute of the legislature in regard to taxation should be in effect until the people had ratified it at a general election, and that the people of the several counties be empowered to regulate taxes within the counties subject to any general law passed thereafter. As there were no enabling acts to carry out county option in taxation, which had been thus approved by the people, and as the legislature (under the amendment just adopted) could pass no tax legislation to be effective until it was approved by the people at the next general election in 1912, three new amendments were submitted by the legislature to the people at this general election-two practically the same as those that were defeated in 1910 and the third practical- 
ly repealing all parts of the one adopted in 19 Io except the provision in regard to the poll tax. All three were opposed by W. S. U'Ren, and the first and second were defeated by fairly close votes, but the third was adopted by 63,881 votes to 47,150 . An initiated act exempting from taxation debts, stock (except bank stock) and bonds was defeated $(66,540$ to 42,49 I votes); and so were a revision of the inheritance tax (by 63,839 to 38,609 votes), a single tax measure $(82,015$ to 31,534 votes) and an amendment providing for an income tax $(52,948$ to 52,702). But household furniture and goods actually in use were exempted from tax. A new banking code, was passed in I9I I-the governor, secretary of state and state treasurer, making up the state banking board, which is to appoint a superintendent of banks. Each bank must report at least five times a year to him; and directors of incorporated state banks must appoint each year a committee of stockholders (not officers) to examine the affairs of the banks at least once every six months. A "blue sky" law like that of Kansas, supervising and licensing the sale of stocks and bonds, was defeated by popular vote in November I9I2. A popular vote of 82,98 I to 2 I,738 approved a constitutional amendment making stockholders in banking corporations liable for the par value of stock held.

On September 30, 1910 the balance in the treasury was $\$ 424,913$ and on September 30, I9I2 the balance was $\$ 933,736$; the receipts for the two years were $\$ 8,307,182$ and the expenditures, $\$ 7,738,359$. There is no state debt.

Education.-A new compulsory education law of 191 I made 9 to 15 years the limit instead of 8 to 14. A county educational board was established in every county having more than 60 school districts. The county school tax was increased from $\$ 7.00$ to $\$ 8.00$ for every child between 4 and 20 at the preceding school census. Evening schools are to be provided in first class districts. New laws were passed for the formation of union high schools, for the certification of teachers, for a retirement fund association in districts with 10,000 children of school age, and for the government of the University of Uregon. - Large appropriations were made for the State Agricultural College and its experiment station-\$273,500 in a single act, and $\$ 70,000$ annually for the State Agricultural College. For the University of Oregon \$1 75,000 was appropriated for a library and museum, and $\$ 328,259$ for an administration building, additional land, equipment etc.; but these two acts were held up by a referendum to the people who voted against them in November 1912 ( 79,376 to 27,3 IO and 78,985 to 29,437 respectively), when they also defeated $(57,279$ votes to 48,701$)$ an act, proposed by initiative, levying a $\frac{B}{10}$ mill tax for university and agricultural college and creating a single board of regents for the two. A bill appropriating $\$ 50,000$ for a dormitory at the Monmouth Normal School was held up by a referendum petition, but a majority of the names on this petition were false signatures, and the appropriation was not voted upon by the people.

In Portland in September 191 I was opened Reed College (non-sectarian; co-educational), on a foundation, "The Reed Institute," endowed by a bequest in 1904 of Mrs. Simeon G. Reed in accordance with the wishes of her husband, who died in 1895 . In the autumn of I912, the first buildings were opened on the permanent campus ( 86 acres), beautifully situated on the E. side of the Willamette river. The work and plans of the college have aroused much interest because the endowment is large (between $\$ 2,000,000$ and $\$ 3,000,000$ ), because the college is working up from no previous educational institution, and because the new faculty is composed so largely of young men. The president is William Trufant Foster (b. 1879), a Harvard graduate (I90I), for a time professor at Bowdoin, and in 1910 lecturer on educational administration at Columbia University. Several other members of the faculty were in their thirties or younger. The choice of many who have taught in secondary schools is indicative of an intention to correlate college and preparatory work. The Reed Extension Courses were opened in December 1911 , one course on the East Side and the other in the West Side of Portland. The college will admit no conditioned or special students and its entrance requirements do not rigidly prescribe subjects to be offered; it undertakes to pay its teachers fair salaries, to keep the ratio of students to instructors low (in I9I2-13, IO to I) and to make a comparatively high expenditure per college student (about \$4IO a ycar).

For the school year 1912 the school population was 189,425 ; total enrollment in public schools, I 30,268; average daily attendance, I 12,057 ; length of the average school year, $1431 / 2$ days; total revenue, $\$ 8,643,701$, and total expenditures, $\$ 6,638,225$.

In 19 I0 the percentage of illiteracy of the population Io years of age and over was 1.89 (3.3 in 1900), ranking Oregon next to the lowest (Iowa, 1.7\%) among the states.

Penal and Charitable Institutions. - In 1911 the legislature created a parole board to investigate the cases of indeterminate sentence, but the governor alone has the power of parole. The name of the State Reform School was changed to the State Training School. An appropriation of $\$ 200,000$ was made for the Eastern Oregon State Hospital, which was begun in June I9IO and opened in December 1912. The building of the Oregon School for Deaf Mutes was transferred to the Sanitorium for the treatment of tuberculosis (1910) in 1911. Two acts proposed by initiative petition and adopted November 1912 abolish contract prison labour of state, and of county, city or town convicts, and authorise their employment on public works and highways $(7,3,800$ to 37,492 votes and 71,367 to 37,731 respectively). A measure abolishing capital punishment was referred to the people and defeated in November $1912(64,578$ to 4I,95I). An "honour" system by which convicts are pledged to observe certain rules and are not constantly policed and kept in confinement has been successfully introduced, kargely 
through the efforts of Governor West. (See articles in Collier's, May 4, 1912, and Review of Reviews (New York), Jan. 1912).

History. - The legislature in I9I I was Republican (by majority of 80 in joint session) but the governor, elected for the term I9I I-I 5, was a Democrat, Oswald West (b. I 873), who had been state land agent in $1903-07$ and a member of the state railroad commission in $1907-10$. He took a particular interest in the state penal institutions, introducing the "honour" system referred to above and putting convicts to work on roads and in state institutions. In June I9I i he personally captured a convict who escaped while at work at the state Home for the Feeble-Minded at Salem. He supported the measure abolishing capital punishment, defeated in November I912. Pending the result of the vote on this measure he had reprieved all condemned murderers. On December I 3 four such criminals were hanged. The political history of the state centres around its direct legislation rather than the issues of the old political parties. Many of the more radical measures were drafted (and strongly urged) by the People's Power League of Oregon, the secretary of which is William Simon U'Ren (b. I 859), the leading exponent of "Oregon" ideas. The publicity pamphlet published by the state and containing all measures (and arguments thereon) to be voted upon by the people in ror 2 contained 256 pages-exclusive of local acts inserted in copies for six counties of the state. The regular ballot was $18 \times 34$ in. In the presidential primaries Woodrow Wilson received 9,588 votes to 7,857 for Clark, and Roosevelt 28,905 to 22,49 I for LaFollette and 20,51 7 for Taft; but the Progressives failed to re-nominate for United States senator Jonathan Bourne, Jr. (b. 1855), president of the National Progressive Republican League and as well known outside the state as U'Ren was within it as a promoter of direct legislation. The Progressives nominated for United States senator A. E. Clarke, the Republicans, Ben Selling, president of the state senate, and the Democrats, Harry Lane. Bourne was nominated by petition and appeared on the ballot as an "Independent Progressive.' The election was a close contest between Selling and Lane, but the latter was successful, and his choice was ratified by the legislature, January 2 I, I9I3. Two Republicans and I Republican-Progressive were elected representatives ${ }^{1}$ in Congress; in the 62 nd Congress there were 2 Republicans-the state has 3 representatives under the new apportionment. The new legislature will have a Republican majority of 62 ( 26 in senate and 36 in house). Woodrow Wilson carried the state, receiving 47,064 votes to 37,600 for Roosevelt, 34 ,673 for Taft and 13,343 for Debs (who had 7,339 in 1908). The Portland Oregonian, which has consistently opposed initiative, referendum, and recall, was the only important Taft organ.

On December 19, I9I2, at Warrenton, the first woman was elected mayor of a municipality in the state; she received a plurality of only I 6 votes. In November 19I 2 Baker voted to retain its commission charter, and a commission charter for Portland was defeated by a narrow margin.

Bibliography.-General Laws, (Salem, I9II); departmental reports; the official IgII Blue Book (ibid.); Wm. I. Marshall, Acquisition of Oregon and the Long Suppressed Evidence ahout Marcus Whitman (2 vols. Seattle, 1911); T. T. Geer (governor in I899-1903), Fifty Years in Oregon (New York, I9II); A. H. Eaton, The Oregon System; the Story of Direct Legislation in Oregon. (New York, I9I2); J. D. Barnett, "The Operation of the Recall in Oregon" in American Political Science Review (Feb., I912); Men of Oregon (Portland, 191 I).

\section{PENNSYLVANIA}

Population (I910) 7,665 , I I ( $21.6 \%$ more than in 1900). In density (I 7 I to the sq. m. ) the state ranked 6 th. The foreign-born whites increased from $15.6 \%$ in 1900 to $18.8 \%$ in 1910 , native-born whites decreasing proportionally. The percentage of negroes remained the same (2.5). The urban population increased from $54.7 \%$ of the total (in 190 places each having more than 2,500 inhabitants) in 1900 to $60.4 \%$ (in 263 such places) in I9ro. Rural (unincorporated) territory contained $36.8 \%$ of the total in 1900 and $32 \%$ in I910. Of the urban population nearly one-half was in two

1 There was one Progressive nominee for representative.

2 See $E$. B, xxi, 105 et seq. 
cities with more than 500,000 inhabitants, about one-eighth in the 8 cities between 50,000 and 500,000 , about one-fifth in the 53 places between 10,000 and 50,000, and another fifth in the 200 places between 2,500 and 10,000 (84 between 5,000 and 10,000 and 116 between 2,500 and 5,000 ).

The following places had more than 25,000 each: Philadelphia, 1,549,008 (1,293,607 in 1900); Pittsburg, 533,905 (451,512 in 1900); Scranton, 129,867; Reading, 96, o7 I Wilkes-Barre, 67,105; Erie, 66,525; Harrisburg, 64,186; Johnstown, 55,482; Altoona, 52,127; Allentown, 51,913; Lancaster, 47,227; York, 44,750; McKeesport, 42,694; Chester, 38,537; New Castle, 36,280; Williamsport, 31,860; Easton, 28, 523 ; Norristown (borough), 27,875; Shenandoah (borough), 25,774; Hazleton, $25,452$.

Agriculture.-The acreage in farms decreased from I 9,37 I, or 5 to $18,586,832$ between I900 and I9IO and the improved land in farms from $13,209,183$ to $12,673,519$; the average farm acreage fell from 86.4 to 84.8 ; and the value of farm property increased from $\$ 1,051,629,173$ to $\$ 1,253,274,862$ ( $\$ 630,430,010$ land; $\$ 410,638,745$ buildings; $\$ 70,726,055$ implements: $\$ 141,480,052$ domestic animals). Of the land area $64.8 \%$ was in farms in 1910. The average value of farm land per acre was $\$ 33.92$. Farms were operated largely by owners $(\mathbf{1} 64,229$ by owners, 3,95 I by managers and 51,105 by tenants). In 1912 (preliminary estimates) the principal crops were: Indian corn, 6I,582,000 bu. (I,449,000 A.); wheat, 22,320,000 bu. (1,240,000 A.); oats, 36,377,000 bu. (I,099,000 A.); barley, 192,000 bu. (7,000 A.); rye, 4,935,ooo bu. $(282,000$ A.); buckwheat, $7,405,000$ bu. (306,000 A.); potatoes, $28,885,000$ bu. (265,ooo A.); hay, 4,537,000 tons $(3,173,000$ A.); and tobacco, $64,090,000$ lbs. $(44,200$ A.). In 1909 (U.S. Census) the value of vegetables other than potatoes was $\$ 10,013,920$; of flowers and plants; $\$ 3,803,418$; nursery products, $\$ 922,569$; small fruits, $\$ 1,175,016$ (strawberries, $\$ 759,154$; currants, $\$ 272,337$ ); orchard fruits, $\$ 8,677,986$ (apples, $\$ 5,557,616$; peaches and nectarines, $\$ 1,351,175$; cherries, $\$ 909,975$; plums and prunes, $\$ 396,005$, and pears $\$ 356,240$ ); grapes, $\$ 850,708$. On Jan. I, I 112 there were on farms: 572,000 horses, 44,000 mules, 943,000 milch cows, 627,000 other neat cattle, 883,000 sheep and I, I 4 I,000 swine.

The state college, co-operating with the Federal department of agriculture, carries on investigations in animal nutrition, and manufactures Swiss types of cheese. The Federal department has a field dairy laboratory at Troy, Bradford county. In I9I I the legislature passed a law requiring that apiaries be inspected twice each summer and forbidding the keeping of diseased bees, and created a commission to investigate chestnut blight; it appropriated $\$ 50,000$ a year for encouraging agriculture through county commissioners. In February 1912 a conference representing 20 states was held at Harrisburg to consider what could be done to check the chestnut tree blight. In September a report was made to the governor by the commission which said that no remedy had yet been found but that attempts to arrest the progress of the disease had met with some success.

Mineral Products. - Total value, I9II, \$414,1 12,373. In coal the state ranked ist with $90,464,067$ tons of anthracite $(\$ 175,189,392)$ and $144,754,163$ tons of bituminous $(\$ 146,347$,858 ); in natural gas, 2 nd, $\$ 18,010,796$ (less than in any year since 1903); and in petroleum, 5th, \$10,894,074 (less than in 1910). A company at Dickson City in I9I I manufactured more than one-third of the briquettes made in the country; another briquette plant at Lansford was rebuilt in 1911 . In pig iron Pennsylvania ranked 1 st, with 9,581,109 tons valued at $\$ 136,328,507$ (not included in the grand total). The value of iron ore was $\$ 539,553$ (5I 4,929 tons). In slate the state ranked Ist with an output valued at $\$ 3,43 I, 35 I$, threefifths of the total for the country; and it was Ist in sand and gravel $(\$ 3,025,267)$, 2nd in clay products, \$20,270,033 (more than one-tenth being pottery), Ist in Portland cement, \$19,306,349 (the state has two large natural cement plants), and in stone, $\$ 8,147,505$ (more than onetenth of the total), the largest item being limestone $(\$ 5,243,045)$, and Ist in lime $\$ 2,688,374$ (more than one-sixth of the country's total).

Manufactures. - In the value of products manufactured Pennsylvania has ranked 2nd since 1859 and in 1909 was 2 nd to New York. In 1904-09 the number of establishments increased from 23,495 to 27,563 and that of persons engaged in manufacturing from 855,392 to $1,002,171$ (wage-earners from 763,282 to 877,543 ); capital invested from $\$ 1,995,837,000$ to) $\$ 2,749,006,000$; and value of products from $\$ 1,955,551,000$ to $\$ 2,626,742,000$. One-third of this total was reported from three industries, in each of which the state ranked Ist: iron and steel works, including rolling-mills, $\$ 500,344,000$, bcing more than one-half the country's total for this industry; foundry and machine-shops, \$210,746,000-and iron and steel from blast furnaces $\$ 168,578,000(56.9 \%$ more than in 1904$)$, being nearly four-fifths of the total for the country. Other industries were: tanning, currying and finishing leather, $\$ 77,926,000$, the state ranking Ist in this industry; the manufacture of woollen, worsted and felt goods, $\$ 77,447,000$; car construction and repairing by steam railway companies, $\$ 76,035,000$; silk manufacture, $\$ 62,061,000\left(57.8 \%\right.$ more than in $\left.19 C_{4}\right)$; lumber and timber, $\$ 57,454,000$; refining petroleum, $\$ 53,088,000$, Pennsylvania ranking 2 nd; slaughtering and meat-packing, $\$ 5 \mathrm{I}$, $85 \mathrm{I}, 000$; coke manufacture, $\$ 51,816,000$, in which the state ranked ist; tobacco manufactures, $\$ 50,161,000$; hosiery and knit goods, $\$ 49,658,000$, in which the state was 2 nd; brewing malt 
liquors, $\$ 47,7$ I 3,000, the state being 2 nd; flour and grist-milling, $\$ 44,783,000$; men's clothing, $\$ 39,682,000$, and women's clothing, $\$ 32,837,000$; cotton goods, $\$ 33,917,000$; glass, $\$ 32,818,000$, the state being Ist; electrical machinery, \$3I,35I,000; railway cars not made by railway companies, $\$ 27,510,000$, the state being Ist; tin and terne plate manufacture, $\$ 25,234,000$, in which the state ranked Ist; carpet and rug-making; excluding rag carpet, \$24,879,000; and boot and shoe manufacturing, $\$ 20,219,000$.

Philadelphia ranked 3 rd among the manufacturing cities of the country with a product value of $\$ 746,076,000$, including I $2 \%$ of the state's output in hosiery and knit goods, $31.8 \%$ of the carpets and rugs, $12.6 \%$ of the woollens and worsteds, and more than $90 \%$ of the women's clothing. Pittsburg $(\$ 243,454,000)$ was 7 th, and there were many large establishments just outside the city limits; the blast furnaces, rolling mills and foundries furnished more than half of the city's total. Other important manufacturing centres were: Reading, $\$ 5$ I, I 35,000; Johnstown, \$48, 106,000; McKeesport, $\$ 42,494,000$-principally pipes and tubes, of which the city is the largest producer in the country; New Castle, $\$ 38,037,500$; South Bethlehem, \$26,417,000; Scranton, \$26,385,000, principally silk; Allentown, $\$ 26,263,000$; Erie, \$24,26,000; and Harrisburg, \$22,725,000.

Transportation. - Railway mileage, January I, 1912, I 1,639.72. In I9 I the legislature passed a uniform bill of lading act, established a state highway department, and planned the development of nearly 300 routes for state highways. The Federal government in I9I I completed the work of increasing the depth of the Delaware below Philadelphia and began work on a channel (12 ft. deep; $200 \mathrm{ft}$. wide) in the Delaware between Philadelphia and Trenton; completed two locks on the Monongahela river and began three dams on the Ohio in the state. The Erie harbour was practically completed in 1912. In Philadelphia the first of a series of municipal piers for trans-Atlantic steamships was completed in I9II.

Legislation.-. The legislature met in regular session from January 3 to May 25, I9I I. It submitted to the people constitutional amendments (ratified in Nov. I9I I) exempting from the debt limit all debts of the City and County of Philadelphia for subways, docks, wharfs, etc.; changing the district courts and common pleas courts of Philadelphia to five common pleas courts each with three judges and replacing the number of common pleas courts in Allegheny county by one common pleas court. Several other amendments went over to the I9I3 legislature; one making it possible for the state to issue bonds for $\$ 50,000,000$ for improving and rebuilding highways; another adding to the list of local or special laws which the legislature shall not pass; another on the election of judges; another for the gradation of property for assessment and taxation, and a new article providing that municipal obligations for waterworks, subways, etc. (except in the case of the City of Philadelphia) should not be considered in reckoning the constitutional debt limit.

Instead of two annual election primaries there is to be one each year, an autumn primary in September of odd numbered years and a spring primary in April of even numbered years. Unnaturalised foreign-born residents are subject to taxes laid in the state, except poll taxes for voters. The term of the director of the legislative reference bureau was changed from "during good behaviour" to four years, and he was made an ex-officio advisor to the legislature. A court of common pleas is required (formerly was permitted) to have jurisdiction in divorce cases, and a new code regulates divorce procedure; a new marital code was passed in 19II. The salaries of state judges were increased-e.g. that of the chief justice of the supreme court to $\$ 13,500$; that of associate justice to $\$ 13,000$, etc.

The I 2 th of October ("Columbus Day") was made a public holiday.

The term of mayor in all cities was made 4 years; that of select councilmen 4 years and that of common councilmen 2 years; in the second class cities the legislative branch was made one council (instead of a select council and a common council) of 5 members with one additional member for each 75,000 of population; in the case of cities between 200,000 and 500,000 the governor appointed the first council to act until. January 1912. Governor Tener's appointees in Pittsburg were re-elected in November.

A city plan commission in Philadelphia was organised in I9I I. Departments of supplies and of city planning and an art commission were added to the ten executive departments in second class cities; and a department of recreation in first class cities. In cities of the first class all plumbers must be licensed and registered and the act specifies the necessary fittings for all buildings. Cities of the second class are allowed to regulate the smoke nuisance.

A commission on the proper and safe construction of buildings was appointed to report to the legislature of 1913 , and a committee was also appointed to report on vaccination. Fire drills are required in public schools and in factories and industrial establishments which employ women. The office of state fire marshal was created, and that of fire marshal in first class cities. The use of fire crackers and of blank cartridges was regulated by two acts, one dealing with their size and another with their contents. There are to be county and city inspectors of weights and measures. A bureau of standards was created as a part of the state department of internal affairs. All baby farms must be licensed, and all midwives must be licensed and registered. Pandering and engaging in the white slave trade were made punishable by imprisonment at hard labour for a minimum term of ten years. Laws forbid the adulteration of sausage, of milk, and of drugs, and the state pharmaceutical examining board was required to build a drug testing laboratory. 
An elaborate code for bituminous coal mining was passed. Boys under I4 and all women and girls are forbidden to work in such mines. Boys under 16 may not work unless an em. ployment certificate is filed and boys under I 8 may not load coal unless they are working with an older workman. Inside buildings in all coal mines must be of incombustible materials. A commission was appointed to codify the anthracite mining laws, and a commission was created on industrial accidents; its report with an elective compensation bill will be acted upon by the 1913 legislature. Hoisting engineers in mines are not to work more than 8 hours a day. Tanneries were omitted from the list of places in which boys under 18 were forbidden to work. If the father of a minor does not contribute to his support for six months, the mother has a right to his services. Blackmailing was made a misdemeanour, and also the soliciting or receiving by an employer or foreman of a price for giving employment.

Finance. - The governors of Ohio, West Virginia and Maryland were invited to a conference on taxing oil, gas and bituminous coal, but nothing was done by these states. The tax commission of 1909 reported in 1911 and was continued for another two years. County sinking fund commissions were created in each county. The insurance laws were thoroughly revised by an act creating an insurance department, the commissioner of which is appointed by the governor. A uniform stock transfer law was passed and directors of banks and of banking concerns were required to take oath of office to administer diligently and honestly. By a law of 191 I estates passing to legally adopted children are not subject to a collateral inheritance tax. There was in the treasury on December I, 191 I, \$12,923,370. The receipts for the fiscal year ending November 30 , I9I2, were $\$ 32,374,890$, and the expenditures $\$ 35,516$,410 , leaving a balance of $\$ 9,781,850$. The state debt was $\$ 651,160$, and a sinking fund had a surplus of $\$ 126,351$ over the amount of this debt.

Education.- In I9I I a school code, drafted by a commission appointed in 1907 and amended by the legislature, was passed. It does away with independent districts under special laws and classifies districts by population, each class having uniform laws; "independent districts" in the future will be districts not co-extensive with other governmental units, and will be controlled by laws for the class to which they belong. A state board of education is created, but it has no very great power, and the superintendent of public instruction is still in control. The state school fund and its income are to be managed by the board of education -its principal function. The state is gradually to take over the 13 "state" normal schools which formerly reccived state recognition and aid, but were local or stock company schools. There will be a larger degree of state control over other teachers' training schools. The new code makes definite provision for industrial education, and authorises the superintendent to appoint an expert assistant in this branch, one in agricultural education and one in drawing. It provides for a medical inspection of pupils. In cities of the first class members of the board of education are appointed by judges of the court of common pleas; but boards of school visitors for each ward are elected by popular vote. In all other districts directors are elected. The school fund is distributed one-half on the basis of the number of paid teachers and the other half on the basis of the school population in the district. The board of directors of any district may establish a retirement fund for teachers. The minimum salary for any public school teacher is raised from $\$ 40$ to $\$ 45$, and after two years of successful teaching from $\$ 50$ to $\$ 55$. The legislature appropriated for the two years I9I2-I3, \$15,000,000 for the support of public schools and normal schools, and $\$ 260,000$ for the normal schools.

Fi or the school year ending June 5, 1911 the enrollment in the public schools was $1,286,273$; the average daily attendance, 1,028,290; and the length of the average school year, 8.52 months. The total expenditures for school purposes were $\$_{42}, \mathbf{1} 37,647$.

In 1910 of the population ro years of age and over $5.9^{\circ}$ (6. I in 1900) was illiterate.

The Polish National Alliance College at Cambridge Springs was opened on October 26, 1912 with an address by President Taft; it had 335 students registered and a faculty of I0 (7 Poles). On June 5, 19 II, Eugene A. Noble (b. 1865), then president of (soucher College, Baltimore, was elected president of Dickinson College, Carlisle; he took office September I, 1912. The year 1912 was marked by a reorganisation of the faculty and administration of the University of Pennsylvania. Late in the year work was begun on graduate school buildings for the University. Bryn Mawr College in I9I I received a bequest of $\$ 750,000$ from Miss Carola Woerishoeffer (1885-191I) ${ }^{1}$ of the class of 1907 . The death in 19I2 of the wiclow of $\mathrm{R}$. N. Carson of Philadelphia releases his bequest of $\$ 6,000,000$ for a college for fatherless girls at Ianghorne. On August 28, 1912, the new Allegheny Observatory was dedicated in Riverview Park, Pittsburg. On April 24, 1912, Allegheny College, Meadville, completed an endowment fund of $\$ 500,000$.

Penal and Charitable Institutions. - The state hospital for the criminal insane at Fairview was practically completed in 1912 , and the homoeopathic state hospital for the insane, at Allentown, is now in use. The I9I I legislature authorised the release of first offence convicts on probation, and the establishment of psychopathic wards, with the permission of the

1 She was a wealthy New Yorker who unostentatiously did much for factory workers in New York and was an investigator of the state bureau of immigration at the time of her premature death in an accident. See the Life (Bryn Mawr, 1912) by her college classmates with introduction by. Illa Tarbell; and C. M. Syford in New England Magazine, October 1912. 
board of public charities, by hospitals which maintain both medical and surgical staffs and give lectures on mental diseases. For indigent patients treated in such wards the state pay's $\$ 2$ a day. A state commission appointed in I9I I is to report on the condition of the feebleminded and epileptic in the state and on the advisability of their being segregated. The legislature appropriated $\$ 25,000$ for the state miners' hospital near Shamokin (and $\$ 60,000$ to complete buildings); $\$ 94,500$ for the similar hospital at Hazleton; $\$ 24,000$ for that at Blossburg; \$2 I,000 for that at Mercer; \$ I 80,000 for that at Fountain Springs; \$2,900,000 for the care and treatment of indigent insane; $\$ 87,500$ for improvements at the south-eastern insane hospital (Norristown); \$250,000 for buildings for the Philadelphia institution for the feeble-minded; $\$ 277,500$ for the eastern Pennsylvania institution for feeble-minded and epileptics at Spring City (and $\$ 280$,ooofor building); and large sums to many private charities, hospitals, etc. The state has purchased 5,000 acres (mostly farming land) in Centre county, for a new western penitentiary; at the end of 1912 construction work had not begun. Philadelphia has begun an experiment, on the Byberry tract, in farming for the mildly insane.

History.-The most interesting tendency in the politics of the state in I9II-I 2 was a movement towards reform, the force of which was affected by quarrels between state politicians and also by the establishment of the National Progressive party. In I9ro a Keystone Independent party nominated two Democrats and two Republicans for the major state offices. The Republican state ticket was elected, but its candidate for governor, John Kinley Tener (b. 1863; a professional baseball player in $x 886$ and I 888-90; a representative in Congress in I 909-I I) received only 4I 5, 6 I I votes to 382 , I 27 for the Keystone candidate, William H. Berry (b. 1852 ; Democrat; state treasurer in I 906-10). The Democratic candidate, Webster Grim (b. 1866; state senator since 1903), had only 129,395 .

In the municipal elections of I9II (November 7) Rudolph Blankenburg (b. I843) defeated by 4,495 votes George Howard Earle (b. 1856), a lawyer who had been chosen at the Republican primaries (September 30) over William S. Vare, whose brothers had been state senators and city contractors implicated in the charges against the previous (Republican) administration of Mayor John Edgar Reyburn. The other Republican nominees were elected. In the Democratic-Keystone fusion primaries Blankenburg, a manufacturer and philanthropist, had defeated D. Clarence Gibboney, president of the Philadelphia Law and Order Society and in I9 Io candidate of the Keystone-Independents for lieutenant-governor. In Pittsburg a fusion candidate was elected judge of the common pleas court. Socialists were elected to office in New Castle, Wheatland and Pymatuning (township).

An attempt was made to reorganise and purify the Democratic organisation in I9i I. James McClurg Guffey (b. I839) was replaced as state chairman of the party by George Wilkins Guthrie (b. I848), who had been mayor of Pittsburg in I906-09; and Vance Criswell McCormick (b. I872), mayor of Harrisburg in 1902-05, was prominent in the reorganisation.

In the presidential campaign of I9I2, Roosevelt carried the Republican primaries (April I3) and delegates-at-large were instructed for him by the state convention (May I). In the primaries, at the Republican national convention, until the delegation "bolted" (June I9), and in the campaign after his nomination by the National Progressive party, he had the support of E. A. van Valkenburg, editor of the Philadelphia North American, and of William Flinn, a contractor of Pittsburg, and a political rival of Boies Penrose (b. I860), Republican, United States senator since I897. Penrose was attacked on the alleged ground that he was an agent in the U.S. Senate of the Standard Oil Company, and an attempt was made to discredit the candidacy of Taft because he was supported by Penrose. Roosevelt secured control of the state party organisation to such a degree that Flinn proposed that electors pledged to him should be put on the ballot as Republicans. This was not done, but on the official ballot there were 8 electoral tickets, the Roosevelt electors appearing thrice, under the headings Roosevelt Progressive, Bull Moose and Washington: ${ }^{1}$ This was, of course, of some advantage to Roosevelt, and he carried the state ( 38 electoral votes), receiving a popular vote of 444,426, to 395,6I9 for Woodrow Wilson, 273,287 for Taft, and 80,9I 5 for Debs, 1 A state organisation of Progressives was called the Washington party. 
whose vote in 1908 was 33,913 . The state representation in Congress was increased under the new apportionment from 32 to 36 by the addition of 4 representatives-atlarge. All the representatives-at-large and 16 elected by districts were Washington party men, 4 were chosen as Republicans (not on Washington ticket) and I 2 as Democrats. ${ }^{2}$ There will be no change in the United States Senate, where Penrose's term expires in 1915, and George Tener Oliver (b. 1848), elected in 1909 to fill out the unexpired term of Philander Chase Knox (who became Secretary of State in President Taft's cabinet), was elected for I9II-I7 on January I, I9II. The Washington party elected a state treasurer and auditor general, and will be strong in the next legislature, where many Republicans were elected by fusion. The Republican membership is 34 in senate and I $_{27}$ in house; Democrats, I 5 in senate and 56 in house; Washington, without fusion, I in senate and I 5 in house; and 9 Keystone candidates in the house. Probably only one senator and only six members of the house are affiliated with Penrose and the "stand pat" wing of the Republican party. On December I2, I912, the House of Representatives of the United States by I 53 to I 9 declared vacant the seat of Charles C. Bowman of the IIth Pennsylvania district, charged with bribery.

The Harrisburg Capitol building fraud cases (see E.B. xiii, $2 \mathrm{Id}$ ) culminated in I91 2 in civil suits compelling an accounting and a restitution of certain moneys.

On August I3, I9 I a negro accused of killing a policeman while resisting arrest was taken by a mob from a hospital in Coatesville and was burned to death. The state constabulary was ordered out. There were threats of more disorder on October 9 when a negro assaulted a white girl. In the lynching case, although many members of the mob were recognised at the time, it was impossible to secure a conviction or a change of venue. On May 3, r912 a prisoner who had confessed complicity was declared not guilty by a jury.

A coal strike in the anthracite region lasted from April I to May I8, I9I2. The strikers got recognition of the union, an increase of wages of about $5 \%$ (they had asked for $20 \%$ ), and a four year agreement (they had wanted an agreement lasting for one year only). There was much rioting and disorder in Scranton and Wilkes-Barre. Another coal strike in the Irwin-Greensburg region, Westmoreland county, began in March roro and ended in a failure on July 5, I9r I.

On September 30, I9I I the dam of the Bayless Paper and Pulp Company at Austin broke and 76 persons were killed. About 200 men working at Austin struck on October 6 for an 8 hour day; they were driven out of the state by the state constabulary. In May I9I a about 6,000 shopmen of the Penr.sylvania Railroad struck for : ccos $_{\circ}$ ition of the union; they were unsuccessful. A strike of 9,000 miners in Panther Creek Valley for the discharge of two non-union workmen ended late in September 101 2 with a victory for the strikers. In June I 9 I 2 the employees of the National Tube Company of Pittsburg went on strike for increased pay and greater conveniences in their working places. They got most of their demands. At Homestead and Braddock there was in November I9I 2 a serious strike of steel workers, to whom a wage increase was granted but whose leaders were discharged. On November 29 the mills attempted in vain to resume work. On the same day the Industrial Workers of the World tried to call a general strike.

After the street-car strike of Ior 2 the Stotesbury management of the Philadelphia Rapid Transit Company introduced an elaborate co-operative plan with definite wage increases, pensions and death benefits.

Bibliography.-Session Laws (Harrisburg, 1911); Smull's Legislative Hand Book, I9Iz (ibid.); the Report on Industrial Statistics (I9II) of the secretary of internal affairs; other official publications; A. C. Myers, ed., Narratives of Early Pennsylvania, W'est New Jersey and Delaware, 1630-1707 (1912); A. Johnson, The Swedish Settlements on the Delarare (2 vols., ('niversity of Pennsylvania, I9I I); E. R. Turner, The Negro in Pennsylrania, 1630-1861 (19II); I. A. Fitch, The Steel Workers (New York, I9II); M. F. Byington, IIomestead: The Households of a Mill Toron (New York, 1911).

On March 23, IS12, died Henry Harriso1 Bingham (b. I $8+1$ ), representative in Congress since 1879, hrigadier-general of volunteers in the Civil War; and on December 27, 1912, John Geiser Mcllenry (b. 1868), Democrat, representative from the 16 th district since 1907. 


\section{RHODE ISLAND ${ }^{1}$}

Population (roro) 542,6ro; $26.6 \%$ more than in 1900 . The state is the most densely populated in the Union; in I9Io it had 508.5 to the sq. $\mathrm{m}$. In I900 $31.2 \%$ were foreignborn and $32.8 \%$ of foreign parentage; in $191032.8 \%$ and $35.9 \%$ The percentage of native whites decreased from 66.6 to 65.4 ; that of whites of native parentage from 33.8 to 29.5 . In I910, $96.7 \%$ of the total was in 25 incorporated places each with more than 2,500 inhabitants; in $1900,95.1 \%$ in 23 such places. In $1910,67.8 \%$ was in the 4 cities and one town, which had each more than 25,000. The following places had more than 5,000 each: Providence, 224,326 (in I900, I 75,597); Pawtucket, 51,622; Woonsocket, 38, I25; Newport, 27,I49; Warwick (town), 26,629; Central Falls, 22,754; Cranston, 2I,I07; East Providence (town), I 5,808; Cumberland (town), I0,107; Lincoln (town), 9,825; Westerly (town), 8,696; Bristol (town), 8,565; Burrillville (town), 7,878; Warren (town), 6,585; Johnston (town), 5,935; Coventry (town), 5,848; North Providence (town), 5,407; and South Kingstown (town), 5, I 76 .

Agriculture.-The acreage in farms decreased from 455,602 to 443,308 between 1900 and I9I0, and the improved land in farms from 187,354 to 178,344 ; but the average farm acreage increased from 82.9 to 83.8 ; and the value of farm property from $\$ 26,989$, I 89 to $\$ 32,990,739$ (\$1 5,009,98I land; \$12,922,879 buildings; \$1,781;407 implements; \$3,276,472 domestic animals). Of the land area $64.9 \%$ was in farms in 1910. The average value of farm land per acre was $\$ 33.86$. Farms were operated largely by owners $(4,087$ by owners, $25 \mathrm{I}$ by managers and 954 by tenants). In 1912 (preliminary estimates) the principal crops were: Indian corn, 456,000 bu. (I I,000 A.); oats, 57,000 bu. (2,000 A.); potatoes, 565,000 bu. (5,000 A.) and hay, 66,000 tons (58,000 A.). In I909 (U.S. Census) vegetables, other than potatoes, were grown on 5,275 acres and were valued at $\$ 636,656$; and orchard fruits were worth \$197,639 (apples, \$147,I25). On January I, I9I2 there were on farms 10,000 horses, 23,000 milch cows, I I,000 other neat cattle, 7,000 sheep, and I6,000 swine.

In 1912 the state agricultural experiment station made important studies of fowl cholera, experiments in manuring and in soil deficiency and field experiments on individual farms.

Mineral Products. - Total value, I9II, \$1,088,475. Stone was valued at $\$ 958,753$. Clay products, another important item, were not reported separately. Mineral waters, from 8 springs, were valued at $\$ 27,036$ ( $22 \%$ less than in I9I0).

Manufactures.-In I904-09 the number of establishments increased from I,6I 7 to $1,95 \mathrm{I}$, and that of persons engaged in manufacturing from I04,299 to I22,64I (wage-earners from 97.318 to $113,538,20.9 \%$ of the total population); the capital invested from $\$ 215.901,000$ to $\$ 290,901,000$; and the value of products from $\$ 202,110,000$ to $\$ 280,344,000$. The principal products were: woollen, worsted and felt goods, $\$ 74,600,000$ (nearly twice as much as in I 899), ranking Rhode Island 3rd in this industry; cotton goods, \$50,313,000 (nearly twice the I 899 product value), the state being 4 th; jewelry, $\$ 20,685,000$; foundry and machine-shop products, \$20,6I2,000; dyeing and finishing textiles, not otherwise reported, \$1 3,956,000; electrical machinery, apparatus and supplies, $\$ 6,410,000$; silverware and plated ware, $\$ 6,198,000$; silk and silk goods, $\$ 4,584,000$; gold and silver, reduced, not from ore, $\$ 4,442,000$; hosiery and knit goods, $\$ 3,866,000$; printing and publishing, $\$ 3,780,000$; malt liquors, $\$ 3,579,000$; and slaughtering and meat-packing, \$3, 156,000.

The principal manufacturing centres were: Providence, $\$ 120,241,000$, including onefourth of the state's textiles, $98.4 \%$ of the manufactures from the precious metals and seventenths of the foundry and machine-shop products; Pawtucket, $\$ 37,696,000,53.4 \%$ being textiles, mostly cotton; Woonsocket, $\$ 28,218,500$, seven-tenths being textiles, mostly woollen; Warwick, \$10,589,000, of which three-quarters was textiles, mostly cotton; Cumberland, $\$ 9,827,000$ (more than five times as much as in 1899 ); East Providence, $\$ 7,146,000$; Cranston, $\$ 5,625,000$ (four times as much as in I899); and Central Falls, $\$ 5,471,000$.

Transportation.- Railway' mileage, January I, I9I2, 2 II.77. The Southern New England Railway Company (chartered April I9Io) secured in I9I I the necessary approval for a line from Palmer, Mass., to Providence, which would give the Central Vermont (controlled by the Grand Trunk) a through line from Montreal to Providence, but November 9 , 1912 work on this extension suddenly stopped. It was suspected that this was the result of an agreement (some terms of which were published) between the Grand Trunk and the New York, New Haven \& Hartford Railway, which has almost a monopoly of transportation in New England; but it was publicly announced that the cessation of work was a part of a general policy of retrenchment by the Grand. Trunk due to the unsettled money market in Europe. A Federal Grand Jury began investigation of this cessation of work on December 3, and on the 23 rd indicted the presidents of the Grand Trunk and the New York, New Haven and Hartford railways for conspiracy. The Grand Trunk had contracted for two steamers to be run from Providence to New York. In I9I I the Federal government began work improving

1. See E. B. xxiii, 248 et seq. 
Providence river and harbour (Act of I9I0), the dredging of an I8-ft. anchorage area in Newport harbour, and the widening and deepening of the Pawtucket (Seekonk) river.

Legislation.- The legislature of Rhode Island held its regular sessions in January I9r I and in January rgr2. An amendment to the constitution providing for biennial terms and biennial elections of the governor, lieutenant governor, secretary of state, attorney-general, general treasurer and state senators and representatives was approved by popular vote on November 7 , I9I. A statute of I9I 2 regulates lobbying and requires the registration on a legislative docket of agents and counsel appearing in behalf of measures before the legislature; and there were created a board of control and supply to control all state institutions - a board of state charities has advisory powers and is a visiting body only-and a public utilities commission of three members appointed by the governor and holding office for six years. The commission is to regulate public utility rates, to require a reasonable service and to insure public safety and safe equipment of common carriers and for public utilities. An appeal lies to the supreme court. Rebating and unjust discrimination are forbidden.

Physicians are required (I9I I) to report to the secretary of state all cases of tuberculosis, cerebro-spinal meningitis and infantile paralysis. The state board of health is directed to investigate conditions connected with such cases and to aid in the suppression of the disease. An annual appropriation was made (I9II) for medical inspection of schools. Cities with 20,ooo or more inhabitants accepting provisions of an act of I9 I f for the abatement of the smoke nuisance are to elect a smoke inspector as a regular officer. On curfew streets, to be designated by the police commissioner or by the chief of police, no child unaccompanied by an adult may loiter after 9 P.M. Providence was authorised to issue $\$ 150,000$ in bonds for public playgrounds and to choose its city officers biennially instead of annually. A state board of examiners of trained nurses was created and the act provides for the registration of all trained nurses. The sale of wood alcohol and all other poisons was regulated by statute in 1912 .

A workmen's compensation act of I9I2 (in effect Oct. I) resembles the Michigan law, except that it contains no provision for the administration of the fund by a state commissioner of insurance. The law does not apply to domestic service, casual labour or agriculture, but applies to all other employers of five or more workmen. The acceptance of the act is filed by the employer with the commissioner of industrial statistics and the defense of negligence, of fellow employee's fault and of assumption of risk are abrogated. Night messenger work between 5 P.M. and IO A.M. may not be done by those under 2 I. A usury law makes $30 \%$ the maximum for an actual loan greater than $\$ 50$ and on a loan less than $\$ 50,5 \%$ for six months and thereafter $2 \mathrm{I}_{2}^{\circ} \circ$ per month. Laws were passed (I9II) forbidding rebating by insurance companies, and the misrepresentation of terms of an insurance policy.

Finance. - An elaborate tax act was passec' in 1912 creating a board of three tax commissioners to have general charge of the assessment of taxes. Every manufacturing, mercantile and miscellaneous corporation must report annually to the tax commissioners, and must pay all annual tax of 4 mills on its "corporate excess"-i.e. a portion of its intangible property as determined by the commissioners. Bank stock, less the value of real estate and United States or state bonds owned by the bank, must pay a tax of 4 mills. Public service corporations must pay I ${ }^{\circ}{ }_{0}$, but telegraph, cable and telephone corporations $2 \%$ and express corporations $3 \%$, on annual gross earnings. Shares of stock in the hands of owners are exempt from tax if the corporations pay a tax on their gross earnings. Towns are to pay to the state treasurer 9 of a mill on all ratable property. Mutual insurance companies must pay $\mathbf{I}^{\circ}$ on their gross premiums; other insurance companies $2^{\circ} \mathrm{o}$. On November 7 , I9I I, the people approved the issue of $\$ 600,000$ in $t^{\prime \prime \prime}$, , thirty year bonds, the third state highway construction loan.

The annual report of the treasurer for the year 1912 shows cash on hand January $I$, $\$ 152,401$; receipts, $\$ 3,250,632$; expenditures, $\$ 3,335,013$; leaving a balance in the treasury Derember 31 of $\$ 68,020$. The bonded deth was $\$ 4,906,507$, and the floating debt, $\$ 150,000$.

Education.- Any city or town may build open air schools. Towns providing manual training and instruction in houschold arts are to receive from the state one-half of the cost of apparatus. The state board of education is to arrange for post-graduate courses in education in Brown University and to appoint persons to take such courses each year.

In 1910 of the population 1o years of age and over $7.7 \%$ was illiterate ( 8.4 in 1900). For the school year I9I2 the school population ( 5 to 18 years) was 122,67 ; total enrollment, 81,799; average daily attendance, 64,878 ; average school year, 9 mos. 13 days; school revenue for the year, $\$ 2,576,106$, and expenditures, $\$ 2,404,652$.

In I 12 a fund of $\$ 1,000,000,-$ the third in the administration of President Faunce, was collected for Brown iniversity.

Charituthe and Penal Institutions. - I law of I 91 I provided for paving working prisoners committed for :orn-payment of fine and costs fify cents a day for the first thirty days of their work and then \$1.On a dily. In I9)12 the presictent of the metal trades department of the 
Providence Council of the American Federation of Labor headed a movement of protest against the state's entering again into contracts for the disposal of convict labour.

History. - In I9II and in I9 2 the state gubernatorial elections resulted in the reelection of Aram J. Pothier (b. I 854), a French Canadian by birth, treasurer of several textile mills in the state, mayor of Woonsocket in $1894-95$, lieutenant-governor of the state in 1898 and governor since I909-a longer term than that of any other governor of the state. He was affiliated with the conservative Republicans, who were peculiarly strong in this manufacturing commonwealth. In Igri he defeated his Democratic rival, Lewis A. Waterman, by 7,394 votes (in a total vote of 7 I, I55); in I9I 2 his plurality was only $2, \mathrm{II}_{2}(34,433$ to $32,32 \mathrm{I})$ over the Democratic nominee, Theodore Francis Green (b. 1867), a prominent lawyer of Providence, the Progressive candidate, Albert H. Humes, receiving 8,274. The Progressive vote, with criticism of the governor for favouring the " machine," explains his decreased plurality. The Socialists polled I,66I votes for governor ( 1,392 in I9I I), the Prohibitionists 724 and the Socialist Labor Party 260. The I9I3 legislature is Republican but has more Democratic members than the I9I 2 session- 6 in the senate (out of 38 ) and 39 in the house, which has 100 members. The state (for the first time) gave its vote to the Democratic presidential electors, as Roosevelt had a much larger following than Humes; the vote was, Woodrow Wilson, 30,4r2; Taft ${ }^{1}$ 27,703; Roosevelt, r6,878; and Debs 2,049 ( 1,365 in 1908 ). Nelson W. Aldrich, United States senator in I88I-I9II, announced that he was not a candidate for re-election, and Henry Frederick Lippitt ${ }^{2}$ (b. 1856) a cotton manufacturer and a conservative Republican, was elected January i 8, ig i to succeed him. As successor to George Peabody Wetmore (b. I846), Rep., United States senator I895I9I3, the new legislature chose (January 21, I9I3) Le Baron Bradford Colt (b. I846), circuit judge since $\mathrm{r} 884$. Two Democrats and one Republican represent the state (which had only two Congressmen-one Democrat and one Republican in I9I I-I 2under the former apportionment) in the 63rd Congress. George Herbert Utter (b. I854), Republican owner and editor of the Westerly Sun, secretary of state in I 89 I-94, lieutenant-governor in I904, governor in 1905-06, and representative in Congress in I9I I-I3, was a candidate for re-election, but died two days before the election. Zenas W. Bliss, lieutenant-governor in I9I2, nominated in his place, was defeated (by $27 \mathrm{I}$ votes) by Peter Goelet Gerry, Democrat, great grandson of Elbridge Gerry. Providence, as usual, voted for the licence of the sale of intoxicating liquors; and it elected as mayor a Democrat, Joseph H. Gainer (unsuccessful in I9II), over Henry Fletcher, Republican, who had served four terms. New Shoreham and West Greenwich for the first time voted for liquor licence, and Smithfield against it, making 30 licence and 8 "no-licence" towns; hereafter the vote on licence will be biennial, instead of annual. In Newport (December 3, I9I2) Patrick J. Boyle, mayor for I3 years, was defeated by William MacLeod, who promised a " business administration."

On June 4, I9I2, died Royal Chapin Taft (b. I823), textile manufacturer and capitalist, and Republican governor of the state in 1888 .

Bibliography.-Public Laws I III, IgI2 (Providence, 2 vols.); Rhode Island Manual IgI2 (ibid.); other official publications; Gertrude S. Kimball. Providence in Colonial Times (1912).

\section{SOUTH CAROLINA ${ }^{3}$}

Population (I910) I,515,400; I3.1\% more than in I900. There was in r900-ro a decrease in the percentage of negroes from 58.4 to 55.2. Foreign-born whites formed less than $0.4 \%$ of the total; native whites, $44.4 \%$ (41.2\% in 1900). Density 49.7 to the sq. m. About three-fourths (in I9oo about four-fifths) of the population was in rural territory (unincorporated). In I9I0, $14.8 \%$ of the total was in the 25 places

1 The delegates to the Republican national convention were instructed for Taft by the state convention (April 24).

${ }^{2}$ His father, Henry Lippitt, was governor in 1875-77; and his brother Charles Warner Lippitt, governor in $1895^{-97}$.

${ }^{3}$ See E. B. xxv, 499 et seq. 
(in $1900,12.8 \%$ in 20 places), each having more than 2,500 inhabitants; there were 13 places with $5, \infty 00$ or more, as follows: Charleston, 58,833 (in I 900, 55,807 ); Columbia, 26,319; Spartanburg, I7,517; Greenville, 15,74I; Anderson, 9,654; Sumter, 8, ro9; Rock Hill, 7,216; Florence, 7,057; Greenwood, 6,614; Orangeburg, 5,906; Union (town), 5,623; Georgetown, 5,530; and Newberry (town), 5,028.

Agriculture.-The acreage in farms decreased from $13,985,014$ to $13,512,028$ between 1900 and 1910 , and the improved land from 5,775,74I to 6,097,999; the average farm acreage fell from 90.0 to 76.6 , but the value of farm property increased from $\$ 153,591,159$ to $\$ 392,128,314$ $(\$ 268,774,854$ land; $\$ 64,113,227$ buildings; \$14,108,853 implements; \$45, I3 1,380 domestic animals). The average value of farm land per acre was $\$ 19.89$. Of the land area $69.2 \%$ was in farms in 1910. Farms were operated largely by tenants (i I I,221 by tenants, 64,350 by owners and 863 by managers). In I9I 2 (preliminary estimates) the principal crops were: Indian corn, $34,278,000$ bu. (1,915,000 A.); wheat, 727,000 bu. $(79,000$ A.); oats, 6,966,000 bu. (324,000 A.); rye, 28,000 bu. (3,000 A.); potatoes, 900,000 bu. (I0,000 A.); hay, 223,000 tons, (194,000 A.); cotton, I, I 84,000 bales (2 I 9 lbs. per A.); tobacco, 24,500,000 lbs. (35,000 A.); and rice, 200,000 bu. (8,000 A.). In I 909 (U.S. Census) the value of vegetables other than potatoes was $\$ 3,705,991$; of small fruits, \$1 I3,254; of orchard fruits, \$956,376; of grapes, $\$ 88,620$. On January I, I9I2 there were on farms: 82,000 horses, I66,000 mules, 185,000 milch cows, 2 15,000 other neat cattle, 34,000 sheep and 797,000 swine.

The legislature gave scholarships in Clemson Agricultural and Mechanical College to the winners in the corn growing contests in boys' corn clubs in I9I I and scholarships in Winthrop College to girls who had cultivated corn and tomatoes extensively. The establishment of boys' corn clubs and of girls' tomato clubs was largely due to J. E. Swearingen, state superintendent of education, who though totally blind has done much for practical education and scientific farming. A crop pest commission was created in 1912 and was empowered to appoint a state entomologist and a state plant pathologist. The legislature also created a state warehouse commission to establish a system of warehouses throughout the state to store cotton and other commodities. The trustees of Clemson Agricultural and Mechanical College were authorised in I9 I to establish two or more experiment stations. In I9I2 the name of the state department of agriculture, commerce and irrigation was changed to the department of agriculture, commerce and industries.

Mineral Products. - Total value, I9I I, \$1,804, I15. Phosphate rock, all land rock, marketed was valued at $\$ 673$, I56 (I69, I 56 tons; tons mined I 82,289). The value of clay products was $\$ 669,794$ (all but $\$ 6,000$ brick and tile). A little gold is still recovered from dry ore; in I9I I the value was $\$ 20$, I00. In that year for the first time a little barytes was reported from the state. The value of mineral waters was $\$+2,099$. Granite was quarried worth $\$ 193,748$, and marble, limestone, etc., brought the total for stone up to $\$ 336,467$.

Manufactures.-In 1904-09 the number of establishments increased from 1,399 to 1,854 and that of persons engaged in manufacturing from 63,071 to 78,040 (wage-earners from $59,441$ to 73,046$)$; capital from $\$ I_{1} 3,422,000$ to $\$ 173,221,000$; and value of products from $\$ 79,376,000$ to $\$$ I I $3,236,000$. In I 909 the products of cotton mills were valued at $\$ 65,930,000$ $-58.2 \%$ of the total for all manufactures; this was about eight-ninths more than in 1899 and ranked the state 3 rd among the cotton manufacturing states, a remarkable showing in view of the recent development of this industry in the South. Among other important products were: lumber and timber, \$13,141,000; cottonseed oil and cake, \$10,903,000; and fertilisers, $\$ 9,025,000$, ranking the state 3 rd in this industry. The principal manufacturing cities were: Charleston, $\$ 6,95 \mathrm{I}, 000$; Columbia, $\$ 5,872,000$; Spartanburg, $\$ 3,276,000$, and Greenville, \$2, I 42,000.

Transportation.-Railway mileage, January I, I9I2,3 3899.64. In I9I2 the Federal government had nearly completed the inland waterway between Charleston and Alligator Creek, and had made the Charleston harbour channel $26 \mathrm{ft}$. deep and $500 \mathrm{ft}$. wide - the depth projected is $28 \mathrm{ft}$. and the width $1,000 \mathrm{ft}$.

Legislation.-The regular session of the legislature was held from January ro to February I8, I9II, and a special session from January 9 to February 29, I9I2. In I II the legislature reorganised the supreme court, which now consists of a chief justice and four associate justices, who hold office for ten years; a majority of the justices must agree on a decision and there must always be an odd number of justices on the bench. The legislature passed concurrent resolutions in I0I urging the adoption of the reciprocity treaty with Canada and an amendment to the Federal Constitution providing for a direct vote for United States senators, and in I 9 I 2 asking for aid from the Federal government for the Catawba Indians of the state.

A law of I9I requires marriage licences. The legislation both in I9I I and I9I2 was very largely on special and local matters. Counties which voted in 1909 on the adoption of the dispensary system may vote for or against, in August 1913, the sale of intoxicating liquors. 
In I912 Jasper county (county-seat, Ridgeland) was created from Beaufort and Hampton counties, and the creation of ill-shaped counties, more than four times as long as their width, was forbidden. The power of the public service commission was extended to Charleston, formerly exempted, as Marion, Spartanburg, Sumter, Union and Conway still are.

Children under $\mathrm{I} 6$ are not permitted to work between 8 P.M. and $6 \mathrm{~A} . \mathrm{M}$. in factories, mines or textile establishments, except to make up time lost by accident or by breakdown of machinery. No child under $12^{1}$ is to be employed in them at. all. Women are not to work in mercantile establishments more than 60 hours a week or 12 a day nor after IO P.M. In cities of 5,000 inhabitants or more no child under I4 (and between IO P.M. and 5 A.M. none under I8) may work as a messenger. A law of I912 prohibits betting, pool-selling and book-making.

Finance.-By a law of I9I I no bank or trust company may act as a guardian, administrator or trustee. All municipal, county and school bonds were exempted from taxation. For interest on the bonded debt the appropriation in 1912 was $\$ 295,980$; the total general appropriation was $\$ 1,993,678$. The report of the treasurer for the year 1912 showed a balance on hand January I of $\$ 725,356$. The receipts were $\$ 3,246,677$, the expenditures $\$ 3,205,817$, and the balance December 3I, 1912, $\$ 766,216$. The state debt was $\$ 6,529,646$ funded and $\$ 164,359$ fundable.

Education.-A commission to examine and revise the school law submitted its report in January I9I I but although the new code was favourably reported in both houses of the legislature it did not become a law either in I9I I or I9I2. Fifty-one beneficiary agricultural scholarships were created in I9I2 in Clemson Agricultural and Mechanical College. The General Education Board in October 1912 voted $\$ 5,000$ to the Penn School at Helena.

For the year ending June 30, I9I2 the school enrollment (no school census is taken) was 331,587 ( 175,307 negroes); the average daily attendance, 227,0I I (II 4,033 negroes); and the length of the school year ranged from 23.5 weeks for whites in cities to 13.8 weeks for negroes in the country. The receipts for school purposes were $\$ 2,904,039$ and the disbursements, $\$ 2,034,169$ for whites and $\$ 346,545$ for negroes.

In 1910 in illiteracy the state's percentage, $25.7 \%$ of the whole population ro years of age and over, was exceeded only by that of Louisiana, $29 \%$. Among whites the percentage was 10.3 ( 13.5 in 1900); among negroes, 38.7 ( 52.8 in 1900).

Penal and Charitable Institutions. - In 1912 the method of capital punishment was changed from hanging to electrocution. All able-bodied male convicts are to be worked on county public works, except in Greenville county. Governor Blease opposed the use of convicts in a hosiery mill which was reported to be a breeding-place of tuberculosis, and, when no action was taken by the legislature, threatened to pardon all convicts thus employed. Circuit judges are authorised to suspend sentence in certain cases, not felonies, and the probate court to act as a juvenile court. Among the appropriations for I9I2 were $\$ 26,000$ for the South Carolina Industrial School (established in I906); $\$ 250,000$ for pensions, and $\$ 17,000$ for the Confederate Infirmary at Columbia.

History.-Coleman Livington Blease (b. 1868), who had been a member of the lower house in 1890-98 and of the state senate in 1904-08 and mayor of Newberry in 1910, took office as governor in rgr I. His administration has occasioned much controversy. $\mathrm{He}$ at once came into collision with the state supreme court over appointments of judges, refusing to commission the nominees of the court but submitting an " eligible" list for the supreme court to choose from; and, in order apparently to remove some negroes who held commissions as notaries public the nullified all the commissions, about 3,000 in number, that were held at the governor's pleasure, and immediately issued new ones to almost all these notaries excepting a few negroes. Moreover he withheld from the pardon board all papers in regard to pardons and paroles, and issued on his own account a very large number of pardons with the result that charges of corruption were freely made by his opponents. In July I9I 2 he was directly accused of selling pardons, and of having negotiated, when he was state senator, with liquor dealers to block any legislation affecting the state dispensary and of joining a syndicate to control the sale of liquor to the dispensary. Agents who were gathering material in support of these accusations refused to go to Columbia, alleging apprehensions of violence, and meetings of the investigating committee were held in Augusta, Ga. In IgI I the governor vetoed a large number of bills, and in I91 2 out of 300 bills he approved only I 4, 8 were passed over his veto, and 278 were not returned to the legislature within the three days specified by the constitution.

${ }_{1}^{1}$ In December I9I2 the commissioner of labour in a report on textile industries said that no children under 12 were employed and that the number of children under 16 had decreased from 8,432 in 1910 to 7,490 in 1912 . 
In the state primary; August 27, I912, Blease was renominated for governor, in spite of the opposition of Ira B. Jones (b. 185I), who resigned the chief-justiceship of the state supreme court in order to be a candidate. Blease's opponents claimed that many more votes were cast than the total number of electors in the state, and on this ground contested the result of the primary; but the state committee held the evidence of fraud insufficient and (October I), declared Blease the party's nominee. The same primary re-nominated Benjamin Ryan Tillman as United States senator, an office he had held since I895. In November Blease received 44, I 22 votes to 208 for Britton (Socialist).

The Democratic state convention, May I6, I9 2, chose delegates to the national convention pledged to Woodrow Wilson, whose boyhood and youth were spent in Columbia, and he carried the state easily in the November election, receiving 48,355 votes to I,293 for Roosevelt, 536 for Taft and I64 for Debs ( 100 in I 908); and 7 Democrats were chosen representatives in congress, -6 being re-elected. There was no Progressive ticket in the state except for presidential electors.

A negro accused of rape was lynched October IO, I9I I, at Honea Path, Anderson county, after being taken from a sheriff. In I9I 2 three negroes were lynched (March 13) at Olar for arson, two at Blacksburg (March 29) for murderous assault, one at Newberry (November 23) for murder; and one at Norway (December 2I) for non-payment of debt, was taken from jail and shot. Governor Blease openly opposed the education of the negro and countenanced lynching by promising in a Fourth of July speech in I 9 I n not to call out the troops to protect negro prisoners from mobs. At the governors' conference held in Richmond, Virginia, in December г 9 г 2 he repeated these sentiments and declared that he would not follow the constitution in protecting prisoners accused of crimes against womanhood. A resolution repudiating his speech was passed by I4 votes to 4. On December 24, I9I2, he pardoned 80 convicts working in chain gangs; of 33 whom he pardoned in November, 15 had been convicted of homicide.

A street car strike in Spartanburg was accompanied by so much violence that three companies of militia were sent to the city, September 24, I912, by Governor Blease.

On November 2I, I9I2 (by 200 to 2I) the commission form of government was adopted in Florence, and in the same year Sumter chose a commission with a city manager (June II, 252 to 72 ; in effect August I3). On April I4, I9I2, the French Protestant Church of Charleston, the only remaining Huguenot church in the United States, celebrated its $225^{\text {th }}$ anniversary. A memorial shaft to the women of the Confederacy was dedicated in Columbia, April II, I9I 2.

Bibliography.-Acts and Joint Resolutions (2 vols., Columbia, I9II and I9I2); A.S. Salley, Jr., ed., Narratives of Early Carolina, I650-I708 (New York, I9II).

\section{SOUTH DAKOTA ${ }^{1}$}

Population (I910) 583,$888 ; 45.4 \%$ more than in 1900 . Density 7.6 to the sq. m. Of the 67 counties only 57 are organised. The greatest rate of increase for any organised county was $1,016.7 \%$ in Stanley count.y. The number of Indians (and Asiatics) decreased in $1900-10$, from $20,30 \mathrm{I}$ to $\mathrm{r}(0,300$. The percentage of foreign-born whites was 22 in 1900 but only 17.2 in 1010 , and of whites of foreign parentage 38.9 in 1900 , and 37.2 in 1910. In rural territory (unincorporated) there was in 190073.4 of the total, and in I910 66.8\%; in the semi-urban territory (incorporated places, each less than 2,500 in population) $16.4 \%$ in 1000 and $20.1^{\circ}$, in 1010 ; and in urban territory one-tenth of the total in 1900 and $13.1 \%$ in 1910 , when there were in this class I 3 cities, as follows:-Sioux Falls, I4,004; Aberdeen, I0,753 (4,087 in 1900); Lead, 8,392; Watertown, 7,010 (3,352 in 1900); Mitchell, 6,515; Huron, 5,791 (2,703 in 1000); Rapid City, 3.854 ( $1,3.42$ in 1000$)$; Vankton, 3.787; Pierre, 3,656; Deadwood, 3,653; Madison, 3,r37; Redfield, 3,060; Brookings, 2,97r.

Agriculture. - The acreage in farms increased from 19,070,616 to 26,016,892 between 1900 and 1910 , and the improved land in farms from $11,285,983$ to $15,827,208$; the average farm acreage fell from $362 .+103.35 .1$ and the value of farm property increased from $\$ 297,525,-$

${ }^{1}$ See E. B. xxr; 506 et seq. 
302 to $\$ 1,166,096,980$ ( $\$ 902,606,75 \mathrm{I}$ land; $\$ 102,474,056$ buildings; $\$ 33,786,973$ implements: $\$ 127,229,200$ domestic animals). Of the land area $52.9 \%$ was in farms in 1910 . The average value of farm land per acre was $\$ 34.69$. Farms were operated largely by owners $(57,984$ by owners, 429 by managers and 19,23 I by tenants). In 1909,500 farms $(63,248$ acres: Pennington county, 19,463; Butte, 14,378 ) were irrigated by enterprises capable of irrigating $\mathrm{I} 28,48 \mathrm{I}$ acres. The acreage included in projects was 201,625. For three-fourths of the acreage streams were the source; for one-fifth, reservoirs. The larger crops irrigated were: wild grasses ( 17,652 acres) and alfalfa (10,005 acres). In 1912 (preliminary estimates) the principal crops were: Indian corn, $76,347,000$ bu. $(2,495,000$ A. $)$; wheat, $52,185,000$ bu. $(3,675,000$ A.); oats, $52,390,000$ bu. (I,550,000 A.); barley, 23,062,000 bu. (887,000 A.); rye 312,000 bu. (16,000 A.); potatoes, 6,510,000 bu. (62,000 A.); hay, 672,000 tons (460,000 A.); and flaxseed, 5,323,000 bu. (6I9,000 A.). In I909 (U.S. Census) the value of vegetables (excluding potatoes) was $\$ 1,033,163$; small fruits, $\$ 47,263$; orchard fruits, $\$ 209,339$ (apples, $\$ 158,729)$. On January I, I 12 there were on farms: 675,000 horses, 13,000 mules, 366,000 milch cows, 894,000 other neat cattle, 605,000 sheep and $1,104,000$ swine.

In 19I I laws were passed permitting counties to maintain demonstration farms or to conduct the county poor farm as a demonstration farm; establishing a demonstration farm at Vivian and a dry farm experiment station in Fall River county; and authorising county commissioners to issue bonds or warrants to pay for seed grain for needy farmers. During the last two years the agricultural experiment station has worked on the hybridisation of small fruits, particularly raspberries, plums and apricots, and on breeding alfalfa and sugar beets. The Federal department of agriculture has a "dry land" farm in Fall River county and a field station on the Bellefourche Reclamation project (see E. B. xxv, 507c). This project irrigated 33,362 acres in $191 \mathrm{I}$, and in November 1912 it was $93.6 \%$ completed.

Mineral Products. - In I9I I, total value, $\$ 8,037,372$. The value of gold was $\$ 7,429,500$, ranking the state 4 th, with an increase of nearly $40 \%$ over the output of I9IO. The output of silver, \$108,200, was nearly three-quarters larger than that of 1910 . The gold comes from low-grade milling-amalgamation-cyaniding ore and the silver from refining gold mill bullion. Stone was the only other important item.

Manufactures. - Total value of factory products for $1909 \$ 17,870,000$, an increase of $36.6 \%$ since I904. The capital invested was $\$ 13,018,000$ (71.6\% more than in 1904); the number of establishments $I, 020$, and the number of persons engaged in manufacturing 5,226 . The principal products were: flour and grist-mill products, $\$ 6,208,000$; butter, cheese and condensed milk, \$2,686,000 (23\% more than in I904); and printing and publishing, \$1,976,000; lumber and timber products, $\$ 945,000$ ( $150.7 \%$ more than in I904). Sioux Falls $(\$ 2,889,000)$ and Aberdeen $(\$ 1,575,000)$ supplied about one-fourth of the total.

Transportation. - Railway mileage, January I, I912, 4,195.82.

Legislation.-The regular session of the legislature was held from January 3 to March 3, I9II. It ratified (Feb. 3, IgIr) the proposed amendment to the Federal Constitution providing for an income tax. By 62,302 votes to 26,8 I 4 the people at the general election in I9I 2 adopted an amendment to the state constitution requiring that, in taxing corporations, franchises, licences to do business in the state, gross carnings, and net income shall be taken into account; and that the power to tax corporate property shall not be surrendered by the state. A primary law, which does away with state and county conventions, provides for publicity pamphlets, and adopts the Oregon plan for the choice of United States senators, was defeated in the legislature, but was proposed by popular initiative petition and was carried ( $5 \mathrm{I}, \mathrm{I} 54$ to 28,892 votes) in November I9I2. Constitutional amendments and referred laws are no longer to be published in official newspapers but are to be printed by the state and distributed through the mails to all electors by the county auditors. A board of immigration was created consisting of the governor, the secretary of state and the commissioner of public and school lands; it was authorised to choose a commissioner of immigration. For the completion of the state capitol $\$ 35,000$ was appropriated. The legislature passed an employers' liability law for common carriers by railroads in intra-state commerce. Contributory negligence does not bar recovery but diminishes damages that may be asked, and assumption of risk is no defence in case of death. A new railroad code was adopted which enlarges the powers of the railway commission. Upon the recommendation of any municipal authority railways must maintain safe crossings over highways. The office of telephone inspector was abolished and the railroad commission was authorised to regulate telephone companies. Telephone and telegraph companies are to be assessed by the state board of assessment, county by county, and are to be taxed on this assessment at count $y$ rates. The railroad commission is required 
to prepare a schedule of express rates " which shall not exceed seventy ( 70 ) per cent of the lowest rates in force on the Ist of January I909." Fire insurance companies which fail to pay losses within 60 days are liable to $10 \%$ added to the amount of loss.

The name of the food and dairy department was changed to food and drug department. All foods which are found to be adulterated and misbranded are to be advertised in official newspapers and a new law gives a wider definition of the term "misbranded." Children under 18 may not frequent pool or billiard rooms. The anti-treat law of 1909 was repealed and all saloons ${ }^{1}$ were required to close at 9 P.M. On December 2 , I9I2 the U. S. Supreme Court upheld the constitutionality of state laws providing penalties for the sale of goods at a lower price in one part of the state than in another to suppress competition.

Cities of the first class may levy a tax for advertising their advantages. Laws in regard to commission government and especially the method of recall of officers and the method of initiative were amended. Lead adopted the commission plan in I9I I and Madison and Watertown (March 23; in effect May I) in 1912. From the western part of Armstrong county the county of Ziebach was created.

Finance. - In I9I I there were created a state board of finance consisting of the governor, treasurer, secretary of state, state auditor and public examiner, with authority to designate and control depositories of state funds, and a banking department under the management of the public examiner who is ex-officio superintendent of banks. The governor was authorised to appoint for a two year term an executive accountant to examine the accounts of all state officers, departments, institutions, etc.

On July I, I9I I there was a balance in the treasury of $\$ 421,156$. Receipts for the ensuing fiscal year were $\$ 3,779,652$ and expenditures $\$ 3,208,519$, leaving a balance, June 30 , 1912 , of $\$ 992,289$. There is no funded debt; on June 30 , 1912 there were outstanding $\$ 500 .-$ 000 in revenue warrants (partly offset by $\$ 44 \mathrm{I}, \mathrm{II} 8$ cash in general fund), $\$ 345,348$ due (general fund) on capitol building debt and \$59,63I of capitol building warrants outstanding, -making a net (unfunded) indebtedness of $\$ 463,86 \mathrm{I}$.

Education. - A new school code was submitted to the legislature in $191 \mathrm{r}$, but was rejected. The legislature required a school district to pay to parents or guardians of pupils living $21 / 2$ miles or more from the nearest school house a certain sum for each day of actual attendance, unless transportation was furnished by the school district. The amount varies from Ioc for $21 / 2$ to 3 miles to $45 \mathrm{c}$ for 5 or 6 miles. Of the population ro years of age and over $92.9 \%$ ( 5 in 1900$)$ was illiterate.

For the year $191 \mathrm{I} \cdots 12$ the school population was 172,074 ; the enrollment in public schools, I $45,36+$; the average daily attendance, 86,792 ; the average school year, 7.4 months; revenue, $\$ 6,079,345$; and expenditures, $\$ 4,984,327$.

Penal and Charitable Institutions. - In I9I I the governor's power of parole was enlarged and a law was passed providing for indeterminate sentence and parole, at the discretion of the court, of first offenders. County commissioners in counties of 15,000 inhabitants or more may establish county hospitals.

History.- In I9II-I 2 the state was controlled by the Republicans, with 34 (out of 45) senators and 99 (out of 104 ) representatives in the state legislature and all executive and administrative officers. Robert Scadden Vessey (b. I858), Republican, who had been a member of the state senate in 1905 and 1907 , and had there introduced and helped to pass much progressive legislation (corporation, banking and railway laws, publication of campaign expenses, etc.), was governor for the two terms, 1909-13, but was not renominated in I9I2. The Republicans nominated Vessey's associate, the lieutenant-governor, Frank M. Byrne, who received 57,299 votes to 53,724 for Edwin S. Johnson (Dem.), 3,578 for Samuel Lovett (Socialist) and 3,486 for O. W. Butterfield (Prohibition). Instead of two congressmen-at-large as under the previous apportionment, South Dakota has in the 63rd Congress three representatives (Republicans) chosen by districts. In the primary (June 4, 1912), Roosevelt received 38, 106 votes to 19,060 for La Follette and 10,944 for Taft; and Robert Jackson Gamble (b. I85 I; representative in Congress $1895-97$ and $\mathrm{I} 899-\mathrm{I} 00 \mathrm{I}$, and since then U.S. senator) was defeated as Republican nominee for United States senator by Thomas Sterling (b. I 851), a lawyer of Vermillion and in I90I-I I dean of the College of Law, University of South Dakota. Sterling was chosen (January 22, I9I3) by the new legislature (I 25 Republicans and 24 Democrats on joint ballot), over Richard Franklin Pettigrew (b. 1848 ), the Democratic choice, senator from South Dakota in I889-19or, who was first a Republican and then $(1896)$ a follower of Bryan, and was a leader in the Senate

1 At clections on April 16, 1912 the majority of towns and cities (including Sioux Falls) voting on liquor licences voted for licence. 
of the opposition to the annexation of the Philippines. There were no Taft electors on the official ballot, but the Roosevelt electors pledged themselves to vote for Taft if it were a question between him and Woodrow Wilson. Roosevelt received the 5 electoral votes of the state, which he carried by 58,8 I I votes to 48,942 for Wilson. Debs received 4,662 votes $(2,846$ in 1908$)$.

Bibliography.-Session Laws, I9I I (Pierre); official reports; W. E. Johnson, South Dakota, a Republic of Friends (Pierre, I911).

\section{TENNESSEE ${ }^{1}$}

Population (1910), 2,I84,780, an increase of $8.1 \%$ since 1900 . The percentage of negroes decreased from 23.8 to 21.7 , and foreign-born whites from 0.9 to 0.8 . Density, 52.4 to the sq. m. In I910 $73.7 \%$ of the total was in rural (unincorporated) territory (in $1900,80.2 \%$ ). In urban territory (incorporated places, each with a population of 2,500 or more) there was $20.2 \%$ in I910, in 29 places ( $16.2 \%$ in 22 such places in I900). In I910 there were I I places with 5,000 or more, as follows: Memphis, I31,105 (IO2,320 in I900); Nashville, I I0,364; Chattanooga, 44,604; Knoxville, 36,346; Jackson, I 5,779; Clarksville, 8,548; Johnson City (town), 8,502; Bristol (town), 7, I 48; Columbia, 5,754; Cleveland, 5,549; Park City (town), 5, I 26.

Agriculture.-The acreage in farms decreased from 20,342,058 to 20,041,657 between I900 and 1910 , and the improved land in farms increased from $10,245,950$ to $10,890,484$; the average farm acreage fell from 90.6 to 81.5 , and the value of farm property increased from $\$ 341,202$, 025 to $\$ 612,520,836$ (\$37 I,4I 5,783 land; \$109, I06,804 buildings; $\$ 2$ I,292, I 7 I implements: $\$ 110,706,078$ domestic animals). Of the land area $75.1 \%$ was in farms in 1910 . The average value of farm land per acre was \$18.53. Farms were operated largely by owners (I44,I25 by owners, 826 by managers and IOI,06I by tenants). In 1912 (preliminary estimates) the principal crops were: Indian corn, $88,298,000$ bu. $(3,332,000$ A.); wheat, $7,077,000$ bu. (674,000 A.); oats, $5,599,000$ bu. (258,000 A.); barley, 52,000 bu. (2,000 A.); rye, 196,000 bu. ( 7,000 A.); buckwheat, 54,000 bu. (3,000 A.); potatoes, 3,344,000 bu. (38,000 A.); hay, I, I 54,000 tons ( 888,000 A.); cotton, 280,000 bales (I 7 I lbs. per A.), and tobacco, 72,600,000 lbs. (IIO,000 A.). In I909 (U.S. Census) the value of vegetables other than potatoes was $\$ 7,015,686$; flowers and plants, $\$ 344,579$; nursery products, $\$ 697,703$; small fruits, $\$ 923,6$ I 3 (strawberries, $\$ 835,739$ ); orchard fruits, $\$ 3,459,077$ (apples, $\$ 2,172,475$; peaches and nectarines, \$1,055,379). On Jan. I, I9I2 there were on farms: 354,000 horses, 279,000 mules, 385,000 milch cows, 576,000 other neat cattle, 762,000 sheep and $1,574,000$ swine. The office of inspector of apiaries was created in I9 I I by a law against keeping foul brood bees or bees with any other infectious or contagious disease. The Smoky Mountain area $(59,213$ acres; Blount and Sevier counties) and the White Top area $(33,619$ acres; Johnson and Sullivan counties, and Washington county, Virginia) were approved in 1912 by the National Forest Reservation Commission for purchase under the (Federal) Weeks act (of March I, I9II) to preserve upland watersheds.

Mineral Products. - Total value, in I91 I, \$17,902,45I. Coal, 6,433, I56 tons $(\$ 7,209,734)$, and the metals are the important minerals. Iron ore amounted to 469,728 tons (marketed; the mined total is more), of which $25 \mathrm{I}, 083$ was hematite and the remainder brown ore. More than one-third of the total comes from one hematite mine near Cardiff. The value of pig iron (not included in the total above) was $\$ 3,439,644$. The output of copper was $18,965,143$ lbs. $(\$ 2,370,643)$, all from the district near Ducktown, where in I9I I sulphuric acid was successfully manufactured from smelter fumes, after suits to abate smoke nuisance. Zinc was valued at \$II4,000 and gold at \$II,900 (more than thrice the output in I9IO). Phosphate rock was valued at \$I, 688,267; and the green-sands of Hardin, McNairy and Henderson counties are being studied as sources of fertiliser potash, samples from McNairy county showing 10.1 to $11.3 \%$ Limestone and marble each were valued at about $\$ 700,000$; sand and gravel $\$ 518,542$; lime $\$ 282,763$. Natural gas was found near Franklin in I910.

Manufactures.-In 1904 o9 the number of establishments increased from 3,I75 to 4,609 and that of persons engaged in manufacturing from 69,287 to $87,672(60,572$ wage-earners to $73,840)$; capital from $\$ 102,439,000$ to $\$ 167,924,000(63.9 \%)$; and the value of products from $\$ 137,960,000$ to $\$ 180,217,000$. In 1909 the two pre-eminent manufactures were: lumber and timber, $\$ 30,457,000$; and flour and grist-mill products, $\$ 29,070,000$. Other large products were: foundry and machine-shop products, $\$ 9,190,000 ;$ car construction and repairs by steam railway companies, $\$ 6,777,000$; cottonseed oil and cake, $\$ 6,593,000$; cotton goods, $\$ 5,201-$, 000 ; iron and steel from blast furnaces, $\$ 4,653,000$; and hosiery and knit goods, $\$ 3,565,000$ ( $119 \%$ more than in 1904 , when the product value was $312.2 \%$ greater than in 1899 ). Of the manufactures, $48.2 \%$ by value came from the 5 cities which had (in 1910) more than 10,000 inhabitants; Memphis, $\$ 30,241,500$, chiefly flour, lumber, cotton-seed oil $(65.5 \%$ of the

1 See E. B. xxvi 619 et seq. 
state's product) and tobacco; Nashville, \$29,650,000; Chattanooga, $\$ 16,036,500$, principally foundry and machine-shop products; Knoxville, \$8, I49,000; and Jackson, \$2,7 10,000.

Transportation. - Railway mileage, Jan. I, I912, 3,945.18. A law of 19 I I permits railways to fill trestles to insure public safety, to build cut-off lines and second tracks to extend main or branch lines, and to condemn real estate for such purposes. The Federal government plans five additional locks in its canalisation of the Cumberland below Nashville.

Legislation.-The legislature met in regular session from January 2 to July 7, I9 I , with a recess from February I 8 to March 27, and one April $21-24$. It ratified, April I I, the proposed amendment to the Federal Constitution providing for a federal income tax. It urged amendments to the Federal Constitution providing for the direct election of United States senators and prohibiting polygamy throughout the United States.

The following proposed amendments to the state constitution were referred to the next session: providing that the secretary of state is to be elected by the voters instead of appointed by the legislature; also the treasurer, with the extension of his term from two to four years; providing that the attorney-general and reporter are to be chosen by popular vote instead of appointed by the judges of the state supreme court; making the governor's term four years and making him ineligible for immediate re-electioninstead of not holding office for more than six years out of eight; and making the term of sheriff, trustee and register, four years instead of two.

No verdict in a case at law is to be set aside on a technical error unless it seems to have affected the result. No decision in a case tried by a jury in a lower court may be reversed by the state superior appellate courts or dismissed upon the merits without an opportunity for oral argument by counsel in the higher court. A new trial is to be awarded on the remittitur of a trial judge in any case where the jury's verdict seems to him to be excessive or due to passion, prejudice, corruption, partiality or unaccountable caprice. The Australian ballot law was extended to two more counties, Coffee and Tipton.

A commission form of government providing for a mayor and four commissioners to be chosen from the two candidates for mayor and eight for commissioner having the highest number of votes at the primary election, for a civil service board of three commissioners with a three year term, for strict civil service rules and for recall, initiative and referendum was passed for Chattanooga (where it went into effect on May 8, after a chancery suit by officials ousted by the new charter), and a similar charter was submitted to the voters of Knoxville and was adopted by $\mathbf{I}, 24 \mathrm{I}$ to 197 votes on August 26, I9I I. LaFollette, Campbell county, received a commission charter from the legislature. The town of St. Elmo in Hamilton county was incorporated in $191 \mathrm{I}$, with a commission form of government. Cities and towns were authorised to establish tuberculosis hospitals.

A stricter pure food law was passed, amending the act of 1907 . The office of state hotel inspector was created by an act requiring fire-escapes, stand-pipes, extinguishers, night watchmen, screening, disinfecting, etc. in all hotels. The state board of examiners of nurses was created to issue certificates to registered nurses who alone may use the letters "R.N." after their names. A law was passed for the protection of the eyesight of newly born infants. The age of consent was raised from 18 to 21 .

Children under It are not to be employed except in agricultural or domestic service during school term or at any time in mills, factories, workshops, laundries, messenger service, etc. In the same employments children under I6 may not be employed without birth certificates; and in dangerous employments, specified in the act, no child under 16 may be employed under any conditions. Children under 18 may not be employed in messenger service bet ween Io P.M. and 5 A.M. Many special acts for separate counties extended into new territory the law for compulsory education of children between 8 and 15. Whages were secured for married working women upon notification from them that their employers are not to pay wages to anyone other than the employee.

Finance. - There was a treasury balance from 1910 of $\$ 317,270$; receipts in I9I 1-12, \$8,735,068 ; expenditures, $\$ 8,267,218$, leaving a balance for 1912 of $\$ 785,120$. The bonded debt was $\$ 15,218,600$ on December $20,1912$.

Education. - The legislature in I9 I failed to pass a new school code because of political strife in the state. Compulsory education was extended to several counties which had not been under the law before. The teaching of agriculture is reguired in all schools, and it is a necessary subject for teachers' certificates. In accordance with the act of 1909 , four state normal schools have been established at Johnson ("ity, Memphis, Murfreesboro, and (for negroes) at Nashville. ()11 January 17, 1911, Bruce Ryburn Payne (b. 1874; graduated Trinity College, N.(., 1896; professor of psychology University of Virginia, 1906-11) was chosen president of the (ieorge Peabody College for teachers in Nashville. He took office in August, immediately after the college had moved from South Nashville to a site adjacent to the campus of Vanderbilt University, where it will re-open in 19I3. On November I, I9I I the Peabody Education Fund gave to the college $\$ 500,000$ on the condition that $\$ 1,000,000$ more be raised from 
other sources. The Peabody Fund Board will dissolve when this condition is met-probably in 1913. To the Peabody College the General Education Board (May 24, 1912) gave \$250,000 , conditioned on the gift of \$150,000 from other sources, to endow the Seaman A. Knapp School of Country Life. Seaman Asahel Knapp (I833-I9II), to whom the school is a memorial, was president of the Iowa State Agricultural College in 188t-86; and then he removed to Lake Charles, Louisiana, where he developed the rice-industry, introducing Japanese and other varieties. From 1903 to his death he was in charge of the important farmers' co-operative demonstration work in the South.

For the year ending June 30, I9I 2 the school population was 756,966 ; the total enrollment, $539,91 \mathrm{I}$; the average daily attendance, 368,888; and the length of the average school year 127 days. The total receipts were $\$ 6,677,263$, and the expenditures $\$ 5,537,030$.

Of the population 10 years of age and over $13.6 \%$ in 1910 (20.7 in 1900) was illiterate; of whites, $9.7 \%$ (I4.I in 1900); negroes, 27.3 (4I.6 in 1900).

Penal and Charitable Institutions. - Juvenile courts were created in $19 \mathrm{I} I$ in Hamilton and Knox counties and a general law was passed giving juvenile jurisdiction to county judges or to the chairmen of county courts. The appropriations for pensions for soldiers and their widows were increased to $\$ 520,000$ and $\$ 210,000$, respectively, and the annual pensions from $\$ 60$ to $\$ 72$ to $\$ 100$. The legislature appropriated $\$ 60,000$ for the Tennessee Reformatory for Boys, near Jordonia, $7 \mathrm{~m}$. N. of Nashville, opened Fetruary I5, I9I2. The state owns 14,000 acres of coal land in Morgan and Anderson counties, and in September I 894 , established near Petros the Brushy Mountain Branch Prison, whose output of coal in November I9I2 averaged I,O00 tons a day. In January 1912 a night school was opened in the state prison.

History.-Benjamin W. Hooper (b. 1870) was elected governor in 1910 , by 133,999 votes (Republican and Fusionist) to 121,674 for U.S. senator Robert Love Hooper, Democrat, after a serious split in the Democratic party between Malcolm R. Patterson (b. I86I; governor I907-II), anti-Prohibitionist leader, and the prohibitionist wing of the party; he was the only Republican elected to state office in I9Io and the first Republican governor of Tennessee since $\mathrm{i} 88_{3}$. The legislature, strongly Democratic, was bitterly opposed to the new governor, and delayed his inauguration until January 25, I II, by having no quorum. The regular Democrats passed a bill taking from the governor the power of appointing the state board of elections, making the board nonpartisan, and increasing its members from three to seven. Governor Hooper vetoed the bill, and to prevent its being passed over his veto more than thirty members of the lower house left the state, so that for much of the session there was again no quorum. This forced the regular Democrats to acquiesce in the veto, and the Republicans and Independent Democrats then returned from Alabama in time to pass the general appropriation bill, which carried an item for interest on the state debt and moneys for official salaries. In another contest with the legislature Governor Hooper vetoed a bill giving $\$ 500$ extra pay to each member, but approved an amended bill reducing the extra pay to $\$ 200$. To succeed U.S. Senator James B. Frazier (b. 1856 ; governor I 903-05), Democrat, the legislature chose Luke Lea (b. I879), also a Democrat, editor of the Nashville Tennessean, who had broken with Patterson ${ }^{1}$ on the liquor question. In I9 2 B. W. Hooper was renominated for governor, and was re-elected in November by a small plurality over Benton McMillin (b. I845; governor 1899-1903), Democrat. The Progressive candidate, W. F. Poston, polled about. $2 \%$ of the combined votes for Hooper and McMillin. The I9I3 legislature (senate, 27 Democrats and 6 Republicans; house, 72 Democrats and 27 Republicans) chose John K. Shields (b. $185^{8}$; justice of the state supreme court since $I 902$ and chief justice since $\mathrm{rg}$ ro) as successor to Robert Love Taylor, ${ }^{2}$ United States senator since I907, who died March 3I, I9I 2.

${ }^{1}$ Patterson was known as a "pardoning" governor and was accused of using this power for political purposes. He pardoned 17 convicts on January 24 , the last day he was in office, and among the 150 he pardoned for murder was (April I3, I9IO) one of his advisers, Duncan B. Cooper, who with his son was convicted of killing Edward W. Carmack (1858-1908), former United States senator and editor of The Tennessean, which had attacked Patterson, and in the control of which Carmack was succeeded by Lea.

2 Taylor was born in Carter county, Tennessee, in $185^{\circ}$, practised law in Nashville, was a representative in Congress in 1879-81 and governor of Tennessee in 1887-91 and $1897^{-99}$. In 1910 he vainly tried to heal the breach among the Democrats, and was then unsuccessful when he tried to defeat the Fusionist candidates for governor. He was editor of $B o b$ Taylor's Magazine in 1905-06 and the Trotwood-Taylor Magazine. Another prominent politician, James Davis Porter (b. I 828) governor in 1875 -79, died on May 8, I912. 
Newall Sanders (b. I850), Republican, a manufacturer of agricultural implements, had been appointed ad interim by the governor, April 8, rgr 2 .

In the pre-convention campaign for the presidency Governor Hooper supported Roosevelt, but after the convention he remained "regular." The state was carried for Woodrow Wilson by I 30,335 votes to 59,444 for Taft, and 53,725 for Roosevelt and 3,492 for Debs ( 1,870 votes in 1908 ). The representatives in Congress are 8 Democrats and 2 Republicans.

There were several lynchings in the state in $\mathrm{I}_{9 \mathrm{I}} \mathrm{I}-\mathrm{I}_{2}$, including: a negro for murder at Gallatin, May 23; another on the same charge at Lafayette, June 8; one accused of assault, taken from jail and hanged at Forest City, October I6, I9r r; one at Memphis for assault, February 15, I91 2; three at Shelbyville, February 19, for murder; and one in Robertson county, May 27, for assault. In January IgI I Judge Sanford of the Federal District Court decided that the Inter-state Commerce Commission may compel interstate carriers to furnish the same accommodation for the same price to negroes as to whites.

In April I9I 2 the state suffered from floods, and Memphis was inundated.

On the Cincinnati, New Orleans \& Texas Pacific Railway, in its third district, between Oakdale and Chattanooga, there was a firemen's strike from March, to 25 , I9II. The strike was arbitrated by Judge Martin A. Knapp of the Board of Mediation; the strikers were taken back and the company agreed not to employ negro firemen north of Oakdale if competent white men could be secured. The white firemen had feared that they would be displaced by negroes.

Bibliography.-Public and Private Acts, IOII (2 vols., Nashville); departmental and official reports; O. F. Temple, Notable Men of Tennessee from I833 to I875 (1912).

\section{TEXAS ${ }^{1}$}

Population (I II0) $3,896,542$ (27.8\% more than in I900), ranking the state below New York, Pennsylvania, Illinois and Ohio only. Density r 4.8 to the sq. $\mathrm{m}$. The proportion of negroes fell from $20.4 \%$ to $17.7 \%$ in $1900-10$; and that of foreign-born whites rose from $5.8 \%$ to $6.2 \%$. The population in rural (unincorporated) districts was $69.4 \%$ (in $1900,77.7 \%$ ). In incorporated places ( 56 in 1900 and 91 in 1910 ) of 2,500 or more there was $24.1 \%$ of the total in I9Io ( $17.1 \%$ in I900). There were 20 places with more than I0,000 each, as follows: San Antonio, 96,6I4; Dallas, 02,104 (42,638 in 1900); Houston, 78,800; Fort Worth, 73,312 (26,688 in 1900); El Paso, 39,279; Galveston, 36,98I; Austin, 29,860; Waco, 26,425; Beaumont, 20,640; Laredo, I4,855; Denison, I3,632; Sherman, I2,412; Marshall, II 452 ; Paris, II, 269; Temple, I0,993; Brownsville, 10,517; Palestine, 10,482; Tyler, 10,400; Cleburne, 10,364; San Angelo, 10,32I. (incorporated I903).

A griculture. - The acreage in farms decreased from $125,807,017$ to 1 I $2,435,067$ between 1900 and 1910, and the improved land in farms increased from 19,576,076 to 27,360,666; the average farm acreage fell from 357.2 to 269 . I, and the value of farm property increased from $\$ 962,476,273$ to $\$ 2,218,645,164$ (\$1,633,207,1 35 land; $\$ 2$ I0,001,260 buildings; $\$ 56,790,260$ implements; $\&_{3} 18,646,509$ domestic animals). Of the land area $67 \%$ was in farms in 1910 . The average value of farm land per acre was $\$ 14.53$. Farms were operated largely by tenants (195,863 by owners, 2,332 by managers and 219,575 by tenants). In 1909 1,088 rice farms $(286,8+7$ acres) were irrigated. Exclusive of rice, 4,150 farms (164,283 acres: Cameron county, 29,439; El Paso, 23,308) were irrigated hy enterprises capable of irrigating 340,64I acres. The acreage included in projects was 753,699. The larger crops irrigated were: alfalfa ( 13,778 acres), Indian corn, $(9,068)$, cotton $(7,474)$, and cultivated grasses $(5,009)$. In 1912 (preliminary estimates) the principal crops were: Indian corn, $153.300,000 \mathrm{bu}$. $(7,300,000 \mathrm{~A}$.): wheat, I I,025,000 bu. $(735,000 \mathrm{~A}$. $)$; oats, $31,140,000$ bu. $(865,000 \mathrm{~A}$.); barley, $176,(100$ bu. $(6,000 \mathrm{~A}$ ) ; rye, 33,000 bu. (2,000 A.); potatoes, $3,276,000$ bu. (52,000 A.); hay, 542,00 ) tons, $(387,000$ A.); cotton, $4,850,000$ bales, (206 lbs. per A.); tobacco, 140,000 lbs. $(200 \mathrm{~A}$.) and rice, $9,429,000 \mathrm{bu} .(265,600 \mathrm{~A}$.). In 1909 (U.S. Census) the value of vegetables (excluding potatoes) was $\$ 8,099,306$; of small fruits, $\$ 480,331$; of orchard fruits, $\$ 1,060,998$ (peaches and nectarines, $\$ 703,649$ ); of grapes, $\$ 78,325$; and of nuts $\$ 562,524$. On January I, I9 I 2 there were on farms: I, I 58,000 horses, 703,000 mules, I,034,000 milch cows, 5, 177,000 other neat cattle, 2,032,000 sheep and 2,544,000 swine.

1 See $E$. B. xxvi, 688 et seq. 
In 19 I I the legislature voted to establish an agricultural experiment station for the culture of tobacco in co-operation with the Federal government; it allowed commissioners courts to appropriate as much as \$I,O00 each for farmers' co-operative demonstration work and to establish county agricultural experiment farms and stations. The Agricultural and Mechanical College was authorised to employ an expert in terracing farm lands to prevent erosion. The office of state sheep inspector was created, and the sale and transportation of sheep with scab was forbidden. The Federal department of agriculture has a dry farming station in the N. part of the "Pan-Handle." In I9II the boll-weevil seemed to be absent from cotton fields in the N. part of the state where it had been abundant in 1910 .

Mineral Products. - Total value, I9II, \$18,817,304. The most important item was petroleum, $9,526,474$ bbls. $(\$ 6,554,552)$. Coal, $1,974,593$ tons $(\$ 3,273,288)$, showed a slight increase over I910 and natural gas a large increase,- total value $\$ 1,014,945$. But the output of asphalt (oil asphalt and refined bitumen) was valued at only $\$ 786,785$, nearly onethird less than in I9I0. Clay products were valued at $\$ 2,659,919$ ( $\$ 132,417$ being pottery); stone at $\$ 588,777(\$ 490,289$ limestone; the remainder granite and sandstone); sand and gravel at $\$ 543,866$ (more than half being gravel); and lime at $\$ 218,007$. The output of salt was 385,200 bbls., valued at $\$ 299,537$. Portland cement was not separately reported for Texas in I9I I; the value was probably more than $\$ 1,000,000$. A little quicksilver was produced, some fuller's earth and about 5 tons of tin, from a mine near El Paso.

Manufactures. - From 1904 to 1909 the number of establishments increased from 3, I58 to 4,588 , and, that of persons engaged in manufacturing from 57,892 to $84,575(49,066$ wageearners to 70,230); capital invested from $\$ 115,665,000$ to $\$ 216,876,000(87.5 \%)$; and the value of products from $\$ 150,528,000$ to $\$ 272,896,000(81.3 \%)$. The most important manufactures in 1909 were: slaughtering and meat-packing products $\$ 42,530,000$ (nearly eight times as much as in 1899 ) ; flour and grist-mill products, $\$ 32,485,000$ (nearly thrice) the product of I 899); lumber and timber products, $\$ 32,201,000(97 \%$ of the lumber cut being shortleaf yellow pine); cottonseed oil and cake, $\$ 29,916,000$, in which Texas ranked Ist; and refined petroleum, in which the state ranked 4th. Other products were: car construction and repairs by steam railway companies, $\$ 13,359,000$; rice, cleaning and polishing, $\$ 8,142,000$ (three-fourths more than in 1904; the industry had hardly begun in 1899), in which Texas ranked 2 nd to Louisiana; foundry and machine-shop products, $\$ 8,068,000$; malt liquors, $\$ 6$,464,000 ; and food preparations, $\$ 5,229,000$. The more important manufacturing cities were: Dallas, \$26,959,000; Houston, \$23,016,000 (thrice what it was in 1899); San Antonio, $\$ 13,435,000$; Fort Worth, $\$ 8,66 \mathrm{I}, 000$ (including large meat-packing plants just outside the city limits); Galveston, $\$ 6,308,000$, mainly flour; Beaumont, $\$ 4,830,600$, principally ricecleaning; Waco, $\$ 4,769,000$, mainly cottonseed products; and Sherman, $\$ 4,676,000$.

Transportation.- Railway mileage, January I, I9I2, I5,038.22., - more than that of any other state. The Federal government completed in I9I I the main Galveston channel, $32 \mathrm{ft}$. deep and $800 \mathrm{ft}$. wide and in I 912 had about half finished the $30 \mathrm{ft}$. channel along the Galveston wharves and the Houston ship channel; in I9I I began the $30 \mathrm{ft}$. channel from Galveston to Port Bolivar, the $40 \mathrm{~m}$. incomplete link between Brazos river and Matagorda Bay in the inland water way from Galveston to Corpus Christi, the Sabine Neches canal (25 ft. deep) to Beaumont, a deep water harbour (20 ft.) at Harbor Island, Aransas Pass, and a lock and dam on White Rock Shoals, Trinity river. Improvement of the Trinity river was delayed in I9I I until a railway could be built to carry supplies for dam-building. The causeway connecting Galveston with the mainland was formally opened, May 25, I9I2.

Legislation.-The regular session of the legislature was held from January io to March II, I9II and a "called" or special session from July 3 I to August 29, which re-districted the state into representative districts. The legislature asked Congress to submit to the states a constitutional amendment providing for the direct election of United States senators and one prohibiting polygamy.

Amendments to the constitution were adopted at the general election of Igra permitting cities of 5,000 or more to adopt or amend a charter by a majority vote; creating a board of prison commissioners; and permitting the legislature to appropriate money for indigent and disabled soldiers and sailors and their wives, and to regulate the terms of trustees of state institutions.

Three new counties were created: Brooks (county-seat, Falfarrias) from parts of Hidalgo, Starr and Zapata; Jim Wells (county-seat, Alice) from part of Nueces; and Willacy (countyseat, Sarita) from parts of Cameron and Hidalgo.

The I2th of October (Columbus Day) was made a legal holiday.

The office of state inspector of masonry was created. Wharf and terminal companies were put under the jurisdiction of the railroad commission. All disabilities of married women in regard to mercantile and trading pursuits were removed. A new penal code was adopted. The legislature voted \$10,000 for a monument (begun in I912) to Gen. Stephen F. Austin (see $E . B$. ii, 940c) in the state cemetery at Austin and \$2,000 for a monument (completed in I9I2) to Elizabeth Crockett, wife of David Crockett (see E. B. vii, 477c), in 
the cemetery at Acton, Hood county. Children under 15 are not to work in factories using dangerous machinery, in distilleries or in breweries or in any business that may be morally or physically dangerous; the fine for violation is $\$ 50$ to $\$ 200$, and each day of employment constitutes a separate offence. The office of inspector of safety appliances in factories was created. Railway brakes are to be inspected by competent persons. The office of dairy and food commissioner was created by an act which forbids the adulteration of food, and a new sanitary code was passed with rules for quarantine and for the report of vital statistics. A law in regard to the examination of nurses was amended and an act regulating the practice of medicine forbids "soliciting or drumming patients or patronage." The sale or gift of spirituous liquors is forbidden in all disorderly houses. Pandering is made a felony, punishable by five years in the penitentiary, and it is no defence that any part of the act was done outside the state; marriage is no bar to the testimony of an injured woman.

The office of public service commissioner in Houston was created in 19II. In 1912 Bishop (only 6 opposing votes), Franklin, Frankston, Willis and McKinney (Nov. 5) adopted the commission form of government. In Dallas in I9I I a suit was brought against the constitutionality of the recall provision in the city charter after the recall of the board of education, but the recall was upheld by the courts.

Finance.-The "called" session of 19 II was summoned largely for appropriations. Although the cash balance in the treasury on July 31,1910 was $\$ 1,360,909$, the balance for the same date in I9I I was only $\$ 32,975$. The tax rate had been reduced in previous years because of the presence in the treasury of fines paid by corporations for violation of the antitrust law and, when these no longer came in, there was a deficiency. The law about state's depositories was amended. In the treasury there was a balance of $\$ 647,467$ on September I, 19 II and of $\$ 793,417$ on August 3I, 19I2, when the state debt was $\$ 3,977,500$, largely a permanent school fund (see $E . B$. xxvi, 692d). The receipts for the fiscal year were $\$$ I 8, I I9,072 , and the expenditures, \$15,973,122.

The election of a single-tax advocate, J. J. Pastoriza, as tax-commissioner of Houston, resulted in a full-value assessment on land and in a cut in the tax-rate from \$I.70 to \$1.30.

Education. - The law in regard to teacher's certification was amended in I9II. Common school districts may establish high schools; and, if a department of agriculture is established in a high school, the state duplicates the outlay therefor for any amount between $\$ 500$ and \$I,500. A state normal school board of regents was created for the state normal schools for whites, and a text book board was created by a law providing for uniform text books.

The most important recent event in the field of higher education was the opening in the autumn of 1912 in Houston of the Rice Institute of Liberal and Technical Learning, founded by the will of William Marsh Rice (d. 1900). ${ }^{1}$ Mr. Rice had established a foundation, incorporated in $189 \mathrm{I}$, and had given it an interest-bearing note of $\$ 200,000$ at that time. The foundation became his residuary legatee and the estate, valued at about $\$ 10,000,000$, was to be used one-half for endowment and one-half for equipment. Dr. Edgar Odell Lovett, then professor of astronomy in Princeton University, was chosen president in 1908. On a site of 300 acres, 3 miles from the centre of the city of Houston, were erected in I9I0-I 2 an administration building ( $50 \mathrm{ft}$. $x 300 \mathrm{ft}$.; Byzantine in style), a residence hall for men (Venetian; brick and stucco) and scientific and technical laboratories with a fine campanile. The Institute sets no "upper limit to its educational endeavour" and makes its "lower limit no lower than the standard entrance requirements of the more conservative universities of the country." Graduate and undergraduate work for both sexes will be carried on by a faculty of science and faculty of letters. There is no charge for tuition and rooms and board are furnished at cost. The Institute was dedicated and opened on the roth of October I9I2.

For the school year 1910-11 the school population ( 7 to 17 years of age) was 968,269 , the enrollment 847,004 , the average daily attendance, 546,481 and the length of the average school year 135 days. Receipts were $\$ 18,072,126$ and expenditures \$14,516,992. On September I, I912 the school population was I, OI 7,I33.

The rate of illiteracy decreased nearly one-third in the decade $1900-10$; in $190014.5 \%$ of the population 10 years old and over was illiterate, and in 1910 only $9.9^{\circ} \%$. In the negro population there was a proportional decrease; in 1900 the rate was 38.2 , in 1910 only 24.6 .

Penal and Charitable Institutions. - In IgI I the board of prison commissioners (created I gI0) was authorised to issue paroles for good conduct, and a law was passed for suspended sentence in first offence, where the punishment is less than 5 years. Two state tuberculosis colonies were established under the supervision of an anti-tuberculosis commission, for which the law appropriated $\$ 100,000$. Among the appropriations were: for the pension depart-

Rice, an ccentric millionaire, died in New York September 23, 1900. In February 1901 his valet, ('harles F. Jone's, confessed that he poisoned Rice under instructions of Albert $T$. Patrick, a lawyer who was a beneficiary of a supposed will of Rice, which experts testified was a forgery: Patrick was tried for murder and was convicted (first degree) in March 1902 and sentenced to death in April I902. A new trial was denied in June 1905 and in December of that year he was re-sentenced. In 1906 a new appeal was taken and in December sentence was commuted to imprisonment for life. (3n November 27, 1912 Patrick was pardoned by Guvernor Dix of New York. 
ment $\$ 523,750$ for I9II and for 1912 (of which $\$ 50,000$ each year was for Confederate pensioners); and $\$ 92,208$ in 1911 and $\$ 91,050$ in 1912 for the Confederate home at Austin.

History.-Prohibition of the sale of intoxicating liquors has recently been the central question in Texas politics, where there is virtually no partisan opposition to the Democratic party. Oscar Branch Colquitt (b. I86I), railroad commissioner in I903-I I and governor in I9I I-I 2, was a leader of the anti-Prohibitionist faction, and the popular vote (July 24, I9II) defeated the proposed amendment for state-wide prohibition by 6,000 votes $(237,393$ to 231,006$)$. In the I9I 2 primary Colquitt was re-nominated with a plurality of 20,000 votes over Judge W. F. Ramsey, but the precedent of giving each governor two terms seems to have caused this, as other nominees were mostly Prohibitionists. Probably there will not however be the necessary two-thirds of the next legislature pledged to prohibition to secure the immediate resubmission of the constitutional amendment to the people. In January IgI the legislature had re-elected to the U.S. Senate Charles A. Culberson (b. I 855; governor I 895-9; and since I 899 senator). At the July primary, Jake Wolters, anti-Prohibitionist, was defeated by Morris Sheppard (b. I875; representative in Congress since I902, when he succeeded his father), who favoured prohibition, to succeed in the U.S. Senate Joseph Weldon Bailey (b. I86.3). Bailey was an able lawyer and was prominent in debate, especially on questions of con-

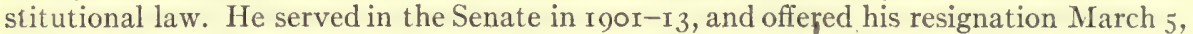
I 9 I, as a protest against the votes of Democratic senators for the Arizona constitution which provided for the recall of judges, but immediately withdrew it; in November I9I 2 he again offered his resignation (to take effect in January 19r3). Governor Colquitt appointed for the remainder of the term Rienzi Melville Johnston (b. I850), editor of the Houston Post, and an anti-Prohibitionist; he was sworn in, January 7, r9I3.

The primary of May 4, Igra was a victory for Woodrow Wilson. He carried the state in the November elections with $22 \mathrm{I}, 435$ votes to. 26,740 for Roosevelt, ${ }^{1}$ I 28,9 I 3 for Taft and 25,472 for Debs (7,570 in 1908). All the representatives in the $63 \mathrm{~d}$ Congress ( 18 , including 2 at large; 16 in the previous decade) from the state will be Democrats. There were two Progressive candidates for Congress and E. C. Lasater was nominated by the Progressives for governor.

There were three lynchings in the state in IgII. A Mexican boy who stabbed a man for cursing him was killed by a mob at Thorndale, June r9; a man was lynched in Farmersville, August $\mathrm{I} 7$, for insulting a woman over a telephone; and a negro, accused of rape, was lynched at Marshall, October 29. In 1912 there was a double lynching

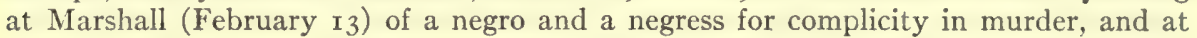
Tyler (May 25) a negro who confessed to having assaulted a white girl was burned to death in the public square.

A fire in the city of Houston on February 2r, I9r 2 did damage to the extent of several million dollars. The town of Washington, where the declaration of Texan independence was signed in 1836 (see E.B. xxvi, 693), was almost destroyed by fire on November 28, I9I2. A new city plan for Dallas prepared by George E. Kessler, landscape architect of St. Louis and Kansas City, was proposed in IgI 2.

Bibliography.-General and Special Laws, IorI (2 vols., Austin); official reports; J. H. Smith, The Annexation of Texas (New York, I9I I); C. W. Ramsdell, Reconstruction in Texas (in Columbia University Studies, I9I0).

\section{UTAH ${ }^{2}$}

Population (1910), 373,351, an increase of $34.9 \%$ since r 900 . The percentage of foreign-born whites decreased from I9.I to I7. Density 4.5 to the sq. m. In I $900,40.3 \%$, and in I9ro, $32.1 \%$ of the total was in rural, unincorporated territory;

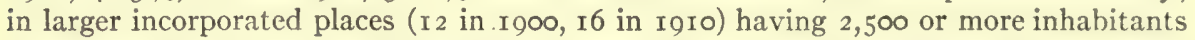
there was $38 . x \%$ in $1900,46.3 \%$ in roro. These were: Salt Lake City, 92,777

${ }^{1}$ Cecil Andrew Lyon (b. 1869) of Sherman, a member of the Republican National Committee in 1904-12, supported Roosevelt; and of the contested seats in the National Convention the committee gave 4 to Roosevelt and 26 to Taft.

${ }^{2}$ See E. B. xxvii, 813 el seq. 
(53,53 In I900); Ogden, 25,580 ( $16,3 \mathrm{I}_{3}$ in I900); Provo City, 8,925; Logan, 7,522; Murray, 4,057; Brigham, 3,685; Spanish Fork, 3,464; Park City, 3,439; Eureka, 3,416; Springville, 3,356; Lehi City, 2,964; Bingham (town), 2,88r; American Fork, 2,797; Nephi, 2,759; Tooele, 2,753; and Richfield, 2,559.

Agriculture.-The acreage in farms decreased from 4,116,951 to $3,397,699$ between 1900 and 1910 , and the improved land in farms increased from $1,032,117$ to $1,368,211$; the average farm acreage fell from 2 I 2.4 to 156.7 , and the value of farm property increased from $\$ 75,175$,I 4 I to $\$ 150,795,201$ ( $\$ 99,482,164$ land; $\$ 18,063,168$ buildings; $\$ 4,468,178$ implements; $\$ 28,-$ 781,691 domestic animals). Of the land area $6.5 \%$ was in farms in 1910 . The average value of farm land per acre was \$29.28. Farms were operated largely by owners ( 19,762 by owners, 194 by managers and 1,720 by tenants). In 1912 (preliminary estimates) the principal crops were: Indian corn, 270,000 bu. (9,000 A.); wheat, 6,059,000 bu. (236,000 A.); oats, 4,222,000 bu. (91,000 A.); barley, I, 125,000 bu. (25,000 A.); potatoes, 3,515,000 bu. (19,000 A.); hay, I,023,000 tons, $(368,000$ A.); rye, 90,000 bu. (6,000 A.) and sugar beets, 442,3 Io tons $(33,950$ A.) (the latter item includes Idaho). In I909 (U. S. Census) the value of vegetables other than potatoes was $\$ 717.776$; of flowers and plants, \$81, I 16; of nursery products, $\$ 188,455$; of small fruits, \$217,327 (strawberries, \$125,854); of orchard fruits, \$640,904 (apples, \$3I9,691 ; peaches and nectarines $\$ 156,451$ ). On January I, I912 there were on farms: 131,000 horses, 2,000 mules, 83,000 milch cows, 356,000 other neat cattle, 1,990,000 sheep, and 79.ooo swine.

The total acreage irrigated in 1909 was $999,410(58.8 \%$ more than in 1899$) ; 957,359$ were supplied from streams. The total cost of irrigation enterprises to July I, I9IO was $\$ 14,028$, 717 , and the estimated final cost of improvements begun was $\$ 17,840,775$. Of cereals $57.3 \%$ by acreage was grown on irrigated land in $1909,92.9 \%$ of corn; $92.4^{\circ}$ of oats; $88 \%$ of alfalfa; $94.5 \%$ of wild, salt, or prairie grasses; $93.3 \%$ of potatoes and $94.9 \%$ of sugar beets. The Strawberry Valley project (Utah and Wasatch counties; see $E$. B. xxvii, 8 I 4 b) of the Federal reclamation service was $69 \%$ completed in November 1912, and the great Strawberry Tunnel about $90 \%$ completed.

In 191 I there was created a board of veterinary medical examiners. Panguitch School in Garfield county was made an experiment station in connection with the Agricultural College. and in I912 the Federal department of agriculture planned a new experiment station near Fphraim on the Manti National Forest. In I9I I-I2 elaborate experiments were made to kill off the alfalfa weevil, a European immigrant, found here only in America. The state experiment station has investigated in irrigated soils the formation and movement of nitrates.

Mineral Products. - Total value, I9II, $\$+1,139,075$. In copper, 142,340,2 I5 lbs., the state ranked 4 th. Other metals were: gold $\$ 4,486,200$, ranking the state 6 th; silver $\$ 6,280$, 500 , ranking the state 2 nd; lead, 55,198 tons, and zinc 7,004 tons. Coal was valued at $\$ 4,248,666(2,513,175$ tons $)$. The out put of salt was 236,178 bbls. (\$I 57,024$)$. Hard asphalt worth $\$ 486,1$ I 4 was marketed in $191 \mathbf{I}$ and in $191 \mathbf{I}-\mathbf{I} 2$ drilling was begun in the northern part of Great Salt Lake for soft asphalt. The petroleum deposits are being developed slowly and phosphate rock has been found in the N.IW. part of the state. Sulphur was taken from San Rafael Canyon in larger quantities than in I9ro. Alunite discovered near Marysville, Piute county, is being studied as source of potash salts and alumina.

Manufactures. - From 1904 to 1909 the number of establishments increased from 606 to 749 and of persons engaged in manufacturing from 9,650 to 14,133 (wage-earners from 8,052 to II,785); capital invested from $\$ 26,004,000$ to $\$ 52,627,000(102.4 \%)$; and the value of products from $\$ 38,926,000$ to $\$ 61,989,000(59.2 \%)$. The three greatest manufacturing industries in 1909 were copper refining and smelting, lead refining and smelting, and the manufacture of beet sugar. Each of these was so largely concentrated under single control that they were not reported in detail by the Federal census; probably their product value was between one-half and two-thirds of the total for all industries. Of the total product value $27.5 \%$ came from Salt Iake City, \$13,35I,250, and Ogden, \$3,713,000.

Transportation.--Railway mileage, January 1, 1912, 2,055.9I.

Legislation.-The regular session of the legislature was held from January 9 to March 9, I0II. It submitted several constitutional amendments for approval at the general election in '1912; one permitting a new county to be formed by statuteformerly only by two-thirds of the popular vote in the district concerned; one exerıpting mortgages from taxation and permitting the abatement or remittance of taxes ois the indigent poor; one creating a state board of equalisation to be appointed by the governor instead of being composed of ex officio members only; one allowing any city of the second class with less than 20,000 inhabitants and any city of the third class or any town upon authorisation to incur an additional indebtedness, up to $8 \%$ of the valuation, for water, lights and sewers, owned and controlled by the municipality and one to increase the pay of members of the legislature from $\$ 4.00$ a day to $\$ 8 . \infty$ a day. All 
these were defeated by large majorities in November I9r2. On March 9, I9I I the house voted against the proposed Federal income tax amendment.

A state flag was adopted, showing the bee-hive, the Mormon symbol, the word "Industry" and the sego lily (Calochortus luteus), which was declared the state flower. The legislature appropriated $\$ 750,000$ for the state capitol (authorised in I91 I; maximum cost, \$2, 500,000 ; work begun late in 1912) and authorised the issue of $\$ 1,000,000$ in capitol building bonds. A state board of architecture was created to examine and license architects and builders. The bureau of statistics was renamed the bureau of immigration, labour and statistics. A uniform warehouse receipt law was passed.

The legislature passed codes for county commissioners, city councils, and town trustces.

A child labour law forbids the employment of children under 14 in dangerous occupations, of women under $2 \mathrm{I}$ in places where alcoholic liquors are manufactured or dispensed, of children under $2 \mathrm{I}$ as messengers between 9 P.M. and 5 A.M. or as messengers to objectionable places at any time in cities of the first and second class, of boys under 12 and of girls under 16 in street trades in first and second class cities, and of boys under I 4 or girls under I 6 for more than 54 hours a week in any employment except domestic service, fruit or vegetable packing or farm work. No woman is to be employed in any manufacturing, mechanical or mercantile establishment, laundry, hotel, restaurant or telegraph or tclephone service, hospital, office or transportation company more than 9 hours a day or 54 hours a week, except for emergency. The inspection of coal and hydro-carbon mines was provided by an act which makes rules for ventilation and safety. It was made a misdemeanour to coerce anyone to join an organisation; anyone commonly practising such coercion is declared a vagrant.

A new code for the liquor traffic provides for local option ${ }^{1}$ (in cities and towns and in rural territory in counties) for the granting of licences by the city councils or town board of trustees, but allows no licence except for a drug-store or hotel within $300 \mathrm{ft}$. of a school or a church or outside of city limits and grants club licences only in the name of a qualified individual. Wholesalers may not construct or rent premises for retail business. Saloons may not be opened between Io P.M. and 6 A.M. It is a misdemeanour to sell or give tobacco, opium or other narcotics to anyone under $2 \mathrm{I}$, and for any minor to have such a drug in his possession. Dairies, creameries, slaughter-houses, etc. are to be inspected under a law which is practically a pure food act. A new law was passed for the reporting of contagious diseases and in regard to quarantine. Physicians and midwives must report cases of infantile blindness to the state board of health and must treat such cases in accordance with its rules. Physicians and superintendents of hospitals are to report cases of venereal diseases but not the names of patients. Teachers must examine pupils for defective sight, hearing or teeth.

The penalty for pandering was set at 20 years in the state prison; for receiving money from a fallen woman without giving a consideration, 2 to 20 years, and for the detention of a woman in a brothel ro years. The commission of a part of the acts outside of the state is no defence and the testimony of an injured woman, even though married, is permitted.

Finance.-The state tax levy for I9II and $19 \mathrm{I} 2$ was $4 \frac{1}{2}$ mills for state purposes, $1 / 2$ mill for high schools, 3 mills for district schools, 5 mills for general county fund, 4 mills for county schools and I mill for the poor fund. 'The powers of the state board of equalisation were specified, and it was permitted to revalue property wrongly assessed. A board of commissioners on revenue taxation was appointed to report to the legislature of I913. Laws were passed for the control of fraternal insurance societies and requiring foreign banking and loan associations to furnish security before doing business in the state and a new banking law applies to all except national banks, makes the secretary of state ex officio bank commissioner and requires the governor to appoint bank examiners. There was in the state treasury, December 31 , I9I I, $\$ 1,728,602$. The receipts for the following year were $\$ 3,668,004$ and the expenditures, \$3,954,594, leaving a balance on hand, December 31, I9I2, of \$1,442,0I2. The state debt amounted to $\$ 1,210,000$.

Education. - In I9I I the state board of education was authorised to take over the establishment of state libraries and gymnasiums, and the state library and gymnasium commission was abolished. The legislature appropriated $\$ 10,000$ for the following two years for state aid in districts where the local levy was not enough to employ a teacher for a term of 28 weeks. A half mill tax was laid for the high school fund, and a permanent fund for the university, including a branch normal school and agricultural college, was set at $28 \%$ of the annual revenue from the general tax levy, exclusive of the state school and high school funds. The cornerstone of a new university library and administration building, for which a $\$ 300,000$ bond issue was authorised in I9II, was laid on October 23, I9I2. In 19I0 the percentage of illiteracy in the population Io years of age and over was 5.6 (5.9 in I900).

For the school year ending June 30 , I9I2, the school population was I 1 4,588; the enrollment, 92,1 29; the average daily attendance, 72,644; the length of the average school year, 34 weeks; the school revenue, $\$ 4,3$ I 8,746 ; and the expenditures, $\$ 3,864,5$ I 9 .

Penal and Charitable Institutions. - In I9I I the legislature reconstituted a board of trustees

${ }^{1}$ In I9I I 86 cities and towns and 1 county voted no licence; I 8 cities and towns and I county for licence. 
of the State Industrial School, passed new laws relating to detention homes for juveniles (in second class cities as well as in first class), and to the juvenile court and its jurisdiction (excluding crimes punishable by death or life imprisonment); created a relief fund for firemen, and authorised the use of convict labour on state roads.

History.-William Spry (b. I864), a Republican and a Mormon, was governor for the term I909-I3 and was re-elected in November I 9 I 2 by 42,552 votes to 36,076 for John F. Tolton, Democrat. The Democratic vote in the rural districts was strong; but the Republican majority in Salt Lake county (including the city) was large. Spry had favoured Roosevelt for the Republican nomination, and after the re-nomination of Taft by the national convention it was for a time supposed that the powerful influence of the Mormon Church, which has usually been exerted in behalf of the Republican party, might oppose Taft because he had not intervened in Mexico, where prosperous Mormons suffered from lawlessness. But Taft's policy was defended in an editorial signed by Joseph Fielding Smith, president of the church, in the Improvement Era, the official of the "quorum" of the church, and although the Progressives nominated candidates for governor (Nephi L. Morris who received 23,59I votes) and two congressmen, the state was carried by Taft, with 42, I00 votes to 36,579 for Wilson 24,174 for Roosevelt and 9,023 for Debs $(4,985$ in I 908$)$. The state for the first time will have two representatives in Congress, - both Republican (one re-elected). The state legislature will again be Republican: senate, 16 Republicans and 2 Democrats; house, 3 I Republicans and I4 Democrats. On January 18, I9I I George Sutherland (b. I862; Republican, representative in Congress in $190 \mathrm{I}-03$ and United States senator since I905) was re-elected to the U.S. Senate. The term of the other senator, Reed Smoot (b. I862; Republican; senator since I903; apostle of the Latter-Day Saints) does not expire until I9I 5. In I9r I Socialist mayors were elected in Eureka (with a full ticket), Manti and Murray (a suburb of Salt Lake City). The Socialist vote in November I 12 was surprisingly large. The incorporated cities of the state, Murray, Logan, Ogden, Provo and Salt Lake City have been operated under commission charters since January I 12 by a law of I9I I.

Attacks on the Mormon church in popular magazines, charging that polygamy was still practised, were answered, April 6, I9I I, by a statement of President J. F. Smith at the annual conference that polygamy was forbidden by the rules of the church.

Employees of the copper mines near Bingham went on strike in September I9r 2. The strikers, mostly Greeks, seized the mines and routed deputies who attempted to draw boiler fires (September I 8 and I9). On October I the deputies killed several men in an attack on the strikers.

Bibliography._-Laws, IOII (Salt Lake City); official reports; articles on copper mines and irrigation in Technical World, December I912.

\section{VERMONT 1}

Population (1910) 355,956 (3.6\% more than in 1900); $85.5 \%$ were native whites, 2 I.I \% whites of foreign parentage, $14 \%$ foreign-born whites, and $0.5 \%$ negroes. The average number to the sq. m. was $39\left(37.7^{\circ}\right.$ in I000). In I910, $47.5 \%$ of the population was in cities and towns of 2,500 inhabitants or over (40.5\% in 1900). The cities and villages with 5,000 inhabitants or over were: Burlington, 20,468 (in 1900, I8,640); Rutland, I3.546; Barre, I0,734; Montpelier, 7,856; St. Johnsbury, 6,693; Brattleboro, 6,5 7 ; St. Albans, 6,381, and Bennington, 6, 2 I I.

Agriculture. - The acreage in farms decreased from $4,724,440$ to $4,663,577$ between 1900 and 1910, and the improved land in farms from 2,126,624 to $1,633,965$; the average farm acreage fell from I 42.7 to I 42.6 and the value of farm property increased from $\$$ ro $8,45 I, 427$ to $\$ 145,399,-$ 728 (\$58,385,327 land; \$54,202,948 buildings; \$10, 168,687 implements; $\$ 22,642,766$ domestic animals). Of the land area $79.9^{\circ}$, was in farms in 1910 . The average value of farm land per acre was $\$ 12.52$. Farms were operated largely liy owners (28,065 by owners, 636 by managers, and 4,008 by tenants). In 1912 (preliminary estimates) the principal crops were: Indian corn, $1,8(00,000$ bu. ( 45,000 A.); wheat, 25,000 bu. (I,000 A.); oats, 3,3 I I,000 bu. $(75,000$ A.); barley, 455,000 bu. (13,000 A.); rye, 20,000 bu. (1,000 A.); buckwheat, 240,000 bu. $(8,000 \mathrm{~A})$; potatoes, $3,640,000$ bu. $(26,000 \mathrm{~A}$.), hay, I,515,000 tons (1,010,000 A.); and tobacco, 170,000 lbs. (100 A.). In 1909 (U.S. Census) the acreage of vegetables other than

1 See E. B. xxvii, 1025 et seq. 
potatoes was 8,548 and the value $\$ 872,183$; the value of small fruits, $\$ 92,030$ (strawherries, $\$ 68,96 \mathrm{c}$ ); of orchard fruits, $\$ 801,365$ (apples, $\$ 752,337$ ), and of maple sirup, $\$ 1,086,933$. ()n January I, I91 2 there were on farms: 84,000 horses, 268,000 milch cows, 168,000 other neat cattle, I I 7,000 sheep, and I I I,000 swine.

Dairying is the most important agricultural industry. In I9II the state experiment station published an important bulletin on the manufacture of ice-cream, besides bulletins on commercial fertilisers, commercial feeding stuffs and the peat and muck deposits of the state. The Federal department of agriculture has a farm at Weybridge near Middlebury where Morgan horses are bred and experiments have been made with Southdown sheep.

In I9I I the governor was authorised to appoint a cattle commissioner whose duty it is to see that no infected live stock is brought into the state and to suppress disease in herds. The legislature passed a stricter law for the prevention of forest fires; made the commissioner .of agriculture an inspector of apiaries, to inspect hives for foul brood, etc.; and authorised him to appoint a state ornithologist.

Mineral Products. -Total value, I9II, $\$ 8,434,516$. The only large items were stone, $\$ 6,145,35 \mathrm{I}$, ranking the state $3 \mathrm{rd}$, and slate, $\$ 1,624,94 \mathrm{I}$, ranking the state 2 nd. Of the stone, $\$ 3,394,930$ was the value of marble and $\$ 2,730,719$ that of granite. The value of lime was \$19I,035. Vermont produces more asbestos than any other state: in I9I I the value was $132 \%$ and the quantity $99 \%$ more than in 1910.

Manufactures.-From 1904 to 1909 the number of establishments increased from 1,699 to $\mathrm{I}, 958$; the number of persons engaged in manufacturing from 37,015 to 38,580 (wage-earners from 33,106 to 33,788 ); capital invested from $\$ 62,659,000$ to $\$ 73,470,000$; and the value of the manufactured product from $\$ 63,084,000$ to $\$ 68,310,000$. The three largest manufactures were in 1909: marble and stone-work, $\$ 12,395,000$; lumber and timber products, $\$ 8,598,000$ $(9.3 \%$ less than in 1904); and butter, cheese and condensed milk, $\$ 8,112,000$. The textile industries, woollen, worsted and felt goods $(\$ 4,497,000)$, hosiery and knit goods $(\$ 1,746,000)$ and cotton goods, all reported smaller product values in 1909 than in 1904 . Other manufactures were: flouring and grist-milling products, $\$ 4,133,000$; paper and wood-pulp, \$3,902,oo0; foundry and machine-shop products, $\$ 3,755$,000; furniture and ref rigerators, $\$ 1,618,000$.

Of the product value $19.5 \%$ came from the three largest cities: Burlington, $\$ 6,800,500$; Barre, $\$ 3,852,000$, including one-fourth of the state's marble and stone-work; and Rutland, $\$ 2,679,500$.

Transportation. - Railway mileage, January I, I912, I,094.89. In I9I I appropriations for highways were increased to $\$ 125,000$ for I9 I and \$150,000 a year thereafter. Railways may use electricity for motive power with the approval of the public service commission. Street railways must carry public school pupils at half fare or less. Many acts were passed for local bridges and highways.

Legislation.--The legislature met in regular session from October 5, ro ro to January 28, I9II, and convened again on October 3, I9I2. The latter session, aroused by the growth of the Latter Day Saints near Sharon (the birth-place of Joseph Smith, the founder), memorialised Congress December 13 , I $9 x_{2}$ for the adoption of an amendment to the Federal Constitution prohibiting polygamy.

In IgI I there was a re-apportionment of state senators in certain counties. The state librarian was required to establish a legislative reference bureau and a state bureau of information was created, in the office of the secretary of state. The secretary of state is required to secure statistical information in regard to the finances of municipalities. Columbus Day (October I2) was made a legal holiday.

The punishment for first degree murder was made life imprisonment, unless the jury returns a verdict with the words "with capital punishment."

A workmen's compensation act, in effect June 28 , I9I I, restricts the fellow servant rule and the defence of assumption of risk and prescribes damages and fixes limits to amounts recoverable for injuries, and forbids suits for damages unless they are brought within two years after the injury and notice has been given within sixty days to the employer. A constitutional amendment was proposed authorising and empowering the legislature to pass laws for compulsory compensation; this was left for action by the next legislature. ${ }^{1}$ No child under 14 is to be employed in a railway, mill, factory, quarry or workshop employing ten or more men; no child under 12 in messenger service, business office, restaurant, bakery or hotel; none under 16 in certain (enumerated) dangerous occupations, and no girl under 18 in an employment which requires her to stand constantly.

The penalty for the white slave traffic was made a fine of $\$ 200$ to $\$ 2,000$, imprisonment for one to ten years or both fine and imprisonment. The state board of health was empowered

${ }^{1}$ Other constitutional amendments which required ratification by the legislature in I9I 3 and then by popular vote are for biennial state elections and biennial sessions of the legislature after. 1915, and for taking from the legislature the power of chartering institutions not under state control, all other charters to be governed by general statutes. 
to frame regulations for the prevention of infantile blindness. No camp or sanatorium for the cure of tuberculosis may be established in the state without the permission of the state board of health. A board of registration of nurses was established and nurses licensed by this board may use the letters "R.N." after their names. The sale of oleomargarine was restricted by an annual tax of $\$ 100$. Liquors and tobacco may not be advertised on bill boards within $200 \mathrm{ft}$. of a church, chapel or school, except by permission of selectmen or council. Villages may be chartered and established on petition of a majority of legal voters therein with the approval of the public service commission. Many special laws in regard to corporations were passed including charter amendments, an act for the incorporation of the village of IVest Glover, and acts to incorporate power, traction, trust, bank and insurance companies, churches, fraternities, clubs, etc. The name of Bennington Center was changed to Old Bennington and that of Franklin Pond or Silver Lake in Franklin town to Lake Carmi. Among many game laws there was one granting a bounty of \$1o for each black bear killed.

Finance.-There was in the state treasury July I, I9I I, \$566, I42. The receipts for the fiscal year $19 \mathrm{I} x-12$ were $\$ 2,303,755$ and the expenditures $\$ 2,350,508$, leaving a balance June 30 , I9I 2 of $\$ 519.388$. In I9 I $\$ 26,000$ a year was appropriated to pay interest on bonds and other debts of the state. The same session of the legislature authorised the issue of $\$ 135,000$ in $6 \%$ certificates, redeemable 1932, to'refund the agricultural college fund loan. In I9I I the governor appointed a commission to introduce a system of bookkeeping in the office of the state treasurer. Enlarged powers were given to the commissioner of taxes, to whom aggrieved tax payers may appeal in regard to appraisal or other action of local listers. The inheritance tax law of igo8 was revised: a tax of $5 \%$ was laid on bequests, except to charities, for religious purposes, or to certain near relatives. Only corporations under supervision of the bank commissioner may (I9II) use the word "trust" in name or advertisement; and the whole savings-bank and trust company law was revised.

Education.--In I9I I the "state" normal school at Randolph Center was discontinued and its buildings were used for an agricultural school; \$IO,000 a year was appropriated. The two other normal schools at Johnson (where a new dormitory was built in I9I2) and Castleton, formerly state schools only in name, were taken over (by lease or purchase). Courses in agriculture are to be given in them, and normal training in certain high schools; 12 courses were provided for 1911 and 15 in 1912 .

The age limits of compulsory schooling were increased in I9I I by the addition of a year, so that they are now 8 to 16 ; "legal pupils" are those between 5 ( 7 in schools having no kindergartens) and 18. A law for medical inspection of schools on vote of annual school meetings was passed in 1911. The state superintendent is to control high-school entrance examinations, and he may grant 5-year certificates to normal school graduates of other states. Towns and incorporated districts may vote pensions (not more than one-half average salary for last 5 years) from school funds to teachers who have served 30 years. School reports are to be of uniform date and form.

In 1910 the percentage of illiteracy of the population Io years of age and over was 3.7 (5.8 in 1900). For the school year I9I I-I 2 the school population was 78,660 ; total enrollment in public schools, 64,518; average daily attendance, 52,160; length of the average school year, 32 wecks; total revenue for schools, $\$ 1,672,896$; and total expenditures, $\$$ I $: 915,344$.

After the death in I9IO of Matthew Henry Buckham (b. I832), president of the University of Vermont since 1871, Guy Potter Benton (b. I 865), president of Miami University, Ohio, was elected his successor on May I 8, I9I I, and he was inaugurated on October 5, I9I I.

Charitable and Penal Institutions. - In I9I I laws were passed regulating transfers from the industrial school to the house of correction; making two superior judges with a secretary chosen by them a commission on probation; and authorising the building of a criminal ward in the state hospital for the insane at Waterbury. \$10,000 a year for five years was voted to the Austine Institution at Brattleboro for the care and education of defective children.

History. - In the state election held on September 3, I9 1 2, 64,839 votes were cast for governor; under the constitution 32,420 votes were necessary for a choice, but there was no popular majority. Allen M. Fletcher, Republican, reccived 26,237 votes; Harlan B. Howe, Democrat, 20,00I; and Frazer Metzger, Progressive, I5,620. No other state officer received a majority and the election was thus thrown into the joint session, which on October 2, chose Fletcher as governor (by 163 votes to 76 for Howe and 32 for Mctzger) and elected the Republican candidates for other state offices, each by a larger plurality than it cast for Fletcher. Two Republicans were elected representatives in Congress ${ }^{1}$ at the September election. Governor Fletcher took office im. mediatcly, succeding John Abner Mead (b. I84I), Republican, who became governor in I)Io after two years as lieutenant-governor, and who was mentioned as a possible successor to James S. Sherman as nominee for vice-president on the Republican ticket.

1 David Johnson Foster (b. I857), Republican, representative in Congress since 1901, dicd on March 21, 19r2. 
The state was carried for Taft in November. He received 23,332 votes to 22, I32 for Roosevelt; I 5,354 for Woodrow Wilson, I,095 for Chafin, and 928 (largely from Barre) for Debs, who had received no votes in 1908 .

The I $25^{t h}$ anniversary of the founding of St. Johnsbury was celebrated, August I 5-r7, I9I2, on the Old Pine golf course, by a historical pageant, planned by William C. Langdon of New York City, with special music by Brookes C. Peters.

Bibliography.-Acts and Resolves (Rutland, I9II); official reports, especially of the commissioner of agriculture (Bellows Falls, I9II), Tercentenary Celebration of the Discovery of Lake Champlain and Vermont (Montpelier, 1910).

\section{VIRGINIA 1}

Population (I9ro) 2,061,6r 2 (II.2\% more than in I900); 66.I \% being native whites, $\mathrm{I} .8 \%$ whites of foreign parentage, $\mathrm{I.3} \%$ foreign-born whites and $32.6 \%$ negroes $(35.7 \%$ in 1900$)$. The average number to the sq. $m$. was 5 I.2 (46.I in I900); the state ranked I 4 th in density, and $76.9 \%$ of the population was "rural," living in towns of less than 2,500 inhabitants or in other rural territory ( $81.7 \%$ in 1900). The urban population was contained in I9 cities and $\mathrm{I} 3$ incorporated towns. The places of 5,000 or more were: Richmond, I27,628 (in I900, 85,050) ; Norfolk, 67,452; Roanoke, 34,874; Portsmouth, 33,I90; Lynchburg, 29,494; Petersburg, 24, I 27 ; Newport News 20, 205; Danville, I 9,020; Alexandria, I 5,329; Staunton, I0,604; Suffolk, 7,008; Charlottesville, 6, 765; Bristol, 6,247; Fredericksburg, 5,874; Winchester, 5,864; Clifton Forge, 5,748; Hampton, 5,505.

Agriculture. - The acreage in farms decreased from $19,907,883$ to $19,495,636$ between I900 and 1910 , and the improved land in farms from $10,094,805$ to $9,870,058$; the average farm acreage fell from 118.6 to 105.9 , and the value of farm property increased from $\$ 323,515,977$ to $\$ 625,065,383(\$ 394,658,9$ I2 land; $\$$ I 37,399, I 50 buildings; $\$$ I 8, I I 5,883 implements; $\$ 74,891,438$ domestic animals). Of the land area $75.7 \%$ was in farms in 1910 . The average value of farm land per acre was \$20.24. Farms were operated largely by owners (133,664 by owners, I, 625 by managers and 48,729 by tenants). In I9I2 (preliminary estimates) the principal crops were: Indian corn, $47,520,000$ bu. (I,980,000 A.); wheat, 8,596,000 bu. (741,000 A.); oats, 3,885,000 bu. (175,000 A.); barley, 250,000 bu. (I0,000 A.); rye, 600,000 bu. (48,000 A.); buckwheat, 516,000 bu. (24,000 A.); potatoes, 8,265,000 bu. (95,000 A.); hay, 889,000 tons (74I,000 A.); cotton, 24,000 bales (266 lbs. per A.) and tobacco, I I2,200,000 lbs. (187,000 A.). In 1909 (U.S. Census) the value of vegetables (excluding potatoes) was \$8,989,467 ; of small fruits, $\$ 67 \mathrm{I}, 843$ (principally strawberries); of orchard fruits, $\$ 3,582,359$ (apples $\$ 3,129,832$ ). On January I, I912 there were on farms: 340,000 horses, 61,000 mules, $35^{2}, 000$ milch cows, 478,000 other neat cattle, 781 ,000 sheep and 880,000 swine.

In 1912 the legislature authorised county supervisors to appropriate $\$ 1,000$ in any county to promote agriculture; passed a new act for the government of the united agricultural board which controls experiment stations; made an appropriation for the examination and testing of dairy cattle to control tuberculosis, supplementing the Federal department of agriculture, which tests herds supplying the District of Columbia; appropriated $\$ 5,000$ for investigating chestnut blight, and passed a law regulating the sale of seed cotton and forbidding it at night. In Arlington is the main experiment farm of the Federal department and at Charlottesville an entomological laboratory. The state truck experiment station, at Norfolk, in I9I2 published investigations of strawberry, potato, and tomato culture. The Massanutten area (I9,322 acres; Page and Rockingham counties), the Natural Bridge area (24,900 acres; Rockbridgre, Bedford, and Botetourt counties) and the White Top area (partly in Tennessee) were approved in 1912 by the National Forest Reservation Commission for purchase for the Eastern or Appalachian National Forests, established by Act of March I, I9I I (Weeks Act).

Mineral Products. - Total value, I9I I, \$13,609,364. The output of coal was $6,864,667$ tons, valued at $\$ 6,254,804$ (a little more than in 1910). Another large product was pig iron, 308,789 tons, valued at $\$ 3,898,285$ (not included in the above total), $30 \%$ less than in 1910 . The value of iron ore $(610,87 \mathrm{I}$ tons) was $\$ 1,146,188$, ranking the state 5 th. The metals were valued as follows: zinc, \$25,992; lead, \$36,000; and gold, $\$ 3$, Ioo. About onc-half the pyrite in the country comes from the state, and more manganese than from any other state. Virginia ranked Ist in millstones, valued at $\$ 17,635$. Mineral waters from 43 springs, including I 2 resorts, were valued at $\$ 298,701$.

Manufactures. - In 1904-09 the number of establishments increased from 3, I 87 to 5,685 and that of persons engaged in manufacturing from 88,898 to 120,797 (wage-earners from 80,285 to 105,676 ); capital invested from $\$ 147,989,000$ to $\$ 216,392,000$; and the value of products from $\$ 148,857,000$ to $\$ 219,794,000$. More than one-third of the total was from the three largest industries: lumber and timber products, $\$ 35,855,000$ (much more than twice as

${ }^{\prime}$ See $E$. B. xxviii, II 7 et seq. 
much as in I899); tobacco manufactures, \$25,385,000; and flour and grist-mill products, $\$ 17,598,000$. Other important products were: car construction and repairs by steam rail. way companies, \$9,956,000; tanned, curried and finished leather, \$8,267,000; fertilisers, $\$ 8,035,000$ (much more than twice the value in $\mathbf{1} 899$ ) largely manufactured from fish, and ranking the state $t_{\text {th }}$ in this industry; graded roasted, cleaned and shelled peanuts, $\$ 7,933$,000 , being four-fifth of the country's product; cotton goods, $\$ 7,490,000$ (nearly thrice as much as in 1899 ); boots and shoes, \$5,809,000; foundry and machine-shop products, \$5,727,000 ; iron and steel from blast furnaces, $\$ 5,389,000$.

Nearly four-ninths of the total product value came from the cities of 10,000 or over (excluding Newport News, which could not be reported separately, but which had in 1904 a product value of $\$ 9,054,000)$. These cities were: Richmond, $\$+7,358,000$; Norfolk, \$ I 0,34I,000; Lynchburg, \$IO, I 88,000 (much more than three times the product in 1899); Petersburg, $\$ 8,895,500$; Roanoke, $\$_{7,261}, 000$; Danville, $\$ 5,389,000$; Alexandria, $\$_{4,+19,500}$ (nearly thrice the output in 1899); Portsmouth, \$1,528,000; and Staunton, \$1,223,000.

Transportation.-Railway mileage, January I, I912, 4,389.12. The Federal government in I9I I secured a depth of $18 \mathrm{ft}$. in the James river between Hampton Roads and Richmond and completed the projected improvements (30 ft. main channel and $30 \mathrm{ft}$. anchorage at Lambert's Point) in Norfolk harbour. In 1912 the approaches to this harbour (I I m. long, $35 \mathrm{ft}$. deep and $400 \mathrm{ft}$. wide) were about two-thirds completed and the channel to Newport News $(3 \mathrm{l} / 4 \mathrm{~m}$. long, $35 \mathrm{ft}$. deep and $400 \mathrm{ft}$. wide) was practically finished.

Legislation.-- The regular session of the legislature met from January to to March I5, IOI2 and submitted to the people for their approval at the general election in November these constitutional amendments: one (adopted 60,176 votes to 16,202) permits the legislature to draw a special charter for any city over 50,000 upon the request of the city and to draw special charters of a form not prescribed by the constitution, but these charters do not go into effect unless adopted by a majority vote of the electors of the city in question; others remove the prohibition against re-election of the city commissioner of revenue (adopted, 58,496 to 20,900 ) and of the city treasurer (adopted, 57,884 to 20,733). Amendments to the charters of Richmond and Norfolk reduced the numbers of wards and thus the size of the councils.

The state was redistricted into ten congressional districts, and the legislature passed a primary election law which makes statutes in regard to regular elections hold in regard to primary elections; candidates are required to pay a fee equal to $5 \%$ of one year's salary in the office that they seek, to make a statement of expense within 20 days after primary election and to limit their expenses to ${ }_{5} 5 \mathrm{c}$ for every vote received by the highest party at the polls at the preceding election. In no instance is the expense to be more than $40 \%$ of the salary of the office. The expenses of the primary are to be paid like other election expenses.

A statute permits no peremptory instruction from a judge to a jury in any case, and another forbids the hearing of cases in the supreme court of appeals on imperfect records and their decision on merely technical points, and requires the court to simplify procedure in regard to bills of exceptions.

Cities of 60,000 and cities within five miles thereof may purchase water works systems by condemnation. Following the Maryland law for Baltimore the legislature provided for "segregation districts for white and colored persons " in cities and towns adopting the act. Members of one race are not to move into a district designated for the other.

The department of mines and the office of inspector of mines were created under the bureau of labour and industrial statistics? the act contains provisions for safety. Factories employing five or more persons and any workplace employing two or more children under 18 or two or more women must be inspected. Fo female and no boy under if may work in a coal mine. The law of 1890 limiting the working hours of females and children under I4 to 10 a day was extended to workshops and mercantile establishments, but does not apply to the latter on Saturday, or to packing fruit and vegetables between July and November, or in country districts or in towns of 2,000 inhabitants or less. The law of 1902 making railways liable for injury to employees was amended and made more severe.

In 1912 laws were passed for the government of the board of medical examiners; for speedier reports of vital statistics; and for the licence, inspection and supervision of maternity hospitals and baby farms. A standard of purity for ice cream and for condensed milk was set, and laws were passed regulating the sale of cider and putting a new tax on the manufacture of liquors. Manufacturers and sellers of intoxicating liquors are forbidden to use the name or likeness of any ( A measure to refer state-wide prohibition to the people was defeated in the senate by 3 to 2.

The legislature voted to have the body of Henry. "Light Horse Harry") Lee (see E. B. xiv, $36 \mathrm{Ib}$ ) brought to Virginia from (umberland Island, Ga.. if the family consented. 
Finance.-Many small changes were made in the tax laws notably in regard to the taxation of bank stockholders; of mineral lands and forests; of the rolling stock of rail road corporations, which is to be assessed in the counties, cities and towns and districts through which the railroad operates and not at the principal offices of the corporation; of railways and canals based on gross transportation receipts and property; of domestic corporations and of incomes in excess of $\$ 2,000$ a year. New statutes were passed regulating accident and insurance policies; policies against injury and disease; insurance companies, trust companies, guarantee and fidelity companies, etc., and state banks.

The balance in the treasury on September 30, I9 I I was $\$ 266,315$, and on October I, I9 12 $\$ 135,038$. During this fiscal year receipts were $\$ 7,052$, r90 and disbursements, $\$ 7,183,467$.

Education.-In 1912 the legislature amended the law of I910 in regard to instruction in agriculture, domestic arts and science and manual training in public. high schools; and the use of agricultural high schools for demonstration work is allowed. The law for retirement of teachers on pay was amended especially by rules for temporary retirement.

In I I I o the population Io years of age and over $15.2 \%$ was illiterate (22.9 in 1900): of whites, 8.I\% (II.I in I900); of negroes, 30 ( 44.6 in I900).

For the school year I9II-I2 the school population was 6I6, I68; the enrollment. 409,397; the average daily attendance, $263,29 \mathrm{I}$; length of the average school year, $6 \frac{2}{3}$ months; revenue for schools and expenditure, $\$ 5,628,208$.

The University of Virginia received in I9I2 a gift of \$125,000 from the Phelps Stokes Fund for a permanent fellowship to study the negro.

Charitable and Penal Institutions. - The act of I9Io for the control of infant offenders by probationary officers was amended in I 912 , and the state board of charities and corrections was required to inspect and supervise agencies or persons placing children in family homes throughout the state. The secretary of the same board was authorised to investigate the condition of the weak minded (not insane or epileptic) and the possibility of surgical aid for indigent crippled. The Virginia colony for the feeble-minded was established on a farm of the Virginia state epileptic colony. A new code was adopted for pensions to Confederate veterans. A county levy of one mill for the Confederate pension fund was authorised, and the legislature appropriated $\$ 3,000$ for Confederate veterans suffering from cancer and therefore not in the soldiers home, and $\$ 2,500$ for needy Confederate women not on the pension roll. Firemen in cities of I00,000 inhabitants or more may be pensioned. Several laws were passed for working convicts on public roads and for the manufacture by convict labour of ground lime-stone and oyster shells for use on public roads.

History. - The state administration and the legislature in IgII-I 2 were, as usual, Democratic. The legislature had only 5 Independents or Republicans in a senate of 40 and 10 in a house of 100 . The Democratic primaries, September 7, I9II, reelected for I9I3-I9 Thomas Staples Martin (b. I847), United States senator since I895 and affiliated with the conservative wing of the party, and chose for the term I9II-I7 Claude Augustus Swanson (b. I862; representative in Congress, I893-I905; governor I906-10), who had been appointed, August I, I9I0, to fill out the unexpired term (I9ro-rI) of John Warwick Daniel (r842-r9ro; representative in Congress, I $88_{5}$ 87 ; senator since I887), who died just after his re-election for I9II-I 7 . In the November rgr 2 elections the state was easily carried by Woodrow Wilson (a native of Staunton), who received 90,332 votes to 23,288 for Taft, 2 I,777 for Roosevelt, 820 for Debs, who had only 255 votes in I908, and 709 for Chafin. Of the ro representatives in the 63rd Congress, 9 will be Democrats and I a Republican (from the gth district)-the same division as in the 62 nd Congress. There was no gubernatorial election: the term of William Hodges Mann (b. I843) is I9Io-I4 (February I). There was no election to the state legislature in $x 012$.

In the attempt to induce West Virginia to pay her part of the debt of Virginia as it was when West Virginia was separated from that state, nothing was actually accomplished. The U.S. Supreme Court (220 U.S. I, March 6, IgI I) recommended a division of the debt, $76.5 \%$ to Virginia, $23.5 \%$ to West Virginia, based on a master's estimate of the value of real and personal property (excluding slaves) in the two parts of the state at the time of the creation of West Virginia; and on October 30, I9I I the court refused to determine questions left open in March. On April 20, Igri the Virginia debt commission asked the governor of West Virginia to arrange a conference. He had already (April r8) called an extra session but had not included in his call any mention of the debt, so that the extra session could not act and nothing could be done until the regular session of January I9I3. When Virginia urged haste, the legislature 
of West Virginia replied (May I9r) that the attorney-general having been elected before the case came up could not represent the actual wishes of the people of the state. As only the legislature can deal with the matter in West Virginia, there has been some question about the authority of the debt commission to act for Virginia.

On March I4, Igr 2 Judge Thornton L. Massie, W. M. Foster, the Carroll county attorney, and the sheriff of the same county were shot to death in the Hillsville courthouse by members of the so-called Allen clan of "Mountaineers" at the moment the judge was sentencing one of their members, whom they rescued. Several of the outlaws were captured and two sentenced to death on September iI; two, for second degree murder, were sentenced to 15 years' imprisonment (August 17 and November 22).

A negro was lynched by a mob at Richmond (August 8, I9I 2) for assault on a woman.

In 1912 the home of John Marshall in Richmond was acquired by the Association for the Preservation of Virginia Antiquities.

Bibliography.-Acts of Assembly IgI2 (Richmond); reports of state departments and officers; F. A. Magruder, Recent Administration in Virginia (Baltimore, 1912); C. R. Lingley, The Transition in Virginia from Colony to Commonwealth (1910); T. B. R. Wright, ed., Westmoreland County, Va., I653-19I2, Pts. I and II (Richmond, Va., I9I2); H. R. Mcllwaine, Journals of the Hlouse of Burgesses of Virginia, I727-34, I736-40 (ibid., I910); and Journals of the House of Burgesses of Virginia 1712-14, 1715, I718, 1720-22, 1723-26 (ibid., 1912).

\section{WASHINGTON 1}

Population (I9IO) I,I4I,990, an increase of I $20.4 \%$ since I900 (a higher rate than in any other state); $76 \%$ were native whites, $24.7 \%$ whites of foreign parentage, $21 . \mathrm{I} \%$ foreign-born whites and $0.5 \%$ negroes. The average number to the sq. $\mathrm{m}$. was 17.1 ( 7.8 in 1900$) ; 53 \%$ of the total lived in places of 2,500 or more $(40.8 \%$ in I 900 ). The cities with 5,000 or more were: Seattle, 237,194 (80,67I in 1900); Spokane, r04,402 $(36,848$ in 1900$)$; Tacoma, 83,743 (37,7 14 in 1900); Everett, $24,814(7,838$ in 1900$)$; Bellingham, 24,298 ( 11,062 in I900); Walla Walla, 19,364 (10,049 in 1900); North Yakima, I4,082 (3,I54 in 1900); Aberdeen, 13,660 (3,747 in I900); Vancouver, 9.300 ( 3,126 in I900); Hoquiam, 8, I7 I (2,608 in I900); Centralia, 7,3 II ( $\mathrm{I}, 600$ in I900); Olympia, 6,996 ( 3,863 in 1900$)$.

Agriculture.-The acreage in farms increased from 8,499,297 to I I 7 I 2,235 between 1900 and 1910 , and in the same period the improved land increased from $3,465,960$ to $6,373,311$; the average farm acreage fell from 256.0 to 208.4 and the value of farm property increased from $\$ 144,040,547$ to $\$ 637,543,4$ II $(\$ 517,421,998$ land; $\$ 54,546,459$ buildings; $\$ 16,709,844$ implements; \$ 48,865 , 1 Io domestic animals). The average value of farm land per acre was $\$+4.18$. Of the land area $27.4 \%$ was in farms in 1910 . Farms were operated largely by owners ( 47,505 by owners, 961 by managers and 7,726 by tenants). In 1912 (preliminary estimates) the principal crops were: Indian corn, 846,000 bu. (3I,000 A.); wheat, 53,728,000 bu. $(2,285,000$ A.); oats, $13,689,000$ bu. (284,000 A.); barley,, $7,869,000$ bu. (183,000 A.); rye, I 80,000 bu. $(9,000 \mathrm{~A}$.); potatoes, $11,356,000$ bu. $(68,000 \mathrm{~A}$.$) ; and hay, 1,707,000$ tons $(776,000 \mathrm{~A}$.). In I 909 (U.S. Census) the total value of vegetables except potatoes was $\$ 2,988,510$ (in $1899, \$ 1,040,668$ ); of flowers and plants and nursery products, $\$ 1,044,907$; that of orchard fruits, \$4,274,124 (apples, \$2,925.761; plums and prunes, \$600,503; cherries, $\$ 278,547$ ); and of small fruits, $\$ 9+1,+15$ (strawberries, $\$ 529,535)$. On January 1 , 1912 there were on farms: 293,000 horses, I 4,000 mules, 205,000 milch cows, 186,000 other neat cattle, 486,000 sheep and 246,000 swine.

The total acreage irrigated in 1909 was 334,378 ( $146.8 \%$ more than in 1899 ) ; 310,426 were supplied from streams. The total cost of irrigation enterprises to July I, 19I0 was $\$ 16,2$ I9, I 49, and the estimated final cost of improvements begun \$22,322, 856. Of the projects (see E. B. xxviii, 35td) of the Federal Reclamation Service, the Okanogan (()kanogan county), completed October 1910, irrigated in 1911 6,349 acres (orchard fruits, hay, (te.); and the Yakima (Yakima, Benton and Kittitas counties) in November 1912 was 19.3 completed in its storage unit, $93 \%$ in its Sunnyside unit and wholly completed in the Tieton unit, and in $191 \mathrm{I}$ irrigated 79,974 acres (forage, hops, fruits and vegetables).

The growing of flower bulbs is an increasing industry. In I9II narcissus and tulip bulbs propagated near Bellingham, flowered (in Washington, D.C.) ten days earlier than bulbs of the same varieties imported from Holland. The Federal department of agriculture is making studies of Puget Siound kelp as a source of iodine and of potash for commercial fertiliser.

Mineral Products. -Total value, I9II, $\$ 15,853,556$. The two largest items were coal,

${ }^{\prime}$ See E. B. xxviii, 353 et seq. 
$3,572,815$ tons $(\$ 8,174,170$; about one-sixth less than in 1910$)$, and clay products $(\$ 2,840$,372 ). Stone was valued at $\$ 1,679,872$ (granite, \$1,345,55I, ranking the state sixth); Portland cement at \$1,496,807; lime, at \$228,933; and sand and gravel, at \$338,400. 'The metal output was valued at $\$ 1,056,017$ (one-eleventh more than in 1910), including gold, $\$ 840,000$ (the largest output in eight years) mostly from the Republic district in Ferry county; silver, $230,300 \mathrm{oz}$. (nearly one-fifth more than in 1910 ), from siliceous smelting ores in Ferry county and copper and lead ores in Stevens county; copper, I95,503 lbs. (more than thrice the I9I0 output), mostly from the Danville district in Ferry county; lead, 424 tons (mine report, from Stevens and Pend Oreille counties; smelter report 6oI tons); and zinc, I2 tons, from the Metaline district, Pend Oreille county. Nearly five-sixths of the metals came from Ferry county, -and all the tungsten marketed. Mineral waters, bottled at 5 springs, were worth $\$$ I 4,654 .

Manufactures. - In 1904-09 the number of establishments increased from $2,75 \mathrm{I}$ to 3,674 and that of persons engaged in manufacturing from $5 I, 459$ to 80,118 (wage-earners from 45,199 to 69,120); capital invested from $\$ 96,953,000$ to $\$ 222,261,000$ (129.2\%); and value of products from $\$ 128,822,000$ to $\$ 220,746,000$ (71.4\%). Among the most important manufactures were lumber and timber, $\$ 89,155,000$ (nearly thrice the product value in 1899 ), in which Washington ranked first, being first in the cut of Douglas fir (five-eighths of the country's total) and of cedar (more than one-half the country's cut) and in the manufacture of shingles (three-fifths of the output of the United States); flour and grist-mill products, $\$$ I 7,853,000; slaughtering and meat-packing, \$ I 5,654,000; canning and preserving \$9,595,000, including fish, especially salmon, and vegetables and fruits; and butter, cheese and condensed milk, \$7,271,000, - of which $\$ 2,979,000$ was the value of condensed milk, in the manufacture of which Washington ranked 3 rd. The product value was nearly equally divided between the 8 cities of 10,000 inhabitants or more and the rest of the state. These cities were: Seattle $\$ 50,569,200$ (more than thrice as much as in I 899); Tacoma, $\$ 22,450,000$ (about $120 \%$ more than in 1899), Spokane, $\$ 18,880,000$ (five times as much as in 1899 ); Everett, $\$ 7,423,000$; Bellingham, \$4,600,000; Aberdeen, \$3,590,000; Walla Walla, \$2,31 7,000, flour being the main product; and North Yakima, \$2, I75,000.

Transportation. - Railway mileage, January I, I9I2, 4,891.72. Statutes provide for the building of county roads and for a permanent highway fund, out of the proceeds of which permanent highways are to be built on the resolution of the county commissioners, after plans have been approved by the highway commissioner. The Federal government in I9I2 was dredging the Columbia river and had practically completed the south jetty and begun the north jetty at the mouth of the river. In the S.W. part of the state, work at Willapa harbour was about one-third done, and that at Gray's outer harbour practically finished. At Olympia, with local co-operation, the deepening of the channel was nearly completed.

Legislation.-The I 2 th session of the legislature was held from January 9 to March 9, I9II. It ratified, January 26 , the proposed I6th amendment to the Federal Constitution providing for a Federal income tax. Three important constitutional amendments were adopted at the regular state election in I9I2: one (IIO, I IO to 43,095) providing for the initiative by a $10 \%$ petition and for referendum by a $6 \%$ petition on any statutory legislation; one ( $\mathrm{I} 2,32 \mathrm{I}$ to 46,372 ) for the recall of all elective public officers except judge of a court of record; and one $(79,940$ to 47,978$)$ striking out the provision that laws shall not go into effect until 90 days after the adjournment of a session.

The legislature objected to Federal interference with fisheries in the state under the treaty of 1908 with Great Britain; and it urged Congress to stop undesirable immigration.

A law of I9I I provides that only the names of the two candidates who receive the highest votes on the separate non-partisan primary ballot (provided for by a law of 1909) for candidates for the supreme court and the superior court shall appear on the general election ballot, and that, if one candidate gets an absolute majority of all votes cast, his shall be the only name to appear on the general election ballot.

The capitol commission was reorganised and provision was made for the completion by December I, I9I2 of a Temple of Justice, which is to be part of a group of six or more state buildings in Olympia. Columbus Day was made a legal holiday.

In a code of 75 pages the state railroad commission was changed to a public service commission to supervise common carriers, gas, electric, water, telephone and telegraph companies and wharfingers and warehouse men, to fix rates and service requirements for these public utilities, and to enforce the law which forbids discrimination; the code requires that the rate shall not be more for a short than for a long haul, makes it necessary to report accidents, and sets with a good deal of detail standards of safety. A minimum train-crew law was passed. A law, declared constitutional by the state supreme court on September 27, I9 I I (in Washington vs. Clausen), made insurance for injured workmen compulsory in the extra hazardous employments listed in the act, which is based on the police powers of the state. Other employers may elect the system of state insurance. Suits for damages are permitted if the injury result from the deliberate intention of the employer. Special contracts are forbidden. To be compensated the loss of earning power must exceed $5 \%$. The maximum compensa- 
tion for death is $\$ 4,000$, to a widow or a dependent widower, $\$ 20$ a month; for each dependent child, not more than thrce in number, $\$ 5$ month, but $\$ 10$ a month if dependent children are left without either parent. For total disability the compensation is $\$ 20$ a month $(\$ 25$ to a married employce with $\$ 5$ extra for each dependent child under 16 , the maximum being $\$ 35$ a month); these sums are discounted $10 \%$ if the injury resulted from the removal of safe-guards by the injured person or with his consent. The administration of the act rests with an industrial insurance department, created by it, but appeal may be made to the courts. Employers must pay to the state a percentage (not to be deducted from the workmen's pay) of the annual payroll. This varies from $0.15 \%$ in the manufacture of cordage, jewelry, etc., to $0.1 \%$ in powder works. Employers who elect insurance pay $90 \%$ of the minimum compulsory rate. The act carried an appropriation of $\$ 150,000$ for the fund. Women, except in canneries, are not to work more than 8 hours a day, and the same law (held constitutional by the state supreme court, March 26, 1912) requires employers to provide seats for women. For the investigation of the bubonic plague in Asia, \$5,000 was appropriated. Two laws were passed regulating the sale of milk and cream. It was made a gross misdemeanour to allow in a concert saloon, a dance house, pool or billiard hall, a place of assignation or a place where opium or any other narcotic drug is used, any person under $2 \mathrm{I}$, or to give or sell to a minor intoxicating liquor or tobacco, and any minor having either in his possession is guilty of a misdemeanour. On September 3, 1912 the state supreme court (State vs. Feilen) held that the law of I909 for the sterilisation (by order of the sentencing court) of habitual criminals, rapists, etc., was not unconstitutional, since it did not provide for a cruel and unusual punishment.

Pend Oreille county (county-seat, Newport) was created in I9I I from the eastern part of Stevens county. A law was passed validating provisions for recall in charters of cities of the first class. Cities between 2,500 and 20,000 may adopt the commission form of government at a special election called by a petition of $25 \%$ of the qualified electors. The following cities have adopted the commission government: Centralia, November 20, I9I I, in effect January 8, I9I2; Chehalis, I9II; Everett, April I6, I9I2 (I,986 to I,928 votes), in effect July I, I912; Hoquiam, June 5, I9II, in effect August I4, I9I I; North Yakima, July 17, 19II, in effect September I8, I9 I I ; Spokane, ${ }^{1}$ December I9I0, in effect March I4, I9 I I ; Tacoma, October 16, I909, in force May I910; and Walla Valla, July 10, I9I I, in effect September I I, I9II. Olympia rejected a commission charter on December 5 , I9 I I by 807 to $73+$ votes, and Vancouver by 958 to 447 votes. A constitutional amendment, deieated in November I 912 by 83,138 to 67,717 , would have removed the prohibition against county officers (except treasurer) holding office for more than two terms. The city of Everett voted in November 1912 to establish the single tax system. In Seattle a charter amendment for the single tax and one for the creation of a department of charities and corrections were defeated on March 5 , 1912. In Tacoma in 1912 an ordinance created a social service board to investigate places of public amusement and to study moral and social conditions of such places, "especialy where young people are concerned."

Finance.-All operating property of street railways is to be taxed as personal property although only the rolling stock of other railways is thus taxed. In the same way standing timber and fishing locations are to be assessed and taxed as personal property. The legislature of I9I I passed an elaborate insurance code of I 40 pages.

In the treasury there was a balance of $\$ 1,245,8+1$ on October I, 1910 and $\$ 2,446,247$ on September 30, I9I2. The receipts for the two years were $\$ 16,911,514$ and the expenditures $\$ 15,711,108$. The state debt in 1912 was: bridge bonds, \$125,000; normal school bonds, $\$ 206,024$; and capitol building fund warrants outstanding, $\$ 920,000$. The levy for state purposes for 1912 was $5 \frac{3}{4}$ mills.

Education.-In I9I I a new law was passed for the certification of teachers and the county superintendent was authorised to register no certificate unless he was satisfied of the good moral character of the teacher. In March I9I I the University of Washington received a gift of \$30,000, styled the Gatzert Foundation, for a bureau of child welfare. Whitman College, at Walla Walla, in 1912 completed an endowment fund of $\$ 100,000$.

For the year ending June 30 , I9I2 the school population was 283,141 ; total enrollment, $224,+10$; average daily attendance, 170,041 ; length of the average school year, 155 days. The total revenue for schools was \$13,671,349, and expenditures \$1 1, I56,404.

In 1910 of the population 10 years of age and over only $2 \%$ was illiterate (in 1900, 3.1\%); only. Oregon of the Parific states, and only Iowa and Nebraska elsewhere in the United States, have a lower rate of illiteracy.

Penal and Charitable Institutions.-In counties of 30,000 or more a judge of the superior court was authorised in I9I I to hold a juvenile court session and keep a separate juvenile record. The state board of control is to fix a price for the jute sacks manufactured in the penitentiary, which are to be sold directly to farms, oyster men and wool growers in the state and only at the discretion of the board upon the open market. For pensions for veterans of the Indian wars of 1855 and $1856 \$ 5,000$ was appropriated. The Northern Hospital for the Insane at Sedro-Woolley, Skagit county, was opened on April I, 191 I.

1 A system of preferential voting was adopted. On November 5, 1912, amendments to the charter, changing from a commission government, were defeated by 15,225 to 9,448 . 
History. - In I III-I 2 the state government was controlled by a strongly progressive type of the Republican party, all the state officers being Republicans and the legislature having 38 Republicans in a senate of 42 and 84 Republicans in a lower house of 96. On January I 7, I 9 I I the legislature chose a Progressive, Miles Poindexter (b. I 868; state superior court, I904-08; representative in Congress, I909-I I), United States senator to succeed the Conservative Republican, Samuel Henry Piles (b. I858), who had served one term. The term of the other senator from Washington, Wesley Livsey Jones (b. 1863; Republican, representative in Congress, I899-I909) does not expire until I9I5. In the state campaign in I9I2 there were three tickets in the field. The Republicans nominated Marion E. Hay (b. I 865) who as lieutenant-governor had become governor, March 29, I909, upon the death of Samuel G. Cosgrove. Progressive though the state Republican party was, the National Progressives organised, and nominated for governor Robert $\mathrm{T}$. Hodges. This break resulted in the election by a small plurality (97,25I to 96,629 for Hay; 77,792 for Hodges) of the Democratic candidate, Ernest Lister, although his campaign lasted only three weeks. The original nominee for governor on the Democratic ticket, Superior Court Judge W. W. Black of Everett, was held ineligible (October Io; State ex rel. Reynolds vs. Howell) by the supreme court of the state, because the constitution provides that supreme and superior court judges during their terms of office are ineligible for any but judicial offices. Republicans were elected to the other state offices and the state senate will be made up of $27 \mathrm{Re}-$ publicans, 9 Democrats and 6 Progressives, and the house of 50 Republicans, 18 Democrats, 28 Progressives and I Socialist (from Mason county).

In the national campaign there were only two county primaries and these were for Roosevelt; but the credentials of the delegates from King county were rejected by the state Republican committee. The national committee (June I5, I9I2) and then the convention followed the ruling of the state committee, reversed the action of the state convention which had chosen Roosevelt delegates-at-large, and settled all contests in favour of Taft. Although it was supposed that putting a state third party ticket in the field would hurt Roosevelt and that the strict affiliation pledge of the primary would turn many votes from Roosevelt to Taft, the state was carried by Roosevelt, who received II3,698 votes, to 86,840 for Woodrow Wilson, 70,445 for Taft, 40 , I 34 for Debs (r4,I77 in I908) and 9,8 Io for Chafin. Three Republicans and (at large) two Progressives were elected representatives in Congress. The former delegation was three, and the state was not re-districted.

The use of the recall in Seattle ${ }^{1}$ and Tacoma was the most notable incident in municipal history during I9II-I2. In Seattle Mayor Hiram C. Gill was recalled (charged among other things with connivance at vice) on February I I, I9 I r, by 3 I,9 I9 votes for George W. Dilling (who thus became mayor) to 25,705 for Gill, whose supporters had endeavoured to restrain the city by injunction from holding the recall election and had secured an order restraining the city comptroller from paying expenses of this election; but this order was over-ruled. Petitions for the recall of Dilling (because he had not dismissed the city jailer for cruelty) and of three councilmen were circulated, and the petitions for the recall of the councilmen were filed but were held insufficient, as containing names numbering only $25 \%$ of the vote for the individual councilmen instead of $25 \%$ "of the entire votes for all candidates for the office.". On December 3I, I9II two of these petitions were filed with additional names, but the corporation counsel, the city council and the courts held that they could not be refiled after an interval of ten days. On March 6, r912 George Fletcher Cotterill (b. 1865; civil engineer, landscape gardener, supporter of municipal ownership, assistant city engineer in 1892-1900, and Democratic candidate for mayor in 1900), was elected mayor by 32,085 votes to $3 \mathrm{I}, 28 \mathrm{I}$ for Gill. In November a petition was filed for the recall of Cotterill for general inefficiency.

In Tacoma Mayor A. V. Fawcett secured in rgro an " anti-treat " ordinance, making

${ }^{1}$ See F. W. Catlett (secretary to the mayor of Seattle), "The Working of the Recall in Seattle," in September 1912 Annals of the American Academy of Political and Social Science. 
It a misdemeanour for a bartender to sell to one person liquor to be drunk on the premises by another. This was sustained March 2I, I 9 II at a referendum election (and by the state supreme court), but meanwhile the city administration, attacked for permitting a vice district, contrary to state law, had made itself unpopular by enforcing a law against prize-fights. The reform element and the sporting element both favoured the recall. On April 4, a recall election was held, but A. H. Barth, Socialist, received so many votes that no candidate had a majority. At a second election, April 18, William V. Seymour was elected by II,222 votes to 10,489 for Fawcett. On May 2, an election was held for the recall of four commissioners; another election on May I6 was necessary for a choice, and then two councilmen were recalled and two retained in office. One of those recalled was re-elected at the next general election. In January rgr 2 Fawcett's friends attempted to recall Seymour, unsuccessfully.

Bibliography. - Session Laws, IOII (Olympia); official reports; C. A. Snowden, History of Washington; the Rise and Progress of an American State, 4 vols. (New York, I909); P. H. W. Ross, Western Gate (ibid., I9I I); and, on workmen's compensation, articles in the New York Independent, October 3, I912, and McClure's, December I912.

\section{WEST VIRGINIA ${ }^{1}$}

Population (I9I0) I,22I,II9; an increase of 27.4\% since I900. Foreign-born whites constituted $2.3 \%$ of the total in 1900 and $4.7 \%$ in I9ro; negroes $4.5 \%$ in 1900 , and $5.3 \%$ in I9ro; and whites of native parentage $88 \%$ in rgoo and 85.3 in roro. In density the state ranked I 5 th $(50.8$ per sq. m.). The rural population decreased from $78.5 \%$ in I 1900 to $70.5 \%$ in I9ro. The urban increased from $13.1 \%$ to $18.7 \%$; there were 228,242 inhabitants in 25 municipalities, each having more than 2,500 inhabitants ( 125,465 in I 6 such places in I900). There were I 2 places of 5,000 or more, as follows: Wheeling, 4I,64I; Huntington, 3I,I6I (II,923 in I900); Charleston, 22,996; Parkersburg, I 7,842; Bluefield, I I, I 88 (4,644 in I900); Martinsburg, ro,698; Fairmont, 9,7 I I ; Clarksburg, 9,20I; Morgantown, 9,I 50 (1895 in 1900); Moundsville, 8,918; Grafton, 7,563 ; and Elkins, 5,260 (2,016 in 1900).

A griculture.-The acreage in farms decreased from $10,654,513$ to $10,026,442$ between 1900 and 1910 , and the improved land in farms increased from $5,498,981$ to $5,521,757$; the average farm acreage fell from II 4.7 to I03.7, and the value of farm property increased from \$203,907,349 to $\$ 314,738,540$ ( $\$ 207,075,759$ land; $\$ 57,3$ I5, 195 buildings; $\$ 7,011,513$ implements; $\$+3,336,073$ domestic animals). Of the land area $65.2 \%$ was in farms in 1910 . The average value of farm land per acre was \$20.65. Farms were operated largely by owners $(75,978$ by owners, 872 by managers and 19,835 by tenants). In 1912 (preliminary estimates) the principal crops were: Indian corn, $24,505,000$ bu. (725,000 A.); wheat, 3,378,000 bu. (233,000 A.); oats, 3, I08,000 bu. (I I I,000 A.); rye, 22 I,000 bu. (I 7,000 A.); buckwheat, 888,000 bu. (37,0no A.); potatoes, $5,264,000$ bu. (47,000 A.); hay, I, 028,000 tons (745,000 A.), and tobac$\mathrm{Co}, 12,008,000$ lbs. (15,800 A.). In I909 (U.S. Census) the value of vegetables (excluding potatoes) was $\$ 4,519,894$; of small fruits, \$191,002; of orchard fruits, \$3,040, I92 (apples, $\$ 2,461,074 ;$ cherries, \$1II,043). On January I, 1912 there were on farms: 182,000 horses, 12,000 mules, 230,000 milch cows, 33I,000 other neat cattle, 838,000 sheep, and 363,000 swine.

In I9I the legislature created the office of state commissioner of agriculture and a state department of agriculture; the commissioner was first elected in 1912 for a four year term. The general appropriation act of 19 I I carried an appropriation of $\$ 5,000$ a year for the inspection of dairies; $\$ 7,500$ a year for the prevention of San Jose scale, and $\$ 4,000$ a year for the promotion of horticulture and truck-gardening.

Mineral Products. - Total value, I9I I, SIOI,948,248. The state ranked 2 nd in quantity of coal, $59,831,580$ tons, and 3 rd in value, $\$ 53,670,515$-these totals being less than in 1910. In natural gas it ranked Ist, $\$ 28,451,907$ (one-fifth more than in 1910; more than seven times as much as in I9O1), about one-third the totil for the United States. In petroleum the state ranked 4 th, with $9,795,464$ bbls. (\$12,767,293; less than in 1910$)$. The value of clay products was $\$+, 333,420$, of which $\$ 2,880,202$ was the value of pottery products, ranking the state 3rd. Sitone was valued at \$1,106,012; lime at $\$ 536,660$; sand and gravel at $\$ 532,388$, of which $\$ 313,758$ was the value of glass sand. The value of pig iron was not reported separately and is not included in the total given above, which however includes the value of iron ore.

Manufactures. - In 1904-09 the number of establishments increased from 2, 109 to 2,556 and that of persons engaged in manufacturing from 48,880 ( 43,758 wage-earners) to 71,463 $(63,893$ wagc-earners); capital invested from $\$ 86,821,000$ to $\$ 150,923,000(73.8 \%)$; and the

1 See E. B. xxviii, 560 et seq. 
value of products from $\$ 99,041,000$ to $\$ 161,950,000(63.5 \%)$. The largest manufactures in I909 were: lumber and timber, $\$ 28,758,000$ (largely yellow poplar and hemlock); iron and steel, steel works and rolling-mills, \$22,435,000; leather, tanned, curried and finished, \$I2,451 , 000; glass, $\$ 7,779,000$; flour and grist-mill products, $\$ 7,696,000$; coke, $\$ 7,563,000$, ranking the state 2 nd in output and 3 rd in value; and cars, built and repaired by steam railway companies, $\$ 6,733,000$. The principal manufacturing centres were: Wheeling, $\$ 27,077,000$; Huntington, \$6,5I I,000; Parkersburg, $\$ 5,498,500$; Charleston, $\$ 3,253,000$; Martinsburg, $\$ 2,515,500$, and Bluefield, \$1,465,000.

Transportation.-Railway mileage, January I, I9I2, 3,648.4I. The Federal government is improving the Little Kanawha river.

Legislation.-The regular session of the legislature was held from January in to February 24, and an extraordinary session May 16-30, I9II. The latter was called to pass a primary election law and to amend the corrupt practices act, especially so as to make it applicable to candidates for the United States Senate, but it passed nothing but appropriations for the expenses of the special session. The regular session submitted to the people, who approved it (164,945 to 72,603 votes), at the November general election in 1912 , a constitutional amendruent for state-wide prohibition (after July I, I9r4) of the sale and manufacture of alcoholic liquors as beverages. The legislature urged the state's congressmen to vote for an amendment to the Federal Constitution, providing for the direct choice of United States senators. The I 2 th of October (Columbus Day) was made a legal holiday. The office of state commissioner of public roads was abolished and the law of 1908 for the registration of voters was amended, especially in regard to the relation of county courts to registration.

The legislature appointed a commission to investigate employers' liability and workmen's compensation, and it submitted part one of an elaborate report late in I9I I. A child labour law permits children under I 6 to be employed only if an employment certificate is filed; children under I 4 to be employed during school hours only on permission of the state commissioner of labour or the county superintendent of schools, and not to be employed at all in any factory, mill, workshop, or manufacturing establishment.

A commission charter, much like the Des Moines plan, was adopted for Parkersburg, March 2I, I9I I, by 208 votes; and the Charleston charter was amended.

The law of 1909 creating a state fire marshal's department was amended by stricter rules for the investigation and report of fires. The sale of cocaine was forbidden except on a physician's prescription. The punishment for the white slave traffic was made imprisonment from six months to one year and a fine of $\$ 100$ to $\$ 500$, and for second conviction imprisonment in the penitentiary from one year to three years. It is no defence that part of the offences were committed outside the state, and marriage is no bar to the testimony of an injured woman.

Finance.-In I9I I the legislature required the assessment, at their true value, of stock in banks, trust companies, etc., and increased most licence taxes, especially those on theatrical and similar performances. A state board for the examination and certification of public accountants was created. The appropriation for the Virginia debt was $\$ 25,000$ for I9I I and the same amount for I9I2. The balance on hand in the treasury on October I, I9IO was $\$ 1,415,337$ and on October I, I9I2, \$I,6I6,515. The receipts during the two fiscal years were $\$ 10,870,901$, and the expenditures, $\$ 10,669,723$.

Education. - The state superintendent of schools called the work of the legislature of I9II "an educational renaissance." The qualifications for county superintendent of schools were increased and the salary was raised $\$ 200$ a year. A new law was passed in regard to teachers' examination and one for the formation of district high schools on the favourable vote of electors in any district and for the classification of high schools-class one for a four year course to receive state aid of $\$ 800$, class two, with three years course to receive state aid of $\$ 600$ and class three with a two years course to receive $\$ 400$ a year - the only limitation being that not more than $\$ 40,000$ is to be spent in this way in any one year. Medical inspection in public schools was made mandatory, in independent school districts; other districts were permitted to appoint medical inspectors. The legislature established, new county high schools in Clay county and in Nicholas county.

On the Ist of October I9II, Thomas Edward Hodges (b. I858) succeeded Daniel Boardman Purinton as president of West Virginia University, in which from I 896 to 1909 he had been head of the department of physics.

For the school year I9II-I2 the school population was 382,938 ; the enrollment in public schools, $284,28 \mathrm{I}$; the average daily attendance, I94,629; and the length of the average school year, 6.8 months. The total revenue was about $\$ 5,000,000$ and the expenditures $\$ 4,958,000$. The percentage of illiteracy in I9ro of the whole population ro years of age and over was 8.3 (II.4 in 1900): among the whites the percentage was 7.6 (10.3 in 1900); among the negroes, $20.3(32.3$ in 1900$)$. 
Penal and Charitable Institutions. - The legislature of I9I I established a state tuberculosis sanitarium and appropriated $\$ 15,000$ for its maintenance and $\$ 10,000$ for its equipment; it is to be at Terra Alta, Preston county. The West Virginia coloured orphans 'home near Huntington, was made a state institution, taking over the buildings of the normal industrial school for coloured orphans. The West Virginia children's home at Elkins was opened in 1911 . A law has been passed, providing that police matrons must be appointed in cities of 5,000 or more.

History.-The legislature in I9I I was Democratic (senate, I5 Democrats and is Republicans; house, 63 Democrats and 23 Republicans) but all state officers were Republicans. William Ellsworth Glasscock (b. I862), Republican, elected governor in 1908 for the term I909-13, immediately after the death of Stephen Benton Elkins, ${ }^{1}$ appointed his son Davis Elkins ad interim to the United States Senate. The Democratic caucus of the legislature chose, January I8, Clarence Wayland Watson (b. I864) for this unexpired term (IgII-I3), and William Edwin Chilton (b. I858; secretary of state I 893-97) to succeed Nathan Bay Scott (b. I842; Republican, senator I899-I9ri), but the Republican members of the state senate left the state to block organisation of the legislature, so that Watson and Chilton were not chosen until the end of the month.

Governor Glasscock was one of the seven governors who called Roosevelt to lead the Republican party, and Roosevelt was successful in the primaries, and the delegatesat-large were instructed for him. But there was no local split in the Republican party. l'rogressives nominated the Republican candidate for governor, Dr. H. D. Hatfield, and the six candidates for Congress, four of whom were elected; in the 62 nd Congress there were 4 Democrats and I Republican from the state. Hatfield was elected governor, receiving 127,942 votes to II9,I73 for Thompson (Democrat), and I5,248 for Hilton (Socialist). The state legislature is Republican (senate, tie; house, 53 Republicans and 33 Democrats) and early in I 9 I 3 chose Judge Nathan Goff (b. I 843 ) to succeed C. IV. Watson as United States senator. Woodrow Wilson carried the state, receiving about I I 3,046 votes to 56,667 for Taft, 78,8 I9 for Roosevelt and I 5,336 for Debs, whose vote in 1908 was 3,679 . In the state campaign interest was centred largely on the amendment for state-wide prohibition, which was carried; on election day bells in most Protestant churches were rung all day long to remind citizens to vote, and the women of the state worked hard for the amendment. The state Federation of Labor opposed it as destroying a great industry.

There was a long continued strike among the coal miners of the Kanawha region in I9I2. At Peyton a deputy was shot, troops being ordered out on July 23, and martial law proclaimed on September 30. Governor Glasscock's offer to arbitrate was refused by the strikers, September 26. Along Cabin Creek deputy sheriffs evicted striking miners, beginning October 8 , and although the governor issued a proclamation, October I $_{4}$, restoring to civil authority parts of Fayette, Raleigh and Kanawha counties, increased disorder made it necessary for him to declare martial law again (November I6) in the Cabin Creek and Paint Creek regions of the Kanawha coal field. Late in the year suit was brought for $\$ 750,000$ damages against the United Mine Workers for interference with business and for injuries to property.

A negro was lynched at Bluefields, September 5, I912, for assault on a woman.

Bibliography.-Acts, IOII (Charleston); other official publications, especially the state geological survey's Forestry and Wood Indusiries (I911); V. A. Lewis, ed., How West Virginia was made (Charleston, I909); D. Dandridge, Historic Shepherdstown (Charlottesville, 1910).

${ }^{1}$ Elkins was born in Ohio in 1840 , graduated at the University of Missouri, 1860, and began the practice of law in 1864 in New Mexico, where he was a member of the legislature in $1864-$ 65. territorial district attorney, attorney-general in 1868-69, and delegate to Congress in 1873-77. He then settled in West Virginia, where he married the daughter of Senator Henry ( iassiaway Davis (b. 1823; Democratic nominee for vice-presidency in 1904), became interested in coal-mining and railway developing and built the town of Elkins, Randolph county. He was secretary of war under l'resident Harrison, 1891-93. In the United States Senate, in which he sat after 1895 , he was a leader of the conservative Republicans, and was known as the sponsor of the Elkins Act or railway law of 1903. 


\section{WISCONSIN ${ }^{1}$}

Population (IgIO) 2,333,860 (I $2.8 \%$ more than in 1900); $77.5 \%$ were native whites $22 \%$ foreign-born whites, and $0.1 \%$ negroes. Density $42.2(37.4$ in 1900$)$ to the sq. $\mathrm{m}$. In $1910,57 \%$ lived in cities or towns of less than 2,500 inhabitants or in other rural territory $(61.8 \%$ in 1900). The cities of 5,000 or over were: Milwaukee, $373,857(285,315$ in 1900); Superior, 40,384; Racine, 38,002; Oshkosh, 33,062; La Crosse, 30,41 7 ; Sheboygan, 26,398; Madison, 25,53 ; Green Bay, 25,236; Kenosha, 21,37 I F Fond du Lac, I 8,797; Eau Claire, I8,310; Appleton, I6,773; Wausau, I6,560; Beloit, I5,I25; Marinette, I4,6 10; Janesville, I3,894; Manitowoc, I3,027; Ashland, I I,594; Chippewa Falls, 8,893; Watertown, 8,829; Waukesha, 8,740; Stevens Point, 8,692; Merrill, 8,689; Antigo, 7,I96; Beaver Dam, 6,758; Grand Rapids, 6,521; West Allis, 6,645; Baraboo, 6,324; South Milwaukee, 6,092; Menasha, 6,081; Marshfield, 5,783; Neenah, 5,734; Rhinelander, 5,637; Oconto, 5,629; Portage, 5,440; and Menomonie, 5,036.

Agriculture.-In I9I0, $59.6 \%$ of the state's area was in farms; I I ,907,606 out of $21,060,066$ acres were improved $(5.9 \%$ more than in 1900). The average number of acres in each farm was I 19; the average value per farm, $\$ 7,978$. The total value of farm property increased in I900-IO from \$8I I,7 I2,000 to \$I,4I3,II9,000 (land, \$9I I,938,000; buildings, \$289,694,000; implements and machinery, $\$ 52,957,000$; and domestic animals, $\$ 158,529,000)$. Of the farms 152,473 were operated by owners and managers and 24,654 by tenants. In 1912 (preliminary estimates) the crops were: hay, 3,600,000 tons (2,250 000 A.); oats, $84,746,000$ bu. $(2,272,000 \mathrm{~A}$.); Indian corn, $58,262,000$ bu. (1,632,000 A.); barley, $24,843,000$ bu. $(845,000$ A.); potatoes, $34,920,000$ bu. (29I,000 A.); rye, 6,240,000 bu. (34I,000 A.); wheat, 3,564,000 bu. (188,000 A.); tobacco, 54,438,000 1bs. (42,200 A.); buckwheat, 289,000 bu. (17,000 A.); sugar beets, 256,124 tons (23,24I A.); and flaxseed, I25,000 bu. (10,000 A.). In I 909 (U.S. Census) the value of vegetables other than potatoes was $\$ 4,593,865$; flowers etc., $\$ 592,839$; nursery products, \$30I,027; small fruits, \$765,437 (strawberries, \$434,97I; cranberries, \$127,212; raspberries, \$114,578); orchard fruits, \$2,087,202 (apples, \$1,896,$68 \mathrm{I})$; grapes, $\$ 25,537$, and nuts $\$ 18,196$. On January I, I9I2 there were on farms: 652,000 horses, I,504,000 milch cows, I,I I6,000 other neat cattle, 847,000 sheep, 2,05I,000 swine. In I9I I a state conservation commission was created; and the agricultural college was authorised to establish three demonstration stations.

Mineral Products. -Total value, I9II, \$12,45I,436 including 559,763 tons of iron ore, valued at $\$ 1,386,616$, but not including 245,152 tons of pig iron $(\$ 3,803,049)$. The output of zinc was one-seventh larger than in 19ro, being 31,809 tons, valued at $\$ 3,626,226$; and that of lead at $\$ 357,030$. Stone was valued at $\$ 2,375$, I02 (granite $\$ 1,382,309$; limestone, $\$ 848$,$363)$; sand and gravel at $\$ 73 \mathrm{I}, 692$; lime at $\$ 96 \mathrm{I}, 558$, and clay products at $\$ \mathrm{I}, \mathrm{I} 58, \mathrm{I} 39$, almost entirely brick and tile. Mineral waters, mostly table water, bottled at 3I springs, including 4 resorts, were valued at $\$ 955,988$. Minor items were metallic paint, asbestos, graphite, etc.

Manufactures.-In I904-09 the number of establishments increased from 8,558 to 9,72 I, and that of persons engaged in manufacturing from 173,572 to 213,426 (wage-earners from I II,391 to I82,583); capital invested from $\$ 412,647,000$ to $\$ 605,657,000(46.8 \%)$; and the value of products from $\$ 41 \mathrm{I}, \mathrm{r} 40$, 000 to $\$ 590,306,000(43.6 \%)$. The state ranked 8 th in value of manufactures. In I 909 the principal manufactures were: lumber and timber, $\$ 57,969,000$; 'foundry and machine-shop products, $\$ 54,124,000$; butter, cheese and condensed milk, $\$ 53,843,000$; leather, $\$ 44,668$, o00; malt liquors, $\$ 32$, I26,000, ranking the state 4th in this industry; flour and grist-mill products, $\$ 31,667,000$; slaughtering and meat-packing, $\$ 27,217,000$; paper and wood pulp, $\$ 25,962,000$; furniture, $\$ 18,656,000$; cars, construction and repairs by steam railways, $\$ 14,332,000$; boots and shoes, $\$ 13,602,000$; automobiles, $\$$ I I,440,000 (more than six times as much as in 1904); agricultural implements, \$I I, II I,O00; and iron and steel from steel works and rolling mills, \$10,733,000.

The larger manufacturing cities were: Milwaukee, \$208,324,000, Ioth manufacturing city in the United States, 3 rd in malt liquors $(\$ 19,643,000)$ and Ist in leather $(\$ 27,484,000)$; Racine, $\$ 24,673,000$, principally agricultural implements, automobiles, and carriages and wagons; Kenosha, \$23,182,000, mainly leather, furniture and automobiles; Oshkosh, \$14,$739,25^{\circ}$, chiefly lumber and timber and matches; La Crosse, \$ I $4, \mathrm{IO}_{3}, 000$; largely from flour mills and breweries; and Sheboygan, \$I I,299,000, mainly furniture and leather.

Transportation.-Railway mileage, January I, I9I2, 7,859.I5 (20I.57 m. more than a year before, the largest increase in any state, - due to the building of $130 \mathrm{~m}$. of "cut-off" by the Chicago \& Northwestern). The Federal government in July I9II with the local authorities, began the improvement of Oconto harbour.

Legislation.-The legislature met in regular session from February i 7 to July I 9 I I and in special session on April 30, I9I2. It ratified (May 26, I9II) the proposed I6th

'See E. B. xxviii, 740 et seq. 
amendment to the Federal Constitution providing for a Federal income tax, and asked Congress to call a constitutional convention to submit an amendment providing for amendment by initiative, and one providing for the initiative, referendum and the recall; also to give Alaska a recognised Territorial government. In November Igr 2 the people approved amendments to the state constitution making 50 years instead of 20 the limit for paying off municipal indebtedness, if the indebtedness is for land bought by cities or counties having a population of 150,000 or more $(46,369$ votes to 34,975$)$; and giving the state, or any city, power to acquire land for public purposes and sell land thus acquired, if it is not needed, with restrictions for its future use $(48,424$ to 33,93 I votes). A measure giving the suffrage to women and taking it away from unnaturalised aliens (who have merely declared their intention to become citizens) after December I, I91 2 was defeated by 227,024 votes to I35,545, probably because of the opposition of the conservative Scandinavian and German elements. Under an amendment ratified in Igro the state was redistricted into congressional and legislative districts in IgIr.

A law of I9II provides for second choice nominations. ${ }^{1}$ No candidate for a judicial or school office is to be nominated or elected on a party ticket nor is any designation of a party or the principles represented by the candidate to be used in the nomination or election of a candidate for such an office. The method of rotation of names on ballots was specified. There is to be an alphabetical arrangement in the most populous district; in ballots for the second district in population the first name alphabetically is to be moved to the last place on the list, and this process is to be repeated for the ballots for each district going down the scale of population. A law provides for an official ballot for the election of candidates for national conventions, and another provides that ballots for presidential elections are to be printed on light blue paper, for referendum votes on pink paper, and for state, municipal and county offices on white paper-the arrangement being by party columns with circles so that a straight ticket may be voted - and that sample ballots be printed on paper different in colour from any official ballots. Each county may vote to adopt or discontinue the coupon ballot. The law of 1907 for the direct choice of delegates to national party conventions was supplemented by a provision for a presidential preference primary.

A new corrupt practices act was passed in I9I I and amended in 1912. Disbursements of candidates are strictly limited to certain classes of expenditures and also in amount-e.g. $\$ 7,500$ for a candidate for the United States Senate and \$150 for state assemblymen. The secretary of state is to send to all voters publicity pamphlets, in which candidates for different offices may secure space at specified rates. A state board of public affairs (whose members serve without salary) was created in I9I I; it is authorised to supervise and inspect "public bodies, to carry on investigations, to make estimates and recommendations for public expenditures," and if necessary to employ experts. In $1911-12$ the board investigated the state school system, especially in rural districts, the auditing of accounts of public institutions, the methods and amounts of state appropriations, - especially the advisability of "continuing appropriations"-immigration, municipal markets, the marketing of agricultural products and the efficiency of state departments. In I9I2 it published a report on agricultural co-operation. A new corle for public printing was adopted in I9II.

First class cities were authorised to have art commissions ${ }^{2}$ and boards of police and fire commissioners; and to employ a city forester. A new code was passed for the government of cities of the second, third and fourth classes under the commission plan. The term of the mayor is six years and no one holding a licence for the sale of intoxicating liquors is eligible. The act provides for initiative, referendum and recall of officers. Other acts provide that any municipal officer, whether under the commission form of government or not, may be removed by recall after six months in office and give the people the right of initiative and referendum on acts of municipal councils and boards of county supervisors. By a resolution of the common council or by a petition of $10^{\circ}$ of the voters of the city, an election may be called for an amendment to a city charter, and the law provides also for a charter convention composed of fifteen delegates elected at large which may draw up a charter subject to the ratification of the people. This "home-rule" act was held unconstitutional, Nay I4, 1912, by the state supreme court. ("ities of the first class are authorised'to build public lavatories and to regulate and prohibit emission of dense smoke in city limits or one mile therefrom.

${ }^{1}$ This law resembles the law in Tasmania in that it gives a greater value to first than to second choice; if no candidate receive's a majority of the first choice votes, the candidate who has the least number of first choice votes is to be dropped and the second choice votes are then to be added to the first choice for all other candidates, this process being repeated until some one candidate has a majority of votes.

2 John Nolen, a Biston landscape architect, in Madison: a Model City (Boston, I911), planned the remodelling of the capital city. 
Wherever there is urban postal free delivery, express companies must deliver free any intra-state shipments by express. Railway corporations are liable for damages by fire from locomotive engines, and engines operated in forests and bush lands must have spark arresters. The railway commission may order any railway to adopt block signals.

It is unlawful for a physician to prescribe intoxicating liquor unless it is necessary for the health of a patient, or to prescribe more than is necessary, under penalty of a fine of \$Io to \$IOO or six months' imprisonment and for a second offence within one year the revocation of the 'doctor's licence. Liquor must not be sold or given away at public auctions; public drinking of intoxicating liquors on railway trains is forbidden, and no intoxicated person is to be allowed on a railway coach. In liquor sale prosecutions the possession of a Federal licence is prima facie evidence of guilt. Stricter laws were passed for the sanitation of bakeshops; against the colouring and adulteration of canned goods and for the protection of food products displayed for sale; dry goods, groceries, clothing and hardware stores are not to be opened on Sunday. The manufacture and sale of certain fireworks and of fire crackers more than three inches long and one-half inch in diameter were forbidden. Pandering was made punishable by imprisonment for from 2 to 20 years; the act permits the testimony of an injured woman, even though she be married, and makes it no defence that a part of the acts forbidden by the law were committed outside the state.

A law in effect on September I, I9I I (held consti? utional by the state supreme court on November 14, I9II) provides for compensation for accidents to workmen but is not compulsory except for the state and municipalities; it applies to all industries but not to casual employees. The employer's choice of compensation must be made in writing. The employee's choice is presumed after the employer has elected compensation. The defence of assumed risk and of fellow service (if there are four or more employees) is abrogated. Suits for damages are not permitted if the employer chooses compensation. There is no reduction in liability because of special contract. Disability must last more than one week to be compensated. ${ }^{1}$ For the death of an employee the compensation is $\$ 100$, if no dependents are left, otherwise four years' earnings-not less than $\$ 1,500$ nor more than $\$ 3,000$, - and this is the limit for compensation for total disabilities; $65 \%$ of the average earnings, if a nurse is required, but $100 \%$ after 90 days; for' partial disability the compensation is $65 \%$ of the wage decrease. Medical and surgical aid are to be paid for, if they last 90 days or less. Disputes are to be settled by an industrial commission, which is empowered besides to establish free employment agencies and to enforce other labour laws. Employers are required to install and maintain safety devices and the exercise of ordinary care is not a sufficient compliance with the law. The law for the safe-guarding of machinery was made explicit. A law was passed against false representation in the employment of labour especially as to the existence of strikes or labour disputes. The industrial commission is to investigate contracts of employment. Contracts for public work must stipulate an eight hour day, except in "extraordinary emergency" which is limited to protection of life or property. Illiterates under I4 are not to be employed; children between 14 and 16 , if employed where there is an evening or continuation school, must attend five hours a week during six months of each year, and their employers must allow a reduction in hours if school and working hours coincide. The age limit for selling newspapers was raised from Io to 12 for boys and from 16 to 18 for girls; for other street trades, from I 2 to 14 for boys and from I 6 to 18 for girls. No boy under 16 may work at a street trade without a permit issued by the state factory inspector, showing school attendance. Boys under I4 may not sell newspapers after 7.30 P.M. in summer or 6.30 P.M. in winter-formerly IO P.M. all the year. Employment in bakeries, restaurants and messenger service was added to trades at which children under 16 should not be employed "required, suffered or permitted to work" - the words in quotation being additional to the previous law-without a written permit. To the list of dangerous occupations in which children under 18 may not be employed were added mining and quarrying. Children under 16 may not work more than 8 hours a day or 48 hours a week (formerly io hours a day and 55 a week), nor may they do night work after 6 P.M. - formerly 9 P.M. Women may not work in manufactories, mechanical or mercantile establishments, laundries or restaurants, confectionery stores, telephone or telegraph offices, with express or transportation companies, more than Io hours day or 55 a week in the day time, nor more than 8 a day or 48 a week, between 8 P.M. and 6 A.M. Night work for one day in a week makes the whole night work under the law. All physicians must report to the state board of health cases of occupational diseases -including lead poisoning and "caisson disease," but not mentioning anthrax, as do similar laws in other states.

Finance.-The joint commission of the legislature on finance was authorised to employ trained experts in accounting and in making public financial statements. An important income tax law was passed in I9II and. was declared constitutional by the state supreme court on January 9, I912. It allows for certain deductions from the gross income such as losses sustained and not insured, taxes on the source of income, interest on bonds exempted from taxation, and salaries and pensions from the United States. Corporations are taxed on their incomes by a scale according to the percentage that the income bears to the assessed

${ }^{1}$ If it lasts more than four weeks the compensation must include the first week. 
valuation. If the income is less than $\mathrm{I} \%$ of the assessed value, the income tax is $1 / 2 \%$ and if the income is $12 \%$ of the assessed value, the tax is $6 \%$. The income tax on individuals is $\mathbf{I} \%$ on the first $\$ \mathbf{I}, 000$ of income, and an additional $1 / 4 \%$ on every extra thousand up to the fifth thousand for which the tax is to be $2 \%$ and an additional $1 / 2 \%$ on each extra thousand up to $\$ 12,000$, so that the tax for $\$ 12,000$ or more is $6 \%$. Exempt from the tax are $\$ 800$ income for an individual, \$1,200 for husband and wife and \$200 additional for each child under 18 or each dependent person.

On June 30 , I9I0 the balance on hand in the general fund was \$I,559,988; on June 30 , $1912, \$ 3,161,512$. The receipts for the two years were $\$ 27,868,781$ and the disbursements $\$ 26,267,256$. The state debt, on June 30 , 1912, was \$2,251,000.

Education.-In I9I I a state board of industrial education was created, composed of six members, three being employers and three skilled employees. The state is to appropriate not more than $\$ 10,000$ to any industrial school and is to give this grant to not more than 30 schools. The board is to have charge of this fund and is to act as a trustce of the Stout Institute in Menomonie (opened 1908). No state aid is to be given to any school for vocational teaching unless teachers in these subjects receive at least $\$ 60$ a month. School boards may levy ${ }_{10}^{3}$ of a mill as a tax for trade schools. The law for teachers' pensions in cities of the first class was slightly amended so that if teachers do not elect to come under the act at the beginning of their service they may do so later on by paying what they would have paid with compound interest; and a law for retirement of teachers elsewhere than in first class cities created an insurance and retirement fund to be managed by a board of five. The fund is to be created by assessments for 25 years, I \% a year (not more than \$I5) for the first 10 years, and $2 \%$ a year (not more than $\$ 30$ ) for the next 15 years; and all who become teachers after September I, I9I I agree thereby to the assessment. Other teachers may elect to come under the provisions of the act before September I, I9I2. From the 7 mill tax for educational purposes the state treasurer is to set aside IOc for every person of school age for the retirement fund. Any teacher leaving the service may have half of the amount paid in. Teachers retired are to receive per annum $\$ 12.50$ for each year of service but in no case more than $\$ 450$.

On the petition of one-half of the voters of the school district a school house may be used for meetings of non-partisan, non-sectarian and non-exclusive associations.

The tax for the university was $\frac{3}{8}$ of a mill and for the normal schools $\frac{1}{6}$ of a mill. A high school in connection with the University was opened in the autumn of 1912. In October 1912 the General Education Board gave \$40,000 to Lawrence College, Appleton.

For the year ending June 30 , I912 the school population was 775,472 , the total enrollment, 435,6II, and the average length of school year, I 70 days. The total revenue for schools was $\$ 13,041,600$ and the expenditures $\$ 12,475,349$.

In 1910 of the population 10 years and over $3.2 \%$ was illiterate ( 4.7 in 1900).

Charitable and Penal Institutions. - County boards of supervisors with the consent of the state board of control may maintain tuberculosis hospitals and in county asylums for the insane a hospital or pavilion may be built for the tuberculous insane. A uniform system of accounting is to be introduced in asylums for the chronic insane. On the grounds of the state prison there is to be erected a hospital for the criminal insane. The law provides for a probation officer in any county having 250,000 inhabitants or more. In I9I I $\$+00,000$ in two annual instalments was appropriated for the revolving fund of the binder twine plant at the state prison at Waupun. The new plant went into operation in November I9I2, with an equipment sufficient to employ 100 convicts and produce $15,000 \mathrm{lbs}$. of binder twine a day.

History.-In I91 I-I 2 the state government was Republican of the progressive type. The senate contained 27 Republicans in a membership of 33 and the assembly 50 in a membership of roo; there were 2 Social Democrats in the senate and $\mathrm{I} 2$ in the assembly. The legislature re-elected (January 24, I9I I) to the United States Senate Robert Marion La Follette (b. 1855), a progressive Republican who had been a representative in Congress in $1885^{-9} \mathrm{I}$, and as governor in Igor-6 had worked for direct election of senators, state control of railway rates and taxation of railway property. IIe was a candidate in I9 2 for the Republican nomination for the presidency and sharply criticized the policies of both Roosevelt and Taft. His physical breakdown, on February 3. induced many of his followers to support Roosevelt, but he re-entered the campaign on March I.3 and six days later carried the state-wide primary in North Dakota (q.v.). In the Wisconsin primaries (April) he defeated Taft by $\mathrm{I} 33.354$ to $47,514,-$ Roosevelt 628 . Twenty-three delegates from the state were instructed for him, and in the national convention ' he received $4 \mathrm{I}$ votes. In the campaign he spoke against Roosevelt in New Jersey and elsewhere. The other senator from Wisconsin is Isaac Stephenson (b. I829), a wealthy lumberman, who represented the state in

${ }^{1}$ Governor IIC Covern was the Progressive candidate for temporary chairman of the Republican convention and received 502 votes to 558 for Senator Elihu Root of New York. 
Congress in $1883-89$ and was chosen in 1907 for the unexpired term of John Coit Sponner (b. 1843; Republican; senator, I885-91 and I897-I907), who resigned. Stephenson was re-elected in 1909 for the term ending I9I5, but it was charged that his election was secured by corruption. La Follette's followers were hostile to Stephenson, although the latter had been a patron of La Follette in his early career; and the state legislature of I9II urged the investigation of the charges against him. The United States Senate ordered an investigation on August I2, I9II, and on February IO, I9I 2 its special committee exonerated him, although it found that he had spent \$100,000 for his election. The Senate adopted this report by a vote of 40 to 34 , March 27 , I9I 2.

In the state campaign there was no separate Progressive ticket, but the Progressives supported Francis Edward McGovern (b. I866), governor in IgI I-I3, renominated at the Republican primaries (September 3 ) and re-elected. His Democratic opponent was Judge John C. Karel, chosen in the primaries $(48,238$ to 36,975$)$ over Adolph J. Schmitz, who had Bryan's backing and favoured the state income-tax law, which Karel disapproved: Karel received I67,316 votes; McGovern, I79,360. The next legislature will be Republican by a small margin in each house. There will be one Socialist in the senate (elected in I9I0) and 6 Socialists in the lower house, elected in I9I2. Woodrow Wilson carried the state, receiving 164,228 votes to 130,695 for Taft, 62,460 for Roosevelt; 33,48I for Debs (who had 28, I 70 in 1908) and 8,526 for Chafin. The comparatively small vote for Roosevelt was due in part to La Follette's attitude toward him and in part to the conservatism of the Scandinavian voters of the state. The Socialist vote, though absolutely large, was comparatively small, and Victor L. Berger (b. I860), representative in $\mathrm{I}_{\mathrm{III}} \mathrm{I} \mathrm{I}_{3}$ from the 5 th district (and the first Socialist to sit in the Federal House of Representatives), was not re-elected. There was a complete re-districting of the state, although the Congressional apportionment was unchanged, apparently in an effort to confine the Socialist strength to one district; and Republicans and Democrats united in a non-partisan nomination against the Socialists in two districts in Milwaukee county, where, although the McGovern Republicans made a third nomination, three non-partisan state senators and $\mathrm{I}_{3}$ non-partisan assemblymen (out of 19) and the two non-partisan nominees for Congress were elected. The rest of the state chose 3 Democrats and 6 Republicans as representatives in Congress. The Socialists in Milwaukee had suffered a defeat in April I9I I, partly losing control of the city, and this loss was increased in November.

The commission form of government was adopted in Janesville (January 23, I9I2 and in Menomonie (January 29) and went into effect in each city on April r6, I9I2. Portage, Rice Lake (February 6; 45 I to I65; in effect April 23) and Superior (January 23; I,59 I to I,390; in effect April 23) also adopted the commission government in 1912.

Bibliography.-Session Laws, IgII and IgI2, 2 vols. (Madison); J. B. Winslow, The Story of a Great Court, - the state supreme court-(I912); F. C. Howe, Wisconsin: An Experiment in Democracy (I912); C. M. McCarthy, The Wisconsin Idea (1912); Charles B. Cory, The Mammals of Illinois and Wisconsin (I912).

\section{WYOMING. ${ }^{1}$}

Population (1910) 145,965; an increase of $57.7 \%$ since I900. Density I.5 to the sq. m. Foreign-born whites were $18.6 \%$ of the total ( $17.9 \%$ in I900); native whites of native parentage $55.3 \%(51.8 \%$ in 1900$)$. In 7 places, each with more than 2,500 inhabitants, there was $29.6 \%$ of the total $(28.8 \%$ in 3 such places in 1900). The purely rural population was $55.1 \%(57.4 \%$ in I900). Incorporated places of 2,000 or more were: Cheyenne, II,320; Sheridan, 8,408 (I,559 in 1900); Laramie, 8,237; Rock Springs, 5,778; Rawlins, 4,256; Casper (town), 2,639 (883 in I900); Evanston (town), 2,583; Douglas (town), 2,246 (734 in 1900).

Agriculture.-The acreage in farms increased from $8,124,536$ to 8,543 , 0 ro between 1900 and I9IO, and the improved land in farms from 792,332 to I,256,I60; the average farm acreage fell from $1,333.0$ to 777.6 and the value of farm property increased from $\$ 67,477,407$ to $\$ 157$, I89,08I ( $\$ 88,908,276$ land; $\$ 9,007,001$ buildings; $\$ 3,668,294$ implements; $\$ 65,605,5$ IO domestic

${ }^{1}$ See E. B. xxviii, 873 et seq. 
animals). Of the land area $13.7 \%$ was in farms in 1910. The average value of farm land per acre was $\$ 10.4$ I. Farms were operated largely by owners $(9,779$ by owners; 3 I I by managers; and $897^{\circ}$ by tenants). In 1912 (preliminary estimates) the principal crops were: Indian cotn, 368,000 bu. (16,000 A.); wheat, $2,18 \mathrm{I}, 000 \mathrm{bu}$. (76,000 A.); oats, 8,569,000 bu. $(205,000$ A.); barley, 374,000 bu. (I I,000 A.); rye, 57,000 bu. (3,000 A.); potatoes, I, 540,000 bu. (I I,000 A.); and hay, 859,000 tons $(452,000$ A.). In I 909 (U.S. Census) the value of vegetables other than potatoes was $\$ 332,120$; of flowers and plants, $\$ 12,280$; of nursery products, $\$ 1,680$; of small fruits, $\$ 13,984$; of orchard fruits, $\$ 39,774$ (apples, $\$ 37,580$ ). On January I, I912, there were on farms: I59,000 horses, 2,000 mules, 35,000 milch cows, 568,000 other neat cattle, 4,969,000 sheep and 43,000 swine.

The total acreage irrigated in I 909 was $1,133,302$ (87.1\% more than in 1899$)$; of this total I, I I 3,774 were supplied from streams. The total cost of irrigation enterprises to July I, I9IO was $\$ 17,700,980$, and the estimated final cost of improvements begun was $\$ 20,425,890$. Of cereals $59 \%$ by acreage was grown on irrigated land in 1909 , and of oats, $61.5 \%$; of wheat, $62.7 \%$; of barley, $58.2 \%$; of alfalfa, $95.3 \%$; of wild, salt, or prairie grasses, $78 \%$, and of sugar beets, 93.I \%. The Shoshone irrigation project (Park county; see E. B. xxviii, 875a) of the Federal Reclamation Service was $50.7 \%$ completed in November 1912 and in I9I I irrigated 14,580 acres, mostly in alfalfa and cereals.

In 19 II the legislature created a board of farm commissioners, which is to appoint a director of experiments in dry farming. The legislature appropriated $\$ 15,000$ for the Wyoming State Fair; \$2,000 for horticultural experiments at the farm near Lander, and $\$ 8,000$ for agricultural experiments on the farm at Cheyenne.

Mineral Products. - Total value, I9II, \$II,486,982. The great item was coal, $6,744,864$ tons $(\$ 10,508,863$; one-tenth less than in I910). The production of natural gas, from Bighorn county mostly, and of petroleum (Uinta, Bighorn, Fremont, Natrona and Johnson counties) was greater than in 1910, but was not reported definitely. The marketing of soft asphalt from Lander began in 1912. The metal output was unimportant: gold, \$2I,300 (six times as much as in 1910), principally from Fremont county; silver, 700 oz. Copper concentrates containing platinum and palladium were shipped in I9I I from the New Rambler mine, 32 $\mathrm{m}$. W. of Laramie. Phosphate rock has been found in the S.W. part of the state; and the potash bearing rocks of the Leucite Hills, estimated to contain $197,000,000$ tons of potash, are a possible source of potash salts for fertiliser.

Manufactures. - The factory products for I 909 were valued at $\$ 6,249,000,77.4 \%$ more than in 1904 . The capital invested was $\$ 6,195,000$ (129.8\% more than in 1904 ) and the number of persons engaged in manufacturing, 3,393 (56.9\% more than in 1904$)$. The principal manufactures were: cars and general shop construction and repairs by steam-railway companies, \$2,337,000; lumber and timber products, \$751,249; and flour and grist-mill products, $\$ 746,000$. Cheyenne had factory products valued at $\$ 1,577,023$.

Transportation.- Railway mileage, January 1, 1912, 1,704.09. The most important recent construction is that of the Chicago, Burlington \& Quincy from Billings, Montana, to the S.E. to join the Colorado Southern at Orin Junction; this is now completed for about $200 \mathrm{~m}$., to Thermopolis.

Legislation.-The legislature met from January io to February $\mathbf{1} 8$, r91 r. It submitted to the voters for their approval at the general election in Igr 2 a constitutional amendment providing for the initiative and referendum both in regard to statutory provisions and constitutional amendments. This received 20,579 votes to 3,446 against, but 2 I,I 49 were necessary to adopt. The legislature asked Congress for 2,000,000 acres of public lands to be used for the creation of a state public road fund; for pensions for soldiers in the Indian wars of 1865 and 1883 ; for the withdrawal of "monopolistic" concessions in Yellowstone Park; for 'assistance in the maintenance of big game in the state (for which $\$ 5, \infty 00$ was appropriated by the legislature); and for the removal from national forests and other reservations of land which would be considered of benefit to settlers.

A direct primary law was passed, which included in its provisions nominations for United States senators. Party ballots are to be on different coloured paper, Republican on white, Democratic on blue and third party on green. An elaborate corrupt practices act limited nominations and election expenses cach to $20 \%$ of one year's salary in the office sought. 'This limit does not include travelling expenses and no matter what the salary in the office sought the expense is not to be limited to an amount less than \$10o for every campaign. Services for hire and contributions by corporations are forbidden. Candidates must make statements of expenses twenty days after election, primary or general, and a committee chairman after the general election. The secretary of state is required to prepare a primary pamphlet and a candidate may have space therein by paying a specified sum. Besides this the secretary of state is required to put out a pamphlet for general election in which political parties may buy space at the rate of $\$ 50$ a page. A new ballot law was passed 
which provides for party columns but includes no party circle and therefore provides no way for voting a straight ticket. There is a blank space left below the name of each candidate in which the voter may insert the name of the candidate for whom he wishes to vote. A new general election law also was passed.

The legislature passed a pure food and drug law and created the office of state chemist. Unfair competition and discrimination in prices within the state were prohibited.

The legislature created the following counties: Platte from the N.W. part of Laramie county; Washakie from the S.E. part of Big Horn county; Hot Springs from the S.W. part of Big Horn; Goshen from the N.E. part of Laramie; Campbell from the W. part of Crook and Weston; Niobrara from the E. part of Converse, and Lincoln from the N. part of Vinta.

An act was passed providing for commission government in first class cities, in special charter cities above 10,000 and in cities and towns of 7,000 inhabitants or more. The question of adoption is to be submitted to the people on the petition of $15 \%$ of the qualified electors. If it is defeated it is not to be re-submitted for two years and then only on petition signed by at least $25 \%$ of the qualified electors. There are to be a mayor and two commissioners to be chosen for a two year term and to be nominated by primary. The mayor has no veto power. The commissioners are authorised to act as police judges. The city government must make monthly statements of expenditures and receipts. The act provides for the recall of municipal officers and for the initiative and referendum. To the close of 1912 only Sheridan had adopted this form (election August I, I9I I; in effect January I, I9I2).

Finance.-In I9I I a new act was passed for the government of the state board of equalisation. Mortgages were exempted from taxation. Banks are to be taxed on all property, moneys, credits and assets but not on capital stock. A state board of accountancy was created to examine and certify public accountants. On September 30, I9I0 the balance in the treasury was $\$ 800,393$; and on September $30,1912, \$ 1,185,048$, and the state debt, \$ I I 7,000. Receipts for the two years were \$2,247,971; expenditures, \$1,863,3 I 7.

Education.-Poll taxes for the educational fund are to go to the county in which they are collected; \$I 50 from the general fund is to be distributed for each teacher in a district and the remainder of the fund goes to the districts pro rata, according to a law passed in I9I $\mathrm{I}$.

In I9IO $3.3 \%$ of the population Io years and over was illiterate (4\% in I900).

For the school year the school population was 35,786 ; the number enrolled in public schools, 26,502; the school funds received, $\$ 1,243,643$, and the expenditures, $\$ 1,003,207$.

Penal and Charitable Institutions. - In I9I I a state commission on prison labour, consisting of the state board of charities and reform and the warden of the penitentiary, was created; it is to supervise the employment of all prisoners in behalf of the state. A system of seven public highways was established and their construction was placed under the supervision of this commission, which was authorised to use convict labour. County commissioners and city authorities are required to co-operate in the expense of these highways. The legislature established the Wyoming Industrial Institute and Reformatory, for which a site at Worland was chosen by popular vote at the general election in 1912.

History.-In I III-I 2 the state officers were Democrats, except the superintendent of public instruction. The governor for I9II-I5, Joseph Maull Carey (b. I845), was Democratic Territorial delegate in Congress $1885^{-90}$, where he introduced the Wyoming statehood bill, Unites States senator in $1890^{-95}$, and author ( 1894 ) of the Carey reclamation law (see E.B. xiii, 640; xx, 244). The state legislature in I9I I was Republican ( 19 in senate and 29 in house to 8 Democrats and 27 Democrats, respectively), and it re-elected Clarence Don Clark (b. I86I; Republican; representative in Congress, I889-93) to the U.S. Senate, in which he had served since I895.

The other United States senator was Francis Emroy Warren (b. I 844), Territorial governor I $885^{-86}$ ad I 889-90, first governor of the state, I 890 , and United States senator since 1890 . His term ends in 1913 , and the campaign in I 12 centred on his re-election, his Democratic rival being John B. Kendrick. The new state legislature has a small Republican majority (about 3 on joint ballot), and on January 28, I9ז3, it reelected Warren. He controls the Republican "machine" in the state, which was for Taft. The state Republican convention instructed delegates for Taft, and in the election he ran second (I4,560 votes) to Wilson (I5,3 ro votes) Roosevelt received 9,232 votes, Debs 2,760 (I,7 I5 in I908), and Chafin 434. A Republican congressman was elected by a plurality of 4,4 IO over the Democratic candidate.

On October 2, г9г a negro convict in the state penitentiary at Rawlins who had assaulted a woman 89 years old was hanged by some of his fellow convicts. On October I 2, 20 convicts escaped from the penitentiary, but all except 3 were recaptured.

On July 26, I9r 2 died William Alford Richards (b. I 849 ), state surveyor-general in $1889-93$, governor in $1895^{-99}$ and commissioner of taxation after I909. 
ALASKA ${ }^{1}$

Population.-In 1910, 64,356 (1.2\% more than in 1900); 36,347 whites; 28,000 natives. Density of white population, about I to $16 \mathrm{sq} . \mathrm{m}$. In the decade $1900-10$ there was a decrease of Indians and Chinese and an increase of whites. There were no incorporated places in 1900 so that comparison for places of the same name in 1900 and I0 Io as given in the I3th Census Bulletin on Alaska is misleading, the former being for districts, the latter for smaller, incorporated areas. ${ }^{2}$ The incorporated places in I910 were: Chena, pop. I38 (native village, 47); Cordova, I, I52 (district, I,779; 173 in I900); Douglas, I,722 (825 in 1900); Eagle, I78 (district, 543; 383 in 1900); Fairbanks, 3,54r; Haines, 445 (85 in I900); Iditarod, incorporated in I9I $\mathrm{I}$; the capital, Juneau, I,644 (district, 5,854; 3,664 in I900); Ketchikan, I,613 (459 in I900); Nome,

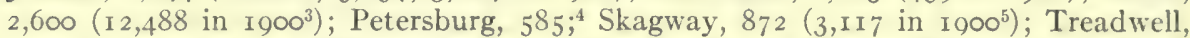
1,222 ( 522 in 1900 ); Valdez, 8I0 (3I 5 in 1900 ), and Wrangell, 743 (district 1,$067 ; 868$ in Ino0). Seward, incorporated in I912, had 534 inhabitants in I910. There are five forts: Fort Wm. H. Seward, 255, near Skagway; Fort Davos, 180, near Nome; Fort Liscum, I62, near Valdez; Fort Yukon, 321, at the junction of the Yukon and Porcupine rivers, and Fort Egbert, I 98, near Eagle. The total population of the Aleutian Islands (see E. B. i, 543) was 1,083 .

A griculture. - The experiment station in $191 \mathrm{I}$ and 1912 was experimenting with hybrid strawberries, crossing cultivated varieties with the wild native berries; with spring grains, especially beardless barley and oats to mature in 90 days or less; with Siberian alfalfas to secure a nitrogenous fertiliser; and, at Kodiak, with milch cows suitable for Alaska. The Fairbanks station is conducted as a model farm. Besides the headquarters station at Sitka, there is a station at Rampart. James Wilson, U.S. secretary of agriculture, prophesies that Alaska will soon supply American farmers with superior cereal seeds. The Tanana Valley: is par excellence the agricultural region of Alaska and except for a slight disadvantage in climate seems to compare favourably with farming land in Norway, Sweden, Finland, and the Russian provinces of Archangel, Vologda and Olonets. In I9Io there were 222 farms with $42,5+4$ acres (2,660 improved); value of farm property, $\$ 1,468,402$. The largest crop (I 909 ) was vegetables, \$186, I34; hay and forage were valued at $\$ 94,933$.

Fauna.-National Bird Reservations were created on Forrester Island and on Hazy Islands by executive orders of January 11, 1912. Four others (Bering Sea, Tuxedni, St. I azaria and Yukon Delta) were set aside in 1909, when a moose reservation was created on Fire Island, in Cook Inlet. There are also two fishery reservations (Yes Bay and Afognak Island) and a fur-seal reservation on the Pribilof Islands (see E. B. xxii, 3I 3 ), where seals have been elaborately studied. In I9I I the value of Alaska furs was $\$ 786,376(\$ 432,913$ being seal). In June 19 I I there were 33,629 reindeer in the Territory; three-fifths were owned by natives, one-ninth by the government, one-seventh by missions, and the remainder by Lapps. In October I9 I reindeer meat was first shipped from Nome to Seattle.

Manufactures and Fisheries. - The number of manufacturing establishments increased in $1904-09$ from 82 to 152 ; the wage-earners from 1,938 to 3.099 ; capital invested from $\$ 10,685,000$ to $\$ 13,060,000$; and the value of products from $\$ 8,2+5,000$ to $\$$ I I $, 340,000$. More than four-fifihs of the value of all manufactured products in 1909 was the value $(\$ 9,190,000)$ of canned and preserved fish. In this industry the Territory leads the United States. In 1899 it produced $17.4^{\circ}$ " hy value of the total for the country; in $1904,29.3^{\circ}$; ; and in 1909 , $26.5^{\circ}$. In 19 II there were 64 salmon canneries and in 1912, 87. Most of the new factories were in south-western Alaska. The increase was due to high prices and large profits in I9II. In IgI I the pack of canned salmon was $2,820,066$ cases (out of $6,122,483$ for the Iacific: coast, including 948,965 from British Columbia) and the value of the salmon fisheries was $\$ 14,593.237$, and of all fishery products (excluding furs) $\$ 16,377,463$. Curing and salting salmon are becoming more important industries. Halibut, cod and herring fishcric's along the Alaska coast are carricel on mostly. by Puget Sound and San Francisco llects and there is no local manufacturing. Some whale fishers have local shore stations.

1 See E. B. i, 472 et seq.

2 See the remarks on inaccuracies of the census by James Wickersham, Territorial delegate, in Ilearings before the Committee on Territories, March 29, 1912.

${ }_{3}$ This was the population of the (ape Nome district, a suldivision of the Second Judicial District, "including persons on vessels in port, census having been taken during the rush to the sold-fields"; the same area in 19 Io had 12,351 inhabitants, not counting those in port.

4 Sitkal, not incorporated, had in r910 a population of 539 , and, in the native village, 500 ; as compared with a total population of 1,396 in 1900 . The population of the district of St. Michael. partly in the Second and partly in the Fourth Judicial Bistrict, was 2,255 in 1910.

${ }^{5}$ Including many labourers in transit. 
Mining.-The production of gold in $191 \mathrm{I}$ was $\$ 16,853,256$ (in 1910, $\$ 16,126,749$ ), of which about one quarter was from siliceous ores, $\$ 86,569$ from copper ores (only $\$ 36,484$ in 1910), and the remainder from placers. In the Innoko-Iditarod region placer production was thrice as great as in I9IO and in the Hot Springs placers more than twice as great, but in general placer mining, apart from dredging (in the Nome region), is declining rapidly. In the Fairbanks region quartz-mining is displacing placer. The production of silver was $460,23 \mathrm{I} \mathrm{oz}$., almost thrice as much as in I9IO; more than two-thirds was from copper ores. The copper production in I9II was $22,314,889 \mathrm{lbs}$., five times as much as in 1910-a striking increase attributable to the first appearance of the Copper River district on the producing list, due to the completion of a railway thither. Since Igl I there have been further copper developments in the Chitina and Prince William Sound regions. Small quantities of coal, silver, and lead were taken out. The production and importation of coal is decreasing, because oil is rapidly supplanting it as fuel and because Congress does not permit the development of coal lands. The Katalla oil field is being developed. Marble and gypsum shipments were little changed. Sixty-three tons of tin were produced, mostly from placers, and this was practically the entire output of the United States. In May I9I2 announcement was made that a ledge of tin ore $3,700 \mathrm{ft}$. long and $12 \mathrm{ft}$. wide had been discovered in the lower Tanana Valley. This may prove a great factor in the wealth of Alaska. In general the development of mining in the Territory awaits a supply of fuel and better transportation facilities. (See Frank L. Hess, "Tin" in Mineral Resources of Alaska, pp. 89-92, I912.)

Transportation. - At the beginning of I912 there were nine railroads in Alaska, with a total constructed mileage of 465 ( $37 \mathrm{I}$ in I9IO). The Alaska Northern Railway is projected from Seward on the S. coast to near Fairbanks on the Tanana river, a length of 450 m., of which 7 I were in operation. The projected line of the Copper River \& Northwestern Railway, through the Copper River Valley from Cordova on Prince William Sound to Copperfield and the Bering River coal district, was completed to Kennecott, 197 m., in April 191 I. Further building will probably be delayed until the coal fields are opened. On Seward Peninsula there are two lines: the Council City and Solomon River, from Penelope creek to Candle, a distance of $100 \mathrm{~m}$. of which 35 were in operation; and the Seward Peninsula Railway from Nome to Lane's Landing, a completed road of $96 \mathrm{~m}$. including the 6 mile McDonald branch. In the interior, the Tanana Valley Railroad from Chena to Chatinka, 45 miles in length, was completed in 1907. In addition to these, the White Pass and Yukon Route from Skagway runs for a short distance through Alaskan territory. A railway from an open Pacific port to the Yukon basin is greatly needed for development of smaller mining projects. The Civil Government Act of I9I2 authorised the President to appoint a railroad commission of four members, which studied the transportation problem and especially routes from seaboard to the coal fields and was to report early in r9I3. It has been suggested that the Federal government should purchase the Alaska Northern railway and extend it to the Matanuska coal fields. The Alaska road commission is constantly at work on wagon roads and trails; since its creation in 1905 it had constructed $2,800 \mathrm{~m}$. of roads and trails. A winter trail from Seward on the Gulf of Alaska has reached the placer mines on the Iditarod river and is aiding the development of Alaska by shortening the winter route to Nome by nearly $300 \mathrm{~m}$. The work of the Enginecr Corps of the United States Army on the St. Michael Canal has been abandoned. Steamer service on the Copper river above Chitina and on the Susitna has been suspended; but river steamers now run on the Kuskokwim to the mouth of the Takotna (600 m.).

Commerce.-The trade between Alaska and the continental United States increases steadily. Shipments of domestic merchandise to Alaska were valued at $\$ 18,809,270$ in the fiscal year ending June 1912 and much more than half of this was the value of manufactured goods ready for consumption $(\$ 10,261,770)$. The shipments from Alaska to the United States in the same period were valued at $\$ 21,597,712$, of which $\$ 14,300,240$ was the value of fish, - canned salmon being valued at $\$ 13,2$ I0,073, - and $\$ 5,040,386$ the value of copper. Of the total, $\$ 10,019,835$ was the value of goods shipped to Seattle, $\$ 5,159,767$ of shipments to Tacoma and $\$ 4,6$ I 4,2 I I of shipments to San Francisco. Exclusive of this merchandise there was shipped from Alaska to the United States $\$ 20,732,597$ in gold and silver, of which $\$ 17$, $490,82 \mathrm{I}$ was gold and silver of domestic origin.

Government and History.-On April 29, г9г2, the Federal Supreme Court held that Alaska is an organised Territory of the United States within the meaning of the Interstate Commerce Act. The Interstate Commerce Commission had not granted the request of the Humboldt Steamship Company that the White Pass \& Yukon railway be required to post rates. The ground for the refusal was lack of jurisdiction. The Supreme Court of the District of Columbia denied a writ of mandamus, on the ground

${ }^{1}$ Built by the Alaska Syndicate,- the "Morgan-Guggenheim trust," - after it gave up its construction work at Controller Bay and at Katalla Bay. Some bridge spans are set on concrete bases on glacial ice. For engineering problems, see an article by D. A. Willey in Scientific American Supplement, July I3, 1912. 
of the commission's discretion in regard to jurisdiction, but the District of Columbia Court of Appeals held that a writ would lie and the Supreme Court affirmed this view.

Congress passed a new civil government bill for the Territory, approved August 24, I912, which creates a Territorial legislature. This is to consist of a senate of 8,2 elected for four years from each of the four judicial divisions, and a lower house of I6 representatives, 4 from each judicial division, elected for two years. Legislators receive $\$$ i 5 for each day's attendance and 15 cents a mile for mileage. The governor may veto bills within three days if the legislature continues in session; otherwise, a bill becomes a law without the governor's approval. His veto may be overridden by a two-thirds vote of each house. The first biennial legislative election (for the session opening March 3, I913) was held on November 5, I9I2; after I914 the Congressional delegate will be chosen at the same election. Sessions are limited to 60 days; special sessions, called by the governor, to 15 days.

In September the Cunningham claims, including 5,250 acres of coal lands, were cancelled by Secretary of the Interior Fisher. They had been disallowed on June 26, I9II. In I9I0, I 2,800 acres of public land on Controller Bay had been withdrawn from the Chugach Forest Reserve for disposition under the land laws. An application for 320 acres filed immediately afterwards was supposed to be made by an agent of the Alaska ("Morgan-Guggenheim") Syndicate, and the charge was made that President Taft on the recommendation of his brother C. P. Taft had issued a secret order which gave to this syndicate the only harbour near the coal fields of the Bering River district. Mr. Gifford Pinchot attacked the President and Secretary Ballinger (Fisher's predecessor), who said that the lands had been opened to entry upon a recommendation from the Forestry Bureau when Mr. Pinchot was its head. President Taft sent a message to Congress dealing with the matter on July 26 , I9II; and it seems certain that the claim (for railway rights on Controller Bay) in question, of Richard S. Ryan, within the limits of the forest reserve, was in no way connected with the Alaska Syndicate, which had another and better claim on the bay, not in the reserve. The Controller Bay terminal commands the Bering River coal field ( $5 \mathrm{~m}$. distant), which is probably smaller but certainly more accessible than the Matanuska field; but the Bay is a poor harbour, readily filling with ice and swept by high winds.

The Alaska question is a complex one, which may well be compared in some respects with that in the Philippines. The late Prof. R. S. Tarr, in an article on "The Alaskan Problem" (North American Review, January I9I 2), called Alaska the "victim of stupid land laws, awakened public conscience, the clamor of the unreasoning mob, and politics." The Congressional policy of limiting land grants (as in the Philippines) prevents grants of sufficient size to warrant the investment of enough capital for adequate development; and the political and social opposition of syndicates and trusts make a change in this policy nearly impossible. Some leasing system for coal lands may offer a solution; but the lease is unlikely to tempt the investment of large sums of capital. The construction of railways is another unsolved problem. Government ownership is urged by two authorities so diverse as Secretary Fisher and Mr. Pinchot,-who differ radically as to routes. Professor Tarr suggested that the wonderful scenery of Alaska might become a valuable asset of railways.

In August I9I 2 James Wickersham (b. I857), Progressive Republican, was reelected delegate to Congress by a large plurality. The governor since October 1909 (term ends I913) has been Walter Eli Clark (b. I869), who had been a miner at Nome in 1900 .

On June 6, rgr 2, Katmai volcano burst into one of the most violent eruptions of modern times. (See G. C. Martin in Nat. Geog. Mag., Feb. 1913.)

Bibliography.-Alfred H. Brooks and others, Mineral Resources of Alaska (Washington, 1912), Bulletin 520 of the U.S. (ieological Survey. It contains a chapter by Brooks, pp. 44-88, on "Railway Routes from the Pacific Seaboard to Fairbanks." The annual report of the governor and census bulletins have been criticised by the Territorial delegate, James Wickersham in the Hearing referred to above and in his speech in Congressional Record, April 24, 1912. For description see E. Higginson, Alaska, the Great Country (I912). 


\section{HAWAII ${ }^{1}$}

Population (I9ro) rgr,909; $24.6 \%$ more than in 1900 . In $1890-1900$ the increase had been $71.1 \%$. The population of the several islands in r9ro was: Oahu, 81,993; Hawaii (island and county) 55,382; Kauai, 23,744, and Nihau, 208 (comprising Kauai county); Kahoolawe, 2; Lanai, I3I, Maui, 28,623, and Molokai, I,791 (constituting the county of Maui- except that part of the island of Molokai is the leper settlement, Kalaupapa district, Kalawao county, with a population of 785); and Midway, 35 (comprised in Honolulu county). The population of Honolulu district (or city) was 52,183. By races the population was as follows: Hawaiians .26,04I, a decrease of 3,746 in the decade; part Hawaiians I 2,506, an increase of 6,628; Spanish I,990 and Porto Ricans 4,890 (these two are newcomers); other Caucasians $\mathrm{I}_{4}, 867$, an increase of 4,290; Chinese $2 \mathrm{I}, 674$, a decrease of 4,088 ; Japanese 79,674, an increase of 18,559 ; Korean, 4,533. The total non-Oriental population has increased both absolutely and relatively. The percentage of native-born increased from 4 I.I to 5 r.I. Special efforts are being made to stimulate the immigration of families of farmers from Spain, Portugal, Russia (Manchuria and Siberia) and the Philippines, and between I906 and I9I 2 I 2,306 of the first three races were brought to Hawaii at an expense of $\$ 893$, I I9. In r910-I 2, 7,973 Filipinos were introduced by the Hawaiian Sugar Planters' Association.

Agriculture.-The I9I2 sugar crop was 595,258 tons. The pineapple industry is increasing rapidly, and it now ranks second to sugar. About 800,000 cases a year are packed. The juice of the pineapple is bottled, and the pack amounts to about 80,000 cases a year. The coffee crop of I9I 2 was smaller than that of I I I I, only $2,127,6$ Io lbs. being exported $(3,7$ I 2,886 in I9I I), but a light crop regularly succeeds a heavy one. The average price in I9I2 was I6. I 5 cents; in I9I I, I2.85. The question of cotton culture is receiving careful consideration; a good quality of cotton can be produced in paying quantities in some localities under certain conditions. In I9I I-I2 the boll-weevil threatened the cotton. In 1912, a forest of native trees, belonging to the Euphorbiaceae, and believed not to exist elsewhere, was discovered in the island of Hawaii by the Territorial botanist, and investigations are being made to determine whether this tree can be added to those now cultivated for rubber. In the fiscal year 1912, I, 384,848 lbs. of hides were exported to the United States. The growing of Bermuda onions is a new industry and in 1912 tobacco was successfully cultivated (and a cigar factory established) in the Kona district. The experiment station has worked on Caravonica and Sea Island cottons, Japanese rice and pineapples; it has demonstration farms in Hawaii and Kaui and a sub-station in Maui, at Nahiku, in the rubber-district.

The most recent complete statistics are for 1910. The number of farms was then 4,320 (90\% more than in 1900$)$, but the total farm area was only $2,590,600$ acres (a little less than in 1900), and the improved acreage, 305,053 (only $3.6 \%$ more than in 1900). The average farm acreage was 599.7 (47.8\% less than in I900) and the average improved acreage, 70.6 $(45.5 \%$ less). Farm property increased in value during the decade from $\$ 74,084,988$ to $\$ 96,363,229$; land, $\$ 78, \mathrm{r} 32,945(38.3 \%$ more than in 1900$)$; buildings, $\$ 4,798,756(35.3 \%$ more); implements and machinery, \$9.024,328 (2 I.4\% less)-principally because sugar machinery was not reported in 1910 , as in 1900 , as agricultural implements, - and domestic animals, $\$ 4,407,200$ (71.5\% more). The average value of farm property was $\$ 22,306(31.6 \%$ less) and the average value of land per acre $\$ 30.16$ ( $39.4 \%$ more). The increase in number of farms was largely in smaller farms, especially those under 20 acres. The proportion of farms under 50 acres increased from less than five-sixths to more than seven-eighths of the total in the decade. The number of white farmers increased $47.9 \%$ and that of coloured farmers more than doubled. In I9IO more than half the total were Japanese $(2,138 ; 4$ times as many as in I910); the Chinese numbered 876 (1 $8 \%$ increase), Hawaiian farmers 468 (488 in 1900), whites 753 (509 in 1900). In I900, 55.2\%, and in 1910, $67 \%$ of all farmers were cash tenants; in the decade the percentage of owners decreased from 30.I to 19.3. These changes were due to the substitution of tenancy agreements for contract labour on sugar plantations.

In 19 Io the value of domestic animals on farms was $\$ 4,292,945$ (neat cattle, $\$ 2,279,026$; horses, \$786,207; mules, $\$ 918,644$; asses and burros, \$19,726; swine, \$1 36,1 I 6 ; sheep, \$137,476 ; goats, $\$ 3,067$; Chinese buffalo, $\$ 12,683$ ); of domestic animals not on farms, $\$ 1,095,474$; of poultry, $\$ 65,3$ ro. Dairy products were small and inaccurately reported. The wool output of 1909 was $\$ 56,293^{\sharp}(4.7 \%$ more than in 1899$)$. All crops in 1909 were valued at $\$ 28,538$,264. The larger items were: sugar cane, $\$ 26,305,747$ (acreage 186,230 ; in $1899,65,687$ ); rice, $\$ 1,068,293$; fruits"and nuts, $\$ 462,902$ (pineapples, $\$ 331$, I 62; bananas, $\$ 103,490$ ); potatoes and other vegetables, \$350,974; coffee, \$2 13,085; Indian corn, \$53,337.

Commerce.-For the and of exports $\$ 55,449,343$. Exports to foreign countries are very variable; the advance from

1 See E. B. xiii, 83 et seq. 
I910 to I9II was about $100 \%$, and the 1912 total was less than half that of 19II. The chief foreign trade is with Japan. Sugar is the great staple of commerce; $1,172,510,960$ lbs. of raw sugar valued at $\$ 48,143,530$, and $32,954,550 \mathrm{lbs}$. of refined sugar valued at $\$ 1,817,979$ were exported to the United States. Next in importance is the export trade in fruits and nuts. Nierchandise from the United States was shipped mostly from San Francisco, about two-thirds of the total; most of the remainder being from Puget Sound and from New York.

Other Industries. - New industries in the Territory are the manufacture of bricks from lava rock, of brooms from broom-corn, and of stock-food from algaroba pods. The scientific production of sugar has been accompanied by the manufacture of excellent sugar-mill machinery which is finding favour in the Orient; a considerable quantity is exported annually to the Philippine Islands. In 1909 there were 500 manufacturing establishments (222 in 1899), giving employment to 5,904 wage-earners $(3,655$ in 1899 ), with a capital of $\$ 23,875,000$ $(\$ 10,746,000$ in 1899$)$ and a product valued at $\$ 47,404,000$ (twice that of 1899$)$. Threefourths of the total value was that of 46 sugar manufactories. The other larger industries were: cleaning and polishing rice, \$2,239,000; canning and preserving pineapples, \$1,591,000, - with great increases since 1909; and slaughtering and meat-packing, \$864,000. Less than one-fourth of the total product value was that of factories in Honolulu $(\$ 10,705,000)$.

Transportation.--In 1912 an American company, the Oceanic, resumed running two steamers from San Francisco to Australia, calling once a month at Honolulu. The Balfour Line, a British Company, started a service, in 1910-I I, between Europe and Pacific Coast ports by way of Honolulu. The Union Oil Co., operating 9 tank steamers and barges, has engaged in the transportation of crude oil from Port San Luis to Hawaii, a traffic also carried on (from Monterey) by the vessels of the Associated Oil Co. The Oahu Railway \& Land Co. has extended its mileage to I $121 / 2 \mathrm{~m}$., and on Hawaii Island the Hilo Railroad Co. is building from Hilo northward through one of the most thickly populated parts of the Territory a line which will probably be completed in I9I3. A street railway in Hilo has been chartered. Wagon roads are constantly being improved and extended. The Federal government is improving Honolulu, Pearl, Hilo and (on Maui) Kahului harbours; in December I9I I the $35 \mathrm{ft}$. channel at Pearl Harbour was completed, work on a dry dock (large enough for any ship that can pass the Panama locks) and on the naval station there was under way, and the "California," the first large war-vessel, used the harbour. In the fiscal year 1913 it is estimated that the projected defenses will be $90 \%$ completed. Interisland traffic is carried on almost entirely by the vessels of the Interisland Steam Navigation Co. which ply regularly among the ports of the Territory. The service is constantly being improved to meet the demands of increasing traffic.

Legislation.--Recent acts of the legislature have had to do chiefly with the schools, public health, local government, taxation, public works, and immigration. The Territory and the counties now rest each upon its own independent financial basis with an elastic system of taxation and with the revenues of each varying according to its needs. Adequate appropriations have been made for water and sewer-works, wharfs and harbour improvements, roads, and public buildings, which had been somewhat neglected for several years. The bureau of immigration has been elevated to a department of immigration, labour, and statistics, with greatly enlarged powers. A law of I9II makes interference with workmen under contract a ground for damages and enticing of workmen a misdemeanour. New and important laws have been enacted on the subject of general sanitation, tuberculosis, pure food, and other hygienic matters. Three new forest reserves were created in $1_{91} I_{-1} 2$ aggregating $8_{5}, 062$ acres, and several new forest reserves were to be set aside in IOI3. In IgI I and I9I 2 the governor urged the creation of a national park to include Kilauea (60 sq. m.) and Mauna Loa (28 sq. m.). The Hawaiian Islands Reservation for birds, created February 3, r909, at the western end of the archipelago, was studied in 19 I $\mathrm{I}$ by an expedition from Iowa State Lniversity (see Year-Book U.S. Department of Agriculture, I 9 i I, pp. I 55-164).

Finance.--In the fiscal year ending June 30 , 1912, the Territory's bonded debt was increased by the issue of $\mathrm{S} 1,500,000$ in 20-30 year $4{ }_{6}^{\circ}$ bonds for public improvements and was rut hy the payment of 850,000 of the $19034^{\circ}, 0$ fire-claims bonds, so that the outstanding bonded delot was then $\$ 5,454,000$, - that is $3.93^{\circ}$ of the assessed valuation. The legal maximum is $\tau^{\prime \prime}$ " of the assessed valuation. Territorial bonds are now acceptable at par (but not ahove market value), instead of $90^{\circ}{ }_{0}$, as security for United States deposits in national banks. The sinking fund at the beginning of the year was $\$ 79,086$. Expenditures were $\$_{4,22}+795$ and receipts $\$ 3.904,503$; and the current cash balance at the end of the year, $\$ 690,55^{\circ}$, - with outstanding warrants for about one-tenth of this sum.

A new tax system was legun in the last fiscal year: instead of a $1_{\%}^{0}$ tax on real and personal property, divided equally between the Territory and the counties, the general property tax varies with estimated needs; the counties get for current expenses not more than $1 / 2 \%$ and 
for improvements and current expenses not more than $\frac{2}{3} \%$ on local property, with enough added to cover charges on county bonds, expense of collecting tax, etc. An income tax of $2 \%$ on incomes above $\$ 1,500$, a $2 \%$ inheritance tax on bequests above $\$ 5,000$, and a $2 \%$ insurance tax on gross premiums less expenses go to general Territorial funds, and a special income tax of $2 \%$ on incomes above $\$ 4,000$ to an immigration and conservation fund.

Commercial banking deposits increased nearly $25 \%$ and savings deposits nearly $10 \%$ in the year.

Education.-The compulsory school-age has been changed from $\mathbf{I}_{5}$ to $\mathrm{I} 7$ years as the maximum, the minimum remaining at 6 . Summer schools are no longer supported by private contributions but have been provided for by legislation. For public schools there is now a varying tax. In I9I2 the enrollment in all schools was 29,909 (one-seventh more than in I9I I) and in public schools, 23,752 (nearly one-sixth increase). The Territory spent $\$ 582,535$ and the counties $\$ 47,800$ on public schools- $\$ 26.53$ per pupil. There were I 56 public and 5 I private schools; $31.09 \%$ of the pupils were Japanese, $17.82 \%$ Portugese, $14.22 \%$ Hawaiians and $13.63 \%$ part-Hawaiians, $10.94 \%$ Chinese. In I9I I the College of Agriculture and Mechanic Arts occupied its permanent quarters in the suburbs of Honolulu, where it has 83.68 acres, including a dairy, poultry and swine experiment station and an astronomical observatory. A building at Honolulu for the Library of Hawaii, to which Andrew Carnegie gave $\$ 100,000$, was completed in 1912 .

Charities.-A decided improvement has been made in the morale of the leper colonies, where lepers are now regarded as patients rather than as outcasts. This policy has greatly increased the number of voluntary surrenders. The number of lepers was 728 (622 at Molokai). In I9I I, the station of the United States Public Health and Marine Hospital Service on Molokai was abandoned, and the patients removed to the receiving hospital at Honolulu. During the year the bacillus of leprosy was cultivated artificially, which was the first confirmation of the work of Clegg and the first great advance in the study of the disease since the discovery of the bacillus in $\mathbf{1} 868$. Various animals were inoculated and several varieties of monkeys developed the disease. Apparently it is the first time that general leprosy has been developed in an animal other than man, and this will have an important bearing on research work in the future. Serum inoculations have so far been negative. A home for non-leprous girls of leprous parents, in addition to that for boys, has been established at Honolulu. There are now 28 boys and $4 \mathrm{I}$ girls in these institutions. Improvements have been made at the Molokai settlement. It now possesses churches, baseball grounds, moving-picture theatres, race-tracks, stores, etc. In I9I2 a new site was chosen for the Territorial prison near Honolulu, to displace the building near the harbour constructed in 1857; and a new insane asylum was being built. At Hilo and Honolulu there were extensive campaigns against rats and mosquitoes as disease carriers.

History.-The sugar planters are the "interests" in the Territory, and in I9I 2 the Republican delegate to Congress (since r903), Prince J. Kuhio Kalanianaole (b. I87 I), accused Governor Walter Francis Frear (b. I863; governor since I907) of being a reactionary and of favouring the "sugar trust." Secretary of the Interior Fisher investigated these charges during a visit to Hawaii in the autumn of I9I 2 and declared that they were unfounded. In the November election Kalanianaole was re-elected by 7,023 votes to 5,770 . for Lincoln L. McCandless (Dem.).

The Roman Catholic and Protestant Episcopal bishops have called attention to the growth of Mormonism in the islands. It is alleged that the missionaries did not at first announce themselves as Latter-Day Saints, but that after they had secured a large following, especially among the natives, some Asiatics and some southern Europeans, they preached polygamy, limiting the number of wives a believer might have only to his ability to support them.

Bibliography. - The various publications of the Bernice Pauahi Bishop Museum of Polynesian Ethnology and Natural History are extremely valuable; the earliest was issued in I9OI, and the newest titles are: The Volcanoes of Kilauea and Mauna Loa (1909); The Making of Bark Cloth (I9II), and New Hawaiian Plants (I9I2). See also L. A. Hallock, Hawaii under King Kalakaua' (New York, 1912).

\section{THE PANAMA CANAL AND CANAL ZONE ${ }^{1}$}

Work on the Panama Canal is rapidly approaching completion. Although the official opening has been set for January I, I9I5, and the Panama-Pacific Exposition ${ }^{2}$

${ }^{1}$ See E. B. xix, 666 et seq.

2 The exposition grounds are between the Presidio and Fort Mason on Golden Gate Channel. The Panama-Pacific Exposition Co., capitalised at $\$ 5,000,000$, is governed by a board of 50 directors, assisted by state and city commissions. An architectural commission has authority in major questions of plans for buildings; and Jules Guérin is "director of color" 
in San Francisco is to be held in 1915, it seems certain that vessels may use the canal in the latter part of 19r3. Some excavaiion will be done by dredges after the waters are let in. By estimates made late in I9I 2 : in the Atlantic division, the concrete work at the N. end of the locks should be finished June 30 and the Gatun spillway on August $\mathrm{I}$; in the Pacific division, the Miraflores spillway on June 30 ; and in the Central division the Culebra cut about July I-but this depends partly on slides such as occurred during the last year and delayed progress somewhat.

On October I, I9I 2 the remaining excavation was estimated at $3 \mathrm{I}, 803, \mathrm{r} 26 \mathrm{cu}$. yds., of which about one half had been added to the estimate during IgII-I2. Of this additional amount, which is nearly $8 \%$ of the grand total of 2 I $2,227,000 \mathrm{cu}$. yds., ${ }^{1}$ nearly I $2,000,000$ cu. yds. was in the Pacific division, including $8,794,000 \mathrm{cu}$. yds. for dry-docks, coaling station and terminal at Balboa; only 4,6 I 5,000 cu. yds. was in the Central division, because of slides and for changes in the Obispo diversion; and 295,000 cu. yds. in the Atlantic division, largely for silting in the finished channel. The total excavation for the fiscal year (July I, I9I I to June 30, I9I2) was 30,302,26I cu. yds.nearly $2,000,000 \mathrm{cu}$. yds. less than in the preceding year and less than in I9I0 or 1909.

Apart from slides, the Central division and particularly the Culebra cut therein is the most difficult part of the canal. On November I it was estimated that the cut was $93.19 \%$ completed. The seriousness of slides in this part of the work has at times been exaggerated. The slides are largely due to abrupt transitions from one geological formation to another. They have occurred usually in dry seasons. Although there is sometimes no danger where the slope is I on 5 or less, there have been slides when the inclination was I on 7 or more. The commission's geologist says that, where there are strong lavas, walls may safely be nearly perpendicular but that there will have to be a slope of $I$ on 5 for soft rocks and I on Io in much sheered soft clay; and that there will be no more danger than in a naturally formed valley when the surface is protected by vegetation-which covers the sides of the cut very rapidly. A slide on the $\mathrm{W}$. bank at Culebra covered 63 acres in I9I 2 and one on the E. side about 50.7 acres. During the last fiscal year (ending June 30 , I I I2), three steam shovels were terracing either side of the cut. Slides at Culebra do not mean an increase of cost over the original estimate, because the cost of excavation and of spoil-disposal has been decreased: the former from I I.5 to $8.88 \mathrm{c}$ per cu. yd., and the latter from I 8.54 to I $5.22 \mathrm{c}$ per cu. yd., although the distance over which waste must be carried has been made nearly one half greater.

On October I9, I9I $293 \%$ of all concrete for locks was in place, the remainder being 296,672 cu. yds. in a total of $4,352,563$; more than $92 \%$ of the concrete for the double three-step locks at Gatun ${ }^{2}$ (Atlantic side), the remainder being $149,670 \mathrm{cu}$. yds. in a total of 2,050,000; more than 9I \% of the spillway for the Gatun dam (to discharge $1_{37,000} \mathrm{cu}$. ft. a second, thus caring for the Chagres' floods), the remainder being I 8,185 cu. yds. out of 225,000 ; about $93 \%$ of the Gatun Dam (II $5 \mathrm{ft}$. high, covering 400 acres and impounding $164 \mathrm{sq}$. m. of water) which held without leakage $57 \mathrm{ft}$. (maximum height estimated $8_{7} \mathrm{ft}$.) of the waters of Gatun Lake at the end of the rainy season; and, nearer the Pacific entrance, more than $99 \%$ of the double one-step Pedro Miguel lock, the remainder being only $7,048 \mathrm{cu}$. yds. out of 889,827 , and more than $90 \%$ of the double two-step lock at Miraflores, the remainder being 139,914 cu. yds. out of I,4 12,736 .

The installation of lock machinery began at Gatun in September rgI I and at Pedro Miguel in January I9I2. A bull-wheel for turning lock gates is one of the valuable inventions ${ }^{3}$ that have grown out of actual work on the canal. All locks are in pairs

and Karl Bitter "director of sculpture." The exposition has a base fund of $\$ 17,500,000$, $\$ 7,500,000$ subscribed by citizens of San Francisco and vicinity, and $\$ 5,000,000$ in bonds from the state and the city each.

1 Of this total only $29,908,000^{-} \mathrm{cu}$. yds. is usable excavation by the French.

${ }_{2}^{2}$ The channel between Gatun locks and the Atlantic was completed on February 24, 1912, through the Mindhi Hills, except a dike separating the cut from the French canal.

${ }^{3}$ Others are a machine for shifting railway tracks used in carrying away spoil, and method of emptying steam shovel buckets by steam instead of by hand. 
so that they may be used simultaneously by ships in opposite directions, and, as there has been delay in installing machinery, work has been pushed in each case on one of the pair so that one flight may be ready for use at the earliest possible moment.

Specifications for a hydro-electric station near the Gatun spillway were issued on September 9, I9I I, calling for three 2,000-kilowatt units. Electric towing engines are to run on tracks on side walls of the locks and no ships are to go through locks under their own power. 1 The maximum amount of water diverted for hydro-electric development will be about $7 \%$ of the minimum water supply, being the excess not required for lockages, evaporation and seepage. To supply the electric current to operate the lock machinery there are to be I6 transformer rooms at Gatun, 8 at Pedro Miguel and $\mathbf{1} 2$ at Miraflores, all transforming from 2,200 volts to 220 .

Terminals were actually planned before they were authorised, so that the delay in starting work on them was reduced to the minimum. On either side there are to be docks I, $000 \mathrm{ft}$. long and $200 \mathrm{ft}$. wide ( 209 on the Atlantic side); piers covered with fireproof steel sheds; fuel oil storage $(80,000$ bbls. capacity) and coaling plants $(200,000$ tons capacity on Atlantic side and 100,000 on the Pacific side); and dry docks, the one now at Cristobal ( $300 \mathrm{ft}$. long, $50 \mathrm{ft}$. wide and $\mathrm{r} 3 \mathrm{ft}$. deep) to be retained on the Atlantic side, and two to be built on the Pacific side, - one I,,$\infty 0 \mathrm{ft}$. long, I ro ft. wide and $35 \mathrm{ft}$. deep, and the other (auxiliary), $350 \mathrm{ft}$. long, $7 \mathrm{I} \mathrm{ft}$. wide and $\mathrm{I}^{\frac{1}{2}} \mathrm{ft}$. deep. At Balboa on the Pacific side a great naval depot is planned, and to make land and build breakwaters here much of the spoil from the Culebra cut has been used.

To make it possible for pilots to keep the course up to turning points concrete "range" light-houses have been built and trocas cut through brush and timber so that these can be sighted. The candle-power of these range lights varies from 2,500 to I 5,000 (at ocean entrances). They will be equipped with electricity where they are readily accessible. Compressed acetylene dissolved in acetone will be used for the more inaccessible beacons and towers and for floating buoys.

Canal fortifications were authorised by act of March 4, I9I I, with an appropriation of $\$ 2,000,000$ for gun and mortar batteries. Forts at either end of the canal are to be fitted each with four I4-in. rifles, six 6-in. guns and twelve I2-in. mortars; and I 2 companies of coast artillery, I battery of field artillery, 4 regiments of infantry and I squadron of cavalry are to be stationed here.

There are other items in the administration of the Canal Zone as interesting as the engineering features. Under William Crawford Gorgas (b. I854) of the U.S. Army, who was made colonel by special act of Congress for his work in Havana on yellow fever (see E. B. xxviii, 9IId), and who became (March 4, r907) a member of the Isthmian Canal Commission, as sanitary officer, the part of the Zone actually occupied has been cleared of yellow fever and of malaria and made one of the healthiest places in the world. In notable contrast with the French ${ }^{2}$ service, which attempted no sewage disposal or water supply, and was curative instead of preventive, actually spreading yellow fever and malaria by having hospitals with unscreened windows and patients' cots set in water-jars (to prevent the approach of ants), were the methods of the American army doctors, who not merely benefitted by the lessons learned in Havana as to malaria and yellow-fever infection from the Anopheles and Stegomyia mosquitoes, but took other preventive measures, installing a pipe-borne water supply and a modern sewage system. A division of municipal engineering (abolished in August 1908) spent nearly $\$ 6,000,000$ on such improvements, about $\$ 3,500,000$ for work in the Zone proper and $\$ 2,250,000$ for sewers and pavements in Panama and Colon. A strict quarantine was enforced and a station built on Culebra Island in Panama Bay at the Pacific entrance. There are main hospitals at Colon and Ancon, about 25 minor hospitals or dispensaries elsewhere, and a sanitorium for convalescents on Taboga Island in the Pacific, $10 \mathrm{~m}$. off the coast.

${ }^{1}$ Lock-gates are protected besides by double chains from damage by ramming.

"See "The French at Panama" in Scribner's, January 1913. Some machinery brought over by the French and discarded has been recovered and used by the American engineersnotably dredges built in Scotland. 
After yellow fever had been stamped out - there has been no case originating in the Canal Zone since December 1905 -there was a campaign against malaria in 1906, and the sickrate was cut from $6.83 \%$ to $1.54 \%$ in 1911 . Plague, typhoid and dysentery have been vigilantiy combatted by the U.S. Army doctors. The care of the general health and comfort of the employees has been minute. There has been a large corps of dentists. Y.M.C.A.'s have been organised and women's clubs - the latter by an expert employed by the government so that married women might be willing to stay in the Zone. ${ }^{1}$ In the last fiscal year the average daily sick was 22.9 I per I,000 employees (23.01 in I909-10; 24.77 for I9IO-II) and the death rate I0.16 (11.34 in preceding year), 9.2I (I0.0 I in preceding year) for whites, 5.9 ( 5.35 preceding year) for whites from the United States, 10.47 (II.8I, in I910-II) for blacks. In I9I n nearly I, 000 labourers were brought from Barbadoes, and the West Indian negro is everywhere in evidence. On June 30 , I9I 2 the total number of employees was 34,957 (including 5,100 Amcricans) - the maximum being 40,159 in November 1912 .

Up to June 30, I9I2, appropriations for the canal were $\$ 293,561,469$, and by the act of August 24, 1912, $\$ 28,980,000$ was appropriated for the expenses of the year I9I2-I3. The estimate for the year I9I $3^{-14}$ is $\$ 30,174,432$. Of the cost as now estimated $(\$ 375,701,000)$, about $69 \%(\$ 259,653,237)$ was charged to the work up to June 30 , I9I 2 , and of this amount more than one eighth $\left(\$ 34,18_{3}, 18_{3}\right)$ in the last fiscal year. Although one of the reasons why a lock canal was recommended was that it would cost Si $\infty 0,000,000$ less than a sea-level canal, the actual cost of the lock canal will be much more than the cost of a sea-level canal $(\$ 250, \infty 00, \infty)$ ) as estimated in January 1906 (see E. B. xx, 67ob). But the slides at the Culebra Cut are considered by many authorities to show conclusively that a sea-level canal would not have been feasible. ${ }^{2}$

An act of August 24, I9I 2, provides for the opening, maintenance, protection, operation, sanitation and government of the canal and the Zone. A governor with a 4 year term and a salary of $\$_{10,000}$ a year is to be appointed by the president with the consent of the Senate. It was President Taft's intention to appoint as governor Col. George II ashington Goethals, ${ }^{3}$ chief engineer of the canal since February I907. As the appointment was for 4 years, opposition was threatened in the Senate, where the Democrats wished such appointments to be made by the new (Democratic) administrationalthough Col. Goethals was suggested for the portfolio of war in President Woodrow Wilson's cabinet. President Taft did not appoint a governor.

The same act authorised the President to frame a system of workmen's compensation for the Zone, and a scheme has been drafted but not put into effect, as Congress made no appropriation therefor. The act ordered the dismissal of the Isthmian Canal Commission upon the completion of the Canal.

Besides, the act exempted from tolls all coastwise vessels but forbade American railways to own ships operating in the Canal (after July I, I9I4, unless the time was extended by the Interstate Commerce Commission, - to which jurisdiction is given-in the case of lines giving beneficial service), prohibited the use of the Canal by ships owned by illegal combinations, and admitted to American registry foreign-built ships owned

1 See Mary C. Humphreys, "The Family"and the Panama Canal," Scribner's, Sept. 1912.

${ }^{2}$ In the opinion of the chief engineer no slides in $1911-12$ were sufficiently serious to have interfered with navigation had they occurred while the canal was in use.

${ }^{3}$ Cioethals was born in Brooklyn, $\mathrm{N}$. Y., on June 29,1858 , studied at the College of the (ity of New York in $1873-76$, and graduated at the U.S. Military Academy in 1880 and ('ntered the engineering corps, being teacher of engineering at the Military Academy until iss. He was lieutenant-colonel of volunteers and chief of engineers in the Spanish American 11 ar and at the close of 1898 returned to the regulars. He graduated at the War College in 1905 and was promoted to colonel (of engineers) on December 3, 1909. For some time he was in charge of engineering construction on the Muscle Shoals Canal on the Tennessee river (sec E. B. xxvi, 625d). In the Canal $/$ one he showed himself not merely an able engincer but a leader of men and an administrator and final judge in the petty and annoying quarrels of a strangely mixed population. Most of the more serious problems of canal construction were met in his administration, although the system of removing spoil was devised by his predecessor, a civilian, John F. Stevens, chief engineer in 1005-07. Goethals received the honorary degree of Dociur of science from Columbia L niversity in June I9I2. 
by Americans and engaged only in foreign trade. For the exemption of coast-wise vessels in its international bearings see under Part I, section i.

On November I4, I9I 2 the President promulgated a schedule of tolls: (I) \$I.20 ${ }^{1}$ per net vessel-ton, each Ioo cu. ft. of actual earning capacity, on merchant vessels with passengers or cargo; (2) $40 \%$ less on merchant vessels in ballast; (3) 50 cents per displacement ton on naval vessels; but (4) the same rate as (1), for transports, colliers, hospital ships and supply ships. These tolls were based on the estimates of Emory Richard Johnson (b. I864; professor of transportation and commerce, University of Pennsylvania since 1896 and a member of the Canal Commission since I899); and they are what the estimated traffic might be expected to bear rather than intended to make the canal a financial success to the government.

Bibliography.- - See the last annual report of the Canal Commission; Farnham Bishop, Panama, Past and Present (1913); articles in Scientific American, November 9, 1912; World's Work, August I9I2; Engineering Magazine, December I912; C. P. Markham, "The Making of the Panama Canal" in Blackwoods, August 1912; Joseph Pennell's Pictures of the Panama Canal (Philadelphia, I9I2); and articles on sanitation in Scribner's, September I9I2, by J. B. Bishop, secretary of the Canal Commission, and in Survey (New York), October 5, I912, by James $T$. Bowles, physiologist to the Commission.

\section{PHILIPPINE ISLANDS ${ }^{2}$}

Population.-No general census has been taken since r903, when the total was $7,635,426$ (see E.B. xxi, 395d). In roro the population of Manila was 234,409 (in I903, 219,928), including 2II,859 Filipinos, I4,093 Chinese, 4, I74 Americans, 2,364 Spaniards and 644 other Europeans.

Agriculture.-In December I9I I an Act was passed creating a sugar-testing laboratory in Manila, to be under the supervision of a sugar chemist who establishes standard samples of classes of sugar. An irrigation code was passed in February 1912, when an irrigation council was created. The chief of the bureau of insular affairs recommended in 1912 legislation to increase from 16 to 50 hectares the maximum land that may be sold to individuals or that may be taken as a homestead. In I9II and 1912 a shortage in rice and in 1912 a plague of locusts, especially in the southern islands, caused great distress; and legislative remedies were attempted.

Communications and Commerce.--Railway construction is being pushed rapidly forward, and in July I9I2 I,034.9 km. were completed. The Manila Railroad Co. in the island of Luzon in 1912 had $704.7 \mathrm{~km}$. in operation on its northern and southern lines, and $602 \mathrm{~km}$. under construction or projected; and the Philippine Railway Co. finished its line on the island of Panay from Iloilo to Capis (110 km.) in 1910 , and its Cebu line ( $96 \mathrm{~km}$.) in 19I I; in I912 its total track was $25 \mathrm{I} \mathrm{km}$. Great advance has been made in the improvement of existing roads, and there are now about a thousand miles of first-class highways throughout all the provinces. The Philippine Commission made special appropriation for the repair of roads, bridges and trails damaged by the severe typhoons of I9II. In I9I2 the North German Lloyd Co. established a monthly service between Manila and European ports. Zamboanga harbour, Mindanao, is to be improved at a cost of $\$ 400,000$. An act of Congress of March 4 , I9I I appropriated more than \$1,500,000 for batteries and defences, especially at Manila and Subig bays. The Philippine legislature in 1912 voted funds, to be available if a similar appropriation were made by Congress, for wireless telegraph installation in parts of the islands inhabited by Moros and other non-Christian tribes.

For the fiscal year 1912 both imports and exports were greater than ever before. The gain in exports during the year was $25 \%$, from $\$ 39,778,629$ to $\$ 50,319,836$; and imports increased in value from $\$ 49,833,722$ to $\$ 54,549,980$, principally in rice, to meet famine conditions resulting from a severe drought. Of exports about $40 \%$ went to the United States, and about the same amount to France, the United Kingdom and Spain. The increase was principally due to larger exports of copra, sugar and cigars. Philippine copra is now an important factor in the world's supply. In I9I2 it was for the first time more valuable than hemp, being worth $\$$ I6, 5 I 4,749 (hemp, $\$$ I $6,283,5$ IO); and about $\$ 9,600$, 000 worth of this was sent to France, mostly Marseilles. About one-fourth as much went to the United States. The export of hemp has decreased since I9IO. Sugar increased in value to $\$ 10,400,575$, about six-sevenths going to the United States. Unmanufactured tobacco exported was valued at $\$ 1,874,69 \mathrm{I}$; and manufactured at $\$ 2,720,5$ OI (about $50 \%$ more than in I9II). Minor exports are hats, which go to France and the United States, maguey fibre, and motherof-pearl shells. Of the total imports about three-eighths was from the United States; second

1 The rate in effect January I, 1913, for the Suez Canal.

2 See E. B. xxi, 392 et seq. 
were the French East Indies $(\$ 9,575,741$.) There was an increase in imported foodstuffs and in iron and steel, but a marked decrease in cotton textiles. Larger imports of raw cotton and yarn show that the textile industry is developing.

Government.-A summer capital has been established at Baguio, capital of Benguet province, in the mountains I $20 \mathrm{~m}$. N. of Manila. There the governor-general and other officials reside from the Ist of March until the Ist of July. A new city is building. The mayor and city council are appointees of the governor-general with the consent of the Philippine Commission. By the act of Congress of February I5, I9I I the term of delegates to the Philippine assembly was made four years, and in accordance with this act the first Tuesday of June was chosen as election day.

In December I910 a parcels post system was established between the Philippines-and Hong Kong, and in October 1912 an inter-island parcels post system.

In January I 1 I capital punishment was abolished. The regular session and a special session in I9I I refused to pass appropriation bills and other administration measures. There was a second regular session in November, December and January 1912 and a special session in February 1912. The legislature limited the power of the Governor-General to deport and expel foreigners by requiring previous investigation with a hearing at which the suspect must be represented by counsel and witnesses. An Act of January 20, 1912 makes liable to fine of 200 pesos, imprisonment for 6 months, or both, any one receiving an advance for personal service under contract and failing to perform the service. Provincial boards were authorised to pay regular wages to unclassified employees disabled for 90 days or less. During the rice famine the Governor-General was authorised to arrange for the sale of foodstuffs at reasonable prices through provincial and municipal governments and for this purpose to buy I5,000 tons of rice. The legislature appropriated I2,000 pesos for the purchase of food plant seeds for distribution. It voted 5,000 pesos to purchase and preserve the birthplace of José Rizal in Calamba, La Laguna; and 25,000 pesos to provide the public schools with copies of a biography of Rizal. It passed an elaborate warehouse receipt law, and revised a part of the corporation law providing for fees for filing articles of corporation. For the invention of a durable, fireproof, waterproof roofing material, a substitute for nipa, a prize of I 5,000 pesos was offered; a technical board is to deal with it.

Finance.-During the fiscal year ending June 30, I9I2 the revenues were $120,754,016$ pesos, and the disbursements $124,257,387$ pesos; and the balance at the end of the year was $28,414,214$ pesos, at the beginning of the year 31,935,586. In May 1912 Governor W. Cameron Forbes announced that the income was sufficient to meet all expenditures including public improvements; and in July President Taft informed Congress that the islands had not been a charge against the United States Treasury and that on all items there was a balance in their favour except for increased expenditures for army and navy. A system of rural credits was introduced in 1911 , the government making loans at $6 \%$ on agricultural property and guaranteeing $4 \%$ to a French syndicate's agricultural bank with a capital of $\$ 10,000,000$. In December I9I I the application of several banking laws was extended to Moro and other non-Christian territory by the Commission. During the fiscal year 1912 deposits in postal savings banks increased from 2,099,474 pesos to $2,388,986$. On December 8 , I9 I I, the legislature authorised the release from the gold standard fund of $I, 698,514$ pesos, which was thus available for public works. The chief of the bureau of insular affairs in his report for 1912 recommends legislation to increase the limit of the bonded debt for improvements and to permit the investment or deposit on proper security of $60 \%$ of the silver certificate reserve. The Territorial bonded debt in 1912 (including $\$ 4,000,000$ municipal bonds of Manila and $\$ 125,000$ of $\mathrm{Cebu})$ was $\$ 16,125,000$. The last legislature failed to pass an appropriation measure; in such circumstances current appropriations are extended.

Charilable and Penal Institutions. - The total number of prisoners on the islands in 1912 was 6,910 , of which one-half were in the Bilibid prison and at the Iwahig Penal Colony. The latter has been a remarkable success as an example of advanced penology. The reservation is $468,710,673 \mathrm{sq}$. metres in extent of which 448 hectares are under cultivation, growing upland rice. A saw-mill and brick-kiln are in full operation. The Culion leper colony in 1912 had 2,615 inmates, largely from Cebu. The sanitary work of the government has been excellent. For the fiscal year 1912 the death rate of government employees was only 5.65 per thousand (8.46 for Americans; 4.44 for Filipinos). Deaths from beri-beri stopped wherever and whenever unpolished rice was used, and it is proposed to use undermilled rice in government institutions. In spite of constant war on rats, the bubonic plague reappeared in Manila in 1912. In the Manila district where the annual deaths from small pox were formerly 6,000, no death from this cause was reported in I9I I and there were few cases in 1912. A sewage system ${ }^{1}$ and a good water supply were installed in 1911, but there was a serious shortage in 1912. Experiments have been made at Manila in sterilising drinking water with ultra-violet rays. The improvement of health conditions elsewhere is scarcely

1. The courts have enjoined the bureau of health from compelling private owners to connect with the sewer system. 
less marked. A hospital with 30 beds has been opened at Bontoc; a temporary hospital is in operation at Butuan; and there has been some success in attempts to vaccinate the wild tribes. Provincial health funds were created and municipalities were authorised to consolidate to form sanitary divisions. In 1912 a committee was appointed to study the causes of the high infant mortality. The legislature of 1912 voted 50,000 pesos to the Philippine Islands Anti-Tuberculosis Society and 12,000 pesos to La Gota de Leche ("The Drop of Milk," a babies' charity) for the protection of infants. In I9I 2 there were 44 pupils in a school for the deaf and blind in Manila.

Education. - The total enrollment for the school year I9II-I2 was 529,655 (about I3\% less than in the preceding year) and the average attendance was 329,073 (nearly $8 \%$ less than in the preceding year; but the ratio of attendance to enrollment was higher). The decrease in enrollment is due to financial reasons, the large expenditures for permanent school buildings, the heavy expense of industrial training, on which so much stress is being laid, and the increase in salaries, almost $10 \%$ during the year to insular Filipino teachers. There were 38 high, 283 intermediate and 3,364 primary schools, with 664 American and 7,696 Filipino teachers. Considerable stress is now laid on industrial instruction, especially hat-making, weaving, carpentry, embroidery, lace making ${ }^{1}$ and agriculture; and in 1912 the administration urged the passage of a law for industrial education of adults. Athletic sports are also receiving more attention. In 1912 the legislature passed an act for the establishment of a school of Household Industries for women in the city of Manila, and appropriated for it I00,000 pesos. The University of the Philippines was organised in its definite form during I9IO-II, and the following colleges are now in operation; Liberal Arts, Medicine and Surgery, Agriculture, Veterinary Science, Law, Engineering, and Fine Arts. The annual appropriation for the University for I9I3 was 575,000 pesos. In August I9I 2 the total registration in the various departments was I,400. Of the high school graduates in I9I I $57 \%$ entered the univarsity, an unusually high ratio. The first president of the University, Murray Bartlett, took office on June I, I9I I, and was inaugurated December 20, I9II. By an Act of January 12, I912, 20 government fellowships for foreign study were established; 5 are to be filled from the teaching staff of the University of the Philippines. An Act of February 6, 1912 created 70 scholarships (at least one for each province or sub-province) in the government forest school at Los Banos, La Laguna; and one of January. 27, 1912 voted 7,000 pesos to maintain 20 government scholarships in the College of Veterinary Science of the University of the Philippines. The provinces and sub-provinces were authorised to grant allowances to students in the University or in other government schools. Private schools are being standardised by the department of education. Many changes are being made in the equipment of Catholic institutions of learning: the Jesuit Ateneo, the Dominican University of $\mathrm{S}$. Tomas, and the Liceo are planning new buildings in the suburbs of Manila; in I9I2 work was begun on new buildings for Santa Scolastica convent at Singalona and a new plant was completed for the Catholic college at Jaro (Iloilo). English is rapidly becoming the language of the people, being increasingly used even in non-government schools, and on January I, I9I3, it became the official language of the courts. The total appropriation for schools in I9I2 was $3,610,000$ pesos and the expenditure, $3,603,685$ (2,612,091 for salaries).

History. - The Secretary of War after five weeks in the islands reported to the President on November 23, I9ro, that the people were unprepared for self-government and that the better if not larger class did not desire it. These were the President's views, which he repeated in an address in January I9 I before the Society of the Carabao - army and navy officers who have seen service in the Philippines,-and those of the Chief of the Bureau of Insular Affairs in his annual report for 1912. In the House of Representatives (Democratic) a bill was introduced March 20, I9I2 (by William A. Jones, Virginial) providing for the qualified independence of the islands on July 4, I9I3 and their complete independence in I92 I; and the Democratic party, which came into power in I9I3, is pledged by its platform to "an immediate declaration of the nation's purpose to recognise the independence of the Philippine Islands as soon as a stable government can be established." The natives and the Americans who are in favour of independence accuse the government and especially commissioner Dean Worcester of exaggerating the number and the lack of civilisation of the non-Christian tribes, and of using this as an argument against the ability of the Filipinos to govern themselves. They say, besides, that land-grant limits are so small as to discourage the investment of capital; that the limits on free exportation to the United States of sugar and tobacco-dictated by the American sugar and tobacco trusts-threaten these industries in the islands; and that the freedom from export duty on hemp, being only on hemp coming directly to the United States and consumed there, is actually a tax on the Filipino hemp growers 1 The Belgian sisters teach lace making in their schools in Manila, Tagudin and Bontoc. 
in the interest of the American " Harvester Trust," which has agents in the Philippines and which by the nature of the case is practically the only exporter in a position to secure a refund of export taxes by proving American consumption. Early members of the Commission pointed out the injustice of "giving these duties to manufacturers of hemp products in the United States." In IgI I nine resolutions (one by McCall of Massachusetts; the others by Democrats), and in IgI 2 one (by W. A. Jones, author of the Independence measure), were introduced in the U.S. House of Representatives for neutralisation of the islands. An act of Congress of March 23, I9I2 gives local citizenship to all who were Spanish subjects in 1899 and to their children and allows the Philippine legislature to provide for others becoming citizens. A protest of the Philippine Assembly against the sale of friars' lands to corporations brought up this matter in Congress, where the Committee on Insular Affairs exonerated the Philippine government. In I9I I the Commission prohibited slavery, peonage and the sale of human beings in certain non-Christian territory; and an effort was made to secure the passage of a similar act by the legislature applying to all the islands.

In Mindanao there was sharp fighting in the autumn and winter of IgI I, and about 40 Moros were killed in December. In Jolo, about 600 Moros were hemmed in and forced to surrender during the same winter. In the Basilan islands an American ensign was killed and several sailors were wounded in September. Otay, an outlaw chief of Samar, was killed by the constabulary in October. In I 912 there was a clash with ladrones on January I4 near Siet Lake, Jolo, in which 20 Moros were killed; and at the very end of the year and early in I9I3 there was more fighting with Moros.

Taal volcano in southwestern Luzon was in explosive eruption January 27 to February 8 , I 9 II. This outbreak, probably the most severe which has occurred in the island in historic times, was at its height on January 30 , when an area of $230 \mathrm{sq} . \mathrm{km}$. (nearly twice that devasted by Mt. Pelée) was laid waste. The mud-coated area was r,940 sq. $\mathrm{km}$. and the loss of life was estimated at $\mathbf{1}, 300$. Earthquakes of a mild type accompanied the eruption. This was the first great outbreak of Taal since I754. In February I9I 2 the legislature appropriated money for a seismological station near Bombon Lake to study the volcano and give warnings of eruptions, and for a launch to be used for rescue work. In July I9II rain fell for nearly a fortnight, and in Luzon about SI, 500,000 worth of property was damaged. On October 16, 1912, a typhoon did damage estimated at $\$ 25,000,000$ and caused the loss of a thousand lives.

The Philippine Commission in I9I 2 was composed of: W. Cameron Forbes, governorgeneral; Newton W. Gilbert (public instruction; acting governor in Igr2); Dean C. Worcester (interior); Charles B. Elliott (commerce and police); Gregorio Araneta (finance and justice); Frank A. Branagan; Rafael Palma; José R. de Luzuriaga; and Juan Sumulong.

Bibliography.-James Henderson Blount (officer U.S. Volunteers in Philippines, I899I9OI and U.S. District Judge there, I90I-05), The American Occupation of the Philippines, I898-1912 (New York, I9I2); (. D. Wiillcox, Head-IIunters of Northern Luson (Kansas City, Missouri, 1912); D. C. Worcester, "Head-Hunters of Northern Luzon" in National Geographical Magazine, Volume 23, pages 833-930 (1912); Eleanor F. Egan, The Philippines (New York, 1912). The report of the secretary of the interior in the r912 report of the Commission contains particularly interesting material, with illustrations, in regard to the natives of Ifugao, their remarkable rice-terraces, etc., and about road-building in Bukidnon. The Philippine Journal of Science is an important organ, not merely for local or Eastern research; and the Bureau of Science is printing E. D. Merrill's Flora of Manila.

\section{PORTO RICO ${ }^{1}$}

Population (I9I0) I,II8,OI2, about one-sixth more than in I899. The principal towns or municipal districts ${ }^{2}$ in 1900 were: San Juan $(48,716)$; Ponce (city, 35,027$)$; Yauco (31.504); Caguas (27,160); Humacao (26,678); San German (22, 143); Aguadilla (2I,4I 19 ); Fajardo (2I,I35); Cayey (I7,7II); Guayama (I 7,379); Mayaguez (I6,59I); Aibonito (10,805); and Arecibo (city, 9,6I 2; district 42,429).

1 See $E$. B. xxii, 124 et seq.

${ }^{2}$ Except where otherwise noted the population is for municipal districts. 
Industries and Commerce.-For the fiscal year 1912 the total exports were valued at $\$+9,-$ 705,413 (an increase of $\$ 9,787,046$ over the previous year); in 1901 the value was $\$ 8,583,967$. Imports in I9I 2 amounted to $\$ 42,926,473$ (an increase of $\$ 4,137,476$ in the year), and in Igri I at $\$ 8,918,136$. The total trade was one-sixth greater in 1912 than in I9II. Of the 1912 trade $87 \%$ was with continental United States, which established free trade with the island in 1901. In I9I2 the island ranked I2th as a purchaser of American goods. Sugar heads the list of exports and the 1912 shipment aggregated 367,145 tons (valued at $\$ 31,544,063$ ) or $63 \%$ of the total export sales. The quantity was the largest ever shipped from the island, being five times as much as in r9or. Tobacco, valued at about $\$ 7,500,000$, holds second place on the export list, and coffee is third with $40, \mathbf{I} 46,365 \mathrm{lbs}$. $(\$ 6,754,9 \mathrm{I} 3)$, more than thrice the amount exported in Igor. More coffee is now being sent to the United States, where it was long practically unknown. The 1912 crop was the largest ever grown on the island. Fruit exported in 1901 amounted to $\$ 109,801$ and in 1912 to $\$ 2,377,762$, the principal increase being in the shipments of oranges, pineapples and grapefruit. The coco-nut industry is extensive and profitable, and the shipments were valued at $\$ 308,883$.

The chief imports in I9I2 were cotton goods valued at $\$ 5,132,693$, manufactures of iron and steel, $\$ 4,977, \mathrm{I} 46$, the largest item being sugar-mill machinery; rice, $\$ 3,866,986$; breadstuffs, \$2,392,863; preserved meats and dairy products, $\$ 3,564,137$; leather manufactures, $\$ 1,266,132$. About three-quarters of the trade goes through San Juan.

The trend of agriculture in the island is toward more intensive methods. Machinery is being substituted for hand labour to a considerable extent; planters are studying the economics of fertilisation; tile drainage is employed in wet lands, and an irrigation scheme which will insure the delivery of 4 acre-feet of water per annum for 35,000 acres of dry lands in the south was three-fourths completed in 1912. The Sugar Producers Association has established an experiment station (opened in I9II) at Rio Piedras, near San Juan, which is supported by a tonnage tax on the industry. Here experiments with fertilisers, lime, different distances of planting, and the study of insect pests are carried on. There is a government agricultural station at Mayaguez. The first annual Insular Fair was held at San Juan, in I9I I.

In 1909 the first census of manufactures was taken. There were 939 manufactories, employing I 5,582 wage-earners, with a capital of $\$ 25,544$, 000 and a product value of $\$ 36,750$,000 , of which $\$ 15,27$ I, 000 was added by manufacture. More than half the total value, $\$ 20,569,000$, was that of sugar and molasses. Dependent on this industry is the distillation of liquors, \$1, I I 7,000. Other manufactures were tobacco, \$6,060,000; coffee, cleaning and polishing, $\$ 5,053,000$ (only $\$ 289,000$ added by manufacture). The four largecities of the island had manufactured products as follows: San Juan, $\$ 3,243,000$; Ponce, $\$ 2,400,000$; Mayaguez, $\$ 2,256,000$; and Caguas, $\$ 124,000$. The manufacture of cigars is rapidly increasing; the output in 1912 was $28 \mathrm{I}, 000,000$, being 14 times as great as in 1901 .

Transportation and Public Works. - The principal steamship lines are: New York and Porto Rico S. S. Co. (of the American, Gulf and West Indies Steamship lines) with a new passenger steamer "Brazos" on the service since November 1912, in addition to three other passenger boats (and four freighters) one each week from New York, stopping at San Juan and (except the "Brazos") at Ponce and Mayaguez, and three boats making weckly trips from New Orleans and one from Galveston and Port Arthur; and the Red D line with weekly sailings from New York to San Juan and Mayaguez (4 steamers). The A. H. Bull Steamship Company has eight freighters making fortnightly sailings between New York and the island. On the island there has been no new railway construction in the last two years. Wagon and automobile roads are being built and improved and there are motor bus lines on the military road between San Juan and Ponce. From Ponce there is a good road to Guayana.

In the fiscal year ending June $30,1912,67 \mathrm{~km}$. of macadamised roads were completed, making $1,069 \mathrm{~km}$. now maintained. Public works of different sorts in 33 municipalities were in course of construction in 1912. The Federal government dredged the San Juan harbour during the year and the Porto Rican legislature created a San Juan harbour commission for the permanent improvement of the city's water-front.

Legislation.-The I9 I legislature was in session from January 9 to March 9, I9r r. It gave the Executive Council the powers of a public service commission. In I I 2 the regular session began January 8 , but as all business was not completed within the 6oday limit a special session was called and the final adjournment was March I4. An act was passed providing that one out of the five members elected biennially from each of the seven districts shall be returned from the minority party. No party may name more than four candidates, and the minority candidate of each party who receives the largest number of votes is elected. Delegates must be residents or tax payers in the district from which they are chosen. Laws were passed promoting the secrecy of the ballot and requiring a new registration of electors. Another important act took all matters of sanitation out of the hands of the municipalities and put them under the control of the Territory, through a non-partisan sanitation service,-even street 
cleaning being done by the Territorial government. A bureau of labour was established. Other acts control the operation of public service corporations, affect the protection and promotion of industry and commerce, and facilitate the administration of justice. Two new municipal governments were established: Hormigueros, from a part of Mayaguez; and Guaynabo, from 4 wards in Rio Piedras and 6 wards in Bayamon.

Education.-The school enrollment in 1912 was 160,657 (10\% more than in I9II, and 6 times as much as in the first year of American administration). The total number of school buildings was I, 168 . The night schools made the most noteworthy progress, and the attendance in I9I I was $75 \%$ greater than in 1910 , the enrollment being $15, \mathrm{I} 38$. Of the pupils $40 \%$ were adults. Instruction in agriculture, manual training, cooking, plain sewing and other practical subjects as well as hygiene, physical culture, and military training has been added to the courses of many schools. Pupils in graded schools learn both English, the medium of instruction since 1906, and Spanish. There are good high schools in San Juan, Ponce and Mayaguez. The University of Porto Rico at Rio Piedras had I,OI9 students, and the department of liberal arts was established in 1910-II, making three departments now in operation. The Insular Library at San Juan, created 1903, contains over 15,000 volumes.

Finance. - The treasury receipts increased one-tenth during the fiscal year I9II-I2, and amounted in all to $\$ 7,8 \mathrm{I} 6,16 \mathrm{I}$ and in spite of increased expenditures the available cash balance increased from $\$ 1,214,000$ at the beginning of the year to $\$ 1,794,555$ at the close (June 30 , I9I2). The tax on alcohol had been raised 2 cents per litre on July I, I9I I. The assessed property value, based on a careful revision, was $\$ 178,275,000,-$ more than twice as much as in I905. The total net bonded indebtedness in I9I2 was $\$ 4,139,760$. Bonds for municipal improvements are to be issued.

Charitable and Penal Institutions. - These consist of the insane asylum with 334 patients in I9I I; the asylum for the blind with an average of 75 inmates for the year; the leper colony on Cabras Island with 25 patients; the girls' charity school with I 52 inmates, and the boy's' charity school with 250 inmates. In the penal institutions 8,032 prisoners were confined during the year. There are about 50 dispensaries and ficld hospitals, in which since $190+$ a campaign has been carried on against the hookworm plague (Uncinariasis), which was introduced with slavery from Africa in the 16th century. Nearly one-third of the population has been treated. Cures are estimated at $40 \%$. The improvement in the general health of the native workman is marked, and this will be furthered by change of diet. In June 1912 the bubonic plague appeared, coming apparently from Trinidad. A careful quarantine was instituted, army surgeons were hurried to the island (June 27) and only sporadic cases were reported after July. In I9II-I2 Major Robert E. Noble, U.S.A., in charge of mosquito extermination in the Canal Zone, was in Porto Rico superintending similar work there, and San Juan and its suburbs were largely freed from mosquitoes.

History.-There is a fast growing sentiment in favour of an elective senate in place of the executive council appointed by the President of the United States and consisting of five Porto Ricans and of six Americans, each of the latter being head of an administrative department-so that administrative and legislative functions are here combined. Admission to American citizenship with full self-government is the demand of a large political party, and on January I $_{7}$, I 9 I 2 the house of delegates voted against American citizenship, except with full self-government. The passage (March i 5, I 1 I 2 ) by the Federal House of Representatives of a bill for the admission to the United States of sugar from any source duty free (which did not become a law) aroused much uneasiness in the island. In February I II the five native members of the council protested against the removal of restrictions upon land-holdings by corporations, suspecting a move to strengthen the "sugar trust." The Unionists in November I9II defeated the Republicans, electing all members of the house of delegates.

In April I9I I there was a cigar makers' strike near San Juan, and the men "out" refused to make any terms until the liberation from custody of a score of anarchists who were arrested for complicity in the assassination of a foreman.

The governor since November 7, 1909, has been George Radcliffe Colton (b. 1865), who served in $1899-1905$ in the Philippine Customs, was then in charge of the Dominican Customs receivership, and in 1907-09 was insular collector of customs in the Philippines. The executive council includes: M. Drew Carrel, secretary; Allan H. Richardson, treasurer; J. W. Bonner, auditor; Wolcott H. Pitkin, Jr., attorney-general; Edward M. Nainter, commissioner of education; John A. Wilson, commissioner of interior; and five native members, José C. Barbosa, Luis Sanchez Morales, Martin Travieso, Jr., Rafael del Valle and Juan Vias Ochoteco. 


\section{SECTION III. FOREIGN COUNTRIES}

Note:-For convenience, the following accounts are given in the alphabetical order of the headings. Dependencies are dealt with under their sovereign country. For Greece, Bulgaria, Servia and Rumania, see under "Greece and the Balkan States." For Hungary see "Austria-Hungary." For the various "Latin Republics" of South and Central America (Argentina, Brazil, Chile, etc. together with Mexico, etc. and Cuba, etc.) see that general heading.

\section{ABYSSINIA 1}

The outstanding feature in the history of Abyssinia in 1909-1 2-the only remaining independent native state in the whole of Africa, for Liberia, if independent, can hardly be regarded as a " native" state-is that despite the incapacity of the Emperor Menelek (E. B. xviii, I 28), owing to an incurable malady, to take any part in state affairs, the country has not fallen into a condition of anarchy. Toward the end of IgIo the Empress Taitu, who had controlled the council of regency, was deposed, as the result of a palace revolution, and all the chiefs of Shoa, the hereditary dominion of Menelek, took oaths of fidelity to Lij Yasu, the grandson of the nugūs. Ras Tessama, the regent, died in April I9I I, when Lij Yasu, then about i6 years old, took control of the administration. The authority of the central government continued, with a few exceptions, to be enforced in the most distant provinces. Friendly relations have been maintained with all the neighbouring powers, and during I9I the boundary separating Abyssinian and Italian Somaliland was delimited from Dolo to the Webi Shebeli.

Lack of easy means of communication hindered the development of trade, and the commercial resources of Abyssinia are as yet scarcely tapped. The continuation of the Jibuti railway (E. B. i, 95a) from Dire Dawa to Adis Ababa (the capital) made slow progress, but the line reached the Hawash river in I9I2. Jibuti remained the chief avenue of trade, with Massawa next in importance, while Gambela, the new trade centre for Western Abyssinia, has in a short period become a thriving town. Gambela is a port on the river Baro, one of the chief headstreams of the Sobat, and lies $60 \mathrm{~m}$. E. of the Sudan-Abyssinian frontier. It is an enclave leased to the Sudan government in 1907. From June to November, when the Sobat is in flood, a monthly steamer service is maintained between Gambela and Khartum, $880 \mathrm{~m}$. distant. The trade figures for Gambela were $£ \mathrm{E} 43,000$ in $1910, £ \mathrm{E} 65,000$ in $191 \mathrm{I}$ and $£ \mathrm{E} 75,000$ in 1912 , mainly representing the export of coffee (for consumption in the Sudan) and of beeswax in transit to Europe. With the rise of Gambela, the town of Gore, $65 \mathrm{~m}$. E. of Gambela, became the chief market of Western Abyssinia, controlling the rich provinces of Jimma, Wallega and Kaffa. In 1912 a branch of the Bank of Abyssinia was opened at Gore. The total trade, estimated in 1905 at $f_{1}, 000,000$, had increased by 1910 to over $£ 2,000,000$. About $50 \%$ of this is viâ Jibuti. Hides and skins, coffee, rubber and wax are the chief exports; cotton goods the principal imports.

See the Consular reports issued by the Foreign Office, London, on Abyssinia, Harrar and Gambela; Capt. Stigand, To Abyssinia through an Unknown Land (London, 1910); Major C. W. Gwynn "A Journey in S. Abyssinia" (with excellent map) in Geog. Jnl. Aug. I9I I; G. Montandon, "A Journey in S. W. Abyssinia" in Geog. Jnl. Oct. I912. For N. Abyssinia consult the Bolletino Soc. Geografia Italiana.

(F. R. CANA.)

\section{AUSTRIA-HUNGARY ${ }^{2}$}

\section{Economic Progress}

The total population of the Monarchy in I9ro was $51,352,429$. Its component parts, Austria, Hungary, and Bosnia-Herzegovina (annexed in 1908), are separately dealt with below; but it is necessary to deal first with the progress of finance, and defence, and trade, which represent the common affairs of the Monarchy under the political Ausgleich of 1867 and the commercial agreement last renewed in r907.

\section{The Whole Monarchy.}

Finance.-The finances of the Monarchy were complicated by the cost of the annexation of Bosnia and Herzegovina during I908-10. The net expenditure during these three years amounted to $£_{76,670,779}$ ( $\ell_{22,240,730}$ in $1908 ; \delta_{26,318,505}$ in $1_{909}$;

${ }^{1}$ See E. B. i, 82 et seq.

${ }^{2}$ See $E$. B. iii, 2 et seq. 
$\{28$, I I I.544 in I010), of which over 30 per cent represented extraordinary military and naval expenditure. Large sums were required to cover the cost of the annexation, and the budget of IGI I provided for a further increase of expenditure on armaments. The estimates of expenditure for I 9 I I and I9I 2 were: (I9II) $£ 22,533,000$, (I9I2) $£ 24,000,000$. As in I() I I the net revenue from the customs amounted to $£ 7, \mathrm{I} 53,000, £ \mathrm{I} 5,380,000$ had to be raised by the proportional contributions, which, according to the agreement of 1907 , were 6.3 .6 per cent for Austria and 34.6 per cent for Hungary. The principal items of

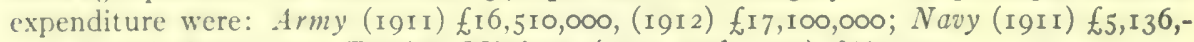
$\infty$, (I912) $f 6,220,000 ;$ Forcign Ministry (I9II and I9I 2) $£ 680, \infty 00$.

Debl.- It the end of 19 Io the common debt amounted to $£ 2$ I6,66r,843. The annual charge amounted to $£ 8,755,788$, of which Hungary contributed $£ 2,525,805$.

Army.-The new army bill, which met with strenuous opposition both in the Austrian and the Hungarian parliament, became law in July I9I2. By its provisions the annual contingent for the common army was increased from I03, I00 to I 59,500 men, of which Austria would provide $9 \mathrm{I}, 3 \mathrm{I} 3$ and Hungary 68,I 87 men. The term of active service was reduced from 3 to 2 years except for cavalry and horse artillery, so that of the yearly recruits 134,500 would be enrolled for two years, 19,000 for three years, and 6000 , who would serve in the navy, for four years. The peace strength of the common army therefore was raised from 295,000 men (in I gri) to 350,000 , and the war strength from 900,000 to $1,500,000$ men. The ycarly contingents for the Austrian Landwehr and for the Hungarian Honvéd were also increased, and the latter thoroughly reorganized. In I9I I the Austrian Landwehr numbered 43,178 men and 4877 officers and staff, and the Hungarian Honvéd 28,443 men and 4327 officers and staff. These changes were calculated to raise the number of recruits for the whole army from 135,750 to 212 ,500 men, or an annual increase of 76,930 . The duration of this act is for 12 years, and the additional cost of the army during that period was calculated at $£ 35,625, \infty 00$. The non-recurring expenditure to introduce these changes amounted to $£_{3}, \mathrm{I} 25, \infty 00$, of which Austria would contribute $£ 2,000, \infty 00$ and Hungary $£$ r, I25,000, and the permanent expenditure was raised by $£ 3,100,000$ yearly. Serajevo, the capital of Bosnia, was to be strongly fortified. In October rgr 2 the Minister of War asked for an extraordinary credit of $£ 10, \infty 00, \infty 0$ for war material and the rearmament of the artillery.

Navy. - In ror r a new shipbuilding programme was adopted, which included the building of 4 "Dreadnoughts" of about 20,000 tons displacement each (to be ready at the end of I9I4); 3 cruisers of about 3500 tons; 6 torpedo destroyers of about 800 tons; 12 torpedo boats, and 6 submarines. The cost was estimated at $£ 13,016,666$, to be spreal in instalments over the six years I9II-I6. The instalment spent in I9I 1 was $£ 2,291,667$, and that in 1912 was $£ 2,800,000$.

At the end of 19 I 2 the effective navy consisted of I "Dreadnought;" I 2 battleships, of which the three newest have a displacement of 14,268 tons each; 3 armoured cruisers; 6 cruisers; 7 torpedo gunboats; 12 destroyers; 69 torpedo boats; and 7 submarines. In the autumn of 1 () I 2 the Admiralty obtained an additional credit in order to replace the three oldest battleships, laid down in 1803 , by three "Dreadnoughts" (to be ready for use in $\mathrm{I} \mathrm{I}_{5}$ ), and for the immediate building of three fast destroyers. This was an addition to the programme adopted in IOII, and the naval estimates for I9I 3 chowed a further increase. The active personnel amounted to 17,500 men, and it was intended to bring up the non-commissioned rank to a total of 20,000 within a year. A new fortified naval base is being prepared at Selenico, on the Dalmatian coast.

Trute. The outstanding feature of the foreign trade has been the growing excess of imports over exports. This so-called " unfavourable balance of trade" which began in Iso; had grown steadily until in Ior I it amounted to over $£ 32,000,000$. Austro-Hungarian conomists have come to consider this state of affairs as a normal condition of the existing connomic development of the country, which is going through the transition from a mainly agricultural to an industrial state. Elsewhere the excess of imports is mainly due to the large importation of foodstuffs and raw materials, while the export of mantiactured goods gruws faster than the imports of similar character from abroad. 
In Austria-Hungary, however; the imports of manufactured goods grow faster than the exports, and this is.considered an unhealthy sign in its industrial development. Causes considered as contributing to this state of affairs are: the increase of population, the desire for better food, and the increasing number of people who abandon agricultural work, so that the exports of agricultural produce have decreased enormously. Thus the huge excess of imports in I9 I was partly due to a larger importation of raw cotton, but also to an increased importation of agricultural produce. Another cause in the opinion of many economists has been the policy inaugurated by the tariff of I906, which greatly increased the duties on foodstuffs. This had not the anticipated effect of stimulating the agricultural productivity of the country so as to enable it to feed its own population, but its effect is felt in the extremely high price of foodstuffs. This has increased the cost of production and handicapped the manufacturers in competing in foreign markets, while neighbouring agricultural countries have retaliated against the heavy duties on their products by imposing high duties on imports from Austria-Hungary.

The imports were valued in 1910 at $£ 118,800,000$, and in 19 I I at $£_{132,900,000}$; exports (I910) $£ 100,700,000,($ I9II) $£ 100,200,00$; showing excess of imports (1910) $£$ I $8,100,000$, (191 I) $£ 32,700,000$. They are classified in Table A.

Table A. Imports and Exports, I9IO, I9II, classified.

\section{Articles}

Raw materials

Semi-manufactured

Manufactured goods

Total
Imports

(in millions of $f$ )

1910 I9II

$65.9: 76.3$

19.8 20. $\quad 2$

$33 . \mathrm{I} \quad 36.5$

118.8 132.9
Exports

(in millions of $£$ )

I9IO I9I I

$36.4 \quad 34.1$

I8. 19.2

$46.3 \quad 46.9$

$100.7 \quad 100.2$

The value of the trade with principal countries (exclusive of bullion and specie) in I9I I was as follows: Imports from Germany $£ 52,617,000$; U. S. A. £I 2,070,000; United Kingdom $£ 9,560,000$; India $£ 9,156,000$; Russia $£ 8,680,000$. Exports to Germany $£ 40,000,000$;

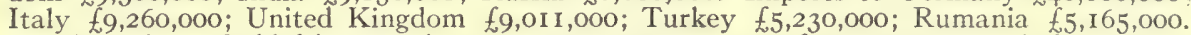

The values of chief imports in I9II were: raw cotton $f$ r $3,019,000$; wool $f 6,128,000$; woollen goods $£ 4,458,000$; coal and coke $£ 8,207,000$; cereals and flour $£ 5,259,000$; seeds and potatoes $£ 6,587,000$; machinery $£ 6,230,000$; metals $£ 5,118,000$. Exports: provisions $£$ IO,217,000; sugar $£ 8,680,000$; eggs $f 4,689$, ooo; wood $f 3,444,000$; brown coal $f 3,025,000$; cotton goods $f_{4}, 076,000$; garments, millinery, etc. $f_{3}, 945,000$; wooden wares $f_{3}, 188$, ooo.

A ustro-Hungarian Bank.-After long delay and strenuous opposition in the Hungarian parliament the charter of the bank, which expired on December I, I9I0, was renewed until December 3I, I9I 7. The new charter differs from the old notably in regard to the obligatory redemption of bank-notes in gold. It does not compel the bank to redeem its notes in gold but throws on the governors the responsibility of deciding the moment when specie payment may be made obligatory without danger to the financial and commercial stability of the Monarchy, and defines the procedure by which the legislative sanction for the enforcement of specie payments is eventually to be obtained. It increases from $f_{16,666,000}$ to $\{25,000,000$ the non-funded bank-note circulation which the bank is entitled to issue without incurring the punitive 5 per cent tax, and like the old charter it authorizes the bank to reckon among its metallic reserve $£_{2}, 500,000$ of foreign gold bills and other gold credits. The funded bank-note circulation remains fixed at two-and-a-half times the amount of the total metallic reserve. The most important proviso of the new charter is the obligation imposed upon the bank to maintain the gold bill policy, by which it has hitherto succeeded in regulating the rates of foreign exchanges in such a manner that, despite the cxistence of an optional gold standard, the Austro-Hungarian currency has been kept on a par with that of gold standard countries. Failure would entail immediate loss of the charter.

\section{A ustria. ${ }^{1}$}

Population.-According to the preliminary results of the census taken on December 3I, I9I0, Austria had a population of $28,567,898$ inhabitants, showing an increase of $2,417,190$ or 9.2 per cent over that of 1900 . Every province shared in the increase, the populations in I910 being respectively as follows: Lower Austria, 3,530,698; Upper Austria, 852,667; Salzburg, 214,997; Styria, I,441,604; Carinthia, 394,735; Carniola. 525,083; Coastland, 894,457; Tirol and Vorarlberg, I,092,292; Bohemia, 6,774,309

${ }^{1}$ See $E$. B. ii, 972 . 
Moravia, 2,620,9r4; Silesia, 756,590; Galicia, 8,022,r 26; Bukowina, 8or,364; and Dalmatia, 646,062. The principal feature revealed by the new census is again the steady decrease of the rural population and the massing of the inhabitants in great towns. Thus, I $4,130,29$ I or 49.5 per cent of the total population were living in places with less than 2000 inhabitants, while in 1900 the proportion of the rural population was 53.6 per cent.

The number of emigrants between I90I-IO was $1,114,547$; during the decade there was a net loss of 660,575 persons.

The census figures gave the population of the principal towns as follows: Vienna, 2,031,498; Trieste, 229,475; Prague, 224,721 ; Lemberg, 206,574; Graz, I 51,668; Cracow, I 50,3 18; Brünn, I 25,008; Czernowitz, 86,870; Pilsen, 81, I65; Žižkow, 72, 195; Pola, 70,I45; Linz, 67.859; Przemysl, 54,069; Innsbruck, 53,r94; Smichow, 51,8 15; Salzburg, 36,210; Wiener-Neustadt, 32,869; Reichenberg, 36,372

Birth rate (I910), 33.4 per thousand; death-rate 21.2 ; marriage rate 7.6

Education.-At the end of 1909 there were 22,24 I public elementary schools with 99,658 teachers and 4,3I4,323 pupils; and 1,208 private elementary schools with 5712 teachers and 139,9 I 5 pupils. The number of children of school age was $4,744,521$, and of these 254,912 remained without any instruction. In 8343 schools the language of instruction was German; in 5917 Czech; in 3001 Polish; in 2594 Ruthenian; in 836 Slovakish; in 530 Servian; in 647 Italian; in I7 I Rumanian; in 3 Hungarian; in 432 schools more than one.

In $1911-12$ there were 316 gymnasia with 105,002 pupils, and 149 realschulen with 49,005 pupils. The number of students at the universities in the winter term I9II-I 2 was: Vienna, I0,097; Lemberg, 5I77; Prague, 4414 in the Czech university and 1965 in the German one; Cracow, 3404; Graz, 2129; Innsbruck, 1327; and Czernowitz, I229.

Finance.-The expenses of Austria have been increasing rapidly during the last few years, and the budgets have been closing with large deficits. The proposals of the finance ministers for increasing revenue have not received the approval of parliament, so that the only course left open was borrowing, with a consequent large increase of the public debt. This increase has amounted during the last ten years to over $£ 80,000,000$.

In 1911 the estimated revenue and expenditure were $\ell_{117,437,824}$ and $\ell_{117,474,864}$ respectively; in 1912 they were $£ 121,541,364$ and $£ 121,528,552$; in $1913, £ 130,730,000$ on both sides. At the end of r910 the special debt of Austria was $£ 287,981,904$, and the charge

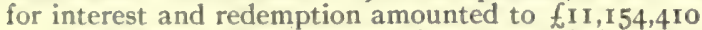

Agriculture.-The harvest of 19 II was below the average on account of the abnormal drought. Of the cultivated area 25,608,700 acres were arable land; 20,345,000 acres were pastures and meadows, and $17,100,000$ acres were forests. The area under the chief crops and their yield in I9II were as follows:-

\begin{tabular}{|c|c|c|c|c|c|}
\hline & $\begin{array}{l}\text { Area } \\
\text { (in } 1,000 \\
\text { of acres). }\end{array}$ & $\begin{array}{l}\text { Yield } \\
\text { (in } 1,000 \\
\text { of cwts.) }\end{array}$ & & $\begin{array}{c}\text { Area } \\
\text { (in } \mathbf{1}, 000 \\
\text { of acres.) }\end{array}$ & $\begin{array}{l}\text { Yield } \\
\text { (in } \mathbf{I}, 000 \\
\text { of cwts.) }\end{array}$ \\
\hline $\begin{array}{l}\text { Wheat } \\
\text { Rye } \\
\text { Barley. } \\
\text { Oats }\end{array}$ & $\begin{array}{l}3,030 \\
5,042 \\
2,732 \\
3,686 \\
\end{array}$ & $\begin{array}{l}32,045 \\
52,880 \\
32,400 \\
45,300\end{array}$ & $\begin{array}{l}\text { Maize } \\
\text { Sugar Beet (i910) } \\
\text { Potatoes (I910) } \\
\text { Vineyards (1910) }\end{array}$ & $\begin{array}{r}754 \\
640 \\
3,105 \\
55^{8}\end{array}$ & $\begin{array}{r}6,070 \\
141,230 \\
267,328 \\
56,03+(1000 \text { gals. })\end{array}$ \\
\hline
\end{tabular}

The produce of silk-cocoons amounted to $4,609,87$ I lbs. In 1910 there were $10,159,808$ cattle, 6,431,966 pigs, and 2,428,586 sheep.

Minerals.-In I9lo the total value of the mining products, exclusive of salt and petroleum, was $£ 13,1+5,000$, and that of the furnace products was $£ 5,956,000$. The amounts of the principal minerals and metals produced were: coal, $13,573,000$ tons $(14,63 \mathrm{I}, 000$ tons in I9I I); lignite, $24,722,000$ tons $(24,863,000$ tons in 1911$)$; iron ore, $2,586,000$ tons; pig iron, $1,482,-$ $O(x)$ tons; graphite, 32,600 tons; lead, 15,200 tons, zinc, 12,200 tons; copper, 1440 tons; mercury, 592 tons; gold, 39 I lbs. (40I lbs. in I9I I); silver, I09.322 lbs.; salt, 341,000 tons. In (ialicia $1,737,000$ tons of petroleum were extracted, valued at $£ \mathrm{I}, 850,000$.

The Austrian government has bought the radium-producing pitchblende mines at Joachimsthal at a cost of about $£ 94,000$, and has thereby obtained what is practically a world's monopoly of radium. The annual production of ore from these mines is estimated at 22,000 lbs., which should contain about 46 grains of radium.

Industries.-During recent years the sugar industry has greatly developed. The number of sugar refineries was 196 in 1911 and 206 in 1912 . The production of sugar amounted to $1,2,32,000$ tons in $1909-10$, and to $1,522,000$ tons in $1910-11$, of which a little over 300,000 tons were produced in llungary. The area under sugar beet is also increasing yearly, being $1,008,000$ acres in 1910-1I, and I, 100,000 acres (426,000 acres being in Hungary). In 1910 64 new industrial companies with a capital of $£ 5,910,000$, and in 191158 companies with a 
capital of $f 5,320,000$ were established. In I9 Io and I9I I I 4 new foundries and engineering works, and I 4 new textile and clothing establishments were opened. The building trade also showed extraordinary activity. In 1909 there were 1999 breweries producing 434, I 70,000 gallons of beer, and 51,566 distilleries producing 34, 106,000 gallons of alcohol.

Communications. - At the end of 1910 Austria had $20,486 \mathrm{~m}$. of railways, of which 7939 $\mathrm{m}$. were state railways, $544 \mathrm{~m}$. companies' lines worked by the state, and $3287 \mathrm{~m}$. companies' lines worked by the companies. The revenue from the state railways was $£ 26,000,000$.

The length of the navigable rivers and canals was $4055 \mathrm{~m}$. of which $825 \mathrm{~m}$. were navigable for steamers. A bill was passed by the Austrian Parliament in 1912 for extending and improving the waterways and canals, on which $£_{1} 15,000,000$ would be spent during the next I5 years. The principal works to be executed are in Galicia, Bohemia and Lower Austria. In Galicia the completion of the Vistula canal by building a canal from Cracow to Oswiecim was undertaken, and also the building of portions of navigable connection between the Oder and the Dniester. Work on the Cracow-Oswiecim canal began during 1912. The works in Bohemia comprise the canalisation and regulation of the middle Elbe from Melnik to Jaromeř, the completion of the Moldau canal in the district and town of Prague, and the continuation of the Moldau canal from Prague to Stechowitz. In Lower Austria, the Vienna-Danube canal is to be enlarged and a winter harbour to be built at Vienna.

Shipping and Navigation.-At the end of $191 \mathrm{I}$ the mercantile marine of Austria included 1794 vessels of 409,864 tons, and a crew of 9776 men. Of the total 338 vessels of 390,333 tons were steamers, and I456 of I9,53I tons sailing vessels. A number of 160 steamers of 368,916 tons were engaged in the oversea trade. At Trieste in I9I I I2,998 vessels of $4,271,073$ tons entered; of these 86 vessels of 283,176 tons were British.

\section{Hungary. ${ }^{1}$}

Population.-According to the census taken on December 3 I, I910, Hungary had a population of $20,886,487$, an increase of $1,631,928$ or 8.5 per cent over I900. In I9I0 there were 742,899 births, 490,689 deaths, and I79,537 marriages. Emigration is decreasing: (I909) II 3,3 I5, (I9I0) 96,324 , (I9II) 54, I73. Allowing for the number who returned the net loss was (I909) 96,330, (I910) 7I,602, (I9II), 23,809.

The census figures for the principal towns were: Budapest, 880,371; Szeged, I 18,328; Szabadka, 94,610; Debreczen, 92,729; Pressburg, 78,223; Zágráb, 79,038; Temesvár, 72,555; Kecskemét, 66,834; Arad, 63,166; Hodmezö-Vásárhely, 62,445; Nagyvárad, 64,169; Kolozsvár, 60,808; Pécs, 49,82 2; Ujpest, 55,I97; Miskolcz, 51,459; Fiume, 49,806 Kassa, 44,2I I; Békéscsaba, 42,599; Györ, 44,300; and Brassó, 41,056.

Education.-In I910 there were 2792 infants' schools with 243,104 infants; and 18,068 elementary schools with 35,554 teachers and $2,172,897$ pupils. Of the 16,455 elementary schools in Hungary Proper Hungarian was the language of instruction in 12,894 schools; Rumanian in 233I; German in 443; Slovakish in 429; Servian in 271; Ruthenian in 69; and other languages in I 8 schools. There were I 87 gymnasia with 63,338 pupils, and 43 realschulen with 14,424 pupils. The number of students at the universities in the winter term 1910-I I was: Budapest, 7548; Kolozsvár, 2359; and Zágráb, 1287. A bill for the establishment of universities at Pressburg and Debreczen was voted by parliament in I9I I.

Finance.-The estimates for I9II-I9I2 were: Revenue, (1911) $f 69,687,797$, (I9I2) $£ 77,180,000 ;$ Expenditure, (I9II) $£ 69,685,720$; (1912) $£ 76,300,000$. These figures show an enormous increase both in revenue and expenditure over those of ten years before.

The chief branches of estimated expenditure in 1912 were:- National Debt, $f 11,903,-$ ooo; Ministry of Commerce, $f_{19} 530,000 ;$ Public Worship and Instruction, $£ 4,035,000$; Ministry of War, $£ 2,638$,000; Contribution of Common Affairs, $£ 3,751$, 000.

Debt.-At the end of 1909 the public debt amounted to $£ 211,474,000$. In 1910 a new loan of $£ 20,833,000$ was raised.

Agriculture. -The harvest of 19 I I was spoilt by the abnormally dry season. The fruit crop was poor and bee-keeping most unsuccessful.

The area under the chief crops and their yield in I9I I were:-

\begin{tabular}{|c|c|c|c|c|c|}
\hline & $\begin{array}{l}\text { Area } \\
\text { (in } 1,000 \\
\text { of acres). }\end{array}$ & $\begin{array}{l}\text { Yield } \\
\text { (in I,00o } \\
\text { of cwts.) }\end{array}$ & . & $\begin{array}{l}\text { Area } \\
\text { (in. I,000 } \\
\text { of acres). }\end{array}$ & $\begin{array}{c}\text { Yield } \\
\text { (in } 1,000 \text { of cwts.) }\end{array}$ \\
\hline $\begin{array}{l}\text { Wheat } \\
\text { Rye } \\
\text { Barley } \\
\text { Oats. }\end{array}$ & $\begin{array}{l}8,914 \\
2,970 \\
2,922 \\
2,931\end{array}$ & $\begin{array}{r}103,550 \\
26,520 \\
32,924 \\
26,782\end{array}$ & $\begin{array}{l}\text { Maize . . } \\
\text { Potatoes } \\
\text { Vineyards (I90o) } \\
\text { Sugar-beet (1910) }\end{array}$ & $\begin{array}{r}7,196 \\
1,744 \\
870 \\
294 \\
\end{array}$ & $\begin{array}{l}81,818 \\
100,100 \\
54,7 \text { 16 (1000 gals.) } \\
58,440\end{array}$ \\
\hline
\end{tabular}

1 See E. B. xiii, 984 et seq. 
In I9I I about 24,000 acres of fresh land were cultivated as vineyards; $2,770,000$ gallons of the famous Tokay wine were produced that year. In I9lo 95,620 cwts. of honey were produced; the produce of silk-cocoons amounted to $2,700,000 \mathrm{lbs}$.

Considerable sums were provided in the budget for irrigation, drainage of marshes, forestry, and cattle breeding. Great efforts have been made to improve the dwellings of agricultural labourers, and in I9I I alone 3600 cottages were built with state assistance.

In 1911 there were in Hungary 6, 183,424 cattle, 2,000,6 II horses, I7,830 asses, 935 mules, $6,415,179$ pigs, $7,696,880$ sheep, and 484, I 7 I goats.

Mining.-The total value of all mining and furnace products in 19 Io was $£ 6,364,000$. The quantity of the leading minerals and metals produced was: lignite, $7,617,000$ tons; coal, 1,282,000 tons; iron ore, I,876,000 tons; pig iron, 494,000 tons; gold, 6,690 lbs.; silver, 27,603 lbs., and salt, 232,000 tons.

Manufactures.-Hungary is primarily an agricultural country, but its manufacturing industries show a steady development. Pursuing its programme of encouraging manufactures, the government during I9II assisted factories to the amount of $\ell_{1}, 875,000$ in the shape of loans, grants of machinery, exemption from taxation, etc.; and the question of developing the water-power of the country for industrial purposes has been under official consideration. Hungary has suffered less than other countries from industrial unrest. A salient feature during the last few years has been an enormous development in the building trade. Thus in Budapest alone six hundred new houses were finished in 19II.

Foreign trade.-The special trade of Hungary during 1910-1911 was:-

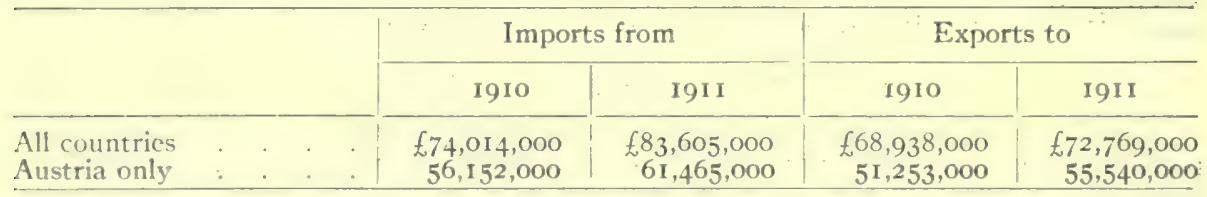

In I9Io the value of the exports to Hungary showed the following percentages: Austria, 75.31; Germany, 8.38; India, 2.15; United Kingdom, 1.74.

Communications. - At the end of I9I t there were $13,022 \mathrm{~m}$. of railway open for traffic. There were $7070 \mathrm{~m}$. of state roads, and great attention has been paid to their improvement, The government has given up the zone tariff on railways, and has raised the price of fares for passengers by one-third. When the zone tariff was introduced in 1889 the number of passengers increased enormously, from $5,500,000$ in 1888 to $16,000,000$ in $1890,35,000,000$ in 19$)(0$, and $67,000,000$ in 1910 , but nearly the whole of this increase went to the main lines. In conserquence these lines became congested, while the secondary lines which were expected to profit by the tariff remained as unprofitable as before.

The harbour and docks at Fiume have been enlarged and improved. The building of two large shipbuilding docks has been begun, and the government has bought land for the crection of a shipbuilding yard. Improvements in the harbour of Budapest were in 1912 (1) be undertaken shortly, and it was also proposed to enlarge the famous Kettenbrücke and to construct another bridge over the Danube.

Shipping and Navigation.-In 1910 the merchant fleet numbered 302 vessels of 111,226 tons, 114 irsucls of 109,83 I tons being steamers. In $1910,35,120$ vessets of $4.5,52,114$ tons entered at all ports, while Fiume alone was entered by 17,880 of 3,031,381 tons.

\section{Bosnia-Herzegovina. ${ }^{1}$}

Constitution.-The constitution promised to Bosnia-Herzegovina at the time of the annexation was proclaimed on February 22,1010 . It extends to them the main provisions of the Austrian Constitution as regards civil rights, and grants the provinces a local Diet (see History below) to deal with all local matters. The bills passed by the Diet must receive the assent of the Austrian and Hungarian governments before they can receive the sanction of the Crown, and all matters relating to the common affairs of the Monarchy are excluded from its legislative competence.

'The provincial government has four departments, for internal affairs, finance, justice, and pullic works, while the chief executive is vested in the Austro-IIungarian Finance Minister, who is also the governor of the provinces.

Populatin. - ( ) I Iecember 3 г, I0 Iо, Bosnia-Herzegovina had a census population of

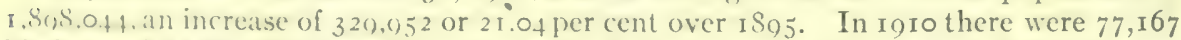
hirths, and 5 r. $\$ 3+$ deaths. The population of the principal towns was: Serajevo, 51,$8 ; 2 ;$ Mostar. I6.385; Banjaluka, 14,793; Tuzla, I I,333 and Bjelina, 10,069.

${ }^{1}$ Sec E. B. iv, 279 el seq. 


\section{AUSTRIA-HUNGARY}

Agriculture.-Nearly 88 per cent of the whole population is engaged in agriculture The area under the chief crops and their yield in I9I were:-

\begin{tabular}{|c|c|c|c|c|c|c|}
\hline & & $\begin{array}{c}\text { Area } \\
\text { (in } \mathbf{I}, 000 \\
\text { acres.) }\end{array}$ & $\begin{array}{c}\text { Yield } \\
\text { (in } 1,000 \\
\text { cwts.) }\end{array}$ & $\begin{array}{l}\text { : } \\
\text {, }\end{array}$ & $\begin{array}{c}\text { Area } \\
\text { (in } \mathrm{I}, 000 \\
\text { acres.) }\end{array}$ & $\begin{array}{l}\text { Yield } \\
\text { (in } \mathbf{I}, 000 \\
\text { cwts.) }\end{array}$ \\
\hline $\begin{array}{l}\text { Wheat } \\
\text { Rye } \\
\text { Barley. }\end{array}$ & $\therefore$ & $\begin{array}{r}194 \\
30 \\
182\end{array}$ & $\begin{array}{r}1,428 \\
192 \\
1,292\end{array}$ & $\begin{array}{l}\text { Oats. } \\
\text { Maize } \\
\text { Potatoes }\end{array}$ & $\begin{array}{r}230 \\
515 \\
50\end{array}$ & $\begin{array}{l}1,568 \\
4,274 \\
1,270\end{array}$ \\
\hline
\end{tabular}

Cattle-breeding and sheep farming are important. In I9 Io there were 2,499,422 sheep, I,393,068 goats, I,308,930 cattle, 527,270 pigs, and 221,97 I horses.

Trade.-The special trade of the provinces (with Austria-Hungary and foreign countries) amounted in 1910 to $f 6,025,000$ imports and $f 5,645,000$ exports. There are $1220 \mathrm{~m}$. of railways open for traffic, and the construction of about $200 \mathrm{~m}$. of new railways was started in 1912.

(O. Brilliant.)

\section{Political History, igo9-igi 2}

The Austro-Hungarian Monarchy.-The energetic and aggressive policy of Baron Aerenthal in annexing Bosnia and Herzegovina (Oct. I3, I908) was certainly expensive, The annexa. but it was successful, and its very success won public opinion both in the tion of Bosnia- a sum of over two millions sterling was paid to her (Feb. 26, I909), but when Herzegovina. Servia and Montenegro also put forward claims for compensation, it seemed for a time that war was inevitable, seeing that Baron Aerenthal would recognise no good ground for the claims. It only demonstrated the strength of the Triple Alliance that Russia, on the recommendation of Germany, withdrew her support from Servia, and when Servia abated her claim (March 30, I909) it was no difficult task to settle matters with Montenegro (April 6, I909). The step, pregnant with so much for Austria-Hungary, which Baron Aerenthal took in October of 1908 was an accomplished fact by the beginning of April of I909, and the conferment upon him of the title of Count by the Emperor on the I 8th of August r909, was a fitting reward for his work.

To maintain the status quo in the Balkans was the aim of Austria-Hungary throughout the years IgIo and IgII; to maintain the status quo was the policy bequeathed by Count Aerenthal on his death in I9I 2 to his successor, Count Berchtold. 1 Count
Aerenthars The new Foreign Minister addressed the Delegations for the first time in Aerenthal's April I9I2, but not until September 24, I9I 2 did he make a striking pro-
successor. nouncement. It was to the effect that as affairs in Macedonia and Albania were becoming "troubled," Austria-Hungary had " proposed to the Powers an exchange of ideas on the Balkan situation." The object in view was to encourage Turkey in the reforms it was then inaugurating to restore order in its European possessions Count Berch- It was all to be done "by means of the unanimous cohesion of the Powers told's Balkan on the basis of maintaining peace and of the status quo in the Balkans."
policy. In short, it was intended to promote an agreement between all the Powers in order to find a via media between the sovereign rights of Turkey and the legitimate interest's of the Balkan peoples. All the Governments signified their approval of the suggestion. But it came too late. By the middle of October hostilities between the allied Balkan States and Turkey had already commenced. The results on AustroHungarian foreign policy are dealt with elsewhere. It remains to trace the course of domestic politics in Austria and Hungary from roog.

Austria.-Whereas in 1909 the prestige of Austria-Hungary as a Power in Europe was enhanced by the policy of Count Aerenthal, its internal condition was greatly

The language question in Bohemia. ${ }^{1}$ Count Leopold Berchtold, born March 18, I863; Secretary of Embassy in Paris, I895; Councillor of Embassy in London, I899; at St. Petersburg, 1903; Ambassador at St. Petersburg, I906; Foreign Minister of the Dual Monarchy February I9, I912. 
to improve the administration. It was proposed to divide Bohemia into numerous districts according to language; there were to be 139 Czech, 95 Germans and 5 mixed areas of this kind. The Bills were debated on February 5th, and the Czech deputies condemnerl the scheme in unmeasured terms and raised a storm in the House by their wild and unruly conduct. "You are a disgrace to Austria," flew across the floor from the German benches, and the sentiment only added fuel to the flame. So impossible did the position become that the House was closed.

Baron von Bienerth (b. $186_{3}$ ), the Premier, sought to win some measure of support from all parties by reconstructing his Cabinet so as to include representatives from Reconsttu- every party. Baron von Härdt became Minister of the Interior; Baron tlon of the Blenerth Cabinet. von Bilinski went to the Treasury; Dr. von Hochenburger obtained the portfolio for Justice; Count Stürgkh became Minister of Education; Herr Wreba, of Railways; Dr. Weiskirchner, of Commerce; Marshal von Georgi, of Defence; Herr Ritt, of Public Works, and Herr Braf of Agriculture. But the Czechs were obdurate and asked as the price of their support the re-opening of the Bohemian Diet which had been closed because of German obstruction. To this demand the Germans were deaf, and hence the Czechs in the Reichsrat had recourse to the same policy to which the Germans in the Bohemian Diet had resorted. Nevertheless the Government maintained itself against a vote of censure on its Bonian land policy, which was moved by Dr. Shushtershitch, one of the Slav deputies, and defeated.

The Ministry continued in office for a little over eight months (Feb. IIth to Oct. 3I, I909). It broke up over the language question, on which the pure German crech ob- Crown Lands-Upper and Lower Austria, Salzburg and Vorarlburg-took struction in up a firm stand. A law passed the Diets of these provinces making German the Reichs- the only language of the schools and of the administration. The Imperial rat.

Cabinet recommended the Bill for the sanction of the Crown, despite the opposition of the two Czech ministers, who, being defeated in the Cabinet, forthwith resigned (Nov, 2d). The victory of the German element in Austria stirred up anew the hate of the Czechs, whose national feelings had been strengthened by the Congress at W'arsaw, held earlier in the year (Aug. I909). They accordingly decided on a policy of thoroughgoing obstruction in the Imperial Diet, and members of the party made speeches of 12 and $I_{3}$ hours duration (Dec. $1_{5}^{-19}, 1909$ ). In consequence of this policy the House sat for 86 consecutive hours, virtually doing nothing. To make such a course impossible in the future, new rules of procedure were adopted (Dec. 19, I909).

The language question had occupied so much parliamentary time that little was left for the consideration of the Budget. But the Budget this year demanded more attenFinance in tion than usual. For the first time since 1888 there was a deficit, the 1909. Herzegovina was responsible for this to some extent; also the cost of the administration, which was steadily increasing, owing largely to national jealousies. In many cases one school would suffice where there were actually two and sometimes even more; but since it became necessary to give each nationality its own schools, the difficulty could not well be avoided. New revenues were therefore necessary, and on the $23 \mathrm{~d}$ of December Inon a provisional budget for six months was agreed to, which included higher spirit duties, a progressive income tax and death duties.

As in the House itself, so in the country, racial antagonism was particularly marked during 1909 , and it must be admitted that the Bienerth ministry showed more energy

Racial feuds in Bohemia.

in repressing outbursts than many of its predecessors. Especially troublesome were the student riots at Prague during the first three months of the year. Not till the police charged the crowd with bayonets (March 28th) was there a cessation of hostilities. The student differences were only one aspect of the racial feuds, which expressed themselves in other ways as well. For instance, in January, there wats an attack on Czech postal officials at Eger; at Cracow the Czech population resolved on a boycott of German commercial houses; on January 29th Baron Sternberg, a prominent ('zech leader, roused German feeling by declaring that Bohemia was 
inhabited by Czechs and robbers. . Though for a time there was a cessation of hostilities, race opposition smouldered. That it had not abated is proved by the fact that the conference of Austrian Catholics fixed for the first week in September in Vienna had to be postponed because it was feared that national ill-feeling would break it up.

The Czechs were not the only discontented element in Austria. There were also difficulties with the Italian subjects of the Empire, who had long been clamouring' for an Italian University at Trieste. But the Slav nationalities had also put for-

The Itallan University Question.

ward a similar request; and while the Government were willing to meet the Italian demand, they were by no means disposed to listen to the Slavs. Hence they were in somewhat of a difficulty. However, a Bill was introduced in the Reichsrat. (Jan. 20, I909) for the establishment of an independent Italian Faculty of law, to be attached to the Vienna University. But this did not content the Italians, chiefly because they considered the capital unsuitable, and more than that, because in the proposed scheme lectures in German were optional. So the scheme was shelved for the moment, and the Italian agitation continued. Several alternative proposals were put forward by the Government, but none of them found acceptance, and on May I4th I9Io, two hundred Italian students demonstrated in front of the Parliament buildings in favour of a full university at Trieste. No sooner did the Italians recommence their campaign than the other nationalities again put forward similar demands. The Czechs, who already had a university of their own at Prague, clamoured for a second one at Brünn; the Ruthenians also demanded a seat of learning, though they were not agreed as to the locality; the Slavonians pressed for a University at Laibach, and the Rumanians asked that the University of Czernowitz should become a Rumanian academic centre. The Government could not possibly satisfy all the demands, partly for lack of funds and partly because it was not politic to accentuate national differences still more. As it was, student riots were numerous enough; on July I, I9I0 a serious conflict between Poles and Ruthenians occurred at Lemberg.

The Agram trial was another illustration of the determined policy of the Government to maintain order with a firm hand. The dissatisfaction of the Slav elements in the The Agram Empire expressed itself in sympathy with the Servians, and it was alleged Trial.

that an extensive Slav movement was on foot to wrest Croatia, Slavonia and Bosnia from Austria-Hungary in order to join them to Servia, with the view of forming a "Greater Servia." Fifty-three persons, mostly traders and teachers, were accused of high treason; the trial lasted from March 3 to October 5, 1909, and thirty-one of the accused were found guilty and sentenced to penal servitude. The evidence was somewhat flimsy, and an appeal was lodged against the decision, which ended (Nov. 22, 1910) in the quashing of the sentences.

An echo of this case was the Friedjung trial. The Servian conspiracy had naturally been commented upon in the press, and among others, Dr. Henry Friedjung, a publicist of some note, had written an article on the subject in the Nene Freie Presse The Friedjung of March 25, 1909, in which he accused the leaders of the Serbo-Croatian Friedjung
case. subsidies from the Servian Government. The three persons named brought an action for libel against Dr. Friedjung (September 9-22, I909), in the course of which it was proved that the documents on which Friedjung had based his accusations had been forged. He thereupon withdrew his charge and the case was dropped.

The racial conflicts were as bitter as ever in the year igro. Nevertheless the smooth drift of foreign affairs left the Government free to become master in its own house.

\section{The}

Emperor's efghteth birthday. Moreover, the personality of the Emperor did much to give it support indirectly; the celebration of his eightieth birthday (Aug. I8, I910) only heightened the patriotic feelings of large masses of people. Hence the work of the Government was facilitated somewhat, and it made fair progress. It strengthened the army and navy, it made commercial treaties with the Balkan States, and it promulgated a constitution for Bosnia-Herzegovina. For defence no less a sum than twelve millions was voted, besides about $£_{900,000}$ annually in addition, and 
for social insurance some three to four millions sterling. The Reichsrat therefore passed bills for extensive loans, and on June 24th the Budget for 19ro was agreed to.

In both Austria and Hungary the ministries appeared to be stronger than the Opposition parties, even though their majorities were very small. The smallness of the majorities, however, rendered their position so uncertain that when a

The Canal Question. question arose on which the parties were not united the situation might become impossible. As a matter of fact it did in Austria; the stone of stumbling was the Canal policy of the Government. As early as Igor the Körber ministry had overcome obstruction by holding out the promise of an extensive programme of public works, more especially the construction of numerous canals, in which Czechs and Germans were alike interested. But the cost of the scheme had proved too high, and though the necessary bills had actually passed, the work was never carried out. Part of the plan had been the canalisation of Galician waterways, and the Poles now pressed for their realisation (Nov. 24, I010). The resolution of Moraszewski was carried by 257 votes to I 28, and for thirteen days longer the Cabinet held out, hoping that the matter Resignation would not be insisted on. The Poles, however, were determined to make of the the most of their victory, and on December I 2 th the Bienerth ministry Bienerth Ministry. resigned. The Emperor requested it to carry on the work of government until a successor should be appointed. In the meantime the House agreed to a provisional budget for three months (Dec. 16th) and also extended the Charter of the Austro-Hungarian Bank until February-19r r.

The reason for the Government's defeat on the Canal issue was the impossibility of uniting the Germans and Czechs, both of whom would, in normal circumstances, have

German and

Czech

opposition

in Bohemia. voted for the Government on this question. But they were as far as ever from any agreement on the language question. An attempt on the part of the Premier to unite them by a personal appeal to the leaders of the opposing "clubs" proved fruitless. Keen as the opposition was in Vienna, it was keener still in Prague, where, as a result of the obstructionist policy of the Germans, the Bohemian Diet had to be adjourned after sitting four days (Feb. 8, roro), because it could do no business. From February 8 th to September 3 oth the Diet was not in session, and as a result, since the local budget could not be got through the House, the Executive had to decide on a policy of economy, which included deleting items of expenditure for humanitarian and educational purposes. No less a sum than three-quarters of a million sterling was thus eliminated, and one consequence was that 280 lunatics had to be released from the State asylums. Nevertheless, the language struggle continued. On Scptember 20, Ioro, a conference took place at Cracow between Germans and Crechs with a view to some settlement, the Germans intimating their readiness to meet the other side half way. Thereupon the Diet was summoned for September 3 oth. On October 20 th the conference was renewed, and a temporary agreement was arrived at. According to this all self-governing communities should choose their official language as they wished. In Prague, however, all notices should be issued in both languages, but the seal of the city and the names of the streets were to remain Czech. It seemed as though some settlement was in view. But on November 17,1010 , the Germans declared their inability to accept the compromise, and once more the Diet had to be closed (I)ec. I 4 th) without any provision having been made for the financial needs of the year. The result was that Bohemia had to face a deficit of over two millions sterling.

The struggle in Bohemia was embittered by an agitation to throw off the authority of the Catholic Church (Los ron Rom Bewegung). On the zoth of April a mass meeting was held in Johannesberg, which resolved on a policy of leaving the Church, Catholic and fixed May isth as the day appointed for the purpose. On May 6th Movement. there was a demonstration in front of the Parliament Buildings by several humired divoreed men and women, who demanded that the Civil Code should hes amenderl as to allow of divorced persons remarrying. and threatened to leave the (hurch oflerwise. From the o, th to the I 3 th of September the Congress of Austrian (atholics met at Innsbruck, and on the is th a counter demonstration of over 
a thousand persons was held, demanding the separation of the State from the Church, and freedom of the schools from clerical influence.

The racial conflict in Bohemia found its counterpart in Galicia and Moravia, where hatred of the German element increased in strength, more especially after the 50oth

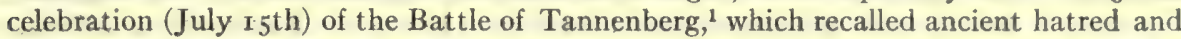
showed itself in persecution. In one community, Themenau, in Lower Austria, the elected corporation was removed (July 28th) because of its anti-German excesses, and was replaced by a Government commissary.

The promulgation of a constitution for Bosnia-Herzegovina was in striking contrast to this last fact. The two provinces had been annexed in I908, and the constitution was proclaimed on February 22, I910. The Diet, chosen by universal Constitution suffrage, is competent to deal with provincial finances, taxes, railways, police

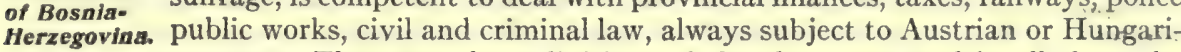
an veto. There are three divisions of the electorate, and in all three the number of representatives in the Diet is fixed according to the number of inhabitants professing each religion. the Jews have one seat, the Roman Catholics sixteen, the Mussulmans twenty-four, and the Orthodox thirty-one. The Government appoints also twenty members, including the spiritual heads of the four religious communities. The President and Vice-Presidents of the Assembly are appointed by the Emperor every session, each religion being represented, and holding the presidency in turn. On June I4th the new Diet was opened by the Emperor in person, the occasion being marked by an attempt on the life of the Governor, General Vareschanin; and one of the first acts of the Diet was to pass a unanimous resolution declaring the constitution too narrow and not in accordance with the wishes of the people.

But the Austrian Cabinet crisis of December roro required immediate attention, and little regard was likely to be had to the demands of the new Diet, though it did receive a good deal of sympathy. On January 9, I9г $\mathrm{x}$, the Cabinet was The New : reconstructed. Baron Bienerth remained, and portfolios were given to in Austria. members of the German, Czech and Polish parties. But the Slav element was strong in the Cabinet; the Germans, therefore, disliked it, and already on its first appearance opposition was threatened. Its immediate work was to reneiv the charter of the Austro-Hungarian Bank. This passed smoothly enough, but further effective work was impossible owing to the opposition of the Czechs and the Social Democrats. The Ministry accordingly appealed to the country, and in The General June the General Election brought about a somewhat different rearrangeElection of ment of parties in the House. The German Nationalists obtained I00
June

seats; the Christian Socialists (Germans) 73; the Social Democrats (German Club) 49; the United Bohemian Club 84; the Social Democrats (Bohemian Club) 25; the Poles 70; the Social Democrats (Polish Club) 9; the Ukraine Union 28; the Croatio-Slavonian Coalition 27; the Dalmatian Club 7; the Unio latina 21; and Independents 23. The result was that the Social Democrats became the most influential party. Moreover, Baron Bienerth, having been defeated at the polls, was succeeded Dr. Stürgkh by Baron Gautsch ${ }^{2}$ as Premier. He did not hold office long; the task of Dr. Sturgkh attempting to unite Germans and Czechs was utterly hopeless, and on
Premier. October 3I, I9II, Baron Gautsch was succeeded by Dr. Stürgkh. ${ }^{3}$ The change of personnel did not denote any change in policy. Parliamentary business showed the same characteristics this year as it did in previous years-obstruction and no progress, and when the end of the year approached no budget had been passed.

It was not very different in I9I2, when the great bone of contention was the Army

${ }^{1}$ Battle of Tannenberg on July 15,1510 , where a Polish-Lithuanian army defeated 80,ooo German Knights under the leadership of Ulrich von Jungingen.

${ }^{2}$ Paul Gautsch von Frankenthurn, born February 26, 1851 ; in the Ministry of Education 1885-1893 and 1895-97; made a peer 1890; Prenier and Mlinister of the Interior 1897-98; Premier 1904-06.

${ }^{3}$ Karl Stürgkh, born October 30, 1859; entered Ministry of Education 1880; Minister of Education I909. 
Bill, which nearly upset the Stürgkh administration. The catastrophe was averted only by the personal appeal of the Emperor. The difficulties of the situaThe Poltical tion were accentuated by the serious misfortune that befell Count Stürgkh,
Situation In 1912. who was threatened with blindness (May 15, 1912), and it was therefore necessary to appoint an acting Premier in Baron von Reinhold, the Minister of the Interior. After much negotiation, the Army Bill was passed, and the crisis averted. The outbreak of the war in the Balkans in October I9I 2 turned attention to matters of foreign policy, and the internal strife of factions flagged in consequence.

Economically the year I9I I was one of fair prosperity, chiefly because of the two successive good harvests (I910-1I). The total volume of trade was large, though manufacturers and traders complained that the margin of profits was inade-

Soclal and Economic Progress.

quate, owing to the continued high prices of food, and the remarkable rise in rents in most of the large towns. In consequence of these burdens on the working classes the Socialists organised a demonstration in the summer. The crowd became so threatening that it was necessary to order a cavalry charge. When the House met the incident was discussed, and during the sitting a man in the gallery fired at Dr. Hochenburger, the Minister of Justice.

Commerce was favourably affected by the various commercial treaties passed in I 909 and I910. The treaty with Servia came into force on January 24, I9 I , and put an end to the long tariff war. Austria stood to gain chiefly by the importation of slaughtered cattle from Servia. These would be supplemented by the exportation of cattle from Bulgaria, by the treaty which came into force on April 22, 1912. With Montenegro likewise a commercial treaty was ratified on March 4, Igr 2.

As regards social legislation, the only enactment of importance was the law (June 3 , I910) forbidding night-work for women, according to the terms of the international agreement of Berne. It came into force on August I, I9I I (in the case of the raw sugar industry it will take effect in 1914 ).

Hungary.--In Hungary the prolonged political crisis of I000 came to an end on January I7-18, I9ro, with the succession by Count Khuen-Hedervary to the Premiership. His Cabinet was one of moderate views, yet when the House met The Khuen- (Jan. 24, I IIO) it passed a vote of lack of confidence in the new ministry Hedervary by an overwhelming majority. The Premier replied by adjourning the
Cabinet. House for eight weeks. The time was utilized by the establishment of the "National Party of Work," under the leadership of Count Tisza. It appealed to the nation for support, pointing out that it was impossible to realize the demands of the Independent and Kossuth parties, seeing that the Crown would never agree The National to the Hungarian word of command, and that an independent Hungarian Party of Bank had not sufficient credit. It was necessary to form a party which
Work. should bring about harmony between the Crown and the people, and make possible a constructive policy. On March 2 ist the House was recalled to be dissolved, and the violent conduct of the members of the Kossuth and Justh parties, followed by street rioting by the Social Democrats, disgusted moderate men still more.

On March $22 \mathrm{~d}$ the House was dissolved, and when in June the new elections were held, the Government received a large majority- 246 seats out of a total of 4.13 , whereas Elections the Independent Party in its two sections received only 85. Consequently Elections the Hungarian Parliament was able after a long interval to get legislative
of 1910 . work done. The House was opened on June 25 , roro, and the speech from the Throne referred to "the most urgent and immediate task of regulating the suffrage question anew." The Government promised to introduce a bill " on the basis of univerUniversal sal suffrage, which while being in full consonance with the unity of the Suffrage. national character of the Hungarian State will yet be in accord with the demands of the development of democracy." Other measures that were passed included a bill sanctioning foreign loans and the Census Bill.

${ }^{1}$ Count Caroly Khuen-Belasi-Hedervary, born June 23, 1849; entered Parliament 1875; Ban of Croatia 1883-1903; Premier 1903 and again in 1910. 
The Independent Party, however, still maintained their old programme and resorted to obstructionist methods in order to make themselves heard. In November I9I I things came to such a pass that it was resolved to adopt new rules of procedure to Obstruction make obstruction impossible. The Opposition was unyielding, and the ment.

House witnessed disgraceful scenes, the upshot of which was that the Cabinet came to an arrangement with the Kossuthists with regard to the Army Bill. But the basis of this agreement the Crown was unable to recognise; whereupon Count Khuen-Hedervary tendered his resignation (March 6, I9I2). At the request of the Crown, however, the Premier agreed to go on acting as First Minister, especially as the Emperor threatened to abdicate if he would not (March 31, 19I2). It was intended that he should try to smooth over the difficulties of the situation. But difficult as the state of affairs was, it was intensified by the policy of the Government in Croatia. In December I9I I the General Elections for the Diet had been held, and the

Government were defeated, obtaining only 21 seats, whereas the SerboAbsolutsm Croatian coalition obtained 24 and the Allied Croatian Right 27. Hence Croatia.

the Diet was dissolved at the end of January 1912, without meeting. Preparations for a new election were at once commenced, but the Government, fearing a recurrence of the results, stopped the electioneering and suspended Croatian autonomy. A new Ban, M. Cuvaj, was appointed as Royal Commissioner (April 3, I9I2), and virtually a despotism was established. A movement of protest at once grew up. By the middle of April 1912 it was beginning to take practical measures, such as the proclamation of a boycott of all goods coming from Hungary.

The Khuen-Hedervary Cabinet was unable to maintain itself, and on April i 7, I912, it resigned. Three days later the Emperor-King entrusted Dr. de Lukacs, Minister of Finance, with the formation of a new Cabinet. The ministers of the late

Resignation of Khuen Hedervary. cabinet joined the new ministry, and Dr. Lukacs attempted to find means of coming to some understanding with the Kossuth Party with a view to introducing the Army Reform measure (April 21, I9I2). The negotiations failed, and the only method of overcoming obstruction in the House seemed to be by an abusive interpretation of the standing orders. Count Tisza, who favoured such a The Lukacs course, was elected President of the Chamber (May 22, I9I2), and before Ministry.

long he carried through his policy with great success. On June 4 , I9I 2 , he secured the adoption of the Army Bill, and-after 36 Opposition deputies had been removed by the police and the rest had left the Chamber-of a bill to increase the annual contingent of Honvéd recruits. His action was approved by the Monarch (June I2, I9I2), but the Opposition were by no means cowed. When Parliament met after the recess (Sept. I7, I9I2) the same tactics were resorted to by the dissatisfied party and similarly met by the President. For two days the Chamber presented a scene of disorder, and on Sept. I8th the majority of the Deputies adjourned sine die.

Despite these proceedings the Hungarian Minister of Finance was able to declare (Sept. 23, I9I 2) that the fiscal year ended with a surplus of over $2 \frac{1}{2}$ millions sterling.

\section{Economic}

Progress.

That was accountable by the fact that the year was on the whole a prosperous one for Hungary. One way in which the improved conditions showed themselves was an enormous development in the building trade. In Buda Pest alone no less than 600 new houses were completed, many of them very large ones. But prices of the necessaries of life, particularly of meat, continued to rule very high in the towns, and in all probability the high price of food contributed to the prosperity of farmers. That agriculture was a profitable business was evidenced by the immense increase in the value of land and the rise in rents.

Obituary. - Of famous people who have died since 1909 the following may be mentioned. 1909:- on July 9, Count Badeni (b. 1836), Austrian Premier from I895 to 1897 (see E. B. iii, 34-36).

1910:-on February 8, Dr. Franz von Juraschek (b. I850), President of the Statistical Commission; on March IO, DR. KARL LUEGER (b. I 844), Chief Burgomaster of Vienna, and a well-known anti-Semite (see E. B. iii, $35^{-38}$ ); on June 29 , Christine Hebrel (b. I8I8), widow of the poet Frederick Hebbel (E. B. xiii, 165), and formerly a famous actress; 
on September 20, Joseph KaIvz (b. $185^{8}$ ), one of the foremost actors of his day (see $E$. $B$. Xvii, 34); on November 2, MAJ. (iEN. ROBERT VON STERNECK (b. 1839), geographer, specially known for researches in the determination of gravity, and for his work in designing pendulum apparatus (see E. B. viii, 809 ; xii, 386 ).

19I1:-on January 22, GABRIEL UGRoN (b. 1848), a well-known Hungarian Clerical Deputy who was a staunch opponent of the Triple Alliance; on February II, BARON ALBERT vos Rothschild (b. I845), head of the Vienna house; on May 4, CharLes DE Hieronymi (b. 1837), Hungarian Minister of the Interior 1893, and of Commerce and Railways 1903-04 and 1909; on Mlay 18, GUSTAV MAHLER (b. 1860), a famous composer and orchestral conductor; on May 23, BARoN Banffy (b. 1844), Premier of Hungary 1895-99 (see E. B. iii, 315); on June I0, ADOLF Wilbrandt (b. 1837 ), the poet, dramatist, novelist, Director of the Hufburg Theatre in Vienna $1881-87$ (see $E$. B. xxviii, 631); on December 25, CouNt FERDINANi ZiCHY (b. 1829), the Hungarian statesman (E. B. xxviii, 979).

1912:- - On February 17, Baron Lors vON AERENTHAL (b. 1854), Foreign Minister of the Dual Monarchy, 1906-I9I2 (see E. B. iii, 25; ix, 95I), whose name will be associated with the annexation of Bosnia-Herzegovina; on August 29, Baron HeINRICH Calice (b. I82I), Austro-Hungarian Ambassador at Constantinople, I880-1906; in September, JARosLAV liRCHLICKY (b. 1853), the Czech poet and dramatist (see E. B. iv, I35); on Dec. 22, David Heistich MÜlleg (b. I846), professor of Semitic Languages at Vienna University, a well-known Orientalist (see $E . B$. xxv, 356a, ii, 264b, xiv, 620c); on Dec. 23. Prince George Constantine Czartoryski (b. 1828), member of the Austrian Upper House, a descendant of the famous Polish family (see E. B. xxi, 9I zb; vii, $72 \mathrm{I}-2$.

Aulhorities.-R. IV. Seton Watson, Absolutism in Croaita (1912); James Baker, Austria: IIer people and their homelund (1912); J. Grunzel, Handelspolitik und A usgleich in OesterreichI'ngarn (1912); F. Heiderich and S. Schlider, Oesterreich-Ungarn als Wirtschaftsgebiet (1912); W. Federn, Der Oesterreichische Volkswirt fur Industrie und Finanzwesen (1912).

(M. Epstein.)

\section{BELGIUM ?}

Population.-The total population of Belgium, accordıng to the census returns of December 3I, I910, was $7,423.784$, an increase of I0.9 I per cent since the census of I900. Of these, 2,822,005 spoke Flemish, and 2,574,S05 French; 700,997 spoke both Flemish and French, and there was besides a very small minority who spoke German. The population of the four chief cities, with their "agglomérations" (Salenbe) were:Brussels 720,347; Antwerp 398,255; Liége 242,357; Ghent $210,428$.

Political History. - The Constitutional provisions which came into force at the death of King Leopold II (see E. B. xvi, 46I) on December 17 , 1909, were a good illustration of the theory that in Belgium all the powers in the State are delegated (Art. 25). Until the oath has been administered to the new king before the Chambers, the prerogatives of the head of the State, under the constitution, are vested in the Cabinet Council (conseil des Ministres), by whom they are exercised in the name of the nation (Art. 79). They are empowered to make decisions and give assent to laws. Belgium virtually ceases to be a monarchy during the interregnum, which lasts, at most, for ten days.

On December I4, 1909, Leopold II was still able to affix his signature to the act which put recruiting for the army on a new footing, a reform on which he was deeply set. That date marks the end of the system of drawing lots and paying substitutes. Military service is now required of one son out of every family, though some, especially ecclesiastics, are still exempt. The period varies from fifteen months to two years. The average peice effective of the army consisted in I9I 2 of about 44,595 men, with a yearly levy of 17,4 I men; the total effective strength in 19 I I was given as 182,770 officers and men. Proposals were being mooted however for putting every able-bodied Belgian through a term of military service, which would greatly increase the fighting strength of the country. ${ }^{2}$

1 See E. B. iii, 668 et seq.

When the Betgian legislature met in November 1912 and the Premier, M. de Broqueville, m.ule hi- ministerial declaration of policy; he made a pointed reference to the probable need of strengthening the army, which formed the theme of an important article on December $3 \mathrm{rl}$ in the London Times from the pen of its military correspondent. Recent events, said iI. de Broquesilh, had compelled the (iovernment to inquire whether the state of their military organisation wats such that it could meet the necessities of the day. In allusion to the suarantee of Belgian interests and neutrality by (ireat Britain by the Treaty of 1839 , he printed out that the grouping of the (ireat Powers had resulted in alliances and ententes which might, in cave of war, "remove from the guarantee the value which the neutrality of 
There has been little change in Belgian policy with the new reign, though in character King Albert is altogether unlike his predecessor. The new King's civil list, as provided by the Constitution (Art. 77), was fixed for the entire reign, at the same amount as that of Leopold $\mathrm{II}-\mathrm{f}_{\mathrm{r}} 32,000$ per annum:

The Government has remained in the hands of the Catholic party. Up to the end of 1912 not a single Socialist burgomaster had been appointed by the king, but in most large cities a Liberal fills that office:

By-elections during Igro had to some extent pulled down the Catholic majority in parliament, but at the general elections of 1912 they were returned in still greater force, a result all the more striking as a sign of public opinion, considering that Proportional Representation is supposed to act as a check on sudden revulsions of this kind. On June 17 th the Cabinet of $\mathbf{M}$. Schollaert, who had been Premier since I908, was obliged to resign over an Education bill. Political feeling went against the proposed plan for dividing State grants between official and voluntary schools (écoles libres) according to the number of pupils. The educational test system (bon scolaire) is a novel form of the subsidized voluntaryism (la liberté subsidiée) in high favour with the Catholic party, and already put in practise by them in social legislation. Liberals and Socialists together made a stand against it, and at the same time started a campaign against plural voting, demanding that Art. 47 of the Constitution be revised and Manhood Suffrage, pure and simple, substituted. Under the system of proportional representation in Belgium, it should be noted, supplementary votes are allotted as follows: one extra vote to heads of families of the age of thirty-five, and to voters possessed either of a property qualification or an income above a certain amount; while two extra votes are given for official status or the higher educational diplomas; but no individual may have more than three votes.

There were I, 72I, 755 qualified electors on the roll of voters for the Chamber in I9I 2; and $1,460,236$ comprised the electorate for the Senate (for which the age qualification of voters has been raised from twenty-five to thirty); but thanks to the plural system, the total number of votes for the Chamber was $2,763,5 \mathrm{I} 3$ and $2,475,679$ for the Senate. In the new parliament there are ror Catholics, 45 Liberals, 38 Socialists and 2 ChristianDemocrats; while in the Senate there are 54 Catholics, 3 I Liberals and 8 Socialist-Radicals; but to these must be added the number of senators returned by the Provincial Councils-I6 Catholics, 7 Liberals and 4 . Socialists. There was no sign of any reappearance of the educational test in the programme of the new government under the leadership of Baron Ch. de Broqueville, who succeeded M. Schollaert. Their policy seemed to be to improve the professional schools, to increase the attendances, and to prolong school-days by raising the age for child labour to 14 or 15 .

Education is of course not compulsory by law in Belgium. The last census returns gave the number of illiterates over the age of eight as $\mathrm{I}, 049,400$, or rather more than $\mathrm{r} 9$ per cent. The number of children in primary schools on December $3 \mathbf{I}$, IgII was I,457,033; in normal schools 5,373 . The attendance at the universities during the academic year I9IO-II was:-Liège 2,790; Louvain 2,630; Brussels I,318; Ghent I, I97.

Social Legislation.-Some further social legislation has been passed, always in the guarantor could alone assure;" and in these circumstances it would be necessary to prevent the occupation of Belgian territory by any belligerent by forces which were exclusively Belgian. The Times correspondent, undoubtedly reflecting the view of the British War Office, welcomed this declaration as pointing at length to a realisation by Belgium that her weakness might prove a danger both to herself and to others. He took the opportunity to repudiate, on behalf of Great Britain, the existence of designs, attributed to her in some Catholic quarters in Belgium, for seizing Antwerp and invading the country if war with Germany should occur. England would not consider that Belgium had done her duty were she to remain indifferent to the passage of a foreign continental army across the Ardennes, but her hope was that Belgium would take her own steps to make such a proceeding too dangerous. This article was approvingly commented on in the Belgian press. On December 5th M. de Broqueville announced that he would prepare a new army scheme, instituting general service, with one-year volunteering,: and assuring the complete defence of the fortified positions of the country by a first line army of 150,000 men, to be increased to 330,000 in war time with a yearly contingent of 33,000 men instead of 19,000 as now. The Government hoped to apply the new reform to the contingent of 19i3.- (Ed.) 
spirit of prudent half-measures, which is the Belgian way of meeting difficulties. The working-day in mines has been reduced by law to nine hours, or at most to ten hours if absolute necessity for it is recognized by royal warrant. The Government is also empowered to reduce the normal hours of work in unhealthy trades (Law of December 31, I (90)), wide discretion being left to the executive.

A new law, regulating mines in general, was the outcome of the discovery of coalseams in La Campine-a district lying in the provinces of Antwerp and Limburg. The fact is important both commercially and politically, for it will bring a great industry, so far confined to the Walloon country (the basins of Liége and Hainaut) into Flanders itself. The old Napoleonic law of 18 Io was recast on June 5, I9I I; State intervention was carried further, and no women may now be employed underground. The same regulation was applied to working at night, which women are now prohibited from doing in factories, (Law of Aug. Io, IgII). Of coal 23,916,560 tons (metric) were mined in r 1910 , and of iron (the production of which was greatly decreased), r 22,960 tons. In I I I I-12 an important new coal-field was being opened up in the Campine.

A law passed June 5, rgr I (and amended May 5, 1912) dealt with old age pensions for miners. Wage earners at the age of sixty, whether natives of Belgium or foreigners, can claim ıod. per day from a fund raised partly by the workers themselves, partly by contributions from employers and the State.

The arbitration boards called Conseils des prud'hommes, for settling disputes between employers and men, have been reorganized under a law passed May 15, I91 2. As these are elective bodies, political considerations are apt to intrude in their composition, and on that account proportional representation and compulsory voting have been introduced for them, along with a bolder innovation, women having votes and being themselves eligible. The Tribunaux de Commerce (commercial courts for settling trade disputes) are also elected by those whose interests are involved; there are I4 of them in the country. Judges in Belgium are appointed by the Goverment, whose choice is apt to fall on men of its own political colour; but the Presentation system (Art. 99 of the Constitution) to some extent restricts the selection, for the councillors of the three Courts of Appeal are nominated from double lists of candidates presentd by the Provincial Councils and by the Courts themselves, while Councillors of the Court of Cassation are nominated from double lists presented by the Senate and by the Court. The Court of Cassation deals only with points of law in cases brought before it, questions of fact being referred to other courts (Art. 95 of the Constitution).

Among recent legislation, mention may be made of the Law of Nationality (June 8, 1909), modifying cert ain provisions of the Civil Code, which is still the Code Napoléon, revised only in certain respects. Birth on Belgian soil confers the rights of citizenship, under given conditions, even upon the children of aliens. This return to the jus soli is a new infringement of the long dominant principle of affiliation. A law for the protection of children (May I6, I9I 2) defines limits at which the patria potestas ceases, and establishes "children's judges." Minors brought before the courts can be handed over to institutions ad hoc, and kept under surveillance and discipline, instead of being subjected to ordinary punishments.

Languages.-The language question looms large from time to time in the history of Belgium. The first half-century of national independence was marked by a French reaction after the "Flamandisation" policy pursued under the Netherlands government ( 1815 to 1830 ). A counter reaction, not yet spent, tends to magnify the political importance of the Flemish element. Flemish is put on a so-called equality with French in the secondary schools, by the Law of May I2, I9Io, which inclines to treat French as a foreign tongue in Flemish-speaking districts and vice versa. In practice, the importance of this law is discounted; for firstly, in the city of Brussels and its suburbs the choice of the principal language is left to the parents; and secondly, the law naturally is not enforced in the voluntary schools (écoles libres) which flourish so largely in Belgium. In these French predominates as before. There has been some talk of "Flamandising" Ghent University, either wholly or in part, but so far nothing has been done. 
Commerce.-The commercial prosperity of Belgium was brilliantly illustrated by the Universal Exhibition held at Brussels in I9Io. The following are the most recent trade returns for " special " commerce (exclusive, that is, of goods received for transit across Belgium). The imports in I9II reached $f_{1} 69,105,110$; and exports, $f_{1} 35,101,700$. Trade with Great Britain for the same period showed imports $£ 20,492,016$ and exports $£_{1} 8,145,553$. With the United States the import trade amounted to $£ 9,166,409$, and

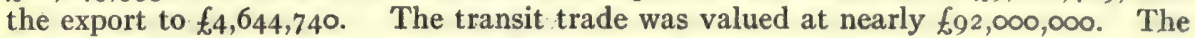
total tonnage of ships arriving at Antwerp in the same year (I III) amounted to I 2,625, I6 6 . Nevertheless, the exchequer is not in a very flourishing condition. Belgians pay little, it is true, in the way of direct taxation, and even the indirect taxation is not excessive. With the growth of State expenditure, however, the adverse balance increases. It is a long while now since any effort has been made to face the financial position, though this has come to be an imperative duty, as may be seen from the increase in the public debt, which has grown from $£ 56,413,863$ in 1880 to $£_{1} 5_{22,238,539}$ at the end of 1910 , a rise of $£ 95,824,676$, or 169.86 per cent. The national three per cents have fallen to 79 , and it was considered expedient to issue treasury bonds at 4 per cent (and even higher) to the amount of $£_{\mathrm{I} 2} 2,444,850$ in $\mathrm{Ig} \mathrm{I} 2$ alone.

For the budget (budget de voies et moyens) of $\mathrm{IgI}_{3}$, the revenue was estimated at $£_{3} 30,040,626$; and the expenditure at $£_{20,386,246}$. There was also a supplementary budget (budget extraordinaire), amounting to another $£ 570,540$. It may be noticed in this connexion that the government is nearly always behind-hand with the budget; it is seldom voted till the spring or even the summer. Hence, for most ministries, Parliament is driven (as in France) to voting "provisional twelfths," a practice which always restricts its power over the purse.

Colonial Administration.-As regards the management of the Belgian Congo (see below) the annual sum of $f_{1} 32,000$ put at King Albert's disposal by the clause inserted in the Treaty of Cession, October I8, I 908 , is applied, as agreed upon, to purely colonial purposes. The Minister for the Colonies renders an account to the Chambers annually. Some alterations were made in the Colonial Law of October I8, I908, on March 29, I9I I, and again on March 5 and May I3, I9I2, but it remains substantially the same. No powers may be delegated to any chartered company or private committee. Speaking generally, the trend of Belgian colonial policy is towards free trade (libertê commerciale), towards abolishing forced labour, and taking moral and physical care of the natives. Different parts of the Domaine which used to lie under a special monopoly (exploitations en régie) have one by one been thrown open to free competition. The Colonial Council has proved equal to its task, in the examination of supplementary legislation for the Belgian Congo within the cognizance of the King (Loi coloniale, Arts. 7 and 24).

Obituary.-MARIE, Countess of Flanders (b. 1845), mother of the King of the Belgians, died November 26, 1912; she was the daughter of Prince Charles of Hohenzollern-Sigmaringen, and married the 3rd son of Leopold I in I867. The death of AUGUSTE BEERNAERT (born at Ostend on July 26,1829 ) on October 6,1912 , removed a leading figure in Belgium. Originally a lawyer, he entered politics and in 1873 first became a minister, being subsequently premier for ten years (1884-94); he was head of a Catholic cabinet at the time of the Revision of the Constitution (1892-93). He was a moderate and cautious statesman. He had taken a prominent part, of late, in the pacifist movement, presiding over the second Peace conference at the Hague in 1907, and being awarded the Nobel Peace Prize (with M. d'Estournelles de Constant) in igog. Among others the death may also be noted of the well-known geologist, EDOUARD FRANçors DUPONT (b. 1841; see E. B. xix, 278a), on March 3I, I9II.

See generally, H. Pirenne, Histoire de Belgique (4 vols., 1902 onwards); A nnuaire statistique de la Belgique et du Congo belge pour I9II (Brussels, I912); P. Errera, Traité de Droit public belge (Paris, I908), and Das Staatsrecht des Königreichs Belgien (Tübingen, 1909); O. Orban, Le Droit constitutionnel de la Belgique (3 vols., Paris-Liége, 1906-II); J. Barthelemy, L'Organisation du suffrage et l'Expérience belge (Paris, 1912).

(PAul ERrera.)

\section{The Belgian Congo. ${ }^{1}$}

Since the transfer of the Congo Free State to Belgium sincere efforts have been made by the Belgian government to effect reforms, under the direction of M. Renkin,

'See E. B. vi, 922 et seg. 
minister for the Colonies, and with the active encouragement of King Albert. By royal decree of March 22, 1910, the right to collect, and to dispose of in trade, the natural products of the soil was restored to the natives. This decree became operative in the whole of Belgian Congo in July r 9 r 2 , parts of the colony having been opened to trade in July Igro and July Igr I respectively. An endeavour was also made to restore the authority of tribal chiefs, a tax in money was substituted for the tax in rubber, and the demands of the reformers were met on nearly every point save that of land tenure. Up to the end of I9I 2 the right of the natives to ownership of tribal lands had not been conceded. The government, moreover, while granting absolute freedom of trade, itself remained a trading concern and entered into keen competition with its rivals. In the later half of $\mathrm{I} g \mathrm{r} 2$ the British and American consuls-general were sent on an extended tour in the Upper Congo to report how the reforms decreed in Brussels were working in practice. Until satisfied that the reforms were in actual operation the British and American governments withheld their recognition of the annexation of the Congo State by Belgium. By the end of ror 2 all the other Powers had recognized the transfer.

During r9IO-I 2 the N.E. frontiers of the colony adjoining Uganda and German East Africa were delimited, and the delimitation of the Congo-Rhodesian frontier was in progress in 1912. By the Franco-German agreement of November I9I 1, which at one point brought the German frontier down to the Congo River, the right of France to pre-emption, should Belgium desire to part with the Congo, was so far modified that it was agreed that in case of territorial changes in the Congo basin, France and Germany would discuss the situation with the other signatories of the Berlin Act of 1885 .

The native population was estimated in 1912 at no mure than $8,000,000$; the white population was between 5,000 and 6,000, of whom nearly 2,000 were government officials and 570 missionaries (350 Roman Catholics, 220 Protestants). The only district in which there is any European agricultural population is Katanga, where the climate resembles that of Northern Rhodesia.

The cost of administration, as was expected under the new régime, exceeds the revenue. In 1910 the revenue was $f_{1}, 340,000$, the expenditure $f_{1}, 612,000$. In 1911 the revenue was $£ 1,620,000$ and the expenditure $£ 2,360,000$. For 1912 the estimates were:- revenue $f_{1}, 815,000$, expenditure, $£_{2}, 661,000$. The public debt (1912) was $£_{10}, 475,000$. The chief products are rubber (still plentiful in the Aruwimi Forest, on the Angola border and in some other regions), ivory, palm oil and palm nuts, copal, cocoa, gold and copper. The gold comes mainly from the Kilo mines; the copper from Katanga. In March I9I I the British firm of Lever Bros. was granted a concession of $20,000,000$ acres in the lower Congo to establish a palm oil industry and soap manufactory. The same firm also obtained a concession in the British gold coast colony.) Gum copal during I9II-12 became an important export; the Congo copal is of excellent quality: On ivory, in which the State largely trades, there are heary duties. In 1910 the value of exports was $f 6,488,000$, that of the imports (chiefly textiles, food stuffs and machinery) $£ 4,757,000$. The bulk of the trade is with Antwerp. The tonnage of shipping clearing Boma in 1910 was $617,000,33$ per cent being Belgian and 25 per cent British. France and Germany came next,

On May 25, I9 2, M. Fuchs, vice-governor at Boma, was appointed governor general of the colony in succession to Lieut.-General Baron Wahis. The Comité spécial du Kislanga had been abolished in March rgro and the administration of the province assumed by the State. It was placed under a vice-governor, M. Wangermée, with headquarters at Elizabethville, a town founded in roio (to serve the copper and tin mines of the district) in a clearing in virgin forest, at the then terminus of the railway from Rhodesia. In July I 9 I the extension N.W. of this railway to Kambove ( $10 \mathrm{~m}$.) was begun. Its completion was expected in March I9r3. From Kambove, another section of about 200 miles will bring the railway to the navigable waters of the Lualuba (upper Congo), thus completing a rail and river steamer service between Cape Town and Beira and the mouth of the Congo.

The founding of Elisal)ethville (named after the Queen of the Belgians) marked a boom in the development of Katanga. Its white population on January I, I912, was I, I32 of whom 519 were Belgians and 228 British. It covered an area of 560 acres and possessed 20 miles of streets. Within a radius of over $100 \mathrm{~m}$ of the town there were no native inhabitants and the govermment in 191 I formulated a scheme for the emigration of Belgian agriculturists thither. The white population of Katanga was in March 1912 between 1800 and 2.000 as 
against 750 in January 1911 . The chief copper deposits of Katanga-one of the richest copper regions in the world - are in the hands of the Union Minière, which started regular smelting at the Star of the Congo mine in August 19II. The company's total output of copper up to May 1912 (when smelting ceased for some months) was I,995 tons.

One of the chief difficulties of the administration is to secure a personnel of the best type; meantime many of the old agents of the Congo State have been retained. One of these officials in the Tanganyika region was in April 1912 sentenced to ten years imprisonment for summarily executing eleven native prisoners, including four women and a child. Other peccant officials have also been imprisoned, but in general "atrocities" are at an end. A second court of appeal has been established at Elisabethville.

See the British Consular Reports, specially Cd.6145 (I912); E. A. J. Paque, Notre Colonie: Étude pratique (Namur 1910); J. H. Harris, Dawn in Darkest Africa (London 1912); and, for current affairs, "Le Mouvement Géographique" (Brussels, weekly).

$$
\text { (F.R. CANA.) }
$$

\section{CHINA ${ }^{1}$}

In constitutional theory Republican China, under the political reorganisation of rgII-I2, retained the territorial heritage of the Chinese Empire intact. In spite of cross-currents in Mongolia, where separatist tendencies had manifested themselves before the establishment of the Republic, and in spite of difficulties with Tibet, the claim embodied in the new Chinese flag, that Chinese suzerainty is acknowledged by Chinese, Manchus, Mongolians, Tibetans and Mahommedans, held good. But, amid so great an upheaval, affecting the economic no less than the political and social affairs of the country, any account of contemporary China is subject to the consideration that it is passing through what is essentially a transitional stage.

Population.-In roro the Minchengpu (Ministry of the Interior) organised a census of the population of the Empire. With the exception of a few districts the enumeration was everywhere restricted to households, and in the case of one province, Szechuan, the census only covered half the total number of prefectures. By multiplying the households by 5 the approximate total of the population has been arrived at, and the official version of the roro census is as follows:-

\begin{tabular}{|c|c|c|c|c|c|}
\hline Province. & Population. & Province. & Population. & Province. & Population. \\
\hline Anhui & I $5,705,920$ & Hupeh. & $24,662,665$ & Kweichow. & 7,665 \\
\hline Chekiang & $19,441,555$ & Kansu & 4,533 & Shansi & 0,17 \\
\hline Chihli & $20,821,145$ & Kiangsi & T7,199,365 & intung & $26,889,3$ \\
\hline Fukien & I I $, 884,275$ & Kiangsu & $26,918,055$ & Shensi & $8,037,22$ \\
\hline Hol & $23,307,830$ & Kwangsi & $5,872,720$ & Szechuan & $16,392,10$ \\
\hline Hunan & $2 \mathrm{I}, 440,820$ & Kwangtung & $25,208,900$ & Yunnan & $7,740,070$ \\
\hline
\end{tabular}

To the total for the Eighteen Provinces $(298,862,220)$, was added the population of the Metropolitan City and Prefectures $\left(4\right.$, I $\left._{4}, 830\right)$, and of Manchuria, Mongolia, Bannermen, \&c. (9,402,975); giving an aggregate of 3 I2,420,025. This census, within the limitations noted, probably represents the nearest computation of the actual population of China. To round it off, we may add $6,500,000$, the Chinese estimate-probably too high - of the population of Tibet, and 6,607,805 for the remainder of the population of Szechuan, making the grand total for all Chinese territory, 325,527,830.

The number of foreigners resident in China is given in the returns for I9I $\mathrm{I}$ of the Maritime Customs as 153,522 , the details being as follows: American 3,470, Austrian 385, Belgian 291, Brazilian 22, British 10,256, Danish 295, Dutch I92, French I,925, German 2,758, Hungarian 26, Italian 424, Japanese 78,306, Norwegian 246, Portuguese 3,224, Russian 51,22I, Spanish 238, Swedish 150, others 93 .

Agriculture.-The only statistics available are those that relate to the movement of agricultural products through the Customs. The export abroad of cereals is not permitted, and such movement as there is through the Customs represents only a small proportion of the total production. The tribute rice sent to Peking from Anhui, Chekiang, Kiangsu and Shantung amounted to 120,000 tons annually. Kaoliang is the staple food in Manchuria: the estimated production of wheat is, however, $10,000,000$ bushels. Apart from silk, the chief products of China in order of export value are (the figures given being for I9I I):beans, including beancake, bean oil, beancurd, $£ 7,261,276$; tea, $£ 5,161,300$; cotton, $£^{2}$,${ }^{1}$ See E. B. vi, 166 et seq. 
909,194; sesamum seed, $£ 1,580,465$; straw-braid, $£ 1,385,863$; vegetable oils (other than bean oil), $f_{1}, 067,152$, or with bean oil $f_{1}, 854,465$.

Before the outbreak of the Revolution considerable progress had been made with the suppression of opium growing. By September I9II it had been established that Manchuria, Shansi and Szechuan were rid of the poppy plant, and in virtue of the agreement between Great Britain and China signed in Peking on May 8, I9I 1, the importation of Indian opium into these provinces was prohibited. The Revolution checked and in many districts put an end to the crusade against opium, but with the gradual re-establishment of authority throughout the country the veto on the poppy was restored. Under the Imperial Government cotton was largely taking the place of the poppy, particularly in the north of China, where official assistance was given in experimenting with American seeds and in other ways. The export of raw cotton from Tientsin rose from $149,102 \mathrm{cwt}$. in 1910 to $461,239 \mathrm{cwt}$. in I II I ; at Tsingtau it rose from $588 \mathrm{cwt}$. in 1909 to I8,5I4 cwt. in 1910 and $47,822 \mathrm{cwt}$. in 1911 .

China in I9I0 contributed 31 per cent to the world's trade in silk. Of the quantity exported, silk and silk products, 68 per cent came from the northern half of the country, including the Yangtze Valley and Chekiang, and 32 per cent from the south.

Straw-braid is manufactured mainly from a wheat with long straw grown on the plain bordering the Yellow river in Western Shantung and Southern Chihli. The export, which reached $18,484,000 \mathrm{tb}$. in 1909 , declined to $18,027,466 \mathrm{th}$. in 1910 and $16,101,067 \mathrm{fb}$. in 1911 .

Industries and Manufactures. - The number of factories in China is still limited enough to make a steady annual increase a feature of the conditions of the country. The new enterprises are both foreign and Chinese, but the Revolution has not modified so far the general antagonism to foreign capital. Among the chief industries, in order of the number of factories, etc., devoted to each, may be mentioned:-Distilleries and breweries (53), cotton spinning and weaving mills (4I), flour mills (40), oil mills (3I), electric light works (3I), docks, shipbuilding and engineering works (24), soap and candle factories (19), mining companies ( 18 ), silk filatures (I7), tobacco factories (16), arsenals (15), cement and brick works (15), waterworks (14).

The 18 mining concerns include foreign concessions and Chinese mines worked with foreign machinery. The annual output of thirteen coal mines worked by foreign machinery is approximately $5,000,000$ tons, with capacity for considerably more. From mines worked by native methods the annual output is probably another $5,000,000$ tons. The Ministry of Commerce and Industry publishes a list of mining permits issued by the Ministry as follows:-Coal, 163 (including 29 in Mongolia, all bearing date May 11, 1911); antimony, 60; gold, 18; sulphur, 12; zinc, 12; lead, 11; copper, 6; iron, 5 . The output of the Tayeh Iron Mines, 70 miles below Hankow, was in 1910303,000 tons of magnetic ore. The export of tin from the Kochiu Mines near Mengtze, Yunnan, has risen from 84,314 cwt. in 1909 to $122,95^{8} \mathrm{cwt}$. in 1910 and $133,792 \mathrm{cwt}$. in $191 \mathrm{I}$. With the help of additional machinery the antimony refining works at Changsha raised their export from 6,983 tons in 1909 to 9,239 tons in 1910 and 9,312 tons in 1911 , regulus, crude and ore. The export of orpiment through the Customs at Tengyueh (Yunnan) was in 1909, 8,764 cwt.; in 1910, I0,7 I0 cwt.; in $1911,6,540 \mathrm{cwt}$.

Commerce. - Tables are given dealing with the foreign trade of China in 1910 and 19 II. The average exchange value of the Haikwan tael for both years is reckoned at $2 \mathrm{~s} .8_{\mathrm{i} i}^{5} \mathrm{~d}$. (Consular reports use this value for I9II, although the Maritime Customs subsequently fixed the average exchange at $2 \mathrm{~S}, 8 \frac{1}{4} \mathrm{~d}$.

Table I. Gross Value of the Foreign Trade.

\begin{tabular}{|c|c|c|c|c|c|}
\hline \multirow[b]{2}{*}{ Year. } & \multirow{2}{*}{$\begin{array}{l}\text { Gross } \\
\text { Imports. }\end{array}$} & \multicolumn{2}{|c|}{ Exports. } & \multirow[b]{2}{*}{ Total. } & \multirow{2}{*}{$\begin{array}{l}\text { Grand } \\
\text { Total. }\end{array}$} \\
\hline & & $\begin{array}{l}\text { Native } \\
\text { Produce. }\end{array}$ & $\begin{array}{l}\text { Foreign } \\
\text { Produce. }\end{array}$ & & \\
\hline $\begin{array}{l}1910 \\
\text { reII }\end{array}$ & $\begin{array}{c}f \\
64,160,966 \\
64,971,838\end{array}$ & $\begin{array}{c}£ \\
51,273,654 \\
50,803,081\end{array}$ & $\begin{array}{c}f \\
1,829,494 \\
1,490,708\end{array}$ & $\begin{array}{c}£ \\
53,103,148 \\
52,293,789\end{array}$ & $\begin{array}{c}\underset{f}{f} \\
\text { I } 17,264,114 \\
\text { I I } 7,265,627\end{array}$ \\
\hline
\end{tabular}

Table II. Net Value of the Foreign Trade.

\begin{tabular}{|c|c|c|c|}
\hline Year. & Net Imports. ${ }^{1}$ & Exports. & Total. \\
\hline $\begin{array}{l}1910 \\
1911\end{array}$ & $\begin{array}{c}E \\
62,331,472 \\
63,481,130\end{array}$ & $\begin{array}{c}f \\
51,273,654 \\
50,803,08 \mathbf{I}\end{array}$ & $\begin{array}{c}\ell \\
113,605,126 \\
114,284,2 \text { I } 1\end{array}$ \\
\hline
\end{tabular}

1 Net imports, i. e. the value of the foreign goods imported direct from foreign countries less the value of the forrign goods re-exported to foreign countries during the year. The amounts given do not include the value of the goods carried coastwise. 
Table III. Value of Foreign Trade from and to Each Country.

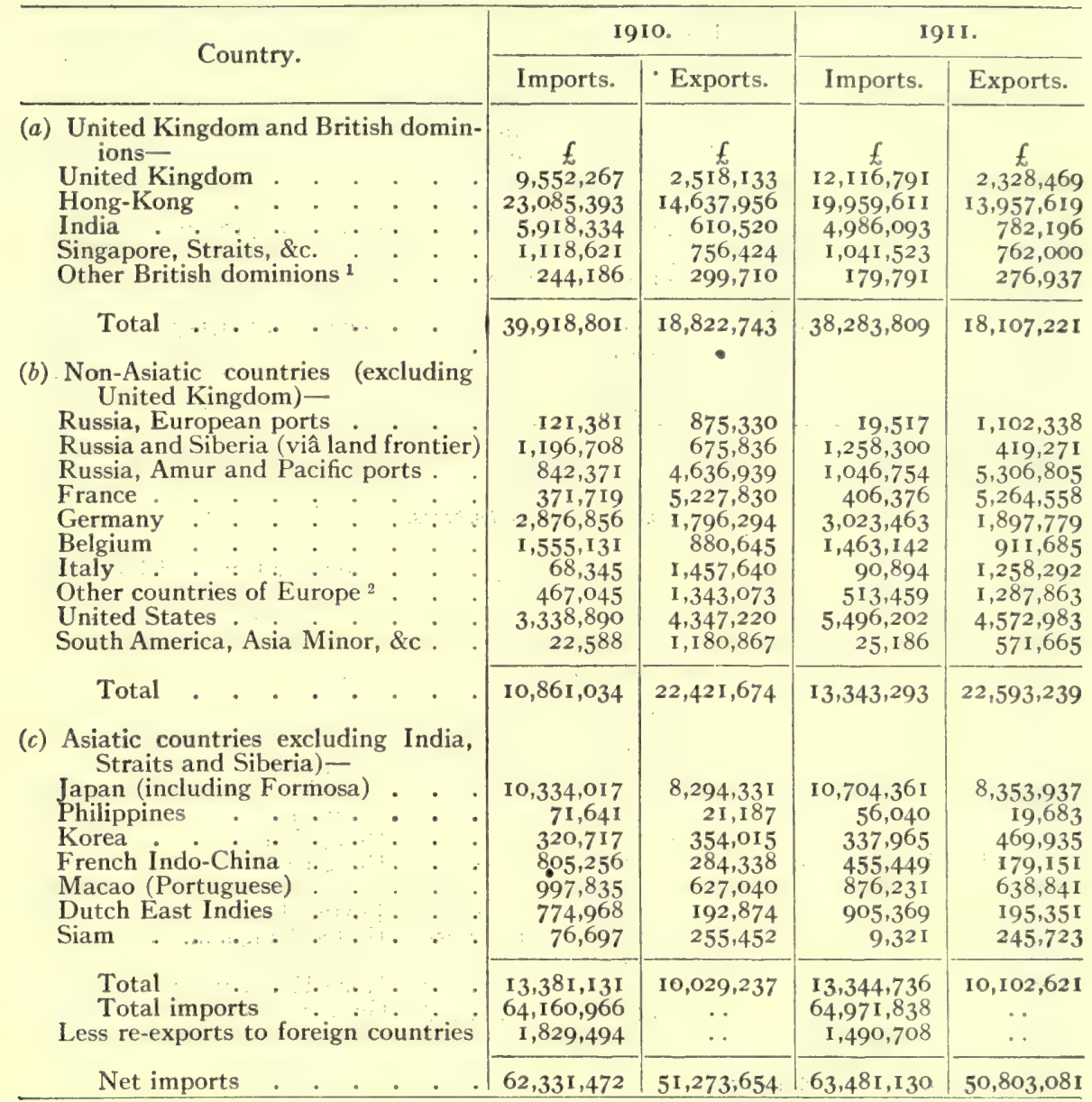

1 Canada, Australia, New Zealand and South Africa (including Mauritius).

${ }^{2}$ Norway, Sweden, Denmark, Netherlands, Spain, Portugal, Switzerland and AustriaHungary.

Note.-The imports from Hong-Kong come originally from, and the exports to HongKong are further carried on to the United Kingdom, the Continent of Europe, America, Japan, Australia, India, the Straits, \&c., and coast ports of China.

Table IV: Foreign and Coast Trade.

(a) Shipping Entered and Cleared in the Foreign and Coast Trade during 1909-I I.

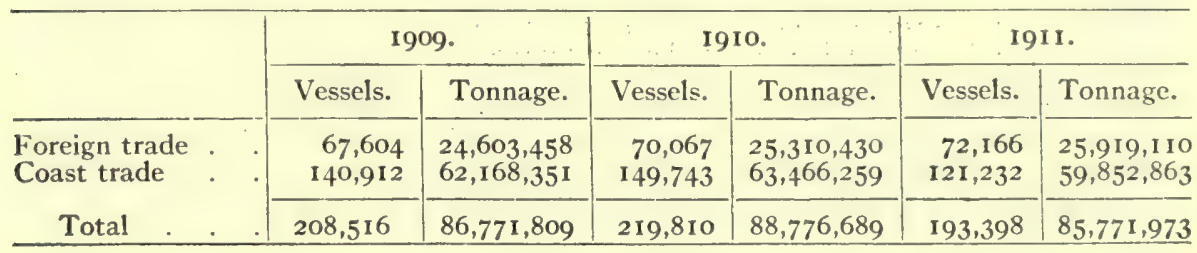


(b) Share taken by each Flag in Igrr.

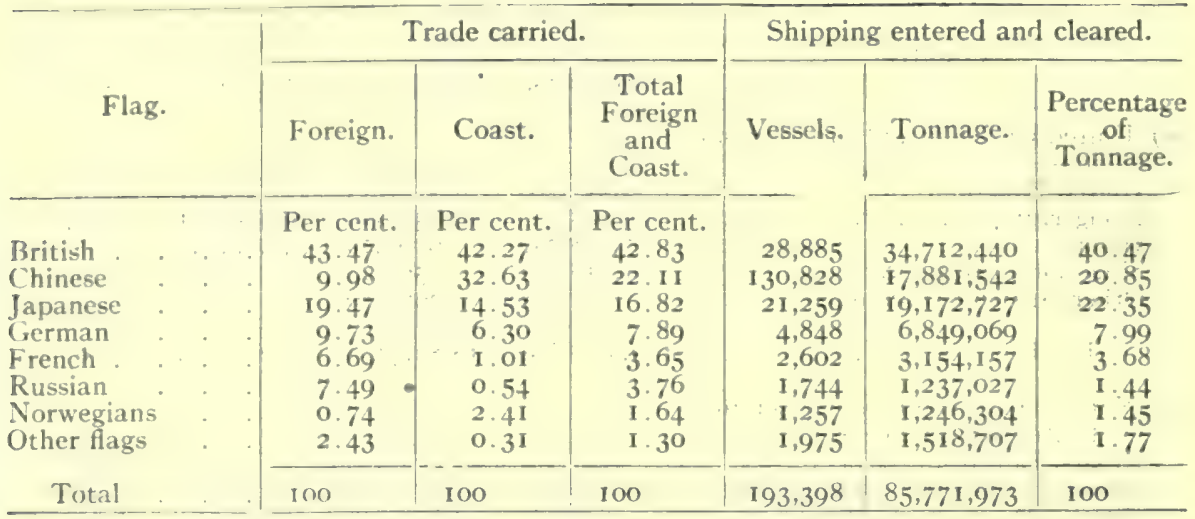

Table V. Chief Imports.

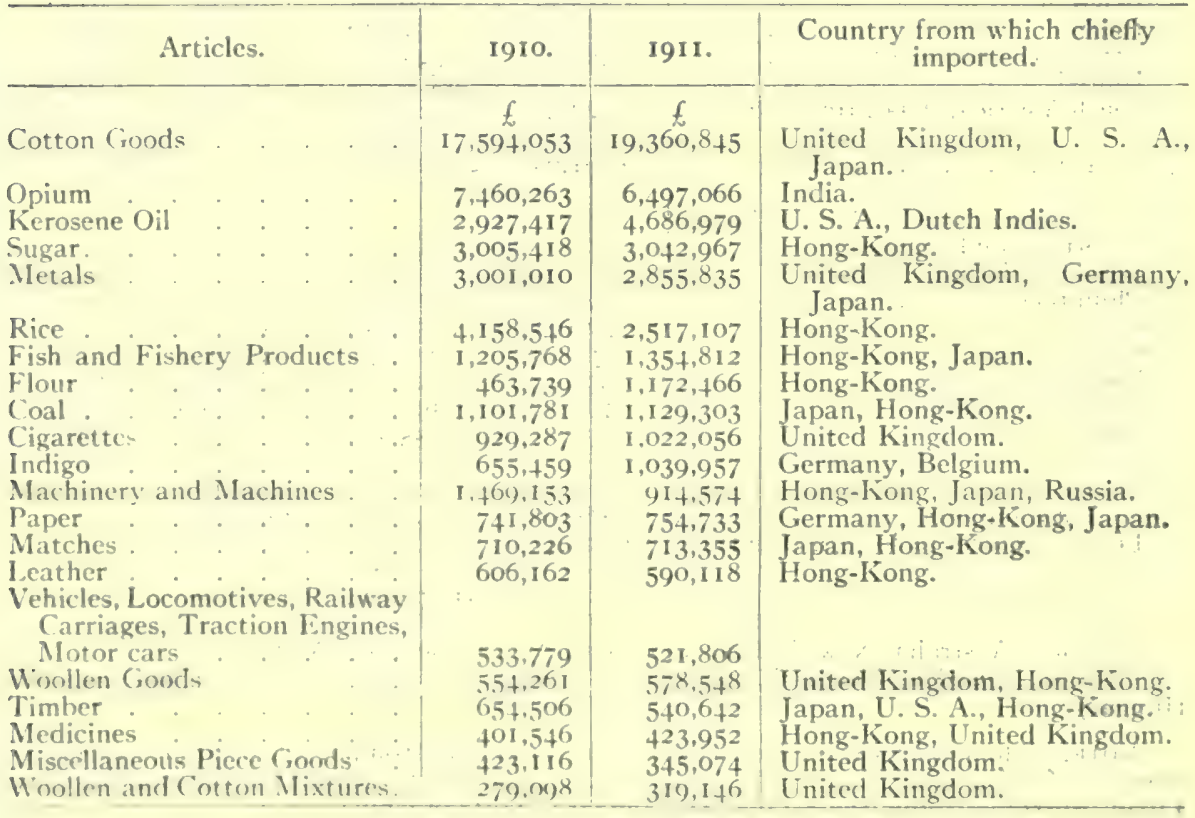

The Maritime Customs. - The revenue of the Maritime Customs was $f_{4}, 789,234$ in 1910 and $f 4.871,085$ in 1911 , the highest amount ever reached.

(1) September 21, 19I I Sir Robert Hart, Inspector (Eeneral of the Chinese Imperial Maritime Customs since November 1863, died in England. He had left Peking in May I008, and the post of Acting Inspector General was held for two years by Sir Robert Bredon, Deputy Inspector General. Mr. F. A. Aglen was made Acting Inspector General in April 1910, and received the substantive appointment on October 25, I9I I.

Finane. - The first attempt to prepare a statement of estimated revenue and expenditure was made hy the Imperial (iovernment for sulmission to the National Assemhly in the sesion of I0I0-II. A Budget for 1912 (China Year Book, 1913) was prepared by the Ministry of Finance in the autumn of $191 \mathbf{1}$, but appears to have undergone revision before being taken as a hasis for provisional estimates by the Republican Ministry of Finance.

The two Budgets (exchange being reckoned at 7.5 Kuping taels to the $\underset{\sim}{f}$ ) are shown in Table VII. 
Table VI. Chief Exports.

Articles.

Silk and Silk Products

Beans and Bean Cake

Tea

Cotton

Skins and Hides, Furs

Seed and Seed Cake

Oils (including Bean Oil)

Metals and Minerals

Straw-braid .

Wool

Animals, live

Groundnuts
I9II,

E.

$12,477,423$

$6 ; 462,591$

$5,161,300$

$2,909,194$

$2,224,059$

$2,177,944$

I, 854,465

I, 337,869

I $, 385,863$

$\mathbf{1}, 778,909$

I,3 I I,744

698,887

680,862

420,029
Countries to whicl. chiefly exported.

Hong-Kong, France, U. S. A.

Russia, Japan.

Russia, United Kingdom.

Japan.

France, U. S. A., United Kingdom.

Netherlands, Germany, Japan.

Hong-Kong, U. S. A.

Hong-Kong, Japan.

France, United Kingdom, U. S. A., Japan.

$1,029,660$. United Kingdom.

620,329 Hong-Kong, Russia.

614,320 France, Hong-Kong, Germany.

Table VII. Revenue and Expenditure.

Land Tax

Salt and Tea Taxes

Salt Tax

Customs Revenue

Sundry Taxes

Likin

Income from Government Properties

Contributions, Licences

Sundry Income

Sale of Official Rank

Public Loans

Extraordinary Income (Ministry of Communications)

Total
Estimated Revenue.

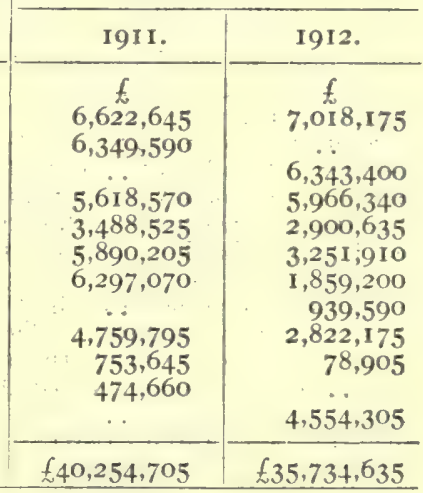

Foreign Affairs

Interior and Constabulary

Finance and Imperial Household and Foreign Loans

Education

War.

Marine

Justice

Posts and Communications

Posts and Communications (Ordinary)

Posts and Communications (Extraordinary)

Agriculture, Commerce and Industry

The Dependencies

Provincial Expenditure

Reserve for Contingencies

Total

Surplus

Deficit
Estimated Expenditure.

\begin{tabular}{|c|c|}
\hline $191 \mathrm{I}$ & 1912. \\
\hline 416,935 & 386,195 \\
\hline $5^{80}, 27^{\circ}$ & 560,530 \\
\hline $14,833,240$ & $13,269,970$ \\
\hline $366,33^{0}$ & 658,365 \\
\hline $10,388,785$ & $9,102,415$ \\
\hline $1,333,060$ & $1,625,700$ \\
\hline 885,840 & 930,535 \\
\hline $5,009,225$ & $\because$ \\
\hline - & 414,535 \\
\hline & $5,467,145$ \\
\hline 727,175 & 703,600 \\
\hline 225,140 & I 68,490 \\
\hline $5,027,115$ & $1,687,305$ \\
\hline$\therefore$ & 800,000 \\
\hline$\{39,793,115$ & $£ 35,774,785$ \\
\hline 461,590 & 40,150 \\
\hline
\end{tabular}

National Debt.-China's outstanding debt at the end of 1912 amounted to frg8, 188,802 , with a total charge for 1913 of $₫ 8,173,836$. The chief items in this debt were as follows:- 
War Loans ( $1894-98) \quad\{37,817,752$ (total charge 1913 for interest and principal $f 3,179,273$ ):

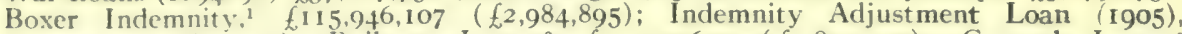

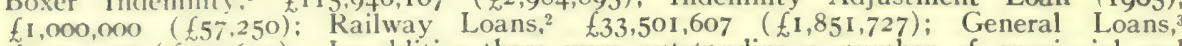
$\{9.923 .336(f, 100,691)$. In addition there were outstanding a number of provincial and private loans, the total amount of which was not published. They exceed $f, 3,500,000$.

Owing to the Revolution no Boxer Indemnity payments were made by China after November I, I9II, and the Powers agreed to the postponement of payments until January I. I9I3. The arrears and interest on deferred payments were estimated to amount on that date to $f 3,329,000$. Towards this sum there would be available from the Maritime and Native Customs a surplus revenue of $£_{1}, 132,000$. The Inspector General of Customs, however, issued a statement in which he placed the total sum required during 1913 to meet all payments for Boxer Indemnity and foreign loans secured on the Customs Revenue at $£ 5,993,000$. Towards this amount he estimated that the Customs would provide $f 5,490,000$ while the Seven Likin Collectorates specified in the 1898 Anglo-German Loan Agreement would add $f 637,500$. In order to be on the safe side the Inspector General suggested that 400,000 taels ( $\$ 55,000$ approximately) should be allotted monthly to form a reserve fund for the services of the loans indicated. This arrangement would leave the greater part of the Salt Revenue (estimated at over $f 6,000,000)$ free for other foreign loans.

Loan Negotiations.- The loan negotiations of the Chinese Government during 1912 attracted considerable attention. During I9I I the Quadruple Syndicate, comprising British, French, German and American banks, had arranged the Currency Loan of $£ 10,000,000$ and the Hukuang Railway Loan of $£ 6,000,000$. The outbreak of the Revolution prevented more than an instalment of the former being handed over, for development purposes in Manchuria. Immediately after the abdication of the Manchu dynasty, the Chinese Government, being in financial straits, approached the Quadruple Syndicate with a view to obtaining a loan for reorganisation purposes, the sum of $f 60,000,000$ being mentioned in this connection. Several advances were made by the Hong-Kong and Shanghai Bank on behalf of the Syndicate, but no decision was arrived at in regard to a comprehensive loan. On March 15, 1912 the Chinese Government signed an agreement for a loan from a syndicate representing the Banque Sino-Belge and the Eastern Bank, secured on the Peking-Kalgan Railway. This loan was regarded by the Quadruple Syndicate as a breach of faith on the part of the Chinese Government in view of certain undertakings given by the latter, and in May the loan was cancelled, except in respect of advances already made. In June Russian and Japanese banks joined the Four Nations Group, which now became a Sextuple Syndicate. Negotiations for the large loan were resumed but no agreement was reached owing to China's reluctance to admit the form of supervision over the expenditure of the loan stipulated for by the banks. The Syndicate also required a monopoly of future loans to China up to $\{60,000,000$ during the next five years. As neither side would give way and the financial embarrassment of the Chinese Government was becoming more acute, the latter decided to apply elsewhere. On August 30 a loan agreement for $f 10,000,000$ was ratified with Messrs. C. Birch Crisp \& ( o. of London, of which half, or $f .5,000,000$, was shortly afterwards issued. The loan was made a first charge on the surplus revenues of the Salt Cabelle. The British Government, however, refused to give its sanction, and further negotiations were suspended, efforts being made to restrict China's dealings to the Sextuple Syndicate.

Communications.-Including the Russian (108I m.) and Japanese $(723 \mathrm{~m}$.) systems in Manchuria, in 1912 there were open to traffic in China 6,028 miles of railway, while $2,000 \mathrm{~m}$. more were nominally or actually under construction. Recent extensions include: the Yunnan Railway (Laokai on the Tongking frontier, to Yunnanfu), opened in April 19io; (anton-Kowloon Railway (I $2 \mathrm{~m}$.), the British section (Kowloon to Sumchun) being opened in October 1910, the Chinese section in October I9II; Tientsin-Pukow Railway! the northernor ( ierman section being opened in February 1912, with the exception of the Yellow River bridge which was not completed until November, the British section in June 1912; the Kirin-('hangchun Railway, opened October 1912. The Canton-Hankow Railway has made but little progress: of the first section from Canton $73 \mathrm{~m}$. were completed by $19 \mathrm{I}$, and trains rall on the $30 \mathrm{~m}$. between Changsha and Chuchou. The Szechuan-Hupeh line and the Ilangehow-Ningpo line have made practically no progress in Chinese hands.

Posts.-On May 28, 19 I I the Chinese Post Office, which had hitherto been under the control of the Inspector Cieneral of Customs, was transferred to the Ministry of Posts and

The Boxer Indemnity amounted to $f 67.500,000$, divided into 5 Series; the rate of interest is 4 per cent and payment is spread over 39 years. The above amount represents the total charges outstanding (interest and principal combined); it does not include the arrears of payment which had accumulated since September 30 , 1911.

Railway ldans are charged on the lines with or without a frovernment guarantee.

These include: I. Japanese L.oan, I) II, of $£ \mathbf{I}, 000,000$ to the Ministry of Communicatiuns: 2. Telegraph I.0an, 19II, of $1500,000: 3$. $\$ 400,000$ advanced of the Currency

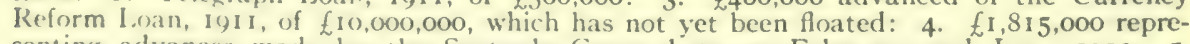
senting advances made by the Sextuple (iroup between February and June 1912: 5 . $£ t, 250,000$ advances from the Belgian. Syndicate as part of loan of $£ 5,000,000$ now cancelled: 6. $£, 5,000,000$ loan floated August 1912 by Messrs. Birch Crisp \& Co. 
Communications. The Postal Secretary, M. Piry, became Postmaster General and the previous organisation was retained. A substantial reduction in telegraph rates throughout the Empire was introduced on June I, 1912.

Government and Administration.-Pending the meeting of a National Convention and the adoption of a permanent Constitution, China remained in I9I 2 under the Provisional Constitution adopted by the Nanking Council. Yuan Shih-kai, as Provisional President, undertook on entering office to retire or seek re-election at the expiration of the term of provisional government, which was fixed at ten months. The Nanking Constitution defined the powers of the Provisional President and stipulated that he had to be elected by a two-thirds majority of the National Council at a session at which three-quarters of the members were present, but did not concern itself with the term of office or method of election of future Presidents of the Republic. The Premier was nominated by the President, but his appointment and that of the other members of the Cabinet were subject to the approval of the National Assembly; he had direct control of the Bureau for Tibetan and Mongolian affairs. Various laws were promulgated during the provisional régime defining the functions and powers of the Cabinet, the Ministries and other departments of State. But the entire system of central and provincial administration was in a transition stage, and the Administration reforms announced by proclamation had not had time to be put into force.

In November I9I2 the following composed the Provisional Government: ${ }^{1}$ President, Yuan Shih-kai; Vice-President, Li Yuan-hung; Premier, Chao Ping-chun; Minister of Foreign Affairs, Liang Ju-hao; Interior, Chao Ping-chun; Finance, Chou Hsueh-hsi; War, Tuan Chi-jui; Navy; Lu Kuan-hsiung; Justice, Hsu Shih-ying; Education, Fan Yuan-cien; Agriculture and Forestry, Chen Chen-hsien; Commerce and Industry, Liu Kuei-yi; Communications, Chu Ch'i-ch'ien. On November I2 however a crisis occurred over the question of negotiating with Russia concerning Mongolia, and Liang Ju-hao resigned. Lu Cheng-hsiang, the late Prime Minister, took his place.

In the Provinces, Governors (under the name of Tutuh) officiated as before the Revolution, variously assisted by a Finance Commissioner, a Law Commissioner, a Civil and a Military Commissioner, Commissioners for Education and Foreign Affairs. In Tibet there was a Government Agent. The affairs of Mongolia and Tibet were nominally under a Bureau controlled by the Cabinet or Premier.

Parliament.-During the period of provisional government in $\mathrm{I} 9 \mathrm{I} 2$ the functions of the National Assembly were performed by a National Council composed of five members from each province elected by the Provincial Assemblies. The chairman was Wu Ching-lien, and Vice-Chairman Tang Hua-lung.

Parliament, under the Republic, was to consist of a Senate (Tsan Yi Yuan) and a House of Representatives (Chung $Y i$ Yuan). The date of the first elections was fixed for December Io, I9I2, Primary elections, and January 10, I9I3, Secondary elections.

The Senate, comprising 274 members, was to be elected as follows: 220 by the Provincial Assemblies (Io Senators to each Province); 27 by the Electoral College of Mongolia; 10 by the Electoral College of Tibet; 3 by the Electoral College of Chinghai (Chinese Turkestan); 8 by the Central Educational Society; and 6 by the Electoral College of Chinese abroad.

The House of Representatives was to consist of 596 members elected by constituencies on the basis of one representative for each 800,000 of the population, with a minimum of 10 representatives for a Province, together with 27 representatives for Mongolia, ro for Tibet and 3 for Chinese Turkestan. The number of representatives allotted to each province for the first election was as follows: Anhui 27, Chekiang 38, Chihli 46, Fukien 24, Honan 32, Hunan 27, Hupeh 26, Kansu 14, Kiangsi 35, Kiangsu 40, Kuangsi 19, Kuangtung 30, Kueichow I3, Shansi 28, Shantung 33, Shensi 21, Sinkiang IO, Szechuan 35, Yunnan 22, Shengking 16, Kirin Io, Heilungkiang Io. Candidates for election as Senators must be thirty years of age and upwards, for election as members of the House of Representatives 25 years and upwards. The qualifications of an elector for the Lower House are: (1) A male citizen over 2 I years of age; (2) Two years' residence; (3) Either payment of direct tax of $\$ 2$ per annum,

${ }_{1}$ The Foreign Office has changed its name from Waiwupu to Waichiaopu; the Ministry of the Interior from Minchengpu to Neiwupu; that of Education from Hsuehpu to Chiaoyupu; that of Justice from Fapu to Shihfapu; that of Finance from 'Tuchihpu to Tsaichengpu; that of Communications from Yuchuanpu to Chiaotungpu, while the Ministry of Agriculture, Commerce and Industry has been divided into two Ministries. 
possession of immovable property of the value of $\$ 500$, graduation from an elementary or higher school, or education equivalent to the latter.

Army. A revised programme of army reorganisation promulgated in 1907 provided for the furmation of 36 divisions of the Luchun or National Army by I9I2. On August 31, I9II the actual strength of the Chinese military forces (officers and men) was returned (China Your Book, 1912) as follows:- National A rmy: 12 divisions (complete or almost complete) I fo, 899; + divisions (incomplete) 25,$101 ; 17$ mixed brigades 74,815 ; total 240,8 I5; Provincial Troops 276,981; grand total 517,796 .

During the revolution the Republicans enlisted a large number of irregular troops, and it was estimated that there were 800,000 men under arms in China when peace was restored.

On August 31, I912, the strength of the army including the Luchun and Provincial Troops was given (China Year Book, I913) at 428,485 officers and men.

A fresh scheme of army reorganisation was still in preparation. Meanwhile service was voluntary, soldiers remaining three years with the colours, then passing into the First Reserve for three years and being finally drafted into the Second Reserve.

Navy.-The Chinese Navy in 1912 consisted of two squadrons: the Cruising Squadron of five cruisers, one destroyer, one gunboat and eight torpedo boats; and the Yangtze Squad. ron of twelve gunboats for river purposes. A third squadron, the Training Squadron, to consist of two cruisers, then under construction, and ten gunboats, was in process of formation, and a scheme of naval reorganisation was occupying attention.

Public Justice. - New civil, criminal and commercial codes have been compiled with Japanese assistance but had not yet been promulgated in 19I2. In the meantime the old laws, except in so far as they were specially abrogated, remained in force. The new judicial system provides for officials with purely judicial powers, with four kinds of courts: (I) the ligh (ourt of Justice (Ta Li Yuan) at Peking, which is the Supreme Court of Appeal; (2) a Provincial High Court (Kao Teng Shen Pan Ting) in each provincial capital; (3) Metropolitan Courts in each principal town $(F u) ;(4)$ Courts of First Instance in small towns. Trial by jury was inaugurated at Shanghai during the period of the revolution, but the system will not be adopted for the present. In 1912 the Minister of Justice was Hsu Shih-ying, the Vice-Minister Wang Shou-chen, and the Chief Justice Chang Tsung-hsiang.

Education.-During the revolution the system of education introduced by the Imperial Government under the reform scheme of 1905 was in abeyance, as ail the universities and colleges and most of the schools were closed. A National Educational Conference was convened by the Ministry of Education in July 1912 and submitted a variety of recommendations as the basis of the future educational system in China.

History, 1910-12.- The revolution and the establishment of a republican form of government dominates entirely the history of I9II and I9I 2, and the events immediately preceding the revolution may first be dealt with. In accordance with the nine years' programme of constitutional reform laid down in 1908 the Provincial Assemblies net in October 1909. The most noticeable result of their inauguration was the impetus given to the demand for an earlier grant of representative government. At the close of the first session more than fifty delegates from various assemblies met in Shanghai and resolved to petition the Throne to grant a parliament within two years. Their request, proffered in Peking in January ioro, was rejected, and until the autumn of that year the Government continued to oppose all recommendations for expediting constitutional reform. On October 2, 19 10 the National Assembly met in Peking, and within a week had approached the question of the earlier opening of Parliament. This time the Government gave way. An edict dated November 4 provided that the date fixed for the establishment of Parliament should be changed from ror6 to 1913. In spite of various appeals and memorials the Throne would not make any further concession on this point. It championed the Grand Council against the attacks of the National Assembly, but finally agreed to order the Commission of Constitutional Reform to frame a constitution for a Cabinet responsible to the representatives of the people.

The Assembly adjourned on January I I, I I I to meet again in October. The early months of the year, however, found the Chinese empire distracted by diplomatic and financial troubles. On the borders of Yunnan a British force had occupied Pienma, which both the British and the Chinesc Government claimed as being within their respective territories, and the presence of foreign troops in the district under dispute was at once magnified into a menace to the integrity of the empire. In Mongolia Russia was seeking to establish consulates at various towns, while the Chinese mind can never for long be free from anxiety in regard to the fate of Manchuria. Although the dread of foreign aggression led to the formation of patriotic associations, including the Citizen 
Army, the country at large was still more agitated over the Government's action in resorting to large foreign loans. Two loans were at this periud the subject of negotiation - one of $f_{1} 0,000,000$ for currency purposes, and a railway loan, subsequently known as the Hukwang Railway (Four Nations') Loan of $£ 6,000, \infty \infty$. Public feeling was opposed to any loan that had not received the assent of the National Assembly, and the demand arose for a special session of that body. Delegates from the provincial assemblies arrived in Peking to press their demand, but their request was refused, and the Currency Loan was signed on April 15, I9r. A month later the Railway Loan agreement was signed. By way of placating public opinion the Throne announced the appointment of a Cabinet in the place of the Grand Council. . The new body comprised eleven Manchus and four Chinese, under the presidency of Prince Ching, who was regarded on all sides as the archmenemy of reform, and its constitution did not go far towards satisfying popular demands.

From the date of the edict sanctioning the Four Nations' Loan for the construction of the Canton-Hankow and Hankow-Szechuan Railways the agitation against the Government steadily gathered force. Szechuan was chiefly concerned in the loan. In spite of the fact that the great western trunk line had long been pledged to foreign capital the province had resolved to build the railway itself. Money had been raised by various devices, and construction had been begun. While the line was making little progress in Chinese hands, it was known that the money raised had been finding its way into channels in no way connected with railway construction or the legitimate investment of railway funds. The people of Szechuan were easily persuaded that they would never see their money again, if the line were handed over to foreign construction, and riots broke out in Chengtu, the capital, in July. Throughout August the conditions in Szechuan remained critical and by September the province was in open rebellion. Chao Erh-feng, Warden of the Tibetan Marches, and one of China's most capable officials, had been appointed Viceroy in August; by the end of September order seemed in a fair way to being re-established. A few days later, however, further rioting occurred in fresh centres, and once more the rebellion gained the upper hand. While the affairs of the province were in this critical condition, a bomb exploded on October 9 in the Russian concession at Hankow. From that moment the Szechuan question became merged in the more formidable problem of the revolution:

The bomb explosion in a house in Hankow was immediately followed by an attempt of the inmates to burn down the premises, but in this they were foiled. Documents revolution. arrests were made. Jui Cheng, Viceroy of Hupeh and Hunan, appreciatrevealing the existence of a revolutionary plot were seized and a number of ing the gravity of the discovery, gave orders for the execution the next dity of four men who were regarded as ringleaders, and he reported to Peking that he had prevented a revolution. He reckoned, however, without the revolutionaries. A meeting the same day among some of the troops in Wuchang gave them their opportunity. Making common cause with the soldiers, they compelled General Li Yuan-hung to put himself at the head of the movement and the revolution began.

The ground in the Yangtze valley had been prepared to some extent during the year. Repeated rumours of an intended rising indicated that revolutionary agents were at work, but little attention was paid to the reports, mainly because the notorious lack of cohesion among the various provinces seemed to foredoom to failure any anti-government movement. The temper of the people, however, had for years been growing more and more hostile to the dynasty. Floods and famine had been of annual occurrence along the Yangtze, and the doctrine that the Manchus were in league with foreigners to partition or destroy the country had been sedulously preached. The revolutionaries had no elaborate organisation prepared; they had been working to stir up as much feeling as possible among the people, and had even imported arms and ammunition for a few centres. When the revolution came, the control of the movement did not extend beyond Wuchang. Emissaries hurried about the country urging the people to revolt, but each locality was left to take care of itself and to carry out its revolution in its own way. 
The Wuchang mutineers bombarded the city on October II, when the capture of the Government mint, containing $£ 300,000$, supplied the movement with the sinews of war. Viceroy Jui Cheng escaped across the river. A Reformed Government was appointed with General Li Yuan-hung as President and General Huang Hsing in command of the military forces. Moving across the Yangtze the revolutionaries captured Hanyang with its Government arsenal, and were now provided with munitions as well as with money. By this time the Peking Government had to some extent realised the seriousness of the situation. The Regent in his alarm turned to the man whom he had banished from the councils of the Empire three years previously, and it was announced that by edict of October I 4 Yuan Shih-kai had been recalled to take up the posts of Viceroy of Hupeh and Hunan and Generalissimo of the Imperial forces.

Yuan Shih-kai, on whom now all eyes were turned, was born in Honan province in 1859. At the age of twenty-three he went with a Chinese detachment to Korea, and three years later ( 1885 ) became Imperial Resident at the Korean Court, a

Yuan

Shih-kal. post which he retained until the outbreak of the Chino-Japanese War in 1894. In I 897 Yuan became Judicial Commissioner of Chihli, and the following year found him in command of an Army Corps. His assistance was sought by the Emperor Kuang Hsu for his reform project, but Yuan Shih-kai sided with the Empress Dowager and helped to carry through the coup d'état of that year. Enjoying the favour of the Empress Dowager, he became Junior Vice-President of the Board of Works in June I899, and in December of that year Acting Governor of Shantung. When the Boxer Rebellion broke out he was Governor of that province and afforded protection to foreigners. On the death of Li Hung-chang he became Viceroy of Chihli (December 190I) with the honorary title of Junior Guardian of the Heir Apparent; and it was during his tenure of office at Tientsin that he laid the foundation of China's modern army. He was summoned to Peking in 1907 , and was a Grand Councillor and a prominent member of the Government at the time of the death of the Empress Dowager and the Emperor Kuang Hsu. Immediately after Prince Chun assumed the Regency, however, Yuan Shih-kai was dismissed from office and ordered to return to his native place (January 2, I909); and he remained in disgrace until now.

A fortnight later Yuan Shih-kai took the field, but virtually in the capacity of a military dictator. In the meantime Imperial troops under General Yin Chang had been in conflict with the revolutionaries in the neighbourhood of Hankow. They had entered the native city, but had fallen back when their communications were threatened. Advancing again, they entered Hankow on October '29, and after three days' fighting they fired the greater part of the city and the revolutionary forces fell back on Hanyang. Indeterminate fighting was continued for the next four weeks, until on November 27 Hanyang fell and the position of the revolutionaries in Wuchang became untenable.

Throughout this period the standard of rebellion had been raised successfully in other parts of China, until fourteen provinces had thrown in their lot with the revolutionaries. Thus, while the chief military operations were going in favour of the Imperialists, the country as a whole was recording its decision with no uncertain voice against the Manchu Government. Nanking held out for the Imperialists until I)ecember 2, but on that day Yuan Shih-kai, recognising the necessity of parleying, acceded to the request of the Wuchang administration for a three days' armistice.

Nothing illustrates better the spontaneous nature of the revolution than the fact that in Shanghai, where the cause was not embraced until November 3, a" military government " had been created which arrogated to itself the conduct of the whole movement. It was here that the republican idea took definite shape, and when the time arrived for negotiations with the Imperialists, the Shanghai administration refused to recognise $\mathbf{L i}$ Yuan-hung's right to conduct the proceedings at Wuchang or Hankow. It insisted that the peace conference should meet at Shanghai.

After the appointment of Yuan Shih-kai the Court in Peking progressed quickly along the path of humiliation. The National Assembly, which had met on October 22, proceeded to assert itself and demanded the right to draw up the Constitution, 
the appointment of a responsible Cabinet from which members of the Imperial family were to be excluded, and an immediate amnesty for all political offenders. The Court hesitated; but when these demands were endorsed by the garrison at Lanchow, which refused to entrain for the front until they were granted, Prince Chun capitulated. Regulations that were to form the basis of China's Constitution were at once drawn up by the Assembly, and in due course the Regent took oath to observe them. Yuan Shih-kai was elected Prime Minister on November 8 and returned from Hankow on November 13. The Regent abdicated on December 6, and affairs of State were formally placed in the hands of the Premier and his Cabinet, the Empress Dowager being associated with the Emperor in matters requiring the Imperial seal or presence.

Even while conducting military operations against the revolutionaries, Yuan Shihkai had endeavoured to arrive at an understanding with them, and he readily agreed to an armistice in order that the two parties might discuss the situation. Yuan Shih-kai and the North stood for a constitutional monarchy; the revolutionary leaders had made up their minds that the Manchu dynasty must be replaced by a republic. Negotiations were opened in Shanghai on December 18 and ten days later the Court had consented to submit the question of the establishment of a republic to a National Convention. Ii could not, however, agree that the convention should be wholly republican in character, and the negotiations were continued throughout January, the prospects of the Manchu dynasty retaining the throne becoming more remote as the days passed.

On December 25 Dr. Sun Yat-sen, the leader of the anti-dynastic movement, arrived at Shanghai. Born in Kuangtung province in 1867 , Sun Yat-sen (Sun Wen)

Sun was the son of a mission convert, and had studied medicine at the Alice

Yatosen. Memorial Hospital at Hong-Kong from 1887 to 1892 , taking his degree of Licentiate of Medicine and Surgery in the latter year. After a brief practice at Macao, he settled in Canton, where he at once espoused the revolutionary cause. The failure of a conspiracy in 1895 caused him to flee to Macao, and from that moment until December I9II he was an exile from Chira. In I896 Dr. Sun Yat-sen was in London, and on October IIth he was seized and taken to the Chinese Legation, where he was confined in order that he might be conveyed back to China. He was liberated at the instance of the British Government. Dr. Sun now devoted himself to the work of spreading his revolutionary propaganda. In Japan he founded a society known as the Tung Meng Hui, which has since played a prominent part in republican politics in China. His agents visited China from time to time and he became the acknowledged head of the Young China party. When the revolution broke out at Wuchang in IgI I Dr. Sun Yat-sen was in England, but he returned at once to China; the Nanking Council (composed of delegates from fourteen provinces) elected him President of the "Chinese Republic," and he took the oath of office on January 1, 1912, "the first day of the first year of the Republic."

On February I 2 the Manchu dynasty came to an end. The first of the Abdication Edicts of February I 2 announced that the Empress Dowager, together with the Emperor, handed over the sovereignty to be the possession of the whole people and declared that the constitution should thenceforth be Republican. Yuan Shih-kai was nominated, "with full powers," to organise a provisional Republican Government. In the second Edict the future status of the Imperial House, as agreed upon with the Republicans, was set forth. The Emperor,was to retain his title and to receive from the Republic the respect due to a foreign sovereign. He would be paid an annuity of Tls. 4,000,000 $\left(£_{533}, 000\right)$ until the establishment of a new currency, when the sum would be $\$ 4,000,000$, and would reside at first in the Imperial Palace and afterwards at the Eho Park, retaining the same bodyguard. He would continue to perform the religious ceremonies at the Imperial Ancestral Temples and Mausolea, and the Republic undertook to complete the Mausoleum of the late Emperor and to charge itself with the services and expense of the removal of the late Emperor's remains to the Mausoleum. The Imperial Clansmen retain their titles and enjoy equal rights with all other citizens.

On February 14, Dr. Sun Yat-sen resigned his position, and, on his recommenda- 
tion, Yuan Shih-kai was elected by the Nanking Council Provisional President of the Republic of China. General Li Yuan-hung became Vice-President, and

The New Republic. a provisional constitution was adopted by the Council on March Io, the day on which Yuan Shih-kai took the oath of office in Peking. The duties of forming a Ministry devolved upon Tang Shao-yi, a former protégé of Yuan Shih-kai's and his delegate at the Shanghai negotiations. Dr. Sun Yat-sen remained in Nanking to assist the Government until April I, when he resigned his official connection with state affairs and started on a tour of the provinces. The following day the National Council decided to transfer the Government to Peking. A new Council (consisting of five members from each province, elected by the Provincial Assembly, and five memuers each from Inner and Outer Mongolia and Tibet and one member from Kokonor) was formally opened on April 29, and continued to define the Republican policy.

In June Tang Shao-yi, who had not been fort unate in his loan negotiations, resigned the Premiership and was succeeded by Lu Cheng-hsiang, the Foreign Minister. A Cabinet crisis was shortly afterwards brought about by the attitude of the Tungmenghui party, which mainly represents Cantonese opinion. Its members contended that the Cabinet shauld be formed from one of the three parties or from none, and they insisted that the Ministers belonging to the Tungmenghui should resign their portfolios in the existing Coalition Cabinet. The President won the day, and the Tungmenghui sought to retrieve its position by amalgamating with another party. In September Lu Chenghsiang was forced by ill-health to resign the premiership and was succeeded by Chao Ping-chen. He became, however, Minister for Foreign Affairs in November, on the resignation of Liang Ju-hao.

For several months the peace of the country was disturbed by numerous mutinies and outbreaks, while a serious plot against the Republican Government was discovered at Wuchang early in August. In connection with the latter two prominent revolutionaries. Chang Chen-wu and Feng Wei, were arrested one evening in Peking, summarily tried during the night and shot at daybreak. The Government's action was severely criticised by the National Assembly, but the President was able to convince a majority of the members, without making public his information, that he had acted in the interests of the Republic. Subsequently the visits to Peking of Dr. Sun Yat-sen, General Huang Hsing, the most prominent revolutionary leader after $\mathrm{Li}$ Yuan-hung, and Chen Chi-mei, at one time Military Governor of Shanghai, served to strengthen the administration by removing the feeling of mutual distrust with which the North and the South were inclined to regard one another.

Tibet. - The return on December 25, 1909 of the Dalai Lama to Lhasa, which he had left on the approach of the Younghusband expedition of r9o4, coincided with a determined attempt on the part of China to strengthen her position in Tibet. A Chinese force was on its way to Lhasa and entered the town on February 12, 1910. The Dalai Lama fled to India and was deposed by the Chinese Government, but Lamaism has never recognised the step. Chinese sovereign rights were from that time exercised with considerable rigour in Tihet. When the revolution broke out in $19 \mathrm{II}$, the small Chinese garrison in Lhasa mutinied in sympathy, hut its excesses stirred the Tibetans to action and the troops found themselves besieged. A state of war was maintained until August, when, after the return of the Dalai L.ama to Lhasa, peace was concluded on condition that the Chinese troops left Tibet viâ India, a small number only remaining as the Chinese Amban's bodyguard. In the meantime the semi-independent chiefs had put an end to Chinese authority in Eastern Tibet. In July 1912 the Peking (invernment despatched an expedition from Chengtu, the capital of Szerhuan, to reconquer Tibet. On August 17 , however, after the force had regained possewion of Batang, the British (iovernmente presented a Memorandum to China defining the attitude of Great Britain towards the Tibetan question. This communication required ('hina to refrain from despatching a military expedition into Tibet, as the re-establishment of (hinese authority would constitute a violation of the Anglo-Chinese Treaty of 1906. Chinese suzerainty in regard to Tibet was recognised, but (ireat Britain could not consent (1) the assertion of ( hinese sovereignty over a State enjoying independent treaty relations with her. Although no definite reply was given to the Memorandum, it was understood that the ( himese (jovernment intended to fall in with British wishes, and towards the end of September the expedition to Tibet was ordered to retire.

Mongolit. - In pursuance of a forward policy in Mongolia the Manchu Government during the latter days of its existence had st rengthened its administrative hold on the country, 
had stationed Chinese troops in Outer Mongolia, and was carrying out a systematic plan of Chinese colonisation. These measures were resented by the Mongolians and led to overtures for Russian protection or mediation in July I9II. The misguider zeal of a new Chinese Amban still further embittered the native population, and the revolution provided the Kutukhtu Lama - the third highest pontiff in the Buddhist hierarchy and the spiritual ruler of the Mongolians-with an opportunity of proclaiming the independence of Outer Mongolia. Russian troops kept the peace between the Mongolians and Chinese, and in October 1912 the St. Petersburg Government accorded recognition to the new State to the extent of sending a special envoy to Urga: A Russo-Mongolian Agreement according to a semi-official communiqué issued in St. Petersburg was concluded on November 3. Russia undertook to assist Mongolia (or the Kutukhtu Lama) to maintain the autonomous régime established and to admit neither the presence of Chinese troops in Mongolian territory nor colonisation by Chinese. The Mongolian sovereign and Government guaranteed to Russian subjects and Russian commerce the full enjoyment of their rights and privileges, and agreed that no other foreign subjects in Mongolia should be granted fuller rights than those accorded to Russian subjects. The Kutukhtu Lama, however, appears not to have carried the whole of Mongolian opinion with him. A certain number of the Khans and princes both of East and West Mongolia claimed incorporation for their country on equal terms in the Chinese Republic, the rulers being allowed to retain their territorial and administrative power and their hereditary titles. Mongol activity was manifested in the late autumn of 1912 on the Manchurian frontier, and conflicts arose with Chinese troops. Whether this activity was merely brigandage or represented a fresh separatist movement in the West, still remained to be proved.

Bibliography.-H. T. M. Bell and H. G. W. Woodhead, The China Year Book for 1912 and 1913 (London); P. H. Kent, The Passing of the Manchus (1912), London; L. Lawton, Empires of the Far East (1912), London; M. A. Stein, Ruins of Desert Cathay, (1912), London; H. B. Morse, The International Relations of the Chinese Empire-The Period of Confict, $1834-1860$ (I9Io), Shanghai and London; R. S. Clark and A. de C. Sowerby, Through Shên-Kan (I9I2), London; J. O. P. Bland, Recent Events and Present Policies in China (1912), London; China Under the Empress Dowager (1910), London; E. F. Fenellosa, Epochs of Chinese and Japanese Art (1912), London; Rev, J. Macgowan, Men and Manners of Modern China (1912), London: R. F. Johnston; Lion and Dragon in Northern China (1910), London; Mary Hooker, Behind the Scenes in Peking.(1912), London; Archdeacon A. E. Moule, My Half Century in China (I9I I); Prof. E. H. Parker, Studies in C'hinese Religion (I910), London; H. A. Geil, Eighteen Capitals of China (I9I I), London; E. J. Dingle, China's Revolution, 19I1-12, London; Princes Der Ling, Two Years in the Forbidden City (I912), London; E. F. Borst-Smith, Caught in the Chinese Revolution (1912), London; Viscount D'Ollone, In Forbidden China; translated by Bernard Miall (1912), London; Henri Borel, The New China, translated by C. Thieme (I912), London; Prof. E. A. Ross, The Changing Chinese (1912), London; Dr. G. Vissering, On Chinese Currency (1912), Batavia; China Mission Year Book, 3 rd year, Shanghai; C. Campbell Brown, $A$ Chinese St. Francis (1912), London.

(H. T. Montague Bell.)

\section{DENMARK ${ }^{1}$}

Economic Progress. - In I9I I the census population of Denmark, with an area of 14,829 sq. m., was $2,757,076$, as against $2,449,540$ in 1901 and 2,588,919 in 1906 . The annual average increase since 1906 has been $1.27 \%$. The capital, Copenhagen, has 559,502 inhabitants, more than all the other Danish towns put together. The population of Iceland, with area of $40,437 \mathrm{sq}$. m., was 85,089 in IgI I against 78,489 in Igor.

In Greenland, with an inhabiced area of 45,000 sq. m., the population numbered I3,517 in I9II, 393 Europeans, as against II,893 and including 272 in I90I. The three West Indian Islands of St. Thomas, St. Croix and St. Jan, with a total area of I 38 sq. m., had a population of 27,IO4 in I9II against 30,527 in I9OI; and the Faeroes, with an area of 5 I I sq. m., advanced from 15,230 inhabitants to 18,005 .

The area cultivated in Denmark is close on five million acres $(4,850,000$ in 1908), the value of the harvest of 1910 being $£ 30,555,000$, and in I9II $£ 37,338,900$. The stock of domestic animals amounted in 1909 to 535,000 horses, $2,254,000$ heads of cattle and $1,466,800$ pigs, besides $11,800,000$ fowls. The value of agricultural exports in 1910 was $£ 24,294,000$, and of agricultural imports fro,878,000; for non-agricultural articles imports were valued at $£ 20,788,000$ and exports at $£ 2,372,000$; the corresponding figures for $191 \mathrm{I}$ being $£ 26,574,500, f_{1} 12,130,900, £_{22}, 497,700$ and $f_{3,2} 39,300$.

The sugar beet industry shows rapid growth, the production in 1910 being about 100,500 tons and in I9I I I 6,150 tons, and several now sugar factories have been planned or have actually started working during the last few years. The small-holding movement continues

I See E: B. viii, 23 et seq. 
to progress with some 700 new holdings annually, or some 6,000 in all since the small-holding act was passed in 1899 . A new law was passed in 1909 further developing this movement.

Two importint laws relating to agricultural export have been passed within recent years, viz. the law of May 27, 1908, dealing with the control of meat exported from Denmark, and a similar one of April 12, 1911, dealing with the control of butter. They were based on section 62 of the British Trade Mark Act 1905, which enabled the Danish farmers to register a common trade mark as against all other trade marks in these articles. Thus all exported meat or bacon receives a public trade mark and a Government stamp showing it to have been passed for export at the control station either as first or second class produce. The agricultural goods for export can therefore receive a trade mark from people who do not trade themselves, but only investigate the quality of the articles. No butter is allowed to be exported that contains over $16 \%$ of water or other preservatives than salt.

Notable strides have latterly been made in Denmark as regards fostering the growth of home industries and increasing the output of articles suitable for export, e.g. newly patented machinery, motor engines, etc. A strong movement has commenced for the purpose of making Denmark an industrial country as well as an agricultural one.

The total revenue for the financial year 1910-II was $£ 7,894,589$, and the expenditure $f .7,731,208$. For $1911-12$ the corresponding figures were $f 9,483,333$ and $f 9,638,889$, the deficit being much smaller than the original estimate of $f \mathbf{I}, \mathbf{1} 89,363$. The estimated revenue for the financial year $1912-13$ was $£ 5,705,688$, and the expenditure $£ 6,351,150$, while the estimated figures for $1913^{-1} 4$ are $£ 6,475,076$ and $£ 6,510,247$.

The national debt on March 3 I , I I I I amounted to $£$ I $8,658,889$ and in 1912 to $£ 19,554$,334. The state assets amounted to $£ 39,441,289$ in I9I I and $£ 40,003,470$ in 1912 .

Political History.-The Ministry of Jens Christian Christensen (b. 1856 ) having been forced by public opinion to resign in October r9o8 (see $E$. B. viii, 39), owing to the scandal caused by the arrest of the Minister of Justice, A. Alberti (b. I 85 I) on a selfconfessed charge of theft and forgery, a new Cabinet was formed by Niels Neergaard (b. I 854). Hopes had widely been expressed for the formation of a national non-party administration during this period of financial and political stress, but the Left Reform party majority in the Folketing asserted itself, and the new members of the Cabinet were drawn from the Moderate Left - the extreme right section of the Government bloc-some of the members of the retiring Ministry also being included. A new Ministry of Trade and Commerce was instituted on this occasion.

Besides having to deal with the Alberti defalcations, extending over nearly twentyfive years and running close up to a million pounds sterling, and with the affairs of the defrauded Zealand Peasants' Savings Bank, the Butter Export Association and other concerns and transactions of Alberti's, the new Cabinet found a number of important questions awaiting its immediate decision. The whole position of the national finances had to be taken in hand, and relations with Iccland seemed as far from a mutually satisfactory solution as ever; the proposals of the joint Danish-Icelandic Commission of $1907-8$ had been rejected at the elections to the Alting in Reykjavik in the summer of 1908 , and the leader of the separat ist movement, Bjarni Jonsson (b. I 846 ), had succeeded $H$. Haffstein (b. I86r) as Minister for Iccland. Then the findings of the Parliamentary Iefence Commission, largely differing from the advice given by the military experts, had to form the subject of a bill dealing with the National Defences and with the much vexed problem of the Copenhagen Land Defences.

In presenting his first budget for $1909-10$ in October $1908 \mathrm{M}$. Neergaard, who comhined the portfolio of I)efence and Finances with that of Prime Minister, showed the deficit of the financial year of $1907-8$ to be $f 403,700$ as against an estimated deficit of $\{222,000$ on the current budget of $\mathrm{r} 008-9$. One cause of the deficit was shown to be the Tariff, passed in the spring. The duties on a number of articles of general consumption, petrol, coal, salt, rice, etc., articles for the use of the shipping and agricultural industries and for home industries generally, had been abolished or greatly reduced without the state obtaining the necessary compensation in other directions. The increase of salaries, the various new railways schemes passed in the previous Rigsdag session, the increased cost of recent social reforms, all combined in making the balancing of the national finances difficult. New sources of income had to be found and a system of economy introduced in the various Government departments.

In February 1 ()o, the Neergaard Cabinet had at last completed its investigation of 
the urgent problem of national defence and of the findings of the Defence Commission, and a Defence bill was introduced in the Folketing on the rath of that month, the day following the national celebrations commemorating the 250 th anniversary of the unsuccessful Swedish attack on the Copenhagen fortifications. The Premier followed on the whole the advice of the military experts both as to the upkeep and the extension of the defence works of Copenhagen on sea and land. The old political war cry of the Left, "no land defences around Copenhagen," was thus surrendered, the Premier himself admitting that he viewed the defence question in a totally different light since forming his Cabinet in the previous autumn. A split in the Government bloc was the inevitable result, this showing itself when the final vote took place on the second reading of the Defence bills. The Premier gathered round him his own little group of nine Moderates, 14 Conservatives and 14 of the 57 members of the Left Reform party. The Left Reform leader, the ex-Premier J. C. Christensen, found 35 members to support his opposition proposal for limiting the fortifications to the sea approaches to Copenhagen, while seven of the Left, Io Radicals and 24 Socialists, were firm opponents of both these proposals. The issue was now referred to the eleciors, a general election to the Folketing taking place on May 25. The result șhowed an increase of the Conservative and Radical parties, both capturing seats from the Christensen party; some 27 members followed the latter, as against the 47 supporters of the Neergaard scheme, with the 24 Socialists and I6 Radicals. An attempt to compromise on the defence bills proved unavailing, as M. Christensen remained obdurate, and the latter had the best of an intricate political situation owing to the indirect help given him by the Radicals and Socialists.

Having concluded a national loan of $f_{2} 2,240,000$ with a French syndicate, the Neergaard Cabinet was obliged to resign at the end of July, the Premiership falling to a former leader of the Left party, Count Holstein-Ledreborg (1839-1912). In spite of public protests and addresses to the king, M. Christensen was appointed Minister of Defence, and M. Neergaard and Count Ahlefeldt-Laurvig (b. I860) agreed to serve in the new Cabinet, retaining their portfolios of Finance and Foreign Affairs respectively. M. Christensen was finally able to get the defence bills through the Rigsdag during the ensuing special summer session, being aided by the various sections of the Left party and by some of the Conservatives, the latter fearing to postpone the solution of this national question any longer. The existing land fortifications of Copenhagen were left intact, but without the necessary supplementary works strongly insisted on by the military experts, the Rigsdag being left to decide in 1922 whether these land forts should be dismantled or not. The chief points in the Defence acts were some new Naval forts outside Copenhagen, coast defence works at various parts of the coast of Zealand, and an increase of the strength of the Danish Navy, chiefly as regards destroyers and submarines. $\quad £ 890,000$ was voted for Naval and Coast Defence works, $£ 350,000$ for the increase of the Navy and $£_{509,440}$ for various Army purposes, besides an increase in the annual Army budget amounting to $f_{\mathbf{1}} 39, \infty 00$.

On October $18 \mathrm{M}$. Christensen resigned the Ministry of Defence, and a few days later, a vote of censure having been carried by a Conservative-Radical-Socialist combination, the Holstein Ministry gave way to the first Radical Government formed in Denmark, that of M. Carl Theodor Zahle (b. I 866). He could only rely on the 44 members of the united Radical and Socialist parties out of the total membership of II4 in the Folketing, so M. Zahle announced his intention of postponing the introduction of the Radical programme, and any question of altering or annulling the Defence Acts, until the voice of the electors had been heard. On one vital point he was able to secure a majority, viz. the proposal to prosecute before the Special Parliamentary Court, the "Rigsret," the two ex-Ministers, M. Christensen and M. Sigurd Berg (b. I868), the latter a former Home Secretary, for neglect of their Ministerial duties in regard to Alberti. M. Christensen was charged with having furnished Alberti with a loan of $f 82,500$ ( $\mathrm{I} \frac{1}{2}$ million kroner) out of the Exchequer a few months previous to his arrest, at a time when the then Minister of Justice was the object of ever-increasing attacks in the Press and in the Rigsdag. M. Berg was accused of grave neglect of duty owing to his refusal 
to order a public investigation of the affairs of the savings bank connected with Alberti the supreme control of the savings banks being vested with the Ministry of Interior:

During 1910 politics were stagnant. The next elections to the Folketing took place on May 20, 1911. While the united Radicals and Socialists maintained their figures the Conservatives lost eight seats to the Left Reform party, once more reunited under the leadership of M. Christensen, who thus controlled 56 out of the 114 members of the Chamber.

The State trial of M. Christensen and M. Berg was concluded on June 17, when M. Christensen was acquitted though admonished and $\mathbf{M}$. Berg sentenced to a fine: In December, when the criminal trial of Alberti himself came on, after two years of judicial investigation of his affairs, he was condemned to eight years' penal servitude.

Soon after the opening of the special session of the Rigsdag, M. Zahle made way (July 4) as Premier to M. Klaus Bernsten (b. I 844), the leader of the moderate section of the Left. Several of the new ministers, including M. Neergaard and Count Ahlefeldt, who both returned to their former posts, belonged to this political group.

On July 19 a bill sanctioning a temporary loan of $£ 2,000,000$ was introduced in the Folketing; and during I9I the chief political debates were concerned with financial

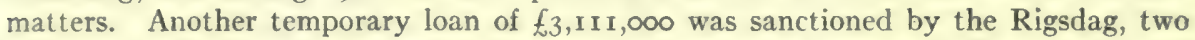
millions of which was in renewal of the previous temporary loan. M. Neergaard introduced that year a scheme of new taxation, comprising extra stamp duties, increased railway fares, a special tax on amusements, increased taxation of beer and spirits, and an increase of income tax on a graduated system. A question long before the Rigsdag wat also settled by the establishment of local church councils.

On February 14, I9I 2 a debate took place on the foreign policy of Denmark, the Foreign Minister once more advocating the necessity of Denmark following a policy of absolute neutrality. As was stated by Count Ahlefeldt, Denmark was neither directly nor indirectly bound by verbal or written agreements, still less by treaties or alliances tending to infringe this principle. The military and naval works agreed to by the Rigsdag in roro were now taken in hand, and a number of Volunteer Corps, armed with the quick-firing " recoil" rifle, were formed in various parts of the country during rgr 2.

The death of King Frederik VIII ( $1843^{-19}$ I $_{2}$ ) took place with tragic suddenness on May 14 in Hamburg, where the King was staying on his way back to Denmark after having spent some time as convalescent at the Riviera after a serious illness earlier in the year. The Crown Prince, Christian Carl Frederik Albert Alexander Vilhelm (b. September 26, 1870), who married Princess Alexandrine Auguste, Duchess of Mecklenburg-Sichwerin (b. December 24, 1879) on April 26, 1898, was proclaimed as Christian X the following day in Copenhagen. The new king at once established his popularity by a speech from the balcony of the Palace of Amalienberg, in which he promised to guard the "happiness, independence and liberty" of Denmark. The burial of King Frederik took place on May 24 at Roskilde cathedral, the chief mourners including the Kings of Sweden, Norway and Greece. The ceremony was unique in the meeting of three Scandinavian kings after a lapse of nearly 550 years.

A loan of $f 4,000,000$ was agreed to by the Rigsdag in June, $2 \frac{1}{2}$ millions being sub. scribed in Great Britain.

The speech from the throne at the opening of the Rigsdag in October announced a Reform bill amending the revised constitution of 1866 , on the lines of a return to the primiples of the original Grundlov of 1849 . The measure was introduced on October 2.3 and passed the Lower House on Dec. I3 by 95 votes to 12 . By it women were given the vote and the right to sit in the Folketing; the minimum age for votes was reduced from 30 to 25 ; the possible number of members of the Folketing was ratien from it to 1.32 ; the duration of the Folketing was extended from 3 years to 4 (that of the Landsting remaining at 8 years); election by privilege and royal nomination to the Landsting was abolished; of the 66 members of the Landsting 54 were to be elected by electors chosen by town and parish councils from among their members in proportion to the number of the inhabitants in their town or rural district, 
and the other 12 to be selected by the 54 ; in case of disagreement between the 1 wo Chambers they were to sit and vote together. The reform was chiefly directed against the Landsting or Upper House, and was hailed with approval by the Radicals and Socialists of the Folketing. Moreover, the once impregnable Conservative majority in the Landsting had dwindled to only one or two votes, owing to the steadily declining number of Conservative "Life Peers." Since Igor every vacancy among the twelve members nominated by the Crown had been filled by a supporter of the Left.

Danish Dependencies. - As regards the Danish dependencies abroad there is little to record between 1909 and 1912 . A Danish Syndicate was formed in 1912 to carry out extensive harbour works for the purpose of making St. Thomas into a big trading depot and coaling station. The Danish Parliament granted the Syndicate a 99 years' concession, and a company was then formed in Copenhagen for raising the capital required, about $f 1,000,000$, in Denmark only, as the scheme was planned as a national undertaking. Only a fourth part of this sum was however subscribed for, and the concession was returned to the State, only a minor extension of the St. Thomas harbour being now contemplated.

In Iceland a change of ministry occurred in $191 \mathrm{I}, \mathrm{M}$. Bjarni Jonsson being defeated in the Alting and succeeded by the proposer of the hostile motion, M. Kristjan Jonsson (b. 1852), a member of another section of the Home Rule party. During its I9I I session the Alting adopted a system of adult franchise. A separate university for Iceland was established at Reykjavik on July 30 .

During 1912 politics in Iceland once more turried in the direction of reopening negotiations as to a settlement of the constitutional difficulties with Denmark; the Minister of I908, Hannes Haffstein, being again returned to power.

In Greenland the establishment of communal councils at the various Eskimo settlements was followed in 1912 by a long-contemplated reform, the complete separation of the management of Greenland trade from the administration of this Danish possession.

Capt. Ejnar Mikkelsen returned to Copenhagen in August, having in spite of great hardships and privations during two years reached the object of his expedition- to the northeastern coast of Greenland in finding traces of the lost nembers of the Mylius-Erichsen expedition (1906-8) and completing the work of this lost explorer.

Obituary.-During 1908 the art world of Denmark lost two of its leading names, LoRENz Frölich (b. 1820) and Frants HenNingsen (b. I850). In 1909 the death of Princess VALDEMAR of Denmark (Princess Marie of Orleans, b. 1865) caused national sorrow; as the inscription on the memorial since erected to this popular Princess says with truth, "She spoke our Tongue and found our Hearts." P. S. KROYER (b. I85I), the artist; EMIL ChR. HANSEN (b. I 842), whose researches concerning the yeast bacillus revolutionised the brewing industry; and the eminent scientist, Professor Juls. Thomsen (b. 1826), Principal of the Polytecknic College, also died in 1909.

The obituary list for I9Io included the jurist Prof. Henning MATZEN (b. I840), member of the Hague Tribunal; the artists Johan Frederik Nikolaj V'ERMEhren (b. I 823 ) and Johan Julius ExNER (b. 1825); and the financier ISAK GLÜCKSTADT (b. I 839), head of the Danske Landmandsbank. In 1911 died the Bishop of Zealand, PEDER MADSEN (b. 1843), and the actor EMIL Poulsen (b. 1842), who "created" so many of Ibsen's characters. In February 1912 G. H. Armauer Hansen, the bacteriologist, died (see $E$. $B . x x, 784 b$ ).

\section{EGYPT 1}

History.-The year roro proved a critical period in the political development of Egypt. The murder of the Prime minister, Boutros Pasha, in February, was followed Unrest of by violent manifestations of Anglophobia. The trial of the Premier's
1910-1t. assassin, a young man named Wardani, gave occasion for many Nationalist demonstrations. Wardani was sentenced to death (May I $3^{\text {th }}$ ) and executed (June 28th), after an appeal for a new trial had been dismissed. The rejection by the general assembly of the scheme to extend the concession of the Suez Canal company - the existing concession does not expire till r968-was another exhibition of Anglophobia, the scheme being rejected not on its merits but to-discredit the British administration. This state of matters followed steps taken by Sir Eldon Gorst, the British Agent, to associate the Egyptians more directly with the conduct of their:own affairs. The experiment, which was on the lines of Lord Cromer's policy, was at tributed by the Egyptians, by the European colonies in Egypt, and by a section of public opinion in Britain, to weakness - in Sir Eldon Gorst's words "to an attempt to pacify the Nationalist agitation by ill-timed concessions and to an intentional diminution of

1 See E. B. ix, 2 I et seq. 
British authority" (Egypt No. I (IgII) p. 3). The general acceptance of this idea led to the comparative failure of the experiment (the provincial councils proved a distinct success). An official declaration made in the House of Commons in June rgri on behalf of the British government that there could be no hope of further progress in Egypt until the agitation against the British occupation ceased had its effect, and for a time the Nationalist agitation died down.

After the murder of Boutros Pasha the cabinet was rearranged. Mohammed Said Pasha, minister of the Interior, became Prime Minister, while retaining his former portfolio. The only new minister was Yusuf Saba Pasha, who became minister of Finance. Sir Joseph Saba, K.C.M.G.,- as he was known in European circles, - a Syrian and a Roman Catholic, had been twenty years at the head of the Egyptian Post office and had earned a well deserved reputation as a capable and zealous administrator. The co-operation of the ministry with the British authorities helped to undo the harm caused by the excesses of the Nationalists. Boutros was a Copt, and the endeavour of the Nationalists to present his murderer as a patriot and defender of Islam produced strained relations between the Copts and the Moslems. Owing to the precautions of the government no serious collision occurred between the two factions, and later the Copts turned their grievances against the government. A Coptic Congress was held at Assuit in Upper Egypt, where the Copt is prosperous but not popular, in March IgII, and a list of grievances was drawn up, but Sir Eldon Gorst had little difficulty in showing that their complaints of unfair treatment by the government were ill founded.

Soon after penning his annual report for I9IO, which constitutes the best apologia for his period of control, the health of Sir Eldon Gorst failed. He returned to England

Lord

Kitchener

becomes

British

Agent. in April IgII; on July 6th he resigned his office, and on the I2th of the same month he died. Four days later (July I6th) Lord Kitchener ${ }^{1}$ was appointed British Agent, a selection popular both in Great Britain and with the majority of Egyptians. Kitchener, who had been made a knight of St. Patrick on July roth, had maintained unimpaired his interest in Egypt and the Sudan, and had early in I 9 I I visited both countries as well as Uganda and British East Africa. He reached Alexandria on September 28, I9I I. Writing six months later, he drew attention to the divisions into political parties and factions of the formerly homogeneous body of Egyptian Moslems; a division which "does nothing to elevate or develop the intelligent character of an oriental race " (Egypt No. I (I9I 2) p. 2). In March I I I2, a few weeks previous to this condemnation of Nationalist activity, Mohammed Bey Farid had delivered an inflammatory address at the annual congress of the party, of which he was president. He then went to Switzerland, but was (April 30, I9I2) sentenced, in his absence, to a year's imprisonment for seditious speaking. He had previously been convicted of a similar offence in January I9II. In July Igr 2 a plot to murder Lord Kitchener, the Khedive and the premier, was discovered by the Cairo police; and on August 13, I912, three young men for their share in the plot were sentenced to fifteen years imprisonment. The investigations made disclosed the existence of a secret society directed against the government, in which many influential Egyptians were involved. This society was shown to be in relation with the Young Turk Committee of Union and Progress, and in September Sheikh Abdul Aziz Shawish, one of the Egyptian Nationalist leaders, who also conducted a newspaper in Turkey, was arrested in Constantinople, charged with being implicated in the conspiracy against the Khedive and Lord Kitchener. Shawish was brought to Cairo, but the evidence against him being inconclusive he was released (Oct. I 8, I $\left.\cap I_{2}\right)$. On Nov. I6th a man named Mukhtar was sentenced at Alexandria to ten years imprisonment for publishing seditious circulars.

These plots and conspiracies were confined to a numerically small party, and the people in general were little concerned. Lord Kitchener, by the firmness of his administration, created a feeling of confidence which the Nationalist plots did not much disturb. (ireater excitement was caused by the outbreak of war in Tripoli (Oct. 1911). Geographical proximity, the close relationship between the people of Benghazi and the

'See E. B. xv, 838 . 
Egyptian Arabs, the bonds of a common religion, and the ties of trade, evoked a deep and widespread sympathy in Egypt for the Arabs of Tripoli. But, notwithstanding the mischievous efforts of some of the native papers, the Egyptians maintained a praiseworthy self restraint. Egypt was declared neutral, and that neutrality was strictly maintained. The war led to definite steps being taken to settle the western maritimefrontier of Egypt. Italy had proclaimed a blockade of the Cyrenaican coast which extended to $27^{\circ} \mathrm{E}$., that is over Ioo m. east of Sollum, the western limit claimed by Egypt. The British government protesting, the Italian claim was waived (Nov. I9II). In December a small Egyptian force occupied the fort of Sollum; the handful of Turks in the fort withdrawing. The British Foreign Office in an official communication (Dec. 20, I9II) stated that as long ago as November 1904 both the Turkish and Italian governments had been notified that the line of the Egyptian western frontier ran up to and included Sollum. Turkey, however, had not admitted the Egyptian claim.

Lord Kitchener diligently sought to improve the lot of the peasantry, who form three-fourths of the population and own one-fourth of the land. He sedulously en-

\section{Economic} couraged improved conditions of agriculture and educational progress. By Progress. repeated tours in the rural districts he made himself personally acquainted with the needs of the people. He developed the Agricultural Department established by Sir E. Gorst in I9I0, extended the Savings Bank system to villages, made usury (i.e. lending money at more than 9 p.c. interest) an offence punishable by fine and imprisonment, and exempted small holdings (up to five Feddans) ${ }^{1}$ from distraint for debt. To save costly law suits local benches of magistrates (styled cantonal tribunals) were instituted to decide summarily trivial cases. In this way Lord Kitchener earned the title of "Friend of the Fellahin." The regard was mutual; "the fellah," wrote Lord Kitchener in April r9г2, "remains the same as he has always been, one of the best and most hard-working types of humanity." He now set himself to teach the fellahin that too much of a good thing might be detrimental. As a result of the immense irrigation works carried out since the British occupation, reclamation of land was pushed northward in the Delta into low-lying areas where there was no natural drainage, while a middle zone had become salted and waterlogged. Thus arose the necessity for drainage works on a large scale. Undrained damp soil, coupled with indiscriminate destruction of bird life and the loss of a quarter of a million of cattle in seven years through disease had led to an enormous increase in cotton pests. The cotton crops of 1908 and I 909 had been poor. There was a record crop in Igro which realised $£ \mathrm{E} .35,840,000$ or $£ 5,700,000$ above the previous best. In I9II, however, the crop was again poor. This instability, combined with the harmful system of mixing different varieties of cotton, caused serious anxiety. During I III and I9I2 special investigations were undertaken to put the industry on a sounder basis. In November IgI 2 a cotton congress was held in Cairo, representatives of master cotton spinners of every European country and of Japan being present. The causes militating against Egyptian cotton were fully considered. Lord Kitchener called attention to the new species of cotton being grown in government experimental farms, and Mr. Dudgeon, director general of the Agricultural department, outlined a scheme whereby in five years sufficient seed for producing species approved by spinners could be obtained to supply the whole of Egypt.

The experiment initiated by Sir Eldon Gorst in I9IO of handing over local education to the provincial councils was continued, funds being provided by a percentage on the land taxes, while the government granted $£ \mathrm{E} .100,000^{2}$ for the building and equipment of schools. The councils took up educational work with enthusiasm.

Several ministerial changes took place in I9r2. On April ist Saad Pasha Zagloud, the minister of Justice and one of the few men of pure Egyptian origin who had attained cabinet rank, resigned; on the I $5^{\text {th }}$ of the same month Sir Joseph Saba also resigned. Yusef Wahba, a Copt, and councillor to the mixed court of appeal at Alexandria, was made minister of Foreign Affairs, Hussein Pasha Ruchdi being transferred from the Foreign Office to the finance ministry.
1 A feddan equals 1.03 acres.
${ }^{2}$ A $€$ E.r.o.o equals fi.o.6. 
Finunce-By 191 i the finances of Egypt had fully recovered from the effects of the (nonomic crisis of 1907 (see $E . B$. ix, 119 ). The revenue in 1911 was $f E .16,793,000$, excecding that of 1910 by fF.827,000 and that of 1907 (the highest figure previously recorded) by if $+25,000$. The expenditure in I9II was $\mathrm{EE} .14,872,000$. The principal sources of resente were: direct taxation $£$ E.5.528,000; customs $£$ E.2, I69,000, railways $£$ E.3,729,000, aubacco fE.1,669,000. Though 1911 was a year of financial prosperity it was marked in the autumn by a series of failures in the banking and business community, but these were fue to antecedent causes, - that of the so-called Bank of Egypt in London, in the words of iir Paul Harvey, financial adviser, being due "to an unsound system of business and finance initiated many years ago." The other failures were ranked as a deferred result of the speculative movement which came to an end with the crisis of 1907. Notwithstanding heavy expenditure on public works the government passed through the lean years of 1908, 1909 and 1910 without having to raise a loan, the reserve fund on January I, 1912 being $£$ E.5.$8+7,000$. The total debt in the hands of the public at the same date was $f 89,117,000$, involving an annual charge of $£ \mathrm{E} \cdot 3,359,000$.

For 1912 the budget figures were:- receipts $£$ E. 15,900,000; expenditure $£ E$. I 5,400,000. For 1913 the estimates were:-receipts $£$ E.I6, I30,000; expenditure $£ E .15,630,000$.

During 1912 the Domains loan was extinguished and the profit on the working of the domains $(f \mathrm{E} .60,000)$ became available for general purposes. A sum of $f \mathrm{E} .250,000$ was set apart in the budget of 1913 for sanitary and other improvements at Cairo, where the new bridge across the Nile at Bulak was completed in 1912, after four years work.

Trude and Shipping. - The total trade of Egypt in I9II amounted to $£$ E. $55,826,000$, (imports $£$ E.27,227,000; exports $£$ E.28,599,000) an increase over 1910 of $£ E .3 .300,000$. Of this total 95 per cent passed through Alexandria. The figures for I9I I include bullion imports $£ E .5,986,000$, and exports $£ E .2,599,000$. The United Kingdom sent 33.5 per cent of the imports and took 45 per cent of the exports. Next in order came France, Turkey, Austria, (jermany and Italy. Owing to the damage by cotton worm, deterioration of seed, and in lower Egypt to cool weather during the summer, the quality of the 19II-I 2 crop was: rather poor and represented a value of only $f \mathrm{E} .29,000,000$, though in quantity it was little inferior to the record crop of I9IO-II. Prices were lower in consequence of the abundant American crop. The chief exports in $19 \mathrm{I} I$ were cotton and textiles $£ E .23,078,000$, cereals, vegetables, \&c. $£$ E.t,064,000, cigarettes $£ E .200,000$, livestock, skins and sugar.

At Jemsa on the Red Sea petroleum in paying quantities has been discovered, and during I 912 the export of crude oil began. Phosphate is being worked near Kosseir. At Alexandria in 191 I the tonnage of ships entering the port was $4,095,000,39$ per cent being British, AustriHungary came next with 10 per cent. During I9I I, 4969 vessels, net tonnage 18,324,000, passed through the Suez Canal, compared with 4533 vessels of 16,581,000 tons in I9Io. The percentage of British vessels was 62 as regards numbers and 64 as regards tonnage. German vessels figured at 13 per cent and 15 per cent respectively, Dutch at 5.7 per cent and 5.3 per cent and French at 4.7 per cent and 4.5 per cent. During the year 17,000 pilgrims passed through Suez for Mecca.

Irrigation.-The task of raising the height of the Assuan dam (sce E. B. xiv, 850) was completed in I912. The basin conversion works were completed in 1911, and the whole area brought under perennial irrigation. The regulator at the head of the Menufia Canalbuilt about $185^{\circ}$-having suddenly collapsed in December 1909 , a new regulator was built by Messrs Aird \& Co. by July 1910 before the arrival of the Nile flood,-a "record" in Egypt for rapid construction. The budget for 1913 set apart $f \mathrm{E} .480,000$ for drainage works, the total estimated cost of the scheme being $£ \mathbf{I}, 192,000$.

Obituary.-The deaths may be noted of ARABI PAsHA (see E. B. ii, 283), the former Nationalist Leader, on September 18,1911 , at the age of 72 ; and of Riaz PAsHa (see $E . B$. xxiii, 281), ex-Prime Minister, on June 18,1911 , at his age of 75 .

(F. R. CANA.)

\section{Anglo-Egyptian Sudan}

The history of the Anglo-Egyptian Sudan in I010-1 2 has been one of marked progress in administration and an equally marked increase in the prosperity of the people, this prosperity being so equally divided that in April rgI2 Lord Kitchener declared that "there is now hardly a poor man in the Sudan." Sir Reginald Wingate, the Sirclar, estimated the population in I () I 2 at well over $3,000,000$, compared with the estimate of $1,853,000$ in 1905 .

In June 1010 the Lado enclave (see E. B. xvi, 60) was taken over from the Belgian government and added to the province of Mongalla. Minor disturbances necessitated small expertitions during 1010-12 in Kordofan, and in Mongalla, where the Anuak and Nuers, who had obtained large quantities of modern firearms from Abyssinia, were fighting among themselves. Up to the end of I 9 I 2 government authority had not been

See E. B. xxvi, 10 el seg. 
fully established in the upper Sobat region. In Sennar in roro sparks of the old fanatical spirit caused two outbreaks, promptly suppressed. These incidents were precipitated by the appearance of Halley's Comet, which the Sudanese connected with the comet that heralded the advent of the Mahdi (Egypt No. I (I9II) P. 75).

The occupation of Wadai by France (see $E$. B. xxviii, 225) drew attention to the question of the boundary between that Sultanate and Darfur, ruled by Sultan Ali Dinar as tributary to the Sudan government. Negotiations were in I9I 2 entered into with France for the fixing of the frontier, Sir Rudolf von Slatin (the Inspector General) being the representative of the Egyptian and British governments. The completion of the railway from Khartum to El Obeid (the capital of Kordofan) in I9I I not only gave an impetus to trade but put the Sudan government in a position to control Darfur and the western frontier generally. An event of considerable importance to the Sudan was the visit paid to it by the King and Queen of England in January 1912, on their return from India. Port Sudan was inspected, and at Sinkat the king held a review at which representatives of almost every tribe-Arab and negro-were present.

Chief attention was concentrated by the administration on the economic, specially the agricultural, development of the country. The experiment of growing cotton on the Gezira plain, begun in 191 I, proved entirely successful, while in the Tokar region near Suakin the cotton output more than doubled during 1907-II. It has been conclusively proved that sugar-cane can be grown along the Nile north of Khartum. The demonstration that the surplus waters of the Nile, not needed for Egypt, can be utilized in the Sudan to render land agriculturally valuable ${ }^{1}$ caused attention to be paid to the system of land tenure. In the Sudan by Moslem law the land is "Kharaji," i.e. it belongs to the original owners and their descendants, and the government is entitled to prevent its alienation. This power is being used to protect the Sudanese from European speculators in land. A cadastral survey showed that in the northern provinces nearly all the land is in private ownership. In the south tribal tenure prevails.

Port Sudan (on the Red Sea) being advantageously placed both for the European and Eastern markets, external trade has made rapid strides. The value of exports (merchandise only) rose from $£$ E.977,600 in 1910 to $£ \mathrm{E} .1,377,000$ in 1911 , an increase of 40 per cent. Imports (exclusive of specie) rose from $f E . I, 348,000$ in 1910 to $£ E$. $1,696,000$ in 1911 ; of this the British share was 46.5 per cent. Cotton goods and food stuffs (chiefly sugar and salt) are the chief imports. The principal exports are cattle and sheep, gum and cotton (seed and lint); other considerable exports being durra, dom nuts and dates. The ability of the Sudanese to take advantage of the increased facilities for trade offered is marked, as the railway returns, among other things, show. In the five years $1907-1 \mathrm{I}$ the profits on the railways rose from $f_{\mathrm{E}} 8 \mathrm{8} 5,000$ to $\mathrm{fE}_{\mathrm{E}} \mathrm{I} 28,000$. The live stock traffic rose from 98,000 animals in 1910 to 172,000 in $191 \mathrm{I}$. Nile traffic also grew largely and a floating dock was built at Halfa, near Khartum, in I9II. While goods traffic is mainly via the Red Sea, passenger traffic still goes via Egypt. In I9I2 a regular mail service between London and Khartum occupying only, nine days was instituted.

The financial situation is sound, as shown by the fact that for 1913 the Sudan government renounced the contribution from the Egyptian treasury, which was $f \mathrm{E}, \mathrm{I} 88,000$ in I9II and £E.163,000 in I9I2. In its stead the government took the Custom dues levied in Egypt on goods for the Sudan, estimated at $\mathrm{fE} .85,000$. The accounts for I9.I I showed a surplus of $£ E .145,000$, receipts being $£ E . I, 664,000$ and expenditure $£ E . I, 519,000$. For I9I 2 the receipts and expenditure were both budgeted for at $£ \mathrm{E} .1,710,000$.

The Reports by the British Agent on Egypt and the Sudan, published yearly as a parliamentary paper give the most trustworthy information concerning those countries. See also the Consular reports on Alexandria, Port Said, \&c: E. A. Wallis Budge, Cook's Handbook for Egypt and the Egyptian Sudan, 3rd Ed. (London, I9II); J. Alexander, The Truth About Egypt (London, I9' I), useful information concerning the Nationalist parties.

(F. R. Cana.)

\section{FRANCE ${ }^{2}$}

Population.-The census returns of r9 I give the total population as 39,60r,509, showing an increase of 349,264 over the census of $1906(39,252,245)$. The average density is about 190 per sq. $m$. Fifteen towns contain over roo, 000 inhabitants, and 134

${ }^{1}$ Irrigation schemes costing some $£_{5}, 000,000$ were in 1912 under consideration.

${ }^{2}$ See E. B. x, 775 et seq. 
exceed 20,000. The population of Paris is 2,888, r10, as against 2,714,068 in rgor. The movement of population in I909-II was as follows:

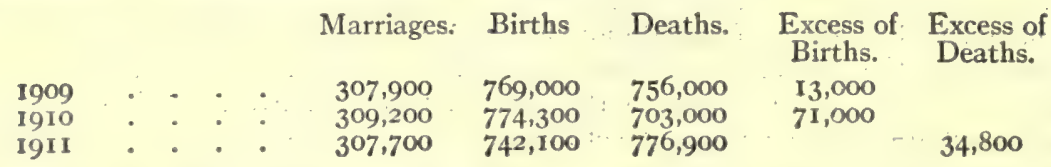

The death rate per thousand in I9ro was I 7.98. The stationary, or relatively declining, population provides a social problem which receives more and more attention from French statesmen and psychologists. One remedy proposed is a bounty on every third child born in a family; another is that only fathers of three children shall be eligible for public employments. In July I9I 2 the Minister of Finance was empowered to form a commission to inquire into the whole problem from a national, social and fiscal point of view. Fathers of families are preferentially treated already under the Old Age Pension Law (Loi des retraites ouvrières et paysannes; see below).

Alcoholic excess is still a mischievous social factor, to which the legislature pays insufficient attention. In February I9 2 the Chamber of Deputies adjourned a measure adopted by the Senate, restricting the number of shops for the sale of alcoholic liquors. The consumption of alcohol is increasing. The total amount of pure alcohol submitted to the payment of duties in 1909 according to the official returns, was $29,524, \mathbf{I} 32$ gallons; in I9 10 $30,778,748$ gallons, and in I9 I $34,628,396$ gallons.

Commerce. - The following are the latest figures for imports and exports, showing

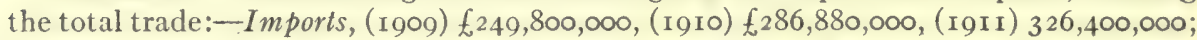
Exports, (I go9) £228,640,000, (I9I0) £249,280,000, (I9II) f246,883,000; Total, (I909)

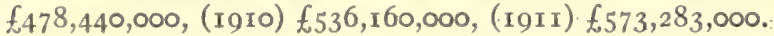

Economic conditions remain about normal; the price of provisions showing, however, a marked upward tendency. In I909, thanks to satisfactory harvests, the country recovered from the crisis of 1907 . In I910 the harvests were not so good; agriculture suffered from the serious floods; the wheat crop was short, and the vintage poor. The country had to fall back largely on foreign supplies during the winter of I9ro-r r, and prices rose perceptibly. The drought of July-August I9 I did much damage to the crops; there were serious complaints of the high price of food, and some disturbances cnsued in the north and west. These circumstances were no doubt only contributory causes of an economic state of things the real origin of which lay still deeper, in the rise of wages for agricultural labour and in the shortening of hours. In response to public complaints the Caillaux Cabinet could devise nothing better than a scheme authorising municipal bakeries and butchers' shops. An indignant protest from small tradespeople followed and the measure was withdrawn by the Poincare Cabinet. The "dear food " crisis was soon followed further by an acute phase of the housing problem in great cities, especially at Paris, where the rents of small apartments have reached alarming proportions owing to the influx of new arrivals. A Tenants Association Fédération des locataires) made noisy demonstrations, and the government took measures 10 allay excitement (see below). Wages have risen perceptibly, on an average 20 per cent to 25 per cent between I 896 and I9II. The Savings Bank Deposits amounted to $\{225,920,000$ on the 3 Ist of December I9IO.

In the mining industry important developments have been in progress, owing to the opening of new ficlds, notably in the Meurthe-and-Moselle basin (Longwy, Nancy, Briey), estimated to contain about 2,300,000,000 tons, the yield in 1909 having reached $10,670,000$ tons; the Normandy basin, worked since 1893, and yielding about 520,000 tons in 1910; and the Anjou basin, where prospecting has been done. France, which formerly imported her mineral ore, is now becoming an exporter. Production has increased as follows:(I 877 ) 2,426,000 tons, (I 900 ) 5,448,000 tons, (I909) II 890,000 tons.

The use of crossed cheques was introdued by a law passed December 22, I9I I.

By another law passed January 5, 1912, the organisation was authorized, in each maritime port, of a ('onseil d'Administration du port a board of control empowered (though not compelled) to take vier the administration of the port on a broad autonomous basis. 
The Land Bank System (Credit agricole) is developing rapidly:-

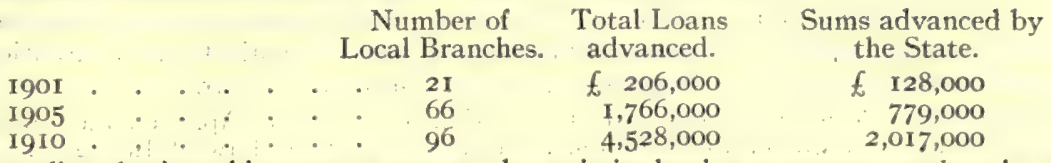

Mutuality also is making great progress, the societies having 4,500,000 members in I9I I, as against $1,200,000$ in 1898 ; the annual takings amounted to $f_{3}, 880,000$,

Social Legislation. - The most important achievement of recent years has been the enactment of the Law of Old Age Pensions (Loi sur les retraites ouvrieres et paysannes) April 4, rgro. Many difficulties have arisen over its application, and in spite of attempted amendments weak spots still remain. After discussions in the Senate from November roog till March roro the draft Bill was laboriously knocked into shape; and the Chamber was so anxious to pass it that very little attention was paid to details and the law was carried with no more than a formal debate (March 26-3I). The law provided for two categories of insured persons, compulsory and optional. Men and women employed in trades, manufactures, the liberal professions or agriculture, and indoor and outdoor servants, aged not less than 65 years, and in the receipt of not more than $f_{\mathrm{I}} 20$ per annum, were brought under the provisions of compulsory insurance. The insured person was to pay, at regular intervals, a sum amounting annually to $7 \mathrm{~s}$. Id. for men, 4s. $9 \mathrm{~d}$. for women and $3 \mathrm{~s}$. $6 \mathrm{~d}$. for minors under the age of eighteen. The employer was to pay a like sum, and both payments to be recorded by affixing adhesive stamps to a card in the keeping of the worker, and renewable annually. The payments were to be made each pay-day, the employer deducting the workman's quota from his wages. An insured person might claim his pension at the age of 65 . The State increased the total of the pension by an annual grant of $f 2.7 \mathrm{~s} .6 \mathrm{~d}$. if the insured person had made thirty annual payments-twenty-eight payments to count as thirty if the person insured had performed two years of military service. If the insured person had made less than thirty payments, but more than fifteen, the State made a grant equivalent to as many times Is. $2 \mathrm{~d}$. as he had made payments. For less than fifteen annual payments the State made no grant. The law also provided a scheme of voluntary insurance for farmers, métayers, market-gardeners, artisans, and persons in business on their own account or with a single workman, or with help from their families; for non-wage-earning members of the families of insured persons, for earners of incomes between $£ \mathrm{r} 20$ and $£ 200$ per annum, and for wives and widows (other than wage-earners) of insured persons belonging to the compulsory category.

The law was put into force on July 3, rgrr. In spite of the efforts of the Government and administration it met with scanty success. The working-classes regarded it with much indifference. By December scarcely a third of the persons coming under the compulsory division had complied with the regulations, and only one-tenth of those qualified for voluntary insurance. Two criticisms were made by those affected. In the first place, by compelling the worker to keep up his payments till the age of 65 , if he was to receive the whole benefit of the state grants, the law left him little hope of drawing his pension, and was organising "annuities for the dead." In the second place, the State grants were inadequate. To meet these objections the law was amended by articles 54 to 62 of the Finance Law of February 27, I912, coming into operation August i; I9I3. By the new regulations the age at which the pension becomes due is lowered to 60 ; the insured person can defer the receipt of his pension till the age of 65 ; the State grant is increased to f3. Igs, 2d. with an added bonus of ro per cent for the insured person of either sex who shall have reared at least three children to the age of sixteen. For women, the birth of each child is to count as a year's insurance. While endeavouring to attract the working-classes by new benefits, the Government tried to secure the application of the law by making the employer liable to carry out its provisions even without the consent of the worker. To this end, the administration, interpreting Article 23 of the Law in its own fashion, held that the employer was bound, with or 
without the worker's consent, to deduct the amount of insurance payable by the workman from his wages, and to pay it over together with his own contribution to the clerk (greffier) of the justice de la paix. Employers stood out against this contention, and won a case on appeal in the Court of Cassation, December II, I9II.

Among other legal enactments may be mentioned the 1 aw of April 30, 1909, forbidding the employment of women and children in certain trades; the Law of July 20 , 1909, prohiliting the use of céruse (white lead paint); the Law of November 27, 1909, which secures women from dismissal from employment on account of child-birth; the Law of March 25, I9I0, suppressing the truck system (économats) and prohibiting employers from selling food or merchandise to their men; the Law of December 28, 1910 , which codified the texts of various labour enactments; the Law of August 5, I9II, regulating the financial operations of authorized trade unions; and the Law of March 30, 1912, regulating hours in mines,

Many strikes have arisen out of disputes about the conditions of work. Besides the great railway strike (see below), much the most serious of them all, mention may be made of the strike on the Southern Railways (Chemin de Fer $d u$ Sud), a local affair in May-June I9Iо; and the strike of inscrits maritimes in April and May I9ro, which at one time seriously interrupted trade and communications between the mother country and Algeria and Corsica. This latter trouble broke out afresh in June I012, spreading from Marseilles to Havre and Dunkerque; at Marseilles the strike lasted for seventy-six days. There was a taxi-cab-drivers strike at Paris from February to April I9I 2.

State Purchase of the Western Railway (Chemin de Fer de l'Ouest).-By virtue of an agreement dated October 28, roo9, the Government bought up the Western Railway, and took over the management, thus greatly extending the scope of state railway administration. The agreement was ratified by Parliament (Law of Dec. 21, I909). It was not long, however, before the management of the "Ouest-Etat " was subjected to sharp criticism. An interpellation in the Chamber (Dec. roro) called attention to the irregularity and insecurity of the service. The Courville accident (March IOII) unhappily showed the complaints to be well founded. The disorganization of the Western suburban service, by which large numbers of people travel to and from Paris daily, called forth vigorous protests and even led to something like riots. As time went on, the "Ouest-Etat" succeeded in getting the train services into better working order, but from a financial point of view considerable scope for criticism remains. In ig i the deficit on the line had risen to $£ 2,960,000$; the net receipts fell to $£, \mathbf{r}, 180,000$ (under the company they used to vary from $£ 2,600,0 \infty 0$ and $£ 3,200,000$ ), while the proportion of working expenses rose to 87 per cent (about 55 per cent in the companies). The estimated deficit for I 9 I 2 was $£ 3,280,000$. Advocates for the purchase are of course able to say that the company handed over the line in poor condition; but their opponents retort that the largest part of the increase in expenditure is due to the higher salaries paid, and to an ill-considered increase in the staff $(5,280$ additions were made in Ior I). A statute regulating promotions, and prohibiting political recommendations, was issued to the State Railways' agents in September I012.

Justice.-Children's Courts (T'ribunaux pour enfants) were established by the Law of July 25 , I I 2 , which asserted that no penal responsibility rests upon children under the age of thirteen. They are removed from the jurisdiction of the ordinary courts, and made amenalle to the civil tribunal sitting in chambre du conseil. Publicity is restricted, and considerable latitude is allowed in the methods to be adopted. Minors bet ween the ages of 1.3 and 18 are left under the jurisdiction of the ordinary courts, but will be dealt with in future by special magistrates, cases being heard privately, the public armitted under restrictions, and no reporting allowed.

Education.-Higher education, stimulated by the universities, which are now constituted as corporate self-governing bodies, is in a flourishing condition. Secondary education, uniler the system of $\mathrm{I}_{00} 2$ by which students are permitted to choose their own course of study, into which the classical languages and literature may enter partially or not at all, give's results which are a good deal discussed. The charges of neglecting the study of French, and of squandering the pupils' attention over too many subjects, are brought against the system. I'rimary education is passing through a critical periorl. 
A systematic struggle begun by some Roman Catholic parents against secular teachers, and secular class books, has provoked a counter movement in defence of secular teaching (" défense de l'École laique"). On the other hand, some teachers holding advanced views have come into conflict with the authorities (see below). Complaints are still heard that school attendances are far from what they ought to be and that the compulsory education principle is too often infringed.

Local Government:-The results of the Paris municipal elections for May 5-12, I9r2, were: United Socialists (Socialistes unifiés) I 5 Independent Socialists 9, Radical-Socialists I4, Republicans (Left) 5, Liberals and Progressives 27, Conservatives ro. 'The Paris municipal budget for 19r2 reached $£_{1} 7,9,07, \infty 00$. A law passed July 31, I9I2, authorized a loan of $£ 8, \infty 00, \infty 0$ for building cheap dwellings. The municipal debt

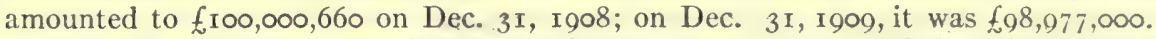

In I9 Io the total number of communes in France was 36,232 . Their ordinary receipts (Paris being excluded) rose in the same year to $£_{24}, 120,000$, and their expenditure to $£ 22,804,000$; while the municipal debt in 1909 was $f 67,610,000$.

Army.-The fighting strength on the pay roll (effectifs budgétaires) in I9I 2 was $28,74 \mathrm{I}$ officers and 555,900 men; the estimate for 1913 was 28,932 officers and 563,500 men. Modifications have been made in the higher command, consequent on the discussion in Parliament which brought about the fall of the Monis ministry (see below). The post of vice-president of the Conseil superieur de la Guerre was abolished and a Chief of the General Staff was appointed instead. The Army Council (Conseil supérieur de la defense nationale) was reconstructed by the decree of July 26 , ror . Both measures aimed at improving the organization of the higher command in peace or war. They have been followed by other changes; younger officers are admitted to the higher grades, and promotion accelerated in the lower. With these ends in view the Law of April II, I II I constituted, a "special reserve" of officers. These officers return to civil life, while continuing to draw pay; but twice a year they must take part in military exercises to keep in training in case of war. The officers' pay was increased in Igro.

Discipline has been put to severe tests of late years by the anti-militarist opinions advanced in certain political and labour quarters, animated by a rather crude humanitarian philosophy. Under the influence of such theories, the power of punishing offenders was withdrawn from non-commissioned officers and subalterns, and put in the hands of captains and majors (Decree of May 27, r910). The measure was rescinded two years later (April 24, I9r2). The legislature acted even more heedlessly when it was enacted that men previously convicted should be drafted into the army. Public opinion, quite rightly, became alarmed at the amount of crime among young soldiers; and it became only too evident that offenders, so far from being influenced for good by military service, were corrupting others. This class of recruits was abolished April I I, I9 I0, and men who had undergone conviction were separated as before into the special corps called bataillons d'Afrique. But at the same time the law suppressed the disciplinary companies, made up of the worst elements and stationed in Algeria; "special sections" were distributed instead in different parts of France. This proved an unlucky innovation, and in rgr 2 the Government had to look for some new plan of organization.

The weakness of the effective forces of France as compared with those of Germany has been a matter of much concern. It has been suggested that their numbers might be augmented by calling up coloured troops whose courage and loyalty have been tried in the colonies; the idea being that such troops as these should be garrisoned in Algeria, so releasing the present Algerian army corps for European service. "In ro ro the Chamber voted the necessary credits for the transfer of a Senegalese battalion, and the experiment appears to have been a success.

Aviation for military purposes has made remarkable headway. In Igro the attention of the Senate was called to the inadequacy of the French aviation service compared with the fleet of dirigibles organized by Germany. The attention, however, more recently paid to the development of aeroplanes has completely reversed the situation, public opinion giving encouragement in the shape of a national subscription (March IoI 2). 
Navy.-While the scheme for a new naval programme had not been definitely voted, some progress was made in building. Two armoured cruisers (cuirassés) of 23,000 tons were launched in September IgII, and by a special law passed in April of that year two more units of the same type were put in hand at the dockyards. The completion of six battleships of the "Danton" type in August I9I I enabled a new division of forces to be made-three squadrons of six armoured ships (cuirassés) each. The Naval programme proposed to the Chamber in I910 provided, on its completion in 1920, for 28 armoured ships (cuirassés), to look-out ships (éclaireurs), 52 sea-going torpedo boats (torpilleurs de haute mer) and Io vessels for foreign stations. It was voted by Parlia ment February-March I9I2. In September I9г2 the Government concentrated all the naval forces in the Mediterranean. Public upinion regarded this as a proof of a common policy arrangement made with Great Britain.

Anxiety as to the quality of the powder supplied for the navy has been caused by the bursting of a gun on the "Gloire," and by the blowing up of the "Liberté" in Toulon harbour (September I9II). Two submarines have been lost with their crews: the "Pluviose" near Calais (May 1910) and thẹ "Vendémiaire" off Cherbourg (June 1912).

\section{Political History.}

The first Briand Cabinet, which came into office on July 23, 1909, lasted till November 2, I910. The Ministry of M. Clemenceau ${ }^{1}$, which preceded it, went out on a personal question on July 20, 1909, in the course of a navy debate which was otherM. Briand's wise unimportant. The Premier, having dragged in a reference to $\mathbf{M}$.

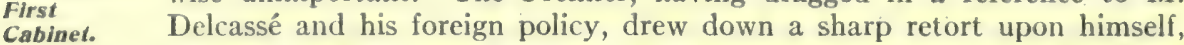
followed by an adverse division. The vote was directed against M. Clemenceau himself rather than against the policy of the ministry. He advised the President of the Republic to send for one of his colleagues, M. Briand, ${ }^{2}$ who found no difficulty in forming a cabinet, taking the Ministry of the Interior himself, and allotting Justice to M. Barthou, Public Works to M. Millerand, ${ }^{3}$ Labour to M. Viviani, Finance to M. Cochery, ${ }^{4}$ War to General Brun (b. 1849), and the Navy to Admiral Boué de Lapey. rère. The Ministerial declaration read in the Chamber on July 27 th clearly outlined the Government's intention of carrying out the social reforms of the previous cabinets; Old Age Pensions, income tax, customs tariff and civil service reform (statut des fonctionnaires) - a programme sure to satisfy the Left, while the Prime Minister's declarations of his faith in Liberalism reassured the Moderates. The session came to an end almost immediately. M. Briand in his Périgueux speech, made on October roth before the reassembling of Parliament, dwelt further on his leanings towards a broad and tolerant policy. He described the narrow policy resulting from the actual political methods in a phrase which was quickly taken up, as "little pools of stagnant water." His new direction of policy made Socialists and Socialist Radicals uneasy, but the Prime Minister was able to calm their apprehensions. The deputies went hard at work as soon as they reassembled (Oct. I009). This session was the last before the general elections, and they felt they must have some practical result to show their constituents. Electoral Reform was the first question that came up (Oct. 2ist-Nov. 8th).

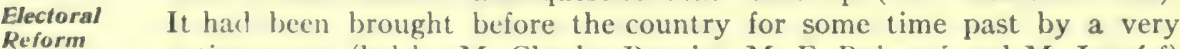
Reform
proposals. active group (led by M. Charles Benoist, M. F. Buisson and M. Jaurés ${ }^{6}$ ) belonging to different parties in the Chamber, who all laid great stress on proportional representation ( $L a$ " R.P."). Public opinion had been roused by a vigourous luturing campaign. 'The new Cabinet was not in favour of the reform, but gave way to the wish of the ('hamber to discuss the proposals drafted by the Universal Suffrage ('ommission. They were taken as a basis for general discussion, and after a debate on the retails the Assembly adopted a resolution in favour of establishing proportional representation (Nov. $8 \mathrm{th}$ ). The reform seemed likely to triumph, when the Pre-

I B. I8.4 ; see $F$. B. vi, 482 .

B. 1862 ; see E. B. iv. 515 .

${ }^{3}$ B. 1859; see E. B. xviii, 465 .
B. I 855; see E. B. vi, 6 I9.

${ }^{6}$ B. I 841 ; see $E . B$. iv, 770 .

${ }^{6}$ B. I859; see E. B. $\mathrm{xv}, 283$. 
mier intervened and made the vote one of confidence in the Ministry, with the result that the Chamber rejected the proposal.

Parliament next voted (Dec. 2I, I909) the purchase of the Western Railway (see above), and then settled down to revise the customs tariff (Law of March 29, 1910).

\section{Tariff}

Revision.

The new taxes strengthened the protective system of 1892 ; duties were raised all round and differences increased between the general tariff on all imports and the minimum tariff on goods imported from countries which have concluded commercial treaties with France, or can claim the benefit of " most favoured nation " treatment. These differences, amounting to twenty or twenty-five per cent, were increased to fifty per cent. The arguments in favour of higher duties were that foreign countries were adopting similar measures, and that fiscal and social legislation were laying new burdens upon home industries.

The budget of r9ro was only promulgated on April 8th. The revenue estimate was $f_{167,423,000}$ to meet an expenditure of $f_{167,411,000}$. The revenue was made up by Budget 1910.

an increase in succession and legacy duties, by taxes on automobiles and advertisements, and finally by issuing bonds (obligations) at short date for $£ 6,380,000$; parliament preferring to have recourse to this questionable method rather than increase the duties on wines and spirits on the eve of the general elections, as the Finance Minister had proposed to do.

The General Elections of I9ro found the state of the country as follows:-Since the religious enactments (Law of Associations; July I, Igor; Law of Separation of situation Church and State, December 9, I905) were passed, the Radical-Socialist at Elections of 1910. Church and State, December 9, I 905 ) were passed, the Radical-Socialist
party who were masters of the political situation had started on a series of social reforms which were resulting in heavy additions to the financial burdens of the country, and in encouraging the masses to make further demands. While the proposed income tax, the increase of existing taxation, and the constant business difficulties, set the capitalist classes reflecting, the masses of wage-earners and small clerks, aware that the Government was yielding under pressure, were putting their claims still higher, and often lost all sense of proportion. The result had been troubles in the South (May-June I907), the riots provoked by the Confederation générale du Travail at Draveil-Vigneux (July I908), and the postmen's strike (March rgog). In presence of these facts, the union of the Left was broken: Socialists and RadicalSocialists (extreme Left) went to the most audacious lengths in urging the popular demands; while the Radicals called a halt and tried to construct a "party of order." The head of the Government, M. Briand, tried to find a formula which would give effect to this new development. He had pointed it out in his Périgueux speech. He was more definite in addressing his constituents at St. Chamond on April i 5th, when he spoke of tolerance and liberalism and showed that the worst enemies of society were party-spirit (sectarisme) and anarchism. To combat the latter he proposed to issue regulations to all officials, which by defining their powers should make them more attentive to their duties; and to convert workmen's syndicates into corporate bodies, so as to confer upon them the right of acquiring and administering property, and thus put an end to their present appearance of being more or less revolutionary clubs. The elections

\section{Result of}

Elections.

were fought on this issue; the Radical-Socialists made common cause with the Socialists, while the Radicals on the other hand dissociated themselves altogether from collectivist candidates. The election returns of April gave the following figures, the corresponding numbers in the previous Chamber being shown in brackets:- Reactionaries (80) 7 I, Nationalists (16) I 7, Progressives (60) 60, Republicans of the Left (82) 93, Radicals and Radical-Socialists (269) 252, Independent Socialists (29) 30, United Socialists (Socialistes unifiés) (55) 74.

It is impossible, where 235 new deputies were concerned, to compare these figures with strict accuracy. But the following points may be noticed. The Socialists made headway at the expense of their Radical allies; fiscal reform seemed to find Chamber. little favour in a country which only returned $\mathrm{I}_{52}$ adherents of $\mathbf{M}$. Caillaux; while Proportional Representation (la "R.P.") on the other hand, found 


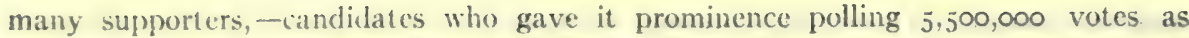
against 2,500,000 voles given to supporters of an "absolute majority" system.

The Vew (hamber met on June I, I9ı. M. Briand put the Government programme before the house at some length. Returning to the broad views expressed at St. Chamond and l'érigueux, he outlined a vast project of administrative reform, involving a new method of popular representation. This was his response to the opinion on Proportional Representation expressed by the country. Plenty of interpellations ensued from Socialists and Radical-Socialists, the latter, with M. Jean Cruppi as their mouthpiece; not hiding their misgivings. Soon afterwards the session came to an end.

A serious railway strike troubled the end of the vacation in October. Railway servants (cheminots) had been asking for improved conditions of work for some time past, and the concessions made by the companies were regarded as insuf-

The Great

Railway

Strike.

ficient. A committee was appointed to arrange for a general strike on October I 5 th. It broke out prematurely on the Nord on the IIth, but in spite of the leaders' efforts the strike never became general. 'Train services were dislocated on the Nord. the Ouest and the Midi. The Eastern railways, the Paris-LyonMéditerranée and the Orléans lines, kept their trains running almost as usual. Reports came from all sides of sabolage (the act of preventing the carrying out of work of any sort, iny damaging tools, plant or material). The Government promptly took energetic measures, " militarization." orders being issued to all railway servants, troops being sent to guard the lines, and proceedings taken against members of the Strike Committee. "Militarization" consisted in calling out all railway servants liable for military service, for a period of twenty-one days' instruction, but leaving them nevertheless to carry on their ordinary work. Refusal on their part would make them liable to be brought before a court-martial. The strike agents were on the other hand dismissed on the lines where the train services were being maintained. 'The strike broke down completely, and by the $\mathrm{I} 8 \mathrm{th}$ all the train services were working as usual; but excitement at the time was intense and left deep traces. Business was hampered for a long while by the dislocated traftic, and sabotage was continued with a rare pertinacity. When parliament reassembled on October 23 rd the Ministry was taken sharply to task by the Left groups. In the course of a string of interpellations between October 25 th and 3 oth there was a visible widening of the rift existing already between the Extreme Left Socialists and RadicalSocialists (led by MM. Jaurès and Cruppi), who decided to swim with the anarchist tide, and the more moderate section which was disposed to form a "party of order." It was the latter section that kept the Ministry in oftice.

The result was a reconstruction of the Cabinet, and the coming in of a second Briand Ministry, which lasted from November 3,1910 , to February 27 , 191 r. In spite of the support received in the Chamber, M. Briand decided that his policy now second turned too obviously on matters remote from those in question when he Briand Ministry. accepted office in the previous year; so he resigned (Nov. 2d), and the President, M. Fallières, ${ }^{2}$ called upon him to form another Cabinet (Nov. $3 \mathrm{rd})$. The new administration showed a marked tendency towards the "group. of order." M. Briand's two Socialist colleagues, MM. Millerand and Viviani, resigned, and the Prime Minister surrounded himself with new men. The programme which he laid before I'arliament (Nov. 8th) was dominated by a policy of "social defence"

-1 rade unions to be restricted to their industrial function, assurances of security to be given for the maintenance of public services. Henceforth it was more obvious than

Split with

Evtreme

Left.

ever that there was a gulf fixed between the Government and its former supporters on the Fixtreme Left. It was shown directly over the question of reinstating railway servants (cheminots) dismissed for taking part in the strike. The Extreme Left asked the Ministry to compel the companies to take back the men, and the Ministry refused to put pressure on the companies. The position of the cabinet grew difficult, however, and its majority melted away. The ittack on social questions proving fruitless, the Extreme Left had recourse to its old

'B. 1855; formerly minister of Commerce.
${ }^{2}$ B. 1841 ; see E. B. x; 154 . 
tactics and brandished the bogey of clericalism. On February 24th MM. Malvy and $\begin{aligned} & \text { M. Briand } \\ & \text { resigns. }\end{aligned}$ gregations was being carried out and reduced the Ministerial majority to
grenter made an interpellation on the way in which the Law of Con-

6. M. Briand, considering that he could not carry on the Government in such precarious conditions, resigned on the $27^{\text {th }}$; and he was succeeded by the Monis ${ }^{1}$ Ministry (March 2-June 23, I9II).

In the crisis which followed M. Briand's resignation, the President of the Republic thought to meet the case by summoning the leaders of the Radical-Socialist minority which had come into collision with the previous Cabinet. M. Monis did,

Monis Ministry. Raymond Poincaré 2 and M Ribot, ${ }^{3}$ but he met with refusals, and ended by surrounding himself with his own party. He took the Ministry of the Interior himself, gave Finance to $\mathbf{M}$. Joseph Caillaux, ${ }^{4}$ Foreign Affairs to M. Cruppi, War to M. Berteaux $^{5}$ and the Navy to M. Delcassé ${ }^{6}$ As far as men were concerned it was a complete change. The political programme on the other hand was scarcely altered at all (measures to prevent the recurrence of railway strikes, income tax, and electoral reform). It was the spirit that was different. This was soon seen when the second debate on the re-instatement of railway servants began in April. The Prime Minister and the Minister of Public Works (M. Dumont), under pressure from the Socialist groups, announced that they meant to break down the resistance of the railway companies. A law was to be passed establishing a disciplinary council which should decide which of the men should be taken back, and revise the dismissals after the strike. The bill was in its preliminary stages when the Ministry fell. At the same time the Government gave vigourous support to a bill making the Railway Servant Pensions Law of Igog retroactive in its scope. That also came to nothing.

The very democratic policy of the Government did not save them difficulties. They had not long been in power when the Délimitation law brought on serious disturbTrouble in
the Champagne districts. ances in Champagne. The object of the Delimitation decree of December 7, I909, had been to restrict the application of the word "champagne" to wines grown in a certain area, namely the department of the Marne and some adjacent communes in the departments of the Aisne and HauteMarne. Trouble had already occurred (Nov. IgIo and Jan. IgII) in various localities in this region where the peasant wine-growers attributed the stagnation in the wine trađe to fraudulent methods of sale; and M. Briand had a law voted (Feb. IO, I9r r) to provide more precisely for that question. Agitation began again in March at other points. This time it was the wine-growers of the Aube who, wanting to sell their wines to the champagne wine-factors, as they had hitherto done, demanded that their area should be included within the champagne zone. As the Government hesitated and took refuge behind the jurisdiction of the Council of State, the Aube wine-growers outside the limits indulged in deplorable demonstrations; those of the Marne, hearing that the Delimitation Law was to be repealed, rose in their turn, and on April $\mathrm{I}$ th-1 2 th there was pillage and incendiarism at Ay and Épernay. Quiet was only restored after a promise that all attempt at delimitation should be given up.

On May 21st, while watching the start of aeroplanes for the Paris-Madrid race, both the Premier and the Minister of War were struck down by one of the machines.

M. Berteaux was killed on the spot. M. Monis was grievously injured, Fatal acci but he continued in office and gave the War portfolio to General Goiran. dent to $\boldsymbol{M}$. The Cabinet found great difficulty in administering the Old Age Pensions
Berteaux.

Law; and their troubles were increased by anxiety over the situation in Morocco, and the necessity of sending an expedition to Fez in April-May (see under

1 Antoine Emmanuel Ernest Monis; b. 1846; minister of Justice 1899-1902; senator.

${ }^{2}$ B. I860; see E. B. xxi, 892 .

${ }^{3}$ B. 1842 ; see $E$. B. xxiii, 285.

${ }^{4}$ B. 1863; minister of Finance, $1899-1902$ and 1906.

${ }^{5} \mathrm{~B} .1852$.

${ }^{6}$ B. 1852 ; see E. B. vii, 953 . 
Morocco). Their scheme of electoral reform was still in progress, when the fall of the Ministry was brought about by a casual incident. A question asked in the Senate (June 2 Ist) and an interpellation later on in the Chamber (June $23 \mathrm{rd}$ ) about Fall of Monis the organization of the command in time of war, drew from General Goiran
Ministry.

a declaration that the supreme decision in such a case rested with the Govcrnment. The prospect of seeing the destinies of the country given into the hands of a body whose competence was doubtful, to say the least, displeased Parliament, and the Chamber having passed to the Order of the Day without giving the vote of confidence demanded by the Government, the Ministry resigned.

In the discussion which resulted in the fall of M. Monis, Parliament had had in mind a question really of persons rather than politics. Little personal enthusiasm was felt Callaux there for the head of the Government, who had often lacked firmness in or Ministry. out of the Chamber; but though he disappeared there was no particular desire to change his policy. M. Fallières thought to meet this view by calling M. Caillaux, one of M. Monis' most brilliant colleagues, to the head of affairs; and he formed his ministry on June $27 \mathrm{th}$. He took the Interior himself, leaving Finance to M. Klotz, ${ }^{1}$ and transferred M. Cruppi to Justice in order to give Foreign Affairs to M. de Selves. ${ }^{2}$ M. Delcassé kept the Navy and M. Messimy ${ }^{3}$ went to the War Office. M. Caillaux gave promise of being "a Government which governs." He firmly rejected the repeated demand for the reinstatement of the railway servants, manifested his intention of putting down sabotage, and took measures against anti-militarism.

The budget of I9I I was not voted till July I2th, after the introduction of seven " provisional twelfths." (These are credits voted month by month so that public service Budget can be carried on without interruption, though the Budget has not been 1911 .

bills has made them nearly always necessary.) The expenditure was estimated at $\ell_{175,458,000}$ and the revenue at $\ell_{175,467,000}$; an increase in the customs yield making it unnecessary to introduce any new taxes of importance.

The real tendencies of the Cabinet soon began to show themselves, on the lines of strict party politics. A circular from M. Messimy (Dec. II, I9II) made officers' promotions in the army dependent upon reports furnished about them by Party polky. the prefects. After all, this only gave a formal sanction to a practice already long standing. The Minister of Public Works, to satisfy the Socialsts, granted mining concessions only to those who would accept special conditions, thus nullifying the clauses of the organic law of 18 ro on the subject. He appointed a commission to consider a Bill aiming at making the posts of railway directors and head officials into government appointments. When the Court of Appeal gave judgment on the interpretation of Article 23 of the Old Age Pensions Law the Labour Minister was up in arms against its decision, which was at variance with the line taken by the Government, and declared that new legislation would soon put an end to it. But before Morocco very long the whole attention of the Ministry was absorbed by foreign affairs. crisis.

The appearance of a German gunboat at Agadir raised the Morocco question in an acute form, which rapidly developed into an international crisis, and the summer was spent in negotiations with Germany (see Part I, Sect. i. "International Affairs "). J'ublic opinion wat ched the attitude of the (rovernment with anxiety, ill-pleased with the desultoriness of negotiations in which it seemed that the conduct of national diplomacy was too often abandoned to mere business men. Such proposed concessions as were made public appeared to be considerable, while the general attitude of the (jovernment seemed incoherent and fecble. It was the nation itself, by an open outhurst of discontent with the proceedings in September, that put more firmness into its leaders; and the conclusion of the agreement of November 4, I9II, while it cleared

I. muis I ucien Klotz; b. I868; president of Inland Revenue Commission.

2 Justin (jermain Casimir de Selves; b. 1848; senator.

: Truple Me Mimy; h. I $8(x)$; rapportcur of budgets for navy (1903), army (1906-7) and colonics (1908). 
up the situation, did not restore to the Cabinet the prestige which it had lost. The agreement itself was subjected to very sharp criticism in both Chambers when it came before them for ratification (Dec. I4th-2oth in the Chamber; Dec. 2 ist to Feb. Fall of 18 th in the Senate). Before the debate was over, the Ministry went Ministry. out, and over that very question. On January 9 th, in consequence of an incident in the Senate during the preliminary stages of the discussion of the treaty, M. de Selves sent in his resignation. M. Caillaux vainly tried to replace him by M. Delcassé, and since other attempted combinations came to nothing, he took the only course open and resigned, on January I0, I9I2.

M. Caillaux's departure was the occasion of a new political grouping. The country was evidently tired of ministerial rearrangements with nothing behind them, suggested by a narrow partisan spirit, or by personal considerations. The govern-

Poincaré "National" Cabinet. ment by the more radical part of the Left had failed to re-establish security at home or abroad. The need of new leadership was felt, and a ministry was wanted which would combine more breadth of mind and more brilliancy than its predecessors. On January I $3^{\text {th }}$ M. Poincaré constructed a Cabinet composed for the most part of men of the first rank. He himself took Foreign Affairs, the department which in the existing condition of Europe was specially important; he gave Finance to M. Klotz, Labour to M. Léon Bourgeois, ${ }^{1}$ War to M. Millerand, the Navy to M. Delcassé, and Justice to M. Briand. So three ex-premiers were included in the Government. People called it " the great ministry," and the " national ministry."

The Senatorial Elections in January further showed the trend of opinion. There was a slight falling off in the numbers of Radical-Socialist Senators and Socialists, and

\section{Senate}

Elections.

advanced candidates were obliged to tone down their programmes. The hundred seats were distributed as follows: Radicals and Radical-Socialists 49, Republicans (Left) 20, Socialists 3, Progressives 23, Reactionaries 5.

It was obvious that the new Cabinet was formed primarily: with a view to foreign affairs: the ratification of the agreement with Germany passed on February Ioth; the carrying out of the agreement; the negotiations with Spain over Morocco

\section{Firm for-} eign and domestic policy. and with England over Tangier. There still remained delicate questions at issue with Italy (the seizure of the "Manouba " and the "Carthage" in January); and the development of the Italo-Turkish war needed watching. These various matters had their echoes in Parliament, notably in M. Poincaré's speech in the Chamber on January $22 \mathrm{nd}$, about incidents arising out of Italy's descent on Africa, and the interpellation on secret treaties and foreign policy at the beginning of March. In home affairs M. Poincare clearly showed that he meant to govern firmly and restore social discipline. M. Millerand withdrew his predecessor's circular about political reports on officers of the army (Feb. I9I2), and (on April 24th) restored to noncommissioned officers and subalterns (lieutenants and sub-lieutenants) the powers of punishing offenders taken from them by regulations issued on May 29, r9ro. After the anarchist attempts in the Rue du Havre (Feb. 27th) and at Chantilly (March 25th), he obtained supplementary credits for the police, and provided them with more inodern methods of detecting and pursuing criminals. The principal offenders were discovered, besieged and killed by armed force at Choisy-le-Roi on April 28th and at Nogent-surMarne on May rith.

The Budget of I 9 I 2 was voted on February 27 th, the revenue amounting to I $_{8} 8$,160,000 and the expenditure to $f_{1} 180,120,000$. The revenue was made up without Budget of $1912 \cdot 13$. recourse to new taxes or loans by means of a new institution, the "provisional account" (Compte provisionnel). This special fund was endowed with resources drawn from an agreement made with the Eastern Railway Company, in which they were empowered to pay off their debt by anticipation; it was augmented further by the surplus declared at the close of the financial year I9I I, and would be drawn upon in future by the requirements of 1913 and I9I4. The budget for I9I3 was introduced without delay; the expenditure was estimated at $£ I 86,585, \infty 00(£ 668, \infty 00$

1 B. 185 I ; see $E$. B. iv, 330 . 
more than in $1(1) 12)$ and the revenue at $f_{1} 80,164, \infty 00$. To cover the probable deficit of f0.421,000 the Ministry proposed to resort to the "provisional account." During the latter part of 1 () 13 a new income tax scheme, a milder version of the project put forward by M. ( aillaux in 1007 , and voted by the Chamber in 1909, passed through its preliminary stages before a commission of the Senate. The more moderate tendencies of the majority in Parliament, and especially the breaking up of the old Left bloc, were shown in May when a new President of the Chamber was elected on the death of M. Brisson. M. Paul Deschanel, ${ }^{1}$ the moderate Left candidate, was elected on a second ballot, out of a number of oddly assorted competitors, entered against him by the Radical groups.

In the Chamber the principal work of the session was the Bill for electoral reform. The discussion went on for a long while (from Feb. I 2 th to July Ioth) and was enlivened by various incidents. The previous ministries had only turned very slowly Electoral towards this reform. M. Briand had been avowedly hostile, and it had Reform BIII. taken a very decided expression of opinion at the general elections to incline him, and his successors after him, to look favourably on proportional representation. The Government groups cast no friendly eye on a reform so highly extolled by a parliamentary minority. It would probably upset the existing distribution of seats. Many of their most eminent members among them were strong supporters of the " absolute majority " system, which returns deputies for each "arrondissement" or each "circonscription." These were nicknamed the "arrondissementiers." M. Combes, ${ }^{2}$ old-fashioned Radicalism incarnate, made a violent speech against proportional representation at a Radical and Socialist-Radical banquet on Junc nth. But the verdict of the general elections was too much present in people's minds not to tell upon votes given in the Chamber. In vain the arrondisscmentiers fulminated against dangers to which the Republic was exposed by the introduction of schemes supported by deputies representing a minority. It was generally thought that there was no danger except for the speakers themselves, who might lose their seats. The measure passed the Chamber on July roth. It provides an election system of "scrutin de liste" by departments, with representation for minorities. The counting of the polls is entrusted to a gerieral revising committee sitting at the headquarters of the department. 'This committee apportions the seats among the lists of candidates according to the number of votes obtained for each list. 'The measure had hardly been passed by the Chamber, hefore M. Clemenceau launched a violent manifesto (July I 2th) against the "so-called reform," calling it " an attack on universal suffrage;" and a propaganda committee was started. At Tours, in October, the Radical-Socialist congress condemned the "R.P." bill, after they themselves had voted for it. The struggle was now carried to the senate. On March I 5 th the Chamber had passed a law providing for the secrecy of the ballot and genuineness of the votes.

In June and for some time after trade was much upset by a new strike of the " inscrits maritimes" at the ports, which in August became more or less confined to Marseilles. (In July 12 th l'arliament rose. In August M. Poincaré went to Russia to confer with the Tsar and his Ministers on the alliance between the two countries, and the new aspects of the Eastern question.

Throughout the summer the Government showed a more and more decided tendency to take the side of "order," by starting proceedings against anti-militarist teachers in the schools. 'The opportunity came up when the Teachers' Unions Federa-

Antr-

Miltharist

Movement. tion C'ongress (Congrès de la Fédération des Sundicats d'Instituteurs), held in August at (hambery, gave its support to the cause of "the Soldier's Halfpenny." This suciety (the Sou du Soldat), under pretext of giving pecuniary aid to young men in barracks, carries on anti-militarist propaganda under the ausprices of the (ieneral Federation of Labour (Confédération générale du travail). (On August 22nd the (iovernment gave the 'Teachers' Cnions notice that they must dissolve before September sath. Surh unions (syndicates) had so far been allowed on sufferance. until a law should be patsed detining the limits within which officials might

P. 1856; sce E. B. viii, 9 ?

${ }^{2}$ B. 1835 ; see E. B. vi, 75 I, 
combine to form associations. Most of them gave in, but a few refractory teachers came before the courts (Oct. I912).

The Confédération générale du trazail, or " C.G.T." as it is often called, after encouraging and sometimes directly citing to riot, softened its tone, when it was discovered that many minds were alienated by its violence, and that new recruits were not coming in. It resolved, by a manifesto of August 1912 , to break both with the Socialist party in Parliament and with anti-militarism or Hervéism (so-called after the name of its founder). ${ }^{1}$ The Havre Congress (Sept. 1912) proclaimed the autonomy and independence of syndicalism and emphasized the revolt against "the politicians." Syndicalism was now divided into two camps, the Reformistes, who believed in State intervention, and the Révolutionnaires, who wanted to abolish the authority of the State. Anti-militarism as such had decidedly fallen off.

At the end of the year political interest centred in the forthcoming election of a new President of the Republic, and it was announced that M. Poincaré, the Premier, would be a candidate. He was eventually elected just after the New Year, M. Briand becoming Prime Minister.

\section{Obituary.}

I9IO.-During this year the following deaths occurred, in addition to those noted in the $E$. B. while it was passing through the press:- The DuC D'ALENÇON (b. 1844), son of the Duc de Nemours (E. B. xix, $37 \mathrm{Ib}$ ); he left a daughter, Louise, who married Prince Alphonso of Bavaria, and a son, Emmanuel, Duc de Vendôme, married to Princess Henrietta of Belgium. LÉON AUCOC (b. 1828), a well-known jurist, and member of the Institute. HENRI BARBOUX (b. I834), a distinguished advocate, and member of the Academy. L. A. BotrGAULT-DUCOUDRAY (b. 1840), the composer and historian of music, author of the opera Thamara and professor at the Conservatoire. The DUC DE CHARTREs (b. I840), son of Ferdinand, Duc d'Orléans $(E . B . x x, 283)$; he had fought in the war between Austria and Italy, the American Civil War, and the Franco-Prussian War, and had published Souvenirs de Voyage (1869) and Lettres el récits de Campagne (1889-90); he left a son, the Duc de Guise, captain in the Danish army. EMILE CHEYSSON (b. 1836), a well-known engincer and socialeconomist, member of the Institute, EDOUARD ColonNe (b. 1838), the orchestral conductor. L.EOPOLD DELISLE (b. 1826), the eminent bibliophile and historian (E. B. vii, 964). EMmanUel Frémiet (b. I824), the famous sculptor ( $E . B$. xi, 96). HenRi Harrisse (b. 1830), a learned student of early American exploration, author of Christophe Colomb (1884) and other works. Father M. J. H. OLLIVIER (b. 1835), a Dominican preacher who for twenty years held the most important positions in Paris. JULES RENARD (b. 1864), a writer who was a member of the Académie des Goncourt. Albert VANDAL (b. I853), the historian, author of Napoléon et Alexandre I, l'Avénement de Bonaparte, etc.

IOI1.-During this year the following persons died, whose biographies (as living in I9I0) are given in the E. B. Henry Houssaye (b. 1848; d. Sept. 23), the historian (E. B. xiii, 828a). Pierre-Émile LeVasseur (b. I828; d. July 9), the economist and geographer (E. B. xvi, 505). Tony Robert Fleury (b. 1837; d. Dec. 8 ), the painter (E. B. xxiii, 403 ). Maurice Rouvier (b. I842; d. June 7), the statesman (E. B. xxiii, 78 I). Felix F. (G. Ziem (b. 1821 ; d. Nov. I1), the painter (E. B. xxviii, 979). Alfred Léon Gérault-Richaro (b. I860; d. Dec. 6). the journalist and deputy (E. B. xi, 766). Auguste Michel-LÉry (b. 1844; d. Sept. 2I), the geologist (E. B. xvi, 519).

Some further details may be added concerning others of historical interest who died in I9I I :- AUguste ANGellier (b, I848; d. Mar. I), the poet, professor of literature at Lille, was the author of a critical Life of Robert Burns and of several volumes of verse, A l'amic perdue, le Chemin des saisons, Dans la lumiere antique etc. Henri Maurice Berteacx (b. 1852), War Minister in the Cabinet of M. Monis, who was killed on May 2 Ist by the fall of an aeroplane, had become Republican deputy for Versailles in I893, and was leader of the Radical-Socialist group; he had been War Minister under M. Combes in 1904 and under M. Rouvier in 1905. EdouARD BORnet (b. 1828; d. Dec. I7) was an eminent botanist who devoted himself to scientific research, working at first on fungi and later on lichens and algae (E. B. i, 590c; xvi, $578 \mathrm{~d}$; and xxvi, 899c). He was elected a member of the Académie des Sciences in 1886 , and received the gold medal of the Linnean Society in 1891 . General Jean Jules Brun (b. 1849; d. Feb. 23) was War Minister in 1909-I 1 ; he introduced various important reforms in the army, notably in the pay of the officers, and the development of military education. Baron ChARETTE de LA CONTRIE (b. I832; d. Oct. 9) was a grandson of the Vendéean general who became famous in the rising of 1793 and was finally shot in 1796; he commanded the Papal Zouaves at Rome (1860-70), and took a brilliant part in the Franco-German War at the battle of Patay (Dec. 2, 1870) at the head of a volunteer regiment recruited from them. Odilon MARC LANNelongue (b. 1840; d. Dec. 21 ) was President

${ }^{1}$ See E. B. $\mathrm{x}, 887$. 
of the Paris Academy of Medicine and one of the most eminent French surgeons. He was a friend of (iambetta, whom he attended in his last hours. He had been a senator since 1906. The I) LC DE LA TREMOĨLLE (b. 1838 ) was a distinguished historian and member of the Académie des Inscriptions. LÉON LEFÈBVRE (b. 1838) was a politician and member of the Institute; a deputy to the Corps Législatif in 1869 , and member of the National Assembly (1871), from 1876 onwards he devoted himself to philanthropic work. MaURICE MaINDRON (b. 1857) was a distinguished entomologist and man of letters; he published Le Tournoi de I auplassans (crowned by the Academy in 1895), Saint-Cendre (1898), L'Arbre de Science (1906) etc. E.RNEST MERCADier (b. 1836; d. July 27) was a well-known physicist and author of numerous discoveries and improvements in electrical science. JEAN CHARLES RODOLPHE RADAU (b. I 835), the astronomer, was a member of the Bureau of Longitudes and of the Académie des Sciences and a frequent contributor of scientific articles to the Revue des deux Mondes. He also published a logarithmical table for astronomical work (E. B. xxiv, 333). Lovis XAvier DE RICARD (b. I 843), the poet, assisted Catulle Mendés to found the Parnasse Contemporain (E.B. xi, 146d). He was specially associated with the revival of "langue d'oc" literature. Lours OScAR Roty (b. I846; d. Mar. 23) was a prominent sculptor and member of the Académie des Beaux-Arts. He took the Prix de Rome in 1875 for a medal and founded a new school of medal-designing in Paris $(E . B$. xviii, 2 b, and xix, 907b). EDMOND SAglio (b. 1828; d. Dec. 7), archaeologist and member of the Institute, is chiefly remembered for his collaboration with Daremberg in the great Diciionnaire des Antiquités grecques et romains. PAUL TOPINARD (b. 1830 ), the anthropologist $(E . B$. xii, $82+a)$, was the first professor at the Paris School of Anthropology, founded in 1876, and was the author of various works, including $L$ 'Anthropologie (I876).

1912.-During this year the following persons died, whose biographies (as living in 1910) are given in the E. B.:-Henri Brisson (b. I 835; d. April I4), the statesman (E. B. iv, 574c). Jean Baptiste Edouard Detallle (b.- I 848 ; d. Dec. 24), the painter (E. $B$. viii, I IOd). LÉon DierX (b. 1838 ; d. June II), the poet (E. B. viii, 2 IOd). Alfred Foulllée (b. I 838 ; d. July I6), the philosopher (E. B. x, 737c). JEAN HeNri GeOrge Laguerre (b. 1858 ), the lawyer and politician (E.B. xvi, 79b). General Hippolyte Langlois (b. 1839 ; d. Feb. 12), the great artillery tactician and member of the Academy ( $E$. $B$. xvii, 177a). H. J. B. Anatole Leroy-Beaulieu (b. I842; d. June I6); the publicist (E. B. xvi, 485b). Jules Massenet (b. 1842; d. Aug. 13), the compeser (E. B. xvii, 866c); his last opera Panurge was completed just before his death. GABRIEL MONOD (b. 1844; d. April 10), the historian (E. B. xviii, 73ob). Jules Henri Poincaré (b. 1854; d. July 17), the astronomer and mathematician (E. B. xxi, 892a). Henri Poincaré began his education at the lycée in Nancy, where he was born; as a boy he served in an ambulance corps during the war of 1870 , and later passed with distinction through the Ecole Polytechnique in mining. In 1879 he took his degree of Docteur és Sciences, and thereupon gave up practical work as a mining engineer to take up a lectureship at Caen. He was transferred in $188 \mathrm{I}$ to the University of Paris, where he lectured on physical mechanics, mathematical physics and astronomical mechanics. In 1889 he won the prize open to the whole world offered by the King of Sweden for a mathematical treatise. By 1887 , when he was elected a member of the Académie des Sciences, he had written 300 works. In I908, when he became a member of the Académie Française, he had written I300. These include Science et Hypothèse, La valcur de la Science, Science et Methode, etc. (see E. B. xxv, 786c; xxvi, 947d; xix, 859c).

Some further details may be added concerning others of historical interest, who died in 1912:-MALrice Bunvoisin (b. 1849; d. March), was the caricaturist who used the pseudonym of "Mars." Besides working principally for the Journal Amusant in Paris, he was a frequent contributor to English illustrated papers and magazines. JulEs CAzOT (b. 1821; d. Nov. 27), minister of justice 1879-82, president of Court of Cassation 1883-84, and life senator. (GEORcies Corloon (b. 1838; d. Feb. 20), vice-president of the Council of State, was a noted lawyer and administrator. Admiral Jules Marie Armant de Cuverville (b. I8.34), had been maritime prefect at Cherbourg (1893), commander of the Mediterranean Siuarlron (1896), chief of the (ieneral Naval Staff (1898), and a senator since 190I. Lours 1)ELAI'NAY-BFIL FYILIE (h. I843; d. Feb. Io) was a famous engineer. Educated at St. Barle and the Ecole Polyterhnigue he entered the Naval Engineering school in 1864 , and in I 86,7 left to join the Belleville works at St. Denis, near Paris. He became a partner and finally hearl of the firm, which produced the well-known Belleville boilers $(E . B$. iv, 145a), and also the automobile called by his name. From 1890 to 1893 he was president of the I.uris (hamber of (ommerce. JEAN Duptis (b. 1829; d. Nov. 29), a pioneer of French trate and exploration in Indo-China. His expedition up the Red River in the early seventics (F. B. xxvii, 6a) led eventually to the French acquisition of Tongking. Judith [JuliF BFEKNIT] (b. 1827; d. Oct. 27), the actress, made her first appearance in Paris at the Folies I) ramatigutes in $18+2$. In 1846 she joined the Théâtre Français, and was a contemporary and rival of .11 me. Rachel. She left the Comédie Française in 1864. Françors-Raovi. I.ARCHE (b. $18($,$) ; d. June 4), the sculptor, won the second Prix de Rome in 1886$, and in 1900) the medaille d'homneur in the Salon for sculpture. One of his best known works, "Les Violettes" ( $\mathrm{r}(89))$. wats plared in the Luxembourg (E. B. xxiv, 509a). Amongst his other works are Jésus dequnt lés docleurs (1890), La Prairie et le Ruisseau (1891), Le Miroir (1892), 
l'A pôtre (1903), Le Printemps (1907), etc. Paul Émile (François) Lecoq de Boisbaudran (b. I838; d. May 3I), the chemist, made his mark in 1875 as the discoverer of gallium. Among his decorations was the Davy medal of the Royal Society. JuLES Joseph LEFĖ (b. 1836; d. Feb. 24), the portrait painter, had been a professor at the École des Beaux-Arts, and was a member of the Institute $(E . B . x x, 503 a)$. CHARLES Loyson (better known as Père Hyacinthe), the famous preacher (b. 1827 ; d. Feb. 9), was educated for the priesthood and entered the Carmelite order. His eloquence drew all Paris to his Advent sermons in Notre Dame between I 865 and I 869 , but his orthodoxy fell under suspicion, and in 1870 he associated himself with Döllinger's protest against the dogma of papal infallibility ( $E$. $B$. xiv, $5 \mathrm{I} 2 \mathrm{~b}$; and $\mathrm{xx}, 67 \mathrm{~d}$ ). Being excommunicated he broke finally with the Church of Rome, and removed first to Geneva and then to London. He married an English lady, Emily Jane Merriman, and settled in Paris in 1877 , where he founded a Gallican Church on Protestant lines. Frédéric PASSY (b. I822; d. June I2), was a well-known economist and "pacifist." He was a nephew of the economist Hippolyte Passy, Finance Minister to Louis Philippe and to Louis Napoleon's Republican Government. Under his uncle's influence Fréderic devoted himself to economic studies, and to that end gave up the appointment as Auditor of the Conseil de Droit, which he had held I846-49. In I860 he began to teach political economy both in Paris and in the provinces. His first work on the subject, Mélanges economiques, appeared in 1857 . True to his Reputlican principles he refused to be reconciled to the Second Empire, and remained, therefore, ineligible for any Government post. He was an ardent free-trader and an admirer of Cobden. In 1867 he founded the Ligue Internationale de la Paix, afterwards known as the Société Française pour l'Arbitrange entre Nations, and for the rest of his life he devoted himself to the promotion of international peace. From I88I to 1899 he was Deputy for the Geine Department. In I9OI he received the Nobel Prize, sharing it with M. Dunant. His published works include De la Propriété Intellectuelle (1859), Leçons d'economique Politique (1860-6I), Le Democratie et l'Instruction (1864), L'Histoire du Travail (1873), Malthus et sa Doctrine (1868), La Solidarité du Travail et du Capital (1875), and Le Petit Poucet du roième Siècle-George Stephenson (1881). L. A. Thłodore-Riviére (b. 1857; d. Nov. I912), sculptor, studied first at his native town Toulouse and afterwards in Paris under Falguière and Mercié. He worked chiefly on statuary in miniature, using bronze and stone, ivory and marble, and ivory and onyx as materials (E. B. xxiv, $5 \mathrm{IOb})$.

\section{French Colonies.}

The census returns for I 906 give the total population of the French colonies as $46,125,510$. The trade returns for 1910 amounted to $f_{4} 8,98 \mathrm{I}, 000$, the total imports being $f_{22,390,000}$, and the exports $£_{26} 6,586,000$. The colonial debt is $£_{24, \infty}, \infty, \infty 00$.

The whole organization of the Colonial Office was changed by the decree of May 20, I9Ir, which swept away the old, practically independent, divisions called Directions, and substituted for them nine departments (Services):-I. Indo-China, 2. Indian Ocean 3. Western and Equatorial Africa, 4. America and Oceania, 5. Audit Department, 6. Staff, 7. Penal Settlements, 8. Military Department, 9. Colonial Administration. A Ioth department, Secretary's Office and General Control, keeps them all in touch.

Algeria. ${ }^{1-}$ In 1906 the population was 5,231,000. The trade'returns of 1910 reached a total of $£ 40,040,000$, of which $£ 20,320$, 000 were imports and $£ 19,720,000$ exports. The budget of I9II provided for a revenue of $£ 5,782,000$.

Trade has been interrupted three times by strikes of the "inscrits maritimes." Two took place in the spring of the years 1909-1o respectively, and one in the summer of 1912. A delicate political problem arose out of the Ouenza question. For some ten years past the colony in general, and the Constantine region in particular, have been clamouring to begin working the Ouenza iron mines, which are expected to yield considerable profits. But for a long while past the Chamber of Deputies has kept on putting off the consideration of the railway scheme on which the working of the mines depends. There was a lively debate upon it on January 21 st and again on March 23 and 26, 1910; then the matter was shelved again. The house was afraid of foreign interference in the affairs of the company applying for the concession. Loud complaints were made in Algeria of the delays in getting the matter settled, and of the ways in which colonial expansion was being hampered by a paternal government at home. At representative meetings resolutions were passed in favour of administrative and financial autonomy for Algeria. The natives, on the other hand, complain that they are put under an official despotism. The better educated among them want guarantees and the exercise of certain political rights. Others, making up their minds to exile, betook themselves to Syria. The welcome they received there was not very encouraging, and the authorities succeeded in stopping emigration. Discontent was further increased when the decree of February 3, I912, came into force, making natives liable, to a very slight

1 See E. B. i, 642 et seq. 
(xtent, however, to military service. Recruiting produced some disturbances at first, but in October 1912 was going on without hindrance.

The railwaty system is in course of active development. The Est-Algérian and BöneGuelma lines were successively bought up; and eight new lines (in all 542 additional miles) are 111 proce's of construction. A commission has been appointed to consider a bill authorizing the construction of a Trans-Sahara Railway, to come out, not at Timbuctoo, as in previous projects of the kind, but on Lake Chad, so as to open up communication with the Belgian Congo and British South Africa.

Tunisia. - In 1910 the total population was $1,923,000$, of whom 42,000 are Frenchmen, $1,7(00,000$ Moslems, 50,000 Jews, 108,000 Italians, and 12,000 Maltese. The imports amounted to $f 4,219,000$ and the exports to $f 4,816,000$. Since the acute agricultural crisis of $1908-\infty)$ business has taken a more satisfactory turn. Trade was brisk in 1912 , the Italian Government buying large quantities of stores and beasts of burden for the troops occupying Tripoli. Here, as in Algeria, the native question is uppermost in people's minds. complaints are made by the Tunisians of the heavy Medjba tax. In former times this used (1) be almost fi per head, but in 1910 it had fallen to fifteen shillings. The Jews, at present amenable to native tribunals, want to be brought under the jurisdiction of the French courts of law. A good deal of land has passed into the hands of European colonists. In 1909 2,400 Frenchmen owned about 700,000 hectares. With property changing hands on so large a scale, there was bound to be friction between colonists and natives, and bad feeling on both sides was shown even at the Conférence consultative; so much so indeed that by a decree of the Beylik (April 30, 1910) the Conference was split into two different sections, which in future will sit separately; their financial powers have been curtailed, and all resolutions passed must be submitted to a newly constituted Conseil supérieur.

serious rioting broke out at Tunis in November 19 I I, caused partly by Moslem excitement over the Italo-Turkish war, partly by a rumour that an Arab cemetery in the city was to be taken over for other purposes. A mob of natives fell upon the Iralian resirlents and a state of siege was proclaimed by a decree of November 13, 19I I. The ringleaders were found guilty and seven of them condemned to death (June 30, 1912).

The Regency of Tunisia was empowered by a law passed on March 28, 1912, to raise a loan of $f 3,620,000$ for the completion of the railway.

Western Africa. ${ }^{2}-$ Population, I1,350,000. Trade in I9I0: imports $£ 6,123,000$ increase of $f_{1} 1,380,000$ over 1909$)$; exports $f 5,007,000$ (or $f_{6} 614,000$ more than in 1909 ).

Railway construction is in active progress. The line from Thies to Kayes is nearly finished. The Guinea line has been brought as far as its provisional terminus at Kouroussa (it is to go to Kankan later on), while the Ivory Coast line has been made as far as Baorhi (about I93 miles). All these lines are only branches, to be linked up bye-and-bye. Still they are paying satisfactory dividends, and doing a great deal for economic development.

The turbulence of certain Ivory Coast tribes made it necessary to disarm them in I999. The pacification of Mauretania was completed by Colonel Gouraud in September 1909. Some alterations were made in the conditions of native labour contracts by a law passed on July 15, 1912. To safeguard the rights of the natives the contractor was compelled to pay vier the sums due to them to the administration, so that in the event of the native worker's derease the money should be paid over to his family. A system of native justice was organized by a decree passed on August I6 providing Native Courts (Tribunaux ethniques) where rases among natives can be brought before judges of their own race.

Equatorial Africa. ${ }^{3}$ - Population about 8,000,000 (before the recent treaty with Germany). Improrts in 1910, $£ 527,000$ (an excess of $£ 82,000$ over the year 1909 ), and exports $£, 985,000$ (or $£ 287,000$ more than in 1909 ).

In June Igog after occupying Abeshr, the chief town of the Wadai, Captain Fiegenschuh f(ll into an ambush laid by the Sultan of Dar-Menalat, and perished with all his escort (January 1910). In November Colonel Moll was killed in a successful engagement against the Massilits, and Colonel Largeau had to go out to re-establish authority in Wadai. On

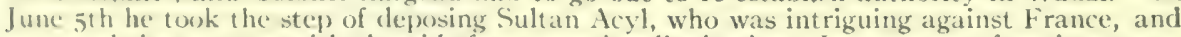
gencroed the country with the aid of seven native dignitaries. Large areas of territory were inded for (jermany by the treaty of November 1911, extending as far east as (ameroon and whe hing the (onge and Ubangi at $t$ wo points. The demarcation of the new frontier was Lexun in December 1912.

Madagascar.'-Population, 2,700,0(0). Imports in I910, fi,383,000 (a decrease of $127,(x x)$ on the returns for I $9(x)$ ), exports, $f_{1} 1,915,000$ (an increase of $f, 72,000$ ).

The Intands of Anjuan, Mohéli and Gratnd Comoro were proclaimed French colonies and hrought under the government of Madagascar by a law passed on August 3, 1912.

Public works are in artive progress, and the very flourishing financial conditions enable these to he carried out with very little borrowing. A very high degree of economic developmest has been the result. With the new roads, the old system of porterage has been swept away, leaving many more hands at dilable for field work. The railways have now opened

i See $E$ B. xxvii, 393 et seq.

2 See F. B. xi, 205 (and allied articles)

3 See E. B. xi, 99 et seq.

thee E. B. xvii, 270 et seq. 
up communication between the coast and the high tableland of the interior where the population is massed, and a perfect econonic revolution has been made by the facilities offerert for the export of heavy products such as rice and manioc. In I 908 the railway from Atananarivo to the coast brought down only 4,700 tons of merchandise; in I9II it carried 34,000 . The internal traffic, amounting in value to $£ 800,000$ at the outset of the French annexation had grown to $f 3,732,000$ in $19.1 \mathrm{I}$.

Indo-China. ${ }^{1}$-Population (1906), I6,300,000. Trade returns for 19II: imports $£ 9,760$,o00 (an increase of $f_{2} 13,000$ on I9ro); exports, $f_{1} 10,000,000$ (a decrease of $\left.f_{1}, 62 \mathrm{I}, 000\right)$.

The condition of the natives is a pressing question. High-handed official methods, the brutality of certain colonials, have largely alienated the people. Unmistakably hostile feeling has been shown over and over again. Administrative reform has been hastened on by the discussion of statements made by M. Violette (deputy for Eure-et-Loir) whose speeches, though not always couched in measured language, have at least succeeded in goading the government into taking action. Excessive centralization and conflicts between local and central authorities have been remedied by decrees passed on October 20, I9II. The supervisio:s and control of the civil services is left as before to the Governor-General. All staff appointments are made by him (except one who is nominated by the central government), and all communications to the staff are made through him; but each local Governor or Resident Supérieur has all the general services of his district under his own direction, with authority over the whole local staffs. Certain financial reforms were likewise made. M. Sarraut succeeded M. Klobukowski as Governor-General on May 9, I9II.

The rice harvest of 19 I I was not very good, but industrial enterprise is flourishing at Tonking. The last section of the Yun-nan railway was opened on April I, I9IO.

The Antilles.-Population (1906), Guadaloupe ${ }^{2}$ and its dependencies, 182,238; Martinique, ${ }^{3}$ I 82,024. Trade returns in I910: Guadaloupe and its dependencies, imports $\ell_{672,-}$ 000 (an increase of $£ 104,000$ over the imports of 1909); and exports, $£ 962,000$ (being an increase of $f 498,000$ over the preceding year). Martinique: imports, $f_{782}, 000$ (an increase of $f_{1} 36,000$ over those of 1909 ), exports, $f_{1}, 103,000$ (or $f_{2} 19,000$ more than in 1909 ).

Political strife, inflamed by hostility between the white and coloured populations, is unfortunately giving trouble in the islands, especially in Guadaloupe. Economic development is hampered by the customs tariff. The protectionist tariff, passed in France in 1892 , being applied in the colonies, keeps foreign goods out of the local market, and impoverishes the budget for the benefit of French manufacturers. At a colonial congress (Congrès des anciennes colonies) held at Paris in October 1909 , it was shown that reform was needed in a system which had been thrust upon the colonies without consulting them.

New Caledonia. ${ }^{4}$-Population (I906): 13,000. Trade returns in I910: exports, $£ 507,000$ (or an increase of $f_{1} 30,000$ on the previous year); exports, $£ 389,000$ (an increase also of $£ 80,000$ over I 1909$)$. The colony has just weathered a serious economic crisis, further aggravated by the administrative system. Excessive centralization is a burden to the inhabitants, who in 1909 took the initiative in starting local self-government. Things have gone better since then, and various industries have been started-copper and nickel mines, blast-furnaces, electricity, and perfumery.

Authorities. - The following recent books may be specially mentioned, for information on contemporary France. (I) General Politics:-J. Bourdeau, Entre deux servitudes; J. C. Bracq, France under the Republic; A. Cheradame, La Crise française; P. Deschanel, L'Organisation de la démocratie; G. Hanotaux, Le démocratie et le travail; I. Hosotte, Histoire de la troisième république; H. Leyret, La tyrannie des politiciens, and La République et les politicens; A. Millerand, Politique de réalisation; Col. Rousset, Histoire générale de la France sous la $3 e$. république; E. Villey, Les périls de la démocratie française; E. A. Vizetelly, Republican France. (2) Social Questions:-H. Clément, La dépopulation en France; Ch. Dawbarn, France and the French. (3) Economics:-A. Arnauné, Le Commerce extérieur et les tarifs de douane; M. Augé-Laribé, L'évolution de la France agricole; Ch. Augier et A. Marvaud, La politique douaniere de la France; V. Cambon, La France au travail; J. Busquet, Les fonctionnaircs et la lutte pour le droit; M. Caudel, Nos libertés politiques; H. Chardon, Le pouvoir administratif; Ch. Georgin, Le statut des fonctionnaires; Ch. Lallemand, Réorganisation administrative; E. Maître, Organisation municipale de Paris. (4) Electoral Reform:-E. Flandin, La représentation proportionnelle; G. Lachapelle, La représentation proportionnelle en France et en Belgique. (5) Labour Questions:-G. Deherme, La crise sociale; S. Finance, Les syndicats professionnels devant les tribunaux et le parlement; Ch. Franck, Les Bourses du travail et la C.G.T.; J. Jaures, L'organisation socialiste de la France; A. Lambert, Le mouvement social en France; M. Leroy, Syndicats et services publics; P. Louis, Le syndicalisme contre l'État; D. Massé, Les retraites ouvric̀res te paysannes; A. Pawlowski, La confédération générale du travail, and Les syndicats jaunes; E. Pothémont, La législation des retraites ouvricres et paysannes; G. Salaün, Les retraites ouvrières et paysannes; G. Weill, Histoire du mourement social en France. (6) Religious Questions:-E. Dufeuille, L'anticléricalisme avant et pendant notre République; A. Mater, La politique religieuse de la République française; J. de Narfon,

Soe E. B. xiv, 490 et seq.

2 See E. B. xii, 645 .

${ }^{3}$ See E: B. xvii, 801 .

${ }^{4}$ See E. B. xix, 468 et seq. 
La séparation des Eglises et de l'État; XXXXX, Ce qu'on a fait de l'Église. (7) Education:F. Buisson, L. Cahen, A. Dessoye, etc., La lutte scolaire en France au XIXe siecle; J. Vaujany, L'École primaire en France sous la ze République. (8) Journalism:-Barbier, P. Matter et Rondelet, Code expliqué de la Presse. (9) The Colonies:-R. Aynard, L'auvre française en Algérie; J. Dykowsky, Le Congo méconnu; D. Gandiani et P. Thiancourt, La Tunisie; J. (i)ulven, L'Afrique équatoriale française; G. Julien, Institutions politiques et sociales de Madagascar; A. Le Chatelier, Politique musulmane; Magnabal, L'Indo-Chine française; A. Messimy and J. Weber, Notre oeuvre coloniale; V. Piquet, La colonisation française dans l'Afrique du Nord; A. Quellien, La politique musulmane dans.l'Afrique occidentale française; M. Rondet-Saint, L'Afrique équatoriale française; $\mathrm{H}$. Russier and $\mathrm{H}$. Brenier, l'Indo-Chine française; J. Saurin, Le peuplement français en Tunisie; P. Suau, La France d Madagascar.

\section{GERMANY 1}

(Maurice Caudel.)

Arca and Population.-Table I shows the area and details of the census of I9ro for Germany and its principal component territories.

\section{Table I.}

\begin{tabular}{|c|c|c|c|c|c|c|c|c|c|c|c|c|}
\hline & & & & & & & & & & $\begin{array}{l}\text { Area } \\
\text { sq. miles. }\end{array}$ & Population. & $\begin{array}{l}\text { Density per } \\
\text { sq. mile. }\end{array}$ \\
\hline Germany & . & . & . & $\because$ & : & $\cdot$ & . & . &. & 203,833 & $64,925,993$ & 3 II \\
\hline \multicolumn{3}{|c|}{ Alsace-Lorraine } & & & . & . & . & . & & 5,601 & $\mathrm{I}, 874,014$ & 335 \\
\hline Anhalt & $\therefore$ & . . & . & $\cdots$ & . & $\therefore$ & & $\therefore$ & . & 888 & 331,128 & 373 \\
\hline Baden. & : & & . & $\because$ & - & - & $\therefore$ & $\because$ & & 5,823 & $2,142,833$ & 368 \\
\hline Bavaria . & . & .. & . & $\cdot$. & . & & & . & & 29,295 & $6 ; 887,291$ & 235 \\
\hline Bremen & . & : & & $\cdot \quad \cdot$ & : & : & . & . & . & 99 & 299,526 & 3,025 \\
\hline Brunswick & . & : & . & . $\quad$. & . & $\cdot$. & & . & & $1,4 \times 8$ & 494,339 & 349 \\
\hline Hamburg & : & : & $\therefore$ & $\therefore$ & $\because$ & - & . & $\therefore$ & 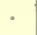 & 160 & $1,014,664$ & 6,342 \\
\hline Hesse : & . & - & . & $\cdot \quad \cdot$ & - & - & · & . & - & 2,969 & $1,282,051$ & 432 \\
\hline Lippe & . & & & $\cdot$ & : & $\cdot$ & · & . & - & 469 & I 50,937 & 322 \\
\hline Lübeck & & & & . & . & & . & . & & II 5 & I 16,599 & 1,014 \\
\hline Mecklenbur & $g-\mathrm{Sc}$ & hwer & rin & & •. & - & · & . & & 5,063 & $639,95^{8}$ & 126 \\
\hline Mecklenbur & $\mathrm{g}-\mathrm{St}$ & relitz & & . & $\therefore$ & . & - & . & 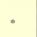 & I, I3I & 106,442 & 94 \\
\hline Oldenburg & . & - & : & . & $\therefore$ & - & - & . & . & 2,482 & 483,042 & 195 \\
\hline Prussia : & . & . & . & $\cdot$. & . & . & . & . & & 134,670 & $40,165,219$ & 298 \\
\hline East Pru & issia & . & & & . & - & : & : & . & 14,287 & $2,064,175$ & I 44 \\
\hline West $\mathrm{Pr}$ & ussia & & & . . & . & . & : & . & . & 9,867 & $1,703,474$ & 173 \\
\hline Berlin Si & tadt & & & & . & . & . & . & . & 24 & $2,071,257$ & 86,302 \\
\hline Branden & burg & $g$ & . & . & . & - & - & . & 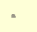 & 15,384 & $4,092,616$ & 266 \\
\hline Pomera! & & & & & . & . & . & & . & I 1,635 & $1,716,92 I$ & 148 \\
\hline Silesia & & . & & . & . & . & . & . & 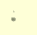 & 15,574 & $5,225,962$ & 335 \\
\hline Posen & . & . & . & ·. . & . & . & . & . & . & I I, 194 & $2,099,83 I$ & 188 \\
\hline Saxony. & & & . & $\cdot$ & & . & . & . & . & 9,757 & $3,089,275$ & 317 \\
\hline Schleswi & $\mathrm{g}-\mathrm{H}_{\mathrm{r}}$ & olstei & in. & •. $\cdot$ & & - & . & . & - & 7,343 & $1,621,004$ & 221 \\
\hline Hanover & & . . & . & $\because$ & . & . & . & . & . & 14,869 & $2,942,436$ & 198 \\
\hline Westpha & lia & . & . & $\cdot$. & . & . & . & . &. & 7,807 & $4,125,096$ & 528 \\
\hline Hesse N & assa & & . & . & & - & . & - & 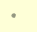 & 6,063 & $2,22 \mathrm{I}, 02 \mathrm{I}$ & 366 \\
\hline Rhinelat & & . & . & $\cdot \quad$. & . & . & . & : & $\therefore$ & 10,425 & $7,121,140$ & 683 \\
\hline Hohenzo & Hlers & & & .. & & . & . & $\therefore$ & 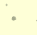 & 441 & 71,011 & 161 \\
\hline Reuss Youn & ger & I.ine & & & . & . & $:$ & . & . & 319 & 152,752 & 479 \\
\hline Reuss EIder & Lin & & & . & . & $\vdots$ & . & . & . & 122 & 72,769 & 596 \\
\hline Saxe-Altenb & urg & & & . & - & & - & . & . & $5 \mathrm{II}$ & 216,128 & 423 \\
\hline Saxe-fobur & $g(x)$ & tha & & & . & . & . & . & . & 764 & 257,177 & 337 \\
\hline Saxe-Meinir & igen & & & & & & & & : & 953 & 278,762 & 292 \\
\hline Saxe-Weima & $\mathrm{r}-\mathrm{E}$ & isena & ach. & & & & . & . & . & 1,394 & 417,149 & 299 \\
\hline Saxony (kin & gdo & m). & & - & . & . & & & $\cdot$ & 5,789 & $4,806,661$ & 830 \\
\hline Schaumburg & $\mathrm{g}-\mathrm{I}, \mathrm{i}$ & ppe & & i. . & & & & $\therefore$ & - & I3I & $46,65^{2}$ & 356 \\
\hline Sihwarzbur & $g-R i$ & udols & stadt & It . & . & & . & . & $\therefore$ & 363 & 100,702 & 277 \\
\hline Sharabur & $\mathrm{g}-\mathrm{So}$ & inder & rshat & Iusen & & & & . & & 333 & 89,917 & $27^{\circ}$ \\
\hline Walderk-Py & rmo & nt . & & . & & & . & . & . & 433 & 61,707 & 143 \\
\hline Wiirltember & & & & & & & & & & 7.532 & $2,437,574$ & 323 \\
\hline
\end{tabular}

The increase per cent in the population in $1005^{-10}$ was 7.1 , being greatest in the Prussian provinces of Brandenburg, Westphalia, and the Rhine province, 15.85, I4.06

'See E. B. xi, 805 et seq. on the Empire generally, and special articles on the various divi. siuns. 
and 10.3 , respectively. The chief foci of population in these provinces are Berlin (and environs) and the industrial district of the Ruhr basin; out of twenty towns with population exceeding I0,000 and returning the greatest increase per cent six are suburbs of Berlin and seven are in the Ruhr district. The city of Berlin, however, returned an increase of only I.5 per cent, and it is clear that the process of decentralisation is at work here. Outside Prussia the maritime towns of Hamburg, Bremen and Lübeck show notably large proportional increases, but in general the greater divisions of Germany do not show such large increases as the three Prussian provinces mentioned.

The kingdom of Saxony is the most densely populated of the larger divisions, but out of the twelve towns which showed descreasing populations, four were in that kingdom. The smallest proportional increase is sound in Upper Alsace and in the eastern and north-eastern parts of Prussia, as in East Prussia and Pomerania, from which there is a large movement to other parts of the kingdom. The total number of towns with populations exceeding 10,000 was $28 \mathrm{I}$ in 1910 , and 48 exceeded 100,000 , these last containing in all a population of $13,823,348$. The average increase of population in the 281 towns has declined from 17.2 in $1900-05$ to 15.05 in $1905^{-10}$. The birth rate of Germany in 1910 was 30.7 per thousand and the death rate I3.I. The birth rate declines, and the continued increase of population is attributed mainly to the fall in the death rate and also to the decrease in emigration, for the number of native emigrants in I9II, namely 22,690 (equal to 0.35 per thousand of the population) was the smallest proportion recorded in twenty years. Of the total, 18,900 emigrated to the United States and 3,428 to other parts of America. The highest proportion of emigrants was from Bremen, Oldenburg, Hanover and Schleswig-Holstein. The marriage rate per thousand in 1910 was 7.7. The total number of foreigners in Germany in I9 IO was I, 259,873, including 634,983 Austrians, I44,I75 Dutch, I37,967 Russians, I04,204 Italians, 19, I40 French, and 18,319 . British.

Towns. - The population in I910 of a number of the chief towns, arranged territorially and including the capitals (mentioned first in each case) of the principal divisions, was as follows. Alsace-Lorraine: Strassburg 178,891, Mülhausen 95,04I; Metz 68,598; Colmar 43,808.-Anhalt: Dessau 56,605--Baden: Karlsruhe I34,313, Mannheim 193,902, Freiburg-im-Breisgau 83,324, Heidelberg 56,016. - Bavaria: Munich 596,467, Nuremberg 333, I 42. Augsburg $^{1}$ I 3 3,415, Würzburg 84,496, Regensburg 52,624.- Bremen: Bremen 247,437, Bremerhaven 24,165.-Brunswick: Brunswick 143,554.-Hamburg: Hamburg 931,035.Hesse: Darmstadt 87,089, Mainz I 10,634. - Lippe: Detmold 14,295. - Lübeck: Lübeck 98,656.-Mecklenburg-Schwerin: Schwerin 42,519, Rostock 65,383. -Oldenburg: Oidenburg 30,242.- Prussia (towns exceeding 100,000 inhabitants): Berlin (stadt) 2,07 I,257, Aachen

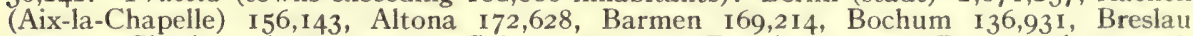
512,105, Charlottenburg 305,978, Cologne 516,527, Danzig 107,337, Dortmund 214,226, Duisburg 229,483, Düsseldorf ${ }^{3} 358,728$, Elberfeld I 70, I95, Erfurt I I I,463, Essen 294,653, Frankfort-on-Main 414,576, Gelsenkirchen I69,5I3, Halle I80,843, Hamborn ${ }^{4}$ IoI,703, Hanover 302,375, Kassel 153,196, Kiel 211,627, Königsberg 245,994, Krefeld 129,406, Magdeburg 279,629, Mülheim II2,580, Posen I56,69I, Rixdorf ${ }^{5}$ 237,289, Saarbrücken ${ }^{6}$ 105,089, Schöneberg ${ }^{5}$ 1 72,823, Stettin 236, I I3, Wiesbaden I09,002, Wilmersdorf ${ }^{5}$ 109,7 16. Reuss Younger Line: Gera 49,276.-Reuss Elder Line: Greiz 23,245. - Saxe-Altenburg: Altenburg 39,976.-Saxe-Coburg-Gotha: Coburg 23,789, Gotha 39,553.-Saxe-Meiningen: Meiningen 17,131.-Saxe-Weimar-Eisenach: Weimar 34,582, Eisenach 38,362, Jena 38,487.- Saxony: Dresden 548,308, Leipzig 589,850, Chemnitz 287,807, Plauen 121,272.Schwarzburg-Rudolstadt: Rudolstadt I 2,937.-Württemberg: Stuttgart 286,2 I 8, Ulm 56, I09.

Agriculture, etc.-The principal crops (in tons) in I9II were: rye, I0,866, II6; oats, 7,704,101; wheat, 4,066,335; barley, 3,159,915. All except oats show a marked increase over the figures for 1910 , a feature which has been generally characteristic of recent years. The area under the vine, on the other hand, decreased gradually but steadily from 1906 to I9I I, being 272,000 acres in the latter year. In Alsace-Lorraine 46.8 per cent of the total area is under cultivation, and 2.3 per cent under vineyards, the highest proportion in any

1 Since Jan. I, I91 I, however, Augsburg has included the Landgemeinde of Pfersee.

2 This figure represents an increase of only 1.5 per cent in the preceding quinquennial period, and the process of decentralisation referred to above in dealing with the population generally is further illustrated by the population of "Greater Berlin," which in I9I0 was $3,7 \mathrm{I} 2,554$, showing an increase of 24 per cent. The centre of business activity extends gradually westward from Leipziger-strasse to Potsdamer and even Tauentzin-strasse. Communications have been improved and extended. The underground railway runs westward to Reichskanzler-platz and Wilhelm-platz and a line is under construction from Nollendorf-platz southward to Schöneberg. Motor-omnibuses have recently been introduced.

${ }^{3}$ An important industrial and art exhibition was held in Düsseldorf in I912.

${ }^{4}$ Created a Stadtgemeinde (municipality) on Apríl I, I9I I.

5 Suburbs of Berlin.

6 Malstatt-Burbach and St. Johann are now united with Saarbrücken. 
German territory, the value of the grape-crop being $\left\{\mathbf{I}, 75^{\circ}, 000\right.$ in I9I. In Baden the vine was cultivated on 38,500 acres in 1911 , the figure being nearly the same as that for Prussia. Wheat is especially important in Bavaria, the crop being 431 , 000 tons in $191 \mathrm{I}$, and also hons, which were cultivated on 43,000 acres out of 66,000 acres in all Germany.

The value of the North Sea and Baltic fishery catches in I9I I was $£$ I,800,000.

Mining and Manufactures. - The total population engaged in these occupations in r910 was $6,617.584$ or 10.2 per cent of the population of the country. According to the census of 1910, textiles occupied 72,000 workers and mines 49,000 in Alsace-Lorraine. In Baden the industries (salt-mines, iron-works, etc.) occupied 246,864 persons, or II.5 per cent of the population. In Bavaria the figures were 566,440, or 8.2 per cent, in Prussia 3,976,709 or 9.9 per cent (the output of coal amounting to $151,000,000$ tons in 19II), in Siaxony 769,443 , or 16.0 per cent, and in Württemberg 242,020 , or 9.9 per cent. Among the smaller states, there is a notable concentration upon textile industries in the two small principalities of Reuss, whene over Io per cent of the population are thus employed.

The output of coal has increased by about 50 per cent in the latest quinquennial period, amounting to $160,700,000$ tons valued at $f 78,600,000$ in $19 \mathrm{I}$, while lignite was raised to the amount of $73,800,000$ tons $(f, 9,200,000)$, and iron ore $23,800,000$ tons $(f 5,000,000)$. The production of pig-iron was $13,500,000$ tons. The ship-building industry shows no great development recently, the number of ships built or building in private yards in I9I I being 49 vessels of war and 1,072 other vessels for service under the national flag, and 3 warships and 241 other vessels for foreign countries. Among other industries which show marked recent changes is that of motor cars, boats and aeroplanes, for which returns of production showed a total value of $\{5,500,000$ in 1910, including 9,368 cars (against 3,887 in 1907), 283 boats and 73 aeroplanes (against 4 in the preceding year). Seven airships were also built, and 2,977 motor engines of various sorts. The brewing industry is a nother showing a marked change, but this is in the direction of a reduction of the number of breweries in the Brausteuergebiet, which was 4,324 in I9Io. The centenary of Krupp's, the famous iron and steel works at Essen, was celebrated on August 8, I9I2, the ceremonies being attended by the Kaiser. In June 1912 the works employed 71,22 I persons.

Commercial development is illustrated by Tables II-III, showing the value of the chief imports and exports, and also the trade with the principal countries, in I9Ir.

Table II. Trade in I0II ( $\mathrm{f}$ slerling, omilling 00,000 )

Imports.

Cotion, cotton yarn, cotton goods

Agricultural produce

Animals and animal produce

Precious metals

Base metals and minerals

Silk and silk goods

Wiol

Wood

Colonial produce

Machinery

Otber goods

Total

\section{Exports.}

Animals and anima! produce Iron and iron goods

40.0 Machinery

90.0 Cotton, yarn, cotton goods

75.4 Coal and coke

15. I Agricultural produce

46. $x$ Clothing and silk goods

8.9 Sugar

9..t Precious metals

I4. I Aniline and other dye-stufis

43. $x$ Copper and brass goods

3.5. Motor cars

154.8 Other goods

\section{Total}

Table III:-Countries traded with IOII ( $f$ slerling, omitling 00,000).

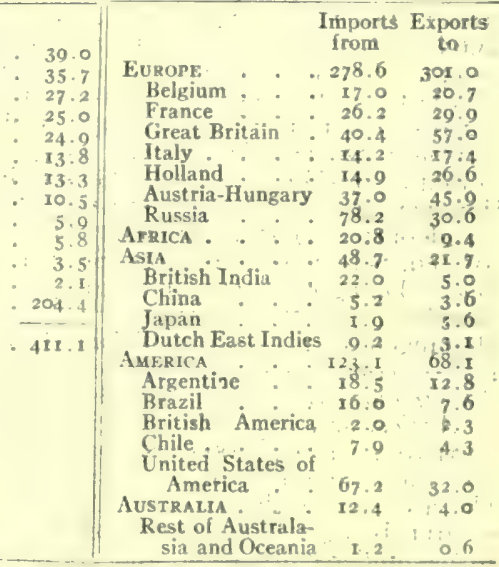

Shipping. - The numbers of the mercantile marine, and their distribution, are as follows for 1912: In Prussia, 2,26(x) of 312,713 tons; Hamburg, 1,348 of 1,676,376 tons; Bremen, 712 of 893.387 ; other states, 412 of $1+1,249$. There were registered at Baltic ports 942 vessels of 316,907 tons, and at North Sea ports 3,790 of 2,706,818 tons; the total being 4.7 .32 of $3,323,725$ tons.

The foreign mercantile shipping in Cerman ports is shown in Table IV for roro.

The sros tonnage handled in the I) uisluurg-Ruhrorter ports, where the largest inland navigation industry is carried on, amounted in one year (1911-12) to 20,570,000. Mannheim, the chief commercial centre on the Upper Rhine, is the largest port on that river, the tonnage of merchant vessels calling in 1910 amounting to nearly 5,000,000. The Kaiser IVilhelm (kiv) camal wats used in 1912 hy 54,012 vessels of $8,558,204$ tons. A canal, proiected in sons, which hram hes off from the I)ortmund-Ems canal, crosses the Weser near Minden and leads tn Hanover, is now open. 
Table IV.

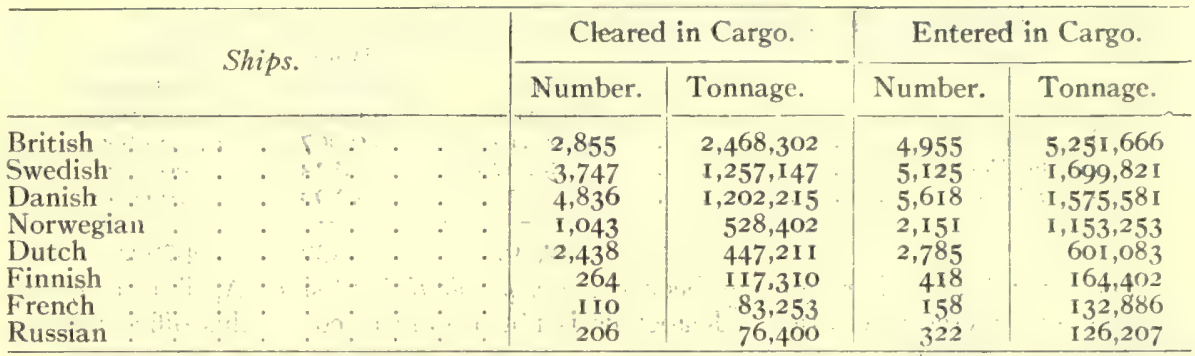

Railways open for traffic in I9Io amounted to $36,68 \mathrm{I}$ miles, of which only 2.286 were under private companies, the rest being under state management. In I910, 531,528,000 tons of goods, including animals, were conveyed by railways, yielding $\mathrm{f} 95,160,000$; and the number of passengers carried was $\mathrm{I}, 54 \mathrm{r}, 000,000$, yielding $f_{4} \mathrm{I}, 800,000$ (as against $f_{35}, 450,000$ in 1906). The new tariff which came into force on May $\mathbf{r}, 1907$ has had the effect of largely increasing the use of the cheapest ( 4 th) class of accommodation by passengers, the receipts for this class having risen from $f 8,940,000$ in 1906 to $f_{1} 14,960,000$ in 1910 .

Finance.-For the financial year ending March 3I, I9I2 the imperial revenue and expenditure each amounted to nearly $f_{1} 60,000,000$. The imperial funded debt at the end of I9II amounted to $£ 227,831,670$. The budget for the financial year beginning April I, I9I2 estimated the', revenue and expenditure at $£ 144,306,755$ (ordinary $£_{1} 137,583,100$; extraordinary $\{6,723,655)$.

In certain of the more important territorial divisions of the empire the total budget figures for I9I I were as follows, in $f 00,000$, the public debt in each case being put within parentheses: Baden, I2,8 (28,0); Bavaria, 35,9 (roo,o); Bremen, 2,5 (13,0); Brunswick, I,5 $(2,5)$; Hamburg, $8,5(35,8)$; Hesse, 5,0 (22,0); Mecklenburg-Schwerin, $2,3(7,1)$; Oldenburg, 2,I (3,7); Prussia, 204,3 (476,0); Saxony, 2 I ,o (44,o); Württemberg, I3,9 (30,0).

Army. - The peace strength of the army in 1912 was 656,144 , including 27,000 officers and 90,000 non-commissioned officers. The total expenditure on the army amounted to $f 40,800,000$ during the financial year I 1 I I-I 2 , and was estimated at $f 42,400,000$ for I9I2-I 3 . By a law of March 27, I9II, and a supplementary law of June I, I9I2, the peace strength of the army was to be increased annually until in 1915 its total strength should reach 544,22 I, exclusive of officers. Prussia and the smaller states will supply 420,939, Bavaria 60,35I, Saxony 4I,625 and Württemberg 2I,296 men. The divisions will include 65I infantry battalions, 5 I 6 cavalry squadrons, 633 field artillery battalions, 48 foot artillery battalions, 33 pioneer battalions, 18 communication units and 25 train battalions.

Navy. - The active naval personnel in 1912 was 64,500 , including 3,300 officers. Total expenditure in I9I I-12 was $£ 22,900,000$, and was estimated at $£ 22,609,540$ in $1912-13$. The following statement is given of the number of warships on April I, I912: Linienschiffe, 32; Küstenpanzerschiffe, 8; Grosser Kreuzer, I 8; Kleine Kreuzer, 4I; Kanonenboote, 9; Schulschiffe, 8; Spezialschiffe, 14 . There are also about 150 smaller vessels (torpedo boats, etc.) for high-sea service and 40 for coast and harbour work, together with 16 submarines.

Education and Science.-The following figures show the attendance at the eleven largest universities during the winter half year I911-12: Berlin 9,829; München 6,797, Leipzig 5, I7o, Bonn 3,998, Halle 2,879, Breslau 2,702, Göttingen 2,505, Freiburg 2,466, Heidelbery 2,231, Strassburg 2,138, Münster 2,126. The Friedrich Wilhelm University at Berlin celebrated its centenary in I9Io. Including the university at Münster, the number of German universities is twenty-one, but at Münster the full faculty of medicine is not yet established. A technical high school was opened at Breslau by the Kaiser on November 29, 19ro, and the number of such schools is now eleven. In Berlin the Kaiser Wilhelm Association for the Advancement of Science was instituted on January II, I9I I, and in the same year a large building was completed for the Royal Library, in Unter den Linden near the university. In Heidelberg a new Academy of Science was founded in July 1909. In Hamburg an institute for tropical diseases was opened in April I9I0 and a mineralogical and geological institute in December, and in October of the same year the new geological department of Baden was opened in Freiburg, replacing the former establishment in Karlsruhe.

Religion.-According to the census of 1910 there were $39,991,42$ I (61.6\%) Evangelical Protestants; 23,82 I, $453(36.7 \%)$ Roman Catholics; $283,946(0.4 \%)$ other Christians; 615,021 (1.0\%) Jews; $208,014(0.3 \%)$ other sects; $6,138(0.0 \%)$ unclassified. The proportion per cent of Roman Catholics was highest in Alsace-Lorraine, 76.2; Baden, 59.3; Prussia, 36.3; Hesse, 3I.0; Württemberg, 30.4. In all the other great divisions the proportion of Protestants is upwards of 90 per cent; in Bremen it is 87 per cent, and 82 per cent in Berlin, where the Roman Catholics number I2 per cent and Jews 4.5 , the last being more numerous there than elsewhere in the Empire.

(L. Mecking; O. J. R. Howarth.) 


\section{German Dependencies. ${ }^{1}$}

The German colonial territories are broadly distributed as follows:-

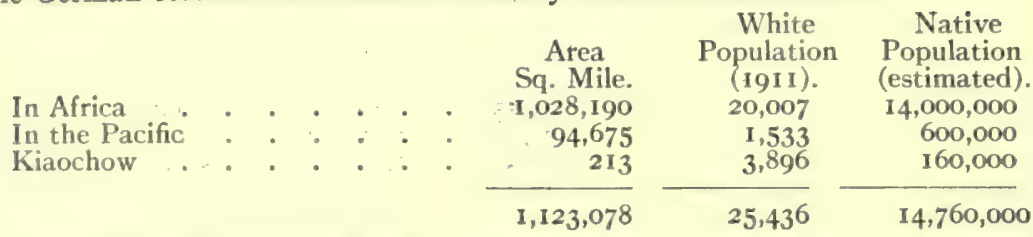

The central administration has been the Reichskolonialamt since April r, 1907, its head being a Secretary of State. Kiaochow is not administered by this office but by the Reichsmarineamt.

Cameroon.-This West African colony had on January I, I9II a white population of I,455 and a native population estimated at $2,700,000$. But by the Franco-German agreement of November 4, I9I I the southern and eastern frontier was changed so that the territory extends to a point on the Congo river and to another on the Ubangi. This change represents an accretion of territory of nearly 100,000 sq. miles, the total area being now 290,000 sq. miles. In recent years Duke Adolf Friedrich of Mecklenburg has assisted the development of the colony by extensive exploration. The principal products are cocoa and rubber, of which there were in 19 I I some 5,000,000 trees each. Bananas, oil-palms and coffee follow in importance. The value of exports amounted in 1910 to $£ 1,000,000$, of which rubber represented $f_{550,000}$, palm products nearly $f_{250}, 000$, and cocoa $£_{1} 50,000$. Imports exceeded $f_{1}, 250,000$ in value. The colony was visited by 529 ships of $1,291,000$ tons. The ordinary expenditure for 1912 was estimated at $f 480,000$; the revenue at $f 320,000$. The native and house tax is the principal item in the latter, amounting to $f 60,000$. A Catholic and three evangelical missions support a number of schools with 28,660 pupils; there are also four government schools with 733 pupils. The military forces in 1910 numbered $1,47 \mathrm{I}$ men, $\mathbf{I}, 300$ of whom were natives.

German East Africa has an area of 384,000 sq. miles, with a population estimated (though roughly) at $10,000,000$. Whites in 1911 numbered 4,227 . Plantations consist chiefly of sisal, rubber, manihot, coffee, cocoa and pepper, and of the total exports to the value of $f_{1}, 0,0,000$ in 1910 , sisal represented $f_{150,000}$, rubber $f_{290,000}$ and copra $f_{1100,000}$. Imports were valued at nearly $\{2,000,000$. The colony was visited in 1910 by 933 vessels of a total tonnage of $2,000,000$. The railways, at the end of 1911 , had a length of 662 miles. The central railway reached Tabora in I9I 2 and the cost of its extension to Lake Tanganyika has been voted by the Reichstag. The Usambara railway reached Moschi in October I9II. The estimated ordinary expenditure amounted to nearly $\ell_{1}, 000,000$ in 1912 , the house and hut tax representing nearly $£ 200,000$, and the revenue was estimated at $f 620,000$. There are a military force of 2,962 men and a police force of $I, 898$, both principally native.

German South West Africa has an area of 322,450 sq. miles, with a white population of 13.962 in I 911 and an estimated native population of 80,000 . The Anglo-German boundary at Walfish Bay was settled by agreement of May 23, 1911. About 29,000,000 acres were being farmed in 1911; cattle numbered 144,000, sheep 400,000 and goats 400,000. Total exports were valued at $£ 1,730,000$ in 1910 . Two years previously the first export from newly discovered diamond-fields had taken place; the value of the stones in 1910 was $£ \mathbf{I}, 350$,000 , and in $191 \mathrm{I}$ and again in 1912 diamonds amounting to about 800,000 carats were obtained. Copper was exported to the value of $\{280,000$ in 1910 . Imports were valued at $\{2,220,000$. Vessels visiting the colony in 1911 numbered 483 , of a total tonnage of 1,328,536. There are four railways, with a mileage of I,186 at the end of I9II. Estimated expenditure (II) I 2), f, I, 800,000 ; revenue $f_{8} 880,000$. Self-government was granted on January 28, 1909, and the Landesrat held its first session in May 1910.

Togo (IVest Africa) has an area of 33,700 sq. miles, an estimated native population of $I,(K X),(K X)$ and a white population (I9II) of 363 . Palm products (kernels and oil) took the chicf place $(f 160,000)$ and rubber the second $(f 60,000)$ in the export trade of 1910 , the total value of which was $f 3(00,000$, while imports were valued at $f 570,000$. Shipping in 1910 had at total tonnage of 577,000 . Railways extend to 201 miles, a line of 100 miles from Lome to Atakpame having been opened on April I, I9II. Estimated expenditure (I9I2) fI60,000, revenue $f_{15}\left(5,(x)\right.$, including a native tax providing $f_{22}, 000$. An agricultural school and a handicraft s showl have been established. A native police force numbers 569 men.

New Guinea.-Cicrman New (iuinea includes Kaiser Wilhelms Land, the Solomon Islands and the Bismarck Archipelago (New Pomerania, New Mecklenburg, New Hanover and the Admiralty Islands), with a total area of 93,000 sq. miles, a native population estimated to exceed $5(x),(x)$, and a white population (I9II) of 723 . Exports were valued at only $f_{1} 180,000$ in 1910 , the principal item being copra; imports at nearly $£_{200,000}$. The revenue

${ }^{\prime}$ See H. Meyer, Das deutsche Kolonialreich, Leipzig, I9 10. 
in I9I I was $f 40,000$; the expenditure $f 70,000$. There is a native police force of about 600 men. From January 18, I9I0 the seat of government has been established at Rabaul. Knowledge of the interior of Kaiser. Wilhelms Land has recently been greatly extended by the work of the German-Dutch boundary commission, which navigated the Kaiserin Augusta river for 600 miles up stream.

Samoa.- The German portion of Samoa has an area of 1,000 sq. miles, with a total population estimated at 37,500 , whites numbering 490 in I9I I. Here cocoa plantations have been considerably extended, the number of plants being estimated at $1,250,000$, and the export of cocod was valued at $£ 28,000$ in 1910 out of a total export trade valued at $£ 180,000$. Imports were valued at $£ 170,000$. R Revenue in 1912 was estimated at $£ 40,000$ and expenditure at $£ 50,000$.

The Caroline, Pelew, Marianne and Marshall Islands have a total land area of 960 sq. miles, and a population estimated at 55.300, whites numbering 320 in I9II. Plantations are devoted almost wholly to the coco-nut palm, except in the Eastern Carolines, where small quantities of Manila hemp, rubber and manihot are raised. In the Marshall and Caroline Islands, however, a new export trade of considerable promise is developing in phosphates, which were valued at $£ 470,000$ in 1910 out of a total value of exports of $£ 550,000$.

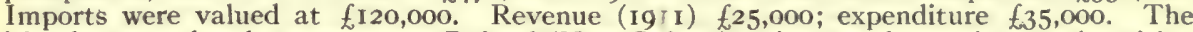
islands are under the governor at Rabaul (New Guinea). A somewhat serious native rising in Ponape which began on October I8, I9I0 was only quelled in February I9I I by the dispatch of a naval force.

Kiaochow (China), with an area of $213 \mathrm{sq}$. miles, has a population estimated at 169,000 , including 3,896 whites in I9II. The town of Tsingtau has a population of 34,000 Chinese and I,62I Europeans, and rose from the eighteenth place among Chinese free ports in I904 to the sixth in I9I0. The chief article of export is straw-braid (value $f 670,000$ in I9I I, when the total exports were valued at $£ 3,000,000$ ). The value of imports (cotton goods and yarn, paper, \&c.) was $£ 3,500,000$. Ships visiting the port in I9I I numbered 555 of a total tonnage of 830,000 , including 176 British (270,000 tons). The Shantung railway carried 900,000 passengers and 700,000 tons of goods in I9II. Estimated revenue (1912) $£ 310,000$; expenditure $\{730,000$. There are a German military force of 2,39 I men and a mainly native police force of I I0. Among educational institutions may be mentioned the GermanChinese high school opened on October 25, 1909.

(L. Mecking.)

\section{Political History.}

The appointment, on July I4, I909, of Herr von Bethmann-Hollweg as Imperial Chancellor in succession to Prince Bülow was but a change of politicians. The old The new questions continued to occupy public attention, and the method adopted Chancellor, for their solution stirred up much popular dissatisfaction. The main issues were those of finance. A deficit of 2,000 million marks (roo millions sterling) was anticipated for the four years 1909 to $\mathrm{r}_{913}$, and ways and means had to be devised to raise a: sum of some 500 million marks ( 25 millions sterling) each year. Bülow suggested a scheme of taxation which while taxing articles of consumption included death duties. ${ }^{1}$ But death duties were bitterly opposed by the Conservative party as "striking at the root of the family," and since the Liberals were very much in favour of the proposed scheme, the working agreement between

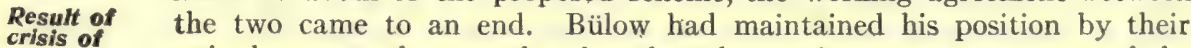
crisis or
1909 . united support; he was therefore forced to resign as a consequence of the breach. The entire blame Bülow himself laid at the door of the Conservative party. But while the Conservatives got their way, - in the amended estimate the property tax found no place, - the bill could be carried only with the aid of the Centre. There was a good deal of truth therefore in Bülow's view that one result of the crisis was to make the Centre party again the most influential group in the Reichstag, a position from which it had been dislodged in 1906.

One other result became apparent - there was general discontent all over the country. The middle classes were particularly dissatisfied that the burden of taxation

1 Bülow's scheme for raising the $£ 25,000,000$ required was by (a) increased matricular contributions of each state to the extent of 80 Pf. per head of the population, $£ 2,400,000$; (b) death duties, $£ 4,600,000$; (c) taxes on spirits, beer, wine, tobacco and advertisements, $£ I 8,000,000$. The scheme as adopted provided (a) duties on spirits, beer, tobacco, sparkling wines, $£ I I, 400,000$; (b) stamp duties, $£ 5,475,000$; (c) taxes on coffee, tea and lighting appliances, $f 4,100,000$; (d) taxes on sugar and railway tickets, $f_{4}, 025,000$. 
should have been shifted on to their shoulders, while the landed men did not bear their fair share. The opposition between the agrarian and the industrial interests had shown itself in the formation of the Hansa Bund (June I2, I909), wherein The Hansa the great captains of industry united against the feudal aristocracy.
Bund.

The immediate (and ostensible) aim of the Bund was to oppose the financial reforms as advocated by the Conservatives and Centre. From the first the Bund asserted that it was an "economic organisation and not a political party," that what it stood for was "a fair economic policy," and that it drew its members from all parties. Its real aim, however, was not to allow the landed interests to hold a monopoly of political power. At its first meeting there were representatives of over I00 Chambers of Commerce and more than 400 other commercial and industrial organisations. Altogether some 6,000 delegates took part in the proceedings.

The Hansa Bund only gave expression to the general discontent which continued for a year and a half, until the general elections in 1912 , the results of which may certainly be attributed to its influence. Even earlier, the popular temper

Sociallst election successes. was showing itself at the Reichstag by-elections, where the Social Democrats were enabled to gain three seats out of a total of five. It was the same in the state elections; everywhere the prevailing discontent expressed itself by sending Social Democrats to the legislatures. The best instance is perhaps that of Saxony, where the elections, on October 2I, I909, took place for the first time on a system of plural voting. According to this, every man who pays direct taxes has one vote. If his income exceeds $£ 80$, or if he owns 2 hectares (about 5 acres) of land, or if, by reason of his having passed the necessary examination, he is qualified for one year's military service, he has two votes. If, however, his income is over $f 100$, or if he is a professional man - lawyer, doctor, high-school teacher, engineer or artist, -- or, being an agriculturist he owns more than 4 hectares (about io acres) of land, he is entitled to three votes. Again, if his income exceeds $£ \mathrm{I} 40$, or if he is the possessor of more than 8 hectares (about 20 acres) of land, he is entitled to four votes. Finally, every man over fifty years of age has an extra vote, but no man may record more than four votes altogether. Such a scheme is broad enough, and therefore the striking success of the Social Democratic party ${ }^{1}$ is of more than ordinary significance.

The new Chancellor was fully alive to the situation, and already in his first speech to the House (December 0, roob) he attempted to discount the successes of the Social Democrats. "I am of opinion that there are large masses among our

Polky of the new Chancellor. revolutionary changes. What our people desires above all else is that it may not be disturbed in its daily work by unrest and experiment; that, on the contrary, it looks for protection to a political policy which is stable and reliable." On the other hand he hinted clearly enough that he had no intention of being influenced by any party; that his aim would be to carry on the government independently of all garties. That was about as far as his programme went, and in reality it was wherein his strength lay. Those who knew Herr von Bethmann-Hollweg were not surprised at this attitude. An excellent administrator, he believed in no sensational policies, but in thoroughness in administrative work. Accordingly he appointed (June I900) sfecialists to the offices rendered vacant by the financial crisis. With the rejection of the Covernment's estimates. Herr Sydow, the Secretary of the Imperial Treasury, hail resigned. His successor was Herr Wermuth. ${ }^{2}$ To the Ministry of the Interior, Herr I)elbrück ${ }^{3}$ was appointed. Herr Sydow ${ }^{4}$ became the Minister of Commerce,

1 The: composition of the Saxony Dret after the elections was as follows: Conservatives, 29) in wace of $f^{6}$ in the previous I)iet). 36 National Liberals (3t previously); Party of the Midhle. (latses, I (no (hatuge), and 25 Sxial l)emocrats (previous Diet 1 ).

"Arlulf Wermuth. lorn March 23, 185.5, Lnder Secretary of the Interior, 1904.

" (lemens 1), lbruck, burn Jan. 19, 1850 , Senior Burgomaster of Danzig, 1896; Governor

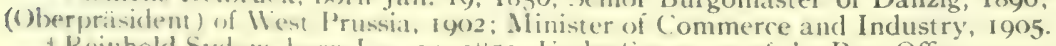

+ Reinhold Srelow, herm Jan. I4, I851; l nder secretary of the Post Office, 1901; Secretary of the Imperial Treasury, 1908. 
and the portfolio of education for Prussia was given to Herr von Trott zu Solz. ${ }^{1}$ In other respects the new Chancellor carried on the policy of his predecessor. His handling of the Polish Question and his attitude to any suggestion for fiscal changes are perhaps as good instances as any. In 1908 a law had been passed faciliThe Polish tating the passing of land in the Polish provinces of Prussia out of The Polish Polish into German hands. The scheme for expropriating Polish land-
Question. owners was at once put into execution and continued all through the year 1909. In that year the commissioners appointed to purchase land reported that they had entered into possession of 29 large estates and 50 small ones, totalling an area of $2 \mathrm{I}, 085$ hectares (about 52,000 acres), at a cost of 27 million marks ( $\left.f_{1}, 350,000\right)$. Of these estates, 5 of the larger and 23 of the smaller had belonged to Poles. So far was the anti-Polish policy of expatriation carried that the Poles were forbidden to build houses on their land. The Poles attempted to evade the letter of the law by living in vans and similar conveyances, but their success was small since the Government dealt harshly with the offenders. The Polish Question did not come to the fore again until comparatively late in 19r2, having been overshadowed by more important events. But towards the end of October in that year the Government decided on a severe application of the Expropriation Law. This brought about a stormy debate in the Diet on October 30, I912. On the one hand the Government had to face the demands of the extreme "Nationalists "; on the other, the Centre was strongly opposed to the anti-Polish policy. Moreover, there was reason to believe that both the Austrian and Russian Governments looked with displeasure on the German treatment of the Poles. Nevertheless, the Chancellor in this matter was following in the footsteps of his predecessor, and the continuity of policy is clear enough.

As for the fiscal policy, Germany had lived for thirty years under Protection, which Bismarck adopted in 1879 in the hope that the increased custom duties would make the Empire financially independent. Herr von Bethmann was as

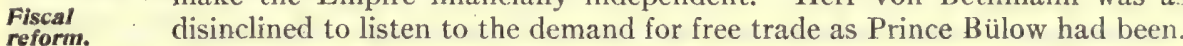
reform. The less so as the year I 900 had been a fairly prosperous one. The country recovered from the economic depression of 1907 , as was proved by the ready subscriptions to loans and the large profits which the joint-stock banks harvested.

In the colonies likewise there had been an upward movement, partly due, it is possible, to the energetic and enterprising policy of Herr. Dernburg, ${ }^{2}$ who was above all else a "business" minister. His commercial, and more especially The his banking experience, stood the colonial administration in good stead. The reports from the colonies showed an increasing trade, and that may have been one reason at any rate for extensive railway activity. No less than 835 miles of new line were being built. It was the first year too in which the colonies were able to make a payment $\left(f_{\mathrm{I}} 7,500\right)$ to the Imperial Exchequer. Acccordingly the colonial estimates were rather less than in previous years - 22 million marks, as against 24 millions in rgo8. The general prosperity was continued in the following year, and to forward it a permanent industrial committee of the colonial adminis1 ration was established (June 27 , I910), composed of representatives of many Chambers of Commerce. The promising picture was only marred by the news of a rising in the Caroline Islands, which occurred on October 18 , 19 ro.

The great question of the day throughout the first half of the year roro was that of the reform of the Prussian franchise. Electoral reform had been in the air during the last year or two; Baden and Saxony both adopted new electoral systems. The fran-: Even the small state of Mecklenburg was awakening to the need of reformchisequestion ing its constitution and adopting a franchise more in accord with the
in Prussia. needs of the day. It was no new question in Prussia. It had been discussed in the Chamber as recently as January 25, I909. That it was the popular will

1 Augustus von Trott zu Solz, born Dec. 29, 1855; Governor of Brandentburg, 1905.

2 Bernard Dernburg, born July 17, 1864, Director of the Darmstädter Bank, 1901-I906; Minister fot the Colonies 1907-1910. 
was made abundantly clear in the press and at mass meetings. It could not well be postponed much longer, and it was promised in the speech from the Throne when the Prussian Diet asscmbled on January I I, Igro. When, however, the Bill at last made its appearance (February I0, I9I0), it was a sore disappointment to the popular wishes. Manifestly, the Bill wanted to do little. The constituencies that had been formed on the basis of a census of half a century back were maintained. No regard whatever was had to the enormous changes that had taken place in Prussia, making it as much an industrial as an agricultural state. Secondly, the division of electors into three classes, arranged according to incomes, was left unaltered. Nor was it proposed to introduce the secret ballot, long since utilised in the Reichstag elections. The Bill however enlarged the basis of the first class of voters by adding an educational qualification to the already existing financial one; it also substituted direct for indirect voting.

The proposal was everywhere condemned. The parties of the Right would have none of it because it did not go far enough; for the parties of the Left it went too far.

Street

demon-

strations.

All over the country large demonstrations were organised, chiefly by the Social Democrats, in favour of complete electoral reform, with the secret ballot and universal suffrage. On February 13, roro there were processions through the streets of Berlin which occasioned a famous proclamation by Herr von Jagow, the chief of police. Its brevity did not lessen its significance. "There is talk of the right to street demonstrations. But the streets are for traffie only. If public authority is disregarded the police have orders to use their weapons. I give inquisitive people fair warning." The demonstrations took place nevertheless, and the Government must have been impressed by them. A special committee of the Diet knocked the Bill about a good deal, and the Government went so far as to accept secret voting, provided a substantial majority of the House could be obtained for the principle. The Conservatives and Centre were solidly opposed to it, recording 2.38 votes; the Liberals and Social Democrats only had I38. The clause was rejected on March I6; the discussion on the Bill as a whole dragged on until May 27, when the (jovernment announced their intention of withdrawing the measure. The Conservatives were pleased, since the old system continued; the progressive parties were not displeased, the way being opened to more extensive reforms in the future.

Greater success attended the activities of the Reichstag during the year; its programme included measures of financial, social and legal reform. Of these, the most Shipping
dues. important under the first heading was the extension of shipping dues on the internal waterways. Shipping dues already existed on the canals and the canalized rivers; they were levied chiefly for the purpose of providing an amortization fund for the cost of construction. But on the free rivers the introduction of shipping dues was still barred by $\$ 54$ of the German constitution. At the instigation of P'russia a bill was introduced (October 27, 1910) in the Reichstag, which proposed the alteration of the article in question, so that the levying of shipping dues might be extended. Further, a bill embodying an increment tax was introduced, 10 round off the financial reforms of the previous year. Two important measures of sucial reform were the institution of Chambers of Labour (parallel to the Chambers of Commerce) and the Insurance Consolidation Bill, which codified the Insurance
Consolldavarious insurance laws, reorganised the supervision of local authorities tion Blil. administering insurance benefits, and extended the older schemes in various directions (See W. H. Dawson, Social Insurance in Germany). No less weighty was the ordinance amending procedure in criminal cases. But while The Potash none of these became law in Igro, the Potash Bill did. The supply of
Bili. to regulate the monopoly and husband the supply by putting a check on overproduction and fining prices.

None of these proposils was calculated to increase party differences, and public opinion was content to colerate the political situation in view of the approaching 
general election, which was expected shortly. It came as a surprise, therefore, when in: June there was a further rearrangement. of office-holders. As in the previous Cabinet year the Chancellor sought out men of administrative ability. Herr von changes. Kiderlen-Waechter ${ }^{1}$ was made Imperial Foreign Secretary in place of Baron von Schoen, who became German Ambassador in Paris, and Herr von Lindequist, ${ }^{2}$ a capable official in the Colonial Office, was appointed Colonial Secretary in succession to Herr Dernburg. In Prussia, also, three portfolios changed hands. Herr von Dallwitz ${ }^{3}$ became Minister of the Interior; Baron Shorlemer ${ }^{4}$ Minister of Agriculture, and Dr. Lentze ${ }^{5}$ Minister of Finance.

Whether the new combination pointed to a more liberal policy was not easy to determine. On the one hand the Imperial Government had recognised the immediate Political tendencies. necessity for formulating a constitution for Alsace-Lorraine, and in Prussia the authorities, after a long struggle, had at last agreed to make cremation

legal (June 4, igro). Nevertheless, the Social Democrats and the Liberals, supported by the comic papers (which in Germany exercise no small influence) maintained that the Chancellor was but a tool in the hands of the reactionaries. Two or three incidents seemed to lend colour to this view. On August 25 the Kaiser broke his long silence by a characteristic speech at Koenigsberg, in which, recalling the coronation of $185 \mathrm{r}$, he gave expression to his belief in the divine right of kings. "Looking on myself as God's instrument, I shall go my way without regard to the ideas and opinions of the time." Questioned as to his attitude to this speech (November 26), the Chancellor stated that it was in no wise unconstitutional, seeing that the King in Prussia is sovereign in his own right. Herr von Bethmann's reply was of a sort to be placed beside the exclamation of von Oldenburg-Januschau, a member of the Conservative party, who on January 29, I910 laid it down in the Imperial Diet that " the King of Prussia or the German Emperor must always be in a position to say. to any lieutenant, "Take ten men with you and close the Reichstag.'"

The growing feeling against the Conservative and Centre coalition was stirred almost to boiling point by the issue of the Papal Encyclical Editae saepe dei, on the occasion of the 300 th anniversary of the canonisation of St. Borromeo: ${ }^{6}$ Papal Ency. In a review of the Reformation the Pope asserted that its German leaders clical against were "proud and rebellious men, foes of the Cross of Christ (uomini formers. orgogliosi e ribelli, nemici della Croce di Christo), worldly men whose belly was their God (il Dio dei quali è il ventre). They did not seek to improve morals," but cast aside the teachings of the Church " in accordance with the wishes of most corrupt (piu corrotti) princes and peoples." There was an outcry in the whole of Protestant Germany. The Encyclical was discussed in the Imperial Chamber and in those of several states. The King of Saxony, himself a Catholic, wrote to the Pope protesting against the language of the document. There was nothing for

The antlmodernist oath. it but its withdrawal, and diplomatic action at the Curia (June II, I9ro) succeeded in obtaining an order to the German bishops not to read the letter in their churches. The storm calmed down, but when the antimodernist oath was demanded (September 8, r910) from teachers, priests and

1 Alfred von Kiderlen-Waechter, born July Io, I852; entered Foreign Office, I 879; Secretary of the Embassy at St. Petersburg, I 88 I-84; at Paris, $1884^{-86}$; in Constantinople, $1886-88$; back in the Foreign Office, 1888-94; German Minister in Hamburg, 1894; in Copenhagen, 1895; in Bucharest 1900.

${ }_{2}$ Friedrich von Lindequist, born September 15, 1862; Consul-General at Cape Town, 1902; Governor of South-West Africa, I905; Under Secretary for Colonies, 1907.

3 Johann von Dallwitz, born September 29,1858; Minister in Berlin for Anhalt and representative of the Duchy in the Federal Council, rgo3; Governor of the Province of Silesia, I909.

${ }^{4}$ Clemens A. Shorlemer-Lieser, born September 29, 1856; Member of the Prussian Upper House, I90I; Governor of the Rhine Province, I905.

${ }^{5}$ Augustus Lentze, born 1860; Senior Burgomaster of Mühlhausen, I894; of Barmen, 1899; of Magdeburg, 1906; Life Member of the Prussian Upper House I906.

${ }^{6}$ Charles Borromeo (1538-1584) was the nephew of Pius IV and one of the moving spirits of the Counter-Reformation. He was canonised in I6Io by Paul IV. See E. B. iv, 274. 
professors of Catholic faculties. promising that they would remain faithful to the doctrines of the Church, bitter feelings were stirred anew. On March 7, I9I2 the question was even discussed in the Prussian Diet, and the Chancellor tried to steer clear between Protestant opinion and the feelings of the Centre. He pointed out that after representations made at Rome, the Pope had agreed to deal leniently with priests who had refused to take the oath. Yet the State would have to guard itself, and therefore in making appointments it would be compelled to limit its choice to those who had abstained from the oath.

All this was hardly conducive to an amicable continuance of joint action between the ultramontane party and the Conservatives. It was the opportunity of the parties of the Left. The Liberals had strengthened their position immensely Party con- by the fusion (March 6, I9I0) of their three wings (Freisinnige Volks-
solidation. partei, Freisinnige Vereinigung and Deutsche Volkspartei) into one strong body, the Deutsche Freisinnige Volkspartei. As for the Social Democrats, they gained most. Of the thirteen by-elections in I010 they won six, thus increasing their strength in the House to fifty-two. These election successes augured well for the future. But apart from that they were gaining support in all directions by organising mass meetings to give expression to the general discontent. The street riots in the Moabit quarter of Berlin (September $24^{-28}$, I9IO) added fuel to the flame. In themselves the incidents would have been of scarcely any importance, but the severity of the police (who in their attacks on the rioters also wounded four English and American journalists) called forth loud protests, and the Social Democrats made the most of them.

Yet while the party was gaining in strength its councils were divided. Should socialist deputies vote for the budgets of non-socialist governments? - that was the The Social question which produced a cleavage in their ranks. Nor was it merely Democrats. of academic interest. It was a matter of practical politics. The South German (Revisionist) wing of the party favoured joint action with the Liberals wherever it was thereby possible to achieve some tangible result. In this spirit the Socialist members of the Baden Diet had voted for the budget. The party in Baden approved their action. But the whole of the German party at its annual congress at Magdeburg (September I 8-24, r9го) expressed its displeasure with the Baden Socialist deputies, whereupon the South Germans withdrew from the congress.

But it would be a mistake to exaggerate the internal differences in the

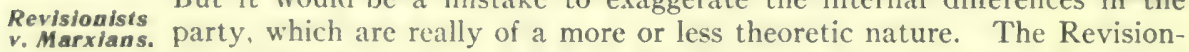
ists certainly stand opposed to the Marxians, but in practical politics the Social Democrats present a united front. The Reichstag elections of ror 2 no less than the party congress at Chemnitz (September $I_{5-21}$, I0I2) bore eloquent testimony to the non-existence of real sectionalism which cuts at the root of things.

The coming elections, perhaps the most important in the history of the German Empire, dominated domestic politics throughout $10 \mathbf{r}_{2}$, and all parties made their preparations accordingly. The excitement seemed to affect the Reichstag itself, which, contrary to its usual methods, worked with such speed that it was able to pass into law a new constitution for Alsace-Lorraine, the codification of the insurance laws and the introduction of shipping dues. The Bill granting a new constitution to the conquered provinces was at last approved by the Federal Council in Alsace- December I 10 and introduced into the House early in the following year.

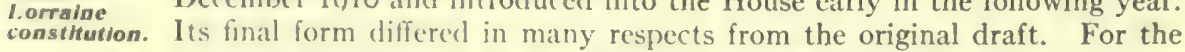

Imperial Government, while willing to grant a new constitution to AlsaceLorraine, was particularly anxious to safeguard the slatus quo in the relationship between the states of the Empire. Accordingly the new state was given no effective influence in the Federal Council. Representatives there were indeed provided for, iut they had no voting power. It was principally against this provision that the Social Democrats organised protest meetings in all parts of Alsace-Lorraine; and in the Reichstag there was also strong feeling against the exclusion. On the first reading of the Bill (January 26, 1011) the Centre, the Liberals and the Social Democrats were 
united against the exclusion clause. It was not surprising therefore that when the Bill was read a second time the Chancellor accepted the Centre amendment, which provided that the territory shall have three votes in the Federal Council. On May 26, I9 I the bill was passed by a large majority ( 2 I to 93), and Alsace-Lorraine became a state of the Federation. According to the new constitution the Emperor exercises sovereign powers in the country, and is represented at Strassburg by a Governor (Statthalter); who is at the head of the Government. Local laws are made by the Emperor with the consent of the two Chambers. The First is composed of various representatives and nominated members; the Second is an elected chamber, voting being by secret ballot and the suffrage universal. With regard to the representation of the new state in the Federal Council, it is not as complete as that of other states. In the first place, the votes of its representatives do not count at all on questions affecting changes in the constitution; secondly, whenever these votes, by being added to those of Prussia, can produce a majority in the Council, they are disregarded.

Important as these measures were, the Morocco crisis nevertheless commanded most attention (see "International Affairs," Part I: Sect. i). The German GovernThe Morocco ment feared lest. French influence in Morocco should become a menace The Morocco to German aspirations, and accordingly it resolved to make sure of "com-
affair. pensation" from France. As this was not immediately forthcoming, Germany without any warning sent a warship, the "Panther," to Agadir, a Moroccan port, ostensibly for the protection of German firms in South Morocco, but in reality to enforce its demand for compensation, and moreover compensation in Morocco itself. In its information to the English Government Germany denied this. But it was evident that in many quarters in Germany the fecling was that a port in Morocico should be ceded to the Germans. By July I5, I9I I the German Government had realised that such a demand would not be tolerated. It therefore asked for territories in other parts of Africa, and after much negotiation two treaties were signed between the two powers (Nov. 4, IOII). In the one, Germany agreed to recognise the French Protectorate in Morocco; by the other France ceded to Germany parts of her Congo colony. The bargain was by no means satisfactory to German public opinion, and among those who were dissatisfied was Herr von Lindequist, the Colonial Secretary himself. He resigned in consequence, and was succeeded by Dr. Solf, who for a time had been Governor of Samoa. Nor was this the end of the matter. On November 9-IO, I9II, when the treaties were discussed in the Reichstag, the Chancellor found scant sympathy when he defended his policy. The press was unanimous in its condemnation, and all parties sought to utilise public feeling for their own ends in the electioneering campaign that was already in progress.

The session closed on:December 5, I9II, and the elections were fixed The general, for the following January. The results will be apparent from the Table,
electons, 1912, for the showing the number of seats for each party.

Composition of German Reichstag I907 and I9I2. The Blue-Black Bloc.

The Opposition.

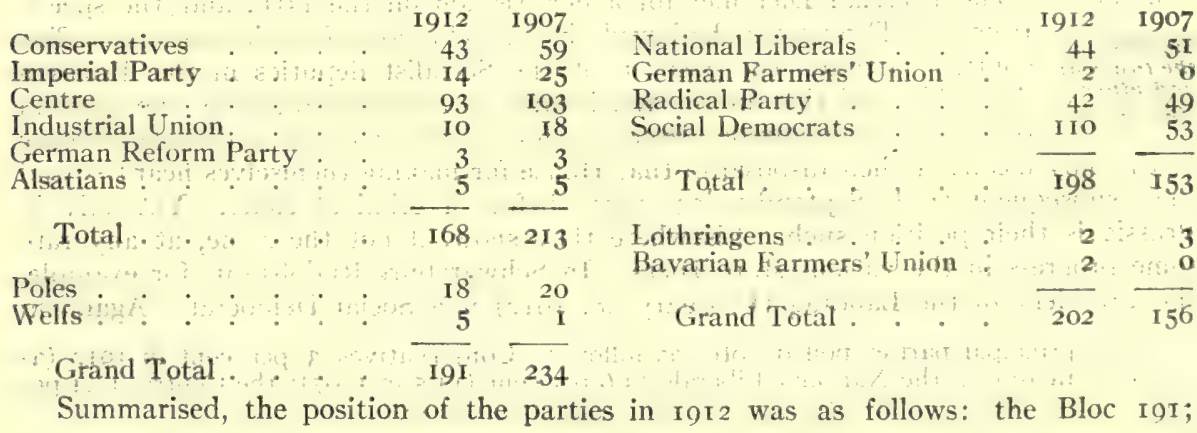


the Opposition 202; Danes I; Independents 3; Total 397. The most striking fact of the elections was the sweeping success of the Social Democrats, who polled 34.8 per cent of the total votes registered (as against 28.9 per cent in 1907). ${ }^{1}$

The new Reichstag opened on February 7, I9I2, and in the speech from the Throne social legislation was promised a first place in the deliberations of the House. A hope was expressed that the state would before long become financially sound, so that, The Sociallsts among other things, the army and the navy might both be strengthened. and the Presidency of The first work of the Reichstag was to elect a President. The choice the Reichstag. fell on Dr Spahn, a member of the Centre, the second strongest party in the House. To have given the Socialists the prize was really too much for all the parties, but the Socialists could not be kept out altogether. Accordingly of the two Vice-Presidents one was a Social Democrat (Herr Scheidemann) and the other a National Liberal (Herr Paasche). But the possibility of a Socialist Speaker was a thorn in the side of the Presidential Board, and Herr Spahn resigned, followed shortly after by Herr Paasche. Sittings were held to fill these vacancies, and for a day or two a Social Democrat presided over the German Reichstag for the first time in its history. On February I4, igi2. Herr Kaempf was elected President and Herr Dove second Vice-President. The Socialist element was still tolerated. But when the day to confirm these elections came round the House had apparently decided to eliminate the Social Democrat.

This was a small affair compared to the difficult financial situation. The troubles of the summer of 1909 seemed to be reviving. The War office and the Admiralty demanded extra expenditure; therefore fresh sources of revenue were Financial necessary. When the Secretary to the Treasury (Herr Wermuth) hinted needs for at fresh taxation, the Centre and the Conservatives were up in arms against a revival of the death duty proposals (February 1912). In the end the army and navy authorities obtained their vote for increased expenditure, but no provision was made for obtaining corresponding revenue. Herr Wermuth regarded this as a wrong principle and resigned in consequence (March 16, I912), being succeeded by Herr Kühn. There can be no doubt that Herr Wermuth's disappearance was a victory for the blue-black bloc. The question remains, if the bloc Triumph objected to fresh taxation, what alternative proposals had they to offer? the Centre. The abolition of the so-called Liebesgabe (the rebate of duty on spirits which is enjoyed by distilleries in regard to the amount of spirits distilled before 1888 ), was their reply - a course which would produce some $£ \mathrm{I}, 500,000$ fresh revenue. But even the Centre party did not for a moment pretend that this would cover the cost of the I)efence Bills. The main thing, however, was that a Parliamentary conllict was avoided - or postponed. But at what cost! It was a surrender 16 the ('entre party' and the acceptance of a policy which was not that of the Imperial ('hancellor, and which was regarded by an able Finance Minister as so unsound that he resigned rather than adopt it.

A new legislative period opened in January I9I 2 for several of the states in the Fiederation. The I'russian I)iet met for a new session on the $\mathbf{5}^{\text {th }}$, and the speech from th: Throne foreshadowed the introduction of an income tax. The

Saclallsts in the Prussian and other
state Dlets.

- the only their sulsectu Prussia is their position such. some progress in the various state Diets. In Schwarzburg-Rudolstadt, for example, the P'resident of the Landtag (February 28, I9I2) is a Social Democrat. Again, in

The principal parties polled votes as follows: Conservatives 3 per cent in I9I2 (as against 4 in 1967 ); the. Natinnal l.jherals 13.6 per cent (14.5 in 1907); the Centre, 16.4 per cent (19.4 ill 1907) and the Radicals 12.3 per cent (10.9 in 1907). 
Württemburg the interim committee (which according to the constitution, is the executive power during the dissolution of the Diet) contained two Socialists (October 5, 1912). At the elections in Bavaria, the second important state in the Empire (February I912), the party increased its strength from 20 to 30 . The remarkable thing about these elections was that Bavaria for the first time in its history obtained a purely Centre ministry, with Freiherr von Hertling at the head. Former ministries had been either liberal or business administrations; a Centre ministry Bavarian
Ultramontane was something new. The justification for it however lay in the great Ultramontane
cabinet. against 35 Liberals and 30 Socialists. Nevertheless feeling in the country and in the press ran high, for the appointment of the new cabinet was regarded as a success for reaction.

Of the smaller states Mecklenburg deserves a word of mention. Mecklenburg has always been regarded as the home of uncompromising conservatism; yet on February Mecklenburg. 18, I909 the Grand Duke received a deputation which presented a petition with forty thousand signatories (the total number of electors there is r46,9ro) demanding a reform of the constitution. The Grand Duke himself was quite agreeable, but the nobility objected, and the notorious influence of the landed proprietors in Mecklenburg was sufficient to make the scheme impossible. One other matter is worthy of mention in connection with Mecklenburg. In November I9Io the Diet agreed to the imposition of a tax on bachelors.

The death on Dec. I2, I9I 2 of Luitpold, Prince Regent of Bavaria (b. I82 I), may be noticed here. He was the third son of King Ludwig I (abdicated I848), and uncle

New Rulers

In Bavaria

and

Luxemburg.

of Ludwig II and the reigning King, Otto. He took a prominent part in

the Franco-German War, but mixed little in politics till 1886 , when Ludwig II was declared incurably insane. Prince Luitpold then became Regent, and he continued in that position when a few months later the King drowned himself, and Prince Otto, who had already been eleven years under restraint, succeeded to the throne. His rule was.wise and economical, and under him Bavarian relations with Prussia steadily improved. He was succeeded in the regency by his son, Prince Ludwig Leopold (b. I845). Mention must be made too of the Duchy of Luxemburg, which though politically independent, is yet for commercial purposes included in the German Zollverein. The reigning Grand Duke William died February 26, I9I2, and was succeeded by his daughter, the Grand-Duchess Marie Adelaide (born June 14, 1894).

The prosperity which showed itself throughout Germany in 1909 continued the next year also. In roro the production of iron established a record ( $14,793,604$ tons) and surpassed that of 1907 . ( $13,045,760$ tons). The same buoyancy was shown in coal production, which reached a total of $152,881,509$ tons, being an increase of 2.63 per cent on the production of the previous year. Foreign

\section{Economic} progress.

trade too was profitable, the total exports showing an increase of 13.35 per cent on those of I909. The railway profits were satisfactory and there was technical progress. For in 1909 the Prussian State Railway Administration was voted a sum

lalway dectrifl: cation. of money in order to make experiments in electric motive power. The line chosen was that between Bitterfeld and Dessau ( 26 kilometres, about I 5 miles) which forms part of the main line between Magdeburg, Leipzig and Halle. The electrification was begun on January 18 , I9I0, and was in working order at the end of the year.

As 1909 was the year of famine prices for wheat, I9 Io registered famine prices for meat. The scarcity of cattle was due largely to the previous bad harvest of fodder, which had made cattle-rearing expensive. Besides, it must be rememHigh price
of meat. bered that even in good years the production of cattle in Germany is not sufficient to satisfy the demand. The high price of meat, therefore, is a consequence, seeing that cattle importation is rendered difficult by the veterinary precautions which are even more prohibitive than the high duties levied on foreign live 
stock. Under the present legislation the importation of live cattle for slaughtering purposes is allowed, with certain restrictions, from Russia, Austria-Hungary, Switzerland, Denmark and the United States. But no importation is permitted from France, Holland and Belgium. To this general law certain modifications were introduced in roro by several states, but only after the outcry against high prices became extremely threatening. Prussia, however, declined to make any concessions; all that it agreed to was to institute a lower railway rate for the transport of slaughtered meat, a concession which was extended to December I9r2. The outbreak of the foot-and-mouth disease in many parts of Germany in r9ro only aggravated the situation, and popular feeling became very threatening in view of the steady rise in the price of meat in I $1 \mathrm{I}$. On October 23, I9II the Chancellor replying to an interpellation on the question gave it as his view that the agitation was unreal. His mistake was brought home to him in September 19I2, when the prevailing distress was sufficiently extensive to extract a promise from him for an enquiry into possible ways and means for mitigating the evil, which he termed "a heavy burden" on the public. On September 28, I9I.2 the scheme for relief (expressly stated to be a temporary measure only) was published. It consisted largely of a relaxation of the existing restrictions. A Bill was promoted in the Reichstag embodying the measure, which was to be in operation from October I. I9I 2 to March 3I, 1914. Yet there was no great improvement, and in the latter Meat riots. part of October (23rd and 24 th) meat riots occurred in Berlin. When the question came before Parliament once again, this time in the Prussian Diet (Oct. 25, r9r2) Herr von Bethmann-Hollweg at last laid bare his policy. It was clearly the duty of the state, he held, to do all it could to improve matters, and it had already gone as far as it was possible with due regard to veterinary precautions. (These excluded the importation of foreign meat.) But as a general proposition, it ought to be the aim of Prussia to keep the home meat production independent of foreign countries, seeing that this was a most important factor in its economic independence, with which its political existence was bound up.

Some such idea must have actuated the Government in its oil scheme (Oct. I5, 1012), which was intended to counteract the influence of the Standard Oil Trust. The proposal was for the establishment, not of an Imperial monopoly. The petro.
leum scheme. but of a joint stock company in which financiers and merchants will organise the wholesale oil trade under Government control. The main idea is to protect the public from foreign monopoly, and to secure for the Empire any profits which the scheme can be made to yield without injury to the consumer. The interesting feature of the plan is that these profits shall not be treated as general revenue but shall be earmarked for social legislation.

In the history of German education the most noteworthy event of the year I900 was the admission of women students to all German universities on the same terms as men. Before that women might be only "visitors" (Hospitantinnen); Womenat the
universities. in the winter Semester $1908-9$ they were registered as fully privileged undergraduates. In that half year their number was 1,108 ; in the following summer it rose to $\mathrm{r}, 432$. The year $\mathrm{r} 000$ is noteworthy also for the plan of a university for frankfort-on-Main (Der. I $_{5}$, I000). The demand for academic teaching in that city came from the locality itself, but the Government is somewhat averse to the scheme and it has not yet been sanctioned. Several noteworthy anniversaries should not be left unmentioned. 'The university of Leipzig celebrated the 5ooth year University of its existence in $\left.\mathrm{I}()_{0}\right)$ (July 30); Berlin recalled the rooth year of its centenaries foundation in IoI (Oct. IO) as did Breslau (Aug. IgrI). Furthermore Breslau won fame in another direction; on November 20, I910 the Eleventh Technical High School in Germany was opened there by the Kaiser. Ohituary.-During lgI the following distinguished Ciermans died, concerning whom

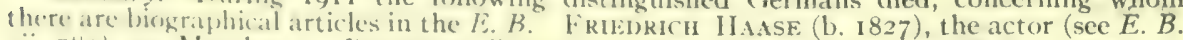

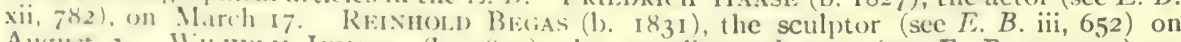

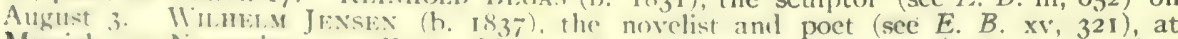
Munich on Noremer 24 . Forix Motr. (b. 1856), the conducter and composer (see 
E. B. xviii, 93Ib), on July I. Friedrich von SpIelhagen (b. 1829), the novelist (see $E$. $B ., x \times v, 667 b$; and $x i, 616 d$ ), at Berlin on February 25. Karl Herman Fritz von Uhde (b. 1848), the painter (see E. B. xxvii, 563c), at Munich on February 26. Prominent politicians also passed away in PAul Singer, the Socialist leader (b. 1844; d. January 30); and Max Liebermann von Sonnenburg, the pan-German and leader of the anti-Semitic party (b. 1859; d. September I 8). The deaths also may be mentioned of Josef UPHLES, the sculptor (b. I850; see $E$. B. xxiv, 50Ia), on January I; GEORG JELlinek, the jurist (b. 1852 ; see $E . B . \times$ xv, 315), on January 12; AlberT LADENBURG, the chemist (b. 1842), on August 22; Hugo voN Tschudi, art director at Munich (b. I85I), on Nov. 24; and the archaeologists, Otto Puchstein (b. 1857) on March Io, and KekUle von Stradonitz (b. 1839), on March 23.

During 1912 the deaths occurred of the following who have "living" biographies in the $E . B$. RichARD ANDREE (b. I835), the geographer and ethnologist (see $E . B . \mathrm{i}, 97 \mathrm{I}$ ), at Leipzig on February 22. JUSTUS SopHUS FELIX DAHN (b. I 834), the historian, jurist and poet (see E. B. vii, 734b), at Breslau on January 3. Theodor GoMPERz (b. 1832), the philosopher and classical scholar (see E. B. xii, 230a), at Baden, on August 29. For Luit Pol D, Prince Regent of Bavaria (E. B. iii, 550d), who died Dec. I2, see above.

Among German public men most importance however attaches to Baron Adolf MARSCHALl VON BIEBERSTEIN, the eminent diplomatist. who died at Badenweiler on September 24, 1912. He was born at Carlsruhe on October 12, I842, his father, Augustus, Baron Marschall von Bieberstein, being Chamberlain to the Grand Duke of Baden, and his mother before her marriage Baroness von Falkenstein. He was educated at the gymnasium of Frankfort-on-Main and at the universities of Heidelberg and Berlin. He studied law and from 187 I to 1882 held various administrative offices in the Grand Duchy of Baden. From 1875 to 1883 he sat in the Upper Chamber of the Baden Diet. In I883 he was sent to Berlin as Minister for Baden in the Federal Council, and from 1884 to 1890 he represented the Council in the Imperial Insurance Office. In I 890 he succeeded Count Herbert Bismarck as Secretary for Foreign Affairs under the Caprivi Chancellorship, and continued to hold that office under Prince von Hohenlohe (see $E . B . x i, 892 \mathrm{c}$ ); but he had incurred the enmity of Prince Bismarck by refusing his advice when he first assumed office, and the result was a fierce press campaign against him which finally obliged him to speak out when he appeared as a witness at the trial of certain journalists in 1896 for lèse-majesté. He was also violently opposed by the Agrarians because he advocated the reduction of corn duties, and in 1897 he resigned office, and a few months later was appointed German Ambassador in Constantinople. There he remained for nearly fifteen years, creating a commanding position for himself and a growing ascendency in Turkish affairs for his Government. To him was largely due the promotion of the Bagdad railway (see $E . B$. iii, I97b, xxvii, 439c). In general European politics Baron Marschall had taken during his Foreign Secretaryship a strongly Imperialist attitude. After the Jameson raid and the Emperor's telegram to President Kruger, it was he who declared in the Reichstag that the maintenance of the independence of the Boer republics was a German interest. He was also an advocate of a strong naval policy for Germany. In 1907 he was principal German delegate in the Hague Conference. In May I9I 2 his appointment to succeed Count Wolff-Metternich as Ambassador to Great Britain raised great expectations as to the influence of his personality on Anglo-German relations, but he had only been installed a short time before his health finally broke down. Another important loss to German public life came in the death of ALFRED VON KIDERLEN-WAECHTER (b. I852, d. Dec. 30, 1912), the Foreign Minister. He was born at Stullgast, the son of Robert Kiderlen, a banker, and Baroness Marie Von Waechter. He fought as a volunteer in the Franco-German War, then studied at the universities, and in 1879 entered the Foreign Office. He held various diplomatic posts, finally going to Bucharest in I 900 and remaining there for ten years, when he became Foreign Secretary.

Other well-known men who died in 1912 may be more briefly mentioned:

Otтo BRAHM (b. 1856 ), director of the Lessing Theatre, Berlin, died on November 28. He was one of the founders of the Independent Theatre, and took the leading part in produeing the plays of Ibsen and Hauptmann.

JOHANN HEINRICH BuRCHARD (b, 1852), Chief Burgomaster of Hamburg, died at Hamburg on September 6. He served in the Franco-Prussian War, and afterwards studied law, becoming Doctor of Laws in 1874 . He entered the Lower House of the Hamburg parliament in 1884 and the Senate in I885. From I887 to the time of his death he represented Hamburg on the Federal Council of the Empire. In 1903, 1906, 1908, 1909 and 1912 he was Ist Burgomaster of the city.

Anton Hubert Fischer (b. I840), Cardinal and Archbishop of Cologne, died at Neuenahr on July 30. For nearly twenty-five years he gave religious instruction at Essex Gymnasium, obtaining his doctor's degreeat Tübingen University. In 1902 he was appointed Archbishop of Cologne, and was made a Cardinal by Leo XIII in the following year. In I909 he presided over the Eucharistic Congress at Cologne. A most notable feature of his policy was his steady support of the "Christian Trade Unions" (see E. B. xxvii, I 47b), powerful unsectarian organisations of labour, largely managed by laymen, and distrusted in some quarters as too independent of Vatican control. 
THEOBald Fischer (b. 1846), the geographer, died on September 17, at Marburg, where he had been professor of geography since 1883. He devoted himself specially to the study of Mediterrinean lands, and his most important work is his Mittelmeerbilder.

MARTIN KirschNer (b. I842), Chief Burgomaster of Berlin, died at Ehrwalt, Tirol, on September 13. After holding administrative posts in Breslau he became second Burgomaster of Berlin in 1892 and First (or Chief) Burgomaster in 1898 .

()TTO KRT:MMEL (b. 1854), the geographer, died at Cologne on October 12. In I883 he became professor of geography at Kiel, and latterly was transferred to Marburg. He was reconnised as the leading German oceanographer, and was a member of the International Council for the Study of the Sea. He was joint author of the article "Ocean and Oceanography" in the E. B. and in 191 I completed a standard treatise on oceanography.

OTto LiEBMANN (b. I $84 \mathrm{I}$ ), the philosopher, died at Jena on January 15. He had been professor at Jena for thirty years. For an account of his philosophy see $E$. $B$. xviii, $236 d$.

PAUL IVALLOT (b. I $8+2$ ), the architect, died on August II. He designed the present Reichstag buildings (see E. B. ii, 442c), and was a professor in the Dresden Academy of Arts.

Literature.-Among recent books (in English) bearing on Germany and German life, the following will be found useful: J. Ellis Barker, Modern Germany, 4th and enlarged edition, brought down to July I912; W. H. Dawson, Social Insurance in Germany (I912), as well as his Growth of Modern Germany (1909); Herbert Perris, Germany and the German Emperor, (1912); Whitman, German Memories (1912); The Report on the Trade and Industries of Germany for 1910 , by Consul General Sir F. Oppenheimer (Cd. 5,465-166).

(M. EPSTEIN.)

\section{GREECE AND THE BALKAN STATES}

\section{Political History, I909-12}

1909.--The agitation in Servia caused by the annexation of Bosnia and Herzegovina by Austria-Hungary in 1908 had led the country to the brink of war with its powerful Servia:

The Bos.

nian Crisis 1909. neighbour. The only chance of a Servian success in such a conflict lay in the hoped-for support of Russia, but when that Power, acting under pressure from Germany, declared that she no longer insisted on the provisions of Article XXV of the Berlin Treaty which regulated the Austrian tenure of the two provinces, the Servian cabinet, in which MM. Milovanovich, Pashich and Ribaratz were the principal figures, recognized the uselessness of further resistance, and on March 3I, I009, Servia addressed to Austria-Hungary a declaration, the text of which had been drawn up by the British Government, to the effect that she would conform to the decisions of the Powers relative to Article XXV of the Berlin Treaty and abandon the attitude of protest and opposition she had hitherto maintained towards Austria-Hungary, reducing her army to its peace effective and disarming her bands of volunteers. At the same time the representatives of the Powers at Belgrade gave assurances to the Servian Government that Austria-Hungary meditated no attack upon the independence or territorial integrity of Servia. On April rst the Austrian reply expressing satisfaction at the resumption of friendly relations was delivered at Belgrade. By a strange coincidence, a provisional commercial arrangement between the two countries expired that very day, and the political struggle was replaced by a war of tariffs.

Europe had scarcely been delivered from the Servian nightmare when the outbreak of a reactionary movement at Constantinople ( $A$ pril $3_{3}$ th) once more produced excursions and alarums in the Balkan Peninsula (sce Tukkey). After the successful The counter march of Mahmoud Shefket with the army of Salonika on Constantinople
revolution in Turkey: hs effects on the $B a$ l. kan stares. the Young Turk faction, which had been driven from power, re-established its authority, and the Sultan Abdul Hamid II was deposed (April 27, 1909). Notwithstanding their profession of Liberal principles, the triumph of the Young Turks was productive of little or no improvement in the condition of the subject races of the ()t toman Empire. An increase of militarism in the administration followerl, and the cloctrine of "Ottomanism," which was explained to the outer world as implying the perfect equality of all Ottoman subjects, was interpreted at home as just ifying the abrogation of the ancient rights of the non-Turkish nationalities. The privileges of the Christian churches were interfered with, political clubs were suppressed, public meetings were forbidden, and every effort was made to extinguish the national sentiments of the various races. The result was the formation of secret conspiracies 
and the appearance of insurgent bands in Macedonia, which were aided and in part recruited by sympathizers in Bulgaria, Servia and Greece, while Albania broke into open revolt. The various nationalities, which the artful policy of Abdul Hamid had maintained in a state of mutual hostility, began to discover that their only hope of preserving their rights, and indeed their existence lay in combination against the common foe. The reconciliation began among the Greek and Bulgarian peasants; in course of time better relations began to prevail between the clergy and upper classes on both sides, which had hitherto been implacably hostile, and ultimately the governments of Athens and Sofia entered into friendly discussions. A close understanding resulted, and the foundations of the future Balkan alliance were laid.

The crisis which arose over the annexation of Bosnia and Herzegovina by AustriaHungary came to an end in April I9o9 with the recognition of the annexation by the Powers. At the same time Montenegro, which had formed an alliance Montenegro: with Servia during the period of tension, succeeded, through the good the port of Antivarl. offices of Italy, in obtaining from $\Lambda$ ustria-Hungary and the Powers the abrogation of various restrictions imposed on her tenure of the port of Antivari by Article XXIX of the Berlin Treaty. It was arranged that Antivari should retain the character of a commercial port, but the administration of the maritime police on the Montenegrin coast by Austria-Hungary, the closure of Antivari to ships of war of all nations, and other irksome provisions of the treaty, were abandoned.

The decision of the four Protecting Powers of Crete to withdraw their troops from the island led to considerable excitement in Greece as the date fixed for the evacuation Greece: (July 27, I909) approached. It was generally believed at Athens that political agi the union of the island with Greece would follow immediately upon the tation over . departure of the troops, but the Young Turks, now secure of power, assumed the Cretan Question.

a threatening attitude, and Mahmoud Shefket Pasha addressed menacing language to the Greek Patriarch. The indignation in Greece was intense, especially in the army, and a secret society, known as the Military League, was formed among the officers. After the embarcation of the international contingents, the Cretans hoisted the Greek flag on the forts of Canea and Candia. The Cretan Government, declaring itself unable to enforce the removal of the flags in compliance with the injunctions of the Powers, resigned, and was succeeded by an executive committee, which at once took an oath of allegiance to King George. The Greek flag at Canea was cut down by a detachment from the international fleet (Aug. I8th), while that at Candia was removed with some difficulty by the local authorities on the following day. Mtanwhile the Porte in two Notes (Aug. 8th, Aug. I3th), demanded from Greece categorical declarations with regard to her intentions both as regards Crete and Macedonia, and received replies which were stated to be satisfactory. The Powers had already (July I3th) addressed a memorandum to Turkey declaring their resolve to maintain her " supreme rights " in Crete; they now, at the suggestion of Great Britain, interpreted these words as implying the sovereignty of Turkey, although on March I 7 th, I897, they had " irrevocably decided " to recognize her "suzerainty" only.

The disappointment felt in Greece at the postponement of the union, the humiliation inflicted by Turkey and the tergiversation of the Powers combined to bring about a

\section{Revolt of} the Military League at Athens. crisis. On the night of August 27, 1909, a number of officers belonging to the Military League marched out of Athens with some 2000 men and occupied a hill in the suburbs. Their demands included a series of radical reforms in the army and navy, the exclusion of the Crown Prince and his brothers from military commands and a number of other changes. M. Ralli, the prime minister; who had succeeded M. Theotokis on July 20 th, resigned and was replaced by M. Mavromichalis. The new government undertook to carry out the greater part of the programme of the League; its leader, Colonel Zorbas, was appointed to the command of the troops at Athens, and the royal princes withdrew from the army. The movement was not antidynastic, but aimed at putting an end to the prolonged maladministration which had involved the country in so many misfortunes. In effect Colonel Zorbas 
and his confederates became for the time the real rulers of the country, and on their initiative a large number of legislative measures were submitted by the government to the Chamber, which passed them with mechanical docility. Some of the new laws met the real requirements of the country, but others betrayed the crude statesmanship of the soldier politicians who devised them. Eventually, however, the popularity of the League declined, dissensions broke out among its members, and a naval mutiny at Salamis (Oct. 20th) indicated a rift in the harmony between the army and navy. The Mavromichalis ministry; which the officers tolerated so long as it carried out their orders, began to display a spirit of independence, and certain features of the new legislation met with opposition. A demand for the immediate settlement of the Cretan Question addressed by the Porte to the Protecting Powers (Nov. Ioth) suggested the fear that Turkey would endeavour to piofit by the distracted condition of Greece.

After the settlement of the various questions arising from the Bulgarian declaration of independence in 1908 the relations between Turkey and Bulgaria had become normal. Bulgaria. On July 23, Igo9, a number of Bulgarian officers attended the celebration of the first anniversary of the restoration of the Turkish Constitution at Constantinople, and during the autumn several Macedonian revolutionaries were expelled from Bulgaria. The efforts of the Young Turks, however, to infringe the privileges of the Christian nationalities in Macedonia caused some uneasiness, and the severities practised by Djavad Pasha during the autumn in putting down a revolt in Northern Albania seemed to indicate that the new régime in Turkey had not abandoned traditional methods of repression. On November 25 th, King Ferdinand paid a short visit to King Peter at Belgrade.

I I I0.- The beginning of the year rgro found Greece in a state of confusion bordcring on chaos. The relations of the Military League with the Mavromichalis government became daily more strained, and at the end of January, M. Mavromichalis Greece: resigned, being replaced in the premiership by M. Stephen Dragoumis, Arrival of
M. Venizelos. who took Colonel Zorbas into his cabinet as minister of War. Conscious of its waning popularity and unable to deal with the perplexities of the situation, the League had already sought the advice of M. Venizelos, the eminent Cretan politician, who had arrived at Athens on January roth. He at once devised a programme which enabled the League to make a triumphant exit from the political arena. He suggested the convocation of a National Assembly to sanction the changes which the military reformers and, indeed, the bulk of the nation desired, and in the space of a few weeks succeeded in inducing not only the officers but the opposition leaders and eventually the king to accept his proposal. The retirement of the Mavromichalis ministry became inevitable. Having practically arranged the affairs of Greece in accordance with his ideas, M. Venizelos returned to Crete on February 28 th.

The new Greek ministry under M. Dragoumis, who was highly respected by all parties, adopted the programme of $\mathrm{M}$. Venizelos, and worked in comparative harmony Convocation with the League, the inclusion of Colonel Zorbas in the cabinet tending to of the Greek moderate the violence of the military junta. King George, who had always National played the part of a constitutional sovereign, was opposed to the convocaAssembly.

tion of an Assembly, on the ground that under the Constitution such a body could only be called into existence by the vote of two successive Chambers. The holding of fresh elections, however, involved the prospect of a rupture with Turkey owing to the resolve of the Cretans to send deputies to the new Chamber, whose admission, the Porte had declared, would constitute a casus belli. In view of this danger, and having received assurances that the League would dissolve, the king personally announced to the Chamber (March 30 th) his decision to summon a revisionary assembly as provided for by clause 107 of the constitution. The League simultaneously issued a manifesto declaring that the interference of the army in political affairs had ceased. Thus came to an end the military pronunciumento, which had been prolonged for a period of six months. If the methods of the officers were crude their intentions were excellent, and the general results of the movement were beneficial for Greece. 
In Thessaly, where a system of land tenure based on Turkish feudal institutions had not yet disappeared, a serious agitation broke out among the peasant cultivators in

Troubles in Thessaly.

March I9ro; the troops were called out and bloodshed took place at Larissa and Karditza. After the annexation of the province to Greece in $\mathrm{I} 88 \mathrm{I}$ many of the Turkish proprietors, who as a rule were easy-going and indulgent to their serfs, had parted with their estates, which the new landlords, for the most part wealthy speculators, endeavoured to administer on business principles. After the outbreak of the military revolution at Athens the cause of the Thessalian peasants was taken up by political agitators, who, with the support: of the League, introduced a measure into the Greek Chamber for the compulsory expropriation of the landlords: This led to the despatch of a sharply worded Turkish Note reminding the Greek Government that the rights of the Moslem proprietors were safe-guarded by the Convention of Constantinople of July 2, I88I. The proposed measure was resisted by M. Dragoumis, and satisfactory assurances were tendered to Turkey.

The relations between Bulgaria and Turkey had once more become strained owing to the severities practised by the Young Turks in Madeconia, and on January 2, I9ro,

\section{Bulgaria:}

relations

with

Turkey. a great meeting of protest was held at Sofia. On January 6th Dr. Daneff; ex-prime minister; was sent to Constantinople with the object of bringing about an understanding, and his mission resulted in a temporary mitigation of the repressive measures carried out by the Turkish authorities. On March 2 Ist King Ferdinand and Queen Eleonore, who had already paid a visit to St. Petersburg (Feb. 23rd), arrived at Constantinople accompanied by the Prime Minister and two other members of the Cabinet, and were cordially welcomed by the Sultan, who gave a banquet in their honour. The Greeks of Constantinople, however, showed ill humour at the visit, and its political effects were marred by the refusal of the Turkish Government to allow the King and Queen to return to Sofia via Mount Athos and Salonika. On June I2th Prince Yusuf Izz-ed-Din, the Turkish heir-apparent, who had previously visited Belgrade, arrived at Sofia, where he spent some days. Some conferences took place between Rifaat Pasha, who accompanied the prince, and Bulgarian statesmen, but no political results of any importance were attained.

The friendly relations existing between Servia and Turkey were strengthened by the visit of King Peter to Constantinople (April 3rd), a few days after the departure of King Servia and Ferdinand. The Servian sovereign was received with great honours and Turkey. met with an effusive welcome from the Greek clergy and population. He was permitted to visit Mount Athos and to return to Servia through Macedonia. The policy of the Young Turks at this period was to play off the Servians against the Bulgarians in Macedonia and against the Albanians of Kossovo, who bad risen in revolt against the imposition of an octroi tax and other vexatious measures of the Turkish authorities. Servia was bound to keep on good terms with Turkey, which dominated her only commercial outlet at Salonika, her Austrian frontier being closed by a tariff war. Hopes, which proved illusory, were held out to Servia that she would be allowed to construct a railway to San Giovanni di Medua on the Adriatic.

On the opening of the Cretan Assembly (May 9, I9ro) all the Christian deputies took an oath of allegiance to King George of Greece. A protest was handed in by Naim Crete. Bey, a Moslem deputy, but he was assaulted by one of his Christian colleagues while another tore up the document. In reply to the remonstrances of the Porte against these proceedings the Protecting Powers declared that nothing had occurred to change the status quo. The Assembly, however; proceeded to vote the exclusion of the Moslem deputies, while steps were taken throughout the island to hinder Moslem officials from exercising their duties. Eventually, after an ultimatum from the Powers, which threatened to land troops and seize the customs, the Assembly revoked its decision (July 9 th) and interference with the Moslem functionaries was abandoned. The proceedings of the Cretan Christians and the sympathy expressed for them in Greece entailed much suffering on the Greeks in Turkey. The " boycott " of Greek commerce, initiated by the Committee of Union and Progress in the previous 
year, was now enforced with extreme rigour. All dealing with Greeks was prohibited, Greek steamers were prevented from taking up or landing passengers or goods, Greek shops were in many places forcibly closed and Greek workmen were forbidden to pursue their avocations. The movement was ostensibly under the direction of Kerim Aga, a quay-porter at Salonika. The embassies at Constantinople protested, but were informed that the Government was powerless. The rejection by the Porte of a demand for compensation to Greek subjects in Turkey led to withdrawal of the Greek minister from Constantinople, but diplomatic relations were not suspended.

At the end of August I9 Io the fiftieth anniversary of the accession of Prince Nicholas of Montenegro was celebrated at Cettigne with great rejoicings in presence of the King and Queen of Italy, King Ferdinand and Prince Boris of Bulgaria, the

Montenegro proclaimed a kingdom.
Crown Princess of Greece and Servia, and other distinguished personages. On the morning of the 28 th, in response to an address from the Sukpshtina, Prince Nicholas assumed the royal dignity, and accompanied by his illustrious guests attended a Te Deum in the historic monastery of Cettigne. The golden wedding of the King and Queen was celebrated next day in the little Vlaska church in which their marriage took place. The festivities continued for three days amid great enthusiasm. The new kingdom was immediately recognized by the Powers.

Elections were held in Greece in August r gro for the Revisionary Assembly, at which M. Venizelos and other Cretan candidates were returned; the latter resigned their mandates at the instance of the Powers, to which Turkey had addressed a protest; but the election of M. Venizelos, who was technically a Greek subject, having received the freedom of Athens, was allowed to stand. The Assem-

bly was opened by King George on September $14^{\text {th }}$, and four days later Greece: the Revisionary Assembly. M. Venizelos arrived from Crete. He firmly resisted a proposal that the Assembly should assume constituent powers, and that body at his suggestion formally invalidated the election of the Cretan deputies. On October $3^{\text {th }} \mathrm{M}$. Dragoumis resigned, and M. Venizelos became Prime Minister. ${ }^{1}$ The leaders of the old political Venizelos Premier. parties at once combined against him, with the result that King George dissolved the Assembly (Oct. 25th). The political leaders responded by proclaiming the abstention of their followers from the ensuing elections, which took place in December and resulted in an overwhelming majority for M. Venizelos, who was now in a position to carry out his programme of reform.

During the summer and autumn of igro the Young Turk Government proceeded to carry out its programme of disarmament in Macedonia. The measure was practically

Turkish

severitles enforced against the Christian population only, the Moslems, with the ia Macedomia: armament was carried out manu militari by Shefket Torgut Pasha and effect on the his troops after the suppression of an Albanian insurrection in the spring.
Balkan States.

The villages were blockaded by the troops during the search for arms, and some 10,000 peasants were beaten or otherwise maltreated. At the same time armed Bosnian colonists were settled in many districts hitherto inhabited by Christians. These proceedings, with regard to which complete reticence was maintained by foreign governments and the greater part of the European press, produced great indignation in Bulgaria, where large numbers of refugees congregated, as well as in Servia and Grece, and gave an impulse to the movement for joint action on the part of those states against Turkey. In the autumn Rumania, apparently prompted by Germany, declared to Turkey that in the event of hostilities between Turkey and Bulgaria Rumania would mobilize all her forces on her Bulgarian frontier.

1 Eleutherios Venizelos was born at Cerigo in 1864 , his family tracing their origin to the Florentine dukes of Athens in the middle ages and claiming a patron saint in St. Philothea Venezela, who was beaten to death by the Turks in 1589 and buried in the Cathedral at Athens. His father having been expelled from Crete by the Turks, Eleutherios studied law at Athensand in (iermany. Although an Hellenic subject, in May 1899 he became Ministèr for foreign affairs in Crete after the island obtained autonomy, but resigned in September.19or owing to differences with Prince George. In opposition however he played a strong part, and from 1906 onward he was the most powerful man in the island. 
IgII.-On January II, Igr I, the Liberal Cabinet of M. Bratiano resigned in Rumania, and was replaced by a Conservative ministry under M. Carp. The new Rumanian

Fall of the Bratiano

Cabinet in Rumania.

Prime Minister possessed only a small following in the Chamber, a large number of the Conservatives having broken away some years previously under the leadership of M. Take Jonesco. A dissolution followed and elections were held in February, at which, owing to strong official pressure, a large ministerial majority was obtained. M. Carp, while maintaining friendly relations with Turkey, did not consider himself bound by the declaration of his predecessor.

On January 3, I9I r, the Bulgarian sobranye decided to send the members of the former Stambolovist ministry, who were charged with various illegalities, before a special commission of enquiry. A speech delivered on this occasion by General

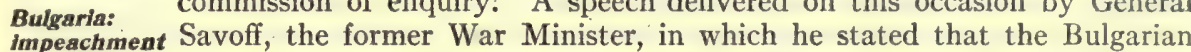
of Stambo- army was perfectly ready for war with Turkey, attracted much attention. lovists.

The prosecution was eventually dropped. Owing to the failure of protracted negotiations for a commercial treaty with Turkey, the outbreak of a tariff war seemed imminent, but a provisional arrangement for one year was eventually concluded (Feb. 3d).

The Greek Revisionary Chamber elected in the previous year met at Athens on January 22nd. Among the changes sanctioned were the revival of a Council of State,

\section{Greece:}

revision of the Consti" tution.

reduction of the number of deputies and of the number necessary to form a quorum, permanent tenure of their appointments by judges and public officials, compulsory elementary education, exclusion of military and naval oficers from the Chamber and permission to foreigners to enter the service of the state. In virtue of the last-mentioned enactment the reorganization of the army was entrusted to French, and that of the navy to British officers (April I4th). The revision of the Constitution was completed on June 5 th.

For several days in March Athens was thrown into a state of confusion owing to an agitation raised by some ultra-patriotic University professors, who demanded that a

The Language Question in Greece. clause should be introduced into the constitution ordaining the exclusive employment of the "purified literary language" in all departments of the state and forbidding the translation of the Scriptures into the spoken tongue. Meetings of students were held, the populace became excited, and it was found necessary to occupy the streets in the neighbourhood of the Chamber with troops. The Government yielded to the demand, but the purists, encouraged by their success, proceeded to insist that the-employment of the popular language in schools should be proscribed by the Constitution, and their leader, Professor Mistriotis, issued a proclamation declaring that the immortal Greek language, the national religion and the race itself, which had civilized the whole world, were in danger, and convoking a public meeting to consider "whether the nation would consent to commit suicide." M. Venizelos thereupon took prompt action. Troops were brought up from Chalcis, the meeting was prohibited, and the professor was brought to his senses by a notification that he would be prosecuted for sedition. Tranquillity was immediately restored.

At the end of March I9I I diplomatic relations between Greece and Rumania, which had been suspended in September $\mathbf{1 9 0 5}$ owing to Rumanian retaliation for outrages

Greece and Rumania. The Thessalian Iand question.

perpetrated by Greek bands on the Vlachs of Macedonia, were resumed through the mediation of Russia and Italy. On April 2nd M. Venizelos announced that the Government had decided to settle the Thessalian land question on the principle of voluntary sale by the landlords, and his assurances were accepted as satisfactory by the Thessalian deputies.

On March 22nd the Democratic Cabinet of M. Malinoff in Bulgaria resigned and was succeeded (March 29th) by a coalition ministry representing the Nationalist and

Bulgaria:

new minis. try; revision of the Constitution.
Progressive parties. M. Gueshoff, the leader of the former, became prime minister, while Dr. Daneff, the Progressist chief, accepted the presidency of the Chamber. The new government endeavoured to initiate a policy of friendship with Turkey in the hope of mitigating the violence of the Young Turk committees in Macedonia, which now displayed itself in a 
series of assassinations of Bulgarian and Greek notables. By the irony of fate the most pacific of Bulgarian governments was destined to make war on Turkey in the following year. In July the Grand Sobranye was convoked to make certain changes in the Constitution resulting for the most part from the proclamation of Bulgarian independence in 1908. The assumption of the royal title was sanctioned, and the King and Government were entrusted with the right to make secret political treaties.

In May IgI I the decision of the Turkish Government to send salaried Cadis or ecclesiastical judges to Crete caused unbounded excitement in the island. The decision, which was attributed to the desire of Turkey to uphold the "sovereign"

Crete: question of the Cadis. rights recognized by the Powers in the preceding year, was approved by Great Britain but deprecated by the other Protecting Powers. The Cretans determined to prevent the landing of the Turkish functionaries by force, and the Canea Government addressed a protest to the Powers. Eventually the Powers induced the. Porte to allow the question to rest.

The sympathy and aid extended by Montenegro to the Catholic Malissori or mountaineers of the Albanian districts south of the Montenegrin frontier in their revolt against Montenegro: the methods of Young Turk administration (see TurkeY) led to critical the revolt relations with Turkey during the summer of IgI $\mathrm{I}$. The revolted districts of the Malissort.

were devastated by a Turkish army under Shefket Torgut Pasha, and large numbers of refugees passed into Montenegro, where they met with a hospitable reception, while Montenegrins fought in the Albanian ranks. Eventually the Porte accepted the greater part of the insurgents' terms (Aug. 2d), and better-relations between Montenegro and Turkey were brought about through Russia.

The outbreak of war between Italy and Turkey (Sept. 29, I9II) produced some excitement in the Balkans and led to military measures on the part of all the states of Warbetween the Peninsula in response to the mobilization of the Turkish army. It was lialy and soon realized, however, that Italy had resolved to exclude the Balkans Turkey: Effect on the Balkan States. from the area of war, and no trouble resulted for the time except in Crete, where armed meetings were held, a "revolutionary" Assembly was convoked, and deputies were elected for the Greek Chamber. The deputies were captured on their departure for Athens by an armed party from the international fleet and taken to Suda (Dec. I 5 th), where they were detained until the dissolution of the Chamber (Jan. 3, r9 I I). In September the Powers had notified to King George of Greece their decision not to fill the vacant post of High Commissioner of Crete.

I912. - The year 1912 opened gloomily in the Balkans. The possibility that the war between Italy and Turkey might bring about a cataclysm in the Peninsula was by no means removed, notwithstanding the neutral attitude of the Balkan

The Balkan States and Macedonia: inception of the Balkan alliance.

States, but the principal danger lay in the deplorable condition of Macedonia. That province, abandoned by Europe, had fallen into a state of anarchy; pillage and murder were everywhere rife, and a campaign of systematic assassination carried out by the local Young Turk committees led to reprisals on the part of the Christian population. The Bulgarian "Internal Organization" resorted to a series of bomb outrages, and a massacre of Christians followed at Ishtib. The state of affairs in Albania and Epirus was no better; the Great Powers looked on with indifference, and the conviction was brought home to statesmen at Athens, Sofia and Belgrade, that nothing but the concerted action of the Balkan States could end an intolerable situation. The tendency towards a combination was strengthened by a meeting of the heirs apparent of the Balkan kingdoms at Sofia on February 2nd, when Prince Boris of Bulgaria attained his majority. The definite conclusion of alliances between Bulgaria and Servia and Bulgaria and Greece followed in a few weeks, while an entente was arrived at between them and Montenegro.

The unrest in Crete was kept alive by a decision of the revolutionary assembly to send deputies to the Greek Chamber (Feb. 2d), and by some murders of Moslem peasants which led to a warning Note from the Protecting Powers. Owing to the quarrels of local politicians a state of chaos resulted in the island, which for some days (March 
I 2 th-I 5th) was without a government. At the end of April, notwithstanding the prohibi tion of the Powers, a number of deputies proceeded to Athens, but a steamer conveying a party of nineteen was intercepted by H.M.S. " Minerva," which brought Crete be- . the deputies to Suda, where they were detained on board as prisoners for comes Greek. more than a month (April $28 \mathrm{th}$-June 6th). On June ist the deputies at Athens vainly endeavoured to force their way into the Chamber, which was surrounded by a strong force of troops; they were ultimately induced to desist from their efforts by M. Venizelos, who informed them that the Government had decided to prorogue the Chamber till October $\mathrm{I}_{4}$ th. On that day Greece addressed an ultimatum to Turkey, and the long protracted Cretan Question found a practical solution in the admission of the deputies to the Chamber. Shortly afterwards M. Dragoumis was despatched to Canea to take over the government in the name: of King George.

On July ist the death of M. Milovanovich (b. I862), Servian prime minister and (since I9o8) minister for foreign affairs, took place at Belgrade. A statesman of reServia: markable tact and shrewdness and a highly amiable man, who in early life death of M. had been a professor of law, he had been a member of various Cabinets, and Milovan- ... was Servian delegate to the Second Hague Conference. He was succeeded ovich.

in the premiership by $\mathbf{M}$. Pashich.

During the summer of I9I2 the condition of Macedonia became more grave; the state of anarchy was increased by a mutiny among the Turkish troops at Monastir, which led to the downfall of the government at Constantinople; another

The approach of war. revolt broke out in Albania; fighting was resumed on the Turco-Montenegrin frontier, and a massacre following the explosion of some bombs took place at Kotchané, which aroused the utmost indignation in Bulgaria. Public attention in that country was distracted for a while by the celebration at Tirnovo of the $25^{\text {th }}$ anniversary of King Ferdinand's pacific reign (Aug. I5th), but agitation for war with Turkey soon broke out afresh. Meanwhile the allied Balkan States, having matured their military plans, determined on making a joint effort to secure a thoroughgoing measure of reforms in the European provinces of Turkey.

On September zoth the allied states mobilized all their forces and Turkey responded by a similar measure on the following day. The Powers at last took alarm and informed

Outbreak the Balkan governments that they would charge themselves with the introof war. duction of reforms in European Turkey (Oct. 7 th). In anticipation of European intervention the Porte had already revived the obsolete Law of the Vilayets of 1880 (Oct. 4 th). Neither the promises of the Powers nor the Turkish Law seemed a sufficient guarantee to the allied states. On October 13 they addressed identic Notes to Turkey demanding a far-reaching series of reforms. The Porte refused to reply, and on October I 5 th broke off relations with Servia and Bulgaria; an effort was made to detach Greece from the alliance by an offer of the sovereignty of Crete and of long-refused railway communication with Europe. Greece, however, delivered an ultimatum demanding the revocation of an embargo laid on Greek vessels in Turkish ports (Oct. I4th). On the I8th Bulgaria, Greece and Servia declared war. Their action had been anticipated by King Nicholas of Montenegro, who on October gth invaded Albania. 1

(J. D. BOURCHIER.)

\section{Greece $^{2}$}

The population was estimated in I9io as $2,631,952$. In I909-I 2 a marked economic improvement throughout the country, largely due to good harvests, was manifested by extension of trade, increased railway traffic, development of the merchant navy, and the stability of the exchange, the drachma having remained steady at par.

Constitution.-A new Constitution came in force on July I, I II. The most important provisions and changes were: the creation of a Council of State, with the double function of that of a consultative body to assist in drafting bills to be presented to the

1 See Part I: sect. i. for an account of the war, and of the international crisis and peace proposals.

See E. B. xii; 428. 
Chamber and to revise new laws and decrees, and that of a supreme court for annulling decisions and acts contrary to law and dealing generally with administrative abuses. It established the principal of the irremovability of public officials during good behaviour thus striking a blow at political jobbery. It widened the electoral law, and reduced the age qualification of deputies from thirty to twenty-five years. Several modifications in the procedure of the Chamber have been introduced, such as the reduction in the number of deputies necessary to constitute a quorum, and new regulations under which bills can be passed into laws. The Chamber must meet annually for not less than three, nor more than six months. The power of verification of the mandates of deputies was transferred from the Chamber to a special tribunal. Other modifications include the transfer of the cost of primary instruction from the local authorities to the state, and an article permitting the appointment of foreigners to the government services.

Legislation.-Other measures passed during I9II were: judicial reforms tending to facilitate and accelerate legal procedure; the introduction of an income tax; and the imposition of a new tax on arable land. Income is assessed for taxation on the rent of the residence of the taxpayer; incomes below $£ 160$ are exempt, as well as the first $£ 160$ of incomes above that amount, while deduction is made at the rate of $\ell_{1} 5$ for every member of the family above five in number living under the same roof; incomes from $£_{1} 60$ to $£_{4} 000$ are taxed on a sliding scale, and all incomes above $£_{4000}$ are taxed 3 per cent.

The tax on the produce of arable land, to replace the old tax on ploughing animals, met with great opposition. It is imposed on cereals of all kinds, and amounts to 5 per cent of the produce, after deducting a certain amount for each household. It may be paid either in kind or specie. When land is let on the metayer system, as is the common practice, the tax varies from a minimum of 2.4 per cent paid by the tenant farmer to 7 per cent paid by the landlord, or 10 per cent if an absentee landlord. Owners of land producing less than 70 bushels of cereals or $10 \mathrm{cwts}$. of beans, peas, etc. are partially or wholly exempt.

Agriculture.-The government has taken various steps to promote agriculture and to better the conditions of the peasants. Foreign experts have been engaged to organize different branches of agriculture, and efforts have been made to drain marshes, improve watercourses, and build roads. A new law has been passed ro reform municipal administration. Under this law each village forms a distinct unit of local government.

Of the cultivated area about $1,200,000$ acres are under cereals, $1,200,000$ acres fallow lands, 5,000,000 acres meadows and pastures, and 2,025,000 acres under woods and forests.

The area under the chief crops and their yield in I9II were:-

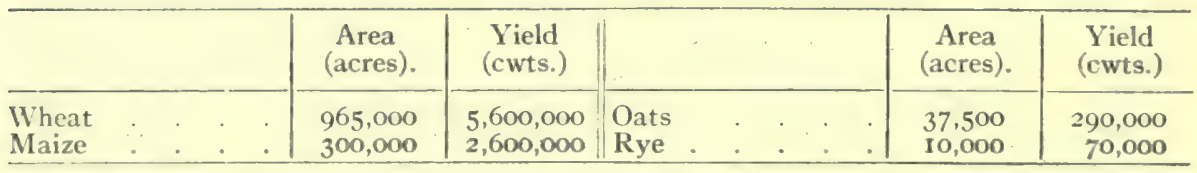

There were about 12,000 acres under cotton, and efforts were being made to encourage cotton plantation and to improve the quality of the product. There were about 40,000 acres under vineyards, and the wine produced in 19 I I amounted to $6,555,000$ gallons. The olive crop of I9I I was one of the best ever produced, amounting to 83.563 tons of olives, and the yield of olive oil was $21,044,000$ gallons. In 1910-I I the currant crop amounted to 144, 196 tons, and that of $1911-12$ to 155,000 tons, of which 113,000 tons were exported.

Minerals.- The mineral output of Greece in 1910 was: iron, $608,3+9$ tons; lead, 185,207 tons; magnesite, 48,913 tons; sulphur, 5I,531 tons; zinc, 37,108 tons; manganese iron, 35,594 tons; iron pyrites, 27,557 tons; emery, 8000 tons; chromite, 7000 tons; lignite, 1500 ions; manganese, 1287 tons; nickel 185 tons; copper, 91 tons; marble, 100,668 cubic feet.

The value of all minerals extracted is estimated at $£ 970,729$. The produce of the blast furnaces was: calcined zinc, 27,567 tons; magnesite, 19,29t tons; and lead, 16,573 tons.

Army. - The task of reorganizing the army was undertaken in $19 \mathrm{I}-12$, with the assistance of a French military mission under General Eydoux. In igi I the peace strength amounted to 1889 officers and 29,36 I men, and the war strength to about i 5,000 men. In I 9 I 2 a new law came into force, under which the war strength was to be raised to about 200,000 men, and it was reckoned that the second reverse and the national guard would add another $50,000 \mathrm{men}$. Military service was fixed to begin at the completion of the nineteenth year, instead of the twenty-first as before, the term of service in the active army being two years. Large sums of money were spent for providing the army with modern armaments, and $f_{1}, 000,000$ was provided in $19 \mathrm{I} 2$ to 
complete the scheme of reorganization. An additional $£ 2,000, \infty 00$ was estimated for during $I 912$ and $I 9 I 3$ as extraordinary expenditure on the army and navy.

Navy. - The reorganization of the navy was also undertaken under a British naval mission headed by Rear-Admiral Lionel G. Tufnell, who was appointed in April Igr I. The only modern vessels prior to October I9I2 were: I armoured cruiser of 10,000 tons displacement, built in I910; 8 fast destroyers, built in 1907; 4 torpedo boats; and I submarine. There were besides three battleships of 4800 tons displacement each, built in $1889-90$. The personnel numbered about 4000 men. A building programme was provided for so as to add to the fleet 2 armoured cruisers, I 2 destroyers, Io torpedo boats, and 2 submarines, at an estimated cost of $£ 5, \infty 00, \infty 00$ to be spread over ten years; in $I 9 I 2, I$ armoured cruiser, I submarine and 9 torpedo boats were under construction. In October I9I 2 Greece added to her navy 4 torpedo boats which had been built in British shipyards for the Argentine government.

Finance.-The estimates of ordinary revenue and expenditure for I911-1912 were:-

\begin{tabular}{|c|c|c|}
\hline & I9II & 1912 \\
\hline $\begin{array}{l}\text { Revenue } \\
\text { Expenditure }\end{array}$ & $\begin{array}{r}f 5,537,871 \\
5,651,532\end{array}$ & $\begin{array}{r}£ 5,745,000 \\
5,698,000\end{array}$ \\
\hline
\end{tabular}

The chief branches of expenditure in I9I I were: Public Debt, $£$ I,342,832; Army, $£_{552,48 I}$; Navy, $f_{340}, 688$; Education, $£ 244,8$ I4; Ministry of the Interior, $£ 547,604$. At the end of I9I I the external debt amounted to $£ 32,493,360$.

Trade. - The trade figures, as shown by a comparison of the totals for the triennial periods 1902-04, 1905-07, and 1908-10, showed a steady progress:-

\begin{tabular}{|c|c|c|c|c|c|c|}
\hline & & & & $1902-04$ & $\quad 1905-07$ & I908-10 \\
\hline $\begin{array}{l}\text { Imports } \\
\text { Exports }\end{array}$ & $\therefore \quad$. & $\therefore \quad$ & $\therefore \quad$. & $\begin{array}{r}£ 16,470,400 \\
10,250,000\end{array}$ & $\begin{array}{r}£_{1} 7,420,000 \\
12,994,000\end{array}$ & $\begin{array}{r}£ \mathrm{I} 8,028,000 \\
\text { I3,998,000 }\end{array}$ \\
\hline Total & $\because$ & $\therefore$ & $\because \quad$. & $f 26,720,400$ & $£ 30 ; 4 \mathrm{r} 4,000$ & $f_{3} 32,026,000$ \\
\hline
\end{tabular}

Of the total trade for 1902-10 Great Britain supplied 30 per cent of the imports and took 16.7 per cent of the exports.

The imports were valued at $£ 6,340,000$ in 1910 , and $£ 6,888,000$ in 1911 ; the exports at $£ 5,502,000$ in 1910 and $£ 5,636,000$ in 1911 .

The value of the trade with the principal countries for 1908 and 1909 is shown as follows:-

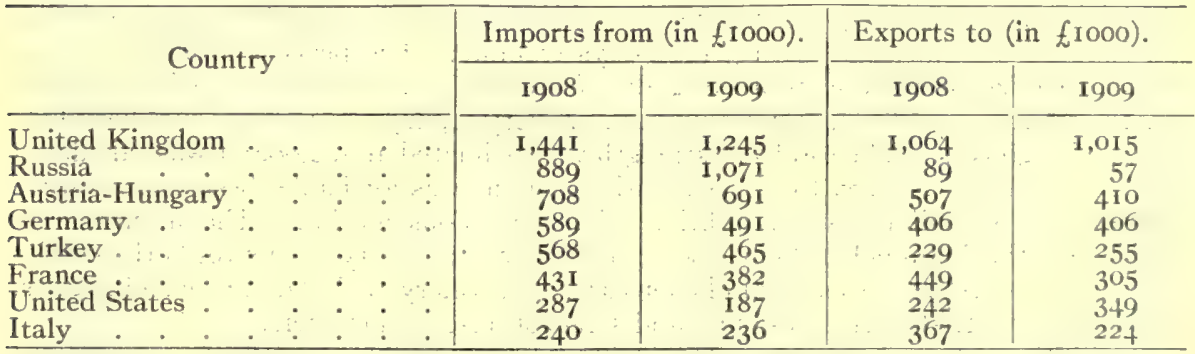

The staple article of export from Greece to the United Kingdom is currants, the value of which amounted to $f_{1}, 716,106$ in 1911 .

The chief articles of import and export in 1910 and 1911 were:-

\begin{tabular}{|c|c|c|c|c|c|c|c|}
\hline Imports (in $f_{\mathrm{I}} \mathrm{IOoo}$ ) & & 1910 & I9I I & Exports (in $£_{1000)}$ & & 1910 & 1911 \\
\hline ts & . & 2,0 & 2,2 & roducts & & 2, & 3,024 \\
\hline 1 & . & 8 & 820 & ores & 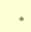 & 1,035 & 965 \\
\hline ls and ores & & 77 & I I & irits & & & 730 \\
\hline$\therefore \quad \cdots$ & $\because$ & 36 & 275 & Oil and olives & & 7 & 3 \\
\hline cals - & . & 294 & 334 & 1 products & & 215 & 220 \\
\hline products & . & 3 & 3 & Fo & & & I63 \\
\hline Animal products & & 239 & 245 & Fishery products & & 57 & 37 \\
\hline
\end{tabular}


Communications.-In I9I I there were 945 miles of railways open for traffic: The merchant navy of Greece has largely increased during the last few years, and in I9I I included 348 steamers of 383,446 tons, and nearly 1000 sailing vessels of about 200,000 tons. In I9I I, 2727 vessels of $3,797,997$ tons entered the port of Piraeus, which has some three-fifths of the total shipping of Greece. Several improvements have been carried out here. Two new dry docks have been built, the quays have been reconstructed to give them a depth of 28 feet, and several jetties have been prolonged and widened. A new quay for the PiraeusLarissa railway was in 1912 under construction. Improvements have also been carried out at several other ports. During 1912 the government proposed to spend about $f 600,000$ for harbour improvements and for building roads.

(O. Brilliant.)

\section{BULGARIA}

According to the census taken on December $3 x$, I9 Io, Bulgaria had a population of $4,329,108$ inhabitants, showing an increase of 293,533 inhabitants over that of 1900. Of these $3,203,8$ Io were Bulgarians, 488, o Io Turks, 98,004 Gipsies, 75,773 Rumanians, 63,487 Greeks, 37,663 Jews and 68,828 of other nationalities. The census population of the principal towns was: Sofia, I02,769; Philippopolis, 47,929; Varna, 41,31 7; Rustchuk, 35,823; Sliven, 25,I4I; Plevna, 23,08I; Shumla, 22,I97; Stara-Zagora, 21,947; Tatar-Pazarjik, I8,o8 I ; Dobritch, I7, I 56; Vidin, I6,473; Yamboli, I 5,954; Vratza, I 5, 1 79; Haskovo, I 5,095; Burgas, I 5,008; Sistova, I3,063; and Trnovo, I 2,625.

Education.-In I909-Io there were 3786 elementary schools with 8697 teachers and 430 ,o I I pupils; and 474 secondary and special schools with 2352 teachers and 67,801 pupils, In I910-I I the University of Sofia was attended by 1673 students.

Finance.-The estimated revenue for I9II was $£ 7,137,000$; and for $1912, £ 7,543,000$. The estimated expenditure for I9I I was $f 7,135,000$; and for $1912 f 7,462,000$. The budget of I9 I however closed with a surplus of nearly $£ 500,000$.

For I9I I the chief branches of expenditure were: Public Debt, $f 1,617,000$; War, $f 1,585,-$ 000 , or about 23 per cent of the whole budget; Public Works, $t$ I, 2 I5,000; Public Instruction $£ 944,000$; and Ministry of the Interior, $£ 418$,000. At the beginning of 1912 the debt consisted of $£ 24,240,000$ consolidated debt and $£ 1,900,000$ floating debt. In the autumn of 1912 a new loan of $£ 7,200,000$ was under consideration.

Army.-Before war broke out in October 1912, the Bulgarian army was already highly thought of in military circles. Service was obligatory for Christians from 20 to 46 years old, with certain exemptions, or from $\mathrm{I} 7$ in war time; the annual recruit contingent being 26,700 , of whom 17,000 went to the infantry. Service with the colours was for two years in the infantry, and three in other arms; in the reserve of the active army, 18 years for infantry and 16 for other arms, with a fortnight's annual training; in the militia - Ist ban, infantry 3 years, other arms 4 , with one to three weeks annual training; 2nd ban, 3 years all arms, with 3 to 7 days training. The peace establishment was 60,000 , organized in 9 divisions of 2 brigades of 2 regiments each, the units being 36 infantry, I c cavalry, 9 artillery, and 3 mountain artillery regiments, 3 fortress artillery battalions of engineers. The total war strength was estimated at 400,000; it was calculated that a first line of 200,000 to 250,000 with 700 guns was available, besides 18 reserve regiments, 36 battalions ist ban militia, 36 half-battalions 2 nd ban. The infantry were armed with the Mannlicher 8-cm. I895 magazine rifle; cavalry with swords (lances for certain regiments) and 1890 Mannlicher carbine; artillery with Maxim machine-guns, shielded Schneider-Canet field-guns, and Creuzot I2-cm. howitzers.

Agriculture.-Agriculture forms the chicf ordinary occupation of fully five-sevenths of the population. Of the total area of $23,797,000$ acres, $7,731,000$ are under crops and grass, $1,576,000$ arable land not cultivated, and 7,602,000 under woods and forests. The area under the chief crops and their yield in 1910 were:-

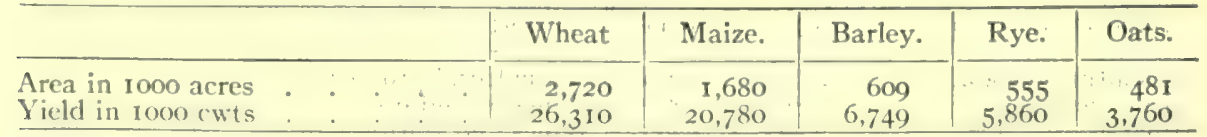

About 200,000 acres are under vineyards, and 18,000 acres under rose gardens, attar of roses being an important manufacture. The value of the cereal crops harvested during 1910 amounted to $\AA_{15,500,000}$. The harvest of 1910 was good and that of 1911 still better.

${ }^{1}$ See $E . B$. iv, 774 . 
In 1905 there were $\mathbf{I}, 695,533$ cattle, 476,872 buffaloes, $8,130,997$ sheep, I,384, II 6 goats, 465,333 pigs, $538,27 \mathrm{I}$ horses, 124,080 asses, and II,947 mules.

Industries. - Native industries, though in an early stage of development, have shown a steady progress both in number and efficiency. Their growth has been fostered by a high protective tariff and by the law for encouragement of native industries which grants them custom exemptions and special railway rebates. In 1909 there were 256 factories in operation, representing a capital of $£ 2,500,000$ and an annual output of nearly $f 3,000,000$. Amongst these were $6 \mathrm{I}$ textile factories whose annual output exceeded $£ 650,000 ; 98$ foodstuffs factories including flour-mills, breweries, and distilleries; 22 tanneries; 16 metal works; 25 chemical works, including those producing attar of roses, soap, and explosives; 18 woodwork factories; and 3 paper mills. Sugar refineries have recently been established.

Trade.-The Imports were valued in 1910 at $£ 7,093,000$, and in I9I $x$ at $£ 7,894,000$; the Exports in 1910 at $£ 5,164,000$, and in 191 I at $£ 7,385,000$.

The following table shows the trade with the principal countries:-

\begin{tabular}{|c|c|c|c|c|}
\hline \multirow{2}{*}{ Country. } & \multicolumn{2}{|c|}{ Imports from (in $£_{1} \mathrm{IO00}$ ) } & \multicolumn{2}{|c|}{ Exports to (in £IOoo) } \\
\hline & I9Io. & I9I-I: & I9I0. & I9II. \\
\hline $\begin{array}{l}\text { United Kingdom and British Pos- } \\
\text { sessions } \\
\text { Austria-Hungary } \\
\text { Germany } \\
\text { France } \\
\text { Turkey } \\
\text { Belgium }\end{array}$ & $\begin{array}{r}907 \\
1,903 \\
1,364 \\
614 \\
841 \\
340 \\
1,123\end{array}$ & $\begin{array}{r}1,999 \\
\mathbf{I}, 885 \\
\mathbf{I}, 590 \\
987 \\
639 \\
202 \\
\mathbf{1}, 392\end{array}$ & $\begin{array}{r}613 \\
313 \\
569 \\
362 \\
1,771 \\
838 \\
698\end{array}$ & $\begin{array}{r}969 \\
423 \\
916 \\
445 \\
1,168 \\
2,151 \\
1,313\end{array}$ \\
\hline
\end{tabular}

In 19 Io the chief articles of import were: cottons, $£ \mathrm{I}, 975,000$; iron, $£ 931,000$; machinery, $£ 791,000$; leather, $£ 367,000$; coal, $f^{1} 32,000$. The chief exports were: wheat, $f, 1,500,000$; maize $£ 539,000$; live stock, $£ 292,000$; attar of roses, $£ 231,000$, and hides and skins $£ 154,000$.

A better idea of the expansion and the possibilities of Bulgarian trade may be obtained perhaps from a comparison of the total triennial figures for 1902-4, 1905-7, and 1908-10:-

\begin{tabular}{|c|c|c|c|}
\hline & $1902-04$ & $\therefore 1905-07$ & $1908-10$ \\
\hline $\begin{array}{l}\text { Imports } \\
\text { Exports }\end{array}$ & $\begin{array}{r}\text { fir }, 309,480 \\
\text { i } 4,776,000\end{array}$ & $\begin{array}{r}f 14,214,530 \\
15,525,150\end{array}$ & $\begin{array}{r}f_{1} 8,765,530 \\
14,114,880\end{array}$ \\
\hline Total & $26,685,480$ & $29,739,680$ & $32,880,4$ IO \\
\hline
\end{tabular}

Of the total imports during I $902-10$, Austria-Hungary supplied rather over $25 \%$, the British Empire $16.6 \%$, Germany $16.7 \%$. Nearly a third of the total was done, however, with Turkey, Servia, Greece and Montenegro. Belgium took the largest share of exports, $22 \%$; the British Empire coming next with rather over $14 \%$.

Railways. - In I9I I Bulgaria had $1270 \mathrm{~m}$. of railways open for traffic, while nearly $200 \mathrm{~m}$. were under construction, the most important being the line from Mezdra to the port of Vidin. Several other lines have been surveyed and orders given for construction. These include lines from Sofia to Karlovo, and thence to Sliven with a branch from Karlovo to Philippopolis; from Nikopolis to Plevna and from Plevna to Gabrovo; from Yamboli to Kizil Agatch, not far from the Turkish frontier; and from Silistria to Kaspitchan.

Harbour Improvements. - Large sums of money have been spent for the improvement of the harbours of Burgas; Varna, Rustchuk and Vidin, and a new harbour was in I9I2 shortly to be constructed at Lom on the Danube. In I 9 ro 6838 vessels of I,990,000 tons entered and 6820 of $1,988,000$ tons cleared at the Black Sea ports, and 10,092 vessels of $1,905,000$ tons entered and 10,078 of $1,903,000$ cleared at the Danube ports. (O. BRILliaNT.)

\section{RUMANIA ${ }^{1}$}

The estimated population in I9II was 7,086,000. There were 299,867 births, 179,072 deaths, and 74,550 marriages. The excess of births over deaths-1 20,795 -was the highest ever recorded. The country is essentially agricultural, and the fine harvests of I909, r910, and r9r I were accompanied by a great development of trade and industry, and by extensive building of public works. Numerous banks and other financial institutions were founded in these years, while all the older institutions increased their capital. An insurance law has been adopted against sickness, accidents, and invalidity, which combines the principles of the German and English laws.

${ }^{1}$ See E. B. xxiii, 827 . 
Elucation.-According to a special census return taken in $1909,60.16$ per cent of the population over 7 years of age could neither read nor write. In 1909-1o there were 5074 elementary schools with 7780 teachers, and 584,935 pupils. The number of children of school age was 938,456 . In $1907-08$ there were 57 secondary schools with 1034 teachers and I 5,7 I pupils, while 9585 pupils attended other technical and special schools. In 1909-10 the university of Bucharest was attended by 3398 students, and that of Jassy by 920.

Finance.-The estimates of $191 \mathrm{I}-12$ balanced at $£ 19,136,000$ revenue and expenditure, and those for I9I2-I3 at $£ 20,225,000$. But the budget of I9II-I2 closed with a realised surplus of over $\ell_{4}, 000,000$. The chief branches of estimated expenditure in 1912-13 were: Army, $£ 2,977,000$; Worship and Public Instruction, $f 1,928,000$; Interior, $£_{3}, 833,000$; Finance,

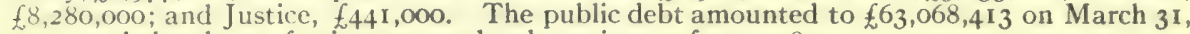
I9I I, and the charge for interest and redemption to $£ 3,544,180$.

A rmy.-By a law passed in 1910 the time of active service was fixed at 2 years in the infantry and 3 years in the other services. The army was organized in 5 complete army corps - a new army corps having been created in the Dobrudja with headquarters at Constanza - and 2 cavalry divisions. In I9 I the peace strength of the army was 4495 officers and staff, $93,6+4$ men, 20,839 horses, and 460 guns. The effective war strength was reckoned at 7600 officers, 280,000 men and 650 guns.

A griculture.-Of the total area of $32,153,600$ acres, $14,909,802$ acres were under cultivation in I9II; I,297,400 acres fallow lands; 2,504,600 acres pastures; I, 213,000 acres meadows; 456,500 acres vineyards and orchards, and 6,935,000 acres under forests.

The figures for area (in I0oo acres) of the chief crops and their yield (in rooo bushels) in I9I I were: Wheat, acres 4825, yield 90,827; Maize, acres 5213, yield I07,288; Barley, acres 1268, yield 25,348; Oats, acres 1003, yield 25,4II; Rye, acres 329, yield 4835; Sugar Beet (1910), acres 32 , yield 303,184 tons; Plums (I9I0), acres 182 , yield $5,838,026$ cwts.; Vineyards, acres 213 , yield $21,868,000$ gallons. The value of all agricultural products in 1910 and I9II amounted to $£ 52,185,000$ and $f 55,766,000$ respectively.

Special efforts have been made during the last few years to develop sericulture, but without much success. In $1911,34,651$ persons were engaged in sericulture, and the production of silk cocoons was 386,800 lbs.

Minerals.-Although the petroleum industry is of recent development, Rumania already ranks fourth among the petroleum-producing countries. In I9Io and I9I I the production amounted to $1,35^{2}, 407$ tons and $1,544,072$ tons, as compared with 250,000 in 1900 . The export from the refineries amounted to 585,862 tons in 1910 , and 679,399 tons in I9I I. The capital invested in petroleum undertakings up to 1910 amounted to $£ 15,000,000$.

In 1912 the government decided to build a pipe-line for the transportation of petroleum from Baicoi in the Prahova district, where the principal wells are now worked, to the seaport of Constanza. Provisions were also made for connecting other districts by branches.

In 19 Io the output of salt was 126,607 tons.

Trade.-The imports were valued at $£ 14,732,000$ in 1909 , and $£ 16,388,000$ in 1910 ; the exports at $£_{18,602,260}$ in 1909 , and $£ 24,660,000$ in 1910 .

The following table shows the trade with the principal countries:

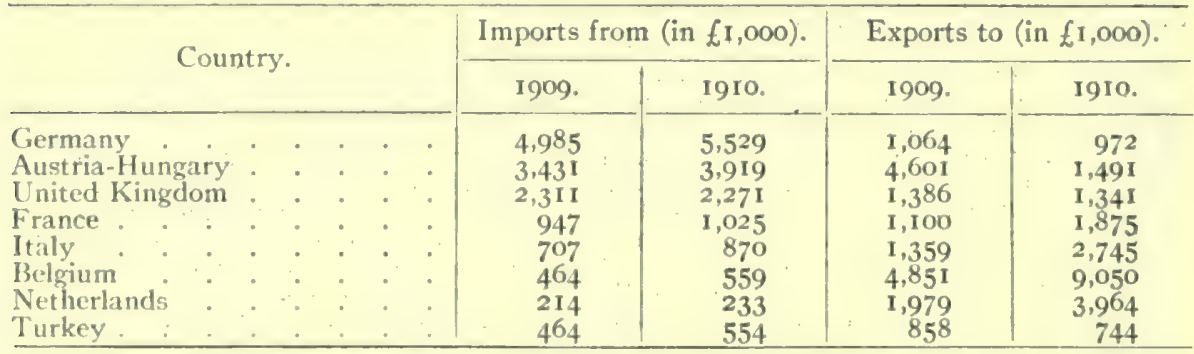

In 1910 the chief articles of import were: cottons, $£_{2}, 648,000$; woollens, $f_{1}, 450,000$;

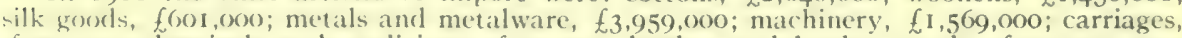
$f_{451,000}$; chemicals and medicines, $f_{33}$ I,000; leather and leather goods, £597,000; garments, millinery and fancy goods, $£$ ( 29,000 ; rubber and rubber goods $£ 302,000$. The chief arlicles of export were: grain (wheat, maize, flour, etc.), fig,590,000; vegetables and seerls, fi,390,(000); timber, $£_{1,098,000}$; petroleum and products, $£ 1,556,000$; cattle, $£ 238,000$; hides and skins, $£$ I19,000; wool, $£ 92,000$.

Communicutions.-In 1912 Rumania had $2230 \mathrm{~m}$. of state-owned railways, and about $200 \mathrm{~m}$. of privately-owned railways.

In I9I the merchant navy consisted of 572 vessels of 167,511 tons, of which 94 vessels of 22,893 tons were steamers.

In I9I0, 36,737 vesisels of $11,028,482$ tons entered, and 36,729 vessels of $11,058,707$ tons clearcel at all the Rumanian ports, and of these 2761 vessels of $3,504,342$ tons entered and 
2750 vessels of $3,514,487$ tons cleared at the seaports. Of 1307 vessels of $2,274,493$ tons which left the Danube (at Sulina) in 1910, 46I vessels of $1,039,493$ tons were British.

Among works lately undertaken to develop the seaport of Constantza are the construction of a slip for ships, opened in 1912; the addition of 8 petroleum reservoirs, and the building of three grain elevators Great works have been started for improving the accommodation of the Danubian ports of Galatz and Braila.

See H. Le Pointe, La Roumanie Moderne (Paris, I910).

(O. BRILliant.)

\section{SERVia}

Acccording to the census taken on December 3I, I9IO, Servia had a population of $2,911,701$, showing an increase of 4I7,93I over that of 1900 . Of the total population $2,528,819$ lived in the country and only 382,882 in towns.

The census population of the chief to rns was: Belgrade, 90;890; Nish, 24,949; Kraguyevats, I8,452; Leskovats, 14,236; Pozharevats, I3,4I I ; Shabats, 12,100; Vranya, II,439; and Pirot, 10,737.

Education.-In 1909 there were 1296 elementary schools with 2584 teachers and 138,434 pupils, and 20 secondary schools with 393 teachers and 7317 pupils. In 1910-II the university of Belgrade was attended by 1025 students:

Finance.-The estimated revenue for I9I.I was $f 4,805,458$, and for I9I $2 f 5,230,588$; Expenditure (I9II) $£ 4,803,262$, (1912) $£ 5,230,588$. The budget of I9I I however closed with a surplus of $£ 400,000$. The chief branches of expenditure in 1912 were: Public Debt, f1,299,248; Army, £I,I8I,I02; Public Works, £73I,692; Public Instruction, £33I,I25; Ministry of the Interior, $£_{1} 196,593$; Ministry of Justice, $£_{12} 1,476$. On January I, I9I 3 , the public debt amounted to $£ 26,362,240$.

Agriculture.-Of the total area of II,930,740 acres, about $4,750,000$ acres are under cultivation, and over $3,800,000$ acres are forests. The following are the figures for the principal crops in I9I I for area (in I000 acres) and yield (in IO0O cwts): Maize, area I492, yield I 3,000 ; Wheat, area 97I, yield 8000; Barley, area 275, yield $3000 ;$ Oats, area 242 , yield I500; Rye, area I16, yield 750; Potatoes, area 30, yield I500; Plums (I910), area 375, yield 6000; Vineyards (1910), area 87, yield 310 (1000 gals.) About 32,000 persons are engaged in sericulture, and the export of silk cocoons was valued at $£ 35,224$ in I9Io. On December 3 I, I9I0 there were 957,918 heads of cattle; $3,808,815$ sheep; 627,427 goats; 863,544 pigs; and 152,617 horses.

Trade. - A comparison of the total triennial figures for 1902-04, I905-07, and 1908-10 shows the progress of Servian trade:-

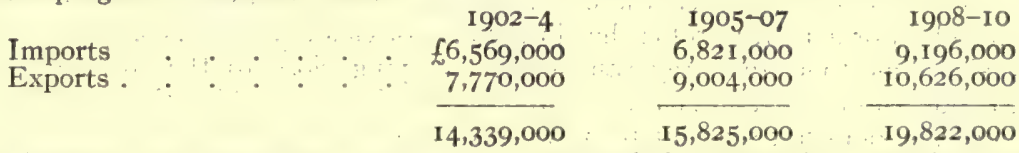

The imports were valued at $\{2,941,403$ in 1909 and $f 3,387,826$ in 1910 ; the exports at $£ 3,719,270$ in $1909, f 3,935,521$ in 1910 , and $f 4,676,640$ in 1911 .

The following table gives the trade with the principal countries:-

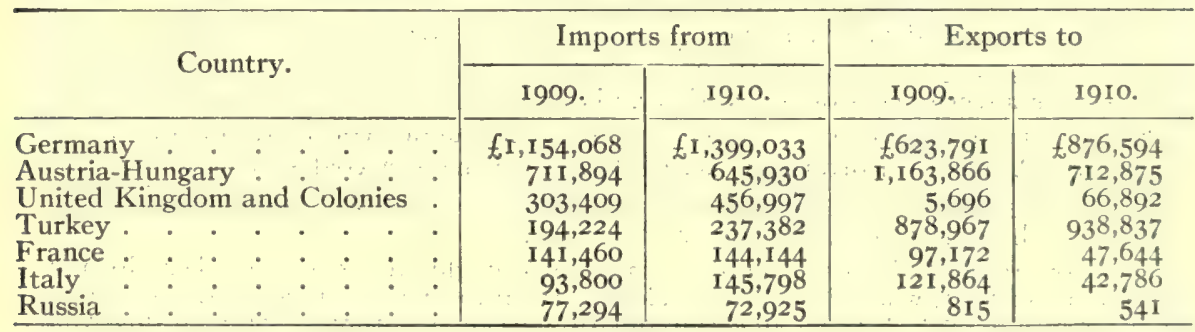

Austria-Hungary during I902-10 provided 40 per cent of the total Servian imports, and took nearly half the exports, but the tariff war which began in 1908 greatly affected the trade with the Dual Monarchy. The exports from Austria-Hungary greatly diminished while those from Germany showed considerable increase. A new commercial treaty with AustriaHungary came into force in 1911 .

Army. - Since 1908 great efforts had been made to increase the efficiency of the army. Under a system of obligatory service, the forces consisted in I9I2 of an active army, organised in three bans, and a militia for home defence. The active army represented a peace footing of 34,000 , but on a war-footing it was expected that 215,000 could take the field. The infantry were armed with the Mauser 1900 rifle (2d ban, Koka Mauser 1880; 3rd ban, Berdan); and the artillery were equipped with the Schneider I908 Q.F. field-gun.

${ }^{1}$ See $E . B$. xxiv, 687 . 
Railways.-Servia has $875 \mathrm{~m}$. of railways open for traffic, of which I55 m. were built in 1911 and $170 \mathrm{~m}$. in 1912 . One of the principal objects in view in the construction of the new lines was to provide the country with a through line from the Danube to the Adriatic. The principal line under construction in 1912 was from Kniazhevats to Nish, expected to be ready in 2 years, while the last part of the Danube-Adriatic railway from Nish through Prokuplye to Merdare, on the Turkish frontier, was under survey. Another line was being constructed in 1912 from Kralyevo to Rashka on the (then) Turkish frontier, intended to open up a rich mineral district.

(O. BRILliant.)

\section{HOLLAND ${ }^{1}$}

Physical Features.-As Holland lies partly below sea-level, the dunes form the country's natural wall of defence against the sea and particular care is taken to keep them in good condition and even to strengthen them. Of late years the increasing use of dune-water, to feed the supply of drinking water, which is obtained by borings and not (as erroneously supposed) from springs at the foot of the dunes, has given rise to the fear that in the end salt, or at least brackish water, would run from the taps. Some experts are of opinion that this is to be found in the dunes below the sweet water. This fear has, however, been proved idle, and according to most Dutch geologists the water obtained from the depth is no other than artesian water. ${ }^{2}$ The violent controversy which has been waged about this question for years has added to our knowledge of the deeper layers of the soil in the western part of the country. But progress in this respect has been far greater still in the eastern provinces, especially owing to the deep borings performed since I 906 by the state officials for the discovery of minerals (Rijksopsporing van Delfstoffen). These borings were made in the south and in the north of Limburg, the east of North Brabant and the east of Gelderland, and in several places depths of $\mathrm{I}, \mathrm{I00}$ metres, at Baarlo (Northern Limburg) in the year I 909 even of $I, 400$ metres, were reached. Among other things they showed that the coalfields in the north and in the south of Limburg are the continuation of that of Westphalia, with which they are connected without interruption; that in the east of North Brabant (de Peel) there is a coalfield extending over a large surface, not too deep to be worked with profit; that in the east of Gelderland large extents of Trias, namely shell-limestone and grey sandstone, are lying close to the surface, whereas rock-salt, potassium salt and coal are found deeper down. of which the potassium salt layer, however, does not seem fit to be worked; that in Holland the temperature only seems to rise slowly at great depth, so that at Winterswijk at a depth of 864 metres it is not more than $38^{\circ} \mathrm{C}$. and in the north of Limburg and the east of North Brabant, at a depth of more than I,, 00 metres, only $34^{\circ} \mathrm{C}$.

The improvement of rivers and canals continues. Work is unceasingly in progress on the Waal, to give it a depth of 3 metres. Negotiations have been in progress between the governments of the Netherlands and of Belgium about making the Maas in South Limburg navigable. A bill has also been under consideration to make the Maas from Venlo to Rotterdam navigable and to make a coal station at Venlo. If this bill is accepted, it would be possible to take the Limburg coal by rail to Venlo and thence by water to Rotterdam and further.

An extraordinarily high temperature and great drought were experienced in Holland in the summer of I9II, when at the Meteorological Institute at De Bilt, near L'trecht, the thermometer rose to $95-7^{\circ} \mathrm{F}$; and an extraordinarily low temperature in the following winter, when on the 3 rd of February the thermometer fell to $-4^{\circ} \mathrm{F}$.

Population.-At the census of December 3I, 1910 the total population was 5,045,I55 (male 2,044,079; female $3,001,0 ; 6$ ), as compared with $5,10,4,137$ in 1900. The figures for provinces were: North Brabant, 63.155; Gelderland, 647,567; South Holland, I,4I8.097; North Holland, I,I22,096; Zeeland, 234.I0I; Utrecht, 292,I3I; Friesland, 362,293; Overyssel, 387,381; Groningen, 331,248; Drente, 176,043; Limburg, 340,053 The population of the principal towns was as follows: Alkmaar, 21,26r; Amersfoort, 23,945; Amsterdam, 573,983; Apeldoorn, 36,507; Arnhem, 64,168; Breda, 27,445; Delft,

1 See E. B. xiii, 587 et seq.

${ }^{2}$ R. D. MI. Verbeek, Drinking-water Supply of A msterdam (The Hague, I9I I). 
34,388; Deventer, 28,005; Dordrecht, 46,862; Emmen, 28,802; Enschede, 34,992; Gouda, 24,704; The Hague, 280,515; Groningen, 75,34I; Haarlem, 69,594; den Helder, 27,358; Hengelo, 20,522; 's Hertogenbosch, 35,214; Hilversum, 31,792; Leeuwarden, 37,014; Leiden, 59,I I4; Maastricht, 37,653; Nijmegen, 56,035; Rotterdam, 426,888; Schiedam, 32,489; Tilburg, 5x,600; Utrecht, 120,208; Vlaardingen, 22,1 24; Vlissingen, 21,575; Zaandam, 24,965; Zwolle, 33,928.

Communications.-Naturally rivers and canals play an important part in traffic; hence large sums are always being spent on construction, improvement and repair; in 1909 the expenditure amounted to 8 million guilders. The most important waterways for transmarine traffic are the New Waterway, from Rotterdam to Hook of Holland, and the North Sea canal, from Amsterdam to Ymuiden. Work is constantly in progress to increase their depths. Whereas in I II I the depth of the New Waterway was 9-9.3 metres at low tide and I0.7-II M. at high tide, the channel of the North Sea canal was widened to 50 M. and its depth brought to I0.5 M. Rotterdam, so favourably situated for the transit trade between England and Germany, appears to be better and better able to compete with its two great rivals Hamburg and Antwerp. The works for the improvement of the canal from Ghent to Terneuzen, which gave a depth of $8.75 \mathrm{M}$. and a breadth of $67 \mathrm{M}$. to this waterway, were completed in 1910 , so that large sea-ships can now reach Ghent. In the province of North Brabant there was begun in I9I0 the important Wilhelmina canal, connecting the South Williams canal north of Helmond with the Maas at Geertruidenberg. The making of new canals in the province of Groningen has also been continued without interruption of late years, as well as the extension and improvement of several harbours, especially that of Rotterdam. Here the new Waal harbour will extend over a surface of 3 Io hectares; but it will also require many millions before it is finished. The new harbour works at Delfzyl have only resulted in making this place a modest rival of the town of Emden situated opposite.

The number of railway lines has also increased. Besides some local lines such as Stadskanaal-Zuidbroek-Delfzijl and Deventer-Raalte-Ommen, the electric line Rotterdam-The Hague-Scheveningen must specially be mentioned, and also the railways through the Haarlemmermeer, which were opened in August 1912, namely (I) Amsterdam-HoofddorpLeiden, (2) Haarlem-Hoofddorp-Nieuwersluis, (3) Amsterdam-Nieuwkoop-Alfen; together they have a length of I Io kilometres. Steam is used here, although the original plan was to use electricity. The line Eindhoven-Weerd is also nearly completed.

Several new tramways were made, and several others, already existing, such as FlushingMiddelburg, Leiden-Katwijk, Leiden-Noordwijk and the town tram-lines of Arnhem, Leiden and Groningen, have begun using electricity as motive power. Electric trains run between Amsterdam-Haarlem-Zandvoort (as well as Haarlem-Zandvoort).

The total length of railways in Holland amounted in 1912 to more than 1950 miles, and that of tramways to more than 1380 miles.

Agriculture.-The amount of arable land increases every year, especially in the east of the country, in consequence of the continued reclamation of high fen grounds, the draining of pools and the cultivation of waste lands. The cultivation of high fen grounds as well as of low fen grounds is, it is true, less extensive than it was formerly when peat was the generally, and almost exclusively, used fuel, but still the yearly production of long lumps of peat (high fen) in Holland amounts to 1800 million pieces, worth $6 \frac{1}{2}$ million guilders, and that of short lumps (low fen) to 700 million pieces, worth $\mathrm{I} \frac{1}{2}$ million guilders. The extent of waste lands is constantly decreasing, for in the years 1909, I9I0 and I9I I respectively 6657,7148 and 9314 hectares were cultivated. The following were the figures (in hectares) for the distribution of the soil, according to the use made of it, in I9I I:-Arable land, 872, I 7 I ; pasture land, I, 213,073 ; garden land, 78,097; wood, 260,923; waste land, 533,807.

In 19II live stock numbered:- Horses, 327,377; oxen, 2,026,943; sheep, 889,036; pigs, $\mathbf{I}, 259,844$.

How important a part agriculture and cattle-breeding play in commerce may be gathered from the fact that from July I9II until April I9I2 there were exported to Germany 525 million kilograms of potatoes, worth over I 3 million guilders, and in I9 I to Belgium 87.5 million kilograms. The production of beetroots amounted to over 2,00o million kilograms, that of beetroot sugar to 255 million kilograms. Of kitchen garden produce there was exported in I9I I to Germany 183.4 million kilograms; the export of bulbs to different countries was 17.3 million kilograms. Of oxen 109,042 head were exported; of beef and veal nearly 15 million kilograms, of which $8_{4}^{1}$ million went to England; 13.5 million kilograms butter to Germany, 5.3 to England and 5 to Belgium; of cheese to those three countries respectively I3, II.8 and I0.I million kilograms; of condensed milk (I9I0) 30.3 million kilograms, 29.4 million being to Erigland. Another important article of export is fish, as in 1910 there were exported 645,427 tons ( 1,000 kilograms) of herring, I6.2 million kilograms fresh sea fish and 7 million kilograms river fish. The whole fleet of sea-fishing craft consists of 5,336 ships, the crews numbering 20,377 men. The most important place for the trade in fresh fish is Ymuiden, where in $19 \mathrm{II}$ nearly $£ 460,000$ worth of fish was brought in.

The total imports were valued at $£ 26 \mathrm{I}, 450,000$, the exports at $£ 204,560,000$, in 1910 . 
The imports from England were valued at $\{24,500,000$, and the exports to England at $£ f^{I}, 600,000$, while for Prussia the figures were about $£ 57,200,000$ and $£ 104,000,000$.

Mining remains restricted to the south of Limburg, but there it extends over a larger surface every year. Stone, used for building, has for years no longer been obtained from the St. Pietersberg near Maastricht but is now found near Valkenberg, Libbe and other places in the Geul valley; 6 coal-mines are being worked, four of which are in private hands and two belong to the state; these six mines, lying in the neighbourhood of Kerkrade and Heerlen, in 1910 produced $I, 292,289$ tons ( $I, 000$ kilograms) of coal, worth 8.2 million guilders, and the number of men working in them was 7,238 , of whom 5,574 were Dutchmen. In 1912 a bill was passed to enlarge the territory of the state mines by buying the so-called Maas-fields. The rich layers of coal which by deep borings have been found in the north of Limburg, the east of North Brabant, and the east of Gelderland, are not being worked yet, neither are the salt-layers near Winterswijk, although the salt is very pure and thick.

So far the working of coal-mines has not had any influence on industrial activity, and the little iron ore that is found in Overyssel and Gelderland has not been smelted in Holland since I885. Yet industrial activity in Holland has become livelier of late years; it manufactures and sends abroad excavating machines, such as dredgers, suction dredgers, elevators, etc. The most important brancn of industry, however, is that of textiles, especially cotton.

Finance. - The budget, in millions of guilders $(12$ guil. $=£ 1)$, has shown the following figures:-

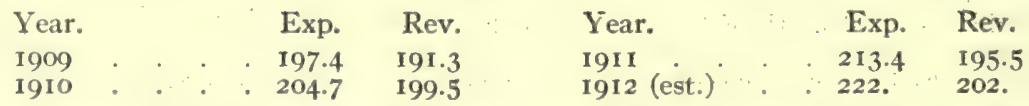

The national debt in I9I2 amounted to $1,105,000,000$ guilders, on which $32,400,000$ guilders interest has to be paid.

Defence.-As to the army, in I9I a new bill (the Militia Bill) was passed, which brought the yearly contingent of the army militia from 17,500 up to 23,000 , that of the navy militia from 600 up to 1000 . In the same year a bill was passed for the raising of officers' pay, after the government in I9lo had had to take back a bill on this subject, which had caused the minister of war to resign. This was specially of importance, because in consequence of this the bill for the improvement of the defence of the coast was also postponed. This bill, which necessitated an expenditure of 46 million guilders and provided amongst other things for the building of a fortress at Flushing, had attracted much notice abroad. In 1912 the government presented a new bill, more restricted and consequently less expensive, for the defence of the coast, in which the fortress at Flushing is kept.

Education.-Mention must be made of the largely increased number of private sectarian schools of late years, since they are largely subsidised by the state. In I912 the Rijkslandbouwschool (state agricultural college) was removed from Wageningen to Groningen and an Indian agricultural school was founded at Deventer. The college for higher education in agriculture, horticulture and forestry remains at Wageningen. The University of Groningen, totally destroyed by fire on the 30 th of August 1906 , was rebult in a more modern style, and the number of laboratories and other scientific institutions, which was already. large before, was further increased. At The Hague there was founded an Academy for the Government of the Dutch Indies (I909), for the higher education of officials there.

Dutch Colonies.- The Dutch colonies in the Malay Archipelago have now a population of 38,000,000, of whom 80,000 are Europeans, 570,000 Chinese, 30,000 Arabs, and 23,000 other immigrant Asiatics. The population of Java alone is $30,100,000,65,000$ being Europeans, 300,000 Chinese, 19,000 Arabs, and 2,800 other immigrant Asiatics. Of late years Dutch authority has been extended over many regions where hitherto it had only existed in name or not at all, such as the interior of Celebes, Flores, Soemba, Soembawa, Timor, Ceram, (fl. The interior of Sumatra has also been subjected entirely and a new residence (Djambi) formed there, while the sultan of Riouw has been dethroned. Of special importance is the increased knowledge gained of Central Celebes and South New Guinea, where the Snow Monntains were reached and snow summits were discovered of more than $16,700 \mathrm{ft}$., such as the Carstenz, Juliana and Wilhelmina summits. This was accomplished in 1909 by an experlition under Mr. H. A. Lorentz, who already in 1907 had pushed his way from the Last-bay, along the North river to the Hellwig mountains, a promontory of the Snow Mounfains. In order to determine the boundary between Dutch and German New Guinea a great combined expedition was at work in 1910 in the basin of the Empress Augusta river. New (ininea was visited not only by Dutch travellers, civil service men and officers, but also) by foreigners, such as the Englishman Pratt, the Swiss Hirschi, and the Dane Mikkelsen. Eispecially remarkable was the discovery in South New Guinea of pygmies, and also of tribes who are still living in the Stone Age, as the use of metals is unknown to them. Another Dutch scientific expedition left Holland in August 1912 for South New Guinea to continue the work begun by the Lorentz expedition. Conducted by Captain A. Franssen Herderschee it will examine the Central Mountains above a height of 2,300 meters $(7,666 \mathrm{ft}$.), the part that was not examined by the preceding expedition. Other important explorations 
were those of Nieuwenkamp in Bali (1906), of Hirschi in Central Borneo (1907), of Moszkowski in Central Sumatra (1907), of Elbert in the Small Sunda Islands (1908), of Wanner in the Moluccas (1909), of Abendanon in Celebes (1909 and 1910), of Kleiweg de Zwaan in the isle of Nias (1910), of Molengraaff in Timor (1910), of Heim and of Rouffaer (1910) in the Small Sunda Islands, of Deninger, Tauern and Strefemann (1910 and 1912) in the Moluccas, especially in the isle of Buru.

The Dutch West Indies consist of the two governments of Surinam and of Curaçao. In I9I I the population of these two together amounted to I47.564, not counting the Indians and the negroes of Surinam, together perhaps some 10,000. The detailed figures were: Surinam, 92,142; Curaçao, 32,585; Aruba, 9,357; Bonaire, 6,383; St. Martin (Dutch), 3,385; St. Eustatius, I,325; Saba, $2,387$.

Of late years our knowledge of Surinam has been greatly increased by a series of scientific expeditions, organised by the Dutch Geographical Society, which have traced all the larger rivers to their sources and drawn maps of them. The government has published a large new map of Curaçao, while those of Aruba and Bonaire will follow soon. There has also appeared a map of Curaçao's capital Willemstad; and a beginning has been made to improve its. harbour, in connection with the approaching completion of the Panama Canal.

Political History.-The cabinet formed in 1905 by Theodoor Herman de Meester (b. I85I) had to resign in 1907 on account of the rejection of the war budget by the Second Chamber. In its place came a cabinet of moderate anti-revolutionaries and Roman Catholics under the leadership of Theodorus Heemskerk (b. 1852). The task assigned to this cabinet was to settle the quarrel with Venezuela, which had opposed the economic development of the colony of Curaçao as much as possible, and finally forbade the Dutch consul-general the country. When lengthy negotiations with Pres. Castro of Venezuela remained fruitless, the Dutch government sent some menof-war to the West Indies. In the beginning of November I 908 a naval demonstration was made and two Venezuelan ships were taken by Dutch war-vessels. The stagnation of trade and the internal difficulties in the republic, which caused the fall of Castro, led in December to the reopening of negotiations with Pres. Gomez. He sent the minister of foreign affairs, Paul, to Europe to carry on the negotiations, and revoked the measures directed against Curaçao. Up to the end of I9I 2, however, the differences between Venezuela and Holland had not been settled.

The elections of June 1907 assured a majority of 60 to the Heemskerk cabinet. Meanwhile it appeared that the opinion of this majority about different political questions was not so undivided that they could set to work energetically on social reform. There was a change in the cabinet, when towards the end of r 909 the minister for the colonies, A. W. F. Idenburg (b. I86I), was made governor general of the Dutch East Indies. He was succeeded by the anti-revolutionary Jan Hendrik de Waal Malefijt (b. I852). In June I9o9 the accusation brought against the ex-premier Dr. Abraham Kuyper (b. 1837 ), that during his ministership he had conferred orders of knighthood in a way that was not quite correct, caused a great stir in the country, and a council of honour was appointed, which acquitted Dr. Kuyper. A bill which caused great difficulties was that for the regulation of the bakers' trade and the prohibition of night labour in it. Discussion was repeatedly postponed, and when at last it was taken up, the measure was rejected in June I9 2, a new bill being subsequently undertaken. Another bill, for the regulation of the defence of the coast, presented in I9I0, met with still greater opposition, not only from military experts but from the public. It would require an expenditure of 46 million guilders, and many people doubted both its necessity and its practical efficiency. The bill attracted considerable attention in France, England and Belgium. In particular, the proposed fortress at Flushing, in regard to which pressure was believed to have been applied from Germany (a supposition strengthened by not very clear communications from the former ambassador in Sweden, van Heekeren, concerning intimations from the German Emperor as to Holland's means of defence), was persistently opposed. Meanwhile the naval minister of the De Meester cabinet, W. J. Cohen Stuart (b. I857), had introduced a naval defence bill, which entailed an expenditure of 80 million guilders. Before it came into the chambers the war minister, Wouter Cool (b. I848), had to resign, on another bill for the raising of officers' pay, in which a regulation of pensions was not 
included. His successor was the Dutch-Indian, Major H. Colijn (b. I869), who had only been a member of the Second Chamber for a short time. A revised labour bill of considerable importance was passed in I9I I; it protects the labour of young persons from I 3 to $I 7$ years old and of women. 'There was also passed a stone-cutters' bill, for the protection of men working in that trade.

Political interest during the first half of IgI centred in the reform of the suffrage. The Social-democratic Labour party, together with the Liberal-democratic league, organised a petition for extending the franchise, which was signed by 317,522 persons, II $5, \infty 00$ of whom were women. On September I9, the day of the opening of the States-General, a procession of 20,000 men and women took it to the minister for home affairs. During this year the militia bill already mentioned was also introduced into the chambers, and after prolonged discussion it was passed, as was also the - bill for raising officers' pay. In 1912 a bird bill was passed which made it possible for Holland to join the convention of Paris, and also a bill (Bouwwet) which allowed important subsidies for the building of private sectarian schools. On May 7 the naval minister, Jan Wentholt (b. $185 \mathrm{I}$ ), left the cabinet, his bill for the building of an ironclad of 7,000 tons for the defence of the Dutch Indies having been rejected; and the naval department and the war department were temporarily combined in one office. A new copyright bill was passed in I9ז2, as a consequence of Holland's joining the convention of Bern.

Obituary.-During rgri two eminent Dutchmen died, JOSEPH ISRAELS (b. I824; d. Aug. 12), the painter (see E. B. xiv, 885), and J. H. VAN'T Hoff (b. 1852; d. March I), the physicist (see E. B. xxvii, 896). The deaths may also be mentioned, during $191 \mathrm{I}$, of Pieter Cornelius Tobias Snellen, the entomologist (b. I834; d. March 29); J. C. De Marez Oijens, Minister of Waterways and Railways (b. 1845; d. Aug. 3); and JonkheER P. J. Sivinderen, jurist and vice-president of the Council of State.

Bibliography.-J. van Baren, Staringh's bodem van Nederland (2nd ed., Amsterdam, I908 ff.); A. A. Beekman, Het Dijk-en Waierschapsrecht in Nederland voor 1795 (2 volumes, The Hague, 1907); Stubmann, Holland und sein Hinterland (Jena, I90I); K. Menne, Die Entwicklung der Niederländer zur Nation (Halle A. S., I902); Oudemans, Onze Flora (Zutphen, I900); H. C. Diferee, De Geschiedenis van den Nederlandschen Handel (3 parts, Amsterdam, 19071908), and Studien bver de geschiedenis van den Nederlandschen Handel (Amsterdam, 1908); P. J. Blok, Geschiedenis van het Nederlandsche Volk 8 volumes, Groningen, 1892-1908, 2nd edition since I9I2); H. Smissaert, Nederland in den aanvang der twintigste eeuw (Leyden, I9I I), Jaarverslag der Rijksopsporing van Delfstoffen (6 volumes, Amsterdam, 1906-1912), Tijdschrift van het Kon. Ned. Aardrijkskundig Genootschap, Verhandelingen van het Geologisch Mijnbouwkundig genootschap voor Nederland en Kolonien, statistics about agriculture, cattle-breeding, horticulture, fishery, trade, etc., published by government; H. Blink, Nederlandsch Oost en West-Indië (2 volumes, Leiden, 1905-1907), D. van Hinloopen Labberton, Geillusireerd Handboek van Insulinde (Amsterdam, I9IO); H. Colijn, Nederlands Indië (2 volumes, Amsterdam, 1911-1912).

(H. ZONDERVAN.)

\section{ITALY 1}

Population.-According to the provisional results of the census of June Io, I9I I, the total resident or "legal " population of Italy was $35,959,077$, and the actual population $34,686,683$. The increase in the actual population since I9or was therefore 2,2 II,430, or 6.6 per cent. The compartments showing the highest rate of increase are Liguria (I0.7 per cent), Lombardy (I 1.4) and Venetia (I 2.I), the provinces showing the highest rate being Milan (I9.2), Treviso (I8.6), and Naples (I7.I). The only compartments showing a decrease are Abruzzi and Molise (0.9) and Basilicata (3.5), but three provinces in Campania show a slight loss, owing to emigration, while Messina (which suffered from the earthquake of December I908) has a decrease of 5.I per cent.

The actual communal populations of towns over 100,000 , with the increase or decrease per cent since I90I, were as follows: Naples, 723,208 $(+27.4)$; Milan, 599,200 $(+20.8)$; Rume, 5.38,63. (+15.9); Turin, 427.733 (+26.5); Palermo, 341.656 (+10.0); Genoa, $272,077$ ( +15.4$)$; Florence, 232,860 (+9.0); Catania $211,699(+40.4)$; Bologna, 172,639 (+I3.I); Venice, 160,727 (+5.7); Messina, 126,172 (-15.3); Leghorn, 105.322 (+6.9); Bari, $103.522(+32.5)$. Foggia, 76.534 , shows an increase of 42.6 per cent. The rate of increase in the towns is thus considerably higher than in the country as a whole.

1 See E. B. xv, I et seq. 
The marriage rate has risen slightly of late years, having been about 7.7 per 1000 since 1905, with a sharp rise to 8.3 in 1908 . The birth rate has varied from 31.4 to 33.4 during the period, averaging about 32.4 ; the illegitimate births were 4.9 per cent for the whole kingdom in 1909. The death rate has varied from 21.9 to 19.6 (I9I0) with the exception of 1908, when the earthquake in Calabria added 77,283 deaths to the total and brought the rate up to 22.6. The total number of emigrants in 1910 was 651,475 (including 242,381 to other parts of Europe, I0,209 to Canada, 262,554 to U.S.A., I9,33I to Brazil, I04,718 to Argentina). The total number of Italians living outside Italy is calculated to be $5,562,730$.

Public Health has improved materially of late years. The deaths from malaria and pellagra have decreased respectively from 4,871 and 2,024 in I 906 to 3,533 and 1,420 in 1909 . On the other hand, tuberculous illnesses show a slight increase $(56,3$ Io to 57,382$)$. In I9 Io and I9I I there were outbreaks of cholera, the majority of cases occurring at the seaport towns and in the south. The latter was the more severe, and there were 15,603 cases, resulting in 5,960 deaths. There was no recurrence in 1912 . The precautionary measures in some of the more remote villages caused rioting among the ignorant classes.

The physical condition of the nation seems to have improved considerably in the last few years, and the generations now growing into manhood show an encouraging progress from the conditions emphasized by Nathan in 1906. The physique and morale of the troops sent to Tripoli were excellent, and the change from ten or twelve years ago is quite marked. This is no doubt mainly due to the years of prosperity which Italy has been enjoying. Sport and games (especially lawn tennis) are spreading to some extent, bicycling is largely indulged in (though little by women in Rome and the south), and football and rowing are becoming popular, while winter sports are beginning to find favour, and are even carried on in the Abruzzi. 'There are, too, a few golf courses (Rome, Florence, Palermo, Varese, etc.)

Agriculture. - The production of grain and maize, allowing for the temporary decreases caused by bad harvests shows little variation (in 1912 the south of Italy and the islands suffered from drought, but the total decline on the average of the last three years was only 350,000 tons); but the wine and oil crops oscillate much more violently. The vintage of 1909 reached nearly 62 million hectolitres, while that of I9Io fell to under 30 million, and that of I9I I was about 42 million. The area under the vine has increased to over I I million acres $(4,477,200$ hectares). The production of olive oil was only 632,000 hectolitres in 1908 , $2,559,200$ in $1909,1,384,580$ in 1910 , and about $1,930,000$ in 1911 .

The estimated production of agrumi (oranges, lemons, etc.) for I9I I was about 635,000 tons, and of chestnuts a little more, the former figure being considerably below the average of the previous two years. A compulsory association among the exporters of citrate of lime from Sicily was founded in 1908 to regulate prices, but its working has not altogether given satisfaction. The production of silk cocoons has also diminished considerably, being 43,300 tons for 1910 and 38,600 for I9I I, according to government figures; those of the Silk Association are somewhat higher. The I9I 2 crop was 15 per cent above that of I9II, but 8 per cent below the average of the preceding five years. The hemp and flax crops were both low in $1911(67,350$ and 2,757 tons). The production of sugar-beet was 1,440,000 tons.

The total value of the whole agricultural production of Italy in 19I0, including forests, was estimated at nearly 28 million sterling. In the district of the Emilia cooperative production is much in vogue:

An International Institute of Agriculture, founded on the initiative of the King of Italy on the suggestion of Mr. David Lubin, was inaugurated in Rome in May 1908, for the collection and publication of statistics and information. Forty-two countries are represented, and the staff is international.

Reafforestation. - The indiscriminate devastation of her forests in the 19 th century has done great harm to Italy, and a vigorous campaign in favour of reafforestation is being made by the "Touring Club Italiano." It is pointed out that, apart from the actual loss of rainfall and of woodland, there is the difficulty of regulating the torrents which descend from the bare hills, and bring with them stones and soil, to the ruin of the fertile land beneath. The hills themselves too become denuded and even disintegrated, and whole villages may be destroyed. There is also the loss of water supply. Harm has sometimes been done by the attempt to introduce cultivation upon steep slopes, where trees were necessary to hold the soil together. See Il Bosco, il Pascolo, il Monte (Milan, I9I I), Il Bosco Conto il Torrente (Milan 1912). Many of the largest subscribers to the propaganda are the electric power companies, who fully understand the importance of well regulated water supplies. In 19 IO about 6,000 acres were reafforested, about half of the area being in Basilicata.

Mining.-The number of mines decreased from 1580 in 1902 to 1044 in 1910 , with an output valued at $£ 3,210$,000. The tonnage of iron has increased very largely, having been 551,000 in I910; but the output of copper has decreased (to 68,000 tons). Zinc increased, but lead diminished: this industry, however, is now in a flourishing condition in Sardinia. The output of antimony has decreased considerably, but that of mercury is nearly doubled (from 44,000 to 87,000 tons). Among the minerals of which the output has recently grown are iron pyrites ( 165,000 tons in 1910$)$, anthracite and lignite $(562,000)$, salt $(500,000)$, asphaltic and bituminous rock $(162,000)$, and graphite $(12,500)$. Sulphur ore has decreased from $3,580,000$ in 1902 to $2,815,000$ tons in 1910 . A compulsory coalition of all the sulphur 
interests in Sicily was marle by the law of August I, I906. The output of stone from quarries, the number of which has been on the increase, had in 1910 a value of over $f 2,000,000$.

Fisheries. - The number of boats has again risen - from 23,908 in 1902 to 26,676 in 1909 , manned by 1 II,272 persons, the value of the catch being nearly $£ 900,000$, according to figures which are believed to be below the truth. The great rise in the price of fish, as of food of all kinds, is noticeable. The sponge fishery, in the water of Lampedusa, produced 31 tons of sponges, and the coral fishery only 50 tons ( 135 tons in 1908 , but the figure varies greatly), and only 515 men were employed. The tunny fisheries have also had varying fortune $(3,800$ in 1908 and 5,700 tons in 1909$)$.

Manufuctures.-Industrial progress has been strongly marked, despite the fact that certain manufactures are still so highly taxed as to render their development difficult, jammaking and the distilling of spirit from surplus wine being cases in point. Considerable progress is visible in almost all the metallurgical industries. The production of pig iron increased from I 35,000 tons in 1906 to 353,000 in 1910 , wrought iron from 237,000 to 3 I I, 000 , steel from 333,000 to 670,000 . Importation of ores and metals continues to increase also (with fluctuations owing to strikes, etc.) owing to the large increase in consumption in Italy. (See Report on Trade of the Consular District of Milan for IOII; No. 4988).

The total quantity of electrical machinery required in 1910 was about 16,000 tons, of which Italy produced more than half. There is a rapid extension of the application of water power to lighting. The production of raw silk shows a considerable decrease (from 6,047 tons in 1906 to 4,891 tons in 1910); and the cotton industry suffered greatly from the war with Turkey, which in 1910 had taken over I0,000 tons of textiles from Italy; though other causes also contributed to the crisis. The value of the chemical output has risen enormously, from $f 4,093,000$ in 1906 to $f 6,001,000$ in 1910 . The production of beet sugar has risen to 173,184 tons, together with 62,700 tons of syrups and molasses. The output of alcohol is slightly above that of 1906 , but is much. below the average. Brewing has increased greatly, from 359,921 hectolitres in $1906-7$ to 598,315 in $1910-11$.

Labour Conditions, etc. - The condition of the working classes has greatly improved. Wages have risen, though owing to the general rise of food prices and rents also there is some difficulty in making them go as far as before, especially as there has been no reduction of taxation on the prime necessaries of life. The number of strikes varied irregularly between 1904 and 1910 , from 628 , involving 110,832 workmen, in 1905 , to 1891 , involving 327,113 workmen in 1907; while in 1910 there were 1021 , involving 172,969 workmen. These figures are far above those for $187 \mathrm{I}-1900$.

There has been a great and continuous rise in the deposits in the various savings banks, credit banks, etc., showing a continuance of hard work and thrift. In IgoI the total of the deposits showed an average of $\left\{3.4 \mathrm{~s}\right.$.od. per head; at the end of 1910 it was over $214 \frac{1}{2}$ millions sterling, an average of nearly $\$ 6.3 \mathrm{~s} .0 d$. per head. In September I9I I the amount in the post office savings banks had risen to nearly 74 millions (and it has risen another $I_{3}^{2}$ millions in the succeeding 12 months): while at the end of June I9I the amount in the ordinary savings banks was over 98 millions, representing a rise of two millions since December 3I, 19I0. At the end of I9Io there were 5,064 co-operative societies, and of these statistics are available for 4,222: these had 817,529 members and a capital of nearly $4 \frac{1}{4}$ millions. The Cassa depositi e Prestiti, which was founded as early as 1863 , has had its functions considerably enlarged by various laws between I896 and I9II. It is a central State chest for voluntary deposits or those ordered by law, which are invested in State bonds or guaranteed bonds or in loans to provinces and communes. Its principal receipts are from the post office savings banks, but it also manages the revenues of certain benevolent and provident institutions, such as the national sickness and old age pension fund, etc. The total funds with which it had to deal in 1910 amounted to nearly $9 \frac{1}{3}$ millions sterling, of which nearly 6 millions came from the Post Office savings banks.

Insurance.-The law of April 4, 1912, constituted a State monopoly of life insurance, and a national institution for carrying it on, which is obliged to invest its capital in State bonds or bonds guaranteed by the Statc. It will place a large amount of capital at the immediate service of the State, which will prevent the necessity of immediate taxation to meet increased expenditure. In 1910, 358,325 workmen were subscribers to the national pension fund (Cassa Nazionale di Previdenza), the number having risen very rapidly since the foundation of the fund, which is an entity independent of the State, though under the supervision of the Ministry of Agriculture, Industry and Commerce.

Commerce. - in 1910 (excluding precious metals and goods in transit) the imports amounted to $f_{1} 29,839,039$, and the exports $f_{83}, 199,095$, showing an increase respectively of alout 4 per cent and II.4 per cent over the preceding year. (See Report on Foreign Trude of Ituly for Ioro: Annual Series No, 4836). The increase in the value of imports is due mainly to the higher price of raw cotton (imported mainly from the United States and British India), and to a larger importation of cereals (from Russia and Rumania), and of indiarubler (from Brazil). As regards exports, an increase of about $f, 3,000,000$ under the head of spirits, wines and oils and of over $f \mathbf{I}, 400,000$ in cotton goods, has taken place, but this was largely due to forced sales of accumulated stocks at a loss, owing to the higher price of the raw material. With the exception of the silk trade, which has a decrease of $f_{1}, 300$, 
ooo in exports, there was a rapid recovery from the world-wide depression of I908, and most trades participated in the general increase. Motor cars, however, showed a slight decrease, owing to the growth of competition in Germany, Belgium and Switzerland. Great Britain purchased no less than 813 out of 2,130 cars exported. On the other hand there has been a large increase both in the importation and the exportation of indiarubber tires.

Imports of live cattle in 1910 reached a very high figure (about 170,000 head), while the exportation dropped to 5,000 head, half the amount of the previous year, owing to the prevalence of foot and mouth disease: but there was an even greater fall in value (over $£ 800,000)$ in the importation of salt and preserved fish, and in preserved meat, cheese, fats, etc. The importation of frozen meat has not hitherto been as successful as expected.

From January Ist to September 30 , I912, the imports were valued at $£ 103,535,000$ and the exports at $f 67,607,000$ being increases of $£ 2,385,000$ and $£ 4,685,000$ respectively over the corresponding period of I9II. It was calculated that between I 898 and I9IO Italian imports had risen I 43 per cent, and her exports I 24 per cent-increases which surpass those of all other countries, except the exportation figures of the United States.

As regards trade with the United Kingdom, which is second to Germany on the list of imports, imports fell by about $\{573,000$, to just over I9 millions, the decrease in coal alone amounting to nearly $f 800,000$ owing to the fall in price, and increased importation from Germany. During the war with Turkey, however, II million tons, valued at about $£$ I2,000,000 , were imported in the year I9II-I2. Power to the amount of nearly $2,000,000$ h.p. is now derived from hydro-electric plant, and Italian electrical engineers have undertaken a number of bold schemes of long distance transmission. Machinery therefore showed a heavy decline $\left(f_{0} I, 286,654\right.$ as against $f_{\mathrm{I}} \mathrm{I}, 85 \mathrm{I}, 690$ in 1909 as in the case of all other countries exporting it to Italy), but scientific instruments, copper, brass and bronze wares and tools, all showed large increases. Exports to the United Kingdom, which is now fifth among Italy's customers, have increased rapidly ( $f 8,416,000$ in I9Io). The increase is mainly in silk tissues, eggs, fruit and preserves, raw hemp, and olive oil.

Shipping. - In 1910 the number of ships that entered and cleared Italian ports was 3I2,689 , with a tonnage of $102,390,908$. The Italian mercantile marine included at the end of I909, 680 steamers, with a tonnage of about 630,000 , and 4,723 sailing ships, with a tonnage of about 440,000 . Of the steamers 49 were over 3,000 tons (more than double the figure for 1906). The Navigazione Generale Italiana now undertakes only Transatlantic services, the subsidized services in the Mediterranean having been taken up by the new Societa Nazionale da Servizi Marittimi.

Ports. - The trade of Genoa amounted to just over 6 million tons of imports (including over 3 million tons of coal), and just under a million tons of exports in I9IO; while the total of shipping entered was 5,970 , with a tonnage of $7,475,583$, of which 139 were in ballast, and of that cleared 5,979, with a tonnage of $7,485,717$, of which no less than 2,257 (mostly colliers) were in ballast: I70,000 passengers were landed, and nearly 190,000 embarked. Of the total shipping 37 per cent were foreign ships. From the figures available there has been a slight decrease in 1911 . The increase is therefore not rapid, as in some other ports, owing to the difficulty of expansion and of providing increased railway facilities, though during the eight years $1903-191$ I $£$ I,600,000 have been spent in railway improvements by the Harbour Board. The new Vittorio Emanuele dock should be ready by igr5. A new trade has been established between the River Plate and Italy in live cattle and frozen meat. The harbour works and railway communications of Messina were not seriously damaged by the earthquake of December 28, 1908. The population was 167,824 on December 31, 1907, and was estimated at 60,000 in 1909 ; by the census of 191 I it had already recovered to $126,-$ 172. Messina, owing to precautionary measures, was not affected by the cholera outbreaks of 1910 and I9Ir. Extensive villages of temporary structures of timber, corrugated iron, and concrete have sprung up. The port of Messina has naturally not yet recovered from the effects of the earthquake, but there has been a steady increase in trade ever since. Owing to the increase in the Transatlantic passenger service, Naples in 1910 obtained the first place among Italian ports for the number and tonnage of ships entered $(7,344$ of $7,542,076$ tons-a rise of nearly 3 million tons since 1906$)$, and cleared ( 7,330 of $7,513,596$ tons). During the war with Turkey, Naples became the principal shipping port for Tripoli. Considerable further expenditure on the harbour has been authorized, and new cranes, etc., are being added. In I9 Io Palermo was third among Italian ports as a passenger harbour. The Palermo ship-building yard is of considerable importance. New ironworks have also been erected. In I9I0 Venice stood third among Italian ports for mercantile trade and fourth in passenger traffic. New cotton docks have been erected here, and a patent fuel and other factories. Taranto is mainly a naval harbour, but in 1909 was adopted as a port of call by the Orient Line for the outward Australian mail.

Finance.-The war with Turkey interfered very little with the national life and prosperity. Foreign capital was not deterred by it, for in the first six months of 1912, which was a period of war, just over $£ 5,000,000$ of new capital were paid up, while in the corresponding period of I9II, which was a period of peace, only a little over $f 3,000,000$ were paid up. A good impression was no doubt produced by the fact that it was not necessary to have recourse to a loan to meet the expenses of the war. The actual amounts placed at the 
disposal of the Ministries of War and Marine respectively by the Minister of Finance during the campaign were $£ 15,440,000$ and $£ 2,880,000$, but about $£ 4,000,000$ of this expenditure was devoted to the replenishment and accumulation of stores and for repairs in dockyards: so that the cost was just under $1,000,000$ lire $(£ 40,000)$ per diem. On the other hand, there remain to be paid (a) the annual contribution of at least $£ 80,000$ representing the loss to the Ottoman treasury of the revenue from Tripoli (by Article X of the treaty of Lausanne Turkey may ask for this to be capitalized at $4 \%$, thus converting it into a single payment of $f, 2,000,000)$, (b) the cost of disbandment and repatriation of the greater part of the troops in Libya. The cost of the war was met by the creation of five year $4 \%$ Exchequer bonds for over $f_{1} 6,800,000$, whereas the floating debt outstanding on June 30 , I9II, was about $£ 4,320,000$. During the war Itatian consols, paying only $3 \frac{1}{2}$ per cent (since January 1 , 1912) fell from 104 to 94 (on October 3I, 19I2, they had recovered to 98 on the Rome bourse, though only quoted at 94-96 in London), and the exchange on London has hardly been higher than 25.60 lire.

During the year from October I, I9II, to September 30, 1912 (which almost exactly covers the duration of the war) the total receipts of the Italian exchequer amounted to fi25,640,000, and the expenditure to $f_{117}, 040,000$, showing increases respectively of $£ 8,280,000$ and $f 4,280,000$ over the preceding 12 months. ${ }^{1}$ The improvement in the yield of taxation was greater than the average advance during the preceding five years. The principal direct and indirect taxes (exclusive of the import duty on grain) and the Post Office revenue yielded $£ 79,800,000$ (as against $£ 78,640,000$ for I9I I ): the gross receipts of the railways, in the year ending June 30 , I9II, were $£_{19,920,000}$ ( $f_{1} 16,240,000$ in $\left.1906-7\right)$, while the improvement between October I, I9II, and September IO, I9I2, as against the corresponding II $\frac{1}{3}$ months of $1910-I I$, amounted to $f_{1}, 480,000$. Of this increase $£ 320,000$ were due to the additional charges for the benefit of the sufferers by the Sicilian earthquake of December I908, so that the net advance was still $£ 240,000$ in excess of the average growth between the years $1906-7$ and I910-II.

The service of debt still represents a large proportion of Italian expenditure, in spite of the reduction of the interest to $3 \frac{1}{2}$ per cent on Consols. In I9Io the total amount of debt was $f_{523}, \mathrm{II} 6,074$ (exclusive of State bonds held by or to be repaid to the State), and the amount paid in interest $£ 20,169,87 \mathrm{I}$, of which only about 12 per cent was paid abroad, the rest being held by home investors.

The cost of the earthquake of December 28, 1908, to the State was covered in four years by the surplus in the budgets and by additional taxes of 2 per cent on business, of $5 \mathrm{C}$ or $10 c$ on railway tickets, etc. Beyond this, however, there were of course large subscriptions raised. These were in the main paid in to an autonomous Central Committee, which has never published detailed accounts. Besides this, various Italian organisations and foreign countries raised funds which they administered independently, though in consultation with the Italian authorities: thus the last half of the British Mansion House Fund (which amounted to about $£ \mathrm{I}+0,000$ in all) was administered by the British Embassy.

Railways, etc. - On November I, I912, a new arrangement of the administration of the State Railways came into existence; the branches into which it is divided are: traffic, locomotives, rolling stock, works department (combining the functions of the engineer and superintendent of the line), health department, solicitors' department, accountants' department. No new lines of any importance have beeen opened since 1908, except a line from Bassano to the Austrian frontier, providing a new route to Trent; but a certain amount of doubling of existing lines has been done, and the construction of complementary lines in Sicily has been begun. The capital value of the railways on June 30, I9I I, was estimated approximately to be $£ 259,500,000$, and the profits were calculated at nearly six millions, or 2.31 per cent on the capital; but this included (a) the actual profit paid over to the treasury - about $\{1,520,000$, (b) the taxes on tickets, on the wages of the personnel, etc., (c) the interest and extinction of some paid by the treasury to the companies which worked the railways until 1906 -about $£ 2,300,000$.

The State Railways have considerably improved in every way. A direct electric line from Rome to Naples (about $120 \mathrm{~m}$.) is in course of construction. Electric power has been extended to the line between Genoa and Busalla, and will be applied to the line from Savona to S. Ciuseppe di Cario, in the line to Turin. Besides the ferry boats crossing the Straits of Messina, the State Railway's now work fast ships from Naples to Palermo and Civitavecchia to Golfo Aranci in Sardinia.

The length of steam and electric tramways (including city tramways) has increased fairly rapidly; at the end of 1911 it was $3,018 \mathrm{~m}$. Motor omnibus services on the highroads carrying mails and passengers are increasing very rapidly in numbers, covering nearly $2,000 \mathrm{~m}$. of rrarls. They receive a subvention from the government and from communes.

Posts, Telegraphs and Telephones. - The number of post offices (including over 700 collecting officers) was 10,238 in 1910 . The number of State telegraph offices has risen to 5,033,

1 This perind does not correspond with the Italian financial year (July Ist to June zoth), nor the balance with that of the ordinary financial returns (above). It is probable that some of the extra war receipts and expenditure are reckoned on both sides of the account. 
while the number of station offices is 1930, as in 1904. The parcel post and money order services are increasing rapidly ( 17 million parcels were sent, and 80 million pounds worth of orders paid in $1909-10$ ), and the value of the foreign orders paid in Italy has gone up to over $9 \frac{1}{2}$ millions, of which over $4 \frac{1}{2}$ millions came from' the U.S.A. (nearly double the whole total of the foreign money orders paid in Italy in I90I-2), while the orders of the Banco di Napoli sent home by emigrants amounted to nearly half a million more.

The length of the telegraph lines has been considerably increased, and on December I, I9ro, the internal telegraph tariff was reduced to 60c. for the first ro words. In 1909-10 there were 219 urban telephone systems and 426 interurban lines. The number of trunk and international calls has increased by over 50 per cent since 1907-8.

Government. - The number of senators has been considerably increased during the present (the 23rd) parliament of the Italian kingdom. From March 24, 1909, to December 31, I9II, I03 were nominated, and 68 died, making, with the 335 already in office, a total of 370. As to the Chamber, the number of deputies (508) remains the same, but the number of electors on the list of I I I I was $3,227,183$, or 9 per cent of the total population, as against 7.6 in 1904. The percentage of voters in the election of 1909 was 65.3 (62.7 in 1904). A bill for almost iniversal male suffrage, however, was passed in the spring of 1912. Those who have served in the army and navy at once become voters; while those who have reached the age of thirty years, even if illiterate, are added to the existing electorate. Women's suffrage has not yet come into practical politics; and the Court of Appeal has ratified the cancellation of the name of Signorina Labriola from the list of Counsel in Rome.

Crime.-The total number of prisoners is on the decrease, and at the end of 1909 there were only 52,155 , of whom 4,323 were women, with a diminution in all the various classes of criminals. There is, however, a slight increase in the number of offcnces, due in part to a continuance of the rise in the number of contravenzioni, and the figure per 100,000 was still 2.439 in 1908 , which is only a little under the average of the quinquennium. It is said (but this remains to be seen) that the deathblow to the Camorra was struck by the Cuocolo murder trial, which, in order to remove it from the atmosphere of Naples, in which it would have been hard to obtain a verdict, took place at Viterbo, near Rome, and ended after about I 7 months on July 8,1912 , in severe sentences on all the accused, over 30 in number, who were supposed to be its leader and chief officials.

Army. - The strength of the army in 1909 showed a considerable increase on previous figures. Of 498,082 who were liable, 108,794 were physically unfit, 127,5=8 were put back for re-examination at the next levy (mostly after medical inspection), 48,865 failed to appear, and 212,895 were enrolled for service. Of these 151,839 were assigned to the active army, 34,079 to the second category (for short training), and only 26,977 to the third category (territorial militia). The former term of service for the active army was 3 years in the infantry and 5 in the cavalry; but it is now 18 months, except for those who do not become efficient, who serve 6 months more. Those who pay $f 48$ and pass an examination serve one year only. They then have one month per annum for another 6 years. The peace establishment (including carabinieri) is nearly I 4,000 officers and 255,000 men.

Navy.-The Italian navy possessed at the end of 1912 four battleships of the Dreadnought type, built in Italian yards, one of about 19,000 tons with twelve 12 -inch guns in four centreline triple turrets, and twenty 5.5-inch guns; while the other three are of 21,500 tons and will have thirteen 12 -inch guns, nine in triple and four in twin superposed turrets. The two ships laid down in 1912 will have twelve 13.5 -inch guns in four turrets. Next come the ships of the Vittorio Emanuele class.

The warships available at the beginning of I9I2 were as follows: battleships, I8 (9 are somewhat antiquated); armoured cruisers, Ist class 15 (each about 7,000 tons), 2 nd class 10,3 rd class II; torpedo vessels, 5 ; destroyers, 23; torpedo boats, 82 ; submarines, 7. At the same time they were building 4 battleships (two Dreadnoughts), 9 destroyers, 30 torpedo-boats and 13 submarines. The naval expenditure for I9 I i was $f 8,379,940$, of which $f 2,277,302$ was for new construction. The personnel on active service in 1910 consisted of 1,927 officers and 27,529 men.

Education.- The number of infant schools has hardly increased at all since I9oI; the total number of elementary: schoolrooms both public and private (the latter having decreased by 2,000 ) has risen from 6I,777 to 68,03I, and the number of pupils from $2,783,349$ to $3,150,249$, or 9.3 per cent of the total population: but there are still not enough classes, while children who live more than $I \frac{1}{4} \mathrm{~m}$. from the school need not attend it. In the poorer villages the three classes are often grouped in most inadequate buildings; while the teachers' salaries are low. In I9II-12 nearly one million sterling was devoted to the increase of funds for elementary and popular education, so that improvements may be expected. The new schools for adult illiterates, founded by the laws of 1904 and 1906 , gave instruction to 128,000 individuals, four-fifths of whom were men; and about three-fifth of them passed the examination imposed on them. In 1909-10 there were 478 Ginnasi with 45,699 scholars (including $23+$ government schools with 32,303 scholars), 500 Technical schools with 83,62 I scholars $(237$ government with 61,492 ), 2 I6 Licei with I4,947 scholars (133 government with 12,125), 102 Technical Institutes with 20,305 scholars (60 government with $16,8+9)$, and 20 Nautical Institutes with 2,026 scholars (I9 government with I,998). These figures show a large 
decrease in the Ginnasi and Licei since 1902, but a much greater increase in the technical schools and institutes, as regards both schools and scholars. The 33 Scuole Normali or training schools for male students had 2,663 pupils in $1909-10$, as against 2,484 in $1908-9$; while those for female students, I02 in number, had 29,792 pupils (exclusive of those not on Govermment footing, of which there were 142 , with 3,37 I students). The total attendance of students at the higher universities and institutes appears to be practically the same as in 1902 (about 28,000). Law, engineering, and economics and commerce show an increase; medicine and surgery and the professional diploma in pharmacy a decrease; while philosophy, mathematics and agriculture show little change.

Antiquitics and Fine Arts.- There has been considerable activity in excavation all over Italy. In Rome itself important work has been done in the further investigation of the lower strata of the buildings on the Palatine; the baths of Caracalla and Diocletian have been further studied. In the Lucus Furrinae, where Caius Gracchus met his death, remains of a sanctuary of various Oriental deities have been found; and numerous minor discoveries have been made in the course of building operations. At Ostia, near Rome, the work of laying bare the remains of the ancient seaport town is being resumed on a large scale, with interesting results. The excavation of Cumae, Paestum and Pompeii is proceeding, and at the last named special care is being taken to preserve the remains of the upper stories, which had balconies and pillared openings, so that the town did not present that monotonous appearance hitherto attributed to it. Among the works of art which have passed into the State Collections may be noted the so-called 'Maiden of Antium' and a fine statue of Augustus, while a splendid statue of a daughter of Niobe found in Rome in 1906 is now in Milan. Numerous prehistoric cemeteries and other objects and buildings have been found all over the country. A number of provincial picture galleries have been reorganised (at Bergamo, Prato, etc.). The publication of a new list of national monuments (Elenco degli Edifici Monumentali) was begun by the Ministry of Public Instruction in $191 \mathrm{I}$.

Rome. ${ }^{1-}$ - Municipal Administration in Rome was in 1912 still in the hands of the coalition (the so-called 'blocco'), with Sig. Ernesto Nathan, the Syndic, at their head. The Municipality has started its own system of tramways and its own electric power and lighting works, and will take over those already existing, constructed by private companies. Other companies run electric trams to the Alban Hills from Rome, and to Civita Costellana, north of Rome (to be extended to Viterbo). The embankment of the Tiber is now practically complete; no serious floods have occurred since 1900 . The death rate was 16.21 per 1 , 000 in I9II. Malaria in Rome is now unknown, and in the Campagna and the Pomptine Marshes it is decreasing rapidly.

A new station has been opened in the Trastevere quarter, on the right bank, close to the new railway bridge over the Tiber. The transformation of Rome into a modern city is procecding apace; the exigencies of traffic are continually calling for the widening of the streets, and the city seems destined to lose much more of its picturesqueness.

The enormous monument to Victor Emmanuel on the Capitoline Hill was inaugurated on June 4, I9II. As a whole, it is fine; but it does not combine well with its venerable surroundings as regards either architecture or colour; though it probably gives us a fair idea of what the immense erections of Imperial Rome must have been. It is said to have cost already at least 2 millions sterling, including the cost of the removal and rebuilding of the Palazzetto di Venezia. The Palace of Justice has cost over $\mathbf{I} \frac{1}{2}$ millions. The various demolitions in the centre and the growth of population have rendered necessary extensive building of working-class dwellings further out, largely on co-operative principles: while the rich display a tendency to abandon flats in favour of houses standing in their own grounds in the outskirts. Rents are higher in Rome than in any other city in Italy.

The architecture of the new quarters of Rome is not remarkable for its taste, though the new I'iano Regolatore della Citta di Roma, drawn up in 1908 by Conum E. Sanjust di Teulada (and published in book form under the above title), allows, far better than was ever done before, for the adequate provision of open spaces. One of the most important of these, the so-called Passeggiata Archeologica, is now completed, and important excavations in connexion with it are being made in the Baths of Caracalla, an interesting Mithraeum hitving been discovered in the subterranean portion, while in the peribolus the libraries cunnected with the Baths have been found.

$\Lambda$ stadium, a new racecourse and a zoological garden have been added to the popular resorts of Rome. An indust rial quarter (new gasworks, storehouses, factories, etc.) is springing ul, outside Portas Paolo, where a river harbour is being made. There is some talk of making a ship canal from the sea.

An International Exhibition was held in Rome in $191 \mathrm{I}$, in connexion with the celebration

${ }^{1}$ Recent works on Rome include S. B. Platner, Ancient Rome (ed. ii), Boston, U.S.A. I9I1; H. Kiepert and Ch. Hülsen, Formae Orbis Romae Antiquae (ed. ii), Berlin, I912; L. Ilautecoeur, Rome el la Renaissance de l'Antiquité a la fin du XVIIIe Siècle (Bibl. des Ec. Franc. fasc, I05), l'aris, I912; H. Stuart Jones, Classical Rome, London n. d.; and Companion to Roman II istory, ()xford, 19i2. British School at Rome (ed. H. Stuart Jones) Catalogue of the Sculptures of the Museo Capitolino, Oxford, 1912. 
of the 5oth anniversary of the foundation of the Italian kingdom. It was divided into four sections - the Archaeological, house in the Baths of Diocletian, which illustrated the various provinces of the Roman Empire, ${ }^{1}$ the Mediaeval and Historical, in the Castle of $\mathrm{S}$. Angelo;

1 A restored model of Ancient Rome, by M. Paul Bigot, was also exhibited.

the Ethnographical, dealing with the various regions of Italy, at the Piazza d'Armi; and the International Fine Arts Exhibition, at the Valle Giulia. At this last the British Pavilion, designed by Mr. E. L. Lutyens, contained, besides contemporary pictures, a splendid exhibition of British masters of the 18th and 19th cent., and is being reconstructed as the permanent home of the British School at Rome, which received a Royal Charter in July I912. The Commissioners of the London Exhibition of I85I have founded nine scholarships for students of painting, architecture and sculpture. The site has been given by the Municipality of Rome. The Third International Congress of Archaeology and the Tenth International Congress of the History of Art were held in Rome in October I9I2.

Turin.-In connexion with the celebration of the 5oth anniversary of the proclamation of the Italian kingdom, an international industrial exhibition was held in Turin in $19 \mathrm{I}$.

Venice. - The famous Campanile of San Marco, which fell on July 14, 1902, has been exactly reconstructed, and was inaugurated on St. Mark's Day (April 25th) 1912.

\section{Italian Dependencies.}

The Italian dependencies-Tripoli, Cyrenaica, Eritrea, Italian Somaliland, and Benadir - have been placed under a Ministry of the Colonies, the first Minister being Signor Bertolini.

Tripoli. - The Italian trade with Tripolitania in 1910 amounted to $£ 128$,000 worth of imports out of a total of $f 477,500$, and $£_{1} 76,000$ worth of exports, a considerable increase on the figures for 1909 ( $f_{64,600}$ and $f_{1} 16,800$ respectively). British exports in 1909 were nearly $f_{160,000}$, and imports in 1910 about the same. Tripoli can now be reached in 48 hours from Rome via Syracuse.

The western frontier of Tripoli (as far as Ghadames) was accurately surveyed for the first time by the Franco-Turkish boundary commission of I910-II, with the result that the position of Ghadames was shifted some miles to the east of that previously assigned to it. M. Pervinquiere at the same time explored the region from the geological point of view. The most recent maps of Tripolitania $(1: 400,000)$ and of Cyrenaica $(1: 600,000)$ were published in I9I I by the Italian Ordnance Survey.

Italian Somaliland. - A minor frontier question which had arisen between Great Britain and Italy owing to the shifting of the mouth of the Juba was settled by the acceptance in IgI 1 by the former of the new mouth as the terminal point of the frontier. A map on the scale of $1: 200,000$ (I9I0) is being published by the Italian Ordnance Survey.

Eritrea.-The budget of I9I0-1I shows an expenditure of $£ 559,000$, of which Italy contributed nearly half. In this is included $f 200,000$ for the construction of the railway from Ghinda to Asmara. Another line is to be built from Asmara to Keren. The railways already working earned $f_{12}, 000$ as against $f 7,480$ in the previous year. The military expenses are now only $£_{1} \mathbf{7 5}, 500$, while the civil expenditure is $£ 383,600$. Products exported from the colony to Italy enjoy preferential duty; the most important are cattle, coffee, wheat and cotton. It has been calculated that Eritrea will be able to produce enough cotton to make Italy independent of American importation, as soon as there are adequate means of transport to the coast. The total external trade is of the annual value of about $£ 700,000$, of which a third is with Italy, while India follows with $f \mathbf{I 5 0 , 0 0 0}$ worth of imports. A new edition of the map on the scale of $I: 100,000$ of the whole colony, and a map on the scale of I :50,000 of part of the colony, have been published by the Italian Ordnance Survey.

(T. Asнiby.)

\section{Political History, Igog-roI2.}

The Italian general election of March I909. had returned a strong majority in favour of Sig. Giolitti, but the Premier found himself confronted with the question of the steamship subsidies, the old agreements with the companies having lapsed. The bill was defective from various points of view, and the Opposition led by Sig. Sonnino delivered a series of vigorous attacks on the measure, which shook the position of the Cabinet so seriously that Sig. Giolitti deemed it prudent to adjourn the debate until the autumn. Sig. Enrico Ferri, the Socialist leader, whose experiences among Italian emigrants in South America had convinced him of Italy's 'need of a more virile foreign policy, delivered a stirring Imperialist speech in the Chamber on June 22nd, which marked his severance from the Socialist party and the beginning of its collapse; subsequently he declared himself willing to accept a portfolio were it offered to him. In October the Tsar Nicholas of Russia visited King Victor Emmanuel at Racconigi, an event destined to establish that entente between Italy and Russia which was to prove an important feature in the international situation. 
When Parliament reassembled in the autumn Sig. Giolitti was forced to modify the bill on the steamship conventions, but on a point of procedure the Cabinet was defeated and resigned (December 2nd). Sig. Sonnino was now called upon for the

\section{Sonnino} Mlaistry. second time to form a Ministry, and he succeeded in gathering some of the best talent in the country; Count Guicciardini took the Ministry for Foreign Affairs, Sig. Luzzatti that of Agriculture and Trade, Sig. Salandra that of the Treasury, Admiral Bettolo that of Marine, while General Spingardi remained at the War Office. The new Cabinet, however, although it enjoyed the favour of the country at large, could not count on the support of the majority in the Chamber which, if it had temporarily seceded from the late Premier, was his creation and still Giolittian at heart, and when the debate on the shipping bill as modified by Sig. Sonnino was resumed in March IgIo it was clear that his Government would be in a minority. On the 2Ist, after a hundred days of office, as in the case of his former Government, he resigned, and Sig. Luzzatti formed a new Cabinet, which included the Marquis di San Giuliano, then Ambassador in Paris (and previously in London), as Minister for Foreign Ministry. Affairs, Signori Tedesco, Facta, Sacchi, and Credaro, Admiral Leonardi Cattolica as Minister of Marine, and General Spingardi as Minister of War. The new Premier, in spite of his financial genius and great self-confidence, proved unequal to the task of leading an administration, and it was obvious that he held office on sufferance under the tutelage of Sig. Giolitti, who was waiting until the steamship bill and one or two other troublesome questions were settled to return to power. Sig. Luzzatti's weakness appeared in his dealings with the various labour agitations, especially in the agrarian riots in Romagna. The $3 \%$ railway loan of $260,000,000$ lire to build new lines and double-track and improve existing ones, was quickly covered, although the net profits of the system remained very low owing to extravagant management. In August of that year a cholera epidemic broke out in Apulia and spread to Naples and other parts of Southern Italy; the sanitary officers dealt vigorously with the disease, but the ignorance and superstition of the peasantry in certain districts rendered their task by no means easy. On December 21 st the Premier presented a bill for extending the franchise and providing for compulsory voting, but on the question of the date when the measure was to come up for discussion although the majority voted for the Government most of the Radicals voted against it; the two Radical Ministers, Signori Sacchi and Credaro, therefore felt bound to resign. The whole Cabinet followed suit on March 18, I9Ir, and the King entrusted the now inevitable Sig. Giolitti with the formation of a new Ministry;

\section{Giolitt}

Ministry. most of the former Ministers, including Sacchi and Credaro, retained their portfolios. A grotesque incident of this crisis was created by Sig. Bissolati, the Socialist deputy; summoned to the Quirinal with a view to being offered a seat in the Cabinet, he went, but refused office ostensibly because he could not make up his mind to don a dress suit, in reality because he feared to lose caste with his more uncompromising followers.

The year I9II being the 5oth anniversary of the creation of the Italian kingdom, great festivities were organised to celebrate the occasion. An international exhibition of fine arts, an ethnographic exhibition of the Italian provinces, and Jubllee of archrological and historical shows were held in Rome, an exhibition of
Itallan Itallan Italian portraits in Florence, and an international industrial exhibition in Turin. The two latter were successful in every way, but the Roman exhibitions, although artistically very beautiful, owing to defective organisation, an unusually hot summer and a second outbreak of cholera, resulted in a considerable deficit.

The Cabinet's programme, presented to the Chamber on April 6th, included the extension of the franchise to all illiterates over 30 years old, thus increasing the number

Franchise and Insurance BIIIs. of voters from three to eight millions, the payment of members, and the creation of a Government monopoly for life insurance. These bills, largely the outcome of a desire to gain the support of the Extreme Left, found little favour in the country, and Sig. Sonnino not having succeeded in retaining office, the more active conduct of parliamentary opposition was undertaken 
by a group of younger members led by Sig. Romeo Gallenga, the member for Perugia. In the debate on the Insurance bill the Government cut a poor figure and was finally induced to limit the proposed monopoly to policies of over: I 5,000 lire capital or I,500 lire of annual interest, while the companies were given ten years during which to liquidate their business for insurances below those figures. Even in this modified form the measure was strongly opposed, and the Government finally agreed to defer the final debate until the autumn. : The Chamber rose on July Ioth.

In the summer Italy had a dispute with the Argentine Republic in consequence of the cholera epidemic. The Argentine Government, professing not to be satisfied with

Dispute with Argentina. the very drastic precautions taken by the Italian authorities, demanded that Argentine medical commissioners be placed on all emigrant steamers bound from Italian ports to Buenos Ayres. The Italian Government, who had its own commissioners on all emigrant vessels; naturally refused to admit this interference with its jurisdiction, whereupon the Argentine established a quite unnecessary quarantine on Italian steamers; Italy retaliated on July zoth by suspending emigration to that country. The truculent attitude of the Argentine appeared to indicate its contempt for Italy, and the latter's energetic action, with its injurious consequences to the trade and agriculture of the Republic, probably came as a painful surprise to that Government, but did much to enhance Italian prestige and the position of Italian citizens throughout South America. Negotiations were eventually instituted for the conclusion of a sanitary convention, which after much laborious discussion was signed on August I 7 th, I912; the document contained all the provisions on which Italy had insisted so as to prevent similar conflicts from arising in future:

During the last few years Italy's relations with the Ottoman Empire had been growing strained; with the advent to power of the new régime the situation became worse

\section{Crisis. with} Turkey.

instead of better, for the Young Turks; in their blind hatred of everything foreign and believing Italy the weakest of the great Powers, lost no opportunity of showing their contempt for her. Italian enterprise was hampered in every way, and in the vilayet of Tripoli, where Italy's reversionary interest had been recognised by Great Britain and France, where much Italian capital had been invested and where the Italian Government had created schools, hospitals, etc., the hostility of the Ottoman authorities was even more marked and the life of Italian residents rendered intolerable. An Italian missionary, Father Guistino, had been murdered by a native at Derna on March 22, I908, and another Italian, Gastone Terreni, near Tripoli by a Turkish Zaptieh on June zoth, with the direct complicity of the local authorities, but it proved impossible to obtain redress for these crimes. Italy's efforts at conciliation proved unavailing and were regarded as proofs of weakness, "incidents" multiplied, and Turkish gunboats even fired on and sank Italian sailing craft in the Red Sea. Italy had originally intended to extend her influence in. Tripolitania only by means of pacific penetration, but with the reopening of the Morocco question, it became clear that the last unoccupied Mediterranean lands were being divided up, and Italy, who with her large emigrant: population has need of more territory where her sons can settle under the national flag, realised that this was her last chance of acquiring a colony.

For some time the Nationalist party, which had come into being at the Florence Congress in December igro, had been conducting a propaganda in favour of a more

War

declared.

vigorous foreign policy and roused public opinion to the need for action; although the Giolitti Cabinet was most anxious to avoid international complications, it could not disregard the new spirit pervading the Italian people. By July it informed the Powers that the conduct of Turkey could no longer be tolerated, and no change for the better having occurred military preparations were begun on September 2oth. On the 23 rd the reservists born in r 888 were called back to the colours, and a Note was presented to the Porte on the 26 th calling its attention to the risks to which Moslem fanaticism was subjecting the Italian residents, and adding that the sending of reinforcements or arms to the African vilayet would be regarded as a very serious act. On the 27 th the Turkish steamer "Derna," flying the German flag, 
arrived at Tripoli and disembarked 15,000 rifles which were distributed among the Arabs. The Italian Government then sent an ultimatum to that of Turkey on the $28 \mathrm{th}$, and no satisfaction having been obtained declared war on the 29th. It is unnecessary here to deal with the events of the war itself, which are fully narrated in Part I: Sect. i. of the YEAR-Book. On November 4th, Italian sovereignty was extended to Tripolitania and Cyrenaica by Royal Decree. Towards the end of November a conflict broke out with France in consequence of the arrest and search by Italian warships of the two French steamers Carthage and Manouba suspected of carrying Turkish officers and contraband; the incident led to a violent outburst of anti-Italian hysteria in France, and although it was eventually referred to arbitration, it made the Italian public realise how little it could count on French sympathy, and served to strengthen the somewhat weakening bonds of the Triple Alliance. On February 22nd, Parliament reassembled, and the bill for converting the sovereignty decree of November 4 th into law was voted by an overwhelming majority amidst scenes of great patriotic enthusiasm.

Various attempts at mediation were made by the Powers; but without success. In July, I9I 2 however, negotiations were instituted between unofficial Italian and The Peace. Turkish delegates in Switzerland, and after laborious discussions, during which the situation in the Balkans became menacing and Montenegro declared war against Turkey, the peace preliminaries were signed at Ouchy on October $\mathrm{I}_{4}$ th, and the final treaty on the $18 \mathrm{th}$. Turkey renounced her sovereignty over Libya and undertook to withdraw her troops, the Sultan preserving only his spiritual authority as Khalif over his former subjects, while Italy agreed to restore the Aegean Islands to Turkey as soon as the Turkish troops had quitted Libya, but the inhabitants were guaranteed liberal reforms and local autonomy. This settlement did not arouse much enthusiasm in Italy, as many believed that, the Balkan States having now declared war against Turkey, Italy might have put herself at their head and eventually acquired great moral prestige throughout the Near East. But the objects for which the war was fought had been achieved, and in view of the situation in the near East the Italian Government wished to have its hands free.

Throughout the campaign officers, soldiers and sailors had shown great bravery, discipline and staying power, while the organisation of the army and the navy proved excellent. Some of the commanders, however, came in for much criticism, and the general conduct of the campaign, inspired apparently by political rather than by military considerations, was disapproved of by a part of public opinion. The total expenses of the undertaking are estimated at 458,000,000 lire, including the value of supplies not. all of which have been used up, and it is remarkable that this sum was paid for out of the budget surpluses of the last few years, redeemable Treasury bills, Treasury reserves, credits with banks, etc., no loan having been raised nor fresh taxation levied. On the conclusion of peace the Treasury still had $386,000, \infty 00$ lire at its disposal. Business was not very much affected by the war, and indeed Italian exports during the period from January ist to September 3oth, I9I2, in spite of the suspension of trade with Turkey, had increased by I $7,000,000$ lire over those of the corresponding period of I 9 I I, and the imports by 59,000,000 lire, while the State's principal revenues, from October Ist, I9 II, to September 3oth, I01 2, had increased by $79,000,000$.

In the field of domestic politics there is little during Ig I 2 to be recorded. An unsuccessful attempt on the King's life by an anarchist named D'Alba on March I 4 th gave Result on occasion for enthusiastic demonstrations of loyalty, showing how deeply Result on attached to the Monarchy the Italian people had become. The various
polics. Government bills - the Insurance Monopoly, the extension of the franchise and payment of members-although not popular, were voted by Parliament without much opposition, as there was a general determination not to embarass the Ministry as long as the war lasted. The Socialist party, which had been gradually losing its hold over the masses for some time past, now found itself wholly out of touch with popular fecling concerning the war, and while it officially condemned the enterprise many of its leaders refused to put party before country, and were " excommunicated " 
in consequence at the Congress of Reggio d'Emilia in June. The result was a definite split up of the party into two separate organisations. Signor Giolitti continued to exercise great authority, although with the conclusion of peace a revival of Opposition activity was to be expected.

Obituary.-Among prominent Italians who have died since December 1909 the following may be noted.

Alessandro Fortis, the statesman (see E. B. xv, 82c); born I $84 \mathrm{I}$, died December 4 , 1909. In 1866 he joined Garibaldi as a volunteer and fought under him in the Trentino, in 1867 at Mentana and in 1870 in France. Under the influence of Aurelio Saffi he became a republican, and was arrested as a Mazzinian conspirator in 1874. In 1876 he abandoned the Republican Party, although still adhering to democratic ideals. Elected deputy for his native town of Forli in I 880, he helped the Royal visit to Romagna, hitherto regarded as a hotbed of anti-monarchical views. He made a reputation as a Parliamentary debater, but lost favour with his constituents who were largely reputlican, and only held his seat with the help of Livio Quartaroli, Mayor of Forli, and Saffi; when they died his position became untenable and he was not re-elected. He then won a seat at Poggio Mirteto, which he continued to represent until his death. He became Minister of Agriculture in the Pelloux Cabinet (1898-99), and in. 1905, on the fall of the Giolitti Cabinet, became Premier. But his administration fell after seven months over the commercial treaty with Spain, which aroused the violent opposition of the Italian vine-growers. He reconstructed the Ministry, but was beaten at once and had to resign.

Vittoria Aganoor, the poetess (see E. B. xiv, 9i2c); died on May 7, i9io. Although of Armenian extraction she was thoroughly Italian in spirit, and from her master, the Abate Zanelli, she imbibed a genuine classical elegance and culture. Her first volume of verse was entitled Nuove liriche; Leggenda eterna followed, and after her death a complete edition of her poems was published. She married Guido Pompili, deputy for Perugia and sometime Under Secretary of State for Foreign Affairs, who after her death under an operation committed suicide.

Angelo Maiorana, the statesman; b. at Catania in 1865 ; d. at Catania on February 9 , 19I0. Graduating in law when only 16 years old, at twenty he was already well known as a writer on constitutional questions, and two years later he was appointed professor at the university of his native town, of which he eventually became rector. He was elected deputy for Catania in 1895, and at once took an active part in politics. A follower of Signor Giolitti, he became Under-Secretary for Finance in 1903, and in the following year was promoted to Ministerial rank. In 1906 he was appointed Minister of the Treasury, and Sig. Giolitti publicly designed him as his successor for the premiership. But his health broke down and he was forced to retire. In 1909 he was Vice-President of the Chamber. His chief works are: Parlimenterismo, Il Principio sovrano della costituzione degli Stati, and La Teoria costituzionale delle entrate e della spesse.

ANDREa Costa, the Socialist leader; b. at Tinola in $185 \mathrm{I}$; d. at Tinola January $19,1910$. The son of a small shop-keeper, at an early age he joined the extreme revolutionary party in Romagna, becoming a prominent member of the "International." He was arrested more than once, but gradually modified his views, and was elected Socialist deputy for Ravenna in 1882 . He was again implicated in revolutionary agitations and arrested, but eventually he came to represent the more moderate section of his party, and was regarded almost as a reactionary by the extremists.

Antonfo Fogazzaro, the novelist; b. at Vicenza 1842 ; d. at Vicenza March 7 I9I I (see E. B. x, 590). His last novel Leila is in a sense a sequel of Il Santo, for it breathes the spirit of the latter's dead hero Benedetto throughout, and shows us the effect of his teaching on his followers. The whole course of Fogazzaro's literary career is a struggle between spirit and matter, the object aimed at being the purity of the soul. In his earlier works from Miranda to Il mistero d'un poeta it is love, as represented by various charming pictures of women, which can save the soul when conscience is not enough. In his later phase the soul is led onward no longer by the redeeming hand of woman but by religious faith.

Princess Maria Clotilde of Savoy, widow of Prince Napoleon ( $E$. B. iv, 197a); b. in I 842 ; d. on June 25, I9II. She was the daughter of Victor Emmanuel II, and her marriage in 1859 to "Plon-Plon" was part of the consideration for the Franco-Sardinian alliance which resulted in the war against Austria. In Paris she led a very secluded life, devoting herself to the education of her children, Princess Laetitia (who married the Duke of Aosta), Prince Victor and Prince Louis Napoleon; and after 1870 she retired to the castle of Mocalieri near Turin, where she died.

Mario RapISARDI, the poet (E. B. xiv, 9I2c); b. in Sicily 1844; d. January 4, I912. At the age of 24 he published Palingenesi, a pompous epical history of humanity, but his Lucifer (I877), a philosophical poem of atheistic tendencies describing the struggle between free thought and religion, showed genuine literary talent. In his Poemetti, a volume of Lyrics, he reached a higher level; and Giustizia, a collection of political poems exalting every form of rebellion, contains some excellent verse. 
Admiral Augusto Atriry; d. March 4, 1912. He entered the Italian navy in 1866 , served at Lissa, and reached the rank of rear-admiral in 1903. In February 1911 he was appointed commander of the Italian fleet in the Mediterranean, and on the outbreak of the war with Turkey (September I9II) he conducted the opening naval operations.

Giovani Pascoli, the poet (see E. B. xiv, 912c); b. at San Mauro in Romagna, December 31, 1855; d. at Barga, April 6, 1912. In 1891 he published his first volume of verse entitled Myricae, and in 1897 his Primi Poemetti. Other volumes-Secondi Poemetti, I canti di Castelvecchio, Odi ed inni, Canti conviviali, Li Canzoni del Re Enzo. In addition he wrote much elegant Latin verse. He was also known as a prose essayist, and for his Dunte studies, which led to his appointment as professor of Italian literature at the university of Bologna. An ardent lover of nature and of simple rustic things, he could never quite reconcile himself to modern progress. He had been a Socialist in his early days and had strongly opposed the Abyssinian campaign of $1895-6$, but in later years he made politics subordinate to patriotism. The Canzoni del Re Enzo tell of the glories of the Mediaeval communes of Italy; the poems published on the occasion of the Jubilee festivities of I9II celebrate the triumphs of Italian unity; while his speech delivered in November I9I I at Barga was the finest piece of prose evoked by the war in Tripoli.

GICLIO RICORDI, the music publisher; b. in 1840; d. at Milan on June 6, I912. He succeeded his father, Tito, in I 888 as head of the firm, founded by his grandfather, Giovanni, in 1808 . He was the personal friend of Verdi and was brought into business relations with many other composers. He was himself a composer of songs and piano music, which he published under the pseudonym of "Jules Burgmein:"

Elisabetta, Ducheșs of Genoa; b. in 1830; d. on August 15, 1912, at Stresa. A daughter of King John of Saxony, she married Ferdinand, Duke of Genoa, son of King Charles Albert of Sardinia and brother of Victor Emmanuel II, in April 1850. Her daughter Margherita afterwards married her cousin Prince Humbert, and became Queen of Italy. Two years after the death of the. Duke of Genoa in 1855 his widow married Marchese Rapallo.

ENRICO ANNIBALE ButTI, the art-critic, novelist and dramatist (see $E$. $B$. xiv, 9i2c); b. $1856 ;$ d. November 26 , 1912 .

Pietro Lacava, the oldest member of the Chamber of Deputies, in which he had sat continuously for 44 years; "formerly minister of Public Works and of Finance; b. 1835; d. December 26, 1912.

(LUIGI VILlaRI.)

\section{JAPAN $^{1}$}

The population of Japan Proper increased from 48,774,285 in 1907 to $52,200,000$ in I $912(26,380,000$ males; $25,820,000$ females). The density is about 350 per sq: m. Korea had a population of 13,46I,300; Formosa 3,443,600; Saghalien 43,000.

Agriculture.--More than 60 per cent of the Japanese population is engaged in agricultural pursuits. The Government have made consistent efforts to encourage co-operative enterprise, and a Law with this object in view was introduced in 1899 , and amended in 1909 , by which special concessions were granted in order to stimulate the industry. Special banks have also been established for facilitating the supply of capital for agricultural purposes. The Co-operative Societies Law had as its object the formation of societies for assisting those with small capital. The societies formed under this Act numbered 8,663 at the end of I9II. In I 1 IO the Government provided facilities for borrowing money at low interest through the Japan Hypothec Bank and the Hokkaido Colonial Bank. A State Agricultural Experimental Station was established in Tokyo with branches in Kyushu, Kinai, (Middle Provinces) and Riku-u (North-eastern Provinces) for the purpose of carrying out investigations relative to soil, fertilisers, seeds, diseases, insect-pests, stock-breeding, and agricultural implements. Horticultural experiments are also carried out in the Horticultural Experimental Station in the Prefecture of Shidzuoka and in many of the local agricultural stations

The chief agricultural products consist of rice, barley and wheat, millet, soy and small red beans, buckwheat, potatoes, cotton, hemp, indigo, and sugar-cane. The cultivation of teat, tobacco and silk are also extensive and growing industries. The total areas, in 1909 and 1910 , under cultivation for these different products are shown in Table $I$.

In 1 igi I the figures $(\mathrm{I}=\mathrm{I} 000)$ for rice were $7,432.7$ acres and $206,406.7$ bushels; barley, rye and wheat $4,412.5$ acres and $108,631.3$ bushels; tea 77.0 acres and $69,894.4$ pounds.

It shruld be noted in regard to tea, that although the total area under cultivation has been considerably reduced, the quantities produced have consistently increased, the year I9II being the most prolific period in the industry. The great attention which has been paid by the Government to questions of cultivation and manufacture at the State Agricultural

1 See E. B. xv, 156 et seq. 
Table I. Agricultural Crops: $I=I 000$.

\begin{tabular}{|c|c|c|c|c|c|c|c|c|c|}
\hline & \multicolumn{2}{|c|}{ xg०g. } & \multicolumn{2}{|c|}{ rgro. . } & \multirow{2}{*}{ i ifi i } & \multicolumn{2}{|r|}{ Igog. } & \multicolumn{2}{|r|}{ rgro. } \\
\hline & Acres. & $\begin{array}{l}\text { Prodn. } \\
\text { Bushels. }\end{array}$ & Acres. : & $\begin{array}{c}\text { Prodn. } \\
\text { Bushels. }\end{array}$ & & Acres. & $\begin{array}{l}\text { Prodn. } \\
\text { lbs. }\end{array}$ & Acres. & $\begin{array}{c}\text { Prodn. } \\
\text { lbs. }\end{array}$ \\
\hline $\begin{array}{l}\text { Rice } \\
\text { Millet } \\
\text { Beans } \\
\text { Buckwheat } \\
\text { Rape Seed } \\
\text { Barley, Rye } \\
\text { and Wheat }\end{array}$ & $\begin{array}{r}7,345.0 \\
564.8 \\
\mathbf{1}, 498.1 \\
393.0 \\
350.4 \\
4,429.7\end{array}$ & $\begin{array}{r}260,090.8 \\
12,986.2 \\
23,162.0 \\
6,319.8 \\
5,218 \cdot 4 \\
106,729 \cdot 3 \\
\end{array}$ & $\begin{array}{r}7,373.6 \\
557.7 \\
1,548.0 \\
391.5 \\
346 . x \\
4,429.1 \\
\end{array}$ & $\begin{array}{r}231,301 \cdot 5 \\
12,477 \cdot 2 \\
21,038: 1 \\
6,505 \cdot 4 \\
5,198 \cdot 3 \\
102,231 \cdot 8\end{array}$ & $\begin{array}{l}\text { Tea } \\
\text { Potatoes } \\
\text { Seed Cotton } \\
\text { Hemp } \\
\text { Leaf Indigo : } \\
\text { Sugar Cane } \\
\text { Tobacco-Leaf }\end{array}$ & $\begin{array}{r}113.0 \\
892.5 \\
10.0 \\
31.8 \\
22.9 \\
47.8 \\
73.4 \\
\end{array}$ & $\begin{array}{r}64,710.3 \\
8,814,448.9 \\
8,056.0 \\
20,544.8 \\
33,170.8 \\
1,577,441.1 \\
94,046.1 \\
\end{array}$ & $\begin{array}{r}76.0 \\
904.0 \\
8.5 \\
30.8 \\
22.2 \\
50.0 \\
74.3\end{array}$ & $\begin{array}{r}67,330.6 \\
8,361,396 \cdot 8 \\
5,957.8 \\
20,073 \cdot 5 \\
35,765 \cdot 1 \\
1,816,134 \cdot 3 \\
91,775 \cdot 7 \\
\end{array}$ \\
\hline
\end{tabular}

Experimental Station has resulted in the reduction of labour, the cost of production, and improvement in the quality of the tea.

Silk.--Sericulture, one of the most valuable industries of Japan has, under the scientific and economic care of the Grovernment, expanded considerably during the last few years. There are two State Sericultural Training Institutes, and a number of Sericultural Schools have also been established in Yokohama and for improving the quality of raw silk a National Graine Factory was erected in I9II-I2, Graines are manufactured here and distributed with the object of improving and unifying cocoons. A Central Cocoons Inquiry Commission is investigating the selection of graine. The production of silk has been as follows $(I=1000):-($ I 908$) 29,051.5$ lbs., (I 909$) 31,225.0$ lbs., (IgIo) $33,302.0$ lbs.

Stock Breeding.-Great attention is given on the part of the Government to the improvement of the breeding of horses and cattle, and stock-breeding farms are established where matters connected with the improvement of rearing and distribution of cattle, sheep, dairy products, and the cultivation of fodder are studied and experimented upon. There are three Government Studs for breeding and one Stallion Remounting Depot for rearing and training. The Government also undertakes to lend bulls and stallions to private applicants for the improvement of breeds. Large pasturages have also been established under the management of the Imperial Household, from which high class horses and cattle are produced. In I9I I a Manufactory was established for the provision of serum for securing immunity from rinderpest. This serum is distributed free in localities where the disease has been prevalent. In I910 the figures for live stock were:-Horses $1,564,643$, Cattle $1,384,183$, Sheep 3,357, Swine 279, 101. The number of slaughter houses in 1910 was 489.

Forests.-Japan, which possesses a fertile soil and humid climate, has very large areas of forest lands, and the total acreage of forests and plains in Japan proper amounts to 55, 12 I, 570 acres, forming about 74 per cent of the total area of the country. Practically one-half of this is occupied by State Forests and Plains. Until recent years forestry was not treated in a practical manner, but as manufacturing industries developed the demand for timber forced home the necessity of conserving forest lands on a scientific basis. During the last few years the Government have reorganised the forestry administration and encouraged afforestation by strictly enforcing the Forestry Act. The production of timber in the year I9Io is valued at $£ 13,110,724$, while the land was afforested to the extent of 271,772 acres at a cost of $£ 332,403$. Incidental to this, also, the improvement of irrigation has been studied and a programme covering all the branches of forestry administration was introduced in I9II extending over a period of eighteen years. Meteorological observatories are to be established in the most important forests and special subventions are granted for the restoration of waste public lands and for promoting and protecting forests. The revenue from the sale of timber and other products and from rentals amounted for $1908-09$ to $£ 949,634$; in I $909-10$ to $£ I, 001,453 ;$ and in $1910-i 1$ to $£ I, 088,505$.

Foreign Trade. - The foreign trade of Japan has shown considerable expansion during the last few years. In 1908 the total value of the exports amounted to $f 37,824,567$, and in I9I I to $f 44,743,388$. The total value of imports for the first named year amounted to $f_{43}, 625,746$, which had advanced to $f_{51} 1,380,570$ in $19 \mathrm{rr}$. The total value of foreign trade for these two years was, therefore, $f 81,450,313$ and $f 96,123,958$. A large part of the export trade is to countries in Asia, of which China is far the most important; but the United States is the principal customer, European countries taking a considerably smaller amount. Of these, France has the 'most extensive dealings, Great Britain coming next. Although Asiatic countries supply the largest proportion of imports (India being chief among them), Great Britain is far the largest exporter, the United States coming third.

Table II shows the value of exports from and imports to foreign countries for I9IO-II.

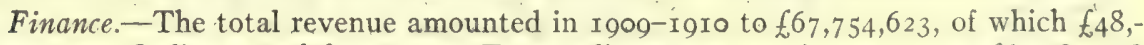
324,2 I 7 was Ordinary and $f_{1} 19,430,4$ I I Extraordinary revenue; in I 9 ro- 19 I I, $f 67,287,378$

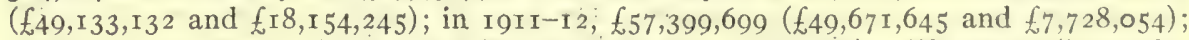

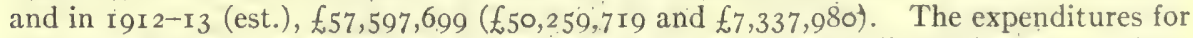
the same periods were as follows, showing Ordinary and Extraordinary: $1909-10, f_{53},-$

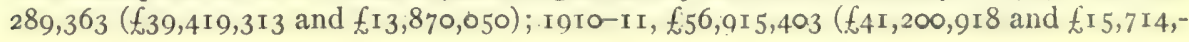


Table II. Exports and Imports: $I=1000$.

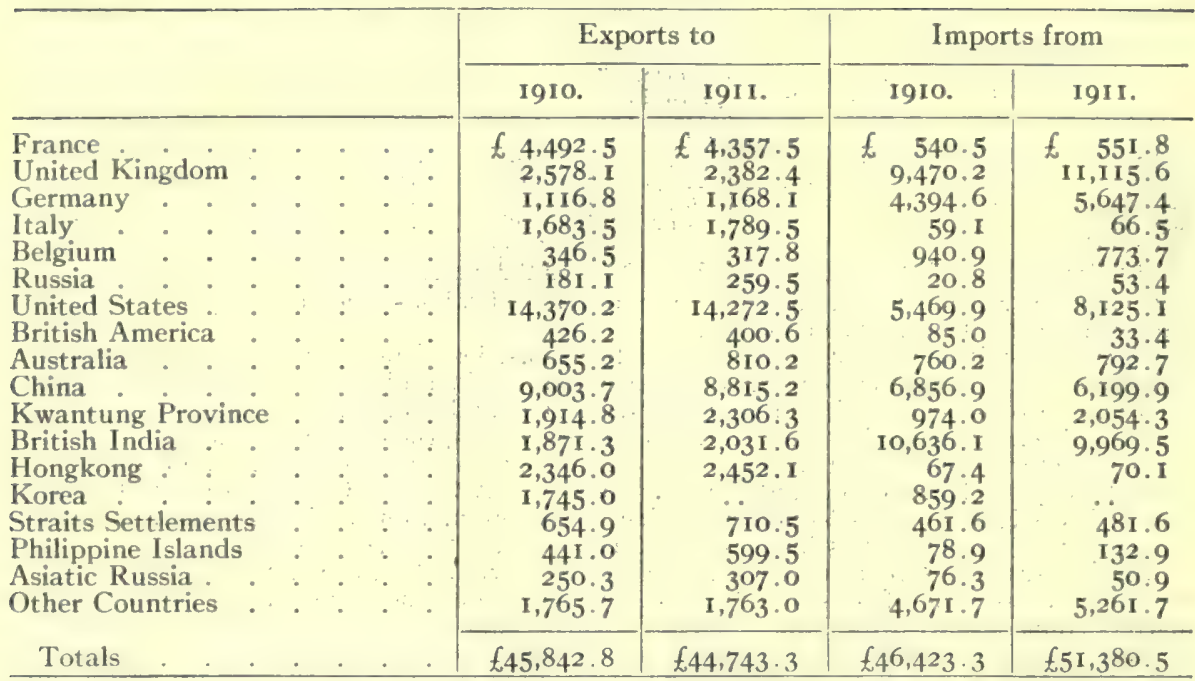

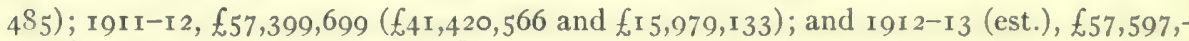
$699\left(f_{4} \mathrm{I}, 207,386\right.$ and $\left.f_{6} \mathrm{I} 6,390,3 \mathrm{I} 3\right)$.

For $1912-13$ the chief items of Ordinary revenue were:-Land Tax $£ 7,540,799$, Income Tax $£_{3}, 272,528$, Excise $£_{4}, 989,220$, Public Undertakings, \&c. $£_{1} 13,136,864$, Telegraph \& Telephones $£ 5,416,944$, Stamps $£_{2}, 717,396$. Extraordinary revenue:-From Naval Replenishment Fund $£_{1}, 200,000$, River Improvement Fund $£_{1}, 516,231$, Sale of State Property $£ 457,963$, Surplus from I9II-12 $£ \mathrm{I}, 550,672$, Public Loans $£ 151,815$.

The chief items in Ordinary Expenditure for $1912-13$ were $(I=I 000)$ :- Imperial Household $£_{450} .0$, Foreign Affairs $£_{428.2}$, Home $£_{1}, 240.7$, Finance $£_{1} 18,567.4$, Army $£ 7,679.0$, Navy $\ell_{4,081.5}$, Justice $\ell_{1} \mathrm{I}, 235.0$, Instruction $\ell_{948.5}$, Agriculture \& Commerce $£_{762} .6$, Communications $f_{58} \mathrm{I}_{4}$. I. Extraordinary expenditure $(I=I 000)$ :- Foreign Affairs $£ 93.6$,

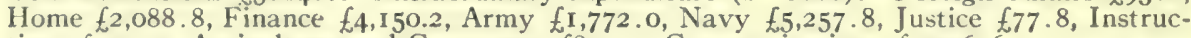
tion $f_{101}$.9. Agriculture and Commerce $f_{841.2}$, Communications $£_{2}, 006.6$.

The National Debt stood at $\{255,370,500$ at the end of $1911-12$, the figures for three years being as follows $(I=1000)$ :-

Amount brought over from preceding year

Amount Issued Redeemed

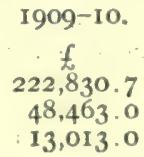

I910-II.

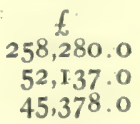

I9I I-I2.

$£$
$265,039.5$
554.0
$10,223.0$

Mining.-For the efficient administration of the Mining Industry, Japan is divided into five districts, each of which is under the control of a mining inspection office. The total area of mining land leased amounts to 7,013,265 acres, and of this area $1,252,146$ acres are occupied by mines actually in operation. The mineral products obtainable in Japan include gold, silver, copper, lead, zinc, coal, iron, antimony, manganese, graphite, sulphur, peat and petroleum. The total number of persons engaged in the mining industry amounted in 1910 to 222,195 , and of these 137,467 were employed in coal mining. The output of the different metals for 19 Io was as follows $(I=I 000)$ :-Gold I 40.3 oz., Silver 4.550.5 oz., Copper 130,530.2 lbs., Lead 10,419.2 lbs., Antimony 345.9 lbs., Sulphur 116,925.8 lbs., Pig Iron 157,894.7 lbs,, Steel 20,744.8 lbs., Iron Pyrites 213,319. I lbs., Coal 15,681 .3 met. tons, Petroleum 76,621.9gals. In I9 I an increase of 58 per cent occurred over the previous year in the number of applications for coal prospecting, and an increase of 337 per cent in applications in regard to sulphur. During the latter year also the value of mineral exports amounted to $£ 4,564,872$, and of imports to $£ 8,680,746$, an increase on the preceding year of $£ 1,659,069$; the increase being chicfly due to the export of coal, and in imports to the larger quantity of iron brought into the country. The capital invested in mining enterprises during 1911 amounted to $£ 4,272,887$. The aggregate nominal capital of mining companies at the end of this vear amounted to $f 22,330,826$, of which $f, 16,389,568$ was paid up.

Fisheries. - The fishing industry was valued in 1910 at about $f 8,018,681$ sterling and has shown remarkable progress during the last few years. In 1908 the fisheries of every descrip- 
tion realised a revenue of $\{7,338,000$, and in 1909 the value was $\{7,759,000$. The number employed in this industry in 1908 amounted to 810,717 and no less than 423,403 vessels of the old Japanese type were engaged therein, in addition to 467 sailing vessels and 130 steamers for trawling and whaling. An important recent development in the industry is the use of oil engines for driving the fishing boats and there are stated to be about 1000 engaged in this section of the business. Pelagic Fishery has made great progress in recent years, the value of deep sea catches amounting in 1910 to 6864,174 . By the Fishery Agreement made with Russia in 1907 the fishing rights of Japan extend as far north as Kamschatka, and the value of catches in these parts has steadily increased. This has been due to a great extent to the introduction of the Pelagic Fishery Encouragement Act, a few years ago. The principal fish caught in Japanese waters are herring, sardine, mackerel, bonito, tunny, grey mullet, salmon, trout and cod, and among marine mammals the whale and seal are extensively caught. Shell-fish of various kinds are also largely produced. An export trade in fish with China has been built up and with Europe and America in fish oil, isinglass, shell buttons, tinned crab, salmon and trout amounting in the aggregate to $£ 1,572,825$ in 1910 , while the total value of manufactures in these directions amounted in the same year to $f 4,479,824$. Fishery and Marine Products' Guilds have been established to the extent of '3,729. A Fisheries' Institute has also been organised in the capital and similar institutions in the provinces, numbering altogether 38 . The largest association connected with this industry is the Dai-Nippon Suisan-Kwai, which receives a special grant from the Government.

Industrial Employment. - The number of operatives employed in different industries in I9I0 was as follows $(\mathrm{I}=1000)$ :- Textiles 426.0 , Machine \& Tool Factories 55.5, Chemical Works 65.5, Food \& Drink Factories 52. I, Printing \& Publishing 19.7, Wood \& Bamboo Work 13.3, Electrical 3.0, Metal Refineries 38.4, Mining Manufactures 15.9. The rate of wages markedly appreciated in nearly every industry during I9I0-12.

Tariff.- The new Tariff came into force in July I9II. Under this tariff raw materials are admitted, as a rule, duty-free; upon partly manufactured goods the duties imposed are light, and on manufactured goods the rates vary from 15 per cent to 40 per cent. Duties as high as 50 per cent are levied on articles of luxury as the extent of their importation is very limited. Under the Tariff Convention with Great Britain a guarantee was given by which ten principal articles of export from Japan to the former country should be exempt from Customs Duty, while concessions were made in the Japanese Customs Duties upon important British merchandise, including cotton and woollen tissues, mixed tissues of wool and cotton, linen yarns, paints and sheet iron. In the Convention with Germany, in consideration of concessions made on the Customs Duties upon important Japanese products, reductions were made by Japan in the duties on goods from Germany, embracing, leather, salicylic acid, quinine, artificial indigo, coal tar dyes, woollen yarns, mixed tissues of wool and cotton, packing paper, zinc plates and sheets, and gas, oil and hot air engines. In regard to the Convention with France, reciprocal treatment was also arranged, France receiving, in consideration of the application of the French minimum rates to important Japanese products, reductions on sardines in oil, butter, wines, olive oil, perfumery, woollen yarns and tissues, binoculars, automobiles, and parts of knitting machines.

Railways. - Of the 6060 miles of railway, 4870 miles belong to the State, the purchase of which from the original companies was completed in 1909; 484 miles were private lines and 706 miles belonged to the South Manchurian Railway Company. For the year I9IO-I I the number of passengers carried on the various systems was $166,888,048$, freight to the extent of $31,718,399$ tons, while traffic receipts amounted to $£_{1} I, 213,921$. The estimated receipts and expenses for $1912-13$ of the Imperial Government Railways are $£_{1} 10,25^{2}, 244$ and $f_{9}, 165,739$ respectively, showing a net profit of $f_{1}, 086,505$. A Light Railways Act was introduced in 1910 which removed certain obstacles to the extension of this type of railway, the result being that a considerable impetus was given to their construction. It is anticipated that light railways will now be laid every year to the value of over a million pounds sterling. The private and light railways at the end of $1910-$ I I numbered 59 having an aggregate capital of $£ 8,096,999$. The number of 'passengers carried during the year amounted to $25,909,254$, and goods to the extent of $2,314,367$ tons, while traffic receipts and expenses amounted to $£ 458$, I9I and $£ 219,535$ respectively. On the South Manchurian Railway the number of passengers carried for the year I9IO-II amounted to $2,349,088$, the total amount of goods to $3,922,164$, the total receipts to $£ 2,537,917$ and the expenditure to $£ 2,158,083$. There are also 38 electric railway companies having an aggregate capital of $f 8,279,217$ with a total mileage of 350 , while an additional iso miles were under construction at the end of I9II. The total extent of projected electric lines was 348 miles, and the Tokyo and Osaka municipalities own 82 miles of tramways open with 7 I miles projected. The Kyoto municipality also have 16 miles in course of construction. 
Shipping and Shipbuilding.-Great attention has been given. to these industries and the progress in construction is shown in the following figures:-

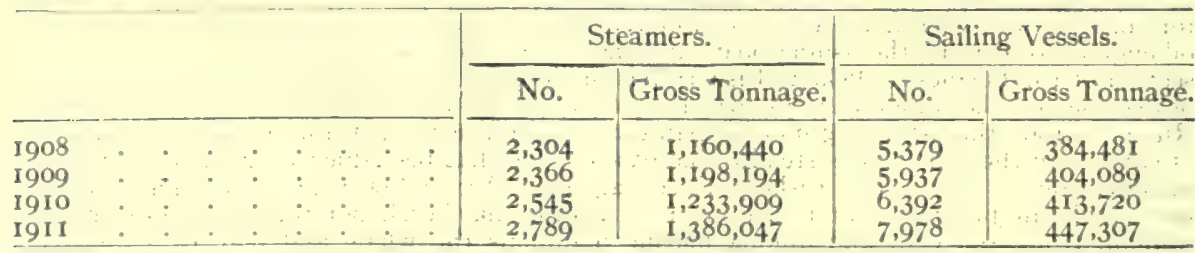

Under a new law Japanese subjects or companies engaging in transportation business receive from the Government navigation subsidies according to mileage, tonnage, speed and age in regard to steel steamships with a gross tonnage of not less than 3,000 tons, a speed of not less than 12 knots per hour and not more than 15 years old, which are registered in the Japanese shipping register. During 1912 the improvement of the Yokohama Harbour pier was begun, and was to be completed in 1916 at a total estimated cost of $f, 1,073,850$.

The total entrances of steamships of all nations, including Japanese, were for the years I908 to I9I I inclusive as follows:- In 1908, 10,330 vessels of 20,104,257 tons; in 1909, 9960 vessels of $19,670,790$ tons; in 1910,9442 vessels of $20,073,680$ tons, and in 1911,8576 vessels of $19,993,397$ tons. Sailing vessels entered Japanese ports in 1908, to the extent of 2,699 with a total tonnage of 111,320 ; in 1909,2370 with a tonnage of $123,66 \mathrm{I}$; in 1910 , the figures were 1726 and 100,107 tons, and in 1911,433 and 60,172 tons. Of the total number of steamships Japan's proportion of the entrances of 1908 was 43 per cent, British vessels figuring to the extent of $32 \frac{1}{2}$ per cent; in 19 I I the respective proportions were 47 per cent and 30.8 per cent. The entrances into and clearances from all ports in 1910 amounted to 13,599 , with an aggregate tonnage of $39,815,225$; in 19 II the figures were 18,026 , and $40,103,283$ tons.

Army and Navy. - The Japanese Army in ror 2 consisted of 936 companies of infantry 95 squadrons of cavalry, I 52 batteries of field artillery, 53 batteries of heavy artillery, ro batteries of mountain artillery, 58 companies of engineers, 38 companies of commissariat, I 2 companies of communication troops, 5 companies of telegraph corps, and an airship corps. Under the new system the Fortress artillery was converted into Siege Artillery. In order to strengthen the efficiency and the mobile power of this corps lighter guns have been adopted and horses provided for their movement. The formation of this corps has had the effect of introducing the unification of organisation of artillery corps in strength, whereas under the old system the strength of a regiment or a battalion varied in different fortresses. Mountain artillery has also been converted into Field artillery: Formerly this brigade consisted of three regiments, but this has now been reduced to one brigade of two regiments, the number of brigades being increased from two to three. Under the system of conscription, able-bodied males of from 77 to 40 are liable for service in the Army. Young men of the better classes who are termed one-year volunteers must pass a scholarship equal to graduates in the Middle School. After a year's service they are enrolled in the Reserve Service with the rank of non-commissioned officer. Teachers in Primary schools undergo the six-weeks' service, having the regular training of the ordinary soldier, after which they are enrolled for territorial service.

The Japanese Navy consisted in I9I 2 of $x_{5}$ battleships with a tonnage of 2 I 2,980; 13 armoured cruisers of 151,303 tons; 47 other war-ships of 165,253 tons; 55 destroyers of 20,508 tons; 77 torpedo boats of 7,258 tons; or a total of 207 vessels of 557,302 tons, compared with 157 vessels with a tonnage of 283,743 tons at the time of the outbreak of the Russo-Japanese War. The bulk of these vessels were constructed abroad, either in England, France or Germany. Great efforts are being made to provide facilities for the construction of battleships in Japanese yards; the present difficulty being the supply and construction of materials. Published figures indicate that were it possible for Japan to construct its own vessels a saving would be effected of about i $8 \%$.

Education. - The educational system which obtained up to 19 I provided for scholars in the primary school entering at the age of six, where they stayed until they were twelve years of age. At the conclusion of this period they were transferred to the Middleschool for five years and then graduated to the High-school for three years, subsequently entering the University for three or four years. These courses occupied some seventeen 
or eighteen years and precluded students entering one of the Universities before the age of 23 or 24 . In many cases, therefore, it was found that their education was not complete until they were about 28 . The unsatisfactoriness of this system was recognised, and in May roro the authorities decided to remodel it. The new programme reduced the course of study in the high-school to two years, and the higher-middle and middle courses were combined, subject to the approval of the authorities, while at the middle school, technical subjects are optional. This new curriculum was introduced in I9I I for the Middle School and in 1912 for the higher grade. Graduates from the latter school are now admitted to the higher school by diploma. The Department of Education is divided into the Minister's Secretariat and their bureaux, which deal respectively with special, general and technical affairs. Several new State Educational Institutions have been or are being organised, including the College of Sciences of the North-Eastern University at Sendai, the College of Engineering at Fukuoka, Sericultural College at Uyeda, the Mining College at Akita, 5th Higher Commercial School at Otaru, 6th Medical School at Niigata, and 7 th Higher Technical School at Yonezawa. The number of schools of all classes in 1908-09 were 34,376 , the number of instructors and teachers I 60,878, the number of students and pupils 6,627, I04, an increase of about 300,000 in the previous year, and graduates, 607,52r. The Department of Education employed 96 foreign teachers, 25 being English, 22 German, 2I American, 6 French, 3 Russian, and other countries 19 . There are 405 Kindergartens where infants from 3 years of age are educated until they are old enough to enter the elementary school.

Physical culture, which includes Military and Gymnastic exercises, is conducted in all schools from the Primary to the University preparatory schools. In the Primary schools there is military drill without arms after the fourth year. In the secondary schools drill is compulsory through the whole five years. During the last three years students are given drill with arms and trained in the practice of giving command. In the High and similar schools, military training with arms is continued. Gymnastic training in Japan is a combination of all the best systems of different countries, and fencing and jujitsu are also taught in many schools.

Religion.-The prevailing religion of Japan, Shintoism, was represented in 1908 by $162 ; 442$ temples or shrines, at which 14,826 ministers officiated. Buddhism, the old religion, was represented by 71,927 temples with 5,268 priests. Christianity, represented by the Protestant, Roman Catholic and Eastern Orthodox churches, possessed II 32; 176 and I74 places of worship respectively in 1909. The total membership of each branch was 75,608, 64, II8, and 31,538. The missionaries, including wives, numbered 931 Protestants, 319 Roman Catholics and 2 Eastern Orthodox, while the native ministers amounted to 563 Protestants, 34 Roman Catholics and 38 Eastern Orthodox.

Poor Law and Charity.- - The State. Relief Fund amounted in the year 1907-8 to about $£ 3,488,437$. The disbursements from this fund for the same year amounted to $£ 53,600$. This included the relief of destitute cases and cases of death not identified. The State also provides for the support of paupers. The hospitals established by the Red-Cross Society at the end of 1909 amounted to twelve institutions, attached to which were 3,787 doctors, pharmaceutists, and nurses. The number of members in this year amounted to $1,525,822$ compared with $1,443,420$ in the previous year. In addition to this there are at the present time 260 asylums and orphanages and about 50 public and private reformatories for boys. There are in addition a number of other hospitals for special diseases. Good work is also being carried out in connection with the Ex-convicts reform, the fund for this purpose totalling approximately $£ \mathbf{1} 80,000$. Fifty-five homes had been established to carry out this work at the end of 1908 ; the number dealt with for this year amounted to 390 . There are in addition five or six other establishments of the same description doing good work.

Justice, Crime, etc.- The criminal code of Japan which came into force in 1909 is in many ways an advance over its predecessor, which was based chiefly on the French model. The new code gives a greater amount of discretionary power to judges. The punishments provided under this code include capital punishment, penal servitude, imprisonment, fines and detention, with confiscation as a subsidiary penalty. Penal servitude ranges from not less than one month. Any attempt on the life of a member of the Imperial Court or a Prince of Royal-blood receives capital punishment and for lèse-majesté, penal servitude varying from two months to five years. The importation or manufacturing of opium is also a punishable offence, the term of imprisonment varying from six months to seven years, and for smoking opium, imprisonment for three years or under. For gambling or lottery and for games of chance a fine is imposed of rooo yen (about $£ 100$ ) or under, and for habitually 
indulging in games of chance, imprisonment for three years or under. The issuing of lottery tickets or acting as lottery agents is also punishable by imprisonment or fines. At the end of the year I909 there were 370 courts in the country; one Supreme Court, seven Appeal, 50 District and 312 Local courts. The number of judges was 13,037 , distributed respectively as to $25,133,598$ and 581 . The number of cases tried in the Supreme Court in this year was 676 ; in the Appeal Court 5,677. The criminal cases tried in these courts numbered 2,453 and 11,353 respectively. At the district and local courts during the same year the number of civil and criminal cases numbered 588,153 , the prosecutions amounting to 230,955 . The number of prisons at the end of 1908 was 149 , in which were 53,619 prisoners, 47,312 of these being convicts. The total revenue derived from prisons in 1908-9 amounted to atout $£_{131}, 59+$ and in $1909-10$ to $£_{125,238}$. The expenditure for all items amounted in the sime years to $£ 589,439$ and $£ 603,327$ respectively. The number of police stations at the end of 1907 was 16,072 , police officers and men numbering 37,110 . The number of suicides in 1908 amounted to 9,600 (5,897 males and 3,703 females). The number of fires occurring in I 908 was I 5,35 I, by which 37,380 houses were destroyed or damaged.

Political History.-The last few years have been marked by a general expansion of Japanese home industries and foreign trade, together with retrenchment in expenditure on Army and Navy, the improvement of conditions of labour, and considerable activity in connection with the construction of inland transport facilities. Briefly, the Government have been concentrating their attention on the economic problems which always accompany a transition in industrial development. The Japanese are essentially an agricultural people, and the building up of manufacturing industries has introduced new economic conditions. This is clearly instanced by the fact that whereas in 1908 the

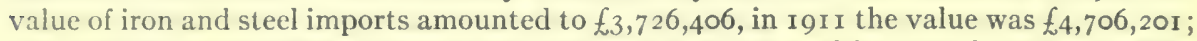
the value of other metals imported in I 908 was $£_{7} 86,566$ and in I9 I $~ £ 1,090,527$, while the imports of machines and machinery were valued in the latter year at $£ 4,692,828$ and $£+3 I_{3}, 4 I_{2}$ respectively. In ten years the figures for these items about trebled.

An important step was taken in I 9 Io by the introduction of a new Tariff of a highly protective character. The objects of this tariff were to provide an increased amount of revenue and to encourage the building up of home industries. Provision, however, was made for the reduction of certain duties on commodities imported from countries with whom conventions had been arranged. Substantial concessions were made to Great Britain by a commercial treaty in April r 9 I i in return for the free entrance into the latter cuuntry of Japanese goods, on which Great Britain levied no duties. In recognition of her treatment, Japan agreed to the entrance of British 'cotton and linen goods and iron and steel manufactures at a considerably reduced rate, these classes of manufacture representing about 80 per cent of the total British exports to Japan.

During 1910 further progress was made in the exploitation and absorption of Korea; an agreement was signed with Russia by which the two Powers agreed to the maintenance of the status quo in Manchuria and to refrain from indulging in any antagonistic rivalry in its development; and a Bill was introduced having as its object the granting of permission to foreigners to hold land, provided that foreign Governments granted similar privileges. This latter Bill was passed after the introduction of an amendment to the effect that such a concession should be restricted to persons and to business firms resident in Japan. The year I I I was chiefly of note for the development of the internal resources of the country and the provision of better transport facilities and accommodation. With this purpose in view the sum of $£ \mathrm{I} 3,484, \infty 00$ was allocated to the improvement of waterways, and $£ 0,800,000$ to the extension and improvement of railways; $£ \mathrm{I}, \infty 00,000$ was devoted to the improvement of roadways in Korea, and nearly $£ 850,000$ to the construction of custom houses; the Harbour Commission also recommended the expenditure of $f_{10,000,000}$ on new harbour works at various ports. The issue of a loan in (ireat Britain for $£ 6,000, \infty 00$ was also carried through for the extension and improvements on the South Manchuria Railway.

The most important political event in I9I I was the renewal in July of the alliance between Japan and Great Britain for a further period of ro years; a new condition was introduced into the terms of the alliance, whereby it was agreed that if either of the contracting parties was at war with a Power with which it had a Treaty of Arbitration neither of the parties should be under an obligation to give its support. Marquis J. 
Komura (b. 1853 ), whose political services to his country were crowned by his diplomacy in making peace with Russia, (E. B. xv, 892), diêd November 24, I9I I. He was created Marquis in I9ro in connection with the annexation of Korea.

In Igr 2 Japan came to an understanding with Russia for defending the interests and policy of both countries in Mongolia. The year was chiefly memorable however for the death of the Emperor Mutso-Hito (b. I852; d. July 3oth), under whom modern Japan had been created (E. B. xix, IO); and for the dramatic suicide, on the occasion of the Emperor's funeral, of General Count Maresuke Nogi (b. I849; d. Sept. I3th), the hero of Port Arthur and Mukden (E. B. xix, 733; xxiii, 926 et seq.).

In 1909 the Japanese Cabinet was formed as follows: Premier and Minister of Finance, Marquis Gen. T. Katsura; Foreign Affairs, Count J. Komura; Home Department, Baron Dr. T. Hirata; Justice, Viscount C. Okabe; Education, E. Komatsubara; Agriculture and Commerce, Baron K. Oura; Navy, Baron Vice-Adm. M. Saito. This Cabinet lasted until August I9 I, when, in consequence of differences on financial policy, Marquis Katsura resigned. Marquis K. Saionji then became Premier, the following being the principal other Ministers: Foreign Affairs, Viscount Y. Uchida; Finance, Tatsuo Yamamoto; Home Affairs, K. Hara; Justice, M. Matsuda; Agriculture and Commerce, Baron S. Makura; Education, S. Haseba; Communications, Count T. Hayashi; Army, Baron Y. Uehara; and Navy, Baron Saito.

A Cabinet crisis occurred on December 2, I9 1 2, by the resignation of the War Minister, Baron Uehara, as the result of his colleagues unanimously deciding, on grounds of economy, against his scheme for establishing two military divisions in Korea. The Prime Minister was faced with the difficulty that, under the regulations in force, the head of the War Office had to be a soldier, and military opinion was entirely on Baron Uehara's side. Being unable to find anyone to take the War Office in his place, on December $4^{\text {th }}$ the Marquis Saionji submitted the resignation of the Cabinet to the Emperor. The Council of Elder Statesmen met on December 6th, consisting of Marshal Yamagata, Marshal Inouye, Marshal Oyama, and Prince Katsura, and recommended the Emperor to send for Count Terauchi, the governor-general of Korea, to form a government. The situation was however a new one in Japan, the struggle being definitely between the military party, controlled by Marshal Yamagata, and the supporters of a policy of retrenchment. Eventually, on December Igth, a new Cabinet was formed under Prince Katsura as Premier, with the following as his colleagues: Foreign Affairs, Baron Kato; Home, Baron Oura; Communications, Baron Goto; Agriculture, M. Nakashoji Ren; Finance, M. Wakatsuki Reijiro; Justice, M. Matsumuro; Education, M. Shibata Kamod; Army, Lt.-Gen. Baron Kikoshi Yasutsuna; Navy, Baron Saito.

Korea. ${ }^{2}-$ The Peninsula of Korea was annexed by the Japanese Government as a result of the Russo-Japanese War. This annexation took place in August 1910, and a GovernorGeneral was appointed by the Japanese Government. In the 1910-II Budget the total revenue was $£ 694,475$ and the expenditure $£ 694,455$. For I9II-12 the total revenue amounted to $\AA 4,874,178$. This revenue was devoted to road-construction to the extent of $£ \mathrm{r}, 024,275$; to Customs Accommodation Works to the extent of $£ 847,263$; to railway construction and improvement to the extent of $f_{3}, 703,895$, spread over a period of years. The estimated revenue and expenditure for $1912-13$ amounted to $f, 5,289,220$. The industrial products of Korea include cotton and linen goods, coloured papers, earthenware, hides, wood and bamboo work, metal work, etc. The staple industry is agriculture, the chief product being rice, while wheat, barley, millet and beans are also produced. Cotton, tobacco, hemp and ginseng are also cultivated and the raising of live-stock is carried out to a small extent. The most important mineral products are gold, copper, iron, graphite and coal; the export of gold amounting in 1910 to $£ 921,848$. The fishing industry, although carried on in a primitive manner, is extensive, and the value of the annual catch reached in 1910 a total of $f 819,420$. The chief fish caught are cod, sardines, lobster, herring, salmon, mackerel, whale, etc. The forests have an extent of about $12,500,000$ acres, red-pine and other conifers being the principal trees. The total foreign trade in I9Io had a value of $£ 7,169,927$ and in I9I I $£ 7,471,539$. Imports were valued at $£ 4,074,567$ in 1910 and exports at $£ 2,039,332$; in 1911 imports were valued at $£ 5,540,068$ and exports at $£ 1,931,471$.

The chief railway is the Seoul-Wiju Railway, which is 309.9 miles in length. The construction of a bridge over the Yalu, commenced in August 1909, was finished during I9I2.

1 See E. B. xv, 908 et seq. 
The Ho-Nam Railway has a length of 175.8 miles; and the Seoul-Wonsan line, I36.3 miles; is being extended by a length of about 20 miles.

Formosa. ${ }^{1}$ - In the chief industry of this island, namely, agriculture, the following were the viclels of products in 1910 (ooo omitted):- Rice $20,769.9$ bushels, Tea 36,708.0 lbs., Sugar 444,642.9 lbs., Salt 265,251.8 lbs., Cane sugar 5,762,394.5 lbs., Sweet Potatoes $1,712,886.4$ lbs., Indigo $42,580.8$ lbs. Of the mineral products coal was the chief, the output for 1910 amounting to 275,800 tons. Sulphur, camphor, gold and silver are also mined. The value of imports and exports was as follows (ooo omitted):- (1910) exports fi,I98.6, imports $£_{1}, 985.2 ;$ (I9II) exports $£_{1}, 217.5$, imports $£ I, 955.5$.

Saghalien.2 - The chief industry of this island is fishing, for salmon and trout. The manufacture of herring oil-cake is also carried on. Agricultural industries have been encouraged since 1906, and at the end of $1911,1,737$ families had settled on the land and every encouragement was being given for the production of cereals and for stock-raising. During the last few years Saghalien has been proved to possess good indications in regard to oil deposits, and prospecting and development work has been carried out.

(Sydney H. North.)

\section{LATIN REPUBLICS OF SOUTH AND CENTRAL AMERICA}

\section{General Survey.}

The 420 th anniversary of the discovery of America by Columbus (October i 2, I492) occurred in I912. The remarkable transformation in both the political; commercial and social conditions of the twenty different American Republics, lying to Progress the South of the United States, and known geographically as "Latinin Latin America. America," which began with the struggle for independence early in the roth century, is, however, a matter of quite modern development; and year by year, particularly in the case of the more important South American countries, national progress now becomes more and more marked. Since 1909, on the whole, the rate has been well maintained. The improvement has not alone been noticeable in those States which possess the largest extent of territory: it is, perhaps, the smaller and less-important countries which have shown the more remarkable advance. In the case of Argentina, Brazil and Chile, a stage had already been reached several years ago, in commercial expansion and social development, which makes at least a further normal progress each year more or less a matter of course. But, while Mexico, with its 767,000 square miles of territory and its population of nearly I $4,000,000$, has lately retrogressed owing to a continuous state of revolution which began in November 1910, it is interesting to note that the Republic of El Salvador, with but little over 9,600 square miles of superficial area and $\mathbf{1}, 200,000$ inhabitants, has shown improvement in each department of its administration, while it has remained commendably free from such disturbing influences as have affected other neighbouring States, notably Nicaragua, Honduras and Cuba.

The year ror 2 proved politically trying for some States and financially perilous for others. Nicaragua has been in a continual state of revolution since I9og when the disturbances in the internal affairs of that country provoked interference by the United Stales. Honduras has been likewise affected by the affairs of her neighbour; while Paraguay has violently changed her Government four times after as many revolutions within two years. Santo Domingo and Haiti have continued their perpetual internal and extornal quarrels, while Ecuador has experienced serious and sanguinary fraternal encounters, resulting in the deaths of several of her prominent politicians. Mexico has known no political peace since the displacement of General Porfirio Diaz in 1910, after a quarter of a century's faithful public service. Argentina, Brazil and Chile have suffered and are still experiencing financial tension, due to a propensity for large expenditure, which is a natural consequence of the rapid exploitation of their natural resources. Nothing like a financial crisis can be said to have occurred to any one of these latter States, but the serious attention of their respective Ministers of Finance has been devoted to curlailing disbursements, in order to avoid injury to the national credit. The somewhat cool reception which the investing public in Europe has offered to several recent government-supported loans-in Brazil especially-shows that the notice of lenders abroad has been attracted to the danger of extravagance.
1 See $E . B . x, 669 t$ seq.
${ }^{2}$ See E. B. xxiv, 54 . 
Venezuela and Colombia have partially redeemed their good name by maintaining their service upon their Public Debts. although in the case of the latter Republic there is Finance. evidence that severe sacrifice has had to be made in order to find the Finance. amounts falling due upon the half-yearly coupons. Guatemala has remained obdurate in regard to the resumption of her interest payments, some fourteen years in arrears, but there is reason to believe that the British and United States Governments, working in union, intend to insist on arrangements being made for the benefitof her long-suffering creditors. A serious warning to both Guatemala and Honduras was contained in Mr. Taft's last message to Congress, the President observing- "Failing an arrangement, it may become impossible for the Government of the United States to escape its obligations in connection with such measures as may become necessary to exact justice to legitimate foreign claims." The poor arrangement arrived at between the bondholders and Costa Rica (another defaulter over long years) has, so far, been adhered to; while Nicaragua, which had suspended payment upon her Debt since January (I9 I 2) resumed with the maturity of the July coupon, which was paid in October. Difficulty was encountered, as usual, in regard to Ecuador's (Guayaquil \& QuitoRailway and Salt Bonds) Debt, but the coupons were eventually paid in driblets. On the other hand, the smallest of the Latin-American States (El Salvador) showed remarkable punctuality in meeting the interest upon her loan, the credit of this Republic consequently standing high on the London and Paris markets. Cuba's financial condition has become acute, and at the end of I 12 it appeared clear that the assistance of the United States would sooner or later be invoked, the Republic's creditors being found for the most part in that country. Mexico's prolonged internal strife has brought down her once-high credit and abundant resources to a very low ebb, and the administration, while confessing to the absolute necessity of further substantial borrowing, has so far found no European or American house willing to make further advances. The good financial standing of Peru has been recognised by the encouragement given to her last appearance in the loan market.

The natural resources of all the Latin-American countries alike have been still further developed, mainly by the aid of foreign capital, which has continued to flow towards this part of the world in spite of the unstable political conditions prevailing in some cases. This may be explained by the fact that in but few instances have the financial interests of foreign investors suffered; indeed, upon comparison, there have been fewer and less serious losses in these countries than in other parts of the world.

One circumstance to be noted is the tendency of the influence of Great Britain in Latin-America to wane by comparison with the commercial progress made by Germany American and both the commercial and political progress made by the United States. and German While the greater part of the transportation by land and sea remains in the commercial hands of British railways and British steamships trading with Argentina, progress.

Brazil, Colombia, Venezuela, Chile (where the former are not State-owned), Cuba, Paraguay and Mexico, the greater part of the Central-American transportation arrangements are now in the hands of the North Americans. Thus, with the one exception of El Salvador, where the principal railway and its allied steamship service remain British, the whole of the railways as well as the steamship transportation services of Panama, Costa Rica, Honduras, Nicaragua and Guatemala have become United States enterprises. In Argentina, Brazil and Paraguay a gigantic combine of American-French interests has latterly acquired control over the systems, some of which were formerly British.

In other branches of commercial enterprise competition has been keenly felt. While neither German nor French interests have hitherto been particularly aggressive in regard to railway construction; both, as well as Dutch and Italian lines, have been energetically competing for steamship traffic; in the dry-goods trade Germany has proved a very formidable rival. United States enterprise has vigorously attacked what were predominantly British Latin-American markets in cotton and woollen goods, hardware, iron and steel manufactures, and, more especially, the British ship-building connection, having drawn away several orders for battleships given out by the Argentine and Brazilian Governments. Even in the frozen-meat trade United States firms have latterly entered 
the field, purchasing several of the more important establishments, while they have constructed others near British factories, the better to compete with them.

The Belgians, again, have encroached to a very great extent upon the British galvanised wire and coal (briquette) trade; and other count ries have entered with greater freedom the Latin-American markets, where a couple of decades ago they were hardly to be found at all. Japan, for instance, has now a valuable Latin-American connection; her enterprising people have a line of steamships running regularly to the principal South American ports, while the formal opening of the Panama Canal, in rgr5, will witness a new service of trading steamers also flying the Japanese flag. The interstate trade between the various Latin-American Republics has likewise increased to a considerable extent, and this fact, combined with the establishment (especially in Mexico and Argentina) of a number of well-equipped factories to use the native-grown raw material, has further reduced British imports into those countries.

The total foreign trade of Latin-America (export and import) may be conservatively estimated at an annual value of $£ 435,000,000$. The increase during the past decade

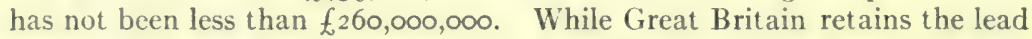
Forelgn in regard to exports to these countries, both the United States and Germany trade.

are fast challenging this superiority. The different Republics of South and Central America in I9IO-I I were customers of Great Britain to the amount of 26.03 per cent of the whole of their imports; the United States supplied 23.3 I per cent, and Germany 15.45 per cent. Trading figures show that the Latin-American States are the largest homogeneous unit in British foreign trade. For the year mentioned, these countries took British goods to the value of $£ 53, \infty 00, \infty 00$, the greater part being manufactured articles. The imports from the United States in I9Io-1 I were valued at $\$ 240,663,222$.

In imports from Latin-America, the United States leads with 34.5 I per cent, followed by Great Britain with 20.99 per cent, Germany with II.4I per cent, and France with 8.20 per cent, and the opening of the Panama Canal is bound to give a further stimulus to North American activity. The total foreign trade of the twenty Latin-American Republics, with their population of $70,000,000$, for the year I910-I I, exceeded $£ 508$,744,806 . Of this total the South American countries (exclusive of Mexico, Central America, Cuba, Haiti and Santo Domingo) were responsible for $£ 468,744,806$, or an increase over the preceding year of nearly $£ 40,000,000$.

During the last fourteen years the foreign trade of Latin-America has grown by 157.4 per cent; taking the States of Mexico and the six Central American Republics apart, we find that the ratio of increase has amounted to 189 per cent in the first, and to 148.6 per cent in the second case. The purchasing power of the Latin-Republics has, therefore, increased at the rate of between II and 12 per cent per annum.

While Great Britain enjoys fully one-third of the entire trade of these countries, her share might well be expected to be substantially greater, since it is mainly with British capital that these South and Central-American States have been opened up, Relative their railways constructed, and their waterworks, telephones, docks and har-

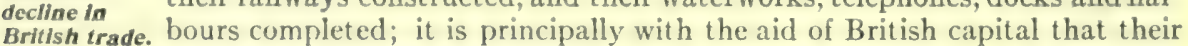
banks and insurance institutions have been brought into being. Moreover, the reinvestments from Great Britain in Latin-American enterprises amount to over $\mathcal{E}_{42,000,000}$ per annum; taking an average for the last three years, one-quarter of the whole amount of foreign capital finding its way into the South and Central-American countries has been of British origin. The sum of such capital invested to date is estimated at $f 685,000,000$ sterling.

For some years past, nevertheless, British trade has by comparison been steadily falling off, while that of the United States has been gaining headway. At the same time Great Britain is more and more dependent upon the products of these countries, more especially of the Argentine Republic, for supplies of wheat and meat, looking to them as the legitimate market for her manufactured goods. The proportions of British trade of late with these countries have increased, it is true; for while in rooo Latin-America took one-eighth of British exported products, by 1905 the total had reached the proportion 
of one-geventh, and by I9Io one-sixth. But about two-thirds of all the British Latin American trade is carried on with only three of the Republics-Argentina, Brazil and Chile:

The problem of Central-American unrest remained during I9 2 . The revolution in Nicaragua has threatened the political stability of the neighbouring States of GuateCentral- mala, Honduras and Costa Rica. The Central-American States collectively American have resented the recent armed interference of the United States in Nicaunest. raguan affairs, but the local issues involved have remained rather obscure, being dominated to a large extent by private financial and commercial interests.

A state of revolution, upon a less serious scale, has been observable in Paraguay. In Brazil, several minor uprisings against constituted authority have been noted; but in these cases the Federal Government has proved competent to deal effectively with the situation. Mexico has presented the most serious and prolonged state of upheaval, one revolution after another occurring in rapid succession; the amount of damage to life and property has proved considerable. Foreign interests, however, have hitherto escaped lightly. The two negro Republics, Santo Domingo and Haiti, have maintained their unenviable reputation for internal disorder, and U.S. Gunboats have been despatched to both in order to protect American interests.

In a diplomatic note presented to the Nicaraguan Government by the United States Minister, Mr. Weitzel, the United States announced a new extension of its policy towards the smaller republics of Latin-America, viz: Santo Domingo, Cuba, GuateUnited States mala, El Salvador, Nicaragua, Honduras, Costa Rica and Panama. They
policy.

have been notified that the Northern Republic would strongly support all duly constituted good governments in these countries; but that it would exert its force, physical and moral, against selfishly inspired revolutions, and that it would protect American legations and American citizens there resident.. In effect, the United States now extends a broad protectorate over the countries mentioned.

For the third or fourth time there has been put forward the proposal of a Confederation of the Central-American States, with the President of Guatemala (Señor Manuel Estrada Cabrera) as the first President. The earliest attempt at such a Confederation was made in I824, when El Salvador, Honduras, Guatemala, Nicaragua and Costa Rica formed themselves into the Central-American Federation, with Señor Manuel José Arce as the first President. It was dissolved in 1839 ; further efforts were made in 1842, when the promoter, General Morazán, lost his life in the attempt, and yet again in 1909 , when Señor José Santos Zelaya, President of Nicaragua, was expelled from his country. There is little reason to anticipate any ultimate success even should the proposal make any further headway.

Early in I9I 2 Dr. Blair, Bishop of the Falkland Islands, visited England for the purpose of raising a sum of $f_{100,000}$ to provide churches, chaplains, schools and nursing homes throughout his vast diocese, comprising the whole western seaboard Anglican of South America and including the Republics of Ecuador, Colombia, Bolivia, Church fund.

Peru, Chile and Argentine-Patagonia as well as the British possession, the Falkland Islands,-in all about 2,000,000 square miles of territory. In spite of a vigorous Press campaign, there was but a meagre response to the Bishop's appeal, and he was obliged to return to his diocese with less than one-fifth of the amount for which he had asked. The Anglican Church in South America remains in a very unsatisfactory condition; the attendances at divine service, even in such large cities as Buenos Aires, Rio de Janeiro, Lima, Santiago, Valparaiso and Asunción, are decidedly scanty.

The year I9r 2 was notable for the large number of new treaties entered into, and old ones ratified, between the different States, the principal exceptions being in the Treaties. cases of Peru with Ecuador, and of Peru with Chile. Boundaries were also adjusted, leaving but few questions of settlement still open.

The amount of newly-invested capital in Latin-American enterprises was somewhat less than during the previous year, the largest borrowers having been Brazil and Chile, 
while a few Argentine industrial (land) and manufacturing issues, a Central American constructional railway project, as well as a Mexican light, traction and power company, and a Brazilian traction company, among others, were well received. A Loans and contracts.

Bolivian tin-mining proposition, on the other hand, was adversely regarded, as were one or two minor enterprises. Several important engineering contracts for works in South America were awarded, the chief among them being the construction of the Valparaiso Dock and Harbour (to Messrs. S. Pearson \& Son), for the sum of about $£ 3, \infty 00, \infty 00$; an enormous reservoir, in connection with the comprehensive sanitary improvements scheme undertaken by the Federal Government of Argentina (awarded to the Cleveland Bridge and Engineering Co. of Darlington) for $£ 3,500,000$; the extension of Buenos Aires port and harbour, involving an outlay of $f 5,000,000$ (awarded to Messrs. C. H. Walker \& Co.); and four destroyers (ordered from Messrs. Cammell Laird \& Co., of Birkenhead); while other port and harbour works were commenced in Mexico, Brazil and Chile.

The great event of the year I913-great from a world-wide as well as a Latin-American point of view-promised to be the completion of the Panama Canal, the huge enterPanama prise undertaken by the United States of America at a cost of over $£ 75,000,-$ Canal.

oo sterling. The official opening is designed to take place in January ror 5 ; but it is probable that the new waterway will be operative for trial purposes considerably before that date.

Attention has been prominently directed to various scandals connected with the rubber industry of Peru, consequent upon the publication in July (1912) of Sir Roger

Casement's belated report upon the slavery conditions prevailing in the

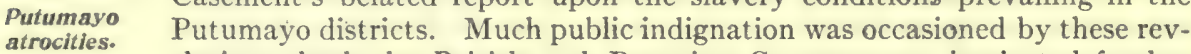
atrocities. elations; both the British and Peruvian Governments instituted further enquiries and appointed Commissioners to proceed to the spot; a Select Committee of the House of Commons sat for several weeks to take evidence; while a prosecution of the parties responsible, British and Peruvian alike, has been promised.

In the following sections on the individual Latin-American Republics, they are taken for convenience of reference in alphabetical order.

\section{ARGENTINA ${ }^{1}$}

Argentina has an area of $1,139,979$ square miles, and the population according to the most recent estimates is 7,I I,9I0, giving an average of 6.I inhabitants per square mile. Imports were valued in I910-I I at $£ 71,161,273$ and exports at $£ 62,991,324$, imports from Great Britain being valued at $£ 21,727,400$ and exports to Great Britain at $f_{1} 8,368,246$. Imports from the United States at $\$ 43,9$ r 8,51 I (U.S. currency) and exports to the United States at $\$ 29,090,732$; in I9II-I2 the imports from the United States were valued at $\$ 5,3,158,179$ and the exports to the United States at $\$ 29,847$, or 6 . The revenue was estimated according to the budget of $1912-13$ at $\$ 348,572,8$ I 2 and the expenditure at $\$ 308,74$ I,620 paper $(\$$ I gold $=4$ S; $\$$ r paper $=$ Is. 9d.). The total public debt amounts to $£$ r 04,5 I 3,655 , the external to $£ 60,285,785$, and the internal to $£ 44,227$,$8 ; 0$. There is about $£ 90,000$ of additional debt made up of cedulas and currency provincial loans and government guarantees. The total mileage of railways is 19,843 , and that of telegraph lines 37,220 . The army has a strength of 24,466 men and 2,444 officers. The navy comprises 27 vessels with a personnel of 3,500 .

Doctor José Figueroa Alcorta entered upon his office as President in March rgo6, at a period when general prosperity prevailed. His succession to President Quintana, who died during his second year of office, gave rise to much jealous feeling; but he surceeded in holding the scale evenly between all parties, and for the most part adhered to the policy of his predecessor.

About this time the shipping returns of the principal ports of the Republic, other than that of Buenos Aires, began to augment; and before roo 6 closed it showed the largest number of vessels entering and clearing on record (aggregate tonnage $2,876,-$

1 See E. B. ii, 460 et seq. 
780). There were also recorded the largest number of patents solicited, 717, of which 637 were granted. In regard to trade-marks 2,324 were solicited and 2,107 were granted.

Early in 1907 was published the report of the Boundary Commission with Brazil, by which the dividing line was decided as follows:-From the mouth of the Cuarein to the mouth of the Pepiriguazú, from the mouth of the Pepiriguazu to the main headwaters of the river San Antonio, and from this point following the bed of the San Antonio to its disembougement into the river Iguazú; from the mouth of the San Antonio following the bed of the Iguazú to its disembougement into the Paraná.

On February 17 , r907, the President appointed a Commission to investigate and revise existing tariff-rates, with the idea of rendering articles of prime necessity cheaper for the consumer. Commerce continued to progress, the total amount for 1907 (including exports $\$ 296,204,369$, and imports $\$ 285,860,693$ ) amounting to $\$ 582,065,052$.

In 1908 the national prosperity continued, the trade balance showing an advance of $\$ \$ 100,000,000$ (about $£ 9,000,000$ ) in exports over the imports, while immigration surpassed all records. The agricultural area showed an increase of $2 \mathrm{r} 6$ per cent as compared with I895. An Arbitration Treaty was concluded with Brazil (Nov. r908), while Argentine delegates were sent to attend the Refrigeration Congress in Paris.

A commission was appointed in I 909 by the Minister of Agriculture and Public Works to design a general system of irrigation throughout the Republic. An executive decree (Nov. ro, I 909) established a National Bibliographic Institute at Buenos Aires, modelled upon that at Brussels. In Buenos Aires considerable improvements were undertaken, a special credit of $1 \$ 7,875,000$ being voted for improving the sanitary system. A new avenue, to cost $1 \$ 8,000,000$ - to be ealled Avenida Centenario, in honour of the hundredth anniversary of Independence-was commenced. The new Carlos Durand Hospital, 300 patients, was opened, the cost being $\$ 550,000$ (gold).

On January 5, I9ro, a protocol was signed in Montevideo between Argentina and Uruguay, in regard to the navigation and use of the waters of the Rio de la Plata. In September the Minister of Foreign Affairs, in a remarkable speech, referred to the fraternity between Chile, Argentina and Brazil, observing: "We are the three strongest nations; we must direct South America upon the path of peace and progress; other countries will see a powerful guarantee for liberty and justice in this triple friendship."

This being the centennial year of the Republic, great rejoicings took place throughout the state, and Argentina was the recipient of numerous congratulations and friendly messages from most foreign governments. The continued prosperity of the country was shown in the revenue increase, which amounted to 7 per cent over the budget anticipation, as compared with 8 per cent for 1909 and 6 per cent for roo8. The total volume of trade showed an increase of $3 \frac{1}{2}$ per cent, the imports increasing by $\$ 49,000,000$ while exports decreased by $\$ 24,725,000$. Among the several exhibitions held in the capital during the year were the International Agricultural, the National Industrial, the International Fine Arts, the International Exhibition of Hygiene and the International Railways and Transport. The Fourth Pan-American Conference, in addition to several other conferences and congresses, was held in Buenos Aires.

In October rgro Dr. Alcorta's presidential term of office came to an end, when Doctor Roque Saenz Peña and Dr. Victorino de la Plaza assumed the offices of President and Vice-President respectively. The new Government met with a friendly welcome, and the President's programme of legislation advocating economies was well received. Towards the end of the year (Dec. I6th) Mr. (now Sir) Walter Beaupre Townley, the British Minister, received notice of transfer to Bucharest, his designated successor being Sir Reginald Thomas Tower, who had served as British Minister in Mexico since 1906. In the last days of the year the British fleet, under Vice-Admiral Arthur Murray Farquhar, visited the River Plate, and met with a cordial reception, a number of entertainments being both offered and returned in connexion with the event. The arrangements in connexion with the demarcation of the Argentine-Chilean boundary progressed satisfactorily. The Andine tunnel, connecting the two Republics of Argentina

1 Pesos. 
and Chile by rail, was completed and opened to traffic early in May, while an agreement was signed between Argentina and Uruguay for the laying of a cable between the capitals of the two countries, to form a part of their national telegraphic departments. Steps wert taken towards establishing wireless communication with Europe, Asia and Africa, stations having already been erected along the Argentine coast. During the latter part of I 10 Mr. James Bryce, British Ambassador to the United States, paid a visit to five of the South American States, including Argentina, calling twice at Buenos Aires.

In January I9I I a series of destructive conflagrations occurred in Buenos Aires, generally attributed to incendiarism; property was destroyed to the value of $£ 3, \infty 00, \infty \infty 0$, including the Custom House and most of its contents, as well as a large number of places of business. On February I 3 th the severe drought - the worst known since 1877 broke. In the following month (March Ioth) two Argentine steamers were seized by Paraguayan insurgents, and several Argentine citizens suffered ill-treatment. Sir Walter B. Townley left Buenos Aires on March 3rd. In the same month, the Argentine Club was opened in London. In April diplomatic relations with Bolivia, after a long period of suspension, were renewed, the Bolivian Minister in Lima, Peru, being selected as the representative at Buenos Aires. In May were held the centennial celebrations of the birth of Sarmiento, a former President of the Republic. Serious scandals in connexion with the administration of the Government Land and Colonies Department were brought to light, and an official investigation was ordered; but, upon the earnest representations of influential parties, the President in June ordered all proceedings to be stopped. On July 29th the new British Minister, Sir Reginald T. Tower, arrived.

An executive prohibition regarding Italian immigration occasioned much ill-feeling between Argentina and Italy. Difficulties had arisen between the two governments owing to Argentina insisting upon sending medical inspectors on board emigrant liners, which were already under the supervision of a medical officer of the Italian navy. Upon the Argentine government refusing to withdraw this measure, in spite of the objection of the Italian government to admitting on board the medical officers of the republic, the Italian Government, "with a view to upholding the national dignity," suspended by decree all emigration to Argentina. The decree was cancelled in August 1912, and the emigration movement from Italy was resumed.

The Foreign Offices of Argentina and Chile entered into a railway agreement between the two countries with the object of preventing a tariff war, and of facilitating international communication. On August 26th the new Argentine " Dreadnought " battleship, the "Rivadavía," was launched at Quincy, Mass., U.S.A.

In September the President vetoed certain subsidies agreed to by Congress, but which had not provided the necessary resources, the Executive exercising his prerogative under article 70 of the Constitution. In this month the Supreme Court of the Argentine Republic ruled that all railway companies were liable to payment of Municipal Taxes, against which decision, appearing to be in contravention of article 8 of the Mitré Law, the different companies petitioned Congress.

A further 2345 miles of new railway were constructed in I9 I I, of which 746 miles were State lines. The total mileage in the Republic now amounted to 19,843 miles. Owing to labour troubles and inundations, some of the railways suffered in their traffic receipts, although dividends were but little affected. The government sanctioned the amalgamation of the Buenos Aires Western and the Buenos Aires Great Southern Railway Companies, with a combined capital of over $£ 68,000,000$, subject to a railway being constructed from Dolores to Ajo, and a deduction on all freights being granted to the Government.

In August 1912 the administrations of the Cordoba Central Railway, the Cordoba and Rosario Railway, and the Cordoba Central Buenos Aires Extension Railway, agreed upon amalgamation subject to the approval of the Argentine Government. A powerful I.ondon-New York Syndicate, in July I912, consummated the combination of an important system of railways in Argentina, including the provinces of Entre Rios and Corrientes. In November the Government refused the offer made by an Anglo-French Syndicate for the acquisition of the State Railways. 
In ror 2 the estimated number of cattle in the Republic was: $29,400,000$ horned beasts; 7,615,000 horses; 67,394,000 sheep. Concurrently with the outbreak in Great Britain of foot and mouth disease, it appeared in a milder form in Argentina. The ports were closed to cattle from Great Britain from July 6th.

The financial resources of the State were proved by Dr. Rosa, Minister of Finance, to be heavily embarrassed, there being a net deficiency of $\$ 70,000,000$; a sum of $\$ 400,000$, $\infty 00$ was due upon public works under construction, and $\$ 70,000, \infty 00$ upon armaments. It was shown that the Agricultural Department absorbed 9 per cent and that official salaries required 40 per cent of the country's total resources; the service of the National Debt called for 25 per cent, thus leaving 26 per cent to meet all other liabilities. In July the Government issued, in Paris, a $4 \frac{1}{2}$ per cent loan for $£_{1} 4,000,000$ ( $\$ 70,000,000$ gold), which was offered at $99 \frac{1}{2}$ per cent. The public financial responsibilities of Argentina amounted to $£ I_{04}, 513,655$, in addition to $£ 90, \infty 00, \infty 00$ of unpaid debts, made up of cedulas and currency debt guaranteed by the National Government and loans issued by the Provincial Government and the Municipality of Buenos Aires. The Currency debt carries no interest, but interest has to be found upon $£_{1} 50,000,000$ (out

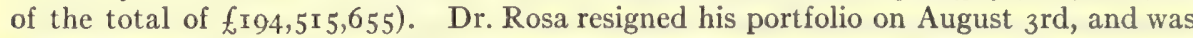
succeeded in office by Señor. Enrique Perez.

Two Argentine-Bolivian Sub-Commissions started on June 28 and July 3, I9I2, escorted by troops drawn from both Republics, to map out the demarcation lines of the frontiers. During the investigations a Bolivian fort (Valibran) was discovered on Argentine territory, no doubt accidentally erected there, the River Pilcomayo, near which the fort was built, frequently changing its bed. Friendly negotiations ensued for the removal of the fort to the Bolivian border. In July, General Roca, formerly President of Argentina, went to Brazil as Special Envoy, and was accorded a brilliant. reception. He retired in September I9 2, and was succeeded by Dr. Lucas Ayarragaray, as Minister. The return to Rio of Dr. Campo Salles, Brazilian Minister at Buenos Aires, took place in July. In this month also Dr. José Figueroa Alcorta, President I906-Io, was offered the post of Special Ambassador to Spain; while the Argentine Minister to London was raised to the dignity of Envoy Extraordinary and Minister Plenipotentiary. On August 5, r9 2, was signed the protocol of a treaty of reciprocity between Argentina and Uruguay, relative to coasting and river navigation commerce.

For the first time during the past decade, the position of the country's trade (in I9I I) showed in an unfavourable light, the trade balance against the Republic amounting to $\$ 42$, I I , I 48, while in I9Io the balance had been in its favour to the amount of $\$ 20,855,399$. For the first 6 months of I9I2 (to June 3 oth) the balance once more showed in favour of the Republic. Serious strikes occurred upon the railways and in the docks, and endured for some months, while bad crop weather, up to August, was experienced.

The cost of living in the capital again increased, and showed an advance of fully roo per cent above that prevailing 20 years ago. (The population of Buenos Aires on October 3I, I9I2, was I,405,06r). Meanwhile dividends and salaries remained unchanged. Railway expenditure has advanced very rapidly, but revenue has shown very little inclination to meet it, rates displaying a tendency to fall. Yellow fever proved troublesome, and a plague of mosquitoes visited the greater part of the country. The Government passed a special vote to fight the danger threatened.

On June 30 th the Government submitted to Congress a law imposing the principle of taxation on land values, the project following closely along the lines of the English Finance Act r909-ro. In July four new destroyers, built by Messrs. Cammell Laird \& Co., of Birkenhead,- " Santiago," "San Luis," "Santa Fé " and "Tucumán,"-which were intended to be added to the Argentine Navy, were completed. The order, however, was subsequently rescinded, and in October these vessels were sold to the Greek Government. In spite of the opposition offered by the Ministers of Foreign Affairs and Finance, the Senate had adopted, by 15 votes to 14 , a minute asking for the const ruction of a third "Dreadnought" (Sept. I 7 th).

General José Inocencio Arias, Governor of the Province of Buenos Aires, and one 
of the leading statesmen of the Republic, died at the age of 75 on September Irth, being succeeded by Colonel de la Serna.

\section{BOLIVIA ${ }^{1}$}

Bolivia has an area of 708,195 square miles, and the population according to the most recent estimates is $2,267,935$, giving an average of 3.38 inhabitants per square mile. Imports were valued in 1910-I I at $£ 5,837,14 \mathrm{I}$ and exports $£ 8,263$, II 7 . Imports from the United States in I910-I I were valued at $\$ 891,624$ (U.S. currency) and exports to the United States at $\$ 327$; in I 9 I I-I 2 , imports at $\$ 991,525$ and exports at $\$ 9,884$. The public

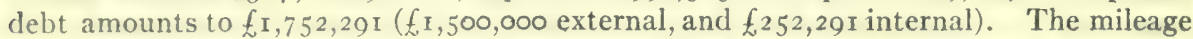
of railways is 860 , and of telegraph lines 3,109 . The army has a strength of 52,500.

A Commercial Treaty between Bolivia and Peru was signed June I, I906, and the Customs Tariff Act of December 3I, I905, came into force that year. The monetary system was reformed, providing for a gold standard (finally. adopted on Dec. 3I, ino8); the national credit improved, and the system of taxation was revised. Concessions for new railways, averaging 8,36 miles, were granted to an American Syndicate. New mining regulations came into force April 2oth. On December i6th the interest on unpaid licences was reduced to 9 per cent per annum; the law of October 1890 and article 6) of the mining rules and regulations of October 28,1882 , were also modified.

The financial resources of the State were increased during I 906 by the payment of the Brazilian and Chilean indemnities, approximately $\$ \mathrm{I}_{4}, 000,000$, being used exclusively in railroad construction. Treaties were signed with Brazil for the verification of the River Verde and the demarcation of the boundary line; it was agreed to extend over the period of one year the negotiations of the arbitration tribunal created for the purpose. $A$ dispute arose between the Government and the Holy See, because of the adoption of an amendment to Article 2 of the Constitution, and a law abolishing ecclesiastical privileges and the establishment of civil marriage. Finally, Bolivia withdrew her diplomatic representative from Rome.

On June 20 , 1907 , a new Land Law, comprising 70 articles, was introduced.

Improvement in the value of farming lands took place in 1908 , the increase in prices since I003 amounting to nearly 50 per cent. On August 6th the 4-years' term of President Ismail Montes ended, when he should have been succeeded by the President-Elect Dr. Fernando E. Guachalla, formerly Bolivian Minister to the United States; he however died in July. Señor Montes continued in office until August I909, when he was succeeded by Señor Eliodoro Villazón, elected to the chief Magistracy for the 4 years ending August 6, I913. Important economic measures were enacted to further the delivery. of native products at the Pacific coast ports; the unification of the railway systems of the Republic, extending to about 400 miles of main line, was determined upon. A commercial treaty was signed with Germany, to last for ten years.

For the years 1909-Io the financial obligations of the Republic were met, despite loss in revenues from Custom House receipts. A loan, amounting to $£_{1}, 500,000$, raised in I'aris (Nov. IOIO), the second foreign indebtedness contracted by Bolivia (and out of which the $f, 500,000$ borrowed in 1908 was to be repaid), was arranged; including principal and interest upon the Home Debt, and upon the $f_{4} 00,000$ Morgan Debt (Dec. I908), the total funded deltt of the Republic amounted to a little over $f, 1,700,000$. The Budget account showed a deficit of 7,553,996 bolivianos (silver), ${ }^{2}$ although the Presidential Message had estimated a surplus.

In January I0I the establishment of a National Bank was authorised, with a capitil of $f, 2,000,000$, one-half contributed by the (iovernment, the remainder by United States financiers. The Mercantile Bank and Banco Francisco Argandona respectively increased their capitals to $f_{\mathrm{I}}, \infty, 0,000$. On July ${ }_{5}$ th the Government sold to the Peruvian Corporation for $f_{374.012}$ the ror kilometres of the Guaqui-La Paz Railway.

Early in ror i a new ('abinet was formed, and an extra Session of Congress was summoned for the purpose of discussing the Chilean P'rotocol concerning railway guarantees;

'See E. B. iv, 166 et seq.

${ }^{2}$ Boliviano silver $=25$ s. 
also an Extradition Treaty and a Treaty of Commerce and Navigation with Brazil were passed. In April three German officers were engaged to instruct the Army. Colonel Fawcett, British Commissioner, continued his work (commenced in roro) of defining the boundary with Peru, the undertaking proving of a prodigious nature. Instead of confining his explorations to the rivers, Colonel Fawcett struck inland in order to investigate the rumours that " white Indians inhabit the unexplored regions."

In March IgI 2 a Consular Convention with Belgium, a General Arbitration Treaty with Brazil, and a Treaty of Peace with Colombia were promulgated. On August 6, Igr 2, the Arica-La Paz Railway was opened, the Presidents of Bolivia and Chile being present. A discovery of coal near Lake Titicaca was made, which meant a great deal to industrial development of the country, all coal hitherto having been imported from Great Britain or Australia at great trouble and expense. The Republic also celebrated the eighty-seventh anniversary of its Independence on August 6, I9 2. On September 23, I9I 2 the Cabinet was further reconstructed after a 15 -months' existence.

A monopoly was created (Sept. Io, Igr2) in the sale of firearms, ammunition, and explosives, the proceeds being devoted to the purchase of war material and erection of a cartridge factory.

\section{BRAZIL 1}

Brazil has an area of $3,2 \mathrm{I} 8,99 \mathrm{I}$ square miles, and the population is $2 \mathrm{r}, 46 \mathrm{r}, 100$ according to most recent estimates, giving an average of 6.6 inhabitants per square mile. Imports were valued at $£ 47,1_{54,000}$ and exports $£_{62,001,287}$ (I909-10). Imports from the United States in 1910-I I were valued at $\$ 27,240,146$ (U.S. currency) and exports to the United States at $\$ 100,867,084$; in I9II-I 2 imports at $\$ 34,678,08 \mathrm{I}$ and exports at

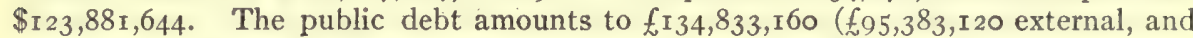
$\left\{39,450\right.$, 040 internal). The mileage of railways is $I_{3,27}$ I and of telegraph lines $72,73 \mathrm{I}$. The army has a strength of 31,823 men and 750 officers. The navy comprises 37 vessels with a personnel of 8,500 .

Upon the death (June rgo9) of Doctor Alfonso Penna during his term of office (ryo6ro) as Chief Magistrate, the Vice-President, Senhor Nile Peçanha succeeded to the Presidency, and served until the end of the interrupted term (Nov. I9ro). The Republic at this time was slowly recovering from the severe commercial depression which had existed for two years. The balance of trade proved to be the greatest ever recorded in the history of the country, and for the first time the aggregate value of imports and exports exceeded the $f \mathrm{I}, 0,0,000$ mark. In other directions $\mathrm{Brazil}$ enjoyed peace and progress, twenty-one different Arbitration Treaties being signed in r9o9-ro, making 28 treaties concluded within a tew years, the countries covered including Chile, Argentina, Portugal, France, Spain, Mexico, Honduras, Venezuela, Panama, Peru, Ecuador, Costa Rica, Cuba, Great Britain, Bolivia, Nicaragua, Norway, China, El Salvador, Switzerland, Haiti and the Dominican Republic. On October 8, x909, a convention was ratified at Rio between Brazil and the United States, establishing the status of naturalized citizens who renew residence in their country of origin. On April 27, 1910, Congress approved the boundary Treaty between Brazil and Uruguay, drawn up on October 30, I909, by which the latter country obtained full rights to the navigation of the Lake Mirim, which lies between the two countries, and also the use of several small islands on the lake. Upon the same date, a treaty was approved with Peru, fixing the boundary between the State of Acre and the river Javary. All rights in this State were, abandoned by Peru; but Brazil ceded a small portion of adjoining territory rich in rubber, and agreed to expend $£ 2, \infty 00, \infty 00$ upon the construction of a railway to a point whence the rubber could be transported by way of the Amazon River to the markets of the world.

A payment of $\$ 540,000$ ( $(\mathrm{r} 08,000)$ was made to Bolivia in connection with the award of the Commission, given on November I 7, I903. Colonel Fawcett continued his work of defining the boundaries between Brazil and Bolivia, joining his party at Matto Grosso in August, and, after being captured by the Paraguayan revolutionaries, ultimately reached

${ }^{1}$ See $E$. B. iv, 438 et seq. 
Buenos Aires on October IIth, and $\mathrm{LaPaz}$ on November gth. Brazil was represented abroad at several important international Congresses, while the State was added by the Brussels Sugar Convention to the list of countries according bounties.

On October 21, I 909, the Department of Agriculture, Industry and Commerce established the Bureau of Animal Industry, designed to promote cattle rearing.

The financial condition of the Republic, which had been somewhat improved under the Presidency of Dr. Alfonso Penna, again showed signs of distress. The Executive found it necessary to issue a decree (Aug. I 2, rgog) reorganizing the financial administration of the Acre Territory, and drawing the attention of the public generally to tne great excess of expenditure over revenue. The increase in the National Debt was explained partly by new loans which had been raised for national improvements, such as increased dock facilities and new railroads. The railway mileage increased by 366 miles, and important concessions were granted to many foreign syndicates and individuals. Port-improvement works were also commenced, or were continued, at Rio de Janeiro, Manáos, Pará, Natal, Cabedello, Pernambuco, Bahía, Santos, Florianopolis and Rio Grande. The line uniting Brazil with Uruguay was completed in July I9I 2.

On January 3, I9I0, financial conditions again being mended, payments on account of the Foreign Debt were resumed, anticipating by eighteen months the time specified in the Funding Loan agreement with foreign bondholders (of June I898), when the amortisation was suspended for thirteen years until June I9II. The Public Debt was

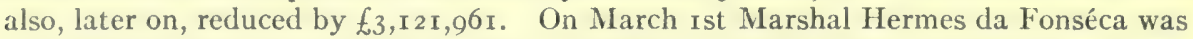
elected President for the ensuing term, and shortly afterwards he commenced a tour of Europe, being well received at most of the foreign Courts. He visited London in September, returning to Brazil in November.

On March I7, I910, a new 4 per cent (gold) Federal Loan for 100,000,000 frs. was floated in Paris, being offered at $89 \frac{1}{2}$ per cent, and intended for the construction of the Goyaz Railway. At the same time, negotiations were authorised for the raising of a loan of $f_{1} \mathrm{I} 0,000,000$ by the House of Rothschild, for the purpose of converting the 5 per cent gold bonds of the Foreign Debt into 4 per cent, thus saving $£ 400,000$ per annum in interest. Financial conditions continued to strengthen, the annual deficit in the revenue showing a considerable reduction. The rate of exchange rose towards the middle of the year to 37 cents ( $\left.\mathrm{I} / 6 \frac{1}{2}\right)$ gold per milreis; but, by decree, the Government established the rate at 32 cents $\left(\frac{1}{4}\right)$ gold.

Commercially the Republic showed the highest total of foreign trade since its history, the exports exceeding the imports by $£_{14}, 926,320$. On June 2, 1910, a surtax of 20 per cent for the port imports at Pará was abolished. On September 22nd an official decree authorised the creation at Rio de Janeiro of a Merchant Ship-Brokers Exchange. On November ${ }_{5}{ }^{\text {th }}$ Marshal Hermes da Fonséca took oflice as President, and shortly afterwards approved a new code of criminal procedure for the Federal district.

Within a few days of the beginning of Marshal da Fonséca's term, the country was confronted with a serious naval mutiny, which broke out on November 24 , rgio, on board the two "Dreadnought" battleships-"Minas Geraes" and "São Paulo." The mutineers, who complained of ill treatment at the hands of their officers, fired upon the capital, causing considerable damage, several people being killed in the streets. The President, who in I904, while head of the military school at Rialengo, had been enabled to prevent the students from joining in the revolution against President Rodriguez Alvez, found much difliculty in dealing with the situation. An amnesty was granted to the mutineers, while a battalion of troops which had joined them was allowed to surrender without undergoing punishment. 'The first mutiny was shortly afterwards followed by a second, which, however, was suppressed with less difficulty.

Apart from political and financial troubles, the progress of the Republic was satisfactory. The Customs returns for In I0 showed an increase of 10,000,000 milreis over the previous year, while the number of factories throughout the Republic increased to 3,300. The rate of exchange was again raised to $\mathbf{I} / 6_{4}^{1}$, but a change of Government shortly following resulted in the rate again being made $\mathbf{I} / 4$. Railway mileage increased 
by 1,162 miles over the previous year, bringing the total mileage of railways in the Republic up to 13,279 miles. Towards the end of I9ro the new Government floatingdock, built by Messrs. Vickers at Barrow-in-Furness, and costing $f$ I 87,700 , arrived at Rio. The number of immigrants in 1910 was 88,564 , a total much above that of the previous ten years, but still below that of the decade preceding.

Following upon the naval mutiny (igro) the navy, by Governmental Decree, was entirely reorganised in I9I. Doctor Nilo Peçanha, ex-President, visited Europe, including London and Paris in June I9I I. The Government successfully concluded arrangements with the Italian Government regarding emigrants from that country entering Brazil. The result was a considerable increase in the number of colonists arriving, over 100,000 Italians leaving. (Sept. 13th) for the Republic through Rio. The total number of immigrants amounted in I9I to I33,600, an increase of 45,036 .

Considerable improvement took place in foreign commerce; excluding specie to the value of $f_{10}, 205,300$, the value of the trade for I I I was $f_{1}$ I29,842,300 (as compared with $£ 122,735,800$ for 1910 ), an increase of $£ 7,106,500$, or 5.7 per cent. The increase in the exports amounted to $f 4,300,000$, making the total exports for ig I equal to I, 005,000 contos $(£ 50,250,000)$. The total receipts of the State Railways amounted to 32,197,000 milreis, which, however, still left a loss upon the working.

The deaths of several prominent Brazilian statesmen and ex-statesmen may here be noted. Dom Joaquim Murtinho died on November I2, I9I1. Early in February I9I2 Baron do Rio Branco, Minister for Foreign Affairs, died at the age of 65 , his successor being Senhor Lauro Severeano Müller, who, under President Alvez, had been Minister of Public Works and Railways. On February 2I, I9I2, Visconde de Ouro Preto, a prominent figure in the days of the Empire, died at the age of 76 ; while on March Ioth Senhor Guinle, a considerable land-owner, died aged 66. In July I9I 2 General Quintino Bocayuva, one of the founders of the Republic, died at the age of 76 .

The better relations established between Brazil and Argentina were proved by the appointment, in July I9 2, of Dr. Roca to represent Argentina at Rio de Janeiro (being succeeded in November I 912 by Dr. Lucas Ayarragaray), and of Dr. Manuel Ferraz de Campo Salles, ex-President of Brazil (1898-I902), to act as Minister to Argentina. The latter was an appointment which gave considerable satisfaction in Argentina, since Dr. Salles, during his administration, had striven to arrive at a good understanding with the neighbouring. Republic, having been the first Brazilian President to visit Argentina (Oct. I910), while President Roca, in July 1899, had at his invitation been the first Argentine President to visit Brazil.

The finances of the Republic continued to show a deficit, although the amount for the year I9I I did not exceed $f_{100,000}$. The National Debt, however, had been increased during the previous year by the sum of $£ 5,57$ I, 363 and frs. $60,000,000$, and now stood at $f_{83}, 383, \mathrm{I} 20$ and frs. $300,000,000$. By the end of 1912 the total deficit was expected to reach 260,000 contos $(£ 1,300, \infty 00)$, and the external and internal international debts to exceed $3,000,000$ contos $\left(f_{1} \mathbf{5}_{50,000,000}\right)$. The financial situation was described by Senhor Serze dello Correa, ex-Minister of Finance, as " extremely delicate," in spite of the fact that the national revenue had nearly doubled in the decade I0OI-Ir. A feature of the Government's policy in order to increase the revenue was the gradual elimination of exemptions from import duty, while full taxation was also imposed upon all materials imported, in all departments-Federal, State and Municipal. This action on the part of the Government seriously affected foreign companies working in Brazil.

As a further effort to save the national treasury from financial loss, the Central Railway (built and operated by the Government at an enormous annual deficit) was offered on lease to a syndicate. In the last days of July igi i a serious collision occurred upon the Central Railway which resulted in the death of over roo persons. The line uniting Brazil with Uruguay was inaugurated at Rivera, the frontier, July I8, I9I 2.

In June i9 I Dr. Rodriguez Alvez, ex-President of the Republic, took over the Presidency of São Paulo from Dr. Albuquerque Lines, who had held it for four years. The State of São Paulo had now reached the apex of its prosperity, immigration progressing 
and railway extension increasing to an unprecedented extent, while the high prices of coffee, upon which its prosperity mainly depends, were well maintained.

On January I3, I9I 2, the Minister of Marine-Admiral Marques Leão-resigned, and was succeeded by Admiral Belfort Vieira. Serious political disturbances occurred this ycar at Bahía (capital of the State of the same name), the Government resigning, and being succeeded temporarily by the President of the Court of Appeal. The troubles arose from the city of Bahía refusing to ohey a writ of Habeas Corpus issued by the Federal Court regarding certain Opposition Deputies. Troubles continued for some time, while a similar condition prevailed in the State of Cera, where, owing to the elections of a new Governor, feeling ran high. In September I912 an outbreak, led by a fanatical monk, occurred in the State of Catharina, but was suppressed by Federal troops

On July 24, I9I 2 the Senate passed a bill making it obligatory upon all States in the Republic to obtain the Federal sanction before contracting any loans. The bill was intended to prevent abuses, and to avoid complications between the different States of the Federation. The State of Rio de Janeiro floated a new loan for $f 3, \infty \infty, \infty \infty$, at 5 per cent in London on September 3 oth, which fell to a discount, the public subscribing less than 20 per cent of the amount.

In May I9I2, at the banquet of the Pan-American Society held in New York, some sensation was occasioned by the Brazilian Ambassador, Senhor da Gama, denouncing the attitude of the United States towards Latin-America, especially the seizure by the American Government of nearly I,000,000 bags of coffee belonging to the Brazilian Coffee Trust; but the United States subsequently released the coffee.

In July I9I 2 a new Brazilian coinage was authorised, the standard gold coin corresponding in weight, denomination and form with the British pound sterling, the silver money to correspond with that of France.

The protracted labour unrest, which first became acute in January, came to a head in August 1912, when serious strikes occurred at both Rio de Janeiro and Santos, the stevedores in both ports refusing to work. Thousands of strikers prevented ships from being loaded and unloaded, and the railways from operating their lines. Heavy losses were incurred by merchant shippers. The Santos strike terminated on September 6th, but a further strike among the employees of the Port of Para Co. occurred on September 28th. In the same month, frosts caused damage to the coffee crops in the State of São Paulo, the loss being equal to 20 per cent, reducing the production to $10, \infty \infty, \infty \infty$ bags.

On September 27, r 9 1 2, the Minister of Agriculture introduced a measure conferring all rights of citizenship upon the Indian population, which had hitherto been regarded in the eyes of the law in the position of orphans.

\section{CHILE $^{1}$}

Chile has an area of 292,580 square miles, and the population according to the most recent estimates is $3,329,030$, giving an average of $\mathbf{I}$.I inhabitants per square mile. Imports in I010-I I (one year) were valued at $£_{2} 6,174,276$ and exports at $£_{2} 25,455,702$. Exports to Great Britain were valued at $f_{1} 1,012,989$ in $191 \mathrm{I}$, and imports from Great Britain at $f,, 382,586$. Exports to the United States in Igro-I I were valued at \$19,$0.11,000$ (U. S. currency) and imports from the United States at \$I 2,044,578; in I 9 I I-I 2, exports at $\$ 20,164.848$ and imports at $\$ 15,491,846$. The revenue was estimated according to the budget of $I_{91} I_{2} I_{3}$ at $£_{1} I_{5}, 799,870$, and the expenditure at $£_{1} I_{7}, 368,045$. The total public debt amounts to $£ 43,056,007$ ( $f 34,728,800$ external and $f, 8,328,007$ internal). The total mileage of railways is $3,57 \mathrm{I}$ and that of telegraph lines 16,407 . The army has a strength of 17,123 men. The navy comprises 28 vessels with a personnel of 6,000 .

Peaceful conditions continued during the early years of President Jorge Montt's tenure of oflice, which began in September 1906, cheap money proving favourable in many ways to business, and contributing to a general and steady improvement in trade. The overtraling and excessive speculation in shares, which had occurred in I908, prac.

1 See E. B. vi, 142 et seq. 
tically ceased by the end of 1909 while accumulations of goods, imported in great haste and undue quantity after the earthquake; were rapidly absorbed. The Government had intended to return to gold currency in January I910, but a new law was passed deferring the conversion for ia further five years.

The condition of the nitrate industry at this time proved very unfavourable, the trade combination, restricting the output, having terminated at the end of April I909, and the efforts to renew it having failed. The:price fell steadily to $\frac{6}{8}$ a quintal.

The Republics of Chile and Argentina celebrated their centenaries in I 9 Io, and the Presidents of the respective States exchanged visits. At the Chilean celebration Great Britain was not represented owing to national mourning, but a special mission of congratulation was subsequently sent to Chile, being entrusted to two British warships. The diplomatic rupture with Peru continued, the Peruvian Minister being recalled from Santiago, while the proposals formulated by Chile in March I9Io, for carrying out the disputed plebiscite in accordance with the Treaty of Ancon were left unanswered. In December I 12 however a settlement was said to be in sight.

On August 16; I910, President Jorge Montt, while on a visit to Bremen, Germany, succumbed to heart complaint. His successor, Señor Elias Temandez Albano, VicePresident, also died at Santiago, September 7 th. The vacant presidency was filled by the election of Don Ramon Barros Luco, November I5, I9ro. His nomination was unopposed, being a matter of compromise between the different Liberal factions, and meeting with the benevolent neutrality of the Conservatives. The political atmosphere, however, was much disturbed at this period, two measures advocated by the Government, but strongly opposed by Congress, being under consideration. These measures were the extension of State primary education, rendering it compulsory, and the Sanitary Code, destined to include compulsory vaccination. The Government was also faced with a heavy deficit, ${ }^{1} \$ 64,000,000$, such amount being due on account current to the Bank of Chile, and borrowed at the highest legal rate, 6 per cent per annum. In spite of the financial stringency existing, the Department of Public Works entered upon an especially wide programme of new undertakings, including railway extensions and the construction of port-works at Valparaiso, San Antonio, Iquíque and Talcuhuáno.

On July 5, I9x $\mathrm{r}$, the award made by King George $\mathrm{V}$, acting as aimable compositeur in the Alsop case dispute between the United States and Chile, was signed and published. This was the second occasion upon which a British sovereign had been appealed to by Chile, the previous award settling the boundary dispute between Argentina and Chile being made by King Edward VII. The Alsop claim had its origin in a certain concession made by Bolivia to Dom Pedro Lopez Gama, a Brazilian, who came to Chile in 1860 , and married a Chilean in 1882 , dying in 1883 . Previous to his death he had mortgaged his concession from the Bolivian Government to Messrs. Alsop \& Co., a Valparaiso firm, which included a number of American citizens. After the war of IS79 between Chile and Bolivia, the former State took over the liabilities in connection with the Alsop claim against Bolivia. Being unable, however, to arrive at a compromise, Mr. Secretary Knox of the United States in November roog sent Chile an ultimatum demanding that "the sum of $\$ I, 000,000(f, 200,000)$ should be paid to the claimants within ro days," or alternatively that the matter be submitted to the Hague tribunal in terms to be dictated by the United States. Eventually it was decided to refer the matter to the friendly arbitration of King Edward VII, and on his death the office devolved upon King George V. The original amount of the claim was $£ 600,000$ with interest; the sum offered by Chile (in 1904) was $£ 90, \infty 00$, while the sum adjudged by the arbitrator to be paid by Chile to the claimant through the United States was $f_{1} 8_{7}, 000$.

The financial position of Chile, which had appeared satisfactory in 1909 , caused some misgivings towards the middle of rgro, the foreign debt at this period amounting to $£_{25}, 636,000$. In the following year (Nov. I9II) a further $£_{5}, 000,000$ was borrowed, in addition to a sum of $£ 2,000,000$ which had been raised towards the end of I 9 I0 for the reconstruction of the Valparaiso harbour and the completion of the Aríca-La Paz

${ }^{1}$ One Chilean gold $s=$ Is. 6 d. 
Railway. General depression was experienced in financial circles, and the economic situation was regarded with some apprehension. The extent of the paper currency was largely responsible for checking the influx of further foreign capital; and after many discussions in the Chamber, the Parliamentary Committees and the Government parties on April 24, I912, agreed not to make any further issue of paper money.

In August I I I a new Ministry had been formed, with Señor Ramón Gutierrez as Premier, succeeding the Ministry which had been formed as recently as the previous April. The new premier recognised the necessity of regulating the national finances, and his first endeavour was to reduce the expenditure. By July Ist the foreign debt of Chile had, however, increased to $\{35,454,475$, since somewhat reduced. In December I9 2 the Government intimated its intention to raise a further internal loan for $£ 5,000$,$\infty$, exclusively destined to renovate the workshops and rolling stock of the State Railways and to double-track certain portions of the lines. Further revenue was also to be raised by loans for the construction of harbours.

The ordinary and extraordinary national revenue for I I I I amounted to $f 8,173,400$ in notes, and to $£ 6,517,200$ in gold. The expenditure both ordinary and extraordinary totalled $£$ IO,2 I 5,300 in notes and $£ 4,558,200$ in gold, thus showing a deficit of $£ 915,000$ in paper and an excess of $f 837,200$ in gold. The addition of these balances to the corresponding figures of $\mathrm{I} 910$ gave the total result, at the end of $\mathrm{I} 9 \mathrm{I} \mathrm{r}$, as a deficit of $£ 4,320$,600 in notes, and an excess of $£ \mathrm{I}, 426,200$ in gold, the net deficit being $£ 2,890,500$. The year 1912 opened with a deficit of $\$ 66,265,939$, to which was added a further sum of $\$ 5,480,883$ corresponding to interest paid to the Bank of Chile. The total amount of deficit thus came to $\$ 7$ I,746,8 I 8 . The year's (I9I3) working was expected to show a deficit of $\$ 4 \mathrm{I}, 45^{2}, 970$ in the absence of the rigid economies recommended. If these should, however, be exercised, the financial year seemed likely to close with a surplus.

On April ro, r912, the Chamber approved a law regulating the framing of the Budget in such a way as to prevent the expenditure exceeding the receipts. The recommendation, however, proved ineffective, the expenditure being maintained at a high rate, and exchange fell with disconcerting rapidity.

The Chilean Railway over the Andes from Arica to La Paz (Bolivia) was completed on March 4, I912, having been commenced in June r909. The distance is about 270 miles, 24 of which are constructed on the rack-system. On December 7, I91 2, Government engincers completed the plans for a new transandine railway through the Maipo River Valley, placing Santiago de Chile, the capital of Chile, in direct communication with Buenos Aires, the capital of Argentina, the journey to occupy but thirty hours.

()n August 8, I9 1 2, the Rivera-Figueroa Ministry resigned, and a new Cabinet, composed of Señores Jara, Rivas, Gana, Vicuña, Villegas-Echiburú, Vienna-Subercaseaux, Oscar Viol, and Hunneus was formed.

The nitrate industry was very prosperous throughout I9 2 , prices advancing steadily: the forward quotation for I0I3 was 7s.6d. per quintal. On October and the Government offered for auction 600 hectares (=1500 acres) of nitrate grounds in the Province of 'Tarapaca. The minimum price was is. for every roo kilogrammes of nitrate in the lots. The results obtained in the south of Pena Grande were so satisfactory, realising

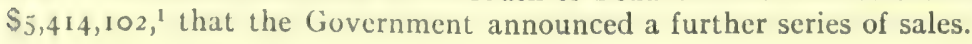

\section{COLOMBIA $^{1}$}

Colombia has an area of $4.38,436$ square miles, and the population according to the most recent estimate is $4,313,000$, giving an average of 9.8 inhabitants per square mile. Imports were valued at $f_{3,405,127}$ and exports $f_{3}, 525,0,30$ in $1909-10$. Imports from the United States in I010-I I were valued at $\$ 4,905,934$ (U. S. currency) and exports to the United States at $\$ 8,994,460$; in $191 \mathrm{I}-12$ imports at $\$ 5,748,859$ and exports at \$i1,219,48I. The total public debt amounts to $£_{3,444,634}(£ 2,786,600$ external, $£_{5} 88,03+$ internal). The total mileage of railways is 614 and that of telegraph lines 
is 10,557. The army has a strength of 7000 men. The navy comprises 9 vessels with a personnel of 850 .

Under the régime of President Rafael Reyes, from I905 onwards, the mineral, agricultural and timber resources of Colombia were actively developed. The despatch of Señor Enrique Cortes to the United States, as Colombian Minister, in 1907, had the effect of directing North American capital to the Republic, and considerable United States investments were made in mines and railways; among the latter was a line between the cities of Palmira and Cartágo, in the Department of Caúca, in addition to that of Nemocón to Santa Rosa de Viterbo. Important tariff modifications were introduced, exempting certain merchandise from the payment of import duties; and a decree was issued for the protection of the national forests, containing specific restrictions applied to the exploitation of rubber and tagua, or vegetable ivory.

In February 1908 a new Province, that of Camilo Torres, was created by the division of the province of Santander into two equal parts. Municipal government was also much encouraged, and increased facilities were afforded to the people for a more decentralised form of government.

Political peace, after a war of three years' duration, was maintained with but few interruptions between $\mathbf{1 9 0 6}$ and I909, when a wide-spread agitation against the government of General Rafael Reyes, and threats against his person, were occasioned by the introduction of an unpopular tripartite treaty between Colombia, Panama and the United States. The entire country protested against ratification. This feeling was so strong that the President's life was endangered, which led to his leaving the country with great secrecy, by way of the little-used port of Santa Marta. He arrived in England, on board a Manchester fruit-boat, accompanied only by his two young sons, on June 28, I9o9. After his departure, the Vice-President, General Jorge Holguin, formerly Minister of War, temporarily occupied the position of Chief Magistrate. His most important enactments were the re-establishment of commercial relations with Venezuela, after a break of several years; the settlement of the long-outstanding boundary question with Peru; and an ad referendum arbitration Convention between Colombia and Peru, covering the navigation of the Amazon river and the commercial rights thereon; while arbitration treaties with Great Britain and France were also signed and approved. The diplomatic and consular services of the republic were reduced to two in Europe and two in America, with a total of eight consulates.

In July I909 revolts took place in the capital, and martial law was proclaimed. Similar disturbances occurred at the chief port of the country, Barranquilla, where the military revolted and a provisional government was set up. The feeling was strong against General Holguin, on account of his close connections with the refugee ex-President Reyes. The popular demand for his resignation and the election of General Ramon Gonzalez Valencia, the Vice-President, was conceded. The election took place on August 4th, the period being for the remainder of General Reyes' unexpired term, about twelve months. The American Minister to Colombia, Mr. Elliott Northcott, on account of the political situation, was unable to leave Barranquilla, and the U.S. Government despatched the cruiser "Tacoma" to protect him. The port of Barranquilla was blockaded by the Colombian gunboat "Cartagéna." Shortly afterwards the revolutionary leader, General Daniel Ortiz, surrendered, and was permitted to go free.

The new Government speedily found that the reported improvement in the Republic's finances during the rule of President Reyes had been exaggerated; as a matter of fact, the State was even more deeply involved financially than before. The Government became seriously embarrassed, having no ready funds with which to meet even pressing obligations, while the fees due to members of Congress remained unpaid. The credit of the country fell very low, exchange being quoted in the ratio of $\mathbf{I}$ to 100 . The reported balance in favour of the country's trade, as in r9o8, also proved to be inaccurate, while the economy which was supposed to have been exercised in the administration under the last President appeared equally fictitious, notwithstanding several decrees that had been issued dealing with the matter. 
During the régime of General Valencia efforts were made to restore the credit of the country, which generally remained under perfectly peaceable conditions. Great monetary stringency nevertheless was experienced, and towards the end of November Igog it appeared doubtful whether the coupon due upon the Foreign Debt would be pail. A few days however before the time expired, a private firm in London, holding considerable interests in Colombia, found the necessary. balance, and the coupon was duly met. Since then, payments have been made with more regularity.

Railway progress continued slowly; a passenger and freight service'was established between the capital of Bogotá and the Magdaléna River port of Gerardót. The agricultural industry of the country also advanced, and at the end of Igog it was estimated to contain 4,000,000 head of cattle.

Diplomatic negotiations with the United States respecting compensation for the loss of Panama, which had been initiated by ex-President Reyes while serving as Special Ambassador at Washington in 1906, were definitely broken off. 'The United States Legation was stoned by a mob on March 8, I9ro, but the Minister, Mr. Northcott, was uninjured. An anti-American sentiment continued to manifest itself, and on March 2 nd some Englishwomen, named Martin, being mistaken for Americans, were mobbed and ill-treated.

In April r g 1о a popular outbreak occurred in Bogotá against Peru, the Legation being attacked by a mob incited by a proclamation issued by the President of Ecuador (General Eloy Alfaro) soliciting Colombia's aid against Peru on account of frontier disputes.

On July I 5, r 9 Io, Señor don Carlos E. Restrepo was elected Constitutional President by Congress, to serve for the four-year term I9I0-I4. Financial stringency was still experienced, and the Government laboured under difficulties. Strict and effective economies, however, were, for the first time, introduced, and the revenues were officially reported to show a surplus. A further limited amount of foreign capital, mostly from the United States, found its way into the country, and among other industries which were thereby developed was that of banana-cultivation, while cattle-breeding upon a more definite basis, and the establishment of packing-houses, was initiated. In this year the President invited a Military Mission from Chile to establish schools, and to reorganise the Colombian Army.

The Centennial Celebration took place between July 20 and August 7, I9ro, when the national fêtes were attended by delegates from all parts of the world.

The financial condition of the country became steadily worse in I $9 \mathrm{I}$, and it appeared from the President's address to Congress in July that "the country was starving itself in order to meet the obligations upon its foreign debt." All classes of officials were without the payment of their salaries, and this extended to a portion of the army and police. The estimated revenue was $\$ 9,779,500$ gold $(f \mathbf{r}, 955,900)$, and the Assembly voted expenses to the amount of $S_{11,768,450}$ gold $(£ 2,353,690)$. In accordance with Laws 33 of 1802 and 59 and 8,3 of I0 to the Government suppressed several official posts, reduced salaries and diminished other expenses by a total of $\$ 2,830,76 \mathrm{r}$ gold $\left(f_{566,152}\right)$. A contract was awarded to an English firm for a new silver coinage, equal to $f_{50,000}$. The long-outstanding dispute between the Government and the Pacific Steam Navigation Company was settled, and a new postal contract was entered into.

In March I 912 the relations between the United States and Colombia threatened to become further strained, in connection with the projected visit to the Latin-American States by Mr. Philander Knox, the United States' Secretary of State. The Colombian Minister at Washington, General Pedro Nel Ospina, addressed a strong letter to the Assistant-Secretary of State at Washington (Mr. Huntington Wilson), stating that " in his opinion the visit of Mr. Philander Knox to Colombia would not be welcome." Although the Minister declared later that "he was authorised by his Government at Bogotá to make this statement," he was recalled at the request of the Washington Government, being replaced by Señor Don Julio Betancourt. A Treaty of Amity between Colombia and Bolivia was signed at La Paz on March 2 rst.

Severe and prolonged drought in the early months of IgI 2 was experienced 
throughout the country, resulting in practically the whole of the river traffic being sus. pended for several months. The British Minister (Mr. Strong) was unable to travel up the Magdaléna River to the capital, while the operations of the largest of the transport undertakings, the Colombia Navigation Company and the Cartagéna (Colombia) Railway Company, were affected owing to the cessation of their traffics. The coffec crop proved a partial failure, some 50 per cent being lost.

Negotiations were subsequently reopened at Washington between the United States, represented by Mr. Huntington Wilson, Assistant Secretary of State, and Colombia, represented by Señor Don Julio Betancourt. Colombian Minister, for a settlement of the outstanding disputes. At the same time there was manifested an agitation among the prominent citizens of the Pacific provinces to force the Colombian Govern. ment to settle the differences with the United States before the opening of the Panama Canal, which would have an important effect upon the development of the provinces along the Pacific Coast, in which one-third of the inhabitants of the Republic reside. In August 1912 the United States Vice-Consul, Mr. William B. Macmaster, was assassinated in Bogotá, after several fruitless attempts upon his life had been made.

\section{COSTA RICA?}

Costa Rica has an area of 23,000 square miles, and the population according to the most recent estimate is $379,55^{\circ}$ (including about 4,000 Indians), giving an average of 16.5 inhabitants per square mile. The imports were valued at $£ \mathrm{I}, 630,500$ and exports $£ 1,728,901$ in I9I0. Imports from the United States in I9IO-II were valued at $\$ 3,473,376$ (U.S. currency) and exports to the United States at. $\$ 4,838,4$ I 6 ; in I9I I-I 2 , imports at $\$ 3,647,187$ and exports at $\$ 3,8 \mathrm{I} 7,86 \mathrm{I}$. The revenue was estimated, accord-

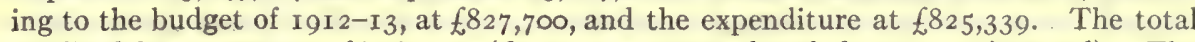
public debt amounts to $£_{6}, 185,234\left(£_{3}, 389,500\right.$ external and $£ 2,795,734$ internal). The total mileage of railways is 427 and that of telegraph lines is 1472.7 . The army has a strength of 1,000 men:

Adverse natural conditions materially militated against the prosperity of Costa Rica in the early months of 1909 . Disastrous storms, the failure of the crops, and stagnation in commercial circles, combined to bring about severe economic depression. In this year the total trade declined by about $\$ 3,500,000(£ 700,000)$.

The Central American Court of Justice, sitting at Cartágo, rendered in I9o9 its furst decision in the settlement of: Central-American questions. This tribunal had been established through the action of the Peace Conference held in Washington at the end of 1907 , the Court being inaugurated in May I908 in a special building provided by the generosity of Mr. Andrew Carnegie at a cost of $\$ 100,000(£ 20, \infty \infty)$.

The unsettled political conditions of Nicaragua, in combination with those prevailing in Guatemala and Honduras, were to some extent reflected in the internal affairs of Costa Rica. In connection with the presidential elections in the month of September, rioting occurred both in the capital of San José and other cities. The two candidates were the retiring president, Señor Iglésias, and.Dr. Ricardo Jiménez, president of the Costa Rican Congress. The latter was elected to succeed Señor Cleto Gonzalez Viquez, and assumed office on May 8, ioro.

The financial conditions of the Republic continued difficult in rgro. Since rgor there had been default upon the foreign loan amounting, with accumulated interest, to approximately $£^{2}, 593,000$. In January I9 I the bondholders were compelled to accept a very unsatisfactory compromise, which was denounced by Lord Avebury, the Chairman of the Bondholders Committee in London, as "dishonourable." An offer submitted by American bankers for settlement of the external debt had been rejected by Congress in October I909: Previous abortive efforts had been made in 1905 and I908.

Notwithstanding the difficulty experienced by foreign bondholders in obtaining any better terms, the government was actually in a stronger financial position than had been the case for several years. Considerable expansion in the revenues of the country had

${ }^{1}$ See E. B. vii, 2 I9 et seq. 
taken place since r 9or. Whereas in that year the receipts from Customs dues amounted to $£_{280,000}$, in 1907 receipts from the same source had totalled $£_{505}, 800$; in 1908 -09 there was a falling off to $£ 442,500$; between $1909-10$, and again from I910-I I an advance was shown in all branches of the government's receipts. Increases were marked in the import trade of all countries except France, while the export trade increased considerably with the United States, advancing from 58.73 per cent in I 909 to 60.22 per cent in I910. The reverse had been the case with Great Britain, the figures falling from 36.02 per cent in 1909 to 35.32 per cent in 1910 .

A serious disaster visited the Republic in May I9ro, when Cartágo-for the second time in its history - was destroyed by an earthquake, entailing great loss of life and irreparable damage to many of the historical buildings, including the but recently completed Central American Court of Justice, which was to have been dedicated and opened in the following month of June. The national disaster occasioned a disturbance in the routine work of the government, and much activity was devoted to effacing, as far as possible, the results of the earthquake, and in rebuilding what had been destroyed.

The Pacific Railway was completed and opened to traffic on October 21, I9ro, affording uninterrupted transportation from the Atlantic to the Pacific side of the Republic.

The dispute between Costa Rica and Panama (dating from I896) regarding the boundary limitations continued to form the subject of diplomatic negotiations, various proposals for arbitration being made but rejected by one side or the other. At last however the question was referred to the arbitral decision of the Chief Justice of the United States, and the Commission returned to New York on October 29, I9I 2.

In November r9ri a loan for $35,000,000$ francs $(£ \mathrm{r}, 400,000)$, at 5 per cent, with amortisation in 40 years, was arranged in France, the price being $91 \frac{1}{2}$.

For the twelve months ending December 30, I9I 1 , the total trade amounted to

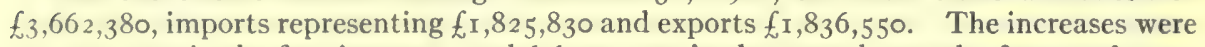
I 2.3 per cent in the first instance, and 6.6 per cent in the second over the figures of r9Io. The share of imports secured by the United Kingdom and Colonies was 17.34 ; by the United States 46.29 , and by Germany r 9.03 per cent. The figures for the United Kingdom had steadily decreased during the past three years, while those of Germany and the United States had correspondingly advanced.

On June 21, I9I2, an eruption of the volcano Poss took place, much damage being occasioned and many lives being lost.

In September I II 2 a new banking institution-the International Bank of Costa Rica -was formed by a group of English, Canadian, American and German financiers.

\section{CUBA $^{1}$}

Cuba has an area of 44,164 square miles, and the population according to the most recent estimate is $2,161,662$, giving an average of 46.2 inhabitants per square mile. Imports were valued in 19 I I at $£ 22,653,399$ and exports at $£_{24,627,275}$. Imports from the United States in Ioro- I were valued at $\$ 60,709,062$ (U.S. currency) and exports to

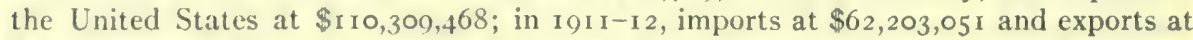

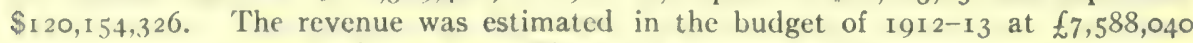
and the expenditure at $f_{6} 6,794,820$. The total public debt amounts to $£$ I9,400,000. The total mileage of railways is 2186 and that of telegraph lines 5033. The army has a strength of 43 II men and 212 officers. The navy comprises 13 vessels with a personnel of $\mathrm{I} 20$.

The Cuban Republic was inaugurated on January 28, 1900, for a second time after the Sranish-American War, in complete independence of American supervision; and the American troops which had been supporting the "provisional government" since President Palma's resignation in 1006, left the island on April ist. Under General José Miguel (iomez (leader of the Miguelista faction) as the new President, and Alfredo Zay:as (leader of the Zayista faction) as the new Vice-President, the administration started well. In the words of a Times correspondent (May 27, I912), it "preserved

1 See E. B. vii, 605. 
unbroken the admirable record of the Americans in matters of public health and sanitation," it did much " to encourage foreign capital, to improve communication by building roads and bridges and by dredging harbours, to develop education, and to forward the agricultural interests of the island;" it " organized an efficient and well-disciplined force of rural guards and preserved the public peace with satisfying vigour."

During I909-10, the first year of General José Miguel Gomez's administration, the public finances of Cuba were put into a better condition, and public order was well preserved. The staple crops proved good, and sold at fair prices. Both the political and commercial outlook appeared bright. In October I9Io, however, much damage was wrought by cyclones over the provinces of Pina del Rio, Havana and Santa Clara.

Trade and commerce continued to improve in I9II, while the population had increased by $58,6 \mathrm{I} 2$ during the last two years. By the end of 1910 , the balance of trade was considerably in favour of Cuba, the excess of exports over imports amounting to

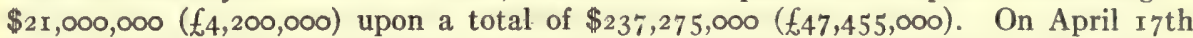
the government ordered the payment of the 732 outstanding bonds issued by the revolutionary government of I896, payment being commenced on October I, I9I I, after which date the bonds ceased to draw interest.

On July I, I9I I, the posts of Envoy Extraordinary and Minister Plenipotentiary were created for Peru, Colombia and Venezuela. The Ministers Resident at Brazil, Chile, Belgium and Norway were raised to the ranks of Envoys Extraordinary and Ministers Plenipotentiary; the post of Minister Resident in Uruguay was abolished, and the Minister Plenipotentiary to the Argentine Republic was accredited to Bolivia, while the Minister Plenipotentiary to Colombia was likewise accredited to Ecuador; the Minister Plenipotentiary in Norway was accredited to Sweden and Denmark; and the Minister in Germany to Russia and Austria. New Consulates-general were created in Paris and Panama; consulates of the first-class in Asunción (Paraguay); La Paz (Bolivia); and San José (Costa Rica); and a consulate of the second-class at Quito (Ecuador).

The financial position of the republic had improved since 1909, when the situation was undoubtedly serious. A rigid economy introduced by the government had continued over a period of two years, and served to leave a small balance of $\$ 1,000,000$ ( $f_{2} 200$,$\infty 00)$ in the treasury, which, by the end of the following year, had increased to $\$ 2, \infty 00$,$\infty 00\left(£_{400,000)}\right.$. The revenues from all sources amounted to $\$ 32,595,552$; of this total $\$ 24,826$, OI 2.were for customs receipts, the port of Havana alone collecting $\$ 17,185,322$. In September I9II a New York banking firm arranged a further loan of $\$ 100,000,000$ $(£ 20,000,000)$, primarily for the redemption of the republic's existing debts, which at this period amounted to $\$ 97,000,000$, of which $\$$ ro,874, roo represented the internal debt; this is being cancelled at the rate of $\$ 50,000$ ( $£$ ro,, 00$)$ per annum.

In November I9I I the following conventions were approved by the senate, and promulgated by the president: (a) Convention for peaceable settlement of international disputes; (b) Convention concerning methods and customs of war on land; $(c)$ Convention concerning rights and duties of neutral Powers and neutral persons in case of war on land; $(d)$ Convention concerning status of merchant vessels of the enemy at the beginning of hostilities; (e) Convention relating to bombardment by naval forces in time of war; $(f)$ Convention for the adaptation to maritime war of the principles of the Geneva Convention. Ratifications of the arbitration agreement between Cuba and Brazil were concluded; a treaty of extradition between Cuba and Venezuela was arranged; and a treaty of friendship with China was projected.

Up to the autumn of IgII, whatever might be the case in Havana, where there was much talk of corruption under President Gomez's administration, in the granting of concessions and the multiplication of offices, the country districts were contented and prosperous. Party politics, however, as between the factions of the "ins" and the " outs," suddenly became complicated at this period by a "campaign of proscription " being started on behalf of the veterans of the war of independence against all officeholders who had then shown Spanish sympathies, with such violence that Congress was forced to suspend the Civil Service laws, and that (apparently at President Gomez's 
own suggestion) a stern Note of warning was sent in January r9 2 from Washington by the United States government. Order was temporarily restored after President Gomez had capitulated to the demands of the Veterans' Association and executed or dismissed a number of the objectionable office-holders, but the ferment again began when one of the dismissed - fficials brought a suit before the Courts and obtained a judgment declaring the suspension of the Civil Service laws to be a breach of the constitution. The situation was also embittered by the fact that the election of President Gomez as president in 1909 (to hold office till Jan. I7, I9I3) had been the result of a Liberal victory at the polls in 1908, and that an arrangement had been effected by him with Señor Zayas by which the latter would be the Liberal candidate in the autumn of 1912, an undertaking which Gomez was no longer inclined to observe; so that the Liberals were divided into two camps while the Conservatives were attacking the Liberal government.

The political unrest and commotion started by the action of the Veterans' Association communicated itself without delay to the army and to the negroes, and in the spring of 1912 the turbulence became increasingly serious. In the east of the island a large number of negroes broke out in open insurrection, and labour troubles were creating much mischief and danger to mills and plantations, particularly in the province of Oriente. The lives of American citizens and others in Cuba, and foreign property conservatively valued at $\$ 220,000,000$, were threatened by this crisis. Mr. Knox, the American Secretary of State, visited Havana in April Igr r, at the conclusion of his tour through the Central American Republics, and at Washington during May it was felt that forcible American intervention might again be necessary. For this purpose eight battleships, with adequate auxiliary equipment, were concentrated at Key West, in order that the right of the United States (under the "Platt amendment" of Igor; E. B. vii, 604) to intervene "for the protection of Cuban independence, and the maintenance of a government adequate for the protection of life, property and individual liberty," might if necessary be vindicated. These preparations occasioned great excitement in the Cuban capital, but succeeded in overawing the insurgents; and towards the end of July conditions improved, the Cuban government having the situation then well in hand. By the close of the year only a few small bands of insurgents remained, while General Ivonet, the negro leader, was eventually captured.

The financial condition of the Republic became acute in the early days of September I)12. The United States presented a peremptory demand for a monthly instalment of $\$ .100,000(£ 80,000)$ towards the cost of sewerage and paving in Havana, on behalf of the American contractors. On September 25 th the Cuban government paid up.

The granting by presidential decree of a concession and a subsidy of $\$ 6,000$ per kilometre for a new railway between Caibarien and Nuevitas, and also between Camaguey and Santa Cruz del Sur, to an American Company, proposing to expend $\$ 25,000,000$ $(f 5, \infty 00,000)$ upon constructing the 305 kilometres, occasioned great opposition upon the part of the Cuban Central Railways - which had held an exclusive concession. The British Ambassador at Washington was appealed to, and on December 2, I9I2, Mr. Bryce lodged an emphatic protest against granting the concession called for by the $\mathrm{Cu}$ ban North Coast Railway, alleging that such concession was granted " under scandalous circumstances, and was prejudicial to the legitimate vested interests of the Cuban Central Railways Company," a British undertaking.

General Mario G. Menocal was elected President and Señor Enrique José Varona Vice-President at a quiet election on November I, I0I2. Less than $50 \%$ of the registered voters went to the polls. The election was a victory for the Conservative party, which had a majority of some 13,000 votes and elected five governors, and secured two senators in each of the provinces except Camaguey where because of the recent death of a senator, three were elected. The eleven newly elected Conservative senators together with two senators formerly Liberals, who fraternised with the Conservatives because of local issues, gave the Conservatives a strength of thirteen against an opposition of eleven in the senate.

In the lower house, after May 20, I9I3, when the newly elected ministry comes into 
power, there will be forty-three Liberals and forty-eight who are listed as Conservatives. Five of the latter, however, are:Liberal " mugwumps"? and they will hold the balance of power. The Liberals claimed that fraud was practised during the election campaign, and the Conservatives replied by counter charges. General Menocal, the new President, had been manager of the largest sugar estate in Cuba for many years. In his programme he promised to cultivate closer relations with the United States, and to seek agricultural and industrial development; and at once to open negotiations for a revision of the tariff with the United States.

\section{ECUADOR ${ }^{1}$}

Ecuador has an area of 116,000 square miles, and the population according to the most recent estimates is $\mathbf{I}, 500,000$,-inclusive of some 200,000 Indians only partly civilised,-giving an average of $\mathbf{I} 2.8$ inhabitants per square mile. Imports were valued at $£_{1}, 604,82 \mathrm{I}$ and exports at $£ 2,733,274$ in $1909-10$. The revenue and expenditure were estimated in the budget of $19 \mathrm{I}_{2}-\mathrm{I}_{3}$ to balance at $f_{\mathrm{I}} \mathrm{I}, 897, \mathrm{I}_{3}$. The total public debt amounted to $f_{4}, \mathrm{r} 80,000$ ( $£_{2}, 680, \infty 00$ external and $£_{1}, 500,000$ internal). The total mileage of railways is 350 and that of telegraph lines $259 \mathrm{I}$. The army has a strength of 7,810 men. The navy comprises 7 vessels with a personnel of 200 .

On January I, I907, General Eloy Alfaro was re-elected president for a further term of 4 years. Under his rule the country made but little progress, numerous revolts and border disputes serving to prevent any advance in its economic or financial conditions.

The boundary question with Peru, which dated from 1822 , became acute in I908, and numerous frontier encounters occurred between armed bands of both nationalities. International conditions improved somewhat later on, when Señor Federico Elguero, the Peruvian Minister to Ecuador, exerted his influence in favour of peace. In I909 the United States, Brazil and Argentina offered their joint mediation, which was accepted at once by Peru, but refused by Ecuador, as were also the alternative suggestions of the arbitration of the King of Spain and a reference to the Hague Tribunal.

In July Igag excitement was caused by the publication of some documents found among the private papers of ex-President Garcia, dealing with the sale of Galapagos Island to the:United States. It appeared that negotiations had also been opened with France, but had been interrupted owing to the belief that the United States would not consent to the acquisition of the island by a European Power. In January Igr I fresh negotiations were entered into between the United States government and President Estrada, with.a view to leasing the island for a term of 99 years in return for the cash payment of $\left.\$ I_{5}, 000,000\left(£_{3}, \infty 00, \infty\right) 0\right)$. Again, however; the offer was rejected, upon the grounds that its acceptance would be unpatriotic.

In September 1909 a financial delegate was sent to Europe for the purpose of arranging a loan of $£ 4, \infty 00, \infty 00$, the proceeds of which were to be used for the reorganisation of the national finances. The negotiations were not successful. Others having for their object the raising of a loan of $£ 2,000,000$ were opened in November I 909, but Congress withheld its assent. A few weeks later an English syndicate advanced the government the sum of $£_{2} 50,000$, at 85 per cent, taking as security 50 per cent of the customs receipts on exports. The finances of the country continued in a very unsatisfactory condition, and on July 2, rgro, the Government defaulted in regard to the interest due on the 4 per cent salt bonds. In the following September, however, the coupon was met, and payments were continued thereafter with more or less regularity. Arrears of interest were also due upon the Guayaquil-Quito railway bonds. In April I9I I Mr. J. P. Cooper, the Secretary of the Council of Foreign Bondholders (representing the Guayaquil-Quito Railway), had visited the Republic, with a view to settling the claims of the bondholders:upon whose coupons the interest had not been paid for over twelve months. Although President Plaza promised in September to remedy the default, payments remained unsatisfied. They were resumed, however, in October.I9I2.

Towards the end of General Alfaro's term of office, political conditions became both

1 See E. B. vii, 910 et seq. 
dangerous and involved. The retiring president, having at first supported the candidature of Señor Emilio Estrada as his successor, repented of his choice, and joined with others in plotting for the election of Señor Emilio María Teran. On July 3, I9ri, Señor Teran was assassinated, his murderer, Colonel Quirola, being in his turn killed by the angry mob and his body beheaded and burnt. Señor Emilio Estrada then came to Quito and took office on August 3 Ist. After serving about four months Señor Emilio Estrada died on December 22, I9rI, and immediately afterwards a struggle took place for the vacant Presidency. The two candidates were General Pedro Montero and General Leonidas Plaza. The former was proclaimed President by the troops stationed at Guayaquil; but a month later he was shot by the populace. General Leonidas Plaza was then offered the provisional Presidency. He however refused, and Señor Carlos Freil Zaldumbido, president of senate at the last Congress, temporarily assumed office. General Plaza continued, however, to be regarded as the popular candidate, and on March 3I, I9 I 2, he was duly elected. He had previously served as president from I 900 to 1904 , and as minister to the United States in I905. General Plaza's position, however, was rendered exceedingly difficult; the whole country was in a state of seething anarchy. In July I 912 a plot was formed to assassinate the President, a Colombian named Carlos Arce and a native named Thomas being implicated, but the conspiracy failed. In September General Plaza took office as Chief Executive.

The finances of the country have begun, notwithstanding its unsettled condition, to show some slight improvement, the revenue having risen from $£_{\mathrm{I}, \mathrm{I}} \mathrm{I00,000}$ in I 905 to $f_{1}, 800,000$ at the end of IgII. The improvement to a great extent is due to the completion of the Guayaquil-Quito railway (in 1908), and, although Ecuador has had to pay rather heavily for its guarantee of interest upon these bonds, there has been a corresponding advantage in increased trade and revenues. Beyond its Railway and Salt bonds' indebtedness (amounting to $£ 3,104,800$ ), the country has only small responsibilities, which may be put at $£ 700,000$ in all. There is no paper currency; a gold basis was established some years back.

The Peruvian and Bolivian Mixed Mission has commenced its duties in regard to the demarcation of the frontiers in accordance with the terms of the previously signed Treaty. The arrangements provided that should any doubt arise on any question, it should be submitted to the Royal Geographical Society of London.

The republic celebrated the ro3d anniversary of its independence on August Io, I9I 2. Considerable difficulty was again experienced that year in obtaining from the government the money to pay the coupon due on the Guayaquil-Quito Railway Bonds. Later it was received in instalments at irregular dates.

The balance of trade for $19 \mathrm{I} 2$ was in favour of Ecuador, the exports amounting to $\ell_{3,427,100}$ as against imports of $£_{1}, 647,660$. The official valuation of the imports, however, is not to be relied upon, as the figures are frequently understated and do not include freight, etc., from Europe, whereas the export totals are calculated at the average cost f.o.b. throughout the year, including all export duties and local charges.

\section{GUATEMALA 1}

Guatemala has an area of $4^{8,290}$ square miles, and the population (of whom 60 per cent are Indians) according to the most recent estimates is $\mathrm{I}, 992,000$, giving an average of $4 \mathrm{I}, 2$ inhabitants per square mile. Imports were valued in I I IO-II at $f_{1}, 3_{304}, 88_{4}$ and exports at $£_{2}, 196,345$, imports from Great Britain being valued at $£_{22} 62,840$ and exports to Great Britain at $£ 264,950$. The revenue was estimated in the budget of I9r $2-13$ at $£_{2}, 48,1,809$ and the expenditure at $£_{2}, 766,278$. The total public debt amounts to $\left.f_{3,4} 8 \mathrm{r}, 800\right)\left(f_{2}, 48 \mathrm{r}, 899\right.$ external and $\ell_{1}, 000,000$ internal $)$. The total mileage of railways is 424 and that of telegraph lines 3974 . The army has a strength of 70,250 men.

At the end of his second presidential term, Señor Manuel Estrada Cabréra was reelected for a period of six years from March i5, Igrr. Following the assassination (July I907) in the streets of Mexico City of ex-President General Manuel Barillas, who 'See E. B. xii, 66r et seq. 
had invaded Guatemala in March 1906, the conditions of the country remained unsettled and several attempts upon the ruling president's own life were made. Drastic steps were taken to restore order, numerous executions and arrests being carried out; towards the end of rigro, however, conditions materially improved.

In February r9io the boundary convention concluded between Guatemala and Honduras (on March I, 1895) was extended for a period of two years, until March I, I9I 2; and on December 8, I9I I the Convention was still further extended until March I, I9I4. In December I9ro a treaty was signed between Guatemala and Mexico, relative to the construction of a bridge across the Sachiata river, connecting the two republics. The bridge has since been completed and opened to traffic. About the same time the works on the Guatemalan section of the Pan-American railroad were begun.

Education continued to make progress; in the early months of I9I I there were open I670 primary and secondary schools, the attendance during the previous year having been 54,000 , thus showing an increase over the preceding twelve months of 250 schools and of 7,org pupils. In April r9I I a general amnesty was granted to nearly all prisoners within the jurisdiction of the law, the gaols of the Republic having become over-filled, especially in respect of political prisoners.

In May I9 I Guatemala ratified the Geneva Convention signed on July 6, I906, for the amelioration of the condition of the sick and wounded of armies in the field. In July arrangements were entered into with a South American syndicate for the loan of $\$ 25,000,000\left(£_{5}, 000,000\right)$, with the proceeds of which it was intended to recall all the paper currency of the country, at the value of I $_{5}$ cents gold on the dollar, and thus place the Republic upon a gold basis. This course, however, was again deferred.

The seven Conventions signed at Managua (Nicaragua), January I9I2, by the Guatemalan delegates to the Fourth Central American Conference, were ratified that year. Renewed efforts were made to arrive at a settlement of the external debt of Guatemala upon the same principle as that which obtained in the case of Honduras and Costa Rica. In November I9I 2 the British Government, after exemplary patience, determined to compel Guatemala to restore the security, which had been alienated, and to renew payment of the coupons upon its debt, amounting, without the arrears of interest (extending over $I_{3}$ years' default) to $f_{1}, 482,800$. The exceptionally indefensible treatment of the foreign bondholders had long occupied the earnest attention and closest efforts of Sir Lionel E. G. Carden, H.B.M. Minister to Guatemala, and it was due to his capable services that the British Government-acting in conjunction with that of Washington-was induced to move energetically in the matter.

Owing to drought, considerable poverty has existed among the native population, the prices of most articles having risen during I9I2. The prospects of an improvement in the economic conditions, however, were bright.

\section{HAITI $^{1}$}

Haiti has an area of 10,200 square miles, and the population (of whom the great majority are negroes) according to the most recent estimates is $2,020,000$, giving an average of 198 per square mile. The expenditure was estimated in the budget of I9II-I9I 2 at $£ \mathrm{I}, 547,550$ (amended figures). The total public debt amounts to $£ 7,737,078$ ( $\AA_{2,469,7 \text { I } 9}$ external and $£ 5,267,359$ internal). The total mileage of railways is $6 \mathrm{r}$ and that of telegraph lines I23. The army has a strength of ,7000 men. The navy comprises 5 vessels with a personnel of 80 .

General Antoine F. C. Simon assumed the presidency of Haiti on December I 7, I908, but failed to introduce any improvement in the government, which still showed evidence of inefficiency in practically every department. In July I909 an arbitration convention was concluded between Haiti and the United States, ratification being exchanged in the following November. In roro the long-outstanding boundary dispute between Haiti and the Dominican Republic was referred to the decision of the Court at the Hague.

On July 14, rgrr, the Haitian Government informed the representatives of Great

${ }^{1}$ See E. B. xii, 824 et seq. 
Britain, France, Germany, Italy and the United States of its refusal to accede to the recent demands for settlement of all outstanding debts within three months. Shortly. afterwards (July 2oth) a revolution broke out, Americans and other foreigners being placed in danger. The United States, German and Italian Legations made urgent requests to their governments for the despatch of warships to Haiti. The United States' gunboats "Petrol" and "Peoria " were consequently despatched to Port-auPrince, and there received on board a number of American women refugees, as well as several native generals who had opposed the revolutionists and the local authorities. The French consul was wounded. The Simon government was finally overthrown, General Firmin, the leader of the revolutionary party, and his followers capturing Portau-Prince. A formal blockade of the ports of St. Marc, Gonaives and Forte Liberté, was proclaimed, but proved ineffective as the government possessed only one warship.

On July 23, Igri, General Jean Jacques Dessalines Michel Cincinnatus Leconte landed at Cape Haitien from exile in Jamaica, and collected a considerable force. Two days later the German cruiser "Bremen" was despatched from Montreal to Port-auIrince. On August $7^{\text {th }}$ General Leconte made his triumphal entry, and was shortly afterwards elected provisional president of the republic. Almost immediately, however, another revolution broke out under the leadership of General Calisthène Fouchard, Haitian Minister to Germany, and former head of the army of the negro republic, the entire State of Haiti from Jeremie to Aux Cayes taking up arms for him, as it had also done in 1908 . He however failed in his attempt.

On August 19, I9I , the United States Government formally recognised General Leconte as president of Haiti. In the early days of September, as his government had shown a disposition to recognise the claims of foreigners, the representatives of the Powers decided not to proceed with their intention of forming an International Commission for the purpose of presenting their claims. On August 8, r9r2, however General Leconte perished in a fire at his palace, caused by an explosion in an adjoining powdermagazine, 300 soldiers and several civilians succumbing at the same time. It was supposed that the cause of the fire was the accidental ignition of quantities of ammunition stored in the cellars of the palace. General Augusto Tancred, formerly minister of public works, was elected to succeed General Leconte, but his rights were disputed by General Saint Just, who led a body of malcontents against him. Senator Lusemburg Cauvin, formerly minister of the interior, was another candidate.

The finances of the country are still involved, although serious efforts have been made to balance the budget. The finances are administered by an American citizen as gencral receiver of customs under the convention with the United States. A compulsory Education Law has been passed, and a contract for a national railroad signed.

\section{HONDURAS ${ }^{1}$}

Honduras has an area of 46,250 square miles, and the population according to the most recent estimates is 553,460 , giving an average of about i 1 inhabitants per square mile. The revenue was estimated in the burlget of $1912-1913$ at $£ 1,095,034$ and the expenditure at $f \mathrm{r}, 0() 2,258$. The total public debt amounts to $£_{2} 4,207,914\left(f_{2} 3,397,240\right.$ external and $£ 810,674$ internal). The total mileage of railways is 57 and that of telegraph lines 3199 . The army has a strength of 2060 men.

In 1008-1909, during the administration of President Miguel R. Davila, unsuccessful attempts were made to solve the settlement of the foreign debt of Honduras. Vari- ous offers were submitted by United States capitalists, but in each case Congress rejected them. The finances of the country remained in an unsatisfactory state, and, pending a more peaceful outlook, there was small encouragement for the introduction of foreign capital. Nevertheless various concessions were granted, mostly to United States citizens, for the navigation of rivers, the construction of railways and the opening of mines. There is great need of a railway between the Atlantic and the Pacific coasts, and another between Amapala and Tegucigalpa. The only railways existing are

1 See E. B. xiii, 649 et seq. 
narrow gauge banana-carrying lines belonging formerly to foreigners, but acquired by the Government on February 9, I9I2, and now known as the National Railways.

On February r6, rgro the mint of Honduras was reopened after having been closed for two years, owing to the fact that most of the silver in bars is exported.

In ror the boundary question with Nicaragua was settled by the award of King Alfonso XIII of Spain, while the settlement of the dispute with Guatemala by consent of the government of that state, was extended for a term of two years. The mining industry made some progress, there being, at the end of I9II, 700 known mines, of which one-third were working. The Rosario has yielded $£ 3,500,000$ on a capital of $£ 250,000$.

On March 28, I9II the political unrest assumed considerable importance, which induced the president, General Miguel Davila, to resign. He was succeeded as provisional president by Dr. Francisco Bertrand, who served until the general elections of November, when he failed to retain his position. General Manuel Bonilla, a previous president, who for years had been a refugee in the United States, was chosen (Nov. 3, I9II) for the term of 4 years (I9I2-I9I6). He assumed office on February I, I9I2, with Dr. Francisco Bograu as Vice-President. A strong feeling of discontent prevailed among the peasant classes, and uprisings occurred in some parts of the country. Many of the ignorant peons recalled General Bonilla's last presidential term, when the country was stricken with an epidemic of yellow fever. The intense heat which prevailed all over the country in the month of June I9I2 likewise contributed to the general feeling of unrest. The banana-crops were almost entirely ruined, cattle died from thirst and lack of pasturage, while vast areas of forest-land were destroyed by conflagrations.

Early in I9I 2 the Government offered to enter into a contract with United States bankers for a loan of $\$ 500,000$ gold $\left(f_{100, \infty}\right)$ in the form of Customs notes, bearing 5 per cent interest, and payable half-yearly. This was followed afterwards by a general reorganisation of the state funds, and a further offer made by United States financiers of $\$ 6,000,000$ gold $(f I, 200,000)$ for 40 years, at 5 per cent; sinking fund, after 5 years I per cent; the proceeds were to be limited to the refunding of the Honduran foreign debt. The contract, however, was not completed, owing to political difficulties. A new bank, known as La Ceiba, was established in the capital, and a similar institution on the northern coast of the republic,

The treaty of commerce, peace and navigation between Honduras and Great Britain, made on January I, I887, the exchange of ratifications of which occurred on February 3 , I900, was extended until April 6, I9I3.

\section{$\mathrm{MEXICO}^{1}$}

Mexico has an area of 767,090 square miles, and the population according to the most recent estimate is $15,063,207$, giving an average of 19.6 inhabitants per square mile. Imports were valued in I9IO-II at $f I 9,201,376$ and exports at $£ 29,490,393$, imports from Great Britain being valued at $£ 2,238,175$ and exports to Great Britain at $£ 3,950,737$. The total public debt amounts to $£ 44,333,932$ ( $£, 30,548,919$ external and $f_{I} 3,785$, OI 3 internal). The total mileage of railways is $15,25 \mathrm{I}$ and that of telegraph lines 46,II2. The full strength of the army is given as 49,332 men and 6336 officers. The navy comprises ro.vessels with a personnel of $I I 63$.

In April I9ro for the eighth time General Porfirio Diaz was elected president; but his new term proved short lived. For some time previously mutterings of discontent had been heard, the general sentiment among the people being that, after so many years of rule under the same executive, a change would prove beneficial. Had the choice been left to General Diaz alone, he would have respected the popular demand; for it was known that he intended to occupy the presidential chair for the last time, having in view as his successor Señor José Yves Limantour, the minister of finance. General Diaz, however, allowed himself to be persuaded against his own judgment, with the result that a revolution, at the head of which Señor Francisco Madero placed himself, broke out in the following November, and gradually spread to all parts of the republic,

i See E. B. xviii, 317 et seq. 
Guerrilla fighting spread in the province of Chihuahua, and extended to El Paso on the American border; and for some time the situation seemed likely to make intervention by the Lnited States necessary. The American government, in view of eventualities, sent a considerable body of troops within striking distance in case of emergencies. Pressure had been put on the United States by the foreign financial houses in Mexico for this purpose, but actual intervention was not required. The octogenarian president, who hat ruled Mexico for more than a generation, being unable to take the field personally, lost his grip upon the army as well as upon the people; and in May I9I I he was compelled to resign and to leave the country (May zoth) with his family. General Diaz arrived at Plymouth June I 5 th on the German steamer "Ypiranga," reaching London the same day, but pausing there but a very short time before proceeding to Switzerland.

After his departure a provisional government was installed under the presidency of Señor Francisco Leon de la Barra, who continued, with some changes in his ministry, to rule until the popular elections in the following October, when Señor Madero was chosen constitutional president for the period r9ro-r6. A number of further revolts almost at once occurred, while several districts were overrun by armed bands of robbers under different leaders, the authorities being unable to cope with the uprisings, which in many respects recalled the early days of Mexican independence, before the strong hand of Diaz had effected so great a reform. The federal army, on the whole, had remained remarkably loyal to the Madero government.

At one time there were four different presidential candidates in the field, namely, General Gomez, Señor Pascual Crosco, Colonel Felix Diaz, a nephew of the ex-president, and General Bernardo Reyes. The last had formerly been governor of the State of Nuevo Leon for nearly twenty-five years under the Diaz régime, and having conspired against Diaz, he was banished from the country. Towards the spring of I910, however, the Diaz government had recalled Reyes in order that he might help to save the situation. Before he landed upon Mexican soil, agents of the Madero party approached him with the idea of his abandoning Diaz and supporting his rival, the inducement being the promise of the portfolio of minister of war in the new government. Reyes at first consented, but changed his mind; and gathering a few malcontents, he set up as an independcut candidate for the presidency. With his small body of followers he undertook a campaign, which soon ended owing to the desertion of his supporters; his surrender as a prisoner of war to the government then followed.

let a fifth candidate presented himself in the person of General Zapata, who, although nominally a supporter of General Gomez, was known to aspire to the presidency. It was generally believed that Zapata and other agitators were being financed by American money, as so many revolutions in Panama, Cuba and Nicaragua had been in previous years, and a strong anti-American feeling was aroused, several citizens of the United States losing their lives, while many others sought safety in flight across the border.

In January I0I I a new government department of Labour was created, while a new legation was established at San Salvador (Republic of El Salvador), making it independent of Guatemala. Congress amended articles 78 and 109 of the constitution, by which the presidential term was extended from 4 to 6 years, and provided that neither president nor vice-president should be eligible for re-election, nor any state governor serve for more than 6 years. An arbitration treaty was ratified December 26, I911, with Brazil.

Although $79,48+$ immigrants entered the republic during 1910-1r, a large number of residents left on account of the revolution. In this year (I9II) little progress was made in new railway construction owing to lack of labour, most of the available peons having cnlisterl as fighters upon one side or the other, and the attention of the railway companies being devoterl to repairs to damaged track and rolling-stock. Altogether, some 8o kilometres were added, bringing up the total length to 10,877 kilometres. The working of the national railways showed a decrease in the earnings of $2,007,752$ pesos $\left(£ 209,75^{2}\right)$.

In March I () I 2, revolutionary conditions still raging, the United States government formally forhade the exportation of arms to Mexico under penalty of $\$ 10,0 \infty 0$ fine, or imprisonment for 2 years. But the decree came too late to have much effect. In May 
several prominent Americans were forcibly deported from Mexico for having again been found supplying the rebels with arms. The situation became more and more acute, and Pres. Taft was said to have threatened to resort to intervention unless some amelioration were manifested. Pres. Madero sent a notification to the United States that "if a single foreign trooper crossed the border there would be war between the two countries." Pres. Taft, however, denied any intention of active intervention. Two Americans were found hanged at Cananea, in the state of Soñora, July 3 Ist.

Great Britain, Germany and France meanwhile addressed enquiries to the United States asking what steps were contemplated in regard to protecting foreign interests in Mexico; and in June, Mr. Philander Knox, the United States' Secretary of State, submitted a plan to create a neutral zone for 15 miles on each side of the Rio Grande, where any troops of either the Mexican or United States armies, during times of revolution and riot, might enter to protect the lives and property of their countrymen.

Early in August 191 2, serious damage was done to the property of the Tominil Mining Co., a British concern, and the intercession of the British foreign office was necessary. A battle between the federal troops and the revolutionaries, lasting several days, was fought some 45 miles from the capital, the losses being very heavy upon both sides. On September 8th permission was given by the United States government for I 200 Mexican federal troops to pass through part of Texas into Mexico to attack fleeing rebels.

The opposition to the government, although crushed in some parts of the country, broke out afresh in others, and in July I9 2 the president found it necessary to request the United States, Great Britain, France, Germany and Spain to accord formal permission to suspend the constitutional guarantees, a request which was declined by all the Powers. Outrages were perpetrated by roving bands of revolutionists; a passenger train was stopped at Tucumán (Aug. II, I912), when 30 of the travellers were murdered and mutilated; on the previous day the town of Ixtapán, in the state of Mexico, was captured by a body of 1000 rebels, who put 300 of the inhabitants to death. American residents at Cananea, the border mining-town, were armed with rifles and ammunition by the United States government. Other mining camps were similarly provided. A further revolution, having for its object the reinstatement of ex-president Diaz, broke out October I 7 th, the port and town of Vera Cruz being seized and held by the reactionaries, at whose head Colonel Felix Diaz, a nephew of the ex-president, placed himself. After a single encounter between the federal troops and the revolutionaries, the latter were defeated and Colonel Felix Diaz was captured (Oct. 24th).

Notwithstanding the turmoil in political circles and the large amount of wanton damage occasioned to property, such as the destruction of railway bridges and trains, the burning of plantations and the pillaging of business houses, the economic condition of the country suffered less than might have been supposed, as was evidenced by the promptitude with which all foreign obligations were met. The house of Speyer Brothers notified the Mexican Government that it was prepared "to offer financial assistance to any moderate amount," a statement which created a favourable effect upon the stock markets of London and Paris. A serious financial condition, however, was revealed in September I9I2, when President Madero admitted in his message to Congress (Sept. 25 th) that only a small amount $(\$ 2,000,000)$ remained out of the last loan for $\$ 20$,$\infty, 0,0$, which had been raised in June (1912). It was decided to borrow a further $\$ 20,000,000$ (gold). Messrs. Speyer Bros. were not, however, applied to, the government deciding to place the issue in Europe, a proposal which, owing to the Diaz revolution of October 17 th-24th, temporarily at least, proved impossible of realisation.

The receipts for I9 I f fell far short of those of the previous year, the revenue showing a decline of $\$ \mathbf{I}, 884,90 \mathrm{I}$, while the expenditure increased by $\$ 8,332,020$. It was found necessary to draw liberally upon the treasury reserves, which by June I 9 I I had already shown a reduction to $\$ y, 4$ I 4, I I9. A paper surplus of $\$ 10,228,478$ for I I I I-I 2 was more apparent than real. In August IgI I the government had borrowed from the banking house of Speyer $£ 2,000,000$, the proceeds being used by the monetary commission in connection with the currency and exchange operations. 
The political troubles of the republic were reflected in the unsettlement of mining, agricultural and other industrial operations; a textile workers' strike occurred at Puébla on August 5, I9 2, and 9,000 operatives came out; railway communications were cut in many places, and even in the towns life and property were not considered safe from mob violence. The British-owned mines at Tominil were again attacked and dynamited, the staff being compelled to seek safety in flight. Both Great Britain and the United States vigorously protested to the Mexican government, without result.

The budget of the fiscal year I91 2-13 provided for an increase of $\$ 2,870,000$ ( $f_{574}$,$\infty 00)$ for the current year, the total amounting to $\$ 55,000, \infty 00$ ( $f_{1}$ I $\left., \infty \infty, \infty, \infty\right)$. Customs and harbour dues showed a decrease of $\$ 5,000,000$ as compared with the previous year, and of $\$ 2,000,000$ on the estimates.

The principal feature in the foreign trade (I9II-I2) was the continued increase in Germany's share of the imports, which showed an advance of 26.12 per cent as compared with 7.76 per cent for Great Britain. Belgium however showed an even larger increase, 73.70 per cent. In the I9IO-II exports the United Kingdom had already taken second place to the United States, while Canada held seventh place in imports.

On February 29, I9 1 2, a presidential decree was published concerning the distribution of government lands, amounting to approximately 10,000,000 hectares situated in the states of Guerréro, Coahuila, Chiápas, Chihuahua, Durango, San Luis Potosi, Soñora, Tabasco, Vera Cruz, Yucatán, and the territories of Tepic and Lower California.

On October 7 th the Chamber of Deputies voted by II 5 to 29 to double the salaries of members, formerly $\$ 8.50(=17 \mathrm{~S}$. per diem) to $\$ 17.00(=34 \mathrm{~s}$. $)$.

Numerous concessions to foreigners were granted for further railway construction, electric power stations, water plants and factory installations; while irrigation schemes upon an excessive scale were commenced. The establishment of an institution known as the Land Bank, for irrigation works, was introduced under government auspices.

In June I9I 2 Mexico City was severely shaken by earthquake, 63 persons being killed and 75 injured, while the damage done to property exceeded $\$$ I 50,000 . On July Ioth disastrous floods which visited the Northern section of the country, affecting an area of 20,000 square miles, damaged property to the extent of several millions of dollars, and caused many lives to be lost. On July 30, I9 I 2 a severe earthquake visited the Guadalajara district (state of Jalísco), rendering ro,,$\infty 0$ people homeless.

In the last days of October IgI 2 the seaport of Acapulco, on the south coast, was almost destroyed by a hurricane.

\section{NICARAGUA ${ }^{1}$}

Nicaragua has an area of 49,200 square miles, and the population according to the most recent estimate is about 600,000 , giving an average of 12.2 inhabitants per square mile. The total public debt amounts to $£_{2,297,736}\left(£_{1}, 276,273\right.$ external and $£_{1}, 021,463$ internal). The mileage of railways is 170 and of telegraph lines 3614 . The army has a strength of 4000 . The navy comprises 10 vessels with a personnel of 170 .

Notwithstanding the programme of peaceful policy laid down by President José Madriz (inaugurated Dec. 2I, 1900), and his general popularity among the people, the Conservative party, led by Generals Emiliano Chamorro and Ména, continued to resist the new government in conjunction with General Juan J. Estrada, governor of Blue. fields. ()ne of the first acts undertaken by President Madriz was to order a court of enquiry into the execution of two Americans named Groce and Cannon "with a view to frunishing those responsible," although it was known that the order to kill the men had been given by the ex-president José Zelaya. Both Groce and Cannon were American mercenaries, fighting against the constituted authority in Nicaragua. The new President's position was rendered doubly difficult by the fact that the United States Government had persistently refused to recognise either him or his government. On the other hand, President 'Taft acknowledged the revolutionary leader General Juan J. Estrada as the Executive, although the United States Congress (Jan. I4, I910) had declined to 
endorse the President's act, and rejected Representative Sulzer's resolution providing for Estrada's recognition as the legitimate President of Nicaragua.

On February 10, I909, the revolutionists, I200 strong, among whom were many United States citizens, under Generals Emiliano Chamorro and Masis, captured Malagalpa, a town of 9000 inhabitants, the Government troops having evacuated it. On February 22, I910, an encounter took place between the forces of General Chamorro and the government troops at Tisma, when the former were completely defeated, Chamorro barely escaping with a handful of his followers. His loss in killed, wounded and captured was 600 ; that of the Government about 300.

Some sensation was occasioned by the publication of a cablegram from the German Emperor addressed to President Madriz, in which His Majesty expressed a desire "for the continuance of the strong friendship which had always animated the relations between the two governments." Although intended to strengthen the hand of the government, the publication of the telegram had little or no effect, for the revolution continued in several different directions, being materially assisted by the continued refusal of the United States government to recognise President Madriz, in spite of the fact that England, France and other European nations had extended such recognition.

The principal leader of the revolutionary faction and candidate for the presidency, General Juan J. Estrada, appealed to the United States to intervene actively; but, while that government failed to respond directly, General Estrada was greatly assisted in his campaign by a large number of American citizens who fought under his banner. President Madriz was finally defeated and compelled to retire, seeking refuge in the neighbouring state of Costa Rica, where he shortly afterwards died.

General Estrada was then elected provisional president under a law issued on September I5, I910, and was succeeded in October I9 I by Señor Adolfo Diaz as Constitutional President for the full term.

In the early days of August I9I 2 a further revolution was promoted by General Luis Ména, minister of war and marine, who refused to resign his portfolio when requested to do so by the president. General Ména seized the forts at Managua, cut the telegraph lines, and took possession of the city of Granada. Here he was engaged by General Chamorro, and later a truce was effected whereby General Ména agreed to resign the position of minister of war in favour of Dr. Barbarossa. Troubles however broke out afresh, the rebels bombarding the capital and causing many casualties among the natives; no foreigners were injured. United States sailors, guarding the presidential palace and the Legation, took part in the repulse. A sanguinary battle occurred August $3 \mathrm{~d}$ when Iooo dead were counted on the field. A pestilence broke out and the situation became extremely serious. The United States gunboat "Annapolis " visited the port of Corinto, and on August 6th landed 100 marines, quartering them at the capital, Managua. The Nicaraguan government was said to have consented. On August $22 \mathrm{~d}$ the Nicaraguan army, composed of 7500 men, was almost annihilated at Leon. On August 24 th additional American troops were landed both at Bluefields and Corinto, 75 in the first named and 2000 in the second named place. On the same day United States Senator Bacon introduced a resolution into the Senate providing for an investigation into the United States interference in Nicaragua, which he declared " was unwarranted." On August 26th I 20 Nicaraguan non-combatants were slain during the bombardment of Managua. Peace was, however, re-established on October 9 th.

The financial and economic conditions of the state naturally suffered severely in consequence of the complicated political situation, and in January I9I 2 the government defaulted in regard to the coupon due upon the 6 per cent (I909) Loan. In June a provisional agreement was entered into for the settlement of the external debt of Nicaragua, through the houses of Messrs. Brown Brothers \& Co., and Messrs. J. \& W. Seligman $\&$ Co., of New York, by which the interest of the 1909 loan was reduced from 6 per cent to 5 per cent, and the entire customs receipts of the republic were given over as security. Considerable improvements took place in the customs revenue, dating from the time when the United States appointed a collector-general (Dec. IgrI), to commence his 
duties January I, I0I2. Resumption of payment upon the Nicaraguan Debt coupons, which was suspended on January Ist took place on October 25, 1912. The coupon due January I, I9I3, was also met.

\section{PANAMA ${ }^{1}$}

Panama has an area of 32,380 square miles, and the population including the Canal Zone (see under United States: section ii) is 386,745 , giving an average of a little less than 13 inhabitants per square mile. Imports were valued in I910-1 I at $£ \mathbf{I , 9 7 3 , 0 0 0}$ and exports at $£ 570,745$, British imports being valued at $£ 453,480$ and exports to Great Britain at $£ 25,034$. The mileage of railways is 5 I (exclusive of $15 \mathrm{I}$ miles of narrow-gauge banana railways), and of telegraph lines 497 . There are $1, \infty 00$ native police. Revenue for I9II-I 2 amounted to $£ 739,177$ and expenditure to $£ 737,265$.

On November 3, I903, Panama had broken away from Colombia, and under the auspices of the United States became an independent Republic. The present constitution was promulgated on February I3, I904, and on February 25th the first president, General Manuel Amador Guerréro, was installed. He served until I908, when he was succeeded by Senor José Domingo de Obaldía, who died in office on March I, I9ro. The second vice-president, Dr. Carlos Antonio Mendoza, then became president, the first vice-president having died in the previous year. Under the aegis of the powerful northern republic, Panama made great progress, both commercially and industrially, while each branch of the administration showed an improvement year by year. The country is very fertile, and offers exceptional possibilities for colonisation. Moreover, it is believed to be very rich in mines, gold bullion being steadily shipped from mining properties near Darien. Agriculture is carried on to a very considerable extent, the latest statistics regarding live stock showing I 20,000 head of animals: 50,000 sheep and goats; cattle 55,000; horses and mules 15,000 . A progressive trade is carried on in bananas; while cacao, rubber, coffee and sugar, of unusually good quality, are produced. In Panama the sugar cane grows continuously for fifteen years without replanting.

The financial condition of the Republic is strong; in $1910 \$ 6, \infty, 0, \infty 00\left(£_{1}, 2 \infty 0, \infty\right)$ lay on deposit in New York Banks, and $\$ 1, \infty 00, \infty \infty 0(£ 200, \infty)$ was lodged in legal institutions. There is no public debt, and no paper money in circulation.

A change in the United States diplomatic representation occurred in April roro, when Mr. R. S. Reynolds Hitt was appointed to Panama; this post he left in the following July, being replaced by Mr. Thomas C. Dawson. Dr. Pablo Aroseména became president on October I, I9ro. He retired on leave of absence February 2d, and resumed office March 7, I912. On November 14, I910, President Taft visited the canal works and spent three days upon the isthmus.

On January I, I9I I, a new tariff came into existence, the ad valorem duty being raised from ro per cent to 15 per cent except upon wheat, flour, corn, rice and alfalfa.

On July 22, I0r2, the third presidential election which had taken place in Panama was held under the direct and invited supervision of the United States. The elections were remarkable for the fact that, for the first time on record, candidates journeyed into the provinces in order to harangue the voters in true democratic style. Dr. Belisario Porras was elected president from October I, I0I2, for four years, by an almost unanimous vote. An innovation was the granting of votes to the military and police forces. The defeated candidate for re-election, President Aroseména, declared at the opening of (ieneral Assembly (Sept. 2d) that the elections "had been very unfair, and that the United States had introduced methods little calculated to insure impartiality."

Mr. Philander Knox, United States Secretary of State, visited Panama in the U.S. warship " Washington" on February 27, I012. In June two Englishwomen arrived en route for Cocos Island in search of some pirates' hidden treasure.

\section{PARAGUAY ${ }^{2}$}

Paraguay has an area of I71,204 square miles, and the population according to the most recent estimate is $715,84 \mathrm{I}$, of whom about $8 \%$ are Indians, giving an average of 
4.6 inhabitants per square mile Imports were valued at $£ \mathrm{I}, 250,496$ and exports $£ 957,-$ $8 I_{3}$ in $1909-10$, imports from Great Britain being valued at $£ 525,098$ and exports to Great Britain $£_{3042}$. The total public debt amounts to $\ell_{2,149,134}\left(f_{7} 63,590\right.$ external and $f \mathbf{I}, 385,544$ internal). The total mileage of railways is 232 and that of telegraph lines 1987 . The army has a strength of 100 officers and $2500 \mathrm{men}$, and the navy comprises 3 vessels with a personnel of 40 .

Towards the end of Igog a movement was set on foot to bring about the downfall of the government of Dr. Emiliano Gonzales Navero (who became president on July 5, I908). There were three political parties in existence - the peon or peasant class, which took no part in the government and desired merely to live a peaceful agricultural life; the whites, mostly descendants of the old Spanish families, who had always been an exclusive class and had equally little to do with politics; and the military party, which was desirous of obtaining control of the administration of the country. In January I9I I the ferment which had been so long in progress broke out in the form of a violent revolution under the leadership of Colonel Albino Jara, minister of war and marine, who had previously headed a mutiny against his own father while the latter was in command of an artillery regiment. Colonel Jara forcibly assumed the office of president in opposition to the constitutional president, Señor Manuel Gondra (formerly minister for foreign affairs), who had been inaugurated November 25, I9I0; but the country soon rose up against the new dictatorial rule, and found a leader in Dr. Riquelme. Colonel Jara then summoned to his aid a number of ex-Chilean officers, "soldiers of fortune." Dr. Riquelme was captured and decapitated, his body being also horribly mutilated. Not one of the Latin-American republics, nor any of the European governments, recognised the presidency of Colonel Jara. In July I9I I Señor Liberto Rojas, who had been president of the Senate, was offered and accepted the provisional presidency of the republic; and Colonel Jara, notwithstanding his attitude towards the constituted authority, was offered the post of minister of war; but subsequently under pressure this offer was cancelled and Colonel Jara continued his revolutionary campaign.

The Governments of Brazil and Argentina at this time showed considerable powers of restraint, refraining from interfering with Paraguayan affairs, although the interests of both states were seriously jeopardised by the reign of anarchy in the neighbouring republic. In December I9I the British and German ministers were appealed to by the so-called Paraguayan government to support its authority, but declined.

A rupture finally took place between Paraguay and Argentina, which resulted in the withdrawal of the minister of the latter republic, Dr. Martinez Campos, from Asunción, and the despatch of the Argentine gunboat "Paraná" to the Paraguayan capital. "President " Jara telegraphed to the Argentine executive: "It is time that a stop was put to this era of Paraguayan revolutions; fomented and organised in the country of your Excellency." The reply to this provocative message was the despatch of two additional Argentine gunboats and two destroyers, to join the flotilla under the command of Rear-Admiral O'Connor in Paraguayan waters. The special envoy from Paraguay, Señor Enrique Solano Lopez, the son of a former president, was refused an audience by the head of the Argentine government.

Early in March I912, for the second time in as many months, Señor Liberto Rojas was deposed from the Presidency and Dr. Pedro Peña was elected in his place. On the 22 of the same month a further revolution took place, this time under the leadership of Dr. Gondra, the former president deposed by Colonel Jara; the nominee for the Chief Executive was also a former president, Dr. Emiliano Gonzalez Navero, who had served as chief magistrate in 1908; he was elected as provisional president March I3, I912. Dr. Peña, the ex-president, with a number of his followers, took refuge in the Uruguayan Legation. A new government was formed with Dr. Gondra as minister of war, and this was at once recognised by the diplomatic corps.

On May I7, I9I 2 in the course of a fresh revolutionary outbreak, Colonel Albino Jara, who had been mortally injured, was captured with many of his officers. He succumbed to his wounds within a few hours. A new presidential election was held in 
July, when Señor Eduardo Schaerer, formerly mayor of Asunción, was elected president and Dr. Pedro Bobadilla vice-president.

The prolonged political upheaval was responsible for severe depression in financial and commercial circles. Early in I9I2 attempts were made to float a new loan for $£_{1}, 000,000$, of which $£ 400,000$ was offered in France. In view of diplomatic representations, however, and after a discussion in the French Chamber, the whole of the money paid on application by subscribers was returned. The budgets of I9I0, I9I I and for the first quarter of 19 I 2 showed the heavy deficit of $\$ 22,000,000$, and a total debt of $\$ 27, \infty 00,000$. Most of the state employes were without salaries. The general financial condition was described " the worst at any time in recent years." Notwithstanding the adverse conditions, the trade and commerce of Paraguay for the year I9IoI I proved rather more favourable than that for the previous twelve months; but the want of money was severely felt. Merchants, while finding it difficult to dispose of stocks during the months of civil war, were enabled to place orders in Europe and elsewhere on the customary terms of long credit; 42 per cent of the imports entering the republic were British. The total value of the goods imported for the year roro had amounted to $f_{1}, \mathbf{I} 96, \infty 00$, purporting to show a large advance over the previous two years, as did the amount of exports, which came to $£ 950,200$. Upon examination, however, the import figures proved misleading, since out of the total above referred to $f_{233,000}$ related to the material for the Paraguayan Central Railway which paid no duty. The progress of the railway suffered considerably in consequence of the political troubles construction was completed to the terminus at Encarnación and the gauge was finally changed throughout. In June a fusion of railway interests was completed by an American-French Syndicate, the Paraguay Central being brought into working association with the North-East Argentine and the Entre Rios railways.

In July I o 2 occurred the death of Señor Juan G. Gonzalez, a former President (I 8 ooo.) who had been deposed and banished to Argentina. In September the British Minister, Sir Reginald T. Tower, paid his first official visit to Asunción.

\section{PERU 1}

Peru has an estimated area of 679,600 square miles (subject to boundary disputes still unsettled), and the population (mainly Indian and mestizos) according to the most recent estimate is $4,900,000$, giving an average of 7.2 inhabitants per square mile. The total public debt amounts to $£ 4,483,230$ ( $£ 680$, ooo external, but authority to raise a fund of $£ 6,000,000$ was granted by Congress on Sept. I 2, I9 $2 ; £ 3,803,230$ internal). The total mileage of railways is 1728 and that of telegraph lines 6475 . The army has a strength of 7000 men, and the navy comprises 14 vessels with a personnel of 250 .

In January 1909 the United States Pacific fleet visited Peruvian waters, and, in compliment to the republic, it was agreed between the United States and the republic of Yanama that any dispute arising out of the treaty of February (rgog) should be referred to the president of Peru for decision.

Notwithstanding advancing prosperity, in May I909 a political uprising took place, and the capital itself upon more than one occasion was the scene of disturbance. , Señor Leguia, who had been president since September I908, was seized by the mob, and his life threatened upon his refusal to sign a document placing the army in charge of political opponents. Timely arrival of a squadron of national troops put an end to the incident.

An executive decree prohibited the entrance into Peru of Chinese emigrants possessing less than $\delta_{500}$ in cash. The government also put into force rules restricting the promiscuous entry of Chinese manual labourers, and passed laws for the alienation of public lands, promoting colonisation and stimulating better-class immigration.

A treaty wats signed in September 1000 between Peru and Colombia, settling the boundaries in the far north-east, the signatories being Senor M. F. Porras for Peru, and Señor Luis Tanco Argaez for Colombia. The frontier line between Peru and Bolivia was definitely fixed from the mouth of the Heath to that of the Vaverija.

1 See E. B. xxi, 264 et seq. 
In January rgro a treaty was signed between Peru and Brazil settling the boundary question so far as those two republics were concerned, but still leaving open that portion of the frontier claimed by Ecuador. Several British officers took part in the Peruvian Brazilian frontier delimitation-namely Colonel Arthur J. Woodroffe, R.E., who had had much experience in defining the boundaries of East Africa, Captain H. S. Toppin, Lieutenant M. R. C. Nanson, and Lieutenant C. G. Moores. The Commission sailed from Europe for the second time on October 20, I9r 2.

The unfriendly relations which had so long existed between Peru and Chile regarding the provinces of Tacna and Aríca were accentuated when in February Ioro the Peruvian minister in Chile, Señor Arturo Garcia, was withdrawn. At the end of 1912 however a friendly settlement was reported to be in progress.

A fresh outbreak of popular fury directed against the Peruvian legation at Bogotá, Colombia, occurred on April I, I9ro, the outcome of an inflammatory proclamation addressed by the president of Ecuador, Señor Eloy Alfáro. This was productive of much angry correspondence and threatened reprisals between the two governments. Peruvian troops were moved to the Ecuadorian frontier, and in the month of May it seemed as if a border war was inevitable. The excitement gradually calmed down, however, and normal conditions were restored. The Ecuadorian frontier question remaining unsettled, the United States, Brazil and Argentina in June offered their joint services as mediators between Peru and Ecuador; the offer was accepted by Peru, but was refused by Ecuador, as was also the suggestion that the whole question should be referred either to King Alfonso XIII of Spain or to the Hague Tribunal.

The boundary dispute between Peru and Ecuador differs materially from the usual squabbles in which " the honour of the flag " and the " dignity of the nation "play prominent parts. Here there is involved a serious question of territory, namely the entire province of Loréto. This large tract of land covers an extensive region in the centre of South America, and is divided into northern and southern sections. Peru claims the northern section from Ecuador, and as this claim means the relinquishing of one-fifth of the whole territory, the objection of Ecuador can be appreciated.

During rgro commerce and finance advanced encouragingly, and education also made headway. The government carried on the policy of providing educational establishments upon the principle initiated by President Manuel Pardo in 1872, whereby education was made free throughout the republic. Wireless telegraphy, introduced into Peru before it was adopted by any other South American republic, showed remarkable progress; aviation also met with encouragement. In September igro the Peruvian aviator, Jorge Chavez-Dartnell, the first man to fly across the Alps, was killed in Switzerland.

On November 3, roro, a new cabinet was formed under Dr. José Salvador Cavero, but was compelled to resign (Dec. Ioth) on account of a vote of censure passed by the Chamber of Deputies upon one of its members, Dr. Porras, minister for foreign relations. The ministel of finance, Dr. Carlos Forero, had previously resigned and had been replaced by Señor Deyada. On Dec. 28th the Cabinet was reformed under Dr. Basadre, being with two exceptions the same as that which held office under Dr. Cavero.

On January 20, I9 I a law was passed providing for compensation for accidents to workmen and employees in receipt of not more than $\ell_{\mathrm{I}} \mathrm{o}$ per annum. In May a law governing the exportation tax upon crude rubber was promulgated, providing that all rubber exported should pay an 8 per cent ad valorem duty based upon the quotation for the commodity prevailing on the Liverpool market.

On October 5, I9 I I further attack upon the Peruvian legation at Bogota, Colombia, took place, the mob stoning the residence and tearing down the escutcheon. The outrage was due to ill-feeling over an alleged encroachment of Peru upon territory claimed by Colombia.

The Ministry soon underwent yet another change, Dr. Agustin Ganoza, former Minister of Justice, becoming premier on October 20, I9II; the attempt to form a Cabinet under Señor Ego-Aguirre on the $\mathrm{r} 2 \mathrm{th}$ of that month had failed. A boycott of Chilean steamers was instituted at the ports of Mollendo and Pisco in December, but 
collapsed owing to the prompt steps taken by the government. The exodus of Peruvians from northern Chile continued unabated, leaving the Chilean mines and nitrate fields bare of labour. In the autumn relations with Chile much improved, public processions being held through the streets of Santiago-de-Chile in honour of Peru's centennial.

A treaty of amity, commerce and navigation between Peru and Cuba was signed at Lima on April 25, I9I2. The Peruvian navy was now reorganised, the Government purchasing a discarded French cruiser, the "Puy de Lome," for the sum of $£$ r 50,000, in addition to two submarines, bringing up the total strength to 9. The new vessels were brought over from France by Rear-Admiral Villvicencio in March.

The presidential elections, which were fixed for May 25, I9I2, were productive of so much political trouble that it was found impossible to hold them upon the date selected. The President, who had been petitioned to postpone the date, refused to interfere, or to summon a Special Congress, leaving the question to be dealt with by the ordinary Congress meeting July 28th. There were two candidates,-Señor Aspillaga, supported by a combination of several important factions, and Señor Guillermo Eduardo Billinghurst, who had been mayor of Lima since I909, vice-president of the republic (1908), and minister to Chile (I900-1902). Señor Billinghurst was elected August I9th. He commenced his term on September 25, I9I2, the period being for 4 years and terminating in I9I6. The President's first Cabinet was composed of Dr. Eliās Malpartida, president of the cabinet and minister of government; Dr. Wenceslao Valera, minister of foreign affairs; Mr. Baldomero F. Maldonado, minister of finance and commerce; General Enrique Verala, minister of War and Navy; Dr. Francisco Moreyra y Riglos, minister of justice, church and instruction; Mr. Fermin Malaga Santolaya, minister of Fomento and public works.

Grave scandals in connection with the conduct of an Anglo-Peruvian concern, the Amazon Rubber Company, whose business was carried on in the district of Putumayo, were brought to light in an official report (July I9I2) made by Sir Roger Casement, British Consul-General at Rio, who was deputed to hold an investigation. It was shown that a terrible system of cruelty prevailed in compelling the natives to collect rubber, and public opinion in England and America was deeply stirred. The Peruvian government was blamed for allowing these scandals to exist, but defended itself by declaring its entire ignorance of the state of affairs, and claiming to have subsequently sent a commission to investigate crimes and punish the offenders. Three further commissions were nominated to draw up a scheme of reforms, while a judge and a commissioner were appointed to reside in the district.

The conditions of trade meanwhile showed further improvement, the revenue from all sources displaying an increase. The estimated revenue for I9I I-I 2 , namely $£ 2,784,-$ 513, was exceeded by $£ 442,904$. With other sums brought in, the excess amounted to 1607,602 . On the other hand the estimated expenditure for the same period was exceedal, amounting to $£ 594,035$, leaving a balance in the treasury of $£ 13,567$. The receipts for the year 1912-I3 were estimated at $£ 3,209,237$ and the expenditure at $£ 2,879,924$, showing a surplus of $£ 329,113$.

The Senate (Sept. II, I9I2) approved an internal loan for $£ 6, \infty 00, \infty$ oo for purposes of national defence, while the Chamber of Deputies (Oct. I 7 th) sanctioned a loan for $\$ 1,500,000(£ 300,000)$ at a maximum interest of 8 per cent.

\section{SALVADOR *}

Salvador has an area of 7225 square miles, and the population according to the most recent estimate is $1,700,000$, giving an average of 235.2 per square mile. Imports were

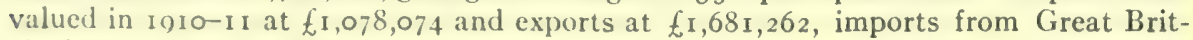
ain being valued at $£_{3} 28,847$ and exports to Great Britain at $£_{104}, 604$. The revenue was estimated according to the budget of $I_{9} I_{2-13}$ at $I_{3}, I_{40}, 4 I_{5}$ pésos gold, and the expenditure at 13,005 , IOI pésos gold ( I péso gold $=4$ s.; i péso paper $=3$ s. Id.). The total public debt amounts to $£^{2}, 585,500$ ( $£ 885,500$ external and $£ \mathrm{I}, 700,000$ internal). The

' See E. B. xxiv, 96. 
total mileage of railways is 97 and that of telegraph lines 2706 . of 5554 men and officers (exclusive of about 18,000 militia).

The army has a strength vessel with a personnel of 10.

The Amapala Conference of November I907, which was held between the presidents of Salvador, Honduras and Nicaragua, was not productive of permanent peace, as had been anticipated. In December I 908 a further effort to stir up revolution in Salvador was made by the then president of Nicaragua, Señor José Santos Zeláya, who also instigated an attack upon General Fernando Figueroa, the president of Salvador. Both attempts proved unsuccessful. A state of excitement and unrest, nevertheless, prevailed all through I 909 , but the strong hand of the government succeeded in suppressing the threatened uprising. In April I 909 the United States found it necessary to despatch three warships to Nicaraguan waters in order to prevent a further incursion into Salvadorian territory. The Government of Salvador at this time showed much self-restraint and great administrative capacity, with the result that the situation was robbed of much of its latent danger, and, while a state of unrest continued in the neighbouring Republics of Nicaragua and Honduras, Salvador settled down to peaceful conditions.

Several important railway contracts were entered into in roro with an American syndicate, more especially one for 75 miles of track connecting Zacapa (in Guatemala), Santa Ana and San Salvador, thus securing communication with the Guatemala railway and forming the eastern-division link of the Pan-American railroad. This contract was followed by another for the construction of a railway from San Salvador to the port of La Libertad, on the Pacific coast. Very slow progress has been made with either project.

General Fernando Figuero, who had been elected president on March I, 1907, retired from office at the end of his four years' service, being succeeded by Dr. Manuel Enrique Araujo (March I, IgII), under whose administration the republic made consistent headway. Not only have the general trade conditions improved, but advancement has been manifested in other directions. The railways, telephones and telegraphs have been extended, and several other important industrial projects initiated. The attention and the resources of the Government have been devoted to the improvement of the cartroads (carretéras) which are used to a large extent for internal traffic. Salvador already possesses one of the best systems of highways in Central America.

On November 5, ror I was celebrated the centennial anniversary of the state's independence, when several additional highways were opened to traffic. The new Salvador line of steamships, inaugurated at the end of r9o8, continued to play an important part in the economic development of the State, and the well-managed Salvador Railway, of which the steamer service forms a subsidiary undertaking, likewise contributed to this advancement. Owing to the favourable public rates which the Salvador line had introduced, a "rate war" had been anticipated; but through skillful administration this was avoided. The Salvador steamship line has succeeded in restoring the British mercantile flag to Central American waters, from which it had entirely disappeared, and is carrying on a very extensive trade between Salvadorian, Guatemalan and Mexican ports.

In 1912 there were 486 primary schools, of which 203 were for males, 200 for females, 83 being mixed; they employ $85 \mathrm{I}$ teachers, 382 being males and 469 females. The number of pupils in the republic is estimated at 29,569, and the total population of school age is I 73,495. In March I9I 2 an officer of the Spanish Civil Guards, Captain Martin Garrido, arrived under contract with the government to reorganise the police force of the country, and to establish a body of Rural Guards for the better protection of life and property in the republic.

The finances at the end of I9I 2 were in a satisfactory state. In I9I I the revenues amounted to $\mathrm{I} 2,359,874$ pésos as compared with Io,620,865 pésos in I9Io. Under the administration of Dr. M. E. Araujo, large repayments have been made on account of the public debt; payments to the army and navy, which under previcus administrations had been in arrear, were liquidated, and have since been regularly maintained. Diplomatic and Consular representatives abroad, who had not been in receipt of salaries for several months, were paid in full; while credits with foreign firms in Europe and the United 
States, also for some time suspended, were renewed. Considerable economy, on the other hand, has been exercised in the control of the public service; expenses not absolutely necessary have been stopped; freedom from custom house dues is no longer permitted; the port of Mazanilla, through which many thousands of tons of goods were formerly smuggled, is now closed; the strictest scrutiny is exercised over the collection of revenues, old collectors having been removed and new ones appointed; firms and bankers who had advanced loans to the government have been induced to suspend interest for 6 months; customs tariffs on articles used by the rich classes have been raised 20 per cent gold, while tariffs upon articles consumed by the poor have been lowered; and finally the stamp-tax has been rigidly enforced.

The practical results of the financial policy of the government include the increase in the revenue in one year of $1,730,008$ pésos; $1,000,000$ pésos of old debts cleared off; many public works of first importance completed and paid for out of revenue; the British foreign debt coupons faithfully met (the.Salvador bonds have recently stood at the highest price attained, namely ror per cent), and. $1,637,000$ pésos of the Internal Debt, in addition to $\$ 1,000,000$ of unpaid salaries, cleared off. The revenue of the state has increased over 16 per cent and the national debt has been reduced by 9 per cent.

\section{SANTO DOMINGO ${ }^{1}$}

Santo Domingo has an area of $\mathrm{I} 9,325$ square miles, and the population according to the census of I9I is 675,000 , giving an average of 34.89 inhabitants per square mile. Imports were valued in I9IO-II at $\ell_{1}, 389,932$ and exports at $\ell_{2,200,98 I}$. The total public debt is $£ 5,000,000$ ( $£ 2,835,700$ external and $£_{2}, 164,300$ internal). The total mileage of railways is 225 , and that of telegraph lines ro2 $\delta$. The army has a strength of 1300 men. The navy comprises 6 vessels with a personnel of 100 .

The year 1909 marked an epoch in the history of the Republic as regards prosperity and progress; trade with the neighbouring republic of Haiti was also more active than in any former year. The completion of two railways was effected, namely the line between Santiago and Moca, and that between Salcedo and Puerto de Sanchez. An extradition treaty with the United States was celebrated on June I9, I900.

The national Bank of Santo Domingo was established in rgro with an authorised capital of $\$ 2,000,000$, the president being a United States citizen and the stock-holders mainly Cuban financiers. A concession was granted to a British corporation for a railway line from Puerto de Sanchez to La Vega. Three important measures were enacted, the mining law, stamp-tax law, and diplomatic reorganization law. The republic had a cash balance of about $\$ 6, \infty 00,000$, which was devoted to public works.

In November roro political dissensions again broke out between Haiti and Santo Domingo, in regard to the boundary dispute, both governments finally agreeing to submit the controversy to the arbitration tribunal of the Hague.

In November I o I President Ramon Caceres was assassinated; Señor Eladio Victoria assumed control of the republic's affairs, and was subsequently elected provisional president (Dec. 6th). His nephew, General Alfrédo Victoria, aged 27, was appointed commander-in-chies of the army and minister of war and marine.

On February 5, IOI 2 at the meeting of the Chamber the election of Señor Eladio Victoria was confirmed, his appointment now being that of constitutional president for the full term of 6 years. On February 28 th a new Cabinet was formed, General Alfrédo Victoria retaining the portfolios of war and marine and assuming in addition the temporary secretaryships of the interior and police. On April isth the pecuniary claims, patent, copyright and trade marks Conventions adopted at Buenos Aires in roro by the Fourth International Conference of American States were ratified.

The finances of the republic which, in accordance with the convention between the United States and the Santo Domingo governments, are placed under the supervision of an American citizen as general receiver of customs, showed marked improvement from I (yo) to I9I 2 , the receipts have increased from $\$ 3,9$ I 4,300 to $\$ 4,257,000$. The 
imports advanced from $\$ 4,425,9$ I 3 in I909 to $\$ 6,257,69$ I in Igro; while the exports improved from $\$ 8$, II 3,690 in 1909 to $\$ 10,849,623$ in I910. During the first quarter of I9I 2 the customs receipts resulted in an increase of $\$ 205,522$ as compared with the corresponding period of I $9 \mathrm{II}$.

On June 5, I 9 I 2 a further revolution broke out under the leadership of one D'Orcilien, the government troops at the first engagement being defeated. Disturbances continued at intervals throughout the months of July, August and September. On September r3, I9I 2 the United States decided to intervene, and despatched the cruiser "Des Moines," and the gunboat "Wheeling," to protect American interests. On September 24th a force of 750 United States marines was despatched to protect the customs houses (which had been seized by the revolutionists), in accordance with the Convention of 1907 .

\section{URUGUAY ${ }^{1}$}

Uruguay has an area of 72,2 IO square miles, and the population according to the most recent estimate is I, I I 2,000, giving an average of I 5.3 inhabitants per square mile. Imports were valued in I9ro-I I at $£ 9,537,423$ and exports $£ 9,263,607$, imports from Great Britain being valued at $f \mathrm{I}, 030,53 \mathrm{I}$ (Jan. to July IgIo) and exports to Greait Britain $f_{437,937}$ (Jan. to July I9II). The revenue was estimated in the budget of I 9 I $2-I_{3}$ at $\$ 35, I_{42}, 380$ and the expenditure at $\$ 35,000,000(\$ \mathrm{I}$ gold $=4 \mathrm{~s} .3 \mathrm{~d}$.). The total public debt amounts to $£_{27}, 8 \mathrm{I}_{3}, 077$ ( $£_{2} 6, \mathrm{I}_{5}, 077$ external and $£_{\mathrm{I}}, 628,000$ internal). The total mileage of railways is $201 \mathrm{I}$ (including lines under construction) and that of telegraph lines $48 \mathrm{rg}$. The army has a strength of $7500 \mathrm{men}$ and 600 officers. The navy comprises 12 vessels with a personnel of 660 .

The presidency of Señor Claudio Williman, which began in I907, was characterised by a cautious financial policy; nevertheless, considerable sums were devoted in I9oo by the Government to the founding of agricultural colonies, the construction of port works, and to the subsidising of certain new railway lines. The general prosperity of the country was shown in the growth of imports and exports. In spite of the Public Debt (amounting to $f 27,8$ I 3,077 ) being a heavy one for a country possessing but little over $\mathrm{I}, 000,000$ inhabitants, the natural resources of the Republic, which are as yet only partially developed, are such that the public credit of Uruguay continues to stand high. On October 30, I909 the Brazilian-Uruguayan Treaty, concerning the joint-ownership of the Mirim lagoon and the Jaguareto river, was signed.

In the early days of IgIo, further insurrections were attempted, the penal code countenancing such revolts and allowing participators to escape punishment. Many of the disturbances took place in Montevideo in connection with the presidential candidature of Señor Battle y Ordoñez (President I903-07). Much public dissatisfaction was occasioned by the large increase in the strength of the army, and the consequent heavy charge on the Budget (1910).

During President Williman's administration, a reduction was made in the exportation duties of meat products, and the light-dues were diminished; the 5 per cent tax on salaries and pensions and the Postal surcharges were eliminated. On the other hand, fees were instituted upon industrial and professional licences. Cable rates were reduced by order of the Government, and provision was made for the tariffs schedule of cable companies to be revised annually.

From January I to February 2, I9I I the South American Postal Congress was held at Montevideo; this provided for the establishment in that city of an International South American postal bureau under the direction of the government of Uruguay. The object of the bureau is to collect, arrange, publish and distribute data of special interest to the postal service of South American countries, including Argentina, Bolivia, Brazil, Chile, Colombia, Ecuador, Paraguay, Peru, Uruguay, and Venezuela.

In March IgIx Señor Battle y Ordoñez was elected president of the republic for the second time. Almost immediately an extreme socialistic policy was put forward, with the result that a strong opposition to the government was created. Among other

1 See E. B. xxvii, 805 et seq. 
measures which were int roduced in rapid succession were-a Labour bill (July), opposed by all foreign interests and especially by the British railway companies; an Insurance Monopoly bill (July), forbidding within the territory of the republic the carrying-on of life. fire and accident insurance operations otherwise than by the State; a bill (August) for the establishment of a state meat-factory, intended to promote open competition with established foreign interests; a bill (August) for the establishment of a state mercantile marine; and a scheme for the construction of a number of economic State railways, also intended to promote competition with the existing lines built with British capital. A state monopoly in the manufacture of matches was announced in August 1912. The threatened Insurance Monopoly drew forth a protest from the British minister at Montevideo, Mr. R. J. Kennedy, after the matter had been raised in the House of Commons (Aug. I 7 th) by Mr. Annan Bryce, M.P. for Inverness Burghs.

Towards the end of May igi I serious industrial strikes occurred, which affected the whole of the labour in Montevideo. So far from attempting to control the situation, the government ostentatiously stood aside; during three days thousands of willing workpeople were unable to follow their occupations. For this period, by decree of the Labour federation, the industrial business and commercial activities of Montevideo were paralysed, the supplies of daily food were interrupted, theatres remained closed, marriages were postponed, and it was difficult even to bury the dead with the customary ceremonies. For eleven days following, public order remained disturbed. The president openly encouraged the strikes, and declined to extend either police or military protection. Further hostility was shown to foreign enterprise by the cancellation of an important contract, entered into in the month of May roro, between the government of Uruguay and the city of Montevideo Public Works Corporation, a British company, although the Chamber of Deputies had formally approved of the contract in October I 910 and the executive had signed it.

In September a legation was created at Havana (Cuba), Señor don Rafael J. Fossalba being appointed first envoy extraordinary and minister plenipotentiary, while Señores Don Juan Zorilla de San Martin and Don José Pedro Massera were appointed to represent the republic on the Permanent Arbitration Court at the Hague.

In August 19 2 Dr. Juilo Herréra y Obes, a former president, passed away. A painful impression was occasioned by President Battle y Ordoñez refusing permission for the deceased to receive burial in the National Pantheon. The Chamber insisted, however, upon this honour being rendered, and the president was compelled to give way.

The financial conditions of the republic show that the national expenditure has been fast overtaking the revenue. The latter was placed (1912-13) at $\$ 28,535,000(£ 5,707,-$ $\infty 00)$ while the former was estimated at $\$ 35$, I32, I I I $(£ 7,026,434)$. A later estimate raised the revenue to $\$_{35}, 1+2,380$, thus showing "a balance of $\$$ ro,, 00 ." but in local financial circles the realization of this estimate was not anticipated.

\section{VENEZUELA ${ }^{1}$}

Venezuela has an area of 393,076 square miles, and the population according to the most recent estimate is $2,713,703$, giving an average of 6.9 inhabitants per square mile. Imports were valued in $1010-11$ at $£ 3,678,979$ and exports $£ 4,536,876$; imports from Great Britain being valued at $\{1,050,772$ and exports to Great Britain $£ 253,275$ (these figures exclude Trinidad, British (juiana and British West Indies). The revenue and expenditure were estimated in the burlget of $1912-13$ to balance at $52,500,800$ bolivars ( 1 bolivar $=0, \frac{1}{2}$ 1.). The total public debt amounts to $£ 7,686,58 \mathrm{I}\left(f_{4}, 36 \mathbf{1}, 420\right.$ external and $£ 3,325$,$16 r$ internal). The total mileage of railways is $5+2$, and of telegraph lines 4899 . The army has a strength of 9600 , and the navy comprises 6 vessels with a personnel of 400 .

After the sentence of exile pronounced upon ex-President Cipriano Castro, which was determined upon immediately after his departure from Venezuela, December r9o8, the conditions of the country began to improve. Commercial prosperity was not only resumed and subseruently maintained, but more harmonious associations with other

1 See E. B. xxiii, 988 et seq. 
countries, which had been rudely interrupted during the latter days of General Castro's term of office, were again instituted. Steps were also taken to settle several outstanding boundary questions with both Great Britain and Colombia; and, with the latter republic, commercial negotiations, as well as the interchange of diplomatic representatives, were resumed. In February I910 the Governments of Venezuela and the United States agreed upon the appointment of the Earl of Desart, who had been in charge of the British case before the International Commission of Inquiry into the Dogger Bank incident (December I904), as third arbiter in the disputes submitted to the Hague.

On April 27, rgro General Juan Vicente Gomez, who had assumed office of President in November I9o8 upon the departure of General Cipriano Castro, was elected Constitutional President for the full term of 4 years. On April 3 oth the Venezuelan Cabinet resigned, but several of the members joined the new Government. Legations were established in Cuba and Nicaragua, while diplomatic relations were re-established with Italy. The government failed to arrive at any arrangement with Great Britain as to an additional duty of 30 per cent upon goods imported from the British West Indies.

Relations with France and the Netherlands remained ruptured. When the new administration was inaugurated, assent had been given to the German Minister's proposal of friendly mediation between Venezuela, France and the Netherlands, the Venezuelan Government being anxious to resume diplomatic intercourse with both States. When, however, an adjustment was expected, both the French and Dutch governments made new demands, which were considered by Venezuela to be unacceptable. The balance of payments owed by Venezuela to Spain for acts committed in the war of Independence remained unsettled; but negotiations on the subject were again resumed. Several other pending diplomatic questions between Venezuela and the United States continued unadjusted, but on the other hand claims in connection with the Asphalt Company's concession were settled by compromise. The decision of the Hague Tribunal by which Venezuela was condemned to pay the sum of $f_{4} 6,867$ in connection with the Orinoco Steam Navigation Company's claim, was also satisfied.

In April rgr I important changes were introduced in the Customs tariff, the whole tariff law being revised. At the end of this year the payment made by Venezuela under the protocols of Washington of 1903 , to Belgium, France, Mexico, the United States, Spain, Holland, Sweden and Norway, amounted to I 5,8 I 7, I 3 I bolivars. The original claims amounted to 21,106,436 bolivars, so that there remained (November 30, I9II) an unpaid balance of $5,289,354$ bolivars. These amounts do not include the sums paid previously to Germany, Great Britain and Italy, aggregating 17,835 , 150 bolivars.

On January 8, rgI 2 the arbitration convention made between Venezuela and Brazil was ratified, the convention to remain in force for 5 years. Negotiations were reopened for the resumption of diplomatic relations between Venezuela and France, French citizens retaining their rights to submit their claims to arbitration. On February $\mathrm{I} 2 \mathrm{th}$ legal time was established throughout the republic at $4 \frac{1}{2}$ hours later than Greenwich, the time being telegraphed every second day from the observatory at Carácas (the capital) to each port. The duplex system of telegraphy was adopted by the government upon the whole of its lines. Wireless telegraph stations were established at La Guaira, Puerto Cabello, Maracaibo and Cumaña. On May I8, I9I 2 an executive decree provided that none but the decimal system should be accepted officially in the law courts, offices of the states and territories of the republic. Several important contracts were entered into between the government and a British and North American corporation, including a sanitation project as well as a paving and a water-supply scheme for the capital; but eventually the syndicate was notified that the work must be stopped.

In August several persons were arrested for smuggling dynamite and munitions of war into the country from Trinidad, while diplomatic representations were made to the British authorities by the Venezuelan government.

In November I 9 I 2 by Presidential decree six Venezuelan foreign legations of the first class were established, assigned as follows:-(I) the United States, Mexico and Cuba; (2) Colombia; (3) Ecuador, Peru and Bolivia; (4) Brazil, Uruguay, Paraguay, Argentina 
and Chile; (5) Spain and Italy; (6) Germany, Belgium and the United Kingdom. In December I9I 2 the Department of Finance deposited in the Bank of the Republic, Carácas, subject to the orders of the respective legations, the balance of the Debt acknowledged in the protocols of Washington of 1903 , and amounting to 349,587 bolivars.

(Percy F. Martin.)

\section{LIBERIA ${ }^{1}$}

Since $1009^{-10}$ the frontier with the French possessions has been limited on the spot by a Franco-Liberian Commission, on which the principal Liberian representatives were two Dutch oflicers, Naval Captain S. P. L'Honoré Naber and Naval Lieutenant J. J. Moret. On the west the frontier with the adjoining British protectorate of Sierra Leone has been changed. Liberia has ceded to Great Britain the small district of Kanre Lahun (a name which should really be pronounced and written Kãre Lauñ), which therefore brings the frontier of Sierra Leone in a loop farther to the north-east. On the other hand, Sierra Leone has ceded to Liberia the district of equivalent size known as the Morro Forest, between the upper River Mano (formerly the boundary) and its western tributary the Morro. This boundary is altogether more satisfactory as it no longer subdivides tribes into different sections under Liberia and Great Britain. It gives to Great Britain better trading access to the river Makona (towards which the Baiima railway will now be carried) and yields to Liberia the whole of the great Gora Forest, valuable for its rubber and timber.

With regard to the flora of Liberia, a few fresh discoveries have been made by Mr. Bunting. Dr. Otto Stapf of Kew has pointed out the existence in Liberia of a valuable fodder grass, the Pennisetum purpureum. This is likely to prove very useful as clearings in the forest increase and greater attention is given to stock raising. From the apparent absence of tsetse fly in much of the Liberian hinterland, and the consequent success which attends cattle breeding, it is hoped that as the country settles down into a peaceable condition the attention of the natives may be more and more concentrated on stock-rearing as well as on agriculture; for the question of food supply in West Africa is becoming a very important one. It is absurd that Liberia should import such enormous quantities of rice, meat and fish, when all these things could be obtained locally if the attention of her inhabitants could be concentrated on the land and the waters of the coast, instead of being almost entirely absorbed by factious political questions, slave-raiding and civil war.

In regard to the fauna of Liberia, the first capture and export of living specimens of the pigmy liberian hippopotamus were made in 1912 by a German big-game hunter, Major Schomburgk, of Hamburg. Two hundred pits were dug by this energetic naturalist (who was assisted in his explorations of Liberia by his wife), and five pigmy hippos in excellent condition were captured, quickly became tame, and were distributed between the zoological gardens of the United States and Germany through the agency of Carl Hagenbeck. For the first time naturalists were able to get a clear idea of the aspect of the pigmy hippopotamus when alive. It was seen to differ from its larger relation not only in size (it is little bigger than a large pig), but in having a more slender muzzle, a more arched profile along the line of the nose, and a less wrinkled body. It stands proportionately higher in the legs, and is obriously much more active on land than Hippopotamus amphibius. According to Major Schomburgk's researches this pigmy hippopotamus, though well able to swim, does not spend much of its time in the water, but leads a life in the dense forest and sleeps on land, very often making long burrows or tunnels in the dense herbage or undergrowth of the jungle. With its fore-feet, in which only the two front hoofs ordinarily touch the ground, it is able to do a great deal of burrowing, and will rapidly conceal itself from sight by digging hollows in the mud, into which it subsides. It would also scem from Schomburgk's researches that Liberia possessed a pigmy form of elephant as well as a hippopotamus, somewhat akin in the shape and size of its ears to the well-marked small variety found in the Cameroon.

As regards minerals, an important discovery of genuine diamonds was made in the western part of Liberia in 1909-10, near the lower St. Paul River, further stones being found in 19II. The diamonds were discovered by agents of a British company engaged in constructing a motor road due east from the river to the coffee-planting districts. Alluvial gold had been discovered by the same company, and it was in the search for gold that diamonds were obtained from the gravel of small streams. These diamonds are of good water, and very similar to those of Brazil. So far no very large stone has been found, but it is believed that such as have been exported (about 154 in number down to I9II) indicate the existence of a matrix in this part of Liberia which may quite possibly furnish stones rivalling those of Brazil and Guiana-countries which greatly resemble Liberia in their petrology. 
A diamond was also obtained from the vicinity of the Finley Mountains in 1912. There has been a slight increase in the output of gold, but nothing at present to indicate that any one part of Liberia is highly auriferous.

The journeys of Captain Braithwaite Wallis, formerly British Consul-General in Liberia (since transferred to French West Africa), an account of which was published in I9I0, threw some light on the cause of the grievous troubles which have recently convulsed the hinterland of Liberia and hindered access to the trading centres. After the successful campaigns ( $1890-1898$ ) of the French against the Mandingo Mahdi, Samori, and his Sofa following, ${ }^{1}$ it is evident that remnants of Samori's army found refuge in the dense forests of Liberia, where they joined with quasi-Mahommedan tribes partly of Mandingo stock in a common hatred of the white man's encroachments. The settlement of these Sofas amongst the Buzi, Toma, and Gbālin tribes provoked further trouble with the French in the form of border raids, and it has become more than ever incumbent on the Liberian Government at Monrovia that the Republic should possess an efficient police force capable of maintaining order in the interior and firmly opposing itself to acts of brigandage and intertribal war.

On January I, ror 2 Mr. Arthur Barclay. was succeeded in the Presidency of the Republic by the Hon. Daniel Howard. Important concessions have been made to the German South American Telegraph Company giving them the right to establish and operate a system of wireless telegraph communication to and within the territory and Republic of Liberia. The concession originally made to a British company in 1890 for the working of the Liberian rubber forests, the planting of rubber trees, etc., has been revised and amended, bringing it more into line with the interests of other foreign traders, and at the same time compensating the company for the past investments and sacrifices which it has made by defining closely the area of its forest preservation and allotting to it at a low rental for a long period areas of unoccupied land for experimental planting purposes. In return this company, which has already achieved considerable success in its introduction of the Hevea or Pará rubber, has agreed to distribute widely amongst the indigenous people of Liberia the seeds and stumps of the Pará tree, which is likely to become much cultivated in the territories of the Republic, so similar in their soil and climate to the regions of Brazil from which the Hevea has been derived. But the most important Act of the Legislature in IgI I was the Loan Act for the negotiation of a loan through the good offices of the United States Government for the refunding and extinguishing of all debts and pecuniary obligations of the Republic, whether foreign or domestic.

This loan, it was arranged, was to be issued in the form of bonds payable in New York both as to principal and interest in gold coin of the United States, the bonds to be issued in such form as might be necessary to secure their admission to the stock exchanges of New York, London, Paris and Germany, the annual interest on the bonds not to exceed five per cent, the bonds to be issued for a period of not less than forty years and to be redeemable under the provisions of the sinking fund at a premium of not more than two and a half per cent of their face value during the first ten years from the issue of the loan and afterwards at par. For the service of this loan there was to be set aside monthly from the revenues assigned to that service a sum not exceeding twenty per cent of the gross receipts during the preceding month, which amount should not be less than 7,600 dollars in United States gold. After the payment of the interest and necessary expenses the residue was to be set aside as a sinking fund and this sinking fund was in no case to be less than 12,500 dollars per annum. The security for this payment of interest and principal and of all charges on the loan was to be the revenues from the customs duties and the rubber tax, also, if need be, the shipping tax on native labourers going abroad for service. The collection and administration of this revenue during the life of the loan were invested in a customs receivership to be administered by a general receiver of customs, who should be from time to time designated by the President of the United States of America, and thereupon commissioned by the President of Liberia and associated with three assistant receivers, to be designated respectively by the governments of the Republic of France, the German Empire, and the United Kingdom of Great Britain and Ireland. The accounts of the general receiver should be rendered monthly to the secretary of the Treasury, whose emoluments and those of his assistant receivers were to be fixed at such amounts as the President of the United States might approve. During the existence of this receivership the general receiver would have

1 See E. B. xxiv, 642d, 643a; xxv, 56d. Samori died in 1900. 
full and complete authority to collect customs and other assigned revenues as he might deem necessary for this purpose, and should be supported by an adequate customs guard and patrol service on land and sea by the Republic of Liberia. And if the Republic should fail to provide an efficient customs guard and patrol service, the general receiver might establish such himself and pay the expenses thereof out of the assigned revenues. For the further security of the revenue during the maintenance of internal peace there was to be maintained during the life of the loan an adequate frontier police force, the officers of which were to be designated by the President of the United States of America. The general receiver of customs (an American $)^{t}$ would also exercise the functions of a financial adviser to the Republic, and co-operate with the secretary of the Treasury to bring order and system into the finances, and further exercise a reasonable control over the expenditure in each fiscal year, and a proper accounting for all the moneys received and disbursed

The conclusion of the loan was made contingent on the settlement of the outstanding claims of the creditors of the Liberian Government. Many of these were Germans, and some delay was caused by the discrepancy between the German claims and the views of the Liberian Government; but on June 25, I9r 2 an agreement was finally reached on a basis described by both sides as "very satisfactory." The negro Republic of Liberia has thus come within somewhat the same financial administrative control on the part of the United States as has so greatly benefited the Republic of Santo Domingo in the West Indies.

The intervention of the United States has checked the ambition of France to eat away by degrees the hinterland of Liberia. The Liberians would add that it has equally checked the desire of the Sierra Leone Government to absorb Liberia from the west. It is doubtful whether such a desire has ever existed, though it is certain that both the British colonial government of Sierra Leone and the local government of French Guinea were becoming increasingly exasperated by the continual disorder prevailing in the Liberian hinterland and the effects that such disorder had on the populations and on the trade of the adjoining territories. It can only be to the advantage of both British Sierra Leone and French Guinea and their respective railway systems that the Republic of Liberia should become a stable, prosperous, and homogeneous state, a great rubberproducing country, and one which by its peculiar vegetable and mineral products rather takes a place of its own in the West African system than becomes a rival to the industries of British and French West Africa.

Statistics.-The approximate revenue of Liberia for 1909 was 378,300 dollars (about $f-7,000)$. The returns for 1910 are not yet published but are said to show a slight increase. The revenue for 1905 (the year before British customs collectors were appointed) was about $\{53,200$. The total annual trade in the last year for which complete statistics are issued (1909) was worth (imports and exports nearly equal) $£ 407,200$. The chief exports are still rubber, palm oil and palm kernels, piassava fibre, coffee, ivory, ginger and camwood.

Bibliography.- "A Journey through the Liberian Hinterland," by Captain C. Braithwaite Wallis, Geographical Journal, I9I0; Op Expeditie met de Franschen . - aan de Fransch-Liberiaansche Grensregelings-expeditie in de jarn 1908 in 1900, by Captain Naber and Lieut. Moret. The Hague, 1910 (an exceedingly interesting and well written work in I) utch on inner Liberia and on the recent political troubles).

(H. H. JoHnston.)

\section{MONACO ${ }^{2}$}

On January 5, I9I I a Constitution was granted by Prince Albert I of Monaco to his subjects. It was based upon a report made by three French juris-consults,-Jules Roche, Louis Renault and André Weiss. The government of the principality is carried on under the authority of the Prince by a minister of state assisted by a council of government consisting of the minister and three councillors nominated by the Prince. These three councillors perform the duties of ministers of the Interior, Finance and Public Wurks. A council of state is established, which includes the minister, a secretary of state, the three councillors, the first president of the Court of Appeal, and the procureurgeneral. The legislative power is exercised by the Prince and a national council. This council is composed of twenty-one members elected for four years by universal direct suffrage with a scrutin de liste, and is presided over by a president and a vice-president

${ }^{1}$ Mr. Reed P. Clark, of New Hampshire, was appointed.

${ }^{2}$ See E. B. xviii, 684 . 
nominated by the Prince. It holds sessions in May and October. The Prince has the power, after consultation with the council of state, to dissolve the national council, but a new election must take place within three months thereafter. All communications from the Prince to the national council must be made through the minister of state. The initiation and sanction of laws, with certain reservations, are made by the Prince, who legalises each law by the promulgation of an edict; but no direct tax can be imposed without the authority of the national council. The constitution gives full individual liberty; no proceedings can be taken against any person, and no punishment can be inflicted, except in accordance with the law. Property is inviolable, and freedom of education and religion, and the right of public peaceable meeting are assured.

By the constitution the principality is divided into three communes corresponding with those which already existed, namely, Monaco, the Condamine, and Monte Carlo. A mayor and communal council is established in each. This council consists of nine members elected for three years by universal suffrage with a scrutin de liste. The courts of justice consist of a tribunal of first instance, a court of appeal, and a Conseil de Revision. The constitution does not alter the judicial organisation heretofore existing, as defined by the Edict of May 18, 1909; with the exception that it establishes a supreme court composed of ten members, five appointed by the Prince, one by the council of state, one by the national council, two by the court of appeal, and one by the civil court of first instance.

A residence of ten years in the principality by a foreigner over the age of twenty-one years, or authorisation granted by the Prince, under Article 13 of the Code Civil, and a residence of three years after the promulgation of the authorisation, is necessary before naturalisation is granted.

The population of the principality in 1908 , the date of the taking of the last census, showed a total of I9,I2I, including 8,24I Italians; 7,306 French; 516 Germans; 39I Swiss; 385 English; 219 Belgians; 210 Austrians; and I,482 Monégasques. Included in these I,482 Monégasques are 847 naturalised subjects, consisting of 676 of Italian origin, 85 of French origin, and the remaining 86 of various other nationalities.

It should be noted that there is a large floating population of a heterogeneous character, which annually visits the principality and must be taken into consideration when attempting any calculation as to the actual number of the population. The principality contains $I, 300$ private houses of an approximate value of $I 77,000,000$ francs. . This does not include the domain of the Prince. The value of the property not built upon, exclusive of the domain of the Prince, is estimated at $150,000,000$ francs. The value of the property of companies authorised to carry on business in the principality, such as hotels, etc, represented by shares and debentures, in January 1909, amounted to 397,000,000 francs.

The reigning Prince (b. I 848 ) is a man of great scientific attainments, and devotes much of his spare time, and a considerable portion of his fortune, to research, especially in oceanography. He has of late given much attention to aviation, and was the first reigning Prince to make an ascent in an aeroplane. He has initiated great improvements in the principality, more particularly in the founding of the Musée Océanographique, and the construction of the harbour, which, when completed, will be formed of two stone-built sea walls, making a rectangular water space of approximately $\mathrm{I} 60,000 \mathrm{sq}$. $\mathrm{ft}$. The south quay is equipped for the handling of merchandise, being connected up with the Paris, Lyons and Mediterranean Railway, while at the quay facing it there is special accommodation for yachts. Recently many of the large Mediterranean liners have made Monaco their port of call, lying off the coast and communicating with the harbour by tendersi

\section{MOROCCO}

Recent History.-At the beginning of rgro there seemed to be an opportunity for France to pursue her work of " pacific penetration" in Morocco free at least from internal troubles. Works of public utility were planned, medical services were organised, and a Franco-Algerian school was opened in Fez. Mulai-el-Kebir, a brother of the Sultan and a pretender to the throne, decided upon submission and removed from his place of refuge at Ain-Sidi-Melluk to Fez. The peaceful progress of the country appeared the more likely through the defeat at Tadia (June I9Io) of Ma-elAïnin. This sheikh and his followers, known as "the Blue men," who came from the Sahara, had greatly troubled the southern borders of the empire, and were bitterly hostile to European influence. Ma-el-Aïnin's withdrawal to the Sahara, after his defeat, was followed by his death at Tiznet (Oct. 28, 1910). Another factor which tended towards peace was the settlement during Igro of the claims made by the suf-

1 See E. B. xviii, 85 I et seq. 
ferers from the bombardment of Casablanca in 1907. This work was carried out by an International Commission which after fourteen months labour awarded $£ 447,000$ as compensation, against a total of $£ \mathbf{r}, 060,000$ claimed. Of the compensation money EI $\$, 000$ was awarded to Moroccan subjects. A convention between Spain and Morocco with regard to the frontiers of the presidio of Ceuta was signed on November I\%, I910. Morocco agreed to pay Spain, in 75 yearly instalments, $£ 2,600, \infty 00$ as compensation for the expenses of the Riff campaign of 1909 .

Before the end of rgro, however, new trouble arose. Mulai Hafid remained inactive at Fez and lost popularity because of his dependence upon France, while the Berber hill tribes were roused to revolt by the exactions of his grand vizier El Glawi, the head of a great Marrakesh clan, one of whose sons was Basha of that city. In October I gro the tribes around Fez rose against the Sultan and by the beginning of IQI I the whole of northern Morocco was in an unsettled condition. Mequinez was captured by the rebels, Mulai Zin, a brother of Mulai Hafid, being proclaimed Sultan there. By March I9I the situation was serious. The Sharada, Beni-Hassen and other tribes proceeded to invest $\mathrm{Fez}$ and there was much fighting. The position of Mulai Hafid and of the Europeans in the capital became one of discomfort, if not of grave peril, and France decided to send a force to disperse the tribesmen. On April 26 a small body under Commandant Brémond reached Fez after four days hard fighting. On the same date France notified the signatories of the Act of Algeciras of the measures she was taking to save the Europeans at Fez. Bremond's force was insufficient to disperse the tribesmen who were gathered round the city, though in numerous engagements he inflicted upon them heavy losses. Reinforcements under General Monier reached Fez on May $2 \mathrm{I}$ and the siege was raised just as the inhabitants were beginning to run short of food. Mulai Hafid received the French troops as friends and with their aid the discomfiture of the rebel tribesmen around Fez was completed, while El Glawi was dismissed from the Grand Vizierate.

General Monier after the pacification of the Fez district proceeded to Mequinez. and obtained the submission of Mulai Zin (June) who was taken to Fez and placed in the Sultan's palace. Meantime General Tontée had pacified the region of the middie Muluya, and all overt opposition to Mulai Hafid's authority was crushed.

The action of France in occupying Fez was followed by the despatch (July I, I9I I) by the German Government of the gunbuat "Panther" to the closed port of Agadir, in Southern Morocco, the ostensible reason given being the peril in which German employés and property were placed by disturbances in the Sus province. In reality Germany challenged the whole position of France in Morocco, and by sending the "Panther" to Agadir forced the reopening of negotiations regarding the situation. The international crisis is discussed elsewhere (see under "International Affairs," Part I: Sect. i). As far as Morocco itself was concerned, the position was defined by the resulting Franco-German agreement of November 4, I9II. By this agreement that of February roon was confirmed. France again agreed to safeguard economic erpuality in Morocco, while (iermany withdrew all opposition to French political action in Morocco. An arrangement for the hearing by an arbitrator of complaints against the French authorities in Morocco (when the consular authorities were unable to settle them) was among the minor provisions of the new convention.

Mulat Hafid accepted the new situation without public protest, and on March 30 , I () I 2 he signed a treaty with lirance which formally ended the independence of Morocco. Mulai Hafid acknowledged a. French protectorate, which was also subsequently recognised by the powers, who withdrew their diplomatic representatives. ${ }^{1}$ In place of the French minister (M. Regnault) (ieneral Lyautey was appointed Resident General. He arrived in Fez on May 25, I0 I 2, and was received by Mulai Hafid, who intimated his desire to abdicate. His helplessness and the loss of the freedom of his country greatly affected him. But the French refused at the time to sanction his abdication.

i Sir Reginald Iister (1865-1912), British Minister to Morocco since October 1908, died at Tangier on November 10, 1912. No successor was appointed. 
The autumn of IgII had witnessed a renewal of lawlessness in Morocco. After General Monier's arrival at Fez in May of that year French officers were placed in command of the Sherifeen troops, and Commandant Brémond was in charge of a mehalla which routed the Ait Yussi (Sept. I9II) who had been pillaging Sifru, to the south of Fez. Not for the first time criticism was occasioned by the inability of the French officers to prevent acts of barbarity by the Moorish soldiers under their command. There was an isolated outbreak, but in the Riff country there was in September and October IgI I renewed and widespread fighting. The sudden occupation by Spain of Laraiche and Al Kasr al Kabir (Alcazar) in June rgI , while the FrancoGerman negotiations were still proceeding, added both to the local and the European uneasiness, Alcazar lying across the road from Tangier to Fez, and thus in hostile hands threatening French communications. ${ }^{1}$ The tact of the Spaniards in maintaining friendly relations with the Moors in the occupied territory eased the local situation. A treaty between Spain and France signed on November 27, I9I2 fixed the extent of the Spanish zone, and settled railway and other questions. Spain obtained control of a continuous strip of northern Morocco extending from the Muluya to Ceuta, as well as the Alcazar-Laraiche region and the Ifni enclave in the south.

Another rising at Sifru at the close of I9II was followed in the spring of IgI 2 by a revolt among the Sherifeen troops at Fez. For three days during April (I 7 th, I8th and Igth) the rebel troops held great part of the city, producing a reign of terror. Many lives were lost, including those of thirty-nine French officers or civilians. General Monier's ${ }^{2}$ arrival with a strong force at $\mathrm{Fez}$ on the 20 th restored order to the city, which was placed under court martial. In the reprisals many innocent persons unfortunately suffered. On General Lyautey's arrival in May, a wiser course was adopted and the proposal to fine the townsmen for a revolt in which they had been the victims was abandoned. The Sherifeen army at Fez was disbanded, a certain number of the troops being allowed to enlist in the French force of occupation.

The advent of a new pretender in the South of Morocco caused further anxiety. This pretender, Hamed el-Hiba, a son of the notorious Ma-el-Ainin, was declared Sultan by the Sus tribes, though it was stated that he described himself simply as the Khalif of one of the imperial princes resident in Tafilalt. On August 18 el-Hiba occupied Marrakesh. Shortly before this event Mulai Hafid had moved to Rabat, and there, on August I2, he was permitted to abdicate the throne, appointing his brother Yusef his successor. (Mulai Hafid immediately after his abdication visited France, and in September I9I 2 took up his residence in Tangier, where Abdul Aziz, the brother whom he had supplanted, was also quartered. Hafid was granted a pension from France.) Mulai Yusef, who was virtually the nominee of the French, at once notified his adhesion to the protectorate treaty. Hiba's troops were routed on September 7 by a French force under Col. Mangin, and the pretender fled south, whither he was not pursued. Nine Frenchmen who had been shut up in Marrakesh were rescued uninjured, and on September so Yusef was formally proclaimed emperor at Marrakesh. His accession had already been accepted by the other Moorish cities. In October General Lyautey occupied Agadir. At that period France had 58,000 troops in Morocco, including a strong detachment of black soldiers from Senegal.

One result of the negotiations between the Powers in I9II-I 2 was the decision that the port of Tangier, while remaining under the nominal sovereignty of Morocco, should be "internationalized." It was placed under the administration of a specially created body, financed from the customs levied at the port as well as from direct taxation.

The agreements with Germany (I9II) and with Spain and Italy (I9I2) accepted the suppression of the Consular Courts, when the other Powers exercising judicial jurisdiction in Morocco also consented to that course. Austria and Russia made

1 One or two "regrettable incidents," such as the arrest of a French consular agent for carrying arms contrary to Spanish regulations, occurred at Alcazar, but they were rectified by the good sense of the French and Spanish governments.

2 On August 31, 1912 General Franchet d'Esperey succeeded General Monier as commander of the French troops in Western Morocco. 
similar declarations. The consent of Great Britain was contingent on the suppression of the consular régime in Egypt.

Economic Conditions.-Some progress has been made in mapping Morocco, but there remain considerable tracts unvisited by Europeans. Trustworthy statistics of the population are still lacking. The British Consul General in I910 considered 5,000,000 to be approximately the correct figure. Fez had a population of about I02,000, Rabat-Salli 47,000, Tangier 46,000 (including 12,000 Jews and 9,000 Europeans), Tetuan 30,000 (including 7,000 Jews and 400 Europeans), Marrakesh 60,000, Casablanca 32,000 (including 5,500 Europeans), Mequinez 24,000. The development of the resources of the empire has been retarded by the internal troubles, by the lack of railways, and the absence of good accommodation at the ports. Up to the close of 1912 practically none of the public works contemplated by the Act of Algeciras (I906) had been begun, though the survey for a railway from Tangier to Fez was undertaken. Only in the Shawia province (in French occupation since 1907 ) has there been any development in agriculture on modern lines. A $2 \mathrm{ft}$. gauge railway was built ( $19 I^{\prime}-I_{2}$ ) between Casablanca and Rabat.

The total trade of Morocco in 1910 was valued at $f 6,456,000$; imports $f 4,190,000$; exports $£ 2,266,000$. This was an increase of $£ 542,000$ or over $9 \%$ on the trade of I 909 , but this increase was due entirely to greater trade with Melilla and on the Algerian-Morocco frontier, the trade at the ports being $£ 573,000$ less than in 1909 and $£ 745,000$ less than in 1908. The decline was largely attributable to shortage in the harvest, for Morocco being a purely agricultural and pastoral country the purchasing power of the people depends on the harvest. Barley, oxen and sheep, skins and hides, wool, almonds and eggs constitute their main exports. At the ports (Melilla excepted) the imports, of which textiles and food stuffs are the chief, totalled in value in $1910 £ 3,468,000$, a decrease of some $12 \%$ compared with I 909 . The decline was more apparent than real as since I 909 a new method of levying duty makes the average value of goods imported considerably less than in former years. The exports in 1910 were valued at $£ 1,575,000$ which compares with $£ 1,807,000$ in 1909 . The trade on the Algerian frontier was valued at $£ 1,001,000$ in 1910 , an increase of $48 \%$ over the previous year. By this route two-thirds of the exports consist of live stock. In return the Moors buy sugar, tea (more drunk in Morocco than coffee), flour and cotton and woollen goods. Taking the whole trade of Morocco the British percentage fell from 39.6 in 1908 to 24.7 in 1910 ; the French percentage increased from 36.6 in 1908 to 41.8 in 1910 ; the German percentage (which had been 14.1 in 1907) decreased from 10.9 in 1908 to 9.8 in 1910; the Spanish percentage rose from 5.3 in 1908 to 17.1 in 19 Io. These four countries take between them over $93 \%$ of the external trade of Morocco. A Franco-Italian declaration of October 28, 1912 assured to Italy most favoured nation treatment in Morocco.

The customs revenue at the ports (since 19 Io under European control) is from $f 400$,000 to $f 500,000$ a year. In 1912 the external indebtedness was $f 12,250,000$.

See Louis Gentil, Le Maroc Physique (Paris, I9I2), an authoritative work; Morocco, No. 4 (I9II)," a British kBlue book, gives the text of recent treaties (London, I9II); "L'Afrique Française" (Paris, monthly), the official organ of the Comité du Maroc; E. D. Morel, Morocco in Diplomacy (London, 1912); Dr. R. Kerr, Morocco After Twenty-Five Years (London, I912); D. Mackenzie, The Khalifate of the West, (London, I9II); Von Otto C. Artbauer, Kreuz und Quer durch Marokko (Stuttgart, I9I I); P. Albin, Le "Coup" d"Agadir (Paris, 1912), and the British Consular reports.

(F. R. Cana.)

\section{NORWAY 1}

Population.-The resident population of Norway in rgro (Dec. I) was 2,392,698, or roughly an increase of 150,000 since 1900 . The chief reasons of the smallness of this growth are the heavy emigration to the United States (190,000 persons) during the period, and the declining birth rate. The largest increase has taken place in the northern, south-eastern and Trondhjem districts, coinciding practically with the development of industrial enterprise, while in the midland peasant districts and the coast districts in the south the population is stationary or declining.

Since 1905 tourist traffic has developed beyond all previous records. A great number of new hotels have been opened, new and more modern conveyances have been supplied including a number of motor cars, and on several lakes motor boats have been introduced. The number of tourists is roughly put down at 50,000 per annum, and the money brought into the country from this traffic is about $£_{I, 000,000}$.

Rallways.-Since the completion of the Christiania-Bergen trunk line (Bergensbanen) in the autumn of 1909 only a few new lines of minor importance have been opened for traffic. The total length of Norwegian railways is now about 1920 miles, I620 of which are owned by the State. In I 908 the Storthing passed a new railway scheme for the construction of

i See E. B. xix, 799 et seq. 
railways at a total length of 320 miles. In 19 ro Norway got her first electric railway, belonging to a private company, but electric traction is to be further expanded, the important line between Christiania and Drammen being actually rebuilt for electric traffic.

A griculture.-According to the latest official statistics (1907) the agricultural area amounts to 2.2 million acres and the area suitable for agriculture to some 820,000 acres. Since 1907 at least some 30,000 acres have been laid under the plough, the percentage being greatest in West and North Norway. The characteristic feature in Norwegian agriculture within the last decade has been the constant increase of small freeholders, having for their specialty the cultivation of root-crops and breeding of cattle. The implements may generally be described as thoroughly modern. The export value of the agricultural products in I9I I, chiefly hay, butter and condensed and sterilized milk and cream, was about $£ I, 800,000$. The produce of an average agricultural year may be valued at $\ell_{14}, 000,000$.

Foresiry. - The total area of forests is approximately $2,750 \mathrm{sq} . \mathrm{m}$., with a value of about $£ 30,000,000$. Upwards of $6 \mathrm{I} .4$ per cent of the forests are grown with pine and fir trees. Next to agriculture forestry ranks highest from a national economic point of view, the export value of its products for the last ten years being annually more than $£ 4,000,000$, besides what is consumed at home. During the last decade forestry has made important progress, chiefly owing to the scientific efforts of the Norwegian Forest Association (1898), which, within the last five years only, has had annually planted between 10 and 12 millions of new trees. It is still, however, the general opinion among forest experts in Norway that the amount of annual lambering exceeds the increase in the natural growth of the trees.

Fisheries. - Up to the close of the I 9 th century the Norwegian fisheries generally retained the character of coast fisheries which they had had for centuries. Since then an enormous change has taken place. The great bank fishery, carried on with fishing steamers and motor vessels chiefly from Aalesund (about I 4,000 inhabitants), though initiated towards the close of the last century, is chiefly a development of the last decade. The same remark also applies to some other important fisheries. At the same time the great coast fisheries have been thoroughly modernized as to outfittings, implements, etc. The Norwegian fishing fleet consists at present of about 14,000 modern vessels, including 183 steamers with an approximate value of $f_{1}, 600,000$. Along with these practical reforms, by which the Norwegian fisheries are now extending over greater areas than formerly, energetic efforts have been made and are being continued to improve the methods for the utilization and the preparation of the produce, its transport, etc., the result being a great expansion of the trade. In $191 \mathrm{I}$ the value of the exports of fishery was estimated at $f 5,400$, 000 as against $f 2,700,000$ in 190I. An important whaling industry has since 1906 been developed in the distant waters of the South Atlantic. At the end of 191 I the number of Norwegian whaling companies was about 50, with a share capital of $£ 1,800,000$, the profits for the season of 19 I I being estimated at about $£ 800,000$.

Mining. - The oldest and most important branch of the mining industry is the working of copper ore and sulphuric pyrites. It seems, however, as if within no distant future the working of iron ore will become the principal mining industry of the country. This is partly because of the extensive deposits of iron, chiefly in North Norway, estimated by official experts at 175 million tons, yielding about 100 million tons of iron, partly because of the rapid development of the electrolytic methods for the melting of iron ore, three important plants having actually been laid down for this industry. The value of the exports of the mining industry for I9II amounts to about $£ 700,000$ as compared with $f 200,000$ in 1901 . In connection with the mining industry must also be mentioned the manufacture of nitrate of calcium, which is gradually developing into an important industry.

Manufactures.-During the first decade of the 2oth century Norway became more and more of a manufacturing country, the number of plants with more than Ioo hands having increased from 149 in 1900 to 220 in 1909. During the same period the total number of hands increased from 80,000 to 105,000 . About 34 per cent of the plants are owned by joint stock companies with a fully paid-up capital of about $£ \mathrm{I} 6,000,000,6 \mathrm{I}$ per cent of which is Norwegian and 39 per cent foreign investment.

Shipping and Commerce. - Since 1900 the Norwegian mercantile fleet has been rapidly passing from sail to steam. In I 9 Io Norway had I 738 steamers and I 205 sailing vessels, with a gross tonnage of respectively $1,470,385$ and 685,072 . Besides the sea-going fleet there was a fleet of 104 motor vessels with a gross tonnage of 5,500 , chiefly employed in the fishing trade. The total value of the merchant fleet is estimated at $£ \mathrm{I} 7,000,000$ and the annual profits to the country at about $£ 5,500,000$. The total personnel is about 37,000 , 20 per cent being supposed to be foreigners. In I9Io Norway was owning 4.5 per cent of the aggregate tonnage of the world. The value of imports has increased from $£, 17,000,000$ in 1901 to $£ 26,000,000$ in 1911 , and the exports within the same period from $£ 8,900,000$ to $f_{1} 6,600,000$, the latter increase being chiefly due to the number of new commercial products within recent years, among them nitrate of calcium and condensed milk and cream. Great Britain and Germany are still the countries principally trading with Norway, the former taking the majority of her exports, the latter supplying most of her imports. The statistics of the last three years, however, show a growing tendency to reverse these figures

Government.-The only important change in the system of parliamentary government 
(see E.B. xix, 804) within the last few years is that, by a measure adopted by the Storthing in 1910 , the members (numbering 123) instead of being paid at a rate of 135.4 d. a day during session have a fixed salary of $£ 166$ for the session irrespectively of its length and in addition to their travelling expenses.

Finance, etc.- Since 1905 the Norwegian state budget has been divided into two chief sections, one embracing the ordinary, the other the extraordinary revenue and expenditure. The annual revenue and expenditure for the two last financial years (by a measure adopted by the Storthing in 1907 the financial year was altered from April-March to July-June) were respectively $£ 6,100,000$ and $£ 6,600,000$. In 1911 the Storthing passed an amendment to the constitution by which Norway is, under ordinary conditions, to have a fixed unassailable reserve of $f 2,222,222$.

Army and Navy. - In 1909 the Storthing passed an army bill (in force since Jan. I, I9I I) by which the former organization of the army was entirely changed. Instead of the old divisions $(E . B$. xix, 805) the conscripts by the new division are enlisted in two units, the line (12 years) and the militia or reserve ( 8 years), the total service being 20 years. Besides these two units there is a second reserve (landstorm), including all men from the 18 th to the 5 oth year of age. In war every man is liable to service from the I 8 th to the 55 th year of age. The country is divided into 47 conscription districts corresponding to the number of infantry battalions. When the new orgarization is worked out in all details Norway will be able to raise an army of about 115,000 men. The military budget shows an annual expenditure of about $£ 800,000$. The navy has been increased by a submarine and two destroyers. For the summer of 1912 the Storthing voted the necessary means for the construction of two battleships and one submarine, two submarines being in construction.

Local Government. - Norway is divided into $6 \mathrm{r}$ town communes and 589 rural communes, the former being administered by councils numbering from 20 to 84 members, the latter by councils of 12 to 48 members. The electoral period is three years. In 1910 the electoral franchise for local county election was extended to women on the same conditions as for men, the suffrage being thereby made universal for both sexes in municipal affairs.

Principal Towns.-In I 899 Christiania began to suffer from a reaction after some years' extraordinary growth, and the result of a disproportionate development was an economic crisis which made the population decline and for some years held the city paralysed. In 1905 the pressure began to give way, and since then the progress has been very satisfactory, the increasing importance of the city having chiefly manifested itself in the extensive port and railway arrangements for the rapidly growing traffic. The population has again increased, being at the municipal census of 1912 (Feb. I) 247,588 . In the period I906-I9II the estimated value of the imports of Christiania increased from $£ 7,500,000$ to $£ 11,400,000$, and her exports from $£ 2,000,000$ to $£ 2,700,000$. At present 50 per cent of the imports and 16 per cent of the exports of Norway are forwarded via Christiania.

The development of Bergen during the past decade, although generally satisfactory, especially since 1906, has not been so rapid as in other leading towns of Norway. The population was in 1912 (Feb. I) 77,983. The chief event in the history of Bergen within recent years has been the establishment of the railway connection with Christiania in 1909. The estimated value of the imports of Bergen, which in 1906 was about $f 3,300,000$, had in 19I I increased to $f_{4}, 100,000$, and the value of her exports within the same period from about $f_{1}, 500,000$ to $f, 3,300,000$.

The population of Trondhjem increased between 1900 and 1910 by more than 7,000, being $45,228 \mathrm{in} 19 \mathrm{IO}$ (Dec. I). Her importance as an exporting town has been established on a broader basis than ever, and extensive port works are being executed to meet the growing demands of the traffic. The chief event in the recent history of the town has been the opening of the Technic Arademy in I9IO. The estimated value of the imports of Trondhjem increased from about $£ 1,600,000$ in 1906 to $£, 2,000,000$ in I9I I, and the value of her exports for the same period from $f, 950,000$ to $£ 1,300,000$.

Stavanger has become the leading town of Norway in the canning industry and the centre of her exportation of tinned fonds. The population rose in 1900-10 by about 7,000, being 37, I I 8 in 1910 (Dec. I). The estimated value of the imports increased from $£ 700,000$ in 1906 to $£ 1,300,000$ in 1911 and the exports from $f 470,000$ to $£, 900,000$.

Recent Political History.-By the dissolution of the Union with Sweden in 1905 the national conflict between the two great political parties of Norway (Conservatives and Liberals) came to an end for ever. The constitutional differences having in all essential points been settled in $188_{4}$, the country was left free to grapple with the social and economic questions of the time. By far the most important of these questions-in fact the pivot of Norwegian politics in r $906-12$-was the so-called "Concession-case," i.e. the right of foreigners as well as natives to hold by government concession real property in Norway, especially forests, mines and waterfalls. At the general elections of 1906, at which was returned a Liberal majority of 77 against 36 Conservatives and ro Socialists, the "Concession-case" had not yet come decisively to the front, but during the second 
half of 1906 and the first half of $\mathrm{IgO} 7$ it quickly grew in importance, and it gradually became obvious that it was about to cause a split in the great Liberal majority.

In October I907 M. Michelsen (b. 1857) withdrew from public life, his government being reconstructed by M. Lövland (b. I 848), foreign minister of the Michelsen administration. During the subsequent six months the split in the Liberal majority became more and more obvious, and finally led to a rupture into "Consolidated Left" and "Liberal Left," the former name being, however, practically dropped in I9r2. In the spring of r9o8 M. Lövland's administration, backed up by the Conservatives and the Liberal Left, was driven to resign by the opposition of the Lefts and the Socialists, who, though not acting in co-operation like the two other parties-a distinction which has been kept up ever since-agreed as to stronger "Concession rules" than those embodied in a bill submitted by the Lövland government. A new government was subsequently formed by the radical leader M. Gunnar Knudsen (b. I848), whose government will for ever be memorable for the Concession Acts of 1909, chiefly the work of the Minister of Justice, M. Johan Castberg (b. I862). These laws, concerning (I) waterfalls, mines and other real property, and (2) forests, were sharply opposed on the preliminary stages by the Conservatives and the Liberal Left, as too strong an encroachment upon private property.

At the general elections of 1909 a new Storthing was returned containing 63 Conservatives and Liberal Left, 47 Radicals, II Socialists and 2 Independents, as against 57 Radicals, 50 Conservatives and Liberal Left, ro Socialists and 6 Independents during the latter half of the past session. When the new Storthing met in January r9ro M. Gunnar Knudsen tendered the resignation of the ministry. Wollert Konow (b. 1845), leader of the Liberal Left, then formed a cabinet consisting of Liberal Lefts and Conservatives, the former party being in a majority within the government, although the latter were in the majority in the Storthing. This caused friction between the two allied parties, which ultimately brought about a crisis resulting in the resignation of $\mathrm{M}$. Konow and some of his Liberal colleagues (Feb. I9I2). The government was reconstructed by M. Bratlie (b. $185_{5}$ ), with the Conservatives as the chief element. Among the members of the Konow administration who passed into the Bratlie Cabinet was the Foreign Minister M. J. Irgens (b. I 869), formerly Norwegian minister in London. When M. Bratlie became Premier he had to resign his seat in the Storthing" (members of the government having no seat in the House by the mandate of the electors), and was replaced by the vice-deputy member ${ }^{1}$ Mlle. Anna Rogstad (b. I 854), who in I9I I had been in the Storthing for about a fortnight during the temporary absence of M. Bratlie. The case attracted general notice, as Mlle. Rogstad was the first female representative in any independent National Assembly,-outside that of Finland, which admitted women in 1907 .

The chief laws passed under the Konow administration were an amendment to the Municipal Act making the municipal suffrage universal for women as well as men, a new Concession act (I9II), and a new municipal taxation act (I9II).

Second only in importance to conflicts over the "Concession-case" in recent politics must be mentioned the continuance of the " maal" controversy (see $E$. $B$. xix, $8 \mathrm{I} 8)$, i.e. the effort to create an entirely independent Norwegian literary language based upon the peasant dialect (landsmaal), descended from the old Norse, in place of the Dano-Norwegian rigsmaal. Generally speaking the rigsmaal and the landsmaal have their respective partisans and opponents in all the political camps: From a party point of view, however, the Conservatives and Liberal Left must be described as the rigsmaal and the Left and the Labour Democrats as the landsmaal party, the Socialists being as a party indifferent to the question.

At the general elections of I9I2 (Oct. 2I), out of 6r candidates returned on the first ballots 37 Radicals (Left and Labour Democrats) were returned, 9 Socialists (or Labour

${ }^{1}$ In Norway every member of the Storthing has a "vice-deputy member," elected in the same way and at the same time. This vice-deputy has to sit in place of the actual member if he is prevented from attending through illness, etc., or is included in the government. 
Party), and 15 Conservatives and Liberal Left,- - these being now the names under which parties are divided. At the second ballots (Nov. 4 for towns and Nov. II for country districts) the Radical wave which had already manifested itself practically swept the country, the final results being 76 Radicals (Left 70 , Labour Democrats 6), 24 Conservatives and Liberal Left, and 23 Socialists. The Government, however, decided to remain in office till the Storthing met in January 1913. The new Storthing contained no woman, the few female vice-deputies who were candidates for some of the Christiania seats being beaten with their male colleagues; there were no women candidates elsewhere either as regular members or as vice-deputies.

The rapid industrial development of the country during the past six years has often brought about friction between workers and employers, resulting in numerous strikes and lockouts. This was especially the case in I9II, when a number of agreements as to conditions and payment of labour expired which were only renewed after protracted negotiations and in some cases very serious conflicts. The most important of these conficts, which created general notice not only within but beyond the frontiers of the country, originated in the Mining Industry. The agreements within that industry expired on January I, I9I I. On October 24, I9Io negotiations were opened, but resulted in a strike, no agreement being arrived at. During the following spring the Employers' Association tried to induce the Norwegian Workmen's Association to prevail upon the striking miners to resume work, but when the latter Association refused to do so the Employers' Association subsequently declared lockout against the organised workers, commencing with the workers in the wood pulp, cellulose and paper mills, and subsequently including the iron industry, until 32,000 workers or about one third of all Norwegian workers were left unemployed. The conflict was finally settled on August 23 , I9I I by special mediation. In the same way was also settled an important strike in the summer of 1912 embracing the steamship engineers and stokers, which at first seemed likely to bring about a deadlock in the regular coast traffic. These conflicts have brought about a growing interest in the establishment of mediation and arbitration courts for the settlement of labour disputes.

Among important recent national events mention must be made of the centenary of the University of Christiania (Sept. 2, I9II), which was celebrated throughout the country and resulted in a national subscription to the University of about $£ 40,000$.

A uthorities. - The chicf source of statistical information is Norges officielle Statistik (I $86 \mathbf{I}-$ I9II) with a complete record on essential subjects of economic and social interest. Amternes ökonomiske Tilstand, official publication (last volume I900-1905), gives a quinquennial summary of the economic and social development of all towns and counties in Norway. For Christiania see also Kristiania, Beretning om den ökonomiske Tilstand (quinquennial, last edition 1906-10, published 1912). For the commercial development of Bergen and other towns, Norges handkalender (published every third year, last edition I91 1-I2) may be recommended. J. V. Heiberg's Unionens Oplösning I005 (I906) is a complete collection of all official documents bearing upon the dissolution of the Union with Sweden. The standard work in Norwegian history within recent years is Norges Hislorie, Exhibited to the Norwegian People, by A. Bugge, E. Hertsberg, Osc. Alb. Johnsen, Yngvar Nielsen, J. E. Sars, and A. Taranger (1910, not completed), of which 6 half-volumes have appeared, embracing the following periods: Period before about 800 A.D. ; about 800-I030; I537-I 588; I 588-I 660; 1660-I 746 and $1884^{-1} 905$.

(S. C. Hamme R.)

\section{PERSIA 1}

Neither the concession of a "constitution" in 1906, nor the abdication of Sultan Mohamed Ali and the accession of his son Sultan Ahmad Mirza (b. I 896 ) in July I 909 , availed to bring order into the Persian chaos. The history of Persia from the opening of the new national council or Mejliss (Majlis) in November rgog is indeed one of progressive anarchy. The actual events are disconnected and in many cases individually unimportant, but their cumulative effect is evidence of the gradual paralysis of the central government. The root cause of this paralysis is not difficult to trace. It lay in the inability of the Mejliss to work with the Cabinet. Votes of censure followed hard upon

${ }^{1}$ See E. B. xxi, 187-202, 244-5. 
the news of any unsatisfactory incident, and the Executive was thus made impotent whenever it was required to act with vigour.

The leading figures in the Government which faced the Mejliss in the autumn of I909 were the Premier, Sipahdar, and the Minister of War, Sardar-i-Assad-thanks to whom

Difficulties of the

Persian

Cabinet. the ex-Shah had been expelled from Persia in September. The Cabinet programme laid emphasis on the need of restoring order after the revolution. But neither police nor troops could be maintained without money, and the government at once attempted to obtain an advance of $£ 500,000$ from Great Britain and Russia. Then their difficulties began. The Mejliss was divided into two groups, of which the larger, known as the moderates, was prepared to work with the government. But the smaller, or extremist group, was animated by the most violent feeling against Russia-feeling to which it did not fail to give noisy expression. This group secured representation on the Foreign Affairs Committee and eventually in the Cabinet. It was thus able to prevent the conclusion of the all-important joint loan, and at the end of four months the Mejliss had really done nothing except harass the Cabinet and provide itself with a debating hall fitted up in luxurious fashion.

The progress of the loan negotiations is thus linked up on the one side with political intrigues in Teheran, and on the other with the situation in the provinces of Azerbaijan and Fars and with the consequent activity of Russia and Britain. The Disorder in triple thread will be discerned in the following narrative. It opens with
south and north.

a serious piece of news which reached Teheran on November 25 th, ten days after the opening of the Mejliss. M. Passek, the Russian Consul-General at Bushire, who was travelling to his post together with his subordinate, was attacked by tribesmen on the road. At the same time Mr. Bill, the British representative at Shiraz, reported a difficult situation in the town, while the general authority of the Governor of Fars was threatened by Kashgais under Soulet-ed-Dowleh, with whom the government vainly negotiated. By the end of November the road from Ispahan was closed and the position had become critical. Consular reports of robberies fill the record of the early months of I9Io, until at last, on April r $_{5}$ th, Mr. Bill was himself attacked by robbers and two Indian sowars were killed. A strong British note was at once presented. Meanwhile matters had been going ill in the north. In November r 909 Sattar Khan, the representative of the new government, was driven out of Ardebil by adherents of the ex-Shah under Rahim Khan. Russian troops were sent to restore order, and a force under Yeprim, the Armenian Chief of Police, came up from Teheran. Yeprim, a capable man, acted with comparative vigour, and by the beginning of February Rahim Khan had fled across the frontier. The extremists in the Assembly believed that he owed his life to Russian protection, and the Prime Minister resigned. This resignation was withdrawn, but its effect on affairs in the north was most unfortunate. Sattar Khan and Bagher Khan, who were joined by Yeprim's men, gave rein to their nationalism, and were reported to be contemplating an attack on Russian banks in Tabriz. St. Petersburg took the alarm and Teheran hurriedly recalled the patriots. But it was not until March Igth, ten days later, that they left for the capital.

In such circumstances the progress of the loan negotiations could not be smooth. The British Government knocked froo, 000 off the sum demanded, but was otherwise willing to lend. The Russians concurred, and in February I910, just when The loan the situation in the north was most difficult, the two Powers submitted their negotiations. conditions. They included demands that the programme of expenditure should be submitted to the two legations, and that French officials should be attached to the Ministry of Finance. A month later the Minister of Finance expressed the view that the Mejliss would be certain to reject these terms, and an alternative project for raising a loan from another source was vetoed by the two Powers. The deadlock continued for a month, when the Cabinet was reconstructed. More time was wasted by the House toying with the idea of an internal loan, but at last, towards the end of May, the appointment of foreign advisers was accepted in principle. The legations reported that circumstances had changed for the better, but a week afterwards all was 
confusion again. A Russian officer of Persian extraction started a movement in Azerbaijan in favour of the ex-Shah. The Russians captured the rebel at once, but the Nationalists were not to be pacified. Matters went from bad to worse. In June there was trouble in Tabriz, followed by Russian action. At the end of the same month the unrest in the south grew more acute, spread to Kermanshah, and found expression in damage to the telegraph. The British issued further warnings. The Nationalists put all the blame on the Cabinet, which they turned out of office on July I 2 th. Four days later a political murder was committed in Teheran. The two Khans from the north had reached the capital, and a serious outbreak appeared imminent.

On receipt of this news Sir Edward Grey suggested an immediate and unconditional advance of money. Taken six months earlier this step might perhaps have saved the situation. But in July the British representative (Sir G. Barclay) had to report that such a proposal would only convince the Nationalists that the two Powers were scheming to put financial fetters on Persia. Besides, $£ 400,000$ would no longer suffice. Sir Edward Grey accordingly fell back on warnings to Persia and an appeal to the Russians to support strong action. Happily the danger was averted by promptitude in Teheran. The Ministry formed in the last week in July was a coalition Government, with Nationalists in charge of Foreign Affairs and Finance. But it saw that the ultra-patriotic elements must be subdued. Their disarmament was ordered, and on August 7 th, after fighting, during which Sattar Khan was wounded, the government asserted its authority.

The effort exhausted its energies. Besides, the health of the Regent, Asad-ul-Mulk, had begun to fail, and intriguers were busy with the question of his successor. The Regent died on September 22nd, and Nasr-ul-Mulk was elected on the folNow Regent lowing day. The choice of a moderate man, reputed capable, was a good elected. omen. But Nasr-ul-Mulk was in Europe, and much was to happen before he reached Teheran. In the closing days of September Sir George Barclay telegraphed that nothing had been done to tranquillize the south. The Minister of the Interior had resigned on the question of Southern policy, and no successor had been appointed. On

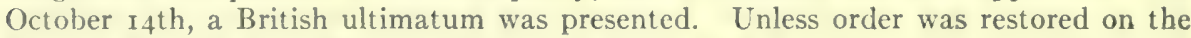
Ispahan-Bushire road within three months police work would be undertaken by a loyal force I,, 00 to I, 200 strong under British officers lent by the Government of India.

It was high time that action was taken, for throughout October chaos had prevailed in the south, and it had even been necessary to land a small force of British blue-jackets at Lingah. The Persian Government, however, pointed to an increase in Customs receipts as proof that things were improving, and explained that the trouble was due partly to the presence of foreign troops, partly to lack of funds. With this latter argument the British Minister agreed. The need of a loan was urgent.

The British ultimatum had, as will be seen below, considerable effect in Teheran, but it resulted in no permanent improvement in the south, and the events there may be noted before returning to the situation in Teheran. Something, indeed, Progress of was done. Nizam-es-Sultanch, who had made a successful Governor of

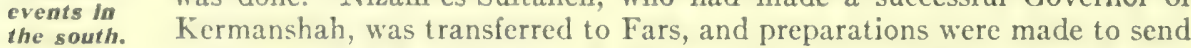
a force of 2,000 to 3,000 men to Shiraz. However, robberies ceased to be recorded after the heginning of December, though the new security was due rather to the severity of the weather than to the vigour of the administration. In January the lititish Government expressed itself fairly satisfied, adding, however, that it would renew it:s demands if need arose. The words were not followed up, though the need arose soon cnough. In March IOII, the road was again blocked, and a little later there was trouble at Shiraz. The troops were without pay and got out of hand. In May Igr I Sir Edward (;rey inquired with some anxicty whether Europeans in Shiraz were safe in case the Shiraz Consulate was attacked, and towards the end of the same month the British Government reported protests from Manchester firms against the insecurity of the roads. Sir George Barclay did not regard these protests as justified, and apart from the strengthening of the Consular guards nothing more was done either then or later. By June IgI anarchy again prevailed, and time brought no improvement. In the autumn 
of IgI 2 Kashgais and Bakhtiari closed the roads from Ispahan to the Gulf, and the British Foreign Secretary when questioned on the matter took the view that only a military occupation of the country - such as Britain was not prepared to undertakewould bring relief. In default of any official explanation regarding the jettisoning of the original plan for policing under British officers, it must be assumed that the intention of the Foreign Office now was to strengthen the hands of the new Regent in his endeavours to bring the extremist party to reason. But the year I9I 2 closed with a still more serious example of general internal insecurity. On December IIth, grave news was

Eckford received from Teheran that a small shooting party, consisting of two British murder. officers, accompanied by 26 Indian sowars, had been attacked by tribesmen near Shiraz and that one of the officers, Captain A. B. Eckford, of the 39 th Central India Horse, had been killed. The attack was made by about 300 of the Boerahmadis tribesmen, and the raid appears to have been made for plunder, as some of the regimental mules were carried off, also a whole caravan of merchandise proceeding to Bushire. On December I 3 th, a strong British note was presented to the Persian Government by the British Minister, pointing out the serious nature of the crime, and asking for the severe punishment of the tribesmen. An answer was received, admitting the seriousness of the offence and promising full reparation.

To return however to the situation at Teheran in I9Io. The British ultimatum of October had convinced the Mejliss that a loan must be raised at once. Only seven situation at weeks after its presentation-a short interval as things go in Persia-a Situation at plan was discussed in open session, and the necessity of some form of foreign
Teheran. control was properly emphasised. The year which had opened not unhopefully thus closed in gloom and confusion. But IgI I brought some improvement, possibly because rumours of the ex-Shah's intended return stirred the government to action. In its opening days Persia applied to the Swedish Government for officers to organise a gendarmerie. This force was originally intended for the province of Fars, but the project was quickly amended to cover the whole country. The Great Powers proved agreeable. The Swedes consented, and three officers-who were later joined by seventeen colleagues-arrived in August igri. Their work has done something to mitigate the dangers of a deplorable situation. In January also application was made for five American financial advisers. On February gth, the Regent reached Teheran. It was March before he took the matter before the Mejliss, but in the interval he had prepared the way for the statesmanlike speech he then delivered. He told the House that the future rested with the Deputies. They must organise themselves into two quite definite parties, must indicate their choice of a Prime Minister, and must accord him proper support. The advice was duly accepted, the Regent's efforts to appease anti-Russian feeling appeared successful, and a Cabinet headed by Sipahdar again assumed office after receiving full promises in advance from the Mejliss. Russia did what she could to give the new government a chance. The debt to the Banque d'Escompte was consolidated, and the Russian force withdrawn from Kasvin. Applicaticn was then made to the Imperial Bank for advance on a loan, and on May 8 th the contract was signed, after Nationalist protest. The nominal sum was $f_{\mathrm{I}} \mathrm{I}, 250,000$, but debt had to be repaid, and only a little over $£ 400,000$ was actually netted.

Four days later the Americans reached Teheran. The American Mission was headed by Mr. Morgan Shuster, who had had experience of Customs work in Cuba and the Philippines. He held the appointment of Treasurer-General, and durMr. Shuster ing the greater part of his stay in Teheran had the services of three Ameriin office. can assistants. His contract was for three years, but he resigned after eight months. Mr. Shuster was capable and keen, and his arrangements for the collection of revenue were probably sound. Unfortunately he cherished ideas about the political regeneration of the country which brought him into conflict with the Great Powers, and he forgot that it was really to their agitation that he owed his appointment at all. He considered himself the servant of the Persian people, a view which in practice involved co-operation with the Nationalists. In this way he drew 
upon himself the incvitable hostility of Russia, without ever realising, it would appear, that a Power to which Persia was heavily in debt would necessarily be alarmed by the fact that a vigorous anti-Russian had assumed control of the Persian finances. Ignoring the realities of the situation, which needed a delicate adjustment of British and Russian relations with Persia, Mr. Shuster acted on the diplomatic fiction of Persian independence. The conditions of Persian government, which provided him with an ineffective Cabinet and an amenable legislature, were formally favourable to a spirited policy on his part. Cabinets came and went; sometimes there was no Cabinet at all; but Mr. Shuster coulo always get laws passed by the Mejliss.

While Mr. Shuster was putting his house in order the Mejliss arranged to spend the loan. At the end of May, however, he was ready to act. He took the view-expressed in a bill drafted by his own hand-that " if a person undertakes a grave responsibility without previously obtaining the necessary powers he is either a fool or a rogue." Two bills gave Mr. Shuster the necessary powers. The first, passed on May zoth, put the loan in his hands, the second, passed on June I3th, made the Treasurer-General Shah of Persia in everything but name. He was given direct control of all financial and fiscal operations and was also empowered to authorise payments, could make economies, and had authority over the personnel. It is not surprising that Russia felt some anxiety about the debt secured on the Northern Customs. Mr. Shuster's first difficulty was with the Cabinet. Sipahdar, finding his demands refused, rushed out into the street and told his coachman to drive to Europe. He went as far as Resht, and returned to Teheran in July. But by refusing to work with him Mr. Shuster undid all the work accomplished by the Regent in the previous four months. Next came a difficulty with M. Mornard, the administrator of Customs, a Belgian officer whom Mr. Shuster accuses of dishonesty. M. Mornard, who was supported by the Russian Government, refused to accept Mr. Shuster as his superior. The Belgian had a case, as it was claimed that his contract made him responsible only to the Persian Government. Mr. Shuster never noticed the claim; for him the law of June I 3 th was final.

This affair took a month to settle, and while it was still causing friction Mr. Shuster requested that Major Stokes, the British military attaché at Teheran, might be permitStokes
Incident. ted to accept the command of the Treasury gendarmerie which he was

about to organise. He stated that the gendarmerie would act especially in the south, but it was clear to Sir George Barclay that any attempt to confine Major Stokes' activities would give a political colour to the appointment. It will be noted that Mr. Shuster ignored the Swedish officers appointed by the Mejliss; his case was that a newcomer would lack " knowledge of the language, habits and modes of thought of the Persian people," and he asked for Major Stokes because he thought him the best man available. The question was referred to London, which consulted St. Petersburg. St. Petersburg suggested either that a Swede should be chosen or that a Russian should be appointed to a separate command in the north. Such was the position on July i8th, when the ex-Shah landed at Gumesh Tepe on the shores of the Caspian. His arrival created the "Stokes incident." It was the desire of the British Government to inform the ex-Shah that he would not be recognised. The Russians, on the contrary, preferred to wait. If Mohamed Ali got to Teheran they were not prepared to turn him out again by force. Sir Edward Grey appears to have desired to remind the Russian Government that British views must be taken into account, and, yielding to further pressure from Mr. Shuster, he now (in a telegram on July 2 I, I III) went so far as to say that before Major Stokes assumed the command he would have to resign his commission. Mr. Shuster interpreted this as acquiescence, overcame the hesitation of the Cabinet-which was on the point of resignation-and formally proposed the appointment. The two Great Powers speedily patched up their differences. A joint note regarding the conduct of the ex-Shah was presented at Teheran, and the Russians suggested that Major Stokes might have Russian subordinates. Sir Edward Grey, who had received a warning telegram from Sir George Barclay, wavered in his support of the Treasurer-General, influenced, as Mr. Shuster believes, by the European crisis over 
Morocco. Fearing that Mr. Stokes might engage in the contest with the ex-Shah, his language became sharper and sharper, until on August 7 th, he said that he would not protest against any objection that Russia might take to the employment of Major Stokes in the north. He held indeed, that such objection would be justified. Two days later he had come round altogether to the Russian views, and Russia no longer hesitated to veto the appointment. Mr. Shuster had committed himself deeply, and his prestige was affected. It is not too much to say that the telegram sent by Sir Edward Grey on July 2 Ist was the beginning of the end for the Treasurer-General.

We must now return to the ex-Shah, premising that the tale of the military operations is too disjointed and in some respects too obscure to be given in any detail. Mohamed Ali had landed in Persia on July $\mathrm{I} 8 \mathrm{th}$, with a very small band, including Ex-Shah's his two brothers. He had evidently expected support on the spot, and not troops
defeated. without reason. The Turcoman and Kurdish tribes of the north had never been loyal to the new government, and in the towns, except Teheran, there was a belief that any change would be for the better. In the capital panic prevailed. The Mejliss declared martial law, but afterwards wasted its energies in brawls with prominent politicians, much to the distress of the unhappy Regent. Yeprim Khan and Mr. Shuster alone kept their heads. Between them they called up and equipped Bakhtiari, and 500 men were hurriedly enrolled in the gendarmerie. Early in August a forward move was made. There were four centres of insurrection. First, there was the ex-Shah himself, who had roused most of the Caspian littoral. Next was Rahim Khan, now called Suja-ed-Dowleh, who was operating about Tabriz. Thirdly there were the tribesmen in the west under Salar-ed-Dowleh, the ex-Shah's brother; and finally Arshad-ed-Dowleh, his best general, was moving on the capital from the southeast. Early in August the ex-Shah's troops were defeated by the government forces at Feruzkuh in the mountains to the north-east of Teheran. The reverse destroyed the morale of the ex-Shah's troops, but the decisive victory was won on September 5 th, when Yeprim attacked Arshad-ed-Dowleh at a point some 40 miles south-east of Teheran and completely defeated him. The rebel leader was captured and was shot the day after the battle. Yeprim hastened on to meet Prince Salar-ed-Dowleh, who had by this time proclaimed himself king. On September 27 th, in a battle well to the south of Teheran, the government won a complete victory, and the capital was freed from danger. By October the insurrection had been practically suppressed except in the north.

The Great Powers, which had been watching events, now re-asserted themselves. Faced with the paralysis of British trade in the south, the British Government decided to bring up troops from India with a view to strengthening the Consular Russia's guards at various places within and without the British sphere. The
forward

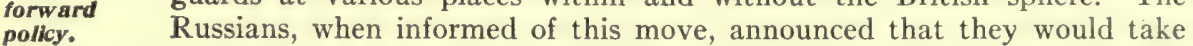
corresponding steps in the north, where the atmosphere was becoming, from their point of view, too British. The news threw the British Foreign Office into a panic and helped to force a crisis. For the situation in the Russian sphere was so bad that if Russia once moved there was no telling where she would stop. Her representations were no longer sure of attention, still less of acceptance, in Teheran. It was there believed that she had connived at the ex-Shah's attempt, and Mr. Shuster was now hand and glove with the extreme Nationalists whom he had made the dominant faction in the Mejliss. He had come to the conclusion that the Russians were utterly antagonistic to all Persian reform, and in the middle of October sent to the London Times a long letter embodying his complaints. The Russian government seizéd the opportunity to inform the London Cabinet that they contemplated measures of extreme urgency. The man of political experience, the Regent, even Yeprim the Chief of Police, realised the fatal tendency of events in Teheran. But a rupture with Russia was inevitable unless either the Mejliss or Mr. Shuster was rendered impotent. So matters dragged on until at last both the Mejliss and Mr. Shuster found their work summarily closed.

Two incidents occasioned the crisis. First, at the beginning of November, Mr. Shuster appointed as his financial agent in Tabriz a Mr. Lecoffre, who had been em- 
ployed at Teheran. On its merits this appointment was defensible. But Mr. Lecoffre was a British subject and a strong Russophobe. The Russians protested, but Mr. Shuster was past all listening. On the contrary, he was forcing a crisis over Friction his attempt to confiscate the properties of the ex-Shah's brother, Shoa-esconcerning Sultaneh. The Prince was officially a Turkish subject, but a house of his close to the Russian Consulate General had been mortgaged to the Russian

bank. When Mr. Shuster's officials arrived at this house, the Russian Consul-General, a strong advocate of a Russian forward policy, sent his men to chase them away. Next day Mr. Shuster dispatched one of his American assistants to explain matters. At the same time he sent a hundred of his gendarmes to seize the house. There was a scene. The Russians accused the gendarmes of aiming their rifles at them. The Persian Government-or Mr. Shuster acting through it-peremptorily demanded the recall of the Russian Consul-General. It was more than the Russians could stand. On November IIth, they presented an ultimatum in Teheran. The Treasury gendarmerie must be withdrawn and an apology tendered. The Persian Prime Minister ordered Mr. Shuster to withdraw his men. Mr. Shuster demanded an order signed by the whole Cabinet, a most unfair proceeding, as he knew there was no Cabinet in existence. Meanwhile the Russians were preparing to back up their ultimatum with 4,000 troops from the Caucasus. As soon as it was clear that an immediate apology would not be forthcoming, Sir Edward Grey strained every nerve to avert a Russian occupation of Teheran. The Russians, fully realising the difficulty of his position, let it be known that if their troops once entered Persia a new situation would be created and it would no longer suffice for the Persians to accept the ultimatum of November IIth. Matters would have to be put on a stable footing for good, and important constitutional changes were suggested. Sir Edward Grey said that Mr. Shuster was the root of all the trouble and advised the Russians to formulate a case against him before marching on the capital. The Russians, who had now got everything they wanted, replied that the formulation of a case would lead to much futile diplomatic friction. But they would think over the idea of demanding the dismissal of Mr. Shuster, and would not move their troops past Resht until the Persians had had ample time to consider their final demands. On November 24th, thirteen days after the presentation of the ultimatum, a Cabinet was finally got together and an apology tendered to the Russian Minister. M. Poklewski intimated, however, that further satisfaction would be required before the Russian troops could be withdrawn, and on November 20 th, a second ultimatum was presented. It demanded that Mr. Shuster Persia should dismiss Mr. Shuster and Mr. Lecoffre, should obtain the Mr. Shuster consent of the two Powers before offering further posts to foreigners, and
dismissed. should pay the costs of the Russian expedition. The ultimatum was laid before the Mejliss on December ist, and was rejected by an unanimous vote, a few Deputies abstaining. With its rejection disappeared the last hope that the Russians would immediately withdraw their troops. The danger now arose that they would march on Teheran and re-instate the ex-Shah. It seemed as though the complete collapse of authority in the capital would provide them with an excuse. There were bread riots, there was danger of fighting between Yeprim's police and the Bakhtiari tribesmen, there were boycotts of British and Russian goods, there was the Mejliss with its open provocation of Russia. The Cabinet tried to destroy the Mejliss, by persuading some twenty deputies to resign and thus make it impossible for a quorum to be formed. 'That plan failing, Ministers asked for full powers. At last, when the Russian troops had reached Kasvin, it was agreed that a small committee of the Mejliss should be empowered to approve the Cabinet's action. The language of the clause ordering Persia to submit her nominations for approval was softened, and on December $24^{\text {th }}$ the ultimatum was accepted. Mr. Shuster handed over his papers on January 7, Ior 2, and a week later was out of Persia. ${ }^{1}$ M. Mornard, the Russian nominee, succeeded him and his gendarmerie was taken over by the Swedes.

The surrender had come a few days too late. On December 2 2nd there were fights

1 Mr. Shuster's own account is given in his book, The Strangling of Persia (1912). 
between the Russians and the Nationalists both at Resht and at Tabriz. Instead of withdrawing their troops the Russians bombarded Tabriz citadel and opened the New Year by executing eight leading Nationalists, among them a prominent

Shuation in 1912.

ecclesiastic. The British Government, regarding these events as a preliminary to a permanent occupation, endeavoured to persuade the Russians to withdraw their advance force at Kasvin. But British efforts were weakened by an attack on the British Consul at Bushire and the necessity of landing a small force at the Gulf Port. It now became clear that the Russians were established at Tabriz. The fact that their dead had been mutilated had inflamed Russian opinion and destroyed all immediate prospect of withdrawal. There was nothing for it but for the two Powers to accept the situation and to discuss the means of providing Persia with a loan and of persuading the ex-Shah to return to Europe and a pension. With his departure the Persians could dismiss their irregular troops, and the work of re-organisation could be taken in hand. No progress was made in regard to the loan, but, in view of the urgent request of $M$. Mornard, it was arranged to advance a small sum. $£ 400, \infty 00$ was suggested, but the Russians insisted that this amount should be halved. The conditions were that the ex-Shah should be pensioned and that the Persian Government should conform its policy to the agreement of I 907 and should consult the Great Powers as to the formation of a small regular army. There was trouble about the formula and much haggling as to the pension. But in March the negotiations hastened to a conclusion. The Russians withdrew their force at Kasvin, Mohamed Ali left for Europe, and on March

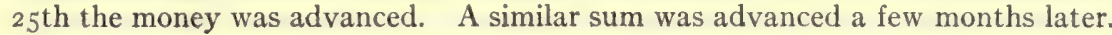

In the summer of I9I 2 there were persistent rumours that the two Powers had decided to partition Persia, and when M. Sazonoff visited England in September it was suggested that the necessary treaty was about to be concluded. It is understood, however, that no such arrangement was made, and though the decisions reached were not made public, the two governments were stated to be in complete accord. Thus at the end of I9I 2 the whole Persian problem still awaited settlement. Unsatisfactory as the status quo remained,- - as was shown in the murder of Capt. Eckford, referred to above,no decisive step was likely to be taken, if either Russia or Great Britain could help it, until the possibility of a wholly new policy had been thoroughly considered. This policy involved the linking up of the Russian and Indian railway systems by the construction of a trans-Persian line. Britain, France and Russia were to finance the work, but no decision had yet been come to, and questions as to route, break of gauge, etc., had not even been raised. - The project had only reached the stage that a Société d'Études had been formed to make an investigation and to submit proposals.

(GEORGE LLOYD.)

\section{PORTUGAL 1}

At the end of I9I 2 the Portuguese Republic, which came into being in October I9ro, had grown in strength and stability, despite the fact that these two years were a period of great social and industrial unrest. Most of the richest families were in exile, voluntary or enforced. Capital was transferred to other countries, and as a result many estates went to ruin and many shops, hotels, theatres and other industrial establishments were closed. The ecclesiastical property, upon which a large number of charitable institutions were dependent, was confiscated. These have been some of the principal causes which have led to widespread destitution, and to emigration on an enormous scale. Great social changes have been taking place. Socialism and Syndicalism have gained a remarkable hold upon the workmen of the towns, and strikes have been organised on a scale, and with a frequency, unknown under the Monarchy. The Republic had hardly been in existence two months when it was compelled to concede the right to strike-at 24 hours' notice- to all classes of labour except Government employés (Dec. 7, I9I0).. Railway strikes have paralysed traffic on many occasions and in all parts of the country; Lisbon has been in darkness owing to the strikes of gas workers and electricians; in May IgI I all the cotton operatives in Oporto left their work; on January 3I,

See E. B. xxii, 134 et seq. 
Ior 2 Lisbon was placed under martial law owing to the dangerous character of the labour disturbances. Attempts have been made to organise a general strike of all workers, and "sabotage" has been common. Poverty, the financial embarrassments bequeathed by the Monarchy, and the exaggerated hopes aroused by the establishment of the Republic, contributed to the industrial unrest. Great discontent was alsc manifested by the agricultural classes, especially in the North, where the Royalist invasions caused considerable distress. The disappearance of the large land-owners, and the exodus of capital, were felt in all parts of the country.

Meanwhile a new governing class came to the fore, its members being for the most part lawyers, journalists or professional men; the Church, the aristocracy and the landowners ceased to exercise political influence. On all sides the visitor to Portugal who knew the country under the Monarchy saw the evidence of a great social transformation; everything was changed, even the names of the streets and the public buildings.

The Constitution.-The Provisional Government, with Dr. Theophilo Braga as its President, remained in power until August 24, I9II. Its three principal achievements were the maintenance of the Republic, the Disestablishment of the Church and the organisation of means to create a new Constitution. The new Electoral Law, under which the Constituent Assembly was elected, was finally decreed on March r8, I9I. It gave the vote to all male Portuguese over twenty-one years old who could read or write, or who supported their parents or other relatives. It included priests and officers of the army and navy; the only exceptions being soldiers on the active list, naturalised Portuguese and persons proscribed for political reasons. This last exception made it impossible to organise a Monarchist party. No soldier, sailor, priest, magistrate, Government contractor or director of a company subsidised by the state was permitted to stand for election, and certain civil 'servants were also excluded. Lisbon and Oporto each formed two constituencies, returning ten deputies apiece. The other districts were limited to four deputies apiece, and the colonies to one. Payment was-fixed at i $7 \mathrm{~s}$ for each sitting of the Assembly.

On the 28 th of May the elections were held. Polling took place in halls, theatres, schools and private houses, instead of in the churches, as had been the previous custom. There was no serious opposition to the candidates put forward by the Government Committees, and the only deputy supposed to be a Monarchist was Senhor Charula, representing the minority at Braganza.

On June Igth, at iा A. M., the Constituent Assembly was formally opened. The President of the Assembly, Senhor Santos Bandeira, read a decree declaring the Monarchy abolished, and the Royal House of Braganza banished for ever from Portugal. This was unanimously approved. It was arranged that the Provisional Government should remain in office pending the enactment of a new Constitution and the election of a President under it. The Constitution was voted on the 2oth of August. It provides for two chambers - the first, or National Council, consisting of 164 members elected by direct suffrage for three years; the second, or Upper Chamber, of 7 I members elected by all the Municipal Councils for six years. Half the members of the Upper Chamber are elected every three years. The President is elected by both Chambers for four years and cannot be re-elected, nor may he be present during the debates in either chamber. His salary is $£ 2,600$ and he receives an allowance of $£ \mathbf{I}, 300$ for expenses. The President and the Ministers are responsible to the nation, and may be brought before the High Court, consisting of the Supreme Court of Justice and a jury of $2 \mathrm{I}$ persons elected from both chambers of Congress. The President's house, for official purposes, is the old Royal Palace at Belem. The Constitution may be revised every ten years.

On August 24th Dr. Manoel Arriaga was elected first President under the new Constitution. A native of Horta in the Azores, he was a man 70 years old-a doctor of laws of Coimbra University and a brilliant orator and journalist. He was proposed for election by a coalition of all the Conservative Republicans, who were opposed by the Radicals under the leadership of Dr. Affonso Costa, the Provisional Minister of Justice. The Conservatives had at the last moment substituted Dr. Arriaga for their original 
candidate, Senhor Braamcamp, as the former represented no single group and had the sympathy of the greater part of the Deputies. Dr. Arriaga received I 2 votes as against 86 cast for Senhor Machado, the Provisional Minister of Foreign Affairs and the nominee of Dr. Costa. When the election was over Dr. Theophilo Braga handed to his successor the formal resignation of the Provisional Government; and on September 3 the first Constitutional Ministry was formed. Its members were: Senhor João Chagas, Premier and Minister of the Interior; Dr. Mello Leotte (Justice); Dr. Duarte Leite (Finance); General Pimentel Castro (War); Senhor J. de Menezes (Marine); Dr. Celestino Almeida (Colonies); Dr. Augusto Vasconcellos (Foreign Affairs); Dr. Paes (Public Works). The Republic was now recognised by all the leading Powers; Brazil had been the first to accord recognition (Nov. I5, r9I0), being followed by the United States (June I9, I9rI), by France (Aug. 24), and finally by Great Britain, Spain, Germany, Italy and Austria-Hungary (Sept. II).

Party Politics.-The conservative Bloc had at the outset a majority of 56 in the Deputies-including 32 Independents-and of 25 in the Senate. The breach between the Bloc and the Radicals soon began to widen; on September 4, indeed, Dr. Costa the Radical leader, threatened to obstruct parliamentary business if the Ministry deviated from the democratic policy of the Provisional Government. On the gth Parliament adjourned, but in view of the imminence of a Royalist invasion it reassembled in special session on October 16 , to discuss a bill for the suppression of conspiracy. A Republican conference was held, in the hope of reaching some understanding which would assure union in the legislature during the winter; but it became apparent that the Republican party had already split into several factions. On November 8, Dr. Almeida, leader of one of the Bloc groups, withdrew his support, and the whole Cabinet resigned. Four days later, a new Coalition Government was formed by Senhor Augusto Vasconcellos, three ministers being Radicals and five belonging to the Bloc. This was regarded as a victory for Dr. Costa. The Government programme included the presentation of an accurate financial statement, the revision of Provincial legislation, and a policy anti-clerical but respectful to all creeds. Some improvement in the finances was effected by efforts to liberate the collection of revenue from local influences; the extravagant increases in official salaries granted by the Provisional Government had already been annulled by the Chagas Ministry. But the Government was unable to retain the confidence of its supporters, and on June 2 I, I9I 2 a third Coalition Government took its place, with Dr. Duarte Leite as Prime Minister.

The Royalist Invasions.-In the spring of -IgI a small force of Royalist refugees had gathered in Spanish Galicia for a raid into Northern Portugal, where the Church and the Monarchy could always count upon some popular support. The Royalist leader was Captain Paiva Couçeiro. The Government created eighteen new military districts and strengthened the frontier garrisons, especially at Braga and Villa Real. On June 15, the Portuguese Minister in Madrid, Senhor Relvas, complained to the Spanish Government that the refugees were using Spanish territory as a base for an attack upon the Republic. He received assurances of goodwill, but no strong action was taken by the Spanish authorities, who had not yet recognised the Republic and who were embarrassed by the activity of Portuguese Republican agitators in several parts of Spain itself. A few consignments of war material were seized as contraband, and the German S.S. "Gemma" was detained at Corcubion and compelled to unload a cargo of rifles and ammunition destined for the Royalists. But Couçeiro and his band of irregulars remained for the most part unmolested. In July a Royalist plot was discovered in the South; a whole regiment of chasseurs was arrested at Valença do Minho in the extreme North; and there were minor outbreaks in various districts. On the $24^{\text {th }}$ and $25^{\text {th }}$ of August two small steamers, the "Foam Queen " and the "Arizona," were seized by the customs authorities at the ports of London and Barrow respectively. The "Foam Queen " carried apparatus for wireless telegraphy and there were fittings for guns and other war material aboard both vessels, which were believed to be intended for the Portuguese Royalists, though their ostensible destination was Bahia Blanca. 
The Royalist cous was planned for the anniversary of the Republican rising of Igro - an insurrection in the North and an invasion were to take place simultaneously. But a premature outbreak at Oporto (September 30 ) was easily quelled, and no widespread popular movement occurred. Captain Couçeiro crossed the frontier on October 3 at the head of about r,000 men, badly armed and equipped. He occupied the village of Vinhaes near Braganza, but was soon compelled to take refuge in the heights of the rugged Serra da Corôa, and by October II had recrossed the frontier, after a few small skirmishes. No further attempt was made in rgrr.

Dom Manoel and the other claimant to the throne, D. Miguel, met at Dover on February 6, 1912 to concert common action for the restoration of the Monarchy-a cause which was now supported by the great wealth of the Miguelites. The exact nature of the compact between the two rival and exiled dynasties has not been made public, though it is certain that Dom Manoel would be accorded a prior claim to the throne, and probable that some matrimonial alliance was contemplated.

On July 7, I 912800 Royalists crossed the frontier near Verin, and a further force of 400 , led by Couçeiro and supported by discontented peasants, took the field near Montalegre. But though an alleged Royalist plot was discovered at Torres Vedras at the same time, this invasion was even less successful than those of $191 \mathrm{I}$; and it ended in the withdrawal of the Royalists after three days. An official Portuguese note dated July I4th complained strongly of the inaction of the Spanish authorities. Señor Canalejas protested against the terms of the note; but on the 17 th, 62 Royalists were arrested by Spanish frontier guards; and on September 3 the Portuguese Government issued a second note stating that all disagreement was at an end. A manifesto was published shortly afterwards by Dom Manoel, thanking Couçeiro and the other Royalists, and stating that his claim to the throne would never be abandoned.

Church and State.-The anti-clerical policy initiated when the Provisional Government was formed evoked opposition in many districts. In February IgII numerous priests were arrested in the North for reading in the churches a Pastoral Letter of Protest signed by all the bishops; and on March 7 an attempt was made by the Lisbon mob to lynch the Bishop of Oporto. The Bishop was removed from his see but granted a pension of $£_{2} 40$.

On April 2 I the Government published the Decree of Separation between Church and State, a document of far-reaching importance for the social and religious history of the country. This Decree was the work of Dr. Affonso Costa, the Minister of Justice. It guarantees full liberty of conscience to all Portuguese citizens; declares that the Roman Catholic Creed is no longer recognised as the State religion; recognises all faiths as of equal authority; and abolishes all State payments for the maintenance of public worship, and all imposts levied for such a purpose. No public body or functionary is permitted to assume any religious office. Public worship is permitted " in places designed for it," and is defined as the meeting of any number of persons for religious purposes in public, or of twenty or more persons in a private house. This definition is held to include religious instruction-and all schools where such instruction is given must be open to the public. All churches and other edifices used for public worship are declared to be inalienable without the consent of the Minister of Justice, and may at any time be expropriated for public purposes at their actual value. Members of a congregation or other religious association may only contribute towards the general expenses of their worship through some charitable body exclusively Portuguese, such as the board of a local hospital, asylum or crèche, but preferably through the Misericordia; and the corporation acting as trustee must apply at least one-third of the money received to acts of beneficence. No funeral ceremony or other act of worship may be performed outside any recognised place of worship without the consent of the municipal authorities. All ecclesiastical buildings and other existing property of the Roman Catholic Church now pertain to the State, which allows free use of them to the various congregations. The existing Roman Catholic Clergy is permitted a like free use of the Episcopal palitces and parsonages. P'ensions are granted to all existing members of the priesthood 
who act as such in Portugal. All present bequests to religious bodies are annulled, and all such bequests are in future illegal. Local and national taxes are imposed on all ecclesiastical property, whether freely granted by the State or otherwise held-such taxes to be paid by the corporation acting as trustee. No minister of any religion may take part in any act of public worship without permission from the competent secular authority, except those who by international convention or very ancient usage possess the right to conduct religious services within their own churches. This last clause of the Decree was introduced to meet the case of the foreign religious communities.

The value of the Church property confiscated under the Decree was $£ 6, \infty, 0, \infty,-a$ smaller sum than had been anticipated. Immediately after its publication the Embassy to the Vatican was suppressed, but it was afterwards replaced by a Legation. On May 5 , a representative meeting of the Portuguese clergy was held in Lisbon, under the Presidency of the Patriarch, Mgr. Mendes Bello. The bishops had refused any stipend from the State, but could not secure any other maintenance for the rural clergy, some of whom preferred the State allowance to destitution. The result was a Papal Encyclical denouncing the Provisional Government, and declaring the Separation Law null and void. On May 23, a further protest was issued, in the form of leaflets distributed broadcast throughout Portugal, while a month later the Patriarch of Lisbon and the Bishop of Guarda issued a second Pastoral, forbidding the clergy to accept the State stipend due on the first of July r9 I. By the 6th of August, however, about r,200 priests out of a total of approximately 6,000 had petitioned the Government to pay them their official stipends, which were of the average value of $£$ i I I.

Towards the close of IgII the Government decided to take action against the bishops. On the 26 th of Novemiber the Bishop of Guarda, Mgr. Viera de Mattos, was expelled from his see for having consistently advocated resistance to the Separation Law. The Vatican then forbade those priests who had accepted the State stipend to continue doing so, but this order was largely disobeyed. On the 29 th of December the Patriarch, the Bishop of Guarda and the Administrator of the diocese of Oporto were ordered to leave their districts within five days and forbidden to return for two years, and on the 6th of January I9I2 a similar sentence was pronounced against the Bishop of Algarve. All emoluments were withdrawn from the Lisbon priests who had signed a declaration of fidelity to the Patriarch. The bishops and Patriarch appealed in vain to President Arriaga, who referred them to the Ministers. Many of the foreign Congregations remonstrated through their diplomatic representatives against certain disabilities imposed by the Separation Law, and the Government promised that it should be revised at the earliest convenient date.

The Political Trials.-Special tribunals were instituted in Lisbon and Oporto, in January I9I I, to try cases of political conspiracy, and insults to the national flag and the President. Since then all persons suspected of reactionary opinions, religious or political, have been in danger. Their houses have been invaded by spies, their correspondence opened. Thousands of innocent persons have been summarily arrested, without the formulation of any definite charge, and have been confined for many months in subterranean dungeons, where they have been herded with the vilest criminals. The chief instrument of this widespread system of espionage and terrorism has been the organisation of the Carbonarios. This powerful secret society had a large share in the revolution by which the Monarchy was overthrown. It has since assumed the functions of an unofficial police force, and has at times proved itself strong enough to attack the Republican Government and the army. Its membérs, who carry arms, are Republicans of the most extreme type; many have also joined its ranks in order to gratify some personal dislike, or to secure the rewards given to successful informers. It is thus a body composed of dangerous fanatics and criminal adventurers. And it has arrogated to itself the power of summary arrest.

Senhor João Chagas, the first Republican Prime Minister, estimated that on October 23, I9I I, there were 2,000 political prisoners awaiting trial, of whom 700 were innocent. In the following January the number had been largely augmented. So notorious was 
the barbarity with which suspects were treated that a Committee of prominent British residents was formed to investigate and if possible to alleviate their condition. The Reports of this Committee were published in the London Morning Post and Paris Figaro in January and March I9I2, and the matter was vigorously taken up by th Italian, Swiss, Austrian and Spanish Press. Several Portuguese Republican newspapers and prominent Conservative Republicans corroborated the findings of the British Committee, and diplomatic representations followed. But the influence of the Carbonarios, and of the Radical Republicans led by Dr. Costa, prevented reform; the proscription of alleged political conspirators continues and hundreds of innocent persons remain imprisoned without trial and in circumstances of great hardship.

Two of the political trials call for special mention. In the first, the accused was Senhor João Franco, the former "Dictator." On December I I, I9ro the Court of Appeal unanimously decided in favour of the accused. The Government retaliated by banishing five of the judges to Goa; but these were reinstated on June 6, I9r I. In the second trial under notice (June I9I2), the accused was the Monarchist leader Captain Paiva Couçeiro, who was sentenced, in absentiâ, to six years solitary confinement and ten years imprisonment in the first class.

New Legislation.--One of the first decrees of the Provisional Government (Nov. 4, I9I0) dealt with the subject of divorce. Among the grounds for divorce now legally admitted are insanity, if pronounced incurable after three years; imprisonment for a long term; and mutual consent. The latter is only granted if both parties are over twenty-five and have been married two years. The Provisional Government attempted to abolish gambling, but this was afterwards legalised, and foreign capital was invited for the establishment of casinos. A decree of the 29th of December made the I.aw of Offences against the Crown applicable to offences against the Republic, and a new Press Law submitted Press offences to trial by jury instead of by a single judge, as formerly. This reform was more apparent than real, for in practice the liberty of the Press has been greatly curtailed under the Republic, and every Monarchist or Clerical newspaper had either ceased to express its opinions or else ceased to exist by March I9II. Duelling was declared illegal in January of that year. By a decree of the $30 t h$ of May Greenwich time was officially adopted, the decree taking effect on January I, 19I2 when all clocks were advanced thirty-seven minutes. On September 5, 19 II the Government adopted the Marconi system of wireless telegraphy.

Finance and Commerce. - The apparent stability of the Republic had a favourable effect upon the national finances. An official note published on May 21, 191 r showed an increase of $f 390,000$ in revenue during the previous three months, despite reductions in the octroi on foodstuffs. Credit seemed good, for on the 6 th of June the $3 \%$ external loan stood higher than at any time during the previous twenty years, and the agio on gold had fallen to $8 \%$. On the 18 th of December the Government presented the budget for I9II-12, showing a total revenue of $£ 16,800,000$, and a reduction in the deficit to $£ 435,000$. The total indebtedness of the nation was returned at $f 191,000,000-a$ sum which would, however, be largely increased by the new naval programme. On January 18, 1912 the Budget for $1912-13$ was presented, showing a deficit increased to $f 800,000$. As there was a doubt about the Covernment estimates, which included impossible sources of revenue and impossib! : means of retrenchment, a committee was appointed to examine the Budget; and by the following May it had calculated the deficit as at least $f \mathbf{I}, 466,000$. On December 7, I9I I the Bank of P'ortugal decided to increase its paper currency by $f 1,300,000$; the reserve of gold to be increased by one-third the value of the notes.

A decree of January 20, I9I I allowed Queen Maria Pia $£ 5.340$ yearly; the balance available from her dowry, $£ 7,555$ yearly, was retained for repayment of advances made to her by the state. She died at Stupinigi on July 8 following. A committee appointed to examine into various loans made by the state to the House of Braganza assessed the total (June 18,1912 ), at nearly $f 800,000$, of which $f 720,000$ had been advanced to King Carlos, $f 24,500$ to the I uke of Oporto and $f_{16,400}$ to Queen Amelia. The Government decided to reimburse itself from King Manoel's property in Portugal.

Commerce.-In 1910 i I,560 vessels of $20,615,388$ tons entered at Portuguese ports. The length of railways open was $1,780 \mathrm{~m}$., of which 665 belonged to the state. The exports were valued at $f 8,073,000$; and the imports at $f 15,581,000$. In April 1911 it was decided to form a British ('hamber of Commerce in Lisbon. The wine trade-the most important branch of foreign commerce-has been affected by the disturbances in the North and by shortage of labour due to emigration. But I912 will be remembered as a vintage year, the port ixeing exceptionally fine, though the quantity fell below expectations.

The Naty-(1) January 19, 19I I a commission appointed to reorganise the navy recommented the immediate acquisition from (ireat Britain of three battleships of the Dreadnought type, similar to the Minas (ieraes of the Brazilian navy. This recommendation 
was adopted in the new naval programme submitted by the Minister of Marine in December I9I I, which involved the purchase of three battleships of 20,000 tons each, three scouts of 3,000 tons, twelve torpedo boats of 820 tons and six submarines. On May I, I9I2 a bill was introduced fixing the naval force at 4,500 men, as compared with 5,687 in 1910 .

(K. G. JAYNE.)

\section{Portuguese Dependencies.}

The Portuguese dependencies occupy a total area of 793,980 square miles in Africa and 8,972 square miles in Asia. The total population in the African territories is estimated at $8 \frac{1}{4}$ millions, and that in the Asiatic territories at about $896, \infty 00$, but for several of the individual territories no recent estimates exist.

The population of Angola (W. Africa: see E. B. ii, 38 ) is estimated at $4,000,000$. That of the chief town, Loanda, was I7,54I according to the census of I9II, and that of Benguella 5,000. Revenue (I9II) £5I5,860; expenditure £704,750. The manufacture of rum, till IgII one of the most important industries, was abolished in I9II, the factories being dismantled under compulsion, an indemnities, covered by a local government loan, being paid to the manufacturers. An industry recently developed is the whale-fishery from Lobito. The Lobito-Katanga railway, which when completed will have a total length of over 800 miles within the colony, was completed in July I9 I for 225 miles.

The islands of St. Thomas (São Thomé) and Principe (est. pop. 45,000), form the province of St. Thomas (W. Africa). This has acquired some notoricty in connection with the abuses disclosed in 1908-o9 relative to the conditions of native labour on the cocoa-plantations (see $E$. $B$. xxiv, $48 \mathrm{~d}$ ). The new regulations, which came into force in I9Io, provided that labour-recruiting should be permitted only in specific zones in Angola; the numbers to be recruited were limited; recruiting agents were to be licensed by government; the recruiting was to be carried on publicly, under the supervision of Portuguese officials and native chiefs; labourers were to be conveyed only by specific routes, and were to be repatriated during four periods annually, half their wages being in the meantime collected by the government and paid over to them on their return home. In January I9II recruiting in Angola was stopped, and a new field was created in Portuguese Guinea. Natives who did not desire repatriation were given the right to enter into new contracts, under regulations designed to prevent compulsion on the part of employers. The general position now appears to be more satisfactory, in the view of British representatives on the spot, though enquiries and statements in the British parliament and elsewhere during rgr 2 still reveal a considerable body of opinion that the abuses have not yet been entirely removed.

The trade of Portuguese East Africa (see E. B. xxii, I63 et seq.) is in great part transit; its total value was $f 8,514,04 \mathrm{I}$ in 1910 . Among industries of recent development may be mentioned the whale fishery near Inhambane, the cultivation of sisal hemp in the Quilimane district, and the exploitation of oil-producing trees. Among recent public works the development of the ocean-beach south of Lourenço Marques as a recreation ground and residential district is of great importance to residents and may become so for visitors from the Transvaal. The Nyasaland Government and the Shire Highlands railway company have determined to extend that line from Port Herald to a point on the Zambezi, contingent upon the construction of a railway from the river to the port of Beira in Portuguese territory, which would divert from Chinde to Beira a large proportion of traffic.

\section{RUSSIA ${ }^{1}$}

There has been no proper census in the Russian Empire since 1897 , but the Central Statistical Committee issues annual estimates of the population, based on the yearly re-

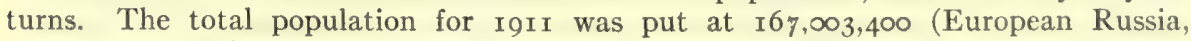
I 20,588,000; Poland, I 2,467,300; Caucasus, I 2,037,200; Siberia, 8,7 I 9,200; Central Asia, 10,197,300; Finland, 3,084,400). The various peoples of Russia have altogether IOI different languages, Russian predominating in $4 \mathrm{I}$ of the 78 provinces, $2 \mathrm{I}$ territories and 2 circuits, into which the country is divided for administration. The population of St. Petersburg is given as $1,962,400$, Moscow $1,533,400$, Warsaw 872,478 ,

${ }^{1}$ See E. B: xxiii, 869 et seq. 
Odessa 505,600, Riga 331,300, Kharkov 236,042, Lodz 208,330; and twenty-one other towns have between 100,000 and 200,000 . Census work has been done in the chief cities since the general numbering of the people in 1897 , and it is considered certain that St. Petersburg now contains over two million inhabitants. The urban population of the whole Empire is $23,177,700$, including Finland (459,000), Caucasus $(1,577,500)$, Siberia $(1,050,600)$ and Central Asia $(1,385,500)$. The rural population is $143,825,700$, of which European Russia counts $104,790,100$. According to information issued by the Chief Medical Inspector of the Ministry for Internal Affairs, the death rate of European Russia in 1909 was 28.9 and the birth rate 43.8 per 1,000 . This was a less favourable year from a sanitary point of view than the two preceding, and the increase of the population was lower than for $\mathrm{I} 2$ years previously, except in 1905 . For 20 years down to 1910 the birth rate generally fluctuated between 47.10 in I903 and 49.5 in 1891 .

An idea may be formed of the insanitary condition of the colntry from the following figures: the total number of sick persons registered by doctors rose from $56,835,200$, or 339

Publuc health. per I, 000, in 1904 to $81,746,072$, or 524 per 1,000 , in 1909 . These details bePublic health. come terribly significant when it is considered that there is only one doctor in European Russia per 7, IOO of the population and in Asiatic Russia per 14,900. Information as to the health of army recruits also bears upon this subject. In 1908 the number of men registered as liable to serve with the colours was I, 280,887 , of whom 679,266 , or 53 per cent, were medically examined, with the result that 73,496 , or 10.8 per cent, were found totally unfit for military service, and 58,606 , or $8.6 \%$, were enrolled in the second category of the militia reserve as being unfit for the regular army on account of sickness and bodily defects, whilst 74,425 , or $10.7^{\circ} \%$, were allowed further time for recovery from illness and physical development.

The past three years in Russia have been notable for several important legislative acts and reforms affecting large classes of the population. Much attention has been bestowed upon reorganisation of peasant administration, peasant justice, land tenure, migration, colonisation and labour insurance.

As a matter of important benefit for the great mass of Russian peasantry, the third Duma (which came into being in November I 907) passed a bill in 1910, which ranks next Local to the one designed to emancipate them from their village communes. justice.

This was the reform of local justice to replace the system introduced in 1889 by Count Tolstoy, the famous reactionary Minister of Alexander III. According to that system, small cases were tried by Volost Courts, the volost being a collective administrative unit comprising many villages and communes. More important cases were dealt with by the Zemskie Nachalniki or Rural Administrators, who combined administrative and judicial functions. These administrators were to be recruited chiefly from amongst the local landed gentry, and in this way Count Tolstoy desired to re-establish the influence of the landlords, which had been lost ever since the peasant reforms of $\mathrm{r} 86 \mathrm{r}$. Tolstoy's measure was most unpopular from the very beginning, and both the volost judges who were elected by the peasants, and the Rural Administrators appointed by the Government, proved themselves incompetent to satisfy modern requirements. As soon as the constitutional régime was introduced the Government recognised the urgency of reform in this direction with a view to substituting both volost courts and rural administrators by trained justices of the peace as in the towns. When the bill came before the legislature both houses accepted the abolition of the judicial functions of the rural administrators, but the projected abolition of the volost courts was stongly opposed in the State Council, and this gave rise to severe criticism. The bill was finally voted by the Council in $\mathrm{r}$ I I with retention of the volost courts under the supervision of local boards of magistrates, constituting in this instance courts of appeal.

()ne of the most remarkable features of the years Ioro and Io I was the manifestation of nationalism by the Government and the Duma. This showed itself in the carrying Nationalism. through of several bills tending to withstand the centrifugal forces which were at work amongst the foreign and heterodox races under Russian rule, and which the cosmopolitan disposition of former central authorities had allowed to attain dangerous proportions. The work of the Government and Duma in this 
respect surprised those persons who thought the Russification policy of the old bureaucratic régime would disappear with the establishment of representative institutions.

Against these denationalising forces the Government brought forward several bills, such as the introduction of Russian zemstvos or County Councils into the six western provinces, the separation of the Holm district from Liublin, and its with-

Introduction of zemstvos into western provinces. drawal from under Polish law, the purchase of the Warsaw-Vienna Railway by the State, and special Russian legislation for Finland. A characteristic in this connection was an order of the Minister of Ways of Communication prohibiting the employment of more than Io per cent of men of non-Russian race on the Government railways. Bills were also introduced for giving zemstvos to Siberia, the Baltic Provinces, and the Don Cossack territory.

The introduction of zemstvos into the western provinces brought on a serious Minis-

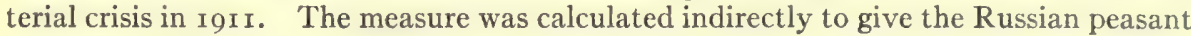
element in the provinces in question a preponderance of representation over Ministerial the Polish land proprietors, who had hitherto elected only Poles to sit in the crisis in 1911. State Council at St. Petersburg. With this in view, the new zemstvos were to be elected by separate national curias or colleges. The Prime Minister, M. Stolypin, explained the measure in a speech to the Duma, and that assembly passed it on June II, I9Io. Very strong opposition, however, was made to parts of it in the State Council, especially to the projected electoral curias, and in March I9I I, in spite of Stolypin's appeals for urgency, the upper chamber, after much debating, threw out the bill altogether. A serious political crisis at once ensued. Stolypin tendered his resignation, which the Tsar declined to accept. Extraordinary means were then resorted to in order to accomplish the desired end. On March 27 th an Imperial ukaz appeared, which suspended the sittings of both legislative chambers for three days. Besides this, two members of the State Council, Durnovo and Trepov, who, it was alleged, had used unfair means to instigate the opposition, were sent into retirement. The Government then obtained the issue of another Imperial ukaz, whereby the establishment of zemstvos in the six provinces was decreed under article 87 of the Fundamental Laws, which enables the Crown to legislate independently when the two chambers are not in session. The only obligation was to obtain the subsequent consent of the legislature to the accomplished fact, which was not difficult after removal of the most dangerous opponents from the State Council. This arbitrary proceeding produced a sharp conflict between the Government and the Duma and Council as soon as the two houses resumed their sittings. Both chambers for the first time sank their differences and united in vehemently denouncing the illegal action of the Government, although the Duma had actually voted for the law in question. As a demonstration, M. Goochkov, the President of the Duma, resigned his post, and was succeeded by M. Rodzianko. All factions in the Duma, except the Nationalists, combined in an effort to overthrow Stolypin, and passed a vote of censure. But the man who had not flinched at his post in I 906 when a bomb exploded in the very midst of his own household was not to be intimidated by the wrath of the Duma, especially now that the Emperor's confidence was secured.

The friendliness created between the State Council and the Duma by this incident did not last long. In the autumn of I9I I the old friction between them was renewed, and the peasant deputies of the Duma made a pilgrimage to the Ministers and other influential personages to complain of the State Council's neglect of measures affecting their class in particular. They declared that they could not face their electors " empty handed" when they returned home to their native villages.

Meanwhile the Premier Stolypin fell a victim to the perilous double game so often played by members of the Russian Secret Police and their agents among the revoluMurder of tionary spies. As a gala performance on September I4, I9I I in the theatre Stolypin. at Kiev, in the presence of the Emperor and the Imperial family, Stolypin was fatally wounded by two revolver shots fired by a Jew named Mordka Bogrov, who at one and the same time was an agent of the Okhrana, or Secret Political Police, and a member of the party of revolutionary terror. He succumbed to his wounds 
nn September 18 th. This tragic end to the ablest and strongest head of the Russian Government since Count Witte had left office produced a great sensation throughout the country and agitated all political parties.

Peter Arcadevich Stolypin was born in I 863, the son of a Russian Admiral of Sevastopol fame, who had married a Princess Gorchakov, so that on his mother's side he was related to the noble line of the descendants of Rurik. Having finished his

Character and work of Stolypin.

\section{InO2, and} education at the University of St. Petersburg, he entered the Government service in 1884 , first in the ministry for Internal Affairs and then in the Department of Agriculture. He was appointed Governor of Grodno in of Saratov in 1905, where he became known as a firm administrator. Internal Affairs, and in July succeeded M. Goremykin as Minister President. He quickly proved himself a capable and wise statesman of strong character and convictions, a good orator with a clear and concise style, an indefatigable worker, and able to give unity and prestige to the Ministerial Council over which he presided. He at first cooperated with the Octobrists and the Duma, and knew how to make use of the latter for the realisation of his programme of national legislation. It was said that the Duma determined the character of Stolypin, while Stolypin to a great extent determined the character of the Duma. Certainly the third Duma, convoked under the operation of Stolypin's modified electoral law and influenced by his able speeches, turned out incomparably more workable and practically useful than either of its two predecessors. His motto was reform and order. To those who objected to the arbitrary and autocratic tendencies of his policy his answer was that until new and better laws were introduced the old and defective ones, which often produced harm as well as good, would be strictly enforced. Amongst the important agrarian reforms which he promoted was the abolition of the tyrannical hold of the antiquated and fast decaying communal system over the Russian peasantry. In a few years time the inhabitants of St. Petersburg will have reason to bless Stolypin's memory on account of his scheme of compulsory sanitation and drainage, which the Municipal Duma of the Russian capital, after long years of culpable neglect, will now be bound to carry out. He resisted everything tending towards compromise with sedition in any form, and maintained the extraordinary and extra-judicial measures of public security and the operation of courts-martial in the face of much opposition. He was the terror of the Finns and the socialist revolutionaries. The latter regarded him as their deadliest enemy, and no less than seven plots and attempts against his life were organised, from August I906, when a bomb was exploded in his summer villa with terrible consequences to his family and visitors, down to the attack at Kiev which unhappily proved fatal.

The death of Stolypin induced the radical opposition to entertain hopes of a change of policy under his successor, but M. Kokovtsov, ${ }^{1}$ the new President of the Council of Ministers, very soon dispelled that illusion. In his first speech to the Duma M. Kokovtsov in this new capacity he laid much stress upon the fact that there would be
as Minister

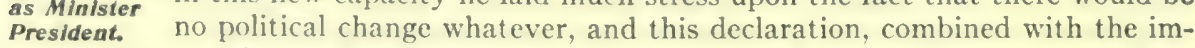
pression produced by the fact of the assassin of Stolypin having been a Jew, gave a fresh stimulus to the Nationalist cause and gained for it the full support of the Octobrists. At a great banquet on October 17 th in memory of the October Manifesto, the Octobrists and Nationalists, under Goochkov and Balashov respectively, joined their forces to pass a whole series of bills initiated by Stolypin. These included the law of equal rights for Russians in Finland, a money contribution from the Finnish to the Russian Exchequer in lieu of personal military service, the separation of the Holm district from Polish control, and the introduction of municipal administration into Polish towns, which was a sop to the Poles after foisting upon them the zemstvo scheme.

1 Vadimir Nikolaievich Kokovtsov was horn in 1847 . After serving in the prison administration, and then as Secretary to the Imperial Council, he became Assistant Minister of Finance under Witte in 1901. In 1904 he was appointed Minister of Finance, and he retained this office as Prime Minister, M. Makarov being appointed Minister of Internal Affairs. In December 1912 the latter made way for M. Maklakov. 
The antagonism between Russia and Finland was reaccentuated by the necessity of enforcing the law of equal rights. In I9 10 the Finnish Diet, after three dissolutions for refusing to entertain the subject of Russian Imperial legislation, continued

\section{Finnish} question. to pursue a provocative policy. In I9I I the claims of Russian subjects in Finland to be allowed to benefit by the aforesaid law and the absolute refusal of the Finnish local authorities to admit its validity, or to grant any rights under it, very much aggravated the bad feeling between the two peoples, and matters were made still worse by the Finnish Courts not rendering any assistance to the Russian judicial officers sent into Finland to prosecute the passive resisters. Finally several members of the magistracy of Viborg, Abo and other Finnish towns were arrested and conveyed to St. Petersburg amidst demonstrations of sympathy from their countrymen, to be tried in the Russian Law Courts. In February I9I 2 an Imperial decree ordered the pilot and lighthouse services of Finland to be placed under the Russian Ministry of Marine, which further embittered Russo-Finnish relations.

A number of publications giving the Russian side of the Finnish Question have becn translated into English and issued by the Russian Commission for Codifying Finnish Laws. Amongst them are, The Legal position of the Grand Duchy of Finland in the Russian Empire, by Baron von der Osten-Sacken; Finland, Its Position in the Russian State, by M. Borodkin; The Finnish Revolution in Preparation, by E. Feodorov, with a preface by G. Dobson; The Rights of Finland according to European Scholars, by Prof. Dr. E. N. Berendts, and The Finnish Question and Equal Rights, by P. Souvorov.

The majority of the third Duma took advantage of every possible opportunity to urge the necessity of extending national education. A distinct attitude of opposition

\section{National} education.

was assumed towards M. Schwartz, Minister of Public Instruction, who had the reputation of a reactionary. His successor, M. Kasso (appointed in roro), was severely censured for his dismissal of a number of professors of the University at Moscow for offering resistance to his measures limiting the independence of university autonomy. The Duma voted a broad scheme of school development which was calculated to establish general elementary instruction throughout the country in about ten years, but this was materially modified by the State Council, which came into acute conflict with the Duma on the question of lay and clerical influence over the proposed schools. The Duma refused to vote money for the latter. When the Emperor last received the members, before the final dissolution of the third Duma, His Majesty remarked, in his farewell speech, that he expected the Duma to vote the necessary funds for the schools in question. On the last day of the session, in order to avoid a vote uncomplimentary to the Emperor, the majority took care to be absent when the question was brought up for discussion, and failing the requisite number of members the bill could not be discussed. This difficulty, however, was easily surmounted, as in the case of the Council's refusal to introduce zemstvos into the six western provinces, that is to say, by again bringing into operation the famous article No. 87 of the Fundamental Laws and providing the necessary funds by the issue of an Imperial ukaz.

It may be mentioned here that the money devoted to elementary education was increased from $23^{\frac{1}{2}}$ million to 72 million roubles in $19 \mathrm{I} 2$.

The work of the third Duma in connection with the budget is considered by all parties as most effective and praiseworthy. Such a result is largely due to the President State of the Budget Commission, M. Alexeinko, formerly professor at the Unibudget. versity of Kharkov. In five years the State revenue increased by $f 45,773,-$

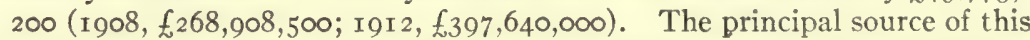
increase is the revenue from railways, ${ }^{1}$ which have produced more receipts for the period mentioned by nearly $£ 20,000,000$. It is worthy of note that whereas before I 907

${ }^{1}$ It may be noted that on January 23, I9II, the Council of Ministers sanctioned the formation of a Société D'Etudes for surveying the route for the projected Great Indian Railway, which is to join the railway systems of Russia and India. The total length of all Russian railways opened for permanent traffic in January I9I 2 is officially given as 69,332 versts, or 46,22 I miles. During I 9 I I new lines were opened for regular traffic over 957 miles and for temporary traffic over 950 miles; new second tracks were laid down over 137 miles; new lines were under construction for 3,967 miles and new lines were projected for 1,654 miles. 
Russian railways always showed a considerable deficit for the Exchequer, the last two budgets of the third Duma were closed with a large net profit of some $£ 16, \infty \infty, \infty, \infty$. During the first two years of the third Duma the latter constantly urged economy and better management of railways, while it recommended the kind of measures most likely to conduce to those ends. On one occasion it took the unusual course of reducing the estimates of the Railway Department by I rouble in order to mark its disapproval of the Government policy in that respect. The credits for education rank first in the relative figures of increased state expenditure. These have been nearly quadrupled since 1907, before which year they amounted to about $43,000,000$ roubles; in I 9 I 2 they came to close upon $170,000,000$ roubles. Next in importance are the assignments in connection with migration to Siberia and agricultural assistance and improvement. The money for these "pet children " of the third Duma, as the President of the Budget Commission called them, has been increased by about $78,000,000$ roubles (from $40,000,000$ roubles before I 907 to I $8,000,000$ roubles in I 9 I 2 ).

The estimates for the budget of I9I3, subject to the scrutiny of the Duma, were balanced at the colossal sum of $3,208,496,96 \mathrm{I}$ roubles, and their chief characteristic is an enormous increase of revenue and expenditure, the latter extending to all branches of the government, and amounting to 335 million roubles more than the expenditure of I9I2, whilst the anticipated revenue is 277 million roubles more than that of I9I 2. Consequently the expenditure for I9I 3 is calculated to exceed the growth of revenue by 78 million roubles.

The attention of the third Duma was much occupied by questions of National Defence. Its unrelenting hostility to the Ministry of Marine and persistent refusal to grant more money led to administrative change and revision in that dedefence. partment (Vice-Admiral Grigorovich becoming Minister in I9II), after which more credit was duly voted. In 1907 the Admiralty estimates amounted to 87,000,000 roubles; in its last Budget the third Duma provided 230,000,000 roubles for the National Navy. Relations with the Ministry of War (to which General Sukhomlinov was appointed in I 900 ) were less strained, and although that Ministry was invariably criticized, more especially the Commissariat Department, the third Duma was induced to satisfy all requirements of the Army to the extent of $545, \infty 00,000$ roubles in 1913 , or $150,000,000$ roubles more than in 1907 .

Russia's finances have never before been in such a flourishing condition as they were at the end of I912. The free resources of the Treasury had attained to the unprecedented sum of $800,000,000$ roubles, and the gold reserve of the State Bank, the State
finance. largest reserve of any bank in the world, was close upon I milliard 572 million roubles. These brilliant results were due to two splendid harvests and an unexampled development of trade and industry. As a matter of fact, in the course of two years only, from r910 to I9I 2 , there was an increase of industrial employment for over 300,000 more workmen.

The Ministry of Commerce and Industry reports that during the first nine months of 19 II there were 295 labour strikes on economic grounds, in which 78,000 workmen Strikes in took part, and which entailed the loss of 540,000 working days. The great-

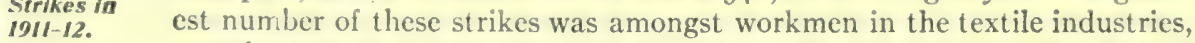
namely, I 19, or 40 per cent, and the number of men involved was greater than in any other industry. The industries producing metal goods were accountable for 34 strikes, those dealing with animal products for 27 , and those for the mechanical treatment of wood for 24 strikes. The most serious strike took place in March I9I2 at the mines of the Lena Goldfields Company in Siberia, and resulted in a wholesale massacre of workmen, hundreds of whom were shot down mercilessly by the troops. Discontent with the management of the mines was the only cause of the disturbance. It roused general public indignation, and the Emperor sent a trusted senator to make a special investigation and prosecute the parties responsible for so much loss of life.

The prosperity of Russia, which is in the main an agricultural country, is almost entirely dependent upon good harvest results. The harvest of I9I I was much inferior 
to that of I9I0, which was very nearly as good as the abundant harvest of I900 in quantity, though not in quality, owing to unfavourable weather. There was a dearth in IgI in I4 provinces and 3 territories, which necessitated the adoption Agriculture. of measures of relief for the peasantry in the famine stricken districts, such as the sale of corn and seed at cost price, loans, reduction of railway rates for transportation, and so forth. The harvest of I9I 2 was considered on the whole to be good, but rather unusual meteorological conditions during the latter part of the year probably marred the expected results. This was certainly the case with the harvest of beetroot for sugar-making. There was even an alarm raised in the press as to the possibility of a sugar famine and the advisability of importing foreign sugar.

For the purpose of establishing more security in kind for advances made on corn by the government, private banks and railway companies, it was decided in 1912 to erect 178 large granaries at railway stations and wharves with an aggregate capacity of one million tons

The employment of improved agricultural machinery and implements is spreading every year. The total value of such machinery acquired in I9IO was estimated at about $£ 9,200,000$ as against $f 8,500,000$ in 1909 .

The Russian grain export trade suffered considerably in I9I I-I2 from the temporary closing of the Dardanelles in consequence of the Turco-Italian and Balkan wars.

The realisation of the great agrarian reforms under the ukaz of November 1906, which emancipated the peasantry from the thraldom of their communes, has been energetically pursued. The number of peasant householders applying for personal tenure from the beginning of this reorganisation of the land down till June I9I I was 2, I60,867, while I,53I,620 had finally left their communes. Besides this, there was a growing tendency for whole communes to have their land distributed into separate allotments and farms, thus enabling the members to adopt individual tenure without direct application. By the law of June I4, I9Io, communes in which there has not been any general redistribution since the first allotment are considered to have passed over to hereditary tenure. On January I, IgI I the number of such communes amounted to II6,043, with $3,489,898$ householders, representing allotments aggregating about 77 million acres.

The purchase price of State land sold to the peasants during 1907-10 was 28,096,973 roubles, most of which is to be paid off by instalments spread over $551 / 2$ years.

Russia's foreign trade is growing rapidly. Its total value, as reported from the British Consulate in St. Petersburg, including the trade of the Caucasus and Finland, both exports and imports (but exclusive of precious metals, for which it has been decided Exports and henceforth not to publish any data), amounted in $191 \mathrm{I}$ to $f 268,405,925$ as comimports. pared with $f_{246,619,092}$ in 1910 , showing an increase of $f 2 \mathrm{I}, 78 \mathrm{I}, 833$, or $8.8 \%$. The exports in I9I I were officially estimated at $£_{1}$ I60, I 83,809 as compared with $\ell_{1}$ I $46,032,505$ in 1910 , an increase of $£ 14,151,304$, or $9.4 \%$, and imports at $£ 108,222,116$ as compared with $f_{100,586,587}$ in 1910 , an increase of $\{7,635,539$, or $7.4 \%$. Compared with the quinquennial period of $1906-10$, the exports in $191 \mathrm{I}$ increased by $33.2 \%$, the imports by $33.7 \%$, and duty on imports by $20 . \mathbf{1} \%$. The average excess value of exports over imports for the 5 years ending I I IO was over 39 million sterling. Russia imported German goods in I9I I for a value of f5o,459, I 55, so that Germany now monopolises nearly $50 \%$ of the Russian import trade. The United Kingdom came next with $£ \mathrm{I} 6,283,070$, or $\mathrm{I} 5 \%$ of the total imports, a small increase over the previous year. There has been a remarkable growth in recent years of imports from the United States. In I9 I I Russia imported American goods valued at $f, 10,668,045$, as compared with $£ 7,798,937$ in 1910 and $£ 6,112,610$ in 1909 . In I9I I Great Britain took Russian exports for $f 35,638,862$ and Germany for $£ 5 I, 866,56 \mathrm{I}$. The principal items of the Russian export trade are grain and grain products, which amounted altogether in I9I I to over 13 million tons, the average for the quinquennial period of I906-1o having been nearly Io million tons. The following are the chief Russian exports taken by the United Kingdom in I9II, with their respective values: cereals for $f_{11}, 169,934$; timber for $f_{6}, 689,312$; cggs for $£ 3,242,530$; butter for $£ 2,945, \mathbf{I} 85$; sugar for $f 2,843,068$; flax for $f_{1}, 979,788$ and game and other food products for $f_{1}, 068,571$. The total values of all these exports to all countries in I9I I were: food stuffs $f$ IO4,608, I 49; timber goods $f$ r 4,982,963; eggs $f 8,544,656$; butter $£ 7,498,4 \mathrm{I} 2$; sugar $£ 5, \mathrm{I} 06,772$; flax $£ 6,757,777$; poultry and game $£ \mathrm{I}, 532,063$.

Chambers of Commerce were introduced into Russia for the first time in the years I910-I I-I2, beginning with the establishment of the Russo-British Chamber at St. PetersChambers of burg, and these new Russian institutions already embrace the chief Latin and commerce. Slavonic countries.

Another Russian movement of British origin in these years was the emulation of General Baden Powell's system of Boy Scouts; but owing to the peculiarities of Russian conditions Boy Scouts. the Scouts in Russia have become potieshniki, play soldiers, or boys playing at soldiers, and are organised and drilled accordingly.

One of the last measures passed by the third Duma was for a comprehensive system of Labour Insurance, which was introduced into the Lower House in June 1908. It applies 
to over $3,000,000$ workmen employed in works, factories, mines, river transport, railways and tramways. Insurance in case of accident is provided for on the Austrian system by territorial mutual societies with capital supplied exclusively by employers, and maninsurance. aged by them under Government control. A second bill was passed for insurance in cases of temporary sickness to be undertaken by societies similar to the German Krankenkassen, the necessary funds in this instance being supplied in the proportions of 3 by the workmen and 5 by the employers. Sick pay is to be granted for periods not exceeding 26 weeks in one year. Considerable opposition was offered to the part of the scheme which provides for medical aid at the expense of employers, but finally, after much discussion in both houses, the bill was made law.

The third Duma, which was the first really working Duma, completed its 5 years term in I9 2, and an Imperial ukaz summoned the fourth Duma, elections being held in the late autumn. In these there is no doubt that the Government exercised The fourth considerable pressure through M. Sabler, the Procurator of the Holy Synod, Duma. on the clerical vote, and through the Zemskie Nachalniki and other local authorities on the peasant vote, also in the matter of distribution of electoral boroughs, arbitrary removal of undesirable voters, and so forth. The result was, however, unsatisfactory for the Government after all its efforts, for its campaign having been apparently directed against the Octobrists, the Opposition came in stronger than ever, and the Octobrists, although they lost Goochkov and other good men, practically lost only ro seats. It seemed likely to be very difficult to arrange for a working majority in the fourth Duma. The returns in November I9I 2 showed its constitution to be as follows: United Right, 229, various parties of the Left, ı09; Ministerial Centre, 80; "Aliens" or Autonomists, I7; miscellaneous, I5. Of the whole 440 members of the Duma only 7 or 8 were members of the first Duma (I906), and of the new party of the Right 45 were priests of the Orthodox clergy, 2 being bishops, the outlook being unpromising for any but reactionary legislation.

In foreign affairs Russian diplomacy has played an active and pacific part, without however, exhibiting enough energetic initiative and success to win popularity at home.

\section{Foreign}

The former Minister for Foreign Affairs, Izvolsky, who in rgro was transaffairs.

ferred to Paris as Russian Ambassador, was severely criticized in the Russian press for not preventing the annexation of Bosnia and Herzegovina, and

his successor M. Sazonov (who in IoI 2 paid important visits to Paris, London, and Berlin) has been criticized at home with equal, if not greater severity, for nearly everything he has done or not done. It was laid to his charge that he neglected to avail himself of the opportunity of the Turco-Italian war to insist upon the Turkish troops withdrawing from the Persian district of Urmia. After the Potsdam interview in I 12 between the German Emperor and the Tsar, accompanied by their respective Ministers, M. Sazonov was sharply criticized for the resultant agreement, whereby Germany received several substantial advantages in return for merely promising not to interfere in Russia's political relations with Persia. Germany, in fact, was given the possibility of accelerating the construction of the Bagdad Railway, and Russia undertook to solicit a concession from Persia for a railway from Khamikan, the last station of the German line on the Turco-Persian frontier, to Teheran, thus facilitating the competition of German goods with those of Russia in the markets of northern Persia. Although Russia continued to proclaim the principle of non-interference in Persian affairs, a Russian Consular officer was insulted by Persian gendarmes, and an ultimatum had to be sent to Teheran and more Russian troops entered the country. English and Russian co-operation at Teheran was severely tried by the reign of Persian anarchy, but good relations were maintained between the governments. Kussia again had trouble with China as to revision of the treaty of $188 \mathrm{I}$, and towards the end of $\mathrm{I} 9 \mathrm{I} 2$ concerning the independence of northern Mongolia. After much hesitation and refusing to accede to Mongolian solicitations for protection against China, Russia concluded a convention with the new Mongolian (iovernment at I rga, recognising the autonomy of that region without impugning the sovereignty of the Chinese over their former province. This gave rise to much ill fecling against Russia in China. The explanation was that Russia was obliged to establish direct relations with northern Mongolia in order to secure the treaty 
rights for her merchants which China had not yet agreed to renew. In IgIr all outstanding accounts were finally settled with Japan, and Russia received back her hospital ship which had been captured during the wär. In the Moroccan crisis of rgIr, betwcen Germany and France, the attitude of England in support of France was undoubtedly assisted by Russia making it plainly understood that the Franco-Russian alliance was still in full force, and especially by the order to refund to Russian banks out of the Russian Exchequer deposit in Germany all sums of money demanded of them from that country. Meanwhile difficulties have arisen between Russia and the United States. In December Igi I. President Taft declared his intention to abrogate the treaty with Russia of 1832 , and the announcement gave great umbrage in Russia, where it was at once understood as a retaliation for Russia's refusal to abolish her restrictions against foreign Jews and American Jews in particular. For some time the situation appeared to threaten a tariff war between the two nations.

In the beginning of I9I 2 Anglo-Russian sympathies were very considerably strengthened by the visit of a British delegation to Russia, composed of representatives of both Houses of Parliament, the Army, Navy, Press and Commerce. They were received by the Emperor and overwhelmed with traditional Russian hospitality at St. Petersburg and Moscow. A British squadron of 3 ships under the command of Admiral Warrender visited Revel for 3 days at the beginning of October I9I 2 .

In September I9I 2 the centennial jubilee of Napoleon's retreat from Moscow was celebrated with much military and religious ceremony in all the chief cities and towns of the Russian Empire, especially on the field of Borodino, where the Tsar reviewed a large number of troops. A distinguished French deputation also attended at Borodino and placed wreaths at the foot of both monuments erected to the Russian and French soldiers respectively who fell here in I8I2. Sperial patriotic performances were given at most Russian theatres, representing Kutuzov's pursuit of the defeated French army.

In October I9I 2 great distress was caused in the Russian Royal family by the scrious illness of the Tsar Nicholas's only son, the Grand-duke Alexis (b. I904). All sorts of

The wild rumours were current, that he had been the victim of a bomb outrage, Tsarevich. that he had been mutilated by his nurse, and so forth. All that was definitely known was that he was very ill, and in a critical state, but his condition improved early in November. It was officially stated on November 3 rd that the child had injured himself in jumping into a boat, and that an internal effusion of blood had been set up, causing great anaemia "which will require a long period of recuperation and may possibly for a long time render difficult the free use of the legs." The question of the succession to the throne came under discussion in connection with this unhappy event, and on December I Ith it was reported that the Grand-duke Dmitri (b. I89I), son of the Tsar's uncle, the Grand-duke Paul, would be made heir-designate.

Obituary.-Besides M. Stolypin, whose death is referred to above, Russian public life has lost an important figure in the editor of the Novoya Vremya, Alexis SERGEIEvich SUVORIN (b. 1834), who died at St. Petersburg on August 24, I912. The son of a serf, who had fought at Borodino and risen from the ranks to be a captain, he was educated at the military school at Voronezh and obtained a commission in 1853 , but, owing to lack of means, decided to become a schoolmaster at Korshovo. In I 858 he translated Beranger's "Captive," and brought out some sketches of country life. In 1860 he got a tutorship at Voronezh and continued to write for the press. In 1863 he removed to St. Petersburg, where for 12 years he was chief sub-editor of the St. Petersburg Viedomosti. His articles, republished in 1866 , caused him to be sentenced to two months' imprisonment, and the whole edition of his book was publicly burnt. In February 1876 he began the publication of the daily Novoya Vremya, making a special feature of the war news from Turkey and becoming his own correspondent in the Balkans. His paper soon became the leading one in Russia, and managed to steer clear of all troubles with the government, supporting the Constitutional régime and, in foreign policy, the French alliance. For over thirty years he contributed personally "Little Letters" on the chief topics of the day. He did much to help the circulation of cheap classics, and he founded a dramatic society and owned a theatre.

Another important figure passed away in Monsgr. ANTONIUs (Alexander Vassilevitch Vadkowski), Metropolitan of St. Petersburg (b. 1846; d. November 15, 1912). At the age of 20 he entered the Ecclesiastical Academy of Kazan and in 1870 became Professor of Pastoral Theology and Homiletics. He also wrote much on scientific subjects and in 1879 became 
editor of the Orthodox Discourser. After the death of his wife and children he became a monk, and in 1883 was made Archimandrite. In 1884 he became Inspector of the Kazan Academy, and in rsiso I'rofensor in the Ecclesiastical Academy of St. Petersburg, and in I893. Archbishop of Finland and member of the Most Holy Governing Synod, of which he was President at the time of his death. He published several collections of his writings and speeches. He was succeeded as Metropolitan of St. Petersburg and President of the Holy Synod by Monsignor Vladimir, Metropolitan of Moscow.

On February 7, 1912 the veteran Russian Field Marshal, and coadjutor of the Emperor Alexander II in his liberal reforms, Count D. A. Milctin, died in the Crimea at the great age of 96 . He was for 20 years Minister of War, and one of the most distinguished statesmen of the reign of the Tsar Emancipator. As Chief of the Military Staff of the Caucasus during the Russian conquest of that country, Milutin was the author of the plan which led to the capture of the elusive Shamyl in his mountain fastness at Gunib. He it was who radically reformed the Russian army, military education and justice in the seventies of the last century. He was always a warm advocate of representative government for Russia. His complete retirement took place in $\mathbf{I} 88 \mathrm{I}$.

Ammiral Dubasov, a well-known Russian naval officer, who was chosen by the Tsar to suppress the insurrection at Moscow in 1905, died in June 1912, aged 67. He first distinguished himself and at once became popular as the hero of the only naval exploit of which the Russians were able to boast in the Russo-Turkish campaign of $1877-78$, when as a young fieutenant in company with Lieutenant Shestakov he succeeded in sinking the Turkish ironclad "Seifi" by means of a mine. He was sent to occupy Port Arthur and Dalny, and also to Paris as Russian delegate to the International Commission of Enquiry into the Dogger Bank incident. In 1905 the Emperor appointed him to put a stop to agrarian outrage and armed revolt in the provinces of Chernigov, Kursk and Poltava. As Governor General of Noscow he showed great courage against the revolutionists. His life was twice attempted, but he only received an injury to his left foot, which, however, soon caused him to retire.

On December I3, I9II the death took place of Professor BEketov, an eminent Russian professor of chemistry who enjoyed a European reputation.

Professor Serge Mcromtseff, President of the first State Duma, and a party to the famous Viborg Manifesto, died at Moscow on October 17, 1910; YURY NICHOLAIVICH MII.tTIN, the founder of the well-known political party of Octobrists, died on Jan. 21, 19I2; and Mrs. Axisa Filosophova, the Russian champion of women's rights and promoter of higher female education, died on March 30, 1912.

The deaths may also be recorded of Nicolas Dmitrievich, Count Osten-Sacken (b. 1831; d. May 22, I9I2), Russian minister successively at Darmstadt, Munich, and finally at Berlin from I 895 until his death; and of GEORGE ROMANOwsKI, fifth Duke of LEvCHTENBER(; (b. 1852; d. May 5, 1912), formerly a Russian officer, who was a descendant of Eugène de Beatuharnais (see E. B. iii, $588 \mathrm{c}$ ), and son of a Russian Grand-duchess.

(GEORGE E. DODSON.)

\section{SIAM 1}

The treaty of I007 with France reduced the area of Siam from 240,000 to 2I 5,000 sq. m. approximately. In 1909 a treaty was concluded with Great Britain, ceding the Malay Protectorates of Trengganu, Kelantan, Kedah and Perlis to that country. This reduced the approximate area of the Kingdom to $198,900 \mathrm{sq}$. $\mathrm{m}$. At the same time Great Britain agreed to a modification of the extra-territorial rights of British subjects, and Siam obtained from the Federated Malay States Govermment on favourable terms a loan for the construction of the Peninsular Railway. The new frontier in the Malay Peninsula was in due course delimitated by a joint commission. The total population in roro numbered 7,561,077. The capital, Bangkok, has a population of 628,675 .

Siam is purcly an agricultural country, rice accounting for some $8+$ percent of the total vilue of the exports. Ip to 1910 there was evidence of a fairly steady growth in the cultisitted area. This connoted a growing revenue and a prosperous trade. But a poor crop for three gears - due to unfavourable climatic conditions and the want of any system of itrigation thas lemporarily given a serious check to the growth of trade and caused a certain amount of distress. The rice export was $1,051,836$ tons in $1910-1 \mathrm{I}$, and 627,468 tons in $19 \mathrm{II}-\mathrm{I} 2$.

The imports for $1910-11$ were valued at $68,205,328$ ticals ( 3 (icals approximately $=f \mathrm{r}$ ), and the exports at $108,909,8 \mathrm{I}$ I ticals.

The: bulk of the tracle is carried out with the two great transhipment ports of Singapore and Hongkong, without any indication of where the goods come from or go to. The estimated revenue for $1911-12$ was ticals $62,320,000$, as compared with ticals $60,523,520$ for the previnus year. The main soure's of revenue are:-Opium (ro millions), Land and Fishery Taxes ( $8 \frac{1}{2}$ millions), (apitation Taxes ( 7.3 millions), Spirits $(6.2$ millions), Customs (6 millions), Railway Traffic ( 4.2 millions), Lottery Farm (3.6 millions), Gambling Farms

See E. B. xxv, 2 et seq. 
(3.5 millions), and Forests, Octroi, Slaughter Licence Fees, Mines, Miscellaneous Fees, and Licences (all over one million).

The expenditure chargeable to revenue for I9II-I2 amounted to ticals $62,235,539$, as compared with ticals $60,522,962$ for I910-II. In I9II-I2 the expenditure chargeable to loan account (railway construction and Bangkok Water Works) amounted to ticals 9,820,838, while in the same year the expenditure chargeable to treasury reserve was ticals $1,854,23 \mathrm{I}$. The Ministry of War (with army) for I9II-I 2 was estimated to cost ticals II 365,460 and the navy ticals 4,000,000. The King's civil list amsunts to ticals 7,000,000 and that of the Queen Mother to ticals 300,000 . The foreign debt amounts to $£ 4,000,000$ bearing interest at $4 \frac{1}{2}$ per cent.

The length of state railways open to traffic is 607 miles. The southern line down the Peninsula to connect with the line to Singapore is under construction, and it has been decided to resume the construction of the northern line to Chiengmai. In I9I2 a Ministry of Communications was formed, but the development of roads and waterways must depend on a return of prosperity and a growing revenue.

After the longest and most illustrious reign in the history of the country, King Chulalongkorn died on October 23, I9I0, and was succeeded by his son, the Crown Prince, under the style and title of Somdetch Phra Paramendr Maha Vajiravudh, Phra Mongkut Klao, King of Siam. The coronation in December Igr I brought together the largest gathering of European royalties ever seen in Asia. The new King is not less an absolute monarch than his predecessor. But the note of the new reign may be found in the royal decree making the very considerable personal property of the King subject to the same taxation as that to which the property of a subject is liable, and in the effort made to stimulate patriotism and a national consciousness by the "Wild Tiger " and "Boy Scout" movements. Siam, however, has not been able to escape the general unrest, and, largely as a reflex from the successful revolution in China, an anti-dynastic conspiracy was hatched early in 1912. This, however, was promptly checkmated and punished, but without undue severity. Local self-government, dealing chiefly with sanitation and education, is being attempted in districts in the interior provinces. Conscription is now enforced throughout the country, both for army and police, and the army organisation is thorough and successful.

A national system of education is in process of organisation and it has been decided to establish a university. At present there is in Bangkok one school in which the final examination reaches the standard of the matriculation examinations at London University. A beginning is being made to make elementary education compulsory for hoys. The education of girls is not yet general.

In the administration of justice, under the treaties with Great Britain and France, European lawyers play an important part as advisers and judges, and the system is found to work satisfactorily.

See W. A. Graham, Siam: A Handbook of Practical, Commercial and Political Information (London, I912); Rev. Daniel McGilvary, D.D., A Half Century Among the Siamese and the Lao (New York, Fleming H. Revell Co., I912); Rev. J. H. Freeman, An Oriental Land of the Free (New York, I910).

(W. H. Mundie.)

\section{SPAIN ${ }^{1}$}

In r9 10 the population of Spain was I9,588,688, an increase of 970,602 since the census of I900. The populations of the chief towns were as follows: Madrid 57 I,539; Barcelona 560,000; Valencia 233,348; Seville I 55,366; Malaga 133,045; Murcia I24,985; Saragossa 105,788. The census showed that 63.7 per cent of the population were illiterate, - a high figure, yet a marked improvement on I 900. In I 9 I the total State expenditure ${ }^{2}$ on education and art was $£ 2,340,000(58,524,586$ p. $)$, of which $f i, 266,000(31,664,746$ p. $)$ were spent on public and primary education.

Agriculture.-The crop-returns for I9I I were in most cases the best for the five years 1907-II, wheat yielding 4,000,000 tons, as compared with $3,740,000$ tons in 1910 . The barley, oats and maize crops were also excellent, while the increase in olive oil and olives amounted to 200 per cent for the year-in the latter case, however, the rgro harvest had

1 See E. B. xxv, 527 et seq.

${ }^{2}$ Conversion is made throughout at the approximate rate of $£ I-25$ pesetas, but a considerable deduction has to be made owing to depreciation. 
been very poor. The vintage was the best since 1908 , and an increase in the acreage under vineyards took place for the first time for many years. Parasitic growths attacked the orange, almond and spice crops, but the orange trade escaped serious injury; with other branches of the fruit export trade it was adversely affected by the British coal strike in I9I2.

Commerce.-Spanish banking, electrical and railway enterprises have continued to attract foreign capital, the most important new venture being the Barcelona Traction, Light and Power Company, a Canadian company with a capital of $£ 8,000,000$. The great development scheme, intended to devote a loan of $£ 60,000,000$ to harbour improvements, railways, irrigation, afforestation and similar public works, never came to fruition, but good progress was niade with the building of new roads, especially motor highways, and the first of the new light railways-a line $18 \mathrm{~m}$. long in Palencia-was opened in I9I2.

()n January I, I9I2, the new tariff came into operation. It involves reductions in the duties on most cotton and some woollen and silk goods, on sewing machines, tools, iron and steel wire ropes, iron and steel plates, paper and cardboard. There are increases in the duties on hemp and linen yarns, washed wool and untanned hides and skins.

The mining industry was impeded not only by the industrial agitation but by the new mining law (Dec. 29, 19I0). This law makes the head rent payable in a lump sum instead of quarterly, the ownership lapsing in default of such payment when due. As the mine owners were not given adequate notice, many mines lapsed, i.e. were confiscated. The export trades, shipping, railway and gas industries all felt the effects of the British coal strike in the early months of I9I2, while the great floods at the same time caused much loss of life and property in southern and south-eastern Spain, especially in the Guadalquivir valley. Near Seville, 15 villages with an aggregate population of 34,000 were totally submerged, and the destruction of crops and live-stock was widespread. Nevertheless the two years I9II and 1912 have been a period of moderate prosperity and expanding trade. The exports for the first three months of 1912 showed an increase over those of 1911 , rising from $£ 9,468,000$ to $£_{10}, 585,000$, while the imports only decreased from $£_{10,296,000}$ to $£_{10}, 279,000$.

Finance.- The Octroi was abolished on June 3, I9II, and a tax on house rents substituted for it. The Canalejas government also endeavoured to lighten the burdens of the poorer classes by reducing the sugar duties to about $25 \mathrm{~s}$. per cwt. and increasing the death duties. These changes were accompanied by numerous much-needed increases in official salaries, and by additional grants for educational purposes.

The national debt on January I, I9 I I, amounted to $£ 39$ I , 49 I, 000 $(9$ I , 787,28 I , 388 pesetas). In the following December, Señor Canalejas persuaded the king to re-enact for I9I 2 the budget of I9II; the Spanish Constitution permitted the budget for one year to be once thus re-enacted. The estimates showed an expenditure of $£ 45,240,000$ ( $1,131,000,000$ p.) and a revenue of $f 45,280,000$ ( $1,132,000,000$ p.); but the war expenditure destroyed this apparent equilibrium. The budget for I9I3, introduced in May 1912, showed a heavy deficit on this account. Señor Navarro Reverter, the Finance Minister, seeing that a foreign loan was impossible and an internal one would be unpopular, arranged to raise the current credit of the Treasury with the Bank of Spain from 75 to I oo million pesetas $(f, 3,400,000$ to $f 4,000,000)$. At the same time the Treasury was empowered to borrow 100 million pesetas from the bank at I per cent; and to reduce the interest on the existing debt of the same amount (owing on account of the American War) from 2 per cent to I per cent also. In return the bank was apparently authorized to issue notes up to the value of 200 million pesetas without covering the extra issue with 50 per cent of gold in reserve, as previously required for all notes issued in exeess of a total of 1,500 million pesetas. The amount of notes in circulation on May 4 , 1912 , was 1,806 million pesetas.

Defence.- The first ship of the new Spanish navy, a gunboat of 800 tons, was launched at (artagena on January 26, $191 \mathrm{I}$; and on February 8 , 1912, the battleship "España" was latunched at Ferrol. This is a vessel of the Dreadnought type, displacing 15,450 tons, and with a contract speed of 19.5 knots. On April 24, I9II, the king inaugurated the first powerful station for wireless telegraphy, at the military camp of Carabanchel, near Madrid.

The Industrial A gitution.-An epidemic of strikes, often accompanied by rioting and the destruction of property, swept over the industrial districts of Spain between () tober roro and July Ior r. In August I 9 I i it culminated in an economic and political (risis of the gravest character. Members of the French General Confederation of Labour had been invited to address a series of meetings in Madrid and Barcelona. They were expelled, by order of the government, owing to the inflammatory nature of their speeches. Disturbances followed in Catalonia, but the repressive measures taken by General Weyler, the Captain General, restored the semblance of order for a few days. The transport workers in Bilbao then struck work, to be followed by the miners and factory hands; and the employers declared a lock-out. Work ceased throughout the district, and the crisis developed rapidly. King Alfonso, who had been visiting England with the Queen (Aug. Ifth-20th), returned hurriedly to Madrid on August 3oth. The 
strike spread to Santander and Asturias, and the General Labour Union decided on a general strike. In many parts of the country the labour disturbances assumed a revolutionary character; rioting and bloodshed were of daily occurrence, and Barcelona, Heulva, Saragossa, Malaga and Valencia appeared to be on the eve of insurrection, the disorder being worst in the last-named province. In the north, General Aguilas, the Captain General of Burgos, took command at Bilbao, with all the troops at his command. The city was placed under martial law, and the strikers dispersed by cavalry charges and the threat of artillery. At Valencia, however, the rioters succeeded in gaining the upper hand (Sept. I8th) and at Cullera and Alcira the Commune was proclaimed. The - exceptionally brutal murder of a magistrate (Señor Lopez Rueda) at Cullera, and of his secretary and the clerk of the court, brought about some revulsion of public feeling and strengthened the hands of the government.

On September Igth martial law was declared throughout Spain, the Constitutional Guarantees not being restored until October 2 nd. On the night of the 19 th, 300 arrests were made; within a few days the prisons were full and the barracks converted into gaols. The publication of two Republican newspapers was suspended; the others decided to cease until the Constitutional Guarantees were restored. These measures succeeded. The funds of the strikers were almost exhausted; the revolutionary organisation was paralysed by the loss of its leaders, and the strikers reluctantly returned to work. Minor outbreaks occurred sporadically after the collapse of the great strike, and in June I9I 2 much anxiety was caused by the widespread symptoms of unrest. At Oviedo the Civil Guard intervened in a strike of miners, shots were exchanged, and the whole mining population ceased work as a protest. In the district of Almeria a general strike was threatened, and great dissatisfaction was shown throughout Spain by the railwaymen, who demanded higher wages and shorter hours. This culminated on October

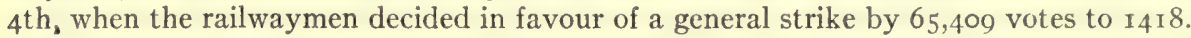
The companies refused to accede to their demands, and the government issued a mobilisation order, recalling to the ranks many reservists who were on strike. This, together with the organisation of a provisional service of trains and the promise of a bill to better the conditions of railway employes led to the collapse of the movement.

Polilics and Legislation.-Señor Canalejas, who had become Prime Minister on February 10, I910, remained in office until he was assassinated on November I2, I9I 2. His policy aimed, it has been said, at "Europeanising" Spain. While maintaining order under many difficulties, he worked for the betterment of the agricultural and industrial classes. During his tenure of office, the government reduced the power of the church in secular affairs, solved numerous financial problems, carried on military operations in Morocco and also conducted a most intricate series of negotiations with France.

The anniversary of the execution of Francisco Ferrer (Oct. I3, I9Io) was the occasion of many Republican demonstrations, but it was not until March 27, I9I I, that

The

Ferrer

question. the debate on the Ferrer trial opened. Meanwhile there had been a split in the Republican party and the government had gained in strength. The Republican leader in Barcelona, Señor Lerroux, had been accused of complicity in certain municipal scandals. He was formally expelled from the party by its chief, Señor Azcarate, who then joined forces with Señor Pablo Iglesias, the Socialist leader, forming a new group in the Cortes - the Republican Socialists. This was in December I9ı. On January I, I9I I, Señor Canalejas resigned, desiring a free hand, which his return to power would give him. He received the royal confidence, and reorganised the Ministry; the new Ministers being Señores Alonso Castrillo (Interior), Amos Salvador (Education) and Gasset (Public Works) - the last-named a leader of the Moret group who had served in five previous cabinets. Before the Cortes opened on March 6th, the Republicans had been further weakened by the exclusion of the Catalinists, and now consisted of three mutually hostile factions-Catalinists, Radical Republicans and Republican Socialists.

The Ferrer debate lasted until midnight of April 8th-9th, ending in the rejection of the Republican motion which asked the government to modify the Code of Military 
Justice and to repeal the Law of Jurisdictions. Señor Canalejas maintained that the Liberal government could not be held responsible for the acts of its predecessors; but a cabinet crisis arose on April rst, owing to the strong feeling in Army circles that Señor Canalejas had not sufficiently defended the action of the Military Judges who condemned Ferrer. The king was summoned to Madrid, and the cabinet was again reconstituted. Only three ministers retained their portofolios, viz: the Prime Minister, Señor Garcia Prieto (Foreign Minister) and Señor Gasset (Public Works). Señor Ruiz Villarino was transferred from the department of Justice to the Interior.

On October 9, I010, two important new bills were introduced in the Senate. The first imposed compulsory military service on clerical as well as lay citizens; the second substituted an asseveration on the honour of a witness for the legal oath

The

religious

question.

on the crucifix. This was the government's reply to the great Roman Catholic demonstration which had taken place a week earlier. The Cadenas Bill, which forbade any further religious orders to settle in Spain until the Associations Bill became law, was carried December 23rd. There were at this time 3,007 nunneries and 794 monasteries in Spain, with 4I,500 nuns and I 2,800 monks; and a large number of members of religious Orders had also entered the country from Portugal. On the 2nd of March the king approved a draft of the new Associations Bill, but on the same day Cardinal Merry del Val, the Papal Secretary of State, informed the government that the Vatican would not be prepared to resume negotiations unless all measures dealing with the religious question were first submitted for its approval. To this Señor Canalejas would not agree; the Associations Bill was introduced at the end of May, and compulsory military service for all classes was legalised on June 29 th. Owing, however, to the urgency of the industrial and Moroccan questions, Señor Canalejas was forced to defer the fulfilment of his anticlerical programme.

On November I 2, I9I I, the Municipal elections were held throughout Spain. They proved a triumph for the Monarchist Parties, which had a majority in most of the large towns, recovering Madrid and Valencia and winning five seats at Barcelona. The Cullera Even Saragossa returned a Monarchist majority for the first time for twenty rrial. years. This was due partly to the disunion among the Republicans, but still more to the success of the government in dealing with the great strike, and to the reaction produced by the Cullera murders. On January I I, I0I 2 , the Supreme Council of War and Marine passed sentence of death upon 7 out of 22 persons arrested at Cullera. It was alleged by the Republicans that torture had been used to secure a confession, but this charge was not substantiated when a medical commission examined the prisoners. Six of these were reprieved, but the seventh, Jover, had been found guilty of murler on three counts, and the government opposed the reprieve. As the king insisted upon it. Señor Canalejas tendered his resignation, declaring the government decision irrevocable. An attempt was made to form a new Cabinet, Señores Montero Rios, Moret and Maura being summoned successively to the palace; but on the following day (Jan. 15, I () I2) Señor Canalejas returned to power, the royal clemency having been exercised in the interval. This crisis strengthened both the Monarchy and the Ministry; and on May 5. In 2 , the Chamber, after an animated debate, reaffirmed its confidence in Señor Canalejas by 180 to 73 .

On November I2, I0 I2, the Prime Minister was shot in the Puerta del Sol, Madrid, as he was walking to the Ministry of the Interior to preside over a Cabinet meeting. The assassin, by name Manuel Pardinas Sarrato, was a native of El Grado Assassination in Huesca, thirt y-two years of age. Parliament immediately adjourned,
of Señor of Señor
Canalejas. and Señor (iarcia Prieto was appointed acting Premier. He was succeeded two days later by ('ount Romanones, who formed a new Liberal Ministry.

Señor Canalejas was fifty-eight years of age, and had been a member of the Cortes for twenty-eight years. He had been very successful at the Bar, had served in the war against the Enited States, in (uba, and had held the portfolios of Public Works, Finance and Justice, and been I'resident of the Chamber. He was probably the ablest Spanish statesman of the preriod which cnded with the fall of Sagasta. 
Between January 5 and I6, I9I I, King Alfonso visited Melilla, where he unveiled a monument to the Spanish soldiers who had fallen in the Riff. In June, the occupation of Alcazar and Laraiche brought about a critical situation, stirong protests

Moroccan affairs.

being made by the French and Moorish governments. Public feeling ran dangerously high, despite the efforts of the Ministerial Press. But the Minister for Foreign Affairs, Señor Garcia Prieto, handled the situation with firmness and tact, and on December 6th, formal negotiations with France were begun, M. Geoffray, the French Ambassador, representing his country, while Sir Maurice de Bunsen, the British Ambassador, was present at the request of both parties. The negotiations terminated successfully in November IgI 2 (see Morocco). In January of that year, the total number of Spanish troops in Morocco had been nearly 35,000. The cost of the war evoked many protests from the Republican party, who denounced the official "policy of adventure." But even they were not unanimous, as Señor Lerroux supported the government on this one question. All the Monarchist parties were in favour of an active Moroccan policy, and the war was not unpopular in the country.

Obituary. - In addition to that of Señor Canalejas, the following deaths may be noted. Maria Teresa Isabella, Infanta of Spain (b. 1882), died at Madrid on September 23, 1912; she was the second daughter of Alphonso XII and Queen Maria Cristina, and was married on January 12, 1906, to Prince Ferdinand of Bavaria. MARCELINO MENÉNDEZ Y PELA Yo (b. 1 856) the scholar and critic (see E. B. xviii, I28d), died at Santander on May 20, I912; he continued his critical and linguistic researches almost up to the day of his death and bequeathed his library of 40,000 volumes to Santander, the town of his birth. José Lopez-Domivguez (b. I825), the statesman and general, died on October 18, I9II; he was war minister in the Posada-Herrera Cabinet of 1883 (see E. B. xxv, 560), and on the death of his uncle, Marshal Serrano, succeeded him as leader of the "Dynastic Left" party; later he joined a coalition which took the name of the Nationalist party, and in 1906 was Prime Minister at the head of an anti-clerical cabinet (see E. B. xxv, 567b). AURELIANO DE BERUETE (b. 1845), the painter and art critic, died at Madrid on January 5, I912. He was a well-known landscape painter (see $E . B . \times x v i i, 978 \mathrm{~b}$ ), wrote the standard work on Velazquez, and was the leading authority on Spanish art.

(K. G. JAYNE.)

\section{SWEDEN 1}

Population.-The census of I910 showed an increase of $7.5 \%$ since 1900 . The population on January I, I9I 2 was $5,561,799$ ( 2,7 I 8,638 males and 2,843 , I6 I females), distributed as follows: Norrland (Northern Division), 953,582; Svealand (Central Division), I,I70,795; Stockholm district (Län), 234,973; Stockholm City, 346,599; Götaland (Southern Division), 2,855,850. There has been a marked increase in the population of the Northern Division since I9ro, a result of the development of the mineral (iron ore) resources in the northernmost districts, and also of new railway and waterworks construction. In Stockholm, the growth of population is still rapid but not as rapid as that before 1900. This is due to the exodus to new suburban residential districts, among which are Lidingön, Djursholm, Saltsjöbaden, Sundbyberg, etc. These outlying districts are not yet incorporated, and the growth of Stockholm must not, therefore, be gauged by the statistics of the city alone but also by those of Stockholm district, the inhabitants of which increased from $I 72,850$ in 1900 to 234,973 .

The excess of births over deaths in I9I0 was I0.462 per thousand. The birth rate for the same year was 24.466 per thousand. The chief towns with a population exceeding 20,000 inhabitants are: Stockholm $(346,599)$, Gothenburg ( 170,606$)$, Malmö (89,7 I9), Norrköping (46,629), Gefle (35,7 I9), Helsingborg $(33,225)$, Örcbro (3I,066), Eskilstuna $(28,485)$, Karlskrona $(27,496)$, Jönköping $(27,226)$, Upsala $(26,586)$, Linköping $(23,02 \mathrm{I})$, Borås $(2 \mathrm{I}, 997)$, Lund $(20,340)$.

Emigration during I910 showed an increase-probably a result of the national strike in I909. The figures published for I906-10 are: (Ig06) 24,704, (I907) 22,978, (I908) I 2,499, (I909) 21,992, (ז 1 го) 27,8 6 . The United States received the largest contingent, but Denmark, Norway and Canada also received considerable numbers. Swedes resident abroad number between $2, \mathrm{I} 20,000$ and $2,245,000$, of whom no less than $\mathrm{I}, 500,000$

${ }^{1}$ See E. B. xxvi, 188 et seq. 
are in America, and 370,000 in Finland. Immigrants to Sweden in rgro numbered 8,142 , chiefly labourers for agriculture and the mining and manufacturing industries.

Agriculture - Of the total land area $3.5 \%$ is meadow land, $50.85 \%$ forest land $36.9 \%$ unproductive land, and $8.75 \%$ cultivated land. The cultivated land comprises $3,633,534$ hektar (about 8,992,996 acres). The rather large percentage of unproductive land includes mountains, marshes and bogs, but the last-named are being reclaimed as a result of the work carried on by the Swedish Moss Culture Society, of Jönköping (founded 1886). About $47.6 \%$ of the cultivated land is under cereals, chiefly oats and rye; $34 \%$ fodder; $5.7 \%$ root crops (about three-quarters potatoes and one-quarter sugar beet); $1.3 \%$ garden and other produce; and $11.4 \%$ fallow. A considerable quantity of fresh fruit is imported into Sweden, but lately a revival of fruit growing has taken place, and experiments in fruit export have even been madle. A society for the promotion of fruit growing (Svenska Pomologiska Föreningen, Atvidaberg) has established a Swedish fruit brand, on the same basis as the Swedish "Rune" butter brand. To facilitate the gathering and exportation of cranberries, the bulk of which go to Germany, the interests are being concentrated.

On an average there are I04 horses per thousand inhabitants and 495 cattle. The average of sheep and pigs is 230 and 155 per thousand inhabitants respectively. The milk production is ahout 2,852 million kilogrammes per annum, equal to I,891 kilogrammes per cow or 549 kilogrammes per head of population. The dairy industry is rapidly developing and the export of butter, and recently casein, is steadily growing. Sweden is again taking a high place in the manufacture of dairy machinery, as several practical milking machines, which have won praise all over the world, have been placed on the market. Pig breeding was taken up during 1910-II on a larger scale than hitherto, and the bacon export is becoming important.

A law was enacted in $\mathbf{1} 909$ for the protection of natural monuments and the creation of national parks. Extensive areas, mostly in the northern provinces of Sweden (e. g. the neighbourhoods of the great fall Stora Sjöfallet, the Sarjek Mountains, and the tourist station Abisko), have been proclaimed national parks under the supervision of the Royal Academy of Science. Hunting, fishing, building, etc., are gencrally prohibited there.

Industries and Manufactures. - In a country where forests cover half the area it is only natural that the sawmill industry should be the most important. Sawn and planed timber still heads the export list, although the output is slowly decreasing, giving way to the more lucrative wood-pulp industry. The erection of new pulp mills, both for mechanical and chemical (sulphate and sulphite) pulp, continues and the output is now considerable. Until recent years the power of the waterfalls which abound in Sweden was not harnessed, except for water-wheels and small factories. The power obtainable from the waterfalls amounts to between three and four million horse power, but only 100,000 horse power is at present utilized. However, the falls are being developed, and by means of water turbines and electric power stations and a network of electric cables cheap power is supplied for many industrial undertakings. A remarkable instance of the utilization of water power is to be found at Trollhättan, where the famous falls drive many new and important works.

The total output of manufactures from 11,435 factories and mills, not including mines and iron works, for I9I0 aggregated $£ 88,087,000$.

Mining.-The following figures relate to I9II. The total production of iron ore from $27^{8}$ mines amounted to $6,150,718$ metric tons, the largest output on record. The figures for IgIn were $5,549,987$ tons, which were again an increase of $42.90 \%$ on the figures for $\mathrm{I}(\mathrm{g})$. The average value of the iron ore shows a n appreciation of $6.2 \%$. The total number ('mployed in the iron ore industry was $10,46 \mathrm{I}$. Of other ores-chiefly zinc, but also silver, copper and lead $-45,88+$ metric tons were obtained from 30 mines. The production of zinc at the new clectric smelting works at Trollhätan is of special interest, and 2,123,641 kilosrammes, valued at I, 106,958 kronor, were produced by this novel process.

Commerce.- Exports in 1910 reached $£ 32,574,900$ and in 1911 aggregated $f, 36,428,600$. The values of the principal exports and imports for 1910 were: Timber, f9,901,168; wood [m. $),\left\{3,993,4^{82}\right.$; iron and steel, $f 3,795,162$; butter, $f_{2}, 425,956$; iron ore, $f 2,369,521$; paper and cardboard, $f_{1}, 770,753 ;$ machinery and implements, $f_{2}, 209,642 ;$ matches, $f_{65} 1,309$.

()f the total exports, Great I3ritain takes about $32^{\circ} \circ$ and Germany about $21 \%$ \%

Imports for 1910 were valued at $f, 36,902,900$, and for 19 I I $f, 38,241,800$. The value of principal imports in 1910 was: Coal and coke, f3,367,924; grain and flour, $£ 3,020,367$;

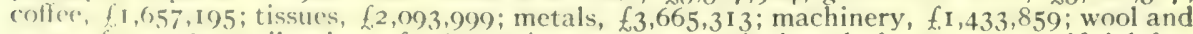
yarn, $\left\{1,250,6,52\right.$; oil cakes, $f 976,83^{8}$; 'cotton yarn and thread $f 1,781,349$; artificial fertilizers, $£ 828,591$; India rubber, $£ 552,55^{8}$.

Of the imports, Germany sends about $35 \frac{1}{2} \%$, and Great Britain $25 \%$.

Finance.-In the I9I3 budget revenue and expenditure were estimated at $\{14,5$ II 500 , as against $f_{1}+1,31,700$ in the 1912 budget. The principal sources of income are customs, income and other taxes, sugar and spirit duties, and railways. The expenditure on the army and nary aggregates $f, 4,5+1,434$, and the other important item is education.

The national debt in Io I I was $f .33,672,009$, as against $f, 29,857,024$ in 1910 . By the end 
of I9II a sum of $\{32,6$ II,III had been sunk in the railways, chiefly obtained by loans. Thus about $96 \%$ of the national debt money has been utilised for railways.

Communications. - The government owns 2,830 miles of the railways, and 5,903 miles belong to private companies. The new "inland line." Ostersund (Jemtland) to Porjus (Lapland) is being pushed forward and the first section, Östersund to Ström (Ångermanland) is finished, as well as the last section, Gellivara to Porjus, where large water-power works are being erected. The second section, from Ström northward, has been started towards the Angerman river. Another important link in the chain of railways has been completed, viz.: the Boden-Morjärv-Lappträsk, which will be extended to Haparanda on the border of Finland. A connecting link between the "inland line" and the central line has been decided upon, viz.: the Sveg-Östersund section. An important project to connect the ports along the Gulf of Bothnia with an East Coast line, from Gefle up to Hernösand, is considered to be financially guaranteed during I9I3. When these lines are completed many lovely parts of northern Sweden will be accessible to the tourist. Even now the Lapland express carries increasing numbers of travellers to the Lapland rivers and lakes and the Abisko tourist station. Work on the electrification of the Kiruna to Riksgränsen (Norwegian frontier) has begun. The power will be obtained from the Porjus electric power station.

The work of deepening and widening the Trollhättan canal has begun and it is estimated that it will be concluded in 1915. The depth will be four metres. The Tisnare canal, extending in all about $\mathbf{1 5}$ miles, and linking together the lakes along the border between Östergötland and Södermanland counties with Lake Tisnaren, was opened in September I912. A new canal, from Nyköping Harbour to the lakes in the county of Södermanland, has been in course of construction during the last few years. The government purchased in 1912 the Södertelje canal, which may be deepened to five metres. The harbours of Stockholm and Gothenburg have been extended, and further developments have been decided upon. Several new harbours for fishing fleets are in course of construction along the West Coast. A new dry dock at Malmö is nearly completed.

As regards telegraphic communication, a Swedish syndicate has applied to the government for a concession to erect a Marconi wireless station in southern Sweden, chiefly intended for communication with a station in Great Britain and transmission thence to America. The authorities however do not favour the granting of a concession to any specific company, but prefer to make the best possible arrangements for wireless with other countries.

Constitution, Government and Administration.-The parliament (Riksdag) consists of two chambers. The electoral reform of 1909 has considerably widened the franchise and introduced a system of proportional representation. Under it the members of the first chamber are now elected for six years, a sixth part of the house being renewed every year. The census of eligibility is lowered to either real property to the value of 50,000 kronor $\left(f_{2}, 750\right)$ or an annual income of 3,000 kronor $\left(f_{1} 65\right)$ on which taxes have been paid. The members receive the same salary as members of the second chamber, $\mathbf{I}, 200$ kronor (f66) per annum. For the elections to the second chamber the country is divided into 56 great electoral districts with 3 to 7 representatives each, all elected proportionally. The former distinction between towns and rural constituencies is abolished. The three greater towns, Stockholm, Gothenburg and Malmö, however, form separate constituencies, and five other towns are aggregated in two constituencies; for the rest, towns and rural constituencies poll together. Eligibility for the lower house necessitates an age of at least 24 years and residence within the constituency. Manhood suffrage is introduced for these elections; fulfilment of military service, however, and payment of rates and taxes for the last three years before the election are required. The whole house is, as formerly, renewed every third year. Even the standing committees of the Riksdag, common to both chambers and with the same number of members from each, are elected by proportional representation. A Supreme Administrative Court (Regeringsrätten) has been established (I 909 ) with a membership of seven justices (regeringsråd). Three members of the Supreme Court of Justice (Hügsta Domstolen) and one member of the Supreme Administrative Court form (since Igro) a separate consultative body (Lagrådet) for giving opinions upon all proposed changes of law. The number of justices in the Supreme Court has been increased from 18 to 24. Jurisdiction in disputed parliamentary elections belongs to the Supreme Administrative Court.

Defence.-A Royal Commission under the personal direction of the Premier and of the ministers of land defence, naval defence and finance, is preparing a drastic reform of the whole defence system. The reservists system (landsstorm) has been reorganised of late, and was tested by a partial mobilisation during the autumn of I9I2.

The navy includes 12 ironclads of 3,100 to 4,270 tons. The building of a larger coast- 
defence cruiser (of 6,800 tons) of the "F" type of warship was decided upon by parliament in 1911 when the Conservatives were in power, but the new Liberal government indicated, shortly after taking office, that they desired to postpone the building of the ship. That this turn of events was not to the liking of the general public was demonstrated in a striking and practical manner by the starting of a private subscription which in less than three months realised fyo6,625. This sum was tendered to, and accepted by, the government, and the building of the warship at a Swedish yard was sanctioned by the Riksdag in May I912.

Educulion. - The public schools for boys have been reorganised and are now divided into two kinds: högre allmänna läroverk (higher public schools) and realskolor (lower public schools, board schools). The latter have only six classes and lead up to examinations (realskole-examen) adapted to the needs of a commercial and industrial life, etc. These six classes are common to the two kinds of schools, and then come the higher public schools, viz., four other classes (gymnasium) with classical and scientific studies, both leading up to student-examen (matriculation examination), an examination for admission to the universities and to several other higher special schools. In certain small towns the "practical schools," or lower public schools, are accessible to children of both sexes, and are then named "boy and girl schools" (samskolor). Generally, however, the higher and middle schools for girls are private, but they often enjoy considerable state aid and are then submitted to special state inspection. In 1909 the number of higher public schools was 38 , and the "practical schools," 77. The school terms comprise 38 weeks in the year. The primary education in the "board schools" (folkskolor) is rapidly developing. "The number of these schools in 1909 was $13,1+6$, with 5,802 male and 13,549 female teachers. Of the children of "school age" (7 to I4 years) 800,684 (or $98.2 \%$ of the whole number) have received instruction; these include 755,197 in the "board schools," 14,380 in higher public schools, 19,566 in private schools, and 8,004 in their homes. Special instruction in gardening and arboriculture was given in I 909 to $96,32 \mathrm{I}$ children; the cost of 784 courses in cookery and domestic economy was defrayed by the state. Instruction in slöjd ("sloyd," manual occupations) was given to 95,070 boys and 170,689 girls in the "board schools," which represents an increase since 1894 of $114 \%$ for boys and $100 \%$ for girls.

Religion. - The Swedish Lutheran Church, comprising more than $99 \%$ of the total population, is provisionally divided into $\mathbf{I} 3$ dioceses which, however, will soon be reduced to 12. Among the dissenters the Methodists and Baptists are most numerous; the Roman (atholics only number about 2,600, and the Jews about 5,000 . Vigorous measures are taken against the Mormon propaganda carried on by American preachers. Interest in religion and the church is increasing remarkably, and has evoked a strong feeling for the careful prescrvation of old church buildings, and for the artistic adornment of the churches. Christian social artivity is also increasing, especially among university students.

Poor Law and Charities. - The burden of maintaining the poor is thrown on the parishes and is, therefore, rather unequally distributed, but a Royal Commission is preparing schemes for a more uniform and practical system of poor relief. In I9Io relief was given to 236,918 persons (90,912 in the towns and I $\$ 6,006$ in rura! districts), i. e. to $4.29 \%$ of the total population. The proportion of paupers varies in the districts between $14.5 \%$ and $0 \%$ (in 8 communes). The number of inhabitants in workhouses, alms-houses or children's homes is 47,204 , all receivers of relief (19.9\% of the whole number); 28,494 (12.1 \%) were boarded out in private house's, and outcloor relief ("home assistance") was given to I $+4,892(61.2 \%$ '). The number of private charitable institutions is great and steadily increasing. A comprehensive sy'stem of sick relief funds has recently been organised by State legislation, and propusals for an Old Age Pension Scheme are being prepared by the government.

Lazi, Justice and Crime. - The latest criminal statistics comprise the five-year period 1901-1905. The number of convicted persons for gross crimes was then yearly, on an average, 2,589 ( 4.9 per $\mathrm{I} 0,(0)$ inhabitants), for lesser crimes 10,345 (I9.8 per I0,000 inhabitants), and for misdemeanour 45,2I I (86.7 per I0,000 inhabitants). No less than $83.8 \%$ of the misclemeanour cases in 1905 consisted of drunkenness and disorderly conduct. The number of prisoners is slowly, but steadily, decreasing; a daily average in the period Igor1005 was $2,95+(2,99) \mathrm{I}$ in the period $1896-1900 ; 3,8+2$ in $1886-90 ; 4,98 \mathrm{I}$ in the period $187 \mathrm{I}-$ 75). Capital punishment is not yet abolished, though the second chamber has more than conce passed resolutions in favour of such a reform. Executions, however, are very rare; nunc took place in the period $190 \mathrm{r}-05$, and since then very few have occurred.

Recent Politics.-After the separation from Norway the Lundeberg Coalition Ministry was succeeded in ()ctuber 1005 by a Liberal Ministry formed by Mr. Karl Statif (b. 1860). His proposals for reform of the franchise being rejected by the Lper House, Mr. Staaff resigned and a new ministry was formed in May Igo6 by the Conservatlive leader, Admiral Lindman (b. 1862). His principal task was to find a solution of the Suftrage ()uestion which both Chambers could accept, and after various compromises his Reform Bill. establishing I'roportional Representation for both Chambers, Universal Manhood Sufirage for the Second ('hamber, and Payment of Members of the 
First Chamber, took final shape in May 1907 and was accepted by both Chambers. Under the Constitution, the Bill could only become law if ratified by the Riksdag after new elections to the Second Chamber, but it was finally passed in 1909, after the elections of 1908 .

The Lindman Ministry was especially eager for practical economic legislation, and during its term of office the Riksdag passed a series of bills for construction of new railways, state purchase of waterfalls, erection of state-owned hydro-electric power stations, etc. The State took over half the shares of the great Kiruna-Gellivara and other mining concerns in Lapland. A thorough-going reform of the income and capital taxation was effected in I910, and industrial development was advanced in various ways.

In I909 a great lockout was followed by a general strike, in August, affecting 285,000 workmen, but the railwaymen and the agricultural labourers did not join, and in September most of the strikers were back at work, the great conflict being finally ended in November. Thanks to the orderly conduct of the workingmen and the firm measures of the Government, order was admirably preserved during the whole conflict.

The General Election of September I9I I, the first since the introduction of Manhood Suffrage and Proportional Representation, was keenly contested and resulted in great successes for the Liberals and Social Democrats (IO2 Liberals, 64 Conservatives, 64 Social Democrats). Mr. Lindman then resigned, Mr. Staaff, the Liberal leader, again becoming Premier (Oct. 7), with Count Albert Ehrensvärd (previously Swedish Minister at Washington) as Foreign Minister. Wishing to gain a sure working majority at the joint sittings of both Chambers on Budget questions on which the Houses were at variance, Mr. Staaff induced the King to dissolve the First Chamber, where the Conservatives had always been in an overwhelming majority. The result of the new elections (Nov.) was a considerable weakening of the Conservative majority in the Upper House (87 Conservatives, 5 I Liberals, 12 Social Democrats).

The chief questions of political interest during the last two years have been the Defence Question and several matters of social legislation. A great scheme of National Insurance and Old Age Pensions is being prepared, the sick relief fund law has been reformed, and several bills for improving the Factory Laws have been passed. The Women's Suffrage Question has been keenly discussed on the platform and in the Riksdag; bills purporting to grant the suffrage to women on the same terms as to men have more than once passed the Second Chamber, but have then been invariably rejected by the Upper House. The creation of Small Holdings is generally recognised to be of great national importance, but opinions differ widely as to the best system of tenure, and violent dissensions have arisen in regard to the respective rights of the State on the one hand and the private occupiers or owners on the other to utilise the waterfalls for generating electric power for industrial enterprises.

Obituary. - The deaths may be noted of:-Rear-Admiral Theodor SANDSTROM (b. ${ }_{853}$; d. Feb. 6, I9I I); Alfred Elis Tornebohm (b. I838; d. Ap. 2 I, I9I I), the geologist (see $E$. $B$. xix, 8or b; xiv, 8 Io a); Johan SeVErin SvendSen (b. I840; d. June I4, I9II), the famous composer (see E. B. xxvi, I75); Christian Lundeberg (b. I842; d. Nov. il, igi i), the statesman who, as premier, conducted the negotiations for the separation from Norway in I905; and August Strindberg (b. 1849; d. May I4, I912), the famous author (see $E$. $B$. xxv, 1038 ).

(VERner SöDERBERG; Louis Zettersten.)

\section{SWITZERLAND ${ }^{1}$}

Population.-The provisional results of the census taken on December $\mathrm{r}$, Igro SuOW that the resident population of Switzerland on that day was 3,74I,97 I as against $3,315,443$ in 1900 , an increase of 426,528 . The details of the 22 Cantons are as follows: Aargau, 229,850; Appenzéll, 72,354; Basel, 211,787 ; Bern, 642,744; Fribourg, I39,200; Gall, St., 30I,I4I; Geneva, I 54,I59; Glarus, 33,2 I I; Graubünden, II8,262; Lucerne, I66,782; Neuchâtel, I32,I84; Schaffhausen, 45,943; Schwyz, 58,347; Soleure, I 16,728; Thurgau, I34,055; Ticino, I 58,556; Unterwalden, 30,014; Uri, 22,055; Valais, I 29,579; Vaud, 3I5,428; Zug, 28, OI3; and Zürich, 500,679. In the rural districts the

1 See $E . B$. xxvi, 239 et seq. 
rate of advance as regards the chief towns is stationary, while in the purely agricultural or pastoral communes a considerable decrease is to be noted. But the larger towns have all very much more numerous populations than in 1900 . So Zürich has advanced to $198,0,30$ (from 150,703 ) and hopes soon to reach the figure 200,000 ; Basel to I 35,163 (from 100,I6I), Geneva to I25,550 (from 104,796), Bern to 85,095 (from 64,227), and Lausanne to 64,142 (from 46,732). No other Swiss town has more than 40,000 inhabitants, though" Great St. Gall" (when the fusion of St. Gall with the neighbouring communes of Tablat and Straubenzell is effected) will (on the results of I9Io) number 75,105 souls, and so rank as the $5^{\text {th }}$ most populous town in Switzerland.

The most striking feature of the census of I9IO, however, is the great increase in the number of the non-Swiss residents in Switzerland, which has risen to $56_{5}, 296$ or about $I_{5}$ per cent (as against 383,424 or $\times 2$ per cent in 1900 ). The influx is all but wholly made up of members of the working class from Germany, France, and Italy, secking better wages and freedom from compulsory military service. Naturally it is the great towns, and especially those near the frontier, which contain the vast majority of these foreigners, though many Italian navvies and masons are employed on the construction of new lines of railway. 'The matter has caused much discussion in Switzerland, for it is of importance from the point of view of the Poor Law and of the Army. But, quite apart from the various international treaties by which foreign powers have secured the rights of their subjects, there are many objections to the compulsory naturalisation of these non-Swiss, even though this be limited to children born in the country, but of foreign parentage. The chief objection perhaps is that, as Swiss and Cantonal citizenship can only be obtained by previous admittance as a member of a commune, the communes have the last word and in many cases are not desirous of increasing the number of those entitled to use the communal property (pastures, \&c), and so ask prohibitory entrance fees. Further, even if the fees were made lower by law or if the poorer communes should charge lower fees, so small a proportion of native-born Swiss inhabit their commune of birth (only $38 \frac{1}{2}$ per cent in I 000 , and probably not over 30 per cent now), that the connection of the new burghers with the communes of which they became members would be simply a paper bond, though those communes might be put to heavy charges in case these new burghers came under the provisions of the Poor Law. The same would be the case with the domicile of the newly naturalised. The creation of a new status of Swiss citizenship (apart from ('antonal or Communal burghership) has been proposed, but such a course would involve difficulties not only with the communes but with the cantons as well. It has been found too, in practice, that the lowering of the entrance fees has not attracted a great proportion of the foreigners resident in Switzerland, many of whom are there for political reasons, while many Swiss employers prefer to employ foreign workmen at lower wages (being not liable to be called out to do military service) rather than to have only Swiss workmen. Such difficulties, however, are part of the price which Switzerland pays for its international position, which in itself is productive of great benefit.

Agriculture.-On April 2I, I9II a new census was taken of the cattle of all kinds in Switzerland, the number being $1,254,950$ as against $1,497,904$ in 1906 . Every eategory has dereased in number, save cows and bullecks, which show a slight increase. This striking derrease is 0 be accounted for in part by the rise in the price of milk, due to the preference of the peasants for prorlucing that article (largely for export in a condensed form or as cheese) rather than for cattle breeding, so that the native supply of meat does not keep pace with the rise in the population and the consequent greater demand. It is said indeed that the native meat supply is now but ${ }_{3}^{2}$ of the quantity demanded. But as the import of live cattle is hinderel by the danger of bringing in infectious diseases, while Germany and France do mot lonk with favour on the passigge of live stock through their respective territories, the import of clead meat has now greatly exceeded that of live stock. But here comes in a further difficulty, the high figure of the import duties on dead meat. The situation has become so awkward that the Federal (jovernment has had to consent to a (provisional) lowering of the duties so ats to enable frozen meat from the Argentine to be brought in, this being sold at a cheaper price; naturally this policy does not approve itself to the peasants or butchers, but has become almost a necessity, owing to the gencral rise in prices. 
Commerce. - The new Customs Tariff of 1906 resulted at first in a considerable unfavourable balance of trade, followed by an increase in 1907, and a new decrease in 1908. But from 1909 onwards Switzerland has shared in the prosperity of international trade throughout Europe. In 19 Io the value of her exports was about $f 47,832,000$ and in I9II about $£ 50,280,000$, while in 19 Io her imports were about $£ 69,800,000$ and in I9 I I about $£ 72,812$, 000 , so that the excess of imports rose from $£ 2,288,000$ in 1910 to $£ 2,448,000$ in I9II. This was due to the value of the increased imports of meat, oats, and other food stuffs. The fall of $£ 520,000$ in the imports in 19 I I from Great Britain was exactly balanced by an equivalent in exports thither. Great Britain was in I9I I the best customer of Switzerland next after Germany, though behind Germany, France, Italy, and Austria-Hungary as regards the value of the goods imported into Switzerland.

Finance.-During 1902 to 1907 there was always a balance on the right side of the Public Accounts, this balance rising as high as $£ 503,000$ in 1905 . But 1908 and 1909 both showed deficits. However, in I9I0 there was again a surplus of $f 22 \mathrm{I}, 000$ (the receipts amounting to $£ 6,674,000$ as against an expenditure of $£ 6,453,000$ ). But in I9I I there was again a deficit, though only of some $£ 10$,ooo, the receipts being $£ 7,838$, 000 as against an expenditure of $f 7,848,000$. With the exception of about $£ 500,000$ annually the receipts of the Federal Treasury are derived from three main sources-Customs Duties, Post Office, Telegraph and Telephone. But in these cases the Customs Duties alone show a constant great surplus, so that they form the backbone of Federal finance. In I908 these Customs Duties were $f 2,810,000$ (a slight falling off on the yield of 1907 ), but in 1909 amounted to $£ 2,970,000$, in 1910 to $£ 3,320,000$, and in I9II to $£ 3,230,000$; the budget estimate for I9I 2 was only $f_{3}$, I9I, 00o, but for 1913 rose to $£ 3,3$ I2, ooo. Swiss statesmen are rather uneasy at the fact that Federal finances depend so largely on a single source of revenue always uncertain, and rendered still more uncertain by the approaching expiration of the tariff treaties. Besides, the expenditure is always increasing, especially for the Army $\left(f_{1}, 690,000\right.$ in 1910 , and $f_{1}, 790,000$ in 1911$)$, the incessant demand for Federal subventions and the as yet unknown expenses of working the new Insurance Law. In I9I I the funded debt of the Swiss Confederation was $£ 4,686$, ooo.

In I9II (Jan. I) the Swiss army numbered 211,567 men, of whom 69,513 were in the Landwehr, and 142,054 in the Auszug. In I910 27,487 young men presented themselves as recruits, 19,460 of whom were "passed," the proportion (70 per cent) being the same as in 1909 , and higher than was the case before the regulations of 1905 (1905, 53 per cent, I906, 55 per cent, 1907,62 per cent, and 1908,67 per cent).

Politics.-The triennial elections for the popularly elected house (the Nationalrath or Conseil National) of the Swiss Parliament took place in the autumn of I9I I, and resulted (as has always been the case since the Federal Constitution came into force in 1848) in giving an overwhelming majority to the Radicals. In consequence of the new census the number of members (one for every 20,000 or fraction over 10,000 of the population, native born or foreigners) was increased from I67 to 189 ; of these I 4 are Radicals, 38 Conservatives, I6 Social Democrats, I4 Centre (Liberal Conservative) and 7 Socialists.

Edward Müller, of Bern (b. I848), colonel in the army, was elected the new President of the Confederation on Dec. I2, I912, by 184 votes out of 196 ; and Arthur Hoffmann, of St. Gall (b. I857), also a colonel, was elected Vice-President. Both are Radicals in politics.

In I909-I9I2 there were two cases of a popular Vote or Referendum, though in neither case one affecting the Federal Constitution. In I9Io a proposal (Initiative) to introduce proportional representation into the elections for the Nationalrath was defeated, though only by a majority of some 25,000 on a total poll of rather over 500,000 voters, while early in I9I 2 the Federal law as to insurance against sickness and accidents was accepted by a majority of some 46,000 votes on a poll of 528,000 . Including 3 popular votes in 1908 (all affirmative), 2 being Amendments to the Constitution and I an Initiative prohibiting the manufacture or sale of absinthe, the statistics as to the Federal Referendum from 1874 to the end of I9I 2 stand at 20 as to Constitutional Amendments ( 44 accepted), 8 "Initiatives " ( 3 only accepted), and $3 \mathrm{I}$ as to Federal laws (I 2 accepted) - in all 59 polls of which 29 only were in the affirmative.

Despite the check to proportional representation suffered through the defeat of the Federal Referendum in I9IO, it was accepted for cantonal legislatures by Lucerne (Igog) and St. Gall (I9II), though rejected in Igr I by Zürich. But 9 cantons have now adopted this plan (in I891 Neuchâtel and Ticino, in I892 Geneva, in I894 Zug, 
in 1895 Soleure, in 1900 Schwyz, in 1905 Basel-Stadt, in I909 Lucerne and in I9I I St. Gall); in general the Radicals oppose it and the Conservatives support it.

The number of the members of the Federal Tribunal was raised in I91 2 from I9 to 24 , in view of the great increase of business expected on the coming into force (Jan. I, I I I ) of the Federal Civil Code. It has also been proposed to increase that of the Federal Executive (Bundesrath or Conseil Fédéral) from 7 to 9 or more, and also to appoint a permanent head of the Political Department (practically a Minister of Foreign Affairs), but neither change has yet been adopted; both proposals are due to the increase of routine business which hinders departmental work, and to the fact that the President elected any given year may not be skilled in foreign affairs. On the other hand in I9I I-I 2 the Federal Council was greatly altered as to its personnel, owing to the death of 4 and retirement of $\mathrm{I}$ of its members, so that 5 new members were elected in I9II-I2, the two seniors having been chosen in 1895 and 1902 respectively. Three of the present members were born between 1845 and 1850 , I in 1857,2 in 1862 and $\mathrm{I} 868$, and the junior as recently as $\mathrm{I} 87 \mathrm{I}$. This junior member (Motta, of Ticino) is also interesting as he replaces the single Roman Catholic Conservative on the Council, one only having been elected from $189 \mathrm{r}$ onwards, though between $\mathrm{r} 848$ and $\mathbf{1} 89 \mathrm{r}$ no member of that shade of opinion was ever chosen. Up to November I9I 243 Federal Councillors had been chosen since 1848 , Vaud having had 8 , Zürich 6 , Bern and Neuchâtel 4 each. Zürich and Bern have had one continuously. But the following 8 cantons have never had a representative on the Federal Council - Uri, Schwyz, Unterwalden, Fribourg, Valais, Schaffhausen, Appenzell, and Zug. It is worthy of note that only one Federal Councillor has failed to be re-elected at the triennial election by the two houses of the Federal Legislature sitting in Congress - this was Challet-Venel in 1873 .

Another scheme for relieving the Federal authorities is the creation of an Administrative Court, which will decide administrative disputes, without troubling the higher powers.

By a decree of the Federal Council (June 23, I0II) the official name of the great Federal Polytechnic School (at Zürich) is to be henceforth "Federal Technical University" - this is to avoid the ordinary sense of "polytechnic" in Germany, where it is used of technical intermediate schools.

The chief event in the international relations of Switzerland in 1009-19r2 was the so-called "Gotthard Convention." The railway was purchased by the Swiss Confederation in virtue of the popular vote in 1898 , but this purchase only took effect on May r, rgog. The two great Powers which granted large subventions towards its construction, Germany and Italy, maintained that this purchase could not be effected without their consent, which would only be given on certain conditions, to which the Swiss statesmen consented by a Convention dated October 13, I000, and to come into force on May I, Ioro. As soon as the text was made known it was seen that the Swiss negotiators had granted very large concessions to the two Powers named, esperially the stipulation that, in case of the transit of persons and goods through Switzerland from or to either of the two countries named, Switzerland was bound to allow to the (ierman and Italian railway lines all advantages or reductions which should at any time be given to the Swiss State Railways (arts. 7-8), the fixing of the Transit dues without possibility of alteration (art. II) and the special reduction in favour of (iermany and Italy of the extra dues on the mountain bits of the St. Gotthard line (art. 12). 'The last named concessions mean a heavy financial loss to the Swiss State Railways, while the other provisions give the two Powers a sort of control over the Swiss Statle Railways, and so seem to infringe the sovereignty of Switzerland. This Convention has been ratified by the (ierman Diet (March I, InIo) and by the Italian Parliament (June Iог2) but was still unadopted by the Swiss Federal Assembly in November Io12. A strong agitation has taken place in Switzerland against it, a petition signed by i 6,000 citizens being presented (May I, I0I I) to the Federal Assembly.

The most important event in the domestic history of Switzerland during I909-1912 was the acceptance (Feb. 4, I9I2), by popular vote, of the Federal law estab- 
lishing insurance against sickness and accidents; it was carried by a majority of 46,000 only on a poll of 528,000 in the face of strong resistance on the part of the foreign insurance companies, who saw their business being taken away.

The following is an outline of some of its chief provisions: ( $\mathrm{r}$ ) only certain trades and occupations are included under its compulsory provisions, railway and steamer employés, factory operatives and artisans or mechanics. Other classes of workmen or workwomen (such as servants, hotel employés and agricultural labeurers) are not subject to these compulsory provisions, for they are protected by another law, by which the employer is responsible for his employés, save in the case when he prefers to insure them himself. (2) The Confederation is responsible for insurance against accidents only. In the case of insurance against sickness the matter is in the hands of the existing Friendly Societies, if they bring their statutes into accordance with this new law. But any canton or "commune" can enact that insurance against sickness shall be compulsory within its jurisdiction. (3) In the case of insurance against sickness the scale of contributions payable by the Confederation to the Friendly Societies is as follows for each person insured (whether compulsorily or of his free will, whether male or female, whether a native born Swiss or a foreigner): children up to and including I 4 years of age, and also men, $3 \frac{1}{2}$ frs. per annum, and women (including childbed benefits) 4 frs. per annum. If, however, a Friendly Society makes a larger contribution than its statutes require, the Confederation can (not must) also make a larger contributory grant. In the special case of dwellers in mountain regions an extra grant up to $7 \mathrm{frs}$. a head is made, over and above the sums given above. In the case of insurance against accidents the law distinguishes between accidents arising in the course of the workman's employment (then the Confederation pays $\frac{1}{8}$ and the employer $\frac{7}{8}$ ) or not in the course of his employment (here the workman must himself pay the premiums, but the Confederation contributes $\frac{1}{4}$ of the amount). (4) The benefits in the case of insurance against sickness are payment of the doctor's and apothecary's fees (the insured having the right of free choice of both doctor and apothecary), as well as a sick allowance of at least I fr. a day. Lying-in women, who suckle their own babies during Io weeks have a right to a grant of at least $20 \mathrm{frs}$. but no payment is made in respect to sick children under the age of I4. In the case of insurance against accidents, widows and orphans, on the death of the bread-winner by accident, receive a pension up to 60 per cent of the amount of the wages formerly received by him, in addition to a grant of $40 \mathrm{frs}$. for funeral expenses. If the injured person is totally incapacitated the grant amounts to from 70 to Ioo per cent of the wages formerly received; if only temporarily incapacitated, the ordinary wages are given as from the third day after the accident. The trades are graded according to their dangerous character, and in this class of trade the premiums are higher.

All native Swiss workmen are entitled to these benefits and also foreign workmen residing in Switzerland, provided their country grants Swiss residents there similar benefits (if not, the pensions are paid on a reduced scale and a lump sum given on leaving Switzerland). The date at which this law comes into force was not definitively settled, as much previous preparatory work has to be done. But it is supposed that the sickness part would be put into operation in the course of 1913 and the accident part probably in 1914.

Swiss Cantons.-Mention has been made above of some important events in several cantons, and, with an allusion to the great strike in the town of Zürich (summer of I912), where the Socialists are acquining more and more power, we may limit our attention to two other great cantons.

Basel.--In I9Io the separation of State and Church was here carried out. The number of the Romanists rose from about 5000 in 1850 to some $4 \mathrm{I}, 000$ in 1910 , thus forming about $\frac{1}{3}$ of the population of the town. But they were unable to obtain favourable terms from the State, the pretext being that their regulations did not allow them to permit their priests to be elected by their parishioners, and that they could not submit their internal regulations for the approval of the State. The Old Catholics (4,500 in I9IO) accepted these conditions, and so obtained a church in full ownership, a lump sum of $f 6,000$ and recognition (like the Protestants) as a "public corporation." The Romanists and the Jews are now only "private corporations" in Basel; the former received the provisional right of user of a church and a lump sum of $£ 8,000$, while the Jews (2397 in 1910$)$, the richest of all these religious communities, were awarded the derisory lump sum of $f 600$.

Geneva. - In I9I0 the electors of the now disestablished Protestant Church decided that women should have a vote in all ecclesiastical matters. In the same year a new Art and History Museum was opened, wherein many scattered collections have been brought together. But the chief event in recent Genevese history relates to its main (or Cornavin) railway station. This, like the line from the town to the French frontier, belonged to the French Paris, Lyons and Mediterranean Railway Company, an obviously anomalous state of things. The result of many deliberations was a final arrangement on March 23, 1912 - it was approved by the Federal Assembly in July, 1912-as between the three parties; the Cornavin railway station, with the line to the French frontier, was ceded (against a considerable 
sum of money) by the French Company to the canton of Ceneva, which passed them over on the same conditions to the Swiss State Railways. This arrangement was to take effect on January 1, 1913, but the French Railway Company (against payment) was to have the right of joint user of the Cornavin station and to pay half the expenses of its upkeep. On the other hand the scheme for the connecting ("raccordement") of the Cornavin station with the Eaux Vives station (for P.L.M. lines to Chamonix and Savoy); $6 \frac{1}{2}$ miles distant, but involving bridges over the Rhone and the Arve, was to be carried out at the joint expense (estimated at nearly I million sterling) of the Confederation $\left(\frac{2}{3}\right)$ and of the canton of Geneva.

According to the Federal census of 1910 , the town of Geneva numbered 57,519 foreigners among its inhabitants, while the native-born Genevese were only 3,63I more than the Swiss from other cantons.

Bibliography, Igog-I9I2. The 4 th Vol. (I648-I798) of J. Dierauer's authoritative Geschichte der schweiz. Eidgenossenschaft appeared at Gotha in 1912, thus worthily completing this great work. In 19 IO IV. Oechsli published at Zürich a new edition of his excellent Quellenbuch. W. Kaustein's Die schweiz. Halbkantone, ihre Entstehung und Rechtsstellung (7ürich, I912) is important for the earlier constitutional history of Switzerland, as is J. Schollenberger's Die schweizerische Eidgenossenschaft von 1874 bis auf die Gegenwart (Berlin, I9IO), a continuation of his Die Schweiz seit 1848 (Berlin, I908) for later times, which are also illustrated in J. Winiger's life of Josef Zemp, I 834-1908 (Lucerne, I910). Very early Swiss history is represented by A. Schenk, La Suisse Préhistorique (Lausanne, I912), by P. E. Martin, Etudes critiques sur la Suisse à l'époque Mérovingienne, 554-715 (Geneva, I910), and by M. Besson, L'Art barbare dans l'ancien diocèse de Lausanne (Lausanne, 1909). A popularly written Swiss history is L. Suter's Schweizer Geschichte für Schule und Haus (Einsiedeln, 1912).

Obituary.-JEAN Henri DUNANT, a well-known writer (b. 1828), died on the 3oth of October, I910; his book Un Souvenir de Solferino (1862) led to the Geneva convention! of I864 and the founding of the Red Cross Society.-ArThur DE Claparine (b. 1852), who died on December I3, I9II, was a leading Swiss geographer, who since 1887 had been several times president of the Geographical Society of Geneva, and also presided over the International Congress of Geography there.-Françors AlPhONSE Forel, the physician and physiographer (b. 18+1), died at Morges, on the 7th of August, 1912; he was the inventor of Forel's xanthometer used in oceanography (see E. B. xix, 980), and (with Prof. Rossi) of a seismic scale (see E. B. viii, 8I8) for measuring earthquake shocks; he wrote an authoritative work on the Lake of (ieneva (see E. B. xi, 593), and also on limnology generally (IItandbuch der Seenkunde), our present knowledge of "seiches" being almost wholly due to him.

(W. A. B. COOlidge.)

\section{The Alps. ${ }^{1}$}

A number of new mountain railways have been opened recently in the Alps. Some lead to the summits of peaks, e.g. the Niesen, 7,763 ft. (Group 6), opened in I9ro, and the Monte Mottarone, 4,892 ft. (Group 7) near Stresa, opened in I9 I I, as was also that up the Monte Brè, 3,06r ft. (Group 6) near Lugano. Some lines lead over mountain passes, e.g. the Bernina Pass, $7,645 \mathrm{ft}$. (Group ro), opened in instalments between roos and 1910 , and the Jaufen Pass, 6,870 ft. (Group I5), opened in I9I ; but that (opened InI2) up to the Jungfraujoch, I I, $385 \mathrm{ft}$. (Group 6), leads only on the Bernese sirle up to the summit of the pass, where is now the loftiest railway station in the Alps. The electric line over the Seefeld or Scharnitz Pass $(3,874 \mathrm{ft}$., Group I3) from Innsbruck by Zirl and Partenkirchen to Reutte was also opened in Ior 2 - it connects the Tirol with Bavaria. It was expected that the Lötschberg line would be opened in Ior.3 in all its length from Frutigen to Brieg, but it passes below the Lötschen Pass, $8,8,42 \mathrm{ft}$. (Group 6). The piercing of the main tunnel was completed on March 31 , I() I I.

Among carriage roads below passes that of the Col du Parpaillon, 9, I93 ft. (Group

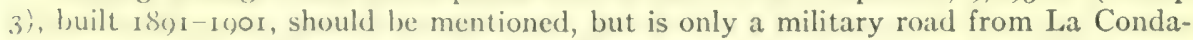
mine, on the col de l'Argentière roarl, to Embrun, and is not well kept up. This road is the second highest in the $\mathrm{Al}_{\text {pes }}$ (next after that over the Stelvio, 0,055 ft.); the tunnel is at a height of $8,557 \mathrm{ft}$. (the pass is $0,103 \mathrm{ft}$.), while the tunnel beneath the Col du Calibier, 8, $72 \mathrm{I} \mathrm{ft}$. (Group 3), is pierced at an elevation of 8,366 ft. only.

It is proposed to instal two wireless telegraph stations on two Alpine summits the Säntis ( $8,216 \mathrm{ft}$., (iroup 9) and the Zugspitze (9,738 ft., Group 13), on the watershed between Tirol and Bavaria.

(W. A. B. COOLIDGE.)

${ }^{1}$ See E. B. i, 737 et seq. 


\section{TURKEY 1}

The population of the Turkish Empire was estimated in Igr I at $25,926,000$. In spite of the difficulties and the unrest following the revolution of 1908 , considerable progress was made up to I $9 \mathrm{I} 2$ in the economic development of the country. The custom house returns showed that Turkey was buying more all round, the railways showed increased earnings, labour was in increased demand and at higher wages. Sir Adam Block, the representative of the British and Dutch bondholders on the Council of the Public Debt Administration, in his report for IgIr said: "What the future may bring no one at this moment can venture to predict, but Turkey must be given the credit of having during the last three years made a serious and determined effort to remodel and reorganize the finances on a sound, if still imperfect basis."

In introducing before parliament in July I 9 I 2 the budget for $\mathrm{I} 9 \mathrm{I} 2-\mathrm{I} 3$ the minister of finance showed that, although the expenditure had increased, the revenue had also improved. He also observed that the customs revenue had not been affected by the war with Italy, which, at that time, had lasted for Io months. He announced that he would shortly introduce a bill for the regulation of the Floating Debt, and another for the creation of a state monopoly on tobacco. As the chamber was dissolved soon afterwards, these bills, as well as the projected monetary reform, remained in abeyance. Other important bills before the chamber which had to be postponed were a new commercial code, and an amended law on real property.

Finance.-Expenditure was estimated in 19 ro-11 at $£ 28,945,000$, and in $191 \mathrm{I}-\mathrm{I} 2$ at $f 31,784,000$; revenue at $£ 22,820,000$ in $1910-11$, and at $£ 24,980$,000 in I9I I-12; the budget showing deficits of $£ 6,125,000$ in I9I0-II, and $£ 6,804,000$ in I9II-I2. For I9I0-I I the revenue exceeded the estimate by about $£_{1} I, 800,000$. For 19 II I-I 2 an extraordinary expenditure for the Army and for public works amounting to $\{2,365$,000 had to be added to the deficit. For I9I I-12 the principal heads of expenditure were: Public Debt, $f_{10}, 379,000$; War, $f_{7}, 895,000$; Gendarmerie, $f_{1}, 525,000$; Marine, $f_{1}, 476,000$; Interior, $f_{1}, \mathbf{I} 89,000$; Finance, $£ 2,505,000$; and Public Works and Commerce, $f_{1}, 363,000$. The principal sources of revenue were: Tithes, $f 6,040,000$; Sheep Tax, $£_{1}, 7$ I 7 ,000; Customs Dues, $£_{4}, 1_{23}, 000$; Land Tax, $£ 2,340,000$; Salt Monopoly, $£_{1}, 026,000 ;$ Annuity from Tobacco Régie, $£ 910,000$; and Military Exemption Tax, $£ 895,000$.

The outstanding debt on September I4, I9I I, amounted to $f_{\text {III }}, 655,674$. There were also authorized loans to the amount of $f_{10}, 526,400$, which had not been issued up to the end of I9II. A reorganization of the Turkish custom-house was undertaken by Sir Richard Crawford in January I909. The customs receipts for I I I I-I 2 had increased by 26 per cent since 1908. The Turkish Government obtained the consent of the British Government for a renewal of the loan of Sir Richard Crawford's services for a further term of two years beginning January 1912, and created for him the post of financial and economical adviser of the empire in addition to his post at the custom-house.

Army. - The reorganisation of the Turkish army during these years was actively carricd on, but the new recruiting law by which the obligation of military service was extended to non-Mahommedans encountered many difficulties. Many of the non-Mahommedans preferred to pay the exemption tax, while a great number of young men emigrated in order to avoid the law altogether. The army consisted of the Nizam or active army, the Ist and 2 d class Redifs, and the Mustahfiz or Landsturm; service being in the Nizam for 3 years (20-22) with the colours and 6 in the Irhtiat (reserve), then 9 years in the Redif and 2 in the Mustahfiz. The Nizam was increased to 14 army corps and 6 independent divisions. With the exception of 4 army corps with two divisions, all the others were organized in three divisions, a Turkish division being composed of 7 battalions in peace and of 10 in war time. The empire was divided into 7 military districts or "inspections" of unequal size and importance. The headquarters of these districts and the number of army corps each district contains were as follows: Constantinople I, Adrianople 3, Salonika 3, Erzingan 3, Damascus 1, Bagdad 2, and Sana I. The independent divisions were: one in Tripoli (Africa), one in the Hejaz, and three in the district of Salonika. An addition to the cavalry was formed by the organisation of the light cavalry called the Hamidieh, recruited from the Kurds in Asia Minor. The object of this addition was to utilise the valuable military material supplied by these tribes. It was proposed to create 65 regiments of this light cavalry, each regiment composed as far as possible of men of the same tribe. The command of each regiment was entrusted to an officer of the regular army assisted by a thief of the tribe, and some of the other officers were also natives. Up to October 191224 such regiments had been created. It was proposed to form 22 companies of frontier guards, composed of 200 men each and formed from vol-

See E. B. xxvii, 426 et seq. 
unteers who had completed their military service. These guards were to be located along the European frontiers of the empire.

The artillery was reorganised, with $35^{\circ}$ batteries of field artillery and 152 companies of fortress artillery. The greater part of the infantry was armed with Mauser magazine rifles, model 1890 , and the artillery was provided with quick-firing Krupp guns.

The war minister alone was made responsible in Turkey for the administration and efficiency of the army. The master-general of the ordnance, who was responsible for war material and who was formerly independent, was put under the war minister. A General Staff department was created and a Military Council established.

The approximate peace effective of the army in $1911-12$ was about 230,000 men. The Nizam war strength was reckoned at 600,000 . With the addition of the Redifs and all other reserves, it was reckoned that the number could be brought up to I, 400,000.

A large force of gendarmerie was also employed, amounting to about 42,000 men, I6,000 mounted; II,000 being stationed in European Turkey. The gendarmerie in the European provinces was provided with several foreign officers-British, French, Italian, etc.-whose services were loaned to Turkey by the respective Governments.

Navy.-The reorganisation of the navy was supervised by two British admirals assisted by a staff of British officers. In October 1912 it consisted of 7 battleships, 4 being small and obsolete, and three of 10,000 tons displacement each (two of the latter were formerly German battleships, launched in 1891 and bought by Turkey in 1910), together with 2 cruisers of 3.800 tons displacement each, 8 destroyers, I 4 torpedo boats, 15 gunboats, and 2 submarines. There were building 2 Drealnoughts of 23,000 tons, equipped with the latest armament, one cruiser, nine destroyers, and a number of submarines. The personnel of the navy was given at about 30,000 men. Naval bases were projected at Salonica and Smyrna, and it was also intended to build a naval harbour at Constantinople.

Minerals.- The Turkish Empire is rich in minerals, and since 1908 a great deal of prosperting has taken place, many claims being filed with the ministry of mines, but little work has actually been done. The value of the total production of the mines amounted in 1908 to $£ I, 00 I, 000$, and the value of the salt extracted amounted to $f I, 229,000$.

Agriculture.-Approximate yields in cwts. of cereals in I9I I : Wheat 30-34,000,000; Barley 22-24,000,000; Maize 20-22,000,000; Rye I0-12,000,000; Oats 9-I 1,000,000. In I9I I the production of silk cocoons amounted to 3,431 , 000 lbs., and that of opium to 2500 boxes. Tobacco is an important crop, and $69,822,834 \mathrm{lbs}$. were exported in I9Io.

Railways. - The original concession granted to the Bagdad Railway Company in 1903 was modified by a series of agreements concluded with the Turkish government in March I()11. In virtue of these agreements the company renounced its right to build beyond Baglad, on the condition that, if the railway were extended from Bagdad to the Persian (iult, the Bagdad Railway Company should have as large a share in the extension as that held by any one non-Ottoman nationality. The company also renounced its lien on revenue to be derived from an increase in the import duties as security for its kilometric guarantees. In return for this cession of its original rights, the company obtained the right to build a branch line from a point near Osmanich to Alexandretta, and a concession for the construction of a port at Alexandretta. It also obtained the right to build a wharf at Payas in connection with the Osmanich-Alexandretta line. This concession was valuable on account of the extremely favourable position of Alexandretta. Work had already started in 1912 both on the harbour and on the railway. The value of the trade passing through Alexandretta has been: imports, $\ell_{2,226,395}$ (I909); $f_{1}, 398,884$ (I910); $£_{1}, 145,135$ (I9II); exports, $£ 1,308,607$ (1909); $\{1,301,025$ (I910); $\{1,044,324$ (1911).

A section of about 150 mile's of the Bagdad line, starting from railhead at Bulgurlu and reaching to the Amanus Mountains is opened for traffic, passing through Bozanti, Dorak and Aclana. There is a station at Aleppo and a line from it to Muslamich (15 kil.) which is continuous with the French line from Aleppo to Hamah and Rayak. At Muslamieh is the junction with the main line from the west. This has now been laid from the eastern end of the Bagrehe Pass (Mt. Amanus) to the Euphrates at Jerablus, where a bridge over the river (now building) is to carry the line on to Harran, Tell Helif, and Mosul. In consequence Alepp' ${ }^{\prime}$ has acquired an acression of Christian inhabitants and new buildings of European character, e. g. Crerman Hospital, Shools and Casino. Construction has been going on from Aleppo in two directions, towards the Amanus Mountains and towards the Euphrates, and a section of 100 miles was expected to be opened for traffic in the early part of 1913. The last section of this railway, namely from Tell Helif to Bagdad, was started in the middle of 1912, construction beginning at Bagdad. The site of the Bagdad railway station has definitely been chrsen on the right bank of the Tigris, and the scheme provides for the construction of a harbour and a custom house.

1 The Saracenic wall has been largely destroyed on the north and east sides of the old city. Since the promuluation of the constitition and the death of Ibrahim Pasha, the rebellious chicf of the Milli Kurds (1909), the province of Aleppo has been tranquil; but the feudial beys and mukhters, whose power has been an institution of N. Syria for many generations, continue hostile to the new order of things. 
The following new railways had been opened, or were in course of construction or had been surveyed, between 1909 and October 1912, in European Turkey: Baba Eski-Kirk Kilisseh, 30 miles, opened (concession granted to the Oriental Company); Monastir-OchridaIannina-Adriatic Sea; Monastir-Istib-Bulgarian frontier; Prizren-Scutari-Adriatic Sea, and the construction of a harbour at Medua; and Uskub-Kalkandele-Gostivar. In Turkey in Asia, besides the work going on in connection with the Bagdad Railway, the following was the state of affairs in October 1912 as regards the principal lines. Tripoli-Homs, in Syria, 65 miles, opened. Soma-Panderma, 120 miles, expected to be opened in 1913; the concession for building this line was granted to the Smyrna-Kassaba Railway Company, and it would establish a connection between the Sea of Marmora and the main line of this company. Ada Bazar-Bolu, Ioo miles, building; concession granted to the Haidar Pasha-Angora Railway Company. Hodeida-Sana, 190 miles, building. Medina-Mecca-Jedda, building by the Hejaz Railway Company. Samsun-Sivas-Erzingan-Erzerum-Trebizond, about I,200 miles; building by the Turkish government. The building of this line has been proceeding very slowly, not only on account of financial difficulties, but also for political reasons. Russia raised objections in virtue of the Black Sea Basin agreement reserving to Russia the sole right of building railways in the northern portion of Asia Minor. The exact interpretation of this agreement was in 1912 a matter of controversy between the two governments.

Among other projects open in 1912 for construction of railways may be mentioned the offer made by an American syndicate (known as the Chester scheme) to build about 1,250 miles of railways in Asia Minor in return for the grant of mining rights in the regions traversed by the railway. The Turkish government, however, had made no decision in the matter. Surveys were being made by English engineers for a railway between Jaffa and Egypt.

The State paid in $1910 £ 572,400$ as kilometric guarantees to the railway companies.

All the railways showed substantial increases both in gross and net profits during I9I I. On the main line of the Haidar Pasha-Angora Railway Company the takings in I9I I exceeded the kilometric guarantee for the first time in the history of the line, and the government in consequence received $f_{1} 3,000$ as its share.

Roads.-A programme of extensive road-building was undertaken after the instalment of the new régime. In I9IO a concession was granted to a French company to build about 6,000 miles of new roads in various parts of the empire, the work to be completed in I9I2 at a cost of about $£_{2}, 000,000$. But both the mileage and the cost were greatly underestimated, and the work had to be abandoned. In the middle of 1912 the Turkish government decided itself to undertake the building of these roads, utilising the surveys and the other preparatory work of the French company. The approximate length of the roads proposed to be built in the various districts was as follows: Constantinople, Adrianople and 1 smid $750 \mathrm{~m}$.; Scutari, Monastir and Iannina $750 \mathrm{~m}$.; Sivas, Erzerum, Van, Trebizond and Samsun I,350 m.; Aleppo, Bagdad and Urfa $750 \mathrm{~m}$.; Smyrna, Konia and Adana $570 \mathrm{~m}$.; Angora and Kastamuni $600 \mathrm{~m}$.; Mezere, Bitlis and Diarbekir $580 \mathrm{~m}$.; Damascus, Beirut, Jerusalem and Lebanon $280 \mathrm{~m}$.; Brusa and Karasi $250 \mathrm{~m}$. About 800 miles of roads have been built or repaired in the Salonika and Kossovo districts.

Harbours.-Preliminary surveys were made for the construction of harbours at Tripoli (Syria), Latakia, Jaffa, Mersina, Rodosto, Heraclea (Black Sea), and Amastris (Black Sea). Agreements were concluded with the National Bank of Turkey (a British financial institution) for the construction and the working of the harbours of Samsun and Trebizond. The estimated cost of these works was $\{2,000,000$. The Hejaz Railway Company is constructing a harbour at Haifa, the sea terminus of the railway, while several other railway companies are engaged in building harbours at their various ports.

Irrigation.-Plans drawn up by Sir William Willcocks provide for the irrigation of an area of 3,500,000 acres in Mesopotamia. The whole region contains about $12,500,000$ acres, but the tracts which can be most profitably irrigated at present have been selected. The total cost of irrigation works proper was estimated at $£ \mathrm{I} 3,730,000$, while the cost of preparing the land for cultivation would amount to $£ 12,465,000$. The total sum necessary for the execution of the project would be $£ 26,195,000$. It was calculated that the rent of the irrigated land would bring in a sum equal to 9 per cent per annum of the total cost spent on these works. Preliminary contracts were signed in 1912 with Sir John Jackson for the building of the Hindia barrage (on a branch of the Euphrates) and the Habbania escape.

Among other irrigation works which have been undertaken in Turkey in Asia are those in the region of Konia, which irrigate about 110,000 acres of land, and were finished in I9I2. These were executed by the Anatolian Railway Company, which has also undertaken the irrigation of about $1,250,000$ acres in the Adana region. Preliminary contracts have been signed with the National Bank of Turkey for the irrigation of nearly $1,000,000$ acres in the Maeander valley in the province of Smyrna, and in the same province about 75,000 acres are to be irrigated in the Gediz valley. Work had started in 1912 for the irrigation of 100,000 acres in the region of Samsun, and of 75,000 acres in the Orontes valley in the region of Antioch. In Albania surveys were made for the irrigation of about 2,000,000 acres in the valleys of the rivers Maritza, Vardar and Drin.

Trade.-The imports were valued in I909-10 at $£_{2} 29,542,000$, and in $1910-1$ I at $£ 35,548$,- 
000 ; the exports at $f_{16} 10,105,000$ in $1909-10$, and at $f_{19} 1940,000$ in $1910-11$. The following table gives the imports and exports according to countries:-

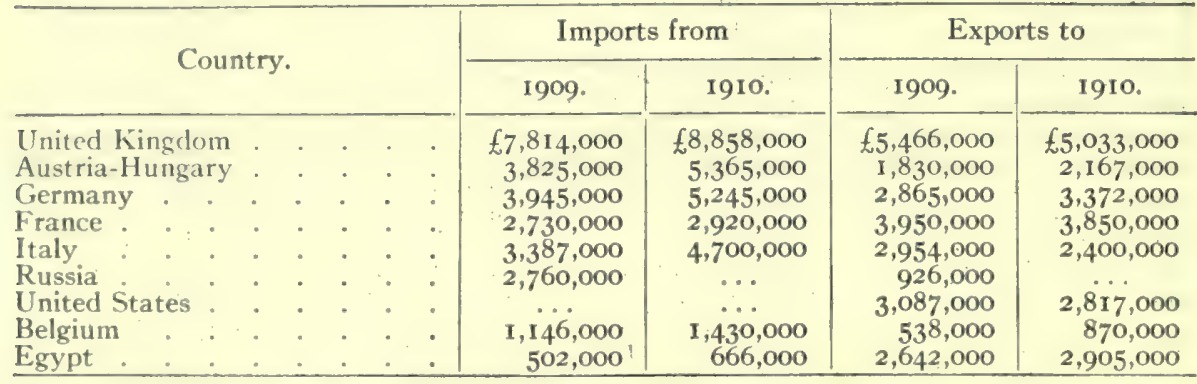

In I9I I the imports from the United Kingdom amounted to $f 9,729,690$, and the exports to the United Kingdom to $£ 5,541,125$. Principal imports from the United Kingdom: cotton goods $f_{6} 6,229,937$; woollen goods $f 704,150$; machinery $£ 375,274 ;$ and coal $£ 352,708$. Principal exports to the United Kingdom: barley $f_{1}, 397,443$; tobacco $£ 408,412$; wool

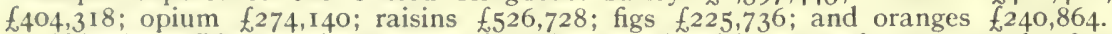

Shipping.-The merchant navy of Turkey consisted in 19 II of 1,083 vessels of 272,519 tons, of which 120 vessels of 66,878 tons were steamers, and 963 vessels of 205,64I tons were sailing vessels. In I9IO there entered and cleared at Constantinople 20,268 vessels of an aggregate tonnage of $19,153,95 I$ tons, of which $8,225,104$ tons were British.

A uthorities.-Sir W. M. Ramsay, The Revolution in Constantinople and Turkey (London, 1909): P. Siebertz, Albanien und die Albanesen (Vienna, I910); A. Philippson, Reisen und Forschungen in westlichen Kleinasien (Gotha, 1910); Sir Edwin Pears, Turkey and its People (London, 19II); Sir W. Willcocks, The Irrigation of Mesopotamia (London, I9Ir); Hakki Bey, De Stamboul à Bagdad (Paris, I91 I)

(O. BRILliant.)

\section{HistoRy, I909-I9I $2^{1}$}

On the 27th of April igo9, in the grand saloon of the War Office at Stamboul, Prince Mahommed Reshad, as Sultan Mahommed V, received the homage of the Young Turk

The new régime in 1909. politicians and generals amid the acclamations of Mahmud Shevket Pasha's troops from Salonica. The Ottoman Senate and Chamber, acting on a fetwa of the Sheikh-ul-Islam, had voted the deposition of Abdul-Hamid II and that same night he was sent to Salonica and interned in the Villa Allatini, a residence assigned at first to the Conte de Robilanti, the Italian general engaged in reorganising the Macedonian gendarmerie.

It might have been thought that the triumph of Young Turkey, and the renewal of the Ottoman Empire on the lines of the Japanese Renaissance, were now assured. The swift mobilisation of the Macedonian troops, the amazing dash for Con-

"Young Turkey" in power. stantinople, and the surrender of the city within twenty-four hours, won the highest opinions in Europe for the Ottoman army and Mahmud Shevket Pasha. The fanatical and reactionary party seemed silenced and subdued for good, terror-stricken as they were by the summary executions of those who plotted the assassinations of Ipril $\mathrm{r} 3 \mathrm{th}$, and by the sentences of exile and penal servitude passed on Abdul-Hamid's creatures. On May 5th Tewfik Pasha was appointed ambassador to London, and was succeeded as Grand Vizier by Husscin Hilmi Pasha, who had worked for a long time on the Macedonian Finance Committee with the delegates of the Great Powers, and so had had a training in European methods. He conHussein
Hilmi's structed a Cabinet entirely of Young Turks, among them notably Talaat Hilmi's
Cabinet. Bey (minister of the Interior), Djavid Bey (Finance), and Halladjian

Effendi (Public Works), and completed the work of foreign collaboration.

M. Laurent, formerly president of the French Cour des Comptes, had aiready been appointed financial adviser to the Ottoman Empire; Admiral Sir Douglas Gamble was at work on the rcorganisation of the navy, and General von der Goltz on the army. ${ }^{1}$ See E. B. xxvii, 442 et seq. 
Another appointment was a bold innovation. For, without regard for the displeasure of the minister of Justice (the Mullah Nejmeddin) and the furious opposition of the Moslem clericals in the Chamber, a French juris-consult and orientalist, Departmental Count Léon Ostrorog, was asked to assist as judicial adviser in carrying out reorganisa" legislative and judicial reform. The organisation of the Customs was ention by

forelgn advisers. trusted to Mr. (afterwards Sir Richard) Crawford; Sir William Willcocks was to start irrigation works in Mesopotamia; and two French civil engineers, MM. Picard and Godard, were called in to advise in the department of Public Works. The energy and enlightenment of Young Turkey was extolled by the whole press of Europe. France and Russia recalled the ambassadors accredited to the ex-Sultan, and replaced them by MM. Bompard and Charikoff, two diplomats of known Liberal sympathies.

Yet it was not long before clouds appeared on the horizon. Albanian chiefs, such as the notorious Issa Boletinatz, a partisan all along of Abdul-Hamid, and Halil Bey, who took occasion later, after April 13th, to declare for the ex-Sultan, who

Discontent in Albania. had lavished pensions and favours upon them both, might be, at any rate at first, a very small minority. But Albanians generally, for the very reason that they had taken part in t'e Revolution of 1908 and in crushing the counter revolution of I909, could not believe that the Young Turks meant to curtail the privileges, or to be more accurate, the licence allowed to the bayukdars and their men, who paid no taxes and took military service or not as they pleased. Now the Young Turks proposed indeed a constitution for Turkey, but it was to be founded upon absolute administrative and legislative uniformity, which meant that everyone alike must pay taxes and serve in the army; it also meant (though they were less ready to put that forward) the strict maintenance of the old Turkish hegemony; and as the principal means to this end, Turkish was to be the one recognised official language. Some demonstrations, supposed to be dangerously separatist in tendency, were made by Ismail Kemal Bey and by Hima Bey at Iannina and Dibra. The Albanians demanded official recognition for their language, and that everyone in office should be able to speak Albanian. At Scutari they refused to have the census taken or to serve in the army. General Djavid Pasha was sent to repress the movement, and with his artillery dispersed some 3,000 Albanians at Ferizovitch on the 17 th of August; he followed this up with measures of extreme rigour, and returned to Mitrovitza on September 25th, leaving a dangerous ferment of rancour and revolt behind him.

The Ottoman Greeks by no means remained indifferent during the tension produced by the Cretan question. From the first they had been dissatisfied because they considCrete. ered themselves insufficiently represented in parliament, and the counter revolution of the I3th of April I 909 was hailed with praise by their press. In fulfilment of a longstanding promise, the Powers withdrew their contingents from Crete on July 27 th. As soon as they left, the Cretans hoisted the Greek flag at Canea and claimed the right of sending deputies to Athens. After vehement protest from the Sublime Porte, the Powers again landed their contingents, and the Turkish flag was once more hoisted by them on the I8th of October. A boycott of Greek goods in Turkey followed and produced some lively irritation.

Other events began to lessen the unanimous sympathy felt for Young Turkey in England and France. To satisfy the almost fierce desire to be independent of Europe which had sprung up in Turkey after the revolution, Djavid Bey, then minis-

Financial troubles. ter of Finance, when borrowing money to meet the annual deficit of the Ottoman budget, decided to raise a loan quite independently of the Ottoman Public Debt administration, and to ignore the preference traditionally given to the Imperial Ottoman Bank. On the 6th of September the press was notified of the issue of a loan in open market, specifying the conditions and revenues offered as guarantee. M. Laurent, the financial adviser, thought the co-operation of the Ottoman Public Debt useful to Turkish credit. His disapproval naturally created a prejudice against the scheme among the European capitalists, the French capitalists in particular, who were repre- 
sented in the council of the Public Debt and the board of the Imperial Ottoman Bank. The latter, fearing lest the loan might be negotiated with an English group, when representatives of Sir Ernest Cassel and Messrs. Baring (founders of the National Bank of Turkey) arrived at Constantinople on the 23rd of September, decided to accept Djavid Bey's terms. But the matter rankled in the minds of French capitalists, and one outcome of it was a crop of press articles hostile to Young Turkey in the following year, with serious political consequences.

Another event occurred in the commercial world, with immediate mischievous effects in politics. Though Hussein Hilmi Pasha enjoyed the esteem and confidence of every European cabinet, and of an important section of the Young Turkish Intrigues party, he had enemies among the Young Turks. The deputy for Kastaagainst the muni, Nejmeddin Mullah, minister of Justice, could not forgive Hilmi for
ministry.

appointing a judicial adviser to assist him, and Rahmi Bey, the very influential Salonica deputy, wanted to put Hakki Bey in power. (Hakki Bey for a long time had been legal adviser to the Sublime Porte, during Abdul-Hamid's reign, and was afterwards minister of the Interior and ambassador at Rome, which post he was filling at the time.) They brought about the fall of Hilmi Pasha over the Lynch affair, a matter which just then made a great noise in Turkey. Two Englishmen, the Messrs. Lynch, owned, by right of ancient firmans, the monopoly of running cargo steamers on the Euphrates and Tigris; Hilmi Pasha confirmed the grant, stipulating that the firm should constitute itself an Ottoman company, and the steamers should ply under the Turkish flag. The grand vizier regarded this concession as a handy counterpoise to German influence in Mesopotamia, where the Bagdad railway scheme was in progress.

An active campaign began among Ottoman deputies. Hilmi Pasha was represented to them as ready to make Mesopotamia a British sphere of influence. On the IIth of December I909, after a stormy sitting, Hilmi secured I 68 votes to 8 upon Fall of a division, but he was given to understand by the party of Union and $\begin{array}{ll}\text { Hussein } & \text { Progress that he no longer possessed their confidence, and on the } 28 \text { th he } \\ \text { Hilml. }\end{array}$ had to resign. Hakki Bey, now Hakki Pasha, was summoned to form a new cabinet. It was the old one over again, except that Mahmud Shevket Pasha agreed to resign the post of generalissimo to go to the War Office, immeasurably strengthening Hakki Pasha's position by doing so. It was well known that the symHakki pathies of both were with the Triple Alliance, and especially with Germany, Pabinet, 1910. and a change in Turkish policy, which hitherto had gravitated towards the Triple Entente, was not long delayed.

Mention has already been made that Young Turkey aimed at uniformity of administration and legislation throughout the Ottoman Empire, and how the very first step towards it was Djavid Pasha's Albanian expedition. The Hakki Cabinct

Coevion of Albanla and Macedonia. determined to carry out the scheme root and branch in the Albanian vilayets, while settling the Macedonian question once for all. The likeliest means to this end, it was supposed, was to disarm the entire Albanian and Macedonian population. The Turkish Government must have known the difficulties in the way. By inmemorial Albanian custom every man goes armed, and every peasant in Macedonia carries a weapon, because the country has been infested for years by wandering bands. Mahmud Shevket Pasha, the War minister, went himself to the spot, and sent General Shevket Torgut Pasha with 50,000 men and a field battery to carry out the disarming at any cost. In Albania this meant nothing less than war. Shevket Torgut's army, marching from east to west, forced the Kachanik passes in April ro Io, reached Prisrend in May, Ipek and Jakova in June, and entered Scutari at the end of the month. He succeeded in disarming the tribesmen on his route, and dismantled the Koules or strongholds of the Albanian chieftains, but it had been done with a brutality which forever destroyed all Albanian loyalty to the Young Turks.

The session of the Ottoman Chamber ended on June 2nd. Djavid Bey's budget for the following session showing a deficit $f \mathrm{~T}_{5}, 000, \infty \infty$, he went to Paris early in July 
to negotiate a loan. But the Imperial Ottoman Bank group, that is to say, the heads of the French money-market, imposed as their conditions that the Imperial Treasury Department should be brought under the supervision of the Ottoman Bank,

Dlavid

Bey's

flnance. and that the Bank should keep some sort of check on the expenditure to see that it did not exceed the estimates, on the system followed before the Revolution of 1908 in Macedonia. Such a scheme had been drawn up by M. Ch. Laurent and even approved by Djavid Bey himself, but it had been thrown out by the Finance Committee of the Chamber of Deputies, as a piece of that foreign interference which Young Turkey professed to dread. Djavid Bey therefore declared that it was quite hopeless to think of getting such conditions accepted by the Chamber, and fell back on a less important group of French capitalists. But M. Laurent and the heads of the money-market were already dissatisfied with Djavid Bey's independent attitude of the year before, and, acting on their advice, M. Cochery said that there were difficulties, it seemed to him, in the way of admitting the

"Young

Turkey" at odds with England.
France and

loan on the recognised list ( la cote). It was an awkward business; all the more awkward because the grand vizier Hakki Pasha's action gave umbrage about this time to the Triple Entente. Leaving Constantinople in August, he had gone first to Bucharest and conferred with M. Djuvara, the Rumanian minister for Foreign Affairs; and then to Marienbad, where he had long and repeated interviews with $\mathbf{M}$. d'Aehrenthal, the Austrian minister for Foreign Affairs. There were rumours of a military agreement between Turkey and Rumania. The Neue Freie Presse announced a rapprochement between Austria and Turkey, and was not contradicted. And upon all this came the news that Turkey was buying two ironclads of Germany. A strong current of hostility set in at Paris, and the press strongly supported the Finance minister's demands. Djavid Bey went back to Constantinople having accomplished nothing; Hakki Pasha who followed him to Paris did no better. In October the loan negotiations were finally broken off; thereupon a violent campaign began in the French press against what was called the uncompromising arrogance of Young Turkey; while, in the Turkish press, a perfect outburst of fury against France and England (where negotiations also had been fruitless) soon degenerated, in the Jeune-Turc newspaper, into an ardent Pan-Islamic and Germanophil campaign against the Triple Entente. One highly characteristic result was a meeting held on October 25th to protest against the action of England and Russia in Persia; the upshot of which was that a Young Turk deputy, Ubeidullah Effendi, sent a telegram to the Emperor of Germany, inviting him to intervene in the character of friend and protector of 300,000,000 Moslems. Djavid Bey, seeing that all hope of a French or English loan was now over, went to the German embassy and begged the good offices of Baron Marschall von Bieberstein to help him to raise the money in Germany. The drift Numerous German Banks formed a syndicate, and on November oth the towards Germany. contract was signed with $M$. von Helferich of the Deutsche Bank, the most important of those concerned. Hakki Pasha had carried out his plan; Turkey was returning to the orbit of Germany. From that time Baron Marschall again became as important a personage as he had been in the reign of Abdul-Hamid. M. Laurent resigned his position in the Turkish service.

Meanwhile, since the Albanians had been disarmed, the turn of the Macedonian Bulgars and Greeks came next. And again the work too often was done by subalterns with revolting brutality. Detachments told off to make the peasants give Provocations up their arms, or point out where rifles were hidden, continually had reand Bulgaria. course to cruel beatings and ill usage, which sometimes ended in death. The Yenidje-Varda affair in September I9ro, when hundreds of Bulgarian peasants were beaten and driven to starvation, and the Bulgarian priest was murdered after a hideous beating, produced reverberations not only throughout the Bulgarian press but all over western Europe. Another step taken in that same month by the Hakki Pasha Cabinet drew down the deadly hate of the Greeks, who were already exasperated by the Turkish boycott of their goods in retaliation for various incidents- 
the oath of allegiance to the king of the Hellenes taken in the Cretan Assembly, the attempt to expel Mahommedan non-juring Cretan deputies, and the election of $\mathbf{M}$. Venizelos as Cretan representative to the Hellenic Chamber in August.

One of many sources of trouble in Macedonia was the struggle between the adherents of the Oecumenical Patriarch and the Bulgarian Exarch for possession of church buildings. ${ }^{1}$ To put an end to the disputes, the Ottoman Parliament voted a law, styled the Church Law, enacting that, if part of the population of a given place owed

Importance

of the

Macedonian

church question. obedience to the Greek Patriarch and part to the Bulgarian Exarch, the party which represented more than two-thirds of the Christian population was to have possession of the existing church, the state undertaking to build another for the minority. When the Government tried to carry this out in practice, the Oecumenical Patriarch claimed that it was a breach of his privileges, and proceeded to call a meeting denominated the "Phanar National Assembly." The Government prohibited the meeting. The Patriarch took no notice and issued a summons to the delegates. On September I 4 th the Government had them arrested and imprisoned. The outcome of these rough and ready methods and abrupt collisions was not only the final estrangement of Ottoman Greeks and Bulgars from the Young Turkish régime, but the reconciliation of Bulgars and Greeks, a remarkable fact with far-reaching results. On the $15^{\text {th }}$ of November Bulgarian delegates waited on the Patriarch; early in December Greek delegates went to the Bulgarian Exarch; and from that time forth a close understanding succeeded to a traditional rivalry.

The discontent, which found no outlet but the press while the Chamber was not sitting, broke out in violent interpellations as soon as the Ottoman Parliament met. All through December I9Io and part of January I9I I, Hakki Pasha had to

Growth

of the opposition in parliament.

weather a series of storms. Albanian, Bulgar and Greek deputies spoke at length, one after another, pouring out facts and dates of misdeeds committed by Government agents during the disarmament. Hakki Pasha, refuting nothing, kept on promising that justice should be done wherever proof of abuses was forthcoming. Turkish deputies also mounted the tribune. The Government, suspecting a plot during the summer, had arrested certain politicians. Lutf Fikri, an opposition deputy, accused prison officials of torturing the prisoners to make them confess. He produced blood-stained cudgels and finger-nails said to have been extracted from victims, and demanded a commission of enquiry (Jan. 2, IgII) which Hakki Pasha refused. The grand vizier obtained a vote of confidence, meanwhile, by a device of parliamentary procedure adopted by the Young Turkish party of Union and Progress. The party used to meet privately before a debate, to decide whether or no there was need to support the Cabinet, no matter what might be said afterwards in public. Parliamentary discipline carried out with lack of tact and discretion did not a little to discredit the party of Union and Progress, an impression gaining ground that purely party considerations overruled all claims of equity and humanity.

So the circle of discontent went on widening, and the task of the Government grew harder and harder. Difficulties followed in the Arab provinces. The Government had Troubles in Arabla.

been obliged in August 19ro to send an expedition against the Druses. In December the Druses rose again; so did the Karak Arabs in Palestine, aided

by Bedouins. They rose against the census and conscription. Government servants were killed. Disturbances were reported at Irak. News of a rising came in January I9II from two provinces,-Yemen, where the Imâm Yahyā, of the Zeidi ${ }^{2}$ See F. B. xx, 333 et seq. Joachim III, the Oecumenical Patriarch here referred to (b. I8.34), died on November 26, 1912. In 1878 he became Oecumenical Patriarch, but owing to clifferences with the Porte as to the trial of ecclesiastics by the secular power he resigned in $I \times 84$, and lived in retirement at various monasteries until $190 I$, when he was restored to the Patriarchate. There followed a severe struggle in Macedonia against the Bulgarian Exarchatr, which he was not strong enough to keep in bounds. He also came into collision with the lloly. Synod owing to his tendency to relax the rigour of church practices. Regarded by the extreme church party as too progressive, and by the younger laity as too conservative in his Macedonian policy, he was still respected as head of the Ottoman Greeks and defender of their interests against the Turkish Government. 
sect, refused to recognise the Sultan as lawful Caliph, and Assir, where an insurrection began under the lead of Seyyid Idris, a chieftain of Moroccan origin. The Government was forced to send out an armed force, weakening the Tripolitan garrison, with effects that proved very serious afterwards.

Still the Hakki Cabinet managed to keep in office, though there were some resignations. Talaat Bey retired, a concession to the Opposition. So did the minister of Hakkl Public Works, Halladjian Effendi, because some of the ministerialists and

Pasha's economic poHcy.

the grand vizier himself thought him too uncompromising, especially with regard to Germany's wishes. On February 28, I9I I there was an announcement in the Terdjeman-i-Hakikat, the Government organ, that Hakki Pasha himself would take over the department of Public Works until the Bagdad Railway question should be settled. This affair, of such great political and financial importance, was concluded almost at once. In the agreement signed on March I 7 th by Hakki Pasha, the conditions under which Germany should complete the line from Helif to Bagdad, and Germany's share in constructing the line from Bagdad to the Persian Gulf, were defined. At the same time the making of the Osmanieh-Alexandretta line was given to Germany, with the concession of Alexandretta harbour. On April Igth Hakki Pasha signed a preliminary agreement with a group of French financiers for the construction of railways in Eastern Anatolia, Macedonia and Albania, and a loan of $f^{\prime} \mathrm{T} 25,000,000$ for the purpose. By further agreements with the Banque Rouvier a loan was to be raised for making some ro,000 kilometres of roadway.

These economical measures were however the only aspect of official activity. Any real collaboration with the foreign advisers in promoting reform was abandoned. Reaction On April I7, I9I I Nejmeddin Mullah, minister of Justice, announced a against internal reform. triumph for the fanatical anti-foreign party. Count Léon Ostrorog, the foreign judicial adviser, weary of seeing his schemes of reform shelved or distorted by Moslem fanaticism, sent in his resignation on the 3 ist of March. The minister's announcement that henceforth there was to be no foreign judicial adviser or inspectors was received with cheers from the "turbaned " party in the Chamber of Deputies, one mullah, deputy for St. John of Acre, declaring that the minister was "indeed defending the sacred Law, like unto a lion." A few days later the Chamber voted the suppression of the post of foreign adviser to the Post and Telegraph department. The Hakki Cabinet might well believe its position secure, with a docile and solid parliamentary majority behind it. Supported by Germany, French capital, and that section of the press which is ruled by Germany and finance; sure of the army, since Mahmud Shevket Pasha was in the Cabinet; and confident that concessions had rallied the fanatical and foreigner-hating elements to the Government, they might have felt themselves unassailable. They were to be cruelly undeceived.

About the rst of April, a small but very warlike Catholic Albanian tribe on the Montenegrin border, that of the Malissori, had risen in revolt. They demanded to be allowed to carry arms, and that their military service should be localised;

Malissort rising in Albania. further they claimed exemption from certain taxes, and that their officials should be of their own race. The benevolent attitude of Montenegro towards the insurgents seemed significant from the first. Rifaat Pasha, minister of Foreign Affairs, might declare in the Chamber that Montenegro was friendly and that all would easily be settled; but the situation rapidly grew worse, and on April I Ith Shevket Torgut Pasha with an army corps was despatched to northern Albania.

At that very moment, a split in the Party of Union and Progress threatened to break up the bloc on which the Hakki Cabinet was based. A cavalry colonel, Saadik Bey, once an influential member of the Union and Progress committee, till he

Split in the party of "Union and Prog: ress." left it on ground of personal discontent, had been secretly working in the army and parliament against the Young Turkish committee for some time past. An enthusiastic Mahommedan mystic, a member of the Mélâmi dervish sect, he carried out his underground propaganda on religious lines, using the tactics which before proved so efficacious against the Young 
Turks and brought about the mutiny of April 13, r909. Then, as now, the Young Turk leaders were called bad Moslems, freethinkers, freemasons, and abettors of Zionism; they were said to be in the hands of Salonica Jews, and Djavid Bey in particular was said to be their tool. Suddenly on April 2oth the effects of the propaganda came to light. There was a split in the bloc. A section of the party of Union and Progress, called the "new group," comprising all the Moslem clericals, turned against the ministry and Djavid Bey. Their political programme comprised strengthening the authority of the Caliph, with strict observance of Moslem traditions, and the prohibition of freemasonry. The committee of Union and Progress tacked about. The programme was to be discussed later at a party congress. Djavid Bey was entreated to resign to soothe the fanatics, and union appeared to be re-established. But in reality the split in the bloc was past mending.

Meantime things were going from bad to worse in northern Albania. Since the Malissori, at the first reverse, simply went over into Montenegro, where they could find rest and fresh supplies and ammunition for a further resistance, it was

Foreign protests against atrocities in Albania. impossible to subdue them. Russia, moreover, warned Turkey to be careful of hostility to the Montenegrins; and to crown all, a violent anti-Turkish press campaign began at Vienna, especially in the Christian-Socialist organs. Shevket Torgut Pasha's troops were accused of unspeakable atrocities; the London press took this up; European public opinion was roused. Even Moslem Albania showed signs of ferment. The Hakki Pasha Cabinet, in its anxiety to secure the loyalty of the Albanians, the Mahommedans among them at any rate, tried to rally them to the Caliphate by working on their fanaticism. A great The Sultan, spectacular Mahommedan demonstration was gut up. In June, after the as Callph, session, Mahommed V went to Salonica and Usküb and thence to Kossovo. visits There, on the famous "Field of Blackbirds," where (in I448) Murad II Kossovo. dealt Balkan Christendom a final blow, the Sultan, acting in the capacity of a Caliph of the old days, personally officiated at a vast Friday assembly for prayer. Thousands of Moslems, attracted by the unexampled ceremony, came from Albania, Macedonia, and even from Bosnia.

The showy Mahommedan demonstration only roused uneasiness and prejudice among Macedonian Christians and such of the Great Powers as ruled Mahommedan subjects; the Triple Entente for some time past had been blaming the Europe Young Turks for their Pan-Islamist tendencies. No intimidating effect

insists on concessions to Albanian Christians. whatever was produced on the Malissori, and the European press took so violent a tone about the atrocities that the Government recalled Shevket Torgut Pasha, and replaced him by Abdullah Pasha. Hostilities moreover were not renewed. At the end of June igi i the Austrian Ambassador, Margrave Pallavicini, expressed to Rifaat Pasha the hope of his Government that the demands of the Catholic Malissori would be considered. Abdullah Pasha was ordered to cease fighting; negotiations began which dragged on till August 2nd, when the Porte conceded, by written agreement, a full amnest y to the Malissori chiefs, and the privileges demanded,- - privileges of capital importance, for they constituted the first breach in the system of uniform administration and Turkish hegemony which so far had been the principal dogma of the old Turkish Empire and Young Turks alike.

The bad impression made on the Ottoman mind when the Government thus surrendered before the revolt of an insignificant tribe which had grown irresistible because it was backed by a little Balkan state with Russia behind it, increased the

Mahommedan reaction against "Young Turkey." excitement produced by two untoward events. On the IIth of July Zekî Bey, an official in the Ottoman Public Debt, was murdered at Makrikieuy near Constantinople. Zekî Bey was an important member of Saadik Bey's opposition, and the murderer was the brother of a Young Turk deputy. In spite of assurances given by the leaders of the party of Union and Progress that they had nothing to do with it and deplored the event, it made a painful impression, and raised a storm in the Opposition newspapers. Then, on the night of 
July 23 rd, a fire broke out at Stamboul, and, a furious north wind blowing at the time, one fifth of the city was laid in ashes. The Moslem population noted the date, the anniversary of the Revolution, and said it was a judgment of God upon the Young Turks for not respecting the traditions of Islam.

But another much greater calamity was to befall Turkey. All the world knew of Italy's long-cherished designs upon Tripoli. Hakki Pasha's Cabinet alone seemed to attach no importance to them, either because the Government believed the The war Italian Minister's diplomatic protestations of friendship, or, as is more $\begin{array}{ll}\text { with } & \text { likely, because the grand vizier considered the friendship of Baron Marschall }\end{array}$ von Bieberstein and his master an absolute guarantee against Italian aggression. After the Agadir incident and the subsequent Moroccan negotiations, which assured France of the possession of Morocco, Italy decided to hurry the pace and get her share of Mahommedan Africa. A pretext was found in the ill-will shown towards Italian economic enterprise in Tripoli under Turkish administration, more particularly over the operations of the famous "Banco di Roma." On September 28th, Di Martino, the Italian chargé d'affaires, handed Hakki Pasha Italy's ultimatum. The Porte was given twenty-four hours notice to order the evacuation of Tripoli and the sanjak of Ben-Ghazi by the Turkish troops. On the 29th war was declared, and Di Martino quitted Constantinople. It was a death-blow for Hakki Pasha's Cabinet. He and his colleague at the Foreign Office were blamed for negligence in diplomacy; Mahmud Shevket Pasha, for withdrawing troops from Tripoli into the Yemen; and Fall of Halil Bey, Minister of the Interior, for administrative negligence. On the Hakkl Pasha. 3oth of September, Hakki Pasha resigned. Turkish opinion went the length of demanding that the Cabinet should be brought before the High Court appointed under the Constitution to try ministers accused of high treason.

Everybody expected Kiamil Pasha and his opposition party to come into power. Things went quite otherwise. The party of Union and Progress still had a majority in the Chamber. Said Pasha was called upon by the Sultan to construct a

\section{Said}

Pasha's

ministry.

cabinet. It was done with some difficulty. Mahmud Shevket Pasha was maintained at the War Office because it was not thought safe to take all authority from the man who had organised the national defence and $\mathrm{knew}$ all its secrets. Two struggles thus began: a war with Italy in Tripoli, carried on by two Young Turkish officers, the famous Enver Bey and Fethi Bey (military attaché at Paris), with admirable energy and persistence; and another conflict as fierce or fiercer at Constantinople, between the Opposition and the party of Union and Progress. Colonel Saadik Bey, working with Kiamil Pasha's adherents, carried on a campaign against the Young Turks, in the army, in political circles, and in town and country. Events made it easy for him. With the reopening of Parliament on November I 4 th, he brought out a programme for a new party of "Liberty and Understanding " ("Liberté et Entente"), which set about organising itself on the lines of the party of Union and Progress, founding clubs all over Constantinople and the provinces. Through their newsNew party papers, the Alemdar and the Tanzimät, and their spokesmen in the Chamof 'Liberty ber, they tried to ruin the Young Turks, blending partly true accusations standing." with obvious calumnies, chief among them the charges of being abettors of Zionism and bought up by the Jews. In Constantinople the campaign had considerable effect. When Rifaat Pasha (minister for Foreign Affairs) went as ambassador to Paris, the victorious candidate for his vacant seat was a member of the partv of Liberty and Understanding, Tahir Haïreddin Bey, editor of the Alemdar. Meanwhile Albanian and Arab deputies were demanding loudly that the privileges given to the Malissori should be extended to Moslem Albanians, insurgent Druses and Karak Arabs. The party of Union and Progress took alarm. The progress of the Opposition meant, they thought, that a reactionary and anti-Turk tide was setting in; and they decided upon immediate dissolution, so that the elections should take place under a Unionist government before the Ententists could capture the provinces.

Said Pasha conceived an ingenious bit of strategy. On the $13^{\text {th }}$ of December he 
brought before the Chamber a proposal to alter Article 35 of the Constitution, and restore to the Sultan the power of dissolving the Chamber without the simultaneous assent of the Senate. If the proposal were adopted, it meant a dissolution, Dissolution for the grand vizier felt sure of the sovereign; thrown out, it still meant of the Chamber. dissolution, for after a Government defeat the party of Union and Progress had a majority in the Senate, and under the existing constitution the assent of the Senate was necessary if the sovereign were to dissolve parliament. The Opposition, hardly feeling ready for a general election, took fright accordingly and formed a bloc,-Arab, Albanian, Greek and Bulgar deputies joining forces with the Mahommedan clericals and some few malcontents, the Turkish nucleus of the party of Liberty and Understanding. But their efforts were vain. After some incredibly stormy scenes in the Chamber and a last attempt to obstruct by abstention, the Sultan, Reconstruc- with the assent of the Senate, dissolved parliament on the I 1 th of January
tion of the ministry. x 912 , and on the 2 2nd a new purely Unionist Cabinet was formed under Said Pasha. Djavid Bey returned to the Public Works department, Talaat Bey to the Posts and Telegraph, Mahmud Shevket Pasha remaining at the War Office, and Prince Said Halim, the Khedive's cousin, President of the Union and Progress group in the Senate, taking the Presidency of the Council of State.

Said Pasha's manifesto in the Daily Telegraph (London) of January 2I, I9I 2, which attracted a great deal of attention, set forth the programme of the new Cabinet; immediate reforms were promised with the collaboration of foreign advisers, and Destruction no official pressure was to be brought to bear upon the elections. Unof the
opposition in fortunately this was only on paper. Except for a long tour of inspection parliament. among the vilayets of Macedonia and Albania, made in February by Hadji Adil Bey, minister of the Interior, accompanied by a former British consulgeneral, Mr. Graves, who was a member of the Reform Committee of the Finance Ministry, nothing was done in the way of reforms. As for the elections, they were worked on the lines known in France under the Second Empire as the "official candidature system." Under pressure from civil (and occasionally military) officials, opposition candidates were almost completely eliminated. It was found, when the new Chamber opened on April I8, I9ז2, that there were hardly ten Opposition members, and among them not one of the principal speakers of the previous parliament.

Albania felt the consequences almost at once. On December I, I I I I Hassan Bey, then Albanian deputy for Prishtina, had said openly that if he were not satisfied with the elections he should raise an insurrection. This he did. On May 9, Fresh
risings in 1912 the news reached Constantinople that Hassan Bey was heading a risings in
Albania. re-elected) with a band of insurgents had taken to the mountains at Dibra.

Disturbances at home added complications to troubles abroad. The very day that parliament opened, Italy bombarded the Dardanelles. The Porte temporarily closed the Straits and so gave umbrage to Russia, who, ceasing to believe in the Italy's
cxtension Young Turkish revolution, had replaced M. Charikoff, so friendly to their cxtension
of the war. cause, by M. de Giers, a much less whole-hearted supporter. The Italians next orcupied the southern Sporades, and on May 6th landed at Rhodes.

But serious as these events might be, their importance was but relative compared with what was passing in Albania. The whole district between Djakova. Ipek and Mitrovitza was in open revolt; Young Turkish officers and officials were

Disasters to "Young Turkey." driven out or murdered, and the movement, although obviously a political one, was also directed towards autonomy, the insurgents demanding (I) the return of the fire-arms taken from them by the Djavid Bey and Torgut Pasha expeditions, (2) official recognition for the Albanian language, (3) localised military service, and (4) Albanian officials for Albania, at the same time as the resignation of the Said ('abinet, another general election, and the trial of the Hakki Cabinet for high treason before the High Court. On May 2 2nd the Government decided to send as reinforcements the first or Constantinople division. This step was not merely use- 
less, it was fatal. Colonel Saadik Bey's subterranean propaganda had made immense progress among the officers of the Constantinople garrison; he had relied upon the want of preparation at Tripoli, on officers passed over, and appointments made

Counter movement in the army. for political reasons by Mahmud Shevket Pasha. A "Society of Saviours of their Country" counted many members among the officers of the first division. In their eyes the Albanians, against whom they were sent by the Government, were not insurgents but their own allies, and before June I9I 2 was out news came that many, both officers and men, were deserting to the Albanians.

Mahmud Shevket Pasha made desperate efforts to repress the movement. On July Ist a law was passed at his instance, severely punishing officers for meddling in politics; then, seeing that his efforts were useless, he sacrificed himself to

Fall of Sald Pasha. calm the movement and resigned (July roth). Even that, it seemed, was not enough. Said Pasha himself resigned on July 17 th and so brought about a Cabinet crisis. The situation was so serious that the Sultan intervened in person. On the Igth of July he issued a manifesto prohibiting officers from meddling in politics and promising an impartial Cabinet. On July 22nd Ghazi Mukhtar Pasha became grand vizier; Kiamil Pasha, President of the Council of State; Nazim Pasha, minister of War; Hussein Hilmi Pasha, minister of State; and an Armenian, legaladviser of the Porte under Sultan Abdul Hamid, Gabriel Effendi Noradoughian, minister for Foreign Affairs. The next day it was decided at a cabinet council to stop the fighting in Albania and to send a conciliation commission to treat. And Ghazl Mukh- then the purely political nature of the movement was made manifest, for tarPasha's even this was not enough. The Albanians, led by the excluded deputies,
ministry.

clamoured for a dissolution and the arraignment of the Hakki Cabinet. On July 25 th the military society of "Saviours of their Country" sent a threatening letter to Halil Bey, President of the Chamber, calling upon the Chamber to dissolve. Just then the Government plainly showed what line they meant to take, by issuing an amnesty (Aug. Ist) to all Abdul-Hamid's high officials, and all ringleaders of the mutiny of April I3, I909 exiled by the Young Turks.

On August 5th the Ghazi Mukhtar Cabinet obtained from the Senate a decision interpretative of the Constitution declaring that the task of the newly-elected Chamber was now completed (this was represented to the Senate as the only way of

Spread of Albanian movement. stopping the Albanian disturbances and keeping the Austrians out of the Sanjak of Novibazar); then, backed by a proclamation issued in the Sultan's name, the grand vizier ignored a vote of want of confidence given after a violent revolutionary speech from Djavid Bey, and closed both the Chamber and the Senate. After this supreme concession made to them, the Albanian insurgents, naturally, only grew bolder. More officers and officials were murdered at Ipek and Mitrovitza (Aug. I8th). Then the Albanians marched on Usküb, and some went on to Salonica, demanding the restoration of Abdul-Hamid. Once again the Porte gave way. Out of fourteen points raised by the Albanians twelve were conceded, among them official recognition of their language, localised military service, appointment of officials able to speak Albanian. Yet it was decided to send troops to stop the march of the insurgents, now very near Salonica. The Albanian advance was Massacres at stopped, but not the disturbances. The Government had lost all authority. Berana and elsewhere.

The Albanians took to plundering the depots for arms, and assassinations continued. News of massacres came from Berana, Sienitza, and Epirus. The Kurds in Asia Minor began to flatter themselves that the days of Abdul Hamid had come back at last, and fell to massacring the luckless Armenians.

There was great excitement in Europe and in the press. The tone of the Balkan journals grew very hostile to Turkey; they spoke of autonomy in the Peninsula, perhaps encouraged by a proposal made by Count Berchtold, Austrian Minister for Foreign Affairs, who, naturally disposed to favour the Albanians, invited the cabinets of Europe to urge the Turkish Government to decentralise their administrative system. The Bulgarian press was particularly violent. The Ishtib massacres of the previous December, 
and above all the quite recent Kotchana massacres (Aug. rst), where over a hundred victims (principally Bulgars) were done to death by the populace or the soldiery after a bomb explosion, had wrought up public feeling in Sofia to the highest pitch. Unrest The official paper, the Mir, brought out a series of articles proclaiming the among Bal- necessity of European control in the Balkans, and declared that the mainkan States. tenance of the status quo meant a continuance of Turkish anarchy till the Christian population was exterminated. Diplomatic difficulties helped to create hostility to Turkey among the Balkan States. Montenegro demanded a rectification of the frontier on the basis of an agreement, already ten years old, which had never been carried out. This the Porte refused. The Turkish Government, having authorised Servia to transport an important consignment of artillery from France across Turkey, now refused to allow the war material either to be forwarded to its destination, or to be sent back to Salonica; and the Servian press in its turn showed intense irritation. A final measure precipitated events. By way of mending matters, the Ottoman Government apparently thought it adroit policy to try a palliative combined with intimidating measures. On September 22nd the Porte made it known through the Stamboul press, that, acting on the application of the ambassadors of the Great Powers, and more especially on the advice given by M. Sazonoff, Russian Minister for Foreign Affairs, to Turkhan Pasha, Turkish Ambassador at St. Petersburg, the Ottoman Government was resolved to extend the privileges granted to Albania to all parts of the Turkish Empire. On the other hand, the semi-official Yeni-Gazette of September 25 th announced that for the forthcoming Grand Manoeuvres at Adrianople, the War minister was there concentrating twelve divisions of effectives, besides calling up the redifs from the Turkish districts of Adrianople, Salonica, Monastir and Uskub. On the 26th the grand Jeune-Turc newspaper published an interview with Gabriel Effendi Noramanoeuvres doughian, Minister of Foreign Affairs, confirming this news, and the paper
ordered at ordered at

also announced that about 300,000 men would shortly be concentrated in

Thrace. On the 3 oth, on the advice of the representatives of England and Russia, who pointed out to the Porte how little the circumstances called for an announcement of manoeuvres on so extraordinary a scale, the War Minister issued a démenti. But it was too late. Bulgaria, Greece, Montenegro and Servia, allies in virtue of agreements concluded in profound secrecy, believing that Turkey had reached the required pitch of civil and military discord and anarchy, decided to profit by the opportunity to realise by force of arms the long-standing ambitions which the Young Turkish Revolution had seemed so sure to bring to nothing. A brief statement of dates and facts is all that remains to be given.

On October Ist the Kings of Bulgaria, Greece and Servia ordered general mobilisation; and in response, on the same date, an Imperial iradé was issued ordering Turkish mobilisation. Still, as mobilisation is not war, efforts were made for peace Mobllisation by European diplomacy, especially by the Triple Entente. On October of Bulgaria, 6th, on the initiative of the ambassadors of France, Great Britain and Servia and
Greece.

23 of the Berlin Treaty, hitherto never carried out, by which a special administration was provided for the vilayets of Turkey in Europe. But the Balkan States, who might perhaps have been satisfied with this concession some weeks sooner, now wanted something more, declaring that they put no confidence what-

Action by the Great Powers. soever in any reforms to be carried out by Turkey alone without the control of the Powers. Montenegro decided to hasten the crisis, and declared war on Turkey on October 8th, when her Minister, M. Plamenatz, left Constantinople. European diplomacy made one more supreme effort. A collective note, drawn up upon an idea conceived by $\mathbf{M}$. Poincaré, the French Premier, was issued simultaneously to the Porte and the four Balkan States. It was declared Montenegro declares war. therein that Europe had decided "to take in hand" the execution of reforms in European Turkey. The note gave satisfaction to none of the parties involved. On October $\mathrm{r}_{4}$ th the Governments of Bulgaria, Greece 
and Servia together issued one note to the plenipotentiaries of Austria-Hungary, France, Germany, Great Britain and Russia, declining the proposal, and another to the Ottoman plenipotentiaries requiring that the reforms should be carried

Collapse of diplomacy.

out under the joint control of the Great Powers and the Balkan States, the appointment of Belgian or Swiss governors, and the immediate demobilisation of the Turkish army. On the same date the Porte declined the proposal of the Great Powers, declaring that Turkey was ready to carry out reforms but could permit no foreign interference whatever. On the 15 th, the Porte having received the communication of the note issued by the Balkan States, recalled the Turkish ministers from Athens, Belgrade and Sofia. On the r6th peace was concluded with Italy, on the basis of a disguised but really complete cession of the vilayets of Tripoli and Cyrenaica. On the 17 th Turkey declared war on Bulgaria and Servia. By a piece of diplomatic finesse, the Greek note was supposed not to have been communicated; to the last Turkey really hoped to detach Greece from the Balkan League. On the 18th Greece declared war on Turkey. MM. Sarafoff, Gryparis and Nenadovitch, ministers of Bulgaria, Greece and Servia, leit Constantinople that same day. The Balkan war was about to begin.

The events of the war and its international aspects are dealt with elsewhere (see "International Affairs," in Part I: Sect. i.), and the direct results in Constantinople need only be noted. Mukhtar's willingness to accept the application of

Klamil suc* ceeds Ghazl Mukhtar as Grand Vizier.

Art. 23 of the treaty of Berlin, agreeably to the suggestions of the foreign ambassadors, had caused the widest dissatisfaction in Stamboul, which manifested itself on October 7 th in a demonstration of the students of Stamboul University, in which some Young Turk politicians partook. This occasioned the proclamation of martial law on October 8th, and the arrest of four or five malcontents, amongst them Obeidullah Effendi, ex-deputy for Aidin, and Aka-Gunduz, an editor of the Tanin, who were respectively condemned to five and seven years' detention in a fortress. On October 29th Ghazi Mukhtar resigned, transmitting the seals to Kiamil Pasha, the avowed object of the resignation being the hope to obtain Great Britain's full support in the conflict with the Balkan States by the accession of Kiamil Pasha to power. In the course of November an attempt was made by some general officers of the old régime, seemingly without the connivance of the cabinet, to suppress the Young Turk party by arresting and deporting to Konia all the ex-ministers, ex-deputies, leading journalists and politicians of the "Union and Progress" party to be found in Constantinople. Djavid Bey, Talaat Bey and a few others managed to escape with the help of foreign friends, but nearly a hundred prominent Unionists were arrested by order of the Court Martial and imprisoned at the War Office at Stamboul. However their detention lasted but a few days. On Nazim Pasha's return to Constantinople, after the signature of the armistice at Chatalja, the composition of the Court Martial was altered, and all the political prisoners released, including even those who, under the preceding Court Martial, had been tried and condemned, as, for instance, the ex-deputy Obeidullah.
(LÉON OSTROROG.) 
GENERAL STATISTICS*

Foreign Trade Statistics of Principal Countries.

( $I=I$ mports; $E=$ Exports.)

\begin{tabular}{|c|c|c|c|c|c|c|c|c|c|c|}
\hline & & $\stackrel{1, \infty}{£}$ & \begin{tabular}{|c|} 
Per \\
Cent of \\
Total.
\end{tabular} & $\begin{array}{l}1, \infty 00 \\
£\end{array}$ & $\left|\begin{array}{c}\text { Per } \\
\text { Cent of } \\
\text { Total. }\end{array}\right|$ & $1, \infty$ & $\left|\begin{array}{c}\text { Per } \\
\text { Cent of } \\
\text { Total. }\end{array}\right|$ & $\stackrel{1, \infty 00}{£}$ & $\begin{array}{l}\text { Per } \\
\text { Cent of } \\
\text { Total. }\end{array}$ & $\begin{array}{l}\text { Tolal. } \\
1, \infty \\
£\end{array}$ \\
\hline \multirow{3}{*}{$\begin{array}{l}\text { United King- } \\
\text { dom (I9II) }\end{array}$} & \multirow{2}{*}{$I^{1}$} & \multicolumn{2}{|c|}{ Animals Living. } & \multicolumn{2}{|c|}{$\begin{array}{c}\text { Food, Drink, E } \\
\text { Tobacco. }\end{array}$} & \multicolumn{2}{|c|}{$\begin{array}{l}\text { Raw \& Semi- } \\
\text { Mamufactured } \\
\text { Materials. }\end{array}$} & \multicolumn{2}{|c|}{$\begin{array}{c}\text { Mamufactured } \\
\text { Arlicles. }\end{array}$} & \\
\hline & & 2,338 & 0.4 & 259,647 & $|45.0|$ & I $78,20 \mathrm{I}$ & 30.8 & $\mathbf{1} 37,2 \mathbf{I}_{2}$ & 23.8 & 577,398 \\
\hline & $\mathrm{E}^{2}$ & $9, \mathbf{I} 33.5$ & 2.0 & $\begin{array}{r}29,037.5 \\
\text { Articles }\end{array}$ & 6.4 & 53,725 & II. 8 & 362,222 & 79.8 & 454,119 \\
\hline \multirow{2}{*}{$\begin{array}{l}\text { Germany } \\
\text { (I9Io) }\end{array}$} & $\int I$ & 13,100 & 3.0 & 108,900 & 24.8 & 249,900 & 56.9 & 67,300 & I5.3 & 439,200 \\
\hline & E & $\begin{array}{r}500 \\
A n^{\prime} l_{s}, P l a\end{array}$ & $\begin{array}{c}0.1 \\
\text { ants, etc. }\end{array}$ & 36,900 & 10.0 & 94,300 & $25 \cdot 7$ & 235,800 & 64.2 & 367,500 \\
\hline \multirow{2}{*}{$\begin{array}{l}\text { United States } \\
\text { (I9IO) }\end{array}$} & I & 2,390 & $\begin{array}{l}0.74 \\
\end{array}$ & 67,988 & 20.96 & 177,377 & 54.68 & 76,609 & 23.62 & 324,364 \\
\hline & E & I,683 & $\begin{array}{r}0.47 \\
4 \text { nimals }\end{array}$ & $\begin{array}{l}76,893 \\
\text { \& Food. }\end{array}$ & $21.5^{8}$ & I 73,688 & 48.76 & 104,003 & 29.19 & 356,267 \\
\hline \multirow{2}{*}{ France (rgro) } & $(I$ & 56,5 & 520 & rg & .7 & 173,828 & 60.6 & 56,584 & 19.7 & 286,932 \\
\hline & E & $\begin{array}{r}34,3 \\
\text { Animals } 8\end{array}$ & E Food. & Miscella & $\begin{array}{l}.8 \\
\text { neous. }\end{array}$ & 77,232 & 31.0 & $\mathbf{1} 37,79^{2}$ & 55.2 & 249,352 \\
\hline \multirow{2}{*}{ Holland (rgro) } & I & 84,954 & 31.2 & 14,810 & $5 \cdot 5$ & I 21,175 & $44 \cdot 5$ & 51,164 & I 8.8 & 272,103 \\
\hline & $\mathbf{E}$ & $\begin{array}{l}79,475 \\
\text { Animals }\end{array}$ & $\begin{array}{l}36.2 \\
\text { Living. }\end{array}$ & $\begin{array}{l}\text { Ir }, 5 \text { II } \\
\text { Food \& I }\end{array}$ & $\begin{array}{c}5 \cdot 2 \\
\text { Drink. }\end{array}$ & 82,639 & 37.7 & 45,738 & $20: 9$ & 219,363 \\
\hline \multirow[t]{2}{*}{ Belgium(19Io) } & (I & 2,240 & I. 3 & 39,361 & 23.1 & $93,042^{3}$ & $54 \cdot 5$ & 35,955 & $21 . I$ & 170,598 \\
\hline & E & 1,809 & 1.3 & \begin{tabular}{|l|}
15,024 \\
Articles of
\end{tabular} & $\begin{array}{l}\text { Ir.o } \\
\text { Food. }\end{array}$ & $66,163^{4}$ & 48.6 & 53,3 OI & 39.1 & I 36,297 \\
\hline \multirow[t]{2}{*}{ Russia (1909) } & $(I$ & 842 & 0.9 & 19,303 & 20.2 & $46,7 \mathbf{I 4}$ & 48.8 & 28,810 & 30.1 & 95,669 \\
\hline & E & $\begin{array}{c}2,74 \mathbf{I} \\
\text { Agric. Prc }\end{array}$ & $\begin{array}{c}\mathbf{1} .8 \\
\text { od., etc. }\end{array}$ & 97,394 & 64.6 & 44,698 & 29.7 & 5,866 & 3.9 & I 50,699 \\
\hline \multirow{2}{*}{$\begin{array}{c}\text { Austria-Hun- } \\
\text { gary (1910) }\end{array}$} & (I & 44,542 & 37.5 & 10,000 & 8.4 & 31,220 & 26.3 & 33,107 & 27.8 & I I 8,869 \\
\hline & $\mathrm{E}$ & $\begin{array}{l}\text { I9,959 } \\
\text { Animals }\end{array}$ & $\begin{array}{l}\mathbf{1} 9.8 \\
(\text { except }\end{array}$ & $\begin{array}{c}9,684 \\
\text { horses) } 8\end{array}$ & $\begin{array}{c}9.6 \\
\text { Food. }\end{array}$ & 24,740 & 24.6 & 46,392 & 46.0 & 100,775 \\
\hline \multirow[t]{2}{*}{ Italy (rgro) } & I & 26,3 & 395 & 20 & 3 & 71,481 & $55 . \mathrm{I}$ & $3 \mathrm{I}, 963$ & 24.6 & I 29,839 \\
\hline & E & $\begin{array}{r}24,5 \\
A \\
\end{array}$ & 1 nimals & \& Food. & & 34,662 & 41.7 & 24,008 & 28.8 & 83,199 \\
\hline \multirow{3}{*}{$\begin{array}{l}\text { Switzerland } \\
\quad \text { (I910) }\end{array}$} & \{ & $2 \mathbf{I}, 4$ & 459 & $3 \circ$ & .7 & 25,048 & 35.9 & 23,294 & $33 \cdot 4$ & $69,80 \mathrm{r}$ \\
\hline & E & & 470 & & .5 & 5,253 & II.O & 36,112 & $75 \cdot 5$ & 47,835 \\
\hline & & Miscella & meous. & $\begin{array}{r}\text { Food, Dri } \\
\text { Tobac }\end{array}$ & ink, \& & & & & & \\
\hline \multirow[t]{2}{*}{ Japan (Igro) } & $\left\{\begin{array}{l}I \\
\end{array}\right.$ & 258 & 0.5 & 4,593 & $9 \cdot 7$ & 32,075 & 67.7 & 10,465 & 22.1 & $47,39 \mathrm{I}$ \\
\hline & E & Animals & Living. & Articles of & f Food. & $\begin{array}{l}27.075 \\
\text { Raw Mat } \\
\text { \& Anin }\end{array}$ & $\begin{array}{l}5 \% .9 \\
\text { tcrials } \\
\text { mals. }\end{array}$ & 14,019 & 29.9 & 46,798 \\
\hline \multirow[t]{2}{*}{ Spain (rgro) } & $\left\{\begin{array}{l}I \\
0\end{array}\right.$ & 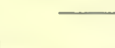 & - & 7,127 & 17.9 & $2 I, 314$ & $53 \cdot 5$ & I I, 373 & 28.6 & 39,8 I 4 \\
\hline & $(\mathrm{E})$ & & & 14,812 & 38.7 & 14,215 & 37.2 & 9,207 & $24 \cdot I$ & 38,234 \\
\hline
\end{tabular}

'Total imports less re-exports. 2 Of U. K. produce. $\mathbf{3}$ Includes diamonds in the rough. 4 Includes diamonds cut.

*The tables here given may be supplemented by those given elsewhere in the YEAR-Book. 
Vital Statistics of Principal Countries, Igro. Per I,00o Persons Living.

\begin{tabular}{|c|c|c|c|c|c|c|c|c|c|}
\hline & $\begin{array}{l}\text { Mar- } \\
\text { riage } \\
\text { Rate. }\end{array}$ & $\begin{array}{l}\text { Birth } \\
\text { Rate. }\end{array}$ & $\begin{array}{l}\text { Death } \\
\text { Rate. }\end{array}$ & & & & $\begin{array}{l}\text { Mar- } \\
\text { riage } \\
\text { Rate. }\end{array}$ & $\begin{array}{l}\text { Birth } \\
\text { Rate. }\end{array}$ & $\begin{array}{l}\text { Death } \\
\text { Rate. }\end{array}$ \\
\hline England and Wales. & 15.0 & $25 . \mathrm{I}$ & 13.5 & Spain & . & . & 14.2 & $33 \cdot I$ & $23 \cdot 3$ \\
\hline Scotland. & 13.0 & 26.2 & $15 \cdot 3$ & Austria & 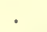 & 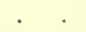 & 15.1 & $32 \cdot 5$ & $2 \mathrm{I} .2$ \\
\hline Ireland & IO: I & $23 \cdot 3$ & 17.1 & France. & $\because$ & & I5.8 & 19.7 & 17.9 \\
\hline United Kingdom & $14 \cdot 3$ & 25.0 & 14.0 & Switzerland ( & $(190$ & 99) & I 4.9 & 25.6 & 16.1 \\
\hline Ontario & 20.7 & $24 \cdot 9$ & 14.0 & Netherlands & 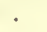 & . & $14 \cdot 3$ & 28.6 & I3.6 \\
\hline Australian Common- & & & & Italy . & & & I 5.5 & 32.9 & 19.6 \\
\hline wealth . & I6. 7 & 26.7 & 10. 4 & Denmark & & . & 14.6 & $27 \cdot 5$ & 12.9 \\
\hline Jamaica & 8.0 & 38.6 & 23.1 & Finland & . & . & 12.2 & 30.2 & 16.6 \\
\hline Ceylon & $10.9^{1}$ & 39.0 & $27 \cdot 3$ & Norway & & . & I 2.4 & $26 . I$ & I3. 5 \\
\hline New Zealand & $\mathrm{I} 6.6$ & 26.2 & 9.7 & Sweden & & . & 12.0 & 24.8 & 14.0 \\
\hline Hungary . & $17 \cdot 3$ & $35 \cdot 7$ & 23.6 & Chile & & . & I I. 5 & 38.4 & $32 \cdot 5$ \\
\hline Japan (1909) & 17.6 & 34.2 & 22.0 & Bulgaria (I90 & & & $\mathbf{1} 8.3$ & 40.6 & 26.6 \\
\hline Rumania . & 18.4 & 39.8 & 25.2 & Servia (1909) & & & 18.7 & 38.7 & $29 \cdot 3$ \\
\hline Belgium (I909) & $15 \cdot 3$ & 23.7 & I5. 8 & United States & & Amer- & & & \\
\hline German Empíre (I909) & I $5 \cdot 5$ & $3 \mathrm{I} \cdot \mathrm{I}$ & 17.2 & ica & & & & & 15.0 \\
\hline Prussia & I5.6 & 30.5 & I6.0 & & & & & & \\
\hline
\end{tabular}

${ }^{1}$ Registered marriages.

Emigration Statistics of Principul Countries.

\begin{tabular}{|c|c|c|c|c|c|c|c|c|c|}
\hline \multirow{2}{*}{\multicolumn{2}{|c|}{ From }} & \multirow[b]{2}{*}{ Date. } & \multirow{2}{*}{$\begin{array}{c}\text { No. of } \\
\text { Emigrants. }\end{array}$} & \multicolumn{5}{|c|}{ Principal Destinations. } & \multirow{2}{*}{$\begin{array}{l}\text { Per } 10, \infty \infty \\
\text { Inhabit- } \\
\text { ants. }\end{array}$} \\
\hline & & & & Europe. & $\begin{array}{l}\text { United } \\
\text { States. }\end{array}$ & $\begin{array}{c}\text { Rest of } \\
\text { America. }\end{array}$ & Africa. & $\begin{array}{l}\text { Australia } \\
\text { and New } \\
\text { Zealand. }\end{array}$ & \\
\hline $\begin{array}{l}\text { Italy } \\
\text { United King }\end{array}$ & gdom & $\begin{array}{l}\text { I9IO } \\
\text { I9II }\end{array}$ & $\begin{array}{l}65 \mathrm{I}, 475 \\
454,527\end{array}$ & $\begin{array}{c}242,381 \\
\ldots\end{array}$ & $\begin{array}{l}262,554 \\
121,814\end{array}$ & $\begin{array}{l}\text { I } 38,2.98 \\
\text { I } 84,860^{2}\end{array}$ & $\begin{array}{c}6,670 \\
30,767^{3}\end{array}$ & $\begin{array}{r}1,079 \\
80,770\end{array}$ & $\begin{array}{l}187.4 \\
100.3\end{array}$ \\
\hline $\begin{array}{l}\text { Spain . } \\
\text { Austria : } \\
\text { Hungary } \\
\text { Russia . }\end{array}$ & . & $\begin{array}{l}1910 \\
1910 \\
1910 \\
\text { I91 }\end{array}$ & $\begin{array}{r}\text { I } 91,76 \text { I } \\
\text { I } 38,867 \\
\text { I } 19,901 \\
84,180\end{array}$ & $\begin{array}{l}5,653 \\
\cdots \\
2,796\end{array}$ & 63,478 & 17,707 & $\begin{array}{c}28,398 \\
\ldots \\
154\end{array}$ & $\begin{array}{l}\ldots \\
\ldots\end{array}$ & $\begin{array}{r}97.9 \\
48.7 \\
57.8 \\
6.7\end{array}$ \\
\hline $\begin{array}{l}\text { Portugal } \\
\text { Sweden } \\
\text { Germany }\end{array}$ & . & $\begin{array}{l}1909 \\
1910 \\
1911\end{array}$ & $\begin{array}{l}38,137 \\
27,816 \\
22,690\end{array}$ & $\begin{array}{r}64 \\
3,169 \\
98\end{array}$ & $\begin{array}{r}37 \\
23,529 \\
18,900\end{array}$ & $\begin{array}{r}989 \\
3,428 \\
\end{array}$ & $\begin{array}{r}8 \\
43 \\
18\end{array}$ & $\begin{array}{r}86 r \\
49 \\
246\end{array}$ & $\begin{array}{r}66.4 \\
50.6 \\
3.5\end{array}$ \\
\hline $\begin{array}{l}\text { Belgium : } \\
\text { Finland : } \\
\text { Norway } \\
\text { Denmark }\end{array}$ & 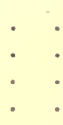 & $\begin{array}{l}1910 \\
1910 \\
1910 \\
1910\end{array}$ & $\begin{array}{r}2 \mathrm{I}, 393 \\
19,007 \\
\mathbf{I} 8,912 \\
8,890\end{array}$ & $\begin{array}{c}\text { I } 7,475 \\
\ldots \\
\ldots \\
\ldots\end{array}$ & \multicolumn{2}{|c|}{$\begin{array}{r}3,600 \\
18,994\end{array}$} & $\begin{array}{r}213 \\
2 \\
17 \\
28\end{array}$ & $\begin{array}{r}\mathrm{I} 4 \\
6 \\
8 \\
8 \mathrm{I}\end{array}$ & $\begin{array}{l}28.7 \\
61.7 \\
80.4 \\
32.5\end{array}$ \\
\hline $\begin{array}{l}\text { Switzerland } \\
\text { France } \\
\text { Netherlands } \\
\text { Bulgaria. } \\
\text { Rumania. }\end{array}$ & $\therefore$ & $\begin{array}{l}1910 \\
1909 \\
1910 \\
1911 \\
1911\end{array}$ & $\begin{array}{l}5,178 \\
5,000 \\
3,220 \\
1,554 \\
1,140\end{array}$ & $\begin{array}{l}\cdots \cdots \\
\cdots \cdots \\
\cdots \cdots \\
{ }_{45}\end{array}$ & $\begin{array}{r}5 \\
3 \\
1,204^{3} \\
821\end{array}$ & $\begin{array}{ll}109 & \\
2 \text { II } & \\
& 350 \\
& 274\end{array}$ & $\begin{array}{l}16 \\
\cdots 9\end{array}$ & $\begin{array}{l}\quad 28 \\
\cdots \cdots \\
\cdots \cdots\end{array}$ & $\begin{array}{r}\text { I3. } \\
1.2 \\
5.4 \\
3.6 \\
\text { I. } 9 \\
\end{array}$ \\
\hline
\end{tabular}

${ }^{1}$ Outward bound passengers of British nationality from the United Kingdom out of Europe. ${ }^{2}$ British North Amer ica. ${ }^{3}$ Cape of Good Hope and Natal.

Immigration into America from Europe.

\begin{tabular}{|c|c|c|c|c|c|c|c|c|c|}
\hline $\begin{array}{l}\text { Nationality of } \\
\text { Immigrants. }\end{array}$ & $\begin{array}{l}\text { Into the } \\
\text { United } \\
\text { States } \\
\text { July } \\
\text { I910 to } \\
\text { June } \\
\text { I9II. } \\
\end{array}$ & $\begin{array}{c}\text { Canada } \\
\text { April } \\
\text { I9ro, } \\
\text { March } \\
\text { I9II. }\end{array}$ & $\begin{array}{c}\text { Argen- } \\
\text { tina } \\
\text { Igr. }\end{array}$ & $\begin{array}{l}\text { Brazil } \\
\text { I } 91 \text { I. }\end{array}$ & $\begin{array}{l}\text { Nationality of } \\
\text { Immigrants }\end{array}$ & \begin{tabular}{|l} 
Into the \\
United \\
States \\
July \\
roro to \\
June. \\
IgIr.
\end{tabular} & $\begin{array}{c}\text { Canada } \\
\text { April } \\
\text { I0IO, } \\
\text { March } \\
\text { IgII. }\end{array}$ & $\begin{array}{c}\text { Argen- } \\
\text { tina } \\
\text { I9II. }\end{array}$ & $\begin{array}{l}\text { Brazil } \\
\text { I } 191 .\end{array}$ \\
\hline $\begin{array}{l}\text { Italy } \\
\text { Austria-Hungary } \\
\text { Rusia and Finland } \\
\text { United Kingdom } \\
\text { Germany } \\
\text { Greece }: \\
\text { Sweden } \\
\text { Turkey } \\
\text { Norway } \\
\text { Portugal }:\end{array}$ & $\begin{array}{r}182,882 \\
159,057 \\
158,721 \\
102,496 \\
32,061 \\
26,226 \\
20,780 \\
14,438 \\
13,950 \\
8,374 \\
\end{array}$ & $\begin{array}{r}8,359 \\
17,598 \\
13,741 \\
120,013 \\
2,595 \\
777 \\
3,213 \\
469 \\
2,169 \\
13 \\
13\end{array}$ & $\begin{array}{r}58,185 \\
4,703 \\
9,737 \\
1,730 \\
3,593 \\
\mathbf{1}, 036 \\
82 \\
13,605 \\
47 \\
2,575\end{array}$ & 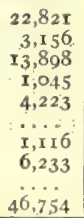 & $\begin{array}{l}\text { Netherlands } \\
\text { France } \\
\text { Denmaark } \\
\text { Belgium } \\
\text { Bulgaria, Servia, } \\
\text { Montenegro } \\
\text { Spain } \\
\text { Switzerland : } \\
\text { Rumania : }\end{array}$ & $\begin{array}{l}8,358 \\
8,022 \\
7,555 \\
5,711 \\
4,695 \\
5,074 \\
3,458 \\
2,522\end{array}$ & $\begin{array}{r}93 \mathrm{r} \\
2,04 \mathrm{I} \\
785 \\
\mathbf{1 , 5 6 3} \\
\mathbf{T , 1 1 8} \\
\mathbf{I} 97 \\
270 \\
511\end{array}$ & $\begin{array}{r}246 \\
4,916 \\
606 \\
425 \\
1,156 \\
\mathbf{1 1 8 , 7 2 3} \\
805 \\
201\end{array}$ & $\begin{array}{c}27,007 \\
\ldots \ldots \\
\ldots\end{array}$ \\
\hline
\end{tabular}


Wheat, Barley, and Oats. Production (Beerbohm)

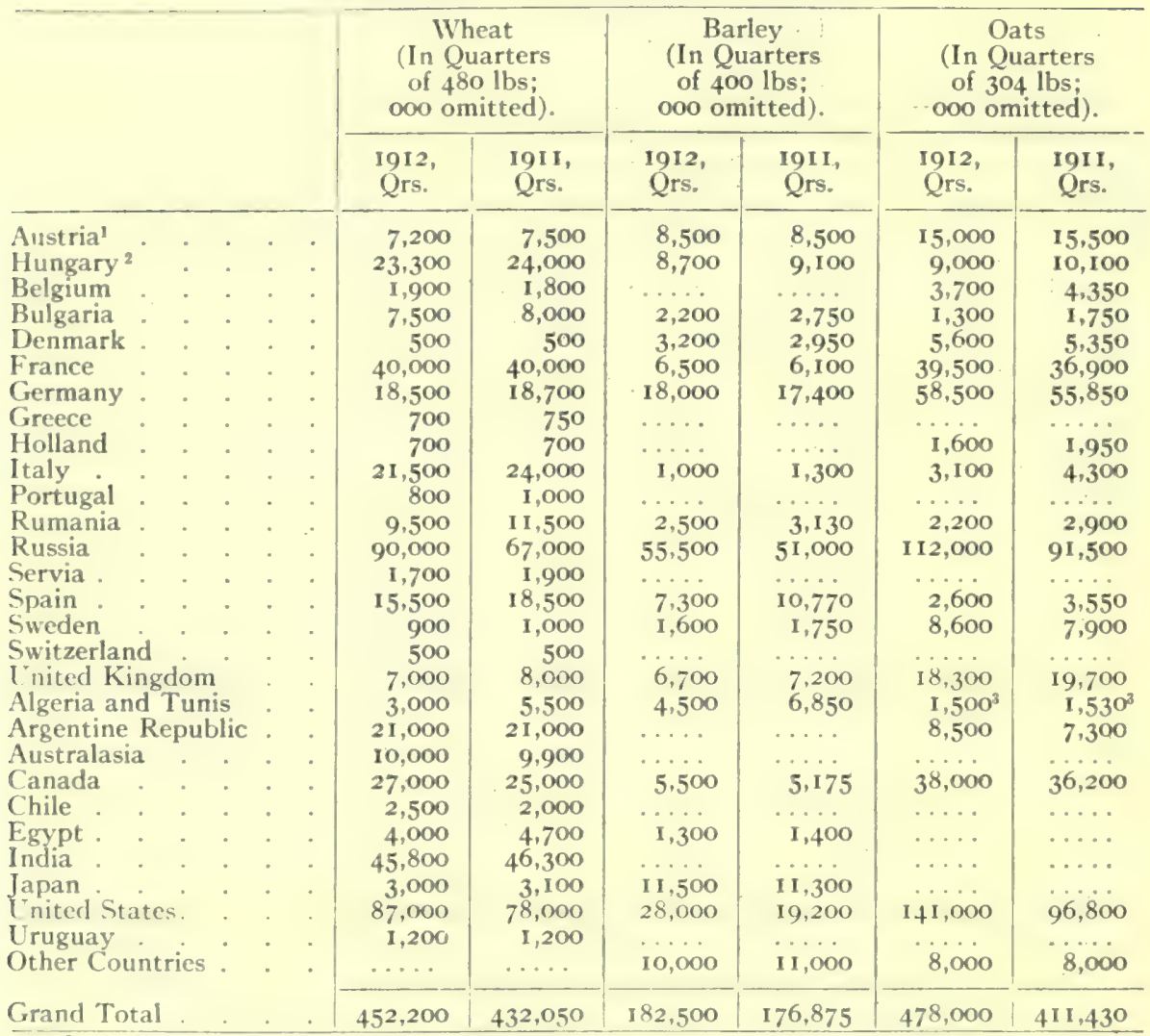

I Including Bosnia-Herzegovina.

2 Including Slavonia and Croatia.

${ }^{3}$ North Africa.

Indian Corn Production in Qrs. of $480 \mathrm{lbs}$. (Beerbohm).
Rye Production

In Qrs. of 480 lbs. (Beerbohm).

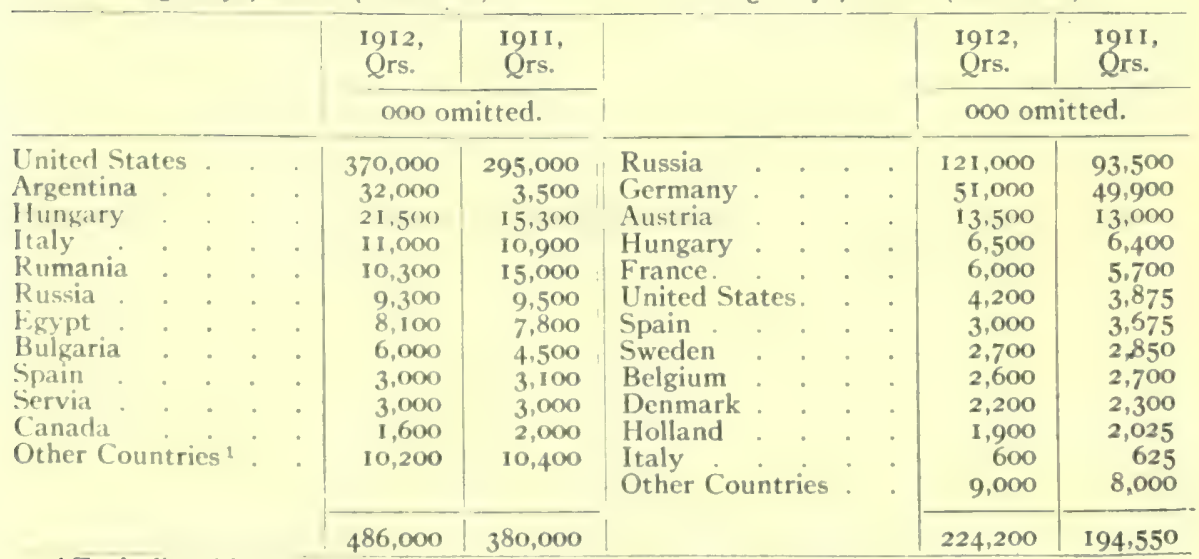

${ }^{1}$ Excluding Mexico, which in 1910 produced $21,560,000$ quarters. 
Hops Production in lbs.

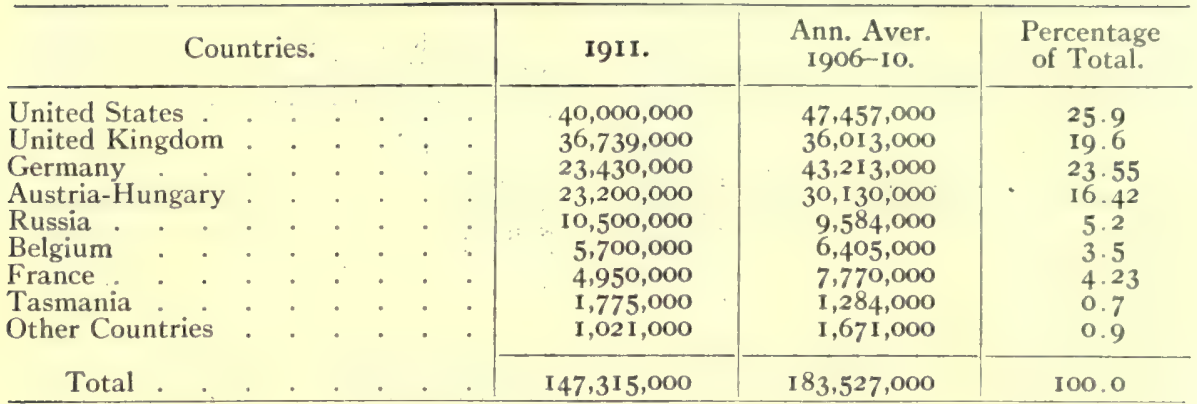

\section{Cane Sugar Production (Messrs. Willett \& Gray's Estimate, I9II-I2).}

Tons.

British India

Cuba

Java .

Hawaii

United States (Louisiana and

Texas)

Porto Rico

Brazil

Argentina

Japan and Formosa

Australia

Mauritius

Philippines

Mexico

Peru.

Santo Domingo and Haiti

British Guiana .

Other Countries

Total
$2,390,000$

I, 850,000

$1,395,000$

535,000

324,000

320,000

235,000

I 80,000

I 79,000

I 73,000

I 70,000

160,000

I 55,000

140,000

100,000

I00,000

570,000

$8,976,000$

\section{Beet Sugar Production (International} Association, etc.), I911-I2.

Russia

Tons.

Germany

Austria-Hungary

$2,080,000$

I, 457,000

I, 154,000

United States

$54 \mathrm{I}, 000$

France

$5^{1} 5,000$

251,000

239,000

I 55,000

I 27,000

I 12,000

107,000

53,000

Other Countries

$6,791,000$

Total Beet

$8,976,000$

Total Cane

Total Beet and Cane

I $5,767,000$

Average Annual Sugar Production, 1906-07 to 1910-II.

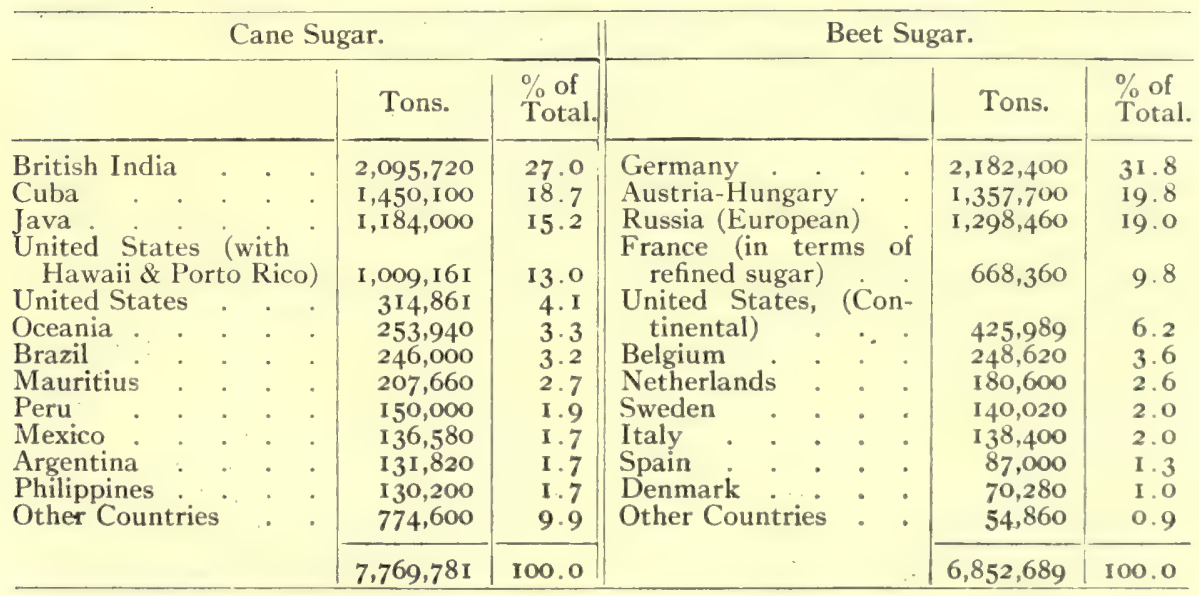


Tons Avoir.

Commonwealth of Australia

United Kingdom

United States

Dominion of Canada, 1909

(iermany

Netherlands .

France

Belgium

Austria-Hungary
238,840 : Raw and Refined

$\{1,673,204$. Raw and Refined (nict imports) 82.43

$\{1,564,076$ In equivalent of Refined

$3,285,771$. Mainly Raw

222,227 . Raw and Refined

I,I 16,012 * . Refined

99,446 . . Refined.

598,357 . . Refined

96,878 . . Refined

534,165 . . Refined

79.90
Per Head of Population, Ibs.

77.05

66.46

$38.6 \mathrm{I}$

37.25

$34 \cdot 13$

29. 12

24.09

Rice Production, I9Io, in millions of lbs.

British India
China (est.)
Japan :
Java
Siam (est.)
French Indo China
Korea (est.)
Formosa (est.)
Philippines (est.)
Italy
88,474
55,000
14,562
7,566
6,824
5,000
3,200
2,892
I, 048 968

Madagascar (est.)

United States.

Egypt .

Spain

Asiatic Russia

Ceylon

Peru (est.)

Mexico

British Guiana (est.)

Other Countries
953

$68 \mathrm{I}$

662

465

363

320

225

125

581

\section{Rubber Production, IOII.}

Amazonas and Brazil

Tons.

39,000

15,000

East Africa (wild) Penang, Borneo, Rangoon, Assam, Madagascar, etc.

Central America, Mexico, etc. .

Plantation

(iuayule from Mexico

Malaysian and extracted from Selutong

5,300

2,500

14,200
Rubber Consumption, I9II.

America and Canada

Tons. 42,000

Germany, Austria, etc.

I 4,000

12,000

United Kingdom

8,500

Russia

8,000

2,000

1,500

Italy
Japan and Australia

88,000

88,000

Tobacco Production, I9IO.

Million lbs.

United States (except Philippines)

British India (est.)

Russian Empire

Austria Hungary

Dutch East Indies

Japanese Empire

Brazil (exports)

iermany

$1,113.4$
450.0
200.7
184.8
128.6
92.7
75.3
63.6

Turkey in Europe

Million lbs.

\section{Cuba}

Santo Domingo

Philippines (1909)

France

Mexico

Other Countries

Total

49.2

46.0

42.0

40.2

36.4

34.7

198.4

$2,756.0$

Average Annual Tobacco Production, 1905-00.

United States (and Porto Riro)

British India

Russian limpire

Austria-llungary

Dutch East Indics

Turkey (including Asiatic)
I.bs.

$766,883,000$ $450,000,000$ $197,4+6,000$ $169,524,000$ $148,972,000$ I00,000,000

Percentage of Total.

31.6
18.6
8.2
7.0
6.1
4.1

31.6

18.6

8.2

7.0

4. I
Lbs.

Percentage of Total.

Japanese Empire
Cermany
Brazil (exports)
Cuba Countries
Other Coun

$94,409,000$

$68,120,000$

52,063,000

$51,797,000$

$324,355,000$

$2,423,569,000$
3.9

2.8

2.2

2. I

13. 4
100.0 
Cotton Production, roro (Bales of $500 \mathrm{lbs}$.).

Bales.

Bales.

United States

I I , 608,958

Mexico (est.)

200,000

$3,874,477$

Turkey in Asia

I 41,000

I, 570,620

Persia (exports)

I 28,03 I

Peru

I I 5,000

688,000

Other Countries

I 96,694

270,000

Total

$19,992,780$

Note. For I9I I the figures were: America 12,I32,000 bales of 500 lbs.; East Indies $4,682,000$ bales of 450 lbs.; Egypt 984,000 bales of 750 lbs.; Brazil, China, Russia in Asia, etc., etc. 3,036,000 bales average $330 \mathrm{lbs}$.

Cotton Consumption, Year Ending August.31, I9I2.

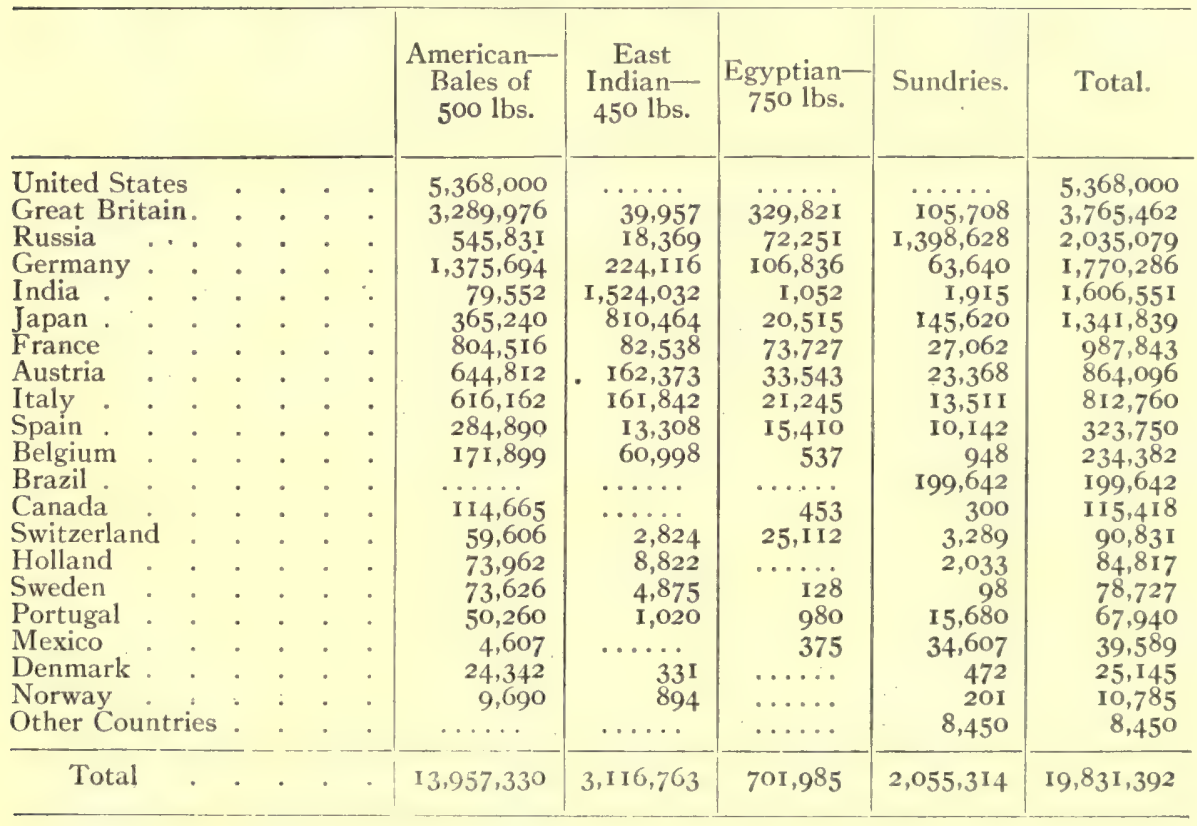

\section{Wool Production.}

The National Association of Vool Manufacturers (U.S.A.) estimate the world's annual production at $2,952,783,000$ lbs.

I.bs.

Australasia

Argentina

United States

Russia (European)

United Kingdom

Uruguay .

British South Africa
$833,611,665$

$414,464,800$

$321,362,75^{\circ}$

$320,000,000$

- I4I,939,600

- 129,961, 170

- 1 I I, 720,000
Lbs.

Turkey (European)

$90,500,000$

France

Russia (Asiatic)

Spain

British India

China

Other Countries
$78,000,000$

$60,000,000$

$52,000,000$

$50,000,000$

$50,000,000$

$299,223,015$ 
Production of Raw Wool in Europe and North America.

\begin{tabular}{c|c|c|c|c}
$\begin{array}{c}\text { United } \\
\text { Kingdom. } \\
\text { Million lbs. }\end{array}$ & $\begin{array}{c}\text { Continent } \\
\text { of Europe. } \\
\text { Million lbs. }\end{array}$ & $\begin{array}{c}\text { North } \\
\text { America. } \\
\text { Million lbs. }\end{array}$ & $\begin{array}{c}\text { Total Production } \\
\text { Europe and North } \\
\text { America. } \\
\text { Million lbs. }\end{array}$ \\
\hline 1910 & 143 & 420 & 333 & 896 \\
1911 & 136 & 420 & 330 & 886 \\
\hline
\end{tabular}

Sources of Imports of Raw Wool into Europe and North America.

\begin{tabular}{c|c|c|c|c|c} 
& $\begin{array}{c}\text { Australasia. } \\
\text { Million lbs. }\end{array}$ & $\begin{array}{c}\text { Cape. } \\
\text { Million lbs. }\end{array}$ & $\begin{array}{c}\text { River Plate. } \\
\text { Million lbs. }\end{array}$ & $\begin{array}{c}\text { Other } \\
\text { Countries. } \\
\text { Million lbs. }\end{array}$ & $\begin{array}{c}\text { Total } \\
\text { Imports. } \\
\text { Million lbs }\end{array}$ \\
\hline I9I0 & 855 & I25 & 433 & 237 & I,650 \\
I9II & 854 & I3I & 449 & $\mathbf{2 4 7}$ & $\mathbf{I} 68 \mathbf{I}$ \\
\hline
\end{tabular}

Supply of Raw Wool in Europe and North America (Home Production plus Imports).

\begin{tabular}{|c|c|c|c|c|}
\hline & $\begin{array}{l}\text { United } \\
\text { Kingdom. } \\
\text { Million lbs. }\end{array}$ & $\begin{array}{l}\text { Continent } \\
\text { of Europe. } \\
\text { Million lbs. }\end{array}$ & $\begin{array}{c}\text { North } \\
\text { America. } \\
\text { Million lbs. }\end{array}$ & $\begin{array}{l}\text { Grand Total. } \\
\text { Million Ibs. }\end{array}$ \\
\hline 1910 & $\begin{array}{l}613 \\
633\end{array}$ & 1,423 & 510 & 2,546 \\
\hline
\end{tabular}

Silk Production.

Chief Sources of

Production

(Raw Silk, including Tussah Silk).

Japan

China, Shanghai

China, Canton

Total China

Italy .

Levant

France

Austria

India (est.)

Spain

Total Pounds

Tussah, Raw

Grand Total

\begin{tabular}{|c|c|c|}
\hline $\begin{array}{c}\text { I912-I3 } \\
\text { (estimated) }\end{array}$ & I9I I-I 2 & I9IO-II \\
\hline lbs. & lbs. & lbs. \\
\hline $\begin{array}{c}21,164,000 \\
9,365,000^{1} \\
5,079,000\end{array}$ & $\begin{array}{c}20,549,000 \\
9,083,000 \\
3,704,000^{2}\end{array}$ & $\begin{array}{r}19,577,000 \\
8,408,000 \\
5,785,000\end{array}$ \\
\hline I $4,444,000$ & I $2,787,000$ & $14,193,000$ \\
\hline $\begin{array}{r}9,094,000 \\
5,633,000 \\
1,102,000 \\
662,000 \\
661,000 \\
176,000\end{array}$ & $\begin{array}{r}7,694,000 \\
6,173,000 \\
882,000 \\
783,000 \\
485,000 \\
187,000\end{array}$ & $\begin{array}{r}8,702,000 \\
6,162,000 \\
701,000 \\
776,000 \\
474,000 \\
183,000\end{array}$ \\
\hline $\begin{array}{r}52,936,000 \\
3,836,000\end{array}$ & $\begin{array}{r}49,540,000 \\
3,715,000\end{array}$ & $\begin{array}{r}50,768,000 \\
3,488,000\end{array}$ \\
\hline $56,772,000$ & $53,255,000$ & $54,256,000$ \\
\hline
\end{tabular}

${ }^{1}$ Excluding Tussah. ${ }^{2}$ II months. 
Wine Production.

France

Italy

Spain

Algeria

Russia

Hungary

Argentine

Austria

Portugal

Chile

Germany

Greece

Rumania

United States

Bulgaria
Imperial Gallons

$990,990,000$

$930,000,000$

$367,358,000$

I $94,326,000$

$94,600,000$

$84,200,000$

$79,090,000$

$63,800,000$

$62,700,000$

$61,600,000$

$57,200,000$

$48,400,000$

$39,600,000$

$29,700,000$

$28,600,000$
Turkey

Switzerland

Servia

Brazil

Uruguay .

Australia

Peru.

Tunis

Cape Colony

Luxemburg .

Bolivia

Mexico

Persia

Total
Imperial Gallons $28,600,000$

2 I, I 20,000

$9,900,000$

$7,700,000$

$5,280,000$

$4,620,000$

$4,180,000$

$3,300,000$

$2,860,000$

I, 870,000

I, 760,000

638,000

I 32,000

$3,224,124,000$

Beer Production.

Imperial Gallons.

Total Production, I9II

- $7,193,092,896$

Total Production, I910

$6,665,504,012$

Increase

$527,588,884$

Principal Beer Producing Countries, IOII.

Imperial Gallons

$$
\begin{array}{r}
\mathbf{I}, 633,764,000 \\
\mathbf{I}, 43 \mathbf{1}, 936,000 \\
\mathbf{I}, 293,886,000 \\
562,540,000 \\
394,724,000
\end{array}
$$

Belgium

Russia

Switzerland

Sweden

Denmark

Imperial Gallons

$363,000,000$

$222,200,000$

$64,900,000$

\begin{tabular}{|c|c|c|c|c|c|c|c|c|c|}
\hline & & & & $\begin{array}{l}\text { Wine, } \\
\text { Imp. } \\
\text { Gal. }\end{array}$ & $\begin{array}{l}\text { Taking } \\
\text { I900 to } \\
\text { be equal } \\
\text { to I00, } \\
\text { I } 909 \text { is } \\
\text { equal to }\end{array}$ & $\begin{array}{l}\text { Beer, } \\
\text { Imp. } \\
\text { Gal. }\end{array}$ & $\begin{array}{l}\text { Taking } \\
\text { I900 to } \\
\text { be equal } \\
\text { to } 100, \\
\text { I909 } \\
\text { equalled }\end{array}$ & $\begin{array}{l}\text { Spirits. } \\
\text { Galls. }\end{array}$ & $\begin{array}{l}\text { Taking } \\
\text { I900 to } \\
\text { be equal } \\
\text { to I00, } \\
\text { I909 } \\
\text { equalled }\end{array}$ \\
\hline United Kingdom & & . & & 0.26 & 68 & 26.2 & 83 & 0.7 & 62 \\
\hline Australia & & . & . & I. 08 & 87 & I I . O & 87 & 0.78 & 87 \\
\hline New Zealand & & . & . & 0.14 & 93 & 9.7 & 106 & 0.74 & 102 \\
\hline Union of S. Africa & & . & . & 0.62 & & I. 3 & & 0.36 & \\
\hline Canada : & . & . & . & o. I0 & I I & $5 \cdot 3$ & I 17 & 0.81 & I I 4 \\
\hline Newfoundland & . & . & . & 0.04 & 13 & 0.29 & 107 & 0.39 & I34 \\
\hline German Empire & . & . & . & 0.97 & 66 & 22.0 & 87 & I. 58 & 94 \\
\hline Netherlands & . & . & . & 0.33 & 89 & & $\ldots$ & 1. 34 & 84 \\
\hline Belgium & . & . & . & 1.01 & 100 & 46.0 & 95 & I. O3 & 57 \\
\hline France. & & . & . & 32.8 & 82 & 7.9 & 133 & I. 32 & 74 \\
\hline Switzerland (1908 & & . & . & .14 .7 & 70 & 15.61 & 106 & 0.73 & 84 \\
\hline Portugal . & . & . & . & 22.8 & 113 & . & . & & . \\
\hline Spain . . & . & . & . & 15.2 & 67 & .. & . & & $\therefore$ \\
\hline Italy . . & . & . & . & 26.0 & II 8 & 0.42 & 300 & 0.56 & 233 \\
\hline Austria . & 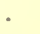 & . & . & 5 & Io & 14.3 & 88 & 1. 32 & 85 \\
\hline Hungary . & . & . & . & 4.0 & 166 & 2.4 & I33 & I. 54 & 87 \\
\hline Bulgaria . & 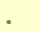 & . & . & 6.8 & 32 & 0.62 & $28 \mathrm{I}$ & 0.10 & 250 \\
\hline Servia. . & 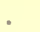 & . & . & $3 \cdot 1$ & 206 & 0.85 & 132 & $\ldots$ & . \\
\hline Rumania . & • & . & . & 4.2 & 32 & 0.60 & 315 & 0.70 & 152 \\
\hline United States & . & . & & $0.5^{8}$ & $18 \mathrm{I}$ & 16.5 & 124 & I. I4 & 109 \\
\hline Russian Empire & . & . & ${ }^{\circ}$ & . : & . & $1.22^{1}$ & 129 & I. IO & III \\
\hline Norway : . & . & . & . & $\ldots$ & . & 4.2 & $7 \mathbf{1}$ & 0.64 & 100 \\
\hline Sweden & 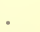 & . & 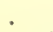 & $\therefore$ & .. & I I. I & 89 & I. 14 & 68 \\
\hline Denmark & & . & & & & I9. I & 86 & 2.16 & 82 \\
\hline
\end{tabular}

$64,900,000$

$61,600,000$

Alcoholic Liquor Consumption per Head of Population.

(Board of Trade Returns, No. 319, I9I I)

${ }^{1}$ Figures for 1908 . 
Tea Exports from Principal Sources.

Lbs.

Lbs.

British India . . . I9II

$254,301,000$

$208,133,000$

Japan . . . . . 1910

$43,489,000$

China . . . . 1910

I $82,070,000$

Java

$33,5+7,000$

Ceylon

1910

Formosa

24,241,000

Tea Consumption of Leading Countries.

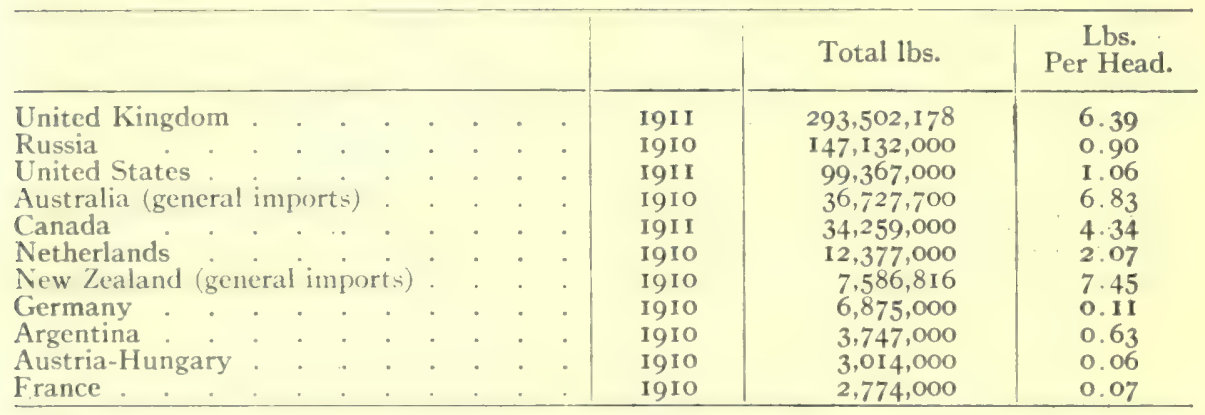

The consumption per head in other countries in I9 Io was: Persia, $0.83 \mathrm{lbs}$; Chile, 0.83 ; Denmark, 0.44; Algeria, 0.3; Switzerland, 0.26; Norway, 0.12; Finland, 0.10; Sweden, 0.09; Rumania, 0.08; Bulgaria, 0.03; Spain, 0.02; Greece, 0.01; Italy, 0.005.

Coffee Production.

Annual Average rgos-9. U. S. Dept. of Agr. est.

Coffee Consumption, roro.

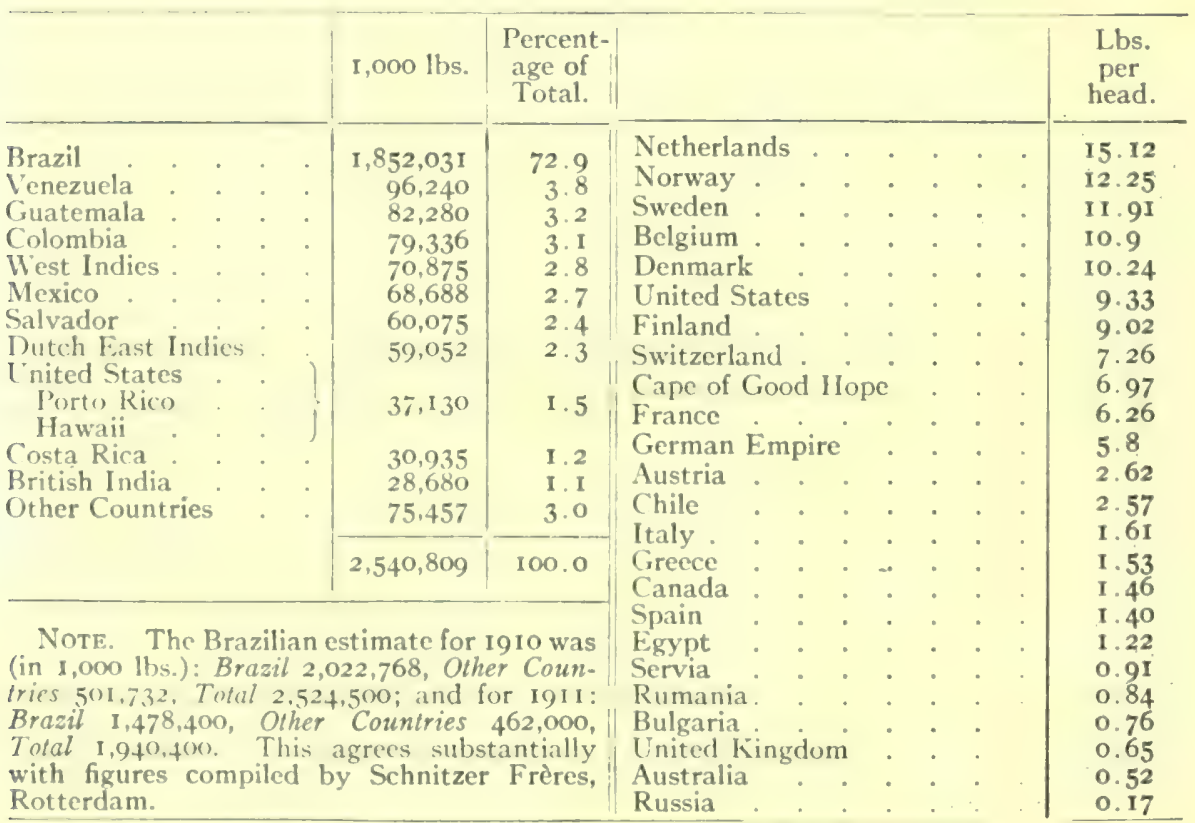


Cocoa Production, I9II.

Tons Percent-

Avoir- age of

dupois. Total.

\begin{tabular}{|c|c|c|c|}
\hline Eсuad & & & 6 \\
\hline $\begin{array}{l}\text { cuado } \\
\text { razil }\end{array}$ & & $\begin{array}{l}39,655 \\
38,376\end{array}$ & \\
\hline Gold Coast & & 34,440 & $\begin{array}{l}\text { I } 3.98 \\
\end{array}$ \\
\hline Thomas (Portu & uese) & 32,964 & 13.4 \\
\hline Trinidad & & 23,813 & 9.7 \\
\hline Santo Domingo & & 19,680 & \\
\hline Venezuela & . & 17,712 & 7.2 \\
\hline Grenada & & 5,904 & \\
\hline German Colonies & . & 4,920 & 2.0 \\
\hline Ceylon. & & $4,23 \mathrm{I}$ & I. 7 \\
\hline Lagos & & 3,739 & I. $5^{2}$ \\
\hline Dutch East Indies & : & 2,952 & \\
\hline Fernando Po. & & $2,95^{2}$ & 1.2 \\
\hline Jamaica. & . & 2,755 & I. I \\
\hline Haiti & & 2,460 & .9 \\
\hline Surinam & & 2,165 & .8 \\
\hline French Colonies & . & I, 574 & .7 \\
\hline & & 1,476 & \\
\hline Dominica & & 1,082 & .4 \\
\hline Belgian Congo & & 984 & .4 \\
\hline Santa Lucia & & 689 & .3 \\
\hline Coun & & 1,771 & \\
\hline
\end{tabular}

Gold Production, rgri ("Mineral Industry")

Transvaal

Oz. Fine.

United States $8,237,723$ $4,655,297$ $2,892,456$ $1,412,483$ $1,202,952$

$628,52 \mathrm{I}$

515,684 484,000 472,280 $25 \mathrm{I}, 45 \mathrm{I}$ I 65,699 165,457 159,692 144,680 I42,719

I 37,927 II 5,385 I09,3I5 I00, 387 532,477 Value t $34,991,620$ I $9,848,664$ I $2,327,090$ $6,021,680$ $5,128,410$ $2,647,894$ $2,198,460$ $2,062,500$ $2,013,432$ I,069,442 7 II, 400 705,375 680,800 616,787 608,500 588,000 $49 \mathrm{I}, 000$ 467,100 428,000 $2,384,583$ Total . 22,526,585 95,991,637

Cocoa Consumption, I911.

United States

Germany

France

Great Britain

Holland

Switzerland

Spain

Austria-Hungary

Belgium

Russia

Italy

Denmark

Canada

Sweden

Norway

Australia

Portugal

Finland

Other Countries

\begin{tabular}{rc}
$\begin{array}{r}\text { Tons } \\
\text { Avoir- } \\
\text { dupois. }\end{array}$ & $\begin{array}{c}\text { Percent- } \\
\text { age of } \\
\text { Total. }\end{array}$ \\
60,320 & 26.4 \\
49,200 & 21.2 \\
28,044 & 12.5 \\
25,092 & 11.0 \\
23,026 & 10.0 \\
10,135 & 4.5 \\
6,200 & 2.7 \\
5,904 & 2.58 \\
4,920 & 2.12 \\
3,936 & 1.72 \\
2,362 & 1.03 \\
1,968 & .86 \\
1,870 & .82 \\
1,378 & .63 \\
984 & .45 \\
787 & .36 \\
197 & .09 \\
98 & .04 \\
2,165 & 1.0 \\
\hline 228,586 & 100.0 \\
\hline
\end{tabular}

Silver Production, IgI I ("Mineral Industry").

\begin{tabular}{|c|c|c|}
\hline Mexi & $\begin{array}{l}\text { Oz. Fine. } \\
87,078,764\end{array}$ & $\begin{array}{l}\text { Value } f \\
8,836,300\end{array}$ \\
\hline United States & $57,796,117$ & $\begin{array}{l}8,830,300 \\
6,353,591\end{array}$ \\
\hline Canada & $33,486,93^{8}$ & $3,695,07$ \\
\hline Australasia & $17,109,503$ & $1,73^{6,17}$ \\
\hline Germany & $14,13^{2}, 805$ & $\mathbf{I}, 4$ \\
\hline Peru (est.) & $8,037,675$ & 815 \\
\hline Belgium (est.) & $8,037,675$ & 815,6 \\
\hline (est.) & $4,822,605$ & 489,8 \\
\hline Bolivia (est.) & $4,179,591$ & 424, I. 2 \\
\hline Spain (est.) & $4,179,591$ & 424,12 \\
\hline ther Countries & $13,047,516$ & $1,344,39$ \\
\hline
\end{tabular}

\section{Aluminium Production.}

Metric Tons. I9I I.

North America 14,400

Switzerland

Germany

Austria

Estimate

Italy

Norway

France

Great Britain (est.)

Total (approx.)
I I, 300

I1, 700

7,300

44,700

\section{Principal Tin Supplies, Ior2.}

Straits Settlements (exports)

Tons Avoir.

Bolivia (exports to Europe)

53,670

22,064

I 2,58 I

Banka (sales in Holland)

15,775 
Copper Production in 1911 .

In 1,000

Metric Tons.

United States

Mexico

Spain and Portugal

Japan

Australasia

Chile .

Peru

Russia

Canada

Germany

Other Countries

Approx. total for World
49 I. 6

61.9

52.9

52.3

$42 \cdot 5$

33.0

28.5

$25 \cdot 9$

25.5

22.3

$43 \cdot 6$

880.0
Lead Production in roII.

In 1,000 Metric Tons.

United States 363.8 Spain

I71:0

German Empire.

I61.3

Mexico

124.6

Belgium

30.8

United Kingdom (est.)

27.1

23.0

Other Countries.

83.0

Total

984.6

Zinc Production, 1911 .

United States

Germany

Belgium

United Kingdom

France

Other Countries

Total .

Metric Tons.

268,378

235,776

195,102

67,907

55,170

55,364

877,697

Pig Iron Production.

United States

Germany and Luxemburg

United Kingdom .

France

Russia

Belgium

Austria-Hungary

Canada.

China

Sweden

Spain

Italy

Other Countries (Approx.)

Approximate total for World

Steel Production, IOII.

(In Tons Avoirdupois)

United States

Germany

United Kingelom

Russia

France

Austria-Hungary (Bosnia-Herzegovina)

Felgium

Canada

Italy

Sweden

Other Countries

$\begin{array}{rr}\text { Bessemer } & \text { Open Hearth } \\ 7,948,000 & 15,599,000 \\ 8,687,500 & 5,691,500 \\ 1,461,000 & 5,000,000 \\ 2,484,000 & 3,813,000 \\ 323,000 & 1,294,000 \\ 1,728,000 & 1,948,500 \\ 210,000 & 134,500 \\ 9031,500 \\ 92,300 & 361,300\end{array}$

Bessemer Open Hearth $7,948,000$

$8,687,500$

.
Tons.

Avoirdupois

$23,649,000$

I $5,322,000$

$9,719,000$

$4,436,000$

$3,465,000$

$2,073,000$

2,061,000

819,000

713,000

613,000

347,000

$298,500)$

I, 484,500

$65,000,000$

Approximate total for World

Other

Methods

I 28,500

403,000

Total.

$23,675,500$

$14,782,000$

$6,461,000$

$3,813,0010$

28,000

39,700

52,000

$14,75^{\circ}$

..
$3,806,000$

2,3II,200

I,914,500

876,250

687,000

453,600

219,950

$59,000,000$

(Harold Macfarlane.) 
IOWA

Scralors-Albert B. Cummins (Rep.), ror5, and William S. Kenyon (Rep.), roro Represenlatives (Republicans, 8; Democrats, 3)

- (harles A. Kennedy (Rep.)

2-Irvin S. Pepper (Dem.)

3-Maurice Connolly (Dem.)

4-Gilluert N. Haugen (Rep.)
5-James W. Good (Rep.)
6-Sant Kirkpatrick (Dem.)
7 - Solomon F. Prouty (Rep.)
8-Horace M. Towner (Rep.)

9 -William R. Green (Rep.)

Io- Frank P. Woods (Rep.)

II-George C. Scott (Rep.)

\section{KANSAS}

Senalors-Joseph L. Bristow (Rep.), ror 5, and William H. Thompson (Dem.), rorg Representatives (Democrats, 5; Republicans 3)

3-Daniel R. Anthony, Jr. (Rep.) 4-Dudley Doolittle (Dem.) 5 - Guy T. Helvering (Dem.) 6-John R. Connelly (Dem.)

7 -George A. Neeley (Dem.) 8-Victor Murdock (Rep.)

2 Joseph Taggart (I)em.)

\section{KENTUCKY}

Senators-William O. Bradley (Rep.), 1915, and Ollie M. James (Dem.), I9ro Representatives (Democrats, 9; Republicans, 2)

I-A. W. Barkley (Dem.)

2-- Augustus O. Stanley (Dem.)

3-Robert Y. Thomas, Jr. (Dem.)

4-Ben Johnson (Dem.)

\section{5-Swagar Sherley (Dem.) \\ 6-Arthur B. Rouse (Dem.) \\ 7-J. Campbell Cantrill (Dem.) \\ 8- Harvey Helm (Dem.)}

\section{LOUISIANA}

Senators-John R. Thornton (Dem.), 1915, and Joseph E. Ransdell (Dem.), roro Representatives (Democrats, 8 )

-Altert Estopinal (Dem.)

2-H. Garland Dupré (Dem.)

3-Robert F. Broussard (Dem.)
4-John T. Watkins (Dem.)
$5-$ J. W. Elder (Dem.)

6 -L. L. Morgan (Dem.)
9- William J. Fields (Dem.)
ro- James W. Langley (Rep.)

II-Caleb Powers (Rep.)
7-L. Lazaro (Dem.)
8 -J. B. Aswell (Dem.)

MAINE

Senalors-Charies F. Johnson (Dem.), I917, and Edwin Chick Burleigh (Rep.), Ioso Representatives (Republicans, 3; Democrats, I)

r-Asher C. Hinds (Rep.)

2-Daniel J. McGillicuddy (Rep.)

\section{MARYLAND}

3-Forrest Goodwin (Rep.) 4-Frank E. Guernsey (Rep.)

Senators-John Walter Smith (Dem.), ror5, and William P. Jackson (Rep.), ad interim Representalives (Democrats, 6 )

I-J. Harry Covington (Dem.)

2-J. Frederick C. Talbott (Dem.) 3-George Konig (Dem.) 4-J. Charles Linthicum (Dem.)
5-Frank O. Smith (Dem.) 6-David J. Lewis (Dem.)

\section{MASSACHUSETTS}

Senators-John Wingate Weeks (Rep.), rorg, and Henry Cabot Iodge (Rep.), ror7

I-Allen T. Treadway (Rep.) 2-Frederick H. Gillett (Rep.) 3-William H. Wilder (Rep.) 4-Samuel E. Winslow (Rep.) 5 -John Jacob Rogers (Rep.) 6-Augustus P. Gardner (Rep.)

Representatives (Republicans, 0; Democrats, 7 )

\begin{tabular}{|c|c|}
\hline Michael F. Phelan (D & Senate \\
\hline erick S. Deitrick (1) & Senate \\
\hline W. R. M & 14-Edward Gilmo \\
\hline (Dem.) & $\begin{array}{l}\text { 15-W llliam S. Greene (Rep.) } \\
\text { 16-Thomas C. Thacher (Dem.) }\end{array}$ \\
\hline & \\
\hline
\end{tabular}

\section{MICHIGAN}

Senalors-Charles F. Townsend (Rep.), ror7, and William Alden Smith (Rep.), rgrg Representatives (Republicans, 10; Democrats, 2; Progressive, $x$ )

I-Frank E. Doremus (I)em.)

2-Samucl W. Beakes (I)em.)

3. J. M. ('. Smith (Kep.)

4-Edward L. Hamilton (Rep.)

5-C. E. Mapes (Rep.)

$$
\begin{aligned}
& \text { 6-Samuel W. Smith (Rep.) } \\
& \text { 7- L. C. Crampton (Rep.) } \\
& \text { 8--Joseph W. Fordney (Rep.) } \\
& \text { 9-James C. McLaughlin (Rep.) } \\
& \text { Io-R. O. Woodruff (Prog.) }
\end{aligned}
$$

\section{MINNESOTA}

Senators-Moses E. Clapp (Rep.), r977, and Knute Nelson (Rep.), rorg Represenlatives (Republicans, 9 ; Democrats, 1 )

-Sydney Anderson (Rep.)

2-Winfield S. Hammond (Dem.)

- Charles R. Davis (Rep.)

4-Frederick C. Stevens (Rep.)

$$
\begin{aligned}
& \text { 5-George R. Smith (Rep.) } \\
& \text { 6-Charles A. Lindbergh (Rep.) } \\
& \text { 7-Andrew J. Volstead (Rep.) } \\
& \text { 8-Clarence B. Miller (Rep.) }
\end{aligned}
$$

I I-F. O. Lindquist (Rep.)

1 2 - H. Olin Young (Rep.)

At large-P. H. Kelley (Rep.)

\section{MISSISSIPPI}

Senolors-John Sharp Williams (Dem.), I917, and James K. Vardaman (Dem.), rorg

--Ezekiel S. Candler. Jr. (Dem.)

2 Hulert D. Stephens (I)em.)

3-Benjamin G. Humphreys (Dem.)

Representalives (Democrats, 8)

4-Thomas U. Sisson (Dem.)
5 Samuel Andrew Witherspoon
(Dem.)

6-Byron P. Harrison (Dem.)

7- Percy E. Quin (Dem.)

8-James W. Collier (Dem.)

\section{MISSOURI}

Senalors-William J. Stone (Dem.), ror 5, and James A. Reed (Dem.), ror 7 kepresenlatives (Democrats, $x_{4}$; Republicans, 2)

1-James T. I.loyd (Dem.)

2--William W. Rucker (Dem.)

3-Joshua W. Alexander (Dem.)

4-Charles F. Bouher (Dem.)

5-William P. Borland (Dem.)

6 - Clement C. Dickinson (Dem.)

$$
\begin{aligned}
& \text { 7-Courtney W. Hamlin (Dem.) } \\
& \text { 8- Dorsey W. Shackleford (Dem.) } \\
& \text { 9-Champ Clark (Dem.) } \\
& \text { Io-Richard Bartholdi (Rep.) } \\
& \text { Is-W. L. Igoe (Dem.) }
\end{aligned}
$$$$
12 \text {-Leonidas C. Dyer (Rep.) }
$$ 
NEBRASKA

Senators-Gilbert M. Hitchcock (Dem.), x91 7, and George W. Norris (Rep.), roro Representatives (Democrats, 3; Republicans, 3)

$\begin{array}{ll}\text { 3-Dan V. Stephens (Dem.) } & \text { 5-Silas R, Barton (Rep.) } \\ \text { 4-Charles H. Sloan (Rep.) } & 6 \text {-Moses P. Kinkaid (Rep.) }\end{array}$

I-John A. Maguire (Dem.)

2-Charles O. Lobeck (Dem.)

NEVADA

Senators-Francis G. Newlands (Dem.), 1915, and Key Pittman (Dem.), ry10 Representalize-Edwin Ewing Roberts ( $\mathrm{Re}_{*}^{*}$.)

\section{NEW HAMPSHIRE}

Senators-Jacob H. Gallinger (Rep.), Ior 5, and -1(I0t9)

Representatives-E. E. Reed (Dem.) and R. B. Stevens (Dem.)

\section{NEW JERSEY}

Senators-James E. Martine (Dem.), I9r7, and William Hughes (Dem.), rgro

I-William J. Browning (Rep.)

2 -J. Thompson Baker (Dem.)

3-Thomas J. Scully (Dem.)

4-Allan B. Walsh (Dem.)
Representatives (Democrats, $\mathrm{Ir}$; Republican, 1 ) 5-William E. Tuttle, Jr. (Dem.) 6-Lewis J. Martin (Dem.) 7-Robert G. Bremner (Dem.) 8-Eugene F. Kinkead (Dem.)

\author{
9 - Walter I. McCoy (Dem.) \\ ro-Edward W. Townsend (Dem.) \\ II - John J. Eagan (Dem.) \\ I2-James A. Hamill (Dem.)
}

\section{NEW MEXICO}

Senators-Thomas B. Catron (Rep.), ror7, and Albert B. Fall (Rep.), roro

Representative-H. B. Ferguson (Dem.)

\section{NEW YORK}

Senators-Elihu Root (Rep.), I915, and James A. O'Gorman (Dem.), IoI7

I-Lathrop Brown (Dem.)

2-Dennis J. O'Leary (Dem.)

3-Frank E. Wilson (Dem.)

4-Harry Howard Dale (Prog.)

5-James P. Maher (Dem.)

6-William M. Calder (Rep.)

7-John J. Fitzgerald (Dem.)

8-Daniel J. Griffin (Dem.)

9-James H. O'Brien (Dem.)

ro-Herman A. Metz (Dem.)

II-Daniel J. Riordan (Dem.)

12 - Henry M. Goldfogle (Dem.)

3-Timothy D. Sullivan (Dem.)2

I4-Jefferson M. Levy (Dem.)

5-Michael F. Conry (Dem.) presentatives (Democrats, 30; Republicans, II; Progressives, 2)

\begin{tabular}{|c|c|}
\hline 6-Peter I Dooling (Dem.) & \\
\hline 7-John F. Carew (Dem.) & 32-Luther W. Mott (Rep.) \\
\hline 8-Thomas Gedney Patten (Dem.) & 33-Charles A. Talcott (Den \\
\hline 9-Walter M. Chandler (Prog.) & 34-George W. Fairchild (Rep.) \\
\hline 20-Francis B. Harrison (Dem.) & 35-John R. Clancy (Dem.) \\
\hline $2 \mathrm{I}$-Henry George, Jr. (Dem.) & 36-Sereno E. Payne (Rep.) \\
\hline 22-H. Bruckner (Dem.) & 37-Edwin S. Underhill (Dem.) \\
\hline 23-Joseph A. Goulden (Dem. & 38-Thomas B. Dunn (Rep.) \\
\hline son R. Oglesby (Dem.) & 39-Henry G. Danforth (Rep.) \\
\hline 25-Ben jamin I. Taylor (Dem.) & 40 -Robert H. Gittins (Dem.) \\
\hline $26-\mathrm{E}$ & $4 I$-Charles B. Smith (Dem.) \\
\hline 27-George McClellan (Dem & 42-Daniel A. Driscoll (Dem.) \\
\hline $28-P$ & 43-Charles M. Hamilt \\
\hline
\end{tabular}

28-Peter G. Ten Eyck (Dem.)

20-James S. Parker (Rep.)

30-Samuel Wallin (Rep.)

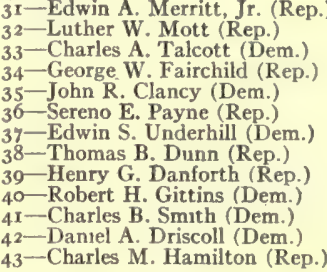

NORTH CAROLINA

Senators-Lee S. Overman (Dem.), r9r5, and Furnifold M. Simmons (Dem.), soro Representatives (Democrats, ro)

5-Charles M. Stedman (Dem.)

0-Edwin X. Webb (Dem.)

ro-James M. Gudger, Jr. (Dem.)
6-Hannibal L. Dodwin (Dem.)

7-Robert N. Page (Dem.)

8-Robert L. Doughton (Dem.)

-Claude Kitchin (Dem.)

3-John M. Faison (Dem.)

4-Edward W. Pou (Dem.)

\section{NORTH DAKOTA}

Senators-Asle J. Gronna (Rep.), roI5, and Porter J. McCumber (Rep.), I9I 7

\section{I-H. T. Helgesen (Rep.) \\ Representatives (Republicans, 3) \\ 2-George M. Young (Rep.) \\ 3-P. D. Norton (Rep.) \\ OHIO}

Senators-Theodore E. Burton (Rep.), 1915, and Atlee Pomerene (Dem.), 1917 Representatives (Democrats, I9; Republicans, 3 )

I-S. Bowdle (Dem.)

2-Alfred G. Allen (Dem.)

3-Warren Gard (Dem.)

4-J. Henry Goeke (Dem.)

5-Timothy T. Ansberry (Dem.)

6-Simeon D. Fess (Rep.)

7-James D. Post (Dem.)

8-Frank B. Willis (Rep.)

$\begin{array}{ll}\text { 9-Isaac R. Sherwood (Dem.) } & \text { I7-William A. Ashbrook (Dem.) } \\ \text { ro-Robert M. Switzer (Rep.) } & \text { 18-John J. Whitacre (Dem.) } \\ \text { II-Horatio C. Claypool (Dem.) } & \text { 19-Ellsworth R. Bathrick (Dem.) } \\ \text { I 2-C. L. Brumbaugh (Dem.) } & \text { 20-William Gordon (Dem.) } \\ \text { I3-John A. Key (Dem.) } & \text { 21-Robert J. Bulkley (Dem.) } \\ \text { I4-William G. Sharpe (Dem.) } & \text { At large-Robert L. Crosser (Dem.) }\end{array}$

I4-William G. Sharpe (Dem.)

I5-George White (Dem.)

16-William B. Francis (Dem.)

\section{OKLAHOMA}

Senators-Thomas P. Gore (Dem.), rox 5, and Robert L. Owen (Dem.), roro Representalives (Republicans, 2; Democrats, 6)
4-Charles D. Carter (Dem.)
5-Scott Ferris (Dem.)
At large-William H. Murray (Dem.)
At large $\rightarrow$ Claude Weaver (Dem.)

-Dirk T. McGuire (Rep.)

3-James S. Davenport (Dem.)

Senators-George E. Chamberlain (Dem.), ror 5, and Harry Lane (Dem.), Igro Representatives (Republicans, 2; Republican-Progressive, I) I-Willis C. Hawley (Rep.)
3-Abraham W. Lafferty (Rep.$2-$ N. J: Sinnott (Rep.) Prog.)

1 See article New Haypshire.

2 Probably will not serve.

- Contested by Democrat, Franklin Leonard, Jr.

- Contested by Julius H. Reiter, Progressive. 
PENNSYLVANIA

Senalors-Boies Penrose (Rep.), 1915, and George T. Oliver (Rep.), 19r7 Representatives (Progressives, 20; Democrats, 12; Republicans, 4)

I-William S. Vare (Prog.) 2-George S. Graham (Rep.) 3-J. Hampton Moore (Prog.) 4-George W. Edmonds (Rep.) 5-Michael Donohoe (Dem.) 6 -J. Washington Logue (Dem.) 7-Thomas S. Butler (Prog.) 8-Robert E. Difenderfer (Dem.) 9-William W. Griest (Prog.) 10-John R. Farr (Prog.)

II-John J. Casey (Dem.) 12 -Robert E. Lee (Dem.) 13 - John H. Rothermel (Dem.)

14-W. D. B. Ainey (Prog.)
15-Edgar R. Kiess (Prog.)
16-John V. Lesher (Dem.)
17-Frank L. Dershem (Dem.)
18-Aaron S. Kreider (Prog.)
19-Warren W. Bailey (Dem.)
20-Andrew R. Brodbeck (Dem.)
21-Charles E. Patton (Prog.)
22-Abraham L. Keister (Prog.)
23-Wooda N. Carr (Dem.)
24-Henry W. Temple (Rep.)
25-Milton W. Shreve (Prog.)
26-A. Mitchell Palmer (Dem.)

RHODE ISLAND
27-Jonathan N, Langham (Rep.) 28-Willis J. Hulings (Prog.) 29-Stephen G. Porter (Prog.) 30-M. Clyde Kelly (Prog.) 31-James Francis Burke (Prog.) 32-Andrew J. Barchfeld (Prog.) At large-Fred E. Lewis (Prog.) At large-Arthur R. Rupley (Prog.) At large-Anderson $\mathbf{H}$. Walters (Prog.)

At large - J. M. Morin (Prog.)

Senator-Henry F. Lippitt (Rep.), I9I7, and LeBaron Bradford Colt (Rep.), rorg Representatives (Democrats, 2; Republican, I)

I-George F. O'Shaunessy (Dem.) 2-Peter G. Gerry (Dem.)

3-Ambrose Kennedy (Rep.) SOUTH CAROLINA

Senator-Ellison D. Smith (Dem.), I015, and Benjamin R. Tillman (Dem.), Iorg

- George S. Legare (Dem.) 2-James F. Byrnes (Dem.) 3-Wyatt Aiken (Dem.)
Representatives (Democrats, 7 )

4-Joseph T. Johnson (Dem.)

5-David E. Finley (Dem.)

6-J. W. Ragsdale (Dem.)

\section{SOUTH DAKOTA}

Senators-Coe I. Crawford (Rep.), Igrs, and Thomas Sterling (Rep.), rorg Representalives (Republicans, 3) 2-Charles H. Burke (Rep.)

\section{TENNESSEE}

Senators-Luke Lea (Dem.), 1917, and John Knight Shields (Dem.), 1919 Representatives (Democrats, 8; Republicans, 2)

-Sam R. Sells (Rep.)

2-Richard W. Austin (Rep.)

3-John A. Moon (Dem.)

4-Cordell Hull (Dem.)

$$
\text { 7-Asbury F. Lever (Dem.) }
$$
3-Eben W. Martin (Rep.)

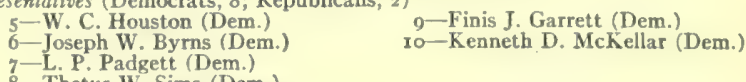

TEXAS

Senalors-Charles A. Culherson (Dem.), I 1 7 , and Morris Sheppard (Dem.), Igrg

¿-H. W. Vaughn (Dem.)

2-Martin Dies (Dem.)

3-James Young (Dem.)

4-Sam Rayburn (Dem.)

5-Jack Beall (Dem.)

6-Rufus Hardy (Dem.) Represeniatives (Democrats 18)

7-Alexander W. Gregg (Dem.)

8-Joseph H. Eagle (Dem.)

9-George F. Burgess (Dem.)

Io-Albert S. Burleson (Dem.)

xi-Robert L. Henry (Dem.)

12 - Oscar Callaway (Dem.)

\section{UTAH}

Senators-Reed Smoot (Rep.), 1015, and George Sutherland (Rep.), I917

Representatives - Joseph Howell (Rep.) and Jacob Johnson (Rep.)

\section{VERMONT}

Senators-William P. Dillingham (Rep.), ro15, and Carroll S. Page (Rep.), I917 Representatives-Frank L. Greene (Rep.) and Frank Pulmley (Rep.)

\section{VIRGINIA}

Senators-Claude A. Swanson (Dem.), 10r7, and Thomas S. Martin (Dem.), roro Representatives (Democrats, 9; Republican, $\mathrm{I}$ )

1-William A. Jones (Dem.)

$2-$ Edward E. Holland (Dem.)

3-Andrew J. Montague (Dem.)

4-Walter A. Watson (Dem.) $5-$ Edward W. Saunders (Dem.)
6 -Carter Glass (Dem.)
7-James Hay (Dem.)
9-C. Bascom Slemp (Rep.) ro-Henry D. Flood (Dem.)

8-Charles C. Carlin (Dem.)

WASHINGTON

Senators-Wesley L. Jones (Rep.), 1015, and Miles Poindexter (Rep.), ror 7 Representatives (Republicans, 3; Progressives, 2)

I-William E. Humphrey (Rep.) 3-William L. LaFollette (Rep.)

2-Albert Johnson (Rep.) At large-J. A. Falconer (Prog.)

At large-J. W. Bryan (Prog.) WEST VIRGINIA

Senators-William E. Chilton (Dem.), 1917, and Nathan Goff (Rep.), (rg19) 14 - James L. Slayden (Dem.) 15-John N. Garner (Dem.) 5-William R. Smith (Dem.) At large-H. W. Sumners (Dem.)

)


1008 Presidential Election.

\begin{tabular}{|c|c|c|c|c|c|c|c|c|c|c|c|c|c|c|}
\hline & & & & & & Electo & Vote & & & Pop & ular Vote & & & \\
\hline & & tale & & & & $\begin{array}{l}\text { Taft } \\
\text { Rep. }\end{array}$ & $\begin{array}{l}\text { Bryan } \\
\text { Dem. }\end{array}$ & $\begin{array}{l}\text { Taft } \\
\text { Rep. }\end{array}$ & $\begin{array}{c}\text { Bryan } \\
\text { Dem. }\end{array}$ & $\begin{array}{l}\text { Debs } \\
\text { Soc. }\end{array}$ & $\begin{array}{l}\text { Chafin } \\
\text { Proh. }\end{array}$ & $\begin{array}{l}\text { Gilhaus } \\
\text { Soc. L. }\end{array}$ & $\left|\begin{array}{c}\text { Watson } \\
\text { Pop. }\end{array}\right|$ & $\begin{array}{l}\text { Hisgen } \\
\text { Ind. }\end{array}$ \\
\hline Alabama & . & . & . & . & . & $\therefore$ & II & 25,308 & 74,474 & $\mathbf{1}, 399$ & 665 & $\ldots$ & I, 568 & 495 \\
\hline Arkansas & . & . & . & : & $\because$ & $\therefore$ & 9 & 56,760 & 87,015 & 5,842 & I, I94 & $\ldots$ & 1,026 & - $\quad 289$ \\
\hline California & & $\because$ & - & . & . & IO & . & 214,398 & 127,492 & 28,659 & 11,770 & $\ldots$ & $\ldots$ & 4,278 \\
\hline Colorado & - & . & . & . & : & . & 5 & 123,700 & 126,644 & 7,974 & 5,559 & $\cdots$ & $\cdots$ & $\ldots$ \\
\hline Connecticu & ut & . & $\cdot$ & . & . & 7 & .. & I I 2,915 & $\cdots 68,255$ & 5,113 & 2,380 & 608 & $\ldots$ & 728 \\
\hline Delaware & . & . & . & . & . & 3 & . & 25,014 & $22,07 \mathrm{I}$ & 239 & 670 & $\ldots$ & $\ldots$ & 30 \\
\hline Florida & . & . & " & - & . & .. & 5 & 10,654 & $3 I, 104$ & 3.747 & 553 & $\ldots$ & I,946 & I, 356 \\
\hline Georgia & - & : & . & . & . & . & $I_{3}$ & 41,692 & 72,413 & $5^{84}$ & 1,059 & $\ldots$ & 16,969 & $=77$ \\
\hline Idaho . & - & . & - & - & . & 3 & .. & $5^{2,621}$ & 36,162 & 6,400 & $9, \mathbf{1} 86$ & $\ldots$ & $\ldots$ & 119 \\
\hline Illinois. & . & . & . & - & . & 27 & . & 629,929 & 450,795 & 34,691 & 29,343 & $1,65 x$ & 633 & 7,709 \\
\hline Indiana & . & . & $\therefore$ & . & . & I5 & . & 348,993 & 338,262 & I3,476 & 18,045 & 643 & 1,193 & 514 \\
\hline Iowa . & - & . & 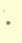 & . & . & 13 & . & 275,210 & $200,77 \mathrm{I}$ & 8,287 & 9,837 & $\ldots$ & $26 x$ & 404 \\
\hline Kansas & $\cdot$ & . & . & . & . & Io & .. & 197,216 & 161,209 & 12,420 & 5,033 & $\cdots$ & $\ldots$ & 68 \\
\hline Kentucky & & . & . & . & . & . & 13 & $235,7 \mathrm{II}$ & 244,092 & 4,060 & 5,887 & 404 & 333 & 200 \\
\hline Louísiana & . & . & . & . & . & . & 9 & $8,95^{8}$ & 63,568 & 2,538 & & $\ldots$ & $\ldots$ & 82 \\
\hline Maine. & . & . & . & . & . & 6 & .. & 66,987 & 35,403 & $\mathbf{x}, 75^{8}$ & $\mathbf{I}, 487$ & $\ldots$ & $\ldots$ & 7or \\
\hline Maryland & & . & $\cdot$ & - & . & 2 & 6 & I 16,513 & I 15,908 & 2.323 & 3,302 & $\cdots$ & $\cdots$ & 485 \\
\hline Massachus & sett & & " & . & . & x6 & . & 265,966 & $\mathbf{I 5 5 , 5 4 3}$ & ro, $78 \mathbf{r}$ & 4,379 & 1, or 8 & $\ldots$ & 19,239 \\
\hline Michigan & - & . & - & . & . & $\mathbf{r} 4$ & .. & 335,580 & $175,77 \mathrm{I}$ & I I, 586 & 16,974 & 1,096 & $\cdots$ & 742 \\
\hline Minnesota & & . & . & $\therefore$ & . & II & .. & 195,843 & 109,401 & 14,527 & II, 107 & $\ldots$ & $\ldots$ & 426 \\
\hline Mississipp & & . & . & - & . & $\cdots$ & 10 & 4,363 & 60,287 & 978 & & $\ldots$ & $x, 276$ & $\ldots$ \\
\hline Missouri & - & . & 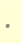 & . & . & 18 & .. & 347,203 & 346,574 & 15,431 & 4,231 & 868 & 1,165 & 402 \\
\hline Montana & . & . & - & . & . & 3 & . & 32,333 & 29,326 & 5,855 & 827 & $\ldots$ & $\cdots$ & $48 \mathrm{r}$ \\
\hline Nebraska & . & . & . & . & . & . & 8 & I 26,997 & $\mathbf{1 3}_{3} \mathbf{1 , 0 9 9}$ & 3,524 & 5,179 & $\cdots$ & $\cdots$ & $\ldots$ \\
\hline Nevada & . & . & - & . & . & . & 3 & 10,775 & I I, 2 I 2 & 2,103 & $\ldots$ & $\ldots$ & $\ldots$ & 436 \\
\hline New Ham & pshi & aire & . & - & . & 4 & .. & 53,149 & 33,653 & $\mathbf{I}, 299$ & 905 & $\cdots$ & $\ldots$ & $5^{8} 4$ \\
\hline New Jerse & & . & . & . & . & $\mathbf{I 2}$ & .. & 265,326 & I 82,567 & Io, 253 & 4,934 & $\mathbf{1}, \mathbf{1}, 96$ & $\ldots$ & 2,922 \\
\hline New York & & . & . & . & . & 39 & . & 870,070 & 667,468 & 38,451 & 22,667 & 3,877 & $\ldots$ & 35,817 \\
\hline North Car & rolin & & . & · & . & . & 12 & I I 4,937 & I36,995 & 378 & $\ldots$ & $\ldots$ & $\ldots$ & $\ldots$ \\
\hline North Dak & kota & & - & . & . & 4 & . & 7,680 & 32,885 & $2,42 \mathrm{I}$ & $\mathbf{I}, 553$ & $\cdots$ & $\ldots$ & 43 \\
\hline Ohio . & . & - & ${ }^{\circ}$ & . & . & 23 & . & 572,312 & 502,721 & 33,795 & II 402 & 720 & $\mathbf{r} 63$ & 475 \\
\hline Oklahoma & & . & . & - & . & .. & 7 & IIO, 474 & $\mathrm{x} 22,363$ & 21,734 & $\ldots$ & $\cdots$ & $4 I_{2}$ & 245 \\
\hline Oregon & . & . & - & . & . & 4 & $\cdots$ & 62,530 & 38,049 & 7,339 & 2,682 & $\ldots$ & $\ldots$ & 289 \\
\hline Pennsylva & nia & & ${ }^{\circ}$ & - & . & 34 & . & 745,779 & $448,77^{8}$ & 33,913 & 36,694 & $I, 222$ & $\ldots$ & $\mathbf{x}, 057$ \\
\hline Rhode Isla & and & & . & . & . & 4 & .. & 43,942 & 24,706 & $\mathbf{x}, 365$ & 1,016 & 183 & $\ldots$ & I, 105 \\
\hline South Car & rolin & & . & . & . & . & 9 & 3,965 & 62,290 & 100 & $\cdots$ & $\cdots$ & $\ldots$ & 43 \\
\hline South Dak & kota & & . & . & . & 4 & . & 67,536 & 40,266 & 2,846 & 4,039 & $\ldots$ & $\ldots$ & 88 \\
\hline Tennessee & & . & . & . & . & . & 12 & I I 8,324 & 135,608 & 1,870 & 300 & $\cdots$ & $\mathrm{I}, 08 \mathrm{I}$ & 332 \\
\hline Texas . & . & . & - & - & . & $\cdots$ & 18 & 65,666 & 217,302 & 7,870 & $x, 634$ & $\ldots$ & $\cdots$ & $\cdots$ \\
\hline Utah . & . & . & - & . & . & 3 & . & 61,028 & $42,60 I$ & 4,895 & $\ldots$ & $\ldots$ & $\ldots$ & 87 \\
\hline Vermont & . & . & . & . & . & 4 & .. & 39,552 & II, 496 & $\ldots$ & 802 & $\ldots$ & $\ldots$ & 804 \\
\hline Virginia & - & . & . & . & . & . & 12 & 52,573 & 82,946 & 255 & $\mathbf{I}, \mathbf{I} \mathbf{I I}$ & 25 & 105 & $5 \mathrm{I}$ \\
\hline Washingto & & - & . & . & . & 5 & $\cdots$ & 106,062 & $58,69 \mathrm{r}$ & 14,177 & 4,700 & $\cdots$ & $\ldots$ & 249 \\
\hline West Virgi & inia & & . & . & . & 7 & . & $\mathbf{1} 37,869$ & $\operatorname{III}, 4$ I 8 & 3,679 & 5,139 & $\ldots$ & $\ldots$ & 46 \\
\hline Wisconsin & & - & . & . & . & 13 & . & 247,747 & 166,632 & 28,170 & $\mathbf{I r}, 572$ & $3 \pi 4$ & $\ldots$. & $\ldots$ \\
\hline Wyoming & & : & 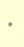 & - & . & 3 & . & 20,846 & $\mathrm{r} 4,918$ & 1,715 & 66 & $\ldots$ & $\ldots$. & 64 \\
\hline Total & . & . & $\cdot$ & . & ' & $32 \mathrm{I}$ & 162 & $7,679,006$ & $6,409,206$ & 420,820 & $25^{2,683}$ & 13,825 & $28,13 \mathrm{I}$ & 83.562 \\
\hline
\end{tabular}


'ror2 Presidential Election.

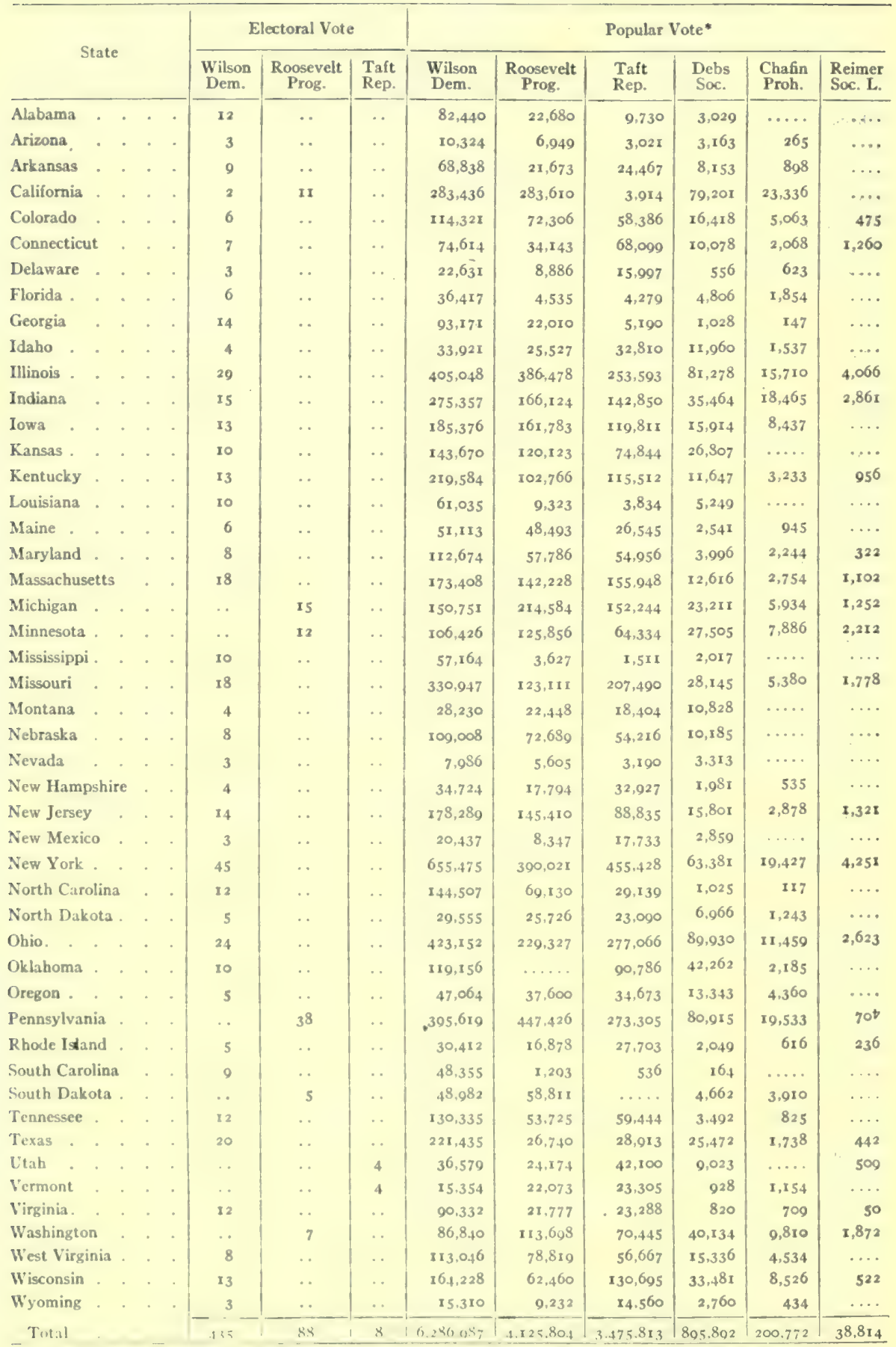

* The popular vote here given is only approximately correct for certain states and therefore for the total. 


\section{Index}

[Note. -The dates given throughout refer to matters specified in the "Diary of Events," pp. v-xliii under the days in question.]

Aakjaer, Jeppe, 213

Abbey, E. A., 249, 250, 539

Abbot, C. G., 95

Abderhalden, E., 123

Abdul Hamid II, 1024, 1152, Nov' 2 '12, (jewel sale) Nov $27 \cdot 12$

Abdullah Pasha, 28, 1158

Abdur Rahim, July 30 '12

Abendanon expedition, 89

Abeokuta, Nig., 650

Abercromby, Hon. J., 159

Aberdare, Wales, 56i

Aberdeen, Scot., 588, (Machar Cathedral), 282

一, Ida., 798

- S. Dak., 906,907

- Wash., 924, 925

Abeshr, Af., 1006

Abington, Mass., 835

Abisko, Swed., 1140

Abnake rug, 253

Aborigines, 153,161

Abor tribe, 102, 611, Mar 31 ' 11, Ap 10 ' 11

Abruzzi, It., 1042, 1043

Abu Simbel, Egy., 263

Abydos, Egy., 260

Abyssinia, 953, May 15'11

Acapuleo, Mex., 138

Acarnania, Gr. 276

Accession oath, 311, 475

Accra, Go. Co., 650

Acetone, 408

Acetylene gas, 385, 408, 412

Acharnanians, 220

Acheson, E. G., 359

Achilles (planet), 94

Acid blast machine, 254

Ackers, B. St. John, 304

Acland, F. N., 14, 487

Acromegaly, 171

Acropolis, 275

Acton, Lord, 191

Acton, Mdx., 256, 561

- Tex. 914

Acyl (Sultan), 1006

Ada, Okla., 891

Ada Bazar, Turk. As., 1151

Adam, J., 219, 221

"Adam Bede," Oct 30 '12

Adams, Alva, 784

-, F. D., 107

一 H., 249

- W.' S., 93

Adams co. Ida, 798

- co., Ohio, 742, 887

Adams, North, Mass., 834

Adamson bill, Dec 5 ' 12

Adana, 1150, 1151

Adare, Cape, Antaret., 99

Addington, May 13 '11

Adelaide, Austr., 680

Adélie Land, Antarct., 101

Aden, India, 612

Adil Bey, Hadji, 1160

Adis Ababa, Aby. 953

Adler, Hermann, 539

Admiralty Is., Pac. O., 1012

Adrenalin, 168

Adrian, Mich., 836

Adrianople, 27, 28, 29, 31, 1162 , Oet 25 '12, Nov 12 12

Adsorption, 127

Adulteration, 326

Adultery, 325

Advent Bay, Arct., 102

Advisory Imperial Council, Ap 27 ' 12

Aegean civilisation, 271

Aegean Islands, 9, 25, 34, July 25 ' 12
Aegina, Gr. 272

Aerenthal, Count, 959, 966 Aerial Navigation Act, 1911,62

Aerolites, 112

Aerolith rescue appliances, 384

Aeronautical maps, 104

- observatory, 111

Aeronautics, $339, \quad 452$, (aerial post) Mar 14, Sep 9 '11, (British Royal Flying Corps) July 26 12.

- Casualties: (Altrichter) Nov 6 '12, (Amesbury) May 19 '12, (army airship) May 4'11, (Astley) Sep 21 '12, (Badel) July 9 '12, (Bayo) June 27 '12, (Beissbarth \& Lang) Oct 19 '12; (Benson) May 25 '11, (Berger and Zunghanns) Sep 21 '12, (Bernard) Mar 10 '12, (Bittner) Sep 21,12 , (Boerner) Jan 19 '12, (Bumbaugh) Sep 26 '12, (Camine) Sep 2 '11, (Cammell) Sep 17'11, (Campbell) Aug 3 '12, (Castellane) Sep 22 '11 (Chandenier) Aug 28 12, (Chotard) Sep 12 '11. (Clark, Mrs.) June 18 '12, (Decroce) Nov 26 '11, (de Grailly) Sep 2 '11, (de Ville d'Avray) Ap 19 '12, (Douai) June 19 '12, (Dubois and Peignam) June 19 '12, (Ehrmann) June' 23 '12, (Engelhardt) Sep 29,11 , (Etienne) June 26,12 , (Eyring) Sep 9 '11, (Falkenhayn) June 21 ' 12 (Fenwick) Aug 13 '12, (Fischer and Kugler) July 27 ' 12 , (Fisher and Mason) May 13 ' 12 , (Frey) Nov 22 '12 (Frisbie' Sep 1 '11, (Gamma airship) Sep 20 '12, (Gericke and Stieler) Oct $21^{\prime} 12$, (Gill) Sep 14 '12, (Gilmour) Feb 17 '12, (Gray, France) Sep 8 '12, (Hamburger) Oet 30 '12, (Hamilton and Wyness-Stuart) Sep 6 '12, (Hardwicke) Dec 15 '12, (Hazelhurst) June 11 '12, Hildebrandt balloon) Jan $16^{\prime} 11$, (Hotchkiss and Bettington) Sep $10^{-\prime} 12$, (Hubert) Sep 11 '11, (Kaskoff) Aug 20 '12, (Kearney) Dec 19 '12, (Kimmerling and Tournet) June 9 '12 (König, June 30 '12, (Lacour) Oct 20 '12, (Laurent) Nov 22 '12, (Lawrence) Dec 19'12, (Leforestier) Sep 5 '11, (Lemartin, Princeteau and Landon) June 18 '11. (Longstaff) Sep 28 '12, (Loraine and Wilson) July 5 ' 12 , (von Loringhoven) Nov 25 '11 (Manzini) Aug 25 '12, (Maréchal) Nov 5 '12,
(Pierre and Paul Dupuy) May 18 '11, (Marron) Sep 2 '11, (Mosca) Nov $29 ' 11$, (Nieuport) Sep 15 '11. (Oliveres) July 15 '12, (Oxley) Dec 6, '11, (Paris collision) Dec 21 '12, (Parke) Deo 15'12, (Parmelee) June 1 '12, (Peck) Sep 11 '12, (Petre) Dec 24 '12, (Petrovices) Nov 5 '12 (Poultrain) Oet 31 ' 12 (Quimby, Miss) July 1 12, (Reeb) Dec 3'11, (Ridge) Aug 18 '11, (Rockwell and Scott) Sep 28 '12, (Ruby) June 1 '12, (Ruchonnet) Jan 12 '12, (Ragazzoni) Sep 25 '12, (Schadt) June 28 12, (Schendal) June '11, (von Schlichting) May 25 '12, (Schriver) Dec 3 '11, (Seville) Mar 13 '12, (Stille and Buchstatter) June 1 , 12, (Thomas) Sep 24 '12, "Transatlantic" a irship) June.2 '12, (Vallon) May 6 '11, (Vedrines) Ap 29 '12, (Verrept) Ap 17 '12, (Visseur) June 8 '12, (Voisin) Sep 26 '12, (Welsh) June 11,12 , (Zeppelin airship) June 28 ' 12.

- Cross-channel flight: (Crombes) May 21'12 (Hamel) Ap 2'12, (Quimby, Miss) Ap 16 '12: Gordon-Bennett Cup: July 1 ' 11 , Oct 7 '11, Nov 23 ' 12 ; Hendon secretary shot Aug 1 '11; hydroplane flights: Aug 9 '12, Aug 26 '12, Sep 5 '12, Dec 22 ' 12 ; military (Hendon) May 12 '11, (France) France 13b; naval 45, May 22 ' 11 ; night flying Sep 26 '12; races (Gt. Britain circuit) July 22 '11, July 26 '11, (Berlin-Vienna) June 9 '12, June 10 '12, (Brooklands - Brighton) May 6 '11. (Chicago) Sep 9 '12, (kuropean circuit) June 18 '11, July 3 '11, July 6 '11, July 7 '11. ("Derby," aerial) June 8 '12, ("Derby," French) June 16 '12, June 17 '12, (New YorkPhiladelphir) Aug 5'11. (Paris-Madrid) May 26 '11, (Paris-Rome) May 31 '11, (Royal Aero Club balloon) June 22 '12, (Stuttgart-Moscow) Nov 1 '12; records (Atwood) Aug 25 '11, (Bagne) June 5 '11. (Bienaime and Rumpelmayer) Nov 14 '11, (Blaschke: height) June 29 '12, (Conte airship: height) June 18 '12, (Fournay: continuous) Sep 11'12, (Fowler) Sep 12 '11, Garros: height) Sep 4 ' 11 , Sep 6

Tunis-Sicily) Dec 18 '12, (Gobe: long distance) Dec 24 '11, (Hawker) Oct 24 '12, (Honeywell: balloon) July 29 ' 12 , (Legagneux: height) Sep 17 '12, (Prier) Ap 12 '11. (Prevost: height) Dec 3 '11, (Salmet: height) Nov 29 '11, (Salmet: non-stop) Mar 7 '12 (Tabuteau: speed) Feb 24 '12, (Vedrines: speed) Jan 13 ' 12 ; war, 25, 45

Aerophor apparatus, 384

Aeschylus, 220

Afghanistan, 611, (Khost rising) May 2, June 13, Aug 14 ' 12

Afognak isl., Alsk., 938

African exploration, 103

Agade (king), see Akkad Agadir, Mor, 2, 67, 154,

Aga Khan, Feb 9 '11

Agamemnon, 220

Aganoor, Vittoria, 101

Aglen, F. A., 974

Agra, Ind., 612, 623

Agram trial, 961

Agrarian crime, 601

Agricultural credit, (U.S.) 726, (Philippines) 948 - Education, 414, (U.S.) 726: see separate state articles under Agriculture and Education

- Show, June 28 '11

Agriculture, 411, 69, 332 
737, Dec 4'11, (Cunningham claims) Aug 29 '12, (fur) 431, (legislature) July 24 ' 12

Alba, D', 1052, Oct 9 '12

Albania: (autonomy) 6, 7,

(finance) 76, (independence) Nov 28 '12, (racial division) 7 , (revolt 1909) 1154. (revolt of Malisgori) 1157, Ap 7, June 3, Aug 3 '11, (revolt 1912) 1031, 1160. Sep 24'12, (Salonika conference) Aug 20 '12, (inquiry) July $27-8 \cdot 12$, (Young Turks) 1030,1153

Albano, E. T. 123

Albany, Ga., 794, 796

- N. Y., 868, 869, (trade) 724, (capitol burnt) 873, Mar 29'12, (Schuyler mansion bought) 871 - Ore. 891

- S. Af., 707, 711

Albarracin, Sp., 158

Albee, Mrs. 253

Albert I. (Belgium), 967 - I. (Monaco), 1104, Jan 7 '11: Jan 23'12

Alberta, Can. 663, 665

Albert Agricultural College, 415

Alberti, A. 984, 986

Albert Nyanza railway, 645

Albert Lea, Minn., 839

Albright, Y. E, 195

- Art Gallery, Buffalo, 249

Albuera centenary, May 16 12

Albuquerque, N. Mex., 865

Alcaens, 220

Alcazar, Mor., 1107, 1139

Alcock, B., Mry 7 '12

Alcohol consumption, 1171

-fuel, 349

Alcorta, Jose F., 1067

Alcutt, Louisa M. 835

Aldrich, Chester H., 853

- N. W., 726, 903, Oct 19 11

Alechin, 455

Alencon, Duo d', 1003

Aleppo, 1150

Alessio, 32, Nov 18 '12

Aleutian Islands, 938

Alexander, Boyd, 538

- Sir George, 230

-, J. W., Ap 27 ' 11

- S., 291

_ Archbp. William, 539

Alexsnder I Land, 99

Alexandra, Queen, 478

Alexandretta, 1150

Alexandria, Egy., 990

—, La., 817, 818

- Va., 921, 922, 724

Al:xandrine, Queen, 986

Alexeinko, 1129

Alexis, (Tsarevitch), 1133

Alfaro, Gen. Eloy, 1083, Jan 29 '11

Alfunso XIII (Spain), 1136. 1139, Jan 5, 15 '11

Algeciras, Act of, 2

Alger, Russell A. 839

Algeria, 1005, 994: (Greenwich time) Mar $10^{\prime} 11$

Ali bin Hamud, 645

Ali Danish, Aug 25 '12

- Dinaz, 991

Alice, Tex, 913

Alien immigration, 323

- labour, 770

Aligarh college, 607

Alkaloids, 123

Allahabad, 613

All-British I'acific Cable, 82

Allchin, Sir W. H., 549
Alleghany Co., Md., 826 Alleghany College, 898

Allegheny Co., Pa., 897

Allegheny Observatory, 898 Allen, J., 702

- R. J., 138

Allen parish, La., 819

Allentown, $\mathrm{Pa} ., 896,897$

Allgood, Sảra, 228

Alliance, O., 882

Alligator creek, S. C., 904

Alloy, 391, 392

- Research, 393

Alma-Tadema, Sir L, 545; July 5 ' 12

Almeida, C., 1121; Jan 12 11

-, Fialho d', 216

- Fortunato d', 217

Almeido, Dom Joāo d', July 27 ' 12

Alor Star (school), 634

Alpena, Mich., 836

Alpera, Sp., 158

Alpha rays, 119

Alpine co., Cal., 776

Alsace-Lorraine, 1008, 1009 1018; Jan 28'11

"Alsatian," 346

Alsberg, C. L., 738, Dec 16 Alsop claim, 1075, July 5 '11

Altamina, Sp., 157

Altberg Pressure Apparatus, 118

Altcar, 456

Altenburg, 1009

Altendorf, 301

Altofts colliery, 383

Alton, IH. 800, 803

Altona, Ger., 1009

Altoona, Pa., 890

Altrichter, Lieut., Nov 6 12

Aluminium, 360, 392

Aluminium-zinc, 394

Alvez, Dr, R., 1073

Alwar, 613

Amadeh, 263

Amador City, Cal., 775

Amana, Asia M., 267

Amsnus Mts. 1150

Amapala, 1086, 1097

Amsstris, 1151

Amazon Rubber Co., 1090

Amblypods, 135

Ameglio, Gen., 24, July 25 12

Amelung, Dr. W., 280

Amenemhat III, 262

Amenhotep III. 263

American Exploration, 103 - Federation of Labor, 742

- Fork. Utah, 916

- Geog. Society, 105

- literature, 200

- painting and sculpture,

- School, Athens, 275

American Sugar Refining Co. Dec 5.12

- Tobacco Co., 736, Noy 8 '11

Americus, Ga., 794

Amery, L. S., M.P., 489, 516

Ames, E. S., 161

Ames, W 232

Amette, Card., 313

Amherst College, Mass. 832,730

Ammianus Marcellinus, 220

Ammon, Temple of, 263

Ammonis, 413

Ammons, Elias M. 784

Ammunition, 372

Amphlett, E. M., 460
Ampthill, Baron, 489

Amritsar, 613

Amsterdam, N. Y., 868

Amundsen, R., 100, Apr 19 '11, Mar 7 '12

Amygdaloid tools, 156

Amyntas III., 278

Anaconda, Mont., 849

Anacosta Flats, D. C., 791

Anslytical Chemistry, 127

Anand Marriage Act, 621

Anaphylaxis, 168

Anath-Bethel, 266

Anatolian Railway Company, 1151

Ancient Monuments, 333

Ancon, Pan., 945

Andaman Is., 152

Andersen, C., 470

- Prof. V., 213

Andersen-Nexö, M., 213

Anderson, A., 602

-, Carl Carey, 887

- C. 397

-, Charles P., 732

-, G. R. L., 452

Larz, 835, Aug 12 '11. Nov 14 ' 12

Anderson, Ind., 805

- S. C. 904

Andes Mts., 104

Andree, R., 1023

Andrew, A. P., July 3 '12

Andreyeff, Leon, 218, 219

Andros Is., 662, 218, 219

Angeli, Diego, 209

Angelico, Fra, Nov 20, 24 11

Angellier, Auguste, 1003

Angiosperms, 145

Anglican Church Congress. Oct 3'11

- House of Convocation, May 4 '11

Angling, 449

Anglo-American Arbitration Treaty, 66, May 17, July 19, Aug 2 '11, (Foreign relations Committee) Aug 5, 12, 15'11; (Panama Canal) 12 (Roosevelt's opinion) May 18, Dec $30^{\prime} 11$, (Senate's decision) Jan 15, Mar 7 '12: ('Taft's speeches) Sep 7, 16, Dec $8,18^{\prime} 11$

- American Fisheries Treaty (1912), 678

- American Peace Celebration, 675; Mar 13 '11, June 4'12

- French Agreement, 67, Nov 22 ' 11 , Nov 24 ' 11

- French entente, 3

- French Wireless Co., 84

- German Chinese Loan 1898,976

- German Congress, Oct 30 '12

- German Friendship Society, May 1'11

- Japanese Alliance, 1060 38 , May 5 ' 11 , July 13 11

- Latin Exhibition May $25)^{\prime} 12$

- Mexican

Pruducts $\mathrm{Co}, 658$

- Newfoundland Development Co., 679

- Russian Agreement, ¡July 10 '12

- Siamese treaty (1909), $1134,633,634,635$

Angols, 1125

Angora, 1151

Angstrom pyrheliometer, 112

Anguilla I., 654

Animal Industry Bureau, Brazil, 1072

Animists, 603

Anjuan I., 1006

Annapolis, Md., 825, Ap 18 '11. May 4'11

Ann Arbor, Mich. 836

Anniston, Als, 765, 766

- Sir William, 488: Feb 15 '11, (Divorce commission) 325 , Nov 11 ' 12

Ansonia, Conn. 785

Anspach, P., 460

Ansteineson, O. A., 214

Antarctic exploration, 99. Nov 20 '11

Anthony, D. R., 814

Anthracite, 396

Anthrax, 165

Anthropoid, 137

Anthropology, (Cultural) 155, (Physical) 147

Antigo, Wis, 931 
Arch shipbuilding system, 349

Arctic exploration, 101

Arctowski, 112

Ardmore, Okla., 888, 891

Arecibo, P. R., 951

Argenta, Ark., 771

Argentina, 1066, (Brazilian relations) 1073, (Centenary) 1075 , (dispute with Italy) 1051, (elections) Ap 7 '12. (finance) 1062, 1069, (Italian immigration) 1043, (Navy) 1066 , 44 , 50, (Paraguayan relations) 1093

Argolid, 278

Argos, 271

Argyll, Duchess of, 479

-, Duke of, 478

Argyle, Scot., 588

Arias, Gen. J. I., 1069

Arica, 1095, 1076

Arica - La Paz railway, 1076, 1071

Aristophanes, 220

Aristotle, 220, 221, 295

Arizona, 768, (state) Aug 15, 19, 21 ' 11 , Feb 14 12, (woman suffrage) 90 "Arizons," 1121

Arkansas, 771

"Arkansas," June 4 '12

Arkansas City, 802, 813

Arkwright, Dr. J. A., 177

"Arlanza," 346

Arlington, Va., 921

Arliss, George, 232

Armenian Church, Deo 23 12

Armitage Robinson, Dean, Mar 25'11

Armour and Co., Sep 5'12

Armoured cruisers, 352,47

Armour-plate, 46, 351, 375

Armsby, Dr. H. P., 421

Armstrong, H. E., 145

,- W. W. 457

_College, Newcastle, 585

Armies, 36

Army Appropriation Bill, U.S., Feb 16, June 13, July 2, Aug 4' 12, (cavalry) Feb 9 '12, (President's veto) June 17 '12, (Maj,-Gen. Wood) May 23, June $10^{\prime} 12$

Arnold, E. V., 221

-, H. J., 784

- T. W., 607

Arnst, R., 468, July $29^{\prime} 11$

Aroids, 145

Arosemena, Pablo, 1092

Arrhythmia, 168

Arriago, Dr. M., 1120, Aug $24 ' 12$

Arrowroot, 657

Arsenic in toys, 326

Arshad-ed-Dowleh, 1117

Art Congress, Oct 16'12

Artemis, 279

Arthropods, 132

Arthur Dunn Cup, 461

Arthur of Connaught, Prince, 479, Nov 10, June 8 '11, (visit to Japan) Aug 26'12

Art Institute, Chicago, 248

Artiodactyls, 135

Artisans' Dwellings, 580

Artistic Copyright, 336

Art sales, (Bennet collection) Oct 4 '11, (Carcano) May 30 '12, (Dollfus) Mar 2, May 20 '12, (Doucet) June 5 '12, (Dutch Masters) Nov 9 12, (Essex Ring) Mav 18 '11, (Farrer) Mar 23'12,
(Gainsborough) Mar 2 (Hoppner) Ap 8,11 , (Mabouse) Aug 31 '11. (Mathy) Dec 18 ' 11 , (Mezzotints) June 26 12, (Raeburn) May 19 '11, July 12 ' 12 , (Rembrandt) May 3, July 12 '12, (Rouart) Dec 9 '12, (Roussel) Mar 25 '12, (Seillière) Mar 9 '11, (silver) Mar 14, Ap 7 '11. Feb 14'12, (Taylor) July 1, 16 '12, (Titian) Mar 2 '11, (Weber) Feb 20'12 (Wertheimer) May 8 '12 Arts and Crafts, 252

Aruwimi Forest, 970

- river, Ugan., 103

Arvada, Col., 784

Arya Samaj, 603, 622, 623

Asad-ul-Mulk, 1114

Asbury Park, N. J., 860

Ascarruiz, A., Sep 23 '12

Ascomycetes, 146

Ascot Gold Cup, June 15 '11; June 20'12

"As d'A tout" June 25 '11

Ashan-Bethel, 266

Ashanti, $647,649,650$

Ashby St. Ledgers, Baron. 488

Ashe, R. W. D., 608, June $17 ' 11$

Asheville, N. C. 877

Ashland, $\mathrm{Ky} \cdot, 815$

- Ore., 891

-Wis., 931

Ashurst, Henry P., 771

Ashmore, S. G., 751

Asia, Central, 102

Ashtabula, O., 882, 884

Askern main colliery, 382

Askwith, Sir G., 521, Oct 10

'11, (degree) June 26 '12

Asmara, Aby., 1049

Aspillaga, Señor, 1096

Asquith, H. H., 485 :

(Anglo-American Ar-

bitration Treaty) Ap 28

'11: (Balkan question) 6 ,

517. Noy 9 '12; (Bible tercentenary) Mar 29'11 (Commons disturbance) 514 , July 24 '11, July 25 '11; (constitutional erisis) 493, July 24 ' 11 , July 22

'11, July 21 '11, May 6

11; (Dublin visit) 11 July 19 '12; (electora) reform) 503, Feb 9 '11;

(Home Rule) 507, Oct 5 '12, July 31 '12; (sugar convention) 14, Aug 7

12, (Welsh disestablishment), May 15 '12, (woman suffrage), 87 , Nov 17 '11, Sep 12 '11. May 6 '12: (Imperial Conference) May 23 '11; (Imperial Defence) July 25 '12; (railway strike) 523, Aug 15 '11; (single tax) 513

Assam, 603, 613

Assaut, L', Feb 2 '12

Assiut, 988

Assmann, R., 11

Assuan. Dec 23'12

Associations Bill, 1138

Assyria: see Babýlonia

Astley, H. J. O., Sep 21 '12

Astley Green colliery, Manchester, 381

Aston, W. G., 541

Aston Manor, 561

Astor, J, J., 751
Astor, W. W. 488

Astoria, Ore., 891, 724

Astra-Torres balloon, 342

Astrographic chart, 99

stronomy, 91, (comet discovered) Sep 24, 29 Dec 4 '11. Sep 9, Oct 19 Nov 4 '12, (moon eclipse) Ap 1 '12, (new stars) Mar 15 '12, Jan 1 '11. (sun eclipse) Ap 17'12

Asturias, Sp., 1137

Atakpame, 1012

Atchafalaya river, La., May $19 ' 12$

Atchison, Kan., 812

Ater, 261

Ateneo, Manila, 949

Athanasian creed, 307

Athena (statue), 279, 280

Athenry, 415

Athens, Ga., 794

-, Gr., 1025, 1026, 1028 $1029,222,275,279$

Athletics, 451, 474, (Oxf. Camb.) Mar 25'11, Mar 23 ' 12

Athos peninsula, Nov 15'12

Athy, 598, 599

Atkinson, E, I, 99

Atlanta, Ga., 794, 795, 796, (labour convention) Nov 13 ' 11 , (trade) 723

Atlantic City, 860, 864, July $6{ }^{\prime} 11$, July 12 '12

Atlantic Fisheries, 64

Allantic Monthly, 199

Atlay, J. B., 552

Atmospheric pressure, 100

Atomic heat, 116

Attar of roses, 1034

Attleborough, 829,832

Atwood, H. N., Aug 25 '1

Aube, Fr. Mar 30 '11

Aubrey, J., 194

Aubry, Admiral A., 22, 25, Mar 412

Auburn, Me., 822

一, N. Y., 868

Auckland, 699

Aucoc, Léon, 1003

Auction bridge, 454

Audoux, Marguerite, 205

Auffenburg, Gen. von, 9 Dec 9'12

Augsburg, 1009

Augusta, Ark., 774

, Ga., 794, 795, 905 (strike riots ) 797

-, Me., 822, 824

Auguste, Gen. T., Aug 9 '12

Aumonier, J., 539

Aurignacian period, 157

Aurora, Ill., 800, 801

Aurora, 110, 112

"Aurora," 100

Au Sable City, July 12 '11

Austen, E. E., 132

Austin, Gen. S. F., 912

Austin, Minn., 839

-, Pa., 900

- Tex, 912

Australia, 100, (Anglican church) 310 , (compulsory service) 694, July 1 '11 (finance) 73, (Imperial defence) Feb 21, Mar 13 Ap 20, Sep 6'11, (monopolies) Feb 28 '11, (navy) 51, Aug 29 '11, Aug 29 12 , (postage reduction) Ap 25'11, (redistribution of seats) Aug 17 '11. (referendum returns) Ap 27 '11, (trang-Australian railway) Sep 14 '12 (wool trade), 441

Australian Literature, 196

Australian Notes Act, 686

Austria-Hungary, 953,104 ; (anti-Hungarian disturbances) Feb 26 '12, (antimilitariam) Nov 9' 12 . (army) 36, June 15, 26, Nov 8 '12; (Balkan policy) $6,7,9$, Oct $8 ' 12$ (blind) 301: (Budapest riots) May 24, Sep 18, Nov 24'12; (coal output) 380 ;(Croatian autonomy) Ap 3 '12, (elections) June 13,20 '11, (emigration) 714, (Emperor's birthday celebration) Aug 17 '12. (Eucharistic Congress) Sep $10^{\prime} 12$, (finance) Nov 25, 27 '12, (Franco-German agreement) Dec 16 '11, (German Emperor's visit) Mar 24 '11; (Hungarian Parliament disorder) June 10, Sep 17 '12, (Hungarian general strike) May 23 '12, (law) 
8, 11 '11, (report) June 7 | Balleny Is, 99

12, (Rifast Pasha's Ballinger, R. A., 737, Mar speech) Jan 21 '11, sections July 27, Dec 21'12

Bagher Khan, 1113

Bagne, Lt., June 5 '11

Baquio, P. I, 948

Bahamas, 662, Aug 16 '12

Bahawalpur, 613

Bahis, 1072, Jan 11 '12

Bahr, Hermann, 207

Baicoi, Rum., 1036

Baiima railway, 1102

Bailey, Cyril, 220

- D. C. 784

- Joseph W., 915

Bain, G. M., 637

Bainbridge, Prof. F. A., 177

Baird, H. C.. 752

Baisch, E., 116

Baker, F. E., Ltd., 355

-, George F., 873

- Harold, M.P.

504 ,

- Newton D. 887

- Sir Richard C., 696

Baker City, Ore., 881,895

- University, Kan., 814

Bakerian Lecture, 116

Bakersfield, Cal., 774, 781

Bakst, Leon, 229

Baku, 410

Bakwena tribe, 706

Balashov, 128

Balcarres, Lord, 488

Balch, E. S., 101

Baldwin, Simeon E., 787

Baldwin, Kan., 814

Balfour, A. J., M.P., 488 , 501: (Anglo-American Arbitration) Ap 28 ' 11 . (Bacon memorial) June 27 '12, (Chamberlain celebration) July 10 '11. (constitutional crisis) 493, 495, May 11, July 24 ' 11 , Dec 3' 12 ; (Declaration of London) June 27 '11: (eugenics) July 24 '12, (Gifford lecturer) Ap 22,12 , (home rule) Nov 6 '11, June 13, Oct 9 '12; (musical congress) May 30 '11, (National Society) Mar 23'11, (Referendum) 483, 490; (syndicalism) Ap 30'12; (Welsh disestablishment) May 14 12

- of Burlrigh, Baron, 489, 483,653 ; Ap 11 ' 12

Balkan "conversations" 5 Aug 16 '12, (Buchlau meeting) Sep 7,12 , (France) Aug 21, 12 (Germany) Aug 17 (Creat Britain) Aug

- Strtes, 5, 1024; (alliance) 1030; (Berchtold's poiicy) 959; (military influence) 43; (mohilisation) 1031: (peace terms) 9 ; see Greece, Bulgaria. Servis etc.

- War, 27: (cholera outbronk) Noy 15,12 (financial effect) 76, 7\%, 80. Oct 12 '12: (foreizn naval guards) Noy $18 \cdot 12$

(IIoly war proclaimed) Nov 8,12 ; (hostilities fuspended) Nov 15 '12,

Nuv 20' 12 ; see also Peace Conference

Ball, John, 462, June 7 '12 Thomas, 751

Ballard, Capt. G., 577

$$
7 \text { '11 }
$$

Balloon, 341, (dirigible) 45, (in exploration) 100,111 (international law) 55 - gun, 372

Ballore, Count de M. de. 107

Ballot, short, in U. S., 745

Bally haise, 415

Ballymena, 595

"Balmoral Castle," 346

Baltshik, Bulg., Oct 19 '12

Baltimore, Md. 824, 825 , 826,827 , (blind) 303 , (Democratic convention) 749, June 25, July 2 '12, (negro legislation) $\mathbf{8 2 8}$, (stevedores' strike) 828

Baluchistan, 613

Bamangwato, 707

Bamboo, 444

Banbury, Sir F. G., M. P., 488

Bandar Maharani, 632

Bandeira, Santos, 1120

Bandolier Kop, 705

Banffy, Baron, 966

Bang, H. Y., 212

-. Prof. W. 196

Bangalore, India, 613

Banganapalle, India, 614

Bangkok, 1134

Bangor, Me., 822, (trade) 723, (fire) Ap 30 '11

-, Waleg, 477, 586

Bangwaketsi, 706

Banister v. Thompson, 310 , June 20'12

Banjaluka, 958

Bankhead, John H., 768

Banking money, 78

Bankipur, 621

Bank rates, 79

Bantam championship, 454

Bantock, Granville, 238

Banyors tribe, 644

Baorhi, 1006

Baptists, (Wales) 306, (general) 319 , (U.S.) 733 Baptist World Alliance Congress, 319

Bar and bottle law (Mass.), 834

Baralong, 706

Barbadoes, 658, (workmen at Panama), 946

Barbarossa, Dr., 1091

Barber, H., June 29 '11

Barberton, O., 887

Barber warp machine, 443

Barboux, Henri, 1003

Barbuda, W. I., 654

Barclay, Pres. Arthur, 1103

- Sir G., 1114, 1116

Barents Sea fisheries, 61

Bari, 1042

Baring Cross, Ark., 771

Barium sulphate, 128

Barker, Granville, 229

Barkley, A. W, 817

Barkow, Dr., 100

Barley, 144, (U.K.) 562 (U.S.) 717, (general) 1166 Barlow, Sir Thomas, 115 179

Barlow-Pope theory, 125

Barnard, E. E., 95

- George Grey, 249

- Kate, 890

Barnardo, Dr. T. J., 329

l3arnes, G. N. M.P. 487

-, William, Jr., 874
Barabon, Wis., 931

Barcelona, 1135

Barclay fan, 381

Barmen, 10(6)
Barnes, W. D, 637

Barnstable, Mass., 723

Baro, Nig., 651

Baroda, 604, 614

Gaekwar of, 614, Dec $16,17,2111$

Baroque style, 246

Barotse tribe, 711

Barr, Robert, 552

Barra, Francisco L de La 1088, Mar 25, May 25 '11

Barracks Act (1890), 530

Barranquilla, 1077

Barre, Vt. 918

Barren river, Ky., 816

Barrès, Maurice, 202

Barreto, Moniz, 217

Barrett, H. Roper, 465

Barrie, Hugh, Sep 21 '12

一, J. M., 231

Barron, Sir Harry, 699

Barros, Gama, 217

Barrow-in-Furness, 560

Barry, Bp. Alfred, 538

$\longrightarrow$, E., 468

- Redmond, 601, Aug 28

Barrymore, Ethel, 232

Barth, A. H., 928

Barthou, Iouis, 996

Bartlesville, Okla., 888, 891

Bartlett, Murray, 949

Barton, Clars, 751

Barton, Sir Edmund, 687 . 693

, Capt. F. R., 645

Barutheres, 135

Barzini, Luigi, 209

Basadre, Enrique, 1095

Baseball, 473, (championship) Oct 26 '11, Oct 16 '12

Basel, 1143, 1144, 1147

Bashford, Dr. E. F., June 14,12

Bashforth, Rev. F., 551

Basilan islands, P. I. 950

Basilicata, It., 1042, 1043

Basri Bey, 1160

Bass, Robert, 859

Bassano, It., 1046

Bass camp, Ariz., 769

Bastar, 614

Basutoland, 703, 706

Bataille, Henri, 233, Nov 26 ' 12

Batesville, Ark., 772

Bath, Me., 822, 723

- Eng., 560, 567, 579

Bathoen, 706 Bathtub Trust," Oct 13 11. Nov 18'12

Bathurst, Charles, M.P., 488

Bathurst, Gam, 648

Baton Rouge, L8., 817, 818

Batten, F. E., 172

Battenberg, Princess Henry of 479

Battle Creek, Mic

Battleships, 44

Bauchi, Nig., 651

Bauer, Cardinal, 313

Baumann, E., 204

Baur, E, 140

Bavaria, 1008, 1009, 1011. (elections, 1912) 1021, (monuments) 283

- Luitpold, Prince Regent of, 1021, Ap 4'11, Dee 12 12

Baxley, Ga., 796

Bay City, Mich., 836, 839

Baykoff, 394

Bayley, Sir Charles, 614

Baynes, D. L. H., 642

Baynton, Barbara, 197

Bayo, Capt., June 27 '12

Bay of Islands, 679

Bayonne, N. J., 860, 868

Bazin, René, 204

Beachey, Lincoln, Aug 5 '11

Beaconsfield, S. Af., 703

Beal Law (Ohio), 885

Beale, C. G., 523, 585

Bean, R. B. 154

Beardmore \& Co. Ltd. 855

Beardmore glacier, Antarct., 100

Bear I., Arct., 102

Beatrice, Neb., 852, 853

Beauchamp, Earl, 488

Beaudé, Père, 199

Beaufort, N. C. 878

-, S. C., 724

Beaufoy Shakespeare, Jul:? 16 '12

Beaumont, André, 343, 452 453, May 31, July 7 ' 11 Aug 9 ' 12

Beaumont, Tex, 912,913

Beaunier, André, 203, 233 
Belgian Literature, 211 - loans.(China) 976, Oct 3 '12

Bergson, Henri, 288

Bergström, H., 213

Beri-beri, 166, 635

Berkeley, 8th Earl of, 126

966, (bank) (blind) 301, (Dutch Queen's visit) July 26 '11 (election 1910) 312 (1912) 316, June 2-4'12 (Latin-American tradc) 1064, (law) 335, (Monuments) 284

Belgrade, 1037, 276

Belize, 658

Bell, Adam Carr, 677

- C. F. Moberly, 539

E. Hamilton, 232

F. H. D., 702

- Dr. Graham, 305

, Sir Hesketh, 650

T, H. J., 224

- Dr. Robert, June 14 '12

-, Theodore A., 779

Bella Donna, 230

Bellaire, O., 883

Belleville, Iil., 800

Believue, $\mathrm{Ky}, 815$

Bellew, Harold Kyrle, 541

Bellingham, Wash., 924 925

Bell Island, Nfd, , 679

Bello, Msgr. Mendes, 1123

Belloc, H. 191

Bellonei, G., 209

Bellows, George, 249

Beloit, Wis., 931

Beltran, Francisco, Mar 4 11

Beltsville, Md., 825

Bemidii, Minn, 839

Benares, 614, 607

Benavente, Jacinto, 215

Bendall, Ernest, 228

Benelli, 209

Benet-Mercie gun, 373

Bengal, 614, 478, 609

-; Eastern, 618, 603

Bengazi, Trip.. Nov 28 Mar 13'12, 22, 23, 24

Benguella, 1125

Benicia, Cal., Oct 18'12

Benker Semang, 629

Benn, W. W., M.P., 487

Bennet Collection, Oet 4'11

Bennett, Arnold, 188, 230, Mar 5'12

$\ldots$ C. E., 222

Bennettites, 145

Bennington, Vt., 920

Benoist, Charles, 996

Benoni, 703

Benson, F. R. 232

- Robert H, Feb 14'12

-, Walter, May 25'11

Bent, Thomas, 698

Benton, Guy P. 920

$\because$ Joel, 752

Bentop, Ark., 774

Benzene, 409

Bepin Chandra Pal, Oet 6 11

Berane, 33, 1161, 5, Aus 14. 21,24 '12

Berbera, 646

Berchtold, Count Leopold, 959 , Feb 20 '12, (Balkan policy) 5, 9, Aug 16:12 (Berlin ralations) May $23,25 ' 12$, Sep 7 ' 12

Berea, 23

Berembang, 628

Beresford, Lord Charles, 488, Feb 9 '11, Sep 26 ' 12 - J: P. 180

Berg, Sigurd, 985

Bergamo, 1048

Bergen, 1110

Berger, Lieut., Sep 21 '12

- . Victor L., 742, 935

Bergsöe, V. 212
Berkeley, Cal. 774, 777

Bering River coal field, 939 Berlin, Can., 665

Ger., 1009, 1011, 1016 1018, 1022, (poisoning epidemic) Dee 27:11

- N. H. 857

- Treaty of, 5

Berliaz, H., 237

Bernam river, 630

Bernard, Bp. J. H., 601

-, M. A., 103

$\longrightarrow$, Suzanne, Oct 10 '12

Bern, 1143

- Copyright Convention, July 5 ' 12

Bernhardt, Sarah, 233, 235, Ap 11 '12, Oct 23 '12

Bernier, Capt, 101

-, Hector, 198

Bernina Pass, 1148

Bernstein, Henry, 233, Feb 2 '12

Berntsen, Klaus, 986

Beron, Léon, Jan 1 '11

Berry, R. J. A., 153

- W. H., 899

Berry "Tricity" system, 364

Berson, Arthur, 111

Berteaux, H. Maurice, 999 1003, May 9 '1

Bertolini, 1049, Nov 21 '12

Bertrand, Francisco, 1087

-, P., 146

Beruete, A. de, 1139

Be.wick, 588

Besanval, Paul, Sep 5 '12

Besier, Rudolf, 231

Bessemer, Ala., 765, 766

Betancourt, Julio, 1079

Betelgeux, 96

Bethmann-Hollweg, Theobald v., 1013, 1022, 2, 3, 8. Sep 7 ' 12

Bethnal Green, July 29 '11

Bethune, Major Gen. E. C. Ap 25'12

Betting, 324, 778, 809, 905

Bettington, Lieut C., Sep 10 ' 12

Bettolo, Admira], 1050

Beveridge, Albert J., 808

Beyers, Gen. C. F., 710

Bezons, Fr., Nov 9 ' 12

Bharatpur, 614

Bhopal, 615

Bhutan, 611

Bibby's mills, Liverpool, Nov 24'11

Bible tercentenary, 323 Mar 21, 29, Ap 25 '11

Biblical MSS., 225

Bicycling, 459

Biddeford, Me., 822

Bielis, 1151

Bienaimé, 341, Nov 1.'12, Nov 14 '11, Nov 23 '12.

Bienerth, Baron von, 963 . 962 , 960, June 26'11

Bierbaum, O. J., 206

Biffen, R. H., 139,413

Bigelow, John, 201, 751

Bigge, Sir W. A. Selby, 584

Biggleswade, 417

Big Heart, Ókla., Ap 12 '11

Bikaner, 615

Bilbac, 1137

Bilbo, Theodore G., 845

Biles, Prof. J. H. 350

Bilgrami, Syed Ali, 611

- Syed Husain, 618

Bilinski, Baron von, 960 ,
- Tristan, 233 Feb 20 '12
Billings, Mont., 849,850

Billiards, 453

Billinghurst, G. E., 1096

Bill of exchange, 330

Billot, Cardinal, 313

Biloxi, Miss., 843

Bingham, Henry $\mathbf{H}_{\text {, }} 900$

- Hiram, 103

Bingham, Utah, 916, 918

Binghamton, N. Y.. 868

Biology and Zoology, 128

Biplane, 343

Birch, Crisp \& Co., see Crisp loan

Bird, Charles \&., 833

Bird life protection, 1042

Birkbeck Bank, June 8, 12, 17 '11

Birkeland-Eyde Co., 360 , 412

Birkenhead, 560, 572

Birmingham, George," 189, 601

Birmingham, Ala., 765, 766 767

$\begin{array}{llll}\text { Eng } & 559, \quad 567,579\end{array}$ 582, (R.C. province) 313 , (South B. by-election) May 3 '11. (university) 584

Birrell, Augustine, M.P. 486,189 , Oct 19 ' 11

Birrell Act, 602

Birseck, 158

Birt, Lt.-Col., 175

Birth rate, $1165,-327$ (France) 992, (New Zealand) 699 , (U.K.) 557

- rate Commission (Australia), 683

Bir Tobras, Trip., 23, Dec 19 ' 11

Bisbee, Ariz., 768

Bishop, B. P.. Museum. Honolulu, 943

Bishop Falls, 679

Bishop, Tex, 914

Bishoprics bill, 309

Bisletti, Cardinal, 313

Bisley, 469, July $12,18,19$ 112

Bismarck, N. D., 879

- Archipelago, 1012

Bissell, Cal., 775

Bissing, $F$. von, 279

Bissolati, 1050

Biton (statue), 279

Bitterfeld, 102

Bitterroot Valley, Mont. 850

Bittner (airman), Sep 21 '12

Bielina, 958

Bjerke, Eilert, 214

Bjerknes, W., 110

Björnson, Björnstjerne, 214,215

Black, Judge W. W. 927

Blackburn, J. H., 455

Blackburn, 560

Black damp, 390

Blackett, W. C., 384

Blackfriars Theatre, 193

Blackham, Maj., 171

Blackman, F, F 144

Black peril, 708, 709

Blackpool, 560, 582

Black river, Wis., Oet 6 '11

Blacksburg, S. C., 906

Black Sea Basin agreement, 1151

Blackshear, Ga., 796

Blacksod bay, 598

Blackwood, William, 545

Blair, Judge, 742

-, W. R. 111

Blake, Edward, 677

Blankenburg, Rudolph, 899

Blantyre, 646

Blaschke, Lieut., June 29 11

Blashfield, Edwin H., 249

Blasting, 387

Blau gas, 407

Bleaching, 438

Blease, Coleman L., 905

Bleckley co., Ga., 795

Blind, The, 300

Bliss, C. N., 751

Bliss, Zenas W., 903

Bloch, E., 119

Block, Sir Adam, 1149

Blodig, Dr.. 466

Bloemfontein, 703

Blomfield, Reginald, 247

Blood, M. , 469

Bloomfield, N. J., 860

Bloomington, IIl., 800

Blossburg, Pa., 899

Blue Bird, 211

Bluefield, W. Va, 928, 929 
Bontoo, P. I., 949

Bonvoisin, Maurice, 1004

Book Sales, (Beaufoy Shakespeare) July 6 '12, (Gutenberg Bible) Ap 25 11. (Hoe library) Ap 25 '11, (Huth library) Nov 15 '11, June 5 '12, (Book of Martyrs) June 12 '12, (Mazarine Bible) Nov 20 '11

Boone, Ia., 809

Boot and shoe trade, 567

Booth, Bramwell, 17, 32.

-, "General" William, 16 545,322 , Aug 29 '12

Booth Fisheries Compsny, 678

Bootle, 560, (by-election) Mar 9'11

Borah, William E., 799

Boraston, John, 489, May 27 ' 12

Bora wind, 112

Borden, Sir F. W., 667 - M. C. D. 787

- R. L. 667, 483, (London visit) July $4,10,16$, 22 '12, (Paris visit) July $27,29 \cdot 12$, (naval policy) 670,51 (reciprocity) Mar 9, Nov 3 '11, (welcome in Canada) Sep 6, 24 , '12, (woman suffrage) 90, Aug 28' 12

Bordentown, N. J., 861

Borglum, G., 246

Boris, Prince, 1028, 1030 , Nov 9 '12

Borneo, see British North Borneo

Bornet, Edouard, 1003

Bornu, 651

Borodino celebration, 1133 . Sep 7'12

Borodkin, 219

Borrelly, Nov 4 '12

Borromeo encyclical, 316 , 1017

Borstal system, 330, 601

Bort, L. Teisserene de, 111

Borup, George, 101

Borzoi dog, 456

Bosanquet, Bernard, 294

- Admiral Sir D. H., 698

Bosnia-Herzegovina, 958, $953,963,960$

Boss, Lewis, 752, 96, 98

Bosschere, Jean de, 212

Bossuet, Jacques Bénigne, C'ct 29 '11

Boston, Eng., 574

- Me8s, $828,829,831$ (blind) 303, (freight rates) Oct 14 '12, (harbour) 829 , (liquor licences) 884, (St Paul's) Oct 7 '12, (strikes) 8:3. June 7 '12, (trade) $72:$; (Inited shoe Mlachiner Company) Bep 19 ' 11 . Mar 2 12, (University) 832

"1915" 835

- and Maine R. R., 857

Buatwick, Gr., 796

Bosworth, W, W, 79J

Botany, 139

Butelho, Abel, 217

Botha, General L., 707. $708,709,710,711,712$ (British general) Aug 14 12, (Imperial defence) Sep 25 '11, (Oxford degree) June $10^{\prime} 11$, (s' African development Nov 6, 21, 11. Aug 2x'12

Bottomley, Horatio, $4 \times 7$. (bankruptcy) Dece 7 '11,
June 11 '12, May 16 '12, | Brady, E. J., 196 (Curtis case) June 30,'11 July 31 ' 11

Boudier-Bakker, Ina, 211 Braga, Theophile, 1120

Boué de Lapeyrère, Ad- Bragg, C., 465

miral, 996

Boulder, Col., 781

Boule, P. M., 147, 156

Bourassa, Henti, June 29

Bourchier, Arthur, 229

Bourdelle, 244

Bourgault-Ducoudray, A., 1003

Bourgeois, Léon, 1001

Bourget, Paul, 205, 233

Bourne, Cardinal, 313, Jan 20 ' 12

-, G. C., 133

- George, 189

- Jonathan, 895,744

- R. C., 468

Bourne, Mass., 254

Bournemouth, 560

Bousfield, L., 173

Boutell, Henry S., Mch 2 '11, Ap 24 '11

Boutens, P.C., 210

Boutros, Pasha, 987

outroux, Emile, Oct 31 '12 Braun, H., 452

Bovey, Prof. H. T. 55

Bovione, Giuseppe, 209

Bow \& Bromley, 484

Bowdoin College, 823

Bowen, York, 238

Bower, Gen. Sir H., Nov 19 , 21'11, Dec 5'11

Bowerman, C. W. M.P. 487

Bowling Green, Ky., 815

- Green, O., 886

Bowls, 453

Bowman, C. C., 900

Bowman, I., 103

-, John G., 811

Bowring, E., 570

Boxer Indemnity, 976, 530, Dec 31 ' 12

Boxing, 453, 473, (JohnsonWells) 321, Sep 27 '11, (Featherweight Championship) Nov 13 '11

Boxted evictions, Jan 8, 30 '12, Feb 23 ' 12

Boyce, Sir R. W, 540

Boycott (hatters' casc), 787

Boyd \& Phillips cylinder, 440

Boyle, Sir Cavendish, 647 Patrick J.. 903

-., William, 228

Boylesve, R. 201

Boy scouts, (Russia) 1131 , (Siam) 1135, (boat accident) Aug 4'12, (Coronation review) July 4 '11

Bozanti, 1150

Bozeman, Mont., 849

Braamcamp Freire, 1121

Braaten, Oskar, 214

Mrabant, North, 1038

Bracoo, Roberto, 208

Brace, William, M. P., 487

Braceville, III., 802

Brudbury, John, Nov 28

Braddock, $\mathrm{Pa} .900$

Braddon, Sir Edward, 691 - W. Ya. 160

Braddon clause, 691,686

Bradford, A. H., 752

- Colonel Sir E. R. C.,541 Gamaliel, $75 \%$

Bradford, $559, \quad 586,441$ (dye-works casualty) Dee 1 '11

Bradley, A. C., 194

-, A. Giranville, 197
Braila, 1037

Braille system, 302

Brainerd, Minn., 839

Brain measurements, 154

Braintree, 568

Braithwaite, W. C., 319

Branch, Anna H., 200

Branco, Baron do Rio, 1073 -, C. C., 217

'11. Dec 9'11

Brandenburg, 1008

Brandes, 164

Brandes, George M. C., 213

Branly, Prof. Edouard, Jan 23 '11

Brantford, 665

Brashear, J., 92

Brasso, 957

1029

Brattleboro, Vt., 918

1066, 1062, 1063, 1065, 104, (Argentina) 1067, (Bolivia) 1070, (Mexico) 1088 (Paraguay) 1093, (Peru) 1095, (law) 335, (navy) $44,48,50$, (revolutions) Nov 25 '11, Nov 8 ' 12

Brazos river, Tex., 913

Bredon, Sir Robert, 974

Breen, John J., 835

Bremen, 1008, 1009

Bremerhaven, 1009

Brémond, Major, 1106, Ap 26 '11

Bré mt. railway, 1148

Brentford, Mch 23 '11

Breslau, 1009, 1011, 1022

Brest, June 11 ' 12

Breuil, Abbé, 156, 158

Brewer, Earl L., 845

Brewer, Me., 822

Briand, Aristide, 996, 997 $998,1001,1003$, (attacked) Jan 17 '11, (Labour speech) Jan 20 '11

Briceville, Tenn., Dec.9 '11

Bridgeman, Adm. Sir F. 577 , Jan 17 ' 11 , Nov 28 '11

Bridyeport, Conn., 78.5. 786, (Socialists) 787. (trade) 723

Bridges, Robert, June 26 '12

Bridgeton, N. J., 860

Briggs, Frank O., 864

一, I. J., 141

Brighsm, Utah, 916

Bright, John, Nov 16'11

Brighton, Eng., 560, June 26 ' 11

- College, 585

Brine, Commander F. G. Nov 15 '11

Brinkley, Capt, Frank, 552

Brisbane cathedral, 310

Brise, Sir Ruggles, 331

Brisson, Henri, 1004, Jan 10 11. Jan 9 '12

Bristol, Conn. 786

- Enk., 559, 573, 585, Oct $17 \cdot 12$

-, Tenn., 909
Brahms, 752

Bridgeworkerg, 742, 809

Bristol, Va., 911

- Co. Mass. 832

- School of Industry, 302

"Bristow, Joseph L., 814 "Britannic," 346

British Admiralty, 577 Aug 29 '11, Sep 7 '12, July 18 '12, (Memorandum for Canada) 52

British and Foreign Blind Association, 302

- and Foreign Bible Society, 323

- Army, 578, 36, (cost) $530,531,534$, (criticism) 41, 42, (Lord Roberts) Dec 15,16 '11, Oct 22 '12, (Manoeuvres) Ang 19'11. Sep 2, 16, '12, (aeronautics) 344 , Feb $28^{\prime} 11$ May 12 ' 11 , Dee 14 ' 11 Aug 30 ' 12

-Association, Aug $30^{\prime} 11$ Sept 4'12

- Bee Keepers' Assoc., 42! Columbia, 663, 664, 665 . (ecclesiastical province) 310 , (elections, 1912) 675 Cotton Growing Assoc., 436 
get) May 16 '11, (1912) Ap 2 ' 12 , (by-elections) 484, (disturbances) July 25 '11, Aug 6, Nov 14'12, (estimates, standing committee on) Dec 14 '11, (Govt. majority drop) July 26, Nov 11, '12, (prorogation) Dec 16'11, (Russian visit) Jan 23 '12, (Sir S. Samuel's seat) Nov 22, Dec 20 '12, (speaker re-elected) Jan 31'11; (State openings) Feb 6, 14 ' 12

British Somaliland, 646

- South African Co., 705

- West Africa, 647

- West Indies, 653

Broadhurst, George, 232

- Henry, 541

Brock, Sir Isaac, Oct 14 '12

- Sir Thos., 245

Brockton, Mass., 828, 829

Brodeur, L. P., 667

Brodmann, Dr. C., 154

Bronx Co. N. Y. 871

Bronze Age, 159, 276

Brooke, C. F. Tucker, 195

- Raja, 628

Brookfield, Charles, 228, Nov 25 ' 11

Brookfield, Mo., 846

Brookhaven, Miss., 843

Brookings, S. Dak., 906

Brooklands, Sur., 354

Brookline, Mass., 828

Brooklyn, Md., 828

- N. Y., 868, Dec 14 '12

Brooks, Sarah, 230

-, Stratton D., 890

-, W. R., 95

Brooks Co., Tex, 913

Broom, R., 134

Broqueville, Baron C. de, 967

Brotherhoods, 322

Broughton, Len., 322

Broward, Napoleon B., 793

Brown, Adrian, 144

-, A. R., 153, 162

—, Elmer E., 873

- E. W., 93,94

- Dr. H. H., 172

-, Joseph M., 797

- Norris, 854

-, Robert B., 887

- \& Co., John, 346

Brown-Boveri system, 386

Brown-Curtis turbines, 347

"Brown Dog," Mar 8'11

Browne, Belmore, July 24 '12

-, Mary, 474

一, T. A., 196

- Walter G., 231

Brownell, William C., 199

Browning, Carl H., 175

- R. W. Barrett, 353

- Centenary, May 7 '12

Brownlee, Dr. 155

Brownsville, Tex., 912, 724

Brown University, 902

Bruce, Sir D., 169, 173

- Sir G. 550

-, W. S., 101

Bruceton, Pa., 383

Bruchesi, Msgr., 312

Brühl, J. W., 125

Brulard, General, Dec 24'12 Brun, Albert, 106

-, General J. J., 1003, 996

Brundidge, Stephen, 774

Brunei, 628

Brunhes, J., 105

Brünn, 956, 961

Brinnecke, W., 100

Brunner, Arnold W. 790 , 876
Brunner, J. F. L., M.P., 487

, Ger., 1008, 1009

- Me., 822

- Md., 824

Brusa, 1151

Brush, George J., 753

Brusoff, V., 218

Brussels, 969

- Sugar Convention, 14, 15, Aug 1, 7 '12

Bryan, Charles P., Aug 12 '11, Nov 14 ' 12

- Nathan P., 793

-, W. J., 748, 854, 750 June 21, 26, July 3 '12

Bryant, W. C. (statue), 249 Bryce, James, 1068, May 6 12 . Nov 13 ' 12

-, Lloyd, Aug 12 '11

Bryn Mawr College, 898

Bubonic Plague, (P.I.) 948, (P.R.) 952

Buccleuch, Duchess of, 556

Buchanan Co., Mo., 848

Bucharest, 1036

Bücheler, Franz, 219

Buchstatter (airman), June 1 '12

Buckham, Matthew H., 920

Buckingham Palace, 248

Buckle, G. E., 192

Buckmaster, S. O., M.P., 489

一, W.. 467

Budapest, 957, 965, 958

Buddhism, 603, 1059

Budka, Dr. Niceta, Sept 12 '12

Bueb, J., 402

Buenos Aires, 1066, 1067 , 1068, 1069, (cholera) 1051, (floods) Ap 26'11

Buffalo, N. Y., 868,869 871, 724, Ap 12, Jan 23 12

Buisson, F. E., 996

-, 118

Bukedi, 645

Bu Kemmesh, Ap 12, 23 '12

Bulawayo, 703, 705

Bulgaria, 1034, 5, 1026 , $1027,1029,1030$, (army) 37,43 , (Austrian relations) 964, Oct 13 '12 Nov 11 '12, (Balkan war) 29, (Hague Conventions) 55, (Kotchana massacre) Aug 1, 9, 13 '12. (Macedonia sympathies) Aug 21, 25'12 Oct 13 '12, (military operations) $27,29, \mathrm{~min}-$ isterial changes 1029, 1030, Feb 25 '11 (mobilisation) Sep 30 '12, (navy) 29, (Sofia fêtes) Feb 2'12, (Tirnovo celebration) Aug 15 '12

Bulkley, Morgan G., 787

Bull, Charles S., 753

- Jacob, 214

- Olaf, 214

Bulleroft main colliery, Eng., 382

Bullet, 373,376

Bullitt, W. M., July 1 '12

Bullock. J, H. Oct 10'12

Bülow, Prince von, 1013

- H. G. von, 236

Bumbaugh, Capt. Sept 26 '12

C. $\mathrm{L}$

Bumpus, H. C. Jan 20 '11

Bumsted and Chandler fan, 381

Bundelkhand, 606

Bundi, 616

Bunting, Sir P. W., 540
"Bunty Pulls the Strings," 227

Bunyan memorial, 318

Burchard, Johann H., 1023

Burchardt, 262

Burgas, 1034

Burge, Dr. H. M., Ap 24 '11

Burger, Gen. Schalk, 710

Burgess, M. J., 383, 395

$\rightarrow$ T. W., 470, Sep 5 ' 11

-, Rev. W. H., 319

Burghclere, Baron, 488

Burgoyne, A. H., M.P., 488

Burke, John, 881

Burkett, Elmer J, 853

Burkheiser process, 405

Burleigh, Edwin C., 824

Burlington, Ia., 809, 810

一, Vt., 918

Burma, 603, 616

Burn, 455

Burnet,.John, 221

Burnett, Sir David, 579

-, John, 513

Burnett Immigration bill, Dec 18 '12

Burnham, Daniel H., 753, 790,804

-, Henry Eben, 859

Burnley, 560

Burns, John, M.P., 486, July 19, Aug 15 '11

-, William J., 809, 864

Burns, Ore., 892

Burrage, Champlin, 319

Burrell, G. A., 385

- Martin, 668

Burrillville, R. I., 901

Burrows, Julius C., 838

-, Rev. W. O., May 23 '12

Burt, Silas W., 753

Burton, Henry, 710

- Theodore E. 887

Burton-on-Trent, 560

Bury, J. B., 190

Bury, 560

Busch, W. 206

Bush, B. F., Ap 3 '11

Bu Sheifa, June 15 '12

Bushey, Herts., 349

Bushire, 1115

Bushmen, 153

Busoni, F. B., Ap 13 '12

Busse, Fred A., 803

Bussell, F. W., 222

Butcher, J. G., M.P., 488

-, S. H., 538, 219

Bute, 588

Butler, Mrs. A. J., 584

- Edward B., Meh 14 '11

-, Sir Harold, 606

-, H. C., 274

Butler, N. M., 748, 847

- Samuel, 188

-, Gen. Sir W., 191, 538

Butlin, Sir Hy. T., 549, 167

Butte, Mont., 849, 850

Butter, 421

Buttermilk, 421

Butti, Enrico, 1054

Butuan, P I. 949

Buxton, Sydney, M.P., 486 523

-, Thomas, 701

Buxton, 579

Buysse, Cyril, 210, 212

Byatt, H. A. 640

Byles, Sir W. P., M.P., 487

Bvrne, Frank M., 908

Cabin Creek, W.'Va., 930

Cable, 81, 365

-, companies, 82

Cabras, 952

Cabot, Arthur T. 753

Cabrera, Manuel E., 1065 1084

Cabrieres, Card., 313

Caceres, Ramon, 1098, Nov 19 ' 11

Cadeby Colliery, 565, July 9 '12, Aug 5 ' 12

Cadenas Bill, 1138

Cadmus, House of, 272

Caesar, 220, 223

"Caesaria" "347

Caguas, P. R., 953

Caillaux, Joseph, 999, June 27 '11, (policy) June 30 ,

Nov 5 '22, Dee 18 ' 11

Caillavet, de, 233

Cairo, Egy., 989

IIl., 800, (floods). 804, Mar 25 ' 12

Caithness, 588

Calabria, 1043

Calais, Fr., June 11 '12

-, Me., 822

Calamba, P. I, 948

Calapata, Sp., 158

Calcium earbide and cyanamide, $359,409,412$

-, sulphide, 119 
Campbell, J. H. M., M.P., 4 is

- Sir J. Logan, 702

-, Lindsay', Aug 3 '12

- N. 114

- Mrs. Patrick, 230, 231

-, Lt. V. L. A., 99

- W. W., 96

Carnpbell-Bannerman, Sir Henry, 530

Campbell Co., Wyo., 937

Campbell-Hepworth, M. W.. 112

Campine colliery, 381

Campton, 817

Canada, 663, 101, 103

(Anglican Church) 310 ,

308, (cathedral) Aug 27

'12, (blind) 303, (British ministers invited) July

31 '12, (Connaught tour)

Aug 28 ' 12 , Oct 13 ' 11 ,

Oct 14 '11, Nov 16 ' 11 ,

(consular service) Sep 17

'12, (finance) 75, Feb 22

'11, Ap 4 '11, (fishing dispute) May 5'11, Sep 6 11, (Free Churches) 317 , Oct 16 '11, (French visit) July 29 '12, (Fur Seal Convention) Oct 11 '12, (Japanese relations) Feb 19 '11, May 19 '11. (London visit) July 4 ' 12 , (mixed marriages) 315 , Feb 22 ' 12 , July 29 ' 12 , (navy) 51, 52, 483, Dec 5 '12, (railways) May 24 '12, July 26 '12, Nov 19 '12, (Reciprocity: see that heading), (Ruthenian church) Sep 12 12 , (trade) 75, (transcontinental ry.) 73 , (WestIndian Agreement) 6.53, 15, Ap 9 '12, (woman suffrage), 90

Canadian Northern Railway, 666

- Pacific Railway, 666

Canalejas, Joz̄o, 1137, 1138 ,

Jan 5 '11. Nov 12 ' 12

Canal rays, 119

Carals, (U.K.) 575, (Augtrian) 962, (Clyde-Fort project) 593: ses under countries

Canal Zone, 943

- Royal Commission, Jan 10 '11

Cansnea, 1089

Cancer, 166, (research fund) Nov 4 '11

Candy Trust," Dec 13 '12

Cane, Lieut., 175

Caneva, Gen., 22

Canevaro case, 65

Canfield, Dorothy, 200, 295

Cannes, Ap 13 ' 12

Cannon, Joseph G., 804

Canon City, Col., 781

Canonsburg, Aug 26 '11

Canterbury, Archbishop of 479 . Feb 6 . Nov $10 \cdot 11$, (Bible tercentenary) Mur 29 '11. (Divorce commis. sion) Nov $20^{\prime} 12$, (Welsh Church) Nov 28 '11

Canterbury, 500

Canton, China, Ap 28 '11, June 21 ' 12

-. I11. 800

- 0.,882, 883,887

- Hankuw railway, 976, 979

- Kowloon railway, 976

Cap (ordnance), 377

Capablanca, J. R., 455

Cape Cod canal, 829
Cape Fear river, N. C., 878 Cape Finisterre," 346

Cape Girardeau, Mo., 846

- May, N. J., 863

- Nome, Alsk. 938

- Province, S. Af., 703

- Town, 703, 705, (university) Dec 21 '12

- Vincent, N. Y., 724

Capital and Labour, 70, 330 330 , (U. S.) 738

- punishment, 331, (Cal.) 779, (Del.) 788, (Ida.) 799, (Mass.) 831, (Minn.) 842, (O.) 884, (Ore.) 894, 895, (P. I.) 948, (S. C.) 905, (Vt.) 919

Capper, Arthur, 814

Capsian age, 158

Capus, Alfred, 233

Caracalla, Baths of, 1048

Caracas, 1101

Carbon, 395

Carbonarios, 1123

Carbonate of lime, 411

Carbondale, Ill., 802

Carbon dioxide, 389, 395

Carbonisation, 397, 402

Carborundum, 359

Carcano art collection, May 30 ' 12

Carchemish

Turk. As., 267

Carden, Sir L. E. G. 1085

Carden Hall, Ches., Sep 16 '12

Cardiff, Tenn., 909

-, Eng., 560, 566, 573, 582 Carding, 442

Carey, J. M., 937

Caribou, Me, 822

Carleton, Will, 753

Carling, Sir John, 677

Carlisle, 9th Earl of, 539 10th Farl of, 546 Alexandra, 231

- Castle, Cumb., 282

Carlton Hotel, Aug 9 '11

Carmack, E. W.. 911

Carmarthen, (by-elections) Jan 14, Aug 22 '12

Carmichael, Baron, 614

- Sir T. G., Feb 3'11

Carnarvon Castle, 476

Carnation, 427

Carnegie, A., 873, 1079 , 593, (arbitration) Dec 12 '11 (offer to Italy) Sep 28 '11, (peace foundation) Dec 14 '11, (pensions) Nov 22 '12, 730, (Institute, Pittsburg) 248, (Institution, D. C.) Jan 20 '11

Caroline Is., 1013, 1015

Carp, P. P., 1029, Jan 11 '11

"Carpathia," 16

Carpenter, Charles, 404

-, F. W Sep 12 '12

- H. C., 394

J. Estlin, 317

Carpentier, 454

Carr, H. W. 288

Carrol, Alexis, 16.5, 167, Oct $10^{\prime} 12$

M. Drew, 952

Carrère, John M., 753

Carriacou, 657

Carrington, Henry B., 753

Carroll, B. F., 811

Carrathers, D., 102

Carson, Sir Edward, M.P. $488,495,597,510,(\mathrm{Bc})$ fast) Sep 16, 27, 12 (Coleraine) Sep 21 '12 (Craigavon) Sep 23 '12. (Dublin) Oct 10 '11. (Enniskillen) sep 18 '12, (Glasgow) Oet 1 '12,
(Home rule finance) 516, Centerville, Ia.., 809

June 14 '12, (Lisburn) Central American FederaSep 19 '12, (Liverpool) tion, 1065

Sep 30 '12, (London- Central Falls, R. I, 901

derry) Sep 20 '12, (Portu- Centralis, Wrsh., 924, 926

down) Sep 25 '12, Central India, 617

(Solemn Covenant) 512 Carson City, Nev., 854, 856 Carstensen, J., Dec 17 ' 12

Cartago, Colom., 1077

-, Cost. Ric., 1079

Carter, T. H., 851

Carthage, Mo., 846

"Carthage," 24

Cartography, 104

Carton, R. C., 231

Cartridge, $373,3 \varepsilon 7$

Cartwright, Sir R., 677

Caruso, 835

Caruthersville, Mo., 849

Carvalho, Mme. de, 217

Casablanca, Mor., 1106 , 1108,64

Casement, Sir Roger, 1066, July 13 ' 12

Casey, E. P., 790

Casper, Wyo., 935

Cassel, Sir E., Aug 14 '11

-, Felix, M.P., 488

Cassirer, E., 294

Castberg, Johan, 1111

Castellane (Airman), Sep 22 ' 11

Castillo Cave, Sp., 156

Castine, Me., 723

Castlebay, 589

Castlerea, 597

Castlereagh, Viscount, 488

Castrillo, Alonso, 1137

Castro, Cipriano, 1100 , Dec 31 ' 12

-, Gen. Pimentel, 112

Catania, 1042

Cater, Rev, Ives, 319

Catharina, Brazil, 1074

Catheart, Lady, 589

Catlin, Theron E., 848

Catonsville, Md., 827

Catron, T. B.. 867

Caueasus, 1125

Cauer, P., 221

Cauvin, Lusemburg, 1086

Cavalleria Rusticana, 240

Cavan, 595

Cave, Basil S., 645

- C. J. P., 111

-. George, M.P., 488, 496

Cave age, 156,137

Cavendish, Lord R., 563

Cavero, Jose Salvador, 109:

Cawdor, 3rd Earl, 489, 542

Cawnpore, 616

Cayey, P. R., 955

Cayuga and Seneca Barge

Canal, N. Y . 870

Carot, Jules, 1004

Ceag lamp, 385

Cecil, Lord Hugh, M.P. 488, 495, July 25'11, (Enniskillen) Sep 18,12 - Lord Robert, M.P. 489, Nov 11 , 12 , (on Welsh Chureh Bill) 517 , (on woman suff rage) 89 Cedar Falls, Ia.. 809

- Keys, Fla., 723

- Rapids, Ia., 809

Celebes Is., 1040, 89

Cellutoid, 235

Cellulose, 444, (in coal) 395

Cementation, 382

Cementite, 394

Censorship, dramatic, 228

Census, (U.K.) 556, May 2511 , (of production) 561, (Ireland) May 26 '11, (blind) 300, (occupations) 562, 435, (woman suff ragists), $88, \mathrm{Ap}_{2}$ '11

- Provinces, India; 617

Centre Party (Germany), 1019, 1020

Century Theatre, 232

Cephalopod, 133

Ceramic," 346

Cerno, W. von, Jan 18 '12

Cesarewitch stakes, Oot 1 '11. Oct 16 '12

Cesnola Collection, 278

Cetacea, 136

Cettigne, 1028

Ceuta, 1106, 1107

Ceylon, 623, (ferry) 606

Cézanne, Paul, 241

Chadwick, 221

Chafin, E. W., 749, July 12 '12

Chagas, Joas, 1121, 1123 , Sept 2 'II

Chagres river, Panama, 944

Chalais-Medon, 340

Chalicotheres, 135 
Charleston, S. C., 904, 906, / Chicago Height3, Ill., 800 724, (wind storm) Aug Chickamauga Camp, 177 27 '11

W. Va, 928, 929

Charlotte, N. C., 877

Charlottenburg, 1009

Charlottesville, Va., 921

Charpentier, Gustave, Oct 26 ' 12

Charterhouse, July 8 '11

Chartres, Due de, 1003

Charula, Señor, 1120

Chatalja, 30, 34, 6, 8

Chateaubriand, A. de, 202

Chatham, Can., 665

Chattrnooga, Tenn., 909, 910,724

Chauvin, Hector, 676

Chavez-Dartnell, J., 1095

Cheape, Leslie, 467

Chehalis, Wash., 926

Cheleken island, 410

Chelles, 156

Chelmsford, Baron, 697

Chelmsford, 568

Chelsea, Mass., 828, 829, 831

Chelses horticultural exhibition, 426

Cheltenham, Glos., 484, Ap 28 ' 12

Chemet (airman); Dec 22 '12

Cheminots, 998

Chemistry, 120 , prize) Nov 12 '12

Chemnitz, 1009

Chena, Alsk., 938

Chen Chen-hsien, 977

Chen Chi-mei, 982

Chendering, 633

Chengtu, 979, Sep 21 '11

Chepachet, R. I., July 18 12

Cheque, crossed, 992

"Cherimaya," June 2 '11

Chermen, Fort, Oct 21 '12

Cherry, R. H., 601

Cherry, In., Nov 13 '11

- Creek, Colo., 784

Chesapeake \& Albemarle Canal, 878

Cheshire, Eng., 566

Cheshire, Conn., 787

Chess, 454

Chester, Eng., 582, (castle) 282

- Pa., 896

Chesterfield, 579

Chester scheme (railways), 1151

Chesterton, F., 453

-, G. K., 189, 192

Chestertown, Md., 824

Cheung Chan Is., Aug 20 ' 12

- Chow Is., 637

Cheyenne, Wyo., 935, 936

Cheylesmore, 3rd Baron, Ap 2 ' 12

Cheysson, Emile, 1003

Chiaoyupu, 977

Chicago, Ill., 800, 801, June 6 '12 (Republican National convention) $\mathbf{7 4 8}$, (Progressive convention) 748 , (mayoralty) 803, (City plan) 804, (court house) 251, (white slave traffic) 739, 803, (fire) Mar 20 '11, (Lumber trust) June 23 11, (railway accident) July 14 ' 12 (Stock Yards Co.) Dec 9 '12, (strikes) Feb 3 '11, Ap 1, May 2 ' 12 , (trade) 723, (wages) May 3 '12, (university) 803

branch, I.W.W., 741
Chickasha, Okla., 888, 889 Chicopee, Mass., 828, 829 Child, W., 454

Child Labour, 328, 329, 944, (U. S.) $770,778,786,789$, $799,819,823,826,830$, $837,841,844,847,858$, $862,878,881,886,893$, $898,902,910,914,917$, $919,922,929,933$

Children's Bureau, U. S. Jan 31 '12, Ap 9'12 - Courts, 329, 994, (U. S.) $779,793,848,851,862$, $881,905,911,918,926$

Chile, 1074, Jan 12 '11, (Alsop case) 1075, July 5 '11, (Argentine railway) 1068 , (navy) 44, 46, 50, (Peruvian relations) 1095, 1096. Nov 11 '12, (Rancagua exploration) July 7 ' 12

Chillicothe, Mo., 846

- $0 ., 883$

Chilton, W. E., 930

Chimaera, 140

China, 971, 102, (Western calendar) Dec 7 '11, (Anglican Church) 310, (armistice) Dec 2, 4, 9, '11, (cabinét) 977, 979, May 8 '11, July 13, 19 , 26, '12, (Emperor's edict) Oct 30 , Noy 10 , Dec 28 , '11, Jan 12,'12, (Finance) 73, (National Assembly) Jan 19 '11, March 22 '12, (new province) Oct 12 '12, (opium agreement) 604, May 8 ' 11 , Dec 16 12, (Paris banquet) March 14 '12, (painting) 243 , (pigtail abolished) Dec 7 '11, (plague) Feb 4 '11, Feb 7'11, (Republic) 10 , 981 , Oet $26^{\prime} 11$, Jan 5, Feb 12, Mar 14 '12, (revolution) 73, Oct 12 , 17,21 , Nov 27 '11, Oct 10 '12, (rice famine) Sep 8 '11, (Russian ultimatum) Feb 18, Feb 21, March 14 19, 27, '11, (St. Petersburg treaty) Feb 16, Mar 4 '11, Sep 6 '12, (trade union) Nov 25 '12

Chinchilla, 433

Chinde, 1125

Chinese foreign loans, 976 , Ap 15 '11, July 13 ' 12 , Mch 25 '12, Ap 27 '12, Oct 3, 24 '12, (default) Dec 31 '12, (Ćrisp loan, see Crisp), (Four Power loan) 9,76, May 29'11, Meh 4, 15'12, Ap 17 '12, (Six Power loan) 976, May 15 ' 12 , July 9 '12, Sep 23 '12, Oct 24'12

Ching, Prince, 979, May 8 '11

Chios, June 1 '12, Nov 24 '12

Chippewa Falls, Wis., 931

Chirol, Sir V., July 30 '12

Chiroptera, 135

Chitina, Alsk., 939

Chiton, 133

Chitral, 621

- fever, 171

Chlamydozoa, 129

Chloral, 142

Chlorophyll, 123

Choate, J. H., Dec 13 '12

Chodat, R., 140
Chisholm, Minn., 839
Choisy le Roi, 1001

Cholera, 1043

Chondriosomes, 143

Chota Nagpur, 614, 478

Chotard, Lt., Sep 12 '11

Chou Hsueh-hsi, 977, Mch 27 ' 12

Christchurch, N. Z, 699

Christensen, H., 215

-, J. C., 984, 985

Christian X, 986

- Princess, 479

Christian Endeavour, July 6 '11

Christiania, 1110, 1112

Christianity, (in India), 603

Christian Science, 733

Christmas Island, 627

Chromidia, 143

Chromium, 393

Chromogen, 140

Chrcmosome, 142

Chronology, Egyptian, 261

Chrysaor (statue), 275

Chrystal, George, 542

Chu Ch'i-ch'ien, 977

Chulalongkorn, 1135

Chun, Prince, 980, 981

Chunky, Miss., 845

Church, Rev. A. J., 552

Church Congress, 311

- Finance Committee, 308

Churchill, Winston, M.P. 485, (Belfast speech) 510, Feb 24 '12, (Admiralty appointment) Oct 23 ' 11 , (Guildhall banquet) Nov 9'11, (on European situation) Nov 29 '12, (on free trade) Ap 7 '11, (on insurance) Sep 11 ' 12 , (ships) 354, July 22, May 15 '12, (Ulster speeches) Aug 10 '12, (woman suffrage) 88 .

- Winston (novelist), 200 Mrs. Winston, Nov 18 '11, Oct 24'12

Cicero, Ill, 800

Cimarron riv., Okla., 888

Cimiez, Ap 12 ' 12

Cincinnati, O., 882,883 724, (companies indicted) Feb 22'12, (fire) Jan 10'11 Cincinnati \& Muskingum Valley R.R. Dec 3'12

Cincinnati, N. O. \& T. P. Ry., 912

Cinema theatre, 233, 324, 581

Cinematograph, 175

"City of Detroit," 346

City Point, V8, 724

- and Suburban, Ap 19'11

- schools (U.S.), 729

Civil Code (Switz.), 1146

- list (U.K.) 475

- Service (U.K.), 531, 534, (Royal Commission) Dec 20 '11, Mar 13 '12

- Service Reform (U.S.) $739,802,803,830,862$, 885

Civita, Levi, 114

Civita Vecchia, 1046

Clackmannan, 588

Claparéde, A. de, 1148

Clapp, M. E., 842

Claremont, N. H., 857

Claremore, Oklı., 889

Clarence colliery, France, 383

Clark, Champ, 747, 783 $804,817,848,875$, June 28 '12, (reciprocity) $\mathbf{6 6 9}$

-, Clarence D., 937

- C. U., 220

_, Rev. H. W., 319

Clark, J. Willis, 584 - Julia, June 18'12 , Reed P., 1104 Walter, 879 Walter E., 940 Wm, C., 753 W. H., 467

Clark Co., Nev., 855

Clarke, A. E., 895

- Sir C. P. 540

- Sir Edward, 528

- Edward A. W., 655

- Sir George (Lord Sydenham), 615

-, George W., 811

-, L. O., June 18 '12

- Marcus, 196

-W. G., 156

Clarksburg, W. Va., 928

Clarksdale, Miss., 844

Clarkston, Ga., 796

Clarksville, Tenn., 909

Classical Scholarship, 219

Claussen, 146

Clay, A.' S. 796

Claybird shooting, 469 
Coal dust, 382

Coalexld and Coalice, 398

Coal fields, 379

Coal Mines Act, (1911) 327, (1912) 379

- mining, 379

- Point mines, 627

- tar, 405

Coast Erosion Commission, June 26 '11

Costbridge, 588

Coatesville, $\mathrm{Pa}_{\text {. }} 899$

Coats, Messrs, 591

Coats Land, Antare., 100

Cobalt, June 6'12

Cobleskill, N. Y., 868

Coburg, 1009

Cocoa, 1173, 1125, 536

Cody, S. F.. Aug 30' 12

Cochery, Georges, 996

Cochin, 617

Cochrane, Francis, 668, 676

Cockburn, G. R. R., 677

Cockerill, 369,370

Cockran, W, Bourke, 875

Cocos Island, 1092

Cocos-Keeling Is. 132, 627

Coderre, Louis, 668, Oct 28 ' 12

Codification, 331

Coelentera, 131

Coeur d'Alene, Ida., 797

Coffee, 1172, (trust, U.S.)

May 18, 24 '12

Coffey, Dennis, 602

Coffeyville, Kan., 812

Cogul, Sp., 158

Coke, 396, 397, 402

'Col. J. M. Schoonmaker,' 346

Colas, Prul, 469

Colby, F. M., 199

Cole, Galbraith, 644, Sep 9 '11

Colchrook Academy, N. H., 8.59

Coleridge-Taylor, Samuel, $238,5 i 3$

Coles, John, 105

Colijn, Major H., 1042

Collie, J. Norman, 103

Collier, Constance, 232

- J. P.. 194

Collier Memorial Dispensary, 600

Collieries: see Mining

Collins, Cornelius V., 873

- D. C., 468

- P. V. 842

- Baron, 542

Collinsville, Okla., 891

Colloids, 127

Collyer, Robert, 751

Colmar, 1009

Cologne, 1009

Colonne, Edouard 1003

Colombia, 1076. (Bolivian relations) 1094,1095

Crolombo, 623

Colon, Paa., 945

Colonial Geography, 106

Colorado, U.S., 781

Colorado Springs, Col., 781. $7 \times 2$

Colour (of flowers), 140

(c)lowan I. 637

(')lruutt, Osear B.. 915

Colton, Geo. R., 1052

Colum, P., 186

Columbir, Mo, 846

- $8 .(\therefore 904$

-.Tenn. 909

Columbis riv. T. S. 925

- Falls, Mont. 849

- University, N. Y., 873

Columbus, G8. 794,79i)

- Miss, 843

- Neb., 856

_, O., 882, 883, Aug 411
Columbus Memorial, D.C. 790

Colvin, James, 701

- Sir Sidney, 189, June 18 '12

Combes, E., 1002

Combs, Leslie, Jan 18 ' 11

Combustion, 121, 400

Comets, 95

Commentary, 383

Commerce (U.K.), 569

- Court (U. S.), 736, Feb 15. Nov 14, Dec 5 '11, June 11, 12 '12, Dec 9 '12 London Associated Chambers of, Mch 14 '11

Commercial Cablo Co. N. Y., 81

- geography, 105

- law, 329

Commission government of cities, U. S., 745, 746, (Ala.) 767, (Ariz.) 771, (Cal.) 777, (Colo.) 783, (Conn.) 780, (Ga.) 796, (Ida.) 798, (III.) 802, (Kan.) 813, (Ky.) 816, (La.) 819,820 , (Me.) 823 , (Mass.) 831, (Mich.) 837 , (Minn.) 843, (Miss.) 844 , (Mont.) 850, (Neb.) 85.3, (Nev.) 855, (N. J.) 862, (N. C.) 878 , (N. D.) 881 , (O.) 88.5, (Okla.) 891 , (Ore.) 895 , (S. C.) 906 (S. D.) 908 , (Tenn.) 910 (Tex.) 914, (Ctab) 918 . (Wash.) 926, (W. Va. 929, (Wis.) 935, (Wyo.) 937

Common," Deo 17 '12

Commont, 156

Commonwealth Bay, 101

Communion of the sick, 308

Companies Act, 330

Company promoting, 329

Compulsory service, (Australia) 694, (New Zealand) 700

Comstock, N. Y., 873

- Mine, Nev, 387

Conant, Luther, Aug 9 '12

Couceiro, Capt. P., 1121 , 1122 , 1124, July 7,9 '12, Nov 21 ' 12

"Concessions case," 1110

Conciliation bill, 87, 88, 503 Concord, Mass., 835

- N. C. 877

-, N. H., 857

Condamine, 1105

Concter, Col. C. R., 538

Condylarthra, 135

Coney Island, N. York, MIay 27 ' 11

Confederate Soldiers, State pensions, (Ala.) 767, (Ark.) 772, (Ga.) 796, (Kv) 817, (Ls.) 820

Confídération générale du travail, 1003

Congella, 70 .

Congested Districts Board. $597,5 \times 9$

Conge, riv., 103

French, 2, 1006, July 1 ' 12 , July 17 ' 11 , Aug 30 '11. 127

Congregationalists, (Wales) 306, (U. S.) 733

Congregational Union, May s 11

Cungregations, Law of $0 ? \Omega$ Congress, $\mathbf{U}^{*}$. S., (list) 1175 . (astembles) Dee 2 '12, (recess) Dee $19^{\prime} 12$

Connaught, Duke of, 479 (Canada) 667, Jan 28,
Oct 6 '11, (Canadian Condova, Alsk., 938 tour) May 6, Aug $28^{\prime} 12$, (Cape University) 711, Dec 21 '12, (Freetown) 649, (Nova Scotia) Aug 14 '12, (Ottawa) Oet 14 '11, (Quebec) Oct 13'11, (St. Helena) 652, (Toronto) Aug 26 ' 12

, Duchess of, 479, May 6

-, Princess Patricia of, 479 -, Prince Arthur of, 479

Connaught, 594, 601

Connecticut, 784

Connell, Richard E. 875

Connemara, 597

Conrad, Joseph, 188

Conservation, (Canada) 664, (U. S.) 737, (Ga.) 795 , (Mass.) 829 , (N. H. 857,858 , (N. Y.) 871, (Tenn.) 909, (Va.) 921, (Wis.) 931

Consols, 532, 537, 77

Constable, P. $_{\text {. }} 451$

Constantinople, 1149, 1150, $1154,1158,1159,1163$, (convention, 1881) 1027, (Naval guards landed) Nov 18 ' 12

Constantza, 1036, 1037

Constitutional crisis (1910), 481

Consular service, British, Sep 17 '12

Consumption: see Tuberculosis

Contraband of war, 58

Controller Bay, Alsk., 940, 737

Convict labour (U. S.), 773, $794,799,814,816,820$, $838,848,856,863,867$, $884,903,905,918,923$, 927, 934, 937

Cook, Sir E. T., 191

-, Joseph, 689

- S. A., 264

- Sir Willism, 587

-, W., 453

Cookery, electric, 304

Cool, Wouter, 1041

Coombs, Dr, C. F., 168

Cooper, D. B., 911

-, Edwin, 582

Cooper, J. P., 1083

Cooper-Key, Major, 471

Cooper process, 405

Co-operation, (at Castlerea) 597, (India) 604, (Japan) 1054, (syndicalist view) 20

Coorg, 617

Coos bay, Ore., 892, 724

Copenhazen, Den., 983

Copper, 102, 566, 1174, (alloys) 394, (use) 392

Copper River, Nlsk., 939

Coptos, Egy., 262

(opts, ass

Copyright, 337, (Cannda) Ap 26 '11, (Holland) 1042, (U. S.) Jan 30, Oct 16 '12, (U, K.) Ap 7 '11 -, artistic, 336

Coquille riv., Ore., 892

Coral reef, 132

Corbett, Bp. J. F, 697

Corcoran Gallery, D. C. 248, Dee 16 ' 12

Cord-itales, 146

Cordeau fuse, 387

Cordeaux, Capt. H. E. S. tit.

Cordele, Ga., 794

Cordite, 373

Cordoba, 1068

Curdova, Ala., 767

Corfu, island, Gr., 275

Corinna, 220

Corinth, Gr., 276

-, Miss., 843

Corinthian Cup, $\mathbf{4 5 5}$

Corinto, 1091

Cork, 595, 598, 602 556

Corn Duty (U.K.), 531 ploration) 268 July 4 ' 12

Cornwall, 566

Coronation Gulf, 101

Coropuna Mt., Peru, 103 , Co., 595, (by-elections) May 22 '11, July 15 '11

Cork \& Orrery, Countese of,

Cornell University, N. Y. 873, (poultry) 425, (ex-

Corning railway accident,

Corona, polarisation of, 91

Coronation (U.K.), 476. (honours list) June 20 '11

Corpus Christi, Tex., 913, 
Cowes regatta, Aug 1, 2, $7 \mid$ Croatan, 879 '11, Aưg 6 '12

Coweta, Okla., 891

Cox, C. F., 754

-, G. B., 887

- Kenyon 249

Coyptepe, Nie., Oct 4'12

Cracow, Aus., 956, 957, 960, (University) 956

Crafts societies (U.S.), 252

Craggs, Helen, 89

Craig, E. H. Cunningham, 658

-, Gordon, 240

-, Capt. J., M.P., 488, July 12 ' 12

- Locke, 879

Craig, Colo., 782

Craigavon Day, 510

Craighead, E. B., 851

Cranberry Is., Me., 253

Crane, W. M., 833

Cranston, R. I., 901

Crater National Forest, Ore, 892 .

Crawford, Sir Richard, 1149

Crawford Noteh, N. H., 858

Crawshay-Williams, E., M. P., 487

Cream, 420

Creamery Butter Manufactures, Dec 14 '12

Credaro, L., 1050

Credé method, 301

Creizenach, Prof., 195

Creodonts, 135

Creosote oil, 356, 400

Creston, Ia., 809

Cretaceous, 135

Crete, 9, 1025, 1027, 1028 , 1030, 1153, (excavations) 272,277

Crewe, Marquess of, 485 488, Feb 14, June 26 ' 12

-, Col. C. P., 710

Crewe, (by-election) 484, (railway accident) July 28 ' 11

Cricket, 456, 474, (Australjans at Lords) May 22 ' 12 , June 26 ' 12 , July 17 '12, (at Manchester) May 28 '12, (at Oval) Aug 22' '12, (championship) Aug 29'11, (Eton and Harrow) July 8 ' 11 , (George V) 476, (M.C.C. in Australia) Dec 21 '11, Jan 3 '12, Jan 17 '12, Feb 13 '12, Mar 1 '12, (Oxford and Cambridge) July 5 ' 11 , July 10 ' 12 , (S. Africans in Australia) Jan 4 '11, Jan 13 '11, Feb 7 '11, Feb 21 '11, Mar 7 '11, (S. Africans in England) June 12 '12, July 17 ' 12 , Aug 13 '12 Crijic, J., 105

Crime (U..K.), 586

Criminal code (Japan), 1059

- law, 330

- law amendment bill. 504

Cripple Creek, Col., 781

Crisfield, Md., 824

Crisp loan (China), 976 Aug 30, Sep 4, 16 , 12, (British legation refuses notification) Oet $15 \cdot$ ' 12 , Chinese Govt.'s decision) Sep 22 '12, (Eleven Powers' pratest). Oct 28 '12, (prospectus) Sep 26 12, (subscriptions) Sep 30 '12

Cristobal, Pan., 945
Croatia, 965

Crocker Land, Arct., 101

Crockett, E., 913

Croesus, 274

Croft, H. Page, M.P., 488

Crofter agitation, 589

- Commissioners, 589

Crofts, E., 540

Croiset, M., 221

Crombes (airman), May 21 '12

Cromer, Earl of, 489, 496, 223

Cronje, Piet Arnoldus, 712

Crookes, Sir W., 360, 412

Crooks, W., M.P., 487

Crookston, Minn,, 839

Crops, Rotation of, 416

Croquet, 458

Crosby, Sir T, 579

Crosco, Pascual, 1088

Cross, 241

Crossley, Bp. O. T. B., Ap 4 '11

Crossley Gas Producer, 399

- Motors, Ltd, 355

Crothers, A. L. 827

-, S. M., 199

一, T. W., 668

Crowe, Sir Eyre, Jan 11 '12

- T 468

Crowley; La., 818

- Co., Col., 782

Crown, The (Gt. Britain), 478,481

Crown Point, N. Y., July 5 12

Crownsville, Md., 826

Croydon, 560

Crozier, Archbp. J. B., 197, 601, Feb 2 ' 11

Crozier, Cape, Antarct. 100

Cruce, Lee, 890

Cruisers, 48, 351

Crum, W. D., 754

Crumpacker, E. D., 808

Cruppi, Jean, 998, 999, 1000, (Speech on foreign relations) Ap 7'11, (vote of confidence) June 16 ' 11

Crustaceans, 138

Crystal Palace (London), June 8 ' 11 , (Sale) Oct 23 '11. Nov 17 ' 11

Cuba, 1080, (U. S: fleet sent), May 23 ' 12 , May 27 '12, June 5 ' 12 , July 25 ' 12

Cubism, 242

Culberson, C, A., 915

Culebra Cut, 945

Culion, P. Is., 166

Cullen-Foley charter, 876

Cullera, 1137, 1138

Cullinan, Sir. T. M., 711

Cullom, S. M., 804

Culme-Seymour, Sir M. 480

Cumberland, Md., 824, 825 -, R. I., 901

- riv., Tenn., 910

Cumming, A., 470

Cummins, A. B., 811

Cumont, Prof June 26 '12

Cunard Steamship Co. Mch 17 '11

Cundall, Miss, 453

Cuneiform, (tablets) 264, (texts) 259

Cunliffe, J. W., 195

Cunningham claims, 940

Cunningham, E. S., 197

-, P., 193

Cuocolo, Gennaro, 1047. Meh 11 '11

Cuprous sulphate, 122

Curacao, 1041
Curie, Madame, Jan 23 '11 Danish Literature, 212

Curling, 458

Curran Committee, N. Y. C., 876

Curran, Julia, Aug 24 '12

Currie, H. A. F., 644

Currier, F. D., 859

Curtis, C., 814

Curtis, Neb., 853

Curtiss, Glenn, 343

Curtis turbo-generator, 347 Curzon of Kedleston, Earl, 478, 489, 495, 496, June 7.'11, (Glasgow Univ.) Jan 25 '11, (on European situation) Nov 29 '12, (national defence) Oct 22 '12, (woman suffrage) Feb 28, Nov 1 12, (Tattershall castle) 583

Cushing, Dr. H., 171

Cutch, 617

Cuttung, W. Bayard, 754

Cuvaj (ban of Croatia), 965

Cuverville, J. M. A. de 1004

Cuyahoga Falls, O., 887

Cyanide process, 393

Cycades, 145

Cycle trade, 567

Cycling, 459

Cyclone, 112

"Cyclops," 347

Cynodontia, 134

Cyprus, 640, Ap 1 '11, (riots) May 27,12, Oct 3 '12, (archæology') 278

Cyrenaica, 24, 989, (annexation) 4

Cyrene, 273

Cyril (of Bulgaria), Nov 9 12

Cytisus Adami, 140

Cytology, 141

Czapek, F., 143

Czartoryski, Prince George C., 966

Czechs, 960

Czekanowski, Prof., 152

Czernowitz, 956, (Úniversity) 956,961

Czuchow, 388

Dacca, 614, 617, (university) 607

Dahl, Knut, 449

Dahlia, 427

Dahlonega, Ga., 796

Dahm, Lieut., Nov 1 '12

Dahn, J. S. Felix, 207, 1023

Daily Citizen, The, 521

Daily News, May 10 '12

Daimler Company, 567

Dairy industry, 420, (U.K.) 563

- schools, 415

Dalai Lama, 11, 982, 611

Dalen, G., Nov 12 '12

Daley, V., 196

Dalkeith poisoning case, Feb 4 '11

Dallas, Tex., 912, 913, 914

Dallas, The, Oreg., 891

Dallwitz, Johann von, 1017

Dalton, Ga., 794

Daly, T. M., 676

Daly City, Cal., 780

Damascus, 1149, 1151

Damophon of Messene, 281

Danbury, Conn. 785, (hatters' boycott) Ap 10'11

Daneff, Dr. S., 1027, 1029 , 6,9 , Nov 11 ' 12

Dangeard, 146

Danglis, Gen., 28

Daniel, John W., 923

Daniels, C. M., 471

- Josephus, 879, 750

Danilo (of Montenegro), 28

D'Annunzio, Gabriele, 208

Dantas, Julio, 217

Danville, Ill., 800

一, Ky., 815

-, Va., 921, 922

Danzig, Ger., 1009

Daphne, Ala., 767

Darbhanga, Maharaja of 614

Dardanelles, 25, 26, 29 (bombardment) Ap 18 '12, (naval engagement) Dec 16 '12, (Russian protest) Ap 23 ' 12

Dar-es-Salaam, 645

Daressy, 262

Darfur, Af. 991

Darjiling, India, 614

"Darkest England," 17

Darling, Lord Stormontb. 550

Darlington, 561

Darmstadt, Ger., 1009

Darrow, C., 742

Dartmoor Shepherd": see 
Decatur, III., 800, 802

Deceased wife's gister, 325 , 310 , June $20^{\prime} 12$

Déchelette, J., 158

Decker, Sarah S. P., 754

Declaration of London, 156. June 27 '11, (condemned by Admirals) June 19 ' 11 , (Chamber of Commerce resolution) Mar 14 '11, (Imperial Conference) June 1 '11, (Italy's decree) 57, (Russian note) 58 , (U.S. ratification) $\mathrm{Ap}$ 24 '12

- of Paris, 56

De Courcy Laffan, Mrs. 555

Decroce (airman), Nov 26 11

Drdeagach, Turk., 31, Nov $22 ' 12$

Dedham ware, 254

Dee, 590,573

Decrfield, Mass., 253

Deer forests, 589

Deer Lodge, Mont., 849

Defectives, 327 , (training,

U.S.) 730 , and articles on

American states under

Education and Charities

De Forest, Baron, 489

De Haan, 166

Dehmel, R., 206

Delagoa Bay, W. Af., Ap 15 '11

De la Mare, W., 187

Delamere, Baron, 644

Deland, Margaret, 200

Delattre, Louis, 212

Delaunay-Belleville, L., 1004

Delaware, 788

- river, Pa., 897

- \& Hudson Company. Feb 21'12

- Lackawanna \& Western R. R., 861, Mar 19'12

Delbrück, C., 1014

Delcasse, Jacques, Dec 21 '12

- Theophile, 1000, 999, 1001

Deledda, Grazia, 208

De Leon, Daniel, 741

Delfzyl, 1034

Delhi, 617, (capital) 478 609, (commissionership) Oct 1'12, (durbar) 477 , (fire) Dec 5'11

"Delhi," 350, 478

Disijunus fort, Turk., Nov 7 ' 12

Delimitation Law, 999

Delisle, L., 1003

Delius, 238

I) -1os, Gir., 276

Delyhi, Gr., 279

Dinnachy sale, May 24 '12

Demerara, 655 $\begin{array}{cl}\text { Democratio } & \text { Party, U.S, } \\ \text { D35, 747, } & \text { Diaphing, } 78 \\ \text { Dee also } & \text { Diarbekir, 1151 }\end{array}$ sevarate states under Diaz, Adolfo, 1091 History 266

De Morgan, W., 188

1) emurrage, 592

Deneen, C. S., 804

Donlam, D. F, 693, 698

Denimger expedition, 1041

Denison, Col. G. T., 197

- II. A. 467

Denman, Barna, 692, Mrh 2 '11, Scp 5'11, Sep 14'12

Denmark, 983, (blind) 301 . (ronstitution reform) ()rt 23, Dec 13 '12, (monuments) 284, (woman suffrage) 90

Dentistry, 179

Denton, C. T., 549

Sir G.648 344

Depew, C. M., 874

Deport, Col., 371

Depôt laying, 100

Derby, 17 th Earl of, 489

Derby, Eng., 567, 568 '11, June 5 '12

Dermoptera, 135

Dernburg, B., 1015

Derry, N. H., 857

Derwent reservoir, 580

de Sanctis, 222

Desart, 5th Earl of, 1101 23 ' 12

Des Chaux, M., 469

Deslandres, H. 91 723

Dessau, 1009, 1021

- retort, 403

Destroyers, 353,49

Detaille, J. B: E., 1004

Detmold, 1009

Detroit, Mich., 836, 723

- river, Mich., 837

Deus, Joao de, 216

Deuteronomy, 266 partei, 1018

"Deutschland," 100 Deventer, 1040 881

Devlin, J., 487

Devonian type, 134 July 11,15 ' 12

Devonport, 560 Feb 14'11

Dewar, Sir James, 122 Dec 28 '12

- Dr. J. A. 712

Dewsbury, 561

Devada, Senor, 1095 son, 351

Dharwar, 605

Dholpur, 618 $23^{\prime} 12$, Oct $26^{\prime} 12$ '11. May'25'11

Dibdin, Sir Letvis, 325

1)ibra, Turk., 33

I) irey, E., 5.39

1)ick C $8 \times 7$

Dickens, Churles, 192

Dickerson, 11. B, 890

Dickie, Mrs., Dec 7 '11

I)jckins, G., 279, 281 sits, June 5 '11

Dickinson, N. Dak. 879

Dicotyledons, 145
Denny, Dr. A., 350

enver, Col., 781, 789 784, (university of) 784

Deperdussin monoplane,

Derby, The, 463, May 31

Derna, Trip., 22, 23, 24, 26

Deschanel, Paul, 1002, May

Des Moines, Ia., 809, 810 , (railway strike) 812 , (town plan) 812 , (trade)

De Soto parish, La., 818

- branch of I. W. W., 741

Deutsche Freisinnige Volks-

Development Act (1909), $536,414,563$, (Ireland) 596, (report) July 17 ' 11

Devils Lake, N. Dak., 879 ,

Devonport, Baron, 528,

Devonshire, 8th Duke of,

De Wet, Gen. C. R., 710.

D'Eyncourt, E. H. TennyDiamond Match Co., Jan. Dóliche, 278

Felix, 1088, 1089, Oct

Porfirio, 1087, May 4

Dickinson College, Pa.
"Dollar-a-day", pension

bill, Dec 12 ' 11

Dollfus art collection, Mar 2, Muy 20 '12

Dolliver, J. P., 811

Dolmen period, 158

Dolo, Abys., 953

mi, Asia M., 273

Party, 494

Diesel engine, 568, 348, 354

$356,400,410$

Digby, Sir Kenelm, 648, June 25 '12

Dilke, Sir C 539

Dilling, G. W., 927

Bill Ap 19'12

ulon, Edmond B., 887

487

Dimitrakopoulos, N., May 31 '12

Dimsdale, Sir J.551

Dindings, The, 625

111

Dionne, N. E. 199

Dionysius of Halicarnassus,

Diphtheria, 167

Dipylon cemetery, 275

Direct Primaries: see Primaries

wa, Abys, 953

le balloons, 341,372 ,

Disciples of Christ, 733

iserth Castle, Wales, 282

Divoree, 324, (Australia) (Bohemia) 962 Nov 11 , 12 (Convocation resolutions) Feb 17 11, (Portugal) 1124.

Dix, F. W. 470

1. B., 122

Dixon, III. 802

Dobell, 130, 146

Dod. W.. 450

Dodgson, Campbell, June

Dec 23 ' 12

oflein, 129

Domaszewski, v., 222

Dominica, 654, 65.5

Donaghey, George W., 773

Doncaster, 566

Don Quicholte (opera), May 17 '12

Dooley, Mr.," 200

D'Orcilien (revolutionary), 11) 99

Dorjieff, 11

Dorno, C., 113 276

Dortinund, 1009
Diels, $11 ., 220$

Dörnfeld, Wilhelm, 271,

Dortmund Ems canal, 1010

Dostoievsky, F. M., 206

Dothan, Als., 765

Doucet, L. J 198

Doughty, Arthur, 197

Douglas, Rev: A. Nov 10

'11, Dec 7'12

-, Gen. Sir C. W: H., 578

- J. W. H. T., 457

Douglas, Alsk., 938

- Ariz., 768

-, Wyo., 935

Douglas-Pennant, : Violet, Dec 18 '11

Douglass, Miss G., 453

Doust, S. N., 465

Dove, Heinrich W., 1020

Dover, Del, 788

Dover, Eng., 573

-, N. H., 857

Dowden, E., 189

Dowling, Bishop A., Jan 31 12

Dowse, Bishop, Nov 22 '12

Draeger rescue appliances, 384

Drago, L, M, 64

Dragoumis, Stephen, 1026 1027, 1028, 1031

Drake, E. M., 468

Drake (play), 230

Drama (Turk.), Oet $28^{\prime} 12$

Drama, 227, (Greek) 221. (in America) 232, 201 , (in Germany) 207, (The Coronation) Jan $27 \cdot 12$ (The Secret Woman) Feb 22 '12, (A Venetian Night) Nov 4 '12, Nov 12 '12

Draper, Eben S., 833

Draveil-Vigneux, 997

Dreadnought type, 47,350 . 375

Dresden, Ger., 1009

-, O., Dec $3^{\prime} 12$

Drew, John, 233

-, Sir T., 538

Drews, Dr. A., 317 
Duckworth, Canon, 542

Dudding, Henry, 552

Dudley, Irving B., Nov 27 '11

Dudley, 579, 582

Duez, M., June 21 '11

Duff Development Co., 632

Dugan, R. S., 96

Dugdale, Lieut. C. F., Nov 25 '11

Duisburg, Ger., 1009

Duke, H. E., 488

Dulaney, L. C., 845

Duluth, Minn., 839, 840, $841,842,724$

Duma, 3rd (Russia), 1126 , 1131

- 4th, 1132

Dumas, Ark., 774

Du Maurier, G., 231

Dumb Persons, 304

Dumbartonshire, 588

Dumfries, 588, 398

Dumont, C. 999

Dumont-Wilden, 212

Dunant, J. H., 1148

Duncan, Lewis J., 851

- Patrick, 709

Dundalk, 595

Dundee, 588, 438

Dunedin, 699

Dundermline, 594, 591

Dungar Memorial College, 615

Dunkirk, Fr., July 11 '12

Dunn, Oscar, 199

Dunne, E. D., 811

- Edward F., 803, 804

- Finley Peter, 200

Dunoyer, L., 117

Dunseith, N.' Dak., 881

Dunstan-on-Tyne, Northumb., 362

Dunville, Mrs. John, June 22 ' 12

Duplex gas engine, 356

Dupont, Edouard F., 969

-, H. A. 789

-, T. C. 788

Dupuis, Jean, 1004

Dupuy, Paul, May 18 '11

Duralumin, 393

Durant, Okla., 888

Durazzo, Turk., 32

Durban, 703, 704, 705

Durbar, Delhi, 609

Durbin, Winfield T., 808

Durham, N. C.. 847

Durham, Eng, 558, 565

- Miners Association, 565 University, 585, Nov. 19 ' 12

Durkheim, E., 160

Düsseldorf, 1009

Durnan, E., 468

Dust mulch, 419

Dutch literature, 209

- Guiana, 104

Duveen. B. J., Dec 4 '11

- Henry J., May 24 '11

-, Joseph J., Mar 27 '11

Dwight-Lloyd process, 390

Dyeing, 443

Dynamite outrages (U.S.) $742,780,809$, Dec 28, 30 '12

Dysentery, 168

Eadie, Dennis, 231

Eads, Col., 781

Eagle, Alsk., 938

Eagle Pass, Tex., 724

Ealing, 556, 561

Eardley-Wilmot, Sir S., 563

Earle, Sir A., 613

- Alice Morse, 754

$\overrightarrow{-}$, George H., 899

Early closing law, 327

Earthquakes, 107, (Alaska) Sept 21 '11, Jan 31 '12,
(California) July 1 '11, Eger, Aus., 960

Jan 4'12, (Germany) Egerton, Sir W., 650, 650, Nov 17 '11. (Mexico Feb 11'12

City) June 7 '11, (Neva- Egg farming, 423

da) Jan 12 '12, (Philip- Eggleston, G. C., 751

pines) 950, (Russian Egypt, 987, (archacology)

Turkestan) Jan 4, 13 '11,

(Turkey) Aug 8, 12 '12

Easington colliery, 382

East Africa Protectorate, 643

- Boothbay, Me., 822

Eastbourne, 560, 579, Aug 19 '12

Fast Chicago, Ind, 805

Eastern Orthodox Churches, (U.S.) 733

Eastern Question, The, 6

East Ham, Eng., 556

East Jordan, Mich., 837

East Lake, Ala., 767

East London (S. Af.), 703. 704

East I othian cropping, 416

East Orange, N. J., 860

Eastman, Mrs. F., July 27 '12

Easton, Md., 824

- , Pa., 896

Eastport, Me., 723

East Rutherford, N. J., 863

East St Louis, Ill, 800, 801

Eaton, D. C., 754

Eau Claire, Wis., 931

"Eavestone," 348

Eberhart, Adolph O., 842

Eberle, Abastenia, 250

Eccles, Dr. W. H., 368

Echelette grating, 118

Echinoderma, 132, 138

Eckford, Capt. A. B., 1115, Dec 11, 13 ' 12

Eclipses, 91

Ecology, 141

Economy and Efficiency Commission, U.S., 725, Ap 4 '12

Ecuador, 1083, 1063, (exploration) 104, (Presidents) Aug 19 '11, Jan 11 ' 11

Eddy, M. G. B., 751

Eddyville, Ky., 817

Edentates, 135

Edge, Sir J., July 5 '11

Edhem Pasha, July 15 '11

Edinburgh, 588, 593, 594 (blind) 301, (George V's visit) 477 , (theatre fire) May 9'11

Edison kinetoscope, 233, 235

Edite saepe dei (encyclical), 1017

Edmonds, J. M., 220

Edmonton, Can., 665

- Eng., 561

Education, 295, 530, (agricultural, U.K.) 415, (Advisory Committee, Imperial) Nov 18 '12, (U) K.) 583 , (single schoo area bill) 314, (technical Scottish) 593, (U.S.) 728 see also countries and states

- Building, Albany, N. Y., 251, 871

Edward VII, 475, 481, (memorial) 245, 587, Noy 9 '11. Dec 19 '12

- Prince of Wales, 475 June 10 '11

Edwards, Enoch, 546

-, J. Passmore, 540

- Noel, 467

Edwardsville, Ill., 802

Eeden, F, van, 210

Eekhoud, G., 211
260, (blind) 301, Oct 3

12 , (cotton growth) 436 (oil) 411, (Gorst's resignation) July 6 '11, (Kitchener), July 15 '11, Nov 7 ' 12 , May 30 ' 12 , (Nationalist conspiracy) Jan 23 ' 11 , Aug 13 ' 12 , Aug 26 ' 12 , Nov 16 ' 12 , (Sollum Bay) Dec 19 '11, (Sudan expedition) Mar 27 '12, Ap 2 '12

-, Bank of (London), 990 Ehrensvärd, Count A., 1143 Ehrhardt, 369, 372

Ehrlich, Dr. Paul, 175

Ehrmann (airman), June 23 ' 12

Eiffel, A. G., 340

- Tower, 367

Eigenhuis, J., 210

Eight hours day, (U.K coal), 380, (shipping) 568, (U.S.) Dec 14' '11, May 31, June 19 ' 12 (Ariz.) 770, (Ida.) 799 (Mass.) 830, (Mont.) 850, (Nev.) 855, (N. J.) 862 , (N. M.) $867,(\mathrm{O}$.) 884, (Ore.) 893

Eijkmann, 166

Eilens, Frl. L., 470

Einstein, Albert, 114

$\rightarrow$, Lewis, July 6 ' 11

Einthoven galvanometer, 168

Eisenach, 1009

Ejectment, The Great, 319 , Oct 4'12

Elassona, Turk., 33

Elbe, canal, 957

Elberfeld, 1009

Elbert expedition; 1041

Elberton, Ga., 794

Elder Dempster Shipping Co., 704

Elder Statesmen (Japan) 1061

Election, general (1910) U.K., 484

Electoral Reform (France), 996,1002

"Electric Arc," 349

Flectric furnace, 391

- heating, 363

- lighting, 363, 407 (mining) 385

- ship propulsion, 347

- Theatre, 235

- trammay, 355

Electrical engineering, 358 (U.K.) 567

- measurements, 361

Electricity, (fertiliser manufacture) 412, (Mining) 382, (Clyde shipbuilding 592,593 , (wool winding) 443 , (cables and "wireless") 86

Electro-cardiography, 168

Electrochemistry and Electrometallurgy, 359

Electrolyte, 128

Elementary Schools (U.K.), 583

Elephant and Castle subway, 582

Elephantine I, Egy., 265

Elgar, Sir E., 238

Elgin, Ill., 800, 801, 802

- Scot. 588

Elgon, mt., 644
Ekenberg, W., 398

Elguero, Federico, 1083

Elibank, Master of, 487 . 491, Aug 7 ' 12

Eliot, Sir Chas., 585

Elisabetta, duchess of Genoa, 1054

Elizabeth, N. J., 860, 863

Elizabethan drama, 193 (stage) 195, 229

Elizabeth City, N. C., 877

Elizabethville, Bel. Cong. 970

Elk Park, N. C., 878

Elkhart, Ind., 805

Elkins, Davis, 930

- Stephen B., 930

Elkins, W. Va., 928, 930

Ellesmere Port, 568

Ellice, Is.. 639

Elliott, W., 469

Elliott, Sir C. A., 542

- Charles B., 950

Sir Henry G., 712

Ellis, F. R., 627

- Sir J. W., 551

-, Sir T. R., 523

Ellsworth, Me., 723

Elmira, N. Y., 868

El Obeid railway, 991 
English Association, Jan 27 'Eulenberg, Herhert, 207 '11

English-Canadian Literature, 197

English Revien, 186

Enid, Okla., 888, 891

Enkomi, Cyprus, 278

Ennis, M. A., 563

Entebbe, 644

Enteric fever, 176

Enver Bey, 24

Environment, 154, 330

Enzyme, 144, 140

Eocene (soil), 417

Eoliths, 156

Epernay riots, 999

Ephemerides, directors of national, 99

Epileptics, marriage of, 327

Epirus, 1030

Episcopal Church, (Scotland) 594 , (U.S.) 732,734

Epps, Washington, 549

Epstein, Jacob, 244

Equality, Ill., 802

Equatorial Africa, 1006

Era steel, 378

Erech (dynasty), 258

Erfurt, 1009

Eруаттs, 219

Erichsen, Mylius, 102

Erie, Pa., 896, 897, 724 (railway accident) Sep 10 $' 12$

- canal, N. Y., 870, Sep 3 '12

Eritrea, 1049

Ermelo, 705

Erne (bozer), 454

Eros (planet), 94

Erzerum, 1151

Fscanaba, Mich., 830

Esch Match Bill, Ap 9 '12

Escherich, Karl, 133

Eshelman-Stetson law, 778, 779

Esher, 2nd Viscount, Mar 24 ' 11

Eskimos, 153, 101, 663

Eskmeals colliery, Cumb., 382

Esperanto, 303

Espin, T. H., Jan 1 '11

Espionage crses, (Dahm) Nov 1 '12, (Eilers) July 5 '12, (Emden) Sep 20 '11. (Graves) July 23 ' 12 , (Grosse) Feb 9 '12, (Kagelmann) Oct 10 '12, (Kiel) Aug 8 '12, (Kostevitsch) Nov 15 '12, (Metz) Oct 19 '12, (Russian) Dec 13 '11, Jan 18 '12, (Schultze) Aug 18 "11, Nov 3 '11. (Stewart) Aug 7 ' 11 , Feb 3 ' 12 . (Mile. Thirion) Oet 13 ' 11 Fissad Pasha, 29, Oet 7 ' 12 Eswen, 1009

Fst-Algérien railway, 1005 Fistate duty, $\mathcal{C} . \mathbf{K}, 532,535$ Estenoz (Cuban rebel), June 27 '12

Ester, 124

Fistrada, Emilio, 1084

- Gen. Juan J, 1091

Etching, 254

Ethnology, 159

Etienne, (airman), June 26 '12

Etng, Mt. It., 106

Ettor, Joseph J., 834, 835

Eucharistic Congress, 312, Sep 10 '12

Eugene, Oreg., 891

Eugenics, 300, 327, (Congress, 1912) July 24 '12

Eulalis, Infanta of Spain, Dec 4 '11
Eureka, Cat., 774, 723

- Utah, 916, 918

Eurich, Dr. F. W. 165

Euripides, 220

European Concert, 4, 6, 8 . 9

Europus, Asia M., 267

Evangelical Association, U.S. 732

Evans, Sir A., 269, 272

一, E. R. G. 99

- Gladys, 89

- L. Worthington, M. P. 488,500

一, Robley D., 755

- Sir S., 350

- William G., 781

Evanston, Wyo., 935

Evansville, Ind., 805, 806, 723

Eveleth, Minn., 839

Everard, Sir Nugent, 417

Everett, Mass., 828

-, Wash., 924, 925, (single tax) 926

Evershed, J., 91

Everywoman, 231

Evesham, 586

Evolution, 109, 136, 149 (convergent) 160

Ewers, H. H., 206

Ewing, Arthur H., 755

Exeter, 560, 484, (gasworks) 402

Exhibitions, regulation of, Oct $26^{\prime} 12$

Exner, Felix, 110

-, J. J., 987

Exodus, The, 262

Exogamy, 160

Exosmosis, 143

Expert witnesses, 334

Exploration and Travel, 99

Explosives, (mining) 387 (storage) Nov 7 '11

Exports and imports, 73 1164, (cotton) 43.

Express Companies, Dec 14 12

Expropriation Law (Ger-

many, 1015

Eye Witness, 186

Eynde, Baron de, 460

Eyring, Raimund, Sept 9 11

Eytinge, Rose, 75.

Faber, Beryl, 555

Fabre, Emile, Dec 13 '11

Fabry, C., 118

Farta, I., 1050

Factories Act 1912 (India), 605

Facroe Is, 983

Fagan, J, B., 230

Fairbairn, Rev. A. M., 545 - G. E., 468

Fairbanks, Alsk., 938, May 8 '11

Fairchild, Edward T., 859

Fairbury, Neb., 85.

Fairfield, Messrs., 346

Fairmont, W. Va., 928

Fairport, O., 884

Fairs, "Punch," 471

Fajardo, P. R. 951

Falconio, Card., 313

Falkberget, Johan, 214

Falkenhavn, Lt. F, von, June $2 \mathrm{i} \cdot 12$

Falkirk, 588

Falkland Is., 652, 1065

Fall, Albert B., 876

Fallières, Pres., 998, Ap 21, July 4, Sep 4, Dec 23 11

Fallon, Nev, 855

Fall River, Mass., 828, 829 . 723
Eydoux, Gen., 1032
Famagusta, Cyprus, 641

Fan Ling, China, 636

Fanring I., 639

Fanny's First Play, 230

Fantham, H. B., 130, 430

Fan Yuan-Cien, 977

Fapu, 977

Fara, Gen., 23

Farber, F., 385

Fargo, N. D 879,880

Faribault, Minn., 839, 843

Farid Bey, Mohammed, 988

Farley, Card., 313

Farmersville, Tex., 915

Farmer, J. B., 142

Farmers Eree List Bill, 735.

May 8, Aug 1, $17^{\prime} 11$

Farming, 415

Farm schools, 415

Farnborough, 339, 344

Farnell, 223

Farnol, J. J., 189

Farrar, Dr. R., 172, Feb 6 11

Farrelly, Hugh P., 814

Farrer, Sir W., Mar 23 '12

Farrow, W. July 21 '12

Fath, E. A., 96

Faulkner, G. A., 457

Fawcett, A. V. 927

-, George, 231

-, Col., 103

Fayetteville, Ga., 794, 795 796

- N. C., 977

Feather river, Cal., 776

Fedden, F. G., 470

Federal Act (1900), 681

Federated Malay States, 628

Federzoni, Luigi, 209

Feeding Standard for cows, 421

Feeney, John, 582

Felker, Samuel D, 859

Felton, Samuel M., Dec 30 12

Feminist movement, 324

Fencing, 459

Feng Wei, 982

Fenn, Henry, 755

Fenwick, R. C. Aug 13 '12

Ferber, Edna, 200

Ferdinand of Bulgaria, 1026, 1027, Oct 18 '12, (Potsdam visit) June 7 '12, (Tirnovo celebration) Aug 15 '12, (at Chatalja) Dec 2 '12, (Vienna visit) June $1,6 \cdot 12$

Ferens, T. R., 582

- Falls, Minn. 839

Ferguson, A. M. \& J., 624

-, Prof. John, 222

Fergusson, J. D., 243

Ferid Pasha, July 20 ' 12

Ferland, A., 198

Fernandina, Fla., 723

Fernbach A., 124

Fernbank, O. July 25 ' 11

Ferranti, S. Z., 364

Ferrer, Francisco, 1137

Ferri, Enrico 1049

Ferris, Woodbridge N., 839

Ferro-alloy, 360

Ferry Co., Ore. 892

Fery, Charles, 118

Fessenden, R. A., 368

Festival of Empire, May 12 ' 11

Fethi Bey, 1159

Feuillerat, A., 193

Feuillet, O., 201

Fever, 171

Fez, Mor, 1105, 1106, 1107 1108, (Moorish rising) Ap 1. 8, May 21'11, May 25. 28, June 21 ' 12

Fibres, New, 444, (jute)

438, (linen) 437, (rope) 440. (wool) 440

Fick, 221

Fiegenschuh, Capt., 1006

Field, 458

Field artillery, $\mathbf{3 7 0}$

Fielder James $F, 864$

Field howitzer, 371

Field Musoum, 803

Fielding, W S , 667, 669 (Budget speech) Ap 4'11, West Indies) 653

Fife, Duchess of, 478, Ap 29 ' 11

- Duke of, 478, Jan 29 '12

Fifeshire, 588, 590

Figgis, Darrell, 190

Figueiredo, F. de, 217

Figuero, Gen. Fernando, 1097

Figure skating, 470

Fiji, 638, Feb 16 ' 12

Filchner, Lieut., 100

Finance, (International) 69 
Fitzgerald-Loretz shrinkage, 114, 115

Fitzgibbon, Ld. Just., 601 Fitzpatrick, Sir Charles, 64 Fiume, Aus., 957, 958

Flagellata, 129

Flamandisation, 968

Flambeaux, Les, 233, Nov 26 ' 11

Flambée, La, 233, Dec 7 '11, Oct 1'12

Flanders, Marie, Countess of, 969 .

Flat River, Mo., 846

Flax, 437, 444

Fleece, 442

Fleetwood, Lancs., 592

Fleming, J. A., 359, 365

- Major, 453

Flemish language, 968

- literature, 212

Flemming, J. K., 676

Flers, De, 233

Fletcher, Miss A., 161

_, Allen M., 920, Oct 2'12

- Judge E. E., June 18, Aug 17 ' 12

-, Henry; 903

- Moulton, Sir J. (Lord Moulton), Aug8'12

Fleury, T. R., 1003

Flexner; Dr. Ș., 169, 172

Flinn, William, 899

Flint, Mich., 836, 837, 838

Flint implement, 150

Flora, preservation of, 137

Florence, Ala,, 765, 766

-, It., 1042, (jubilee exhibition) 1050 (Fra Angelico stolen) Nav 2024 '11

Florence, S. C., 904, 906

Florida, 791, (University) of) 793

- East Coast Railway, 792

-, Mo., 84 i

Florina, 32

Flushing, 1010, 1041

Fly, house, 176

"Flying Fox," Mar 18 '11

Flynn, William J., Dec 17 12

"Foam Queen," 1121

Fogazzaro, Antonio, 208, 1053

Folk, Joseph W., 848

Folk-lore, 187

Folkestone, 178

Folkston, Ga., 796

Fond du lac, Wis., 931

Fonson, 212

Food riots (France), 992

- Taxes (U.K.), 518,519

Foot and mouth disease, 599

Football, 447, 460, 473

Foote, Mary H. 200

Forbes, Capt. C. J. F. S. 163

一, K., 585

-, Mrs. Stanhope, 555

W. Cameron, 950, Feb , 12

Forbes Quarry, Gib., 147

Forcados, Nig., 651

Ford, H. A., 450

-, I. N., 755

-, Dr. W. W, 177

Fordham University, N. $\mathbf{Y}$. 873

Forel, Francois A., 1148

Forero, Carlos, 1095

Forest City, Ark., 774

- Park, Ill., 802

Forfar, Scot., 588

Forgery, 331

Form IV., Nov 17 '11

- VIII., May 9, Nov 17 11
Formamide, 126

Formose, 1054, 1062

Forrester Island, 938

Forsdyke, F. J., 278

Forster, H. W., M.P., 489, 500

Forsyth, Mont., 851

Fort Churchill, Can., 663

- Collins, Col. 781, 782

- Crook, Neb., Oet 15 '11

- Davis, Alsk., 938

- Dodge, Ia, 809

- Egbert, Alsk., 938

Fortescue, G. K., 552

- Hon. J. W., 190

Forth river, 590, 593

Fortis, Alessandro, 1053

Fort Lewis, Col, 782

- Liscum, Alsk., 938

- MeHenry channel, Md., 825

- Madison, Ia., 809

Ridgely Park, Minn.

- Scott, Kan., 812

- Smith, Ark.; 771, 772

- Wayne, Ind., 805, 806

-Wm. H. Seward, Alsk., 938

- Worth, Tex., 912, 913

- Yukon, Alsk., 938

Foss, Eugene N., 833

一, Sam W. 755

Fossil, (man) 147, (plants) 395

Foster, B. S., 467

-, D. J., 920

, George R., 457

570, July 2 '12

-, Murphy J., 820

, W. M., 924

, William T., 894

Föttinger transformer, 347

Fouchard, Gen. Calisthène, 1086

Fouillée, Alfred, 287, 1004

Foul brood, 430

Fountain Springs, Pa., 899

Fourny, G., 344, Sept 11 ,15

Four Powers loan (China), 976,979

Fourier's series, 365

Four-in-hand driving, 455

Fournier d'Albe, E. E., 120

Fowler, A., 91

-, G H., 105

- R., Sept 12 '11

- Warde, 223

Fox,- William H., Dec 14 '12

-, Williams C., July 6 "11

Fox, 425

Fox hunting, 464

Foy, W., 159

"Fram," 100

Frampton, Sir George, 245

France, Anatole, 205

France, 991-1008, (aeronautics) 342,344 , Sep 19 '11, (Anglo-French relations) 2, 4, Feb 2, 14 '11, Nov 22 '11, Dec 17 ' 11 , (anti-militarism) Dec 16 '12, (army) 36, 39, 40, 41, 43 , Sep 12 ' 11 , Sep 10 12, (art) 247, (Balkan policy) Oct 5 ' 12 , Nov 5 , 13 '12, Dec 21 '12, (blind) 301 (champagne legislation) Feb $6^{3} 11$, Ap 10'11. June 7 '11, (Congo rights) 970, (cotton trade) 435. (depopulation commission) Noy 5 23 '12, (drama) 233, (Dutch visit) July 4'11, (electoral reform bill)
July 18 '12, (English Franco-8panish Convention school children) May 25 (1910), 1106

'12, (finance) 71, July 20

'12, (food prices) Sep 7

'11, Nov 2 '11, (food riots) Sep 1, 6, 13 '11,

(Foreign Office) Nov 14, 30 '11, (foreign politics) Ap 7 '11. July 20 '12 (German relations) May 8 '11, July 9'11, (Greenwich time) Jan 26 '11,

Mar $10^{\prime} 11$, (Italian relations) 1107, Jan 22 '12, Oct 28 '12, (Japanese tariff) 1057, (law) 335.

Nov 16 '12, (Liberia) 1102, Jan 9 '11, (liquor traffic) Jan 18'11, (literature) 201, (monuments) 284, (Morocco) 2, 3, 4, (national fête) July 14 '11, (navy: see French navy), (Presidenoy) 1003 , Dec 24, 27 '12, (railway ac cidenta) (Blainville) Sep 15 '12, (Courville) Feb 14 '11, (Labataut) . Aug 6 '12, (Lozanne) Aug 6 ', 12 (Longpré) Nov 18 '12, (Merville) Sep 23 '12, (Montreuil-Bellay) Nov $23^{\prime} 11$, (Paris) Jan $6^{\prime} 12$, May 18 ' 12 , (Vire) Jan 15 '11, (Russian alliance) 1132,1133 , Jan 15 '11, Aug 11 '12, Sep 5 ''12, (sabotage) Aug 3 '11, (strikes and lock outs) (miners) Mar 11 '12, (dockers) Nov 17 '11, July 4, 11 '12, (seamenBrest) June 11'12. (seamen, Calais) June 11 ' 12 , (seamen, Hayre) June 10 '12, July 5, 9 '12, Aug 2 '12, (seamen, Marseilles) June 20 '12, Sep 4 ' 12 , (Paris taxi-cabs) Nov 28

'11, Feb 1.'12, (spy system) Nov 23 ' 11 , Feb 1 '12, (syndicalism) 17 19, 21 . Noy 26 ' 12 , (Teachers' Unions) Aug 24 '12, (Turkish relations) 1153, 1155, May 27 '11

“France," 346

France, Institute of, Jan 4 11

Franchet d'Esperey, Gen. 1107

Franchise question (U.S.), 742

- Reform Bill, 503, June 17 , July 8,12 ' 12

Francis Ferdinand (of Austria), Nov 22 ' 12

Francis Joseph, Emperor, 961,965 , Sep 24, Nov 6

Francis, David R., 848

Franco, Joāo, 1124

Franco-American Arbitration Treaty, Aug 2 '11,68

-Danish Arbitration Treaty, 67

-German

Agreement

(1911), 3, 1106, 60, 1001, (Austria-Hungary's assent) Dec 16 '11, (French debates) Deo 14, 20, 23 . 26 '11, (German debates) Nov 9, 11 '11. (M. Fallières) Dec 23 '11, (Mulai Hafid's assent) Nov 9 '11, (secret negotiations disclosed) Dec 29 '11, (territories ceded) 1006

1107 , Dec 22 '11, Nov 27

12, Dec 17 ' 12

Francotte, 223

Frankfort, Ky., 815, 816

Frankfurt am Main, 1009. 1022

Franklin, N. H., 857 , Tenn.,

-Furnace Mines, N. J. 860

Frankston, Texag, 7

Fraser, Sir T. R., 166

一, W. 702

-, William, 707

Fraunhofer grating, 118

Frazer, Charles Edward, 692

-, J. G., 160

Frazier, James B., 911

Freake, F. 467

Frear, Walter F., 943

Frederick VIII (of Den- 
Friedländer, L. 219

Friendly societies, 499 , Oct 12 ' 11

Froebel system, 298

Froitzheim, O., 465

Frölich, Lorenz, 987

Frost, Meadows, 635

Frostburg, Md., 824, 827

Frothingham, Louis A., 833

Frugoni, Gen., 23

Fry, Roger, 243

Frye, William P., 755

$F_{13}, 978$

Fuchs, (Bel. Cong.), 970

Fuels, 395-402; (ships) 347. (mas engines) 356

Fulham, 556

Fuller, F. C., 650

- Sir J. M. Fleetwood, 698 - Sir T E. 712

Fullerton, G. S., 290

Fulton, A. G., 469

Fulton, Mo., 846

Fungi, 133, 144, 146

Funk, C., 166

-, I., 756

- Frank L., 804

Fur Industry, 431, (Alaska product) 938

Furnace, 391, (elect ric) 364

Furness, Baron, 551 4.451

Fur Seal Convention, 675

Fused-silica standard, 120

Futrelle, Jacques, 756

Futurist painters, 243

Gabritschewsky, 178

Gabrovo, Bulg., 1035

Gadsden, Ala., 765

Gaelic League, 598, 602

Gainer, Josenh H., 903

Gainesville, Fla., 791

- Ga, 794

Gairdner, James, E45

Galapagos Is., 1083

Galatz, Rum., 1037

Galena, Kan., 812

Galesburz, III., 800

Galicia, Aus., 963, (canals) 957,962

Gallenga, Romeo, 1051

Galletti system, 83

Galley Hill skeleton, 149

Gallic War, 220

Gallinger, J. M., Dec 16 '12 Gallinule," Jan 9'12

Galsworthy, John, 188, 231, Nov 23 ' 12

Galt, Can., 665

Galton, Sir Francis, 155

Galveston, Tex., 912, 913, 724

Galway, Col. Sir H. L., 648, 652

Galway, 595, 602

Gama, 472

$\div$ Pedro L. 1075

Gambela, Abys., 953

Ciambia, 64s

Gamble, Sir Douglas, 1152 R. J. $90 \mathrm{~s}$

Ciambling. 324

Games: see Sports

Gamma Geminorum, 90

- Rays, 119

(iand, F., 161

Gisnoza, A. 1095

Giarden cities, 253,580

Garrliner. Balfour, 238

(., E. Norman, 223

Giurdiner, Me. 822

Gardner, F, 281

- Obadiah, 822

Trust 301

Girthausen, V., 222, 22"

Garficld; $\AA$. J., 860 , sijo

Garforth, W. E., 383

Ciargas, Fr. 157

Garbwal, India, 618
Garnett, T., 570

Garrard, A. C., 99

Garrett, John W., Dec 14 '11

Garrod, Private A. G., July 22 ' 11

Garros, R., 344, 452, June 17 '12, (height record) Dec 11 '12, (TunisSicily flight) Dec 18 '12 Garstang, J., 263, 268

Garton, A. S. 468

Garvin, J. L., 193, 519

Gary, Ind., 805, 391

-, W. Va., 381

Gas, illuminating, 402, 407

- analysis, 128

- engine, 355,349

Gaseous Fuel, 400

Gassiat, J., 462

Gassett, J. O., 216

Gas stoves, 401

- suction plant, 349

- turbines, 349

Gastonia, N. C., 877

Gastropod, 133

Gátes, 142

-, George A., 756

- John W., 756

Gateshead, 560

Gatun, Pan., 944

Gatzert Foundation, 730 , 926

Gauguin, Paul, 241

Gaunt, Mary, 197

Gauss Expedition, 100

Gautsch von Frankenthurn, Baron, 963, June 26' 11

Gavault, Paul, Oct 31 '12

Gaynor, William J., 875

Gebhardt and Ǩoenig, Messrs., 381

Geddes, Prof. P., 152

Geelong, Austr., 696

Geertruidenberg, Holl., 1039

Geerts, 142

Geffrey, Sir R., 581

Gefle, 1141

Geikie, Sir A., 221

Gelderland, 1038

Gellivara, 1141

Gelsenkirchen, 1009

Gemini, 95

General Baking Company, June 14'11

- Education Board, 729

- Deficiency Appropriation Bill, Aug 26 ' 12

- Post Office (Londor) Aug 24 '12

Genetics, 139

Geneva, 1143, 1144, 1145 , 1147

Gennadius, J., 9

Genoa, It., 1042, 1045, 1040

- Duchess of, 1054

Geodesy, 10.4

Geographical Society, American, May 13 '11

- Society, Royal, 105, Nov 15 '12, Ap is' 11

Geography, Exploration and Travel, 99

Geology, 106, 113, 150, 156 (icometric Are, 271

George $V_{\text {, (England) } 475}$ 479. (Agricultural Show visit) June 28 '11, (Aldershot visit) May 14 '12. (Bangor Colleze) July 14 '11. (Chancellor, Capo University) 711, (Council of State) Nov 10'11, (County Hall, London) Mar 9'12, (dock visit) 529, July 6' 12 , (Dominion Premicrs) June 21 ' 11 . (Edward VII nemorial)
Nov 9 '11, (Festival of Empire) May 12 '11, (fleet reviows) June 24 '11, May 7 '12, (Immingham dock) July 22 '12,

(Khedive, meeting with) Nov 20 '11, (levée) Feb $21^{\prime} 11$, (Malta visit) 643 (Mylius libel case) 480 .

Feb 1 '11, (Protestant Churches deputation) Mar 21 '11, (royal prerogative) 493 , (submarine trip) May $9 \cdot 12$, (Sudan visit) 991, (Thanksgiving service) Feb 6 '12, (Vic toria Memorial) May 6 '11. (Yorkshire visit) 565 , July 8, '12,(Welsh National library) July 15 '11 (of Greece), 1026, Nov 12 ' 12

- (of Cumberland), May $20, ' 12$

George, Rev. H. B., 538

- Stefan, 206

George, S. Af., 310

Georgetown, D. C., 790

- S. C. 904

Georgi, Gen. F, von, 960

Georgia, 794, Ap 20'12

Gera, 1009

Geran Law (N. J.), 862

Gerard, John, 549

Gerardot, 1078

Gercke, Prof, A., 224

Gericke, Lieut. (airman), Oct 21 ' 12

German, E., 238

-, W., 670

German East Africa, 1012

German Empire, 1008 1024, Mar 29 '12, (air ships) 342 , May $16^{\prime} 11$ Oct 10, 21 ' 12, (AlsaceLorraine constitution Jan 28, May 11, 26, '11 May 17 '12, (AngloGerman relations) $3,4,8$, Dec 5'11, Feb 7, 15, May 23 '12, (armaments) Mar 30 '11, Mar 22 ' 12 (army) 36, 40, 42, (Field Artillery) 371, 372, Feb 24 , Sep 13 '11, Sep 12 '11, (Austrian relations) Mar 24, Nov 22 '12, (Balkan Policy) Aug 17, Dec 2 '12, (Bavaria) Nov 14 '11, Feb 5, Aug 21 '12, (Blind) 301, (Bober Valley dam) Nov 16 ' 12 (coal output) 380 , (cotton trade) 435 , (Defence Bills) Jan 29 Ap 15,22 , May 21 , 1 ? (earthquake) Nov 17, '11 (elections) 316, Jan 20 Feb $16{ }^{\prime} 12$, (espionage) Sept 20, Dec 1311 , Aug 4 . Oct 10 ' 12 , (explorations) 100 (extradition treaty) Jan 31 ' 11 (finance) $71,72,78$, June 1. Nov 25 '12, (Franchise Bill) May 26 '11, (Frederick-the-Great bi-centenary) Jan 23, May 30 12. (Insurance, indust rial) May 22, 30 ' 11 . (Japanese tariff treaty) 1057, June 24, July 15'11. (Jesuit law) Dec 4 '12 (Krupp centenary) Ang 12, (law) 335, (ldse majeste) July $9 . ' 12$ (meat riots) Oet 23 '12 (literature) 205, (mine explosions) (Lothringen) Aug 8,0 '12, (Mengede)

Dec 18 '12, (Oberhausen) July 3 '12, (Moroceo question) $2,3,4,1106$, (navy : see German Nayy). (protection) Oct 23 '11, (Russian relations) 1132 , Aug 19 '11, July 7 ' 12 , (savings banks) Sept 9 '11, Nov 27, 28'12, (shipping dues) 1016, (socialism) Feb 5, Aug 21 , Sept 10 '11, Jan 12 12, (South American trade) 1064, (strikes) (Westphalian miners) Mar 11 '12, (Dortmund miners) Mar 4'12, (Ham. burg ship-building) $\mathrm{Ap}$ 30 '12, (Tripoli, designs) 4, (Turkish relations) 1155, Mar 21 '11

- Evangelical Synod, 734. Navy, 1011, 52, 53, 44, 
Girouard, Desire, 676

- Sir Percy, 644

Gitsham, 452

Giustino, Father, 1051

Glaciation, 113

Glacier, 113

- National Park, Mont., 850

Gladiolus, 427

Gladstone, Viscount, 711 Jan 24, Sept 2 '11

$\rightarrow$ W. G. C., M.P., 489

- Dock, Lanes. 573

Glamorganshire, Wales, 581

Gland (diseases), 171

Glanders, 178

Glasgow, 579, 593, 588, (by-elections) July 6 '11, Feb 24 ' 12 , (coal export) 591. (Colonial Premiers visit) July 6 ' 11 , (fire) Sept 3, 4 '11, (infantile mortality) 588, .. (land taxation conference) Sept 28. '12, (technical college) 593, (trade and manufacture) 591, (university) 593 , Jan 25 ' 11

Glasnevin, Ire., 415

Glasscock; William E., 930

Glauke, Gr, 276

Glawi, El, 1106, Nov'23 '12

Glenconner, 1st Baron, Mar 3 ' 1

Glennville, Ga., 796

Glen Rack, N. J., 863

"Glenside," Mar 24 "11

Globe, Ariz., 768, 769

Globus, 105

"Gloire," 996

Glossina marsitans, 174

- palpalis, 173

Gloucester, Eng., 560, (byelection) Feb $24: 11$

- Mass, 828, 829, 723

Glover, S., 402

Glover-West process, 403

Glückstadt, Isak, 987

Glucoside, 140

Gnome engine, 45

Gobe (airman), Dec 24 '11

Gobert, A. H. 465

-, E., 158

Godard (engineer), 1153

Godavari river, 606

Goecke, 394

Goethals, George W., 946

Goff, Nathan, 930

Gogebic, Mich., 836

Goiran, Gen., 999

Gokhale, G. K. 609, 606 , 709 , July $30^{\prime}: 12$

Gold, E., 110

Gold, $1173,71,566,393$. (imports; U.K.) 572, (in Jersey) 567, (Rhodesia) 706, (8: Africa) 706; (W Africa) 649 , (U.S.) 719 ; see also. under countries and states

Gold Coast, 649, Ap 29 '11. Aug 23 ' 12

Golden, John, 834

Goldenwiser, A. A., 160

Goldfield, Nev:, 854

Goldman, C. 'S., 496

-, Emma, 781

Goldmining shares, 77

Goldsboro, N. C., 877

Goldsborough, Phillips 827

Goldschmidt, H., 391

- R., 83, 368

Goldsmith, H. M., 468

-, J. H., 468

Golf, 462, (amateur championshin) June $7 \cdot 12$ (international match) June 1 '12, (News of the
World championship) Oct | Grand Canyon, Ariz., 769 4 ' 12 , (U.S. championship) Sept 7 '12

Goltz, Gen. von der, 1152

Gomes, E. H., 162

Gomex; Pres. J. M., 1080

- J. V., 1101, 1041

Gompers; S., June 24 '12, Nov 23 '12

Gomperz, T., 1023

Gondra, M., 1093, Jan 19 '11

Gonzales; Juan G., 1094

Goochkov, 1127

Goodall Dr. E. W., 167

Goodfellow, W., 102

Gooding, Ida., 798

Goodwin, W. W., 219, 751

Goodwood Cup, July 27 ' 11 ; Aug 1 '12

Goold-Adams, Sir H. H., 641

Goosieff, N., 218

Gordon, Adam I Lindsay, 196

-, W. T., 146

Gordon-Bennett Race, 344, 452

Gore, Bp. C., Aug 28 '11, Ap 30 ' 12

Gore, Abyss., 953

Gorell, 1st Baron, 324

Goremykin, J.'L., 1128

Gorgas, W. C., 945

Gorgon (statue), 275

Gorki, Maxim, 218, 219

Gorleston School for Blind, 302

Gorman, A. P., 827

Gorrie, Dr. J. 792

Gorst, Sir Eidon, 987, 988, 989,539

Gorter, Herman, 210

Gortyna, Crete, 271

Goshen Co., Wyo., 937

Gosling, E., 527

Gosse, E., 188, 189

Goswami Bahadur, R. K. Lal, 614

Gotch, F., 472

Gota de Leche, La, 949

Goto, Baron, 1061

Gotha, 1009

Gotthard Convention, 1146

Göttingen, 1011

Gough, Sir C. J. S., 548

Gouin, Sir L., 675

Gould, Geo. J., Ap 3 '11

Goulding, 452

-, E. A., M.P., 488

Goulet lamp, 385

Gouraud, General, July 5 '12

Gournia, Crete, 270

Govan, 588, 594, (by-election) Dec 22 ' 11

Gow, A. C., Dec 6 '11

Gowenlock, Miss, 453

Gower, Wates, 157

Graaf, Sir D. P. de V., 710, 570

Grabow, La., 821

Grace, E. M., 540

Graebner, F., 159

Graft-hybrids, 140

Grafton, C. C., 756

Grafton, W. Va., 928

- Galleries, 240

Graham, W. A., 632

Graham.Land, 101

Graham-Smith, Dr., 430

Grahams Town, 703

Grailly, Lt. de, Sep 2 '11

Grainger, Percy, 238

Grain Standards Board, Can. 675

Gramophone, 235

Gran, Gerhard, 215

- -, Wis., 931

Grants Pass, Ore., 891

Green river, $\mathrm{Ky}$, 816
City), 876

- Comoro, 1006

- Falls, Nfdld., 679

"Grandfather clause": see

Negro (suffrage)

GrandForks, N. Dak. , 879, 880

- Haven, Mich., 723

- Island, Neb., 852, 853

- Junction, Col., 781, 782, 783

- lake, Nfdld., 679

- National, Mar 24 '11

- Prix de Paris, June 25

Grand Rapids, Mich., 836, $837,839,723$

Grand Trunk Ry., 901, Dec 3,23 ' 12

- Trunk Pacific : Railway, 656

Grand Valley, Col., 781

Grangemouth, 591

Granito di Belmonte, Card., 313

Grant, Frederiek D., 751

Grant Co., N. M., 867

Grantham, Sir W. 543

Granton, 591

Granular bed process, 401

Graphite, 394, 359

Grass Valley, Cal., 775

Gratwick Laboratory, N. Y., 971

Gravel river, Can,, 103

Graves, A. K., July 23 ' 12

Gray, Judge G., 64

-, George, 453

Gray's Harbor, Wash., 925

Grayson Co., Ky., 815

Graz, Aus, 956

Great Eastern Railway, Aug 31'11

Great Falls, Mont., 849

Great Meadows prison, N, Y., 873

Great Northern, Piccadilly \& Brompton Railway, Sep 4'12

Great Northern Railway, 575

- Salt Lake, 916

- Western Railway, 574

Greece, 1031-1034, 1025 $1026,1027,1028,1029$ 1030, 5, (archaeology) 274, (armistice) 34, (army), (ancient art) 279, (Athens University). Ap 7 " 12 , (Balkan operations), 1031, (church) Dec 6'12, (constitution) 1029, (Cretan annexation) 1025, June 1, Oet 14'12, (elections) Mar 25 '12, (emigration to U.S.) 714, (Hague convention) $5 \overline{5}$, (independence celebration) Ap 8 '12, ("literary language") Mar 11 '11, (Military operations) 33, (naval operations) 34 (navy) 29, 49, July 25'12, (Rumania, relations with) 1029, (Turkish relations) 1027, 1031 Sep 8 '12, (Venizelos election) 1028

Greeley, Col., 781, 783

Green, T. F., 903

- Bay, Wis., 931

- Cove Springs, Fla., 793

Greene, Francis B., 832

- , Sir W. C., Oct 22 ' 12

Greenock, 588

Greensburg, $\mathrm{Pa}$., 900

- B. C., 904

- time, 104

- , S. C., 904

Greg, W. W, 194

-, Lady, 186, 228

-. J. W.. 273

-, W, K., 133

Greif, Martin, 206

Greiz, Ger., 1009

Grenada, W. I., 656

Grenfell, B. T. 219

- , Hon. W. H., 471

Greenball, 8., 470
Greenland, 101, 983, 987

Greensboro, N. C. , 877, 878

Greenville, Miss., 843, $\mathbf{8 4 5}$

Greenwich, Conn., 785

-, Eng., 556, Aug 9 '11

Greenwood, Miss., 843

Greer, Bp. D. H., Ap $19^{\prime} 11$

Gregerson, Dr., Mar 31 '11

Gregory, Dean R., 543

Grenadines, W. I., 658

Gresser, Lawrence, 876 
Guadaloupe, 1007

Guaira, La, 1101

Guaqui La Paz railway, $10 \% 0$

Guatemala, 1084, (debt repudiation) 1063

Guayaquil-Quito railway 1084

Guayams, P. R., 951

Guaynabo, P. R., 952

Gubbins, Sir C. O'Grady. 710,712

Guelph, Can., 665

Guerrero, Manuel A., 1092

Gueshoff, J. E., 1029

Guest, Hon. F, E., 487

Giuffey, J. M., 899

Guggenheim, B., 756

-. S., 784

Guicciardini, Count, 1050

Guild, Curtis, Ap 24'11

Guinea, New (German), 101

Guinea, Portuguese, 125

Guinle, Senor, 1073

Guitry, Sacha, 233

Gujarat, 604

"Gulfoil," 347

Gulfport, Miss., 843, 844 , 724

Gulland, J. W, 487

Gumesh Tepe, 1116

Gumuljina, 31, Nov 22 '12

Gun, 373, (naval) 376, 46, (trade, U. K.), 567

Gunn, G., 457

Gunnison, Miss.- 845

Gunnison tunnel, Col., 781

Guntur, India, 620

Gustav V (of Sweden), July 24 ' 12

-Adolf (of Sweden), Nov 23 ' 12

Gust-meteorology, 340

Gutenberg Bible sale, Ap 25 ' 12

Guthrie, George W., 899

Guthrie, Okla., 888, 889, 890

Guti, Asia M., 259

Gutierrez, Ramon, 1076

Gutowsky, 394

Gutterson (athlete), 452

Ciwalior, Maharajah 618,467 , July $26^{\prime} 11$

$-618$

Gwynne-Vaughen, D. T., 146

Gymnospermos, 145

(ivör, Aus,, 957

Haan, Lieut, de, 104

Haarlemmemeer, 1037

Hase, Friedrich, 1022

Habbania Escape scheme, 1151

Haber, Fritz, 389, 117

Habibullah Khan, 619

Hackensack, N. J., 860

Hackenschmidt, G., 474

Ilackney, 556, May 24'12

Haddington, 282, Ap $19^{\prime} 11$ (Balfour's speerh) 501

Ifaddon-Smith, G. B., Aug 16 ' 12

Madfield, Sir R., 391, 378

Hadji Adil Bey, July 4 ' 12

IIadley, Herbert S., 848

Haematin, 123

Hacerdt, Baron von, 960

H:Ifnet, H. J., 215

Haffatein, Hannes, 984,987

Hilugerstown, Md. 824, 482.5

llaggard, Sir H. Rider, 570

II:1ggart, Alexander, 676

Hagia 'Triada, 270

Ilague, The, 1040

- Conventions $1907), 51,55,56,63$

- Tribungl, 55, 64, (fisheries award) 678 , (opium convention, 1911) 604,' Handicraft societies, 252

(Panama Canal) 12, Handsworth, 561

(Savarkar) Feb 24'11

Haidar Pasha-Angora Railway, 1151

Haiffa, 1151

Hailey, W. M., Oct 1 '12

Haines, Al., 938

Haines, John M., 799

-, William T., 824

Haireddin Bey, Tahir, 1159

Haiti, 1085, Feb 7 '11, July 5 '11, (revolution) Feb 2 '11, July 28 '11, Aug 1,4 11, (S. Domingo dispute) 1062, 1098, (U.S. intervention) 1065,740 , July $18^{\prime \prime} 11$

Hakki Pasha, 1154, 1155 , $1156,1157,1158,1159$

Halbherr, Prof. F., 270, 273

Haldane, 1st Viscount, $485^{\circ}$

Mar 24, Ap 14 '11, June 10 '12, (Aberdeen speech) Oct 9'11, (army defence)

Dec 16 '11, (Berlin mission) 4, Feb 7 '12, (Bristol Univ.) Oct 17 ' 12 , (Eighty Club) Nov 29 '12, (Oxford) Aug 3'11, (woman suffrage) 503

-, J. S., 385,390

W. S. 563

Halden, Charles ab der, 199 Hale, Eugene, 824

- G. E., 92

Half timers, 435

Halfa, 991

Halifax, Robert, 189

Halifax, Can., 663, 665, 670,310

-, Eng., 560, June 21 '12

Halil Bey, 1153, 1159, 1161

Hall, A. D., 563

—, Edith, 271

- Luther E., 820

- \& Sons, Robert, 443 - Mrs. W. Russell, May

Halladjian Effendi, 1152, 1157

Hallé, Lady, 540

Halle, 1009, 1011

Halley's comet, 95, 991

Halm, J., 97

Halsbury, Earl of, 489,493 , 494, July 26' 11

- Club, 501

Hamborn, 1009

$1009,1011, \mathrm{Dec}$ 20 ' 12

- American Packet Co.,

Jan 4 '11

Hamburger, Lieut., Oct 30 Hamel, G., Ap 2, June 8 '12 May 6'11

Hamerton, A. E., 173

Hamidich Cavalry, 1149

"Hamidiyeh," Nov 21 "12

Hamilton, Major E., 580

- Sir J. A., Aug 8 '12

- Capt. P., Sep 6 '12

- Sir R. Vesey, $\mathbf{5 4 7}$

- R. W. 3:32

Hunilton, Can, 663, 665 Hirt, G. C. 634

-, 111,8022 $(1,8 \times 2,8 \times 3$

Hammersmith, 556

II

Hammond, W., 460

Hammond, Ind., 805

Jumon, M., Ap 12 '11

IIampstead, $556^{\circ}$

llampton, Va., 92

Hamsun, K., 214 llarrod, B. M., 756

July 22 '12

Hangchow-Ningpo Ry., 976 ankey, Capt. Maurice, Feb 29 ' 12

, 979,980

1'12

Hanley, Edward W, 887

486,

(1) 113

, Louis B., 882

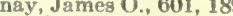

Hannover, H., 393

nover, 1009

1014

- G. H. A., 987

Hanyang, China, 980

Hara, K., 1061

raban, J. T., Jar 22 '12

ben, Sir H, 543

Harborne, 302

, V. M.P.

(1) M.P." 487 16 '11 (of Penhurst), , Sep 25 ' 11 Hardt, Ernst, 207

'12 -, Laurence, M.P., 497 Thomas, 188

"Hardy," 400

Iardy machine, 381

389

Harland \& Wolff, 346

Harmon, Judson, 747, 887

ny, 239,365

Harner, Dr. W. H. 177

rran, 1150

Harrar, 646

Farris, Frank, 189

- George, 832

W., Dec 28 '11, 803 89. 896, 897

703

Harrison, Carter H., 803, $\operatorname{sn} 411$

Mit $\mathrm{H}, 175$

Jane, 223

-, J. F., 467

- S. C. 600

Hartford, Ark. 774

- Conn. 785, 723

Hartlev, J. S., 751 Sir W., 585

Hurtley College, 585

Hartwell, Alíred S., Feb 2 11

Harty, Hamilton, 238

Hartzell, Ala, 767

Harub, Khalifa bin, 645

Harvard University, 730 , 832 , June 3 ' 12

Harvey, D., 173

-, Sergt. G. H., July 19 '12

-, Martin, 230

, W. E., M.P., 487

Harvey, Ill., 802

Harwood, George, 546

Haseba, S., 1061

Haskovo, Bulg., 1034

Haspels, G. F., 210

Hassam, Childe, Dec 16 '12

Hassan Bey, 1160

- Riaz Pasha, Dee 7 '12

Hasseck, James, June 17 '11

Hastings, B. Macdonald, 227

Hastings, Neb., 852

- Eng., 560

Haszard, F. L., 676

Hata, S., 175

Hatfield, Dr. H. D., 930

- J. G., 47

Hatti, 267

Hattiesburg, Miss., 843, 844

Hatzidakis, Dr., 270

Haukland, A., 214

Haultain, F. W. G., 676

Hauptmann, Gerhart, 207

Hausa States, 651

Hauser Lake Dam, 850

Haussling, 864

Haüy, Valentin, 301

Havana, 1081, Dee 8'11

Haverhill, Mass, 828, 829

Havre, Fr., Jan 10, July 5,

9, Aug 2 ' 12

-, Mont., 849

- de Grace, Md., 821

Hawaii, 941. Feb 2'11

Hawarden Bridge, 568

Hawas river, Aby., 953

Hawke, Viscount, 457

“'Hawke," 350 
Healy, T. M., M.P., 487, | Hernosand, 1141 488

Hearne, J. W., 457

Hearst, W. H, 675

- W. R. 780

Heart, (Surgery of) 165 , (disease) 168

Heath, R. W., 465

Heathcote, J. M., 554

Heaton, Noel, 270

Heaviside, O., 365

Hebbel, Christina, 965

Heberden, C. B. 584

Hebert case, 316 , Feb 22 12

Hector (planet), 94

Hedervary, Count Khuen, 964,965, Ap 17 ' 12

Hedgeland, Rev. Preb. Philip, 583

Hedges, Job Elmer, 875

Heemskerk, Theodorus, 1041

Heerlen; 1040

Hefner candle, 118

Hegel, G. W. F., 295

Heiberg, G., 214

-, Hermann, 207

Heidelberg, 1009 (fossil jaw) 147

Heim expedition, 100, 104

Heindlhofer, 118

Heinold, Baron von, Máy 15 ' 12

Heiser, Dr., 166

Heiskell, J. N., 774

Heitland, W. E. 222

Hejaz, Turk., 1149, (railway) 1151

Helbling, Dr, 466

Helena (of Servia), Sept 3 '11

Helena, Ark., 771

- Mont. 849, 850

Helium, 119

Hellenistic age, 281

Hellens, Franz, 212

Hellmann, J. G. Gustav, 110

Hellstrom, F, O, 882

Hellyer, F. E., 468

Helmond, Holl., 1039

Helmsley, Viscount, M.P. 488

Hemans, Lawton T., 838

Hemmerde, E. G., M.P. 489

Hemstitching, 438

Henderson, A., M.P., 523

- Admiral Sir R., 51, 696. Mar 13, Ap 20 ' 11

Henderson, Ky., 815, 816

Hendriksen, K., 103

Heney, T. W.. 197

Henley regatta, 468, July 8 '11, July 6 ' 12

Henningsen, Frants, 987

Henry, Sir Edward, Nev 27 ' 12

- O., 200

"Henry VIII," 229

Henson, Canon Hensley. Oct 29 '12

Henty, E. C., 468

Hepton, Sir W., 585

Heraclea, 1151

Heraclitus, 220

Heraeus mercury lamp, 118

Herbert, J. A., 226

Herderschee, A. Franssen, 102,1040

Herdman, A. L., 702

Heredity, 139, 154

Hereford, 582, Mar 8 '12

Hergesell, H., 111

Herglotz, G., 114

Hering, C., 365

Hermaut, Abel, Jan 23 '12

Hermosillo, July 10 ' 12
Herodotus, 220

Heroult, Paul, 360, 364

Herréra y Obes, Julio, 1100

Herrick, Myron T. Feb 15 12

$\rightarrow$, Robert, 200

Herries, W. H., 702

Herrin, William F. 779

Herring Fishing Act (1839), 592

- trade (U.K.), 568

Herschel, Sir W, 98

Hertford, 582, Nov 23 '11

Hertwig, Oscar, 142

Hertzian Wave, 118

Hertzog, General, 707, 709, 710, 711, Dec 28'12

Hertzsprung, E., 95

Hervieu, Paul, 233

Hervoitch, M. de, June 8 '12

Hesketh-Bell, Sir H., 655

Hesse, Hermann, 206

Hew, T., 471

Hewett, Sir J. P., 623

- R. S. 470

Hewins, W. A. S., M.P., 489

Hewith, Lunghi, 451

Hewitt, H. R., 565

Hewlett, Maurice, 188

Heyburn, William B., 799

Heyermans, Herman, 211

Heyland, H. H., 468

Heyn, 392

Hiba, Hamed el, 1107 Aug 22,29 ' 12 , Noy 23 ' 12

Hibbard, Frederick C., 847

Hibben, John G., 863

Hibbing, Minn, 839

Hibernia, N. J., Oct 20 '11

Hibernian Society, July 1 '12

Hichens, Robert, 188, 230

Hickman, Ky., 817

Hieronymi, Charles de, 966

Higgins, Henry B., 693

Higginson, 'T. W., 199, 751

High Point, N. C. 877

Hildebrandsons, H. H., 110

Hill, C., 457

- Dr. D. Jayne, Ap 14, Aug 12 ' 11

- Frank Davis, 757

- Ebenezer J., 787

-, H. Stavely, M.P., 488

-, John F., 824

- Leonard, 389

Octavia, 545

Hill Tippera, 618

Hilles, Charles D., Ap 4 '.11. July 9 ' 12

Hills, J. W., M.P., 488

Hillier, Alfred P., 543

Hillsboro, Ill., 802

Hillsville, Va., 924

Hillquit, Morris, 742

Hilmi Pasha, Hussein, 1152. 1154, 1161, Aug 20 '12

Hilo harbour, 942

Hilton, H., 462

Himalayan survey, 611

Hindia Barrage scheme, 1151

Hindle Wakes, 227

Hindus, 603

Hingham, Mass, 829

Hinks, A. R., 98, 104

Hinton, Arthur, 238

Hippopotamus, 1102

Hirata, Baron T., 1061

Hird, F. W., 469

Hirschi expedition, 1041

Hirst, G. H., 458

Hirth, H., June 10,'12

Hispanic Museum, N. Y. C. 249

Hitchcock, Edward, 757

- Frank H. 739
Hitchcock G. M., 853

Hitt, R. S. Reynolds, 1092

Hittites, 267, 266

Hjort, J., 104

Hoadley-Knight machine, 381

Hobble skirt, 443

Hobbs, H. B., 457

Hobhouse, Charles, M.P. 487

Hoboken, N. J., 860, 863

Hochenberger, Victor von, 960,964

Hockey, 462

Hocking Canal, O., 883

Hodeida, 1151

Hodgenville, Ky., Nov 9 '11

Hodges, George M., 814

- Robert T., 927

-. Thomas E., 929

-, William C., 794

Hodgson, B. T., Jan 3 '12

- Sir F, M., 648

- G. R., 471

- Shadworth, 287, 552

Hodmezo-Vasarhaly, 957

Hodson, T. C., 162

Hoe art collection, Feb 18 11

- library, Ap 25 '11

Hoek, P. P. C., 65

Hoffman, Herman S., 757

Hoffmann, Arthur, 1145

Hoffmann, Hans, 207

Hofmannstahl, Hugo von,

Hogarth, D. G., 268

-., Miss, 453

Hoke Co, N. C. 878

Holbrooke, Joseph, 238

Holden, 1st Baron, 546

Holdenville, Okla., 891

Holectypoid sea urchin, 132

Holguin, Gen. Jorge, 1077

Holkar (Maharajah), 618

Holland, 1038, (Dutch exploration) 102, (Miners' Congress) July 8 ' 12 , (Ryks Museum) Jan 13 '11, (Steengracht gallery) May 31'13

-, Mich., 836, 838

Hólleaux, Eugene M., 276

Holm, E. 214

Holmes, C. J., 243

- Rev, E. F., Ap 4'11

E. G. A., 295, Mar 21

11. May.13'11

-, Bp. George, 677

--, Rice, 220

W. H. 161

Holmes-Alderson apparatus, 389

Holmes-Ralph lamp, 389

Holmfirth div., Yorks. June 20 '12

Holmgren, E., 133

Holmium, 121

Hölscher, Dr., 261, 265

Holst, A. R., 210

Holstein-Ledreborg, Count, 985

Holton, Kans., 813

Holyoke, Mass, 828, 829

Holzamer, Wilhelm, 207

"Holzapfel," 349

Homalodotheria, 135

Home I., 627

Homer, Winslow, 250, 249

Homeric question, 220

- scholia, 219

Homerton, 305

Home Rule Bill, 506, 491, (Albert Hall demonstration) June 14 '12, (Mr. Asquith) May 6, June 19, Oet 5, Nov 22 ' 12 , (Mr. Balfour) Nov 6 '11, Ap

14. June 13, Oct 9 ' 12 , (Ballyroney demonetration) Sep 26 '12, (Belfart demonstrations) Feb 8 Ap 9, July 10, Sep 14, 27, 12, (Bonar Law) Deo ?

'11. July 27, Oct 10 '12, (Boyne celebration) July 12 '12, (Sir E. Carson) Oct 10 '11, Sep 16'12, (A. Chamberlain) May 7 , Feb 8, Sep 11, 12 '12 (Coleraine demonstration) Sep 21 '12, (Craigavon demonstration) Sep 23 '11, (Dromore demonstration) Sep $24 \quad 12$ (Dublin demonstration) Mar 30 '12, (Enniskillen demonstration) Sep 18 '12, (finance) 515,516 (Glasgow demonstration) Oct 1'12, (Govt, defeat) Nov 11 '12, (Nationalist 
Hope (Hawkins), Anthony, : Hughes, Samuel, 668 158

-. J. F., M.P., 496

Hupe, Ark., 774

Hopkins, Cyril G., 800

Hopkinsville, Ky., 815

Hops, 417, 718,1167

Hopwood, Sir F., 563, 577

Hoquiam, Wash. 924

Hordern, H. V. 457, 458

Hordlicka: see Hrdlicka

Horine, G., 452

Hormigueros, P. R., 952

Horncastle, 486, Feb 17 ' 11

Horne, Rev. Silvester, M. P., 487

Horniman, Annie E. F., 228

Hornsey, 561

Horse breeding, 455, 463

- racing, 403, 474

Horsfall, D. D., 468

Horsley, Sir Victor, 87

Horticulture, 426

Horváth, Frl. O. 470

Hose, C. 162, 166

Hosiery trade, 567

Hospitals, 587

Hotchkiss, Lt., Sep 10 '12

-, Miss H., 465

- Wm. N., 875

Hotch kiss gun, 373

Hot Springs, Alsk., 939

一, Ark., 771, 772

- Co., Wyo. 937

Hötzendorff, Gen. von, 9, Dec 10,12

Houghton, Stanley, 227 July 15 ' 12 , Nov 7 ' 12

Houlton. Me, 822, 723

Houme, La., 818

Houndsditch murders, Jan 3, May 12 ' 11

Hours of Labour: see Labour Laws

Housing question, 580, 325 Housman, A. E., 186

- Laurence, Jan 27 '12

Houssaye, Henry, 190, 1003

Houston, C. E. Oet 10 ' 12

Houston, D. F., 750

Houston, Tex.923, 924, 925,724 , Feb 20, Oet 12 ' 12

IIoustoun, R, A., 118

Hovden, A., 214

How, 220

Howard C. E. June 15 '11 Daniel, 1103 H. Clay, Jan 18 '11

- Dr. L. O. 176

- de Walden, 8th Baron, Mar 9 '11

Howden reservoir, Derby 580

Howe, H. M., 394

- Harlan B., 920

-, B. G., 303

Howell, E. E. 757

Iowells, W. D., 199

Jowitzer, 369,371

Howrah, 618

Hoxie, Vinnie R, 889

Hoyt, John Wesley, 757

Hrdlicka, Dr. A., 153, 161

Hsu Shih-ving, 977, 978

IIuang Haing, Gen., 980, $0 \times 2$

Huhert (airman), Sen 11'11 IIuddersfirld, Yorks., 56S Hudson, C., 468

- W. H. 189

Hudson river, Nov 11 ' 12

Ifudson Bay, 101, 62, 66:3 Hueffer, Ford Madox, 189 Huerta, Gen., July 4 ' 12 Hughes, Charles J., 784 -.John, 697

- J. Percival, 489

- Marian R., 555

T. J., Dec $18^{\prime} 11$

William, 864 694 979 Hull, Can., 665 $5 \cdot 11$

Humacro, P. R., 951

Humble bee, 431

Hume, Allan O., 547 ball, June 6 ' 12

Hunger strike, 89

Hunt, A. S., 219, 224

- Henry T. 887

- Margaret, 555

- M. L. 195

Hunter, J. B., 784

, Robert, 787

Hunting, 464 pital) 832

- Eilsworth, 113

一. N. Y., 868

- W. Va., 928, 929 Sept 5'12

Hurlstone, W., 238

Huron, S. Dak., 906

Hutchinson, A., 413 June 5 '12

Hutti mine, 605

- J. Arthur, 449

Hutukhta Lama, 10 '12 son, Charles

Hybrid, 140 29 ' 12

Uyderabad, 618

Hydrates, 126

Hidraulic lift, 387

Hydrocarbons, 499

Hydrocellulose, 398

Hvpnotism, 170

Hyraces, 135

Hythe, June 11 '12 1.

Ibadan. 650

Ibos, 6.50 20 '12

Ibsen, H., 214

- Sizurd, 215

Ice, 126, 469
William Morris, 692,

Hukuang railway loan, 976 ,

Hull, H. C., 710, May 18 '12

—, Eng., 574, 582, (election petition) June 1, July

Hull House, Chicago, 253

Hulzen, G. H. J. van, 210

Humes, Albert H., 903

Humfrey, J. C. W., 394

Humphreys, W. J., 110 Hundred Years Ago"

Hungary, 957, 964, (army expense) 954, (blind) 301, (monuments) 283, (national debt) 954; see also Austria-Hungary

Hungerford, Sir E., 451

Hunneus, Senhor, 1076

Hunnyburn, E. W., 584

一, George W. P., 771

America, 1165, Australia

Huntington, Ind., 805

Huntington bay (N. Y.),

Huntsville, Ala., 765, 766

Hurlingham Club, 466, 474

Hurlock, W., Aug 20 '12

Hurshid Pasha, July 16 '12

Hutchinson, Kan, 812

Huth Library, Nov 15 '11,

Hutton, Rev. A. W., 549

Hwang-hui, Gen, Aug 17

Hyacinthe, Père, spe Loy-

Hyde, Charles H., 876, Nov

Hyde Park, Mass., 831

Hydro-aeroplane, 45, 343

Iannina (Yanina, Janina), $1151,11.53,6,34$, Dec 1 .

Ibrahim Pasha, 1150, Aug 682, Canada 663, 73, S.

Ice cream, 420

- hockey, 463

celand, 983, 984, 987, 90

Ichneutae, 219, 224

Idaho, 797

- Falls, 797, 798

deal Home Exhibition, Ap

Idenburg, A. W. F, 1041

diot schools, 295

Iditarod, Alaska, 938

If ni, Mor., 1107

Ifugao, 950

Iglesias, Pablo, 1137

Ilford, 556,561

Iliama, Mt., Alsk., June 13 12

Iljyn, 394

Ilkeston by-election, June 28 ' 12

Illing worth, P. H., 487, 583, Aug 7 ' 12

Ilinois, 800 Ap 10 '12 (cyclone) Ap 20 '12, (railway accident) Jan 22 '12 (Republican party conference) Dec $188^{\prime} 12$, (university of) 803

Illiteracy, (Spain) 1135, 1036, see under "Education" in country and state articles

Iluminated MSS., 226

Ilorin, 650

Imam, Syed Ali, 609

Imbros, Aegean Isl., Oct 31 112

Immigration, 155, 323, Africa 703, 709

Immingham, Lincs., 574, July 22 ' 12

Immorality, 324

"Imperator," 346

Imperial Conference (1911) 482 , 483, May 23 '11, June 20 ' 11 , (Canadian resolutions) 667, (Declsration of London) June 11

- Defence, 482, 41, (Canada) 670-674, (Australia) 604, (Defence Committee) Ap 19 '11, July 25 12, (New Zealand) 700, 701, (S. Africa) 710,711 , (Lord Roberts) Ap 3 '11 - Defence Act (1888), 530

- Education Conference, Ap 25 ' 11

Imperial Steamship Company, Ap 6 '11

- Tobacco Trust, 598

- Trade Commission, 570

Imports, 435, 1164, 570; $8 \mathrm{ee}$ under country articles

Inpressionism, 241

Im Thurn, Sir E., 639

Incheape, Baron, 570

Income Tax: (British) 576 , 530 el seq., (Greece) 1032, (United Stateg) 734, (Ariz.) 770, (Ark.) 772, (Cal.) 776, (Colo, 782 (Conn.) 786 , (Hawaii) 943, (Ids.) 798, (Ind.) 807 , (Iowa) 810 (Kans.) 813, (La.) 818 (Ie.) 822 , (Mass.) 830 (Mich.) 837, (Minn. 840, (Miss.) 844, (Mo.) 847. (Mont) $\times 50$, (Neb.) 852, (Nev $185 \overline{5}$, (N. H 858 , (N. Y.) 876 , (N. C. 878, (N. D.) $880,(\mathrm{O}$. 885, (Ore.) 892, (S. D
Imperialism, 482, 490

907, (Tens.) ติ10, (Utah) 917, (Wash.) 825, (Wis.)

Indecent document (law) 324

Independence, Kan., 812

-, Mo., 846

Indeterminats sentence, 331

India, 603: (Geog.) 102, (Abor expedition) 611, Dec 5, Ap 8, Nov $19^{\prime} 11$, (aerial post) Mar 14.'11, (Aligarh University) Feb 9 '11, (Angliean Church) 310 , (army) 36, (Bombay rioting) Jan 12 ' 11 , Mar 12 ' 12 , foapital, change of) 478 , Dec 12

15 '11, Feb 22 '12, (coal)

380 , (Coronation Dun-

bar) 609 , Dec 12, July 26

'11, (cyclonic storm) Nov 22 '12, iDacea conspiracy) Ap 2 ' 12 , Aug 7 '11, (Edward VII memo- 
Ingersoll-Rand Campany, 381

Inheritance Tax (U.S.), (Cal.) 779, (Mass.) 831, (Minn.) 841, (N. C.) 878, (O.) $885,(\mathrm{Vt})$.

Inhambane, 1125

Inishkea, 598

Initiative (U.S.) 746, (Ariz.) 769, (Ark:) 772, (Cal.) 776, (Col.) 782, (Conn.) 786, (Ida.) 798, (III.) 801 , (Ind.) 807, (La.) 819 , (Me.) 823, (Mass.) 831, (Minn.) 842, (Miss.) 844, (Mo.) 847, (Mont.) 847, (Nev.) 855 (N. J.) 862 , (N. D.) 880 , (O.) 884 ; (Ore.) 892, (Tenn.) :910, (Wash.) 925, (Wis.) 932, (Wyo.) 936

Inman, M., 453

Innes-Ker, Lord A, 467

Inness, George, 247

Innoko-Iditarod region, Alsk., 939

Innsbruck, 956,962

Inoculation; 176

Inopos valley; 276

Inouye, Marshal, 1061

Insanity, 299, 325

Insectivores, 135

Insurance, 328, (France) 993, (Germany) 335, 1016, (Italy) 1044, 1052, (Rumania) 1035 , (Russia) 1132, (Sweden) 1143, (Switzerland) 1:146, 1147, (Uruguay) 1100

- Act (U.K.), 498, 520 328, (Advisory Committee) Ap 10, Aug 14, Oct 2 '12, "Amend the Act" League) Ap 13, 23, '12, (Associations' \& Corporations' deputations) June 27 '11, (Brit. Med. Assoc.) Nov 24 '11, Ap 3, '11, Deo 6 ' '12, (byelections affected), 484, (domestio servants' protest) Nov 28 '11, June 27

'12. (English Commissioners) Nov 28 '11, (Friendly Societies) : Oot 12,19 , Nov 27 '11, (Hurlock prosecution) Aug 20 '12, (Irish Commissioners) Dec . $7^{\prime}$ '11,

(Irish sanatorium benefit) 600, (Joint Committee) Jan 1 '12, (Medical Oct 3, Dee 5' 12, (Prnels closed) Dec $31,{ }^{\prime} 12$, (Plender report) July 11 '12, (Queen's Hall protest meeting) Dec $19^{\prime} 11$ (sanatorium benefit) July 22,24 '12, (Scottish Commissioners) Dec 20'11, (Scottish: Medical Council) Ap $13{ }^{2} 12$, (state medical service scheme) July 26 ' 12 (third reading) Dec 6 '11, (Unemployment Insurance regulations) May $10 \quad 12$ (Welsh Commissioners) Dec 18 '11, (women's deputation) June 16 ' 11 .

Insurance, state (U.S.) 737 . (Mass;) 830, (N. J., old age) 863 , (O.) 886 , (Wash.) 925

Intaglio gravure, 255 Intensive farming, 416 Interest, rate of, 79
Interferometer, 389

Internal-Combustion gines, 45

International Exhibition, Dublin, 598

- Flower show, May 22. 24 ' 12

- Law, 54, May 4'11

- Law, Institute of, 62

- Prize Court, 55, 56

- Radío Telegraphio Convention, 85

- Winder machine, 443

- Woman Suffrage Alliance, 90

Ionising media, 126

Iowa, 809,811

- City, Ia., 809

Ipek, Turk, 1160, Oat 31 12

Iphigenia, 220, 230

Ipoh, Mal. Penin., 630

Ipswich, Norfolk, 560,156 ; 149

Ireland, 594, 506, 557 (census returns) May 26.'11, (George V's visit) 476 Ap 3'11, (National University of) 602, (potato disease) July 24,12 , (Protestant statistics) 320 , (railway strike) Sep 21, Oct 4'11

Irgens, M. J., 1111

Irish Agricultural Organization Society, 596, 599

- Game Protection Society 601

- Labourers Act, 600

- language, 602

- plays, 227, 232

Universities Act, . 566, 602

Iron, 390, 566, Gen. statistics 25a

Iron-Carbon, 394

"Iron Duke," 350

"Ironquill," see Ware, E. F.

Ironton, O., 883

Ironwood, Mich., 836

Irrationalism, 288

Irrigation, (Egypt) 990, S. Africa) 711, (U.. S.) $849,852,854,865,880$, $888,891,904,907,912$, $916,924,936,951$

Irvine, W. H., 698

Irving, H. B., 232

-, Laurence, 229, 233

- Martin H., 697

İrvington, N. J., 860, 863

Irwin, Pa., 900

Isaachsen, G,:102

Isaacs, Isaac, 693

- Sir Rufus, 487, 516 , June 11 '12

Isherwood, J. W. 349

Ishpeming, Mich,, 836, Feb 6'11

Ishtib, 1162, 1030, Oct 27 12

Island river, N. G., 102

Isle of Wight disease, 130 , 143

Islington, Baron, 610, 653, July 30 '12

Ismail Kemal Bey, 8, Nov 28 ' 12

Ismay, Bruce, June 4'12

Isomer sm, 124, 125

Isopata, 269

Isoprene, 124

Isothermal stratum, 111

Ispahan, 1114, 1115

Israels, Joseph, 1042

Isthmian Canal Commis. sion, 946

"Istria" (ýacht), 478
Italy, 1042-1054, (Agri- | James river, Va., 922 culture, International Jameson, Miss D. R., 470 Institute) May: 14 '11, - H. M., 471

(Archaeological Co ngress) Oet 9'12, Ap 8 '11, (Argentine relations) 1068, (army) 5, 37, (Camorra trial) Mar 11 '11, July 8 ' 12 , (Carnegie Hero Fund) Sep 28 '11, (cholera riots) Oct 16 '11, (coal output) 380, (Declaration of Lonidon) 57 (French relations) Oct 28 '12, (Giolitti Ministry) Mar $30^{\prime}, 11$, Ap 6 ' 11 , (Hague Conventions) 55 (Haitian relations) July 5 '11, (jubilee celebrations) Mar 27 '11, (law) 335 (literature) 208, (navy) $44,46,47,48,49,50$, (Palace of Justice, Rome) Jan 11' 11, (Second chamber) Jan 7:'11, (Treaty of Paris) 53, (Triple Alliance) Dec 18 '12, (Tripoli War') 4, 2227 . Sep $29^{\prime} 11$, Oct 26 ' 11 , Feb 23 '12, (Turin Exhibition) Ap 29 '11, (Victor Emmanuel statue) June 4 '11

Itard, Dr., 295

Ithaca (Homeric), 276

Ivan Constantinovitch, Duke, Sep 3 '11

Ivanoff, Gen., 28

-, M., 219

Iyearh, Viscount; 602 , (Radium Institute) Aug 14 ' 11

Ivonet, Gen., 1082

Ivory Coast, 1006

- nut, 640

Ixtapar, 1089

Iyer, L. K. A. K., 162

Izvolsky, A. P., 1132

Izzet, Pasha, 6

Jacks, L. P., 189

Jackson, A. M. T., 607

- A. N. S., 452 , July 10 12

-, Capt E. C. 577

-, F. J., 645

-, Sir H., Nov 22 '12

- Sir John, 1151

-, John B., Aug 12' '11

Jackson, Mïch., 836, 838

一, Miss., 843, 844

Tenn. 909, 910

Jacksonville, Ala., 767

-, Fla., 791, 792, (street car strike) 794, (trade) 723

一, Ill., 800, 802

Jacques-Doucet collection, June 5 ' 12

Jaffa, 1151

Jagersfontein, 703

Jaggar, T. A., 757

Jaggard, W., 194

Jagow's placard, 1016

Jahn, E., 146

Jains, 603

Jaipur, 618

Jaisalmer, 619

Jakobsson, W., 470

Jamaica, 654, 659, Feb 25 '12, Nov 18 ' 12

- bay. N. Y. 870

James (of Hereford), Baron, 539

-, Edgar, 232

- Henry, 188, June 26 '12

-, H. P. Aug 12 '11

-..Ollie M., 749,817

-, William, 287

James Peak, Col., 782

Sir L. Starr, 707, Feb 19 '12, Aug 10 '12

Jamestown, N. D., 879

- , N. Y., 868

-, St. Helena, 652

Jamieson, Dr. Lyster, 132

ammes, Francis, 205

Jamsitji, 467

Janesville, Wis., 931, 935

Janeway, E. G., 757

Janowsky, 454

Japan; 1054-1062, 101, (army) 37, (anarchism) Jan 24 '11, (Anglican Church) 310, (British relations) Jan 21, Ap 3 '11, (cabinet crisis) Dec 2, 19 '12, (Canadian relations) Feb 19, May 19 '11 (Emperor's death) July 29, Sept 13 ' 12 , (German relations) June 24, July 15 '11, (law) 335 . (Mongolian relations) 10 , (Port Arthur opened) 
Jeyes, S. H., 543

Jibuti, 953

Jiménez, J. R., 215

- Ricardo, 1079

Jim Crow Law: sec Negro (Segregation)

Jim Wells Co., Tex., 913

Jind, 619

Jinja, 645

Joachim III, 1156

Joachimsthal, 956

Joohelson, 161

Jodhpur, 619

- Maharajah of, 619

Joel, J. B., May 31'11

Johannesburg, S. Af., 703, 705

- Zeerust railway, 705

Johansson, C. E. 472

John, Augustus, 243

Johns Hopkins University, 826

Johnson, Charkes F., 824

-, Edwin S., 908

- Hiram W., 779, 748

Aug 7 ' 12

- Jack, 454, 473

—,John A., 842

- Martin N. 882

- R. M. 915

- Tom L., 757

- (skaters) 470

Johnson City, Tenn., 909, 910

Johnston, H. W., 449

- Mary, 200

- R. I 901

Johnstone, Miss J., 460

Johnstown, $\mathrm{Pa}_{\text {. }}, 896,897$

Johore, 631

-, Straits of 626

-Bahru, 632

Joint Exchequer Board (Ireland), 516

Joliet, III., 800.803

Joline, A. H 757

Jolloff and Mandingo, 648

Jolo, P. I., 950

Jölsen, Ragnhild, 214

Jones, Adrian, 245

- Charles F., 915

-, F. Wood, 132

- H. C., 466

- Henry Arthur, 230

- Inigo, 195

- Ira B. 906

- John Paul (runner). 452

John Paul (statue), 791

- Rufus, 319

Stuart 281

T. R., 539

Wesley $L, 927$

William A 949

William D., 856

Jonesboro, Ark., 771, 773

Jonesco, Take, 1029

Jonsson, Bjarni, 984, 987

-, Kristjan, 987

Joplin Mo, 846

Jordonia, Tenn., 911

Jörgensen, J. J., 213

Joseph (boxer), 454

Jouguet, 222

Jouve, 392

Jowet, F. W., 487

- Rev, Dr. J. H., 322

Joyee, T, A 161

Joynson-Hicks, W., M.P., $4 \times 9$

Jubiti, 646

Judicial Separation, 325

Judith (Julir- Bernat), 1004

Jui Cheng, 979

Jukitch, L., June 8, Aug 12 ' 12

Jullian, C. 223

Junction City, Kan., 812, Katmai, mt., Alsk., June 813
Juneau, 723, 938

Jungfrau railway, 1148

Junker, Dr., 260, 263

Junker Type motor, 348

Junod, H., 161

Junqueiro, Guerra, 216

"Jupiter," 347

Jupiter group (planets), 94

Juraschek, Franz von, 965

Jurisprudence, 334

Justh party, 964

Jute, 438, 591, 440, 605

"Jutlandia" 356

Juvenile Courts, see Children's Courts

Juvenile Offenders, 331

Kachler, F., 470

Kaempf, Prof., 120

Kahann, J

Kaffirs, 708

Kagelmann (spy), Oct 10 12

Kagwa, Sir A polo, 645

Kahanamoku, D. P., 471

Kahoolawe, Haw , 941

Kahrstedt, 222

Kainz, Joseph, 966

"Kaiser Franz Josef I," 346

Kaiser Wilhelm canal, 1010

Kalabaktepé, 274

Kalamazoo, Mich. 836

Kalammu (king) 266

Kalanianaole, J. H., 943

Kalat, 613, 619

Kaler, James Otis, 758

Kalgoorlie, 685

Kalimati, 605

Kalispell, Mont., 849

Kalkandele, 1151

Kalk-stickstoff, 412

Kalodere, May 30 '12

Kambobe, 970

Kamod, Shibata, 1061

Kampala, 645

Kampar, 630

Kanawha, 930

Little, river, w. Va. 929

Kandy, 623

"Kangaroo" closure, 512

Kanin cape, 62

Kankakee, III., 800

Kankan, W. Af., 1006

Kano, 650, 651

Kanre Lahun, 1102,648

ansas, 812, (woman suf-

frage) 90,813 , Nov 5

-City, Mo., 846, 847, 848 , 724

Kant, 294

Kapp, G., 369

Kaptereff, Prof, 219

Kapteyn, J. C., 97, 98

Kapurthala, 619

Kara-eyuk, 259

Karditza, 1027

Karel, J. C., 935

Karlsruhe, 1009

Karsavina, 230

Kashgar, June 10 '12

Kashmir, 619

Kaskoff, Lieut, Aug 20 '12

Kaspitchan, 1035

Kasea, 957

Kassel, 1009

Kasso, M. 1120

Kasvin, 1115, Feb 11, Nov I6'11

Katalmata, 271

Kitalla, Alsk., 939

atang8, 705, 970

14 ' 12
-Wilhelm Land, 1012

Kalka tribes, 10

Karlovo, 1035

Kastamuni, 1151
Kato, Baron, 1061, Dec 19 12

Katsura, Prince, 1061, Jan 21 '11, Aug 19, '12, (Cabinet) Dec 17 '12, (European tour) July 6,21 ' 12 (Grand Chamberlain) Aug 13 '12

Kauai, Haw., 941

Kavarna, Oet 21 ' 12

Kaveri river, 606

Kaye, G. W. C., 120

Kayes, 1006

Kayser, Lieut., 104

-, E., 118

Keane, A. H. 552

Kearney, H., Dec 19 '12

Kearney, Neb., 852, 853

Kearny, Gen. P, 863

Kearny, N. J., 860

Kecskemet, 957

Kedah, 634

Kedney, J. S., 758

Keeble, Prof. F., 140

Keele, J., 103

Keene, N. H. 857

Keftin race, 272

Keighley, Oct 27 '11

Kekule von Stratonitz, R. 1023

Kelantan, 631, 632

Kellaws, C., 457

Keller, Helen, 874

Keller Leleux \& Cie, 364

Kellermann, B., 206

Kellogg Toasted Corn

Flake Co., Dec 26' 12

Kemp, Albert E., 668 i11

Kendall, Calvin N., 863

-, A. I., 803

-, P. F, 127

Kendrick, J, M., 758

Kennebec Co., Me., 822

- river, Me 822

Kennedy, Neil, Feb 29 '12

Kennelly, A. E., 365

Kenosha, Wis., 931

Kent, O., 886

- Eng., 566, (by-election) July 7 '11

Kentucky, 815

Kenyon, F. G., 225

-, W. S., 811

Keokuk, Ia. 809,810

Keppel, F., 758

Keren, 1049

Kerim Aga, 1028

Kerkrade, 1040

Kermanshah, 1114, June 1, Sep 20 ' 12

Kermode, I. I., 400

Kern, Prof., 163

- J. W. 808

Kesselstatt death mask, 194

Kessler, George E., 913

Kester, Vaughan, 758

Ketchikan, Alsk., 938

Kewanee, Ill., 802

Keystone party, 899

Keytesville, Mo., 847

Key West, Fla., 791, 792, 723

Khairpur, 619

Khama, 707

Khamikan, 1132

Khani tribe, 268

Kharan, 613, 619

Khargah Oasis, 263

Kharkov, 1126

Kharput, 268

Khartum, 991, 310, Jan 26 '12

Khasi language, 164

Khudadad Khan, 619

Khuen-Hedervary, Count C. 964,965

Khyber pass, 621

TKiackta, 10

Kiamil Pasha, 1159, 1161

1163, July 20 '12, ' (appointment) Oet 29. '11. (military situation) Nov $6,15^{\prime} 12$

Kiaochow, 1012, 1013

Kidd, E. L., 458

Kidderminster, 579

Kiderlen-Waechter, Alfred v., 1017, 123, Aug 4' '11,

Nov 17 11, Dec 30 '12

Kidsgrove, Oet 2 '11

Kidston, R., 146

-, W. J., 698

Kiel, 1009, Dec 21, 24 '12

Kielland, A., 214, 215

Kiev, 1127

Kikor river, 103

Kikuyu tribe, 644

Kilauea mt, 109,942

"Kilbroney," July 27 '11

Kiliktepé, 274, 272

Kilindini, 644

Kilkenny, 595, 598

Killiney, 600

Kilmarnock, 588, Sept 26 
15 '11, Nov 20 '11, Koppers, H, 404

(conspiracy against) Körber, E. K. von, 962 July 2 '12, (Egyptian Kordofan, 990

policy) 989, May 30 ' 12 ,

Nov 7 '12, (in Australia) 690 , (in Glasgow) July 6 '11; (in Khartum) Feb 23 '12; (in Malta) May 29 ' 12

Kitchin, C., 879

-, Dean G. W., 548

- W. W. 879

Kite flying, 111

Kitson (tennis player), 465

Kittel, Prof., 265

Kiukiang, Oet 24 '11

Kiviat, $\mathbf{A}, 452$

Kivu lake, 644

Kizil Agatch, 1035

Kjellin, F. A., 365

Klaatsch, Prof. H., 149

Klamath Falls, Ore., 891

- project, Ore., 891, 892

Klaus, F., 454

Kleiweg de Zwaan expedition, 1041

Klemm (Russ. minister), Sept 8 '12

Klobukowski, A., 1007

K̇lochkoff, M., 219

Klossovski, A., 110

Klotz, L. L. 1000, 1001, July 20 '12

Knapp, Herman, 758

-, S. A., 911, 729

Knebworth, 580

Kniazhevats, 1038

Knibbs, G. H., 682

Knight, H. J. C., May 9 '11

Knights, 220

Knights Bachelor, Society of, May 21 ' 12

Knights Key, Fla., 792

Knights of Columbus, 790

Knobel, E. B., 261

Knoblauch, E., 230, Mar 5 ' 12

Knott, J. Proctor, 758

Knox (engine driver), 525, Dec 7, 14'12

-, Philander C., 900, 1078, $1082,1089,1092$ (treaty with Honduras) Jan 10 11. (visit to Cuba) Ap 11 ' 12

-, George W., 758

Knox Land, 101

Knoxville, Tenn., 909, 910, 724

Knubel, J., 466

Knudsen, Gunnar, 1111

Koch, Dr. Robert, 634, 165

Kodiak, Alsk., 938

Kodyar irrigation, 623

Koenigsberger, Jacob, 388

-, J. G., 119

Koeppen, V., 114

Koerbing-Clerk engine, 356

Koester, Admiral von, June 10 '12

Kohlbrugge, Dr., 154

Kohlemainen, H., 451

Kokomo, Ind, 885

Kokonor, 982

Kokovtsov, V, N., 1128, 9 Sep 19 '11, (in Moscow) Ap 17 '12, (on Peace efforts) Dec 18 ' 12

Kolhapur, 619

Kolozsvar, 957

Kolyma bay, 102

Komatsubaira, E., 1061

Komura, Marquess, 1061, Nov 24 '11

Konia, 1151

König, Berno, June 30, '12

Königsberg, 1009

Konnoh tribe, 648

Konow, Wollert, 1111

Sep 28 '12

Koritza, Dec 23 '12

Koskelo (boxer), 472

Kosseir, 990 Blackbirds") 1158 15 ' 12

Kota Bahru, 632

Kotah, 606, 619

Oct 24 ' 12

Kouroussa, 1006

Koutchino, 340

Kovacs, M., June 7 '12

Kowloon, 635, 636

Krabbe, G. B., 470

Kraguyevatz, 1037

Krakatoa I., 114

Kralyevo, 1038

Kramberger, Prof., 147

Kramer (cyclist), 459

-., Karl, Oet 2 '11

Krapina, 147

Krarup cable, 366

Krefeld, 1009

Kreuzer, O., 465

Kriva, Oct 15 '12

Kriz, Dr, 157 10 '12 470

Kronstadt, June 11 '11

Kroyer, P. S., 987

Krugersdorp, 703

Kruja, July 8 ' 12

Krümmel, Otto, 1024

Krupp, F., 1010, 369

- process, 376,378 Aug 2 ' 11

Kuala Kangsar, 632

- Kubu, 631

- Lumpur, 626, 631

- Tembiling, 631

- Trengganu, 633

Kuang Hsu, 980

Ku-Bau, 258

Kuch Behar, 619

-, Maharajah of, 619

Kühn, August, 1020

Kumasi, 650

Kummukh race, 268

Kunath, 404

Kundt dust tube, 117

Kunfuda, A., Jan 7 ' 12

Kuprin, A. 218

Kurds, 1149, 1161

Kuropatkin, Gen., 219

Kuskokwim riv. 939

Kutincheff, Gen., 28

Kuyper, A., 1041

Labelle, 676 16 ' 12 Women, etc.

-, alien, 770 741,742

-, chambers of, 1016 1 '12
(Col.) 78s, (Conn.) 786, Lamp8, 363, 384

(Del.) 789, (Haw.) 942, Lampedusa Isl., 1044

(Ida.) 799, (Ill.) 802, Lanai, Haw:, 941

(Ind.) 806,807 , (Ia.) 810 , Lanarkshire, 588, (by-elec-

(Kan.) 813, (Ky.) 816, tion) Mar 9'11

(conspiracy) Aug 25,12,

Kossovo, 1151, ("Field of

Kossuth party, 964,965

Kostevitsch, Capt.' Nov

Kotchana, 5, 1031, 1162,

Kotoku, Dr., Jan 18 '11

Kozhani, Oet 25 '12

Krobatkin, Gell, 9, Deo

Krupp von Bohlen, G.,

Kumanovo, 31, Oet 24 '12

Kuprulu, 32, Oct 28 '12

Labouchère, H., 546, Jan

Labour: see Child Labour,

- American Federation of,

- bureau, Saskatch., 327

exchange, 568, 533, Feb

- legislation, (France), 994 - legislation, (U.S.) 737

(Ark.) 773, (Cal.) 778,
(La.) 819, (Md.) 826 ,

(Mass.) 830, (Mich.) 837 ,

(Minn.) 841, (Miss.) 844

(Mo.) 847 (Mont.) 850,

(Neb.) 852, (Nev.) 855, (N. H.) 858 , (N. J. 862 (N. M.) 867, (N. Y.) 871, (N. C.) 878 , (N. D.) 881 , (O.) 884,885 , (Ore.) 893 , (Pa.) 898, (P. I.) 948, (P. R.) 952, (R. I.) 902, (S. C.) 905 , (S. D.) 907 , Tenn.) 910, (Tex.) 914, (Utah) 917, (Vt.) 919, (Va.) 922 , (Wash.) 925 (W. Va.) 929, (Wis.) 933 - party (Australia), 688, 689

\section{- party (U.K.) 490, 491,} 20. (by-elections) July 4'12. (conference at Birmingham) Ap 17 '11, (conference at Leicester) Feb 1 '11, (minimum wage bill) 527, (syndicalist view) 20 , (woman suffrage) 88

- unions, 741, 742

- unrest, 17, 327

Labrador, 678 .

Labriola, Signorina, 1047

Labuan, 626

Labyrinth, 262

La Campine, 968

Lacava, P., 1054

La Chapelle-aux-Saints, 147

Lachine, 665

Laconia, N. H., 857

Lacour, Amédé, Oct 20 '12

La Crosse, Wis., 931

Lacrosse, 464

Lacy, John, 194

Ladenburg; A., 1023

Lado enclave, 990

Ladysmith, 703

La Farge, J. 250

Lafayette, May 9'11

Lafayette, Ind., 805

- La., 818

- Mo., 848

-, Tenn., 912

La Ferrassie, 147

La Flesche, 161

La Follette, Robert M 934, 747, 882, (at Chicago) Oct 16 '11, (at (Philadelphia) Feb 2 '12, (Wool-tariff) July 27 ' 11 LaFollette, Tenn., 910

Lafon, A 202

Lagardelle, Hubert, 20, 21

Lagash, 258,

Lagos, 650, 651

La Grande, Ore., 891

La Grange, Ga., 794

Laguerre, J. H. G., 1004

Lahad Datu, 627

Lahonton lake, Nev., 855

Lahore, 620

Laibach, 961

Lake Charles, La., 817, 818

Lake Albert, 644

- City, Fla. 791, 794

- House, Salisbury, 583

Lake Kiogo, 645

Lakeland, Ky., 817

Lakewood, O., 882

Lalaune, Dr., 157

Lamar College, Ga., 796

Lambert, G. M.P. 487

Lambeth County Hall, 581

Lammasch, H., 64
La Naulette, 147

Lancashire, 558, 565, 566. 568, 434, Aug 2'11

Lancaster, Mass., 832

- O., 882

- Pa., 896

Lanchow 981

Land \& Native Riehts Ordinance (Nig.), 651

Lander, Wyo., 936

Landon (airman), June 18 '11

Land policy (U. S.), 737, 940,949

question (U.K.), 513 Oct 16 ' 12 , (taxation) 536 , Sep 28 ' 12 , (valuation) 535, (small holdings) 415

Landry, A., 668

一, D. Y, 676

Landscape gardening, 426

Landsteiner, Dr., 173

Landtag, 1020

Land tax (Australia), 690

- Transfer Acts, Feb 10 '12

Landwehr. 954

Lane, A. P. 469 
Las Vegas, N. M., 865

Latakia, 1151

Lathrop, Julia C., Ap-17 '12

I, atin America, 1062

Iaue, E., 114

Laurel, Miriss., 843

Laureneon, G., 701

Laurent, C., 1152

- (airman), Nov 22 '12

"Laurentic," 347

Lauricocha, lake 104

Laurier, Sir Wilfrid, 667 $668,670,674$, Jan 31 , July 29 '11, (naval policy), 51, July 28 ' 11 , (on reeiprocity) Sep 19,11 ; May 30 12, (speech to Colonial Premiers) June 17 '11

I ausanne, 1144

Laussel, 157

Iavedan, H., 233

I avigne (boxer) , 454

Law, A. Bonar, M.P., 488, $489,501,502,510,511$, $512,513,514,515,516$, $517,518,519$, Nov 12 ' 11 , (address in Leeds) Nov 16'11, (address to Unionists) Jain 26 '12, (at Ashton-under-Lyne) 518 . (at Belfast) $510, \mathrm{Ap} 8^{\prime} 12$, (at Blenheim) July 27 ' 12 , (at Bootle) Dec 7'11, (on by-elections) Oct 11 '12, (on fall of consols) July 18 '12, (on militarism) Nov 8 '12, (on Referendum) 483, (on tariff reform) Nov 8'11, May 21. Dec 16 '12, (Primrose League speech) May 10 '12, (reply to ${ }^{\mathrm{Mr}}$

一, E., 193

Law, 323-339, (ancient) 223

Lawes-Wittewronge, Sir C. B., 540

Jawler, Gen. M. K., 802

Lawn tennis, 464,474

Lawrance, Sir J. C., 550, Mar 21'12

Lawrence, Chester, Dec 19 '12

- George, 675

Mr. and Mrs. Pethick, 88,89

- W. J., 195

Lawrence, Kan., 812

- Mass., 828, 829, 831,

(liguor licence) 834 ,

(st rikes) 741, 834, Mar 14, Sep 30 '12

Lawrenceville, Ga. 736

Lawson, H. 196

Iawton, Okla., 888

I.ayton, P., 303

I.A, H. C., 190

Homer, 758

- Luke, 911

Learl, S. Dak., 906, 9n8

Lead, 1174, 566, 393, 326, (Sartinia) 104:3

I. (isulville, Col., 781

J,eal, Gomez, 216

1. āo, Admiral Mnrques, 1074

Leatham, C. A., 467

- H. W. 46 i

Ieather, 567

Leatherhead, 302

Leavenworth, Kan., 812, 813

I.ebanon, N. H., 857 Syria, 1151

lebda, 25, June 13 '12

I, ebedef, P. N. 117

Lebena, 271
Leblane (airman), 341, Nov Leuchtenberg, 5th duke of, 1134

Lebrun, General, Feb 23, Leukas Isl., 271, 276 '11

Lecithin, 143

Lecoffre, 1117, Nov 29 '11

Leconte, Gen. C., 1086 Aug 14'11, Aug 8 '12

Lecog de Boisbaudran, P. E., 1005

Le Couteur, P. R., 458

Ledingham, Dr., I.C.G. 177

Ledoux (boxer), 454

Lee, A. H., 488

-, Sir Sidney, 190, 192

Leeds, 560, 579, (University) 585

Lee-Enfield rifle, 374

Leeward Islands, 654, Mar 9 '12

Lefebvre, J. J., 1005

Léon, 1004

Leforestier (airman), Sep 5 11

Legagneux (airman), 453, Sep 17 '12

Legendre, Dr., 102

Leghorn, 1042

Legislative etc. Appropriation Bill, U.S., May 10 June 1, Aug 15, 22 '12

Legros, A., 244, 539, 7

Leguia, A. B:, 1094

Lehi City, Utah, 916

Lehigh Valley Railroad, 861 , July 6 '11

Lehmann, A. G. L. 116

-, F. W., July 1 '12

Le Hunte, Sir G., 662

Leicester, $560,567,582$

Leichart, F., 104

Leigh, Mary, 89, Aug 6 '12, Sep 20' 12

Leighton, John, 554

Leinster, 594, 601

Leipzig, Ger., 1009, (Uni- Liberty \& Understanding, versity) 1011,1022

Leishman, J. G. A., Aug 12 , Dee 20 '11

-, Sir W, 176

Leite, Duarte, 1121

Leith, 588, 591

Leitrim, 596

Lemaire, E., 382

Lemaitre, J. 204

Lemartin (airman), Junr 18 ' 11

Lemberg, 956, 961, May 13 ' 12

Le Mériot, Oct 31 '11

I.emming, C., 452

Lemoine, Sir J. M., 199, 677

Lemonnier, C., 211

Lenéru, Marie 203

L'Enfant, P. C. Memorial, 791

I.engyell, 233

Lennox, Haughton, 678

Leon, Ponce de, 792 , R., 216

Leon, Nie., Oct 6 '12

Leonids, 112

Leopold II, 966

Leotte, Mello, 1121

Le Pautre, 247

Lepel, Baron von, 84

Lepeschin, W. W., 14:3

I,eprosy, 166, 943, 948, 952

Le Roy, G., 211

Leroy-Beaulien, H. J. B. A. 1004

Terroux, 1137, 1139

I.eskovats, 1037

I.essimore, P. J., 469

I.etchworth, 580

Leuba, J. H. 161

Ieurchars, Col. Genrge, 707. 710,712 , Dec 12,12
Leutze, A. 1017

Levaditi, Dr., 173

Levasseur, P. E., 1003

Lever, Sir W., Oct 4 '11,

Nov 12 ' 12

- Bros., 970

Leviek, G. M., 99

evis-Mirepoix, Mlle. de, 204

Levuka, 639

Lévy-Bruhl, L., 160

Lewanika, 711

Lewes, V., 395

Lewes (bishopric), 309

Lewis, B. R., 461

-, Sir Elliott, 698

-, Sir G. H., 543

-, Ida, 759

一, John, Mar 9 '11

一, J. K., 487

-, T ${ }, 98$

Lewis Co., Ida., 798

Lewis gun, 373

Lewisham, 556

Lewiston, Ida., 797, 798

-, Me., 822

-, Mont., 849

Lexington, Ky., 815, 816, 817, (trotting record) Oot 8 '12

\section{-, Mo., 846}

Leyton, 561

Lhassa, 11, 982

Liang Ju-hao, 977

ibel, 332

Liberal Party (U.K), 491

Liberal Unionist Council, Mar 9 '12

Liberia, 1102, 648, Nov 6 '12, (treaty with France) Jan 9 ' 11

Liberté," 996

Party of, 1159

Libreville, 103

Lice, 173

License 331, (copyright) 338, (drama) 229

Cicensing, (U.K.), 532, 535

Liceo, Manita, 949

Lich field diuceses, 309

Lichnowsky, Prince, Oct 16 '12

Lick Observatory, 91

Lidgett, Dr. J. Scott, 321

Lidzbarski, 266

Lie, S., 214

Liebermann von Sonnenburg, Max, 1023

Iiebesgabe tax, 1020

Liebmann, Otto, 1024

Tienhart, L. F, 206

Lievin, 382

Lightermen, 528

Lighting, 407

lignite, 396

Jigonier, $\mathrm{Pa}$, July 6 ' 12

Liguria, 1042

Li-Hon-Hung, July 18 ' 12

Li-Huan-Hung, Oct 26 'il

Lij Yasu, 953, May 15 '11

Liliencron, D. von, 206

Lilleshall Co., Ltd., 355

Lillie, D. G., 99

Lilly, Ga, 796

I ima, O., 882, 887

I imantour, Jose Yves, 1087

Limba tribe, 648

Limburg, 1038, 1040

Lime, 405, 412,

Limerick, 595, 598

Lincoln, Abraham, Nov 9 ' 11
- Sam, Aug 15 '11

Lichtenberg, R. von, 278

lignose, 395

Lincoln, Ill., 800

-, Eng., 560, 580

-, Neb., 852, 853, 724

一, R. I., 901

- Co., Wyo., 937

Lincoln Memorial, Washington, D. C., 4, Dec 14

Lincolnshire, Marquis of (Lord Carrington), Feb 14 '12

Lincolnshire, Eng., 558, $566,568,574$

Lindequist, $F$. von, 3,1017 , 1019

Lindman, Admiral, 1142

Lindsay, Lady, 555

-, W. M., 225

Lindsey, Ben, 784

Linen, 437, 598

Lines, Dr. A., 1073

Lineville, Ala., 767

Lingah, 1114

Linlithgow Marquess of, 687

Iinoleum, 591 
Livingston, Mont., 849 Livingstone, David, 322 Living wage, 327

$\mathrm{Li}$ Yuan-hung, 977, 979 Llanelly, 524

Llanystumdwy, 90

Llewellyn, T. L., 385

-, W., May 8,12

Lloyd, Capt., 466

- L. S., 468

Lloyd-George, D., 485, 489, $491,497,533,477,414$, (B. M. A. conferences) Oet 9 ' 11 , Oct 2, 23, Nov 7 '12, (budget) May 16 '11, (deputation of domestic servants) Nov 28 '11. (finanoe discussed) 533-537, July 18 ' 12 , (friendly societies) June 29 , Oct 9, Nov 27 ' 11 , (Insurance Act) 498, $499,500,520$, June 10 '11, (at Kennington) July 12 ' 12 , (land policy campaign) 513, July 22 ' 12 , (at Llanystumdwy) Sep 21 '12, (Moroceo speech) 3 , (railway strike) 522, 523, 524, Aug 16 '11, (on single tax) Oct 7 ' 12 , (Welsh Church Bill) 505, Aug 29, Dec 29'11, (woman suffrage) $\mathbf{5 0 3}$, (Transport - workers strike) 528,88 , Nov 24 Dec 16 ' 11 , Feb 23 '12

Lloyd's Register, 346

Loanda, P., 1125

Lobbying, (U.S.), Laws against, $795,819,880$, 902

Lobito, 1125

- Katanga railway, 1125

Lochee of Gowrie, Baron, 543

Lockett, Capt. V. N., 467

Lockhart, Sir J. H. S., 638

Lockhart, Miss., $\mathbf{8 4 5}$

Lockyer, Sir N., 114

-, W. J. S., 114

Lodge, H. C., July 27 '12

-, Sir O., 115

Loeb, Morris, 759

Loeb Library, 220

Loew, E. A., 225

Logan, Bruce, 468

Logan, Utah, 916, 918

Logansport, Ind., 805

Lohman, Anna de Savornin, 211

- Savornin, 64

Löhr, Marie, 231

Lom, 1035

Lombardy, 1042

Lome, 1012

Lonauli, 605

London, Jack, 200

London, Can., 663, 665

- Eng., (borough councils) Nov 1 ' 12 , (City census) Ap 25 '11, (conference of 1908-09) 56, (County Council) Mar 14 ,11, Ap 2 '12, (Declaration of 503, (docks) Aug 3 '11, (general Omnibus Co.) Nov 1 '11, (Moor Lane fire) July 23 ' 12 , (municipal govt.) 578, (Museum of) Mar 24 '11, (port of) 572, (Tower of) Mar 21 11, (Traffic) 575, (university) 585, Feb 19 '12, Mar 21 ' 12

- \& North Western railway, 575 , Feb 15 '12

Londonderry, 6th Marquess of, 489 , Sept 26 ' 12
Londanderry, 595, 598

Lones, 221

Long, Robt. W. 808 Walter, M.P., 488, 501, May 11, June 14 '12

Long Beach, Cal., 774.

- Branch; N. J., 860, 862

Longeroft, C. A., 471

Longford Co., 595

Long Island, agricultura] school, 868

Longman, Mary E. B., 250

Longport, N. J., 863

Longstaff. J. L., Sept 28 '12

Longworthy, J.' G., 470

Lonsdale, H. A. O., 453

-, Sir J. B., 488

-, belt, 453

Loom, 434, 439, 443

Loomis, C. B., 759

-, E. J., 759

Lopez-Dominguez, José, 1139

Lopizzo, Anna, 834

Lorain, O., 882, 883, 887

Loraine, Capt. E. B., July 5 '12

-, Robert, 232

Lord, Capt., Aug 16 '12

Lords, House of, 492, 494 497. (Reconstitution Bill) May 22 ' 11

Loreburn, Baron, 479, 485. 488, (resignation) 503, 88 , June 10 ' 12 , (woman suffrage) Feb 28 ' 12

Lorentz, H. A., 1040

Lorentz river, 103

Loreto, 1095

Lorge, Duc de, July 26 '12

Lorient, Nov 17 '11

Lorimer, William (Glasgow) 570

William (U.S.), 803, 143 , July 13 '12

Loringhoven, Lieut, von, Nov 25 ' 11

Los Angeles, Cai., 774, 775, $776,777,779,723$, (dynamite explosions) 780, Dec 2, 28 '12, (earthquake) July 1 '11'

Los von Rom movement, 962

Loti, Pierre, 204

Lötschberg railway, 1148 , Mar 31,11

Lotsy, Prof., 145

Lough, T., M.P., 487

Lougheed, James A., 668

Louis, Georges, May 17 '12

Louise (Princess Royal), Dec 13 ' 11

Louisiana, 817, (oil) 410

Louisville, Ky., 815, 816, 723

-, Miss., 845

Lourenco Marques, 1125

Louth, (by-election) Feb 23, Mar 15 '11

Love, Dr. G. Kerr, 305

Loveling, Virginie, 212

Lovett, Dr. E. O., 914

S., 908

Lövland, J. G., 111

Low, Dr. A. M., 355

- Gen. Sir R. C., 540

Lowe, Dr., 389

Lowell, Percival, 94

Lowell, Mass., 828, 829 , 831, (liquor licence) 834, (strike) 835, Mar 26 '12

- Observatory, 94

Lowie, R. H., 160

Lowther J. W: M.P $497,514,90$, Jan 31 ' 11 , May 3 ' 11

Lowther Lodge, London, 105, July 26 '12
Loxley Chase, Sheffield, 581

Loyson, Charles, 1005, Feb 9 '12

Lozeau, A., 198

Lualuba river, 970

Lübeck, 1009

Lubin, David, 1043

Lucas, Baron, 488

-, Sir C. P., 197

- E. V., 189 Dec $14 ; 12$

-, Lieut. M. H., 456

Luce, Robert, 833

Lucerne, 1145

Lu Cheng-hsiang, 977, 982, June 29 ' 12

Lucie river, 104

Lucking, A. 839

Lucknow, 620

Luco, Ramon B., 1075

Ludden, P. A., 759

Ludendorff, H., 97

Lüders, 471

Ludlow, J. M. F., 543

Lueger, Karl, 965

Lugal-zaggisi, 258

Lugard, Sir F. J. D., 636 , 650

Lugari, Card., 313

Lukacs, Dr. de, 965, June 3 '12, Ap 20 '12

Lu Kuan-hsiung, 977

Lule Burgas, 30

Lumber trade, 678, (U.S.) May 19 '11, Sep 27'11

Lumiere autochrome plate, 254

Lund, T. F., 214

Lundeberg, Chr., 1143

Lunn, A., 466

-, G. B., 874, 876, 742

Lupus, 176

Lurgan, 595

Luschan, F. von, 266, 153

Lutherans, (U. S.), 734

Luton, 561, (by-election) July 20 ' 11

Lutyens, E, L., 1049

Luxembourg Gallery, Aug 12 ' 12

Luxemburg, 1021

Luxemburg, Grand-duke of, 1021. Feb 23'12

Luzzatti, C., 1050, Mar 18 '11

Lyall, Sir Alfred, 539, Feb 15 ' 11

Lyallpur, 604

Lyautey, Gen., 1106, 1107 , Ap 27, Oct 31 '12, (at Fez) May 24 '12

Lycosura, 281

Lyly, John, 193

Lymm, 566

Lynch Bros., 1154

Lynchburg, Va., 921, 922

Lynching, (Ala.) 768 . (Ark) 774, (Cal.) 781, (Fla.) 794, (Ga.) 797, (Ky.) 817, (La.) 821, (Md.) 828, (Miss.) 845, (Mo.) 849, (Mont.) 851, (Neb.) 851 , (N. C.) 879 (N. D.) 882 , (Okla.) 890 , (Pa.) 900 , (S. C.) 906, (Tenn.) 912, (Va.) 924 (W. V8.) 930, (Wyo.) 937

Lyne, Felicia, Nov 25 '11

- Sir William, 687

Lynn, Mass, 828, 829, 835

Lyon, Cecil A., 915

Lyons, Neil, 189

Lysistrata, 220

Lyttelton, Alfred, M.P. 488,517

Lytton, Hon. N. S., 471

Maal controversy, 1111

Mass river, 1038

Mabee, J. P., 677

Mabuse, Jan, 243

McAdoo, W. G., 750

McAlester, Okla., 888, 891

McAlpin, Hotel (N. Y. City), 876

Macalister, R. A. \$., 272 , 264,279

Macallum, Sir H. E., 624

Macao, 637

MacArthur, Arthur, 759

- R. S., 733

Macartney, C. G. 457

Macbeth, R. W., 538

Macbeth, 229

MacCameron, R. L. 759

MacColl, D. S. Feb 3'11

McBride, Sir Richard, 675

McCall, S. W 833,950

McCandless, L. L. 943

McCarrison, Col. R., 171

McCarthy, Justin, 545

- Lillah, 231 
Mackeprang, M., 214

Mackinder, H. J., M.P., 488

Mchinley, John C., 848 - William B., 804

McKinley mt., July 24 '12

McKinney, Tex., 914

Mackinnon, D., 468

Mackinnon Road Station, o 43

Mackintosh, Hugh R., 317

Maclagan, Archbishop, 528

McLane, M. Jean (Mrs. Johansen), 250

McLaren, W. S. B., M.P. 547

MrIaurin, Anselm J., 845

McLean, George E., 811

- George P. 787

IIaclellan's Castle, 282

Mcleod, H. F., 676

- Rev. Dr. Norman, 543

MacLeod, William, 903

Meloughlin, Dr. John, Memorial, 893

- M. F. 47.

MeManigal, Ortie, 742, 809

Maemaster, William B., 1073

Macmichael, H. A., 162

Macmillan, D. B., 101

-, Sir D. H., 676

McMillin, Benton, 911

Mc.lurdo sound, 99

MeNairy Co., Tenn., 909

Mc Namara, J. J., 742, 780 , 809, Dec 2, 5 '11

T. J., MIP. 487

Mi. Neal, 890

MacNeili, J. G. Swift, M.P. 487

- Ronald, M.P. 489, 515

Me Nicol, J., Dec 20 '11

MeNulty, Thomas F., 827

Macomb, Ill. 801

Macon, Ga., 794, 795, 796

Macphail, Andrew, 197, 198

Macquairie I. Antarct. 100

McReynolds, J. C., 750

MacTaggart, J. McT. E. 287

MrVail, Dr. J. C., Dec 20 '11

MeVea (boxer), 454

MacVeagh, Franklin, July 3' 12

MacWhirter, John, 543

Mada tribe, 651

Madagascar, 1006

Madan, Falconer, 584, June 1 '12

Madeira, Dec 15'11

Madero, Francesco, 1087. May 15, Aug 31 '11, (elected President) Oct 1 '11

Madge, W. C., July 30 '12

Madhavlal, Sir Chinubhui, 613

Madison, N. J., Oet 24 '12

- S. Dak., 906, 908

Wis., 931, 932, July 29

$$
12
$$

Madras, 620,310

Madrid, 1135

Madriz. José, 1090

Madsen, Peder, 987

- gun, 373

Macander river, 274, 1151

Ma-el-Ainin, 1105

Macterlinck, M., 211, 204 Noy 9 '11

Mafeking, 705

Magadi Soda lake, 644

Magdalenian Age, 157

Magdeburg, 1009

Magneton, 120

Maknolia, Ark., 773

Maguire, W. J., Dec 7 '11 Mandan, $N$.

Mainz, 1009
Mahasneh, 260

Mahler, Gustav, 966

Mahmud Shevket Pasha, $1152,1154,1157,1159$ 1160,1161 , (grand vizier) 10

Mahommed V., (Turkey) 1152

- Ali, (Persia) 1112, 1116 1117,1119 , July 18 ' 11 , July 31 '11, Aug 22 '11

Mahommedans, 603, Ap 10 '11, (Nedjif manifesto) Jan 18 ' 11

Mahool, John B., 827

Mahsud tribe, 621

Maikop, 410

Maillol, 244

Maindron, Maurice, 1004

Maine, Sir Henry, 323

Maine, 821

Maiorana, Angelo, 1053

Maioresco, T., Oct 26 '12

Maisonneuve, 665

Maitland, F. W., 334

Majaroff, M. 9

Major, Elliott W., 848

Majorana, Q., 368

Makarov, A. A., 1128, Dec 29,12

Maklakov, N. A., 1128 , Dec $29^{\prime} 12$

Makona river, 1102

Makura, Baron S., 1061

Malabari, Behramji Merwanji, 611

Malacca, 625, 626

Malaga, 1135

Malagalpa, 1091

Malan, F. S., 710, 712

Malaria, 945, 1043

Malatesta, May 20 '12, June 17 ' 12

Malay Archipelago, 1040 Aug 24 '12

- Peninsula, 625, 164, 153 - States, Federated, 628, 1134 , Nov 12 ' 12

Malby, George R., 875

Malden, Masa., 828

Maldonado, B. F., 1096

Malecka, Miss K., 68, Feb 13 '12, May 10 '12, (pardoned) June 10 '12, June 13 ' 12

Malefijt, J. H. de Waal, 1041

Malinoff, M., 1029

Malissori revolt, 1157, 1030, Oet 11 '12, (Turkish concessions) 1158

Mallalieu, W. F., 759

Mallet, J. W., 759

Mallock, J. M. 440

Malmesbury, 5th Earl of, 489

Malpartida, Eliss, 1096

Malta, 642, June 1'12, May 12, (George V's visit) Jan 24 ' 12

- fever, 169

Maltby colliery, 387

Mambaro river, 102

Mammals, 133

Man, Isle of, 557,580

Managua, 1085, 1091

Manchester, Conn., 785

- Eng. 559, (by-elections) 484. Mar 5 , Aug 8'12, (librarieg) 582, (port of 573 , (university) 585

Manchu dynasty, 981

Manchuria, 1060, 172, Nov $28 \cdot 12$

Mandalay 620
Mandingo tribe, 1103

Manet, E., 241

Manetho, 261

Manford, Okla., 891

Manger to Cross, From,

Mangin, Col., 1107, Sep 5 7, Aug 29 ' 12

Manhattan, Kan, 812,813

Manhood suffrage, (U.K.) 503, (Sweden) 1142

Manikya, Birendra Kishore, 618

Manila, P. I., 947, 948, 949, Feb $25 ; 11$

Manistee, Mich., 836

Manitoba, 663, 665

Manitowoc, Wis., 931

Mankato, Minn., 839, 843

Mann, Thomas, 206

-, Tom, 521, May 9, June 22,12

- William H., 923

Mannering, Edward, Sep 22 '11

Manners, Hon. J. N., 471

Mannheim, 1009, 1010

Manning, Sir W. H., 646

Manoel, Dom, 1122

Manouba," 1052, 24, Jan 19 ' 12

Mansfield, Eng., 566

-, O., 882, 887

Manson, Sir P. 174

Manti, Utah, 918

Manure, 409, 412, 416, 417

Manzini, Lieut.. Aug 25 '12

Maori, 699

Map Committee, 104

Mappin, Sir F., 585

Maracaibo, 1101

Marañon river, 104

Marathon race, 449,452

Maraviglia, M., 209

Marblehead, Mass., 723

Marchal, E., 142

Marconi System, 83, 367, (inquiry) Oct $11 ' 12$

Maréchal, Lieut., Nov 5 '12

Margate City, N. J., 862

Margoliouth, D. S., 220

Marianne Is., 1013

Maria Pia, Queen, July 5 '11. Aug 1 '12

- Teresa Isabella, Infanta, 1139, Sep 23'12 - Adelaide (Luremburg). 1021

- Clotilde, Princess, 1053

Marie Princess Valdemar (of Denmark), 987

- Pierre, 171

Mariendorf, 402

Marietta, Ga., 794, 796

Marignac, Galissart de, 106

Marignacite, 106

Marin, F, R, 216

Marine animals, 138

- engineering, 345,568

Marinette, Wis., 931

Marinetti, F, T. 209

Marion, Ind., 805 $-, 0 ., 883$

Mariquita," 472

Maritime Conference, International, Oet 9 ' 11

Maritza river, 1151

Marjoribanks, Major, 173

Market Gardening, 417

Markham, Sir A. B., M.P. 487

Marks, Oliver, 630

Marlay, C. B., 554

Marlborough, Duke of, 489 , 495

Marot (architect), 247

Marquette, 836, 837, 723

Marquina, Eduardo, 215

Marrakesh, 1107, 1108

Marriage, 324, 333, 299 315

Married Women's Protection Act, 325

Marriott, R., 454

Marron (airman), Sep 2 '11

"Mars:" see Bonvoisin, M.

Mars (planet), 93

Marss Tobruk, 22, Oct 10 . Dec 22 ' 11

Marschall von Bieberstein, Baron, 1023, Mar 9, June 18 , Sep 24 '12, (Turkish influence) 1155

Marsden, Bp. 8. E., 697

Marseilles, 994, June 20, 
Matagorda bay, Tex., 913 Matanuska coalfield, Alsk. 939, 940, Mar 16 '11

Maternity benefit, (U.K.) 498, (Australia), 684

Mathew, Rev. A. H., 311

Mathias, R., Mar 31 '11

Mathieson, J. A., 675

-, Oscar, 470

Mathys art collection, Dec $18 * 11$

Matisse, Henri, 242

Matsuda, M., 1061

Matsimuro, 1061

Matthews, J. M., 124

-. J. T., 457

— P. D., 458

-, Shailer, 932

Mattoon, Ill., 800

Mattos, Mgr. V. de, 1123

Matzen, Henning, 987

Maude, Aylmer, 191

Mauer jaw, 147, 148

Maui, Haw., 941

Mauna Loa, Haw., 7

Maunder, A., 469

Mauretania, 1006

Maurice, Sir John F., 547

Mauritius, 646, July 11 '11, Jan 18 '11, Oct 24

Maurras, C., 202

Mauve, Anton, 242

Mavromichalis, C., 1025 , 1026

Mawson, 100 , Nov 20 '11

Maxima cura decree, 314

Maxwell, Robert, 676

-, W. G., 634

- William H., 872

Maxwell-Hertz Theory, 115

May, Sir F. H. 636,639 , July 4 ' 12

Mayaguez, P. R., 951

Mayer, A. G., 131

Mayfield, Ky., 815

Mayne, Rutherford, 227

Maynooth, 602

Mayor, Prof. J. E. B., 538

Maysville, Ky., 815

Mazarine bible, Nov 20 '11

Mead, John Abner, 920

- Wm. R., Dec 12 '12

Meadow Brook Club, U.S. 474

Meares, Iredell, 870

Meat, (Berlin riots) 1022 (Irish trade) 599, (Switzerland) 1144

Mecca, 990, 1151

Mecklenburg, Duke of, 1012

Merklenburg, 1015, 1021

Medford, Ore., 891

Medical Act (Can.), 675

Medicine, 165-185, (antityphoid serum) May 7 '12, (Cambridge Research Hospital) May 24 '12, (cancer) May 8 12, (Dumdum parasite) Feb 14 '12, (patent medicines) May 9 '12

"Medina," 346

Medina, 1151

- Co., O., 883

Medjba tax, 1006

Medusae, 131

Meester, $\mathbf{J}$. de, 210

- T. H. de, 1041

Megaseism, 107

Meiklejohn, A., 832

Meiningen, 1009

Mejliss, 1112

Melanesians 153, . 162

Melbourne, 698, 245

Melecari, Dora, 208

Melilk, 1108, 1134, Dee 27 '11
Melnik, 957

Melville, G: W., 760

Melville, La.; 821, May 19 '12

TIs., Can., 101

Memorial Continental $\mathrm{Hall}$ D. C., 790

Memphis, Egy., 263

-, Tenn., 909, 910, 912, 724

Mena dynasty, 260

Mena, Gen. Luis, 1090, 1091, Oct $7^{\prime} 11$, Sep 25 '12

Menander, 219, 225

Men and Religion Forward Movement, 732

Menard, R., 202

Menard Co. Ill., Feb 14 '1

Menasha, Wis., 931

Mendelism, 139, 140, 155 , (agriculture) 413, (beekeeping) 430, (sheep breeding) 442

Mendi tribe, 648

Mendoza, Dr. C. A., 1092

Menelek, 953

Menendez y Pelayo, M. 1139

Menezes, J. de, 1121

Mengkibo, 632

Mengo, 644

Meningitis, 169

Meniscotheres, 135

Menkaura temple, 261

Menominee, Mich., 836

Menomonie, Wis., 931,935

Menotyphla, 135

Mental defectives, 299, 300, 327, (U. S.) 730, (Colo.) 783, (Del.) 789, (Ida.) 799, (Ill.) 803, (Ia.) 811, (Me.) 823, (Md.) 826 (Mass.) 833, (Mo.) 848, (N. J.) $863,730,(\mathrm{~N} . \mathrm{C}$ ) 879 , (O.) 886, (Okla.) 889, (Ore.) 895 , (Pa.) 899 (Va.) 923, (Wash.) 730

Mentuhotep Neb-hapt-ra, 262

Menufia canal, 990

Mequinez, 1106, 1108

Mercadier, Ernest, 1004

Mercer, Pa., 899

Merchant Ships, 345

Mercury, 121

Merdare, 1038

Meredith, George, 188

-, J. E., 452, 474

- Sir William, 676

Merewether, Sir E. M., 649

Merezhkovsky, S. D., 218

Mergheb, Feb 27 '12

Meriden, Conn.; 785

Meridian, Miss., 843, 844

Merino, 441

Meroe, 263

Merriam, Charles E., 803

Merrill, Wis., 931

Merriman, J. X., 710

Merritt, H. N., 453

Merry, William L, July 6 '11

- del Val, Card., 1138

Mersey, 1st Baron, 16, 350 May 2 '12

Mersey river, 573

Mersina, 1151

Mergsin, 632

Mertens, Dr., 255

Merthyr Tydfil, 560

Mesa Verde National Park, U. S., 286

Mesilim (King), 258

Mesopotamia, 1151

Mesozoic, 135

Mesquita, M. de, 217

Messina, It, 1042, 1046 (earthquake losses) 1045
Messins, S, Af, 704, 705

Messimy, Adolphe, 1000

Meston, Sir J. S., 623

Metabolism, 144

Metallurgy, 390-395

Metaphyta, 130

Metatheria, 135

Metazoa, 130

Metchnikoff, E., 421, May 7 '12,

"Meteor," 472

Meteorology, 110, (aeronautics) 339

Meteors, 112

Methane, 396, 409

Methil, 591

Methodist churches in U.S., 732,733

- conference (1911), 319, Oct 16 ' 11

Methuen, Lord, Jan 27 '11, Ap 24 ' 12

Metropolis, Gr., 277

Motropolitan Museum, New York, 248

Metuchen, N. J., 863

Metzger, Frazer, 920

Meux, Admiral Hon Sir H., 578

Mexico, 1087, 1062, (cabinet resignation) Mar 24 '11, (Pres, Diaz resigns) May 25 '11, earthquake) 1090, June 7'11, (finance) 1063, (Guatemala treaty) 1085 , (International Boundary Commission June 15'11, (oil) 410, (Madero elected President) Oct 1 '11, (revolutions) 1065,1062 , 740 , (U.S. relations) Mar 9, 22, Ap 17 ' 11

-. Mo., 846

Mey (physicist), 112

Meydum, 261

Meyer, E., 220, 221, 223, 261

-, Rev. F. B., 321

, H., 103, 106

Kuno, 187

-, R., 409

Meyers, Henry L., 851

Meyier, F. de, 210

Mezdra, 1035

Mezere, 1151

Mezzograph Screen, 256

Miami, Fla, 792

- and Erie canal, O, 883

Michalëis, Karin, 213

-, Max, 705, Nov 9 ' 12

-, Sophus, 213

"Michael Sars," 104

Michel, General, Nov 11 '12

Michel Lévy, Auguste, 1003

Michelsen, C, 1111

Michigan, 835, 90, Nov 5 '12

- City, Ind., 805

- lake, U. S., Sep 15 '12

Micou, R, W, 760

Micronesian languages, 162

Microphone, 368, 133

Middlesborough, Eng., 560 582, Mar 27'11 -, Kу., 815

Middleton, R., 189

Middletown, Comm., 785,787 $-, 883$

Midleton, 9th Viscount, 489

Midlothian, (by-election) 484, Sep 10 ' 12

Midnapur case, 610

Midway Id., Haw., 941

Mieses (chess), 454

Mighels, P. V., 760

Miguel, Dom, 1122

Mikkelson, Capt. Ejnar. 101,987

Milan, 1042

Milburn, D., 467

Miles, E. H., 471

Miles City, Mont., 849

Milestones, 230, Mar 5 '12

Miletus, 272, 273

Milham, W. H, 110

Military engineering, 369

Milk, 421

Milk River project, Mont., 849

Milking machine, 422

Mill, John Stuart, June 25 '11

Mille, W. C. de, 232

Miller, C. D. \& G. A., 467

- C. H., 200

- Charles R. 789

J. Maxwell, Ap 18 '11

Millerand, Alexandre, 996, 998, 1001, Dec 15 '1

Millet, F. D., 250, 751

Milligan, G., 225

Millionard, Gen., Feb 7 '11 
Misrata, 26

Missions, 322, 603, 731

Mississippi, 843 sity) 844

- river, (floods) 821,845 , 774, 849, (improvement) 840

Missoula, Mont., 849,850 Missouri, 846

- river, 849

Mistriotis, Prof, 1029

Mitchell, John, Mar 1 '11

- P. Chalmers, 136

- Silas Weir, 200

Mitrovitzs, 1160

Mitsui, 414

Mitteis, L. 225

Moabit riots, 1018

Moberly, Mo., 846

Mobile, Ala., 765, 766, 767, 723

Mochlos, I., 271

Modernism, 1017, 733

Modesto, Cal., 777

Mody, Sir Hormersjee, 637

Moffat, Graham, 227

- Dr. James, 322

Moheli I. Af, 1006

Moissan, H., 365

Moisture test for butter. 421

Moizo, Lieut., Sep 11 '12

Moldau eanal, 957

Molengrasf, Dr., 103, 1041

Moline, III, 800, 801, 802

Molise, 1042

Moll, Col. 106

Mollison, Dr. W. 152

Mollusea, 133

Molokai, Haw., 941, 943

Molybdenum, 393

Mombasa, 645, Sep 9 '11

Mombert, Alfred, 206

Mona, May 2 '11, Mar 15

Monaco, 1104

Monaco, Prince of, 1105 ,

May 2 '11, Mar 15 '12, $156,101,105$, Jan 7 ' 11 , 23

Monaghan, Thomas M.

Mona Lisa: see Gioconda, Ja

Monasteraki, 271

Monastir, 1151, 1031 (Servian occupation) 32 , Nov 15, 17 '12

Mond, Sir A., M.P., 487

-, Robert, 263

Monégasques, 1105

Monel metal, 392

Monet. Claude, 241

Monetary Commission. U. S, 726, Dec 21 ' 11 , Jan 8 '12

Money Trust, $72, \mathrm{U}, \mathrm{S}$. investigation, 726, Dec 9 , 19 '12

Money, H. de S., 845

-, L. G. Chiozza, M.P. 487

- R. H., Aug 19 '12

trust (U.S.), 726, Ap 27 '12, May 18 ' 12

Mrnuzilla, 990

Mongolia, 10, 982, (military demonstration) Nov 18 '12, (Russian consulates) 978. (Russo-Chinese negotiations) 1132, sep 18, Nov 4 '12, (Russo-Japanese Agrecment) 1061 , (separatism) 971

Monier, Gen. 1106, 1107

Monis, A. E. E., 999, Mar 1 11, Ap 10 '11, May 21 '11

"Ionitoria," 349

Monk, F. D., 668, Oct 18 ' 12
Mon-Khmer language, 164| Morel E D 648

Mommouthshire, 581

Monocotyledons, 145

Monod, Gabriel, 1004, 190

Monongahela river, $\mathbf{P a}$. 897

Monoplanes, 343

Monotreme, 134

Monroe, La., 817, 818

Mons, Jan 3 '12

Montagu, E. S., 487, 606

- H. G., Aug 15, Sep 3 '12 - and Co., Samuel, 74

Montalegre, 1122

Montana, 849, (university) 851

Montclair, N. J., 860

Monte Carlo, 1105

Montenegro, 1025, 1028 (Antivari explosion) Nov 2 ' 12 , (Austrian treaty) 964, (Berane massacre) Aug 14'12 Aug 24'12, Oct 3'12, (Bosnia com pensation claims) 959 (cabinet resignation) Aug 1. 12. (Cettigne demonstration) Oet 2 '12, (frontier claims) 1162, (frontier fighting) Aug 5 '12, Sep 26 '12, (Hague Convention) 55, (Ischafkisch fighting) Sep 11 '12, (Malissori revolt) 1030 1158, (military operations) 33, (ministry) June 19 '12, (Turkish Minister's departure) Aug 7 '12, (Turkish blockhouse attacked) Aug 3 '12, Aug 17 '12, (Tuzi fighting) Sep 16 '12, (War with Turkey) 1031

Monte Penedo," 348

Monterey, Cal., 777

Montero, Pedro, 1084

Montes, Ismail, 1070

Montessori, Maria, 295

Montevideo, 1099, 1100 . Jan 9, May 23 '11

一, L. M., 198

-, R., 460

Montgomery, Ala. 766,767

Monticello, Ark., 773

Montpelier, Vt., 918

Montreal, 463, 665, 666

Montserrat, 654

Montsiva, 706

Montt, Jorge, 1074

Monuments, Protection of Ancient, 281-286

Monypenny, W. F., 553, 191

Moody, W. V., 199

Moon, 93

Moon Law (Ia.), 810

Moon printing, 303

Moor, sir F, R, 707

Moore, Admiral Sir A., 578, May 14'12

-, F., 469

-, George, 187

- G. E., 291

- Hainson, 327

- H. F. 131

- Sir J. W., 110

-, William, M.P. 488

- W. H., June $22^{\prime} 12$

- W. L. 110

Moor Lamp, 363

Moorehead, John H., 854

Moran, Cardinal P. F. 696

Morant, Sir R., 584

Moravia, 963

Moray firth, 588, 592, 61

Morazan, Gen. 1065

More, Paul E, 199

Moreau, Emile, Ap 11 '12
Morel, E, D., 648

Moret, Lt. J. J., 1102

Morgan, Dr. Campbell, 322 , Edwin V., May 24 '11, Jan 18 '12

一, Dr. H. A., 552

J. Pierpont, 726, Oet 3 12. Book of Martyrs, June 12 '12, (collection withdrawn) Jan 27 '12, (Luther autograph) May 3 '11

Morgan-Guggenheim syndicate, 939

Morgan horses, 919

Morgan, La, 818

Morgantown, W. Va., 928

Morin, Paul, 198

Morison, Donald, 65

-, Rosa, 555

-, Sir Theodore, July 30

Morley (of Blackburn) Viscount, 485, 488, 493, 496, (on democracy) June 28 '12, Councillor of State), 479, Nov 10 '11, (English Association) Jan 27 '11, (India), Feb 22 12, (Persian affairs) Dec 7 '11, (Reciprocity), Mar 6 '11

Mormons, 918, 919, 941

Mornard incident, 1116, Dec 24 ' 12

Morning Leader, May 10

Morocco, 1105-1108, 2-4, 103, 1000, 1019, (Agadir incident) July 1 ' 11 . July 9 '11, (Berber attacks) Ap 2 '11, (M. Caillaux's speech) Nov 5 '11, (Darel-Kadi siege) Dec 21 '12, (El Hiba) Aug 22 '12. Nov $23,12,76$, (French protectorate) Jan 25 '12, Mar 30 '12, July 1 '12, (George V's coronation) June 2 '11, (Germany and France) June 7 '11, Aug 30 '11, Sept 12 '11, Oct 25 '11, (Italy), 1051, (M. Jaurè speech) Mar 8 '12, (Mr. Lloyd George's speech) July 21 '11, (Genera Lyautey's appointment) Ap 27 '12, May 24 '12, (Madrid protest) Aug '11, Mehedia) July 6 '12, (Mekinez) May 4 12, (Melilla) Oct 14 '11, Dec 23 '11, Dec 27 11. (Mulai Hafid's ab dication) Aug 12 '12, (Mulai Yusef) Aug 13 '12, (pretenders to Sultanate) May 18 '12, July 5 '12, (M. Ribot's speech) Feb 9 '12, (Riff chiefs) Nov 27 11, Mar 22 (Russia) July 10 '11, (Sefru) May $30 \cdot 12$ June 14 '12, (Shawia) Aug 16 '12, (Sidi Kacem) Sept 15 '12, (Spanish relations) 1139 , Dec 7 '11 Aug 28, Oct 25 '12, (Suk-el-Arba fighting) Aug 25, 29 '12, (Sus tribes) Nov 23 '12, (Zemmer fighting) Feb 29 ' 12

Moros, 950

Iorphology, 139

Morrell, Philip, M.P. 487

Morris, Sir Daniel, 653

Morris, Sir Edward, 678, June 10 '11

H. M. 470

-, N. L., 918

Morris eanal, N. J., 861

Morrison, Dr. G. E., Aug 1 12

Ap 12 ' 11

Morriseey, John, 678

Morristown, N. J., 860

Morrisville, N. Y, 868

Morro Forest, 1102

Morse, Charles W., May 24

'11, Jan $18^{\prime} 12$

, H. N., 126

Morse Code, 367

Mortera, Count, Dec 12 '12

Mortimer, Corporal, 468

Morton, Paul, 760

Mosca (airman), Nov 29 '11

Moschi, 1012

Moscow, Ida., 799

- Rusg., 1125

Moskowski expedition, 1041 
Mulford (motorist), 465

Mülhausen, 1009

Mülheim, 1009

Müller, D. H., 966

- Edouard, 1145, Dec 12 12

-, Lauro S., 1073

Muller-Thurgau, 144

Multitubereulati, 135

Muluya river, 103, 1107

Muncie, Ind, 805

Munda language, 165

Munich, 1009, 1011

Municipal Office Building, N. Y. City, 876

- ownership (U.S.), (Cal.) 780, (Mass.) 835, (Minn.) 842,843

Munir Pasha, 22

Munn expedition Sep 17 '12 Munro, R., 158

-, W. B., 198

Munsey, F, A., Sep 16, "12

Münster, 1011

Munster, 594, 601

- Institute, Cork, 415

Murcin, 1135

Murdoch, W. L., 696

Murdock, Victor, 814

Murfree, Mary N., 200

Murfreesboro, Tenn., 910

Muri, 651

Murlin, Lemuel H., 832

Murray, C. Gideon, 658

-, G. R. M., 541

- Gilbert, 192, 220, 221

- Sir John, 104, 132

-, John, 698, May 16 '12

- John A., 676

- Col. J. H. P., 680

- J. T., 193

-' T. C., 228

Murray, Utah, 916, 918

Murtinho, Jogquim, 1073

Muscatine, Ia, 809,810 , 811

“Mushroom," Ap 19 '11

Music, 236-240, (Ariadne auf Naxos) Oot 25 '12, (Crown of India) Mar 11 '12, (Die Brautwahl) Ap 13'12, (Don Quichotte) May 17 '12, (Girl of the Golden West) June 29'11. (The Jewels of the Madonna) May 30 '12, (King Harlequin) Nov 8 '12, (Mona) May 2 '11, Mar 15 '12, (Quo Vadis) Nov 13 ' 11

Musical Congress, International, May 30 '11

Music Halls, 229, 240, 231 , (Royal visit) 476, July 1 '12

Musil, A., 102

Muskegon, Mich., 836

Muski, 267

Muskogee, Okla., 888

Muslamieh, 1150

Musselman, Amos S., 839

Musselshell Co., Mont., 850

Mustafa Pasha, Oct 18'12

Mustafiz, 1149

Mutsuhito, Emperor, 1061 , July 29, Aug 27, Sep 13

Muttra, 606

Mycenae, 275, 272, 276

Myers, A. M., 701

Mylius, Edward, 480, Feb 1 '11

Mylius-Erichsen: expedition, 987

Mymensingh ease, 610 , June $18^{\prime} 12$, July 26 ' 12

Myopia, 302

Myrand, Ernest, 198

Myres, J. L., 279
Myron, 279

Mysore, 605, 620

Mytilene, Nov 21 '12

Myxomycetes, 146

Naba Tsibeni, 707

Naber, Capt. S. P. L'H. 1102

Nabha, 621

- Rajah of, 621

Nadi, N., 460

Naef, A., 133

Nagl, Cardinal, 313

Nagpur, 607, 617

Nagyvarad, 957

Nahiku, Haw., 941

Naim Bey, 1027

Nainter, E. M., 952

Nairobi, 643,644

Namasagoli, 645

Nampa, Ida., 798, 799

Nanking, 977, 980, Nov 10 . 25 , '11, (mutiny) Ap 12 12

Naphtha, 102

Naples, 1042, 1045, 1046 (Vulcanological Inst.) 106

Narâm-Sin, 259

Narragansett Bay, R. L. 829

Nash, Francis P., 760

- , Vaughan, 563

Náshua, N. H., 857

Nashville, Tenn., 909, 910 724, (Peabody College) 910,911

Nasik, 607

Nasr-ul-Mulk, 1114

Natal, 703 (Índian immigration) $709,610, J$ an 3 '11

Natchez, Miss., 843, 844

Natchitoches, La., 819

Nathan, E. S., 1048

- Sir Mathew, 709

Nathorst, A. G., 146

National Academy of Design. N. Y. 249 Conservative Union, May 9 '12

- Debt, (U.K, ) 532, 537 . 576

- Gallery, London, 244

- Liberal Federation, 515

- Policy Tariff (Can.) 669 - Society, London, Mar 23 Oct 16 '11

- Telephone Co., 530, 531

- Union of Women's Suf frage Societies, 88

Nationalists, Irish, 490, 506 , 476

Native labour, 708, 1125 , (recruiting), 328

- labour Ordinance, Rhodesia, 706

- law and custom, 332

Natural Bridge, Va., 921

Naturalisation,

(U.K.),

- 483, (Belgian) 968

Naugatuck, Conn., 785, 787

Nauroz Khan, Sir, 619

Nautel, W. B., 668

Navajo reservation, N. M., 867

Naval Ordnance Construction, $375-379,46$

- Prize Bill, 502, 56, July 3 Dec 7, 12 ' 11

- War Staff, 577

Navero, E. G., 1093

Navigation Bill, 685

Navigazione Generale Italiana, 1045

Naville, Dr. E, 260

Navy, 44-51, 345-354, see British Nayy, French navy etc.

Nawanagar, Jam of, 458

Nazim Pasha, 1161, 6, 29
Neanderthal skeleton, 147, 137

Nebraska, 851

- City, Neb., 852, 853

Nebulae, 96

Needles project, Cal., 775

Neenah, Wis., 931

Neergaard, Niels, 984

Neferarkara, 261

Nefermaat, 261

Negri, Ada, 208

Negri Sembilan, 629, 631

Negritos, 164

Negro (in U. S.), 714 (illiteracy) 715 and see under separate states, (miscegenation) 772, (segregation) $819,821,828,845$ 912,922 , (sufírage) 773 , $819,827,890$, (welfare) $768,796,923$; see also Lynching

Nejmeddin Mullah, 1153, 1157

Nelligan, Emile, 198

Nelson, E. W., 138

- Knute, 842

Nemec, B., 142

Nemocón, Colom., 1077

Neolithic age, 158

Nephi, Utah, 916, 419

"Neptune," 347 , 350

Nernst theory, 117

Nesham, H. P., 450

Neshat Bey, 23

Nestor (planet), 94

Ne Temere decree, 315,675 , June 17'12

Neuendorff, B., 195

Neuropathology, 169

Neustadter, Caroline W., Feb 1 ' 12

Nevada, 854, Jan 4 ' 12 , (university) 856

-, Mo., 846, 848

"Nevada," 347

Nevinson, H. W., 189

Nevis, 654

New, H. S., 808

New Age, 186

New Albany, Ind., 805

Newall, H. F., 91

-, Miss Q., 450

Newara Eliya, 623

Newark, N. J., 860, 864, 724

-, O., 882

New Bedford, Mass., 828 829,723 , (strike) 835

Newborn, N. C., 877, 724

Newberry, S. C., 904

Newbolt, H. J., 187

New Britain, Conn., 785

- Brunswick, Can., 663, 665,675

- Brunswick, 'N. J., 860 . 863

Newburgh, N. Y., 868

Newburyport, Mass., 829

New Caledonia, 1007

- Castle, Del., 788

- Castle, Pa., 896, 897

Newcastle-on-Tyne, Eng. 559,585 , Oct 5 ' 11 , Sep 4 ' 12

Newcomb, Simon, 93, 113,

New Cross, London, Sep '11

New Decatur, Ala, 765

New Forest, Hants., 581

Newfoundland, 678,64

New Gibson, N. Y., July 4 12

- Guinea, Dutch, 1040 , 102

- Guinea, German, 1012, July 10 ' 12

- Hampshire, 856

- Hanover, N. G., 1012

New Haven, Conn., 785, 723 - Iberia, La., 817

Jersey, 859, May 20 June 13 ' 12

Newlands, F. G. 856

New London, Conn., 785, 723, (rowing) 473, (women's college) 787

- Madrid, Mo.s 849

- Mecklenburg, 1012

- Mexico, 865, (U.S.) Aug 19 '11, Jan 6 '12

Newman, Ga. 794

New Orleans, La., 817,818 , 819,820 , (commission government) 819 , (trade) 723

- Pomerania, 1012

Newport, Ky,, 815, 816

- R. L., 901, 724, Sep 4 '12

-, Vt., 724

Wales, 560, 566 
Oct 11 '12, Oct 16 '12, (elections) Dec 20 '11, (Waibi miners' strike) May 13, Nov 30 '12

"New Zealand," 701

-Nez Perce, Ida., 798

"Niagara," 346

Niagara river, N. Y, 870

- Falls, N. Y. 868, 869 $724,359,361$

Nicaragua, $1090,740,1063$. Jan 1 '11, (Honduras boundary) 1087, (Laloma explosion) May 31 '11, (marines landed) Aug 4 '12, (Managua garrison massacred) Aug 17 '12, (Masaya re-captured) Oct 4 '12, (newspaper staffs arrested) Mar 6'12, (President elected) Oct 7 '11. (revolutions) 1062. 1065,1079 , Sep 25 '12

Nice, Fr., Sep 8'11

Nicholas (of Montenegro) 1028 , July $20^{\prime} 11$, Oct 9 '12, (Vienna visit) June 8 'i2

- II (of Russia), 1127, 1129 , 1133, July 4, 24, Aug 11 ' 12

- Grand Duke, 456, Dec 10 '12

Nicholls, Francis T., 821

Nicholson, E. B. 584, 553

- J. W. 96

- M. 200

- Sir'W., Ap 26 '12

Nichrome, 393

Nickals, C. P., 467

- P. W. 467

Nickel, 392

Nickel-on-glass, 120

Nicobar Is., 613,621

Nicobarese language, 164

Nicolay, Helen, 201

Nicosia, 279, 640, 641

Nidvi Plain, 276

Nielsen, Yngvar, 215

Niemzovitch (ehess), 455

Niese, B., 222

Niesen mt., 1148

Niess\}, G. K., von, 112

Nietzsche, F.,206

Nieuport (airman), Sep 15

-11, (monoplane), 344

Nieuwenkamp expedition, 1041

Nigeria, 650

Night blindness, 155

Nightingale, Rev. B., 319

- Florence, 165

Viigata, 1059

Nihav, Haw, 941

Nijingky (dancer), 230

Nikaria Aug 2 '12

Nikisch, A. 236

Nikopolis, 1035

Niles, Dr. G. M., 170

Nilsen, Capt, 100

Vineveh, 260

Ninkada, 651

"Niobe," 670

Niobrara Co., Wyo, 937

ish, 1037, 1038

Nishan Tash inscription 2 tis

Niton, 119, 121

Vitric acid, 360

Vitrogen, 121, 399, 409, 419

Nitrolime, 412

Nixon, G. S., 856

Nizam-es-Sultaneh, 1114

Nizami Pasha, Osman, 6, 9

Nobel Prize, Dec 10, Nov 11 , Oet 10, Nov 12 '12

Noble, E. A., 898, June 5 '11
Noble, J. W. 760

- R. E., 952

Noble comb, 442

Nobre, A., 216

Noether, M., 114

Nogales, Ariz, 768, 723

Nogent-sur-Marne, 1001

Nogi, Count, 1061, Sep 13

Noir, I. Reid, 156

Nolen, John, 932

Nome, Alsk., 938

Nomes, 262

Noradoughian, Gabriel Effendi, 1161

Norden, 224

Nordenskiöld, E., 161

Norfolk, Duke of, 489,496

Norfolk, Neb. $85^{\circ}$

- Va., 921, 922, 724

- Eng., 416, May 30 '12

Norgate, Kate, 191

Normal, Ala., 767

Norman, Canon, Mar 27 '12

-, Sir Henry, Aug 5 '12

Regine, 215

"Normannia," 347

Norris, G. W. 854

Norristown, Pa., 896, 899

North, E. P., 760

Northampton, Eng., $\mathbf{5 6 0}$

$567,579,580,582$

Torthamptonshire. 566

North Carolina, 877

Nortbcliffe, 1st Baron, 193. 679

Northcote, Lord, 539

Northcott, Elliott, 1077. Jan 9, Dec 21'11

North Dakota, 879

- Eastern Railway, 522 , 525, Dec 7. Dec 14' 12

Northern Territories, W. Af. 649,650

- Territory, Austr., 680

Northfield, 561

Northfleet, Kent, 157

North Platte project, Neb. 852

North Pole, 99

Northrup, Cymis, 842

North Sea, 1039

North Sea fisheries, 61, 592

Northumberland, 559,565

Northumberland, Duke of 495 , Nov 19 '12

Northumberland Miners' Association, 565

North West Passage, 101

North West Territories, Can., 663

Northwestern University, Ill. 803

Northwich, 566

North Yakima, Wash., 924 925

Norton, P. D., 882

-, R., 273

Vortoni, A. D. 848

Norway, 1108-1112, (geog.) 102, (literature) 214.

(blind) 301, (frontier dispute) 64, (Spitzbergen claims) 60, (woman suffrage) 90. Mar 17 '11. (cabinet resignation) Feb 16 '12

Norwich, Conn., 785

- Eng. 560, 564, June 28 '11, (Hoods) 582, Aug 26 12

- Crag, Norf., 156

Norwood, O. 882

Nosema apis, 430,130 bombycis, 131

Notodden, 412, 361

Notre Dame Bay, 679
Nottingham, 559, 567, 580, | Odessa, 1126

582, (elections) May 19

'11, Ap 19 '12, (University College) 586

Nottinghamshire, 559, 565

Novikovich, 8 .

Nova Scotia, 663, 665, Aug 14 '12, (elections) 675

Novaya Zemlya, 102

Novel, Archbp., Dec 2 '12

Novibazar, Sanjak of, 32, Oct 23 '12

Novikoff (dancer), 230

Nowicki, R., 390

Noyes, Alfred, 187

Nubia, 260

Nuers tribe, 990

Nugent, J. R., 864

Nukualof a, 640

Nuremberg, 1009

Nürnberg engine, 355

Nutley, N. J., 863

Nutochondria, 143

Nuttall, Prof., 132

Nye, George B., 887

Wallace G. 843

Nye Co., Nev., 854

Nykoping, 1141

Oahu, Haw, 941

Oakland, Cal., 774, 776, 777,781

Oak Park, Ill., 800

Oaks, The, 464, June 2 '11

June 7 ' 12

Oates, E. J., 587

Oats, 1166, (U.K.) 562, (U.S.) 717

Obaldia, J. D. de, 1092

Obeidullah Effendi, 1155 , 1163

Oberlin College, O., 886

Obermaier, Prof., 156

Obituary, (Australia) 696 (Austria-Hungary) 965 , (Belgium) 969, (British) 538, (Canada) 676, (Denmark) 987, (Egypt) 990, (France) 1003, (Germany) 1022, (Holland) 1042, (India) 611, (Italy) 1053, (Japan) 1061, (New Zealand) 702, (Newfoundland) 679 , (Russia) 1133, (South Africa) 712, (Spain) 1139, (Sweden) 1143, (Switzerland) 1148, (U.S.A.) 751

Oborne, James, 677

O'Brien, Lt.-Col. C. R. M. 647

Ignatius, 602

Thomas, J., Aug 12 '11 William, M.P., 487 Nov 15 '12

O'Callaghan, C. L., 458

Occupational Diseasea, Reporting of, (Cal.) 778 (Conn.) 786, (III.) 802, (Md.) 825, (N. J.) 862 p (N. Y.) 871, (Wis.) 933 Oceana." 350

Ocean City, N. J., 862

Ocean I., Fiji, 639

Oceanography, 104, (Monaco) $1105, \operatorname{Jan} 23$ '11

Ochelhäuser engine, 355

Ochrida, Turk., 1151, Nov 23 ' 12

O'Connell, Cardinal, 313, Nov 30 '11

O'Connor, Charles, 601

- Richard, 697

-, R. E., 693

- T. P. M. P 487

(bonto, Wis., 931

(Octavia," 472

Octobrists, 1132

Odda, 409, 412, 360

Oddie, T. L., 856

Odum, Ga., 796

Oelwein, Ia., 809

Ogbomosho, 650

Ogetti, Ugo, 209

Ogilvie, W., 677

Ogle, W. 549

Ogowe basin, 103 90,884

- canal, O., 883

O'Dowd, 8, 197

Oedipus Rex, 230, Jan. 15

- Tyrannus, 220

Oetteking, Dr., 153

'Fallon, III 804

Ogden, Utah, 916, 918

Ogdensburg, N. Y,; 724

O'Gorman, James A., 874

O'Grady, James, M.P., 529

Ohannes Bey Kouyoumjian, Dec 23 '12

Ohio, 882, Sept 3 '12, May 22 ' 12 (woman gufirage) 
Astical province) 310, Otaru, 1059

(elections) 675, Aug 15 Otay,950

'11, (fires) July 10, Aug 1 Othello, 229

11. (heat) July 3 '11

Oodnadatta, 685,680

Opelousas, La.; 821

Openhym, A. W. 873

Opera, 240

Ophel, mt., 264

Ophthalmia, 301, 303

Opis, 258

Opium, 972, 604, May 8 11 (Borneo) 628, (Hongkong) 636, (Japan) 1059, (Straits Settlements) 626 (Weihaiwei) 638

- and Drug Act, Can., 674

- Conference, Dec 1'11

Oporto, 1120, 1122, 1123 (cooper's strike) Oct 28 '12, (tramcar accident) Dec 10 '11

Opossum, Australian, 433

Oppenheim, Max von, 268

Optophone, 120

"Orama," 346

Orange, Conn., 785

- N.J., 860,863

Orangeburg, S. C., 904

Orange Free State, 703

Orchard house, Concord Mass., 835

Orchomones, 277

Ordek-Burnu, 266

Order of Merit, June 20 '11, Mar 8, 15.'12

Ordnance, $\quad 369-372$, $375-$ 379

- Survey Office, 104

Ordofiez, Batele y, 1099, Mar 1'11.

Ordway, Col. 782

O'Rear, E. C, 817

Oregon, 891, 744, Nov 5 12, (university) 894

- City, Ore. 891, 893

- plan (choice of senators) $745,776,810,813,850$ $855,861,885,890,907$

Oriel Coll., Ox., Seri 28 '11

Orinoco S. S. Co, 65

"Orion," 350

Orissa, 478: see Behar

Orkney Is., 588

Ormsby-Gore, W., M.P.

Ornaments rubric, 308

Orofino, Ida., 798

Orontes river, 1151

Orr, Miss, 453

Orrego, R., Jan 12 '11

Ortigao, R., 216

Ortiz, Gen. Daniel, 1077

Osborn, C. S., 839

- H. F. 134, 101

Osborne judgment 491, 497, Feb 25' 11

Oscillatoriae, 129

Oshkosh, Wis., 931

Oshogbo, 650

Oskaloosa, Ia., 809

Osmanieh, 1150

Osmotic pressure, 126

Osmundaceae, 146

Osorkon II, 265

Ospina, Gen. Pedro, 1078

Osten-Sacken, N.D., Count 1134, May 22'12

Osteopathy, 182

Ostersund, 1141

Ostia, 1048

Ostrich feathers, 704

Ostrorog, Count Leon. 1153,1157

Ostrovo lake, 277

Ostwald, W., 127

Oswego, N. Y, 724

- canal. N. Y 870

Oswiecim Canal, 957

- Ill., 802

Oudh, 623 489 210 tions, 220 389 224 1080
Palestine, Tex., 912

Palestine Archaeology, 264

Palisa, $J ., 94$

Palliser, C. Wray, 702

tis, James," 758

Ottawa, Can., 663, 665, July 31 ' 12

- Kan., 812

Ottumwa, Ia., 809, 810

Otway, Sir A. J., 547

Ouachits river, Ark., 772

Ouchy, 1052, Oct 18'12

Ouenza, 1005

Oura, Baron K., 1061

Outhwaite, R. L., M.P.

Overbergh, C. $\operatorname{van}, 161$

Overbrook (U.S.), 303

Overduyi-Heyligers, Mrs.,

Overman, L. S., 729

Overton, C. E.; 143

Oviedo, 1137, June 4'12

Owatonna, Minn., 839

Owen, E, 452

-, R. L., 890

-, Sir W., 697

Owens, Sir C.J. 570

Owensboro, Ky., 815,816

Owings Mills; Md., 826

Oxford, Eng., 584, 309, (Colonial Premiers) June $10^{\prime} 11$, (divinity degrees) Dec 3 '12, (Encaenia celebration) June 26'12, (Gladstone professorship) July 23 '12, Nov 19 '12

- N. Y. 873

- Co., Me., 822

Oxford Library of Transla-

Oxfordshire, 559, 566

Oxley, H, Dec 6 '11

Oxy-acetylene, 408

Oxydases, 140

Oxygen, 395, 407, 384, 122,

Oxyrhynchus Papyri, 220,

Oyama, Marshal, 1061

Oyster fishing, 132

- tax. Md. 826

Paasche, H., 1020

Pacanha, Nilo, 1071

Pachyammos, 270

Pacific Phosphate Co., 639 - railway (Costa Rica),

Padfield, W. A., 402

Paducah, Ky, 815, 816

Paes, Dr., 1121

Paestum, 1048

Pagasae, 280, 276

Page, Carroll S., 729

- Commission, 871

Paget, Bp. Francis, 544

-, Sir John R., 544

-, Bp. Luke, 544

-. Stephen, 544

Pahang, Mal. Penin., 631

Pain, Barry, 189

Paine, A. B., 201

- J. A. 761

Paint Creek, W. Va., 930

Painting, 240, 248, May 3 '12, (miniatures stolen) July 27, Aug 2'12

Paisley, 588, 591

Pakenham, Capt., Nov 28

Palaeography, 224, 222, 265

Palaeolithic age, 148, 156

Palaeontology, 148, 113

Palaeozoic period, 146

Palaung-Wa-Riang, 164

Palencia, 1136

Palermo, 1042, 1045, 1046

- stone, 261
Palma, R. de, 465

Palmer, G. W., 586

-, Howard, 103

-, H. J., 676

_. Sir Walter, 538

Palmer, Mass., 501

Palmira, 1077

Pamlico sound, N. C., 878

Panama, 1092, 1078

- Canal and Canal Zone,

943, 51, (bond issue) May

16 , June 17 ' 11 , (expenditure) 725,946 , (fortifica-

tion) 945, $\operatorname{Jan} 12,21$ '11,

(islands) Aug 28 '11,

(labour plot) 809 , (West

Indian labour) 946, 658 ,

- Canal Act, 11-14, 60 $946,947,740$, Aug 9 '12, (arbitration question) Dec 13 '12, (British protest) July 11, Aug 17 27 '12, (libel suit) Jan 3 11. (tolls) 740, Aug 8. Nov 13 '12

- Pacific Exposition, 934

Pan-American Congress, 1067, July 20 '12

Panderma, 1151

Pankhurst, Christabel, 89

Emmeline, 89, Mar 1

'12, Oct 21'12

Panormus, 273

"Panther," 1106, 2

Pantolambdids, 135

Papermaking, 444, 678

Paphos, 278

Paprikoff, Gen., 9

Papke (boxer), 46.5

Papua, 680, 103, 153, 163

Papyria, 219, 224, 265

Papyrus plant, 44

Para, 1072, Aug 30 '12

Paraffin oil, 119

Paragould, Ark., 771

Paraguay, 1092, 1062, 1065 , Feb 27'12

Parana, Oct 25'12

- river, 104

Parasites, 130

Parcel post, (U. S.) 739, (P. I.) 948

Pardo, Manuel, 1095

Paredes, Juan, Jan 10 '11

Paret, William, 761

Parinacochas lake, 104

Paris, Fr., 992, 995, (food prices agitation) Sep 11

11, 1001, Motor omnibus accident) Sep 27 ' 11 , (taxi cab strike) 994, Nov 28 '11. Feb 1 '12, (Ten ants Association), 992

- Ky., 815

— Tex. 912

Treaty of, 59

Park City, Tenn, 909

- City, Utah, 916

Parke, J, C. 465

Lieut. W. Dec 15'12

Parker, A. B., 749, June 24 12

- Sir Gilbert, M.P., 488

- Prof. Herschell, July 24 ${ }^{3} 12$

Mar 15

-, Sir R. J., Nov 4 '12

Parkersburg, W. Va., 928, 090

Parkin, G. R., 197

Parks, C. C. 784

Parks law, 766

Parliament Act, 491, 496,
- L. N., 230, Sep 3 '12

481. (effect on Home Rule) 514, 515, (Kangaroo closure") Ap 3 '11. (referendum amendment) Ap 26'11

Parmelee, Philip, June 1 '12 Parnell, C. S. (monument), Oct 1'11

Parpaillon, Col. du, 1148

Parr, Lady Julian, 458

Parrott, T. M., 195

Parry, Sir H. 238

Parseval dirigible, 342

Parsons, A. Mar 22'11

- Sir C. A., 108, 347, 568

Parsons, Kan., 812, 813

- Pond, 679

Parthenon, 275

Partick, 588, 594

Pasadena, Cal., 774, 781

Pascarella, C.. 208

Paschen, F., 118

Paschinger, P., 113

Pascoli, Giovanni, 1054

Pashich, N., 1031, 1024, 7 .

Nov 9 '12

Pass-a-Grille, Fla., 793 
Peace Conference, International, Aug 3 '11

Peake, A. H., 698

Pearce, G. F., 692

- H., 468

$\longrightarrow$, J. B., 784

Pearl fishery, 132

- Harbor, Haw. 942

Penrsons, Dr. D. K., 761 Ap 14'11

Peary, R. E., 101

- Arctic Club, 101

Pease, H. P., M.P., 489

- J. A., M.P. 487

Peat, 398, 1039

Pecs, Hung., 957

Pedersen, Prof., 84

Pedro Miguel lock, Pan. 944, 945

Peek, P., Sept 11 '12

Peel, Viscount, 496, 545

Peers, C. R., 281

Peet, T. E., 222

Peffer, W. A., 761

Pegasug (statue), 275

Pegler, S. J., 457

Pégny, C., 205

Peignam, Lieut, June 19

Peirce, H. H. D., Ap 27'11

Peirene, 276

Pekin, Ill, 802

Peking, China, 978, 980, 982, Ap 24, Oct 25 '11, (Advisory Council) Ap 29, Aug $20^{\prime} 12$, (military mutiny) Feb 29. Mar 2

Pelagic fishing, 431, 1057

Pelayo, M. M. y, 216

Pelew Is. 1013

Pelham, Prof, 223

Pellagra, 170, 1043, 817

Pelletier, Sir C. A., 676

-, L. P., 668

Pelly river, Can., 103

Pemba, 645

Pembina, N. D., 724

Peña, Pedro, 1093, Feb 27 12

- R. S., 1067

Penallta colliery, 386

Penang, 625, 626

Pendleton, Fllen F., 932

Pendleton, Ore. 891

Pend Oreille Co., Wash. 926

Penggaram, 632

Penguin, 100

Penitentiary Congress, 331

Penley, W. S., 546

Pen Mar, Md., Dec 7 '12

Penna, Alfonso, 1071

Pennell, H. L. L., 99

Pennewill, \$. 8., 789

Penning, W. L. 210

Pennington Co., Minn., 841

Pennisetum purpureum, 1102

Pennsylvania, U. B., 895 Ap 13, May 8 ' 12 , (university) 898

- Academy, Phila., 248

Railroad Station, New York City, 251, 876

- School, Phila. 303

Penubscot river, Me., 822

Penrose, B., 899

Pensacola, Fla, 791, 792, 723

Pension Bill, U.S., 725, Feb 2, Mis 11 '12

Pensions, State, in US. (Ala.) 767, (Ark.) 77\%, (Conn.) 787, (Ga.) 796, (III.) 803 , ( $\mathrm{Ky}$.) 816 , (Md.) 826, (Mass.) 830 (Minn.) $842,($ N.J.) 863 (N. Y.) 872, (Penn.) 898,
(Tenn) 911, (Utah) 918, Petermann I, 90

(Va.) 923, (Wis.) 934: Peter Pan (statue), 245

for widowed mothers, Peters, B. C., 921

etc. (Col.) 782, (III.)

802, (Mo.) 848

Pensions to teachers, Carnegie Foundation, 730

Penzance, 417, 583

eonage, (Ala.) 767, (Fla.) 794, (P. I.) 950

Peoria, Ill., 800, 801, 723

Pequaket, N. H., 253

Perak, 630

Perchino, 456

Percy, Enrique, 1069

-, Le Roy, 845

Periptychids, 135

Péringuey, Dr. L., 153, 159

Periquet Capt., 103

Père Marquette R.R., Dec 30 '12

Perissodactyls, 135

Perjury, 331

Perkins, G. W, 882

Perkins Institute, 303

Perks, Sir Robert, 319

Perky, K. I., 799

Perlepe, 32

Perley, G. H., 668

Perlis, 634

Perm, Russ., Feb 21 '11

Permian, 113

Permutet water-softener, 443

Pernter, J M, 110

Peroxydases, 140

Perrodin, Lieut, 465

Perseids, 112

Persia, 1112, 102, 59, (Anglo-Russian note) Feb 18 '12, (Anti-British boycott) Dec 14 '11, (apology to Russia) Nov $10^{\prime} 11$, (appeal to British Govt.) Oct 19, Nov 18 '11, (appeal to U.S.) Dec 4 '11, (British Minister's note) Jan 23. Oct 10 '11 (Eckford murder) Dec 13 '12, (Indian regiment sent) Oct $3{ }^{\prime} 11$, (Mejliss crisis) Dec $12,18,24{ }^{\prime} 11$ Ap 27 '12, (oil) 411, (partition) Sep 30 '12, (railways) Aug 19, July 15, 27 '12, (Russian ultimatum) 1132, Nov 18 Dec 17 '11, July 17 '12, (Sir E. Grey's statement) Nov 30 '11, Feb 21'12, Pertab Singh, Sir, 619

Perth, 588

Perth Ámboy, N. J., 860, 864,724

Peru, Ind. 805

, S. Am., 1094, 1063, 103 Aug 19 '12, (Bolivian treaty) 1070, (Brazilian tresty) 1071, (Chilean treaty) 1065, 1075, Noy 11 '12, (Colombian relations) 1077, 1078, Jan 18 '11, (Feuador treaty) 1065, 1083, Jan 4 '11. (Putumavo atrocities) 1066, July 13, 19, Sep 13 12. (strike riots) Ap 16 '12. (students' Congress) July 20 '12

Pervinquiere, M. 1049

Peshawar, 621

Petaluma, Cal., 777, (eggfarms) 423

Peter (of Servia), 1026. 1027, Nov 23'12, (Paris visit) Nov 16 '11, (Rusaisn visit) Sep 2 ' 11

Peterborough, Can., 665

-, Eng., 507
Petersburg, Alsk. 938

- Va, 921, 922, 724

Peterson, J. B., 808

Petit, H., 116

Petkoff, A. Aug 16 '11

Peto, B. E., M.P., 488

Petre, E., Dec 24'12

Petrie, W. M. Flinders, 260

Petrol, 399, 408

engine, 354

Petroleum, 409, (German Govt. scheme) 1022

Peterson, J. B., 808

Petros, Tenn., 911

Petrovics, Lieut, Nov 5 ' 12

Petsofa figurines, 270

Pettersen, Prof., 112

Pettigrew, R. F, 908

Pewee Valley, Ky., 817

Peyton, W. Va., 930

Pheasant, 469

heidias, 275

Phelps-Stokes, Caroline, 873

- Fund, 873, 796, 923

Phenacodonts, 135

Phenol phthalein, 128

Philadelphia, Pa., 896, 897. 724, (blind) 303, (fire) Feb 4 '12, (intercollegiate games) 474, (miners' agreement signed) May 20 ' 12 , (navigation congress) May 23' 12, (Rapid Transit Co.) 900

Philae, 263

Philippine Is. '947, 636, 104, (Friars' Lands) 950, May 22 '12, (legislature) Feb 2, 7 '12, (typhoon) Oct 16 '12, (University) 949 , (volcano eruption) Jan 30 '11

Philippopolis, 1034, 1035

Phillimore, G. G., 334

Phillips, D. G., 199, 761,

- Stephen, 231

Phillipsburg, N. J, 860

Phillips Co., Kan., 813

Phillpotts, Eden, 228

Philology, 162

Philosophy, 287-295

Philp, R., 698

Phlebotomus fever, 171

Phlox, herbaceous, 428

Phocis, 277

Phoenix, Ariz., 768, 769, 771

Pholidota, 135

Phormium fiax, 444

Photography, 337, 119

Photophone, 119

Photosynthesis, 144

Phylakopi Is., 271

Phylogeny, 134

Physical anthropology, 147

- chemistry, 125

- science, 114-120

Piacenza, Dr. 466

Piano d'Orte, 412

Picasso, P., 242

ichon, 8. J. M. Jan 15 '11. Dec 23 '11

Pickering, W. H., 565

Pickersgill, Sir John, 649

Pickthall, Marjory, 198

Pickwick, 233

Pienma, 978

Pierce, G. W. 367

- Rev. W 319

- Fordyce Oil Association. Tex. 736

Pierre, S. D., 906

Pierson, A. T.. 761

Pietermaritzburg, 703, 705

Piet Relief, 705

Pigeon shooting, 469

Pihahiroth, 262

Pike Co., Ark., $77^{2}$

Piles, S. H., 927

Pilkington, T., 463, June 20

Pilley's Island, 679

Pilobolus, 143

Pilotage, Compulsory, 350 Mar 24'11

Pilots, aeroplane, 344

Pilsen, 956

Piltdown, 137

Pina del Rio, 1081

Pinchot, G., 737, 940

Pine Bluff, Ark., 771, 772

- Creek, 680,685

- Knot, Ky., 816

Pinellas Co., Fla, 793

Pinero, Sir A. 230, Feb 17 12

Pintsch lights, 407

Piqua, O., 883

Piraeus, 1034

Piranesi, 257

Pirot, 1037 
Pöch, Dr., 153

Podgoritza, 28

Podmore, Frank, 538

Podocarpoids, 145

Poduyevo, Oct 20 '12

Poë, Admiral Sir E., 578

Poe, Edgar Allan, 828

Poel, W, 229

Poetic8, 220

Poetsch process, 381

Pognon, 266

Poincaré, J. Henri, 98, 368, 1004

-, Raymond, 999, 1001 1002, 1003, 6, 8, 9, Jan 13 '12, (candidature for presidency) Dec 26 '12, (gunboats seized by Italians) $\operatorname{Jan} 22$ '12, (on Balkan War) Oot 4, 26 , Dec 5, 21 '12, (on European concert) Nov 13 '12, (on home politics) July 20 '12, (on political situation) Ap 15 '12, (reply toM. Clémenceau) July 25, '12, (Russiar mission) Aug 5, 11, 16 '12, (President) 1003

Poindexter, M., 927, Dec 5 '11

Point Tupper, N. S., July 12 ' 12

Poison, 326, 143

Poklewski, M., 1118

Pokrovsky, Prof., 219

Pola, 956

Poland, 1125, 1015

Polar exploration, 99

Pole star, 95

Police (U.K.), 586

Polio-myelitis, 172, Aug 16 '12

Polish College, Pa., 898

Pollard, A. W., 194

Pollination, 430

Polo, 466, 474

Polson, Mont., 850

"Poltaver," July 10 '11

Polymerisation, 409

Polynesian language, 162

Polypeptides, 123

Pomairols, C. de, 204

Pomare, Dr., 702

Pomerene, Atlee, 887

Pomona, Cal., 774, 776, 777

Pompeii, 1048

Pompili, Cardinal, 313

Ponape, 1013

Ponce, P. R., 950, 951

Ponsonby, A., M.P., 487

Pont-de-Gaurne, 157

Pontiac, Mich., 836, 837

Ponting, H. G., 99

Pontoppidan, H., 213

Poole, R. Lane, 191

Poona, 615, 621, Ap 8 '11

Poor relief, 586

Pope, Hugh, 466

- Sir Joseph, 675

Poplar, 578

- Bluff, Mo., 846

Popovich, M., 9

Popper, Dr. 173

Porcelain fillings, 181

Porifera, 131

Porjus, 1141

Porras, Belisario, 1092

-, M. F., 1095

Porritt, E., 197

Portadown, 595

Portage, Wis., 931, 935

Port Arthur Sep 12 '11

- Arthur, Tex., 724

- Augusta, 685, 681

- au-Prince, 1086

- Authorities, National Assoc. of U.S., Dee 10'12 - Bell, 645
Port Bolivar, Tex., 913

- Churchill, 101

- Darwin, 685, 680

- Dickson, 631

- Edward, 638

- Elizabeth, 703, 704

Porter, Dr. Ánnie, 430, 130 - James Davis, 911

- Sydney, 200

Port Herald, 646, 1125

- Huron, Mich., 723

Portier process, 381

Portland, Jam, 659

-, Me., 821, 822, 723

, Ore., 891, 892, 894, 895. 724

Port Louis, Mauritius, 646 - Nelson, Can., 663, 101

Port of London Authority, 528, Jan 27 ' 11, May 30 '12, (restrictions on lightermen) June 21 '12, (vote of confidence) July 11 ' 12

- of Spain, Trin., 661

Porto Novo, Dah, 651

Porto-Riche, G. de, 233

Porto Rico, 950, (university) 952

Port Royin, Jam 659

Portsmouth, Eng., 560, 579,587

一, N. H., 857, 724

一, O., 882

-, Va., 921, 922, 724

Port Stanley, Falkland Is. 652

- Sudan, 991

- Swettenham, 630

- Talbot, 566

- Townsend, Wash., 724

Portugal, 1119-1125, Dec 15 '12, (anti-republican rising) Sep 30 , Oct 6,19 '11, (Candos rioting) Nov 7 '12, (Chagas ministry) Sep 2 '11, (church dignitaries expelled) Dec 29 '11, (conspirators arrested) July 16 , Oct 3,25 ' 12 (elections) May 29'11, (exile decree sanctioned) June 19 '11, (Parliament opened) Nov 12 '12, (railway strike) Jan 11, 14 '11, (Republic recognized by France) Aug 25 '11, (by U.S.) June 19'11, (Royalist rising) June 29, July $7,12,14$ ' 12 , (sale of Queen's jewels) Aug 1 12, (Valle de Torno riot ing) Nov 7 '12, (Vasconcellos ministry) Nov 11 '11

Portuguese East Africa, 1125

Portuguese Literature, 216

Posen, 1009

Poss, mt., Costa Rica, 1080 Poster, 256

Post-impressionism, 240, $244,246,229$

Postnikoff, Capt., Sep 8 '11

Post Office, (U.K.) 576, 531,533 , (U.S.) 739

- Saving Banks, Sep 16 '11

Poston, W, F, 911

Potash Bill, 1016

Potato, 417, 562, 144, (disease in Ireland). July 24 '12, (Cyprus) 641, (U.S.) 428,717

Potential effect, 120

Potentiometer, 358

Pothier, A. J., 903

Potter, Louis M., 761

Pottery, 277, 276, 278
Pouget, Emile, 21

Poughkeepsie, N. Y., 868, 473, Ap $28^{\prime} 12$

Poulsen, E., 987

一, F., 278

- V., 368, 84

- arc generator, 367

Poultrain, Lt., Oet 31 '12

Poultry, 422

"Pourquoi Pas?" 99

Powell, E. W., 468

Poynting, J. H., 115

Pozharevats, 1037

Pragmatism, 287, 290

Prague, 956, 962, 957, (Slav festival) June 30 ' 12 , (university) 856, 960

Prahova, 1036

Prandtl, Dr., 340

Pratt, Kan., 813

-, C. H., 832

Prayer, Book of Common, 307

Predmost, Moravia, 157

Preference, Imperial, 482 , 518, (Australia) 693, (New Zealand) 699

Preisigke, 223

Premerstein, Dr. A., 279

Prendergast, Archbp. E. F. May 27'11

-, William A., 875

Prerogative, Royal, 481, 493

Presbyterianism, 317, 594, Oct 4 '12, (U.S.) 732, 734

Preseott, Ariz. 768

Presque Isle, Me., 822

Pressburg, 957

Press Union, Empire, June 17 '11

Preston, J. H., 827

Preston, Eng., 560

Prestrud, Lieut., 100

Preto, Visconde de Ouro, 1073

Pretoria, 703, 705

- Pietersburg railway, 705

Pretyman, E. G., M.P., 488

Preuss, K. T., 161

Prevention of Crimes Act, 330,601 of Seditious Meetings

Act, India, 610

Preveza, 34, Sep 30 '11, Nov 3 ' 12

Prevost (airman), Dec 3 '11

Prezzotini, G., 209

Pribilof Is., Alsk., 938, 431

Price, Gen. S., memorial, 847

Prier, P., Ap 12 '11

Priestley, R, E. 99

Prieto, Garcia, 1138, 1139

Primaries, U.S. 744: direct (Ala.) 767, (III.) 801, (La.) 819, (Me.) 823, (Mass:) 830, (Minn.) 840, (N. Y.) 871 , (N. D.) 880 , (O.) 884 , (S. D.) 907 ; presidential preference (III.) 801, (Md.) 825, (Mass.) 830, (Mich.) 837, (Neb.) 852, (N. J.) 861, (Wis.) 932

Primates, 135

Primrose, Hon. Neil, M.P., 487

Primula kewensis, 142

Prince Edward Island, 663, 665,675

"Prince Palatine," 464 Sep 13 '11, June 20 '12

Princeteau (airman), June 18 '11

Princeton University, N. J. 863

Theological Seminary, N. J., 863

Prince William Sound, Alsk., 939

Pringsheim, E. 117

Printing, 302, Feb 1, Mar 2 '11

Prinz, Hermann, 180

Prishtina, 32, July 20 ' 12 , Oct 22 '12

Prisrend, 7, 1151, Oct 31 '12

Private Bill Legislation Act 593

Prize, 56

- Court, International, 56

Probation system, 331

Proboscidea, 135

Probyn, Sir Leslie, 659, 649

Process Work, 254

Prochaska, Herr, 7, Nov 20 12, Dec 17 ' 12

Proctor Law (Ind.), 807 Professional Schools in U. S., 730

Profit sharing, 330 
Pulley, C. T., 582

- Sir Joseph, 582

Punjab, 603, 607, 621

Pupin, M. I., 365

Purcell, W. E., 882

Purcell, Okla., 890

Pure Food \& Drugg Act (U.S.) 738, Jan 17,12

Purple Mountain, China, Dec 1'11

Put-in-Bay, O., 886

Putnam, G. Haven 201

-, George Palmer, 201

Putnik, Gen., 28

Pütterism, 138

Putumayo, 1096, 1066, July 13 , Sep 13 ' 12 , (enquiry) Oet 22, Nov 6 , 12 (missions to) 322 , (Papal Encyclical) Aug 8 ' 12

Pygmy race, 151, 1040

Pyle, Howard, 751

Pylos, 272

Pymatuning, Pa., 899

Quanta of Energy, 115

Quantavis diligentia, 315

Quartermaine, L., 239

Quebec, Can.; 663, 665, 198, June 29 ' 12

- Province, Can., 663, 665. 675, May 16 '12

Queen Bess, La., 818

Queen Mary's Psalter, 226

Queen Mary's Hostel, London, 585

- Maud mts., 100

Queensland, 698

Queiroz, E. de, 216

Quénisset, M., Sep 24 '11

Querido, I. 210

Quibell, J. E., 261

Quicke, E. O., 471

Quicunque Vult, 307

Quilimane, 1125

Quiller-Couch, Sir A., 584, 188

Quilter, Sir C., 544

Quimby, Harriet, Ap 16 , July 1 '12

Quincy, Ill., 800, 801

$\rightarrow$ Mass. 828

Quinn, R., 196

Quintana, Pres., 1066

Quintero, J. A., 216

Q. S. A., 216

Quirola, 1084

Quo Vadis, Nov 13 '11

Raab, 567

Raabe, W. 207

Rabat-Sallí, 1108

Rabaul, 1013

Racconigi, 1049

Racine, Wis, 931

Racquets, 467

Radau, J. C. R., 1004

Radiation, 110, 115

Radioactivity, 119, 108

Radionoff, 218

Radiotelegraph Act, U. B., $\times 4$

Rarlistelegraphy, 83, 307, 110

Radium, 119, 567, 956 Institute, Aug 14 '11

Raeford, N.C., 878

Ragazzoni, L., Sep 25 '12

IRagland, Ala., 767

Rahamima, 651

Rahim Khan 1113

Rahmi Bey, 1154

Rahway, N. J., 863

Raifteisen banks, 726

Railophone, 36!), Av 20 '11 Railway, Commission
(I.K.), 523, Oct 20, Noy 19 '11

- Companies Association (London), Dec 1, 11 '11

- Electrification, 361
Railway lamps, 407

Railwaymen's Unions, 523, Nov $4 \cdot 11$

Railways, (new construction) 73, (U.K.) 574, (oil fuel) 410, (French) 994, 998, (Scotch) 592, (U.S.) 736; see also under countries and states

Railway strike (U.K.), 522

Raitt, W., 444

Rajputana, 622

Raleigh, Sir W., 190

Raleigh, N. C., 877,878

Ralston, S. M., 808

Ramnad, 620

Rampart, Alsk., 938

Rampur, 622

- Nawab of, Feb 9 '11

Ramsay, Sir W., 409, 121, 119, Aug 30 ' 11

Ramsbottom, A. E. W., 708

Ramsey, W. F., 915

Rand, 704

Randall-MacIver, Dr., 262

Randegger, A., 544

Randolph Center, Vt., 920

Randlestown, 417

Ranelagh, 467

Rangihiroa, Te, 701

Rangcon, 605, 607, 622

Ranke, J., 262

Rannatum, 258

Ransdell, J. E., 821

Ransford, V. S. 457

Ransome, A., 190

Rantidi, 278

Rapid City, S. Dak., 908

Rapisardi, Mario, 1053

Rashdall, Hastings, 287

Rashka, 1038

Ras Tessama, 953

Rat infection, 172

Rateau turbine, 347

Raton, N. M., 865

Rattray, 159

Ravel, 238

Ravenseroft, Gladys, 462

Rawling, G. C., 102

Rawlins, Wyo., 935

Rawson, Sir Harry, 538

Ray, E., 462

Rayleigh, Baron, 340, 116 , 368

Rayner, I, 827

Razoomnik, Ivan, 219

Rea, Russell, 642

- Samuel, Noy 13 '12

Readersburg, Mont, Jan 18 ' 11

Reading, Eng. 560, 579, $583,586,309$

-, $\mathrm{Pa}, 896,897$

- Cosl case, Dec 16 '12

Realism, 290

Reapportionment Bill (U) S.), Ap 27, Aug 3, 8'11

Resson, rule of, 736

Rebell, H., 202

Rebello, Gen. Brito, 217

Recall in U.S.; of officials, 746, 747, (Ariz.) 769) (Ark.) 773, (Cal.) 776, 777, (Col.) 783, (Fla.) 793, (Ida.) 708, (La. 819, (Me.) 823, (Mass.) 831, (Miss.) 844, (Mont.) 850 , (N. D.) 880 , (Tex.) 914. (W ash.) 920,927. (Wis.) 932, (Wyo.) 937 of decisions (Col.) 783, of legislation (Col.) 783, (N. M.) 860

Reciprocity Agreement, $490,502,668-670$, (Balfour's speeeh) Mar 8'11, (Buard of Trade's attitude) Jan 31 '11, (Borden's attack) May 6 '11, (debate in House of | Remsen, Ira, 826

Lords) May 18 '11, Remster Judge, 806

(Demoeratic Party on) Ren, Nakashoji, 1061

Feb 7, Ap 12 '11, (Field- Renard, J., 1003

ing's statement) Feb 16 Renfrewshire, 588

'11. (Laurier's speech) Renkin, M. 969

Sep 19 '11, (Lord Mor- Reno, Nev., 854, 855, 856

ley's reply) Mar 6 '11, Renton, A. W , 334

(Roosevelt's defence) Repertory theatre, 228

Feb 11 '11. (Root's Repplier, Agnes, 199 amendment). June 8 '11, Reptiles, 134

(Taft's defence) Feb 11,

June 1, July 26 '11

Red Crag, 150, 156

Redding, Cal., July 1 '11

-, Conn., Feb $18^{\prime} 11$

Redifield, S. Dak., 906

Redfield, W. C., 750

Redford, G. A., 228, 324, Dec 21 '11

Red Lake, Minn., Feb 18 '11

Redlands, Cal., 774, 776

Red Lodge, Mont., 849

Redmond, John, M.P., 487. $490,506,511,513,515$, 597, (on Home Rule) Sep 15, Oct 9, 10, 22 '11, Nov 2 '11, (Parnell monument unveiled) Oct 1 '11, (on Welsh disestablishment) Ap 21 '11

Redonda, W. I., 65

Redondo, Cal., 774

Redoubt, Alsk., June 13 '12

Red Sea, 24

- Wing, Minn., 839

Reeb (airman), Dee 3 '11

Reece, T., 453

Reed, Albert \& Co., 679

一, J. A., 848

-, Myrtle, 762

-, Mrs. Simeon G., 894

- College, Ore, 894

Referendum, (U.K,) 483, $490,492,493,518,519$, (U.S.) 746, 747: and see Initiative

Reformatory system, 330

Refractive power, 125

Regal (motorist), 465

Regener, E., 119

Regina, 663, July 1 '12

Regnard, P., 105

Regnier, H. de, 201, Jan 18 12

Reichenberg, 956

Reichstag, 1020

Reid, A. E. H., 103

- C. A., 103

Miss E, 458

- Sir George, 687

- John D., 668

Whitelaw, 751, Nov 1 Mar 29 '11, Dec 15, 20 '12

Reijiro, Wakatsuki, 1061

Reimer, A. E., 749, 742

Rein, Signaun, 214

"Reina Victoria," 346

Reindeer in Alasks, 938

Reinhardt, Max, 240, 229 , Deo 23 '11, Jan 15, Nov $8: 12$

Reinhold, Baron von, 964

Reisner, Dr., 159, 260

Reitman, Dr. B., 781

Relspsing fever, 173

Relativity, 114

Religion, 306-323, (ancient 223, (psychology of) 160

Religious Tract Society, 323

Relvas, 1121

Rembrandt, 243

- intaglio process, 255

Remedioz, Dr. Mendes dos, 217

Party (U.S) $735,747,748$, June $7 \cdot 12$ (National convention) June 18 '12, (Roosevelt eandidacy) June 13 '12, (Taft condidacy) June 14 '12, (conference of governors) Dec 7 '12

Reshid Pasha, 9, 10

Resht, 1116

Resins, 396

Resta, D., 470

Restan, 268

Retort, vertical, 402

Retting, 439

Reuter, Gabriele, 207

Reverter, Navarro, 1136

Rewa, 622

Rex, Ga, 796

Rexer gun, 373

Reybura, J. E., 899

Reyes, Bernardo, 1088 Nov 18 '11 
Ridge, W. Pett, 189

Ridgefield Park, N. J., 863

Ridgeland, S. C., 905

Ridgeway, W., 221

Ridgewood, N. J., 863

Ridgway, F. E., Sep 7 '1

Ridley, Viscount, 489

Ries, $\mathbf{H}, 404$ :

Rifaat Paska, 1027, Jan 21 '11

Riff country, 1107

Rifle, 373, (shooting) 469 , July 22 ' 11 , July 12,18 '12: see also Bisley

Riga, 1126

Rigg's disease, 180

Righi, A., 117

"Right to work" Bill, 491

Riglos, F, M. Y., 1096

Riley, J. W., 200, July 12 '11

Rilke, R. M., 206

Rima, 611

Rinderpest, 1055, 634

Ringdal, P. M., 842

Rio, Alcalde del, 156

Rio de Janeiro, 1072, 1073, 1074, Aug 1 '12

Rio Piedrasz, P. R., 950, 951

Rio Tinto shares, 78

Riouw, Sultan of, 1040

Riquelme, Dr., 1093

Risley, Sir H. H., 541

Rissik, J., 708

Ritchiv, Sir George, Aug 10 ' 12

-, Sir J. T., Bart., 551

-, M. J. C., 465

- Sir R. T. 547

Ritson, Capt. R. G: 467

Ritt, Councillor, 860

Ritter, C., 221

Ritz Carlton Hotel (N. Y. City), 876

"Rivadavia," 1068

Rivas, Manuel, 1076

- M. L. 215

River and Harbour Appropriation Bill, U. S., Jan 31'11, May 9' 12

-Genesee, N: Y., 724

Rivers, W. H. R., 159

Rivers and Harbours congress, U. S., Dec 4'12

Riverside, Cal., 774

Riviere, L. A. T., 1005

Rixdorf, 1009

Rizal, Jose, memorial, 948

Riza Pasha, Hassan, 29

Road Board (U.K.) 575,

Rosnoke, Va., 921, 922

Robbers, Herman, 210

Roberts, Earl, Ap 3, Dec 15 '11, Jan 2, Oct 22 '12

一, E. A., 692

-, E E., 856

$\rightarrow$ E. S., 552

-, Rhys, 220

-, R. R, 438

Robertson, J. Forbes, 232

- J. M., M.P., 487

Robie, Frederick, 824

Robinson, Brooke, 582

-, B. L., 132

-Gen. C. W., 197

-E. A., 200

- Geofirey, 192

-, Joseph Taylor, 773

-, L.; 228

-Col. S., 171

Roblin, Sir R. P., 67.5

Robson, Lord, Aug 8'12

Rnca, Gen., 1069, 1073

Rochdale, 560

Roche, W. J., 668

Rochelle, Ill., 802

Rochester, (Ëng) 568, 583 , 579
Rochester, Minn., 839

-, N. H., 857

, N. Y., 868, 869, Sep 3,

12

Rochez, Dr., 172

öchling, H., 365

Rock Creek drive, D. C., 791

Rockefeller, J. D., Dec 4

- Institute, 165

Rockford, Ill., 800, 801

Rock gardening, 426

Rockhill, W. W., Ap 24 '11

Rock Hill, S. C., 904

- Island Ill., 800, 802

Rockland, Me., 822

Rockport, Me., 822

-, Miss., 845

Rock Springs, Wyo., 935

Rockwell, Lieut. L., Sep 28 '12

Rocky Mount, N. C. 877 - mts., 664

Rodenbaugh, T. F., 762

Rodentia, 135

Rodgers, W.C., 773, 135

Rodin, A., 244, 245

Rodosto, 1151, Nov 10, 22 12

Rodriguez, W. E., 803

Rodriguez, Ind. O., 646

Rodzianko, M. V., 1127, Nov 28 '12

Roessler, Karl, 231

Rogers, B. B., 220

-' Rev. J. Guinness, 544

$-R_{.}, 668,675$

$\rightarrow$ Mrs. W. B., 832

Rogstad, Anna, 90, 1111

Rojas, Libertio, 1093, Jan 15, Feb 27' 12

"Rolandseck," 348

Rolland, R., 203

Roller skating, 470

Rolling-mill, 391

Rolls (statue), 882

Rolph, J., 780

Romagna, 1050

Roman Catholic Church, 311-317, Oct 29, Nov 30 '11, (Bolivia) 1070, (Scotland) 594, (Spain 1138. (Switzerland) 1147 (U.S.) 733 , Dec 2 ' 12

Roman Foss Way, Lincs., 576

Romanones, Count, Nov 14, Dec 31 ' 12

Rome, Ga., 794

- It. 1042, 1048, 1049 1050,243

Romeo \& Juliet, 229

Ronald, Landon, 238

Ronaldshay, Earl of, 488, July 30 ' 12

Ronzevalle, Père, 268

Roodepoort-Maraisburg, 703

Rooke, Irene, 228

Rookwood pottery, 254

Roosevelt, Theodore, 747 , $748,750,740$, Jan $30 ' 12$ (arrival in Chicago) June 15 '12, (campaign funds investigation) Oct 4 '12 (Third Party Convention) Aug 5 '12

Root, E., 748, 934, June 8 '11'

Rope manufacture, 440

Roraback, A., 787

Rordam, V., 213

Rosa, J. M., 1069

Roscoe, J., 161

Roscommon 596

Rose, J. Holland, 191

Rosebery, Earl of, 488, 191 June 19 '11, July 1 '12, (on Dickens) Feb 24 '11 (on army efficiency) Dec 2 '12, (land taxation) Sep 28 '12, (libraries) Oct 16 '11, (Scottish industries) Mar 13'11, (Thackeray) June 30 '11, (universities) Sep $15^{\prime} 11$

Roseburg, Oreg., 891

Rosedale, Kan. 812

Rose law (Ohio), 885

Rosenberg, Prof, 142

Rosendal, H., 214

Rosenhain, W., 394

Rosenkranz, Baron P. A. V., 213

Rosenthal, Herman, 876 July 16, Sep 14, Oet 7, 24, Nov 19 ' 12

Rosewater, V., June 6 ' 12

Rosher, J. B., 468

Ross, Sir Chas. D., 575

- Sir George, Nov 23 '12

一, H C., 167

一, H. V. L., 452

一, W., 678

Ross and Cromarty, 588, June 14 ' 11

Ross rifle, 469

Ross Soa, 100

Rostand, E., 205

Rostock, 1009

Rostowzew, 223

Rostrapo, Carlos E., 1078

Roswell, N. M., 865

Rosyth, 591, 593, 594, 344

Rotation of crops, 415

Rotatory power, 125

Rotch, A. L., 762, 111

Rothamsted, 412

Rotherham, Baron, 586

Rotherham, Yorks., 560 , 565

Rothschild, Baron Albert von, 966

Rotterdam, $103 y$

Roty, L, O., 1004

Rouen, Fr., 882

Rouffaer expedition, 1041

Roundup Mont. 850

Rousseau, Blanche, 212

- , J. J., June 28 '12

Roussel collection, Mar 25 '12

Routhier, Sir A. B., 198

Routledge, W. S. and K. 162

Rouvier, Maurice, 1003

Rowing, 467, 473, July 19 '12

Rowland, J., Dec 18 '11

Rowlatt, S. A. T., Aug 8 '12

Roxburgh, T. L., 655

Roxburgh, Scot., 588

Roy, Camille, 198

Royal Academy, 243, May 6. July 27, Aug 2'12

- Academy of Music, June 22 ' 12

- Agricultural Show, July 1 '12

- Aircraft Factory, 342 344

- College of Science, Dublin, 415

- Flying Corps, 344, 578, 45

- Geographical Society, 105

- Mail Steam Packet Co., 654

- Society of Canada, 197

- Society, July $15^{\prime} 12$ - Society of Medicine, May 21, July 1' 12

Ruanda country, 103

Rubber, 1168, 77, 124,

(Borneo cultivation) 628,

(Brazil) 1071, (Ceylon)

624, (Hawaii) 941, (Jamaica) 660, (Johore)

632, (Liberia) 1103

(Malay States) 629

(Straits Settlements) 625

- offset machine, 255

Rubel, 392

Rubens, H., 118

Rubensohn, Dr., 265

Rubinstein (chess), 454

Ruchdi, Hussein Pasha, 989

Ruchonnet (airman), Jan 12 ' 12

Rudolstadt, 1009

Ruer, 394

Ruff, 394

Ruffer, A., 168

Rügen, July 29 '12

Ruhmer, E., 368

Ruislip, 580

Ruiz, J. M. M, 216

Rumania, 1035-1037, 1028

(Bukarest rioting) Jan 21 
Saba Pasha, Sir J., 988, 989 Sabatier, Prof., Nov 12 '12 Sabbe, Maurice, 212

Sabillasville, Md., 827

Sabine Neches canal, 913

Sable, Russian, 433

Sabotage, 21, 998, 741.

Sabugosa, Count de, 217

Sacchi, E., 1050

Sachi, 605

Sachs, Frank, 471

Saco, Me., 822

- river, Me., 822

Sacramento, Cal, 774, 776 777

- river, Cal., 779

Sadler, E., 245

—, Sir J. Hayes, 644

-, M. E., 585

Safety lamp, 384

Sage, Mrs. Russell, 818 , (Sage foundation) 303

Saghalien I., 1054, 1062

Sag Harbor, N. Y, 725

Saginaw, Mich., 836, 838

Saglio, Edmond, 1004

Sah, Sir Kirti, 618

Sahara railway, 1006

Sahura, 261

Said $\mathrm{H}_{\mathrm{alim}}$, Prince, 1160, sep 11 ' 12 Mohammed. 988

Said Pasha (Turkey), 1159,

1160,1161 , Oct 4, 19 '11

Sain-noyau, 10

St. Albans, Vt., 918

St. Aldwyn, Viscount, 489

St. Andrews, 282, 593, Sep 13 ' 11

St. Audries, Barnn, 488

St. Augustine, Fla., 791, 793,723

- Cyr, 340

- Boniface, 665

- Brélade's Bay (fossil), 147

- Catherine's, 665

- Charles, Mo., 846

- Cloud, Minn., 839, 843

- Croix, 983

St. Davids, Baron, 488, 575 , July $27{ }^{\prime} 11$

St. Elmo, Tenn., 910

St. Francis Xavier Coll. N. Y., 873

- Gall, 1144, 1145

St. Gaudens, A., 246, Oct 1 11

St. Helena, 652

- Heleng, 560

- Jan, 983

St. John, Florence, 555

- John, Can., 663, 665, 666

- John's, Nfld., 678, 679

- Johns, Ore., 891

- Johnsbury, Vt., 918, 921

- Johns river, Fla., 792

- Joseph, Mich., 838

- Joseph, Mo., 846, 847, 848,724

St. Just, Gen., 1086

St. Kitts, 654

Lawrence Co., N. Y. Sis

- Iawrence University, N. Y., 868

- Jeger, 463, Sep 13 '11. Sep 11 '12

- Louis, Mo., 846, 847, 724, June 24 ' 11

- Lucia, 657

- Mary, Jamaica, 659

- Mary'A, Ga., 723

- Mary's, 0. 887

- Mary's Co., Md., 827

- Mary's river, Mich.. 836

- Michael, Alsk., 938

- Paul, Minn., 839, 840,
Ap 30 '12, (commission government) 843 , (trade) 723,840

St. Paul's bridge, 582

- Paul's Cathedral, Feb 6 '12

- Petersburg, 1125. (treaty, 1881) Feb 16, Mar 4'11, Sep 6'12

Thomas, W. Af., 1125

- Thomas, W. I., 983, 987 - Vincent, 657

Saintsbury, George, 190

Saionji, Marquis K., 1061, Dec 4 ' 12

Saito, Baron M., 1061

Saiyid Hussin Bilgrami, 618

Sakjegeuzi, 267

Sakkara, Egy., 261, 264

Salamis, 1026

Salandri, Sig., 1050

Salar-ed-Dowleh, 1117, Oct 26, Sep 13 '12, (Kermanghah) June 1, Sept 20'12

Salar Jung, 612

Salchow, O., 470

Salem, Mass., 828, 829, 831, 832,723

-, N. J., 862

- O. 887

- Ore., 891, 892, 895

Salford, 560

Salimulla, Sir Khwaja, 617

Salina, Kan., 812

Saline river, Ark., 772

Salih Pasha, Gen, 9

Salisbury; 4th Marquess of 489,495

Salisbury, Md., 824, 826

-, N. C., 877

-, S. Af., 706

- Eng., 583

Salles, Dr. Campo, 1069 , 1073

Salmet (airman), Nov 29 '11, Mar 7 '12'

Salmon, Sir Nowell, 547

Salmon, 449

Salonika, 1151, (army corps) 1149, (Bulgarian entry) 30 , Nov 9 ' 12 , (Greek capture) 33, 34, (surrender) Nov 8 '12, (tumulus) 278

Salt gabelle, 976

- industry, 566, 719

Salting, George, 538

Salt Lake City, Utah, 915 , $916,918,725$

- river, Ariz., Mar 18 '11

Salustri, C. A., 208

Salvador, Amos, 1137

Salvador, C. Am., 1096, 1062, 1088, (debt payments) 1063, (President elected) Jan $10^{\prime} 11$

Salvargan, 175

Salvation Army, 16, 320 . 679, Aug 20 '12

Salzburg, 956

Samar, P. I. 950

Samaria, 265

Samarra, 250

Sambon, Dr. L. W., 170

Samoa, 1013

Samori, 1103

Samos, Nov 24, Aug 30 '12 (Cretans in) Sep 21 ' 12 , (Turkish troops) Oct 4 , Sep 22 ' 12

Sampson, R. A., 94

Samsonov, M. 120

Samsun, 1151

Samuel, Herbert, M.P. 487. Sep 28 '11, 82, (dramatic censorship) 228. (Home Rule) 516 Nov 19 ' 12
Samuel, Sir S. M., 74, Nov 22 , Dec 20 ' 12

Sanaa, 1149

San Angelo, Tex., 912

- Antonio, Tex., 912, 913

San Bernardino, Cal., 774, 776,777

Sandakan, 627, 628

Sanders, Jared Y., 820

Sand-fly, 171

Sandhal, G., 470

Sandhurst, 2nd Baron, 228, Feb 14 '12

San Diego, Cal., 774, 776, 780,724, Ap 8 ' 12,741

Sandpoint, Ida., 797

Sandstrom, Theodor, 1143, 112

Sandur, 622

Sandusky, O., 882, 724

Sandwith, Dr. F. M., 170

Sandy, Beds., 417

Sandy Hook, Dec 9 '12

Sandys, George, M.P., 488 -, Sir J. E., 224

San Fernando, W. I., 662

Sanford, Judge, 912

Sanford, Me., 822

San Francisco, Cal., 774, Jan 19 '11, (government) 777, (harbour) 776, (municipal elections) 780 , 776, (Panama Exposition) 410,943 , Feb 11 '11, (street railway) 780, (trade) 723,776

- Francisco Telegraph $\mathrm{Co}_{\text {. }}$ 84

Sanger, Lord George, 544, Nov 30 ' 11

-, Charles Robert, 762

San German, P. R., 950 San Giovanni de Medua 33,1027 , Nov 16 '12

San Giuliano, Marquis di, 1050, Dec 18 '12, 66

San Giuseppe di Cairo railway, 1046

Sangoni pass, 34

Sangster, Margaret E., 762 Sanitation, 325

San Jose, Cal., 774, 776

- Jose, Costa Rica, 1079

- Juan, P. R., 950, 951, 725

Sankhkara, 262

San Lorenzo, Peru, 104

- Luis Obispo, Cal., 776,

- Mateo, Cal., 777

- Rafael canyon, Utah, 916

Santa Barbara, Cal., 774, Oet 16 ' 11

- Clara, Cuba, 108

- Cruz, Cal. 774, 777

- Fe, N. M., 865, 866

- Fé Co., N. M., 867

- Monica Cal, 774

- Mura, 276

- Rita, N. M., 865

- Rosa de Viterbo, Colom. 1077

Santander, Colom., 1077

- Sp., 1137

Santiago, Chile, 1076

Santo Domingo, 1098 (Haitian relations) 1062 1085, (Presidency) Nov 19. Dec 2 '11, Dec 2 '12, (revolution) Sep 13 '12, (U.S. intervention) 1065, Dec 12, 19, Sep 24'12

Santolaya, F, M., 1096

S. Tomas University. Manila, 949

Santos, Braz., 1074

Sao Paulo, Braz., 1073, 1074

"Sao Paulo," 1072

Sapir, Dr., 161

Sapon, 442

Sappho, 220

Sapulpa, Okla., 888

Sapuntsakis, Gen., 28

Sara, India, 606

Saracho, J. M., Sep 23 '12

Saragossa, 1135

Sarasin, Fritz, 158

Sardar-i-Assad, 1113

Sardar Yakub Khan, 619

Sardinia, 1046

Sardis, 274

Sargent, John S., 249

Sargon I., 259

Sarita, Tex., 913

Sarjek mts. Swed. 1140

Sarmiente, Pres., 1068

"Sarnia," 347

Sarrato, M.P., 1138

Sarraut, Albert, 1007

Saskatchewan, 663, 665, July 12 ' 12

Sattar Khan, 1113

Saturation current, 120 
Sehneider gun, 367, 371

- Danglis gun, 372

Sehnitzler, Arthur, 207

Schoen, Baron v., 1017

Schofield, S. C. A., 452

Sehollaert, F., 967, June 8 '11

Schomburgk, Major, 1102

Schöneberg, 1009

Schönherr, K., 361

- Karl, 207

School hygiene, U. S., 730

Schoop process, 393

Schorlemer-Lieser.

v, 1017

Schōyen, Rolf Hjort, 214

Schrader, H., 279

Schrank, John, Ot 14, Noy 22 ' 12

Schreiner, P. W., 709

Schubart, W.. 225

Schuler, G. F. H., 197

Schultz, Max, Aug 18, Nov 3 ' 11

Schumacher process, 390

Schurman, Jacob G., Aug 16 ' 12

- W., 211

Schuster, A., 92

-, E., 328

Schütte-Lanz dirigible, 342

Schuyler, Montgomery, Jr., Dec 17 ' 12

Schuyler Mansion, Albany, 871

Schwaiger, Imre, July 6 '12

Schwalbe, C. G., 147

Schwartz, M., 1129

Schwarz, E. H. L, 109

Sehwarzburg-Rudolstadt, 1020

Schwarzschild, Karl, 96

Schwerin, 1009

Scioto Co., O., 887

- river, O., 883

Sciracco, 112

Sclavo's serum, 165

Scopas, 276

Scotland, 587-594, 557, 320 (George V's visit) July 17, 19 '11

- Church of, 594, 318, May 28, 30 ' 11, Ap 4 '12, (Prayerbook) 308

Scott, A. Mc., Aug 6 '12

-, Corporal Frank, Sep 28 12

一, Cyril, 238

一, D. H., 146

-, Gilbert, 582

- Sir J. E. A. Murray, 554

-, Hon. M. 462

-, Nathan B., 930

- Capt. R. Falcon, 99 100, Ap 1 '12, Jan 3 ' 12 , (Baffin Land expedition) Sep 17 '12

- W. 675

Scottish Education Act (1908), 593

Scott $v$. Scott, 334

"Scout," 48

Scranton, Pa., 896, 897, 900

Seruggs, W. L, , 762

Scudder, Janet, 250

Sculling, 468, May 1, July $8,29 \cdot 11$

Sculpture, 244, 245, 246, 249

Scunthorpe, 568

Scurvy, 166, 100

Scutari, 1151, (martial law) Sep 18 '12, (siege) 33 (Turkish troops) Ap 3 '11 Dec 16 '12

Seaforth, 573

Seager, R. B., 270

Seal, Fur, 431, 101

Searles lake, Cal., 775
Seattle, Wash., 924, 925, Servia, 1037, 1038, 1024, (recall) 927

Sea-urchin, 132

Sebele, 706

Secondary schools, U. S. 729

Second Choice Voting (Md.) 825, (Minn.) 840, 841, (N. D.) 880 , (Wash.) 926, (Wis.) 932

Secret Woman, The, 228

Sedalia, Mo, 846, 847

Seddon, F. H., Mar 4, 14 '12 Seditious Meetings Bill, (India), Mar $20^{\circ} 11$

Sedro-Woolley, Wash., 926 Seebohm, Dr. Frederic, 553 Seed Control Act (Can.) 674

Seeley, H. G., 134

Seely, Col. J.' E. B., M.P. 487, June 12, Dec 5 '12

Séguin, E., 295

Seibert, 385

Seidel, E., 742

Seidl, J., 236

Seillière art collection, Mar 9'11

"Selandia," 348, 356

Selangor, 629,630

Selati railway, 705

Selbie, Dr. W. B., 322

Selborne, 2nd Earl of, 489 . 492,495 , July 26,21 ' 11 , July 23 ' 12

Selby, 311

Selenico, 954

Selenium, 120, (photometer) 95,120

Selenka expedition, 148

Self-doffer machine, 443

Self-starter, 409

Selfridji, Oct 23' 12

Seligmann, C. G., 162

Selkirk Range, 103

Selling, Ben, 895

Selma, Ala. 765

Selves, J. G. C. de, 1000 , 1001,3 , Jan 9 ' 12

Semantan, 631

Semitic archaeology, 264, 259

Semple, E. M., 105

Senate, Chinese, 977

-, (Irish Home Rule Bill) $507,509,511,513$

Senators, U. S., $\mathbf{7 4 4}$, (list) 1175 , direet vote 744 Ap 13, June 12, July 5 '11, (Áriz.) 770, (Kan.) 813, (Ky.) 816, (Mass.) 830, (Mich.) 837, (Minn.) 840, (Mont.) 850, (Nev.) 855, (N. D.) 880 , (O. 884, (Ore.) 892 , (S. C.) 904, (Tenn.) 910, (Tex.) 913, (W. Va.) 929, (Wyo.) 936; and see Oregon plan Sendai, Jap., 1059 Seneca, Mo., 846 Seneferu, pyramid 261

Sennacherib, 259

Sennar, 991

Seoul Wiju railway, 1061

- Wonsau railway, 1062

Separation Law (Portugal) 1122

Sequoyah statue, 889

Serajevo, 958, 954, Feb 18 '12

Serapis, 274

Sergeyenko, P. A., 218

Sergi, Dr. Sergio, 154

Serna, Col de la, 1070

Sero-therapy, 178

Serrania Ronda mts., 157

Serrato, Nov 12 ' 12

Serum, 167

Servants of India, 609, 621
$1025,1027,1028,1030$ $1031,5,6,7,8$, (Austrian commercial treaty) 964, (Austro-Russian note) Oet 13. '12, (Bosnian question) 1024, 959, Feb 5 , Sep 9,12'12, ("Greater Servia") 961, (Great Powers' recommendation) 9 , (Macedonian autonomy) Oct 13 '12, (maritime aspirations) Nov 8, 9, Dec 20 '12, (military operations) 31 , 32. (parliament) Oct 5 '12, (Premier's death) July 1'12, (Sienitza massacre) Aug 24'12

Setterwall, C., 465

Settle, T., 402

-, Thomas, 879

Setzen, 10

Seurat, G., 241

Seva Sadan, 611, 621

Sevastopol, Aug 26 '12

Severini, 243

Seville, Lieut., Mar 13 '12

Seville, Sp., 1135, 1136

Seward, A. C., 146

-, Alsk., 938

Sex, 170, 142, 327

Seychelles, 647

Seymour, William V., 928

Seyyid Idris, 1157

Shabats, 1037

Shackleton, D. J., 87, Nov 28 ' 11

-, Sir E., 101

Shadwell Fish Market, 581

Shafroth, John F., 784

Shahsevens, July 17 '12

Shakespear, J., 162

Shakespeare" (recent research), 229

Shakespeare Ball, June 20 '11

Shallenberger, A. C., 854

Shalmanesser II., 266

Shamokin, Pa., 899

"'Shamrock," 472

Shanghai, 980, 981, 638, Nov 10 '11

Shan States, 616

Shantung, Mar 27 '12

Shantz, 141

Sharpe, Sir Alfred, 646

,- P., 440

Sharru-Kin, 259

Sha Tau Kok, Hongkong, 636

Shaw, G. Bernard, 230, 89

-, R. Norman, 546

-, W. N., 110

Shawia, 1108

Shawish, Sheikh Abdul Aziz, 988, Sep 3 '12

Shawnee, Okla., 888,889

Sheboygan, Wis., 931 488

Sheehan, William F., 874

Sheep breeding, 440

Sheepshanks, Bp. J. 548

Sheffield, Baron, 488, 304 Sheffield, Ala., 767

- Eng. 560, 579, 309. 568,585

Sheikh-ul-Islam, Nov 8'12 Shelbyville, Tenn., 912 Sheldon, Edward, 201

-, George R., Aug 20 '12

Shell (ordnance), 376

Shell fish, 569

Shelley's case, Rule in, 825

Shenandoah, $\mathrm{Pa}_{\mathrm{a}}, 896$

Sheng Hsuan-Huai, Oct 25 11
Shaft sinking, 381

Shee, Major Archer, M.P.

Sheng Kan-pao, $\operatorname{Jan} 6^{\prime} 11$

Shepard, Edward M. 874

Sheppard, Morris, 915

Sheppey, I. of, 344

Shepstone, A. J., 712

Sherbro tribe, 648

Sheridan, Wyo., 935, 937

Sherman, J. 8. 763, 748,

June 22, Oct $30^{\prime} 12$

- Lawrence $\mathbf{Y}$., 804

Sherman, Tex., 912, 913

Sherman Anti-trust Act 736, Dec 5 ' 11

Sherwell, A. J., M.P., 487

Sherwood, W. H., 762

Shetland I8., 588

Shevket Pasha, Mahmud, $1152,1154,1157,1159$ $1160,1161,1024$

Shevket Torgut Pasha, $1154,1157,1158,1160$ 1028,1030

Shields, Frederic, 191

$\longrightarrow$, H. J., 468 
Sifru, 1107

sifton, Clifford, 670

Sigatoka, 638

Signac, 241

Sikhs, 603

Sikkim, 622

Silistria, 1035

Silk, 1170, 444, 443, 567 . $972,1044,1055$

Silkworm, 131

Sillon, Le, 312

Silver, $1173,566,572$, curreney) 73

Silver City, N. Mex. 865

Silver fox, 433

Silver-on-glass, 120

Simiidae, 148

Simmons, F. McLendel, 879

-. P., Jan 19 '11

Simon, Gen. A. F. C., 1085

- Sir John, M.P., 487, 516

Simpson, G. C., 99

- L. T. B., 467

- process, 377

Sims, Charles, Ap 25 '12

- W. S. Jan 10 '11

Simulium, 170

Sinai $m t ., 102$

Sinclair, A., 228

Sindhia, Maharajah, 618

Singalona, P. I., 949

Singrpore, 625, 626, 1134

Singer, Paul, 1023, Feb 5

Singh, Sir Prabhu Narayan, 614

, Sir Sawai Jai, 613

Single tax, 513, (Mo.) 847, (Wash) 926

Sinha, Satyendra PrasanDa, 609

Sinjerli, 268

Sinkat, 991

Sinking Fund, 532, 534

Sinn Fein, 598

Sioux City, Ia., 809, 810, 723

- Falls, S. D., 906, 907

Sipabdar, 1113,1110

Sirenia, 135

Siret, 158

Sirmur, 622

Siroceo fan, 381

Sir Sandford mt., B. C., 103

Siskol machine, 381

Sistova, 103.

Sitka, Alsk., 938

Sivas, 1151

Six Powers loan, 976

Sjenica, 32

Skagway, Alsk., 938,

Skating, 469

Skeat, W. W., 546

Skeens river, 379

Ski-ing, 470

Ski-kjoring, 471

skillman, N. J, 963

Skinner, C A 468

Skiptchanik, Öt 11 '12

sikjoldborg, J., 213

skoulidis, 8, 9

Skrowhegan, Me., 822

skues, G., 449

Sladen, F. W. L., 431

Slatin, Sir R, von, 981

Sleeping sickness, 173, 120, 644

Sleigh, Dr. H. P., 172

Slizo, 595, 596

Slipher, E., 94

sliven, 1034, 1035

Siolev, H. C., 706

Sly, F. G., July 30 '12

Simall arms, 373, 374

simall colleres in U. 8., 730

small holdings, 415, 429, 589
Smallpox in Philippines, 948

Smart, George, 470

- W. Dec 27 '11

Smartt, Sir Thomas, 707, 711, Ap 19 ' 12

Smethwick, 560

Smichow, 956

Smiley, A. K., 763

Smith, Arthur, 280

- Capt. E. J. 16

—, Elliot, \15:3, 159

F. E., M.P., 488, 495 , 512, 519, (Boyne celebration) July 12 ' 12 , (Home Rule) Sep 20, 25, 30 '12, (Imperial Preference) Dec $20^{\prime} 12$, (tariff reform) Nov 8 '11, (Welsh church) 505

\section{- Gerrit, 763}

- Goldwin, 191

-, Mrs. Greenhough, 470

-, G. A., 235

- H. C., 851

- Herbert K., 787

-, Sir H. I.. 523

一, Hoke, 796, 797

-, Hugh, 65

—, James, Jr., 864

- John Bernhardt, 763

- Joseph F , 918

- Marcus Aurelius, 771

- M. Stainforth, 68, 103

- Paul, 763

- R., 454

-, Reginald, 157

- R. Le Blanc, 468

- W. A. 839,350

Smith law, Ala., 766

Smithfield, R. I., 903

Smith Sound, 679

Smoke Abatement, 397

Smoot, Reed, 918, Mar 29 '12

Smuts, General, 710, 712, Mar 1'11

Smyly, Sir P. C., 649

Smyrns, 1151

Smyth, Ethel, 238, 89

Smythe, C. J., 708

- Iionel, Nov 8 '11

Snead-Cox, J. G, 191

Snellen, P. C. T., 1042

Snowden, Philip, M.P., 487, 90 , Nov 5 ' 12

Snowflake, Ariz , 769

Snowy range, N. G., 102

Soares, Lt., July 9 ' 12

Sobat, 991

Sobhuza, 707

Social Democratic Party, Ap 14 '11

Socialism, 17-21, (U.K.) $490,520,521,522,523$, 529, (U. S.) 742, (Ark.) 774, (Cal.) 780, (Conn.) 787, (Fls.) 794, (III.) 804 (Kan.) 814, (Mich.) 838, (Minn.) 843, (Mont.) 851, (Nev.) 856, (N.Y.) 874, (().) 8.57, (Okla) 890, (Pa.) 899, (R. I 903, (Utah) 918, (Wash.) 927, (W is.) 935, (Austria) 963, 964, (France) 996, $997,998,999,1000,1002$ 1003, (Germany) 1014, 1018,1020

Social settlements, 321

Socrates, 221

Soda, carbonate of, 643

Sodertelje canal, 1141

Sofas tribe, 1103

Sofia, 1027, 1034, 1035

Soil cultivation, 418,429

Sokol Society, $\mathbf{4 4 7}$

Solnnum Daruinanum, 141

Soldene, Enily, 555
Solemn Covenant, 511, 512 Soley, J. R., 763

Solid Fuel, 395

Solf, W., 1019

Sollas, Prof., 156, 157

Sollum, 989

Solms, Count, 146

Solomon $\mathrm{I}_{8,}, 640,1012$

Soltau, 223

Solutrian Age, 157

Soma 1151

Somaliland; (British) 646, (Italian) 1049, (surveys)

$$
103
$$

Somers, Mont., 850

Somerset, Duke of, 495

Somersetshire, $559, \quad 565$, 579, (by-elections) 486, July 21 , Nov $21^{\prime} 11$

Somersworth, N. H., 857

Somervell, A. 238

Somerville, Mass, 828,829

Somme river, 156

Sommerfeld, A., 368

Sonde 148

Sonnenschein, E. A., 222

Sonnino, Baron, 1049

Sophie Newcomb Coll., 253

Sophocles, 219, 220, 224

Sopwith, T. O. M., June 8 12

- biplane, 344

Sorel, Georges, 19

Borolla, J., 249

Sotheby's, June 5, 26 '12

Sou du Soldat, 1002

Sougenet, L., 212

Soulet-ed-Dowleh, 1113

Souter, W. F \& Co. 439

South Africa, 702-712 (Anglican Church) 310 , (anniversary of Union) May 30 '11, (Botha cabinet) Dec 20'12, (Defence Bill published) Nov 30 '11, (mail contract) Sep 6 '12, (ministerial crisis) June 26 '12, (Party Congresses) Noy 20'12, (trades \& industries report) Feb 26 '12

Southampton, $560,573,585$

South and Central America, 1062-1102

South Australia, 698, Aug 8 , Sept 13'11

- Bend Ind., 805, 806

- Bethlehem, $\mathbf{P a}_{\text {a. }} 897$

- Boston, 829, 252

- Carolina, 903

- Dakota, 906

Southend, 556, 561

Southern College, La, 820

- Pacific R.R., Dec 2, 20 '12

- Rhodesian League, 705

South Georgia, Falkland Is., 652

- Kingston, R. I., 901

- Manchurian Railwsy, 1057,1060

- Milwaukee, Wis., 931

- Omaha, Neb., 852

- Pole, 100

Southport, 560

South Shields, 560, 573

Southwest Pass, La., 818

Sowerby, Miss K. G., 227. Mar 18 ' 12

Soya bean, 414

Spask, P. 212

Spahn, P., 1020

Spain, 1135-1139, (Cabinet resignation) Jan 14 , Mar 11 12, (centenary of Cortes of Cadiz) Oct 3 '12, (Cullera rioters) Jan 11, 12 '12, (FrancoSpanish treaty) Nov 14,

27, Dee 17 '12, (law) 336, (literature) 215, (Morocco) 1106, 1107, 1108, (navy) 49, 50, (Portuguese Royalists) 1122 , July 29 ' 12 , (protection of monuments) 285, (railway gtrike) Oct $1,10^{\prime} 12$

Spanish Fork, Utah, 916

Sparassodonts, 135

Spargo, John, 742

Sparks, -Nev., 854

Sparsholt, 564

Sparta, 279, 272

Spartanburg, S. C., : 904, 906

Spastic paralysis, 165

Spectrograph, 118

Spectroheliograph, 91

Spectroscopy, 118

Speculum metal 120

Speer, Emory, Mar 24 '11 
Standards, Bureau of, 118 Standring, Miss D, 459

Stanford, Sir Charles, 238 Stanmore, 1st Baron, 547

Stannus, Dr, Hugh, 170

Stanton, W:, 470

- , Dr., 166

Stapf, Otto, 1102

Stara-Zagora, 1034

Starr; Frederick, 803

Stasisano, Major, 364, 391

State Department building,

D. C., 790

State Medical service society, July 26 ' 12

Staten Island, 861

Statesboro, Ga., 796

Statham vi Stathara, Dec 21 ' 11

Staunton, Va., 921, 922

Stavanger, 1108

Stead, J. E., 391

一, W. T., 546

Steam Boilers, 357

Stebbins, J., 95, 120

Stechowitz, 957

"Stedfast," 464

Steel, 391, 567, 591, 1174

Steel-Maitland, A. H., M. P. 489

Steelton, 665

Steel Trust (U.S.), May 27 '11, Aug 2, 16 ' 12

Stefansson, V., 101, Sep 9 '12

Steffens, 225

Stein, Sir M. A., 102

一, S., 417

Steinitz (chess), 454

Stelae, 280

Stella, Mo, 846

Stephanovich, Gen, 28

Stephen\$, Major G. W., 676

Stephenson, Dr. C., 564

- Gen. Sir F. C. A., 541

- , Isaac, $954 ; 955,743$

Sterilisation of criminals, 327, (Ia.) 811, (N. J.) 863 , (N. Y.) 872, (Wash.)
926

- of soil, 429

Sterling, T., 908 .

Sternberg, Baron, 960

Sterneck, Gen. R. von, 966 Stettin, 1009

Steuben, Gen. yon, $\operatorname{Sep} 3$ '11

Steubenville, O., 882, 883

Stevens, Alfred, 244

-, John F., 946

_John L., 811

- R. L., fund, 865

Stevenson, H. W. 453

Stevens Point, Wis., 931

Steward, Sir W., 702 .

Stewart. Bertrand, Aug 7 '11, Jan 31, Feb 3'12

Stewart, John A., 221

†.J. M'Kellar, 288

-, Samuel V., 851

Stewart Island, 99

Stieler, Oct 21 ' 12

Stileman, Rev. C. H., July 12 ' 12

Still, Dr. A. T., 183

Stille, Lieut., June 1 '12

Stillwater, Minn, 839

Stimson, H. L., May 16 '11

Stirling, E. C., 153

Stirling, 588, 590, 282

Stock, Elliot, 544

Stockfisch System, 382

Stockholm, 1139, 448

Stockport, 560

Stocks and Shares, 76

Stockton, Cal., 774, 776, 777

\section{-, Me., 822}

Stockton-on-Tees, 561

Stoermer, Carl, 112, 110
Stoicism, Roman, 221

Stoke-on-Trent, 560 ; 583, 309,302

Stoker, Bram, 553

Stokes, L., 247

-, Major, 1116, 1117

Stoll, $0 ., 112$

Stolypin, P. A., 1127, 1128 ,

Mar 20, Sep 14, 18, 22 '11

Stone age, 159

Stone dust, 383

Stone Mountain, Ga. 790

Stonington, Conn., 723

Stora Sjöfallet, 1140

Storbeck, 454

Storer, W. 554

Storey, P., 456

Storrs, Conn., 785

Storthing, 1111

Story-Maskelyne; M. H. N., 544

Stotesbury, E. T., 900

Stourbridge, 579

Strachan-Davidson, J, L., 223

Strachey, George, 547

-, Henry, 547

Straits Settlements, 625 , 636

Strasburg, 1009, 1011

Stratford, Can., 665

- on Avon, Eng., Ap 17, 20 '11

Stratos, 276

Stratton, F. J. M., 92

Straus, Isidor, 764

$\longrightarrow$ Oscar S., 875. Ap 24 '11

Strauss, Enil, 206

- Richard, 240, 207, Oct 25 '12

Strawberry Valley, Utah, 916

Strawberry (fruit), $\mathbf{5 6 4}$

Streator, Ill., 800

Street, G. S., 189

Streetville, Ont., Oát 29 '12

Strefemann expedition, 1041

Strepyian period, 156

Stretton, Hesba, 544

Streuvel, S., 212

Strickłand,'Sir Gerald, 697, 698

Strikes and lockonts, (A r gentina) 1069, (Australia) 693, (Brazil) 1074, (Canada) July 26, $30^{\prime} 12$, (Hungary) May 23 '12, (Italy) 1044, (New Zealand) May 13, Nov 30

'12, (Norway) 1112, (Peru) Ap 16 ?12, (Rus(sia) 1130, Ap 18, 25 '12, (Sweden) 1143, (Switzerland) May 12 ?11, July 12 '12, (Uruguay) 1100 , May 23'11

-, France, 994, (Brest seamen) June 11' 12, (Calais seamen) June 11 ' 12 , (Dunkîrk dockers) July 11 '12, (Havre dockers) July 5, 9 ! 12 , (Havre seamen) June 10, Aug 2 ' 12 . (Marseilles seamen) June 20 , 22, Sep 4'12, (miners) Jan 3, Mar 11' '12, (Paris taxi-cabs) Nov 28 ' 11 , Feb 1 '12, (railway) 998, (Lorient) Nov 17' '11

-, Germany, (Hamburg (Krel dockyard) Deo 21 24 '12, (miners) Mar 4 :12

- Portugal, 1119, Jan 11, 14 '11, (Lisbon gasworkers) Jan 14 '11, (Lis-
bon shop assistants). Jan
11 '11, (Lisbon textile workers) May 4 '12, (Lig bon tramway men) June 21,22 ' 12 , (Lisbon general) Jan 29, 31,12 , (Oporto eoopers) Oct 28 '12

, Spain, 1136, (Funchal searnen) Dec 15 '11, (railway) Sep 26, Oct 1, $5, \quad 10,12$, (Valencia) Sep 18 '11

$\rightarrow$ U.K., general 520, 521, (Dundee carters) Dec 19, 24 '11, (Edinburgh'shipbuilding) Mar 11 '11, (Glasgow): July 13 '11, Jan 29, Feb 9, 10 '12, (Hull aeamen) June: 27 '11, (Ireland) 598, Sep 16, 27, Oct 4 11, (Lan-
cashire cotton) Dec 20 '11, Jan 19 '12, (Leeds colliery) Sep 20 ' 11 . (Liverpool dockers) June 27 '11, July 22 '12, (London printing trade) Feb 1 '11, (London tailors) May 1, 24, June 4 '12 (London taxi-cabs) Mar 18 ' 12 , Oet 31 , Nov 9 Dec 31 '12, (Manchester cotton) Dec 27'11, (Manchester carters). July 4 '11, (Manchester dock) July 8 '11, (Knox case) 525, Dec 7, 14-'12, (Northumberland miners) July 17 '11, (Oldham cotton workers) Oct 1 '12, (P. \& O. shipping) May 7,8 '12, (schoolboys) Sep 8 '11, (seamen's) June 14, 28, July 3 ' 11 (Southampton) June 24 11, (Tilbury Docks) Feb 2 '12

- English coal strike, (1912) 525-527, 565, Mar 1' 12 , (ballot) $\operatorname{Jan} 9,18$ '12. (codl owners and miners meet) Feb 22' 12 , (Government conference) Mar 8 '12, (Derbyshire miners) Feb 26, 12 (Joint conference) Mar $5,12,26$ '12, (Miners' national conference) Feb 27 '12, (minimum wage figures) Mar 23 '12, (resumption of work) Mar 27. Ap 4 '12, (S. Lan cashire riot) Ap 10,12

- English transport workers and railways (1911) 522-525, (dookers'. provisional agreement) Aug 10 '11;' (Home Office agreement) Aug 18 '11, (Liverpool cargo men) Aưg 14, 21 '11, (Liverpool railway porters) Aug 7 '11, (Liverpool seamen) Aug 10.11; (Liverpool transport workers) Aug $14,15,16,24,31,11$ (London carmen) Ang 8 '11, (general railwaymen) Aug 16, 18, 19 '11. (Surrey Commereial Docks) Aug 4 '11, (Sir A. Rollit's award) Aug 6 '11, (Trgfalgar Square demonistration) Aug 6.'11

- English dockers and transport-workers (1912) $527-529$, May 21, 23 '12 (Mr. Asquith's conference) July 16 '12, (Sir

E. Clarke's repnrt) May 28 '12, (compromise rejected) July 18 '12, (Devonport conference) July 12, 15 '12, (enquiry opened). May 24,12 (Home Office conference) May 31 '12, (Hyde Park demonstration) July 14 '12, (Mr. Lloyd George's statement) June $5 \quad 12$, (national strike) June 4 10, 11 '12, (police protection) May $27 \cdot 12$, (Port of London Authority). May $30 \quad 12$, (revolver shooting) July 31 '12, (rioting) July 10 12. (Tilbury docks fighting) Aug 19 '12, (Tower Hill demonstration) July 24 '12, (Trafalgar Square demonstration) May 26 
(N. Y., Susg \& W. Ry. coal handlers) 864, (Passaic and Paterson, N. J., vilk-workers) 864 , (Pennsylvania freight dockers) July 13 , 12 , (Pennsylvania $\mathbf{R}$. $\mathbf{R}$. shopmen) 900, (Pittsburg National Tube Co.) 900 , (Pennsylvania coal) 900, (Spartanburg, 8. C. atreet car) 906, (steel workers, Homestead and Braddock, Pa.) 900, (telegraphers) Nov 8 '11, (Utah copper miners) 918, (Utica, N. Y., cotton milis) 876 , (West Warren, Mass., cotton mills) 735 , (W. Virginia coal) 930 (Yazoo \& Miss. Valley R. R.) 845

Strindberg, August, 1143

Ström, 1141

Strömgren, Elis, 95

Strowger automatic system, 366

Strunnikoff, N., 470

Struthers, O.,883

Strutt, Hon. R. J., 109, 119

Struve, Hermann, 93

Stuart, Ruth McEnery, 200

-W. J. Cohen, 1041

Stubbs, Bp. C. W., 548

-, Walter R., 814

Student Christian movement, 322

Studley, John P., 787

Studniczka, F., 280, 279

Stumpf, Prof., 347

Sturge, W. Allen, 156

Sturgis Law, 823

Stürgkh, Count Karl, 960 , 963. May 15'12, (foreign policy) Dec 15 '11

Stuttgart, 1009

Subansiri river, 102

Subig bay, P. I., 947

Submarines, 49,353

Submarine Cables, 80

- telephone, 366

Subsoiling, 419

Suda Bay, 1030, 1031

Sudan, Anglo-Egyptian, 990, 437, Mar 27, Ap 15 '12

Sudermann, H., 207

Suess, E. 109

Suez canal, 68, 990, 987

Suffolk, Eing., 559

Suffolk, Va.921

Sugar, 1167, 1168, (U.K taxation) 532, (British growing) 418, (U.S.) 718, $818,941,951$

- Bill (U.S.), Mar 15 '12, 051

- Bounties Convention, 14, 15, Aug 7'12

Suja-ed-Dowleh, 1117

Sukhomlinov, Gen., 1130 , Dec 30 '12

Sukkur, 606

Suling, 1037

Sullivan, J, 454

- Roger C., 804

8ulloway, Cyrus Adams, 859

Sulphide ore, 393

Sulphur, 119, 1043

Sulphur Springs Valley, Ariz, 769

Sultan Tepé, Oct 31 '12

Sulzer, Win., 875, (resolution) Dec 13 '11

Sumatra, 1040

Summary Jurisdiction Act (1895), 325

Summerfield, Sardis, 856
Summerville, Ga, 796

Sumpner, Dr., 359

Sumter, 8. C., 904, 905, 906 Sumuran, 230

Sun, 91, 92, 93

Sun River project, Mont. 849

Sunday schools, 311

Sunderland, 560, 573

Sungei Lembing, 631

Sunnis, Jain 18 '11

Sunspots, 113, 92

Sunstar," 463, May 31, Ap 26 '11

Sun Yat-sen, Dr., 981, 882 Aug 24 '12, (elected President). Dec 29' 11 , (resignation) Ap 1.'12, (Republican manifesto) Jan 5 '12

Superior, Wis., 931; 935

Super-tax (U.K.), 535, 536

Supilo, 961

Surface combustion, 400

Surgery, 165

Surinam, 1041

Surrey, 559, Aug 13 '11

Susemihl, Fr., 219

Susitna river, Alsk, 939

Sussex, Eng., 559, 564, 41

Sustentation Funds, 319

Sutherland, George, 918

Sutherland, Scot., 588, 589

Sutro, Alfred, 230

Sutton, J. R., 113

Suva, 639

Suvoria, A. S., 1133

Svalof, 414

Svendsen, Johan S., 1143

Sviatoi cape, 62

Swale Valley railways, 575 Swan, J. M., 705

-, S. E., 468

-, Hunter \& Co., 568, 346

Swann, Rev. S., Sep 12 ' 11

Swansea, $560,566,573$

Swanson, Claude A., 923

Swanston, H. E., 468

Swarth, Helène, 210

Swat, 621

Swayne, Sir E. J. E., 658

Swaythling, Baron, 544

Swaziland, 703,707

Swearingen, J. E., 904

Sweden, 1139-1143, 64, (general election) Sep 29 11. Malmstatt railway accident) June $16 \quad 12$, (ministry) Sep 30, Oct 7 '11. (Olympic ames) July $6-12,447-449$, (Persian gendarmerie) 1115, Jan 3 '11, (Riksdag) Jan 16 '12, (Spitzbergen claims) 60 , (woman suffrage) 90, June 17 '11

Swedish Moss Culture Society, 1140

Sweeney, M., 451

"Sweeper II." May 1 '12

Sweet, Dr. Henry, 552

-, W. D., 882

Sweet-Escott, Sir E. B., 639, Feb 16 '12

Swenson, Laurits S., Ap 27 11

Swimming, 470, Sep 5 '11

Swinderen, P. J., 1042

Swindon, 561

3witzerland,

1143-1148, (army manoeuvres) Sep 3 '12, (civil code) Jan 1 '12. German Emperor's visit) Sep 6 '12, (Labour Legislation Congress) Sep 10, 12, (President elected) Dec 12'12

Sword bayonet, 373
Sycamore, Ga., 796

Sydenham, Lord, 615

Sydney, Australia, 697, 683, 680,693

Sydney, Can, 665

Sydow, Reinhold, 1014

Syed Abdul Ohad, Jan 4 '11

- Ameer Ali, July 5 ' 11

Sykes, Major P. M., 102

Sykesville, Md., 827

Symbiosis, 141

Symons, Arthur, 189

Syndicalism, 17, 491, 520,

(Mr. Balfour's speech)

Ap 30 '12, (Bowman sentenced) Mar 22:12,

(British Trade Union Congress) Sep 6 '12,

(France) 1003, Nov 26

12, (Tom Mann). Mar 19. May 9, 20, June -22

12. (Portugal) 1119

Syndicalist, The, 521

Synge, J. M., 227, 186

Synthetic rubber, 121, 124

Syphilis, 175, 129

Syracuse, N.' Y., 868, 869, 724

zzabadka, 957

Szabo, Rosa, Sep 12 '12

Szechuen, 971, 979, Sep 12 '11

- Hupeh railway, 976

Szekeresy, Lt., Sep 24 '12

Szeged, 957

Taal mt., P. I, 950, 107

Tabora, 1012

Tabriz, 1113, 1117, 1119, Dec 23 '11

Tabuteau (airman), Feb 24 '12

Tacna, 1095

Tacoma, Wash. 924, 925 , 926, (recall) 927

Tadia, 1105

Taffianel, J., 383

Taft, Lorado, 790

-, R. C. 903

- President W. H., 734, $735,747,748$, Oct 16 ' 11 , (arbitration treaties) Sep 7, 16, Deo 8, 18 '11. (Canadian reciprocity: see Reciprocity) (Commission on Industrial Relations), Deo 17 '12, (Cotton Bill vetoed) Aug 22 '11. (criminal law administration) May. 13, 24 11, Messages to Congress, Dec 6, 19 '12, (Message on economy) 725,726 (Mexican intervention) 1089, (Panams Canal) 60, (Panama journey) Dec 19 '12, (Presidential nomination) Aug 1, Nov 12 '11. (Toledo speech) Mar 8' 12, (Trust question) 736, Dec 5 ' 11 (on typhoid) 177 :

Tagalie," 464, June 5 '12 Taggart, Thomas; 808

- W. H, 181

Tahsin Pasha, Hassan; 28 Taipeng, 630

Tait, Sir Melbourne, 676

Taitu (empress), 953

Talaat Bey, 1152, 1157,

1163, Nov 16 Aug 6 '12

Talamo, E., 296

Talbot, B., 391

- Bp. E., Jan 20 '11, Jan

Taliaferro, James P., 793

Talladegs, Ala, 765,767

Tallahsasee, Fla., 791

Tallulah river, Ga. 796

Taman penin., 411

Tammany Hall, 874, 875

Tampa, Fla., 791, 792, 723

Tampico, Mex., Oct 20'12

Tanana valley, Alsk., 988

Tanered, Gen. A;, 1086

Tanga, 645

Tang Hua-lung, 977

Tangier, 1107, 1108

Tang Sheo-yi, 982, Jan 6 11, Jan 2, Mar 29, June $17 \cdot 12$

Tannin, 123

Tansley, A. G., 141

Tant-Iron, 392

Tappahannock, Va.; 724

Taranto, 1045

Tariff. Reform (U.K.), 482, $489,490,491,518,519$ (Bonar Law) Dec 16 '12

(Grosvenor House dinner)

Oct 16 '12, (F, E. Smith) 
Tenement dwellings, 580

Tener, John K, 899

Tennant, F., 466

-, Sir Edward, Mar 3 '11 , H. J., M.P., 487, June 14 '12

Tennessee, 909

Tennis, 471

Tennyson d'Eyncourt, E. H., 351, July 29 ' 12

Teran, Emilio M, 1084

Terauchi, Count, 1081, Dec 6. Feb 17, Sep $28^{\prime} 12$

Termites, 133

Terne museum, Rome, 280

Terneuzen, 1039

Terpene, 123

Terpineol, 123

Terra Alta, W. Va., 930

"Terra Nova," 99

Terra Nova Bay, 99

Terra nullius (Int. law), 61

Terre Haute, Ind., 805, 806

Terrell, Joseph M., 796

Terreni, Gastone, 1051

Territorial force (U.K.), 36 , 42,578 , (director-general) Ap 25' 12 , (Sir J. French) Dec 13 '11, (Col. Seely) Dec 5 ' 12

Territorial waters, 61, 678, 592

Terry' Edward O'C., 546

- Ellen, 232

-, Fred, 229

- Phytlis, 229, 231

Tertiary cóal, 396

- ungulates, 148

Tetuan, 1108

Tewfik Pasha, 1152, July $18,19 \cdot 12$

Texarkana, Ark., 771

Texas, 912, (prohibition) July 24 ' 11

Textilose, 439

Thackeray centenary, June 30 '11

Thackeray, Sir V. D., 605

Thames, 157, 582

Tharaud Brothers, 203

Thasos, 278, Oct 31 '12

Thayer, Nathaniel, 832

Thearle, Dr., 349

Thebes, 263, 272

Theism, 292

Themenau, 963

Theobald, 132

Theognis, 220

Theopompus, 221

Theotokis, G. N., 1025

Thessaly, 1027, 1029, 276

Thief River Falls, 841

Thiès, 1006

Thika river, 644

Thirion, Mlle., Oct 13 '11

Thomas, Augustus, 232, 201 -, Charles S., 784

D. A., 525

Edith M., 200

Edward, 190

G. A. 453

Havard, 245

J., 692

Northcote W. 333, 161

Thomasville, Ga., 794

Thomism, 294

Thompson, Carmi, Nov 20 ' 12

-, Denman, 764

-, Sir E. M., 225

- Fountain, L., 882

- Frederick W. 678

-, Rev. J. M., 311, 317

- William H., 814

W. Mitchell, M.P., 488

Thompson v. Dibdin, 325,

June 17, $20^{\prime} 12$

Thomsen, Juls, 987
Thomson, J. A., 192 - Sir J. J., 116, Mar 15

-, Dr. Theodore, 177

Thorburn, J. J., 649

Thorén, P., 470

Thorianite, 119

Thorndale, Tex., 915

Thorne, Will, M.P., 487

Thornton, John R, 820

-, W. M., 120

Thornycroft engine, 354

Thorpe, James, 452

Thothmes III., 263

Thrace, 277

Throop, Pa.; Ap 7 '11

Thucydides, 221, 275

"Thunderer," 573

Thureau-Dangin, P., 258

Thurston, Katherine $\mathbf{5 4 5}$

- E., 162

Thury, Prof., 386

"Thyrsis" (statue), 245

Tibet, 11, 982, 971, 611 (Dalai Lama) June 24 '12, (Lhasa fighting) May 15, Aug 2 '12, (Litang captured) Sep 14 '12, (peace) Aug 21 '12, (Powers' protest) Aug 17. Sep 16, Dec 26 ' 12 , (Chinese republic proclaimed) Ap 4 '12

Tibullus, 225

Ticino, 1146

Ticks, 132

Tickle, J. Z., 565

Tientsin-Pukow railway, 976

Tiffin; O., 882

Tilak, 607

Tillamook bay, Ore., 892

Tillett, Ben, 529, July 24 12

Tillman, Benjamin R., 906

Tillodonts, 135

Tilt Cove, 679

Timanus, E, Clay, 827

Timber (U.K.), 563

Time-reckoning, Jan 26, Mar.10'11, Oct 15 '12

Times, The, 192, 186, Sep 10 '12

Timini tribe; 648

Timor, 103

Tin, 1173, 393, 566

Tinayre, Marcelle, 205

Tinné, C. E., 468

Tin plate trade, 568

Tippins Law (Ga.), 796

Tipple, Ezra S., Oct 24 '12

Tirnovo, 1034, 1031

Tiryns, 271, 272

Tisch, Dr., 335

Tisma, 1091

Tisnare canal, 1141

Tisza, Count, 964, 965 May 22, June 7, 12 ' 12

"Titanic" Disaster, 15, 16 350,85 , (Bruce Ismay's evidence) June 4 '12, ("Californian" explanation) Aug 16 '12, (London enquiry) May 2, July 3, 30, Oct 7' 12 , (Mansion House fund) Ap 17 July 2 ' 12, (memorial service) Ap 19, 26,12 , (U. S. investigation) $\mathrm{Ap}$ 17. May 28 '12

Tìtanium, 391

Titchener, E. B., 112

Titicaca lake, 1071

Tiznet, 1105

Tobacco, 1168, (Trish) 598 (Rhodesia) 705, (Turkish) 1150 , (U.K.) 417 , 535, 564, (U.S.) $717, \mathrm{Ap}$ 22 '12, May $29^{\prime} 11$
Tobogganing, 471

Todhunter, $466^{\circ}$

Todrofi, Gen., 28

Toft, A., 587

Togo, 1012

"Toiler," 348

Tokar, 991

Tokhma Su valley, 268

Tokyo, 1054

Toldi, E, 471

Toledo, Marc de, Jan 23 '12

Toledo, O, 882, 883, 884, 724, (Am. Fed. of Labor) 742, (companies' cases) Oct 12 '11, Jan 4, June 11 ' 12

Tolman, L, M., 114

Tolstoi, Count L., 206, 218, Mar 10 '11

Tolton, John F., 918

Tombelaine lamp, 385

Tominil, 1090

Tongan Is., 639

Tonk, 623

Tonkawa, Okla., 889

Tooele, Utah, 916

Tooth decay, 179

- fillings, 181

Topeka, Kan., 812, 813

Topinard, Paul, 1004

Torday, E., 161

Tornebohm, Alfred E, 1143

Toro, 644

Toronto, 663, 665, Aug 26, July $30^{\prime} 12$

Torpedo craft, 46, 49, 351

Torralba, 156

Torras, La., May 1 '12

Torres Vedras, 1122

Torrey, Bradford, 764

Torrington, Conn., 785

Torsch, Charles H., 827

Totemism, 160

Tottenham, 561

Touohard, G. F., 474

Touring Club Italiano, 1043

Tournet (airman), June 9 '12

Toutée, Gen., 1106

Tovey, Rev, D. C., 553

Tower, Sir R. T., 1067

Tower, Minn., 843

Town planning, 326 , (U.K.)

580,594 , (U.S.) 787, 790,

$805,812,823,828,831$

$839,843,847,862,876$ $886,897,915,932$

Townley, Sir W, B., 1067

Townsend, Charles E., 838

-, Meredith $\mathrm{W}_{.,}, 541$

Townshend, E. L., 456

Townsley, Col. C. P., Aug 31 '12

Towson, Md., 826

Tozier, Josephine, 295

"Tracery," 464, Sep 11 '12

Tracheotomy, 168

Trade, International, 1164 $75,569,570$

- Board of, (U.K.) 70 , 350 , Sep 4 ' 12

- Disputes Act, (U.K.) 491,521

- marks (Australia), 692 (Denmark) 984

- Union Congress Sep 4, 5 '11, Sep 2, 3, 6'12

- unions, 524, 328,.997 (syndicelism) 20: see also Labour and Labour Unions

Trade wind, 112

Trafalgar celebrations, Oet 21 ' 12

Trainer, Corporal J., July 22 ' 11

Trajan, 278

'rrammell, Park, 794

Tramways (U. K.), 576, 592

Trans-Australian railway, Sep 14 '12

Trans-Persian railway, July 15 '12

Transport workers' strike, 527, 529: see also Strike

Transvaal, 703, Aug 28 '12

Traquhair, Ramsay H, 551

Trarieux, Gabriel, 233

Trasimene lake, Sep 9 ' 11

Traube, L., 219, 222, 225

Travancore, 623,604

Travers, J. D., 462, Sep 7 12

Traverse City, Mich., 830

Trawling industry, 569

Treadwell, Alsk., 938

Trebizond, 1151

Tredegar, Monm., Aug 19 '11

Tree, Sir H. Beerbohm, 229 
Troutbeck, John, 550

Troy, Ala,, 767

-, N. Y., 868, 869

- $\mathrm{Pa}_{\text {., }} 896$

Truckee-Cargon project, Nev., 855

Trumbauer, Horace, 832

Trumper, V.. 457

Trust question, 736, state laws (Ariz.) 770, (Conn.) 786, (Ida.) 799, (Ill.) 801, (Mo.) 847 , (N. M.) 866, (W. Va.) 937

Trypanosoma rhodesiense, 130

Tsarevich (of Russia), 1133, Oct 22 ' 12

Tschudi, Hugo von, 1023

Tseng-Ting-ling, General, Sep 14 ' 12

Tsetse fly, 174

Tsinanfu, June 14 '12

Tringtan, 1013

Tsushima, battle of, 375

Tuan Chi-jui, 977

Tube railways, London, 575 , July 27 ' 12

Tuberculosis, 175, 176, (general legislation) 325 , 326,327 , (U.K., sanatoria) 587, (Welsh fund) 582, (Irish organization) 600, (notification) Nov 16 '11, (Prevention Committee) Feb 20 '12, July 19 '11, (Royal Commission) July 11, Dec 20'11, (British Insurance Act provision) 498

Tuberculin, 176

Tubulidentata, 135

Tuc d'Audoubert 158

Tucson, Ariz., 768, 769

Tucuman, Mex. 1089

Tueumcari, N. M., 865

Tudor, Frank Gwynne, 692

Tufnell, Admiral L. G., 1033

Tulagi, 640

Tullibardine, Marquess of, 488

"Tullibardine," Aug 1 '12

Tulloch, Lt. Forbes, 174

Tulsa, Okla., 888, 891

Tung Merg Hui, 981

Tunksten, 393

Tunis, 1006, (Arab riots) Nov 8 '11, June $29^{\prime} 12$, (Franco-Turkish frontier) Mar 16 '11, (Pres. Fallières' visit) Ap 21 '11

Tupais, 135

Turah, 260

Turbines, 356, 347, 400

Turbo-drag machinery, 440

Turco-Italian War, 22-27, 4, 1051, 1159, 59, 68, (airman taken prisoner) Sep 11 ' 12 , (Arabs and Italians) Jan 18, Mar 2 '12, (Arab slaughter) Oct 30 , Nov 1, 2 '11, (arbitration terms) Mar 9 '12, (Balkan consequences) 1030, (blockade of Tripoli) Oct 3 '11, (bombardment) Oct 4, 19 '11, (Dardanelles) Nov 23 ' 11 (financial results on Italy) 1045, (French policy) 1001, Jan 22, Oct 21 12, (intervention proposals) Oct 1, Nov 6,'11, Ap 12,23 '12, (islands 12 , (Italian outrages alleged) Nov 20 '11, (Italians leave Turkey) May
20 '12, (Italian victory) U Union, S. C., 904

Nov 26 '11, Oot 5 '11, Union and Progress, Party ("Kaiserieh" captured) Dec 21 '11, ("'Manouba'

seized) Jan 19 '12, Union Castle line, 704

("Menzaleh" seized) Dec Union Springs, Ala., 768

22 '11, (peace) 1052, Oct

18 '12. (Powers, appeal

to) Sep 30 , Oct 9 '11,

(wells, poisoning of) July 16 ' 12

Turgéniev, I., 218, 219

Turin, 1042, 1049, 1050

Turkestan, Jan 13, May 23 12 , Jan 4'11

Turkey, 1149-1163, ("Ot-

tomanism") 1024, 1025

(Italian war) 4, 5, 22-27,

(Balkan erisis and war)

5-10, 27-34

Turnbull, H., 449

Turner, Ethel, 197

-, H. H., 97

- Prof. Lyon, 319

Turning Point, The: see Flamber, $\mathbf{L a}$

Tuscaloosa, Ala., 765, 767

Tushetu, 10

Tuskan, Dr., 961

Tuskegee, Ala., 765, 766, 768

Tuzi, Oct 14 '12

Tuzla, 958

Tvedt, Jens, 214

Twain, Mark: see Clemens, S. L.

Tweed, John, 244

Tweed, 443

Tweedie, L. J., 676

Twelfth Night, 229

Twin Falls, Ida., 797

Twining, Louisa, 554

- Admiral N. C., 377

Two Harbors, Minn., 843

Two Thousand Guineas, Ap 26 '11, May 1'12

Tyler, Tex., 912,915

Tylissos, 270

Tynemount," 348

Tynemouth, 560

Typhoid fever, 176

Tyrone, 595, (by-election) Oct 6 '11

Uchida, Viscount Y., 1061 Udaipur, 623

Udi, 651

Uehara, Baron, 1061, Dec 2 ' 12

Uganda, 103, 644,

Ugron, Gabriel, 966

Uhde, K. H. F. von, 1023

Ujpest, 957

Ulm. 1009

Ulster, 595, 594, 596, 598, $601,510,511$, (solemn Covenant) 512, (Craigavon Day), 510

- Dairy School, 415

- Day, July 12'12

Ultra-violet ray' in water purification, 948

Umatilla Project, Ore., 891

Unamuno y Jugo, M. de 216

Uncompahgre valley, Col. 781

Underground Flectric Railways $\mathrm{Co}, 575$

Underbill, Evelyn, 294

Underwood, Oscar, 735 768,794 , June 28 ' 12

Underwood bill, June 1 '11

Undset, Sigrid, 215

Unemployed Workmen's Act (1905), 533, 594

Unemployment (U.K.), 520

- insurance, 498

Ungulata, 135

Union, N. J., 860 uador) Jan 15 '12, (education) 728 , (finance) 725,74 , (fisheries regulations) Jan 13, Sep 6'11, (floods) Sep 30 '11, Ap 3, July 25 ' 12 , (foreign commerce) 722, (FrancoAmerican Arbitration 'Treaty) Aug 2 '11, (German relations) May 17 '11, June 3, 13 '12, (Governors' Conference) Sep 12 '11, Dec 3'12, (Hajtian affairs) 1086, July 5 , 28, '11, (Honduras loan) Jan 26, Feb 15'11, (Honduras revolution) Jan 22 '11, Feb 3 '11. (Japanese relations) Feb 21, 24, Ap 4, July 17 ' 11 , May 1 '12, (labour commission) Feb 2, Aug 15, 24 '12, (labour dept. created) July 17 ' 12 , (labour leaders convicted) June 24 '12, (Latin American policy) 1074. (Latin American trade) 1064, (law) 336, Mar 3, Dec 21 '11, Jan 24 "12, (manufactures) 718, (merit system) Deo 21 '11, (Mexican intervention) 1088, Jan 21, Ap 15'11, Ap 17, Sep 11 12, (mining and mineral products) 718 , (ministers appointed) (Árgentina) Dec 14 11, (Belgium) Aug 12 ' 11 , Nov 20 '12, (Colombia) Aug 21 '11. (Costa Rica) July 6 ' 11 , (Cuba) Aug 12 '11, (Dominican Republic) July 6 '11, (Ecuador) July 6 '11, (Greece and Montenegro) Aug 16 '12, (Honduras) July 6 '11, (Netherlands and Luxemburg) Aug 12 '11. (Nicaragua) Dec 21 ' 11 . (Norway) Ap 27 "11, (Panama) July 6 '11, (Paraguay and Uruguay) June 30 '11, (Portugal) Mar 2, May 24'11, Jan 25 '12, (Rumania, Servia and Bulgaria) Aug 12 '11. (Siam) Sep 12 '12, (Switzerland) Ap 24 ' 11 , (Venezuela) Dec 21 ' 11 , (Monroe Doctrine) Aug $2 \cdot 12$, (navy) 727, (New Mexico statehood) Aug 15,21 '11, Jan 6 ' 12 , (Nicaraguan intervention) Aug 24, 28, Sep 25 '12, (Nicaraguan loan) June 9 ' 11 , Jan 1, '11, (oil industry) 410,719 , (postal changes) Aug 26, Dec 10, 21 11, Feb 22, Oct 15,12 , (Postal Sayings Banks) Jan 3 '11, (Post Office Appropriation Bill) May 2, Aug 13 '12. (Presidential campaign and Election) 748, $749,750,1180$, Nov 5 ' 12 , (prohibition laws) Sep 11 '11, and see Prohibition, (railway companies sued) Aug 2, Oct 4'11, June 5 ' 12 (railway rates) Nov 9 '11, Ap 13 , June 7 , 12, (railway safety appliances) Oet 30 '11, (Railway Securities Commission) Dec 11 
11. (Russian treaty abrogated) 1133, Dec 19 '11. (Santo Domingo) Sep 24, Dec 12 '12, (Secretary of 'State's tour) Feb 22, Ap 11 '12, (shipping) Ap 20, 25, Aug 10 '12, (t a r iff board) Mar 4, Jan 30'11, July 23 ' 12 , (tariff revision) Feb 21 '12, (chemical schedule) July 3 '12, (cotton schedule) Mar 26, Aug 14'12, (steel and iron) Jan 29 ' 12 , (trust question) 736, Nov 16 , Dec 5'11, (wages and prices) Feb 2, Mar 9, 18 12

- States Navy, 727, 347. 673, Dec 21 '11, (casualties) ("Arkansas") June 4 '12, "Delaware") Jan 17 '11, (submarine "Geo") May 16 '12 ("Vermont") Nov 2 '12 ("Walke") Oct 1 '12, (guns) May 28, July 5 Aug 19 '12, (launchings) ("Arkansas") Jan 14 '11, (“Moreno") Sep 23 '11, ("New York") Oct 30 , '12, ("Texas") May 18 "12, ("Wyoming",) Ap 25 '11, ("Marine") Dec 8 '11, Mar 16 '12, (President's review) Nov 11 '11, (speed record "Florida,") Mar 25 '12 (in Turkish waters) Oct 8 '12

- States Steel Corporation, Dec 24 '12

- States Supreme Court. (Alaska coal) Dec 4 '11, (Chicago Stock Yards Co.) Dec 9 '12 (Federal Corporation tax) Mar 13 '11, (Federal hours of service) Jan 9 ' 12 , (intoxicating liquor, transit) Jan 22 ' 12 , (initiative and referendum) Feb 19 '12, (interstate and intrastate rates) Ap 1 '12, (labour leaders) May 15 "11, ("Mainline grant") Feb 26 '12, (patented articles) Mar 11,12 (Reading coal case) Dec 16 ' 12 , (rules) Dec 22 '11, Nov 4 '12, (Sherman law) 736, (Standard Oil) May 15 ' 11

Universal Races Congress, July $26, ' 11$

Universities of the Empire, Congress of, 584, July 2 12

University College, Cork, 602

- College, Dublin, 602

- College, Galway, 602

University Magazine (Canada), 197

Upavon, Wilts,, 344

Uphues, Josef, 1023

Uppdal, Kristofer, 214

Ural, Russ., 410

Uranus, 94

Urban, C. 235

Ur dynasty, 259

Ure, Alexander, Sep 11 '11

U'Ren, William S., 895

Urfa, 1151

Urfirnis pottery, 277

Urgg, 10,983

Ur-Ninâ (king), 258
Ursa Major, 97

Urubamba river, 103

Uruguay, 1099, Mar 1 '11. (Argentine treaty) 1067. 1069, (Brazilian boundary) 1071, (Postal Congress) Jan 9 '11

Urukagina (king), 258

Usambora, 1012

Uskub, 1151, 31, Nov 2 '12

Usman Ali Khan, 618

Utah, 915, 419

Utica, N. Y., 868, 869, 876

Utter, George H., 903

Uyeda, 1059

Vaccine-therapy, 176, 178

Vachell, H. A., 231

Vahsel, Capt. R., 100

Vajiravudh (of Siam), 1135. Dec 2'11

Valdez, Alsk., 938; Sep 21 '11

Valdosta, Ga., 794, 796

Valenca do Minho, 1121

Valencia, Gen. R. G., 1077

Valencia, Sp., 1135, 1137

Valentine, R.G., Sep 10 '12

Valentine, Neb., 854

Valera, W., 1096

Valibran, A., 1069

Valishevsky, 219

Valkenberg, 1040

Vallejo, Cal., 774, 777

Vallery-Radot, R., 204

Valley City, N. D., 879

Valliant, Okla., 891

Vallon (airman), May 6 '11

Valona, 8

Valparaiso, 1066

-. Ind., 809

Van, 1151

Vanadium, 391

Vanbrugh, Irene, 231

Vanceboro, N. C., 879

Vancouver, B. C. 663, 665 -, Wash., 924, 926

Vandal, Albert, 1003, 190

Vanderbilt Cup, 46

Hotel (N. Y. City) N. Y., 27

Van der Byl, C., 460

Van der Byl, P. V. G., 468 Van der Schalk, H. R. H. 210

Van der Tunk, 164

Van de Woestijne, K., 212

Van Deyssel, L., 210

Van Dyke, Henry, 200

Van Eyck, Brothers, 243

Van Gogh, V., 241

Van Gogh-Kaulback, Anna, 211

Van Heekeren, 104

Vaniman, L., July 2 '12

Van Lear, T., 843

Van Loov, J. 210

Vannutelli, Cardinal, 312

Vanrees range, N. G., 102

Van Rossum, Cardinal, 313

Van Scheltema, C. S. A. 210

Van Stuwe, J. R., 211

Van Syckel, Bennet, 861

Van't Hoff, J. H., 1042

Van Valkenburg, E. A., 899

Van Zype, G., 212.

Vardaman, James K., 845

Vardar river, 1151

Vardon, H., 462, Oct 4 '12

Vare, W. S., 899

Varela, Gen. Enrique, 1096

Vareschanin, General, 963

Varisco, B. 287, 292

Varns, 1034, 1035, 29, (naval engagement) 34 , Oet 19 ' 12

Vasconcellos, A., 1121, Sep 2, Nov 16 ' 11

-, Dr. Leite de, 217
Vasconcellos, Mme, M. de, Vilarino, Ruiz, 1138 217

Vascular cryptogam, 146 Vassilieva, N., May 12 '11

Vatersay Raid (1898), 589

Vaughan, G. T., 165

Vedel, Valdemar, 214

Védrines, Jules, 343, 344, 453, (acrident) Ap $29^{\prime} 12$ (aeroplane circuit race) July 26 ' 11 , (international aviation cup) Sep 9 '12, (Paris-Madrid race) May 26 '11, (speed record) Jan 13 '12

"Vendémiaire," 996

Venetia, 1042

Venezuela, 1100, (Colombian relations) 1077 , (Dutch dispute) 1041, (public debt) 1063

Venice, 1042, (campanile) 1049,248

Venizelos, E., 1026, 1028 , 1029, Mar 2, 25 '12, Venlo, 1038

Ventilation in mines, 381 , 388

Ventnor City, N. J., 863

Vera Cruz, Mex., 1089, Oct 16,23 , 12

Verhaeren, E., 211

Veria, Oct 29 ' 12

Verin, 1122

Veritas Society, 350

Vermehren, J. F. N., 987

Vermeulen, E., 212

Vermilion Co., Ill. Mar 14, Ap 19 '11

Vermont, 918, (elections) Sep 3 ' 12

Vermont breed, 441

Verner, Col. Willoughby, 157

Verrall, Arthur W. 552 , $584,219,221$, Feb 22 ' 1

Verrept, John, Ap 17 '12

Verweí, Albert, 210

Vesnich, Milerko, 9

"Vespasian," 347

Vessey, Robert S., 908

Vestments, 307, 310

Vesuvius, mt., 107

Viale, Admiral, 25

Vicente, Gil, 217

Vicksburg, Miss., 843, 844, 845

Vico, Cardinal, 313

Victor Emmanuel II, 1048 , June 4'11

- Emmanuel III, 1049 , 1052, 245, Jan 11'11

Victoria Eugénie (of Spain), Dec 12 ' 11

Victoria, Gen. Alfredo, 1098 - Eladio, 1098

Victoria, Australia, 697. Feb 3; Nov 18 '11, May 16 ' 12

一, B. C., 663, 665, 666 Hongkong, 635 - Nyanza, 645, 173

Victoria Cross, 477 Memorial, Lond., 245, May 16 ' 11

Vicuña, Claudio, 1076

Vidin, 1034, 1035

Viebig, Klara, 207

Vieira, Admiral B., 1074

-, Lopes, 217

Vienna, 956, (British Ambassador'g alleged interview) Nov 7 '11, (burgomaster) Dec 23 '12, (food riots) Sep 17 '11, (Lord Mayor's visit) Sep 9 '11, (university) 961,956

Vienna-Danube canal, 957

Vienna-Subercaseaux, 1076 1031,1162

Vilhena, H. de, 217

Villa Real, May 28 ' 12 - Rica, Ga., 796

Villazon, Eliodore, 1070 '12 '11

- Melius de, 708

Vincennes, Ind., 805

Vincent, Sir E., 570 , 11

一, H., 264

- Dr., 177 Aug 22 '11, July 4 ' 12

Vineland, N. J., 730

Vinhaes, 1122

Vilayets, Law of the, 5,

Villaespesa, Francisco, 215

Ville d'Avray, Lt. de, Ap 9

Villegas-Echiburí, E. 1076

Villiers, Sir F. H., Sep 25

-, Jacobus de, Baron, 711

, George E., 842, Oct 18

Vinci, Leonardio da, 243. 
Wage Boards (U.S.), 737

Wageningen, 1040

Wages, 70, 327, (Australia) 682 , (U.S.) 737

Wagner, E., 112

- R., 236

- (motorist), 465

Wagoner, Okla., 891

Wahba, Yusef, 989

Wahis, Baron, 970

Wainwright, 260

Wakefield, Bp. H. R., Sep 5 '11

Wakefield, 561, 583

Walden inversion, 124

Waldoboro, Me., 723

Waldstein, Sir C., 245, Nov 14 '11

Wales, Prince of, see Edward, Prince of Wales

Wales, $556,557,566,476$, 477, June 26, July 31 , Sep 21 12, (Welsh Church) 504, 505, 515, 517,307 , (strikes) Dec 28 ,' 11 , Aug 12, 27 '12, (Taff Vale railway accident) Jan 23 '11

Walker, Miss-A. B., 460

-, Miss C. A., 460

- Sir E. 670

- Joseph, 833

- Sir Samuel, 545, 602

- R. v. Mar 28 '12

Walkerville, 665

Wallace, C. W.. 193

William 238

Wallace, Ida 797

Wallasey, $556,561,579$

Walla Walla, Wash., 924, $925,926^{\circ}$

Waller, A. D., 168

- Lewis. 232

- Mrs. Lewis, 555

Wall gardening, 426

Wallis, Capt., B., 1103

Wallot, P., 1024

Wallsend, 579

Walsall, 560,567

Walsh, Davicl J., 833

-, John R., May 24 '11

-, T. J., 851

- W. L., 676

Walter, Eugene, 230

Walters, H. B, 281

Waltham, Mass., 828

Walthamstow, 556,561

Wandsworth, Baron, 547

Wandsworth, 556

Wangermée, 970

Wang Shou-chew, 978

Wanner expedition, 1041

Wantage, Baroness, 586

"Waratah," 350, Feb 22 ' 11

Warburton, 132

Ward, Elizabeth Stuart Phelps, 751

F. W. 197

Mrs. Humphry, 188

James, 292

Sir Joseph, 701, 570 ,

183, Mar 11, June 10 '11

J. Q. A., 250

Rowland, 551

W. H. 247

Wilfrid, 191

I) 1 .. 7017

Wurdani, 987

Ward-Lfonard system, 386

Warre, Eusecte F 784

"Warlingham," Oct 16 "12

Warm Springs, Mont 851

Warner, P. F. 457

-.W William, $84 \mathrm{~s}$

Warping, 44:3

Warren, F, E., 937

Henry W. 764

T. II. 584, Feb 16''1!

Warren, O., 883
Warren, R. I., 901

Warrender, Sir George, Dec 13 ' 12

Warrenton, Ore., 895

Warrington, 560

Warsaw, 1125, 1127

Warwick, R. I., 901

Warwickshire, 559, Aug 29 '11

Waseca, Minn., 839

Washakie Co., Wyo., 937

Washington (state), U.S. 924, (dry farming) 419 , (university of) 926,730

- D. C. 790, (American Peace Society) Dee 8'11. Applied Chemistry Congress) Sep 4'12, (Daughters of the Revolution) Ap 17'11, (Hygiene and Demography Congress) Sep 23' 12

-, N. C., 877

- Co., Me., 822

- party, 899

Wassermann, Jakob; 207

W', Dr., 167, 175

aterbury, L., and M.,467

Waterbury, Conn, 785,787

Waterford, 595

Watez gardening, 426

Waterloo, Can., 665

- Ia., 809

Waterman, L. A. 903

Wiaters-Pierce Co., Tex. 736

Water supply (U.K.), 580

Watertown, N. Y., 868

- S. D., 906, 908

-, Wis., 931

Waterville, Me., 822, 823

Watkins, A. S., 749, July 12 ' 12

- L. W. 839

Watson, C.W. 930

-. John C., 688

-.J. J., 170

-, Robert Spence, 545

Rosamund Marriott 545

Watt, Sir George, 260

- Sir Thomas, 712

-, W. A., 698, May 16 '12

Watterson, Henry, 817

Watteyne, V., 383

Watts, E. H., July 21 '12

-, G. F., 705

- Mary S. 200

- Sir. Philip, 351

Waukegan, Ill., 800, 801 802 , Nov 25 ' 12

W aukesha, Wis, 931

Waukie mines, 1065

Wausau, Wis., 931

Wavertree, 580

Waves, light, 118

-, sound, 117

Wavill, June 15 '11

Waycross, Ga, 794

Weardale, Baron, 488

Weather bureau, 110

Weaver, James B., 751

Veaving, 435, 443, 439

Webb, Alexnnder $8 ., 764$

- Sir Aston, 248, 581

- F. W. 587

- Capt. M. 470

- Sidney, 563, 19, 21

Webb City, Mo.. 816

Weber, Herr, 46i

- collection, Feb "20 '12

Webi Shebeli, river, 953

Webster, H, 161

Webster City, In., 809

- claim, Ap 3 '11

- Giroves, Mo. 840

Wechselmann, Dr, 175

Weddell sea, 101

Wedderburn, A. H. M., 468
Wedderburn, Sir W., 608

Wedekind, F., 207

Wedgwood, J. C., M.P. 487,300

Weeks, J. W., 833

- T. H., 161

Weg apparatus, 384

Wegener, A., 110

Weihaiwei, 637

Weill, 262

Weimar, 1009

Weinberg, A., 154

Weingartner, F., 236

Weinman, A. A., 249

Weir, J. G., 545

Weir City, Kan., 814

Weiser, Ida., 797

Weiskirchner, Dr., 360 Dec 23 '12

Weiss, P., 120

Weitzel, G. T., 1065, Dec 21 '11

Welby, Baron, 488

-, Victoria, Lady, 555

Welding; 408

Wellcome, 159

Wellesley College, Mass. 832

Wellington, Kan, 812

- N. Z., 699

- Memorial Lond. 244

Wells, Bombardier, 454

-, H. B., 468

- H. G., 188

-, J., 220

- Matt (boxer), 454

$\rightarrow$ Rolla, Aug 5 ' 12

Wellston, Mo., 846

Welsh, A., June 11 '12

, F, 454

Welsh Disestablishment, $307,504,505,515,517$, Ap 23, May 16 ' 12 , (Archbp. of Canterbury speeches) Ap 22, Oct 8 '12, (Asquith's 'speech) May 15 '12, (Balfour's speech) May 14 '12, (Cardiff demonstration) June 29 '12, (Hyde Park demonstration) June 12 '12, (Redmond's speech) Ap 21'11, (F. E. Smaith's specch) May 13 '12

Wendelin, S., 471

Wenlock, Baron, 547

Wentholt, Jan, 1042

Weobley Castle, 282

Wermuth, Adolf, 1014, 1020, Mar 16 '12

Werver, A., 125

Wernher, Sir J. C., 550

Werriwa, 691

Wertheimer,

May 8'12

Wesleyan Church, 319

- University, Conn. 787

West, Sir Algernon, Jan 18

'Mrs. Horace, Jan 18 '11

-, Mrs. Horace

- Sir Raymond, 550

West Africa, British, 647652

- Allis, Wis., 931

- Australia, 698, Nov 5 '12

Westboro, Mass. 832

West Bromwich, 560

Westbrook, Me., 822

Westbury, N. Y, 474

-, Eng. Feb 22'11

Westerley, R. I., 903

Western Federation of Miners, 741

Western Maryland R.R. 825, Dec 7 ' 12

Westernport, Md. 825

Western Reserve University, O., 886

Western Union Telegraph Co., 81

Westfalia type, 384

West Greenwich, R. I., 903

Ham, London, 559, June 20 , July $8: 11$

- Hartlepool. 560

- Indies, 653-662, 14, 15, $437,1041,987$, Ap 9 ' 12

Westinghouse frame gear, 347

winder, 386

Westminster, Duchess of, Oct 12 '12

Westminster, Md., 824

- Cathedral 312, 313

- Hospital, Lond., 179

West New York, N. J., 860

Weston, D. Aug 7'11. Aug 17 '12

Weston, Eng.5 566

West Orange, N. J., 860

Westphalia, 1008

West Point, N. Y., Aug 31 
White Star Co., 350

Whitman, Charles S., 876

Whitman College, Wash., 926

Whitney, H. B., 466

$\rightarrow$ Sir James, 675

Whitty, W. J., 457

Whymper, E., 539

Wicheler, 212

Wichita, Kan, 812, 813

Wickersh am, James, 940

Wickham, Dean E. C., 538

Wicklow, 595 , July 13 ' 11

Widdop process, 255

Widener, Harry E., 832

- P. H. B., 243

Widin, see Vidin

Wied, Gustav, 213

Wiegand, T., 272, 273, 279

Wieland, 146

Wien, W., 116, 367

Wiener-Neustadt, 956

Wiesbaden, 1009

Wỉesen, von, 218

Wigan, 560

Wiggin, Kate Douglas, 231

Wiggins, H. F, R., 468

Wigtown, 588

Wilamowitz - Moellendorff, U., 222

Wilbrandt, Adolf, 207, 966

Wilcken, Ulrich, 225

Wildenbruch, E. von, 208

Wildenrey, H., 214

Wilding, A, F., 465

Wildwood, N."J., 863

Wiley, Dr. H. W., 738, Jan 17, Mar 15, Dec 16 '12

Wilhelmina (queen), July 4 '11, July 26 , June 1 ' 12

Wilhelmina canal, 1039

- mt., N. G., 103

Wilkes-Barre, Pa., 896, 900, May 18 ' 12

Wilkes Land, 101

Wilkie, J. E., Dec 17 '12

Wilks, Mark, Oct 2, 14 '12

Willacy Co., Tex, 913

Willapa harbour, Wash., 925

Willcock, R. E., 326

Willcocks, Sir W., 1151, 1153

Willemstad, 1041

Willesden, 561, 309

William II, German Emperor), 1017, Aug 27, Sept 3, Oct 18 '11, (Bern visit) Sept 6 '12, (Bober Valley dam inaugurated) Nov 16 '12, (at Lothringen mine) Aug 9 '12, (at Kiel) June 21, Sep 5 '11, (at Krupp centenary) Aug 8 '12 (London visit) May 15, 20 '11, (Tsar of Russia) July 4 ' 12 , (at Swiss army manoeuvres) Sep 3 ' 12

Williams, B., 470

,- C., 467

- G.' H., statue, 893

- Hudson, 220

-, John Sharp, 845

- Sir Ralph Champney, 697

一, Talcott, 873

- Vaughan, 238

Williamson, Noel, Mar 31 '11

-, O. K., 466

-, R. W., 162

Williamsonia, 146

Williamsport, $\mathrm{Pa}, 896$

Williman, Claudio, 1099

Willimantic, Conn., 785

Wills, Tex., 914

Williston, N. D., 879,880

Willmore, J. G., 168
"Willonyx," June 15, Oct 11 '11

Willoughby, R. P., 460

Willoughby, Prof., 330

Willoughby de Broke, Baron, 489, 495

Wills, Sir Alfred, 550

Willson, A. E., 817

Willy, Colette, 205

Wilm, 393

Wilmington, Del., 788, 723, June 21 '11, June 13 ' 12

- N. C., 877, 724

Wilson, Ảdmiral Sir A. K. 577, June 26 '12

一, E. A., 99

- E. B., 142

-, E. W., 99

Huntingdon, 1078

H. V., 131

-, Mona, Nov 28 '11

-, R., July 5 ' 12

William B., 729, 750

- Woodrow, 748, 863, 875 , Feb 12, June 28,'12, (election) 1180, Nov 5 '12, and see under History in article on each state, (Baltimore nomination) July 2 ' 12 , (tarifi revision promised) Nov 15'12, (inauguration) 750 , (cabinet) 750

Wilson, N. C., 877

Wimbledon, 561

Winans, L., Oct 30 '12

Winchester, Eng., 583, 311

-, Ky., 815

-, Va., 921

Wind, 112,340

Windham, Conn., 785

Windle, Sir B., 602

Windsor, Can., 665

Windward Islands, 656, 657

Winfield, Kan., 812

Wingfield, G., 856

Wingfield Sculls, 468

Winkler, H., 140

Winnipeg, 663, 665

Winnsboro, La., 821

Winogradoff, Baron von, $\operatorname{Jan} 18^{\prime} 12$

Winona, Minn., 839

Winsford, 566

Winslow, 460

Winston, N. C., 877,878

Winter, John Strange, 539

Winter's Tale, 229

Winterswijk, 1040

Winterton, 6th earl, 488

Wireless Telegraphy and Telephony, 367-369,83, $350,45,99,705,1148$

Wiscasset, $\mathrm{Me}_{2}, 723$

Wisconsin, 931, (woman suffrage) 90, 932, (university of) 934,730

Wise, B. R., 687

Wislicenus, Paul, 194

Wisner, Edward, 820

Wissler, Clark, 161

Wister, Owen, 200

Witcheraft, 333

Woerishoeffer, Carola, 898

Wolfe, Gen., Jan 2 '11

Wolff, Julius, 206

- Pierre, 233

Wolf-Ferrari, May 30 '12

Wölfflin, H., 219

Wolff-Metternich, Count von, May 9 ' 12

Wolf lamp, 385

Wollaston, A. F. R., 162

Wolmer, Viscount, M.P. 488

- P. H., 279

Wolters, J 915

Wolverhampton, 1st Viscount, 539
Wolverhampton, 560

Woman suffrage, 87-90,

503, (City Temple disturbance) Nov 29 '11, (Lord Curzon's speech) Nov 1 '12, (Denmark) 986, (fire alarms) Dec 10 '12, (English Franchise Bili) Dec 10 '12, (Holland) 1042, (Italy) 1047, (Men's Society for women's rights) Jan 3 '12, (Norway) 1110, 1111, (S. Australia) 698, (suffragist marriage) $\mathrm{Jan} 13$ '12, (Sweden) 1143, (U. S.A.) 746, 750, (Áriz.) 770, (Cal.) 776, (Kan.) 813, (Ky.) 816, (Mich.) 837, (N. J.) 865, (N. M.) 866, (N. Y.) 872 , (Ohio) 884, (Ore.) 892, Nov 5 '12, (Wis.) 932

Women, (Austrian labour legislation) 964, (Belgian mining laws) 968, (cotton trade, U.K.) 435, (divorce grievances) 324, (ecclesiastical vote in Geneva) 1147, (French labour legislation) 994, (German universities opened) 1022, (in Norwegian literature) 214 , (wages and labour, U.S.) 737, (Ariz.) 770, (Cal.) 778, (Conn). 786, (Ill.) 802, (Ky) 816, (Me.) 823, (Md.) 826, (Mass.) 830, (Mo.) 847, (N. J.) 862 , (N. Y.) 871 , (S. C.) 905, (U.) 917, (Va.) 922, (Wash.) 927, (Wis.) 933

Women's Freedom League, 88

- National Health Association, 600

- Social and Political Union, 87,89 , Oct 17 ' 12 - Suffrage Societies, National Union of, Nov 9 '11

Wonga lighthouse, Nov 16 '12

Wood, Cyrus E., Jan 25 '12 - Sir Evelyn, Mar 21 '11 - Sir H., 238

-, Josiah, 676

- Major-Gen. Leonard, 727 , May 22, June 10 '12 $\rightarrow$ M., 582

- R. W., 117, 120

-T. McKinnon, M.P. 487 . Feb 14'12

-, William, 451

- Col. William, 197

-, William M., 835

Woodall, H, W, 402

Woodbridge, F. J. E., 290

Woodbury Co., Iowa, 810

Woodcock, Dr. H. M., 129

Woodroffe, Col. A. J., 103

W'Justice J. G., Aug 17' 12 875

Woodville, Ga., 796

Woodward, Dr. A. S., 137

Woodward, Ala., 766

- Co., Okla., 888

Wool manufacture, $440-$ $443,1169,1170,572,598$

- Bill (U.S.), 735, July 27. Aug 17 '11, Ap 1. July 25, Aug $9,16,12$

- combers, 442

- sorters, 165

Woolley, F. E., 457

Woolwich, 556

Woolworth Building (N. Y. City), 251, 870

Woonsocket, R. I., 901

Worcester, Dean C., 949. 950

-, Franklin, 859

Worcester, Mass., 828, 829. 833

-, Eng., 559, 560, 583, 303 Wordsworth, Bp. John, 541

Workers' Dwellings Act, 1910 (N. Z.), 325

Workmen's Compensation see Labour laws and Employers' Liability

Works, John Downey, 779

Worland, Wyo., 937

World's Armies and their development, $35-44$

World's navies, 44-54

Worm, 133

Wormald, L. G., 468

Worst, J. H., 418

Wotherspoon, W. L., 388 
Yellow River bridge, 976 | Young, G. J., 387

Yellowstone river, Mont., -, G. Winthrop, 466 849

Yemen, 1156, 1159

- Lafayette, 811

- W. 402

-, W, Douglas, 655

Yeprim, 1113, 1117, 1118, Young Men's Christian May 20 '12

Yerington, Nev., 855

Yes bay, Alsk., 938

Yin Chang, Gen., 980

Ymuiden, 1039

Yokohama, 1055, 1058

Yolamchef, M. T. A. 102

Yonezawa, 1059

"Yongala," Mar 28 '11

Association, 322, 581

Youngstown, O., 882, 883

Young Turks, 1152, 1024

Yountville, Cal., 779

Yoxall, Sir J. H., M.P., 487

Yuan Shih-kai, 980, 977, 981

Yukon, 663

Yuma, Ariz., 768, 769

Yunnan railway, $97 \mathrm{~s}$

Yusuf Izz-ed-Din, 1027

Nov 20 '12

York, Arehbishop of, 325, Nov 28 '11, Nov 11 ' 12

York, Neb., 852

-, $\mathrm{Pa}$. 896

-, Eng., 560

Zagloud, Saad Pasha, 989

Zagrab, 957

Zahle, C. T., 985

Zaila, 646

Zakir, 266

442

Yoruba tribe, 650

Zaldumbido, C. F., 1084

Zamboanga harbour, P. I. 947

Young, Evan E., July 6 Zander, Dr. R., 430

'11. Sep 4'12
Zanesville, Ohio, 882

Zangwill, Israel, 228

Zanzibar, 645, Nov 13 '11

Zanzur, 25

Zapata, Gen., 1088, May 25 ' 12

Zaria, 651

Zayas, Alfredo, 1080

Zbysco, 472

Zeeman effect, 118

Zeki Bey, 1158, July 11 '11

Zekki Pasha, 28, 31

Zelaya, Jose Santos, 1065, 1090,1097

Zelig, Jack, Oct 5 '12

Zeller, Prof., 221

Zeltner, F. de, 158

Zemskie Nachalniki, 1126

Zemstvo, 1127

Zeppelin dirigible, 342,372

Zeuglodonts, 136

Zeus (statue), 275

Zia Pasha, July 20, Aug 13 '12 Zichy, Count Ferdinand,
966
Ziebach Co., S. D., 908

Ziem, Félix F. G., 1003

Zikhovich, Gen., 28

Zine, 1174, 566, 393

Zinjirli, 266

Zionist Congress, Aug 9 '11

Zita, Archduchess, Oct 21 '11

Zoelly turbine, 347

Zola, E., 201, 209

Zomba, 646

Zoological Society, London, 128

- Station, Naples, 128

Zoology, see Biology and Zoology

Zorbas, Col., 1025, 1026

Zouaragu tribe, 650

Zuara, 24, 26, Dec 16 ' 11

Zucker, Dr., 222, 265

Zuloaga, I., 249

Zurich, 1143, 1145, 1146. 1147, (rioting) May 12

'11, (strike) July 12 '12.

Zwaardemaker, H., 118

Note

References will also be found throughout this volume to related matter contained in the $\mathbf{I I t h}$ edition of the Encyclopaedia Britannica (abbreviated as E.B.). For subjects not dealt with in the YEAR-BOoK, reference should be made to the Encyclopaedia Britannica, and its own Index Volume. 


\section{THE NEW}

\section{Encyclopaedia Britannica}

(Published by the Press of the University of Cambridge)

\section{THE MOST SUCCESSFUL BOOK OF OUR TIME-A NEW INVENTORY AND AUTHORITATIVE SUMMARY \\ OF THE ACCUMULATED EXPERIENCE AND KNOWLEDGE OF ALL AGES}

A book that lives-its eleven successive editions-the product of a serious co-operative effort by 1,500 specialists - written by authorities selected from 21 countries (214 Americans) -8 years in the making - cost $\$ 1,500,000$ to produce - issued not volume by volume, but as a complete whole - most comprehensive in scope and detailed in treatment-a book of practical things as well as of learningwritten in readable and interesting style - convenient for referenceprovided with an index of 500,000 entries - of indispensable value to owners of the Britannica Year-Book.

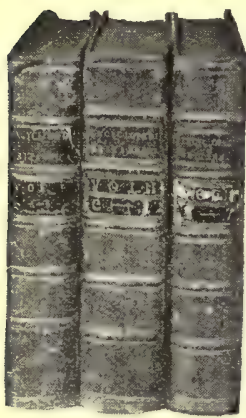

First Edition

Encyclopædia Britannica 1768

Once in a century perhaps a book is written which is a thing of life. It survives the vicissitudes of changing standards and becomes a part of world literature. In 1768, twenty years before the outbreak of the French Revolution, and while America was still a British colony, such a book was written. It was the first edition of the Encyclopædia Britannica, in three modest volumes. From generation to generation the heritage of this greatest of all works of reference has been passed on. And with each successive generation its scope has been broadened, until now eleven successful new editions have been issued, culminating in the present new work in 28 volumes and Index, whose magnitude can only be suggested by the statement that it comprises 40,000 articles, 44,000,000 words of text, 8,000 illustrations and maps, and an index volume of 500,000 entries.

Not a Book
Merely, but an
Institution.

It is a significant fact that of the twenty or more notable encyclopædias published in various countries since the first issue of the Encyclopædia Britannica, some never attained to a second edition, and only the German "Brockhaus" can claim continued existence of more than fifty years. Why have not these encyclopædias been issued afresh in successive generations, and what is the secret of the extraordinary vitality of the Encyclopædia Britannica, first issued in 1768-71,

"The best, the most practical, and the most up-to-date of Encyclopadias in the English language."-The Sun, New York. 
and now published again in a magnificent new Eleventh Edition under the auspices of the Cambridge University Press?

Because the Encyclopædia Britannica is more than a book-it is an institution. It has endured because it deserved to endure. It has come to be the vehicle by which men of learning, men of action and practical experts can best hand down their knowledge for the instruction of the public,knowledge which in many cases has been in advance of the age and not available to the reader in any other work. The utility of such a work at once appeals to a very wide circle, to all intelligent persons, in fact.

\begin{tabular}{|l|}
\hline By Specialists \\
for Non- \\
Specialists. \\
\hline
\end{tabular}

When a manufacturer is considering the purchase of a patent on a new machine, he consults a specialist on patent law. When a railroad company is planning to build a new terminal, its officers consult with specialists on real estate, specialists on engineering, specialists on architecture. We are living in an age of specialization. To each one of us comes, inevitably, an immediate need for specialized information. This information must be exact, it must be accurate, it must be such information as only an authority can give.

An Interna-
tional Work.

The new Encyclopædia Britannica answers this need. It gives the kind of information demanded. It does so because the new Encyclopædia Britannica was projected and then produced as a co-operative undertaking on the part of the most competent authorities without regard to country. The Editors recognized that, in a large sense, the whole civilised world is now one in thought, in intellectual sympathy, and in aspiration. They therefore approached their task in no merely national spirit, but in the spirit which recognises that scholarship to-day knows no nationality. The 40,000 articles were written by some 1,500 contributors, representing the highest scholarship and the best practical knowledge of the twentieth century wherever these could be found. In pursuance of this policy, not British scholars alone, but the leading American, French, and German authorities, and the best authorities of eighteen other countries, were enlisted as contributors.

The World's Best Authorities.
The Editor-in-chief, before sclecting his contributors, consulted the great authorities in each field of learning or practical achievement concerning the allotment of articles, the choice of the best writers, the arrangement of the material, and the best method of its presentation. All the great institutions of learning were represented,--the universities of Oxford, London, Edinburgh, Birmingham, Paris, Berlin,

"A monument to the learning of the Anglo-Saxon race such as no other people has ever reared to itself." - The Nation, New York. 
Göttingen, Vienna, Kioto; and in America, Harvard, Yale, Columbia, Johns Hopkins, Chicago, Pennsylvania, Princeton, Toronto-and many more;--universities and centres of research everywhere gave their ablest minds to the preparation of a new and comprehensive summary of all that is known, a restatement, in the light of developments to 1910-1911, of the knowledge acquired by mankind through 6,000 years of progress.

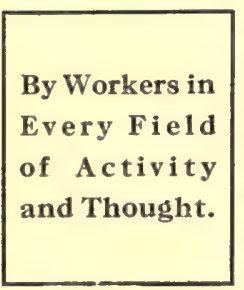

This cosmopolitan body of contributors includes: members of the staffs of institutions of learning, fellows of the Royal Society, Presidents and Secretaries of other learned societies throughout the world, staffs of the great museums, national collections and libraries, of observatories, laboratories and surveys, ministers, diplomats and government officials, theologians, lawyers, physicians and surgeons, engineers and architects, business men and manufacturers, naval and military officers, historians and archaeologists, sociologists and economists, geographers and explorers, biologists and agriculturists, mathematicians, physicists and chemists, geologists, astronomers and meteorologists.

\begin{tabular}{|l|}
\hline $\begin{array}{l}\text { Issued as a } \\
\text { Complete } \\
\text { Whole. }\end{array}$ \\
\hline
\end{tabular}

To secure the greatest possible efficiency for this work in actual service, an entirely new plan was applied to its publication. It was not produced, as is the usual custom for large works, a volume or a few volumes at a time (fourteen years elapsed, for example, between the publication of the first volume and the publication of the last volume of an earlier edition, the Ninth, of the Encyclopædia Britannica). The Eleventh Edition was written and published as a complete whole. Under the constant direction and supervision of an expert editorial staff of $64 \mathrm{mem}-$ bers, with headquarters in London and New York, the 1,500 contributors throughout the world worked simultaneously at the contents of the whole 28 volumes of text from $\mathrm{A}$ to $\mathrm{Z}$.

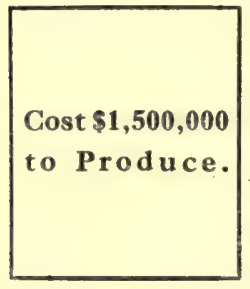

The whole of the manuscript was in the hands of the editor for revision and correction before a single page went to the printer. Eight years were required to produce the work on this new plan and an outlay of $\$ 1,500,000$ (an expenditure on a single work never equalled in the history of publishing) before a copy was offered for sale. The result is a more harmonious, more complete, up-to-date and unified work, free from inconsistencies, repetitions and similar faults to a degree impossible under a less expensive plan. All the volumes from the first to the last are equally up-to-date.

"By the best authorities and expressed in a literary form which makes details and discussions alike intelligible."-The Times, London. 
A partial classification of the 40,000 articles in this greatest work of universal reference, illustrating its enormous range, covering all the interests of the man or woman of to-day.

(The figures include biographies.)

458 articles on History and Science of Mankind

Development of Human Race and of Civilization

RaCes and Antiquity of Man

MYTHOLOGY

FOLK-LORE

161 articles on ARt, Monuments And Implements of Antiquity

Relics of EARLy MaN

2,376 articles on Painting, Sculpture, Music

Minor Arts and Crafts (Ceramics, Mosaic, Enamel, Photog. RAPHY, ETC.)

561 articles on Architecture (Principles, Terms and History)

277 articles on Astronomy (Constellations, Solar System, Comets, etc.) TELESCOPES AND OTHER INSTRUMENTS

1,886 articles on History and Cultivation of Plants

Cultivation of Fruit and Flowers

History and Habits of Animals, Insect Life

Agriculture and Stock Raising

547 articles on Chemistry (History and Principles)

CoMposition OF SUBSTANCES

Chemical Industries

492 articles on Welfare of the Individual, Social Betterment

Life of the Community and State, Legislation

Trade and Commerce

Finance

172 articles on Edvcatron, Methods of Teaching

Histories of Universities, Academies, Schools

419 articles on Engineering (Construction, Rallways, Tunnels, Canals, BRIDGES, ETC.)

Balloons and Flying Machines

USE OF STEAM AND ELECTRICITY

WATER POWER

MACHINERY

11,341 articles on Countries, Provinces, Departments, States, Cities, Towns

Travel and Exploration

Mountains, Rivers, Lakes, Oceans, etc.

740 articles on STRUCTURE OF THE EARTH

Change of Structure (Earthquakes, Volcanoes, etc.)

Mining

GEMS AND MINERALS

"A useful, working library which goes far to meet the needs of any man or woman who desires to partake in some degree of 'the best that has been thought and said in the world." "-Review of Reviews, New York. 


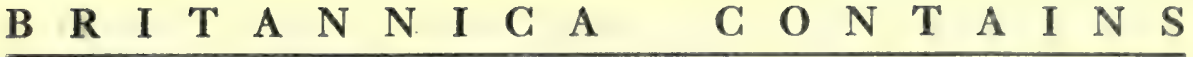

6,292 articles on History of all Countries and in all Ages

Great Political Movements

554 articles on Industries, Manufactures and Occupations, with Statistics

285 articles on Languages, Ancient and Modern

STUDY OF WORDS

Methods OF WRITING

1,302 articles on LAW

LAWS OF Different Countries

Legal Terms and Processes

COURTS

Government

Political Parties

4,136 articles on Literatures of all Countries

Great Works and Writers

PERIODicals AND NeWSPAPERS

253 articles on Mathematics

644 articles on Cause, Treatment and Prevention of Disease

Physiology and Hygiene

ANATOMY AND SURGERY

VIVISECTION

320 articles on Armies and Navies of the World

FORTIFICATIONS

STRATEGY AND TACTICS

Arms, Ammunition and Equipment

WARS AND BATTLES

643 articles on History of Thought

Schools of Philosophy

ETHICS

Psychic Phenomena and Research

285 articles on Physics (Light, Heat, Sound, Magnetism, Electricity, etc.)

Practical Application (Lighting, Heating, Telegraph, TELEPHONE)

Physical Phenomena

NEW THEORIES

3,049 articles on Primitive, Ancient and Non-Christian Religions

Christianity (History, Doctrines and Sects)

History and Criticism of the Bible, Koran, etc.

RELIGIOUS PRACTICES

264 articles on Laws and Rules of Sports and Games

History OF SPORTS AND GAMES

Drama, the Theatre and the Stage

DANCING

1,674 articles on Miscellaneous Subjects

Note.-All the principal articles are signed. Eminent authorities, therefore, assume responsibility for the trustworthiness of the information they supply.

"Probably no other work has ever gathered together as contributors such a body of experts as those who have been engaged in writing this edition of the Britannica."-The Outlook, New York. 
An Inspira. tion-the Use of India Paper.

On the physical side the revolutionary innovation of printing this large work, 29 volumes of 1,000 pages each, on thin but strong and opaque India paper, has added greatly to its charm and usefulness, reducing the weight of a volume from nine $1 \mathrm{bs}$. to under three lbs., and compressing the equivalent of 440 octavo rolumes, the contents of an entire library, into 29 inches of shelf room. This altogether novel idea which has now spread throughout the world has been characterised as an "inspiration of genius." More than 92 per cent. of the subscribers to this edition have preferred the Cambridge India paper format, in its flexible imported leather bindings, so convenient to handle, attractive in appearance, and economical of housc-room. The paper is the same as that on which the Britannica Year-Book is printed.

\begin{tabular}{l} 
A Library of \\
M ore Than \\
400 Volumes. \\
\hline
\end{tabular}

The new Encyclopædia Britannica is to be thought of rather as a complete library than a book. Its $44,000,000$ words, if published separately, would fill 440 volumes of the ordinary octavo size, 100,000 words to the volume. This library comprises: A History of All Nations, an International Dictionary of Biography, an exhaustive Gazetteer of the World, an adequate connected History of Modern Europe, an Encyclopædia of Religion, Philosophy and Sociology; a Library of Languages and Literature, a Handbook to All the Arts and Sciences, Manufactures, and Engineering; a Complete Atlas of the World, an Exhaustive Compendium of Sports and Games. The Bibliographies appended to the major articles are an Index to the Literature of the World.

The vast riches of entertainment and useful knowledge in the new Encyclopædia Britannica have been made

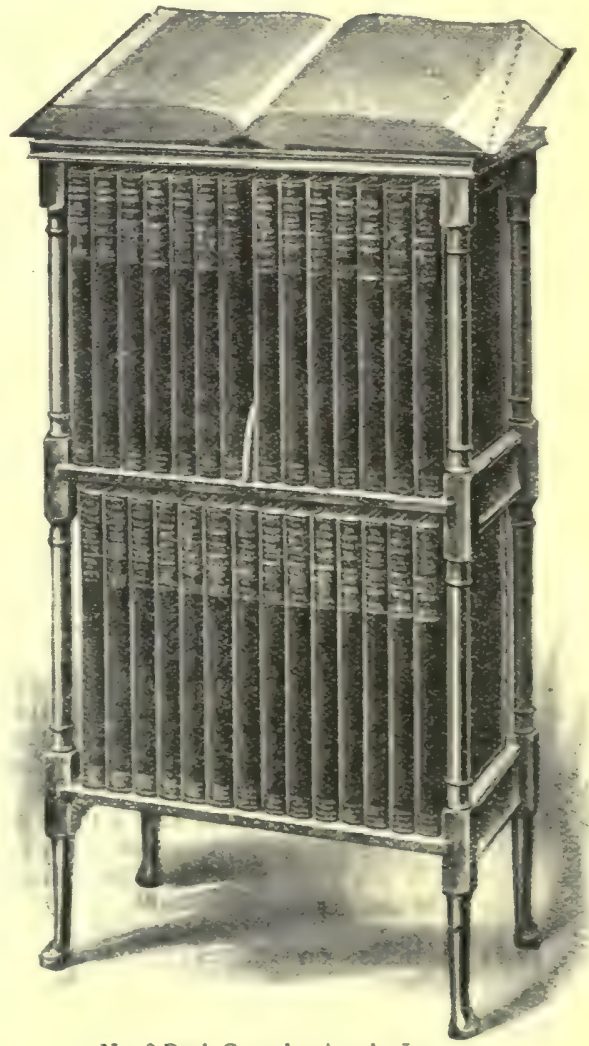

No. 2 Book-Case showing the India Paper Volumes bound in full Sheepskin. The index Volume (on ordinary paper) is seen on top.

"Requisitioned and elicited from men at the hear of their professions. all over the world."-The Evening Post, Chicago. 
easily accessible. For the first time in the history of this work, thousands of short articles, which give the seeker for information exactly what he wants without loss of time, have bcen included under separate headings. These shorter articles have been written with the same care and with the same fidelity that mark the extended treatment of major subjects which has always given the Encyclopædia Britannica a reputation for thoroughness and interesting fullness of treatment. The result is an unparalleled union of efficiency for quick and convenient consultation and readableness.

\begin{tabular}{|l|}
\hline The Instant \\
Answer to \\
Every \\
Question. \\
\hline
\end{tabular}

A feature unique in a work of general reference, and of prime importance to anyone seeking information, is the Index (Vol. 29). This volume contains an analytical alphabetical list of 500,000 references and a classified table of contents, of the $44,000,000$ words of text. By referring to this Index, any desired information, the answer to any reasonable question may now be found instantly. The inquirer need never be at a loss where to find what he wants. To an encyclopædia an index is as necessary as a directory for the finding of addresses in a large city, yet the Encyclopædia Britannica is the only work of general reference which is indexed. In other encyclopædias much information not entered under its own heading-and the number of headings is necessarily limited-is hopelessly buried without a clue to aid in its. discovery.

Practical
Things by
Practical
Men.

Great as had been the reputation of the Encyclopredia Britannica as a book of learning, the new Eleventh Edition has achieved the added distinction of being the most practical work of general reference. The common objects and interests of everyday life, the various occupations of men and women, our food and drink, the clothes we wear and all that enters into their making, from raw material to the finished product, our sports and games, from marbles to aviation, the house and all it contains, furniture, carpets, pictures, porcelain, glassware, etc., the garden and its management; in short, everything that can yield the answer to a question or afford practical guidance is in this work. It is typical of the book that the manager of a great tile and pottery factory writes on ceramics, a practising magician of international fame on conjuring, a dog expert on dogs, a golf champion on golf, and a book-binder on book-binding, to cite only a few examples among thousands.

In the new Encyclopædia Britannica the owner of the Britannica Year-Book will have a work for useful service in home or office, and for delightful recreation, which will prove invaluable with continued possession; he will have, in fact, at his immediate command, the best of all human knowledge to-day on every subject that can fairly be the source of curiosity, require explanation or fall within the scope of efforts at intellectual self-improvement.

\footnotetext{
"The greatest and most modern of all instruments of general knowiedge." T. P.'s Weekly, London.
} 


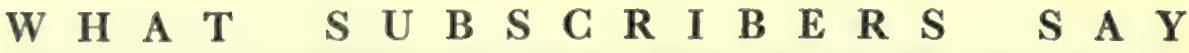

\section{A Final Authority on Every-Day Questions}

"The feeling which one has that in consulting these volumes he will obtain an absolutely authoritative opinion is alone worth the cost of the work." - Prof. Henry Crew (Northwestern University).

I am constantly turning to the new edition of the Encyclopadia Britannica as a book of reference for general use on all kinds of subjects, and I have been surprised and delighted at the wealth and variety of in. formation which it contains. If former editions of the work were for scholars, this edition meets the needs of intelligent readers in general." Jacob Gould Schurman (President of Cornell University).

"It gives me pleasure to express the great satisfaction I derive from constant reference to the new Britannica. Hardly a day passes that I do not refer to it." W. B. Dean.

"Its new arrangement makes it a handy book of reference in every respect, and I feel fully satisfied that in it I have a mine of almost inexhaustible knowledge and usefulness." $-A$. J. Freeborn.

"It is a day of specialization, and, broadly speaking, the penalty of specialization is ignorance. The subject matter of the new Britannica does much to mitigate that penalty." C. P. Scott.

"Indispensable to the student, particularly because of the high scholarship and great research disclosed by many of the special articles the counterparts of which cannot be found elsewhere." -Fred. L. Rosemond.

\section{A Valuable Addition to the Resources of the Home}

"Every professional man, and every family with growing children, seeking information, should have this invaluable work in the library." -Judge J. P. Gorter (Maryland Supreme Court).

"I bought two copies of the new edition of the Encyclopædia Britannica (India paper, flexible covers) for the benefit of my two sets of grandchildren, who are at the most inquisitive age.

The Cambridge University Press has rendered a great public service, especially to the rising generation, by constructing and distributing widely this Eleventh Edition of the Britannica, fresh in its contents, and ingenious and pleasing in mechanical execution."-Charles W. Eliot (President Emeritus of Harvard University).

"My own children have begun to use it in connection with their studies. ... I regard it as one of the treasures of my library." - J. W. Magruder.

"My children are at least the third generation of constant Britannica readers in this family." - L. C. Grant. "I wish every family in the world might be in possession of it."-Mrs. H. S. Smith.

"By its purchase I have secured access to a university education." - J. F. Kingsley.

Beyond doubt the only encyclopæedia that no man, rich or poor, can do without.... It is the people's university." - Judson T. Cull.

My children feel the same fascination in it that I do."-W. G. Hale.

No educated home can afford to be without the set."-R. R. Govin.

\section{An Enjoyable Com- panion for a Life-time}

"The new edition with its lightness and brightness is a luxury which tempts one to use it at all leisure moments."-Horace White.

I often find myself picking up a volume and reading whatever I open to, with pleasure and instruction. I do think that the library of any business or professional man is not complete without it."-Henry Atwater.

"It is not possible for anyone with a healthy curiosity in the world and its affairs to take down one of the volumes and fail to find information that will hold his attention and broaden his knowledge."-James H.Collins.

"The India paper makes your book what no encyclopædia worth mentioning has been hitherto - a comfortable book to associate with and to live with." - Prof. John Ira Bennett.

"One turns to the articles to learn, and one lingers over each volume to enjoy the charm of real literature. It is, I believe, an unprecedented thing to have at hand a work which assembles all necessary facts in language that is at the same time forceful and fascinating." - James Hay, Jr.

"The lightness of the books, the beauty of the type, the interesting style of all the articles are so inviting that I can hardly keep my hands off the books."-R. H. Life,

"In sheer physical convenience this edition does for the acquisition of information a service similar to that which the electric car has for rapid transit."-Prof. C. C. Arbuthnot.

More than 100,000 Americans are now using the new Encyclopædia Britannica. They include men and women in all walks of life, and in all circumstances. It has proved its value as an investment to persons of limited means as well as to those who in their choice of books need have no regard to expense. 
A large prospectus of the New Encyclopaedia Britannica, containing many specimen pages, illustrations, coloured plates, maps, lists of contributors, and extracts from articles, will be sent free to any reader of the Britannica Year-Book upon application to The Manager, The Encyclopaedia Britannica, 120 West 32d Street, New York. 




\section{University of Toronto}

Library

DO NOT

REMOVE

THE

GARD

FROM

THIS

POCKET 
